DATE DUE

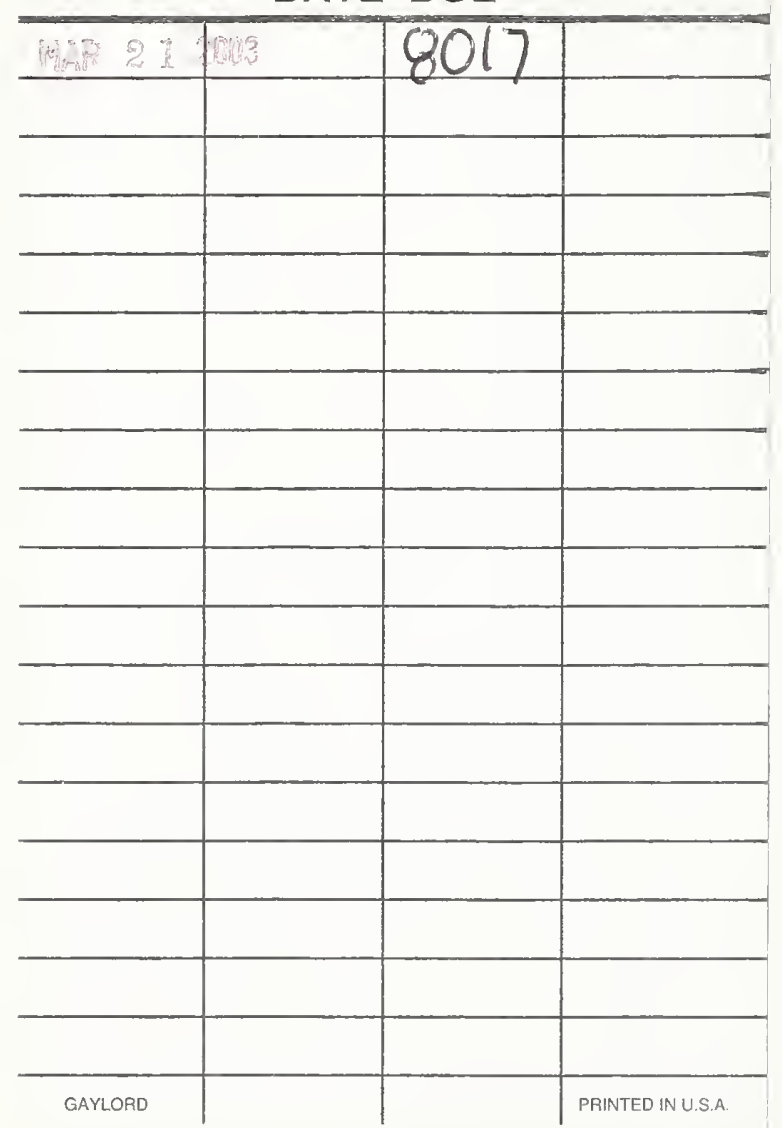


NATIONAL INSTITUTE OF STANDARDS \& TECHNOLOGY

Research Information Center

Gaithersburg, MD 20890 


\section{Al1100 990132}

UNITEO STATES EPARTMENT OF COMMERCE PUBLICATION

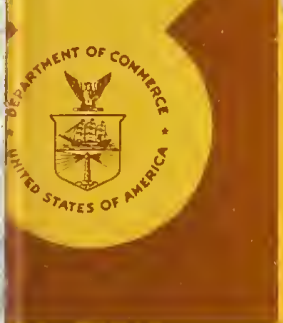

NBS

PUBLICATIONS
A11100990132

United States. Insti/Thermocouple refere

QC100.U556 V125;1974 C.1 NBS-PUB-C 1974

\section{Thermocouple Reference Tables Based on the IPTS-68}

U.S. PARTMENT

OF COMMERCE National

Bureau of Standards 
The National Bureau of Standards ${ }^{1}$ was established by an act of Congress March 3, 1901. The Bureau's overall goal is to strengthen and advance the Nation's science and technology and facilitate their effective application for public benefit. To this end, the Bureau conducts research and provides: (1) a basis for the Nation's physical measurement system, (2) scientific and technological services for industry and government, (3) a technical basis for equity in trade, and (4) technical services to promote public safety. The Bureau consists of the Institute for Basic Standards, the Institute for Materials Research, the Institute for Applied Technology, the Institute for Computer Sciences and Technology, and the Office for Information Programs.

THE INSTITUTE FOR BASIC STANDARDS provides the central basis within the United States of a complete and consistent system of physical measurement; coordinates that system with measurement systems of other nations; and furnishes essential services leading to accurate and uniform physical measurements throughout the Nation's scientific community, industry. and commerce. The Institute consists of a Center for Radiation Research, an Office of Measurement Services and the following divisions:

Applied Mathematics - Electricity - Mechanics - Heat — Optical Physics - Nuclear Sciences ${ }^{2}$ - Applied Radiation " - Quantum Electronics ${ }^{3}$ — Electromagnetics ${ }^{3}$ — Time and Frequency" - Laboratory Astrophysics " Cryogenics *.

THE INSTITUTE FOR MATERIALS RESEARCH conducts materials research leading to improved methods of measurement, standards, and data on the properties of well-characterized materials needed by industry, commerce, educational institutions, and Government; provides advisory and research services to other Government agencies; and develops, produces, and distributes standard reference materials. The Institute consists of the Office of Standard Reference Materials and the following divisions:

Analytical Chemistry - Polymers - Metallurgy - Inorganic Materials - Reactor Radiation - Physical Chemist $\mathbf{r} y$.

THE INSTITUTE FOR APPLIED TECHNOLOGY provides technical services to promote the use of available technology and to facilitate technological innovation in industry and Government; cooperates with public and private organizations leading to the development of technological standards (including mandatory safety standards), codes and methods of test; and provides technical advice and services to Government agencies upon request. The Institute consists of a Center for Building Technology and the following divisions and offices:

Engineering and Product Standards - Weights and Measures — Invention and Innova. tion - Product Evaluation Technology - Electronic Technology - Technical Analysis - Measurement Engineering - Structures, Materials, and Life Safety ${ }^{*}$ - Building Environment ${ }^{4}$ - Technical Evaluation and Application ${ }^{4}$ - Fire Technology.

THE INSTITUTE FOR COMPUTER SCIENCES AND TECHNOLOGY conducts research and provides technical services designed to aid Government agencies in improving cost effectiveness in the conduct of their programs through the selection, acquisition, and effective utilization of automatic data processing equipment; and serves as the principal focus within the executive branch for the development of Federal standards for automatic data processing equipment, techniques, and computer languages. The Institute consists of the following divisions:

Computer Services - Systems and Software - Computer Systems Engineering - Information Technology.

THE OFFICE FOR INFORMATION PROGRAMS promotes optimum dissemination and accessibility of scientific information generated within NBS and other agencies of the Federal Government; promotes the development of the National Standard Reference Data System and a system of information analysis centers dealing with the broader aspects of the National Measurement System; provides appropriate services to ensure that the NBS staff has optimum accessibility to the scientific information of the world. The Office consists of the following organizational units:

Office of Standard Reference Data - Office of Information Activities - Office of Technical Publications - Library - Office of International Relations.

${ }^{1}$ Headquarters and Laboratories at Gaithersburg, Maryland, unless otherwise noted; mailing address Washington, D.C. 20234.

${ }^{2} \mathrm{Part}$ of the Center for Radiation Research.

3 Located at Boulder. Colorado 80302.

- Part of the Center for Building Technology. 


\section{Thermocouple Reference Tables Based on the IPTS-68}

Robert L. Powell, William J. Hall, Clyde H. Hyink, Jr., and Larry L. Sparks

Cryogenics Division

Institute for Basic Standards

National Bureau of Standards

Boulder, Colorado 80302

and

George W. Burns, Margaret G. Scroger, and

Harmon H. Plumb

Heat Division

Institute for Basic Standards

National Bureau of Standards

Washington, D.C. 20234
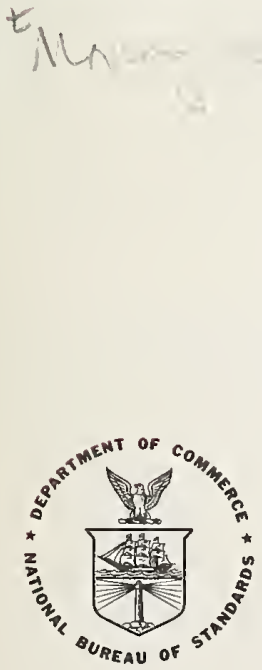

U.S. DEPARTMENT OF COMMERCE, Frederick B. Dent, Secrefary NATIONAL BUREAU OF STANDARDS, Richard W. Roberts, Director Issued March 1974 
Library of Congress Catalog Number: 73-600214

\section{National Bureau of Standards Monograph 125}

Nat. Bur. Stand. (U.S.), Monogr. 125, 410 pages (Mar. 1974) CODEN: NBSMA6

(Supersedes NBS Circular 561 issued April 27, 1955)

For sale by the Superintendent of Documents, U.S. Government Printing Office, Washington, D.C. 20402 (Order by SD Catalog No. C13.44:125). Price $\$ 4.55$

Stock Number 0303-01177 


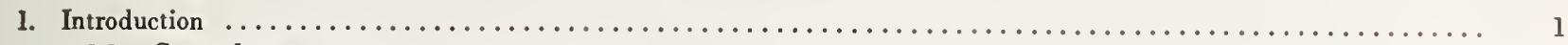

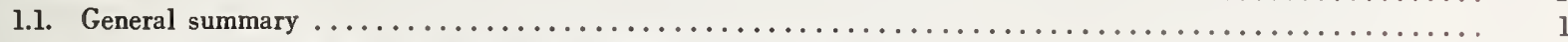

1.2. Temperature scale and platinum thermoelectric reference standard, $\mathrm{Pt}-67 \ldots \ldots \ldots \ldots$

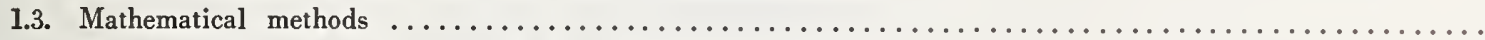

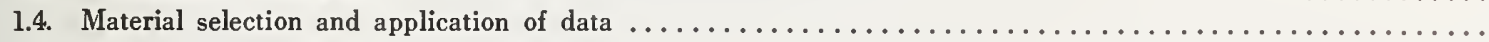

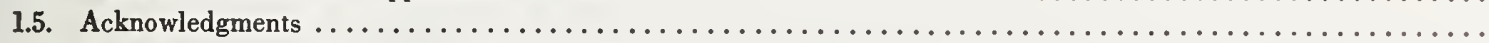

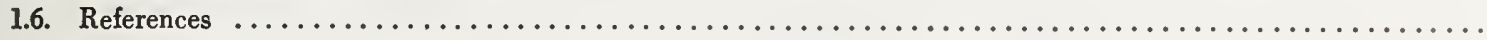

\section{Noble Metal Thermocouple Combinations}

2. Type S: Platinum-10\% rhodium alloy versus platinum thermocouples $\ldots \ldots \ldots \ldots \ldots$

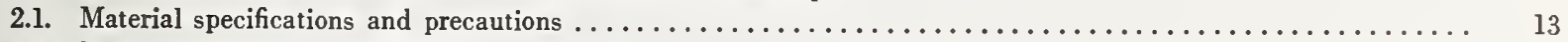

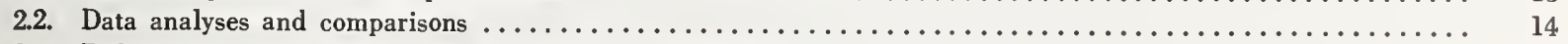

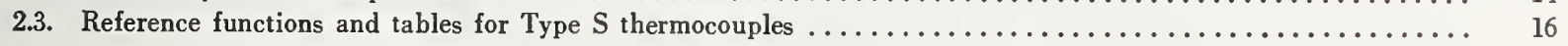

3. Type R: Platinum-13\% rhodium alloy versus platinum thermocouples $\ldots \ldots \ldots \ldots \ldots \ldots$

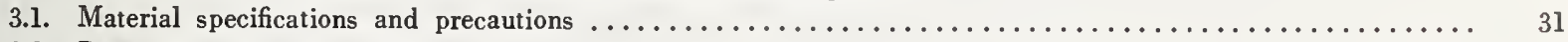

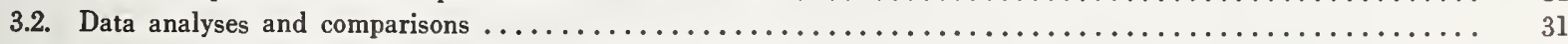

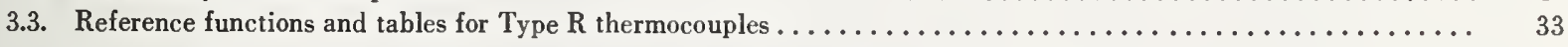

4. Type B: Platinum-30\% rhodium alloy versus platinum $-6 \%$ rhodium alloy thermocouples $\ldots \ldots \ldots . \ldots \ldots$

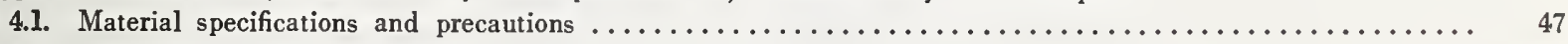

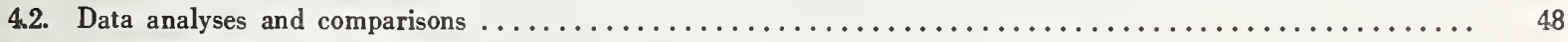

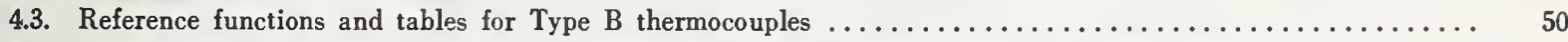

4.4. Reference functions and tables for the positive thermoelement, Type BP, a platinum-30\% rhodium alloy versus

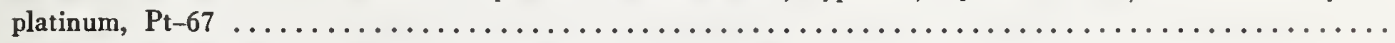

4.5. Reference functions and tables for the negative thermoelement, Type BN, a platinum-6\% rhodium alloy ver-

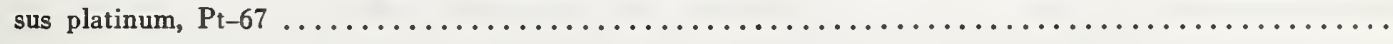

\section{Base Metal Thermocouple Combinations}

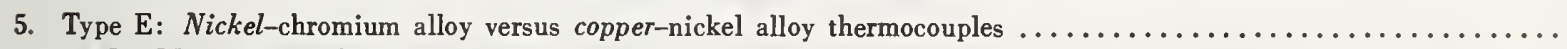

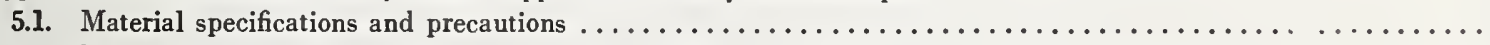

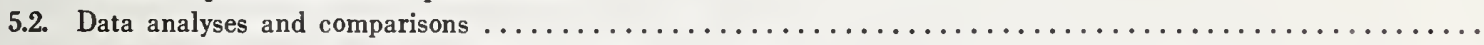

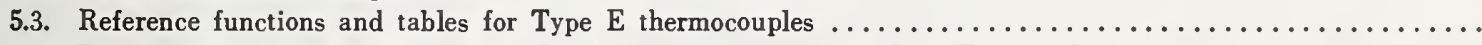

Reference functions and tables for the positive thermoelement, Type EP, a nickel-chromium alloy versus platinum, Pt-67 (See section 7.4)

Reference functions and tables for platinum, $\mathrm{Pt}-67$, versus the negative thermoelement, Type EN, a coppernickel alloy (See section 8.5)

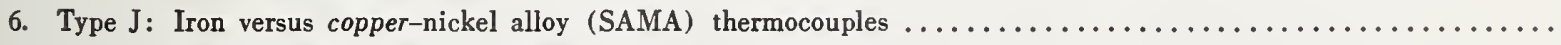

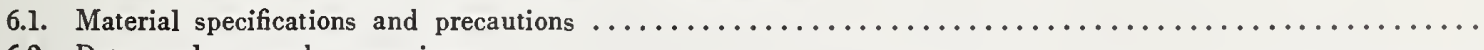

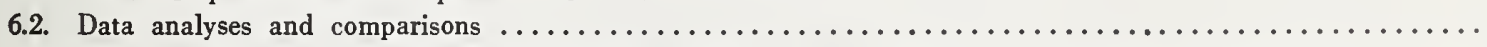

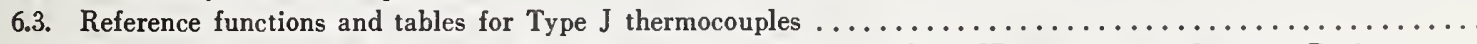

6.4. Reference functions and tables for the positive thermoelement, Type JP, iron versus platinum, Pt-67 ....

6.5. Reference functions and tables for platinum, Pt-67, versus the negative thermoelement, Type JN, a copper.

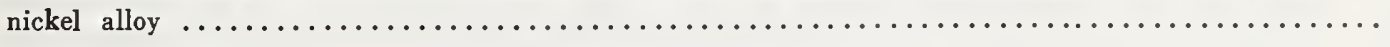

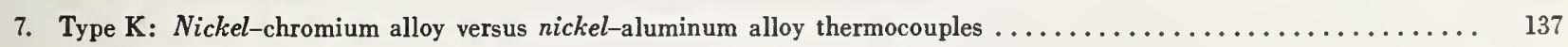

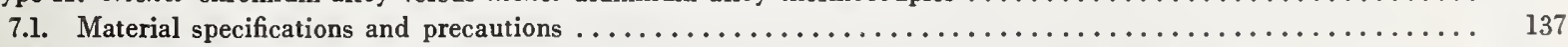

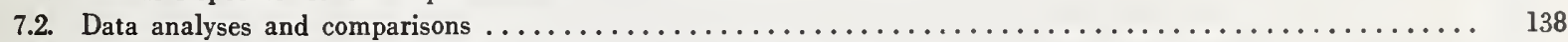

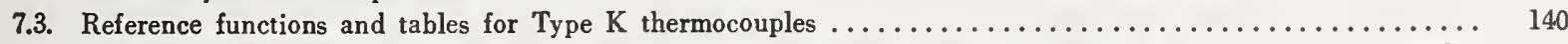

7.4. Reference functions and tables for the positive thermoelement, Type KP, a nickel-chromium alloy versus plat-

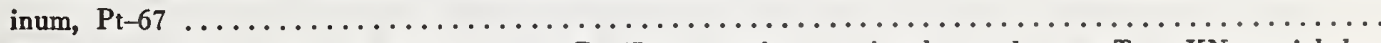

7.5. Reference functions and tables for platinum, Pt-67, versus the negative thermoelement, Type KN, a nickel-

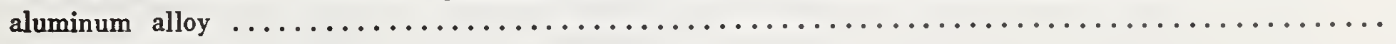

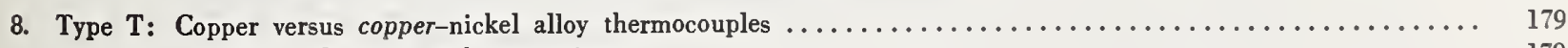

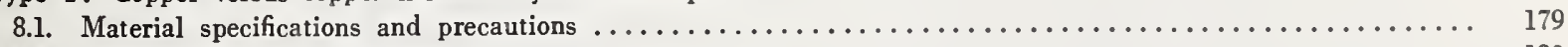

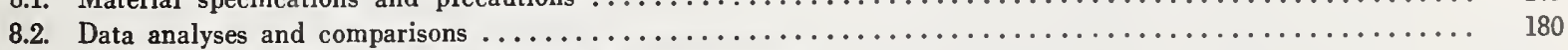

8.3. Reference functions and tables for $\mathrm{Type} \mathrm{T}$ thermocouples $\ldots \ldots \ldots \ldots \ldots \ldots$ 
8.4. Reference functions and tables for the positive thermoelement, Type TP, copper versus platinum, Pt-67....

8.5. Reference functions and tables for platinum, $\mathrm{Pt}-67$, versus the negative thermoelement, Type TN, a copper-

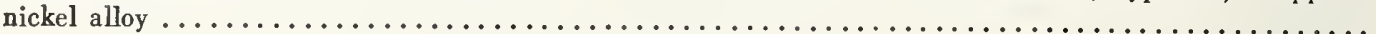

\section{Appendices}

Al. General introduction

A2. Supplementary data for Type S-Platinum-10\% rhodium alloy versus platinum thermocouples

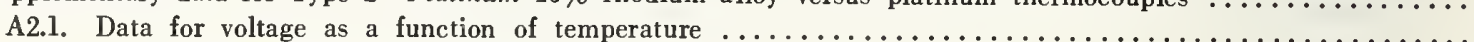

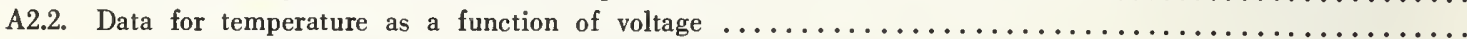

A3. Supplementary data for Type $\mathrm{R}$-Platinum-13\% rhodium alloy versus platinum thermocouples ............

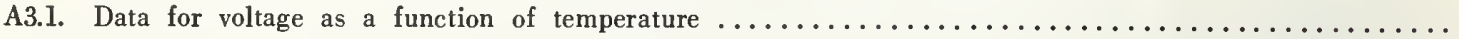

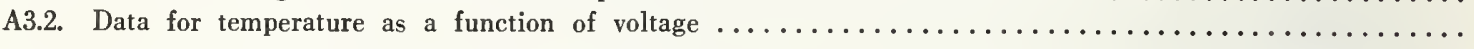

A4. Supplementary data for Type B-Platinum-30\% rhodium alloy versus platinum-6\% rhodium alloy thermocouples . 251

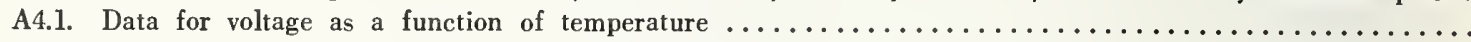

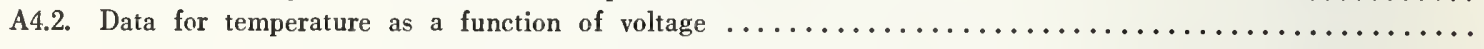

A5. Supplementary data for Type E-Nickel-chromium alloy versus copper-nickel alloy thermocouples

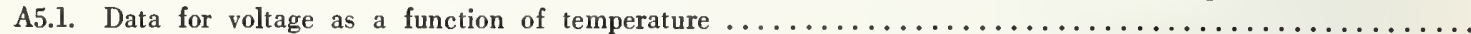

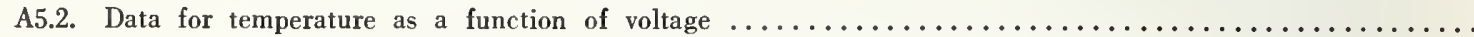

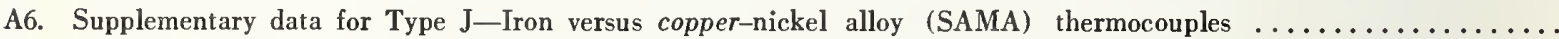

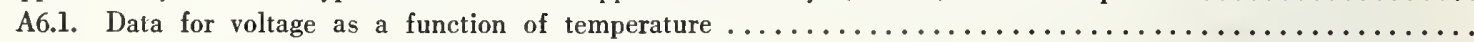

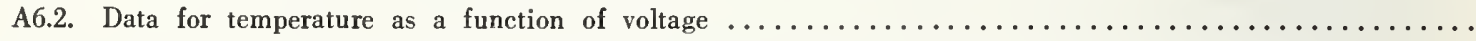

A7. Supplementary data for Type $\mathrm{K}$-Nickel-chromium alloy versus nickel-aluminum alloy thermocouples...........

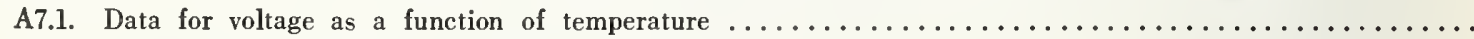

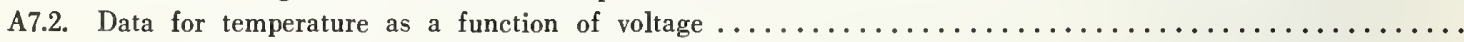

A8. Supplementary data for Type T-Copper versus copper-nickel alloy thermocouples ................ 385

A8.1. Data for voltage as a function of temperature. . . . . . . . . . . . . . . . . . . . . .

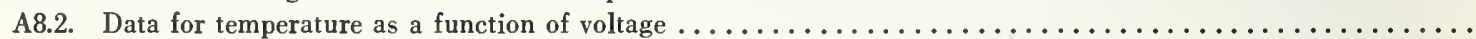

\section{List of Figures}

2.2.1. Deviations of thermolectric voltages of Type $S$ thermocouples-comparisons of values given in this Monograph to those for typical thermocouples which conform to the previous Type S standard (NBS Circular 561) ......

2.2.2. Deviation of thermoelectric voltages of Type $S$ thermocouples--comparison of values given in this Monograph to ex-

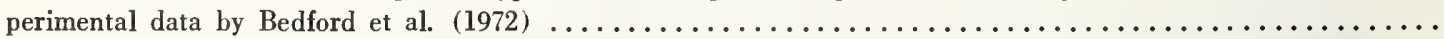

2.2.3. Difference in thermoelectric voltages for Type $S$ thermocouples-comparison of values given in this Monograph to

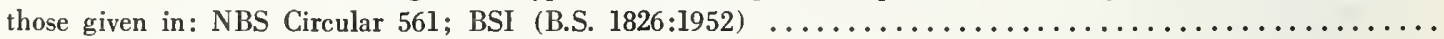

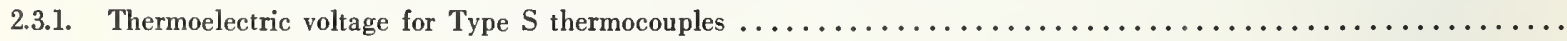

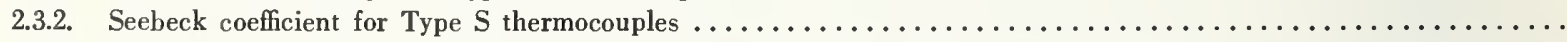

2.3.3. Second derivative of thermoelectric voltage for Type $S$ thermocouples $\ldots \ldots \ldots \ldots \ldots \ldots \ldots \ldots \ldots \ldots \ldots \ldots \ldots \ldots \ldots \ldots \ldots$

3.2.1. Deviations of thermoelectric voltage of Type $R$ thermocouples-comparison of values given in this Monograph to those for typical thermocouples which conform to the previous Type $\mathrm{R}$ standard (NBS Circular 561) ........

3.2.2. Deviation of thermoelectric voltages of Type $R$ thermocouples-comparison of values given in this Monograph to

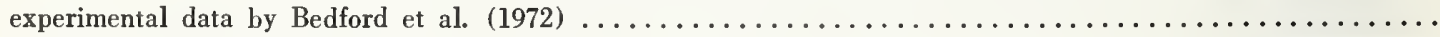

3.2.3. Differences in thermoelectric voltages for Type $\mathbf{R}$ thermocouples-comparison of values given in this Monograph

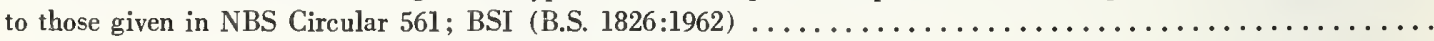

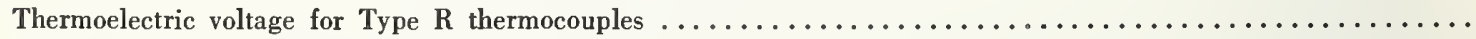

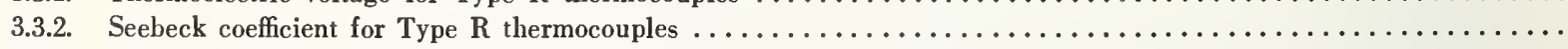

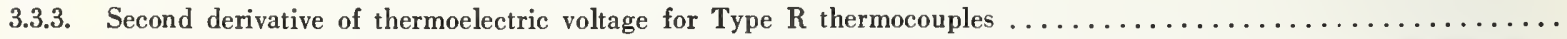

4.2.1. Deviations in thermoelectric voltages of Type $B$ thermocouples-comparison of values given in this Monograph to

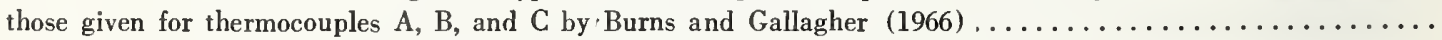

4.2.2. Deviations of thermoelectric voltages of Type $\mathrm{BP}$ thermoelements versus platinum, $\mathrm{Pt}-67$ - comparison of values given in this Monograph to those given for thermocouple materials A, B, and C by Burns and Gallagher (1966)....

4.2.3. Deviations of thermoelectric voltages of Type $\mathrm{BN}$ thermoelements versus platinum, $\mathrm{Pt}-67$ - comparison of values given in this Monograph to those given for thermocouple materials A, B, and C by Burns and Gallagher (1966) ....

4.2.4. Difference in thermoelectric voltages for Type B thermocouples-comparison of values given in this Monograph to

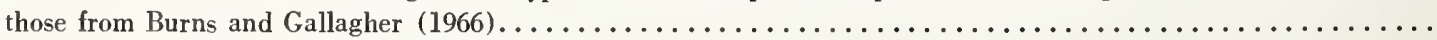

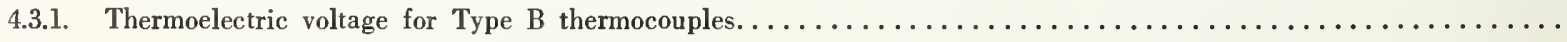

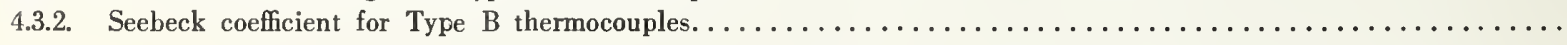


4.3.3. Second derivative of thermoelectric voltage for Type $B$ thermocouples

4.4.1. Thermoelectric voltage for Type BP thermoelements versus platinum, Pt-67

4.4.2. Seebeck coefficient for Type BP thermoelements versus platinum, Pt-67 .....................64

4.4.3. Second derivative of thermoelectric voltage for Type BP thermoelements versus platinum, Pt-67 ........ 64

4.5.1. Thermoelectric voltage for Type $\mathrm{BN}$ thermoelements versus platinum, $\mathrm{Pt}-67 \ldots \ldots \ldots \ldots \ldots$

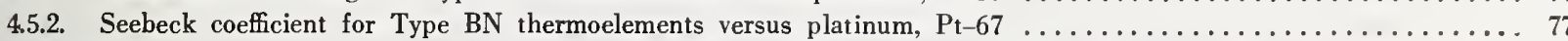

4.5.3. Second derivative of thermoelectric voltage for Type BN thermoelements versus platinum, Pt-67 ........ 77

5.2.1. Differences in thermoelectric voltages for Type $\mathrm{E}$ thermocouples-comparison of values given in this Monograph to

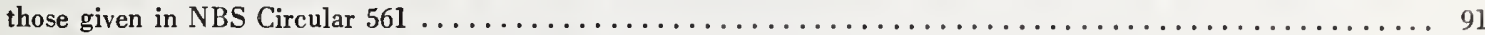

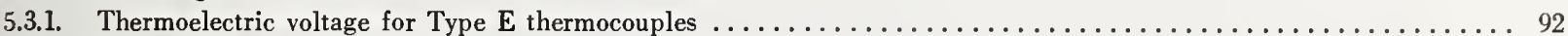

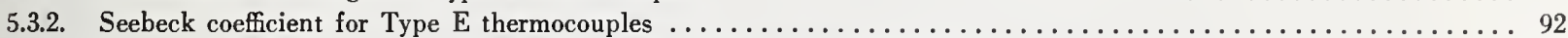

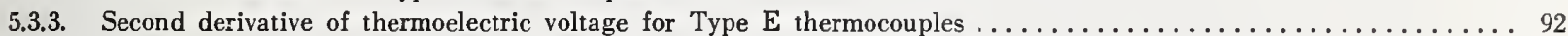

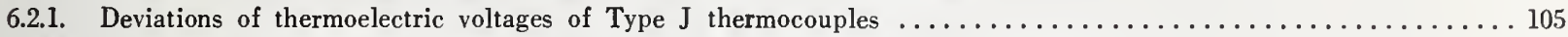

6.2.2. Deviations of thermoelectric voltages of Type JP thermoelements versus platinum, Pt-67 $\ldots \ldots \ldots \ldots \ldots$

6.2.3. Deviations of thermoelectric voltages of platinum, $\mathrm{Pt}-67$, versus $\mathrm{JN}$ thermoelements $\ldots \ldots \ldots \ldots \ldots \ldots \ldots \ldots \ldots$

6.2.4. Differences in the thermoelectric voltages for Type $J$ thermocouples-comparison of values given in this Monograph

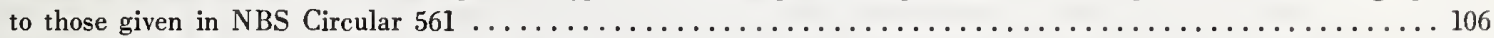

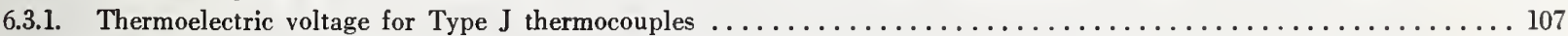

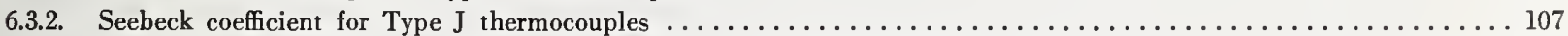

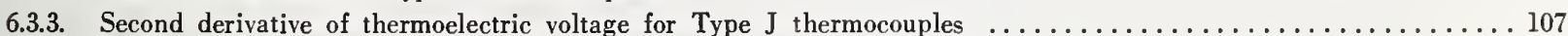

6.4.1. Thermoelectric voltage for Type JP thermoelements versus platinum, $\mathrm{Pt}-67 \ldots \ldots \ldots \ldots \ldots$

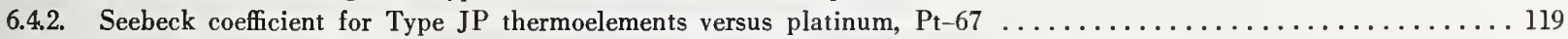

6.4.3. Second derivative of thermoelectric voltage for Type JP thermoelements versus platinum, Pt-67 .........119

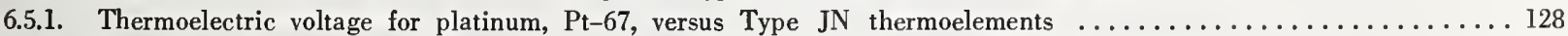

6.5.2. Seebeck coefficient for platinum, Pt-67, versus Type JN thermoelements $\ldots \ldots \ldots \ldots \ldots \ldots \ldots \ldots \ldots \ldots \ldots$

6.5.3. Second derivative of thermoelectric voltage for platinum, $\mathrm{Pt}-67$, versus Type JN thermoelements ........ 128

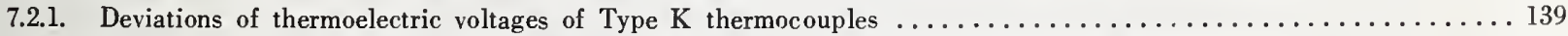

7.2.2. Deviations of thermoelectric voltages of Type KP (or EP) thermoelements versus platinum, Pt-67 ........ 139

7.2.3. Deviations of the thermoelectric voltages of platinum, $\mathrm{Pt}-67$, versus Type $\mathrm{KN}$ thermoelements ............. 139

7.2.4. Differences in the thermoelectric voltages for Type $\mathrm{K}$ thermocouples-comparison of values given in this Mono-

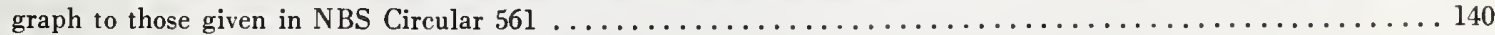

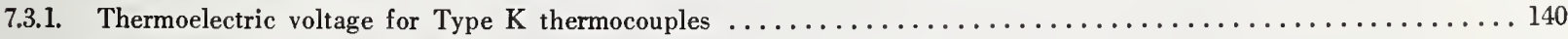

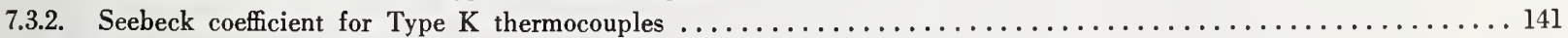

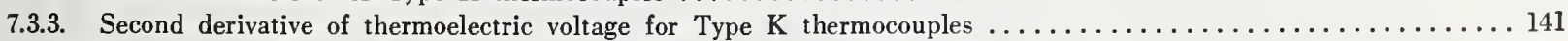

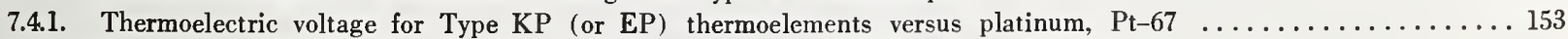

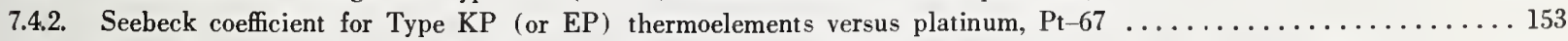

7.4.3. Second derivative of thermoelectric voltage for Type KP (or EP) thermcelements versus platinum, Pt-67 ..... 153

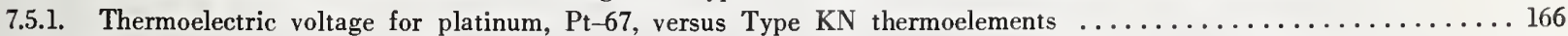

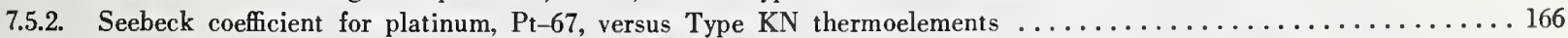

7.5.3. Second derivative of thermoelectric voltage for platinum, $\mathrm{Pt}-67$, versus Type $\mathrm{KN}$ thermoelements $\ldots \ldots \ldots \ldots$

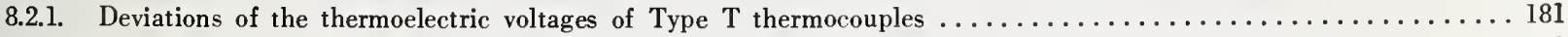

8.2.2. Deviations in the thermoelectric voltage of Type TP thermoelements versus platinum, Pt-67.......... 181

8.2.3. Deviations in the thermoelectric voltages of platinum, $\mathrm{Pt}-67$, versus Type TN (or EN) thermoelements ....... 181

8.2.4. Difference in the thermoelectric voltages for Type $T$ thermocouples - comparison of values given in this Monograph

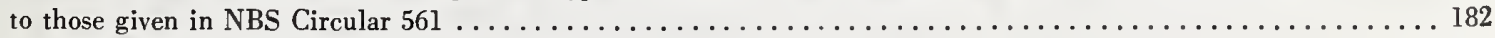

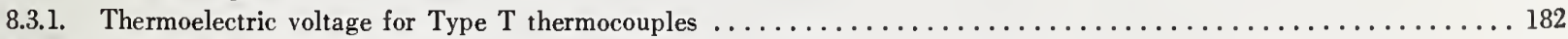

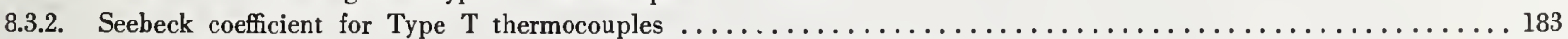

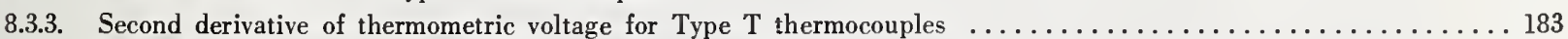

8.4.1. Thermoelectric voltage for Type TP thermoelements versus platinum, Pt $-67 \ldots \ldots \ldots \ldots$

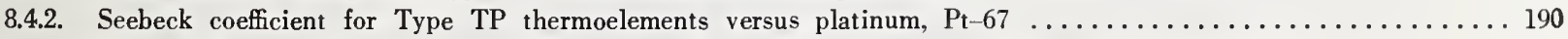

8.4.3. Second derivative of thermoelectric voltage for Type TP thermoelements versus platinum, Pt $-67 \ldots \ldots \ldots$

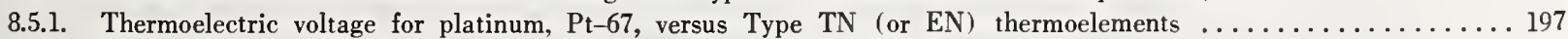

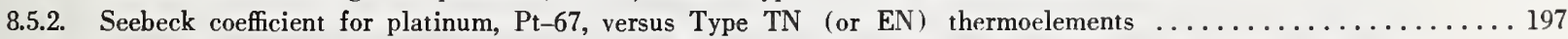

8.5.3. Second derivative of thermoelectric voltage for platinum, Pt-67, versus Type TN (or EN) thermoelements ...... 197

Table

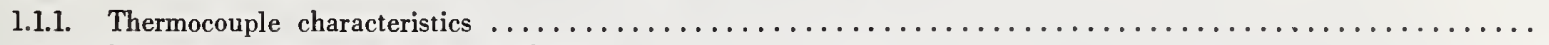

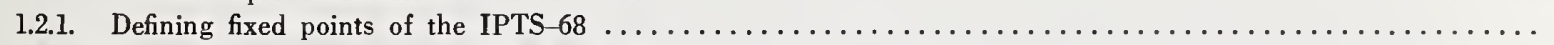

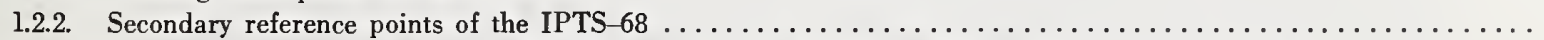

1.2.3. Approximate differences between IPTS-68 and IPTS-48; values tabulated are $\left(\mathrm{T}_{6 s}-\mathrm{T}_{4 \mathrm{~s}}\right) \mathrm{K} \ldots \ldots \ldots \ldots$

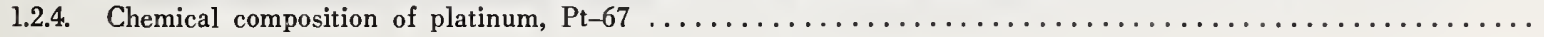


2.3.2. Type $S$ thermocouples-thermoelectric voltages, $E(T)$, Seebeck coefficients, $S(T)$, and first derivative of the

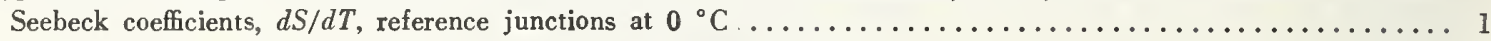

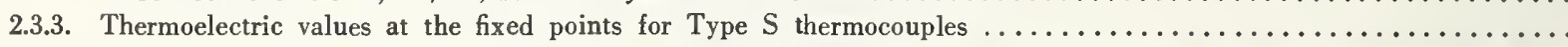

2.3.4. Estimated maximum errors that occur when using reduced-bit arithmetic for the power series expansion for the

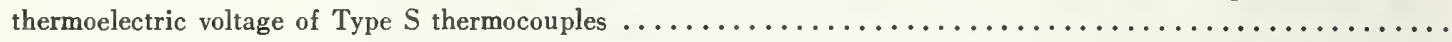

3.3.1. Power series expansion for the thermoelectric voltage of Type $\mathbf{R}$ thermocouples $\ldots \ldots \ldots \ldots \ldots \ldots \ldots \ldots . \ldots \ldots$

3.3.2. Type $\mathrm{R}$ thermocouples-thermoelectric voltages, $E(T)$, Seebeck coefficients, $S(T)$, and first derivative of the

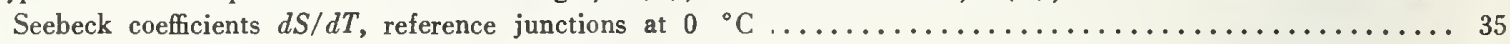

3.3.3. Thermoelectric values at the fixed points for Type $\mathrm{R}$ thermocouples $\ldots \ldots \ldots \ldots \ldots \ldots \ldots \ldots \ldots \ldots . \ldots \ldots$

3.3.4. Estimated maximum errors that occur when using reduced-bit arithmetic for the power series expansion for the

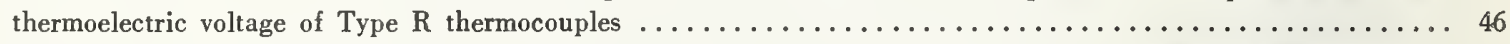

4.2.1. Deviations in thermoelectric voltage between tabular values in this Monograph and the earlier Degussa calibra.

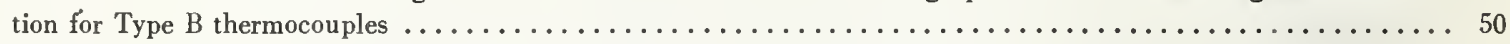

4.3.1. Power series expansion for the thermoelectric voltage of Type $B$ thermocouples ................... 51

4.3.2. Type B thermocouples-thermoelectric voltages, $E(T)$, Seebeck coefficients, $S(T)$, and first derivative of the See-

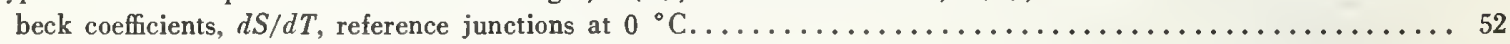

4.3.3. Thermoelectric values at the fixed points for Type B thermocouples $\ldots \ldots \ldots \ldots \ldots \ldots \ldots \ldots \ldots \ldots \ldots \ldots \ldots \ldots$

4.3.4. Estimated maximum errors that occur when using reduced-bit arithmetic for the power series expansion for the

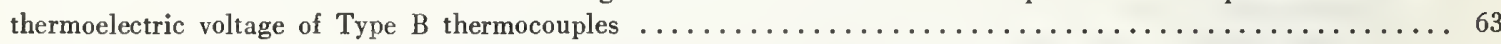

4.4.1. Power series expansion for the thermoelectric voltage of Type BP thermoelements versus platinum, Pt-67 ... 64

4.4.2. Type BP thermoelements versus platinum, Pt-67-thermoelectric voltages, $\mathrm{E}(T)$, Seebeck coefficients, $\mathrm{S}(T)$, and first derivative of the Seebeck coefficients, $d S / d T$, reference junctions at $0{ }^{\circ} \mathrm{C} \ldots \ldots \ldots \ldots \ldots \ldots \ldots$

4.4.3. Thermoelectric values at the fixed points for Type BP thermoelements versus platinum, $\mathrm{Pt}-67 \ldots \ldots \ldots \ldots . \ldots 76$

4.4.4. Estimated maximum errors that occur when using reduced-bit arithmetic for the power series expansion for the thermoelectric voltage of Type $\mathrm{BP}$ thermoelements versus platinum, $\mathrm{Pt}-67 \ldots \ldots \ldots \ldots \ldots \ldots \ldots \ldots . \ldots 76$

4.5.1. Power series expansion for the thermoelectric voltage of the Type BN thermoelements versus platinum, Pt-67 .. 77

4.5.2. Type BN thermoelements versus platinum, Pt-67-thermoelectric voltages, $E(T)$, Seebeck coefficients, $S(T)$, and first derivative of the Seebeck coefficients, $d S / d T$, reference junctions at $0{ }^{\circ} \mathrm{C} \ldots \ldots \ldots \ldots \ldots \ldots \ldots \ldots .78$

4.5.3. Thermoelectric values at the fixed points for Type BN thermoelements versus platinum, Pt-67 $\ldots \ldots \ldots . . .89$

4.5.4. Estimated maximum errors that occur when using reduced-bit arithmetic for the power series expansion for the thermoelectric voltage of Type $\mathrm{BN}$ thermoelements versus platinum, $\mathrm{Pt}-67 \ldots \ldots \ldots \ldots \ldots \ldots \ldots \ldots . \ldots . \ldots 9$

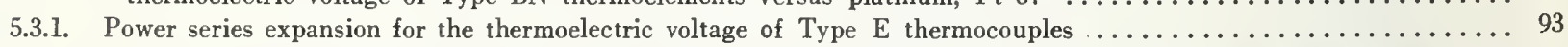

5.3.2. Type E thermocouples-thermoelectric voltages, $E(T)$, Seebeck coefficients, $S(T)$, and first derivative of the

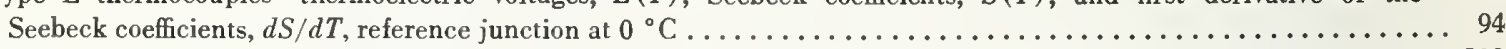

5.3.3. Thermoelectric values at the fixed points for Type $\mathbf{E}$ thermocouples ........................ 102

5.3.4. Estimated maximum errors that occur when using reduced-bit arithmetic for the powers series expansion for the

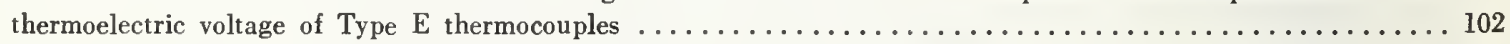

6.3.1. Power series expansion for the thermoelectric voltage of Type $J$ thermocouples .................... 107

6.3.2. Type J thermocouples-thermoelectric voltages, $E(T)$, Seebeck coefficients, $S(T)$, and first derivative of the

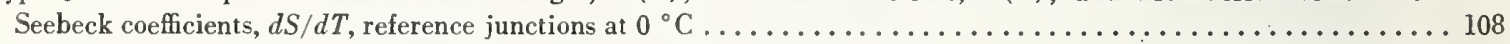

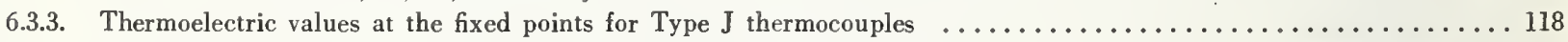

6.3.4. Estimated maximum errors that occur when using reduced-bit arithmetic for the power series expansion for the

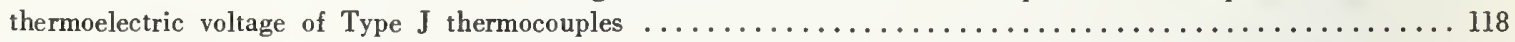

6.4.1. Power series expansion for the thermoelectric voltage of Type JP thermoelements versus platinum, Pt-67 ... 119

6.4.2. Type JP thermoelements versus platinum, Pt-67-thermoelectric voltages, $E(T)$, Seebeck coefficients, $S(T)$, and

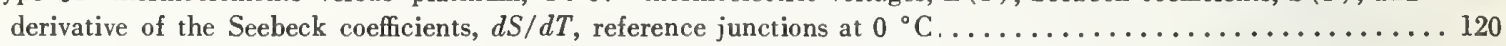

6.4.3. Thermoelectric values at the fixed points for Type JP thermoelements versus platinum, $\mathrm{Pt}-67 \ldots \ldots \ldots \ldots \ldots 127$

6.4.4. Estimated maximum errors that occur when using reduced-bit arithmetic for the power series expansion for the thermoelectric voltage of Type JP thermoelements versus platinum, $\mathrm{Pt}-67 \ldots \ldots \ldots \ldots \ldots \ldots \ldots \ldots \ldots \ldots$

6.5.1. Power series expansion for the thermoelectric voltage of platinum, Pt-67, versus Type JN thermoelements $\ldots \ldots 128$

6.5.2. Platinum, $\mathrm{Pt}-67$, versus Type JN thermoelements-thermoelectric voltages, $E(T)$, Seebeck coefficients, $S(T)$, and first derivative of the Seebeck coefficients, $d S / d T$, reference junctions at $0^{\circ}{ }^{\circ} \mathrm{C} \ldots \ldots \ldots \ldots \ldots \ldots \ldots \ldots \ldots$

6.5.3. Thermoelectric values at the fixed points for platinum, Pt-67, versus Type JN thermoelements ............ 136

6.5.4. Estimated maximum errors that occur when using reduced-bit arithmetic for the power series expansion for the thermoelectric voltage of platinum, $\mathrm{Pt}-67$, versus $\mathrm{JN}$ thermoelements $\ldots \ldots \ldots \ldots \ldots \ldots \ldots \ldots \ldots \ldots \ldots \ldots \ldots$

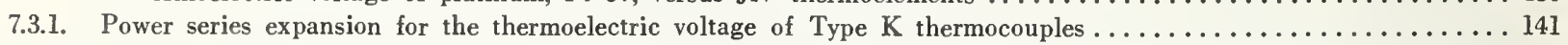

7.3.2. Type $\mathrm{K}$ thermocouples - thermoelectric voltages, $E(T)$, Seebeck coefficients, $S(T)$, and first derivative of the See-

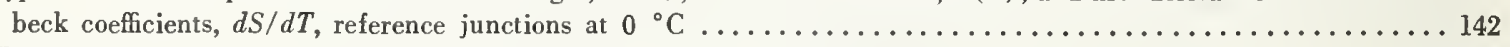

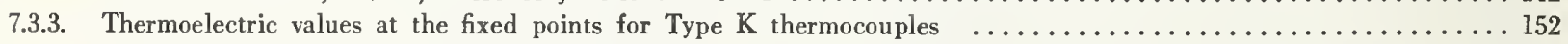

7.3.4. Estimated maximum errors that occur when using reduced-bit arithmetic for the power series expansion for the

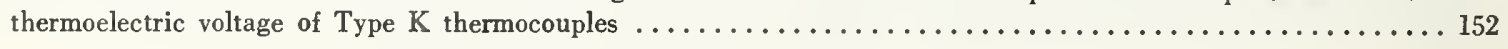


7.4.1. Power series expansion for the thermoelectric voltage of Type KP (or EP) thermoelements versus platinum, Pt-67

7.4.2. Type KP (or EP) thermoelements versus platinum, $\mathrm{Pt}-67$-thermoelectric voltages, $E(T)$, Seebeck coefficients, $S(T)$, and first derivative of the Seebeck coefficients, $d S / d T$, reference junctions at $0{ }^{\circ} \mathrm{C} \ldots \ldots \ldots$

7.4.3. Thermoelectric values at the fixed points for Type KP (or EP) thermoelements versus platinum, Pt-67 ...... 165

7.4.4. Estimated maximum errors that occur when using reduced-bit arithmetic for the powers series expansion for the thermoelectric voltage for Type KP (or EP) thermoelements versus platinum, Pt-67 .................

7.5.1. Power series expansions for the thermoelectric voltage of platinum, Pt-67, versus Type KN thermoelements .... 167

7.5.2. Platinum, $\mathrm{Pt}-67$, versus Type $\mathrm{KN}$ thermoelements- thermoelectric voltages, $E(T)$, Seebeck coefficients, $S(T)$, and

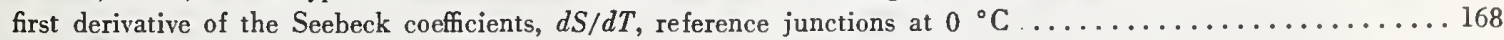

7.5.3. Thermoelectric values at the fixed points for platinum, $\mathrm{Pt}-67$, versus Type $\mathrm{KN}$ thermoelements ................

7.5.4. Estimated maximum errors that occur when using reduced-bit arithmetic for the power series expansion for the thermoelectric voltage of platinum, $\mathrm{Pt}-67$, versus Type $\mathrm{KN}$ thermoelements $\ldots \ldots \ldots \ldots \ldots \ldots$

8.3.1. Power series expansion for the thermoelectric voltage of Type $\mathrm{T}$ thermocouples $\ldots \ldots \ldots \ldots \ldots \ldots \ldots \ldots \ldots$

8.3.2. Type $\mathrm{T}$ thermocouples-thermoelectric voltages, $E(T)$, Seebeck coefficients, $S(T)$, and first derivative of the See-

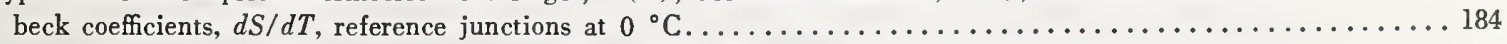

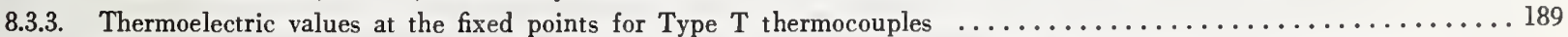

8.3.4. Estimated maximum errors that occur when using reduced-bit arithmetic for the power series expansion for the

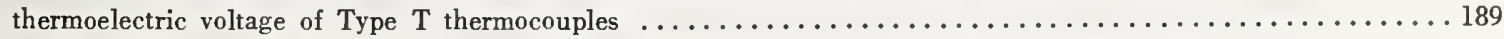

8.4.1. Power series expansion for the thermoelectric voltage of Type TP thermoelements versus platinum, Pt-67 ..... 190

8.4.2. Type TP thermoelements versus platinum, $\mathrm{Pt}-67$-thermoelectric voltages, $E(T)$, Seebeck coefficients, $S(T)$, and

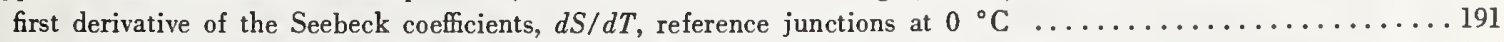

8.4.3. Thermoelectric values at the fixed points for Type TP thermoelements versus platinum, Pt-67 .......... 196

8.4.4. Estimated maximum errors that occur when using reduced-bit arithmetic for the power series expansion for the thermoelectric voltage of Type TP thermoelements versus platinum, $\mathrm{Pt}-67 \ldots \ldots \ldots$

8.5.1. Power series expansion for the thermoelectric voltage of platinum, $P_{t} X 67$, versus Type TN (or EN) thermoelements. 197

8.5.2. Platinum, Pt-67, versus Type TN (or EN) thermoelements-thermoelectric voltages, $E(T)$, Seebeck coefficients, $S(T)$, and first derivative of the Seebeck coefficients, $d S / d T$, reference junctions at $0{ }^{\circ} \mathrm{C} \ldots \ldots \ldots \ldots \ldots$

8.5.3. Thermoelectric values at the fixed points for platinum, $\mathrm{Pt}-67$, versus type TN (or EN) thermoelements ........ 206

8.5.4. Estimated maximum errors that occur when using reduced-bit arithmetic for the power series expansion for the

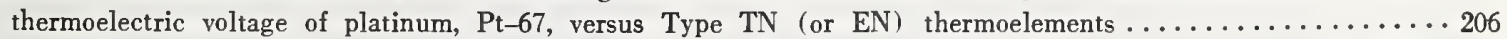

A2.1.1. Type $\mathrm{S}$ thermocouples-thermoelectric voltage as a function of temperature $\left({ }^{\circ} \mathrm{C}\right)$, reference junctions at $0{ }^{\circ} \mathrm{C} . .208$

A2.1.2. Type $S$ thermocouples-thermoelectric voltage as a funtion of temperature $\left({ }^{\circ} \mathrm{F}\right)$, reference junctions at $32{ }^{\circ} \mathrm{F} \ldots 212$

A2.1.3. Type $\mathrm{S}$ thermocouples-quadratic, cubic, and quartic approximations to the data as a function of temperature

$\left({ }^{\circ} \mathrm{C}\right)$ in selected temperatures ranges. The expansion is of the form $E=a_{0}+a_{1} T+a_{2} T^{2}+a_{3} T^{3}+a_{4} T^{4}$ where $E$

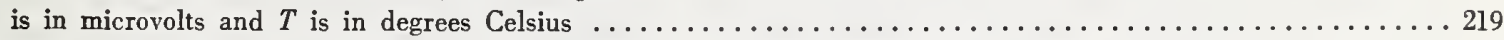

A2.2.1. Type $\mathrm{S}$ thermocouples-temperature $\left({ }^{\circ} \mathrm{C}\right)$ as a function of thermoelectric voltage, reference junctions at $0{ }^{\circ} \mathrm{C} \cdots 220$

A2.2.2. Type $S$ thermocouples-temperature $\left({ }^{\circ} \mathrm{F}\right)$ as a function of thermoelectric voltage, reference junctions at $32{ }^{\circ} \mathrm{F} . .224$

A2.2.3. Type $S$ thermocouples-quadratic, cubic, and quartic approximations to the data as a function of voltage in selected temperature ranges $\left({ }^{\circ} \mathrm{C}\right)$. The expansion is of the form $T=a_{0}+a_{1} E+a_{2} E^{2}+a_{3} E^{3}+a_{4} E^{4}$ where $E$ is in microvolts and $T$ is in degrees Celsius . . . . . . . . . . . . . . . . . . . . . . . . . . .

A3.1.1. Type $R$ thermocouples-thermoelectric voltage as a function of temperature $\left({ }^{\circ} \mathrm{C}\right)$, reference junctions at $0{ }^{\circ} \mathrm{C} . .229$

A3.1.2. Type $R$ thermocouples-thermoelectric voltage as a function of temperature $\left({ }^{\circ} \mathrm{F}\right.$ ), reference junctions at $32{ }^{\circ} \mathrm{F} . .233$

A3.1.3. Type $\mathrm{R}$ thermocouples-quadratic, cubic, and quartic approximations to the data as a function of temperature $\left({ }^{\circ} \mathrm{C}\right)$ in selected temperature ranges. The expansion is of the form $E=a_{0}+a_{1} T+a_{2} T^{2}+a_{3} T^{3}+a_{4} T^{4}$ where $E$

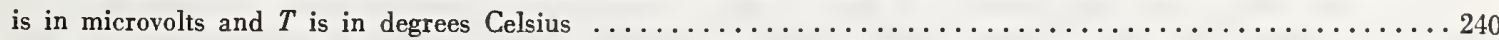

A3.2.1. Type $\mathrm{R}$ thermocouples-temperature $\left({ }^{\circ} \mathrm{C}\right)$ as a function of thremoelectric voltage, reference junctions at $0{ }^{\circ} \mathrm{C} . .241$ A3.2.2. Type $\mathrm{R}$ thermocouples-temperature $\left({ }^{\circ} \mathrm{F}\right)$ as a function of thermoelectric voltage, reference junctions at $32{ }^{\circ} \mathrm{F} . .246$ A3.2.3. Type $R$ thermocouples-quadratic, cubic, and quartic approximations to the data as a function of voltage in selected temperature ranges $\left({ }^{\circ} \mathrm{C}\right)$. The expansion is of the form $T=a_{0}+a_{1} E+a_{2} E^{2}+a_{3} E^{3}+a_{4} E^{4}$ where $E$ is in microvolts and $T$ is in $\operatorname{deg} r e e s$ Celsius. . . . . . . . . . . . . . . . . . . . . . . . . . . .

A4.1.1. Type B thermocouples-thermoelectric voltage as a function of temperature $\left({ }^{\circ} \mathrm{C}\right)$, reference junctions at $0{ }^{\circ} \mathrm{C} \cdot 252$ A4.1.2. Type B thermocouples-thermoelectric voltage as a function of temperature ( ${ }^{\circ} \mathrm{F}$ ), reference junctions at $32{ }^{\circ} \mathrm{F} . .255$ A4.1.3. Type B thermocouples-quadratic, cubic, and quartic approximations to the data as a function of temperature $\left({ }^{\circ} \mathrm{C}\right)$ in selected temperature ranges. The expansion is of the form $E=a_{0}+a_{1} T+a_{2} T^{2}+a_{3} T^{3}+a_{1} T^{4}$ where $E$ is in microvolts and $T$ is in degrees Celsius. . . . . . . . . . . . . . . . . . . . . . . . . . . .

A4.2.1. Type B thermocouples-temperature $\left({ }^{\circ} \mathrm{C}\right)$ as a function of thermoelectric voltage, reference junctions at $0^{\circ} \mathrm{C} \ldots \ldots 263$ A4.2.2. Type B thermocouples-temperature $\left({ }^{\circ} \mathrm{F}\right)$ as a function of thermoelectric voltage, reference junctions at $32{ }^{\circ} \mathrm{F} . .266$ A4.2.3. Type B thermocouples-quadratic, cubic, and quartic approximations to the data as a function of voltage in seselected temperature ranges $\left({ }^{\circ} \mathrm{C}\right)$. The expansion is of the form $T=a_{0}+a_{1} E+a_{2} E^{2}+a_{3} E^{3}+a_{4} E^{4}$ where $E$ is

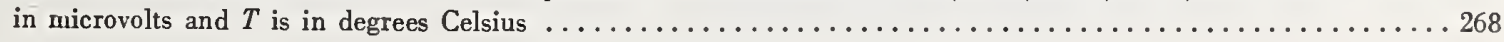


A5.1.1. Type $\mathrm{E}$ thermocouples-thermoelectric voltage as a function of temperature $\left({ }^{\circ} \mathrm{C}\right)$, reference junctions at $0{ }^{\circ} \mathrm{C} . .269$

A5.1.2. Type $\mathrm{E}$ thermocouples-thremoelectric voltage as a function of temperature $\left({ }^{\circ} \mathrm{F}\right)$, reference junctions at $32{ }^{\circ} \mathrm{F} . .272$

A5.1.3. Type E thermocouples-quadratic, cubic, and quartic approximations to the data as a function of temperature

$\left({ }^{\circ} \mathrm{C}\right)$ in selected temperature ranges. The expansion is of the form $E=a_{0}+a_{1} T+a_{2} T^{2}+a_{3} T^{3}+a_{4} T^{4}$ where $E$

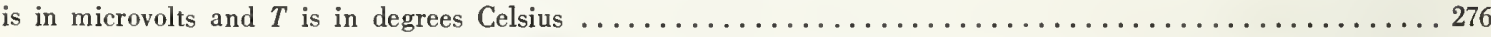

A5.2.1. Type $\mathrm{E}$ themiocouples-temperature $\left({ }^{\circ} \mathrm{C}\right)$ as a function of thermoelectric voltage, reference junctions at ${ }^{\circ} \mathrm{C} . .277$

A5.2.2. Type $\mathrm{E}$ thermocouples-temperature $\left({ }^{\circ} \mathrm{F}\right)$ as a function of thermoelectric voltage, reference junctions at $32{ }^{\circ} \mathrm{F} . .292$

A5.2.3. Type $\mathrm{E}$ thermocouples-quadratic, cubic, and quartic approximations to the data as a function of voltage in selected temperature ranges $\left({ }^{\circ} \mathrm{C}\right)$. The expansion is of the form $T=a_{0}+a_{1} E+a_{2} E^{2}+a_{3} E^{3}+a_{4} E^{4}$ where $E$ is

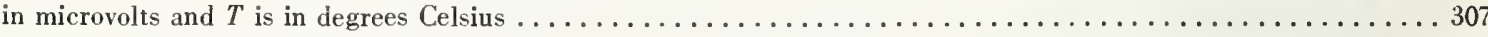

A6.1.1. Type $\mathrm{J}$ thermocouples - thermoelectric voltage as a function of temperature $\left({ }^{\circ} \mathrm{C}\right)$, reference junctions at $0{ }^{\circ} \mathrm{C} . .309$

A6.1.2. Type $\mathrm{J}$ thermocouples-thermoelectric voltage as a function of temperature $\left({ }^{\circ} \mathrm{F}\right)$, reference junctions at $32{ }^{\circ} \mathrm{F} . .612$

A6.1.3. Type $J$ thermocouples-quadratic, cubic, and quartic approximations to the data as a function of temperature

$\left({ }^{\circ} \mathrm{C}\right)$ in selected temperature ranges. The expansion is of the form $E=a_{6}+a_{1} T+a_{2} T^{2}+a_{3} T^{3}+a_{4} T^{4}$ where $E$

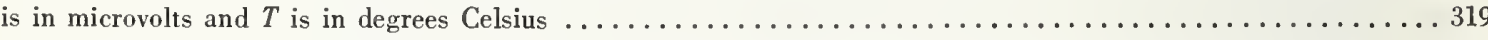

A6.2.1. Type $\mathrm{J}$ thermocouples-temperature $\left({ }^{\circ} \mathrm{C}\right)$ as a function of thermoelectric voltage, reference junctions at $0{ }^{\circ} \mathrm{C} . . .320$

A6.2.2. Type $\mathrm{J}$ thermocouples-temperature $\left({ }^{\circ} \mathrm{F}\right)$ as a function of thermoelectric voltage, reference junctions at $32{ }^{\circ} \mathrm{F} . .335$

A6.2.3. Type $J$ thermocouples-quadratic, cubic, and quartic approximations to the data as a function of voltage in selected temperature ranges $\left({ }^{\circ} \mathrm{C}\right)$. The expansion is of the form $T=a_{0}+a_{1} E+a_{2} E^{2}+a_{3} E^{3}+a_{4} E^{4}$ where $E$ is

in microvolts and $T$ is in degrees Celsius . . . . . . . . . . . . . . . . . . . . . . . . . . . . . .

A7.1.1. Type $\mathrm{K}$ thermocouples-thermoelectric voltage as a function of temperature $\left({ }^{\circ} \mathrm{C}\right)$, reference junctions at $0{ }^{\circ} \mathrm{C} . .351$

A7.1.2. Type $\mathrm{K}$ thermocouples-thermoelectric voltage as a function of temperature $\left({ }^{\circ} \mathrm{F}\right)$, reference junctions at $32{ }^{\circ} \mathrm{F} . .355$

A7.1.3. Type $\mathrm{K}$ thermocouples-quadratic, eubic, and quartic approximations to the data as a function of temperature

$\left({ }^{\circ} \mathrm{C}\right)$ in selected temperature ranges. The expansion is of the form $E=a_{0}+a_{1} T+a_{2} T^{2}+a_{3} T^{3}+a_{4} T^{4}$ where $E$

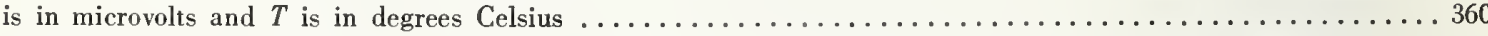

A7.2.1. Type $\mathrm{K}$ thermocouples-temperature $\left({ }^{\circ} \mathrm{C}\right)$ as a function of thermoelectric voltage, reference junctions at $0{ }^{\circ} \mathrm{C} \ldots 361$

A7.2.2. Type $\mathrm{K}$ thermocouples-temperature $\left({ }^{\circ} \mathrm{F}\right)$ as a function of thermoelectric voltage, reference junctions at $32{ }^{\circ} \mathrm{F} . .373$

A7.2.3. Type $\mathrm{K}$ thermocouples-quadratic, cubic, and quartic approximations to the data as a function of voltage in selected temperature ranges $\left({ }^{\circ} \mathrm{C}\right)$. The expansion is of the form $T=a_{0}+a_{1} E+a_{2} E^{2}+a_{3} E^{3}+a_{4} E^{4}$ where $E$ is in microvolts and $T$ is in degrees Celsius . . . . . . . . . . . . . . . . . . . . . . . . . . . . . .

A8.1.1. Type $\mathrm{T}$ thermocouples-thermoelectric voltage as a function of temperature $\left({ }^{\circ} \mathrm{C}\right)$, reference junctions at $0{ }^{\circ} \mathrm{C} \ldots 385$

A8.1.2. Type $\mathrm{T}$ thermocouples-thermoelectric voltage as a function of temperature $\left({ }^{\circ} \mathrm{F}\right)$, reference junctions at $32{ }^{\circ} \mathrm{F} . .387$

A8.1.3. Type $\mathrm{T}$ thermocouples-quadratic, cubic, and quartic approximations to the data as a function of temperature

$\left({ }^{\circ} \mathrm{C}\right)$ in selected temperature ranges. The expansion is of the form $E=a_{0}+a_{1} T+a_{2} T^{2}+a_{3} T^{3}+a_{4} T^{4}$ where $E$

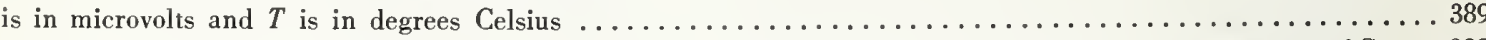

A8.2.1. Type $\mathrm{T}$ thermocouples-temperature $\left({ }^{\circ} \mathrm{C}\right)$ as a function of thermoelectric voltage, reference junctions at $0{ }^{\circ} \mathrm{C} . . .390$

A8.2.2. Type $\mathrm{T}$ thermocouples-temperature $\left({ }^{\circ} \mathrm{F}\right)$ as a function of thermoelectric voltage, reference junctions at $32^{\circ} \mathrm{F} . .396$

A8.2.3. Type $T$ thermocouples-quadratic, cubic and quartic approximations to the data as a function of voltage in se-

lected temperature ranges $\left({ }^{\circ} \mathrm{C}\right)$. The expansion is of the form $T=a_{0}+a_{1} E+a_{2} E^{2}+a_{3} E^{3}+a_{4} E^{4}$ where $E$ is

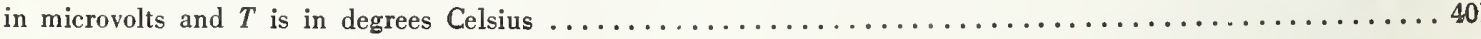




\title{
Thermocouple Reference Tables Based on the IPTS-68
}

\author{
Robert L. Powell, William J. Hall, Clyde H. Hyink, Jr., Larry L. Sparks, \\ George W. Burns, Margaret G. Scroger, and Harmon H. Plumb
}

\begin{abstract}
Revision of the International Practical Temperature Scale requires that there be changes for all accurately tabulated thermophysical values. Revised reference data for thermocouples have been generated in a cooperative program between groups of the National Bureau of Standards in Boulder and Gaithersburg. This Monograph contains tables, analytic expressions, various approximations, and explanatory text. Only the standard letter-designated thermocouples are described: noble metal Types S, R, and B and base metal Types E, J, K, and T. Their appropriate "single-leg" or thermoelement versus $\mathrm{Pt}-67$ values are also included. The new reference data reflect not only revisions in the temperature scale, but also slight changes in the materials themselves and improvements in data fitting methods. The temperature ranges vary for different types, from a low of $-270{ }^{\circ} \mathrm{C}$ for Type $\mathrm{E}$ to a high of $1820^{\circ} \mathrm{C}$ for Type $\mathrm{B}$. The main functions and tables are given in terms of Celsius degrees and microvolts. Tables in the appendices represent the data with less precision, in millivolts, and in degrees Fahrenheit as well as Celsius. Approximate quadratic, cubic, and quartic analytic expressions are also given for each thermocouple type in various temperature ranges.
\end{abstract}

Key words: Base metal alloys; noble metal alloys; temperature scale; temperature standards; thermocouples; thermometry.

\section{Introduction}

\subsection{General Summary}

Adoption of the new temperature scale, IPTS-68, requires that all accurate thermophysical data be ad. justed to fit the new temperatures. Although, as of July 1972 , no national laboratory had fully realized the new scale, as many thermometry calibrations as possible are being revised. The new scale depends on a large number of primary and secondary fixed points with designated interpolation equations and devices for obtaining intermediate temperatures. Hust [1969]* has written an extensive review and compilation of temperature scales, with an emphasis on temperatures below $0{ }^{\circ} \mathrm{C}$, that includes suggested methods of converting from older scales to present ones. A brief review of changes in the temperature scale is included in the next section. The new thermocouple reference data are based on the IPTS-68 for temperatures above $20 \mathrm{~K}\left(-253{ }^{\circ} \mathrm{C}\right)$ and on the NBS helium-gas acoustical velocity scale from 4 to $20 \mathrm{~K}$. The latter is referred to as NBS P 2-20 (1965), and is a national practical scale maintained by germanium thermometers in the Temperature Section of the National Bureau of Standards in Gaithersburg. The IPTS-68 is not defined down to liquid helium temperatures, but the NBS P 2-20 (1965) provides a workable scale from 2 to $20 \mathrm{~K}$.

Even if the temperature scale had not been changed, the old tables in NBS Circular 561 [Shenker et al., 1955] might well have been changed for other reasons: there have been significant modifications in the chemical composition of some of the materials; a new platinum thermoelectric reference standard has been adopted; reference values for each material, both positive and negative legs of the thermocouple type, are needed for calibration and production control to insure interchangeability; greater precision in thermom-

- References cited are listed in section 1.6. etry instrumentation has led to a need for smoother tables and also for values of the derivatives; and the prevalence of computer-aided numerical analysis requires functional representations and approximations. There was also a change in the voltage reference, but the new "NBS as-maintained volt", NBS Tech. News Bull. [1968b], is so little different from the old voltage standard that the change does not significantly affect thermocouple tables. Values in this Monograph reflect the above changes and needs.

Close cooperation with wire manufacturers and instrument suppliers was insured by formation of an ad hoc advisory committee within the American Society for Testing and Materials (ASTM) chaired by D. I. Finch. Several potential trouble areas were resolved during their preliminary reviews. About eighteen people received and commented on preliminary copies of the tables, functions, and graphs.

In the following paragraphs, the sources of thermocouple data, the methods of numerical analysis, and the types of tables, graphs, and functions are summarized. Table 1.1.1 gives a list of the standard thermocouple materials included in this Monograph, a description of their composition and representative trade names, and the range of temperatures for each type.

Four main sources of data were used in generating the new functions and tables: (1) earlier publications containing orginal research data, (2) unpublished calibration certificates from the files of the Temperature Section of the National Bureau of Standards in Gaithersburg, (3) low-temperature functions published by Sparks et al. [1972] in NBS Monograph 124, and (4) adjusted values from old thermocouple tables such as NBS Circular 561. Further comments for each thermocouple type are given in each appropriate chapter. In summary, much of the fundamental data for generating the new thermocouple tables comes from 


\section{THERMOCOUPLE COMBINATIONS}

\begin{tabular}{c|c|l}
\hline Type designation a & Temperature Range, ${ }^{\circ} \mathrm{C}$ & \multicolumn{1}{|c}{ Materials } \\
\hline $\mathrm{B}$ & 0 to 1820 & Platinum-30\% rhodium versus platinum-6\% rhodium. \\
$\mathrm{E}$ & -270 to 1000 & Nickel-chromium alloy versus a copper -nickel alloy. \\
$\mathrm{J}$ & -210 to 1200 & Iron versus another slightly different copper - nickel alloy. \\
$\mathrm{K}$ & -270 to 1372 & Nickel-chromium alloy versus nickel-aluminum alloy. \\
$\mathrm{R}$ & -50 to 1767 & Platinum-13\% rhodium versus platinum. \\
$\mathrm{S}$ & -50 to 1767 & Platinum-10\% rhodium versus platinum. \\
$\mathrm{T}$ & -270 to 400 & Copper versus a copper-nickel alloy. \\
\hline
\end{tabular}

SINGLE-LEG MATERIALS

\begin{tabular}{|c|c|}
\hline$\ldots \mathrm{N}$ & The negative wire in a combination. \\
\hline$\ldots P$ & 'The positive wire in a combination. \\
\hline $\mathrm{BN}$ & Platinum-nominal $6 \mathrm{wt} \%$ rhodium. \\
\hline $\mathrm{BP}$ & Platinum-nominal $30 \mathrm{wt} \%$ rhodium. \\
\hline EN or TN & $\begin{array}{l}\text { A copper-nickel alloy, constantan: Cupron }{ }^{1} \text {, Advance }{ }^{3} \text {, ThermoKanthal } \mathrm{JN}^{2} \text {; nominally } 55 \% \mathrm{Cu} \text {, } \\
45 \% \mathrm{Ni} \text {; often referred to as Adams constantan. }\end{array}$ \\
\hline $\mathrm{EP}$ or $\mathrm{KP}$ & $\begin{array}{l}\text { A nickel-chromium alloy: } \text { Chromel }^{4}, \text { Tophel }^{1}, \mathrm{~T}-1^{3} \text {, ThermoKanthal } \mathrm{KP}^{2} \text {; nominally } 90 \% \mathrm{Ni} \text {, } \\
10 \% \mathrm{Cr} \text {. }\end{array}$ \\
\hline JN & $\begin{array}{l}\text { A copper-nickel alloy similar to, but not always interchangeable with, EN and TN; SAMA } \\
\text { specification. }\end{array}$ \\
\hline JP & Iron: ThermoKanthal JP²; nominally $99.5 \% \mathrm{Fe}$. \\
\hline $\mathrm{KN}$ & $\begin{array}{l}\text { A nickel-aluminum alloy: Alumel }{ }^{4}, \mathrm{Nial}^{1}, \mathrm{~T}^{-2}{ }^{3} \text {, ThermoKanthal } \mathrm{KN}^{2} \text {; nominally } 95 \% \mathrm{Ni}, 2 \% \mathrm{Al} \text {, } \\
2 \% \mathrm{Mn}, 1 \% \mathrm{Si} \text {. }\end{array}$ \\
\hline $\mathrm{RN}, \mathrm{SN}$ & High-purity platinum. \\
\hline RP & Platinum-13 wt $\%$ rhodium. \\
\hline SP & Platinum-10 wt\% rhodium. \\
\hline TP & Copper, usually Electrolytic Tough Pitch. \\
\hline
\end{tabular}

a The letter designations used in this Monograph follow the recommendations of Committee E-20 of the American Society for Testing and Materials. The letter type, e.g., Type T, designates the thermoelectric properties, not the precise chemical composition. Thermocouples of a given type may have variations in composition as long as the resultant thermoelectric properties remain within the established limits of error.

\section{Registered Trademarks:}

Trademark-Wilbur B. Driver Co.

Trademark - Kanthal Corp.

Trademark-Driver-Harris Co.

Trademark-Hoskins Manufacturing Co.

The use of trade names does not constitute an endoresement of any manufacturer's products. All materials manufactured in compliance with the established thermoelectric voltage standards are equally acceptable.

published research papers, but also there was extensive use of unpublished calibrations and test data. Values for Types S, R, and B and most of Type J are also based on published research.

After general introductory material, discussions for each type of thermocouple are included in each chapter. The text covers such items as recommended temperature ranges, nominal chemical composition, special precautions on usage, and other similar descriptions not usually included with tables. For each type of material, there are four classes of numerical information: functional representations, complete tables, abbreviated tables, and various approximations. The abbreviated tables and approximations appear in the appendices.

Functional representations are given in tables in the form of coefficients for power series expansions. For Type K only, additional parameters for an exponential term are also included. Orders of the series expansions range from two to fourteen. The functions can be used 
directly for calculating thermal voltages as they were in this Monograph. However, for values at the highest temperatures and for high orders, there may be round-off errors on some computers that have relatively few binary bits in their floating point routines. Tables give the round-off errors that would occur for computers that have $12,16,24$, or 27 binary bits (about 4, 5, 7, or 8 digits) in the coefficient of their floating point numbers. The tables in this Monograph were generated using 36 binary bit (about 11 digit) arithmetic routines. Generally the round-off error is insignificant for machines with 24 bits or more.

Functions, and complete tables also, are given for both the total thermocouple combination, such as Type $\mathrm{K}$, and the single-leg combinations, such as Types KP and $\mathrm{KN}$.

With some exceptions, the complete tables include the thermal voltage, $\mathrm{E}$, (usually to the nearest 0.1 or 0.01 microvolt), the Seebeck coefficient, S, $(0.001$ $\mu \mathrm{V} /{ }^{\circ} \mathrm{C}$ ), and the temperature derivative of the Seebeck coefficient, $d S / d T\left(0.01 \mathrm{nV} / \mathrm{C}^{2}\right)$, all as a function of temperature, which is given at one degree intervals for each of the appropriate temperature ranges. Values for one thermocouple combination, Type J, are given with reduced precision at temperatures which are above the transformation temperature of the JP material, $760{ }^{\circ} \mathrm{C}$. Since many calibrations are performed at the primary and secondary fixed-point temperatures on the IPTS-68, tables which give values of $E, S$, and $d S / d T$ at various fixed points are also included. Two sets of figures show (1) deviations between the new and old standard tabular values and (2) deviations between the new tabular values and experimental values for typical thermocouples that represent present-day material.

Abbreviated tables for each type of material give voltage only $(0.1$ or $1 \mu \mathrm{V})$ as a function of temperature $\left(1{ }^{\circ} \mathrm{C}\right.$ or $\left.{ }^{\circ} \mathrm{F}\right)$ and the reverse, temperature $(0.01$ ${ }^{\circ} \mathrm{C}$ or $\left.{ }^{\circ} \mathrm{F}\right)$ as a function of voltage $(0.01 \mathrm{mV})$. Those tables are in the appendices. Additional "three-place" $(0.001 \mathrm{mV}$ or $1 \mu \mathrm{V})$ tables, not included in this Monograph, have been produced and were made available at cost to the ASTM and wire manufacturers for their publication of special industrial tables.

To satisfy various special needs, e.g., for small online computers or for desk calculators, we have generated low-order approximations to the voltage versus temperature equation for each thermocouple type in a few representative temperature ranges. For example, there are voltage to temperature (and the reverse) approximations for Type B thermocouples in twelve different temperature ranges for second, third, and fourth order. Quadratic equations suitable for calculating variable reference junction corrections are also included. Coefficients and the range of errors are given for all approximations. A similar project was carried out a few years ago by Fazzalari and Leonette [1969] who based their approximations on values from NBS Circular 561.
1.2. Temperature Scale and Platinum Thermoelectric Reference Standard, Pt-67

Temperatures above $20 \mathrm{~K}$ are expressed on the International Practical Temperature Scale adopted in 1968, IPTS-68. Below $20 \mathrm{~K}$, temperatures are expressed on the National Bureau of Standards acoustical temperature scale, NBS P 2-20 (1965). The definitions of these scales and differences from earlier scales are briefly discussed below.

During October 1968 the International Committee of Weights and Measures adopted the new International Practical Temperature Scale designated as IPTS-68 [CIPM, 1969]. This scale is defined in terms of a series of fixed points, a resistance versus temper. ature function, and interpolation formulas for specified instruments used to realize the scale. The defining fixed points, extending from $13.81 \mathrm{~K}$ to $1337.58 \mathrm{~K}$, are given in table 1.2.1. The secondary fixed points are tabulated in table 1.2.2. In the interest of brevity the detailed description of the IPTS-68 is omitted here; however, the reader can find the details in the above reference.

The NBS P 2-20 (1965) temperature scale is described by Plumb and Cataland [1965a, b, 1966]. This scale, based on acoustical thermometry, extends from 2 to $20 \mathrm{~K}$.

The tabulated voltages in these thermocouple tables differ from previous standard reference tables for several reasons, including changes in the defining temperature scale. Other causes for change are discussed in later sections. The differences' between the current scales and the earlier ones are generally small but not necessarily negligible. A recent review of temperature scale differences by Hust [1969] treats the subject in detail, including present as well as older frequently used temperature scales. Since the bulk of existing thermocouple tables are based on the superseded IPTS-48, the temperature differences between the IPTS-68 and the IPTS-48 are tabulated in table 1.2.3 for convenience. It is noted that below $0{ }^{\circ} \mathrm{C}$ the deviations tend to be oscillatory with a maximum deviation of $34 \mathrm{mK}$ at $-70{ }^{\circ} \mathrm{C}$. The deviations become somewhat more systematic above $0{ }^{\circ} \mathrm{C}$, with a value of $150 \mathrm{mK}$ at $600{ }^{\circ} \mathrm{C}$. Above $600{ }^{\circ} \mathrm{C}$ the deviations are nearly linear with temperature. At $2000{ }^{\circ} \mathrm{C}$ the deviation is $3.2 \mathrm{~K}$. For further details regarding deviations at lower temperatures, the reader is referred to the article by Hust.

Wherever necessary the primary data were corrected to be on the current temperature scales before the curve fitting procedures were begun. 
Assigned value of International

Practical Temperature

Equilibrium state

Equilibrium between the solid, liquid and vapor phases of equilibrium hydrogen (triple point of equilibrium hydrogen)

Equilibrium between the liquid and vapor phases of equilibrium hydrogen at a pressure of $33330.6 \mathrm{~N} / \mathrm{m}^{2}(25 / 76$ standard atmosphere)

Equilibrium between the liquid and vapor phases of equilibrium hydrogen (boiling point of equilibrium hydrogen)

Equilibrium between the liquid and vapor phases of neon (boiling point of neon)

Equilibrium between the solid, liquid and vapor phases of oxygen (triple point of oxygen)

Equilibrium between the liquid and vapor phases of oxygen (boiling point of oxygen)

Equilibrium between the solid, liquid and vapor phases of water (triple point of water) ${ }^{\mathrm{c}}$

Equilibrium between the liquid and vapor phases of water (boiling point of water) ${ }^{\text {b. c }}$

Equilibrium between the solid and liquid phases of zinc (freezing point of zinc)

Equilibrium between the solid and liquid phases of silver (freezing point of silver)

Equilibrium between the solid and liquid phases of gold (freezing point of gold)

\begin{tabular}{c|c}
$T_{68}(\mathrm{~K})$ & $t_{68}\left({ }^{\circ} \mathrm{C}\right)$ \\
13.81 & -259.34 \\
17.042 & -256.108 \\
20.28 & -252.87 \\
27.102 & -246.048 \\
54.361 & -218.789 \\
90.188 & -182.962 \\
273.16 & 0.01 \\
373.15 & 100 \\
692.73 & 419.58 \\
1235.08 & 961.93 \\
1337.58 & 1064.43 \\
\hline
\end{tabular}

a Except for the triple points and one equilibrium hydrogen point $(17.042 \mathrm{~K})$ the assigned values of temperature are for equilibrium states at a pressure $p_{0}=1$ standard atmosphere $\left(101325 \mathrm{~N} / \mathrm{m}^{2}\right)$. In the realization of the fixed points small departures from the assigned temperatures will occur as a result of the differing immersion depths of thermometers or the failure to realize the required pressure exactly. If due allowance is made for these small temperature differences, they will not affect the accuracy of realization of the Scale. The magnitudes of these differences are given in section III of the original article by CIPM [1969].

$\mathrm{b}$ The equilibrium state between the solid and liquid phases of tin (freezing point of tin) has the assigned value of $t_{68}=231.9681{ }^{\circ} \mathrm{C}$ and may be used as an alternative to the boiling point of water.

c The water used should have the isotopic composition of ocean water, see section III, 4, of the orginal article by CIPM [1969].

\section{TABLE 1.2.2. Secondary reference points of the IPTS-68}

Equilibrium between the solid, liquid, and vapor phases of normal hydrogen (triple point of normal hydrogen)

Equilibrium between the liquid and vapor phases of normal hydrogen (boiling point of normal hydrogen)

$$
\lg \frac{p}{p_{0}}=A+\frac{B}{T_{68}}+C T_{68}+D T_{68}^{2}
$$

$$
A=1.734791, \quad B=-44.62368 \mathrm{~K}, \quad C=0.0231869 \mathrm{~K}^{-1} \text {, }
$$

for the temperature range from $13.956 \mathrm{~K}$ to $30 \mathrm{~K}$.

Equilibrium between the solid, liquid, and vapor phases of neon (triple point of neon)

Equilibrium between the liquid and vapor phases of neon

$$
\lg \frac{p}{p_{0}}=A+\frac{B}{T_{68}}+C T_{68}+D T_{88}^{2}
$$

$A=4.61152, \quad B=-106.3851 \mathrm{~K}, \quad C=-0.0368331 \mathrm{~K}^{-1}$, $D=4.24802 \times 10^{-4} \mathrm{~K}^{-2}$ for the temperature range from $24.555 \mathrm{~K}$ to $40 \mathrm{~K}$.

Equilibrium between the solid, liquid and vapor phases of nitrogen (triple point of nitrogen) Equilibrium between the liquid and vapor phases of nitrogen (boiling point of nitrogen)

International Practical Temperature

\begin{tabular}{c|c}
\hline$T_{68}(\mathrm{~K})$ & $t_{68}\left({ }^{\circ} \mathrm{C}\right)$ \\
\hline 13.956 & -259.194 \\
20.397 & -252.753 \\
& \\
& \\
24.555 & -248.595 \\
& \\
& \\
& \\
63.148 & -210.002 \\
77.348 & -195.802
\end{tabular}


International Practical

Temperature

quilibrium state

$$
\underset{\lg \frac{p}{p_{0}}}{=} A+\frac{B}{T_{68}}+\mathrm{C} \lg \frac{T_{68}}{T_{0}}+D T_{68}+E T_{68}^{2}
$$
$A=5.893139, \quad B=-404.13105 \mathrm{~K}, \quad C=-2.3749, \quad D=-0.0142505 \mathrm{~K}^{-1}$,
$E=72.5342 \times 10^{-6} \mathrm{~K}^{-2}$

for the temperature range from $63.148 \mathrm{~K}$ to $84 \mathrm{~K}$.

Equilibrium between the liquid and vapor phases of oxygen

$$
\underset{p_{0}}{\stackrel{p}{-}}=A+\frac{B}{T_{68}}+C \lg \frac{T_{68}}{T_{0}}+D T_{68}+E T_{68}^{2}
$$

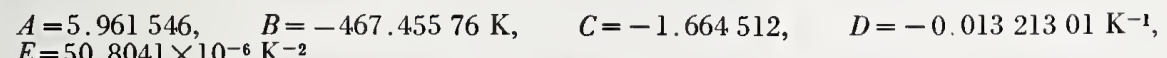
$E=50.8041 \times 10^{-6} \mathrm{~K}^{-2}$

for the temperature range from $54.361 \mathrm{~K}$ to $94 \mathrm{~K}$.

Equilibrium between the solid and vapor phases of carbon dioxide (sublimation point of carbon dioxide)

$$
T_{68}=\left[194.674+12.264\left(\frac{p}{p_{0}}-1\right)-9.15\left(\frac{p}{p_{0}}-1\right)^{2}\right] \mathrm{K}
$$

for the temperature range from $194 \mathrm{~K}$ to $195 \mathrm{~K}$.

Equilibrium between the solid and liquid phases of mercury (freezing point of mercury) ${ }^{\mathrm{b}}$

Equilibrium between ice and air-saturated water (ice point)

Equilibrium between the solid, liquid and vapor phases of phenoxybenzene (diphenyl ether) (triple point of phenoxybenzene)

Equilibrium between the solid, liquid and vapor phases of benzoic acid (triple point of benzoic acid) Equilibrium between the solid and liquid phases of indium (freezing point of indium) ${ }^{b}$

Equilibrium between the solid and liquid phases of bismuth (freezing point of bismuth) ${ }^{b}$

Equilibrium between the solid and liquid phases of cadmium (freezing point of cadmium) ${ }^{b}$

Equilibrium between the solid and liquid phases of lead (freezing point of lead) ${ }^{b}$

Equilibrium between the liquid and vapor phases of mercury (boiling point of mercury)

$$
t_{63}=\left[356.66+55.552\left(\frac{p}{p_{0}}-1\right)-23.03\left(\frac{p}{p_{0}}-1\right)^{2}+14.0\left(\frac{p}{p_{0}}-1\right)^{3}\right]^{\circ} \mathrm{C}
$$

for $p=90 \times 10^{3} \mathrm{~N} / \mathrm{m}^{2}$ to $104 \times 10^{3} \mathrm{~N} / \mathrm{m}^{2}$.

Equilibrium between the liquid and vapor phases of sulphur (boiling point of sulphur)

$$
t_{68}=\left[444.674+69.010\left(\frac{p}{p_{0}}-1\right)-27.48\left(\frac{p}{p_{0}}-1\right)^{2}+19.14\left(\frac{p}{p_{0}}-1\right)^{3}\right]^{\circ} \mathrm{C}
$$

for $p=90 \times 10^{3} \mathrm{~N} / \mathrm{m}^{2}$ to $104 \times 10^{3} \mathrm{~N} / \mathrm{m}^{2}$.

Equilibrium between the solid and liquid phases of the copper-aluminum eutectic

Equilibrium between the solid and liquid phases of antimony (freezing point of antimony) ${ }^{b}$

Equilibrium between the solid and liquid phases of aluminum (freezing point of aluminum)

Equilibrium between the solid and liquid phases of copper (freezing point of copper)

Equilibrium between the solid and liquid phases of nickel (freezing point of nickel)

Equilibrium between the solid and liquid phases of cobalt (freezing point of cobalt)

Equilibrium between the solid and liquid phases of palladium (freezing point of palladium)

Equilibrium between the solid and liquid phases of platinum (freezing point of platinum)

Equilibrium between the solid and liquid phases of rhodium (freezing point of rhodium)

Equilibrium between the solid and liquid phases of iridium (freezing point of iridium)

\begin{tabular}{l|l}
717.824 & 444.674 \\
& \\
& \\
821.38 & 548.23 \\
903.89 & 630.74 \\
933.52 & 660.37 \\
1357.6 & 1084.5 \\
1728 & 1455 \\
1767 & 1494 \\
1827 & 1554 \\
2045 & 1772 \\
2236 & 1963 \\
2720 & 2447 \\
3660 & 3387
\end{tabular}

Equation numbers refer to those used in CIPM [1969].

b See the original article by CIPM [1969] for the effect of pressure variations on these freezing points. 
TABLE 1.2.3. Approximate differences between IPTS-68 and IPTS-48; values tabulated are $\left(T_{68}-T_{48}\right) K$

\begin{tabular}{|c|c|c|c|c|c|c|c|c|c|c|c|}
\hline$t_{68},{ }^{\circ} \mathrm{C}$ & 0 & -10 & -20 & -30 & -40 & -50 & -60 & -70 & -80 & -90 & -100 \\
\hline-100 & 0.022 & 0.013 & 0.003 & -0.006 & -0.013 & -0.013 & -0.005 & 0.007 & 0.012 & & \\
\hline-0 & 0.000 & 0.006 & 0.012 & 0.018 & 0.024 & 0.029 & 0.032 & 0.034 & 0.033 & 0.029 & 0.022 \\
\hline$t_{68}{ }^{\circ} \mathrm{C}$ & 0 & 10 & 20 & 30 & 40 & 50 & 60 & 70 & 80 & 90 & 100 \\
\hline 0 & 0.000 & -0.004 & -0.007 & -0.009 & -0.010 & -0.010 & -0.010 & -0.008 & -0.006 & -0.003 & 0.000 \\
\hline 100 & 0.000 & 0.004 & 0.007 & 0.012 & 0.016 & 0.020 & 0.025 & 0.029 & 0.034 & 0.038 & 0.043 \\
\hline 200 & 0.043 & 0.047 & 0.051 & 0.054 & 0.058 & 0.061 & 0.064 & 0.067 & 0.069 & 0.071 & 0.073 \\
\hline 300 & 0.073 & 0.074 & 0.075 & 0.076 & 0.077 & 0.077 & 0.077 & 0.077 & 0.077 & 0.076 & 0.076 \\
\hline 400 & 0.076 & 0.075 & 0.075 & 0.075 & 0.074 & 0.074 & 0.074 & 0.075 & 0.076 & 0.077 & 0.079 \\
\hline 500 & 0.079 & 0.082 & 0.085 & 0.089 & 0.094 & 0.100 & $\begin{array}{lll}0 & 108\end{array}$ & 0.116 & 0.126 & 0.137 & 0.150 \\
\hline 600 & 0.150 & 0.165 & 0.182 & 0.200 & 0.23 & 0.25 & 0.28 & 0.31 & 0.34 & 0.36 & 0.39 \\
\hline 700 & 0.39 & 0.42 & 0.45 & 0.47 & 0.50 & 0.53 & 0.56 & 0.58 & 0.61 & 0.64 & 0.67 \\
\hline 800 & 0.67 & 0.70 & 0.72 & 0.75 & 0.78 & 0.81 & 0.84 & 0.87 & 0.89 & 0.92 & 0.95 \\
\hline 900 & 0.95 & 0.98 & 1.01 & 1.04 & 1.07 & 1.10 & 1.12 & 1.15 & 1.18 & 1.21 & 1.24 \\
\hline 1000 & 1.24 & 1.27 & 1.30 & 1.33 & 1.36 & 1.39 & 1.42 & 1.44 & & & \\
\hline$t_{68}{ }^{\circ}{ }^{\circ} \mathrm{C}$ & 0 & 100 & 200 & 300 & 400 & 500 & 600 & 700 & 800 & 900 & 1000 \\
\hline 1000 & & 1.5 & 1.7 & 1.8 & 2.0 & 2.2 & 2.4 & 2.6 & 2.8 & 3.0 & 3.2 \\
\hline 2000 & 3.2 & 3.5 & 3.7 & 4.0 & 4.2 & 4.5 & 4.8 & 5.0 & 5.3 & 5.6 & 5.9 \\
\hline 3000 & 5.9 & 6.2 & 6.5 & 6.9 & 7.2 & 7.5 & 7.9 & 8.2 & 8.6 & 9.0 & 9.3 \\
\hline
\end{tabular}

Tabular values of the thermoelectric voltage are given in this Monograph for various single thermoelements versus platinum, $\mathrm{Pt}-67$, which is the designation for the new platium thermoelectric reference standard that is maintained by the Temperature Section of NBS. It replaces the former standard, $\mathrm{Pt}-27$, which was used from 1922 until 1973. A history of $\mathrm{Pt}-27$ was given by Wichers [1962]. The high purity platinum standard reference material, designated SRM No. 680 , that was issued in 1967 by the NBS Office of Standard Reference Materials, NBS Tech. News Bull. [1968a], provides the basis for $\mathrm{Pt}-67$. More specifically, $\mathrm{Pt}-67$ is a selected portion of SRM No. 680 that was set aside to serve as the thermoelectric reference standard.

The material for Pt-67 (SRM No. 680) was prepared at the Sigmund Cohn Corp. by induction melting of high purity platinum sponge in a zirconium silicate crucible, and casting into a platinum-lined watercooled copper mold. The ingot was worked down and drawn into wire taking the utmost precautions to min. imize contamination. This lot of platinum wire received extensive characterization under the direction of the NBS Office of Standard Reference Materials. It was found satisfactory with respect to homogeneity and was subsequently certified for chemical composition. Cooperating with NBS in this extensive analytical program were: Matthey Bishop, Inc.; Sigmund Cohn
Corp.; Engelhard Industries, Inc.; Johnson, Matthey and Co., Ltd.; and RCA Laboratories.

The chemical composition of $\mathrm{Pt}-67$ is given in table 1.2.4. where the data are the recommended values taken from the provisional certificate of analysis for SRM No. 680 that was issued by the NBS-Office of

TABLE 1.2.4. Chemical composition of platinum, $P_{t-67}$

\begin{tabular}{r|c}
\hline & $\begin{array}{c}\text { Concentration in } \\
\text { ppm by wt }\end{array}$ \\
\hline Copper & 0.1 \\
Silver & 0.1 \\
Palladium & 0.2 \\
Lead & $<1$ \\
Iron & 0.7 \\
Nickel & $<1$ \\
Gold & $<1$ \\
Magnesium & $<1$ \\
Zirconium & $<0.1$ \\
Rhodium & $<0.2$ \\
Iridium & $<0.01$ \\
Oxygen & 4 \\
\hline
\end{tabular}


Standard Reference Materials [1967]. The elemental analyses were made by one or more of the following methods: optical emission spectrography, spark source mass spectrography (isotopic dilution), polarography, spectrophotometry, activation analysis, and vacuum fusion.

The temperature coefficient of electrical resistance between 0 and $100{ }^{\circ} \mathrm{C}$ is commonly used as an indicator of the quality of platinum used in thermometry. Two specimens from the lot of $\mathrm{Pt}-67$ wire were tested by each of four cooperating laboratories and the values reported for the temperature coefficient of resistance ranged from $0.003926_{0}$ to $0.003927_{5} \mathrm{~K}^{-1}$ while the mean of the values reported was $0.003926_{9} \mathrm{~K}^{-1}$. Another sensitive measure of both chemical purity and the state of physical perfection is the residual resistance ratio, $R R R=R_{273 \mathrm{~K}} / R_{0}$. For most pure metals $R_{4 \mathrm{~K}}$ is experimentally the same as the residual value $\mathrm{R}_{0}$, which allows the use of a liquid heluim determination. Values of $R R R$ as determined by the Cryogenics Division, NBS, Boulder, for five specimens that were taken at equally separated points along the lot of wire ranged from about 3400 to 3700 [Sparks and Hust, 1973]. The mean of these five measurements was about 3500 . Specimen preparation prior to these tests consisted of cleaning in aqua regia for 12 minutes at $50{ }^{\circ} \mathrm{C}$, rinsing in distilled water and annealing in air at $600{ }^{\circ} \mathrm{C}$ for $\mathrm{I}$ hour followed by slow cooling to room temperature.

Each of four cooperating laboratories also determined the thermoelectric voltage of two specimens of $\mathrm{Pt}-67$ against the former standard, $\mathrm{Pt}-27$. For a measuring junction temperature of $1200{ }^{\circ} \mathrm{C}$ and with the reference junctions at $0{ }^{\circ} \mathrm{C}$, values of -9 and -10 $\mu \mathrm{V}$ were reported. ( $\mathrm{Pt}-67$ is thermoelectrically negative with respect to $\mathrm{Pt}-27$.) The value obtained and used by NBS is $-9 \mu \mathrm{V}$, based upon $\mathrm{Pt}-27$ as it was maintained at NBS since 1950. Measurements at NBS indicated that when the reference junction is at $0{ }^{\circ} \mathrm{C}$ the thermoelectric voltage-temperature relationship of Pt-67 versus $\mathrm{Pt}-27$ could be approximated by $E=$ $-7.5 \times 10^{-3} t_{68}$, where $E$ is the thermoelectric voltage in absolute microvolts and $t_{68}$ is the temperature in degrees Celsius (IPTS-68). This relationship was found to be valid over the range -195 to $1200^{\circ} \mathrm{C}$ to within the estimated limits of experimental uncertainty (about $\pm 1 \mu \mathrm{V}$ below $600{ }^{\circ} \mathrm{C}$, increasing to about $\pm 2 \mu \mathrm{V}$ at $1200{ }^{\circ} \mathrm{C}$ ). Sufficient data were not available to substantiate its validity beyond this temperature range; however, data available for other thermometry grade platinum wires support its extrapolation to higher temperatures but not to lower temperatures. The above results were obtained with specimens of Pt-67 wire which had been electrically annealed in air for 10 minutes at $1200{ }^{\circ} \mathrm{C}$ and slowly cooled to room temperature.

Cochrane [1970], and Rhys and Taimsalu [1969] have studied the effects of trace impurities on the electrical properties of platinum. Cochrane gives a discussion of the relationship between the chemical composition of $\mathrm{Pt}-67$ and its electrical properties.

\subsection{Mathematical Methods}

Several basic assumptions concerning desirable methods and objectives were made in fitting the data: we decided to fit the entire temperature range, or at least as large a range as possible, with convergent polynomials, of moderately high order if necessary. This is sometimes referred to as a global fit. An alternative would have been to fit the data with short-range interpolating functions, or spline functions, each appropriate in a relatively narrow temperature range. The latter methods have been most generally used for generating thermocouple tables in the past. The advantages of the methods chosen for this Monograph are that they permit tables, functions, and their derivatives that are smooth over a large range. Tables generated with short range fitting techniques are often discontinuous or wavy. Unfortunately most of the functions used to generate the tables had to have joins: those for types $S$ and $R$ because of the discontinuities in the first derivatives (with respect to $t_{68}$ ) of their thermoelectric voltages near the antimony point and at the gold point; those for Types $\mathrm{E}, \mathrm{K}$, and T, because the original source data and functions for temperatures lower than $0{ }^{\circ} \mathrm{C}$ were different from those above $0{ }^{\circ} \mathrm{C}$. However, at those joins, the upper and lower functions were constrained to have equal values to prevent discontinuities in the voltage. For Types $\mathrm{E}, \mathrm{K}$, and T, the first derivatives (Seebeck coefficients) were also constrained to be equal at $0{ }^{\circ} \mathrm{C}$. For Types $\mathrm{S}$ and $\mathrm{R}$, the functions were taken directly from the research by Bedford et al. [1972] who left a discontinuity in the first derivatives to reflect the discontinuities in the IPTS-68.

We had been fitting accurate thermodynamic data for some time before this project began, so we had available a general collection of fitting programs and subroutines. It was therefore relatively easy to modify our earlier computer programs to satisfy the special needs of fitting thermocouple data. Our general mathematical methods were described in a paper presented at the Fifth Temperature Symposium [Powell et al., 1972]. Briefly, the methods consist of least squares fitting with orthogonal functions, using Bjorck's [1967] algorithm for the Gram-Schmidt method. Whenever necessary constraints were placed on the voltage or the first derivative to give smooth joins. The proper order of polynomial was selected using the method described in our analysis paper [Powell et al., 1972]. The thermocouple data were neither weighted nor transformed in the fitting procedures, but were occasionally constrained in their values and first derivatives at joins.

Using the altered mathematical methods and computer programs, the procedures for determining the thermocouple functions were relatively straightforward. However, the project computations were quite tedious and lengthy. Most of the functions and tables had to be regenerated several times to comply with the special desires of the various prime users of thermocouple tables and to reflect changes in input data after completion of preliminary or interim tables. This was 
especially true for Type $\mathbf{S}$ and $\mathrm{R}$ thermocouples.

Fortunately, functions were already available for the low temperature portions of the Types $\mathrm{E}, \mathrm{K}$ and $\mathrm{T}$ tables and, near the end of the project, for the Types $\mathrm{S}$ and $\mathrm{R}$ tables. Wherever necessary the data were converted to the IPTS-68 and referenced to Pt-67 before fitting by polynomial functions.

We made a preliminary fit to all of the high-quality data that were available for each type of material. A fairly small proportion (about $10 \%$ ) of the data was so poor that it was not used at all. After a rough curve was determined for the total data set, a few of the best thermocouples were selected for refined fitting. The selected thermocouples represented those with values that were nearest the average and smoothest. This selection process also resulted in favoring specific thermocouples whose values were near the adjusted values from NBS Circular 561. If too many, more than two or three, thermocouples are selected for the final fit, then their general differences tend to mask small changes in values that they all share in common. That is, details of specific curve fitting are lost if too many different data sets are taken for input values. Therefore final functions were obtained from one or two of the most representative thermocouples for each type. The determined functions were then used to generate the tabular values presented in this Monograph.

Values for the Types $\mathrm{J}$ and $\mathrm{K}$ thermocouples represented special problems: the positive thermoelement (iron) of the Type $\mathrm{J}$ thermocouple undergoes a phase transformation at $760{ }^{\circ} \mathrm{C}$. Above that temperature the Seebeck coefficient has a different functional dependence on temperature. Therefore a second function was specified for the Type $\mathrm{J}$ thermocouple above its transformation temperature. The negative thermoelement (a nickel-manganese-aluminum-silicon alloy) of the Type $\mathrm{K}$ thermocouple has a magnetic transformation between 150 and $200{ }^{\circ} \mathrm{C}$. The transformation temperature depends on the composition. Since the com. position varies significantly, so does the transformation temperature, varying from 10 to $50{ }^{\circ} \mathrm{C}$ about an average value of about $170{ }^{\circ} \mathrm{C}$. The magnetic transformation causes a measurable change in the Seebeck coefficient within about $200{ }^{\circ} \mathrm{C}$ of the transformation temperature. This perturbation in Seebeck coefficient, and therefore in total thermal voltage, was treated separately from the overall curve. It was fit with an exponential term.

In addition to the standard thermocouples, the "single legs", or individual thermoelements versus platinum, $\mathrm{Pt}-67$, were also analyzed. In general, we developed functions for the most important thermoelement and for the total thermocouple combination, and then determined the functions for the second thermoelement by subtraction. The noble metal combinations were exceptions: the negative thermoelement of both Type $\mathrm{S}$ and Type $\mathrm{R}$ thermocouples is already high-purity platinum, though not $\mathrm{Pt}-67$. Hence no thermoelement tables are necessary for those two types. For Type B, data for the individual thermoelements versus platinum were better than the total. We there- fore fit each thermoelement separately and then obtained the total value by subtraction; symbolically $B=(B P-\mathrm{Pt})-(B N-\mathrm{Pt})$.

The programs that we used to fit the thermocouple data utilized double precision routines, which on our computer allow 12 binary bits for the exponent and signs and 84 bits for the fraction in a floating point number. The tabular values were calculated using single precision routines ( 12 and 36 bits, respectively) containing 11 significant digits in the input coefficients of the polynomials. Actually 36 binary bits is equivalent to only 10.8 decimal digits so there were occasional round-off errors in converting the digital coefficients to their binary representations. However these occasional round-off errors in the coefficients do not usually propagate errors into the tabular values. For example, we estimated for one of the tables that the probability is less than 0.001 that there is a computational error of one in the last digit of a tabular value.

A majority of the computers in this country, however, use less than 36 binary bits for the fractional part of a single precision floating point number. Many of the smaller on-line or portable units even have as few as 12 bits available for the fractions in floating point arithmetic (this is equivalent to approximately 4 decimal digits). The reduction in number of available bits will of course lead to computational errors, especially for higher order equations and the highest range of temperatures. In some extreme cases, the errors can be greater than $1000 \mu \mathrm{V}$.

Since test calculations on each type of computer would have involved excessive costs, we developed a program that simulated computers with fewer available binary bits. The program changed the appropriate binary bit in the coefficients that was equivalent to the last available bit in machines with $12,16,24$, or 27 binary bits. The differences between the values calculated with the full 36 bits and those values calculated with an error in an earlier bit were considered to be representative of the errors caused by reducedbit machines. The differences in methods of roundingoff used in different computer models were not entered into the calculations.

Because the errors are dependent on the temperature range as well as the number of bits used in the machine, the tables of estimated maximum errors are broken into several temperature ranges. The estimated maximum errors that occur when reduced-bit arithmetic is used are given in the second table for each type of thermocouple.

\subsection{Material Selection and Application of Data}

It is not appropriate to include in this Monograph all of the properties and precautions for each of the thermocouple types. However, much of the more important information is included: history of development and early applications, typical chemical composition, temperature range, atmospheric restrictions, effect of impurities, handling techniques and precautions, standard limits of error, typical deviation plots, 
and, of course, the tabular thermoelectric data and generating functions. More detailed information on the properties of each thermoelement can be obtained from the earlier NBS publication, Monograph 40 by Caldwell [1962] and from the ASTM manual, STP 470 edited by Benedict [1970]. The latter book and, more thoroughly, the ASTM STP 4.92 by Pollock [1971] discuss the background theory of thermocouple systems. The pamphlet by Pollock, though short, is an excellent review of the basic theory of thermoelectric phenomena in metals and alloys.

For the sake of discussion, thermocouple system errors can be divided into four types: environmental, electrical measurement, data reduction, and material variability. Environmentally caused errors (such as excessive radiation or conduction losses, poor reference junction control, slow time response, viscous heating, and nonrepresentative probe location) are especially important, often dominant, in field and factory installations. Errors traceable to electrical instruments and data reduction techniques can usually be well controlled and held to satisfactorily low levels. Only the fourth source of errors, material variability (including calibration errors) are discussed further in this Monograph.

For accurate measurements, the thermoelements should be tested, and probably spot calibrated, by the ultimate user. Tests for homogeneity and other sig. nificant properties have been described by Sparks et al. [Monograph 124, 1972] for low temperatures and by Roeser and Lonberger [1958] for high temperatures. These tests are necessary in order to determine the homogeneity characteristics of each type of wire and to determine the most representative wires. Dip tests performed on these materials provide information on short range, medium range, and long range inhomogeneities and compare the materials to existing standards.

No thermal voltage is developed when a loop of homogeneous wire is subjected to a temperature gradient. Similarly, no voltage is generated when two identical wires are joined and the pair of wires is placed in a temperature gradient. The problem in practical thermometry is, however, that the ideal characteristics "homogeneous" and "identical" are not sufficiently well approximated for real thermocouple materials. Actually, a loop of wire placed in a large temperature gradient will usually produce a resultant voltage, sometimes as large as $10 \mu \mathrm{V}$ for poor materials. If wire from one spool is connected to wire from a different spool of the same nominal composition, their junction is placed in a controlled temperature. bath, and the free ends are held at room temperature, then a significant voltage may result; we have observed readings as large as hundreds of microvolts for some base metal alloys. These variable spurious voltages caused by inter-lot variations, inhomogeneities, physical imperfections, and chemical impurities are usually the main source of imprecision and inaccuracy for thermocouple measurements under controlled laboratory conditions.
For descriptive convenience, we have divided inhomogeneities into four categories based on their distance of separation:

(1) Short-range inhomogeneities occur in a single wire and are separated by less than five meters, often being within a few centimeters of each other.

(2) Medium-range inhomogeneities occur in wires that are from a single spool but are more than five meters apart.

(3) Long-range inhomogeneities are found in wires that are from the same general stock but are from different spools.

(4) Inter-lot variations in chemical composition, thermal treatment and handling occur in materials produced by different manufacturers, or even in wire produced by the same manufacturer at different times.

The latter two categories of inhomogeneities lead to much larger spurious voltages, especially in cryogenic systems. Well-prepared thermocouple wire can have short-range inhomogeneity effects as low as $0.1 \mu \mathrm{V}$; alloys from different manufacturers often have interlot variations as large as $100 \mu \mathrm{V}$.

Commercial thermocouple materials are manufactured under quality controls that insure that their thermoelectric voltages will remain within accepted limits of error (usually as specified by ANSI, ASTM, and ISA standards). For example, thermoelectric voltages of base-metal materials may vary by several hundred microvolts from lot to lot without exceeding the recognized limits of error. It is commercially impractical to produce thermocouple materials that are highly uniform from lot to lot.

Because of this commercial variability, an extremely important criteria for accurate thermocouple system design is that all of the thermocouple material of a particular type come from the same lot. Sufficient material should be ordered at the initiation of a project to insure that replacement or additional material will not need to be obtained from other lots or manufacturers, material which, though well within specified error limits, may have significantly different thermoelectric properties from the original.

The letter designations used in this Monograph follow the recommendations of Committee E-20 of the American Society for Testing and Materials. The letter type, e.g., Type T, designates the thermoelectric properties, not the precise chemical composition. Thermocouples of a given type may have variations in composition as long as the resultant thermoelectric properties remain within the established limits of error.

We also follow conventional practice in two other respects: (1) the thermoelement with the more positive absolute thermoelectric voltage of the two thermo. couple materials is listed first, e.g., nickel-chromium alloy versus nickel-aluminum alloy for the Type $\mathrm{K}$ thermocouple; and (2) the reference junction is assumed to be at $0{ }^{\circ} \mathrm{C}$, the ice point.

The number of significant figures to be carried in reference tables is often a matter of personal preference and is somewhat arbitrary. In this Monograph, the voltage resolution in the main tables is usually 
$0.01 \mu \mathrm{V}$. That represents more precision than can be obtained with any but the best instrument systems. Especially at high temperatures the quoted precisions can not be easily achieved. A good estimate of the overall inaccuracy of the data for each thermocouple type may be obtained from the standard deviation of the data fit which is given for each thermocouple type. In addition, the industrial recommended limits of error are also quoted. The experimental imprecision below $0{ }^{\circ} \mathrm{C}$ is usually 10 to 100 times better than it is at high temperatures.

It should be stressed that thermocouple material that conforms elosely to the high temperature tabular values may not necessarily conform closely at low temperatures (below $0{ }^{\circ} \mathrm{C}$ ) and vice versa. If thermocouples are to be used for accurate measurements both above and below $0{ }^{\circ} \mathrm{C}$, then the material must be calibrated in the full temperature range, both above and below $0{ }^{\circ} \mathrm{C}$.

\subsection{Acknowledgments}

A project of this magnitude does not, of course, represent the efforts of only a few people. In the Boulder Laboratories, C. H. Hyink did most of the actual processing of programs and preparation of auxiliary tables, and D. J. Fraunfelder helped complete many of the tables. The advisory and review committee representing industry was headed by D. I. Finch of Leeds and Northrup Company. His assistance was essential for making the Monograph more valuable, so that the quoted values would be most representative of modern materials, and so that the textual matter and tables would be satisfactory for many types of users. Many others on that committee were especially helpful in supplying information on materials, especially the late B. Brenner of Sigmund Cohn Corp., A. J. Gottlieb of Wilber B. Driver Co., C. L. Guettel of Driver-Harris Co., F. S. Sibley of Hoskins Manu. facturing Co., J. D. Sine of Honeywell Inc., and E. D. Zysk of Engelhard Minerals and Chemicals Corporation. R. K. Adams and W. W. Johnston of the Oak Ridge National Laboratory gave valuable advice based on their extensive calibration experience, and supplied copies of many special calibrations that were especially useful in establishing average values for recently produced material. D. H. Sinclair and I. Warshawsky of NASA Lewis Research Center and J. D. Sine of Honeywell Inc. made valuable suggestions for the final version of the text.

\subsection{References}

Acken, J. S., Some Properties of Platinum-Rhodium Alloys,' J. Res. Nat. Bur. Stand. (U.S.) 12, 249 [1934] RP650.

Aliotta, J., Effects of Impurities on the Thermoelectric Properties of Platinum, Instruments and Control Systems 45, 106107 [1972].

American Society for Testing and Materials, Manual on the Use of Thermocouples in Temperature Measurement, ASTM Special Tech. Publ. 470, Editorial Chairman, R. P. Benedict [Am. Soc. Test. Mat., Philadelphia, 1970].

American Society for Testing and Materials, 1972 Annual Book of Standards, Part 30, Am. Soc. Test. Mat., Philadelphia [1972].
Barber, C. R., The E.M.F.-Temperature Calibration of Platinum, $10 \%$ Rhodium-Platinum and Platinum, 13\% Rhodium -Platinum Thermocouples over the Temperature Range $0^{\circ}$ $1,760{ }^{\circ}$ C., Proc. Phys. Soc. 63B, 492-503 [1950].

Bedford, R. E., Reference Tables for Platinum 20\% Rhodium/ Platinum 5\% Rhodium Thermocouples, Rev. Sci. Instr. 35, 1177 [1964].

Bedford, R. E., Reference Tables for Platinum-40\% Rhodium/ Platinum-20\% Rhodium Thermocouples, Rev. Sci. Instr. 36, 1571 [1965].

Bedford, R. E., Ma, C. K., Barber, C. R., Chandler, T. R., Quinn, T. J., Burns, G. W., and Scroger, M., New Reference Tables for Platinum 10\% Rhodium/Platinum and Platinum 13\% Rhodium/Platinum Thermocouples, Temperature, Vol. 4, p. 1585, Instrument Society of America, Pittsburgh, Pennsylvania [1972].

Bennett, H. E., Noble Metal Thermocouples, 2nd Edition, Johnson, Matthey and Co., London, [1958].

Bjork, A., Solving Least Squares Problems by Gram-Schmidt Orthogonalization BIT, Nordisk Tidsprift for Informationshehandling 7, 1-21 [1967].

British Standards Inst., Reference Tables for Thermocouples, (Platinum/Rhodium v. Platinum), B.S. 1826: 1952 (British Standards House, London, [1952].

Burley, N. A., Solute Depletion and Thermo-emf Drift in Nickel-base Thermocouple Alloys, J. Inst. Metals 97, 252254 [1969].

Burley, N. A., Nicrosil and Nisil: Highly Stable Nickel-base Alloys for Thermocouples, Temperature, Vol. 4, p. 1677, Instrument Society of America, Pittsburgh, Pennsylvania [1972].

Burley, N. A., and Acklund, R. G., The Stability of Thermoemf/Temperature Characteristics of Nickel-base Thermocouples, Jour. of Australian Inst. of Metals, 12 [1967].

Burns, G. W., Chairman special task group of ASTM Committee E20.04.01, privately circulated modification of the tabular data given in letter by Guettel [1967], letter to members of the ASTM special task group [Sept. 15, 1967].

Burns, G. W., and Gallagher, J. S. [1970] Office notes used for Type B calibration calculations. Values were adjusted to be on the IPTS-68 and to be referenced to Pt-67.

Burns, G. W., and Gallagher, J. S., Reference Tables for the $\mathrm{Pt}-30$ percent $\mathrm{Rh}$ versus $\mathrm{Pt}-6$ percent Thermocouple, J. Res. Nat. Bur. Stand. (U.S.) 70C (Eng. and Instr.) 89-125 [1966].

Caldwell, F. R., Thermocouple Materials, Nat. Bur. Stand. (U.S.) Monogr. 40, 47 pages [1962].

Caldwell, F. R., Temperature of Thermocouple Reference Junctions in an Ice Bath, J. Res. Nat. Bur. Stand. (U.S.) 69C (Engr. and Instr.) 95-101 [1965].

CIPM - Comite International des Poids et Mesures, International Practical Temperature Scale of 1968, Metrologia 5, 35-44 [1969].

Cochrane, J., Relationship of Chemical Composition to the Electric Properties of Platinum, Engelhard Tech. Bull. 11, 58-73 [1970]. Also presented in Temperature, Vol. 4, p. 1619 (Instrument Society of America, Pittsburgh, Pennsylvania, 1972).

Corruccini, R. J., and Shenker, H., Modified 1913 Reference Tables for Iron-Constantan Thermocouples, J. Res. Nat. Bur. Stand. (U.S.) 50, 229-248 [1953].

Dahl, A. J., The Stability of Base-metal Thermocouples in Air from 800 to $2200^{\circ} \mathrm{F}$, in Temperature, Its Measurement and Control in Science and Industry, Vol. 2, 1283-1266, Reinhold Pub. Corp. New York [1941].

Ehringer, H., Uber die Lebensdauer von $\mathrm{Pt}$ Rh-thermoelementen, Metall 8, 596-598 [1954].

Fairchild, C. O., and Schmitt, F. M., Life Tests of PlatinumPlatinum-Rhodium Thermo-couples, Chem. Met. Eng. 26, 158-160 [1922].

Fazzalari, F. A., and Leonette, P. E., Handbook of Polynomial Regression Coefficients for Estimating Temperature in Degrees Celsius from Millivolts, IBM Components Div., East Fishkill (N.Y.) Report MP 220156 [1969].

Finch, D. I., U. S. Patent No. 2,325,759 [Aug. 3, 1943].

Foote, P. D., Fairchild, C. O., and Harrison, T. R., Pyrometric Practice, Tech. Pap. BS 14, 306 [1920] T170. 
Glawe, G. E., Thermal Electromotive Force Change for Some Noble and Refractory-Metal Thermocouples at $1600 \mathrm{~K}$ in Vacuum, Air, and Argon, Nat. Aero. and Space Agency Tech. Note TN-D7027 [Dec. 1970]. Also presented as, Long-Term Drift of Some Noble and Refractory-metal Thermocouples at $1600 \mathrm{~K}$ in Air, Argon, and Vacuum, Temperature, Vol. 4, p. 1645 (Instrument Society of America, Pittsburgh, Pennsylvania, 1972).

Guettel, C. L., Unpublished tables of thermal emf-temperature values for Types $K, E$, and $T$ thermoelement materials versus Pt-27 in general use by industry and based upon NBS experimental data, a privately circulated letter to a task group and several members of SAE and ASTM thermometry conlmittees, [July 31, 1967].

Hendricks, J. W., and McElroy, J. L., Report presented to Sec. 2, Sub. IV of ASTM E-20 Comm., Am. Soc. Test. Mat. An nual .Meeting, Chicago [June 25, 1964].

Hansen, M., and Anderko, K., Constitution of Binary Alloys, McGraw-Hill Book Co., New York [1958].

Hust, J. G., A Compilation and Historical Review of Temperature Scale Differences, Cryogenics 9, 443-455 [1969].

Le Chatelier, H., Compt. Rend. 102, 819 [1886]. Additional papers were published in Journal de Physique and Annallen der Physik during 1887.

Lindeck, S., Report Brit. Assoc. for Advance. of Science, 134 [1892].

McLaren, E. H., and Murdock, E. G., New Considerations on the Preparation, Properties and Limitations of the Standard Thermocouple for Thermometry. Temperature, Vol. 4, p. 1543, Instrument Society of America, Pittsburgh, Pennsylvania [1972].

Nat. Acad. of Sciences and Nat. Res. Council. International Critical Tables, Vol. 1, 59 McGraw.Hill Book Co., N.Y. [1926].

NBS Office of Standard Reference Materials, Certificate of Analysis on Standard Reference Materials 680 and 681, High Purity and Doped Platinum [Dec. 28, 1967].

Nat. Bur. Stand. (U.S.), New Platinum Standards, NBS Tech. News Bull. 52, 62 [1968a].

Nat. Bur. of Stand. (U.S.) Reference Base of the Volt to be Changed, NBS Tech. News Bull. 52, 204-206 [1968b].

Obrowski, W., and Prinz, W., Neu Bestimmte Grundwerte fur die Thermopaarkombination $\mathrm{Pt} 30 \% \mathrm{Rh}-\mathrm{Pt} 6 \% \mathrm{Rh}$, Arch. Eisenhuttenwesen 33, 1-4. [1962].

Plumb, H. H., and Cataland, G., Acoustical Thermometer, Science 150, 155-161 [1965a].

Plumb, H. H., and Cataland, G., An Absolute Temperature Scale from $4{ }^{\circ} \mathrm{K}$ to $20^{\circ} \mathrm{K}$ Determined from Measurement with an Acoustical Thermometer, J. Res. Nat. Bur. Stand. (Phys. and Chem.) 69A, No. 375 [1965b].

Plumb, H. H., and Cataland, G., Acoustical Thermometer and the National Bureau of Standards Provisional Temperature Scale 2-20 (1965), Metrologia 2, 127-139 [1966].

Pollock, D. D., The Theory and Properties of Thermocouple Elements, ASTM Special Tech. Publ. 492 Am. Soc. Test. Mat., Philadelphia [1971].

Powell, R. L., Hall, W. J., and Hust, J. G., The Fitting of Resistance Thermometer Data by Orthogonal Functions, Tem. perature, Vol. 4, p. 14:23, Instrument Society of America, Pittsburgh, Pennsylvania [1972].
Potts, J. F., Jr., and McElroy, D. L., in Temperature, Its Measurement and Control in Science and Industry, Vol. 3, Edited by C. M. Herzfeld, F. G. Brickwedde, A. I. Dahl, and J. D. Hardy, Part 2, 243-264, Reinhold Publishing Corp., New York [1962].

Quinn, T. J., and Chandler, T. R. D., A New Determination of the Freezing Point of Platinum, Metrologia 7, 132-133 [1971].

Rhys, D. W., and Taimsalu, P., Effect of Alloying Additions on the Thermoelectric Properties of Platinum, Engelhard Tech. Bull. 10, 41-47 [1969].

Roeser, W. F., and Dahl, A. I., Reference Tables for IronConstantan and Copper-Constantan Thermocouples, J. Res. Nat. Bur. of Stand. (U.S.) 20, 337-355 [1938] RP1080.

Roeser, W. F., Dahl, A. I., and Gowens, G. J., Standard Tables for Chromel-Alumel Thermocouples, J. Res. Nat. Bur. Stand. (U.S.) 14, 239-246 [1935] RP767.

Roeser, W. F., and Lonberger, S. T., Methods of Testing Thermocouples and Thermocouple Materials, Nat. Bur. Stand. (U.S.) Circular 590, 23 pages [1958].

Roeser, W. F., and Wensel, H. T., Reference Tables for Platinum to Platinum-Rhodium Thermocouples, J. Res. Nat. Bur. Stand. (U.S.) 10, 275-279 [1933] RP530.

Scott, R. B., Calibration of Thermocouples at Low Temperatures, J. Res. Nat. Bur. Stand. (U.S.) 25, 459-474 [1940] RP1339.

Shenker, H., Lauritzen, J. I., Jr., and Corruccini, R. J., Reference Tables for Thermocouples, Nat. Bur. Stand. (U.S.) Circular 508, 73 pages [1951].

Shenker, H., Lauritzen, J. I., Jr., Corruccini, R. J., and Lonberger, S. T., Reference Tables for Thermocouples, Nat. Bur. Stand. (U.S.) Circular 561, 87 pages [1955].

Sine, J. D., Data sheet shown at Advisory Committee meeting [June 4, 1971] at ASTM headquarters, based on Honeywell in-house calibrations.

Sparks, L. L., and Hust, J. G., Thermoelectric Voltage of Platinum Thermocouple Wire, $\mathrm{Pt}-67$, versus Common Thermocouple Materials between $76 \mathrm{~K}$ and the Ice Fixed Point, 273.15 K, Nat. Bur. Stand. (U.S.), to be published in the Special Publication 260 series [1973].

Sparks, L. L., and Powell, R. L., Low Temperature Thermocouples: KP, "Normal" Silver, and Copper versus Au-0.02 at\% $\mathrm{Fe}$ and $\mathrm{Au}-0.07$ at\% Fe, J. Res. Nat. Bur. Stand. (U.S.) 76A (Phys. and Chem.) 263-283 [1972a].

Sparks, L. L., Powell, R. L., and Hall, W. J., Reference Tables for Low-temperature Thermocouples, Nat. Bur. Stand. (U.S.) Monogr. 124, 61 pages [June 1972].

Walker, B. E., Ewing, C. T., and Miller, R. R., Thermoelectric Instability of Some Noble Metal Thermocouples at High Temperatures, Rev. Sci. Instr. 33, 1029-1040 [1962].

Walker, B. E., Ewing, C. T., and Miller, R. R., Study of the Instability of Noble Metal Thermocouples in Vacuum, Rev. Sci. Instr. 36, 601-606 [1965].

Wang, T. P., Gottlieb, A. J., Starr, C. D., The Emf Stability of Type K Thermocouple Alloys, Paper no. 690426, National Air Transportation Meeting, Soc. Auto. Engr., New York, N.Y. [April 21-24, 1969].

Wichers, E., The History of $\mathrm{Pt}-27$, in Temperature, Its Measurement and Control in Science and Industry, Vol. 3, Edited by C. M. Herzfeld, F. G. Brickwedde, A. I. Dahl, and J. D. Hardy, Part 1, 259-262, (Reinhold Publishing Corp., New York [1962]). 


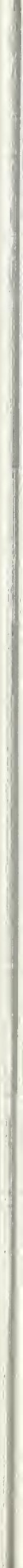




\section{Type S-Platinum-10\% Rhodium Alloy Versus Platinum Thermocouples}

\subsection{Material Specifications and Precautions}

This type is often referred to by the nominal chemical composition of its positive thermoelement: platinum * $-10 \%$ rhodium. Until this year the composition was somewhat different from the nominal 10 percent rhodium, usually about $9.91 \mathrm{wt} \%$. However, as a result of the recent research by Bedford et al. [1972], the composition of the positive thermoelement has been established to be platinum-10.00 $\pm 0.05 \mathrm{wt} \%$ rhodiun. The negative thermoelement is commercially pure platinum. Differences between this commercial material and the platinum thermoelectric reference standard, $\mathrm{Pt}-67$, are described in the next section. Differences between Pt-67 and the earlier standard $\mathrm{Pt}-27$ are summarized in section 1.2. The effect of differences in rhodium content of the positive thermoelement is described later in this section.

The platinum-10\% rhodium thermocouple was developed and tested by Le Chatelier [1886] almost a century ago. Because of his pioneer work, this type of thermocouple was often referred to as the Le Chatelier couple. In this country the ASTM (E23068) and ISA (C96.1-64) standards for this thermocouple type have been taken from NBS Circular 561 by Shenker et al. [1955]. The reference tables given in NBS Circular 561 were based on functions given by Roeser and Wensel [1933], as revised to conform with the IPTS-48. In Great Britain, the British Standards Institution (BSI) Table B.S. 1826:1952 for this thermocouple type was based on the research by Barber [1950]. There were considerable differences between the American and British reference tables because of small differences in rhodium content and in different realizations of the temperature scales. Differences between the values given in this Monograph and those given in the previous NBS and BSI tables are shown in the next section.

The early research by Le Chatelier [1886] demonstrated the main advantages of the platinum-10\% rhodium thermoelement: reproducibility, stability, and usefulness to moderately high temperature. An ASTM manual, STP 470 [1970], and Bennett [1958] have described many of the properties of noble metal thermocouples. For many industrial applications, the Type $\mathbf{R}$ or $\mathrm{B}$ noble metal thermocouples (described in the next two chapters) have preferable characteristics and are often used instead of Type $\mathrm{S}$ systems. How ever, Type $S$ thermocouples remain the standard for determining temperatures between $630.74{ }^{\circ} \mathrm{C}$ and the freezing point of gold $\left(1064.43{ }^{\circ} \mathrm{C}\right)$. The CIPM [1969] article details the temperature scale definition in this range and includes specifications on the limits of the thermocouple voltage. The other fixed point used for determining the constants in the specified quadratic interpolation formula of the thermoelectric voltage is the freezing point of silver, $961.93{ }^{\circ} \mathrm{C}$.

Because of the differences between the British and

* Throughout this Monograph in the thermocouple designations an italicized word indicates the primary constituent of an alloy.
American standards for Type $\mathrm{S}$ thermocouples, an international program was begun several years ago to rectify the unsatisfactory disagreements and to establish a common set of standard reference tables. The program involved cooperation of three national laboratories: the National Bureau of Standards (USA), the National Physical Laboratory (UK) and the National Research Council (Canada) and of seven manufacturers in Great Britain and the United States. The thoroughly documented results have been published by Bedford et al. [1972].

Their research has confirmed that Type $S$ thermocouples can be used from $-50{ }^{\circ} \mathrm{C}$ up to the platinum melting point $1767.6{ }^{\circ} \mathrm{C}$ (incidentally found to not be $1772{ }^{\circ} \mathrm{C}$ as listed in the CIPM article). They may be used intermittently at temperatures up to the platinum melting point and continuously up to about $1400{ }^{\circ} \mathrm{C}$. The ultimate useful life of the thermocouple is governed primarily by physical problems of impurity diffusion and grain growth which lead to mechanical failure. The thermocouple is most reliable when used in a clean oxidizing atmosphere (air) but may also be used in inert gaseous atmospheres or in a vacuum for short periods of time. However, as noted in section 4, Type B thermocouples are generally more suitable for these applications. Continued use of Type $\mathrm{S}$ thermocouples at high temperatures, above about $1400{ }^{\circ} \mathrm{C}$, leads to excessive grain growth in the platinum thermoelement. Stability of the thermocouple at high temperatures depends primarily upon the quality of the materials used for protecting and insulating the thermocouple. High purity alumina with low iron content appears to be the most suitable material for mechanically supporting and protecting the thermo. couple wires.

The ASTM manual STP 470 [1970] indicates the following restrictions on the use of Type $S$ thermocouples at high temperatures: They should not be used in reducing atmospheres, nor in those containing metallic vapor (such as lead or zinc), nonmetallic vapors (such as arsenic, phosphorus, or sulfur) or easily reduced oxides, unless suitably protected with nonmetallic protecting tubes. They should never be inserted directly into a metallic primary tube.

The positive thermoelement, platinum-10\% rhodium, is unstable in a thermal neutron flux because the rhodium converts to palladium. The negative thermoelement, pure platinum, is relatively stable to neutron transmutation. However, fast neutron bombardment will cause physical damage, which will change the thermoelectric voltage unless it is annealed out.

McLaren and Murdock [1972] have described several precautions that must be taken to insure accurate measurements in the intermediaie temperature range, including the defined range from 630.74 to $1064.43^{\circ} \mathrm{C}$. They emphasized the importance of annealing techniques.

Both thermoelements of Type $S$ thermocouples are sensitive to impurity contamination. In fact the Type 
$\mathrm{R}$ thermocouple described in the next section was developed essentially because of iron contamination effects in some British platinum-10\% rhodium wires. Cochrane [1970] and Aliotta [1972] have recently given detailed descriptions of the effects of various impurities on the thermoelectric voltages of platinum based thermocouple materials. At present good alloy material typically contains less than 500 atomic ppm of impurities; good pure platinum, less than 100 atomic ppm of impurities. High temperature impurity contamination usually causes negative drifts in calibration, the extent of which will depend on the type and amount of chemical contaminant. Volatilization of rhodium from the positive thermoelement or diffusion of rhodium from the positive thermoelement into the pure platinum negative thermoelement will also cause negative drifts in the thermoelectric output.

At the gold point, $1064.43{ }^{\circ} \mathrm{C}$, the thermoelectric voltage of Type $\mathrm{S}$ thermocouples increases by about $340 \mu \mathrm{V}(\sim 3 \%)$ per weight percent increase in rhodium content; the Seebeck coefficient increases by about 4 percent per weight percent increase at the same temperature.

The thermoelectric voltages of platinum based thermocouples are sensitive to their heat treatments. In particular, quenching from high temperatures should be avoided. Before annealing, platinum and platinumrhodium alloy wires should be degreased with solvents such as trichloroethane or trichloroethylene and then may be rinsed with distilled water. After cleaning, they should be annealed by the techniques recommended by Bedford et al. [1972] : Anneal electrically in air at $1450{ }^{\circ} \mathrm{C}$ for 30 minutes and then slowly cool them to room temperature. The air should be dust free, of course. After assembly in insulating and protecting tubes, the thermocouple should be reannealed for one hour at $1100{ }^{\circ} \mathrm{C}$ or for 30 minutes at $1400{ }^{\circ} \mathrm{C}$ and then slowly cooled (about 30 minutes) to room temperature.

The Office of Standard Reference Materials of the National Bureau of Standards has prepared a large lot of reference grade platinum wire approximately $0.5 \mathrm{~mm}$ in diameter. The material has been thoroughly characterized chemically and electrically and is available from the National Bureau of Standards as Standard Reference Material-SRM No. 680. A selected portion of that material has been set aside for use as a thermoelectric reference standard by the Temperature Section of the NBS. It is referred to as $\mathrm{Pt}-67$. A description of the chemical composition and electrical properties of $\mathrm{Pt}-67$ is given in section 1.2.

ASTM Standard E230-72 in the Annual Book of ASTM Standards [1972] specifies that the standard limits of error for Type $\mathrm{S}$ commercial thermocouples be $\pm 1.4{ }^{\circ} \mathrm{C}$ between 0 and $538{ }^{\circ} \mathrm{C}$ and $\pm 1 / 4$ percent between 538 and $1482{ }^{\circ} \mathrm{C}$. Limits of error are not specified for Type $\mathrm{S}$ thermocouples below $0{ }^{\circ} \mathrm{C}$. The recommended upper temperature limit for continuous use of protected thermocouples, $1482{ }^{\circ} \mathrm{C}$, applies to AWG $24,(0.5 \mathrm{~mm})$ wire.

\subsection{Data Analyses and Comparisons}

The fitting functions for Type $\mathrm{S}$ thermocouples are taken directly from the original research recently published by Bedford et al. [1972]. Their values for thermoelectric voltages were based on the IPTS-68 and therefore no temperature scale corrections were necessary. They used a high-purity platinum, but not $\mathrm{Pt}-67$, as the negative thermoelement. We made only one modification to their functional expressions: the basic voltage function above $1064{ }^{\circ} \mathrm{C}$ is also expressed as a simple power series in this Monograph. For completeness their reduced temperature expression is also included in table 2.3.1.

Bedford et al. [1972] carried out research on twelve meters of wire for each thermoelement from each of four American and two British manufacturers. The National Bureau of Standards and the National Re. search Council calibrated the thermocouples from $-50{ }^{\circ} \mathrm{C}$ to the gold freezing point $\left(1064.43^{\circ} \mathrm{C}\right)$; the National Physics Laboratory performed the measurements at higher temperatures. The authors gave a very thorough description of their measurement and analysis techniques.

Bedford et al. [1972] based their fitting functions and tables on a selected lot of wire from one manufacturer, labeled A. As a first step, they fit the values in the defined temperature range $630.74{ }^{\circ} \mathrm{C}$ to 1064.43 ${ }^{\circ} \mathrm{C}$ by a quadratic function. Next, all of the data below $630.74{ }^{\circ} \mathrm{C}$ was fit with a sixth degree function that was constrained in value at $0{ }^{\circ} \mathrm{C}$ and $630.74{ }^{\circ} \mathrm{C}$. The fit had a standard deviation of $0.53 \mu \mathrm{V}$ for 70 experimental points. The temperature range above $1064.43{ }^{\circ} \mathrm{C}$ was split in two: one range was from $1064.43{ }^{\circ} \mathrm{C}$ to $1665{ }^{\circ} \mathrm{C}$; the other, from $1665{ }^{\circ} \mathrm{C}$ to $1767.6{ }^{\circ} \mathrm{C}$ (their measured value for the melting point of platinum; see also Quinn and Chandler [1971]). They used a reduced temperature variable for the fitting above $1064{ }^{\circ} \mathrm{C}$. A cubic function constrained at 1064.43 ${ }^{\circ} \mathrm{C}$ was used for the first upper range; another cubic function constrained at $1665{ }^{\circ} \mathrm{C}$ was used for the second range. The first fit had a standard deviation of $1.4 \mu \mathrm{V}$ for eight points; the second, $2.0 \mu \mathrm{V}$ for eight points. The maximum difference that they found between any two sets of wires was about $50 \mu \mathrm{V}$ at $1767{ }^{\circ} \mathrm{C}$.

The values for thermoelectric voltages given in this Monograph were compared to those given in 53 calibrations (dated between 1966 and 1970) from the Temperature Section of the National Bureau of Standards in Gaithersburg. All of the wires were from the older, nominally 10 percent rhodium material; none were from the newer, precisely 10 percent rhodium material used for the international comparison. Deviations are shown in figure 2.2.1. for five thermocouples representative of the older material. All values were adjusted to the IPTS-68. The systematic trend between the old material and the new tables is obvious. Deviations for thermocouples from six different manufacturers measured by Bedford et al. [1972] (all are the newer, accurately 10\% rhodium material) are shown in figure 2.2.2. Material A was used by Bedford 


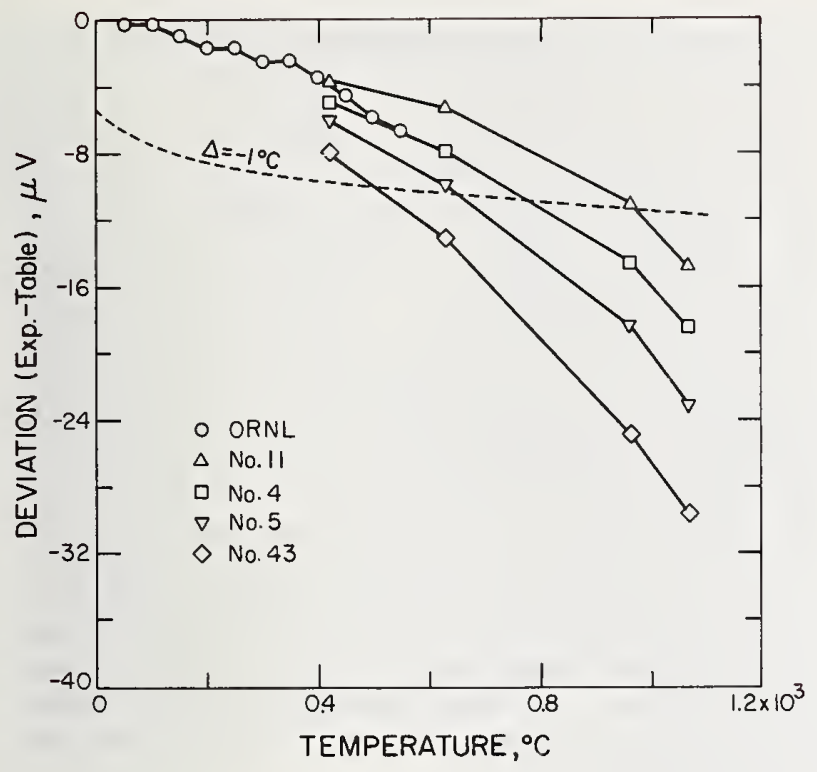

Figure 2.2.1. Deviations of thermoelectric voltages of Type $S$ thermocouples-comparison of values given in this Mono. graph to those for typical thermocouples which conform to the previous Type $S$ standard (NBS Circular 561).

Experimental values for thermocouples Nos. 4, 5, 11, 43 and ORNL are from selected calibrations by the Temperature Section (NBS, Gaithers burg). Values from the previous calibrationa are adjuated to the IPTS -68 , Tbe dashed line indicates a deviation of $1{ }^{\circ} \mathrm{C}$.

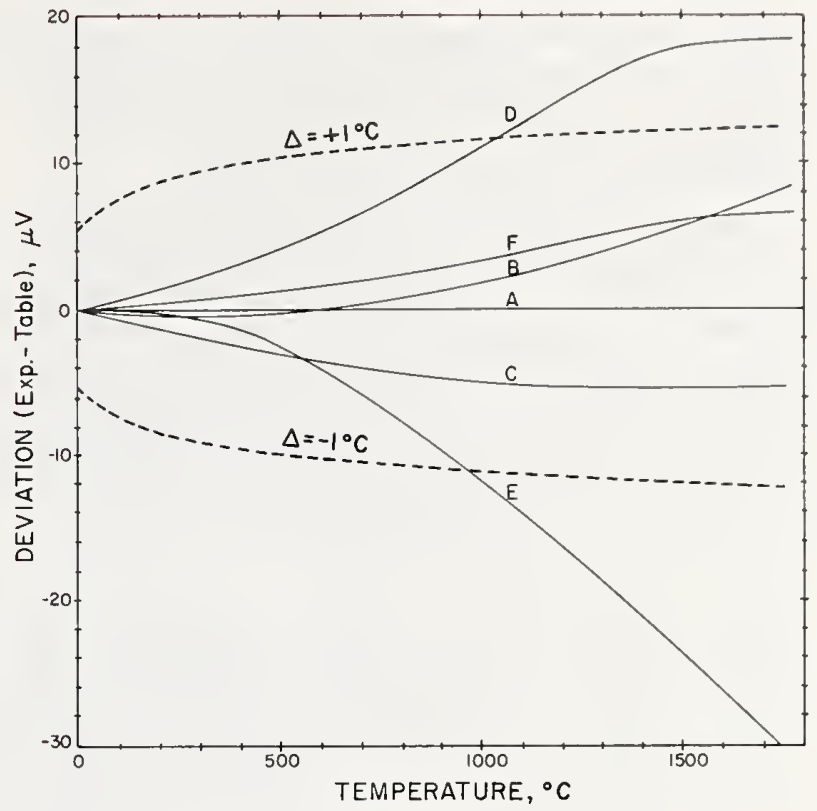

Figure 2.2.2. Deviation of thermoelectric voltages of Type $S$ thermocouples-comparison of values given in this Mono. graph to experimental data by Bedford, et al. [1972].

All values are expressed on the IPTS -68 . The dashed linea indicate a deviation of $1^{\circ} \mathrm{C}$

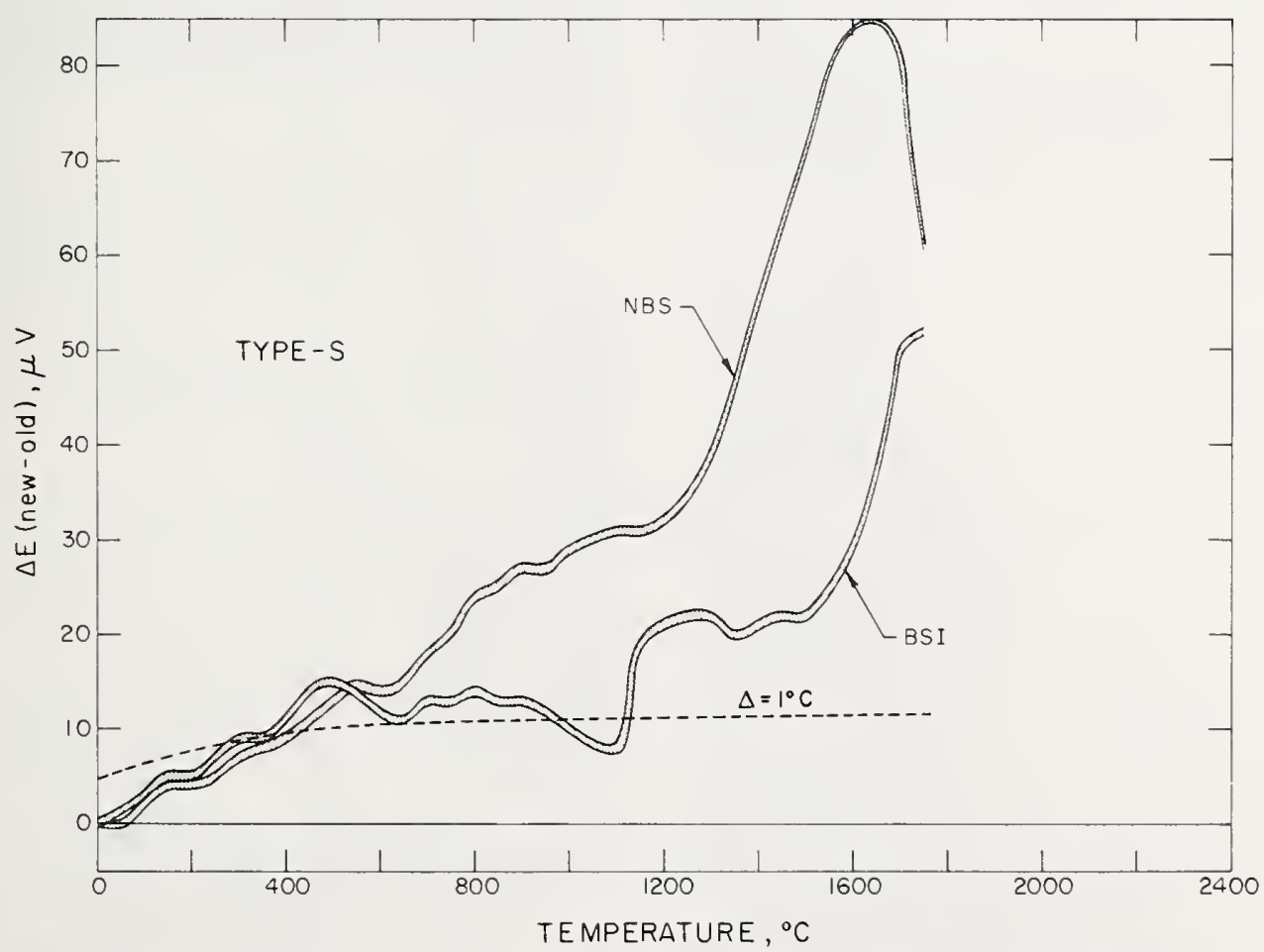

Figure 2.2.3. Difference in thermoelectric voltages for Type $S$ thermocouples-comparison of values given in this Monograph to those given in: NBS Circular 561; BSI (B.S. 1826:1952).

The width of the sbaded curves indicates the round-off uncertainty in the previous tabular values. Values from the previous standarda are adjusted to the IPTS -68 . The dashed line jndicates a deviation of $i^{\circ} \mathrm{C}$. 
et al. [1972] for generation of their recommended functions. The negative thermoelement (Material A) was about $6 \mu \mathrm{V}$ positive with respect to $\mathrm{Pt}-67$ at $1064.43{ }^{\circ} \mathrm{C}$, which is typical of present day thermocouple-quality (reference grade) platinum.

Deviations between values given in this Monograph and those given by Shenker et al. [1955] in NBS Circular 561 and by the British Standards Institute [1952] are shown in figure 2.2.3. The earlier values were adjusted to the IPTS-68. The deviation curves indicate differences caused by variation in material composition, experimental error, and fitting techniques. The width of the curve represents the round-off uncertainty $(1 \mu \mathrm{V})$ in the tabular values quoted in the two previous standard tables.

The reference tables for Type $\mathrm{S}$ thermocouples given in this Monograph were derived by Bedford et al. [1972] in such a way that the thermoelectric voltage, $E$, is a continuous function of temperature $\left(t_{68}\right)$ over the whole range. However, there are discontinuities in some derivatives at some of the joins in tempera- ture ranges. These discontinuities can be clearly seen in figure 2.3.3. Bedford et al. [1972] have explained why the discontinuities are necessary: the Seebeck coefficient is discontinuous at $630.74{ }^{\circ} \mathrm{C}$, the lower limit of the defined temperature range. These discontinuities are implicit in the definition of the IPTS68, see CIPM [1969]. At 630.74 ${ }^{\circ} \mathrm{C}$ the standard interpolating instrument is changed from a platinum resistance thermometer to a Type $\mathrm{S}$ thermocouple. Above the gold freezing point, $1064.43{ }^{\circ} \mathrm{C}$, an optical pyrometer is most commonly used to measure temperatures. It would be fortunate if the three methods actually joined smoothly at the two temperatures 630.74 and $1064.43{ }^{\circ} \mathrm{C}$. However, they do not, and the discontinuities in derivatives are reflected in the values for Type $S$ and Type $R$ thermocouples. At $630.74{ }^{\circ} \mathrm{C}$ the discontinuities in Seebeck coefficients are 0.18 percent for both Type $S$ and $R$ thermocouples (higher values above $630.74{ }^{\circ} \mathrm{C}$ ). At $1064.43{ }^{\circ} \mathrm{C}$ the discontinuities in Seebeck coefficients were so small, less than 0.1 percent, that they could be removed mathematically.

\subsection{Reference Functions and Tables for Type S Thermocouples}

The coefficients for the four sets of equations for the thermoelectric voltage of Type $\mathrm{S}$ thermocouples are given in table 2.3.1. The reduced temperature expressicns generated by Bedford et al. [1972] are included. The errors caused by using reduced bit arithmetic for calculating values of the functions are given in table 2.3.4.

The primary reference values for Type $S$ thermocouples are given in table 2.3.2. Values at selected fixed

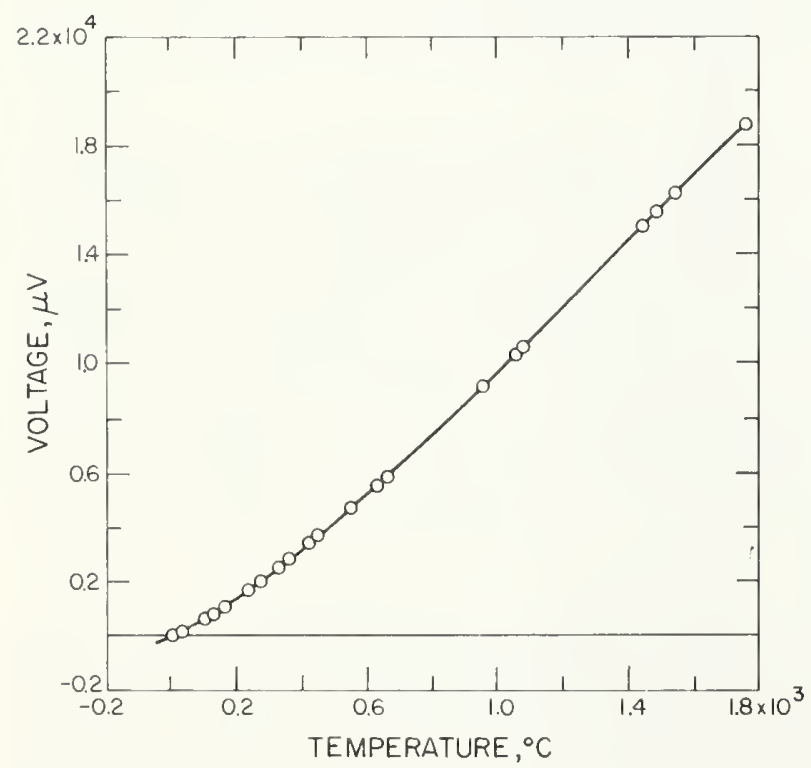

Figure 2.3.1. Thermoelectric voltage for Type $S$ thermocouples.

The circles indicate values at various thermometric fixed points on the IPTS -68 . points are given in table 2.3.3. Graphs of the thermoelectric voltage, its first derivative (Seebeck coeffcient), and second derivative are given in figures 2.3.1, 2.3.2, and 2.3.3, respectively. Discontinuities in the second derivative are apparent in figure 2.3.3. As discussed in the previous section, these discontinuities result from equations for different temperature regions being joined without constraints on their derivatives.

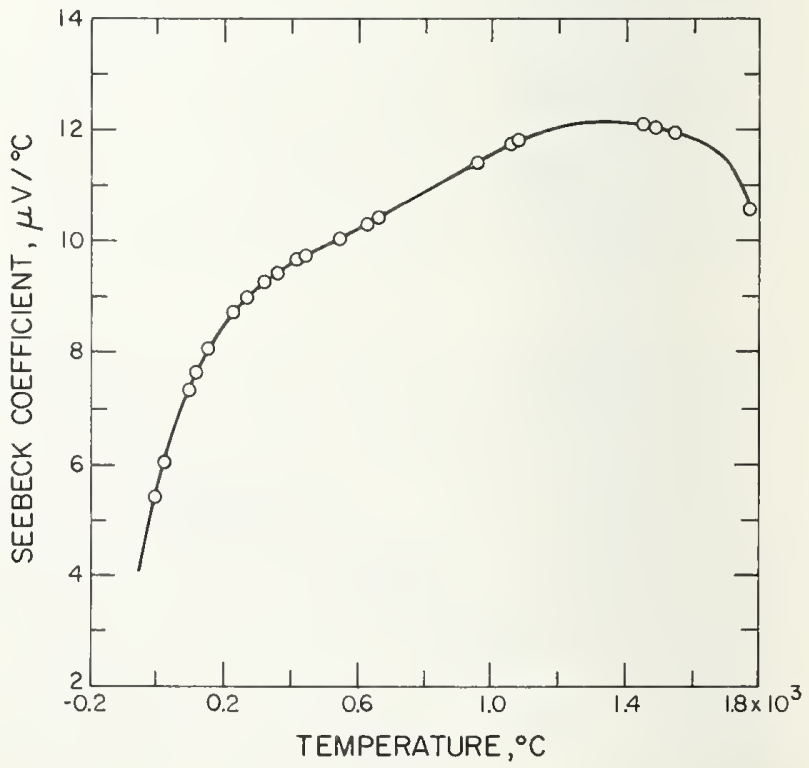

Figcre 2.3.2. Seebeck coefficient for Type S thermocouples. The circles indicate values at various thermometric fixed points on the IPTS-68. 


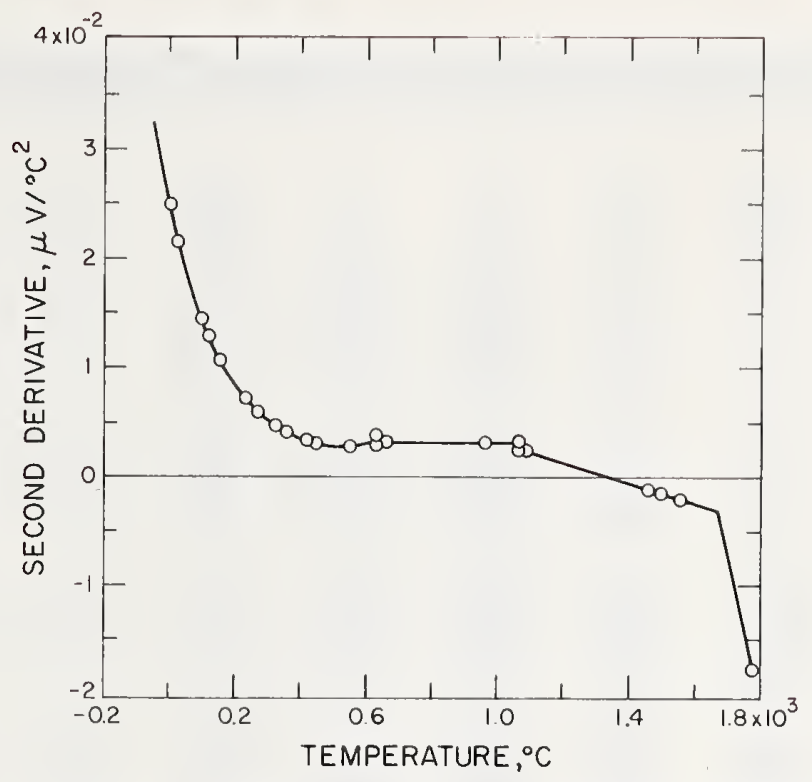

FIGURE 2.3.3. Second derivative of thermoelectric voltage for Type $S$ thermocouples.

The circles indicate values at various thermometric fxed points on the IPTS-68.

TABLE 2.3.1. Power series expansion for the thermoelectric voltage of Type $S$ thermocouples

\begin{tabular}{|c|c|c|c|}
\hline Temperature range & Degree & Coefficients & Term \\
\hline-50 to $630.74^{\circ} \mathrm{C}$ & 6 & $\begin{array}{r}5.3995782346 \ldots \\
1.2519770000 \times 10^{-2} \\
-2.2448217997 \times 10^{-6} \\
2.8452164949 \times 10^{-8} \\
-2.2440584544 \times 10^{-11} \\
8.5054166936 \times 10^{-15}\end{array}$ & $\begin{array}{l}T \\
T^{2} \\
T^{3} \\
T^{4} \\
T^{6} \\
T^{6}\end{array}$ \\
\hline 630.74 to $1064.43^{\circ} \mathrm{C}$ & 2 & $\begin{array}{c}-2.9824481615 \times 10^{2} \\
8.2375528221 \quad \ldots \\
1.6453909942 \times 10^{-3}\end{array}$ & $\begin{array}{l}\cdots \\
T^{1} \\
T^{2}\end{array}$ \\
\hline 1064.43 to $1665{ }^{\circ} \mathrm{C}$ & 3 & $\begin{array}{r}1.2766292175 \times 10^{3} \\
3.4970908041 \quad \ldots \\
6.3824648666 \times 10^{-3} \\
-1.5722424599 \times 10^{-6}\end{array}$ & $\begin{array}{l}\cdots \\
T^{1} \\
T^{2} \\
T^{3}\end{array}$ \\
\hline 1665 to $1767.6^{\circ} \mathrm{C}$ & 3 & $\begin{array}{r}9.7846655361 \times 10^{4} \\
-1.7050295632 \times 10^{2} \\
1.1088699768 \times 10^{-1} \\
-2.2494070849 \times 10^{-5}\end{array}$ & $\begin{array}{l}\cdots \\
T^{1} \\
T^{2} \\
T^{3}\end{array}$ \\
\hline $\begin{array}{r}1064.43 \text { to } 1665^{\circ} \mathrm{C} \\
T^{*}=\frac{T-1365}{300}\end{array}$ & 3 & $\begin{array}{r}1.3943438677 \times 10^{4} \\
3.6398686553 \times 10^{3} \\
-5.0281206140 \ldots \\
-4.2450546418 \times 10^{1}\end{array}$ & $\begin{array}{l}\cdots \\
T^{* 1} \\
T^{* 2} \\
T^{* 3}\end{array}$ \\
\hline $\begin{array}{r}1665 \text { to } 1767.6{ }^{\circ} \mathrm{C} \\
T^{*}=\frac{T-1715}{50}\end{array}$ & 3 & $\begin{array}{r}1.8113083153 \times 10^{4} \\
5.6795375480 \times 10^{2} \\
-1.2112492121 \times 10^{1} \\
-2.8117588563 \quad \ldots\end{array}$ & $\begin{array}{l}\cdots \\
T^{*_{1}} \\
T^{*_{2}} \\
T_{2}^{* 3}\end{array}$ \\
\hline
\end{tabular}


TABLE 2.3.2. Type $S$ thermocouples-thermoelectric voltages, $\mathrm{E}(\mathrm{T})$, Seebeck coefficients, $\mathrm{S}(\mathrm{T})$, and first derivative of the Seebeck coefficients, $\mathrm{dS} / \mathrm{dT}$, reference junctions at $0{ }^{\circ} \mathrm{C}$

\begin{tabular}{|c|c|c|c|c|c|c|c|c|c|c|c|}
\hline $\begin{array}{r}\mathrm{T} \\
{ }^{\circ} \mathrm{C}\end{array}$ & $\underset{\mu V}{E}$ & $\underset{\mu V /{ }^{\circ} \mathrm{C}}{S}$ & $\begin{array}{l}\mathrm{dS} / \mathrm{dT} \\
\mathrm{nV} /{ }^{\circ} \mathrm{C}^{2}\end{array}$ & $\begin{array}{l}\mathrm{T} \\
{ }^{\circ} \mathrm{C}\end{array}$ & $\begin{array}{c}E \\
\mu V\end{array}$ & $\underset{\mu \mathrm{V} /{ }^{\circ} \mathrm{C}}{\mathrm{S}}$ & $\begin{array}{l}d S / d T \\
n V /{ }^{\circ} C^{2}\end{array}$ & $\begin{array}{l}\mathrm{T} \\
{ }^{\circ} \mathrm{C}\end{array}$ & $\begin{array}{c}E V \\
\mu V\end{array}$ & $\stackrel{S}{\mu V^{\circ}{ }^{\circ} \mathrm{C}}$ & $\begin{array}{l}\mathrm{dS} / \mathrm{dT} \\
\mathrm{nV} /{ }^{\circ} \mathrm{C}^{2}\end{array}$ \\
\hline & & & & $\begin{array}{l}-40 \\
-39 \\
-38 \\
-37 \\
-36\end{array}$ & $\begin{array}{l}-194.44 \\
-190.14 \\
-185.81 \\
-181.45 \\
-177.06\end{array}$ & $\begin{array}{l}4 \cdot 283 \\
4 \cdot 314 \\
4.344 \\
4 \cdot 375 \\
4.405\end{array}$ & $\begin{array}{l}31.00 \\
30.84 \\
30.68 \\
30.51 \\
30.35\end{array}$ & $\begin{array}{l}-20 \\
-19 \\
-18 \\
-17 \\
-16\end{array}$ & $\begin{array}{r}-102.80 \\
-97.91 \\
-93.00 \\
-88.06 \\
-83.09\end{array}$ & $\begin{array}{l}4.871 \\
4.899 \\
4.926 \\
4.954 \\
4.981\end{array}$ & $\begin{array}{l}27.87 \\
27.73 \\
27.58 \\
27.43 \\
27.28\end{array}$ \\
\hline & & & & $\begin{array}{l}-35 \\
-34 \\
-33 \\
-32 \\
-31\end{array}$ & $\begin{array}{l}-172.64 \\
-168.19 \\
-163.71 \\
-159.20 \\
-154.66\end{array}$ & $\begin{array}{l}4.436 \\
4.466 \\
4.496 \\
4.526 \\
4.555\end{array}$ & $\begin{array}{l}30.19 \\
30.03 \\
29.87 \\
29.71 \\
29.56\end{array}$ & $\begin{array}{l}-15 \\
-14 \\
-13 \\
-12 \\
-11\end{array}$ & $\begin{array}{l}-78.10 \\
-73.08 \\
-68.03 \\
-62.95 \\
-57.85\end{array}$ & $\begin{array}{l}5.008 \\
5.036 \\
5.062 \\
5.089 \\
5.116\end{array}$ & $\begin{array}{l}27.14 \\
26.99 \\
26.85 \\
26.71 \\
26.56\end{array}$ \\
\hline $\begin{array}{l}-50 \\
-49 \\
-48 \\
-47 \\
-46\end{array}$ & $\begin{array}{l}-235.69 \\
-231.71 \\
-227.69 \\
-223.65 \\
-219.57\end{array}$ & $\begin{array}{l}3.964 \\
3.997 \\
4.029 \\
4.062 \\
4.094\end{array}$ & $\begin{array}{l}32.69 \\
32.51 \\
32.34 \\
32.17 \\
32.00\end{array}$ & $\begin{array}{l}-30 \\
-29 \\
-28 \\
-27 \\
-26\end{array}$ & $\begin{array}{l}-150.09 \\
-145.49 \\
-140.86 \\
-136.20 \\
-131.52\end{array}$ & $\begin{array}{l}4.585 \\
4.614 \\
4.643 \\
4.672 \\
4.701\end{array}$ & $\begin{array}{l}29.40 \\
29.24 \\
29.09 \\
28.93 \\
28.78\end{array}$ & $\begin{array}{l}-10 \\
-9 \\
-8 \\
-7 \\
-6\end{array}$ & $\begin{array}{l}-52.72 \\
-47.57 \\
-42.38 \\
-37.18 \\
-31.94\end{array}$ & $\begin{array}{l}5.142 \\
5.169 \\
5.195 \\
5.221 \\
5.247\end{array}$ & $\begin{array}{l}26.42 \\
26.28 \\
26.14 \\
26.00 \\
25.86\end{array}$ \\
\hline $\begin{array}{l}-45 \\
-44 \\
-43 \\
-42 \\
-41\end{array}$ & $\begin{array}{l}-215.46 \\
-211.32 \\
-207.15 \\
-202.94 \\
-198.71\end{array}$ & $\begin{array}{l}4 \cdot 126 \\
4 \cdot 157 \\
4 \cdot 189 \\
4 \cdot 220 \\
4 \cdot 252\end{array}$ & $\begin{array}{l}31.83 \\
31.67 \\
31.50 \\
31.33 \\
31.17\end{array}$ & $\begin{array}{l}-25 \\
-24 \\
-23 \\
-22 \\
-21\end{array}$ & $\begin{array}{l}-126.80 \\
-122.06 \\
-117.29 \\
-112.49 \\
-107.66\end{array}$ & $\begin{array}{l}4.730 \\
4.758 \\
4.787 \\
4.815 \\
4.843\end{array}$ & $\begin{array}{l}28.63 \\
28.48 \\
28.32 \\
28.17 \\
28.02\end{array}$ & $\begin{array}{l}-5 \\
-4 \\
-3 \\
-2 \\
-1\end{array}$ & $\begin{array}{r}-26.68 \\
-21.40 \\
-16.09 \\
-10.75 \\
-5.39\end{array}$ & $\begin{array}{l}5.273 \\
5.298 \\
5.324 \\
5.349 \\
5.374\end{array}$ & $\begin{array}{l}25 \cdot 72 \\
25.58 \\
25.45 \\
25.31 \\
25.17\end{array}$ \\
\hline-40 & $-194 \cdot 44$ & $4 \cdot 283$ & 31.00 & -20 & $-102 \cdot 80$ & 4.871 & 27.87 & 0 & 0.00 & 5.400 & 25.04 \\
\hline
\end{tabular}


TABLE 2.3.2. Type $S$ thermocouples-thermoelectric voltages, $\mathrm{E}(\mathrm{T})$, Seebeck coefficients, $\mathrm{S}(\mathrm{T})$, and first derivative of the Seebeck coefficients, $\mathrm{dS} / \mathrm{dT}$, reference junctions at $0{ }^{\circ} \mathrm{C}$-Continued

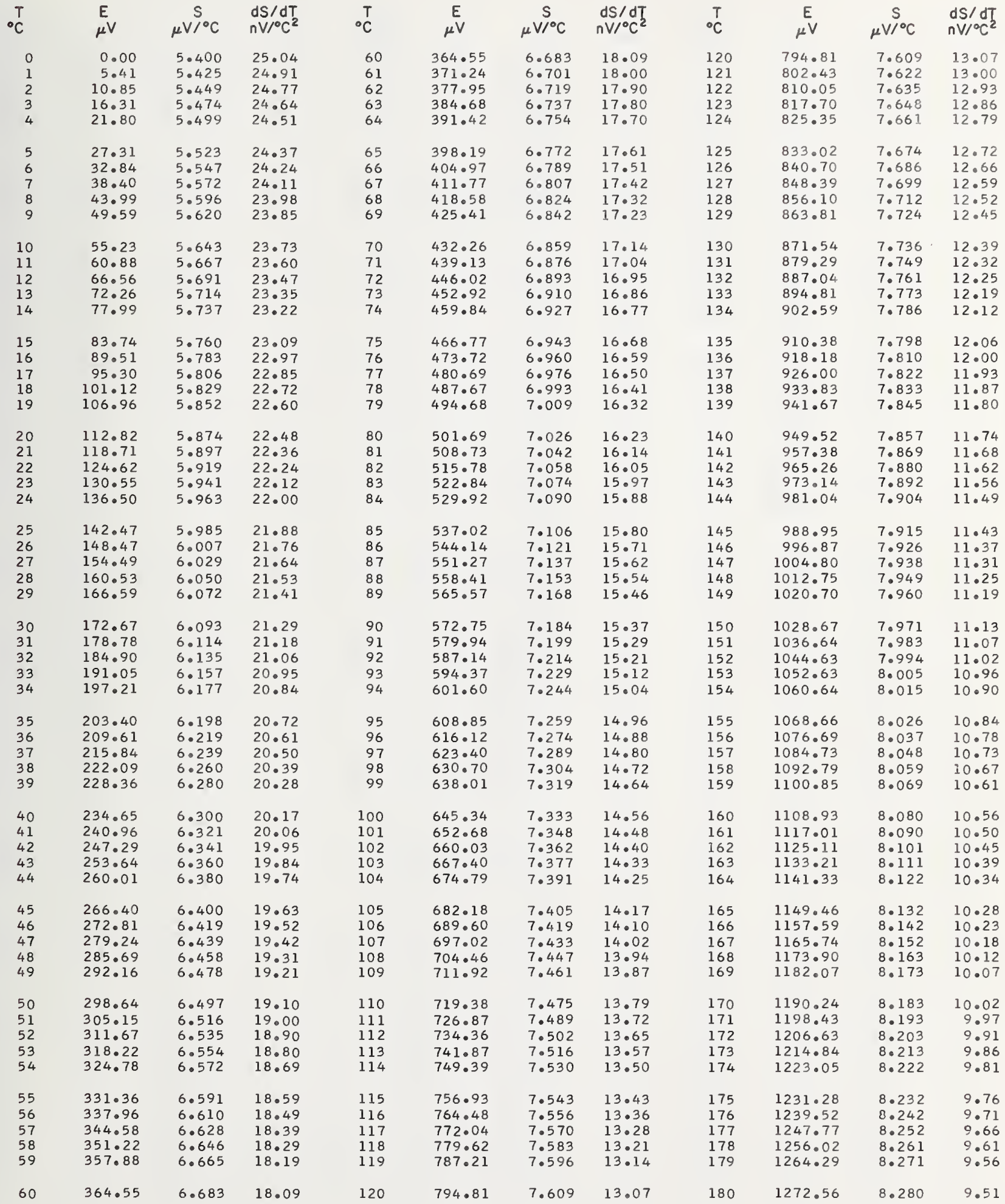


TABLE 2.3.2. Type $\mathbf{S}$ thermocouples-thermoelectric voltages, $\mathrm{E}(\mathrm{T})$, Seebeck coefficients, $\mathrm{S}(\mathrm{T})$, and first derivative of the Seebeck coefficients, $\mathrm{dS} / \mathrm{dT}$, reference junctions at $0{ }^{\circ} \mathrm{C}$-Continued

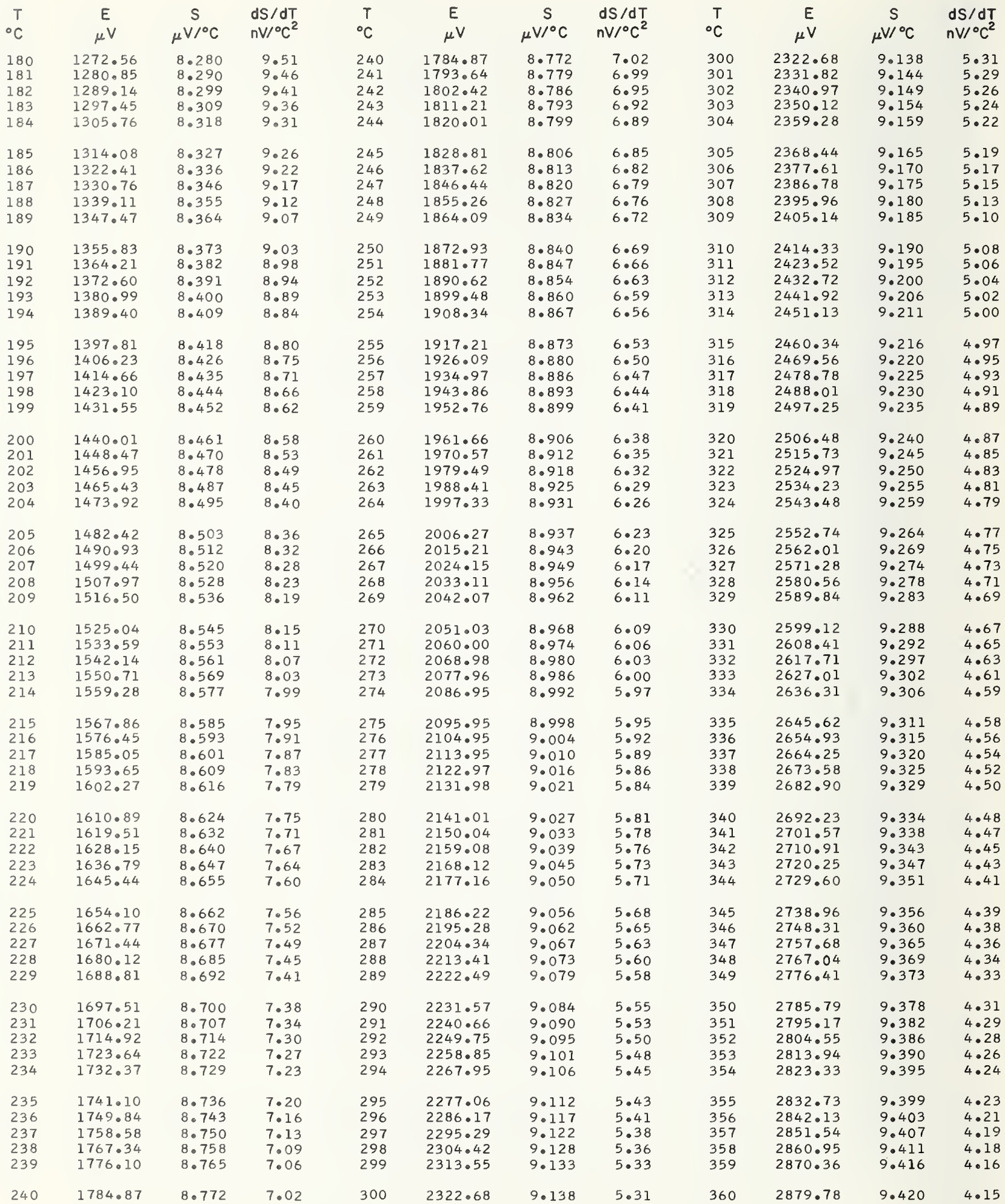


TABLE 2.3.2. Type S thermocouples-thermoelectric voltages, $\mathrm{E}(\mathrm{T})$, Seebeck coefficients, $\mathrm{S}(\mathrm{T})$, and first derivative of the Seebeck coefficients, $\mathrm{dS} / \mathrm{dT}$, reference junctions at $0{ }^{\circ} \mathrm{C}-$ Continued

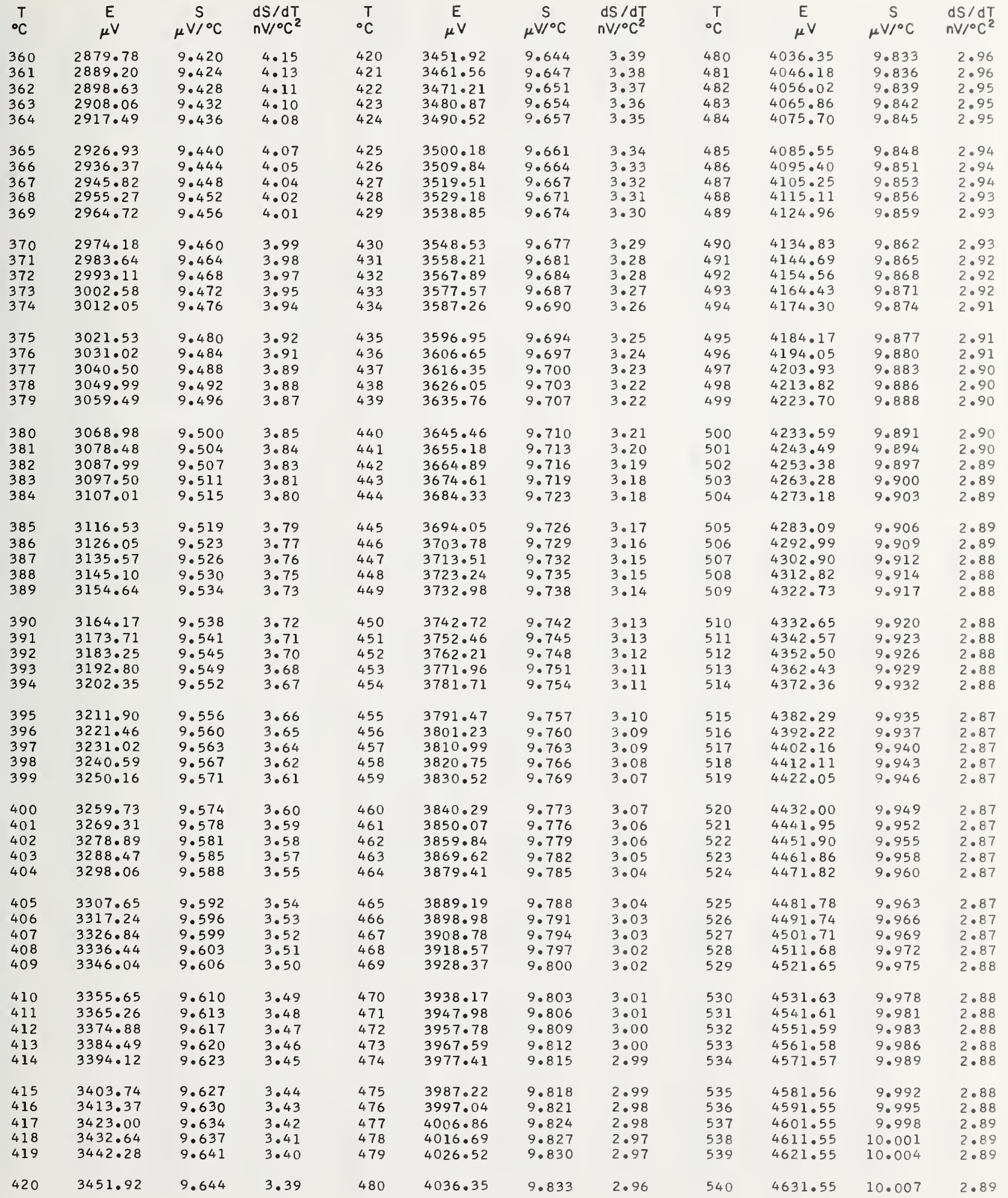


TABLE 2.3.2. Type $S$ thermocouples-thermoelectric voltages, $\mathrm{E}(\mathrm{T})$, Seebeck coefficients, $\mathrm{S}(\mathrm{T})$, and first derivative of the Seebeck coefficients, $\mathrm{dS} / \mathrm{dT}$, reference junctions at $0^{\circ} \mathrm{C}$-Continued

\begin{tabular}{|c|c|c|c|c|c|c|c|c|c|c|c|}
\hline${ }^{\top} \mathrm{C}$ & $\begin{array}{c}E \\
\mu V\end{array}$ & $\stackrel{S}{\mu V /{ }^{\circ} \mathrm{C}}$ & $\begin{array}{l}\mathrm{dS} / \mathrm{dT} \\
\mathrm{nV} /{ }^{\circ} \mathrm{C}^{2}\end{array}$ & ${ }^{\mathrm{T}}$ & $\begin{array}{c}E \\
\mu V\end{array}$ & $\underset{\mu V /^{\circ} \mathrm{C}}{S}$ & $\begin{array}{l}\mathrm{dS} / \mathrm{d} T \\
\mathrm{nV} /{ }^{\circ} \mathrm{C}^{2}\end{array}$ & ${ }^{\circ} \mathrm{C}$ & $\begin{array}{c}E \\
\mu V\end{array}$ & $\stackrel{\mathrm{S}}{\mu \mathrm{V} /{ }^{\circ} \mathrm{C}}$ & $\begin{array}{l}\mathrm{dS} / \mathrm{dT} \\
\mathrm{nV} /{ }^{\circ} \mathrm{C}^{2}\end{array}$ \\
\hline $\begin{array}{l}540 \\
541 \\
542 \\
543 \\
544\end{array}$ & $\begin{array}{l}4631.55 \\
4641.56 \\
4651.57 \\
4661.59 \\
4671.60\end{array}$ & $\begin{array}{l}10.007 \\
10.009 \\
10.012 \\
10.015 \\
10.018\end{array}$ & $\begin{array}{l}2.89 \\
2.89 \\
2.90 \\
2.90 \\
2.90\end{array}$ & $\begin{array}{l}600 \\
601 \\
602 \\
603 \\
604\end{array}$ & $\begin{array}{l}5237.30 \\
5247.49 \\
5257.68 \\
5267.88 \\
5278.08\end{array}$ & $\begin{array}{l}10.189 \\
10.192 \\
10.195 \\
10.199 \\
10.202\end{array}$ & $\begin{array}{l}3.27 \\
3.28 \\
3.29 \\
3.30 \\
3.31\end{array}$ & $\begin{array}{l}660 \\
661 \\
662 \\
663 \\
664\end{array}$ & $\begin{array}{l}5855.27 \\
5865.68 \\
5876.10 \\
5886.52 \\
5896.94\end{array}$ & $\begin{array}{l}10.409 \\
10.413 \\
10.416 \\
10.419 \\
10.423\end{array}$ & $\begin{array}{l}3.29 \\
3.29 \\
3.29 \\
3.29 \\
3.29\end{array}$ \\
\hline $\begin{array}{l}545 \\
546 \\
547 \\
548 \\
549\end{array}$ & $\begin{array}{l}4681.62 \\
4691.64 \\
4701.67 \\
4711.70 \\
4721.73\end{array}$ & $\begin{array}{l}10.021 \\
10.024 \\
10.027 \\
10.030 \\
10.033\end{array}$ & $\begin{array}{l}2.90 \\
2.91 \\
2.91 \\
2.91 \\
2.92\end{array}$ & $\begin{array}{l}605 \\
606 \\
607 \\
608 \\
609\end{array}$ & $\begin{array}{l}5288.28 \\
5298.49 \\
5308.70 \\
5318.91 \\
5329.13\end{array}$ & $\begin{array}{l}10.205 \\
10.208 \\
10.212 \\
10.215 \\
10.219\end{array}$ & $\begin{array}{l}3.32 \\
3.33 \\
3 \cdot 34 \\
3.36 \\
3.37\end{array}$ & $\begin{array}{l}665 \\
666 \\
667 \\
668 \\
669\end{array}$ & $\begin{array}{l}5907.36 \\
5917.79 \\
5928.22 \\
5938.65 \\
5949.09\end{array}$ & $\begin{array}{l}10.426 \\
10.429 \\
10.433 \\
10.436 \\
10.439\end{array}$ & $\begin{array}{l}3.29 \\
3.29 \\
3.29 \\
3.29 \\
3.29\end{array}$ \\
\hline $\begin{array}{l}550 \\
551 \\
552 \\
553 \\
554\end{array}$ & $\begin{array}{l}4731.76 \\
4741.80 \\
4751.84 \\
4761.88 \\
4771.93\end{array}$ & $\begin{array}{l}10.036 \\
10.039 \\
10.041 \\
10.044 \\
10.047\end{array}$ & $\begin{array}{l}2.92 \\
2.92 \\
2.93 \\
2.93 \\
2.93\end{array}$ & $\begin{array}{l}610 \\
611 \\
612 \\
613 \\
614\end{array}$ & $\begin{array}{l}5339.35 \\
5349.57 \\
5359.80 \\
5370.03 \\
5380.27\end{array}$ & $\begin{array}{l}10.222 \\
10.225 \\
10.229 \\
10.232 \\
10.236\end{array}$ & $\begin{array}{l}3.38 \\
3.39 \\
3.41 \\
3.42 \\
3.43\end{array}$ & $\begin{array}{l}670 \\
671 \\
672 \\
673 \\
674\end{array}$ & $\begin{array}{l}5959.53 \\
5969.98 \\
5980.42 \\
5990.87 \\
6001.33\end{array}$ & $\begin{array}{l}10.442 \\
10.446 \\
10.449 \\
10.452 \\
10.456\end{array}$ & $\begin{array}{l}3.29 \\
3.29 \\
3.29 \\
3.29 \\
3.29\end{array}$ \\
\hline $\begin{array}{l}560 \\
561 \\
562 \\
563 \\
564\end{array}$ & $\begin{array}{l}4832.27 \\
4842.33 \\
4852.40 \\
4862.47 \\
4872.55\end{array}$ & $\begin{array}{l}10.065 \\
10.068 \\
10.071 \\
10.074 \\
10.077\end{array}$ & $\begin{array}{l}2.96 \\
2.96 \\
2.97 \\
2.97 \\
2.98\end{array}$ & $\begin{array}{l}620 \\
621 \\
622 \\
623 \\
624\end{array}$ & $\begin{array}{l}5441.74 \\
5452.00 \\
5462.26 \\
5472.53 \\
5482.79\end{array}$ & $\begin{array}{l}10.256 \\
10.260 \\
10.263 \\
10.267 \\
10.271\end{array}$ & $\begin{array}{l}3.52 \\
3.53 \\
3.54 \\
3.56 \\
3.57\end{array}$ & $\begin{array}{l}680 \\
681 \\
682 \\
683 \\
684\end{array}$ & $\begin{array}{l}6064 \cdot 12 \\
6074 \cdot 60 \\
6085.08 \\
6095.56 \\
6106.05\end{array}$ & $\begin{array}{l}10.475 \\
10.479 \\
10.482 \\
10.485 \\
10.488\end{array}$ & $\begin{array}{l}3.29 \\
3.29 \\
3.29 \\
3.29 \\
3.29\end{array}$ \\
\hline $\begin{array}{l}565 \\
566 \\
567 \\
568 \\
569\end{array}$ & $\begin{array}{l}4882.63 \\
4892.71 \\
4902.79 \\
4912.88 \\
4922.97\end{array}$ & $\begin{array}{l}10.080 \\
10.083 \\
10.086 \\
10.089 \\
10.092\end{array}$ & $\begin{array}{l}2.99 \\
2.99 \\
3.00 \\
3.00 \\
3.01\end{array}$ & $\begin{array}{l}625 \\
626 \\
627 \\
628 \\
629\end{array}$ & $\begin{array}{l}5493.07 \\
5503.34 \\
5513.62 \\
5523.91 \\
5534.19\end{array}$ & $\begin{array}{l}10.274 \\
10.278 \\
10.281 \\
10.285 \\
10.289\end{array}$ & $\begin{array}{l}3.59 \\
3.61 \\
3.62 \\
3.64 \\
3.65\end{array}$ & $\begin{array}{l}685 \\
686 \\
687 \\
688 \\
689\end{array}$ & $\begin{array}{l}6116.54 \\
6127.03 \\
6137.53 \\
6148.03 \\
6158.53\end{array}$ & $\begin{array}{l}10.492 \\
10.495 \\
10.498 \\
10.502 \\
10.505\end{array}$ & $\begin{array}{l}3.29 \\
3.29 \\
3.29 \\
3.29 \\
3.29\end{array}$ \\
\hline $\begin{array}{l}570 \\
571 \\
572 \\
573 \\
574\end{array}$ & $\begin{array}{l}4933.06 \\
4943.16 \\
4953.26 \\
4963.36 \\
4973.47\end{array}$ & $\begin{array}{l}10.095 \\
10.098 \\
10.101 \\
10.104 \\
10.107\end{array}$ & $\begin{array}{l}3.01 \\
3.02 \\
3.03 \\
3.03 \\
3.04\end{array}$ & $\begin{array}{l}630 \\
631 \\
632 \\
633 \\
634\end{array}$ & $\begin{array}{l}5544.48 \\
5554.78 \\
5565.10 \\
5575.42 \\
5585.74\end{array}$ & $\begin{array}{l}10.292 \\
10.314 \\
10.317 \\
10.321 \\
10.324\end{array}$ & $\begin{array}{l}3.67 \\
3.29 \\
3.29 \\
3.29 \\
3.29\end{array}$ & $\begin{array}{l}690 \\
691 \\
692 \\
693 \\
694\end{array}$ & $\begin{array}{l}6169.04 \\
6179.55 \\
6190.06 \\
6200.58 \\
6211.10\end{array}$ & $\begin{array}{l}10.508 \\
10.511 \\
10.515 \\
10.518 \\
10.521\end{array}$ & $\begin{array}{l}3.29 \\
3.29 \\
3.29 \\
3.29 \\
3.29\end{array}$ \\
\hline $\begin{array}{l}580 \\
581 \\
582 \\
583 \\
584\end{array}$ & $\begin{array}{l}5034.16 \\
5044.29 \\
5054.42 \\
5064.55 \\
5074.69\end{array}$ & $\begin{array}{l}10.125 \\
10.128 \\
10.131 \\
10.135 \\
10.138\end{array}$ & $\begin{array}{l}3.08 \\
3.09 \\
3.10 \\
3.11 \\
3.11\end{array}$ & $\begin{array}{l}640 \\
641 \\
642 \\
643 \\
644\end{array}$ & $\begin{array}{l}5647.74 \\
5658.09 \\
5668.44 \\
5678.79 \\
5689.14\end{array}$ & $\begin{array}{l}10 \cdot 344 \\
10 \cdot 347 \\
10 \cdot 350 \\
10 \cdot 354 \\
10 \cdot 357\end{array}$ & $\begin{array}{l}3.29 \\
3.29 \\
3.29 \\
3.29 \\
3.29\end{array}$ & $\begin{array}{l}700 \\
701 \\
702 \\
703 \\
704\end{array}$ & $\begin{array}{l}6274.28 \\
6284.83 \\
6295 \cdot 37 \\
6305.92 \\
6316.47\end{array}$ & $\begin{array}{l}10.541 \\
10.544 \\
10.548 \\
10.551 \\
10.554\end{array}$ & $\begin{array}{l}3.29 \\
3.29 \\
3.29 \\
3.29 \\
3.29\end{array}$ \\
\hline $\begin{array}{l}585 \\
586 \\
587 \\
588 \\
589\end{array}$ & $\begin{array}{l}5084 \cdot 83 \\
5094 \cdot 97 \\
5105.12 \\
5115.27 \\
5125.42\end{array}$ & $\begin{array}{l}10.141 \\
10.144 \\
10.147 \\
10.150 \\
10.153\end{array}$ & $\begin{array}{l}3.12 \\
3.13 \\
3.14 \\
3.15 \\
3.16\end{array}$ & $\begin{array}{l}645 \\
646 \\
647 \\
648 \\
649\end{array}$ & $\begin{array}{l}5699.50 \\
5709.86 \\
5720.23 \\
5730.60 \\
5740.97\end{array}$ & $\begin{array}{l}10.360 \\
10.363 \\
10.367 \\
10.370 \\
10.373\end{array}$ & $\begin{array}{l}3.29 \\
3.29 \\
3.29 \\
3.29 \\
3.29\end{array}$ & $\begin{array}{l}705 \\
706 \\
707 \\
708 \\
709\end{array}$ & $\begin{array}{l}6327.03 \\
6337.59 \\
6348.15 \\
6358.72 \\
6369.29\end{array}$ & $\begin{array}{l}10.558 \\
10.561 \\
10.564 \\
10.567 \\
10.571\end{array}$ & $\begin{array}{l}3.29 \\
3.29 \\
3.29 \\
3.29 \\
3.29\end{array}$ \\
\hline $\begin{array}{l}590 \\
591 \\
592 \\
593 \\
594\end{array}$ & $\begin{array}{l}5135.57 \\
5145.73 \\
5155.89 \\
5166.06 \\
5176.22\end{array}$ & $\begin{array}{l}10.157 \\
10.160 \\
10.163 \\
10.166 \\
10.169\end{array}$ & $\begin{array}{l}3.17 \\
3.17 \\
3.18 \\
3.19 \\
3.20\end{array}$ & $\begin{array}{l}650 \\
651 \\
652 \\
653 \\
654\end{array}$ & $\begin{array}{l}5751.34 \\
5761.72 \\
5772.10 \\
5782.49 \\
5792.87\end{array}$ & $\begin{array}{l}10.377 \\
10.380 \\
10.383 \\
10.386 \\
10.390\end{array}$ & $\begin{array}{l}3.29 \\
3.29 \\
3.29 \\
3.29 \\
3.29\end{array}$ & $\begin{array}{l}710 \\
711 \\
712 \\
713 \\
714\end{array}$ & $\begin{array}{l}6379.86 \\
6390.43 \\
6401.01 \\
6411.60 \\
6422.18\end{array}$ & $\begin{array}{l}10.574 \\
10.577 \\
10.581 \\
10.584 \\
10.587\end{array}$ & $\begin{array}{l}3.29 \\
3.29 \\
3.29 \\
3.29 \\
3.29\end{array}$ \\
\hline $\begin{array}{l}595 \\
596 \\
597 \\
598 \\
599\end{array}$ & $\begin{array}{l}5186.40 \\
5196.57 \\
5206.75 \\
5216.93 \\
5227.11\end{array}$ & $\begin{array}{l}10.172 \\
10.176 \\
10.179 \\
10 \cdot 182 \\
10.185\end{array}$ & $\begin{array}{l}3.21 \\
3.22 \\
3.23 \\
3.24 \\
3.25\end{array}$ & $\begin{array}{l}655 \\
656 \\
657 \\
658 \\
659\end{array}$ & $\begin{array}{l}5803.27 \\
5813.66 \\
5824.06 \\
5834.46 \\
5844.86\end{array}$ & $\begin{array}{l}10.393 \\
10.396 \\
10.400 \\
10.403 \\
10.406\end{array}$ & $\begin{array}{l}3.29 \\
3.29 \\
3.29 \\
3.29 \\
3.29\end{array}$ & $\begin{array}{l}715 \\
716 \\
717 \\
718 \\
719\end{array}$ & $\begin{array}{l}6432.77 \\
6443.36 \\
6453.96 \\
6464.56 \\
6475.16\end{array}$ & $\begin{array}{l}10.590 \\
10.594 \\
10.597 \\
10.600 \\
10.604\end{array}$ & $\begin{array}{l}3.29 \\
3.29 \\
3.29 \\
3.29 \\
3.29\end{array}$ \\
\hline 600 & 5237.30 & 10.189 & 3.27 & 660 & 5855.27 & 10.409 & 3.29 & 720 & 6485.76 & 10.607 & 3.29 \\
\hline
\end{tabular}


TABLE 2.3.2. Type $S$ thermocouples-thermoelectric voltages, $\mathrm{E}(\mathrm{T})$, Seebeck coefficients, $\mathrm{S}(\mathrm{T})$, and first derivative of the Seebeck coefficients, $\mathrm{dS} / \mathrm{dT}$, reference junctions at $0{ }^{\circ} \mathrm{C}$-Continued

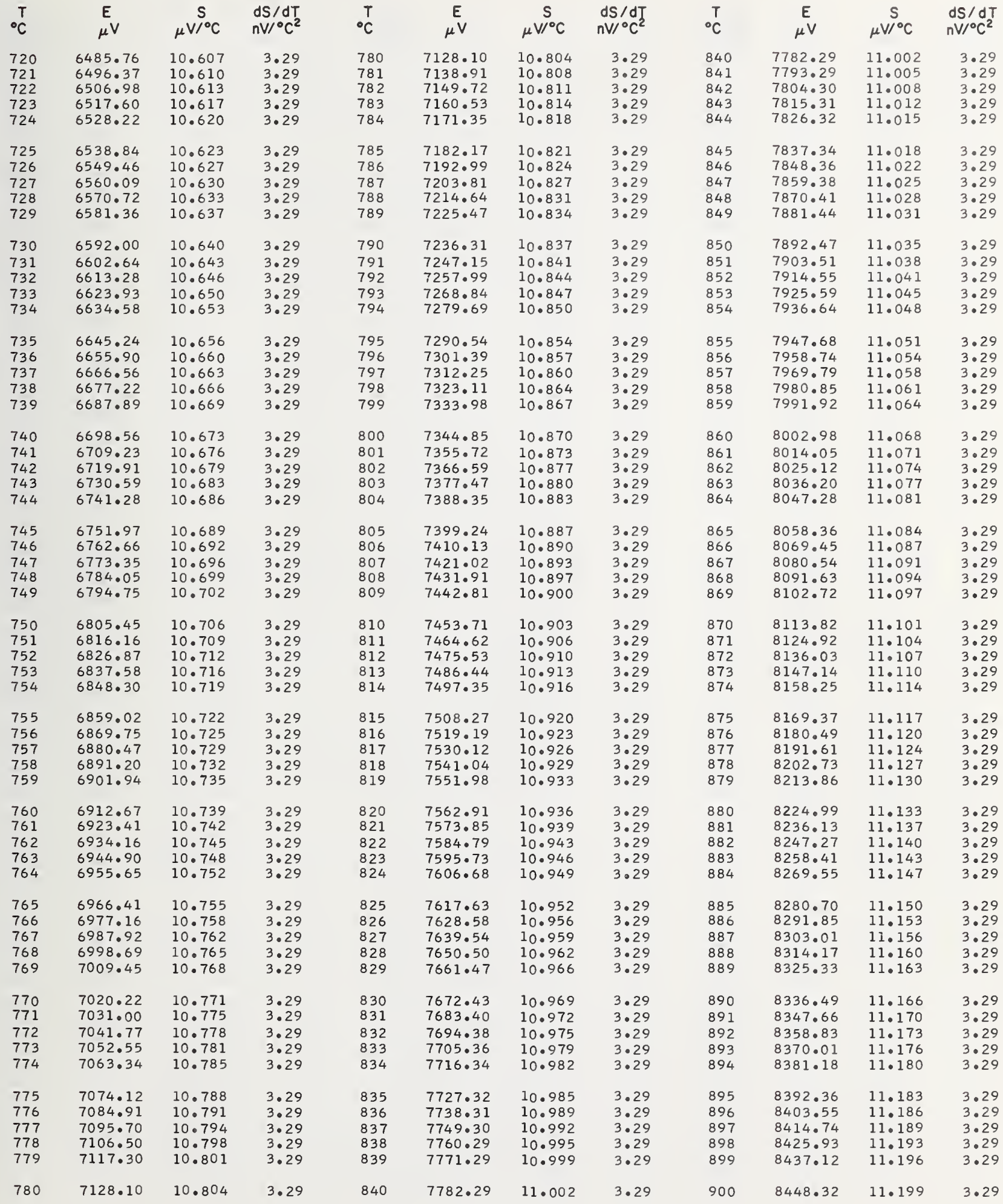


TABLE 2.3.2. Type S thermocouples-thermoelectric voltages, $\mathrm{E}(\mathrm{T})$, Seebeck coefficients, $\mathrm{S}(\mathrm{T})$, and first derivative of the Seebeck coefficients, $\mathrm{dS} / \mathrm{dT}$, reference junctions at $0{ }^{\circ} \mathrm{C}$-Continued

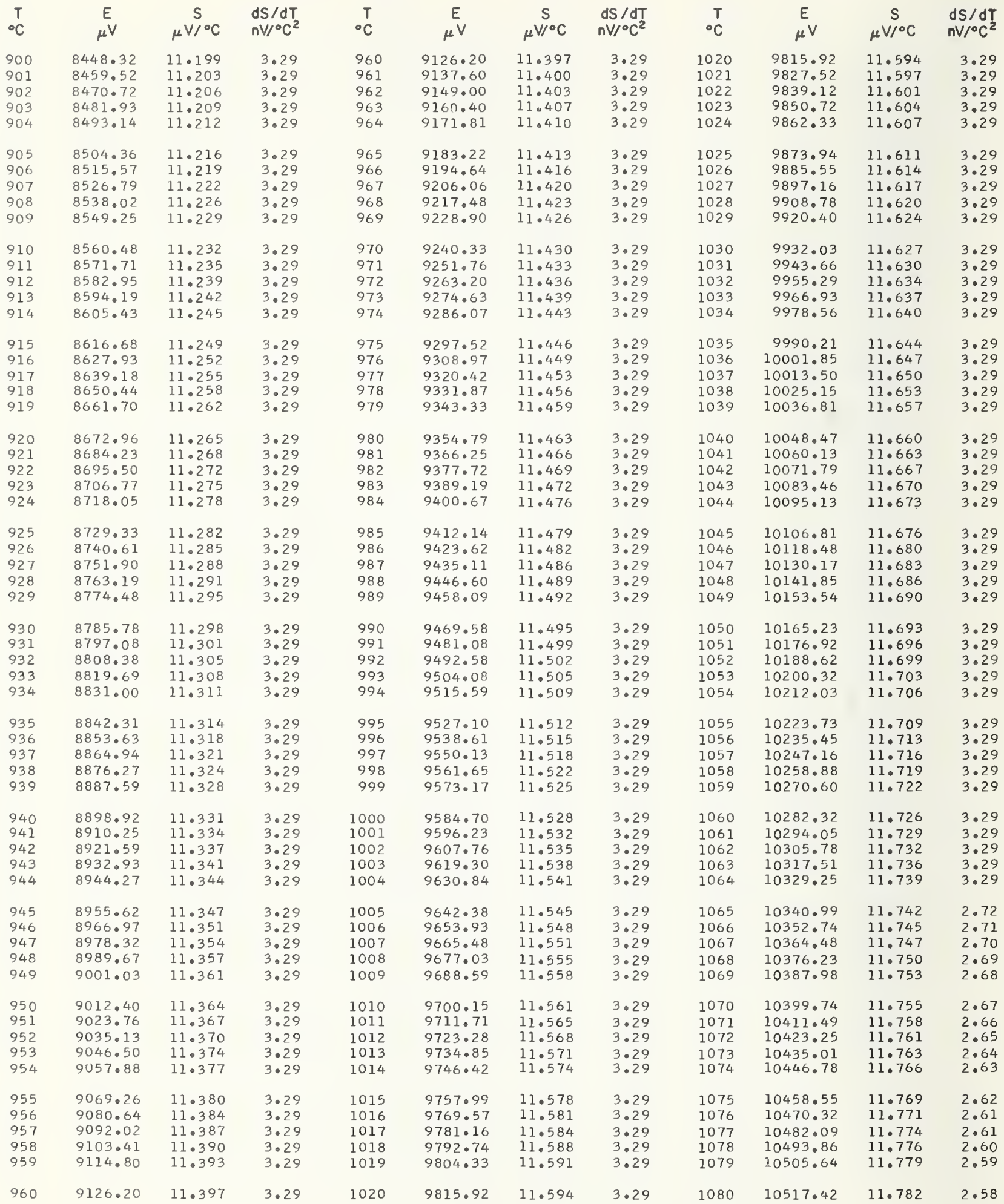


TABLE 2.3.2. Type S thermocouples-thermoelectric voltages, E(T), Seebeck coefficients, S(T), and first derivative of the Seebeck coefficients, $\mathrm{dS} / \mathrm{d} \mathrm{T}$, reference junctions at $0{ }^{\circ} \mathrm{C}$-Continued

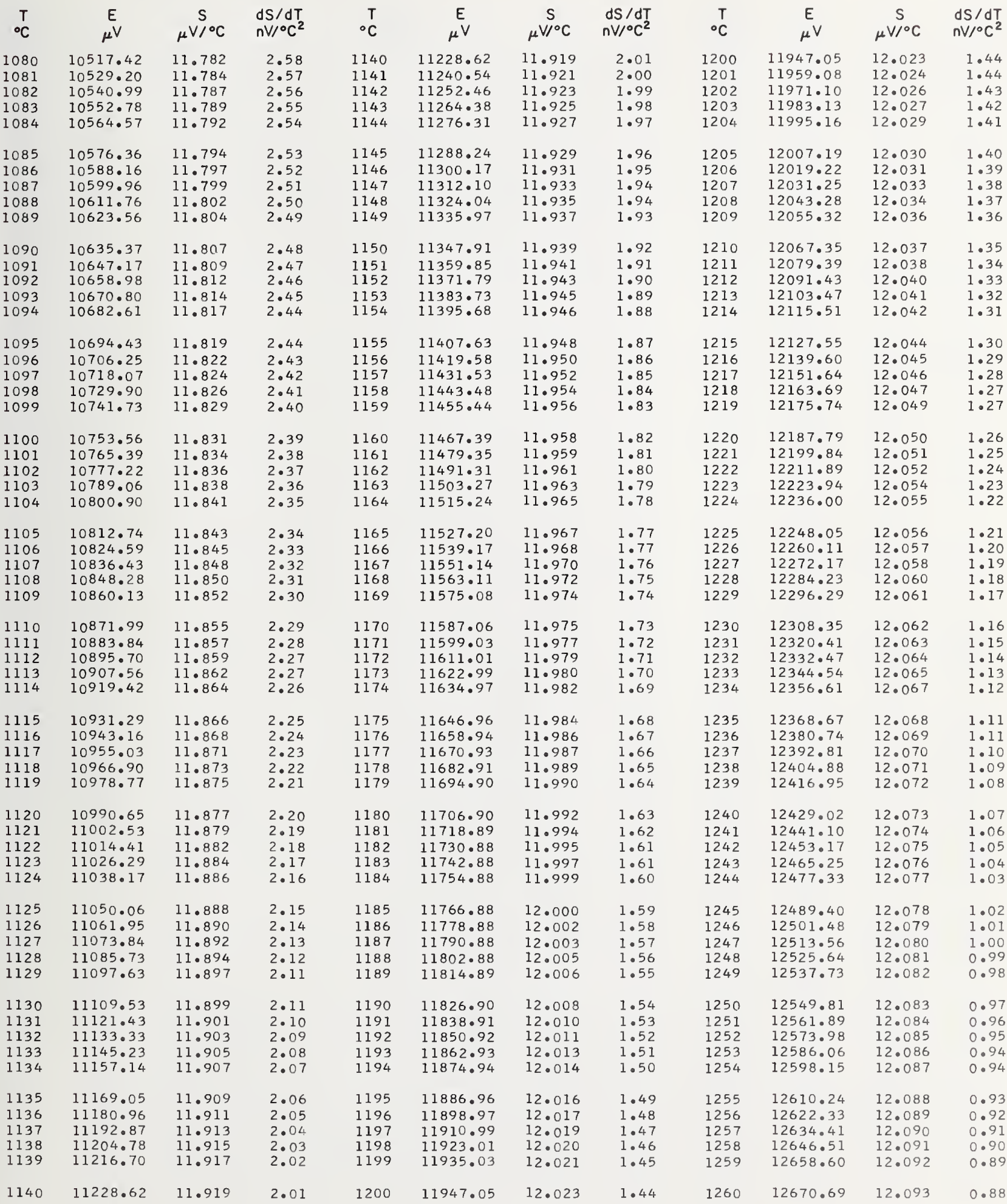


TABLE 2.3.2. Type $S$ thermocouples-thermoelectric voltages, $\mathrm{E}(\mathrm{T})$, Seebeck coefficients, $\mathrm{S}(\mathrm{T})$, and first derivative of the Seebeck coefficients, $\mathrm{dS} / \mathrm{dT}$, reference junctions at $0{ }^{\circ} \mathrm{C}$-Continued

\begin{tabular}{|c|c|c|c|c|c|c|c|c|c|c|c|}
\hline${ }^{\mathrm{T}} \mathrm{C}$ & $\begin{array}{c}E \\
\mu V\end{array}$ & $\underset{\mu V /{ }^{\circ} \mathrm{C}}{S}$ & $\begin{array}{l}\mathrm{dS} / \mathrm{dT} \\
\mathrm{nV} /{ }^{\circ} \mathrm{C}^{2}\end{array}$ & $\begin{array}{l}{ }^{\circ} \mathrm{C} \\
{ }^{\mathrm{C}}\end{array}$ & $\begin{array}{c}E \\
\mu V\end{array}$ & $\stackrel{\mathrm{S}}{\mu \mathrm{V}^{\circ}{ }^{\circ} \mathrm{C}}$ & $\begin{array}{l}\mathrm{d} S / \mathrm{dT} \\
\mathrm{nV} /{ }^{\circ} \mathrm{C}^{2}\end{array}$ & ${ }^{\circ} \mathrm{C}$ & $\underset{\mu V}{E}$ & $\underset{\mu V /{ }^{\circ} \mathrm{C}}{S}$ & $\begin{array}{l}d S / d T \\
n V /{ }^{\circ} C^{2}\end{array}$ \\
\hline $\begin{array}{l}1260 \\
1261 \\
1262 \\
1263 \\
1264\end{array}$ & $\begin{array}{l}12670.69 \\
12682.78 \\
12694.88 \\
12706.97 \\
12719.07\end{array}$ & $\begin{array}{l}12.093 \\
12.093 \\
12.094 \\
12.095 \\
12.096\end{array}$ & $\begin{array}{l}0.88 \\
0.87 \\
0.86 \\
0.85 \\
0.84\end{array}$ & $\begin{array}{l}1320 \\
1321 \\
1322 \\
1323 \\
1324\end{array}$ & $\begin{array}{l}13397.49 \\
13409.62 \\
13421.75 \\
13433.87 \\
13446.00\end{array}$ & $\begin{array}{l}12.128 \\
12.129 \\
12.129 \\
12.129 \\
12.130\end{array}$ & $\begin{array}{l}0.31 \\
0.30 \\
0.29 \\
0.28 \\
0.28\end{array}$ & $\begin{array}{l}1380 \\
1381 \\
1382 \\
1383 \\
1384\end{array}$ & $\begin{array}{l}14125.41 \\
14137.54 \\
14149.67 \\
14161.80 \\
14173.93\end{array}$ & $\begin{array}{l}12.130 \\
12.130 \\
12.130 \\
12.129 \\
12.129\end{array}$ & $\begin{array}{l}-0.25 \\
-0.26 \\
-0.27 \\
-0.28 \\
-0.29\end{array}$ \\
\hline $\begin{array}{l}1265 \\
1266 \\
1267 \\
1268 \\
1269\end{array}$ & $\begin{array}{l}12731.16 \\
12743 \cdot 26 \\
12755 \cdot 36 \\
12767.46 \\
12779.56\end{array}$ & $\begin{array}{l}12.097 \\
12.098 \\
12.099 \\
12.099 \\
12.100\end{array}$ & $\begin{array}{l}0.83 \\
0.82 \\
0.81 \\
0.80 \\
0.79\end{array}$ & $\begin{array}{l}1325 \\
1326 \\
1327 \\
1328 \\
1329\end{array}$ & $\begin{array}{l}13458.13 \\
13470.26 \\
13482.39 \\
13494.52 \\
13506.66\end{array}$ & $\begin{array}{l}12.130 \\
12.130 \\
12.130 \\
12.131 \\
12.131\end{array}$ & $\begin{array}{l}0.27 \\
0.26 \\
0.25 \\
0.24 \\
0.23\end{array}$ & $\begin{array}{l}1385 \\
1386 \\
1387 \\
1388 \\
1389\end{array}$ & $\begin{array}{l}14186.06 \\
14198.19 \\
14210.32 \\
14222.45 \\
14234.57\end{array}$ & $\begin{array}{l}12.129 \\
12.128 \\
12.128 \\
12.128 \\
12.127\end{array}$ & $\begin{array}{l}-0.30 \\
-0.31 \\
-0.32 \\
-0.33 \\
-0.34\end{array}$ \\
\hline $\begin{array}{l}1270 \\
1271 \\
1272 \\
1273 \\
1274\end{array}$ & $\begin{array}{l}12791.66 \\
12803.76 \\
12815.86 \\
12827.96 \\
12840.07\end{array}$ & $\begin{array}{l}12.101 \\
12.102 \\
12.102 \\
12.103 \\
12.104\end{array}$ & $\begin{array}{l}0.78 \\
0.78 \\
0.77 \\
0.76 \\
0.75\end{array}$ & $\begin{array}{l}1330 \\
1331 \\
1332 \\
1333 \\
1334\end{array}$ & $\begin{array}{l}13518.79 \\
13530.92 \\
13543.05 \\
13555.18 \\
13567.31\end{array}$ & $\begin{array}{l}12.131 \\
12.131 \\
12.131 \\
12.132 \\
12.132\end{array}$ & $\begin{array}{l}0.22 \\
0.21 \\
0.20 \\
0.19 \\
0.18\end{array}$ & $\begin{array}{l}1390 \\
1391 \\
1392 \\
1393 \\
1394\end{array}$ & $\begin{array}{l}14246.70 \\
14258.83 \\
14270.96 \\
14283.08 \\
14295.21\end{array}$ & $\begin{array}{l}12.127 \\
12.127 \\
12.126 \\
12.126 \\
12.126\end{array}$ & $\begin{array}{l}-0.35 \\
-0.36 \\
-0.37 \\
-0.38 \\
-0.39\end{array}$ \\
\hline $\begin{array}{l}1275 \\
1276 \\
1277 \\
1278 \\
1279\end{array}$ & $\begin{array}{l}12852.17 \\
12864.28 \\
12876.38 \\
12888.49 \\
12900.60\end{array}$ & $\begin{array}{l}12.105 \\
12.105 \\
12.106 \\
12.107 \\
12.108\end{array}$ & $\begin{array}{l}0.74 \\
0.73 \\
0.72 \\
0.71 \\
0.70\end{array}$ & $\begin{array}{l}1335 \\
1336 \\
1337 \\
1338 \\
1339\end{array}$ & $\begin{array}{l}13579.44 \\
13591.58 \\
13603.71 \\
13615.84 \\
13627.97\end{array}$ & $\begin{array}{l}12.132 \\
12.132 \\
12.132 \\
12.132 \\
12.133\end{array}$ & $\begin{array}{l}0.17 \\
0.16 \\
0.15 \\
0.14 \\
0.13\end{array}$ & $\begin{array}{l}1395 \\
1396 \\
1397 \\
1398 \\
1399\end{array}$ & $\begin{array}{l}14307.33 \\
14319.46 \\
14331.58 \\
14343.71 \\
14355.83\end{array}$ & $\begin{array}{l}12.125 \\
12.125 \\
12.124 \\
12.124 \\
12.124\end{array}$ & $\begin{array}{l}-0.39 \\
-0.40 \\
-0.41 \\
-0.42 \\
-0.43\end{array}$ \\
\hline $\begin{array}{l}1280 \\
1281 \\
1282 \\
1283 \\
1284\end{array}$ & $\begin{array}{l}12912.70 \\
12924.81 \\
12936.92 \\
12949.03 \\
12961.14\end{array}$ & $\begin{array}{l}12.108 \\
12.109 \\
12.110 \\
12.110 \\
12.111\end{array}$ & $\begin{array}{l}0.69 \\
0.68 \\
0.67 \\
0.66 \\
0.65\end{array}$ & $\begin{array}{l}1340 \\
1341 \\
1342 \\
1343 \\
1344\end{array}$ & $\begin{array}{l}13640.11 \\
13652.24 \\
13664 \cdot 37 \\
13676.50 \\
13688.64\end{array}$ & $\begin{array}{l}12.133 \\
12.133 \\
12.133 \\
12.133 \\
12.133\end{array}$ & $\begin{array}{l}0.12 \\
0.11 \\
0.11 \\
0.10 \\
0.09\end{array}$ & $\begin{array}{l}1400 \\
1401 \\
1402 \\
1403 \\
1404\end{array}$ & $\begin{array}{l}14367.95 \\
14380.08 \\
14392.20 \\
14404.32 \\
14416.44\end{array}$ & $\begin{array}{l}12.123 \\
12.123 \\
12.122 \\
12.122 \\
12.121\end{array}$ & $\begin{array}{l}-0.44 \\
-0.45 \\
-0.46 \\
-0.47 \\
-0.48\end{array}$ \\
\hline $\begin{array}{l}1285 \\
1286 \\
1287 \\
1288 \\
1289\end{array}$ & $\begin{array}{l}12973.25 \\
12985.37 \\
12997.48 \\
13009.59 \\
13021.71\end{array}$ & $\begin{array}{l}12.112 \\
12.112 \\
12.113 \\
12.114 \\
12.114\end{array}$ & $\begin{array}{l}0.64 \\
0.63 \\
0.62 \\
0.61 \\
0.61\end{array}$ & $\begin{array}{l}1345 \\
1346 \\
1347 \\
1348 \\
1349\end{array}$ & $\begin{array}{l}13700.77 \\
13712.90 \\
13725.04 \\
13737.17 \\
13749.30\end{array}$ & $\begin{array}{l}12.133 \\
12.133 \\
12.133 \\
12.133 \\
12.133\end{array}$ & $\begin{array}{l}0.08 \\
0.07 \\
0.06 \\
0.05 \\
0.04\end{array}$ & $\begin{array}{l}1405 \\
1406 \\
1407 \\
1408 \\
1409\end{array}$ & $\begin{array}{l}14428.56 \\
14440.69 \\
14452.81 \\
14464.92 \\
14477.04\end{array}$ & $\begin{array}{l}12.121 \\
12.120 \\
12.120 \\
12.119 \\
12.119\end{array}$ & $\begin{array}{l}-0.49 \\
-0.50 \\
-0.51 \\
-0.52 \\
-0.53\end{array}$ \\
\hline $\begin{array}{l}1290 \\
1291 \\
1292 \\
1293 \\
1294\end{array}$ & $\begin{array}{l}13033.82 \\
13045.94 \\
13058.05 \\
13070.17 \\
13082.28\end{array}$ & $\begin{array}{l}12.115 \\
12.115 \\
12.116 \\
12.116 \\
12.117\end{array}$ & $\begin{array}{l}0.60 \\
0.59 \\
0.58 \\
0.57 \\
0.56\end{array}$ & $\begin{array}{l}1350 \\
1351 \\
1352 \\
1353 \\
1354\end{array}$ & $\begin{array}{l}13761.44 \\
13773.57 \\
13785.71 \\
13797.84 \\
13809.97\end{array}$ & $\begin{array}{l}12.134 \\
12.134 \\
12.134 \\
12.134 \\
12.134\end{array}$ & $\begin{array}{r}0.03 \\
0.02 \\
0.01 \\
0.00 \\
-0.01\end{array}$ & $\begin{array}{l}1410 \\
1411 \\
1412 \\
1413 \\
1414\end{array}$ & $\begin{array}{l}14489.16 \\
14501.28 \\
14513.40 \\
14525.52 \\
14537.63\end{array}$ & $\begin{array}{l}12.118 \\
12.118 \\
12.117 \\
12.117 \\
12.116\end{array}$ & $\begin{array}{l}-0.54 \\
-0.55 \\
-0.56 \\
-0.56 \\
-0.57\end{array}$ \\
\hline $\begin{array}{l}1295 \\
1296 \\
1297 \\
1298 \\
1299\end{array}$ & $\begin{array}{l}13094.40 \\
13106.52 \\
13118.64 \\
13130.76 \\
13142.88\end{array}$ & $\begin{array}{l}12.118 \\
12.118 \\
12.119 \\
12.119 \\
12.120\end{array}$ & $\begin{array}{l}0.55 \\
0.54 \\
0.53 \\
0.52 \\
0.51\end{array}$ & $\begin{array}{l}1355 \\
1356 \\
1357 \\
1358 \\
1359\end{array}$ & $\begin{array}{l}13822 \cdot 11 \\
13834.24 \\
13846.37 \\
13858.51 \\
13870.64\end{array}$ & $\begin{array}{l}12.134 \\
12.134 \\
12.133 \\
12.133 \\
12.133\end{array}$ & $\begin{array}{l}-0.02 \\
-0.03 \\
-0.04 \\
-0.05 \\
-0.06\end{array}$ & $\begin{array}{l}1415 \\
1416 \\
1417 \\
1418 \\
1419\end{array}$ & $\begin{array}{l}14549.75 \\
14561.86 \\
14573.98 \\
14586.09 \\
14598.20\end{array}$ & $\begin{array}{l}12.116 \\
12.115 \\
12.114 \\
12.114 \\
12.113\end{array}$ & $\begin{array}{l}-0.58 \\
-0.59 \\
-0.60 \\
-0.61 \\
-0.62\end{array}$ \\
\hline $\begin{array}{l}1300 \\
1301 \\
1302 \\
1303 \\
1304\end{array}$ & $\begin{array}{l}13155.00 \\
13167.12 \\
13179.24 \\
13191.36 \\
13203.48\end{array}$ & $\begin{array}{l}12.120 \\
12.121 \\
12.121 \\
12.122 \\
12.122\end{array}$ & $\begin{array}{l}0.50 \\
0.49 \\
0.48 \\
0.47 \\
0.46\end{array}$ & $\begin{array}{l}1360 \\
1361 \\
1362 \\
1363 \\
1364\end{array}$ & $\begin{array}{l}13882.77 \\
13894.91 \\
13907.04 \\
13919.17 \\
13931.31\end{array}$ & $\begin{array}{l}12.133 \\
12.133 \\
12.133 \\
12.133 \\
12.133\end{array}$ & $\begin{array}{l}-0.06 \\
-0.07 \\
-0.08 \\
-0.09 \\
-0.10\end{array}$ & $\begin{array}{l}1420 \\
1421 \\
1422 \\
1423 \\
1424\end{array}$ & $\begin{array}{l}14610.32 \\
14622.43 \\
14634.54 \\
14646.65 \\
14658.76\end{array}$ & $\begin{array}{l}12.112 \\
12.112 \\
12.111 \\
12.111 \\
12.110\end{array}$ & $\begin{array}{l}-0.63 \\
-0.64 \\
-0.65 \\
-0.66 \\
-0.67\end{array}$ \\
\hline $\begin{array}{l}1305 \\
1306 \\
1307 \\
1308 \\
1309\end{array}$ & $\begin{array}{l}13215.60 \\
13227.73 \\
13239.85 \\
13251.97 \\
13264.10\end{array}$ & $\begin{array}{l}12.123 \\
12 \cdot 123 \\
12 \cdot 124 \\
12 \cdot 124 \\
12.124\end{array}$ & $\begin{array}{l}0.45 \\
0.44 \\
0.44 \\
0.43 \\
0.42\end{array}$ & $\begin{array}{l}1365 \\
1366 \\
1367 \\
1368 \\
1369\end{array}$ & $\begin{array}{l}13943.44 \\
13955.57 \\
13967.70 \\
13979.84 \\
13991.97\end{array}$ & $\begin{array}{l}12.133 \\
12 \cdot 133 \\
12.133 \\
12.133 \\
12.132\end{array}$ & $\begin{array}{l}-0.11 \\
-0.12 \\
-0.13 \\
-0.14 \\
-0.15\end{array}$ & $\begin{array}{l}1425 \\
1426 \\
1427 \\
1428 \\
1429\end{array}$ & $\begin{array}{l}14670.87 \\
14682.98 \\
14695.09 \\
14707.20 \\
14719.30\end{array}$ & $\begin{array}{l}12.109 \\
12.109 \\
12.108 \\
12.107 \\
12.106\end{array}$ & $\begin{array}{l}-0.68 \\
-0.69 \\
-0.70 \\
-0.71 \\
-0.72\end{array}$ \\
\hline $\begin{array}{l}1310 \\
1311 \\
1312 \\
1313 \\
1314\end{array}$ & $\begin{array}{l}13276 \cdot 22 \\
13288.35 \\
13300.47 \\
13312.60 \\
13224.72\end{array}$ & $\begin{array}{l}12.125 \\
12.125 \\
12.126 \\
12.126 \\
12.126\end{array}$ & $\begin{array}{l}0.41 \\
0.40 \\
0.39 \\
0.38 \\
0.37\end{array}$ & $\begin{array}{l}1370 \\
1371 \\
1372 \\
1373 \\
1374\end{array}$ & $\begin{array}{l}14004 \cdot 10 \\
14016 \cdot 23 \\
14028 \cdot 37 \\
14040 \cdot 50 \\
14052.63\end{array}$ & $\begin{array}{l}12.132 \\
12.132 \\
12 \cdot 132 \\
12.132 \\
12.132\end{array}$ & $\begin{array}{l}-0.16 \\
-0.17 \\
-0.18 \\
-0.19 \\
-0.20\end{array}$ & $\begin{array}{l}1430 \\
1431 \\
1432 \\
1433 \\
1434\end{array}$ & $\begin{array}{l}14731.41 \\
14743.51 \\
14755.62 \\
14767.72 \\
14779.83\end{array}$ & $\begin{array}{l}12.106 \\
12.105 \\
12.104 \\
12.103 \\
12.103\end{array}$ & $\begin{array}{l}-0.72 \\
-0.73 \\
-0.74 \\
-0.75 \\
-0.76\end{array}$ \\
\hline $\begin{array}{l}1315 \\
1316 \\
1317 \\
1318 \\
1319\end{array}$ & $\begin{array}{l}13336.85 \\
13348 \cdot 98 \\
13361.10 \\
13373.23 \\
13385.36\end{array}$ & $\begin{array}{l}12.127 \\
12.127 \\
12.127 \\
12.128 \\
12.128\end{array}$ & $\begin{array}{l}0.36 \\
0.35 \\
0.34 \\
0.33 \\
0.32\end{array}$ & $\begin{array}{l}1375 \\
1376 \\
1377 \\
1378 \\
1379\end{array}$ & $\begin{array}{l}14064.76 \\
14076.89 \\
14089.02 \\
14101.15 \\
14113.28\end{array}$ & $\begin{array}{l}12.131 \\
12.131 \\
12.131 \\
12.131 \\
12.130\end{array}$ & $\begin{array}{l}-0.21 \\
-0.22 \\
-0.22 \\
-0.23 \\
-0.24\end{array}$ & $\begin{array}{l}1435 \\
1436 \\
1437 \\
1438 \\
1439\end{array}$ & $\begin{array}{l}14791.93 \\
14804.03 \\
14816.13 \\
14828.23 \\
14840.33\end{array}$ & $\begin{array}{l}12.102 \\
12.101 \\
12.100 \\
12.100 \\
12.099\end{array}$ & $\begin{array}{l}-0.77 \\
-0.78 \\
-0.79 \\
-0.80 \\
-0.81\end{array}$ \\
\hline 1320 & 13397.49 & 12.128 & 0.31 & 1380 & 14125.41 & 12.130 & -0.25 & 1440 & 14852.43 & 12.098 & -0.82 \\
\hline
\end{tabular}


TABLE 2.3.2. Type $S$ thermocouples-thermoelectric voltages, E(T), Seebeck coefficients, S(T), and first derivative of the Seebeck coefficients, $\mathrm{dS} / \mathrm{dT}$, reference junctions at $0{ }^{\circ} \mathrm{C}-$ Continued

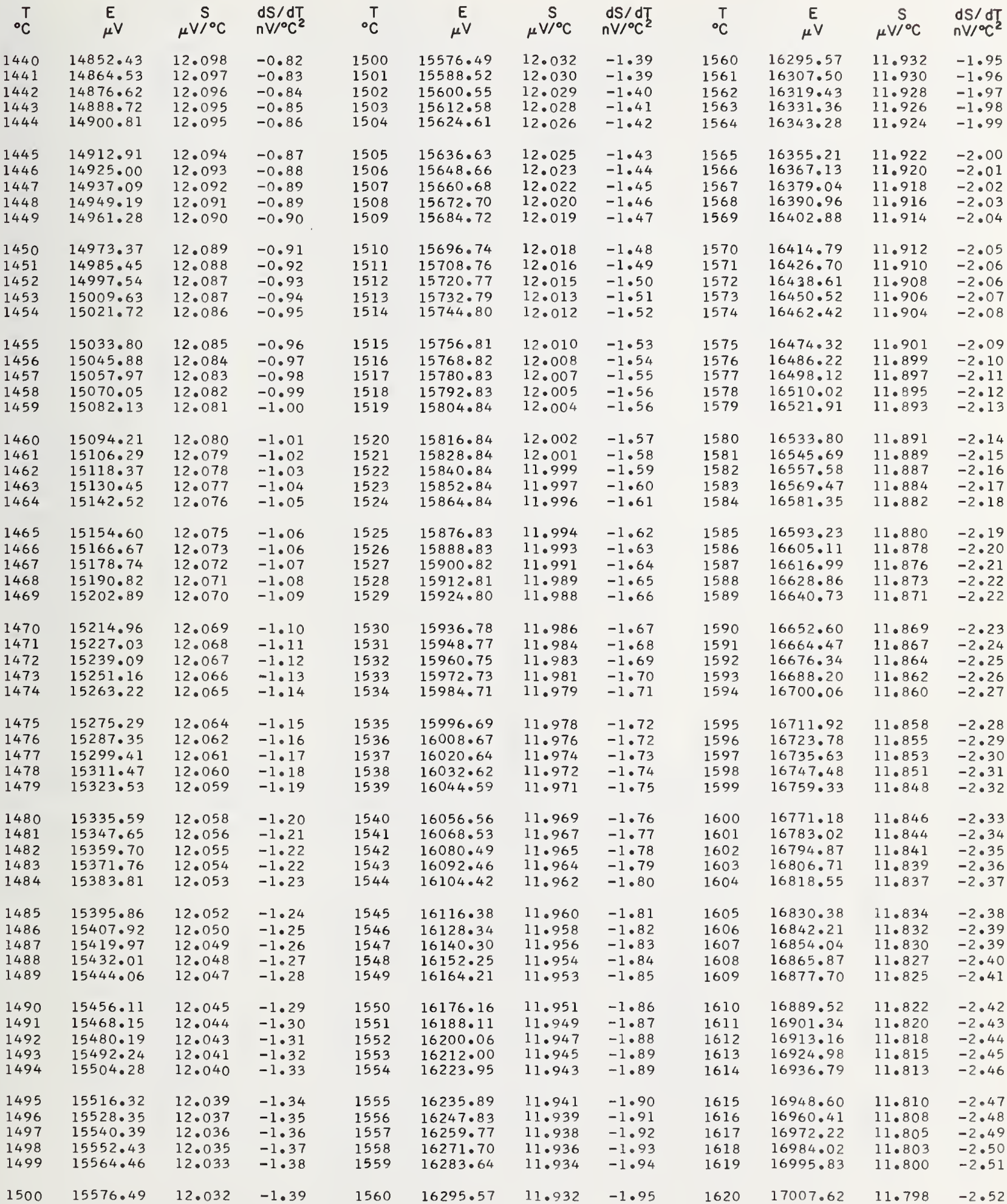


TABLE 2.3.2. Type S thermocouples-thermoelectric voltages, $\mathrm{E}(\mathrm{T})$, Seebeck coefficients, $\mathrm{S}(\mathrm{T})$, and first derivative of the Seebeck coefficients, $\mathrm{dS} / \mathrm{dT}$, reference junctions at $0{ }^{\circ} \mathrm{C}-$-Continued

\begin{tabular}{|c|c|c|c|c|c|c|c|c|c|c|c|}
\hline $\begin{array}{l}\mathrm{T} \\
{ }^{\circ} \mathrm{C}\end{array}$ & $\begin{array}{c}E \\
\mu V\end{array}$ & $\underset{\mu V /{ }^{\circ} \mathrm{C}}{S}$ & $\begin{array}{l}\mathrm{dS} / \mathrm{dT} \\
\mathrm{nV} /{ }^{\circ} \mathrm{C}^{2}\end{array}$ & ${ }^{\mathrm{T}} \mathrm{C}$ & $\begin{array}{l}E \\
\mu V\end{array}$ & $\stackrel{S}{\mu V /{ }^{\circ} \mathrm{C}}$ & $\begin{array}{l}\mathrm{dS} / \mathrm{dT} \\
\mathrm{nV} /{ }^{\circ} \mathrm{C}^{2}\end{array}$ & ${ }^{\circ} \mathrm{C}$ & $\underset{\mu V}{E}$ & $\stackrel{\mathrm{S}}{\mu \mathrm{V} /{ }^{\circ} \mathrm{C}}$ & $\begin{array}{l}d S / d T \\
n V /{ }^{\circ} C^{2}\end{array}$ \\
\hline $\begin{array}{l}1620 \\
1621 \\
1622 \\
1623 \\
1624\end{array}$ & $\begin{array}{l}17007.62 \\
17019.42 \\
17031.21 \\
17043.01 \\
17054.79\end{array}$ & $\begin{array}{l}11.798 \\
11.795 \\
11.793 \\
11.790 \\
11.788\end{array}$ & $\begin{array}{l}-2.52 \\
-2.53 \\
-2.54 \\
-2.55 \\
-2.56\end{array}$ & $\begin{array}{l}1680 \\
1681 \\
1682 \\
1683 \\
1684\end{array}$ & $\begin{array}{l}17710 \cdot 54 \\
17722 \cdot 16 \\
17733 \cdot 77 \\
17745 \cdot 37 \\
17756 \cdot 97\end{array}$ & $\begin{array}{l}11.616 \\
11.611 \\
11.605 \\
11.600 \\
11.595\end{array}$ & $\begin{array}{l}-4.97 \\
-5.10 \\
-5.24 \\
-5.37 \\
-5.51\end{array}$ & $\begin{array}{l}1740 \\
1741 \\
1742 \\
1743 \\
1744\end{array}$ & $\begin{array}{l}18393.68 \\
18404.75 \\
18415.80 \\
18426.85 \\
18437.87\end{array}$ & $\begin{array}{l}11.075 \\
11.062 \\
11.048 \\
11.035 \\
11.021\end{array}$ & $\begin{array}{l}-13.06 \\
-13.20 \\
-13.33 \\
-13.47 \\
-13.60\end{array}$ \\
\hline $\begin{array}{l}1625 \\
1626 \\
1627 \\
1628 \\
1629\end{array}$ & $\begin{array}{l}17066.58 \\
17078.36 \\
17090.15 \\
17101.92 \\
17113.70\end{array}$ & $\begin{array}{l}11.785 \\
11.782 \\
11.780 \\
11.777 \\
11.775\end{array}$ & $\begin{array}{l}-2.56 \\
-2.57 \\
-2.58 \\
-2.59 \\
-2.60\end{array}$ & $\begin{array}{l}1685 \\
1686 \\
1687 \\
1688 \\
1689\end{array}$ & $\begin{array}{l}17768 \cdot 56 \\
17780 \cdot 14 \\
17791.72 \\
17803 \cdot 30 \\
17814.87\end{array}$ & $\begin{array}{l}11.589 \\
11.583 \\
11.577 \\
11.572 \\
11.565\end{array}$ & $\begin{array}{l}-5.64 \\
-5.78 \\
-5.91 \\
-6.05 \\
-6.18\end{array}$ & $\begin{array}{l}1745 \\
1746 \\
1747 \\
1748 \\
1749\end{array}$ & $\begin{array}{l}18448.89 \\
18459.89 \\
18470.88 \\
18481.85 \\
18492.81\end{array}$ & $\begin{array}{l}11.008 \\
10.994 \\
10.980 \\
10.966 \\
10.952\end{array}$ & $\begin{array}{l}-13.74 \\
-13.87 \\
-14.01 \\
-14.14 \\
-14.28\end{array}$ \\
\hline $\begin{array}{l}1630 \\
1631 \\
1632 \\
1633 \\
1634\end{array}$ & $\begin{array}{l}17125.47 \\
17137.24 \\
17149.01 \\
17160.78 \\
17172.54\end{array}$ & $\begin{array}{l}11.772 \\
11.769 \\
11.767 \\
11.764 \\
11.762\end{array}$ & $\begin{array}{l}-2.61 \\
-2.62 \\
-2.63 \\
-2.64 \\
-2.65\end{array}$ & $\begin{array}{l}1690 \\
1691 \\
1692 \\
1693 \\
1694\end{array}$ & $\begin{array}{l}17826.43 \\
17837.99 \\
17849.54 \\
17861.08 \\
17872.61\end{array}$ & $\begin{array}{l}11.559 \\
11.553 \\
11.546 \\
11.540 \\
11.533\end{array}$ & $\begin{array}{l}-6.32 \\
-6.45 \\
-6.59 \\
-6.72 \\
-6.86\end{array}$ & $\begin{array}{l}1750 \\
1751 \\
1752 \\
1753 \\
1754\end{array}$ & $\begin{array}{l}18503.75 \\
18514.68 \\
18525.60 \\
18536.50 \\
18547.38\end{array}$ & $\begin{array}{l}10.937 \\
10.923 \\
10.908 \\
10.893 \\
10.879\end{array}$ & $\begin{array}{l}-14.41 \\
-14.55 \\
-14.68 \\
-14.82 \\
-14.95\end{array}$ \\
\hline $\begin{array}{l}1635 \\
1636 \\
1637 \\
1638 \\
1639\end{array}$ & $\begin{array}{l}17184.30 \\
17196.06 \\
17207.81 \\
17219.57 \\
17231.32\end{array}$ & $\begin{array}{l}11.759 \\
11.756 \\
11.754 \\
11.751 \\
11.748\end{array}$ & $\begin{array}{l}-2.66 \\
-2.67 \\
-2.68 \\
-2.69 \\
-2.70\end{array}$ & $\begin{array}{l}1695 \\
1696 \\
1697 \\
1698 \\
1699\end{array}$ & $\begin{array}{l}17884.14 \\
17895.67 \\
17907.18 \\
17918.69 \\
17930.19\end{array}$ & $\begin{array}{l}11.526 \\
11.519 \\
11.512 \\
11.504 \\
11.497\end{array}$ & $\begin{array}{l}-6.99 \\
-7.13 \\
-7.26 \\
-7.40 \\
-7.53\end{array}$ & $\begin{array}{l}1755 \\
1756 \\
1757 \\
1758 \\
1759\end{array}$ & $\begin{array}{l}18558.25 \\
18569.11 \\
18579.95 \\
18590.78 \\
18601.59\end{array}$ & $\begin{array}{l}10.864 \\
10.848 \\
10.833 \\
10.818 \\
10.802\end{array}$ & $\begin{array}{l}-15.09 \\
-15.22 \\
-15.36 \\
-15.49 \\
-15.63\end{array}$ \\
\hline $\begin{array}{l}1640 \\
1641 \\
1642 \\
1643 \\
1644\end{array}$ & $\begin{array}{l}17243.06 \\
17254.81 \\
17266.55 \\
17278.29 \\
17290.02\end{array}$ & $\begin{array}{l}11.745 \\
11.743 \\
11.740 \\
11.737 \\
11.735\end{array}$ & $\begin{array}{l}-2.71 \\
-2.72 \\
-2.72 \\
-2.73 \\
-2.74\end{array}$ & $\begin{array}{l}1700 \\
1701 \\
1702 \\
1703 \\
1704\end{array}$ & $\begin{array}{l}17941.68 \\
17953.17 \\
17964.65 \\
17976.12 \\
17987.58\end{array}$ & $\begin{array}{l}11.489 \\
11.482 \\
11.474 \\
11.466 \\
11.457\end{array}$ & $\begin{array}{l}-7.67 \\
-7.80 \\
-7.94 \\
-8.07 \\
-8.21\end{array}$ & $\begin{array}{l}1760 \\
1761 \\
1762 \\
1763 \\
1764\end{array}$ & $\begin{array}{l}18612.38 \\
18623.16 \\
18633.92 \\
18644.67 \\
18655.40\end{array}$ & $\begin{array}{l}10.786 \\
10.771 \\
10.755 \\
10.738 \\
10.722\end{array}$ & $\begin{array}{l}-15.76 \\
-15.90 \\
-16.03 \\
-16.17 \\
-16.30\end{array}$ \\
\hline $\begin{array}{l}1645 \\
1646 \\
1647 \\
1648 \\
1649\end{array}$ & $\begin{array}{l}17301.76 \\
17313.49 \\
17325.21 \\
17336.94 \\
17348.66\end{array}$ & $\begin{array}{l}11.732 \\
11.729 \\
11.726 \\
11.724 \\
11.721\end{array}$ & $\begin{array}{l}-2.75 \\
-2.76 \\
-2.77 \\
-2.78 \\
-2.79\end{array}$ & $\begin{array}{l}1705 \\
1706 \\
1707 \\
1708 \\
1709\end{array}$ & $\begin{array}{l}17999.03 \\
18010.48 \\
18021.91 \\
18033.34 \\
18044.76\end{array}$ & $\begin{array}{l}11.449 \\
11.441 \\
11.432 \\
11.424 \\
11.415\end{array}$ & $\begin{array}{l}-8.34 \\
-8.48 \\
-8.61 \\
-8.75 \\
-8.88\end{array}$ & $\begin{array}{l}1765 \\
1766 \\
1767 \\
1768\end{array}$ & $\begin{array}{l}18666.11 \\
18676.81 \\
18687.49 \\
18698.16\end{array}$ & $\begin{array}{l}10.706 \\
10.689 \\
10.673 \\
10.656\end{array}$ & $\begin{array}{l}-16.44 \\
-16.57 \\
-16.71 \\
-16.84\end{array}$ \\
\hline $\begin{array}{l}1650 \\
1651 \\
1652 \\
1653 \\
1654\end{array}$ & $\begin{array}{l}17360.38 \\
17372.10 \\
17383.81 \\
17395.52 \\
17407.23\end{array}$ & $\begin{array}{l}11.718 \\
11.715 \\
11.712 \\
11.709 \\
11.707\end{array}$ & $\begin{array}{l}-2.80 \\
-2.81 \\
-2.82 \\
-2.83 \\
-2.84\end{array}$ & $\begin{array}{l}1710 \\
1711 \\
1712 \\
1713 \\
1714\end{array}$ & $\begin{array}{l}18056 \cdot 17 \\
18067.57 \\
18078.96 \\
18090.35 \\
18101.72\end{array}$ & $\begin{array}{l}11.406 \\
11.397 \\
11.388 \\
11.378 \\
11.369\end{array}$ & $\begin{array}{l}-9.02 \\
-9.15 \\
-9.29 \\
-9.42 \\
-9.56\end{array}$ & & & & \\
\hline $\begin{array}{l}1655 \\
1656 \\
1657 \\
1658 \\
1659\end{array}$ & $\begin{array}{l}17418.93 \\
17430.64 \\
17442.34 \\
17454.03 \\
17465.73\end{array}$ & $\begin{array}{l}11.704 \\
11.701 \\
11.698 \\
11.695 \\
11.692\end{array}$ & $\begin{array}{l}-2.85 \\
-2.86 \\
-2.87 \\
-2.88 \\
-2.89\end{array}$ & $\begin{array}{l}1715 \\
1716 \\
1717 \\
1718 \\
1719\end{array}$ & $\begin{array}{l}18113.08 \\
18124.44 \\
18135.78 \\
18147.12 \\
18158.44\end{array}$ & $\begin{array}{l}11.359 \\
11.349 \\
11.339 \\
11.329 \\
11.319\end{array}$ & $\begin{array}{r}-9.69 \\
-9.82 \\
-9.96 \\
-10.09 \\
-10.23\end{array}$ & & & & \\
\hline $\begin{array}{l}1660 \\
1661 \\
1662 \\
1663 \\
1664\end{array}$ & $\begin{array}{l}17477.42 \\
17489.11 \\
17500.79 \\
17512.47 \\
17524.15\end{array}$ & $\begin{array}{l}11.689 \\
11.687 \\
11.684 \\
11.681 \\
11.678\end{array}$ & $\begin{array}{l}-2.89 \\
-2.90 \\
-2.91 \\
-2.92 \\
-2.93\end{array}$ & $\begin{array}{l}1720 \\
1721 \\
1722 \\
1723 \\
1724\end{array}$ & $\begin{array}{l}18169.75 \\
18181.06 \\
18192.35 \\
18203.63 \\
18214.91\end{array}$ & $\begin{array}{l}11.309 \\
11.299 \\
11.288 \\
11.277 \\
11.266\end{array}$ & $\begin{array}{l}-10.36 \\
-10.50 \\
-10.63 \\
-10.77 \\
-10.90\end{array}$ & & & & \\
\hline $\begin{array}{l}1665 \\
1666 \\
1667\end{array}$ & $\begin{array}{l}17535.83 \\
17547.50 \\
17559.17\end{array}$ & $\begin{array}{l}11.675 \\
11.672 \\
11.669\end{array}$ & $\begin{array}{l}-2.94 \\
-3.08 \\
-3.21\end{array}$ & $\begin{array}{l}1725 \\
1726 \\
1727\end{array}$ & $\begin{array}{l}18226.17 \\
18237.42 \\
18248.66\end{array}$ & $\begin{array}{l}11 \cdot 255 \\
11 \cdot 244 \\
11 \cdot 233\end{array}$ & $\begin{array}{l}-11.04 \\
-11.17 \\
-11.31\end{array}$ & & & & \\
\hline $\begin{array}{l}1668 \\
1669\end{array}$ & $\begin{array}{l}17570.84 \\
17582.50\end{array}$ & $\begin{array}{l}11.665 \\
11.662\end{array}$ & $\begin{array}{l}-3.35 \\
-3.48\end{array}$ & $\begin{array}{l}1728 \\
1729\end{array}$ & $\begin{array}{l}18259 \cdot 88 \\
18271 \cdot 10\end{array}$ & $\begin{array}{l}11.222 \\
11.210\end{array}$ & $\begin{array}{l}-11 \cdot 44 \\
-11 \cdot 58\end{array}$ & & & & \\
\hline $\begin{array}{l}1670 \\
1671 \\
1672 \\
1673 \\
1674\end{array}$ & $\begin{array}{l}17594.16 \\
17605.82 \\
17617.47 \\
17629.12 \\
17640.77\end{array}$ & $\begin{array}{l}11.658 \\
11.655 \\
11.651 \\
11.647 \\
11.643\end{array}$ & $\begin{array}{l}-3.62 \\
-3.75 \\
-3.89 \\
-4.02 \\
-4.16\end{array}$ & $\begin{array}{l}1730 \\
1731 \\
1732 \\
1733 \\
1734\end{array}$ & $\begin{array}{l}18282.30 \\
18293.50 \\
18304.68 \\
18315.85 \\
18327.00\end{array}$ & $\begin{array}{l}11 \cdot 199 \\
11.187 \\
11.175 \\
11.163 \\
11.151\end{array}$ & $\begin{array}{l}-11.71 \\
-11.85 \\
-11.98 \\
-12.12 \\
-12.25\end{array}$ & & & & \\
\hline $\begin{array}{l}1675 \\
1676 \\
1677 \\
1678 \\
1679\end{array}$ & $\begin{array}{l}17652.41 \\
17664.04 \\
17675.68 \\
17687.30 \\
17698.93\end{array}$ & $\begin{array}{l}11.639 \\
11.634 \\
11.630 \\
11.625 \\
11.620\end{array}$ & $\begin{array}{l}-4.29 \\
-4.43 \\
-4.56 \\
-4.70 \\
-4.83\end{array}$ & $\begin{array}{l}1735 \\
1736 \\
1737 \\
1738 \\
1739\end{array}$ & $\begin{array}{l}18338.15 \\
18349.28 \\
18360.40 \\
18371.51 \\
18382.60\end{array}$ & $\begin{array}{l}11.138 \\
11.126 \\
11.113 \\
11.101 \\
11.088\end{array}$ & $\begin{array}{l}-12.39 \\
-12.52 \\
-12.66 \\
-12.79 \\
-12.93\end{array}$ & & & & \\
\hline 80 & 17710.54 & 11.616 & -4.97 & 1740 & 18393.68 & 11.075 & 13.06 & & & & \\
\hline
\end{tabular}


TABLE 2.3.3. Thermoelectric values at the fixed points for Type $S$ thermocouples

\begin{tabular}{|c|c|c|c|c|}
\hline Fixed point & $\begin{array}{l}\text { Temp. } \\
{ }^{\circ} \mathrm{C}\end{array}$ & $\underset{\mu \mathrm{V}}{E}$ & $\stackrel{S}{S} /^{\circ} \mathrm{C}$ & $\begin{array}{c}d S / d T \\
\mathrm{nV} /{ }^{\circ} \mathrm{C}^{2}\end{array}$ \\
\hline $\begin{array}{l}\text { Mercury FP } \\
\text { Ice Point } \\
\text { Ether TP } \\
\text { Water BP } \\
\text { Benzoic TP } \\
\text { Indium FP } \\
\text { Tin FP } \\
\text { Bismuth FP } \\
\text { Cadmium FP } \\
\text { Lead FP } \\
\text { Mercury BP } \\
\text { Zinc FP } \\
\text { Sulphur BP } \\
\text { Cu.Al FP } \\
\text { Antimony FP* } \\
\text { Aluminum FP } \\
\text { Silver FP } \\
\text { Gold FP* } \\
\text { Copper FP } \\
\text { Nickel FP } \\
\text { Cobalt FP } \\
\text { Palladium FP } \\
\text { Platinum FP }\end{array}$ & $\begin{array}{c}-38.862 \\
0.000 \\
26.87 \\
100.000 \\
122.37 \\
156.634 \\
231.9681 \\
271.442 \\
321.108 \\
327.502 \\
356.66 \\
419.580 \\
444.674 \\
548.23 \\
630.74 \\
660.37 \\
961.93 \\
1064.43 \\
1084.5 \\
1455 \\
1494 \\
1554 . \\
1767.6\end{array}$ & $\begin{array}{r}-189.54 \\
0.00 \\
153.70 \\
645.34 \\
812.88 \\
1081.79 \\
1714.64 \\
2063.97 \\
2516.72 \\
2575.94 \\
2848.34 \\
3447.87 \\
3690.88 \\
4714.00 \\
5552.10 \\
5859.12 \\
9148.20 \\
10334.30 \\
10570.46 \\
15033.80 \\
15504.28 \\
16223.95 \\
18693.89\end{array}$ & $\begin{array}{r}4.318 \\
5.400 \\
6.026 \\
7.333 \\
7.640 \\
8.044 \\
8.714 \\
8.977 \\
9.246 \\
9.276 \\
9.406 \\
9.643 \\
9.725 \\
10.030 \\
10.295 \\
10.411 \\
11.403 \\
11.740 \\
11.793 \\
12.085 \\
12.040 \\
11.943 \\
10.663\end{array}$ & $\begin{array}{r}30.79 \\
25.04 \\
21.66 \\
14.56 \\
12.91 \\
10.75 \\
7.30 \\
6.04 \\
4.85 \\
4.72 \\
4.20 \\
3.39 \\
3.17 \\
2.91 \\
3.68 \\
3.29 \\
3.29 \\
3.29 \\
2.53 \\
-0.96 \\
-1.33 \\
-1.89 \\
-16.79\end{array}$ \\
\hline
\end{tabular}

*Junction point of different functions.

TABLE 2.3.4. Estimated maximum errors that occur when using reduced-bit arithmetic for the power series expansion for the thermoelectric voltage of Type $S$ thermocouples

\begin{tabular}{|c|c|c|c|c|c|c|}
\hline \multirow[b]{2}{*}{ Temperature range } & \multirow[b]{2}{*}{ Degree } & \multicolumn{5}{|c|}{ Estimated maximum error in microvolts } \\
\hline & & $12 \mathrm{Bit}$ & $16 \mathrm{Bit}$ & $24 \mathrm{Bit}$ & $27 \mathrm{Bit}$ & $36 \mathrm{Bit}$ \\
\hline $\begin{array}{l}-50 \text { to } 200^{\circ} \mathrm{C} \\
200 \text { to } 400^{\circ} \mathrm{C} \\
400 \text { to } 631{ }^{\circ} \mathrm{C} \\
632 \text { to } 800^{\circ} \mathrm{C} \\
800 \text { to } 1064{ }^{\circ} \mathrm{C} \\
1065 \text { to } 1200^{\circ} \mathrm{C} \\
1200 \text { to } 1400^{\circ} \mathrm{C} \\
1400 \text { to } 1665{ }^{\circ} \mathrm{C} \\
1666 \text { to } 1768{ }^{\circ} \mathrm{C}\end{array}$ & $\begin{array}{l}6 \\
6 \\
6 \\
2 \\
2 \\
3 \\
3 \\
3 \\
3\end{array}$ & $\begin{array}{l}0.2 \\
0.3 \\
2 \\
4 \\
5 \\
6 \\
7 \\
9 \\
50\end{array}$ & $\begin{array}{l}0.03 \\
0.04 \\
0.07 \\
0.2 \\
0.3 \\
0.4 \\
0.5 \\
0.6 \\
4\end{array}$ & $\begin{array}{r}<0.01 \\
<0.01 \\
<0.01 \\
<0.01 \\
<0.01 \\
<0.01 \\
<0.01 \\
<0.01 \\
0.02\end{array}$ & $\begin{array}{l}<0.01 \\
<0.01 \\
<0.01 \\
<0.01 \\
<0.01 \\
<0.01 \\
<0.01 \\
<0.01 \\
<0.01\end{array}$ & $\begin{array}{l}<0.01 \\
<0.01 \\
<0.01 \\
<0.01 \\
<0.01 \\
<0.01 \\
<0.01 \\
<0.01 \\
<0.01\end{array}$ \\
\hline
\end{tabular}




\section{TYPE R-Platinum-13\% Rhodium Alloy Versus Platinum Thermocouples}

\subsection{Material Specifications and Precautions}

This type is also often referred to by the nominal chemical composition of its positive thermoelement: platinum-13\% rhodium. Until this year the composition was somewhat different from the nominal 13 percent rhodium, usually about 12.85 wt \%. However, as a result of the recent research by Bedford et al. [1972], the composition of the positive thermoelement has been established to be platinum-13.00 \pm 0.05 wt $\%$ rhodium. The negative thermoelement is commercially pure platinum. Differences between this commercial material and the platinum thermoelectric reference standard, $\mathrm{Pt}-67$, are described in the next section. Differences between Pt-67 and the former standard $\mathrm{Pt}-27$ are summarized in section 1.2. The effect of differences in rhodium content on the positive thermoelement is described later in this section.

During the early years of this century the platinum $-13 \%$ rhodium versus platinum thermocouple was developed and tested in this country to give agreement with the British platinum-10\% rhodium versus platinum thermocouples which had been found to have significant iron contamination. Fairchild and Schmitt [1922] discovered during prolonged high-temperature tests that American and British platinum-10\% rhodium versus platinum thermocouples differed significantly from each other in thermoelectric output and stability. The main chemical difference was traced to an 0.34 percent iron impurity in the British positive thermoelement which was presumably caused by the use of impure rhodium. Many instruments and systems had been calibrated on the basis of the thermoelectric voltages of the older, impure platinum-10\% rhodium material. Therefore, when pure rhodium was used for alloying in order to improve the stability characteristics, the composition had to be changed to give thermoelectric values near the previous ones. When the more pure rhodium was used, it was found that about 13 percent rhodium had to be alloyed into the platinum to approximately match the previous platinum-10\% rhodium British wire. That is the highly pragmatic reason for the development of the Type $\mathrm{R}$ thermocouple.

Type $\mathrm{R}$ thermocouples have a higher Seebeck coefficient than do Type $S$ thermocouples, about 12 percent larger over much of the range. Type $R$ thermocouples are not standard interpolating instruments on the IPTS-68 for the $630.74{ }^{\circ} \mathrm{C}$ to gold freezing point range. Other than the above two items, and remarks on the history of development and the composition, all of the comments from the previous chapter on Type $\mathrm{S}$ also apply to Type R.

However, for emphasis the precautions and restrictions on usage are repeated: They should not be used in reducing atmospheres, nor in those containing metallic vapor (such as lead or zinc), nonmetallic vapors (such as arsenic, phosphorus, or sulfur) or easily reduced oxides, unless suitably protected with nonmetallic protecting tubes. They should never be inserted directly into a metallic primary tube. Glawe [1970] has described the effects on thermoelectric voltages that occur from prolonged exposure at elevated temperatures in vacuum, air, and argon atmospheres.

ASTM Standard E230-72 in the Annual Book of ASTM Standards [1972] specifies that the standard limits of error for Type $\mathrm{R}$ commercial thermocouples be $\pm 1.4{ }^{\circ} \mathrm{C}$ between 0 and $538{ }^{\circ} \mathrm{C}$ and $\pm 1 / 4$ per. cent between 538 and $1482{ }^{\circ} \mathrm{C}$. Limits of error are not specified for Type $\mathrm{R}$ thermocouples below $0{ }^{\circ} \mathrm{C}$. The recommended upper temperature limit for continuous service of protected Type $R$ thermocouples is $1482{ }^{\circ} \mathrm{C}$ and applies to AWG $24(0.5 \mathrm{~mm})$ wire.

\subsection{Data Analyses and Comparisons}

The fitting functions for Type $\mathrm{R}$ thermocouples are taken directly from the original research recently published by Bedford et al. [1972]. Their values for thermoelectric voltages were based on the IPTS-68 and therefore no temperature scale corrections were necessary. We made only one modification to their functional expressions: the basic voltage function above $1064{ }^{\circ} \mathrm{C}$ is also expressed as a simple power series in this Monograph. For completeness their reduced temperature expression is also included in table 3.3.1.

Bedford et al. [1972] carried out research on twelve meters of wire for each thermoelement from each of four American and three British manufacturers. The National Bureau of Standards and the National Research Council calibrated the thermocouples from $-50{ }^{\circ} \mathrm{C}$ to the gold freezing point $\left(1064.43^{\circ} \mathrm{C}\right)$; the National Physical Laboratory performed the measurements at higher temperatures. The authors gave a very thorough description of their measurement and analysis techniques.

Bedford et al. [1972] based their fitting functions and tables on average values for selected lots of wire from two manufacturers, labeled A and D. As a first step, they fit the values in the Type $\mathrm{S}$ defined tempera. ture range $630.74{ }^{\circ} \mathrm{C}$ to $1064.43{ }^{\circ} \mathrm{C}$ by a cubic function. The fit had a standard deviation of $0.26 \mu \mathrm{V}$ for seven experimental points. Next, all of the data below $630.74{ }^{\circ} \mathrm{C}$ was fit with a seventh degree function that was constrained in value at $0{ }^{\circ} \mathrm{C}$ and $630.74{ }^{\circ} \mathrm{C}$. The fit had a standard deviation of $0.26 \mu \mathrm{V}$ for 70 experimental points. The temperature range above 1064.43 ${ }^{\circ} \mathrm{C}$ was split in two: one range was from $1064.43{ }^{\circ} \mathrm{C}$ to $1665{ }^{\circ} \mathrm{C}$; the other, from $1665{ }^{\circ} \mathrm{C}$ to $1767.6{ }^{\circ} \mathrm{C}$ (their measured value for the melting point of platinum; see also Quinn and Chandler [1971]). They used a reduced temperature variable for the fitting above $1064.43{ }^{\circ} \mathrm{C}$. A cubic function constrained at $1064.43{ }^{\circ} \mathrm{C}$ was used for the first upper range; another cubic function constrained at $1665^{\circ} \mathrm{C}$ was used for the 


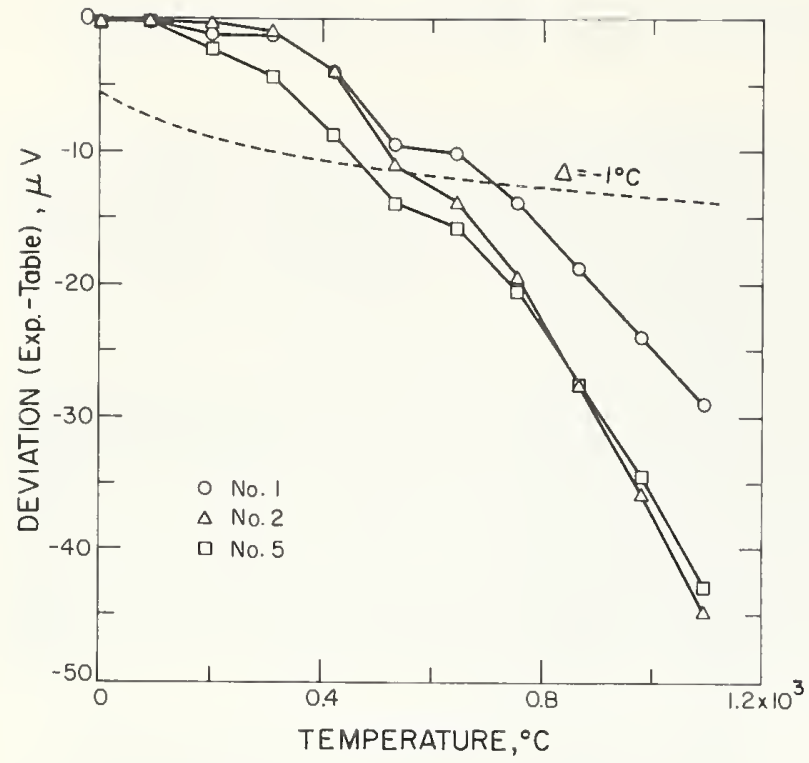

Figure 3.2.1. Deviations of thermoelectric voltages of Type $R$ thermocouples-comparison of values given in this Monograph to those for typical thermocouples which conform to the previous Type $R$ standard (NBS Circular 561).

Experimental values for thermocouples Nos. 1,2, and 5 are from selected calibrations by the Temperature Section (NBS, Gaithersburg). Values from the previous calibrations are adjusted to the IPTS-68. The dashed line indicates a deviation of $1^{\circ} \mathrm{C}$.

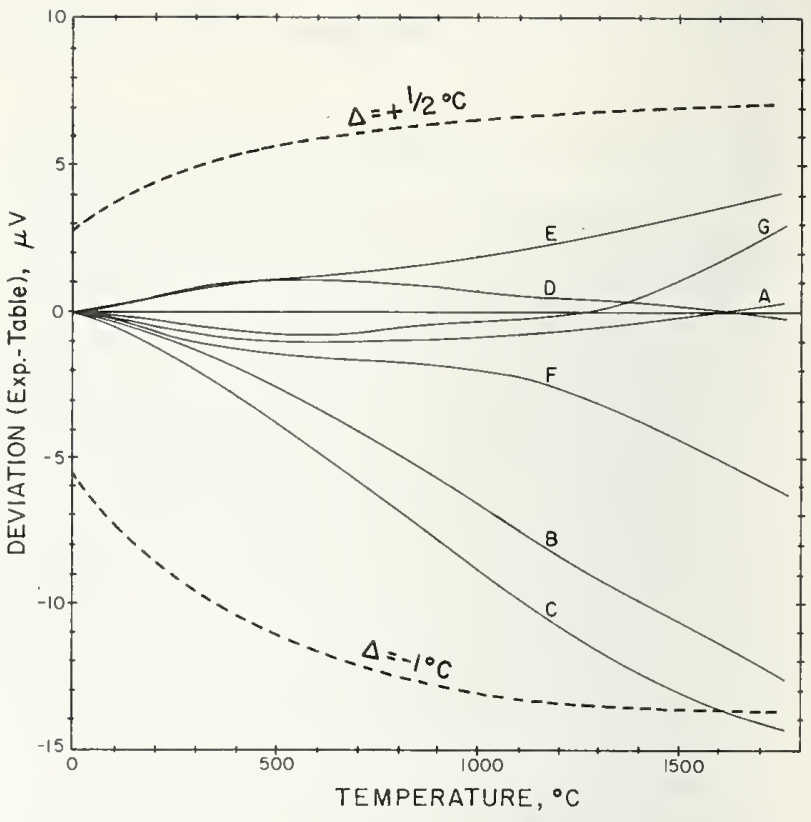

Figure 3.2.2. Deviation of thermoelectric voltages of Type $R$ thermocouples-comparison of values given in this Monograph to experimental data by Bedford, et al. [1972].

All values are expressed on the IPTS-68. The upper and lower dashed lines indicate deviations of $+1 / 2$ and $-1 \cdot \mathrm{C}$ respectively.

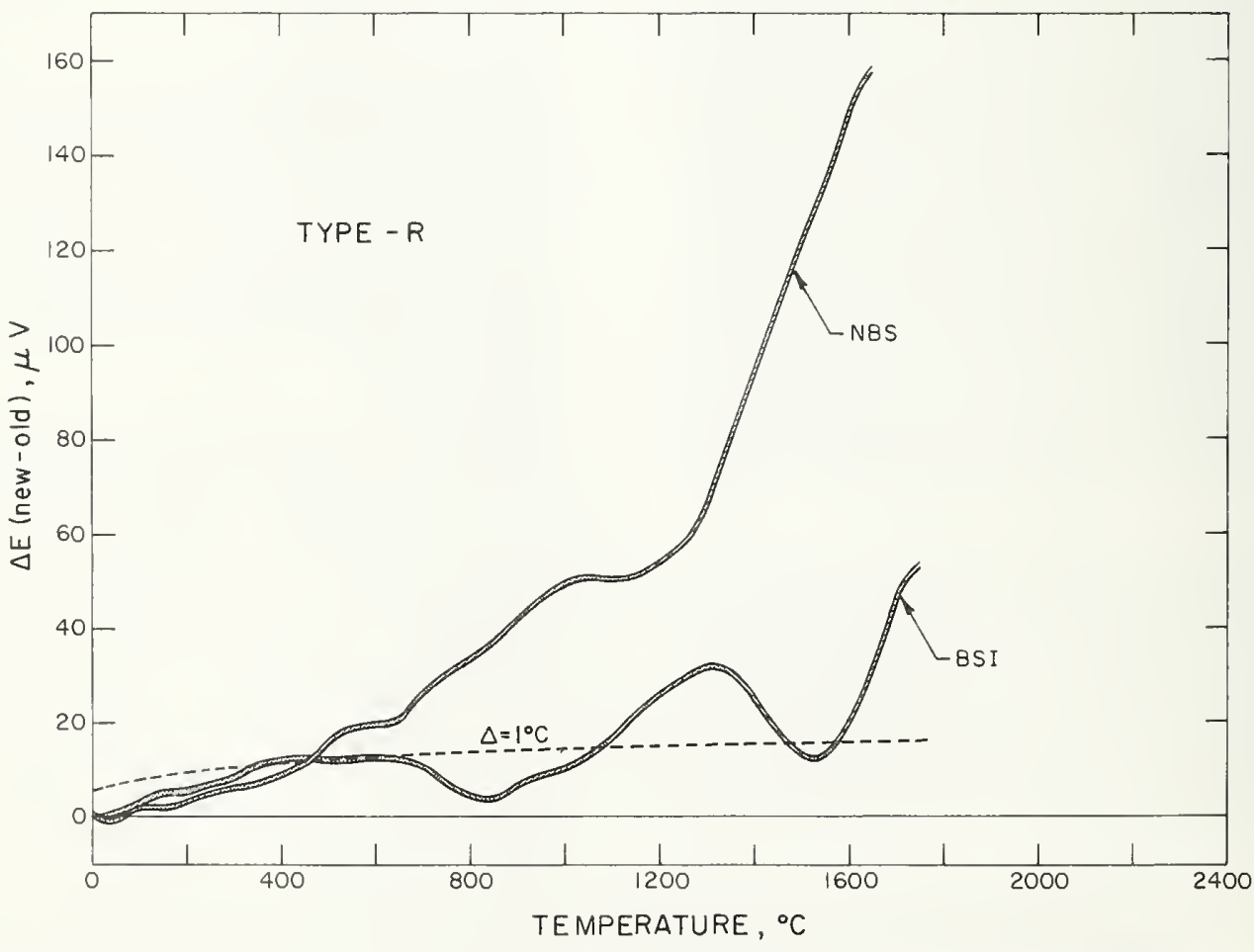

Figure 3.2.3. Difference in thermoelectric voltages for Type $R$ thermocouples-comparison of values given in this Monograph to those given in: NBS Circular 561; BSI (B.S. 1826:1952).

The width of the shaded curves indicates the round-off uncertainty in the previous tabular values. Values from previous standards are adjusted to the IPTS -68 . Tbe dashed line indicates a deviation of $1^{\circ} \mathrm{C}$. 
second range. The first had a standard deviation of $1.0 \mu \mathrm{V}$ for eight points; the second, $1.5 \mu \mathrm{V}$ for eight points. The maximum difference that they found between any two sets of wires was about $20 \mu \mathrm{V}$ at $1767{ }^{\circ} \mathrm{C}$.

The values for thermoelectric voltages given in this Monograph were compared to those given in 6 calibrations (dated between 1966 and 1970) from the Temperature Section of the National Bureau of Standards in Gaithersburg. All of the thermocouples had the older, nominally 13 percent rhodium material for their positive thermoelement; none were from the newer, precisely 13 percent rhodium material that was used for the international comparison. Deviations are shown in figure 3.2.1 for three thermocouples representative of the older material. All values were adjusted to the IPTS-68. The systematic trend between the old material and the new tables is obvious. Deviations for thermocouples from seven different manufacturers measured by Bedford et al. [1972] (all of the newer, accurately $13 \%$ rhodium material) are shown in figure 3.2.2. An average of materials $A$ and D was used by Bedford et al. [1972] for generation of their recommended functions. The negative thermoelements of materials $\mathrm{A}$ and $\mathrm{D}$ were about $6 \mu \mathrm{V}$ positive and $1 \mu \mathrm{V}$ negative, respectively, relative to $\mathrm{Pt}-67$ at $1064.43{ }^{\circ} \mathrm{C}$. Note that this is slightly different from the negative thermoelements that they used for Type $S$ thermocouples.

Deviations between values given in this Monograph and those given by Shenker et al. [1955] in NBS Circular 561 and by the British Standards Institute [1952] are shown in figure 3.2.3. The earlier values were on the IPTS -48 but have been adjusted to be on the IPTS-68 for this comparison. The deviation curves indicate differences caused by variations in material

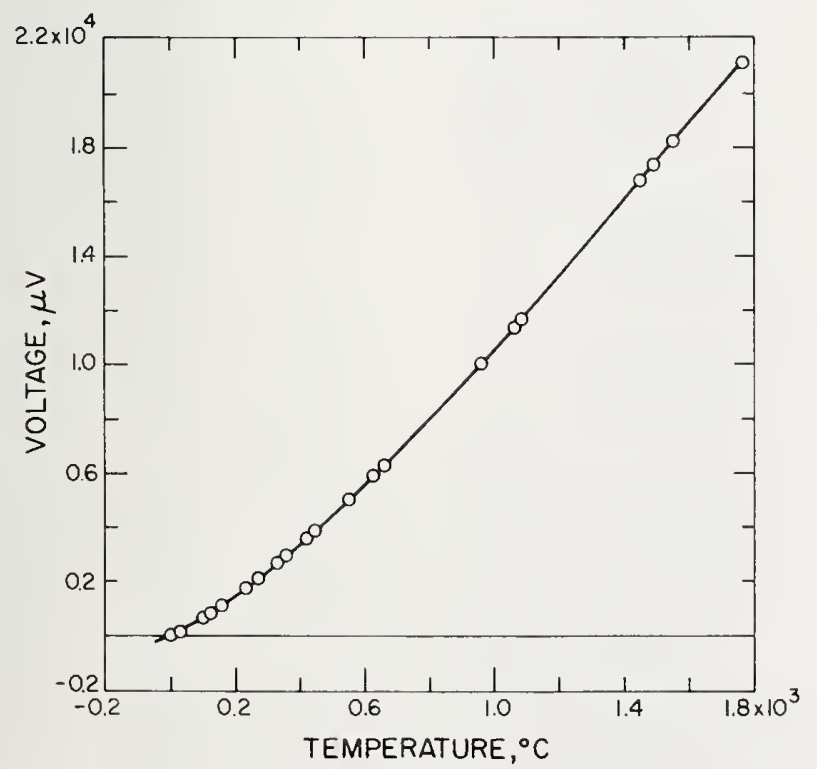

Figure 3.3.1. Thermoelectric voltage for Type $R$ thermocouples.

The circles indicate values at various thermometric fixed points on the 1PTS-68. composition, experimental error and fitting techniques, in decreasing order of importance. The width of the curves represent the round-off uncertainty $(1 \mu \mathrm{V})$ in the tabular values quoted in the two previous standard tables.

The reference tables for Type $\mathrm{R}$ thermocouples given in this Monograph were derived by Bedford et al. [1972] in such a way that the thermoelectric voltage, $E$, is a continuous function of temperature $\left(t_{68}\right)$ over the whole range. However, there are discontinuities in some derivatives at some of the joins in temperature ranges. These discontinuities can be clearly seen in figure 3.3.3. Bedford et al. [1972] have explained why the discontinuities are necessary. Their comments are summarized in the previous chapter.

\subsection{Reference Functions and Tables for Type $\mathbf{R}$ Thermocouples}

The coefficients for the four sets of equations for the thermoelectric voltage of Type $R$ thermocouples are given in table 3.3.1. The reduced temperature expressions generated by Bedford et al. [1972] are included. The errors caused by using reduced bit arithmetic for calculating values of the functions are given in table 3.3.4.

The primary reference values for Type $R$ thermocouples are given in table 3.3.2. Values at selected fixed points are given in table 3.3.3. Graphs of the thermoelectric voltage, its first derivative (Seebeck coefficient), and second derivative are given in figures 3.3.1, 3.3.2, and 3.3.3, respectively. As with Type S thermocouples, there are discontinuities in the second derivatives where equations for different temperature regions are joined.

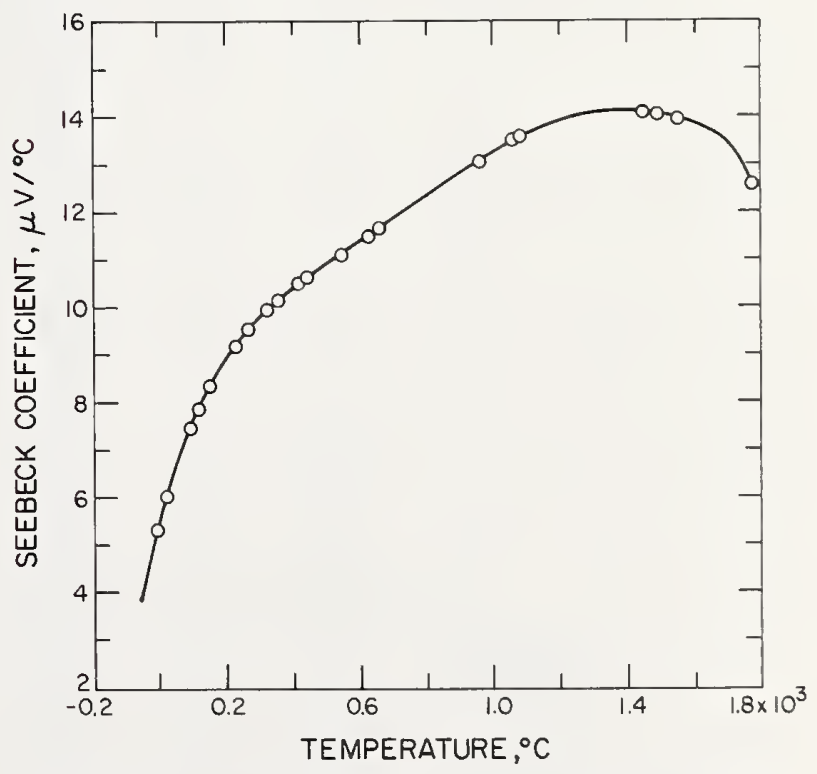

Figune 3.3.2. Seebeck coefficient for Type $R$ thermocouples. The circles indicate values at various thermometric fixed points on the IPTS -68 . 


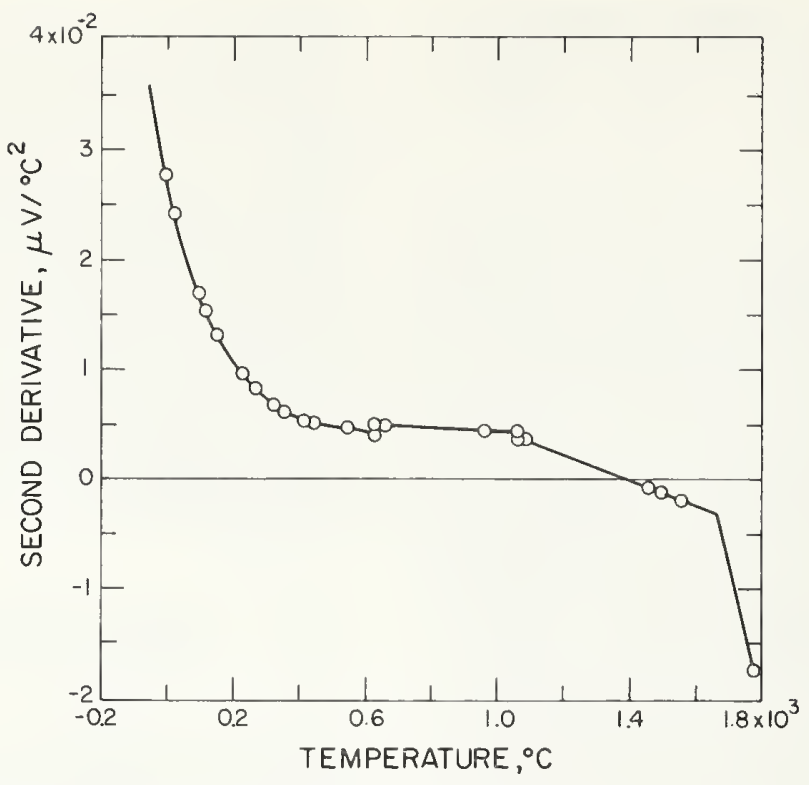

Figure 3.3.3. Second derivative of thermoelectric voltage for Type $R$ thermocouples.

The circles indicate values at various thermometric fixed points on the IPTS 68 .

TABLE 3.3.1. Power series expansion for the thermoelectric voltage of Type $R$ thermocouples

\begin{tabular}{|c|c|c|c|}
\hline Temperature range & Degree & Coefficients & Term \\
\hline-50 to $630.74{ }^{\circ} \mathrm{C}$ & 7 & $\begin{array}{r}5.2891395059 \times 10 \\
1.3911109947 \times 10^{-2} \\
-2.4005238430 \times 10^{-5} \\
3.6201410595 \times 10^{-8} \\
-4.4645019036 \times 10^{-11} \\
3.8497691865 \times 10^{-14} \\
-1.5372641559 \times 10^{-17}\end{array}$ & $\begin{array}{l}T \\
T^{2} \\
T^{3} \\
T^{4} \\
T^{5} \\
T^{6} \\
T^{7}\end{array}$ \\
\hline 630.74 to $1064.43^{\circ} \mathrm{C}$ & 3 & $\begin{array}{r}-2.6418007025 \times 10^{2} \\
8.0468680747 \times 10 \\
2.9892293723 \times 10^{-3} \\
-2.6876058617 \times 10^{-7}\end{array}$ & $\begin{array}{l}T^{1} \\
T^{2} \\
T^{3}\end{array}$ \\
\hline 1064.43 to $1665^{\circ} \mathrm{C}$ & 3 & $\begin{array}{r}1.4901702702 \times 10^{3} \\
2.8639867552 \times 10^{-3} \\
8.0823631189 \times 10^{-6} \\
-1.9338477638 \times 10^{-6}\end{array}$ & $\begin{array}{l}\ddot{T}^{\circ} \\
T^{2} \\
T^{3}\end{array}$ \\
\hline 1665 to $1767.6^{\circ} \mathrm{C}$ & 3 & $\begin{array}{r}9.5445559910 \times 10^{4} \\
-1.6642500359 \times 10^{2} \\
1.0975743239 \times 10^{-1} \\
-2.2289216980 \times 10^{-5}\end{array}$ & $\begin{array}{l}T^{\mathrm{i}} \\
T^{2} \\
T^{3}\end{array}$ \\
\hline $\begin{array}{r}1064.43 \text { to } 1665^{\circ} \mathrm{C} \\
T^{*}=\frac{T-1365}{300}\end{array}$ & 3 & $\begin{array}{r}1.5540414086 \times 10^{4} \\
4.2357772712 \times 10^{3} \\
1.4693087343 \times 10^{1} \\
-5.2213889624 \times 10^{1}\end{array}$ & $\begin{array}{l}T^{* 1} \\
T^{* 2} \\
T^{* 3}\end{array}$ \\
\hline $\begin{array}{r}1665 \text { to } 1767.6^{\circ} \mathrm{C} \\
T^{*}=\frac{T-1715}{50}\end{array}$ & 3 & $\begin{array}{r}2.0416695016 \times 10^{4} \\
6.6850914082 \times 10^{2} \\
-1.2301472524 \times 10^{1} \\
-2.7861521235 \quad \ldots\end{array}$ & $\begin{array}{l}T^{* 1} \\
T^{* 2} \\
T^{* 3}\end{array}$ \\
\hline
\end{tabular}


TABLE 3.3.2. Type $\boldsymbol{R}$ thermocouples-thermoelectric voltages, E(T), Seebeck cofficients, S(T), and first derivative of the Seebeck coefficients, $\mathrm{dS} / \mathrm{dT}$, reference junctions at $0^{\circ} \mathrm{C}$

\begin{tabular}{|c|c|c|c|c|c|c|c|c|c|c|c|}
\hline${ }^{\circ} \mathrm{C}$ & ${ }_{\mu V}^{E}$ & $\mu \stackrel{S}{\mu} /{ }^{\circ} \mathrm{C}$ & $\begin{array}{l}\mathrm{dS} / \mathrm{dT} \\
\mathrm{nV} /{ }^{\circ} \mathrm{C}^{2}\end{array}$ & ${ }^{\circ} \mathrm{C}$ & $\begin{array}{c}\mathrm{E} \\
\mu \mathrm{V}\end{array}$ & $\frac{\mathrm{S}}{\mu \mathrm{V} /{ }^{\circ} \mathrm{C}}$ & $\begin{array}{l}\mathrm{dS} / \mathrm{dT} \\
\mathrm{nV} /{ }^{\circ} \mathrm{C}^{2}\end{array}$ & ${ }^{\circ} \mathrm{C}$ & ${ }_{\mu V}^{E}$ & $\frac{\mathrm{S}}{\mu \mathrm{V} /{ }^{\circ} \mathrm{C}}$ & $\begin{array}{l}\mathrm{dS} / \mathrm{dT} \\
\mathrm{nV} /{ }^{\circ} \mathrm{C}^{2}\end{array}$ \\
\hline & & & & $\begin{array}{l}-40 \\
-39 \\
-38 \\
-37 \\
-36\end{array}$ & $\begin{array}{l}-187.67 \\
-183.61 \\
-179.50 \\
-175.37 \\
-171.20\end{array}$ & $\begin{array}{l}4.051 \\
4 \cdot 085 \\
4.119 \\
4.153 \\
4.187\end{array}$ & $\begin{array}{l}34.34 \\
34 \cdot 16 \\
33.97 \\
33.79 \\
33.61\end{array}$ & $\begin{array}{l}-20 \\
-19 \\
-18 \\
-17 \\
-16\end{array}$ & $\begin{array}{r}-100.02 \\
-95.30 \\
-90.55 \\
-85.77 \\
-80.96\end{array}$ & $\begin{array}{l}4.703 \\
4.733 \\
4.764 \\
4.795 \\
4.825\end{array}$ & $\begin{array}{l}30.88 \\
30.72 \\
30.56 \\
30.40 \\
30.24\end{array}$ \\
\hline & & & & $\begin{array}{l}-35 \\
-34 \\
-33 \\
-32 \\
-31\end{array}$ & $\begin{array}{l}-166 \cdot 99 \\
-162 \cdot 76 \\
-158 \cdot 48 \\
-154 \cdot 18 \\
-149 \cdot 84\end{array}$ & $\begin{array}{l}4 \cdot 221 \\
4 \cdot 254 \\
4 \cdot 287 \\
4 \cdot 320 \\
4 \cdot 353\end{array}$ & $\begin{array}{l}33 \cdot 44 \\
33 \cdot 26 \\
33.08 \\
32 \cdot 91 \\
32.73\end{array}$ & $\begin{array}{l}-15 \\
-14 \\
-13 \\
-12 \\
-11\end{array}$ & $\begin{array}{l}-76 \cdot 12 \\
-71 \cdot 25 \\
-66 \cdot 35 \\
-61 \cdot 42 \\
-56 \cdot 46\end{array}$ & $\begin{array}{l}4.855 \\
4.885 \\
4.915 \\
4.945 \\
4.974\end{array}$ & $\begin{array}{l}30.0 \\
29.9 \\
29.7 \\
29.6 \\
29.4\end{array}$ \\
\hline $\begin{array}{l}-50 \\
-49 \\
-48 \\
-47 \\
-46\end{array}$ & $\begin{array}{l}-226 \cdot 44 \\
-222 \cdot 72 \\
-218 \cdot 97 \\
-215 \cdot 18 \\
-211.36\end{array}$ & $\begin{array}{l}3.698 \\
3.735 \\
3.770 \\
3.806 \\
3.842\end{array}$ & $\begin{array}{l}36.23 \\
36.03 \\
35.84 \\
35.65 \\
35.46\end{array}$ & $\begin{array}{l}-30 \\
-29 \\
-28 \\
-27 \\
-26\end{array}$ & $\begin{array}{l}-145 \cdot 48 \\
-141.07 \\
-136 \cdot 64 \\
-132 \cdot 17 \\
-127.67\end{array}$ & $\begin{array}{l}4 \cdot 386 \\
4 \cdot 418 \\
4 \cdot 450 \\
4 \cdot 482 \\
4.514\end{array}$ & $\begin{array}{l}32.56 \\
32 \cdot 39 \\
32.22 \\
32.05 \\
31.88\end{array}$ & $\begin{array}{r}-10 \\
-9 \\
-8 \\
-7 \\
-6\end{array}$ & $\begin{array}{l}-51 \cdot 48 \\
-46 \cdot 46 \\
-41 \cdot 41 \\
-36 \cdot 33 \\
-31 \cdot 23\end{array}$ & $\begin{array}{l}5.004 \\
5.033 \\
5.062 \\
5.091 \\
5.120\end{array}$ & $\begin{array}{l}29.31 \\
29.15 \\
29.00 \\
28.85 \\
28.70\end{array}$ \\
\hline $\begin{array}{l}-45 \\
-44 \\
-43 \\
-42 \\
-41\end{array}$ & $\begin{array}{l}-207.50 \\
-203.60 \\
-199.67 \\
-195.71 \\
-191.71\end{array}$ & $\begin{array}{l}3.877 \\
3.912 \\
3.947 \\
3.982 \\
4.017\end{array}$ & $\begin{array}{l}35.27 \\
35.08 \\
34.89 \\
34.71 \\
34.52\end{array}$ & $\begin{array}{l}-25 \\
-24 \\
-23 \\
-22 \\
-21\end{array}$ & $\begin{array}{l}-123 \cdot 14 \\
-118 \cdot 58 \\
-113 \cdot 99 \\
-109 \cdot 36 \\
-104 \cdot 71\end{array}$ & $\begin{array}{l}4.546 \\
4.578 \\
4.609 \\
4.641 \\
4.672\end{array}$ & $\begin{array}{l}31 \cdot 71 \\
31 \cdot 54 \\
31 \cdot 38 \\
31 \cdot 21 \\
31 \cdot 05\end{array}$ & $\begin{array}{l}-5 \\
-4 \\
-3 \\
-2 \\
-1\end{array}$ & $\begin{array}{l}-26.09 \\
-20.93 \\
-15.74 \\
-10.52 \\
-5 \cdot 28\end{array}$ & $\begin{array}{l}5.148 \\
5.177 \\
5.205 \\
5.233 \\
5.261\end{array}$ & $\begin{array}{l}28 \cdot 5 \\
28 \cdot 4 \\
28 \cdot 2 \\
28 \cdot 1 \\
27 \cdot 9\end{array}$ \\
\hline-40 & -187.67 & 4.051 & $34 \cdot 34$ & -20 & -100.02 & $4 \cdot 703$ & 30.88 & 0 & 0.00 & 5.289 & 21.8 \\
\hline
\end{tabular}


TABLE 3.3.2. Type $\boldsymbol{R}$ thermocouples-thermoelectric voltages, $\mathrm{E}(\mathrm{T})$, Seebeck coefficients, $\mathrm{S}(\mathrm{T})$, and first derivative of the Seebeck coefficients, $\mathrm{dS} / \mathrm{dT}$, reference junctions at $0{ }^{\circ} \mathrm{C}-$-Continued

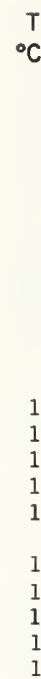

${ }^{\circ} \mathrm{C}$

10
$E$
$\mu V$
0.

0.00
5.30

10.63

15.99

21.38

26.79

32.23

37.70

43.19

48.71

54.26

59.83

65.43

71.06

76.71

82.39

88.09

93.82

99.58

105.36

$111 \cdot 16$

116.99

122.85

128.73

134.63

140.56

146.52

152.49

158.50

164.52

170.57

176.65

182.75

188.87

195.01

$201 \cdot 18$

207.38

213.59

219.83

226.09

232.38

238.68

245.01

251.36

257.74

264.13

270.55

276.99

283.46

289.94

296.45

302.97

309.52

316.09

322.69

329.30

335.93

342.59

349.27

355.96

362.68
$S$

5. 289

5.317

5.344

5.372

5.399

5.426

5.454

5.480

5.507

5.534

5.560

5.587

5.613

5.639

5.665

5.691

5. 716

5.742

5.767

5.793

5.818

5.843

5.868

5.893

5. 917

5.942

5.966

5.991

6.015

6.039

6.063

6.087

6.110

6.134

6.157

6.181

6.204

6.227

6.250

6.273

6.296

6.318

6.341

6.363

6.385

6.408

6.430

6.452

6.474

6.495

6.517

6.539

6.560

6.581

6.603

6.624

6.645

6.666

6.686

6.707

6.728 $d S / d T$

27.82

27.54

27.39

27.25

27.11

26.97

26.83

26.70
26.56

26.42

26.29

26.15

26.02

25.89

25.76

25.63

25.37

25.24

25.11

24.98

24.85

24.73

24.60

24.48

24.36

24.23

24.11

23.99

23.87

23. 75

23.63

23.51

23.39

23.28

$23 \cdot 16$

23.04

22.93

22.82

22.70

22.59

22.48

22.36

22.14

22.03

21.93

21.82

21.71

21.60

21.50

21.39

$21 \cdot 28$

21.08

20.97

20. 87

20.77

20.57

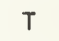

${ }^{\circ} \mathrm{C}$

E

$60 \quad 362.68$

61

62

63
64

65

66

67

69

70

71

72

74

75

76
77

78

79

80

81
82

82

84

85

86
87

89

90

91

92

93
94

95

96
97

97

99

100

101
102

103

104

105

106

107

108

109

110

111

112

114

115

116

117

119

120

362.68
369.42
376.18
382.95

389.75

396.57

403.41

410.27

$417 \cdot 15$

424.05

430.97

437.91

444.87

451.84 
TABLE 3.3.2. Type $R$ thermocouples-thermoelectric voltages, E(T), Seebeck coefficients, S(T), and first derivative of the Seebeck coefficients, $\mathrm{dS} / \mathrm{dT}$, reference junctions at $0{ }^{\circ} \mathrm{C}$-Continued

\begin{tabular}{|c|c|c|c|c|c|c|c|c|c|c|c|}
\hline${ }^{\circ} \mathrm{T}$ & $\begin{array}{c}E \\
\mu V\end{array}$ & $\stackrel{S}{\mu V /{ }^{\circ} \mathrm{C}}$ & $\begin{array}{l}d S / d T \\
n V /{ }^{\circ} C^{2}\end{array}$ & ${ }^{\circ} \mathrm{C}$ & $\begin{array}{c}E \\
\mu V\end{array}$ & $\begin{array}{c}\mathrm{S} \\
\mu \mathrm{V} /{ }^{\circ} \mathrm{C}\end{array}$ & $\begin{array}{l}d S / d T \\
n V /{ }^{\circ} C^{2}\end{array}$ & ${ }^{\top} \mathrm{C}$ & $\begin{array}{c}E \\
\mu V\end{array}$ & $\stackrel{\mathrm{S}}{\mu \mathrm{V} /{ }^{\circ} \mathrm{C}}$ & $\begin{array}{l}d S / d T \\
n V /{ }^{\circ} C^{2}\end{array}$ \\
\hline $\begin{array}{l}185 \\
186 \\
187 \\
188 \\
189\end{array}$ & $\begin{array}{l}1336.77 \\
1345.44 \\
1354.13 \\
1362.84 \\
1371.55\end{array}$ & $\begin{array}{l}8.673 \\
8.684 \\
8.696 \\
8.707 \\
8.719\end{array}$ & $\begin{array}{l}11.60 \\
11.55 \\
11.51 \\
11.46 \\
11.41\end{array}$ & $\begin{array}{l}245 \\
246 \\
247 \\
248 \\
249\end{array}$ & $\begin{array}{l}1876.36 \\
1885.66 \\
1894.96 \\
1904.27 \\
1913.59\end{array}$ & $\begin{array}{l}9.289 \\
9.298 \\
9.307 \\
9.316 \\
9.325\end{array}$ & $\begin{array}{l}9.07 \\
9.04 \\
9.00 \\
8.96 \\
8.93\end{array}$ & $\begin{array}{l}305 \\
306 \\
307 \\
308 \\
309\end{array}$ & $\begin{array}{l}2448.83 \\
2458.61 \\
2468.40 \\
2478.19 \\
2487.99\end{array}$ & $\begin{array}{l}9.775 \\
9.783 \\
9.790 \\
9.797 \\
9.804\end{array}$ & $\begin{array}{l}7.26 \\
7.24 \\
7.21 \\
7.19 \\
7.16\end{array}$ \\
\hline $\begin{array}{l}190 \\
191 \\
192 \\
193 \\
194\end{array}$ & $\begin{array}{l}1380.27 \\
1389.01 \\
1397.76 \\
1406.51 \\
1415.28\end{array}$ & $\begin{array}{l}8.730 \\
8.741 \\
8.753 \\
8.764 \\
8.775\end{array}$ & $\begin{array}{l}11 \cdot 36 \\
11 \cdot 31 \\
11 \cdot 26 \\
11.22 \\
11.17\end{array}$ & $\begin{array}{l}250 \\
251 \\
252 \\
253 \\
254\end{array}$ & $\begin{array}{l}1922.92 \\
1932.26 \\
1941.61 \\
1950.96 \\
1960.33\end{array}$ & $\begin{array}{l}9.334 \\
9.343 \\
9.351 \\
9.360 \\
9.369\end{array}$ & $\begin{array}{l}8.89 \\
8.86 \\
8.83 \\
8.79 \\
8.76\end{array}$ & $\begin{array}{l}310 \\
311 \\
312 \\
313 \\
314\end{array}$ & $\begin{array}{l}2497.80 \\
2507.62 \\
2517.44 \\
2527.27 \\
2537.10\end{array}$ & $\begin{array}{l}9.811 \\
9.819 \\
9.826 \\
9.833 \\
9.840\end{array}$ & $\begin{array}{l}7.14 \\
7.11 \\
7.09 \\
7.06 \\
7.04\end{array}$ \\
\hline $\begin{array}{l}200 \\
201 \\
202 \\
203 \\
204\end{array}$ & $\begin{array}{l}1468.13 \\
1476.98 \\
1485.84 \\
1494.71 \\
1503.59\end{array}$ & $\begin{array}{l}8.841 \\
8.852 \\
8.863 \\
8.874 \\
8.884\end{array}$ & $\begin{array}{l}10.89 \\
10.85 \\
10.80 \\
10.75 \\
10.71\end{array}$ & $\begin{array}{l}260 \\
261 \\
262 \\
263 \\
264\end{array}$ & $\begin{array}{l}2016 \cdot 70 \\
2026.12 \\
2035.56 \\
2045.00 \\
2054.45\end{array}$ & $\begin{array}{l}9.421 \\
9.429 \\
9.438 \\
9.446 \\
9.455\end{array}$ & $\begin{array}{l}8.56 \\
8.52 \\
8.49 \\
8.46 \\
8.43\end{array}$ & $\begin{array}{l}320 \\
321 \\
322 \\
323 \\
324\end{array}$ & $\begin{array}{l}2596 \cdot 27 \\
2606 \cdot 15 \\
2616.05 \\
2625 \cdot 94 \\
2635.85\end{array}$ & $\begin{array}{l}9.882 \\
9.889 \\
9.895 \\
9.902 \\
9.909\end{array}$ & $\begin{array}{l}6.90 \\
6.88 \\
6.86 \\
6.83 \\
6.81\end{array}$ \\
\hline $\begin{array}{l}205 \\
206 \\
207 \\
208 \\
209\end{array}$ & $\begin{array}{l}1512.47 \\
1521.38 \\
1530.29 \\
1539.21 \\
1548.14\end{array}$ & $\begin{array}{l}8.895 \\
8.906 \\
8.916 \\
8.927 \\
8.937\end{array}$ & $\begin{array}{l}10.67 \\
10.62 \\
10.58 \\
10.53 \\
10.49\end{array}$ & $\begin{array}{l}265 \\
266 \\
267 \\
268 \\
269\end{array}$ & $\begin{array}{l}2063.91 \\
2073.37 \\
2082.85 \\
2092.33 \\
2101.83\end{array}$ & $\begin{array}{l}9.463 \\
9.472 \\
9.480 \\
9.488 \\
9.497\end{array}$ & $\begin{array}{l}8.40 \\
8.36 \\
8.33 \\
8.30 \\
8.27\end{array}$ & $\begin{array}{l}325 \\
326 \\
327 \\
328 \\
329\end{array}$ & $\begin{array}{l}2645.76 \\
2655.68 \\
2665.61 \\
2675.54 \\
2685.48\end{array}$ & $\begin{array}{l}9.916 \\
9.923 \\
9.929 \\
9.936 \\
9.943\end{array}$ & $\begin{array}{l}6.79 \\
6.77 \\
6.75 \\
6.72 \\
6.70\end{array}$ \\
\hline $\begin{array}{l}210 \\
211 \\
212 \\
213 \\
214\end{array}$ & $\begin{array}{l}1557.08 \\
1566.04 \\
1575.00 \\
1583.97 \\
1592.96\end{array}$ & $\begin{array}{l}8.948 \\
8.958 \\
8.969 \\
8.979 \\
8.989\end{array}$ & $\begin{array}{l}10.45 \\
10.40 \\
10.36 \\
10.32 \\
10.28\end{array}$ & $\begin{array}{l}270 \\
271 \\
272 \\
273 \\
274\end{array}$ & $\begin{array}{l}2111.33 \\
2120.84 \\
2130.35 \\
2139.88 \\
2149.41\end{array}$ & $\begin{array}{l}9.505 \\
9.513 \\
9.521 \\
9.529 \\
9.538\end{array}$ & $\begin{array}{l}8.24 \\
8.21 \\
8.18 \\
8.15 \\
8.12\end{array}$ & $\begin{array}{l}330 \\
331 \\
332 \\
333 \\
334\end{array}$ & $\begin{array}{l}2695 \cdot 43 \\
2705 \cdot 38 \\
2715 \cdot 34 \\
2725 \cdot 31 \\
2735.28\end{array}$ & $\begin{array}{l}9.950 \\
9.956 \\
9.963 \\
9.970 \\
9.976\end{array}$ & $\begin{array}{l}6.68 \\
6.66 \\
6.64 \\
6.62 \\
6.60\end{array}$ \\
\hline $\begin{array}{l}220 \\
221 \\
222 \\
223 \\
224\end{array}$ & $\begin{array}{l}1647.08 \\
1656.13 \\
1665 \cdot 20 \\
1674.27 \\
1683.36\end{array}$ & $\begin{array}{l}9.050 \\
9.060 \\
9.070 \\
9.080 \\
9.090\end{array}$ & $\begin{array}{r}10.03 \\
9.99 \\
9.94 \\
9.90 \\
9.86\end{array}$ & $\begin{array}{l}280 \\
281 \\
282 \\
283 \\
284\end{array}$ & $\begin{array}{l}2206.78 \\
2216.37 \\
2225.97 \\
2235.58 \\
2245.19\end{array}$ & $\begin{array}{l}9.586 \\
9.594 \\
9.602 \\
9.609 \\
9.617\end{array}$ & $\begin{array}{l}7.94 \\
7.91 \\
7.88 \\
7.85 \\
7.82\end{array}$ & $\begin{array}{l}340 \\
341 \\
342 \\
343 \\
344\end{array}$ & $\begin{array}{l}2795 \cdot 25 \\
2805 \cdot 27 \\
2815.30 \\
2825 \cdot 33 \\
2835.37\end{array}$ & $\begin{array}{l}10.015 \\
10.022 \\
10.028 \\
10.035 \\
10.041\end{array}$ & $\begin{array}{l}6.48 \\
6.46 \\
6.44 \\
6.42 \\
6.40\end{array}$ \\
\hline $\begin{array}{l}225 \\
226 \\
227 \\
228 \\
229\end{array}$ & $\begin{array}{l}1692.45 \\
1701.56 \\
1710.67 \\
1719.80 \\
1728.93\end{array}$ & $\begin{array}{l}9.100 \\
9.110 \\
9.119 \\
9.129 \\
9.139\end{array}$ & $\begin{array}{l}9.82 \\
9.78 \\
9.75 \\
9.71 \\
9.67\end{array}$ & $\begin{array}{l}285 \\
286 \\
287 \\
288 \\
289\end{array}$ & $\begin{array}{l}2254.81 \\
2264.44 \\
2274.08 \\
2283.72 \\
2293.37\end{array}$ & $\begin{array}{l}9.625 \\
9.633 \\
9.641 \\
9.648 \\
9.656\end{array}$ & $\begin{array}{l}7.79 \\
7.77 \\
7.74 \\
7.71 \\
7.68\end{array}$ & $\begin{array}{l}345 \\
346 \\
347 \\
348 \\
349\end{array}$ & $\begin{array}{l}2845.41 \\
2855.46 \\
2865.52 \\
2875.58 \\
2885.65\end{array}$ & $\begin{array}{l}10.047 \\
10.054 \\
10.060 \\
10.067 \\
10.073\end{array}$ & $\begin{array}{l}6 \cdot 38 \\
6 \cdot 36 \\
6 \cdot 34 \\
6 \cdot 32 \\
6 \cdot 30\end{array}$ \\
\hline $\begin{array}{l}230 \\
231 \\
232 \\
233 \\
234\end{array}$ & $\begin{array}{l}1738.08 \\
1747.23 \\
1756.39 \\
1765.56 \\
1774.75\end{array}$ & $\begin{array}{l}9.149 \\
9.158 \\
9.168 \\
9.177 \\
9.187\end{array}$ & $\begin{array}{l}9.63 \\
9.59 \\
9.55 \\
9.51 \\
9.47\end{array}$ & $\begin{array}{l}290 \\
291 \\
292 \\
293 \\
294\end{array}$ & $\begin{array}{l}2303.03 \\
2312.70 \\
2322.37 \\
2332.06 \\
2341.75\end{array}$ & $\begin{array}{l}9.664 \\
9.671 \\
9.679 \\
9.687 \\
9.694\end{array}$ & $\begin{array}{l}7.65 \\
7.63 \\
7.60 \\
7.57 \\
7.55\end{array}$ & $\begin{array}{l}350 \\
351 \\
352 \\
353 \\
354\end{array}$ & $\begin{array}{l}2895.73 \\
2905.81 \\
2915.90 \\
2925.99 \\
2936.09\end{array}$ & $\begin{array}{l}10.079 \\
10.085 \\
10.092 \\
10.098 \\
10.104\end{array}$ & $\begin{array}{l}6.28 \\
6.27 \\
6.25 \\
6.23 \\
6.21\end{array}$ \\
\hline $\begin{array}{l}235 \\
236 \\
237 \\
238 \\
239\end{array}$ & $\begin{array}{l}1783.94 \\
1793.14 \\
1802.35 \\
1811.57 \\
1820.80\end{array}$ & $\begin{array}{l}9.196 \\
9.206 \\
9.215 \\
9.224 \\
9.234\end{array}$ & $\begin{array}{l}9.44 \\
9.40 \\
9.36 \\
9.33 \\
9.29\end{array}$ & $\begin{array}{l}295 \\
296 \\
297 \\
298 \\
299\end{array}$ & $\begin{array}{l}2351.45 \\
2361.15 \\
2370.86 \\
2380.58 \\
2390 \cdot 31\end{array}$ & $\begin{array}{l}9.702 \\
9.709 \\
9.717 \\
9.724 \\
9.731\end{array}$ & $\begin{array}{l}7.52 \\
7.49 \\
7.47 \\
7.44 \\
7.41\end{array}$ & $\begin{array}{l}355 \\
356 \\
357 \\
358 \\
359\end{array}$ & $\begin{array}{l}2946.20 \\
2956.31 \\
2966.43 \\
2976.56 \\
2986.69\end{array}$ & $\begin{array}{l}10.110 \\
10.117 \\
10.123 \\
10.129 \\
10.135\end{array}$ & $\begin{array}{l}6.19 \\
6.18 \\
6.16 \\
6.14 \\
6.12\end{array}$ \\
\hline 240 & 1830.04 & 9.243 & $9 \cdot 25$ & 300 & 2400.05 & 9.739 & 7.39 & 360 & 2996.83 & 10.141 & 6.11 \\
\hline
\end{tabular}


TABLE 3.3.2. Type $\boldsymbol{R}$ thermocouples-thermoelectric voltages, E(T), Seebeck coefficients, S(T), and first derivative of the Seebeck coefficients, $\mathrm{dS} / \mathrm{dT}$, reference junctions at $0{ }^{\circ} \mathrm{C}$-Continued

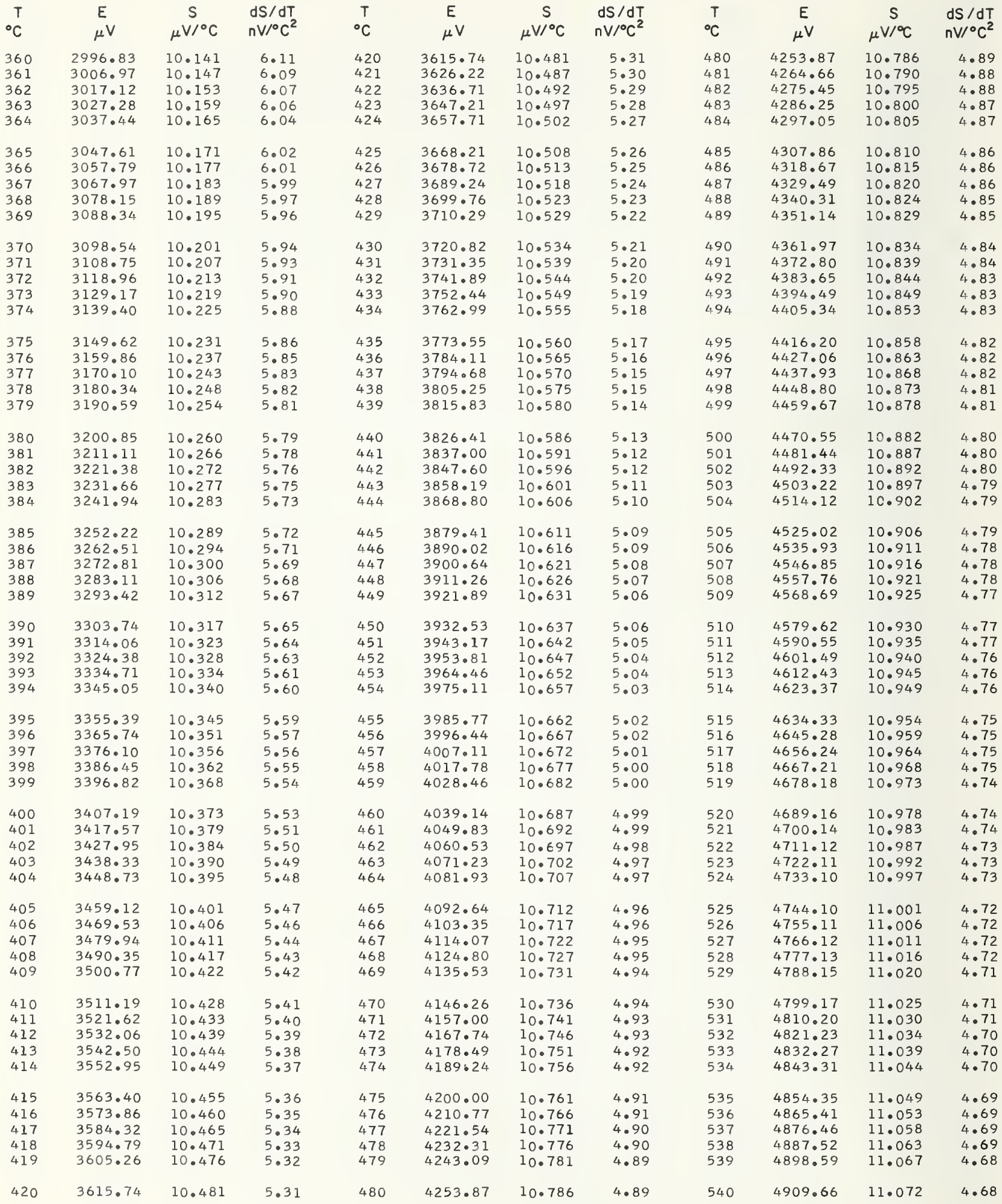


TABLE 3.3.2. Type $\boldsymbol{R}$ thermocouples-thermoelectric voltages, E(T), Seebeck coefficients, $\mathrm{S}(\mathrm{T})$, and first derivative of the Seebeck coefficients, $\mathrm{dS} / \mathrm{dT}$, reference junctions at $0^{\circ} \mathrm{C}$-Continued

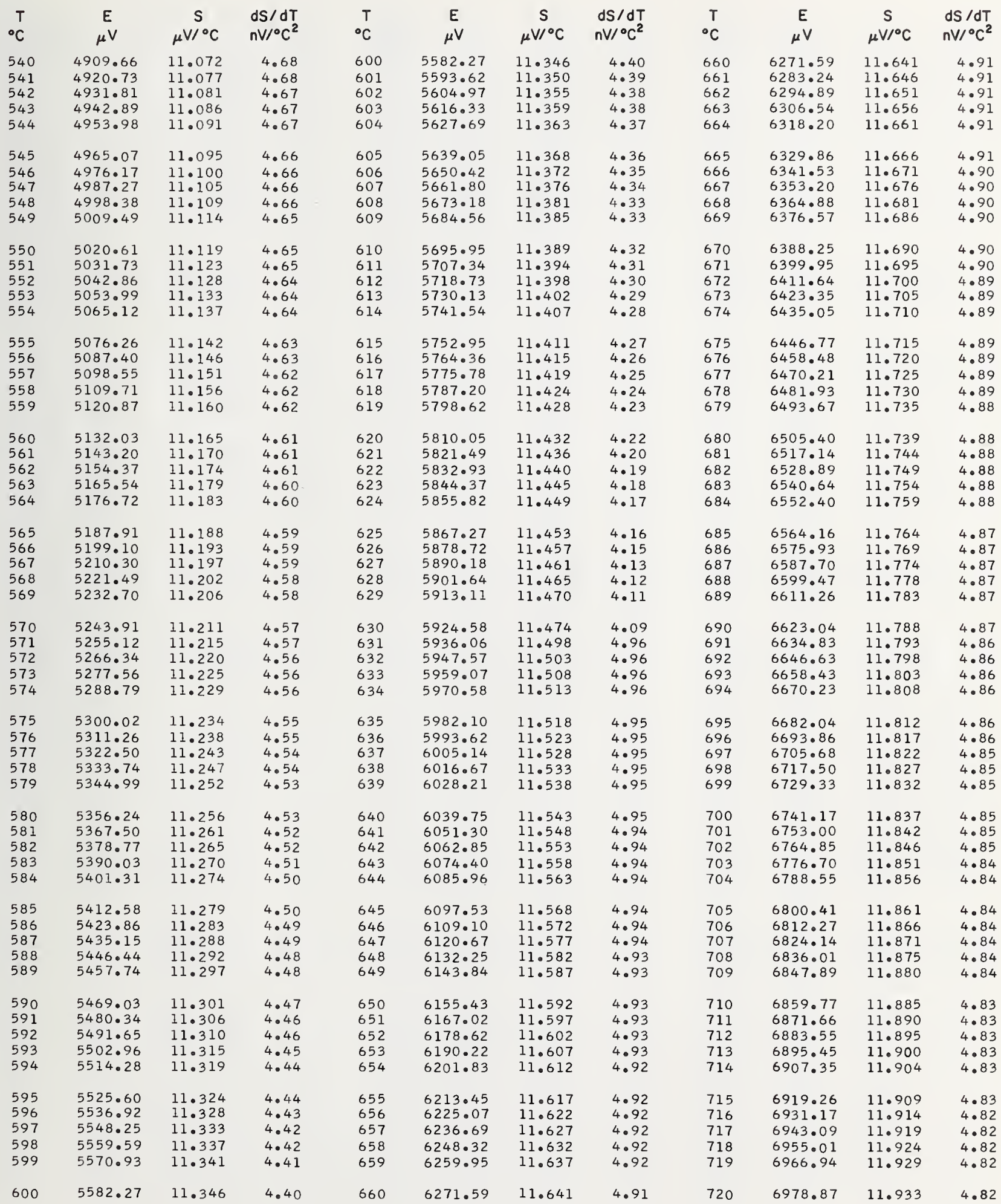


TABLE 3.3.2. Type $\boldsymbol{R}$ thermocouples-thermoelectric voltages, $\mathrm{E}(\mathrm{T})$, Seebeck coefficients, $\mathrm{S}(\mathrm{T})$, and first derivative of the Seebeck coefficients, $\mathrm{dS} / \mathrm{dT}$, reference junctions at $0{ }^{\circ} \mathrm{C}$-Continued

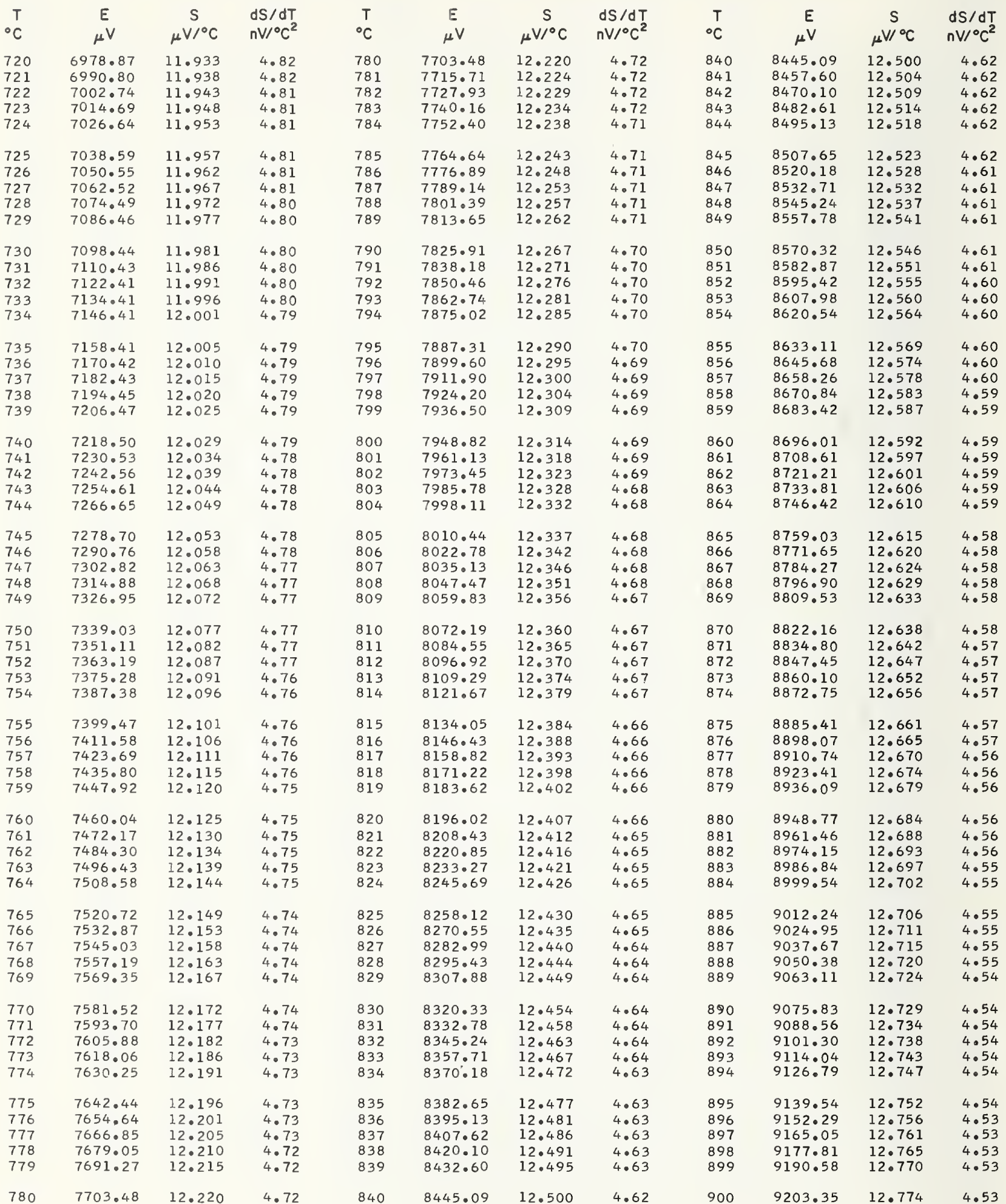


TABLE 3.3.2. Type $\boldsymbol{R}$ thermocouples-thermoelectric voltages, $\mathrm{E}(\mathrm{T})$, Seebeck coefficients, $\mathrm{S}(\mathrm{T})$, and first derivative of the Seebeck coefficients, $\mathrm{dS} / \mathrm{dT}$, reference junctions at $0{ }^{\circ} \mathrm{C}$-Continued

\begin{tabular}{|c|c|c|c|c|c|c|c|c|c|c|c|}
\hline${ }^{\circ} \mathrm{C}$ & $\underset{\mu V}{E}$ & $\mu V^{\circ}{ }^{\circ} \mathrm{C}$ & $\begin{array}{l}\mathrm{dS} / \mathrm{dT} \\
\mathrm{nV} /{ }^{\circ} \mathrm{C}^{2}\end{array}$ & ${ }^{\circ} \mathrm{C}$ & $\underset{\mu V}{E}$ & $\stackrel{\mathrm{VV}^{\circ}{ }^{\circ} \mathrm{C}}{\mathrm{S}}$ & $\begin{array}{l}\mathrm{dS} / \mathrm{d} T \\
\mathrm{nV} /{ }^{\circ} \mathrm{C}^{2}\end{array}$ & ${ }^{\circ} \mathrm{C}$ & $\underset{\mu V}{E}$ & $\underset{\mu V^{\circ} \mathrm{C}}{\mathrm{S}}$ & $\begin{array}{l}\mathrm{dS} / \mathrm{d} T \\
\mathrm{nV} /{ }^{\circ} \mathrm{C}^{2}\end{array}$ \\
\hline $\begin{array}{l}905 \\
906 \\
907 \\
908 \\
909\end{array}$ & $\begin{array}{l}9267.28 \\
9280.08 \\
9292.88 \\
9305.69 \\
9318.50\end{array}$ & $\begin{array}{l}12.797 \\
12.802 \\
12.806 \\
12.811 \\
12.815\end{array}$ & $\begin{array}{l}4.52 \\
4.52 \\
4.52 \\
4.51 \\
4.51\end{array}$ & $\begin{array}{l}965 \\
966 \\
967 \\
968 \\
969\end{array}$ & $\begin{array}{l}10043.18 \\
10056.24 \\
10069.32 \\
10082.39 \\
10095.47\end{array}$ & $\begin{array}{l}13.065 \\
13.070 \\
13.074 \\
13.079 \\
13.083\end{array}$ & $\begin{array}{l}4.42 \\
4.42 \\
4.42 \\
4.42 \\
4.42\end{array}$ & $\begin{array}{l}1025 \\
1026 \\
1027 \\
1028 \\
1029\end{array}$ & $\begin{array}{l}10834.99 \\
10848.32 \\
10861.66 \\
10875.00 \\
10888.34\end{array}$ & $\begin{array}{l}13.328 \\
13.332 \\
13.336 \\
13.341 \\
13.345\end{array}$ & $\begin{array}{l}4 \cdot 33 \\
4 \cdot 32 \\
4 \cdot 32 \\
4 \cdot 32 \\
4 \cdot 32\end{array}$ \\
\hline $\begin{array}{l}910 \\
911 \\
912 \\
913 \\
914\end{array}$ & $\begin{array}{l}9331.32 \\
9344.14 \\
9356.97 \\
9369.80 \\
9382.63\end{array}$ & $\begin{array}{l}12.820 \\
12.824 \\
12.829 \\
12.833 \\
12.838\end{array}$ & $\begin{array}{l}4.51 \\
4.51 \\
4.51 \\
4.51 \\
4.50\end{array}$ & $\begin{array}{l}970 \\
971 \\
972 \\
973 \\
974\end{array}$ & $\begin{array}{l}10108.56 \\
10121.65 \\
10134.74 \\
10147.84 \\
10160.94\end{array}$ & $\begin{array}{l}13.087 \\
13.092 \\
13.096 \\
13.101 \\
13.105\end{array}$ & $\begin{array}{l}4.41 \\
4.41 \\
4.41 \\
4.41 \\
4.41\end{array}$ & $\begin{array}{l}1030 \\
1031 \\
1032 \\
1033 \\
1034\end{array}$ & $\begin{array}{l}10901.69 \\
10915.04 \\
10928.39 \\
10941.75 \\
10955.12\end{array}$ & $\begin{array}{l}13.349 \\
13.354 \\
13.358 \\
13.362 \\
13.367\end{array}$ & $\begin{array}{l}4 \cdot 32 \\
4 \cdot 32 \\
4 \cdot 31 \\
4 \cdot 31 \\
4 \cdot 31\end{array}$ \\
\hline $\begin{array}{l}920 \\
921 \\
922 \\
923 \\
924\end{array}$ & $\begin{array}{l}9459.74 \\
9472.61 \\
9485.48 \\
9498.36 \\
9511.24\end{array}$ & $\begin{array}{l}12.865 \\
12.869 \\
12.874 \\
12.878 \\
12.883\end{array}$ & $\begin{array}{l}4.49 \\
4.49 \\
4.49 \\
4.49 \\
4.49\end{array}$ & $\begin{array}{l}980 \\
981 \\
982 \\
983 \\
984\end{array}$ & $\begin{array}{l}10239.65 \\
10252.78 \\
10265.92 \\
10279.07 \\
10292.21\end{array}$ & $\begin{array}{l}13.131 \\
13.136 \\
13.140 \\
13.145 \\
13.149\end{array}$ & $\begin{array}{l}4 \cdot 40 \\
4 \cdot 40 \\
4 \cdot 39 \\
4 \cdot 39 \\
4 \cdot 39\end{array}$ & $\begin{array}{l}1040 \\
1041 \\
1042 \\
1043 \\
1044\end{array}$ & $\begin{array}{l}11035.39 \\
11048.79 \\
11062.19 \\
11075.59 \\
11089.00\end{array}$ & $\begin{array}{l}13.392 \\
13.397 \\
13.401 \\
13.405 \\
13.410\end{array}$ & $\begin{array}{l}4 \cdot 30 \\
4 \cdot 30 \\
4 \cdot 30 \\
4 \cdot 30 \\
4 \cdot 29\end{array}$ \\
\hline $\begin{array}{l}925 \\
926 \\
927 \\
928 \\
929\end{array}$ & $\begin{array}{l}9524.12 \\
9537.01 \\
9549.90 \\
9562.80 \\
9575.71\end{array}$ & $\begin{array}{l}12.887 \\
12.892 \\
12.896 \\
12.901 \\
12.905\end{array}$ & $\begin{array}{l}4.49 \\
4.49 \\
4.48 \\
4.48 \\
4.48\end{array}$ & $\begin{array}{l}985 \\
986 \\
987 \\
988 \\
989\end{array}$ & $\begin{array}{l}10305.36 \\
10318.52 \\
10331.68 \\
10344.84 \\
10358.01\end{array}$ & $\begin{array}{l}13.153 \\
13.158 \\
13.162 \\
13.167 \\
13.171\end{array}$ & $\begin{array}{l}4 \cdot 39 \\
4 \cdot 39 \\
4 \cdot 39 \\
4 \cdot 39 \\
4 \cdot 38\end{array}$ & $\begin{array}{l}1045 \\
1046 \\
1047 \\
1048 \\
1049\end{array}$ & $\begin{array}{l}11102.41 \\
11115.83 \\
11129.25 \\
11142.67 \\
11156.10\end{array}$ & $\begin{array}{l}13.414 \\
13.418 \\
13.422 \\
13.427 \\
13.431\end{array}$ & $\begin{array}{l}4 \cdot 29 \\
4 \cdot 29 \\
4 \cdot 29 \\
4 \cdot 29 \\
4 \cdot 29\end{array}$ \\
\hline $\begin{array}{l}930 \\
931 \\
932 \\
933 \\
934\end{array}$ & $\begin{array}{l}9588.61 \\
9601.52 \\
9614.44 \\
9627.36 \\
9640.29\end{array}$ & $\begin{array}{l}12.909 \\
12.914 \\
12.918 \\
12.923 \\
12.927\end{array}$ & $\begin{array}{l}4.48 \\
4.48 \\
4.48 \\
4.47 \\
4.47\end{array}$ & $\begin{array}{l}990 \\
991 \\
992 \\
993 \\
994\end{array}$ & $\begin{array}{l}10371.18 \\
10384 \cdot 36 \\
10397.54 \\
10410.73 \\
10423.92\end{array}$ & $\begin{array}{l}13.175 \\
13.180 \\
13.184 \\
13.188 \\
13.193\end{array}$ & $\begin{array}{l}4 \cdot 38 \\
4 \cdot 38 \\
4 \cdot 38 \\
4 \cdot 38 \\
4 \cdot 38\end{array}$ & $\begin{array}{l}1050 \\
1051 \\
1052 \\
1053 \\
1054\end{array}$ & $\begin{array}{l}11169.53 \\
11182.97 \\
11196.41 \\
11209.86 \\
11223.31\end{array}$ & $\begin{array}{l}13.435 \\
13.440 \\
13.444 \\
13.448 \\
13.452\end{array}$ & $\begin{array}{l}4 \cdot 29 \\
4 \cdot 28 \\
4 \cdot 28 \\
4 \cdot 28 \\
4 \cdot 28\end{array}$ \\
\hline $\begin{array}{l}940 \\
941 \\
942 \\
943 \\
944\end{array}$ & $\begin{array}{l}9717.93 \\
9730.89 \\
9743.85 \\
9756.81 \\
9769.78\end{array}$ & $\begin{array}{l}12.954 \\
12.959 \\
12.963 \\
12.968 \\
12.972\end{array}$ & $\begin{array}{l}4.46 \\
4.46 \\
4.46 \\
4.46 \\
4.46\end{array}$ & $\begin{array}{l}1000 \\
1001 \\
1002 \\
1003 \\
1004\end{array}$ & $\begin{array}{l}10503 \cdot 16 \\
10516.38 \\
10529.60 \\
10542.83 \\
10556.07\end{array}$ & $\begin{array}{l}13.219 \\
13.223 \\
13.228 \\
13.232 \\
13.236\end{array}$ & $\begin{array}{l}4 \cdot 37 \\
4 \cdot 36 \\
4 \cdot 36 \\
4 \cdot 36 \\
4 \cdot 36\end{array}$ & $\begin{array}{l}1060 \\
1061 \\
1062 \\
1063 \\
1064\end{array}$ & $\begin{array}{l}11304.10 \\
11317.58 \\
11331.06 \\
11344.55 \\
11358.05\end{array}$ & $\begin{array}{l}13.478 \\
13.482 \\
13.487 \\
13.491 \\
13.495\end{array}$ & $\begin{array}{l}4 \cdot 27 \\
4 \cdot 27 \\
4 \cdot 27 \\
4 \cdot 26 \\
4 \cdot 26\end{array}$ \\
\hline $\begin{array}{l}945 \\
946 \\
947 \\
948 \\
949\end{array}$ & $\begin{array}{l}9782.76 \\
9795.74 \\
9808.72 \\
9821.71 \\
9834.70\end{array}$ & $\begin{array}{l}12.976 \\
12.981 \\
12.985 \\
12.990 \\
12.994\end{array}$ & $\begin{array}{l}4.45 \\
4.45 \\
4.45 \\
4.45 \\
4.45\end{array}$ & $\begin{array}{l}1005 \\
1006 \\
1007 \\
1008 \\
1009\end{array}$ & $\begin{array}{l}10569.31 \\
10582.55 \\
10595.80 \\
10609.05 \\
10622.30\end{array}$ & $\begin{array}{l}13.241 \\
13.245 \\
13.250 \\
13.254 \\
13.258\end{array}$ & $\begin{array}{l}4 \cdot 36 \\
4 \cdot 36 \\
4 \cdot 35 \\
4 \cdot 35 \\
4 \cdot 35\end{array}$ & $\begin{array}{l}1065 \\
1066 \\
1067 \\
1068 \\
1069\end{array}$ & $\begin{array}{l}11371.54 \\
11385.04 \\
11398.55 \\
11412.06 \\
11425.57\end{array}$ & $\begin{array}{l}13.499 \\
13.503 \\
13.507 \\
13.511 \\
13.514\end{array}$ & $\begin{array}{l}3.81 \\
3.80 \\
3.78 \\
3.77 \\
3.76\end{array}$ \\
\hline $\begin{array}{l}950 \\
951 \\
952 \\
953 \\
954\end{array}$ & $\begin{array}{l}9847.70 \\
9860.70 \\
9873.70 \\
9886.71 \\
9899.73\end{array}$ & $\begin{array}{l}12.999 \\
13.003 \\
13.008 \\
13.012 \\
13.017\end{array}$ & $\begin{array}{l}4.45 \\
4.44 \\
4.44 \\
4.44 \\
4.44\end{array}$ & $\begin{array}{l}1010 \\
1011 \\
1012 \\
1013 \\
1014\end{array}$ & $\begin{array}{l}10635.57 \\
10648.83 \\
10662.10 \\
10675.37 \\
10688.65\end{array}$ & $\begin{array}{l}13.263 \\
13.267 \\
13.271 \\
13.276 \\
13.280\end{array}$ & $\begin{array}{l}4 \cdot 35 \\
4 \cdot 35 \\
4 \cdot 35 \\
4 \cdot 34 \\
4 \cdot 34\end{array}$ & $\begin{array}{l}1070 \\
1071 \\
1072 \\
1073 \\
1074\end{array}$ & $\begin{array}{l}11439.09 \\
11452.61 \\
11466.13 \\
11479.66 \\
11493.19\end{array}$ & $\begin{array}{l}13.518 \\
13.522 \\
13.526 \\
13.529 \\
13.533\end{array}$ & $\begin{array}{l}3.75 \\
3.74 \\
3.73 \\
3.71 \\
3.70\end{array}$ \\
\hline $\begin{array}{l}955 \\
956 \\
957 \\
958 \\
959\end{array}$ & $\begin{array}{l}9912.74 \\
9925.77 \\
9938.80 \\
9951.83 \\
9964.86\end{array}$ & $\begin{array}{l}13.021 \\
13.025 \\
13.030 \\
13.034 \\
13.039\end{array}$ & $\begin{array}{l}4.44 \\
4.44 \\
4.44 \\
4.43 \\
4.43\end{array}$ & $\begin{array}{l}1015 \\
1016 \\
1017 \\
1018 \\
1019\end{array}$ & $\begin{array}{l}10701.93 \\
10715.22 \\
10728.51 \\
10741.81 \\
10755.10\end{array}$ & $\begin{array}{l}13.284 \\
13.289 \\
13.293 \\
13.297 \\
13.302\end{array}$ & $\begin{array}{l}4 \cdot 34 \\
4 \cdot 34 \\
4 \cdot 34 \\
4 \cdot 34 \\
4 \cdot 34\end{array}$ & $\begin{array}{l}1075 \\
1076 \\
1077 \\
1078 \\
1079\end{array}$ & $\begin{array}{l}11506.72 \\
11520.26 \\
11533.80 \\
11547.35 \\
11560.90\end{array}$ & $\begin{array}{l}13.537 \\
13.540 \\
13.544 \\
13.548 \\
13.551\end{array}$ & $\begin{array}{l}3.69 \\
3.68 \\
3.67 \\
3.66 \\
3.64\end{array}$ \\
\hline 960 & 9977.90 & 13.043 & $4 \cdot 43$ & 1020 & 10768.41 & 13.306 & $4 \cdot 33$ & 1080 & 11574.45 & 13.555 & 3.63 \\
\hline
\end{tabular}


TABLE 3.3.2. Type $\boldsymbol{R}$ thermocouples-thermoelectric voltages, E(T), Seebeck coefficients, S(T), and first derivative of the Seebeck coefficients, $\mathrm{dS} / \mathrm{dT}$, reference junctions at $0{ }^{\circ} \mathrm{C}$-Continued

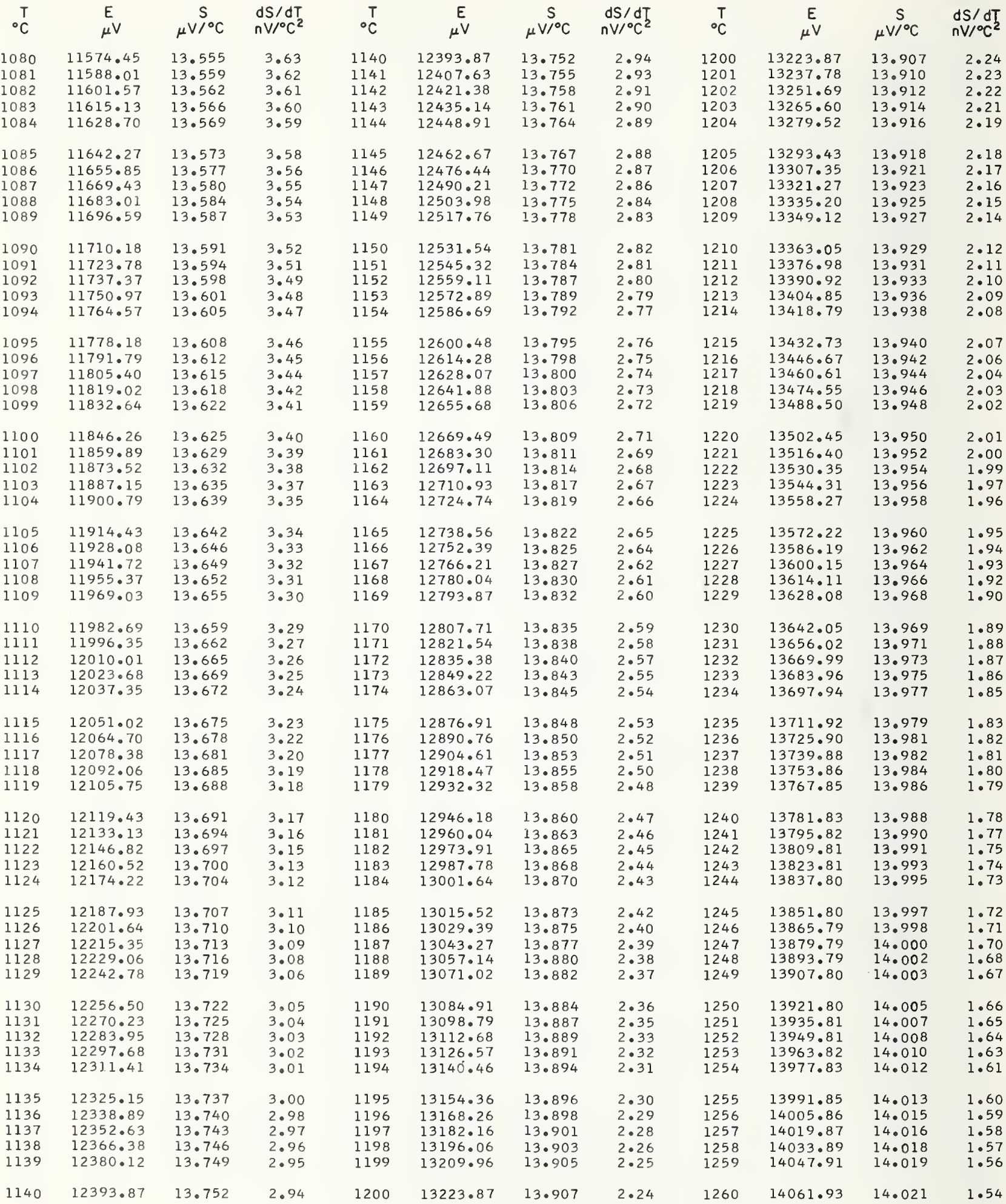


TABLE 3.3.2. Type $\boldsymbol{R}$ thermocouples-thermoelectric voltages, E(T), Seebeck coefficients, S(T), and first derivative of the Seebeck coefficients, $\mathrm{dS} / \mathrm{dT}$, reference junctions at $0{ }^{\circ} \mathrm{C}$-Continued

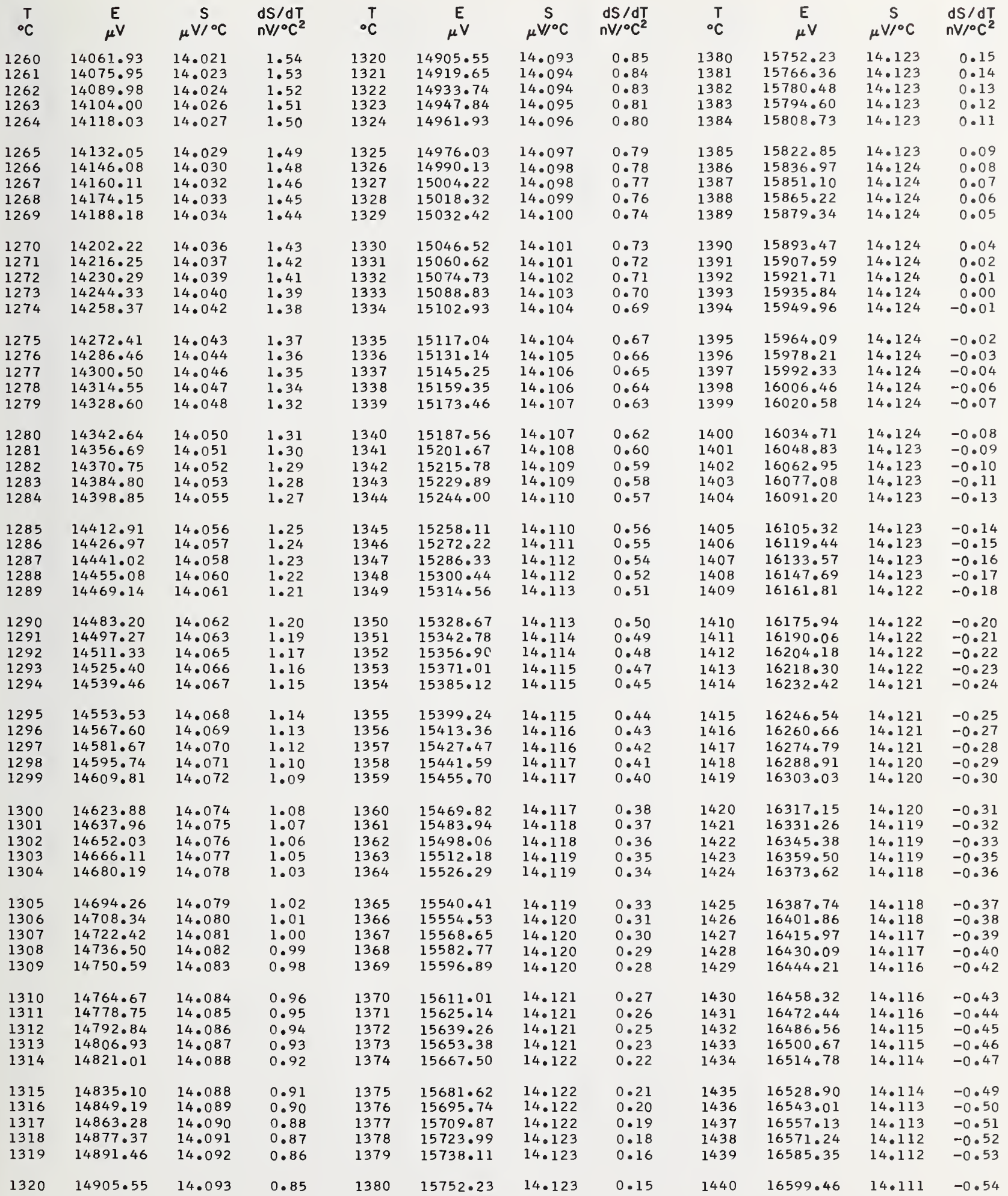


TABLE 3.3.2. Type $\boldsymbol{R}$ thermocouples-thermoelectric voltages, $\mathrm{E}(\mathrm{T})$, Seebeck coefficients, $\mathrm{S}(\mathrm{T})$, and first derivative of the Seebeck coefficients, $\mathrm{dS} / \mathrm{dT}$, reference junctions at $0{ }^{\circ} \mathrm{C}$-Continued

\begin{tabular}{|c|c|c|c|c|c|c|c|c|c|c|c|}
\hline $\begin{array}{r}\mathrm{T} \\
{ }^{\circ} \mathrm{C}\end{array}$ & $\begin{array}{c}E \\
\mu V\end{array}$ & $\stackrel{\mathrm{S}}{\mu \mathrm{V} /{ }^{\circ} \mathrm{C}}$ & $\begin{array}{l}\mathrm{dS} / \mathrm{dT} \\
\mathrm{nV} /{ }^{\circ} \mathrm{C}^{2}\end{array}$ & ${ }^{\top} \mathrm{C}$ & $\begin{array}{c}E \\
\mu V\end{array}$ & $\begin{array}{c}\mathrm{S} \\
\mu \mathrm{V} /{ }^{\circ} \mathrm{C}\end{array}$ & $\begin{array}{l}\mathrm{dS} / \mathrm{dT} \\
\mathrm{nV} /{ }^{\circ} \mathrm{C}^{2}\end{array}$ & $\begin{array}{l}\mathrm{T} \\
{ }^{\circ} \mathrm{C}\end{array}$ & $\begin{array}{c}E \\
\mu V\end{array}$ & $\stackrel{\mathrm{S}}{\mu \mathrm{V} /{ }^{\circ} \mathrm{C}}$ & $\begin{array}{l}\mathrm{dS} / \mathrm{dT} \\
\mathrm{nV} /{ }^{\circ} \mathrm{C}^{2}\end{array}$ \\
\hline $\begin{array}{l}1440 \\
1441 \\
1442 \\
1443 \\
1444\end{array}$ & $\begin{array}{l}16599.46 \\
16613.57 \\
16627.68 \\
16641.79 \\
16655.90\end{array}$ & $\begin{array}{l}14.111 \\
14.111 \\
14.110 \\
14.109 \\
14.109\end{array}$ & $\begin{array}{l}-0.54 \\
-0.56 \\
-0.57 \\
-0.58 \\
-0.59\end{array}$ & $\begin{array}{l}1500 \\
1501 \\
1502 \\
1503 \\
1504\end{array}$ & $\begin{array}{l}17444 \cdot 73 \\
17458.79 \\
17472.84 \\
17486.90 \\
17500.95\end{array}$ & $\begin{array}{l}14.058 \\
14.056 \\
14.055 \\
14.054 \\
14.053\end{array}$ & $\begin{array}{l}-1.24 \\
-1.25 \\
-1.26 \\
-1.27 \\
-1.29\end{array}$ & $\begin{array}{l}1560 \\
1561 \\
1562 \\
1563 \\
1564\end{array}$ & $\begin{array}{l}18285.54 \\
18299.50 \\
18313.46 \\
18327.42 \\
18341.37\end{array}$ & $\begin{array}{l}13.962 \\
13.960 \\
13.958 \\
13.956 \\
13.954\end{array}$ & $\begin{array}{l}-1.94 \\
-1.95 \\
-1.96 \\
-1.97 \\
-1.98\end{array}$ \\
\hline $\begin{array}{l}1445 \\
1446 \\
1447 \\
1448 \\
1449\end{array}$ & $\begin{array}{l}16670.01 \\
16684.12 \\
16698.22 \\
16712.33 \\
16726.44\end{array}$ & $\begin{array}{l}14.108 \\
14.108 \\
14.107 \\
14.106 \\
14.106\end{array}$ & $\begin{array}{l}-0.60 \\
-0.61 \\
-0.62 \\
-0.64 \\
-0.65\end{array}$ & $\begin{array}{l}1505 \\
1506 \\
1507 \\
1508 \\
1509\end{array}$ & $\begin{array}{l}17515.00 \\
17529.05 \\
17543.10 \\
17557.15 \\
17571.20\end{array}$ & $\begin{array}{l}14.051 \\
14.050 \\
14.049 \\
14.047 \\
14.046\end{array}$ & $\begin{array}{l}-1.30 \\
-1.31 \\
-1.32 \\
-1.33 \\
-1.34\end{array}$ & $\begin{array}{l}1565 \\
1566 \\
1567 \\
1568 \\
1569\end{array}$ & $\begin{array}{l}18355.33 \\
18369.28 \\
18383.23 \\
18397.17 \\
18411.12\end{array}$ & $\begin{array}{l}13.952 \\
13.950 \\
13.948 \\
13.946 \\
13.944\end{array}$ & $\begin{array}{l}-1.99 \\
-2.01 \\
-2.02 \\
-2.03 \\
-2.04\end{array}$ \\
\hline $\begin{array}{l}1450 \\
1451 \\
1452 \\
1453 \\
1454\end{array}$ & $\begin{array}{l}16740.54 \\
16754 \cdot 65 \\
16768 \cdot 75 \\
16782.86 \\
16796.96\end{array}$ & $\begin{array}{l}14.105 \\
14.104 \\
14.104 \\
14.103 \\
14.102\end{array}$ & $\begin{array}{l}-0.66 \\
-0.67 \\
-0.68 \\
-0.69 \\
-0.71\end{array}$ & $\begin{array}{l}1510 \\
1511 \\
1512 \\
1513 \\
1514\end{array}$ & $\begin{array}{l}17585 \cdot 24 \\
17599 \cdot 29 \\
17613 \cdot 33 \\
17627 \cdot 37 \\
17641.41\end{array}$ & $\begin{array}{l}14.045 \\
14.043 \\
14.042 \\
14.041 \\
14.039\end{array}$ & $\begin{array}{l}-1.36 \\
-1.37 \\
-1.38 \\
-1.39 \\
-1.40\end{array}$ & $\begin{array}{l}1570 \\
1571 \\
1572 \\
1573 \\
1574\end{array}$ & $\begin{array}{l}18425.06 \\
18439.00 \\
18452.94 \\
18466.88 \\
18480.82\end{array}$ & $\begin{array}{l}13.942 \\
13.940 \\
13.938 \\
13.936 \\
13.934\end{array}$ & $\begin{array}{l}-2.05 \\
-2.06 \\
-2.08 \\
-2.09 \\
-2.10\end{array}$ \\
\hline $\begin{array}{l}1455 \\
1456 \\
1457 \\
1458 \\
1459\end{array}$ & $\begin{array}{l}16811.06 \\
16825.16 \\
16839.26 \\
16853.36 \\
16867.46\end{array}$ & $\begin{array}{l}14.102 \\
14.101 \\
14.100 \\
14.099 \\
14.099\end{array}$ & $\begin{array}{l}-0.72 \\
-0.73 \\
-0.74 \\
-0.75 \\
-0.76\end{array}$ & $\begin{array}{l}1515 \\
1516 \\
1517 \\
1518 \\
1519\end{array}$ & $\begin{array}{l}17655.45 \\
17669.49 \\
17683.52 \\
17697.56 \\
17711.59\end{array}$ & $\begin{array}{l}14.038 \\
14.036 \\
14.035 \\
14.033 \\
14.032\end{array}$ & $\begin{array}{l}-1.41 \\
-1.43 \\
-1.44 \\
-1.45 \\
-1.46\end{array}$ & $\begin{array}{l}1575 \\
1576 \\
1577 \\
1578 \\
1579\end{array}$ & $\begin{array}{l}18494.75 \\
18508.68 \\
18522.61 \\
18536.53 \\
18550.46\end{array}$ & $\begin{array}{l}13.932 \\
13.930 \\
13.928 \\
13.926 \\
13.923\end{array}$ & $\begin{array}{l}-2.11 \\
-2.12 \\
-2.13 \\
-2.14 \\
-2.16\end{array}$ \\
\hline $\begin{array}{l}1460 \\
1461 \\
1462 \\
1463 \\
1464\end{array}$ & $\begin{array}{l}16881.56 \\
16895.66 \\
16909.75 \\
16923.85 \\
16937.94\end{array}$ & $\begin{array}{l}14.098 \\
14.097 \\
14.096 \\
14.096 \\
14.095\end{array}$ & $\begin{array}{l}-0.78 \\
-0.79 \\
-0.80 \\
-0.81 \\
-0.82\end{array}$ & $\begin{array}{l}1520 \\
1521 \\
1522 \\
1523 \\
1524\end{array}$ & $\begin{array}{l}17725.62 \\
17739.65 \\
17753.58 \\
17767.70 \\
17781.73\end{array}$ & $\begin{array}{l}14.030 \\
14.029 \\
14.028 \\
14.026 \\
14.025\end{array}$ & $\begin{array}{l}-1.47 \\
-1.48 \\
-1.50 \\
-1.51 \\
-1.52\end{array}$ & $\begin{array}{l}1580 \\
1581 \\
1582 \\
1583 \\
1584\end{array}$ & $\begin{array}{l}18564 \cdot 38 \\
18578.30 \\
18592.22 \\
18606.14 \\
18620.05\end{array}$ & $\begin{array}{l}13.921 \\
13.919 \\
13.917 \\
13.915 \\
13.913\end{array}$ & $\begin{array}{l}-2.17 \\
-2.18 \\
-2.19 \\
-2.20 \\
-2.21\end{array}$ \\
\hline $\begin{array}{l}1465 \\
1466 \\
1467 \\
1468 \\
1469\end{array}$ & $\begin{array}{l}16952.04 \\
16966.13 \\
16980.22 \\
16994.32 \\
17008.41\end{array}$ & $\begin{array}{l}14.094 \\
14.093 \\
14.092 \\
14.091 \\
14.090\end{array}$ & $\begin{array}{l}-0.83 \\
-0.85 \\
-0.86 \\
-0.87 \\
-0.88\end{array}$ & $\begin{array}{l}1525 \\
1526 \\
1527 \\
1528 \\
1529\end{array}$ & $\begin{array}{l}17795.75 \\
17809.78 \\
17823.80 \\
17837.82 \\
17851.83\end{array}$ & $\begin{array}{l}14.023 \\
14.021 \\
14.020 \\
14.018 \\
14.017\end{array}$ & $\begin{array}{l}-1.53 \\
-1.54 \\
-1.55 \\
-1.56 \\
-1.58\end{array}$ & $\begin{array}{l}1585 \\
1586 \\
1587 \\
1588 \\
1589\end{array}$ & $\begin{array}{l}18633.96 \\
18647.87 \\
18661.78 \\
18675.68 \\
18689.58\end{array}$ & $\begin{array}{l}13.910 \\
13.908 \\
13.906 \\
13.904 \\
13.901\end{array}$ & $\begin{array}{l}-2.23 \\
-2.24 \\
-2.25 \\
-2.26 \\
-2.27\end{array}$ \\
\hline $\begin{array}{l}1470 \\
1471 \\
1472 \\
1473 \\
1474\end{array}$ & $\begin{array}{l}17022.50 \\
17036.59 \\
17050.67 \\
17064.76 \\
17078.85\end{array}$ & $\begin{array}{l}14.090 \\
14.089 \\
14.088 \\
14.087 \\
14.086\end{array}$ & $\begin{array}{l}-0.89 \\
-0.90 \\
-0.92 \\
-0.93 \\
-0.94\end{array}$ & $\begin{array}{l}1530 \\
1531 \\
1532 \\
1533 \\
1534\end{array}$ & $\begin{array}{l}17865.85 \\
17879.86 \\
17893.88 \\
17907.89 \\
17921.90\end{array}$ & $\begin{array}{l}14.015 \\
14.014 \\
14.012 \\
14.010 \\
14.009\end{array}$ & $\begin{array}{l}-1.59 \\
-1.60 \\
-1.61 \\
-1.62 \\
-1.63\end{array}$ & $\begin{array}{l}1590 \\
1591 \\
1592 \\
1593 \\
1594\end{array}$ & $\begin{array}{l}18703.48 \\
18717.38 \\
18731.28 \\
18745.17 \\
18759.06\end{array}$ & $\begin{array}{l}13.899 \\
13.897 \\
13.894 \\
13.892 \\
13.890\end{array}$ & $\begin{array}{l}-2 \cdot 28 \\
-2 \cdot 30 \\
-2 \cdot 31 \\
-2.32 \\
-2 \cdot 33\end{array}$ \\
\hline $\begin{array}{l}1475 \\
1476 \\
1477 \\
1478 \\
1479\end{array}$ & $\begin{array}{l}17092.93 \\
17107.02 \\
17121.10 \\
17135.18 \\
17149.27\end{array}$ & $\begin{array}{l}14.085 \\
14.084 \\
14.083 \\
14.082 \\
14.081\end{array}$ & $\begin{array}{l}-0.95 \\
-0.96 \\
-0.97 \\
-0.98 \\
-1.00\end{array}$ & $\begin{array}{l}1535 \\
1536 \\
1537 \\
1538 \\
1539\end{array}$ & $\begin{array}{l}17935.90 \\
17949.91 \\
17963.92 \\
17977.92 \\
17991.92\end{array}$ & $\begin{array}{l}14 \cdot 007 \\
14.005 \\
14 \cdot 004 \\
14.002 \\
14 \cdot 000\end{array}$ & $\begin{array}{l}-1.65 \\
-1.66 \\
-1.67 \\
-1.68 \\
-1.69\end{array}$ & $\begin{array}{l}1595 \\
1596 \\
1597 \\
1598 \\
1599\end{array}$ & $\begin{array}{l}18772.95 \\
18786.84 \\
18800.72 \\
18814.60 \\
18828.48\end{array}$ & $\begin{array}{l}13.887 \\
13.885 \\
13.883 \\
13.880 \\
13.878\end{array}$ & $\begin{array}{l}-2 \cdot 34 \\
-2 \cdot 35 \\
-2 \cdot 37 \\
-2 \cdot 38 \\
-2 \cdot 39\end{array}$ \\
\hline $\begin{array}{l}1480 \\
1481 \\
1482 \\
1483 \\
1484\end{array}$ & $\begin{array}{l}17163.35 \\
17177.43 \\
17191.50 \\
17205.58 \\
17219.66\end{array}$ & $\begin{array}{l}14.080 \\
14.079 \\
14.078 \\
14.077 \\
14.076\end{array}$ & $\begin{array}{l}-1.01 \\
-1.02 \\
-1.03 \\
-1.04 \\
-1.05\end{array}$ & $\begin{array}{l}1540 \\
1541 \\
1542 \\
1543 \\
1544\end{array}$ & $\begin{array}{l}18005.92 \\
18019.92 \\
18033.91 \\
18047.91 \\
18061.90\end{array}$ & $\begin{array}{l}13.999 \\
13.997 \\
13.995 \\
13.994 \\
13.992\end{array}$ & $\begin{array}{l}-1.70 \\
-1.72 \\
-1.73 \\
-1.74 \\
-1.75\end{array}$ & $\begin{array}{l}1600 \\
1601 \\
1602 \\
1603 \\
1604\end{array}$ & $\begin{array}{l}18842.36 \\
18856.23 \\
18870.10 \\
18883.97 \\
18897.84\end{array}$ & $\begin{array}{l}13.876 \\
13.873 \\
13.871 \\
13.868 \\
13.866\end{array}$ & $\begin{array}{l}-2.40 \\
-2.41 \\
-2.42 \\
-2.44 \\
-2.45\end{array}$ \\
\hline $\begin{array}{l}1485 \\
1486 \\
1487 \\
1488 \\
1489\end{array}$ & $\begin{array}{l}17233.73 \\
17247.81 \\
17261.88 \\
17275.95 \\
17290.03\end{array}$ & $\begin{array}{l}14.075 \\
14 \cdot 074 \\
14.073 \\
14.072 \\
14.071\end{array}$ & $\begin{array}{l}-1.07 \\
-1.08 \\
-1.09 \\
-1.10 \\
-1.11\end{array}$ & $\begin{array}{l}1545 \\
1546 \\
1547 \\
1548 \\
1549\end{array}$ & $\begin{array}{l}18075.89 \\
18089.88 \\
18103.87 \\
18117.85 \\
18131.84\end{array}$ & $\begin{array}{l}13.990 \\
13.988 \\
13.987 \\
13.985 \\
13.983\end{array}$ & $\begin{array}{l}-1.76 \\
-1.77 \\
-1.79 \\
-1.80 \\
-1.81\end{array}$ & $\begin{array}{l}1605 \\
1606 \\
1607 \\
1608 \\
1609\end{array}$ & $\begin{array}{l}18911.71 \\
18925.57 \\
18939.43 \\
18953.29 \\
18967.14\end{array}$ & $\begin{array}{l}13.863 \\
13.861 \\
13.859 \\
13.856 \\
13.854\end{array}$ & $\begin{array}{l}-2.46 \\
-2.47 \\
-2.48 \\
-2.49 \\
-2.50\end{array}$ \\
\hline $\begin{array}{l}1490 \\
1491\end{array}$ & $\begin{array}{l}17304 \cdot 10 \\
17318 \cdot 16\end{array}$ & $\begin{array}{l}14.069 \\
14.068\end{array}$ & $\begin{array}{l}-1.12 \\
-1.14\end{array}$ & $\begin{array}{l}1550 \\
1551\end{array}$ & $\begin{array}{l}18145.82 \\
18159.80\end{array}$ & $\begin{array}{l}13.981 \\
13.979\end{array}$ & $\begin{array}{l}-1.82 \\
-1.83\end{array}$ & $\begin{array}{l}1610 \\
1611\end{array}$ & $\begin{array}{l}18980.99 \\
18994.84\end{array}$ & $\begin{array}{l}13.851 \\
13.848\end{array}$ & $\begin{array}{l}-2.52 \\
-2.53\end{array}$ \\
\hline $\begin{array}{l}1492 \\
1493 \\
1494\end{array}$ & $\begin{array}{l}17332 \cdot 23 \\
17346 \cdot 30 \\
17260 \cdot 36\end{array}$ & $\begin{array}{l}14.067 \\
14.066 \\
14.065\end{array}$ & $\begin{array}{l}-1.15 \\
-1.16 \\
-1.17\end{array}$ & $\begin{array}{l}1552 \\
1553 \\
1554\end{array}$ & $\begin{array}{l}18173 \cdot 78 \\
18187.75 \\
18201.73\end{array}$ & $\begin{array}{l}13.977 \\
13.976 \\
13.974\end{array}$ & $\begin{array}{l}-1.84 \\
-1.85 \\
-1.87\end{array}$ & $\begin{array}{l}1612 \\
1613 \\
1614\end{array}$ & $\begin{array}{l}19008.69 \\
19022.53 \\
19036.38\end{array}$ & $\begin{array}{l}13.846 \\
13.843 \\
13.841\end{array}$ & $\begin{array}{l}-2.54 \\
-2.55 \\
-2.56\end{array}$ \\
\hline $\begin{array}{l}1495 \\
1496 \\
1497 \\
1498 \\
1499\end{array}$ & $\begin{array}{l}17374.43 \\
17388.49 \\
17402.55 \\
17416.61 \\
17430.67\end{array}$ & $\begin{array}{l}14.064 \\
14.062 \\
14.061 \\
14.060 \\
14.059\end{array}$ & $\begin{array}{l}-1.18 \\
-1.19 \\
-1.21 \\
-1.22 \\
-1.23\end{array}$ & $\begin{array}{l}1555 \\
1556 \\
1557 \\
1558 \\
1559\end{array}$ & $\begin{array}{l}18215.70 \\
18229.67 \\
18243.64 \\
18257.61 \\
18271.57\end{array}$ & $\begin{array}{l}13.972 \\
13.970 \\
13.968 \\
13.966 \\
13.964\end{array}$ & $\begin{array}{l}-1.88 \\
-1.89 \\
-1.90 \\
-1.91 \\
-1.92\end{array}$ & $\begin{array}{l}1615 \\
1616 \\
1617 \\
1618 \\
1619\end{array}$ & $\begin{array}{l}19050.22 \\
19064.05 \\
19077.89 \\
19091.72 \\
19105.55\end{array}$ & $\begin{array}{l}13.838 \\
13.836 \\
13.833 \\
13.831 \\
13.828\end{array}$ & $\begin{array}{l}-2.57 \\
-2.59 \\
-2.60 \\
-2.61 \\
-2.62\end{array}$ \\
\hline 1500 & 17444.73 & 14.058 & $-1 \cdot 24$ & 1560 & $18285.54^{\circ}$ & 13.962 & -1.94 & 1620 & 19119.37 & 13.825 & -2.63 \\
\hline
\end{tabular}


TABLE 3.3.2. Type R thermocouples-thermoelectric voltages, E(T), Seebeck coefficients, S(T), and first derivative of the Seebeck coefficients, $\mathrm{dS} / \mathrm{dT}$, reference junctions at $0{ }^{\circ} \mathrm{C}-$ Continued

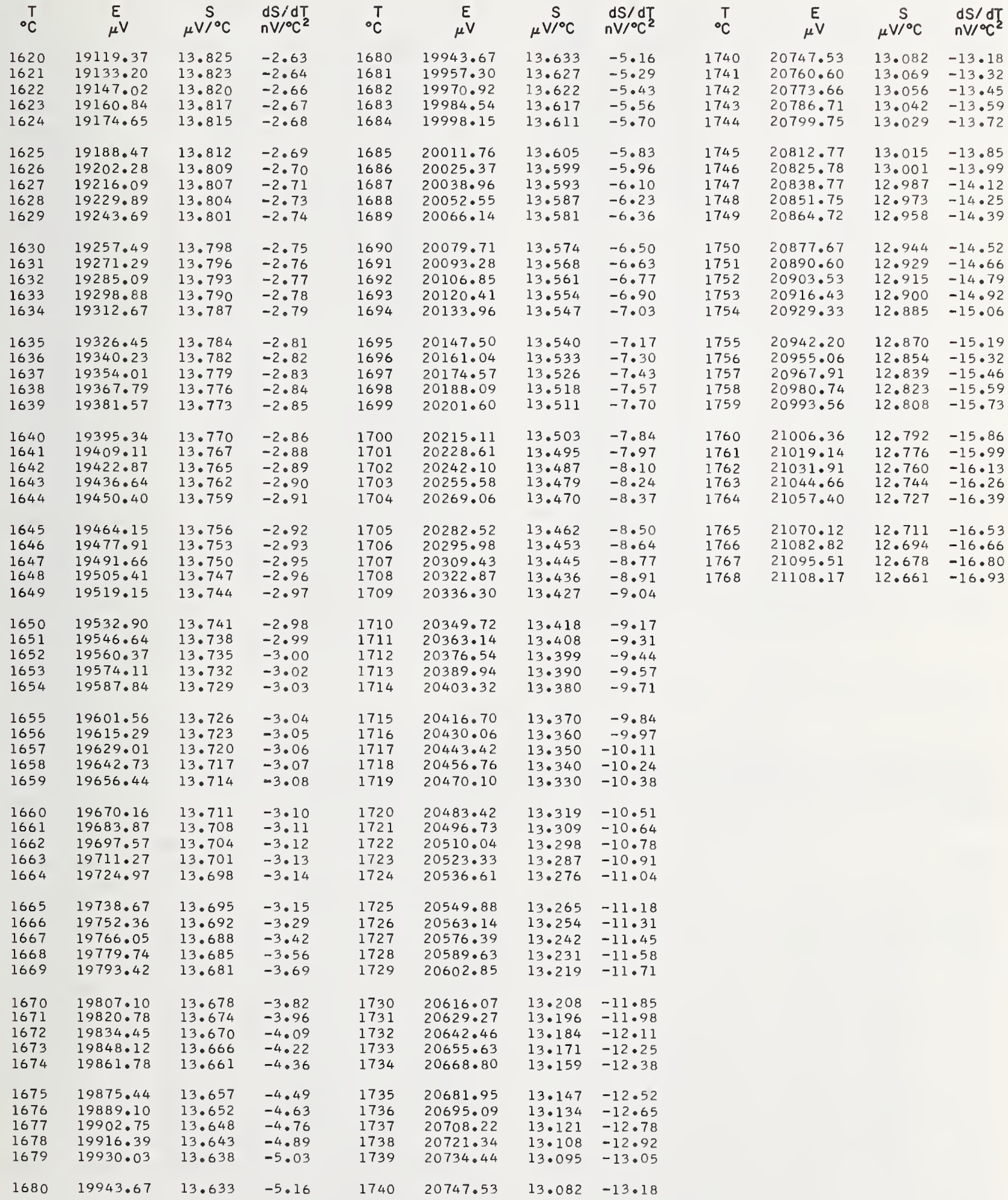


TABLE 3.3.3. Thermoelectric values at the fixed points for Type $R$ thermocouples

\begin{tabular}{|c|c|c|c|c|}
\hline Fixed point & $\begin{array}{l}\text { Temp. } \\
{ }^{\circ} \mathrm{C}\end{array}$ & $\begin{array}{c}E \\
\mu \mathrm{V}\end{array}$ & $\underset{\mu \mathrm{V} /{ }^{\circ} \mathrm{C}}{\mathrm{S}}$ & $\begin{array}{l}d S / d T \\
\mathrm{nV} /{ }^{\circ} \mathrm{C}^{2}\end{array}$ \\
\hline $\begin{array}{l}\text { Mercury FP } \\
\text { Ice Point } \\
\text { Ether TP } \\
\text { Water BP } \\
\text { Benzoic TP } \\
\text { Indium FP } \\
\text { Tin FP } \\
\text { Bismuth FP } \\
\text { Cadmium FP } \\
\text { Lead FP } \\
\text { Mercury BP } \\
\text { Zinc FP } \\
\text { Sulphur BP } \\
\text { Cu-Al FP } \\
\text { Antimony FP* } \\
\text { Aluminum FP } \\
\text { Silver FP } \\
\text { Gold FP* } \\
\text { Copper FP } \\
\text { Nickel FP } \\
\text { Cobalt FP } \\
\text { Palladium FP } \\
\text { Platinum FP }\end{array}$ & $\begin{array}{l}-38.862 \\
0.000 \\
26.87 \\
100.000 \\
122.37 \\
156.634 \\
231.9681 \\
271.442 \\
321.108 \\
327.502 \\
356.66 \\
419.580 \\
444.674 \\
548.23 \\
630.74 \\
660.37 \\
961.93 \\
1064.43 \\
1084.5 \\
1455 \\
1494 \\
1554 \\
1767.6\end{array}$ & $\begin{array}{r}-183.05 \\
0.00 \\
151.72 \\
647.23 \\
818.57 \\
1095.62 \\
1756.10 \\
2125.04 \\
2607.22 \\
2670.59 \\
2962.99 \\
3611.34 \\
3875.95 \\
5000.94 \\
5933.08 \\
6275.90 \\
10003.09 \\
11363.85 \\
11635.49 \\
16811.06 \\
17360.36 \\
18201.73 \\
21103.11\end{array}$ & $\begin{array}{r}4.090 \\
5.289 \\
5.987 \\
7.476 \\
7.837 \\
8.322 \\
9.167 \\
9.517 \\
9.889 \\
9.933 \\
10.121 \\
10.479 \\
10.609 \\
11.110 \\
11.477 \\
11.643 \\
13.052 \\
13.497 \\
13.571 \\
14.102 \\
14.065 \\
13.974 \\
12.668\end{array}$ & $\begin{array}{r}34.13 \\
27.82 \\
24.25 \\
16.98 \\
15.31 \\
13.12 \\
9.55 \\
8.19 \\
6.88 \\
6.74 \\
6.16 \\
5.31 \\
5.10 \\
4.65 \\
4.08 \\
4.91 \\
4.43 \\
4.26 \\
3.58 \\
-0.72 \\
-1.17 \\
-1.87 \\
-16.88\end{array}$ \\
\hline
\end{tabular}

*Junction point of different functions.

TABLE 3.3.4. Estimated maximum errors that occur when using reduced-bit arithmetic for the power series expansion for the thermoelectric voltage of Type $R$ thermocouples

\begin{tabular}{|c|c|c|c|c|c|c|}
\hline \multirow[b]{2}{*}{ Temperature range } & \multirow[b]{2}{*}{ Degree } & \multicolumn{5}{|c|}{ Estimated maximum error in microvolts } \\
\hline & & $12 \mathrm{Bit}$ & $16 \mathrm{Bit}$ & 24. Bit & $27 \mathrm{Bit}$ & 36 Bit \\
\hline-50 to $200^{\circ} \mathrm{C}$ & 7 & 0.6 & 0.01 & $<0.01$ & $<0.01$ & $<0.01$ \\
\hline 200 to $400^{\circ} \mathrm{C}$ & 7 & 2 & 0.03 & $<0.01$ & $<0.01$ & $<0.01$ \\
\hline 400 to $631{ }^{\circ} \mathrm{C}$ & 7 & 4 & 0.1 & $<0.01$ & $<0.01$ & $<0.01$ \\
\hline 632 to $800^{\circ} \mathrm{C}$ & 3 & 3 & 0.2 & $<0.01$ & $<0 \quad 01$ & $<0.01$ \\
\hline 800 to $1064{ }^{\circ} \mathrm{C}$ & 3 & 3 . & 0.2 & $<0.01$ & $<0.01$ & $<0.01$ \\
\hline 1065 to $1200^{\circ} \mathrm{C}$ & 3 & 6 & 0.4 & $<0.01$ & $<0.01$ & $<0.01$ \\
\hline 1200 to $1400{ }^{\circ} \mathrm{C}$ & 3 & 7 & 0.5 & $<0.01$ & $<0.01$ & $<0.01$ \\
\hline 1400 to $1665^{\circ} \mathrm{C}$ & 3 & 9 & 0.6 & $<0.01$ & $<0.01$ & $<0.01$ \\
\hline 1666 to $1768^{\circ} \mathrm{C}$ & 3 & 50 & 4 & 0.02 & $<0.01$ & $<0.01$ \\
\hline
\end{tabular}




\section{TYPE B-Platinum-30\% Rhodium Alloy Versus Platinum- 6\% Rhodium Alloy Thermocouples}

\section{I. Material Specifications and Precautions}

This type is often referred to by the nominal chemical composition of its thermoelements-platinum$30 \%$ rhodium versus platinum-6\% rhodium or "30-6". The actual composition is somewhat different however. The positive thermoelement, $\mathrm{BP}$, is usually a platinum alloy with $29.60 \pm 0.2 \mathrm{wt} \%$ rhodium; the negative thermoelement, $\mathrm{BN}$, usually has $6.12 \pm$ 0.02 wt $\%$ rhodium. The effect of differences in rho. dium content are described later in this section. Because of its favorable characteristics, the 30-6 thermocouple has rapidly gained acceptance and become widely used in this country. The Temperature Section of the National Bureau of Standards, as requested by the American Society for Testing and Materials, Committee E-20, prepared reference tables for the thermocouple to facilitate its use and calibration. Thermocouples were obtained from three manufacturers in the United States and from one European manufacturer and were calibrated by conventional methods. The results were published by Burns and Gallagher [1966].

The 30-6 thermocouple was first introduced in Europe by Degussa of Hanau, Germany. Reference curves and tables were published for their thermo. couple by Obrowski and Prinz [1962]. The values of thermoelectric voltage were represented by a set of cubic equations developed from typical values at various thermometric fixed points. Differences between the values given in this Monograph and the ones reported by Obrowski and Prinz [1962] are given in the next section.

Studies by Ehringer [1954.], by Walker, Ewing, and Miller [1962 and 1965], and by Glawe [1970] have demonstrated that thermocouples in which both legs are platinum-rhodium alloys are suitable for reliable temperature measurements at high temperatures. Such thermocouples have been shown to offer the following distinct advantages over the more familiar Type S (platinum-10\% rhodium versus platinum) and Type $\mathrm{R}$ (platinum-13\% rhodium versus platinum) thermo. couples at high temperatures: (1) improved stability, (2) increased mechanical strength, and (3) higher possible operating temperatures. In addition to the platinum-rhodium thermocouple combinations which have standardized letter designations, Types S, R, and $\mathrm{B}$, there are two other infrequently used combinations: platinum-20\% rhodium versus platinum-5\% rhodium, and platinum- $40 \%$ rhodium versus platinum$20 \%$ rhodium, referred to respectively as $20-5$ and 40-20 thermocouples. Reference tables for the 20-5 and 40-20 thermocouples (based on the IPTS-48) were published by Bedford [1964 and 1965].

Of the three combinations where platinum-rhodium alloys are used in the negative leg, the 30-6 thermocouple offers the most favorable overall characteristics and is the only one with a standardized letter designation. Although the thermoelectric characteristics of the 30-6 thermocouple and the 20-5 thermocouple are similar, the 30-6 thermocouple offers a slightly greater Seebeck coefficient at the higher temperatures and it also has a somewhat higher tensile strength. Under similar conditions of temperature and environment, the 30-6 thermocouple shows less grain growth and less drift in calibration than either Type $\mathrm{S}$ or Type $\mathrm{R}$ thermocouples. Various physical properties of these types of thermocouples are described in the ASTM Manual STP 470 [1970] on the use of thermocouples.

The research by Burns and Gallagher [1966] indicated that the 30-6 thermocouple can be used intermittently (for several hours) up to $1800{ }^{\circ} \mathrm{C}$ and continuously (for several hundred hours) at temperatures up to about $1750{ }^{\circ} \mathrm{C}$ with only small changes in calibration. The maximum temperature limit for the thermocouple is governed, primarily, by the melting point of the $\mathrm{Pt}-6$ percent $\mathrm{Rh}$ thermoelement which is estimated to be about $1820^{\circ} \mathrm{C}$ by Acken [1934]. The thermocouple is most reliable when used in a clean oxidizing atmosphere (air) but has also been used successfully in neutral atmospheres or vacuum by Walker et al. [1962], Hendricks and McElroy [1964], Walker et al. [1965], and Glawe [1970]. The stability of the thermocouple at high temperatures has been shown by Walker et al. [1962] to depend, primarily, upon the quality of the materials used for protecting and insulating the thermocouple. High purity alumina with low iron-content appears to be the most suitable material available today for the purpose.

The ASTM Manual STP 470 [1970] indicates the following restrictions on the use of Type B thermocouples at high temperatures:

They should not be used in reducing atmospheres, nor those containing metallic or nonmetallic vapors, unless suitably protected with nonmetallic protecting tubes. They should never be inserted directly into a metallic primary protecting tube.

At temperatures below $450{ }^{\circ} \mathrm{C}$ the Seebeck coefficient of Type B thermocouples becomes quite small and is almost negligible in the normal room temperature range. Consequently, in most applications the reference junction temperature of the thermocouple does not need to be controlled or even known, as long at it is between 0 and $50{ }^{\circ} \mathrm{C}$. For example, as shown by the reference tables, the voltage developed by the thermocouple with the reference junction at $0{ }^{\circ} \mathrm{C}$ undergoes a reversal in sign at about $43{ }^{\circ} \mathrm{C}$, and between 0 and $50{ }^{\circ} \mathrm{C}$ varies from a minimum of about $-3 \mu \mathrm{V}$ near $20{ }^{\circ} \mathrm{C}$ to a maximum of about $2 \mu \mathrm{V}$ at $50{ }^{\circ} \mathrm{C}$. Therefore, in use, if the reference junction of the thermocouple is within the range 0 to $50^{\circ} \mathrm{C}$, then a $0{ }^{\circ} \mathrm{C}$ reference junction temperature can be assumed and the error introduced will not exceed $3 \mu \mathrm{V}$. At high temperatures (above $1100{ }^{\circ} \mathrm{C}$ ) an additional error of $3 \mu \mathrm{V}$ (about $0.3{ }^{\circ} \mathrm{C}$ ) in the measurements would be significant in most instances. 
Burns and Gallagher [1966] found significant differences in the purity of the platinum-rhodium thermoelements from the various manufacturers. Appreciable amounts of $\mathrm{Fe}, \mathrm{Ir}, \mathrm{Au}, \mathrm{Pd}, \mathrm{Si}$, and $\mathrm{Al}$ were detected in some of the platinum-rhodium wires as well as small traces of $\mathrm{Ca}, \mathrm{Mg}, \mathrm{B}$, and $\mathrm{Cu}$. The amounts of impurities varied significantly from wire to wire.

In order to study the effect of varying the rhodium content of the alloys, Burns and Gallagher [1966] measured the thermoelectric voltages of four wires near 29.60 percent rhodium and of five wires near 6.12 percent rhodium. They calculated that a 0.1 percent change in the rhodium content of the platinumnominally $30 \%$ rhodium thermoelement produces a corresponding change in the thermocouple voltage of about $15 \mu \mathrm{V}$ at $1500{ }^{\circ} \mathrm{C}$. In contrast a change of only 0.01 percent in the rhodium content of platinumnominally $6 \%$ rhodium thermoelement also produces a voltage change of about $15 \mu \mathrm{V}$ at this temperature. In both cases, a decrease in the rhodium content decreases the thermoelectric voltage of that thermoelement with respect to platinum.

The thermoelectric voltage of Type B thermocouples is sensitive to their history of annealing, heat treatment and quenching. Burns and Gallagher [1966] recommend an electrical anneal in air for one hour at about $1450{ }^{\circ} \mathrm{C}$, followed by slow cooling. Calibration of Type $\mathrm{B}$ wires above $1600{ }^{\circ} \mathrm{C}$ is undesirable in most circumstances.

ASTM Standard E230-72 in the Annual Book of ASTM Standards [1972] specifies that the standard limits of error for Type B commercial thermocouples be $\pm 1 / 2$ percent between 871 and $1705^{\circ} \mathrm{C}$. Limits of error are not specified for Type B thermocouples below $871{ }^{\circ} \mathrm{C}$. The recommended upper temperature limit for protected thermocouples, $1705{ }^{\circ} \mathrm{C}$, applies to $\mathrm{AWG}$ $24.0 .5 \mathrm{~mm})$ wire.

The information of Burns and Gallagher [1966], after updating, can be summarized as follows:

(1) Nearly all 30-6 thermocouples produced by manufacturers in this country will have thermoelectric voltages that agree with the values given in this Monograph to within the equivalent of \pm 0.5 percent of the temperature in the range 500 to $1800{ }^{\circ} \mathrm{C}$ and to within $\pm 15 \mu \mathrm{V}$ for temperatures below $500{ }^{\circ} \mathrm{C}$.

(2) Calibration of a particular 30-6 thermocouple at four points (about $600,1064,1300$, and $1554{ }^{\circ} \mathrm{C}$ ) will be sufficient to construct a deviation curve from the reference table such that the resulting calibration will be accurate to within $\pm 6 \mu \mathrm{V}$ up to $1064^{\circ} \mathrm{C}$, the equivalent of about $\pm 3{ }^{\circ} \mathrm{C}$ up to $1554{ }^{\circ} \mathrm{C}$, and the equivalent of about $\pm 5{ }^{\circ} \mathrm{C}$ above.

(3) Actual calibration of the thermocouple above about $1600{ }^{\circ} \mathrm{C}$ is not recommended, since some instability may result in the thermocouple. Values above $1600{ }^{\circ} \mathrm{C}$ may be accurately determined by extrapolation.

(4) High purity alumina is recommended for insulation and protection of the thermocouple but caution should be, exercised at temperatures above about 1600 ${ }^{\circ} \mathrm{C}$ for errors introduced by the electrical conductance of the insulators.
(5) The use of large diameter wires (at least 0.5 $\mathrm{mm}$ or AWG24) and larger size insulating tubes is recommended for operating temperatures above 1500 or $1600{ }^{\circ} \mathrm{C}$, so as to give the thermocouple added strength and to minimize errors due to electrical leakage.

(6) In most instances the reference junction temperature need not be controlled since the emf and thermoelectric power of the thermocouple at normal room temperatures are very small.

\subsection{Data Analyses and Comparisons}

The fitting functions for Type B thermocouples are based completely on original research data that had been analyzed previously by Burns and Gallagher $[1966,1970]$. The values for single thermoelements versus platinum were adjusted to be on the IPTS-68 and to be relative to the present platinum thermoelectric reference standard, $\mathrm{Pt}-67$. The differences between $\mathrm{Pt}-67$ and the former standard, $\mathrm{Pt}-27$, are summarized in section 1.2. The method of analysis was also different, of course. In particular, the method of "principal points" and spline fitting was not used for com. putations in this Monograph.

The data on the single thermoelements versus platinum were considered more precise than those for the total Type B combination. Therefore, data for the separate single thermoelements were used in the fitting procedures and the total combination was obtained by direct subtraction of the $\mathrm{BN}$ values given in the tables from the BP values. For all other thermocouple combinations, the total voltage is obtained by addition of functions for the two separate thermoelements. However, for the Type B thermocouples, both thermoelements are positive with respect to $\mathrm{Pt}-67$.

For the positive thermoelement, $P t-30 \% \mathrm{Rh}$ (BP), two wires were selected for fitting: $\mathrm{Bl}$ and $\mathrm{B} 3$ as described in section 4 of the article by Burns and Gallagher [1966]. There were 59 experimental points between 24 and $1820{ }^{\circ} \mathrm{C}$ including three extrapolated points above the highest temperature measured by Burns and Gallagher [1966], $1750{ }^{\circ} \mathrm{C}$. With an eight term function, the standard deviation of the fit was $0.8 \mu \mathrm{V}$.

Two different wires, also marked B1 and B3, were used for fitting of the negative thermoelement, BN. Again there were 59 experimental points, including three extrapolated points above $1750{ }^{\circ} \mathrm{C}$. With an eight term function, the standard deviation of the fit was $0.9 \mu \mathrm{V}$.

The values for thermoelectric voltages given in this Monograph were compared to those given in 20 calibrations (dated between 1967 and 1970) from the Temperature Section of the National Bureau of Standards in Gaithersburg and to those quoted for two other thermocouples investigated by Burns and Gallagher [1966]. In most cases the deviations were linear in temperature and usually smooth, within the precision of the data. Deviations between values in this Monograph and values reported by Burns and Gallagher [1966] for thermocouples A, B, and C are shown in figures $4.2 .1,4.2 .2$, and 4.2 .3 , for Types B, 


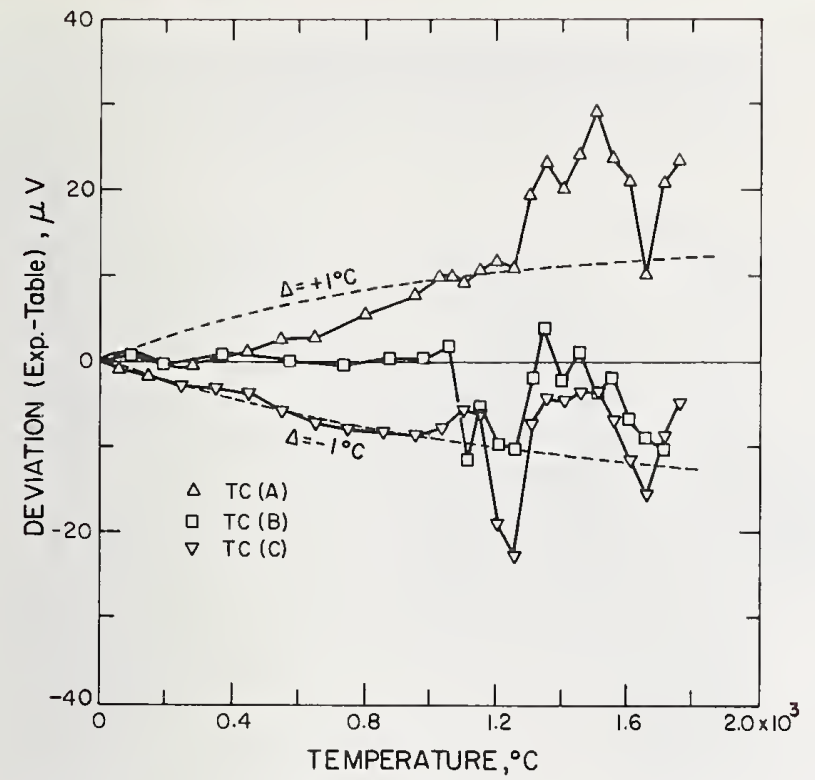

F1GURE 4.2.1. Deviations in thermoelectric voltages of Type $B$ thermocouples-comparison of values given in this Monograph to those given for thermocouples $A, B$, and $C$ by Burns and Gallagher [1966].

Values from the previous puhlication are adjusted to the IPTS-68. The Values from the previous puhlication are
dashed lines indicate a deviation of $1^{\circ} \mathrm{C}$.

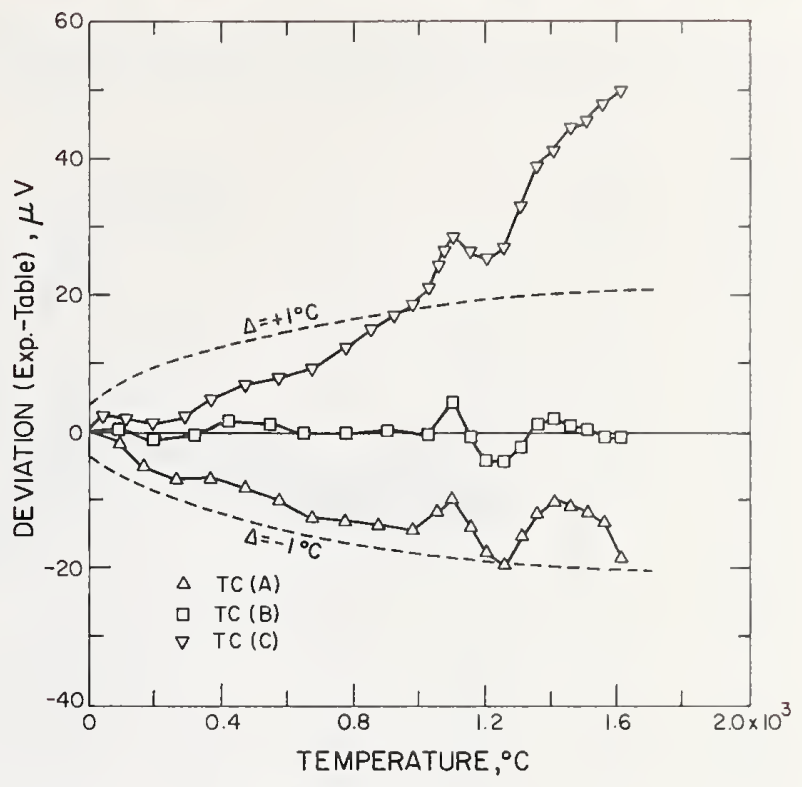

Figure 4.2.2. Deviations of thermoelectric voltages of Type $B P$ thermoelements versus platinum, $\mathrm{Pt}-67$ - comparison of values given in this Monograph to those given for thermocouple materials $A, B$, and $C$ by Burns and Gallagher [1966].

Values from the previous puhlication are adjusted to the IPTS-68. The dashed lines indicate a deviation of $1{ }^{\circ} \mathrm{C}$.

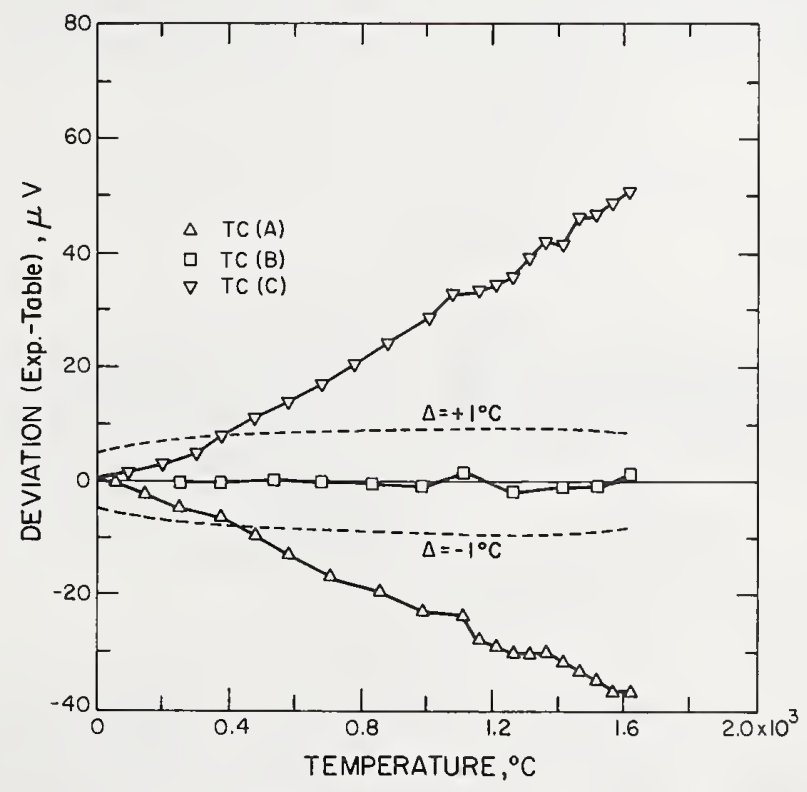

Figure 4.2.3. Deviations of thermoelectric voltages of Type

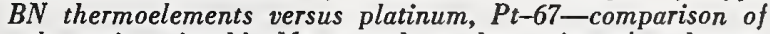
values given in this Monograph to those given for thermocouple materials A, B, and C by Burns and Gallagher [1966]. Values from the previous puhlication are adjusted to the IPTS-68. The dashed lines indicate a deviation of $1^{\circ} \mathrm{C}$.

$\mathrm{BP}$, and $\mathrm{BN}$, respectively. All values were adjusted to the IPTS-68 scale.

Deviations between values given in this Monograph and those given by Burns and Gallagher [1966] are shown in figure 4.2.4. The earlier values were adjusted to the IPTS-68. The deviation curve indicates differences caused by the different fitting techniques. The width of the curve represents the round-off un. 


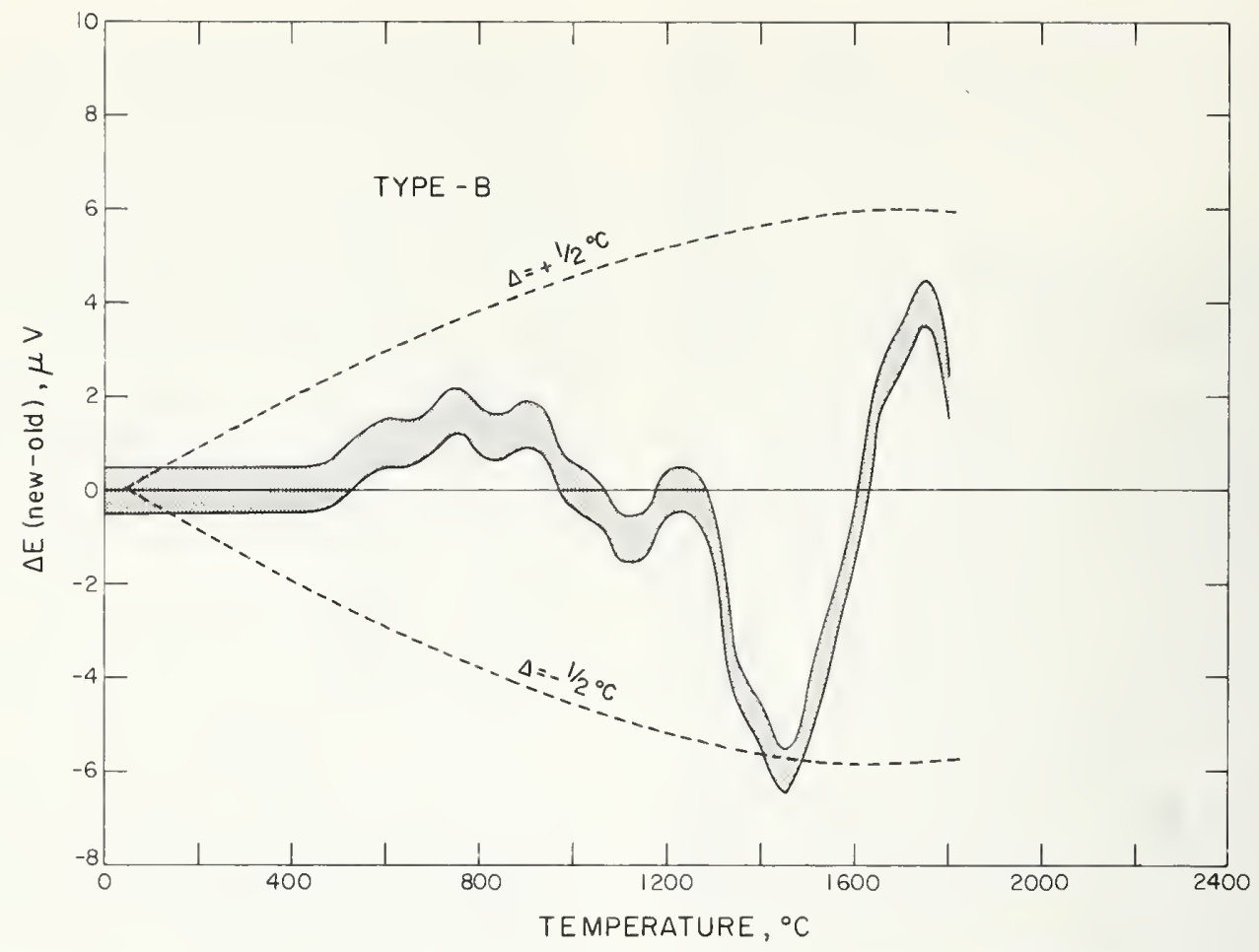

Figure 4.2.4. Difference in thermoelectric voltages for Type B thermocouples-comparison of values given in this Monograph to those from Burns and Gallagher [1966].

The width of the shaded curve indicates the round-off uncertainty in the previous tabular values. Values from the previous publication are adjusted to the IPTS -68 . The dashed lines indicate a deviation of $1 / 2{ }^{\circ} \mathrm{C}$.

TABLE 4.2.1. Deviation in thermoelectric voltage between tabular values in this Monograph and the earlier Degussa calibration for Type B thermocouples

\begin{tabular}{c|c}
\hline \hline & $\begin{array}{c}\text { Deviation } \\
\text { Temp., }{ }^{\circ} \mathrm{C}\end{array}$ \\
\hline 500 & -5 \\
600 & -3 \\
700 & -0 \\
800 & -0 \\
900 & -2 \\
1000 & -3 \\
1100 & -4 \\
1200 & -5 \\
1300 & -7 \\
1400 & -3 \\
1500 & +6 \\
1600 & +19 \\
1700 & +29 \\
1800 & +34 \\
& \\
\hline
\end{tabular}

certainty $(\mathrm{I} \mu \mathrm{V})$ in the tabular values quoted by Burns and Gallagher [1966].

Deviations between values given in this Monograph and those given by Obrowski and Prinz [1962] for the Degussa calibration are tabulated in table 4.2.1. The older values have been adjusted to be on the IPTS-68.

\subsection{Reference Functions and Tables for Type B Thermocouples}

The coefficients for the eighth degree expansion for the thermoelectric voltage of Type B thermocouples are given in table 4.3.1. The errors caused by using reduced bit arithmetic for calculating values of the functions are given in table 4.3.4.

The primary reference values for Type B thermocouples are given in table 4,3.2. Values at selected fixed points are given in table 4.3.3. Graphs of the thermoelectric voltage, its first derivative (Seebeck coefficient), and second derivative are given in figures 4.3.1, 4.3.2, and 4.3.3, respectively. 
TABLE 4.3.1. Power series expansion for the thermoelectric voltage of Type B thermocouples

\begin{tabular}{|c|c|c|c|}
\hline $\begin{array}{c}\text { Tempera- } \\
\text { ture } \\
\text { range }\end{array}$ & Degree & Coefficients & Term \\
\hline $\begin{array}{l}0 \text { to } \\
\quad 1820^{\circ} \mathrm{C}\end{array}$ & 8 & $\begin{array}{r}-2.4674601620 \times 10^{-1} \\
5.9102111169 \times 10^{-3} \\
-1.4307123430 \times 10^{-6} \\
2.1509149750 \times 10^{-9} \\
-3.1757800720 \times 10^{-12} \\
2.4010367459 \times 10^{-15} \\
-9.0928148159 \times 10^{-19} \\
1.3299505137 \times 10^{-22}\end{array}$ & $\begin{array}{l}T \\
T^{2} \\
T^{3} \\
T^{4} \\
T^{5} \\
T^{6} \\
T^{7} \\
T^{8}\end{array}$ \\
\hline
\end{tabular}

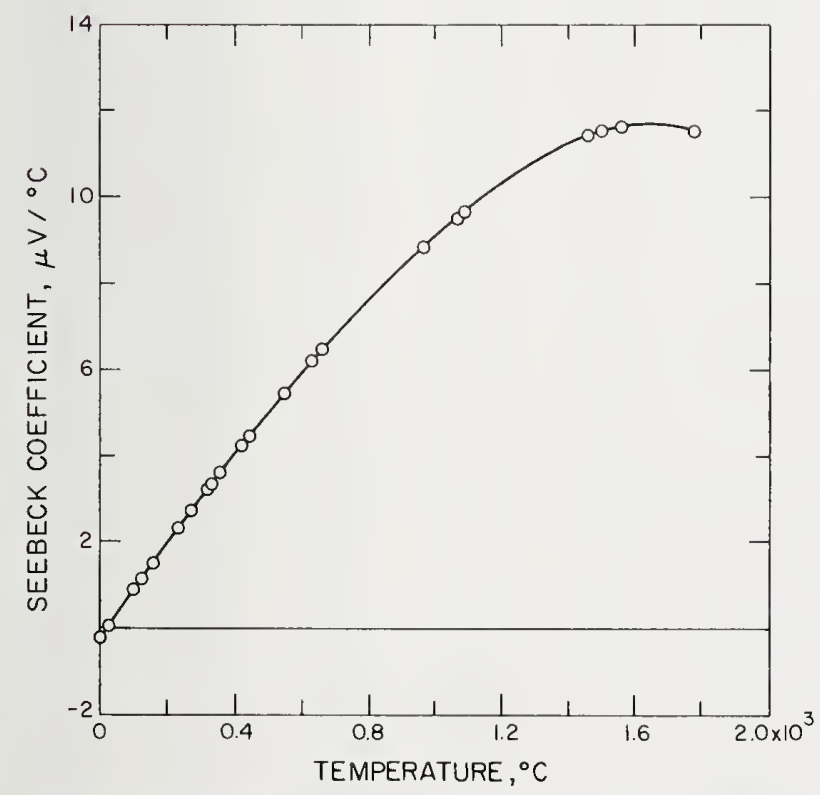

Figure 4.3.2. Seebeck coefficient for Type B thermocouples. The circles indicate values at various thermometric fixed points on the IPTS -68 .

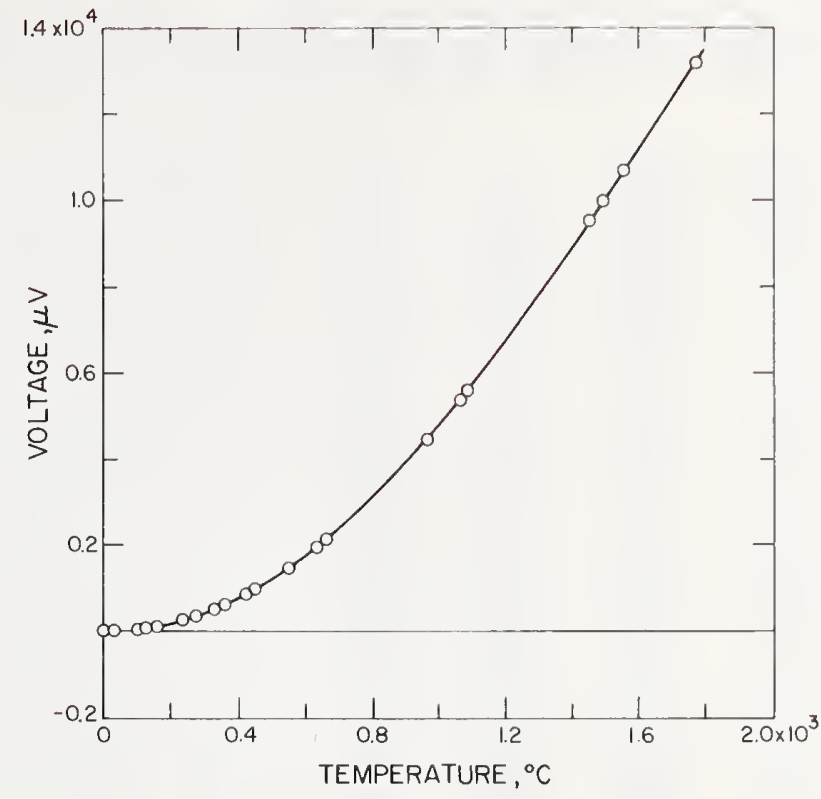

Figure 4.3.1. Thermoelectric voltage for Type B thermocouples.

The circles indicate values at various thermometric fixed points on the IPT S-68.

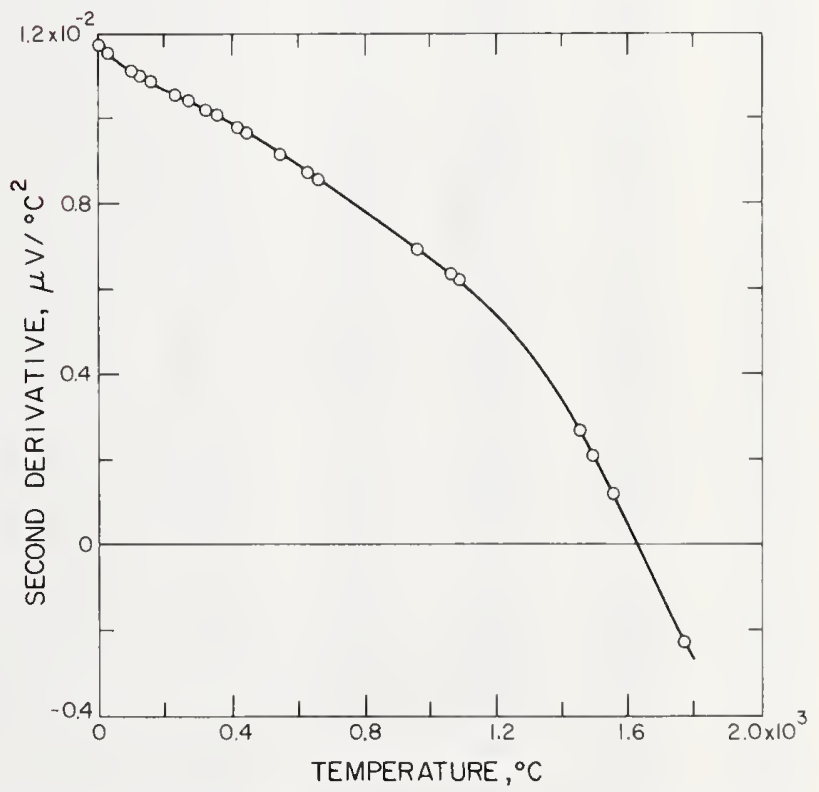

Figure 4.3.3. Second derivative of thermoelectric voltage for Type B thermocouples.

The circles indicate values at various thermometric fixed points on the IPTS -68 . 
TABLE 4.3.2. Type B thermocouples-thermoelectric voltages, $\mathrm{E}(\mathrm{T})$, Seebeck coefficients, $\mathrm{S}(\mathrm{T})$, and first derivative of the Seebeck coefficients, $\mathrm{dS} / \mathrm{dT}$, reference junctions at $0^{\circ} \mathrm{C}$

\begin{tabular}{|c|c|c|c|c|c|c|c|c|c|c|c|}
\hline${ }^{\top} \mathrm{T}$ & $\underset{\mu V}{E}$ & $\underset{\mu V /{ }^{\circ} \mathrm{C}}{\mathrm{S}}$ & $\begin{array}{l}d S / d T \\
n V /{ }^{\circ} C^{2}\end{array}$ & $\begin{array}{r}\mathrm{T} \\
{ }^{\circ} \mathrm{C}\end{array}$ & $\underset{\mu V}{E}$ & $\underset{\mu \mathrm{V} /{ }^{\circ} \mathrm{C}}{\mathrm{S}}$ & $\begin{array}{l}d S / d T \\
n V /{ }^{\circ} C^{2}\end{array}$ & ${ }^{\circ} \mathrm{C}$ & $\underset{\mu V}{E V}$ & $\begin{array}{c}\mathrm{S} \\
\mu \mathrm{V} /{ }^{\circ} \mathrm{C}\end{array}$ & $\begin{array}{l}d S / d T \\
n V /{ }^{\circ} C^{2}\end{array}$ \\
\hline $\begin{array}{l}0 \\
1 \\
2 \\
3 \\
4\end{array}$ & $\begin{array}{r}0.00 \\
-0.24 \\
-0.47 \\
-0.69 \\
-0.89\end{array}$ & $\begin{array}{l}-0.247 \\
-0.235 \\
-0.223 \\
-0.211 \\
-0.200\end{array}$ & $\begin{array}{l}11.82 \\
11.81 \\
11.80 \\
11.79 \\
11.79\end{array}$ & $\begin{array}{l}60 \\
61 \\
62 \\
63 \\
64\end{array}$ & $\begin{array}{l}6.19 \\
6.64 \\
7.11 \\
7.59 \\
8.07\end{array}$ & $\begin{array}{l}0.449 \\
0.460 \\
0.471 \\
0.483 \\
0.494\end{array}$ & $\begin{array}{l}11 \cdot 39 \\
11 \cdot 38 \\
11 \cdot 37 \\
11 \cdot 37 \\
11 \cdot 36\end{array}$ & $\begin{array}{l}120 \\
121 \\
122 \\
123 \\
124\end{array}$ & $\begin{array}{l}53.40 \\
54.53 \\
55.66 \\
56.81 \\
57.97\end{array}$ & $\begin{array}{l}1.122 \\
1.133 \\
1.144 \\
1.155 \\
1.166\end{array}$ & $\begin{array}{l}11.07 \\
11.06 \\
11.06 \\
11.05 \\
11.05\end{array}$ \\
\hline $\begin{array}{l}5 \\
6 \\
7 \\
8 \\
9\end{array}$ & $\begin{array}{l}-1.09 \\
-1.27 \\
-1.44 \\
-1.60 \\
-1.74\end{array}$ & $\begin{array}{l}-0.188 \\
-0.176 \\
-0.164 \\
-0.152 \\
-0.141\end{array}$ & $\begin{array}{l}11.78 \\
11.77 \\
11.76 \\
11.75 \\
11.75\end{array}$ & $\begin{array}{l}65 \\
66 \\
67 \\
68 \\
69\end{array}$ & $\begin{array}{r}8.57 \\
9.09 \\
9.61 \\
10.14 \\
10.69\end{array}$ & $\begin{array}{l}0.506 \\
0.517 \\
0.528 \\
0.540 \\
0.551\end{array}$ & $\begin{array}{l}11 \cdot 36 \\
11 \cdot 35 \\
11 \cdot 34 \\
11 \cdot 34 \\
11 \cdot 33\end{array}$ & $\begin{array}{l}125 \\
126 \\
127 \\
128 \\
129\end{array}$ & $\begin{array}{l}59.15 \\
60.33 \\
61.52 \\
62.73 \\
63.94\end{array}$ & $\begin{array}{l}1.177 \\
1.188 \\
1.199 \\
1.210 \\
1.221\end{array}$ & $\begin{array}{l}11.04 \\
11.04 \\
11.03 \\
11.03 \\
11.02\end{array}$ \\
\hline $\begin{array}{l}10 \\
11 \\
12 \\
13 \\
14\end{array}$ & $\begin{array}{l}-1.88 \\
-2.00 \\
-2.11 \\
-2.21 \\
-2.30\end{array}$ & $\begin{array}{l}-0.129 \\
-0.117 \\
-0.106 \\
-0.094 \\
-0.082\end{array}$ & $\begin{array}{l}11.74 \\
11.73 \\
11.72 \\
11.71 \\
11.71\end{array}$ & $\begin{array}{l}70 \\
71 \\
72 \\
73 \\
74\end{array}$ & $\begin{array}{l}11.24 \\
11.81 \\
12.39 \\
12.98 \\
13.58\end{array}$ & $\begin{array}{l}0.562 \\
0.574 \\
0.585 \\
0.596 \\
0.608\end{array}$ & $\begin{array}{l}11 \cdot 33 \\
11 \cdot 32 \\
11 \cdot 31 \\
11 \cdot 31 \\
11.30\end{array}$ & $\begin{array}{l}130 \\
131 \\
132 \\
133 \\
134\end{array}$ & $\begin{array}{l}65.17 \\
66.41 \\
67.66 \\
68.92 \\
70.19\end{array}$ & $\begin{array}{l}1.232 \\
1.243 \\
1.254 \\
1.265 \\
1.276\end{array}$ & $\begin{array}{l}11.02 \\
11.02 \\
11.01 \\
11.01 \\
11.00\end{array}$ \\
\hline $\begin{array}{l}15 \\
16 \\
17 \\
18 \\
19\end{array}$ & $\begin{array}{l}-2.38 \\
-2.44 \\
-2.49 \\
-2.53 \\
-2.56\end{array}$ & $\begin{array}{l}-0.070 \\
-0.059 \\
-0.047 \\
-0.035 \\
-0.024\end{array}$ & $\begin{array}{l}11.70 \\
11.69 \\
11.68 \\
11.67 \\
11.67\end{array}$ & $\begin{array}{l}75 \\
76 \\
77 \\
78 \\
79\end{array}$ & $\begin{array}{l}14 \cdot 20 \\
14 \cdot 82 \\
15.46 \\
16.10 \\
16.76\end{array}$ & $\begin{array}{l}0.619 \\
0.630 \\
0.641 \\
0.653 \\
0.664\end{array}$ & $\begin{array}{l}11 \cdot 30 \\
11.29 \\
11.29 \\
11.28 \\
11.27\end{array}$ & $\begin{array}{l}135 \\
136 \\
137 \\
138 \\
139\end{array}$ & $\begin{array}{l}71.47 \\
72.76 \\
74.07 \\
75.38 \\
76.71\end{array}$ & $\begin{array}{l}1.287 \\
1.298 \\
1.309 \\
1.320 \\
1.331\end{array}$ & $\begin{array}{l}11.00 \\
10.99 \\
10.99 \\
10.98 \\
10.98\end{array}$ \\
\hline $\begin{array}{l}20 \\
21 \\
22 \\
23 \\
24\end{array}$ & $\begin{array}{l}-2.58 \\
-2.59 \\
-2.58 \\
-2.57 \\
-2.54\end{array}$ & $\begin{array}{r}-0.012 \\
-0.000 \\
0.011 \\
0.023 \\
0.035\end{array}$ & $\begin{array}{l}11.66 \\
11.65 \\
11.64 \\
11.64 \\
11.63\end{array}$ & $\begin{array}{l}80 \\
81 \\
82 \\
83 \\
84\end{array}$ & $\begin{array}{l}17.43 \\
18.11 \\
18.80 \\
19.51 \\
20.22\end{array}$ & $\begin{array}{l}0.675 \\
0.686 \\
0.698 \\
0.709 \\
0.720\end{array}$ & $\begin{array}{l}11 \cdot 27 \\
11.26 \\
11 \cdot 26 \\
11.25 \\
11.25\end{array}$ & $\begin{array}{l}140 \\
141 \\
142 \\
143 \\
144\end{array}$ & $\begin{array}{l}78.04 \\
79.39 \\
80.75 \\
82.12 \\
83.50\end{array}$ & $\begin{array}{l}1.342 \\
1.353 \\
1.364 \\
1.375 \\
1.386\end{array}$ & $\begin{array}{l}10.98 \\
10.97 \\
10.97 \\
10.96 \\
10.96\end{array}$ \\
\hline $\begin{array}{l}25 \\
26 \\
27 \\
28 \\
29\end{array}$ & $\begin{array}{l}-2.50 \\
-2.44 \\
-2.38 \\
-2.31 \\
-2.22\end{array}$ & $\begin{array}{l}0.046 \\
0.058 \\
0.069 \\
0.081 \\
0.093\end{array}$ & $\begin{array}{l}11.62 \\
11.61 \\
11.61 \\
11.60 \\
11.59\end{array}$ & $\begin{array}{l}85 \\
86 \\
87 \\
88 \\
89\end{array}$ & $\begin{array}{l}20.95 \\
21.69 \\
22.43 \\
23.19 \\
23.96\end{array}$ & $\begin{array}{l}0.731 \\
0.743 \\
0.754 \\
0.765 \\
0.776\end{array}$ & $\begin{array}{l}11 \cdot 24 \\
11 \cdot 24 \\
11 \cdot 23 \\
11 \cdot 23 \\
11 \cdot 22\end{array}$ & $\begin{array}{l}145 \\
146 \\
147 \\
148 \\
149\end{array}$ & $\begin{array}{l}84.89 \\
86.29 \\
87.71 \\
89.13 \\
90.57\end{array}$ & $\begin{array}{l}1.397 \\
1.408 \\
1.419 \\
1.430 \\
1.441\end{array}$ & $\begin{array}{l}10.95 \\
10.95 \\
10.95 \\
10.94 \\
10.94\end{array}$ \\
\hline $\begin{array}{l}30 \\
31 \\
32 \\
33 \\
34\end{array}$ & $\begin{array}{l}-2.12 \\
-2.01 \\
-1.89 \\
-1.76 \\
-1.61\end{array}$ & $\begin{array}{l}0.104 \\
0.116 \\
0.127 \\
0.139 \\
0.151\end{array}$ & $\begin{array}{l}11.58 \\
11.58 \\
11.57 \\
11.56 \\
11.56\end{array}$ & $\begin{array}{l}90 \\
91 \\
92 \\
93 \\
94\end{array}$ & $\begin{array}{l}24.75 \\
25.54 \\
26.34 \\
27.16 \\
27.99\end{array}$ & $\begin{array}{l}0.788 \\
0.799 \\
0.810 \\
0.821 \\
0.832\end{array}$ & $\begin{array}{l}11 \cdot 22 \\
11 \cdot 21 \\
11 \cdot 20 \\
11 \cdot 20 \\
11.19\end{array}$ & $\begin{array}{l}150 \\
151 \\
152 \\
153 \\
154\end{array}$ & $\begin{array}{l}92.01 \\
93.47 \\
94.94 \\
96.42 \\
97.91\end{array}$ & $\begin{array}{l}1.452 \\
1.463 \\
1.474 \\
1.485 \\
1.495\end{array}$ & $\begin{array}{l}10.93 \\
10.93 \\
10.92 \\
10.92 \\
10.92\end{array}$ \\
\hline $\begin{array}{l}35 \\
36 \\
37 \\
38 \\
39\end{array}$ & $\begin{array}{l}-1.45 \\
-1.29 \\
-1.11 \\
-0.92 \\
-0.71\end{array}$ & $\begin{array}{l}0.162 \\
0.174 \\
0.185 \\
0.197 \\
0.208\end{array}$ & $\begin{array}{l}11.55 \\
11.54 \\
11.54 \\
11.53 \\
11.52\end{array}$ & $\begin{array}{l}95 \\
96 \\
97 \\
98 \\
99\end{array}$ & $\begin{array}{l}28.82 \\
29.67 \\
30.53 \\
31.41 \\
32.29\end{array}$ & $\begin{array}{l}0.844 \\
0.855 \\
0.866 \\
0.877 \\
0.888\end{array}$ & $\begin{array}{l}11 \cdot 19 \\
11 \cdot 18 \\
11.18 \\
11 \cdot 17 \\
11.17\end{array}$ & $\begin{array}{l}155 \\
156 \\
157 \\
158 \\
159\end{array}$ & $\begin{array}{r}99.41 \\
100.92 \\
102.44 \\
103.98 \\
105.52\end{array}$ & $\begin{array}{l}1.506 \\
1.517 \\
1.528 \\
1.539 \\
1.550\end{array}$ & $\begin{array}{l}10.91 \\
10.91 \\
10.90 \\
10.90 \\
10.90\end{array}$ \\
\hline $\begin{array}{l}40 \\
41 \\
42 \\
43 \\
44\end{array}$ & $\begin{array}{r}-0.50 \\
-0.27 \\
-0.04 \\
0.21 \\
0.47\end{array}$ & $\begin{array}{l}0.220 \\
0.231 \\
0.243 \\
0.254 \\
0.266\end{array}$ & $\begin{array}{l}11.51 \\
11.51 \\
11.50 \\
11.49 \\
11.49\end{array}$ & $\begin{array}{l}100 \\
101 \\
102 \\
103 \\
104\end{array}$ & $\begin{array}{l}33.18 \\
34.09 \\
35.00 \\
35.93 \\
36.87\end{array}$ & $\begin{array}{l}0.900 \\
0.911 \\
0.922 \\
0.933 \\
0.944\end{array}$ & $\begin{array}{l}11 \cdot 16 \\
11 \cdot 16 \\
11 \cdot 15 \\
11 \cdot 15 \\
11.14\end{array}$ & $\begin{array}{l}160 \\
161 \\
162 \\
163 \\
164\end{array}$ & $\begin{array}{l}107.08 \\
108.64 \\
110.22 \\
111.81 \\
113.41\end{array}$ & $\begin{array}{l}1.561 \\
1.572 \\
1.583 \\
1.594 \\
1.604\end{array}$ & $\begin{array}{l}10.89 \\
10.89 \\
10.88 \\
10.88 \\
10.87\end{array}$ \\
\hline $\begin{array}{l}45 \\
46 \\
47 \\
48 \\
49\end{array}$ & $\begin{array}{l}0.74 \\
1.03 \\
1.32 \\
1.63 \\
1.94\end{array}$ & $\begin{array}{l}0.277 \\
0.289 \\
0.300 \\
0.312 \\
0.323\end{array}$ & $\begin{array}{l}11.48 \\
11.47 \\
11.47 \\
11.46 \\
11.45\end{array}$ & $\begin{array}{l}105 \\
106 \\
107 \\
108 \\
109\end{array}$ & $\begin{array}{l}37.82 \\
38.78 \\
39.75 \\
40.74 \\
41.73\end{array}$ & $\begin{array}{l}0.955 \\
0.966 \\
0.978 \\
0.989 \\
1.000\end{array}$ & $\begin{array}{l}11 \cdot 14 \\
11.13 \\
11.13 \\
11.12 \\
11.12\end{array}$ & $\begin{array}{l}165 \\
166 \\
167 \\
168 \\
169\end{array}$ & $\begin{array}{l}115.02 \\
116.64 \\
118.27 \\
119.91 \\
121.56\end{array}$ & $\begin{array}{l}1.615 \\
1.626 \\
1.637 \\
1.648 \\
1.659\end{array}$ & $\begin{array}{l}10.87 \\
10.87 \\
10.86 \\
10.86 \\
10.85\end{array}$ \\
\hline $\begin{array}{l}50 \\
51 \\
52 \\
53 \\
54\end{array}$ & $\begin{array}{l}2.27 \\
2.61 \\
2.96 \\
3.33 \\
3.70\end{array}$ & $\begin{array}{l}0.335 \\
0.346 \\
0.357 \\
0.369 \\
0.380\end{array}$ & $\begin{array}{l}11.45 \\
11.44 \\
11.44 \\
11.43 \\
11.42\end{array}$ & $\begin{array}{l}110 \\
111 \\
112 \\
113 \\
114\end{array}$ & $\begin{array}{r}42.74 \\
43.75 \\
44.78 \\
45.82 \\
46.87\end{array}$ & $\begin{array}{l}1.011 \\
1.022 \\
1.033 \\
1.044 \\
1.055\end{array}$ & $\begin{array}{l}11.11 \\
11.11 \\
11.10 \\
11.10 \\
11.09\end{array}$ & $\begin{array}{l}170 \\
171 \\
172 \\
173 \\
174\end{array}$ & $\begin{array}{l}123.23 \\
124.90 \\
126.59 \\
128.29 \\
129.99\end{array}$ & $\begin{array}{l}1.670 \\
1.680 \\
1.691 \\
1.702 \\
1.713\end{array}$ & $\begin{array}{l}10.85 \\
10.85 \\
10.84 \\
10.84 \\
10.83\end{array}$ \\
\hline $\begin{array}{l}55 \\
56 \\
57 \\
58 \\
59\end{array}$ & $\begin{array}{l}4.09 \\
4.48 \\
4.89 \\
5.31 \\
5.75\end{array}$ & $\begin{array}{l}0.392 \\
0.403 \\
0.415 \\
0.426 \\
0.437\end{array}$ & $\begin{array}{l}11.42 \\
11.41 \\
11.40 \\
11.40 \\
11.39\end{array}$ & $\begin{array}{l}115 \\
116 \\
117 \\
118 \\
119\end{array}$ & $\begin{array}{l}47.93 \\
49.00 \\
50.08 \\
51.18 \\
52.28\end{array}$ & $\begin{array}{l}1.066 \\
1.078 \\
1.089 \\
1.100 \\
1.111\end{array}$ & $\begin{array}{l}11.09 \\
11.09 \\
11.08 \\
11.08 \\
11.07\end{array}$ & $\begin{array}{l}175 \\
176 \\
177 \\
178 \\
179\end{array}$ & $\begin{array}{l}131.71 \\
133.44 \\
135.18 \\
136.93 \\
138.69\end{array}$ & $\begin{array}{l}1.724 \\
1.735 \\
1.745 \\
1.756 \\
1.757\end{array}$ & $\begin{array}{l}10.83 \\
10.83 \\
10.82 \\
10.82 \\
10.81\end{array}$ \\
\hline 60 & 6.19 & 0.449 & 11.39 & 120 & 53.40 & 1.122 & 11.07 & 180 & 140.47 & 1.778 & 10.81 \\
\hline
\end{tabular}


TABLE 4.3.2. Type B thermocouples-thermoelectric voltages, $\mathrm{E}(\mathrm{T})$, Seebeck coefficients, $\mathrm{S}(\mathrm{T})$, and first derivative of the Seebeck coefficients, $\mathrm{dS} / \mathrm{dT}$, reference junctions at $0{ }^{\circ} \mathrm{C}$-Continued

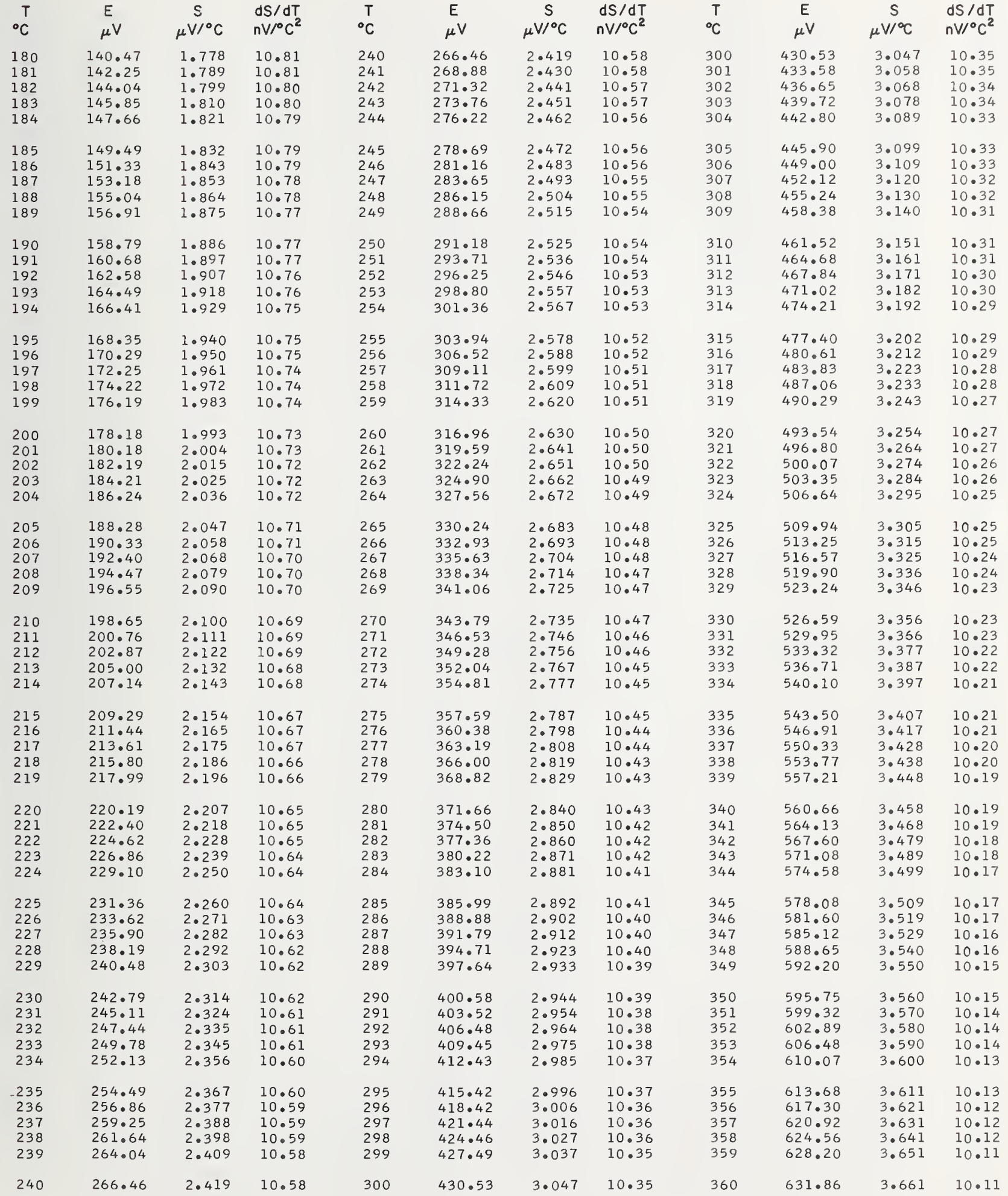


TABLE 4.3.2. Type B thermocouples-thermoelectric voltages, E(T), Seebeck coefficients, $\mathrm{S}(\mathrm{T})$, and first derivative of the Seebeck coefficients, $\mathrm{dS} / \mathrm{dT}$, reference junctions at $0{ }^{\circ} \mathrm{C}$-Continued

\begin{tabular}{|c|c|c|c|c|c|c|c|c|c|c|c|}
\hline $\begin{array}{l}\mathrm{T} \\
{ }^{\circ} \mathrm{C}\end{array}$ & $\begin{array}{c}E \\
\mu V\end{array}$ & $\stackrel{S}{\mu V /{ }^{\circ} \mathrm{C}}$ & $\begin{array}{l}\mathrm{dS} / \mathrm{dT} \\
\mathrm{nV} /{ }^{\circ} \mathrm{C}^{2}\end{array}$ & ${ }^{\circ} \mathrm{C}$ & $\begin{array}{c}E \\
\mu V\end{array}$ & $\underset{\mu \mathrm{V} /{ }^{\circ} \mathrm{C}}{\mathrm{S}}$ & $\begin{array}{l}d S / d T \\
n V /{ }^{\circ} C^{2}\end{array}$ & $\begin{array}{c}\mathrm{T} \\
{ }^{\circ} \mathrm{C}\end{array}$ & $\underset{\mu V}{E}$ & $\underset{\mu \mathrm{V} /{ }^{\circ} \mathrm{C}}{\mathrm{S}}$ & $\begin{array}{l}\mathrm{dS} / \mathrm{dT} \\
\mathrm{nV} /{ }^{\circ} \mathrm{C}^{2}\end{array}$ \\
\hline $\begin{array}{l}360 \\
361 \\
362 \\
363 \\
364\end{array}$ & $\begin{array}{l}631.86 \\
635.53 \\
639.20 \\
642.89 \\
646.58\end{array}$ & $\begin{array}{l}3.661 \\
3.671 \\
3.681 \\
3.691 \\
3.702\end{array}$ & $\begin{array}{l}10.11 \\
10.10 \\
10.10 \\
10.09 \\
10.09\end{array}$ & $\begin{array}{l}420 \\
421 \\
422 \\
423 \\
424\end{array}$ & $\begin{array}{l}869.57 \\
873.83 \\
878.11 \\
882.39 \\
886.68\end{array}$ & $\begin{array}{l}4.260 \\
4.270 \\
4.279 \\
4.289 \\
4.299\end{array}$ & $\begin{array}{l}9.85 \\
9.84 \\
9.84 \\
9.83 \\
9.83\end{array}$ & $\begin{array}{l}480 \\
481 \\
482 \\
483 \\
484\end{array}$ & $\begin{array}{l}1142.71 \\
1147.56 \\
1152.41 \\
1157.28 \\
1162.16\end{array}$ & $\begin{array}{l}4.842 \\
4.852 \\
4.861 \\
4.871 \\
4.880\end{array}$ & $\begin{array}{l}9.56 \\
9.56 \\
9.55 \\
9.55 \\
9.54\end{array}$ \\
\hline $\begin{array}{l}365 \\
366 \\
367 \\
368 \\
369\end{array}$ & $\begin{array}{l}650.29 \\
654.01 \\
657.73 \\
661.47 \\
665.22\end{array}$ & $\begin{array}{l}3.712 \\
3.722 \\
3.732 \\
3.742 \\
3.752\end{array}$ & $\begin{array}{l}10.09 \\
10.08 \\
10.08 \\
10.07 \\
10.07\end{array}$ & $\begin{array}{l}425 \\
426 \\
427 \\
428 \\
429\end{array}$ & $\begin{array}{l}890.99 \\
895.30 \\
899.63 \\
903.96 \\
908.30\end{array}$ & $\begin{array}{l}4 \cdot 309 \\
4 \cdot 319 \\
4 \cdot 329 \\
4.338 \\
4.348\end{array}$ & $\begin{array}{l}9.82 \\
9.82 \\
9.81 \\
9.81 \\
9.80\end{array}$ & $\begin{array}{l}485 \\
486 \\
487 \\
488 \\
489\end{array}$ & $\begin{array}{l}1167.04 \\
1171.94 \\
1176.84 \\
1181.75 \\
1186.68\end{array}$ & $\begin{array}{l}4.890 \\
4.899 \\
4.909 \\
4.919 \\
4.928\end{array}$ & $\begin{array}{l}9.54 \\
9.54 \\
9.53 \\
9.53 \\
9.52\end{array}$ \\
\hline $\begin{array}{l}370 \\
371 \\
372 \\
373 \\
374\end{array}$ & $\begin{array}{l}668 \cdot 98 \\
672 \cdot 74 \\
676 \cdot 52 \\
680 \cdot 31 \\
684 \cdot 10\end{array}$ & $\begin{array}{l}3.762 \\
3.772 \\
3.782 \\
3.792 \\
3.802\end{array}$ & $\begin{array}{l}10.06 \\
10.06 \\
10.06 \\
10.05 \\
10.05\end{array}$ & $\begin{array}{l}430 \\
431 \\
432 \\
433 \\
434\end{array}$ & $\begin{array}{l}912.66 \\
917.02 \\
921.39 \\
925.77 \\
930.17\end{array}$ & $\begin{array}{l}4 \cdot 358 \\
4 \cdot 368 \\
4 \cdot 378 \\
4 \cdot 387 \\
4 \cdot 397\end{array}$ & $\begin{array}{l}9.80 \\
9.80 \\
9.79 \\
9.79 \\
9.78\end{array}$ & $\begin{array}{l}490 \\
491 \\
492 \\
493 \\
494\end{array}$ & $\begin{array}{l}1191.61 \\
1196.55 \\
1201.50 \\
1206.47 \\
1211.44\end{array}$ & $\begin{array}{l}4.938 \\
4.947 \\
4.957 \\
4.966 \\
4.976\end{array}$ & $\begin{array}{l}9.52 \\
9.51 \\
9.51 \\
9.50 \\
9.50\end{array}$ \\
\hline $\begin{array}{l}375 \\
376 \\
377 \\
378 \\
379\end{array}$ & $\begin{array}{l}687.91 \\
691.73 \\
695.56 \\
699.39 \\
703.24\end{array}$ & $\begin{array}{l}3.812 \\
3.822 \\
3.832 \\
3.842 \\
3.852\end{array}$ & $\begin{array}{l}10.04 \\
10.04 \\
10.03 \\
10.03 \\
10.03\end{array}$ & $\begin{array}{l}435 \\
436 \\
437 \\
438 \\
439\end{array}$ & $\begin{array}{l}934.57 \\
938.98 \\
943.40 \\
947.83 \\
952.27\end{array}$ & $\begin{array}{l}4.407 \\
4.417 \\
4.427 \\
4.436 \\
4.446\end{array}$ & $\begin{array}{l}9.78 \\
9.77 \\
9.77 \\
9.76 \\
9.76\end{array}$ & $\begin{array}{l}495 \\
496 \\
497 \\
498 \\
499\end{array}$ & $\begin{array}{l}1216.42 \\
1221.41 \\
1226.41 \\
1231.42 \\
1236.43\end{array}$ & $\begin{array}{l}4.985 \\
4.995 \\
5.004 \\
5.014 \\
5.023\end{array}$ & $\begin{array}{l}9.49 \\
9.49 \\
9.48 \\
9.48 \\
9.47\end{array}$ \\
\hline $\begin{array}{l}380 \\
381 \\
382 \\
383 \\
384\end{array}$ & $\begin{array}{l}707.10 \\
710.97 \\
714.84 \\
718.73 \\
722.63\end{array}$ & $\begin{array}{l}3.862 \\
3.872 \\
3.882 \\
3.892 \\
3.902\end{array}$ & $\begin{array}{l}10.02 \\
10.02 \\
10.01 \\
10.01 \\
10.00\end{array}$ & $\begin{array}{l}440 \\
441 \\
442 \\
443 \\
444\end{array}$ & $\begin{array}{l}956.73 \\
961.19 \\
965 \cdot 66 \\
970.14 \\
974.63\end{array}$ & $\begin{array}{l}4.456 \\
4.466 \\
4.475 \\
4.485 \\
4.495\end{array}$ & $\begin{array}{l}9.75 \\
9.75 \\
9.74 \\
9.74 \\
9.74\end{array}$ & $\begin{array}{l}500 \\
501 \\
502 \\
503 \\
504\end{array}$ & $\begin{array}{l}1241.46 \\
1246.50 \\
1251.55 \\
1256.60 \\
1261.67\end{array}$ & $\begin{array}{l}5.033 \\
5.042 \\
5.051 \\
5.061 \\
5.070\end{array}$ & $\begin{array}{l}9.47 \\
9.46 \\
9.46 \\
9.45 \\
9.45\end{array}$ \\
\hline $\begin{array}{l}385 \\
386 \\
387 \\
388 \\
389\end{array}$ & $\begin{array}{l}726 \cdot 54 \\
730 \cdot 45 \\
734 \cdot 38 \\
738 \cdot 32 \\
742 \cdot 27\end{array}$ & $\begin{array}{l}3.912 \\
3.922 \\
3.932 \\
3.942 \\
3.952\end{array}$ & $\begin{array}{r}10.00 \\
10.00 \\
9.99 \\
9.99 \\
9.98\end{array}$ & $\begin{array}{l}445 \\
446 \\
447 \\
448 \\
449\end{array}$ & $\begin{array}{l}979 \cdot 13 \\
983.64 \\
988.16 \\
992.68 \\
997 \cdot 22\end{array}$ & $\begin{array}{l}4.505 \\
4.514 \\
4.524 \\
4.534 \\
4.543\end{array}$ & $\begin{array}{l}9.73 \\
9.73 \\
9.72 \\
9.72 \\
9.71\end{array}$ & $\begin{array}{l}505 \\
506 \\
507 \\
508 \\
509\end{array}$ & $\begin{array}{l}1266.74 \\
1271.83 \\
1276.92 \\
1282.02 \\
1287.14\end{array}$ & $\begin{array}{l}5.080 \\
5.089 \\
5.099 \\
5.108 \\
5.118\end{array}$ & $\begin{array}{l}9.44 \\
9.44 \\
9.43 \\
9.43 \\
9.42\end{array}$ \\
\hline $\begin{array}{l}390 \\
391 \\
392 \\
393 \\
394\end{array}$ & $\begin{array}{l}746 \cdot 22 \\
750 \cdot 19 \\
754 \cdot 17 \\
758 \cdot 15 \\
762.15\end{array}$ & $\begin{array}{l}3.962 \\
3.972 \\
3.982 \\
3.992 \\
4.002\end{array}$ & $\begin{array}{l}9.98 \\
9.97 \\
9.97 \\
9.97 \\
9.96\end{array}$ & $\begin{array}{l}450 \\
451 \\
452 \\
453 \\
454\end{array}$ & $\begin{array}{l}1001.77 \\
1006.33 \\
1010.90 \\
1015.47 \\
1020.06\end{array}$ & $\begin{array}{l}4.553 \\
4.563 \\
4.573 \\
4.582 \\
4.592\end{array}$ & $\begin{array}{l}9.71 \\
9.70 \\
9.70 \\
9.69 \\
9.69\end{array}$ & $\begin{array}{l}510 \\
511 \\
512 \\
513 \\
514\end{array}$ & $\begin{array}{l}1292.26 \\
1297.39 \\
1302.53 \\
1307.68 \\
1312.84\end{array}$ & $\begin{array}{l}5.127 \\
5.136 \\
5.146 \\
5.155 \\
5.165\end{array}$ & $\begin{array}{l}9.42 \\
9.41 \\
9.41 \\
9.40 \\
9.40\end{array}$ \\
\hline $\begin{array}{l}395 \\
396 \\
397 \\
398 \\
399\end{array}$ & $\begin{array}{l}766.16 \\
770.18 \\
774.20 \\
778.24 \\
782.29\end{array}$ & $\begin{array}{l}4.012 \\
4.022 \\
4.032 \\
4.042 \\
4.052\end{array}$ & $\begin{array}{l}9.96 \\
9.95 \\
9.95 \\
9.94 \\
9.94\end{array}$ & $\begin{array}{l}455 \\
456 \\
457 \\
458 \\
459\end{array}$ & $\begin{array}{l}1024.66 \\
1029.26 \\
1033.88 \\
1038.51 \\
1043.14\end{array}$ & $\begin{array}{l}4.602 \\
4.611 \\
4.621 \\
4.631 \\
4.640\end{array}$ & $\begin{array}{l}9.68 \\
9.68 \\
9.67 \\
9.67 \\
9.66\end{array}$ & $\begin{array}{l}515 \\
516 \\
517 \\
518 \\
519\end{array}$ & $\begin{array}{l}1318.01 \\
1323.19 \\
1328.38 \\
1333.58 \\
1338.78\end{array}$ & $\begin{array}{l}5.174 \\
5.183 \\
5.193 \\
5.202 \\
5.211\end{array}$ & $\begin{array}{l}9.39 \\
9.39 \\
9.38 \\
9.38 \\
9.37\end{array}$ \\
\hline $\begin{array}{l}400 \\
401 \\
402 \\
403 \\
404\end{array}$ & $\begin{array}{l}786.35 \\
790.41 \\
794.49 \\
798.58 \\
802.67\end{array}$ & $\begin{array}{l}4.062 \\
4.072 \\
4.082 \\
4.092 \\
4.102\end{array}$ & $\begin{array}{l}9.93 \\
9.93 \\
9.93 \\
9.92 \\
9.92\end{array}$ & $\begin{array}{l}460 \\
461 \\
462 \\
463 \\
464\end{array}$ & $\begin{array}{l}1047.79 \\
1052.44 \\
1057.11 \\
1061.78 \\
1066.46\end{array}$ & $\begin{array}{l}4.650 \\
4.660 \\
4.669 \\
4.679 \\
4.689\end{array}$ & $\begin{array}{l}9.66 \\
9.66 \\
9.65 \\
9.65 \\
9.64\end{array}$ & $\begin{array}{l}520 \\
521 \\
522 \\
523 \\
524\end{array}$ & $\begin{array}{l}1344.00 \\
1349.22 \\
1354.46 \\
1359.70 \\
1364.96\end{array}$ & $\begin{array}{l}5.221 \\
5.230 \\
5.240 \\
5.249 \\
5.258\end{array}$ & $\begin{array}{l}9.37 \\
9.36 \\
9.36 \\
9.35 \\
9.35\end{array}$ \\
\hline $\begin{array}{l}405 \\
406 \\
407 \\
408 \\
409\end{array}$ & $\begin{array}{l}806.78 \\
810.90 \\
815.02 \\
819.16 \\
823.31\end{array}$ & $\begin{array}{l}4 \cdot 112 \\
4 \cdot 122 \\
4 \cdot 131 \\
4.141 \\
4.151\end{array}$ & $\begin{array}{l}9.91 \\
9.91 \\
9.90 \\
9.90 \\
9.89\end{array}$ & $\begin{array}{l}465 \\
466 \\
467 \\
468 \\
469\end{array}$ & $\begin{array}{l}1071.16 \\
1075.86 \\
1080.57 \\
1085.29 \\
1090.03\end{array}$ & $\begin{array}{l}4.698 \\
4.708 \\
4.717 \\
4.727 \\
4.737\end{array}$ & $\begin{array}{l}9.64 \\
9.63 \\
9.63 \\
9.62 \\
9.62\end{array}$ & $\begin{array}{l}525 \\
526 \\
527 \\
528 \\
529\end{array}$ & $\begin{array}{l}1370.22 \\
1375.49 \\
1380.77 \\
1386.06 \\
1391.37\end{array}$ & $\begin{array}{l}5.268 \\
5.277 \\
5.286 \\
5.296 \\
5.305\end{array}$ & $\begin{array}{l}9.34 \\
9.34 \\
9.33 \\
9.33 \\
9.32\end{array}$ \\
\hline $\begin{array}{l}410 \\
411 \\
412 \\
413 \\
414\end{array}$ & $\begin{array}{l}827.46 \\
831.63 \\
835.80 \\
839.99 \\
844.18\end{array}$ & $\begin{array}{l}4 \cdot 161 \\
4.171 \\
4.181 \\
4.191 \\
4.201\end{array}$ & $\begin{array}{l}9.89 \\
9.89 \\
9.88 \\
9.88 \\
9.87\end{array}$ & $\begin{array}{l}470 \\
471 \\
472 \\
473 \\
474\end{array}$ & $\begin{array}{l}1094.77 \\
1099.52 \\
1104.28 \\
1109.05 \\
1113.83\end{array}$ & $\begin{array}{l}4 \cdot 746 \\
4.756 \\
4 \cdot 766 \\
4.775 \\
4.785\end{array}$ & $\begin{array}{l}9.61 \\
9.61 \\
9.60 \\
9.60 \\
9.59\end{array}$ & $\begin{array}{l}530 \\
531 \\
532 \\
533 \\
534\end{array}$ & $\begin{array}{l}1396.67 \\
1401.99 \\
1407.32 \\
1412.66 \\
1418.01\end{array}$ & $\begin{array}{l}5.314 \\
5.324 \\
5.333 \\
5.342 \\
5.351\end{array}$ & $\begin{array}{l}9.32 \\
9.31 \\
9.31 \\
9.30 \\
9.30\end{array}$ \\
\hline $\begin{array}{l}415 \\
416 \\
417 \\
418 \\
419\end{array}$ & $\begin{array}{l}848.39 \\
852.61 \\
856.83 \\
861.07 \\
865.31\end{array}$ & $\begin{array}{l}4.211 \\
4.220 \\
4.230 \\
4.240 \\
4.250\end{array}$ & $\begin{array}{l}9.87 \\
9.86 \\
9.86 \\
9.85 \\
9.85\end{array}$ & $\begin{array}{l}475 \\
476 \\
477 \\
478 \\
479\end{array}$ & $\begin{array}{l}1118.62 \\
1123.42 \\
1128.23 \\
1133.05 \\
1137.87\end{array}$ & $\begin{array}{l}4.794 \\
4.804 \\
4.813 \\
4.823 \\
4.833\end{array}$ & $\begin{array}{l}9.59 \\
9.58 \\
9.58 \\
9.57 \\
9.57\end{array}$ & $\begin{array}{l}535 \\
536 \\
537 \\
538 \\
539\end{array}$ & $\begin{array}{l}1423.36 \\
1428.73 \\
1434.10 \\
1439.49 \\
1444.88\end{array}$ & $\begin{array}{l}5.361 \\
5.370 \\
5.379 \\
5.389 \\
5.398\end{array}$ & $\begin{array}{l}9.29 \\
9.29 \\
9.28 \\
9.28 \\
9.27\end{array}$ \\
\hline 420 & 869.57 & 4.260 & 9.85 & 480 & 1142.71 & 4.842 & 9.56 & 540 & 1450.28 & 5.407 & 9.27 \\
\hline
\end{tabular}


TABLE 4.3.2. Type B thermocouples-thermoelectric voltages, E(T), Seebeck coefficients, $\mathrm{S}(\mathrm{T})$, and first derivative of the Seebeck coefficients, $\mathrm{dS} / \mathrm{dT}$, reference junctions at $0{ }^{\circ} \mathrm{C}-$ Continued

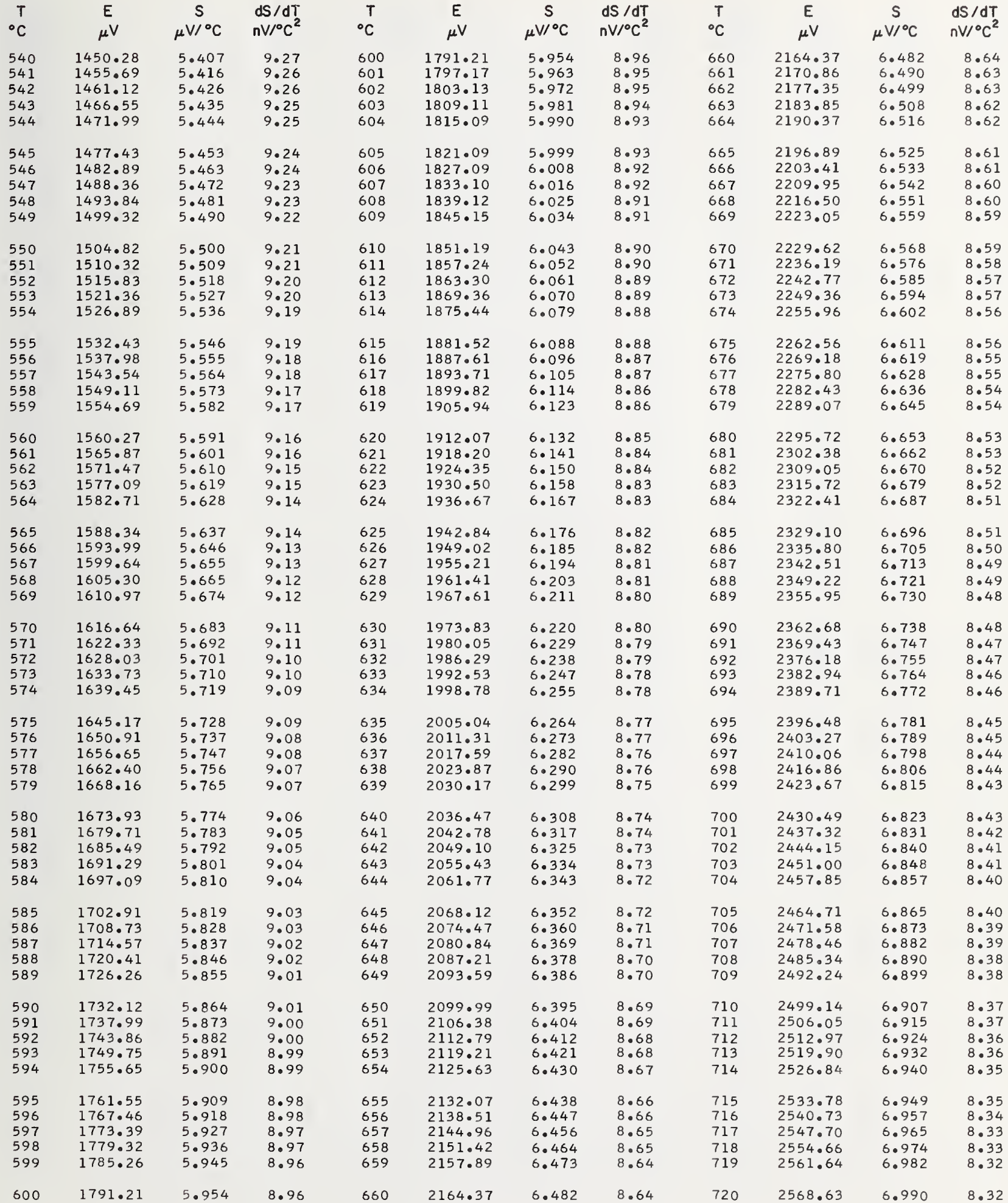


TABLE 4.3.2. Type B thermocouples-thermoelectric voltages, $\mathrm{E}(\mathrm{T})$, Seebeck coefficients, $\mathrm{S}(\mathrm{T})$, and first derivative of the Seebeck coefficients, $\mathrm{dS} / \mathrm{dT}$, reference junctions at $0{ }^{\circ} \mathrm{C}$-Continued

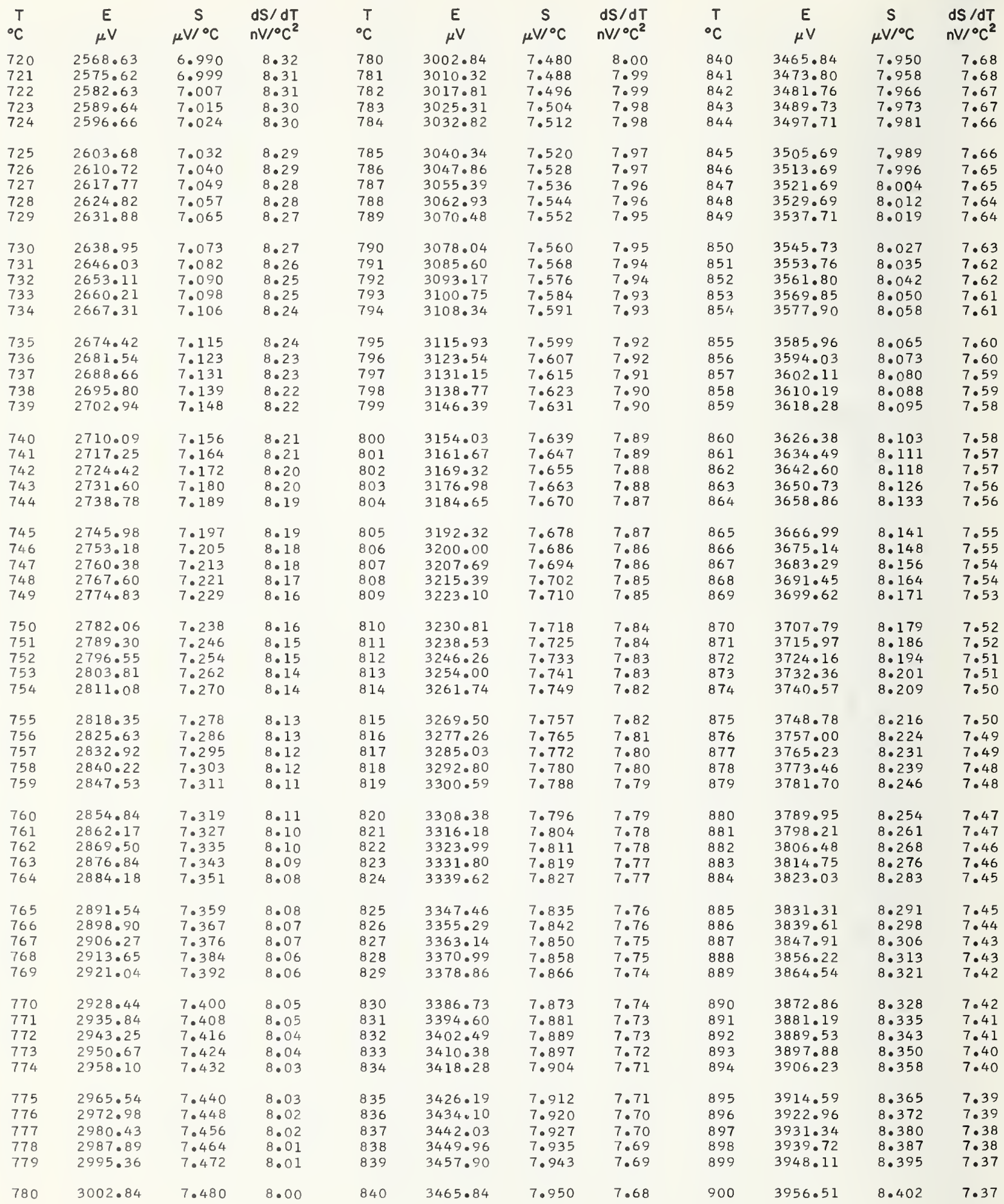


TABLE 4.3.2. Type B thermocouples-thermoelectric voltages, E(T), Seebeck coefficients, $\mathrm{S}(\mathrm{T})$, and first derivative of the Seebeck coefficients, $\mathrm{dS} / \mathrm{dT}$, reference junctions at $0{ }^{\circ} \mathrm{C}-$ Continued

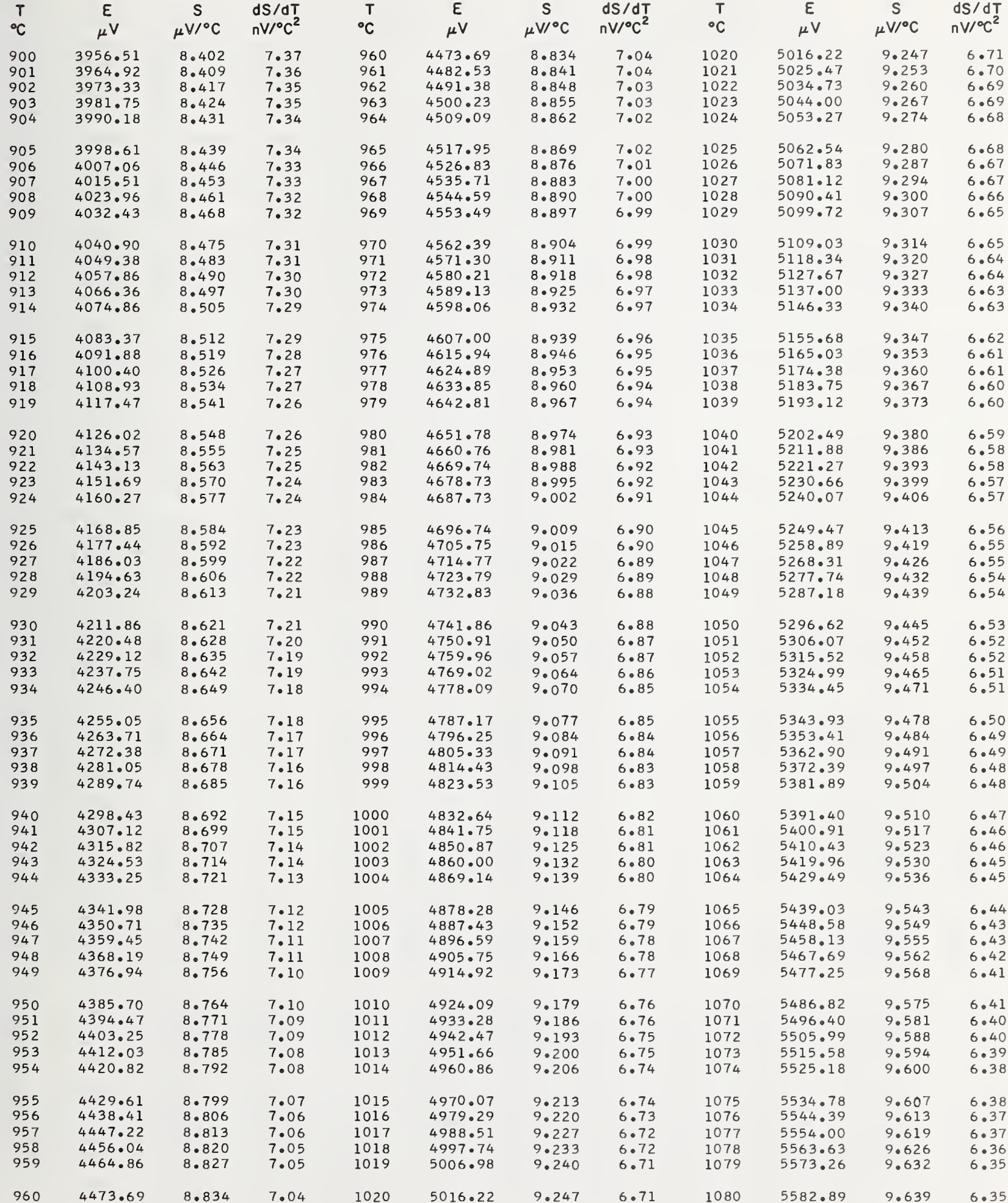


TABLE 4.3.2. Type B thermocouples-thermoelectric voltages, E(T), Seebeck coefficients, $\mathrm{S}(\mathrm{T})$, and first derivative of the Seebeck coefficients, $\mathrm{dS} / \mathrm{dT}$, reference junctions at $0{ }^{\circ} \mathrm{C}$-Continued

\begin{tabular}{|c|c|c|c|c|c|c|c|c|c|c|c|}
\hline${ }^{\mathrm{T}} \mathrm{C}$ & $\underset{\mu V}{E}$ & $\stackrel{S}{S} /{ }^{\circ} \mathrm{C}$ & $\begin{array}{l}\mathrm{dS} / \mathrm{dT} \\
\mathrm{nV} /{ }^{\circ} \mathrm{C}^{2}\end{array}$ & ${ }^{\circ} \mathrm{C}$ & $\underset{\mu V}{E}$ & $\underset{\mu \mathrm{V}^{\circ} \mathrm{C}}{\mathrm{S}}$ & $\begin{array}{l}\mathrm{dS} / \mathrm{dT} \\
\mathrm{nV} /{ }^{\circ} \mathrm{C}^{2}\end{array}$ & ${ }^{\circ} \mathrm{C}$ & $\underset{\mu V}{E V}$ & $\underset{\mu V /^{\circ} \mathrm{C}}{S}$ & $\begin{array}{l}d S / \delta T \\
n V /{ }^{\circ} C^{2}\end{array}$ \\
\hline $\begin{array}{l}1080 \\
1081 \\
1082 \\
1083 \\
1084\end{array}$ & $\begin{array}{l}5582.89 \\
5592.53 \\
5602.18 \\
5611.84 \\
5621.50\end{array}$ & $\begin{array}{l}9.639 \\
9.645 \\
9.651 \\
9.658 \\
9.664\end{array}$ & $\begin{array}{l}6.35 \\
6.34 \\
6.33 \\
6.33 \\
6.32\end{array}$ & $\begin{array}{l}1140 \\
1141 \\
1142 \\
1143 \\
1144\end{array}$ & $\begin{array}{l}6172.40 \\
6182.41 \\
6192.42 \\
6202.45 \\
6212.47\end{array}$ & $\begin{array}{l}10.008 \\
10.014 \\
10.020 \\
10.025 \\
10.031\end{array}$ & $\begin{array}{l}5.95 \\
5.94 \\
5.94 \\
5.93 \\
5.92\end{array}$ & $\begin{array}{l}1200 \\
1201 \\
1202 \\
1203 \\
1204\end{array}$ & $\begin{array}{l}6783.31 \\
6793.66 \\
6804.02 \\
6814.39 \\
6824.76\end{array}$ & $\begin{array}{l}10.352 \\
10.357 \\
10.363 \\
10.368 \\
10.374\end{array}$ & $\begin{array}{l}5.51 \\
5.50 \\
5.49 \\
5.48 \\
5.47\end{array}$ \\
\hline $\begin{array}{l}1085 \\
1086 \\
1087 \\
1088 \\
1089\end{array}$ & $\begin{array}{l}5631.16 \\
5640.84 \\
5650.52 \\
5660.20 \\
5669.89\end{array}$ & $\begin{array}{l}9.670 \\
9.676 \\
9.683 \\
9.689 \\
9.695\end{array}$ & $\begin{array}{l}6.32 \\
6.31 \\
6.30 \\
6.30 \\
6.29\end{array}$ & $\begin{array}{l}1145 \\
1146 \\
1147 \\
1148 \\
1149\end{array}$ & $\begin{array}{l}6222.51 \\
6232.55 \\
6242.60 \\
6252.65 \\
6262.71\end{array}$ & $\begin{array}{l}10.037 \\
10.043 \\
10.049 \\
10.055 \\
10.061\end{array}$ & $\begin{array}{l}5.92 \\
5.91 \\
5.90 \\
5.89 \\
5.89\end{array}$ & $\begin{array}{l}1205 \\
1206 \\
1207 \\
1208 \\
1209\end{array}$ & $\begin{array}{l}6835.14 \\
6845.52 \\
6855.91 \\
6866.30 \\
6876.70\end{array}$ & $\begin{array}{l}10.379 \\
10.385 \\
10.390 \\
10.395 \\
10.401\end{array}$ & $\begin{array}{l}5.47 \\
5.46 \\
5.45 \\
5.44 \\
5.43\end{array}$ \\
\hline $\begin{array}{l}1090 \\
1091 \\
1092 \\
1093 \\
1094\end{array}$ & $\begin{array}{l}5679.59 \\
5689.30 \\
5699.01 \\
5708.73 \\
5718.45\end{array}$ & $\begin{array}{l}9.702 \\
9.708 \\
9.714 \\
9.720 \\
9.727\end{array}$ & $\begin{array}{l}6.28 \\
6.28 \\
6.27 \\
6.26 \\
6.26\end{array}$ & $\begin{array}{l}1150 \\
1151 \\
1152 \\
1153 \\
1154\end{array}$ & $\begin{array}{l}6272.77 \\
6282.84 \\
6292.91 \\
6303.00 \\
6313.08\end{array}$ & $\begin{array}{l}10.067 \\
10.073 \\
10.079 \\
10.084 \\
10.090\end{array}$ & $\begin{array}{l}5.88 \\
5.87 \\
5.87 \\
5.86 \\
5.85\end{array}$ & $\begin{array}{l}1210 \\
1211 \\
1212 \\
1213 \\
1214\end{array}$ & $\begin{array}{l}6887.10 \\
6897.51 \\
6907.92 \\
6918.34 \\
6928.77\end{array}$ & $\begin{array}{l}10.406 \\
10.412 \\
10.417 \\
10.423 \\
10.428\end{array}$ & $\begin{array}{l}5.43 \\
5.42 \\
5.41 \\
5.40 \\
5.39\end{array}$ \\
\hline $\begin{array}{l}1095 \\
1096 \\
1097 \\
1098 \\
1099\end{array}$ & $\begin{array}{l}5728.18 \\
5737.92 \\
5747.66 \\
5757.41 \\
5767.16\end{array}$ & $\begin{array}{l}9.733 \\
9.739 \\
9.746 \\
9.752 \\
9.758\end{array}$ & $\begin{array}{l}6.25 \\
6.25 \\
6.24 \\
6.23 \\
6.23\end{array}$ & $\begin{array}{l}1155 \\
1156 \\
1157 \\
1158 \\
1159\end{array}$ & $\begin{array}{l}6323 \cdot 18 \\
6333.28 \\
6343.38 \\
6353.49 \\
6363.61\end{array}$ & $\begin{array}{l}10.096 \\
10.102 \\
10.108 \\
10.114 \\
10.119\end{array}$ & $\begin{array}{l}5.85 \\
5.84 \\
5.83 \\
5.82 \\
5.82\end{array}$ & $\begin{array}{l}1215 \\
1216 \\
1217 \\
1218 \\
1219\end{array}$ & $\begin{array}{l}6939.20 \\
6949.64 \\
6960.08 \\
6970.52 \\
6980.98\end{array}$ & $\begin{array}{l}10.433 \\
10.439 \\
10.444 \\
10.449 \\
10.455\end{array}$ & $\begin{array}{l}5.39 \\
5.38 \\
5.37 \\
5.36 \\
5.35\end{array}$ \\
\hline $\begin{array}{l}1100 \\
1101 \\
1102 \\
1103 \\
1104\end{array}$ & $\begin{array}{l}5776.92 \\
5786.69 \\
5796.46 \\
5806.24 \\
5816.03\end{array}$ & $\begin{array}{l}9.764 \\
9.770 \\
9.777 \\
9.783 \\
9.789\end{array}$ & $\begin{array}{l}6.22 \\
6.21 \\
6.21 \\
6.20 \\
6.19\end{array}$ & $\begin{array}{l}1160 \\
1161 \\
1162 \\
1163 \\
1164\end{array}$ & $\begin{array}{l}6373.73 \\
6383.86 \\
6393.99 \\
6404.13 \\
6414.28\end{array}$ & $\begin{array}{l}10.125 \\
10.131 \\
10.137 \\
10.143 \\
10.148\end{array}$ & $\begin{array}{l}5.81 \\
5.80 \\
5.79 \\
5.79 \\
5.78\end{array}$ & $\begin{array}{l}1220 \\
1221 \\
1222 \\
1223 \\
1224\end{array}$ & $\begin{array}{l}6991.43 \\
7001.90 \\
7012.36 \\
7022.84 \\
7033.32\end{array}$ & $\begin{array}{l}10.460 \\
10.466 \\
10.471 \\
10.476 \\
10.481\end{array}$ & $\begin{array}{l}5 \cdot 34 \\
5.34 \\
5 \cdot 33 \\
5.32 \\
5.31\end{array}$ \\
\hline $\begin{array}{l}1105 \\
1106 \\
1107 \\
1108 \\
1109\end{array}$ & $\begin{array}{l}5825.82 \\
5835.62 \\
5845.42 \\
5855.24 \\
5865.05\end{array}$ & $\begin{array}{l}9.795 \\
9.801 \\
9.808 \\
9.814 \\
9.820\end{array}$ & $\begin{array}{l}6.19 \\
6.18 \\
6.17 \\
6.17 \\
6.16\end{array}$ & $\begin{array}{l}1165 \\
1166 \\
1167 \\
1168 \\
1169\end{array}$ & $\begin{array}{l}6424.43 \\
6434.59 \\
6444.75 \\
6454.92 \\
6465.09\end{array}$ & $\begin{array}{l}10.154 \\
10.160 \\
10.166 \\
10.172 \\
10.177\end{array}$ & $\begin{array}{l}5.77 \\
5.77 \\
5.76 \\
5.75 \\
5.74\end{array}$ & $\begin{array}{l}1225 \\
1226 \\
1227 \\
1228 \\
1229\end{array}$ & $\begin{array}{l}7043.80 \\
7054.29 \\
7064.79 \\
7075.29 \\
7085.79\end{array}$ & $\begin{array}{l}10.487 \\
10.492 \\
10.497 \\
10.503 \\
10.508\end{array}$ & $\begin{array}{l}5 \cdot 30 \\
5 \cdot 29 \\
5 \cdot 29 \\
5 \cdot 28 \\
5 \cdot 27\end{array}$ \\
\hline $\begin{array}{l}1110 \\
1111 \\
1112 \\
1113 \\
1114\end{array}$ & $\begin{array}{l}5874.87 \\
5884.70 \\
5894.54 \\
5904.38 \\
5914.23\end{array}$ & $\begin{array}{l}9.826 \\
9.832 \\
9.838 \\
9.844 \\
9.851\end{array}$ & $\begin{array}{l}6.15 \\
6.15 \\
6.14 \\
6.13 \\
6.13\end{array}$ & $\begin{array}{l}1170 \\
1171 \\
1172 \\
1173 \\
1174\end{array}$ & $\begin{array}{l}6475.27 \\
6485.46 \\
6495.65 \\
6505.85 \\
6516.05\end{array}$ & $\begin{array}{l}10.183 \\
10.189 \\
10.194 \\
10.200 \\
10.206\end{array}$ & $\begin{array}{l}5.74 \\
5.73 \\
5.72 \\
5.71 \\
5.71\end{array}$ & $\begin{array}{l}1230 \\
1231 \\
1232 \\
1233 \\
1234\end{array}$ & $\begin{array}{l}7096.30 \\
7106.82 \\
7117.34 \\
7127.86 \\
7138.40\end{array}$ & $\begin{array}{l}10.513 \\
10.518 \\
10.524 \\
10.529 \\
10.534\end{array}$ & $\begin{array}{l}5.26 \\
5.25 \\
5.24 \\
5.24 \\
5.23\end{array}$ \\
\hline $\begin{array}{l}1115 \\
1116 \\
1117 \\
1118 \\
1119\end{array}$ & $\begin{array}{l}5924.08 \\
5933.94 \\
5943.81 \\
5953.68 \\
5963.56\end{array}$ & $\begin{array}{l}9.857 \\
9.863 \\
9.869 \\
9.875 \\
9.881\end{array}$ & $\begin{array}{l}6.12 \\
6.11 \\
6.11 \\
6.10 \\
6.09\end{array}$ & $\begin{array}{l}1175 \\
1176 \\
1177 \\
1178 \\
1179\end{array}$ & $\begin{array}{l}6526 \cdot 26 \\
6536.47 \\
6546.69 \\
6556.92 \\
6567 \cdot 15\end{array}$ & $\begin{array}{l}10.212 \\
10.217 \\
10.223 \\
10.229 \\
10.234\end{array}$ & $\begin{array}{l}5.70 \\
5.69 \\
5.68 \\
5.68 \\
5.67\end{array}$ & $\begin{array}{l}1235 \\
1236 \\
1237 \\
1238 \\
1239\end{array}$ & $\begin{array}{l}7148.93 \\
7159.48 \\
7170.02 \\
7180.57 \\
7191.13\end{array}$ & $\begin{array}{l}10.539 \\
10.545 \\
10.550 \\
10.555 \\
10.560\end{array}$ & $\begin{array}{l}5.22 \\
5.21 \\
5.20 \\
5.19 \\
5.18\end{array}$ \\
\hline $\begin{array}{l}1120 \\
1121 \\
1122 \\
1123 \\
1124\end{array}$ & $\begin{array}{l}5973.44 \\
5983.33 \\
5993.23 \\
6003.13 \\
6013.04\end{array}$ & $\begin{array}{l}9.887 \\
9.893 \\
9.899 \\
9.906 \\
9.912\end{array}$ & $\begin{array}{l}6.09 \\
6.08 \\
6.07 \\
6.07 \\
6.06\end{array}$ & $\begin{array}{l}1180 \\
1181 \\
1182 \\
1183 \\
1184\end{array}$ & $\begin{array}{l}6577.39 \\
6587.63 \\
6597.88 \\
6608.13 \\
6618.39\end{array}$ & $\begin{array}{l}10.240 \\
10.246 \\
10.251 \\
10.257 \\
10.263\end{array}$ & $\begin{array}{l}5.66 \\
5.65 \\
5.65 \\
5.64 \\
5.63\end{array}$ & $\begin{array}{l}1240 \\
1241 \\
1242 \\
1243 \\
1244\end{array}$ & $\begin{array}{l}7201 \cdot 70 \\
7212 \cdot 26 \\
7222 \cdot 84 \\
7233 \cdot 41 \\
7244 \cdot 00\end{array}$ & $\begin{array}{l}10.565 \\
10.571 \\
10.576 \\
10.581 \\
10.586\end{array}$ & $\begin{array}{l}5 \cdot 18 \\
5.17 \\
5 \cdot 16 \\
5 \cdot 15 \\
5.14\end{array}$ \\
\hline $\begin{array}{l}1125 \\
1126 \\
1127 \\
1128 \\
1129\end{array}$ & $\begin{array}{l}6022.95 \\
6032.88 \\
6042.80 \\
6052.73 \\
6062.67\end{array}$ & $\begin{array}{l}9.918 \\
9.924 \\
9.930 \\
9.936 \\
9.942\end{array}$ & $\begin{array}{l}6.05 \\
6.05 \\
6.04 \\
6.03 \\
6.03\end{array}$ & $\begin{array}{l}1185 \\
1186 \\
1187 \\
1188 \\
1189\end{array}$ & $\begin{array}{l}6628.66 \\
6638.93 \\
6649.21 \\
6659.49 \\
6669.78\end{array}$ & $\begin{array}{l}10.268 \\
10.274 \\
10.279 \\
10.285 \\
10.291\end{array}$ & $\begin{array}{l}5.62 \\
5.62 \\
5.61 \\
5.60 \\
5.59\end{array}$ & $\begin{array}{l}1245 \\
1246 \\
1247 \\
1248 \\
1249\end{array}$ & $\begin{array}{l}7254.59 \\
7265.18 \\
7275.78 \\
7286.38 \\
7296.99\end{array}$ & $\begin{array}{l}10.591 \\
10.596 \\
10.601 \\
10.607 \\
10.612\end{array}$ & $\begin{array}{l}5.13 \\
5.12 \\
5 \cdot 11 \\
5.11 \\
5 \cdot 10\end{array}$ \\
\hline $\begin{array}{l}1130 \\
1131 \\
1132 \\
1133 \\
1134\end{array}$ & $\begin{array}{l}6072.62 \\
6082.57 \\
6092.53 \\
6102.49 \\
6112.46\end{array}$ & $\begin{array}{l}9.948 \\
9.954 \\
9.960 \\
9.966 \\
9.972\end{array}$ & $\begin{array}{l}6.02 \\
6.01 \\
6.01 \\
6.00 \\
5.99\end{array}$ & $\begin{array}{l}1190 \\
1191 \\
1192 \\
1193 \\
1194\end{array}$ & $\begin{array}{l}6680.07 \\
6690 \cdot 37 \\
6700.67 \\
6710.98 \\
6721.30\end{array}$ & $\begin{array}{l}10.296 \\
10.302 \\
10.307 \\
10.313 \\
10.318\end{array}$ & $\begin{array}{l}5.58 \\
5.58 \\
5.57 \\
5.56 \\
5.55\end{array}$ & $\begin{array}{l}1250 \\
1251 \\
1252 \\
1253 \\
1254\end{array}$ & $\begin{array}{l}7307.61 \\
7318.23 \\
7328.85 \\
7339.48 \\
7350.11\end{array}$ & $\begin{array}{l}10.617 \\
10.622 \\
10.627 \\
10.632 \\
10.637\end{array}$ & $\begin{array}{l}5.09 \\
5.08 \\
5.07 \\
5.06 \\
5.05\end{array}$ \\
\hline $\begin{array}{l}1135 \\
1136 \\
1137 \\
1138 \\
1139\end{array}$ & $\begin{array}{l}6122.43 \\
6132.41 \\
6142.40 \\
6152.39 \\
6162.39\end{array}$ & $\begin{array}{r}9.978 \\
9.984 \\
9.990 \\
9.996 \\
10.002\end{array}$ & $\begin{array}{l}5.99 \\
5.98 \\
5.97 \\
5.97 \\
5.96\end{array}$ & $\begin{array}{l}1195 \\
1196 \\
1197 \\
1198 \\
1199\end{array}$ & $\begin{array}{l}6731.62 \\
6741.95 \\
6752.28 \\
6762.62 \\
6772.96\end{array}$ & $\begin{array}{l}10.324 \\
10.330 \\
10.335 \\
10.341 \\
10.346\end{array}$ & $\begin{array}{l}5.55 \\
5.54 \\
5.53 \\
5.52 \\
5.51\end{array}$ & $\begin{array}{l}1255 \\
1256 \\
1257 \\
1258 \\
1259\end{array}$ & $\begin{array}{l}7360.75 \\
7371.40 \\
7382.05 \\
7392.70 \\
7403.36\end{array}$ & $\begin{array}{l}10.642 \\
10.647 \\
10.652 \\
10.657 \\
10.662\end{array}$ & $\begin{array}{l}5.04 \\
5.03 \\
5.03 \\
5.02 \\
5.01\end{array}$ \\
\hline 1140 & 6172.40 & 10.008 & 5.95 & 1200 & 6783.31 & 10.352 & 5.51 & 1260 & 7414.03 & 10.667 & 5.00 \\
\hline
\end{tabular}


TABLE 4.3.2. Type B thermocouples-thermoelectric voltages, E(T), Seebeck coefficients, $\mathrm{S}(\mathrm{T})$, and first derivative of the Seebeck coefficients, $\mathrm{dS} / \mathrm{dT}$, reference junctions at $0{ }^{\circ} \mathrm{C}$-Continued

\begin{tabular}{|c|c|c|c|c|c|c|c|c|c|c|c|}
\hline${ }^{\circ} \mathrm{C}$ & $\underset{\mu V}{E}$ & $\stackrel{\mathrm{S}}{\mu \mathrm{V} /{ }^{\circ} \mathrm{C}}$ & $\begin{array}{l}\mathrm{dS} / \mathrm{dT} \\
\mathrm{nV} /{ }^{\circ} \mathrm{C}^{2}\end{array}$ & ${ }^{\circ} \mathrm{C}$ & $\begin{array}{c}E \\
\mu V\end{array}$ & $\underset{\mu V^{\prime \circ} \mathrm{C}}{S}$ & $\begin{array}{l}\mathrm{dS} / \mathrm{dT} \\
\mathrm{nV} /{ }^{\circ} \mathrm{C}^{2}\end{array}$ & ${ }^{\circ} \mathrm{C}$ & $\underset{\mu V}{E}$ & $\begin{array}{c}S \\
\mu V /{ }^{\circ} \mathrm{C}\end{array}$ & $\begin{array}{l}\mathrm{dS} / \mathrm{dT} \\
\mathrm{nV} /{ }^{\circ} \mathrm{C}^{2}\end{array}$ \\
\hline $\begin{array}{l}1260 \\
1261 \\
1262 \\
1263 \\
1264\end{array}$ & $\begin{array}{l}7414.03 \\
7424.70 \\
7435.37 \\
7446.05 \\
7456.74\end{array}$ & $\begin{array}{l}10.667 \\
10.672 \\
10.677 \\
10.682 \\
10.687\end{array}$ & $\begin{array}{l}5.00 \\
4.99 \\
4.98 \\
4.97 \\
4.96\end{array}$ & $\begin{array}{l}1320 \\
1321 \\
1322 \\
1323 \\
1324\end{array}$ & $\begin{array}{l}8062.71 \\
8073.67 \\
8084.62 \\
8095.58 \\
8106.55\end{array}$ & $\begin{array}{l}10.950 \\
10.954 \\
10.959 \\
10.963 \\
10.968\end{array}$ & $\begin{array}{l}4 \cdot 41 \\
4 \cdot 40 \\
4 \cdot 39 \\
4 \cdot 38 \\
4 \cdot 37\end{array}$ & $\begin{array}{l}1380 \\
1381 \\
1382 \\
1383 \\
1384\end{array}$ & $\begin{array}{l}8727.27 \\
8738.47 \\
8749.67 \\
8760.87 \\
8772.08\end{array}$ & $\begin{array}{l}11.195 \\
11.199 \\
11.203 \\
11.206 \\
11.210\end{array}$ & $\begin{array}{l}3.75 \\
3.73 \\
3.72 \\
3.71 \\
3.70\end{array}$ \\
\hline $\begin{array}{l}1265 \\
1266 \\
1267 \\
1268 \\
1269\end{array}$ & $\begin{array}{l}7467.42 \\
7478.12 \\
7488.82 \\
7499.52 \\
7510.23\end{array}$ & $\begin{array}{l}10.692 \\
10.697 \\
10.702 \\
10.707 \\
10.712\end{array}$ & $\begin{array}{l}4 \cdot 95 \\
4.94 \\
4.93 \\
4.92 \\
4.92\end{array}$ & $\begin{array}{l}1325 \\
1326 \\
1327 \\
1328 \\
1329\end{array}$ & $\begin{array}{l}8117.52 \\
8128.49 \\
8139.47 \\
8150.45 \\
8161.44\end{array}$ & $\begin{array}{l}10.972 \\
10.976 \\
10.981 \\
10.985 \\
10.989\end{array}$ & $\begin{array}{l}4 \cdot 36 \\
4 \cdot 35 \\
4 \cdot 34 \\
4 \cdot 33 \\
4 \cdot 32\end{array}$ & $\begin{array}{l}1385 \\
1386 \\
1387 \\
1388 \\
1389\end{array}$ & $\begin{array}{l}8783.29 \\
8794.51 \\
8805.73 \\
8816.95 \\
8828.18\end{array}$ & $\begin{array}{l}11.214 \\
11.217 \\
11.221 \\
11.225 \\
11.228\end{array}$ & $\begin{array}{l}3.69 \\
3.67 \\
3.66 \\
3.65 \\
3.64\end{array}$ \\
\hline $\begin{array}{l}1270 \\
1271 \\
1272 \\
1273 \\
1274\end{array}$ & $\begin{array}{l}7520.95 \\
7531.67 \\
7542.39 \\
7553.12 \\
7563.85\end{array}$ & $\begin{array}{l}10.717 \\
10.722 \\
10.726 \\
10.731 \\
10.736\end{array}$ & $\begin{array}{l}4.91 \\
4.90 \\
4.89 \\
4.88 \\
4.87\end{array}$ & $\begin{array}{l}1330 \\
1331 \\
1332 \\
1333 \\
1334\end{array}$ & $\begin{array}{l}8172.43 \\
8183.43 \\
8194.43 \\
8205.43 \\
8216.44\end{array}$ & $\begin{array}{l}10.994 \\
10.998 \\
11.002 \\
11.006 \\
11.011\end{array}$ & $\begin{array}{l}4 \cdot 31 \\
4 \cdot 30 \\
4 \cdot 29 \\
4 \cdot 28 \\
4 \cdot 27\end{array}$ & $\begin{array}{l}1390 \\
1391 \\
1392 \\
1393 \\
1394\end{array}$ & $\begin{array}{l}8839.41 \\
8850.64 \\
8861.88 \\
8873.12 \\
8884.36\end{array}$ & $\begin{array}{l}11.232 \\
11.236 \\
11.239 \\
11.243 \\
11.246\end{array}$ & $\begin{array}{l}3.63 \\
3.61 \\
3.60 \\
3.59 \\
3.58\end{array}$ \\
\hline $\begin{array}{l}1275 \\
1276 \\
1277 \\
1278 \\
1279\end{array}$ & $\begin{array}{l}7574.59 \\
7585.33 \\
7596.08 \\
7606.84 \\
7617.59\end{array}$ & $\begin{array}{l}10.741 \\
10.746 \\
10.751 \\
10.756 \\
10.760\end{array}$ & $\begin{array}{l}4.86 \\
4.85 \\
4.84 \\
4.83 \\
4.82\end{array}$ & $\begin{array}{l}1335 \\
1336 \\
1337 \\
1338 \\
1339\end{array}$ & $\begin{array}{l}8227.45 \\
8238.47 \\
8249.49 \\
8260.52 \\
8271.55\end{array}$ & $\begin{array}{l}11.015 \\
11.019 \\
11.023 \\
11.028 \\
11.032\end{array}$ & $\begin{array}{l}4 \cdot 26 \\
4 \cdot 25 \\
4.23 \\
4.22 \\
4 \cdot 21\end{array}$ & $\begin{array}{l}1395 \\
1396 \\
1397 \\
1398 \\
1399\end{array}$ & $\begin{array}{l}8895.61 \\
8906.86 \\
8918.12 \\
8929.38 \\
8940.64\end{array}$ & $\begin{array}{l}11.250 \\
11.254 \\
11.257 \\
11.261 \\
11.264\end{array}$ & $\begin{array}{l}3.57 \\
3.55 \\
3.54 \\
3.53 \\
3.52\end{array}$ \\
\hline $\begin{array}{l}1280 \\
1281 \\
1282 \\
1283 \\
1284\end{array}$ & $\begin{array}{l}7628.36 \\
7639.12 \\
7649.90 \\
7660.67 \\
7671.46\end{array}$ & $\begin{array}{l}10.765 \\
10.770 \\
10.775 \\
10.780 \\
10.784\end{array}$ & $\begin{array}{l}4.81 \\
4.80 \\
4.79 \\
4.78 \\
4.77\end{array}$ & $\begin{array}{l}1340 \\
1341 \\
1342 \\
1343 \\
1344\end{array}$ & $\begin{array}{l}8282.58 \\
8293.62 \\
8304.66 \\
8315.71 \\
8326.76\end{array}$ & $\begin{array}{l}11.036 \\
11.040 \\
11.045 \\
11.049 \\
11.053\end{array}$ & $\begin{array}{l}4.20 \\
4 \cdot 19 \\
4.18 \\
4.17 \\
4.16\end{array}$ & $\begin{array}{l}1400 \\
1401 \\
1402 \\
1403 \\
1404\end{array}$ & $\begin{array}{l}8951.91 \\
8963.18 \\
8974.45 \\
8985.73 \\
8997.01\end{array}$ & $\begin{array}{l}11.268 \\
11.271 \\
11.275 \\
11.278 \\
11.282\end{array}$ & $\begin{array}{l}3.50 \\
3.49 \\
3.48 \\
3.47 \\
3.45\end{array}$ \\
\hline $\begin{array}{l}1285 \\
1286 \\
1287 \\
1288 \\
1289\end{array}$ & $\begin{array}{l}7682.24 \\
7693.03 \\
7703.83 \\
7714.63 \\
7725.44\end{array}$ & $\begin{array}{l}10.789 \\
10.794 \\
10.799 \\
10.803 \\
10.808\end{array}$ & $\begin{array}{l}4.76 \\
4.76 \\
4.75 \\
4.74 \\
4.73\end{array}$ & $\begin{array}{l}1345 \\
1346 \\
1347 \\
1348 \\
1349\end{array}$ & $\begin{array}{l}8337.81 \\
8348.87 \\
8359.94 \\
8371.00 \\
8382.08\end{array}$ & $\begin{array}{l}11.057 \\
11.061 \\
11.065 \\
11.069 \\
11.073\end{array}$ & $\begin{array}{l}4 \cdot 15 \\
4 \cdot 14 \\
4 \cdot 12 \\
4 \cdot 11 \\
4 \cdot 10\end{array}$ & $\begin{array}{l}1405 \\
1406 \\
1407 \\
1408 \\
1409\end{array}$ & $\begin{array}{l}9008.29 \\
9019.58 \\
9030.87 \\
9042.16 \\
9053.46\end{array}$ & $\begin{array}{l}11.285 \\
11.289 \\
11.292 \\
11.295 \\
11.299\end{array}$ & $\begin{array}{l}3.44 \\
3.43 \\
3.42 \\
3.40 \\
3.39\end{array}$ \\
\hline $\begin{array}{l}1290 \\
1291 \\
1292 \\
1293 \\
1294\end{array}$ & $\begin{array}{l}7736.25 \\
7747.06 \\
7757.88 \\
7768.71 \\
7779.54\end{array}$ & $\begin{array}{l}10.813 \\
10.818 \\
10.822 \\
10.827 \\
10.832\end{array}$ & $\begin{array}{l}4.72 \\
4.71 \\
4.70 \\
4.69 \\
4.68\end{array}$ & $\begin{array}{l}1350 \\
1351 \\
1352 \\
1353 \\
1354\end{array}$ & $\begin{array}{l}8393.15 \\
8404.23 \\
8415.31 \\
8426.40 \\
8437.49\end{array}$ & $\begin{array}{l}11.078 \\
11.082 \\
11.086 \\
11.090 \\
11.094\end{array}$ & $\begin{array}{l}4.09 \\
4.08 \\
4.07 \\
4.06 \\
4.05\end{array}$ & $\begin{array}{l}1410 \\
1411 \\
1412 \\
1413 \\
1414\end{array}$ & $\begin{array}{l}9064.76 \\
9076.06 \\
9087.37 \\
9098.68 \\
9109.99\end{array}$ & $\begin{array}{l}11.302 \\
11.306 \\
11.309 \\
11.312 \\
11.316\end{array}$ & $\begin{array}{l}3.38 \\
3.37 \\
3.35 \\
3.34 \\
3.33\end{array}$ \\
\hline $\begin{array}{l}1295 \\
1296 \\
1297 \\
1298 \\
1299\end{array}$ & $\begin{array}{l}7790.37 \\
7801.21 \\
7812.05 \\
7822.90 \\
7833.75\end{array}$ & $\begin{array}{l}10.836 \\
10.841 \\
10.846 \\
10.850 \\
10.855\end{array}$ & $\begin{array}{l}4.67 \\
4.66 \\
4.65 \\
4.64 \\
4.63\end{array}$ & $\begin{array}{l}1355 \\
1356 \\
1357 \\
1358 \\
1359\end{array}$ & $\begin{array}{l}8448.59 \\
8459.69 \\
8470.79 \\
8481.90 \\
8493.01\end{array}$ & $\begin{array}{l}11.098 \\
11.102 \\
11.106 \\
11.110 \\
11.114\end{array}$ & $\begin{array}{l}4.04 \\
4.02 \\
4.01 \\
4.00 \\
3.99\end{array}$ & $\begin{array}{l}1415 \\
1416 \\
1417 \\
1418 \\
1419\end{array}$ & $\begin{array}{l}9121.31 \\
9132.63 \\
9143.95 \\
9155.28 \\
9166.61\end{array}$ & $\begin{array}{l}11.319 \\
11.322 \\
11.325 \\
11.329 \\
11.332\end{array}$ & $\begin{array}{l}3.32 \\
3.30 \\
3.29 \\
3.28 \\
3.26\end{array}$ \\
\hline $\begin{array}{l}1300 \\
1301 \\
1302 \\
1303 \\
1304\end{array}$ & $\begin{array}{l}7844.61 \\
7855.47 \\
7866.34 \\
7877.21 \\
7888.09\end{array}$ & $\begin{array}{l}10.860 \\
10.864 \\
10.869 \\
10.873 \\
10.878\end{array}$ & $\begin{array}{l}4.62 \\
4.61 \\
4.60 \\
4.59 \\
4.58\end{array}$ & $\begin{array}{l}1360 \\
1361 \\
1362 \\
1363 \\
1364\end{array}$ & $\begin{array}{l}8504.13 \\
8515.25 \\
8526.37 \\
8537.50 \\
8548.63\end{array}$ & $\begin{array}{l}11.118 \\
11.122 \\
11.126 \\
11.130 \\
11.134\end{array}$ & $\begin{array}{l}3.98 \\
3.97 \\
3.96 \\
3.94 \\
3.93\end{array}$ & $\begin{array}{l}1420 \\
1421 \\
1422 \\
1423 \\
1424\end{array}$ & $\begin{array}{l}9177.95 \\
9189.28 \\
9200.62 \\
9211.97 \\
9223.31\end{array}$ & $\begin{array}{l}11.335 \\
11.339 \\
11.342 \\
11.345 \\
11.348\end{array}$ & $\begin{array}{l}3.25 \\
3.24 \\
3.23 \\
3.21 \\
3.20\end{array}$ \\
\hline $\begin{array}{l}1305 \\
1306 \\
1307 \\
1308 \\
1309\end{array}$ & $\begin{array}{l}7898.97 \\
7909.85 \\
7920.74 \\
7931.64 \\
7942.53\end{array}$ & $\begin{array}{l}10.883 \\
10.887 \\
10.892 \\
10.896 \\
10.901\end{array}$ & $\begin{array}{l}4.57 \\
4.56 \\
4.55 \\
4.54 \\
4.53\end{array}$ & $\begin{array}{l}1365 \\
1366 \\
1367 \\
1368 \\
1369\end{array}$ & $\begin{array}{l}8559.77 \\
8570.91 \\
8582.05 \\
8593.20 \\
8604.35\end{array}$ & $\begin{array}{l}11.138 \\
11.142 \\
11.146 \\
11.149 \\
11.153\end{array}$ & $\begin{array}{l}3.92 \\
3.91 \\
3.90 \\
3.89 \\
3.88\end{array}$ & $\begin{array}{l}1425 \\
1426 \\
1427 \\
1428 \\
1429\end{array}$ & $\begin{array}{l}9234.66 \\
9246.02 \\
9257.37 \\
9268.73 \\
9280.09\end{array}$ & $\begin{array}{l}11.351 \\
11.355 \\
11.358 \\
11.361 \\
11.364\end{array}$ & $\begin{array}{l}3.19 \\
3.17 \\
3.16 \\
3.15 \\
3.13\end{array}$ \\
\hline $\begin{array}{l}1310 \\
1311 \\
1312 \\
1313 \\
1314\end{array}$ & $\begin{array}{l}7953.44 \\
7964.34 \\
7975.26 \\
7986.17 \\
7997.09\end{array}$ & $\begin{array}{l}10.905 \\
10.910 \\
10.914 \\
10.919 \\
10.923\end{array}$ & $\begin{array}{l}4 \cdot 52 \\
4.51 \\
4.50 \\
4.49 \\
4.48\end{array}$ & $\begin{array}{l}1370 \\
1371 \\
1372 \\
1373 \\
1374\end{array}$ & $\begin{array}{l}8615.51 \\
8626.67 \\
8637.83 \\
8648.99 \\
8660.17\end{array}$ & $\begin{array}{l}11.157 \\
11.161 \\
11.165 \\
11.169 \\
11.173\end{array}$ & $\begin{array}{l}3.86 \\
3.85 \\
3.84 \\
3.83 \\
3.82\end{array}$ & $\begin{array}{l}1430 \\
1431 \\
1432 \\
1433 \\
1434\end{array}$ & $\begin{array}{l}9291.46 \\
9302.83 \\
9314.20 \\
9325.57 \\
9336.95\end{array}$ & $\begin{array}{l}11 \cdot 367 \\
11 \cdot 370 \\
11 \cdot 373 \\
11 \cdot 376 \\
11.380\end{array}$ & $\begin{array}{l}3.12 \\
3.11 \\
3.09 \\
3.08 \\
3.07\end{array}$ \\
\hline $\begin{array}{l}1315 \\
1316 \\
1317 \\
1318 \\
1319\end{array}$ & $\begin{array}{l}8008.02 \\
8018.95 \\
8029.88 \\
8040.82 \\
8051.77\end{array}$ & $\begin{array}{l}10.928 \\
10.932 \\
10.937 \\
10.941 \\
10.946\end{array}$ & $\begin{array}{l}4.47 \\
4.46 \\
4.45 \\
4.44 \\
4.43\end{array}$ & $\begin{array}{l}1375 \\
1376 \\
1377 \\
1378 \\
1379\end{array}$ & $\begin{array}{l}8671.34 \\
8682 \cdot 52 \\
8693.70 \\
8704 \cdot 89 \\
8716.08\end{array}$ & $\begin{array}{l}11 \cdot 176 \\
11.180 \\
11.184 \\
11.188 \\
11.191\end{array}$ & $\begin{array}{l}3.81 \\
3.79 \\
3.78 \\
3.77 \\
3.76\end{array}$ & $\begin{array}{l}1435 \\
1436 \\
1437 \\
1438 \\
1439\end{array}$ & $\begin{array}{l}9348 \cdot 33 \\
9359 \cdot 72 \\
9371.10 \\
9382.49 \\
9393.89\end{array}$ & $\begin{array}{l}11.383 \\
11.386 \\
11.389 \\
11.392 \\
11.395\end{array}$ & $\begin{array}{l}3.05 \\
3.04 \\
3.03 \\
3.01 \\
3.00\end{array}$ \\
\hline 1320 & 8062.71 & 10.950 & 4.41 & 1380 & 8727.27 & $11 \cdot 195$ & 3.75 & 1440 & 9405.28 & 11.398 & 2.99 \\
\hline
\end{tabular}


TABLE 4.3.2. Type B thermocouples-thermoelectric voltages, E(T), Seebeck coefficients, $\mathrm{S}(\mathrm{T})$, and first derivative of the Seebeck coefficients, $\mathrm{d} \mathrm{S} / \mathrm{dT}$, reference junctions at $0{ }^{\circ} \mathrm{C}$-Continued

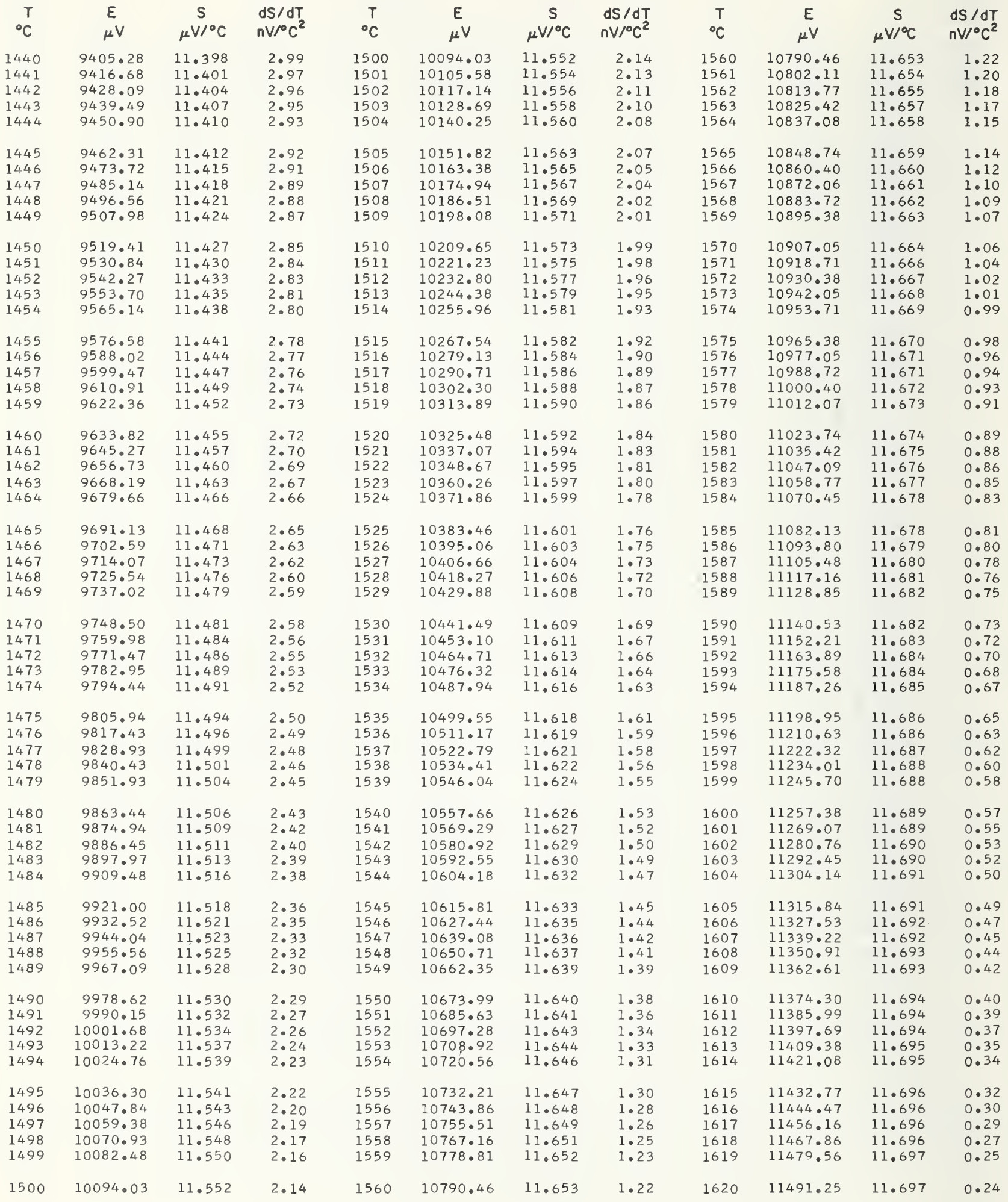


TABLE 4.3.2. Type B thermocouples-thermoelectric voltages, $\mathrm{E}(\mathrm{T})$, Seebeck coefficients, $\mathrm{S}(\mathrm{T})$, and first derivative of the Scebeck coefficients, $\mathrm{dS} / \mathrm{dT}$, reference junctions at $0{ }^{\circ} \mathrm{C}$-Continued

\begin{tabular}{|c|c|c|c|c|c|c|c|c|c|c|c|}
\hline${ }^{\mathrm{T}} \mathrm{C}$ & $\begin{array}{c}E \\
\mu V\end{array}$ & $\underset{\mu V /{ }^{\circ} \mathrm{C}}{S}$ & $\begin{array}{l}\mathrm{dS} / \mathrm{dT} \\
\mathrm{nV} /{ }^{\circ} \mathrm{C}^{2}\end{array}$ & ${ }^{\mathrm{T}} \mathrm{C}$ & $\begin{array}{c}E \\
\mu V\end{array}$ & $\begin{array}{c}\mathrm{S} \\
\mu \mathrm{V}^{\circ} \mathrm{C}\end{array}$ & $\begin{array}{l}d S / d T \\
n V /{ }^{\circ} C^{2}\end{array}$ & $\begin{array}{c}\mathrm{T} \\
{ }^{\circ} \mathrm{C}\end{array}$ & $\underset{\mu V}{E}$ & $\begin{array}{c}\mathrm{S} \\
\mu \mathrm{V} /{ }^{\circ} \mathrm{C}\end{array}$ & $\begin{array}{l}\mathrm{dS} / \mathrm{dT} \\
\mathrm{nV} /{ }^{\circ} \mathrm{C}^{2}\end{array}$ \\
\hline $\begin{array}{l}1625 \\
1626 \\
1627 \\
1628 \\
1629\end{array}$ & $\begin{array}{l}11549.74 \\
11561.44 \\
11573.14 \\
11584.83 \\
11596.53\end{array}$ & $\begin{array}{l}11.698 \\
11.698 \\
11.698 \\
11.698 \\
11.698\end{array}$ & $\begin{array}{l}0.15 \\
0.14 \\
0.12 \\
0.10 \\
0.09\end{array}$ & $\begin{array}{l}1685 \\
1686 \\
1687 \\
1688 \\
1689\end{array}$ & $\begin{array}{l}12251.29 \\
12262.97 \\
12274.64 \\
12286.32 \\
12297.99\end{array}$ & $\begin{array}{l}11.677 \\
11.676 \\
11.675 \\
11.674 \\
11.674\end{array}$ & $\begin{array}{l}-0.85 \\
-0.86 \\
-0.88 \\
-0.89 \\
-0.91\end{array}$ & $\begin{array}{l}1745 \\
1746 \\
1747 \\
1748 \\
1749\end{array}$ & $\begin{array}{l}12949.81 \\
12961.40 \\
12973.00 \\
12984.59 \\
12996.18\end{array}$ & $\begin{array}{l}11.597 \\
11.595 \\
11.594 \\
11.592 \\
11.590\end{array}$ & $\begin{array}{l}-1.80 \\
-1.82 \\
-1.83 \\
-1.85 \\
-1.86\end{array}$ \\
\hline $\begin{array}{l}1630 \\
1631 \\
1632 \\
1633 \\
1634\end{array}$ & $\begin{array}{l}11608.23 \\
11619.93 \\
11631.63 \\
11643.33 \\
11655.03\end{array}$ & $\begin{array}{l}11.698 \\
11.698 \\
11.699 \\
11.699 \\
11.699\end{array}$ & $\begin{array}{l}0.07 \\
0.05 \\
0.04 \\
0.02 \\
0.00\end{array}$ & $\begin{array}{l}1690 \\
1691 \\
1692 \\
1693 \\
1694\end{array}$ & $\begin{array}{l}12309.66 \\
12321.34 \\
12333.01 \\
12344.68 \\
12356.35\end{array}$ & $\begin{array}{l}11.673 \\
11.672 \\
11.671 \\
11.670 \\
11.669\end{array}$ & $\begin{array}{l}-0.93 \\
-0.94 \\
-0.96 \\
-0.98 \\
-0.99\end{array}$ & $\begin{array}{l}1750 \\
1751 \\
1752 \\
1753 \\
1754\end{array}$ & $\begin{array}{l}13007.77 \\
13019.36 \\
13030.94 \\
13042.52 \\
13054.11\end{array}$ & $\begin{array}{l}11.588 \\
11.586 \\
11.584 \\
11.582 \\
11.580\end{array}$ & $\begin{array}{l}-1.88 \\
-1.89 \\
-1.91 \\
-1.92 \\
-1.94\end{array}$ \\
\hline $\begin{array}{l}1640 \\
1641 \\
1642 \\
1643 \\
1644\end{array}$ & $\begin{array}{l}11725.22 \\
11736.91 \\
11748.61 \\
11760.31 \\
11772.01\end{array}$ & $\begin{array}{l}11.698 \\
11.698 \\
11.698 \\
11.698 \\
11.698\end{array}$ & $\begin{array}{l}-0.10 \\
-0.11 \\
-0.13 \\
-0.15 \\
-0.16\end{array}$ & $\begin{array}{l}1700 \\
1701 \\
1702 \\
1703 \\
1704\end{array}$ & $\begin{array}{l}12426.34 \\
12438.00 \\
12449.66 \\
12461.32 \\
12472.98\end{array}$ & $\begin{array}{l}11.663 \\
11.661 \\
11.660 \\
11.659 \\
11.658\end{array}$ & $\begin{array}{l}-1.09 \\
-1.11 \\
-1.12 \\
-1.14 \\
-1.16\end{array}$ & $\begin{array}{l}1760 \\
1761 \\
1762 \\
1763 \\
1764\end{array}$ & $\begin{array}{l}13123.55 \\
13135.12 \\
13146.69 \\
13158.25 \\
13169.81\end{array}$ & $\begin{array}{l}11.568 \\
11.566 \\
11.564 \\
11.562 \\
11.560\end{array}$ & $\begin{array}{l}-2.03 \\
-2.04 \\
-2.06 \\
-2.07 \\
-2.09\end{array}$ \\
\hline $\begin{array}{l}1645 \\
1646 \\
1647 \\
1648 \\
1649\end{array}$ & $\begin{array}{l}11783.71 \\
11795.40 \\
11807.10 \\
11818.80 \\
11830.50\end{array}$ & $\begin{array}{l}11.698 \\
11.697 \\
11.697 \\
11.697 \\
11.697\end{array}$ & $\begin{array}{l}-0.18 \\
-0.20 \\
-0.21 \\
-0.23 \\
-0.25\end{array}$ & $\begin{array}{l}1705 \\
1706 \\
1707 \\
1708 \\
1709\end{array}$ & $\begin{array}{l}12484.64 \\
12496.30 \\
12507.95 \\
12519.60 \\
12531.26\end{array}$ & $\begin{array}{l}11.657 \\
11.656 \\
11.655 \\
11.653 \\
11.652\end{array}$ & $\begin{array}{l}-1.17 \\
-1.19 \\
-1.20 \\
-1.22 \\
-1.24\end{array}$ & $\begin{array}{l}1765 \\
1766 \\
1767 \\
1768 \\
1769\end{array}$ & $\begin{array}{l}13181.37 \\
13192.93 \\
13204.48 \\
13216.03 \\
13227.58\end{array}$ & $\begin{array}{l}11.558 \\
11.556 \\
11.554 \\
11.552 \\
11.550\end{array}$ & $\begin{array}{l}-2.10 \\
-2.12 \\
-2.13 \\
-2.15 \\
-2.16\end{array}$ \\
\hline $\begin{array}{l}1650 \\
1651 \\
1652 \\
1653 \\
1654\end{array}$ & $\begin{array}{l}11842.19 \\
11853.89 \\
11865.58 \\
11877.28 \\
11888.98\end{array}$ & $\begin{array}{l}11.696 \\
11.696 \\
11.696 \\
11.696 \\
11.695\end{array}$ & $\begin{array}{l}-0.26 \\
-0.28 \\
-0.30 \\
-0.31 \\
-0.33\end{array}$ & $\begin{array}{l}1710 \\
1711 \\
1712 \\
1713 \\
1714\end{array}$ & $\begin{array}{l}12542.91 \\
12554.56 \\
12566.21 \\
12577.86 \\
12589.50\end{array}$ & $\begin{array}{l}11.651 \\
11.650 \\
11.648 \\
11.647 \\
11.646\end{array}$ & $\begin{array}{l}-1.25 \\
-1.27 \\
-1.29 \\
-1.30 \\
-1.32\end{array}$ & $\begin{array}{l}1770 \\
1771 \\
1772 \\
1773 \\
1774\end{array}$ & $\begin{array}{l}13239.13 \\
13250.68 \\
13262.22 \\
13273.77 \\
13285.31\end{array}$ & $\begin{array}{l}11.547 \\
11.545 \\
11.543 \\
11.541 \\
11.539\end{array}$ & $\begin{array}{l}-2.17 \\
-2.19 \\
-2.20 \\
-2.22 \\
-2.23\end{array}$ \\
\hline $\begin{array}{l}1660 \\
1661 \\
1662 \\
1663 \\
1664\end{array}$ & $\begin{array}{l}11959.14 \\
11970.83 \\
11982.53 \\
11994.22 \\
12005.91\end{array}$ & $\begin{array}{l}11.693 \\
11.693 \\
11.692 \\
11.692 \\
11.691\end{array}$ & $\begin{array}{l}-0.43 \\
-0.45 \\
-0.46 \\
-0.48 \\
-0.50\end{array}$ & $\begin{array}{l}1720 \\
1721 \\
1722 \\
1723 \\
1724\end{array}$ & $\begin{array}{l}12659.35 \\
12670.99 \\
12682.62 \\
12694.26 \\
12705.89\end{array}$ & $\begin{array}{l}11.637 \\
11.636 \\
11.635 \\
11.633 \\
11.632\end{array}$ & $\begin{array}{l}-1.41 \\
-1.43 \\
-1.45 \\
-1.46 \\
-1.48\end{array}$ & $\begin{array}{l}1780 \\
1781 \\
1782 \\
1783 \\
1784\end{array}$ & $\begin{array}{l}13354.50 \\
13366.02 \\
13377.54 \\
13389.06 \\
13400.58\end{array}$ & $\begin{array}{l}11.525 \\
11.523 \\
11.520 \\
11.518 \\
11.516\end{array}$ & $\begin{array}{l}-2.31 \\
-2.33 \\
-2.34 \\
-2.36 \\
-2.37\end{array}$ \\
\hline $\begin{array}{l}1665 \\
1666 \\
1667 \\
1668 \\
1669\end{array}$ & $\begin{array}{l}12017.60 \\
12029.29 \\
12040.98 \\
12052.67 \\
12064.36\end{array}$ & $\begin{array}{l}11.691 \\
11.690 \\
11.690 \\
11.689 \\
11.688\end{array}$ & $\begin{array}{l}-0.51 \\
-0.53 \\
-0.55 \\
-0.56 \\
-0.58\end{array}$ & $\begin{array}{l}1725 \\
1726 \\
1727 \\
1728 \\
1729\end{array}$ & $\begin{array}{l}12717.52 \\
12729.15 \\
12740.78 \\
12752.40 \\
12764.03\end{array}$ & $\begin{array}{l}11.630 \\
11.629 \\
11.627 \\
11.626 \\
11.624\end{array}$ & $\begin{array}{l}-1.49 \\
-1.51 \\
-1.52 \\
-1.54 \\
-1.56\end{array}$ & $\begin{array}{l}1785 \\
1786 \\
1787 \\
1788 \\
1789\end{array}$ & $\begin{array}{l}13412.09 \\
13423.60 \\
13435.11 \\
13446.62 \\
13458.13\end{array}$ & $\begin{array}{l}11.513 \\
11.511 \\
11.508 \\
11.506 \\
11.504\end{array}$ & $\begin{array}{l}-2.38 \\
-2.40 \\
-2.41 \\
-2.42 \\
-2.44\end{array}$ \\
\hline $\begin{array}{l}1670 \\
1671 \\
1672 \\
1673 \\
1674\end{array}$ & $\begin{array}{l}12076.05 \\
12087.73 \\
12099.42 \\
12111.11 \\
12122.79\end{array}$ & $\begin{array}{l}11.688 \\
11.687 \\
11.687 \\
11.686 \\
11.685\end{array}$ & $\begin{array}{l}-0.60 \\
-0.61 \\
-0.63 \\
-0.65 \\
-0.66\end{array}$ & $\begin{array}{l}1730 \\
1731 \\
1732 \\
1733 \\
1734\end{array}$ & $\begin{array}{l}12775.65 \\
12787.27 \\
12798.89 \\
12810.51 \\
12822.13\end{array}$ & $\begin{array}{l}11.623 \\
11.621 \\
11.619 \\
11.618 \\
11.616\end{array}$ & $\begin{array}{l}-1.57 \\
-1.59 \\
-1.60 \\
-1.62 \\
-1.63\end{array}$ & $\begin{array}{l}1790 \\
1791 \\
1792 \\
1793 \\
1794\end{array}$ & $\begin{array}{l}13469.63 \\
13481.13 \\
13492.63 \\
13504.12 \\
13515.61\end{array}$ & $\begin{array}{l}11.501 \\
11.499 \\
11.496 \\
11.494 \\
11.491\end{array}$ & $\begin{array}{l}-2.45 \\
-2.46 \\
-2.48 \\
-2.49 \\
-2.50\end{array}$ \\
\hline $\begin{array}{l}1675 \\
1676 \\
1677 \\
1678 \\
1679\end{array}$ & $\begin{array}{l}12134.48 \\
12146.16 \\
12157.85 \\
12169.53 \\
12181.21\end{array}$ & $\begin{array}{l}11.685 \\
11.684 \\
11.683 \\
11.683 \\
11.682\end{array}$ & $\begin{array}{l}-0.68 \\
-0.70 \\
-0.71 \\
-0.73 \\
-0.75\end{array}$ & $\begin{array}{l}1735 \\
1736 \\
1737 \\
1738 \\
1739\end{array}$ & $\begin{array}{l}12833.75 \\
12845.36 \\
12856.97 \\
12868.58 \\
12880.19\end{array}$ & $\begin{array}{l}11.614 \\
11.613 \\
11.611 \\
11.609 \\
11.608\end{array}$ & $\begin{array}{l}-1.65 \\
-1.67 \\
-1.68 \\
-1.70 \\
-1.71\end{array}$ & $\begin{array}{l}1795 \\
1796 \\
1797 \\
1798 \\
1799\end{array}$ & $\begin{array}{l}13527.10 \\
13538.59 \\
13550.08 \\
13561.56 \\
13573.04\end{array}$ & $\begin{array}{l}11.489 \\
11.486 \\
11.484 \\
11.481 \\
11.479\end{array}$ & $\begin{array}{l}-2.52 \\
-2.53 \\
-2.54 \\
-2.56 \\
-2.57\end{array}$ \\
\hline 1680 & 12192.89 & 11.681 & -0.76 & 1740 & $12891 \cdot 80$ & 11.606 & -1.73 & 1800 & 13584.52 & 11.476 & -2.58 \\
\hline
\end{tabular}


TABLE 4.3.2. Type B thermocouples-thermoelectric voltages, E(T), Seebeck coefficients, S(T), and first derivative of the Seebeck coefficients, $\mathrm{dS} / \mathrm{dT}$, reference junctions at $0{ }^{\circ} \mathrm{C}$-Continued

\begin{tabular}{|c|c|c|c|c|c|c|c|c|c|c|c|}
\hline${ }^{\circ} \mathrm{C}$ & $\underset{\mu V}{E V}$ & $\underset{\mu V /{ }^{\circ} \mathrm{C}}{\mathrm{S}}$ & $\begin{array}{l}d S / d T \\
n V /{ }^{\circ} C^{2}\end{array}$ & $\begin{array}{c}\mathrm{T} \\
{ }^{\circ} \mathrm{C}\end{array}$ & $\underset{\mu V}{E}$ & $\underset{\mu V /{ }^{\circ} \mathrm{C}}{S}$ & $\begin{array}{l}d S / d T \\
n V /{ }^{\circ} \mathrm{C}^{2}\end{array}$ & $\begin{array}{r}\mathrm{T} \\
{ }^{\circ} \mathrm{C}\end{array}$ & ${ }_{\mu V}^{E V}$ & $\underset{\mu V /{ }^{\circ} \mathrm{C}}{\mathrm{S}}$ & $\begin{array}{l}d S / d T \\
n V /{ }^{\circ} C^{2}\end{array}$ \\
\hline $\begin{array}{l}1800 \\
1801 \\
1802 \\
1803 \\
1804\end{array}$ & $\begin{array}{l}13584.52 \\
13595.99 \\
13607.46 \\
13618.93 \\
13630.40\end{array}$ & $\begin{array}{l}11.476 \\
11.473 \\
11.471 \\
11.468 \\
11.466\end{array}$ & $\begin{array}{l}-2.58 \\
-2.59 \\
-2.61 \\
-2.62 \\
-2.63\end{array}$ & $\begin{array}{l}1810 \\
1811 \\
1812 \\
1813 \\
1814\end{array}$ & $\begin{array}{l}13699.14 \\
13710.59 \\
13722.04 \\
13733.48 \\
13744.92\end{array}$ & $\begin{array}{l}11.450 \\
11.447 \\
11.444 \\
11.441 \\
11.439\end{array}$ & $\begin{array}{l}-2.71 \\
-2.72 \\
-2.73 \\
-2.74 \\
-2.76\end{array}$ & 1820 & 13813.50 & 11.422 & $-2 \cdot 83$ \\
\hline $\begin{array}{l}1805 \\
1806 \\
1807 \\
1808 \\
1809\end{array}$ & $\begin{array}{l}13641.86 \\
13653.33 \\
13664.78 \\
13676.24 \\
13687.69\end{array}$ & $\begin{array}{l}11.463 \\
11.460 \\
11.458 \\
11.455 \\
11.452\end{array}$ & $\begin{array}{l}-2.65 \\
-2.66 \\
-2.67 \\
-2.68 \\
-2.70\end{array}$ & $\begin{array}{l}1815 \\
1816 \\
1817 \\
1818 \\
1819\end{array}$ & $\begin{array}{l}13756.36 \\
13767.79 \\
13779.22 \\
13790.65 \\
13802.08\end{array}$ & $\begin{array}{l}11.436 \\
11.433 \\
11.430 \\
11.428 \\
11.425\end{array}$ & $\begin{array}{l}-2.77 \\
-2.78 \\
-2.79 \\
-2.80 \\
-2.81\end{array}$ & & & & \\
\hline 1810 & 13699.14 & 11.450 & $-2 \cdot 71$ & 1820 & 13813.50 & 11.422 & $-2 \cdot 83$ & & & & \\
\hline
\end{tabular}


TABLE 4.3.3. Thermoelectric values at the fixed points for Type B thermocouples

\begin{tabular}{|c|c|c|c|c|}
\hline Fixed point & $\begin{array}{c}\text { Temp. } \\
{ }^{\circ} \mathrm{C}\end{array}$ & $\begin{array}{c}E \\
\mu \mathrm{V}\end{array}$ & $\begin{array}{c}S \\
\mu \mathrm{V} /{ }^{\circ} \mathrm{C}\end{array}$ & $\begin{array}{l}d S / d T \\
\mathrm{nV} /{ }^{\circ} \mathrm{C}^{2}\end{array}$ \\
\hline Ice point & 0.000 & 0.00 & -0.247 & 11.82 \\
\hline Ether TP & 26.870 & -2.39 & 0.068 & 11.61 \\
\hline Water BP & 100.000 & 33.18 & 0.900 & 11.16 \\
\hline Benzoic TP & 122.370 & 56.09 & 1.148 & 11.06 \\
\hline Indium FP & 156.634 & 101.88 & 1.524 & 10.90 \\
\hline Tin FP & 231.9681 & 247.37 & 2.334 & 10.61 \\
\hline Bismuth FP & 271.442 & 347.74 & 2.750 & 10.46 \\
\hline Cadmium FP & 321.108 & 497.15 & 3.265 & 10.27 \\
\hline Lead FP & 327.502 & 518.24 & 3.331 & 10.24 \\
\hline Mercury BP & 356.660 & 619.69 & 3.627 & 10.12 \\
\hline Zinc FP & 419.580 & 867.78 & 4.256 & 9.85 \\
\hline Sulphur BP & 444.674 & 977.66 & 4.501 & 9.73 \\
\hline $\mathrm{Cu}-\mathrm{Al} \mathrm{FP}$ & 548.23 & 1495.10 & 5.483 & 9.22 \\
\hline Antimony FP & 630.74 & 1978.43 & 6.227 & 8.79 \\
\hline Aluminum FP & 660.37 & 2166.77 & 6.485 & 8.64 \\
\hline Silver FP & 961.93 & 4490.76 & 8.848 & 7.03 \\
\hline Gold FP & 1064.43 & 5433.59 & 9.539 & 6.44 \\
\hline Copper FP & 1084.5 & 5626.33 & 9.667 & 6.32 \\
\hline Nickel FP & 1455 & 9576.58 & 11.441 & 2.78 \\
\hline Cobalt FP & 1494 & 10024.76 & 11.539 & 2.23 \\
\hline Palladium FP & 1554 & 10720.56 & 11.646 & 1.31 \\
\hline Platinum FP & 1772 & 13262.22 & 11.543 & -2.20 \\
\hline
\end{tabular}

TABLE 4.3.4. Estimated maximum errors that occur when using reduced-bit arithmetic for the power series expansion for the thermoelectric voltage of Type B thermocouples

\begin{tabular}{|c|c|c|c|c|c|c|}
\hline \multirow[b]{2}{*}{ Temperature range } & \multirow[b]{2}{*}{ Degree } & \multicolumn{5}{|c|}{ Estimated maximum error in microvolts } \\
\hline & & $12 \mathrm{Bit}$ & $16 \mathrm{Bit}$ & 24 Bit & 27 Bit & 36 Bit \\
\hline 0 to $200^{\circ} \mathrm{C}$ & 8 & 0.1 & $<0.01$ & $<0.01$ & $<0.01$ & $<0.01$ \\
\hline 200 to $400{ }^{\circ} \mathrm{C}$ & 8 & 0.3 & 0.02 & $<0.01$ & $<0.01$ & $<0.01$ \\
\hline 400 to $600{ }^{\circ} \mathrm{C}$ & 8 & 0.8 & 0.03 & $<0.01$ & $<0.01$ & $<0.01$ \\
\hline 600 to $800{ }^{\circ} \mathrm{C}$ & 8 & 2 & 0.05 & $<0.01$ & $<0.01$ & $<0.01$ \\
\hline 800 to $1000^{\circ} \mathrm{C}$ & 8 & 4 & 0.06 & $<0.01$ & $<0.01$ & $<0.01$ \\
\hline 1000 to $1200{ }^{\circ} \mathrm{C}$ & 8 & 7 & 0.06 & $<0.01$ & $<0.01$ & $<0.01$ \\
\hline 1200 to $1400{ }^{\circ} \mathrm{C}$ & 8 & 10 & 0.06 & $<0.01$ & $<0.01$ & $<0.01$ \\
\hline 1400 to $1600{ }^{\circ} \mathrm{C}$ & 8 & 20 & 0.06 & 0.02 & $<0.01$ & $<0.01$ \\
\hline 1600 to $1820^{\circ} \mathrm{C}$ & 8 & 40 & 0.09 & 0.03 & $<0.01$ & $<0.01$ \\
\hline
\end{tabular}


4.4. Reference functions and Tables for the Positive Thermoelement, Type BP, a Platinum-30\% Rhodium Alloy Versus Platinum, Pt -67

The coefficients for the eighth degree expansion for the thermoelectric voltage of Type BP thermoelements versus Pt-67 are given in table 4.4.1. The errors caused by using reduced bit arithmetic for calculating values of the functions are given in table 4.4.4.

The primary reference values for Type BP thermoelements versus $\mathrm{Pt}_{\mathrm{t}}-67$ are given in table 4.4.2. Values at selected fixed points are given in table 4.4.3. Graphs of the thermoelectric voltage, its first derivative (Seebeck coefficient), and second derivative are given in figures 4.4.1, 4.4.2, and 4.4.3, respectively.

TABLE 4.4.1. Power series expansion for the thermoelectric voltage of Type BP thermoelements versus platinum, $\mathrm{Pt}-67$

\begin{tabular}{c|c|c|c}
\hline \hline $\begin{array}{c}\text { Tempera- } \\
\text { ture } \\
\text { range }\end{array}$ & Degree & Coefficients & Term \\
\hline & & & \\
0 to & 8 & 4.8193620846 & $T$ \\
$1820{ }^{\circ} \mathrm{C}$ & & $1.5702235198 \times 10^{-2}$ & $T^{2}$ \\
& & $-2.2802418012 \times 10^{-6}$ & $T^{3}$ \\
& & $3.1247260577 \times 10^{-8}$ & $T^{4}$ \\
& & $-2.7550122645 \times 10^{-11}$ & $T^{5}$ \\
& & $1.5024838175 \times 10^{-14}$ & $T^{6}$ \\
& & $-4.6480201964 \times 10^{-18}$ & $T^{7}$ \\
& & & \\
& & & \\
\hline
\end{tabular}

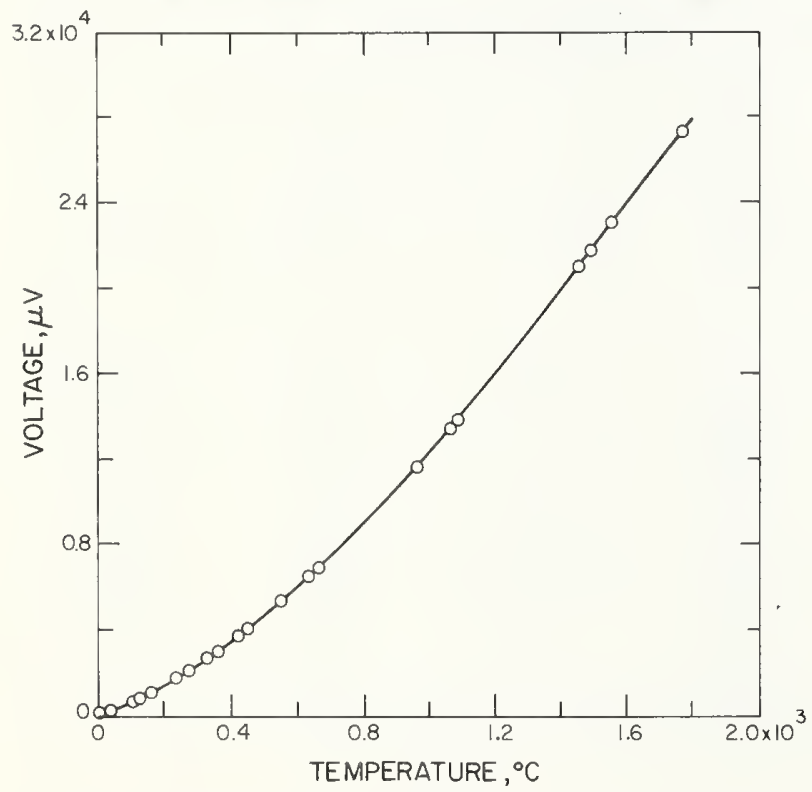

Figure 4.4.1. Thermoelectric voltage for Type BP thermoelements versus platinum, Pt-67.

The circles indicate values at various thermometric fixed points on the IPTS -68 .

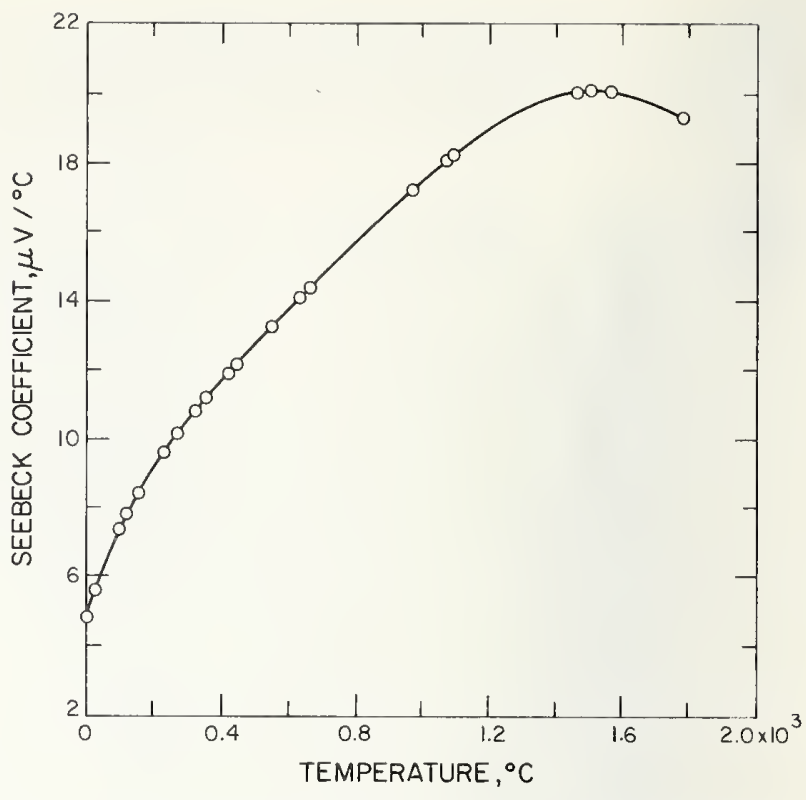

FigURE 4.2.2. Seebeck coefficient for Type BP thermoelements versus platinum, $P t-67$.

The circles indicate values at various thermometric fixed points on the IPTS -68 .

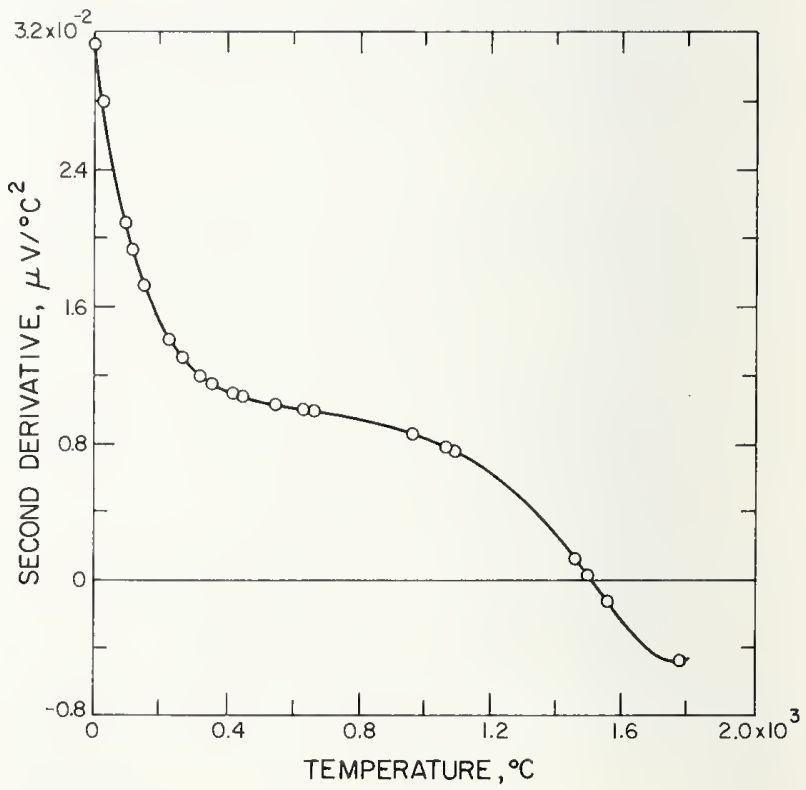

FIGURE 4.4.3. Second derivative of thermoelectric voltage for Type BP thermoelements versus platinum, Pt-67.

The circles indicate values at various thermometric fixed points on the IPTS -68 . 
TABle 4.4.2. Type BP thermoelements versus platinum, Pt-67-Thermoelectric voltages, E(T), Seebeck coefficients, $\mathrm{S}(\mathrm{T})$, and first derivative of the Seebeck coefficients, $d S / d T$, reference junctions at $\mathrm{O}{ }^{\circ} \mathrm{C}$

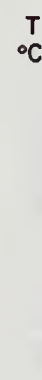

${ }^{\top} \mathrm{C}$

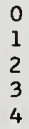

13

17

18

2

24

27

3

34

3

38

39

$45 \quad 246.71$

$46 \quad 252.83$

$47 \quad 258.98$

$48 \quad 265.14$

$49 \quad 271.34$

$50 \quad 277.56$

$51 \quad 283.81$

290.08

296.37

302.70

309.04

315.41

321.81

328.23

334.68

341.15 $\mu \mathrm{V} /{ }^{\circ} \mathrm{C}$

$d S / d T$

4.819

4. 851

4.882

4.913

4. 944

4. 975

5.005

5.036

5. 066

5. 097

5. 127

5. 157

5. 187

5.216
5.246

5. 275

5.305

5.334

5.363

5. 392

5.421

5.450
5.478

5.478

5. 535

5. 564

5.592

5.620

5. 648

5.676

5. 703

5.731

5.758

5. 786

5.813

5.840

5.867

5.894

5. 921

5.947

5.974

6.000

6.027

6. 053

6.079

6. 105

6. 131

6.157

6.182

6. 208

6.233

6.259

6.309

6.334

6.359

6.384

6.409

$6.483 \quad 24.43$
31.40

31.13

30.86

30.73

30.60

30.33

30.20

29.94

29.82

29.56

29.43

. 18

29.06

28.81

28.69
28.57

28.45

28.33

28.21

27.97

27.86

27.62

27.51

27.28

27.17

27.05

26.94

26.72

26.61

26.50

6.39

26.17

25.96

25.85

25.75

25.54

$25 \cdot 44$

25.23

25.13

25.03

24.93

24.73

24.53

$\begin{array}{cc}{ }^{T} \mathrm{C} & E \\ 60 & \mu V \\ 61 & 341.15 \\ 62 & 347.64 \\ 63 & 354.16 \\ 64 & 360.71 \\ & 367.27 \\ 65 & 373.87 \\ 66 & 380.48 \\ 67 & 387.12 \\ 68 & 393.78 \\ 69 & 400.47\end{array}$

$\stackrel{\mathrm{S}}{\mu \mathrm{V}^{\circ} \mathrm{C}}$

$d S / d T$
$n V /{ }^{\circ} C^{2}$

$6.483 \quad 24.43$

$6.507 \quad 24.34$

$6.531 \quad 24.24$

$6.556 \quad 24.14$

$6.580 \quad 24.05$

$6.604 \quad 23.95$

$6.628 \quad 23.86$

$6.651 \quad 23.76$

$6.675 \quad 23.67$

$6.699 \quad 23.58$

407.18

413.91

420.67

427.45

434.26

6.722

6.746

23.49

23.39

6.792

6.815

$23 \cdot 21$
23.12

441.08

447.93

454.81

461.70

468.62

$6.861 \quad 22.95$

$6.907 \quad 22.86$

$6.930 \quad 22.68$

475.56

482.53

489.51

496.52

503.55

6.998

22.51

$020 \quad 22.34$

510.61

517.68

524.78

531.90

539.04

546.20

553.39

560.59

567.82

575.07

582.34

589.64

596.95

604.29

611.64

619.02

626.42

633.84

641.28

648.74

656.22

663.72

671.24

678.79

686.35

7.064

7.109

7.131

7. 152

7. 174

7. 196

7. 218

7.239

7.261

7.282

7. 303

7.325

7.346

7.367

7. 388

7.409

7.430

7.450

7.471

7.492

7.512

7.533

7.553

7.573

$22 \cdot 17$

22.08

22.00

21.92

21.76

21.67

21.59

21.51

21.43

21.35

21.28

21.20

21.12

21.04

20.96

20.89

20.81

20.74
20.66

20.59

20.51

20.44

693.93

7. 594

20.29

110

111

701.54

709.16

7.614

20.22

113
114

716.81

7.634

20.15

20.08

20.01

115

116

117

118

732.15 
TABLE 4.4.2. Type BP thermoelements versus platinum, Pt-67-thermoelectric voltages, E(T), Seebeck coefficients, $\mathrm{S}(\mathrm{T})$, and first derivative of the Seebeck coefficients, $d S / d T$, reference junctions at $0{ }^{\circ} \mathrm{C}$-Continued

\begin{tabular}{|c|c|c|c|c|c|c|c|c|c|c|c|}
\hline${ }_{{ }^{\circ} \mathrm{C}}^{\mathrm{T}}$ & $\begin{array}{c}E \\
\mu V\end{array}$ & $\underset{\mu V /{ }^{\circ} \mathrm{C}}{\mathrm{S}}$ & $\begin{array}{l}d S / d T \\
n V /{ }^{\circ} C^{2}\end{array}$ & $\begin{array}{c}\mathrm{T} \\
{ }^{\circ} \mathrm{C}\end{array}$ & $\underset{\mu V}{E}$ & $\underset{\mu V /^{\circ} \mathrm{C}}{S}$ & $\begin{array}{l}\mathrm{dS} / \mathrm{d} T \\
\mathrm{nV} /{ }^{\circ} \mathrm{C}^{2}\end{array}$ & $\begin{array}{l}\mathrm{T} \\
{ }^{\circ} \mathrm{C}\end{array}$ & $\begin{array}{c}E \\
\mu V\end{array}$ & $\stackrel{\mathrm{S}}{\mu \mathrm{V} /{ }^{\circ} \mathrm{C}}$ & $\begin{array}{l}d S / d T \\
n V /{ }^{\circ} C^{2}\end{array}$ \\
\hline $\begin{array}{l}185 \\
186 \\
187 \\
188 \\
189\end{array}$ & $\begin{array}{l}1315.81 \\
1324.76 \\
1333.72 \\
1342.69 \\
1351.69\end{array}$ & $\begin{array}{l}8.936 \\
8.952 \\
8.968 \\
8.984 \\
9.000\end{array}$ & $\begin{array}{l}15.93 \\
15.88 \\
15.84 \\
15.79 \\
15.75\end{array}$ & $\begin{array}{l}245 \\
246 \\
247 \\
248 \\
249\end{array}$ & $\begin{array}{l}1879.21 \\
1889.04 \\
1898.88 \\
1908.74 \\
1918.61\end{array}$ & $\begin{array}{l}9.822 \\
9.836 \\
9.849 \\
9.863 \\
9.877\end{array}$ & $\begin{array}{l}13.75 \\
13.72 \\
13.69 \\
13.66 \\
13.63\end{array}$ & $\begin{array}{l}305 \\
306 \\
307 \\
308 \\
309\end{array}$ & $\begin{array}{l}2492.33 \\
2502.94 \\
2513.56 \\
2524.19 \\
2534.83\end{array}$ & $\begin{array}{l}10.601 \\
10.614 \\
10.626 \\
10.638 \\
10.651\end{array}$ & $\begin{array}{l}12.34 \\
12.32 \\
12.30 \\
12.28 \\
12.26\end{array}$ \\
\hline $\begin{array}{l}190 \\
191 \\
192 \\
193 \\
194\end{array}$ & $\begin{array}{l}1360.69 \\
1369.72 \\
1378.76 \\
1387.81 \\
1396.88\end{array}$ & $\begin{array}{l}9.015 \\
9.031 \\
9.047 \\
9.062 \\
9.078\end{array}$ & $\begin{array}{l}15.71 \\
15.66 \\
15.62 \\
15.58 \\
15.54\end{array}$ & $\begin{array}{l}250 \\
251 \\
252 \\
253 \\
254\end{array}$ & $\begin{array}{l}1928.49 \\
1938.39 \\
1948.30 \\
1958.22 \\
1968.16\end{array}$ & $\begin{array}{l}9.890 \\
9.904 \\
9.917 \\
9.931 \\
9.944\end{array}$ & $\begin{array}{l}13.61 \\
13.58 \\
13.55 \\
13.52 \\
13.49\end{array}$ & $\begin{array}{l}310 \\
311 \\
312 \\
313 \\
314\end{array}$ & $\begin{array}{l}2545.49 \\
2556.16 \\
2566.84 \\
2577.53 \\
2588.24\end{array}$ & $\begin{array}{l}10.663 \\
10.675 \\
10.687 \\
10.699 \\
10.712\end{array}$ & $\begin{array}{l}12.25 \\
12.23 \\
12.21 \\
12.19 \\
12.18\end{array}$ \\
\hline $\begin{array}{l}200 \\
201 \\
202 \\
203 \\
204\end{array}$ & $\begin{array}{l}1451.63 \\
1460.80 \\
1470.00 \\
1479.21 \\
1488.43\end{array}$ & $\begin{array}{l}9.170 \\
9.186 \\
9.201 \\
9.216 \\
9.231\end{array}$ & $\begin{array}{l}15.29 \\
15.25 \\
15.21 \\
15.17 \\
15.14\end{array}$ & $\begin{array}{l}260 \\
261 \\
262 \\
263 \\
264\end{array}$ & $\begin{array}{l}2028.07 \\
2038.10 \\
2048.15 \\
2058.20 \\
2068.28\end{array}$ & $\begin{array}{l}10.025 \\
10.038 \\
10.052 \\
10.065 \\
10.078\end{array}$ & $\begin{array}{l}13.33 \\
13.31 \\
13.28 \\
13.26 \\
13.23\end{array}$ & $\begin{array}{l}320 \\
321 \\
322 \\
323 \\
324\end{array}$ & $\begin{array}{l}2652.73 \\
2663.52 \\
2674.32 \\
2685.13 \\
2695.96\end{array}$ & $\begin{array}{l}10.784 \\
10.796 \\
10.808 \\
10.820 \\
10.833\end{array}$ & $\begin{array}{l}12.07 \\
12.06 \\
12.04 \\
12.02 \\
12.01\end{array}$ \\
\hline $\begin{array}{l}205 \\
206 \\
207 \\
208 \\
209\end{array}$ & $\begin{array}{l}1497.67 \\
1506.92 \\
1516.19 \\
1525.47 \\
1534.77\end{array}$ & $\begin{array}{l}9.246 \\
9.261 \\
9.276 \\
9.291 \\
9.306\end{array}$ & $\begin{array}{l}15.10 \\
15.06 \\
15.02 \\
14.98 \\
14.94\end{array}$ & $\begin{array}{l}265 \\
266 \\
267 \\
268 \\
269\end{array}$ & $\begin{array}{l}2078.36 \\
2088.46 \\
2098.57 \\
2108.69 \\
2118.83\end{array}$ & $\begin{array}{l}10.091 \\
10.105 \\
10.118 \\
10.131 \\
10.144\end{array}$ & $\begin{array}{l}13.21 \\
13.18 \\
13.16 \\
13.13 \\
13.11\end{array}$ & $\begin{array}{l}325 \\
326 \\
327 \\
328 \\
329\end{array}$ & $\begin{array}{l}2706.80 \\
2717.65 \\
2728.51 \\
2739.39 \\
2750.27\end{array}$ & $\begin{array}{l}10.845 \\
10.856 \\
10.868 \\
10.880 \\
10.892\end{array}$ & $\begin{array}{l}11.99 \\
11.98 \\
11.96 \\
11.94 \\
11.93\end{array}$ \\
\hline $\begin{array}{l}210 \\
211 \\
212 \\
213 \\
214\end{array}$ & $\begin{array}{l}1544.09 \\
1553.42 \\
1562.76 \\
1572.12 \\
1581.49\end{array}$ & $\begin{array}{l}9.321 \\
9.336 \\
9.351 \\
9.366 \\
9.381\end{array}$ & $\begin{array}{l}14.91 \\
14.87 \\
14.83 \\
14.80 \\
14.76\end{array}$ & $\begin{array}{l}270 \\
271 \\
272 \\
273 \\
274\end{array}$ & $\begin{array}{l}2128.98 \\
2139.15 \\
2149.32 \\
2159.51 \\
2169.71\end{array}$ & $\begin{array}{l}10.157 \\
10.170 \\
10.183 \\
10.196 \\
10.209\end{array}$ & $\begin{array}{l}13.08 \\
13.06 \\
13.03 \\
13.01 \\
12.99\end{array}$ & $\begin{array}{l}330 \\
331 \\
332 \\
333 \\
334\end{array}$ & $\begin{array}{l}2761.17 \\
2772.08 \\
2783.00 \\
2793.94 \\
2804.88\end{array}$ & $\begin{array}{l}10.904 \\
10.916 \\
10.928 \\
10.940 \\
10.952\end{array}$ & $\begin{array}{l}11.91 \\
11.90 \\
11.88 \\
11.87 \\
11.85\end{array}$ \\
\hline $\begin{array}{l}220 \\
221 \\
222 \\
223 \\
224\end{array}$ & $\begin{array}{l}1638.04 \\
1647.51 \\
1657.00 \\
1666.51 \\
1676.03\end{array}$ & $\begin{array}{l}9.469 \\
9.483 \\
9.498 \\
9.512 \\
9.526\end{array}$ & $\begin{array}{l}14.55 \\
14.51 \\
14.48 \\
14.44 \\
14.41\end{array}$ & $\begin{array}{l}280 \\
281 \\
282 \\
283 \\
284\end{array}$ & $\begin{array}{l}2231 \cdot 20 \\
2241.50 \\
2251.80 \\
2262.12 \\
2272.45\end{array}$ & $\begin{array}{l}10.287 \\
10.300 \\
10.312 \\
10.325 \\
10.338\end{array}$ & $\begin{array}{l}12.85 \\
12.83 \\
12.80 \\
12.78 \\
12.76\end{array}$ & $\begin{array}{l}340 \\
341 \\
342 \\
343 \\
344\end{array}$ & $\begin{array}{l}2870.81 \\
2881.84 \\
2892.88 \\
2903.93 \\
2914.99\end{array}$ & $\begin{array}{l}11.023 \\
11.034 \\
11.046 \\
11.058 \\
11.070\end{array}$ & $\begin{array}{l}11.77 \\
11.75 \\
11.74 \\
11.72 \\
11.71\end{array}$ \\
\hline $\begin{array}{l}225 \\
226 \\
227 \\
228 \\
229\end{array}$ & $\begin{array}{l}1685.56 \\
1695.11 \\
1704.67 \\
1714.25 \\
1723.84\end{array}$ & $\begin{array}{l}9.541 \\
9.555 \\
9.570 \\
9.584 \\
9.598\end{array}$ & $\begin{array}{l}14.37 \\
14.34 \\
14.31 \\
14.27 \\
14.24\end{array}$ & $\begin{array}{l}285 \\
286 \\
287 \\
288 \\
289\end{array}$ & $\begin{array}{l}2282.80 \\
2293.15 \\
2303.52 \\
2313.91 \\
2324.30\end{array}$ & $\begin{array}{l}10.351 \\
10.363 \\
10.376 \\
10.389 \\
10.401\end{array}$ & $\begin{array}{l}12.74 \\
12.72 \\
12.70 \\
12.67 \\
12.65\end{array}$ & $\begin{array}{l}345 \\
346 \\
347 \\
348 \\
349\end{array}$ & $\begin{array}{l}2926.07 \\
2937.15 \\
2948.25 \\
2959.36 \\
2970.49\end{array}$ & $\begin{array}{l}11.081 \\
11.093 \\
11.105 \\
11.216 \\
11.128\end{array}$ & $\begin{array}{l}11.70 \\
11.68 \\
11.67 \\
11.66 \\
11.64\end{array}$ \\
\hline $\begin{array}{l}230 \\
231 \\
232 \\
233 \\
234\end{array}$ & $\begin{array}{l}1733.45 \\
1743.07 \\
1752.70 \\
1762.35 \\
1772.01\end{array}$ & $\begin{array}{l}9.612 \\
9.626 \\
9.641 \\
9.655 \\
9.669\end{array}$ & $\begin{array}{l}14.21 \\
14.18 \\
14.15 \\
14.11 \\
14.08\end{array}$ & $\begin{array}{l}290 \\
291 \\
292 \\
293 \\
294\end{array}$ & $\begin{array}{l}2334.71 \\
2345.13 \\
2355.56 \\
2366.01 \\
2376.47\end{array}$ & $\begin{array}{l}10.414 \\
10.427 \\
10.439 \\
10.452 \\
10.464\end{array}$ & $\begin{array}{l}12.63 \\
12.61 \\
12.59 \\
12.57 \\
12.55\end{array}$ & $\begin{array}{l}350 \\
351 \\
352 \\
353 \\
354\end{array}$ & $\begin{array}{l}2981.62 \\
2992.77 \\
3003.92 \\
3015.09 \\
3026.27\end{array}$ & $\begin{array}{l}11.140 \\
11.151 \\
11.163 \\
11.174 \\
11.186\end{array}$ & $\begin{array}{l}11.63 \\
11.62 \\
11.60 \\
11.59 \\
11.58\end{array}$ \\
\hline $\begin{array}{l}235 \\
236 \\
237 \\
238 \\
239\end{array}$ & $\begin{array}{l}1781.68 \\
1791.37 \\
1801.08 \\
1810.80 \\
1820.53\end{array}$ & $\begin{array}{l}9.683 \\
9.697 \\
9.711 \\
9.725 \\
9.739\end{array}$ & $\begin{array}{l}14.05 \\
14.02 \\
13.99 \\
13.96 \\
13.93\end{array}$ & $\begin{array}{l}295 \\
296 \\
297 \\
298 \\
299\end{array}$ & $\begin{array}{l}2386.94 \\
2397.42 \\
2407.92 \\
2418.42 \\
2428.94\end{array}$ & $\begin{array}{l}10.477 \\
10.490 \\
10.502 \\
10.514 \\
10.527\end{array}$ & $\begin{array}{l}12.53 \\
12.51 \\
12.49 \\
12.47 \\
12.45\end{array}$ & $\begin{array}{l}355 \\
356 \\
357 \\
358 \\
359\end{array}$ & $\begin{array}{l}3037.46 \\
3048.67 \\
3059.88 \\
3071.11 \\
3082.35\end{array}$ & $\begin{array}{l}11.198 \\
11.209 \\
11.221 \\
11.232 \\
11.244\end{array}$ & $\begin{array}{l}11.57 \\
11.55 \\
11.54 \\
11.53 \\
11.52\end{array}$ \\
\hline 4 & 1830.27 & 9.753 & 13.90 & 300 & 2439.48 & 10.539 & 12.43 & 360 & 3093.60 & 11.255 & 11.50 \\
\hline
\end{tabular}


TABLE 4.4.2. Type BP thermoelements versus platinum, Pt-67-thermoelectric voltages, E(T), Seebeck coefficients, $\mathrm{S}(\mathrm{T})$, and first derivative of the Seebeck coefficients, $d S / d T$,

reference junctions at $0{ }^{\circ} \mathrm{C}$-Continued

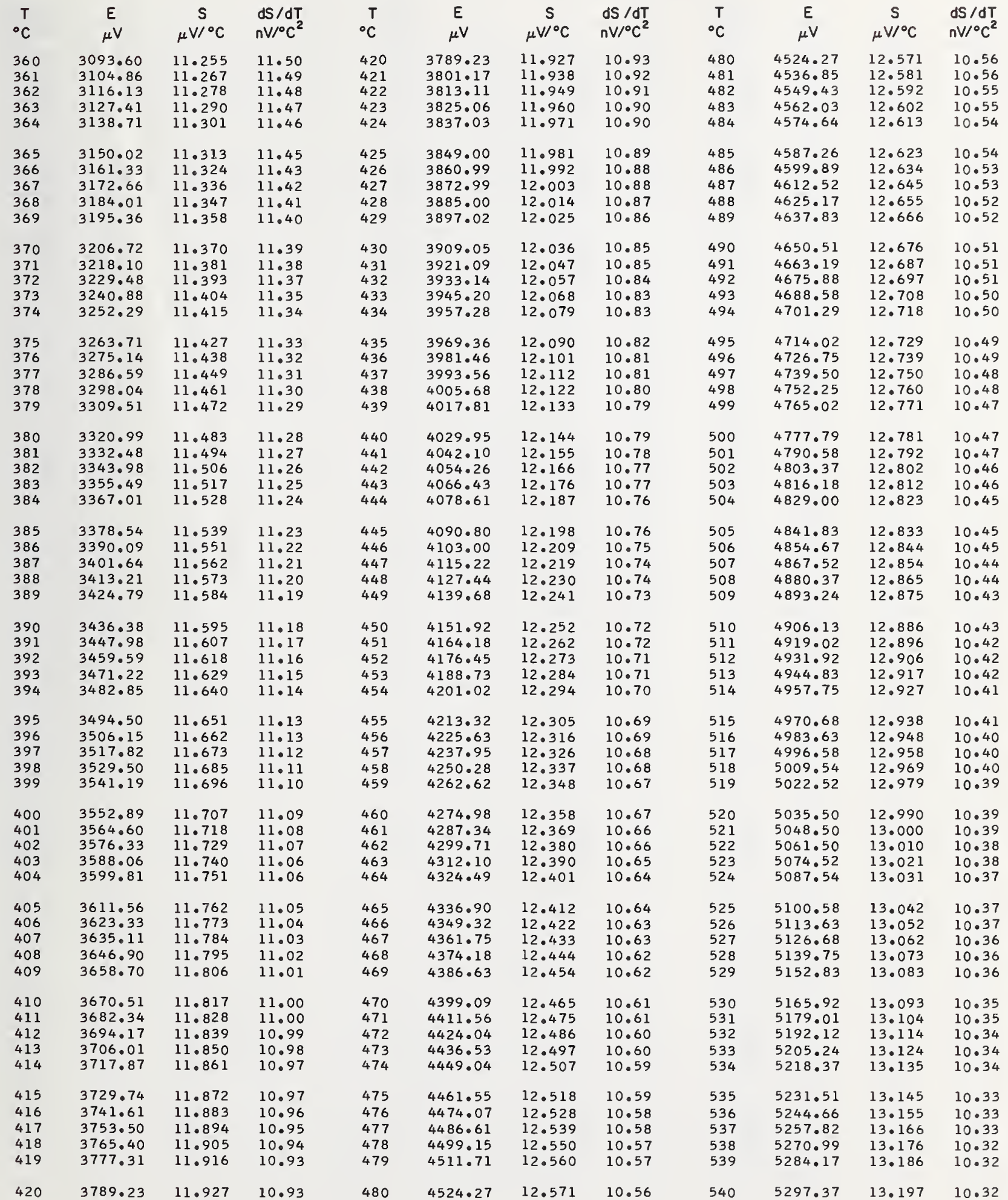


TABlE 4.4.2. Type BP thermoelements versus platinum, Pt-67-thermoelectric voltages, E(T), Seebeck coefficients, $\mathrm{S}(\mathrm{T})$, and first derivative of the Seebeck coefficients, $d S / d T$, reference junctions at $0^{\circ} \mathrm{C}$-Continued

\begin{tabular}{|c|c|c|c|c|c|c|c|c|c|c|c|}
\hline${ }^{\circ} \mathrm{C}$ & $\begin{array}{c}E \\
\mu V\end{array}$ & $\begin{array}{c}S \\
\mu \mathrm{V} /{ }^{\circ} \mathrm{C}\end{array}$ & $\begin{array}{l}d S / d T \\
n V /{ }^{\circ} C^{2}\end{array}$ & ${ }^{\top} \mathrm{C}$ & $\underset{\mu V}{E}$ & $\stackrel{S}{\mu \mathrm{V} /{ }^{\circ} \mathrm{C}}$ & $\begin{array}{l}\mathrm{dS} / \mathrm{dT} \\
\mathrm{nV} /{ }^{\circ} \mathrm{C}^{2}\end{array}$ & ${ }^{\circ} \mathrm{C}$ & $\begin{array}{c}E \\
\mu V\end{array}$ & $\underset{\mu \mathrm{V} /{ }^{\circ} \mathrm{C}}{S}$ & $\begin{array}{l}d S / d T \\
n V /{ }^{\circ} C^{2}\end{array}$ \\
\hline 540 & 5297.37 & 13.197 & 10.32 & 600 & 6107.61 & 13.810 & 10.12 & 660 & 6954.31 & 14.412 & 9.95 \\
\hline 541 & 5310.57 & 13.207 & $10 \cdot 31$ & 601 & 6121.43 & 13.820 & 10.12 & 661 & 6968.73 & 14.422 & 9.94 \\
\hline 542 & 5323.78 & 13.217 & 10.31 & 602 & 6135.25 & 13.830 & 10.12 & 662 & 6983.15 & 14.432 & 9.94 \\
\hline 543 & 5337.00 & 13.228 & 10.30 & 603 & 6149.09 & 13.840 & 10.11 & 663 & 6997.59 & 14.442 & 9.94 \\
\hline 544 & $5350 \cdot 24$ & $13 \cdot 238$ & $10 \cdot 30$ & 604 & 6162.93 & 13.850 & 10.11 & 664 & 7012.03 & 14.451 & 9.93 \\
\hline 545 & 5363.48 & 13.248 & 10.30 & 605 & 6176.79 & 13.860 & 10.11 & 665 & 7026.49 & 14.461 & 9.93 \\
\hline 546 & 5376.73 & 13.258 & 10.29 & 606 & 6190.65 & 13.870 & 10.11 & 666 & 7040.96 & 14.471 & 9.93 \\
\hline 547 & 5390.00 & 13.269 & 10.29 & 607 & 6204.53 & 13.880 & $10 \cdot 10$ & 667 & 7055.43 & 14.481 & 9.92 \\
\hline 548 & 5403.27 & 13.279 & 10.29 & 608 & 6218.41 & 13.891 & 10.10 & 668 & 7069.92 & 14.491 & 9.92 \\
\hline 549 & 5416.55 & 13.289 & $10 \cdot 28$ & 609 & 6232.31 & 13.901 & $10 \cdot 10$ & 669 & 7084.42 & 14.501 & 9.92 \\
\hline 550 & 5429.85 & 13.300 & 10.28 & 610 & 6246.22 & 13.911 & 10.09 & 670 & 7098.92 & 14.511 & 9.91 \\
\hline 551 & 5443.15 & 13.310 & $10 \cdot 28$ & 611 & 6260.13 & 13.921 & 10.09 & 671 & 7113.44 & 14.521 & 9.91 \\
\hline 552 & 5456.47 & 13.320 & 10.27 & 612 & 6274.06 & 13.931 & 10.09 & 672 & 7127.96 & 14.531 & 9.91 \\
\hline 553 & 5469.79 & 13.330 & 10.27 & 613 & 6287.99 & 13.941 & 10.08 & 673 & 7142.50 & 14.541 & 9.91 \\
\hline 554 & 5483.13 & 13.341 & 10.27 & 614 & 6301.94 & 13.951 & 10.08 & 674 & 7157.05 & 14.551 & 9.90 \\
\hline 555 & 5496.47 & 13.351 & 10.26 & 615 & 6315.90 & 13.961 & 10.08 & 675 & 7171.60 & 14.561 & 9.90 \\
\hline 556 & 5509.83 & 13.361 & 10.26 & 616 & 6329.86 & 13.971 & 10.08 & 676 & 7186.17 & 14.570 & 9.90 \\
\hline 557 & 5523.20 & 13.372 & 10.26 & 617 & 6343.84 & 13.981 & 10.07 & 677 & 7200.74 & 14.580 & 9.89 \\
\hline 558 & 5536.57 & $13 \cdot 382$ & $10 \cdot 25$ & 618 & 6357.82 & 13.991 & 10.07 & 678 & 7215.33 & 14.590 & 9.89 \\
\hline 559 & 5549.96 & 13.392 & 10.25 & 619 & 6371.82 & 14.001 & 10.07 & 679 & 7229.92 & 14.600 & $9 \cdot 89$ \\
\hline 560 & 5563.36 & 13.402 & 10.25 & 620 & 6385.83 & 14.012 & 10.06 & 680 & 7244.53 & 14.610 & 9.88 \\
\hline 561 & 5576.77 & 13.413 & $10 \cdot 24$ & 621 & 6399.84 & 14.022 & 10.06 & 681 & 7259.14 & 14.620 & 9.88 \\
\hline 562 & 5590.18 & 13.423 & 10.24 & 622 & 6413.87 & 14.032 & 10.06 & 682 & 7273.77 & 14.630 & 9.88 \\
\hline 563 & 5603.61 & 13.433 & 10.24 & 623 & 6427.91 & 14.042 & 10.06 & 683 & 7288.40 & $14 \cdot 640$ & 9.87 \\
\hline 564 & 5617.05 & 13.443 & 10.23 & 624 & 6441.95 & 14.052 & 10.05 & 684 & 7303.05 & 14.650 & 9.87 \\
\hline 565 & 5630.50 & 13.453 & 10.23 & 625 & 6456.01 & 14.062 & 10.05 & 685 & 7317.70 & 14.659 & 9.87 \\
\hline 566 & 5643.96 & 13.464 & 10.23 & 626 & 6470.08 & 14.072 & 10.05 & 686 & 7332.37 & 14.669 & 9.87 \\
\hline 567 & 5657.42 & 13.474 & 10.23 & 627 & 6484.15 & 14.082 & 10.04 & 687 & 7347.04 & 14.679 & 9.86 \\
\hline 568 & 5670.90 & 13.484 & 10.22 & 628 & 6498.24 & 14.092 & 10.04 & 688 & 7361.72 & 14.689 & 9.86 \\
\hline 569 & 5684.39 & 13.494 & 10.22 & 629 & 6512.34 & 14.102 & 10.04 & 689 & 7376.42 & 14.699 & $9 \cdot 86$ \\
\hline 570 & 5697.89 & 13.505 & 10.22 & 630 & 6526.45 & 14.112 & 10.03 & 690 & 7391.12 & 14.709 & 9.85 \\
\hline 571 & 5711.40 & 13.515 & 10.21 & 631 & 6540.56 & $14 \cdot 122$ & 10.03 & 691 & 7405.84 & 14.719 & 9.85 \\
\hline 572 & 5724.92 & 13.525 & 10.21 & 632 & 6554.69 & 14.132 & 10.03 & 692 & 7420.56 & 14.728 & 9.85 \\
\hline 573 & 5738.45 & 13.535 & 10.21 & 633 & 6568.83 & 14.142 & 10.03 & 693 & 7435.29 & 14.738 & 9.34 \\
\hline 574 & 5751.99 & 13.545 & 10.20 & 634 & 6582.97 & 14.152 & 10.02 & 694 & 7450.04 & $14 \cdot 748$ & 9.84 \\
\hline 575 & 5765.54 & 13.556 & $10 \cdot 20$ & 635 & 6597.13 & $14 \cdot 162$ & 10.02 & 695 & 7464.79 & 14.758 & 9.84 \\
\hline 576 & 5779.10 & 13.566 & 10.20 & 636 & 6611.30 & 14.172 & 10.02 & 696 & 7479.55 & 14.768 & 9.83 \\
\hline 577 & 5792.67 & 13.576 & 10.19 & 637 & 6625.48 & 14.182 & 10.01 & 697 & 7494.32 & 14.778 & 9.83 \\
\hline 578 & $5806 \cdot 26$ & 13.586 & $10 \cdot 19$ & 638 & 6639.66 & 14.192 & 10.01 & 698 & 7509.11 & 14.787 & 9.83 \\
\hline 579 & 5819.85 & 13.596 & 10.19 & 639 & 6653.86 & 14.202 & 10.01 & 699 & 7523.90 & 14.797 & 9.82 \\
\hline 580 & 5833.45 & 13.607 & $10 \cdot 18$ & 640 & 6668.07 & 14.212 & 10.00 & 700 & 7538.70 & 14.807 & 9.82 \\
\hline 581 & 5847.06 & 13.617 & 10.18 & 641 & 6682.28 & 14.222 & 10.00 & 701 & 7553.51 & 14.817 & 9.82 \\
\hline 582 & 5860.68 & 13.627 & 10.18 & 642 & 6696.51 & 14.232 & 10.00 & 702 & 7568.34 & 14.827 & 9.82 \\
\hline 583 & 5874.31 & 13.637 & 10.17 & 643 & 6710.75 & 14.242 & $10 \cdot 00$ & 703 & 7583.17 & 14.837 & 9.81 \\
\hline 584 & 5887.96 & 13.647 & 10.17 & 644 & 6725.00 & 14.252 & 9.99 & 704 & 7598.01 & 14.846 & 9.81 \\
\hline 585 & 5901.61 & 13.657 & 10.17 & 645 & 6739.25 & 14.262 & 9.99 & 705 & 7612.86 & 14.856 & 9.81 \\
\hline 586 & 5915.27 & 13.668 & 10.17 & 646 & 6753.52 & 14.272 & 9.99 & 706 & 7627.72 & 14.866 & 9.80 \\
\hline 587 & 5928.94 & 13.678 & 10.16 & 647 & 6767.80 & $14 \cdot 282$ & 9.98 & 707 & 7642.59 & 14.876 & 9.80 \\
\hline 588 & 5942.63 & 13.688 & 10.16 & 648 & 6782.08 & 14.292 & 9.98 & 708 & 7657.47 & 14.886 & 9.80 \\
\hline 589 & 5956.32 & 13.698 & 10.16 & 649 & 6796.38 & 14.302 & 9.98 & 709 & $7672 \cdot 36$ & 14.895 & 9.79 \\
\hline 590 & 5970.02 & 13.708 & 10.15 & 650 & 6810.69 & $14 \cdot 312$ & 9.98 & 710 & 7687.26 & 14.905 & 9.79 \\
\hline 591 & 5983.74 & 13.718 & 10.15 & 651 & 6825.01 & 14.322 & 9.97 & 711 & 7702.17 & 14.915 & 9.79 \\
\hline 592 & 5997.46 & 13.729 & 10.15 & 652 & 6839.33 & 14.332 & 9.97 & 712 & 7717.09 & 14.925 & 9.78 \\
\hline 593 & 6011.19 & 13.739 & 10.14 & 653 & 6853.67 & 14.342 & 9.97 & 713 & 7732.02 & 14.934 & 9.78 \\
\hline 594 & 6024.94 & 13.749 & 10.14 & 654 & 6868.02 & 14.352 & 9.96 & 714 & 7746.96 & $14 \cdot 944$ & 9.78 \\
\hline 595 & 6038.69 & 13.759 & $10 \cdot 14$ & 655 & 6882.37 & 14.362 & 9.96 & 715 & 7761.91 & 14.954 & 9.77 \\
\hline 596 & 6052.46 & 13.769 & 10.14 & 656 & 6896.74 & 14.372 & 9.96 & 716 & 7776.87 & 14.964 & 9.77 \\
\hline 597 & $6066 \cdot 23$ & 13.779 & 10.13 & 657 & 6911.12 & $14 \cdot 382$ & 9.95 & 717 & 7791.84 & 14.974 & 9.77 \\
\hline 598 & 6080.01 & 13.789 & 10.13 & 658 & 6925.50 & 14.392 & 9.95 & 718 & 7806.82 & 14.983 & 9.76 \\
\hline 599 & 6093.81 & 13.800 & 10.13 & 659 & 6939.90 & 14.402 & 9.95 & 719 & 7821.80 & 14.993 & 9.76 \\
\hline 600 & 6107.61 & 13.810 & $10 \cdot 12$ & 660 & 6954.31 & 14.412 & 9.95 & 720 & 7836.80 & 15.003 & 9.76 \\
\hline
\end{tabular}


TABLE 4.4.2. Type BP thermoelements versus platinum, Pt-67-thermoelectric voltages, $\mathrm{E}(\mathrm{T})$, Seebeck coefficients, $\mathrm{S}(\mathrm{T})$, and first derivative of the Seebeck coeficients, dS/dT,

reference junctions at $\mathrm{O}{ }^{\circ} \mathrm{C}$-Continued

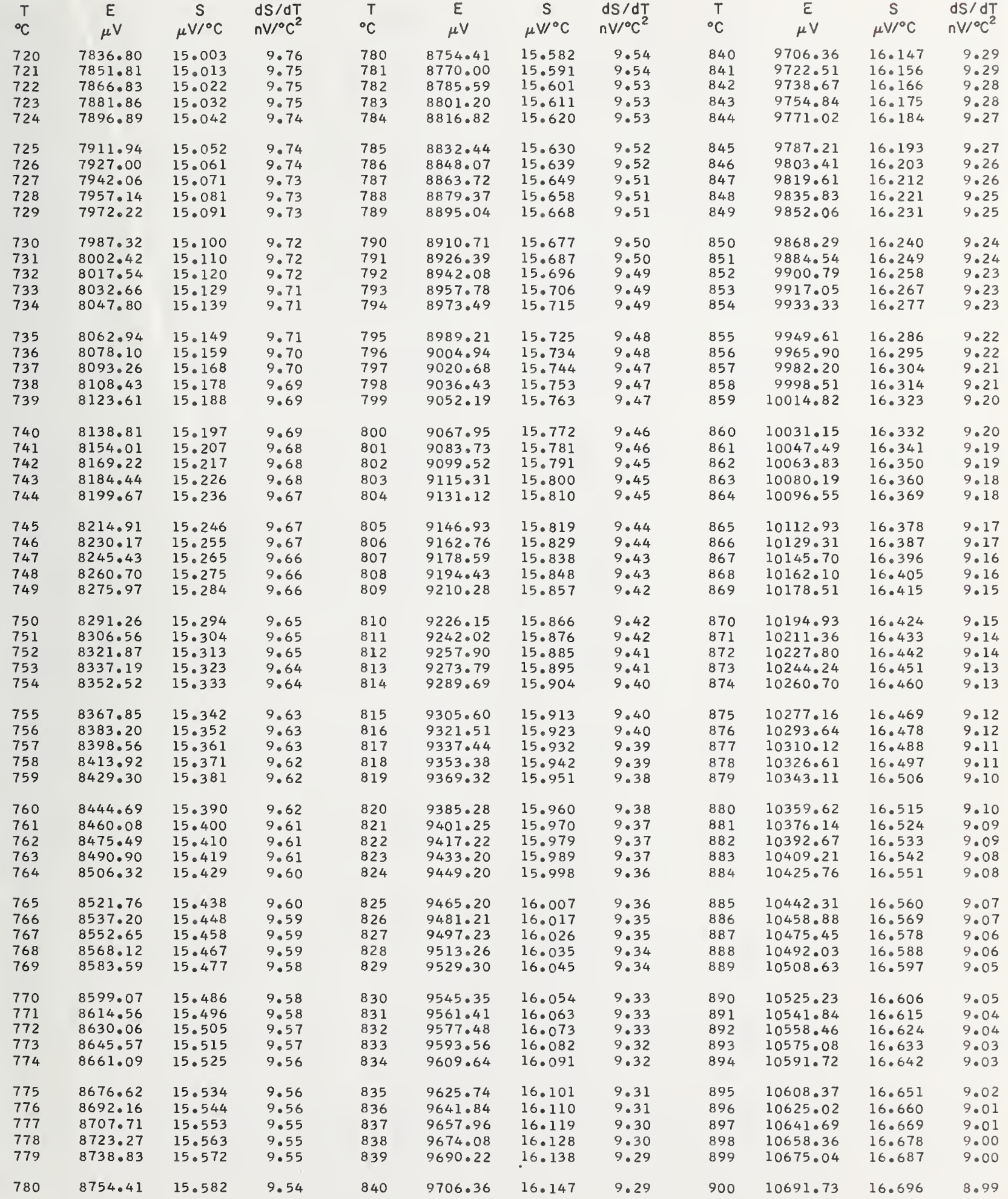


TABLE 4.4.2. Type BP thermoelements versus platinum, $\mathrm{Pt}-67$-thermoelectric voltages, $\mathrm{E}(\mathrm{T})$, Seebeck coefficients, S(T), and firsi derivative of the Seebeck coefficients, dS/dT, reference junctions at $0{ }^{\circ} \mathrm{C}$-Continued

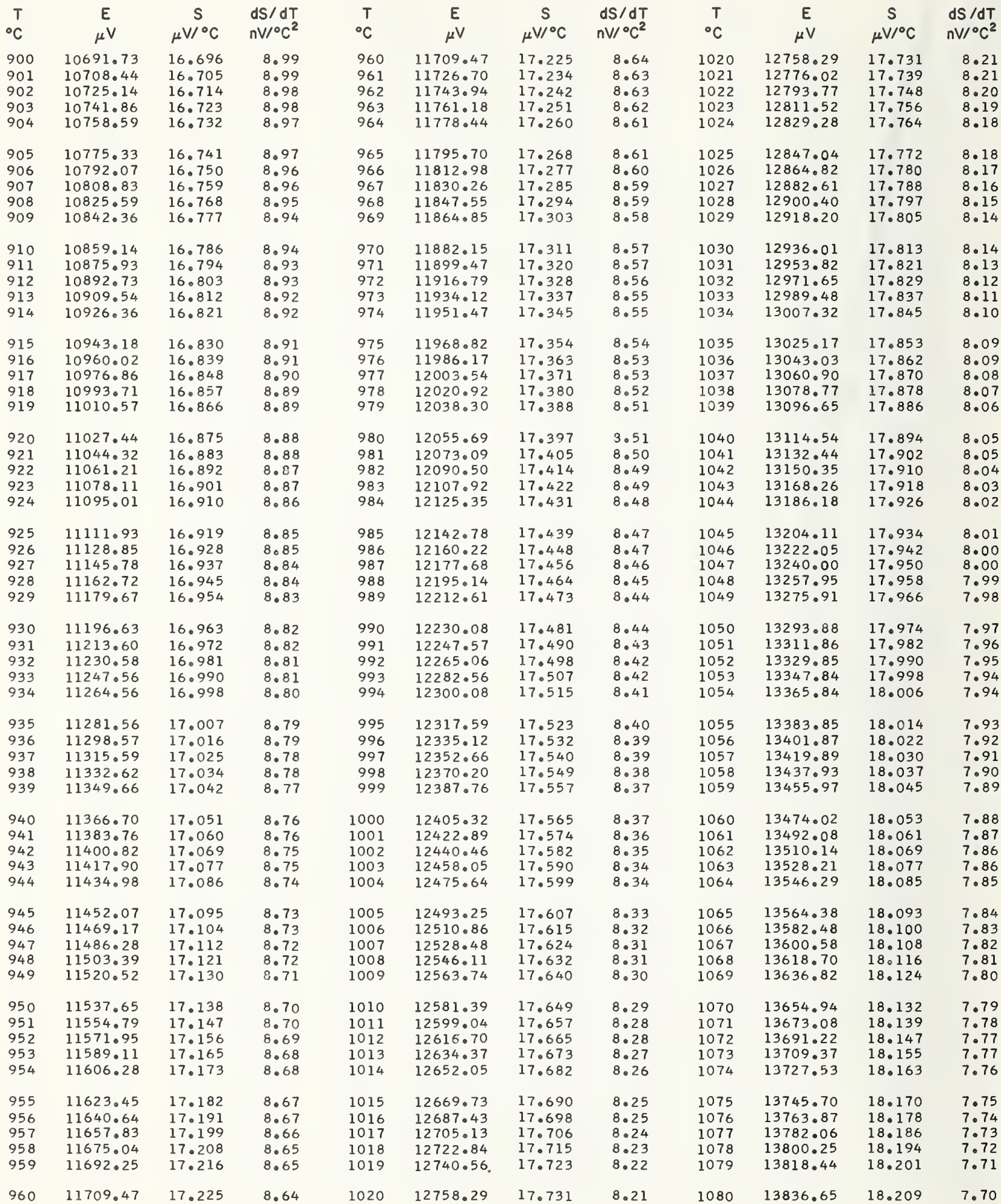


TABLE 4.4.2. Type BP thermoelements versus platinum, Pt-67-thermoelectric voltages, E(T), Seebeck coefficients, $\mathrm{S}(\mathrm{T})$, and first derivative of the Seebeck coefficients, dS/dT,

referenci junctions at $0^{\circ} \mathrm{C}$-Continued

\begin{tabular}{|c|c|c|c|c|c|c|c|c|c|c|c|}
\hline${ }^{\circ} \mathrm{C}$ & $\underset{\mu V}{E}$ & ${ }_{\mu V /{ }^{\circ} \mathrm{C}}^{S}$ & $\begin{array}{l}d S / d T \\
n V /{ }^{\circ} C^{2}\end{array}$ & ${ }^{\circ} \mathrm{C}$ & $\underset{\mu V}{E}$ & $\underset{\mu \mathrm{V} /{ }^{\circ} \mathrm{C}}{\mathrm{S}}$ & $\begin{array}{l}\mathrm{dS} / \mathrm{dT} \\
\mathrm{nV} /{ }^{\circ} \mathrm{C}^{2}\end{array}$ & ${ }^{\top} \mathrm{C}$ & $\underset{\mu V}{E V}$ & $\mu \stackrel{S}{S} /{ }^{\circ} \mathrm{C}$ & $\begin{array}{l}d S / d T \\
n V /{ }^{\circ} C^{2}\end{array}$ \\
\hline $\begin{array}{l}1085 \\
1086 \\
1087 \\
1088 \\
1089\end{array}$ & $\begin{array}{l}13927.79 \\
13946.04 \\
13964.30 \\
13982.57 \\
14000.84\end{array}$ & $\begin{array}{l}18.247 \\
18.255 \\
18.263 \\
18.270 \\
18.278\end{array}$ & $\begin{array}{l}7.65 \\
7.64 \\
7.63 \\
7.62 \\
7.61\end{array}$ & $\begin{array}{l}1145 \\
1146 \\
1147 \\
1148 \\
1149\end{array}$ & $\begin{array}{l}15036.05 \\
15054.74 \\
15073.44 \\
15092.14 \\
15110.86\end{array}$ & $\begin{array}{l}18.688 \\
18.695 \\
18.702 \\
18.709 \\
18.716\end{array}$ & $\begin{array}{l}7.02 \\
7.00 \\
6.99 \\
6.98 \\
6.97\end{array}$ & $\begin{array}{l}1205 \\
1206 \\
1207 \\
1208 \\
1209\end{array}$ & $\begin{array}{l}16169.53 \\
16188.62 \\
16207.71 \\
16226.81 \\
16245.92\end{array}$ & $\begin{array}{l}19.087 \\
19.093 \\
19.099 \\
19.105 \\
19.112\end{array}$ & $\begin{array}{l}6.25 \\
6.23 \\
6.22 \\
6.20 \\
6.19\end{array}$ \\
\hline $\begin{array}{l}1090 \\
1091 \\
1092 \\
1093 \\
1094\end{array}$ & $\begin{array}{l}14019.12 \\
14037.41 \\
14055.71 \\
14074.01 \\
14092.33\end{array}$ & $\begin{array}{l}18.286 \\
18.293 \\
18.301 \\
18.308 \\
18.316\end{array}$ & $\begin{array}{l}7.60 \\
7.59 \\
7.58 \\
7.57 \\
7.56\end{array}$ & $\begin{array}{l}1150 \\
1151 \\
1152 \\
1153 \\
1154\end{array}$ & $\begin{array}{l}15129.58 \\
15148.30 \\
15167.04 \\
15185.78 \\
15204.52\end{array}$ & $\begin{array}{l}18.723 \\
18.730 \\
18.737 \\
18.744 \\
18.751\end{array}$ & $\begin{array}{l}6.96 \\
6.95 \\
6.93 \\
6.92 \\
6.91\end{array}$ & $\begin{array}{l}1210 \\
1211 \\
1212 \\
1213 \\
1214\end{array}$ & $\begin{array}{l}16265.04 \\
16284.16 \\
16303.29 \\
16322.42 \\
16341.56\end{array}$ & $\begin{array}{l}19.118 \\
19.124 \\
19.130 \\
19.136 \\
19.142\end{array}$ & $\begin{array}{l}6.18 \\
6.16 \\
6.15 \\
6.13 \\
6.12\end{array}$ \\
\hline $\begin{array}{l}1100 \\
1101 \\
1102 \\
1103 \\
1104\end{array}$ & $\begin{array}{l}14202.36 \\
14220.72 \\
14239.09 \\
14257.47 \\
14275.86\end{array}$ & $\begin{array}{l}18.361 \\
18.369 \\
18.376 \\
18.384 \\
18.391\end{array}$ & $\begin{array}{l}7.50 \\
7.49 \\
7.48 \\
7.47 \\
7.46\end{array}$ & $\begin{array}{l}1160 \\
1161 \\
1162 \\
1163 \\
1164\end{array}$ & $\begin{array}{l}15317.15 \\
15335.95 \\
15354.75 \\
15373.56 \\
15392.38\end{array}$ & $\begin{array}{l}18.792 \\
18.799 \\
18.806 \\
18.813 \\
18.819\end{array}$ & $\begin{array}{l}6.84 \\
6.83 \\
6.81 \\
6.80 \\
6.79\end{array}$ & $\begin{array}{l}1220 \\
1221 \\
1222 \\
1223 \\
1224\end{array}$ & $\begin{array}{l}16456.52 \\
16475.70 \\
16494.89 \\
16514.09 \\
16533.29\end{array}$ & $\begin{array}{l}19.179 \\
19.185 \\
19.191 \\
19.197 \\
19.203\end{array}$ & $\begin{array}{l}6.03 \\
6.02 \\
6.00 \\
5.99 \\
5.97\end{array}$ \\
\hline $\begin{array}{l}1105 \\
1106 \\
1107 \\
1108 \\
1109\end{array}$ & $\begin{array}{l}14294.26 \\
14312.66 \\
14331.07 \\
14349.49 \\
14367.91\end{array}$ & $\begin{array}{l}18.399 \\
18.406 \\
18.413 \\
18.421 \\
18.428\end{array}$ & $\begin{array}{l}7.45 \\
7.44 \\
7.43 \\
7.42 \\
7.41\end{array}$ & $\begin{array}{l}1165 \\
1166 \\
1167 \\
1168 \\
1169\end{array}$ & $\begin{array}{l}15411.20 \\
15430.03 \\
15448.86 \\
15467.71 \\
15486.56\end{array}$ & $\begin{array}{l}18.826 \\
18.833 \\
18.840 \\
18.846 \\
18.853\end{array}$ & $\begin{array}{l}6.78 \\
6.76 \\
6.75 \\
6.74 \\
6.73\end{array}$ & $\begin{array}{l}1225 \\
1226 \\
1227 \\
1228 \\
1229\end{array}$ & $\begin{array}{l}16552.49 \\
16571.70 \\
16590.92 \\
16610.15 \\
16629.37\end{array}$ & $\begin{array}{l}19.209 \\
19.215 \\
19.221 \\
19.227 \\
19.233\end{array}$ & $\begin{array}{l}5.96 \\
5.94 \\
5.93 \\
5.91 \\
5.90\end{array}$ \\
\hline $\begin{array}{l}1110 \\
1111 \\
1112 \\
1113 \\
1114\end{array}$ & $\begin{array}{l}14386.34 \\
14404.78 \\
14423.23 \\
14441.68 \\
14460.14\end{array}$ & $\begin{array}{l}18.436 \\
18.443 \\
18.450 \\
18.458 \\
18.465\end{array}$ & $\begin{array}{l}7.40 \\
7.39 \\
7.38 \\
7.37 \\
7.36\end{array}$ & $\begin{array}{l}1170 \\
1171 \\
1172 \\
1173 \\
1174\end{array}$ & $\begin{array}{l}15505.41 \\
15524.28 \\
15543.15 \\
15562.02 \\
15580.91\end{array}$ & $\begin{array}{l}18.860 \\
18.867 \\
18.873 \\
18.880 \\
18.887\end{array}$ & $\begin{array}{l}6.71 \\
6.70 \\
6.69 \\
6.68 \\
6.66\end{array}$ & $\begin{array}{l}1230 \\
1231 \\
1232 \\
1233 \\
1234\end{array}$ & $\begin{array}{l}16648.61 \\
16667.85 \\
16687.10 \\
16706.35 \\
16725.61\end{array}$ & $\begin{array}{l}19.238 \\
19.244 \\
19.250 \\
19.256 \\
19.262\end{array}$ & $\begin{array}{l}5.88 \\
5.87 \\
5.85 \\
5.84 \\
5.82\end{array}$ \\
\hline $\begin{array}{l}1120 \\
11121 \\
1122 \\
1123 \\
1124\end{array}$ & $\begin{array}{l}14571.07 \\
14589.58 \\
14608.10 \\
14626.63 \\
14645.16\end{array}$ & $\begin{array}{l}18.509 \\
18.516 \\
18.524 \\
18.531 \\
18.538\end{array}$ & $\begin{array}{l}7.30 \\
7.29 \\
7.27 \\
7.26 \\
7.25\end{array}$ & $\begin{array}{l}1180 \\
1181 \\
1182 \\
1183 \\
1184\end{array}$ & $\begin{array}{l}15694.34 \\
15713.27 \\
15732.21 \\
15751.15 \\
15770.10\end{array}$ & $\begin{array}{l}18.926 \\
18.933 \\
18.939 \\
18.946 \\
18.953\end{array}$ & $\begin{array}{l}6.59 \\
6.57 \\
6.56 \\
6.55 \\
6.53\end{array}$ & $\begin{array}{l}1240 \\
1241 \\
1242 \\
1243 \\
1244\end{array}$ & $\begin{array}{l}16841.29 \\
16860.59 \\
16879.89 \\
16899.20 \\
16918.52\end{array}$ & $\begin{array}{l}19.296 \\
19.302 \\
19.308 \\
19.314 \\
19.319\end{array}$ & $\begin{array}{l}5.73 \\
5.71 \\
5.70 \\
5.68 \\
5.66\end{array}$ \\
\hline $\begin{array}{l}1125 \\
1126 \\
1127 \\
1128 \\
1129\end{array}$ & $\begin{array}{l}14663.70 \\
14682.25 \\
14700.81 \\
14719.37 \\
14737.94\end{array}$ & $\begin{array}{l}18.546 \\
18.553 \\
18.560 \\
18.567 \\
18.574\end{array}$ & $\begin{array}{l}7.24 \\
7.23 \\
7.22 \\
7.21 \\
7.20\end{array}$ & $\begin{array}{l}1185 \\
1186 \\
1187 \\
1188 \\
1189\end{array}$ & $\begin{array}{l}15789.06 \\
15808.02 \\
15826.99 \\
15845.97 \\
15864.95\end{array}$ & $\begin{array}{l}18.959 \\
18.966 \\
18.972 \\
18.979 \\
18.985\end{array}$ & $\begin{array}{l}6.52 \\
6.51 \\
6.49 \\
6.48 \\
6.47\end{array}$ & $\begin{array}{l}1245 \\
1246 \\
1247 \\
1248 \\
1249\end{array}$ & $\begin{array}{l}16937.84 \\
16957.17 \\
16976.50 \\
16995.84 \\
17015.18\end{array}$ & $\begin{array}{l}19.325 \\
19.331 \\
19.336 \\
19.342 \\
19.347\end{array}$ & $\begin{array}{l}5.65 \\
5.63 \\
5.62 \\
5.60 \\
5.59\end{array}$ \\
\hline $\begin{array}{l}1130 \\
1131 \\
1132 \\
1133 \\
1134\end{array}$ & $\begin{array}{l}14756.52 \\
14775.11 \\
14793.70 \\
14812.30 \\
14830.91\end{array}$ & $\begin{array}{l}18.582 \\
18.589 \\
18.596 \\
18.603 \\
18.610\end{array}$ & $\begin{array}{l}7.19 \\
7.18 \\
7.17 \\
7.15 \\
7.14\end{array}$ & $\begin{array}{l}1190 \\
1191 \\
1192 \\
1193 \\
1194\end{array}$ & $\begin{array}{l}15883.94 \\
15902.93 \\
15921.93 \\
15940.94 \\
15959.95\end{array}$ & $\begin{array}{l}18.992 \\
18.998 \\
19.004 \\
19.011 \\
19.017\end{array}$ & $\begin{array}{l}6.45 \\
6.44 \\
6.43 \\
6.41 \\
6.40\end{array}$ & $\begin{array}{l}1250 \\
1251 \\
1252 \\
1253 \\
1254\end{array}$ & $\begin{array}{l}17034.53 \\
17053.89 \\
17073.25 \\
17092.62 \\
17111.99\end{array}$ & $\begin{array}{l}19.353 \\
19.359 \\
19.364 \\
19.370 \\
19.375\end{array}$ & $\begin{array}{l}5.57 \\
5.55 \\
5.54 \\
5.52 \\
5.50\end{array}$ \\
\hline $\begin{array}{l}1135 \\
1136 \\
1137 \\
1138 \\
1139\end{array}$ & $\begin{array}{l}14849.52 \\
14868.14 \\
14886.77 \\
14905.40 \\
14924.05\end{array}$ & $\begin{array}{l}18.617 \\
18.625 \\
18.632 \\
18.639 \\
18.646\end{array}$ & $\begin{array}{l}7.13 \\
7.12 \\
7.11 \\
7.10 \\
7.09\end{array}$ & $\begin{array}{l}1195 \\
1196 \\
1197 \\
1198 \\
1199\end{array}$ & $\begin{array}{l}15978.97 \\
15998.00 \\
16017.03 \\
16036.07 \\
16055.12\end{array}$ & $\begin{array}{l}19.024 \\
19.030 \\
19.036 \\
19.043 \\
19.049\end{array}$ & $\begin{array}{l}6.39 \\
6.37 \\
6.36 \\
6.34 \\
6.33\end{array}$ & $\begin{array}{l}1255 \\
1256 \\
1257 \\
1258 \\
1259\end{array}$ & $\begin{array}{l}17131.37 \\
17150.75 \\
17170.14 \\
17189.54 \\
17208.93\end{array}$ & $\begin{array}{l}19.381 \\
19.386 \\
19.392 \\
19.397 \\
19.402\end{array}$ & $\begin{array}{l}5.49 \\
5.47 \\
5.46 \\
5.44 \\
5.42\end{array}$ \\
\hline 1140 & $14942 \cdot 70$ & 18.653 & 7.07 & 1200 & 16074.17 & 19.055 & 6.32 & 1260 & 17228.34 & 19.408 & 5.41 \\
\hline
\end{tabular}


TABLE 4.4.2. Type BP thermoelements versus platinum, Pt-67-thermoelectric voltages, E(T), Seebeck coefficients, $\mathrm{S}(\mathrm{T})$, and first derivative of the Seebeck coefficients, $d S / d T$, reference junctions at $0{ }^{\circ} \mathrm{C}$-Continued

\begin{tabular}{|c|c|c|c|c|c|c|c|c|c|c|c|}
\hline $\begin{array}{c}\mathrm{T} \\
{ }^{\circ} \mathrm{C}\end{array}$ & ${ }_{\mu V}^{E}$ & $\underset{\mu V /{ }^{\circ} \mathrm{C}}{S}$ & $\begin{array}{l}\mathrm{dS} / \mathrm{dT} \\
\mathrm{nV} /{ }^{\circ} \mathrm{C}^{2}\end{array}$ & ${ }^{\top} \mathrm{T}$ & $\underset{\mu V}{E}$ & $\underset{\mu V^{\circ}{ }^{\circ} \mathrm{C}}{\mathrm{S}}$ & $\begin{array}{l}d S / d T \\
n V /{ }^{\circ} C^{2}\end{array}$ & ${ }^{\circ} \mathrm{C}$ & $\underset{\mu V}{E}$ & $\underset{\mu V /{ }^{\circ} \mathrm{C}}{\mathrm{S}}$ & $\begin{array}{l}d S / d T \\
n V /{ }^{\circ} C^{2}\end{array}$ \\
\hline 1260 & 17228.34 & 19.408 & 5.41 & 1320 & 18401.92 & 19.701 & 4.33 & 1380 & 19591.04 & 19.924 & 3.09 \\
\hline 1261 & 17247.75 & 19.413 & 5.39 & 1321 & 18421.63 & 19.705 & 4.31 & 1381 & 19610.97 & 19.927 & 3.06 \\
\hline 1262 & 17267.17 & 19.419 & 5.37 & 1322 & 18441.33 & 19.709 & 4.29 & 1382 & 19630.90 & 19.930 & 3.04 \\
\hline 1263 & 17286.59 & 19.424 & 5.36 & 1323 & 18461.04 & 19.714 & 4.27 & 1383 & 19650.83 & 19.933 & 3.02 \\
\hline 1264 & 17306.01 & 19.429 & 5.34 & 1324 & 18480.76 & 19.718 & 4.25 & 1384 & 19670.76 & 19.936 & 3.00 \\
\hline 1265 & 17325.45 & 19.435 & 5.32 & 1325 & 18500.48 & 19.722 & 4.23 & 1385 & 19690.70 & 19.939 & 2.98 \\
\hline 1266 & 17344.88 & 19.440 & 5.31 & 1326 & 18520.20 & 19.726 & 4.21 & 1386 & 19710.64 & 19.942 & 2.95 \\
\hline 1267 & 17364.33 & 19.445 & 5.29 & 1327 & 18539.93 & 19.731 & $4 \cdot 19$ & 1387 & 19730.59 & 19.945 & 2.93 \\
\hline 1268 & 17383.77 & 19.451 & 5.27 & 1328 & 18559.67 & 19.735 & 4.17 & 1388 & 19750.53 & 19.948 & 2.91 \\
\hline 1269 & 17403.23 & 19.456 & 5.26 & 1329 & 18579.40 & 19.739 & 4.15 & 1389 & 19770.48 & 19.951 & 2.89 \\
\hline 1270 & 17422.69 & 19.461 & 5.24 & 1330 & 18599.14 & 19.743 & $4 \cdot 13$ & 1390 & 19790.44 & 19.954 & 2.86 \\
\hline 1271 & 17442.15 & 19.466 & 5.22 & 1331 & 18618.89 & $19 \cdot 747$ & $4 \cdot 11$ & 1391 & 19810.39 & 19.957 & $2 \cdot 84$ \\
\hline 1272 & 17461.62 & 19.472 & 5.20 & 1332 & 18638.64 & 19.751 & 4.09 & 1392 & 19830.35 & 19.960 & 2.82 \\
\hline 1273 & 17481.09 & 19.477 & 5.19 & 1333 & 18658.39 & 19.755 & 4.07 & 1393 & 19850.31 & 19.962 & $2 \cdot 80$ \\
\hline 1274 & 17500.57 & 19.482 & 5.17 & 1334 & 18678.15 & 19.760 & 4.05 & 1394 & 19870.27 & 19.965 & 2.77 \\
\hline 1275 & 17520.06 & 19.487 & 5.15 & 1335 & 18697.91 & 19.764 & 4.03 & 1395 & 19890.24 & 19.968 & 2.75 \\
\hline 1276 & 17539.55 & 19.492 & 5.14 & 1336 & 18717.68 & 19.768 & 4.01 & 1396 & 19910.21 & 19.971 & 2.73 \\
\hline 1277 & 17559.04 & 19.497 & 5.12 & 1337 & 18737.45 & 19.772 & 3.99 & 1397 & 19930.18 & 19.973 & 2.71 \\
\hline 1278 & 17578.54 & 19.502 & 5.10 & 1338 & 18757.22 & 19.776 & 3.97 & 1398 & 19950.16 & 19.976 & 2.68 \\
\hline 1279 & 17598.05 & 19.508 & 5.08 & 1339 & 18777.00 & 19.780 & 3.95 & 1399 & 19970.13 & 19.979 & 2.66 \\
\hline 1280 & 17617.56 & 19.513 & 5.07 & 1340 & 18796.78 & 19.783 & 3.93 & 1400 & 19990.11 & 19.981 & 2.64 \\
\hline 1281 & 17637.07 & 19.518 & 5.05 & 1341 & 18816.56 & 19.787 & 3.91 & 1401 & 20010.10 & 19.984 & 2.61 \\
\hline 1282 & 17656.59 & 19.523 & 5.03 & 1342 & 18836.35 & 19.791 & 3.89 & 1402 & 20030.08 & 19.987 & 2.59 \\
\hline 1283 & 17676.12 & 19.528 & 5.01 & 1343 & 18856.15 & 19.795 & 3.87 & 1403 & 20050.07 & 19.989 & 2.57 \\
\hline 1284 & 17695.65 & 19.533 & 5.00 & 1344 & 18875.94 & 19.799 & 3.85 & 1404 & 20070.06 & 19.992 & 2.55 \\
\hline 1285 & 17715.18 & 19.538 & 4.98 & 1345 & 18895.74 & 19.803 & 3.83 & 1405 & 20090.05 & 19.994 & 2.52 \\
\hline 1286 & 17734.72 & 19.543 & 4.96 & 1346 & 18915.55 & 19.807 & 3.81 & 1406 & 20110.05 & 19.997 & 2.50 \\
\hline 1287 & 17754.27 & $19 \cdot 548$ & 4.94 & 1347 & 18935.36 & 19.811 & 3.79 & 1407 & 20130.05 & 19.999 & 2.48 \\
\hline 1288 & 17773.82 & 19.553 & 4.93 & 1348 & 18955.17 & 19.814 & 3.77 & 1408 & 20150.05 & 20.002 & 2.45 \\
\hline 1289 & 17793.37 & 19.557 & 4.91 & 1349 & 18974.99 & 19.818 & 3.75 & 1409 & 20170.05 & 20.004 & 2.43 \\
\hline 1290 & 17812.93 & 19.562 & 4.89 & 1350 & 18994.81 & 19.822 & 3.73 & 1410 & 20190.06 & 20.007 & 2.41 \\
\hline 1291 & 17832.50 & 19.567 & $4 \cdot 87$ & 1351 & 19014.63 & 19.826 & 3.71 & 1411 & 20210.06 & 20.009 & 2.38 \\
\hline 1292 & 17852.07 & 19.572 & $4 \cdot 85$ & 1352 & 19034.46 & 19.829 & 3.69 & 1412 & 20230.07 & 20.011 & 2.36 \\
\hline 1293 & 17871.64 & 19.577 & 4.84 & 1353 & 19054.29 & 19.833 & 3.67 & 1413 & 20250.09 & 20.014 & $2 \cdot 34$ \\
\hline 1294 & 17891.22 & 19.582 & 4.82 & 1354 & 19074.12 & 19.837 & 3.65 & 1414 & 20270.10 & 20.016 & 2.31 \\
\hline 1295 & 17910.81 & 19.587 & 4.80 & 1355 & 19093.96 & 19.840 & 3.62 & 1415 & 20290.12 & 20.018 & 2.29 \\
\hline 1296 & 17930.39 & 19.591 & 4.78 & 1356 & 19113.80 & 19.844 & 3.60 & 1416 & 20310.14 & 20.021 & 2.27 \\
\hline 1297 & 17949.99 & 19.596 & 4.76 & 1357 & 19133.65 & 19.847 & 3.58 & 1417 & 20330.16 & 20.023 & 2.24 \\
\hline 1298 & 17969.59 & 19.601 & 4.74 & 1358 & 19153.50 & 19.851 & 3.56 & 1418 & 20350.18 & 20.025 & 2.22 \\
\hline 1299 & 17989.19 & 19.606 & 4.73 & 1359 & 19173.35 & 19.855 & 3.54 & 1419 & 20370.21 & 20.027 & 2.20 \\
\hline 1300 & 18008.80 & 19.610 & 4.71 & 1360 & 19193.21 & 19.858 & 3.52 & 1420 & 20390.24 & 20.030 & 2.17 \\
\hline 1301 & 18028.41 & 19.615 & 4.69 & 1361 & 19213.07 & 19.862 & 3.50 & 1421 & 20410.27 & 20.032 & 2.15 \\
\hline 1302 & 18048.03 & 19.620 & 4.67 & 1362 & 19232.93 & 19.865 & 3.48 & 1422 & 20430.30 & 20.034 & 2.12 \\
\hline 1303 & 18067.65 & 19.624 & 4.65 & 1363 & 19252.80 & 19.868 & 3.46 & 1423 & 20450.34 & 20.036 & 2.10 \\
\hline 1304 & 18087.28 & 19.629 & 4.63 & 1364 & 19272.67 & 19.872 & 3.43 & 1424 & 20470.37 & 20.038 & 2.08 \\
\hline 1305 & 18106.91 & 19.634 & 4.62 & 1365 & 19292.54 & 19.875 & 3.41 & 1425 & 20490.41 & 20.040 & 2.05 \\
\hline 1306 & 18126.54 & 19.638 & 4.60 & 1366 & 19312.42 & 19.879 & 3.39 & 1426 & 20510.45 & 20.042 & 2.03 \\
\hline 1307 & 18146.18 & 19.643 & 4.58 & 1367 & 19332.30 & 19.882 & 3.37 & 1427 & 20530.50 & 20.044 & 2.01 \\
\hline 1308 & 18165.83 & 19.647 & 4.56 & 1368 & 19352.18 & 19.886 & 3.35 & 1428 & 20550.54 & 20.046 & 1.98 \\
\hline 1309 & 18185.48 & $19 \cdot 652$ & $4 \cdot 54$ & 1369 & 19372.07 & 19.889 & 3.33 & 1429 & 20570.59 & 20.048 & 1.96 \\
\hline 1310 & 18205.13 & 19.657 & 4.52 & 1370 & 19391.96 & 19.892 & 3.31 & 1430 & 20590.64 & 20.050 & 1.93 \\
\hline 1311 & 18224.79 & 19.661 & 4.50 & 1371 & 19411.85 & 19.895 & 3.28 & 1431 & 20610.69 & 20.052 & 1.91 \\
\hline 1312 & 18244.46 & 19.666 & 4.48 & 1372 & 19431.75 & 19.899 & 3.26 & 1432 & 20630.74 & 20.054 & 1.89 \\
\hline 1313 & 18264.12 & 19.670 & 4.46 & 1373 & 19451.65 & 19.902 & 3.24 & 1433 & 20650.80 & 20.056 & 1.86 \\
\hline 1314 & 18283.80 & 19.674 & 4.45 & 1374 & 19471.55 & 19.905 & 3.22 & 1434 & 20670.85 & 20.058 & 1.84 \\
\hline 1315 & 18303.47 & 19.679 & 4.43 & 1375 & 19491.46 & 19.908 & 3.20 & 1435 & 20690.91 & 20.059 & 1.81 \\
\hline 1316 & 18323.15 & 19.683 & 4.41 & 1376 & 19511.37 & 19.912 & 3.17 & 1436 & 20710.97 & 20.061 & 1.79 \\
\hline 1317 & 18342.84 & 19.688 & 4.39 & 1377 & 19531.28 & 19.915 & 3.15 & 1437 & 20731.03 & 20.063 & 1.77 \\
\hline 1318 & 18362.53 & 19.692 & 4.37 & 1378 & 19551.20 & 19.918 & 3.13 & 1438 & 20751.10 & 20.065 & 1.74 \\
\hline 1319 & $18382 \cdot 22$ & 19.696 & $4 \cdot 35$ & 1379 & $19571 \cdot 12$ & 19.921 & 3.11 & 1439 & 20771.16 & 20.066 & 1.72 \\
\hline 1320 & 18401.92 & 19.701 & 4.33 & 1380 & 19591.04 & 19.924 & 3.09 & 1440 & 20791.23 & 20.068 & 1.69 \\
\hline
\end{tabular}


TABLE 4.4.2. Type BP thermoelements versus platinum, Pt-67-thermoelectric voltages, $\mathrm{E}(\mathrm{T})$, Seebeck coefficients, S(T), and first derivative of the Seebeck coefficients, dS/dT, reference junctions at $0^{\circ} \mathrm{C}$-Continued

\begin{tabular}{|c|c|c|c|c|c|c|c|c|c|c|c|}
\hline${ }^{\mathrm{T}} \mathrm{C}$ & $\begin{array}{c}E \\
\mu V\end{array}$ & $\stackrel{S}{S V /{ }^{\circ} \mathrm{C}}$ & $\begin{array}{l}\mathrm{dS} / \mathrm{dT} \\
\mathrm{nV} /{ }^{\circ} \mathrm{C}^{2}\end{array}$ & $\begin{array}{r}\mathrm{T} \\
{ }^{\circ} \mathrm{C}\end{array}$ & $\begin{array}{c}E \\
\mu V\end{array}$ & $\begin{array}{c}S \\
\mu V^{\circ} \mathrm{C}\end{array}$ & $\begin{array}{l}\mathrm{dS} / \mathrm{dT} \\
\mathrm{nV} /{ }^{\circ} \mathrm{C}^{2}\end{array}$ & $\begin{array}{r}\mathrm{T} \\
{ }^{\circ} \mathrm{C}\end{array}$ & $\begin{array}{c}\mathrm{E} \\
\mu \mathrm{V}\end{array}$ & $\stackrel{\mathrm{S}}{\mu \mathrm{V} /{ }^{\circ} \mathrm{C}}$ & $\begin{array}{l}d S / d T \\
n V /{ }^{\circ} C^{2}\end{array}$ \\
\hline $\begin{array}{l}1440 \\
1441 \\
1442 \\
1443 \\
1444\end{array}$ & $\begin{array}{l}20791.23 \\
20811.30 \\
20831.37 \\
20851.44 \\
20871.52\end{array}$ & $\begin{array}{l}20.068 \\
20.070 \\
20.072 \\
20.073 \\
20.075\end{array}$ & $\begin{array}{l}1.69 \\
1.67 \\
1.64 \\
1.62 \\
1.59\end{array}$ & $\begin{array}{l}1500 \\
1501 \\
1502 \\
1503 \\
1504\end{array}$ & $\begin{array}{l}21997.48 \\
22017.60 \\
22037.73 \\
22057.85 \\
22077.98\end{array}$ & $\begin{array}{l}20.125 \\
20.125 \\
20.125 \\
20.125 \\
20.126\end{array}$ & $\begin{array}{l}0.19 \\
0.16 \\
0.14 \\
0.11 \\
0.09\end{array}$ & $\begin{array}{l}1560 \\
1561 \\
1562 \\
1563 \\
1564\end{array}$ & $\begin{array}{l}23204.40 \\
23224.49 \\
23244.58 \\
23264.66 \\
23284.75\end{array}$ & $\begin{array}{l}20.090 \\
20.089 \\
20.088 \\
20.086 \\
20.085\end{array}$ & $\begin{array}{l}-1.34 \\
-1.37 \\
-1.39 \\
-1.42 \\
-1.44\end{array}$ \\
\hline $\begin{array}{l}1445 \\
1446 \\
1447 \\
1448 \\
1449\end{array}$ & $\begin{array}{l}20891.59 \\
20911.67 \\
20931.75 \\
20951.83 \\
20971.91\end{array}$ & $\begin{array}{l}20.076 \\
20.078 \\
20.079 \\
20.081 \\
20.082\end{array}$ & $\begin{array}{l}1.57 \\
1.55 \\
1.52 \\
1.50 \\
1.47\end{array}$ & $\begin{array}{l}1505 \\
1506 \\
1507 \\
1508 \\
1509\end{array}$ & $\begin{array}{l}22098 \cdot 10 \\
22118 \cdot 23 \\
22138 \cdot 36 \\
22158 \cdot 48 \\
22178 \cdot 61\end{array}$ & $\begin{array}{l}20 \cdot 126 \\
20.126 \\
20.126 \\
20.126 \\
20.126\end{array}$ & $\begin{array}{r}0.06 \\
0.04 \\
0.01 \\
-0.01 \\
-0.04\end{array}$ & $\begin{array}{l}1565 \\
1566 \\
1567 \\
1568 \\
1569\end{array}$ & $\begin{array}{l}23304.83 \\
23324.92 \\
23345.00 \\
23365.08 \\
23385.15\end{array}$ & $\begin{array}{l}20.083 \\
20.082 \\
20.080 \\
20.079 \\
20.077\end{array}$ & $\begin{array}{l}-1.47 \\
-1.49 \\
-1.52 \\
-1.54 \\
-1.57\end{array}$ \\
\hline $\begin{array}{l}1450 \\
1451 \\
1452 \\
1453 \\
1454\end{array}$ & $\begin{array}{l}20991.99 \\
21012.08 \\
21032.16 \\
21052.25 \\
21072.34\end{array}$ & $\begin{array}{l}20.084 \\
20.085 \\
20.087 \\
20.088 \\
20.089\end{array}$ & $\begin{array}{l}1.45 \\
1.42 \\
1.40 \\
1.37 \\
1.35\end{array}$ & $\begin{array}{l}1510 \\
1511 \\
1512 \\
1513 \\
1514\end{array}$ & $\begin{array}{l}22198.73 \\
22218.86 \\
22238.98 \\
22259.11 \\
22279.24\end{array}$ & $\begin{array}{l}20.126 \\
20.126 \\
20.125 \\
20.125 \\
20.125\end{array}$ & $\begin{array}{l}-0.07 \\
-0.09 \\
-0.12 \\
-0.14 \\
-0.17\end{array}$ & $\begin{array}{l}1570 \\
1571 \\
1572 \\
1573 \\
1574\end{array}$ & $\begin{array}{l}23405 \cdot 23 \\
23425 \cdot 31 \\
23445 \cdot 38 \\
23465 \cdot 45 \\
23485.52\end{array}$ & $\begin{array}{l}20.076 \\
20.074 \\
20.072 \\
20.071 \\
20.069\end{array}$ & $\begin{array}{l}-1.59 \\
-1.62 \\
-1.64 \\
-1.67 \\
-1.69\end{array}$ \\
\hline $\begin{array}{l}1455 \\
1456 \\
1457 \\
1458 \\
1459\end{array}$ & $\begin{array}{l}21092.43 \\
21112.52 \\
21132.61 \\
21152.71 \\
21172.80\end{array}$ & $\begin{array}{l}20.091 \\
20.092 \\
20.093 \\
20.095 \\
20.096\end{array}$ & $\begin{array}{l}1.32 \\
1.30 \\
1.28 \\
1.25 \\
1.23\end{array}$ & $\begin{array}{l}1515 \\
1516 \\
1517 \\
1518 \\
1519\end{array}$ & $\begin{array}{l}22299.36 \\
22319.49 \\
22339.61 \\
22359.73 \\
22379.86\end{array}$ & $\begin{array}{l}20.125 \\
20.125 \\
20.125 \\
20.124 \\
20.124\end{array}$ & $\begin{array}{l}-0.19 \\
-0.22 \\
-0.25 \\
-0.27 \\
-0.30\end{array}$ & $\begin{array}{l}1575 \\
1576 \\
1577 \\
1578 \\
1579\end{array}$ & $\begin{array}{l}23505.59 \\
23525.66 \\
23545.72 \\
23565.78 \\
23585.84\end{array}$ & $\begin{array}{l}20.067 \\
20.066 \\
20.064 \\
20.062 \\
20.060\end{array}$ & $\begin{array}{l}-1.72 \\
-1.74 \\
-1.77 \\
-1.79 \\
-1.82\end{array}$ \\
\hline $\begin{array}{l}1460 \\
1461 \\
1462 \\
1463 \\
1464\end{array}$ & $\begin{array}{l}21192.90 \\
21213.00 \\
21233.10 \\
21253.20 \\
21273.30\end{array}$ & $\begin{array}{l}20.097 \\
20.098 \\
20.099 \\
20.101 \\
20.102\end{array}$ & $\begin{array}{l}1.20 \\
1.18 \\
1.15 \\
1.13 \\
1.10\end{array}$ & $\begin{array}{l}1520 \\
1521 \\
1522 \\
1523 \\
1524\end{array}$ & $\begin{array}{l}22399.98 \\
22420.11 \\
22440.23 \\
22460.35 \\
22480.47\end{array}$ & $\begin{array}{l}20.124 \\
20.123 \\
20.123 \\
20.123 \\
20.122\end{array}$ & $\begin{array}{l}-0.32 \\
-0.35 \\
-0.37 \\
-0.40 \\
-0.43\end{array}$ & $\begin{array}{l}1580 \\
1581 \\
1582 \\
1583 \\
1584\end{array}$ & $\begin{array}{l}23605.90 \\
23625.96 \\
23646.02 \\
23666.07 \\
23686.12\end{array}$ & $\begin{array}{l}20.058 \\
20.057 \\
20.055 \\
20.053 \\
20.051\end{array}$ & $\begin{array}{l}-1.84 \\
-1.87 \\
-1.89 \\
-1.91 \\
-1.94\end{array}$ \\
\hline $\begin{array}{l}1465 \\
1466 \\
1467 \\
1468 \\
1469\end{array}$ & $\begin{array}{l}21293.40 \\
21313.50 \\
21333.61 \\
21353.71 \\
21373.82\end{array}$ & $\begin{array}{l}20.103 \\
20.104 \\
20.105 \\
20.106 \\
20.107\end{array}$ & $\begin{array}{l}1.08 \\
1.05 \\
1.03 \\
1.00 \\
0.98\end{array}$ & $\begin{array}{l}1525 \\
1526 \\
1527 \\
1528 \\
1529\end{array}$ & $\begin{array}{l}22500.60 \\
22520.72 \\
22540.84 \\
22560.96 \\
22581.08\end{array}$ & $\begin{array}{l}20.122 \\
20.121 \\
20.121 \\
20.120 \\
20.120\end{array}$ & $\begin{array}{l}-0.45 \\
-0.48 \\
-0.50 \\
-0.53 \\
-0.55\end{array}$ & $\begin{array}{l}1585 \\
1586 \\
1587 \\
1588 \\
1589\end{array}$ & $\begin{array}{l}23706.17 \\
23726.22 \\
23746.27 \\
23766.31 \\
23786.35\end{array}$ & $\begin{array}{l}20.049 \\
20.047 \\
20.045 \\
20.043 \\
20.041\end{array}$ & $\begin{array}{l}-1.96 \\
-1.99 \\
-2.01 \\
-2.04 \\
-2.06\end{array}$ \\
\hline $\begin{array}{l}1470 \\
1471 \\
1472 \\
1473 \\
1474\end{array}$ & $\begin{array}{l}21393.93 \\
21414.04 \\
21434.14 \\
21454.25 \\
21474.37\end{array}$ & $\begin{array}{l}20.108 \\
20.109 \\
20.110 \\
20.111 \\
20.111\end{array}$ & $\begin{array}{l}0.95 \\
0.93 \\
0.90 \\
0.88 \\
0.85\end{array}$ & $\begin{array}{l}1530 \\
1531 \\
1532 \\
1533 \\
1534\end{array}$ & $\begin{array}{l}22601.20 \\
22621.32 \\
22641.44 \\
22661.55 \\
22681.67\end{array}$ & $\begin{array}{l}20.119 \\
20.119 \\
20.118 \\
20.117 \\
20.117\end{array}$ & $\begin{array}{l}-0.58 \\
-0.60 \\
-0.63 \\
-0.66 \\
-0.68\end{array}$ & $\begin{array}{l}1590 \\
1591 \\
1592 \\
1593 \\
1594\end{array}$ & $\begin{array}{l}23806.39 \\
23826.43 \\
23846.47 \\
23866.50 \\
23886.53\end{array}$ & $\begin{array}{l}20.039 \\
20.037 \\
20.035 \\
20.032 \\
20.030\end{array}$ & $\begin{array}{l}-2.08 \\
-2.11 \\
-2.13 \\
-2.16 \\
-2.18\end{array}$ \\
\hline $\begin{array}{l}1475 \\
1476 \\
1477 \\
1478 \\
1479\end{array}$ & $\begin{array}{l}21494.48 \\
21514.59 \\
21534.70 \\
21554.82 \\
21574.93\end{array}$ & $\begin{array}{l}20.1112 \\
20.113 \\
20.114 \\
20.115 \\
20.115\end{array}$ & $\begin{array}{l}0.83 \\
0.80 \\
0.77 \\
0.75 \\
0.72\end{array}$ & $\begin{array}{l}1535 \\
1536 \\
1537 \\
1538 \\
1539\end{array}$ & $\begin{array}{l}22701.79 \\
22721.90 \\
22742.02 \\
22762.13 \\
22782.25\end{array}$ & $\begin{array}{l}20.116 \\
20.115 \\
20.115 \\
20.114 \\
20.113\end{array}$ & $\begin{array}{l}-0.71 \\
-0.73 \\
-0.76 \\
-0.78 \\
-0.81\end{array}$ & $\begin{array}{l}1595 \\
1596 \\
1597 \\
1598 \\
1599\end{array}$ & $\begin{array}{l}23906.56 \\
23926.59 \\
23946.61 \\
23966.63 \\
23986.65\end{array}$ & $\begin{array}{l}20.028 \\
20.026 \\
20.024 \\
20.021 \\
20.019\end{array}$ & $\begin{array}{l}-2.20 \\
-2.23 \\
-2.25 \\
-2.28 \\
-2.30\end{array}$ \\
\hline $\begin{array}{l}1480 \\
1481 \\
1482 \\
1483 \\
1484\end{array}$ & $\begin{array}{l}21595.05 \\
21615.17 \\
21635.28 \\
21655.40 \\
21675.52\end{array}$ & $\begin{array}{l}20.116 \\
20.117 \\
20.117 \\
20.118 \\
20.119\end{array}$ & $\begin{array}{l}0.70 \\
0.67 \\
0.65 \\
0.62 \\
0.60\end{array}$ & $\begin{array}{l}1540 \\
1541 \\
1542 \\
1543 \\
1544\end{array}$ & $\begin{array}{l}22802.36 \\
22822.47 \\
22842.58 \\
22862.69 \\
22882.80\end{array}$ & $\begin{array}{l}20.112 \\
20.111 \\
20.110 \\
20.110 \\
20.109\end{array}$ & $\begin{array}{l}-0.84 \\
-0.86 \\
-0.89 \\
-0.91 \\
-0.94\end{array}$ & $\begin{array}{l}1600 \\
1601 \\
1602 \\
1603 \\
1604\end{array}$ & $\begin{array}{l}24006.67 \\
24026.69 \\
24046.70 \\
24066.71 \\
24086.72\end{array}$ & $\begin{array}{l}20.017 \\
20.014 \\
20.012 \\
20.010 \\
20.007\end{array}$ & $\begin{array}{l}-2.32 \\
-2.35 \\
-2.37 \\
-2.39 \\
-2.42\end{array}$ \\
\hline $\begin{array}{l}1485 \\
1486 \\
1487 \\
1488 \\
1489\end{array}$ & $\begin{array}{l}21695.64 \\
21715.76 \\
21735.88 \\
21756.00 \\
21776.12\end{array}$ & $\begin{array}{l}20.119 \\
20.120 \\
20.120 \\
20.121 \\
20.121\end{array}$ & $\begin{array}{l}0.57 \\
0.55 \\
0.52 \\
0.50 \\
0.47\end{array}$ & $\begin{array}{l}1545 \\
1546 \\
1547 \\
1548 \\
1549\end{array}$ & $\begin{array}{l}22902.91 \\
22923.01 \\
22943.12 \\
22963.23 \\
22983.33\end{array}$ & $\begin{array}{l}20.108 \\
20.107 \\
20.106 \\
20.105 \\
20.104\end{array}$ & $\begin{array}{l}-0.96 \\
-0.99 \\
-1.01 \\
-1.04 \\
-1.06\end{array}$ & $\begin{array}{l}1605 \\
1606 \\
1607 \\
1608 \\
1609\end{array}$ & $\begin{array}{l}24106.73 \\
24126.73 \\
24146.73 \\
24166.73 \\
24186.73\end{array}$ & $\begin{array}{l}20.005 \\
20.002 \\
20.000 \\
19.997 \\
19.995\end{array}$ & $\begin{array}{l}-2.44 \\
-2.46 \\
-2.49 \\
-2.51 \\
-2.53\end{array}$ \\
\hline $\begin{array}{l}1490 \\
1491 \\
1492 \\
1493 \\
1494\end{array}$ & $\begin{array}{l}21796.24 \\
21816.36 \\
21836.49 \\
21856.61 \\
21876.73\end{array}$ & $\begin{array}{l}20.122 \\
20.122 \\
20.123 \\
20.123 \\
20.123\end{array}$ & $\begin{array}{l}0.45 \\
0.42 \\
0.39 \\
0.37 \\
0.34\end{array}$ & $\begin{array}{l}1550 \\
1551 \\
1552 \\
1553 \\
1554\end{array}$ & $\begin{array}{l}23003.43 \\
23023.53 \\
23043.64 \\
23063.74 \\
23083.83\end{array}$ & $\begin{array}{l}20.102 \\
20.101 \\
20.100 \\
20.099 \\
20.098\end{array}$ & $\begin{array}{l}-1.09 \\
-1.12 \\
-1.14 \\
-1.17 \\
-1.19\end{array}$ & $\begin{array}{l}1610 \\
1611 \\
1612 \\
1613 \\
1614\end{array}$ & $\begin{array}{l}24206.72 \\
24226.71 \\
24246.70 \\
24266.69 \\
24286.67\end{array}$ & $\begin{array}{l}19.992 \\
19.990 \\
19.987 \\
19.985 \\
19.982\end{array}$ & $\begin{array}{l}-2.56 \\
-2.58 \\
-2.60 \\
-2.63 \\
-2.65\end{array}$ \\
\hline $\begin{array}{l}1495 \\
1496 \\
1497 \\
1498 \\
1499\end{array}$ & $\begin{array}{l}21896.86 \\
21916.98 \\
21937.10 \\
21957.23 \\
21977.35\end{array}$ & $\begin{array}{l}20.124 \\
20.124 \\
20.124 \\
20.125 \\
20.125\end{array}$ & $\begin{array}{l}0.32 \\
0.29 \\
0.27 \\
0.24 \\
0.22\end{array}$ & $\begin{array}{l}1555 \\
1556 \\
1557 \\
1558 \\
1559\end{array}$ & $\begin{array}{l}23103.93 \\
23124.03 \\
23144.12 \\
23164 \cdot 22 \\
23184.31\end{array}$ & $\begin{array}{l}20.097 \\
20.096 \\
20.094 \\
20.093 \\
20.092\end{array}$ & $\begin{array}{l}-1.22 \\
-1.24 \\
-1.27 \\
-1.29 \\
-1.32\end{array}$ & $\begin{array}{l}1615 \\
1616 \\
1617 \\
1618 \\
1619\end{array}$ & $\begin{array}{l}24306.65 \\
24326.63 \\
24346.60 \\
24366.58 \\
24386.55\end{array}$ & $\begin{array}{l}19.979 \\
19.977 \\
19.974 \\
19.971 \\
19.968\end{array}$ & $\begin{array}{l}-2.67 \\
-2.69 \\
-2.72 \\
-2.74 \\
-2.76\end{array}$ \\
\hline & 48 & & & 660 & 204.40 & 000 & 1 & & 4406.51 & 9.966 & \\
\hline
\end{tabular}


TABLE 4.4.2. Type BP thermoelements versus platinum, Pt-67-thermoelectric valtages, E(T), Seebeck coefficients, $\mathrm{S}(\mathrm{T})$, and first derivative of the Seebeck coefficients, $d S / d T$,

reference junctions at $0{ }^{\circ} \mathrm{C}$-Continued

\begin{tabular}{|c|c|c|c|c|c|c|c|c|c|c|c|}
\hline${ }^{\mathrm{T}} \mathrm{C}$ & ${ }_{\mu V}^{E}$ & $\stackrel{S}{\mu V /{ }^{\circ} \mathrm{C}}$ & $\begin{array}{l}d S / d T \\
n V /{ }^{\circ} C^{2}\end{array}$ & ${ }^{\top} \mathrm{C}$ & $\begin{array}{c}E \\
\mu V\end{array}$ & $\stackrel{S}{\mu V /{ }^{\circ} \mathrm{C}}$ & $\begin{array}{l}d S / d T \\
n V /{ }^{\circ} C^{2}\end{array}$ & ${ }^{\top}{ }^{\top} \mathrm{C}$ & $\underset{\mu V}{E}$ & $\underset{\mu V /{ }^{\circ} \mathrm{C}}{S}$ & $\begin{array}{l}d S / d T \\
n V /{ }^{\circ} C^{2}\end{array}$ \\
\hline $\begin{array}{l}1620 \\
1621 \\
1622 \\
1623 \\
1624\end{array}$ & $\begin{array}{l}24406.51 \\
24426.48 \\
24446.44 \\
24466.40 \\
24486.35\end{array}$ & $\begin{array}{l}19.966 \\
19.963 \\
19.960 \\
19.957 \\
19.954\end{array}$ & $\begin{array}{l}-2.78 \\
-2.81 \\
-2.83 \\
-2.85 \\
-2.87\end{array}$ & $\begin{array}{l}1680 \\
1681 \\
1682 \\
1683 \\
1684\end{array}$ & $\begin{array}{l}25598.69 \\
25618.44 \\
25638.20 \\
25657.95 \\
25677.70\end{array}$ & $\begin{array}{l}19.762 \\
19.758 \\
19.754 \\
19.750 \\
19.746\end{array}$ & $\begin{array}{l}-3.95 \\
-3.97 \\
-3.99 \\
-4.00 \\
-4.02\end{array}$ & $\begin{array}{l}1740 \\
1741 \\
1742 \\
1743 \\
1744\end{array}$ & $\begin{array}{l}26776.78 \\
26796.28 \\
26815.77 \\
26835.26 \\
26854.74\end{array}$ & $\begin{array}{l}19.501 \\
19.497 \\
19.492 \\
19.488 \\
19.483\end{array}$ & $\begin{array}{l}-4.61 \\
-4.61 \\
-4.62 \\
-4.62 \\
-4.63\end{array}$ \\
\hline $\begin{array}{l}1625 \\
1626 \\
1627 \\
1628 \\
1629\end{array}$ & $\begin{array}{l}24506.31 \\
24526.26 \\
24546.20 \\
24566.15 \\
24586.09\end{array}$ & $\begin{array}{l}19.951 \\
19.949 \\
19.946 \\
19.943 \\
19.940\end{array}$ & $\begin{array}{l}-2.89 \\
-2.92 \\
-2.94 \\
-2.96 \\
-2.98\end{array}$ & $\begin{array}{l}1685 \\
1686 \\
1687 \\
1688 \\
1689\end{array}$ & $\begin{array}{l}25697.44 \\
25717.18 \\
25736.92 \\
25756.65 \\
25776.38\end{array}$ & $\begin{array}{l}19.742 \\
19.738 \\
19.734 \\
19.730 \\
19.725\end{array}$ & $\begin{array}{l}-4.03 \\
-4.05 \\
-4.06 \\
-4.08 \\
-4.09\end{array}$ & $\begin{array}{l}1745 \\
1746 \\
1747 \\
1748 \\
1749\end{array}$ & $\begin{array}{l}26874.23 \\
26893.70 \\
26913.17 \\
26932.64 \\
26952.10\end{array}$ & $\begin{array}{l}19.478 \\
19.474 \\
19.469 \\
19.464 \\
19.460\end{array}$ & $\begin{array}{l}-4.63 \\
-4.63 \\
-4.64 \\
-4.64 \\
-4.64\end{array}$ \\
\hline $\begin{array}{l}1630 \\
1631 \\
1632 \\
1633 \\
1634\end{array}$ & $\begin{array}{l}24606.03 \\
24625.96 \\
24645.89 \\
24665.82 \\
24685.75\end{array}$ & $\begin{array}{l}19.937 \\
19.934 \\
19.931 \\
19.928 \\
19.925\end{array}$ & $\begin{array}{l}-3.00 \\
-3.02 \\
-3.05 \\
-3.07 \\
-3.09\end{array}$ & $\begin{array}{l}1690 \\
1691 \\
1692 \\
1693 \\
1694\end{array}$ & $\begin{array}{l}25796.10 \\
25815.82 \\
25835.54 \\
25855.25 \\
25874.95\end{array}$ & $\begin{array}{l}19.721 \\
19.717 \\
19.713 \\
19.709 \\
19.705\end{array}$ & $\begin{array}{l}-4.11 \\
-4.12 \\
-4.14 \\
-4.15 \\
-4.16\end{array}$ & $\begin{array}{l}1750 \\
1751 \\
1752 \\
1753 \\
1754\end{array}$ & $\begin{array}{l}26971.56 \\
26991.01 \\
27010.46 \\
27029.90 \\
27049.34\end{array}$ & $\begin{array}{l}19.455 \\
19.451 \\
19.446 \\
19.441 \\
19.437\end{array}$ & $\begin{array}{l}-4.64 \\
-4.65 \\
-4.65 \\
-4.65 \\
-4.65\end{array}$ \\
\hline $\begin{array}{l}1635 \\
1636 \\
1637 \\
1638 \\
1639\end{array}$ & $\begin{array}{l}24705.67 \\
24725.59 \\
24745.51 \\
24765.42 \\
24785.33\end{array}$ & $\begin{array}{l}19.921 \\
19.918 \\
19.915 \\
19.912 \\
19.909\end{array}$ & $\begin{array}{l}-3.11 \\
-3.13 \\
-3.15 \\
-3.17 \\
-3.19\end{array}$ & $\begin{array}{l}1695 \\
1696 \\
1697 \\
1698 \\
1699\end{array}$ & $\begin{array}{l}25894.66 \\
25914.35 \\
25934.05 \\
25953.74 \\
25973.43\end{array}$ & $\begin{array}{l}19.701 \\
19.696 \\
19.692 \\
19.688 \\
19.684\end{array}$ & $\begin{array}{l}-4 \cdot 18 \\
-4 \cdot 19 \\
-4 \cdot 20 \\
-4 \cdot 22 \\
-4 \cdot 23\end{array}$ & $\begin{array}{l}1755 \\
1756 \\
1757 \\
1758 \\
1759\end{array}$ & $\begin{array}{l}27068.78 \\
27088.21 \\
27107.63 \\
27127.05 \\
27146.47\end{array}$ & $\begin{array}{l}19.432 \\
19.427 \\
19.423 \\
19.418 \\
19.413\end{array}$ & $\begin{array}{l}-4.65 \\
-4.65 \\
-4.66 \\
-4.66 \\
-4.66\end{array}$ \\
\hline $\begin{array}{l}1640 \\
1641 \\
1642 \\
1643 \\
1644\end{array}$ & $\begin{array}{l}24805.24 \\
24825.14 \\
24845.05 \\
24864.94 \\
24884.84\end{array}$ & $\begin{array}{l}19.906 \\
19.902 \\
19.899 \\
19.896 \\
19.893\end{array}$ & $\begin{array}{l}-3.21 \\
-3.24 \\
-3.26 \\
-3.28 \\
-3.30\end{array}$ & $\begin{array}{l}1700 \\
1701 \\
1702 \\
1703 \\
1704\end{array}$ & $\begin{array}{l}25993.11 \\
26012.78 \\
26032.46 \\
26052.13 \\
26071.79\end{array}$ & $\begin{array}{l}19.680 \\
19.675 \\
19.671 \\
19.667 \\
19.662\end{array}$ & $\begin{array}{l}-4 \cdot 24 \\
-4 \cdot 26 \\
-4 \cdot 27 \\
-4 \cdot 28 \\
-4 \cdot 29\end{array}$ & $\begin{array}{l}1760 \\
1761 \\
1762 \\
1763 \\
1764\end{array}$ & $\begin{array}{l}27165.88 \\
27185.29 \\
27204.69 \\
27224.08 \\
27243.48\end{array}$ & $\begin{array}{l}19.409 \\
19.404 \\
19.399 \\
19.395 \\
19.390\end{array}$ & $\begin{array}{l}-4.66 \\
-4.66 \\
-4.66 \\
-4.65 \\
-4.65\end{array}$ \\
\hline $\begin{array}{l}1645 \\
1646 \\
1647 \\
1648 \\
1649\end{array}$ & $\begin{array}{l}24904.73 \\
24924.62 \\
24944.50 \\
24964.38 \\
24984.26\end{array}$ & $\begin{array}{l}19.889 \\
19.886 \\
19.883 \\
19.879 \\
19.876\end{array}$ & $\begin{array}{l}-3.32 \\
-3.34 \\
-3.36 \\
-3.38 \\
-3.40\end{array}$ & $\begin{array}{l}1705 \\
1706 \\
1707 \\
1708 \\
1709\end{array}$ & $\begin{array}{l}26091.45 \\
26111.11 \\
26130.76 \\
26150.41 \\
26170.05\end{array}$ & $\begin{array}{l}19.658 \\
19.654 \\
19.650 \\
19.645 \\
19.641\end{array}$ & $\begin{array}{l}-4 \cdot 31 \\
-4 \cdot 32 \\
-4 \cdot 33 \\
-4 \cdot 34 \\
-4 \cdot 35\end{array}$ & $\begin{array}{l}1765 \\
1766 \\
1767 \\
1768 \\
1769\end{array}$ & $\begin{array}{l}27262.86 \\
27282.25 \\
27301.63 \\
27321.00 \\
27340.37\end{array}$ & $\begin{array}{l}19.385 \\
19.381 \\
19.376 \\
19.371 \\
19.367\end{array}$ & $\begin{array}{l}-4.65 \\
-4.65 \\
-4.65 \\
-4.65 \\
-4.64\end{array}$ \\
\hline $\begin{array}{l}1650 \\
1651 \\
1652 \\
1653 \\
1654\end{array}$ & $\begin{array}{l}25004.13 \\
25024.00 \\
25043.87 \\
25063.73 \\
25083.60\end{array}$ & $\begin{array}{l}19.872 \\
19.869 \\
19.866 \\
19.862 \\
19.859\end{array}$ & $\begin{array}{l}-3.42 \\
-3.44 \\
-3.46 \\
-3.48 \\
-3.49\end{array}$ & $\begin{array}{l}1710 \\
1711 \\
1712 \\
1713 \\
1714\end{array}$ & $\begin{array}{l}26189 \cdot 69 \\
26209 \cdot 32 \\
26228.95 \\
26248.58 \\
26268.20\end{array}$ & $\begin{array}{l}19.637 \\
19.632 \\
19.628 \\
19.623 \\
19.619\end{array}$ & $\begin{array}{l}-4 \cdot 36 \\
-4 \cdot 38 \\
-4.39 \\
-4.40 \\
-4.41\end{array}$ & $\begin{array}{l}1770 \\
1771 \\
1772 \\
1773 \\
1774\end{array}$ & $\begin{array}{l}27359.73 \\
27379.09 \\
27398.45 \\
27417.80 \\
27437.14\end{array}$ & $\begin{array}{l}19.362 \\
19.358 \\
19.353 \\
19.348 \\
19.344\end{array}$ & $\begin{array}{l}-4.64 \\
-4.64 \\
-4.63 \\
-4.63 \\
-4.63\end{array}$ \\
\hline $\begin{array}{l}1655 \\
1656 \\
1657 \\
1658 \\
1659\end{array}$ & $\begin{array}{l}25103.45 \\
25123.31 \\
25143.16 \\
25163.00 \\
25182.84\end{array}$ & $\begin{array}{l}19.855 \\
19.852 \\
19.848 \\
19.845 \\
19.841\end{array}$ & $\begin{array}{l}-3.51 \\
-3.53 \\
-3.55 \\
-3.57 \\
-3.59\end{array}$ & $\begin{array}{l}1715 \\
1716 \\
1717 \\
1718 \\
1719\end{array}$ & $\begin{array}{l}26287.82 \\
26307.43 \\
26327.04 \\
26346.04 \\
26366.24\end{array}$ & $\begin{array}{l}19.615 \\
19.610 \\
19.606 \\
19.601 \\
19.597\end{array}$ & $\begin{array}{l}-4.42 \\
-4.43 \\
-4.44 \\
-4.45 \\
-4.46\end{array}$ & $\begin{array}{l}1775 \\
1776 \\
1777 \\
1778 \\
1779\end{array}$ & $\begin{array}{l}27456.49 \\
27475.82 \\
27495.15 \\
27514.48 \\
27533.80\end{array}$ & $\begin{array}{l}19.339 \\
19.334 \\
19.330 \\
19.325 \\
19.321\end{array}$ & $\begin{array}{l}-4.62 \\
-4.62 \\
-4.61 \\
-4.61 \\
-4.60\end{array}$ \\
\hline $\begin{array}{l}1660 \\
1661 \\
1662 \\
1663 \\
1664\end{array}$ & $\begin{array}{l}25202.68 \\
25222.52 \\
25242.35 \\
25262.18 \\
25282.00\end{array}$ & $\begin{array}{l}19.837 \\
19.834 \\
19.830 \\
19.826 \\
19.823\end{array}$ & $\begin{array}{l}-3.61 \\
-3.63 \\
-3.64 \\
-3.66 \\
-3.68\end{array}$ & $\begin{array}{l}1720 \\
1721 \\
1722 \\
1723 \\
1724\end{array}$ & $\begin{array}{l}26385.83 \\
26405.42 \\
26425.01 \\
26444.59 \\
26464.17\end{array}$ & $\begin{array}{l}19.592 \\
19.588 \\
19.583 \\
19.579 \\
19.574\end{array}$ & $\begin{array}{l}-4.47 \\
-4.47 \\
-4.48 \\
-4.49 \\
-4.50\end{array}$ & $\begin{array}{l}1780 \\
1781 \\
1782 \\
1783 \\
1784\end{array}$ & $\begin{array}{l}27553.12 \\
27572.44 \\
27591.75 \\
27611.05 \\
27630.35\end{array}$ & $\begin{array}{l}19.316 \\
19.311 \\
19.307 \\
19.302 \\
19.298\end{array}$ & $\begin{array}{l}-4.60 \\
-4.59 \\
-4.58 \\
-4.58 \\
-4.57\end{array}$ \\
\hline $\begin{array}{l}1665 \\
1666 \\
1667 \\
1668 \\
1669\end{array}$ & $\begin{array}{l}25301.82 \\
25321.64 \\
25341.46 \\
25361.27 \\
25381.07\end{array}$ & $\begin{array}{r}19.819 \\
19.815 \\
19.812 \\
19.808 \\
19.804\end{array}$ & $\begin{array}{l}-3.70 \\
-3.72 \\
-3.73 \\
-3.75 \\
-3.77\end{array}$ & $\begin{array}{l}1725 \\
1726 \\
1727 \\
1728 \\
1729\end{array}$ & $\begin{array}{l}26483.74 \\
26503.31 \\
26522.87 \\
26542.43 \\
26561.98\end{array}$ & $\begin{array}{l}19.570 \\
19.565 \\
19.561 \\
19.556 \\
19.552\end{array}$ & $\begin{array}{l}-4.51 \\
-4.52 \\
-4.53 \\
-4.53 \\
-4.54\end{array}$ & $\begin{array}{l}1785 \\
1786 \\
1787 \\
1788 \\
1789\end{array}$ & $\begin{array}{l}27649.65 \\
27668.94 \\
27688.22 \\
27707.50 \\
27726.78\end{array}$ & $\begin{array}{l}19.293 \\
19.288 \\
19.284 \\
19.279 \\
19.275\end{array}$ & $\begin{array}{l}-4.56 \\
-4.56 \\
-4.55 \\
-4.54 \\
-4.53\end{array}$ \\
\hline $\begin{array}{l}1670 \\
1671 \\
1672 \\
1673 \\
1674\end{array}$ & $\begin{array}{l}25400.87 \\
25420.67 \\
25440.47 \\
25460.26 \\
25480.04\end{array}$ & $\begin{array}{l}19.800 \\
19.797 \\
19.793 \\
19.789 \\
19.785\end{array}$ & $\begin{array}{l}-3.79 \\
-3.80 \\
-3.82 \\
-3.84 \\
-3.86\end{array}$ & $\begin{array}{l}1730 \\
1731 \\
1732 \\
1733 \\
1734\end{array}$ & $\begin{array}{l}26581.53 \\
26601.08 \\
26620.62 \\
26640.15 \\
26659.68\end{array}$ & $\begin{array}{l}19.547 \\
19.543 \\
19.538 \\
19.534 \\
19.529\end{array}$ & $\begin{array}{l}-4.55 \\
-4.55 \\
-4.56 \\
-4.57 \\
-4.57\end{array}$ & $\begin{array}{l}1790 \\
1791 \\
1792 \\
1793 \\
1794\end{array}$ & $\begin{array}{l}27746.05 \\
27765.32 \\
27784.58 \\
27803.84 \\
27823.10\end{array}$ & $\begin{array}{l}19.270 \\
19.266 \\
19.261 \\
19.257 \\
19.252\end{array}$ & $\begin{array}{l}-4.52 \\
-4.51 \\
-4.50 \\
-4.49 \\
-4.48\end{array}$ \\
\hline $\begin{array}{l}1675 \\
1676 \\
1677 \\
1678 \\
1679\end{array}$ & $\begin{array}{l}25499.83 \\
25519.61 \\
25539.38 \\
25559.15 \\
25578.92\end{array}$ & $\begin{array}{l}19.781 \\
19.777 \\
19.773 \\
19.770 \\
19.766\end{array}$ & $\begin{array}{l}-3.87 \\
-3.89 \\
-3.91 \\
-3.92 \\
-3.94\end{array}$ & $\begin{array}{l}1735 \\
1736 \\
1737 \\
1738 \\
1739\end{array}$ & $\begin{array}{l}26679.21 \\
26698.73 \\
26718.25 \\
26737.76 \\
26757.27\end{array}$ & $\begin{array}{l}19.524 \\
19.520 \\
19.515 \\
19.511 \\
19.506\end{array}$ & $\begin{array}{l}-4.58 \\
-4.59 \\
-4.59 \\
-4.60 \\
-4.60\end{array}$ & $\begin{array}{l}1795 \\
1796 \\
1797 \\
1798 \\
1799\end{array}$ & $\begin{array}{l}27842.35 \\
27861.59 \\
27880.84 \\
27900.07 \\
27919.30\end{array}$ & $\begin{array}{l}19.248 \\
19.243 \\
19.239 \\
19.234 \\
19.230\end{array}$ & $\begin{array}{l}-4.47 \\
-4.46 \\
-4.45 \\
-4.44 \\
-4.43\end{array}$ \\
\hline 1680 & 25598.69 & 19.762 & -3.95 & 1740 & 26776.78 & 19.501 & -4.61 & 1800 & 27938.53 & 19.226 & $-4 \cdot 41$ \\
\hline
\end{tabular}


TABle 4.4.2. Type BP thermoelements versus platinum, Pt-67-thermoelectric voltages, E(T), Seebeck coefficients, $\mathrm{S}(\mathrm{T})$, and first derivative of the Seebeck coefficients, $d S / d T$, reference junctions at $0{ }^{\circ} \mathrm{C}$-Continued

\begin{tabular}{|c|c|c|c|c|c|c|c|c|c|c|c|}
\hline $\begin{array}{c}\mathrm{T} \\
{ }^{\circ} \mathrm{C}\end{array}$ & $\begin{array}{c}E \\
\mu V\end{array}$ & $\underset{\mu \mathrm{V} /{ }^{\circ} \mathrm{C}}{\mathrm{S}}$ & $\begin{array}{l}d S / d T \\
n V /{ }^{\circ} C^{2}\end{array}$ & $\begin{array}{l}\mathrm{T} \\
{ }^{\circ} \mathrm{C}\end{array}$ & $\begin{array}{c}E \\
\mu V\end{array}$ & $\underset{\mu \mathrm{V} /{ }^{\circ} \mathrm{C}}{\mathrm{S}}$ & $\begin{array}{l}d S / d T \\
n V /{ }^{\circ} C^{2}\end{array}$ & ${ }^{\circ} \mathrm{C}$ & $\underset{\mu V}{E}$ & $\begin{array}{c}\mathrm{S} \\
\mu \mathrm{V} /{ }^{\circ} \mathrm{C}\end{array}$ & $\begin{array}{l}\mathrm{dS} / \mathrm{dT} \\
\mathrm{nV} /{ }^{\circ} \mathrm{C}^{2}\end{array}$ \\
\hline $\begin{array}{l}1800 \\
1801 \\
1802 \\
1803 \\
1804\end{array}$ & $\begin{array}{l}27938.53 \\
27957.76 \\
27976.97 \\
27996.19 \\
28015.40\end{array}$ & $\begin{array}{l}19.226 \\
19.221 \\
19.217 \\
19.212 \\
19.208\end{array}$ & $\begin{array}{l}-4.41 \\
-4.40 \\
-4.39 \\
-4.38 \\
-4.36\end{array}$ & $\begin{array}{l}1810 \\
1811 \\
1812 \\
1813 \\
1814\end{array}$ & $\begin{array}{l}28130.57 \\
28149.75 \\
28168.93 \\
28188.10 \\
28207.26\end{array}$ & $\begin{array}{l}19.182 \\
19.178 \\
19.174 \\
19.169 \\
19.165\end{array}$ & $\begin{array}{l}-4 \cdot 27 \\
-4 \cdot 26 \\
-4 \cdot 24 \\
-4 \cdot 22 \\
-4 \cdot 20\end{array}$ & 1820 & $28322 \cdot 18$ & 19.140 & -4.09 \\
\hline $\begin{array}{l}1805 \\
1806 \\
1807 \\
1808 \\
1809\end{array}$ & $\begin{array}{l}28034.60 \\
28053.81 \\
28073.00 \\
28092.20 \\
28111.39\end{array}$ & $\begin{array}{l}19.204 \\
19.199 \\
19.195 \\
19.191 \\
19.186\end{array}$ & $\begin{array}{l}-4 \cdot 35 \\
-4 \cdot 33 \\
-4 \cdot 32 \\
-4 \cdot 30 \\
-4 \cdot 29\end{array}$ & $\begin{array}{l}1815 \\
1816 \\
1817 \\
1818 \\
1819\end{array}$ & $\begin{array}{l}28226.43 \\
28245.59 \\
28264.74 \\
28283.89 \\
28303.04\end{array}$ & $\begin{array}{l}19.161 \\
19.157 \\
19.153 \\
19.148 \\
19.144\end{array}$ & $\begin{array}{l}-4 \cdot 19 \\
-4 \cdot 17 \\
-4 \cdot 15 \\
-4 \cdot 13 \\
-4 \cdot 11\end{array}$ & & & & \\
\hline 810 & 28130.57 & 19.182 & $-4 \cdot 27$ & 1820 & $28322 \cdot 18$ & 19.140 & -4.09 & & & & \\
\hline
\end{tabular}


TABLE 4.4.3. Thermoelectric values at the fixed points for Type BP thermoelements versus platinum, $\mathrm{Pt}-67$

\begin{tabular}{|c|c|c|c|c|}
\hline Fixed point & $\begin{array}{c}\text { Temp. } \\
{ }^{\circ} \mathrm{C}\end{array}$ & $\begin{array}{c}E \\
\mu \mathrm{V}\end{array}$ & $\begin{array}{c}S \\
\mu \mathrm{V} /{ }^{\circ} \mathrm{C}\end{array}$ & $\begin{array}{c}d S / d T \\
\mathrm{nV} /{ }^{\circ} C^{\jmath}\end{array}$ \\
\hline $\begin{array}{l}\text { Ice point } \\
\text { Ether TP } \\
\text { Water BP } \\
\text { Benzoic TP } \\
\text { Indium FP } \\
\text { Tin FP } \\
\text { Bismuth FP } \\
\text { Cadmium FP } \\
\text { Lead FP } \\
\text { Mercury BP } \\
\text { Zinc FP } \\
\text { Sulphur BP } \\
\text { Cu-Al FP } \\
\text { Antimony FP } \\
\text { Aluminum FP } \\
\text { Silver FP } \\
\text { Gold FP } \\
\text { Copper FP } \\
\text { Nickel FP } \\
\text { Cobalt FP } \\
\text { Palladium FP } \\
\text { Platinum FP }\end{array}$ & $\begin{array}{l}0.000 \\
26.870 \\
100.000 \\
122.370 \\
156.634 \\
231.9681 \\
271.442 \\
321.108 \\
327.502 \\
356.660 \\
419.580 \\
444.674 \\
548.23 \\
630.74 \\
660.37 \\
961.93 \\
1064.43 \\
1084.5 \\
1455 \\
1494 \\
1554 \\
1772\end{array}$ & $\begin{array}{r}0.00 \\
140.41 \\
619.02 \\
789.39 \\
1068.91 \\
1752.39 \\
2143.64 \\
2664.68 \\
2733.97 \\
3056.07 \\
3784.23 \\
4086.83 \\
5406.32 \\
6536.89 \\
6959.64 \\
11742.73 \\
13554.07 \\
13918.67 \\
21092.43 \\
21876.73 \\
23083.83 \\
27398.45\end{array}$ & $\begin{array}{r}4.819 \\
5.616 \\
7.388 \\
7.838 \\
8.465 \\
9.640 \\
10.176 \\
10.798 \\
10.874 \\
11.217 \\
11.922 \\
12.194 \\
13.281 \\
14.119 \\
14.415 \\
17.242 \\
18.088 \\
18.244 \\
20.091 \\
20.123 \\
20.098 \\
19.353\end{array}$ & $\begin{array}{r}31.40 \\
27.99 \\
20.96 \\
19.36 \\
17.31 \\
14.15 \\
13.05 \\
12.06 \\
11.95 \\
11.55 \\
10.93 \\
10.76 \\
10.29 \\
10.03 \\
9.94 \\
8.63 \\
7.84 \\
7.66 \\
1.32 \\
0.34 \\
-1.19 \\
-4.63\end{array}$ \\
\hline
\end{tabular}

TABLE 4.4.4. Estimated maximum errors that occur when using reduced-bit arithmetic for the power series expansion for the thermoelectric voltage of Type BP thermoelements versus platinum, $\mathrm{Pt}-67$

\begin{tabular}{|c|c|c|c|c|c|c|}
\hline \multirow[b]{2}{*}{ Temperature range } & \multirow[b]{2}{*}{ Degree } & \multicolumn{5}{|c|}{ Estimated maximum error in microvolts } \\
\hline & & $12 \mathrm{Bit}$ & $16 \mathrm{Bit}$ & $24 \mathrm{Bit}$ & $27 \mathrm{Bit}$ & 36 Bit \\
\hline 0 to $200{ }^{\circ} \mathrm{C}$ & 8 & 0.2 & $<0.1$ & $<0.01$ & $<0.01$ & $<0.01$ \\
\hline 200 to $400 \mathrm{C}$ & 8 & 0.4 & 0.1 & $<0.01$ & $<0.01$ & $<0.01$ \\
\hline 400 to $600^{\circ} \mathrm{C}$ & 8 & 2 & 0.2 & $<0.01$ & $<0.01$ & $<0.01$ \\
\hline 600 to $800^{\circ} \mathrm{C}$ & 8 & 6 & 0.7 & $<0.01$ & $<0.01$ & $<0.01$ \\
\hline 800 to $1000^{\circ} \mathrm{C}$ & 8 & 15 & 2 & $<0.01$ & $<0.01$ & $<0.01$ \\
\hline 1000 to $1200^{\circ} \mathrm{C}$ & 8 & 30 & 5 & 0.02 & $<0.01$ & $<0.01$ \\
\hline 1200 to $1400^{\circ} \mathrm{C}$ & 8 & 60 & 10 & 0.03 & $<0.01$ & $<0.01$ \\
\hline 1400 to $1600^{\circ} \mathrm{C}$ & 8 & 100 & 20 & 0.06 & $<0.01$ & $<0.01$ \\
\hline 1600 to $1820^{\circ} \mathrm{C}$ & 8 & 200 & 40 & 0.1 & $<0.01$ & $<0.01$ \\
\hline
\end{tabular}




\subsection{Reference Functions and Tabes for the Negative Thermoelement, Type BN, a Platinum-6\% Rhodium Alloy Versus Platinum, $\mathrm{Pt}-67$}

The coefficients for the eighth degree expansion for the thermoelectric voltage of Type BN thermoelements versus $\mathrm{Pt}-67$ are given in table 4.5.1. The errors caused by using reduced bit arithmetic for calculating values of the functions are given in table 4.5.4.

The primary reference values for Type BN thermoelements versus $\mathrm{Pt}-67$ are given in table 4.5.2. Values at selected fixed points are given in table 4.5.3. Graphs of the thermoelectric voltage, its first derivative (Seebeck coefficient), and second derivative are given in figures $4.5 .1,4.5 .2$, and 4.5 .3 , respectively.

TABle 4.5.1. Power series expansion for the thermoelectric voltage of Type BN thermoelements versus platinum, $\mathrm{Pt}-67$

\begin{tabular}{|c|c|c|c|}
\hline $\begin{array}{c}\text { Tempera- } \\
\text { ture } \\
\text { range }\end{array}$ & Degree & Coefficients & Term \\
\hline $\begin{array}{l}0 \text { to } \\
1820^{\circ} \mathrm{C}\end{array}$ & 8 & $\begin{array}{r}5.0661081008 \times \\
9.7920240809 \times 10^{-3} \\
-2.1371705669 \times 10^{-5} \\
2.9096345602 \times 10^{-8} \\
-2.4374352573 \times 10^{-11} \\
1.2623801429 \times 10^{-14} \\
-3.7387387148 \times 10^{-18} \\
4.7918630894 \times 10^{-22}\end{array}$ & $\begin{array}{l}T \\
T^{2} \\
T^{3} \\
T^{4} \\
T^{5} \\
T^{6} \\
T^{7} \\
T^{8}\end{array}$ \\
\hline
\end{tabular}

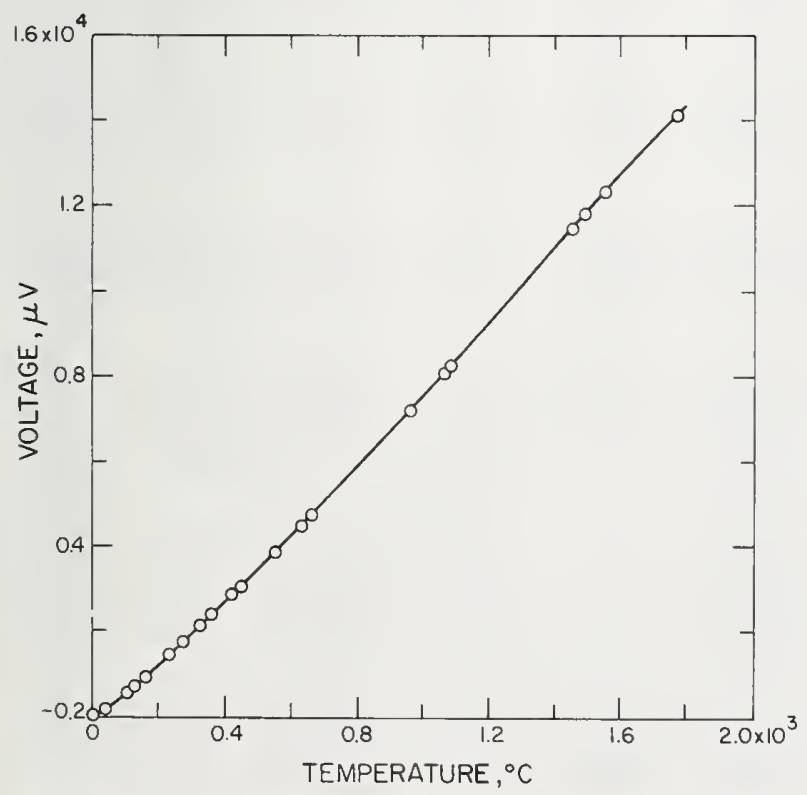

Figure 4.5.1. Thermoelectric voltage for Type BN thermoelements versus platinum, $P_{t-67}$.

The circles indicate values at various thermometric fixed points on the IPTS-68.

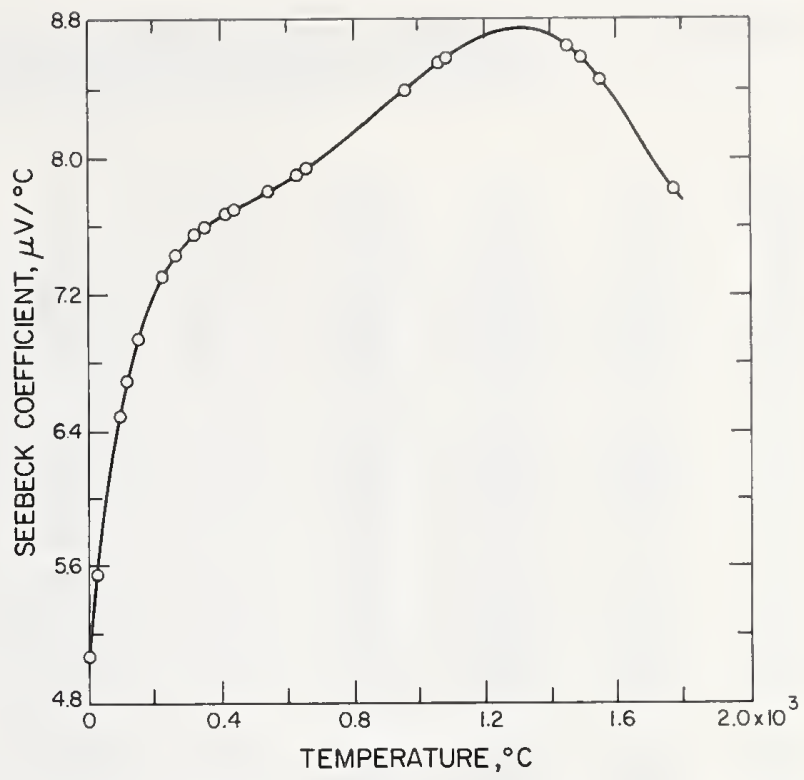

Figure 4.5.2. Seebeck coefficient for Type BN thermoelements versus platinum, $P t-67$.

The circles indicate values at various thermometric fixed points on the IPTS $\rightarrow 68$.

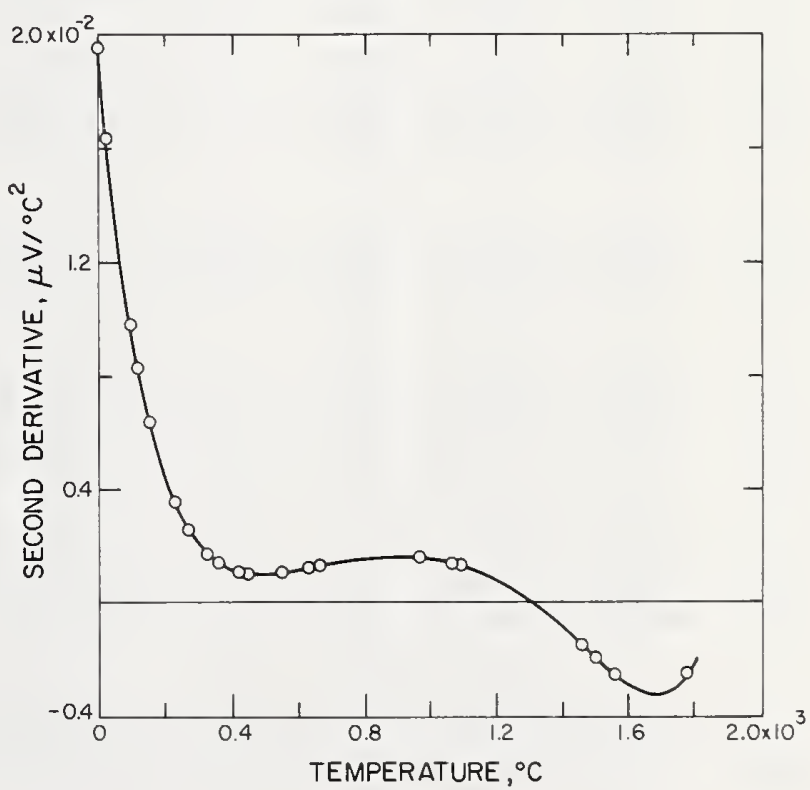

Figure 4.5.3. Second derivative of thermoelectric voltage for Type BN thermoelements versus platinum, Pt-67.

The circles indicate values at various thermometric fixed points on the IPTS -68 . 
TABLE 4.5.2. Type BN thermoelements versus platinum, Pt-67-thermoelectric voltages, $\mathrm{E}(\mathrm{T})$, Seebeck coefficients, S(T), and first derivative of the Seebeck coefficients, dS/dT,

reference junctions at $0^{\circ} \mathrm{C}$

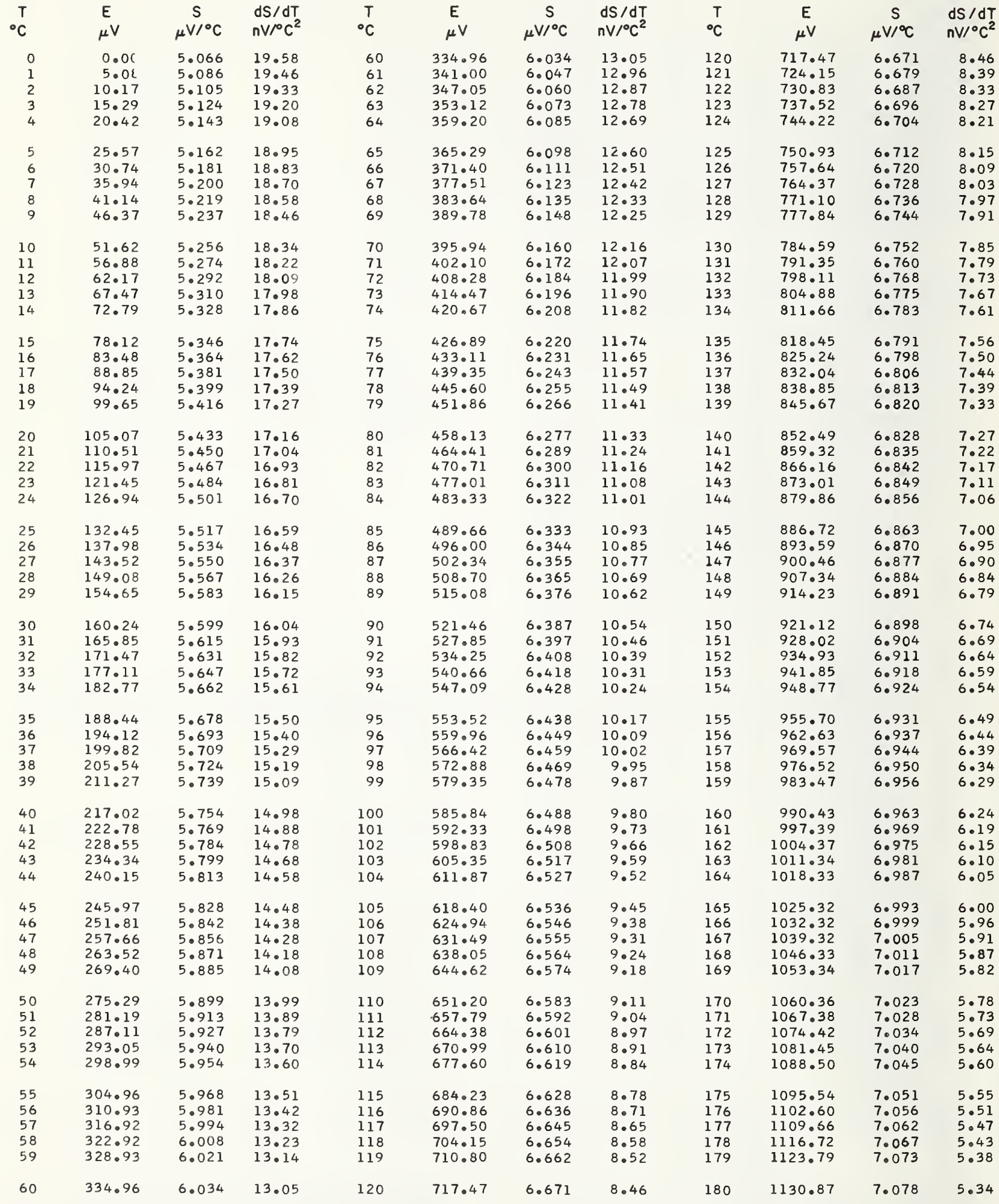


TABLE 4.5.2. Type BN thermoelements versus platinum, $\mathrm{Pt}-67$-thermoelectric voltages, $\mathrm{E}(\mathrm{T})$, Seebeck coefficients, $\mathrm{S}(\mathrm{T})$, and first derivative of the Seebeck coefficients, $\mathrm{dS} / \mathrm{dT}$, reference junctions at $0^{\circ} \mathrm{C}$-Continued

\begin{tabular}{|c|c|c|c|c|c|c|c|c|c|c|c|}
\hline $\begin{array}{l}T \\
{ }^{\circ} \mathrm{C}\end{array}$ & $\begin{array}{c}E \\
\mu V\end{array}$ & $\underset{\mu V /{ }^{\circ} \mathrm{C}}{S}$ & $\begin{array}{l}d S / d T \\
n V / c^{2}\end{array}$ & ${ }^{\circ} \mathrm{C}$ & $\begin{array}{c}E \\
\mu V\end{array}$ & $\begin{array}{c}S \\
\mu \mathrm{V} /{ }^{\circ} \mathrm{C}\end{array}$ & $\begin{array}{l}d S / d T \\
n V /{ }^{\circ} C^{2}\end{array}$ & $\begin{array}{l}\mathrm{T} \\
{ }^{\circ} \mathrm{C}\end{array}$ & $\begin{array}{c}E \\
\mu V\end{array}$ & $\begin{array}{c}S \\
\mu V /{ }^{\circ} \mathrm{C}\end{array}$ & $\begin{array}{l}d S / d T \\
n V /{ }^{\circ} C^{2}\end{array}$ \\
\hline $\begin{array}{l}180 \\
181 \\
182 \\
183 \\
184\end{array}$ & $\begin{array}{l}1130.87 \\
1137.95 \\
1145.03 \\
1152.13 \\
1159.22\end{array}$ & $\begin{array}{l}7.078 \\
7.083 \\
7.089 \\
7.094 \\
7.099\end{array}$ & $\begin{array}{l}5.34 \\
5.30 \\
5.26 \\
5.22 \\
5.18\end{array}$ & $\begin{array}{l}240 \\
241 \\
242 \\
243 \\
244\end{array}$ & $\begin{array}{l}1563.82 \\
1571.15 \\
1578.49 \\
1585.83 \\
1593.18\end{array}$ & $\begin{array}{l}7.333 \\
7.337 \\
7.340 \\
7.343 \\
7.346\end{array}$ & $\begin{array}{l}3.32 \\
3.29 \\
3.27 \\
3.24 \\
3.21\end{array}$ & $\begin{array}{l}300 \\
301 \\
302 \\
303 \\
304\end{array}$ & $\begin{array}{l}2008.95 \\
2016.44 \\
2023.93 \\
2031.43 \\
2038.93\end{array}$ & $\begin{array}{l}7.492 \\
7.494 \\
7.496 \\
7.498 \\
7.500\end{array}$ & $\begin{array}{l}2.08 \\
2.07 \\
2.05 \\
2.04 \\
2.02\end{array}$ \\
\hline $\begin{array}{l}185 \\
186 \\
187 \\
188 \\
189\end{array}$ & $\begin{array}{l}1166.32 \\
1173.43 \\
1180.54 \\
1187.66 \\
1194.78\end{array}$ & $\begin{array}{l}7.104 \\
7.109 \\
7.115 \\
7.120 \\
7.125\end{array}$ & $\begin{array}{l}5.14 \\
5.10 \\
5.06 \\
5.02 \\
4.98\end{array}$ & $\begin{array}{l}245 \\
246 \\
247 \\
248 \\
249\end{array}$ & $\begin{array}{l}1600.52 \\
1607.88 \\
1615.23 \\
1622.59 \\
1629.95\end{array}$ & $\begin{array}{l}7.350 \\
7.353 \\
7.356 \\
7.359 \\
7.362\end{array}$ & $\begin{array}{l}3.19 \\
3.16 \\
3.14 \\
3.11 \\
3.09\end{array}$ & $\begin{array}{l}305 \\
306 \\
307 \\
308 \\
309\end{array}$ & $\begin{array}{l}2046.43 \\
2053.93 \\
2061.44 \\
2068.95 \\
2076.46\end{array}$ & $\begin{array}{l}7.502 \\
7.504 \\
7.506 \\
7.508 \\
7.510\end{array}$ & $\begin{array}{l}2.01 \\
1.99 \\
1.98 \\
1.96 \\
1.95\end{array}$ \\
\hline $\begin{array}{l}190 \\
191 \\
192 \\
193 \\
194\end{array}$ & $\begin{array}{l}1201.91 \\
1209.04 \\
1216.18 \\
1223.32 \\
1230.47\end{array}$ & $\begin{array}{l}7.130 \\
7.134 \\
7.139 \\
7.144 \\
7.149\end{array}$ & $\begin{array}{l}4.94 \\
4.90 \\
4.86 \\
4.82 \\
4.78\end{array}$ & $\begin{array}{l}250 \\
251 \\
252 \\
253 \\
254\end{array}$ & $\begin{array}{l}1637.31 \\
1644.68 \\
1652.05 \\
1659.42 \\
1666.80\end{array}$ & $\begin{array}{l}7 \cdot 365 \\
7 \cdot 368 \\
7 \cdot 371 \\
7 \cdot 374 \\
7.377\end{array}$ & $\begin{array}{l}3.06 \\
3.04 \\
3.02 \\
2.99 \\
2.97\end{array}$ & $\begin{array}{l}310 \\
311 \\
312 \\
313 \\
314\end{array}$ & $\begin{array}{l}2083.97 \\
2091.48 \\
2099.00 \\
2106.51 \\
2114.03\end{array}$ & $\begin{array}{l}7.512 \\
7.514 \\
7.516 \\
7.518 \\
7.520\end{array}$ & $\begin{array}{l}1.94 \\
1.92 \\
1.91 \\
1.89 \\
1.88\end{array}$ \\
\hline $\begin{array}{l}195 \\
196 \\
197 \\
198 \\
199\end{array}$ & $\begin{array}{l}1237.62 \\
1244.77 \\
1251.93 \\
1259.10 \\
1266.27\end{array}$ & $\begin{array}{l}7.154 \\
7.158 \\
7.163 \\
7.168 \\
7.172\end{array}$ & $\begin{array}{l}4.75 \\
4.71 \\
4.67 \\
4.63 \\
4.60\end{array}$ & $\begin{array}{l}255 \\
256 \\
257 \\
258 \\
259\end{array}$ & $\begin{array}{l}1674.18 \\
1681.56 \\
1688.94 \\
1696.33 \\
1703.72\end{array}$ & $\begin{array}{l}7.380 \\
7.383 \\
7.386 \\
7.389 \\
7.392\end{array}$ & $\begin{array}{l}2.95 \\
2.92 \\
2.90 \\
2.88 \\
2.85\end{array}$ & $\begin{array}{l}315 \\
316 \\
317 \\
318 \\
319\end{array}$ & $\begin{array}{l}2121.55 \\
2129.07 \\
2136.60 \\
2144.13 \\
2151.65\end{array}$ & $\begin{array}{l}7.522 \\
7.523 \\
7.525 \\
7.527 \\
7.529\end{array}$ & $\begin{array}{l}1.87 \\
1.85 \\
1.84 \\
1.83 \\
1.82\end{array}$ \\
\hline $\begin{array}{l}200 \\
201 \\
202 \\
203 \\
204\end{array}$ & $\begin{array}{l}1273.44 \\
1280.62 \\
1287.81 \\
1295.00 \\
1302.19\end{array}$ & $\begin{array}{l}7.177 \\
7.182 \\
7.186 \\
7.191 \\
7.195\end{array}$ & $\begin{array}{l}4.56 \\
4.53 \\
4.49 \\
4.45 \\
4.42\end{array}$ & $\begin{array}{l}260 \\
261 \\
262 \\
263 \\
264\end{array}$ & $\begin{array}{l}1711.11 \\
1718.51 \\
1725.91 \\
1733.31 \\
1740.71\end{array}$ & $\begin{array}{l}7.395 \\
7.397 \\
7.400 \\
7.403 \\
7.406\end{array}$ & $\begin{array}{l}2.83 \\
2.81 \\
2.79 \\
2.77 \\
2.74\end{array}$ & $\begin{array}{l}320 \\
321 \\
322 \\
323 \\
324\end{array}$ & $\begin{array}{l}2159.18 \\
2166.71 \\
2174.25 \\
2181.78 \\
2189.32\end{array}$ & $\begin{array}{l}7.531 \\
7.533 \\
7.534 \\
7.536 \\
7.538\end{array}$ & $\begin{array}{l}1.80 \\
1.79 \\
1.78 \\
1.77 \\
1.75\end{array}$ \\
\hline $\begin{array}{l}205 \\
206 \\
207 \\
208 \\
209\end{array}$ & $\begin{array}{l}1309.39 \\
1316.59 \\
1323.79 \\
1331.00 \\
1338.22\end{array}$ & $\begin{array}{l}7.199 \\
7.204 \\
7.208 \\
7.212 \\
7.217\end{array}$ & $\begin{array}{l}4.38 \\
4.35 \\
4.32 \\
4.28 \\
4.25\end{array}$ & $\begin{array}{l}265 \\
266 \\
267 \\
268 \\
269\end{array}$ & $\begin{array}{l}1748.12 \\
1755.53 \\
1762.94 \\
1770.36 \\
1777.78\end{array}$ & $\begin{array}{l}7.409 \\
7.411 \\
7.414 \\
7.417 \\
7.419\end{array}$ & $\begin{array}{l}2.72 \\
2.70 \\
2.68 \\
2.66 \\
2.64\end{array}$ & $\begin{array}{l}325 \\
326 \\
327 \\
328 \\
329\end{array}$ & $\begin{array}{l}2196.86 \\
2204.40 \\
2211.94 \\
2219.49 \\
2227.03\end{array}$ & $\begin{array}{l}7.540 \\
7.541 \\
7.543 \\
7.545 \\
7.547\end{array}$ & $\begin{array}{l}1.74 \\
1.73 \\
1.72 \\
1.71 \\
1.70\end{array}$ \\
\hline $\begin{array}{l}210 \\
211 \\
212 \\
213 \\
214\end{array}$ & $\begin{array}{l}1345.44 \\
1352.66 \\
1359.89 \\
1367.12 \\
1374.35\end{array}$ & $\begin{array}{l}7.221 \\
7.225 \\
7.229 \\
7.233 \\
7.237\end{array}$ & $\begin{array}{l}4.21 \\
4.18 \\
4.15 \\
4.11 \\
4.08\end{array}$ & $\begin{array}{l}270 \\
271 \\
272 \\
273 \\
274\end{array}$ & $\begin{array}{l}1785.20 \\
1792.62 \\
1800.05 \\
1807.47 \\
1814.91\end{array}$ & $\begin{array}{l}7.422 \\
7.424 \\
7.427 \\
7.430 \\
7.432\end{array}$ & $\begin{array}{l}2.62 \\
2.60 \\
2.58 \\
2.56 \\
2.54\end{array}$ & $\begin{array}{l}330 \\
331 \\
332 \\
333 \\
334\end{array}$ & $\begin{array}{l}2234.58 \\
2242.13 \\
2249.68 \\
2257.23 \\
2264.79\end{array}$ & $\begin{array}{l}7.548 \\
7.550 \\
7.552 \\
7.553 \\
7.555\end{array}$ & $\begin{array}{l}1.68 \\
1.67 \\
1.66 \\
1.65 \\
1.64\end{array}$ \\
\hline $\begin{array}{l}215 \\
216 \\
217 \\
218 \\
219\end{array}$ & $\begin{array}{l}1381.59 \\
1388.84 \\
1396.08 \\
1403.34 \\
1410.59\end{array}$ & $\begin{array}{l}7.242 \\
7.246 \\
7.250 \\
7.254 \\
7.257\end{array}$ & $\begin{array}{l}4.05 \\
4.02 \\
3.99 \\
3.95 \\
3.92\end{array}$ & $\begin{array}{l}275 \\
276 \\
277 \\
278 \\
279\end{array}$ & $\begin{array}{l}1822.34 \\
1829.77 \\
1837.21 \\
1844.65 \\
1852.10\end{array}$ & $\begin{array}{l}7.435 \\
7.437 \\
7.440 \\
7.442 \\
7.445\end{array}$ & $\begin{array}{l}2.52 \\
2.50 \\
2.48 \\
2.46 \\
2.44\end{array}$ & $\begin{array}{l}335 \\
336 \\
337 \\
338 \\
339\end{array}$ & $\begin{array}{l}2272.34 \\
2279.90 \\
2287.46 \\
2295.02 \\
2302.58\end{array}$ & $\begin{array}{l}7.556 \\
7.558 \\
7.560 \\
7.561 \\
7.563\end{array}$ & $\begin{array}{l}1.63 \\
1.62 \\
1.61 \\
1.60 \\
1.59\end{array}$ \\
\hline $\begin{array}{l}220 \\
221 \\
222 \\
223 \\
224\end{array}$ & $\begin{array}{l}1417.85 \\
1425.11 \\
1432.38 \\
1439.65 \\
1446.93\end{array}$ & $\begin{array}{l}7.261 \\
7.265 \\
7.269 \\
7.273 \\
7.277\end{array}$ & $\begin{array}{l}3.89 \\
3.86 \\
3.83 \\
3.80 \\
3.77\end{array}$ & $\begin{array}{l}280 \\
281 \\
282 \\
283 \\
284\end{array}$ & $\begin{array}{l}1859.54 \\
1866.99 \\
1874.44 \\
1881.90 \\
1889.35\end{array}$ & $\begin{array}{l}7.447 \\
7.449 \\
7.452 \\
7.454 \\
7.457\end{array}$ & $\begin{array}{l}2.42 \\
2.40 \\
2.39 \\
2.37 \\
2.35\end{array}$ & $\begin{array}{l}340 \\
341 \\
342 \\
343 \\
344\end{array}$ & $\begin{array}{l}2310.14 \\
2317.71 \\
2325.28 \\
2332.84 \\
2340.41\end{array}$ & $\begin{array}{l}7.564 \\
7.566 \\
7.568 \\
7.569 \\
7.571\end{array}$ & $\begin{array}{l}1.58 \\
1.57 \\
1.56 \\
1.55 \\
1.54\end{array}$ \\
\hline $\begin{array}{l}225 \\
226 \\
227 \\
228 \\
229\end{array}$ & $\begin{array}{l}1454.21 \\
1461.49 \\
1468.77 \\
1476.06 \\
1483.36\end{array}$ & $\begin{array}{l}7.280 \\
7.284 \\
7.288 \\
7.292 \\
7.295\end{array}$ & $\begin{array}{l}3.74 \\
3.71 \\
3.68 \\
3.65 \\
3.62\end{array}$ & $\begin{array}{l}285 \\
286 \\
287 \\
288 \\
289\end{array}$ & $\begin{array}{l}1896.81 \\
1904.27 \\
1911.73 \\
1919.20 \\
1926.66\end{array}$ & $\begin{array}{l}7.459 \\
7.461 \\
7.464 \\
7.466 \\
7.468\end{array}$ & $\begin{array}{l}2.33 \\
2.31 \\
2.30 \\
2.28 \\
2.26\end{array}$ & $\begin{array}{l}345 \\
346 \\
347 \\
348 \\
349\end{array}$ & $\begin{array}{l}2347.99 \\
2355.56 \\
2363.13 \\
2370.71 \\
2378.29\end{array}$ & $\begin{array}{l}7.572 \\
7.574 \\
7.575 \\
7.577 \\
7.578\end{array}$ & $\begin{array}{l}1.53 \\
1.52 \\
1.51 \\
1.50 \\
1.49\end{array}$ \\
\hline $\begin{array}{l}230 \\
231 \\
232 \\
233 \\
234\end{array}$ & $\begin{array}{l}1490.65 \\
1497.95 \\
1505.26 \\
1512.57 \\
1519.88\end{array}$ & $\begin{array}{l}7.299 \\
7.302 \\
7.306 \\
7.309 \\
7.313\end{array}$ & $\begin{array}{l}3.59 \\
3.56 \\
3.54 \\
3.51 \\
3.48\end{array}$ & $\begin{array}{l}290 \\
291 \\
292 \\
293 \\
294\end{array}$ & $\begin{array}{l}1934.13 \\
1941.60 \\
1949.08 \\
1956.55 \\
1964.03\end{array}$ & $\begin{array}{l}7.470 \\
7.473 \\
7.475 \\
7.477 \\
7.479\end{array}$ & $\begin{array}{l}2.24 \\
2.23 \\
2.21 \\
2.19 \\
2.18\end{array}$ & $\begin{array}{l}350 \\
351 \\
352 \\
353 \\
354\end{array}$ & $\begin{array}{l}2385.87 \\
2393.45 \\
2401.03 \\
2408.61 \\
2416.20\end{array}$ & $\begin{array}{l}7.580 \\
7.581 \\
7.583 \\
7.584 \\
7.586\end{array}$ & $\begin{array}{l}1.48 \\
1.47 \\
1.46 \\
1.46 \\
1.45\end{array}$ \\
\hline $\begin{array}{l}235 \\
236 \\
237 \\
238 \\
239\end{array}$ & $\begin{array}{l}1527.19 \\
1534.51 \\
1541.83 \\
1549.16 \\
1556.48\end{array}$ & $\begin{array}{l}7.316 \\
7.320 \\
7.323 \\
7.327 \\
7.330\end{array}$ & $\begin{array}{l}3.45 \\
3.43 \\
3.40 \\
3.37 \\
3.34\end{array}$ & $\begin{array}{l}295 \\
296 \\
297 \\
298 \\
299\end{array}$ & $\begin{array}{l}1971.51 \\
1978.99 \\
1986.48 \\
1993.97 \\
2001.45\end{array}$ & $\begin{array}{l}7.481 \\
7.484 \\
7.486 \\
7.488 \\
7.490\end{array}$ & $\begin{array}{l}2.16 \\
2.15 \\
2.13 \\
2.11 \\
2.10\end{array}$ & $\begin{array}{l}355 \\
356 \\
357 \\
358 \\
359\end{array}$ & $\begin{array}{l}2423.78 \\
2431.37 \\
2438.96 \\
2446.55 \\
2454.14\end{array}$ & $\begin{array}{l}7.587 \\
7.589 \\
7.590 \\
7.591 \\
7.593\end{array}$ & $\begin{array}{l}1.44 \\
1.43 \\
1.42 \\
1.41 \\
1.41\end{array}$ \\
\hline 240 & 1563.82 & 7.333 & 3.32 & 300 & 2008.95 & 7.492 & 2.08 & 360 & 2461.74 & 7.594 & 1.40 \\
\hline
\end{tabular}


TABLE 4.5.2. Type BN thermoelements versus platinum, Pt-67-thermoelectric voltages, E(T), Seebeck coefficients, $\mathrm{S}(\mathrm{T})$, and first derivative of the Seebeck coefficients, $\mathrm{dS} / \mathrm{dT}$, reference junctions at $O{ }^{\circ} \mathrm{C}$-Continued

\begin{tabular}{|c|c|c|c|c|c|c|c|c|c|c|c|}
\hline${ }^{\circ} \mathrm{C}$ & ${ }_{\mu V}^{E}$ & $\stackrel{\mathrm{S}}{\mu \mathrm{V} /{ }^{\circ} \mathrm{C}}$ & $\begin{array}{l}\mathrm{dS} / \mathrm{dT} \\
\mathrm{nV} /{ }^{\circ} \mathrm{C}^{2}\end{array}$ & ${ }^{\circ} \mathrm{C}$ & $\begin{array}{l}E \\
\mu V\end{array}$ & $\underset{\mu V /{ }^{\circ} \mathrm{C}}{S}$ & $\begin{array}{l}\mathrm{dS} / \mathrm{dT} \\
\mathrm{nV} /{ }^{\circ} \mathrm{C}^{2}\end{array}$ & $\begin{array}{l}\mathrm{T} \\
{ }^{\circ} \mathrm{C}\end{array}$ & $\underset{\mu V}{E}$ & $\stackrel{S}{\mu V^{\circ} \mathrm{C}}$ & $\begin{array}{l}d S / d T \\
n V /{ }^{\circ} C^{2}\end{array}$ \\
\hline $\begin{array}{l}365 \\
366 \\
367 \\
368 \\
369\end{array}$ & $\begin{array}{l}2499.72 \\
2507.33 \\
2514.93 \\
2522.53 \\
2530.14\end{array}$ & $\begin{array}{l}7.601 \\
7.602 \\
7.604 \\
7.605 \\
7.606\end{array}$ & $\begin{array}{l}1.36 \\
1.35 \\
1.34 \\
1.34 \\
1.33\end{array}$ & $\begin{array}{l}425 \\
426 \\
427 \\
428 \\
429\end{array}$ & $\begin{array}{l}2958.02 \\
2965.69 \\
2973.36 \\
2981.04 \\
2988.71\end{array}$ & $\begin{array}{l}7.672 \\
7.673 \\
7.675 \\
7.676 \\
7.677\end{array}$ & $\begin{array}{l}1.07 \\
1.06 \\
1.06 \\
1.06 \\
1.06\end{array}$ & $\begin{array}{l}485 \\
486 \\
487 \\
488 \\
489\end{array}$ & $\begin{array}{l}3420.21 \\
3427.95 \\
3435.68 \\
3443.42 \\
3451.16\end{array}$ & $\begin{array}{l}7.734 \\
7.735 \\
7.736 \\
7.737 \\
7.738\end{array}$ & $\begin{array}{l}1.00 \\
1.00 \\
1.00 \\
1.00 \\
1.00\end{array}$ \\
\hline $\begin{array}{l}370 \\
371 \\
372 \\
373 \\
374\end{array}$ & $\begin{array}{l}2537.75 \\
2545.35 \\
2552.96 \\
2560.58 \\
2568.19\end{array}$ & $\begin{array}{l}7.608 \\
7.609 \\
7.610 \\
7.612 \\
7.613\end{array}$ & $\begin{array}{l}1.32 \\
1.32 \\
1.31 \\
1.30 \\
1.30\end{array}$ & $\begin{array}{l}430 \\
431 \\
432 \\
433 \\
434\end{array}$ & $\begin{array}{l}2996.39 \\
3004.07 \\
3011.75 \\
3019.43 \\
3027.11\end{array}$ & $\begin{array}{l}7.678 \\
7.679 \\
7.680 \\
7.681 \\
7.682\end{array}$ & $\begin{array}{l}1.05 \\
1.05 \\
1.05 \\
1.05 \\
1.04\end{array}$ & $\begin{array}{l}490 \\
491 \\
492 \\
493 \\
494\end{array}$ & $\begin{array}{l}3458.89 \\
3466.63 \\
3474.37 \\
3482.11 \\
3489.86\end{array}$ & $\begin{array}{l}7.739 \\
7.740 \\
7.741 \\
7.742 \\
7.743\end{array}$ & $\begin{array}{l}1.00 \\
1.00 \\
1.00 \\
1.00 \\
1.00\end{array}$ \\
\hline $\begin{array}{l}380 \\
381 \\
382 \\
383 \\
384\end{array}$ & $\begin{array}{l}2613.89 \\
2621.51 \\
2629.13 \\
2636.76 \\
2644.38\end{array}$ & $\begin{array}{l}7.621 \\
7.622 \\
7.623 \\
7.624 \\
7.626\end{array}$ & $\begin{array}{l}1.26 \\
1.25 \\
1.25 \\
1.24 \\
1.24\end{array}$ & $\begin{array}{l}440 \\
441 \\
442 \\
443 \\
444\end{array}$ & $\begin{array}{l}3073.22 \\
3080.91 \\
3088.60 \\
3096.29 \\
3103.98\end{array}$ & $\begin{array}{l}7.688 \\
7.689 \\
7.690 \\
7.691 \\
7.692\end{array}$ & $\begin{array}{l}1.03 \\
1.03 \\
1.03 \\
1.03 \\
1.03\end{array}$ & $\begin{array}{l}500 \\
501 \\
502 \\
503 \\
504\end{array}$ & $\begin{array}{l}3536.33 \\
3544.08 \\
3551.83 \\
3559.58 \\
3567.33\end{array}$ & $\begin{array}{l}7.749 \\
7.750 \\
7.751 \\
7.752 \\
7.753\end{array}$ & $\begin{array}{l}1.00 \\
1.00 \\
1.01 \\
1.01 \\
1.01\end{array}$ \\
\hline $\begin{array}{l}385 \\
386 \\
387 \\
388 \\
389\end{array}$ & $\begin{array}{l}2652.01 \\
2659.64 \\
2667.26 \\
2674.89 \\
2682.53\end{array}$ & $\begin{array}{l}7.627 \\
7.628 \\
7.629 \\
7.631 \\
7.632\end{array}$ & $\begin{array}{l}1.23 \\
1.22 \\
1.22 \\
1.21 \\
1.21\end{array}$ & $\begin{array}{l}445 \\
446 \\
447 \\
448 \\
449\end{array}$ & $\begin{array}{l}3111.67 \\
3119.37 \\
3127.06 \\
3134.76 \\
3142.46\end{array}$ & $\begin{array}{l}7.693 \\
7.694 \\
7.695 \\
7.696 \\
7.697\end{array}$ & $\begin{array}{l}1.02 \\
1.02 \\
1.02 \\
1.02 \\
1.02\end{array}$ & $\begin{array}{l}505 \\
506 \\
507 \\
508 \\
509\end{array}$ & $\begin{array}{l}3575.09 \\
3582.84 \\
3590.59 \\
3598.35 \\
3606.11\end{array}$ & $\begin{array}{l}7.754 \\
7.755 \\
7.756 \\
7.757 \\
7.758\end{array}$ & $\begin{array}{l}1.01 \\
1.01 \\
1.01 \\
1.01 \\
1.01\end{array}$ \\
\hline $\begin{array}{l}390 \\
391 \\
392 \\
393 \\
394\end{array}$ & $\begin{array}{l}2690.16 \\
2697.79 \\
2705.43 \\
2713.06 \\
2720.70\end{array}$ & $\begin{array}{l}7.633 \\
7.634 \\
7.635 \\
7.637 \\
7.638\end{array}$ & $\begin{array}{l}1.20 \\
1.20 \\
1.19 \\
1.19 \\
1.18\end{array}$ & $\begin{array}{l}450 \\
451 \\
452 \\
453 \\
454\end{array}$ & $\begin{array}{l}3150.15 \\
3157.85 \\
3165.55 \\
3173.25 \\
3180.96\end{array}$ & $\begin{array}{l}7.698 \\
7.699 \\
7.700 \\
7.701 \\
7.702\end{array}$ & $\begin{array}{l}1.02 \\
1.02 \\
1.01 \\
1.01 \\
1.01\end{array}$ & $\begin{array}{l}510 \\
511 \\
512 \\
513 \\
514\end{array}$ & $\begin{array}{l}3613.87 \\
3621.62 \\
3629.38 \\
3637.15 \\
3644.91\end{array}$ & $\begin{array}{l}7.759 \\
7.760 \\
7.761 \\
7.762 \\
7.763\end{array}$ & $\begin{array}{l}1.01 \\
1.01 \\
1.01 \\
1.01 \\
1.02\end{array}$ \\
\hline $\begin{array}{l}400 \\
401 \\
402 \\
403 \\
404\end{array}$ & $\begin{array}{l}2766.55 \\
2774.19 \\
2781.84 \\
2789.49 \\
2797.13\end{array}$ & $\begin{array}{l}7.645 \\
7.646 \\
7.647 \\
7.648 \\
7.649\end{array}$ & $\begin{array}{l}1.15 \\
1.15 \\
1.15 \\
1.14 \\
1.14\end{array}$ & $\begin{array}{l}460 \\
461 \\
462 \\
463 \\
464\end{array}$ & $\begin{array}{l}3227.19 \\
3234.90 \\
3242.61 \\
3250.32 \\
3258.03\end{array}$ & $\begin{array}{l}7.709 \\
7.710 \\
7.711 \\
7.712 \\
7.713\end{array}$ & $\begin{array}{l}1.01 \\
1.01 \\
1.00 \\
1.00 \\
1.00\end{array}$ & $\begin{array}{l}520 \\
521 \\
522 \\
523 \\
524\end{array}$ & $\begin{array}{l}3691.50 \\
3699.27 \\
3707.04 \\
3714.81 \\
3722.59\end{array}$ & $\begin{array}{l}7.769 \\
7.770 \\
7.771 \\
7.772 \\
7.773\end{array}$ & $\begin{array}{l}1.02 \\
1.02 \\
1.02 \\
1.03 \\
1.03\end{array}$ \\
\hline $\begin{array}{l}405 \\
406 \\
407 \\
408 \\
409\end{array}$ & $\begin{array}{l}2804.78 \\
2812.44 \\
2820.09 \\
2827.74 \\
2835.40\end{array}$ & $\begin{array}{l}7.650 \\
7.652 \\
7.653 \\
7.654 \\
7.655\end{array}$ & $\begin{array}{l}1.13 \\
1.13 \\
1.13 \\
1.12 \\
1.12\end{array}$ & $\begin{array}{l}465 \\
466 \\
467 \\
468 \\
469\end{array}$ & $\begin{array}{l}3265.74 \\
3273.46 \\
3281.17 \\
3288.89 \\
3296.61\end{array}$ & $\begin{array}{l}7.714 \\
7.715 \\
7.716 \\
7.717 \\
7.718\end{array}$ & $\begin{array}{l}1.00 \\
1.00 \\
1.00 \\
1.00 \\
1.00\end{array}$ & $\begin{array}{l}525 \\
526 \\
527 \\
528 \\
529\end{array}$ & $\begin{array}{l}3730.36 \\
3738.13 \\
3745.91 \\
3753.69 \\
3761.46\end{array}$ & $\begin{array}{l}7.774 \\
7.775 \\
7.776 \\
7.777 \\
7.778\end{array}$ & $\begin{array}{l}1.03 \\
1.03 \\
1.03 \\
1.03 \\
1.03\end{array}$ \\
\hline $\begin{array}{l}410 \\
411 \\
412 \\
413 \\
414\end{array}$ & $\begin{array}{l}2843.05 \\
2850.71 \\
2858.37 \\
2866.02 \\
2873.68\end{array}$ & $\begin{array}{l}7.656 \\
7.657 \\
7.658 \\
7.659 \\
7.661\end{array}$ & $\begin{array}{l}1.11 \\
1.11 \\
1.11 \\
1.10 \\
1.10\end{array}$ & $\begin{array}{l}470 \\
471 \\
472 \\
473 \\
474\end{array}$ & $\begin{array}{l}3304.32 \\
3312.04 \\
3319.76 \\
3327.48 \\
3335.21\end{array}$ & $\begin{array}{l}7.719 \\
7.720 \\
7.721 \\
7.722 \\
7.723\end{array}$ & $\begin{array}{l}1.00 \\
1.00 \\
1.00 \\
1.00 \\
1.00\end{array}$ & $\begin{array}{l}530 \\
531 \\
532 \\
533 \\
534\end{array}$ & $\begin{array}{l}3769.24 \\
3777.02 \\
3784.80 \\
3792.58 \\
3800.37\end{array}$ & $\begin{array}{l}7.779 \\
7.780 \\
7.781 \\
7.782 \\
7.783\end{array}$ & $\begin{array}{l}1.03 \\
1.04 \\
1.04 \\
1.04 \\
1.04\end{array}$ \\
\hline $\begin{array}{l}415 \\
416 \\
417 \\
418 \\
419\end{array}$ & $\begin{array}{l}2881.35 \\
2889.01 \\
2896.67 \\
2904.34 \\
2912.00\end{array}$ & $\begin{array}{l}7.662 \\
7.663 \\
7.664 \\
7.665 \\
7.666\end{array}$ & $\begin{array}{l}1.10 \\
1.09 \\
1.09 \\
1.09 \\
1.08\end{array}$ & $\begin{array}{l}475 \\
476 \\
477 \\
478 \\
479\end{array}$ & $\begin{array}{l}3342.93 \\
3350.65 \\
3358.38 \\
3366.10 \\
3373.83\end{array}$ & $\begin{array}{l}7.724 \\
7.725 \\
7.726 \\
7.727 \\
7.728\end{array}$ & $\begin{array}{l}1.00 \\
1.00 \\
1.00 \\
1.00 \\
1.00\end{array}$ & $\begin{array}{l}535 \\
536 \\
537 \\
538 \\
539\end{array}$ & $\begin{array}{l}3808.15 \\
3815.93 \\
3823.72 \\
3831.51 \\
3839.30\end{array}$ & $\begin{array}{l}7.784 \\
7.785 \\
7.786 \\
7.787 \\
7.788\end{array}$ & $\begin{array}{l}1.04 \\
1.04 \\
1.04 \\
1.05 \\
1.05\end{array}$ \\
\hline 420 & 2919.67 & 7.667 & 1.08 & 480 & 3381.56 & 7.729 & 1.00 & 540 & 3847.08 & 7.789 & 1.05 \\
\hline
\end{tabular}


TABLE 4.5.2. Type BN thermoelements versus platinum, $\mathrm{Pl}-67$-thermoelectric voltages, $\mathrm{E}(\mathrm{T})$, Seebeck coefficients, $\mathrm{S}(\mathrm{T})$, and first derivative of the Seebeck coefficients, $\mathrm{dS} / \mathrm{dT}$, reference junctions at $0{ }^{\circ} \mathrm{C}-$ Continued

\begin{tabular}{|c|c|c|c|c|c|c|c|c|c|c|c|}
\hline${ }^{\circ} \mathrm{C}$ & $\begin{array}{c}E \\
\mu V\end{array}$ & $\stackrel{S}{\mu V /{ }^{\circ} \mathrm{C}}$ & $\begin{array}{l}\mathrm{dS} / \mathrm{dT} \\
\mathrm{nV} /{ }^{\circ} \mathrm{C}^{2}\end{array}$ & $\begin{array}{r}{ }^{\top} \\
{ }^{\circ} \mathrm{C}\end{array}$ & $\underset{\mu V}{E}$ & $\stackrel{S}{\mu V^{\circ}{ }^{\circ} \mathrm{C}}$ & $\begin{array}{l}d S / d T \\
n V /{ }^{\circ} C^{2}\end{array}$ & ${ }^{\circ} \mathrm{C}$ & $\begin{array}{c}E \\
\mu V\end{array}$ & $\begin{array}{c}\mathrm{S} \\
\mu \mathrm{V} /{ }^{\circ} \mathrm{C}\end{array}$ & $\begin{array}{l}d S / d T \\
n V /{ }^{\circ} C^{2}\end{array}$ \\
\hline $\begin{array}{l}540 \\
541 \\
542 \\
543 \\
544\end{array}$ & $\begin{array}{l}3847.08 \\
3854.87 \\
3862.67 \\
3870.46 \\
3878.25\end{array}$ & $\begin{array}{l}7.789 \\
7.791 \\
7.792 \\
7.793 \\
7.794\end{array}$ & $\begin{array}{l}1.05 \\
1.05 \\
1.05 \\
1.05 \\
1.06\end{array}$ & $\begin{array}{l}600 \\
601 \\
602 \\
603 \\
604\end{array}$ & $\begin{array}{l}4316.41 \\
4324 \cdot 26 \\
4332.12 \\
4339 \cdot 98 \\
4347.84\end{array}$ & $\begin{array}{l}7.856 \\
7.857 \\
7.858 \\
7.859 \\
7.860\end{array}$ & $\begin{array}{l}1.17 \\
1.17 \\
1.17 \\
1.17 \\
1.18\end{array}$ & $\begin{array}{l}660 \\
661 \\
662 \\
663 \\
664\end{array}$ & $\begin{array}{l}4789.94 \\
4797.87 \\
4805.80 \\
4813.74 \\
4821.67\end{array}$ & $\begin{array}{l}7.930 \\
7.931 \\
7.933 \\
7.934 \\
7.935\end{array}$ & $\begin{array}{l}1.31 \\
1.31 \\
1.31 \\
1.31 \\
1.32\end{array}$ \\
\hline $\begin{array}{l}545 \\
546 \\
547 \\
548 \\
549\end{array}$ & $\begin{array}{l}3886.04 \\
3893.84 \\
3901.64 \\
3909.43 \\
3917.23\end{array}$ & $\begin{array}{l}7.795 \\
7.796 \\
7.797 \\
7.798 \\
7.799\end{array}$ & $\begin{array}{l}1.06 \\
1.06 \\
1.06 \\
1.06 \\
1.06\end{array}$ & $\begin{array}{l}605 \\
606 \\
607 \\
608 \\
609\end{array}$ & $\begin{array}{l}4355.70 \\
4363.56 \\
4371.43 \\
4379.29 \\
4387.16\end{array}$ & $\begin{array}{l}7.862 \\
7.863 \\
7.864 \\
7.865 \\
7.866\end{array}$ & $\begin{array}{l}1.18 \\
1.18 \\
1.18 \\
1.19 \\
1.19\end{array}$ & $\begin{array}{l}665 \\
666 \\
667 \\
668 \\
669\end{array}$ & $\begin{array}{l}4829.61 \\
4837.54 \\
4845.48 \\
4853.42 \\
4861.36\end{array}$ & $\begin{array}{l}7.937 \\
7.938 \\
7.939 \\
7.941 \\
7.942\end{array}$ & $\begin{array}{l}1.32 \\
1.32 \\
1.32 \\
1.33 \\
1.33\end{array}$ \\
\hline $\begin{array}{l}550 \\
551 \\
552 \\
553 \\
554\end{array}$ & $\begin{array}{l}3925.03 \\
3932.83 \\
3940.63 \\
3948.44 \\
3956.24\end{array}$ & $\begin{array}{l}7.800 \\
7.801 \\
7.802 \\
7.803 \\
7.804\end{array}$ & $\begin{array}{l}1.07 \\
1.07 \\
1.07 \\
1.07 \\
1.07\end{array}$ & $\begin{array}{l}610 \\
611 \\
612 \\
613 \\
614\end{array}$ & $\begin{array}{l}4395.02 \\
4402.89 \\
4410.76 \\
4418.63 \\
4426.50\end{array}$ & $\begin{array}{l}7.868 \\
7.869 \\
7.870 \\
7.871 \\
7.872\end{array}$ & $\begin{array}{l}1.19 \\
1.19 \\
1.20 \\
1.20 \\
1.20\end{array}$ & $\begin{array}{l}670 \\
671 \\
672 \\
673 \\
674\end{array}$ & $\begin{array}{l}4869.31 \\
4877.25 \\
4885.19 \\
4893.14 \\
4901.09\end{array}$ & $\begin{array}{l}7.943 \\
7.945 \\
7.946 \\
7.947 \\
7.949\end{array}$ & $\begin{array}{l}1.33 \\
1.33 \\
1 \cdot 33 \\
1.34 \\
1.34\end{array}$ \\
\hline $\begin{array}{l}560 \\
561 \\
562 \\
563 \\
564\end{array}$ & $\begin{array}{l}4003.09 \\
4010 \cdot 90 \\
4018 \cdot 71 \\
4026.52 \\
4034.34\end{array}$ & $\begin{array}{l}7.811 \\
7.812 \\
7.813 \\
7.814 \\
7.815\end{array}$ & $\begin{array}{l}1.08 \\
1.09 \\
1.09 \\
1.09 \\
1.09\end{array}$ & $\begin{array}{l}620 \\
621 \\
622 \\
623 \\
624\end{array}$ & $\begin{array}{l}4473 \cdot 76 \\
4481 \cdot 64 \\
4489 \cdot 52 \\
4497 \cdot 40 \\
4505.29\end{array}$ & $\begin{array}{l}7.880 \\
7.881 \\
7.882 \\
7.883 \\
7.884\end{array}$ & $\begin{array}{l}1.21 \\
1.22 \\
1.22 \\
1.22 \\
1.22\end{array}$ & $\begin{array}{l}680 \\
681 \\
682 \\
683 \\
684\end{array}$ & $\begin{array}{l}4948.80 \\
4956.76 \\
4964.72 \\
4972.68 \\
4980.64\end{array}$ & $\begin{array}{l}7.957 \\
7.958 \\
7.959 \\
7.961 \\
7.962\end{array}$ & $\begin{array}{l}1.35 \\
1.35 \\
1.36 \\
1.36 \\
1.36\end{array}$ \\
\hline $\begin{array}{l}565 \\
566 \\
567 \\
568 \\
569\end{array}$ & $\begin{array}{l}4042.15 \\
4049.97 \\
4057.79 \\
4065.61 \\
4073.43\end{array}$ & $\begin{array}{l}7.816 \\
7.817 \\
7.818 \\
7.820 \\
7.821\end{array}$ & $\begin{array}{l}1.09 \\
1.10 \\
1.10 \\
1.10 \\
1.10\end{array}$ & $\begin{array}{l}625 \\
626 \\
627 \\
628 \\
629\end{array}$ & $\begin{array}{l}4513.17 \\
4521.06 \\
4528.95 \\
4536.83 \\
4544.72\end{array}$ & $\begin{array}{l}7.886 \\
7.887 \\
7.888 \\
7.889 \\
7.891\end{array}$ & $\begin{array}{l}1.23 \\
1.23 \\
1.23 \\
1.23 \\
1.23\end{array}$ & $\begin{array}{l}685 \\
686 \\
687 \\
688 \\
689\end{array}$ & $\begin{array}{l}4988.60 \\
4996.57 \\
5004.53 \\
5012.50 \\
5020.47\end{array}$ & $\begin{array}{l}7.963 \\
7.965 \\
7.966 \\
7.968 \\
7.969\end{array}$ & $\begin{array}{l}1.36 \\
1.37 \\
1.37 \\
1.37 \\
1.37\end{array}$ \\
\hline $\begin{array}{l}570 \\
571 \\
572 \\
573 \\
574\end{array}$ & $\begin{array}{l}4081.25 \\
4089.07 \\
4096.89 \\
4104.72 \\
4112.54\end{array}$ & $\begin{array}{l}7.822 \\
7.823 \\
7.824 \\
7.825 \\
7.826\end{array}$ & $\begin{array}{l}1.10 \\
1.11 \\
1.11 \\
1.11 \\
1.11\end{array}$ & $\begin{array}{l}630 \\
631 \\
632 \\
633 \\
634\end{array}$ & $\begin{array}{l}4552.62 \\
4560.51 \\
4568.40 \\
4576.30 \\
4584.19\end{array}$ & $\begin{array}{l}7.892 \\
7.893 \\
7.894 \\
7.896 \\
7.897\end{array}$ & $\begin{array}{l}1.24 \\
1.24 \\
1.24 \\
1.24 \\
1.25\end{array}$ & $\begin{array}{l}690 \\
691 \\
692 \\
693 \\
694\end{array}$ & $\begin{array}{l}5028.44 \\
5036.41 \\
5044.38 \\
5052.36 \\
5060.33\end{array}$ & $\begin{array}{l}7.970 \\
7.972 \\
7.973 \\
7.974 \\
7.976\end{array}$ & $\begin{array}{l}1.37 \\
1.38 \\
1.38 \\
1.38 \\
1.38\end{array}$ \\
\hline $\begin{array}{l}580 \\
581 \\
582 \\
583 \\
584\end{array}$ & $\begin{array}{l}4159 \cdot 52 \\
4167.35 \\
4175.19 \\
4183.02 \\
4190.86\end{array}$ & $\begin{array}{r}7.833 \\
7.834 \\
7.835 \\
7.836 \\
7.837\end{array}$ & $\begin{array}{l}1.12 \\
1.13 \\
1.13 \\
1.13 \\
1.13\end{array}$ & $\begin{array}{l}640 \\
641 \\
642 \\
643 \\
644\end{array}$ & $\begin{array}{l}4631.60 \\
4639 \cdot 50 \\
4647.41 \\
4655.32 \\
4663.22\end{array}$ & $\begin{array}{l}7.904 \\
7.906 \\
7.907 \\
7.908 \\
7.909\end{array}$ & $\begin{array}{l}1.26 \\
1.26 \\
1.27 \\
1.27 \\
1.27\end{array}$ & $\begin{array}{l}700 \\
701 \\
702 \\
703 \\
704\end{array}$ & $\begin{array}{l}5108 \cdot 21 \\
5116.19 \\
5124.18 \\
5132.17 \\
5140.16\end{array}$ & $\begin{array}{l}7.984 \\
7.986 \\
7.987 \\
7.988 \\
7.990\end{array}$ & $\begin{array}{l}1.40 \\
1.40 \\
1.40 \\
1.40 \\
1.40\end{array}$ \\
\hline $\begin{array}{l}585 \\
586 \\
587 \\
588 \\
589\end{array}$ & $\begin{array}{l}4198 \cdot 70 \\
4206 \cdot 54 \\
4214 \cdot 38 \\
4222.22 \\
4230.06\end{array}$ & $\begin{array}{l}7.839 \\
7.840 \\
7.841 \\
7.842 \\
7.843\end{array}$ & $\begin{array}{l}1.13 \\
1.14 \\
1.14 \\
1.14 \\
1.14\end{array}$ & $\begin{array}{l}645 \\
646 \\
647 \\
648 \\
649\end{array}$ & $\begin{array}{l}4671.13 \\
4679.05 \\
4686.96 \\
4694 \cdot 87 \\
4702.79\end{array}$ & $\begin{array}{l}7.911 \\
7.912 \\
7.913 \\
7.915 \\
7.916\end{array}$ & $\begin{array}{l}1.27 \\
1.27 \\
1.28 \\
1.28 \\
1.28\end{array}$ & $\begin{array}{l}705 \\
706 \\
707 \\
708 \\
709\end{array}$ & $\begin{array}{l}5148.15 \\
5156.14 \\
5164.13 \\
5172.13 \\
5180.12\end{array}$ & $\begin{array}{l}7.991 \\
7.993 \\
7.994 \\
7.995 \\
7.997\end{array}$ & $\begin{array}{l}1.41 \\
1.41 \\
1.41 \\
1.41 \\
1.42\end{array}$ \\
\hline $\begin{array}{l}590 \\
591 \\
592 \\
593 \\
594\end{array}$ & $\begin{array}{l}4237.91 \\
4245.75 \\
4253.60 \\
4261.44 \\
4269.29\end{array}$ & $\begin{array}{l}7.844 \\
7.845 \\
7.847 \\
7.848 \\
7.849\end{array}$ & $\begin{array}{l}1.15 \\
1.15 \\
1.15 \\
1.15 \\
1.15\end{array}$ & $\begin{array}{l}650 \\
651 \\
652 \\
653 \\
654\end{array}$ & $\begin{array}{l}4710.70 \\
4718.62 \\
4726.54 \\
4734.46 \\
4742.38\end{array}$ & $\begin{array}{l}7.917 \\
7.918 \\
7.920 \\
7.921 \\
7.922\end{array}$ & $\begin{array}{l}1.28 \\
1.29 \\
1.29 \\
1.29 \\
1.29\end{array}$ & $\begin{array}{l}710 \\
711 \\
712 \\
713 \\
714\end{array}$ & $\begin{array}{l}5188 \cdot 12 \\
5196 \cdot 12 \\
5204 \cdot 12 \\
5212 \cdot 12 \\
5220.13\end{array}$ & $\begin{array}{l}7.998 \\
8.000 \\
8.001 \\
8.002 \\
8.004\end{array}$ & $\begin{array}{l}1.42 \\
1.42 \\
1.42 \\
1.42 \\
1.43\end{array}$ \\
\hline $\begin{array}{l}595 \\
596 \\
597 \\
598 \\
599\end{array}$ & $\begin{array}{l}4277.14 \\
4284.99 \\
4292.84 \\
4300.70 \\
4308.55\end{array}$ & $\begin{array}{l}7.850 \\
7.851 \\
7.852 \\
7.853 \\
7.855\end{array}$ & $\begin{array}{l}1.16 \\
1.16 \\
1.16 \\
1.16 \\
1.17\end{array}$ & $\begin{array}{l}655 \\
656 \\
657 \\
658 \\
659\end{array}$ & $\begin{array}{l}4750.31 \\
4758.23 \\
4766.15 \\
4774.08 \\
4782.01\end{array}$ & $\begin{array}{l}7.924 \\
7.925 \\
7.926 \\
7.927 \\
7.929\end{array}$ & $\begin{array}{l}1.30 \\
1.30 \\
1.30 \\
1.30 \\
1.30\end{array}$ & $\begin{array}{l}715 \\
716 \\
717 \\
718 \\
719\end{array}$ & $\begin{array}{l}5228 \cdot 13 \\
5236 \cdot 14 \\
5244 \cdot 14 \\
5252 \cdot 15 \\
5260.16\end{array}$ & $\begin{array}{l}8.005 \\
8.007 \\
8.008 \\
8.010 \\
8.011\end{array}$ & $\begin{array}{l}1.43 \\
1.43 \\
1.43 \\
1.43 \\
1.44\end{array}$ \\
\hline 0 & 4316.41 & 7.856 & 17 & 660 & 4789.94 & 0 & 1.31 & 720 & 268.17 & 2 & 1.44 \\
\hline
\end{tabular}


TABLE 4.5.2. Type BN thermoelements versus platinum, Pt-67-thermoelectric voltages, $\mathrm{E}(\mathrm{T})$, Seebeck coefficients, $\mathrm{S}(\mathrm{T})$, and first derivative of the Seebeck coefficients, $\mathrm{dS} / \mathrm{dT}$,

reference junctions at $0{ }^{\circ} \mathrm{C}$-Continued

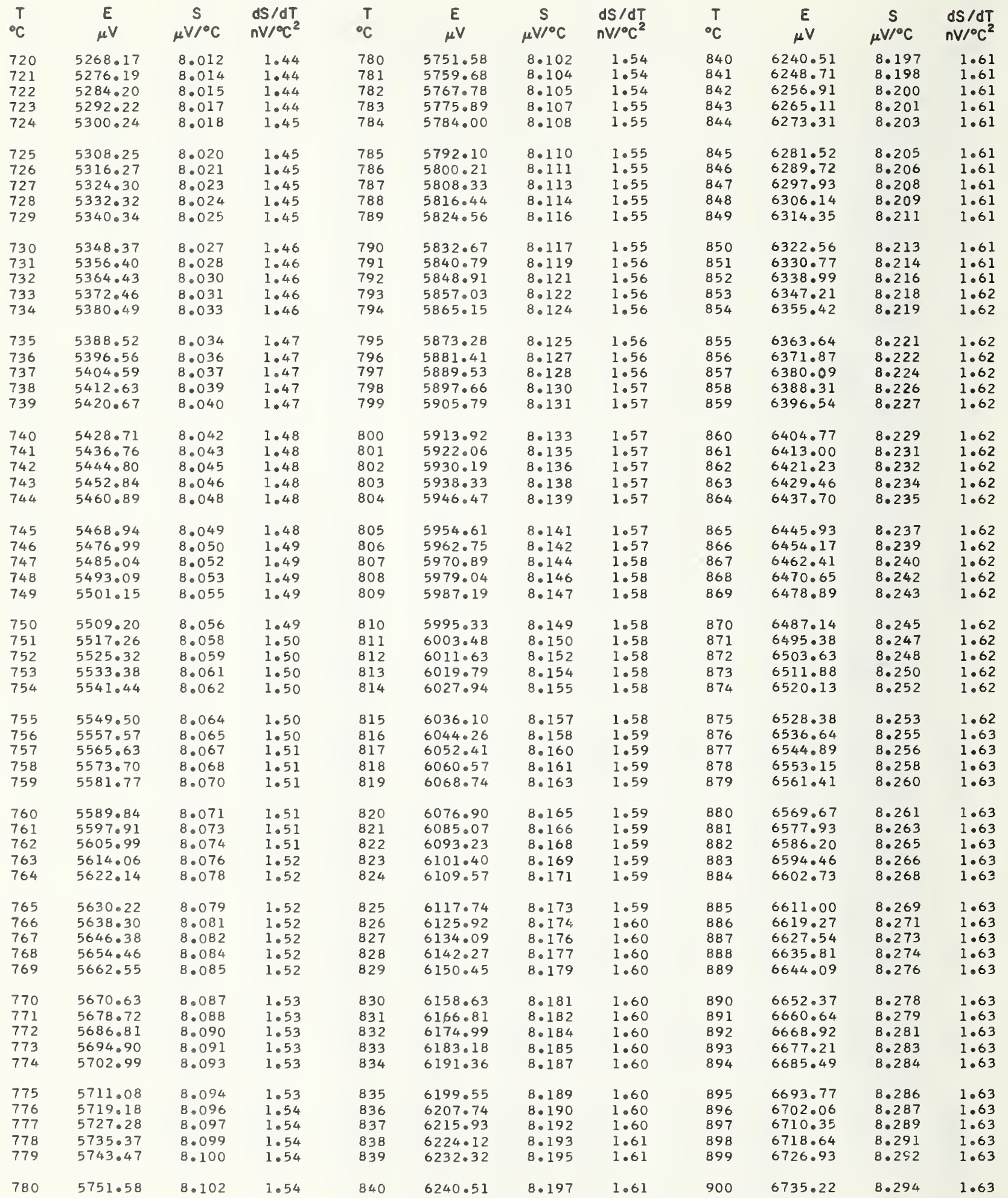


TABLE 4.5.2. Type BN thermoelements versus platinum, $\mathbf{P t}-67$-thermoelectric voltages, $\mathrm{E}(\mathrm{T})$, Seebeck coefficients, $\mathrm{S}(\mathrm{T})$, and first derivative of the Seebeck coefficients, $\mathrm{dS} / \mathrm{dT}$,

reference junctions at $0{ }^{\circ} \mathrm{C}$-Continued

\begin{tabular}{|c|c|c|c|c|c|c|c|c|c|c|c|}
\hline${ }^{\circ} \mathrm{T}$ & $\underset{\mu V}{E}$ & $\underset{\mu V /{ }^{\circ} \mathrm{C}}{S}$ & $\begin{array}{l}d S / d T \\
n V /{ }^{\circ} C^{2}\end{array}$ & ${ }^{\top} \mathrm{T}$ & $\underset{\mu}{E} V$ & $\underset{\mu \mathrm{V} /{ }^{\circ} \mathrm{C}}{\mathrm{S}}$ & $\begin{array}{l}d S / d T \\
n V /{ }^{\circ} C^{2}\end{array}$ & ${ }^{\top} \mathrm{T}$ & $\underset{\mu V}{E}$ & $\begin{array}{c}S \\
\mu V /{ }^{\circ} \mathrm{C}\end{array}$ & $\begin{array}{l}d S / d T \\
n V /{ }^{\circ} C^{2}\end{array}$ \\
\hline $\begin{array}{l}900 \\
901 \\
902 \\
903 \\
904\end{array}$ & $\begin{array}{l}6735.22 \\
6743.52 \\
6751.81 \\
6760.11 \\
6768.41\end{array}$ & $\begin{array}{l}8.294 \\
8.296 \\
8.297 \\
8.299 \\
8.300\end{array}$ & $\begin{array}{l}1.63 \\
1.63 \\
1.63 \\
1.63 \\
1.63\end{array}$ & $\begin{array}{l}960 \\
961 \\
962 \\
963 \\
964\end{array}$ & $\begin{array}{l}7235.78 \\
7244.17 \\
7252.56 \\
7260.96 \\
7269.35\end{array}$ & $\begin{array}{l}8.391 \\
8.393 \\
8.394 \\
8.396 \\
8.397\end{array}$ & $\begin{array}{l}1.60 \\
1.60 \\
1.59 \\
1.59 \\
1.59\end{array}$ & $\begin{array}{l}1020 \\
1021 \\
1022 \\
1023 \\
1024\end{array}$ & $\begin{array}{l}7742.06 \\
7750.55 \\
7759.03 \\
7767.52 \\
7776.01\end{array}$ & $\begin{array}{l}8.484 \\
8.486 \\
8.487 \\
8.489 \\
8.490\end{array}$ & $\begin{array}{l}1.51 \\
1.51 \\
1.50 \\
1.50 \\
1.50\end{array}$ \\
\hline $\begin{array}{l}905 \\
906 \\
907 \\
908 \\
909\end{array}$ & $\begin{array}{l}6776.71 \\
6785.02 \\
6793.32 \\
6801.63 \\
6809.93\end{array}$ & $\begin{array}{l}8.302 \\
8.304 \\
8.305 \\
8.307 \\
8.309\end{array}$ & $\begin{array}{l}1.63 \\
1.63 \\
1.63 \\
1.63 \\
1.63\end{array}$ & $\begin{array}{l}965 \\
966 \\
967 \\
968 \\
969\end{array}$ & $\begin{array}{l}7277.75 \\
7286.15 \\
7294.55 \\
7302.95 \\
7311.36\end{array}$ & $\begin{array}{l}8.399 \\
8.400 \\
8.402 \\
8.404 \\
8.405\end{array}$ & $\begin{array}{l}1.59 \\
1.59 \\
1.59 \\
1.59 \\
1.59\end{array}$ & $\begin{array}{l}1025 \\
1026 \\
1027 \\
1028 \\
1029\end{array}$ & $\begin{array}{l}7784.50 \\
7793.00 \\
7801.49 \\
7809.98 \\
7818.48\end{array}$ & $\begin{array}{l}8.492 \\
8.493 \\
8.495 \\
8.496 \\
8.498\end{array}$ & $\begin{array}{l}1.50 \\
1.50 \\
1.49 \\
1.49 \\
1.49\end{array}$ \\
\hline $\begin{array}{l}910 \\
911 \\
912 \\
913 \\
914\end{array}$ & $\begin{array}{l}6818.24 \\
6826.55 \\
6834.87 \\
6843.18 \\
6851.50\end{array}$ & $\begin{array}{l}8.310 \\
8.312 \\
8.313 \\
8.315 \\
8.317\end{array}$ & $\begin{array}{l}1.63 \\
1.63 \\
1.63 \\
1.63 \\
1.63\end{array}$ & $\begin{array}{l}970 \\
971 \\
972 \\
973 \\
974\end{array}$ & $\begin{array}{l}7319.77 \\
7328.17 \\
7336.58 \\
7344.99 \\
7353.41\end{array}$ & $\begin{array}{l}8.407 \\
8.408 \\
8.410 \\
8.412 \\
8.413\end{array}$ & $\begin{array}{l}1.59 \\
1.59 \\
1.58 \\
1.58 \\
1.58\end{array}$ & $\begin{array}{l}1030 \\
1031 \\
1032 \\
1033 \\
1034\end{array}$ & $\begin{array}{l}7826.98 \\
7835.48 \\
7843.98 \\
7852.49 \\
7860.99\end{array}$ & $\begin{array}{l}8.499 \\
8.501 \\
8.502 \\
8.504 \\
8.505\end{array}$ & $\begin{array}{l}1.49 \\
1.48 \\
1.48 \\
1.48 \\
1.48\end{array}$ \\
\hline $\begin{array}{l}915 \\
916 \\
917 \\
918 \\
919\end{array}$ & $\begin{array}{l}6859 \cdot 81 \\
6868.13 \\
6876.45 \\
6884.78 \\
6893.10\end{array}$ & $\begin{array}{l}8.318 \\
8.320 \\
8.322 \\
8.323 \\
8.325\end{array}$ & $\begin{array}{l}1.63 \\
1.62 \\
1.62 \\
1.62 \\
1.62\end{array}$ & $\begin{array}{l}975 \\
976 \\
977 \\
978 \\
979\end{array}$ & $\begin{array}{l}7361.82 \\
7370.23 \\
7378.65 \\
7387.07 \\
7395.49\end{array}$ & $\begin{array}{l}8.415 \\
8.416 \\
8.418 \\
8.419 \\
8.421\end{array}$ & $\begin{array}{l}1.58 \\
1.58 \\
1.58 \\
1.58 \\
1.58\end{array}$ & $\begin{array}{l}1035 \\
1036 \\
1037 \\
1038 \\
1039\end{array}$ & $\begin{array}{l}7869.50 \\
7878.00 \\
7886.51 \\
7895.02 \\
7903.53\end{array}$ & $\begin{array}{l}8.507 \\
8.508 \\
8.510 \\
8.511 \\
8.513\end{array}$ & $\begin{array}{l}1.48 \\
1.47 \\
1.47 \\
1.47 \\
1.47\end{array}$ \\
\hline $\begin{array}{l}920 \\
921 \\
922 \\
923 \\
924\end{array}$ & $\begin{array}{l}6901.43 \\
6909.75 \\
6918.08 \\
6926.41 \\
6934.74\end{array}$ & $\begin{array}{l}8.326 \\
8.328 \\
8.330 \\
8.331 \\
8.333\end{array}$ & $\begin{array}{l}1.62 \\
1.62 \\
1.62 \\
1.62 \\
1.62\end{array}$ & $\begin{array}{l}980 \\
981 \\
982 \\
983 \\
984\end{array}$ & $\begin{array}{l}7403.91 \\
7412.34 \\
7420.76 \\
7429.19 \\
7437.62\end{array}$ & $\begin{array}{l}8.423 \\
8.424 \\
8.426 \\
8.427 \\
8.429\end{array}$ & $\begin{array}{l}1.57 \\
1.57 \\
1.57 \\
1.57 \\
1.57\end{array}$ & $\begin{array}{l}1040 \\
1041 \\
1042 \\
1043 \\
1044\end{array}$ & $\begin{array}{l}7912.05 \\
7920.56 \\
7929.08 \\
7937.60 \\
7946.12\end{array}$ & $\begin{array}{l}8.514 \\
8.516 \\
8.517 \\
8.518 \\
8.520\end{array}$ & $\begin{array}{l}1.46 \\
1.46 \\
1.46 \\
1.46 \\
1.45\end{array}$ \\
\hline $\begin{array}{l}925 \\
926 \\
927 \\
928 \\
929\end{array}$ & $\begin{array}{l}6943.08 \\
6951.41 \\
6959.75 \\
6968.09 \\
6976.43\end{array}$ & $\begin{array}{l}8.335 \\
8.336 \\
8.338 \\
8.339 \\
8.341\end{array}$ & $\begin{array}{l}1.62 \\
1.62 \\
1.62 \\
1.62 \\
1.62\end{array}$ & $\begin{array}{l}985 \\
986 \\
987 \\
988 \\
989\end{array}$ & $\begin{array}{l}7446.05 \\
7454.48 \\
7462.91 \\
7471.34 \\
7479.78\end{array}$ & $\begin{array}{l}8.430 \\
8.432 \\
8.434 \\
8.435 \\
8.437\end{array}$ & $\begin{array}{l}1.57 \\
1.57 \\
1.56 \\
1.56 \\
1.56\end{array}$ & $\begin{array}{l}1045 \\
1046 \\
1047 \\
1048 \\
1049\end{array}$ & $\begin{array}{l}7954.64 \\
7963.16 \\
7971.68 \\
7980.21 \\
7988.73\end{array}$ & $\begin{array}{l}8.521 \\
8.523 \\
8.524 \\
8.526 \\
8.527\end{array}$ & $\begin{array}{l}1.45 \\
1.45 \\
1.45 \\
1.44 \\
1.44\end{array}$ \\
\hline $\begin{array}{l}930 \\
931 \\
932 \\
933 \\
934\end{array}$ & $\begin{array}{l}6984 \cdot 77 \\
6993.11 \\
7001.46 \\
7009.81 \\
7018.15\end{array}$ & $\begin{array}{l}8.343 \\
8.344 \\
8.346 \\
8.347 \\
8.349\end{array}$ & $\begin{array}{l}1.62 \\
1.62 \\
1.62 \\
1.62 \\
1.62\end{array}$ & $\begin{array}{l}990 \\
991 \\
992 \\
993 \\
994\end{array}$ & $\begin{array}{l}7488 \cdot 22 \\
7496.66 \\
7505.10 \\
7513.54 \\
7521.98\end{array}$ & $\begin{array}{l}8.438 \\
8.440 \\
8.441 \\
8.443 \\
8.445\end{array}$ & $\begin{array}{l}1.56 \\
1.56 \\
1.56 \\
1.56 \\
1.55\end{array}$ & $\begin{array}{l}1050 \\
1051 \\
1052 \\
1053 \\
1054\end{array}$ & $\begin{array}{l}7997.26 \\
8005.79 \\
8014.32 \\
8022.85 \\
8031.39\end{array}$ & $\begin{array}{l}8.529 \\
8.530 \\
8.531 \\
8.533 \\
8.534\end{array}$ & $\begin{array}{l}1.44 \\
1.44 \\
1.43 \\
1.43 \\
1.43\end{array}$ \\
\hline $\begin{array}{l}935 \\
936 \\
937 \\
938 \\
939\end{array}$ & $\begin{array}{l}7026.50 \\
7034.86 \\
7043.21 \\
7051.56 \\
7059.92\end{array}$ & $\begin{array}{l}8.351 \\
8.352 \\
8.354 \\
8.356 \\
8.357\end{array}$ & $\begin{array}{l}1.62 \\
1.62 \\
1.62 \\
1.61 \\
1.61\end{array}$ & $\begin{array}{l}995 \\
996 \\
997 \\
998 \\
999\end{array}$ & $\begin{array}{l}7530.43 \\
7538.88 \\
7547.32 \\
7555.77 \\
7564.23\end{array}$ & $\begin{array}{l}8.446 \\
8.448 \\
8.449 \\
8.451 \\
8.452\end{array}$ & $\begin{array}{l}1.55 \\
1.55 \\
1.55 \\
1.55 \\
1.55\end{array}$ & $\begin{array}{l}1055 \\
1056 \\
1057 \\
1058 \\
1059\end{array}$ & $\begin{array}{l}8039.92 \\
8048.46 \\
8057.00 \\
8065.54 \\
8074.08\end{array}$ & $\begin{array}{l}8.536 \\
8.537 \\
8.539 \\
8.540 \\
8.541\end{array}$ & $\begin{array}{l}1.43 \\
1.42 \\
1.42 \\
1.42 \\
1.42\end{array}$ \\
\hline $\begin{array}{l}940 \\
941 \\
942 \\
943 \\
944\end{array}$ & $\begin{array}{l}7068.28 \\
7076.64 \\
7085.00 \\
7093.36 \\
7101.73\end{array}$ & $\begin{array}{l}8.359 \\
8.360 \\
8.362 \\
8.364 \\
8.365\end{array}$ & $\begin{array}{l}1.61 \\
1.61 \\
1.61 \\
1.61 \\
1.61\end{array}$ & $\begin{array}{l}1000 \\
1001 \\
1002 \\
1003 \\
1004\end{array}$ & $\begin{array}{l}7572.68 \\
7581.13 \\
7589.59 \\
7598.05 \\
7606.51\end{array}$ & $\begin{array}{l}8.454 \\
8.455 \\
8.457 \\
8.458 \\
8.460\end{array}$ & $\begin{array}{l}1.54 \\
1.54 \\
1.54 \\
1.54 \\
1.54\end{array}$ & $\begin{array}{l}1060 \\
1061 \\
1062 \\
1063 \\
1064\end{array}$ & $\begin{array}{l}8082.62 \\
8091.16 \\
8099.71 \\
8108.25 \\
8116.80\end{array}$ & $\begin{array}{l}8.543 \\
8.544 \\
8.546 \\
8.547 \\
8.549\end{array}$ & $\begin{array}{l}1.41 \\
1.41 \\
1.41 \\
1.40 \\
1.40\end{array}$ \\
\hline $\begin{array}{l}945 \\
946 \\
947 \\
948 \\
949\end{array}$ & $\begin{array}{l}7110.09 \\
7118.46 \\
7126.83 \\
7135.20 \\
7143.57\end{array}$ & $\begin{array}{l}8 \cdot 367 \\
8 \cdot 368 \\
8 \cdot 370 \\
8 \cdot 372 \\
8.373\end{array}$ & $\begin{array}{l}1.61 \\
1.61 \\
1.61 \\
1.61 \\
1.61\end{array}$ & $\begin{array}{l}1005 \\
1006 \\
1007 \\
1008 \\
1009\end{array}$ & $\begin{array}{l}7614.97 \\
7623.43 \\
7631.89 \\
7640.36 \\
7648.83\end{array}$ & $\begin{array}{l}8.462 \\
8.463 \\
8.465 \\
8.466 \\
8.468\end{array}$ & $\begin{array}{l}1.54 \\
1.53 \\
1.53 \\
1.53 \\
1.53\end{array}$ & $\begin{array}{l}1065 \\
1066 \\
1067 \\
1068 \\
1069\end{array}$ & $\begin{array}{l}8125.35 \\
8133.90 \\
8142.45 \\
8151.01 \\
8159.56\end{array}$ & $\begin{array}{l}8.550 \\
8.551 \\
8.553 \\
8.554 \\
8.555\end{array}$ & $\begin{array}{l}1.40 \\
1.40 \\
1.39 \\
1.39 \\
1.39\end{array}$ \\
\hline $\begin{array}{l}950 \\
951 \\
952 \\
953 \\
954\end{array}$ & $\begin{array}{l}7151.95 \\
7160.32 \\
7168.70 \\
7177.08 \\
7185.46\end{array}$ & $\begin{array}{l}8.375 \\
8.377 \\
8.378 \\
8.380 \\
8.381\end{array}$ & $\begin{array}{l}1.61 \\
1.61 \\
1.60 \\
1.60 \\
1.60\end{array}$ & $\begin{array}{l}1010 \\
1011 \\
1012 \\
1013 \\
1014\end{array}$ & $\begin{array}{l}7657 \cdot 29 \\
7665 \cdot 76 \\
7674.24 \\
7682.71 \\
7691 \cdot 18\end{array}$ & $\begin{array}{l}8.469 \\
8.471 \\
8.472 \\
8.474 \\
8.475\end{array}$ & $\begin{array}{l}1.53 \\
1.53 \\
1.52 \\
1.52 \\
1.52\end{array}$ & $\begin{array}{l}1070 \\
1071 \\
1072 \\
1073 \\
1074\end{array}$ & $\begin{array}{l}8168.12 \\
8176.68 \\
8185.24 \\
8193.80 \\
8202.36\end{array}$ & $\begin{array}{l}8.557 \\
8.558 \\
8.560 \\
8.561 \\
8.562\end{array}$ & $\begin{array}{l}1.38 \\
1.38 \\
1.38 \\
1.37 \\
1.37\end{array}$ \\
\hline $\begin{array}{l}955 \\
956 \\
957 \\
958 \\
959\end{array}$ & $\begin{array}{l}7193.84 \\
7202.23 \\
7210.61 \\
7219.00 \\
7227.39\end{array}$ & $\begin{array}{l}8.383 \\
8.385 \\
8.386 \\
8.388 \\
8.389\end{array}$ & $\begin{array}{l}1.60 \\
1.60 \\
1.60 \\
1.60 \\
1.60\end{array}$ & $\begin{array}{l}1015 \\
1016 \\
1017 \\
1018 \\
1019\end{array}$ & $\begin{array}{l}7699 \cdot 66 \\
7708 \cdot 14 \\
7716 \cdot 62 \\
7725 \cdot 10 \\
7733.58\end{array}$ & $\begin{array}{l}8.477 \\
8.478 \\
8.480 \\
8.481 \\
8.483\end{array}$ & $\begin{array}{l}1.52 \\
1.52 \\
1.51 \\
1.51 \\
1.51\end{array}$ & $\begin{array}{l}1075 \\
1076 \\
1077 \\
1078 \\
1079\end{array}$ & $\begin{array}{l}8210.92 \\
8219.48 \\
8228.05 \\
8236.62 \\
8245.19\end{array}$ & $\begin{array}{l}8.564 \\
8.565 \\
8.566 \\
8.568 \\
8.569\end{array}$ & $\begin{array}{l}1.37 \\
1.37 \\
1.36 \\
1.36 \\
1.36\end{array}$ \\
\hline 960 & 7235 & 8.391 & 1.60 & 1020 & 7742 & 8.484 & 1.51 & 1080 & 3253. & 8.571 & \\
\hline
\end{tabular}


TABLE 4.5.2. Type BN thermoelements versus platinum, $\mathrm{Pt}-67$-thermoelectric voltages, $\mathrm{E}(\mathrm{T})$, Seebeck coefficients, $\mathrm{S}(\mathrm{T})$, and first derivative of the Seebeck coefficients, $\mathrm{dS} / \mathrm{dT}$,

reference junctions at $\mathrm{O}^{\circ} \mathrm{C}$-Continued

\begin{tabular}{|c|c|c|c|c|c|c|c|c|c|c|}
\hline$E_{\mu V}$ & $\mu \stackrel{S}{S}$ & $\begin{array}{l}\mathrm{dS} / \mathrm{dT} \\
\mathrm{nV} /{ }^{\circ} \mathrm{C}^{2}\end{array}$ & ${ }^{\circ} \mathrm{T}$ & $\underset{\mu V}{E}$ & $\mu \stackrel{S}{S}{ }^{\circ} \mathrm{C}$ & $\begin{array}{l}\mathrm{dS} / \mathrm{dT} \\
\mathrm{nV} /{ }^{\circ} \mathrm{C}^{2}\end{array}$ & ${ }^{\top} \mathrm{C}$ & $\underset{\mu V}{E}$ & $\mu \stackrel{S}{S} /^{\circ} \mathrm{C}$ & $\begin{array}{l}\mathrm{dS} / \mathrm{dT} \\
\mathrm{nV} /{ }^{\circ} \mathrm{C}^{2}\end{array}$ \\
\hline $\begin{array}{l}8296.63 \\
8305.20 \\
8313.78 \\
8322.36 \\
8330.95\end{array}$ & $\begin{array}{l}8.577 \\
8.579 \\
8.580 \\
8.581 \\
8.583\end{array}$ & $\begin{array}{l}1.34 \\
1.33 \\
1.33 \\
1.33 \\
1.32\end{array}$ & $\begin{array}{l}1145 \\
1146 \\
1147 \\
1148 \\
1149\end{array}$ & $\begin{array}{l}8813 \cdot 54 \\
8822.19 \\
8830.84 \\
8839 \cdot 50 \\
8848.15\end{array}$ & $\begin{array}{l}8.651 \\
8.652 \\
8.653 \\
8.654 \\
8.655\end{array}$ & $\begin{array}{l}1.10 \\
1.10 \\
1.09 \\
1.09 \\
1.08\end{array}$ & $\begin{array}{l}1205 \\
1206 \\
1207 \\
1208 \\
1209\end{array}$ & $\begin{array}{l}9334.39 \\
9343.10 \\
9351.81 \\
9360.52 \\
9369.23\end{array}$ & $\begin{array}{l}8.708 \\
8.708 \\
8.709 \\
8.710 \\
8.711\end{array}$ & $\begin{array}{l}0.78 \\
0.77 \\
0.77 \\
0.76 \\
0.76\end{array}$ \\
\hline $\begin{array}{l}8339.53 \\
8348.11 \\
8356.70 \\
8365.29 \\
8373.88\end{array}$ & $\begin{array}{l}8.584 \\
8.585 \\
8.587 \\
8.588 \\
8.589\end{array}$ & $\begin{array}{l}1.32 \\
1.32 \\
1.31 \\
1.31 \\
1.31\end{array}$ & $\begin{array}{l}1150 \\
1151 \\
1152 \\
1153 \\
1154\end{array}$ & $\begin{array}{l}8856.81 \\
8865.46 \\
8874.12 \\
8882.78 \\
8891.44\end{array}$ & $\begin{array}{l}8.656 \\
8.657 \\
8.658 \\
8.659 \\
8.661\end{array}$ & $\begin{array}{l}1.08 \\
1.07 \\
1.07 \\
1.06 \\
1.06\end{array}$ & $\begin{array}{l}1210 \\
1211 \\
1212 \\
1213 \\
1214\end{array}$ & $\begin{array}{l}9377.94 \\
9386.65 \\
9395.36 \\
9404.08 \\
9412.79\end{array}$ & $\begin{array}{l}8.711 \\
8.712 \\
8.713 \\
8.714 \\
8.714\end{array}$ & $\begin{array}{l}0.75 \\
0.74 \\
0.74 \\
0.73 \\
0.72\end{array}$ \\
\hline $\begin{array}{l}8425.43 \\
8434.03 \\
8442.63 \\
8451.23 \\
8459.83\end{array}$ & $\begin{array}{l}8.597 \\
8.598 \\
8.600 \\
8.601 \\
8.602\end{array}$ & $\begin{array}{l}1.29 \\
1.28 \\
1.28 \\
1.27 \\
1.27\end{array}$ & $\begin{array}{l}1160 \\
1161 \\
1162 \\
1163 \\
1164\end{array}$ & $\begin{array}{l}8943.42 \\
8952.09 \\
8960.76 \\
8969.43 \\
8978.10\end{array}$ & $\begin{array}{l}8.667 \\
8.668 \\
8.669 \\
8.670 \\
8.671\end{array}$ & $\begin{array}{l}1.03 \\
1.02 \\
1.02 \\
1.01 \\
1.01\end{array}$ & $\begin{array}{l}1220 \\
1221 \\
1222 \\
1223 \\
1224\end{array}$ & $\begin{array}{l}9465.09 \\
9473.81 \\
9482.53 \\
9491.25 \\
9499.97\end{array}$ & $\begin{array}{l}8.719 \\
9.719 \\
8.720 \\
8.721 \\
8.721\end{array}$ & $\begin{array}{l}0.69 \\
0.68 \\
0.67 \\
0.67 \\
0.66\end{array}$ \\
\hline $\begin{array}{l}8468.43 \\
8477.04 \\
8485.64 \\
8494.25 \\
8502.86\end{array}$ & $\begin{array}{l}8.603 \\
8.605 \\
8.606 \\
8.607 \\
8.608\end{array}$ & $\begin{array}{l}1.27 \\
1.26 \\
1.26 \\
1.26 \\
1.25\end{array}$ & $\begin{array}{l}1165 \\
1166 \\
1167 \\
1168 \\
1169\end{array}$ & $\begin{array}{l}8986.77 \\
8995.44 \\
9004.11 \\
9012.79 \\
9021.46\end{array}$ & $\begin{array}{l}8.672 \\
8.673 \\
8.674 \\
8.675 \\
8.676\end{array}$ & $\begin{array}{l}1.00 \\
1.00 \\
0.99 \\
0.99 \\
0.98\end{array}$ & $\begin{array}{l}1225 \\
1226 \\
1227 \\
1228 \\
1229\end{array}$ & $\begin{array}{l}9508.69 \\
9517.41 \\
9526.14 \\
9534.86 \\
9543.58\end{array}$ & $\begin{array}{l}8.722 \\
8.723 \\
8.723 \\
8.724 \\
8.725\end{array}$ & $\begin{array}{l}0.65 \\
0.65 \\
0.64 \\
0.63 \\
0.63\end{array}$ \\
\hline $\begin{array}{l}8511.47 \\
8520.08 \\
8528.69 \\
8537.30 \\
8545.92\end{array}$ & $\begin{array}{l}8.610 \\
8.611 \\
8.612 \\
8.613 \\
8.615\end{array}$ & $\begin{array}{l}1.25 \\
1.24 \\
1.24 \\
1.24 \\
1.23\end{array}$ & $\begin{array}{l}1170 \\
1171 \\
1172 \\
1173 \\
1174\end{array}$ & $\begin{array}{l}9030.14 \\
9038.82 \\
9047.50 \\
9056.18 \\
9064.86\end{array}$ & $\begin{array}{l}8.677 \\
8.678 \\
8.679 \\
8.680 \\
8.681\end{array}$ & $\begin{array}{l}0.98 \\
0.97 \\
0.97 \\
0.96 \\
0.96\end{array}$ & $\begin{array}{l}1230 \\
1231 \\
1232 \\
1233 \\
1234\end{array}$ & $\begin{array}{l}9552.31 \\
9561.03 \\
9569.76 \\
9578.49 \\
9587.21\end{array}$ & $\begin{array}{l}8.725 \\
8.726 \\
8.726 \\
8.727 \\
8.728\end{array}$ & $\begin{array}{l}0.62 \\
0.61 \\
0.61 \\
0.60 \\
0.59\end{array}$ \\
\hline $\begin{array}{l}8597.62 \\
8606.25 \\
8614.87 \\
8623.50 \\
8632.12\end{array}$ & $\begin{array}{l}8.622 \\
8.623 \\
8.624 \\
8.626 \\
8.627\end{array}$ & $\begin{array}{l}1.21 \\
1.20 \\
1.20 \\
1.20 \\
1.19\end{array}$ & $\begin{array}{l}1180 \\
1181 \\
1182 \\
1183 \\
1184\end{array}$ & $\begin{array}{l}9116.96 \\
9125.64 \\
9134.33 \\
9143.02 \\
9151.71\end{array}$ & $\begin{array}{l}8.686 \\
8.687 \\
8.688 \\
8.689 \\
8.690\end{array}$ & $\begin{array}{l}0.92 \\
0.92 \\
0.91 \\
0.91 \\
0.90\end{array}$ & $\begin{array}{l}1240 \\
1241 \\
1242 \\
1243 \\
1244\end{array}$ & $\begin{array}{l}9639.59 \\
9648.32 \\
9657.05 \\
9665.79 \\
9674.52\end{array}$ & $\begin{array}{l}8.731 \\
8.732 \\
8.732 \\
8.733 \\
8.733\end{array}$ & $\begin{array}{l}0.55 \\
0.55 \\
0.54 \\
0.53 \\
0.52\end{array}$ \\
\hline $\begin{array}{l}8640.75 \\
8649.38 \\
8658.01 \\
8666.64 \\
8675.27\end{array}$ & $\begin{array}{l}8.628 \\
8.629 \\
8.630 \\
8.631 \\
8.633\end{array}$ & $\begin{array}{l}1.19 \\
1.18 \\
1.18 \\
1.18 \\
1.17\end{array}$ & $\begin{array}{l}1185 \\
1186 \\
1187 \\
1188 \\
1189\end{array}$ & $\begin{array}{l}9160.40 \\
9169.09 \\
9177.78 \\
9186.48 \\
9195.17\end{array}$ & $\begin{array}{l}8.691 \\
8.692 \\
8.693 \\
8.694 \\
8.694\end{array}$ & $\begin{array}{l}0.90 \\
0.89 \\
0.89 \\
0.88 \\
0.87\end{array}$ & $\begin{array}{l}1245 \\
1246 \\
1247 \\
1248 \\
1249\end{array}$ & $\begin{array}{l}9683.25 \\
9691.99 \\
9700.72 \\
9709.46 \\
9718.19\end{array}$ & $\begin{array}{l}8.734 \\
8.734 \\
8.735 \\
8.735 \\
8.736\end{array}$ & $\begin{array}{l}0.52 \\
0.51 \\
0.50 \\
0.50 \\
0.49\end{array}$ \\
\hline $\begin{array}{l}8683.90 \\
8692.54 \\
8701.17 \\
8709.81 \\
8718.45\end{array}$ & $\begin{array}{l}8.634 \\
8.635 \\
8.636 \\
8.637 \\
8.638\end{array}$ & $\begin{array}{l}1.17 \\
1.16 \\
1.16 \\
1.15 \\
1.15\end{array}$ & $\begin{array}{l}1190 \\
1191 \\
1192 \\
1193 \\
1194\end{array}$ & $\begin{array}{l}9203.87 \\
9212.56 \\
9221.26 \\
9229.96 \\
9238.65\end{array}$ & $\begin{array}{l}8.695 \\
8.696 \\
8.697 \\
8.698 \\
8.699\end{array}$ & $\begin{array}{l}0.87 \\
0.86 \\
0.86 \\
0.85 \\
0.85\end{array}$ & $\begin{array}{l}1250 \\
1251 \\
1252 \\
1253 \\
1254\end{array}$ & $\begin{array}{l}9726.93 \\
9735.66 \\
9744.40 \\
9753.14 \\
9761.88\end{array}$ & $\begin{array}{l}8.736 \\
8.737 \\
8.737 \\
8.738 \\
8.738\end{array}$ & $\begin{array}{l}0.48 \\
0.47 \\
0.47 \\
0.46 \\
0.45\end{array}$ \\
\hline $\begin{array}{l}8727.09 \\
8735.73 \\
8744.37 \\
8753.01 \\
8761.65\end{array}$ & $\begin{array}{l}8.640 \\
8.641 \\
8.642 \\
8.643 \\
8.644\end{array}$ & $\begin{array}{l}1.15 \\
1.14 \\
1.14 \\
1.13 \\
1.13\end{array}$ & $\begin{array}{l}1195 \\
1196 \\
1197 \\
1198 \\
1199\end{array}$ & $\begin{array}{l}9247.35 \\
9256.05 \\
9264.75 \\
9273.46 \\
9282.16\end{array}$ & $\begin{array}{l}8.700 \\
8.700 \\
8.701 \\
8.702 \\
8.703\end{array}$ & $\begin{array}{l}0.84 \\
0.83 \\
0.83 \\
0.82 \\
0.82\end{array}$ & $\begin{array}{l}1255 \\
1256 \\
1257 \\
1258 \\
1259\end{array}$ & $\begin{array}{l}9770.62 \\
9779.35 \\
9788.09 \\
9796.83 \\
9805.57\end{array}$ & $\begin{array}{l}8.739 \\
8.739 \\
8.739 \\
8.740 \\
8.740\end{array}$ & $\begin{array}{l}0.45 \\
0.44 \\
0.43 \\
0.42 \\
0.42\end{array}$ \\
\hline 8770.30 & $8 \cdot 645$ & $1 \cdot 12$ & 1200 & 9290.86 & 8.704 & 0.81 & 1260 & $9814 \cdot 31$ & 8.741 & 0.41 \\
\hline
\end{tabular}


TABLE 4.5.2. Type BN thermoelements versus platinum, $\mathrm{Pt}-67$-thermoelectric voltages, $\mathrm{E}(\mathrm{T})$, Seebeck coefficients, S(T), and first derivative of the Seebeck coefficients, dS/dT, reference junctions at $0{ }^{\circ} \mathrm{C}$-Continued

\begin{tabular}{|c|c|c|c|c|c|c|c|c|c|c|c|}
\hline${ }^{\circ} \mathrm{C}$ & ${ }_{\mu V}^{E}$ & $\stackrel{S}{S} /{ }^{\circ} \mathrm{C}$ & $\begin{array}{l}d S / d T \\
n V /{ }^{\circ} C^{2}\end{array}$ & ${ }^{\circ} \mathrm{C}$ & $\underset{\mu V}{E}$ & $\underset{\mu V /{ }^{\circ} \mathrm{C}}{S}$ & $\begin{array}{l}d S / d T \\
n V /{ }^{\circ} C^{2}\end{array}$ & ${ }^{\circ} \mathrm{C}$ & $\underset{\mu V}{E}$ & $\stackrel{\mathrm{S}}{\mathrm{S} /{ }^{\circ} \mathrm{C}}$ & $\begin{array}{l}d S / d T \\
n V /{ }^{\circ} C^{2}\end{array}$ \\
\hline 1260 & 9814.31 & 8.741 & 0.41 & 1320 & 10339.21 & 8.751 & -0.08 & 1380 & 10863.77 & 8.729 & -0.66 \\
\hline 1261 & 9823.05 & 8.741 & 0.40 & 1321 & 10347.96 & 8.751 & -0.09 & 1381 & 10872.50 & 8.728 & -0.67 \\
\hline 1262 & 9831.80 & 8.742 & 0.39 & 1322 & 10356.71 & 8.751 & -0.10 & 1382 & 10881.23 & 8.728 & -0.68 \\
\hline 1263 & 9840.54 & 8.742 & 0.39 & 1323 & 10365.46 & 8.751 & -0.11 & 1383 & 10889.96 & 8.727 & -0.69 \\
\hline 1264 & 9849.28 & 8.742 & 0.38 & 1324 & 10374.21 & 8.750 & -0.12 & 1384 & 10898.68 & 8.726 & -0.70 \\
\hline 1265 & 9858.02 & 8.743 & 0.37 & 1325 & 10382.96 & 8.750 & -0.13 & 1385 & 10907.41 & 8.725 & -0.71 \\
\hline 1266 & 9866.76 & 8.743 & 0.36 & 1326 & 10391.71 & 8.750 & -0.14 & 1386 & 10916.14 & 8.725 & -0.72 \\
\hline 1267 & 9875.51 & 8.743 & 0.36 & 1327 & 10400.46 & 8.750 & -0.15 & 1387 & 10924.86 & 8.724 & -0.73 \\
\hline 1268 & 9884.25 & 8.744 & 0.35 & 1328 & 10409.21 & 8.750 & -0.16 & 1388 & 10933.58 & 8.723 & -0.74 \\
\hline 1269 & 9893.00 & 8.744 & 0.34 & 1329 & 10417.96 & 8.750 & -0.17 & 1389 & 10942.31 & 8.723 & -0.75 \\
\hline 1270 & 9901.74 & 8.744 & 0.33 & 1330 & 10426.71 & 8.750 & -0.18 & 1390 & 10951.03 & 8.722 & -0.76 \\
\hline 1271 & 9910.48 & 8.745 & 0.32 & 1331 & 10435.46 & 8.749 & -0.18 & 1391 & 10959.75 & 8.721 & -0.77 \\
\hline 1272 & 9919.23 & 8.745 & 0.32 & 1332 & 10444.21 & 8.749 & -0.19 & 1392 & 10968.47 & 8.720 & -0.78 \\
\hline 1273 & 9927.97 & 8.745 & 0.31 & 1333 & 10452.96 & 8.749 & -0.20 & 1393 & 10977.19 & 8.719 & -0.79 \\
\hline 1274 & 9936.72 & 8.746 & 0.30 & 1334 & 10461.71 & 8.749 & -0.21 & 1394 & 10985.91 & 8.719 & -0.80 \\
\hline 1275 & 9945.47 & 8.746 & 0.29 & 1335 & 10470.46 & 8.749 & -0.22 & 1395 & 10994.63 & 8.718 & -0.81 \\
\hline 1276 & 9954.21 & 8.746 & 0.29 & 1336 & 10479.21 & 8.748 & -0.23 & 1396 & 11003.35 & 8.717 & -0.82 \\
\hline 1277 & 9962.96 & 8.747 & 0.28 & 1337 & 10487.95 & 8.748 & -0.24 & 1397 & 11012.06 & 8.716 & -0.84 \\
\hline 1278 & 9971.71 & 8.747 & 0.27 & 1338 & 10496.70 & 8.748 & -0.25 & 1398 & 11020.78 & 8.715 & -0.85 \\
\hline 1279 & 9980.45 & 8.747 & 0.26 & 1339 & 10505.45 & 8.748 & -0.26 & 1399 & 11029.49 & 8.715 & -0.86 \\
\hline 1280 & 9989.20 & 8.747 & 0.25 & 1340 & 10514.20 & 8.747 & -0.27 & 1400 & 11038.21 & 8.714 & -0.87 \\
\hline 1281 & 9997.95 & 8.748 & 0.25 & 1341 & 10522.94 & 8.747 & -0.28 & 1401 & 11046.92 & 8.713 & -0.88 \\
\hline 1282 & 10006.69 & 8.748 & 0.24 & 1342 & 10531.69 & 8.747 & -0.29 & 1402 & 11055.63 & 8.712 & -0.89 \\
\hline 1283 & 10015.44 & 8.748 & 0.23 & 1343 & 10540.44 & 8.747 & -0.30 & 1403 & $11064 \cdot 34$ & 8.711 & -0.90 \\
\hline 1284 & $10024 \cdot 19$ & 8.748 & 0.22 & 1344 & 10549.18 & 8.746 & -0.31 & 1404 & 11073.05 & 8.710 & -0.91 \\
\hline 1285 & 10032.94 & 8.749 & 0.21 & 1345 & 10557.93 & 8.746 & -0.32 & 1405 & 11081.76 & 8.709 & -0.92 \\
\hline 1286 & 10041.69 & 8.749 & 0.21 & 1346 & 10566.68 & 8.746 & -0.32 & 1406 & 11090.47 & 8.708 & -0.93 \\
\hline 1287 & 10050.44 & 8.749 & 0.20 & 1347 & 10575.42 & 8.745 & -0.33 & 1407 & 11099.18 & 8.707 & -0.94 \\
\hline 1288 & 10059.19 & 8.749 & 0.19 & 1348 & 10584.17 & 8.745 & -0.34 & 1408 & 11107.89 & 8.706 & -0.95 \\
\hline 1289 & 10067.93 & 8.749 & 0.18 & 1349 & 10592.91 & 8.745 & -0.35 & 1409 & 11116.59 & 8.705 & -0.96 \\
\hline 1290 & 10076.68 & 8.749 & 0.17 & 1350 & 10601.66 & 8.744 & -0.36 & 1410 & 11125.30 & 8.704 & -0.97 \\
\hline 1291 & 10085.43 & 8.750 & 0.16 & 1351 & 10610.40 & 8.744 & -0.37 & 1411 & 11134.00 & 8.703 & -0.98 \\
\hline 1292 & 10094.18 & 8.750 & 0.16 & 1352 & 10619.14 & 8.743 & -0.38 & 1412 & 11142.71 & 8.703 & -0.99 \\
\hline 1293 & 10102.93 & 8.750 & 0.15 & 1353 & 10627.89 & 8.743 & -0.39 & 1413 & 11151.41 & 8.702 & -1.00 \\
\hline 1294 & 10111.68 & 8.750 & 0.14 & 1354 & 10636.63 & 8.743 & -0.40 & 1414 & 11160.11 & 8.700 & -1.01 \\
\hline 1295 & 10120.43 & 8.750 & 0.13 & 1355 & 10645.37 & 8.742 & -0.41 & 1415 & 11168.81 & 8.699 & -1.03 \\
\hline 1296 & 10129.18 & 8.750 & 0.12 & 1356 & 10654.11 & 8.742 & -0.42 & 1416 & 11177.51 & 8.698 & -1.04 \\
\hline 1297 & 10137.93 & 8.750 & 0.11 & 1357 & 10662.86 & 8.741 & -0.43 & 1417 & 11186.21 & 8.697 & -1.05 \\
\hline 1298 & 10146.68 & 8.751 & 0.11 & 1358 & 10671.60 & 8.741 & -0.44 & 1418 & 11194.90 & 8.696 & -1.06 \\
\hline 1299 & 10155.44 & 8.751 & 0.10 & 1359 & 10680.34 & 8.741 & -0.45 & 1419 & 11203.60 & 8.695 & -1.07 \\
\hline 1300 & 10164.19 & 8.751 & 0.09 & 1360 & 10689.08 & 8.740 & -0.46 & 1420 & 11212.29 & 8.694 & -1.08 \\
\hline 1301 & 10172.94 & 8.751 & 0.08 & 1361 & 10697.82 & 8.740 & -0.47 & 1421 & 11220.99 & 8.693 & -1.09 \\
\hline 1302 & 10181.69 & 8.751 & 0.07 & 1362 & 10706.56 & 8.739 & -0.48 & 1422 & 11229.68 & 8.692 & -1.10 \\
\hline 1303 & 10190.44 & 8.751 & 0.06 & 1363 & 10715.30 & 8.739 & -0.49 & 1423 & 11238.37 & 8.691 & -1.11 \\
\hline 1304 & 10199.19 & 8.751 & 0.06 & 1364 & 10724.03 & 8.738 & -0.50 & 1424 & 11247.06 & 8.690 & -1.12 \\
\hline 1305 & 10207.94 & 8.751 & 0.05 & 1365 & 10732.77 & 8.738 & -0.51 & 1425 & 11255.75 & 8.689 & -1.13 \\
\hline 1306 & 10216.69 & 8.751 & 0.04 & 1366 & 10741.51 & 8.737 & -0.52 & 1426 & 11264.44 & 8.688 & -1.14 \\
\hline 1307 & 10225.44 & 8.751 & 0.03 & 1367 & 10750.25 & 8.737 & -0.53 & 1427 & 11273.13 & 8.686 & $-1 \cdot 15$ \\
\hline 1308 & 10234.19 & 8.751 & 0.02 & 1368 & 10758.98 & 8.736 & -0.54 & 1428 & 11281.81 & 8.685 & -1.17 \\
\hline 1309 & 10242.95 & 8.751 & 0.01 & 1369 & 10767.72 & 8.736 & -0.55 & 1429 & 11290.50 & 8.684 & $-1 \cdot 18$ \\
\hline 1310 & 10251.70 & 8.751 & 0.00 & 1370 & 10776.45 & 8.735 & -0.56 & 1430 & 11299.18 & 8.683 & -1.19 \\
\hline 1311 & 10260.45 & 8.751 & -0.01 & 1371 & 10785.19 & 8.734 & -0.57 & 1431 & 11307.86 & 8.682 & -1.20 \\
\hline 1312 & 10269.20 & 8.751 & -0.01 & 1372 & 10793.92 & 8.734 & -0.58 & 1432 & 11316.54 & 8.680 & -1.21 \\
\hline 1313 & 10277.95 & 8.751 & -0.02 & 1373 & 10802.66 & 8.733 & -0.59 & 1433 & 11325.22 & 8.679 & -1.22 \\
\hline 1314 & 10286.70 & 8.751 & -0.03 & 1374 & 10811.39 & 8.733 & -0.60 & 1434 & 11333.90 & 8.678 & -1.23 \\
\hline 1315 & 10295.45 & 8.751 & -0.04 & 1375 & 10820.12 & 8.732 & -0.61 & 1435 & 11342.58 & 8.677 & -1.24 \\
\hline 1316 & 10304.20 & 8.751 & -0.05 & 1376 & 10828.85 & 8.731 & -0.62 & 1436 & 11351.25 & 8.676 & -1.25 \\
\hline 1317 & 10312.96 & 8.751 & -0.06 & 1377 & 10837.58 & 8.731 & -0.63 & 1437 & 11359.93 & 8.674 & -1.26 \\
\hline 1318 & 10321.71 & 8.751 & -0.07 & 1378 & 10846.32 & 8.730 & -0.64 & 1438 & 11368.60 & 8.673 & -1.27 \\
\hline 1319 & 10330.46 & 8.751 & -0.08 & 1379 & 10855.05 & 8.730 & -0.65 & 1439 & 11377.28 & 8.672 & -1.28 \\
\hline 1320 & 10339.21 & 8.751 & -0.08 & 1380 & 10863.77 & 8.729 & -0.66 & 1440 & 11385.95 & 8.670 & -1.30 \\
\hline
\end{tabular}


TABLE 4.5.2. Type BN thermoelements versus platinum, Pt-67-thermoelectric voltages, E(T), Seebeck coefficients, $\mathrm{S}(\mathrm{T})$, and first derivative of the Seebeck coefficients, $\mathrm{dS} / \mathrm{dT}$, reference junctions at $0{ }^{\circ} \mathrm{C}$-Continued

\begin{tabular}{|c|c|c|c|c|c|c|c|c|c|c|c|}
\hline $\begin{array}{l}{ }^{\top} \mathrm{C} \\
{ }^{\circ} \mathrm{C}\end{array}$ & $\underset{\mu V}{E V}$ & $\stackrel{S}{S V /{ }^{\circ} \mathrm{C}}$ & $\begin{array}{l}\mathrm{dS} / \mathrm{dT} \\
\mathrm{nV} /{ }^{\circ} \mathrm{C}^{2}\end{array}$ & ${ }^{\circ} \mathrm{C}$ & $\underset{\mu V}{E}$ & $\underset{\mu \mathrm{V} /{ }^{\circ} \mathrm{C}}{S}$ & $\begin{array}{l}\mathrm{dS} / \mathrm{dT} \\
\mathrm{nV} /{ }^{\circ} \mathrm{C}^{2}\end{array}$ & ${ }^{\circ} \mathrm{C}$ & ${ }_{\mu V}^{E V}$ & $\stackrel{S}{S V /{ }^{\circ} \mathrm{C}}$ & $\begin{array}{l}d S / d T \\
n V /{ }^{\circ} C^{2}\end{array}$ \\
\hline $\begin{array}{l}1440 \\
1441 \\
1442 \\
1443 \\
1444\end{array}$ & $\begin{array}{l}11385.95 \\
11394.62 \\
11403.29 \\
11411.95 \\
11420.62\end{array}$ & $\begin{array}{l}8.670 \\
8.669 \\
8.668 \\
8.667 \\
8.665\end{array}$ & $\begin{array}{l}-1.30 \\
-1.31 \\
-1.32 \\
-1.33 \\
-1.34\end{array}$ & $\begin{array}{l}1500 \\
1501 \\
1502 \\
1503 \\
1504\end{array}$ & $\begin{array}{l}11903.45 \\
11912.02 \\
11920.59 \\
11929.16 \\
11937.72\end{array}$ & $\begin{array}{l}8.573 \\
8.571 \\
8.569 \\
8.567 \\
8.565\end{array}$ & $\begin{array}{l}-1.95 \\
-1.96 \\
-1.97 \\
-1.98 \\
-1.99\end{array}$ & $\begin{array}{l}1560 \\
1561 \\
1562 \\
1563 \\
1564\end{array}$ & $\begin{array}{l}12413.94 \\
12422.38 \\
12430.81 \\
12439.24 \\
12447.67\end{array}$ & $\begin{array}{l}8.437 \\
8.435 \\
8.432 \\
8.430 \\
8.427\end{array}$ & $\begin{array}{l}-2.56 \\
-2.57 \\
-2.58 \\
-2.59 \\
-2.60\end{array}$ \\
\hline $\begin{array}{l}1445 \\
1446 \\
1447 \\
1448 \\
1449\end{array}$ & $\begin{array}{l}11429.28 \\
11437.95 \\
11446.61 \\
11455.27 \\
11463.93\end{array}$ & $\begin{array}{l}8.664 \\
8.663 \\
8.661 \\
8.660 \\
8.658\end{array}$ & $\begin{array}{l}-1.35 \\
-1.36 \\
-1.37 \\
-1.38 \\
-1.39\end{array}$ & $\begin{array}{l}1505 \\
1506 \\
1507 \\
1508 \\
1509\end{array}$ & $\begin{array}{l}11946.29 \\
11954.85 \\
11963.41 \\
11971.97 \\
11980.53\end{array}$ & $\begin{array}{l}8.563 \\
8.561 \\
8.559 \\
8.557 \\
8.555\end{array}$ & $\begin{array}{l}-2.00 \\
-2.02 \\
-2.03 \\
-2.04 \\
-2.05\end{array}$ & $\begin{array}{l}1565 \\
1566 \\
1567 \\
1568 \\
1569\end{array}$ & $\begin{array}{l}12456.09 \\
12464.52 \\
12472.94 \\
12481.35 \\
12489.77\end{array}$ & $\begin{array}{l}8.424 \\
8.422 \\
8.419 \\
8.416 \\
8.414\end{array}$ & $\begin{array}{l}-2.61 \\
-2.61 \\
-2.62 \\
-2.63 \\
-2.64\end{array}$ \\
\hline $\begin{array}{l}1450 \\
1451 \\
1452 \\
1453 \\
1454\end{array}$ & $\begin{array}{l}11472.58 \\
11481.24 \\
11489.90 \\
11498.55 \\
11507.20\end{array}$ & $\begin{array}{l}8.657 \\
8.656 \\
8.654 \\
8.653 \\
8.651\end{array}$ & $\begin{array}{l}-1.40 \\
-1.42 \\
-1.43 \\
-1.44 \\
-1.45\end{array}$ & $\begin{array}{l}1510 \\
1511 \\
1512 \\
1513 \\
1514\end{array}$ & $\begin{array}{l}11989.08 \\
11997.63 \\
12006.18 \\
12014.73 \\
12023.27\end{array}$ & $\begin{array}{l}8.553 \\
8.551 \\
8.549 \\
8.547 \\
8.545\end{array}$ & $\begin{array}{l}-2.06 \\
-2.07 \\
-2.08 \\
-2.09 \\
-2.10\end{array}$ & $\begin{array}{l}1570 \\
1571 \\
1572 \\
1573 \\
1574\end{array}$ & $\begin{array}{l}12498.18 \\
12506.59 \\
12515.00 \\
12523.40 \\
12531.81\end{array}$ & $\begin{array}{l}8.411 \\
8.409 \\
8.406 \\
8.403 \\
8.401\end{array}$ & $\begin{array}{l}-2.65 \\
-2.66 \\
-2.67 \\
-2.68 \\
-2.68\end{array}$ \\
\hline $\begin{array}{l}1455 \\
1456 \\
1457 \\
1458 \\
1459\end{array}$ & $\begin{array}{l}11515.85 \\
11524.50 \\
11533.15 \\
11541.79 \\
11550.44\end{array}$ & $\begin{array}{l}8.650 \\
8.648 \\
8.647 \\
8.645 \\
8.644\end{array}$ & $\begin{array}{l}-1.46 \\
-1.47 \\
-1.48 \\
-1.49 \\
-1.50\end{array}$ & $\begin{array}{l}1515 \\
1516 \\
1517 \\
1518 \\
1519\end{array}$ & $\begin{array}{l}12031.82 \\
12040.36 \\
12048.90 \\
12057.44 \\
12065.97\end{array}$ & $\begin{array}{l}8.543 \\
8.540 \\
8.538 \\
8.536 \\
8.534\end{array}$ & $\begin{array}{l}-2.11 \\
-2.12 \\
-2.13 \\
-2.14 \\
-2.15\end{array}$ & $\begin{array}{l}1575 \\
1576 \\
1577 \\
1578 \\
1579\end{array}$ & $\begin{array}{l}12540.21 \\
12548.60 \\
12557.00 \\
12565.39 \\
12573.77\end{array}$ & $\begin{array}{l}8.398 \\
8.395 \\
8.392 \\
8.390 \\
8.387\end{array}$ & $\begin{array}{l}-2.69 \\
-2.70 \\
-2.71 \\
-2.72 \\
-2.73\end{array}$ \\
\hline $\begin{array}{l}1460 \\
1461 \\
1462 \\
1463 \\
1464\end{array}$ & $\begin{array}{l}11559.08 \\
11567.72 \\
11576.36 \\
11585.00 \\
11593.64\end{array}$ & $\begin{array}{l}8.642 \\
8.641 \\
8.639 \\
8.638 \\
8.636\end{array}$ & $\begin{array}{l}-1.51 \\
-1.53 \\
-1.54 \\
-1.55 \\
-1.56\end{array}$ & $\begin{array}{l}1520 \\
1521 \\
1522 \\
1523 \\
1524\end{array}$ & $\begin{array}{l}12074.50 \\
12083.04 \\
12091.56 \\
12100.09 \\
12108.61\end{array}$ & $\begin{array}{l}8.532 \\
8.530 \\
8.528 \\
8.525 \\
8.523\end{array}$ & $\begin{array}{l}-2.16 \\
-2.17 \\
-2.18 \\
-2.19 \\
-2.21\end{array}$ & $\begin{array}{l}1580 \\
1581 \\
1582 \\
1583 \\
1584\end{array}$ & $\begin{array}{l}12582.16 \\
12590.54 \\
12598.92 \\
12607.30 \\
12615.68\end{array}$ & $\begin{array}{l}8.384 \\
8.382 \\
8.379 \\
8.376 \\
8.373\end{array}$ & $\begin{array}{l}-2.74 \\
-2.74 \\
-2.75 \\
-2.76 \\
-2.77\end{array}$ \\
\hline $\begin{array}{l}1465 \\
1466 \\
1467 \\
1468 \\
1469\end{array}$ & $\begin{array}{l}11602.28 \\
11610.91 \\
11619.54 \\
11628.17 \\
11636.80\end{array}$ & $\begin{array}{l}8.635 \\
8.633 \\
8.631 \\
8.630 \\
8.628\end{array}$ & $\begin{array}{l}-1.57 \\
-1.58 \\
-1.59 \\
-1.60 \\
-1.61\end{array}$ & $\begin{array}{l}1525 \\
1526 \\
1527 \\
1528 \\
1529\end{array}$ & $\begin{array}{l}12117.14 \\
12125.66 \\
12134.17 \\
12142.69 \\
12151.20\end{array}$ & $\begin{array}{l}8.521 \\
8.519 \\
8.516 \\
8.514 \\
8.512\end{array}$ & $\begin{array}{l}-2.22 \\
-2.23 \\
-2.24 \\
-2.25 \\
-2.26\end{array}$ & $\begin{array}{l}1585 \\
1586 \\
1587 \\
1588 \\
1589\end{array}$ & $\begin{array}{l}12624.05 \\
12632.42 \\
12640.78 \\
12649.15 \\
12657.51\end{array}$ & $\begin{array}{l}8.370 \\
8.368 \\
8.365 \\
8.362 \\
8.359\end{array}$ & $\begin{array}{l}-2.78 \\
-2.78 \\
-2.79 \\
-2.80 \\
-2.81\end{array}$ \\
\hline $\begin{array}{l}1470 \\
1471 \\
1472 \\
1473 \\
1474\end{array}$ & $\begin{array}{l}11645.43 \\
11654.05 \\
11662.68 \\
11671.30 \\
11679.92\end{array}$ & $\begin{array}{l}8.627 \\
8.625 \\
8.623 \\
8.622 \\
8.620\end{array}$ & $\begin{array}{l}-1.62 \\
-1.64 \\
-1.65 \\
-1.66 \\
-1.67\end{array}$ & $\begin{array}{l}1530 \\
1531 \\
1532 \\
1533 \\
1534\end{array}$ & $\begin{array}{l}12159.71 \\
12168.22 \\
12176.73 \\
12185.23 \\
12193.73\end{array}$ & $\begin{array}{l}8.510 \\
8.507 \\
8.505 \\
8.503 \\
8.501\end{array}$ & $\begin{array}{l}-2.27 \\
-2.28 \\
-2.29 \\
-2.30 \\
-2.31\end{array}$ & $\begin{array}{l}1590 \\
1591 \\
1592 \\
1593 \\
1594\end{array}$ & $\begin{array}{l}12665.86 \\
12674.22 \\
12682.57 \\
12690.92 \\
12699.27\end{array}$ & $\begin{array}{l}8.356 \\
8.354 \\
8.351 \\
8.348 \\
8.345\end{array}$ & $\begin{array}{l}-2.82 \\
-2.82 \\
-2.83 \\
-2.84 \\
-2.85\end{array}$ \\
\hline $\begin{array}{l}1475 \\
1476 \\
1477 \\
1478 \\
1479\end{array}$ & $\begin{array}{l}11688 \cdot 54 \\
11697 \cdot 16 \\
11705.77 \\
11714 \cdot 39 \\
11723.00\end{array}$ & $\begin{array}{l}8.618 \\
8.617 \\
8.615 \\
8.613 \\
8.612\end{array}$ & $\begin{array}{l}-1.68 \\
-1.69 \\
-1.70 \\
-1.71 \\
-1.72\end{array}$ & $\begin{array}{l}1535 \\
1536 \\
1537 \\
1538 \\
1539\end{array}$ & $\begin{array}{l}12202.23 \\
12210.73 \\
12219.23 \\
12227.72 \\
12236.21\end{array}$ & $\begin{array}{l}8.498 \\
8.496 \\
8.494 \\
8.491 \\
8.489\end{array}$ & $\begin{array}{l}-2 \cdot 32 \\
-2 \cdot 33 \\
-2 \cdot 34 \\
-2 \cdot 35 \\
-2 \cdot 36\end{array}$ & $\begin{array}{l}1595 \\
1596 \\
1597 \\
1598 \\
1599\end{array}$ & $\begin{array}{l}12707.61 \\
12715.95 \\
12724.09 \\
12732.63 \\
12740.96\end{array}$ & $\begin{array}{l}8.342 \\
8.339 \\
8.337 \\
8.334 \\
8.331\end{array}$ & $\begin{array}{l}-2.85 \\
-2.86 \\
-2.87 \\
-2.88 \\
-2.88\end{array}$ \\
\hline $\begin{array}{l}1480 \\
1481 \\
1482 \\
1483 \\
1484\end{array}$ & $\begin{array}{l}11731.61 \\
11740.22 \\
11748.83 \\
11757.43 \\
11766.04\end{array}$ & $\begin{array}{l}8.610 \\
8.608 \\
8.606 \\
8.605 \\
8.603\end{array}$ & $\begin{array}{l}-1.73 \\
-1.74 \\
-1.76 \\
-1.77 \\
-1.78\end{array}$ & $\begin{array}{l}1540 \\
1541 \\
1542 \\
1543 \\
1544\end{array}$ & $\begin{array}{l}12244.70 \\
12253.18 \\
12261.66 \\
12270.14 \\
12278.62\end{array}$ & $\begin{array}{l}8.487 \\
8.484 \\
8.482 \\
8.479 \\
8.477\end{array}$ & $\begin{array}{l}-2.37 \\
-2.38 \\
-2.39 \\
-2.40 \\
-2.41\end{array}$ & $\begin{array}{l}1600 \\
1601 \\
1602 \\
1603 \\
1604\end{array}$ & $\begin{array}{l}12749.29 \\
12757.61 \\
12765.94 \\
12774.26 \\
12782.58\end{array}$ & $\begin{array}{l}8.328 \\
8.325 \\
8.322 \\
8.319 \\
8.316\end{array}$ & $\begin{array}{l}-2.89 \\
-2.90 \\
-2.91 \\
-2.91 \\
-2.92\end{array}$ \\
\hline $\begin{array}{l}1485 \\
1486 \\
1487 \\
1488 \\
1489\end{array}$ & $\begin{array}{l}11774.64 \\
11783.24 \\
11791.84 \\
11800.43 \\
11809.03\end{array}$ & $\begin{array}{l}8.601 \\
8.599 \\
8.597 \\
8.596 \\
8.594\end{array}$ & $\begin{array}{l}-1.79 \\
-1.80 \\
-1.81 \\
-1.82 \\
-1.83\end{array}$ & $\begin{array}{l}1545 \\
1546 \\
1547 \\
1548 \\
1549\end{array}$ & $\begin{array}{l}12287.10 \\
12295.57 \\
12304.04 \\
12312.51 \\
12320.98\end{array}$ & $\begin{array}{l}8.475 \\
8.472 \\
8.470 \\
8.467 \\
8.465\end{array}$ & $\begin{array}{l}-2.42 \\
-2.43 \\
-2.44 \\
-2.45 \\
-2.46\end{array}$ & $\begin{array}{l}1605 \\
1606 \\
1607 \\
1608 \\
1609\end{array}$ & $\begin{array}{l}12790.89 \\
12799.20 \\
12807.51 \\
12815.82 \\
12824.12\end{array}$ & $\begin{array}{l}8.313 \\
8.310 \\
8.308 \\
8.305 \\
8.302\end{array}$ & $\begin{array}{l}-2.93 \\
-2.93 \\
-2.94 \\
-2.95 \\
-2.95\end{array}$ \\
\hline $\begin{array}{l}1490 \\
1491 \\
1492 \\
1493 \\
1494\end{array}$ & $\begin{array}{l}11817.62 \\
11826.21 \\
11834.80 \\
11843.39 \\
11851.98\end{array}$ & $\begin{array}{l}8.592 \\
8.590 \\
8.588 \\
8.586 \\
8.585\end{array}$ & $\begin{array}{l}-1.84 \\
-1.85 \\
-1.86 \\
-1.88 \\
-1.89\end{array}$ & $\begin{array}{l}1550 \\
1551 \\
1552 \\
1553 \\
1554\end{array}$ & $\begin{array}{l}12329.44 \\
12337.90 \\
12346.36 \\
12354.82 \\
12363.27\end{array}$ & $\begin{array}{l}8.462 \\
8.460 \\
8.457 \\
8.455 \\
8.452\end{array}$ & $\begin{array}{l}-2.47 \\
-2.47 \\
-2.48 \\
-2.49 \\
-2.50\end{array}$ & $\begin{array}{l}1610 \\
1611 \\
1612 \\
1613 \\
1614\end{array}$ & $\begin{array}{l}12832.42 \\
12840.72 \\
12849.01 \\
12857.30 \\
12865.59\end{array}$ & $\begin{array}{l}8.299 \\
8.296 \\
8.293 \\
8.290 \\
8.287\end{array}$ & $\begin{array}{l}-2.96 \\
-2.97 \\
-2.97 \\
-2.98 \\
-2.98\end{array}$ \\
\hline $\begin{array}{l}1495 \\
1496 \\
1497 \\
1498 \\
1499\end{array}$ & $\begin{array}{l}11860 \cdot 56 \\
11869 \cdot 14 \\
11877 \cdot 72 \\
11886 \cdot 30 \\
11894.87\end{array}$ & $\begin{array}{l}8.583 \\
8.581 \\
8.579 \\
8.577 \\
8.575\end{array}$ & $\begin{array}{l}-1.90 \\
-1.91 \\
-1.92 \\
-1.93 \\
-1.94\end{array}$ & $\begin{array}{l}1555 \\
1556 \\
1557 \\
1558 \\
1559\end{array}$ & $\begin{array}{l}12371.72 \\
12380.17 \\
12388.62 \\
12397.06 \\
12405.50\end{array}$ & $\begin{array}{l}8.450 \\
8.447 \\
8.445 \\
8.442 \\
8.440\end{array}$ & $\begin{array}{l}-2.51 \\
-2.52 \\
-2.53 \\
-2.54 \\
-2.55\end{array}$ & $\begin{array}{l}1615 \\
1616 \\
1617 \\
1618 \\
1619\end{array}$ & $\begin{array}{l}12873.88 \\
12882.16 \\
12890.44 \\
12898.72 \\
12906.99\end{array}$ & $\begin{array}{l}8.284 \\
8.281 \\
8.278 \\
8.275 \\
8.272\end{array}$ & $\begin{array}{l}-2.99 \\
-3.00 \\
-3.00 \\
-3.01 \\
-3.01\end{array}$ \\
\hline 1500 & 11903.45 & 8.573 & -1.95 & 1560 & 12413.94 & 8.437 & -2.56 & 1620 & 12915.26 & 8.269 & -3.02 \\
\hline
\end{tabular}


TABLE 4.5.2. Type BN thermoelements versus platinum, Pt-67-thermoelectric voltages, $\mathrm{E}(\mathrm{T})$, Seebeck coefficients, $\mathrm{S}(\mathrm{T})$, and first derivative of the Seebeck coefficients, $\mathrm{dS} / \mathrm{dT}$, reference junctions at $0{ }^{\circ} \mathrm{C}$-Continued

\begin{tabular}{|c|c|c|c|c|c|c|c|c|c|c|c|}
\hline $\begin{array}{l}{ }^{\top} \\
{ }^{\circ} \mathrm{C}\end{array}$ & $\begin{array}{l}E \\
\mu V\end{array}$ & $\begin{array}{c}\mathrm{S} \\
\mu \mathrm{V} /{ }^{\circ} \mathrm{C}\end{array}$ & $\begin{array}{l}d S / d T \\
n V /{ }^{\circ} C^{2}\end{array}$ & ${ }^{\circ} \mathrm{C}$ & $\begin{array}{c}E \\
\mu V\end{array}$ & $\begin{array}{c}\mathrm{S} \\
\mu \mathrm{V} /{ }^{\circ} \mathrm{C}\end{array}$ & $\begin{array}{l}d S / d T \\
n V /{ }^{\circ} \mathrm{C}^{2}\end{array}$ & $\begin{array}{c}\mathrm{T} \\
{ }^{\circ} \mathrm{C}\end{array}$ & $\begin{array}{c}E \\
\mu V\end{array}$ & $\stackrel{S}{S V^{\circ} \mathrm{C}}$ & $\begin{array}{l}d S / d T \\
n V /{ }^{\circ} C^{2}\end{array}$ \\
\hline $\begin{array}{l}1620 \\
1621 \\
1622 \\
1623 \\
1624\end{array}$ & $\begin{array}{l}12915.26 \\
12923.53 \\
12931.79 \\
12940.05 \\
12948.31\end{array}$ & $\begin{array}{l}8.269 \\
8.266 \\
8.263 \\
8.260 \\
8.257\end{array}$ & $\begin{array}{l}-3.02 \\
-3.03 \\
-3.03 \\
-3.04 \\
-3.04\end{array}$ & $\begin{array}{l}1680 \\
1681 \\
1682 \\
1683 \\
1684\end{array}$ & $\begin{array}{l}13405.79 \\
13413.87 \\
13421.95 \\
13430.02 \\
13438.09\end{array}$ & $\begin{array}{l}8.081 \\
8.077 \\
8.074 \\
8.071 \\
8.068\end{array}$ & $\begin{array}{l}-3.19 \\
-3.19 \\
-3.19 \\
-3.19 \\
-3.19\end{array}$ & $\begin{array}{l}1740 \\
1741 \\
1742 \\
1743 \\
1744\end{array}$ & $\begin{array}{l}13884.98 \\
13892.87 \\
13900.76 \\
13908.65 \\
13916.54\end{array}$ & $\begin{array}{l}7.895 \\
7.893 \\
7.890 \\
7.887 \\
7.884\end{array}$ & $\begin{array}{l}-2.88 \\
-2.87 \\
-2.86 \\
-2.85 \\
-2.84\end{array}$ \\
\hline $\begin{array}{l}1625 \\
1626 \\
1627 \\
1628 \\
1629\end{array}$ & $\begin{array}{l}12956.57 \\
12964.82 \\
12973.07 \\
12981.31 \\
12989.56\end{array}$ & $\begin{array}{l}8.254 \\
8.251 \\
8.248 \\
8.244 \\
8.241\end{array}$ & $\begin{array}{l}-3.05 \\
-3.05 \\
-3.06 \\
-3.06 \\
-3.07\end{array}$ & $\begin{array}{l}1685 \\
1686 \\
1687 \\
1688 \\
1689\end{array}$ & $\begin{array}{l}13446.16 \\
13454.22 \\
13462.28 \\
13470.33 \\
13478.39\end{array}$ & $\begin{array}{l}8.065 \\
8.061 \\
8.058 \\
8.055 \\
8.052\end{array}$ & $\begin{array}{l}-3.19 \\
-3.19 \\
-3.18 \\
-3.18 \\
-3.18\end{array}$ & $\begin{array}{l}1745 \\
1746 \\
1747 \\
1748 \\
1749\end{array}$ & $\begin{array}{l}13924.42 \\
13932.30 \\
13940.18 \\
13948.05 \\
13955.92\end{array}$ & $\begin{array}{l}7.881 \\
7.878 \\
7.876 \\
7.873 \\
7.870\end{array}$ & $\begin{array}{l}-2.83 \\
-2.81 \\
-2.80 \\
-2.79 \\
-2.78\end{array}$ \\
\hline $\begin{array}{l}1630 \\
1631 \\
1632 \\
1633 \\
1634\end{array}$ & $\begin{array}{l}12997.80 \\
13006.03 \\
13014 \cdot 27 \\
13022.50 \\
13030.72\end{array}$ & $\begin{array}{l}8.238 \\
8.235 \\
8.232 \\
8.229 \\
8.226\end{array}$ & $\begin{array}{l}-3.07 \\
-3.08 \\
-3.08 \\
-3.09 \\
-3.09\end{array}$ & $\begin{array}{l}1690 \\
1691 \\
1692 \\
1693 \\
1694\end{array}$ & $\begin{array}{l}13486.44 \\
13494.49 \\
13502.53 \\
13510.57 \\
13518.61\end{array}$ & $\begin{array}{l}8.049 \\
8.046 \\
8.042 \\
8.039 \\
8.036\end{array}$ & $\begin{array}{l}-3.18 \\
-3.18 \\
-3.18 \\
-3.17 \\
-3.17\end{array}$ & $\begin{array}{l}1750 \\
1751 \\
1752 \\
1753 \\
1754\end{array}$ & $\begin{array}{l}13963.79 \\
13971.66 \\
13979.52 \\
13987.38 \\
13995.24\end{array}$ & $\begin{array}{l}7.867 \\
7.864 \\
7.862 \\
7.859 \\
7.856\end{array}$ & $\begin{array}{l}-2.76 \\
-2.75 \\
-2.74 \\
-2.73 \\
-2.71\end{array}$ \\
\hline $\begin{array}{l}1635 \\
1636 \\
1637 \\
1638 \\
1639\end{array}$ & $\begin{array}{l}13038.95 \\
13047.17 \\
13055.39 \\
13063.60 \\
13071.82\end{array}$ & $\begin{array}{l}8.223 \\
8.220 \\
8.217 \\
8.214 \\
8.210\end{array}$ & $\begin{array}{l}-3.10 \\
-3.10 \\
-3.11 \\
-3.11 \\
-3.11\end{array}$ & $\begin{array}{l}1695 \\
1696 \\
1697 \\
1698 \\
1699\end{array}$ & $\begin{array}{l}13526.64 \\
13534.67 \\
13542.70 \\
13550.73 \\
13558.75\end{array}$ & $\begin{array}{l}8.033 \\
8.030 \\
8.026 \\
8.023 \\
8.020\end{array}$ & $\begin{array}{l}-3.17 \\
-3.17 \\
-3.16 \\
-3.16 \\
-3.16\end{array}$ & $\begin{array}{l}1755 \\
1756 \\
1757 \\
1758 \\
1759\end{array}$ & $\begin{array}{l}14003.09 \\
14010.94 \\
14018.79 \\
14026.64 \\
14034.48\end{array}$ & $\begin{array}{l}7.854 \\
7.851 \\
7.848 \\
7.845 \\
7.843\end{array}$ & $\begin{array}{l}-2.70 \\
-2.69 \\
-2.67 \\
-2.66 \\
-2.64\end{array}$ \\
\hline $\begin{array}{l}1640 \\
1641 \\
1642 \\
1643 \\
1644\end{array}$ & $\begin{array}{l}13080.02 \\
13088.23 \\
13096.43 \\
13104.63 \\
13112.83\end{array}$ & $\begin{array}{l}8.207 \\
8.204 \\
8.201 \\
8.198 \\
8.195\end{array}$ & $\begin{array}{l}-3.12 \\
-3.12 \\
-3.13 \\
-3.13 \\
-3.13\end{array}$ & $\begin{array}{l}1700 \\
1701 \\
1702 \\
1703 \\
1704\end{array}$ & $\begin{array}{l}13566.77 \\
13574.78 \\
13582.79 \\
13590.80 \\
13598.81\end{array}$ & $\begin{array}{l}8.017 \\
8.014 \\
8.011 \\
8.008 \\
8.004\end{array}$ & $\begin{array}{l}-3.15 \\
-3.15 \\
-3.15 \\
-3.14 \\
-3.14\end{array}$ & $\begin{array}{l}1760 \\
1761 \\
1762 \\
1763 \\
1764\end{array}$ & $\begin{array}{l}14042.33 \\
14050.17 \\
14058.00 \\
14065.84 \\
14073.67\end{array}$ & $\begin{array}{l}7.840 \\
7.838 \\
7.835 \\
7.832 \\
7.830\end{array}$ & $\begin{array}{l}-2.63 \\
-2.61 \\
-2.60 \\
-2.58 \\
-2.57\end{array}$ \\
\hline $\begin{array}{l}1645 \\
1646 \\
1647 \\
1648 \\
1649\end{array}$ & $\begin{array}{l}13121.02 \\
13129.21 \\
13137.40 \\
13145.58 \\
13153.76\end{array}$ & $\begin{array}{l}8.192 \\
8.189 \\
8.185 \\
8.182 \\
8.179\end{array}$ & $\begin{array}{l}-3.14 \\
-3.14 \\
-3.14 \\
-3.15 \\
-3.15\end{array}$ & $\begin{array}{l}1705 \\
1706 \\
1707 \\
1708 \\
1709\end{array}$ & $\begin{array}{l}13606.81 \\
13614.81 \\
13622.81 \\
13630.80 \\
13638.79\end{array}$ & $\begin{array}{l}8.001 \\
7.998 \\
7.995 \\
7.992 \\
7.989\end{array}$ & $\begin{array}{l}-3.13 \\
-3.13 \\
-3.12 \\
-3.12 \\
-3.12\end{array}$ & $\begin{array}{l}1765 \\
1766 \\
1767 \\
1768 \\
1769\end{array}$ & $\begin{array}{l}14081.49 \\
14089.32 \\
14097.14 \\
14104.97 \\
14112.78\end{array}$ & $\begin{array}{l}7.827 \\
7.825 \\
7.822 \\
7.820 \\
7.817\end{array}$ & $\begin{array}{l}-2.55 \\
-2.53 \\
-2.52 \\
-2.50 \\
-2.48\end{array}$ \\
\hline $\begin{array}{l}1650 \\
1651 \\
1652 \\
1653 \\
1654\end{array}$ & $\begin{array}{l}13161.94 \\
13170.12 \\
13178.29 \\
13186.45 \\
13194.62\end{array}$ & $\begin{array}{l}8.176 \\
8.173 \\
8.170 \\
8.167 \\
8.163\end{array}$ & $\begin{array}{l}-3.15 \\
-3.16 \\
-3.16 \\
-3.16 \\
-3.16\end{array}$ & $\begin{array}{l}1710 \\
1711 \\
1712 \\
1713 \\
1714\end{array}$ & $\begin{array}{l}13646.78 \\
13654.76 \\
13662.74 \\
13670.72 \\
13678.70\end{array}$ & $\begin{array}{l}7.986 \\
7.983 \\
7.979 \\
7.976 \\
7.973\end{array}$ & $\begin{array}{l}-3.11 \\
-3.11 \\
-3.10 \\
-3.09 \\
-3.09\end{array}$ & $\begin{array}{l}1770 \\
1771 \\
1772 \\
1773 \\
1774\end{array}$ & $\begin{array}{l}14120.60 \\
14128.41 \\
14136.22 \\
14144.03 \\
14151.84\end{array}$ & $\begin{array}{l}7.815 \\
7.812 \\
7.810 \\
7.807 \\
7.805\end{array}$ & $\begin{array}{l}-2.47 \\
-2.45 \\
-2.43 \\
-2.41 \\
-2.40\end{array}$ \\
\hline $\begin{array}{l}1655 \\
1656 \\
1657 \\
1658 \\
1659\end{array}$ & $\begin{array}{l}13202.78 \\
13210.94 \\
13219.10 \\
13227.25 \\
13235.40\end{array}$ & $\begin{array}{l}8.160 \\
8.157 \\
8.154 \\
8.151 \\
8.148\end{array}$ & $\begin{array}{l}-3.17 \\
-3.17 \\
-3.17 \\
-3.17 \\
-3.18\end{array}$ & $\begin{array}{l}1715 \\
1716 \\
1717 \\
1718 \\
1719\end{array}$ & $\begin{array}{l}13686.67 \\
13694.64 \\
13702.60 \\
13710.57 \\
13718.53\end{array}$ & $\begin{array}{l}7.970 \\
7.967 \\
7.964 \\
7.961 \\
7.958\end{array}$ & $\begin{array}{l}-3.08 \\
-3.08 \\
-3.07 \\
-3.07 \\
-3.06\end{array}$ & $\begin{array}{l}1775 \\
1776 \\
1777 \\
1778 \\
1779\end{array}$ & $\begin{array}{l}14159.64 \\
14167.44 \\
14175.24 \\
14183.04 \\
14190.83\end{array}$ & $\begin{array}{l}7.803 \\
7.800 \\
7.798 \\
7.796 \\
7.793\end{array}$ & $\begin{array}{l}-2 \cdot 38 \\
-2.36 \\
-2.34 \\
-2 \cdot 32 \\
-2.30\end{array}$ \\
\hline $\begin{array}{l}1660 \\
1661 \\
1662 \\
1663 \\
1664\end{array}$ & $\begin{array}{l}13243.54 \\
13251.69 \\
13259.83 \\
13267.96 \\
13276.09\end{array}$ & $\begin{array}{l}8.144 \\
8.141 \\
8.138 \\
8.135 \\
8.132\end{array}$ & $\begin{array}{l}-3.18 \\
-3.18 \\
-3.18 \\
-3.18 \\
-3.18\end{array}$ & $\begin{array}{l}1720 \\
1721 \\
1722 \\
1723 \\
1724\end{array}$ & $\begin{array}{l}13726.48 \\
13734.44 \\
13742.39 \\
13750.33 \\
13758.28\end{array}$ & $\begin{array}{l}7.955 \\
7.952 \\
7.949 \\
7.946 \\
7.943\end{array}$ & $\begin{array}{l}-3.05 \\
-3.05 \\
-3.04 \\
-3.03 \\
-3.02\end{array}$ & $\begin{array}{l}1780 \\
1781 \\
1782 \\
1783 \\
1784\end{array}$ & $\begin{array}{l}14198.63 \\
14206.42 \\
14214.20 \\
14221.99 \\
14229.77\end{array}$ & $\begin{array}{l}7.791 \\
7.789 \\
7.786 \\
7.784 \\
7.782\end{array}$ & $\begin{array}{l}-2 \cdot 28 \\
-2 \cdot 26 \\
-2.24 \\
-2.22 \\
-2.20\end{array}$ \\
\hline $\begin{array}{l}1665 \\
1666 \\
1667 \\
1668 \\
1669\end{array}$ & $\begin{array}{l}13284.22 \\
13292.35 \\
13300.48 \\
13308.60 \\
13316.71\end{array}$ & $\begin{array}{l}8.128 \\
8.125 \\
8.122 \\
8.119 \\
8.116\end{array}$ & $\begin{array}{l}-3.19 \\
-3.19 \\
-3.19 \\
-3.19 \\
-3.19\end{array}$ & $\begin{array}{l}1725 \\
1726 \\
1727 \\
1728 \\
1729\end{array}$ & $\begin{array}{l}13766.22 \\
13774.16 \\
13782.09 \\
13790.02 \\
13797.95\end{array}$ & $\begin{array}{l}7.940 \\
7.937 \\
7.934 \\
7.931 \\
7.928\end{array}$ & $\begin{array}{l}-3.02 \\
-3.01 \\
-3.00 \\
-2.99 \\
-2.98\end{array}$ & $\begin{array}{l}1785 \\
1786 \\
1787 \\
1788 \\
1789\end{array}$ & $\begin{array}{l}14237.55 \\
14245.33 \\
14253.11 \\
14260.88 \\
14268.65\end{array}$ & $\begin{array}{l}7.780 \\
7.778 \\
7.775 \\
7.773 \\
7.771\end{array}$ & $\begin{array}{l}-2.18 \\
-2.16 \\
-2.14 \\
-2.12 \\
-2.09\end{array}$ \\
\hline $\begin{array}{l}1670 \\
1671 \\
1672 \\
1673 \\
1674\end{array}$ & $\begin{array}{l}13324.83 \\
13332.94 \\
13341.05 \\
13349.15 \\
13357.25\end{array}$ & $\begin{array}{l}8.112 \\
8.109 \\
8.106 \\
8.103 \\
8.100\end{array}$ & $\begin{array}{l}-3.19 \\
-3.19 \\
-3.19 \\
-3.19 \\
-3.19\end{array}$ & $\begin{array}{l}1730 \\
1731 \\
1732 \\
1733 \\
1734\end{array}$ & $\begin{array}{l}13805 \cdot 88 \\
13813.80 \\
13821.72 \\
13829.64 \\
13837.55\end{array}$ & $\begin{array}{l}7.925 \\
7.922 \\
7.919 \\
7.916 \\
7.913\end{array}$ & $\begin{array}{l}-2.98 \\
-2.97 \\
-2.96 \\
-2.95 \\
-2.94\end{array}$ & $\begin{array}{l}1790 \\
1791 \\
1792 \\
1793 \\
1794\end{array}$ & $\begin{array}{l}14276.42 \\
14284.19 \\
14291.96 \\
14299.72 \\
14307.48\end{array}$ & $\begin{array}{l}7.769 \\
7.767 \\
7.765 \\
7.763 \\
7.761\end{array}$ & $\begin{array}{l}-2.07 \\
-2.05 \\
-2.03 \\
-2.00 \\
-1.98\end{array}$ \\
\hline $\begin{array}{l}1675 \\
1676\end{array}$ & $\begin{array}{l}13365 \cdot 35 \\
13373.44\end{array}$ & $\begin{array}{l}8.097 \\
8.093\end{array}$ & $\begin{array}{l}-3.19 \\
-3.19\end{array}$ & $\begin{array}{l}1735 \\
1736\end{array}$ & $\begin{array}{l}13845.47 \\
13853.37\end{array}$ & $\begin{array}{l}7.910 \\
7.907\end{array}$ & $\begin{array}{l}-2.93 \\
-2.92\end{array}$ & $\begin{array}{l}1795 \\
1796\end{array}$ & $\begin{array}{l}14315.24 \\
14323.00\end{array}$ & $\begin{array}{l}7.759 \\
7.757\end{array}$ & $\begin{array}{l}-1.96 \\
-1.93\end{array}$ \\
\hline $\begin{array}{l}1677 \\
1678 \\
1679\end{array}$ & $\begin{array}{l}13381.54 \\
13389.62 \\
13397.71\end{array}$ & $\begin{array}{l}8.090 \\
8.087 \\
8.084\end{array}$ & $\begin{array}{l}-3.19 \\
-3.19 \\
-3.19\end{array}$ & $\begin{array}{l}1737 \\
1738 \\
1739\end{array}$ & $\begin{array}{l}13861.28 \\
13869.18 \\
13877.08\end{array}$ & $\begin{array}{l}7.904 \\
7.901 \\
7.898\end{array}$ & $\begin{array}{l}-2.91 \\
-2.90 \\
-2.89\end{array}$ & $\begin{array}{l}1797 \\
1798 \\
1799\end{array}$ & $\begin{array}{l}14330.76 \\
14338.51 \\
14346.27\end{array}$ & $\begin{array}{l}7.755 \\
7.753 \\
7.751\end{array}$ & $\begin{array}{l}-1.91 \\
-1.88 \\
-1.86\end{array}$ \\
\hline 680 & 13405.79 & 8.081 & 3.19 & 1740 & $13884 \cdot 98$ & 7.895 & $-2 \cdot 88$ & 1800 & 14354.02 & 7.750 & -1.83 \\
\hline
\end{tabular}


TABLE 4.5.2. Type BN thermoelements versus platinum, $\mathrm{Pt}-67$ - thermoelectric voltages, $\mathrm{E}(\mathrm{T}), \mathrm{Seebeck}$ coefficients, $\mathrm{S}(\mathrm{T})$, and first derivative of the Seebeck coefficients, $\mathrm{dS} / \mathrm{dT}$, reference junctions at $0{ }^{\circ} \mathrm{C}-$ Continued

\begin{tabular}{|c|c|c|c|c|c|c|c|c|c|c|c|}
\hline $\begin{array}{r}\mathrm{T} \\
{ }^{\circ} \mathrm{C}\end{array}$ & $\underset{\mu V}{E V}$ & $\underset{\mu V /{ }^{\circ} \mathrm{C}}{S}$ & $\begin{array}{l}\mathrm{dS} / \mathrm{dT} \\
\mathrm{nV} /{ }^{\circ} \mathrm{C}^{2}\end{array}$ & $\begin{array}{r}\mathrm{T} \\
{ }^{\circ} \mathrm{C}\end{array}$ & $\begin{array}{c}E \\
\mu V\end{array}$ & $\underset{\mu \mathrm{V} /{ }^{\circ} \mathrm{C}}{\mathrm{S}}$ & $\begin{array}{l}\mathrm{dS} / \mathrm{dT} \\
\mathrm{nV} /{ }^{\circ} \mathrm{C}^{2}\end{array}$ & $\begin{array}{l}\mathrm{T} \\
{ }^{\circ} \mathrm{C}\end{array}$ & $\begin{array}{c}E \\
\mu V\end{array}$ & $\begin{array}{c}S \\
\mu V /^{\circ} \mathrm{C}\end{array}$ & $\begin{array}{l}\mathrm{dS} / \mathrm{dT} \\
\mathrm{nV} /{ }^{\circ} \mathrm{C}^{2}\end{array}$ \\
\hline 1800 & 14354.02 & 7.750 & -1.83 & 1810 & 14431.42 & 7.733 & -1.57 & 1820 & 14508.68 & 7.718 & -1.27 \\
\hline 1801 & 14361.76 & 7.748 & -1.81 & 1811 & $14439 \cdot 16$ & 7.731 & -1.54 & & & & \\
\hline 1802 & 14369.51 & 7.746 & -1.78 & 1812 & 14446.89 & 7.729 & -1.51 & & & & \\
\hline 1803 & 14377.26 & 7.744 & -1.76 & 1813 & 14454.62 & 7.728 & -1.48 & & & & \\
\hline 1804 & 14385.00 & 7.742 & -1.73 & 1814 & $14462 \cdot 34$ & 7.727 & -1.45 & & & & \\
\hline 1805 & 14392.74 & 7.741 & -1.70 & 1815 & 14470.07 & 7.725 & -1.42 & & & & \\
\hline 1806 & $14400 \cdot 48$ & 7.739 & -1.68 & 1816 & 14477.79 & 7.724 & $-1 \cdot 39$ & & & & \\
\hline $\begin{array}{l}1807 \\
1808\end{array}$ & $\begin{array}{l}14408.22 \\
14415.96\end{array}$ & $\begin{array}{l}7.737 \\
7.736\end{array}$ & $\begin{array}{l}-1.65 \\
-1.62\end{array}$ & 1817 & 14485.52 & 7.722 & -1.36 & & & & \\
\hline 1809 & $\begin{array}{l}14415.96 \\
14423.69\end{array}$ & $\begin{array}{l}7.136 \\
7.734\end{array}$ & $\begin{array}{l}-1.62 \\
-1.59\end{array}$ & $\begin{array}{l}1818 \\
1819\end{array}$ & $\begin{array}{l}14493.24 \\
14500.96\end{array}$ & $\begin{array}{l}7.721 \\
7.720\end{array}$ & $\begin{array}{l}-1.33 \\
-1.30\end{array}$ & & & & \\
\hline 1810 & 14431.42 & 7.733 & -1.57 & 1820 & 14508.68 & 7.718 & -1.27 & & & & \\
\hline
\end{tabular}


TABLE 4.5.3. Thermoelectric values at the fixed points for Type BN thermoelements versus platinum, Pt-67

\begin{tabular}{|c|c|c|c|c|}
\hline Fixed point & $\begin{array}{c}\text { Temp. } \\
{ }^{\circ} \mathrm{C}\end{array}$ & $\begin{array}{c}E \\
\mu \mathrm{V}\end{array}$ & $\begin{array}{c}S \\
\mu \mathrm{V} /{ }^{\circ} \mathrm{C}\end{array}$ & $\begin{array}{l}d S / d T \\
\mathrm{nV} /{ }^{\circ} \mathrm{C}\end{array}$ \\
\hline $\begin{array}{l}\text { Ice point } \\
\text { Ether TP } \\
\text { Water BP } \\
\text { Benzoic TP } \\
\text { Indium FP } \\
\text { Tin FP } \\
\text { Bismuth FP } \\
\text { Cadmium FP } \\
\text { Lead FP } \\
\text { Mercury BP } \\
\text { Zinc FP } \\
\text { Sulphur BP } \\
\text { Cu-Al FP } \\
\text { Antimony FP } \\
\text { Aluminum FP } \\
\text { Silver FP } \\
\text { Gold FP } \\
\text { Copper FP } \\
\text { Nickel FP } \\
\text { Cobalt FP } \\
\text { Palladium FP } \\
\text { Platinum FP }\end{array}$ & $\begin{array}{l}0.000 \\
26.870 \\
100.000 \\
122.370 \\
156.634 \\
231.9681 \\
271.442 \\
321.108 \\
327.502 \\
356.660 \\
419.580 \\
444.674 \\
548.23 \\
630.74 \\
660.37 \\
961.93 \\
1064.43 \\
1084.5 \\
1455 \\
1494 \\
1554 \\
1772\end{array}$ & $\begin{array}{r}0.00 \\
142.80 \\
585.84 \\
733.30 \\
967.03 \\
1505.03 \\
1795.90 \\
2167.53 \\
2215.73 \\
2436.38 \\
2916.45 \\
3109.17 \\
3911.23 \\
4558.46 \\
4792.87 \\
7251.97 \\
8120.48 \\
8292.34 \\
11515.85 \\
11851.98 \\
12363.27 \\
14136.22\end{array}$ & $\begin{array}{l}5.066 \\
5.548 \\
6.488 \\
6.690 \\
6.941 \\
7.306 \\
7.426 \\
7.533 \\
7.544 \\
7.589 \\
7.667 \\
7.693 \\
7.798 \\
7.893 \\
7.931 \\
8.394 \\
8.549 \\
8.577 \\
8.650 \\
8.585 \\
8.452 \\
7.810\end{array}$ & $\begin{array}{r}19.58 \\
16.38 \\
9.80 \\
8.31 \\
6.41 \\
3.54 \\
2.59 \\
1.79 \\
1.71 \\
1.42 \\
1.08 \\
1.02 \\
1.06 \\
1.24 \\
1.31 \\
1.60 \\
1.40 \\
1.34 \\
-1.46 \\
-1.89 \\
-2.50 \\
-2.43\end{array}$ \\
\hline
\end{tabular}

TABLE 4.5.4. Estimated maximum errors that occur when using reduced-bit arithmetic for the power series expansion for the thermoelectric voltage of Type BN thermoelements versus platinum, $\mathrm{Pt}-67$

\begin{tabular}{|c|c|c|c|c|c|c|}
\hline \multirow[b]{2}{*}{ Temperature range } & \multirow[b]{2}{*}{ Degree } & \multicolumn{5}{|c|}{ Estimated maximum error in microvolts } \\
\hline & & 12 Bit & 16 Bit & 24 Bit & 27 Bit & 36 Bit \\
\hline 0 to $200^{\circ} \mathrm{C}$ & 8 & 03 & $<0.1$ & $<0 \quad 01$ & $<0.01$ & $<001$ \\
\hline 200 to $400^{\circ} \mathrm{C}$ & 8 & 0.6 & 0.1 & $<0.01$ & $<0.01$ & $<0.01$ \\
\hline 400 to $600^{\circ} \mathrm{C}$ & 8 & 0.9 & $0 .{ }^{\prime}$ & $<0.01$ & $<0.01$ & $<0.01$ \\
\hline 600 to $800^{\circ} \mathrm{C}$ & 8 & 2 & 0.1 & $<0.01$ & $<0.01$ & $<0.01$ \\
\hline 800 to $1000^{\circ} \mathrm{C}$ & 8 & 4 & 0.5 & $<0.01$ & $<0.01$ & $<0.01$ \\
\hline 1000 to $1200^{\circ} \mathrm{C}$ & 8 & 9 & 2 & 0.02 & $<0.01$ & $<0.01$ \\
\hline 1200 to $1400^{\circ} \mathrm{C}$ & 8 & 20 & 4 & 0.03 & $<0.01$ & $<0.01$ \\
\hline 1400 to $1600^{\circ} \mathrm{C}$ & 8 & 50 & 7 & 0.07 & $<0.01$ & $<0.01$ \\
\hline 1600 to $1820 \mathrm{C}$ & 8 & 100 & 14 & 0.2 & 0.02 & $<0.01$ \\
\hline
\end{tabular}




\section{TYPE E-Nickel-Chromium Alloy Versus Copper-Nickel Alloy Thermocouples}

\subsection{Material Specifications and Precautions}

This type, and the other base-metal types, do not have specific chemical compositions given in standards; rather, any material that fits the specified table within certain limits (see the end of this section) can be considered to be a Type $\mathrm{E}$ thermocouple. The positive thermoelement, EP, is the same material as KP. The negative thermoelement, EN, is the same material as TN. Their nominal chemical compositions are given in chapters 7 and 8, respectively.

The Type $\mathrm{E}$ thermocouple, as a combination of two specific thermoelements, does not have a well-documented history. The first officially recognized reference tables that we are aware of were those calculated by Shenker et al. [1955] in NBS Circular 561. They based their tables upon a combination of data for KP versus platinum and platinum versus $\mathrm{TN}$, where the primary data were taken from earlier NBS Research Papers.

Extensive research on the subzero properties of Type $\mathrm{E}$ thermocouples has been carried out by members of the Cryogenics Division in Boulder. That research has been summarized and tabulated by Sparks et al. [1972] in NBS Monograph 124. They showed that Type $\mathrm{E}$ thermocouples are very useful down to about liquid hydrogen temperatures (n.b.p. $20.28 \mathrm{~K}$ ) where their Seebeck coefficient is about $8 \mu \mathrm{V} /{ }^{\circ} \mathrm{C}$. They may even be used down to liquid helium temperatures $(4.2 \mathrm{~K})$ though their Seebeck coefficient becomes quite low at $4 \mathrm{~K}$, only about $2 \mu \mathrm{V} /{ }^{\circ} \mathrm{C}$. Both thermoelements of Type $\mathrm{E}$ thermocouples have a rela. tively low thermal conductivity, good resistance to corrosion in moist atmospheres, and reasonably good homogeneity. Because of these three reasons, and their relatively high Seebeck coefficients, Type E thermocouples have been recommended by Sparks et al. [1972] to be the most useful of the commercially standardized thermocouple combinations for subzero temperature measurements.

For operation below $20 \mathrm{~K}$ the nonstandardized combination KP versus gold -0.07 at $\%$ iron is recommended. The properties of this combination have been described by Sparks et al. [1972a].

Type E thermocouples also have the largest Seebeck coefficient above $0{ }^{\circ} \mathrm{C}$ of any of the standardized thermocouples. For that reason they are being used more often whenever environmental conditions permit.

Type $\mathrm{E}$ thermocouples are recommended by the ASTM Manual [1970] for use in the temperature range from -250 to $871{ }^{\circ} \mathrm{C}$ in oxidizing or inert atmospheres. The negative thermoelement is subject to deterioration above about $871{ }^{\circ} \mathrm{C}$, but the thermocouple may be used up to $1000{ }^{\circ} \mathrm{C}$ for short periods. The ASTM Manual [1970] indicates the following restrictions on the use of Type $E$ thermocouples at high temperatures:

They should not be used in sulfurous, reducing, or alternately reducing and oxidizing atmospheres unless suitably protected with protecting tubes. They should not be used in vacuum (at high temperatures) for extended times because the chromium in the positive thermoelement vaporizes out of solution and alters the calibration. They should also not be used in atmospheres that promote "green-rot" corrosion (those with low, but not negligible, oxygen content).

The negative thermoelement, a copper-nickel alloy, is subject to composition changes under thermal neutron irradiation since the copper is converted to nickel and zinc.

Neither thermoelement of Type E thermocouples is very sensitive to minor changes in composition or impurity level because both are already heavily alloyed. Similarly they are also not extremely sensitive to minor differences in heat treatment (provided that the treatment does not violate any of the restrictions mentioned above). For most general applications they may be used with the heat treatment given by the wire manufacturers. However, when the highest accuracy is sought, additional preparatory heat treatments may be desirable in order to enhance their performance. Details on this and other phases of the use and behavior of Type KP thermoelements (EP is the same as KP) are given in publications by Potts and McElroy [1962], and N. A. Burley [1969 and 1972].

ASTM Standard E230-72 in the Annual Book of ASTM Standards [1972] specifies that the standard limits of error for Type E commercial thermocouples be $\pm 1.7^{\circ} \mathrm{C}$ between 0 and $316^{\circ} \mathrm{C}$ and $\pm 1 / 2$ percent between 316 and $871{ }^{\circ} \mathrm{C}$. Limits of error are not specified for Type $\mathrm{E}$ thermocouples below $0{ }^{\circ} \mathrm{C}$. Type E thermocouples can also be supplied to meet special limits of error, which are less than the standard limits of error given above: $\pm 11 / 4{ }^{\circ} \mathrm{C}$ between 0 and $316^{\circ} \mathrm{C}$ and $\pm 3 / 8$ percent between 316 and $871{ }^{\circ} \mathrm{C}$. The recommended upper temperature limit for protected thermocouples, $871{ }^{\circ} \mathrm{C}$, applies to AWG $8(3.3 \mathrm{~mm})$ wire. For smaller wires the recommended upper temperature decreases to $649{ }^{\circ} \mathrm{C}$ for AWG 14 (1.6 mm), $538^{\circ} \mathrm{C}$ for AWG $20(0.8 \mathrm{~mm})$, and $427^{\circ} \mathrm{C}$ for AWG 24 or $28(0.5$ or $0.3 \mathrm{~mm})$.

\subsection{Data Analyses and Comparisons}

The fitting functions for Type $\mathrm{E}$ thermocouples are based on two sets of data: below $0{ }^{\circ} \mathrm{C}$, the research and equations of Sparks et al. [1972] were used di. rectly; above $0{ }^{\circ} \mathrm{C}$, values from NBS Circular 561 [1955] were used after being modified to be on the IPTS-68.

Sparks et al. [1972] based their recommended low temperature values for the positive thermoelement, $\mathrm{EP}$ or $\mathrm{KP}$, on a selected wire that was most representative of three calibrated wires selected from nine spools made by three different manufacturers. Similarly, the negative thermoelement, EN or TN, represented the best wire from three calibrated wires taken from ten spools supplied by four different manufac- 
turers. The wires for both positive and negative thermoelements were selected after completion of careful spot calibration and inhomogeneity tests as described in Monograph 124. Values for the single thermoelements are given versus platinum, Pt-67. Thermoelectric values for both thermoelements and the combination were relatively difficult to fit precisely. Values for the positive thermoelement required a 12th degree power series to fit 68 points between about -270 and $0{ }^{\circ} \mathrm{C}$ with an imprecision of $0.12 \mu \mathrm{V}$; the negative thermoelement required a 13th degree power series to give $0.12 \mu \mathrm{V}$; and the combination (fit independently), 13th degree for the same imprecision. In Monograph 124 the two thermoelements and the total combination were fit independently; for this Monograph equations for the total combination and for the positive thermoelement were used directly but the equation for the negative thermoelement $w$ as obtained by subtraction, symbolically, $E N=E-E P$. Therefore, the equation for $T N(\equiv E N)$ given in this Monograph will differ very slightly from the ${ }^{\circ} \mathrm{C}$ transformation of the one given in Monograph 124. The difference in calculated values will usually be less than the imprecision of the fits, $0.12 \mu \mathrm{V}$.

The data on Type $E$ thermocouples were much more sparse above $0{ }^{\circ} \mathrm{C}$ than they were below. In particular there were insufficient data on current Type EN material. Data points for Type E were selected from NBS Circular 561, adjusted to the present temperature scale, IPTS-68, and fit with a constrained power series. The power series was constrained to have the same values for the thermoelectric voltage and Seebeck coefficient at $0{ }^{\circ} \mathrm{C}$ as those obtained from the low temperature equations. A ninth degree equation (with constrained constant and linear term) fit 21 selected key data points between 0 and $1001{ }^{\circ} \mathrm{C}$ with an imprecision of $4.4 \mu \mathrm{V}$. Note that this is about 35 times poorer than the low temperature fit. The second derivative was not constrained at the join.

Fortunately, there was a large amount of good data for the positive thermoelement, EP or KP. The fit was based on 93 data points from three thermoelement calibrations (selected from a set of 13 calibrations) provided by the Temperature Section of the National Bureau of Standards and from a set of selected values in a widely distributed, but unpublished, NBS thermoelement table [Burns, 1967]. All of the high temperature values had to be adjusted to be on the IPTS-68 and to be referenced to Pt-67. A seventh degree equation, with the constant and linear terms constrained to match the low temperature values, had a fitting imprecision of $6.0 \mu \mathrm{V}$ for a range from 0 to $1371{ }^{\circ} \mathrm{C}$.

The tables and graphs for the two thermoelements, $\mathrm{EP}$, and EN, are given in different chapters. Values for EP, identical with $\mathrm{KP}$, are given in chapter 7; for EN, identical with TN, in chapter 8.

The values for the thermoelectric voltages of Type $E$ thermocouples given in this Monograph were compared to those given by Shenker et al. [1955] in NBS Circular 561. The deviations are shown in figure 5.2.1. The values from NBS Circular 561 were ad-

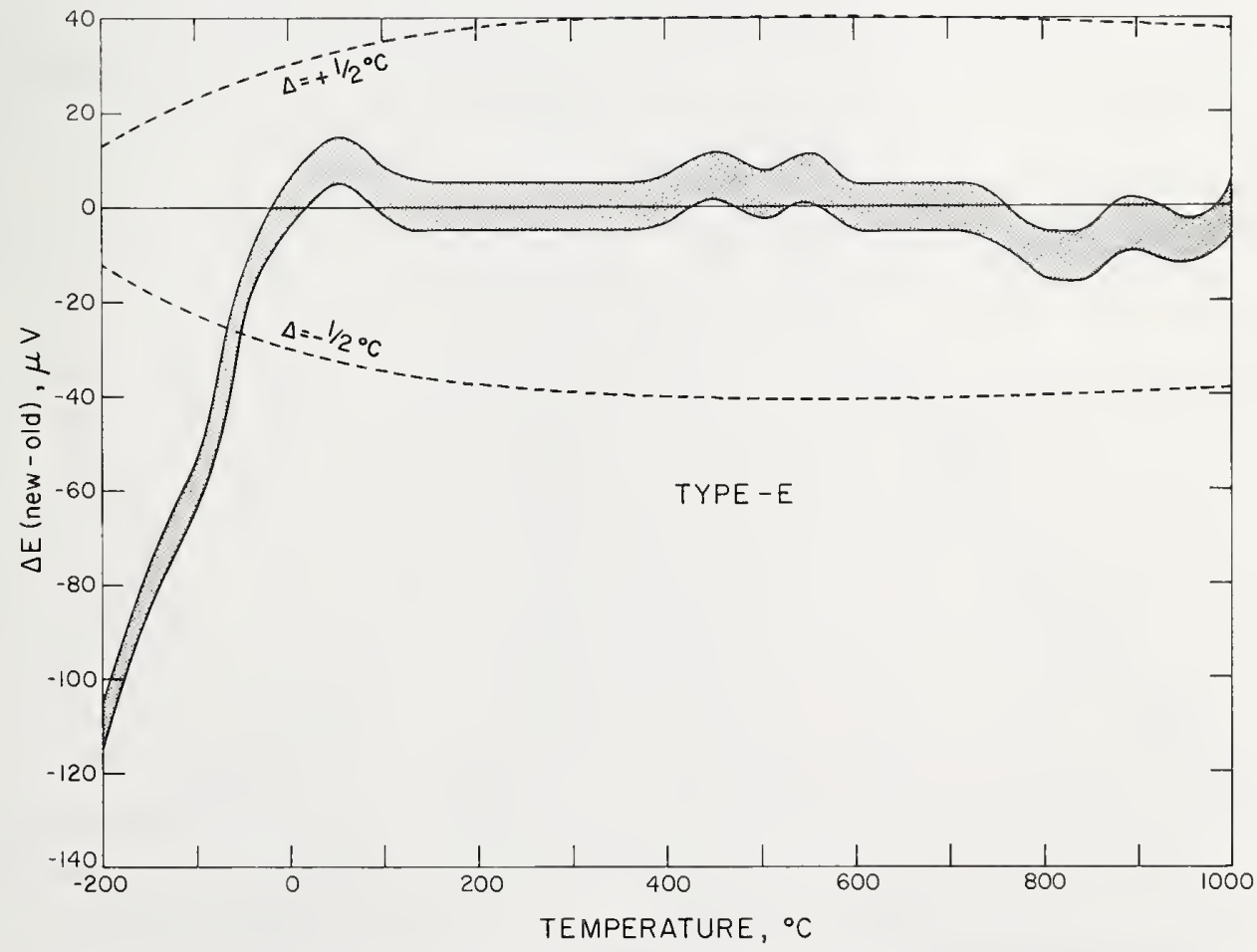

Figure 5.2.1. Differences in thermoelectric voltages for Type $E$ thermocouples-comparison of of values given in this Monograph to those given in NBS Circular 561.

The width of the shaded curve indicates the round-off uncertainty in the previous tabular values. Values from the previous publication are adjusted to the IPTS -68 . The dashed linea indicate a deviation of $1 / 2{ }^{\circ} \mathrm{C}$. 
justed to the IPTS-68. Above $0{ }^{\circ} \mathrm{C}$, the deviations between the values in this Monograph and those in NBS Circular 561 are caused primarily by the differences in fitting techniques. Below $0{ }^{\circ} \mathrm{C}$, the deviations are caused primarily by chemical composition changes in the thermoelements. Present day materials are slightly different in some of the minor additives. The width of the curve represents the round-off uncertainty $(10 \mu \mathrm{V})$ in the tabular values quoted in the previous tables.

\subsection{Reference Functions and Tables for Type E Thermocouples}

The coefficients for the thirteenth degree expansion for the thermoelectric voltage of Type $E$ thermocouples below $0{ }^{\circ} \mathrm{C}$ are given in table 5.3.1. The coefficients for the ninth degree expansion above $0{ }^{\circ} \mathrm{C}$ are also given in table 5.3.1. The errors caused by reduced-bit arithmetic for calculating values of the functions are given in table 5.3.4.

The primary reference values for Type $E$ thermocouples are given in table 5.3.2. Values at selected fixed points are given in table 5.3.3. Graphs of the thermoelectric voltage, its first derivative (Seebeck coefficient) and second derivative are given in figures 5.3.1, 5.3.2, and 5.3.3, respectively. The irregular dip in the second derivative near $0{ }^{\circ} \mathrm{C}$ is a result of the fitting techniques at the join of two regions, it is not a real physical phenomenon.

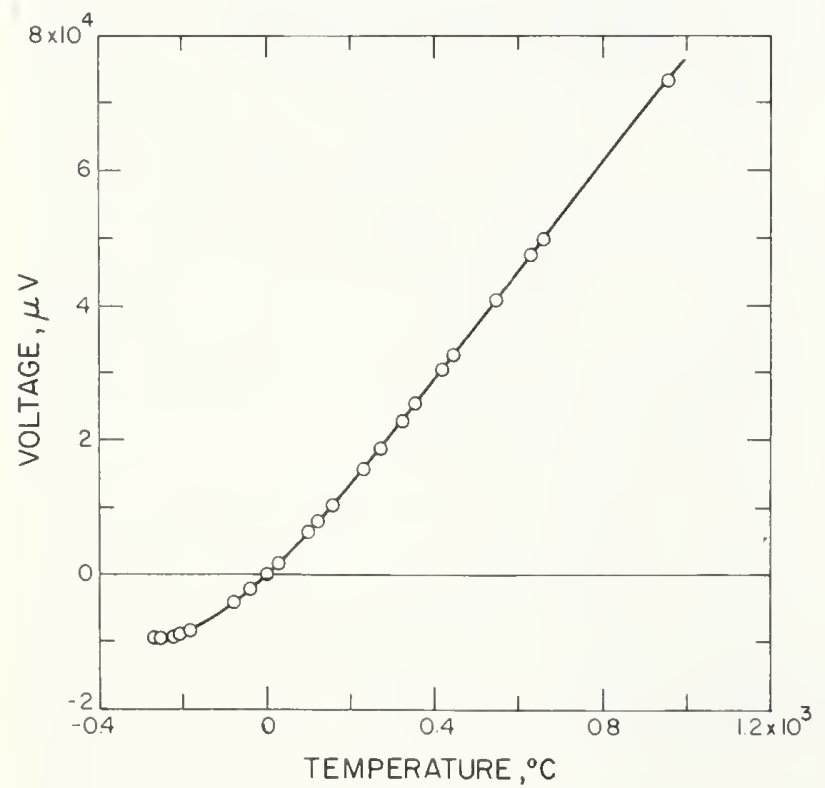

Figure 5.3.1. Thermoelectric voltage for Type $E$ thermo. couples.

The circles indicate values at various thermometric fixed points on the IPTS-68.
It should be stressed that Type $\mathbf{E}$ thermocouple materials that conform closely to the high temperature tabular values may not necessarily conform closely at low temperatures (below $0^{\circ} \mathrm{C}$ ) and vice versa. If Type $E$ thermocouples are to be used for accurate measurements both above and below $0{ }^{\circ} \mathrm{C}$, then the material must be calibrated in the full temperature range, both above and below ${ }^{\circ} \mathrm{C}$. Special selection of material will usually be required.

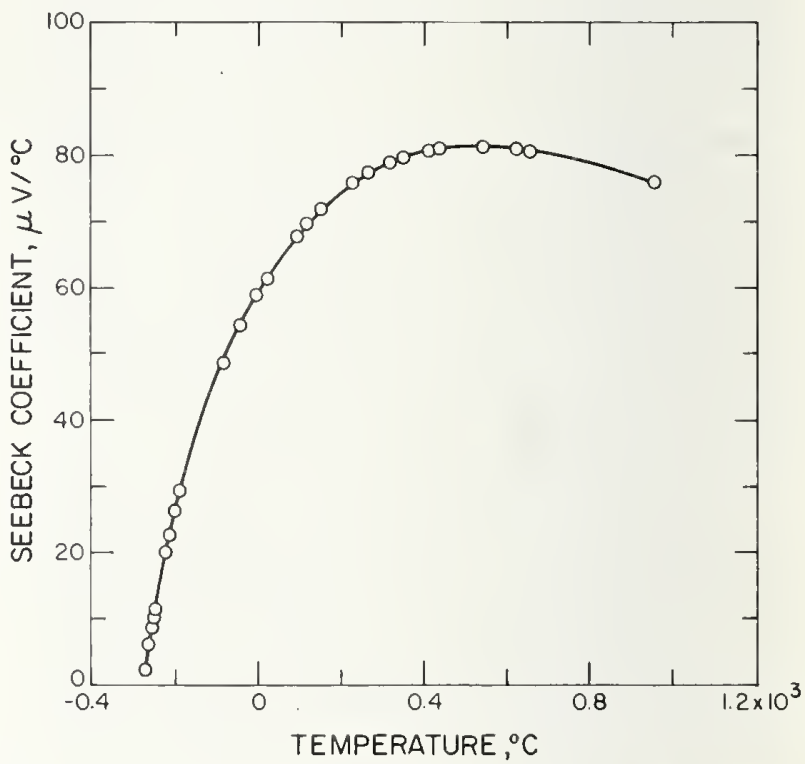

Figure 5.3.2. Seebeck coefficient for Type E thermocouples. The circles indicate values at various thermometric fixed points on the IPTS-68.

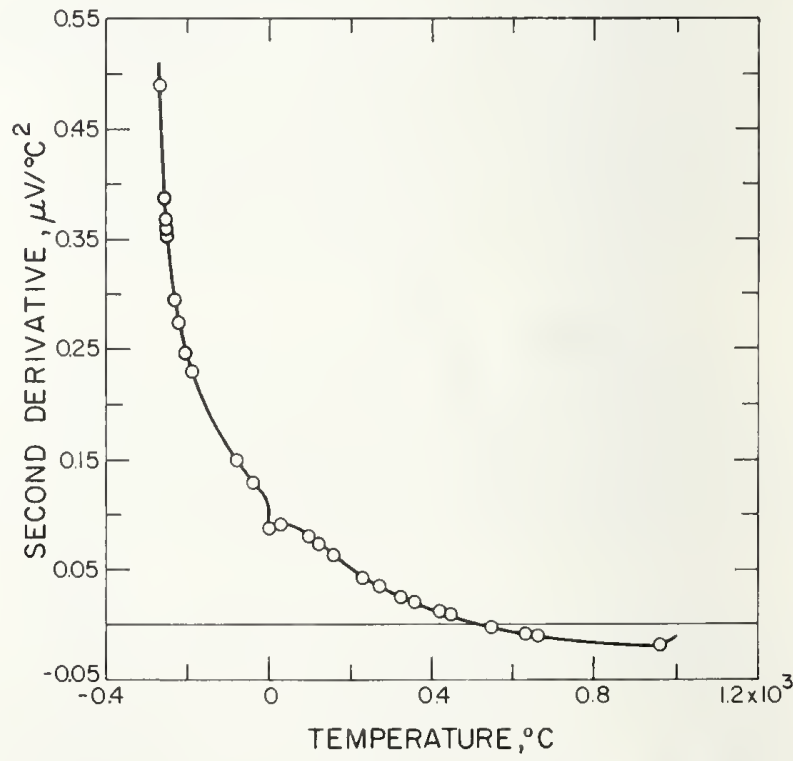

Figure 5.3.3. Second derivative of thermoelectric voltage for Type E thermocouples.

The circles indicate values at various thermometric fixed points on the The circles indicate values at various thermometric fred points on the at the join of two regions, it is not a real physical phenomenon. 
TABLE 5.3.1. Power series expansion for the thermoelectric voltage of Type $E$ thermocouples

\begin{tabular}{|c|c|c|c|}
\hline $\begin{array}{c}\text { Tempera- } \\
\text { ture } \\
\text { range }\end{array}$ & Degree & Coefficients & Term \\
\hline $\begin{array}{c}-270 \text { to } \\
0^{\circ} \mathrm{C}\end{array}$ & 13 & $\begin{array}{r}5.8695857799 \times 10^{1} \\
5.1667517705 \times 10^{-2} \\
-4.4652683347 \times 10^{-4} \\
-1.7346270905 \times 10^{-5} \\
-4.8719368427 \times 10^{-7} \\
-8.8896550447 \times 10^{-9} \\
-1.0930767375 \times 10^{-10} \\
-9.1784535039 \times 10^{-13} \\
-5.2575158521 \times 10^{-16} \\
-2.0169601996 \times 10^{-17} \\
-4.9502138782 \times 10^{-20} \\
-7.0177980633 \times 10^{-23} \\
-4.3671808488 \times 10^{-26}\end{array}$ & $\begin{array}{l}T \\
T^{2} \\
T^{3} \\
T^{4} \\
T^{5} \\
T^{6} \\
T^{7} \\
T^{8} \\
T^{9} \\
T^{10} \\
T^{11} \\
T^{12} \\
T^{13}\end{array}$ \\
\hline $\begin{array}{l}0 \text { to } 1000 \\
{ }^{\circ} \mathrm{C}\end{array}$ & 9 & $\begin{array}{r}5.8695857799 \times 10^{1} \\
4.3110945462 \times 10^{-2} \\
5.7220358202 \times 10^{-5} \\
-5.4020668085 \times 10^{-7} \\
1.5425922111 \times 10^{-9} \\
-2.4850089136 \times 10^{-12} \\
2.3389721459 \times 10^{-15} \\
-1.1946296815 \times 10^{-16} \\
2.5561127497 \times 10^{-22}\end{array}$ & $\begin{array}{l}T \\
T^{2} \\
T^{3} \\
T^{4} \\
T^{5} \\
T^{6} \\
T^{7} \\
T^{6} \\
T^{9}\end{array}$ \\
\hline
\end{tabular}


TABLE 5.3.2. Type E thermocouples-thermoelectric voltages, $\mathrm{E}(\mathrm{T})$, Seebeck coefficients, $\mathrm{S}(\mathrm{T})$, and first derivative of the Seebeck coefficients, $\mathrm{dS} / \mathrm{dT}$, reference junctions at $0^{\circ} \mathrm{C}$

\begin{tabular}{|c|c|c|c|c|c|c|c|c|c|c|c|}
\hline $\begin{array}{l}\mathrm{T} \\
{ }^{\circ} \mathrm{C}\end{array}$ & $\underset{\mu V}{E}$ & $\underset{\mu V /{ }^{\circ} \mathrm{C}}{S}$ & $\begin{array}{l}d S / d T \\
n V /{ }^{\circ} C^{2}\end{array}$ & $\begin{array}{l}{ }^{\top} \\
{ }^{\circ} \mathrm{C}\end{array}$ & $\underset{\mu V}{E}$ & $\underset{\mu \mathrm{V} /{ }^{\circ} \mathrm{C}}{S}$ & $\begin{array}{l}\mathrm{dS} / \mathrm{dT} \\
\mathrm{nV} /{ }^{\circ} \mathrm{C}^{2}\end{array}$ & $\begin{array}{l}\mathrm{T} \\
{ }^{\circ} \mathrm{C}\end{array}$ & $\begin{array}{c}E \\
\mu V\end{array}$ & $\frac{\mathrm{S}}{\mu \mathrm{V} /{ }^{\circ} \mathrm{C}}$ & $\begin{array}{l}d S / d T \\
n V /{ }^{\circ} C^{2}\end{array}$ \\
\hline $\begin{array}{l}-270 \\
-269 \\
-268 \\
-267 \\
-266\end{array}$ & $\begin{array}{l}-9835.03 \\
-9833.22 \\
-9830.93 \\
-9828.16 \\
-9824.93\end{array}$ & $\begin{array}{l}1.549 \\
2.052 \\
2.535 \\
3.000 \\
3.450\end{array}$ & $\begin{array}{l}514.24 \\
492.52 \\
473.56 \\
457.05 \\
442.72\end{array}$ & $\begin{array}{l}-240 \\
-239 \\
-238 \\
-237 \\
-236\end{array}$ & $\begin{array}{l}-9604.15 \\
-9590.78 \\
-9577.06 \\
-9563.00 \\
-9548.61\end{array}$ & $\begin{array}{l}13.199 \\
13.544 \\
13.888 \\
14.229 \\
14.568\end{array}$ & $\begin{array}{l}346 \cdot 27 \\
344 \cdot 35 \\
342 \cdot 35 \\
340 \cdot 26 \\
338.10\end{array}$ & $\begin{array}{l}-210 \\
-209 \\
-208 \\
-207 \\
-206\end{array}$ & $\begin{array}{l}-9062.86 \\
-9040.21 \\
-9017.30 \\
-8994.12 \\
-8970.67\end{array}$ & $\begin{array}{l}22.507 \\
22.779 \\
23.048 \\
23.316 \\
23.581\end{array}$ & $\begin{array}{l}272.79 \\
270.59 \\
268.44 \\
266.35 \\
264.30\end{array}$ \\
\hline $\begin{array}{l}-265 \\
-264 \\
-263 \\
-262 \\
-261\end{array}$ & $\begin{array}{l}-9821.27 \\
-9817.17 \\
-9812.65 \\
-9807.72 \\
-9802.39\end{array}$ & $\begin{array}{l}3.886 \\
4.311 \\
4.726 \\
5.132 \\
5.531\end{array}$ & $\begin{array}{l}430.32 \\
419.62 \\
410.41 \\
402.52 \\
395.77\end{array}$ & $\begin{array}{l}-235 \\
-234 \\
-233 \\
-232 \\
-231\end{array}$ & $\begin{array}{l}-9533.87 \\
-9518.80 \\
-9503.39 \\
-9487.65 \\
-9471.59\end{array}$ & $\begin{array}{l}14.905 \\
15.240 \\
15.572 \\
15.902 \\
16.230\end{array}$ & $\begin{array}{l}335.86 \\
333.55 \\
331.18 \\
328.74 \\
326.25\end{array}$ & $\begin{array}{l}-205 \\
-204 \\
-203 \\
-202 \\
-201\end{array}$ & $\begin{array}{l}-8946.96 \\
-8922.98 \\
-8898.75 \\
-8874.25 \\
-8849.50\end{array}$ & $\begin{array}{l}23.844 \\
24.106 \\
24.365 \\
24.623 \\
24.878\end{array}$ & $\begin{array}{l}262.31 \\
260.37 \\
258.49 \\
256.65 \\
254.87\end{array}$ \\
\hline $\begin{array}{l}-260 \\
-259 \\
-258 \\
-257 \\
-256\end{array}$ & $\begin{array}{l}-9796.66 \\
-9790.54 \\
-9784.04 \\
-9777.15 \\
-9769.89\end{array}$ & $\begin{array}{l}5.924 \\
6.311 \\
6.694 \\
7.073 \\
7.449\end{array}$ & $\begin{array}{l}390.00 \\
385.07 \\
380.87 \\
377.27 \\
374.19\end{array}$ & $\begin{array}{l}-230 \\
-229 \\
-228 \\
-227 \\
-226\end{array}$ & $\begin{array}{l}-9455.19 \\
-9438.48 \\
-9421.44 \\
-9404.09 \\
-9386.41\end{array}$ & $\begin{array}{l}16.555 \\
16.877 \\
17.197 \\
17.514 \\
17.829\end{array}$ & $\begin{array}{l}323.72 \\
321.14 \\
318.53 \\
315.90 \\
313.24\end{array}$ & $\begin{array}{l}-200 \\
-199 \\
-198 \\
-197 \\
-196\end{array}$ & $\begin{array}{l}-8824.50 \\
-8799.24 \\
-8773.73 \\
-8747.97 \\
-8721.96\end{array}$ & $\begin{array}{l}25.132 \\
25.385 \\
25.635 \\
25.884 \\
26.132\end{array}$ & $\begin{array}{l}253.13 \\
251.44 \\
249 \cdot 80 \\
248.20 \\
246.64\end{array}$ \\
\hline $\begin{array}{l}-255 \\
-254 \\
-253 \\
-252 \\
-251\end{array}$ & $\begin{array}{l}-9762.25 \\
-9754.25 \\
-9745.87 \\
-9737.13 \\
-9728.02\end{array}$ & $\begin{array}{l}7.822 \\
8.192 \\
8.560 \\
8.927 \\
9.291\end{array}$ & $\begin{array}{l}371.52 \\
369.20 \\
367.15 \\
365.31 \\
363.63\end{array}$ & $\begin{array}{l}-225 \\
-224 \\
-223 \\
-222 \\
-221\end{array}$ & $\begin{array}{l}-9368.43 \\
-9350.13 \\
-9331.53 \\
-9312.62 \\
-9293.41\end{array}$ & $\begin{array}{l}18.141 \\
18.450 \\
18.756 \\
19.060 \\
19.362\end{array}$ & $\begin{array}{l}310.58 \\
307.91 \\
305.23 \\
302.57 \\
299.92\end{array}$ & $\begin{array}{l}-195 \\
-194 \\
-193 \\
-192 \\
-191\end{array}$ & $\begin{array}{l}-8695.70 \\
-8669.20 \\
-8642.46 \\
-8615.47 \\
-8588.25\end{array}$ & $\begin{array}{l}26.378 \\
26.622 \\
26.865 \\
27.106 \\
27.347\end{array}$ & $\begin{array}{l}245.13 \\
243.65 \\
242.22 \\
240.82 \\
239.45\end{array}$ \\
\hline $\begin{array}{l}-250 \\
-249 \\
-248 \\
-247 \\
-246\end{array}$ & $\begin{array}{l}-9718.55 \\
-9708.71 \\
-9698.52 \\
-9687.96 \\
-9677.05\end{array}$ & $\begin{array}{r}9.654 \\
10.015 \\
10.375 \\
10.733 \\
11.090\end{array}$ & $\begin{array}{l}362.06 \\
360.56 \\
359.10 \\
357.65 \\
356.19\end{array}$ & $\begin{array}{l}-220 \\
-219 \\
-218 \\
-217 \\
-216\end{array}$ & $\begin{array}{l}-9273.90 \\
-9254.09 \\
-9233.99 \\
-9213.59 \\
-9192.91\end{array}$ & $\begin{array}{l}19.660 \\
19.956 \\
20.250 \\
20.540 \\
20.829\end{array}$ & $\begin{array}{l}297.28 \\
294.67 \\
292.08 \\
289.53 \\
287.01\end{array}$ & $\begin{array}{l}-190 \\
-189 \\
-188 \\
-187 \\
-186\end{array}$ & $\begin{array}{l}-8560.78 \\
-8533.08 \\
-8505.14 \\
-8476.96 \\
-8448.55\end{array}$ & $\begin{array}{l}27.585 \\
27.823 \\
28.059 \\
28.294 \\
28.528\end{array}$ & $\begin{array}{l}238.12 \\
236.81 \\
235.54 \\
234.29 \\
233.06\end{array}$ \\
\hline $\begin{array}{l}-245 \\
-244 \\
-243 \\
-242 \\
-241\end{array}$ & $\begin{array}{l}-9665.78 \\
-9654.16 \\
-9642.18 \\
-9629.85 \\
-9617.18\end{array}$ & $\begin{array}{l}11.446 \\
11.800 \\
12.152 \\
12.503 \\
12.852\end{array}$ & $\begin{array}{l}354.69 \\
353.15 \\
351.54 \\
349.86 \\
348.11\end{array}$ & $\begin{array}{l}-215 \\
-214 \\
-213 \\
-212 \\
-211\end{array}$ & $\begin{array}{l}-9171.94 \\
-9150.68 \\
-9129.14 \\
-9107.32 \\
-9085.23\end{array}$ & $\begin{array}{l}21.114 \\
21.398 \\
21.679 \\
21.957 \\
22.233\end{array}$ & $\begin{array}{l}284.53 \\
282.09 \\
279.69 \\
277.34 \\
275.04\end{array}$ & $\begin{array}{l}-185 \\
-184 \\
-183 \\
-182 \\
-181\end{array}$ & $\begin{array}{l}-8419.90 \\
-8391.03 \\
-8361.92 \\
-8332.59 \\
-8303.02\end{array}$ & $\begin{array}{l}28.750 \\
28.991 \\
29.221 \\
29.450 \\
29.678\end{array}$ & $\begin{array}{l}231.86 \\
230.69 \\
229.53 \\
228.39 \\
227.27\end{array}$ \\
\hline 240 & -9604.15 & 13.199 & 346.27 & -210 & -9062.86 & 22.507 & 272.79 & -180 & -8273.23 & 29.905 & $226 \cdot 16$ \\
\hline
\end{tabular}


TABLE 5.3.2. Type E thermocouples-thermoelectric voltages, $\mathrm{E}(\mathrm{T})$, Seebeck coefficients, $\mathrm{S}(\mathrm{T})$, and first derivative of the Seebeck coefficients, $\mathrm{dS} / \mathrm{dT}$, reference junctions at $0{ }^{\circ} \mathrm{C}$-Continued

\begin{tabular}{|c|c|c|c|c|c|c|c|c|c|c|c|}
\hline${ }^{\mathrm{T}} \mathrm{C}$ & $\begin{array}{c}E V \\
\mu V\end{array}$ & $\stackrel{S}{\mu V /{ }^{\circ} \mathrm{C}}$ & $\begin{array}{l}d S / d T \\
n V /{ }^{\circ} C^{2}\end{array}$ & $\begin{array}{c}\mathrm{T} \\
{ }^{\circ} \mathrm{C}\end{array}$ & $\begin{array}{c}E \\
\mu V\end{array}$ & $\stackrel{S}{S}$ & $\begin{array}{l}\mathrm{dS} / \mathrm{dT} \\
\mathrm{nV} /{ }^{\circ} \mathrm{C}^{2}\end{array}$ & ${ }^{\circ} \mathrm{C}$ & $\begin{array}{c}E \\
\mu V\end{array}$ & $\stackrel{\mathrm{S}}{\mu \mathrm{V} /{ }^{\circ} \mathrm{C}}$ & $\begin{array}{l}\mathrm{dS} / \mathrm{dT} \\
\mathrm{nV} /{ }^{\circ} \mathrm{C}^{2}\end{array}$ \\
\hline $\begin{array}{l}-180 \\
-179 \\
-178 \\
-177 \\
-176\end{array}$ & $\begin{array}{l}-8273.23 \\
-8243.21 \\
-8212.97 \\
-8182.50 \\
-8151.81\end{array}$ & $\begin{array}{l}29.905 \\
30.131 \\
30.355 \\
30.579 \\
30.801\end{array}$ & $\begin{array}{l}226.16 \\
225.07 \\
223.99 \\
222.92 \\
221.87\end{array}$ & $\begin{array}{l}-120 \\
-119 \\
-118 \\
-117 \\
-116\end{array}$ & $\begin{array}{l}-6106.80 \\
-6064.91 \\
-6022.85 \\
-5980.62 \\
-5938.21\end{array}$ & $\begin{array}{l}41.797 \\
41.972 \\
42.146 \\
42.319 \\
42.492\end{array}$ & $\begin{array}{l}175.08 \\
174.47 \\
173.85 \\
173.24 \\
172.64\end{array}$ & $\begin{array}{l}-60 \\
-59 \\
-58 \\
-57 \\
-56\end{array}$ & $\begin{array}{l}-3305.75 \\
-3254.48 \\
-3203.06 \\
-3151.51 \\
-3099.82\end{array}$ & $\begin{array}{l}51.207 \\
51.346 \\
51.484 \\
51.622 \\
51.760\end{array}$ & $\begin{array}{l}139.22 \\
138.70 \\
138.19 \\
137.69 \\
137.18\end{array}$ \\
\hline $\begin{array}{l}-175 \\
-174 \\
-173 \\
-172 \\
-171\end{array}$ & $\begin{array}{l}-8120.90 \\
-8089.77 \\
-8058.42 \\
-8026.85 \\
-7995.06\end{array}$ & $\begin{array}{l}31.022 \\
31.243 \\
31.462 \\
31.680 \\
31.897\end{array}$ & $\begin{array}{l}220.82 \\
219.79 \\
218.76 \\
217.74 \\
216.73\end{array}$ & $\begin{array}{l}-115 \\
-114 \\
-113 \\
-112 \\
-111\end{array}$ & $\begin{array}{l}-5895.64 \\
-5852.88 \\
-5809.96 \\
-5766.87 \\
-5723.61\end{array}$ & $\begin{array}{l}42.665 \\
42.836 \\
43.008 \\
43.178 \\
43.348\end{array}$ & $\begin{array}{l}172.03 \\
171.43 \\
170.83 \\
170.23 \\
169.63\end{array}$ & $\begin{array}{l}-55 \\
-54 \\
-53 \\
-52 \\
-51\end{array}$ & $\begin{array}{l}-3047.99 \\
-2996.02 \\
-2943.92 \\
-2891.69 \\
-2839.31\end{array}$ & $\begin{array}{l}51.897 \\
52.033 \\
52.169 \\
52.305 \\
52.440\end{array}$ & $\begin{array}{l}136.68 \\
136.19 \\
135.69 \\
135.20 \\
134.71\end{array}$ \\
\hline $\begin{array}{l}-170 \\
-169 \\
-168 \\
-167 \\
-166\end{array}$ & $\begin{array}{l}-7963.05 \\
-7930.83 \\
-7898.39 \\
-7865.74 \\
-7832.88\end{array}$ & $\begin{array}{l}32.114 \\
32.329 \\
32.543 \\
32.756 \\
32.969\end{array}$ & $\begin{array}{l}215.73 \\
214.73 \\
213.74 \\
212.75 \\
211.78\end{array}$ & $\begin{array}{l}-110 \\
-109 \\
-108 \\
-107 \\
-106\end{array}$ & $\begin{array}{l}-5680.17 \\
-5636.57 \\
-5592.80 \\
-5548.86 \\
-5504.76\end{array}$ & $\begin{array}{l}43.517 \\
43.686 \\
43.854 \\
44.022 \\
44.189\end{array}$ & $\begin{array}{l}169.03 \\
168.43 \\
167.83 \\
167.23 \\
166.63\end{array}$ & $\begin{array}{l}-50 \\
-49 \\
-48 \\
-47 \\
-46\end{array}$ & $\begin{array}{l}-2786.81 \\
-2734.17 \\
-2681.39 \\
-2628.48 \\
-2575.44\end{array}$ & $\begin{array}{l}52.574 \\
52.708 \\
52.841 \\
52.974 \\
53.107\end{array}$ & $\begin{array}{l}134.22 \\
133.73 \\
133.24 \\
132.76 \\
132.27\end{array}$ \\
\hline $\begin{array}{l}-165 \\
-164 \\
-163\end{array}$ & $\begin{array}{l}-7799.81 \\
-7766.52 \\
-7733.03\end{array}$ & $\begin{array}{l}33.180 \\
33.390 \\
33.600\end{array}$ & $\begin{array}{l}210.80 \\
209.84 \\
208.87\end{array}$ & $\begin{array}{l}-105 \\
-104 \\
-103\end{array}$ & $\begin{array}{l}-5460.49 \\
-5416.05 \\
-5371.45\end{array}$ & $\begin{array}{l}44.355 \\
44.521 \\
44.686\end{array}$ & $\begin{array}{l}166.02 \\
165.42 \\
164.81\end{array}$ & $\begin{array}{l}-45 \\
-44 \\
-43\end{array}$ & $\begin{array}{l}-2522.27 \\
-2468.97 \\
-2415.53\end{array}$ & $\begin{array}{l}53.239 \\
53.371 \\
53.502\end{array}$ & $\begin{array}{l}131.79 \\
131.30 \\
130.82\end{array}$ \\
\hline $\begin{array}{l}-162 \\
-161\end{array}$ & $\begin{array}{l}-7699.32 \\
-7665.41\end{array}$ & $\begin{array}{l}33.808 \\
34.015\end{array}$ & $\begin{array}{l}207.92 \\
206.97\end{array}$ & $\begin{array}{l}-102 \\
-101\end{array}$ & $\begin{array}{l}-5326.68 \\
-5281.74\end{array}$ & $\begin{array}{l}44.850 \\
45.014\end{array}$ & $\begin{array}{l}164.20 \\
163.59\end{array}$ & $\begin{array}{l}-42 \\
-41\end{array}$ & $\begin{array}{l}-2361 \cdot 96 \\
-2308 \cdot 27\end{array}$ & $\begin{array}{l}53.632 \\
53.762\end{array}$ & $\begin{array}{l}130.33 \\
129.85\end{array}$ \\
\hline $\begin{array}{l}-160 \\
-159 \\
-158 \\
-157 \\
-156\end{array}$ & $\begin{array}{l}-7631.29 \\
-7596.97 \\
-7562.44 \\
-7527.70 \\
-7492.77\end{array}$ & $\begin{array}{l}34.222 \\
34.427 \\
34.632 \\
34.836 \\
35.038\end{array}$ & $\begin{array}{l}206.02 \\
205.09 \\
204.15 \\
203.23 \\
202.31\end{array}$ & $\begin{array}{l}-100 \\
-99 \\
-98 \\
-97 \\
-96\end{array}$ & $\begin{array}{l}-5236.65 \\
-5191.39 \\
-5145.97 \\
-5100.39 \\
-5054.64\end{array}$ & $\begin{array}{l}45.178 \\
45.340 \\
45.502 \\
45.664 \\
45.825\end{array}$ & $\begin{array}{l}162.98 \\
162.36 \\
161.75 \\
161.13 \\
160.51\end{array}$ & $\begin{array}{l}-40 \\
-39 \\
-38 \\
-37 \\
-36\end{array}$ & $\begin{array}{l}-2254.44 \\
-2200.48 \\
-2146.40 \\
-2092.18 \\
-2037.84\end{array}$ & $\begin{array}{l}53.892 \\
54.021 \\
54.150 \\
54.278 \\
54.406\end{array}$ & $\begin{array}{l}129.37 \\
128.89 \\
128.41 \\
127.94 \\
127.46\end{array}$ \\
\hline $\begin{array}{l}-155 \\
-154 \\
-153 \\
-152 \\
-151\end{array}$ & $\begin{array}{l}-7457.63 \\
-7422.29 \\
-7386.75 \\
-7351.00 \\
-7315.06\end{array}$ & $\begin{array}{l}35.240 \\
35.441 \\
35.641 \\
35.840 \\
36.039\end{array}$ & $\begin{array}{l}201.40 \\
200.50 \\
199.60 \\
198.71 \\
197.83\end{array}$ & $\begin{array}{l}-95 \\
-94 \\
-93 \\
-92 \\
-91\end{array}$ & $\begin{array}{l}-5008.74 \\
-4962.67 \\
-4916.45 \\
-4870.07 \\
-4823.53\end{array}$ & $\begin{array}{l}45.985 \\
46.144 \\
46.303 \\
46.462 \\
46.619\end{array}$ & $\begin{array}{l}159.89 \\
159.26 \\
158.64 \\
158.02 \\
157.39\end{array}$ & $\begin{array}{l}-35 \\
-34 \\
-33 \\
-32 \\
-31\end{array}$ & $\begin{array}{l}-1983.37 \\
-1928.78 \\
-1874.05 \\
-1819.20 \\
-1764.23\end{array}$ & $\begin{array}{l}54.533 \\
54.660 \\
54.786 \\
54.912 \\
55.037\end{array}$ & $\begin{array}{l}126.99 \\
126.53 \\
126.06 \\
125.61 \\
125.16\end{array}$ \\
\hline $\begin{array}{l}-150 \\
-149 \\
-148 \\
-147 \\
-146\end{array}$ & $\begin{array}{l}-7278.93 \\
-7242.59 \\
-7206.06 \\
-7169.34 \\
-7132.42\end{array}$ & $\begin{array}{l}36.236 \\
36.433 \\
36.628 \\
36.823 \\
37.017\end{array}$ & $\begin{array}{l}196.96 \\
196.10 \\
195.24 \\
194.40 \\
193.56\end{array}$ & $\begin{array}{l}-90 \\
-89 \\
-88 \\
-87 \\
-86\end{array}$ & $\begin{array}{l}-4776.83 \\
-4729.97 \\
-4682.96 \\
-4635.80 \\
-4588.48\end{array}$ & $\begin{array}{l}46.776 \\
46.933 \\
47.089 \\
47.244 \\
47.398\end{array}$ & $\begin{array}{l}156.76 \\
156.14 \\
155.51 \\
154.89 \\
154.26\end{array}$ & $\begin{array}{l}-30 \\
-29 \\
-28 \\
-27 \\
-26\end{array}$ & $\begin{array}{l}-1709.13 \\
-1653.91 \\
-1598.56 \\
-1543.09 \\
-1487.49\end{array}$ & $\begin{array}{l}55.162 \\
55.286 \\
55.411 \\
55.534 \\
55.657\end{array}$ & $\begin{array}{l}124.71 \\
124.28 \\
123.85 \\
123.43 \\
123.03\end{array}$ \\
\hline $\begin{array}{l}-145 \\
-144 \\
-143 \\
-142 \\
-141\end{array}$ & $\begin{array}{l}-7095.30 \\
-7058.00 \\
-7020.50 \\
-6982.81 \\
-6944.93\end{array}$ & $\begin{array}{l}37.210 \\
37.403 \\
37.594 \\
37.785 \\
37.975\end{array}$ & $\begin{array}{l}192.74 \\
191.92 \\
191.11 \\
190.32 \\
189.53\end{array}$ & $\begin{array}{l}-85 \\
-84 \\
-83 \\
-82 \\
-81\end{array}$ & $\begin{array}{l}-4541.00 \\
-4493.37 \\
-4445.59 \\
-4397.65 \\
-4349.57\end{array}$ & $\begin{array}{l}47.552 \\
47.706 \\
47.858 \\
48.010 \\
48.162\end{array}$ & $\begin{array}{l}153.64 \\
153.01 \\
152.39 \\
151.77 \\
151.16\end{array}$ & $\begin{array}{l}-25 \\
-24 \\
-23 \\
-22 \\
-21\end{array}$ & $\begin{array}{l}-1431.77 \\
-1375.93 \\
-1319.97 \\
-1263.88 \\
-1207.67\end{array}$ & $\begin{array}{l}55.780 \\
55.903 \\
56.025 \\
56.146 \\
56.268\end{array}$ & $\begin{array}{l}122.63 \\
122.24 \\
121.86 \\
121.49 \\
121.13\end{array}$ \\
\hline $\begin{array}{l}-140 \\
-139 \\
-138 \\
-137 \\
-136\end{array}$ & $\begin{array}{l}-6906.86 \\
-6868.60 \\
-6830.15 \\
-6791.52 \\
-6752.70\end{array}$ & $\begin{array}{l}38.164 \\
38.352 \\
38.540 \\
38.727 \\
38.913\end{array}$ & $\begin{array}{l}188.75 \\
187.99 \\
187.23 \\
186.48 \\
185.75\end{array}$ & $\begin{array}{l}-80 \\
-79 \\
-78 \\
-77 \\
-76\end{array}$ & $\begin{array}{l}-4301.33 \\
-4252.94 \\
-4204.40 \\
-4155.72 \\
-4106.88\end{array}$ & $\begin{array}{l}48.313 \\
48.463 \\
48.613 \\
48.762 \\
48.910\end{array}$ & $\begin{array}{l}150.54 \\
149.93 \\
149 \cdot 33 \\
148.72 \\
148.12\end{array}$ & $\begin{array}{l}-20 \\
-19 \\
-18 \\
-17 \\
-16\end{array}$ & $\begin{array}{r}-1151.34 \\
-1094.90 \\
-1038.33 \\
-981.64 \\
-924.83\end{array}$ & $\begin{array}{l}56.389 \\
56.509 \\
56.630 \\
56.749 \\
56.869\end{array}$ & $\begin{array}{l}120.78 \\
120.43 \\
120.09 \\
119.74 \\
119.39\end{array}$ \\
\hline $\begin{array}{l}-135 \\
-134 \\
-133 \\
-132 \\
-131\end{array}$ & $\begin{array}{l}-6713.70 \\
-6674.50 \\
-6635.13 \\
-6595.57 \\
-6555.83\end{array}$ & $\begin{array}{l}39.098 \\
39.283 \\
39.467 \\
39.650 \\
39.833\end{array}$ & $\begin{array}{l}185.02 \\
184.30 \\
183.59 \\
182.89 \\
182.20\end{array}$ & $\begin{array}{l}-75 \\
-74 \\
-73 \\
-72 \\
-71\end{array}$ & $\begin{array}{l}-4057.90 \\
-4008.77 \\
-3959.49 \\
-3910.06 \\
-3860.49\end{array}$ & $\begin{array}{l}49.058 \\
49.205 \\
49.352 \\
49.498 \\
49.643\end{array}$ & $\begin{array}{l}147.53 \\
146.94 \\
146.35 \\
145.77 \\
145.20\end{array}$ & $\begin{array}{l}-15 \\
-14 \\
-13 \\
-12 \\
-11\end{array}$ & $\begin{array}{l}-867.90 \\
-810.85 \\
-753.68 \\
-696.40 \\
-639.00\end{array}$ & $\begin{array}{l}56.988 \\
57.107 \\
57.226 \\
57.344 \\
57.461\end{array}$ & $\begin{array}{l}119.03 \\
118.66 \\
118.26 \\
117.82 \\
117.34\end{array}$ \\
\hline $\begin{array}{l}-130 \\
-129 \\
-128 \\
-127 \\
-126\end{array}$ & $\begin{array}{l}-6515.91 \\
-6475.80 \\
-6435.52 \\
-6395.05 \\
-6354.40\end{array}$ & $\begin{array}{l}40.014 \\
40 \cdot 196 \\
40.376 \\
40.556 \\
40.735\end{array}$ & $\begin{array}{l}181.52 \\
180.85 \\
180.18 \\
179.52 \\
178.87\end{array}$ & $\begin{array}{l}-70 \\
-69 \\
-68 \\
-67 \\
-66\end{array}$ & $\begin{array}{l}-3810.78 \\
-3760.92 \\
-3710.91 \\
-3660.76 \\
-3610.47\end{array}$ & $\begin{array}{l}49.788 \\
49.933 \\
50.076 \\
50.220 \\
50.362\end{array}$ & $\begin{array}{l}144.63 \\
144.06 \\
143.50 \\
142.95 \\
142.40\end{array}$ & $\begin{array}{l}-10 \\
-9 \\
-8 \\
-7 \\
-6\end{array}$ & $\begin{array}{l}-581.48 \\
-523.84 \\
-466.09 \\
-408.22 \\
-350.24\end{array}$ & $\begin{array}{l}57.578 \\
57.695 \\
57.811 \\
57.926 \\
58.040\end{array}$ & $\begin{array}{l}116.80 \\
116.19 \\
115.48 \\
114.66 \\
113.71\end{array}$ \\
\hline $\begin{array}{l}-125 \\
-124 \\
-123 \\
-122 \\
-121\end{array}$ & $\begin{array}{l}-6313.58 \\
-6272.58 \\
-6231.40 \\
-6190.04 \\
-6148.51\end{array}$ & $\begin{array}{l}40.914 \\
41.092 \\
41.269 \\
41.446 \\
41.622\end{array}$ & $\begin{array}{l}178.22 \\
177.58 \\
176.95 \\
176.32 \\
175.70\end{array}$ & $\begin{array}{l}-65 \\
-64 \\
-63 \\
-62 \\
-61\end{array}$ & $\begin{array}{l}-3560.04 \\
-3509.46 \\
-3458.75 \\
-3407.89 \\
-3356.89\end{array}$ & $\begin{array}{l}50.504 \\
50.646 \\
50.787 \\
50.928 \\
51.068\end{array}$ & $\begin{array}{l}141.86 \\
141.32 \\
140.79 \\
140.26 \\
139.74\end{array}$ & $\begin{array}{l}-5 \\
-4 \\
-3 \\
-2 \\
-1\end{array}$ & $\begin{array}{r}-292.14 \\
-233.93 \\
-175.61 \\
-117.18 \\
-58.64\end{array}$ & $\begin{array}{l}58.153 \\
58.265 \\
58.375 \\
58.484 \\
58.591\end{array}$ & $\begin{array}{l}112.59 \\
111.28 \\
109.74 \\
107.93 \\
105.82\end{array}$ \\
\hline 120 & $-6106 \cdot 80$ & 41.797 & 175.08 & -60 & -3305.75 & 51.207 & 139.22 & 0 & 0.00 & 58.696 & 86.22 \\
\hline
\end{tabular}


TABLE 5.3.2. Type $\boldsymbol{E}$ thermocouples-thermoelectric voltages, E(T), Seebeck coefficients, $\mathrm{S}(\mathrm{T})$, and first deriative of the Seebeck coefficients, $\mathrm{dS} / \mathrm{dT}$, reference junctions at $0{ }^{\circ} \mathrm{C}$-Continued

\begin{tabular}{|c|c|c|c|c|c|c|c|c|c|c|c|}
\hline${ }^{\circ} \mathrm{C}$ & $\underset{\mu V}{E}$ & $\stackrel{S}{\mu V /{ }^{\circ} \mathrm{C}}$ & $\begin{array}{l}d S / d T \\
n V /{ }^{\circ} C^{2}\end{array}$ & ${ }^{\mathrm{T}} \mathrm{C}$ & $\begin{array}{l}E V \\
\mu V\end{array}$ & $\begin{array}{c}\mathrm{S} \\
\mu \mathrm{V} /{ }^{\circ} \mathrm{C}\end{array}$ & $\begin{array}{l}\mathrm{dS} / \mathrm{dT} \\
\mathrm{nV} /{ }^{\circ} \mathrm{C}^{2}\end{array}$ & ${ }^{\circ} \mathrm{C}$ & $\begin{array}{c}E \\
\mu V\end{array}$ & $\stackrel{S}{\mu \mathrm{V} /{ }^{\circ} \mathrm{C}}$ & $\begin{array}{l}d S / d T \\
n V /{ }^{\circ} C^{2}\end{array}$ \\
\hline $\begin{array}{l}0 \\
1 \\
2 \\
3 \\
4\end{array}$ & $\begin{array}{r}0.0 \\
58.7 \\
117.6 \\
176.5 \\
235.5\end{array}$ & $\begin{array}{l}58.696 \\
58.782 \\
58.869 \\
58.956 \\
59.043\end{array}$ & $\begin{array}{l}86.22 \\
86.56 \\
86.88 \\
87.19 \\
87.49\end{array}$ & $\begin{array}{l}60 \\
61 \\
62 \\
63 \\
64\end{array}$ & $\begin{array}{l}3683.4 \\
3747.6 \\
3811.8 \\
3876.1 \\
3940.5\end{array}$ & $\begin{array}{l}64.110 \\
64.199 \\
64.288 \\
64.377 \\
64.465\end{array}$ & $\begin{array}{l}89.26 \\
89.09 \\
88.93 \\
88.76 \\
88.58\end{array}$ & $\begin{array}{l}120 \\
121 \\
122 \\
123 \\
124\end{array}$ & $\begin{array}{l}7682.9 \\
7752.0 \\
7821.2 \\
7890.4 \\
7959.7\end{array}$ & $\begin{array}{l}69.054 \\
69.128 \\
69.202 \\
69.276 \\
69.349\end{array}$ & $\begin{array}{l}74.18 \\
73.87 \\
73.57 \\
73.27 \\
72.96\end{array}$ \\
\hline $\begin{array}{l}5 \\
6 \\
7 \\
8 \\
9\end{array}$ & $\begin{array}{l}294.6 \\
353.7 \\
413.0 \\
472.4 \\
531.8\end{array}$ & $\begin{array}{l}59.131 \\
59.219 \\
59.307 \\
59.396 \\
59.484\end{array}$ & $\begin{array}{l}37.78 \\
88.06 \\
88.32 \\
88.57 \\
88.81\end{array}$ & $\begin{array}{l}65 \\
66 \\
67 \\
68 \\
69\end{array}$ & $\begin{array}{l}4005.1 \\
4069.7 \\
4134.3 \\
4199.1 \\
4264.0\end{array}$ & $\begin{array}{l}64.554 \\
64.642 \\
64.730 \\
64.818 \\
64.906\end{array}$ & $\begin{array}{l}88.40 \\
88.22 \\
88.03 \\
87.84 \\
87.64\end{array}$ & $\begin{array}{l}125 \\
126 \\
127 \\
128 \\
129\end{array}$ & $\begin{array}{l}8029.1 \\
8098.6 \\
8168.1 \\
8237.7 \\
8307.4\end{array}$ & $\begin{array}{l}69.421 \\
69.494 \\
69.566 \\
69.638 \\
69.710\end{array}$ & $\begin{array}{l}72.66 \\
72.35 \\
72.05 \\
71.74 \\
71.43\end{array}$ \\
\hline $\begin{array}{l}10 \\
11 \\
12 \\
13 \\
14\end{array}$ & $\begin{array}{l}591.3 \\
650.9 \\
710.6 \\
770.4 \\
830.3\end{array}$ & $\begin{array}{l}59.573 \\
59.662 \\
59.752 \\
59.841 \\
59.931\end{array}$ & $\begin{array}{l}89.04 \\
89.25 \\
89.46 \\
89.66 \\
89.84\end{array}$ & $\begin{array}{l}70 \\
71 \\
72 \\
73 \\
74\end{array}$ & $\begin{array}{l}4328.9 \\
4394.0 \\
4459.1 \\
4524.3 \\
4589.6\end{array}$ & $\begin{array}{l}64.993 \\
65.081 \\
65.168 \\
65.255 \\
65.341\end{array}$ & $\begin{array}{l}87.44 \\
87.24 \\
87.03 \\
86.82 \\
86.60\end{array}$ & $\begin{array}{l}130 \\
131 \\
132 \\
133 \\
134\end{array}$ & $\begin{array}{l}8377.1 \\
8446.9 \\
8516.8 \\
8586.8 \\
8656.8\end{array}$ & $\begin{array}{l}69.781 \\
69.852 \\
69.923 \\
69.993 \\
70.063\end{array}$ & $\begin{array}{l}71.13 \\
70.82 \\
70.51 \\
70.20 \\
69.90\end{array}$ \\
\hline $\begin{array}{l}20 \\
21 \\
22 \\
23 \\
24\end{array}$ & $\begin{array}{l}1191.5 \\
1252.1 \\
1312.7 \\
1373.4 \\
1434.2\end{array}$ & $\begin{array}{l}60.473 \\
60.564 \\
60.655 \\
60.746 \\
60.837\end{array}$ & $\begin{array}{l}90.73 \\
90.84 \\
90.95 \\
91.04 \\
91.13\end{array}$ & $\begin{array}{l}80 \\
81 \\
82 \\
83 \\
84\end{array}$ & $\begin{array}{l}4983.2 \\
5049.1 \\
5115.1 \\
5181.2 \\
5247.3\end{array}$ & $\begin{array}{l}65.857 \\
65.942 \\
66.027 \\
66.112 \\
66.196\end{array}$ & $\begin{array}{l}85.25 \\
85.01 \\
84.77 \\
84.53 \\
84.28\end{array}$ & $\begin{array}{l}140 \\
141 \\
142 \\
143 \\
144\end{array}$ & $\begin{array}{l}9078 \cdot 4 \\
9148.9 \\
9219 \cdot 5 \\
9290 \cdot 2 \\
9360.9\end{array}$ & $\begin{array}{l}70.477 \\
70.545 \\
70.612 \\
70.680 \\
70.747\end{array}$ & $\begin{array}{l}68.05 \\
67.74 \\
67.43 \\
67.12 \\
66.82\end{array}$ \\
\hline $\begin{array}{l}25 \\
26 \\
27 \\
28 \\
29\end{array}$ & $\begin{array}{l}1495.0 \\
1556.0 \\
1617.1 \\
1678.2 \\
1739.5\end{array}$ & $\begin{array}{l}60.928 \\
61.019 \\
61.110 \\
61.202 \\
61.293\end{array}$ & $\begin{array}{l}91.21 \\
91.28 \\
91.33 \\
91.39 \\
91.43\end{array}$ & $\begin{array}{l}85 \\
86 \\
87 \\
88 \\
89\end{array}$ & $\begin{array}{l}5313.5 \\
5379.9 \\
5446.3 \\
5512.8 \\
5579.3\end{array}$ & $\begin{array}{l}66.280 \\
66.364 \\
66.448 \\
66.531 \\
66.614\end{array}$ & $\begin{array}{l}84.03 \\
83.78 \\
83.53 \\
83.28 \\
83.02\end{array}$ & $\begin{array}{l}145 \\
146 \\
147 \\
148 \\
149\end{array}$ & $\begin{array}{l}9431.7 \\
9502.5 \\
9573.4 \\
9644.4 \\
9715.4\end{array}$ & $\begin{array}{l}70.813 \\
70.880 \\
70.946 \\
71.011 \\
71.077\end{array}$ & $\begin{array}{l}66.51 \\
66.20 \\
65.90 \\
65.59 \\
65.28\end{array}$ \\
\hline $\begin{array}{l}30 \\
31 \\
32 \\
33 \\
34\end{array}$ & $\begin{array}{l}1800.8 \\
1862.2 \\
1923.8 \\
1985.4 \\
2047.1\end{array}$ & $\begin{array}{l}61.385 \\
61.476 \\
61.568 \\
61.659 \\
61.751\end{array}$ & $\begin{array}{l}91.46 \\
91.49 \\
91.51 \\
91.52 \\
91.52\end{array}$ & $\begin{array}{l}90 \\
91 \\
92 \\
93 \\
94\end{array}$ & $\begin{array}{l}5646.0 \\
5712.7 \\
5779.6 \\
5846.5 \\
5913.4\end{array}$ & $\begin{array}{l}66.697 \\
66.780 \\
66.862 \\
66.944 \\
67.026\end{array}$ & $\begin{array}{l}82.76 \\
82.50 \\
82.23 \\
81.96 \\
81.70\end{array}$ & $\begin{array}{l}150 \\
151 \\
152 \\
153 \\
154\end{array}$ & $\begin{array}{r}9786.5 \\
9857.7 \\
9929.0 \\
10000.3 \\
10071.6\end{array}$ & $\begin{array}{l}71.142 \\
71.207 \\
71.271 \\
71.335 \\
71.399\end{array}$ & $\begin{array}{l}64.98 \\
64.67 \\
64.37 \\
64.06 \\
63.76\end{array}$ \\
\hline $\begin{array}{l}40 \\
41 \\
42 \\
43 \\
44\end{array}$ & $\begin{array}{l}2419.2 \\
2481.6 \\
2544.0 \\
2606.5 \\
2669.2\end{array}$ & $\begin{array}{l}62.299 \\
62.391 \\
62.482 \\
62.573 \\
62.664\end{array}$ & $\begin{array}{l}91 \cdot 38 \\
91 \cdot 33 \\
91 \cdot 27 \\
91 \cdot 21 \\
91.14\end{array}$ & $\begin{array}{l}100 \\
101 \\
102 \\
103 \\
104\end{array}$ & $\begin{array}{l}6317.1 \\
6384.6 \\
6452.2 \\
6520.0 \\
6587.7\end{array}$ & $\begin{array}{l}67.511 \\
67.591 \\
67.671 \\
67.750 \\
67.829\end{array}$ & $\begin{array}{l}80.04 \\
79.76 \\
79.48 \\
79.19 \\
78.91\end{array}$ & $\begin{array}{l}160 \\
161 \\
162 \\
163 \\
164\end{array}$ & $\begin{array}{l}10501.2 \\
10573.0 \\
10644.8 \\
10716.8 \\
10788.8\end{array}$ & $\begin{array}{l}71.776 \\
71.838 \\
71.900 \\
71.961 \\
72.022\end{array}$ & $\begin{array}{l}61.94 \\
61.64 \\
61.34 \\
61.04 \\
60.74\end{array}$ \\
\hline $\begin{array}{l}45 \\
46 \\
47 \\
48 \\
49\end{array}$ & $\begin{array}{l}2731.9 \\
2794.7 \\
2857.6 \\
2920.6 \\
2983.6\end{array}$ & $\begin{array}{l}62.756 \\
62.847 \\
62.938 \\
63.028 \\
63.119\end{array}$ & $\begin{array}{l}91.07 \\
90.99 \\
90.90 \\
90.81 \\
90.71\end{array}$ & $\begin{array}{l}105 \\
106 \\
107 \\
108 \\
109\end{array}$ & $\begin{array}{l}6655.6 \\
6723.6 \\
6791.6 \\
6859.7 \\
6927.9\end{array}$ & $\begin{array}{l}67.908 \\
67.987 \\
68.065 \\
68.143 \\
68.220\end{array}$ & $\begin{array}{l}78.62 \\
78.33 \\
78.04 \\
77.75 \\
77.46\end{array}$ & $\begin{array}{l}165 \\
166 \\
167 \\
168 \\
169\end{array}$ & $\begin{array}{l}10860.8 \\
10932.9 \\
11005.1 \\
11077.3 \\
11149.6\end{array}$ & $\begin{array}{l}72.082 \\
72.143 \\
72.203 \\
72.262 \\
72.322\end{array}$ & $\begin{array}{l}60.44 \\
60.15 \\
59.85 \\
59.55 \\
59.26\end{array}$ \\
\hline $\begin{array}{l}50 \\
51 \\
52 \\
53 \\
54\end{array}$ & $\begin{array}{l}3046.8 \\
3110.0 \\
3173.4 \\
3236.8 \\
3300.4\end{array}$ & $\begin{array}{l}63.210 \\
63.300 \\
63.391 \\
63.481 \\
63.571\end{array}$ & $\begin{array}{l}90 \cdot 60 \\
90 \cdot 49 \\
90.37 \\
90.25 \\
90.13\end{array}$ & $\begin{array}{l}110 \\
111 \\
112 \\
113 \\
114\end{array}$ & $\begin{array}{l}6996.1 \\
7064.5 \\
7132.9 \\
7201.4 \\
7269.9\end{array}$ & $\begin{array}{l}68.298 \\
68.375 \\
68.451 \\
68.528 \\
68.604\end{array}$ & $\begin{array}{l}77.17 \\
76.87 \\
76.58 \\
76.28 \\
75.98\end{array}$ & $\begin{array}{l}170 \\
171 \\
172 \\
173 \\
174\end{array}$ & $\begin{array}{l}11222.0 \\
11294.4 \\
11366.9 \\
11439.4 \\
11512.0\end{array}$ & $\begin{array}{l}72.381 \\
72.440 \\
72.498 \\
72.557 \\
72.614\end{array}$ & $\begin{array}{l}58.96 \\
58.67 \\
58.37 \\
58.08 \\
57.79\end{array}$ \\
\hline $\begin{array}{l}55 \\
56 \\
57 \\
58 \\
59\end{array}$ & $\begin{array}{l}3364.0 \\
3427.7 \\
3491.5 \\
3555.4 \\
3619.3\end{array}$ & $\begin{array}{l}63.661 \\
63.751 \\
63.841 \\
63.931 \\
64.020\end{array}$ & $\begin{array}{l}89.99 \\
89.86 \\
89.71 \\
89.57 \\
89.41\end{array}$ & $\begin{array}{l}115 \\
116 \\
117 \\
118 \\
119\end{array}$ & $\begin{array}{l}7338.6 \\
7407.3 \\
7476.1 \\
7545.0 \\
7613.9\end{array}$ & $\begin{array}{l}68.680 \\
68.755 \\
68.831 \\
68.905 \\
68.980\end{array}$ & $\begin{array}{l}75.68 \\
75.38 \\
75.08 \\
74.78 \\
74.48\end{array}$ & $\begin{array}{l}175 \\
176 \\
177 \\
178 \\
179\end{array}$ & $\begin{array}{l}11584.6 \\
11657.3 \\
11730.1 \\
11802.9 \\
11875.8\end{array}$ & $\begin{array}{l}72.672 \\
72.729 \\
72.787 \\
72.843 \\
72.900\end{array}$ & $\begin{array}{l}57.50 \\
57.21 \\
56.92 \\
56.63 \\
56.34\end{array}$ \\
\hline 60 & 3683.4 & 64.110 & 89.26 & 120 & 7682.9 & 69.054 & 74.18 & 180 & 11948.7 & 72.956 & 56.06 \\
\hline
\end{tabular}


TABLE 5.3.2. Type E thermocouples-thermoelectric voltages, E(T), Seebeck coefficients, $\mathrm{S}(\mathrm{T})$, and first deriative of the Seebeck coefficients, $\mathrm{dS} / \mathrm{dT}$, reference junctions at $0{ }^{\circ} \mathrm{C}-$ Continued

\begin{tabular}{|c|c|c|c|c|c|c|c|c|c|c|c|}
\hline${ }^{\top} \mathrm{T}$ & ${ }_{\mu V}^{E V}$ & $\begin{array}{c}\mathrm{S} \\
\mu \mathrm{V} /{ }^{\circ} \mathrm{C}\end{array}$ & $\begin{array}{l}\mathrm{dS} / \mathrm{dT} \\
\mathrm{nV} /{ }^{\circ} \mathrm{C}^{2}\end{array}$ & $\begin{array}{l}T \\
{ }^{\circ} \mathrm{C}\end{array}$ & $\begin{array}{c}E \\
\mu V\end{array}$ & $\begin{array}{c}\mathrm{S} \\
\mu V /{ }^{\circ} \mathrm{C}\end{array}$ & $\begin{array}{l}d S / d T \\
n V /{ }^{\circ} C^{2}\end{array}$ & ${ }^{\circ} \mathrm{C}$ & $\begin{array}{c}E V \\
\mu V\end{array}$ & $\begin{array}{c}\mathrm{S} \\
\mu \mathrm{V} /{ }^{\circ} \mathrm{C}\end{array}$ & $\begin{array}{l}d S / d T \\
n V /{ }^{\circ} C^{2}\end{array}$ \\
\hline $\begin{array}{l}180 \\
181 \\
182 \\
183 \\
184\end{array}$ & $\begin{array}{l}11948.7 \\
12021.7 \\
12094.7 \\
12167.8 \\
12241.0\end{array}$ & $\begin{array}{l}72.956 \\
73.012 \\
73.068 \\
73.123 \\
73.178\end{array}$ & $\begin{array}{l}56.06 \\
55.77 \\
55.48 \\
55.20 \\
54.92\end{array}$ & $\begin{array}{l}240 \\
241 \\
242 \\
243 \\
244\end{array}$ & $\begin{array}{l}16417.2 \\
16493.0 \\
16568.9 \\
16644.9 \\
16720.8\end{array}$ & $\begin{array}{l}75.839 \\
75.879 \\
75.920 \\
75.960 \\
76.000\end{array}$ & $\begin{array}{l}40.67 \\
40.44 \\
40.22 \\
40.00 \\
39.78\end{array}$ & $\begin{array}{l}300 \\
301 \\
302 \\
303 \\
304\end{array}$ & $\begin{array}{l}21033.1 \\
21111.1 \\
21189.0 \\
21267.0 \\
21345.0\end{array}$ & $\begin{array}{l}77.910 \\
77.939 \\
77.967 \\
77.996 \\
78.024\end{array}$ & $\begin{array}{l}28.91 \\
28.74 \\
28.57 \\
28.40 \\
28.23\end{array}$ \\
\hline $\begin{array}{l}185 \\
186 \\
187 \\
188 \\
189\end{array}$ & $\begin{array}{l}12314.2 \\
12387.4 \\
12460.7 \\
12534.1 \\
12607.5\end{array}$ & $\begin{array}{l}73.233 \\
73.287 \\
73.341 \\
73.395 \\
73.449\end{array}$ & $\begin{array}{l}54.63 \\
54.35 \\
54.07 \\
53.79 \\
53.51\end{array}$ & $\begin{array}{l}245 \\
246 \\
247 \\
248 \\
249\end{array}$ & $\begin{array}{l}16796.8 \\
16872.9 \\
16949.0 \\
17025.1 \\
17101.3\end{array}$ & $\begin{array}{l}76.039 \\
76.079 \\
76.118 \\
76.157 \\
76.196\end{array}$ & $\begin{array}{l}39.56 \\
39.34 \\
39.12 \\
38.90 \\
38.69\end{array}$ & $\begin{array}{l}305 \\
306 \\
307 \\
308 \\
309\end{array}$ & $\begin{array}{l}21423 \cdot 0 \\
21501 \cdot 1 \\
21579 \cdot 2 \\
21657 \cdot 3 \\
21735 \cdot 5\end{array}$ & $\begin{array}{l}78.052 \\
78.080 \\
78.108 \\
78.136 \\
78.163\end{array}$ & $\begin{array}{l}28.07 \\
27.90 \\
27.73 \\
27.57 \\
27.40\end{array}$ \\
\hline $\begin{array}{l}190 \\
191 \\
192 \\
193 \\
194\end{array}$ & $\begin{array}{l}12681.0 \\
12754.5 \\
12828.1 \\
12901.7 \\
12975.4\end{array}$ & $\begin{array}{l}73.502 \\
73.555 \\
73.608 \\
73.661 \\
73.713\end{array}$ & $\begin{array}{l}53.24 \\
52.96 \\
52.68 \\
52.41 \\
52.13\end{array}$ & $\begin{array}{l}250 \\
251 \\
252 \\
253 \\
254\end{array}$ & $\begin{array}{l}17177.5 \\
17253.8 \\
17330.1 \\
17406.4 \\
17482.8\end{array}$ & $\begin{array}{l}76.234 \\
76.273 \\
76.311 \\
76.349 \\
76.387\end{array}$ & $\begin{array}{l}38.47 \\
38.26 \\
38.04 \\
37.83 \\
37.62\end{array}$ & $\begin{array}{l}310 \\
311 \\
312 \\
313 \\
314\end{array}$ & $\begin{array}{l}21813.6 \\
21891.8 \\
21970.1 \\
22048.3 \\
22126.6\end{array}$ & $\begin{array}{l}78.190 \\
78.218 \\
78.245 \\
78.271 \\
78.298\end{array}$ & $\begin{array}{l}27.24 \\
27.08 \\
26.91 \\
26.75 \\
26.59\end{array}$ \\
\hline $\begin{array}{l}195 \\
196 \\
197 \\
198 \\
199\end{array}$ & $\begin{array}{l}13049.2 \\
13123.0 \\
13196.8 \\
13270.7 \\
13344.6\end{array}$ & $\begin{array}{l}73.765 \\
73.817 \\
73.868 \\
73.919 \\
73.970\end{array}$ & $\begin{array}{l}51.86 \\
51.59 \\
51.32 \\
51.05 \\
50.78\end{array}$ & $\begin{array}{l}255 \\
256 \\
257 \\
258 \\
259\end{array}$ & $\begin{array}{l}17559.2 \\
17635.6 \\
17712.1 \\
17788.6 \\
17865.2\end{array}$ & $\begin{array}{l}76.424 \\
76.461 \\
76.499 \\
76.535 \\
76.572\end{array}$ & $\begin{array}{l}37.41 \\
37.20 \\
36.99 \\
36.79 \\
36.58\end{array}$ & $\begin{array}{l}315 \\
316 \\
317 \\
318 \\
319\end{array}$ & $\begin{array}{l}22204 \cdot 9 \\
22283.3 \\
22361.6 \\
22440.0 \\
22518.4\end{array}$ & $\begin{array}{l}78.325 \\
78.351 \\
78.377 \\
78.403 \\
78.429\end{array}$ & $\begin{array}{l}26.43 \\
26.27 \\
26.11 \\
25.95 \\
25.79\end{array}$ \\
\hline $\begin{array}{l}200 \\
201 \\
202 \\
203 \\
204\end{array}$ & $\begin{array}{l}13418.6 \\
13492.7 \\
13566.8 \\
13640.9 \\
13715.1\end{array}$ & $\begin{array}{l}74.021 \\
74.071 \\
74.121 \\
74.171 \\
74.221\end{array}$ & $\begin{array}{l}50.51 \\
50.24 \\
49.98 \\
49.71 \\
49.45\end{array}$ & $\begin{array}{l}260 \\
261 \\
262 \\
263 \\
264\end{array}$ & $\begin{array}{l}17941.8 \\
18018.4 \\
18095.1 \\
18171.8 \\
18248.5\end{array}$ & $\begin{array}{l}76.609 \\
76.645 \\
76.681 \\
76.717 \\
76.752\end{array}$ & $\begin{array}{l}36.38 \\
36.17 \\
35.97 \\
35.77 \\
35.57\end{array}$ & $\begin{array}{l}320 \\
321 \\
322 \\
323 \\
324\end{array}$ & $\begin{array}{l}22596.9 \\
22675.4 \\
22753.8 \\
22832.4 \\
22910.9\end{array}$ & $\begin{array}{l}78.455 \\
78.480 \\
78.506 \\
78.531 \\
78.556\end{array}$ & $\begin{array}{l}25.64 \\
25.48 \\
25.32 \\
25.17 \\
25.01\end{array}$ \\
\hline $\begin{array}{l}205 \\
206 \\
207 \\
208 \\
209\end{array}$ & $\begin{array}{l}13789.4 \\
13863.7 \\
13938.0 \\
14012.4 \\
14086.8\end{array}$ & $\begin{array}{l}74 \cdot 270 \\
74 \cdot 319 \\
74 \cdot 368 \\
74.417 \\
74.465\end{array}$ & $\begin{array}{l}49.19 \\
48.93 \\
48.67 \\
48.41 \\
48.15\end{array}$ & $\begin{array}{l}265 \\
266 \\
267 \\
268 \\
269\end{array}$ & $\begin{array}{l}18325.3 \\
18402.1 \\
18478.9 \\
18555.8 \\
18632.7\end{array}$ & $\begin{array}{l}76.788 \\
76.823 \\
76.858 \\
76.893 \\
76.928\end{array}$ & $\begin{array}{l}35.37 \\
35.17 \\
34.97 \\
34.77 \\
34.57\end{array}$ & $\begin{array}{l}325 \\
326 \\
327 \\
328 \\
329\end{array}$ & $\begin{array}{l}22989 \cdot 5 \\
23068 \cdot 1 \\
23146 \cdot 7 \\
23225 \cdot 3 \\
23304 \cdot 0\end{array}$ & $\begin{array}{l}78.581 \\
78.606 \\
78.630 \\
78.655 \\
78.679\end{array}$ & $\begin{array}{l}24 \cdot 86 \\
24 \cdot 70 \\
24 \cdot 55 \\
24 \cdot 39 \\
24 \cdot 24\end{array}$ \\
\hline $\begin{array}{l}210 \\
211 \\
212 \\
213 \\
214\end{array}$ & $\begin{array}{l}14161.3 \\
14235.9 \\
14310.5 \\
14385.1 \\
14459.8\end{array}$ & $\begin{array}{l}74.513 \\
74.561 \\
74.608 \\
74.655 \\
74.702\end{array}$ & $\begin{array}{l}47.89 \\
47.63 \\
47.38 \\
47.12 \\
46.87\end{array}$ & $\begin{array}{l}270 \\
271 \\
272 \\
273 \\
274\end{array}$ & $\begin{array}{l}18709.6 \\
18786.6 \\
18863.6 \\
18940.7 \\
19017.8\end{array}$ & $\begin{array}{l}76.962 \\
76.997 \\
77.031 \\
77.065 \\
77.098\end{array}$ & $\begin{array}{l}34.38 \\
34.18 \\
33.99 \\
33.80 \\
33.61\end{array}$ & $\begin{array}{l}330 \\
331 \\
332 \\
333 \\
334\end{array}$ & $\begin{array}{l}23382.7 \\
23461.4 \\
23540.1 \\
23618.9 \\
23697.7\end{array}$ & $\begin{array}{l}78.703 \\
78.727 \\
78.751 \\
78.775 \\
78.798\end{array}$ & $\begin{array}{l}24.09 \\
23.94 \\
23.79 \\
23.64 \\
23.49\end{array}$ \\
\hline $\begin{array}{l}215 \\
216 \\
217 \\
218 \\
219\end{array}$ & $\begin{array}{l}14534.5 \\
14609.3 \\
14684.1 \\
14758.9 \\
14833.9\end{array}$ & $\begin{array}{l}74 \cdot 749 \\
74.796 \\
74.842 \\
74.888 \\
74.934\end{array}$ & $\begin{array}{l}46.62 \\
46.37 \\
46.12 \\
45.87 \\
45.62\end{array}$ & $\begin{array}{l}275 \\
276 \\
277 \\
278 \\
279\end{array}$ & $\begin{array}{l}19094.9 \\
19172.0 \\
19249.2 \\
19326.4 \\
19403.7\end{array}$ & $\begin{array}{l}77.132 \\
77.165 \\
77.198 \\
77.231 \\
77.264\end{array}$ & $\begin{array}{l}33.41 \\
33.22 \\
33.03 \\
32.85 \\
32.66\end{array}$ & $\begin{array}{l}335 \\
336 \\
337 \\
338 \\
339\end{array}$ & $\begin{array}{l}23776.5 \\
23855 \cdot 3 \\
23934 \cdot 2 \\
24013.1 \\
24092.0\end{array}$ & $\begin{array}{l}78.822 \\
78.845 \\
78.868 \\
78.891 \\
78.914\end{array}$ & $\begin{array}{l}23.34 \\
23.19 \\
23.04 \\
22.89 \\
22.75\end{array}$ \\
\hline $\begin{array}{l}220 \\
221 \\
222 \\
223 \\
224\end{array}$ & $\begin{array}{l}14908.8 \\
14983.8 \\
15058.9 \\
15134.0 \\
15209.1\end{array}$ & $\begin{array}{l}74.979 \\
75.024 \\
75.069 \\
75.114 \\
75.159\end{array}$ & $\begin{array}{l}45.37 \\
45.13 \\
44.88 \\
44.64 \\
44.40\end{array}$ & $\begin{array}{l}280 \\
281 \\
282 \\
283 \\
284\end{array}$ & $\begin{array}{l}19480.9 \\
19558.3 \\
19635.6 \\
19713.0 \\
19790.4\end{array}$ & $\begin{array}{l}77.296 \\
77.329 \\
77.361 \\
77.393 \\
77.425\end{array}$ & $\begin{array}{l}32.47 \\
32.29 \\
32.10 \\
31.92 \\
31.73\end{array}$ & $\begin{array}{l}340 \\
341 \\
342 \\
343 \\
344\end{array}$ & $\begin{array}{l}24170.9 \\
24249.8 \\
24328.8 \\
24407.8 \\
24486.8\end{array}$ & $\begin{array}{l}78.937 \\
78.959 \\
78.982 \\
79.004 \\
79.026\end{array}$ & $\begin{array}{l}22.60 \\
22.45 \\
22.31 \\
22.16 \\
22.02\end{array}$ \\
\hline $\begin{array}{l}225 \\
226 \\
227 \\
228 \\
229\end{array}$ & $\begin{array}{l}15284.3 \\
15359.5 \\
15434.8 \\
15510.1 \\
15585.4\end{array}$ & $\begin{array}{l}75.203 \\
75.247 \\
75.291 \\
75.334 \\
75.378\end{array}$ & $\begin{array}{l}44.16 \\
43.92 \\
43.68 \\
43.44 \\
43.20\end{array}$ & $\begin{array}{l}285 \\
286 \\
287 \\
288 \\
289\end{array}$ & $\begin{array}{l}19867.8 \\
19945.3 \\
20022.8 \\
20100.3 \\
20177.9\end{array}$ & $\begin{array}{l}77.457 \\
77.488 \\
77.519 \\
77.550 \\
77.581\end{array}$ & $\begin{array}{l}31.55 \\
31.37 \\
31.19 \\
31.01 \\
30.83\end{array}$ & $\begin{array}{l}345 \\
346 \\
347 \\
348 \\
349\end{array}$ & $\begin{array}{l}24565.9 \\
24644.9 \\
24724.0 \\
24803.1 \\
24882.2\end{array}$ & $\begin{array}{l}79.048 \\
79.070 \\
79.091 \\
79.113 \\
79.134\end{array}$ & $\begin{array}{l}21.87 \\
21.73 \\
21.58 \\
21.44 \\
21.30\end{array}$ \\
\hline $\begin{array}{l}230 \\
231 \\
232 \\
233 \\
234\end{array}$ & $\begin{array}{l}15660.8 \\
15736.3 \\
15811.8 \\
15887.3 \\
15962.9\end{array}$ & $\begin{array}{l}75.421 \\
75.464 \\
75.506 \\
75.549 \\
75.591\end{array}$ & $\begin{array}{l}42.97 \\
42.73 \\
42.50 \\
42.27 \\
42.03\end{array}$ & $\begin{array}{l}290 \\
291 \\
292 \\
293 \\
294\end{array}$ & $\begin{array}{l}20255.5 \\
20333.1 \\
20410.8 \\
20488.5 \\
20566.2\end{array}$ & $\begin{array}{l}77.612 \\
77.643 \\
77.673 \\
77.703 \\
77.733\end{array}$ & $\begin{array}{l}30.65 \\
30.47 \\
30.30 \\
30.12 \\
29.94\end{array}$ & $\begin{array}{l}350 \\
351 \\
352 \\
353 \\
354\end{array}$ & $\begin{array}{l}24961.4 \\
25040.5 \\
25119.7 \\
25198.9 \\
25278.2\end{array}$ & $\begin{array}{l}79.155 \\
79.177 \\
79.197 \\
79.218 \\
79.239\end{array}$ & $\begin{array}{l}21.15 \\
21.01 \\
20.87 \\
20.73 \\
20.59\end{array}$ \\
\hline $\begin{array}{l}235 \\
236 \\
237 \\
238 \\
239\end{array}$ & $\begin{array}{l}16038.5 \\
16114.1 \\
16189.8 \\
16265.6 \\
16341.3\end{array}$ & $\begin{array}{l}75.633 \\
75.674 \\
75.716 \\
75.757 \\
75.798\end{array}$ & $\begin{array}{l}41.80 \\
41.57 \\
41.35 \\
41.12 \\
40.89\end{array}$ & $\begin{array}{l}295 \\
296 \\
297 \\
298 \\
299\end{array}$ & $\begin{array}{l}20643.9 \\
20721.7 \\
20799.5 \\
20877.4 \\
20955.2\end{array}$ & $\begin{array}{l}77.763 \\
77.793 \\
77.822 \\
77.852 \\
77.881\end{array}$ & $\begin{array}{l}29.77 \\
29.60 \\
29.42 \\
29.25 \\
29.08\end{array}$ & $\begin{array}{l}355 \\
356 \\
357 \\
358 \\
359\end{array}$ & $\begin{array}{l}25357.4 \\
25436.7 \\
25516.0 \\
25595.3 \\
25674.6\end{array}$ & $\begin{array}{r}79.259 \\
79.280 \\
79.300 \\
79.320 \\
79.340\end{array}$ & $\begin{array}{l}20.45 \\
20.31 \\
20.17 \\
20.03 \\
19.89\end{array}$ \\
\hline 240 & 16417.2 & 75.839 & 40.67 & 300 & 21033.1 & 77.910 & 28.91 & 360 & $25754 \cdot 0$ & 79.360 & 19.75 \\
\hline
\end{tabular}


TABLE 5.3.2. Type $\boldsymbol{E}$ thermocouples-thermoelectric voltages, $\mathrm{E}(\mathrm{T})$, Seebeck coefficients, $\mathrm{S}(\mathrm{T})$, and first deriative of the Seebeck coefficients, $\mathrm{dS} / \mathrm{dT}$, reference junctions at $0{ }^{\circ} \mathrm{C}$-Continued

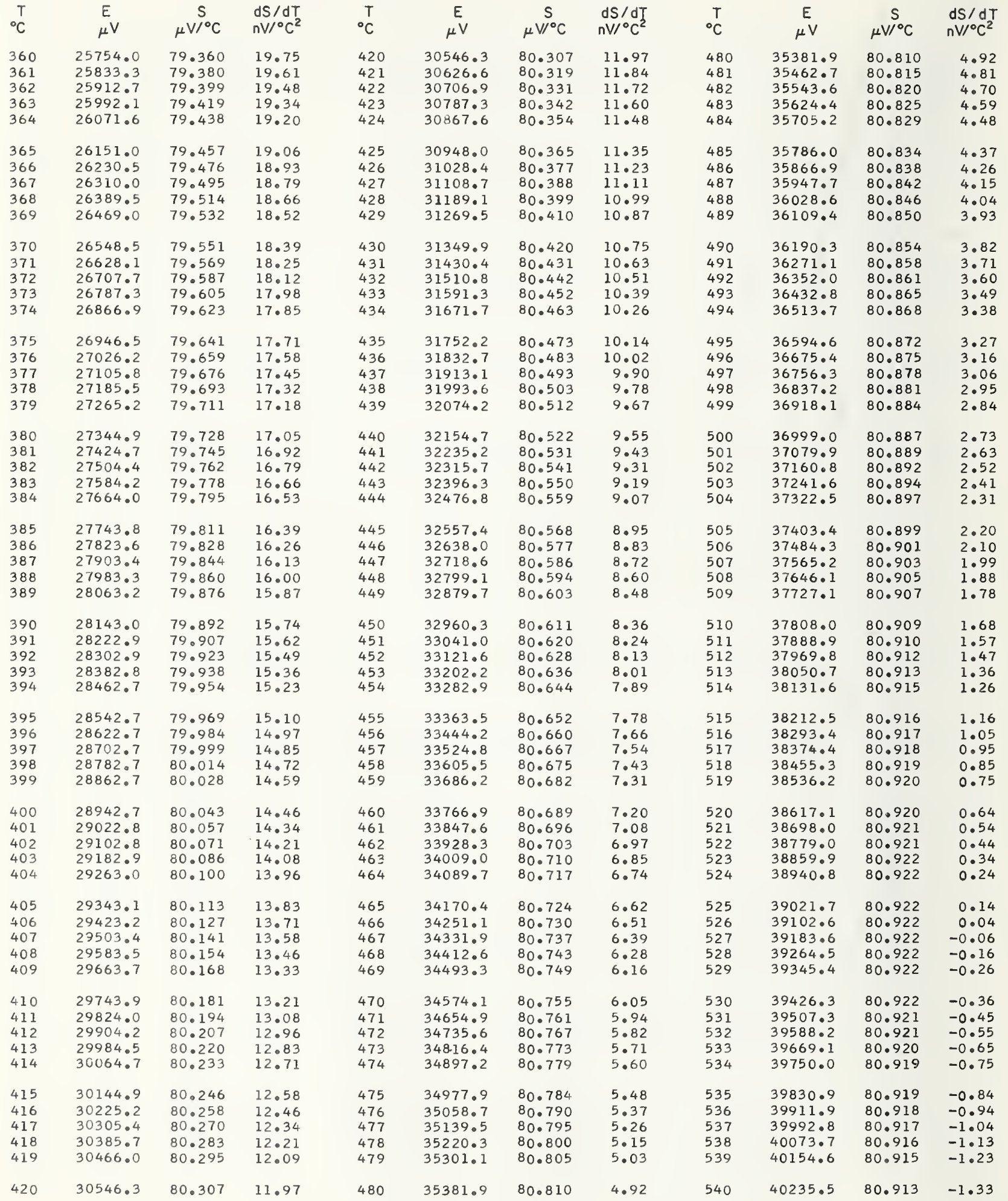


TABLE 5.3.2. Type $\boldsymbol{E}$ thermocouples-thermoelectric voltages, $\mathrm{E}(\mathrm{T})$, Seebeck coefficients, $\mathrm{S}(\mathrm{T})$, and first deriative of the Seebeck coefficients, $\mathrm{dS} / \mathrm{dT}$, reference junctions at $0{ }^{\circ} \mathrm{C}-$ Continued

\begin{tabular}{|c|c|c|c|c|c|c|c|c|c|c|c|}
\hline $\begin{array}{l}\mathrm{T} \\
{ }^{\circ} \mathrm{C}\end{array}$ & ${ }_{\mu V}^{E V}$ & $\stackrel{S}{S V^{\circ} \mathrm{C}}$ & $\begin{array}{l}\mathrm{dS} / \mathrm{dT} \\
\mathrm{nV} /{ }^{\circ} \mathrm{C}^{2}\end{array}$ & ${ }^{\circ} \mathrm{C}$ & $\underset{\mu V}{E}$ & $\stackrel{S}{S V^{\circ}{ }^{\circ} \mathrm{C}}$ & $\begin{array}{l}\mathrm{dS} / \mathrm{dT} \\
\mathrm{nV} /{ }^{\circ} \mathrm{C}^{2}\end{array}$ & ${ }^{\circ} \mathrm{C}$ & $\underset{\mu V}{E V}$ & $\begin{array}{c}S \\
\mu V /{ }^{\circ} \mathrm{C}\end{array}$ & $\begin{array}{l}d S / d T \\
n V /{ }^{\circ} C^{2}\end{array}$ \\
\hline $\begin{array}{l}540 \\
541 \\
542 \\
543 \\
544\end{array}$ & $\begin{array}{l}40235.5 \\
40316.4 \\
40397.3 \\
40478.2 \\
40559.2\end{array}$ & $\begin{array}{l}80.913 \\
80.912 \\
80.910 \\
80.909 \\
80.907\end{array}$ & $\begin{array}{l}-1.33 \\
-1.42 \\
-1.52 \\
-1.61 \\
-1.70\end{array}$ & $\begin{array}{l}600 \\
601 \\
602 \\
603 \\
604\end{array}$ & $\begin{array}{l}45084.7 \\
45165.4 \\
45246.0 \\
45326.7 \\
45407.3\end{array}$ & $\begin{array}{l}80.676 \\
80.669 \\
80.663 \\
80.656 \\
80.650\end{array}$ & $\begin{array}{l}-6.36 \\
-6.43 \\
-6.50 \\
-6.57 \\
-6.64\end{array}$ & $\begin{array}{l}660 \\
661 \\
662 \\
663 \\
664\end{array}$ & $\begin{array}{l}49911.5 \\
49991.6 \\
50071.8 \\
50151.9 \\
50232.1\end{array}$ & $\begin{array}{l}80.181 \\
80.171 \\
80.161 \\
80.151 \\
80.141\end{array}$ & $\begin{array}{r}-9.89 \\
-9.94 \\
-9.98 \\
-10.03 \\
-10.08\end{array}$ \\
\hline $\begin{array}{l}545 \\
546 \\
547 \\
548 \\
549\end{array}$ & $\begin{array}{l}40640.1 \\
40721.0 \\
40801.9 \\
40882.8 \\
40963.7\end{array}$ & $\begin{array}{l}80.905 \\
80.904 \\
80.902 \\
80.900 \\
80.898\end{array}$ & $\begin{array}{l}-1.80 \\
-1.89 \\
-1.98 \\
-2.08 \\
-2.17\end{array}$ & $\begin{array}{l}605 \\
606 \\
607 \\
608 \\
609\end{array}$ & $\begin{array}{l}45488 \cdot 0 \\
45568 \cdot 6 \\
45649 \cdot 3 \\
45729.9 \\
45810.5\end{array}$ & $\begin{array}{l}80.643 \\
80.636 \\
80.629 \\
80.623 \\
80.616\end{array}$ & $\begin{array}{l}-6.71 \\
-6.78 \\
-6.85 \\
-6.91 \\
-6.98\end{array}$ & $\begin{array}{l}665 \\
666 \\
667 \\
668 \\
669\end{array}$ & $\begin{array}{l}50312.2 \\
50392.4 \\
50472.5 \\
50552.6 \\
50632.7\end{array}$ & $\begin{array}{l}80.131 \\
80.121 \\
80.111 \\
80.100 \\
80.090\end{array}$ & $\begin{array}{l}-10.12 \\
-10.17 \\
-10.21 \\
-10.25 \\
-10.30\end{array}$ \\
\hline $\begin{array}{l}550 \\
551 \\
552 \\
553 \\
554\end{array}$ & $\begin{array}{l}41044.6 \\
41125.5 \\
41206.4 \\
41287.2 \\
41368.1\end{array}$ & $\begin{array}{l}80.895 \\
80.893 \\
80.891 \\
80.888 \\
80.886\end{array}$ & $\begin{array}{l}-2.26 \\
-2.35 \\
-2.44 \\
-2.53 \\
-2.62\end{array}$ & $\begin{array}{l}610 \\
611 \\
612 \\
613 \\
614\end{array}$ & $\begin{array}{l}45891.1 \\
45971.7 \\
46052.3 \\
46132.9 \\
46213.5\end{array}$ & $\begin{array}{l}80.609 \\
80.602 \\
80.594 \\
80.587 \\
80.580\end{array}$ & $\begin{array}{l}-7.05 \\
-7.12 \\
-7.18 \\
-7.25 \\
-7.31\end{array}$ & $\begin{array}{l}670 \\
671 \\
672 \\
673 \\
674\end{array}$ & $\begin{array}{l}50712.8 \\
50792.8 \\
50872.9 \\
50952.9 \\
51033.0\end{array}$ & $\begin{array}{l}80.080 \\
80.069 \\
80.059 \\
80.048 \\
80.038\end{array}$ & $\begin{array}{l}-10.34 \\
-10.39 \\
-10.43 \\
-10.47 \\
-10.51\end{array}$ \\
\hline $\begin{array}{l}560 \\
561 \\
562 \\
563 \\
564\end{array}$ & $\begin{array}{l}41853.4 \\
41934.3 \\
42015.1 \\
42096.0 \\
42176.8\end{array}$ & $\begin{array}{l}80.868 \\
80.865 \\
80.862 \\
80.858 \\
80.855\end{array}$ & $\begin{array}{l}-3.16 \\
-3.25 \\
-3.33 \\
-3.42 \\
-3.51\end{array}$ & $\begin{array}{l}620 \\
621 \\
622 \\
623 \\
624\end{array}$ & $\begin{array}{l}46696.8 \\
46777.4 \\
46857.9 \\
46938.4 \\
47018.9\end{array}$ & $\begin{array}{l}80.535 \\
80.527 \\
80.519 \\
80.511 \\
80.504\end{array}$ & $\begin{array}{l}-7.70 \\
-7.76 \\
-7.83 \\
-7.89 \\
-7.95\end{array}$ & $\begin{array}{l}680 \\
681 \\
682 \\
683 \\
684\end{array}$ & $\begin{array}{l}51513.0 \\
51593.0 \\
51673.0 \\
51752.9 \\
51832.8\end{array}$ & $\begin{array}{l}79.974 \\
79.963 \\
79.953 \\
79.942 \\
79.931\end{array}$ & $\begin{array}{l}-10.76 \\
-10.80 \\
-10.84 \\
-10.88 \\
-10.92\end{array}$ \\
\hline $\begin{array}{l}565 \\
566 \\
567 \\
568 \\
569\end{array}$ & $\begin{array}{l}42257.7 \\
42338.5 \\
42419.4 \\
42500.2 \\
42581.1\end{array}$ & $\begin{array}{l}80.851 \\
80.848 \\
80.844 \\
80.840 \\
80.836\end{array}$ & $\begin{array}{l}-3.59 \\
-3.68 \\
-3.77 \\
-3.85 \\
-3.93\end{array}$ & $\begin{array}{l}625 \\
626 \\
627 \\
628 \\
629\end{array}$ & $\begin{array}{l}47099.4 \\
47179.9 \\
47260.4 \\
47340.9 \\
47421.3\end{array}$ & $\begin{array}{l}80.496 \\
80.488 \\
80.479 \\
80.471 \\
80.463\end{array}$ & $\begin{array}{l}-8.01 \\
-8.07 \\
-8.13 \\
-8.19 \\
-8.25\end{array}$ & $\begin{array}{l}685 \\
686 \\
687 \\
688 \\
689\end{array}$ & $\begin{array}{l}51912.8 \\
51992.7 \\
52072.6 \\
52152.5 \\
52232.4\end{array}$ & $\begin{array}{l}79.920 \\
79.909 \\
79.898 \\
79.887 \\
79.876\end{array}$ & $\begin{array}{l}-10.96 \\
-11.00 \\
-11.04 \\
-11.08 \\
-11.12\end{array}$ \\
\hline $\begin{array}{l}570 \\
571 \\
572 \\
573 \\
574\end{array}$ & $\begin{array}{l}42661.9 \\
42742.7 \\
42823.6 \\
42904.4 \\
42985.2\end{array}$ & $\begin{array}{l}80.832 \\
80.828 \\
80.824 \\
80.820 \\
80.816\end{array}$ & $\begin{array}{l}-4.02 \\
-4.10 \\
-4.19 \\
-4.27 \\
-4.35\end{array}$ & $\begin{array}{l}630 \\
631 \\
632 \\
633 \\
634\end{array}$ & $\begin{array}{l}47501.8 \\
47582.2 \\
47662.7 \\
47743.1 \\
47823.5\end{array}$ & $\begin{array}{l}80.455 \\
80.446 \\
80.438 \\
80.430 \\
80.421\end{array}$ & $\begin{array}{l}-8.31 \\
-8.37 \\
-8.43 \\
-8.48 \\
-8.54\end{array}$ & $\begin{array}{l}690 \\
691 \\
692 \\
693 \\
694\end{array}$ & $\begin{array}{l}52312 \cdot 2 \\
52392 \cdot 1 \\
52471.9 \\
52551.8 \\
52631.6\end{array}$ & $\begin{array}{l}79.865 \\
79.853 \\
79.842 \\
79.831 \\
79.820\end{array}$ & $\begin{array}{l}-11.16 \\
-11.19 \\
-11.23 \\
-11.27 \\
-11.30\end{array}$ \\
\hline $\begin{array}{l}580 \\
581 \\
582 \\
583 \\
584\end{array}$ & $\begin{array}{l}43470.0 \\
43550.8 \\
43631.6 \\
43712.3 \\
43793.1\end{array}$ & $\begin{array}{l}80.788 \\
80.783 \\
80.778 \\
80.773 \\
80.768\end{array}$ & $\begin{array}{l}-4.84 \\
-4.92 \\
-5.00 \\
-5.08 \\
-5.16\end{array}$ & $\begin{array}{l}640 \\
641 \\
642 \\
643 \\
644\end{array}$ & $\begin{array}{l}48305.9 \\
48386.3 \\
48466.6 \\
48547.0 \\
48627.3\end{array}$ & $\begin{array}{l}80.369 \\
80.360 \\
80.351 \\
80.342 \\
80.333\end{array}$ & $\begin{array}{l}-8.88 \\
-8.93 \\
-8.98 \\
-9.04 \\
-9.09\end{array}$ & $\begin{array}{l}700 \\
701 \\
702 \\
703 \\
704\end{array}$ & $\begin{array}{l}53110.3 \\
53190.1 \\
53269.8 \\
53349.5 \\
53429.2\end{array}$ & $\begin{array}{l}79.751 \\
79.740 \\
79.728 \\
79.716 \\
79.705\end{array}$ & $\begin{array}{l}-11.52 \\
-11.56 \\
-11.59 \\
-11.63 \\
-11.66\end{array}$ \\
\hline $\begin{array}{l}585 \\
586 \\
587 \\
588 \\
589\end{array}$ & $\begin{array}{l}43873.9 \\
43954.6 \\
44035.4 \\
44116.1 \\
44196.9\end{array}$ & $\begin{array}{l}80.763 \\
80.757 \\
80.752 \\
80.747 \\
80.741\end{array}$ & $\begin{array}{l}-5.23 \\
-5.31 \\
-5.39 \\
-5.47 \\
-5.54\end{array}$ & $\begin{array}{l}645 \\
646 \\
647 \\
648 \\
649\end{array}$ & $\begin{array}{l}48707.7 \\
48788.0 \\
48868.3 \\
48948.6 \\
49028.9\end{array}$ & $\begin{array}{l}80.324 \\
80.315 \\
80.305 \\
80.296 \\
80.287\end{array}$ & $\begin{array}{l}-9.14 \\
-9.20 \\
-9.25 \\
-9.30 \\
-9.35\end{array}$ & $\begin{array}{l}705 \\
706 \\
707 \\
708 \\
709\end{array}$ & $\begin{array}{l}53508 \cdot 9 \\
53588 \cdot 6 \\
53668 \cdot 3 \\
53747.9 \\
53827.6\end{array}$ & $\begin{array}{l}79.693 \\
79.681 \\
79.670 \\
79.658 \\
79.646\end{array}$ & $\begin{array}{l}-11.70 \\
-11.73 \\
-11.77 \\
-11.80 \\
-11.84\end{array}$ \\
\hline $\begin{array}{l}590 \\
591 \\
592 \\
593 \\
594\end{array}$ & $\begin{array}{l}44277.6 \\
44358.4 \\
44439.1 \\
44519.8 \\
44600.5\end{array}$ & $\begin{array}{l}80.736 \\
80.730 \\
80.724 \\
80.718 \\
80.713\end{array}$ & $\begin{array}{l}-5.62 \\
-5.69 \\
-5.77 \\
-5.84 \\
-5.92\end{array}$ & $\begin{array}{l}650 \\
651 \\
652 \\
653 \\
654\end{array}$ & $\begin{array}{l}49109.2 \\
49189.4 \\
49269.7 \\
49349.9 \\
49430.2\end{array}$ & $\begin{array}{l}80.277 \\
80.268 \\
80.258 \\
80.249 \\
80.239\end{array}$ & $\begin{array}{l}-9.40 \\
-9.45 \\
-9.50 \\
-9.55 \\
-9.60\end{array}$ & $\begin{array}{l}710 \\
711 \\
712 \\
713 \\
714\end{array}$ & $\begin{array}{l}53907.2 \\
53986 \cdot 9 \\
54066 \cdot 5 \\
54146 \cdot 1 \\
54225 \cdot 7\end{array}$ & $\begin{array}{l}79.634 \\
79.622 \\
79.610 \\
79.598 \\
79.586\end{array}$ & $\begin{array}{l}-11.87 \\
-11.90 \\
-11.94 \\
-11.97 \\
-12.00\end{array}$ \\
\hline $\begin{array}{l}595 \\
596 \\
597 \\
598 \\
599\end{array}$ & $\begin{array}{l}44681.2 \\
44761.9 \\
44842.6 \\
44923.3 \\
45004.0\end{array}$ & $\begin{array}{l}80.707 \\
80.701 \\
80.694 \\
80.688 \\
80.682\end{array}$ & $\begin{array}{l}-5.99 \\
-6.07 \\
-6.14 \\
-6.21 \\
-6.28\end{array}$ & $\begin{array}{l}655 \\
656 \\
657 \\
658 \\
659\end{array}$ & $\begin{array}{l}49510.4 \\
49590.6 \\
49670.9 \\
49751.1 \\
49831.3\end{array}$ & $\begin{array}{l}80.230 \\
80.220 \\
80.210 \\
80.201 \\
80.191\end{array}$ & $\begin{array}{l}-9.65 \\
-9.70 \\
-9.75 \\
-9.80 \\
-9.84\end{array}$ & $\begin{array}{l}715 \\
716 \\
717 \\
718 \\
719\end{array}$ & $\begin{array}{l}54305.3 \\
54384.8 \\
54464.4 \\
54543.9 \\
54623.5\end{array}$ & $\begin{array}{l}79.574 \\
79.562 \\
79.550 \\
79.538 \\
79.526\end{array}$ & $\begin{array}{l}-12.04 \\
-12.07 \\
-12.10 \\
-12.14 \\
-12.17\end{array}$ \\
\hline 600 & 45084.7 & 80.676 & -6.36 & 660 & 49911.5 & 80.181 & -9.89 & 720 & 54703.0 & 79.514 & 2.2 \\
\hline
\end{tabular}


TABLE 5.3.2. Type $\boldsymbol{E}$ thermocouples-thermoelectric voltages, E(T), Seebeck coefficients, $\mathrm{S}(\mathrm{T})$, and first deriative of the Seebeck coefficients, $\mathrm{dS} / \mathrm{dT}$, reference junctions at $0{ }^{\circ} \mathrm{C}$-Continued

72

722

723

724

725

726
727

728
729

730

731

732

733
734

73

73

737

738
739

740

74

742

743

744

74

74

747

749

750
751

752

753
754

75

756

757

758
759

760

76
76

763

764

765

766

767

768

769

77

771

772
773

774

775

776

777

778
779

780
${ }_{\mu V}$ $\mu \mathrm{V} /{ }^{\circ} \mathrm{C}$ $d S / d T$
$n V /{ }^{\circ} \mathrm{C}^{2}$

54703.0 54782.5 54862.0

54941.5
55020.9

79.514

79.502

$79.489-12.27$

55100.4

55259.3

55338.7

55418 . 1

55497.5 55576.9 55656.3 55735.6

55815.0

55894.3

55973.6

56052.9

56132.2

56211.5

56290.8

56370.0

56449.3

56528.5

56607.7

56686.9

56766.1

56845.3

56924.5

57003.6

57082.8

57161.9

57241.0

57320.1

57399.2

57478.3

57557.3

57636.4

57715.4

57873.4

57952.4

58031.4

58110.4

58189.3

58268.3

58347.2

58426.1

58505.0

58583.9

58662.7

58741.6

58820.4

58899.3

58978.1

59056.9

59135.7

59214.5

59293.2

59372.0

79.477
79.465

79.452

79.440

79.428

79.415

79.403

79.390

79.378

79.365

79.352

79.340

79.327

79.314

79.302

79.289

79.276

79.263

79.250

79.238

79.225

79.212

79.199

79.186

79.173

79.160

79.146

79.133

79.120

79.107

79.094

79.080

79.067

79.054

79.040

79.027

79.014

79.000

78.987

78.973

78.959

78.946

78.932

78.919

78.905

78.891

78.877

78.863

78.850

78.836

78.822

78.780

$\begin{array}{ll}78.752 & -14.11 \\ 78.738 & -14.14\end{array}$

59450.7

$78.723-14.18$
780

781

782

783
784

785

786

787

788
789

790

791

792

793

794

795

796

797

798

799

800

801

802

803

804

805

806

807

808

809

810

811

812

813

814

815

816

817

818

819

820

821

822

823
824

825

826

827

828

829

830

831

832

833

834

835

836

837

838

839

840

\section{$\underset{\mu V}{E}$}

$\stackrel{\mathrm{S}}{\mathrm{S} /{ }^{\circ} \mathrm{C}}$ $d S / d T$

$59450.7 \quad 78.723 \quad-14.18$

$\begin{array}{lll}59529.4 & 78.709 & -14.21\end{array}$

$\begin{array}{lll}59608.1 & 78.695 & -14.25\end{array}$

$59686.8 \quad 78.681-14.29$

$\begin{array}{llll}59765.5 & 78.666 & -14.33\end{array}$

$\begin{array}{lll}59844.1 & 78.652 & -14.36\end{array}$

$59922.8 \quad 78.638 \quad-14.40$

$60001.4 \quad 78.623-14.44$

$60080.0 \quad 78.609-14.48$

60158.6

60237.2

60315.8

60394.3

60472.9

60551.4

60629.9

60708.4

60786.9

60865.4

60943.8

78.59

78.580

$78.551-14.63$

$78.536-14.67$

$78.521-14.71$

$78.507-14.75$

$78.492-14.79$

$78.477-14.83$

$\begin{array}{ll}78.462 & -14.87\end{array}$

$78.447-14.91$

61022.3

61100.7

61179.

61257.5

61335.9

61414.2

61492.6

61570.9

61649.2

61727.6

61805.8

61884.1

61962.4

62040.6

62118.8

62197.

62275.2

62353.4 
TABLE 5.3.2. Type $\boldsymbol{E}$ thermocouples-thermoelectric voltages, $\mathrm{E}(\mathrm{T})$, Seebeck coefficients, $\mathrm{S}(\mathrm{T})$, and first deriative of the Seebeck coefficients, $\mathrm{dS} / \mathrm{dT}$, reference junctions at $0^{\circ} \mathrm{C}$-Continued

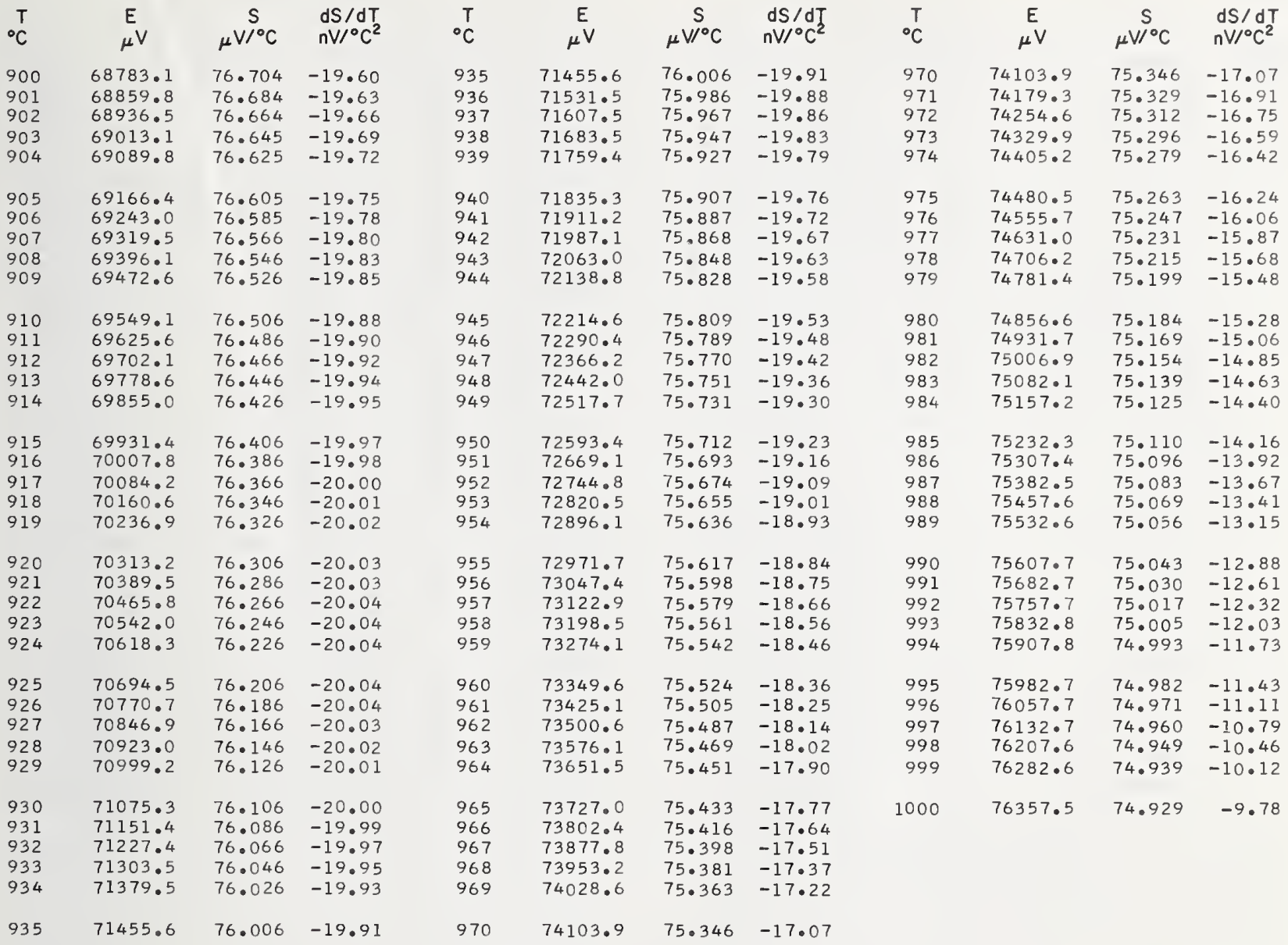


TABLE 5.3.3. Thermoelectric values at the fixed points for Type E thermocouples

\begin{tabular}{|c|c|c|c|c|}
\hline Fixed point & $\underset{ }{\text { Temp. }}{ }^{\circ} \mathrm{C}$ & $\begin{array}{c}E \\
\mu \mathrm{V}\end{array}$ & $\begin{array}{c}S \\
\mu \mathrm{V} /{ }^{\circ} \mathrm{C}\end{array}$ & $\begin{array}{c}d S / d T \\
\mathrm{nV} /{ }^{\circ} \mathrm{C}^{2}\end{array}$ \\
\hline $\begin{array}{l}\text { Helium NBP } \\
\text { Hydrogen TP } \\
\text { Hydrogen NBP } \\
\text { Neon TP } \\
\text { Neon NBP } \\
\text { Oxygen TP } \\
\text { Nitrogen TP } \\
\text { Nitrogen NBP } \\
\text { Oxygen NBP } \\
\text { Carbon Dioxide SP } \\
\text { Mercury FP } \\
\text { Ice point* } \\
\text { Ether TP } \\
\text { Water BP } \\
\text { Benzoic TP } \\
\text { Indium FP } \\
\text { Tin FP } \\
\text { Bismuth FP } \\
\text { Cadmium FP } \\
\text { Lead FP } \\
\text { Mercury BP } \\
\text { Zinc FP } \\
\text { Sulphur BP } \\
\text { Cu-Al FP } \\
\text { Antimony FP } \\
\text { Aluminum FP } \\
\text { Silver FP }\end{array}$ & $\begin{array}{c}-268.935 \\
-259.340 \\
-252.870 \\
-248.595 \\
-246.048 \\
-218.789 \\
-210.002 \\
-195.802 \\
-182.962 \\
-78.476 \\
-38.862 \\
0.000 \\
26.870 \\
100.000 \\
122.370 \\
156.634 \\
231.9681 \\
271.442 \\
321.108 \\
327.502 \\
356.660 \\
419.580 \\
444.674 \\
548.23 \\
630.74 \\
660.37 \\
961.93\end{array}$ & $\begin{array}{r}-9833.09 \\
-9792.66 \\
-9744.75 \\
-9704.62 \\
-9677.58 \\
-9249.87 \\
-9062.90 \\
-8716.78 \\
-8360.81 \\
-4227.53 \\
-2193.03 \\
0.00 \\
1609.1 \\
6317.1 \\
7846.8 \\
10259.9 \\
15809.4 \\
18820.7 \\
22683.9 \\
23186.2 \\
25489.1 \\
30512.6 \\
32531.2 \\
40901.4 \\
47561.4 \\
49941.2 \\
73495.5\end{array}$ & $\begin{array}{r}2.084 \\
6.180 \\
8.608 \\
10.181 \\
11.073 \\
20.018 \\
22.507 \\
26.181 \\
29.230 \\
48.541 \\
54.039 \\
58.696 \\
61.099 \\
67.512 \\
89.229 \\
71.566 \\
75.505 \\
77.012 \\
78.483 \\
78.643 \\
79.293 \\
80.30 ! \\
80.565 \\
80.899 \\
80.449 \\
80.177 \\
75.489\end{array}$ & $\begin{array}{r}491.21 \\
388.66 \\
366.90 \\
359.97 \\
356.26 \\
294.12 \\
272.80 \\
246.34 \\
229.48 \\
149.61 \\
128.82 \\
86.22 \\
91.33 \\
80.04 \\
73.46 \\
62.96 \\
42.51 \\
34.10 \\
25.46 \\
24.47 \\
20.22 \\
12.02 \\
8.99 \\
-2.10 \\
-8.35 \\
-9.91 \\
-18.15\end{array}$ \\
\hline
\end{tabular}

*Junction point of different functions.

TABLE 5.3.4. Esimated maximum errors that occur when using reduced-bit arithmetic for the power series expansion for the thermoelectric voltage of Type E thermocouples

\begin{tabular}{|c|c|c|c|c|c|c|}
\hline \multirow[b]{2}{*}{ Temperature range } & \multirow[b]{2}{*}{ Degree } & \multicolumn{5}{|c|}{ Estimated maximum error in microvolts } \\
\hline & & 12 Bit & $16 \mathrm{Bit}$ & 24. Bit & $27 \mathrm{Bit}$ & 36 Bit \\
\hline-270 to $-200{ }^{\circ} \mathrm{C}$ & 13 & $(\stackrel{*}{*})$ & 300 & 0.4 & 0.1 & $<0.01$ \\
\hline-200 to $\quad 0^{\circ} \mathrm{C}$ & 13 & 800 & 20 & 0.2 & 0.02 & $<0.01$ \\
\hline 0 to $200^{\circ} \mathrm{C}$ & 9 & 3 & 0.2 & $<0.01$ & $<0.01$ & $<0.01$ \\
\hline 200 to $\quad 4.00{ }^{\circ} \mathrm{C}$ & 9 & 7 & 0.2 & $<0.01$ & $<0.01$ & $<0.01$ \\
\hline 400 to $\quad 600^{\circ} \mathrm{C}$ & 9 & 70 & 0.5 & 0.03 & $<0.01$ & $<0.01$ \\
\hline 600 to $\quad 800{ }^{\circ} \mathrm{C}$ & 9 & 400 & 15 & 0.2 & 0.02 & $<0.01$ \\
\hline 800 to $1000{ }^{\circ} \mathrm{C}$ & 9 & $(*)$ & 90 & 0.6 & 0.1 & $<0.01$ \\
\hline
\end{tabular}

*A high-order polynomial with a low-bit machine causes extreme error. 


\section{TYPE J-Iron Versus Copper-Nickel Alloy (SAMA) Thermocouples}

\subsection{Material Specifications and Precautions}

This is one of the most common types of industrial thermocouples, because of its relatively high Seebeck coefficient and low cost. It has been reported that more than 200 tons of Type J materials are supplied annually to industry in this country. However, it is least suitable for accurate thermometry because there are significant nonlinear deviations in the thermoelectric output from different manufacturers. These irregular deviations lead to difficulties in obtaining accurate calibrations based on a limited number of calibration points. The positive thermoelement is commercially pure $(99.5 \% \mathrm{Fe})$ iron, usually containing significant impurity levels of carbon, chromium, copper, manganese, nickel, phosphorus, silicon, and sulfur. Thermocouple wire represents such a small fraction of the total production of commercial iron wire that the producers do not control the chemical composition to maintain constant thermoelectric properties. Instead, instrument companies and thermocouple fabricators select material most suitable for their thermocouple usage. The total and specific types of impurities that occur in commercial iron change with time, location of primary ores, and methods of smelting. Many unusual lots have been selected in the past, for example spools of industrial iron wire and even scrapped rails from an elevated train line. At present, iron wire that most closely fits these tables has about 0.25 percent $\mathrm{Mn}$ and 0.12 percent copper plus other minor impurities.

The negative thermoelement for Type J thermocouples is a copper-nickel alloy known ambiguously as constantan. The word constantan has commonly referred to copper-nickel alloys with anything from 45 to 60 percent of copper, often with minor impurities of carbon, iron, or manganese. Constantan for Type J thermocouples usually contains about 55 percent copper, 45 percent nickel, and a small but thermoelectrically significant amount of iron and manganese, about 0.1 percent or more. It should be emphasized that Type JN thermoelements are NOT generally interchangeable with Type TN (or EN) thermoelements, although they are all referred to as "constantan". In order to provide some differentiation in nomenclature, Type JN is often referred to as SAMA constantan.

Suppliers of Type $\mathbf{J}$ thermocouples usually select heats of iron and well-matched batches of constantan so that the total output of the combination closely fits the Type $\mathrm{J}$ table up to $760{ }^{\circ} \mathrm{C}$. In fact, with care in selection, Type J thermocouples can be produced that will fit calibration tables as accurately as the more expensive Type $\mathrm{K}$ thermocouples. While the overall thermocouple will conform to the limits of error published in ASTM or ISA standards (or even have closer limits of error), it should be emphasized that Type JP and JN thermoelements as supplied by different companies are not generally interchangeable.

The grandfather of the Type J thermocouple tables in this Monograph was the commercial table printed by Leeds and Northrup in 1913 and incorporated in a later NBS paper, Foote, Fairchild, and Harrison [1920] and the NAS-NRC International Critical Tables [1926]. They covered the range from 0 to $760{ }^{\circ} \mathrm{C}$. The usefulness of an iron versus coppernickel alloy thermocouple had been shown as early as [1892] by Lindeck. By the 1930's a number of different tables had been published for iron versus constantan thermocouples because of a lack of standardization and differences in the irons used by various thermocouple manufacturers. Although other tables for iron versus constantan thermocouples came into existence, the 1913 table was the most commonly used for instrument calibrations. Until the late 1930's however, thermocouples did not conform accurately to this curve. Therefore Roeser and Dahl [1938] obtained a representative selection of both materials and carefully remeasured their thermoelectric properties between -200 and $1000{ }^{\circ} \mathrm{C}$. Their results were representative of material used by the military at that time, but deviated significantly from the 1913 table. Because the new tables differed by up to 2 percent from the previous tables, they were not generally accepted as a replacement for the earlier iron versus constantan tables. To somewhat ease the confusion, the tables generated by Roeser and Dahl [1938] were referred to as Type $\mathrm{Y}$ or RP 1080 iron versus constantan. Their tables were used by several military groups but were not generally used in civilian applications.

In an effort to promote uniformity, a section of the Scientific Apparatus Makers of America (SAMA) initiated a new program in 1948. A research project was established at the National Bureau of Standards and the results were published in 1953 by Corruccini and Shenker. The resultant tables were very close to the 1913 ones and have generally been accepted as the Type J, iron versus constantan, thermocouple standards (NBS Circular 56l; Shenker et al. [1955]). After modifications for temperature scale changes, their research results were used for generating the functions given in this Monograph.

Type J thermocouples are recommended by the ASTM [1970] for use in the temperature range from 0 to $760{ }^{\circ} \mathrm{C}$ in vacuum, oxidizing, reducing, or inert atmospheres. If used for extended times above $500^{\circ} \mathrm{C}$, heavy gage wires are recommended because the oxidation rate is rapid at elevated temperatures. The ASTM Manual STP 470 [1970] indicates the following restrictions on the use of Type J thermocouples:

They should not be used in sulfurous atmospheres above $500{ }^{\circ} \mathrm{C}$. Because of potential rusting and embrittlement, they are not recommended for sub-zero temperatures. They should not be cycled above $760^{\circ} \mathrm{C}$ even for a short time if accurate readings below $760{ }^{\circ} \mathrm{C}$ are desired at a later time.

The positive thermoelement, iron, is relatively insensitive to composition changes under thermal neutron irradiation, but does exhibit a slight increase in manganese content. The negative thermoelement, a 
copper-nickel alloy, is subject to substantial composition changes under thermal neutron irradiation since copper is converted to nickel and zinc.

Both thermoelements of Type $J$ thermocouples are variable in thermoelectric output because of compositional variations in the iron and in the copper-nickel alloy. Corruccini and Shenker [1953] found an order of magnitude variation in both the manganese $(0.03$ to $0.38 \%)$ and copper $(0.02$ to $0.15 \%)$ impurities in the iron thermoelements, even though the materials were presumably specially selected lots of material. Not only were the thermoelectric voltages of different iron thermoelements different by as much as 2 percent, the output curves were sometimes different in shape. The negative thermoelements also differed by as much as 2 percent, but their deviations tended to be much more linear. At present the manufacturers are controlling the compositions and the matching of thermoelements more carefully and therefore deviations from the standards should be considerably less than those observed by Corruccini and Shenker [1953].

Finch [1943] has shown that the Seebeck coefficient of iron at $500{ }^{\circ} \mathrm{C}$ is increased by additions of $\mathrm{Cr}, \mathrm{Mn}$, or $\mathrm{S}$ but decreased by additions of $\mathrm{Ni}, \mathrm{Si}, \mathrm{Sn}, \mathrm{P}$, and $\mathrm{Cu}$ (for impurity level above 0.1 percent). Manufacturers select the negative thermoelement to match a given lot of positive material. The composition of the coppernickel alloy therefore also varies significantly. The average composition is around 55 percent copper and there is usually a significant impurity amount of iron.

Annealing below $760{ }^{\circ} \mathrm{C}$ for short periods does not significantly alter the thermoelectric properties of Type J thermocouples.

Commercial iron undergoes a magnetic transforma. tion near $769{ }^{\circ} \mathrm{C}$ and a $a-\gamma$ crystal transformation near $910{ }^{\circ} \mathrm{C}$ (see Hansen and Anderko [1958]). Both of these transformations, especially the latter, seriously affect the thermoelectric properties of iron, and therefore of Type $\mathrm{J}$ thermocouples. It is for that reason that iron versus constantan thermocouples are not recom. mended as a standardized type above $760{ }^{\circ} \mathrm{C}$. If Type J thermocouples are taken to high temperatures, especially above $900{ }^{\circ} \mathrm{C}$, they will lose the accuracy of their calibration when they are recycled to lower temperatures. If Type $\mathrm{J}$ thermocouples are used at temperatures above $760{ }^{\circ} \mathrm{C}$, only the largest wire, AWG $8(3.3 \mathrm{~mm})$ should be used and they should be held at the measured temperature for 10 to $20 \mathrm{~min}$. utes before readings are taken. The output of the Type $J$ thermocouples may change by as much as 40 $\mu \mathrm{V}$ (or $1{ }^{\circ} \mathrm{C}$ equivalent) per minute when first brought up to temperatures near $900{ }^{\circ} \mathrm{C}$.

ASTM Standard E230-72 in the Annual Book of ASTM Standards [1972] specifies that the standard limits of error for Type $\mathrm{J}$ commercial thermocouples be $\pm 2.2{ }^{\circ} \mathrm{C}$ between 0 and $277^{\circ} \mathrm{C}$ and $\pm 3 / 4$ percent between 277 and $760{ }^{\circ} \mathrm{C}$. Limits of error are not specified for Type $\mathrm{J}$ thermocouples below $0{ }^{\circ} \mathrm{C}$ or above $760{ }^{\circ} \mathrm{C}$. Type $\mathrm{J}$ thermocouples can also be supplied to meet special limits of error, which are equal to one-half the limits given above. The recom. mended upper temperature limit for protected thermo- couples, $760{ }^{\circ} \mathrm{C}$, applies to AWG $8(3.3 \mathrm{~mm})$ wire. For smaller wires the recommended upper temperature decreases to $593{ }^{\circ} \mathrm{C}$ for AWG $14(1.6 \mathrm{~mm}), 482{ }^{\circ} \mathrm{C}$ for $A W G 20(0.8 \mathrm{~mm})$, and $371{ }^{\circ} \mathrm{C}$ for AWG 24 or $28(0.5$ or $0.3 \mathrm{~mm})$.

\subsection{Data Analyses and Comparisons}

The fitting functions for Type $J$ thermocouples are based primarily on the data reported by Corruccini and Shenker [1953]. The values for single thermoelements versus platinum were adjusted to be on the IPTS-68 and to be relative to the new platinum reference standard, $\mathrm{Pt}-67$. The differences between $\mathrm{Pt}-67$ and the former standard, $\mathrm{Pt}-27$, are summarized in section 1.2. The method of analysis used in this Monograph was different than that used by Corruccini and Shenker [1953]; they used divided differences, Lagrangian interpolation, and linear interpolation to construct their tables from the experimental data points. Our methods are described in the first chapter of this Monograph. The high temperature functions for the Type J thermocouple have also been adjusted to fit some recent experimental points in the extended range near $1135{ }^{\circ} \mathrm{C}$ reported by Sine [1971].

Thermocouple $A-1$ in the paper by Corruccini and Shenker [1953] was used as the basis for fitting the functions for Type $J$ thermocouples between -210 and $+760{ }^{\circ} \mathrm{C}$. There were 27 experimental points in this temperature range. With a seven term function the standard deviation of the fit was $4.8 \mu \mathrm{V}$.

Twenty-three experimental points for the thermoelement A-1 in the paper by Corruccini and Shenker [1953] were used to generate functions for Type JP thermoelements versus $\mathrm{Pt}-67$. With a seven term function the standard deviation of the fit was $4.4 \mu \mathrm{V}$.

The fitting function for $\mathrm{Pt}-67$ versus Type JN thermoelements was obtained by subtraction of the Type JP function from the Type J function.

Fitting functions for Type $\mathrm{J}$ thermocouples between 760 and $1200{ }^{\circ} \mathrm{C}$ were based upon 11 experimental points from Corruccini and Shenker [1953] and eight experimental points provided by Sine [1971]. The function was extrapolated smoothly above the highest experimental points (near $1134^{\circ} \mathrm{C}$ ) to $1200^{\circ} \mathrm{C}$. The function was constrained to have the same thermoelectric voltage and Seebeck coefficient at $760^{\circ} \mathrm{C}$ as those calculated for the temperature range below $760{ }^{\circ} \mathrm{C}$. The standard deviation of the fit for a 6 term equation was about $14 \mu \mathrm{V}$. The function and values for Type $\mathrm{J}$ thermocouples above $760{ }^{\circ} \mathrm{C}$ are thus not suitable for precise temperature measurements and the thermocouple should not be used as a standardized type above $760^{\circ} \mathrm{C}$. The values for temperatures above $760{ }^{\circ} \mathrm{C}$ given in this Monograph should be used only as a guide and rough approximation.

Values for thermoelectric voltages of Type J thermocouples given in this Monograph were compared to those for three thermocouples, $A-1, F-1$, and $F-5$, studied by Corruccini and Shenker [1953] and to those for three thermocouples calibrated by the Temperature Section of the National Bureau of Standards, Gaithersburg. The deviations are shown in figure 6.2.1. All values were adjusted to the IPTS-68. 
Similarly, the deviations for Type JP thermoelements versus $\mathrm{Pt}-67$ and $\mathrm{Pt}-67$ versus $\mathrm{JN}$ thermoelements are given in figures 6.2.2 and 6.2.3. The number of thermoelements used for these comparisons was different however: values for four JP thermoelements calibrated by the Temperature Section of the National Bureau of Standards, Gaithersburg, are shown; for JN, no individual calibrations from that group are included. In both these figures there is also a comparison to data for the thermoelements of thermocouple

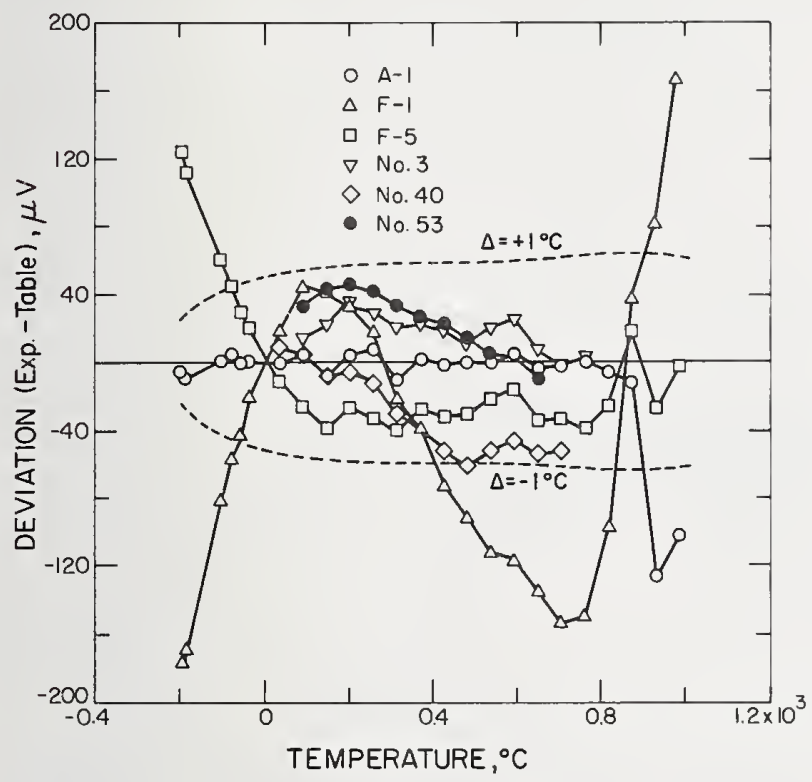

Figure 6.2.1. Deviations of thermoelectric voltages of Type J thermocouples-comparison of values given in this Monograph to those given by: $A-1, F-1$, and $F-5$, Corruccini and Shenker [1953]; Nos. 3, 40, and 53, selected calibrations from the Temperature Section (NBS, Gaithersburg).

Values from previous puhlications and tests are adjusted to the IPTS-68. The dashed lines indicate a deviation of $1{ }^{\circ} \mathrm{C}$.
A-1 from Corruccini and Shenker [1953] and to values from the widely distributed, but unpublished, industrial tables prepared by Burns [1967].

Deviations between values given in this Monograph and those given in NBS Circular 561 are shown in figure 6.2.4. The earlier values were adjusted to the IPTS-68. The width of the curve indicates the roundoff uncertainty $(10 \mu \mathrm{V})$ in the tabular values given in NBS Circular 561.

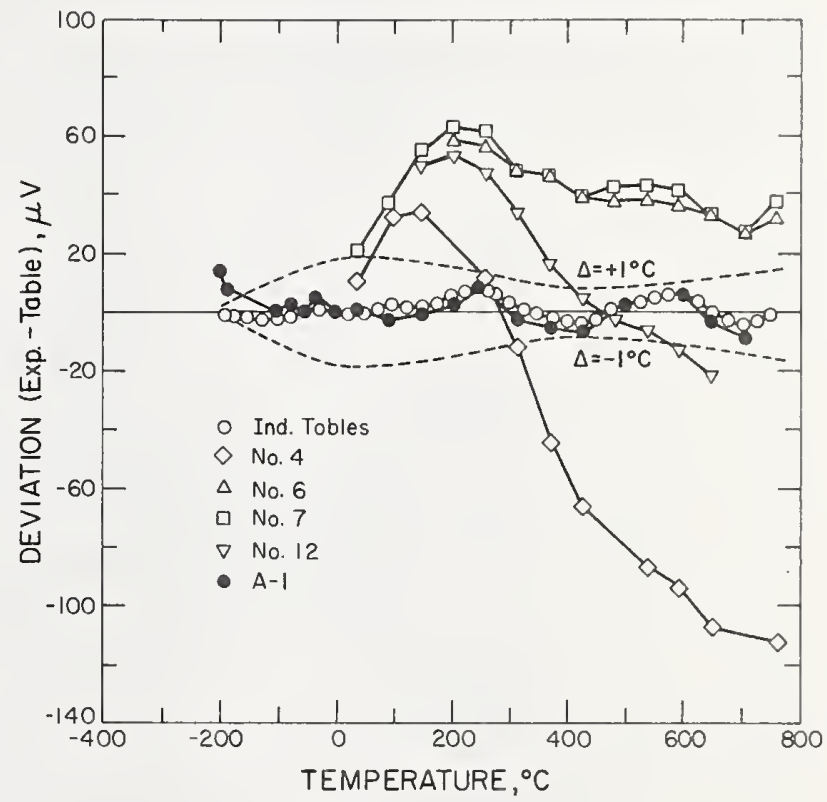

Figure 6.2.2. Deviations of thermoelectric voltages of Type $J P$ thermoelements versus platinum, $P t-67$-comparison of values given in this Monograph to those given by: $A-1$, Corruccini and Shenker [1953], Nos. 4, 6, 7, and 12, selected calibrations from the Temperature Section (NBS, Gaithers. burg); Ind. Tables, unpublished NBS áata by Burns [1967].

Values from previous puhlications and tests are adjusted to the IPTS-68. The dashed lines indicate a deviation of $1{ }^{\circ} \mathrm{C}$. 


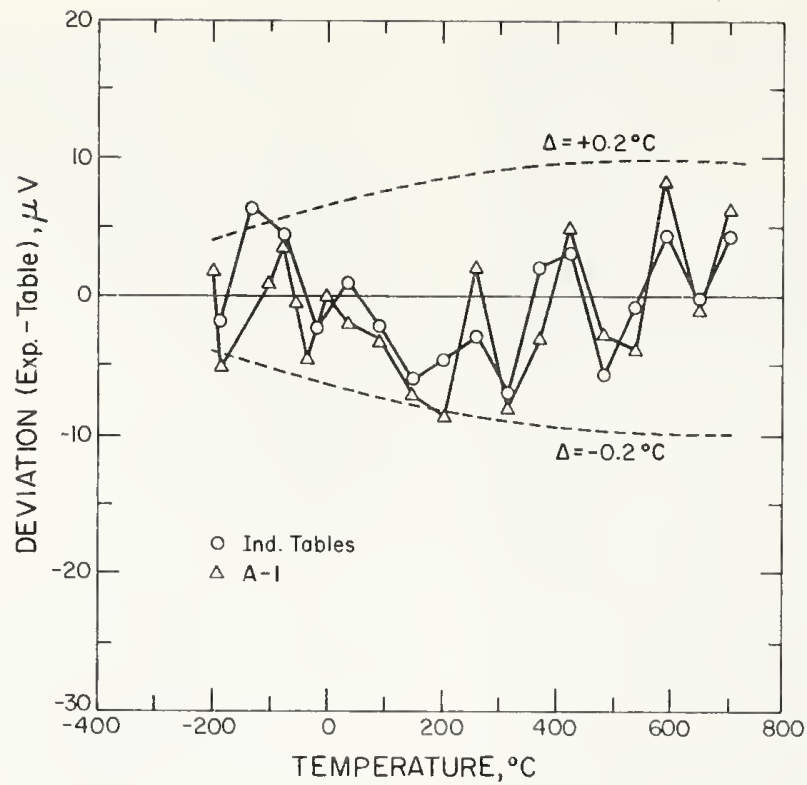

Figure 6.2.3. Deviations of thermoelectric voltages of platinum, Pt-67, versus Type JN thermoelements-comparison of values given in this Monograph to those given by: A-1, Corruccini and Shenker [1953]; Ind. Tables, unpublished NBS data by Burns [1967].

Values from previous publications and tests are expressed on tbe IPTS -68 .

The dashed lines indicate a deviation of $0.2^{\circ} \mathrm{C}$.

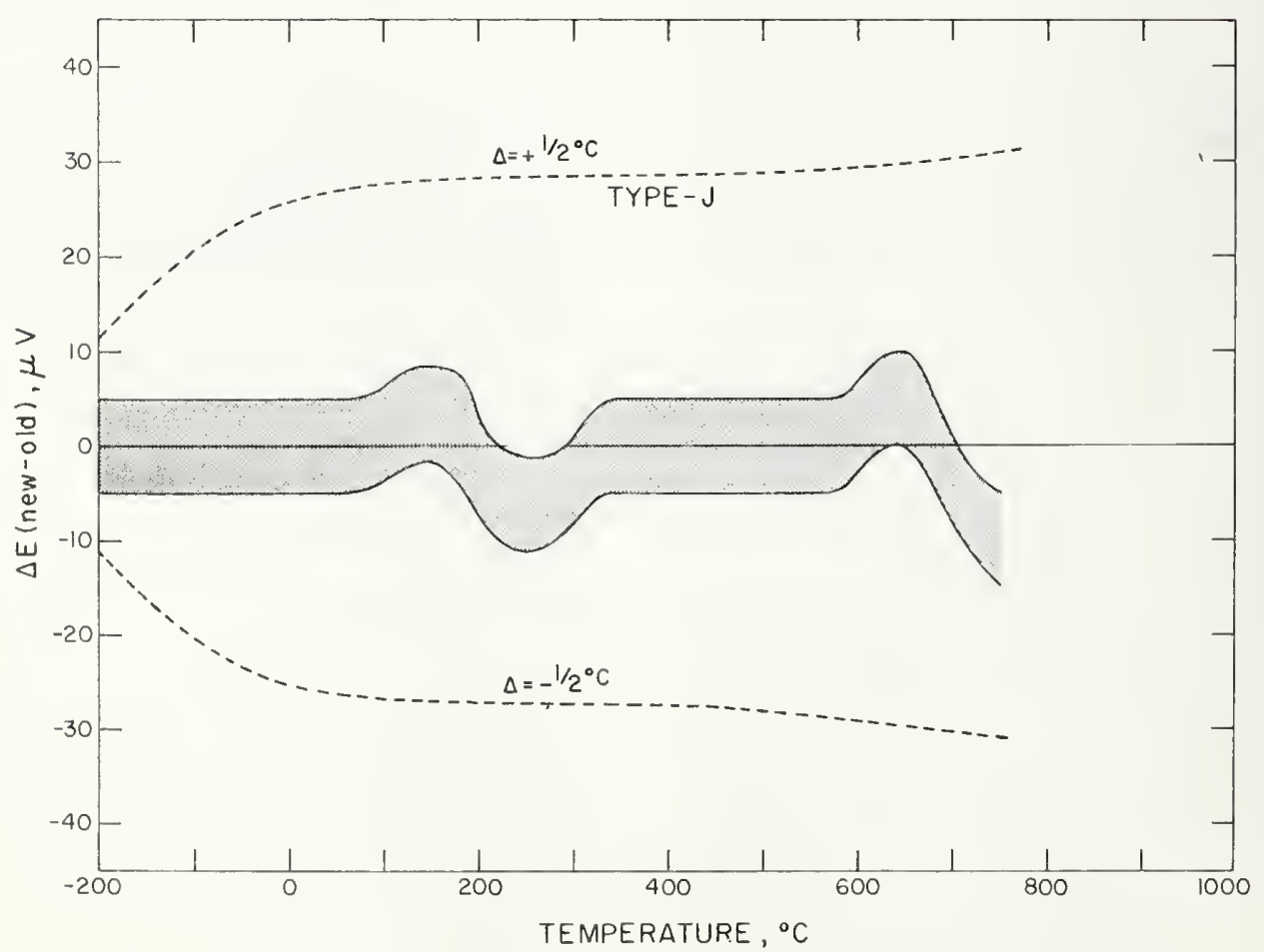

Figure 6.2.4. Difference in the thermoelectric voltages for Type $J$ thermocouples-comparison of values given in this Monograph to those given in NBS Circular 561.

Values from the previous standard are adjusted to the IPTS -68 . The dashed lines indicate a deviation of $1 / 2{ }^{\circ} \mathrm{C}$. 


\subsection{Reference Functions and Tables for Type J Thermocouples}

The coefficients for the seventh degree expansion for the thermoelectric voltage of Type $\mathrm{J}$ thermocouples below $760{ }^{\circ} \mathrm{C}$ are given in table 6.3.1. The coefficients for the fifth degree expansion above $760{ }^{\circ} \mathrm{C}$ are also given in table 6.3.1. The errors caused by reduced bit arithmetic for calculating values of the functions are given in table 6.3.4.

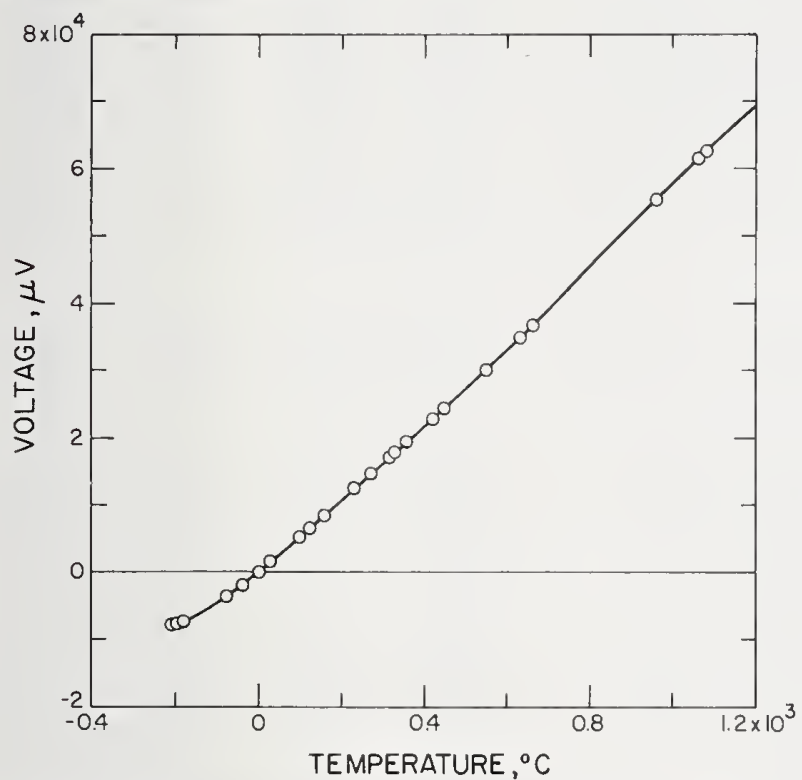

FIGURE 6.3.1. Thermoelectric voltage for Type $J$ thermo. couples.

The circles indicate values at various thermometric fixed points on the IPTS -68 .

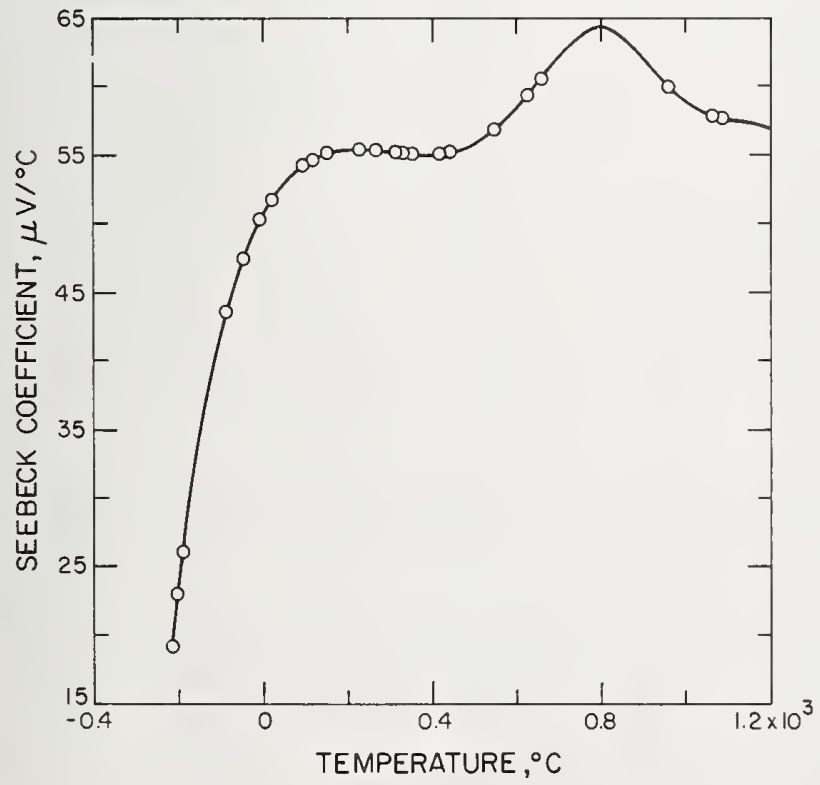

Figure 6.3.2. Seebeck coefficient for Type J thermocouples. The circles indicate values at various thermometric fixed points on the TPTS -68 .
The primary reference values for Type $\mathrm{J}$ thermocouples are given in table 6.3.2. Values at selected fixed points are given in table 6.3.3. Graphs of the thermoelectric voltage, its first derivative (Seebeck coefficient), and second derivative are given in figures $6.3 .1,6.3 .2$, and 6.3 .3 , respectively.

Values above $760{ }^{\circ} \mathrm{C}$ are given as a guide only: thermoelectric properties of Type $J$ thermocouples are not stable above $760{ }^{\circ} \mathrm{C}$ and the thermocouple should NOT be considered to be a standardized type above this temperature.

TABLE 6.3.1. Power series expansion for the thermoelectric voltage of Type $J$ thermocouples

\begin{tabular}{|c|c|c|c|}
\hline $\begin{array}{c}\text { Tempera- } \\
\text { ture } \\
\text { range }\end{array}$ & Degree & Coefficients & Term \\
\hline $\begin{array}{r}-210 \text { to } \\
760^{\circ} \mathrm{C}\end{array}$ & 7 & $\begin{array}{r}5.0372753027 \times 10^{1} \\
3.0425491284 \times 10^{-2} \\
-8.5669750464 \times 10^{-5} \\
1.3348825735 \times 10^{-7} \\
-1.7022405966 \times 10^{-10} \\
1.9416091001 \times 10^{-13} \\
-9.6391844859 \times 10^{-17}\end{array}$ & $\begin{array}{l}T \\
T^{2} \\
T^{3} \\
T^{4} \\
T^{5} \\
T^{6} \\
T^{7}\end{array}$ \\
\hline $\begin{array}{l}760 \text { to } \\
1200{ }^{\circ} \mathrm{C}\end{array}$ & 5 & $\begin{array}{r}2.9721751778 \times 10^{5} \\
-1.5059632873 \times 10^{3} \\
3.2051064215 \times \ldots \\
-3.2210174230 \times 10^{-3} \\
1.5949968788 \times 10^{-6} \\
-3.1239801752 \times 10^{-10}\end{array}$ & $\begin{array}{l}\cdots \\
T^{2} \\
T^{3} \\
T^{4} \\
T^{5}\end{array}$ \\
\hline
\end{tabular}

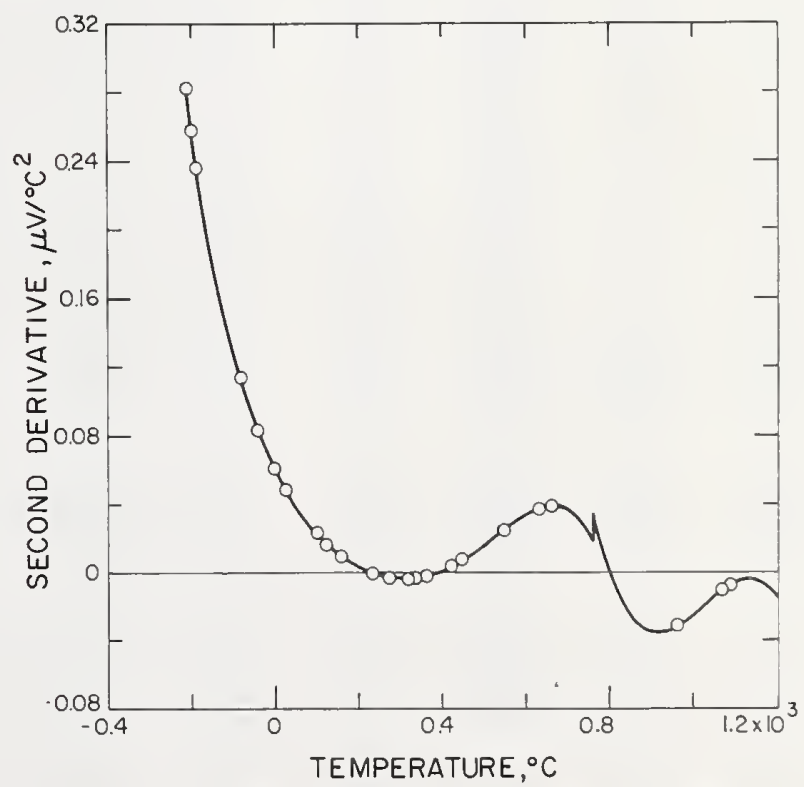

Figure 6.3.3. Second derivative of thermoelectric voltage for Type J thermocouples.

The circles indicate values at various thermometric fxed points on the IPTS -68 . 
TABLE 6.3.2. Type J thermocouples-thermoelectric voltages, E(T), Seebeck coefficients, $\mathrm{S}(\mathrm{T})$, and first derivative of the Seebeck coefficients, $\mathrm{dS} / \mathrm{dT}$, reference junctions at $0^{\circ} \mathrm{C}$

\begin{tabular}{|c|c|c|c|c|c|c|c|c|c|c|c|}
\hline $\begin{array}{l}\mathrm{T} \\
{ }^{\circ} \mathrm{C}\end{array}$ & $\begin{array}{c}E \\
\mu V\end{array}$ & $\underset{\mu V /{ }^{\circ} \mathrm{C}}{S}$ & $\begin{array}{l}\mathrm{dS} / \mathrm{dT} \\
\mathrm{nV} /{ }^{\circ} \mathrm{C}^{2}\end{array}$ & $\begin{array}{l}\mathrm{T} \\
{ }^{\circ} \mathrm{C}\end{array}$ & $\begin{array}{c}E \\
\mu V\end{array}$ & $\begin{array}{c}\mathrm{S} \\
\mu \mathrm{V} /{ }^{\circ} \mathrm{C}\end{array}$ & $\begin{array}{l}d S / d T \\
n V /{ }^{\circ} C^{2}\end{array}$ & $\begin{array}{l}\mathrm{T} \\
{ }^{\circ} \mathrm{C}\end{array}$ & $\underset{\mu V}{E}$ & $\begin{array}{c}\mathrm{S} \\
\mu \mathrm{V} /{ }^{\circ} \mathrm{C}\end{array}$ & $\begin{array}{l}\mathrm{dS} / \mathrm{dT} \\
\mathrm{nV} /{ }^{\circ} \mathrm{C}^{2}\end{array}$ \\
\hline $\begin{array}{l}-210 \\
-209 \\
-208 \\
-207 \\
-206\end{array}$ & $\begin{array}{l}-8095.6 \\
-8076.3 \\
-8056.8 \\
-8037.0 \\
-8016.9\end{array}$ & $\begin{array}{l}19.126 \\
19.409 \\
19.690 \\
19.969 \\
20.247\end{array}$ & $\begin{array}{l}283.95 \\
282.06 \\
280.19 \\
278.32 \\
276.47\end{array}$ & $\begin{array}{l}-200 \\
-199 \\
-198 \\
-197 \\
-196\end{array}$ & $\begin{array}{l}-7890.5 \\
-7868.5 \\
-7846.2 \\
-7823.7 \\
-7800.9\end{array}$ & $\begin{array}{l}21.873 \\
22.137 \\
22.400 \\
22.662 \\
22.921\end{array}$ & $\begin{array}{l}265.58 \\
263.80 \\
262.04 \\
260.28 \\
258.54\end{array}$ & $\begin{array}{l}-190 \\
-189 \\
-188 \\
-187 \\
-186\end{array}$ & $\begin{array}{l}-7658.7 \\
-7634.2 \\
-7609.4 \\
-7584.3 \\
-7559.0\end{array}$ & $\begin{array}{l}24.441 \\
24.689 \\
24.934 \\
25.179 \\
25.421\end{array}$ & $\begin{array}{l}248.29 \\
246.61 \\
244.95 \\
243.30 \\
241.66\end{array}$ \\
\hline $\begin{array}{l}-205 \\
-204 \\
-203 \\
-202 \\
-201\end{array}$ & $\begin{array}{l}-7996.5 \\
-7975.8 \\
-7954.9 \\
-7933.7 \\
-7912.2\end{array}$ & $\begin{array}{l}20.522 \\
20.796 \\
21.068 \\
21.338 \\
21.606\end{array}$ & $\begin{array}{l}274.63 \\
272.79 \\
270.97 \\
269.17 \\
267.37\end{array}$ & $\begin{array}{l}-195 \\
-194 \\
-193 \\
-192 \\
-191\end{array}$ & $\begin{array}{l}-7777.8 \\
-7754.5 \\
-7730.9 \\
-7707.1 \\
-7683.1\end{array}$ & $\begin{array}{l}23.179 \\
23.435 \\
23.689 \\
23.941 \\
24.192\end{array}$ & $\begin{array}{l}256.80 \\
255.08 \\
253.37 \\
251.66 \\
249.97\end{array}$ & $\begin{array}{l}-185 \\
-184 \\
-183 \\
-182 \\
-181\end{array}$ & $\begin{array}{l}-7533.5 \\
-7507.7 \\
-7481.7 \\
-7455.4 \\
-7428.9\end{array}$ & $\begin{array}{l}25.662 \\
25.901 \\
26.139 \\
26.375 \\
26.609\end{array}$ & $\begin{array}{l}240.02 \\
238.40 \\
236.79 \\
235.19 \\
233.59\end{array}$ \\
\hline-200 & -7890.5 & 21.873 & 265.58 & -190 & -7658.7 & 24.441 & 248.29 & -180 & -7402.2 & 26.842 & 232.01 \\
\hline
\end{tabular}


TABLE 6.3.2. Type J thermocouples-thermoelectric voltages, E(T), Seebeck coefficients, S(T), and first derivative of the Seebeck coefficients, $\mathrm{dS} / \mathrm{dT}$, reference iunctions at $0^{\circ} \mathrm{C}$-Continued

\begin{tabular}{|c|c|c|c|c|c|c|c|c|c|c|c|}
\hline $\begin{array}{r}T \\
{ }^{\circ} \mathrm{C}\end{array}$ & $\underset{\mu V}{E}$ & $\underset{\mu V /{ }^{\circ} \mathrm{C}}{S}$ & $\begin{array}{l}\mathrm{dS} / \mathrm{dT} \\
n \mathrm{~V} /{ }^{\circ} \mathrm{C}^{2}\end{array}$ & $\begin{array}{l}\mathrm{T} \\
{ }^{\circ} \mathrm{C}\end{array}$ & $\underset{\mu V}{E}$ & $\stackrel{\mathrm{S}}{\mu \mathrm{V} /{ }^{\circ} \mathrm{C}}$ & $\begin{array}{l}\mathrm{dS} / \mathrm{d} T \\
\mathrm{nV} /{ }^{\circ} \mathrm{C}^{2}\end{array}$ & ${ }^{\circ} \mathrm{C}$ & $\mu{ }_{\mu}^{E}$ & $\stackrel{\mathrm{S}}{\mu \mathrm{V} /{ }^{\circ} \mathrm{C}}$ & $\begin{array}{l}d S / d T \\
n V /{ }^{\circ} C^{2}\end{array}$ \\
\hline $\begin{array}{l}-180 \\
-179 \\
-178 \\
-177 \\
-176\end{array}$ & $\begin{array}{l}-7402.2 \\
-7375.2 \\
-7348.0 \\
-7320.6 \\
-7293.0\end{array}$ & $\begin{array}{l}26.842 \\
27.073 \\
27.303 \\
27.531 \\
27.757\end{array}$ & $\begin{array}{l}232.01 \\
230.44 \\
228.87 \\
227.32 \\
225.77\end{array}$ & $\begin{array}{l}-120 \\
-119 \\
-118 \\
-117 \\
-116\end{array}$ & $\begin{array}{l}-5426.0 \\
-5387.7 \\
-5349.3 \\
-5310.6 \\
-5271.9\end{array}$ & $\begin{array}{l}38.240 \\
38.392 \\
38.543 \\
38.693 \\
38.842\end{array}$ & $\begin{array}{l}152.79 \\
151.70 \\
150.63 \\
149.55 \\
148.49\end{array}$ & $\begin{array}{l}-60 \\
-59 \\
-58 \\
-57 \\
-56\end{array}$ & $\begin{array}{l}-2892 \cdot 5 \\
-2846.7 \\
-2800.9 \\
-2755.0 \\
-2709.0\end{array}$ & $\begin{array}{l}45.669 \\
45.767 \\
45.864 \\
45.961 \\
46.056\end{array}$ & $\begin{array}{l}98.27 \\
97.53 \\
96.79 \\
96.05 \\
95.32\end{array}$ \\
\hline $\begin{array}{l}-175 \\
-174 \\
-173 \\
-172 \\
-171\end{array}$ & $\begin{array}{l}-7265.1 \\
-7237.0 \\
-7208.7 \\
-7180.2 \\
-7151.4\end{array}$ & $\begin{array}{l}27.982 \\
28.206 \\
28.428 \\
28.648 \\
28.867\end{array}$ & $\begin{array}{l}224.23 \\
222.71 \\
221.19 \\
219.68 \\
218.18\end{array}$ & $\begin{array}{l}-1115 \\
-1114 \\
-1113 \\
-1112 \\
-1111\end{array}$ & $\begin{array}{l}-5233.0 \\
-5193.9 \\
-5154.7 \\
-5115.3 \\
-5075.8\end{array}$ & $\begin{array}{l}38.990 \\
39.137 \\
39.283 \\
39.428 \\
39.571\end{array}$ & $\begin{array}{l}147 \cdot 43 \\
146 \cdot 37 \\
145 \cdot 33 \\
144 \cdot 29 \\
143.25\end{array}$ & $\begin{array}{l}-55 \\
-54 \\
-53 \\
-52 \\
-51\end{array}$ & $\begin{array}{l}-2662.9 \\
-2616.7 \\
-2570.4 \\
-2524.0 \\
-2477.5\end{array}$ & $\begin{array}{l}46.151 \\
46.245 \\
46.339 \\
46.432 \\
46.524\end{array}$ & $\begin{array}{l}94.59 \\
93.87 \\
93.15 \\
92.43 \\
91.72\end{array}$ \\
\hline $\begin{array}{l}-170 \\
-169 \\
-168 \\
-167 \\
-166\end{array}$ & $\begin{array}{l}-7122.4 \\
-7093.2 \\
-7063.8 \\
-7034.2 \\
-7004.4\end{array}$ & $\begin{array}{l}29.085 \\
29.301 \\
29.515 \\
29.728 \\
29.940\end{array}$ & $\begin{array}{l}216.69 \\
215 \cdot 21 \\
213.74 \\
212 \cdot 28 \\
210.83\end{array}$ & $\begin{array}{l}-110 \\
-109 \\
-108 \\
-107 \\
-106\end{array}$ & $\begin{array}{l}-5036.2 \\
-4996.4 \\
-4956.5 \\
-4916.4 \\
-4876.2\end{array}$ & $\begin{array}{l}39.714 \\
39.856 \\
39.996 \\
40.136 \\
40.275\end{array}$ & $\begin{array}{l}142.22 \\
141.20 \\
140.19 \\
139.18 \\
138.18\end{array}$ & $\begin{array}{l}-50 \\
-49 \\
-48 \\
-47 \\
-46\end{array}$ & $\begin{array}{l}-2431.0 \\
-2384.3 \\
-2337.6 \\
-2290.7 \\
-2243.8\end{array}$ & $\begin{array}{l}46.615 \\
46.706 \\
46.796 \\
46.885 \\
46.974\end{array}$ & $\begin{array}{l}91.02 \\
90.32 \\
89.62 \\
88.93 \\
88.24\end{array}$ \\
\hline $\begin{array}{l}-165 \\
-164 \\
-163 \\
-162 \\
-161\end{array}$ & $\begin{array}{l}-6974.3 \\
-6944.1 \\
-6913.6 \\
-6882.9 \\
-6852.1\end{array}$ & $\begin{array}{l}30.150 \\
30.358 \\
30.566 \\
30.771 \\
30.976\end{array}$ & $\begin{array}{l}209.38 \\
207.94 \\
206.52 \\
205.10 \\
203.69\end{array}$ & $\begin{array}{l}-105 \\
-104 \\
-103 \\
-102 \\
-101\end{array}$ & $\begin{array}{l}-4835.9 \\
-4795.4 \\
-4754.8 \\
-4714.0 \\
-4673.1\end{array}$ & $\begin{array}{l}40.413 \\
40.549 \\
40.685 \\
40.820 \\
40.953\end{array}$ & $\begin{array}{l}137.18 \\
136.19 \\
135.21 \\
134.23 \\
133.26\end{array}$ & $\begin{array}{l}-45 \\
-44 \\
-43 \\
-42 \\
-41\end{array}$ & $\begin{array}{l}-2196.8 \\
-2149.7 \\
-2102.5 \\
-2055.2 \\
-2007.8\end{array}$ & $\begin{array}{l}47.062 \\
47.149 \\
47.235 \\
47.321 \\
47.406\end{array}$ & $\begin{array}{l}87.56 \\
86.88 \\
86.21 \\
85.54 \\
84.87\end{array}$ \\
\hline $\begin{array}{l}-160 \\
-159 \\
-158 \\
-157 \\
-156\end{array}$ & $\begin{array}{l}-6821.0 \\
-6789.7 \\
-6758.2 \\
-6726.6 \\
-6694.7\end{array}$ & $\begin{array}{l}31.179 \\
31.380 \\
31.581 \\
31.779 \\
31.977\end{array}$ & $\begin{array}{l}202 \cdot 29 \\
200.90 \\
199 \cdot 51 \\
198.14 \\
196 \cdot 77\end{array}$ & $\begin{array}{r}-100 \\
-99 \\
-98 \\
-97 \\
-96\end{array}$ & $\begin{array}{l}-4632.1 \\
-4590.9 \\
-4549 \cdot 7 \\
-4508.2 \\
-4466.7\end{array}$ & $\begin{array}{l}41.086 \\
41.218 \\
41.349 \\
41.479 \\
41.608\end{array}$ & $\begin{array}{l}132 \cdot 30 \\
131 \cdot 34 \\
130 \cdot 39 \\
129 \cdot 44 \\
128.50\end{array}$ & $\begin{array}{l}-40 \\
-39 \\
-38 \\
-37 \\
-36\end{array}$ & $\begin{array}{l}-1960.4 \\
-1912.9 \\
-1865.2 \\
-1817.5 \\
-1769.8\end{array}$ & $\begin{array}{l}47.491 \\
47.575 \\
47.658 \\
47.741 \\
47.823\end{array}$ & $\begin{array}{l}84.21 \\
83.55 \\
82.90 \\
82.25 \\
81.60\end{array}$ \\
\hline $\begin{array}{l}-155 \\
-154 \\
-153 \\
-152 \\
-151\end{array}$ & $\begin{array}{l}-6662 \cdot 6 \\
-6630 \cdot 3 \\
-6597 \cdot 9 \\
-6565 \cdot 2 \\
-6532 \cdot 4\end{array}$ & $\begin{array}{l}32.173 \\
32.368 \\
32.561 \\
32.753 \\
32.944\end{array}$ & $\begin{array}{l}195.41 \\
194.06 \\
192.72 \\
191.38 \\
190.06\end{array}$ & $\begin{array}{l}-95 \\
-94 \\
-93 \\
-92 \\
-91\end{array}$ & $\begin{array}{l}-4425.0 \\
-4383.2 \\
-4341.3 \\
-4299.3 \\
-4257.1\end{array}$ & $\begin{array}{l}41.736 \\
41.863 \\
41.989 \\
42.114 \\
42.239\end{array}$ & $\begin{array}{l}127.56 \\
126.63 \\
125.71 \\
124.79 \\
123.88\end{array}$ & $\begin{array}{l}-35 \\
-34 \\
-33 \\
-32 \\
-31\end{array}$ & $\begin{array}{l}-1721.9 \\
-1673.9 \\
-1625.9 \\
-1577.8 \\
-1529.6\end{array}$ & $\begin{array}{l}47.904 \\
47.985 \\
48.065 \\
48.144 \\
48.223\end{array}$ & $\begin{array}{l}80.96 \\
80.32 \\
79.69 \\
79.06 \\
78.43\end{array}$ \\
\hline $\begin{array}{l}-150 \\
-149 \\
-148 \\
-147 \\
-146\end{array}$ & $\begin{array}{l}-6499.3 \\
-6466.1 \\
-6432.7 \\
-6399.1 \\
-6365.3\end{array}$ & $\begin{array}{l}33.133 \\
33.321 \\
33.508 \\
33.694 \\
33.878\end{array}$ & $\begin{array}{l}188.74 \\
187.43 \\
186.13 \\
184.84 \\
183.55\end{array}$ & $\begin{array}{l}-90 \\
-89 \\
-88 \\
-87 \\
-86\end{array}$ & $\begin{array}{l}-4214.8 \\
-4172.4 \\
-4129.8 \\
-4087.1 \\
-4044.4\end{array}$ & $\begin{array}{l}42.362 \\
42.485 \\
42.606 \\
42.727 \\
42.847\end{array}$ & $\begin{array}{l}122.98 \\
122.08 \\
121.18 \\
120.29 \\
119.41\end{array}$ & $\begin{array}{l}-30 \\
-29 \\
-28 \\
-27 \\
-26\end{array}$ & $\begin{array}{l}-1481.4 \\
-1433.0 \\
-1384.6 \\
-1336.1 \\
-1287.6\end{array}$ & $\begin{array}{l}48.301 \\
48.378 \\
48.455 \\
48.531 \\
48.607\end{array}$ & $\begin{array}{l}77.81 \\
77.19 \\
76.58 \\
75.97 \\
75.36\end{array}$ \\
\hline $\begin{array}{l}-145 \\
-144 \\
-143 \\
-142 \\
-141\end{array}$ & $\begin{array}{l}-6331 \cdot 3 \\
-6297 \cdot 2 \\
-6262 \cdot 8 \\
-6228 \cdot 3 \\
-6193 \cdot 6\end{array}$ & $\begin{array}{l}34.061 \\
34.242 \\
34.423 \\
34.602 \\
34.780\end{array}$ & $\begin{array}{l}182.28 \\
181.01 \\
179.75 \\
178.49 \\
177.25\end{array}$ & $\begin{array}{l}-85 \\
-84 \\
-83 \\
-82 \\
-81\end{array}$ & $\begin{array}{l}-4001.4 \\
-3958.4 \\
-3915.3 \\
-3872.0 \\
-3828.6\end{array}$ & $\begin{array}{l}42.966 \\
43.084 \\
43.201 \\
43.317 \\
43.433\end{array}$ & $\begin{array}{l}118.53 \\
117.66 \\
116.79 \\
115.93 \\
115.07\end{array}$ & $\begin{array}{l}-25 \\
-24 \\
-23 \\
-22 \\
-21\end{array}$ & $\begin{array}{l}-1238.9 \\
-1190.2 \\
-1141.4 \\
-1092.5 \\
-1043.6\end{array}$ & $\begin{array}{l}48.682 \\
48.757 \\
48.830 \\
48.904 \\
48.976\end{array}$ & $\begin{array}{l}74.76 \\
74.16 \\
73.56 \\
72.97 \\
72.38\end{array}$ \\
\hline $\begin{array}{l}-140 \\
-139 \\
-138 \\
-137 \\
-136\end{array}$ & $\begin{array}{l}-6158 \cdot 8 \\
-6123 \cdot 7 \\
-6088.5 \\
-6053 \cdot 1 \\
-6017.5\end{array}$ & $\begin{array}{l}34.956 \\
35.132 \\
35.306 \\
35.479 \\
35.651\end{array}$ & $\begin{array}{l}176.01 \\
174.78 \\
173.55 \\
172.34 \\
171.13\end{array}$ & $\begin{array}{l}-80 \\
-79 \\
-78 \\
-77 \\
-76\end{array}$ & $\begin{array}{l}-3785.2 \\
-3741.6 \\
-3697.8 \\
-3654.0 \\
-3610.1\end{array}$ & $\begin{array}{l}43.548 \\
43.661 \\
43.774 \\
43.886 \\
43.998\end{array}$ & $\begin{array}{l}114.22 \\
113.37 \\
112.53 \\
111.70 \\
110.87\end{array}$ & $\begin{array}{l}-20 \\
-19 \\
-18 \\
-17 \\
-16\end{array}$ & $\begin{array}{l}-994.6 \\
-945.5 \\
-896.3 \\
-847.1 \\
-797.8\end{array}$ & $\begin{array}{l}49.049 \\
49.120 \\
49.191 \\
49.261 \\
49.331\end{array}$ & $\begin{array}{l}71.80 \\
71.22 \\
70.64 \\
70.07 \\
69.50\end{array}$ \\
\hline $\begin{array}{l}-135 \\
-134 \\
-133 \\
-132 \\
-131\end{array}$ & $\begin{array}{l}-5981.8 \\
-5945.9 \\
-5909.8 \\
-5873.6 \\
-5837.2\end{array}$ & $\begin{array}{l}35.821 \\
35.990 \\
36.159 \\
36.326 \\
36.491\end{array}$ & $\begin{array}{l}169.93 \\
168.74 \\
167.55 \\
166.37 \\
165.20\end{array}$ & $\begin{array}{l}-75 \\
-74 \\
-73 \\
-72 \\
-71\end{array}$ & $\begin{array}{l}-3566.0 \\
-3521.8 \\
-3477.6 \\
-3433.2 \\
-3388.7\end{array}$ & $\begin{array}{l}44 \cdot 108 \\
44 \cdot 218 \\
44 \cdot 327 \\
44 \cdot 435 \\
44 \cdot 542\end{array}$ & $\begin{array}{l}110.04 \\
109.22 \\
108.41 \\
107.60 \\
106.80\end{array}$ & $\begin{array}{l}-15 \\
-14 \\
-13 \\
-12 \\
-11\end{array}$ & $\begin{array}{l}-748.4 \\
-699.0 \\
-649.5 \\
-599.9 \\
-550.3\end{array}$ & $\begin{array}{l}49.400 \\
49.469 \\
49.537 \\
49.605 \\
49.672\end{array}$ & $\begin{array}{l}68.93 \\
68.37 \\
67.81 \\
67.26 \\
66.70\end{array}$ \\
\hline $\begin{array}{l}-130 \\
-129 \\
-128 \\
-127 \\
-126\end{array}$ & $\begin{array}{l}-5800.6 \\
-5763.9 \\
-5727.0 \\
-5689.9 \\
-5652.7\end{array}$ & $\begin{array}{l}36.656 \\
36.819 \\
36.982 \\
37.143 \\
37.303\end{array}$ & $\begin{array}{l}164.04 \\
162.88 \\
161.73 \\
160.59 \\
159.46\end{array}$ & $\begin{array}{l}-70 \\
-69 \\
-68 \\
-67 \\
-66\end{array}$ & $\begin{array}{l}-3344.1 \\
-3299.4 \\
-3254.6 \\
-3209.7 \\
-3164.7\end{array}$ & $\begin{array}{l}44.648 \\
44.754 \\
44.859 \\
44.963 \\
45.066\end{array}$ & $\begin{array}{l}106.00 \\
105.20 \\
104.41 \\
103.63 \\
102.85\end{array}$ & $\begin{array}{r}-10 \\
-9 \\
-8 \\
-7 \\
-6\end{array}$ & $\begin{array}{l}-500.6 \\
-450.8 \\
-401.0 \\
-351.1 \\
-301.1\end{array}$ & $\begin{array}{l}49.738 \\
49.804 \\
49.869 \\
49.934 \\
49.998\end{array}$ & $\begin{array}{l}66.15 \\
65.61 \\
65.07 \\
64.53 \\
63.99\end{array}$ \\
\hline $\begin{array}{l}-125 \\
-124 \\
-123 \\
-122 \\
-121\end{array}$ & $\begin{array}{l}-5615.3 \\
-5577.8 \\
-5540.1 \\
-5502.2 \\
-5464.2\end{array}$ & $\begin{array}{l}37.462 \\
37.620 \\
37.776 \\
37.932 \\
38.086\end{array}$ & $\begin{array}{l}158.33 \\
157.21 \\
156.09 \\
154.99 \\
153.88\end{array}$ & $\begin{array}{l}-65 \\
-64 \\
-63 \\
-62 \\
-61\end{array}$ & $\begin{array}{l}-3119.6 \\
-3074.3 \\
-3029.0 \\
-2983.6 \\
-2938.1\end{array}$ & $\begin{array}{l}45.168 \\
45.270 \\
45.371 \\
45.471 \\
45.571\end{array}$ & $\begin{array}{r}102.07 \\
101.30 \\
100.54 \\
99.78 \\
99.02\end{array}$ & $\begin{array}{l}-5 \\
-4 \\
-3 \\
-2 \\
-1\end{array}$ & $\begin{array}{r}-251 \cdot 1 \\
-201 \cdot 0 \\
-150 \cdot 8 \\
-100 \cdot 6 \\
-50 \cdot 3\end{array}$ & $\begin{array}{l}50.062 \\
50.125 \\
50.188 \\
50.250 \\
50.312\end{array}$ & $\begin{array}{l}63.46 \\
62.93 \\
62.41 \\
61.89 \\
61.37\end{array}$ \\
\hline & 5426.0 & $38.2,2$ & 52 & -60 & -2892.5 & 45,660 & 08777 & & & 0.373 & \\
\hline
\end{tabular}


TABLE 6.3.2. Type J thermocouples-thermoelectric voltages, $\mathrm{E}(\mathrm{T})$, Seebeck coefficients, $\mathrm{S}(\mathrm{T})$, and first derivative of the Seebeck coefficients, $\mathrm{dS} / \mathrm{dT}$, reference junctions at $0^{\circ} \mathrm{C}$-Continued

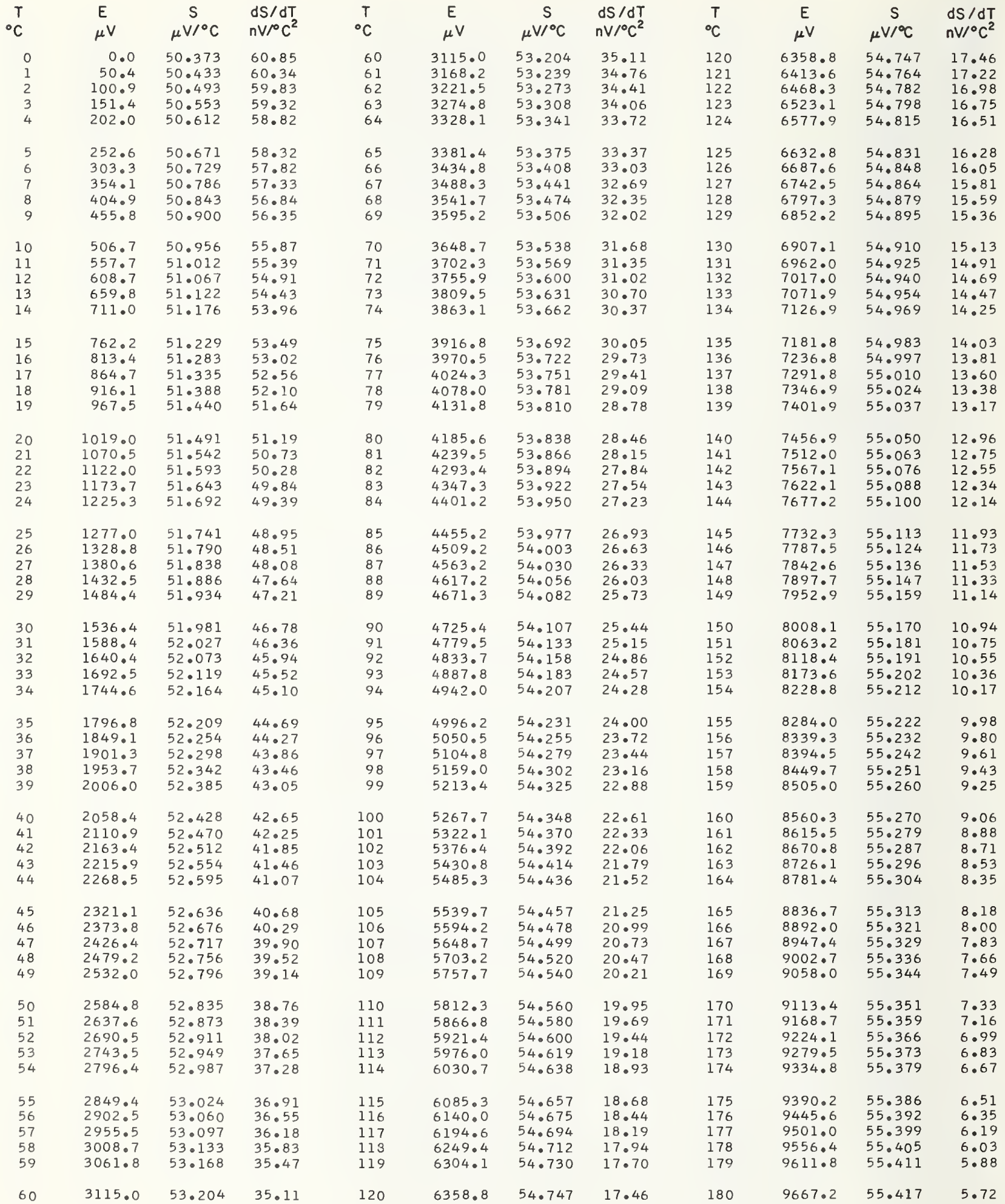


TABLE 6.3.2. Type J thermocouples-thermoelectric voltages, E(T), Seebeck coefficients, $\mathrm{S}(\mathrm{T})$, and first derivative of the Seebeck coefficients, $\mathrm{dS} / \mathrm{dT}$, reference junctions at $0^{\circ} \mathrm{C}$-Continued

\begin{tabular}{|c|c|c|c|c|c|c|c|c|c|c|c|}
\hline $\begin{array}{c}\mathrm{T} \\
{ }^{\circ} \mathrm{C}\end{array}$ & $\begin{array}{c}E \\
\mu V\end{array}$ & $\underset{\mu V /{ }^{\circ} \mathrm{C}}{S}$ & $\begin{array}{l}\mathrm{dS} / \mathrm{dT} \\
\mathrm{nV} /{ }^{\circ} \mathrm{C}^{2}\end{array}$ & ${ }^{\circ} \mathrm{C}$ & $\underset{\mu V}{E}$ & $\underset{\mu V / /{ }^{\circ} \mathrm{C}}{S}$ & $\begin{array}{l}\mathrm{dS} / \mathrm{dT} \\
\mathrm{nV} /{ }^{\circ} \mathrm{C}^{2}\end{array}$ & ${ }^{\mathrm{T}} \mathrm{C}$ & $\underset{\mu V}{E}$ & $\underset{\mu V /{ }^{\circ} \mathrm{C}}{S}$ & $\begin{array}{l}d S / d T \\
n V /{ }^{\circ} C^{2}\end{array}$ \\
\hline $\begin{array}{l}180 \\
181 \\
182 \\
183 \\
184\end{array}$ & $\begin{array}{l}9667.2 \\
9722.7 \\
9778.1 \\
9833.5 \\
9888.9\end{array}$ & $\begin{array}{l}55.417 \\
55.422 \\
55.428 \\
55.433 \\
55.438\end{array}$ & $\begin{array}{l}5.72 \\
5.57 \\
5.42 \\
5.27 \\
5.12\end{array}$ & $\begin{array}{l}240 \\
241 \\
242 \\
243 \\
244\end{array}$ & $\begin{array}{l}12997.7 \\
13053.2 \\
13108.7 \\
13164.3 \\
13219.8\end{array}$ & $\begin{array}{l}55.529 \\
55.528 \\
55.527 \\
55.526 \\
55.524\end{array}$ & $\begin{array}{l}-1.21 \\
-1.29 \\
-1.36 \\
-1.44 \\
-1.51\end{array}$ & $\begin{array}{l}300 \\
301 \\
302 \\
303 \\
304\end{array}$ & $\begin{array}{l}16325.1 \\
16380.5 \\
16435.8 \\
16491.2 \\
16546.5\end{array}$ & $\begin{array}{l}55.359 \\
55.355 \\
55.351 \\
55.348 \\
55.344\end{array}$ & $\begin{array}{l}-3.76 \\
-3.77 \\
-3.78 \\
-3.78 \\
-3.78\end{array}$ \\
\hline $\begin{array}{l}185 \\
186 \\
187 \\
188 \\
189\end{array}$ & $\begin{array}{r}9944.4 \\
9999.8 \\
10055.3 \\
10110.7 \\
10166.2\end{array}$ & $\begin{array}{l}55.443 \\
55.448 \\
55.453 \\
55.458 \\
55.462\end{array}$ & $\begin{array}{l}4.97 \\
4.82 \\
4.68 \\
4.54 \\
4.39\end{array}$ & $\begin{array}{l}245 \\
246 \\
247 \\
248 \\
249\end{array}$ & $\begin{array}{l}13275.3 \\
13330.8 \\
13386.4 \\
13441.9 \\
13497.4\end{array}$ & $\begin{array}{l}55.522 \\
55.521 \\
55.519 \\
55.517 \\
55.516\end{array}$ & $\begin{array}{l}-1.59 \\
-1.66 \\
-1.73 \\
-1.80 \\
-1.87\end{array}$ & $\begin{array}{l}305 \\
306 \\
307 \\
308 \\
309\end{array}$ & $\begin{array}{l}16601.9 \\
16657.2 \\
16712.5 \\
16767.9 \\
16823.2\end{array}$ & $\begin{array}{l}55.340 \\
55.336 \\
55.332 \\
55.329 \\
55.325\end{array}$ & $\begin{array}{l}-3.79 \\
-3.79 \\
-3.78 \\
-3.78 \\
-3.78\end{array}$ \\
\hline $\begin{array}{l}190 \\
191 \\
192 \\
193 \\
194\end{array}$ & $\begin{array}{l}10221.7 \\
10277.1 \\
10332.6 \\
10388.1 \\
10443.6\end{array}$ & $\begin{array}{l}55.466 \\
55.470 \\
55.475 \\
55.478 \\
55.482\end{array}$ & $\begin{array}{l}4.25 \\
4.11 \\
3.97 \\
3.84 \\
3.70\end{array}$ & $\begin{array}{l}250 \\
251 \\
252 \\
253 \\
254\end{array}$ & $\begin{array}{l}13552.9 \\
13608.4 \\
13663.9 \\
13719.4 \\
13775.0\end{array}$ & $\begin{array}{l}55.514 \\
55.512 \\
55.510 \\
55.508 \\
55.505\end{array}$ & $\begin{array}{l}-1.93 \\
-2.00 \\
-2.06 \\
-2.13 \\
-2.19\end{array}$ & $\begin{array}{l}310 \\
311 \\
312 \\
313 \\
314\end{array}$ & $\begin{array}{l}16878.5 \\
16933.8 \\
16989.1 \\
17044.5 \\
17099.8\end{array}$ & $\begin{array}{l}55.321 \\
55.317 \\
55.314 \\
55.310 \\
55.306\end{array}$ & $\begin{array}{l}-3.78 \\
-3.77 \\
-3.76 \\
-3.76 \\
-3.75\end{array}$ \\
\hline $\begin{array}{l}195 \\
196 \\
197 \\
198 \\
199\end{array}$ & $\begin{array}{l}10499.0 \\
10554.5 \\
10610.0 \\
10665.5 \\
10721.0\end{array}$ & $\begin{array}{l}55.486 \\
55.489 \\
55.493 \\
55.496 \\
55.499\end{array}$ & $\begin{array}{l}3.56 \\
3.43 \\
3.30 \\
3.17 \\
3.04\end{array}$ & $\begin{array}{l}255 \\
256 \\
257 \\
258 \\
259\end{array}$ & $\begin{array}{l}13830.5 \\
13886.0 \\
13941.5 \\
13997.0 \\
14052.5\end{array}$ & $\begin{array}{l}55.503 \\
55.501 \\
55.499 \\
55.496 \\
55.494\end{array}$ & $\begin{array}{l}-2.25 \\
-2.31 \\
-2.37 \\
-2.43 \\
-2.48\end{array}$ & $\begin{array}{l}315 \\
316 \\
317 \\
318 \\
319\end{array}$ & $\begin{array}{l}17155.1 \\
17210.4 \\
17265.7 \\
17321.0 \\
17376.2\end{array}$ & $\begin{array}{l}55.302 \\
55.299 \\
55.295 \\
55.291 \\
55.287\end{array}$ & $\begin{array}{l}-3.74 \\
-3.73 \\
-3.71 \\
-3.70 \\
-3.69\end{array}$ \\
\hline $\begin{array}{l}200 \\
201 \\
202 \\
203 \\
204\end{array}$ & $\begin{array}{l}10776.5 \\
10832.0 \\
10887.5 \\
10943.0 \\
10998.5\end{array}$ & $\begin{array}{l}55.502 \\
55.505 \\
55.508 \\
55.510 \\
55.513\end{array}$ & $\begin{array}{l}2.91 \\
2.78 \\
2.66 \\
2.53 \\
2.41\end{array}$ & $\begin{array}{l}260 \\
261 \\
262 \\
263 \\
264\end{array}$ & $\begin{array}{l}14107.9 \\
14163.4 \\
14218.9 \\
14274.4 \\
14329.9\end{array}$ & $\begin{array}{l}55.491 \\
55.489 \\
55.486 \\
55.483 \\
55.481\end{array}$ & $\begin{array}{l}-2.54 \\
-2.59 \\
-2.64 \\
-2.70 \\
-2.75\end{array}$ & $\begin{array}{l}320 \\
321 \\
322 \\
323 \\
324\end{array}$ & $\begin{array}{l}17431.5 \\
17486.8 \\
17542.1 \\
17597.4 \\
17652.6\end{array}$ & $\begin{array}{l}55.284 \\
55.280 \\
55.276 \\
55.273 \\
55.269\end{array}$ & $\begin{array}{l}-3.67 \\
-3.65 \\
-3.63 \\
-3.61 \\
-3.59\end{array}$ \\
\hline $\begin{array}{l}205 \\
206 \\
207 \\
208 \\
209\end{array}$ & $\begin{array}{l}11054.1 \\
11109.6 \\
11165.1 \\
11220.6 \\
11276.1\end{array}$ & $\begin{array}{l}55.515 \\
55.517 \\
55.519 \\
55.521 \\
55.523\end{array}$ & $\begin{array}{l}2.29 \\
2.17 \\
2.05 \\
1.93 \\
1.81\end{array}$ & $\begin{array}{l}265 \\
266 \\
267 \\
268 \\
269\end{array}$ & $\begin{array}{l}14385.4 \\
14440.8 \\
14496.3 \\
14551.8 \\
14607.3\end{array}$ & $\begin{array}{l}55.478 \\
55.475 \\
55.472 \\
55.469 \\
55.466\end{array}$ & $\begin{array}{l}-2.79 \\
-2.84 \\
-2.89 \\
-2.93 \\
-2.98\end{array}$ & $\begin{array}{l}325 \\
326 \\
327 \\
328 \\
329\end{array}$ & $\begin{array}{l}17707.9 \\
17763.2 \\
17818.4 \\
17873.7 \\
17928.9\end{array}$ & $\begin{array}{l}55.266 \\
55.262 \\
55.259 \\
55.255 \\
55.252\end{array}$ & $\begin{array}{l}-3.57 \\
-3.55 \\
-3.52 \\
-3.50 \\
-3.47\end{array}$ \\
\hline $\begin{array}{l}210 \\
211 \\
212 \\
213 \\
214\end{array}$ & $\begin{array}{l}11331.7 \\
11387.2 \\
11442.7 \\
11498.2 \\
11553.8\end{array}$ & $\begin{array}{l}55.525 \\
55.527 \\
55.528 \\
55.530 \\
55.531\end{array}$ & $\begin{array}{l}1.69 \\
1.58 \\
1.47 \\
1.35 \\
1.24\end{array}$ & $\begin{array}{l}270 \\
271 \\
272 \\
273 \\
274\end{array}$ & $\begin{array}{l}14662.7 \\
14718.2 \\
14773.6 \\
14829.1 \\
14884.6\end{array}$ & $\begin{array}{l}55.463 \\
55.460 \\
55.457 \\
55.454 \\
55.451\end{array}$ & $\begin{array}{l}-3.02 \\
-3.06 \\
-3.11 \\
-3.14 \\
-3.18\end{array}$ & $\begin{array}{l}330 \\
331 \\
332 \\
333 \\
334\end{array}$ & $\begin{array}{l}17984.2 \\
18039.4 \\
18094.7 \\
18149.9 \\
18205.2\end{array}$ & $\begin{array}{l}55.248 \\
55.245 \\
55.241 \\
55.238 \\
55.235\end{array}$ & $\begin{array}{l}-3.45 \\
-3.42 \\
-3.39 \\
-3.36 \\
-3.32\end{array}$ \\
\hline $\begin{array}{l}215 \\
216 \\
217 \\
218 \\
219\end{array}$ & $\begin{array}{l}11609.3 \\
11664.8 \\
11720.4 \\
11775.9 \\
11831.4\end{array}$ & $\begin{array}{l}55.532 \\
55.533 \\
55.534 \\
55.535 \\
55.536\end{array}$ & $\begin{array}{l}1.13 \\
1.03 \\
0.92 \\
0.81 \\
0.71\end{array}$ & $\begin{array}{l}275 \\
276 \\
277 \\
278 \\
279\end{array}$ & $\begin{array}{l}14940.0 \\
14995.4 \\
15050.9 \\
15106.3 \\
15161.8\end{array}$ & $\begin{array}{l}55.448 \\
55.444 \\
55.441 \\
55.438 \\
55.435\end{array}$ & $\begin{array}{l}-3.22 \\
-3.26 \\
-3.29 \\
-3.32 \\
-3.36\end{array}$ & $\begin{array}{l}335 \\
336 \\
337 \\
338 \\
339\end{array}$ & $\begin{array}{l}18260.4 \\
18315.6 \\
18370.8 \\
18426.1 \\
18481.3\end{array}$ & $\begin{array}{l}55.231 \\
55.228 \\
55.225 \\
55.221 \\
55.218\end{array}$ & $\begin{array}{l}-3.29 \\
-3.26 \\
-3.22 \\
-3.18 \\
-3.14\end{array}$ \\
\hline $\begin{array}{l}220 \\
221 \\
222 \\
223 \\
224\end{array}$ & $\begin{array}{l}11887.0 \\
11942.5 \\
11998.0 \\
12053.6 \\
12109.1\end{array}$ & $\begin{array}{l}55.536 \\
55.537 \\
55.537 \\
55.538 \\
55.538\end{array}$ & $\begin{array}{l}0.60 \\
0.50 \\
0.40 \\
0.30 \\
0.20\end{array}$ & $\begin{array}{l}280 \\
281 \\
282 \\
283 \\
284\end{array}$ & $\begin{array}{l}15217.2 \\
15272.6 \\
15328.1 \\
15383.5 \\
15438.9\end{array}$ & $\begin{array}{l}55.431 \\
55.428 \\
55.424 \\
55.421 \\
55.417\end{array}$ & $\begin{array}{l}-3.39 \\
-3.42 \\
-3.45 \\
-3.48 \\
-3.50\end{array}$ & $\begin{array}{l}340 \\
341 \\
342 \\
343 \\
344\end{array}$ & $\begin{array}{l}18536.5 \\
18591.7 \\
18646.9 \\
18702.1 \\
18757.3\end{array}$ & $\begin{array}{l}55.215 \\
55.212 \\
55.209 \\
55.206 \\
55.203\end{array}$ & $\begin{array}{l}-3.11 \\
-3.06 \\
-3.02 \\
-2.98 \\
-2.94\end{array}$ \\
\hline $\begin{array}{l}225 \\
226 \\
227 \\
228 \\
229\end{array}$ & $\begin{array}{l}12164.7 \\
12220.2 \\
12275.7 \\
12331.3 \\
12386.8\end{array}$ & $\begin{array}{l}55.538 \\
55.538 \\
55.538 \\
55.538 \\
55.538\end{array}$ & $\begin{array}{r}0.11 \\
0.01 \\
-0.09 \\
-0.18 \\
-0.27\end{array}$ & $\begin{array}{l}285 \\
286 \\
287 \\
288 \\
289\end{array}$ & $\begin{array}{l}15494.3 \\
15549.7 \\
15605.1 \\
15660.5 \\
15715.9\end{array}$ & $\begin{array}{l}55.414 \\
55.410 \\
55.407 \\
55.403 \\
55.400\end{array}$ & $\begin{array}{l}-3.53 \\
-3.55 \\
-3.57 \\
-3.60 \\
-3.62\end{array}$ & $\begin{array}{l}345 \\
346 \\
347 \\
348 \\
349\end{array}$ & $\begin{array}{l}18812.5 \\
18867.7 \\
18922.9 \\
18978.1 \\
19033.3\end{array}$ & $\begin{array}{l}55.200 \\
55.197 \\
55.195 \\
55.192 \\
55.189\end{array}$ & $\begin{array}{l}-2.89 \\
-2.85 \\
-2.80 \\
-2.75 \\
-2.70\end{array}$ \\
\hline $\begin{array}{l}230 \\
231 \\
232 \\
233 \\
234\end{array}$ & $\begin{array}{l}12442.4 \\
12497.9 \\
12553.4 \\
12609.0 \\
12664.5\end{array}$ & $\begin{array}{l}55.537 \\
55.537 \\
55.537 \\
55.536 \\
55.535\end{array}$ & $\begin{array}{l}-0.36 \\
-0.45 \\
-0.54 \\
-0.63 \\
-0.72\end{array}$ & $\begin{array}{l}290 \\
291 \\
292 \\
293 \\
294\end{array}$ & $\begin{array}{l}15771.3 \\
15826.7 \\
15882.1 \\
15937.5 \\
15992.9\end{array}$ & $\begin{array}{l}55.396 \\
55.392 \\
55.389 \\
55.385 \\
55.381\end{array}$ & $\begin{array}{l}-3.64 \\
-3.65 \\
-3.67 \\
-3.69 \\
-3.70\end{array}$ & $\begin{array}{l}350 \\
351 \\
352 \\
353 \\
354\end{array}$ & $\begin{array}{l}19088.5 \\
19143.7 \\
19198.9 \\
19254.1 \\
19309.2\end{array}$ & $\begin{array}{l}55.186 \\
55.184 \\
55.181 \\
55.179 \\
55.176\end{array}$ & $\begin{array}{l}-2.65 \\
-2.60 \\
-2.54 \\
-2.49 \\
-2.43\end{array}$ \\
\hline $\begin{array}{l}235 \\
236 \\
237 \\
238 \\
239\end{array}$ & $\begin{array}{l}12720.0 \\
12775.6 \\
12831.1 \\
12886.6 \\
12942.2\end{array}$ & $\begin{array}{l}55.535 \\
55.534 \\
55.533 \\
55.532 \\
55.531\end{array}$ & $\begin{array}{l}-0.80 \\
-0.88 \\
-0.97 \\
-1.05 \\
-1.13\end{array}$ & $\begin{array}{l}295 \\
296 \\
297 \\
298 \\
299\end{array}$ & $\begin{array}{l}16048.3 \\
16103.6 \\
16159.0 \\
16214.4 \\
16269.7\end{array}$ & $\begin{array}{l}55.378 \\
55.374 \\
55.370 \\
55.366 \\
55.363\end{array}$ & $\begin{array}{l}-3.72 \\
-3.73 \\
-3.74 \\
-3.75 \\
-3.76\end{array}$ & $\begin{array}{l}355 \\
356 \\
357 \\
358 \\
359\end{array}$ & $\begin{array}{l}19364.4 \\
19419.6 \\
19474.7 \\
19529.9 \\
19585.1\end{array}$ & $\begin{array}{l}55.174 \\
55.171 \\
55.169 \\
55.167 \\
55.165\end{array}$ & $\begin{array}{l}-2.38 \\
-2.32 \\
-2.26 \\
-2.20 \\
-2.14\end{array}$ \\
\hline 240 & 12997.7 & 55.529 & -1.21 & 300 & 16325.1 & 55.359 & -3.76 & 360 & 19640.2 & 55.163 & -2.08 \\
\hline
\end{tabular}


TABLE 6.3.2. Type J thermocouples-thermoelectric voltages, E(T), Seebeck coefficients, S(T), and first derivative of the Seebeck coefficients, $\mathrm{dS} / \mathrm{dT}$, reference junctions at $0^{\circ} \mathrm{C}$-Continued

\begin{tabular}{|c|c|c|c|c|c|c|c|c|c|c|c|}
\hline${ }^{\circ} \mathrm{T}$ & ${ }_{\mu V}^{E}$ & $\mu V /^{\circ} \mathrm{C}$ & $\begin{array}{l}d S / d T \\
n V /{ }^{\circ} C^{2}\end{array}$ & $\begin{array}{c}\mathrm{T} \\
{ }^{\circ} \mathrm{C}\end{array}$ & $\underset{\mu V}{E}$ & $\mu \mathrm{V} /{ }^{\circ} \mathrm{C}$ & $\begin{array}{l}d S / d T \\
n V /{ }^{\circ} C^{2}\end{array}$ & ${ }^{\circ} \mathrm{C}$ & $\underset{\mu V}{E}$ & $\mu \mathrm{V}^{\circ}{ }^{\circ} \mathrm{C}$ & $\begin{array}{l}d S / d T \\
n V /{ }^{\circ} C^{2}\end{array}$ \\
\hline $\begin{array}{l}360 \\
361 \\
362 \\
363 \\
364\end{array}$ & $\begin{array}{l}19640.2 \\
19695.4 \\
19750.6 \\
19805.7 \\
19860.9\end{array}$ & $\begin{array}{l}55.163 \\
55.161 \\
55.159 \\
55.157 \\
55.155\end{array}$ & $\begin{array}{l}-2.08 \\
-2.02 \\
-1.95 \\
-1.89 \\
-1.82\end{array}$ & $\begin{array}{l}420 \\
421 \\
422 \\
423 \\
424\end{array}$ & $\begin{array}{l}22949.1 \\
23004 \cdot 3 \\
23059.5 \\
23114.7 \\
23169.9\end{array}$ & $\begin{array}{l}55.190 \\
55.194 \\
55.198 \\
55.202 \\
55.206\end{array}$ & $\begin{array}{l}3.64 \\
3.77 \\
3.90 \\
4.02 \\
4.15\end{array}$ & $\begin{array}{l}480 \\
481 \\
482 \\
483 \\
484\end{array}$ & $\begin{array}{l}26272.1 \\
26327.8 \\
26383.5 \\
26439.2 \\
26494.9\end{array}$ & $\begin{array}{l}55.667 \\
55.680 \\
55.693 \\
55.706 \\
55.720\end{array}$ & $\begin{array}{l}12.73 \\
12.90 \\
13.08 \\
13.25 \\
13.43\end{array}$ \\
\hline $\begin{array}{l}365 \\
366 \\
367 \\
368 \\
369\end{array}$ & $\begin{array}{l}19916.0 \\
19971.2 \\
20026.3 \\
20081.5 \\
20136.6\end{array}$ & $\begin{array}{l}55.153 \\
55.151 \\
55.150 \\
55.148 \\
55.147\end{array}$ & $\begin{array}{l}-1.75 \\
-1.68 \\
-1.61 \\
-1.54 \\
-1.47\end{array}$ & $\begin{array}{l}425 \\
426 \\
427 \\
428 \\
429\end{array}$ & $\begin{array}{l}23225 \cdot 1 \\
23280 \cdot 3 \\
23335 \cdot 5 \\
23390 \cdot 8 \\
23446.0\end{array}$ & $\begin{array}{l}55.210 \\
55.215 \\
55.219 \\
55.224 \\
55.228\end{array}$ & $\begin{array}{l}4.28 \\
4.42 \\
4.55 \\
4.68 \\
4.82\end{array}$ & $\begin{array}{l}485 \\
486 \\
487 \\
488 \\
489\end{array}$ & $\begin{array}{l}26550.6 \\
26606.4 \\
26662.1 \\
26717.9 \\
26773.7\end{array}$ & $\begin{array}{l}55.733 \\
55.747 \\
55.761 \\
55.775 \\
55.789\end{array}$ & $\begin{array}{l}13.60 \\
13.78 \\
13.95 \\
14.13 \\
14.31\end{array}$ \\
\hline $\begin{array}{l}370 \\
371 \\
372 \\
373 \\
374\end{array}$ & $\begin{array}{l}20191.8 \\
20246.9 \\
20302.1 \\
20357.2 \\
20412.3\end{array}$ & $\begin{array}{l}55.145 \\
55.144 \\
55 \cdot 142 \\
55.141 \\
55.140\end{array}$ & $\begin{array}{l}-1.40 \\
-1.32 \\
-1.25 \\
-1.17 \\
-1.09\end{array}$ & $\begin{array}{l}430 \\
431 \\
432 \\
433 \\
434\end{array}$ & $\begin{array}{l}23501.2 \\
23556.5 \\
23611.7 \\
23666.9 \\
23722.2\end{array}$ & $\begin{array}{l}55.233 \\
55.238 \\
55.243 \\
55.249 \\
55.254\end{array}$ & $\begin{array}{l}4.95 \\
5.09 \\
5.22 \\
5.36 \\
5.50\end{array}$ & $\begin{array}{l}490 \\
491 \\
492 \\
493 \\
494\end{array}$ & $\begin{array}{l}26829 \cdot 5 \\
26885 \cdot 3 \\
26941.1 \\
26996 \cdot 9 \\
27052 \cdot 8\end{array}$ & $\begin{array}{l}55.804 \\
55.818 \\
55.833 \\
55.848 \\
55.863\end{array}$ & $\begin{array}{l}14.49 \\
14.66 \\
14.84 \\
15.02 \\
15.20\end{array}$ \\
\hline $\begin{array}{l}380 \\
381 \\
382 \\
383 \\
384\end{array}$ & $\begin{array}{l}20743.2 \\
20798.3 \\
20853.4 \\
20908.6 \\
20963.7\end{array}$ & $\begin{array}{l}55.135 \\
55.135 \\
55.134 \\
55.134 \\
55.133\end{array}$ & $\begin{array}{l}-0.60 \\
-0.52 \\
-0.43 \\
-0.34 \\
-0.25\end{array}$ & $\begin{array}{l}440 \\
441 \\
442 \\
443 \\
444\end{array}$ & $\begin{array}{l}24053.8 \\
24109.1 \\
24164.4 \\
24219.7 \\
24275.0\end{array}$ & $\begin{array}{l}55.290 \\
55.296 \\
55.303 \\
55.309 \\
55.316\end{array}$ & $\begin{array}{l}6.35 \\
6.49 \\
6.64 \\
6.79 \\
6.93\end{array}$ & $\begin{array}{l}500 \\
501 \\
502 \\
503 \\
504\end{array}$ & $\begin{array}{l}27388.2 \\
27444.2 \\
27500.2 \\
27556.2 \\
27612.2\end{array}$ & $\begin{array}{l}55.957 \\
55.974 \\
55.990 \\
56.007 \\
56.024\end{array}$ & $\begin{array}{l}16.28 \\
16.47 \\
16.65 \\
16.83 \\
17.01\end{array}$ \\
\hline $\begin{array}{l}385 \\
386 \\
387 \\
388 \\
389\end{array}$ & $\begin{array}{l}21018 \cdot 8 \\
21074 \cdot 0 \\
21129 \cdot 1 \\
21184 \cdot 2 \\
21239 \cdot 4\end{array}$ & $\begin{array}{l}55 \cdot 133 \\
55.133 \\
55.133 \\
55.133 \\
55.133\end{array}$ & $\begin{array}{r}-0.16 \\
-0.07 \\
0.02 \\
0.11 \\
0.21\end{array}$ & $\begin{array}{l}445 \\
446 \\
447 \\
448 \\
449\end{array}$ & $\begin{array}{l}24330.4 \\
24385.7 \\
24441.0 \\
24496.4 \\
24551.7\end{array}$ & $\begin{array}{l}55.323 \\
55.330 \\
55.338 \\
55.345 \\
55.353\end{array}$ & $\begin{array}{l}7.08 \\
7.23 \\
7.38 \\
7.53 \\
7.68\end{array}$ & $\begin{array}{l}505 \\
506 \\
507 \\
508 \\
509\end{array}$ & $\begin{array}{l}27668 \cdot 2 \\
27724 \cdot 3 \\
27780.4 \\
27836 \cdot 4 \\
27892.5\end{array}$ & $\begin{array}{l}56.041 \\
56.058 \\
56.076 \\
56.093 \\
56.111\end{array}$ & $\begin{array}{l}17.20 \\
17.38 \\
17.56 \\
17.75 \\
17.93\end{array}$ \\
\hline $\begin{array}{l}390 \\
391 \\
392 \\
393 \\
394\end{array}$ & $\begin{array}{l}21294.5 \\
21349.6 \\
21404.8 \\
21459.9 \\
21515.0\end{array}$ & $\begin{array}{l}55 \cdot 133 \\
55 \cdot 134 \\
55.134 \\
55 \cdot 135 \\
55.135\end{array}$ & $\begin{array}{l}0.30 \\
0.40 \\
0.50 \\
0.60 \\
0.69\end{array}$ & $\begin{array}{l}450 \\
451 \\
452 \\
453 \\
454\end{array}$ & $\begin{array}{l}24607.1 \\
24662.4 \\
24717.8 \\
24773.2 \\
24828.6\end{array}$ & $\begin{array}{l}55 \cdot 361 \\
55.368 \\
55.376 \\
55.385 \\
55.393\end{array}$ & $\begin{array}{l}7.83 \\
7.99 \\
8.14 \\
8.30 \\
8.45\end{array}$ & $\begin{array}{l}510 \\
511 \\
512 \\
513 \\
514\end{array}$ & $\begin{array}{l}27948 \cdot 7 \\
28004 \cdot 8 \\
28061 \cdot 0 \\
28117 \cdot 1 \\
28173.3\end{array}$ & $\begin{array}{l}56 \cdot 129 \\
56.148 \\
56 \cdot 166 \\
56 \cdot 185 \\
56.203\end{array}$ & $\begin{array}{l}18.12 \\
18.30 \\
18.49 \\
18.67 \\
18.86\end{array}$ \\
\hline $\begin{array}{l}400 \\
401 \\
402 \\
403 \\
404\end{array}$ & $\begin{array}{l}21845.9 \\
21901.0 \\
21956.2 \\
22011.3 \\
22066.5\end{array}$ & $\begin{array}{l}55.141 \\
55.143 \\
55.144 \\
55.146 \\
55.148\end{array}$ & $\begin{array}{l}1.31 \\
1.42 \\
1.53 \\
1.64 \\
1.75\end{array}$ & $\begin{array}{l}460 \\
461 \\
462 \\
463 \\
464\end{array}$ & $\begin{array}{l}25161.1 \\
25216.5 \\
25272.0 \\
25327.5 \\
25383.0\end{array}$ & $\begin{array}{l}55.447 \\
55.456 \\
55.466 \\
55.476 \\
55.486\end{array}$ & $\begin{array}{r}9.40 \\
9.56 \\
9.72 \\
9.88 \\
10.04\end{array}$ & $\begin{array}{l}520 \\
521 \\
522 \\
523 \\
524\end{array}$ & $\begin{array}{l}28510.9 \\
28567.2 \\
28623.6 \\
28679.9 \\
28736.3\end{array}$ & $\begin{array}{l}56.320 \\
56.340 \\
56.360 \\
56.381 \\
56.401\end{array}$ & $\begin{array}{l}19.97 \\
20.16 \\
20.34 \\
20.53 \\
20.72\end{array}$ \\
\hline $\begin{array}{l}405 \\
406 \\
407 \\
408 \\
409\end{array}$ & $\begin{array}{l}22121.6 \\
22176.8 \\
22231.9 \\
22287.1 \\
22342.2\end{array}$ & $\begin{array}{l}55.149 \\
55.151 \\
55.153 \\
55.155 \\
55.158\end{array}$ & $\begin{array}{l}1.86 \\
1.97 \\
2.08 \\
2.20 \\
2.31\end{array}$ & $\begin{array}{l}465 \\
466 \\
467 \\
468 \\
469\end{array}$ & $\begin{array}{l}25438.4 \\
25493.9 \\
25549.5 \\
25605.0 \\
25660.5\end{array}$ & $\begin{array}{l}55.496 \\
55.506 \\
55.516 \\
55.527 \\
55.538\end{array}$ & $\begin{array}{l}10.21 \\
10.37 \\
10.54 \\
10.70 \\
10.87\end{array}$ & $\begin{array}{l}525 \\
526 \\
527 \\
528 \\
529\end{array}$ & $\begin{array}{l}28792.7 \\
28849.2 \\
28905.6 \\
28962.1 \\
29018.6\end{array}$ & $\begin{array}{l}56.422 \\
56.443 \\
56.464 \\
56.485 \\
56.507\end{array}$ & $\begin{array}{l}20.90 \\
21.09 \\
21.28 \\
21.46 \\
21.65\end{array}$ \\
\hline $\begin{array}{l}410 \\
411 \\
412 \\
413 \\
414\end{array}$ & $\begin{array}{l}22397.4 \\
22452.5 \\
22507.7 \\
22562.9 \\
22618.0\end{array}$ & $\begin{array}{l}55.160 \\
55.163 \\
55.165 \\
55.168 \\
55.171\end{array}$ & $\begin{array}{l}2.43 \\
2.54 \\
2.66 \\
2.78 \\
2.90\end{array}$ & $\begin{array}{l}470 \\
471 \\
472 \\
473 \\
474\end{array}$ & $\begin{array}{l}25716 \cdot 1 \\
25771 \cdot 6 \\
25827 \cdot 2 \\
25882 \cdot 7 \\
25938.3\end{array}$ & $\begin{array}{l}55.549 \\
55.560 \\
55.571 \\
55.583 \\
55.594\end{array}$ & $\begin{array}{l}11.03 \\
11.20 \\
11.37 \\
11.54 \\
11.71\end{array}$ & $\begin{array}{l}530 \\
531 \\
532 \\
533 \\
534\end{array}$ & $\begin{array}{l}29075 \cdot 1 \\
29131.7 \\
29188 \cdot 2 \\
29244 \cdot 8 \\
29301.4\end{array}$ & $\begin{array}{l}56.529 \\
56.551 \\
56.573 \\
56.595 \\
56.618\end{array}$ & $\begin{array}{l}21.84 \\
22.02 \\
22.21 \\
22.40 \\
22.58\end{array}$ \\
\hline $\begin{array}{l}415 \\
416 \\
417 \\
418 \\
419\end{array}$ & $\begin{array}{l}22673.2 \\
22728.4 \\
22783.6 \\
22838.7 \\
22893.9\end{array}$ & $\begin{array}{l}55.174 \\
55.177 \\
55.180 \\
55.183 \\
55.187\end{array}$ & $\begin{array}{l}3.02 \\
3.14 \\
3.27 \\
3.39 \\
3.52\end{array}$ & $\begin{array}{l}475 \\
476 \\
477 \\
478 \\
479\end{array}$ & $\begin{array}{l}25993.9 \\
26049 \cdot 5 \\
26105 \cdot 2 \\
26160.8 \\
26216.5\end{array}$ & $\begin{array}{l}55.606 \\
55.618 \\
55.630 \\
55.642 \\
55.655\end{array}$ & $\begin{array}{l}11.88 \\
12.05 \\
12.22 \\
12.39 \\
12.56\end{array}$ & $\begin{array}{l}535 \\
536 \\
537 \\
538 \\
539\end{array}$ & $\begin{array}{l}29358.0 \\
29414.7 \\
29471.4 \\
29528.1 \\
29584.8\end{array}$ & $\begin{array}{l}56.640 \\
56.663 \\
56.686 \\
56.709 \\
56.733\end{array}$ & $\begin{array}{l}22.77 \\
22.95 \\
23.14 \\
23.33 \\
23.51\end{array}$ \\
\hline 20 & 22949.1 & 55.190 & 3.64 & 480 & 26272.1 & 55.667 & 12.73 & 540 & 29641.5 & 56.756 & 23.70 \\
\hline
\end{tabular}


TABLE 6.3.2. Type J thermocouples-thermoelectric voltages, $\mathrm{E}(\mathrm{T})$, Seebeck coefficients, $\mathrm{S}(\mathrm{T})$, and first derivative of the Seebeck coefficients, $\mathrm{dS} / \mathrm{dT}$, reference junctions at $0{ }^{\circ} \mathrm{C}$-Continued

\begin{tabular}{|c|c|c|c|c|c|c|c|c|c|c|c|}
\hline${ }^{\circ} \mathrm{C}$ & $\underset{\mu V}{E}$ & $\mu \mathrm{S} /{ }^{\circ} \mathrm{C}$ & $\begin{array}{l}d S / d T \\
n V /{ }^{\circ} C^{2}\end{array}$ & ${ }^{\circ} \mathrm{T}$ & $\underset{\mu V}{E}$ & ${ }_{\mu} \mathrm{V}^{\circ}{ }^{\circ} \mathrm{C}$ & $\begin{array}{l}d S / d T \\
n V /{ }^{\circ} C^{2}\end{array}$ & ${ }^{\circ} \mathrm{T}$ & $\underset{\mu V}{E V}$ & $\stackrel{S}{S /^{\circ} \mathrm{C}}$ & $\begin{array}{l}d S / d T \\
n V /{ }^{\circ} C^{2}\end{array}$ \\
\hline $\begin{array}{l}540 \\
541\end{array}$ & $\begin{array}{l}29641.5 \\
29698.3\end{array}$ & $\begin{array}{l}56.756 \\
56.780\end{array}$ & $\begin{array}{l}23.70 \\
23.88\end{array}$ & $\begin{array}{l}600 \\
601\end{array}$ & $\begin{array}{l}33096.0 \\
33154.5\end{array}$ & $\begin{array}{l}58.496 \\
58.529\end{array}$ & $\begin{array}{l}33.83 \\
33.97\end{array}$ & $\begin{array}{l}660 \\
661\end{array}$ & $\begin{array}{l}36670.8 \\
36731.6\end{array}$ & $\begin{array}{l}60.715 \\
60.754\end{array}$ & $\begin{array}{l}38.84 \\
38.85\end{array}$ \\
\hline $\begin{array}{l}541 \\
542\end{array}$ & 29755.1 & 56.804 & 24.07 & $\begin{array}{l}601 \\
602\end{array}$ & $\begin{array}{l}33154.5 \\
33213.1\end{array}$ & 58.564 & 34.11 & 662 & 36792.3 & 60.793 & $\begin{array}{l}38.85 \\
38.85\end{array}$ \\
\hline 543 & 29811.9 & 56.828 & 24.25 & 603 & 33271.7 & 58.598 & 34.25 & 663 & 36853.1 & 60.831 & 38.85 \\
\hline 544 & 29868.8 & 56.853 & $24 \cdot 44$ & 604 & 33330.3 & 58.632 & $34 \cdot 38$ & 664 & 36914.0 & 60.870 & 38.85 \\
\hline 545 & 29925.6 & 56.877 & 24.62 & 605 & 33388.9 & 58.666 & 34.52 & 665 & 36974.9 & 60.909 & 38.84 \\
\hline 546 & 29982.5 & 56.902 & 24.81 & 606 & 33447.6 & 58.701 & 34.65 & 666 & 37035.8 & 60.948 & 38.83 \\
\hline 547 & 30039.4 & 56.927 & 24.99 & 607 & 33506.3 & 58.736 & 34.78 & 667 & 37096.8 & 60.987 & 38.82 \\
\hline 548 & 30096.4 & 56.952 & 25.17 & 608 & 33565.1 & 58.771 & 34.91 & 668 & 37157.8 & 61.026 & 38.81 \\
\hline 549 & 30153.3 & 56.977 & $25 \cdot 36$ & 609 & 33623.9 & 58.806 & 35.04 & 669 & 37218.8 & 61.064 & 38.79 \\
\hline 550 & 30210.3 & 57.003 & 25.54 & 610 & 33682.7 & 58.841 & 35.16 & 670 & 37279.9 & 61.103 & 38.77 \\
\hline 551 & 30267.3 & 57.028 & 25.72 & 611 & 33741.6 & 58.876 & 35.29 & 671 & 37341.0 & 61.142 & 38.74 \\
\hline 552 & 30324.4 & 57.054 & 25.90 & 612 & 33800.5 & 58.911 & 35.41 & 672 & 37402.2 & 61.181 & 38.71 \\
\hline 553 & 30381.4 & 57.080 & 26.08 & 613 & 33859.4 & 58.947 & 35.53 & 673 & 37463.4 & 61.219 & 38.68 \\
\hline 554 & 30438.5 & 57.106 & 26.27 & 614 & 33918.4 & 58.982 & 35.65 & 674 & $37524 \cdot 6$ & 61.258 & 38.64 \\
\hline 555 & 30495.7 & 57.133 & 26.45 & 615 & 33977.4 & 59.018 & 35.77 & 675 & 37585.9 & 61.297 & 38.60 \\
\hline 556 & 30552.8 & 57.159 & 26.63 & 616 & 34036.4 & 59.054 & 35.89 & 676 & 37647.2 & 61.335 & 38.56 \\
\hline 557 & 30610.0 & 57.186 & 26.81 & 617 & 34095.5 & 59.090 & 36.00 & 677 & 37708.6 & 61.374 & 38.51 \\
\hline 558 & 30667.2 & 57.213 & 26.99 & 618 & 34154.6 & 59.126 & 36.11 & 678 & 37770.0 & 61.412 & 38.46 \\
\hline 559 & 30724.4 & 57.240 & $27 \cdot 16$ & 619 & 34213.7 & $59 \cdot 162$ & 36.23 & 679 & 37831.4 & 61.451 & 38.41 \\
\hline 560 & 30781.6 & 57.267 & $27 \cdot 34$ & 620 & 34272.9 & 59.198 & 36.33 & 680 & 37892.9 & 61.489 & 38.35 \\
\hline 561 & 30838.9 & 57.295 & 27.52 & 621 & 34332.1 & 59.235 & 36.44 & 681 & 37954.4 & 61.527 & 38.29 \\
\hline 562 & 30896.2 & 57.322 & 27.70 & 622 & 34391.4 & 59.271 & 36.55 & 682 & 38015.9 & 61.566 & 38.22 \\
\hline 563 & 30953.6 & 57.350 & 27.88 & 623 & 34450.6 & 59.308 & 36.65 & 683 & 38077.5 & 61.604 & 38.15 \\
\hline 564 & 31010.9 & 57.378 & 28.05 & 624 & 34510.0 & $59 \cdot 345$ & $36 \cdot 75$ & 684 & 38139.1 & 61.642 & 38.08 \\
\hline 565 & 31068.3 & 57.406 & 28.23 & 625 & 34569.3 & 59.381 & 36.85 & 685 & $38200 \cdot 8$ & 61.680 & 38.00 \\
\hline 566 & 31125.7 & 57.434 & 28.40 & 626 & 34628.7 & 59.418 & 36.95 & 686 & 38262.5 & 61.718 & 37.92 \\
\hline 567 & 31183.2 & 57.463 & 28.58 & 627 & 34688.2 & 59.455 & 37.04 & 687 & 38324.2 & 61.756 & 37.83 \\
\hline 568 & 31240.7 & 57.492 & 28.75 & 628 & 34747.6 & 59.492 & 37.14 & 688 & 38386.0 & 61.794 & 37.74 \\
\hline 569 & 31298.2 & 57.520 & 28.92 & 629 & 34807.2 & 59.529 & 37.23 & 689 & 38447.8 & 61.831 & 37.65 \\
\hline 570 & 31355.7 & 57.549 & 29.09 & 630 & 34866.7 & 59.567 & 37.32 & 690 & 38509.7 & 61.869 & 37.55 \\
\hline 571 & 31413.3 & 57.579 & 29.27 & 631 & 34926.3 & 59.604 & 37.40 & 691 & 38571.6 & 61.906 & 37.45 \\
\hline 572 & 31470.9 & 57.608 & 29.44 & 632 & 34985.9 & 59.642 & 37.49 & 692 & 38633.5 & 61.944 & 37.34 \\
\hline 573 & 31528.5 & 57.637 & 29.61 & 633 & 35045.6 & 59.679 & 37.57 & 693 & 38695.4 & 61.981 & 37.23 \\
\hline 574 & 31586.1 & 57.667 & $29 \cdot 78$ & 634 & 35105.3 & 59.717 & 37.65 & 694 & 38757.4 & 62.018 & 37.11 \\
\hline 575 & 31643.8 & 57.697 & 29.94 & 635 & 35165.0 & 59.754 & 37.73 & 695 & 38819.5 & 62.055 & 36.99 \\
\hline 576 & 31701.5 & 57.727 & 30.11 & 636 & 35224.8 & 59.792 & 37.80 & 696 & 38881.6 & 62.092 & 36.87 \\
\hline 577 & 31759.3 & 57.757 & 30.28 & 637 & 35284.6 & 59.830 & 37.88 & 697 & 38943.7 & 62.129 & 36.74 \\
\hline 578 & 31817.1 & 57.788 & 30.44 & 638 & 35344.4 & 59.868 & 37.95 & 698 & 39005.8 & $62 \cdot 166$ & 36.61 \\
\hline 579 & 31874.9 & 57.818 & 30.61 & 639 & 35404.3 & 59.906 & 38.01 & 699 & 39068.0 & 62.202 & 36.47 \\
\hline 580 & 31932.7 & 57.849 & 30.77 & 640 & 35464.3 & 59.944 & 38.08 & 700 & 39130.2 & 62.239 & 36.33 \\
\hline 581 & 31990.6 & 57.880 & 30.94 & 641 & 35524.2 & 59.982 & 38.14 & 701 & 39192.5 & 62.275 & 36.18 \\
\hline 582 & 32048.5 & 57.911 & 31.10 & 642 & 35584.2 & 60.020 & 38.20 & 702 & 39254.8 & 62.311 & 36.03 \\
\hline 583 & 32106.4 & 57.942 & 31.26 & 643 & $35644 \cdot 3$ & 60.058 & 38.26 & 703 & 39317.1 & 62.347 & 35.87 \\
\hline 584 & 32164.3 & 57.973 & 31.42 & 644 & 35704.3 & 60.097 & $38 \cdot 32$ & 704 & 39379.5 & $62 \cdot 383$ & 35.71 \\
\hline 585 & 32222.3 & 58.005 & 31.58 & 645 & 35764.5 & 60.135 & 38.37 & 705 & 39441.9 & 62.418 & 35.55 \\
\hline 586 & 32280.3 & 58.036 & 31.74 & 646 & 35824.6 & 60.173 & 38.42 & 706 & 39504.3 & 62.454 & 35.38 \\
\hline 587 & 32338.4 & 58.068 & 31.89 & 647 & 35884.8 & 60.212 & 38.47 & 707 & 39566.8 & 62.489 & 35.20 \\
\hline 588 & 32396.5 & 58.100 & 32.05 & 648 & 35945.0 & 60.250 & 38.52 & 708 & 39629.3 & 62.524 & 35.02 \\
\hline 589 & 32454.6 & 58.132 & 32.21 & 649 & 36005.3 & 60.289 & 38.56 & 709 & 39691.8 & 62.559 & 34.84 \\
\hline 590 & 32512.7 & 58.165 & 32.36 & 650 & 36065.6 & 60.328 & 38.60 & 710 & 39754.4 & 62.594 & 34.65 \\
\hline 591 & 32570.9 & 58.197 & 32.51 & 651 & 36126.0 & 60.366 & 38.64 & 711 & 39817.0 & 62.629 & 34.45 \\
\hline 592 & 32629.1 & 58.230 & 32.66 & 652 & 36186.3 & 60.405 & 38.67 & 712 & 39879.7 & 62.663 & 34.25 \\
\hline 593 & 32687.4 & 58.262 & 32.81 & 653 & 36246.8 & 60.443 & 38.70 & 713 & 39942.3 & 62.697 & 34.04 \\
\hline 594 & 32745.7 & 58.295 & 32.96 & 654 & 36307.2 & 60.482 & 38.73 & 714 & 40005.0 & 62.731 & 33.83 \\
\hline 595 & 32804.0 & $58 \cdot 328$ & 33.11 & 655 & 36367.7 & 60.521 & 38.75 & 715 & 40067.8 & 62.765 & 33.62 \\
\hline 596 & 32862.3 & 58.361 & 33.26 & 656 & 36428.3 & 60.560 & 38.78 & 716 & 40130.6 & 62.798 & 33.40 \\
\hline 597 & 32920.7 & 58.395 & 33.40 & 657 & 36488.8 & 60.598 & 38.80 & 717 & 40193.4 & 62.832 & 33.17 \\
\hline 598 & 32979.1 & 58.428 & 33.55 & 658 & 36549.5 & 60.637 & 38.81 & 718 & 40256.2 & 62.865 & 32.94 \\
\hline 599 & 33037.6 & 58.462 & 33.69 & 659 & 36610.1 & 60.676 & 38.83 & 719 & 40319.1 & 62.897 & 32.70 \\
\hline 600 & 33096.0 & 58.496 & 33.83 & 660 & 36670.8 & 60.715 & 38.84 & 720 & 40382.0 & 62.930 & 32.46 \\
\hline
\end{tabular}


TABLE 6.3.2. Type J thermocouples-thermoelectric voltages, E(T), Seebeck coefficients, $\mathrm{S}(\mathrm{T})$, and first derivative of the Seebeck coefficients, $\mathrm{dS} / \mathrm{dT}$, reference junctions at $0^{\circ} \mathrm{C}$-Continued

\begin{tabular}{|c|c|c|c|c|c|c|c|c|c|c|c|}
\hline${ }^{\circ} \mathrm{C}$ & ${ }_{\mu V}^{E V}$ & $\underset{\mu V /^{\circ} \mathrm{C}}{S}$ & $\begin{array}{l}\mathrm{dS} / \mathrm{dT} \\
\mathrm{nV} /{ }^{\circ} \mathrm{C}^{2}\end{array}$ & ${ }^{\circ} \mathrm{C}$ & $\underset{\mu V}{E}$ & $\underset{\mu V /{ }^{\circ} \mathrm{C}}{S}$ & $\begin{array}{l}\mathrm{dS} / \mathrm{dT} \\
\mathrm{nV} /{ }^{\circ} \mathrm{C}^{2}\end{array}$ & ${ }^{\circ} \mathrm{C}$ & $\underset{\mu V}{E}$ & $\underset{\mu V /^{\circ} \mathrm{C}}{\mathrm{S}}$ & $\begin{array}{l}\mathrm{dS} / \mathrm{dT} \\
\mathrm{nV} /{ }^{\circ} \mathrm{C}^{2}\end{array}$ \\
\hline $\begin{array}{l}720 \\
721 \\
722 \\
723 \\
724\end{array}$ & $\begin{array}{l}40382.0 \\
40445.0 \\
40508.0 \\
40571.0 \\
40634.0\end{array}$ & $\begin{array}{l}62.930 \\
62.962 \\
62.994 \\
63.026 \\
63.058\end{array}$ & $\begin{array}{l}32.46 \\
32.21 \\
31.96 \\
31.70 \\
31.43\end{array}$ & $\begin{array}{l}735 \\
736 \\
737 \\
738 \\
739\end{array}$ & $\begin{array}{l}41329 \cdot 5 \\
41392 \cdot 9 \\
41456 \cdot 3 \\
41519 \cdot 8 \\
41583 \cdot 3\end{array}$ & $\begin{array}{l}63.386 \\
63.414 \\
63.442 \\
63.469 \\
63.496\end{array}$ & $\begin{array}{l}28.13 \\
27 \cdot 80 \\
27.45 \\
27.11 \\
26.75\end{array}$ & $\begin{array}{l}750 \\
751 \\
752 \\
753 \\
754\end{array}$ & $\begin{array}{l}42283 \cdot 2 \\
42347 \cdot 0 \\
42410 \cdot 8 \\
42474.6 \\
42538 \cdot 5\end{array}$ & $\begin{array}{l}63.767 \\
63.789 \\
63.811 \\
63.832 \\
63.853\end{array}$ & $\begin{array}{l}22 \cdot 41 \\
21.98 \\
21.53 \\
21.08 \\
20.63\end{array}$ \\
\hline $\begin{array}{l}725 \\
726 \\
727 \\
728 \\
729\end{array}$ & $\begin{array}{l}40697.1 \\
40760.2 \\
40823 \cdot 3 \\
40886.5 \\
40949.7\end{array}$ & $\begin{array}{l}63.089 \\
63.120 \\
63.151 \\
63.181 \\
63.211\end{array}$ & $\begin{array}{l}31.16 \\
30.88 \\
30.60 \\
30.31 \\
30.02\end{array}$ & $\begin{array}{l}740 \\
741 \\
742 \\
743 \\
744\end{array}$ & $\begin{array}{l}41646.8 \\
41710 \cdot 3 \\
41773 \cdot 9 \\
41837 \cdot 4 \\
41901.1\end{array}$ & $\begin{array}{l}63.522 \\
63.549 \\
63.574 \\
63.600 \\
63.625\end{array}$ & $\begin{array}{l}26.39 \\
26.02 \\
25.65 \\
25.27 \\
24.88\end{array}$ & $\begin{array}{l}755 \\
756 \\
757 \\
758 \\
759\end{array}$ & $\begin{array}{l}42602 \cdot 3 \\
42666 \cdot 2 \\
42730 \cdot 1 \\
42794 \cdot 1 \\
42858 \cdot 0\end{array}$ & $\begin{array}{l}63.873 \\
63.893 \\
63.913 \\
63.932 \\
63.950\end{array}$ & $\begin{array}{l}20.16 \\
19.69 \\
19.22 \\
18.73 \\
18.24\end{array}$ \\
\hline $\begin{array}{l}730 \\
731 \\
732 \\
733 \\
734\end{array}$ & $\begin{array}{l}41012.9 \\
41076.2 \\
41139.5 \\
41202.8 \\
41266.1\end{array}$ & $\begin{array}{l}63.241 \\
63.271 \\
63.300 \\
63.329 \\
63.358\end{array}$ & $\begin{array}{l}29.72 \\
29.42 \\
29.10 \\
28.79 \\
28.46\end{array}$ & $\begin{array}{l}745 \\
746 \\
747 \\
748 \\
749\end{array}$ & $\begin{array}{l}41964.7 \\
42028.4 \\
42092.0 \\
42155.8 \\
42219.5\end{array}$ & $\begin{array}{l}63.650 \\
63.674 \\
63.698 \\
63.721 \\
63.744\end{array}$ & $\begin{array}{l}24.48 \\
24 \cdot 08 \\
23.68 \\
23.26 \\
22.84\end{array}$ & 760 & 42922.0 & 63.968 & $17 \cdot 74$ \\
\hline 735 & $41329 \cdot 5$ & 63.386 & 28.13 & 750 & 42283.2 & 63.767 & $22 \cdot 41$ & & & & \\
\hline
\end{tabular}


TABLE 6.3.2. Type J thermocouples extended range-thermoelectric voliages, E(T), Seebeck coefficients, $\mathrm{S}(\mathrm{T})$, and first derivative of the Seebeck coefficients $d S / d T$,

reference junctions at $0^{\circ} \mathrm{C}$

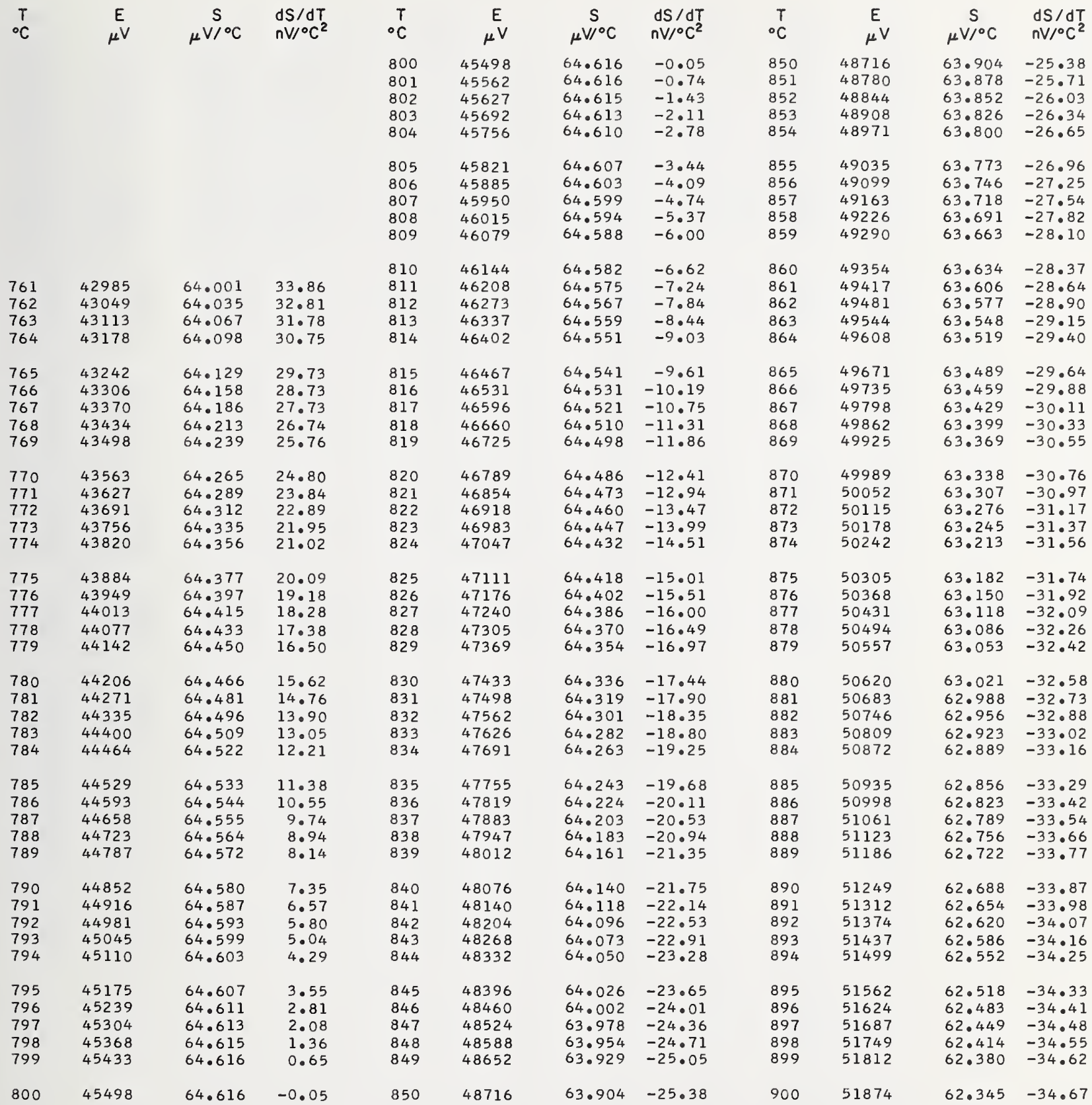


TABLE 6.3.2. Type J thermocouples extended range-thermoelectric voltages, $\mathrm{E}(\mathrm{T})$, Seebeck coefficients, $\mathrm{S}(\mathrm{T})$, and first derivative of the Seebeck coefficients, $\mathrm{dS} / \mathrm{dT}$, reference junctions at $0^{\circ} \mathrm{C}-$ Continued

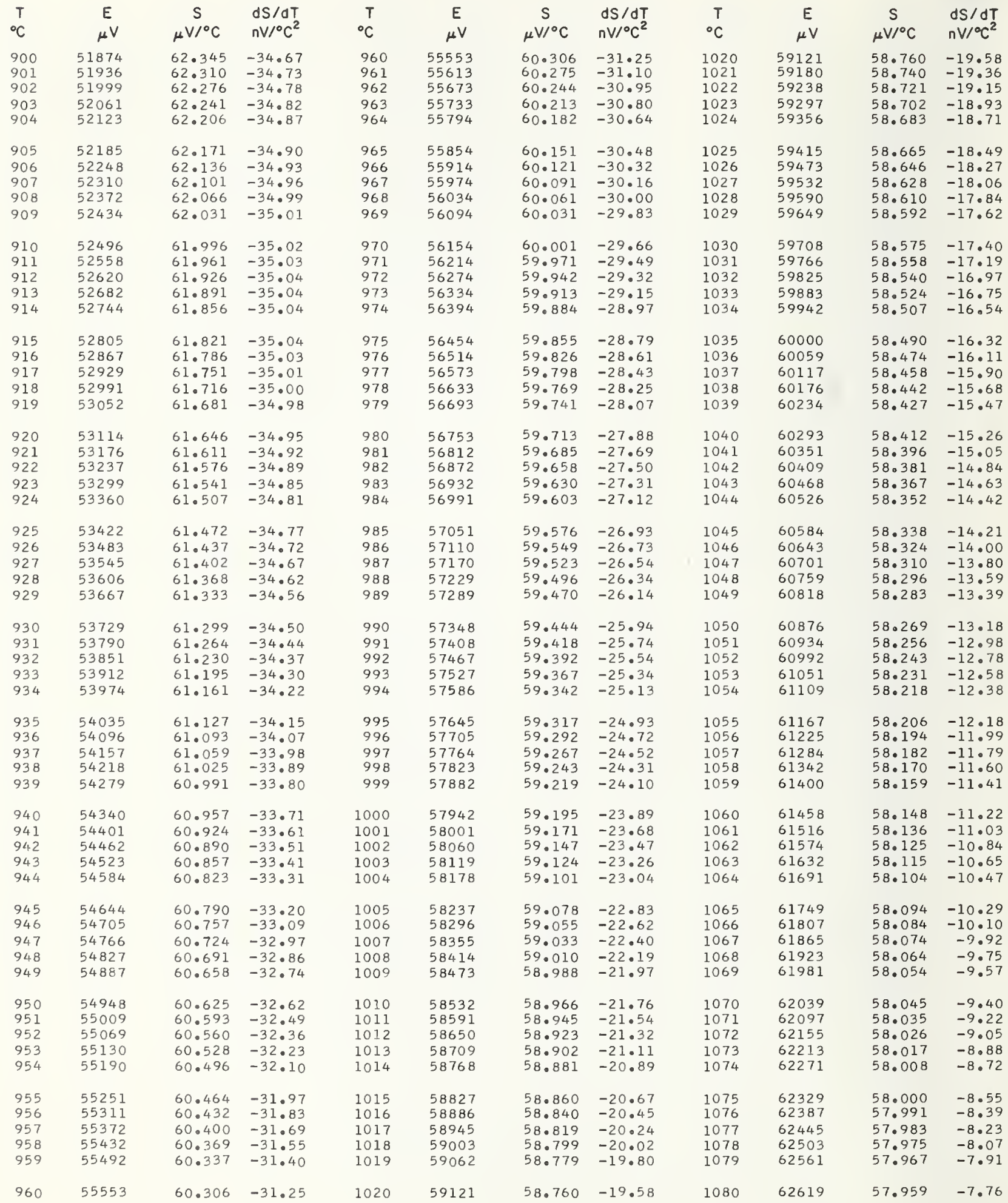


TABLE 6.3.2. Type J thermocouples extended range-thermoelectric voltages, E(T), Seebeck coefficients, $\mathrm{S}(\mathrm{T})$, and first derivative of the Seebeck coefficients, dS/dT,

reference junctions at $0^{\circ} \mathrm{C}$-Continued

\begin{tabular}{|c|c|c|c|c|c|c|c|c|c|c|c|}
\hline${ }^{\circ} \mathrm{C}$ & $\underset{\mu V}{E}$ & $\stackrel{S}{S V /{ }^{\circ} \mathrm{C}}$ & $\begin{array}{l}d S / d T \\
n V /{ }^{\circ} C^{2}\end{array}$ & ${ }^{\mathrm{T}} \mathrm{C}$ & $\underset{\mu V}{E}$ & $\stackrel{S}{\mu V /{ }^{\circ} \mathrm{C}}$ & $\begin{array}{l}\mathrm{dS} / \mathrm{dT} \\
\mathrm{nV} /{ }^{\circ} \mathrm{C}^{2}\end{array}$ & ${ }^{\circ} \mathrm{C}$ & $\underset{\mu V}{E}$ & $\stackrel{\mathrm{S}}{\mu \mathrm{V} /{ }^{\circ} \mathrm{C}}$ & $\begin{array}{l}\mathrm{dS} / \mathrm{d} T \\
\mathrm{nV} /{ }^{\circ} \mathrm{C}^{2}\end{array}$ \\
\hline $\begin{array}{l}1080 \\
1081 \\
1082 \\
1083 \\
1084\end{array}$ & $\begin{array}{l}62619 \\
62677 \\
62735 \\
62793 \\
62851\end{array}$ & $\begin{array}{l}57.959 \\
57.951 \\
57.944 \\
57.936 \\
57.929\end{array}$ & $\begin{array}{l}-7.76 \\
-7.61 \\
-7.46 \\
-7.31 \\
-7.16\end{array}$ & $\begin{array}{l}1120 \\
1121 \\
1122 \\
1123 \\
1124\end{array}$ & $\begin{array}{l}64932 \\
64990 \\
65048 \\
65106 \\
65163\end{array}$ & $\begin{array}{l}57.744 \\
57.740 \\
57.736 \\
57.733 \\
57.729\end{array}$ & $\begin{array}{l}-3.79 \\
-3.76 \\
-3.73 \\
-3.70 \\
-3.68\end{array}$ & $\begin{array}{l}1160 \\
1161 \\
1162 \\
1163 \\
1164\end{array}$ & $\begin{array}{l}67239 \\
67297 \\
67354 \\
67412 \\
67469\end{array}$ & $\begin{array}{l}57.577 \\
57.571 \\
57.565 \\
57.559 \\
57.553\end{array}$ & $\begin{array}{l}-5.75 \\
-5.90 \\
-6.05 \\
-6.20 \\
-6.37\end{array}$ \\
\hline $\begin{array}{l}1085 \\
1086 \\
1087 \\
1088 \\
1089\end{array}$ & $\begin{array}{l}62909 \\
62967 \\
63024 \\
63082 \\
63140\end{array}$ & $\begin{array}{l}57.922 \\
57.915 \\
57.908 \\
57.902 \\
57.895\end{array}$ & $\begin{array}{l}-7.02 \\
-6.88 \\
-6.74 \\
-6.61 \\
-6.47\end{array}$ & $\begin{array}{l}1125 \\
1126 \\
1127 \\
1128 \\
1129\end{array}$ & $\begin{array}{l}65221 \\
65279 \\
65337 \\
65394 \\
65452\end{array}$ & $\begin{array}{l}57.725 \\
57.722 \\
57.718 \\
57.714 \\
57.711\end{array}$ & $\begin{array}{l}-3.66 \\
-3.65 \\
-3.64 \\
-3.63 \\
-3.63\end{array}$ & $\begin{array}{l}1165 \\
1166 \\
1167 \\
1168 \\
1169\end{array}$ & $\begin{array}{l}67527 \\
67585 \\
67642 \\
67700 \\
67757\end{array}$ & $\begin{array}{l}57.546 \\
57.539 \\
57.533 \\
57.526 \\
57.519\end{array}$ & $\begin{array}{l}-6.53 \\
-6.71 \\
-6.88 \\
-7.07 \\
-7.25\end{array}$ \\
\hline $\begin{array}{l}1090 \\
1091 \\
1092 \\
1093 \\
1094\end{array}$ & $\begin{array}{l}63198 \\
63256 \\
63314 \\
63372 \\
63430\end{array}$ & $\begin{array}{l}57.889 \\
57.882 \\
57.876 \\
57.870 \\
57.864\end{array}$ & $\begin{array}{l}-6.34 \\
-6.21 \\
-6.09 \\
-5.97 \\
-5.84\end{array}$ & $\begin{array}{l}1130 \\
1131 \\
1132 \\
1133 \\
1134\end{array}$ & $\begin{array}{l}65510 \\
65567 \\
65625 \\
65683 \\
65741\end{array}$ & $\begin{array}{l}57.707 \\
57.703 \\
57.700 \\
57.696 \\
57.692\end{array}$ & $\begin{array}{l}-3.63 \\
-3.64 \\
-3.65 \\
-3.66 \\
-3.68\end{array}$ & $\begin{array}{l}1170 \\
1171 \\
1172 \\
1173 \\
1174\end{array}$ & $\begin{array}{l}67815 \\
67872 \\
67930 \\
67987 \\
68045\end{array}$ & $\begin{array}{l}57.511 \\
57.504 \\
57.496 \\
57.488 \\
57.480\end{array}$ & $\begin{array}{l}-7.45 \\
-7.65 \\
-7.85 \\
-8.07 \\
-8.28\end{array}$ \\
\hline $\begin{array}{l}1095 \\
1096 \\
1097 \\
1098 \\
1099\end{array}$ & $\begin{array}{l}63488 \\
63545 \\
63603 \\
63661 \\
63719\end{array}$ & $\begin{array}{l}57.859 \\
57.853 \\
57.847 \\
57.842 \\
57.837\end{array}$ & $\begin{array}{l}-5.73 \\
-5.61 \\
-5.50 \\
-5.39 \\
-5.29\end{array}$ & $\begin{array}{l}1135 \\
1136 \\
1137 \\
1138 \\
1139\end{array}$ & $\begin{array}{l}65798 \\
65856 \\
65914 \\
65971 \\
66029\end{array}$ & $\begin{array}{l}57.689 \\
57.685 \\
57.681 \\
57.677 \\
57.674\end{array}$ & $\begin{array}{l}-3.70 \\
-3.73 \\
-3.76 \\
-3.79 \\
-3.83\end{array}$ & $\begin{array}{l}1175 \\
1176 \\
1177 \\
1178 \\
1179\end{array}$ & $\begin{array}{l}68102 \\
68160 \\
68217 \\
68274 \\
68332\end{array}$ & $\begin{array}{l}57.471 \\
57.463 \\
57.454 \\
57.445 \\
57.435\end{array}$ & $\begin{array}{l}-8.51 \\
-8.73 \\
-8.97 \\
-9.21 \\
-9.45\end{array}$ \\
\hline $\begin{array}{l}1100 \\
1101 \\
1102 \\
1103 \\
1104\end{array}$ & $\begin{array}{l}63777 \\
63835 \\
63892 \\
63950 \\
64008\end{array}$ & $\begin{array}{l}57.831 \\
57.826 \\
57.821 \\
57.816 \\
57.811\end{array}$ & $\begin{array}{l}-5.18 \\
-5.08 \\
-4.99 \\
-4.89 \\
-4.80\end{array}$ & $\begin{array}{l}1140 \\
1141 \\
1142 \\
1143 \\
1144\end{array}$ & $\begin{array}{l}66087 \\
66144 \\
66202 \\
66260 \\
66317\end{array}$ & $\begin{array}{l}57.670 \\
57.666 \\
57.662 \\
57.658 \\
57.654\end{array}$ & $\begin{array}{l}-3.88 \\
-3.93 \\
-3.98 \\
-4.04 \\
-4.10\end{array}$ & $\begin{array}{l}1180 \\
1181 \\
1182 \\
1183 \\
1184\end{array}$ & $\begin{array}{l}68389 \\
68447 \\
68504 \\
68562 \\
68619\end{array}$ & $\begin{array}{l}57.426 \\
57.416 \\
57.406 \\
57.396 \\
57.385\end{array}$ & $\begin{array}{r}-9.71 \\
-9.96 \\
-10.23 \\
-10.50 \\
-10.77\end{array}$ \\
\hline $\begin{array}{l}1105 \\
1106 \\
1107 \\
1108 \\
1109\end{array}$ & $\begin{array}{l}64066 \\
64124 \\
64181 \\
64239 \\
64297\end{array}$ & $\begin{array}{l}57.807 \\
57.802 \\
57.797 \\
57.793 \\
57.788\end{array}$ & $\begin{array}{l}-4.71 \\
-4.63 \\
-4.55 \\
-4.47 \\
-4.39\end{array}$ & $\begin{array}{l}1145 \\
1146 \\
1147 \\
1148 \\
1149\end{array}$ & $\begin{array}{l}66375 \\
66433 \\
66490 \\
66548 \\
66605\end{array}$ & $\begin{array}{l}57.650 \\
57.646 \\
57.641 \\
57.637 \\
57.632\end{array}$ & $\begin{array}{l}-4 \cdot 17 \\
-4.24 \\
-4.32 \\
-4.40 \\
-4.48\end{array}$ & $\begin{array}{l}1185 \\
1186 \\
1187 \\
1188 \\
1189\end{array}$ & $\begin{array}{l}68676 \\
68734 \\
68791 \\
68848 \\
68906\end{array}$ & $\begin{array}{l}57.374 \\
57.363 \\
57.351 \\
57.340 \\
57.327\end{array}$ & $\begin{array}{l}-11.05 \\
-11.34 \\
-11.64 \\
-11.94 \\
-12.24\end{array}$ \\
\hline $\begin{array}{l}1110 \\
1111 \\
1112 \\
1113 \\
1114\end{array}$ & $\begin{array}{l}64355 \\
64413 \\
64470 \\
64528 \\
64586\end{array}$ & $\begin{array}{l}57.784 \\
57.780 \\
57.776 \\
57.771 \\
57.767\end{array}$ & $\begin{array}{l}-4.32 \\
-4.25 \\
-4.19 \\
-4.12 \\
-4.07\end{array}$ & $\begin{array}{l}1150 \\
1151 \\
1152 \\
1153 \\
1154\end{array}$ & $\begin{array}{l}66663 \\
66721 \\
66778 \\
66836 \\
66894\end{array}$ & $\begin{array}{l}57.628 \\
57.623 \\
57.619 \\
57.614 \\
57.609\end{array}$ & $\begin{array}{l}-4.57 \\
-4.67 \\
-4.77 \\
-4.87 \\
-4.98\end{array}$ & $\begin{array}{l}1190 \\
1191 \\
1192 \\
1193 \\
1194\end{array}$ & $\begin{array}{l}68963 \\
69020 \\
69078 \\
69135 \\
69192\end{array}$ & $\begin{array}{l}57.315 \\
57.302 \\
57.289 \\
57.276 \\
57.262\end{array}$ & $\begin{array}{l}-12.56 \\
-12.88 \\
-13.20 \\
-13.53 \\
-13.87\end{array}$ \\
\hline $\begin{array}{l}1115 \\
1116 \\
1117 \\
1118 \\
1119\end{array}$ & $\begin{array}{l}64644 \\
64701 \\
64759 \\
64817 \\
64875\end{array}$ & $\begin{array}{l}57.763 \\
57.759 \\
57.755 \\
57.751 \\
57.748\end{array}$ & $\begin{array}{l}-4.01 \\
-3.96 \\
-3.91 \\
-3.87 \\
-3.83\end{array}$ & $\begin{array}{l}1155 \\
1156 \\
1157 \\
1158 \\
1159\end{array}$ & $\begin{array}{l}66951 \\
67009 \\
67066 \\
67124 \\
67182\end{array}$ & $\begin{array}{l}57.604 \\
57.599 \\
57.593 \\
57.588 \\
57.582\end{array}$ & $\begin{array}{l}-5.10 \\
-5.22 \\
-5.34 \\
-5.48 \\
-5.61\end{array}$ & $\begin{array}{l}1195 \\
1196 \\
1197 \\
1198 \\
1199\end{array}$ & $\begin{array}{l}69249 \\
69307 \\
69364 \\
69421 \\
69478\end{array}$ & $\begin{array}{l}57.248 \\
57.234 \\
57.219 \\
57.204 \\
57.188\end{array}$ & $\begin{array}{l}-14.22 \\
-14.57 \\
-14.93 \\
-15.29 \\
-15.66\end{array}$ \\
\hline 1120 & 64932 & 57.744 & -3.79 & 1160 & 67239 & 57.577 & -5.75 & 1200 & 69536 & 57.173 & $-16 \cdot 04$ \\
\hline
\end{tabular}


TABLE 6.3.3. Thermoelectric values at the fixed points for Type J thermocouples

\begin{tabular}{|c|c|c|c|c|}
\hline Fixed point & $\begin{array}{c}\text { Temp. } \\
{ }^{\circ} \mathrm{C}\end{array}$ & $\begin{array}{c}E \\
\mu \mathrm{V}\end{array}$ & $\begin{array}{c}S \\
\mu \mathrm{V} /{ }^{\circ} \mathrm{C}\end{array}$ & $\begin{array}{c}d S / d T \\
\mathrm{nV} /{ }^{\circ} \mathrm{C}^{2}\end{array}$ \\
\hline $\begin{array}{l}\text { Nitrogen TP } \\
\text { Nitrogen NBP } \\
\text { Oxygen NBP } \\
\text { Carbon Dioxide SP } \\
\text { Mercury FP } \\
\text { Ice point } \\
\text { Ether TP } \\
\text { Water BP } \\
\text { Benzoic TP } \\
\text { Indium FP } \\
\text { Tin FP } \\
\text { Bismuth FP } \\
\text { Cadmium FP } \\
\text { Lead FP } \\
\text { Mercury BP } \\
\text { Zinc FP } \\
\text { Sulphur BP } \\
\text { Cu-Al FP } \\
\text { Antimony FP } \\
\text { Aluminum FP } \\
\text { Silver FP } \\
\text { Gold FP } \\
\text { Copper FP }\end{array}$ & $\begin{array}{r}-210.002 \\
-195.802 \\
-182.962 \\
-78.476 \\
-38.862 \\
0.000 \\
26.870 \\
100.000 \\
122.370 \\
156.634 \\
231.9681 \\
271.442 \\
321.108 \\
327.502 \\
356.660 \\
419.580 \\
444.674 \\
548.23 \\
630.74 \\
660.37 \\
961.93 \\
1064.43 \\
1084.5\end{array}$ & $\begin{array}{r}-8095.7 \\
-7796.3 \\
-7480.7 \\
-3718.7 \\
-1906.3 \\
0.0 \\
1373.9 \\
5267.7 \\
6488.6 \\
8374.3 \\
12551.7 \\
14742.7 \\
17492.8 \\
17846.2 \\
19456.0 \\
22925.9 \\
24312.3 \\
30109.5 \\
34910.8 \\
36693.3 \\
55669 \\
61716 \\
62880\end{array}$ & $\begin{array}{l}19.126 \\
22.972 \\
26.148 \\
43.721 \\
47.586 \\
50.373 \\
51.832 \\
54.348 \\
54.788 \\
55.238 \\
55.537 \\
55.459 \\
55.280 \\
55.257 \\
55.170 \\
55.189 \\
55.321 \\
56.985 \\
59.594 \\
60.729 \\
60.246 \\
58.100 \\
57.926\end{array}$ & $\begin{array}{r}283.95 \\
258.19 \\
236.73 \\
112.93 \\
83.46 \\
60.85 \\
48.13 \\
22.61 \\
16.89 \\
9.68 \\
-0.54 \\
-3.08 \\
-3.65 \\
-3.51 \\
-2.28 \\
3.59 \\
7.03 \\
25.21 \\
37.38 \\
38.84 \\
-30.96 \\
-10.39 \\
-7.09\end{array}$ \\
\hline
\end{tabular}

TABLE 6.3.4. Estimated maximum errors that occur when using reduced-bit arithmetic for the power series expansion for the thermoelectric voltage of Type J thermocouples

\begin{tabular}{|c|c|c|c|c|c|c|}
\hline \multirow[b]{2}{*}{ Temperature range } & \multirow[b]{2}{*}{ Degree } & \multicolumn{5}{|c|}{ Estimated maximum error in microvolts } \\
\hline & & 12 Bit & $16 \mathrm{Bit}$ & 24. Bit & $27 \mathrm{Bit}$ & $36 \mathrm{Bit}$ \\
\hline-210 to $-100{ }^{\circ} \mathrm{C}$ & 7 & 3 & 0.2 & $<0.1$ & $<0.1$ & $<0.1$ \\
\hline-100 to $\quad 0^{\circ} \mathrm{C}$ & 7 & 2 & 0.1 & $<0.1$ & $<0.1$ & $<0.1$ \\
\hline 0 to $200{ }^{\circ} \mathrm{C}$ & 7 & 4 & 0.2 & $<0.1$ & $<0.1$ & $<0.1$ \\
\hline $400 \mathrm{C}$ & 7 & 12 & 0.3 & $<0.1$ & $<0.1$ & $<0.1$ \\
\hline 400 to $600^{\circ} \mathrm{C}$ & 7 & 40 & 0.7 & $<0.1$ & $<0.1$ & $<0.1$ \\
\hline 600 to $\quad 760{ }^{\circ} \mathrm{C}$ & 7 & 80 & 2 & $<0.1$ & $<0.1$ & $<0.1$ \\
\hline 760 to $1000{ }^{\circ} \mathrm{C}$ & 5 & $\left(^{*}\right.$ & 60 & 0.3 & $<1.0$ & $<1.0$ \\
\hline 1000 to $1200{ }^{\circ} \mathrm{C}$ & 5 & $(*)$ & 90 & 0.3 & $<1.0$ & $<1.0$ \\
\hline
\end{tabular}

*A high-order polynomial with a low-bit machine causes extreme error. 


\subsection{Reference Functions and Tables for the Positive Thermoelement, Type JP, Iron Versus Platinum, $\mathbf{P t}-67$}

The coefficients for the seventh degree expansion for the thermoelectric voltage of Type JP thermoelements versus $\mathrm{Pt}-67$ below $760{ }^{\circ} \mathrm{C}$ are given in table 6.4.1. The errors caused by using reduced bit arithmetic for calculating values of the functions are given in table 6.4.4.

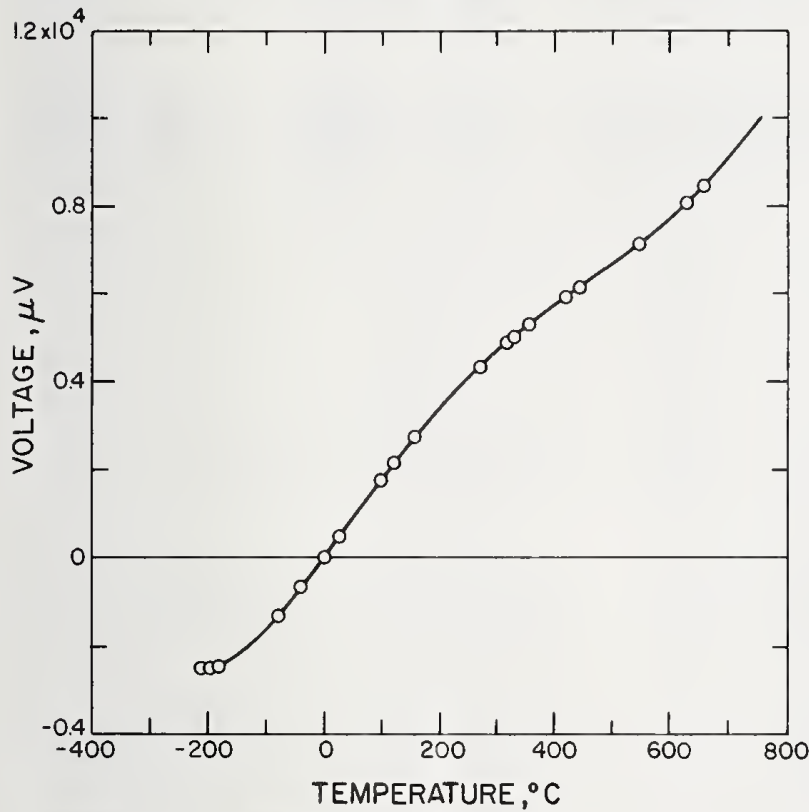

Figure 6.4.1. Thermoelectric voltage for Type JP thermoelements versus platinum, $P_{t}-67$.

The circles indicate values at various thermometric fixed points on the IPTS -68 .

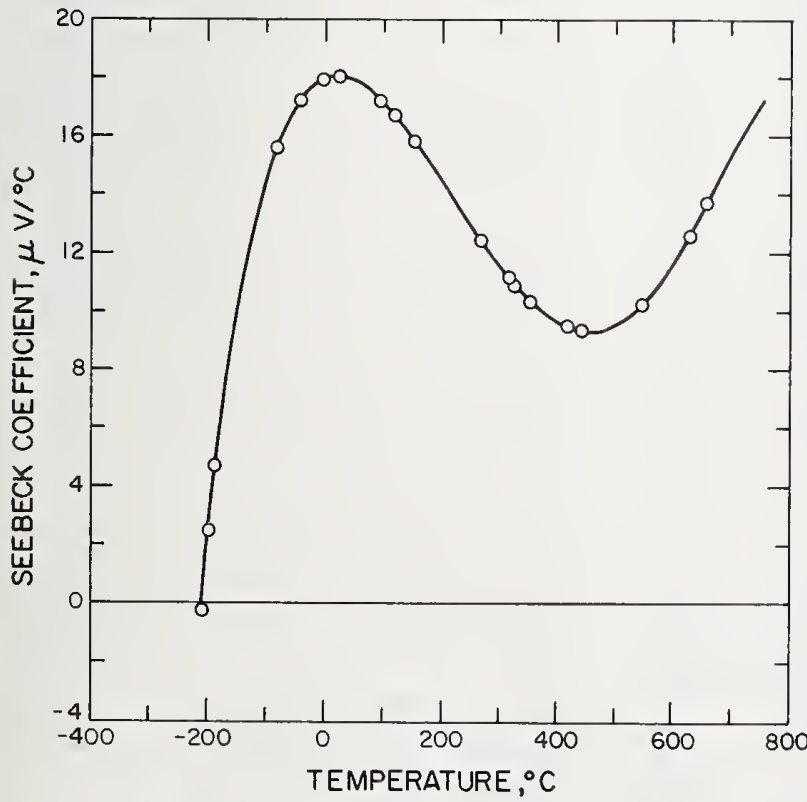

Figure 6.4.2. Seebeck coeficient for Type JP thermoelements versus platinum, $\mathrm{Pt}-67$.

The circles indicate values at various thermometric fxed points on the IPTS -68 .
The primary reference values for Type JP thermoelements versus $\mathrm{Pt}-67$ are given in table 6.4.2. Values at selected fixed points are given in table 6.4.3. Graphs of the thermoelectric voltage, its first derivative (Seebeck coefficient), and second derivative are given in figures 6.4.1, 6.4.2, and 6.4.3, respectively.

Because of the lack of stability of Type J thermocouples above $760{ }^{\circ} \mathrm{C}$, no reference functions are given for Type JP above $760^{\circ} \mathrm{C}$.

The tables in this section merely give average values for industrial materials which have a wide variability. The tables in this section do NOT contain standardized values. Neither the ASTM nor the ISA recognize Type JP or JN thermoelements as standardized materials.

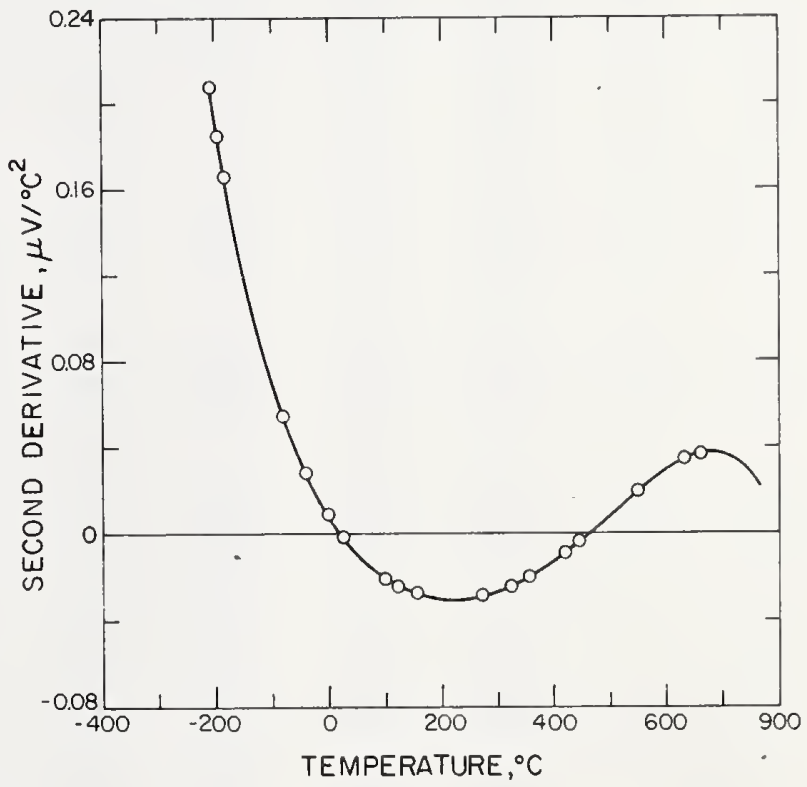

Figure 6.4.3. Second derivative of thermoelectric voltage for Type JP thermoelements versus platinum, $P t-67$.

The circles indicate values at various thermometric fixed pointe on the IPTS -68 .

TABLE 6.4.1. Power series expansion for the thermo. electric voltage of Type JP thermoelements versus platinum, $\mathrm{Pt}-67$

\begin{tabular}{c|c|c|c}
\hline $\begin{array}{c}\text { Tempera- } \\
\text { ture } \\
\text { range }\end{array}$ & Degree & Coefficients & \\
\hline & & & Term \\
\hline 210 to & 7 & $1.7910320204 \times 10^{1}$ & $T$ \\
$760^{\circ} \mathrm{C}$ & & $4.6647761097 \times 10^{-3}$ & $T^{2}$ \\
& & $-7.1172460609 \times 10^{-5}$ & $T^{3}$ \\
& & $1.3372217238 \times 10^{-7}$ & $T^{4}$ \\
& & $-1.5045762690 \times 10^{-10}$ & $T^{5}$ \\
& & $1.5339015011 \times 10^{-13}$ & $T^{6}$ \\
& & $-7.5257947432 \times 10^{-17}$ & $T^{7}$ \\
& & & \\
\hline
\end{tabular}


TABLE 6.4.2. Type JP thermoelements versus platinum, Pt-67-thermoelectric voltages, E(T), Seebeck coefficients, $\mathrm{S}(\mathrm{T})$, and first derivative of the Seebeck coefficients, $\mathrm{dS} / \mathrm{dT}$, reference junctions at $0{ }^{\circ} \mathrm{C}$

\begin{tabular}{|c|c|c|c|c|c|c|c|c|c|c|c|}
\hline $\begin{array}{r}{ }^{\top} \mathrm{C} \\
{ }^{\circ} \mathrm{C}\end{array}$ & $\underset{\mu V}{E}$ & $\underset{\mu \mathrm{V} /{ }^{\circ} \mathrm{C}}{\mathrm{S}}$ & $\begin{array}{l}d S / d T \\
n V /{ }^{\circ} C^{2}\end{array}$ & ${ }^{\circ} \mathrm{C}$ & $\begin{array}{c}E \\
\mu V\end{array}$ & $\begin{array}{c}S \\
\mu V^{\circ}{ }^{\circ} \mathrm{C}\end{array}$ & $\begin{array}{l}\mathrm{dS} / \mathrm{dT} \\
\mathrm{nV} /{ }^{\circ} \mathrm{C}^{2}\end{array}$ & $\begin{array}{r}T \\
{ }^{\circ} \mathrm{C}\end{array}$ & $\begin{array}{c}E \\
\mu V\end{array}$ & $\begin{array}{c}S \\
\mu \mathrm{V} /{ }^{\circ} \mathrm{C}\end{array}$ & $\begin{array}{l}\mathrm{dS} / \mathrm{dT} \\
\mathrm{nV} /{ }^{\circ} \mathrm{C}^{2}\end{array}$ \\
\hline $\begin{array}{l}-210 \\
-209 \\
-208 \\
-207 \\
-206\end{array}$ & $\begin{array}{l}-2560.3 \\
-2560.5 \\
-2560.5 \\
-2560.3 \\
-2559.9\end{array}$ & $\begin{array}{r}-0.303 \\
-0.096 \\
0.110 \\
0.313 \\
0.515\end{array}$ & $\begin{array}{l}207.88 \\
206.19 \\
204.50 \\
202.82 \\
201.16\end{array}$ & $\begin{array}{l}-200 \\
-199 \\
-198 \\
-197 \\
-196\end{array}$ & $\begin{array}{l}-2553.2 \\
-2551.4 \\
-2549.4 \\
-2547.3 \\
-2544.9\end{array}$ & $\begin{array}{l}1.693 \\
1.883 \\
2.072 \\
2.260 \\
2.445\end{array}$ & $\begin{array}{l}191.37 \\
189.77 \\
188.18 \\
186.61 \\
185.04\end{array}$ & $\begin{array}{l}-190 \\
-189 \\
-188 \\
-187 \\
-186\end{array}$ & $\begin{array}{l}-2527.0 \\
-2523.4 \\
-2519.6 \\
-2515.6 \\
-2511.5\end{array}$ & $\begin{array}{l}3.528 \\
3.703 \\
3.876 \\
4.049 \\
4.219\end{array}$ & $\begin{array}{l}175.81 \\
174.31 \\
172.81 \\
171.33 \\
169.85\end{array}$ \\
\hline $\begin{array}{l}-205 \\
-204 \\
-203 \\
-202 \\
-201\end{array}$ & $\begin{array}{l}-2559.2 \\
-2558.4 \\
-2557.4 \\
-2556.2 \\
-2554.8\end{array}$ & $\begin{array}{l}0.716 \\
0.914 \\
1.111 \\
1.307 \\
1.501\end{array}$ & $\begin{array}{l}199.50 \\
197.86 \\
196.22 \\
194.59 \\
192.98\end{array}$ & $\begin{array}{l}-195 \\
-194 \\
-193 \\
-192 \\
-191\end{array}$ & $\begin{array}{l}-2542.4 \\
-2539.7 \\
-2536.8 \\
-2533.7 \\
-2530.4\end{array}$ & $\begin{array}{l}2.630 \\
2.812 \\
2.994 \\
3.173 \\
3.351\end{array}$ & $\begin{array}{l}183.48 \\
181.93 \\
180.38 \\
178.85 \\
177.33\end{array}$ & $\begin{array}{l}-185 \\
-184 \\
-183 \\
-182 \\
-181\end{array}$ & $\begin{array}{l}-2507.2 \\
-2502.7 \\
-2498.1 \\
-2493.3 \\
-2488.3\end{array}$ & $\begin{array}{l}4.388 \\
4.556 \\
4.722 \\
4.887 \\
5.050\end{array}$ & $\begin{array}{l}168.38 \\
166.92 \\
165.47 \\
164.02 \\
162.59\end{array}$ \\
\hline-200 & -2553.2 & 1.693 & 191.37 & -190 & -2527.0 & 3.528 & 175.81 & -180 & $-2483 \cdot 2$ & 5.212 & $161 \cdot 16$ \\
\hline
\end{tabular}


TABLE 6.4.2. Type JP thermoelements versus platinum, Pt-67-thermoelectric voltages, $\mathrm{E}(\mathrm{T})$, Secbcck coefficients, $\mathrm{S}(\mathrm{T})$, and first dcrivative of the Seebeck coefficients, $\mathrm{dS} / \mathrm{d} \mathrm{T}$,

reference junctions at $O^{\circ} \mathrm{C}$-Continued

\begin{tabular}{|c|c|c|c|c|c|c|c|c|c|c|c|}
\hline${ }^{\top} \mathrm{T}$ & $\begin{array}{c}E V \\
\mu V\end{array}$ & $\begin{array}{c}S \\
\mu V /{ }^{\circ} \mathrm{C}\end{array}$ & $\begin{array}{l}d S / d T \\
n V /{ }^{\circ} C^{2}\end{array}$ & $\begin{array}{l}\mathrm{T} \\
{ }^{\circ} \mathrm{C}\end{array}$ & $\begin{array}{c}E \\
\mu V\end{array}$ & $\underset{\mu \mathrm{V} /{ }^{\circ} \mathrm{C}}{S}$ & $\begin{array}{l}d S / d T \\
n V /{ }^{\circ} C^{2}\end{array}$ & $\begin{array}{l}\mathrm{T} \\
{ }^{\circ} \mathrm{C}\end{array}$ & $\begin{array}{c}E \\
\mu V\end{array}$ & $\underset{\mu V /{ }^{\circ} \mathrm{C}}{\mathrm{S}}$ & $\begin{array}{l}d S / d T \\
n V /{ }^{\circ} C^{2}\end{array}$ \\
\hline $\begin{array}{l}-180 \\
-179 \\
-178 \\
-177 \\
-176\end{array}$ & $\begin{array}{l}-2483.2 \\
-2477.9 \\
-2472.4 \\
-2466.8 \\
-2461.0\end{array}$ & $\begin{array}{l}5.212 \\
5.372 \\
5.532 \\
5.689 \\
5.845\end{array}$ & $\begin{array}{l}161.16 \\
159 \cdot 75 \\
158 \cdot 34 \\
156.94 \\
155.55\end{array}$ & $\begin{array}{l}-120 \\
-119 \\
-118 \\
-117 \\
-116\end{array}$ & $\begin{array}{l}-1927.1 \\
-1914.5 \\
-1901.7 \\
-1888.9 \\
-1876.0\end{array}$ & $\begin{array}{l}12.611 \\
12.701 \\
12.789 \\
12.877 \\
12.963\end{array}$ & $\begin{array}{l}89.91 \\
88.94 \\
87.97 \\
87.01 \\
86.05\end{array}$ & $\begin{array}{l}-60 \\
-59 \\
-58 \\
-57 \\
-56\end{array}$ & $\begin{array}{r}-1040.6 \\
-1024.1 \\
-1007.6 \\
-991.0 \\
-974.4\end{array}$ & $\begin{array}{l}16.456 \\
16.497 \\
16.537 \\
16.577 \\
16.616\end{array}$ & $\begin{array}{l}41.44 \\
40.79 \\
40.14 \\
39.49 \\
38.85\end{array}$ \\
\hline $\begin{array}{l}-175 \\
-174 \\
-173 \\
-172 \\
-171\end{array}$ & $\begin{array}{l}-2455.1 \\
-2449.0 \\
-2442.8 \\
-2436.4 \\
-2429.9\end{array}$ & $\begin{array}{l}6.000 \\
6.154 \\
6.306 \\
6.457 \\
6.606\end{array}$ & $\begin{array}{l}154.17 \\
152.79 \\
151.42 \\
150.07 \\
148.72\end{array}$ & $\begin{array}{l}-115 \\
-114 \\
-113 \\
-112 \\
-111\end{array}$ & $\begin{array}{l}-1863.0 \\
-1849.9 \\
-1836.7 \\
-1823.4 \\
-1810.1\end{array}$ & $\begin{array}{l}13.049 \\
13.133 \\
13.217 \\
13.300 \\
13.382\end{array}$ & $\begin{array}{l}85.11 \\
84.16 \\
83.22 \\
82.29 \\
81.37\end{array}$ & $\begin{array}{l}-55 \\
-54 \\
-53 \\
-52 \\
-51\end{array}$ & $\begin{array}{l}-957.8 \\
-941.1 \\
-924.4 \\
-907.7 \\
-890.9\end{array}$ & $\begin{array}{l}16.655 \\
16.693 \\
16.730 \\
16.767 \\
16.803\end{array}$ & $\begin{array}{l}38.21 \\
37.58 \\
36.96 \\
36.33 \\
35.71\end{array}$ \\
\hline $\begin{array}{l}-170 \\
-169 \\
-168 \\
-167 \\
-166\end{array}$ & $\begin{array}{l}-2423.2 \\
-2416.4 \\
-2409.4 \\
-2402.3 \\
-2395.0\end{array}$ & $\begin{array}{r}6.754 \\
701 \\
046 \\
7.190 \\
7.333\end{array}$ & $\begin{array}{l}147.38 \\
146.04 \\
144.72 \\
143.40 \\
142.09\end{array}$ & $\begin{array}{l}-110 \\
-109 \\
-108 \\
-107 \\
-106\end{array}$ & $\begin{array}{l}-1796.7 \\
-1783.2 \\
-1769.6 \\
-1755.9 \\
-1742.2\end{array}$ & $\begin{array}{l}13.463 \\
13.543 \\
13.622 \\
13.700 \\
13.777\end{array}$ & $\begin{array}{l}80.45 \\
79.54 \\
78.63 \\
77.73 \\
76.83\end{array}$ & $\begin{array}{l}-50 \\
-49 \\
-48 \\
-47 \\
-46\end{array}$ & $\begin{array}{l}-874 \cdot 1 \\
-857 \cdot 2 \\
-840.3 \\
-823 \cdot 4 \\
-806.4\end{array}$ & $\begin{array}{l}16.838 \\
16.873 \\
16.907 \\
16.941 \\
16.974\end{array}$ & $\begin{array}{l}35.10 \\
34.49 \\
33.88 \\
33.28 \\
32.68\end{array}$ \\
\hline $\begin{array}{l}-165 \\
-164 \\
-163 \\
-162 \\
-161\end{array}$ & $\begin{array}{l}-2387.6 \\
-2380.1 \\
-2372.4 \\
-2364.6 \\
-2356.6\end{array}$ & $\begin{array}{l}7.474 \\
7.615 \\
7.753 \\
7.891 \\
8.027\end{array}$ & $\begin{array}{l}140.79 \\
139.50 \\
138.21 \\
136.94 \\
135.67\end{array}$ & $\begin{array}{l}-105 \\
-104 \\
-103 \\
-102 \\
-101\end{array}$ & $\begin{array}{l}-1728.4 \\
-1714.5 \\
-1700.5 \\
-1686.5 \\
-1672.4\end{array}$ & $\begin{array}{l}13.854 \\
13.929 \\
14.004 \\
14.077 \\
14.150\end{array}$ & $\begin{array}{l}75 \cdot 94 \\
75.06 \\
74 \cdot 18 \\
73.31 \\
72.44\end{array}$ & $\begin{array}{l}-45 \\
-44 \\
-43 \\
-42 \\
-41\end{array}$ & $\begin{array}{l}-789.5 \\
-772.4 \\
-755.4 \\
-738.3 \\
-721.2\end{array}$ & $\begin{array}{l}17.006 \\
17.038 \\
17.069 \\
17.100 \\
17.130\end{array}$ & $\begin{array}{l}32.09 \\
31.50 \\
30.91 \\
30.33 \\
29.76\end{array}$ \\
\hline $\begin{array}{l}-160 \\
-159 \\
-158 \\
-157 \\
-156\end{array}$ & $\begin{array}{l}-2348.5 \\
-2340.3 \\
-2331.9 \\
-2323.4 \\
-2314.8\end{array}$ & $\begin{array}{l}8.162 \\
8.296 \\
8.429 \\
8.560 \\
8.690\end{array}$ & $\begin{array}{l}134.41 \\
133.15 \\
131.91 \\
130.67 \\
129.44\end{array}$ & $\begin{array}{l}-100 \\
-99 \\
-98 \\
-97 \\
-96\end{array}$ & $\begin{array}{l}-1658.2 \\
-1643.9 \\
-1629.6 \\
-1615.2 \\
-1600.7\end{array}$ & $\begin{array}{l}14.222 \\
14.293 \\
14.364 \\
14.433 \\
14.502\end{array}$ & $\begin{array}{l}71.58 \\
70.73 \\
69.88 \\
69.03 \\
68.19\end{array}$ & $\begin{array}{l}-40 \\
-39 \\
-38 \\
-37 \\
-36\end{array}$ & $\begin{array}{l}-704.0 \\
-686.9 \\
-669.7 \\
-652.4 \\
-635.2\end{array}$ & $\begin{array}{l}17.159 \\
17.188 \\
17.216 \\
17.244 \\
17.271\end{array}$ & $\begin{array}{l}29.18 \\
28.61 \\
28.05 \\
27.49 \\
26.93\end{array}$ \\
\hline $\begin{array}{l}-155 \\
-154 \\
-153 \\
-152 \\
-151\end{array}$ & $\begin{array}{l}-2306.1 \\
-2297.2 \\
-2288.2 \\
-2279.0 \\
-2269.8\end{array}$ & $\begin{array}{l}8.819 \\
8.946 \\
9.073 \\
9.198 \\
9.322\end{array}$ & $\begin{array}{l}128.22 \\
127.00 \\
125.79 \\
124.59 \\
123.40\end{array}$ & $\begin{array}{l}-95 \\
-94 \\
-93 \\
-92 \\
-91\end{array}$ & $\begin{array}{l}-1586.2 \\
-1571.6 \\
-1556.9 \\
-1542.2 \\
-1527.4\end{array}$ & $\begin{array}{l}14.570 \\
14.637 \\
14.703 \\
14.768 \\
14.832\end{array}$ & $\begin{array}{l}67.36 \\
66.53 \\
65.71 \\
64.89 \\
64.08\end{array}$ & $\begin{array}{l}-35 \\
-34 \\
-33 \\
-32 \\
-31\end{array}$ & $\begin{array}{l}-617.9 \\
-600.6 \\
-583.2 \\
-565.9 \\
-548.5\end{array}$ & $\begin{array}{l}17.298 \\
17.324 \\
17.350 \\
17.375 \\
17.399\end{array}$ & $\begin{array}{l}26 \cdot 38 \\
25 \cdot 83 \\
25 \cdot 28 \\
24 \cdot 74 \\
24 \cdot 20\end{array}$ \\
\hline $\begin{array}{l}-150 \\
-149 \\
-148 \\
-147 \\
-146\end{array}$ & $\begin{array}{l}-2260.4 \\
-2250.9 \\
-2241.3 \\
-2231.5 \\
-2221.6\end{array}$ & $\begin{array}{l}9.445 \\
9.566 \\
9.587 \\
9.806 \\
9.924\end{array}$ & $\begin{array}{l}122.22 \\
121.04 \\
119.87 \\
118.70 \\
117.55\end{array}$ & $\begin{array}{l}-90 \\
-89 \\
-88 \\
-87 \\
-86\end{array}$ & $\begin{array}{l}-1512.5 \\
-1497.6 \\
-1482.6 \\
-1467.5 \\
-1452.4\end{array}$ & $\begin{array}{l}14.896 \\
14.959 \\
15.021 \\
15.082 \\
15.143\end{array}$ & $\begin{array}{l}63.27 \\
62.47 \\
61.68 \\
60.89 \\
60.10\end{array}$ & $\begin{array}{l}-30 \\
-29 \\
-28 \\
-27 \\
-26\end{array}$ & $\begin{array}{l}-531.1 \\
-513.6 \\
-496.2 \\
-478.7 \\
-461.2\end{array}$ & $\begin{array}{l}17.423 \\
17.447 \\
17.469 \\
17.492 \\
17.514\end{array}$ & $\begin{array}{l}23.67 \\
23.14 \\
22.51 \\
22.09 \\
21.57\end{array}$ \\
\hline $\begin{array}{l}-145 \\
-144 \\
-143 \\
-142 \\
-141\end{array}$ & $\begin{array}{l}-2211.7 \\
-2201.6 \\
-2191.3 \\
-2181.0 \\
-2170.6\end{array}$ & $\begin{array}{l}10.041 \\
10.157 \\
10.272 \\
10.385 \\
10.498\end{array}$ & $\begin{array}{l}116.40 \\
115.26 \\
114.12 \\
112.99 \\
111.87\end{array}$ & $\begin{array}{l}-85 \\
-84 \\
-83 \\
-82 \\
-81\end{array}$ & $\begin{array}{l}-1437.3 \\
-1422.0 \\
-1406.7 \\
-1391.4 \\
-1376.0\end{array}$ & $\begin{array}{l}15.203 \\
15.262 \\
15.320 \\
15.377 \\
15.434\end{array}$ & $\begin{array}{l}59.32 \\
58.55 \\
57.78 \\
57.02 \\
56.26\end{array}$ & $\begin{array}{l}-25 \\
-24 \\
-23 \\
-22 \\
-21\end{array}$ & $\begin{array}{l}-443.7 \\
-426.1 \\
-408.6 \\
-391.0 \\
-373.4\end{array}$ & $\begin{array}{l}17.535 \\
17.556 \\
17.576 \\
17.596 \\
17.615\end{array}$ & $\begin{array}{l}21.06 \\
20.55 \\
20.04 \\
19.53 \\
19.03\end{array}$ \\
\hline $\begin{array}{l}-140 \\
-139 \\
-138 \\
-137 \\
-136\end{array}$ & $\begin{array}{l}-2160.0 \\
-2149.4 \\
-2138.6 \\
-2127.7 \\
-2116.7\end{array}$ & $\begin{array}{l}10.609 \\
10.719 \\
10.828 \\
10.936 \\
11.043\end{array}$ & $\begin{array}{l}110.76 \\
109.65 \\
108.55 \\
107.46 \\
106.38\end{array}$ & $\begin{array}{l}-80 \\
-79 \\
-78 \\
-77 \\
-76\end{array}$ & $\begin{array}{l}-1360.5 \\
-1345.0 \\
-1329.4 \\
-1313.8 \\
-1298.1\end{array}$ & $\begin{array}{l}15.490 \\
15.545 \\
15.599 \\
15.653 \\
15.706\end{array}$ & $\begin{array}{l}55.50 \\
54.75 \\
54.01 \\
53.27 \\
52.54\end{array}$ & $\begin{array}{l}-20 \\
-19 \\
-18 \\
-17 \\
-16\end{array}$ & $\begin{array}{l}-355.7 \\
-338.1 \\
-320.4 \\
-302.8 \\
-285.1\end{array}$ & $\begin{array}{l}17.634 \\
17.652 \\
17.670 \\
17.687 \\
17.704\end{array}$ & $\begin{array}{l}18.54 \\
18.04 \\
17.55 \\
17.07 \\
16.59\end{array}$ \\
\hline $\begin{array}{l}-135 \\
-134 \\
-133 \\
-132 \\
-131\end{array}$ & $\begin{array}{l}-2105.6 \\
-2094.4 \\
-2083.1 \\
-2071.7 \\
-2060.2\end{array}$ & $\begin{array}{l}11.149 \\
11.254 \\
11.358 \\
11.460 \\
11.562\end{array}$ & $\begin{array}{l}105.30 \\
104.23 \\
103.16 \\
102.10 \\
101.05\end{array}$ & $\begin{array}{l}-75 \\
-74 \\
-73 \\
-72 \\
-71\end{array}$ & $\begin{array}{l}-1282.4 \\
-1266.6 \\
-1250.8 \\
-1234.9 \\
-1219.0\end{array}$ & $\begin{array}{l}15.758 \\
15.809 \\
15.860 \\
15.910 \\
15.959\end{array}$ & $\begin{array}{l}51.81 \\
51.08 \\
50.36 \\
49.65 \\
48.94\end{array}$ & $\begin{array}{l}-15 \\
-14 \\
-13 \\
-12 \\
-11\end{array}$ & $\begin{array}{l}-267.4 \\
-249.6 \\
-231.9 \\
-214.1 \\
-196.4\end{array}$ & $\begin{array}{l}17.720 \\
17.736 \\
17.752 \\
17.767 \\
17.781\end{array}$ & $\begin{array}{l}16.11 \\
15.63 \\
15.16 \\
14.69 \\
14.23\end{array}$ \\
\hline $\begin{array}{l}-130 \\
-129 \\
-128 \\
-127 \\
-126\end{array}$ & $\begin{array}{l}-2048.6 \\
-2036.9 \\
-2025.1 \\
-2013.1 \\
-2001.1\end{array}$ & $\begin{array}{l}11.662 \\
11.762 \\
11.860 \\
11.958 \\
12.054\end{array}$ & $\begin{array}{r}100.01 \\
98.97 \\
97.94 \\
96.91 \\
95.89\end{array}$ & $\begin{array}{l}-70 \\
-69 \\
-68 \\
-67 \\
-66\end{array}$ & $\begin{array}{l}-1203.0 \\
-1186.9 \\
-1170.9 \\
-1154.7 \\
-1138.6\end{array}$ & $\begin{array}{l}16.008 \\
16.056 \\
16.103 \\
16.149 \\
16.195\end{array}$ & $\begin{array}{l}48.23 \\
47.53 \\
46.84 \\
46.15 \\
45.46\end{array}$ & $\begin{array}{r}-10 \\
-9 \\
-8 \\
-7 \\
-6\end{array}$ & $\begin{array}{l}-178.6 \\
-160.8 \\
-142.9 \\
-125.1 \\
-107.3\end{array}$ & $\begin{array}{l}17.795 \\
17.809 \\
17.822 \\
17.834 \\
17.847\end{array}$ & $\begin{array}{l}13.76 \\
13.31 \\
12.85 \\
12.40 \\
11.95\end{array}$ \\
\hline $\begin{array}{l}-125 \\
-124 \\
-123 \\
-122 \\
-121\end{array}$ & $\begin{array}{l}-1989.0 \\
-1976.8 \\
-1964.5 \\
-1952.2 \\
-1939.7\end{array}$ & $\begin{array}{l}12.149 \\
12.244 \\
12.337 \\
12.430 \\
12.521\end{array}$ & $\begin{array}{l}94.88 \\
93.87 \\
92.87 \\
91.88 \\
90.89\end{array}$ & $\begin{array}{l}-65 \\
-64 \\
-63 \\
-62 \\
-61\end{array}$ & $\begin{array}{l}-1122.3 \\
-1106.1 \\
-1089.8 \\
-1073.4 \\
-1057.0\end{array}$ & $\begin{array}{l}16.240 \\
16.285 \\
16.329 \\
16.372 \\
16.414\end{array}$ & $\begin{array}{l}44 \cdot 78 \\
44 \cdot 10 \\
43.43 \\
42.76 \\
42.10\end{array}$ & $\begin{array}{l}-5 \\
-4 \\
-3 \\
-2 \\
-1\end{array}$ & $\begin{array}{l}-89.4 \\
-71.6 \\
-53.7 \\
-35.8 \\
-17.9\end{array}$ & $\begin{array}{l}17.858 \\
17.870 \\
17.880 \\
17.891 \\
17.901\end{array}$ & $\begin{array}{r}11.51 \\
11.06 \\
10.63 \\
10.19 \\
9.76\end{array}$ \\
\hline-120 & -1927.1 & 12.611 & 89.91 & -60 & -1040.6 & 16.456 & 41.44 & 0 & 0 & 17.910 & 33 \\
\hline
\end{tabular}


TABlE 6.4.2. Type JP thermoelements versus p!atinum, Pt-67-thermoelectric voltages, $\mathrm{E}(\mathrm{T})$, Seebech coefficients, S(T), and first derivative of the Seebeck coefficients, $\mathrm{dS} / \mathrm{dT}$,

reference junctions at $O{ }^{\circ} \mathrm{C}$-Continued

\begin{tabular}{|c|c|c|c|c|c|c|c|c|c|c|c|}
\hline$T$ & $\underset{\mu V}{E V}$ & $\stackrel{S}{\mu V /{ }^{\circ} \mathrm{C}}$ & $\begin{array}{l}d S / d T \\
n V / c^{2}\end{array}$ & $\begin{array}{l}\mathrm{T} \\
{ }^{\circ} \mathrm{C}\end{array}$ & $\underset{\mu V}{E V}$ & $\underset{\mu \mathrm{V} /{ }^{\circ} \mathrm{C}}{\mathrm{S}}$ & $\begin{array}{l}d S / d T \\
n V /{ }^{\circ} C^{2}\end{array}$ & ${ }^{\top} \mathrm{C}$ & $\underset{\mu V}{E V}$ & $\underset{\mu V /{ }^{\circ} \mathrm{C}}{S}$ & $\begin{array}{l}\mathrm{dS} / \mathrm{dT} \\
\mathrm{nV} /{ }^{\circ} \mathrm{C}^{2}\end{array}$ \\
\hline $\begin{array}{l}0 \\
1 \\
2 \\
3 \\
4\end{array}$ & $\begin{array}{r}0.0 \\
17.9 \\
35.8 \\
53.8 \\
71.7\end{array}$ & $\begin{array}{l}17.910 \\
17.919 \\
17.928 \\
17.936 \\
17.944\end{array}$ & $\begin{array}{l}9.33 \\
8.90 \\
8.48 \\
8.06 \\
7.65\end{array}$ & $\begin{array}{l}60 \\
61 \\
62 \\
63 \\
64\end{array}$ & $\begin{array}{l}1077.7 \\
1095.5 \\
1113.3 \\
1131.0 \\
1148.8\end{array}$ & $\begin{array}{l}17.808 \\
17.797 \\
17.785 \\
17.773 \\
17.761\end{array}$ & $\begin{array}{l}-11.11 \\
-11.37 \\
-11.63 \\
-11.89 \\
-12.14\end{array}$ & $\begin{array}{l}120 \\
121 \\
122 \\
123 \\
124\end{array}$ & $\begin{array}{l}2117.8 \\
2134.6 \\
2151.3 \\
2168.0 \\
2184.6\end{array}$ & $\begin{array}{l}16.745 \\
16.722 \\
16.698 \\
16.675 \\
16.651\end{array}$ & $\begin{array}{l}-23.13 \\
-23.27 \\
-23.41 \\
-23.55 \\
-23.69\end{array}$ \\
\hline $\begin{array}{l}5 \\
6 \\
7 \\
8 \\
9\end{array}$ & $\begin{array}{r}89.7 \\
107.6 \\
125.6 \\
143.5 \\
161.5\end{array}$ & $\begin{array}{l}17.952 \\
17.959 \\
17.965 \\
17.972 \\
17.977\end{array}$ & $\begin{array}{l}7.23 \\
6.82 \\
6.42 \\
6.01 \\
5.61\end{array}$ & $\begin{array}{l}65 \\
66 \\
67 \\
68 \\
69\end{array}$ & $\begin{array}{l}1166.6 \\
1184.3 \\
1202.0 \\
1219.7 \\
1237.5\end{array}$ & $\begin{array}{l}17.749 \\
17.737 \\
17.724 \\
17.711 \\
17.698\end{array}$ & $\begin{array}{l}-12.40 \\
-12.65 \\
-12.90 \\
-13.14 \\
-13.39\end{array}$ & $\begin{array}{l}125 \\
126 \\
127 \\
128 \\
129\end{array}$ & $\begin{array}{l}2201.3 \\
2217.9 \\
2234.5 \\
2251.0 \\
2267.6\end{array}$ & $\begin{array}{l}16.627 \\
16.604 \\
16.580 \\
16.555 \\
16.531\end{array}$ & $\begin{array}{l}-23.83 \\
-23.96 \\
-24.09 \\
-24.22 \\
-24.35\end{array}$ \\
\hline $\begin{array}{l}10 \\
11 \\
12 \\
13 \\
14\end{array}$ & $\begin{array}{l}179.5 \\
197.5 \\
215.5 \\
233.5 \\
251.5\end{array}$ & $\begin{array}{l}17.983 \\
17.988 \\
17.992 \\
17.997 \\
18.001\end{array}$ & $\begin{array}{l}5.22 \\
4.82 \\
4.43 \\
4.04 \\
3.66\end{array}$ & $\begin{array}{l}70 \\
71 \\
72 \\
73 \\
74\end{array}$ & $\begin{array}{l}1255.1 \\
1272.8 \\
1290.5 \\
1308.1 \\
1325.8\end{array}$ & $\begin{array}{l}17.684 \\
17.670 \\
17.656 \\
17.642 \\
17.628\end{array}$ & $\begin{array}{l}-13.63 \\
-13.87 \\
-14.10 \\
-14.34 \\
-14.57\end{array}$ & $\begin{array}{l}130 \\
131 \\
132 \\
133 \\
134\end{array}$ & $\begin{array}{l}2284.1 \\
2300.6 \\
2317.1 \\
2333.5 \\
2349.9\end{array}$ & $\begin{array}{l}16.507 \\
16.482 \\
16.457 \\
16.433 \\
16.408\end{array}$ & $\begin{array}{l}-24.48 \\
-24.61 \\
-24.73 \\
-24.85 \\
-24.97\end{array}$ \\
\hline $\begin{array}{l}20 \\
21 \\
22 \\
23 \\
24\end{array}$ & $\begin{array}{l}359.5 \\
377.5 \\
395.6 \\
413.6 \\
431.6\end{array}$ & $\begin{array}{l}18.016 \\
18.017 \\
18.018 \\
18.018 \\
18.018\end{array}$ & $\begin{array}{r}1.41 \\
1.04 \\
0.68 \\
0.32 \\
-0.04\end{array}$ & $\begin{array}{l}80 \\
81 \\
82 \\
83 \\
84\end{array}$ & $\begin{array}{l}1431.3 \\
1448.8 \\
1466.3 \\
1483.8 \\
1501.3\end{array}$ & $\begin{array}{l}17.536 \\
17.520 \\
17.504 \\
17.487 \\
17.471\end{array}$ & $\begin{array}{l}-15.93 \\
-16.14 \\
-16.36 \\
-16.57 \\
-16.79\end{array}$ & $\begin{array}{l}140 \\
141 \\
142 \\
143 \\
144\end{array}$ & $\begin{array}{l}2447.9 \\
2464.2 \\
2480.4 \\
2496.6 \\
2512.7\end{array}$ & $\begin{array}{l}16.256 \\
16.230 \\
16.204 \\
16.178 \\
16.152\end{array}$ & $\begin{array}{l}-25.66 \\
-25.77 \\
-25.88 \\
-25.99 \\
-26.09\end{array}$ \\
\hline $\begin{array}{l}25 \\
26 \\
27 \\
28 \\
29\end{array}$ & $\begin{array}{l}449.6 \\
467.6 \\
485.6 \\
503.7 \\
521.7\end{array}$ & $\begin{array}{l}18.018 \\
18.018 \\
18.017 \\
18.015 \\
18.014\end{array}$ & $\begin{array}{l}-0.39 \\
-0.74 \\
-1.09 \\
-1.43 \\
-1.78\end{array}$ & $\begin{array}{l}85 \\
86 \\
87 \\
88 \\
89\end{array}$ & $\begin{array}{l}1518.7 \\
1536.2 \\
1553.6 \\
1571.0 \\
1588.4\end{array}$ & $\begin{array}{l}17.454 \\
17.437 \\
17.419 \\
17.402 \\
17.384\end{array}$ & $\begin{array}{l}-17.00 \\
-17.20 \\
-17.41 \\
-17.61 \\
-17.82\end{array}$ & $\begin{array}{l}145 \\
146 \\
147 \\
148 \\
149\end{array}$ & $\begin{array}{l}2528.9 \\
2545.0 \\
2561.1 \\
2577.1 \\
2593.2\end{array}$ & $\begin{array}{l}16.126 \\
16.100 \\
16.074 \\
16.047 \\
16.021\end{array}$ & $\begin{array}{l}-26.19 \\
-26.30 \\
-26.40 \\
-26.49 \\
-26.59\end{array}$ \\
\hline $\begin{array}{l}30 \\
31 \\
32 \\
33 \\
34\end{array}$ & $\begin{array}{l}539.7 \\
557.7 \\
575.7 \\
593.7 \\
611.7\end{array}$ & $\begin{array}{l}18.012 \\
18.010 \\
18.007 \\
18.004 \\
18.001\end{array}$ & $\begin{array}{l}-2.11 \\
-2.45 \\
-2.79 \\
-3.12 \\
-3.45\end{array}$ & $\begin{array}{l}90 \\
91 \\
92 \\
93 \\
94\end{array}$ & $\begin{array}{l}1605.8 \\
1623.1 \\
1640.5 \\
1657.8 \\
1675.1\end{array}$ & $\begin{array}{l}17.366 \\
17.348 \\
17.330 \\
17.311 \\
17.293\end{array}$ & $\begin{array}{l}-18.02 \\
-18.21 \\
-18.41 \\
-18.60 \\
-18.80\end{array}$ & $\begin{array}{l}150 \\
151 \\
152 \\
153 \\
154\end{array}$ & $\begin{array}{l}2609.2 \\
2625.2 \\
2641.1 \\
2657.0 \\
2672.9\end{array}$ & $\begin{array}{l}15.994 \\
15.967 \\
15.940 \\
15.913 \\
15.886\end{array}$ & $\begin{array}{l}-26.69 \\
-26.78 \\
-26.87 \\
-26.96 \\
-27.05\end{array}$ \\
\hline $\begin{array}{l}40 \\
41 \\
42 \\
43 \\
44\end{array}$ & $\begin{array}{l}719.6 \\
737.6 \\
755.6 \\
773.5 \\
791.5\end{array}$ & $\begin{array}{l}17.974 \\
17.969 \\
17.963 \\
17.957 \\
17.950\end{array}$ & $\begin{array}{l}-5.37 \\
-5.68 \\
-5.98 \\
-6.29 \\
-6.59\end{array}$ & $\begin{array}{l}100 \\
101 \\
102 \\
103 \\
104\end{array}$ & $\begin{array}{l}1778.5 \\
1795.7 \\
1812.8 \\
1830.0 \\
1847.1\end{array}$ & $\begin{array}{l}17.176 \\
17.156 \\
17.136 \\
17.116 \\
17.095\end{array}$ & $\begin{array}{l}-19.91 \\
-20.09 \\
-20.26 \\
-20.44 \\
-20.61\end{array}$ & $\begin{array}{l}160 \\
161 \\
162 \\
163 \\
164\end{array}$ & $\begin{array}{l}2767.8 \\
2783.5 \\
2799.2 \\
2814.8 \\
2830.4\end{array}$ & $\begin{array}{l}15.723 \\
15.695 \\
15.667 \\
15.640 \\
15.612\end{array}$ & $\begin{array}{l}-27.56 \\
-27.64 \\
-27.71 \\
-27.79 \\
-27.86\end{array}$ \\
\hline $\begin{array}{l}45 \\
46 \\
47 \\
48 \\
49\end{array}$ & $\begin{array}{l}809.4 \\
827.4 \\
845.3 \\
863.2 \\
881.2\end{array}$ & $\begin{array}{l}17.944 \\
17.937 \\
17.929 \\
17.922 \\
17.914\end{array}$ & $\begin{array}{l}-6.89 \\
-7.19 \\
-7.49 \\
-7.78 \\
-8.07\end{array}$ & $\begin{array}{l}105 \\
106 \\
107 \\
108 \\
109\end{array}$ & $\begin{array}{l}1864 \cdot 2 \\
1881.2 \\
1898 \cdot 3 \\
1915.3 \\
1932.3\end{array}$ & $\begin{array}{l}17.075 \\
17.054 \\
17.033 \\
17.012 \\
16.990\end{array}$ & $\begin{array}{l}-20.78 \\
-20.95 \\
-21.12 \\
-21.28 \\
-21.45\end{array}$ & $\begin{array}{l}165 \\
166 \\
167 \\
168 \\
169\end{array}$ & $\begin{array}{l}2846.0 \\
2861.6 \\
2877.2 \\
2892.7 \\
2908.2\end{array}$ & $\begin{array}{l}15.584 \\
15.556 \\
15.528 \\
15.500 \\
15.471\end{array}$ & $\begin{array}{l}-27.94 \\
-28.01 \\
-28.08 \\
-28.15 \\
-28.22\end{array}$ \\
\hline $\begin{array}{l}50 \\
51 \\
52 \\
53 \\
54\end{array}$ & $\begin{array}{l}899.1 \\
917.0 \\
934.9 \\
952.7 \\
970.6\end{array}$ & $\begin{array}{l}17.905 \\
17.897 \\
17.888 \\
17.879 \\
17.870\end{array}$ & $\begin{array}{l}-8.36 \\
-8.64 \\
-8.93 \\
-9.21 \\
-9.49\end{array}$ & $\begin{array}{l}110 \\
111 \\
112 \\
113 \\
114\end{array}$ & $\begin{array}{l}1949 \cdot 3 \\
1966 \cdot 2 \\
1983 \cdot 2 \\
2000.1 \\
2017.0\end{array}$ & $\begin{array}{l}16.969 \\
16.947 \\
16.925 \\
16.903 \\
16.881\end{array}$ & $\begin{array}{l}-21.61 \\
-21.77 \\
-21.93 \\
-22.09 \\
-22.24\end{array}$ & $\begin{array}{l}170 \\
171 \\
172 \\
173 \\
174\end{array}$ & $\begin{array}{l}2923.6 \\
2939.0 \\
2954.4 \\
2969.8 \\
2985.2\end{array}$ & $\begin{array}{l}15.443 \\
15.415 \\
15.387 \\
15.358 \\
15.330\end{array}$ & $\begin{array}{l}-28.28 \\
-28.35 \\
-28.41 \\
-28.47 \\
-28.53\end{array}$ \\
\hline $\begin{array}{l}55 \\
56 \\
57 \\
58 \\
59\end{array}$ & $\begin{array}{r}988.5 \\
1006.3 \\
1024.2 \\
1042.0 \\
1059.8\end{array}$ & $\begin{array}{l}17.860 \\
17.850 \\
17.840 \\
17.830 \\
17.819\end{array}$ & $\begin{array}{r}-9.76 \\
-10.04 \\
-10.31 \\
-10.58 \\
-10.84\end{array}$ & $\begin{array}{l}115 \\
116 \\
117 \\
118 \\
119\end{array}$ & $\begin{array}{l}2033.8 \\
2050.7 \\
2067.5 \\
2084.3 \\
2101.1\end{array}$ & $\begin{array}{l}16.859 \\
16.836 \\
16.814 \\
16.791 \\
16.768\end{array}$ & $\begin{array}{l}-22.39 \\
-22.54 \\
-22.69 \\
-22.84 \\
-22.99\end{array}$ & $\begin{array}{l}175 \\
176 \\
177 \\
178 \\
179\end{array}$ & $\begin{array}{l}3000.5 \\
3015.8 \\
3031.0 \\
3046.2 \\
3061.4\end{array}$ & $\begin{array}{l}15.301 \\
15.272 \\
15.244 \\
15.215 \\
15.186\end{array}$ & $\begin{array}{l}-28.59 \\
-28.65 \\
-28.70 \\
-28.76 \\
-28.81\end{array}$ \\
\hline 60 & 1077.7 & 17.808 & $-11 \cdot 11$ & 120 & 2117.8 & 16.745 & $-23 \cdot 13$ & 180 & 3076.6 & 15.157 & -28.86 \\
\hline
\end{tabular}


TABLE 6.4.2. Type JP thermoelements versus p!atinum, Pt-67-thermoclcctric voltages, E(T), Seebeck coefficients, $\mathrm{S}(\mathrm{T})$, and first dcrivative of the Seebcck coefficients, $\mathrm{dS} / \mathrm{dT}$, reference junctions at $\mathrm{O}^{\circ} \mathrm{C}$-Continued

\begin{tabular}{|c|c|c|c|c|c|c|c|c|c|c|c|}
\hline${ }^{\circ} \mathrm{C}$ & $\begin{array}{c}E \\
\mu V\end{array}$ & $\begin{array}{c}S \\
\mu V \cdot{ }^{\circ} \mathrm{C}\end{array}$ & $\begin{array}{l}\mathrm{dS} / \mathrm{dT} \\
\mathrm{nV} /{ }^{\circ} \mathrm{C}^{2}\end{array}$ & ${ }^{\circ} \mathrm{C}$ & $\begin{array}{c}E \\
\mu V\end{array}$ & $\stackrel{\mathrm{S}}{\mu \mathrm{V} /{ }^{\circ} \mathrm{C}}$ & $\begin{array}{l}\mathrm{dS} / \mathrm{dT} \\
\mathrm{nV} /{ }^{\circ} \mathrm{C}^{2}\end{array}$ & ${ }^{\circ} \mathrm{C}$ & $\begin{array}{c}E \\
\mu V\end{array}$ & $\begin{array}{c}\mathrm{S} \\
\mu \mathrm{V} /{ }^{\circ} \mathrm{C}\end{array}$ & $\begin{array}{l}d S / d T \\
n V /{ }^{\circ} C^{2}\end{array}$ \\
\hline $\begin{array}{l}180 \\
181 \\
182 \\
183 \\
184\end{array}$ & $\begin{array}{l}3076.6 \\
3091.8 \\
3106.9 \\
3122.0 \\
3137.0\end{array}$ & $\begin{array}{l}15.157 \\
15.129 \\
15.100 \\
15.071 \\
15.042\end{array}$ & $\begin{array}{l}-28.86 \\
-28.91 \\
-28.96 \\
-29.01 \\
-29.05\end{array}$ & $\begin{array}{l}240 \\
241 \\
242 \\
243 \\
244\end{array}$ & $\begin{array}{l}3933.0 \\
3946.4 \\
3959.7 \\
3973.0 \\
3986.3\end{array}$ & $\begin{array}{l}13.381 \\
13.352 \\
13.322 \\
13.293 \\
13.263\end{array}$ & $\begin{array}{l}-29.58 \\
-29.55 \\
-29.53 \\
-29.50 \\
-29.47\end{array}$ & $\begin{array}{l}300 \\
301 \\
302 \\
303 \\
304\end{array}$ & $\begin{array}{l}4684 \cdot 2 \\
4695.9 \\
4707.5 \\
4719.1 \\
4730.7\end{array}$ & $\begin{array}{l}11.693 \\
11.668 \\
11.642 \\
11.616 \\
11.590\end{array}$ & $\begin{array}{l}-26.02 \\
-25.92 \\
-25.83 \\
-25.73 \\
-25.64\end{array}$ \\
\hline $\begin{array}{l}185 \\
186 \\
187 \\
188 \\
189\end{array}$ & $\begin{array}{l}3152.0 \\
3167.0 \\
3182.0 \\
3197.0 \\
3211.9\end{array}$ & $\begin{array}{l}15.012 \\
14.983 \\
14.954 \\
14.925 \\
14.896\end{array}$ & $\begin{array}{l}-29.10 \\
-29.14 \\
-29.19 \\
-29.23 \\
-29.27\end{array}$ & $\begin{array}{l}245 \\
246 \\
247 \\
248 \\
249\end{array}$ & $\begin{array}{l}3999.5 \\
4012.8 \\
4025.9 \\
4039.1 \\
4052.2\end{array}$ & $\begin{array}{l}13.234 \\
13.204 \\
13.175 \\
13.146 \\
13.116\end{array}$ & $\begin{array}{l}-29 \cdot 44 \\
-29 \cdot 41 \\
-29 \cdot 37 \\
-29.34 \\
-29 \cdot 30\end{array}$ & $\begin{array}{l}305 \\
306 \\
307 \\
308 \\
309\end{array}$ & $\begin{array}{l}4742.3 \\
4753.9 \\
4765.4 \\
4776.9 \\
4788.4\end{array}$ & $\begin{array}{l}11.565 \\
11.539 \\
11.514 \\
11.488 \\
11.463\end{array}$ & $\begin{array}{l}-25.54 \\
-25.44 \\
-25.34 \\
-25.24 \\
-25.14\end{array}$ \\
\hline $\begin{array}{l}190 \\
191 \\
192 \\
193 \\
194\end{array}$ & $\begin{array}{l}3226.7 \\
3241.6 \\
3256.4 \\
3271.2 \\
3286.0\end{array}$ & $\begin{array}{l}14.866 \\
14.837 \\
14.808 \\
14.778 \\
14.749\end{array}$ & $\begin{array}{l}-29.30 \\
-29.34 \\
-29 \cdot 38 \\
-29.41 \\
-29.44\end{array}$ & $\begin{array}{l}250 \\
251 \\
252 \\
253 \\
254\end{array}$ & $\begin{array}{l}4065 \cdot 3 \\
4078 \cdot 4 \\
4091 \cdot 5 \\
4104 \cdot 5 \\
4117 \cdot 4\end{array}$ & $\begin{array}{l}13.087 \\
13.058 \\
13.029 \\
12.999 \\
12.970\end{array}$ & $\begin{array}{l}-29 \cdot 27 \\
-29.23 \\
-29.19 \\
-29.15 \\
-29.11\end{array}$ & $\begin{array}{l}310 \\
311 \\
312 \\
313 \\
314\end{array}$ & $\begin{array}{l}4799 \cdot 8 \\
4811 \cdot 2 \\
4822 \cdot 6 \\
4834 \cdot 0 \\
4845 \cdot 4\end{array}$ & $\begin{array}{l}11.438 \\
11.413 \\
11.388 \\
11.363 \\
11.339\end{array}$ & $\begin{array}{l}-25.04 \\
-24.94 \\
-24.83 \\
-24.73 \\
-24.62\end{array}$ \\
\hline $\begin{array}{l}195 \\
196 \\
197 \\
198 \\
199\end{array}$ & $\begin{array}{l}3300.7 \\
3315.4 \\
3330.1 \\
3344.7 \\
3359.4\end{array}$ & $\begin{array}{l}14.720 \\
14.690 \\
14.661 \\
14.631 \\
14.601\end{array}$ & $\begin{array}{l}-29.47 \\
-29.51 \\
-29.53 \\
-29.56 \\
-29.59\end{array}$ & $\begin{array}{l}255 \\
256 \\
257 \\
258 \\
259\end{array}$ & $\begin{array}{l}4130 \cdot 4 \\
4143.3 \\
4156.2 \\
4169 \cdot 1 \\
4181.9\end{array}$ & $\begin{array}{l}12.941 \\
12.912 \\
12.883 \\
12.854 \\
12.825\end{array}$ & $\begin{array}{l}-29.07 \\
-29.02 \\
-28.98 \\
-28.93 \\
-28.89\end{array}$ & $\begin{array}{l}315 \\
316 \\
317 \\
318 \\
319\end{array}$ & $\begin{array}{l}4856 \cdot 7 \\
4868 \cdot 0 \\
4879 \cdot 3 \\
4890 \cdot 5 \\
4901.8\end{array}$ & $\begin{array}{l}11.314 \\
11.290 \\
11.265 \\
11.241 \\
11.217\end{array}$ & $\begin{array}{l}-24.51 \\
-24.41 \\
-24.30 \\
-24.19 \\
-24.07\end{array}$ \\
\hline $\begin{array}{l}200 \\
201 \\
202 \\
203 \\
204\end{array}$ & $\begin{array}{l}3373.9 \\
3388.5 \\
3403.0 \\
3417.5 \\
3432.0\end{array}$ & $\begin{array}{l}14 \cdot 572 \\
14.542 \\
14.513 \\
14.483 \\
14.453\end{array}$ & $\begin{array}{l}-29.61 \\
-29.64 \\
-29.66 \\
-29.68 \\
-29.70\end{array}$ & $\begin{array}{l}260 \\
261 \\
262 \\
263 \\
264\end{array}$ & $\begin{array}{l}4194 \cdot 7 \\
4207 \cdot 5 \\
4220 \cdot 3 \\
4233 \cdot 0 \\
4245.7\end{array}$ & $\begin{array}{l}12.796 \\
12.768 \\
12.739 \\
12.710 \\
12.681\end{array}$ & $\begin{array}{l}-28.84 \\
-28.79 \\
-28.74 \\
-28.69 \\
-28.64\end{array}$ & $\begin{array}{l}320 \\
321 \\
322 \\
323 \\
324\end{array}$ & $\begin{array}{l}4913 \cdot 0 \\
4924 \cdot 1 \\
4935 \cdot 3 \\
4946 \cdot 4 \\
4957 \cdot 5\end{array}$ & $\begin{array}{l}11.193 \\
11.169 \\
11.145 \\
11.122 \\
11.098\end{array}$ & $\begin{array}{l}-23.96 \\
-23.85 \\
-23.73 \\
-23.62 \\
-23.50\end{array}$ \\
\hline $\begin{array}{l}205 \\
206 \\
207 \\
208 \\
209\end{array}$ & $\begin{array}{l}3446.4 \\
3460.8 \\
3475.2 \\
3489.6 \\
3503.9\end{array}$ & $\begin{array}{l}14.423 \\
14.394 \\
14.364 \\
14.334 \\
14.304\end{array}$ & $\begin{array}{l}-29.72 \\
-29.74 \\
-29.75 \\
-29.77 \\
-29.78\end{array}$ & $\begin{array}{l}265 \\
266 \\
267 \\
268 \\
269\end{array}$ & $\begin{array}{l}4258 \cdot 4 \\
4271 \cdot 0 \\
4283 \cdot 6 \\
4296.2 \\
4308.8\end{array}$ & $\begin{array}{l}12.653 \\
12.624 \\
12.596 \\
12.567 \\
12.539\end{array}$ & $\begin{array}{l}-28.58 \\
-28.53 \\
-28.47 \\
-28.42 \\
-28.36\end{array}$ & $\begin{array}{l}325 \\
326 \\
327 \\
328 \\
329\end{array}$ & $\begin{array}{l}4968.6 \\
4979.7 \\
4990 \cdot 7 \\
5001.8 \\
5012.7\end{array}$ & $\begin{array}{l}11.075 \\
11.051 \\
11.028 \\
11.005 \\
10.982\end{array}$ & $\begin{array}{l}-23.38 \\
-23.27 \\
-23.15 \\
-23.03 \\
-22.90\end{array}$ \\
\hline $\begin{array}{l}210 \\
211 \\
212 \\
213 \\
214\end{array}$ & $\begin{array}{l}3518.2 \\
3532.4 \\
3546.7 \\
3560.9 \\
3575.0\end{array}$ & $\begin{array}{l}14.275 \\
14.245 \\
14.215 \\
14.185 \\
14.155\end{array}$ & $\begin{array}{l}-29.79 \\
-29.80 \\
-29.81 \\
-29.82 \\
-29.83\end{array}$ & $\begin{array}{l}270 \\
271 \\
272 \\
273 \\
274\end{array}$ & $\begin{array}{l}4321 \cdot 3 \\
4333 \cdot 8 \\
4346 \cdot 2 \\
4358 \cdot 7 \\
4371.1\end{array}$ & $\begin{array}{l}12.511 \\
12.482 \\
12.454 \\
12.426 \\
12.398\end{array}$ & $\begin{array}{l}-28 \cdot 30 \\
-28 \cdot 24 \\
-28 \cdot 18 \\
-28.11 \\
-28.05\end{array}$ & $\begin{array}{l}330 \\
331 \\
332 \\
333 \\
334\end{array}$ & $\begin{array}{l}5023.7 \\
5034.7 \\
5045.6 \\
5056.5 \\
5067.4\end{array}$ & $\begin{array}{l}10.959 \\
10.936 \\
10.914 \\
10.891 \\
10.869\end{array}$ & $\begin{array}{l}-22.78 \\
-22.66 \\
-22.53 \\
-22.41 \\
-22.28\end{array}$ \\
\hline $\begin{array}{l}215 \\
216 \\
217 \\
218 \\
219\end{array}$ & $\begin{array}{l}3589.2 \\
3603.3 \\
3617.4 \\
3631.4 \\
3645.4\end{array}$ & $\begin{array}{l}14.126 \\
14.096 \\
14.066 \\
14.036 \\
14.006\end{array}$ & $\begin{array}{l}-29.83 \\
-29.84 \\
-29.84 \\
-29.84 \\
-29.84\end{array}$ & $\begin{array}{l}275 \\
276 \\
277 \\
278 \\
279\end{array}$ & $\begin{array}{l}4383 \cdot 5 \\
4395 \cdot 8 \\
4408 \cdot 2 \\
4420.5 \\
4432.7\end{array}$ & $\begin{array}{l}12.370 \\
12.342 \\
12.314 \\
12.286 \\
12.258\end{array}$ & $\begin{array}{l}-27.99 \\
-27.92 \\
-27.85 \\
-27.79 \\
-27.72\end{array}$ & $\begin{array}{l}335 \\
336 \\
337 \\
338 \\
339\end{array}$ & $\begin{array}{l}5078.2 \\
5089.1 \\
5099.9 \\
5110.7 \\
5121.4\end{array}$ & $\begin{array}{l}10.847 \\
10.825 \\
10.803 \\
10.781 \\
10.759\end{array}$ & $\begin{array}{l}-22.15 \\
-22.03 \\
-21.90 \\
-21.77 \\
-21.63\end{array}$ \\
\hline $\begin{array}{l}220 \\
221 \\
222 \\
223 \\
224\end{array}$ & $\begin{array}{l}3659.4 \\
3673 \cdot 4 \\
3687 \cdot 3 \\
3701.2 \\
3715.1\end{array}$ & $\begin{array}{l}13.976 \\
13.947 \\
13.917 \\
13.887 \\
13.857\end{array}$ & $\begin{array}{l}-29.84 \\
-29.84 \\
-29.84 \\
-29.83 \\
-29.83\end{array}$ & $\begin{array}{l}280 \\
281 \\
282 \\
283 \\
284\end{array}$ & $\begin{array}{l}4445.0 \\
4457.2 \\
4469.4 \\
4481.5 \\
4493.7\end{array}$ & $\begin{array}{l}12.231 \\
12.203 \\
12.176 \\
12.148 \\
12.121\end{array}$ & $\begin{array}{l}-27.65 \\
-27.58 \\
-27.50 \\
-27.43 \\
-27.35\end{array}$ & $\begin{array}{l}340 \\
341 \\
342 \\
343 \\
344\end{array}$ & $\begin{array}{l}5132.2 \\
5142.9 \\
5153.6 \\
5164.3 \\
5175.0\end{array}$ & $\begin{array}{l}10.738 \\
10.716 \\
10.695 \\
10.674 \\
10.653\end{array}$ & $\begin{array}{l}-21.50 \\
-21.37 \\
-21.23 \\
-21.10 \\
-20.96\end{array}$ \\
\hline $\begin{array}{l}225 \\
226 \\
227 \\
228 \\
229\end{array}$ & $\begin{array}{l}3728.9 \\
3742.7 \\
3756.5 \\
3770.3 \\
3784.0\end{array}$ & $\begin{array}{l}13.827 \\
13.797 \\
13.768 \\
13.738 \\
13.708\end{array}$ & $\begin{array}{l}-29.82 \\
-29.81 \\
-29.81 \\
-29.80 \\
-29.78\end{array}$ & $\begin{array}{l}285 \\
286 \\
287 \\
288 \\
289\end{array}$ & $\begin{array}{l}4505.8 \\
4517.9 \\
4529.9 \\
4541.9 \\
4553.9\end{array}$ & $\begin{array}{l}12.093 \\
12.066 \\
12.039 \\
12.012 \\
11.985\end{array}$ & $\begin{array}{l}-27.28 \\
-27.20 \\
-27.12 \\
-27.05 \\
-26.97\end{array}$ & $\begin{array}{l}345 \\
346 \\
347 \\
348 \\
349\end{array}$ & $\begin{array}{l}5185.6 \\
5196.2 \\
5206.8 \\
5217.4 \\
5228.0\end{array}$ & $\begin{array}{l}10.632 \\
10.611 \\
10.591 \\
10.570 \\
10.550\end{array}$ & $\begin{array}{l}-20.83 \\
-20.69 \\
-20.55 \\
-20.41 \\
-20.27\end{array}$ \\
\hline $\begin{array}{l}230 \\
231 \\
232 \\
233 \\
234\end{array}$ & $\begin{array}{l}3797.7 \\
3811.4 \\
3825.0 \\
3838.6 \\
3852.2\end{array}$ & $\begin{array}{l}13.678 \\
13.648 \\
13.619 \\
13.589 \\
13.559\end{array}$ & $\begin{array}{l}-29.77 \\
-29.76 \\
-29.74 \\
-29.73 \\
-29.71\end{array}$ & $\begin{array}{l}290 \\
291 \\
292 \\
293 \\
294\end{array}$ & $\begin{array}{l}4565.9 \\
4577.9 \\
4589.8 \\
4601.7 \\
4613.5\end{array}$ & $\begin{array}{l}11.958 \\
11.931 \\
11.904 \\
11.878 \\
11.851\end{array}$ & $\begin{array}{l}-26.88 \\
-26.80 \\
-26.72 \\
-26.63 \\
-26.55\end{array}$ & $\begin{array}{l}350 \\
351 \\
352 \\
353 \\
354\end{array}$ & $\begin{array}{l}5238 \cdot 5 \\
5249 \cdot 0 \\
5259 \cdot 5 \\
5270 \cdot 0 \\
5280.5\end{array}$ & $\begin{array}{l}10.530 \\
10.509 \\
10.490 \\
10.470 \\
10.450\end{array}$ & $\begin{array}{l}-20.13 \\
-19.98 \\
-19.84 \\
-19.69 \\
-19.55\end{array}$ \\
\hline $\begin{array}{l}235 \\
236 \\
237 \\
238 \\
239\end{array}$ & $\begin{array}{l}3865.7 \\
3879.2 \\
3892.7 \\
3906.2 \\
3919.6\end{array}$ & $\begin{array}{l}13.530 \\
13.500 \\
13.470 \\
13.441 \\
13.411\end{array}$ & $\begin{array}{l}-29.69 \\
-29.67 \\
-29.65 \\
-29.63 \\
-29.60\end{array}$ & $\begin{array}{l}295 \\
296 \\
297 \\
298 \\
299\end{array}$ & $\begin{array}{l}4625.4 \\
4637.2 \\
4649.0 \\
4660.7 \\
4672.5\end{array}$ & $\begin{array}{l}11.825 \\
11.798 \\
11.772 \\
11.746 \\
11.720\end{array}$ & $\begin{array}{l}-26 \cdot 46 \\
-26.38 \\
-26 \cdot 29 \\
-26 \cdot 20 \\
-26.11\end{array}$ & $\begin{array}{l}355 \\
356 \\
357 \\
358 \\
359\end{array}$ & $\begin{array}{l}5290.9 \\
5301.3 \\
5311.7 \\
5322.1 \\
5332.5\end{array}$ & $\begin{array}{l}10.431 \\
10.411 \\
10.392 \\
10.373 \\
10.354\end{array}$ & $\begin{array}{l}-19.40 \\
-19.25 \\
-19.11 \\
-18.96 \\
-18.81\end{array}$ \\
\hline 240 & 3933.0 & 13.381 & -29.58 & 300 & 4684.2 & 11.693 & -26.02 & 360 & 5342.8 & 10.336 & -18.65 \\
\hline
\end{tabular}


TABle 6.4.2. Type JP thermoelements versus platinum, Pt-67-thermoelectric voltages, E! T), Seebeck coefficients, $\mathrm{S}(\mathrm{T})$. and first derivative of the Seebeck coefficients, $\mathrm{dS} / \mathrm{dT}$,

reference junctions at $\mathrm{O}^{\circ} \mathrm{C}$-Continued

\begin{tabular}{|c|c|c|c|c|c|c|c|c|c|c|c|}
\hline $\begin{array}{l}\mathrm{T} \\
{ }^{\circ} \mathrm{C}\end{array}$ & $\begin{array}{l}E \\
\mu V\end{array}$ & $\underset{\mu V /{ }^{\circ} \mathrm{C}}{S}$ & $\begin{array}{l}d S / d T \\
n V /{ }^{\circ} C^{2}\end{array}$ & ${ }^{\circ} \mathrm{C}$ & $\begin{array}{c}E \\
\mu V\end{array}$ & $\underset{\mu \mathrm{V} /{ }^{\circ} \mathrm{C}}{\mathrm{S}}$ & $\begin{array}{l}d S / d T \\
n V /{ }^{\circ} C^{2}\end{array}$ & $\begin{array}{r}{ }^{\top} \\
{ }^{\circ} \mathrm{C}\end{array}$ & $\underset{\mu V}{E}$ & $\begin{array}{c}\mathrm{S} \\
\mu \mathrm{V} /{ }^{\circ} \mathrm{C}\end{array}$ & $\begin{array}{l}d S / d T \\
n V /{ }^{\circ} C^{2}\end{array}$ \\
\hline $\begin{array}{l}365 \\
366 \\
367 \\
368 \\
369\end{array}$ & $\begin{array}{l}5394.3 \\
5404.5 \\
5414.7 \\
5424.9 \\
5435.1\end{array}$ & $\begin{array}{l}10.244 \\
10.226 \\
10.209 \\
10.191 \\
10.174\end{array}$ & $\begin{array}{l}-17.88 \\
-17.73 \\
-17.57 \\
-17.41 \\
-17.25\end{array}$ & $\begin{array}{l}425 \\
426 \\
427 \\
428 \\
429\end{array}$ & $\begin{array}{l}5982.8 \\
5992.3 \\
6001.8 \\
6011.2 \\
6020.7\end{array}$ & $\begin{array}{l}9.483 \\
9.476 \\
9.469 \\
9.463 \\
9.457\end{array}$ & $\begin{array}{l}-7.01 \\
-6.81 \\
-6.60 \\
-6.40 \\
-6.19\end{array}$ & $\begin{array}{l}485 \\
486 \\
487 \\
488 \\
489\end{array}$ & $\begin{array}{l}6546.8 \\
6556.3 \\
6565.7 \\
6575.2 \\
6584.7\end{array}$ & $\begin{array}{l}9.449 \\
9.456 \\
9.462 \\
9.469 \\
9.476\end{array}$ & $\begin{array}{l}6.17 \\
6.40 \\
6.64 \\
6.87 \\
7.10\end{array}$ \\
\hline $\begin{array}{l}370 \\
371 \\
372 \\
373 \\
374\end{array}$ & $\begin{array}{l}5445.3 \\
5455.4 \\
5465.6 \\
5475.7 \\
5485.8\end{array}$ & $\begin{array}{l}10.157 \\
10.140 \\
10.123 \\
10.106 \\
10.090\end{array}$ & $\begin{array}{l}-17.09 \\
-16.93 \\
-16.77 \\
-16.61 \\
-16.44\end{array}$ & $\begin{array}{l}430 \\
431 \\
432 \\
433 \\
434\end{array}$ & $\begin{array}{l}6030.2 \\
6039.6 \\
6049.0 \\
6058.5 \\
6067.9\end{array}$ & $\begin{array}{l}9.450 \\
9.445 \\
9.439 \\
9.433 \\
9.428\end{array}$ & $\begin{array}{l}-5.99 \\
-5.78 \\
-5.57 \\
-5.36 \\
-5.15\end{array}$ & $\begin{array}{l}490 \\
491 \\
492 \\
493 \\
494\end{array}$ & $\begin{array}{l}6594 \cdot 2 \\
6603 \cdot 6 \\
6613 \cdot 1 \\
6622 \cdot 6 \\
6632 \cdot 2\end{array}$ & $\begin{array}{l}9.483 \\
9.491 \\
9.498 \\
9.506 \\
9.514\end{array}$ & $\begin{array}{l}7.33 \\
7.57 \\
7.80 \\
8.03 \\
8.26\end{array}$ \\
\hline $\begin{array}{l}380 \\
381 \\
382 \\
383 \\
384\end{array}$ & $\begin{array}{l}5546.0 \\
5556.0 \\
5566.0 \\
5575.9 \\
5585.9\end{array}$ & $\begin{array}{l}9.994 \\
9.979 \\
9.963 \\
9.948 \\
9.934\end{array}$ & $\begin{array}{l}-15.44 \\
-15.27 \\
-15.10 \\
-14.93 \\
-14.76\end{array}$ & $\begin{array}{l}440 \\
441 \\
442 \\
443 \\
444\end{array}$ & $\begin{array}{l}6124.4 \\
6133.8 \\
6143.2 \\
6152.6 \\
6162.0\end{array}$ & $\begin{array}{l}9.401 \\
9.397 \\
9.394 \\
9.390 \\
9.387\end{array}$ & $\begin{array}{l}-3.89 \\
-3.67 \\
-3.46 \\
-3.24 \\
-3.03\end{array}$ & $\begin{array}{l}500 \\
501 \\
502 \\
503 \\
504\end{array}$ & $\begin{array}{l}6689.4 \\
6699 \cdot 0 \\
6708 \cdot 6 \\
6718 \cdot 1 \\
6727.8\end{array}$ & $\begin{array}{l}9.568 \\
9.578 \\
9.588 \\
9.598 \\
9.609\end{array}$ & $\begin{array}{r}9.67 \\
9.90 \\
10.13 \\
10.37 \\
10.60\end{array}$ \\
\hline $\begin{array}{l}385 \\
386 \\
387 \\
388 \\
389\end{array}$ & $\begin{array}{l}5595.8 \\
5605.7 \\
5615.6 \\
5625.5 \\
5635.4\end{array}$ & $\begin{array}{l}9.919 \\
9.904 \\
9.890 \\
9.876 \\
9.862\end{array}$ & $\begin{array}{l}-14.58 \\
-14.41 \\
-14.23 \\
-14.06 \\
-13.88\end{array}$ & $\begin{array}{l}445 \\
446 \\
447 \\
448 \\
449\end{array}$ & $\begin{array}{l}6171.4 \\
6180.7 \\
6190.1 \\
6199.5 \\
6208.9\end{array}$ & $\begin{array}{r}9.384 \\
9.382 \\
9.379 \\
9.377 \\
9.375\end{array}$ & $\begin{array}{l}-2.81 \\
-2.60 \\
-2.38 \\
-2.16 \\
-1.95\end{array}$ & $\begin{array}{l}505 \\
506 \\
507 \\
508 \\
509\end{array}$ & $\begin{array}{l}6737.4 \\
6747.0 \\
6756.6 \\
6766.3 \\
6775.9\end{array}$ & $\begin{array}{l}9.619 \\
9.630 \\
9.642 \\
9.653 \\
9.665\end{array}$ & $\begin{array}{l}10.84 \\
11.07 \\
11.30 \\
11.54 \\
11.77\end{array}$ \\
\hline $\begin{array}{l}390 \\
391 \\
392 \\
393 \\
394\end{array}$ & $\begin{array}{l}5645 \cdot 2 \\
5655.1 \\
5664 \cdot 9 \\
5674.7 \\
5684.5\end{array}$ & $\begin{array}{l}9.848 \\
9.835 \\
9.821 \\
9.808 \\
9.795\end{array}$ & $\begin{array}{l}-13.70 \\
-13.53 \\
-13.35 \\
-13.17 \\
-12.99\end{array}$ & $\begin{array}{l}450 \\
451 \\
452 \\
453 \\
454\end{array}$ & $\begin{array}{l}6218.2 \\
6227.6 \\
6237.0 \\
6246.4 \\
6255.7\end{array}$ & $\begin{array}{l}9.373 \\
9.371 \\
9.370 \\
9.369 \\
9.368\end{array}$ & $\begin{array}{l}-1.73 \\
-1.51 \\
-1.29 \\
-1.07 \\
-0.85\end{array}$ & $\begin{array}{l}510 \\
511 \\
512 \\
513 \\
514\end{array}$ & $\begin{array}{l}6785.6 \\
6795 \cdot 3 \\
6805.0 \\
6814.7 \\
6824.4\end{array}$ & $\begin{array}{l}9.676 \\
9.689 \\
9.701 \\
9.714 \\
9.726\end{array}$ & $\begin{array}{l}12.01 \\
12.24 \\
12.47 \\
12.71 \\
12.94\end{array}$ \\
\hline $\begin{array}{l}400 \\
401 \\
402 \\
403 \\
404\end{array}$ & $\begin{array}{l}5743.0 \\
5752.8 \\
5762.5 \\
5772.1 \\
5781.8\end{array}$ & $\begin{array}{l}9.720 \\
9.708 \\
9.697 \\
9.685 \\
9.674\end{array}$ & $\begin{array}{l}-11.89 \\
-11.70 \\
-11.51 \\
-11.33 \\
-11.14\end{array}$ & $\begin{array}{l}460 \\
461 \\
462 \\
463 \\
464\end{array}$ & $\begin{array}{l}6311.9 \\
6321.3 \\
6330.7 \\
6340.0 \\
6349.4\end{array}$ & $\begin{array}{l}9.367 \\
9.367 \\
9.368 \\
9.369 \\
9.370\end{array}$ & $\begin{array}{l}0.48 \\
0.70 \\
0.93 \\
1.15 \\
1.38\end{array}$ & $\begin{array}{l}520 \\
521 \\
522 \\
523 \\
524\end{array}$ & $\begin{array}{l}6883.0 \\
6892.8 \\
6902.7 \\
6912.5 \\
6922.4\end{array}$ & $\begin{array}{l}9.808 \\
9.823 \\
9.837 \\
9.852 \\
9.868\end{array}$ & $\begin{array}{l}14.35 \\
14.58 \\
14.81 \\
15.04 \\
15.28\end{array}$ \\
\hline $\begin{array}{l}405 \\
406 \\
407 \\
408 \\
409\end{array}$ & $\begin{array}{l}5791.5 \\
5801.2 \\
5810.8 \\
5820.4 \\
5830.1\end{array}$ & $\begin{array}{l}9.663 \\
9.652 \\
9.642 \\
9.631 \\
9.621\end{array}$ & $\begin{array}{l}-10.95 \\
-10.76 \\
-10.57 \\
-10.38 \\
-10.18\end{array}$ & $\begin{array}{l}465 \\
466 \\
467 \\
468 \\
469\end{array}$ & $\begin{array}{l}6358.8 \\
6368.1 \\
6377.5 \\
6386.9 \\
6396.3\end{array}$ & $\begin{array}{l}9.372 \\
9.374 \\
9.376 \\
9.378 \\
9.380\end{array}$ & $\begin{array}{l}1.60 \\
1.83 \\
2.05 \\
2.28 \\
2.50\end{array}$ & $\begin{array}{l}525 \\
526 \\
527 \\
528 \\
529\end{array}$ & $\begin{array}{l}6932.2 \\
6942.1 \\
6952.0 \\
6962.0 \\
6971.9\end{array}$ & $\begin{array}{l}9.883 \\
9.899 \\
9.914 \\
9.930 \\
9.947\end{array}$ & $\begin{array}{l}15.51 \\
15.74 \\
15.97 \\
16.21 \\
16.44\end{array}$ \\
\hline $\begin{array}{l}410 \\
411 \\
412 \\
413 \\
414\end{array}$ & $\begin{array}{l}5839.7 \\
5849.3 \\
5858.9 \\
5868.5 \\
5878.0\end{array}$ & $\begin{array}{l}9.611 \\
9.601 \\
9.591 \\
9.582 \\
9.572\end{array}$ & $\begin{array}{l}-9.99 \\
-9.80 \\
-9.60 \\
-9.41 \\
-9.21\end{array}$ & $\begin{array}{l}470 \\
471 \\
472 \\
473 \\
474\end{array}$ & $\begin{array}{l}6405 \cdot 7 \\
64,15 \cdot 0 \\
6424 \cdot 4 \\
6433 \cdot 8 \\
6443.2\end{array}$ & $\begin{array}{l}9.383 \\
9.386 \\
9.389 \\
9.392 \\
9.395\end{array}$ & $\begin{array}{l}2.73 \\
2.96 \\
3.19 \\
3.41 \\
3.64\end{array}$ & $\begin{array}{l}530 \\
531 \\
532 \\
533 \\
534\end{array}$ & $\begin{array}{l}6981.8 \\
6991.8 \\
7001.8 \\
7011.8 \\
7021.8\end{array}$ & $\begin{array}{r}9.963 \\
9.980 \\
9.997 \\
10.014 \\
10.032\end{array}$ & $\begin{array}{l}16.67 \\
16.90 \\
17.13 \\
17.36 \\
17.59\end{array}$ \\
\hline $\begin{array}{l}415 \\
416 \\
417 \\
418 \\
419\end{array}$ & $\begin{array}{l}5887.6 \\
5897.2 \\
5906.7 \\
5916.3 \\
5925.8\end{array}$ & $\begin{array}{l}9.563 \\
9.554 \\
9.546 \\
9.537 \\
9.529\end{array}$ & $\begin{array}{l}-9.02 \\
-9.82 \\
-8.62 \\
-3.42 \\
-8.22\end{array}$ & $\begin{array}{l}475 \\
476 \\
477 \\
478 \\
479\end{array}$ & $\begin{array}{l}6452.6 \\
6462.0 \\
6471.4 \\
6480.8 \\
6490.2\end{array}$ & $\begin{array}{r}9.399 \\
9.403 \\
9.407 \\
9.412 \\
9.417\end{array}$ & $\begin{array}{l}3.87 \\
4.10 \\
4.33 \\
4.56 \\
4.79\end{array}$ & $\begin{array}{l}535 \\
536 \\
537 \\
538 \\
539\end{array}$ & $\begin{array}{l}7031.9 \\
7041.9 \\
7052.0 \\
7062.1 \\
7072.2\end{array}$ & $\begin{array}{l}10.050 \\
10.068 \\
10.086 \\
10.104 \\
10.123\end{array}$ & $\begin{array}{l}17.82 \\
18.05 \\
18.28 \\
18.51 \\
18.74\end{array}$ \\
\hline 420 & 5935.3 & 9.521 & -8.02 & 480 & 6499.7 & 9.421 & 5.02 & 540 & 7082.4 & $10 \cdot 142$ & 18.97 \\
\hline
\end{tabular}


TABLE 6.4.2. Type JP thermoelements versus p!atinum, Pt-67-thermoelectric voltages, $\mathrm{E}(\mathrm{T})$, Seebech coefficients, $\mathrm{S}(\mathrm{T})$, and first derivative of the Seebeck coefficients, $\mathrm{dS} / \mathrm{dT}$,

reference junctions at $\mathrm{O}^{\circ} \mathrm{C}$-Continued

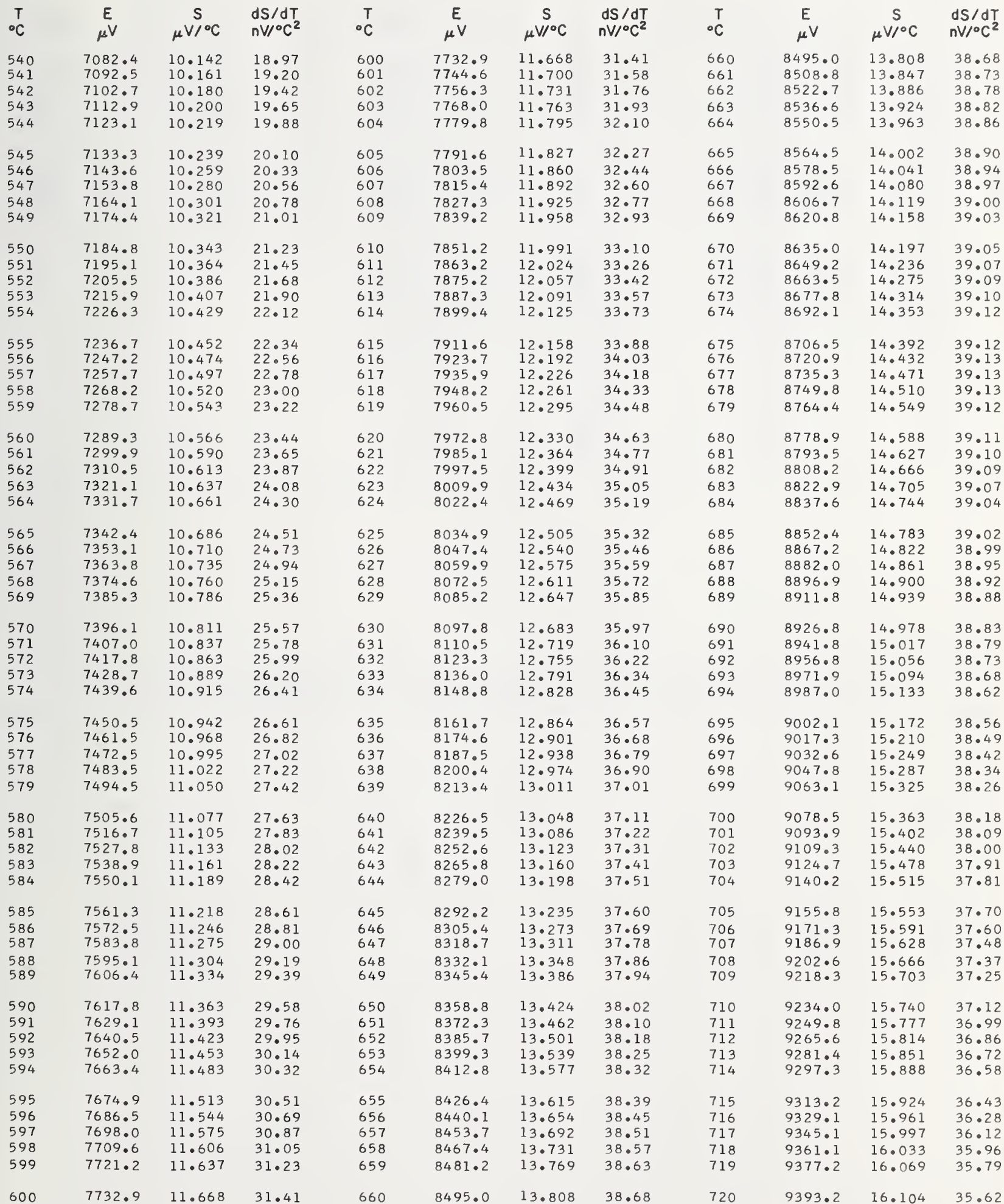


TABle 6.4.2. Type JP thermoelements versus platinum, $\mathrm{Pt}-67$-thermoelectric voltages, $\mathrm{E}(\mathrm{T})$, Seebeck coefficients, S(T), and first derivative of the Seebeck coefficients, $\mathrm{dS} / \mathrm{dT}$, reference junctions at $0{ }^{\circ} \mathrm{C}$-Continued

\begin{tabular}{|c|c|c|c|c|c|c|c|c|c|c|c|}
\hline${ }^{\circ} \mathrm{T}$ & $\underset{\mu V}{E}$ & $\underset{\mu V /{ }^{\circ} \mathrm{C}}{\mathrm{S}}$ & $\begin{array}{l}d S / d T \\
n V /{ }^{\circ} C^{2}\end{array}$ & ${ }^{\top} \mathrm{T}$ & $\underset{\mu V}{E}$ & $\underset{\mu V /{ }^{\circ} \mathrm{C}}{S}$ & $\begin{array}{l}d S / d T \\
n V /{ }^{\circ} C^{2}\end{array}$ & $\begin{array}{r}\mathrm{T} \\
{ }^{\circ} \mathrm{C}\end{array}$ & $\underset{\mu V}{E}$ & $\underset{\mu V /{ }^{\circ} \mathrm{C}}{\mathrm{S}}$ & $\begin{array}{l}d S / d T \\
n V /{ }^{\circ} C^{2}\end{array}$ \\
\hline $\begin{array}{l}720 \\
721 \\
722 \\
723 \\
724\end{array}$ & $\begin{array}{l}9393.2 \\
9409.4 \\
9425.5 \\
9441.7 \\
9457.9\end{array}$ & $\begin{array}{l}16.104 \\
16.140 \\
16.175 \\
16.211 \\
16.245\end{array}$ & $\begin{array}{l}35.62 \\
35.45 \\
35.27 \\
35.08 \\
34.89\end{array}$ & $\begin{array}{l}735 \\
736 \\
737 \\
738 \\
739\end{array}$ & $\begin{array}{l}9638.7 \\
9655.3 \\
9672.0 \\
9688.7 \\
9705.4\end{array}$ & $\begin{array}{l}16.617 \\
16.649 \\
16.681 \\
16.713 \\
16.744\end{array}$ & $\begin{array}{l}32.47 \\
32.22 \\
31.96 \\
31.70 \\
31.43\end{array}$ & $\begin{array}{l}750 \\
751 \\
752 \\
753 \\
754\end{array}$ & $\begin{array}{l}9891 \cdot 5 \\
9908 \cdot 5 \\
9925 \cdot 7 \\
9942.8 \\
9960.0\end{array}$ & $\begin{array}{l}17.073 \\
17.101 \\
17.128 \\
17.155 \\
17.182\end{array}$ & $\begin{array}{l}28 \cdot 12 \\
27.78 \\
27.44 \\
27.09 \\
26.74\end{array}$ \\
\hline $\begin{array}{l}725 \\
726 \\
727 \\
728 \\
729\end{array}$ & $\begin{array}{l}9474.2 \\
9490.5 \\
9506.8 \\
9523.2 \\
9539.6\end{array}$ & $\begin{array}{l}16 \cdot 280 \\
16 \cdot 315 \\
16 \cdot 349 \\
16.383 \\
16.417\end{array}$ & $\begin{array}{l}34.70 \\
34.50 \\
34.29 \\
34.08 \\
33.87\end{array}$ & $\begin{array}{l}740 \\
741 \\
742 \\
743 \\
744\end{array}$ & $\begin{array}{l}9722.2 \\
9739.0 \\
9755.8 \\
9772.7 \\
9789.5\end{array}$ & $\begin{array}{l}16.776 \\
16.807 \\
16.837 \\
16.868 \\
16.898\end{array}$ & $\begin{array}{l}31.16 \\
30.88 \\
30.60 \\
30.31 \\
30.01\end{array}$ & $\begin{array}{l}755 \\
756 \\
757 \\
758 \\
759\end{array}$ & $\begin{array}{r}9977.2 \\
9994.4 \\
10011.6 \\
10028.9 \\
10046.2\end{array}$ & $\begin{array}{l}17.209 \\
17.235 \\
17.261 \\
17.286 \\
17.311\end{array}$ & $\begin{array}{l}26.38 \\
26.01 \\
25.64 \\
25.26 \\
24.88\end{array}$ \\
\hline $\begin{array}{l}730 \\
731 \\
732 \\
733 \\
734\end{array}$ & $\begin{array}{l}9556.0 \\
9572.5 \\
9589.0 \\
9605.5 \\
9622.1\end{array}$ & $\begin{array}{l}16.451 \\
16.485 \\
16.518 \\
16.551 \\
16.584\end{array}$ & $\begin{array}{l}33.65 \\
33.42 \\
33.19 \\
32.96 \\
32.72\end{array}$ & $\begin{array}{l}745 \\
746 \\
747 \\
748 \\
749\end{array}$ & $\begin{array}{l}9806.4 \\
9823.4 \\
9840.4 \\
9857.4 \\
9874.4\end{array}$ & $\begin{array}{l}16.928 \\
16.958 \\
16.987 \\
17.016 \\
17.044\end{array}$ & $\begin{array}{l}29.71 \\
29.40 \\
29.09 \\
28.77 \\
28.45\end{array}$ & 760 & 10063.5 & $17 \cdot 336$ & 24.48 \\
\hline
\end{tabular}


TABLE 6.4.3. Thermoelectric values at the fixed points for Type JP thermoelements versus platinum, $\mathrm{Pt}-67$

\begin{tabular}{l|r|r|r|r}
\hline \hline \multicolumn{1}{c|}{ Fixed point } & $\begin{array}{c}\text { Temp. } \\
{ }^{\circ} \mathrm{C}\end{array}$ & $\begin{array}{c}E \\
\mu \mathrm{V}\end{array}$ & $\begin{array}{c}S \\
\mu \mathrm{V} /{ }^{\circ} \mathrm{C}\end{array}$ & $\begin{array}{c}d S / d T \\
\mathrm{nV} /{ }^{\circ} \mathrm{C}^{2}\end{array}$ \\
\hline Nitrogen TP & -210.002 & -2560.3 & -0.303 & 207.88 \\
Nitrogen NBP & -195.802 & -2544.4 & 2.482 & 184.73 \\
Oxygen NBP & -182.962 & -2497.9 & 4.728 & 165.41 \\
Carbon Dioxide SP & -78.476 & -1336.9 & 15.573 & 54.36 \\
Mercury FP & -38.862 & -684.5 & 17.192 & 28.54 \\
Ice point & 0.000 & 0.0 & 17.910 & 9.33 \\
Ether TP & 26.870 & 483.3 & 18.017 & -1.04 \\
Water BP & 100.000 & 1778.5 & 17.176 & -19.91 \\
Benzoic TP & 122.370 & 2157.5 & 16.690 & -23.47 \\
Indium FP & 156.634 & 2714.7 & 15.815 & -27.28 \\
Tin FP & 231.9681 & 3824.6 & 13.620 & -29.74 \\
Bismuth FP & 271.442 & 4339.3 & 12.470 & -28.21 \\
Cadmium FP & 321.108 & 4925.4 & 11.167 & -23.84 \\
Lead FP & 327.502 & 4996.3 & 11.017 & -23.09 \\
Mercury BP & 356.660 & 5308.2 & 10.399 & -19.16 \\
Zinc FP & 419.580 & 5931.3 & 9.524 & -8.11 \\
Sulphur BP & 444.674 & 6168.3 & 9.385 & -2.88 \\
Cu-Al FP & 548.23 & 7166.5 & 10.305 & 20.83 \\
Antimony FP & 630.74 & 8107.2 & 12.709 & 36.06 \\
Aluminum FP & 660.37 & 8500.1 & 13.822 & 38.70 \\
\hline
\end{tabular}

TABLE 6.4.4. Estimated maximum errors that occur when using reduced-bit arithmetic for the power series expansion for the thermoelectric voltage of Type JP thermoelements versus platinum, $\mathrm{Pt}-67$

\begin{tabular}{|c|c|c|c|c|c|c|}
\hline \multirow[b]{2}{*}{ Temperature range } & \multirow[b]{2}{*}{ Degree } & \multicolumn{5}{|c|}{ Estimated maximum error in microvolts } \\
\hline & & $12 \mathrm{Bit}$ & $16 \mathrm{Bit}$ & 24. Bit & 27 Bit & $36 \mathrm{Bit}$ \\
\hline $\begin{array}{rr}-210 \text { to } & -100^{\circ} \mathrm{C} \\
-100 \text { to } & 0^{\circ} \mathrm{C} \\
0 \text { to } & 200{ }^{\circ} \mathrm{C} \\
200 \text { to } & 4.00{ }^{\circ} \mathrm{C} \\
400 \text { to } & 600{ }^{\circ} \mathrm{C} \\
600 \text { to } & 760^{\circ} \mathrm{C}\end{array}$ & $\begin{array}{l}7 \\
7 \\
7 \\
7\end{array}$ & $\begin{array}{l}2 \\
0.8 \\
1 \\
2 \\
20 \\
6\end{array}$ & $\begin{array}{l}<0.1 \\
<0.1 \\
<0.1 \\
<0.1 \\
\quad 1 \\
\quad 4\end{array}$ & $\begin{array}{l}<0.1 \\
<0.1 \\
<0.1 \\
<0.1 \\
<0.1 \\
<01\end{array}$ & $\begin{array}{l}<0.1 \\
<0.1 \\
<0.1 \\
<0.1 \\
<0.1 \\
<0.1\end{array}$ & $\begin{array}{l}<0.1 \\
<0.1 \\
<0.1 \\
<0 . \\
<0.1 \\
<0.1\end{array}$ \\
\hline
\end{tabular}


6.5. Reference Functions and Tables for Platinum, $\mathrm{Pt}-67$, Versus the Negative Thermoelement, Type JN, a Copper-Nickel Alloy

The coefficients for the seventh degree expansion for the thermoelectric voltage of $\mathrm{Pt}-67$ versus Type JN thermoelements below $760{ }^{\circ} \mathrm{C}$ are given in table 6.5.1. The errors caused by using reduced bit arithmetic for calculating values of the functions are given in table 6.5.4.

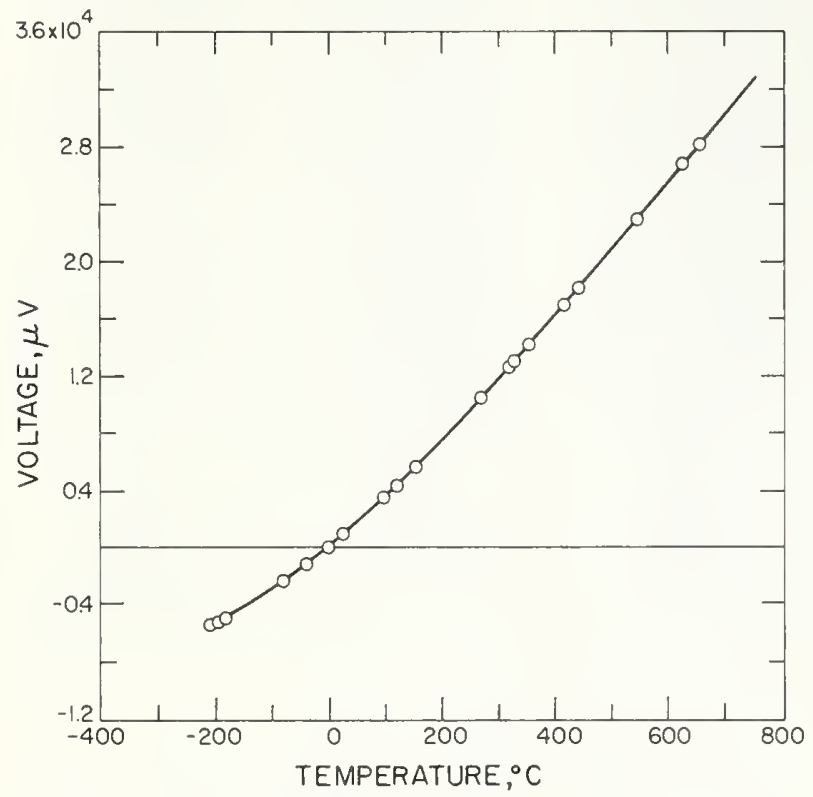

Figure 6.5.1. Thermoelectric voltage for platinum, $P t-67$, versus Type JN thermoelements.

The circles indicate values at various thermometric fixed points on the IPTS -68 .

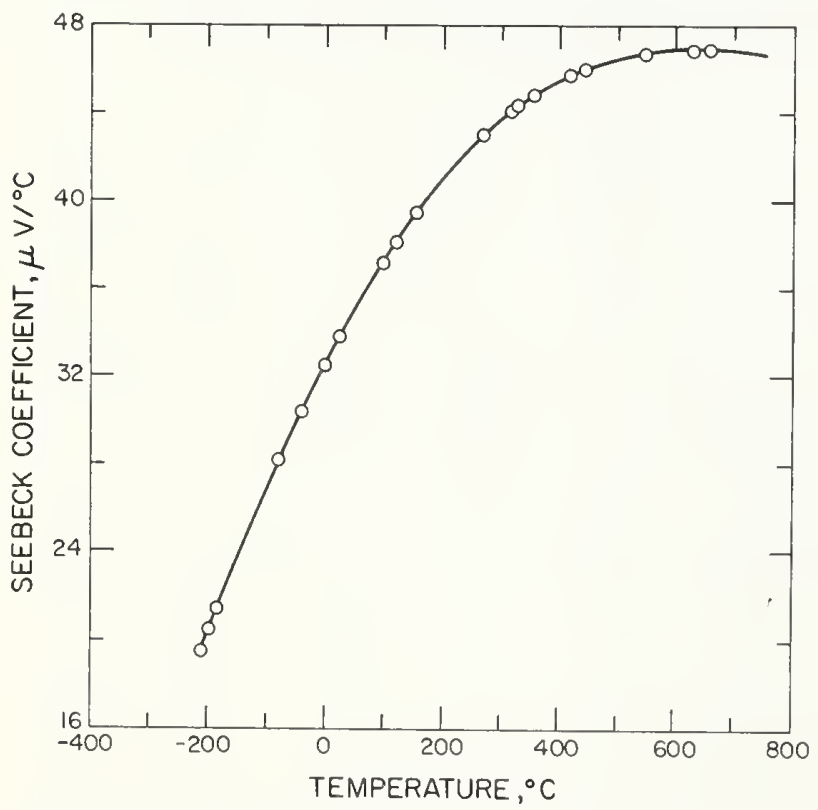

Figure 6.5.2. Seebeck coefficient for platinum, $P t-67$, versus Type JN thermoelements.

The circles indicate values at various thermometric fixed points on the IPTS-68.
The primary reference values for $\mathrm{Pt}-67$ versus Type $\mathrm{JN}$ thermoelements are given in table 6.5.2. Values at selected fixed points are given in table 6.5.3. Graphs of the thermoelectric voltage, its first derivative (Seebeck coefficient), and second derivative are given in figures $6.5 .1,6.5 .2$, and 6.5 .3 , respectively.

Because of the lack of stability of Type J thermocouples above $760{ }^{\circ} \mathrm{C}$, no reference functions are given for Type $\mathrm{JN}$ above $760{ }^{\circ} \mathrm{C}$.

The tables in this section merely give average values for industrial materials which have a wide variability. The tables in this section do NOT contain standardized values. Neither the ASTM nor the ISA recognize Type JP or JN thermoelements as standardized materials.

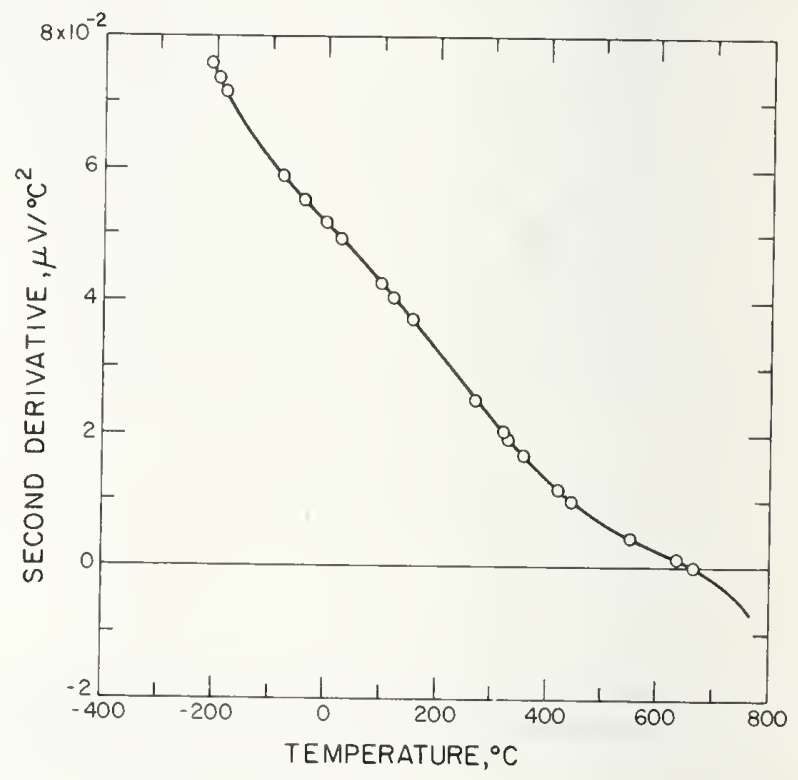

Figure 6.5.3. Second derivative of thermoelectric voltage for platinum, $P t-67$, versus Type JN thermoelements.

The circles indicate values at various thermometric fixed points on the IPTS -68 .

TABLE 6.5.1. Power series expansion for the thermoelectric voltage of platinum, $\mathrm{Pt}-67$, versus Type JN thermoelements

\begin{tabular}{c|c|c|c}
\hline \hline $\begin{array}{c}\text { Tempera- } \\
\text { ture } \\
\text { range }\end{array}$ & Degree & Coefficients & \\
\hline & & & Term \\
\hline 210 to & 7 & $3.2462432823 \times 10^{1}$ & $T$ \\
$760^{\circ} \mathrm{C}$ & & $2.5760715174 \times 10^{-2}$ & $T^{2}$ \\
& & $-1.4497289855 \times 10^{-6}$ & $T^{3}$ \\
& & $-2.3391503000 \times 10^{-10}$ & $T^{4}$ \\
& & $-1.9766432760 \times 10^{-11}$ & $T^{6}$ \\
& & $4.0770759899 \times 10^{-14}$ & $T^{6}$ \\
& & $-2.1133897427 \times 10^{-17}$ & $T^{7}$ \\
\hline
\end{tabular}


TABlE 6.5.2. Platinum, Pt-67, versus Type IN thermoelements-thermoelectric voltages, E(T), Seebeck coefficients, $\mathrm{S}(\mathrm{T})$, and first derivative of the Seebeck coefficients, $\mathrm{dS} / \mathrm{dT}$, reference junctions at $0^{\circ} \mathrm{C}$

\begin{tabular}{|c|c|c|c|c|c|c|c|c|c|c|c|}
\hline${ }^{\circ} \mathrm{C}$ & $\underset{\mu V}{E}$ & $\stackrel{S}{S} /^{\circ} \mathrm{C}$ & $\begin{array}{l}d S / d T \\
n V /{ }^{\circ} C^{2}\end{array}$ & ${ }^{\circ} \mathrm{C}$ & $\underset{\mu V}{E}$ & $\underset{\mu V /{ }^{\circ} \mathrm{C}}{S}$ & $\begin{array}{l}\mathrm{dS} / \mathrm{dT} \\
\mathrm{nV} /{ }^{\circ} \mathrm{C}^{2}\end{array}$ & ${ }^{\circ} \mathrm{C}$ & $\underset{\mu V}{E}$ & $\stackrel{S}{S}$ & $\begin{array}{l}\mathrm{dS} / \mathrm{dT} \\
\mathrm{nV} /{ }^{\circ} \mathrm{C}^{2}\end{array}$ \\
\hline $\begin{array}{l}-210 \\
-209 \\
-208 \\
-207 \\
-206\end{array}$ & $\begin{array}{l}-5535.3 \\
-5515.8 \\
-5496.3 \\
-5476.7 \\
-5457.0\end{array}$ & $\begin{array}{l}19.429 \\
19.505 \\
19.581 \\
19.656 \\
19.732\end{array}$ & $\begin{array}{l}76.07 \\
75.88 \\
75.69 \\
75.50 \\
75.31\end{array}$ & $\begin{array}{l}-200 \\
-199 \\
-198 \\
-197 \\
-196\end{array}$ & $\begin{array}{l}-5337.2 \\
-5317.0 \\
-5296.7 \\
-5276.4 \\
-5255.9\end{array}$ & $\begin{array}{l}20.180 \\
20.254 \\
20.328 \\
20.402 \\
20.475\end{array}$ & $\begin{array}{l}74.21 \\
74.03 \\
73.85 \\
73.68 \\
73.50\end{array}$ & $\begin{array}{l}-190 \\
-189 \\
-188 \\
-187 \\
-186\end{array}$ & $\begin{array}{l}-5131.8 \\
-5110.8 \\
-5089.8 \\
-5068.7 \\
-5047.5\end{array}$ & $\begin{array}{l}20.913 \\
20.986 \\
21.058 \\
21.130 \\
21.202\end{array}$ & $\begin{array}{l}72.47 \\
72.30 \\
72.14 \\
71.97 \\
71.81\end{array}$ \\
\hline $\begin{array}{l}-205 \\
-204 \\
-203 \\
-202 \\
-201\end{array}$ & $\begin{array}{l}-5437.2 \\
-5417.4 \\
-5397.5 \\
-5377.5 \\
-5357.4\end{array}$ & $\begin{array}{l}19.807 \\
19.882 \\
19.957 \\
20.031 \\
20.106\end{array}$ & $\begin{array}{l}75.12 \\
74.94 \\
74.75 \\
74.57 \\
74.39\end{array}$ & $\begin{array}{l}-195 \\
-194 \\
-193 \\
-192 \\
-191\end{array}$ & $\begin{array}{l}-5235.4 \\
-5214.8 \\
-5194.2 \\
-5173.4 \\
-5152.6\end{array}$ & $\begin{array}{l}20.549 \\
20.622 \\
20.695 \\
20.768 \\
20.841\end{array}$ & $\begin{array}{l}73.33 \\
73.15 \\
72.98 \\
72.81 \\
72.64\end{array}$ & $\begin{array}{l}-185 \\
-184 \\
-183 \\
-182 \\
-181\end{array}$ & $\begin{array}{l}-5026.3 \\
-5005.0 \\
-4983.6 \\
-4962.2 \\
-4940.6\end{array}$ & $\begin{array}{l}21.274 \\
21.345 \\
21.417 \\
21.488 \\
21.559\end{array}$ & $\begin{array}{l}71.65 \\
71.48 \\
71.32 \\
71.16 \\
71.00\end{array}$ \\
\hline-200 & $-5337 \cdot 2$ & 20.180 & $74 \cdot 21$ & -190 & $-5131 \cdot 8$ & 20.913 & 72.47 & -180 & $-4919 \cdot 0$ & 21.630 & 70.84 \\
\hline
\end{tabular}


TABlE 6.5.2. Platinum, Pt-67, versus Type IN thermoelements-thermoelectric voltages, E(T), Seebeck coefficients, S(T), and first derivative of the Seebeck coefficients, $\mathrm{dS} / \mathrm{dT}$, reference junctions at $0^{\circ} \mathrm{C}-$ Continued

\begin{tabular}{|c|c|c|c|c|c|c|c|c|c|c|c|}
\hline${ }^{\circ} \mathrm{C}$ & ${ }_{\mu V}^{E}$ & $\underset{\mu V /{ }^{\circ} \mathrm{C}}{S}$ & $\begin{array}{l}\mathrm{dS} / \mathrm{dT} \\
\mathrm{nV} /{ }^{\circ} \mathrm{C}^{2}\end{array}$ & $\begin{array}{c}\mathrm{T} \\
{ }^{\circ} \mathrm{C}\end{array}$ & $\begin{array}{l}E \\
\mu V\end{array}$ & $\underset{\mu V /^{\circ} \mathrm{C}}{S}$ & $\begin{array}{l}\mathrm{dS} / \mathrm{dT} \\
\mathrm{nV} /{ }^{\circ} \mathrm{C}^{2}\end{array}$ & ${ }^{\circ} \mathrm{C}$ & $\underset{\mu V}{E}$ & $\stackrel{S}{\mu V^{\circ}{ }^{\circ} \mathrm{C}}$ & $\begin{array}{l}d S / d T \\
n V /{ }^{\circ} C^{2}\end{array}$ \\
\hline $\begin{array}{l}-180 \\
-179 \\
-178 \\
-177 \\
-176\end{array}$ & $\begin{array}{l}-4919.0 \\
-4897.4 \\
-4875.6 \\
-4853.8 \\
-4832.0\end{array}$ & $\begin{array}{l}21.630 \\
21.701 \\
21.771 \\
21.842 \\
21.912\end{array}$ & $\begin{array}{l}70.84 \\
70.69 \\
70.53 \\
70.38 \\
70.22\end{array}$ & $\begin{array}{l}-120 \\
-119 \\
-118 \\
-117 \\
-116\end{array}$ & $\begin{array}{l}-3498.9 \\
-3473.3 \\
-3447.5 \\
-3421.7 \\
-3395.9\end{array}$ & $\begin{array}{l}25.628 \\
25.691 \\
25.754 \\
25.816 \\
25.879\end{array}$ & $\begin{array}{l}62.88 \\
62.77 \\
62.65 \\
62.54 \\
62.43\end{array}$ & $\begin{array}{l}-60 \\
-59 \\
-58 \\
-57 \\
-56\end{array}$ & $\begin{array}{l}-1851.9 \\
-1822.6 \\
-1793.3 \\
-1764.0 \\
-1734.6\end{array}$ & $\begin{array}{l}29.213 \\
29.270 \\
29.327 \\
29.383 \\
29.440\end{array}$ & $\begin{array}{l}56.83 \\
56.74 \\
56.65 \\
56.56 \\
56.47\end{array}$ \\
\hline $\begin{array}{l}-175 \\
-174 \\
-173 \\
-172 \\
-171\end{array}$ & $\begin{array}{l}-4810.0 \\
-4788.0 \\
-4765.9 \\
-4743.7 \\
-4721.5\end{array}$ & $\begin{array}{l}21.982 \\
22.052 \\
22.122 \\
22.192 \\
22.261\end{array}$ & $\begin{array}{l}70.07 \\
69.92 \\
69.77 \\
69.62 \\
69.47\end{array}$ & 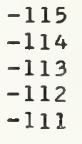 & $\begin{array}{l}-3370.0 \\
-3344.0 \\
-3318.0 \\
-3291.9 \\
-3265.7\end{array}$ & $\begin{array}{l}25.941 \\
26.003 \\
26.066 \\
26.128 \\
26.190\end{array}$ & $\begin{array}{l}62 \cdot 32 \\
62 \cdot 21 \\
62 \cdot 10 \\
61 \cdot 99 \\
61 \cdot 88\end{array}$ & $\begin{array}{l}-55 \\
-54 \\
-53 \\
-52 \\
-51\end{array}$ & $\begin{array}{l}-1705.1 \\
-1675.6 \\
-1646.0 \\
-1616.3 \\
-1586.7\end{array}$ & $\begin{array}{l}29.496 \\
29.553 \\
29.609 \\
29.665 \\
29.721\end{array}$ & $\begin{array}{l}56 \cdot 37 \\
56 \cdot 28 \\
56.19 \\
56.10 \\
56.01\end{array}$ \\
\hline $\begin{array}{l}-170 \\
-169 \\
-168 \\
-167 \\
-166\end{array}$ & $\begin{array}{l}-4699.2 \\
-4676.9 \\
-4654.4 \\
-4631.9 \\
-4609.3\end{array}$ & $\begin{array}{l}22.331 \\
22.400 \\
22.469 \\
22.538 \\
22.607\end{array}$ & $\begin{array}{l}69.32 \\
69.17 \\
69.02 \\
68.88 \\
68.73\end{array}$ & $\begin{array}{l}-110 \\
-109 \\
-108 \\
-107 \\
-106\end{array}$ & $\begin{array}{l}-3239.5 \\
-3213.2 \\
-3186.9 \\
-3160.5 \\
-3134.0\end{array}$ & $\begin{array}{l}26.251 \\
26.313 \\
26.375 \\
26.436 \\
26.498\end{array}$ & $\begin{array}{l}61.78 \\
61.67 \\
61.56 \\
61.45 \\
61.35\end{array}$ & $\begin{array}{l}-50 \\
-49 \\
-48 \\
-47 \\
-46\end{array}$ & $\begin{array}{l}-1556.9 \\
-1527.1 \\
-1497.2 \\
-1467.3 \\
-1437.3\end{array}$ & $\begin{array}{l}29.777 \\
29.833 \\
29.889 \\
29.944 \\
30.000\end{array}$ & $\begin{array}{l}55.92 \\
55.83 \\
55.74 \\
55.65 \\
55.56\end{array}$ \\
\hline $\begin{array}{l}-165 \\
-164 \\
-163 \\
-162 \\
-161\end{array}$ & $\begin{array}{l}-4586.7 \\
-4564.0 \\
-4541.2 \\
-4518.4 \\
-4495.5\end{array}$ & $\begin{array}{l}22.675 \\
22.744 \\
22.812 \\
22.880 \\
22.949\end{array}$ & $\begin{array}{l}68.59 \\
68.45 \\
68.30 \\
68.16 \\
68.02\end{array}$ & $\begin{array}{l}-105 \\
-104 \\
-103 \\
-102 \\
-101\end{array}$ & $\begin{array}{l}-3107.5 \\
-3080.9 \\
-3054.2 \\
-3027.5 \\
-3000.8\end{array}$ & $\begin{array}{l}26.559 \\
26.620 \\
26.681 \\
26.742 \\
26.803\end{array}$ & $\begin{array}{l}61 \cdot 24 \\
61 \cdot 14 \\
61.03 \\
60.93 \\
60.82\end{array}$ & $\begin{array}{l}-45 \\
-44 \\
-43 \\
-42 \\
-41\end{array}$ & $\begin{array}{l}-1407.3 \\
-1377.2 \\
-1347.1 \\
-1316.9 \\
-1286.7\end{array}$ & $\begin{array}{l}30.056 \\
30.111 \\
30.166 \\
30.222 \\
30.277\end{array}$ & $\begin{array}{l}55.47 \\
55.38 \\
55.29 \\
55.20 \\
55.11\end{array}$ \\
\hline $\begin{array}{l}-160 \\
-159 \\
-158 \\
-157 \\
-156\end{array}$ & $\begin{array}{l}-4472.5 \\
-4449.4 \\
-4426.3 \\
-4403.1 \\
-4379.9\end{array}$ & $\begin{array}{l}23.017 \\
23.084 \\
23.152 \\
23.220 \\
23.287\end{array}$ & $\begin{array}{l}67.88 \\
67.74 \\
67.60 \\
67.47 \\
67.33\end{array}$ & $\begin{array}{l}-100 \\
-99 \\
-98 \\
-97 \\
-96\end{array}$ & $\begin{array}{l}-2973.9 \\
-2947.0 \\
-2920.1 \\
-2893.1 \\
-2666.0\end{array}$ & $\begin{array}{l}26.864 \\
26.924 \\
26.985 \\
27.046 \\
27.106\end{array}$ & $\begin{array}{l}60.72 \\
60.61 \\
60.51 \\
60.41 \\
60.31\end{array}$ & $\begin{array}{l}-40 \\
-39 \\
-38 \\
-37 \\
-36\end{array}$ & $\begin{array}{l}-1256.4 \\
-1226.0 \\
-1195.6 \\
-1165.1 \\
-1134.6\end{array}$ & $\begin{array}{l}30.332 \\
30.387 \\
30.442 \\
30.496 \\
30.551\end{array}$ & $\begin{array}{l}55.02 \\
54.94 \\
54.85 \\
54.76 \\
54.67\end{array}$ \\
\hline $\begin{array}{l}-155 \\
-154 \\
-153 \\
-152 \\
-151\end{array}$ & $\begin{array}{l}-4356.5 \\
-4333.2 \\
-4309.7 \\
-4286.2 \\
-4262.6\end{array}$ & $\begin{array}{l}23.354 \\
23.421 \\
23.488 \\
23.555 \\
23.622\end{array}$ & $\begin{array}{l}67.19 \\
67.06 \\
66.92 \\
66.79 \\
66.66\end{array}$ & $\begin{array}{l}-95 \\
-94 \\
-93 \\
-92 \\
-91\end{array}$ & $\begin{array}{l}-2838.8 \\
-2811.6 \\
-2784.4 \\
-2757.1 \\
-2729.7\end{array}$ & $\begin{array}{l}27.166 \\
27.226 \\
27.286 \\
27.346 \\
27.406\end{array}$ & $\begin{array}{l}60.20 \\
60.10 \\
60.00 \\
59.90 \\
59.80\end{array}$ & $\begin{array}{l}-35 \\
-34 \\
-33 \\
-32 \\
-31\end{array}$ & $\begin{array}{l}-1104.0 \\
-1073.4 \\
-1042.7 \\
-1011.9 \\
-981.1\end{array}$ & $\begin{array}{l}30.606 \\
30.660 \\
30.715 \\
30.769 \\
30.823\end{array}$ & $\begin{array}{l}54.58 \\
54.49 \\
54.40 \\
54.32 \\
54.23\end{array}$ \\
\hline $\begin{array}{l}-150 \\
-149 \\
-148 \\
-147 \\
-146\end{array}$ & $\begin{array}{l}-4238.9 \\
-4215.2 \\
-4191.4 \\
-4167.6 \\
-4143.7\end{array}$ & $\begin{array}{l}23.689 \\
23.755 \\
23.821 \\
23.888 \\
23.954\end{array}$ & $\begin{array}{l}66.53 \\
66.40 \\
66.26 \\
66.14 \\
66.01\end{array}$ & $\begin{array}{l}-90 \\
-89 \\
-88 \\
-87 \\
-86\end{array}$ & $\begin{array}{l}-2702.3 \\
-2674.8 \\
-2647.2 \\
-2619.6 \\
-2591.9\end{array}$ & $\begin{array}{l}27.466 \\
27.526 \\
27.585 \\
27.645 \\
27.704\end{array}$ & $\begin{array}{l}59.70 \\
59.60 \\
59.50 \\
59.40 \\
59.30\end{array}$ & $\begin{array}{l}-30 \\
-29 \\
-28 \\
-27 \\
-26\end{array}$ & $\begin{array}{l}-950.3 \\
-919.4 \\
-888.4 \\
-857.4 \\
-826.4\end{array}$ & $\begin{array}{l}30.878 \\
30.932 \\
30.986 \\
31.040 \\
31.093\end{array}$ & $\begin{array}{l}54.14 \\
54.05 \\
53.96 \\
53.88 \\
53.79\end{array}$ \\
\hline $\begin{array}{l}-145 \\
-144 \\
-143 \\
-142 \\
-141\end{array}$ & $\begin{array}{l}-4119.7 \\
-4095.6 \\
-4071.5 \\
-4047.3 \\
-4023.1\end{array}$ & $\begin{array}{l}24.020 \\
24.085 \\
24.151 \\
24.217 \\
24.282\end{array}$ & $\begin{array}{l}65.88 \\
65.75 \\
65.62 \\
65.50 \\
65.37\end{array}$ & $\begin{array}{l}-85 \\
-84 \\
-83 \\
-82 \\
-81\end{array}$ & $\begin{array}{l}-2564.2 \\
-2536.4 \\
-2508.5 \\
-2480.6 \\
-2452.7\end{array}$ & $\begin{array}{l}27.763 \\
27.822 \\
27.881 \\
27.940 \\
27.999\end{array}$ & $\begin{array}{l}59.21 \\
59.11 \\
59.01 \\
58.91 \\
58.81\end{array}$ & $\begin{array}{l}-25 \\
-24 \\
-23 \\
-22 \\
-21\end{array}$ & $\begin{array}{l}-795.2 \\
-764.1 \\
-732.8 \\
-701.6 \\
-670.2\end{array}$ & $\begin{array}{l}31.147 \\
31.201 \\
31.254 \\
31.308 \\
31.361\end{array}$ & $\begin{array}{l}53.70 \\
53.61 \\
53.53 \\
53.44 \\
53.35\end{array}$ \\
\hline $\begin{array}{l}-140 \\
-139 \\
-138 \\
-137 \\
-136\end{array}$ & $\begin{array}{l}-3998.7 \\
-3974.4 \\
-3949.9 \\
-3925.4 \\
-3900.8\end{array}$ & $\begin{array}{l}24.347 \\
24.413 \\
24.478 \\
24.543 \\
24.607\end{array}$ & $\begin{array}{l}65.25 \\
65.12 \\
65.00 \\
64.88 \\
64.75\end{array}$ & $\begin{array}{l}-80 \\
-79 \\
-78 \\
-77 \\
-76\end{array}$ & $\begin{array}{l}-2424.6 \\
-2396.5 \\
-2368.4 \\
-2340.2 \\
-2311.9\end{array}$ & $\begin{array}{l}28.058 \\
28.117 \\
28.175 \\
28.234 \\
28.292\end{array}$ & $\begin{array}{l}58.72 \\
58.62 \\
58.52 \\
58.43 \\
58.33\end{array}$ & $\begin{array}{l}-20 \\
-19 \\
-18 \\
-17 \\
-16\end{array}$ & $\begin{array}{l}-638.8 \\
-607.4 \\
-575.9 \\
-544.3 \\
-512.7\end{array}$ & $\begin{array}{l}31.415 \\
31.468 \\
31.521 \\
31.574 \\
31.627\end{array}$ & $\begin{array}{l}53.26 \\
53.18 \\
53.09 \\
53.00 \\
52.91\end{array}$ \\
\hline $\begin{array}{l}-135 \\
-134 \\
-133 \\
-133 \\
-132 \\
-131\end{array}$ & $\begin{array}{l}-3876.2 \\
-3851.5 \\
-3826.7 \\
-3801.9 \\
-3777.0\end{array}$ & $\begin{array}{l}24.672 \\
24.737 \\
24.801 \\
24.865 \\
24.930\end{array}$ & $\begin{array}{l}64.63 \\
64.51 \\
64.39 \\
64.27 \\
64.15\end{array}$ & $\begin{array}{l}-75 \\
-74 \\
-73 \\
-72 \\
-71\end{array}$ & $\begin{array}{l}-2283.6 \\
-2255.2 \\
-2226.8 \\
-2198.3 \\
-2169.7\end{array}$ & $\begin{array}{l}28.350 \\
28.409 \\
28.467 \\
28.525 \\
28.583\end{array}$ & $\begin{array}{l}58.24 \\
58.14 \\
58.05 \\
57.95 \\
57.86\end{array}$ & $\begin{array}{l}-15 \\
-14 \\
-13 \\
-12 \\
-11\end{array}$ & $\begin{array}{l}-481.1 \\
-449.4 \\
-417.6 \\
-385.8 \\
-354.0\end{array}$ & $\begin{array}{l}31.680 \\
31.733 \\
31.785 \\
31.838 \\
31.890\end{array}$ & $\begin{array}{l}52.83 \\
52.74 \\
52.65 \\
52.57 \\
52.48\end{array}$ \\
\hline $\begin{array}{l}-130 \\
-129 \\
-128 \\
-127 \\
-126\end{array}$ & $\begin{array}{l}-3752.0 \\
-3727.0 \\
-3701.9 \\
-3676.8 \\
-3651.5\end{array}$ & $\begin{array}{l}24.994 \\
25.058 \\
25.121 \\
25.185 \\
25.249\end{array}$ & $\begin{array}{l}64.03 \\
63.91 \\
63.80 \\
63.68 \\
63.56\end{array}$ & $\begin{array}{l}-70 \\
-69 \\
-68 \\
-67 \\
-66\end{array}$ & $\begin{array}{l}-2141.1 \\
-2112.5 \\
-2083.7 \\
-2055.0 \\
-2026.1\end{array}$ & $\begin{array}{l}28.640 \\
28.698 \\
28.756 \\
28.813 \\
28.871\end{array}$ & $\begin{array}{l}57.76 \\
57.67 \\
57.58 \\
57.48 \\
57.39\end{array}$ & $\begin{array}{r}-10 \\
-9 \\
-8 \\
-7 \\
-6\end{array}$ & $\begin{array}{l}-322 \cdot 0 \\
-290.1 \\
-258 \cdot 0 \\
-226.0 \\
-193.8\end{array}$ & $\begin{array}{l}31.943 \\
31.995 \\
32.047 \\
32.100 \\
32.152\end{array}$ & $\begin{array}{l}52.39 \\
52.30 \\
52.22 \\
52.13 \\
52.04\end{array}$ \\
\hline $\begin{array}{l}-125 \\
-124 \\
-123 \\
-122 \\
-121\end{array}$ & $\begin{array}{l}-3626.3 \\
-3600.9 \\
-3575.5 \\
-3550.0 \\
-3524.5\end{array}$ & $\begin{array}{l}25.312 \\
25.376 \\
25.439 \\
25.502 \\
25.565\end{array}$ & $\begin{array}{l}63.45 \\
63.33 \\
63.22 \\
63.10 \\
62.99\end{array}$ & $\begin{array}{l}-65 \\
-64 \\
-63 \\
-62 \\
-61\end{array}$ & $\begin{array}{l}-1997.2 \\
-1968.3 \\
-1939.2 \\
-1910.2 \\
-1881.0\end{array}$ & $\begin{array}{l}28.928 \\
28.985 \\
29.042 \\
29.099 \\
29.156\end{array}$ & $\begin{array}{l}57.29 \\
57.20 \\
57.11 \\
57.02 \\
56.92\end{array}$ & $\begin{array}{l}-5 \\
-4 \\
-3 \\
-2 \\
-1\end{array}$ & $\begin{array}{r}-161.7 \\
-129.4 \\
-97.2 \\
-64.8 \\
-32.4\end{array}$ & $\begin{array}{l}32.204 \\
32.256 \\
32.307 \\
32.359 \\
32.411\end{array}$ & $\begin{array}{l}51.96 \\
51.87 \\
51.78 \\
51.70 \\
51.61\end{array}$ \\
\hline-120 & -3498.9 & 25.628 & 62.88 & -60 & -1851.9 & 29.213 & 56.83 & 0 & 0.0 & 32.462 & $51 \cdot 52$ \\
\hline
\end{tabular}


TABle 6.5.2. Platinum, Pt-67, versus Type JN thermoelements-thermoelectric voltages, E(T), Seebeck coefficients, $\mathrm{S}(\mathrm{T})$, and first derivative of the Seebeck coefficients, $\mathrm{dS} / \mathrm{dT}$, reference junctions at $0^{\circ} \mathrm{C}$-Continued

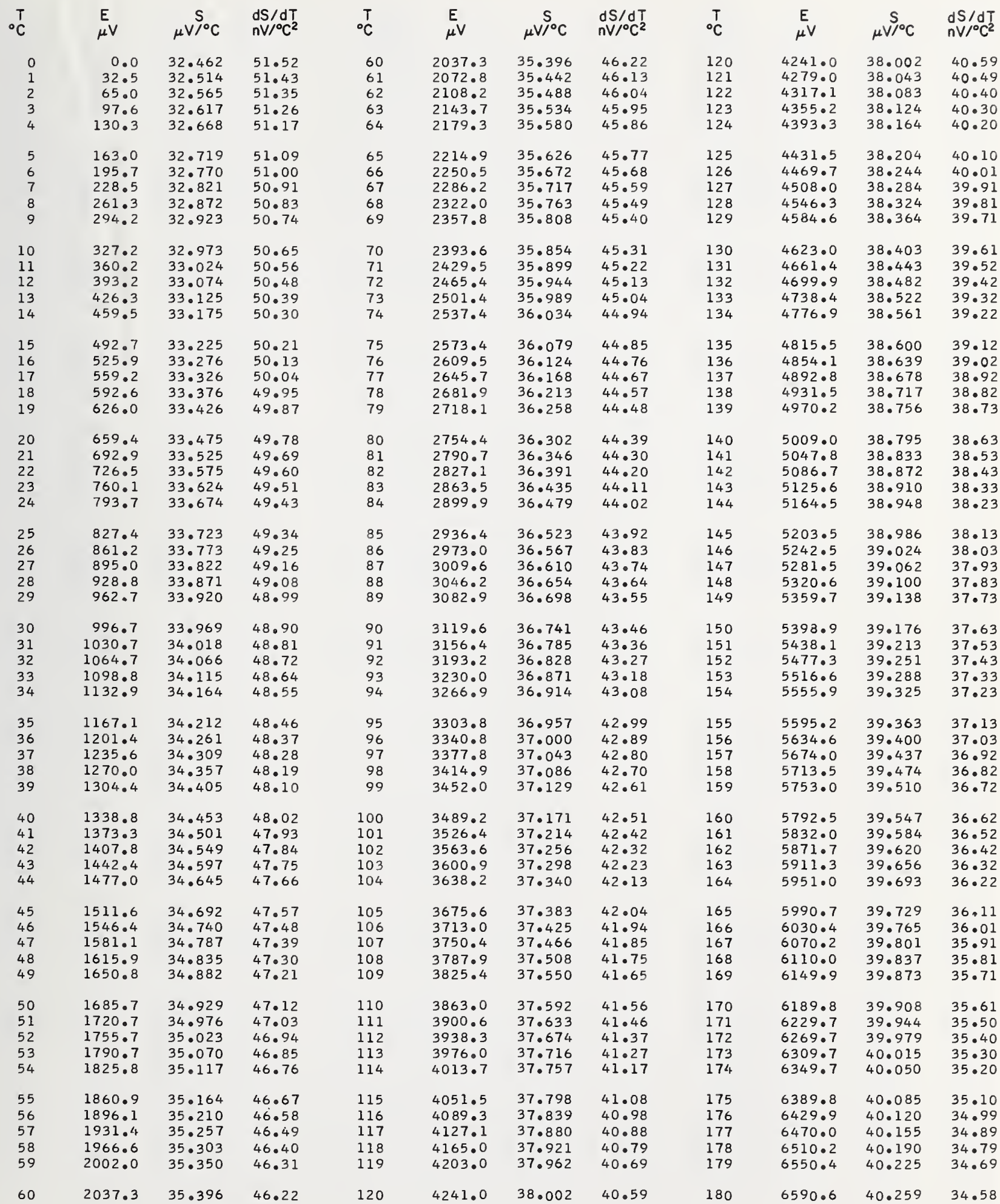


TABle 6.5.2. Platinum, Pt-67, versus Type IN thermoelements-thermoelectric voltages, E(T), Seebeck coefficients, $\mathrm{S}(\mathrm{T})$, and first derivative of the Seebeck coefficients, $\mathrm{dS} / \mathrm{dT}$,

reference junctions at $0^{\circ} \mathrm{C}$-Continued

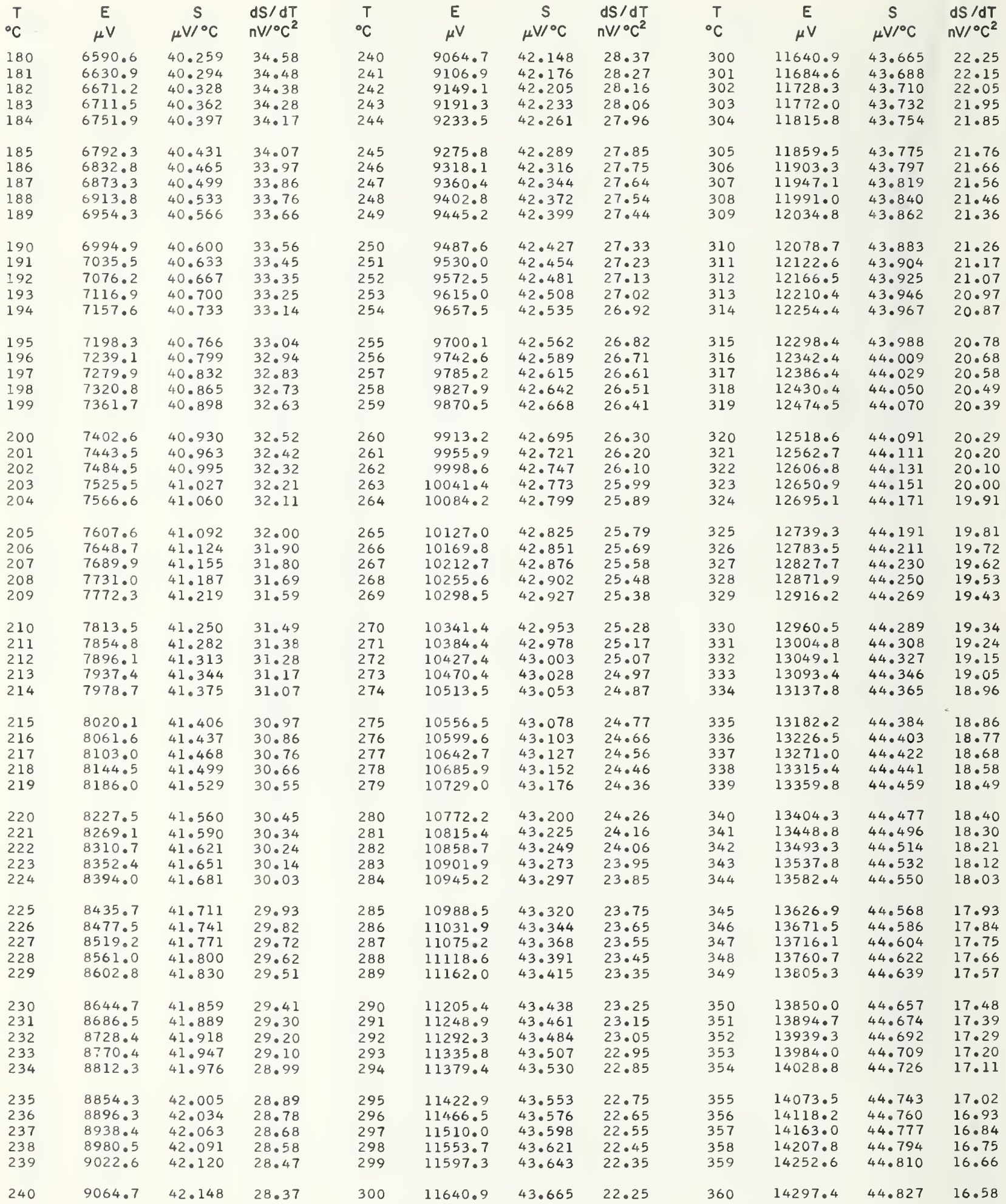


TABle 6.5.2. Platinum, Pt-67, versus Type IN thermoelements-thermoelectric voltages, E(T), Seebeck coefficients, S(T). and first derivative of the Seebeck coefficients, dS/dT,

reference junctions at $\mathrm{O}^{\circ} \mathrm{C}-$ Continued

\begin{tabular}{|c|c|c|c|c|c|c|c|c|c|c|c|}
\hline${ }^{\circ} \mathrm{C}$ & $\begin{array}{c}E \\
\mu V\end{array}$ & $\stackrel{S}{S{ }^{\circ}{ }^{\circ} \mathrm{C}}$ & $\begin{array}{l}d S / d T \\
n V /{ }^{\circ} C^{2}\end{array}$ & ${ }^{\circ} \mathrm{C}$ & $\underset{\mu V}{E}$ & $\underset{\mu \mathrm{V} /{ }^{\circ} \mathrm{C}}{\mathrm{S}}$ & $\begin{array}{l}\mathrm{dS} / \mathrm{dT} \\
\mathrm{nV} /{ }^{\circ} \mathrm{C}^{2}\end{array}$ & $\begin{array}{l}\mathrm{T} \\
{ }^{\circ} \mathrm{C}\end{array}$ & $\underset{\mu V}{E}$ & $\stackrel{S}{S V^{\circ} \mathrm{C}}$ & $\begin{array}{l}d S / d T \\
n V /{ }^{\circ} C^{2}\end{array}$ \\
\hline $\begin{array}{l}365 \\
366 \\
367 \\
368 \\
369\end{array}$ & $\begin{array}{l}14521.8 \\
14566.7 \\
14611.6 \\
14656.6 \\
14701.5\end{array}$ & $\begin{array}{l}44.909 \\
44.925 \\
44.941 \\
44.957 \\
44.973\end{array}$ & $\begin{array}{l}16.13 \\
16.05 \\
15.96 \\
15.87 \\
15.78\end{array}$ & $\begin{array}{l}425 \\
426 \\
427 \\
428 \\
429\end{array}$ & $\begin{array}{l}17242.3 \\
17288.0 \\
17333.8 \\
17379.5 \\
17425.3\end{array}$ & $\begin{array}{l}45.727 \\
45.738 \\
45.750 \\
45.761 \\
45.772\end{array}$ & $\begin{array}{l}11.30 \\
11.22 \\
11.15 \\
11.08 \\
11.01\end{array}$ & $\begin{array}{l}485 \\
486 \\
487 \\
488 \\
489\end{array}$ & $\begin{array}{l}20003 \cdot 8 \\
20050 \cdot 1 \\
20096 \cdot 4 \\
20142 \cdot 7 \\
20189 \cdot 0\end{array}$ & $\begin{array}{l}46.284 \\
46.291 \\
46.299 \\
46.306 \\
46.313\end{array}$ & $\begin{array}{l}7.43 \\
7.37 \\
7.32 \\
7.26 \\
7.21\end{array}$ \\
\hline $\begin{array}{l}370 \\
371 \\
372 \\
373 \\
374\end{array}$ & $\begin{array}{l}14746.5 \\
14791.5 \\
14836.5 \\
14881.5 \\
14926.6\end{array}$ & $\begin{array}{l}44.988 \\
45.004 \\
45.020 \\
45.035 \\
45.051\end{array}$ & $\begin{array}{l}15.70 \\
15.61 \\
15.52 \\
15.44 \\
15.35\end{array}$ & $\begin{array}{l}430 \\
431 \\
432 \\
433 \\
434\end{array}$ & $\begin{array}{l}17471.1 \\
17516.9 \\
17562.7 \\
17608.5 \\
17654.3\end{array}$ & $\begin{array}{l}45.783 \\
45.794 \\
45.804 \\
45.815 \\
45.826\end{array}$ & $\begin{array}{l}10.94 \\
10.86 \\
10.79 \\
10.72 \\
10.65\end{array}$ & $\begin{array}{l}490 \\
491 \\
492 \\
493 \\
494\end{array}$ & $\begin{array}{l}20235 \cdot 3 \\
20281.6 \\
20328 \cdot 0 \\
20374 \cdot 3 \\
20420 \cdot 6\end{array}$ & $\begin{array}{l}46 \cdot 320 \\
46 \cdot 328 \\
46 \cdot 335 \\
46 \cdot 342 \\
46 \cdot 349\end{array}$ & $\begin{array}{l}7.15 \\
7.10 \\
7.04 \\
6.99 \\
6.94\end{array}$ \\
\hline $\begin{array}{l}380 \\
381 \\
382 \\
383 \\
384\end{array}$ & $\begin{array}{l}15197.2 \\
15242.3 \\
15287.5 \\
15332.6 \\
15377.8\end{array}$ & $\begin{array}{l}45.141 \\
45.156 \\
45.171 \\
45.185 \\
45.200\end{array}$ & $\begin{array}{l}14.84 \\
14.76 \\
14.67 \\
14.59 \\
14.50\end{array}$ & $\begin{array}{l}440 \\
441 \\
442 \\
443 \\
444\end{array}$ & $\begin{array}{l}17929.4 \\
17975.3 \\
18021.2 \\
18067.1 \\
18113.1\end{array}$ & $\begin{array}{l}45.889 \\
45.899 \\
45.909 \\
45.919 \\
45.929\end{array}$ & $\begin{array}{r}10.23 \\
10.17 \\
10.10 \\
10.03 \\
9.96\end{array}$ & $\begin{array}{l}500 \\
501 \\
502 \\
503 \\
504\end{array}$ & $\begin{array}{l}20698.8 \\
20745.2 \\
20791.6 \\
20838.0 \\
20884.5\end{array}$ & $\begin{array}{l}46.389 \\
46.396 \\
46.402 \\
46.409 \\
46.415\end{array}$ & $\begin{array}{l}6.62 \\
6.57 \\
6.51 \\
6.46 \\
6.41\end{array}$ \\
\hline $\begin{array}{l}385 \\
386 \\
387 \\
388 \\
389\end{array}$ & $\begin{array}{l}15423.0 \\
15468.3 \\
15513.5 \\
15558.8 \\
15604.0\end{array}$ & $\begin{array}{l}45.214 \\
45.229 \\
45.243 \\
45.257 \\
45.271\end{array}$ & $\begin{array}{l}14.42 \\
14.34 \\
14.26 \\
14.17 \\
14.09\end{array}$ & $\begin{array}{l}445 \\
446 \\
447 \\
448 \\
449\end{array}$ & $\begin{array}{l}18159.0 \\
18204.9 \\
18250.9 \\
18296.9 \\
18342.8\end{array}$ & $\begin{array}{l}45.939 \\
45.949 \\
45.959 \\
45.968 \\
45.978\end{array}$ & $\begin{array}{l}9.90 \\
9.83 \\
9.76 \\
9.69 \\
9.63\end{array}$ & $\begin{array}{l}505 \\
506 \\
507 \\
508 \\
509\end{array}$ & $\begin{array}{l}20930.9 \\
20977.3 \\
21023.7 \\
21070.2 \\
21116.6\end{array}$ & $\begin{array}{l}46.422 \\
46.428 \\
46.434 \\
46.441 \\
46.447\end{array}$ & $\begin{array}{l}6.36 \\
6.31 \\
6.26 \\
6.21 \\
6.16\end{array}$ \\
\hline $\begin{array}{l}390 \\
391 \\
392 \\
393 \\
394\end{array}$ & $\begin{array}{l}15649.3 \\
15694.6 \\
15739.9 \\
15785.2 \\
15830.5\end{array}$ & $\begin{array}{l}45 \cdot 285 \\
45 \cdot 299 \\
45.313 \\
45 \cdot 327 \\
45.341\end{array}$ & $\begin{array}{l}14.01 \\
13.93 \\
13.84 \\
13.76 \\
13.68\end{array}$ & $\begin{array}{l}450 \\
451 \\
452 \\
453 \\
454\end{array}$ & $\begin{array}{l}18388.8 \\
18434.8 \\
18480.8 \\
18526.8 \\
18572.8\end{array}$ & $\begin{array}{l}45.988 \\
45.997 \\
46.007 \\
46.016 \\
46.025\end{array}$ & $\begin{array}{l}9.56 \\
9.50 \\
9.43 \\
9.37 \\
9.30\end{array}$ & $\begin{array}{l}510 \\
511 \\
512 \\
513 \\
514\end{array}$ & $\begin{array}{l}21163 \cdot 1 \\
21209 \cdot 5 \\
21256 \cdot 0 \\
21302 \cdot 4 \\
21348 \cdot 9\end{array}$ & $\begin{array}{l}46.453 \\
46.459 \\
46.465 \\
46.471 \\
46.477\end{array}$ & $\begin{array}{l}6.11 \\
6.06 \\
6.01 \\
5.96 \\
5.91\end{array}$ \\
\hline $\begin{array}{l}400 \\
401 \\
402 \\
403 \\
404\end{array}$ & $\begin{array}{l}16102.8 \\
16148.3 \\
16193.7 \\
16239.2 \\
16284.6\end{array}$ & $\begin{array}{l}45.421 \\
45.434 \\
45.448 \\
45.461 \\
45.473\end{array}$ & $\begin{array}{l}13.20 \\
13.12 \\
13.04 \\
12.96 \\
12.88\end{array}$ & $\begin{array}{l}460 \\
461 \\
462 \\
463 \\
464\end{array}$ & $\begin{array}{l}18849.2 \\
18895.2 \\
18941.3 \\
18987.4 \\
19033.5\end{array}$ & $\begin{array}{l}46.080 \\
46.089 \\
46.098 \\
46.106 \\
46.115\end{array}$ & $\begin{array}{l}8.92 \\
8.86 \\
8.79 \\
8.73 \\
8.67\end{array}$ & $\begin{array}{l}520 \\
521 \\
522 \\
523 \\
524\end{array}$ & $\begin{array}{l}21627 \cdot 9 \\
21674 \cdot 4 \\
21720.9 \\
21767 \cdot 4 \\
21814.0\end{array}$ & $\begin{array}{l}46.511 \\
46.517 \\
46.523 \\
46.528 \\
46.534\end{array}$ & $\begin{array}{l}5.63 \\
5.58 \\
5.53 \\
5.49 \\
5.44\end{array}$ \\
\hline $\begin{array}{l}405 \\
406 \\
407 \\
408 \\
409\end{array}$ & $\begin{array}{l}16330.1 \\
16375.6 \\
16421.1 \\
16466.6 \\
16512.2\end{array}$ & $\begin{array}{l}45.486 \\
45.499 \\
45.512 \\
45.524 \\
45.537\end{array}$ & $\begin{array}{l}12.81 \\
12.73 \\
12.65 \\
12.57 \\
12.50\end{array}$ & $\begin{array}{l}465 \\
466 \\
467 \\
468 \\
469\end{array}$ & $\begin{array}{l}19079.7 \\
19125.8 \\
19171.9 \\
19218.1 \\
19264.2\end{array}$ & $\begin{array}{l}46 \cdot 124 \\
46 \cdot 132 \\
46 \cdot 141 \\
46.149 \\
46.158\end{array}$ & $\begin{array}{l}8.61 \\
8.55 \\
8.48 \\
8.42 \\
8.36\end{array}$ & $\begin{array}{l}525 \\
526 \\
527 \\
528 \\
529\end{array}$ & $\begin{array}{l}21860 \cdot 5 \\
21907.1 \\
21953 \cdot 6 \\
22000 \cdot 2 \\
22046.7\end{array}$ & $\begin{array}{l}46.539 \\
46.544 \\
46.550 \\
46.555 \\
46.560\end{array}$ & $\begin{array}{l}5 \cdot 39 \\
5 \cdot 35 \\
5 \cdot 30 \\
5 \cdot 26 \\
5 \cdot 21\end{array}$ \\
\hline $\begin{array}{l}410 \\
411 \\
412 \\
413 \\
414\end{array}$ & $\begin{array}{l}16557.7 \\
16603.3 \\
16648.8 \\
16694.4 \\
16740.0\end{array}$ & $\begin{array}{l}45.549 \\
45.562 \\
45.574 \\
45.586 \\
45.598\end{array}$ & $\begin{array}{l}12.42 \\
12.34 \\
12.27 \\
12.19 \\
12.11\end{array}$ & $\begin{array}{l}470 \\
471 \\
472 \\
473 \\
474\end{array}$ & $\begin{array}{l}19310.4 \\
19356.6 \\
19402.7 \\
19448.9 \\
19495.1\end{array}$ & $\begin{array}{l}46 \cdot 166 \\
46 \cdot 174 \\
46 \cdot 182 \\
46 \cdot 191 \\
46 \cdot 199\end{array}$ & $\begin{array}{l}8.30 \\
8.24 \\
8.18 \\
8.12 \\
8.06\end{array}$ & $\begin{array}{l}530 \\
531 \\
532 \\
533 \\
534\end{array}$ & $\begin{array}{l}22093 \cdot 3 \\
22139 \cdot 8 \\
22186.4 \\
22233.0 \\
22279.6\end{array}$ & $\begin{array}{l}46.565 \\
46.571 \\
46.576 \\
46.581 \\
46.586\end{array}$ & $\begin{array}{l}5.17 \\
5.12 \\
5.08 \\
5.03 \\
4.99\end{array}$ \\
\hline $\begin{array}{l}415 \\
416 \\
417 \\
418 \\
419\end{array}$ & $\begin{array}{l}16785.6 \\
16831.2 \\
16876.8 \\
16922.5 \\
16968.1\end{array}$ & $\begin{array}{l}45.611 \\
45.623 \\
45.634 \\
45.646 \\
45.658\end{array}$ & $\begin{array}{l}12.04 \\
11.96 \\
11.89 \\
11.81 \\
11.74\end{array}$ & $\begin{array}{l}475 \\
476 \\
477 \\
478 \\
479\end{array}$ & $\begin{array}{l}19541.3 \\
19587.5 \\
19633.8 \\
19680.0 \\
19726.2\end{array}$ & $\begin{array}{l}46.207 \\
46.215 \\
46.223 \\
46.231 \\
46.238\end{array}$ & $\begin{array}{l}8.00 \\
7.95 \\
7.89 \\
7.83 \\
7.77\end{array}$ & $\begin{array}{l}535 \\
536 \\
537 \\
538 \\
539\end{array}$ & $\begin{array}{l}22326 \cdot 2 \\
22372 \cdot 8 \\
22419 \cdot 4 \\
22466 \cdot 0 \\
22512 \cdot 6\end{array}$ & $\begin{array}{l}46.591 \\
46.596 \\
46.601 \\
46.605 \\
46.610\end{array}$ & $\begin{array}{l}4.94 \\
4.90 \\
4.86 \\
4.81 \\
4.77\end{array}$ \\
\hline+20 & 17013.8 & 45.670 & 11.66 & 480 & 19772.5 & $46 \cdot 246$ & 7.71 & 540 & 22559.2 & 46.615 & 4.73 \\
\hline
\end{tabular}


TABlE 6.5.2. Platinum, Pt_67, versus Type IN thermoelements-thermoelectric voltages, E(T), Seebeck coefficients, $\mathrm{S}(\mathrm{T})$, and first derivative of the Seebeck coefficients, $\mathrm{dS} / \mathrm{dT}$,

reference junctions at $0^{\circ} \mathrm{C}-$ Continued

\begin{tabular}{|c|c|c|c|c|c|c|c|c|c|c|c|}
\hline${ }^{\circ} \mathrm{C}$ & $\begin{array}{l}\mathrm{E} \\
\mu \mathrm{V}\end{array}$ & $\begin{array}{c}S \\
\mu V /{ }^{\circ} \mathrm{C}\end{array}$ & $\begin{array}{l}\mathrm{dS} / \mathrm{dT} \\
\mathrm{nV} /{ }^{\circ} \mathrm{C}^{2}\end{array}$ & $\begin{array}{l}\top \\
{ }^{\circ} \mathrm{C}\end{array}$ & $\begin{array}{c}E^{V} V \\
\end{array}$ & $\stackrel{S}{S} /^{\circ} \mathrm{C}$ & $\begin{array}{l}\mathrm{dS} / \mathrm{dT} \\
\mathrm{nV} /{ }^{\circ} \mathrm{C}^{2}\end{array}$ & ${ }^{\circ} \mathrm{C}$ & $\begin{array}{c}E \\
\mu V\end{array}$ & ${ }_{\mu \mathrm{V} /{ }^{\circ} \mathrm{C}}^{\mathrm{S}}$ & $\begin{array}{l}\mathrm{dS} / \mathrm{dT} \\
\mathrm{nV} /{ }^{\circ} \mathrm{C}^{2}\end{array}$ \\
\hline $\begin{array}{l}545 \\
546 \\
547 \\
548 \\
549\end{array}$ & $\begin{array}{l}22792.3 \\
22839.0 \\
22885.6 \\
22932.2 \\
22978.9\end{array}$ & $\begin{array}{l}46.638 \\
46.643 \\
46.647 \\
46.651 \\
46.656\end{array}$ & $\begin{array}{l}4.52 \\
4.47 \\
4.43 \\
4.39 \\
4.35\end{array}$ & $\begin{array}{l}605 \\
606 \\
607 \\
608 \\
609\end{array}$ & $\begin{array}{l}25597.3 \\
25644.1 \\
25691.0 \\
25737.8 \\
25784.7\end{array}$ & $\begin{array}{l}46.839 \\
46.841 \\
46.843 \\
46.846 \\
46.848\end{array}$ & $\begin{array}{l}2.25 \\
2.21 \\
2.18 \\
2.14 \\
2.10\end{array}$ & $\begin{array}{l}665 \\
666 \\
667 \\
668 \\
669\end{array}$ & $\begin{array}{l}28410.4 \\
28457.3 \\
28504 \cdot 2 \\
28551.1 \\
28598.0\end{array}$ & $\begin{array}{l}46.907 \\
46.907 \\
46.907 \\
46.907 \\
46.907\end{array}$ & $\begin{array}{l}-0.06 \\
-0.10 \\
-0.15 \\
-0.19 \\
-0.24\end{array}$ \\
\hline $\begin{array}{l}550 \\
551 \\
552 \\
553 \\
554\end{array}$ & $\begin{array}{l}23025.6 \\
23072.2 \\
23118.9 \\
23165.6 \\
23212.2\end{array}$ & $\begin{array}{l}46.660 \\
46.664 \\
46.669 \\
46.673 \\
46.677\end{array}$ & $\begin{array}{l}4.31 \\
4.27 \\
4.23 \\
4.19 \\
4.15\end{array}$ & $\begin{array}{l}610 \\
611 \\
612 \\
613 \\
614\end{array}$ & $\begin{array}{l}25831.5 \\
25878.4 \\
25925.2 \\
25972.1 \\
26018.9\end{array}$ & $\begin{array}{l}46.850 \\
46.852 \\
46.854 \\
46.856 \\
46.858\end{array}$ & $\begin{array}{l}2.07 \\
2.03 \\
2.00 \\
1.96 \\
1.93\end{array}$ & $\begin{array}{l}670 \\
671 \\
672 \\
673 \\
674\end{array}$ & $\begin{array}{l}28644.9 \\
28691.8 \\
28738.7 \\
28785.6 \\
28832.5\end{array}$ & $\begin{array}{l}46.906 \\
46.906 \\
46.906 \\
46.905 \\
46.905\end{array}$ & $\begin{array}{l}-0.29 \\
-0.33 \\
-0.38 \\
-0.42 \\
-0.47\end{array}$ \\
\hline $\begin{array}{l}560 \\
561 \\
562 \\
563 \\
564\end{array}$ & $\begin{array}{l}23492.4 \\
23539.1 \\
23585.8 \\
23632.5 \\
23679.2\end{array}$ & $\begin{array}{l}46.701 \\
46.705 \\
46.709 \\
46.713 \\
46.716\end{array}$ & $\begin{array}{l}3.91 \\
3.87 \\
3.83 \\
3.79 \\
3.75\end{array}$ & $\begin{array}{l}620 \\
621 \\
622 \\
623 \\
624\end{array}$ & $\begin{array}{l}26300.1 \\
26347.0 \\
26393.9 \\
26440.7 \\
26487.6\end{array}$ & $\begin{array}{l}46.869 \\
46.870 \\
46.872 \\
46.874 \\
46.875\end{array}$ & $\begin{array}{l}1.71 \\
1.67 \\
1.64 \\
1.60 \\
1.56\end{array}$ & $\begin{array}{l}680 \\
681 \\
682 \\
683 \\
684\end{array}$ & $\begin{array}{l}29113.9 \\
29160.8 \\
29207.7 \\
29254.6 \\
29301.5\end{array}$ & $\begin{array}{l}46.901 \\
46.900 \\
46.899 \\
46.899 \\
46.898\end{array}$ & $\begin{array}{l}-0.76 \\
-0.81 \\
-0.86 \\
-0.91 \\
-0.97\end{array}$ \\
\hline $\begin{array}{l}565 \\
566 \\
567 \\
568 \\
569\end{array}$ & $\begin{array}{l}23725.9 \\
23772.6 \\
23819.4 \\
23866.1 \\
23912.8\end{array}$ & $\begin{array}{l}46.720 \\
46.724 \\
46.728 \\
46.731 \\
46.735\end{array}$ & $\begin{array}{l}3.71 \\
3.67 \\
3.64 \\
3.60 \\
3.56\end{array}$ & $\begin{array}{l}625 \\
626 \\
627 \\
628 \\
629\end{array}$ & $\begin{array}{l}26534.5 \\
26581.4 \\
26628.2 \\
26675.1 \\
26722.0\end{array}$ & $\begin{array}{l}46.877 \\
46.878 \\
46.880 \\
46.881 \\
46.883\end{array}$ & $\begin{array}{l}1.53 \\
1.49 \\
1.45 \\
1.42 \\
1.38\end{array}$ & $\begin{array}{l}685 \\
686 \\
687 \\
688 \\
689\end{array}$ & $\begin{array}{l}29348.4 \\
29395.3 \\
29442.2 \\
29489.1 \\
29536.0\end{array}$ & $\begin{array}{l}46.897 \\
46.896 \\
46.894 \\
46.893 \\
46.892\end{array}$ & $\begin{array}{l}-1.02 \\
-1.07 \\
-1.12 \\
-1.18 \\
-1.23\end{array}$ \\
\hline $\begin{array}{l}570 \\
571 \\
572 \\
573 \\
574\end{array}$ & $\begin{array}{l}23959.6 \\
24006 \cdot 3 \\
24053 \cdot 1 \\
24099 \cdot 8 \\
24146.6\end{array}$ & $\begin{array}{l}46 \cdot 738 \\
46 \cdot 742 \\
46 \cdot 745 \\
46 \cdot 749 \\
46 \cdot 752\end{array}$ & $\begin{array}{l}3.52 \\
3.48 \\
3.45 \\
3.41 \\
3.37\end{array}$ & $\begin{array}{l}630 \\
631 \\
632 \\
633 \\
634\end{array}$ & $\begin{array}{l}26768.9 \\
26815.8 \\
26862.7 \\
26909.5 \\
26956.4\end{array}$ & $\begin{array}{l}46.884 \\
46.885 \\
46.887 \\
46.888 \\
46.889\end{array}$ & $\begin{array}{l}1.34 \\
1.31 \\
1.27 \\
1.23 \\
1.19\end{array}$ & $\begin{array}{l}690 \\
691 \\
692 \\
693 \\
694\end{array}$ & $\begin{array}{l}29582.9 \\
29629.8 \\
29676.7 \\
29723.6 \\
29770.5\end{array}$ & $\begin{array}{l}46.891 \\
46.890 \\
46.888 \\
46.887 \\
46.885\end{array}$ & $\begin{array}{l}-1.28 \\
-1.34 \\
-1.39 \\
-1.45 \\
-1.50\end{array}$ \\
\hline $\begin{array}{l}580 \\
581 \\
582 \\
583 \\
584\end{array}$ & $\begin{array}{l}24427.1 \\
24473.9 \\
24520.7 \\
24567.5 \\
24614.2\end{array}$ & $\begin{array}{l}46.772 \\
46 \cdot 775 \\
46 \cdot 778 \\
46.781 \\
46.784\end{array}$ & $\begin{array}{l}3.15 \\
3.11 \\
3.07 \\
3.04 \\
3.00\end{array}$ & $\begin{array}{l}640 \\
641 \\
642 \\
643 \\
644\end{array}$ & $\begin{array}{l}27237.8 \\
27284.7 \\
27331.6 \\
27378.5 \\
27425.4\end{array}$ & $\begin{array}{l}46.896 \\
46.896 \\
46.897 \\
46.898 \\
46.899\end{array}$ & $\begin{array}{l}0.97 \\
0.93 \\
0.89 \\
0.85 \\
0.81\end{array}$ & $\begin{array}{l}700 \\
701 \\
702 \\
703 \\
704\end{array}$ & $\begin{array}{l}30051.7 \\
30098.6 \\
30145.5 \\
30192.4 \\
30239.2\end{array}$ & $\begin{array}{l}46.875 \\
46.873 \\
46.871 \\
46.869 \\
46.867\end{array}$ & $\begin{array}{l}-1.85 \\
-1.91 \\
-1.97 \\
-2.03 \\
-2.09\end{array}$ \\
\hline $\begin{array}{l}585 \\
586 \\
587 \\
588 \\
589\end{array}$ & $\begin{array}{l}24661.0 \\
24707.8 \\
24754.6 \\
24801.4 \\
24848.2\end{array}$ & $\begin{array}{l}46.787 \\
46.790 \\
46.793 \\
46.796 \\
46.798\end{array}$ & $\begin{array}{l}2.96 \\
2.93 \\
2.89 \\
2.86 \\
2.82\end{array}$ & $\begin{array}{l}645 \\
646 \\
647 \\
648 \\
649\end{array}$ & $\begin{array}{l}27472.3 \\
27519.2 \\
27566.1 \\
27613.0 \\
27659.9\end{array}$ & $\begin{array}{l}46.900 \\
46.901 \\
46.901 \\
46.902 \\
46.903\end{array}$ & $\begin{array}{l}0.77 \\
0.73 \\
0.69 \\
0.65 \\
0.61\end{array}$ & $\begin{array}{l}705 \\
706 \\
707 \\
708 \\
709\end{array}$ & $\begin{array}{l}30286.1 \\
30333.0 \\
30379.8 \\
30426.7 \\
30473.5\end{array}$ & $\begin{array}{l}46.865 \\
46.863 \\
46.861 \\
46.858 \\
46.856\end{array}$ & $\begin{array}{l}-2.16 \\
-2.22 \\
-2.28 \\
-2.35 \\
-2.41\end{array}$ \\
\hline $\begin{array}{l}590 \\
591 \\
592 \\
593 \\
594\end{array}$ & $\begin{array}{l}24895.0 \\
24941.8 \\
24988.6 \\
25035.4 \\
25082.2\end{array}$ & $\begin{array}{l}46.801 \\
46.804 \\
46.807 \\
46.809 \\
46.812\end{array}$ & $\begin{array}{l}2.78 \\
2.75 \\
2.71 \\
2.68 \\
2.64\end{array}$ & $\begin{array}{l}650 \\
651 \\
652 \\
653 \\
654\end{array}$ & $\begin{array}{l}27706.8 \\
27753.7 \\
27800.6 \\
27847.5 \\
27894.4\end{array}$ & $\begin{array}{l}46.903 \\
46.904 \\
46.904 \\
46.905 \\
46.905\end{array}$ & $\begin{array}{l}0.57 \\
0.53 \\
0.49 \\
0.45 \\
0.41\end{array}$ & $\begin{array}{l}710 \\
711 \\
712 \\
713 \\
714\end{array}$ & $\begin{array}{l}30520.4 \\
30567.2 \\
30614.1 \\
30660.9 \\
30707.8\end{array}$ & $\begin{array}{l}46.854 \\
46.851 \\
46.849 \\
46.846 \\
46.843\end{array}$ & $\begin{array}{l}-2.48 \\
-2.54 \\
-2.61 \\
-2.68 \\
-2.74\end{array}$ \\
\hline $\begin{array}{l}595 \\
596 \\
597 \\
598 \\
599\end{array}$ & $\begin{array}{l}25129.0 \\
25175.8 \\
25222.7 \\
25269.5 \\
25316.3\end{array}$ & $\begin{array}{l}46.815 \\
46.817 \\
46.820 \\
46.822 \\
46.825\end{array}$ & $\begin{array}{l}2.60 \\
2.57 \\
2.53 \\
2.50 \\
2.46\end{array}$ & $\begin{array}{l}655 \\
656 \\
657 \\
658 \\
659\end{array}$ & $\begin{array}{l}27941.3 \\
27988.2 \\
28035.1 \\
28082.0 \\
28128.9\end{array}$ & $\begin{array}{l}46.906 \\
46.906 \\
46.906 \\
46.907 \\
46.907\end{array}$ & $\begin{array}{l}0.37 \\
0.33 \\
0.29 \\
0.24 \\
0.20\end{array}$ & $\begin{array}{l}715 \\
716 \\
717 \\
718 \\
719\end{array}$ & $\begin{array}{l}30754.6 \\
30801.5 \\
30848.3 \\
30895.1 \\
30942.0\end{array}$ & $\begin{array}{l}46.840 \\
46.838 \\
46.835 \\
46.832 \\
46.829\end{array}$ & $\begin{array}{l}-2.81 \\
-2.88 \\
-2.95 \\
-3.02 \\
-3.09\end{array}$ \\
\hline 0 & 25363.1 & 46.827 & 2.42 & 660 & 28175.8 & 46.907 & 0.16 & 720 & 30988.8 & 46.826 & -3.17 \\
\hline
\end{tabular}


TABle 6.5.2. Platinum, Pt-67, versus Type IN thermoelements-thermoelectric voltages, E(T), Seebeck coefficients, $\mathrm{S}(\mathrm{T})$, and first derivative of the Seebeck coefficients, $\mathrm{dS} / \mathrm{dT}$, reference junctions at $O^{\circ} \mathrm{C}$-Continued

\begin{tabular}{|c|c|c|c|c|c|c|c|c|c|c|c|}
\hline${ }^{\circ} \mathrm{C}$ & ${ }_{\mu V}^{E}$ & $\begin{array}{c}S \\
\mu \vee /^{\circ} \mathrm{C}\end{array}$ & $\begin{array}{l}\mathrm{dS} / \mathrm{dT} \\
\mathrm{nV} /{ }^{\circ} \mathrm{C}^{2}\end{array}$ & ${ }^{\circ} \mathrm{C}$ & $\begin{array}{c}E \\
\mu V\end{array}$ & $\begin{array}{c}S \\
\mu V^{\circ} \mathrm{C}\end{array}$ & $\begin{array}{l}d S / d T \\
n V /{ }^{\circ} C^{2}\end{array}$ & ${ }^{\circ} \mathrm{C}$ & $\begin{array}{c}E \\
\mu V\end{array}$ & $\begin{array}{c}S \\
\mu V^{\circ} \mathrm{C}\end{array}$ & $\begin{array}{l}\mathrm{dS} / \mathrm{dT} \\
\mathrm{nV} /{ }^{\circ} \mathrm{C}^{2}\end{array}$ \\
\hline $\begin{array}{l}720 \\
721 \\
722 \\
723 \\
724\end{array}$ & $\begin{array}{l}30988.8 \\
31035.6 \\
31082.4 \\
31129.3 \\
31176.1\end{array}$ & $\begin{array}{l}46.826 \\
46.822 \\
46.819 \\
46.816 \\
46.812\end{array}$ & $\begin{array}{l}-3.17 \\
-3.24 \\
-3.31 \\
-3.39 \\
-3.46\end{array}$ & $\begin{array}{l}735 \\
736 \\
737 \\
738 \\
739\end{array}$ & $\begin{array}{l}31690.8 \\
31737.6 \\
31784.3 \\
31831.1 \\
31877.8\end{array}$ & $\begin{array}{l}46.769 \\
46.765 \\
46.761 \\
46.756 \\
46.751\end{array}$ & $\begin{array}{l}-4.34 \\
-4.42 \\
-4.51 \\
-4.60 \\
-4.68\end{array}$ & $\begin{array}{l}750 \\
751 \\
752 \\
753 \\
754\end{array}$ & $\begin{array}{l}32391 \cdot 8 \\
32438 \cdot 5 \\
32485 \cdot 2 \\
32531 \cdot 8 \\
32578 \cdot 5\end{array}$ & $\begin{array}{l}46.694 \\
46.689 \\
46.683 \\
46.677 \\
46.671\end{array}$ & $\begin{array}{l}-5.71 \\
-5.81 \\
-5.91 \\
-6.01 \\
-6.11\end{array}$ \\
\hline $\begin{array}{l}725 \\
726\end{array}$ & 31222.9 & 46.809 & -3.54 & 740 & 31924.6 & $\begin{array}{l}46.747 \\
46.74 ?\end{array}$ & $\begin{array}{l}-4.77 \\
-4.86\end{array}$ & $\begin{array}{l}755 \\
756\end{array}$ & $32625 \cdot 2$ & $\begin{array}{l}46.665 \\
46.658\end{array}$ & $\begin{array}{l}-6 \cdot 21 \\
-6 \cdot 32\end{array}$ \\
\hline $\begin{array}{l}726 \\
727 \\
728 \\
729\end{array}$ & $\begin{array}{l}31316.5 \\
31363.3 \\
31410.1\end{array}$ & $\begin{array}{l}46.805 \\
46.802 \\
46.798 \\
46.794\end{array}$ & $\begin{array}{l}-3.61 \\
-3.69 \\
-3.77 \\
-3.85\end{array}$ & $\begin{array}{l}741 \\
742 \\
743 \\
744\end{array}$ & $\begin{array}{l}31971 \cdot 3 \\
32018 \cdot 1 \\
32064 \cdot 8 \\
32111 \cdot 5\end{array}$ & $\begin{array}{l}46 \cdot 742 \\
46 \cdot 737 \\
46 \cdot 732 \\
46.727\end{array}$ & $\begin{array}{l}-4 \cdot 86 \\
-4.95 \\
-5.04 \\
-5.13\end{array}$ & $\begin{array}{l}156 \\
757 \\
758 \\
759\end{array}$ & $\begin{array}{l}32671.8 \\
32718.5 \\
32765.2 \\
32811.8\end{array}$ & $\begin{array}{l}46.658 \\
46.652 \\
46.645 \\
46.639\end{array}$ & $\begin{array}{l}-6 \cdot 32 \\
-6.42 \\
-6 \cdot 53 \\
-6.64\end{array}$ \\
\hline $\begin{array}{l}730 \\
731 \\
732 \\
733 \\
734\end{array}$ & $\begin{array}{l}31456.9 \\
31503.7 \\
31550.5 \\
31597.2 \\
31644.0\end{array}$ & $\begin{array}{l}46.790 \\
46.786 \\
46.782 \\
46.778 \\
46.774\end{array}$ & $\begin{array}{l}-3.93 \\
-4.01 \\
-4.09 \\
-4.17 \\
-4.25\end{array}$ & $\begin{array}{l}745 \\
746 \\
747 \\
748 \\
749\end{array}$ & $\begin{array}{l}32158.2 \\
32205.0 \\
32251.7 \\
32299.4 \\
32345.1\end{array}$ & $\begin{array}{l}46.722 \\
46.716 \\
46.711 \\
46.706 \\
46.700 .\end{array}$ & $\begin{array}{l}-5.23 \\
-5.32 \\
-5.42 \\
-5.51 \\
-5.61\end{array}$ & 760 & 32858.4 & 46.632 & -6.75 \\
\hline 735 & 31690.8 & 46.769 & $-4 \cdot 34$ & 750 & 32391.8 & 46.694 & -5.71 & & & & \\
\hline
\end{tabular}


TABLE 6.5.3. Thermoelectric values at the fixed points for platinum, $\mathrm{Pt}-67$, versus Type JN thermoelements

\begin{tabular}{|c|c|c|c|c|}
\hline Fixed poin! & $\begin{array}{c}\text { Temp. } \\
{ }^{\circ} \mathrm{C}\end{array}$ & $\begin{array}{c}E \\
\mu \mathrm{V}\end{array}$ & $\underset{\mu \mathrm{V} /{ }^{\circ} \mathrm{C}}{S}$ & $\begin{array}{c}d S / d T \\
\mathrm{nV} /{ }^{\circ} \mathrm{C}^{2}\end{array}$ \\
\hline Nitrogen TP & -210.002 & -5535.4 & 19.429 & 76.07 \\
\hline Nitrogen NBP & -195.802 & -5251.9 & 20.490 & 73.47 \\
\hline Oxygen NBP & -182.962 & -4982.8 & 21.419 & 71.32 \\
\hline Carbon Dioxide SP & -78.476 & -2381.8 & 28.147 & 58.57 \\
\hline Mercury FP & -38.862 & -1221.8 & 30.394 & 54.92 \\
\hline Ice point & 0.000 & 0.0 & 32.462 & 51.52 \\
\hline Ether TP & 26.870 & 890.6 & 33.815 & 49.18 \\
\hline Water BP & 100.000 & 3489.2 & 37.171 & 42.51 \\
\hline Benzoic TP & 122.370 & 4331.2 & 38.098 & 40.36 \\
\hline Indium $\mathrm{FP}$ & 156.634 & 5659.6 & 39.423 & 36.96 \\
\hline Tin $\mathrm{FP}$ & 231.9681 & 8727.1 & 41.917 & 29.20 \\
\hline Bismuth FP & 271.442 & 10403.4 & 42.989 & 25.13 \\
\hline Cadmium FP & 321.108 & 12567.4 & 44.113 & 20.19 \\
\hline Lead FP & 327.502 & 12849.9 & 44.240 & 19.57 \\
\hline Mercury BP & 356.660 & 14147.8 & 44.771 & 16.87 \\
\hline Zinc FP & 419.580 & 16994.6 & 45.665 & 11.69 \\
\hline Sulphur BP & 444.674 & 18144.0 & 45.936 & 9.92 \\
\hline $\mathrm{Cu}-\mathrm{Al} \mathrm{FP}$ & 548.23 & 22943.0 & 46.652 & 4.38 \\
\hline Antimony FP & 630.74 & 26803.6 & 46.885 & 1.32 \\
\hline Aluminum FP & 660.37 & 28193.2 & 46.907 & 0.14 \\
\hline
\end{tabular}

TABLE 6.5.4. Estimated maximum errors that occur when using reduced-bit arithmetic for the power series expansion for the thermoelectric voltage of platinum, $\mathrm{Pt}-67$, versus Type JN thermoelements

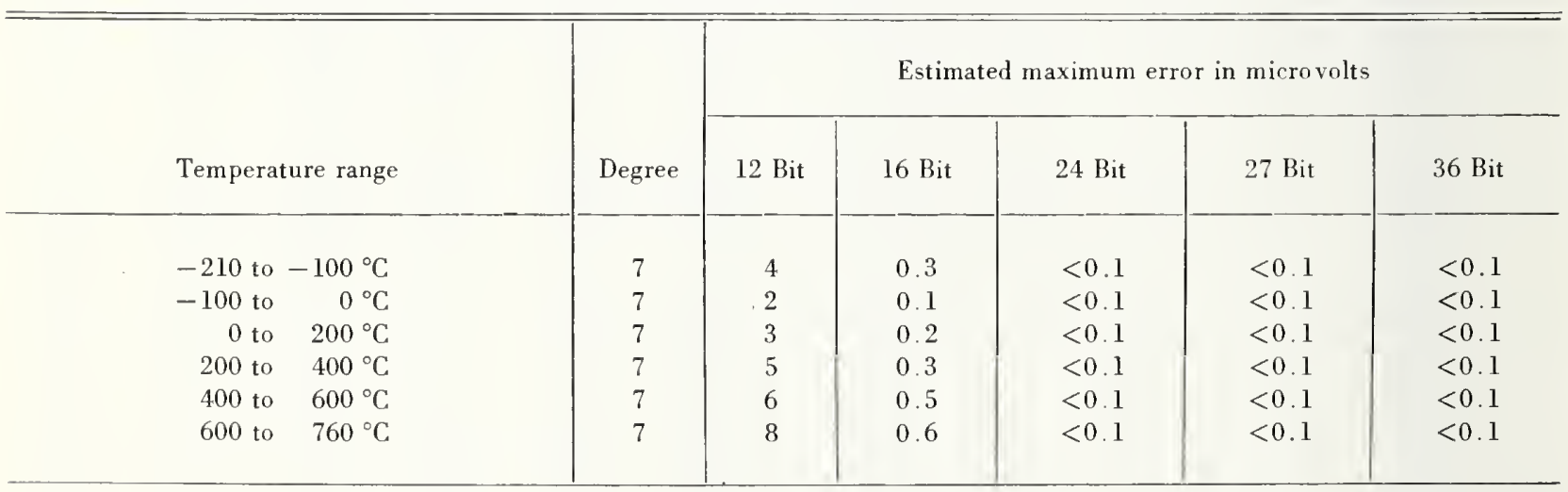




\section{TYPE K-Nickel-Chromium Alloy Versus Nickel-Aluminum Alloy Thermocouples}

\subsection{Material Specifications and Precautions}

This type is more resistant to oxidation at elevated temperatures than the Types $\mathrm{E}, \mathrm{J}$ or $\mathrm{T}$ thermocouples and consequently it finds wide application at temperatures above $500{ }^{\circ} \mathrm{C}$. The positive thermoelement, $\mathrm{KP}$, which is the same as EP, is an alloy that typically contains about 89 to 90 percent nickel, 9 to nearly 9.5 percent chromium, both silicon and iron in amounts up to about 0.5 percent, plus smaller amounts of other constituents such as carbon, manganese, cobalt and niobium. The negative thermoelement, $\mathrm{KN}$, is typically composed of about 95 to 96 percent nickel, 1 to 1.5 percent silicon, 1 to 2.3 percent aluminum, 1.6 to 3.2 percent manganese, up to about 0.5 percent cobalt and smaller amounts of other constituents such as iron, copper and lead. Type KN thermoelements with modified compositions are also available for use in special applications. These include alloys in which the manganese and aluminum contents are reduced or eliminated, while the silicon and cobalt contents are increased.

Type K thermocouples were developed in 1906 and were known originally as "Chromel" 1 versus "Alumel" 1 thermocouples. The Hoskins Manufacturing Company was the sole manufacturer of these thermocouples in this country until the mid-1940's. After this time other Type $\mathrm{K}$ thermocouples such as Topel ${ }^{2}$ versus $\mathrm{Nial}^{2}, \mathrm{~T}_{1}{ }^{3}$ versus $\mathrm{T}_{2}{ }^{3}$, and Thermo Kanthal $\mathrm{KP}^{4}$ versus ThermoKanthal $\mathrm{KN}^{4}$ were in. troduced commercially.

The first reference tables for Type $\mathrm{K}$ thermocouples to gain general industry-wide acceptance were the ones prepared by Roeser et al. in 1935 . They based their tables upon the calibrations of 30 samples of No. 8 AWG Type KP and Type KN thermoelements, except that below $0{ }^{\circ} \mathrm{C}$ they used only two samples each of the $\mathrm{KP}$ and $\mathrm{KN}$ thermoelements. The thermoelements were all furnished by the Hoskins Manufacturing Co. (the only manufacturer at the time), and they were selected by the manufacturer from 100 production tests. The tabular values of Roeser et al. [1935] were corrected by Shenker et al. [1951 and 1955] to account for changes in the temperature scales and electrical units and presented in NBS Circular 561.

Extensive research on the subzero properties of Type $\mathrm{K}$ thermocouples was performed by members of the Cryogenics Division in Boulder. That research was summarized and tabulated by Sparks et al. [1972] in NBS Monograph 124. While they found the Type E thermocouple to be the most satisfactory of the standardized letter-designated type thermocouples for measurements down to liquid hydrogen temperature $(20.28$ $\mathrm{K})$, Type $\mathrm{K}$ thermocouples may also be used at these temperatures. However, their Seebeck coefficient (about $4 \mu \mathrm{V} / \mathrm{K}$ at $20 \mathrm{~K}$ ) is only about one-half of that of Type $\mathrm{E}$ thermocouples. Furthermore, the ther-

\footnotetext{
1 Trademark-Hoskins Manufacturing Company.

2 Trademark-Wilbur B. Driver Company.

3 Trademark-Driver IIarria Company.

- Trademark-Kanthal Corporation.
}

moelectric homogeneity of $\mathrm{KN}$ thermoelements is generally not quite as good as that of EN thermoelements. Both the KP and the KN thermoelements do have a relatively low thermal conductivity and good resistance to corrosion in moist atmospheres at low temperatures.

Type $\mathrm{K}$ thermocouples are recommended by the ASTM [1970] for continuous use at temperatures within the range -250 to $1260{ }^{\circ} \mathrm{C}$ in oxidizing or inert atmospheres. Both the $\mathrm{KP}$ and the $\mathrm{KN}$ thermoelements are subject to oxidation when used in air above about $850{ }^{\circ} \mathrm{C}$, but even so, Type $\mathrm{K}$ thermocouples may be used at temperatures up to about $1350{ }^{\circ} \mathrm{C}$ for short periods with only small changes in calibration. When oxidation occurs it normally leads to a gradual increase in the thermoelectric voltage with time. The magnitude of the change in the thermoelectric voltage and the physical life of the thermocouple will depend upon such factors as the temperature, time at temperature, diameter of the thermoelements and conditions of use. The thermoelectric instability of Type $\mathrm{K}$ thermocouples in air at elevated temperatures has been carefully studied by Dahl [1941], Potts and McElroy [1962], Burley and Ackland [1967] and by Wang et al. [1969] and their work should be consulted for details.

In addition, the ASTM Manual STP 470 [1970] gives the following restrictions on the use of Type $\mathrm{K}$ thermocouples:

They should not be used in sulfurous, reducing, or alternately reducing and oxidizing atmospheres unless suitably protected with protecting tubes. They should not be used in vacuum (at high temperatures) for extended times because the chromium in the positive thermoelement vaporizes out of solution and alters the calibration. They should also not be used in atmos. pheres that promote "green-rot" corrosion (those with low, but not negligible, oxygen content).

Both thermoelements of Type $\mathrm{K}$ thermocouples are reasonably stable, thermoelectrically, under neutron irradiation since the resulting changes in their chem. ical compositions due to transmutation are small. The KN thermoelements are somewhat less stable than the $\mathrm{KP}$ thermoelements in that they experience a small increase in the iron content accompanied by a slight decrease in the manganese and cobalt contents.

Neither thermoelement of a Type K thermocouple is very sensitive to minor changes in composition or impurity level because both are already heavily alloyed. Similarly, they are also not extremely sensitive to minor differences in heat treatment (provided that the treatment does not violate any of the restrictions mentioned above). For most general applications they may be used with the heat treatment routinely given by the wire manufacturer. However, when extreme accuracy is sought, the thermoelements may require additional preparatory heat treatments in order to achieve the desired results. Details on this and other phases of the use and behavior of Type $K$ thermocouples are given in the articles by Potts and McElroy [1962], and Burley [1969 and 1971]. 
ASTM Standard E230-72 in the Annual Book of ASTM Standards [1972] specifies that the standard limits of error for Type $K$ commercial thermocouples be $\pm 2.2{ }^{\circ} \mathrm{C}$ between 0 and $277{ }^{\circ} \mathrm{C}$ and $\pm 3 / 4$ percent between 277 and $1260{ }^{\circ} \mathrm{C}$. Limits of error are not specified for Type $\mathrm{K}$ thermocouples below $0{ }^{\circ} \mathrm{C}$. Type $\mathrm{K}$ thermocouples can also be supplied to meet special limits of error, which are equal to one half the standard limits of error given above. The recommended upper temperature limit for protected Type K thermocouples, $1260{ }^{\circ} \mathrm{C}$, applies for AWG $8(3.3 \mathrm{~mm})$ wire. For smaller wires it decreases to $1093{ }^{\circ} \mathrm{C}$ for AWG 14 (1.6 mm), $982{ }^{\circ} \mathrm{C}$ for AWG $20(0.8 \mathrm{~mm})$, and $871{ }^{\circ} \mathrm{C}$ for AWG 24 or 28 ( 0.5 or $0.3 \mathrm{~mm}$ ).

While limits of error for single-leg thermoelements versus platinum are not given in ASTM Standard E230-72, the Type KP and KN thermoelements are supplied, by comınon practice, to a voltage tolerance equivalent to one half the tolerance specified for the Type K thermocouple.

\subsection{Data Analyses and Comparisons}

The fitting functions for Type $\mathrm{K}$ thermocouples are based on three sets of data: below $0{ }^{\circ} \mathrm{C}$, the research and equations of Sparks et al. [1972] were used directly; above $0{ }^{\circ} \mathrm{C}$, values from NBS Circular 561, Shenker et al. [1955] were used after being modified to be on the new IPTS-68. Also used for fitting above $0{ }^{\circ} \mathrm{C}$ were two representative calibrations from the Temperature Section of the National Bureau of Stand. ards in Gaithersburg. Unfortunately there were no data available for both high- and low-temperature calibrations on the same spool or lot of present-day material. This deficiency leads to difficulties in join. ing high-and low-temperature calibration curves near $0{ }^{\circ} \mathrm{C}$.

Sparks et al. [1972] based their recommended low temperature values for the positive thermoelement, $\mathrm{KP}$, on a selected wire that was most representative of three wires selected from nine spools made by three different manufacturers. Material from all nine spools was certified by their manufacturers to be within the special limits of error (as listed in the last section) at high temperatures. Similarly, the negative thermoelement, KN, represented the most representative wire from a similar sampling. The wires for both positive and negative thermoelements were selected after completion of careful spot calibration and inhomogeneity tests as described in Monograph 124, Sparks et al. [1972]. Values for the single thermoelements are given versus the platinum reference standard, $\mathrm{Pt}-67$. Thermoelectric values for both thermoelements and the combination were relatively difficult to fit precisely. Values for the positive thermoelement required a 12th degree power series to fit 68 points between about -270 and $0{ }^{\circ} \mathrm{C}$ with an imprecision of $0.12 \mu \mathrm{V}$; the negative thermoelement required a 12th degree power series to give $0.13 \mu \mathrm{V}$; and the combination (fit independently), 10th degree for an imprecision of 0.08 1.V. In Monograph 124 the two thermoelements and the total combination were fit independently; for this Monograph equations for the total combination and for the positive thermoelement were used directly but the negative values were obtained by subtraction, sym. bolically, $K N=K-K P$. Therefore the equation for KN given in this Monograph will differ very slightly from the ${ }^{\circ} \mathrm{C}$ transformation of the one given in Mono. graph 124. The difference in calculated values will usually be less than the imprecision of the separate fits, $0.13 \mu \mathrm{V}$.

Representative calibration data on Type $\mathrm{K}$ thermo. couples are mucli more sparse above $0^{\circ} \mathrm{C}$ than they are below. Some of the data points for Type $\mathrm{K}$ were selected from NBS Circular 561, adjusted to the present temperature scale, IPTS-68. The others were taken from two representative calibrations for Type K thermocouples that were furnished by the Temperature Section of the National Bureau of Standards, Gaithersburg. The fitting power series was constrained to have the same values for the thermoelectric voltage and Seebeck coefficient at $0{ }^{\circ} \mathrm{C}$ as those obtained from the low temperature equations. A tenth degree equa. tion (with constrained constant and linear term and a three constant exponential term) fit 63 selected key tabular and experimental data points between 0 and $1402{ }^{\circ} \mathrm{C}$ with an imprecision of $7.8 \mu \mathrm{V}$. Note that this is almost 100 times greater than for the low tem. perature fit. The second derivative was not constrained at the join.

Fortunately there was a large amount of good data for the positive thermoelenient, KP. The fit was based on 93 data points from three calibrations (selected from a set of 13 calibrations) provided by the Tem. perature Section of the National Bureau of Standards and from a set of selected values in a widely dis. tributed, but unpublished, NBS thermoelement table [Burns, 1967]. All of the high temperature values had to be adjusted to be on the IPTS-68 and to be referenced to $\mathrm{Pt}-67$. A seventh degree equation, with the constant and linear terms constrained to match the low temperature values, had a fitting imprecision of $6.0 \mu \mathrm{V}$ for a range from 0 to $1371{ }^{\circ} \mathrm{C}$.

The values for thermoelectric voltages of Type $K$ thermocouples given in this Monograph were compared to those given by Shenker et al. [1955] in NBS Circular 561, to those given by Sparks et al. [1972], and to four representative calibrations from the Tem. perature Section of the National Bureau of Standards, Gaithersburg. The deviations are shown in figure 7.2.1. The values from NBS Circular 561 were adjusted to the IPTS- 68 . Above $0{ }^{\circ} \mathrm{C}$, the deviations between the values in this Monograph and those in NBS Circular 561 are caused primarily by the differences in fitting techniques. Below $0{ }^{\circ} \mathrm{C}$, the deviations are caused primarily by chemical composition changes in the thermoelements. The modern materials are slightly different in some of the minor additives. Similar graphs for the Type KP and KN thermoelements are given in figures 7.2.2 and 7.2.3.

Deviations between values given in this Monograph and those given in NBS Circular 561 are shown more clearly in figure 7.2.4. The earlier values were adjusted to the IPTS-68. The width of the curve indicates the roundoff uncertainty $(10 \mu \mathrm{V})$ in the tabular values given in NBS Circular 561. 


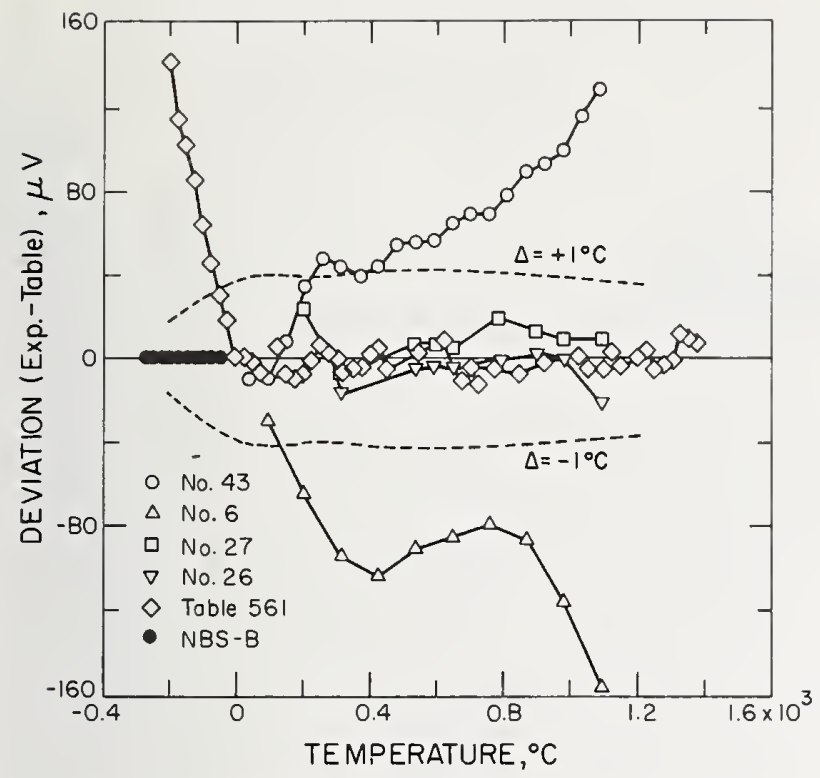

Figure 7.2.1. Deviations of thermoelectric voltages of Type $K$ thermocouples-comparison of values given in this Monograph to those given by: Table 561, NBS Circular 561; NBS-B, Sparks, et al. [1972]; Nos. 6, 26, 27, and 43, selected calibrations from the Temperature Section (NBS, Gaithersburg).

Values from previous publications and tests are adjusted to the IPTS 68 . The dashed lines indicate a deviation of $1^{\circ} \mathrm{C}$.

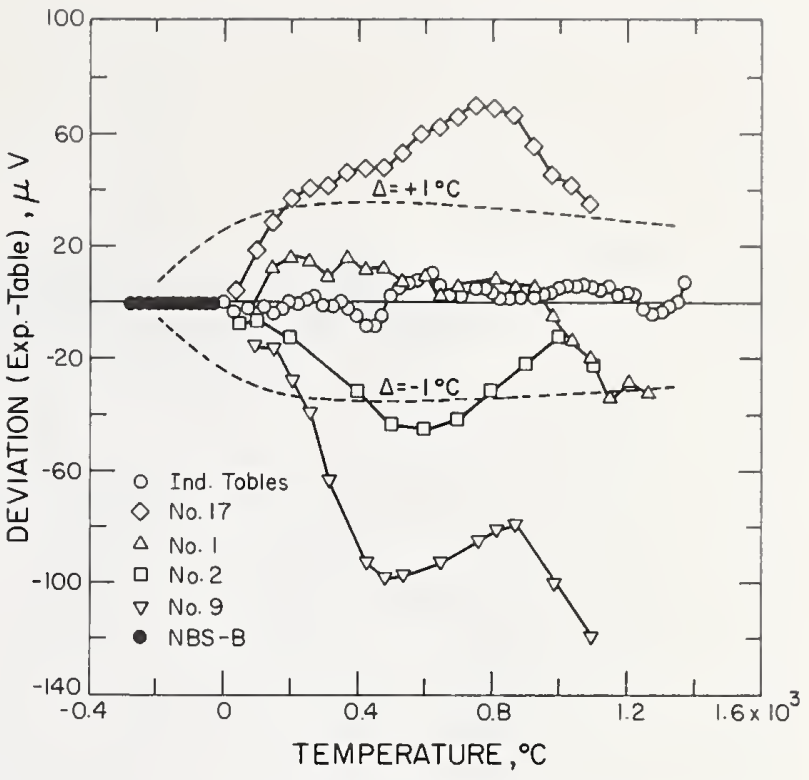

Figure 7.2.2. Deviations of thermoelectric voltages of Type $K P$ (or EP) thermoelements versus platinum, Pt-67-comparison of values in this Monograph to those given by: Ind. Tables, unpublished NBS data by Burns [1967]; NBS-B, Sparks, et al. [1972]; Nos. 1, 2, 9 and 17, selected calibrations from the Temperature Section (NBS, Gaithersburg). Values from previous publications and tests are adjusted to the IPTS -68 . The dashed lines indicate a deviation of $1^{\circ} \mathrm{C}$.

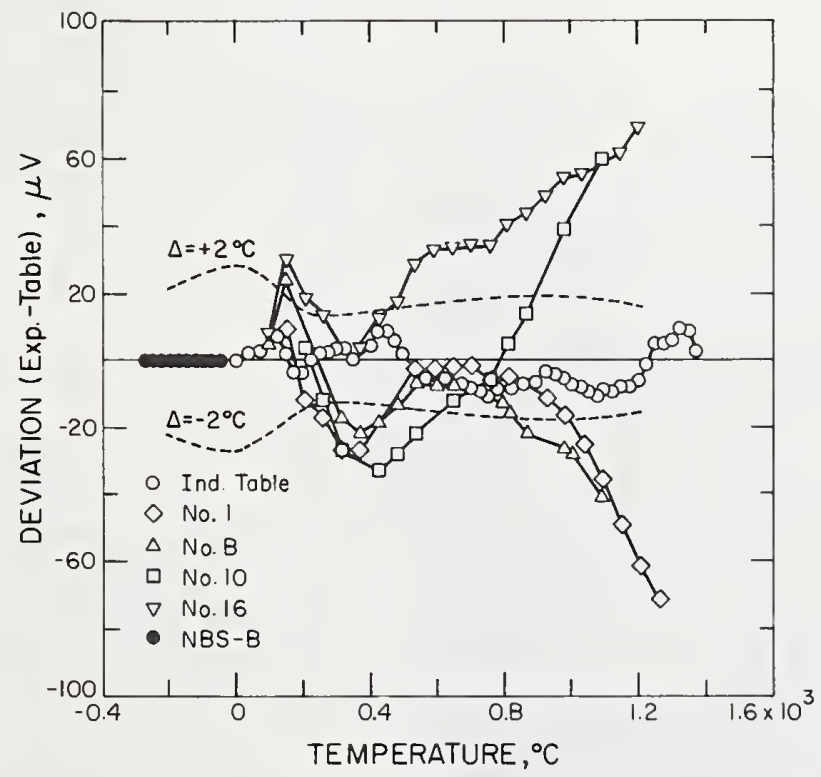

Figure 7.2.3. Deviations of the thermoelectric voltages of platinum, $P t-67$, versus Type $K N$ thermoelements-comparison of values given in this Monograph to those given by: Ind. Table, unpublished NBS data by Burns [1967]; NBS-B, Sparks, et al. [1972]; Nos. 1, 8, 10, and 16, selected calibrations from the Temperature Section (NBS, Gaithersburg). Values from previous publications and tests are adjusted to the IPTS -68 . The dashed lines indicate a deviation of $2^{\circ} \mathrm{C}$. 


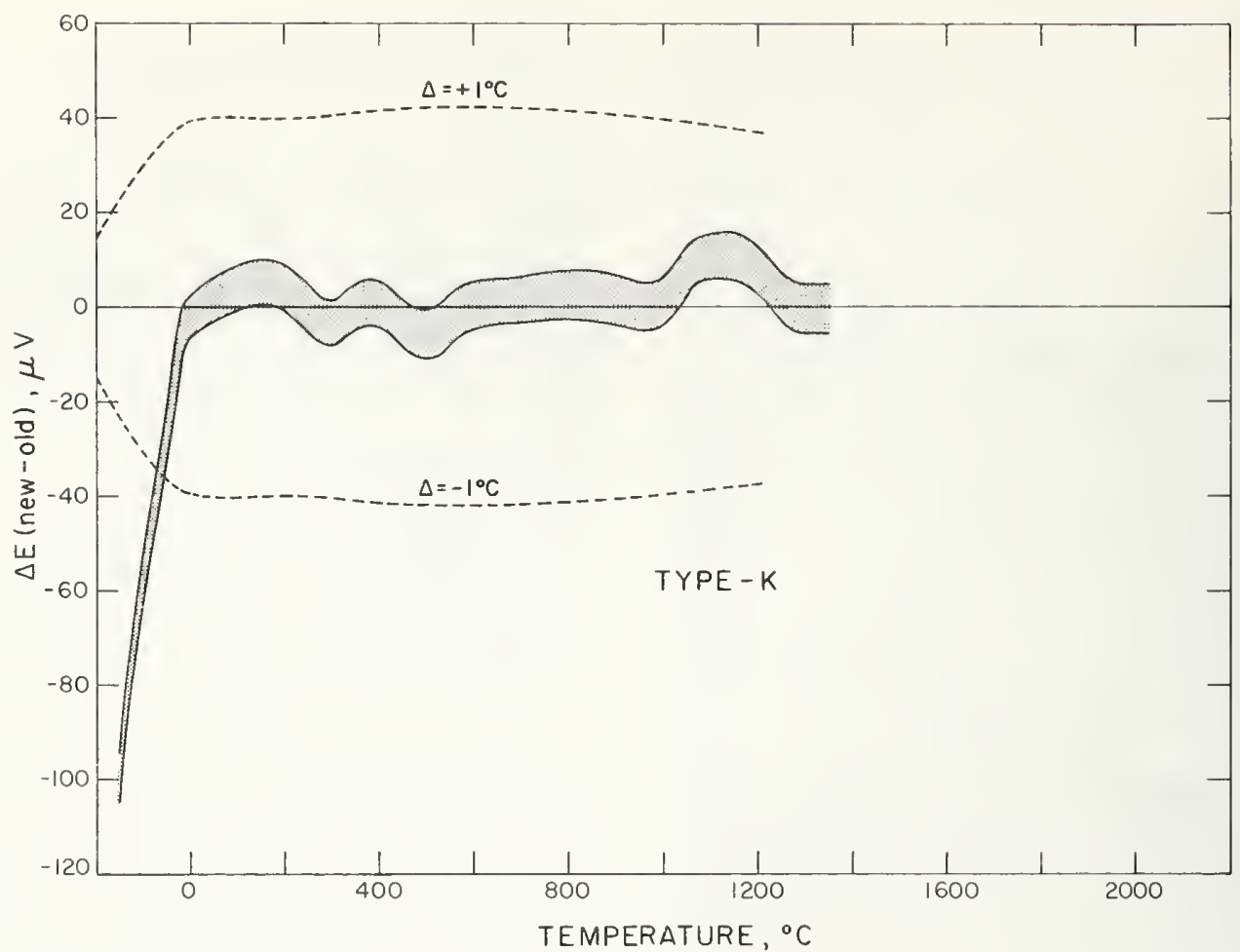

F1GURE 7.2.4. Differences in the thermoelectric voltages for Type $K$ thermocouples-comparison of values given in this Monograph to those given in NBS Circular 561.

The width of the shaded curve indicates the round-off uncertainty in the previous tabular values. Values from NBS Circular 561 are adjusted to the 1PTS -68 . The dashed lines indicate a deviation of $1{ }^{\circ} \mathrm{C}$.

\subsection{Reference Functions and Tables for Type K Thermocouples}

The coefficients for the tenth degree expansion for the thermoelectric voltage of Type $K$ thermocouples below $0{ }^{\circ} \mathrm{C}$ are given in table 7.3.1. The coefficients for the eighth degree expansion plus an exponential term for use above $0{ }^{\circ} \mathrm{C}$ are also given in table 7.3.1. The errors caused by using reduced bit arithmetic for calculating values of the functions are given in table 7.3.4.

The primary reference values for Type $K$ thermocouples are given in table 7.3.2. Values at selected fixed points are given in table 7.3.3. Graphs of the thermoelectric voltage, its first derivative (Seebeck coefficient), and second derivative are given in figures 7.3.1, 7.3.2, and 7.3.3, respectively.

It should be stressed that Type $\mathbb{K}$ thermocouple materials that conform closely to the high temperature values may not necessarily conform closely at low temperatures (below $0^{\circ} \mathrm{C}$ ) and vice versa. If Type $K$ thermocouples are to be used for accurate measurements both above and below $0{ }^{\circ} \mathrm{C}$, then the material must be calibrated in the full temperature range, both above and below $0{ }^{\circ} \mathrm{C}$. Special selection of material will often be required.

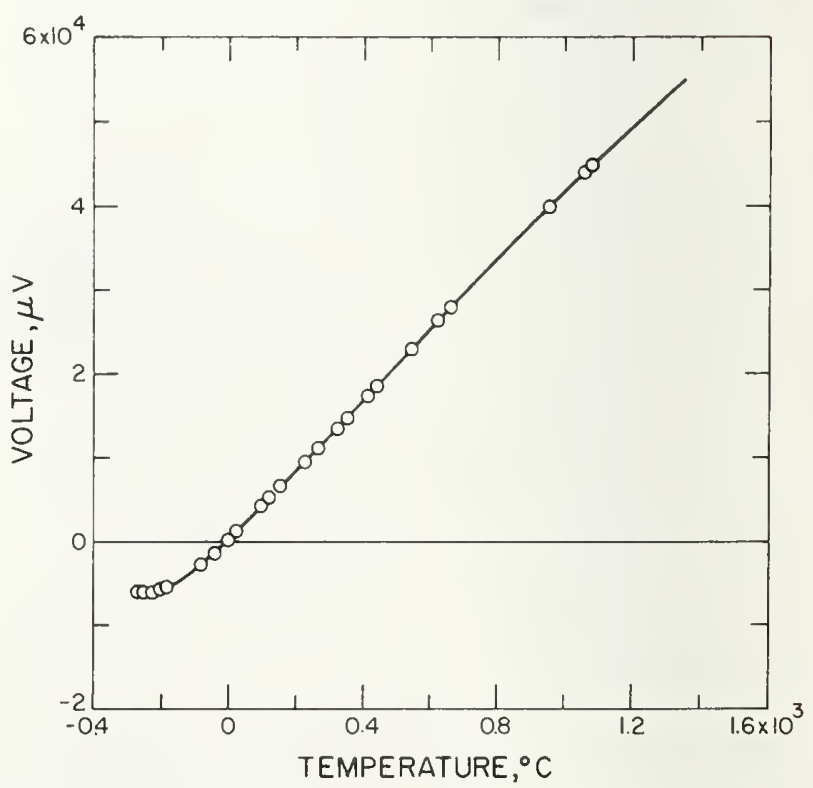

Figure 7.3.1. Thermoelectric voltage for Type $K$ thermocouples.

The circles indicate values at various thermometric fixed points on the IPTS-68. 


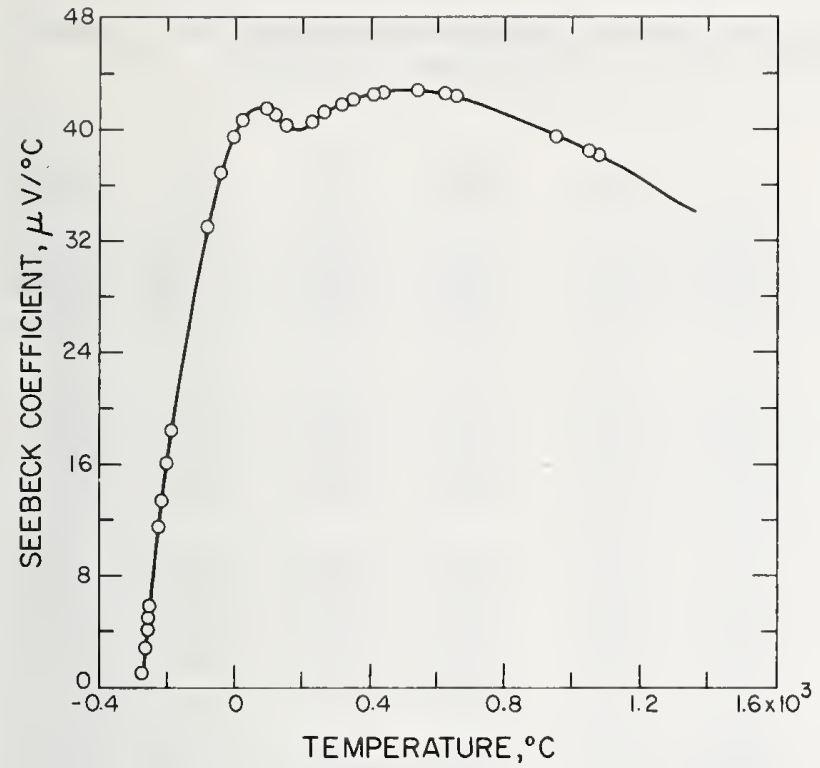

Figure 7.3.2. Seebeck coefficient for Type $K$ thermocouples. The circles indicate values at various thermometric fixed points on the IPTS -68 .

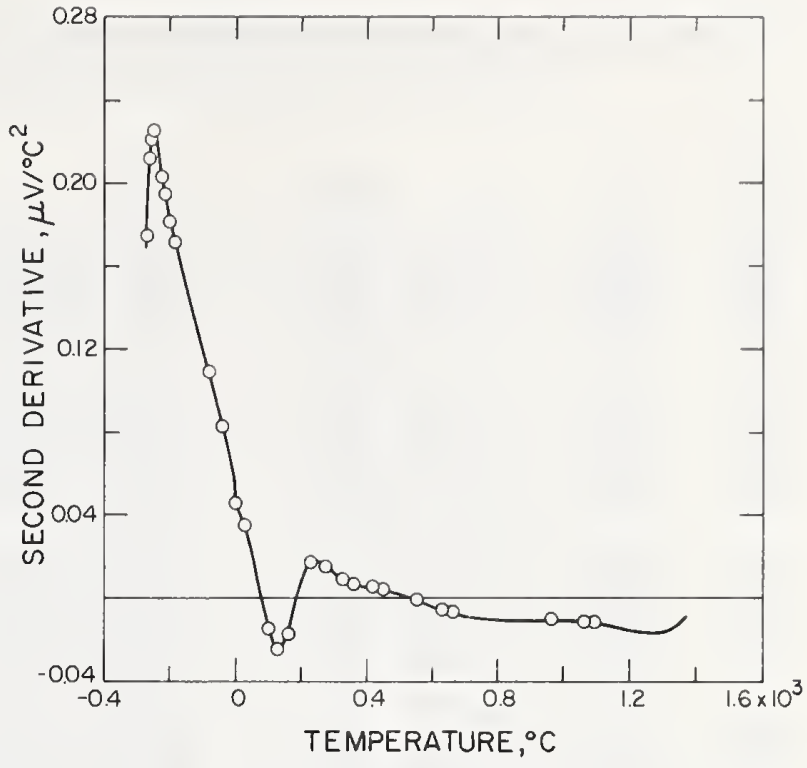

FIgURE 7.3.3. Second derivative of thermoelectric voltage for Type $K$ thermocouples. The circles indicate values at various thermometric fixed points on the
IPTS -68 .

TABLE 7.3.1. Power series expansion for the thermoelectric voltage of Type $K$ thermocouples

\begin{tabular}{|c|c|c|c|}
\hline $\begin{array}{c}\text { Tempera- } \\
\text { ture } \\
\text { range }\end{array}$ & Degree & Coefficients & Term \\
\hline $\begin{array}{c}-270 \text { to } \\
0^{\circ} \mathrm{C}\end{array}$ & 10 & $\begin{array}{r}3.9475433139 \times 10^{1} \\
2.7465251138 \times 10^{-2} \\
-1.6565406716 \times 10^{-4} \\
-1.5190912392 \times 10^{-6} \\
-2.4581670924 \times 10^{-8} \\
-2.4757917816 \times 10^{-10} \\
-1.5585276173 \times 10^{-12} \\
-5.9729921255 \times 10^{-15} \\
-1.2688801216 \times 10^{-19} \\
-1.1382797374 \times 10^{-20}\end{array}$ & $\begin{array}{l}T \\
T^{2} \\
T^{3} \\
T^{4} \\
T^{5} \\
T^{6} \\
T^{7} \\
T^{8} \\
T^{9} \\
T^{10}\end{array}$ \\
\hline $\begin{array}{l}0 \text { to } \\
\quad 1372{ }^{\circ} \mathrm{C}\end{array}$ & $8+\exp$ & $\begin{aligned}-1.8533063273 \times 10^{1} \\
3.8918344612 \times 10^{1} \\
1.6645154356 \times 10^{-2} \\
-7.8702374448 \times 10^{-6} \\
2.2835785557 \times 10^{-7} \\
-3.5700231258 \times 10^{-10} \\
2.9932909136 \times 10^{-13} \\
-1.2849848798 \times 10^{-16} \\
2.2239974336 \times 10^{-20} \\
+125 \exp \left[-\frac{1}{2}\left(\frac{T-127}{65}\right)\right.\end{aligned}$ & $\begin{array}{l}T \\
T \\
T^{2} \\
T^{3} \\
T^{4} \\
T^{5} \\
T^{6} \\
T^{7} \\
T^{8} \\
7\end{array}$ \\
\hline
\end{tabular}


TABLE 7.3.2. Type $K$ thermocouples-thermoelectric voltages, $\mathrm{E}(\mathrm{T})$, Seebeck coefficients, $\mathrm{S}(\mathrm{T})$, and first derivative of the Seebeck coefficients, $\mathrm{dS} / \mathrm{dT}$, reference junctions at $0{ }^{\circ} \mathrm{C}$

\begin{tabular}{|c|c|c|c|c|c|c|c|c|c|c|c|}
\hline $\begin{array}{l}\mathrm{T} \\
{ }^{\circ} \mathrm{C}\end{array}$ & $\begin{array}{l}E \\
\mu V\end{array}$ & $\underset{\mu V /{ }^{\circ} \mathrm{C}}{S}$ & $\begin{array}{l}d S / O T \\
n V /{ }^{\circ} C^{2}\end{array}$ & $\begin{array}{l}\mathrm{T} \\
{ }^{\circ} \mathrm{C}\end{array}$ & $\underset{\mu V}{E}$ & $\underset{\mu \mathrm{V} /{ }^{\circ} \mathrm{C}}{\mathrm{S}}$ & $\begin{array}{l}d S / d T \\
n V /{ }^{\circ} C^{2}\end{array}$ & ${ }^{\circ} \mathrm{C}$ & $\underset{\mu V}{E}$ & $\underset{\mu V / /{ }^{\circ} \mathrm{C}}{S}$ & $\begin{array}{l}\mathrm{dS} / \mathrm{dT} \\
\mathrm{nV} /{ }^{\circ} \mathrm{C}^{2}\end{array}$ \\
\hline $\begin{array}{l}-270 \\
-269 \\
-268 \\
-267 \\
-266\end{array}$ & $\begin{array}{l}-6457.82 \\
-6456.99 \\
-6455.99 \\
-6454.81 \\
-6453.45\end{array}$ & $\begin{array}{l}0.739 \\
0.911 \\
1.088 \\
1.270 \\
1.458\end{array}$ & $\begin{array}{l}168.65 \\
174.56 \\
180.02 \\
185.07 \\
189.72\end{array}$ & $\begin{array}{l}-240 \\
-239 \\
-238 \\
-237 \\
-236\end{array}$ & $\begin{array}{l}-6343.92 \\
-6336.72 \\
-6329.29 \\
-6321.63 \\
-6313.76\end{array}$ & $\begin{array}{l}7.096 \\
7.319 \\
7.541 \\
7.762 \\
7.983\end{array}$ & $\begin{array}{l}222.90 \\
222.30 \\
221.63 \\
220.91 \\
220.14\end{array}$ & $\begin{array}{l}-210 \\
-209 \\
-208 \\
-207 \\
-206\end{array}$ & $\begin{array}{l}-6034.63 \\
-6021.16 \\
-6007.49 \\
-5993.64 \\
-5979.59\end{array}$ & $\begin{array}{l}13.373 \\
13.566 \\
13.759 \\
13.950 \\
14.141\end{array}$ & $\begin{array}{l}193.87 \\
192.89 \\
191.92 \\
190.96 \\
190.02\end{array}$ \\
\hline $\begin{array}{l}-265 \\
-264 \\
-263 \\
-262 \\
-261\end{array}$ & $\begin{array}{l}-6451.90 \\
-6450.15 \\
-6448.20 \\
-6446.06 \\
-6443.71\end{array}$ & $\begin{array}{l}1.650 \\
1.846 \\
2.045 \\
2.248 \\
2.455\end{array}$ & $\begin{array}{l}193.98 \\
197.89 \\
201.46 \\
204.70 \\
207.64\end{array}$ & $\begin{array}{l}-235 \\
-234 \\
-233 \\
-232 \\
-231\end{array}$ & $\begin{array}{l}-6305.67 \\
-6297.36 \\
-6288.83 \\
-6280.08 \\
-6271.12\end{array}$ & $\begin{array}{l}8.202 \\
8.421 \\
8.639 \\
8.856 \\
9.073\end{array}$ & $\begin{array}{l}219.32 \\
218.47 \\
217.57 \\
216.65 \\
215.70\end{array}$ & $\begin{array}{l}-205 \\
-204 \\
-203 \\
-202 \\
-201\end{array}$ & $\begin{array}{l}-5965.36 \\
-5950.93 \\
-5936.32 \\
-5921.52 \\
-5906.53\end{array}$ & $\begin{array}{l}14.330 \\
14.519 \\
14.707 \\
14.893 \\
15.079\end{array}$ & $\begin{array}{l}189.08 \\
188.17 \\
187.26 \\
186.37 \\
185.49\end{array}$ \\
\hline $\begin{array}{l}-260 \\
-259 \\
-258 \\
-257 \\
-256\end{array}$ & $\begin{array}{l}-6441 \cdot 15 \\
-6438 \cdot 38 \\
-6435 \cdot 40 \\
-6432 \cdot 20 \\
-6428 \cdot 79\end{array}$ & $\begin{array}{l}2.664 \\
2.875 \\
3.089 \\
3.305 \\
3.522\end{array}$ & $\begin{array}{l}210.29 \\
212.67 \\
214.79 \\
216.67 \\
218.31\end{array}$ & $\begin{array}{l}-230 \\
-229 \\
-228 \\
-227 \\
-226\end{array}$ & $\begin{array}{l}-6261.93 \\
-6252.54 \\
-6242.93 \\
-6233.11 \\
-6223.08\end{array}$ & $\begin{array}{r}9.288 \\
9.502 \\
9.715 \\
9.927 \\
10.139\end{array}$ & $\begin{array}{l}214.72 \\
213.72 \\
212.70 \\
211.67 \\
210.62\end{array}$ & $\begin{array}{l}-200 \\
-199 \\
-198 \\
-197 \\
-196\end{array}$ & $\begin{array}{l}-5891.36 \\
-5876.00 \\
-5860.46 \\
-5844.74 \\
-5828.84\end{array}$ & $\begin{array}{l}15.264 \\
15.449 \\
15.632 \\
15.814 \\
15.996\end{array}$ & $\begin{array}{l}184.63 \\
183.78 \\
182.94 \\
182.12 \\
181.30\end{array}$ \\
\hline $\begin{array}{l}-255 \\
-254 \\
-253 \\
-252 \\
-251\end{array}$ & $\begin{array}{l}-6425 \cdot 15 \\
-6421 \cdot 30 \\
-6417 \cdot 23 \\
-6412 \cdot 94 \\
-6408 \cdot 42\end{array}$ & $\begin{array}{l}3.741 \\
3.962 \\
4.183 \\
4.406 \\
4.629\end{array}$ & $\begin{array}{l}219.74 \\
220.97 \\
222.01 \\
222.87 \\
223.57\end{array}$ & $\begin{array}{l}-225 \\
-224 \\
-223 \\
-222 \\
-221\end{array}$ & $\begin{array}{l}-6212.83 \\
-6202.38 \\
-6191.72 \\
-6180.85 \\
-6169.77\end{array}$ & $\begin{array}{l}10.349 \\
10.558 \\
10.766 \\
10.973 \\
11.178\end{array}$ & $\begin{array}{l}209.57 \\
208.51 \\
207.44 \\
206.37 \\
205.30\end{array}$ & $\begin{array}{l}-195 \\
-194 \\
-193 \\
-192 \\
-191\end{array}$ & $\begin{array}{l}-5812.75 \\
-5796.48 \\
-5780.03 \\
-5763.41 \\
-5746.61\end{array}$ & $\begin{array}{l}16.177 \\
16.357 \\
16.537 \\
16.715 \\
16.893\end{array}$ & $\begin{array}{l}180.50 \\
179.72 \\
178.94 \\
178.18 \\
177.43\end{array}$ \\
\hline $\begin{array}{l}-250 \\
-249 \\
-248 \\
-247 \\
-246\end{array}$ & $\begin{array}{l}-6403.68 \\
-6398.71 \\
-6393.53 \\
-6388.11 \\
-6382.47\end{array}$ & $\begin{array}{l}4.853 \\
5.077 \\
5.302 \\
5.526 \\
5.751\end{array}$ & $\begin{array}{l}224.10 \\
224.49 \\
224.75 \\
224.87 \\
224.88\end{array}$ & $\begin{array}{l}-220 \\
-219 \\
-218 \\
-217 \\
-216\end{array}$ & $\begin{array}{l}-6158.49 \\
-6147.01 \\
-6135.32 \\
-6123.43 \\
-6111.34\end{array}$ & $\begin{array}{l}11.383 \\
11.587 \\
11.789 \\
11.991 \\
12.192\end{array}$ & $\begin{array}{l}204 \cdot 23 \\
203.17 \\
202.10 \\
201.04 \\
199.99\end{array}$ & $\begin{array}{l}-190 \\
-189 \\
-188 \\
-187 \\
-186\end{array}$ & $\begin{array}{l}-5729.62 \\
-5712.47 \\
-5695.13 \\
-5677.62 \\
-5659.94\end{array}$ & $\begin{array}{l}17.070 \\
17.246 \\
17.422 \\
17.597 \\
17.771\end{array}$ & $\begin{array}{l}176.69 \\
175.96 \\
175.24 \\
174.53 \\
173.83\end{array}$ \\
\hline $\begin{array}{l}-245 \\
-244 \\
-243 \\
-242 \\
-241\end{array}$ & $\begin{array}{l}-6376.61 \\
-6370.52 \\
-6364.21 \\
-6357.67 \\
-6350.91\end{array}$ & $\begin{array}{l}5.976 \\
6.201 \\
6.425 \\
6.649 \\
6.873\end{array}$ & $\begin{array}{l}224.78 \\
224.58 \\
224.28 \\
223.90 \\
223.44\end{array}$ & $\begin{array}{l}-215 \\
-214 \\
-213 \\
-212 \\
-211\end{array}$ & $\begin{array}{l}-6099.05 \\
-6086.56 \\
-6073.87 \\
-6060.98 \\
-6047.90\end{array}$ & $\begin{array}{l}12.391 \\
12.589 \\
12.787 \\
12.983 \\
13.179\end{array}$ & $\begin{array}{l}198.95 \\
197.91 \\
196.89 \\
195.87 \\
194.86\end{array}$ & $\begin{array}{l}-185 \\
-184 \\
-183 \\
-182 \\
-181\end{array}$ & $\begin{array}{l}-5642.08 \\
-5624.05 \\
-5605.85 \\
-5587.47 \\
-5568.92\end{array}$ & $\begin{array}{l}17.944 \\
18.117 \\
18.289 \\
18.461 \\
18.632\end{array}$ & $\begin{array}{l}173.14 \\
172.46 \\
171.79 \\
171.12 \\
170.47\end{array}$ \\
\hline-240 & -6343.92 & 7.096 & 222.90 & -210 & -6034.63 & $13 \cdot 373$ & 193.87 & -180 & -5550.21 & 18.802 & 169.82 \\
\hline
\end{tabular}


TABLE 7.3.2. Type $K$ thermocouples-thermoelectric voltages, $\mathrm{E}(\mathrm{T})$, Seebeck coefficients, $\mathrm{S}(\mathrm{T})$, and first derivative of the Seebeck coefficients, $\mathrm{dS} / \mathrm{dT}$, reference junctions at $0{ }^{\circ} \mathrm{C}$-Continued

\begin{tabular}{|c|c|c|c|c|c|c|c|c|c|c|c|}
\hline${ }^{\circ} \mathrm{C}$ & $\begin{array}{l}E \\
\beta\end{array}$ & $\stackrel{\mathrm{S}}{\mu \mathrm{V} /{ }^{\circ} \mathrm{C}}$ & $\begin{array}{l}\mathrm{dS} / \mathrm{dT} \\
\mathrm{nV} /{ }^{\circ} \mathrm{C}^{2}\end{array}$ & ${ }^{\circ} \mathrm{C}$ & ${ }_{\mu}^{E} V$ & $\stackrel{\mathrm{S}}{\mu \mathrm{V}^{\circ} \mathrm{C}}$ & $\begin{array}{l}d S / d T \\
n V /{ }^{\circ} C^{2}\end{array}$ & ${ }^{\circ} \mathrm{C}$ & ${ }_{\mu V}^{E V}$ & $\stackrel{\mathrm{S}}{\mu \mathrm{V} /{ }^{\circ} \mathrm{C}}$ & $\begin{array}{l}\mathrm{dS} / \mathrm{dT} \\
\mathrm{nV} /{ }^{\circ} \mathrm{C}^{2}\end{array}$ \\
\hline $\begin{array}{l}-180 \\
-179 \\
-178 \\
-177 \\
-176\end{array}$ & $\begin{array}{l}-5550.21 \\
-5531.32 \\
-5512.27 \\
-5493.04 \\
-5473.65\end{array}$ & $\begin{array}{l}18.802 \\
18.971 \\
19.140 \\
19.308 \\
19.476\end{array}$ & $\begin{array}{l}169.82 \\
169.18 \\
168.54 \\
167.91 \\
167.29\end{array}$ & $\begin{array}{l}-120 \\
-119 \\
-118 \\
-117 \\
-116\end{array}$ & $\begin{array}{l}-4137.85 \\
-4109.86 \\
-4081.73 \\
-4053.47 \\
-4025.08\end{array}$ & $\begin{array}{l}27.927 \\
28.061 \\
28.195 \\
28.328 \\
28.460\end{array}$ & $\begin{array}{l}134.45 \\
133.84 \\
133.23 \\
132.62 \\
132.01\end{array}$ & $\begin{array}{l}-60 \\
-59 \\
-58 \\
-57 \\
-56\end{array}$ & $\begin{array}{l}-2242.51 \\
-2207.59 \\
-2172.58 \\
-2137.47 \\
-2102.26\end{array}$ & $\begin{array}{l}34.872 \\
34.968 \\
35.064 \\
35.159 \\
35.253\end{array}$ & $\begin{array}{l}96.56 \\
95.90 \\
95.24 \\
94.59 \\
93.93\end{array}$ \\
\hline $\begin{array}{l}-175 \\
-174 \\
-173 \\
-172 \\
-171\end{array}$ & $\begin{array}{l}-5454.09 \\
-5434.36 \\
-5414.47 \\
-5394.41 \\
-5374.19\end{array}$ & $\begin{array}{l}19.643 \\
19.809 \\
19.975 \\
20.140 \\
20.305\end{array}$ & $\begin{array}{l}166.67 \\
166.06 \\
165.45 \\
164.85 \\
164.25\end{array}$ & $\begin{array}{l}-115 \\
-114 \\
-113 \\
-112 \\
-111\end{array}$ & $\begin{array}{l}-3996.55 \\
-3967.89 \\
-3939.10 \\
-3910.19 \\
-3881.14\end{array}$ & $\begin{array}{l}28.592 \\
28.723 \\
28.853 \\
28.983 \\
29.113\end{array}$ & $\begin{array}{l}131.40 \\
130.79 \\
130.17 \\
129.56 \\
128.95\end{array}$ & $\begin{array}{l}-55 \\
-54 \\
-53 \\
-52 \\
-51\end{array}$ & $\begin{array}{l}-2066.96 \\
-2031.57 \\
-1996.08 \\
-1960.50 \\
-1924.83\end{array}$ & $\begin{array}{l}35.347 \\
35.439 \\
35.532 \\
35.623 \\
35.714\end{array}$ & $\begin{array}{l}93.27 \\
92.62 \\
91.96 \\
91.30 \\
90.65\end{array}$ \\
\hline $\begin{array}{l}-170 \\
-169 \\
-168 \\
-167 \\
-166\end{array}$ & $\begin{array}{l}-5353.80 \\
-5333.25 \\
-5312.54 \\
-5291.66 \\
-5270.63\end{array}$ & $\begin{array}{l}20.469 \\
20.632 \\
20.795 \\
20.957 \\
21.119\end{array}$ & $\begin{array}{l}163.66 \\
163.06 \\
162.47 \\
161.89 \\
161.31\end{array}$ & $\begin{array}{l}-110 \\
-109 \\
-108 \\
-107 \\
-106\end{array}$ & $\begin{array}{l}-3851.96 \\
-3822.66 \\
-3793.22 \\
-3763.66 \\
-3733.98\end{array}$ & $\begin{array}{l}29.241 \\
29.369 \\
29.497 \\
29.623 \\
29.750\end{array}$ & $\begin{array}{l}128.33 \\
127.71 \\
127.10 \\
126.48 \\
125.86\end{array}$ & $\begin{array}{l}-50 \\
-49 \\
-48 \\
-47 \\
-46\end{array}$ & $\begin{array}{l}-1889.07 \\
-1853.23 \\
-1817.29 \\
-1781.26 \\
-1745.14\end{array}$ & $\begin{array}{l}35.805 \\
35.894 \\
35.983 \\
36.072 \\
36.159\end{array}$ & $\begin{array}{l}89.99 \\
89.33 \\
88.68 \\
88.02 \\
87.37\end{array}$ \\
\hline $\begin{array}{l}-165 \\
-164 \\
-163 \\
-162 \\
-161\end{array}$ & $\begin{array}{l}-5249.43 \\
-5228.07 \\
-5206.55 \\
-5184.87 \\
-5163.03\end{array}$ & $\begin{array}{l}21.280 \\
21.440 \\
21.600 \\
21.759 \\
21.918\end{array}$ & $\begin{array}{l}160.72 \\
160.15 \\
159.57 \\
158.99 \\
158.42\end{array}$ & $\begin{array}{l}-105 \\
-104 \\
-103 \\
-102 \\
-101\end{array}$ & $\begin{array}{l}-3704.16 \\
-3674.23 \\
-3644.16 \\
-3613.98 \\
-3583.67\end{array}$ & $\begin{array}{l}29.875 \\
30.000 \\
30.124 \\
30.248 \\
30.371\end{array}$ & $\begin{array}{l}125.24 \\
124.62 \\
124.00 \\
123.38 \\
122.76\end{array}$ & $\begin{array}{l}-45 \\
-44 \\
-43 \\
-42 \\
-41\end{array}$ & $\begin{array}{l}-1708.94 \\
-1672.65 \\
-1636.27 \\
-1599.81 \\
-1563.27\end{array}$ & $\begin{array}{l}36.246 \\
36.333 \\
36.419 \\
36.504 \\
36.588\end{array}$ & $\begin{array}{l}86.71 \\
86.06 \\
85.40 \\
84.75 \\
84.10\end{array}$ \\
\hline $\begin{array}{l}-160 \\
-159 \\
-158 \\
-157 \\
-156\end{array}$ & $\begin{array}{l}-5141.03 \\
-5118.88 \\
-5096.57 \\
-5074.10 \\
-5051.47\end{array}$ & $\begin{array}{l}22.076 \\
22.234 \\
22.391 \\
22.547 \\
22.703\end{array}$ & $\begin{array}{l}157.85 \\
157.27 \\
156.70 \\
156.13 \\
155.56\end{array}$ & $\begin{array}{l}-100 \\
-99 \\
-98 \\
-97 \\
-96\end{array}$ & $\begin{array}{l}-3553.23 \\
-3522.68 \\
-3492.00 \\
-3461.21 \\
-3430.29\end{array}$ & $\begin{array}{l}30.494 \\
30.615 \\
30.737 \\
30.857 \\
30.977\end{array}$ & $\begin{array}{l}122.14 \\
121.51 \\
120.89 \\
120.26 \\
119.64\end{array}$ & $\begin{array}{l}-40 \\
-39 \\
-38 \\
-37 \\
-36\end{array}$ & $\begin{array}{l}-1526.64 \\
-1489.92 \\
-1453.13 \\
-1416.25 \\
-1379.29\end{array}$ & $\begin{array}{l}36.672 \\
36.755 \\
36.837 \\
36.919 \\
37.000\end{array}$ & $\begin{array}{l}83.45 \\
82.80 \\
82.15 \\
81.50 \\
80.85\end{array}$ \\
\hline $\begin{array}{l}-155 \\
-154 \\
-153 \\
-152 \\
-151\end{array}$ & $\begin{array}{l}-5028.69 \\
-5005.76 \\
-4982.67 \\
-4959.42 \\
-4936.03\end{array}$ & $\begin{array}{l}22.858 \\
23.013 \\
23.167 \\
23.320 \\
23.473\end{array}$ & $\begin{array}{l}154.99 \\
154.42 \\
153.85 \\
153.27 \\
152.70\end{array}$ & $\begin{array}{l}-95 \\
-94 \\
-93 \\
-92 \\
-91\end{array}$ & $\begin{array}{l}-3399.25 \\
-3368.10 \\
-3336.82 \\
-3305.43 \\
-3273.92\end{array}$ & $\begin{array}{l}31.096 \\
31.215 \\
31.333 \\
31.451 \\
31.567\end{array}$ & $\begin{array}{l}119.01 \\
118.39 \\
117.76 \\
117.13 \\
116.50\end{array}$ & $\begin{array}{l}-35 \\
-34 \\
-33 \\
-32 \\
-31\end{array}$ & $\begin{array}{l}-1342.25 \\
-1305.13 \\
-1267.93 \\
-1230.65 \\
-1193.29\end{array}$ & $\begin{array}{l}37.081 \\
37.161 \\
37.240 \\
37.319 \\
37.397\end{array}$ & $\begin{array}{l}80.20 \\
79.55 \\
78.91 \\
78.26 \\
77.61\end{array}$ \\
\hline $\begin{array}{l}-150 \\
-149 \\
-148 \\
-147 \\
-146\end{array}$ & $\begin{array}{l}-4912.48 \\
-4888.77 \\
-4864.92 \\
-4840.92 \\
-4816.76\end{array}$ & $\begin{array}{l}23.626 \\
23.778 \\
23.929 \\
24.080 \\
24.230\end{array}$ & $\begin{array}{l}152.13 \\
151.56 \\
150.98 \\
150.41 \\
149.83\end{array}$ & $\begin{array}{l}-90 \\
-89 \\
-88 \\
-87 \\
-86\end{array}$ & $\begin{array}{l}-3242.30 \\
-3210.55 \\
-3178.70 \\
-3146.73 \\
-3114.64\end{array}$ & $\begin{array}{l}31.684 \\
31.799 \\
31.914 \\
32.028 \\
32.142\end{array}$ & $\begin{array}{l}115.87 \\
115.24 \\
114.61 \\
113.97 \\
113.34\end{array}$ & $\begin{array}{l}-30 \\
-29 \\
-28 \\
-27 \\
-26\end{array}$ & $\begin{array}{l}-1155.85 \\
-1118.34 \\
-1080.75 \\
-1043.09 \\
-1005.35\end{array}$ & $\begin{array}{l}37.474 \\
37.551 \\
37.627 \\
37.702 \\
37.777\end{array}$ & $\begin{array}{l}76.97 \\
76.32 \\
75.67 \\
75.03 \\
74.38\end{array}$ \\
\hline $\begin{array}{l}-145 \\
-144 \\
-143 \\
-142 \\
-141\end{array}$ & $\begin{array}{l}-4792.46 \\
-4768.00 \\
-4743.40 \\
-4718.65 \\
-4693.75\end{array}$ & $\begin{array}{l}24.379 \\
24.528 \\
24.677 \\
24.825 \\
24.972\end{array}$ & $\begin{array}{l}149.26 \\
148.68 \\
148.10 \\
147.52 \\
146.94\end{array}$ & $\begin{array}{l}-85 \\
-84 \\
-83 \\
-82 \\
-81\end{array}$ & $\begin{array}{l}-3082.44 \\
-3050.13 \\
-3017.71 \\
-2985.17 \\
-2952.53\end{array}$ & $\begin{array}{l}32.255 \\
32.368 \\
32.479 \\
32.590 \\
32.701\end{array}$ & $\begin{array}{l}112.71 \\
112.07 \\
111.43 \\
110.80 \\
110.16\end{array}$ & $\begin{array}{l}-25 \\
-24 \\
-23 \\
-22 \\
-21\end{array}$ & $\begin{array}{l}-967.54 \\
-929.65 \\
-891.69 \\
-853.66 \\
-815.55\end{array}$ & $\begin{array}{l}37.851 \\
37.924 \\
37.997 \\
38.069 \\
38.140\end{array}$ & $\begin{array}{l}73.73 \\
73.08 \\
72.43 \\
71.77 \\
71.11\end{array}$ \\
\hline $\begin{array}{l}-140 \\
-139 \\
-138 \\
-137 \\
-136\end{array}$ & $\begin{array}{l}-4668.71 \\
-4643.52 \\
-4618.18 \\
-4592.70 \\
-4567.07\end{array}$ & $\begin{array}{l}25.118 \\
25.264 \\
25.410 \\
25.555 \\
25.699\end{array}$ & $\begin{array}{l}146.36 \\
145.77 \\
145.19 \\
144.60 \\
144.01\end{array}$ & $\begin{array}{l}-80 \\
-79 \\
-78 \\
-77 \\
-76\end{array}$ & $\begin{array}{l}-2919.77 \\
-2886.91 \\
-2853.93 \\
-2820.85 \\
-2787.66\end{array}$ & $\begin{array}{l}32.811 \\
32.920 \\
33.028 \\
33.136 \\
33.244\end{array}$ & $\begin{array}{l}109.52 \\
108.88 \\
108.24 \\
107.60 \\
106.95\end{array}$ & $\begin{array}{l}-20 \\
-19 \\
-18 \\
-17 \\
-16\end{array}$ & $\begin{array}{l}-777.38 \\
-739.13 \\
-700.81 \\
-662.43 \\
-623.97\end{array}$ & $\begin{array}{l}38.211 \\
38.281 \\
38.351 \\
38.419 \\
38.488\end{array}$ & $\begin{array}{l}70.45 \\
69.79 \\
69.12 \\
68.44 \\
67.76\end{array}$ \\
\hline $\begin{array}{l}-135 \\
-134 \\
-133 \\
-132 \\
-131\end{array}$ & $\begin{array}{l}-4541.30 \\
-4515.38 \\
-4489.33 \\
-4463.13 \\
-4436.78\end{array}$ & $\begin{array}{l}25.843 \\
25.986 \\
26.129 \\
26.270 \\
26.412\end{array}$ & $\begin{array}{l}143.42 \\
142.83 \\
142.24 \\
141.65 \\
141.06\end{array}$ & $\begin{array}{l}-75 \\
-74 \\
-73 \\
-72 \\
-71\end{array}$ & $\begin{array}{l}-2754.36 \\
-2720.96 \\
-2687.45 \\
-2653.84 \\
-2620.12\end{array}$ & $\begin{array}{l}33.350 \\
33.456 \\
33.562 \\
33.666 \\
33.770\end{array}$ & $\begin{array}{l}106.31 \\
105.67 \\
105.02 \\
104.37 \\
103.73\end{array}$ & $\begin{array}{l}-15 \\
-14 \\
-13 \\
-12 \\
-11\end{array}$ & $\begin{array}{l}-585.45 \\
-546.87 \\
-508.21 \\
-469.49 \\
-430.70\end{array}$ & $\begin{array}{l}38.555 \\
38.622 \\
38.688 \\
38.753 \\
38.818\end{array}$ & $\begin{array}{l}67.07 \\
66.37 \\
65.66 \\
64.94 \\
64.21\end{array}$ \\
\hline $\begin{array}{l}-130 \\
-129 \\
-128 \\
-127 \\
-126\end{array}$ & $\begin{array}{l}-4410.30 \\
-4383.68 \\
-4356.92 \\
-4330.02 \\
-4302.97\end{array}$ & $\begin{array}{l}26.553 \\
26.693 \\
26.832 \\
26.971 \\
27.110\end{array}$ & $\begin{array}{l}140.46 \\
139.87 \\
139.27 \\
138.67 \\
138.07\end{array}$ & $\begin{array}{l}-70 \\
-69 \\
-68 \\
-67 \\
-66\end{array}$ & $\begin{array}{l}-2586.30 \\
-2552.37 \\
-2518.34 \\
-2484.21 \\
-2449.98\end{array}$ & $\begin{array}{l}33.874 \\
33.977 \\
34.079 \\
34.180 \\
34.281\end{array}$ & $\begin{array}{l}103.08 \\
102.43 \\
101.78 \\
101.13 \\
100.48\end{array}$ & $\begin{array}{r}-10 \\
-9 \\
-8 \\
-7 \\
-6\end{array}$ & $\begin{array}{l}-391.86 \\
-352.94 \\
-313.97 \\
-274.93 \\
-235.83\end{array}$ & $\begin{array}{l}38.881 \\
38.945 \\
39.007 \\
39.068 \\
39.129\end{array}$ & $\begin{array}{l}63.47 \\
62.71 \\
61.94 \\
61.15 \\
60.33\end{array}$ \\
\hline $\begin{array}{l}-125 \\
-124 \\
-123 \\
-122 \\
-121\end{array}$ & $\begin{array}{l}-4275.80 \\
-4248.48 \\
-4221.03 \\
-4193.44 \\
-4165.71\end{array}$ & $\begin{array}{l}27.247 \\
27.385 \\
27.521 \\
27.657 \\
27.792\end{array}$ & $\begin{array}{l}137.47 \\
136.87 \\
136.26 \\
135.66 \\
135.05\end{array}$ & $\begin{array}{l}-65 \\
-64 \\
-63 \\
-62 \\
-61\end{array}$ & $\begin{array}{l}-2415.65 \\
-2381.22 \\
-2346.69 \\
-2312.06 \\
-2277.34\end{array}$ & $\begin{array}{l}34.381 \\
34.481 \\
34.579 \\
34.678 \\
34.775\end{array}$ & $\begin{array}{l}99.83 \\
99.17 \\
98.52 \\
97.86 \\
97.21\end{array}$ & $\begin{array}{l}-5 \\
-4 \\
-3 \\
-2 \\
-1\end{array}$ & $\begin{array}{r}-196.67 \\
-157.45 \\
-118.17 \\
-78.84 \\
-39.45\end{array}$ & $\begin{array}{l}39.189 \\
39.248 \\
39.306 \\
39.364 \\
39.420\end{array}$ & $\begin{array}{l}59.50 \\
58.64 \\
57.76 \\
56.85 \\
55.91\end{array}$ \\
\hline-120 & -4137.85 & 27.927 & 134.45 & -60 & $-2242 \cdot 51$ & 34.872 & 96.56 & 0 & 0.00 & 39.475 & 54.93 \\
\hline
\end{tabular}


TABLE 7.3.2. Type $\mathbb{K}$ thermocouples-thermoelectric voltages, $\mathrm{E}(\mathrm{T})$, Seebeck coefficients, $\mathrm{S}(\mathrm{T})$, and first derivative of the Seebeck coefficients, $\mathrm{dS} / \mathrm{dT}$, reference junctions at $0{ }^{\circ} \mathrm{C}$-Continued

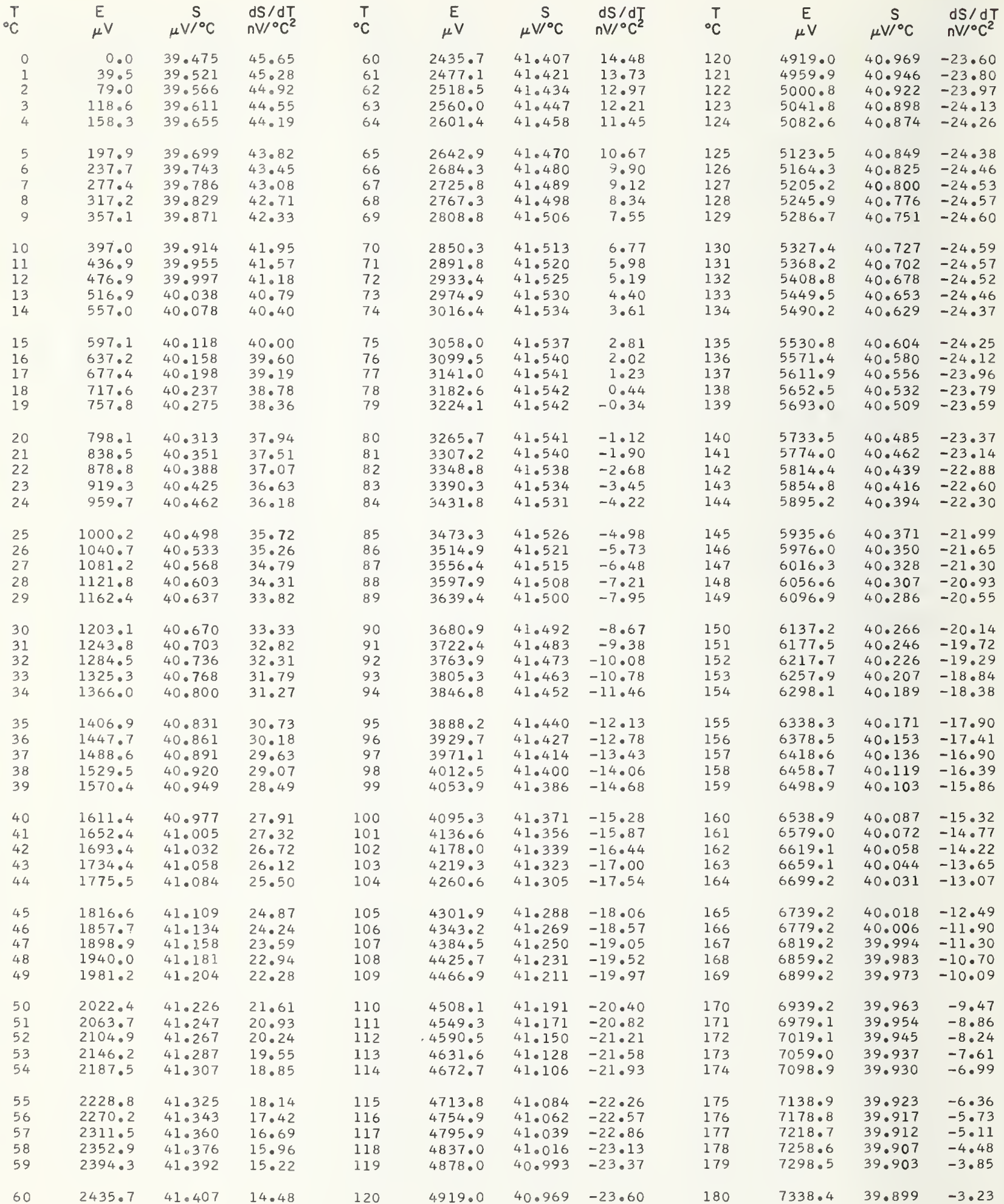


TABLE 7.3.2. Type $\boldsymbol{K}$ thermocouples-thermoelectric voltages, E(T), Seebeck coefficients, $\mathrm{S}(\mathrm{T})$, and first derivative of the Seebeck coefficients, $\mathrm{dS} / \mathrm{dT}$, reference junctions at $0{ }^{\circ} \mathrm{C}-$ Continued

\begin{tabular}{|c|c|c|c|c|c|c|c|c|c|c|c|}
\hline${ }^{\circ} \mathrm{C}$ & $\underset{\mu V}{E}$ & $\mu \mathrm{V} /{ }^{\circ} \mathrm{C}$ & $\begin{array}{l}d S / d T \\
n V /{ }^{\circ} C^{2}\end{array}$ & ${ }^{\circ} \mathrm{C}$ & $\underset{\mu V}{E}$ & $\underset{\mu V /{ }^{\circ} \mathrm{C}}{S}$ & $\begin{array}{c}d S / d T \\
n V /{ }^{\circ} C^{2}\end{array}$ & ${ }^{\circ} \mathrm{T}$ & $\underset{\mu V}{E}$ & $\stackrel{\mathrm{S}}{\mathrm{S} /{ }^{\circ} \mathrm{C}}$ & $\begin{array}{l}\mathrm{dS} / \mathrm{dT} \\
\mathrm{nV} /{ }^{\circ} \mathrm{C}^{2}\end{array}$ \\
\hline $\begin{array}{l}180 \\
181 \\
182 \\
183 \\
184\end{array}$ & $\begin{array}{l}7338.4 \\
7378.3 \\
7418.2 \\
7458.1 \\
7498.0\end{array}$ & $\begin{array}{l}39.899 \\
39.896 \\
39.894 \\
39.892 \\
39.891\end{array}$ & $\begin{array}{l}-3.23 \\
-2.60 \\
-1.98 \\
-1.36 \\
-0.75\end{array}$ & $\begin{array}{l}240 \\
241 \\
242 \\
243 \\
244\end{array}$ & $\begin{array}{l}9745.2 \\
9785.7 \\
9826.3 \\
9866.9 \\
9907.5\end{array}$ & $\begin{array}{l}40.542 \\
40.560 \\
40.578 \\
40.596 \\
40.614\end{array}$ & $\begin{array}{l}18.03 \\
18.05 \\
18.05 \\
18.05 \\
18.03\end{array}$ & $\begin{array}{l}300 \\
301 \\
302 \\
303 \\
304\end{array}$ & $\begin{array}{l}12207.4 \\
12248.9 \\
12290.4 \\
12331.9 \\
12373.4\end{array}$ & $\begin{array}{l}41.459 \\
41.470 \\
41.481 \\
41.492 \\
41.503\end{array}$ & $\begin{array}{l}11.21 \\
11.09 \\
10.96 \\
10.83 \\
10.71\end{array}$ \\
\hline $\begin{array}{l}185 \\
186 \\
187 \\
188 \\
189\end{array}$ & $\begin{array}{l}7537.9 \\
7577.8 \\
7617.7 \\
7657.6 \\
7697.4\end{array}$ & $\begin{array}{l}39.891 \\
39.891 \\
39.892 \\
39.893 \\
39.895\end{array}$ & $\begin{array}{r}-0.14 \\
0.46 \\
1.06 \\
1.66 \\
2.24\end{array}$ & $\begin{array}{l}245 \\
246 \\
247 \\
248 \\
249\end{array}$ & $\begin{array}{r}9948.1 \\
9988.7 \\
10029.4 \\
10070.1 \\
10110.8\end{array}$ & $\begin{array}{l}40.632 \\
40.650 \\
40.668 \\
40.686 \\
40.704\end{array}$ & $\begin{array}{l}18.01 \\
17.98 \\
17.95 \\
17.90 \\
17.85\end{array}$ & $\begin{array}{l}305 \\
306 \\
307 \\
308 \\
309\end{array}$ & $\begin{array}{l}12414.9 \\
12456.4 \\
12497.9 \\
12539.5 \\
12581.0\end{array}$ & $\begin{array}{l}41.514 \\
41.524 \\
41.534 \\
41.545 \\
41.555\end{array}$ & $\begin{array}{l}10 \cdot 59 \\
10 \cdot 47 \\
10 \cdot 35 \\
10 \cdot 24 \\
10 \cdot 13\end{array}$ \\
\hline $\begin{array}{l}190 \\
191 \\
192 \\
193 \\
194\end{array}$ & $\begin{array}{l}7737.3 \\
7777.2 \\
7817.1 \\
7857.1 \\
7897.0\end{array}$ & $\begin{array}{l}39.898 \\
39.901 \\
39.904 \\
39.909 \\
39.914\end{array}$ & $\begin{array}{l}2.82 \\
3.40 \\
3.96 \\
4.52 \\
5.07\end{array}$ & $\begin{array}{l}250 \\
251 \\
252 \\
253 \\
254\end{array}$ & $\begin{array}{l}10151.5 \\
10192.2 \\
10233.0 \\
10273.7 \\
10314.5\end{array}$ & $\begin{array}{l}40.722 \\
40.739 \\
40.757 \\
40.775 \\
40.792\end{array}$ & $\begin{array}{l}17.80 \\
17.73 \\
17.66 \\
17.58 \\
17.50\end{array}$ & $\begin{array}{l}310 \\
311 \\
312 \\
313 \\
314\end{array}$ & $\begin{array}{l}12622.6 \\
12664.1 \\
12705.7 \\
12747.3 \\
12788.9\end{array}$ & $\begin{array}{l}41.565 \\
41.575 \\
41.585 \\
41.595 \\
41.604\end{array}$ & $\begin{array}{r}10.02 \\
9.91 \\
9.80 \\
9.70 \\
9.60\end{array}$ \\
\hline $\begin{array}{l}195 \\
196 \\
197 \\
198 \\
199\end{array}$ & $\begin{array}{l}7936.9 \\
7976.8 \\
8016.7 \\
8056.7 \\
8096.6\end{array}$ & $\begin{array}{l}39.919 \\
39.925 \\
39.931 \\
39.938 \\
39.946\end{array}$ & $\begin{array}{l}5.61 \\
6.14 \\
6.67 \\
7.18 \\
7.68\end{array}$ & $\begin{array}{l}255 \\
256 \\
257 \\
258 \\
259\end{array}$ & $\begin{array}{l}10355.3 \\
10396.1 \\
10437.0 \\
10477.8 \\
10518.7\end{array}$ & $\begin{array}{l}40.810 \\
40.827 \\
40.844 \\
40.862 \\
40.879\end{array}$ & $\begin{array}{l}17.41 \\
17.32 \\
17.22 \\
17.12 \\
17.01\end{array}$ & $\begin{array}{l}315 \\
316 \\
317 \\
318 \\
319\end{array}$ & $\begin{array}{l}12830.5 \\
12872.1 \\
12913.8 \\
12955.4 \\
12997.0\end{array}$ & $\begin{array}{l}41.614 \\
41.623 \\
41.633 \\
41.642 \\
41.651\end{array}$ & $\begin{array}{l}9.50 \\
9.40 \\
9.30 \\
9.21 \\
9.12\end{array}$ \\
\hline $\begin{array}{l}200 \\
201 \\
202 \\
203 \\
204\end{array}$ & $\begin{array}{l}8136.6 \\
8176.5 \\
8216.5 \\
8256.5 \\
8296.4\end{array}$ & $\begin{array}{l}39.953 \\
39.962 \\
39.971 \\
39.980 \\
39.990\end{array}$ & $\begin{array}{r}8.17 \\
8.66 \\
9.13 \\
9.59 \\
10.03\end{array}$ & $\begin{array}{l}260 \\
261 \\
262 \\
263 \\
264\end{array}$ & $\begin{array}{l}10559.6 \\
10600.5 \\
10641.4 \\
10682.3 \\
10723.3\end{array}$ & $\begin{array}{l}40.896 \\
40.912 \\
40.929 \\
40.946 \\
40.962\end{array}$ & $\begin{array}{l}16.90 \\
16.78 \\
16.66 \\
16.53 \\
16.41\end{array}$ & $\begin{array}{l}320 \\
321 \\
322 \\
323 \\
324\end{array}$ & $\begin{array}{l}13038.7 \\
13080.4 \\
13122.0 \\
13163.7 \\
13205.4\end{array}$ & $\begin{array}{l}41.660 \\
41.669 \\
41.678 \\
41.687 \\
41.695\end{array}$ & $\begin{array}{l}9.03 \\
8.94 \\
8.86 \\
8.77 \\
8.69\end{array}$ \\
\hline $\begin{array}{l}205 \\
206 \\
207 \\
208 \\
209\end{array}$ & $\begin{array}{l}8336.4 \\
8376.4 \\
8416.5 \\
8456.5 \\
8496.5\end{array}$ & $\begin{array}{l}40.000 \\
40.011 \\
40.022 \\
40.033 \\
40.045\end{array}$ & $\begin{array}{l}10.47 \\
10.89 \\
11.31 \\
11.71 \\
12.09\end{array}$ & $\begin{array}{l}265 \\
266 \\
267 \\
268 \\
269\end{array}$ & $\begin{array}{l}10764.3 \\
10805.2 \\
10846.2 \\
10887.3 \\
10928.3\end{array}$ & $\begin{array}{l}40.979 \\
40.995 \\
41.011 \\
41.027 \\
41.043\end{array}$ & $\begin{array}{l}16.28 \\
16.14 \\
16.01 \\
15.87 \\
15.73\end{array}$ & $\begin{array}{l}325 \\
326 \\
327 \\
328 \\
329\end{array}$ & $\begin{array}{l}13247.1 \\
13288.8 \\
13330.5 \\
13372.3 \\
13414.0\end{array}$ & $\begin{array}{l}41.704 \\
41.713 \\
41.721 \\
41.730 \\
41.738\end{array}$ & $\begin{array}{l}8.61 \\
8.53 \\
8.46 \\
8.38 \\
8.31\end{array}$ \\
\hline $\begin{array}{l}210 \\
211 \\
212 . \\
213 \\
214\end{array}$ & $\begin{array}{l}8536.6 \\
8576.6 \\
8616.7 \\
8656.8 \\
8696.9\end{array}$ & $\begin{array}{l}40.058 \\
40.070 \\
40.083 \\
40.097 \\
40.110\end{array}$ & $\begin{array}{l}12.47 \\
12.83 \\
13.18 \\
13.52 \\
13.85\end{array}$ & $\begin{array}{l}270 \\
271 \\
272 \\
273 \\
274\end{array}$ & $\begin{array}{l}10969.3 \\
11010.4 \\
11051.5 \\
111092.6 \\
11133.7\end{array}$ & $\begin{array}{l}41.058 \\
41.074 \\
41.089 \\
41.104 \\
41.119\end{array}$ & $\begin{array}{l}15.59 \\
15.44 \\
15.30 \\
15.15 \\
15.00\end{array}$ & $\begin{array}{l}330 \\
331 \\
332 \\
333 \\
334\end{array}$ & $\begin{array}{l}13455.7 \\
13497.5 \\
13539.3 \\
13581.0 \\
13622.8\end{array}$ & $\begin{array}{l}41.746 \\
41.754 \\
41.763 \\
41.771 \\
41.779\end{array}$ & $\begin{array}{l}8.24 \\
8.17 \\
8.11 \\
8.04 \\
7.98\end{array}$ \\
\hline $\begin{array}{l}215 \\
216 \\
217 \\
218 \\
219\end{array}$ & $\begin{array}{l}8737.0 \\
8777.2 \\
8817.3 \\
8857.5 \\
8897.6\end{array}$ & $\begin{array}{l}40.124 \\
40.139 \\
40.153 \\
40.168 \\
40.183\end{array}$ & $\begin{array}{l}14.16 \\
14.46 \\
14.75 \\
15.02 \\
15.28\end{array}$ & $\begin{array}{l}275 \\
276 \\
277 \\
278 \\
279\end{array}$ & $\begin{array}{l}11174.8 \\
11216.0 \\
11257.1 \\
11298.3 \\
11339.5\end{array}$ & $\begin{array}{l}41.134 \\
41.149 \\
41.164 \\
41.178 \\
41.193\end{array}$ & $\begin{array}{l}14 \cdot 85 \\
14.70 \\
14.55 \\
14.40 \\
14.25\end{array}$ & $\begin{array}{l}335 \\
336 \\
337 \\
338 \\
339\end{array}$ & $\begin{array}{l}13664.6 \\
13706.4 \\
13748.2 \\
13790.0 \\
13831.8\end{array}$ & $\begin{array}{l}41.787 \\
41.795 \\
41.802 \\
41.810 \\
41.818\end{array}$ & $\begin{array}{l}7.92 \\
7.86 \\
7.80 \\
7.74 \\
7.68\end{array}$ \\
\hline $\begin{array}{l}220 \\
221 \\
222 \\
223 \\
224\end{array}$ & $\begin{array}{l}8937.8 \\
8978.0 \\
9018.3 \\
9058.5 \\
9098.8\end{array}$ & $\begin{array}{l}40.199 \\
40.214 \\
40.230 \\
40.246 \\
40.263\end{array}$ & $\begin{array}{l}15.53 \\
15.77 \\
15.99 \\
16.21 \\
16.40\end{array}$ & $\begin{array}{l}280 \\
281 \\
282 \\
283 \\
284\end{array}$ & $\begin{array}{l}11380.7 \\
11421.9 \\
11463.1 \\
11504.4 \\
11545.6\end{array}$ & $\begin{array}{l}41.207 \\
41.221 \\
41.235 \\
41.248 \\
41.262\end{array}$ & $\begin{array}{l}14.09 \\
13.94 \\
13.79 \\
13.64 \\
13.49\end{array}$ & $\begin{array}{l}340 \\
341 \\
342 \\
343 \\
344\end{array}$ & $\begin{array}{l}13873.6 \\
13915.4 \\
13957.3 \\
13999.1 \\
14041.0\end{array}$ & $\begin{array}{l}41.825 \\
41.833 \\
41.841 \\
41.848 \\
41.856\end{array}$ & $\begin{array}{l}7.63 \\
7.58 \\
7.52 \\
7.47 \\
7.43\end{array}$ \\
\hline $\begin{array}{l}225 \\
226 \\
227 \\
228 \\
229\end{array}$ & $\begin{array}{l}9139.0 \\
9179.3 \\
9219.6 \\
9259.9 \\
9300.3\end{array}$ & $\begin{array}{l}40.279 \\
40.296 \\
40.313 \\
40.330 \\
40.347\end{array}$ & $\begin{array}{l}16.59 \\
16.77 \\
16.93 \\
17.08 \\
17.22\end{array}$ & $\begin{array}{l}285 \\
286 \\
287 \\
288 \\
289\end{array}$ & $\begin{array}{l}11586.9 \\
11628.2 \\
11669.5 \\
11710.8 \\
11752.1\end{array}$ & $\begin{array}{l}41.275 \\
41.289 \\
41.302 \\
41.315 \\
41.327\end{array}$ & $\begin{array}{l}13.34 \\
13.19 \\
13.04 \\
12.89 \\
12.74\end{array}$ & $\begin{array}{l}345 \\
346 \\
347 \\
348 \\
349\end{array}$ & $\begin{array}{l}14082.8 \\
14124.7 \\
14166.6 \\
14208.4 \\
14250.3\end{array}$ & $\begin{array}{l}41.863 \\
41.870 \\
41.878 \\
41.885 \\
41.892\end{array}$ & $\begin{array}{l}7.38 \\
7.33 \\
7.29 \\
7.24 \\
7.20\end{array}$ \\
\hline $\begin{array}{l}230 \\
231 \\
232 \\
233 \\
234\end{array}$ & $\begin{array}{l}9340.6 \\
9381.0 \\
9421.4 \\
9461.8 \\
9502.2\end{array}$ & $\begin{array}{l}40.364 \\
40.382 \\
40.399 \\
40.417 \\
40.434\end{array}$ & $\begin{array}{l}17.35 \\
17.46 \\
17.57 \\
17.66 \\
17.75\end{array}$ & $\begin{array}{l}290 \\
291 \\
292 \\
293 \\
294\end{array}$ & $\begin{array}{l}11793.4 \\
11834.8 \\
11876.1 \\
11917.5 \\
11958.9\end{array}$ & $\begin{array}{l}41.340 \\
41.353 \\
41.365 \\
41.377 \\
41.389\end{array}$ & $\begin{array}{l}12.60 \\
12.45 \\
12.31 \\
12.17 \\
12.02\end{array}$ & $\begin{array}{l}350 \\
351 \\
352 \\
353 \\
354\end{array}$ & $\begin{array}{l}14292.2 \\
14334.1 \\
14376.0 \\
14418.0 \\
14459.9\end{array}$ & $\begin{array}{l}41.899 \\
41.906 \\
41.914 \\
41.921 \\
41.928\end{array}$ & $\begin{array}{l}7.16 \\
7.11 \\
7.07 \\
7.04 \\
7.00\end{array}$ \\
\hline $\begin{array}{l}235 \\
236 \\
237 \\
238 \\
239\end{array}$ & $\begin{array}{l}9542.7 \\
9583.1 \\
9623.6 \\
9664.1 \\
9704.6\end{array}$ & $\begin{array}{l}40.452 \\
40.470 \\
40.488 \\
40.506 \\
40.524\end{array}$ & $\begin{array}{l}17.82 \\
17.88 \\
17.93 \\
17.98 \\
18.01\end{array}$ & $\begin{array}{l}295 \\
296 \\
297 \\
298 \\
299\end{array}$ & $\begin{array}{l}12000.3 \\
12041.7 \\
12083.1 \\
12124.5 \\
12166.0\end{array}$ & $\begin{array}{l}41.401 \\
41.413 \\
41.425 \\
41.436 \\
41.448\end{array}$ & $\begin{array}{l}11.88 \\
11.75 \\
11.61 \\
11.48 \\
11.34\end{array}$ & $\begin{array}{l}355 \\
356 \\
357 \\
358 \\
359\end{array}$ & $\begin{array}{l}14501.8 \\
14543.8 \\
14585.7 \\
14627.7 \\
14669.6\end{array}$ & $\begin{array}{l}41.935 \\
41.942 \\
41.948 \\
41.955 \\
41.962\end{array}$ & $\begin{array}{l}6.96 \\
6.92 \\
6.89 \\
6.85 \\
6.82\end{array}$ \\
\hline 240 & 9745.2 & $40 \cdot 542$ & 18.03 & 300 & 12207.4 & 41.459 & 11.21 & 360 & 14711.6 & 41.969 & 6.78 \\
\hline
\end{tabular}


TABLE 7.3.2. Type $K$ thermocouples-thermoelectric voltages, E(T), Seebeck coefficients, $\mathrm{S}(\mathrm{T})$, and first derivative of the Seebeck coefficients, $\mathrm{dS} / \mathrm{dT}$, reference junctions at $0{ }^{\circ} \mathrm{C}$-Continued

\begin{tabular}{|c|c|c|c|c|c|c|c|c|c|c|c|}
\hline $\begin{array}{l}\mathrm{T} \\
{ }^{\circ} \mathrm{C}\end{array}$ & $\underset{\mu V}{E}$ & $\mu \mathrm{V} /{ }^{\circ} \mathrm{C}$ & $\begin{array}{l}\mathrm{dS} / \mathrm{dT} \\
\mathrm{nV} /{ }^{\circ} \mathrm{C}^{2}\end{array}$ & ${ }^{\circ} \mathrm{C}$ & $\underset{\mu V}{E}$ & ${ }_{\mu \mathrm{V} /{ }^{\circ} \mathrm{C}}^{\mathrm{S}}$ & $\begin{array}{l}\mathrm{dS} / \mathrm{dT} T \\
\mathrm{nV} /{ }^{\circ} \mathrm{C}^{2}\end{array}$ & ${ }^{\circ} \mathrm{C}$ & $\underset{\mu V}{E}$ & $\mu V^{V^{\circ} \mathrm{C}}$ & $\begin{array}{l}\mathrm{d} S / d T \\
n V /{ }^{\circ} \mathrm{C}^{2}\end{array}$ \\
\hline $\begin{array}{l}365 \\
366 \\
367 \\
368 \\
369\end{array}$ & $\begin{array}{l}14921.5 \\
14963.5 \\
15005.5 \\
15047.5 \\
15089.6\end{array}$ & $\begin{array}{l}42.002 \\
42.009 \\
42.016 \\
42.022 \\
42.029\end{array}$ & $\begin{array}{l}6.62 \\
6.59 \\
6.56 \\
6.53 \\
6.50\end{array}$ & $\begin{array}{l}425 \\
426 \\
427 \\
428 \\
429\end{array}$ & $\begin{array}{l}17452.6 \\
17494.9 \\
17537.3 \\
17579.7 \\
17622.0\end{array}$ & $\begin{array}{l}42 \cdot 351 \\
42 \cdot 356 \\
42 \cdot 360 \\
42.365 \\
42 \cdot 370\end{array}$ & $\begin{array}{l}4.95 \\
4.92 \\
4.88 \\
4.85 \\
4.82\end{array}$ & $\begin{array}{l}485 \\
486 \\
487 \\
488 \\
489\end{array}$ & $\begin{array}{l}20001.2 \\
20043.8 \\
20086.4 \\
20129.0 \\
20171.6\end{array}$ & $\begin{array}{l}42.580 \\
42.582 \\
42.585 \\
42.587 \\
42.589\end{array}$ & $\begin{array}{l}2.53 \\
2.48 \\
2.44 \\
2.39 \\
2.34\end{array}$ \\
\hline $\begin{array}{l}370 \\
371 \\
372 \\
373 \\
374\end{array}$ & $\begin{array}{l}15131.6 \\
15173.6 \\
15215.7 \\
15257.7 \\
15299.8\end{array}$ & $\begin{array}{l}42.035 \\
42.042 \\
42.048 \\
42.054 \\
42.061\end{array}$ & $\begin{array}{l}6.48 \\
6.45 \\
6.42 \\
6.39 \\
6.36\end{array}$ & $\begin{array}{l}430 \\
431 \\
432 \\
433 \\
434\end{array}$ & $\begin{array}{l}17664.4 \\
17706.8 \\
17749.2 \\
17791.5 \\
17833.9\end{array}$ & $\begin{array}{l}42 \cdot 375 \\
42 \cdot 380 \\
42 \cdot 384 \\
42 \cdot 389 \\
42.394\end{array}$ & $\begin{array}{l}4 \cdot 78 \\
4.75 \\
4.72 \\
4.68 \\
4.65\end{array}$ & $\begin{array}{l}490 \\
491 \\
492 \\
493 \\
494\end{array}$ & $\begin{array}{l}20214 \cdot 1 \\
20256 \cdot 7 \\
20299 \cdot 3 \\
20341.9 \\
20384 \cdot 5\end{array}$ & $\begin{array}{l}42.592 \\
42.594 \\
42.596 \\
42.598 \\
42.600\end{array}$ & $\begin{array}{l}2.29 \\
2.24 \\
2.19 \\
2.15 \\
2.10\end{array}$ \\
\hline $\begin{array}{l}380 \\
381 \\
382 \\
383 \\
384\end{array}$ & $\begin{array}{l}15552.3 \\
15594.4 \\
15636.5 \\
15678.6 \\
15720.7\end{array}$ & $\begin{array}{l}42.099 \\
42.105 \\
42.111 \\
42.117 \\
42.123\end{array}$ & $\begin{array}{l}6.20 \\
6.18 \\
6.15 \\
6.13 \\
6.10\end{array}$ & $\begin{array}{l}440 \\
441 \\
442 \\
443 \\
444\end{array}$ & $\begin{array}{l}18088.4 \\
18130.8 \\
18173.2 \\
18215.7 \\
18258.1\end{array}$ & $\begin{array}{l}42.421 \\
42.425 \\
42.430 \\
42.434 \\
42.439\end{array}$ & $\begin{array}{l}4 \cdot 43 \\
4 \cdot 40 \\
4 \cdot 36 \\
4 \cdot 32 \\
4 \cdot 28\end{array}$ & $\begin{array}{l}500 \\
501 \\
502 \\
503 \\
504\end{array}$ & $\begin{array}{l}20640.2 \\
20682.8 \\
20725.4 \\
20768.0 \\
20810.6\end{array}$ & $\begin{array}{l}42.612 \\
42.614 \\
42.616 \\
42.617 \\
42.619\end{array}$ & $\begin{array}{l}1.80 \\
1.75 \\
1.70 \\
1.65 \\
1.60\end{array}$ \\
\hline $\begin{array}{l}385 \\
386 \\
387 \\
388 \\
389\end{array}$ & $\begin{array}{l}15762.8 \\
15805.0 \\
15847.1 \\
15889.3 \\
15931.4\end{array}$ & $\begin{array}{l}42.129 \\
42.135 \\
42.141 \\
42.147 \\
42.153\end{array}$ & $\begin{array}{l}6.07 \\
6.05 \\
6.02 \\
6.00 \\
5.97\end{array}$ & $\begin{array}{l}445 \\
446 \\
447 \\
448 \\
449\end{array}$ & $\begin{array}{l}18300.5 \\
18343.0 \\
18385.4 \\
18427.9 \\
18470.3\end{array}$ & $\begin{array}{l}42.443 \\
42.447 \\
42.451 \\
42.455 \\
42.459\end{array}$ & $\begin{array}{l}4 \cdot 25 \\
4.21 \\
4.17 \\
4.13 \\
4.09\end{array}$ & $\begin{array}{l}505 \\
506 \\
507 \\
508 \\
509\end{array}$ & $\begin{array}{l}20853.3 \\
20895.9 \\
20938.5 \\
20981.1 \\
21023.7\end{array}$ & $\begin{array}{l}42.620 \\
42.622 \\
42.623 \\
42.625 \\
42.626\end{array}$ & $\begin{array}{l}1.55 \\
1.50 \\
1.44 \\
1.39 \\
1.34\end{array}$ \\
\hline $\begin{array}{l}390 \\
391 \\
392 \\
393 \\
394\end{array}$ & $\begin{array}{l}15973.6 \\
16015.7 \\
16057.9 \\
16100.1 \\
16142.2\end{array}$ & $\begin{array}{l}42.159 \\
42.165 \\
42.171 \\
42.177 \\
42.183\end{array}$ & $\begin{array}{l}5.94 \\
5.92 \\
5.89 \\
5.87 \\
5.84\end{array}$ & $\begin{array}{l}450 \\
451 \\
452 \\
453 \\
454\end{array}$ & $\begin{array}{l}18512.8 \\
18555.3 \\
18597.7 \\
18640.2 \\
18682.7\end{array}$ & $\begin{array}{l}42.464 \\
42.468 \\
42.472 \\
42.476 \\
42.479\end{array}$ & $\begin{array}{l}4.05 \\
4.01 \\
3.97 \\
3.94 \\
3.89\end{array}$ & $\begin{array}{l}510 \\
511 \\
512 \\
513 \\
514\end{array}$ & $\begin{array}{l}21066.4 \\
21109 \cdot 0 \\
21151.6 \\
21194 \cdot 3 \\
21236.9\end{array}$ & $\begin{array}{l}42.628 \\
42.629 \\
42.630 \\
42.631 \\
42.632\end{array}$ & $\begin{array}{l}1.29 \\
1.24 \\
1.19 \\
1.14 \\
1.08\end{array}$ \\
\hline $\begin{array}{l}400 \\
401 \\
402 \\
403 \\
404\end{array}$ & $\begin{array}{l}16395.4 \\
16437.7 \\
16479.9 \\
16522.1 \\
16564.4\end{array}$ & $\begin{array}{l}42 \cdot 217 \\
42 \cdot 223 \\
42 \cdot 229 \\
42 \cdot 234 \\
42 \cdot 240\end{array}$ & $\begin{array}{l}5.68 \\
5.66 \\
5.63 \\
5.60 \\
5.57\end{array}$ & $\begin{array}{l}460 \\
461 \\
462 \\
463 \\
464\end{array}$ & $\begin{array}{l}18937.6 \\
18980.1 \\
19022.7 \\
19065.2 \\
19107.7\end{array}$ & $\begin{array}{l}42.502 \\
42.506 \\
42.509 \\
42.513 \\
42.516\end{array}$ & $\begin{array}{l}3.65 \\
3.61 \\
3.56 \\
3.52 \\
3.48\end{array}$ & $\begin{array}{l}520 \\
521 \\
522 \\
523 \\
524\end{array}$ & $\begin{array}{l}21492.7 \\
21535 \cdot 3 \\
21578.0 \\
21620.6 \\
21663.3\end{array}$ & $\begin{array}{l}42.638 \\
42.639 \\
42.639 \\
42.640 \\
42.641\end{array}$ & $\begin{array}{l}0.77 \\
0.72 \\
0.66 \\
0.61 \\
0.56\end{array}$ \\
\hline $\begin{array}{l}405 \\
406 \\
407 \\
408 \\
409\end{array}$ & $\begin{array}{l}16606.6 \\
16648.9 \\
16691.1 \\
16733.4 \\
16775.6\end{array}$ & $\begin{array}{l}42.246 \\
42.251 \\
42.257 \\
42.262 \\
42.267\end{array}$ & $\begin{array}{l}5.55 \\
5.52 \\
5.49 \\
5.46 \\
5.43\end{array}$ & $\begin{array}{l}465 \\
466 \\
467 \\
468 \\
469\end{array}$ & $\begin{array}{l}19150.2 \\
19192.7 \\
19235.2 \\
19277.8 \\
19320.3\end{array}$ & $\begin{array}{l}42.520 \\
42.523 \\
42.527 \\
42.530 \\
42.533\end{array}$ & $\begin{array}{l}3.44 \\
3.39 \\
3.35 \\
3.31 \\
3.26\end{array}$ & $\begin{array}{l}525 \\
526 \\
527 \\
528 \\
529\end{array}$ & $\begin{array}{l}21705 \cdot 9 \\
21748 \cdot 5 \\
21791 \cdot 2 \\
21833 \cdot 8 \\
21876.5\end{array}$ & $\begin{array}{l}42.641 \\
42.642 \\
42.642 \\
42.642 \\
42.643\end{array}$ & $\begin{array}{l}0.51 \\
0.45 \\
0.40 \\
0.35 \\
0.29\end{array}$ \\
\hline $\begin{array}{l}410 \\
411 \\
412 \\
413 \\
414\end{array}$ & $\begin{array}{l}16817.9 \\
16860.2 \\
16902.5 \\
16944.7 \\
16987.0\end{array}$ & $\begin{array}{l}42.273 \\
42.278 \\
42.284 \\
42.289 \\
42.294\end{array}$ & $\begin{array}{l}5.41 \\
5.38 \\
5.35 \\
5.32 \\
5.29\end{array}$ & $\begin{array}{l}470 \\
471 \\
472 \\
473 \\
474\end{array}$ & $\begin{array}{l}19362.8 \\
19405.4 \\
19447.9 \\
19490.5 \\
19533.0\end{array}$ & $\begin{array}{l}42 \cdot 536 \\
42.540 \\
42.543 \\
42.546 \\
42.549\end{array}$ & $\begin{array}{l}3.22 \\
3.17 \\
3.13 \\
3.08 \\
3.04\end{array}$ & $\begin{array}{l}530 \\
531 \\
532 \\
533 \\
534\end{array}$ & $\begin{array}{l}21919.1 \\
21961.8 \\
22004 \cdot 4 \\
22047 \cdot 0 \\
22089.7\end{array}$ & $\begin{array}{l}42.643 \\
42.643 \\
42.643 \\
42.643 \\
42.643\end{array}$ & $\begin{array}{l}0.24 \\
0.19 \\
0.13 \\
0.08 \\
0.02\end{array}$ \\
\hline $\begin{array}{l}415 \\
416 \\
417 \\
418 \\
419\end{array}$ & $\begin{array}{l}17029.3 \\
17071.6 \\
17113.9 \\
17156.3 \\
17198.6\end{array}$ & $\begin{array}{l}42 \cdot 300 \\
42 \cdot 305 \\
42 \cdot 310 \\
42 \cdot 315 \\
42 \cdot 320\end{array}$ & $\begin{array}{l}5.26 \\
5.23 \\
5.20 \\
5.17 \\
5.14\end{array}$ & $\begin{array}{l}475 \\
476 \\
477 \\
478 \\
479\end{array}$ & $\begin{array}{l}19575.6 \\
19618.1 \\
19660.7 \\
19703.2 \\
19745.8\end{array}$ & $\begin{array}{l}42.552 \\
42.555 \\
42.558 \\
42.561 \\
42.564\end{array}$ & $\begin{array}{l}2.99 \\
2.95 \\
2.90 \\
2.86 \\
2.81\end{array}$ & $\begin{array}{l}535 \\
536 \\
537 \\
538 \\
539\end{array}$ & $\begin{array}{l}22132 \cdot 3 \\
22175 \cdot 0 \\
22217 \cdot 6 \\
22260 \cdot 3 \\
22302.9\end{array}$ & $\begin{array}{l}42.643 \\
42.643 \\
42.643 \\
42.643 \\
42.643\end{array}$ & $\begin{array}{l}-0.03 \\
-0.08 \\
-0.14 \\
-0.19 \\
-0.25\end{array}$ \\
\hline+20 & 17240.9 & $42 \cdot 325$ & 5.11 & 480 & 19788.4 & 42.566 & 2.76 & 540 & 22345.5 & 42.643 & $-0 \cdot 30$ \\
\hline
\end{tabular}


TABLE 7.3.2. Type $K$ thermocouples-thermoelectric voltages, $\mathrm{E}(\mathrm{T})$, Seebeck coefficients, $\mathrm{S}(\mathrm{T})$, and first derivative of the Seebeck coefficients, $\mathrm{dS} / \mathrm{dT}$, reference junctions at $0{ }^{\circ} \mathrm{C}-$ Continued

\begin{tabular}{|c|c|c|c|c|c|c|c|c|c|c|c|}
\hline $\begin{array}{l}\mathrm{T} \\
{ }^{\circ} \mathrm{C}\end{array}$ & $\begin{array}{c}E \\
\mu V\end{array}$ & $\stackrel{\mathrm{S}}{\mu \mathrm{V} /{ }^{\circ} \mathrm{C}}$ & $\begin{array}{l}d S / d T \\
n V /{ }^{\circ} C^{2}\end{array}$ & $\begin{array}{r}\mathrm{T} \\
{ }^{\circ} \mathrm{C}\end{array}$ & $\begin{array}{c}E \\
\mu V\end{array}$ & $\begin{array}{c}\mathrm{S} \\
\mu \mathrm{V} /{ }^{\circ} \mathrm{C}\end{array}$ & $\begin{array}{l}\mathrm{dS} / \mathrm{dT} \\
\mathrm{nV} /{ }^{\circ} \mathrm{C}^{2}\end{array}$ & $\begin{array}{l}\mathrm{T} \\
{ }^{\circ} \mathrm{C}\end{array}$ & $\underset{\mu V}{E}$ & $\begin{array}{c}\mathrm{S} \\
\mu \mathrm{V} /{ }^{\circ} \mathrm{C}\end{array}$ & $\begin{array}{l}\mathrm{dS} / \mathrm{dT} \\
\mathrm{nV} /{ }^{\circ} \mathrm{C}^{2}\end{array}$ \\
\hline $\begin{array}{l}540 \\
541 \\
542 \\
543 \\
544\end{array}$ & $\begin{array}{l}22345.5 \\
22388.2 \\
22430.8 \\
22473.5 \\
22516.1\end{array}$ & $\begin{array}{l}42.643 \\
42.642 \\
42.642 \\
42.641 \\
42.641\end{array}$ & $\begin{array}{l}-0.30 \\
-0.35 \\
-0.41 \\
-0.46 \\
-0.52\end{array}$ & $\begin{array}{l}600 \\
601 \\
602 \\
603 \\
604\end{array}$ & $\begin{array}{l}24901.6 \\
24944.1 \\
24986.6 \\
25029.2 \\
25071.7\end{array}$ & $\begin{array}{l}42.527 \\
42.523 \\
42.519 \\
42.516 \\
42.512\end{array}$ & $\begin{array}{l}-3.55 \\
-3.60 \\
-3.65 \\
-3.71 \\
-3.76\end{array}$ & $\begin{array}{l}660 \\
661 \\
662 \\
663 \\
664\end{array}$ & $\begin{array}{l}27445.0 \\
27487.2 \\
27529.4 \\
27571.6 \\
27613.8\end{array}$ & $\begin{array}{l}42.224 \\
42.217 \\
42.211 \\
42.204 \\
42.197\end{array}$ & $\begin{array}{l}-6.46 \\
-6.51 \\
-6.55 \\
-6.59 \\
-6.63\end{array}$ \\
\hline $\begin{array}{l}545 \\
546 \\
547 \\
548 \\
549\end{array}$ & $\begin{array}{l}22558.8 \\
22601.4 \\
22644.0 \\
22686.7 \\
22729.3\end{array}$ & $\begin{array}{l}42.640 \\
42.640 \\
42.639 \\
42.638 \\
42.638\end{array}$ & $\begin{array}{l}-0.57 \\
-0.63 \\
-0.68 \\
-0.74 \\
-0.79\end{array}$ & $\begin{array}{l}605 \\
606 \\
607 \\
608 \\
609\end{array}$ & $\begin{array}{l}25114.2 \\
25156.7 \\
25199.2 \\
25241.7 \\
25284.2\end{array}$ & $\begin{array}{l}42.508 \\
42.504 \\
42.501 \\
42.497 \\
42.493\end{array}$ & $\begin{array}{l}-3.81 \\
-3.86 \\
-3.92 \\
-3.97 \\
-4.02\end{array}$ & $\begin{array}{l}665 \\
666 \\
667 \\
668 \\
669\end{array}$ & $\begin{array}{l}27656.0 \\
27698.2 \\
27740.4 \\
27782.6 \\
27824.7\end{array}$ & $\begin{array}{l}42.191 \\
42.184 \\
42.177 \\
42.170 \\
42.164\end{array}$ & $\begin{array}{l}-6.68 \\
-6.72 \\
-6.76 \\
-6.80 \\
-6.84\end{array}$ \\
\hline $\begin{array}{l}550 \\
551 \\
552 \\
553 \\
554\end{array}$ & $\begin{array}{l}22771.9 \\
22814.6 \\
22857.2 \\
22899.9 \\
22942.5\end{array}$ & $\begin{array}{l}42.637 \\
42.636 \\
42.635 \\
42.634 \\
42.633\end{array}$ & $\begin{array}{l}-0.84 \\
-0.90 \\
-0.95 \\
-1.01 \\
-1.06\end{array}$ & $\begin{array}{l}610 \\
611 \\
612 \\
613 \\
614\end{array}$ & $\begin{array}{l}25326.7 \\
25369.2 \\
25411.7 \\
25454.1 \\
25496.6\end{array}$ & $\begin{array}{l}42.489 \\
42.484 \\
42.480 \\
42.476 \\
42.472\end{array}$ & $\begin{array}{l}-4.07 \\
-4.12 \\
-4.17 \\
-4.22 \\
-4.28\end{array}$ & $\begin{array}{l}670 \\
671 \\
672 \\
673 \\
674\end{array}$ & $\begin{array}{l}27866.9 \\
27909 \cdot 0 \\
27951.2 \\
27993.3 \\
28035.5\end{array}$ & $\begin{array}{l}42.157 \\
42.150 \\
42.143 \\
42.136 \\
42.129\end{array}$ & $\begin{array}{l}-6.89 \\
-6.93 \\
-6.97 \\
-7.01 \\
-7.05\end{array}$ \\
\hline $\begin{array}{l}555 \\
556 \\
557 \\
558 \\
559\end{array}$ & $\begin{array}{l}22985.1 \\
23027.8 \\
23070.4 \\
23113.0 \\
23155.6\end{array}$ & $\begin{array}{l}42.632 \\
42.631 \\
42.630 \\
42.628 \\
42.627\end{array}$ & $\begin{array}{l}-1.12 \\
-1.17 \\
-1.23 \\
-1.28 \\
-1.34\end{array}$ & $\begin{array}{l}615 \\
616 \\
617 \\
618 \\
619\end{array}$ & $\begin{array}{l}25539.1 \\
25581.5 \\
25624.0 \\
25666.5 \\
25708.9\end{array}$ & $\begin{array}{l}42.468 \\
42.463 \\
42.459 \\
42.454 \\
42.450\end{array}$ & $\begin{array}{l}-4.33 \\
-4.38 \\
-4.43 \\
-4.48 \\
-4.53\end{array}$ & $\begin{array}{l}675 \\
676 \\
677 \\
678 \\
679\end{array}$ & $\begin{array}{l}28077.6 \\
28119.7 \\
28161.8 \\
28203.9 \\
28246.0\end{array}$ & $\begin{array}{l}42.122 \\
42.115 \\
42.108 \\
42.100 \\
42.093\end{array}$ & $\begin{array}{l}-7.09 \\
-7.13 \\
-7.17 \\
-7.21 \\
-7.25\end{array}$ \\
\hline $\begin{array}{l}560 \\
561 \\
562 \\
563 \\
564\end{array}$ & $\begin{array}{l}23198.3 \\
23240.9 \\
23283.5 \\
23326.1 \\
23368.8\end{array}$ & $\begin{array}{l}42.626 \\
42.624 \\
42.623 \\
42.621 \\
42.620\end{array}$ & $\begin{array}{l}-1.39 \\
-1.45 \\
-1.50 \\
-1.55 \\
-1.61\end{array}$ & $\begin{array}{l}620 \\
621 \\
622 \\
623 \\
624\end{array}$ & $\begin{array}{l}25751.4 \\
25793.8 \\
25836.2 \\
25878.7 \\
25921.1\end{array}$ & $\begin{array}{l}42.445 \\
42.441 \\
42.436 \\
42.431 \\
42.427\end{array}$ & $\begin{array}{l}-4.58 \\
-4.63 \\
-4.68 \\
-4.73 \\
-4.78\end{array}$ & $\begin{array}{l}680 \\
681 \\
682 \\
683 \\
684\end{array}$ & $\begin{array}{l}28288.1 \\
28330.2 \\
28372 \cdot 3 \\
28414 \cdot 3 \\
28456.4\end{array}$ & $\begin{array}{l}42.086 \\
42.079 \\
42.071 \\
42.064 \\
42.056\end{array}$ & $\begin{array}{l}-7.29 \\
-7.33 \\
-7.37 \\
-7.40 \\
-7.44\end{array}$ \\
\hline $\begin{array}{l}565 \\
566 \\
567 \\
568 \\
569\end{array}$ & $\begin{array}{l}23411.4 \\
23454.0 \\
23496.6 \\
23539.2 \\
23581.8\end{array}$ & $\begin{array}{l}42.618 \\
42.616 \\
42.615 \\
42.613 \\
42.611\end{array}$ & $\begin{array}{l}-1.66 \\
-1.72 \\
-1.77 \\
-1.83 \\
-1.88\end{array}$ & $\begin{array}{l}625 \\
626 \\
627 \\
628 \\
629\end{array}$ & $\begin{array}{l}25963.5 \\
26005.9 \\
26048.4 \\
26090.8 \\
26133.2\end{array}$ & $\begin{array}{l}42.422 \\
42.417 \\
42.412 \\
42.407 \\
42.402\end{array}$ & $\begin{array}{l}-4.83 \\
-4.88 \\
-4.93 \\
-4.98 \\
-5.03\end{array}$ & $\begin{array}{l}685 \\
686 \\
687 \\
688 \\
689\end{array}$ & $\begin{array}{l}28498.4 \\
28540.5 \\
28582.5 \\
28624.6 \\
28666.6\end{array}$ & $\begin{array}{l}42.049 \\
42.041 \\
42.034 \\
42.026 \\
42.019\end{array}$ & $\begin{array}{l}-7.48 \\
-7.52 \\
-7.56 \\
-7.59 \\
-7.63\end{array}$ \\
\hline $\begin{array}{l}570 \\
571 \\
572 \\
573 \\
574\end{array}$ & $\begin{array}{l}23624.4 \\
23667.1 \\
23709.7 \\
23752.3 \\
23794.9\end{array}$ & $\begin{array}{l}42.609 \\
42.607 \\
42.605 \\
42.603 \\
42.601\end{array}$ & $\begin{array}{l}-1.94 \\
-1.99 \\
-2.05 \\
-2.10 \\
-2.15\end{array}$ & $\begin{array}{l}630 \\
631 \\
632 \\
633 \\
634\end{array}$ & $\begin{array}{l}26175.6 \\
26218.0 \\
26260.4 \\
26302.7 \\
26345.1\end{array}$ & $\begin{array}{l}42.397 \\
42.392 \\
42.387 \\
42.382 \\
42.376\end{array}$ & $\begin{array}{l}-5.08 \\
-5.12 \\
-5.17 \\
-5.22 \\
-5.27\end{array}$ & $\begin{array}{l}690 \\
691 \\
692 \\
693 \\
694\end{array}$ & $\begin{array}{l}28708 \cdot 6 \\
28750.6 \\
28792 \cdot 6 \\
28834 \cdot 6 \\
28876.6\end{array}$ & $\begin{array}{l}42.011 \\
42.003 \\
41.996 \\
41.988 \\
41.980\end{array}$ & $\begin{array}{l}-7.67 \\
-7.70 \\
-7.74 \\
-7.78 \\
-7.81\end{array}$ \\
\hline $\begin{array}{l}575 \\
576 \\
577 \\
578 \\
579\end{array}$ & $\begin{array}{l}23837.5 \\
23880.1 \\
23922.7 \\
23965.3 \\
24007.8\end{array}$ & $\begin{array}{l}42.599 \\
42.597 \\
42.594 \\
42.592 \\
42.589\end{array}$ & $\begin{array}{l}-2.21 \\
-2.26 \\
-2.32 \\
-2.37 \\
-2.43\end{array}$ & $\begin{array}{l}635 \\
636 \\
637 \\
638 \\
639\end{array}$ & $\begin{array}{l}26387.5 \\
26429.9 \\
26472.2 \\
26514.6 \\
26556.9\end{array}$ & $\begin{array}{l}42 \cdot 371 \\
42.366 \\
42.360 \\
42.355 \\
42.349\end{array}$ & $\begin{array}{l}-5.32 \\
-5.37 \\
-5.41 \\
-5.46 \\
-5.51\end{array}$ & $\begin{array}{l}695 \\
696 \\
697 \\
698 \\
699\end{array}$ & $\begin{array}{l}28918.6 \\
28960.5 \\
29002.5 \\
29044.4 \\
29086.4\end{array}$ & $\begin{array}{l}41.972 \\
41.964 \\
41.957 \\
41.949 \\
41.941\end{array}$ & $\begin{array}{l}-7.85 \\
-7.88 \\
-7.92 \\
-7.95 \\
-7.99\end{array}$ \\
\hline $\begin{array}{l}580 \\
581 \\
582 \\
583 \\
584\end{array}$ & $\begin{array}{l}24050.4 \\
24093.0 \\
24135.6 \\
24178.2 \\
24220.8\end{array}$ & $\begin{array}{l}42.587 \\
42.585 \\
42.582 \\
42.579 \\
42.577\end{array}$ & $\begin{array}{l}-2.48 \\
-2.53 \\
-2.59 \\
-2.64 \\
-2.70\end{array}$ & $\begin{array}{l}640 \\
641 \\
642 \\
643 \\
644\end{array}$ & $\begin{array}{l}26599.3 \\
26641.6 \\
26684.0 \\
26726.3 \\
26768.6\end{array}$ & $\begin{array}{l}42 \cdot 344 \\
42.338 \\
42.333 \\
42.327 \\
42.321\end{array}$ & $\begin{array}{l}-5.56 \\
-5.60 \\
-5.65 \\
-5.70 \\
-5.74\end{array}$ & $\begin{array}{l}700 \\
701 \\
702 \\
703 \\
704\end{array}$ & $\begin{array}{l}29128.3 \\
29170.2 \\
29212 \cdot 2 \\
29254 \cdot 1 \\
29296.0\end{array}$ & $\begin{array}{l}41.933 \\
41.925 \\
41.917 \\
41.908 \\
41.900\end{array}$ & $\begin{array}{l}-8.02 \\
-8.06 \\
-8.09 \\
-8.12 \\
-8.16\end{array}$ \\
\hline $\begin{array}{l}585 \\
586 \\
587 \\
588 \\
589\end{array}$ & $\begin{array}{l}24263.3 \\
24305.9 \\
24348.5 \\
24391.0 \\
24433.6\end{array}$ & $\begin{array}{l}42.574 \\
42.571 \\
42.568 \\
42.565 \\
42.563\end{array}$ & $\begin{array}{l}-2.75 \\
-2.80 \\
-2.86 \\
-2.91 \\
-2.96\end{array}$ & $\begin{array}{l}645 \\
646 \\
647 \\
648 \\
649\end{array}$ & $\begin{array}{l}26810.9 \\
26853.2 \\
26895.5 \\
26937.9 \\
26980.1\end{array}$ & $\begin{array}{l}42.315 \\
42.310 \\
42.304 \\
42.298 \\
42.292\end{array}$ & $\begin{array}{l}-5.79 \\
-5.84 \\
-5.88 \\
-5.93 \\
-5.97\end{array}$ & $\begin{array}{l}705 \\
706 \\
707 \\
708 \\
709\end{array}$ & $\begin{array}{l}29337.9 \\
29379.8 \\
29421.6 \\
29463.5 \\
29505.4\end{array}$ & $\begin{array}{l}41.892 \\
41.884 \\
41.876 \\
41.867 \\
41.859\end{array}$ & $\begin{array}{l}-8.19 \\
-8.22 \\
-8.26 \\
-8.29 \\
-8.32\end{array}$ \\
\hline $\begin{array}{l}590 \\
591 \\
592 \\
593 \\
594\end{array}$ & $\begin{array}{l}24476.2 \\
24518.7 \\
24561.3 \\
24603.8 \\
24646.4\end{array}$ & $\begin{array}{l}42.560 \\
42.556 \\
42.553 \\
42.550 \\
42.547\end{array}$ & $\begin{array}{l}-3.02 \\
-3.07 \\
-3.13 \\
-3.18 \\
-3.23\end{array}$ & $\begin{array}{l}650 \\
651 \\
652 \\
653 \\
654\end{array}$ & $\begin{array}{l}27022.4 \\
27064.7 \\
27107.0 \\
27149.3 \\
27191.5\end{array}$ & $\begin{array}{l}42.286 \\
42.280 \\
42.274 \\
42.268 \\
42.262\end{array}$ & $\begin{array}{l}-6.02 \\
-6.06 \\
-6.11 \\
-6.15 \\
-6.20\end{array}$ & $\begin{array}{l}710 \\
711 \\
712 \\
713 \\
714\end{array}$ & $\begin{array}{l}29547.2 \\
29589.1 \\
29630.9 \\
29672.8 \\
29714.6\end{array}$ & $\begin{array}{l}41.851 \\
41.842 \\
41.834 \\
41.826 \\
41.817\end{array}$ & $\begin{array}{l}-8.35 \\
-8.39 \\
-8.42 \\
-8.45 \\
-8.48\end{array}$ \\
\hline $\begin{array}{l}595 \\
596 \\
597 \\
598 \\
599\end{array}$ & $\begin{array}{l}24688.9 \\
24731.5 \\
24774.0 \\
24816.5 \\
24859.1\end{array}$ & $\begin{array}{l}42.544 \\
42.540 \\
42.537 \\
42.534 \\
42.530\end{array}$ & $\begin{array}{l}-3.28 \\
-3.34 \\
-3.39 \\
-3.44 \\
-3.50\end{array}$ & $\begin{array}{l}655 \\
656 \\
657 \\
658 \\
659\end{array}$ & $\begin{array}{l}27233.8 \\
27276.0 \\
27318.3 \\
27360.5 \\
27402.8\end{array}$ & $\begin{array}{l}42.255 \\
42.249 \\
42.243 \\
42.236 \\
42.230\end{array}$ & $\begin{array}{l}-6.24 \\
-6 \cdot 29 \\
-6 \cdot 33 \\
-6 \cdot 37 \\
-6.42\end{array}$ & $\begin{array}{l}715 \\
716 \\
717 \\
718 \\
719\end{array}$ & $\begin{array}{l}29756.4 \\
29798.2 \\
29840.0 \\
29881.8 \\
29923.6\end{array}$ & $\begin{array}{l}41.809 \\
41.800 \\
41.791 \\
41.783 \\
41.774\end{array}$ & $\begin{array}{l}-8.51 \\
-8.54 \\
-8.57 \\
-8.60 \\
-8.63\end{array}$ \\
\hline 600 & 24901.6 & 42.527 & -3.55 & 660 & 27445.0 & 42.224 & -6.46 & 720 & 29965.3 & 41.766 & -8.66 \\
\hline
\end{tabular}


TABLE 7.3.2. Type $\boldsymbol{K}$ thermocouples-thermoelectric voltages, $\mathrm{E}(\mathrm{T})$, Seebeck coefficients, $\mathrm{S}(\mathrm{T})$, and first derivative of the Seebeck coefficients, $\mathrm{dS} / \mathrm{dT}$, reference junctions at $0^{\circ} \mathrm{C}$-Continued

\begin{tabular}{|c|c|c|c|c|c|c|c|c|c|c|c|}
\hline${ }^{\circ} \mathrm{C}$ & $\begin{array}{c}E \\
\mu V\end{array}$ & $\stackrel{S}{\mu V /{ }^{\circ} \mathrm{C}}$ & $\begin{array}{l}d S / d T \\
n V /{ }^{\circ} C^{2}\end{array}$ & ${ }^{\circ} \mathrm{C}$ & $\underset{\mu V}{E}$ & $\stackrel{S}{\mathrm{SV}^{\circ}{ }^{\circ} \mathrm{C}}$ & $\begin{array}{l}d S / d T \\
n V /{ }^{\circ} C^{2}\end{array}$ & $\begin{array}{r}\mathrm{T} \\
{ }^{\circ} \mathrm{C}\end{array}$ & $\underset{\mu V}{E}$ & $\underset{\mu \mathrm{V} /{ }^{\circ} \mathrm{C}}{\mathrm{S}}$ & $\begin{array}{l}\mathrm{dS} / \mathrm{dT} \\
\mathrm{nV} /{ }^{\circ} \mathrm{C}^{2}\end{array}$ \\
\hline $\begin{array}{l}720 \\
721 \\
722 \\
723 \\
724\end{array}$ & $\begin{array}{l}29965.3 \\
30007.1 \\
30048.8 \\
30090.6 \\
30132.3\end{array}$ & $\begin{array}{l}41.766 \\
41.757 \\
41.748 \\
41.740 \\
41.731\end{array}$ & $\begin{array}{l}-8.66 \\
-8.69 \\
-8.72 \\
-8.75 \\
-8.78\end{array}$ & $\begin{array}{l}780 \\
781 \\
782 \\
783 \\
784\end{array}$ & $\begin{array}{l}32454 \cdot 7 \\
32495.9 \\
32537.1 \\
32578.3 \\
32619.5\end{array}$ & $\begin{array}{l}41.202 \\
41.192 \\
41.182 \\
41.172 \\
41.162\end{array}$ & $\begin{array}{r}-9.98 \\
-9.99 \\
-10.01 \\
-10.02 \\
-10.03\end{array}$ & $\begin{array}{l}840 \\
841 \\
842 \\
843 \\
844\end{array}$ & $\begin{array}{l}34908 \cdot 5 \\
34949 \cdot 1 \\
34989 \cdot 7 \\
35030 \cdot 2 \\
35070 \cdot 8\end{array}$ & $\begin{array}{l}40.585 \\
40.574 \\
40.564 \\
40.553 \\
40.543\end{array}$ & $\begin{array}{l}-10.47 \\
-10.48 \\
-10.48 \\
-10.48 \\
-10.48\end{array}$ \\
\hline $\begin{array}{l}725 \\
726 \\
727 \\
728 \\
729\end{array}$ & $\begin{array}{l}30174.0 \\
30215.8 \\
30257.5 \\
30299.2 \\
30340.9\end{array}$ & $\begin{array}{l}41.722 \\
41.713 \\
41.704 \\
41.695 \\
41.687\end{array}$ & $\begin{array}{l}-8.81 \\
-8.83 \\
-8.86 \\
-8.89 \\
-8.92\end{array}$ & $\begin{array}{l}785 \\
786 \\
787 \\
788 \\
789\end{array}$ & $\begin{array}{l}32660.6 \\
32701.8 \\
32742.9 \\
32784.0 \\
32825.2\end{array}$ & $\begin{array}{l}41 \cdot 152 \\
41.142 \\
41 \cdot 132 \\
41.122 \\
41.112\end{array}$ & $\begin{array}{l}-10.05 \\
-10.06 \\
-10.07 \\
-10.09 \\
-10.10\end{array}$ & $\begin{array}{l}845 \\
846 \\
847 \\
848 \\
849\end{array}$ & $\begin{array}{l}35111.3 \\
35151.8 \\
35192.3 \\
35232.8 \\
35273.3\end{array}$ & $\begin{array}{l}40.532 \\
40.522 \\
40.512 \\
40.501 \\
40.491\end{array}$ & $\begin{array}{l}-10.49 \\
-10.49 \\
-10.49 \\
-10.49 \\
-10.49\end{array}$ \\
\hline $\begin{array}{l}730 \\
731 \\
732 \\
733 \\
734\end{array}$ & $\begin{array}{l}30382.5 \\
30424.2 \\
30465.9 \\
30507.5 \\
30549.2\end{array}$ & $\begin{array}{l}41.678 \\
41.669 \\
41.660 \\
41.651 \\
41.642\end{array}$ & $\begin{array}{l}-8.94 \\
-8.97 \\
-9.00 \\
-9.02 \\
-9.05\end{array}$ & $\begin{array}{l}790 \\
791 \\
792 \\
793 \\
794\end{array}$ & $\begin{array}{l}32866.3 \\
32907.4 \\
32948.4 \\
32989.5 \\
33030.6\end{array}$ & $\begin{array}{l}41.102 \\
41.091 \\
41.081 \\
41.071 \\
41.061\end{array}$ & $\begin{array}{l}-10.11 \\
-10.12 \\
-10.14 \\
-10.15 \\
-10.16\end{array}$ & $\begin{array}{l}850 \\
851 \\
852 \\
853 \\
854\end{array}$ & $\begin{array}{l}35313.8 \\
35354.3 \\
35394.8 \\
35435.2 \\
35475.7\end{array}$ & $\begin{array}{l}40.480 \\
40.470 \\
40.459 \\
40.449 \\
40.438\end{array}$ & $\begin{array}{l}-10.49 \\
-10.49 \\
-10.50 \\
-10.50 \\
-10.50\end{array}$ \\
\hline $\begin{array}{l}740 \\
741 \\
742 \\
743 \\
744\end{array}$ & $\begin{array}{l}30798.9 \\
30840.4 \\
30882.0 \\
30923.6 \\
30965.1\end{array}$ & $\begin{array}{l}41.587 \\
41.578 \\
41.568 \\
41.559 \\
41.550\end{array}$ & $\begin{array}{l}-9.20 \\
-9.22 \\
-9.25 \\
-9.27 \\
-9.30\end{array}$ & $\begin{array}{l}800 \\
801 \\
802 \\
803 \\
804\end{array}$ & $\begin{array}{l}33276.8 \\
33317.8 \\
33358.8 \\
33399.7 \\
33440.7\end{array}$ & $\begin{array}{l}41.000 \\
40.990 \\
40.979 \\
40.969 \\
40.959\end{array}$ & $\begin{array}{l}-10.22 \\
-10.23 \\
-10.24 \\
-10.25 \\
-10.26\end{array}$ & $\begin{array}{l}860 \\
861 \\
862 \\
863 \\
864\end{array}$ & $\begin{array}{l}35718.1 \\
35758.5 \\
35798.8 \\
35839.2 \\
35879.5\end{array}$ & $\begin{array}{l}40.375 \\
40.365 \\
40.354 \\
40.344 \\
40.333\end{array}$ & $\begin{array}{l}-10.50 \\
-10.50 \\
-10.50 \\
-10.50 \\
-10.50\end{array}$ \\
\hline $\begin{array}{l}745 \\
746 \\
747 \\
748 \\
749\end{array}$ & $\begin{array}{l}31006.7 \\
31048.2 \\
31089.7 \\
31131.3 \\
31172.8\end{array}$ & $\begin{array}{l}41.541 \\
41.531 \\
41.522 \\
41.513 \\
41.503\end{array}$ & $\begin{array}{l}-9 \cdot 32 \\
-9 \cdot 34 \\
-9 \cdot 36 \\
-9 \cdot 39 \\
-9.41\end{array}$ & $\begin{array}{l}805 \\
806 \\
807 \\
808 \\
809\end{array}$ & $\begin{array}{l}33481.6 \\
33522.6 \\
33563.5 \\
33604.4 \\
33645.4\end{array}$ & $\begin{array}{l}40.949 \\
40.938 \\
40.928 \\
40.918 \\
40.907\end{array}$ & $\begin{array}{l}-10.27 \\
-10.28 \\
-10.29 \\
-10.30 \\
-10.31\end{array}$ & $\begin{array}{l}865 \\
866 \\
867 \\
868 \\
869\end{array}$ & $\begin{array}{l}35919 \cdot 8 \\
35960 \cdot 2 \\
36000 \cdot 5 \\
36040 \cdot 8 \\
36081 \cdot 1\end{array}$ & $\begin{array}{l}40.323 \\
40.312 \\
40.302 \\
40.291 \\
40.281\end{array}$ & $\begin{array}{l}-10.50 \\
-10.50 \\
-10.50 \\
-10.49 \\
-10.49\end{array}$ \\
\hline $\begin{array}{l}750 \\
751 \\
752 \\
753 \\
754\end{array}$ & $\begin{array}{l}31214.3 \\
31255.8 \\
31297.2 \\
31338.7 \\
31380.2\end{array}$ & $\begin{array}{l}41.494 \\
41.484 \\
41.475 \\
41.465 \\
41.456\end{array}$ & $\begin{array}{l}-9.43 \\
-9.45 \\
-9.47 \\
-9.50 \\
-9.52\end{array}$ & $\begin{array}{l}810 \\
811 \\
812 \\
813 \\
814\end{array}$ & $\begin{array}{l}33686.3 \\
33727.2 \\
33768.0 \\
33808.9 \\
33849.8\end{array}$ & $\begin{array}{l}40.897 \\
40.887 \\
40.876 \\
40.866 \\
40.856\end{array}$ & $\begin{array}{l}-10.32 \\
-10.32 \\
-10.33 \\
-10.34 \\
-10.35\end{array}$ & $\begin{array}{l}870 \\
871 \\
872 \\
873 \\
874\end{array}$ & $\begin{array}{l}36121.3 \\
36161.6 \\
36201.8 \\
36242.1 \\
36282.3\end{array}$ & $\begin{array}{l}40.270 \\
40.260 \\
40.249 \\
40.239 \\
40.228\end{array}$ & $\begin{array}{l}-10.49 \\
-10.49 \\
-10.49 \\
-10.49 \\
-10.49\end{array}$ \\
\hline $\begin{array}{l}760 \\
761 \\
762 \\
763 \\
764\end{array}$ & $\begin{array}{l}31628.7 \\
31670.1 \\
31711.5 \\
31752.9 \\
31794.2\end{array}$ & $\begin{array}{l}41.398 \\
41.389 \\
41.379 \\
41.369 \\
41.360\end{array}$ & $\begin{array}{l}-9.64 \\
-9.66 \\
-9.68 \\
-9.69 \\
-9.71\end{array}$ & $\begin{array}{l}820 \\
821 \\
822 \\
823 \\
824\end{array}$ & $\begin{array}{l}34094.7 \\
34135.5 \\
34176.3 \\
34217.0 \\
34257.8\end{array}$ & $\begin{array}{l}40.794 \\
40.783 \\
40.773 \\
40.762 \\
40.752\end{array}$ & $\begin{array}{l}-10.39 \\
-10.39 \\
-10.40 \\
-10.40 \\
-10.41\end{array}$ & $\begin{array}{l}880 \\
881 \\
882 \\
883 \\
884\end{array}$ & $\begin{array}{l}36523.5 \\
36563.7 \\
36603.8 \\
36644.0 \\
36684.1\end{array}$ & $\begin{array}{l}40.165 \\
40.155 \\
40.144 \\
40.134 \\
40.123\end{array}$ & $\begin{array}{l}-10.48 \\
-10.47 \\
-10.47 \\
-10.47 \\
-10.47\end{array}$ \\
\hline $\begin{array}{l}765 \\
766 \\
767 \\
768 \\
769\end{array}$ & $\begin{array}{l}31835.6 \\
31876.9 \\
31918.3 \\
31959.6 \\
32000.9\end{array}$ & $\begin{array}{l}41 \cdot 350 \\
41 \cdot 340 \\
41.330 \\
41.321 \\
41.311\end{array}$ & $\begin{array}{l}-9.73 \\
-9.75 \\
-9.77 \\
-9.79 \\
-9.80\end{array}$ & $\begin{array}{l}825 \\
826 \\
827 \\
828 \\
829\end{array}$ & $\begin{array}{l}34298.6 \\
34339.3 \\
34380.0 \\
34420.7 \\
34461.4\end{array}$ & $\begin{array}{l}40.742 \\
40.731 \\
40.721 \\
40.710 \\
40.700\end{array}$ & $\begin{array}{l}-10.41 \\
-10.42 \\
-10.42 \\
-10.43 \\
-10.43\end{array}$ & $\begin{array}{l}885 \\
886 \\
887 \\
888 \\
889\end{array}$ & $\begin{array}{l}36724 \cdot 2 \\
36764 \cdot 3 \\
36804 \cdot 4 \\
36844 \cdot 5 \\
36884 \cdot 6\end{array}$ & $\begin{array}{l}40.113 \\
40.102 \\
40.092 \\
40.082 \\
40.071\end{array}$ & $\begin{array}{l}-10.47 \\
-10.46 \\
-10.46 \\
-10.46 \\
-10.46\end{array}$ \\
\hline $\begin{array}{l}770 \\
771 \\
772 \\
773 \\
774\end{array}$ & $\begin{array}{l}32042.2 \\
32083.5 \\
32124.8 \\
32166.1 \\
32207.4\end{array}$ & $\begin{array}{l}41.301 \\
41.291 \\
41.281 \\
41.271 \\
41.262\end{array}$ & $\begin{array}{l}-9.82 \\
-9.84 \\
-9.85 \\
-9.87 \\
-9.89\end{array}$ & $\begin{array}{l}830 \\
831 \\
832 \\
833 \\
834\end{array}$ & $\begin{array}{r}34502.1 \\
34542.8 \\
34583.5 \\
.34624 .2 \\
34664.8\end{array}$ & $\begin{array}{l}40.689 \\
40.679 \\
40.669 \\
40.658 \\
40.648\end{array}$ & $\begin{array}{l}-10.44 \\
-10.44 \\
-10.45 \\
-10.45 \\
-10.45\end{array}$ & $\begin{array}{l}890 \\
891 \\
892 \\
893 \\
894\end{array}$ & $\begin{array}{l}36924.6 \\
36964.7 \\
37004 \cdot 7 \\
37044.8 \\
37084.8\end{array}$ & $\begin{array}{l}40.061 \\
40.050 \\
40.040 \\
40.029 \\
40.019\end{array}$ & $\begin{array}{l}-10.45 \\
-10.45 \\
-10.45 \\
-10.44 \\
-10.44\end{array}$ \\
\hline $\begin{array}{l}775 \\
776 \\
777 \\
778 \\
779\end{array}$ & $\begin{array}{l}32248.6 \\
32289.9 \\
32331.1 \\
32372.3 \\
32413.5\end{array}$ & $\begin{array}{l}41 \cdot 252 \\
41 \cdot 242 \\
41 \cdot 232 \\
41 \cdot 222 \\
41.212\end{array}$ & $\begin{array}{l}-9.90 \\
-9.92 \\
-9.93 \\
-9.95 \\
-9.96\end{array}$ & $\begin{array}{l}835 \\
836 \\
837 \\
838 \\
839\end{array}$ & $\begin{array}{l}34705.4 \\
34746.1 \\
34786.7 \\
34827.3 \\
34867.9\end{array}$ & $\begin{array}{l}40.637 \\
40.627 \\
40.616 \\
40.606 \\
40.595\end{array}$ & $\begin{array}{l}-10.46 \\
-10.46 \\
-10.46 \\
-10.47 \\
-10.47\end{array}$ & $\begin{array}{l}895 \\
896 \\
897 \\
898 \\
899\end{array}$ & $\begin{array}{l}37124 \cdot 8 \\
37164 \cdot 8 \\
37204 \cdot 8 \\
37244.8 \\
37284.8\end{array}$ & $\begin{array}{l}40.008 \\
39.998 \\
39.987 \\
39.977 \\
39.967\end{array}$ & $\begin{array}{l}-10.44 \\
-10.44 \\
-10.43 \\
-10.43 \\
-10.43\end{array}$ \\
\hline 78 & 32454.7 & 41.202 & 9.98 & 840 & $34908 \cdot 5$ & 40.585 & -10.47 & 900 & 37324.7 & 39.956 & -10.42 \\
\hline
\end{tabular}


TABLE 7.3.2. Type $\boldsymbol{K}$ thermocouples-thermoelectric voltages, $\mathrm{E}(\mathrm{T})$, Seebeck coefficients, $\mathrm{S}(\mathrm{T})$, and first derivative of the Seebeck coefficients, $\mathrm{dS} / \mathrm{dT}$, reference junctions at $0{ }^{\circ} \mathrm{C}$-Continued

\begin{tabular}{|c|c|c|c|c|c|c|c|c|c|c|c|}
\hline${ }^{\circ} \mathrm{C}$ & $\begin{array}{l}\mathrm{E} \\
\mu \mathrm{V}\end{array}$ & $\mu^{\mathrm{S}} /^{\circ} \mathrm{C}$ & $\begin{array}{l}\mathrm{dS} / \mathrm{dT} \\
\mathrm{nV} / \mathrm{C}^{2}\end{array}$ & ${ }^{\circ} \mathrm{C}$ & $\begin{array}{l}\mathrm{E} \\
\mu \mathrm{V}\end{array}$ & $\stackrel{\mathrm{S}}{\mu \mathrm{V} /{ }^{\circ} \mathrm{C}}$ & $\begin{array}{l}\mathrm{dS} / \mathrm{dT} \\
\mathrm{nV} /{ }^{\circ} \mathrm{C}^{2}\end{array}$ & ${ }^{\mathrm{T}}$ & $\begin{array}{c}E \\
\mu V\end{array}$ & $\stackrel{\mathrm{S}}{\mu \mathrm{V} /{ }^{\circ} \mathrm{C}}$ & $\begin{array}{l}d S / d T \\
n V /{ }^{\circ} C^{2}\end{array}$ \\
\hline $\begin{array}{l}905 \\
906 \\
907 \\
908 \\
909\end{array}$ & $\begin{array}{l}37524.4 \\
37564.3 \\
37604.2 \\
37644.0 \\
37683.9\end{array}$ & $\begin{array}{l}39.904 \\
39.894 \\
39.883 \\
39.873 \\
39.863\end{array}$ & $\begin{array}{l}-10.41 \\
-10.40 \\
-10.40 \\
-10.40 \\
-10.39\end{array}$ & $\begin{array}{l}965 \\
966 \\
967 \\
968 \\
969\end{array}$ & $\begin{array}{l}39900 \cdot 0 \\
39939 \cdot 3 \\
39978.6 \\
40017 \cdot 8 \\
40057.1\end{array}$ & $\begin{array}{l}39.285 \\
39.275 \\
39.265 \\
39.255 \\
39.244\end{array}$ & $\begin{array}{l}-10 \cdot 25 \\
-10.24 \\
-10 \cdot 24 \\
-10 \cdot 24 \\
-10.24\end{array}$ & $\begin{array}{l}1025 \\
1026 \\
1027 \\
1028 \\
1029\end{array}$ & $\begin{array}{l}42238 \cdot 6 \\
42277 \cdot 3 \\
42315 \cdot 9 \\
42354 \cdot 6 \\
42393 \cdot 2\end{array}$ & $\begin{array}{l}38.667 \\
38.656 \\
38.646 \\
38.636 \\
38.625\end{array}$ & $\begin{array}{l}-10.47 \\
-10.48 \\
-10.49 \\
-10.50 \\
-10.51\end{array}$ \\
\hline $\begin{array}{l}910 \\
911 \\
912 \\
913 \\
914\end{array}$ & $\begin{array}{l}37723.8 \\
37763.6 \\
37803.4 \\
37843.3 \\
37883.1\end{array}$ & $\begin{array}{l}39.852 \\
39.842 \\
39.831 \\
39.821 \\
39.811\end{array}$ & $\begin{array}{l}-10.39 \\
-10.39 \\
-10.38 \\
-10.38 \\
-10.38\end{array}$ & $\begin{array}{l}970 \\
971 \\
972 \\
973 \\
974\end{array}$ & $\begin{array}{l}40096.3 \\
40135.5 \\
40174.7 \\
40214.0 \\
40253.2\end{array}$ & $\begin{array}{l}39.234 \\
39.224 \\
39.214 \\
39.203 \\
39.193\end{array}$ & $\begin{array}{l}-10.24 \\
-10.24 \\
-10.24 \\
-10.24 \\
-10.24\end{array}$ & $\begin{array}{l}1030 \\
1031 \\
1032 \\
1033 \\
1034\end{array}$ & $\begin{array}{l}42431 \cdot 8 \\
42470 \cdot 4 \\
42509 \cdot 0 \\
42547 \cdot 6 \\
42586.2\end{array}$ & $\begin{array}{l}38.614 \\
38.604 \\
38.593 \\
38.583 \\
38.572\end{array}$ & $\begin{array}{l}-10.52 \\
-10.53 \\
-10.54 \\
-10.55 \\
-10.56\end{array}$ \\
\hline $\begin{array}{l}920 \\
921 \\
922 \\
923 \\
924\end{array}$ & $\begin{array}{l}38121.8 \\
38161.5 \\
38201.2 \\
38241.0 \\
38280.7\end{array}$ & $\begin{array}{l}39.748 \\
39.738 \\
39.728 \\
39.717 \\
39.707\end{array}$ & $\begin{array}{l}-10.36 \\
-10.35 \\
-10.35 \\
-10.35 \\
-10.34\end{array}$ & $\begin{array}{l}980 \\
981 \\
982 \\
983 \\
984\end{array}$ & $\begin{array}{l}40488 \cdot 1 \\
40527 \cdot 3 \\
40566 \cdot 4 \\
40605.5 \\
40644.6\end{array}$ & $\begin{array}{l}39.132 \\
39.121 \\
39.111 \\
39.101 \\
39.091\end{array}$ & $\begin{array}{l}-10.25 \\
-10.25 \\
-10.25 \\
-10.25 \\
-10.25\end{array}$ & $\begin{array}{l}1040 \\
1041 \\
1042 \\
1043 \\
1044\end{array}$ & $\begin{array}{l}42817.5 \\
42856.0 \\
42894.5 \\
42932.9 \\
42971.4\end{array}$ & $\begin{array}{l}38.509 \\
38.498 \\
38.487 \\
38.477 \\
38.466\end{array}$ & $\begin{array}{l}-10.63 \\
-10.64 \\
-10.66 \\
-10.67 \\
-10.68\end{array}$ \\
\hline $\begin{array}{l}925 \\
926 \\
927 \\
928 \\
929\end{array}$ & $\begin{array}{l}38320.4 \\
38360.1 \\
38399.7 \\
38439.4 \\
38479.1\end{array}$ & $\begin{array}{l}39.697 \\
39.686 \\
39.676 \\
39.666 \\
39.655\end{array}$ & $\begin{array}{l}-10 \cdot 34 \\
-10 \cdot 34 \\
-10.33 \\
-10.33 \\
-10.33\end{array}$ & $\begin{array}{l}985 \\
986 \\
987 \\
988 \\
989\end{array}$ & $\begin{array}{l}40683.7 \\
40722.7 \\
40761.8 \\
40800.9 \\
40839.9\end{array}$ & $\begin{array}{l}39.080 \\
39.070 \\
39.060 \\
39.050 \\
39.039\end{array}$ & $\begin{array}{l}-10.26 \\
-10.26 \\
-10.26 \\
-10.26 \\
-10.26\end{array}$ & $\begin{array}{l}1045 \\
1046 \\
1047 \\
1048 \\
1049\end{array}$ & $\begin{array}{l}43009 \cdot 9 \\
43048 \cdot 3 \\
43086 \cdot 8 \\
43125 \cdot 2 \\
43163 \cdot 6\end{array}$ & $\begin{array}{l}38.455 \\
38.445 \\
38.434 \\
38.423 \\
38.413\end{array}$ & $\begin{array}{l}-10.7 \\
-10.7 \\
-10.7 \\
-10.7 \\
-10.7\end{array}$ \\
\hline $\begin{array}{l}930 \\
931 \\
932 \\
933 \\
934\end{array}$ & $\begin{array}{l}38518.7 \\
38558.4 \\
38598.0 \\
38637.6 \\
38677.2\end{array}$ & $\begin{array}{l}39.645 \\
39.635 \\
39.624 \\
39.614 \\
39.604\end{array}$ & $\begin{array}{l}-10.32 \\
-10.32 \\
-10.32 \\
-10.31 \\
-10.31\end{array}$ & $\begin{array}{l}990 \\
991 \\
992 \\
993 \\
994\end{array}$ & $\begin{array}{l}40878.9 \\
40918 \cdot 0 \\
40957 \cdot 0 \\
40996.0 \\
41035.0\end{array}$ & $\begin{array}{l}39.029 \\
39.019 \\
39.009 \\
38.998 \\
38.988\end{array}$ & $\begin{array}{l}-10.27 \\
-10.27 \\
-10.27 \\
-10.28 \\
-10.28\end{array}$ & $\begin{array}{l}1050 \\
1051 \\
1052 \\
1053 \\
1054\end{array}$ & $\begin{array}{l}43202 \cdot 0 \\
43240.4 \\
43278.8 \\
43317.2 \\
43355.5\end{array}$ & $\begin{array}{l}38.402 \\
38.391 \\
38.380 \\
38.369 \\
38.359\end{array}$ & $\begin{array}{l}-10.77 \\
-10.78 \\
-10.80 \\
-10.81 \\
-10.83\end{array}$ \\
\hline $\begin{array}{l}940 \\
941 \\
942 \\
943 \\
944\end{array}$ & $\begin{array}{l}38914.7 \\
38954.2 \\
38993.7 \\
39033.2 \\
39072.7\end{array}$ & $\begin{array}{l}39.542 \\
39.532 \\
39.521 \\
39.511 \\
39.501\end{array}$ & $\begin{array}{l}-10.29 \\
-10.29 \\
-10.29 \\
-10.28 \\
-10.28\end{array}$ & $\begin{array}{l}1000 \\
1001 \\
1002 \\
1003 \\
1004\end{array}$ & $\begin{array}{l}41268.7 \\
41307.6 \\
41346.5 \\
41385.4 \\
41424.3\end{array}$ & $\begin{array}{l}38.926 \\
38.916 \\
38.906 \\
38.895 \\
38.885\end{array}$ & $\begin{array}{l}-10 \cdot 30 \\
-10 \cdot 31 \\
-10 \cdot 31 \\
-10 \cdot 31 \\
-10.32\end{array}$ & $\begin{array}{l}1060 \\
1061 \\
1062 \\
1063 \\
1064\end{array}$ & $\begin{array}{l}43585 \cdot 5 \\
43623 \cdot 8 \\
43662 \cdot 1 \\
43700 \cdot 3 \\
43738.6\end{array}$ & $\begin{array}{l}38.293 \\
38.282 \\
38.271 \\
38.260 \\
38.249\end{array}$ & $\begin{array}{l}-10.93 \\
-10.95 \\
-10.96 \\
-10.98 \\
-11.00\end{array}$ \\
\hline $\begin{array}{l}945 \\
946 \\
947 \\
948 \\
949\end{array}$ & $\begin{array}{l}39112.2 \\
39151.7 \\
39191.2 \\
39230.7 \\
39270.1\end{array}$ & $\begin{array}{l}39.491 \\
39.480 \\
39.470 \\
39.460 \\
39.449\end{array}$ & $\begin{array}{l}-10.28 \\
-10.28 \\
-10.27 \\
-10.27 \\
-10.27\end{array}$ & $\begin{array}{l}1005 \\
1006 \\
1007 \\
1008 \\
1009\end{array}$ & $\begin{array}{l}41463 \cdot 2 \\
41502 \cdot 1 \\
41540 \cdot 9 \\
41579 \cdot 8 \\
41618 \cdot 6\end{array}$ & $\begin{array}{l}38.875 \\
38.864 \\
38.854 \\
38.844 \\
38.833\end{array}$ & $\begin{array}{l}-10 \cdot 32 \\
-10.33 \\
-10.34 \\
-10 \cdot 34 \\
-10.35\end{array}$ & $\begin{array}{l}1065 \\
1066 \\
1067 \\
1068 \\
1069\end{array}$ & $\begin{array}{l}43776 \cdot 8 \\
43815 \cdot 1 \\
43853 \cdot 3 \\
43891 \cdot 5 \\
43929 \cdot 7\end{array}$ & $\begin{array}{l}38.238 \\
38.227 \\
38.216 \\
38.205 \\
38.194\end{array}$ & $\begin{array}{l}-11.02 \\
-11.04 \\
-11.06 \\
-11.07 \\
-11.09\end{array}$ \\
\hline $\begin{array}{l}950 \\
951 \\
952 \\
953 \\
954\end{array}$ & $\begin{array}{l}39309.6 \\
39349.0 \\
39388.4 \\
39427.8 \\
39467.2\end{array}$ & $\begin{array}{l}39.439 \\
39.429 \\
39.419 \\
39.408 \\
39.398\end{array}$ & $\begin{array}{l}-10.27 \\
-10.27 \\
-10.26 \\
-10.26 \\
-10.26\end{array}$ & $\begin{array}{l}1010 \\
1011 \\
1012 \\
1013 \\
1014\end{array}$ & $\begin{array}{l}41657.5 \\
41696 \cdot 3 \\
41735.1 \\
41773 \cdot 9 \\
41812.7\end{array}$ & $\begin{array}{l}38.823 \\
38.813 \\
38.802 \\
38.792 \\
38.782\end{array}$ & $\begin{array}{l}-10.35 \\
-10.36 \\
-10.37 \\
-10.37 \\
-10.38\end{array}$ & $\begin{array}{l}1070 \\
1071 \\
1072 \\
1073 \\
1074\end{array}$ & $\begin{array}{l}43967 \cdot 9 \\
44006 \cdot 0 \\
44044 \cdot 2 \\
44082 \cdot 4 \\
44120 \cdot 5\end{array}$ & $\begin{array}{l}38.183 \\
38.172 \\
38.161 \\
38.150 \\
38.139\end{array}$ & $\begin{array}{l}-11.11 \\
-11 \cdot 13 \\
-11 \cdot 15 \\
-11 \cdot 17 \\
-11.19\end{array}$ \\
\hline $\begin{array}{l}955 \\
956 \\
957 \\
958 \\
959\end{array}$ & $\begin{array}{l}39506.6 \\
39546.0 \\
39585.4 \\
39624.8 \\
39664.1\end{array}$ & $\begin{array}{l}39.388 \\
39.378 \\
39.367 \\
39.357 \\
39.347\end{array}$ & $\begin{array}{l}-10.26 \\
-10.26 \\
-10.25 \\
-10.25 \\
-10.25\end{array}$ & $\begin{array}{l}1015 \\
1016 \\
1017 \\
1018 \\
1019\end{array}$ & $\begin{array}{l}41851.4 \\
41890.2 \\
41929.0 \\
41967.7 \\
42006.4\end{array}$ & $\begin{array}{l}38.771 \\
38.761 \\
38.750 \\
38.740 \\
38.730\end{array}$ & $\begin{array}{l}-10.39 \\
-10.39 \\
-10.40 \\
-10.41 \\
-10.42\end{array}$ & $\begin{array}{l}1075 \\
1076 \\
1077 \\
1078 \\
1079\end{array}$ & $\begin{array}{l}44158.6 \\
44196.8 \\
44234 \cdot 9 \\
44273 \cdot 0 \\
44311.1\end{array}$ & $\begin{array}{l}38.127 \\
38.116 \\
38.105 \\
38.094 \\
38.082\end{array}$ & $\begin{array}{l}-11 \cdot 21 \\
-11.24 \\
-11.26 \\
-11 \cdot 28 \\
-11 \cdot 30\end{array}$ \\
\hline & 9703.4 & 39.337 & -10.25 & .020 & 42045.2 & 38.719 & -10.43 & 1080 & $44349 \cdot 1$ & 8.071 & -11. \\
\hline
\end{tabular}


TABLE 7.3.2. Type $K$ thermocouples-thermoelectric voltages, $\mathrm{E}(\mathrm{T})$, Seebeck coefficients, $\mathrm{S}(\mathrm{T})$, and first derivative of the Seebeck coefficients, $\mathrm{dS} / \mathrm{dT}$, reference junctions at $0{ }^{\circ} \mathrm{C}$-Continued

\begin{tabular}{|c|c|c|c|c|c|c|c|c|c|c|c|}
\hline $\begin{array}{l}\mathrm{T} \\
{ }^{\circ} \mathrm{C}\end{array}$ & $\begin{array}{c}E \\
\mu V\end{array}$ & $\begin{array}{c}S \\
\mu V /{ }^{\circ} \mathrm{C}\end{array}$ & $\begin{array}{l}d S / d T \\
n V /{ }^{\circ} C^{2}\end{array}$ & $\begin{array}{r}\mathrm{T} \\
{ }^{\circ} \mathrm{C}\end{array}$ & $\begin{array}{c}E \\
\mu V\end{array}$ & $\begin{array}{c}S \\
\mu V /^{\circ} \mathrm{C}\end{array}$ & $\begin{array}{l}\mathrm{dS} / \mathrm{dT} \\
\mathrm{nV} /{ }^{\circ} \mathrm{C}^{2}\end{array}$ & $\begin{array}{l}\mathrm{T} \\
{ }^{\circ} \mathrm{C}\end{array}$ & $\underset{\mu V}{E}$ & $\underset{\mu V /{ }^{\circ} \mathrm{C}}{\mathrm{S}}$ & $\begin{array}{l}\mathrm{dS} / \mathrm{dT} \\
\mathrm{nV} /{ }^{\circ} \mathrm{C}^{2}\end{array}$ \\
\hline $\begin{array}{l}1080 \\
1081 \\
1082 \\
1083 \\
1084\end{array}$ & $\begin{array}{l}44349.1 \\
44387.2 \\
44425.3 \\
44463.3 \\
44501.3\end{array}$ & $\begin{array}{l}38.071 \\
38.060 \\
38.048 \\
38.037 \\
38.025\end{array}$ & $\begin{array}{l}-11.32 \\
-11.34 \\
-11.37 \\
-11.39 \\
-11.41\end{array}$ & $\begin{array}{l}1140 \\
1141 \\
1142 \\
1143 \\
1144\end{array}$ & $\begin{array}{l}46612.1 \\
46649.4 \\
46686.8 \\
46724.1 \\
46761.4\end{array}$ & $\begin{array}{l}37.344 \\
37.331 \\
37.318 \\
37.305 \\
37.292\end{array}$ & $\begin{array}{l}-13.03 \\
-13.06 \\
-13.10 \\
-13.13 \\
-13.17\end{array}$ & $\begin{array}{l}1200 \\
1201 \\
1202 \\
1203 \\
1204\end{array}$ & $\begin{array}{l}48828.0 \\
48864.5 \\
48901.0 \\
48937.5 \\
48973.9\end{array}$ & $\begin{array}{l}36.499 \\
36.484 \\
36.469 \\
36.454 \\
36.438\end{array}$ & $\begin{array}{l}-15.12 \\
-15.16 \\
-15.19 \\
-15.22 \\
-15.25\end{array}$ \\
\hline $\begin{array}{l}1085 \\
1086 \\
1087 \\
1088 \\
1089\end{array}$ & $\begin{array}{l}44539.4 \\
44577.4 \\
44615.4 \\
44653.3 \\
44691.3\end{array}$ & $\begin{array}{l}38.014 \\
38.003 \\
37.991 \\
37.980 \\
37.968\end{array}$ & $\begin{array}{l}-11.44 \\
-11.46 \\
-11.48 \\
-11.51 \\
-11.53\end{array}$ & $\begin{array}{l}1145 \\
1146 \\
1147 \\
1148 \\
1149\end{array}$ & $\begin{array}{l}46798.7 \\
46835.9 \\
46873.2 \\
46910.4 \\
46947.7\end{array}$ & $\begin{array}{l}37.278 \\
37.265 \\
37.252 \\
37.239 \\
37.225\end{array}$ & $\begin{array}{l}-13.20 \\
-13.23 \\
-13.27 \\
-13.30 \\
-13.34\end{array}$ & $\begin{array}{l}1205 \\
1206 \\
1207 \\
1208 \\
1209\end{array}$ & $\begin{array}{l}49010.3 \\
49046.8 \\
49083.2 \\
49119.5 \\
49155.9\end{array}$ & $\begin{array}{l}36.423 \\
36.408 \\
36.392 \\
36.377 \\
36.362\end{array}$ & $\begin{array}{l}-15.29 \\
-15.32 \\
-15.35 \\
-15.38 \\
-15.41\end{array}$ \\
\hline $\begin{array}{l}1090 \\
1091 \\
1092 \\
1093 \\
1094\end{array}$ & $\begin{array}{l}44729.3 \\
44767.2 \\
44805.2 \\
44843.1 \\
44881.0\end{array}$ & $\begin{array}{l}37.957 \\
37.945 \\
37.933 \\
37.922 \\
37.910\end{array}$ & $\begin{array}{l}-11.55 \\
-11.58 \\
-11.60 \\
-11.63 \\
-11.65\end{array}$ & $\begin{array}{l}1150 \\
1151 \\
1152 \\
1153 \\
1154\end{array}$ & $\begin{array}{l}46984.9 \\
47022.1 \\
47059.3 \\
47096.5 \\
47133.6\end{array}$ & $\begin{array}{l}37.212 \\
37.199 \\
37.185 \\
37.172 \\
37.158\end{array}$ & $\begin{array}{l}-13.37 \\
-13.41 \\
-13.44 \\
-13.48 \\
-13.51\end{array}$ & $\begin{array}{l}1210 \\
1211 \\
1212 \\
1213 \\
1214\end{array}$ & $\begin{array}{l}49192 \cdot 3 \\
49228 \cdot 6 \\
49264 \cdot 9 \\
49301.2 \\
49337.5\end{array}$ & $\begin{array}{l}36.346 \\
36.331 \\
36.315 \\
36.300 \\
36.284\end{array}$ & $\begin{array}{l}-15.44 \\
-15.47 \\
-15.50 \\
-15.53 \\
-15.56\end{array}$ \\
\hline $\begin{array}{l}1095 \\
1096 \\
1097 \\
1098 \\
1099\end{array}$ & $\begin{array}{l}44918.9 \\
44956.8 \\
44994.7 \\
45032.6 \\
45070.4\end{array}$ & $\begin{array}{l}37.899 \\
37.887 \\
37.875 \\
37.863 \\
37.852\end{array}$ & $\begin{array}{l}-11.68 \\
-11.70 \\
-11.73 \\
-11.76 \\
-11.78\end{array}$ & $\begin{array}{l}1155 \\
1156 \\
1157 \\
1158 \\
1159\end{array}$ & $\begin{array}{l}47170.8 \\
47207.9 \\
47245.0 \\
47282.2 \\
47319.3\end{array}$ & $\begin{array}{l}37.145 \\
37.131 \\
37.118 \\
37.104 \\
37.090\end{array}$ & $\begin{array}{l}-13.55 \\
-13.58 \\
-13.62 \\
-13.65 \\
-13.69\end{array}$ & $\begin{array}{l}1215 \\
1216 \\
1217 \\
1218 \\
1219\end{array}$ & $\begin{array}{l}49373 \cdot 8 \\
49410.1 \\
49446.3 \\
49482 \cdot 5 \\
49518.8\end{array}$ & $\begin{array}{l}36.269 \\
36.253 \\
36.238 \\
36.222 \\
36.206\end{array}$ & $\begin{array}{l}-15.59 \\
-15.62 \\
-15.65 \\
-15.67 \\
-15.70\end{array}$ \\
\hline $\begin{array}{l}1100 \\
1101 \\
1102 \\
1103 \\
1104\end{array}$ & $\begin{array}{l}45108.3 \\
45146.1 \\
45183.9 \\
45221.7 \\
45259.5\end{array}$ & $\begin{array}{l}37.840 \\
37.828 \\
37.816 \\
37.804 \\
37.792\end{array}$ & $\begin{array}{l}-11.81 \\
-11.84 \\
-11.86 \\
-11.89 \\
-11.92\end{array}$ & $\begin{array}{l}1160 \\
1161 \\
1162 \\
1163 \\
1164\end{array}$ & $\begin{array}{l}47356.3 \\
47393.4 \\
47430.5 \\
47467.5 \\
47504.5\end{array}$ & $\begin{array}{l}37.077 \\
37.063 \\
37.049 \\
37.035 \\
37.021\end{array}$ & $\begin{array}{l}-13.73 \\
-13.76 \\
-13.80 \\
-13.83 \\
-13.87\end{array}$ & $\begin{array}{l}1220 \\
1221 \\
1222 \\
1223 \\
1224\end{array}$ & $\begin{array}{l}49555.0 \\
49591.1 \\
49627.3 \\
49663.5 \\
49699.6\end{array}$ & $\begin{array}{l}36.190 \\
36.175 \\
36.159 \\
36.143 \\
36.127\end{array}$ & $\begin{array}{l}-15.73 \\
-15.76 \\
-15.78 \\
-15.81 \\
-15.83\end{array}$ \\
\hline $\begin{array}{l}1105 \\
1106 \\
1107 \\
1108 \\
1109\end{array}$ & $\begin{array}{l}45297.3 \\
45335.1 \\
45372.9 \\
45410.6 \\
45448.3\end{array}$ & $\begin{array}{l}37.780 \\
37.768 \\
37.756 \\
37.744 \\
37.732\end{array}$ & $\begin{array}{l}-11.94 \\
-11.97 \\
-12.00 \\
-12.03 \\
-12.06\end{array}$ & $\begin{array}{l}1165 \\
1166 \\
1167 \\
1168 \\
1169\end{array}$ & $\begin{array}{l}47541.5 \\
47578.5 \\
47615.5 \\
47652.5 \\
47689.5\end{array}$ & $\begin{array}{l}37.007 \\
36.994 \\
36.980 \\
36.966 \\
36.952\end{array}$ & $\begin{array}{l}-13.90 \\
-13.94 \\
-13.97 \\
-14.01 \\
-14.05\end{array}$ & $\begin{array}{l}1225 \\
1226 \\
1227 \\
1228 \\
1229\end{array}$ & $\begin{array}{l}49735.7 \\
49771.8 \\
49807.9 \\
49844.0 \\
49880.0\end{array}$ & $\begin{array}{l}36.111 \\
36.096 \\
36.080 \\
36.064 \\
36.048\end{array}$ & $\begin{array}{l}-15.86 \\
-15.88 \\
-15.91 \\
-15.93 \\
-15.96\end{array}$ \\
\hline $\begin{array}{llll}1 & 1 & 1 & 0 \\
1 & 1 & 1 & 1 \\
1 & 1 & 1 & 2 \\
1 & 1 & 1 & 3 \\
1 & 1 & 1 & 4\end{array}$ & $\begin{array}{l}45486.1 \\
45523.8 \\
45561.5 \\
45599.2 \\
45636.9\end{array}$ & $\begin{array}{l}37.720 \\
37.708 \\
37.696 \\
37.684 \\
37.672\end{array}$ & $\begin{array}{l}-12.09 \\
-12.11 \\
-12.14 \\
-12.17 \\
-12.20\end{array}$ & $\begin{array}{l}1170 \\
1171 \\
1172 \\
1173 \\
1174\end{array}$ & $\begin{array}{l}47726.4 \\
47763.3 \\
47800.3 \\
47837.2 \\
47874.0\end{array}$ & $\begin{array}{l}36.937 \\
36.923 \\
36.909 \\
36.895 \\
36.881\end{array}$ & $\begin{array}{l}-14.08 \\
-14.12 \\
-14.15 \\
-14.19 \\
-14.22\end{array}$ & $\begin{array}{l}1230 \\
1231 \\
1232 \\
1233 \\
1234\end{array}$ & $\begin{array}{l}49916.1 \\
49952.1 \\
49988.1 \\
50024.1 \\
50060.1\end{array}$ & $\begin{array}{l}36.032 \\
36.016 \\
36.000 \\
35.984 \\
35.968\end{array}$ & $\begin{array}{l}-15.98 \\
-16.00 \\
-16.02 \\
-16.04 \\
-16.07\end{array}$ \\
\hline 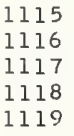 & $\begin{array}{l}45674.5 \\
45712.2 \\
45749.8 \\
45787.4 \\
45825.1\end{array}$ & $\begin{array}{l}37.660 \\
37.647 \\
37.635 \\
37.623 \\
37.610\end{array}$ & $\begin{array}{l}-12.23 \\
-12.26 \\
-12.29 \\
-12.32 \\
-12.35\end{array}$ & $\begin{array}{l}1175 \\
1176 \\
1177 \\
1178 \\
1179\end{array}$ & $\begin{array}{l}47910.9 \\
47947.8 \\
47984.6 \\
48021.5 \\
48058.3\end{array}$ & $\begin{array}{l}36.867 \\
36.852 \\
36.838 \\
36.824 \\
36.809\end{array}$ & $\begin{array}{l}-14 \cdot 26 \\
-14.30 \\
-14.33 \\
-14.37 \\
-14.40\end{array}$ & $\begin{array}{l}1235 \\
1236 \\
1237 \\
1238 \\
1239\end{array}$ & $\begin{array}{l}50096.0 \\
50132.0 \\
50167.9 \\
50203.8 \\
50239.7\end{array}$ & $\begin{array}{l}35.952 \\
35.936 \\
35.919 \\
35.903 \\
35.887\end{array}$ & $\begin{array}{l}-16.09 \\
-16.11 \\
-16.13 \\
-16.14 \\
-16.16\end{array}$ \\
\hline $\begin{array}{l}11220 \\
1121 \\
11222 \\
11223 \\
1122\end{array}$ & $\begin{array}{l}45862.7 \\
45900.3 \\
45937.8 \\
45975.4 \\
46013.0\end{array}$ & $\begin{array}{l}37.598 \\
37.586 \\
37.573 \\
37.561 \\
37.548\end{array}$ & $\begin{array}{l}-12.38 \\
-12.41 \\
-12.44 \\
-12.48 \\
-12.51\end{array}$ & $\begin{array}{l}1180 \\
1181 \\
1182 \\
1183 \\
1184\end{array}$ & $\begin{array}{l}48095.1 \\
48131.9 \\
48168.6 \\
48205.4 \\
48242.1\end{array}$ & $\begin{array}{l}36.795 \\
36.780 \\
36.766 \\
36.751 \\
36.737\end{array}$ & $\begin{array}{l}-14.44 \\
-14.47 \\
-14.51 \\
-14.54 \\
-14.58\end{array}$ & $\begin{array}{l}1240 \\
1241 \\
1242 \\
1243 \\
1244\end{array}$ & $\begin{array}{l}50275.6 \\
50311.4 \\
50347.3 \\
50383.1 \\
50418.9\end{array}$ & $\begin{array}{l}35.871 \\
35.855 \\
35.839 \\
35.822 \\
35.806\end{array}$ & $\begin{array}{l}-16.18 \\
-16.20 \\
-16.21 \\
-16.23 \\
-16.25\end{array}$ \\
\hline $\begin{array}{l}1125 \\
1126 \\
1127 \\
1128 \\
1129\end{array}$ & $\begin{array}{l}46050.5 \\
46088.0 \\
46125.5 \\
46163.1 \\
46200.5\end{array}$ & $\begin{array}{l}37.536 \\
37.523 \\
37.511 \\
37.498 \\
37.485\end{array}$ & $\begin{array}{l}-12.54 \\
-12.57 \\
-12.60 \\
-12.63 \\
-12.67\end{array}$ & $\begin{array}{l}1185 \\
1186 \\
1187 \\
1188 \\
1189\end{array}$ & $\begin{array}{l}48278.9 \\
48315.6 \\
48352.3 \\
48389.0 \\
48425.6\end{array}$ & $\begin{array}{l}36.722 \\
36.708 \\
36.693 \\
36.678 \\
36.663\end{array}$ & $\begin{array}{l}-14.61 \\
-14.65 \\
-14.68 \\
-14.72 \\
-14.75\end{array}$ & $\begin{array}{l}1245 \\
1246 \\
1247 \\
1248 \\
1249\end{array}$ & $\begin{array}{l}50454 \cdot 7 \\
50490.5 \\
50526.3 \\
50562.0 \\
50597.8\end{array}$ & $\begin{array}{l}35.790 \\
35.774 \\
35.757 \\
35.741 \\
35.725\end{array}$ & $\begin{array}{l}-16.26 \\
-16.28 \\
-16.29 \\
-16.30 \\
-16.31\end{array}$ \\
\hline 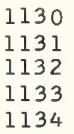 & $\begin{array}{l}46238.0 \\
46275.5 \\
46312.9 \\
46350.4 \\
46387.8\end{array}$ & $\begin{array}{l}37.473 \\
37.460 \\
37.447 \\
37.434 \\
37.422\end{array}$ & $\begin{array}{l}-12.70 \\
-12.73 \\
-12.76 \\
-12.80 \\
-12.83\end{array}$ & $\begin{array}{l}1190 \\
1191 \\
1192 \\
1193 \\
1194\end{array}$ & $\begin{array}{l}48462.3 \\
48498.9 \\
48535.6 \\
48572.2 \\
48608.8\end{array}$ & $\begin{array}{l}36.649 \\
36.634 \\
36.619 \\
36.604 \\
36.589\end{array}$ & $\begin{array}{l}-14.79 \\
-14.82 \\
-14.86 \\
-14.89 \\
-14.92\end{array}$ & $\begin{array}{l}1250 \\
1251 \\
1252 \\
1253 \\
1254\end{array}$ & $\begin{array}{l}50633 \cdot 5 \\
50669.2 \\
50704.9 \\
50740.5 \\
50776.2\end{array}$ & $\begin{array}{l}35.708 \\
35.692 \\
35.676 \\
35.659 \\
35.643\end{array}$ & $\begin{array}{l}-16.33 \\
-16.34 \\
-16.35 \\
-16.36 \\
-16.36\end{array}$ \\
\hline $\begin{array}{l}1135 \\
1136 \\
1137 \\
1138 \\
1139\end{array}$ & $\begin{array}{l}46425.2 \\
46462.6 \\
46500.0 \\
46537.4 \\
46574.8\end{array}$ & $\begin{array}{l}37.409 \\
37.396 \\
37.383 \\
37.370 \\
37.357\end{array}$ & $\begin{array}{l}-12.86 \\
-12.90 \\
-12.93 \\
-12.96 \\
-13.00\end{array}$ & $\begin{array}{l}1195 \\
1196 \\
1197 \\
1198 \\
1199\end{array}$ & $\begin{array}{l}48645.4 \\
48681.9 \\
48718.5 \\
48755.0 \\
48791.5\end{array}$ & $\begin{array}{l}36.574 \\
36.559 \\
36.544 \\
36.529 \\
36.514\end{array}$ & $\begin{array}{l}-14.96 \\
-14.99 \\
-15.03 \\
-15.06 \\
-15.09\end{array}$ & $\begin{array}{l}1255 \\
1256 \\
1257 \\
1258 \\
1259\end{array}$ & $\begin{array}{l}50811.8 \\
50847.4 \\
50883.0 \\
50918.6 \\
50954.2\end{array}$ & $\begin{array}{l}35.627 \\
35.610 \\
35.594 \\
35.578 \\
35.561\end{array}$ & $\begin{array}{l}-16.37 \\
-16 \cdot 38 \\
-16.38 \\
-16.39 \\
-16.40\end{array}$ \\
\hline 40 & 46612.1 & 37.344 & -13.03 & 1200 & 48828.0 & 36.499 & $-15 \cdot 12$ & 1260 & 50989.7 & 35.545 & $-16 \cdot 40$ \\
\hline
\end{tabular}


TABLE 7.3.2. Type K thermocouples-thermoelectric voltages, E(T), Seebeck coefficients, S(T), and first derivative of the Seebeck coefficients, $\mathrm{dS} / \mathrm{dT}$, reference junctions at $0^{\circ} \mathrm{C}$-Continued

\begin{tabular}{|c|c|c|c|c|c|c|c|c|c|c|c|}
\hline $\begin{array}{l}T \\
{ }^{\circ} \mathrm{C}\end{array}$ & $\underset{\mu V}{E}$ & $\underset{\mu V /{ }^{\circ} \mathrm{C}}{S}$ & $\begin{array}{l}d S / d T \\
n V /{ }^{\circ} C^{2}\end{array}$ & ${ }^{\top} \mathrm{C}$ & $\underset{\mu V}{E}$ & $\underset{\mu V /{ }^{\circ} \mathrm{C}}{S}$ & $\begin{array}{l}d S / d T \\
n V /{ }^{\circ} c^{2}\end{array}$ & ${ }^{\top}{ }^{\top} \mathrm{C}$ & $\underset{\mu V}{E}$ & $\underset{\mu V /{ }^{\circ} \mathrm{C}}{S}$ & $\begin{array}{l}d S / d T \\
n V /{ }^{\circ} C^{2}\end{array}$ \\
\hline $\begin{array}{l}1260 \\
1261 \\
1262 \\
1263 \\
1264\end{array}$ & $\begin{array}{l}50989.7 \\
51025.3 \\
51060.8 \\
51096.3 \\
51131.8\end{array}$ & $\begin{array}{l}35.545 \\
35.528 \\
35.512 \\
35.496 \\
35.479\end{array}$ & $\begin{array}{l}-16.40 \\
-16.40 \\
-16.40 \\
-16.41 \\
-16.41\end{array}$ & $\begin{array}{l}1300 \\
1301 \\
1302 \\
1303 \\
1304\end{array}$ & $\begin{array}{l}52398.5 \\
52433.4 \\
52468.2 \\
52503.1 \\
52537.9\end{array}$ & $\begin{array}{l}34.897 \\
34.881 \\
34.865 \\
34.850 \\
34.834\end{array}$ & $\begin{array}{l}-15.71 \\
-15.67 \\
-15.62 \\
-15.58 \\
-15.53\end{array}$ & $\begin{array}{l}1340 \\
1341 \\
1342 \\
1343 \\
1344\end{array}$ & $\begin{array}{l}53782 \cdot 4 \\
53816.7 \\
53851 \cdot 0 \\
53885.3 \\
53919 \cdot 6\end{array}$ & $\begin{array}{l}34.319 \\
34.307 \\
34.294 \\
34.282 \\
34.270\end{array}$ & $\begin{array}{l}-12.64 \\
-12.52 \\
-12.40 \\
-12.28 \\
-12.15\end{array}$ \\
\hline $\begin{array}{l}1265 \\
1266 \\
1267 \\
1268 \\
1269\end{array}$ & $\begin{array}{l}51167.3 \\
51202.7 \\
51238.2 \\
51273.6 \\
51309.0\end{array}$ & $\begin{array}{l}35.463 \\
35.446 \\
35.430 \\
35.414 \\
35.397\end{array}$ & $\begin{array}{l}-16.41 \\
-16.40 \\
-16.40 \\
-16.40 \\
-16.39\end{array}$ & $\begin{array}{l}1305 \\
1306 \\
1307 \\
1308 \\
1309\end{array}$ & $\begin{array}{l}52572.8 \\
52607.6 \\
52642.4 \\
52677.2 \\
52711.9\end{array}$ & $\begin{array}{l}34.819 \\
34.803 \\
34.788 \\
34.772 \\
34.757\end{array}$ & $\begin{array}{l}-15.48 \\
-15.43 \\
-15.38 \\
-15.33 \\
-15.27\end{array}$ & $\begin{array}{l}1345 \\
1346 \\
1347 \\
1348 \\
1349\end{array}$ & $\begin{array}{l}53953 \cdot 8 \\
53988 \cdot 1 \\
54022 \cdot 3 \\
54056 \cdot 6 \\
54090 \cdot 8\end{array}$ & $\begin{array}{l}34.258 \\
34.246 \\
34.234 \\
34.222 \\
34.211\end{array}$ & $\begin{array}{l}-12.03 \\
-11.90 \\
-11.76 \\
-11.63 \\
-11.49\end{array}$ \\
\hline $\begin{array}{l}1270 \\
1271 \\
1272 \\
1273 \\
1274\end{array}$ & $\begin{array}{l}51344.4 \\
51379.7 \\
51415.1 \\
51450.4 \\
51485.8\end{array}$ & $\begin{array}{l}35.381 \\
35.364 \\
35.348 \\
35.332 \\
35.315\end{array}$ & $\begin{array}{l}-16 \cdot 39 \\
-16 \cdot 38 \\
-16 \cdot 38 \\
-16 \cdot 37 \\
-16.36\end{array}$ & $\begin{array}{l}1310 \\
1311 \\
1312 \\
1313 \\
1314\end{array}$ & $\begin{array}{l}52746.7 \\
52781.4 \\
52816.1 \\
52850.8 \\
52885.5\end{array}$ & $\begin{array}{l}34.742 \\
34.727 \\
34.711 \\
34.696 \\
34.681\end{array}$ & $\begin{array}{l}-15.21 \\
-15.16 \\
-15.10 \\
-15.03 \\
-14.97\end{array}$ & $\begin{array}{l}1350 \\
1351 \\
1352 \\
1353 \\
1354\end{array}$ & $\begin{array}{l}54125.0 \\
54159.2 \\
54193.4 \\
54227.5 \\
54261.7\end{array}$ & $\begin{array}{l}34.199 \\
34.188 \\
34.177 \\
34.166 \\
34.155\end{array}$ & $\begin{array}{l}-11.35 \\
-11.21 \\
-11.06 \\
-10.91 \\
-10.76\end{array}$ \\
\hline $\begin{array}{l}1275 \\
1276 \\
1277 \\
1278 \\
1279\end{array}$ & $\begin{array}{l}51521.1 \\
51556.4 \\
51591.6 \\
51626.9 \\
51662.1\end{array}$ & $\begin{array}{l}35.299 \\
35.283 \\
35.266 \\
35.250 \\
35.234\end{array}$ & $\begin{array}{l}-16 \cdot 35 \\
-16 \cdot 34 \\
-16 \cdot 32 \\
-16 \cdot 31 \\
-16.30\end{array}$ & $\begin{array}{l}1315 \\
1316 \\
1317 \\
1318 \\
1319\end{array}$ & $\begin{array}{l}52920.2 \\
52954 \cdot 8 \\
52989.5 \\
53024.1 \\
53058.7\end{array}$ & $\begin{array}{l}34.666 \\
34.652 \\
34.637 \\
34.622 \\
34.607\end{array}$ & $\begin{array}{l}-14.90 \\
-14.84 \\
-14.77 \\
-14.70 \\
-14.63\end{array}$ & $\begin{array}{l}1355 \\
1356 \\
1357 \\
1358 \\
1359\end{array}$ & $\begin{array}{l}54295.8 \\
54330 \cdot 0 \\
54364 \cdot 1 \\
54398 \cdot 2 \\
54432.3\end{array}$ & $\begin{array}{l}34.144 \\
34 \cdot 134 \\
34.123 \\
34.113 \\
34.103\end{array}$ & $\begin{array}{r}-10.61 \\
-10.45 \\
-10.30 \\
-10.13 \\
-9.97\end{array}$ \\
\hline $\begin{array}{l}1280 \\
1281 \\
1282 \\
1283 \\
1284\end{array}$ & $\begin{array}{l}51697.4 \\
51732.6 \\
51767.8 \\
51802.9 \\
51838.1\end{array}$ & $\begin{array}{l}35.217 \\
35.201 \\
35.185 \\
35.169 \\
35.152\end{array}$ & $\begin{array}{l}-16.28 \\
-16.26 \\
-16.25 \\
-16.23 \\
-16.21\end{array}$ & $\begin{array}{l}1320 \\
1321 \\
1322 \\
1323 \\
1324\end{array}$ & $\begin{array}{l}53093.3 \\
53127.9 \\
53162.5 \\
53197.1 \\
53231.6\end{array}$ & $\begin{array}{l}34.593 \\
34.578 \\
34.564 \\
34.549 \\
34.535\end{array}$ & $\begin{array}{l}-14.55 \\
-14.47 \\
-14.40 \\
-14.32 \\
-14.23\end{array}$ & $\begin{array}{l}1360 \\
1361 \\
1362 \\
1363 \\
1364\end{array}$ & $\begin{array}{l}54466.4 \\
54500.5 \\
54534.6 \\
54568.7 \\
54602.7\end{array}$ & $\begin{array}{l}34.093 \\
34.084 \\
34.074 \\
34.065 \\
34.055\end{array}$ & $\begin{array}{l}-9.80 \\
-9.63 \\
-9.46 \\
-9.28 \\
-9.11\end{array}$ \\
\hline $\begin{array}{l}1285 \\
1286 \\
1287 \\
1288 \\
1289\end{array}$ & $\begin{array}{l}51873.2 \\
51908.4 \\
51943.5 \\
51978.6 \\
52013.7\end{array}$ & $\begin{array}{l}35.136 \\
35.120 \\
35.104 \\
35.088 \\
35.072\end{array}$ & $\begin{array}{l}-16.19 \\
-16.16 \\
-16.14 \\
-16.12 \\
-16.09\end{array}$ & $\begin{array}{l}1325 \\
1326 \\
1327 \\
1328 \\
1329\end{array}$ & $\begin{array}{l}53266.1 \\
53300.6 \\
53335.1 \\
53369.6 \\
53404.1\end{array}$ & $\begin{array}{l}34.521 \\
34.507 \\
34.493 \\
34.479 \\
34.465\end{array}$ & $\begin{array}{l}-14.15 \\
-14.06 \\
-13.98 \\
-13.89 \\
-13.79\end{array}$ & $\begin{array}{l}1365 \\
1366 \\
1367 \\
1368 \\
1369\end{array}$ & $\begin{array}{l}54636.8 \\
54670.8 \\
54704.9 \\
54738.9 \\
54772.9\end{array}$ & $\begin{array}{l}34.046 \\
34.038 \\
34.029 \\
34.021 \\
34.012\end{array}$ & $\begin{array}{l}-8.92 \\
-8.74 \\
-8.55 \\
-8.36 \\
-8.17\end{array}$ \\
\hline $\begin{array}{l}1290 \\
1291 \\
1292 \\
1293 \\
1294\end{array}$ & $\begin{array}{l}52048.7 \\
52083.8 \\
52118.8 \\
52153.8 \\
52188.8\end{array}$ & $\begin{array}{l}35.055 \\
35.039 \\
35.023 \\
35.007 \\
34.991\end{array}$ & $\begin{array}{l}-16.06 \\
-16.03 \\
-16.00 \\
-15.97 \\
-15.94\end{array}$ & $\begin{array}{l}1330 \\
1331 \\
1332 \\
1333 \\
1334\end{array}$ & $\begin{array}{l}53438.6 \\
53473.0 \\
53507.4 \\
53541.8 \\
53576.2\end{array}$ & $\begin{array}{l}34.451 \\
34.438 \\
34.424 \\
34.411 \\
34.397\end{array}$ & $\begin{array}{l}-13.70 \\
-13.60 \\
-13.51 \\
-13.41 \\
-13.30\end{array}$ & $\begin{array}{l}1370 \\
1371 \\
1372\end{array}$ & $\begin{array}{l}54806.9 \\
54840.9 \\
54874.9\end{array}$ & $\begin{array}{l}34.004 \\
33.996 \\
33.989\end{array}$ & $\begin{array}{l}-7.97 \\
-7.77 \\
-7.57\end{array}$ \\
\hline $\begin{array}{l}1295 \\
1296 \\
1297 \\
1298 \\
1299\end{array}$ & $\begin{array}{l}52223.8 \\
52258.8 \\
52293.7 \\
52328.7 \\
52363.6\end{array}$ & $\begin{array}{l}34.976 \\
34.960 \\
34.944 \\
34.928 \\
34.912\end{array}$ & $\begin{array}{l}-15.90 \\
-15.87 \\
-15.83 \\
-15.79 \\
-15.75\end{array}$ & $\begin{array}{l}1335 \\
1336 \\
1337 \\
1338 \\
1339\end{array}$ & $\begin{array}{l}53610.6 \\
53645.0 \\
53679.4 \\
53713.7 \\
53748.1\end{array}$ & $\begin{array}{l}34.384 \\
34 \cdot 371 \\
34.358 \\
34.345 \\
34.332\end{array}$ & $\begin{array}{l}-13.20 \\
-13.09 \\
-12.98 \\
-12.87 \\
-12.76\end{array}$ & & & & \\
\hline 1300 & 52398.5 & 34.897 & -15.71 & 1340 & 53782.4 & 34.319 & $-12 \cdot 64$ & & & & \\
\hline
\end{tabular}


TABLE 7.3.3. Thermoelectric values at the fixed points for Type $K$ thermocouples

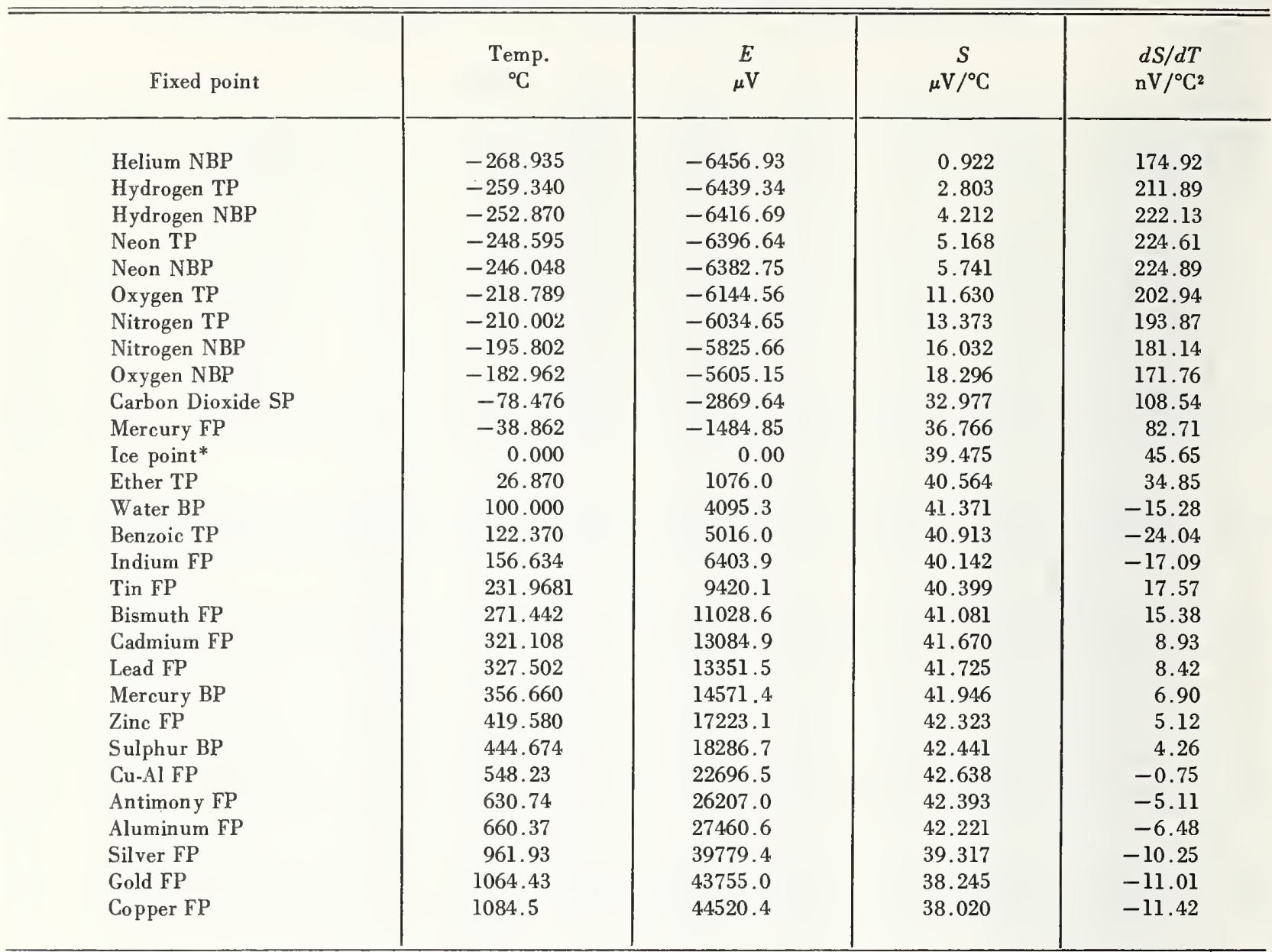

*Junction point of different functions.

TABLE 7.3.4. Estimated maximum errors that occur when using reduced-bit arithmetic for the power series expansion for the thermoelectric voltage of Type $K$ thermocouples

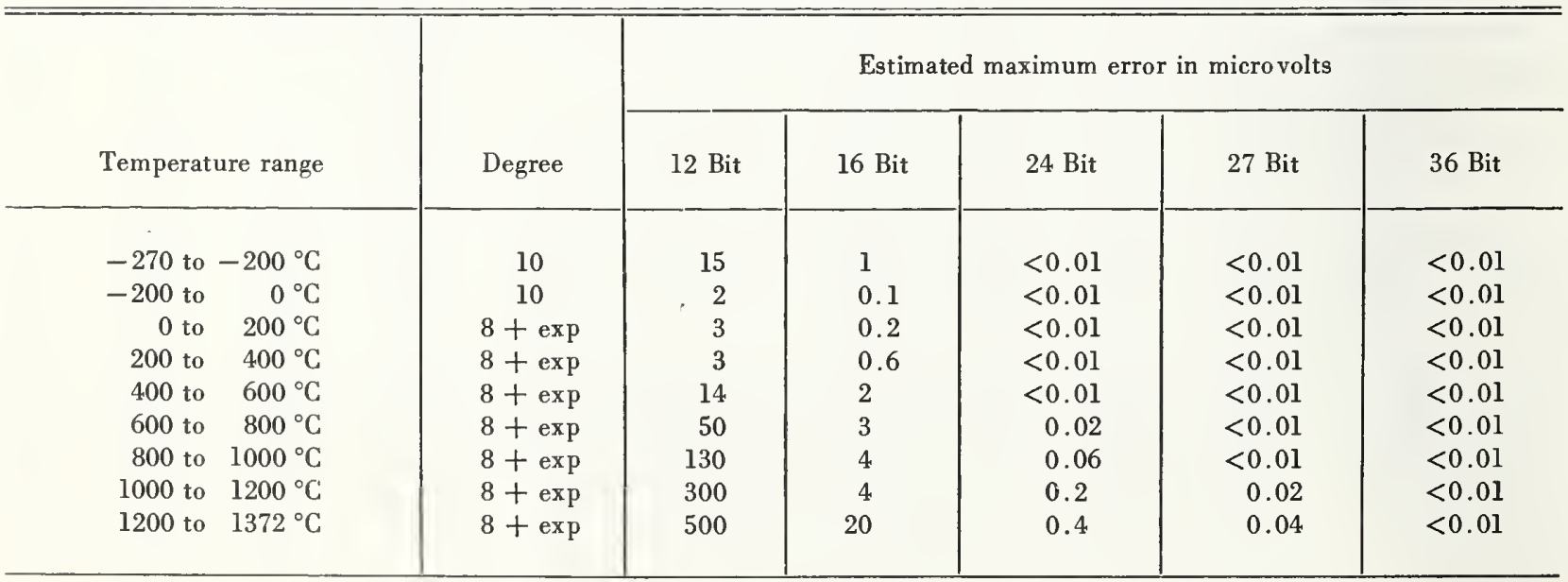


7.4. Reference Functions and Tables for the Positive Thermoelement, Type KP, a Nickel-Chromium Alloy Versus Platinum, $\mathrm{Pt}-67$

The coefficients for the twelfth degree expansion for the thermoelectric voltage of Type KP (or EP) thermo. elements versus $\mathrm{Pt}-67$ below $0{ }^{\circ} \mathrm{C}$ are given in table 7.4.1. The coefficients for the sixth degree expansion above $0{ }^{\circ} \mathrm{C}$ are also given in table 7.4.1. The errors caused by using reduced bit arithmetic for calculating values of the functions are given in table 7.4.4.

The primary reference values for Type KP (or EP) thermoelements versus $\mathrm{Pt}-67$ are given in table 7.4.2. Values at selected fixed points are given in table 7.4.3. Graphs of the thermoelectric voltage, its first derivative (Seebeck coefficient), and second derivative are given in figures 7.4.1, 7.4.2, and 7.4.3, respectively.

It should be stressed that Type KP (or EP) thermoelement material that conforms closely to the high temperature tabular values may not necessarily conform closely at low temperatures (below $0^{\circ} \mathrm{C}$ ) and vice versa. If Type KP (or EP) thermoelements are to be used for accurate measurements both above and below $0{ }^{\circ} \mathrm{C}$, then the material must be calibrated in the full temperature range, both above and below $0{ }^{\circ} \mathrm{C}$. Special selection of material will often be required.

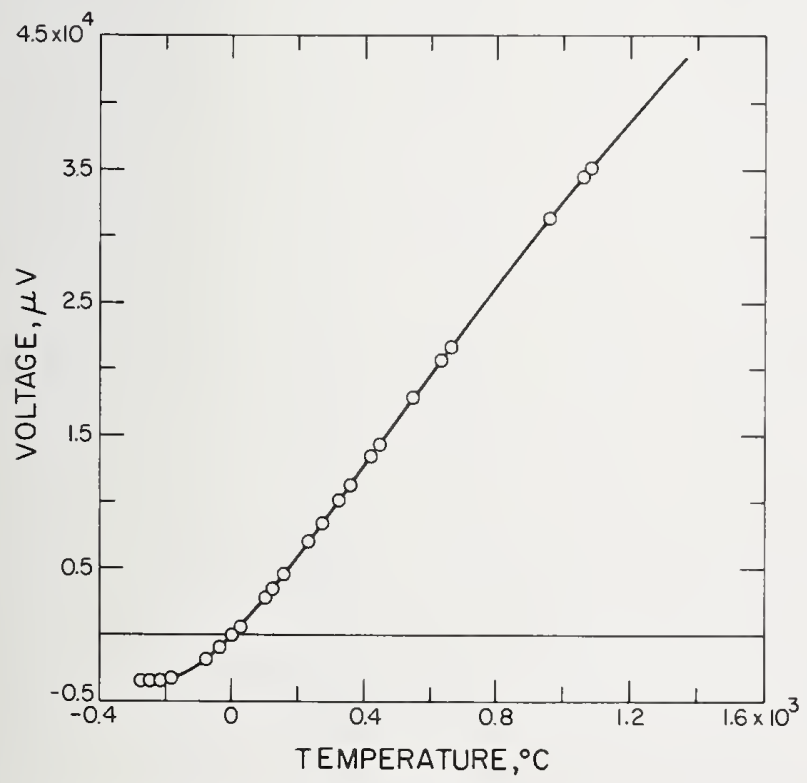

Ficure 7.4.1. Thermoelectric voltage for Type KP (or EP) thermoelements versus platinum, Pt-67.

The circles indicate values at various thermometric fixed points on the IPTS -68 .

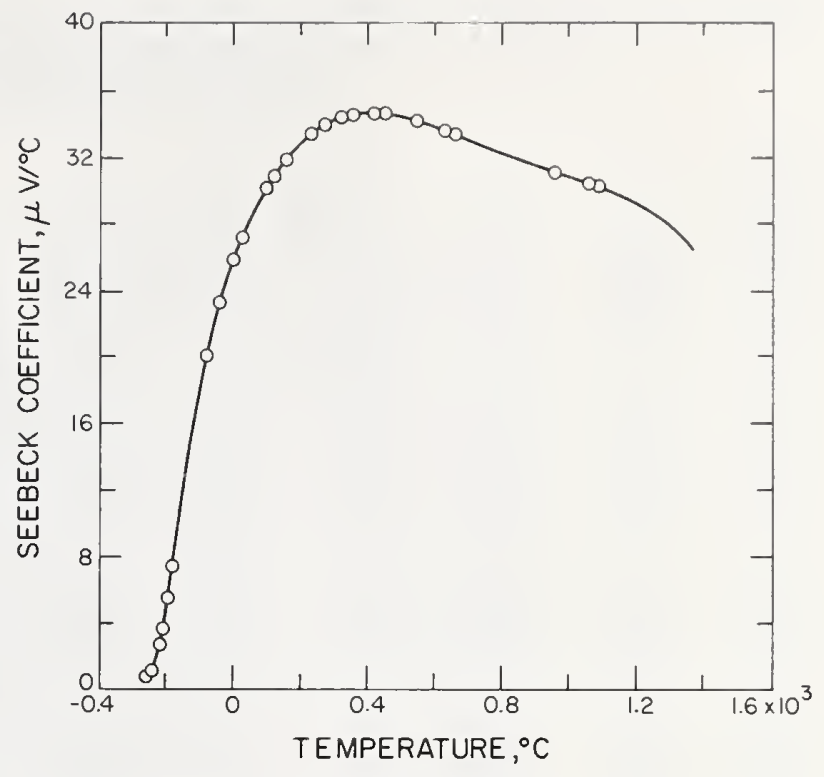

Ficure 7.4.2. Seebeck coefficient for Type KP (or EP) thermoelements versus platinum, Pt-67.

The circles indicate values at various thermometric fixed points on the IPTS-68.

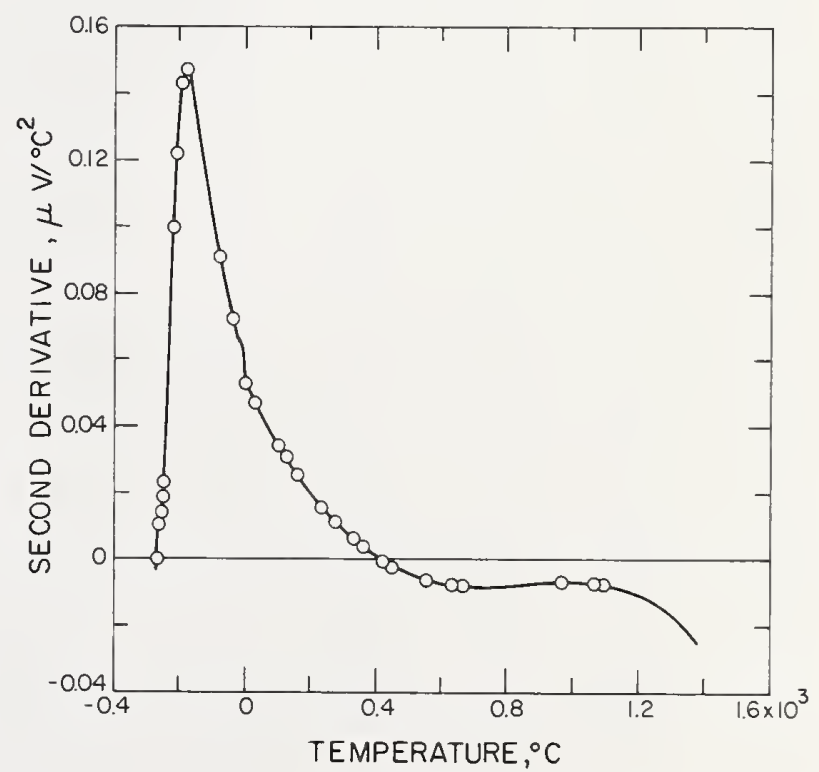

Figure 7.4.3. Second derivative of thermoelectric voltage for Type KP (or EP) thermoelements versus platinum, $P t-67$. The circles indicate values at various thermometric fixed points on the
IPTS-68. 
TABle 7.4.1. Power series expansion for the thermoelectric voltage of Type KP (or EP) thermoelements versus platinum, $\mathrm{Pt}-67$

\begin{tabular}{|c|c|c|c|}
\hline $\begin{array}{c}\text { Tempera- } \\
\text { ture } \\
\text { range }\end{array}$ & Degree & Coefficients & Term \\
\hline $\begin{array}{c}-270 \text { to } \\
0^{\circ} \mathrm{C}\end{array}$ & 12 & $\begin{array}{l}2.5835710133 \times 10^{1} \\
2.7202146415 \times 10^{-2} \\
-3.8345637644 \times 10^{-4} \\
-1.6841065632 \times 10^{-5} \\
-4.4654164515 \times 10^{-7} \\
-7.0161464011 \times 10^{-9} \\
-7.0114175503 \times 10^{-11} \\
-4.5711262093 \times 10^{-13} \\
-1.9366901505 \times 10^{-15} \\
-5.1348097562 \times 10^{-18} \\
-7.7268515186 \times 10^{-21} \\
-5.0290738536 \times 10^{-24}\end{array}$ & $\begin{array}{l}T \\
T^{2} \\
T^{3} \\
T^{4} \\
T^{5} \\
T^{6} \\
T^{7} \\
T^{8} \\
T^{8} \\
T^{10} \\
T^{11} \\
T^{12}\end{array}$ \\
\hline $\begin{array}{l}0 \text { to } \\
1372{ }^{\circ} \mathrm{C}\end{array}$ & 6 & $\begin{array}{r}2.5835710133 \times 10^{1} \\
2.6122152288 \times 10^{-2} \\
-3.3553323755 \times 10^{-5} \\
1.5901401017 \times 10^{-8} \\
-6.0374933939 \times 10^{-13} \\
-1.2087501500 \times 10^{-15}\end{array}$ & $\begin{array}{l}T \\
T^{2} \\
T^{3} \\
T^{4} \\
T^{5} \\
T^{6}\end{array}$ \\
\hline
\end{tabular}


TABlE 7.4.2. Type KP (or EP) thermoelements versus platinum, Pt-67-thermoelectric voltages, $\mathrm{E}(\mathrm{T})$, Seebeck coefficients, $\mathrm{S}(\mathrm{T})$, and first derivative of the Seebeck coefficients,

$\mathrm{dS} / \mathrm{dT}$, reference junctions at $0^{\circ} \mathrm{C}$

\begin{tabular}{|c|c|c|c|c|c|c|c|c|c|c|c|}
\hline${ }^{\mathrm{T}} \mathrm{C}$ & $\underset{\mu V}{E}$ & $\mu \stackrel{S}{S} /{ }^{\circ} \mathrm{C}$ & $\begin{array}{l}\mathrm{dS} / \mathrm{dT} \\
\mathrm{nV} /{ }^{\circ} \mathrm{C}^{2}\end{array}$ & ${ }^{\circ} \mathrm{C}$ & ${ }_{\mu V}^{E V}$ & $\stackrel{\mathrm{S}}{\mathrm{V}^{\circ}{ }^{\circ} \mathrm{C}}$ & $\begin{array}{l}\mathrm{dS} / \mathrm{dT} \\
\mathrm{nV} /{ }^{\circ} \mathrm{C}^{2}\end{array}$ & ${ }^{\circ} \mathrm{C}$ & $\underset{\mu V}{E V}$ & $\stackrel{\mathrm{S}}{\mu \mathrm{I}^{\circ} \mathrm{C}}$ & $\begin{array}{l}\mathrm{dS} / \mathrm{dT} \\
\mathrm{nV} /{ }^{\circ} \mathrm{C}^{2}\end{array}$ \\
\hline $\begin{array}{l}-270 \\
-269 \\
-268 \\
-267 \\
-266\end{array}$ & $\begin{array}{l}-3557.78 \\
-3556.94 \\
-3556.09 \\
-3555.24 \\
-3554.38\end{array}$ & $\begin{array}{l}0.849 \\
0.847 \\
0.849 \\
0.852 \\
0.857\end{array}$ & $\begin{array}{r}-3.36 \\
-0.16 \\
2.41 \\
4.46 \\
6.07\end{array}$ & $\begin{array}{l}-240 \\
-239 \\
-238 \\
-237 \\
-236\end{array}$ & $\begin{array}{l}-3527.94 \\
-3526.63 \\
-3525.28 \\
-3523.89 \\
-3522.46\end{array}$ & $\begin{array}{l}1.289 \\
1.327 \\
1.367 \\
1.409 \\
1.455\end{array}$ & $\begin{array}{l}35.96 \\
38.58 \\
41.30 \\
44.11 \\
46.99\end{array}$ & $\begin{array}{l}-210 \\
-209 \\
-208 \\
-207 \\
-206\end{array}$ & $\begin{array}{l}-3459.76 \\
-3455.99 \\
-3452.11 \\
-3448.10 \\
-3443.96\end{array}$ & $\begin{array}{l}3.701 \\
3.824 \\
3.949 \\
4.075 \\
4.204\end{array}$ & $\begin{array}{l}121.78 \\
123.84 \\
125.80 \\
127.67 \\
129.45\end{array}$ \\
\hline $\begin{array}{l}-265 \\
-264 \\
-263 \\
-262 \\
-261\end{array}$ & $\begin{array}{l}-3553.52 \\
-3552.65 \\
-3551.78 \\
-3550.89 \\
-3550.00\end{array}$ & $\begin{array}{l}0.864 \\
0.872 \\
0.880 \\
0.890 \\
0.900\end{array}$ & $\begin{array}{l}7.31 \\
8.26 \\
8.99 \\
9.55 \\
9.99\end{array}$ & $\begin{array}{l}-235 \\
-234 \\
-233 \\
-232 \\
-231\end{array}$ & $\begin{array}{l}-3520.98 \\
-3519.45 \\
-3517.87 \\
-3516.24 \\
-3514.54\end{array}$ & $\begin{array}{l}1.503 \\
1.555 \\
1.609 \\
1.667 \\
1.727\end{array}$ & $\begin{array}{l}49.95 \\
52.97 \\
56.04 \\
59.15 \\
62.29\end{array}$ & $\begin{array}{l}-205 \\
-204 \\
-203 \\
-202 \\
-201\end{array}$ & $\begin{array}{l}-3439.69 \\
-3435.29 \\
-3430.76 \\
-3426.09 \\
-3421.29\end{array}$ & $\begin{array}{l}4.334 \\
4.466 \\
4.600 \\
4.735 \\
4.871\end{array}$ & $\begin{array}{l}131.13 \\
132.72 \\
134.21 \\
135.61 \\
136.91\end{array}$ \\
\hline $\begin{array}{l}-260 \\
-259 \\
-258 \\
-257 \\
-256\end{array}$ & $\begin{array}{l}-3549.09 \\
-3548.18 \\
-3547.25 \\
-3546.32 \\
-3545.37\end{array}$ & $\begin{array}{l}0.910 \\
0.920 \\
0.931 \\
0.942 \\
0.954\end{array}$ & $\begin{array}{l}10.36 \\
10.70 \\
11.05 \\
11.42 \\
11.86\end{array}$ & $\begin{array}{l}-230 \\
-229 \\
-228 \\
-227 \\
-226\end{array}$ & $\begin{array}{l}-3512.78 \\
-3510.95 \\
-3509.06 \\
-3507.10 \\
-3505.06\end{array}$ & $\begin{array}{l}1.791 \\
1.858 \\
1.929 \\
2.002 \\
2.079\end{array}$ & $\begin{array}{l}65.45 \\
68.63 \\
71.81 \\
74.99 \\
78.15\end{array}$ & $\begin{array}{l}-200 \\
-199 \\
-198 \\
-197 \\
-196\end{array}$ & $\begin{array}{l}-3416.35 \\
-3411.27 \\
-3406.05 \\
-3400.69 \\
-3395.20\end{array}$ & $\begin{array}{l}5.008 \\
5.147 \\
5.287 \\
5.428 \\
5.569\end{array}$ & $\begin{array}{l}138.13 \\
139.25 \\
140.29 \\
141.24 \\
142.10\end{array}$ \\
\hline $\begin{array}{l}-255 \\
-254 \\
-253 \\
-252 \\
-251\end{array}$ & $\begin{array}{l}-3544.41 \\
-3543.44 \\
-3542.45 \\
-3541.45 \\
-3540.44\end{array}$ & $\begin{array}{l}0.966 \\
0.979 \\
0.992 \\
1.006 \\
1.021\end{array}$ & $\begin{array}{l}12.38 \\
12.99 \\
13.73 \\
14.58 \\
15.58\end{array}$ & $\begin{array}{l}-225 \\
-224 \\
-223 \\
-222 \\
-221\end{array}$ & $\begin{array}{l}-3502.94 \\
-3500.74 \\
-3498.45 \\
-3496.08 \\
-3493.62\end{array}$ & $\begin{array}{l}2.158 \\
2.241 \\
2.327 \\
2.416 \\
2.508\end{array}$ & $\begin{array}{l}81.29 \\
84.41 \\
87.49 \\
90.53 \\
93.52\end{array}$ & $\begin{array}{l}-195 \\
-194 \\
-193 \\
-192 \\
-191\end{array}$ & $\begin{array}{l}-3389.56 \\
-3383.77 \\
-3377.84 \\
-3371.77 \\
-3365.56\end{array}$ & $\begin{array}{l}5.712 \\
5.855 \\
5.999 \\
6.143 \\
6.288\end{array}$ & $\begin{array}{l}142.89 \\
143.59 \\
144.21 \\
144.76 \\
145.24\end{array}$ \\
\hline $\begin{array}{l}-250 \\
-249 \\
-248 \\
-247 \\
-246\end{array}$ & $\begin{array}{l}-3539.41 \\
-3538.36 \\
-3537.30 \\
-3536.22 \\
-3535.11\end{array}$ & $\begin{array}{l}1.037 \\
1.055 \\
1.074 \\
1.094 \\
1.116\end{array}$ & $\begin{array}{l}16.71 \\
18.00 \\
19.43 \\
21.01 \\
22.73\end{array}$ & $\begin{array}{l}-220 \\
-219 \\
-218 \\
-217 \\
-216\end{array}$ & $\begin{array}{l}-3491.07 \\
-3488.41 \\
-3485.66 \\
-3482.81 \\
-3479.85\end{array}$ & $\begin{array}{l}2.603 \\
2.701 \\
2.802 \\
2.905 \\
3.012\end{array}$ & $\begin{array}{r}96.45 \\
99.33 \\
102.13 \\
104.87 \\
107.54\end{array}$ & $\begin{array}{l}-190 \\
-189 \\
-188 \\
-187 \\
-186\end{array}$ & $\begin{array}{l}-3359.20 \\
-3352.69 \\
-3346.04 \\
-3339.24 \\
-3332.29\end{array}$ & $\begin{array}{l}6.434 \\
6.580 \\
6.726 \\
6.872 \\
7.019\end{array}$ & $\begin{array}{l}145.65 \\
145.99 \\
146.26 \\
146.47 \\
146.63\end{array}$ \\
\hline $\begin{array}{l}-245 \\
-244 \\
-243 \\
-242 \\
-241\end{array}$ & $\begin{array}{l}-3533.98 \\
-3532.83 \\
-3531.65 \\
-3530.45 \\
-3529.21\end{array}$ & $\begin{array}{l}1.139 \\
1.165 \\
1.193 \\
1.222 \\
1.255\end{array}$ & $\begin{array}{l}24.61 \\
26.62 \\
28.77 \\
31.04 \\
33.44\end{array}$ & $\begin{array}{l}-215 \\
-214 \\
-213 \\
-212 \\
-211\end{array}$ & $\begin{array}{l}-3476.79 \\
-3473.61 \\
-3470.32 \\
-3466.92 \\
-3463.40\end{array}$ & $\begin{array}{l}3.120 \\
3.232 \\
3.346 \\
3.462 \\
3.580\end{array}$ & $\begin{array}{l}110.12 \\
112.63 \\
115.05 \\
117.38 \\
119.63\end{array}$ & $\begin{array}{l}-185 \\
-184 \\
-183 \\
-182 \\
-181\end{array}$ & $\begin{array}{l}-3325.20 \\
-3317.96 \\
-3310.58 \\
-3303.04 \\
-3295.36\end{array}$ & $\begin{array}{l}7.165 \\
7.312 \\
7.459 \\
7.606 \\
7.752\end{array}$ & $\begin{array}{l}146.73 \\
146.77 \\
146.76 \\
146.71 \\
146.61\end{array}$ \\
\hline 240 & $-3527 \cdot 94$ & 1.289 & 35.96 & -210 & -3459.76 & 3.701 & 121.78 & -180 & -3287.54 & 7.899 & 146.47 \\
\hline
\end{tabular}


TABLE 7.4.2. Type KP (or EP) thermoelements versus platinum, $\mathbf{P t - 6 7 - t h e r m o e l e c t r i c ~ v o l t a g e s , ~}$ $\mathrm{E}(\mathrm{T})$, Seebeck coefficients, $\mathrm{S}(\mathrm{T})$, and first derivative of the Seebeck coefficients,

$\mathrm{dS} / \mathrm{dT}$, reference junctions at $0^{\circ} \mathrm{C}$-Continued

\begin{tabular}{|c|c|c|c|c|c|c|c|c|c|c|c|}
\hline${ }^{\circ} \mathrm{C}$ & $\begin{array}{c}E \\
\mu V\end{array}$ & $\stackrel{S}{\mathrm{~S} V /{ }^{\circ} \mathrm{C}}$ & $\begin{array}{l}d S / d T \\
n V /{ }^{\circ} C^{2}\end{array}$ & $\begin{array}{r}\mathrm{T} \\
{ }^{\circ} \mathrm{C}\end{array}$ & $\begin{array}{c}E \\
\mu V\end{array}$ & $\stackrel{S}{\mu V /{ }^{\circ} \mathrm{C}}$ & $\begin{array}{l}\mathrm{dS} / \mathrm{dT} \\
\mathrm{nV} /{ }^{\circ} \mathrm{C}^{2}\end{array}$ & $\begin{array}{c}\mathrm{T} \\
{ }^{\circ} \mathrm{C}\end{array}$ & $\begin{array}{c}E \\
\mu V\end{array}$ & $\begin{array}{c}S \\
\mu V^{\circ} \mathrm{C}\end{array}$ & $\begin{array}{l}\mathrm{dS} / \mathrm{dT} \\
\mathrm{nV} /{ }^{\circ} \mathrm{C}^{2}\end{array}$ \\
\hline $\begin{array}{l}-180 \\
-179 \\
-178 \\
-177 \\
-176\end{array}$ & $\begin{array}{l}-3287.54 \\
-3279.57 \\
-3271.45 \\
-3263.18 \\
-3254.77\end{array}$ & $\begin{array}{l}7.899 \\
8.045 \\
8.192 \\
8.337 \\
8.483\end{array}$ & $\begin{array}{l}146.47 \\
146.29 \\
146.07 \\
145.82 \\
145.53\end{array}$ & $\begin{array}{l}-120 \\
-119 \\
-118 \\
-117 \\
-116\end{array}$ & $\begin{array}{l}-2565 \cdot 84 \\
-2549.96 \\
-2533.96 \\
-2517.84 \\
-2501.62\end{array}$ & $\begin{array}{l}15.828 \\
15.942 \\
16.056 \\
16.169 \\
16.282\end{array}$ & $\begin{array}{l}114.74 \\
114.11 \\
113.47 \\
112.83 \\
112.19\end{array}$ & $\begin{array}{l}-60 \\
-59 \\
-58 \\
-57 \\
-56\end{array}$ & $\begin{array}{l}-1431.58 \\
-1409.88 \\
-1388.10 \\
-1366.24 \\
-1344.29\end{array}$ & $\begin{array}{l}21.658 \\
21.741 \\
21.823 \\
21.904 \\
21.985\end{array}$ & $\begin{array}{l}82.55 \\
82.10 \\
81.65 \\
81.19 \\
80.72\end{array}$ \\
\hline $\begin{array}{l}-175 \\
-174 \\
-173 \\
-172 \\
-171\end{array}$ & $\begin{array}{l}-3246.22 \\
-3237.52 \\
-3228.67 \\
-3219.68 \\
-3210.55\end{array}$ & $\begin{array}{l}8.629 \\
8.774 \\
8.918 \\
9.063 \\
9.206\end{array}$ & $\begin{array}{l}145.22 \\
144.87 \\
144.51 \\
144.11 \\
143.70\end{array}$ & $\begin{array}{l}-115 \\
-114 \\
-113 \\
-112 \\
-111\end{array}$ & $\begin{array}{l}-2485.28 \\
-2468.83 \\
-2452.27 \\
-2435.60 \\
-2418.82\end{array}$ & $\begin{array}{l}16.394 \\
16.505 \\
16.615 \\
16.725 \\
16.835\end{array}$ & $\begin{array}{l}111.54 \\
110.90 \\
110.25 \\
109.61 \\
108.96\end{array}$ & $\begin{array}{l}-55 \\
-54 \\
-53 \\
-52 \\
-51\end{array}$ & $\begin{array}{l}-1322.27 \\
-1300.16 \\
-1277.98 \\
-1255.71 \\
-1233.37\end{array}$ & $\begin{array}{l}22.065 \\
22.145 \\
22.225 \\
22.304 \\
22.383\end{array}$ & $\begin{array}{l}80 \cdot 25 \\
79.77 \\
79.29 \\
78.80 \\
78.30\end{array}$ \\
\hline $\begin{array}{l}-170 \\
-169 \\
-168 \\
-167 \\
-166\end{array}$ & $\begin{array}{l}-3201.27 \\
-3191.85 \\
-3182.28 \\
-3172.57 \\
-3162.73\end{array}$ & $\begin{array}{l}9.350 \\
9.493 \\
9.636 \\
9.778 \\
9.919\end{array}$ & $\begin{array}{l}143.27 \\
142.82 \\
142.35 \\
141.87 \\
141.38\end{array}$ & $\begin{array}{l}-110 \\
-109 \\
-108 \\
-107 \\
-106\end{array}$ & $\begin{array}{l}-2401 \cdot 93 \\
-2384 \cdot 93 \\
-2367 \cdot 83 \\
-2350 \cdot 62 \\
-2333.30\end{array}$ & $\begin{array}{l}16.943 \\
17.051 \\
17.159 \\
17.265 \\
17.371\end{array}$ & $\begin{array}{l}108 \cdot 32 \\
107.68 \\
107.03 \\
106.39 \\
105.75\end{array}$ & $\begin{array}{l}-50 \\
-49 \\
-48 \\
-47 \\
-46\end{array}$ & $\begin{array}{l}-1210.95 \\
-1188.45 \\
-1165.87 \\
-1143.22 \\
-1120.49\end{array}$ & $\begin{array}{l}22.461 \\
22.538 \\
22.615 \\
22.692 \\
22.768\end{array}$ & $\begin{array}{l}77.79 \\
77.28 \\
76.77 \\
76.25 \\
75.72\end{array}$ \\
\hline $\begin{array}{l}-165 \\
-164 \\
-163 \\
-162 \\
-161\end{array}$ & $\begin{array}{l}-3152.74 \\
-3142.61 \\
-3132.33 \\
-3121.92 \\
-3111.37\end{array}$ & $\begin{array}{l}10.060 \\
10.201 \\
10.341 \\
10.481 \\
10.620\end{array}$ & $\begin{array}{l}140.87 \\
140.36 \\
139.83 \\
139.30 \\
138.76\end{array}$ & $\begin{array}{l}-105 \\
-104 \\
-103 \\
-102 \\
-101\end{array}$ & $\begin{array}{l}-2315.87 \\
-2298.35 \\
-2280.71 \\
-2262.97 \\
-2245.13\end{array}$ & $\begin{array}{l}17.477 \\
17.582 \\
17.686 \\
17.789 \\
17.892\end{array}$ & $\begin{array}{l}105.12 \\
104.49 \\
103.86 \\
103 \cdot 24 \\
102.62\end{array}$ & $\begin{array}{l}-45 \\
-44 \\
-43 \\
-42 \\
-41\end{array}$ & $\begin{array}{l}-1097.68 \\
-1074.80 \\
-1051.85 \\
-1028.82 \\
-1005.72\end{array}$ & $\begin{array}{l}22.843 \\
22.918 \\
22.992 \\
23.066 \\
23.140\end{array}$ & $\begin{array}{l}75.19 \\
74.66 \\
74.13 \\
73.60 \\
73.07\end{array}$ \\
\hline $\begin{array}{l}-160 \\
-159 \\
-158 \\
-157 \\
-156\end{array}$ & $\begin{array}{l}-3100.68 \\
-3089.86 \\
-3078.89 \\
-3067.79 \\
-3056.55\end{array}$ & $\begin{array}{l}10.758 \\
10.896 \\
11.034 \\
11.170 \\
11.307\end{array}$ & $\begin{array}{l}138.22 \\
137.67 \\
137.12 \\
136.56 \\
136.00\end{array}$ & $\begin{array}{l}-100 \\
-99 \\
-98 \\
-97 \\
-96\end{array}$ & $\begin{array}{l}-2227 \cdot 19 \\
-2209 \cdot 14 \\
-2191.00 \\
-2172 \cdot 75 \\
-2154 \cdot 40\end{array}$ & $\begin{array}{l}17.995 \\
18.096 \\
18.197 \\
18.298 \\
18.398\end{array}$ & $\begin{array}{r}102.00 \\
101.39 \\
100.79 \\
100.19 \\
99.60\end{array}$ & $\begin{array}{l}-40 \\
-39 \\
-38 \\
-37 \\
-36\end{array}$ & $\begin{array}{l}-982.54 \\
-959.29 \\
-935.97 \\
-912.58 \\
-889.12\end{array}$ & $\begin{array}{l}23.212 \\
23.285 \\
23.357 \\
23.428 \\
23.499\end{array}$ & $\begin{array}{l}72.55 \\
72.03 \\
71.51 \\
71.01 \\
70.51\end{array}$ \\
\hline $\begin{array}{l}-155 \\
-154 \\
-153 \\
-152 \\
-151\end{array}$ & $\begin{array}{l}-3045.18 \\
-3033.67 \\
-3022.02 \\
-3010.24 \\
-2998.33\end{array}$ & $\begin{array}{l}11.442 \\
11.578 \\
11.712 \\
11.846 \\
11.980\end{array}$ & $\begin{array}{l}135.44 \\
134.87 \\
134.31 \\
133.74 \\
133.17\end{array}$ & $\begin{array}{l}-95 \\
-94 \\
-93 \\
-92 \\
-91\end{array}$ & $\begin{array}{l}-2135.95 \\
-2117.41 \\
-2098.76 \\
-2080.02 \\
-2061.18\end{array}$ & $\begin{array}{l}18.497 \\
18.596 \\
18.694 \\
18.792 \\
18.889\end{array}$ & $\begin{array}{l}99.02 \\
98.44 \\
97.87 \\
97.31 \\
96.76\end{array}$ & $\begin{array}{l}-35 \\
-34 \\
-33 \\
-32 \\
-31\end{array}$ & $\begin{array}{l}-865.58 \\
-841.98 \\
-818.31 \\
-794.56 \\
-770.75\end{array}$ & $\begin{array}{l}23.569 \\
23.639 \\
23.708 \\
23.777 \\
23.845\end{array}$ & $\begin{array}{l}70.02 \\
69.55 \\
69.10 \\
68.66 \\
68.24\end{array}$ \\
\hline $\begin{array}{l}-150 \\
-149 \\
-148 \\
-147 \\
-146\end{array}$ & $\begin{array}{l}-2986.28 \\
-2974.10 \\
-2961.79 \\
-2949.35 \\
-2936.78\end{array}$ & $\begin{array}{l}12.113 \\
12.245 \\
12.377 \\
12.508 \\
12.638\end{array}$ & $\begin{array}{l}132.60 \\
132.03 \\
131.46 \\
130.89 \\
130.32\end{array}$ & $\begin{array}{l}-90 \\
-89 \\
-88 \\
-87 \\
-86\end{array}$ & $\begin{array}{l}-2042.24 \\
-2023.21 \\
-2004.08 \\
-1984.86 \\
-1965.54\end{array}$ & $\begin{array}{l}18.985 \\
19.081 \\
19.176 \\
19.271 \\
19.366\end{array}$ & $\begin{array}{l}96.21 \\
95.68 \\
95.15 \\
94.63 \\
94.11\end{array}$ & $\begin{array}{l}-30 \\
-29 \\
-28 \\
-27 \\
-26\end{array}$ & $\begin{array}{l}-746.87 \\
-722.93 \\
-698.91 \\
-674.83 \\
-650.68\end{array}$ & $\begin{array}{l}23.913 \\
23.981 \\
24.048 \\
24.115 \\
24.182\end{array}$ & $\begin{array}{l}67.84 \\
67.47 \\
67.12 \\
66.80 \\
66.50\end{array}$ \\
\hline $\begin{array}{l}-145 \\
-144 \\
-143 \\
-142 \\
-141\end{array}$ & $\begin{array}{l}-2924.07 \\
-2911.24 \\
-2898.28 \\
-2885.19 \\
-2871.97\end{array}$ & $\begin{array}{l}12.768 \\
12.898 \\
13.027 \\
13.155 \\
13.283\end{array}$ & $\begin{array}{l}129.74 \\
129.17 \\
128.59 \\
128.02 \\
127.44\end{array}$ & $\begin{array}{l}-85 \\
-84 \\
-83 \\
-82 \\
-81\end{array}$ & $\begin{array}{l}-1946.13 \\
-1926.62 \\
-1907.02 \\
-1887.33 \\
-1867.54\end{array}$ & $\begin{array}{l}19.460 \\
19.553 \\
19.646 \\
19.738 \\
19.830\end{array}$ & $\begin{array}{l}93.61 \\
93.11 \\
92.62 \\
92.14 \\
91.67\end{array}$ & $\begin{array}{l}-25 \\
-24 \\
-23 \\
-22 \\
-21\end{array}$ & $\begin{array}{l}-626.47 \\
-602.18 \\
-577.84 \\
-553.42 \\
-528.95\end{array}$ & $\begin{array}{l}24 \cdot 248 \\
24 \cdot 314 \\
24.380 \\
24.446 \\
24.511\end{array}$ & $\begin{array}{l}66.23 \\
65.99 \\
65.78 \\
65.59 \\
65.44\end{array}$ \\
\hline $\begin{array}{l}-140 \\
-139 \\
-138 \\
-137 \\
-136\end{array}$ & $\begin{array}{l}-2858.62 \\
-2845.15 \\
-2831.55 \\
-2817.82 \\
-2803.97\end{array}$ & $\begin{array}{l}13.410 \\
13.536 \\
13.662 \\
13.788 \\
13.913\end{array}$ & $\begin{array}{l}126.86 \\
126.28 \\
125.70 \\
125.11 \\
124.52\end{array}$ & $\begin{array}{l}-80 \\
-79 \\
-78 \\
-77 \\
-76\end{array}$ & $\begin{array}{l}-1847.67 \\
-1827.70 \\
-1807.64 \\
-1787.50 \\
-1767.26\end{array}$ & $\begin{array}{l}19.922 \\
20.012 \\
20.103 \\
20.193 \\
20.283\end{array}$ & $\begin{array}{l}91.20 \\
90.74 \\
90.29 \\
89.84 \\
89.40\end{array}$ & $\begin{array}{l}-20 \\
-19 \\
-18 \\
-17 \\
-16\end{array}$ & $\begin{array}{l}-504.40 \\
-479.79 \\
-455.12 \\
-430.38 \\
-405.57\end{array}$ & $\begin{array}{l}24.577 \\
24.642 \\
24.707 \\
24.772 \\
24.837\end{array}$ & $\begin{array}{l}65.30 \\
65.19 \\
65.10 \\
65.03 \\
64.96\end{array}$ \\
\hline $\begin{array}{l}-135 \\
-134 \\
-133 \\
-132 \\
-131\end{array}$ & $\begin{array}{l}-2790.00 \\
-2775.90 \\
-2761.68 \\
-2747.33 \\
-2732.87\end{array}$ & $\begin{array}{l}14.037 \\
14.161 \\
14.284 \\
14.406 \\
14.528\end{array}$ & $\begin{array}{l}123.94 \\
123 \cdot 34 \\
122 \cdot 75 \\
122.15 \\
121.55\end{array}$ & $\begin{array}{l}-75 \\
-74 \\
-73 \\
-72 \\
-71\end{array}$ & $\begin{array}{l}-1746.93 \\
-1726.51 \\
-1706.01 \\
-1685.42 \\
-1664.74\end{array}$ & $\begin{array}{l}20.372 \\
20.461 \\
20.549 \\
20.637 \\
20.724\end{array}$ & $\begin{array}{l}88.96 \\
88.53 \\
88.10 \\
87.67 \\
87.25\end{array}$ & $\begin{array}{l}-15 \\
-14 \\
-13 \\
-12 \\
-11\end{array}$ & $\begin{array}{l}-380.70 \\
-355.77 \\
-330.77 \\
-305.71 \\
-280.58\end{array}$ & $\begin{array}{l}24.902 \\
24.967 \\
25.032 \\
25.096 \\
25.161\end{array}$ & $\begin{array}{l}64 \cdot 90 \\
64 \cdot 83 \\
64 \cdot 75 \\
64.64 \\
64.50\end{array}$ \\
\hline $\begin{array}{l}-130 \\
-129 \\
-128 \\
-127 \\
-126\end{array}$ & $\begin{array}{l}-2718.28 \\
-2703.57 \\
-2688.74 \\
-2673.79 \\
-2658.72\end{array}$ & $\begin{array}{l}14.649 \\
14.770 \\
14.890 \\
15.009 \\
15.128\end{array}$ & $\begin{array}{l}120.95 \\
120.34 \\
119.73 \\
119.12 \\
118.50\end{array}$ & $\begin{array}{l}-70 \\
-69 \\
-68 \\
-67 \\
-66\end{array}$ & $\begin{array}{l}-1643.97 \\
-1623.11 \\
-1602.17 \\
-1581.14 \\
-1560.03\end{array}$ & $\begin{array}{l}20.811 \\
20.898 \\
20.984 \\
21.070 \\
21.155\end{array}$ & $\begin{array}{l}86.82 \\
86.40 \\
85.98 \\
85.56 \\
85.14\end{array}$ & $\begin{array}{l}-10 \\
-9 \\
-8 \\
-7 \\
-6\end{array}$ & $\begin{array}{l}-255.38 \\
-230.13 \\
-204.80 \\
-179.42 \\
-153.97\end{array}$ & $\begin{array}{l}25.225 \\
25.290 \\
25.353 \\
25.417 \\
25.480\end{array}$ & $\begin{array}{l}64.30 \\
64.03 \\
63.68 \\
63.21 \\
62.61\end{array}$ \\
\hline $\begin{array}{l}-125 \\
-124 \\
-123 \\
-122 \\
-121\end{array}$ & $\begin{array}{l}-2643.53 \\
-2628.23 \\
-2612.81 \\
-2597.27 \\
-2581.61\end{array}$ & $\begin{array}{l}15.246 \\
15.364 \\
15.481 \\
15.597 \\
15.713\end{array}$ & $\begin{array}{l}117.89 \\
117.26 \\
116.64 \\
116.01 \\
115.38\end{array}$ & $\begin{array}{l}-65 \\
-64 \\
-63 \\
-62 \\
-61\end{array}$ & $\begin{array}{l}-1538.83 \\
-1517.55 \\
-1496.19 \\
-1474.73 \\
-1453.20\end{array}$ & $\begin{array}{l}21.240 \\
21.325 \\
21.409 \\
21.492 \\
21.576\end{array}$ & $\begin{array}{l}84.71 \\
84.29 \\
83.86 \\
83.43 \\
82.99\end{array}$ & $\begin{array}{l}-5 \\
-4 \\
-3 \\
-2 \\
-1\end{array}$ & $\begin{array}{r}-128.46 \\
-102.89 \\
-77.25 \\
-51.56 \\
-25.81\end{array}$ & $\begin{array}{l}25.542 \\
25.603 \\
25.664 \\
25.723 \\
25.780\end{array}$ & $\begin{array}{l}61.85 \\
60.89 \\
59.71 \\
58.27 \\
56.51\end{array}$ \\
\hline-120 & -2565.84 & $15 \cdot 828$ & $114 \cdot 74$ & -60 & $-1431 \cdot 58$ & 21.658 & 82.55 & 0 & 0.00 & 25.836 & 54.40 \\
\hline
\end{tabular}


TABLE 7.4.2. Type KP (or EP) thermoelements versus platinum, $\mathbf{P l}-67$-thermoelectric voltages, $\mathrm{E}(\mathrm{T})$, Seebeck coefficients, $\mathrm{S}(\mathrm{T})$, and first derivative of the Seebeck coefficients,

$\mathrm{dS} / \mathrm{dT}$, reference junctions at $0^{\circ} \mathrm{C}$-Continued

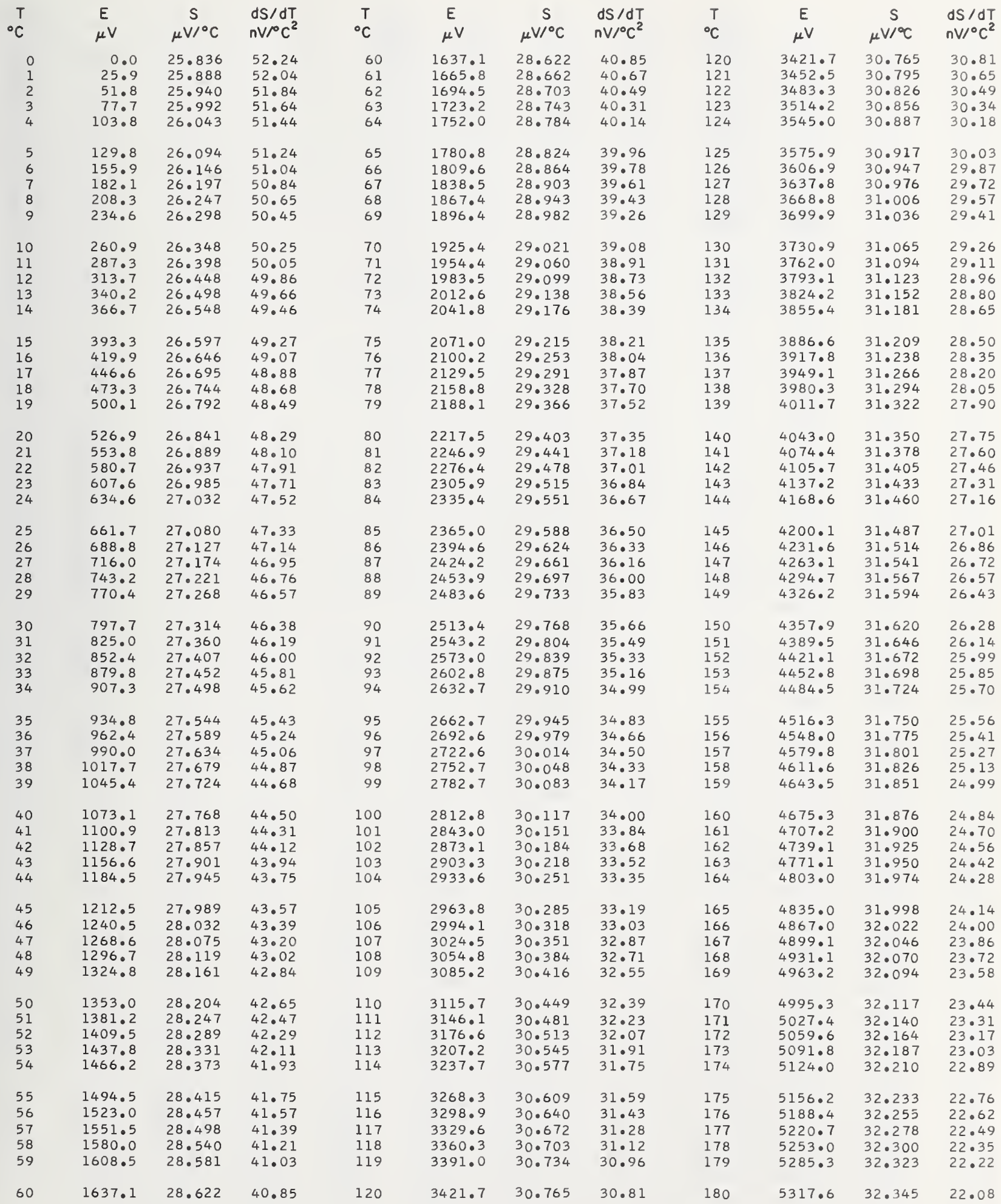


TABLE 7.4.2. Type KP (or EP) thermoelements versus platinum, Pt-67-thermoelectric voltages, $\mathrm{E}(\mathrm{T})$, Seebeck coefficients, $\mathrm{S}(\mathrm{T})$, and first derivative of the Seebeck coefficients,

$\mathrm{dS} / \mathrm{dT}$, reference junctions at $0^{\circ} \mathrm{C}$-Continued

\begin{tabular}{|c|c|c|c|c|c|c|c|c|c|c|c|}
\hline $\begin{array}{l}\mathrm{T} \\
{ }^{\circ} \mathrm{C}\end{array}$ & $\begin{array}{l}E \\
\mu V\end{array}$ & $\begin{array}{c}\mathrm{S} \\
\mu \mathrm{V} /{ }^{\circ} \mathrm{C}\end{array}$ & $\begin{array}{l}d S / d T \\
n V /{ }^{\circ} C^{2}\end{array}$ & ${ }^{\circ} \mathrm{C}$ & $\begin{array}{c}E \\
\mu V\end{array}$ & $\begin{array}{c}\mathrm{S} \\
\mu \mathrm{V} /{ }^{\circ} \mathrm{C}\end{array}$ & $\begin{array}{l}d S / d T \\
n V /{ }^{\circ} C^{2}\end{array}$ & $\begin{array}{l}\mathrm{T} \\
{ }^{\circ} \mathrm{C}\end{array}$ & $\begin{array}{c}E \\
\mu V\end{array}$ & $\begin{array}{c}S \\
\mu V /{ }^{\circ} \mathrm{C}\end{array}$ & $\begin{array}{l}\mathrm{dS} / \mathrm{dT} \\
\mathrm{nV} /{ }^{\circ} \mathrm{C}^{2}\end{array}$ \\
\hline $\begin{array}{l}180 \\
181 \\
182 \\
183 \\
184\end{array}$ & $\begin{array}{l}5317.6 \\
5350.0 \\
5382.4 \\
5414.8 \\
5447.2\end{array}$ & $\begin{array}{l}32.345 \\
32.367 \\
32.389 \\
32.410 \\
32.432\end{array}$ & $\begin{array}{l}22.08 \\
21.95 \\
21.81 \\
21.68 \\
21.54\end{array}$ & $\begin{array}{l}240 \\
241 \\
242 \\
243 \\
244\end{array}$ & $\begin{array}{l}7293.4 \\
7326.9 \\
7360.3 \\
7393.8 \\
7427.3\end{array}$ & $\begin{array}{l}33.440 \\
33.454 \\
33.469 \\
33.483 \\
33.497\end{array}$ & $\begin{array}{l}14.63 \\
14.52 \\
14.40 \\
14.29 \\
14.18\end{array}$ & $\begin{array}{l}300 \\
301 \\
302 \\
303 \\
304\end{array}$ & $\begin{array}{l}9322 \cdot 2 \\
9356 \cdot 3 \\
9390.5 \\
9424 \cdot 6 \\
9458.8\end{array}$ & $\begin{array}{l}34.125 \\
34.133 \\
34.141 \\
34.150 \\
34.158\end{array}$ & $\begin{array}{l}8.40 \\
8.31 \\
8.21 \\
8.12 \\
8.03\end{array}$ \\
\hline $\begin{array}{l}185 \\
186 \\
187 \\
188 \\
189\end{array}$ & $\begin{array}{l}5479.6 \\
5512.1 \\
5544.6 \\
5577.1 \\
5609.6\end{array}$ & $\begin{array}{l}32.453 \\
32.475 \\
32.496 \\
32.517 \\
32.538\end{array}$ & $\begin{array}{l}21.41 \\
21.28 \\
21.15 \\
21.01 \\
20.88\end{array}$ & $\begin{array}{l}245 \\
246 \\
247 \\
248 \\
249\end{array}$ & $\begin{array}{l}7460.8 \\
7494.3 \\
7527.8 \\
7561.4 \\
7594.9\end{array}$ & $\begin{array}{l}33.512 \\
33.526 \\
33.539 \\
33.553 \\
33.567\end{array}$ & $\begin{array}{l}14.07 \\
13.95 \\
13.84 \\
13.73 \\
13.62\end{array}$ & $\begin{array}{l}305 \\
306 \\
307 \\
308 \\
309\end{array}$ & $\begin{array}{l}9492.9 \\
9527.1 \\
9561.3 \\
9595.5 \\
9629.7\end{array}$ & $\begin{array}{l}34.166 \\
34.174 \\
34.181 \\
34.189 \\
34.197\end{array}$ & $\begin{array}{l}7.94 \\
7.84 \\
7.75 \\
7.66 \\
7.57\end{array}$ \\
\hline $\begin{array}{l}190 \\
191 \\
192 \\
193 \\
194\end{array}$ & $\begin{array}{l}5642.2 \\
5674.7 \\
5707.3 \\
5739.9 \\
5772.6\end{array}$ & $\begin{array}{l}32.559 \\
32.580 \\
32.600 \\
32.621 \\
32.641\end{array}$ & $\begin{array}{l}20.75 \\
20.62 \\
20.49 \\
20.36 \\
20.23\end{array}$ & $\begin{array}{l}250 \\
251 \\
252 \\
253 \\
254\end{array}$ & $\begin{array}{l}7628.5 \\
7662.1 \\
7695.7 \\
7729.3 \\
7763.0\end{array}$ & $\begin{array}{l}33.581 \\
33.594 \\
33.607 \\
33.621 \\
33.634\end{array}$ & $\begin{array}{l}13.51 \\
13.40 \\
13.29 \\
13.18 \\
13.07\end{array}$ & $\begin{array}{l}310 \\
311 \\
312 \\
313 \\
314\end{array}$ & $\begin{array}{l}9663.9 \\
9698 \cdot 1 \\
9732 \cdot 3 \\
9766 \cdot 5 \\
9800 \cdot 7\end{array}$ & $\begin{array}{l}34.204 \\
34.212 \\
34.219 \\
34 \cdot 226 \\
34.233\end{array}$ & $\begin{array}{l}7.48 \\
7.39 \\
7.30 \\
7.21 \\
7.12\end{array}$ \\
\hline $\begin{array}{l}200 \\
201 \\
202 \\
203 \\
204\end{array}$ & $\begin{array}{l}5968 \cdot 8 \\
6001 \cdot 5 \\
6034 \cdot 3 \\
6067 \cdot 1 \\
6100.0\end{array}$ & $\begin{array}{l}32.760 \\
32.779 \\
32.799 \\
32.818 \\
32.837\end{array}$ & $\begin{array}{l}19.46 \\
19.33 \\
19.20 \\
19.08 \\
18.95\end{array}$ & $\begin{array}{l}260 \\
261 \\
262 \\
263 \\
264\end{array}$ & $\begin{array}{l}7965.0 \\
7998.7 \\
8032.4 \\
8066.2 \\
8099.9\end{array}$ & $\begin{array}{l}33.710 \\
33.723 \\
33.735 \\
33.747 \\
33.759\end{array}$ & $\begin{array}{l}12 \cdot 42 \\
12 \cdot 32 \\
12 \cdot 21 \\
12.10 \\
12 \cdot 00\end{array}$ & $\begin{array}{l}320 \\
321 \\
322 \\
323 \\
324\end{array}$ & $\begin{array}{l}10006 \cdot 3 \\
10040 \cdot 6 \\
10074 \cdot 8 \\
10109 \cdot 1 \\
10143 \cdot 4\end{array}$ & $\begin{array}{l}34 \cdot 275 \\
34 \cdot 281 \\
34 \cdot 288 \\
34 \cdot 294 \\
34 \cdot 300\end{array}$ & $\begin{array}{l}6.59 \\
6.50 \\
6.41 \\
6.32 \\
6.24\end{array}$ \\
\hline $\begin{array}{l}205 \\
206 \\
207 \\
208 \\
209\end{array}$ & $\begin{array}{l}6132.8 \\
6165.7 \\
6198.6 \\
6231.5 \\
6264.4\end{array}$ & $\begin{array}{l}32.856 \\
32.874 \\
32.893 \\
32.911 \\
32.930\end{array}$ & $\begin{array}{l}18.82 \\
18.70 \\
18.57 \\
18.45 \\
18.32\end{array}$ & $\begin{array}{l}265 \\
266 \\
267 \\
268 \\
269\end{array}$ & $\begin{array}{l}8133.7 \\
8167.5 \\
8201.3 \\
8235.1 \\
8268.9\end{array}$ & $\begin{array}{l}33.771 \\
33.783 \\
33.794 \\
33.806 \\
33.818\end{array}$ & $\begin{array}{l}11.89 \\
11.79 \\
11.68 \\
11.58 \\
11.47\end{array}$ & $\begin{array}{l}325 \\
326 \\
327 \\
328 \\
329\end{array}$ & $\begin{array}{l}10177.7 \\
10212.0 \\
10246.4 \\
10280.7 \\
10315.0\end{array}$ & $\begin{array}{l}34 \cdot 306 \\
34 \cdot 312 \\
34 \cdot 319 \\
34 \cdot 324 \\
34.330\end{array}$ & $\begin{array}{l}6.15 \\
6.07 \\
5.98 \\
5.89 \\
5.81\end{array}$ \\
\hline $\begin{array}{l}210 \\
211 \\
212 \\
213 \\
214\end{array}$ & $\begin{array}{l}6297.3 \\
6330.3 \\
6363.3 \\
6396.2 \\
6429.3\end{array}$ & $\begin{array}{l}32.948 \\
32.966 \\
32.984 \\
33.002 \\
33.020\end{array}$ & $\begin{array}{l}18.20 \\
18.08 \\
17.95 \\
17.83 \\
17.71\end{array}$ & $\begin{array}{l}270 \\
271 \\
272 \\
273 \\
274\end{array}$ & $\begin{array}{l}8302.7 \\
8336.5 \\
8370.4 \\
8404.2 \\
8438.1\end{array}$ & $\begin{array}{l}33.829 \\
33.840 \\
33.852 \\
33.863 \\
33.874\end{array}$ & $\begin{array}{l}11.37 \\
11.26 \\
11.16 \\
11.06 \\
10.96\end{array}$ & $\begin{array}{l}330 \\
331 \\
332 \\
333 \\
334\end{array}$ & $\begin{array}{l}10349.3 \\
10383.7 \\
10418.0 \\
10452.4 \\
10486.7\end{array}$ & $\begin{array}{l}34 \cdot 336 \\
34 \cdot 342 \\
34 \cdot 347 \\
34 \cdot 353 \\
34 \cdot 358\end{array}$ & $\begin{array}{l}5.72 \\
5.64 \\
5.56 \\
5.47 \\
5.39\end{array}$ \\
\hline $\begin{array}{l}220 \\
221 \\
222 \\
223 \\
224\end{array}$ & $\begin{array}{l}6627.7 \\
6660.8 \\
6694.0 \\
6727.1 \\
6760.3\end{array}$ & $\begin{array}{l}33.124 \\
33.141 \\
33.158 \\
33.174 \\
33.191\end{array}$ & $\begin{array}{l}16.98 \\
16.86 \\
16.74 \\
16.62 \\
16.50\end{array}$ & $\begin{array}{l}280 \\
281 \\
282 \\
283 \\
284\end{array}$ & $\begin{array}{l}8641.5 \\
8675.5 \\
8709.4 \\
8743.4 \\
8777.4\end{array}$ & $\begin{array}{l}33.938 \\
33.948 \\
33.958 \\
33.968 \\
33.978\end{array}$ & $\begin{array}{r}10.35 \\
10.25 \\
10.15 \\
10.05 \\
9.95\end{array}$ & $\begin{array}{l}340 \\
341 \\
342 \\
343 \\
344\end{array}$ & $\begin{array}{l}10693.0 \\
10727.4 \\
10761.8 \\
10796.2 \\
10830.6\end{array}$ & $\begin{array}{l}34.389 \\
34.394 \\
34.399 \\
34.403 \\
34.408\end{array}$ & $\begin{array}{l}4.89 \\
4 \cdot 81 \\
4.73 \\
4.65 \\
4.57\end{array}$ \\
\hline $\begin{array}{l}225 \\
226 \\
227 \\
228 \\
229\end{array}$ & $\begin{array}{l}6793.5 \\
6826.7 \\
6860.0 \\
6893.2 \\
6926.5\end{array}$ & $\begin{array}{l}33.207 \\
33.224 \\
33.240 \\
33.256 \\
33.272\end{array}$ & $\begin{array}{l}16.38 \\
16.26 \\
16.14 \\
16.02 \\
15.90\end{array}$ & $\begin{array}{l}285 \\
286 \\
287 \\
288 \\
289\end{array}$ & $\begin{array}{l}8811.3 \\
8845.3 \\
8879.3 \\
8913.4 \\
8947.4\end{array}$ & $\begin{array}{l}33.988 \\
33.998 \\
34.008 \\
34.017 \\
34.027\end{array}$ & $\begin{array}{l}9.85 \\
9.75 \\
9.65 \\
9.55 \\
9.46\end{array}$ & $\begin{array}{l}345 \\
346 \\
347 \\
348 \\
349\end{array}$ & $\begin{array}{l}10865.0 \\
10899 \cdot 4 \\
10933.8 \\
10968.2 \\
11002.7\end{array}$ & $\begin{array}{l}34.413 \\
34.417 \\
34.421 \\
34.426 \\
34.430\end{array}$ & $\begin{array}{l}4 \cdot 49 \\
4.41 \\
4.33 \\
4.25 \\
4.17\end{array}$ \\
\hline $\begin{array}{l}230 \\
231 \\
232 \\
233 \\
234\end{array}$ & $\begin{array}{l}6959.8 \\
6993.1 \\
7026.4 \\
7059.7 \\
7093.0\end{array}$ & $\begin{array}{l}33.288 \\
33.303 \\
33.319 \\
33.335 \\
33.350\end{array}$ & $\begin{array}{l}15.79 \\
15.67 \\
15.55 \\
15.44 \\
15.32\end{array}$ & $\begin{array}{l}290 \\
291 \\
292 \\
293 \\
294\end{array}$ & $\begin{array}{r}8981.4 \\
9015.4 \\
9049.5 \\
9083.6 \\
9117.6\end{array}$ & $\begin{array}{l}34.036 \\
34.045 \\
34.055 \\
34.064 \\
34.073\end{array}$ & $\begin{array}{l}9.36 \\
9.26 \\
9.16 \\
9.07 \\
8.97\end{array}$ & $\begin{array}{l}350 \\
351 \\
352 \\
353 \\
354\end{array}$ & $\begin{array}{l}11037 \cdot 1 . \\
11071.5 \\
11106 \cdot 0 \\
11140 \cdot 4 \\
11174.9\end{array}$ & $\begin{array}{l}34.434 \\
34.438 \\
34.442 \\
34.446 \\
34.450\end{array}$ & $\begin{array}{l}4.10 \\
4.02 \\
3.94 \\
3.86 \\
3.78\end{array}$ \\
\hline $\begin{array}{l}235 \\
236 \\
237 \\
238 \\
239\end{array}$ & $\begin{array}{l}7126.4 \\
7159.8 \\
7193.2 \\
7226.6 \\
7260.0\end{array}$ & $\begin{array}{l}33.365 \\
33.380 \\
33.395 \\
33.410 \\
33.425\end{array}$ & $\begin{array}{l}15.20 \\
15.09 \\
14.97 \\
14.86 \\
14.75\end{array}$ & $\begin{array}{l}295 \\
296 \\
297 \\
298 \\
299\end{array}$ & $\begin{array}{r}9151.7 \\
9185.8 \\
9219.9 \\
9254.0 \\
9288.1\end{array}$ & $\begin{array}{l}34.082 \\
34.091 \\
34.099 \\
34.108 \\
34.116\end{array}$ & $\begin{array}{l}8.88 \\
8.78 \\
8.69 \\
8.59 \\
8.50\end{array}$ & $\begin{array}{l}355 \\
356 \\
357 \\
358 \\
359\end{array}$ & $\begin{array}{l}11209 \cdot 3 \\
11243 \cdot 8 \\
11278 \cdot 2 \\
11312 \cdot 7 \\
11347.2\end{array}$ & $\begin{array}{l}34.454 \\
34.457 \\
34.461 \\
34.464 \\
34.468\end{array}$ & $\begin{array}{l}3.71 \\
3.63 \\
3.55 \\
3.48 \\
3.40\end{array}$ \\
\hline 240 & 7293.4 & 33.440 & 14.63 & 300 & 9322.2 & 34.125 & 8.40 & 360 & 11381.6 & 34.471 & 3.33 \\
\hline
\end{tabular}


TABLE 7.4.2. Type KP (or EP) thermoelements versus platinum, Pt-67-thermoelectric voltages, $\mathrm{E}(\mathrm{T})$, Seebeck coefficients, $\mathrm{S}(\mathrm{T})$, and first derivative of the Seebeck coefficients,

$\mathrm{dS} / \mathrm{dT}$, reference junctions at $0^{\circ} \mathrm{C}$-Continued

\begin{tabular}{|c|c|c|c|c|c|c|c|c|c|c|c|}
\hline $\begin{array}{r}{ }^{\top} \\
{ }^{\circ} \mathrm{C}\end{array}$ & $\underset{\mu V}{E}$ & $\underset{\mu V /{ }^{\circ} \mathrm{C}}{S}$ & $\begin{array}{l}d S / d T \\
n V /{ }^{\circ} C^{2}\end{array}$ & ${ }^{\top} \mathrm{C}$ & $\begin{array}{c}E \\
\mu V\end{array}$ & $\begin{array}{c}S \\
\mu V /^{\circ} \mathrm{C}\end{array}$ & $\begin{array}{l}d S / d T \\
n V /{ }^{\circ} C^{2}\end{array}$ & $\begin{array}{l}\mathrm{T} \\
{ }^{\circ} \mathrm{C}\end{array}$ & $\begin{array}{c}E \\
\mu V\end{array}$ & $\underset{\mu V /{ }^{\alpha} \mathrm{C}}{S}$ & $\begin{array}{l}d S / d T \\
n V /{ }^{\circ} C^{2}\end{array}$ \\
\hline $\begin{array}{l}360 \\
361 \\
362 \\
363 \\
364\end{array}$ & $\begin{array}{l}11381.6 \\
11416.1 \\
11450.6 \\
11485.1 \\
11519.5\end{array}$ & $\begin{array}{l}34.471 \\
34.474 \\
34.478 \\
34.481 \\
34.484\end{array}$ & $\begin{array}{l}3.33 \\
3.25 \\
3.18 \\
3.10 \\
3.03\end{array}$ & $\begin{array}{l}420 \\
421 \\
422 \\
423 \\
424\end{array}$ & $\begin{array}{l}13453.3 \\
13487.9 \\
13522.4 \\
13557.0 \\
13591.5\end{array}$ & $\begin{array}{l}34.546 \\
34.545 \\
34.544 \\
34.543 \\
34.542\end{array}$ & $\begin{array}{l}-0.67 \\
-0.73 \\
-0.79 \\
-0.85 \\
-0.90\end{array}$ & $\begin{array}{l}480 \\
481 \\
482 \\
483 \\
484\end{array}$ & $\begin{array}{l}15522.9 \\
15557.3 \\
15591.7 \\
15626.1 \\
15660.5\end{array}$ & $\begin{array}{l}34.410 \\
34.406 \\
34.403 \\
34.399 \\
34.395\end{array}$ & $\begin{array}{l}-3.69 \\
-3.73 \\
-3.77 \\
-3.81 \\
-3.85\end{array}$ \\
\hline $\begin{array}{l}365 \\
366 \\
367 \\
368 \\
369\end{array}$ & $\begin{array}{l}11554.0 \\
11588.5 \\
11623.0 \\
11657.5 \\
11692.0\end{array}$ & $\begin{array}{l}34.487 \\
34.490 \\
34.493 \\
34.495 \\
34.498\end{array}$ & $\begin{array}{l}2.95 \\
2.88 \\
2.81 \\
2.73 \\
2.66\end{array}$ & $\begin{array}{l}425 \\
426 \\
427 \\
428 \\
429\end{array}$ & $\begin{array}{l}13626.0 \\
13660.6 \\
13695.1 \\
13729.7 \\
13764.2\end{array}$ & $\begin{array}{l}34.542 \\
34.541 \\
34.539 \\
34.538 \\
34.537\end{array}$ & $\begin{array}{l}-0.96 \\
-1.02 \\
-1.07 \\
-1.13 \\
-1.19\end{array}$ & $\begin{array}{l}485 \\
486 \\
487 \\
488 \\
489\end{array}$ & $\begin{array}{l}15694.9 \\
15729.3 \\
15763.7 \\
15798.1 \\
15832.4\end{array}$ & $\begin{array}{l}34.391 \\
34.387 \\
34.383 \\
34.379 \\
34.375\end{array}$ & $\begin{array}{l}-3.89 \\
-3.94 \\
-3.98 \\
-4.02 \\
-4.06\end{array}$ \\
\hline $\begin{array}{l}370 \\
371 \\
372 \\
373 \\
374\end{array}$ & $\begin{array}{l}11726.5 \\
11761.0 \\
11795.5 \\
11830.0 \\
11864.5\end{array}$ & $\begin{array}{l}34.501 \\
34.503 \\
34.506 \\
34.508 \\
34.510\end{array}$ & $\begin{array}{l}2.59 \\
2.52 \\
2.44 \\
2.37 \\
2.30\end{array}$ & $\begin{array}{l}430 \\
431 \\
432 \\
433 \\
434\end{array}$ & $\begin{array}{l}13798.7 \\
13833 \cdot 3 \\
13867 \cdot 8 \\
13902.3 \\
13936.9\end{array}$ & $\begin{array}{l}34.536 \\
34.535 \\
34.533 \\
34.532 \\
34.531\end{array}$ & $\begin{array}{l}-1.24 \\
-1.30 \\
-1.35 \\
-1.41 \\
-1.46\end{array}$ & $\begin{array}{l}490 \\
491 \\
492 \\
493 \\
494\end{array}$ & $\begin{array}{l}15866.8 \\
15901.2 \\
15935.5 \\
15969.9 \\
16004.3\end{array}$ & $\begin{array}{l}34.371 \\
34.367 \\
34.363 \\
34.359 \\
34.354\end{array}$ & $\begin{array}{l}-4 \cdot 10 \\
-4 \cdot 14 \\
-4 \cdot 18 \\
-4 \cdot 22 \\
-4 \cdot 26\end{array}$ \\
\hline $\begin{array}{l}375 \\
376 \\
377 \\
378 \\
379\end{array}$ & $\begin{array}{l}11899.0 \\
11933.5 \\
11968.1 \\
12002.6 \\
12037.1\end{array}$ & $\begin{array}{l}34.513 \\
34.515 \\
34.517 \\
34.519 \\
34.521\end{array}$ & $\begin{array}{l}2.23 \\
2.16 \\
2.09 \\
2.02 \\
1.95\end{array}$ & $\begin{array}{l}435 \\
436 \\
437 \\
438 \\
439\end{array}$ & $\begin{array}{l}13971.4 \\
14005.9 \\
14040.5 \\
14075.0 \\
14109.5\end{array}$ & $\begin{array}{l}34.529 \\
34.528 \\
34.526 \\
34.524 \\
34.523\end{array}$ & $\begin{array}{l}-1.51 \\
-1.57 \\
-1.62 \\
-1.68 \\
-1.73\end{array}$ & $\begin{array}{l}495 \\
496 \\
497 \\
498 \\
499\end{array}$ & $\begin{array}{l}16038.6 \\
16073.0 \\
16107.3 \\
16141.6 \\
16176.0\end{array}$ & $\begin{array}{l}34.350 \\
34.346 \\
34.342 \\
34.337 \\
34.333\end{array}$ & $\begin{array}{l}-4 \cdot 30 \\
-4.33 \\
-4 \cdot 37 \\
-4.41 \\
-4.45\end{array}$ \\
\hline $\begin{array}{l}380 \\
381 \\
382 \\
383 \\
384\end{array}$ & $\begin{array}{l}12071.6 \\
12106.1 \\
12140.7 \\
12175.2 \\
12209.7\end{array}$ & $\begin{array}{l}34.523 \\
34.525 \\
34.527 \\
34.528 \\
34.530\end{array}$ & $\begin{array}{l}1.88 \\
1.81 \\
1.74 \\
1.67 \\
1.60\end{array}$ & $\begin{array}{l}440 \\
441 \\
442 \\
443 \\
444\end{array}$ & $\begin{array}{l}14144.0 \\
14178.5 \\
14213.1 \\
14247.6 \\
14282.1\end{array}$ & $\begin{array}{l}34.521 \\
34.519 \\
34.517 \\
34.515 \\
34.513\end{array}$ & $\begin{array}{l}-1.78 \\
-1.83 \\
-1.89 \\
-1.94 \\
-1.99\end{array}$ & $\begin{array}{l}500 \\
501 \\
502 \\
503 \\
504\end{array}$ & $\begin{array}{l}16210.3 \\
16244.6 \\
16279 \cdot 0 \\
16313.3 \\
16347.6\end{array}$ & $\begin{array}{l}34.328 \\
34.324 \\
34.319 \\
34.315 \\
34.310\end{array}$ & $\begin{array}{l}-4.49 \\
-4.52 \\
-4.56 \\
-4.60 \\
-4.64\end{array}$ \\
\hline $\begin{array}{l}385 \\
386 \\
387 \\
388 \\
389\end{array}$ & $\begin{array}{l}12244.3 \\
12278.8 \\
12313.3 \\
12347.9 \\
12382.4\end{array}$ & $\begin{array}{l}34.532 \\
34.533 \\
34.534 \\
34.536 \\
34.537\end{array}$ & $\begin{array}{l}1.53 \\
1.47 \\
1.40 \\
1.33 \\
1.26\end{array}$ & $\begin{array}{l}445 \\
446 \\
447 \\
448 \\
449\end{array}$ & $\begin{array}{l}14316.6 \\
14351.1 \\
14385.6 \\
14420.1 \\
14454.6\end{array}$ & $\begin{array}{l}34.511 \\
34.509 \\
34.507 \\
34.505 \\
34.503\end{array}$ & $\begin{array}{l}-2.04 \\
-2.09 \\
-2.14 \\
-2.20 \\
-2.25\end{array}$ & $\begin{array}{l}505 \\
506 \\
507 \\
508 \\
509\end{array}$ & $\begin{array}{l}16381.9 \\
16416.2 \\
16450.5 \\
16484.8 \\
16519.1\end{array}$ & $\begin{array}{l}34.305 \\
34.301 \\
34.296 \\
34.291 \\
34.286\end{array}$ & $\begin{array}{l}-4 \cdot 67 \\
-4 \cdot 71 \\
-4 \cdot 75 \\
-4 \cdot 78 \\
-4.82\end{array}$ \\
\hline $\begin{array}{l}390 \\
391 \\
392 \\
393 \\
394\end{array}$ & $\begin{array}{l}12416.9 \\
12451.5 \\
12486.0 \\
12520.5 \\
12555.1\end{array}$ & $\begin{array}{l}34.538 \\
34.540 \\
34.541 \\
34.542 \\
34.543\end{array}$ & $\begin{array}{l}1.20 \\
1.13 \\
1.06 \\
1.00 \\
0.93\end{array}$ & $\begin{array}{l}450 \\
451 \\
452 \\
453 \\
454\end{array}$ & $\begin{array}{l}14489.1 \\
14523.6 \\
14558.1 \\
14592.6 \\
14627.1\end{array}$ & $\begin{array}{l}34.500 \\
34.498 \\
34.496 \\
34.493 \\
34.491\end{array}$ & $\begin{array}{l}-2.30 \\
-2.35 \\
-2.40 \\
-2.45 \\
-2.50\end{array}$ & $\begin{array}{l}510 \\
511 \\
512 \\
513 \\
514\end{array}$ & $\begin{array}{l}16553.4 \\
16587.6 \\
16621.9 \\
16656.2 \\
16690.5\end{array}$ & $\begin{array}{l}34.282 \\
34.277 \\
34.272 \\
34.267 \\
34.262\end{array}$ & $\begin{array}{l}-4.85 \\
-4.89 \\
-4.92 \\
-4.96 \\
-4.99\end{array}$ \\
\hline $\begin{array}{l}395 \\
396 \\
397 \\
398 \\
399\end{array}$ & $\begin{array}{l}12589.6 \\
12624.2 \\
12658.7 \\
12693.3 \\
12727.8\end{array}$ & $\begin{array}{l}34.544 \\
34.544 \\
34.545 \\
34.546 \\
34.546\end{array}$ & $\begin{array}{l}0.87 \\
0.80 \\
0.74 \\
0.67 \\
0.61\end{array}$ & $\begin{array}{l}455 \\
456 \\
457 \\
458 \\
459\end{array}$ & $\begin{array}{l}14661.6 \\
14696.1 \\
14730.6 \\
14765.1 \\
14799.5\end{array}$ & $\begin{array}{l}34.488 \\
34.486 \\
34.483 \\
34.480 \\
34.478\end{array}$ & $\begin{array}{l}-2.54 \\
-2.59 \\
-2.64 \\
-2.69 \\
-2.74\end{array}$ & $\begin{array}{l}515 \\
516 \\
517 \\
518 \\
519\end{array}$ & $\begin{array}{l}16724 \cdot 7 \\
16759 \cdot 0 \\
16793.2 \\
16827.5 \\
16861.7\end{array}$ & $\begin{array}{l}34.257 \\
34.252 \\
34.247 \\
34.242 \\
34.236\end{array}$ & $\begin{array}{l}-5.03 \\
-5.06 \\
-5.09 \\
-5.13 \\
-5.16\end{array}$ \\
\hline $\begin{array}{l}400 \\
401 \\
402 \\
403 \\
404\end{array}$ & $\begin{array}{l}12762.4 \\
12796.9 \\
12831.5 \\
12866.0 \\
12900.6\end{array}$ & $\begin{array}{l}34.547 \\
34.548 \\
34.548 \\
34.548 \\
34.549\end{array}$ & $\begin{array}{l}0.55 \\
0.48 \\
0.42 \\
0.36 \\
0.29\end{array}$ & $\begin{array}{l}460 \\
461 \\
462 \\
463 \\
464\end{array}$ & $\begin{array}{l}14834.0 \\
14868 \cdot 5 \\
14903 \cdot 0 \\
14937.4 \\
14971.9\end{array}$ & $\begin{array}{l}34.475 \\
34.472 \\
34.469 \\
34.466 \\
34.463\end{array}$ & $\begin{array}{l}-2.79 \\
-2.83 \\
-2.88 \\
-2.93 \\
-2.97\end{array}$ & $\begin{array}{l}520 \\
521 \\
522 \\
523 \\
524\end{array}$ & $\begin{array}{l}16895.9 \\
16930.2 \\
16964.4 \\
16998.6 \\
17032.8\end{array}$ & $\begin{array}{l}34.231 \\
34.226 \\
34.221 \\
34.216 \\
34.210\end{array}$ & $\begin{array}{l}-5.19 \\
-5.23 \\
-5.26 \\
-5.29 \\
-5.32\end{array}$ \\
\hline $\begin{array}{l}405 \\
406 \\
407 \\
408 \\
409\end{array}$ & $\begin{array}{l}12935.1 \\
12969.6 \\
13004.2 \\
13038.7 \\
13073.3\end{array}$ & $\begin{array}{l}34.549 \\
34.549 \\
34.549 \\
34.549 \\
34.549\end{array}$ & $\begin{array}{r}0.23 \\
0.17 \\
0.11 \\
0.04 \\
-0.02\end{array}$ & $\begin{array}{l}465 \\
466 \\
467 \\
468 \\
469\end{array}$ & $\begin{array}{l}15006.4 \\
15040.8 \\
15075.3 \\
15109.7 \\
15144.2\end{array}$ & $\begin{array}{l}34.461 \\
34.457 \\
34.454 \\
34.451 \\
34.448\end{array}$ & $\begin{array}{l}-3.02 \\
-3.07 \\
-3.11 \\
-3.16 \\
-3.20\end{array}$ & $\begin{array}{l}525 \\
526 \\
527 \\
528 \\
529\end{array}$ & $\begin{array}{l}17067.0 \\
17101.2 \\
17135.4 \\
17169.6 \\
17203.8\end{array}$ & $\begin{array}{l}34.205 \\
34.200 \\
34.194 \\
34.189 \\
34.183\end{array}$ & $\begin{array}{l}-5.36 \\
-5.39 \\
-5.42 \\
-5.45 \\
-5.48\end{array}$ \\
\hline $\begin{array}{l}410 \\
411 \\
412 \\
413 \\
414\end{array}$ & $\begin{array}{l}13107.8 \\
13142.4 \\
13176.9 \\
13211.5 \\
13246.0\end{array}$ & $\begin{array}{l}34.549 \\
34.549 \\
34.549 \\
34.549 \\
34.549\end{array}$ & $\begin{array}{l}-0.08 \\
-0.14 \\
-0.20 \\
-0.26 \\
-0.32\end{array}$ & $\begin{array}{l}470 \\
471 \\
472 \\
473 \\
474\end{array}$ & $\begin{array}{l}15178.6 \\
15213.1 \\
15247.5 \\
15281.9 \\
15316.4\end{array}$ & $\begin{array}{l}34.445 \\
34.442 \\
34.438 \\
34.435 \\
34.431\end{array}$ & $\begin{array}{l}-3.25 \\
-3.29 \\
-3.34 \\
-3.38 \\
-3.43\end{array}$ & $\begin{array}{l}530 \\
531 \\
532 \\
533 \\
534\end{array}$ & $\begin{array}{l}17238.0 \\
17272 \cdot 2 \\
17306 \cdot 3 \\
17340 \cdot 5 \\
17374.6\end{array}$ & $\begin{array}{l}34.178 \\
34.172 \\
34.167 \\
34.161 \\
34.155\end{array}$ & $\begin{array}{l}-5.51 \\
-5.54 \\
-5.58 \\
-5.61 \\
-5.64\end{array}$ \\
\hline $\begin{array}{l}415 \\
416 \\
417 \\
418 \\
419\end{array}$ & $\begin{array}{l}13280.6 \\
13315.1 \\
13349.7 \\
13384.2 \\
13418.8\end{array}$ & $\begin{array}{l}34.548 \\
34.548 \\
34.547 \\
34.547 \\
34.546\end{array}$ & $\begin{array}{l}-0.38 \\
-0.44 \\
-0.50 \\
-0.56 \\
-0.61\end{array}$ & $\begin{array}{l}475 \\
476 \\
477 \\
478 \\
479\end{array}$ & $\begin{array}{l}15350.8 \\
15385.2 \\
15419.7 \\
15454.1 \\
15488.5\end{array}$ & $\begin{array}{l}34.428 \\
34.425 \\
34.421 \\
34.417 \\
34.414\end{array}$ & $\begin{array}{l}-3.47 \\
-3.51 \\
-3.56 \\
-3.60 \\
-3.64\end{array}$ & $\begin{array}{l}535 \\
536 \\
537 \\
538 \\
539\end{array}$ & $\begin{array}{l}17408.8 \\
17442.9 \\
17477.1 \\
17511.2 \\
17545.4\end{array}$ & $\begin{array}{l}34.150 \\
34.144 \\
34.138 \\
34.133 \\
34.127\end{array}$ & $\begin{array}{l}-5.67 \\
-5.69 \\
-5.72 \\
-5.75 \\
-5.78\end{array}$ \\
\hline 420 & 13453.3 & 34.546 & -0.67 & 480 & 15522.9 & 34.410 & -3.69 & 540 & 17579.5 & 34.121 & -5.81 \\
\hline
\end{tabular}


TABLE 7.4.2. Type KP (or EP) thermoelements versus platinum, Pt-67-thermoelectric voltages, $\mathrm{E}(\mathrm{T})$, Seebeck coefficients, $\mathrm{S}(\mathrm{T})$, and first derivative of the Seebeck coefficients,

$\mathrm{dS} / \mathrm{dT}$, reference junctions at $0^{\circ} \mathrm{C}$-Continued

\begin{tabular}{|c|c|c|c|c|c|c|c|c|c|c|c|}
\hline${ }^{\circ} \mathrm{C}$ & ${ }_{\mu V}^{E V}$ & $\begin{array}{c}S \\
\mu V^{\prime}{ }^{\circ} \mathrm{C}\end{array}$ & $\begin{array}{l}\mathrm{dS} / \mathrm{dT} \\
\mathrm{nV} /{ }^{\circ} \mathrm{C}^{2}\end{array}$ & ${ }^{\circ} \mathrm{C}$ & $\begin{array}{c}E \\
\mu V\end{array}$ & $\frac{\mathrm{S}}{\mu \mathrm{V} /{ }^{\circ} \mathrm{C}}$ & $\begin{array}{l}\mathrm{dS} / \mathrm{dT} \\
\mathrm{nV} /{ }^{\circ} \mathrm{C}^{2}\end{array}$ & $\begin{array}{l}{ }^{\top} \mathrm{C} \\
{ }^{\mathrm{C}}\end{array}$ & $\stackrel{E}{\mu V}$ & $\stackrel{S}{\mu V /{ }^{\circ} \mathrm{C}}$ & $\begin{array}{l}\mathrm{dS} / \mathrm{dT} \\
\mathrm{nV} /{ }^{\circ} \mathrm{C}^{2}\end{array}$ \\
\hline $\begin{array}{l}545 \\
546 \\
547 \\
548 \\
549\end{array}$ & $\begin{array}{l}17750.0 \\
17784.1 \\
17818.2 \\
17852.3 \\
17886.3\end{array}$ & $\begin{array}{l}34.092 \\
34.086 \\
34.080 \\
34.074 \\
34.068\end{array}$ & $\begin{array}{l}-5.95 \\
-5.98 \\
-6.01 \\
-6.03 \\
-6.06\end{array}$ & $\begin{array}{l}605 \\
606 \\
607 \\
608 \\
609\end{array}$ & $\begin{array}{l}19783.9 \\
19817.6 \\
19851.3 \\
19885.0 \\
19918.6\end{array}$ & $\begin{array}{l}33.692 \\
33.685 \\
33.678 \\
33.671 \\
33.663\end{array}$ & $\begin{array}{l}-7.24 \\
-7.26 \\
-7.27 \\
-7.29 \\
-7.30\end{array}$ & $\begin{array}{l}665 \\
666 \\
667 \\
668 \\
669\end{array}$ & $\begin{array}{l}21791.9 \\
21825 \cdot 2 \\
21858.4 \\
21891.6 \\
21924.8\end{array}$ & $\begin{array}{l}33.235 \\
33.227 \\
33.220 \\
33.212 \\
33.204\end{array}$ & $\begin{array}{l}-7.89 \\
-7.90 \\
-7.90 \\
-7.91 \\
-7.92\end{array}$ \\
\hline $\begin{array}{l}550 \\
551 \\
552 \\
553 \\
554\end{array}$ & $\begin{array}{l}17920.4 \\
17954.4 \\
17988.5 \\
18022.5 \\
18056.6\end{array}$ & $\begin{array}{l}34.062 \\
34.055 \\
34.049 \\
34.043 \\
34.037\end{array}$ & $\begin{array}{l}-6.09 \\
-6.11 \\
-6.14 \\
-6.17 \\
-6.19\end{array}$ & $\begin{array}{l}610 \\
611 \\
612 \\
613 \\
614\end{array}$ & $\begin{array}{l}19952.3 \\
19985.9 \\
20019.6 \\
20053.2 \\
20086.8\end{array}$ & $\begin{array}{l}33.656 \\
33.649 \\
33.641 \\
33.634 \\
33.627\end{array}$ & $\begin{array}{l}-7.32 \\
-7 \cdot 33 \\
-7.35 \\
-7.36 \\
-7.38\end{array}$ & $\begin{array}{l}670 \\
671 \\
672 \\
673 \\
674\end{array}$ & $\begin{array}{l}21958 \cdot 0 \\
21991 \cdot 2 \\
22024 \cdot 4 \\
22057 \cdot 6 \\
22090 \cdot 7\end{array}$ & $\begin{array}{l}33.196 \\
33.188 \\
33.180 \\
33.172 \\
33.164\end{array}$ & $\begin{array}{l}-7.92 \\
-7.93 \\
-7.93 \\
-7.94 \\
-7.94\end{array}$ \\
\hline $\begin{array}{l}560 \\
561 \\
562 \\
563 \\
564\end{array}$ & $\begin{array}{l}18260.7 \\
18294.7 \\
18328.7 \\
18362.7 \\
18396.6\end{array}$ & $\begin{array}{l}33.999 \\
33.993 \\
33.987 \\
33.980 \\
33.974\end{array}$ & $\begin{array}{l}-6.34 \\
-6.37 \\
-6.39 \\
-6.41 \\
-6.44\end{array}$ & $\begin{array}{l}620 \\
621 \\
622 \\
623 \\
624\end{array}$ & $\begin{array}{l}20288.5 \\
20322.1 \\
20355.6 \\
20389.2 \\
20422.7\end{array}$ & $\begin{array}{l}33.582 \\
33.575 \\
33.567 \\
33.560 \\
33.552\end{array}$ & $\begin{array}{l}-7.46 \\
-7.47 \\
-7.49 \\
-7.50 \\
-7.51\end{array}$ & $\begin{array}{l}680 \\
681 \\
682 \\
683 \\
684\end{array}$ & $\begin{array}{l}22289.6 \\
22322.7 \\
22355.8 \\
22388.9 \\
22422.0\end{array}$ & $\begin{array}{l}33.116 \\
33.108 \\
33.100 \\
33.092 \\
33.084\end{array}$ & $\begin{array}{l}-7.97 \\
-7.97 \\
-7.98 \\
-7.98 \\
-7.99\end{array}$ \\
\hline $\begin{array}{l}565 \\
566 \\
567 \\
568 \\
569\end{array}$ & $\begin{array}{l}18430.6 \\
18464.6 \\
18498.5 \\
18532.5 \\
18566.4\end{array}$ & $\begin{array}{l}33.967 \\
33.961 \\
33.954 \\
33.948 \\
33.941\end{array}$ & $\begin{array}{l}-6.46 \\
-6.48 \\
-6.51 \\
-6.53 \\
-6.55\end{array}$ & $\begin{array}{l}625 \\
626 \\
627 \\
628 \\
629\end{array}$ & $\begin{array}{l}20456.3 \\
20489.8 \\
20523.4 \\
20556.9 \\
20590.4\end{array}$ & $\begin{array}{l}33.545 \\
33.537 \\
33.529 \\
33.522 \\
33.514\end{array}$ & $\begin{array}{l}-7.52 \\
-7.54 \\
-7.55 \\
-7.56 \\
-7.57\end{array}$ & $\begin{array}{l}685 \\
686 \\
687 \\
688 \\
689\end{array}$ & $\begin{array}{l}22455 \cdot 1 \\
22488 \cdot 1 \\
22521.2 \\
22554 \cdot 3 \\
22587 \cdot 3\end{array}$ & $\begin{array}{l}33.076 \\
33.068 \\
33.061 \\
33.053 \\
33.045\end{array}$ & $\begin{array}{l}-7.99 \\
-7.99 \\
-8.00 \\
-8.00 \\
-8.00\end{array}$ \\
\hline $\begin{array}{l}570 \\
571 \\
572 \\
573 \\
574\end{array}$ & $\begin{array}{l}18600.4 \\
18634.3 \\
18668.2 \\
18702.1 \\
18736.1\end{array}$ & $\begin{array}{l}33.935 \\
33.928 \\
33.922 \\
33.915 \\
33.908\end{array}$ & $\begin{array}{l}-6.58 \\
-6.60 \\
-6.62 \\
-6.64 \\
-6.66\end{array}$ & $\begin{array}{l}630 \\
631 \\
632 \\
633 \\
634\end{array}$ & $\begin{array}{l}20623.9 \\
20657.4 \\
20690.9 \\
20724.4 \\
20757.9\end{array}$ & $\begin{array}{l}33.507 \\
33.499 \\
33.492 \\
33.484 \\
33.476\end{array}$ & $\begin{array}{l}-7.58 \\
-7.60 \\
-7.61 \\
-7.62 \\
-7.63\end{array}$ & $\begin{array}{l}690 \\
691 \\
692 \\
693 \\
694\end{array}$ & $\begin{array}{l}22620.3 \\
22653.4 \\
22686.4 \\
22719.4 \\
22752.4\end{array}$ & $\begin{array}{l}33.037 \\
33.028 \\
33.020 \\
33.012 \\
33.004\end{array}$ & $\begin{array}{l}-8.00 \\
-8.01 \\
-8.01 \\
-8.01 \\
-8.02\end{array}$ \\
\hline $\begin{array}{l}580 \\
581 \\
582 \\
583 \\
584\end{array}$ & $\begin{array}{l}18939.4 \\
18973.3 \\
19007.1 \\
19041.0 \\
19074.8\end{array}$ & $\begin{array}{l}33.868 \\
33.861 \\
33.854 \\
33.848 \\
33.841\end{array}$ & $\begin{array}{l}-6.79 \\
-6.81 \\
-6.83 \\
-6.85 \\
-6.87\end{array}$ & $\begin{array}{l}640 \\
641 \\
642 \\
643 \\
644\end{array}$ & $\begin{array}{l}20958.6 \\
20992.0 \\
21025.5 \\
21058.9 \\
21092.3\end{array}$ & $\begin{array}{l}33.430 \\
33.423 \\
33.415 \\
33.407 \\
33.400\end{array}$ & $\begin{array}{l}-7.69 \\
-7.70 \\
-7.71 \\
-7.72 \\
-7.73\end{array}$ & $\begin{array}{l}700 \\
701 \\
702 \\
703 \\
704\end{array}$ & $\begin{array}{l}22950 \cdot 3 \\
22983 \cdot 3 \\
23016 \cdot 2 \\
23049 \cdot 1 \\
23082.1\end{array}$ & $\begin{array}{l}32.956 \\
32.948 \\
32.940 \\
32.932 \\
32.924\end{array}$ & $\begin{array}{l}-8.03 \\
-8.03 \\
-8.03 \\
-8.03 \\
-8.03\end{array}$ \\
\hline $\begin{array}{l}585 \\
586 \\
587 \\
588 \\
589\end{array}$ & $\begin{array}{l}19108.6 \\
19142.5 \\
19176.3 \\
19210.1 \\
19243.9\end{array}$ & $\begin{array}{l}33.834 \\
33.827 \\
33.820 \\
33.813 \\
33.806\end{array}$ & $\begin{array}{l}-6.89 \\
-6.91 \\
-6.93 \\
-6.95 \\
-6.97\end{array}$ & $\begin{array}{l}645 \\
646 \\
647 \\
648 \\
649\end{array}$ & $\begin{array}{l}21125.7 \\
21159.0 \\
21192.4 \\
21225.8 \\
21259.2\end{array}$ & $\begin{array}{l}33.392 \\
33.384 \\
33.376 \\
33.369 \\
33.361\end{array}$ & $\begin{array}{l}-7.74 \\
-7.75 \\
-7.76 \\
-7.77 \\
-7.77\end{array}$ & $\begin{array}{l}705 \\
706 \\
707 \\
708 \\
709\end{array}$ & $\begin{array}{l}23115.0 \\
23147.9 \\
23180 \cdot 8 \\
23213.7 \\
23246.6\end{array}$ & $\begin{array}{l}32.916 \\
32.908 \\
32.900 \\
32.892 \\
32.884\end{array}$ & $\begin{array}{l}-8.03 \\
-8.04 \\
-8.04 \\
-8.04 \\
-8.04\end{array}$ \\
\hline $\begin{array}{l}590 \\
591 \\
592 \\
593 \\
594\end{array}$ & $\begin{array}{l}19277.7 \\
19311.5 \\
19345.3 \\
19379.1 \\
19412.9\end{array}$ & $\begin{array}{l}33.799 \\
33.792 \\
33.785 \\
33.778 \\
33.771\end{array}$ & $\begin{array}{l}-6.99 \\
-7.00 \\
-7.02 \\
-7.04 \\
-7.06\end{array}$ & $\begin{array}{l}650 \\
651 \\
652 \\
653 \\
654\end{array}$ & $\begin{array}{l}21292.5 \\
21325.9 \\
21359 \cdot 2 \\
21392 \cdot 5 \\
21425.9\end{array}$ & $\begin{array}{l}33.353 \\
33.345 \\
33.337 \\
33.330 \\
33.322\end{array}$ & $\begin{array}{l}-7.78 \\
-7.79 \\
-7.80 \\
-7.81 \\
-7.82\end{array}$ & $\begin{array}{l}710 \\
711 \\
712 \\
713 \\
714\end{array}$ & $\begin{array}{l}23279 \cdot 5 \\
23312 \cdot 3 \\
23345 \cdot 2 \\
23378 \cdot 1 \\
23410 \cdot 9\end{array}$ & $\begin{array}{l}32.876 \\
32.868 \\
32.860 \\
32.852 \\
32.844\end{array}$ & $\begin{array}{l}-8.04 \\
-8.04 \\
-8.04 \\
-8.04 \\
-8.04\end{array}$ \\
\hline $\begin{array}{l}595 \\
596 \\
597 \\
598 \\
599\end{array}$ & $\begin{array}{l}19446.6 \\
19480.4 \\
19514.1 \\
19547.9 \\
19581.6\end{array}$ & $\begin{array}{l}33.764 \\
33.757 \\
33.750 \\
33.743 \\
33.735\end{array}$ & $\begin{array}{l}-7.08 \\
-7.09 \\
-7.11 \\
-7.13 \\
-7.14\end{array}$ & $\begin{array}{l}655 \\
656 \\
657 \\
658 \\
659\end{array}$ & $\begin{array}{l}21459.2 \\
21492.5 \\
21525.8 \\
21559.1 \\
21592.4\end{array}$ & $\begin{array}{l}33.314 \\
33.306 \\
33.298 \\
33.290 \\
33.283\end{array}$ & $\begin{array}{l}-7.82 \\
-7.83 \\
-7.84 \\
-7.85 \\
-7.85\end{array}$ & $\begin{array}{l}715 \\
716 \\
717 \\
718 \\
719\end{array}$ & $\begin{array}{l}23443.7 \\
23476.6 \\
23509.4 \\
23542.2 \\
23575.0\end{array}$ & $\begin{array}{l}32.836 \\
32.828 \\
32.820 \\
32.812 \\
32.804\end{array}$ & $\begin{array}{l}-8.04 \\
-8.04 \\
-8.04 \\
-8.04 \\
-8.04\end{array}$ \\
\hline 600 & 19615.4 & 33.728 & $-7 \cdot 16$ & 660 & 21625.7 & 33.275 & -7.86 & 720 & 23607.8 & 32.796 & -8.04 \\
\hline
\end{tabular}


TABLE 7.4.2. Type KP (or EP) thermoelements versus platinum, Pt-67-thermoelectric voltages, $\mathrm{E}(\mathrm{T})$, Seebeck coefficients, $\mathrm{S}(\mathrm{T})$, and first derivative of the Seebeck coefficients,

$\mathrm{dS} / \mathrm{dT}$, reference junctions at $0^{\circ} \mathrm{C}$-Continued

\begin{tabular}{|c|c|c|c|c|c|c|c|c|c|c|c|}
\hline${ }^{\top} \mathrm{T}$ & $\underset{\mu V}{E}$ & $\underset{\mu V /{ }^{\circ} \mathrm{C}}{\mathrm{S}}$ & $\begin{array}{l}\mathrm{dS} / \mathrm{dT} \\
\mathrm{nV} /{ }^{\circ} \mathrm{C}^{2}\end{array}$ & ${ }^{\circ} \mathrm{C}$ & $\underset{\mu V}{E}$ & $\underset{\mu \mathrm{V} /{ }^{\circ} \mathrm{C}}{\mathrm{S}}$ & $\begin{array}{l}\mathrm{dS} / \mathrm{dT} \\
\mathrm{nV} /{ }^{\circ} \mathrm{C}^{2}\end{array}$ & ${ }^{\circ} \mathrm{C}$ & $\underset{\mu V}{E}$ & $\underset{\mu V /{ }^{\circ} \mathrm{C}}{S}$ & $\begin{array}{l}d S / d T \\
n V /{ }^{\circ} C^{2}\end{array}$ \\
\hline $\begin{array}{l}720 \\
721 \\
722 \\
723 \\
724\end{array}$ & $\begin{array}{l}23607.8 \\
23640.6 \\
23673.4 \\
23706.2 \\
23738.9\end{array}$ & $\begin{array}{l}32.796 \\
32.788 \\
32.780 \\
32.771 \\
32.763\end{array}$ & $\begin{array}{l}-8.04 \\
-8.04 \\
-8.04 \\
-8.04 \\
-8.04\end{array}$ & $\begin{array}{l}780 \\
781 \\
782 \\
783 \\
784\end{array}$ & $\begin{array}{l}25561.2 \\
25593 \cdot 5 \\
25625.8 \\
25658 \cdot 1 \\
25690.4\end{array}$ & $\begin{array}{l}32.318 \\
32.310 \\
32.302 \\
32.294 \\
32.286\end{array}$ & $\begin{array}{l}-7.85 \\
-7.84 \\
-7.83 \\
-7.83 \\
-7.82\end{array}$ & $\begin{array}{l}840 \\
841 \\
842 \\
843 \\
844\end{array}$ & $\begin{array}{l}27486.3 \\
27518.2 \\
27550.0 \\
27581.9 \\
27613.7\end{array}$ & $\begin{array}{l}31.859 \\
31.851 \\
31.844 \\
31.836 \\
31.829\end{array}$ & $\begin{array}{l}-7.44 \\
-7.43 \\
-7.42 \\
-7.41 \\
-7.40\end{array}$ \\
\hline $\begin{array}{l}725 \\
726 \\
727 \\
728 \\
729\end{array}$ & $\begin{array}{l}23771.7 \\
23804.5 \\
23837.2 \\
23869.9 \\
23902.7\end{array}$ & $\begin{array}{l}32.755 \\
32.747 \\
32.739 \\
32.731 \\
32.723\end{array}$ & $\begin{array}{l}-8.03 \\
-8.03 \\
-8.03 \\
-8.03 \\
-8.03\end{array}$ & $\begin{array}{l}785 \\
786 \\
787 \\
788 \\
789\end{array}$ & $\begin{array}{l}25722.7 \\
25754.9 \\
25787.2 \\
25819.5 \\
25851.7\end{array}$ & $\begin{array}{l}32.278 \\
32.271 \\
32.263 \\
32.255 \\
32.247\end{array}$ & $\begin{array}{l}-7.82 \\
-7.81 \\
-7.81 \\
-7.80 \\
-7.79\end{array}$ & $\begin{array}{l}845 \\
846 \\
847 \\
848 \\
849\end{array}$ & $\begin{array}{l}27645.5 \\
27677 \cdot 3 \\
27709.2 \\
27741.0 \\
27772.7\end{array}$ & $\begin{array}{l}31.821 \\
31.814 \\
31.807 \\
31.799 \\
31.792\end{array}$ & $\begin{array}{l}-7.40 \\
-7.39 \\
-7.38 \\
-7.37 \\
-7.37\end{array}$ \\
\hline $\begin{array}{l}730 \\
731 \\
732 \\
733 \\
734\end{array}$ & $\begin{array}{l}23935.4 \\
23968 \cdot 1 \\
24000.8 \\
24033.5 \\
24066.2\end{array}$ & $\begin{array}{l}32.715 \\
32.707 \\
32.699 \\
32.691 \\
32.683\end{array}$ & $\begin{array}{l}-8.03 \\
-8.03 \\
-8.02 \\
-8.02 \\
-8.02\end{array}$ & $\begin{array}{l}790 \\
791 \\
792 \\
793 \\
794\end{array}$ & $\begin{array}{l}25883.9 \\
25916.2 \\
25948.4 \\
25980.6 \\
26012.8\end{array}$ & $\begin{array}{l}32.239 \\
32.232 \\
32.224 \\
32.216 \\
32.208\end{array}$ & $\begin{array}{l}-7.79 \\
-7.78 \\
-7.78 \\
-7.77 \\
-7.76\end{array}$ & $\begin{array}{l}850 \\
851 \\
852 \\
853 \\
854\end{array}$ & $\begin{array}{l}27804.5 \\
27836 \cdot 3 \\
27868 \cdot 1 \\
27899 \cdot 9 \\
27931.6\end{array}$ & $\begin{array}{l}31.785 \\
31.777 \\
31.770 \\
31.763 \\
31.755\end{array}$ & $\begin{array}{l}-7.36 \\
-7.35 \\
-7.34 \\
-7.33 \\
-7.33\end{array}$ \\
\hline $\begin{array}{l}735 \\
736 \\
737 \\
738 \\
739\end{array}$ & $\begin{array}{l}24098.9 \\
24131.5 \\
24164.2 \\
24196.8 \\
24229.5\end{array}$ & $\begin{array}{l}32.675 \\
32.667 \\
32.659 \\
32.651 \\
32.643\end{array}$ & $\begin{array}{l}-8.02 \\
-8.02 \\
-8.02 \\
-8.01 \\
-8.01\end{array}$ & $\begin{array}{l}795 \\
796 \\
797 \\
798 \\
799\end{array}$ & $\begin{array}{l}26045.0 \\
26077 \cdot 2 \\
26109 \cdot 4 \\
26141.6 \\
26173.8\end{array}$ & $\begin{array}{l}32.201 \\
32.193 \\
32.185 \\
32.177 \\
32.170\end{array}$ & $\begin{array}{l}-7.76 \\
-7.75 \\
-7.74 \\
-7.74 \\
-7.73\end{array}$ & $\begin{array}{l}855 \\
856 \\
857 \\
858 \\
859\end{array}$ & $\begin{array}{l}27963.4 \\
27995.1 \\
28026 \cdot 9 \\
28058 \cdot 6 \\
28090.3\end{array}$ & $\begin{array}{l}31.748 \\
31.741 \\
31.733 \\
31.726 \\
31.719\end{array}$ & $\begin{array}{l}-7.32 \\
-7.31 \\
-7.30 \\
-7.29 \\
-7.29\end{array}$ \\
\hline $\begin{array}{l}740 \\
741 \\
742 \\
743 \\
744\end{array}$ & $\begin{array}{l}24262.1 \\
24294.8 \\
24327.4 \\
24360.0 \\
24392.6\end{array}$ & $\begin{array}{l}32.635 \\
32.627 \\
32.619 \\
32.611 \\
32.603\end{array}$ & $\begin{array}{l}-8.01 \\
-8.01 \\
-8.00 \\
-8.00 \\
-8.00\end{array}$ & $\begin{array}{l}800 \\
801 \\
802 \\
803 \\
804\end{array}$ & $\begin{array}{l}26206.0 \\
26238.1 \\
26270.3 \\
26302.4 \\
26334.5\end{array}$ & $\begin{array}{l}32.162 \\
32.154 \\
32.146 \\
32.139 \\
32.131\end{array}$ & $\begin{array}{l}-7.72 \\
-7.72 \\
-7.71 \\
-7.70 \\
-7.70\end{array}$ & $\begin{array}{l}860 \\
861 \\
862 \\
863 \\
864\end{array}$ & $\begin{array}{l}28122.0 \\
28153.7 \\
28185.4 \\
28217.1 \\
28248.8\end{array}$ & $\begin{array}{l}31.711 \\
31.704 \\
31.697 \\
31.690 \\
31.682\end{array}$ & $\begin{array}{l}-7.28 \\
-7.27 \\
-7.26 \\
-7.26 \\
-7.25\end{array}$ \\
\hline $\begin{array}{l}745 \\
746 \\
747 \\
748 \\
749\end{array}$ & $\begin{array}{l}24425.2 \\
24457.8 \\
24490.4 \\
24523.0 \\
24555.5\end{array}$ & $\begin{array}{l}32.595 \\
32.587 \\
32.579 \\
32.571 \\
32.563\end{array}$ & $\begin{array}{l}-7.99 \\
-7.99 \\
-7.99 \\
-7.99 \\
-7.98\end{array}$ & $\begin{array}{l}805 \\
806 \\
807 \\
808 \\
809\end{array}$ & $\begin{array}{l}26366.7 \\
26398.8 \\
26430.9 \\
26463.0 \\
26495.1\end{array}$ & $\begin{array}{l}32.123 \\
32.116 \\
32.108 \\
32.100 \\
32.093\end{array}$ & $\begin{array}{l}-7.69 \\
-7.68 \\
-7.68 \\
-7.67 \\
-7.66\end{array}$ & $\begin{array}{l}865 \\
866 \\
867 \\
868 \\
869\end{array}$ & $\begin{array}{l}28280.5 \\
28312.2 \\
28343 \cdot 8 \\
28375 \cdot 5 \\
28407.1\end{array}$ & $\begin{array}{l}31.675 \\
31.668 \\
31.661 \\
31.653 \\
31.646\end{array}$ & $\begin{array}{l}-7.24 \\
-7.23 \\
-7.22 \\
-7.22 \\
-7.21\end{array}$ \\
\hline $\begin{array}{l}750 \\
751 \\
752 \\
753 \\
754\end{array}$ & $\begin{array}{l}24588 \cdot 1 \\
24620 \cdot 6 \\
24653 \cdot 2 \\
24685 \cdot 7 \\
24718 \cdot 2\end{array}$ & $\begin{array}{l}32.555 \\
32.547 \\
32.539 \\
32.531 \\
32.523\end{array}$ & $\begin{array}{l}-7.98 \\
-7.98 \\
-7.97 \\
-7.97 \\
-7.97\end{array}$ & $\begin{array}{l}810 \\
811 \\
812 \\
813 \\
814\end{array}$ & $\begin{array}{l}26527.2 \\
26559 \cdot 3 \\
26591.3 \\
26623.4 \\
26655.5\end{array}$ & $\begin{array}{l}32.085 \\
32.077 \\
32.070 \\
32.062 \\
32.054\end{array}$ & $\begin{array}{l}-7.66 \\
-7.65 \\
-7.64 \\
-7.64 \\
-7.63\end{array}$ & $\begin{array}{l}870 \\
871 \\
872 \\
873 \\
874\end{array}$ & $\begin{array}{l}28438.8 \\
28470 \cdot 4 \\
28502 \cdot 0 \\
28533 \cdot 7 \\
28565.3\end{array}$ & $\begin{array}{l}31.639 \\
31.632 \\
31.625 \\
31.617 \\
31.610\end{array}$ & $\begin{array}{l}-7.20 \\
-7.19 \\
-7.19 \\
-7.18 \\
-7.17\end{array}$ \\
\hline $\begin{array}{l}755 \\
756 \\
757 \\
758 \\
759\end{array}$ & $\begin{array}{l}24750.8 \\
24783.3 \\
24815.8 \\
24848.3 \\
24880.8\end{array}$ & $\begin{array}{l}32.515 \\
32.507 \\
32.499 \\
32.491 \\
32.483\end{array}$ & $\begin{array}{l}-7.96 \\
-7.96 \\
-7.95 \\
-7.95 \\
-7.95\end{array}$ & $\begin{array}{l}815 \\
816 \\
817 \\
818 \\
819\end{array}$ & $\begin{array}{l}26687.5 \\
26719.6 \\
26751.6 \\
26783.6 \\
26815.6\end{array}$ & $\begin{array}{l}32.047 \\
32.039 \\
32.032 \\
32.024 \\
32.016\end{array}$ & $\begin{array}{l}-7.62 \\
-7.61 \\
-7.61 \\
-7.60 \\
-7.59\end{array}$ & $\begin{array}{l}875 \\
876 \\
877 \\
878 \\
879\end{array}$ & $\begin{array}{l}28596.9 \\
28628.5 \\
28660.1 \\
28691.7 \\
28723.2\end{array}$ & $\begin{array}{l}31.603 \\
31.596 \\
31.589 \\
31.582 \\
31.574\end{array}$ & $\begin{array}{l}-7.16 \\
-7.15 \\
-7.15 \\
-7.14 \\
-7.13\end{array}$ \\
\hline $\begin{array}{l}760 \\
761 \\
762 \\
763 \\
764\end{array}$ & $\begin{array}{l}24913.2 \\
24945.7 \\
24978.2 \\
25010.6 \\
25043.1\end{array}$ & $\begin{array}{l}32.476 \\
32.468 \\
32.460 \\
32.452 \\
32.444\end{array}$ & $\begin{array}{l}-7.94 \\
-7.94 \\
-7.93 \\
-7.93 \\
-7.92\end{array}$ & $\begin{array}{l}820 \\
821 \\
822 \\
823 \\
824\end{array}$ & $\begin{array}{l}26847.7 \\
26879.7 \\
26911.7 \\
26943.6 \\
26975.6\end{array}$ & $\begin{array}{l}32.009 \\
32.001 \\
31.994 \\
31.986 \\
31.978\end{array}$ & $\begin{array}{l}-7.59 \\
-7.58 \\
-7.57 \\
-7.56 \\
-7.56\end{array}$ & $\begin{array}{l}880 \\
881 \\
882 \\
883 \\
884\end{array}$ & $\begin{array}{l}28754 \cdot 8 \\
28786.4 \\
28817 \cdot 9 \\
28849 \cdot 5 \\
28881.0\end{array}$ & $\begin{array}{l}31.567 \\
31.560 \\
31.553 \\
31.546 \\
31.539\end{array}$ & $\begin{array}{l}-7.12 \\
-7.12 \\
-7.11 \\
-7.10 \\
-7.09\end{array}$ \\
\hline $\begin{array}{l}765 \\
766 \\
767 \\
768 \\
769\end{array}$ & $\begin{array}{l}25075.5 \\
25107.9 \\
25140.4 \\
25172.8 \\
25205.2\end{array}$ & $\begin{array}{l}32.436 \\
32.428 \\
32.420 \\
32.412 \\
32.404\end{array}$ & $\begin{array}{l}-7.92 \\
-7.92 \\
-7.91 \\
-7.91 \\
-7.90\end{array}$ & $\begin{array}{l}825 \\
826 \\
827 \\
828 \\
829\end{array}$ & $\begin{array}{l}27007.6 \\
27039.6 \\
27071.5 \\
27103.5 \\
27135.4\end{array}$ & $\begin{array}{l}31.971 \\
31.963 \\
31.956 \\
31.948 \\
31.941\end{array}$ & $\begin{array}{l}-7.55 \\
-7.54 \\
-7.53 \\
-7.53 \\
-7.52\end{array}$ & $\begin{array}{l}885 \\
886 \\
887 \\
888 \\
889\end{array}$ & $\begin{array}{l}28912.5 \\
28944 \cdot 1 \\
28975 \cdot 6 \\
29007 \cdot 1 \\
29038.6\end{array}$ & $\begin{array}{l}31.532 \\
31.525 \\
31.518 \\
31.511 \\
31.504\end{array}$ & $\begin{array}{l}-7.09 \\
-7.08 \\
-7.07 \\
-7.06 \\
-7.06\end{array}$ \\
\hline $\begin{array}{l}770 \\
771 \\
772 \\
773 \\
774\end{array}$ & $\begin{array}{l}25237.6 \\
25270.0 \\
25302.4 \\
25334.7 \\
25367.1\end{array}$ & $\begin{array}{l}32.396 \\
32.388 \\
32.381 \\
32.373 \\
32.365\end{array}$ & $\begin{array}{l}-7.90 \\
-7.89 \\
-7.89 \\
-7.88 \\
-7.88\end{array}$ & $\begin{array}{l}830 \\
831 \\
832 \\
833 \\
834\end{array}$ & $\begin{array}{l}27167.4 \\
27199 \cdot 3 \\
27231.2 \\
27263.1 \\
27295.0\end{array}$ & $\begin{array}{l}31.933 \\
31.926 \\
31.918 \\
31.911 \\
31.903\end{array}$ & $\begin{array}{l}-7.51 \\
-7.50 \\
-7.50 \\
-7.49 \\
-7.48\end{array}$ & $\begin{array}{l}890 \\
891 \\
892 \\
893 \\
894\end{array}$ & $\begin{array}{l}29070.1 \\
29101.6 \\
29133.1 \\
29164.6 \\
29196.0\end{array}$ & $\begin{array}{l}31.496 \\
31.489 \\
31.482 \\
31.475 \\
31.468\end{array}$ & $\begin{array}{l}-7.05 \\
-7.04 \\
-7.03 \\
-7.03 \\
-7.02\end{array}$ \\
\hline $\begin{array}{l}775 \\
776 \\
777 \\
778 \\
779\end{array}$ & $\begin{array}{l}25399.5 \\
25431.8 \\
25464.2 \\
25496.5 \\
25528.8\end{array}$ & $\begin{array}{l}32 \cdot 357 \\
32 \cdot 349 \\
32 \cdot 341 \\
32.333 \\
32.325\end{array}$ & $\begin{array}{l}-7.87 \\
-7.87 \\
-7.86 \\
-7.86 \\
-7.85\end{array}$ & $\begin{array}{l}835 \\
836 \\
837 \\
838 \\
839\end{array}$ & $\begin{array}{l}27326.9 \\
27358.8 \\
27390.7 \\
27422.6 \\
27454.5\end{array}$ & $\begin{array}{l}31.896 \\
31.888 \\
31.881 \\
31.873 \\
31.866\end{array}$ & $\begin{array}{l}-7.47 \\
-7.47 \\
-7.46 \\
-7.45 \\
-7.44\end{array}$ & $\begin{array}{l}895 \\
896 \\
897 \\
898 \\
899\end{array}$ & $\begin{array}{l}29227.5 \\
29259.0 \\
29290.4 \\
29321.9 \\
29353.3\end{array}$ & $\begin{array}{l}31.461 \\
31.454 \\
31.447 \\
31.440 \\
31.433\end{array}$ & $\begin{array}{l}-7.01 \\
-7.01 \\
-7.00 \\
-6.99 \\
-6.98\end{array}$ \\
\hline & 25561.2 & 32.318 & -7.85 & 40 & $27486 \cdot 3$ & 31.859 & $-7 \cdot 44$ & 900 & 29384.7 & & \\
\hline
\end{tabular}


TABLE 7.4.2. Type KP (or EP) thermoelements versus platinum, Pt-67-thermoelectric voltages, $\mathrm{E}(\mathrm{T})$, Seebeck coefficients, S(T), and first derivative of the Seebeck coefficients, $\mathrm{dS} / \mathrm{dT}$, reference junctions at $0^{\circ} \mathrm{C}$-Continued

\begin{tabular}{|c|c|c|c|c|c|c|c|c|c|c|c|}
\hline $\begin{array}{l}\mathrm{T} \\
{ }^{\circ} \mathrm{C}\end{array}$ & $\underset{\mu V}{E}$ & $\stackrel{S}{\mu V /{ }^{\circ} \mathrm{C}}$ & $\begin{array}{l}d S / d T \\
n V /{ }^{\circ} C^{2}\end{array}$ & $\begin{array}{r}{ }^{\circ} \mathrm{C} \\
\end{array}$ & $\begin{array}{c}E \\
\mu V\end{array}$ & $\underset{\mu \mathrm{V} /{ }^{\circ} \mathrm{C}}{\mathrm{S}}$ & $\begin{array}{l}\mathrm{dS} / \mathrm{dT} \\
\mathrm{nV} /{ }^{\circ} \mathrm{c}^{2}\end{array}$ & $\begin{array}{l}\mathrm{T} \\
{ }^{\circ} \mathrm{C}\end{array}$ & $\begin{array}{c}E \\
\mu V\end{array}$ & $\underset{\mu V /{ }^{\circ} \mathrm{C}}{S}$ & $\begin{array}{l}d S / d T \\
n V /{ }^{\circ} C^{2}\end{array}$ \\
\hline $\begin{array}{l}900 \\
901 \\
902 \\
903 \\
904\end{array}$ & $\begin{array}{l}29384.7 \\
29416.2 \\
29447.6 \\
29479.0 \\
29510.4\end{array}$ & $\begin{array}{l}31.426 \\
31.419 \\
31.412 \\
31.405 \\
31.399\end{array}$ & $\begin{array}{l}-6.98 \\
-6.97 \\
-6.96 \\
-6.96 \\
-6.95\end{array}$ & $\begin{array}{l}960 \\
961 \\
962 \\
963 \\
964\end{array}$ & $\begin{array}{l}31258.0 \\
31289.0 \\
31320.0 \\
31351.0 \\
31382.0\end{array}$ & $\begin{array}{l}31.019 \\
31.012 \\
31.005 \\
30.999 \\
30.992\end{array}$ & $\begin{array}{l}-6.65 \\
-6.65 \\
-6.64 \\
-6.64 \\
-6.64\end{array}$ & $\begin{array}{l}1020 \\
1021 \\
1022 \\
1023 \\
1024\end{array}$ & $\begin{array}{l}33107.2 \\
33137.8 \\
33168.4 \\
33199.0 \\
33229.6\end{array}$ & $\begin{array}{l}30.622 \\
30.615 \\
30.609 \\
30.602 \\
30.596\end{array}$ & $\begin{array}{l}-6.64 \\
-6.65 \\
-6.65 \\
-6.65 \\
-6.66\end{array}$ \\
\hline $\begin{array}{l}905 \\
906 \\
907 \\
908 \\
909\end{array}$ & $\begin{array}{l}29541.8 \\
29573.2 \\
29604.5 \\
29635.9 \\
29667.3\end{array}$ & $\begin{array}{l}31 \cdot 392 \\
31.385 \\
31.378 \\
31.371 \\
31.364\end{array}$ & $\begin{array}{l}-6.94 \\
-6.93 \\
-6.93 \\
-6.92 \\
-6.91\end{array}$ & $\begin{array}{l}965 \\
966 \\
967 \\
968 \\
969\end{array}$ & $\begin{array}{l}31413.0 \\
31444.0 \\
31475.0 \\
31505.9 \\
31536.9\end{array}$ & $\begin{array}{l}30.986 \\
30.979 \\
30.972 \\
30.966 \\
30.959\end{array}$ & $\begin{array}{l}-6.63 \\
-6.63 \\
-6.63 \\
-6.62 \\
-6.62\end{array}$ & $\begin{array}{l}1025 \\
1026 \\
1027 \\
1028 \\
1029\end{array}$ & $\begin{array}{l}33260.2 \\
33290.8 \\
33321.4 \\
33352.0 \\
33382.5\end{array}$ & $\begin{array}{l}30.589 \\
30.582 \\
30.576 \\
30.569 \\
30.562\end{array}$ & $\begin{array}{l}-6.66 \\
-6.67 \\
-6.67 \\
-6.68 \\
-6.68\end{array}$ \\
\hline $\begin{array}{l}910 \\
911 \\
912 \\
913 \\
914\end{array}$ & $\begin{array}{l}29698.6 \\
29730.0 \\
29761.3 \\
29792.7 \\
29824.0\end{array}$ & $\begin{array}{l}31.357 \\
31 \cdot 350 \\
31 \cdot 343 \\
31.336 \\
31.329\end{array}$ & $\begin{array}{l}-6.91 \\
-6.90 \\
-6.89 \\
-6.89 \\
-6.88\end{array}$ & $\begin{array}{l}970 \\
971 \\
972 \\
973 \\
974\end{array}$ & $\begin{array}{l}31567.8 \\
31598.8 \\
31629.7 \\
31660.7 \\
31691.6\end{array}$ & $\begin{array}{l}30.952 \\
30.946 \\
30.939 \\
30.933 \\
30.926\end{array}$ & $\begin{array}{l}-6.62 \\
-6.62 \\
-6.62 \\
-6.61 \\
-6.61\end{array}$ & $\begin{array}{l}1030 \\
1031 \\
1032 \\
1033 \\
1034\end{array}$ & $\begin{array}{l}33413.1 \\
33443.6 \\
33474.2 \\
33504 \cdot 7 \\
33535.3\end{array}$ & $\begin{array}{l}30.555 \\
30.549 \\
30.542 \\
30.535 \\
30.529\end{array}$ & $\begin{array}{l}-6.69 \\
-6.69 \\
-6.70 \\
-6 \cdot 70 \\
-6.71\end{array}$ \\
\hline $\begin{array}{l}915 \\
916 \\
917 \\
918 \\
919\end{array}$ & $\begin{array}{l}29855.3 \\
29886.7 \\
29918.0 \\
29949.3 \\
29980.6\end{array}$ & $\begin{array}{l}31 \cdot 322 \\
31.316 \\
31.309 \\
31.302 \\
31.295\end{array}$ & $\begin{array}{l}-6.88 \\
-6.87 \\
-6.86 \\
-6.86 \\
-6.85\end{array}$ & $\begin{array}{l}975 \\
976 \\
977 \\
978 \\
979\end{array}$ & $\begin{array}{l}31722.5 \\
31753.4 \\
31784.3 \\
31815.2 \\
31846.1\end{array}$ & $\begin{array}{l}30.919 \\
30.913 \\
30.906 \\
30.900 \\
30.893\end{array}$ & $\begin{array}{l}-6.61 \\
-6.61 \\
-6.61 \\
-6.60 \\
-6.60\end{array}$ & $\begin{array}{l}1035 \\
1036 \\
1037 \\
1038 \\
1039\end{array}$ & $\begin{array}{l}33565.8 \\
33596.3 \\
33626.8 \\
33657 \cdot 3 \\
33687.8\end{array}$ & $\begin{array}{l}30.522 \\
30.515 \\
30.509 \\
30.502 \\
30.495\end{array}$ & $\begin{array}{l}-6.71 \\
-6.72 \\
-6.73 \\
-6.73 \\
-6.74\end{array}$ \\
\hline $\begin{array}{l}920 \\
921 \\
922 \\
923 \\
924\end{array}$ & $\begin{array}{l}30011.9 \\
30043.2 \\
30074.4 \\
30105.7 \\
30137.0\end{array}$ & $\begin{array}{l}31.288 \\
31.281 \\
31.275 \\
31.268 \\
31.261\end{array}$ & $\begin{array}{l}-6.84 \\
-6.84 \\
-6.83 \\
-6.83 \\
-6.82\end{array}$ & $\begin{array}{l}980 \\
981 \\
982 \\
983 \\
984\end{array}$ & $\begin{array}{l}31877.0 \\
31907.9 \\
31938.8 \\
31969.7 \\
32000.5\end{array}$ & $\begin{array}{l}30.886 \\
30.880 \\
30.873 \\
30.866 \\
30.860\end{array}$ & $\begin{array}{l}-6.60 \\
-6.60 \\
-6.60 \\
-6.60 \\
-6.60\end{array}$ & $\begin{array}{l}1040 \\
1041 \\
1042 \\
1043 \\
1044\end{array}$ & $\begin{array}{l}33718 \cdot 3 \\
33748 \cdot 8 \\
33779 \cdot 3 \\
33809 \cdot 7 \\
33840 \cdot 2\end{array}$ & $\begin{array}{l}30.488 \\
30.482 \\
30.475 \\
30.468 \\
30.461\end{array}$ & $\begin{array}{l}-6.75 \\
-6.75 \\
-6.76 \\
-6.77 \\
-6.77\end{array}$ \\
\hline $\begin{array}{l}925 \\
926 \\
927 \\
928 \\
929\end{array}$ & $\begin{array}{l}30168.2 \\
30199.5 \\
30230.7 \\
30262.0 \\
30293.2\end{array}$ & $\begin{array}{l}31.254 \\
31.247 \\
31.240 \\
31.234 \\
31.227\end{array}$ & $\begin{array}{l}-6.81 \\
-6.81 \\
-6.80 \\
-6.80 \\
-6.79\end{array}$ & $\begin{array}{l}985 \\
986 \\
987 \\
988 \\
989\end{array}$ & $\begin{array}{l}32031.4 \\
32062.2 \\
32093.1 \\
32123.9 \\
32154.7\end{array}$ & $\begin{array}{l}30.853 \\
30.847 \\
30.840 \\
30.834 \\
30.827\end{array}$ & $\begin{array}{l}-6.60 \\
-6.59 \\
-6.59 \\
-6.59 \\
-6.59\end{array}$ & $\begin{array}{l}1045 \\
1046 \\
1047 \\
1048 \\
1049\end{array}$ & $\begin{array}{l}33870.7 \\
33901.1 \\
33931.6 \\
33962.0 \\
33992.4\end{array}$ & $\begin{array}{l}30.455 \\
30.448 \\
30.441 \\
30.434 \\
30.427\end{array}$ & $\begin{array}{l}-6.78 \\
-6.79 \\
-6.80 \\
-6.81 \\
-6.81\end{array}$ \\
\hline $\begin{array}{l}930 \\
931 \\
932 \\
933 \\
934\end{array}$ & $\begin{array}{l}30324.4 \\
30355.6 \\
30386.8 \\
30418.0 \\
30449.2\end{array}$ & $\begin{array}{l}31.220 \\
31.213 \\
31.206 \\
31.200 \\
31.193\end{array}$ & $\begin{array}{l}-6.78 \\
-6.78 \\
-6.77 \\
-6.77 \\
-6.76\end{array}$ & $\begin{array}{l}990 \\
991 \\
992 \\
993 \\
994\end{array}$ & $\begin{array}{l}32185.6 \\
32216.4 \\
32247.2 \\
32278.0 \\
32308.8\end{array}$ & $\begin{array}{l}30.820 \\
30.814 \\
30.807 \\
30.801 \\
30.794\end{array}$ & $\begin{array}{l}-6.59 \\
-6.59 \\
-6.59 \\
-6.59 \\
-6.59\end{array}$ & $\begin{array}{l}1050 \\
1051 \\
1052 \\
1053 \\
1054\end{array}$ & $\begin{array}{l}34022 \cdot 9 \\
34053 \cdot 3 \\
34083 \cdot 7 \\
34114 \cdot 1 \\
34144.5\end{array}$ & $\begin{array}{l}30.421 \\
30.414 \\
30.407 \\
30.400 \\
30.393\end{array}$ & $\begin{array}{l}-6.82 \\
-6.83 \\
-6.84 \\
-6.85 \\
-6.86\end{array}$ \\
\hline $\begin{array}{l}935 \\
936 \\
937 \\
938 \\
939\end{array}$ & $\begin{array}{l}30480.4 \\
30511.6 \\
30542.8 \\
30574.0 \\
30605.1\end{array}$ & $\begin{array}{l}31.186 \\
31.179 \\
31.173 \\
31.166 \\
31.159\end{array}$ & $\begin{array}{l}-6.76 \\
-6.75 \\
-6.75 \\
-6.74 \\
-6.74\end{array}$ & $\begin{array}{l}995 \\
996 \\
997 \\
998 \\
999\end{array}$ & $\begin{array}{l}32339.6 \\
32370.4 \\
32401.1 \\
32431.9 \\
32462.7\end{array}$ & $\begin{array}{l}30.787 \\
30.781 \\
30.774 \\
30.768 \\
30.761\end{array}$ & $\begin{array}{l}-6.59 \\
-6.59 \\
-6.59 \\
-6.59 \\
-6.60\end{array}$ & $\begin{array}{l}1055 \\
1056 \\
1057 \\
1058 \\
1059\end{array}$ & $\begin{array}{l}34174.9 \\
34205.3 \\
34235.6 \\
34266.0 \\
34296.4\end{array}$ & $\begin{array}{l}30.386 \\
30.379 \\
30.373 \\
30.366 \\
30.359\end{array}$ & $\begin{array}{l}-6.87 \\
-6.88 \\
-6.89 \\
-6.90 \\
-6.90\end{array}$ \\
\hline $\begin{array}{l}940 \\
941 \\
942 \\
943 \\
944\end{array}$ & $\begin{array}{l}30636.3 \\
30667.4 \\
30698.6 \\
30729.7 \\
30760.8\end{array}$ & $\begin{array}{l}31.152 \\
31.146 \\
31.139 \\
31.132 \\
31.126\end{array}$ & $\begin{array}{l}-6.73 \\
-6.73 \\
-6.72 \\
-6.72 \\
-6.71\end{array}$ & $\begin{array}{l}1000 \\
1001 \\
1002 \\
1003 \\
1004\end{array}$ & $\begin{array}{l}32493.4 \\
32524.2 \\
32554.9 \\
32585.7 \\
32616.4\end{array}$ & $\begin{array}{l}30.754 \\
30.748 \\
30.741 \\
30.735 \\
30.728\end{array}$ & $\begin{array}{l}-6.60 \\
-6.60 \\
-6.60 \\
-6.60 \\
-6.60\end{array}$ & $\begin{array}{l}1060 \\
1061 \\
1062 \\
1063 \\
1064\end{array}$ & $\begin{array}{l}34326.7 \\
34357.1 \\
34387.4 \\
34417.7 \\
34448.1\end{array}$ & $\begin{array}{l}30.352 \\
30.345 \\
30.338 \\
30.331 \\
30.324\end{array}$ & $\begin{array}{l}-6.92 \\
-6.93 \\
-6.94 \\
-6.95 \\
-6.96\end{array}$ \\
\hline $\begin{array}{l}945 \\
946 \\
947 \\
948 \\
949\end{array}$ & $\begin{array}{l}30792.0 \\
30823.1 \\
30854.2 \\
30885.3 \\
30916.4\end{array}$ & $\begin{array}{l}31.119 \\
31.112 \\
31.105 \\
31.099 \\
31.092\end{array}$ & $\begin{array}{l}-6.71 \\
-6.70 \\
-6.70 \\
-6.69 \\
-6.69\end{array}$ & $\begin{array}{l}1005 \\
1006 \\
1007 \\
1008 \\
1009\end{array}$ & $\begin{array}{l}32647 \cdot 1 \\
32677 \cdot 8 \\
32708.6 \\
32739 \cdot 3 \\
32770.0\end{array}$ & $\begin{array}{l}30.721 \\
30.715 \\
30.708 \\
30.702 \\
30.695\end{array}$ & $\begin{array}{l}-6.60 \\
-6.60 \\
-6.61 \\
-6.61 \\
-6.61\end{array}$ & $\begin{array}{l}1065 \\
1066 \\
1067 \\
1068 \\
1069\end{array}$ & $\begin{array}{l}34478.4 \\
34508.7 \\
34539.0 \\
34569.3 \\
34599.6\end{array}$ & $\begin{array}{l}30.317 \\
30.310 \\
30.303 \\
30.296 \\
30.289\end{array}$ & $\begin{array}{l}-6.97 \\
-6.98 \\
-6.99 \\
-7.00 \\
-7.01\end{array}$ \\
\hline $\begin{array}{l}950 \\
951 \\
952 \\
953 \\
954\end{array}$ & $\begin{array}{l}30947.5 \\
30978.5 \\
31009.6 \\
31040.7 \\
31071.8\end{array}$ & $\begin{array}{l}31.085 \\
31.079 \\
31.072 \\
31.065 \\
31.059\end{array}$ & $\begin{array}{l}-6.69 \\
-6.68 \\
-6.68 \\
-6.67 \\
-6.67\end{array}$ & $\begin{array}{l}1010 \\
1011 \\
1012 \\
1013 \\
1014\end{array}$ & $\begin{array}{l}32800.7 \\
32831.3 \\
32862.0 \\
32892.7 \\
32923.4\end{array}$ & $\begin{array}{l}30.688 \\
30.682 \\
30.675 \\
30.669 \\
30.662\end{array}$ & $\begin{array}{l}-6.61 \\
-6.61 \\
-6.62 \\
-6.62 \\
-6.62\end{array}$ & $\begin{array}{l}1070 \\
1071 \\
1072 \\
1073 \\
1074\end{array}$ & $\begin{array}{l}34629.9 \\
34660.2 \\
34690.4 \\
34720.7 \\
34751.0\end{array}$ & $\begin{array}{l}30.282 \\
30.275 \\
30.268 \\
30.261 \\
30.254\end{array}$ & $\begin{array}{l}-7.03 \\
-7.04 \\
-7.05 \\
-7.06 \\
-7.08\end{array}$ \\
\hline $\begin{array}{l}955 \\
956 \\
957 \\
958 \\
959\end{array}$ & $\begin{array}{l}31102.8 \\
31133.9 \\
31164.9 \\
31195.9 \\
31227.0\end{array}$ & $\begin{array}{l}31.052 \\
31.045 \\
31.039 \\
31.032 \\
31.025\end{array}$ & $\begin{array}{l}-6.67 \\
-6.66 \\
-6.66 \\
-6.66 \\
-6.65\end{array}$ & $\begin{array}{l}1015 \\
1016 \\
1017 \\
1018 \\
1019\end{array}$ & $\begin{array}{l}32954.0 \\
32984.7 \\
33015.3 \\
33045.9 \\
33076.6\end{array}$ & $\begin{array}{l}30.655 \\
30.649 \\
30.642 \\
30.635 \\
30.629\end{array}$ & $\begin{array}{l}-6.63 \\
-6.63 \\
-6.63 \\
-6.63 \\
-6.64\end{array}$ & $\begin{array}{l}1075 \\
1076 \\
1077 \\
1078 \\
1079\end{array}$ & $\begin{array}{l}34781.2 \\
34811.5 \\
34841 \cdot 7 \\
34871.9 \\
34902.1\end{array}$ & $\begin{array}{l}30.247 \\
30.240 \\
30.233 \\
30.226 \\
30.218\end{array}$ & $\begin{array}{l}-7.09 \\
-7.10 \\
-7.12 \\
-7.13 \\
-7.14\end{array}$ \\
\hline 960 & 31258.0 & 31.019 & -6.65 & 1020 & 33107.2 & 30.622 & -6.64 & 1080 & 34932.4 & 30.211 & $-7 \cdot 16$ \\
\hline
\end{tabular}


TABLE 7.4.2. Type KP (or EP) thermoelements versus platinum, Pt-67-thermoelectric voltages. $\mathrm{E}(\mathrm{T})$, Seebeck coefficients, $\mathrm{S}(\mathrm{T})$, and first derivative of the Seebeck coefficients,

$\mathrm{dS} / \mathrm{dT}$, reference junctions al $0^{\circ} \mathrm{C}$-Continued

\begin{tabular}{|c|c|c|c|c|c|c|c|c|c|c|c|}
\hline${ }^{\circ} \mathrm{C}$ & $\underset{\mu V}{E}$ & $\mu V^{\circ}{ }^{\circ} \mathrm{C}$ & $\begin{array}{l}d S / d T \\
n V /{ }^{\circ} C^{2}\end{array}$ & ${ }^{\circ} \mathrm{C}$ & $\underset{\mu V}{E}$ & $\underset{\mu V /{ }^{\circ} \mathrm{C}}{\mathrm{S}}$ & $\begin{array}{l}d S / d T \\
n V /{ }^{\circ} C^{2}\end{array}$ & ${ }^{\circ} \mathrm{C}$ & $\underset{\mu V}{E}$ & $\mu{\mathrm{V} /{ }^{\circ} \mathrm{C}}^{\mathrm{S}}$ & $\begin{array}{l}\mathrm{d} S / \mathrm{dT} \\
\mathrm{nV} /{ }^{\circ} \mathrm{C}^{\mathrm{C}}\end{array}$ \\
\hline $\begin{array}{l}1085 \\
1086 \\
1087 \\
1088 \\
1089\end{array}$ & $\begin{array}{l}35083.3 \\
35113.5 \\
35143.7 \\
35173.8 \\
35204.0\end{array}$ & $\begin{array}{l}30.175 \\
30.168 \\
30.161 \\
30.154 \\
30.146\end{array}$ & $\begin{array}{l}-7.23 \\
-7.25 \\
-7.26 \\
-7.28 \\
-7.29\end{array}$ & $\begin{array}{l}1145 \\
1146 \\
1147 \\
1148 \\
1149\end{array}$ & $\begin{array}{l}36880.2 \\
36909.9 \\
36939.6 \\
36969.2 \\
36998.9\end{array}$ & $\begin{array}{l}29.706 \\
29.697 \\
29.689 \\
29.680 \\
29.672\end{array}$ & $\begin{array}{l}-8.55 \\
-8.58 \\
-8.61 \\
-8.64 \\
-8.68\end{array}$ & $\begin{array}{l}1205 \\
1206 \\
1207 \\
1208 \\
1209\end{array}$ & $\begin{array}{l}38645 \cdot 9 \\
38675 \cdot 0 \\
38704 \cdot 1 \\
38733 \cdot 2 \\
38762 \cdot 3\end{array}$ & $\begin{array}{l}29.129 \\
29.118 \\
29.107 \\
29.096 \\
29.085\end{array}$ & $\begin{array}{l}-10.8 \\
-10.9 \\
-10.9 \\
-11.0 \\
-11.0\end{array}$ \\
\hline $\begin{array}{l}1090 \\
1091 \\
1092 \\
1093 \\
1094\end{array}$ & $\begin{array}{l}35234 \cdot 1 \\
35264 \cdot 2 \\
35294 \cdot 4 \\
35324 \cdot 5 \\
35354 \cdot 6\end{array}$ & $\begin{array}{l}30.139 \\
30.132 \\
30.124 \\
30.117 \\
30.110\end{array}$ & $\begin{array}{l}-7.31 \\
-7.33 \\
-7.34 \\
-7.36 \\
-7.38\end{array}$ & $\begin{array}{l}1150 \\
1151 \\
1152 \\
1153 \\
1154\end{array}$ & $\begin{array}{l}37028.6 \\
37058.2 \\
37087.9 \\
37117.5 \\
37147.2\end{array}$ & $\begin{array}{l}29.663 \\
29.654 \\
29.645 \\
29.637 \\
29.628\end{array}$ & $\begin{array}{l}-8.71 \\
-8.74 \\
-8.77 \\
-8.80 \\
-8.83\end{array}$ & $\begin{array}{l}1210 \\
1211 \\
1212 \\
1213 \\
1214\end{array}$ & $\begin{array}{l}38791 \cdot 4 \\
38820 \cdot 5 \\
38849 \cdot 5 \\
38878 \cdot 6 \\
38907 \cdot 6\end{array}$ & $\begin{array}{l}29.074 \\
29.063 \\
29.052 \\
29.041 \\
29.029\end{array}$ & $\begin{array}{l}-11.1 \\
-11.1 \\
-11.2 \\
-11.2 \\
-11.3\end{array}$ \\
\hline $\begin{array}{l}1100 \\
1101 \\
1102 \\
1103 \\
1104\end{array}$ & $\begin{array}{l}35535 \cdot 1 \\
35565 \cdot 2 \\
35595 \cdot 2 \\
35625 \cdot 3 \\
35655.3\end{array}$ & $\begin{array}{l}30.065 \\
30.057 \\
30.050 \\
30.042 \\
30.035\end{array}$ & $\begin{array}{l}-7.48 \\
-7.50 \\
-7.52 \\
-7.54 \\
-7.56\end{array}$ & $\begin{array}{l}1160 \\
1161 \\
1162 \\
1163 \\
1164\end{array}$ & $\begin{array}{l}37324.8 \\
37354 \cdot 3 \\
37383.9 \\
37413.5 \\
37443.0\end{array}$ & $\begin{array}{l}29.574 \\
29.565 \\
29.556 \\
29.547 \\
29.538\end{array}$ & $\begin{array}{l}-9.03 \\
-9.06 \\
-9.10 \\
-9.13 \\
-9.17\end{array}$ & $\begin{array}{l}1220 \\
1221 \\
1222 \\
1223 \\
1224\end{array}$ & $\begin{array}{l}39081.6 \\
39110.5 \\
39139 \cdot 5 \\
39168.4 \\
39197.3\end{array}$ & $\begin{array}{l}28.961 \\
28.949 \\
28.937 \\
28.926 \\
28.914\end{array}$ & $\begin{array}{l}-11.6 \\
-11.6 \\
-11.7 \\
-11.7 \\
-11.8\end{array}$ \\
\hline $\begin{array}{l}1105 \\
1106 \\
1107 \\
1108 \\
1109\end{array}$ & $\begin{array}{l}35685.4 \\
35715.4 \\
35745.4 \\
35775.4 \\
35805.4\end{array}$ & $\begin{array}{l}30.027 \\
30.020 \\
30.012 \\
30.004 \\
29.997\end{array}$ & $\begin{array}{l}-7.58 \\
-7.60 \\
-7.62 \\
-7.64 \\
-7.66\end{array}$ & $\begin{array}{l}1165 \\
1166 \\
1167 \\
1168 \\
1169\end{array}$ & $\begin{array}{l}37472.5 \\
37502.1 \\
37531.6 \\
37561.1 \\
37590.6\end{array}$ & $\begin{array}{l}29.529 \\
29.519 \\
29.510 \\
29.501 \\
29.492\end{array}$ & $\begin{array}{l}-9.20 \\
-9.24 \\
-9.27 \\
-9.31 \\
-9.35\end{array}$ & $\begin{array}{l}1225 \\
1226 \\
1227 \\
1228 \\
1229\end{array}$ & $\begin{array}{l}39226.2 \\
39255 \cdot 1 \\
39284 \cdot 0 \\
39312 \cdot 9 \\
39341.8\end{array}$ & $\begin{array}{l}28.902 \\
28.890 \\
28.878 \\
28.866 \\
28.854\end{array}$ & $\begin{array}{l}-11.8 \\
-11.9 \\
-11.9 \\
-12.0 \\
-12.1\end{array}$ \\
\hline $\begin{array}{llll}1 & 1 & 1 & 0 \\
1 & 1 & 1 & 1 \\
1 & 1 & 1 & 2 \\
1 & 1 & 1 & 3 \\
1 & 1 & 1 & 4\end{array}$ & $\begin{array}{l}35835.4 \\
35865.4 \\
35895.4 \\
35925.3 \\
35955.3\end{array}$ & $\begin{array}{l}29.989 \\
29 \cdot 981 \\
29.974 \\
29.966 \\
29.958\end{array}$ & $\begin{array}{l}-7.68 \\
-7.70 \\
-7.72 \\
-7.74 \\
-7.76\end{array}$ & $\begin{array}{l}1170 \\
1171 \\
1172 \\
1173 \\
1174\end{array}$ & $\begin{array}{l}37620.1 \\
37649.5 \\
37679.0 \\
37708.5 \\
37737.9\end{array}$ & $\begin{array}{l}29.482 \\
29.473 \\
29.463 \\
29.454 \\
29.444\end{array}$ & $\begin{array}{l}-9.38 \\
-9.42 \\
-9.46 \\
-9.49 \\
-9.53\end{array}$ & $\begin{array}{l}1230 \\
1231 \\
1232 \\
1233 \\
1234\end{array}$ & $\begin{array}{l}39370 \cdot 6 \\
39399 \cdot 4 \\
39428 \cdot 3 \\
39457 \cdot 1 \\
39485.9\end{array}$ & $\begin{array}{l}28.842 \\
28.830 \\
28.817 \\
28.805 \\
28.793\end{array}$ & $\begin{array}{l}-12 \cdot 1 \\
-12 \cdot 2 \\
-12 \cdot 2 \\
-12 \cdot 3 \\
-12 \cdot 3\end{array}$ \\
\hline $\begin{array}{l}1120 \\
1121 \\
1122 \\
1123 \\
1124\end{array}$ & $\begin{array}{l}36134 \cdot 9 \\
36164 \cdot 8 \\
36194.7 \\
36224.6 \\
36254 \cdot 5\end{array}$ & $\begin{array}{l}29.911 \\
29.903 \\
29.895 \\
29.888 \\
29.880\end{array}$ & $\begin{array}{l}-7.90 \\
-7.92 \\
-7.94 \\
-7.97 \\
-7.99\end{array}$ & $\begin{array}{l}1180 \\
1181 \\
1182 \\
1183 \\
1184\end{array}$ & $\begin{array}{l}37914.4 \\
37943.8 \\
37973.2 \\
38002.5 \\
38031.9\end{array}$ & $\begin{array}{l}29 \cdot 386 \\
29 \cdot 377 \\
29 \cdot 367 \\
29 \cdot 357 \\
29.347\end{array}$ & $\begin{array}{l}-9.76 \\
-9.80 \\
-9.84 \\
-9.89 \\
-9.93\end{array}$ & $\begin{array}{l}1240 \\
1241 \\
1242 \\
1243 \\
1244\end{array}$ & $\begin{array}{l}39658.4 \\
39687.1 \\
39715.8 \\
39744.5 \\
39773.2\end{array}$ & $\begin{array}{l}28.717 \\
28.704 \\
28.692 \\
28.679 \\
28.666\end{array}$ & $\begin{array}{l}-12 \cdot 7 \\
-12 \cdot 8 \\
-12 \cdot 8 \\
-12 \cdot 9 \\
-12 \cdot 9\end{array}$ \\
\hline $\begin{array}{l}1125 \\
1126 \\
1127 \\
1128 \\
1122\end{array}$ & $\begin{array}{l}36284 \cdot 4 \\
36314.2 \\
36344 \cdot 1 \\
36373.9 \\
36403.8\end{array}$ & $\begin{array}{l}29.872 \\
29.864 \\
29.855 \\
29.847 \\
29.839\end{array}$ & $\begin{array}{l}-8.02 \\
-8.04 \\
-3.07 \\
-8.09 \\
-8.12\end{array}$ & $\begin{array}{l}1185 \\
1186 \\
1187 \\
1188 \\
1189\end{array}$ & $\begin{array}{l}38061.2 \\
38090.5 \\
38119 \cdot 9 \\
38149 \cdot 2 \\
38178.5\end{array}$ & $\begin{array}{l}29.337 \\
29.327 \\
29 \cdot 317 \\
29 \cdot 307 \\
29.297\end{array}$ & $\begin{array}{r}-9.97 \\
-10.01 \\
-10.05 \\
-10.09 \\
-10.13\end{array}$ & $\begin{array}{l}1245 \\
1246 \\
1247 \\
1248 \\
1249\end{array}$ & $\begin{array}{l}39801.8 \\
39830 \cdot 5 \\
39859 \cdot 1 \\
39887 \cdot 7 \\
39916.3\end{array}$ & $\begin{array}{l}28.653 \\
28.640 \\
28.627 \\
28.613 \\
28.600\end{array}$ & $\begin{array}{l}-13 \cdot 0 \\
-13 \cdot 1 \\
-13 \cdot 1 \\
-13 \cdot 2 \\
-13 \cdot 3\end{array}$ \\
\hline $\begin{array}{l}11130 \\
11131 \\
11132 \\
1133 \\
1134\end{array}$ & $\begin{array}{l}36433.6 \\
36463.5 \\
36493.3 \\
36523.1 \\
36552.9\end{array}$ & $\begin{array}{l}29.831 \\
29.823 \\
29.815 \\
29.807 \\
29.798\end{array}$ & $\begin{array}{l}-8.14 \\
-8.17 \\
-8.19 \\
-8.22 \\
-8.25\end{array}$ & $\begin{array}{l}1190 \\
1191 \\
1192 \\
1193 \\
1194\end{array}$ & $\begin{array}{l}38207.8 \\
38237.1 \\
38266.3 \\
38295.6 \\
38324.8\end{array}$ & $\begin{array}{l}29.287 \\
29.277 \\
29.266 \\
29.256 \\
29.246\end{array}$ & $\begin{array}{l}-10.18 \\
-10.22 \\
-10.26 \\
-10.31 \\
-10.35\end{array}$ & $\begin{array}{l}1250 \\
1251 \\
1252 \\
1253 \\
1254\end{array}$ & $\begin{array}{l}39944 \cdot 9 \\
39973 \cdot 5 \\
40002 \cdot 1 \\
40030 \cdot 6 \\
40059 \cdot 2\end{array}$ & $\begin{array}{l}28.587 \\
28.573 \\
28.560 \\
28.546 \\
28.533\end{array}$ & $\begin{array}{l}-13.3 \\
-13.4 \\
-13.5 \\
-13.5 \\
-13.6\end{array}$ \\
\hline $\begin{array}{l}1135 \\
1136 \\
1137 \\
1138 \\
1139\end{array}$ & $\begin{array}{l}36582 \cdot 7 \\
36612 \cdot 5 \\
36642 \cdot 2 \\
36672 \cdot 0 \\
36701.8\end{array}$ & $\begin{array}{l}29 \cdot 790 \\
29 \cdot 782 \\
29 \cdot 774 \\
29 \cdot 765 \\
29.757\end{array}$ & $\begin{array}{l}-8 \cdot 27 \\
-8.30 \\
-8.33 \\
-8.35 \\
-8.38\end{array}$ & $\begin{array}{l}1195 \\
1196 \\
1197 \\
1198 \\
1199\end{array}$ & $\begin{array}{l}38354 \cdot 1 \\
38383.3 \\
38412.5 \\
38441.7 \\
38470.9\end{array}$ & $\begin{array}{l}29.235 \\
29.225 \\
29.214 \\
29.204 \\
29.193\end{array}$ & $\begin{array}{l}-10.40 \\
-10.44 \\
-10.49 \\
-10.53 \\
-10.58\end{array}$ & $\begin{array}{l}1255 \\
1256 \\
1257 \\
1258 \\
1259\end{array}$ & $\begin{array}{l}40087 \cdot 7 \\
40116 \cdot 2 \\
40144 \cdot 7 \\
40173 \cdot 2 \\
40201 \cdot 7\end{array}$ & $\begin{array}{l}28.519 \\
28.505 \\
28.492 \\
28.478 \\
28.464\end{array}$ & $\begin{array}{l}-13.7 \\
-13.7 \\
-13.8 \\
-13.9 \\
-13.9\end{array}$ \\
\hline 40 & 36731.5 & 29.748 & $-8 \cdot 41$ & 1200 & 38500.1 & $29 \cdot 183$ & $-10 \cdot 62$ & 1260 & $40230 \cdot 1$ & 28.450 & -14 \\
\hline
\end{tabular}




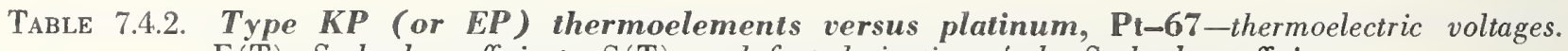
$\mathrm{E}(\mathrm{T})$, Seebeck coefficients, $\mathrm{S}(\mathrm{T})$, and first derivative of the Seebeck coefficients.

$\mathrm{dS} / \mathrm{dT}$, reference junctions at $0^{\circ} \mathrm{C}$-Continued

\begin{tabular}{|c|c|c|c|c|c|c|c|c|c|c|c|}
\hline${ }^{\top} \mathrm{C}$ & $\begin{array}{c}E \\
\mu V\end{array}$ & $\stackrel{S}{S V /{ }^{\circ} \mathrm{C}}$ & $\begin{array}{l}d S / d T \\
n V /{ }^{\circ} C^{2}\end{array}$ & ${ }^{\circ} \mathrm{C}$ & $\begin{array}{c}E \\
\mu V\end{array}$ & $\begin{array}{c}\mathrm{S} \\
\mu \mathrm{V} /{ }^{\circ} \mathrm{C}\end{array}$ & $\begin{array}{l}d S / d T \\
n V /{ }^{\circ} C^{2}\end{array}$ & ${ }^{\circ} \mathrm{C}$ & $\begin{array}{c}E \\
\mu V\end{array}$ & $\underset{\mu V /{ }^{\circ} \mathrm{C}}{S}$ & $\begin{array}{l}\mathrm{dS} / \mathrm{dT} \\
\mathrm{nV} /{ }^{\circ} \mathrm{C}^{2}\end{array}$ \\
\hline $\begin{array}{l}1260 \\
1261 \\
1262 \\
1263 \\
1264\end{array}$ & $\begin{array}{l}40230.1 \\
40258.6 \\
40287.0 \\
40315.4 \\
40343.8\end{array}$ & $\begin{array}{l}28.450 \\
28.436 \\
28.422 \\
28.407 \\
28.393\end{array}$ & $\begin{array}{l}-14.03 \\
-14.10 \\
-14.17 \\
-14.24 \\
-14.31\end{array}$ & $\begin{array}{l}1300 \\
1301 \\
1302 \\
1303 \\
1304\end{array}$ & $\begin{array}{l}41356 \cdot 1 \\
41383 \cdot 9 \\
41411.7 \\
41439 \cdot 5 \\
41467.3\end{array}$ & $\begin{array}{l}27.830 \\
27.812 \\
27.795 \\
27.778 \\
27.761\end{array}$ & $\begin{array}{l}-17.09 \\
-17.17 \\
-17.26 \\
-17.35 \\
-17.43\end{array}$ & $\begin{array}{l}1340 \\
1341 \\
1342 \\
1343 \\
1344\end{array}$ & $\begin{array}{l}42454 \cdot 7 \\
42481.7 \\
42508.8 \\
42535.8 \\
42562.8\end{array}$ & $\begin{array}{l}27.073 \\
27.052 \\
27.031 \\
27.010 \\
26.989\end{array}$ & $\begin{array}{l}-20.86 \\
-20.97 \\
-21.07 \\
-21.18 \\
-21.28\end{array}$ \\
\hline $\begin{array}{l}1265 \\
1266 \\
1267 \\
1268 \\
1269\end{array}$ & $\begin{array}{l}40372.2 \\
40400.6 \\
40428 \cdot 9 \\
40457.3 \\
40485.6\end{array}$ & $\begin{array}{l}28 \cdot 379 \\
28 \cdot 364 \\
28 \cdot 350 \\
28 \cdot 335 \\
28 \cdot 321\end{array}$ & $\begin{array}{l}-14.38 \\
-14.45 \\
-14.52 \\
-14.59 \\
-14.66\end{array}$ & $\begin{array}{l}1305 \\
1306 \\
1307 \\
1308 \\
1309\end{array}$ & $\begin{array}{l}41495.0 \\
41522.8 \\
41550 \cdot 5 \\
41578.2 \\
41605.9\end{array}$ & $\begin{array}{l}27.743 \\
27.726 \\
27.708 \\
27.690 \\
27.672\end{array}$ & $\begin{array}{l}-17.52 \\
-17.61 \\
-17.70 \\
-17.78 \\
-17.87\end{array}$ & $\begin{array}{l}1345 \\
1346 \\
1347 \\
1348 \\
1349\end{array}$ & $\begin{array}{l}42589.8 \\
42616.7 \\
42643.7 \\
42670.6 \\
42697.5\end{array}$ & $\begin{array}{l}26.967 \\
26.946 \\
26.924 \\
26.903 \\
26.881\end{array}$ & $\begin{array}{l}-21.39 \\
-21.50 \\
-21.60 \\
-21.71 \\
-21.82\end{array}$ \\
\hline $\begin{array}{l}1270 \\
1271 \\
1272 \\
1273 \\
1274\end{array}$ & $\begin{array}{l}40513.9 \\
40542.2 \\
40570.5 \\
40598.8 \\
40627.0\end{array}$ & $\begin{array}{l}28.306 \\
28.291 \\
28.276 \\
28.261 \\
28.246\end{array}$ & $\begin{array}{l}-14.73 \\
-14.81 \\
-14.88 \\
-14.95 \\
-15.02\end{array}$ & $\begin{array}{l}1310 \\
1311 \\
1312 \\
1313 \\
1314\end{array}$ & $\begin{array}{l}41633.5 \\
41661.2 \\
41688.8 \\
41716.4 \\
41744.0\end{array}$ & $\begin{array}{l}27.654 \\
27.636 \\
27.618 \\
27.600 \\
27.582\end{array}$ & $\begin{array}{l}-17.96 \\
-18.05 \\
-18.14 \\
-18.23 \\
-18.33\end{array}$ & $\begin{array}{l}1350 \\
1351 \\
1352 \\
1353 \\
1354\end{array}$ & $\begin{array}{l}42724 \cdot 3 \\
42751 \cdot 2 \\
42778 \cdot 0 \\
42804 \cdot 8 \\
42831 \cdot 6\end{array}$ & $\begin{array}{l}26.859 \\
26.837 \\
26.815 \\
26.793 \\
26.771\end{array}$ & $\begin{array}{l}-21.93 \\
-22.04 \\
-22.15 \\
-22.26 \\
-22.37\end{array}$ \\
\hline $\begin{array}{l}1275 \\
1276 \\
1277 \\
1278 \\
1279\end{array}$ & $\begin{array}{l}40655.2 \\
40683.5 \\
40711.7 \\
40739.9 \\
40768.1\end{array}$ & $\begin{array}{l}28.231 \\
28.216 \\
28.201 \\
28.186 \\
28.170\end{array}$ & $\begin{array}{l}-15.10 \\
-15.17 \\
-15.25 \\
-15.32 \\
-15.40\end{array}$ & $\begin{array}{l}1315 \\
1316 \\
1317 \\
1318 \\
1319\end{array}$ & $\begin{array}{l}41771.6 \\
41799 \cdot 1 \\
41826.7 \\
41854 \cdot 2 \\
41881.7\end{array}$ & $\begin{array}{l}27.563 \\
27.545 \\
27.526 \\
27.508 \\
27.489\end{array}$ & $\begin{array}{l}-18.42 \\
-18.51 \\
-18.60 \\
-18.69 \\
-18.79\end{array}$ & $\begin{array}{l}1355 \\
1356 \\
1357 \\
1358 \\
1359\end{array}$ & $\begin{array}{l}42858 \cdot 4 \\
42885 \cdot 1 \\
42911.8 \\
42938 \cdot 5 \\
42965.2\end{array}$ & $\begin{array}{l}26.748 \\
26.726 \\
26.703 \\
26.680 \\
26.657\end{array}$ & $\begin{array}{l}-22.48 \\
-22.59 \\
-22.70 \\
-22.82 \\
-22.93\end{array}$ \\
\hline $\begin{array}{l}1280 \\
1281 \\
1282 \\
1283 \\
1284\end{array}$ & $\begin{array}{l}40796.2 \\
40824.4 \\
40852.5 \\
40880.6 \\
40908.7\end{array}$ & $\begin{array}{l}28.155 \\
28.139 \\
28.124 \\
28.108 \\
28.092\end{array}$ & $\begin{array}{l}-15.48 \\
-15.55 \\
-15.63 \\
-15.71 \\
-15.78\end{array}$ & $\begin{array}{l}1320 \\
1321 \\
1322 \\
1323 \\
1324\end{array}$ & $\begin{array}{l}41909.2 \\
41936.6 \\
41964.1 \\
41991.5 \\
42018.9\end{array}$ & $\begin{array}{l}27.470 \\
27.451 \\
27.432 \\
27.413 \\
27.394\end{array}$ & $\begin{array}{l}-18.88 \\
-18.98 \\
-19.07 \\
-19.17 \\
-19.26\end{array}$ & $\begin{array}{l}1360 \\
1361 \\
1362 \\
1363 \\
1364\end{array}$ & $\begin{array}{l}42991.8 \\
43018.4 \\
43045.0 \\
43071.6 \\
43098.2\end{array}$ & $\begin{array}{l}26.634 \\
26.611 \\
26.588 \\
26.565 \\
26.541\end{array}$ & $\begin{array}{l}-23.04 \\
-23.16 \\
-23.27 \\
-23.39 \\
-23.51\end{array}$ \\
\hline $\begin{array}{l}1285 \\
1286 \\
1287 \\
1288 \\
1289\end{array}$ & $\begin{array}{l}40936.8 \\
40964.9 \\
40992.9 \\
41021.0 \\
41049.0\end{array}$ & $\begin{array}{l}28.077 \\
28.061 \\
28.045 \\
28.029 \\
28.013\end{array}$ & $\begin{array}{l}-15.86 \\
-15.94 \\
-16.02 \\
-16.10 \\
-16.18\end{array}$ & $\begin{array}{l}1325 \\
1326 \\
1327 \\
1328 \\
1329\end{array}$ & $\begin{array}{l}42046.3 \\
42073.6 \\
42101.0 \\
42128.3 \\
42155.6\end{array}$ & $\begin{array}{l}27 \cdot 375 \\
27 \cdot 355 \\
27 \cdot 336 \\
27 \cdot 316 \\
27.296\end{array}$ & $\begin{array}{l}-19.36 \\
-19.46 \\
-19.55 \\
-19.65 \\
-19.75\end{array}$ & $\begin{array}{l}1365 \\
1366 \\
1367 \\
1368 \\
1369\end{array}$ & $\begin{array}{l}43124 \cdot 7 \\
43151 \cdot 2 \\
43177 \cdot 7 \\
43204 \cdot 1 \\
43230 \cdot 6\end{array}$ & $\begin{array}{l}26.518 \\
26.494 \\
26.470 \\
26.446 \\
26.422\end{array}$ & $\begin{array}{l}-23.62 \\
-23.74 \\
-23.86 \\
-23.98 \\
-24.09\end{array}$ \\
\hline $\begin{array}{l}1290 \\
1291 \\
1292 \\
1293 \\
1294\end{array}$ & $\begin{array}{l}41077.0 \\
41105.0 \\
41132.9 \\
41160.9 \\
41188.8\end{array}$ & $\begin{array}{l}27.996 \\
27.980 \\
27.964 \\
27.947 \\
27.931\end{array}$ & $\begin{array}{l}-16.26 \\
-16.34 \\
-16.42 \\
-16.50 \\
-16.59\end{array}$ & $\begin{array}{l}1330 \\
1331 \\
1332 \\
1333 \\
1334\end{array}$ & $\begin{array}{l}42182.9 \\
42210.2 \\
42237.4 \\
42264.7 \\
42291.9\end{array}$ & $\begin{array}{l}27.277 \\
27.257 \\
27.237 \\
27.217 \\
27.196\end{array}$ & $\begin{array}{l}-19.85 \\
-19.95 \\
-20.05 \\
-20.15 \\
-20.25\end{array}$ & $\begin{array}{l}1370 \\
1371 \\
1372\end{array}$ & $\begin{array}{l}43257.0 \\
43283.4 \\
43309.7\end{array}$ & $\begin{array}{l}26 \cdot 398 \\
26 \cdot 374 \\
26 \cdot 349\end{array}$ & $\begin{array}{l}-24 \cdot 21 \\
-24 \cdot 33 \\
-24.45\end{array}$ \\
\hline $\begin{array}{l}1295 \\
1296 \\
1297 \\
1298 \\
1299\end{array}$ & $\begin{array}{l}41216 \cdot 8 \\
41244 \cdot 7 \\
41272 \cdot 5 \\
41300 \cdot 4 \\
41328.3\end{array}$ & $\begin{array}{l}27.914 \\
27.897 \\
27.880 \\
27.864 \\
27.847\end{array}$ & $\begin{array}{l}-16.67 \\
-16.75 \\
-16.84 \\
-16.92 \\
-17.00\end{array}$ & $\begin{array}{l}1335 \\
1336 \\
1337 \\
1338 \\
1339\end{array}$ & $\begin{array}{l}42319.0 \\
42346.2 \\
42373.4 \\
42400.5 \\
42427.6\end{array}$ & $\begin{array}{l}27.176 \\
27.156 \\
27.135 \\
27.115 \\
27.094\end{array}$ & $\begin{array}{l}-20.35 \\
-20.45 \\
-20.55 \\
-20.66 \\
-20.76\end{array}$ & & & & \\
\hline 1300 & 41356.1 & 27.830 & -17.09 & 1340 & 42454.7 & 27.073 & -20.86 & & & & \\
\hline
\end{tabular}


TABLE 7.4.3. Thermoelectric values at the fixed points for Type KP (or EP) thermoelements versus platinum, $\mathrm{Pt}-67$

\begin{tabular}{|c|c|c|c|c|}
\hline Fixed point & $\begin{array}{c}\text { Temp. } \\
{ }^{\circ} \mathrm{C}\end{array}$ & $\begin{array}{c}E \\
\mu V\end{array}$ & $\begin{array}{c}S \\
\mu \mathrm{V} /{ }^{\circ} \mathrm{C}\end{array}$ & $\begin{array}{c}d S / d T \\
\mathrm{nV} / / \mathrm{C}^{2}\end{array}$ \\
\hline $\begin{array}{l}\text { Helium NBP } \\
\text { Hydrogen TP } \\
\text { Hydrogen NBP } \\
\text { Neon TP } \\
\text { Neon NBP } \\
\text { Oxygen TP } \\
\text { Nitrogen TP } \\
\text { Nitrogen NBP } \\
\text { Oxygen NBP } \\
\text { Carbon Dioxide SP } \\
\text { Mercury FP } \\
\text { Ice point* } \\
\text { Ether TP } \\
\text { Water BP } \\
\text { Benzoic TP } \\
\text { Indium FP } \\
\text { Tin FP } \\
\text { Bismuth FP } \\
\text { Cadmium FP } \\
\text { Lead FP } \\
\text { Mercury BP } \\
\text { Zinc FP } \\
\text { Sulphur BP } \\
\text { Cu-Al FP } \\
\text { Antimony FP } \\
\text { Aluminum FP } \\
\text { Silver FP } \\
\text { Gold FP } \\
\text { Copper FP }\end{array}$ & $\begin{array}{r}-268.935 \\
-259.340 \\
-252.870 \\
-248.595 \\
-246.048 \\
-218.789 \\
-210.002 \\
-195.802 \\
-182.962 \\
-78.476 \\
-38.862 \\
0.000 \\
26.870 \\
100.000 \\
122.370 \\
156.634 \\
231.9681 \\
271.442 \\
321.108 \\
327.502 \\
356.660 \\
419.580 \\
444.674 \\
548.23 \\
630.74 \\
660.37 \\
961.93 \\
1064.43 \\
1084.5\end{array}$ & $\begin{array}{r}-3556.88 \\
-3548.49 \\
-3542.32 \\
-3537.93 \\
-3535.16 \\
-3487.84 \\
-3459.76 \\
-3394.09 \\
-3310.29 \\
-1817.20 \\
-956.08 \\
0.00 \\
712.4 \\
2812.8 \\
3494.7 \\
4568.2 \\
7025.3 \\
8351.5 \\
10044.3 \\
10263.6 \\
11266.5 \\
13438.8 \\
14305.4 \\
17860.1 \\
20648.7 \\
21638.0 \\
31317.8 \\
34461.1 \\
35068.2\end{array}$ & $\begin{array}{r}0.847 \\
0.917 \\
0.994 \\
1.062 \\
1.114 \\
2.722 \\
3.701 \\
5.597 \\
7.465 \\
20.060 \\
23.295 \\
25.836 \\
27.168 \\
30.117 \\
30.837 \\
31.791 \\
33.319 \\
33.845 \\
34.282 \\
34.322 \\
34.460 \\
34.546 \\
34.512 \\
34.072 \\
33.501 \\
33.272 \\
31.006 \\
30.321 \\
30.179\end{array}$ & $\begin{array}{r}0.03 \\
10.59 \\
13.83 \\
18.56 \\
22.65 \\
99.92 \\
121.77 \\
142.26 \\
146.76 \\
90.50 \\
71.96 \\
52.24 \\
46.97 \\
34.00 \\
30.44 \\
25.32 \\
15.56 \\
11.22 \\
6.49 \\
5.94 \\
3.58 \\
-0.65 \\
-2.03 \\
-6.04 \\
-7.59 \\
-7.86 \\
-6.64 \\
-6.96 \\
-7.22\end{array}$ \\
\hline
\end{tabular}

*Junction point of different functions.

TABLE 7.4.4. Estimated maximum errors that occur when using reduced-bit arithmetic for the power series expansion for the thermoelectric voltage for Type KP (or EP) thermoelements versus platinum, $\mathrm{Pt}-67$

\begin{tabular}{|c|c|c|c|c|c|c|}
\hline \multirow[b]{2}{*}{ Temperature range } & \multirow[b]{2}{*}{ Degree } & \multicolumn{5}{|c|}{ Estimated maximum error in microvolts } \\
\hline & & 12 Bit & $16 \mathrm{Bit}$ & $24 \mathrm{Bit}$ & 27 Bit & 36 Bit \\
\hline-270 to $-200{ }^{\circ} \mathrm{C}$ & 12 & $\left({ }^{*}\right)$ & 500 & 2 & 0.1 & $<0.01$ \\
\hline-200 to $\quad 0^{\circ} \mathrm{C}$ & 12 & 400 & 50 & 0.2 & $<0.01$ & $<0.01$ \\
\hline 0 to $200{ }^{\circ} \mathrm{C}$ & 6 & 2 & 0.07 & $<0.01$ & $<0.01$ & $<0.01$ \\
\hline 200 to $400^{\circ} \mathrm{C}$ & 6 & 3 & 0.08 & $<0.01$ & $<0.01$ & $<0.01$ \\
\hline 400 to $600^{\circ} \mathrm{C}$ & 6 & 4 & 0.08 & $<0.01$ & $<0.01$ & $<0.01$ \\
\hline 600 to $\quad 800^{\circ} \mathrm{C}$ & 6 & 6 & 0.2 & $<0.01$ & $<0.01$ & $<0.01$ \\
\hline 800 to $1000^{\circ} \mathrm{C}$ & 6 & 9 & 0.5 & $<0.01$ & $<0.01$ & $<0.01$ \\
\hline 1000 to $1200^{\circ} \mathrm{C}$ & 6 & 11 & 0.9 & 0.01 & $<0.01$ & $<0.01$ \\
\hline 1200 to $1372{ }^{\circ} \mathrm{C}$ & 6 & 13 & 1 & 0.02 & $<0.01$ & $<0.01$ \\
\hline
\end{tabular}

*A high-order polynomial with a low-bit machine causes extreme error. 


\subsection{Reference Functions and Tables for Plat- inum, $\mathrm{Pt}-67$, Versus the Negative Ther- moelement, Type $\mathrm{KN}$, a Nickel-Aluminum Alloy}

The coefficients for the twelfth degree expansion for the thermoelectric voltage of $\mathrm{Pt}-67$ versus Type $\mathrm{KN}$ thermoelements below $0{ }^{\circ} \mathrm{C}$ are given in table 7.5.1. The coefficients for the eighth degree expansion plus an exponential term for use above $0{ }^{\circ} \mathrm{C}$ are also given in table 7.5.1. The errors caused by using reduced bit arithmetic for calculating values of the functions are given in table 7.5.4.

The primary reference values for $\mathrm{Pt}-67$ versus Type $\mathrm{KN}$ thermoelements are given in table 7.5.2. Values at selected fixed points are given in table 7.5.3. Graphs of the thermoelectric voltage, its first derivative (Seebeck coefficient), and second derivative are given in figures 7.5.1, 7.5.2, and 7.5.3, respectively.

It should be stressed that Type KN thermoelement material that conforms closely to the high temperature tabular values may not necessarily conform closely at low temperatures (below $0^{\circ} \mathrm{C}$ ) and vice versa. If type $\mathrm{KN}$ thermoelements are to be used for accurate measurements both above and below $0{ }^{\circ} \mathrm{C}$, then the material must be calibrated in the full temperature range, both above and below $0{ }^{\circ} \mathrm{C}$. Special selection of material will often be required.

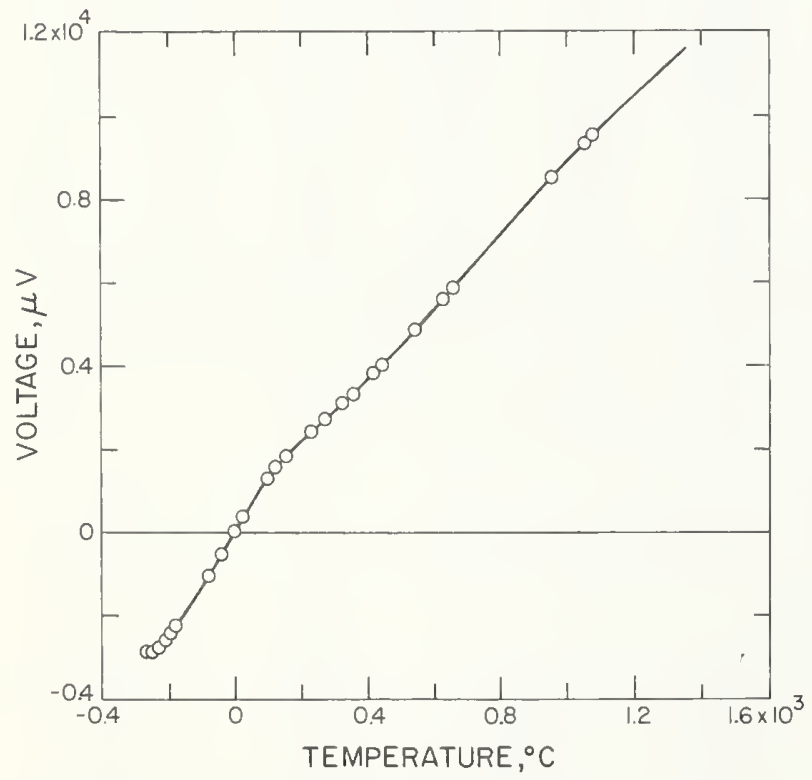

Figure 7.5.1. Thermoelectric voltage for platinum, Pt-67, versus Type KN thermoelements.

The circles indicate values at various thermometric fixed points on the IPTS -68 .

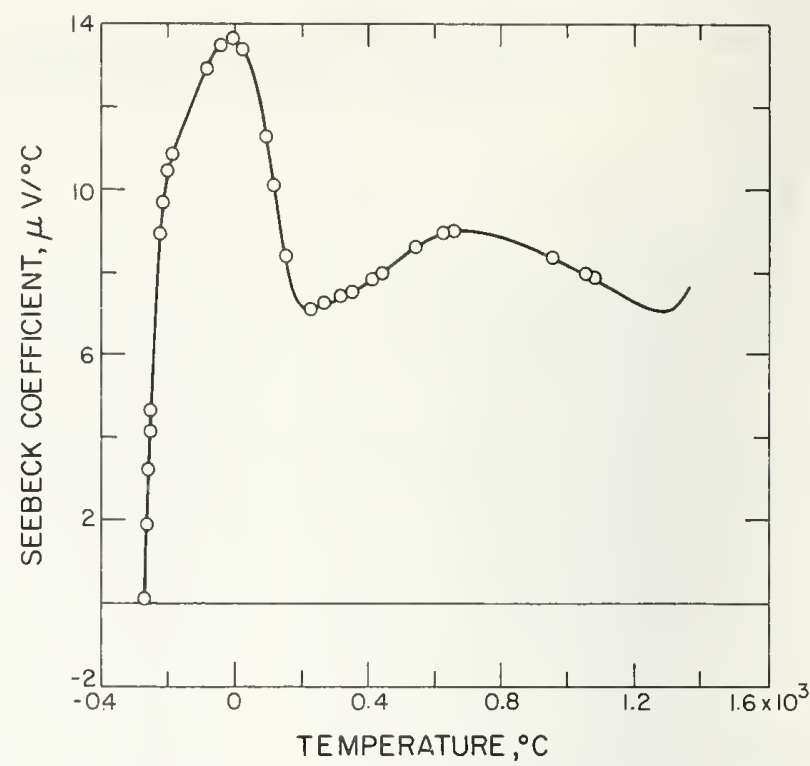

Figure 7.5.2. Seebeck coefficient for platinum, Pt-67, versus Type $K N$ thermoelements.

The circles indicate values at various thermometric fixed points on the IPTS -68 .

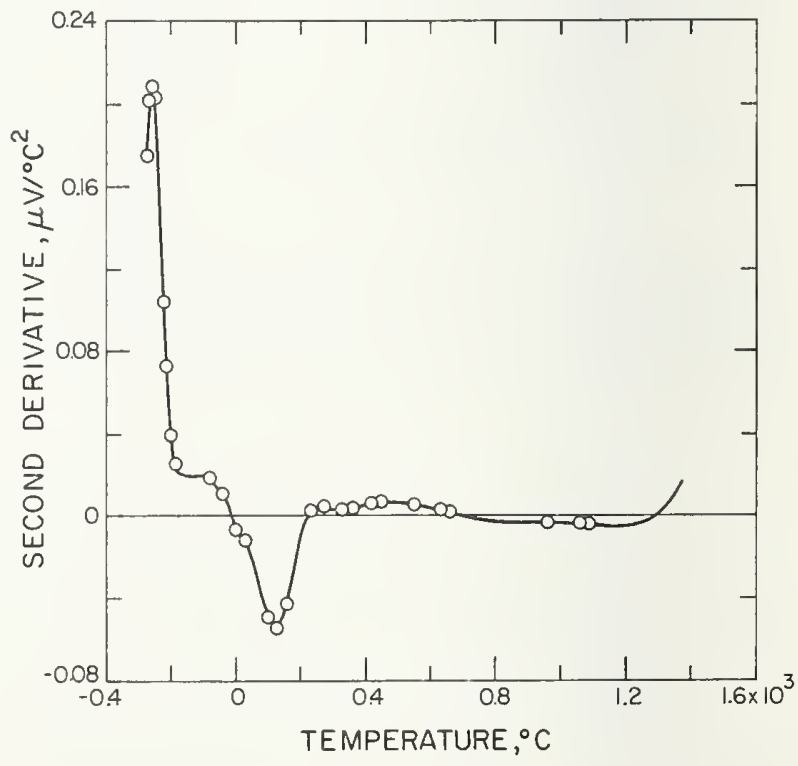

Figure 7.5.3. Second derivative of thermoelectric voltage for platinum, $P t-67$, versus Type $K N$ thermoelements.

The circles indicate values at various thermometric fixed points on the IPTS -68 . 
TABLE 7.5.1. Power series expansion for the thermoelectric voltage of platinum, $\mathrm{Pt}-67$, versus $K N$ thermoelements

\begin{tabular}{|c|c|c|c|}
\hline $\begin{array}{c}\text { Tempera- } \\
\text { ture } \\
\text { range }\end{array}$ & Degree & Coefficients & Term \\
\hline $\begin{array}{c}-270 \text { to } \\
0^{\circ} \mathrm{C}\end{array}$ & 12 & $\begin{array}{l}1.3639723006 \times 10^{1} \\
2.6310472300 \times 10^{-4} \\
2.1780230928 \times 10^{-4} \\
1.5321974393 \times 10^{-5} \\
4.2195997423 \times 10^{-7} \\
6.7685672229 \times 10^{-8} \\
6.8555647886 \times 10^{-11} \\
4.5113962880 \times 10^{-13} \\
1.9240013493 \times 10^{-16} \\
5.1234269588 \times 10^{-18} \\
7.7268515186 \times 10^{-21} \\
5.0290738536 \times 10^{-24}\end{array}$ & $\begin{array}{l}T \\
T^{2} \\
T^{3} \\
T^{4} \\
T^{5} \\
T^{6} \\
T^{7} \\
T^{8} \\
T^{9} \\
T^{10} \\
T^{11} \\
T^{12}\end{array}$ \\
\hline $\begin{array}{l}0 \text { to } \\
\quad 1372{ }^{\circ} \mathrm{C}\end{array}$ & $8+\exp$ & $\begin{array}{l}-1.8533063273 \times 10^{1} \\
1.3082634479 \times 10^{1} \\
-9.4769979320 \times 10^{-3} \\
-4.5149050693 \times 10^{-5} \\
2.1245645455 \times 10^{-7} \\
-3.5639856324 \times 10^{-10} \\
3.0053784151 \times 10^{-13} \\
-1.2849848798 \times 10^{-16} \\
2.2239974336 \times 10^{-20} \\
+125 \exp \left[-\frac{1}{2}\left(\frac{T-127}{65}\right)^{2}\right.\end{array}$ & $\begin{array}{l}\cdots \\
T \\
T^{2} \\
T^{3} \\
T^{4} \\
T^{5} \\
T^{8} \\
T^{7} \\
T^{8} \\
\end{array}$ \\
\hline
\end{tabular}


TABle 7.5.2. Platinum, Pt-67, versus Type KN thermoelements-thermoelectric voltages, E(T), Seebeck coefficients, $\mathrm{S}(\mathrm{T})$, and first derivative of the Seebeck coefficients, $\mathrm{dS} / \mathrm{dT}$,

reference junctions at $0^{\circ} \mathrm{C}$

\begin{tabular}{|c|c|c|c|c|c|c|c|c|c|c|c|}
\hline $\begin{array}{c}T \\
{ }^{\circ} \mathrm{C}\end{array}$ & $\begin{array}{c}E \\
\mu V\end{array}$ & $\underset{\mu V /{ }^{\circ} \mathrm{C}}{\mathrm{S}}$ & $\begin{array}{l}d S / d T \\
n V /{ }^{\circ} C^{2}\end{array}$ & ${ }^{\circ}{ }^{\top} \mathrm{C}$ & $\begin{array}{c}E \\
\mu V\end{array}$ & $\begin{array}{c}\mathrm{S} \\
\mu \mathrm{V} /{ }^{\circ} \mathrm{C}\end{array}$ & $\begin{array}{l}d S / d T \\
n V /{ }^{\circ} C^{2}\end{array}$ & ${ }^{\circ} \mathrm{C}$ & $\begin{array}{c}E \\
\mu V\end{array}$ & $\underset{\mu \mathrm{V} /{ }^{\circ} \mathrm{C}}{\mathrm{S}}$ & $\begin{array}{l}\mathrm{dS} / \mathrm{dT} \\
\mathrm{nV} /{ }^{\circ} \mathrm{C}^{2}\end{array}$ \\
\hline $\begin{array}{l}-270 \\
-269 \\
-268 \\
-267 \\
-266\end{array}$ & $\begin{array}{l}-2900.03 \\
-2900.06 \\
-2899.91 \\
-2899.58 \\
-2899.07\end{array}$ & $\begin{array}{r}-0.110 \\
0.063 \\
0.239 \\
0.418 \\
0.601\end{array}$ & $\begin{array}{l}172.01 \\
174.72 \\
177.61 \\
180.61 \\
183.65\end{array}$ & $\begin{array}{l}-240 \\
-239 \\
-238 \\
-237 \\
-236\end{array}$ & $\begin{array}{l}-2815.99 \\
-2810.09 \\
-2804.00 \\
-2797.74 \\
-2791.30\end{array}$ & $\begin{array}{l}5.807 \\
5.992 \\
6.174 \\
6.353 \\
6.528\end{array}$ & $\begin{array}{l}186.94 \\
183.72 \\
180.33 \\
176.81 \\
173.15\end{array}$ & $\begin{array}{l}-210 \\
-209 \\
-208 \\
-207 \\
-206\end{array}$ & $\begin{array}{l}-2574.87 \\
-2565.16 \\
-2555.38 \\
-2545.54 \\
-2535.64\end{array}$ & $\begin{array}{l}9.672 \\
9.743 \\
9.810 \\
9.875 \\
9.937\end{array}$ & $\begin{array}{l}72.09 \\
69.05 \\
66.11 \\
63.29 \\
60.56\end{array}$ \\
\hline $\begin{array}{l}-265 \\
-264 \\
-263 \\
-262 \\
-261\end{array}$ & $\begin{array}{l}-2898.37 \\
-2897.50 \\
-2896.43 \\
-2895.16 \\
-2893.71\end{array}$ & $\begin{array}{l}0.786 \\
0.974 \\
1.165 \\
1.359 \\
1.555\end{array}$ & $\begin{array}{l}186.68 \\
189.63 \\
192.47 \\
195.16 \\
197.65\end{array}$ & $\begin{array}{l}-235 \\
-234 \\
-233 \\
-232 \\
-231\end{array}$ & $\begin{array}{l}-2784.69 \\
-2777.90 \\
-2770.95 \\
-2763.84 \\
-2756.58\end{array}$ & $\begin{array}{l}6.699 \\
6.867 \\
7.030 \\
7.190 \\
7.345\end{array}$ & $\begin{array}{l}169.37 \\
165.50 \\
161.54 \\
157.50 \\
153.41\end{array}$ & $\begin{array}{l}-205 \\
-204 \\
-203 \\
-202 \\
-201\end{array}$ & $\begin{array}{l}-2525.67 \\
-2515.64 \\
-2505.56 \\
-2495.43 \\
-2485.25\end{array}$ & $\begin{array}{r}9.996 \\
10.053 \\
10.107 \\
10.159 \\
10.208\end{array}$ & $\begin{array}{l}57.95 \\
55.45 \\
53.05 \\
50.76 \\
48.58\end{array}$ \\
\hline $\begin{array}{l}-260 \\
-259 \\
-258 \\
-257 \\
-256\end{array}$ & $\begin{array}{l}-2892.05 \\
-2890.20 \\
-2888.14 \\
-2885.88 \\
-2883.42\end{array}$ & $\begin{array}{l}1.754 \\
1.955 \\
2.158 \\
2.362 \\
2.568\end{array}$ & $\begin{array}{l}199.93 \\
201.97 \\
203.74 \\
205.24 \\
206.45\end{array}$ & $\begin{array}{l}-230 \\
-229 \\
-228 \\
-227 \\
-226\end{array}$ & $\begin{array}{l}-2749.16 \\
-2741.59 \\
-2733.87 \\
-2726.01 \\
-2718.02\end{array}$ & $\begin{array}{l}7.496 \\
7.644 \\
7.787 \\
7.925 \\
8.060\end{array}$ & $\begin{array}{l}149.27 \\
145.09 \\
140.89 \\
136.68 \\
132.47\end{array}$ & $\begin{array}{l}-200 \\
-199 \\
-198 \\
-197 \\
-196\end{array}$ & $\begin{array}{l}-2475.02 \\
-2464.74 \\
-2454.41 \\
-2444.05 \\
-2433.64\end{array}$ & $\begin{array}{l}10.256 \\
10.301 \\
10.345 \\
10.387 \\
10.427\end{array}$ & $\begin{array}{l}46.50 \\
44.52 \\
42.65 \\
40.88 \\
39.20\end{array}$ \\
\hline $\begin{array}{l}-255 \\
-254 \\
-253 \\
-252 \\
-251\end{array}$ & $\begin{array}{l}-2880.75 \\
-2877.87 \\
-2874.78 \\
-2871.49 \\
-2867.98\end{array}$ & $\begin{array}{l}2.775 \\
2.983 \\
3.191 \\
3.399 \\
3.607\end{array}$ & $\begin{array}{l}207.37 \\
207.98 \\
208.29 \\
208.29 \\
207.99\end{array}$ & $\begin{array}{l}-225 \\
-224 \\
-223 \\
-222 \\
-221\end{array}$ & $\begin{array}{l}-2709.90 \\
-2701.64 \\
-2693.26 \\
-2684.77 \\
-2676.15\end{array}$ & $\begin{array}{l}8.190 \\
8.317 \\
8.439 \\
8.556 \\
8.670\end{array}$ & $\begin{array}{l}128.28 \\
124.10 \\
119.95 \\
115.85 \\
111.79\end{array}$ & $\begin{array}{l}-195 \\
-194 \\
-193 \\
-192 \\
-191\end{array}$ & $\begin{array}{l}-2423.19 \\
-2412.71 \\
-2402.19 \\
-2391.64 \\
-2381.05\end{array}$ & $\begin{array}{l}10.465 \\
10.502 \\
10.538 \\
10.572 \\
10.604\end{array}$ & $\begin{array}{l}37.62 \\
36.13 \\
34.73 \\
33.42 \\
32.19\end{array}$ \\
\hline $\begin{array}{l}-250 \\
-249 \\
-248 \\
-247 \\
-246\end{array}$ & $\begin{array}{l}-2864.27 \\
-2860.35 \\
-2856.23 \\
-2851.90 \\
-2847.36\end{array}$ & $\begin{array}{l}3.815 \\
4.022 \\
4.228 \\
4.433 \\
4.636\end{array}$ & $\begin{array}{l}207.39 \\
206.50 \\
205.32 \\
203.87 \\
202.15\end{array}$ & $\begin{array}{l}-220 \\
-219 \\
-218 \\
-217 \\
-216\end{array}$ & $\begin{array}{l}-2667.43 \\
-2658.59 \\
-2649.66 \\
-2640.62 \\
-2631.49\end{array}$ & $\begin{array}{l}8.780 \\
8.886 \\
8.988 \\
9.086 \\
9.180\end{array}$ & $\begin{array}{r}107.78 \\
103.84 \\
99.97 \\
96.17 \\
92.45\end{array}$ & $\begin{array}{l}-190 \\
-189 \\
-188 \\
-187 \\
-186\end{array}$ & $\begin{array}{l}-2370.43 \\
-2359.78 \\
-2349.09 \\
-2338.38 \\
-2327.65\end{array}$ & $\begin{array}{l}10.636 \\
10.667 \\
10.696 \\
10.724 \\
10.752\end{array}$ & $\begin{array}{l}31.04 \\
29.97 \\
28.98 \\
28.06 \\
27.20\end{array}$ \\
\hline $\begin{array}{l}-245 \\
-244 \\
-243 \\
-242 \\
-241\end{array}$ & $\begin{array}{l}-2842.63 \\
-2837.69 \\
-2832.55 \\
-2827.22 \\
-2821.70\end{array}$ & $\begin{array}{l}4.837 \\
5.036 \\
5.233 \\
5.427 \\
5.618\end{array}$ & $\begin{array}{l}200.18 \\
197.96 \\
195.52 \\
192.86 \\
189.99\end{array}$ & $\begin{array}{l}-215 \\
-214 \\
-213 \\
-212 \\
-211\end{array}$ & $\begin{array}{l}-2622.26 \\
-2612.95 \\
-2603.55 \\
-2594.06 \\
-2584.50\end{array}$ & $\begin{array}{l}9.271 \\
9.358 \\
9.441 \\
9.521 \\
9.598\end{array}$ & $\begin{array}{l}88.82 \\
85.28 \\
81.84 \\
78.49 \\
75.24\end{array}$ & $\begin{array}{l}-185 \\
-184 \\
-183 \\
-182 \\
-181\end{array}$ & $\begin{array}{l}-2316.88 \\
-2306.09 \\
-2295.27 \\
-2284.43 \\
-2273.56\end{array}$ & $\begin{array}{l}10.779 \\
10.805 \\
10.830 \\
10.855 \\
10.879\end{array}$ & $\begin{array}{l}26.42 \\
25.69 \\
25.02 \\
24.41 \\
23.86\end{array}$ \\
\hline-240 & -2815.99 & 5.807 & 186.94 & -210 & $-2574 \cdot 87$ & 9.672 & 72.09 & -180 & -2262.67 & 10.903 & $23 \cdot 35$ \\
\hline
\end{tabular}


Table 7.5.2. Platinum, Pt-67, versus Type KN thermoelements-thermoelectric voltages, $\mathrm{E}(\mathrm{T})$, Seebeck coefficients, $\mathrm{S}(\mathrm{T})$, and first derivative of the Seebeck coefficients, dS/dT,

reference junctions at $0^{\circ} \mathrm{C}$-Continued

\begin{tabular}{|c|c|c|c|c|c|c|c|c|c|c|c|}
\hline${ }^{\top} \mathrm{C}$ & $\underset{\mu V}{E}$ & $\mu \stackrel{S}{S} /{ }^{\circ} \mathrm{C}$ & $\begin{array}{l}\mathrm{dS} / \mathrm{dT} \\
\mathrm{nV} /{ }^{\circ} \mathrm{C}^{2}\end{array}$ & ${ }^{\circ} \mathrm{C}$ & $\underset{\mu V}{E}$ & $\stackrel{\mathrm{S}}{\mathrm{S} /{ }^{\circ} \mathrm{C}}$ & $\begin{array}{l}\mathrm{dS} / \mathrm{dT} \\
\mathrm{nV} /{ }^{\circ} \mathrm{C}^{2}\end{array}$ & ${ }^{\circ} \mathrm{C}$ & $\underset{\mu V}{E}$ & $\begin{array}{c}\mathrm{S} \\
\mu \mathrm{V}^{\circ} \mathrm{C}\end{array}$ & $\begin{array}{l}d S / d T \\
n V /{ }^{\circ} C^{2}\end{array}$ \\
\hline $\begin{array}{l}-180 \\
-179 \\
-178 \\
-177 \\
-176\end{array}$ & $\begin{array}{l}-2262.67 \\
-2251.76 \\
-2240.82 \\
-2229.86 \\
-2218.88\end{array}$ & $\begin{array}{l}10.903 \\
10.926 \\
10.949 \\
10.971 \\
10.993\end{array}$ & $\begin{array}{l}23.35 \\
22.89 \\
22.47 \\
22.10 \\
21.76\end{array}$ & $\begin{array}{l}-120 \\
-119 \\
-118 \\
-117 \\
-116\end{array}$ & $\begin{array}{l}-1572.01 \\
-1559.90 \\
-1547.77 \\
-1535.63 \\
-1523.46\end{array}$ & $\begin{array}{l}12.099 \\
12.119 \\
12.139 \\
12.159 \\
12.178\end{array}$ & $\begin{array}{l}19.70 \\
19.73 \\
19.76 \\
19.79 \\
19.82\end{array}$ & $\begin{array}{l}-60 \\
-59 \\
-58 \\
-57 \\
-56\end{array}$ & $\begin{array}{l}-810.93 \\
-797.71 \\
-784.47 \\
-771.23 \\
-757.96\end{array}$ & $\begin{array}{l}13.214 \\
13.228 \\
13.241 \\
13.255 \\
13.268\end{array}$ & $\begin{array}{l}14.01 \\
13.80 \\
13.60 \\
13.40 \\
13.21\end{array}$ \\
\hline $\begin{array}{l}-175 \\
-174 \\
-173 \\
-172 \\
-171\end{array}$ & $\begin{array}{l}-2207.87 \\
-2196.85 \\
-2185.80 \\
-2174.73 \\
-2163.65\end{array}$ & $\begin{array}{l}11.014 \\
11.036 \\
11.057 \\
11.078 \\
11.098\end{array}$ & $\begin{array}{l}21.46 \\
21.19 \\
20.95 \\
20.74 \\
20.55\end{array}$ & $\begin{array}{l}-115 \\
-114 \\
-113 \\
-112 \\
-111\end{array}$ & $\begin{array}{l}-1511.27 \\
-1499.06 \\
-1486.83 \\
-1474.58 \\
-1462.32\end{array}$ & $\begin{array}{l}12.198 \\
12.218 \\
12.238 \\
12.258 \\
12.278\end{array}$ & $\begin{array}{l}19.86 \\
19.89 \\
19.92 \\
19.95 \\
19.98\end{array}$ & $\begin{array}{l}-55 \\
-54 \\
-53 \\
-52 \\
-51\end{array}$ & $\begin{array}{l}-744.69 \\
-731.40 \\
-718.10 \\
-704.79 \\
-691.46\end{array}$ & $\begin{array}{l}13.281 \\
13.294 \\
13.307 \\
13.319 \\
13.332\end{array}$ & $\begin{array}{l}13.02 \\
12.84 \\
12.67 \\
12.51 \\
12.35\end{array}$ \\
\hline $\begin{array}{l}-170 \\
-169 \\
-168 \\
-167 \\
-166\end{array}$ & $\begin{array}{l}-2152.54 \\
-2141.41 \\
-2130.26 \\
-2119.09 \\
-2107.90\end{array}$ & $\begin{array}{l}11.119 \\
11.139 \\
11.159 \\
11.179 \\
11.199\end{array}$ & $\begin{array}{l}20 \cdot 39 \\
20 \cdot 25 \\
20.12 \\
20.02 \\
19.93\end{array}$ & $\begin{array}{l}-110 \\
-109 \\
-108 \\
-107 \\
-106\end{array}$ & $\begin{array}{l}-1450.03 \\
-1437.72 \\
-1425.39 \\
-1413.04 \\
-1400.68\end{array}$ & $\begin{array}{l}12.298 \\
12.318 \\
12.338 \\
12.358 \\
12.378\end{array}$ & $\begin{array}{l}20.01 \\
20.04 \\
20.06 \\
20.09 \\
20.11\end{array}$ & $\begin{array}{l}-50 \\
-49 \\
-48 \\
-47 \\
-46\end{array}$ & $\begin{array}{l}-678.13 \\
-664.78 \\
-651.41 \\
-638.04 \\
-624.65\end{array}$ & $\begin{array}{l}13.344 \\
13.356 \\
13.368 \\
13.380 \\
13.392\end{array}$ & $\begin{array}{l}12.20 \\
12.05 \\
11.91 \\
11.78 \\
11.64\end{array}$ \\
\hline $\begin{array}{l}-165 \\
-164 \\
-163 \\
-162 \\
-161\end{array}$ & $\begin{array}{l}-2096.69 \\
-2085.46 \\
-2074.21 \\
-2062.95 \\
-2051.66\end{array}$ & $\begin{array}{l}11.219 \\
11.239 \\
11.259 \\
11.278 \\
11.298\end{array}$ & $\begin{array}{l}19.85 \\
19.79 \\
19.74 \\
19.69 \\
19.66\end{array}$ & $\begin{array}{l}-105 \\
-104 \\
-103 \\
-102 \\
-101\end{array}$ & $\begin{array}{l}-1388.29 \\
-1375.88 \\
-1363.45 \\
-1351.00 \\
-1338.53\end{array}$ & $\begin{array}{l}12.398 \\
12.418 \\
12.439 \\
12.459 \\
12.479\end{array}$ & $\begin{array}{l}20 \cdot 12 \\
20 \cdot 14 \\
20 \cdot 14 \\
20 \cdot 15 \\
20 \cdot 14\end{array}$ & $\begin{array}{l}-45 \\
-44 \\
-43 \\
-42 \\
-41\end{array}$ & $\begin{array}{l}-611.26 \\
-597.85 \\
-584.43 \\
-570.99 \\
-557.55\end{array}$ & $\begin{array}{l}13.403 \\
13.415 \\
13.426 \\
13.437 \\
13.448\end{array}$ & $\begin{array}{l}11.52 \\
11.39 \\
11.27 \\
11.15 \\
11.02\end{array}$ \\
\hline $\begin{array}{l}-160 \\
-159 \\
-158 \\
-157 \\
-156\end{array}$ & $\begin{array}{l}-2040.35 \\
-2029.02 \\
-2017.67 \\
-2006.31 \\
-1994.92\end{array}$ & $\begin{array}{l}11.318 \\
11.337 \\
11.357 \\
11.377 \\
11.396\end{array}$ & $\begin{array}{l}19.63 \\
19.60 \\
19.59 \\
19.57 \\
19.56\end{array}$ & $\begin{array}{l}-100 \\
-99 \\
-98 \\
-97 \\
-96\end{array}$ & $\begin{array}{l}-1326.05 \\
-1313.54 \\
-1301.01 \\
-1288.46 \\
-1275.89\end{array}$ & $\begin{array}{l}12.499 \\
12.519 \\
12.539 \\
12.559 \\
12.579\end{array}$ & $\begin{array}{l}20.14 \\
20.12 \\
20.10 \\
20.07 \\
20.04\end{array}$ & $\begin{array}{l}-40 \\
-39 \\
-38 \\
-37 \\
-36\end{array}$ & $\begin{array}{l}-544.10 \\
-530.63 \\
-517.16 \\
-503.67 \\
-490.17\end{array}$ & $\begin{array}{l}13.459 \\
13.470 \\
13.481 \\
13.492 \\
13.502\end{array}$ & $\begin{array}{l}10.90 \\
10.77 \\
10.63 \\
10.49 \\
10.34\end{array}$ \\
\hline $\begin{array}{l}-155 \\
-154 \\
-153 \\
-152 \\
-151\end{array}$ & $\begin{array}{l}-1983.52 \\
-1972.09 \\
-1960.65 \\
-1949.18 \\
-1937.70\end{array}$ & $\begin{array}{l}11.416 \\
11.435 \\
11.455 \\
11.474 \\
11.494\end{array}$ & $\begin{array}{l}19.55 \\
19.55 \\
19.54 \\
19.54 \\
19.53\end{array}$ & $\begin{array}{l}-95 \\
-94 \\
-93 \\
-92 \\
-91\end{array}$ & $\begin{array}{l}-1263.30 \\
-1250.69 \\
-1238.06 \\
-1225.41 \\
-1212.74\end{array}$ & $\begin{array}{l}12.599 \\
12.619 \\
12.639 \\
12.659 \\
12.679\end{array}$ & $\begin{array}{l}19.99 \\
19.94 \\
19.88 \\
19.82 \\
19.74\end{array}$ & $\begin{array}{l}-35 \\
-34 \\
-33 \\
-32 \\
-31\end{array}$ & $\begin{array}{l}-476.67 \\
-463.15 \\
-449.62 \\
-436.09 \\
-422.54\end{array}$ & $\begin{array}{l}13.512 \\
13.522 \\
13.532 \\
13.542 \\
13.551\end{array}$ & $\begin{array}{r}10.18 \\
10.00 \\
9.81 \\
9.60 \\
9.37\end{array}$ \\
\hline $\begin{array}{l}-150 \\
-149 \\
-148 \\
-147 \\
-146\end{array}$ & $\begin{array}{l}-1926.19 \\
-1914.67 \\
-1903.13 \\
-1891.57 \\
-1879.98\end{array}$ & $\begin{array}{l}11.513 \\
11.533 \\
11.552 \\
11.572 \\
11.591\end{array}$ & $\begin{array}{l}19.53 \\
19.53 \\
19.52 \\
19.52 \\
19.52\end{array}$ & $\begin{array}{l}-90 \\
-89 \\
-88 \\
-87 \\
-86\end{array}$ & $\begin{array}{l}-1200.05 \\
-1137.35 \\
-1174.62 \\
-1161.87 \\
-1149.10\end{array}$ & $\begin{array}{l}12.699 \\
12.718 \\
12.738 \\
12.757 \\
12.776\end{array}$ & $\begin{array}{l}19.66 \\
19.56 \\
19.46 \\
19.35 \\
19.23\end{array}$ & $\begin{array}{l}-30 \\
-29 \\
-28 \\
-27 \\
-26\end{array}$ & $\begin{array}{l}-408.98 \\
-395.42 \\
-381.84 \\
-368.26 \\
-354.67\end{array}$ & $\begin{array}{l}13.561 \\
13.570 \\
13.578 \\
13.587 \\
13.595\end{array}$ & $\begin{array}{l}9.12 \\
8.85 \\
8.55 \\
8.23 \\
7.88\end{array}$ \\
\hline $\begin{array}{l}-145 \\
-144 \\
-143 \\
-142 \\
-141\end{array}$ & $\begin{array}{l}-1868.38 \\
-1856.76 \\
-1845.12 \\
-1833.46 \\
-1821.78\end{array}$ & $\begin{array}{l}11.611 \\
11.630 \\
11.650 \\
11.669 \\
11.689\end{array}$ & $\begin{array}{l}19.51 \\
19.51 \\
19.51 \\
19.50 \\
19.50\end{array}$ & $\begin{array}{l}-85 \\
-84 \\
-83 \\
-82 \\
-81\end{array}$ & $\begin{array}{l}-1136.32 \\
-1123.51 \\
-1110.69 \\
-1097.85 \\
-1084.98\end{array}$ & $\begin{array}{l}12.796 \\
12.815 \\
12.833 \\
12.852 \\
12.871\end{array}$ & $\begin{array}{l}19.10 \\
18.96 \\
18.81 \\
18.65 \\
18.49\end{array}$ & $\begin{array}{l}-25 \\
-24 \\
-23 \\
-22 \\
-21\end{array}$ & $\begin{array}{l}-341.07 \\
-327.47 \\
-313.85 \\
-300.23 \\
-286.61\end{array}$ & $\begin{array}{l}13.602 \\
13.610 \\
13.617 \\
13.623 \\
13.629\end{array}$ & $\begin{array}{l}7.50 \\
7.09 \\
6.65 \\
6.18 \\
5.68\end{array}$ \\
\hline $\begin{array}{l}-140 \\
-139 \\
-138 \\
-137 \\
-136\end{array}$ & $\begin{array}{l}-1810.08 \\
-1798.37 \\
-1786.63 \\
-1774.87 \\
-1763.09\end{array}$ & $\begin{array}{l}11.708 \\
11.728 \\
11.747 \\
11.767 \\
11.786\end{array}$ & $\begin{array}{l}19.50 \\
19.49 \\
19.49 \\
19.49 \\
19.49\end{array}$ & $\begin{array}{l}-80 \\
-79 \\
-78 \\
-77 \\
-76\end{array}$ & $\begin{array}{l}-1072.10 \\
-1059.21 \\
-1046.29 \\
-1033.35 \\
-1020.40\end{array}$ & $\begin{array}{l}12.889 \\
12.907 \\
12.925 \\
12.943 \\
12.961\end{array}$ & $\begin{array}{l}18.32 \\
18.14 \\
17.95 \\
17.76 \\
17.55\end{array}$ & $\begin{array}{l}-20 \\
-19 \\
-18 \\
-17 \\
-16\end{array}$ & $\begin{array}{l}-272.97 \\
-259.34 \\
-245.70 \\
-232.05 \\
-218.40\end{array}$ & $\begin{array}{l}13.634 \\
13.639 \\
13.644 \\
13.647 \\
13.650\end{array}$ & $\begin{array}{l}5.15 \\
4.59 \\
4.01 \\
3.41 \\
2.80\end{array}$ \\
\hline $\begin{array}{l}-135 \\
-134 \\
-133 \\
-132 \\
-131\end{array}$ & $\begin{array}{l}-1751.30 \\
-1739.48 \\
-1727.65 \\
-1715.79 \\
-1703.92\end{array}$ & $\begin{array}{l}11.806 \\
11.825 \\
11.845 \\
11.864 \\
11.884\end{array}$ & $\begin{array}{l}19.49 \\
19.49 \\
19.49 \\
19.50 \\
19.50\end{array}$ & $\begin{array}{l}-75 \\
-74 \\
-73 \\
-72 \\
-71\end{array}$ & $\begin{array}{r}-1007.43 \\
-994.45 \\
-981.44 \\
-968.42 \\
-955.38\end{array}$ & $\begin{array}{l}12.978 \\
12.996 \\
13.013 \\
13.029 \\
13.046\end{array}$ & $\begin{array}{l}17 \cdot 35 \\
17 \cdot 14 \\
16.92 \\
16 \cdot 70 \\
16.48\end{array}$ & $\begin{array}{l}-15 \\
-14 \\
-13 \\
-12 \\
-11\end{array}$ & $\begin{array}{l}-204.75 \\
-191.10 \\
-177.44 \\
-163.78 \\
-150.13\end{array}$ & $\begin{array}{l}13.653 \\
13.655 \\
13.656 \\
13.657 \\
13.657\end{array}$ & $\begin{array}{r}2.17 \\
1.54 \\
0.91 \\
0.30 \\
-0.28\end{array}$ \\
\hline $\begin{array}{l}-130 \\
-129 \\
-128 \\
-127 \\
-126\end{array}$ & $\begin{array}{l}-1692.02 \\
-1680.11 \\
-1668.18 \\
-1656.23 \\
-1644.25\end{array}$ & $\begin{array}{l}11.903 \\
11.923 \\
11.942 \\
11.962 \\
11.982\end{array}$ & $\begin{array}{l}19.51 \\
19.52 \\
19.53 \\
19.55 \\
19.56\end{array}$ & $\begin{array}{l}-70 \\
-69 \\
-68 \\
-67 \\
-66\end{array}$ & $\begin{array}{l}-942.33 \\
-929.26 \\
-916.17 \\
-903.07 \\
-889.95\end{array}$ & $\begin{array}{l}13.062 \\
13.079 \\
13.094 \\
13.110 \\
13.126\end{array}$ & $\begin{array}{l}16.25 \\
16.03 \\
15.80 \\
15.57 \\
15.34\end{array}$ & $\begin{array}{r}-10 \\
-9 \\
-8 \\
-7 \\
-6\end{array}$ & $\begin{array}{r}-136.47 \\
-122.82 \\
-109.16 \\
-95.51 \\
-81.86\end{array}$ & $\begin{array}{l}13.656 \\
13.655 \\
13.653 \\
13.651 \\
13.649\end{array}$ & $\begin{array}{l}-0.83 \\
-1.32 \\
-1.74 \\
-2.06 \\
-2.28\end{array}$ \\
\hline $\begin{array}{l}-125 \\
-124 \\
-123 \\
-122 \\
-121\end{array}$ & $\begin{array}{l}-1632.26 \\
-1620.25 \\
-1608.22 \\
-1596.17 \\
-1584.10\end{array}$ & $\begin{array}{l}12.001 \\
12.021 \\
12.040 \\
12.060 \\
12.080\end{array}$ & $\begin{array}{l}19.58 \\
19.60 \\
19.62 \\
19.65 \\
19.67\end{array}$ & $\begin{array}{l}-65 \\
-64 \\
-63 \\
-62 \\
-61\end{array}$ & $\begin{array}{l}-876.82 \\
-863.67 \\
-850.51 \\
-837.33 \\
-824.14\end{array}$ & $\begin{array}{l}13.141 \\
13.156 \\
13.171 \\
13.185 \\
13.200\end{array}$ & $\begin{array}{l}15.11 \\
14.88 \\
14.66 \\
14.44 \\
14.22\end{array}$ & $\begin{array}{l}-5 \\
-4 \\
-3 \\
-2 \\
-1\end{array}$ & $\begin{array}{l}-68.21 \\
-54.57 \\
-40.92 \\
-27.28 \\
-13.64\end{array}$ & $\begin{array}{l}13.647 \\
13.645 \\
13.643 \\
13.641 \\
13.640\end{array}$ & $\begin{array}{l}-2.35 \\
-2.25 \\
-1.95 \\
-1.42 \\
-0.60\end{array}$ \\
\hline-120 & -1572.01 & 12.099 & 19.70 & -60 & $-810 \cdot 93$ & 13.214 & 14.01 & 0 & 0.00 & 13.640 & 0.53 \\
\hline
\end{tabular}


TABle 7.5.2. Platinum, $\mathbf{P t}-67$, versus Type $K N$ thermoelements-thermoelectric voltages, $\mathrm{E}(\mathrm{T})$, Seebeck coefficients, $\mathrm{S}(\mathrm{T})$, and first derivative of the Seebeck coefficients, $\mathrm{dS} / \mathrm{dT}$,

reference junctions at $0^{\circ} \mathrm{C}-$ Continued

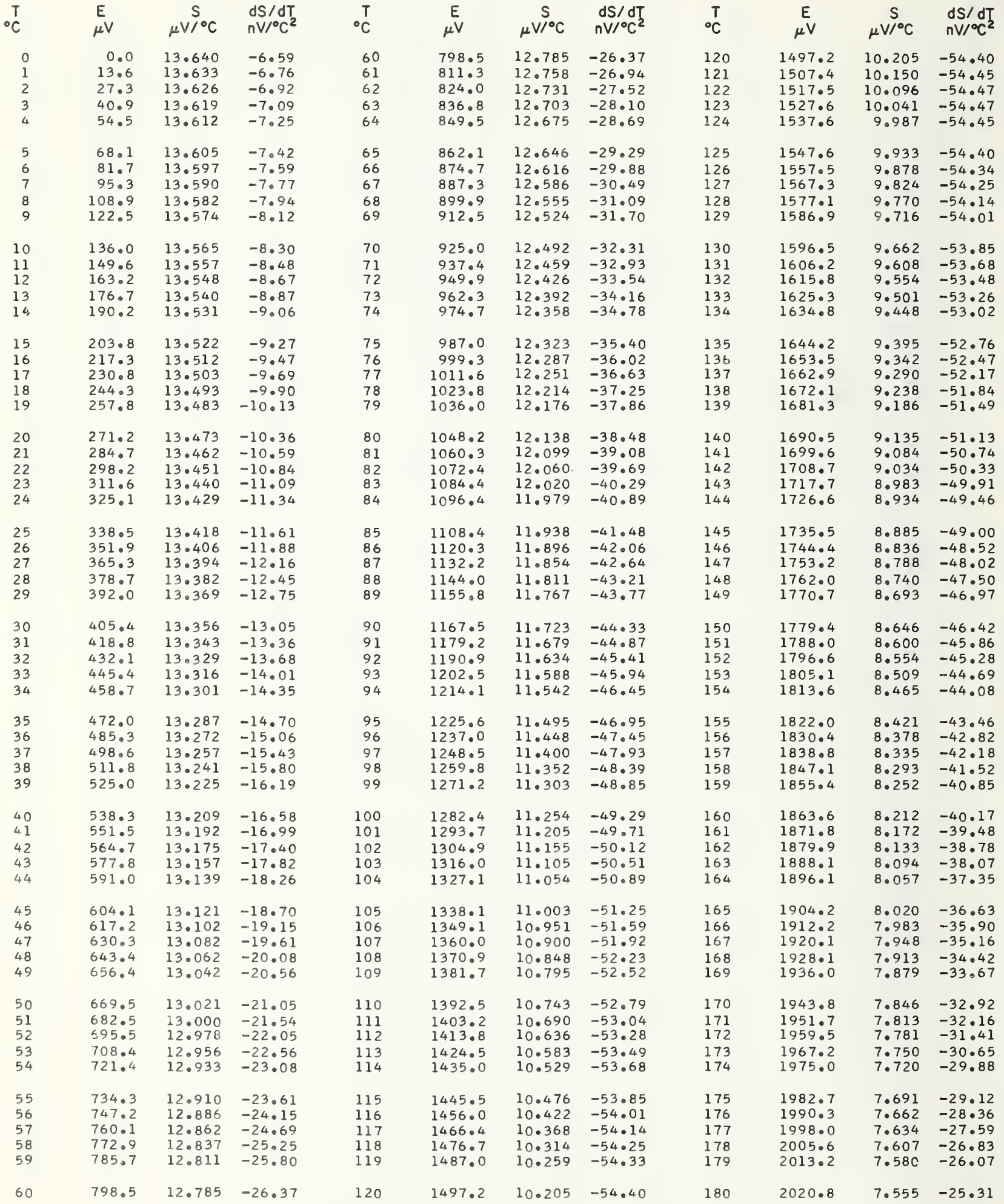


TABLE 7.5.2. Platinum, Pt-67, versus Type KN thermoelements-thermoelectric voltages, E(T), Seebeck coefficients, $\mathrm{S}(\mathrm{T})$, and first derivative of the Seebeck coefficients, $\mathrm{dS} / \mathrm{dT}$,

reference junctions at $0^{\circ} \mathrm{C}$-Continued

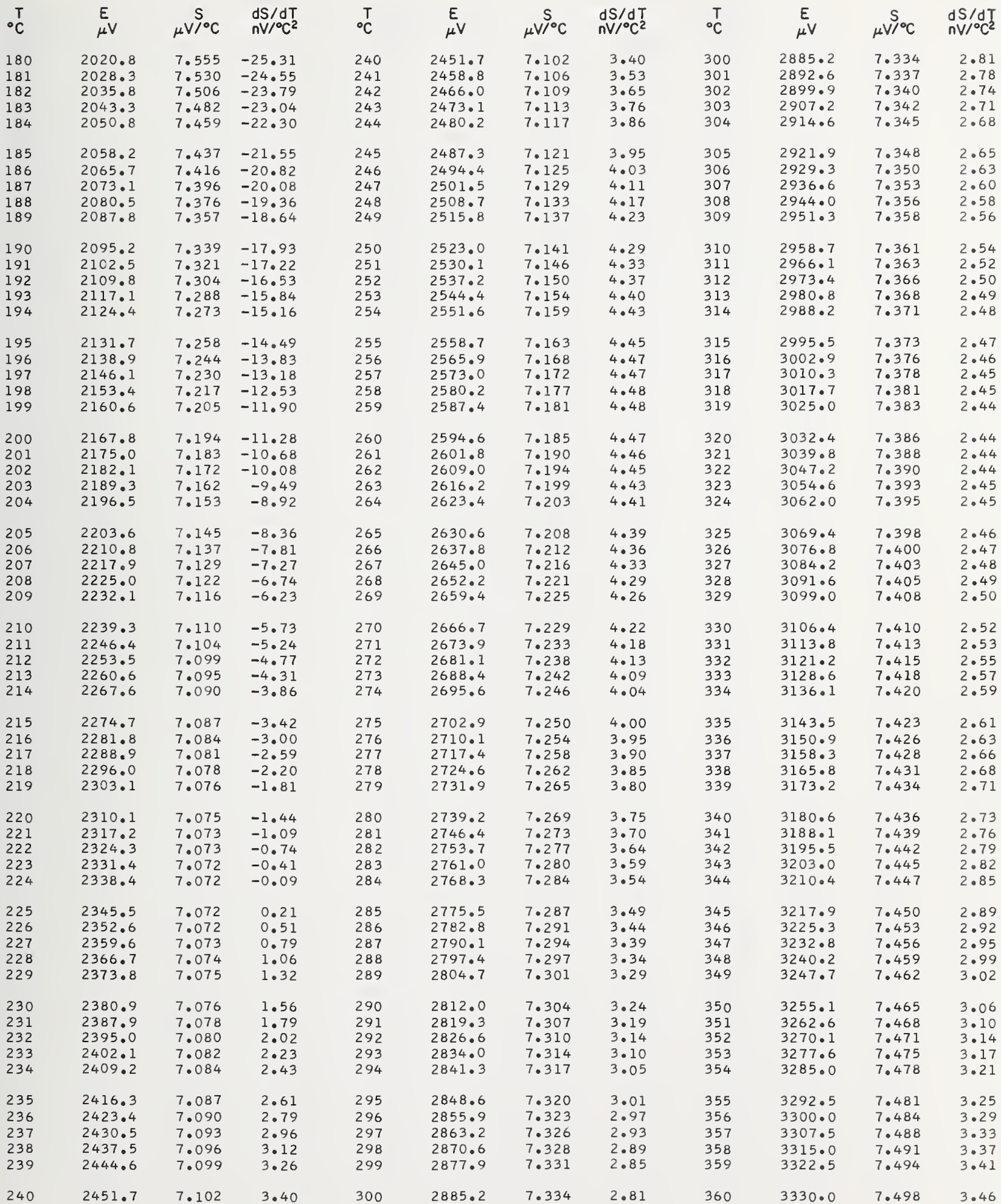


TABLE 7.5.2. Platinum, Pt-67, versus Type $K N$ thermoelements-thermoelectric voltages, E(T), Seebeck coeffcients, $\mathrm{S}(\mathrm{T})$, and first derivative of the Seebeck coeffcients, $\mathrm{dS} / \mathrm{dT}$, reference junctions at $0^{\circ} \mathrm{C}$-Continued

\begin{tabular}{|c|c|c|c|c|c|c|c|c|c|c|c|}
\hline${ }^{\mathrm{T}} \mathrm{C}$ & $\begin{array}{c}E \\
\mu V\end{array}$ & $\underset{\mu V /{ }^{\circ} \mathrm{C}}{S}$ & $\begin{array}{l}\mathrm{dS} / \mathrm{dT} \\
\mathrm{nV} /{ }^{\circ} \mathrm{C}^{2}\end{array}$ & ${ }^{\circ} \mathrm{C}$ & $\underset{\mu V}{E}$ & $\begin{array}{c}S \\
\mu V^{\circ} \mathrm{C}\end{array}$ & $\begin{array}{l}d S / d T \\
n V /{ }^{\circ} C^{2}\end{array}$ & ${ }^{\circ} \mathrm{C}$ & $\underset{\mu V}{E}$ & $\underset{\mu \mathrm{V} /{ }^{\circ} \mathrm{C}}{\mathrm{S}}$ & $\begin{array}{l}\mathrm{dS} / \mathrm{dT} \\
\mathrm{nV} /{ }^{\circ} \mathrm{C}^{2}\end{array}$ \\
\hline $\begin{array}{l}365 \\
366 \\
367 \\
368 \\
369\end{array}$ & $\begin{array}{l}3367.5 \\
3375.0 \\
3382.5 \\
3390.1 \\
3397.6\end{array}$ & $\begin{array}{l}7.516 \\
7.519 \\
7.523 \\
7.527 \\
7.531\end{array}$ & $\begin{array}{l}3.67 \\
3.71 \\
3.76 \\
3.80 \\
3.84\end{array}$ & $\begin{array}{l}425 \\
426 \\
427 \\
428 \\
429\end{array}$ & $\begin{array}{l}3826.5 \\
3834.4 \\
3842.2 \\
3850.0 \\
3857.8\end{array}$ & $\begin{array}{l}7.809 \\
7.815 \\
7.821 \\
7.827 \\
7.833\end{array}$ & $\begin{array}{l}5.91 \\
5.93 \\
5.96 \\
5.98 \\
6.00\end{array}$ & $\begin{array}{l}485 \\
486 \\
487 \\
488 \\
489\end{array}$ & $\begin{array}{l}4306 \cdot 3 \\
4314 \cdot 5 \\
4322.7 \\
4330.9 \\
4339 \cdot 1\end{array}$ & $\begin{array}{l}8.188 \\
8.195 \\
8.201 \\
8.208 \\
8.214\end{array}$ & $\begin{array}{l}6.43 \\
6.42 \\
6.41 \\
6.41 \\
6.40\end{array}$ \\
\hline $\begin{array}{l}370 \\
371 \\
372 \\
373 \\
374\end{array}$ & $\begin{array}{l}3405.1 \\
3412.6 \\
3420.2 \\
3427.7 \\
3435.3\end{array}$ & $\begin{array}{l}7.534 \\
7.538 \\
7.542 \\
7.546 \\
7.550\end{array}$ & $\begin{array}{l}3.89 \\
3.93 \\
3.98 \\
4.02 \\
4.06\end{array}$ & $\begin{array}{l}430 \\
431 \\
432 \\
433 \\
434\end{array}$ & $\begin{array}{l}3865.7 \\
3873.5 \\
3881.4 \\
3889.2 \\
3897.1\end{array}$ & $\begin{array}{l}7.839 \\
7.845 \\
7.851 \\
7.857 \\
7.863\end{array}$ & $\begin{array}{l}6.03 \\
6.05 \\
6.07 \\
6.09 \\
6.11\end{array}$ & $\begin{array}{l}490 \\
491 \\
492 \\
493 \\
494\end{array}$ & $\begin{array}{l}4347 \cdot 3 \\
4355 \cdot 6 \\
4363.8 \\
4372 \cdot 0 \\
4380.3\end{array}$ & $\begin{array}{l}8.220 \\
8.227 \\
8.233 \\
8.240 \\
8.246\end{array}$ & $\begin{array}{l}6 \cdot 39 \\
6 \cdot 38 \\
6 \cdot 37 \\
6 \cdot 36 \\
6 \cdot 35\end{array}$ \\
\hline $\begin{array}{l}380 \\
381 \\
382 \\
383 \\
384\end{array}$ & $\begin{array}{l}3480.7 \\
3488.2 \\
3495.8 \\
3503.4 \\
3511.0\end{array}$ & $\begin{array}{l}7.576 \\
7.580 \\
7.584 \\
7.589 \\
7.593\end{array}$ & $\begin{array}{l}4.33 \\
4.37 \\
4.41 \\
4.45 \\
4.50\end{array}$ & $\begin{array}{l}440 \\
441 \\
442 \\
443 \\
444\end{array}$ & $\begin{array}{l}3944.4 \\
3952.3 \\
3960.2 \\
3968.1 \\
3976.0\end{array}$ & $\begin{array}{l}7.900 \\
7.906 \\
7.913 \\
7.919 \\
7.925\end{array}$ & $\begin{array}{l}6.21 \\
6.23 \\
6.25 \\
6.26 \\
6.28\end{array}$ & $\begin{array}{l}500 \\
501 \\
502 \\
503 \\
504\end{array}$ & $\begin{array}{l}4429.9 \\
4438 \cdot 1 \\
4446.4 \\
4454.7 \\
4463.0\end{array}$ & $\begin{array}{l}8.284 \\
8.290 \\
8.296 \\
8.303 \\
8.309\end{array}$ & $\begin{array}{l}6.29 \\
6.27 \\
6.26 \\
6.25 \\
6.23\end{array}$ \\
\hline $\begin{array}{l}385 \\
386 \\
387 \\
388 \\
389\end{array}$ & $\begin{array}{l}3518.6 \\
3526.2 \\
3533.8 \\
3541.4 \\
3549.0\end{array}$ & $\begin{array}{l}7.598 \\
7.602 \\
7.607 \\
7.612 \\
7.616\end{array}$ & $\begin{array}{l}4.54 \\
4.58 \\
4.62 \\
4.67 \\
4.71\end{array}$ & $\begin{array}{l}445 \\
446 \\
447 \\
448 \\
449\end{array}$ & $\begin{array}{l}3983.9 \\
3991.9 \\
3999.8 \\
4007.8 \\
4015.7\end{array}$ & $\begin{array}{l}7.931 \\
7.938 \\
7.944 \\
7.950 \\
7.957\end{array}$ & $\begin{array}{l}6.29 \\
6.30 \\
6.32 \\
6.33 \\
6.34\end{array}$ & $\begin{array}{l}505 \\
506 \\
507 \\
508 \\
509\end{array}$ & $\begin{array}{l}4471.4 \\
4479 \cdot 7 \\
4488.0 \\
4496 \cdot 3 \\
4504.7\end{array}$ & $\begin{array}{l}8.315 \\
8.321 \\
8.328 \\
8.334 \\
8.340\end{array}$ & $\begin{array}{l}6.22 \\
6.20 \\
6.19 \\
6.17 \\
6.16\end{array}$ \\
\hline $\begin{array}{l}390 \\
391 \\
392 \\
393 \\
394\end{array}$ & $\begin{array}{l}3556.6 \\
3564.3 \\
3571.9 \\
3579.5 \\
3587.2\end{array}$ & $\begin{array}{l}7.621 \\
7.626 \\
7.630 \\
7.635 \\
7.640\end{array}$ & $\begin{array}{l}4.75 \\
4.79 \\
4.83 \\
4.87 \\
4.91\end{array}$ & $\begin{array}{l}450 \\
451 \\
452 \\
453 \\
454\end{array}$ & $\begin{array}{l}4023.7 \\
4031.6 \\
4039.6 \\
4047.6 \\
4055.6\end{array}$ & $\begin{array}{l}7.963 \\
7.969 \\
7.976 \\
7.982 \\
7.989\end{array}$ & $\begin{array}{l}6.35 \\
6.36 \\
6.37 \\
6.38 \\
6.39\end{array}$ & $\begin{array}{l}510 \\
511 \\
512 \\
513 \\
514\end{array}$ & $\begin{array}{l}4513 \cdot 0 \\
4521 \cdot 4 \\
4529 \cdot 7 \\
4538 \cdot 1 \\
4546.4\end{array}$ & $\begin{array}{l}8.346 \\
8.352 \\
8.358 \\
8.364 \\
8.370\end{array}$ & $\begin{array}{l}6.14 \\
6.13 \\
6.111 \\
6.09 \\
6.08\end{array}$ \\
\hline $\begin{array}{l}400 \\
401 \\
402 \\
403 \\
404\end{array}$ & $\begin{array}{l}3633.1 \\
3640.8 \\
3648.4 \\
3656.1 \\
3663.8\end{array}$ & $\begin{array}{l}7.670 \\
7.676 \\
7.681 \\
7.686 \\
7.691\end{array}$ & $\begin{array}{l}5.14 \\
5.17 \\
5.21 \\
5.25 \\
5.28\end{array}$ & $\begin{array}{l}460 \\
461 \\
462 \\
463 \\
464\end{array}$ & $\begin{array}{l}4103.6 \\
4111.7 \\
4119.7 \\
4127.7 \\
4135.8\end{array}$ & $\begin{array}{l}8.027 \\
8.033 \\
8.040 \\
8.046 \\
8.053\end{array}$ & $\begin{array}{l}6.43 \\
6.44 \\
6.44 \\
6.45 \\
6.45\end{array}$ & $\begin{array}{l}520 \\
521 \\
522 \\
523 \\
524\end{array}$ & $\begin{array}{l}4596.8 \\
4605.2 \\
4613.6 \\
4622.0 \\
4630.4\end{array}$ & $\begin{array}{l}8.407 \\
8.413 \\
8.418 \\
8.424 \\
8.430\end{array}$ & $\begin{array}{l}5.96 \\
5.94 \\
5.92 \\
5.90 \\
5.88\end{array}$ \\
\hline $\begin{array}{l}405 \\
406 \\
407 \\
408 \\
409\end{array}$ & $\begin{array}{l}3671.5 \\
3679.2 \\
3686.9 \\
3694.6 \\
3702.3\end{array}$ & $\begin{array}{l}7.697 \\
7.702 \\
7.707 \\
7.713 \\
7.718\end{array}$ & $\begin{array}{l}5.32 \\
5.35 \\
5.38 \\
5.42 \\
5.45\end{array}$ & $\begin{array}{l}465 \\
466 \\
467 \\
468 \\
469\end{array}$ & $\begin{array}{l}4143.8 \\
4151.9 \\
4160.0 \\
4168.0 \\
4176.1\end{array}$ & $\begin{array}{l}8.059 \\
8.066 \\
8.072 \\
8.079 \\
8.085\end{array}$ & $\begin{array}{l}6.46 \\
6.46 \\
6.46 \\
6.46 \\
6.47\end{array}$ & $\begin{array}{l}525 \\
526 \\
527 \\
528 \\
529\end{array}$ & $\begin{array}{l}4638.9 \\
4647.3 \\
4655.8 \\
4664.2 \\
4672.7\end{array}$ & $\begin{array}{l}8.436 \\
8.442 \\
8.448 \\
8.454 \\
8.459\end{array}$ & $\begin{array}{l}5.86 \\
5.84 \\
5.82 \\
5.80 \\
5.78\end{array}$ \\
\hline $\begin{array}{l}410 \\
411 \\
412 \\
413 \\
414\end{array}$ & $\begin{array}{l}3710.1 \\
3717.8 \\
3725.5 \\
3733.3 \\
3741.0\end{array}$ & $\begin{array}{l}7.724 \\
7.729 \\
7.735 \\
7.740 \\
7.746\end{array}$ & $\begin{array}{l}5.48 \\
5.52 \\
5.55 \\
5.58 \\
5.61\end{array}$ & $\begin{array}{l}470 \\
471 \\
472 \\
473 \\
474\end{array}$ & $\begin{array}{l}4184 \cdot 2 \\
41.92 \cdot 3 \\
4200 \cdot 4 \\
4208 \cdot 5 \\
4216 \cdot 6\end{array}$ & $\begin{array}{l}8.092 \\
8.098 \\
8.105 \\
8.111 \\
8.117\end{array}$ & $\begin{array}{l}6.47 \\
6.47 \\
6.47 \\
6.47 \\
6.47\end{array}$ & $\begin{array}{l}530 \\
531 \\
532 \\
533 \\
534\end{array}$ & $\begin{array}{l}4681.1 \\
4689.6 \\
4698.1 \\
4706.6 \\
4715.0\end{array}$ & $\begin{array}{l}8.465 \\
8.471 \\
8.477 \\
8.482 \\
8.488\end{array}$ & $\begin{array}{l}5.75 \\
5.73 \\
5.71 \\
5.68 \\
5.66\end{array}$ \\
\hline $\begin{array}{l}415 \\
416 \\
417 \\
418 \\
419\end{array}$ & $\begin{array}{l}3748.7 \\
3756.5 \\
3764.3 \\
3772.0 \\
3779.8\end{array}$ & $\begin{array}{l}7.751 \\
7.757 \\
7.763 \\
7.768 \\
7.774\end{array}$ & $\begin{array}{l}5.64 \\
5.67 \\
5.70 \\
5.73 \\
5.75\end{array}$ & $\begin{array}{l}475 \\
476 \\
477 \\
478 \\
479\end{array}$ & $\begin{array}{l}4224.8 \\
4232.9 \\
4241.0 \\
4249 \cdot 2 \\
4257.3\end{array}$ & $\begin{array}{l}8.124 \\
8.130 \\
8.137 \\
8.143 \\
8.150\end{array}$ & $\begin{array}{l}6.46 \\
6.46 \\
6.46 \\
6.46 \\
6.45\end{array}$ & $\begin{array}{l}535 \\
536 \\
537 \\
538 \\
539\end{array}$ & $\begin{array}{l}4723.5 \\
4732.0 \\
4740.5 \\
4749.0 \\
4757.6\end{array}$ & $\begin{array}{l}8.494 \\
8.499 \\
8.505 \\
8.510 \\
8.516\end{array}$ & $\begin{array}{l}5.64 \\
5.61 \\
5.59 \\
5.56 \\
5.54\end{array}$ \\
\hline 420 & 3787.6 & 7.780 & 5.78 & 480 & $4265 \cdot 5$ & 8.156 & 6.45 & 540 & 4766.1 & 8.522 & 5.51 \\
\hline
\end{tabular}


TABLE 7.5.2. Platinum, Pt-67, versus Type KN thermoelements-thermoelectric voltages, E(T), Seebeck coefficients, $\mathrm{S}(\mathrm{T})$, and first derivative of the Seebeck coefficients, $\mathrm{dS} / \mathrm{dT}$,

reference junctions at $0^{\circ} \mathrm{C}-$ Continued

\begin{tabular}{|c|c|c|c|c|c|c|c|c|c|c|c|}
\hline $\begin{array}{r}\mathrm{T} \\
{ }^{\circ} \mathrm{C}\end{array}$ & ${ }_{\mu V}^{E V}$ & $\stackrel{S}{\mu V /{ }^{\circ} \mathrm{C}}$ & $\begin{array}{l}d S / d T \\
n V /{ }^{\circ} C^{2}\end{array}$ & ${ }^{\circ} \mathrm{T}$ & $\begin{array}{c}E \\
\mu V\end{array}$ & $\begin{array}{c}S \\
\mu V /^{\circ} \mathrm{C}\end{array}$ & $\begin{array}{l}d S / d T \\
n V /{ }^{\circ} C^{2}\end{array}$ & $\begin{array}{l}\mathrm{T} \\
{ }^{\circ} \mathrm{C}\end{array}$ & $\begin{array}{c}E \\
\mu V\end{array}$ & $\stackrel{S}{\mu V /{ }^{\circ} \mathrm{C}}$ & $\begin{array}{l}d S / d T \\
n V /{ }^{\circ} C^{2}\end{array}$ \\
\hline $\begin{array}{l}540 \\
541 \\
542 \\
543 \\
544\end{array}$ & $\begin{array}{l}4766.1 \\
4774.6 \\
4783.1 \\
4791.7 \\
4800.2\end{array}$ & $\begin{array}{l}8.522 \\
8.527 \\
8.533 \\
8.538 \\
8.543\end{array}$ & $\begin{array}{l}5.51 \\
5.49 \\
5.46 \\
5.43 \\
5.41\end{array}$ & $\begin{array}{l}600 \\
601 \\
602 \\
603 \\
604\end{array}$ & $\begin{array}{l}5286.2 \\
5295.0 \\
5303.8 \\
5312.7 \\
5321.5\end{array}$ & $\begin{array}{l}8.798 \\
8.802 \\
8.805 \\
8.809 \\
8.813\end{array}$ & $\begin{array}{l}3.61 \\
3.58 \\
3.54 \\
3.50 \\
3.47\end{array}$ & $\begin{array}{l}660 \\
661 \\
662 \\
663 \\
664\end{array}$ & $\begin{array}{l}5819.3 \\
5828.3 \\
5837.2 \\
5846.2 \\
5855.1\end{array}$ & $\begin{array}{l}8.949 \\
8.950 \\
8.951 \\
8.953 \\
8.954\end{array}$ & $\begin{array}{l}1.40 \\
1.36 \\
1.32 \\
1.29 \\
1.25\end{array}$ \\
\hline $\begin{array}{l}545 \\
546 \\
547 \\
548 \\
549\end{array}$ & $\begin{array}{l}4808.7 \\
4817.3 \\
4825.9 \\
4834.4 \\
4843.0\end{array}$ & $\begin{array}{l}8.549 \\
8.554 \\
8.559 \\
8.565 \\
8.570\end{array}$ & $\begin{array}{l}5.38 \\
5.35 \\
5.33 \\
5.30 \\
5.27\end{array}$ & $\begin{array}{l}605 \\
606 \\
607 \\
608 \\
609\end{array}$ & $\begin{array}{l}5330.3 \\
5339.1 \\
5347.9 \\
5356.7 \\
5365.6\end{array}$ & $\begin{array}{l}8.816 \\
8.819 \\
8.823 \\
8.826 \\
8.829\end{array}$ & $\begin{array}{l}3.43 \\
3.40 \\
3.36 \\
3.32 \\
3.29\end{array}$ & $\begin{array}{l}665 \\
666 \\
667 \\
668 \\
669\end{array}$ & $\begin{array}{l}5864.1 \\
5873.0 \\
5882.0 \\
5891.0 \\
5899.9\end{array}$ & $\begin{array}{l}8.955 \\
8.956 \\
8.958 \\
8.959 \\
8.960\end{array}$ & $\begin{array}{l}1.22 \\
1.18 \\
1.14 \\
1.11 \\
1.07\end{array}$ \\
\hline $\begin{array}{l}550 \\
551 \\
552 \\
553 \\
554\end{array}$ & $\begin{array}{l}4851.6 \\
4860.1 \\
4868.7 \\
4877.3 \\
4885.9\end{array}$ & $\begin{array}{l}8.575 \\
8.581 \\
8.586 \\
8.591 \\
8.596\end{array}$ & $\begin{array}{l}5.24 \\
5.21 \\
5.19 \\
5.16 \\
5.13\end{array}$ & $\begin{array}{l}610 \\
611 \\
612 \\
613 \\
614\end{array}$ & $\begin{array}{l}5374.4 \\
5383.2 \\
5392.1 \\
5400.9 \\
5409.8\end{array}$ & $\begin{array}{l}8.833 \\
8.836 \\
8.839 \\
8.842 \\
8.845\end{array}$ & $\begin{array}{l}3.25 \\
3.21 \\
3.18 \\
3.14 \\
3.10\end{array}$ & $\begin{array}{l}670 \\
671 \\
672 \\
673 \\
674\end{array}$ & $\begin{array}{l}5908.9 \\
5917.8 \\
5926.8 \\
5935.8 \\
5944.7\end{array}$ & $\begin{array}{l}8.961 \\
8.962 \\
8.963 \\
8.964 \\
8.965\end{array}$ & $\begin{array}{l}1.04 \\
1.00 \\
0.96 \\
0.93 \\
0.89\end{array}$ \\
\hline $\begin{array}{l}555 \\
556 \\
557 \\
558 \\
559\end{array}$ & $\begin{array}{l}4894.5 \\
4903.1 \\
4911.7 \\
4920.3 \\
4928.9\end{array}$ & $\begin{array}{l}8.601 \\
8.606 \\
8.611 \\
8.616 \\
8.621\end{array}$ & $\begin{array}{l}5.10 \\
5.07 \\
5.04 \\
5.01 \\
4.98\end{array}$ & $\begin{array}{l}615 \\
616 \\
617 \\
618 \\
619\end{array}$ & $\begin{array}{l}5418.6 \\
5427.5 \\
5436.3 \\
5445.2 \\
5454.0\end{array}$ & $\begin{array}{l}8.848 \\
8.851 \\
8.854 \\
8.857 \\
8.860\end{array}$ & $\begin{array}{l}3.07 \\
3.03 \\
2.99 \\
2.95 \\
2.92\end{array}$ & $\begin{array}{l}675 \\
676 \\
677 \\
678 \\
679\end{array}$ & $\begin{array}{l}5953.7 \\
5962.7 \\
5971.6 \\
5980.6 \\
5989.6\end{array}$ & $\begin{array}{l}8.966 \\
8.966 \\
8.967 \\
8.968 \\
8.969\end{array}$ & $\begin{array}{l}0.86 \\
0.82 \\
0.79 \\
0.75 \\
0.72\end{array}$ \\
\hline $\begin{array}{l}560 \\
561 \\
562 \\
563 \\
564\end{array}$ & $\begin{array}{l}4937.6 \\
4946.2 \\
4954.8 \\
4963.5 \\
4972.1\end{array}$ & $\begin{array}{l}8.626 \\
8.631 \\
8.636 \\
8.641 \\
8.646\end{array}$ & $\begin{array}{l}4.95 \\
4.92 \\
4.89 \\
4.86 \\
4.83\end{array}$ & $\begin{array}{l}620 \\
621 \\
622 \\
623 \\
624\end{array}$ & $\begin{array}{l}5462.9 \\
5471.7 \\
5480.6 \\
5489.5 \\
5498.4\end{array}$ & $\begin{array}{l}8.863 \\
8.866 \\
8.869 \\
8.872 \\
8.875\end{array}$ & $\begin{array}{l}2.88 \\
2.84 \\
2.81 \\
2.77 \\
2.73\end{array}$ & $\begin{array}{l}680 \\
681 \\
682 \\
683 \\
684\end{array}$ & $\begin{array}{l}5998.5 \\
6007.5 \\
6016.5 \\
6025.4 \\
6034.4\end{array}$ & $\begin{array}{l}8.970 \\
8.970 \\
8.971 \\
8.971 \\
8.972\end{array}$ & $\begin{array}{l}0.68 \\
0.65 \\
0.61 \\
0.58 \\
0.54\end{array}$ \\
\hline $\begin{array}{l}565 \\
566 \\
567 \\
568 \\
569\end{array}$ & $\begin{array}{l}4980.8 \\
4989.4 \\
4998.1 \\
5006.7 \\
5015.4\end{array}$ & $\begin{array}{l}8.651 \\
8.655 \\
8.660 \\
8.665 \\
8.670\end{array}$ & $\begin{array}{l}4.80 \\
4.77 \\
4.73 \\
4.70 \\
4.67\end{array}$ & $\begin{array}{l}625 \\
626 \\
627 \\
628 \\
629\end{array}$ & $\begin{array}{l}5507.2 \\
5516.1 \\
5525.0 \\
5533.9 \\
5542.8\end{array}$ & $\begin{array}{l}8.877 \\
8.880 \\
8.883 \\
8.885 \\
8.888\end{array}$ & $\begin{array}{l}2.69 \\
2.66 \\
2.62 \\
2.58 \\
2.55\end{array}$ & $\begin{array}{l}685 \\
686 \\
687 \\
688 \\
689\end{array}$ & $\begin{array}{l}6043.4 \\
6052.4 \\
6061.3 \\
6070.3 \\
6079.3\end{array}$ & $\begin{array}{l}8.972 \\
8.973 \\
8.973 \\
8.974 \\
8.974\end{array}$ & $\begin{array}{l}0.51 \\
0.47 \\
0.44 \\
0.41 \\
0.37\end{array}$ \\
\hline $\begin{array}{l}570 \\
571 \\
572 \\
573 \\
574\end{array}$ & $\begin{array}{l}5024.1 \\
5032.8 \\
5041.4 \\
5050.1 \\
5058.8\end{array}$ & $\begin{array}{l}8.674 \\
8.679 \\
8.684 \\
8.688 \\
8.693\end{array}$ & $\begin{array}{l}4.64 \\
4.61 \\
4.57 \\
4.54 \\
4.51\end{array}$ & $\begin{array}{l}630 \\
631 \\
632 \\
633 \\
634\end{array}$ & $\begin{array}{l}5551.7 \\
5560.5 \\
5569.4 \\
5578.3 \\
5587.2\end{array}$ & $\begin{array}{l}8.890 \\
8.893 \\
8.895 \\
8.898 \\
8.900\end{array}$ & $\begin{array}{l}2.51 \\
2.47 \\
2.43 \\
2.40 \\
2.36\end{array}$ & $\begin{array}{l}690 \\
691 \\
692 \\
693 \\
694\end{array}$ & $\begin{array}{l}6088.3 \\
6097 \cdot 2 \\
6106.2 \\
6115.2 \\
6124.2\end{array}$ & $\begin{array}{l}8.975 \\
8.975 \\
8.975 \\
8.975 \\
8.976\end{array}$ & $\begin{array}{l}0.34 \\
0.30 \\
0.27 \\
0.24 \\
0.20\end{array}$ \\
\hline $\begin{array}{l}575 \\
576 \\
577 \\
578 \\
579\end{array}$ & $\begin{array}{l}5067.5 \\
5076.2 \\
5084.9 \\
5093.6 \\
5102.3\end{array}$ & $\begin{array}{l}8.697 \\
8.702 \\
8.706 \\
8.710 \\
8.715\end{array}$ & $\begin{array}{l}4.48 \\
4.44 \\
4.41 \\
4.38 \\
4.34\end{array}$ & $\begin{array}{l}635 \\
636 \\
637 \\
638 \\
639\end{array}$ & $\begin{array}{l}5596.1 \\
5605.0 \\
5613.9 \\
5622.9 \\
5631.8\end{array}$ & $\begin{array}{l}8.902 \\
8.905 \\
8.907 \\
8.909 \\
8.911\end{array}$ & $\begin{array}{l}2.32 \\
2.28 \\
2.25 \\
2.21 \\
2.17\end{array}$ & $\begin{array}{l}695 \\
696 \\
697 \\
698 \\
699\end{array}$ & $\begin{array}{l}6133.1 \\
6142.1 \\
6151.1 \\
6160.1 \\
6169.0\end{array}$ & $\begin{array}{l}8.976 \\
8.976 \\
8.976 \\
8.976 \\
8.976\end{array}$ & $\begin{array}{l}0.17 \\
0.14 \\
0.10 \\
0.07 \\
0.04\end{array}$ \\
\hline $\begin{array}{l}580 \\
581 \\
582 \\
583 \\
584\end{array}$ & $\begin{array}{l}5111.0 \\
5119.8 \\
5128.5 \\
51137.2 \\
5146.0\end{array}$ & $\begin{array}{l}8.719 \\
8.723 \\
8.728 \\
8.732 \\
8.736\end{array}$ & $\begin{array}{l}4.31 \\
4.28 \\
4.24 \\
4.21 \\
4.17\end{array}$ & $\begin{array}{l}640 \\
641 \\
642 \\
643 \\
644\end{array}$ & $\begin{array}{l}5640.7 \\
5649.6 \\
5658.5 \\
5667.4 \\
5676.3\end{array}$ & $\begin{array}{l}8.913 \\
8.916 \\
8.918 \\
8.920 \\
8.922\end{array}$ & $\begin{array}{l}2.14 \\
2.10 \\
2.06 \\
2.02 \\
1.99\end{array}$ & $\begin{array}{l}700 \\
701 \\
702 \\
703 \\
704\end{array}$ & $\begin{array}{l}6178.0 \\
6187.0 \\
6196.0 \\
6204.9 \\
6213.9\end{array}$ & $\begin{array}{l}8.976 \\
8.976 \\
8.976 \\
8.976 \\
8.976\end{array}$ & $\begin{array}{l}0.01 \\
-0.03 \\
-0.06 \\
-0.09 \\
-0.12\end{array}$ \\
\hline $\begin{array}{l}585 \\
586 \\
587 \\
588 \\
589\end{array}$ & $\begin{array}{l}5154.7 \\
5163.4 \\
5172.2 \\
5180.9 \\
5189.7\end{array}$ & $\begin{array}{l}8.740 \\
8.744 \\
8.748 \\
8.752 \\
8.756\end{array}$ & $\begin{array}{l}4.14 \\
4.11 \\
4.07 \\
4.04 \\
4.00\end{array}$ & $\begin{array}{l}645 \\
646 \\
647 \\
648 \\
649\end{array}$ & $\begin{array}{l}5685.3 \\
5694.2 \\
5703.1 \\
5712.0 \\
5721.0\end{array}$ & $\begin{array}{l}8.924 \\
8.926 \\
8.927 \\
8.929 \\
8.931\end{array}$ & $\begin{array}{l}1.95 \\
1.91 \\
1.88 \\
1.84 \\
1.80\end{array}$ & $\begin{array}{l}705 \\
706 \\
707 \\
708 \\
709\end{array}$ & $\begin{array}{l}6222.9 \\
6231.9 \\
6240.8 \\
6249.8 \\
6258.8\end{array}$ & $\begin{array}{l}8.976 \\
8.976 \\
8.976 \\
8.975 \\
8.975\end{array}$ & $\begin{array}{l}-0.16 \\
-0.19 \\
-0.22 \\
-0.25 \\
-0.28\end{array}$ \\
\hline $\begin{array}{l}590 \\
591 \\
592 \\
593 \\
594\end{array}$ & $\begin{array}{l}5198.4 \\
5207.2 \\
5216.0 \\
5224.7 \\
5233.5\end{array}$ & $\begin{array}{l}8.760 \\
8.764 \\
8.768 \\
8.772 \\
8.776\end{array}$ & $\begin{array}{l}3.97 \\
3.93 \\
3.90 \\
3.86 \\
3.83\end{array}$ & $\begin{array}{l}650 \\
651 \\
652 \\
653 \\
654\end{array}$ & $\begin{array}{l}5729.9 \\
5738.8 \\
5747.8 \\
5756.7 \\
5765.7\end{array}$ & $\begin{array}{l}8.933 \\
8.935 \\
8.936 \\
8.938 \\
8.940\end{array}$ & $\begin{array}{l}1.76 \\
1.73 \\
1.69 \\
1.65 \\
1.62\end{array}$ & $\begin{array}{l}710 \\
711 \\
712 \\
713 \\
714\end{array}$ & $\begin{array}{l}6267.8 \\
6276.7 \\
6285.7 \\
6294.7 \\
6303.7\end{array}$ & $\begin{array}{l}8.975 \\
8.974 \\
8.974 \\
8.974 \\
8.973\end{array}$ & $\begin{array}{l}-0.32 \\
-0.35 \\
-0.38 \\
-0.41 \\
-0.44\end{array}$ \\
\hline $\begin{array}{l}595 \\
596 \\
597 \\
598 \\
599\end{array}$ & $\begin{array}{l}5242.3 \\
5251.1 \\
5259.9 \\
5268.7 \\
5277.4\end{array}$ & $\begin{array}{l}8.780 \\
8.784 \\
8.787 \\
8.791 \\
8.795\end{array}$ & $\begin{array}{l}3.79 \\
3.76 \\
3.72 \\
3.68 \\
3.65\end{array}$ & $\begin{array}{l}655 \\
656 \\
657 \\
658 \\
659\end{array}$ & $\begin{array}{l}5774.6 \\
5783.5 \\
5792.5 \\
5801.4 \\
5810.4\end{array}$ & $\begin{array}{l}8.941 \\
8.943 \\
8.944 \\
8.946 \\
8.947\end{array}$ & $\begin{array}{l}1.58 \\
1.54 \\
1.51 \\
1.47 \\
1.43\end{array}$ & $\begin{array}{l}715 \\
716 \\
717 \\
718 \\
719\end{array}$ & $\begin{array}{l}6312.6 \\
6321.6 \\
6330.6 \\
6339.6 \\
6348.5\end{array}$ & $\begin{array}{l}8.973 \\
8.972 \\
8.972 \\
8.971 \\
8.971\end{array}$ & $\begin{array}{l}-0.47 \\
-0.50 \\
-0.53 \\
-0.56 \\
-0.59\end{array}$ \\
\hline 600 & 5286.2 & 8.798 & 3.61 & 660 & 5819.3 & 8.949 & 1.40 & 720 & 6357.5 & 8.970 & -0.62 \\
\hline
\end{tabular}


TABle 7.5.2. Platinum, Pt-67, versus Type $K \boldsymbol{N}$ thermoelements-thermoelectric voltages, $\mathrm{E}(\mathrm{T})$, Seebeck coefficients, $\mathrm{S}(\mathrm{T})$, and first derivative of the Seebeck coefficients, $\mathrm{dS} / \mathrm{dT}$, reference junctions at $0^{\circ} \mathrm{C}$-Continued

\begin{tabular}{|c|c|c|c|c|c|c|c|c|c|c|c|}
\hline${ }^{\circ} \mathrm{C}$ & $\underset{\mu V}{E}$ & $\mu V{ }^{\circ}{ }^{\circ} \mathrm{C}$ & $\begin{array}{l}\mathrm{dS} / \mathrm{dT} \\
\mathrm{nV} /{ }^{\circ} \mathrm{C}^{2}\end{array}$ & ${ }^{\circ} \mathrm{C}$ & $\underset{\mu V}{E}$ & $\mu \mathrm{V} /{ }^{\circ} \mathrm{C}$ & $\begin{array}{l}\mathrm{dS} / \mathrm{dT} \\
\mathrm{nV} /{ }^{\circ} \mathrm{C}^{2}\end{array}$ & ${ }^{\circ} \mathrm{C}$ & $\underset{\mu V}{E}$ & ${ }_{\mu \mathrm{V} /{ }^{\circ} \mathrm{C}}^{\mathrm{S}}$ & $\begin{array}{l}\mathrm{dS} / \mathrm{dT} \\
\mathrm{nV} /{ }^{\circ} \mathrm{C}^{2}\end{array}$ \\
\hline $\begin{array}{l}725 \\
726 \\
727 \\
728 \\
729\end{array}$ & $\begin{array}{l}6402.3 \\
6411 \cdot 3 \\
6420.3 \\
6429.2 \\
6438.2\end{array}$ & $\begin{array}{l}8.967 \\
8.966 \\
8.965 \\
8.964 \\
8.963\end{array}$ & $\begin{array}{l}-0.77 \\
-0.80 \\
-0.83 \\
-0.86 \\
-0.89\end{array}$ & $\begin{array}{l}785 \\
786 \\
787 \\
788 \\
789\end{array}$ & $\begin{array}{l}6938.0 \\
6946.8 \\
6955.7 \\
6964.6 \\
6973.5\end{array}$ & $\begin{array}{l}8.874 \\
8.871 \\
8.869 \\
8.867 \\
8.864\end{array}$ & $\begin{array}{l}-2.23 \\
-2.25 \\
-2.27 \\
-2.29 \\
-2.31\end{array}$ & $\begin{array}{l}845 \\
846 \\
847 \\
848 \\
849\end{array}$ & $\begin{array}{l}7465.8 \\
7474 \cdot 5 \\
7483.2 \\
7491.9 \\
7500.6\end{array}$ & $\begin{array}{l}8.711 \\
8.708 \\
8.705 \\
8.702 \\
8.699\end{array}$ & $\begin{array}{l}-3.09 \\
-3.10 \\
-3.11 \\
-3.12 \\
-3.13\end{array}$ \\
\hline $\begin{array}{l}730 \\
731 \\
732 \\
733 \\
734\end{array}$ & $\begin{array}{l}6447.2 \\
6456.1 \\
6465.1 \\
6474.0 \\
6483.0\end{array}$ & $\begin{array}{l}8.962 \\
8.961 \\
8.960 \\
8.959 \\
8.958\end{array}$ & $\begin{array}{l}-0.91 \\
-0.94 \\
-0.97 \\
-1.00 \\
-1.03\end{array}$ & $\begin{array}{l}790 \\
791 \\
792 \\
793 \\
794\end{array}$ & $\begin{array}{l}6982.3 \\
6991.2 \\
7000.0 \\
7008.9 \\
7017.7\end{array}$ & $\begin{array}{l}8.862 \\
8.860 \\
8.857 \\
8.855 \\
8.853\end{array}$ & $\begin{array}{l}-2.32 \\
-2.34 \\
-2.36 \\
-2.38 \\
-2.40\end{array}$ & $\begin{array}{l}850 \\
851 \\
852 \\
853 \\
854\end{array}$ & $\begin{array}{l}7509.3 \\
7518.0 \\
7526.7 \\
7535.4 \\
7544.0\end{array}$ & $\begin{array}{l}8.695 \\
8.692 \\
8.689 \\
8.686 \\
8.683\end{array}$ & $\begin{array}{l}-3.14 \\
-3.14 \\
-3.15 \\
-3.16 \\
-3.17\end{array}$ \\
\hline $\begin{array}{l}740 \\
741 \\
742 \\
743 \\
744\end{array}$ & $\begin{array}{l}6536.7 \\
6545.7 \\
6554.6 \\
6563.6 \\
6572.5\end{array}$ & $\begin{array}{l}8.952 \\
8.951 \\
8.949 \\
8.948 \\
8.947\end{array}$ & $\begin{array}{l}-1.19 \\
-1.22 \\
-1.24 \\
-1.27 \\
-1.30\end{array}$ & $\begin{array}{l}800 \\
801 \\
802 \\
803 \\
804\end{array}$ & $\begin{array}{l}7070.8 \\
7079.7 \\
7088.5 \\
7097.3 \\
7106.2\end{array}$ & $\begin{array}{l}8.838 \\
8.835 \\
8.833 \\
8.830 \\
8.828\end{array}$ & $\begin{array}{l}-2.50 \\
-2.52 \\
-2.53 \\
-2.55 \\
-2.57\end{array}$ & $\begin{array}{l}860 \\
861 \\
862 \\
863 \\
864\end{array}$ & $\begin{array}{l}7596.1 \\
7604.7 \\
7613.4 \\
7622.1 \\
7630.7\end{array}$ & $\begin{array}{l}8.664 \\
8.660 \\
8.657 \\
8.654 \\
8.651\end{array}$ & $\begin{array}{l}-3.22 \\
-3.23 \\
-3.24 \\
-3.24 \\
-3.25\end{array}$ \\
\hline $\begin{array}{l}745 \\
746 \\
747 \\
748 \\
749\end{array}$ & $\begin{array}{l}6581.5 \\
6590.4 \\
6599.4 \\
6608.3 \\
6617.2\end{array}$ & $\begin{array}{l}8.946 \\
8.944 \\
8.943 \\
8.941 \\
8.940\end{array}$ & $\begin{array}{l}-1.32 \\
-1.35 \\
-1.38 \\
-1.40 \\
-1.43\end{array}$ & $\begin{array}{l}805 \\
806 \\
807 \\
808 \\
809\end{array}$ & $\begin{array}{l}7115.0 \\
7123.8 \\
7132.6 \\
7141.4 \\
7150.3\end{array}$ & $\begin{array}{l}8.825 \\
8.823 \\
8.820 \\
8.817 \\
8.815\end{array}$ & $\begin{array}{l}-2.58 \\
-2.60 \\
-2.61 \\
-2.63 \\
-2.64\end{array}$ & $\begin{array}{l}865 \\
866 \\
867 \\
868 \\
869\end{array}$ & $\begin{array}{l}7639.4 \\
7648.0 \\
7656.7 \\
7665.3 \\
7673.9\end{array}$ & $\begin{array}{l}8.648 \\
8.644 \\
8.641 \\
8.638 \\
8.634\end{array}$ & $\begin{array}{l}-3.26 \\
-3.26 \\
-3.27 \\
-3.28 \\
-3.29\end{array}$ \\
\hline $\begin{array}{l}750 \\
751 \\
752 \\
753 \\
754\end{array}$ & $\begin{array}{l}6626.2 \\
6635.1 \\
6644.1 \\
6653.0 \\
6661.9\end{array}$ & $\begin{array}{l}8.939 \\
8.937 \\
8.936 \\
8.934 \\
8.933\end{array}$ & $\begin{array}{l}-1.45 \\
-1.48 \\
-1.50 \\
-1.53 \\
-1.55\end{array}$ & $\begin{array}{l}810 \\
811 \\
812 \\
813 \\
814\end{array}$ & $\begin{array}{l}7159.1 \\
7167.9 \\
7176.7 \\
7185.5 \\
7194.3\end{array}$ & $\begin{array}{l}8.812 \\
8.810 \\
8.807 \\
8.804 \\
8.801\end{array}$ & $\begin{array}{l}-2.66 \\
-2.67 \\
-2.69 \\
-2.70 \\
-2.72\end{array}$ & $\begin{array}{l}870 \\
871 \\
872 \\
873 \\
874\end{array}$ & $\begin{array}{l}7682.6 \\
7691.2 \\
7699.8 \\
7708.4 \\
7717.1\end{array}$ & $\begin{array}{l}8.631 \\
8.628 \\
8.625 \\
8.621 \\
8.618\end{array}$ & $\begin{array}{l}-3.29 \\
-3.30 \\
-3.30 \\
-3.31 \\
-3.32\end{array}$ \\
\hline $\begin{array}{l}760 \\
761 \\
762 \\
763 \\
764\end{array}$ & $\begin{array}{l}6715.5 \\
6724.4 \\
6733.3 \\
6742.3 \\
6751.2\end{array}$ & $\begin{array}{l}8.923 \\
8.921 \\
8.919 \\
8.918 \\
8.916\end{array}$ & $\begin{array}{l}-1.70 \\
-1.72 \\
-1.74 \\
-1.77 \\
-1.79\end{array}$ & $\begin{array}{l}820 \\
821 \\
822 \\
823 \\
824\end{array}$ & $\begin{array}{l}7247.1 \\
7255.8 \\
7264.6 \\
7273.4 \\
7282.2\end{array}$ & $\begin{array}{l}8.785 \\
8.782 \\
8.779 \\
8.776 \\
8.774\end{array}$ & $\begin{array}{l}-2.80 \\
-2.81 \\
-2.83 \\
-2.84 \\
-2.85\end{array}$ & $\begin{array}{l}880 \\
881 \\
882 \\
883 \\
884\end{array}$ & $\begin{array}{l}7768 \cdot 7 \\
7777 \cdot 3 \\
7785 \cdot 9 \\
7794 \cdot 5 \\
7803.1\end{array}$ & $\begin{array}{l}8.598 \\
8.595 \\
8.591 \\
8.588 \\
8.584\end{array}$ & $\begin{array}{l}-3 \cdot 35 \\
-3 \cdot 36 \\
-3 \cdot 36 \\
-3 \cdot 37 \\
-3 \cdot 37\end{array}$ \\
\hline $\begin{array}{l}765 \\
766 \\
767 \\
768 \\
769\end{array}$ & $\begin{array}{l}6760.1 \\
6769.0 \\
6777.9 \\
6786.8 \\
6795.7\end{array}$ & $\begin{array}{l}8.914 \\
8.912 \\
8.910 \\
8.909 \\
8.907\end{array}$ & $\begin{array}{l}-1.81 \\
-1.83 \\
-1.86 \\
-1.88 \\
-1.90\end{array}$ & $\begin{array}{l}825 \\
826 \\
827 \\
828 \\
829\end{array}$ & $\begin{array}{l}7290.9 \\
7299.7 \\
7308.5 \\
7317.2 \\
7326.0\end{array}$ & $\begin{array}{l}8.771 \\
8.768 \\
8.765 \\
8.762 \\
8.759\end{array}$ & $\begin{array}{l}-2.87 \\
-2.88 \\
-2.89 \\
-2.90 \\
-2.92\end{array}$ & $\begin{array}{l}885 \\
886 \\
887 \\
888 \\
889\end{array}$ & $\begin{array}{l}7811.7 \\
7820.2 \\
7828.8 \\
7837.4 \\
7846.0\end{array}$ & $\begin{array}{l}8.581 \\
8.578 \\
8.574 \\
8.571 \\
8.568\end{array}$ & $\begin{array}{l}-3.38 \\
-3.38 \\
-3.39 \\
-3.39 \\
-3.40\end{array}$ \\
\hline $\begin{array}{l}770 \\
771 \\
772 \\
773 \\
774\end{array}$ & $\begin{array}{l}6804.6 \\
6813.5 \\
6822.4 \\
6831.3 \\
6840.2\end{array}$ & $\begin{array}{l}8.905 \\
8.903 \\
8.901 \\
8.899 \\
8.897\end{array}$ & $\begin{array}{l}-1.92 \\
-1.94 \\
-1.97 \\
-1.99 \\
-2.01\end{array}$ & $\begin{array}{l}830 \\
831 \\
832 \\
833 \\
834\end{array}$ & $\begin{array}{l}7334 \cdot 8 \\
7343.5 \\
7352.3 \\
7361.0 \\
7369.8\end{array}$ & $\begin{array}{l}8.756 \\
8.753 \\
8.750 \\
8.747 \\
8.744\end{array}$ & $\begin{array}{l}-2.93 \\
-2.94 \\
-2.95 \\
-2.96 \\
-2.97\end{array}$ & $\begin{array}{l}890 \\
891 \\
892 \\
893 \\
894\end{array}$ & $\begin{array}{l}7854.5 \\
7863.1 \\
7871.6 \\
7880.2 \\
7888.7\end{array}$ & $\begin{array}{l}8.564 \\
8.561 \\
8.557 \\
8.554 \\
8.550\end{array}$ & $\begin{array}{l}-3.40 \\
-3.41 \\
-3.41 \\
-3.42 \\
-3.42\end{array}$ \\
\hline $\begin{array}{l}775 \\
776 \\
777 \\
778 \\
779\end{array}$ & $\begin{array}{l}6849.1 \\
6858.0 \\
6866.9 \\
6875.8 \\
6884.7\end{array}$ & $\begin{array}{l}8.895 \\
8.893 \\
8.891 \\
8.889 \\
8.887\end{array}$ & $\begin{array}{l}-2.03 \\
-2.05 \\
-2.07 \\
-2.09 \\
-2.11\end{array}$ & $\begin{array}{l}835 \\
836 \\
837 \\
838 \\
839\end{array}$ & $\begin{array}{l}7378.5 \\
7387.2 \\
7396.0 \\
7404.7 \\
7413.5\end{array}$ & $\begin{array}{l}8.741 \\
8.738 \\
8.735 \\
8.732 \\
8.729\end{array}$ & $\begin{array}{l}-2.98 \\
-3.00 \\
-3.01 \\
-3.02 \\
-3.03\end{array}$ & $\begin{array}{l}895 \\
896 \\
897 \\
898 \\
899\end{array}$ & $\begin{array}{l}7897 \cdot 3 \\
7905.8 \\
7914.4 \\
7922.9 \\
7931.5\end{array}$ & $\begin{array}{l}8.547 \\
8.544 \\
8.540 \\
8.537 \\
8.533\end{array}$ & $\begin{array}{l}-3.43 \\
-3.43 \\
-3.43 \\
-3.44 \\
-3.44\end{array}$ \\
\hline 780 & 6893.6 & 8.884 & -2.13 & 840 & 7422.2 & 8.726 & -3.04 & 900 & 7940.0 & 8.530 & -3.45 \\
\hline
\end{tabular}


TABLE 7.5.2. Platinum, Pt-67, versus Type KN thermoelements-thermoelectric voltages, $\mathrm{E}(\mathrm{T})$, Seebeck coefficients, $\mathrm{S}(\mathrm{T})$, and first derivative of the Seebeck coefficients, $\mathrm{dS} / \mathrm{dT}$, reference junctions at $0^{\circ} \mathrm{C}-$ Continued

\begin{tabular}{|c|c|c|c|c|c|c|c|c|c|c|c|}
\hline${ }^{\circ} \mathrm{C}$ & $\underset{\mu V}{E}$ & $\stackrel{S}{S} /^{\circ} \mathrm{C}$ & $\begin{array}{l}\mathrm{dS} / \mathrm{d} T \\
\mathrm{nV} /{ }^{\circ} \mathrm{C}^{2}\end{array}$ & ${ }^{\circ} \mathrm{C}$ & $\underset{\mu V}{E}$ & $\underset{\mu V^{\circ} \mathrm{C}}{S}$ & $\begin{array}{l}\mathrm{dS} / \mathrm{dT} \\
\mathrm{nV} /{ }^{\circ} \mathrm{C}^{2}\end{array}$ & ${ }^{\circ} \mathrm{C}$ & $\underset{\mu V}{E}$ & $\underset{\mu \mathrm{V} /{ }^{\circ} \mathrm{C}}{\mathrm{S}}$ & $\begin{array}{l}d S / d T \\
n V /{ }^{\circ} C^{2}\end{array}$ \\
\hline $\begin{array}{l}900 \\
901 \\
902 \\
903 \\
904\end{array}$ & $\begin{array}{l}7940.0 \\
7948.5 \\
7957.0 \\
7965.6 \\
7974.1\end{array}$ & $\begin{array}{l}8.530 \\
8.526 \\
8.523 \\
8.519 \\
8.516\end{array}$ & $\begin{array}{l}-3.45 \\
-3.45 \\
-3.45 \\
-3.46 \\
-3.46\end{array}$ & $\begin{array}{l}960 \\
961 \\
962 \\
963 \\
964\end{array}$ & $\begin{array}{l}8445.5 \\
8453.8 \\
8462.1 \\
8470.4 \\
8478.7\end{array}$ & $\begin{array}{l}8.318 \\
8.314 \\
8.311 \\
8.307 \\
8.303\end{array}$ & $\begin{array}{l}-3.60 \\
-3.60 \\
-3.61 \\
-3.61 \\
-3.61\end{array}$ & $\begin{array}{l}1020 \\
1021 \\
1022 \\
1023 \\
1024\end{array}$ & $\begin{array}{l}8938.0 \\
8946.1 \\
8954.2 \\
8962.2 \\
8970.3\end{array}$ & $\begin{array}{l}8.097 \\
8.093 \\
8.090 \\
8.086 \\
8.082\end{array}$ & $\begin{array}{l}-3.78 \\
-3.79 \\
-3.79 \\
-3.80 \\
-3.80\end{array}$ \\
\hline $\begin{array}{l}905 \\
906 \\
907 \\
908 \\
909\end{array}$ & $\begin{array}{l}7982.6 \\
7991.1 \\
7999.6 \\
8008.1 \\
8016.6\end{array}$ & $\begin{array}{l}8.513 \\
8.509 \\
8.506 \\
8.502 \\
8.499\end{array}$ & $\begin{array}{l}-3.47 \\
-3.47 \\
-3.47 \\
-3.48 \\
-3.48\end{array}$ & $\begin{array}{l}965 \\
966 \\
967 \\
968 \\
969\end{array}$ & $\begin{array}{l}8487.0 \\
8495.3 \\
8503.6 \\
8511.9 \\
8520.2\end{array}$ & $\begin{array}{l}8.300 \\
8.296 \\
8.293 \\
8.289 \\
8.285\end{array}$ & $\begin{array}{l}-3.61 \\
-3.61 \\
-3.62 \\
-3.62 \\
-3.62\end{array}$ & $\begin{array}{l}1025 \\
1026 \\
1027 \\
1028 \\
1029\end{array}$ & $\begin{array}{l}8978.4 \\
8986.5 \\
8994.6 \\
9002.6 \\
9010.7\end{array}$ & $\begin{array}{l}8.078 \\
8.074 \\
8.070 \\
8.067 \\
8.063\end{array}$ & $\begin{array}{l}-3.81 \\
-3.81 \\
-3.82 \\
-3.82 \\
-3.83\end{array}$ \\
\hline $\begin{array}{l}910 \\
911 \\
912 \\
913 \\
914\end{array}$ & $\begin{array}{l}8025.1 \\
8033.6 \\
8042.1 \\
8050.6 \\
8059.1\end{array}$ & $\begin{array}{l}8.495 \\
8.492 \\
8.488 \\
8.485 \\
8.481\end{array}$ & $\begin{array}{l}-3.48 \\
-3.49 \\
-3.49 \\
-3.49 \\
-3.49\end{array}$ & $\begin{array}{l}970 \\
971 \\
972 \\
973 \\
974\end{array}$ & $\begin{array}{l}8528.5 \\
8536.7 \\
8545.0 \\
8553.3 \\
8561.6\end{array}$ & $\begin{array}{l}8.282 \\
8.278 \\
8.274 \\
8.271 \\
8.267\end{array}$ & $\begin{array}{l}-3.62 \\
-3.63 \\
-3.63 \\
-3.63 \\
-3.63\end{array}$ & $\begin{array}{l}1030 \\
1031 \\
1032 \\
1033 \\
1034\end{array}$ & $\begin{array}{l}9018.7 \\
9026.8 \\
9034.9 \\
9042.9 \\
9051.0\end{array}$ & $\begin{array}{l}8.059 \\
8.055 \\
8.051 \\
8.047 \\
8.044\end{array}$ & $\begin{array}{l}-3.83 \\
-3.84 \\
-3.84 \\
-3.85 \\
-3.85\end{array}$ \\
\hline $\begin{array}{l}915 \\
916 \\
917 \\
918 \\
919\end{array}$ & $\begin{array}{l}8067.5 \\
8076.0 \\
8084.5 \\
8093.0 \\
8101.4\end{array}$ & $\begin{array}{l}8.478 \\
8.474 \\
8.471 \\
8.467 \\
8.464\end{array}$ & $\begin{array}{l}-3.50 \\
-3.50 \\
-3.50 \\
-3.51 \\
-3.51\end{array}$ & $\begin{array}{l}975 \\
976 \\
977 \\
978 \\
979\end{array}$ & $\begin{array}{l}8569.8 \\
8578.1 \\
8586.3 \\
8594.6 \\
8602.8\end{array}$ & $\begin{array}{l}8.264 \\
8.260 \\
8.256 \\
8.253 \\
8.249\end{array}$ & $\begin{array}{l}-3.63 \\
-3.64 \\
-3.64 \\
-3.64 \\
-3.64\end{array}$ & $\begin{array}{l}1035 \\
1036 \\
1037 \\
1038 \\
1039\end{array}$ & $\begin{array}{l}9059.0 \\
9067.0 \\
9075.1 \\
9083.1 \\
9091.1\end{array}$ & $\begin{array}{l}8.040 \\
8.036 \\
8.032 \\
8.028 \\
8.024\end{array}$ & $\begin{array}{l}-3.86 \\
-3.86 \\
-3.87 \\
-3.87 \\
-3.88\end{array}$ \\
\hline $\begin{array}{l}920 \\
921 \\
922 \\
923 \\
924\end{array}$ & $\begin{array}{l}8109.9 \\
8118.3 \\
8126.8 \\
8135.3 \\
8143.7\end{array}$ & $\begin{array}{l}8.460 \\
8.457 \\
8.453 \\
8.450 \\
8.446\end{array}$ & $\begin{array}{l}-3.51 \\
-3.51 \\
-3.52 \\
-3.52 \\
-3.52\end{array}$ & $\begin{array}{l}980 \\
981 \\
982 \\
983 \\
984\end{array}$ & $\begin{array}{l}8611.1 \\
8619.3 \\
8627.6 \\
8635.8 \\
8644.0\end{array}$ & $\begin{array}{l}8.245 \\
8.242 \\
8.238 \\
8.234 \\
8.231\end{array}$ & $\begin{array}{l}-3.65 \\
-3.65 \\
-3.65 \\
-3.65 \\
-3.66\end{array}$ & $\begin{array}{l}1040 \\
1041 \\
1042 \\
1043 \\
1044\end{array}$ & $\begin{array}{l}9099.1 \\
9107.2 \\
9115.2 \\
9123.2 \\
9131.2\end{array}$ & $\begin{array}{l}8.020 \\
8.017 \\
8.013 \\
8.009 \\
8.005\end{array}$ & $\begin{array}{l}-3.89 \\
-3.89 \\
-3.90 \\
-3.90 \\
-3.91\end{array}$ \\
\hline $\begin{array}{l}925 \\
926 \\
927 \\
928 \\
929\end{array}$ & $\begin{array}{l}8152.1 \\
8160.6 \\
8169.0 \\
8177.5 \\
8185.9\end{array}$ & $\begin{array}{l}8.443 \\
8.439 \\
8.436 \\
8.432 \\
8.429\end{array}$ & $\begin{array}{l}-3.53 \\
-3.53 \\
-3.53 \\
-3.53 \\
-3.54\end{array}$ & $\begin{array}{l}985 \\
986 \\
987 \\
988 \\
989\end{array}$ & $\begin{array}{l}8652.3 \\
8660.5 \\
8668.7 \\
8676.9 \\
8685.2\end{array}$ & $\begin{array}{l}8.227 \\
8.223 \\
8.220 \\
8.216 \\
8.212\end{array}$ & $\begin{array}{l}-3.66 \\
-3.66 \\
-3.67 \\
-3.67 \\
-3.67\end{array}$ & $\begin{array}{l}1045 \\
1046 \\
1047 \\
1048 \\
1049\end{array}$ & $\begin{array}{l}9139.2 \\
9147.2 \\
9155.2 \\
9163.2 \\
9171.2\end{array}$ & $\begin{array}{l}8.001 \\
7.997 \\
7.993 \\
7.989 \\
7.985\end{array}$ & $\begin{array}{l}-3.92 \\
-3.92 \\
-3.93 \\
-3.93 \\
-3.94\end{array}$ \\
\hline $\begin{array}{l}930 \\
931 \\
932 \\
933 \\
934\end{array}$ & $\begin{array}{l}8194.3 \\
8202.7 \\
8211.2 \\
8219.6 \\
8228.0\end{array}$ & $\begin{array}{l}8.425 \\
8.421 \\
8.418 \\
8.414 \\
8.411\end{array}$ & $\begin{array}{l}-3.54 \\
-3.54 \\
-3.54 \\
-3.54 \\
-3.55\end{array}$ & $\begin{array}{l}990 \\
991 \\
992 \\
993 \\
994\end{array}$ & $\begin{array}{l}8693.4 \\
8701.6 \\
8709.8 \\
8718.0 \\
8726.2\end{array}$ & $\begin{array}{l}8.209 \\
8.205 \\
8.201 \\
8.198 \\
8.194\end{array}$ & $\begin{array}{l}-3.67 \\
-3.68 \\
-3.68 \\
-3.68 \\
-3.69\end{array}$ & $\begin{array}{l}1050 \\
1051 \\
1052 \\
1053 \\
1054\end{array}$ & $\begin{array}{l}9179.2 \\
9187.1 \\
9195.1 \\
9203.1 \\
9211.0\end{array}$ & $\begin{array}{l}7.981 \\
7.977 \\
7.973 \\
7.969 \\
7.965\end{array}$ & $\begin{array}{l}-3.95 \\
-3.95 \\
-3.96 \\
-3.97 \\
-3.97\end{array}$ \\
\hline $\begin{array}{l}935 \\
936 \\
937 \\
938 \\
939\end{array}$ & $\begin{array}{l}8236.4 \\
8244.8 \\
8253.2 \\
8261.6 \\
8270.0\end{array}$ & $\begin{array}{l}8.407 \\
8.404 \\
8.400 \\
8.397 \\
8.393\end{array}$ & $\begin{array}{l}-3.55 \\
-3.55 \\
-3.55 \\
-3.56 \\
-3.56\end{array}$ & $\begin{array}{l}995 \\
996 \\
997 \\
998 \\
999\end{array}$ & $\begin{array}{l}8734.4 \\
8742.6 \\
8750.7 \\
8758.9 \\
8767.1\end{array}$ & $\begin{array}{l}8.190 \\
8.187 \\
8.183 \\
8.179 \\
8.176\end{array}$ & $\begin{array}{l}-3.69 \\
-3.69 \\
-3.69 \\
-3.70 \\
-3.70\end{array}$ & $\begin{array}{l}1055 \\
1056 \\
1057 \\
1058 \\
1059\end{array}$ & $\begin{array}{l}9219.0 \\
9227.0 \\
9234.9 \\
9242.9 \\
9250.8\end{array}$ & $\begin{array}{l}7.961 \\
7.957 \\
7.953 \\
7.949 \\
7.945\end{array}$ & $\begin{array}{l}-3.98 \\
-3.99 \\
-3.99 \\
-4.00 \\
-4.01\end{array}$ \\
\hline $\begin{array}{l}940 \\
941 \\
942 \\
943 \\
944\end{array}$ & $\begin{array}{l}8278.4 \\
8286.8 \\
8295.2 \\
8303.5 \\
8311.9\end{array}$ & $\begin{array}{l}8.389 \\
8.386 \\
8.382 \\
8.379 \\
8.375\end{array}$ & $\begin{array}{l}-3.56 \\
-3.56 \\
-3.56 \\
-3.57 \\
-3.57\end{array}$ & $\begin{array}{l}1000 \\
1001 \\
1002 \\
1003 \\
1004\end{array}$ & $\begin{array}{l}8775.3 \\
8783.4 \\
8791.6 \\
8799.8 \\
8807.9\end{array}$ & $\begin{array}{l}8.172 \\
8.168 \\
8.165 \\
8.161 \\
8.157\end{array}$ & $\begin{array}{l}-3.70 \\
-3.71 \\
-3.71 \\
-3.72 \\
-3.72\end{array}$ & $\begin{array}{l}1060 \\
1061 \\
1062 \\
1063 \\
1064\end{array}$ & $\begin{array}{l}9258.8 \\
9266.7 \\
9274.6 \\
9282.6 \\
9290.5\end{array}$ & $\begin{array}{l}7.941 \\
7.937 \\
7.933 \\
7.929 \\
7.925\end{array}$ & $\begin{array}{l}-4.01 \\
-4.02 \\
-4.03 \\
-4.04 \\
-4.04\end{array}$ \\
\hline $\begin{array}{l}945 \\
946 \\
947 \\
948 \\
949\end{array}$ & $\begin{array}{l}8320.3 \\
8328.7 \\
8337.0 \\
8345.4 \\
8353.7\end{array}$ & $\begin{array}{l}8.372 \\
8.368 \\
8.365 \\
8.361 \\
8.357\end{array}$ & $\begin{array}{l}-3.57 \\
-3.57 \\
-3.57 \\
-3.58 \\
-3.58\end{array}$ & $\begin{array}{l}1005 \\
1006 \\
1007 \\
1008 \\
1009\end{array}$ & $\begin{array}{l}8816.1 \\
8824.2 \\
8832.4 \\
8840.5 \\
8848.7\end{array}$ & $\begin{array}{l}8.153 \\
8.150 \\
8.146 \\
8.142 \\
8.138\end{array}$ & $\begin{array}{l}-3.72 \\
-3.73 \\
-3.73 \\
-3.73 \\
-3.74\end{array}$ & $\begin{array}{l}1065 \\
1066 \\
1067 \\
1068 \\
1069\end{array}$ & $\begin{array}{l}9298 \cdot 4 \\
9306 \cdot 3 \\
9314 \cdot 3 \\
9322 \cdot 2 \\
9330 \cdot 1\end{array}$ & $\begin{array}{l}7.921 \\
7.917 \\
7.913 \\
7.909 \\
7.905\end{array}$ & $\begin{array}{l}-4.05 \\
-4.06 \\
-4.06 \\
-4.07 \\
-4.08\end{array}$ \\
\hline $\begin{array}{l}950 \\
951 \\
952 \\
953 \\
954\end{array}$ & $\begin{array}{l}8362.1 \\
8370.5 \\
8378.8 \\
8387.1 \\
8395.5\end{array}$ & $\begin{array}{l}8.354 \\
8.350 \\
8.347 \\
8.343 \\
8.339\end{array}$ & $\begin{array}{l}-3.58 \\
-3.58 \\
-3.58 \\
-3.59 \\
-3.59\end{array}$ & $\begin{array}{l}1010 \\
1011 \\
1012 \\
1013 \\
1014\end{array}$ & $\begin{array}{l}8856.8 \\
8864.9 \\
8873.1 \\
8881.2 \\
8889.3\end{array}$ & $\begin{array}{l}8.135 \\
8.131 \\
8.127 \\
8.123 \\
8.120\end{array}$ & $\begin{array}{l}-3.74 \\
-3.75 \\
-3.75 \\
-3.75 \\
-3.76\end{array}$ & $\begin{array}{l}1070 \\
1071 \\
1072 \\
1073 \\
1074\end{array}$ & $\begin{array}{l}9338.0 \\
9345.9 \\
9353.8 \\
9361.7 \\
9369.6\end{array}$ & $\begin{array}{l}7.901 \\
7.897 \\
7.893 \\
7.889 \\
7.885\end{array}$ & $\begin{array}{l}-4.09 \\
-4.09 \\
-4.10 \\
-4.11 \\
-4.12\end{array}$ \\
\hline $\begin{array}{l}955 \\
956 \\
957 \\
958 \\
959\end{array}$ & $\begin{array}{l}8403.8 \\
8412.2 \\
8420.5 \\
8428.8 \\
8437.1\end{array}$ & $\begin{array}{l}8.336 \\
8.332 \\
8.329 \\
8.325 \\
8.321\end{array}$ & $\begin{array}{l}-3.59 \\
-3.59 \\
-3.60 \\
-3.60 \\
-3.60\end{array}$ & $\begin{array}{l}1015 \\
1016 \\
1017 \\
1018 \\
1019\end{array}$ & $\begin{array}{l}8897.4 \\
8905.5 \\
8913.7 \\
8921.8 \\
8929.9\end{array}$ & $\begin{array}{l}8.116 \\
8.112 \\
8.108 \\
8.105 \\
8.101\end{array}$ & $\begin{array}{l}-3.76 \\
-3.77 \\
-3.77 \\
-3.77 \\
-3.78\end{array}$ & $\begin{array}{l}1075 \\
1076 \\
1077 \\
1078 \\
1079\end{array}$ & $\begin{array}{l}9377.4 \\
9385.3 \\
9393.2 \\
9401.1 \\
9408.9\end{array}$ & $\begin{array}{l}7.880 \\
7.876 \\
7.872 \\
7.868 \\
7.864\end{array}$ & $\begin{array}{l}-4 \cdot 12 \\
-4 \cdot 13 \\
-4 \cdot 14 \\
-4 \cdot 15 \\
-4 \cdot 16\end{array}$ \\
\hline 960 & 8445.5 & 8.318 & -3.60 & 1020 & 8938.0 & 8.097 & $-3 \cdot 78$ & 1080 & 9416.8 & 7.860 & -4.16 \\
\hline
\end{tabular}


TABLE 7.5.2. Platinum, Pi-67, versus Type KN thermoelements-thermoelectric voltages, E(T), Seebeck coefficients, $\mathrm{S}(\mathrm{T})$, and first derivative of the Seebeck coefficients, $\mathrm{dS} / \mathrm{dT}$, reference junctions at $0^{\circ} \mathrm{C}-$ Continued

\begin{tabular}{|c|c|c|c|c|c|c|c|c|c|c|c|}
\hline $\begin{array}{l}\mathrm{T} \\
{ }^{\circ} \mathrm{C}\end{array}$ & $\begin{array}{c}E \\
\mu V\end{array}$ & $\underset{\mu V /{ }^{\circ} \mathrm{C}}{\mathrm{S}}$ & $\begin{array}{l}\mathrm{dS} / \mathrm{dT} \\
\mathrm{nV} /{ }^{\circ} \mathrm{C}^{2}\end{array}$ & ${ }^{\circ} \mathrm{C}$ & $\begin{array}{l}E \\
\mu V\end{array}$ & $\stackrel{S}{\mu V /{ }^{\circ} \mathrm{C}}$ & $\begin{array}{l}d S / d T \\
n V /{ }^{\circ} C^{2}\end{array}$ & $\begin{array}{l}T \\
{ }^{\circ} \mathrm{C}\end{array}$ & $\begin{array}{c}E \\
\mu V\end{array}$ & $\begin{array}{c}\mathrm{S} \\
\mu \mathrm{V} /{ }^{\circ} \mathrm{C}\end{array}$ & $\begin{array}{l}d S / d T \\
n V /{ }^{\circ} C^{2}\end{array}$ \\
\hline $\begin{array}{l}1080 \\
1081 \\
1082 \\
1083 \\
1084\end{array}$ & $\begin{array}{l}9416.8 \\
9424.6 \\
9432.5 \\
9440.3 \\
9448.2\end{array}$ & $\begin{array}{l}7.860 \\
7.856 \\
7.851 \\
7.847 \\
7.843\end{array}$ & $\begin{array}{l}-4.16 \\
-4.17 \\
-4.18 \\
-4.19 \\
-4.20\end{array}$ & $\begin{array}{l}1140 \\
1141 \\
1142 \\
1143 \\
1144\end{array}$ & $\begin{array}{l}9880.6 \\
9888.2 \\
9895.8 \\
9903.3 \\
9910.9\end{array}$ & $\begin{array}{l}7.596 \\
7.591 \\
7.586 \\
7.582 \\
7.577\end{array}$ & $\begin{array}{l}-4.62 \\
-4.62 \\
-4.63 \\
-4.64 \\
-4.64\end{array}$ & $\begin{array}{l}1200 \\
1201 \\
1202 \\
1203 \\
1204\end{array}$ & $\begin{array}{l}10327.9 \\
10335.2 \\
10342.5 \\
10349.8 \\
10357.1\end{array}$ & $\begin{array}{l}7.316 \\
7.312 \\
7.307 \\
7.303 \\
7.298\end{array}$ & $\begin{array}{l}-4 \cdot 50 \\
-4 \cdot 49 \\
-4 \cdot 47 \\
-4 \cdot 46 \\
-4 \cdot 44\end{array}$ \\
\hline $\begin{array}{l}1085 \\
1086 \\
1087 \\
1088 \\
1089\end{array}$ & $\begin{array}{l}9456.0 \\
9463.9 \\
9471.7 \\
9479.5 \\
9487.4\end{array}$ & $\begin{array}{l}7.839 \\
7.835 \\
7.830 \\
7.826 \\
7.822\end{array}$ & $\begin{array}{l}-4.20 \\
-4.21 \\
-4.22 \\
-4.23 \\
-4.24\end{array}$ & $\begin{array}{l}1145 \\
1146 \\
1147 \\
1148 \\
1149\end{array}$ & $\begin{array}{l}9918.5 \\
9926.1 \\
9933.6 \\
9941.2 \\
9948.8\end{array}$ & $\begin{array}{l}7.572 \\
7.568 \\
7.563 \\
7.558 \\
7.554\end{array}$ & $\begin{array}{l}-4.65 \\
-4.65 \\
-4.65 \\
-4.66 \\
-4.66\end{array}$ & $\begin{array}{l}1205 \\
1206 \\
1207 \\
1208 \\
1209\end{array}$ & $\begin{array}{l}10364.4 \\
10371.7 \\
10379.0 \\
10386.3 \\
10393.6\end{array}$ & $\begin{array}{l}7.294 \\
7.290 \\
7.285 \\
7.281 \\
7.276\end{array}$ & $\begin{array}{l}-4.43 \\
-4.41 \\
-4.39 \\
-4.38 \\
-4.36\end{array}$ \\
\hline $\begin{array}{l}1090 \\
1091 \\
1092 \\
1093 \\
1094\end{array}$ & $\begin{array}{l}9495.2 \\
9503.0 \\
9510.8 \\
9518.6 \\
9526.4\end{array}$ & $\begin{array}{l}7.818 \\
7.813 \\
7.809 \\
7.805 \\
7.801\end{array}$ & $\begin{array}{l}-4 \cdot 24 \\
-4.25 \\
-4.26 \\
-4.27 \\
-4.28\end{array}$ & $\begin{array}{l}1150 \\
1151 \\
1152 \\
1153 \\
1154\end{array}$ & $\begin{array}{l}9956.3 \\
9963.9 \\
9971.4 \\
9978.9 \\
9986.5\end{array}$ & $\begin{array}{l}7.549 \\
7.544 \\
7.540 \\
7.535 \\
7.530\end{array}$ & $\begin{array}{l}-4.67 \\
-4.67 \\
-4.67 \\
-4.68 \\
-4.68\end{array}$ & $\begin{array}{l}1210 \\
1211 \\
1212 \\
1213 \\
1214\end{array}$ & $\begin{array}{l}10400.9 \\
10408 \cdot 1 \\
10415 \cdot 4 \\
10422.7 \\
10429.9\end{array}$ & $\begin{array}{l}7.272 \\
7.268 \\
7.263 \\
7.259 \\
7.255\end{array}$ & $\begin{array}{l}-4 \cdot 34 \\
-4 \cdot 32 \\
-4 \cdot 30 \\
-4 \cdot 28 \\
-4 \cdot 26\end{array}$ \\
\hline $\begin{array}{l}1095 \\
1096 \\
1097 \\
1098 \\
1099\end{array}$ & $\begin{array}{l}9534.2 \\
9542.0 \\
9549.8 \\
9557.6 \\
9565.4\end{array}$ & $\begin{array}{l}7.796 \\
7.792 \\
7.788 \\
7.783 \\
7.779\end{array}$ & $\begin{array}{l}-4 \cdot 28 \\
-4.29 \\
-4.30 \\
-4 \cdot 31 \\
-4.32\end{array}$ & $\begin{array}{l}1155 \\
1156 \\
1157 \\
1158 \\
1159\end{array}$ & $\begin{array}{r}9994.0 \\
10001.5 \\
10009.0 \\
10016.6 \\
10024.1\end{array}$ & $\begin{array}{l}7.526 \\
7.521 \\
7.516 \\
7.512 \\
7.507\end{array}$ & $\begin{array}{l}-4.68 \\
-4.69 \\
-4.69 \\
-4.69 \\
-4.69\end{array}$ & $\begin{array}{l}1215 \\
1216 \\
1217 \\
1218 \\
1219\end{array}$ & $\begin{array}{l}10437.2 \\
10444.4 \\
10451.7 \\
10458.9 \\
10466.1\end{array}$ & $\begin{array}{l}7.251 \\
7.246 \\
7.242 \\
7.238 \\
7.234\end{array}$ & $\begin{array}{l}-4 \cdot 23 \\
-4 \cdot 21 \\
-4 \cdot 19 \\
-4 \cdot 16 \\
-4 \cdot 14\end{array}$ \\
\hline $\begin{array}{l}1100 \\
1101 \\
1102 \\
1103 \\
1104\end{array}$ & $\begin{array}{l}9573.1 \\
9580.9 \\
9588.7 \\
9596.4 \\
9604.2\end{array}$ & $\begin{array}{l}7.775 \\
7.771 \\
7.766 \\
7.762 \\
7.757\end{array}$ & $\begin{array}{l}-4 \cdot 33 \\
-4 \cdot 33 \\
-4 \cdot 34 \\
-4 \cdot 35 \\
-4.36\end{array}$ & $\begin{array}{l}1160 \\
1161 \\
1162 \\
1163 \\
1164\end{array}$ & $\begin{array}{l}10031.6 \\
10039.1 \\
10046.6 \\
10054.0 \\
10061.5\end{array}$ & $\begin{array}{l}7.502 \\
7.498 \\
7.493 \\
7.488 \\
7.484\end{array}$ & $\begin{array}{l}-4 \cdot 70 \\
-4 \cdot 70 \\
-4 \cdot 70 \\
-4 \cdot 70 \\
-4 \cdot 70\end{array}$ & $\begin{array}{l}1220 \\
1221 \\
1222 \\
1223 \\
1224\end{array}$ & $\begin{array}{l}10473.4 \\
10480 \cdot 6 \\
10487 \cdot 8 \\
10495.0 \\
10502.2\end{array}$ & $\begin{array}{l}7.230 \\
7.226 \\
7.222 \\
7.218 \\
7.214\end{array}$ & $\begin{array}{l}-4.11 \\
-4.09 \\
-4.06 \\
-4.03 \\
-4.00\end{array}$ \\
\hline $\begin{array}{l}1105 \\
1106 \\
1107 \\
1108 \\
1109\end{array}$ & $\begin{array}{l}9612.0 \\
9619.7 \\
9627.5 \\
9635.2 \\
9642.9\end{array}$ & $\begin{array}{l}7.753 \\
7.749 \\
7.744 \\
7.740 \\
7.736\end{array}$ & $\begin{array}{l}-4.37 \\
-4.37 \\
-4.38 \\
-4.39 \\
-4.40\end{array}$ & $\begin{array}{l}1165 \\
1166 \\
1167 \\
1168 \\
1169\end{array}$ & $\begin{array}{l}10069 \cdot 0 \\
10076.5 \\
10084.0 \\
10091.4 \\
10098.9\end{array}$ & $\begin{array}{l}7.479 \\
7.474 \\
7.469 \\
7.465 \\
7.460\end{array}$ & $\begin{array}{l}-4 \cdot 70 \\
-4 \cdot 70 \\
-4 \cdot 70 \\
-4 \cdot 70 \\
-4 \cdot 70\end{array}$ & $\begin{array}{l}1225 \\
1226 \\
1227 \\
1228 \\
1229\end{array}$ & $\begin{array}{l}10509.5 \\
10516.7 \\
10523.9 \\
10531.1 \\
10538.3\end{array}$ & $\begin{array}{l}7.210 \\
7.206 \\
7.202 \\
7.198 \\
7.194\end{array}$ & $\begin{array}{l}-3.97 \\
-3.94 \\
-3.91 \\
-3.88 \\
-3.85\end{array}$ \\
\hline 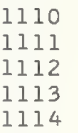 & $\begin{array}{l}9650 \cdot 7 \\
9658 \cdot 4 \\
9666 \cdot 1 \\
9673 \cdot 8 \\
9681.6\end{array}$ & $\begin{array}{l}7.731 \\
7.727 \\
7.722 \\
7.718 \\
7.713\end{array}$ & $\begin{array}{l}-4.41 \\
-4.42 \\
-4.42 \\
-4.43 \\
-4.44\end{array}$ & $\begin{array}{l}1170 \\
1171 \\
1172 \\
1173 \\
1174\end{array}$ & $\begin{array}{l}10106.4 \\
10113.8 \\
10121.3 \\
10128.7 \\
10136.1\end{array}$ & $\begin{array}{l}7.455 \\
7.451 \\
7.446 \\
7.441 \\
7.437\end{array}$ & $\begin{array}{l}-4 \cdot 70 \\
-4 \cdot 70 \\
-4 \cdot 70 \\
-4 \cdot 70 \\
-4.69\end{array}$ & $\begin{array}{l}1230 \\
1231 \\
1232 \\
1233 \\
1234\end{array}$ & $\begin{array}{l}10545.5 \\
10552.6 \\
10559.8 \\
10567.0 \\
10574.2\end{array}$ & $\begin{array}{l}7.190 \\
7.186 \\
7.183 \\
7.179 \\
7.175\end{array}$ & $\begin{array}{l}-3.82 \\
-3.78 \\
-3.75 \\
-3.71 \\
-3.67\end{array}$ \\
\hline $\begin{array}{l}1115 \\
1116 \\
1117 \\
1118 \\
1119\end{array}$ & $\begin{array}{l}9689.3 \\
9697.0 \\
9704.7 \\
9712.4 \\
9720.1\end{array}$ & $\begin{array}{l}7.709 \\
7.705 \\
7.700 \\
7.696 \\
7.691\end{array}$ & $\begin{array}{l}-4.45 \\
-4.45 \\
-4.46 \\
-4.47 \\
-4.48\end{array}$ & $\begin{array}{l}1175 \\
1176 \\
1177 \\
1178 \\
1179\end{array}$ & $\begin{array}{l}10143.6 \\
10151.0 \\
10158.4 \\
10165.8 \\
10173.3\end{array}$ & $\begin{array}{l}7.432 \\
7.427 \\
7.422 \\
7.418 \\
7.413\end{array}$ & $\begin{array}{l}-4.69 \\
-4.69 \\
-4.69 \\
-4.68 \\
-4.68\end{array}$ & $\begin{array}{l}1235 \\
1236 \\
1237 \\
1238 \\
1239\end{array}$ & $\begin{array}{l}10581.4 \\
10588.5 \\
10595.7 \\
10602.9 \\
10610.0\end{array}$ & $\begin{array}{l}7.171 \\
7.168 \\
7.164 \\
7.161 \\
7.157\end{array}$ & $\begin{array}{l}-3.64 \\
-3.60 \\
-3.56 \\
-3.52 \\
-3.48\end{array}$ \\
\hline $\begin{array}{l}1120 \\
1121 \\
1122 \\
1123 \\
1124\end{array}$ & $\begin{array}{l}9727.8 \\
9735.4 \\
9743.1 \\
9750.8 \\
9758.5\end{array}$ & $\begin{array}{l}7.687 \\
7.682 \\
7.678 \\
7.673 \\
7.669\end{array}$ & $\begin{array}{l}-4.49 \\
-4.49 \\
-4.50 \\
-4.51 \\
-4.52\end{array}$ & $\begin{array}{l}1180 \\
1181 \\
1182 \\
1183 \\
1184\end{array}$ & $\begin{array}{l}10180.7 \\
10188.1 \\
10195.5 \\
10202.9 \\
10210.3\end{array}$ & $\begin{array}{l}7.408 \\
7.404 \\
7.399 \\
7.394 \\
7.390\end{array}$ & $\begin{array}{l}-4.67 \\
-4.67 \\
-4.66 \\
-4.66 \\
-4.65\end{array}$ & $\begin{array}{l}1240 \\
1241 \\
1242 \\
1243 \\
1244\end{array}$ & $\begin{array}{l}10617.2 \\
10624.3 \\
10631.5 \\
10638.6 \\
10645.8\end{array}$ & $\begin{array}{l}7.154 \\
7.150 \\
7.147 \\
7.144 \\
7.140\end{array}$ & $\begin{array}{l}-3.43 \\
-3.39 \\
-3.35 \\
-3.30 \\
-3.25\end{array}$ \\
\hline $\begin{array}{l}1125 \\
1126 \\
1127 \\
1128 \\
1129\end{array}$ & $\begin{array}{l}9766.1 \\
9773.8 \\
9781.5 \\
9789.1 \\
9796.8\end{array}$ & $\begin{array}{l}7.664 \\
7.660 \\
7.655 \\
7.651 \\
7.646\end{array}$ & $\begin{array}{l}-4.52 \\
-4.53 \\
-4.54 \\
-4.54 \\
-4.55\end{array}$ & $\begin{array}{l}1185 \\
1186 \\
1187 \\
1188 \\
1189\end{array}$ & $\begin{array}{l}10217.7 \\
10225.0 \\
10232.4 \\
10239.8 \\
10247.2\end{array}$ & $\begin{array}{l}7.385 \\
7.380 \\
7.376 \\
7.371 \\
7.367\end{array}$ & $\begin{array}{l}-4.65 \\
-4.64 \\
-4.63 \\
-4.63 \\
-4.62\end{array}$ & $\begin{array}{l}1245 \\
1246 \\
1247 \\
1248 \\
1249\end{array}$ & $\begin{array}{l}10652.9 \\
10660.0 \\
10667.2 \\
10674.3 \\
10681.4\end{array}$ & $\begin{array}{l}7.137 \\
7.134 \\
7.131 \\
7.128 \\
7.125\end{array}$ & $\begin{array}{l}-3.21 \\
-3.16 \\
-3.11 \\
-3.06 \\
-3.01\end{array}$ \\
\hline $\begin{array}{l}11130 \\
11132 \\
11132 \\
1133 \\
1134\end{array}$ & $\begin{array}{l}9804.4 \\
9812.0 \\
9819.7 \\
9827.3 \\
9834.9\end{array}$ & $\begin{array}{l}7.641 \\
7.637 \\
7.632 \\
7.628 \\
7.623\end{array}$ & $\begin{array}{l}-4.56 \\
-4.56 \\
-4.57 \\
-4.58 \\
-4.58\end{array}$ & $\begin{array}{l}1190 \\
1191 \\
1192 \\
1193 \\
1194\end{array}$ & $\begin{array}{l}10254.5 \\
10261.9 \\
10269.2 \\
10276.6 \\
10283.9\end{array}$ & $\begin{array}{l}7.362 \\
7.357 \\
7.353 \\
7.348 \\
7.344\end{array}$ & $\begin{array}{l}-4.61 \\
-4.60 \\
-4.59 \\
-4.58 \\
-4.57\end{array}$ & $\begin{array}{l}1250 \\
1251 \\
1252 \\
1253 \\
1254\end{array}$ & $\begin{array}{l}10688.5 \\
10695.7 \\
10702.8 \\
10709.9 \\
10717.0\end{array}$ & $\begin{array}{l}7.122 \\
7.119 \\
7.116 \\
7.113 \\
7.110\end{array}$ & $\begin{array}{l}-2.96 \\
-2.90 \\
-2.85 \\
-2.79 \\
-2.73\end{array}$ \\
\hline $\begin{array}{l}1135 \\
1136 \\
1137 \\
1138 \\
1139\end{array}$ & $\begin{array}{l}9842.5 \\
9850.2 \\
9857.8 \\
9865.4 \\
9873.0\end{array}$ & $\begin{array}{l}7.619 \\
7.614 \\
7.609 \\
7.605 \\
7.600\end{array}$ & $\begin{array}{l}-4.59 \\
-4.60 \\
-4.60 \\
-4.61 \\
-4.61\end{array}$ & $\begin{array}{l}1195 \\
1196 \\
1197 \\
1198 \\
1199\end{array}$ & $\begin{array}{l}10291.3 \\
10298.6 \\
10305.9 \\
10313.3 \\
10320.6\end{array}$ & $\begin{array}{l}7.339 \\
7.334 \\
7.330 \\
7.325 \\
7.321\end{array}$ & $\begin{array}{l}-4.56 \\
-4.55 \\
-4.54 \\
-4.53 \\
-4.51\end{array}$ & $\begin{array}{l}1255 \\
1256 \\
1257 \\
1258 \\
1259\end{array}$ & $\begin{array}{l}10724.1 \\
10731.2 \\
10738.3 \\
10745.4 \\
10752.5\end{array}$ & $\begin{array}{l}7.108 \\
7.105 \\
7.102 \\
7.100 \\
7.097\end{array}$ & $\begin{array}{l}-2.68 \\
-2.62 \\
-2.56 \\
-2.49 \\
-2.43\end{array}$ \\
\hline 1140 & 9880.6 & 7.596 & $-4 \cdot 62$ & 1200 & 10327.9 & 7.316 & $-4 \cdot 50$ & 1260 & 10759.6 & 7.095 & -2.37 \\
\hline
\end{tabular}


TABLE 7.5.2. Platinum, Pt-67, versus Type $K N$ thermoelements-thermoelectric voltages, $E(T)$, Seebeck coefficients, $\mathrm{S}(\mathrm{T})$, and first derivative of the Seebeck coefficients, $\mathrm{dS} / \mathrm{dT}$, reference junctions at $0^{\circ} \mathrm{C}$-Continued

\begin{tabular}{|c|c|c|c|c|c|c|c|c|c|c|c|}
\hline${ }^{\circ} \mathrm{C}$ & $\underset{\mu V}{E}$ & $\underset{\mu V /{ }^{\circ} \mathrm{C}}{S}$ & $\begin{array}{l}d S / d T \\
n V /{ }^{\circ} C^{2}\end{array}$ & $\begin{array}{l}\mathrm{T} \\
{ }^{\circ} \mathrm{C}\end{array}$ & ${ }_{\mu}^{E} V$ & $\underset{\mu V /^{\circ} \mathrm{C}}{S}$ & $\begin{array}{l}d S / d T \\
n V /{ }^{\circ} C^{2}\end{array}$ & ${ }^{\circ} \mathrm{C}$ & $\underset{\mu V}{E}$ & $\stackrel{S}{S}$ & $\begin{array}{l}d S / d T \\
n V /{ }^{\circ} C^{2}\end{array}$ \\
\hline $\begin{array}{l}1260 \\
1261 \\
1262 \\
1263 \\
1264\end{array}$ & $\begin{array}{l}10759.6 \\
10766.7 \\
10773.8 \\
10780.9 \\
10788.0\end{array}$ & $\begin{array}{l}7.095 \\
7.093 \\
7.090 \\
7.088 \\
7.086\end{array}$ & $\begin{array}{l}-2.37 \\
-2.30 \\
-2.24 \\
-2.17 \\
-2.10\end{array}$ & $\begin{array}{l}1300 \\
1301 \\
1302 \\
1303 \\
1304\end{array}$ & $\begin{array}{l}11042.4 \\
11049.4 \\
11056.5 \\
11063.6 \\
11070.6\end{array}$ & $\begin{array}{l}7.067 \\
7.068 \\
7.070 \\
7.072 \\
7.073\end{array}$ & $\begin{array}{l}1.38 \\
1.51 \\
1.64 \\
1.77 \\
1.90\end{array}$ & $\begin{array}{l}1340 \\
1341 \\
1342 \\
1343 \\
1344\end{array}$ & $\begin{array}{l}11327.7 \\
11335.0 \\
11342.2 \\
11349.5 \\
11356.8\end{array}$ & $\begin{array}{l}7.246 \\
7.255 \\
7.263 \\
7.272 \\
7.281\end{array}$ & $\begin{array}{l}8.22 \\
8.45 \\
8.67 \\
8.90 \\
9.13\end{array}$ \\
\hline $\begin{array}{l}1265 \\
1266 \\
1267 \\
1268 \\
1269\end{array}$ & $\begin{array}{l}10795.1 \\
10802.2 \\
10809.2 \\
10816.3 \\
10823.4\end{array}$ & $\begin{array}{l}7.084 \\
7.082 \\
7.080 \\
7.078 \\
7.076\end{array}$ & $\begin{array}{l}-2.03 \\
-1.96 \\
-1.88 \\
-1.81 \\
-1.73\end{array}$ & $\begin{array}{l}1305 \\
1306 \\
1307 \\
1308 \\
1309\end{array}$ & $\begin{array}{l}11077.7 \\
11084.8 \\
11091.9 \\
11099.0 \\
11106.0\end{array}$ & $\begin{array}{l}7.075 \\
7.078 \\
7.080 \\
7.082 \\
7.085\end{array}$ & $\begin{array}{l}2.04 \\
2.18 \\
2.32 \\
2.46 \\
2.60\end{array}$ & $\begin{array}{l}1345 \\
1346 \\
1347 \\
1348 \\
1349\end{array}$ & $\begin{array}{l}11364.1 \\
11371.4 \\
11378.7 \\
11386.0 \\
11393.3\end{array}$ & $\begin{array}{l}7.290 \\
7.300 \\
7.310 \\
7.320 \\
7.330\end{array}$ & $\begin{array}{r}9.36 \\
9.60 \\
9.84 \\
10.08 \\
10.33\end{array}$ \\
\hline $\begin{array}{l}1270 \\
1271 \\
1272 \\
1273 \\
1274\end{array}$ & $\begin{array}{l}10830.5 \\
10837.5 \\
10844.6 \\
10851.7 \\
10858.8\end{array}$ & $\begin{array}{l}7.075 \\
7.073 \\
7.072 \\
7.070 \\
7.069\end{array}$ & $\begin{array}{l}-1.66 \\
-1.58 \\
-1.50 \\
-1.42 \\
-1.33\end{array}$ & $\begin{array}{l}1310 \\
1311 \\
1312 \\
1313 \\
1314\end{array}$ & $\begin{array}{llll}1 & 1 & 1 & 13.1 \\
1 & 1 & 120.2 \\
1 & 1 & 127.3 \\
1 & 1 & 134.4 \\
1 & 1 & 14 & 4.5\end{array}$ & $\begin{array}{l}7.087 \\
7.090 \\
7.093 \\
7.096 \\
7.0100\end{array}$ & $\begin{array}{l}2.75 \\
2.90 \\
3.05 \\
3.20 \\
3.36\end{array}$ & $\begin{array}{l}1350 \\
1351 \\
1352 \\
1353 \\
1354\end{array}$ & $\begin{array}{l}11400 \cdot 6 \\
11408 \cdot 0 \\
11415 \cdot 3 \\
11422.7 \\
11430.1\end{array}$ & $\begin{array}{l}7.340 \\
7.351 \\
7.362 \\
7.373 \\
7.385\end{array}$ & $\begin{array}{l}10.58 \\
10.83 \\
11.09 \\
11.34 \\
11.61\end{array}$ \\
\hline $\begin{array}{l}1275 \\
1276 \\
1277 \\
1278 \\
1279\end{array}$ & $\begin{array}{l}10865.8 \\
10872.9 \\
10880.0 \\
10887.0 \\
10894.1\end{array}$ & $\begin{array}{l}7.068 \\
7.066 \\
7.065 \\
7.064 \\
7.063\end{array}$ & $\begin{array}{l}-1.25 \\
-1.16 \\
-1.08 \\
-0.99 \\
-0.90\end{array}$ & $\begin{array}{l}1315 \\
1316 \\
1317 \\
1318 \\
1319\end{array}$ & $\begin{array}{l}11148.6 \\
11155.7 \\
11162.8 \\
11169.9 \\
11177.0\end{array}$ & $\begin{array}{l}7.103 \\
7.107 \\
7.110 \\
7.114 \\
7.118\end{array}$ & $\begin{array}{l}3.51 \\
3.67 \\
3.83 \\
4.00 \\
4.16\end{array}$ & $\begin{array}{l}1355 \\
1356 \\
1357 \\
1358 \\
1359\end{array}$ & $\begin{array}{l}11437.5 \\
11444.9 \\
11452.3 \\
11459.7 \\
11467.2\end{array}$ & $\begin{array}{l}7.396 \\
7.408 \\
7.421 \\
7.433 \\
7.446\end{array}$ & $\begin{array}{l}11.87 \\
12.14 \\
12.41 \\
12.68 \\
12.96\end{array}$ \\
\hline $\begin{array}{l}1280 \\
1281 \\
1282 \\
1283 \\
1284\end{array}$ & $\begin{array}{l}10901.1 \\
10908.2 \\
10915.3 \\
10922.3 \\
10929.4\end{array}$ & $\begin{array}{l}7.062 \\
7.062 \\
7.061 \\
7.060 \\
7.060\end{array}$ & $\begin{array}{l}-0.81 \\
-0.71 \\
-0.62 \\
-0.52 \\
-0.42\end{array}$ & $\begin{array}{l}1320 \\
1321 \\
1322 \\
1323 \\
1324\end{array}$ & $\begin{array}{l}11184.2 \\
11191.3 \\
11198.4 \\
11205.6 \\
11212.7\end{array}$ & $\begin{array}{l}7.123 \\
7.127 \\
7.132 \\
7.136 \\
7.141\end{array}$ & $\begin{array}{l}4.33 \\
4.50 \\
4.68 \\
4.85 \\
5.03\end{array}$ & $\begin{array}{l}1360 \\
1361 \\
1362 \\
1363 \\
1364\end{array}$ & $\begin{array}{l}11474.6 \\
11482.1 \\
11489.6 \\
11497.1 \\
11504.6\end{array}$ & $\begin{array}{l}7.459 \\
7.472 \\
7.486 \\
7.500 \\
7.514\end{array}$ & $\begin{array}{l}13.24 \\
13.53 \\
13.81 \\
14.11 \\
14.40\end{array}$ \\
\hline $\begin{array}{l}1285 \\
1286 \\
1287 \\
1288 \\
1289\end{array}$ & $\begin{array}{l}10936.5 \\
10943.5 \\
10950.6 \\
10957.6 \\
10964.7\end{array}$ & $\begin{array}{l}7.060 \\
7.059 \\
7.059 \\
7.059 \\
7.059\end{array}$ & $\begin{array}{r}-0.32 \\
-0.22 \\
-0.12 \\
-0.01 \\
0.09\end{array}$ & $\begin{array}{l}1325 \\
1326 \\
1327 \\
1328 \\
1329\end{array}$ & $\begin{array}{l}11219.8 \\
11227.0 \\
111234.1 \\
11241.3 \\
11248.5\end{array}$ & $\begin{array}{l}7.146 \\
7.152 \\
7.157 \\
7.163 \\
7.169\end{array}$ & $\begin{array}{l}5.21 \\
5.39 \\
5.58 \\
5.77 \\
5.96\end{array}$ & $\begin{array}{l}1365 \\
1366 \\
1367 \\
1368 \\
1369\end{array}$ & $\begin{array}{l}11512.1 \\
11519.6 \\
11527.2 \\
11534.7 \\
11542.3\end{array}$ & $\begin{array}{l}7.529 \\
7.544 \\
7.559 \\
7.574 \\
7.590\end{array}$ & $\begin{array}{l}14.70 \\
15.00 \\
15.31 \\
15.61 \\
15.93\end{array}$ \\
\hline $\begin{array}{l}1290 \\
1291 \\
1292\end{array}$ & $\begin{array}{l}10971.7 \\
10978.8 \\
10985.9\end{array}$ & $\begin{array}{l}7.059 \\
7.059 \\
7.060\end{array}$ & $\begin{array}{l}0.20 \\
0.31 \\
0.42\end{array}$ & $\begin{array}{l}1330 \\
1331 \\
1332\end{array}$ & $\begin{array}{l}11255.6 \\
11262.8 \\
11270.0\end{array}$ & $\begin{array}{l}7.175 \\
7.181 \\
7.187\end{array}$ & $\begin{array}{l}6.15 \\
6.34 \\
6.54\end{array}$ & $\begin{array}{l}1370 \\
1371 \\
1372\end{array}$ & $\begin{array}{l}11549.9 \\
11557.5 \\
11565.2\end{array}$ & $\begin{array}{l}7.606 \\
7.623 \\
7.639\end{array}$ & $\begin{array}{l}16 \cdot 24 \\
16 \cdot 56 \\
16.88\end{array}$ \\
\hline $\begin{array}{l}1293 \\
1294\end{array}$ & $\begin{array}{l}10992.9 \\
11000.0\end{array}$ & $\begin{array}{l}7.060 \\
7.061\end{array}$ & $\begin{array}{l}0.53 \\
0.65\end{array}$ & $\begin{array}{l}1333 \\
1334\end{array}$ & $\begin{array}{l}11277.2 \\
11284.4\end{array}$ & $\begin{array}{l}7.194 \\
7.201\end{array}$ & $\begin{array}{l}6.74 \\
6.95\end{array}$ & & & & \\
\hline $\begin{array}{l}1295 \\
1296 \\
1297 \\
1298 \\
1299\end{array}$ & $\begin{array}{l}11007.0 \\
11014.1 \\
11021.2 \\
11028.2 \\
11035.3\end{array}$ & $\begin{array}{l}7.062 \\
7.062 \\
7.063 \\
7.064 \\
7.066\end{array}$ & $\begin{array}{l}0.77 \\
0.88 \\
1.01 \\
1.13 \\
1.25\end{array}$ & $\begin{array}{l}1335 \\
1336 \\
1337 \\
1338 \\
1339\end{array}$ & $\begin{array}{l}11291.6 \\
11298.8 \\
11306.0 \\
11313.2 \\
11320.5\end{array}$ & $\begin{array}{l}7.208 \\
7.215 \\
7.223 \\
7.230 \\
7.238\end{array}$ & $\begin{array}{l}7.15 \\
7.36 \\
7.57 \\
7.79 \\
8.00\end{array}$ & & & & \\
\hline 1300 & 11042.4 & 7.067 & 1.38 & 1340 & 11327.7 & 7.246 & $8 \cdot 22$ & & & & \\
\hline
\end{tabular}


TABLE 7.5.3. Thermoelectric values at the fixed points for platinum, $\mathrm{Pt}-67$, versus Type $K N$ thermoelements

\begin{tabular}{|c|c|c|c|c|}
\hline Fixed point & $\begin{array}{c}\text { Temp. } \\
{ }^{\circ} \mathrm{C}\end{array}$ & $\begin{array}{c}E \\
\mu \mathrm{V}\end{array}$ & $\begin{array}{c}S \\
\mu \mathrm{V} /{ }^{\circ} \mathrm{C}\end{array}$ & $\begin{array}{c}d S / d T \\
\mathrm{nV} /{ }^{\circ} \mathrm{C}^{2}\end{array}$ \\
\hline $\begin{array}{l}\text { Helium NBP } \\
\text { Hydrogen TP } \\
\text { Hydrogen NBP } \\
\text { Neon TP } \\
\text { Neon NBP } \\
\text { Oxygen TP } \\
\text { Nitrogen TP } \\
\text { Nitrogen NBP } \\
\text { Oxygen NBP } \\
\text { Carbon Dioxide SP } \\
\text { Mercury FP } \\
\text { Ice point* } \\
\text { Ether TP } \\
\text { Water BP } \\
\text { Benzoic TP } \\
\text { Indium FP } \\
\text { Tin FP } \\
\text { B smuth FP } \\
\text { Cadmium FP } \\
\text { Lead FP } \\
\text { Mercury BP } \\
\text { Zinc FP } \\
\text { Sulphur BP } \\
\text { Cu-Al FP } \\
\text { Antimony FP } \\
\text { Aluminum FP } \\
\text { Silver FP } \\
\text { Gold FP } \\
\text { Copper FP }\end{array}$ & $\begin{array}{c}-268.935 \\
-259.340 \\
-252.870 \\
-248.595 \\
-246.048 \\
-218.789 \\
-210.002 \\
-195.802 \\
-182.962 \\
-78.476 \\
-38.862 \\
0.000 \\
26.870 \\
100.000 \\
122.370 \\
156.634 \\
231.9681 \\
271.442 \\
321.108 \\
327.502 \\
356.660 \\
419.580 \\
444.674 \\
548.23 \\
630.74 \\
660.37 \\
961.93 \\
1064.43 \\
1084.5\end{array}$ & $\begin{array}{c}-2900.05 \\
-2890.85 \\
-2874.36 \\
-2858.71 \\
-2847.58 \\
-2656.72 \\
-2574.89 \\
-2431.57 \\
-2294.86 \\
-1052.44 \\
-528.77 \\
0.00 \\
363.6 \\
1282.5 \\
1521.3 \\
1835.7 \\
2394.8 \\
2677.1 \\
3040.6 \\
3087.9 \\
3304.9 \\
3784.3 \\
3981.4 \\
4836.4 \\
5558.2 \\
5822.6 \\
8461.5 \\
9293.9 \\
9452.1\end{array}$ & $\begin{array}{r}0.075 \\
1.886 \\
3.218 \\
4.106 \\
4.626 \\
8.908 \\
9.672 \\
10.435 \\
10.831 \\
12.917 \\
13.472 \\
13.640 \\
13.396 \\
11.254 \\
10.076 \\
8.351 \\
7.080 \\
7.235 \\
7.388 \\
7.404 \\
7.486 \\
7.777 \\
7.929 \\
8.566 \\
8.892 \\
8.949 \\
8.311 \\
7.924 \\
7.841\end{array}$ & $\begin{array}{r}174.90 \\
201.30 \\
208.30 \\
206.05 \\
202.24 \\
103.02 \\
72.10 \\
38.88 \\
25.00 \\
18.04 \\
10.75 \\
-6.59 \\
-12.12 \\
-49.29 \\
-54.47 \\
-42.41 \\
2.01 \\
4.16 \\
2.44 \\
2.48 \\
3.32 \\
5.77 \\
6.28 \\
5.29 \\
2.48 \\
1.38 \\
-3.61 \\
-4.05 \\
-4.20\end{array}$ \\
\hline
\end{tabular}

*Junction point of different functions.

TABLE 7.5.4. Estimated maximum errors that occur when using reduced-bit arithmetic for the power series expansion for the thermoelectric voltage of platinum, $\mathrm{Pt}-67$, versus Type $K N$ thermoelements

\begin{tabular}{|c|c|c|c|c|c|c|}
\hline \multirow[b]{2}{*}{ Temperature range } & \multirow[b]{2}{*}{ Degree } & \multicolumn{5}{|c|}{ Estimated maximum error in microvolts } \\
\hline & & 12 Bit & 16 Bit & 24 Bit & $27 \mathrm{Bit}$ & $36 \mathrm{Bit}$ \\
\hline-270 to $-200^{\circ} \mathrm{C}$ & 12 & $(*)$ & 500 & 2 & 0.2 & $<0.01$ \\
\hline-200 to & 12 & $\left({ }^{*}\right)$. & 70 & 0.2 & 0.02 & $<0.01$ \\
\hline 0 to $200^{\circ} \mathrm{C}$ & $8+\exp$ & $i$ & 0.04 & $<0.01$ & $<0.01$ & $<0.01$ \\
\hline 200 to $400{ }^{\circ} \mathrm{C}$ & $8+\exp$ & 4 & 0.07 & $<0.01$ & $<0.01$ & $<0.01$ \\
\hline 400 to $600{ }^{\circ} \mathrm{C}$ & $8+\exp$ & 20 & 0.8 & $<0.01$ & $<0.01$ & $<0.01$ \\
\hline 600 to $800{ }^{\circ} \mathrm{C}$ & $8+\exp$ & 90 & 3 & $<0.01$ & $<0.01$ & $<0.01$ \\
\hline 800 to $1000^{\circ} \mathrm{C}$ & $8+\exp$ & 300 & 8 & $<0.01$ & $<0.01$ & $<0.01$ \\
\hline 1000 to $1200{ }^{\circ} \mathrm{C}$ & $8+\exp$ & 800 & 15 & 0.04 & 0.02 & $<0.01$ \\
\hline 1200 to $1372{ }^{\circ} \mathrm{C}$ & $8+\exp$ & $(*)$ & 30 & 0.1 & 0.05 & $<0 \quad 01$ \\
\hline
\end{tabular}

*A high-order polynomial with a low-bit machine causes extreme error 


\section{TYPE T-Copper Versus Copper-Nickel Alloy -Thermocouples}

\subsection{Material Specifications and Precautions}

This type is one of the older and more popular thermocouples for determining temperatures within the range from about $300{ }^{\circ} \mathrm{C}$ down to the hydrogen normal boiling point $\left(-252.87{ }^{\circ} \mathrm{C}\right)$. It is at present the only one of the standardized letter-designated type thermocouples for which limits of error are specified below $0{ }^{\circ} \mathrm{C}$. The positive thermoelement, TP, is typically electrolyic tough pitch copper that conforms to ASTM Specification B3 for soft or annealed bare copper wire. Such material is about 99.95 percent pure copper with an oxygen content varying from 0.02 to 0.07 percent (depending on sulfur content) and with other im. purities totaling about 0.01 percent. Above about $-195{ }^{\circ} \mathrm{C}$ the thermoelectric properties of Type TP thermoelements, which satisfy the above conditions, are exceptionally uniform and exhibit little variation between different lots. Below about $76 \mathrm{~K}$ the thermoelectric properties are affected more strongly by the presence of dilute transition metal solutes, particularly irori.

The negative thermoelement, TN (or EN), is a copper-nickel alloy known ambiguously as constantan. As discussed in section 6.1, the word constantan refers to a family of copper-nickel alloys containing anywhere from 45 to 60 percent copper. These alloys also typically contain small percentages of manganese and iron as well as other trace impurities such as carbon, magnesium, silicon, cobalt, etc. Constantan is also known by various trade names such as Advance ${ }^{1}$ and Cupron ${ }^{2}$. The constantan for Type $T$ thermocouples usually contains about 55 percent copper, 45 percent nickel, and small but thermoelectrically significant amounts of iron and manganese, about 0.1 percent or larger. It should be emphasized that Type TN (or EN) thermoelements are NOT generally interchangeable with Type JN thermoelements, although they are all referred to as "constantan". In order to provide some differentiation in nomenclature, Type TN (or EN) is often referred to as Adams' constantan and Type JN is usually referred to as SAMA constantan.

The thermoelectric relations for Type TN and EN thermoelements are the same, that is the voltage versus temperature equations and tables for platinum versus Type TN thermoelements is typical for both types of thermoelements over the temperature range recommended for each corresponding thermocouple type. However, it should not be assumed that Type TN and $\mathrm{EN}$ thermoelements are always interchangeable or that they have the same commercial limits of error.

The first reference tables for Type $T$ thermocouples to be used on an industry-wide basis were those prepared by Roeser and Dahl [1938]. They indicated that their tabular values were intended primarily for use above $0{ }^{\circ} \mathrm{C}$. They presented tabular values below $0^{\circ} \mathrm{C}$ as a matter of convenience only and the values

\footnotetext{
1 Trademark-Driver Harris Company.
}

2 Trademark-Wilbur B. Driver Company. were based upon measurements of only a relatively few samples. The values above $0{ }^{\circ} \mathrm{C}$ were derived from measurements of the thermoelectric voltage on nine samples of copper versus platinum, $\mathrm{Pt}-27$, between 0 and $1000{ }^{\circ} \mathrm{C}$ and on twenty-seven samples of constantan versus platinum between 0 and $800{ }^{\circ} \mathrm{C}$. The samples were furnished by the various pyrometer instrument manufacturers at that time. Several years later, more representative tabular values were established by Scott [1940] for the subzero temperature range. The tabular values of Roeser and Dahl [1938] above $0{ }^{\circ} \mathrm{C}$ were combined with those of Scott [1940] and also corrected for changes in the temperature scales and electrical units by Shenker et al. [1951 and 1955]. The last revision of the tables in 1955 was presented in NBS Circular 561.

Extensive research on the subzero properties of Type $\mathrm{T}$ thermocouples was performed by members of the Cryogenic Division in Boulder. That research was summarized and tabulated by Sparks et al. [1972] in NBS Monograph 124. They indicate that Type T thermocouples may be used down to liquid hydrogen temperatures (about $20 \mathrm{~K}$ ), but of the standardized letter-designated type thermocouples they emphasize that Type $\mathrm{E}$ thermocouples possess the most desirable characteristics in this range. The thermoelectric homogeneity of most Type TP and TN (or EN) thermoelements is reasonably good. However, the Seebeck coefficient of Type $\mathrm{T}$ thermocouples is moderately small at subzero temperatures (about $5.6 \mu \mathrm{V} / \mathrm{K}$ at $20 \mathrm{~K}$ ), being roughly two-thirds that of Type $\mathrm{E}$ thermocouples. This, together with the high thermal conductivity of Type TP thermoelements, is the major reason why Type $T$ thermocouples are less suitable for use in the subzero range than Type $\mathbb{E}$ thermocouples. In addition, there is considerable variability in the thermoelectric properties of Type TP thermoelements at temperatures below about $76 \mathrm{~K}$ caused by variations in the amounts and types of impurities present in these nearly pure materials. For these reasons, Type T thermocouples are generally unsuitable for use below about $20 \mathrm{~K}$.

Type $\mathrm{T}$ thermocouples are recommended by the ASTM [1970] for use in the temperature range from -184 to $371{ }^{\circ} \mathrm{C}$ in vacuum or in oxidizing, reducing or inert atmospheres. The recommended upper temperature limit for continuous service of protected Type $\mathrm{T}$ thermocouples is set at $371{ }^{\circ} \mathrm{C}$ for AWG 14 (1.6 $\mathrm{mm}$ ) thermoelements since Type TP thermoelements oxidize rapidly above this temperature. However, the thermoelectric properties of Type TP thermoelements are apparently not grossly affected by oxidation since Roeser and Dahl [1938] observed negligible changes in the thermoelectric voltage of Nos. 12, 18 and 22 AWG Type TP thermoelements after heating for 30 hours in air at $500{ }^{\circ} \mathrm{C}$. At this temperature the Type TN thermoelements have good resistance to oxidation and exhibit only small changes in thermal emf with long exposure in air, as shown by the studies of Dahl [1941]. Higher operating tem- 
peratures, up to at least $700{ }^{\circ} \mathrm{C}$, are possible in vacuum or in inert atmospheres, where the deterioration of the Type TP thermoelement is no longer a problem. Operation of Type $\mathrm{T}$ thermocouples in hydrogen atmospheres at temperatures above about $370{ }^{\circ} \mathrm{C}$ is not recommended since severe embrittlement of the Type TP thermoelements may occur.

Type $\mathrm{T}$ thermocouples are not well suited for use in nuclear environments since both thermoelements are subject to significant changes in composition under thermal neutron irradiation. The copper in the thermoelements is converted to nickel and zinc.

Because of the high thermal conductivity of Type TP thermoelements, special care should be exercised in the use of the thermocouples to insure that both the measuring and reference junctions assume the desired temperatures. Caldwell [1965] has determined the errors that arise from insufficient immersion of Type TP thermoelements in ice baths and his work should be consulted for details.

ASTM Standard E230-72 in the Annual Book of ASTM Standards [1972] specifies that the standard limits of error for Type $\mathrm{T}$ commercial thermocouples be \pm 2 percent between -101 and $-59^{\circ} \mathrm{C}, \pm 0.8^{\circ} \mathrm{C}$ between -59 and $93{ }^{\circ} \mathrm{C}$ and $\pm 3 / 4$ percent between 93 and $371{ }^{\circ} \mathrm{C}$. Type $\mathrm{T}$ thermocouples can also be supplied to meet special limits of error, which are equal to one half the standard limits of error given above (plus a limit of error of \pm 1 percent is specified between -184 and $-59{ }^{\circ} \mathrm{C}$ ). The recommended upper temperature limit for protected Type $\mathrm{T}$ thermocouples, $371{ }^{\circ} \mathrm{C}$, applies to AWG $14(1.6 \mathrm{~mm})$ wire. For smaller wires it decreases to $260{ }^{\circ} \mathrm{C}$ for $\mathrm{AWG}$ $20(0.8 \mathrm{~mm})$ and $240{ }^{\circ} \mathrm{C}$ for AWG 24 or 28 (0.5 or $0.3 \mathrm{~mm})$.

\subsection{Data Analyses and Comparisons}

The fitting functions for Type $\mathrm{T}$ thermocouples are based on two sets of data: below $0{ }^{\circ} \mathrm{C}$, the research and equations of Sparks et al. [1972] were used directly; above $0{ }^{\circ} \mathrm{C}$, values from NBS Circular 561 [1955] were used after being adjusted to the IPTS68. Unfortunately there were no data for both highand low-temperature calibrations on the same spool or lot of present-day material. This deficiency leads to difficulties in joining high- and low-temperature calibration curves near $0{ }^{\circ} \mathrm{C}$.

Sparks et al. [1972] based their recommended low temperature values for the positive thermoelement, $\mathrm{TP}$, on a selected wire that was most representative of two calibrated wires selected from four spools made by two different manufacturers. Material from all spools was certified by their manufacturers to be within the special limits of error (as listed in the last section) at high temperatures. Similarly, the negative thermoelement, TN, represented the best wire from three calibrated wires taken from ten spools supplied by four different manufacturers. The wires for both positive and negative thermoelements were selected after completion of careful spot calibration and inhomogeneity tests as described in Monograph 124. Values for the single thermoelements are given versus the platinum reference standard, $\mathrm{Pt}-67$. Thermoelectric values for both thermoelements and the combination were relatively difficult to fit precisely. Values for the positive thermoelement required a 14th degree power series to fit 68 points between about -270 and $0{ }^{\circ} \mathrm{C}$ with an imprecision of $0.12 \mu \mathrm{V}$; the negative thermoelement required a 13th degree power series to give $0.12 \mu \mathrm{V}$; and the combination (fit independently), 14th degree for an imprecision of $0.06 \mu \mathrm{V}$. In Monograph 124 the two thermoelements and the total combination were fit independently; for this Monograph, equations for the total combination were used directly but the nega. tive and positive thermoelement values were obtained by subtraction, symbolically, $T N(\equiv E N)=E-$ $E P(\equiv K P)$ and $T P=T-T N$. Therefore, the equations for TP and TN given in this Monograph will differ very slightly from the ${ }^{\circ} \mathrm{C}$ transformation of the ones given in Monograph 124. The difference in calculated values will usually be less than the im. precision of the fits, $0.12 \mu \mathrm{V}$.

The data on Type $\mathrm{T}$ thermocouples are much more sparse above $0{ }^{\circ} \mathrm{C}$ than they are below. In particular there were no data on current Type TP material. Data points for Type $T$ were selected from NBS Circular 561, adjusted to the present temperature scale, IPTS68 , and fit with a constrained power series. The power series was constrained to have the same values for the thermoelectric voltage and Seebeck coefficient at $0{ }^{\circ} \mathrm{C}$ as those obtained from the low temperature equations. An eighth degree equation (with constrained constant and linear term) fit 17 selected key data points between 0 and $400{ }^{\circ} \mathrm{C}$ with an imprecision of $0.7 \mu \mathrm{V}$. Note that this is not much worse than the low temperature fit. The second derivative was not constrained at the join.

The values for thermoelectric voltages of Type $T$ thermocouples given in this Monograph were compared to those given by Shenker et al. [1955] in NBS Circular 561, to those given by Sparks et al. [1972], and to four representative calibrations from the Tempera. ture Section of the National Bureau of Standards, Gaithersburg. The deviations are shown in figure 8.2.1. The values from NBS Circular 561 were adjusted to the IPTS-68. Above $0{ }^{\circ} \mathrm{C}$ the deviations between the values in this Monograph and those in NBS Circular 561 are caused primarily by the differences in fitting techniques. Below $0{ }^{\circ} \mathrm{C}$, the deviations are caused primarily by chemical composition changes in the thermoelements. Present-day materials are slightly different in some of the minor additives.

Similar comparison graphs for the Type TP and TN thermoelements are given in figures 8.2.2. and 8.2.3. However, for Type TP thermoelements versus $\mathrm{Pt}-67$, comparisons could only be made to values from the lower temperature tables [Sparks et al. 1972] and to values from the widely distributed, but unpublished, industrial tables prepared by Burns [1967].

Deviations between values given in this Monograph and those given in NBS Circular 561 are also shown in figure 8.2.4. The earlier values were adjusted to the IPTS-68. The width of the curve indicates the roundoff uncertainty $(1 \mu \mathrm{V})$ in the tabular values given in NBS Circular 561. 


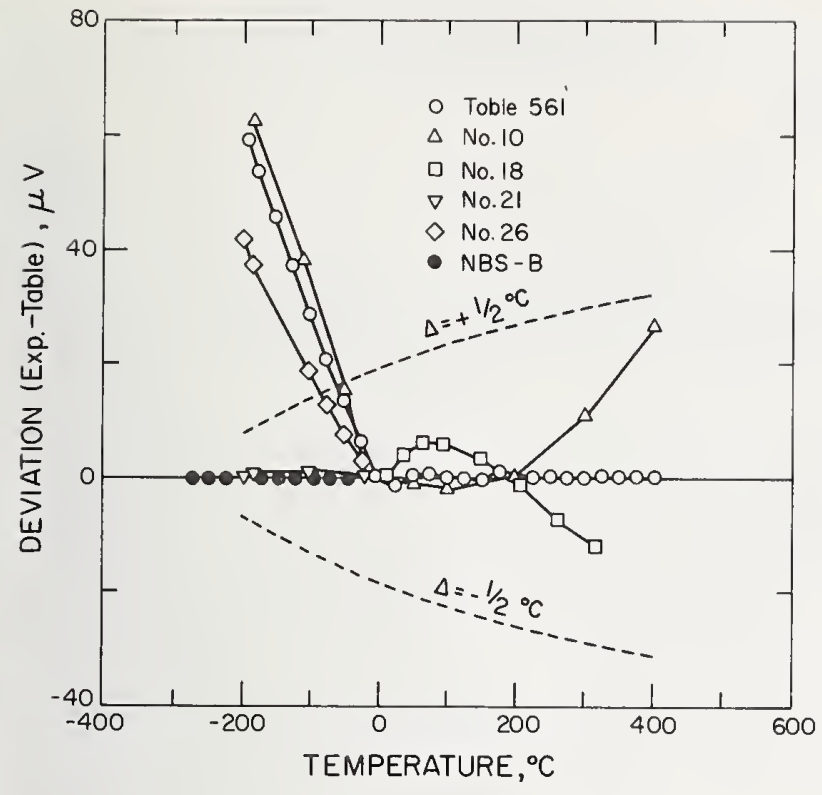

Figure 8.2.1. Deviations of the thermoelectric voltage of Type $T$ thermocouples - comparison of values given in this Monograph to those given by: Table 561, NBS Circular 561; NBS-B, Sparks, et al. [1972]; Nos. 10, 18, 21 and 26, se. lected calibrations from the Temperature Section (NBS, Gaithersburg).

Values from previous publications and tests are adjusted to the IPTS 68 . The dashed lines indicate a deviaion of $1 / 2{ }^{\circ} \mathrm{C}$.

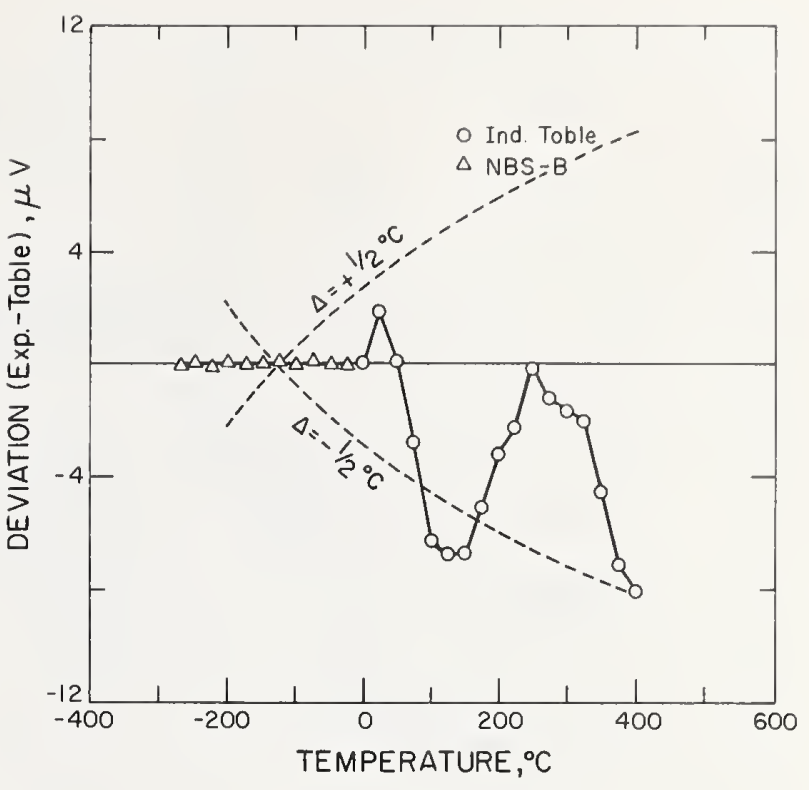

Figure 8.2.2. Deviations in the thermoelectric voltage of Type TP thermoelements versus platinum, Pt-67-comparison of the values given in this Monograph to those given by: Ind. Table, unpublished NBS data by Burns [1967]; NBS-B, Sparks, et al. [1972].

Values from previous publications are adjusted to the IPTS-68. The dashed lines indicate a deviation of $1 / 2{ }^{\circ} \mathrm{C}$.

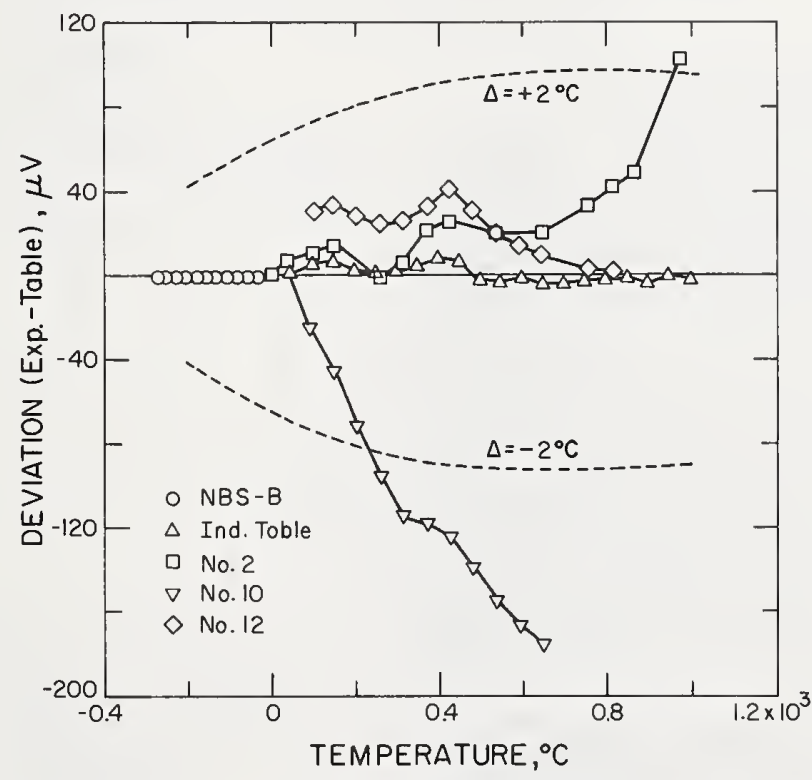

Figure 8.2.3. Deviations in the thermoelectric voltages of platinum, Pt-67, versus Type TN (or EN) thermoelements-comparison of values given in this Monograph to those given by: Ind. Table, unpublished NBS data by Burns [1967]; NBS-B, Sparks, et al. [1972]; Nos. 2, 10, and 12, selected calibrations from the Temperature Section (NBS, Gaithersburg). Values from previous publications and tests are adjusted to the IPTS -68 . The dashed lines indicate a deviation of $2^{\circ} \mathrm{C}$. 


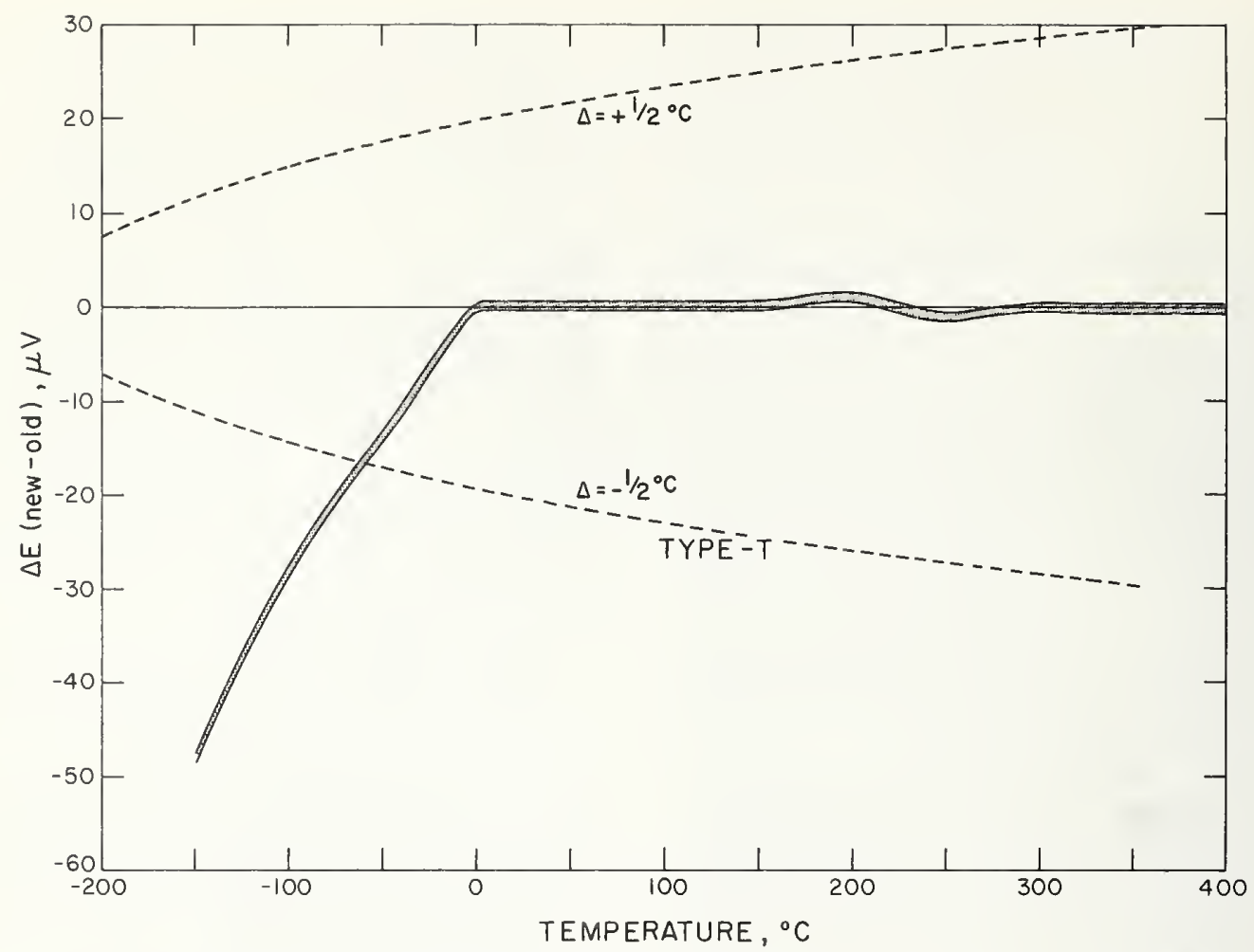

Ficure 8.2.4. Difference in the thermoelectric voltages for Type $T$ thermocouples-comparison of values given in this Monograph to those given in NBS Circular 561.

The width of the shaded curve indicates the round-off uncertainty in the previous tabular values. Values from the previous standard are adjusted to the $\mathrm{PPTS}-68$. The dashed lines indicate a deviation of $1 / 2{ }^{\circ} \mathrm{C}$.

\subsection{Reference Functions and Tables for Type T Thermocouples}

The coefficients for the fourteenth degree expansion for the thermoelectric voltage of Type $\mathrm{T}$ thermocouples below $0{ }^{\circ} \mathrm{C}$ are given in table 8.3.1. The coefficients for the eighth degree expansion above $0{ }^{\circ} \mathrm{C}$ are also given in table 8.3.1. The errors caused by reduced bit arithmetic for calculating values of the functions are given in table 8.3.4.

The primary reference values for Type $\mathrm{T}$ thermocouples are given in table 8.3.2. Values at selected fixed points are given in table 8.3.3. Graphs of the thermoelectric voltage, its first derivative (Seebeck coefficient), and second derivative are given in figures 8.3.1, 8.3.2, and 8.3.3, respectively. The irregular dip in the second derivative near $0{ }^{\circ} \mathrm{C}$ is a result of the fitting techniques at the join of two regions, it is not a real physical phenomenon.

It should be stressed that Type T thermocouple materials that conform closely to the high temperature tabular values may not necessarilly conform closely at low temperatures (below $0^{\circ} \mathrm{C}$ ) and vice versa. If type $\mathrm{T}$ thermocouples are to be used for accurate measurements both above and below $0^{\circ} \mathrm{C}$, then the material must be calibrated in the full temperature range, both above and below $0^{\circ} \mathrm{C}$. Special selection of material will usually be required.

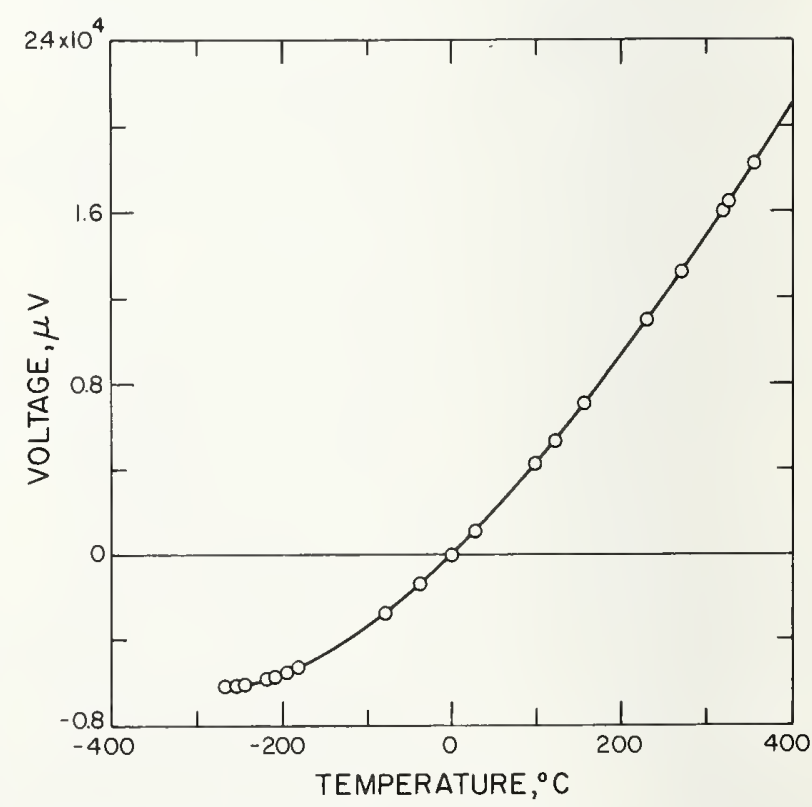

Figure 8.3.1. Thermoelectric voltage for Type $T$ thermocouples.

The circles indicate values at various thermometric fixed points on the IPTS-68. 


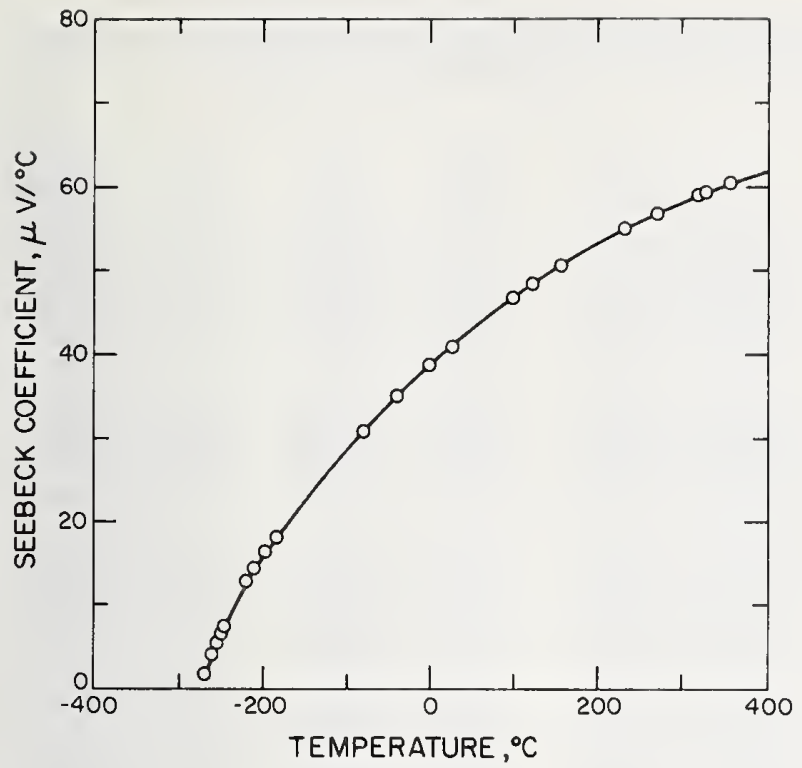

Ficure 8.3.2. Seebeck coefficient for Type T thermocouples. The circles indicate values at various thermometric fixed points on the IPTS -68 .

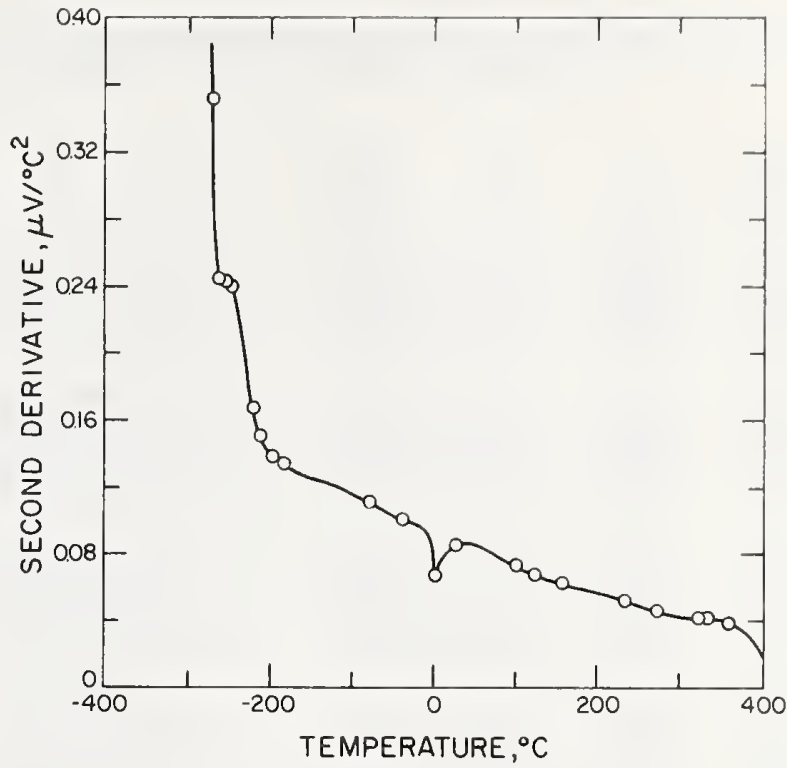

Figure 8.3.3. Second derivative of thermoelectric voltage for Type $T$ thermocouples.

The circles indicate values at various thermometric faxed points on the IPTS -68 .

TABle 8.3.1. Power series expansion for the thermoelectric voltage of Type $T$ thermocouples

\begin{tabular}{|c|c|c|c|}
\hline $\begin{array}{c}\text { Tempera- } \\
\text { ture } \\
\text { range }\end{array}$ & Degree & Coefficients & Term \\
\hline $\begin{array}{c}-270 \text { to } \\
0^{\circ} \mathrm{C}\end{array}$ & 14 & $\begin{array}{l}3.8740773840 \times 10^{1} \\
4.4123932482 \times 10^{-2} \\
1.1405238498 \times 10^{-4} \\
1.9974406568 \times 10^{-5} \\
9.0445401187 \times 10^{-7} \\
2.2766018504 \times 10^{-8} \\
3.6247409380 \times 10^{-10} \\
3.8648924201 \times 10^{-12} \\
2.8298678519 \times 10^{-14} \\
1.4281383349 \times 10^{-16} \\
4.8833254364 \times 10^{-19} \\
1.0803474683 \times 10^{-21} \\
1.3949291026 \times 10^{-24} \\
7.9795893156 \times 10^{-28}\end{array}$ & $\begin{array}{l}T \\
T^{2} \\
T^{3} \\
T^{4} \\
T^{5} \\
T^{6} \\
T^{7} \\
T^{8} \\
T^{9} \\
T^{10} \\
T^{11} \\
T^{12} \\
T^{13} \\
T^{14}\end{array}$ \\
\hline $\begin{array}{l}0 \text { to } \\
\quad 400^{\circ} \mathrm{C}\end{array}$ & 8 & $\begin{array}{r}3.8740773840 \times 10^{1} \\
3.3190198092 \times 10^{-2} \\
2.0714183645 \times 10^{-4} \\
-2.1945834823 \times 10^{-6} \\
1.1031900550 \times 10^{-8} \\
-3.0927581898 \times 10^{-11} \\
4.5653337165 \times 10^{-14} \\
-2.7616878040 \times 10^{-17}\end{array}$ & $\begin{array}{l}T \\
T^{2} \\
T^{3} \\
T^{4} \\
T^{6} \\
T^{6} \\
T^{7} \\
T^{8}\end{array}$ \\
\hline
\end{tabular}


TABle 8.3.2 Type $\boldsymbol{T}$ thermocouples-thermoelectric voltages, $\mathrm{E}(\mathrm{T})$, Seebeck coefficients, $\mathrm{S}(\mathrm{T})$, and first derivative of the Seebeck coefficients, $\mathrm{dS} / \mathrm{dT}$, reference junctions at $0{ }^{\circ} \mathrm{C}$

\begin{tabular}{|c|c|c|c|c|c|c|c|c|c|c|c|}
\hline${ }^{\circ} \mathrm{C}$ & $\begin{array}{c}E V \\
\mu V\end{array}$ & $\stackrel{\mathrm{S}}{\mu \mathrm{V} /{ }^{\circ} \mathrm{C}}$ & $\begin{array}{l}\mathrm{dS} / \mathrm{dT} \\
\mathrm{nV} /{ }^{\circ} \mathrm{C}^{2}\end{array}$ & $\begin{array}{l}{ }^{\top} \mathrm{C} \\
{ }^{\circ} \mathrm{C}\end{array}$ & $\underset{\mu V}{E}$ & $\stackrel{S}{S V /{ }^{\circ} \mathrm{C}}$ & $\begin{array}{l}\mathrm{dS} / \mathrm{dT} \\
\mathrm{nV} /{ }^{\circ} \mathrm{C}^{2}\end{array}$ & ${ }^{\mathrm{T}} \mathrm{C}$ & $\underset{\mu V}{E}$ & $\underset{\mu V /{ }^{\circ} \mathrm{C}}{S}$ & $\begin{array}{l}d S / d T \\
n V /{ }^{\circ} C^{2}\end{array}$ \\
\hline $\begin{array}{l}-270 \\
-269 \\
-268 \\
-267 \\
-266\end{array}$ & $\begin{array}{l}-6257 \cdot 59 \\
-6256 \cdot 38 \\
-6254 \cdot 82 \\
-6252.93 \\
-6250.74\end{array}$ & $\begin{array}{l}1.016 \\
1.385 \\
1.726 \\
2.044 \\
2.343\end{array}$ & $\begin{array}{l}384.94 \\
354.18 \\
328.78 \\
308.01 \\
291.24\end{array}$ & $\begin{array}{l}-240 \\
-239 \\
-238 \\
-237 \\
-236\end{array}$ & $\begin{array}{l}-6105.09 \\
-6096.25 \\
-6087.18 \\
-6077.89 \\
-6068.38\end{array}$ & $\begin{array}{l}8.726 \\
8.954 \\
9.180 \\
9.404 \\
9.624\end{array}$ & $\begin{array}{l}230.04 \\
227.51 \\
224.81 \\
221.96 \\
218.98\end{array}$ & $\begin{array}{l}-210 \\
-209 \\
-208 \\
-207 \\
-206\end{array}$ & $\begin{array}{l}-5753.25 \\
-5738.87 \\
-5724.34 \\
-5709.67 \\
-5694.85\end{array}$ & $\begin{array}{l}14.305 \\
14.454 \\
14.602 \\
14.748 \\
14.893\end{array}$ & $\begin{array}{l}149.59 \\
148.23 \\
146.96 \\
145.79 \\
144.70\end{array}$ \\
\hline $\begin{array}{l}-265 \\
-264 \\
-263 \\
-262 \\
-261\end{array}$ & $\begin{array}{l}-6248.26 \\
-6245.49 \\
-6242.45 \\
-6239.17 \\
-6235.62\end{array}$ & $\begin{array}{l}2.628 \\
2.900 \\
3.163 \\
3.419 \\
3.670\end{array}$ & $\begin{array}{l}277.85 \\
267.34 \\
259.25 \\
253.16 \\
248.73\end{array}$ & $\begin{array}{l}-235 \\
-234 \\
-233 \\
-232 \\
-231\end{array}$ & $\begin{array}{l}-6058.64 \\
-6048.69 \\
-6038.53 \\
-6028 \cdot 16 \\
-6017.58\end{array}$ & $\begin{array}{r}9.842 \\
10.056 \\
10.267 \\
10.475 \\
10.680\end{array}$ & $\begin{array}{l}215.90 \\
212.73 \\
209.49 \\
206.21 \\
202.91\end{array}$ & $\begin{array}{l}-205 \\
-204 \\
-203 \\
-202 \\
-201\end{array}$ & $\begin{array}{l}-5679.88 \\
-5664.77 \\
-5649.52 \\
-5634.13 \\
-5618.59\end{array}$ & $\begin{array}{l}15.038 \\
15.181 \\
15.323 \\
15.465 \\
15.605\end{array}$ & $\begin{array}{l}143.71 \\
142.79 \\
141.95 \\
141.18 \\
140.47\end{array}$ \\
\hline $\begin{array}{l}-260 \\
-259 \\
-258 \\
-257 \\
-256\end{array}$ & $\begin{array}{l}-6231.83 \\
-6227.79 \\
-6223.51 \\
-6218.98 \\
-6214.21\end{array}$ & $\begin{array}{l}3.917 \\
4.162 \\
4.405 \\
4.646 \\
4.888\end{array}$ & $\begin{array}{l}245.63 \\
243.58 \\
242.34 \\
241.72 \\
241.53\end{array}$ & $\begin{array}{l}-230 \\
-229 \\
-228 \\
-227 \\
-226\end{array}$ & $\begin{array}{l}-6006 \cdot 80 \\
-5995.82 \\
-5984.64 \\
-5973.27 \\
-5961.71\end{array}$ & $\begin{array}{l}10.881 \\
11.079 \\
11.274 \\
11.465 \\
11.653\end{array}$ & $\begin{array}{l}199.61 \\
196.31 \\
193.05 \\
189.83 \\
186.66\end{array}$ & $\begin{array}{l}-200 \\
-199 \\
-198 \\
-197 \\
-196\end{array}$ & $\begin{array}{l}-5602.92 \\
-5587.10 \\
-5571.15 \\
-5555.05 \\
-5538.82\end{array}$ & $\begin{array}{l}15.746 \\
15.885 \\
16.024 \\
16.163 \\
16.301\end{array}$ & $\begin{array}{l}139.82 \\
139.23 \\
138.68 \\
138.18 \\
137.72\end{array}$ \\
\hline $\begin{array}{l}-255 \\
-254 \\
-253 \\
-252 \\
-251\end{array}$ & $\begin{array}{l}-6209.20 \\
-6203.95 \\
-6198.46 \\
-6192.72 \\
-6186.75\end{array}$ & $\begin{array}{l}5.130 \\
5.371 \\
5.614 \\
5.856 \\
6.098\end{array}$ & $\begin{array}{l}241.63 \\
241.90 \\
242.21 \\
242.49 \\
242.68\end{array}$ & $\begin{array}{l}-225 \\
-224 \\
-223 \\
-222 \\
-221\end{array}$ & $\begin{array}{l}-5949.97 \\
-5938.04 \\
-5925.93 \\
-5913.64 \\
-5901.18\end{array}$ & $\begin{array}{l}11.838 \\
12.020 \\
12.199 \\
12.376 \\
12.549\end{array}$ & $\begin{array}{l}183.56 \\
180.54 \\
177.62 \\
174.78 \\
172.05\end{array}$ & $\begin{array}{l}-195 \\
-194 \\
-193 \\
-192 \\
-191\end{array}$ & $\begin{array}{l}-5522.45 \\
-5505.95 \\
-5489.30 \\
-5472.52 \\
-5455.61\end{array}$ & $\begin{array}{l}16.438 \\
16.575 \\
16.712 \\
16.848 \\
16.984\end{array}$ & $\begin{array}{l}137.29 \\
136.90 \\
136.53 \\
136.18 \\
135.85\end{array}$ \\
\hline $\begin{array}{l}-250 \\
-249 \\
-248 \\
-247 \\
-246\end{array}$ & $\begin{array}{l}-6180.53 \\
-6174.07 \\
-6167.36 \\
-6160.41 \\
-6153.22\end{array}$ & $\begin{array}{l}6.341 \\
6.584 \\
6.826 \\
7.068 \\
7.309\end{array}$ & $\begin{array}{l}242.71 \\
242.54 \\
242.16 \\
241.52 \\
240.63\end{array}$ & $\begin{array}{l}-220 \\
-219 \\
-218 \\
-217 \\
-216\end{array}$ & $\begin{array}{l}-5888.54 \\
-5875.74 \\
-5862.77 \\
-5849.63 \\
-5836.33\end{array}$ & $\begin{array}{l}12.720 \\
12.888 \\
13.054 \\
13.217 \\
13.378\end{array}$ & $\begin{array}{l}169.43 \\
166.92 \\
164.53 \\
162.25 \\
160.09\end{array}$ & $\begin{array}{l}-190 \\
-189 \\
-188 \\
-187 \\
-186\end{array}$ & $\begin{array}{l}-5438.55 \\
-5421.37 \\
-5404.04 \\
-5386.59 \\
-5368.99\end{array}$ & $\begin{array}{l}17.120 \\
17.255 \\
17.390 \\
17.525 \\
17.660\end{array}$ & $\begin{array}{l}135.54 \\
135.25 \\
134.96 \\
134.68 \\
134.41\end{array}$ \\
\hline $\begin{array}{l}-245 \\
-244 \\
-243 \\
-242 \\
-241\end{array}$ & $\begin{array}{l}-6145.80 \\
-6138.13 \\
-6130.22 \\
-6122.08 \\
-6113.70\end{array}$ & $\begin{array}{l}7.549 \\
7.788 \\
8.025 \\
8.261 \\
8.494\end{array}$ & $\begin{array}{l}239.48 \\
238.08 \\
236.41 \\
234.52 \\
232.38\end{array}$ & $\begin{array}{l}-215 \\
-214 \\
-213 \\
-212 \\
-211\end{array}$ & $\begin{array}{l}-5822.88 \\
-5809.26 \\
-5795.49 \\
-5781.56 \\
-5767.48\end{array}$ & $\begin{array}{l}13.537 \\
13.694 \\
13.850 \\
14.003 \\
14.155\end{array}$ & $\begin{array}{l}158.06 \\
156.14 \\
154.33 \\
152.64 \\
151.06\end{array}$ & $\begin{array}{l}-185 \\
-184 \\
-183 \\
-182 \\
-181\end{array}$ & $\begin{array}{l}-5351.27 \\
-5333.40 \\
-5315.41 \\
-5297.28 \\
-5279.02\end{array}$ & $\begin{array}{l}17.794 \\
17.928 \\
18.062 \\
18.195 \\
18.328\end{array}$ & $\begin{array}{l}134.14 \\
133.88 \\
133.61 \\
133.35 \\
133.09\end{array}$ \\
\hline-240 & -6105.09 & 8.726 & 230.04 & -210 & $-5753 \cdot 25$ & 14.305 & 149.59 & -180 & -5260.62 & 18.461 & 132.82 \\
\hline
\end{tabular}


TABLE 8.3.2 Type $\boldsymbol{T}$ thermocouples-thermoelectric voltages, $\mathrm{E}(\mathrm{T})$, Seebeck coefficients, $\mathrm{S}(\mathrm{T})$, and first derivative of the Seebeck coefficients, $\mathrm{dS} / \mathrm{dT}$, reference junctions at $0^{\circ} \mathrm{C}$-Continued

\begin{tabular}{|c|c|c|c|c|c|c|c|c|c|c|c|}
\hline${ }^{\mathrm{T}} \mathrm{C}$ & ${ }_{\mu V}^{E}$ & 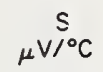 & $\begin{array}{l}d S / d T \\
n V /{ }^{\circ} C^{2}\end{array}$ & ${ }^{\mathrm{T}} \mathrm{C}$ & $\underset{\mu V}{E}$ & $\underset{\mu V^{\circ} \mathrm{C}}{S}$ & $\begin{array}{l}d S / d T \\
n V /{ }^{\circ} C^{2}\end{array}$ & $\begin{array}{l}\mathrm{T} \\
{ }^{\circ} \mathrm{C}\end{array}$ & $\underset{\mu V}{E}$ & $\underset{\mu V /{ }^{\circ} \mathrm{C}}{\mathrm{S}}$ & $\begin{array}{l}d S / d T \\
n V /{ }^{\circ} C^{2}\end{array}$ \\
\hline $\begin{array}{l}-180 \\
-179 \\
-178 \\
-177 \\
-176\end{array}$ & $\begin{array}{l}-5260.62 \\
-5242.10 \\
-5223.44 \\
-5204.64 \\
-5185.72\end{array}$ & $\begin{array}{l}18.461 \\
18.594 \\
18.727 \\
18.859 \\
18.991\end{array}$ & $\begin{array}{l}132.82 \\
132.55 \\
132.29 \\
132.01 \\
131.74\end{array}$ & $\begin{array}{l}-120 \\
-119 \\
-118 \\
-117 \\
-116\end{array}$ & $\begin{array}{l}-3922.62 \\
-3896.54 \\
-3870.33 \\
-3844.00 \\
-3817.56\end{array}$ & $\begin{array}{l}26 \cdot 026 \\
26 \cdot 147 \\
26 \cdot 268 \\
26 \cdot 388 \\
26.508\end{array}$ & $\begin{array}{l}120.94 \\
120.72 \\
120.49 \\
120.26 \\
120.02\end{array}$ & $\begin{array}{l}-60 \\
-59 \\
-58 \\
-57 \\
-56\end{array}$ & $\begin{array}{l}-2152.41 \\
-2119.52 \\
-2086.52 \\
-2053.42 \\
-2020.21\end{array}$ & $\begin{array}{l}32.840 \\
32.946 \\
33.052 \\
33.158 \\
33.264\end{array}$ & $\begin{array}{l}106.55 \\
106.25 \\
105.94 \\
105.63 \\
105.31\end{array}$ \\
\hline $\begin{array}{l}-175 \\
-174 \\
-173 \\
-172 \\
-171\end{array}$ & $\begin{array}{l}-5166.66 \\
-5147.47 \\
-5128.16 \\
-5108.71 \\
-5089.12\end{array}$ & $\begin{array}{l}19.122 \\
19.254 \\
19.385 \\
19.515 \\
19.646\end{array}$ & $\begin{array}{l}131.47 \\
131.19 \\
130.91 \\
130.63 \\
130.35\end{array}$ & $\begin{array}{l}-115 \\
-114 \\
-113 \\
-112 \\
-111\end{array}$ & $\begin{array}{l}-3790.99 \\
-3764.30 \\
-3737.49 \\
-3710.57 \\
-3683.52\end{array}$ & $\begin{array}{l}26.628 \\
26.748 \\
26.867 \\
26.986 \\
27.105\end{array}$ & $\begin{array}{l}119.77 \\
119.52 \\
119.26 \\
119.00 \\
118.73\end{array}$ & $\begin{array}{l}-55 \\
-54 \\
-53 \\
-52 \\
-51\end{array}$ & $\begin{array}{l}-1986.89 \\
-1953.47 \\
-1919.94 \\
-1886.31 \\
-1852.58\end{array}$ & $\begin{array}{l}33.369 \\
33.474 \\
33.578 \\
33.682 \\
33.786\end{array}$ & $\begin{array}{l}104.98 \\
104.66 \\
104.32 \\
103.99 \\
103.66\end{array}$ \\
\hline $\begin{array}{l}-170 \\
-169 \\
-168 \\
-167 \\
-166\end{array}$ & $\begin{array}{l}-5069.41 \\
-5049.57 \\
-5029.60 \\
-5009.50 \\
-4989.27\end{array}$ & $\begin{array}{l}19.776 \\
19.906 \\
20.036 \\
20.165 \\
20.294\end{array}$ & $\begin{array}{l}130.07 \\
129.79 \\
129.51 \\
129.24 \\
128.96\end{array}$ & $\begin{array}{l}-110 \\
-109 \\
-108 \\
-107 \\
-106\end{array}$ & $\begin{array}{l}-3656.36 \\
-3629.07 \\
-3601.67 \\
-3574.15 \\
-3546.52\end{array}$ & $\begin{array}{l}27.224 \\
27.342 \\
27.460 \\
27.578 \\
27.695\end{array}$ & $\begin{array}{l}118.46 \\
118.19 \\
117.91 \\
117.64 \\
117.36\end{array}$ & $\begin{array}{l}-50 \\
-49 \\
-48 \\
-47 \\
-46\end{array}$ & $\begin{array}{l}-1818.74 \\
-1784.80 \\
-1750.75 \\
-1716.61 \\
-1682.36\end{array}$ & $\begin{array}{l}33.889 \\
33.993 \\
34.095 \\
34.198 \\
34.300\end{array}$ & $\begin{array}{l}103.33 \\
103.00 \\
102.68 \\
102.36 \\
102.05\end{array}$ \\
\hline $\begin{array}{l}-165 \\
-164 \\
-163 \\
-162 \\
-161\end{array}$ & $\begin{array}{l}-4968.91 \\
-4948.43 \\
-4927.81 \\
-4907.07 \\
-4886.20\end{array}$ & $\begin{array}{l}20.423 \\
20.551 \\
20.680 \\
20.808 \\
20.936\end{array}$ & $\begin{array}{l}128.70 \\
128.43 \\
128.17 \\
127.91 \\
127.67\end{array}$ & $\begin{array}{l}-105 \\
-104 \\
-103 \\
-102 \\
-101\end{array}$ & $\begin{array}{l}-3518.76 \\
-3490.89 \\
-3462.90 \\
-3434.80 \\
-3406.58\end{array}$ & $\begin{array}{l}27.812 \\
27.929 \\
28.046 \\
28.162 \\
28.278\end{array}$ & $\begin{array}{l}117.08 \\
116.80 \\
116.52 \\
116.24 \\
115.96\end{array}$ & $\begin{array}{l}-45 \\
-44 \\
-43 \\
-42 \\
-41\end{array}$ & $\begin{array}{l}-1648.01 \\
-1613.55 \\
-1579.00 \\
-1544.34 \\
-1509.59\end{array}$ & $\begin{array}{l}34.402 \\
34.504 \\
34.605 \\
34.706 \\
34.807\end{array}$ & $\begin{array}{l}101.75 \\
101.46 \\
101.18 \\
100.92 \\
100.67\end{array}$ \\
\hline $\begin{array}{l}-160 \\
-159 \\
-158 \\
-157 \\
-156\end{array}$ & $\begin{array}{l}-4865.20 \\
-4844.07 \\
-4822.81 \\
-4801.43 \\
-4779.93\end{array}$ & $\begin{array}{l}21.063 \\
21.190 \\
21.318 \\
21.444 \\
21.571\end{array}$ & $\begin{array}{l}127.42 \\
127.19 \\
126.96 \\
126.74 \\
126.52\end{array}$ & $\begin{array}{l}-100 \\
-99 \\
-98 \\
-97 \\
-96\end{array}$ & $\begin{array}{l}-3378.24 \\
-3349.79 \\
-3321.22 \\
-3292.54 \\
-3263.74\end{array}$ & $\begin{array}{l}28.394 \\
28.510 \\
28.625 \\
28.740 \\
28.855\end{array}$ & $\begin{array}{l}115.69 \\
115.42 \\
115.15 \\
114.88 \\
114.62\end{array}$ & $\begin{array}{l}-40 \\
-39 \\
-38 \\
-37 \\
-36\end{array}$ & $\begin{array}{l}-1474.73 \\
-1439.77 \\
-1404.72 \\
-1369.56 \\
-1334.30\end{array}$ & $\begin{array}{l}34.907 \\
35.008 \\
35.108 \\
35.208 \\
35.308\end{array}$ & $\begin{array}{r}100.43 \\
100.22 \\
100.01 \\
99.83 \\
99.66\end{array}$ \\
\hline $\begin{array}{l}-155 \\
-154 \\
-153 \\
-152 \\
-151\end{array}$ & $\begin{array}{l}-4758.29 \\
-4736.53 \\
-4714.64 \\
-4692.63 \\
-4670.49\end{array}$ & $\begin{array}{l}21.697 \\
21.824 \\
21.950 \\
22.075 \\
22.201\end{array}$ & $\begin{array}{l}126 \cdot 31 \\
126 \cdot 12 \\
125 \cdot 92 \\
125.74 \\
125.57\end{array}$ & $\begin{array}{l}-95 \\
-94 \\
-93 \\
-92 \\
-91\end{array}$ & $\begin{array}{l}-3234.83 \\
-3205.80 \\
-3176.66 \\
-3147.41 \\
-3118.04\end{array}$ & $\begin{array}{l}28.969 \\
29.084 \\
29.198 \\
29.311 \\
29.425\end{array}$ & $\begin{array}{l}114.37 \\
114.12 \\
113.87 \\
113.63 \\
113.40\end{array}$ & $\begin{array}{l}-35 \\
-34 \\
-33 \\
-32 \\
-31\end{array}$ & $\begin{array}{l}-1298.94 \\
-1263.49 \\
-1227.93 \\
-1192.27 \\
-1156.52\end{array}$ & $\begin{array}{l}35.407 \\
35.507 \\
35.606 \\
35.705 \\
35.804\end{array}$ & $\begin{array}{l}99.52 \\
99.38 \\
99.26 \\
99.16 \\
99.07\end{array}$ \\
\hline $\begin{array}{l}-150 \\
-149 \\
-148 \\
-147 \\
-146\end{array}$ & $\begin{array}{l}-4648.23 \\
-4625.84 \\
-4603.33 \\
-4580.69 \\
-4557.92\end{array}$ & $\begin{array}{l}22.327 \\
22.452 \\
22.577 \\
22.702 \\
22.827\end{array}$ & $\begin{array}{l}125.40 \\
125.23 \\
125.08 \\
124.93 \\
124.79\end{array}$ & $\begin{array}{l}-90 \\
-89 \\
-88 \\
-87 \\
-86\end{array}$ & $\begin{array}{l}-3088.56 \\
-3058.96 \\
-3029.26 \\
-2999.44 \\
-2969.50\end{array}$ & $\begin{array}{l}29.538 \\
29.651 \\
29.764 \\
29.877 \\
29.989\end{array}$ & $\begin{array}{l}113.17 \\
112.95 \\
112.73 \\
112.51 \\
112.30\end{array}$ & $\begin{array}{l}-30 \\
-29 \\
-28 \\
-27 \\
-26\end{array}$ & $\begin{array}{l}-1120.67 \\
-1084.71 \\
-1048.66 \\
-1012.51 \\
-976.26\end{array}$ & $\begin{array}{l}35.903 \\
36.002 \\
36.101 \\
36.200 \\
36.299\end{array}$ & $\begin{array}{l}98.99 \\
98.91 \\
98.84 \\
98.76 \\
98.69\end{array}$ \\
\hline $\begin{array}{l}-145 \\
-144 \\
-143 \\
-142 \\
-141\end{array}$ & $\begin{array}{l}-4535.03 \\
-4512.02 \\
-4488.88 \\
-4465.62 \\
-4442.23\end{array}$ & $\begin{array}{l}22.952 \\
23.076 \\
23.201 \\
23.325 \\
23.449\end{array}$ & $\begin{array}{l}124 \cdot 65 \\
124 \cdot 51 \\
124 \cdot 38 \\
124 \cdot 26 \\
124 \cdot 13\end{array}$ & $\begin{array}{l}-85 \\
-84 \\
-83 \\
-82 \\
-81\end{array}$ & $\begin{array}{l}-2939.46 \\
-2909.30 \\
-2879.03 \\
-2848.65 \\
-2818.16\end{array}$ & $\begin{array}{l}30.101 \\
30.213 \\
30.325 \\
30.437 \\
30.548\end{array}$ & $\begin{array}{l}112.10 \\
111.89 \\
111.70 \\
111.50 \\
111.31\end{array}$ & $\begin{array}{l}-25 \\
-24 \\
-23 \\
-22 \\
-21\end{array}$ & $\begin{array}{l}-939.91 \\
-903.47 \\
-866.92 \\
-830.28 \\
-793.54\end{array}$ & $\begin{array}{l}36.397 \\
36.496 \\
36.594 \\
36.693 \\
36.791\end{array}$ & $\begin{array}{l}98.60 \\
98.50 \\
98.37 \\
98.23 \\
98.05\end{array}$ \\
\hline $\begin{array}{l}-140 \\
-139 \\
-138 \\
-137 \\
-136\end{array}$ & $\begin{array}{l}-4418.72 \\
-4395.08 \\
-4371.32 \\
-4347.44 \\
-4323.43\end{array}$ & $\begin{array}{l}23.573 \\
23.697 \\
23.821 \\
23.945 \\
24.068\end{array}$ & $\begin{array}{l}124.01 \\
123.89 \\
123.77 \\
123.65 \\
123.52\end{array}$ & $\begin{array}{l}-80 \\
-79 \\
-78 \\
-77 \\
-76\end{array}$ & $\begin{array}{l}-2787.55 \\
-2756.84 \\
-2726.01 \\
-2695.08 \\
-2664.03\end{array}$ & $\begin{array}{l}30.659 \\
30.770 \\
30.881 \\
30.992 \\
31.102\end{array}$ & $\begin{array}{l}111.11 \\
110.92 \\
110.73 \\
110.54 \\
110.35\end{array}$ & $\begin{array}{l}-20 \\
-19 \\
-18 \\
-17 \\
-16\end{array}$ & $\begin{array}{l}-756.70 \\
-719.76 \\
-682.73 \\
-645.59 \\
-608.36\end{array}$ & $\begin{array}{l}36.889 \\
36.986 \\
37.084 \\
37.181 \\
37.278\end{array}$ & $\begin{array}{l}97.83 \\
97.58 \\
97.27 \\
96.91 \\
96.50\end{array}$ \\
\hline $\begin{array}{l}-135 \\
-134 \\
-133 \\
-132 \\
-131\end{array}$ & $\begin{array}{l}-4299.30 \\
-4275.05 \\
-4250.67 \\
-4226.17 \\
-4201.55\end{array}$ & $\begin{array}{l}24.192 \\
24.315 \\
24.438 \\
24.561 \\
24.684\end{array}$ & $\begin{array}{l}123.40 \\
123.27 \\
123.14 \\
123.01 \\
122.87\end{array}$ & $\begin{array}{l}-75 \\
-74 \\
-73 \\
-72 \\
-71\end{array}$ & $\begin{array}{l}-2632.87 \\
-2601.61 \\
-2570.23 \\
-2538.74 \\
-2507.14\end{array}$ & $\begin{array}{l}31.213 \\
31.323 \\
31.432 \\
31.542 \\
31.652\end{array}$ & $\begin{array}{l}110.15 \\
109.96 \\
109.76 \\
109.55 \\
109.34\end{array}$ & $\begin{array}{l}-15 \\
-14 \\
-13 \\
-12 \\
-11\end{array}$ & $\begin{array}{l}-571.04 \\
-533.62 \\
-496.10 \\
-458.49 \\
-420.78\end{array}$ & $\begin{array}{l}37.374 \\
37.470 \\
37.565 \\
37.659 \\
37.753\end{array}$ & $\begin{array}{l}96.03 \\
95.49 \\
94.90 \\
94.25 \\
93.54\end{array}$ \\
\hline $\begin{array}{l}-130 \\
-129 \\
-128 \\
-127 \\
-126\end{array}$ & $\begin{array}{l}-4176.81 \\
-4151.94 \\
-4126.95 \\
-4101.83 \\
-4076.60\end{array}$ & $\begin{array}{l}24.807 \\
24.930 \\
25.052 \\
25.175 \\
25.297\end{array}$ & $\begin{array}{l}122.73 \\
122.58 \\
122.42 \\
122.26 \\
122.09\end{array}$ & $\begin{array}{l}-70 \\
-69 \\
-68 \\
-67 \\
-66\end{array}$ & $\begin{array}{l}-2475.44 \\
-2443.62 \\
-2411.70 \\
-2379.67 \\
-2347.52\end{array}$ & $\begin{array}{l}31.761 \\
31.870 \\
31.979 \\
32.087 \\
32.195\end{array}$ & $\begin{array}{l}109.12 \\
108.90 \\
108.67 \\
108.43 \\
108.19\end{array}$ & $\begin{array}{r}-10 \\
-9 \\
-8 \\
-7 \\
-6\end{array}$ & $\begin{array}{l}-382.98 \\
-345.09 \\
-307.10 \\
-269.03 \\
-230.86\end{array}$ & $\begin{array}{l}37.846 \\
37.939 \\
38.030 \\
38.121 \\
38.211\end{array}$ & $\begin{array}{l}92.79 \\
92.01 \\
91.20 \\
90.41 \\
89.64\end{array}$ \\
\hline $\begin{array}{l}-125 \\
-124 \\
-123 \\
-122 \\
-121\end{array}$ & $\begin{array}{l}-4051.24 \\
-4025.76 \\
-4000.16 \\
-3974.43 \\
-3948.59\end{array}$ & $\begin{array}{l}25.419 \\
25.541 \\
25.662 \\
25.784 \\
25.905\end{array}$ & $\begin{array}{l}121.92 \\
121.74 \\
121.55 \\
121.35 \\
121.15\end{array}$ & $\begin{array}{l}-65 \\
-64 \\
-63 \\
-62 \\
-61\end{array}$ & $\begin{array}{l}-2315.27 \\
-2282.92 \\
-2250.45 \\
-2217.88 \\
-2185.20\end{array}$ & $\begin{array}{l}32.303 \\
32.411 \\
32.519 \\
32.626 \\
32.733\end{array}$ & $\begin{array}{l}107.94 \\
107.68 \\
107.41 \\
107.13 \\
106.85\end{array}$ & $\begin{array}{l}-5 \\
-4 \\
-3 \\
-2 \\
-1\end{array}$ & $\begin{array}{r}-192.61 \\
-154.26 \\
-115.83 \\
-77.31 \\
-38.70\end{array}$ & $\begin{array}{l}38.301 \\
38.389 \\
38.477 \\
38.565 \\
38.653\end{array}$ & $\begin{array}{l}88.94 \\
88.35 \\
87.92 \\
87.70 \\
87.79\end{array}$ \\
\hline 20 & -3922.62 & 26.026 & 120.94 & -60 & -2152.41 & 32.840 & 106.55 & 0 & 10 & 8.741 & $\cdot 3$ \\
\hline
\end{tabular}


TABLE 8.3.2 Type $T$ thermocouples-thermoelectric voltages, E(T), Seebeck coefficients, S(T), and first derivative of the Seebeck coefficients, $\mathrm{dS} / \mathrm{dT}$, reference junctions at $0{ }^{\circ} \mathrm{C}$-Continued

\begin{tabular}{|c|c|c|c|c|c|c|c|c|c|c|c|}
\hline${ }^{\circ} \mathrm{C}$ & $\underset{\mu V}{E}$ & $\underset{\mu V /{ }^{\circ} \mathrm{C}}{\mathrm{S}}$ & $\begin{array}{l}d S / d T \\
n V /{ }^{\circ} C^{2}\end{array}$ & ${ }^{\circ} \mathrm{T}$ & $\underset{\mu V}{E}$ & $\underset{\mu V /{ }^{\circ} \mathrm{C}}{S}$ & $\begin{array}{l}d S / d T \\
n V /{ }^{\circ} C^{2}\end{array}$ & ${ }^{\circ} \mathrm{C}$ & $\underset{\mu V}{E}$ & $\stackrel{\mathrm{S} /{ }^{\circ} \mathrm{C}}{\mathrm{S}}$ & $\begin{array}{l}d S / d T \\
n V /{ }^{\circ} C^{2}\end{array}$ \\
\hline $\begin{array}{l}0 \\
1 \\
2 \\
3 \\
4\end{array}$ & $\begin{array}{r}0.0 \\
38.8 \\
77.6 \\
116.5 \\
155.5\end{array}$ & $\begin{array}{l}38.741 \\
38.808 \\
38.876 \\
38.945 \\
39.016\end{array}$ & $\begin{array}{l}66.38 \\
67.60 \\
68.76 \\
69.88 \\
70.94\end{array}$ & $\begin{array}{l}60 \\
61 \\
62 \\
63 \\
64\end{array}$ & $\begin{array}{l}2467.5 \\
2511.2 \\
2555.0 \\
2598.8 \\
2642.8\end{array}$ & $\begin{array}{l}43.649 \\
43.733 \\
43.815 \\
43.898 \\
43.980\end{array}$ & $\begin{array}{l}83.20 \\
82.98 \\
82.75 \\
82.52 \\
82.28\end{array}$ & $\begin{array}{l}120 \\
121 \\
122 \\
123 \\
124\end{array}$ & $\begin{array}{l}5227.0 \\
5275.3 \\
5323.5 \\
5371.9 \\
5420.3\end{array}$ & $\begin{array}{l}48.181 \\
48.250 \\
48.318 \\
48.385 \\
48.453\end{array}$ & $\begin{array}{l}68.26 \\
68.06 \\
67.86 \\
67.67 \\
67.47\end{array}$ \\
\hline $\begin{array}{l}5 \\
6 \\
7 \\
8 \\
9\end{array}$ & $\begin{array}{l}194.6 \\
233.7 \\
272.9 \\
312.1 \\
351.5\end{array}$ & $\begin{array}{l}39.087 \\
39.160 \\
39.233 \\
39.307 \\
39.382\end{array}$ & $\begin{array}{l}71.96 \\
72.94 \\
73.86 \\
74.75 \\
75.59\end{array}$ & $\begin{array}{l}65 \\
66 \\
67 \\
68 \\
69\end{array}$ & $\begin{array}{l}2686.8 \\
2730.9 \\
2775.1 \\
2819.3 \\
2863.7\end{array}$ & $\begin{array}{l}44.063 \\
44.145 \\
44.226 \\
44.308 \\
44.389\end{array}$ & $\begin{array}{l}82.04 \\
81.79 \\
81.55 \\
81.29 \\
81.04\end{array}$ & $\begin{array}{l}125 \\
126 \\
127 \\
128 \\
129\end{array}$ & $\begin{array}{l}5468 \cdot 8 \\
5517 \cdot 3 \\
5566.0 \\
5614 \cdot 7 \\
5663.4\end{array}$ & $\begin{array}{l}48.520 \\
48.587 \\
48.654 \\
48.721 \\
48.788\end{array}$ & $\begin{array}{l}67.28 \\
67.09 \\
66.91 \\
66.72 \\
66.54\end{array}$ \\
\hline $\begin{array}{l}10 \\
11 \\
12 \\
13 \\
14\end{array}$ & $\begin{array}{l}390.9 \\
430.4 \\
470.0 \\
509.6 \\
549.4\end{array}$ & $\begin{array}{l}39.458 \\
39.535 \\
39.613 \\
39.691 \\
39.770\end{array}$ & $\begin{array}{l}76.39 \\
77.15 \\
77.86 \\
78.55 \\
79.19\end{array}$ & $\begin{array}{l}70 \\
71 \\
72 \\
73 \\
74\end{array}$ & $\begin{array}{l}2908.1 \\
2952.6 \\
2997.2 \\
3041.9 \\
3086.6\end{array}$ & $\begin{array}{l}44.470 \\
44.550 \\
44.631 \\
44.711 \\
44.791\end{array}$ & $\begin{array}{l}80.78 \\
80.52 \\
80.26 \\
79.99 \\
79.73\end{array}$ & $\begin{array}{l}130 \\
131 \\
132 \\
133 \\
134\end{array}$ & $\begin{array}{l}5712.2 \\
5761.1 \\
5810.1 \\
5859 \cdot 1 \\
5908.2\end{array}$ & $\begin{array}{l}48.854 \\
48.921 \\
48.987 \\
49.053 \\
49.118\end{array}$ & $\begin{array}{l}66 \cdot 36 \\
66 \cdot 19 \\
66 \cdot 01 \\
65.84 \\
65.67\end{array}$ \\
\hline $\begin{array}{l}20 \\
21 \\
22 \\
23 \\
24\end{array}$ & $\begin{array}{l}789.4 \\
829.7 \\
870.1 \\
910.6 \\
951.1\end{array}$ & $\begin{array}{l}40.255 \\
40.338 \\
40.420 \\
40.504 \\
40.587\end{array}$ & $\begin{array}{l}82.33 \\
82.74 \\
83.12 \\
83.47 \\
83.80\end{array}$ & $\begin{array}{l}80 \\
81 \\
82 \\
83 \\
84\end{array}$ & $\begin{array}{l}3356.8 \\
3402 \cdot 1 \\
3447.5 \\
3492.9 \\
3538.5\end{array}$ & $\begin{array}{l}45.264 \\
45.342 \\
45.420 \\
45.497 \\
45.574\end{array}$ & $\begin{array}{l}78.10 \\
77.83 \\
77.56 \\
77.29 \\
77.01\end{array}$ & $\begin{array}{l}140 \\
141 \\
142 \\
143 \\
144\end{array}$ & $\begin{array}{l}6204.1 \\
6253.6 \\
6303.2 \\
6352.9 \\
6402.6\end{array}$ & $\begin{array}{l}49.509 \\
49.574 \\
49.639 \\
49.703 \\
49.767\end{array}$ & $\begin{array}{l}64 \cdot 69 \\
64 \cdot 53 \\
64 \cdot 38 \\
64 \cdot 23 \\
64 \cdot 07\end{array}$ \\
\hline $\begin{array}{l}25 \\
26 \\
27 \\
28 \\
29\end{array}$ & $\begin{array}{r}991.7 \\
1032.5 \\
1073.3 \\
1114.1 \\
1155.1\end{array}$ & $\begin{array}{l}40.671 \\
40.756 \\
40.840 \\
40.925 \\
41.010\end{array}$ & $\begin{array}{l}84.10 \\
84.37 \\
84.62 \\
84.84 \\
85.04\end{array}$ & $\begin{array}{l}85 \\
86 \\
87 \\
88 \\
89\end{array}$ & $\begin{array}{l}3584.1 \\
3629.8 \\
3675.5 \\
3721.4 \\
3767.3\end{array}$ & $\begin{array}{l}45.651 \\
45.728 \\
45.804 \\
45.880 \\
45.956\end{array}$ & $\begin{array}{l}76 \cdot 74 \\
76.47 \\
76.20 \\
75.93 \\
75.66\end{array}$ & $\begin{array}{l}145 \\
146 \\
147 \\
148 \\
149\end{array}$ & $\begin{array}{l}6452 \cdot 4 \\
6502 \cdot 3 \\
6552 \cdot 2 \\
6602 \cdot 2 \\
6652 \cdot 2\end{array}$ & $\begin{array}{l}49.831 \\
49.895 \\
49.959 \\
50.022 \\
50.086\end{array}$ & $\begin{array}{l}63.93 \\
63.78 \\
63.63 \\
63.49 \\
63.34\end{array}$ \\
\hline $\begin{array}{l}30 \\
31 \\
32 \\
33 \\
34\end{array}$ & $\begin{array}{l}1196.2 \\
1237.3 \\
1278.5 \\
1319.8 \\
1361.2\end{array}$ & $\begin{array}{l}41.095 \\
41.180 \\
41.266 \\
41.351 \\
41.437\end{array}$ & $\begin{array}{l}85.22 \\
85.37 \\
85.50 \\
85.62 \\
85.71\end{array}$ & $\begin{array}{l}90 \\
91 \\
92 \\
93 \\
94\end{array}$ & $\begin{array}{l}3813.3 \\
3859.4 \\
3905.5 \\
3951.7 \\
3998.0\end{array}$ & $\begin{array}{l}46.032 \\
46.107 \\
46.182 \\
46.257 \\
46.331\end{array}$ & $\begin{array}{l}75.39 \\
75.13 \\
74.86 \\
74.60 \\
74.34\end{array}$ & $\begin{array}{l}150 \\
151 \\
152 \\
153 \\
154\end{array}$ & $\begin{array}{l}6702.4 \\
6752.5 \\
6802.8 \\
6853.1 \\
6903.5\end{array}$ & $\begin{array}{l}50.149 \\
50.212 \\
50.275 \\
50.338 \\
50.400\end{array}$ & $\begin{array}{l}63.20 \\
63.06 \\
62.92 \\
62.78 \\
62.65\end{array}$ \\
\hline $\begin{array}{l}40 \\
41 \\
42 \\
43 \\
44\end{array}$ & $\begin{array}{l}1611.4 \\
1653.4 \\
1695.5 \\
1737.6 \\
1779.9\end{array}$ & $\begin{array}{l}41.952 \\
42.038 \\
42.124 \\
42.209 \\
42.295\end{array}$ & $\begin{array}{l}85.89 \\
85.87 \\
85.83 \\
85.77 \\
85.70\end{array}$ & $\begin{array}{l}100 \\
101 \\
102 \\
103 \\
104\end{array}$ & $\begin{array}{l}4277.3 \\
4324.2 \\
4371.0 \\
4418.0 \\
4465.0\end{array}$ & $\begin{array}{l}46.773 \\
46.845 \\
46.918 \\
46.990 \\
47.062\end{array}$ & $\begin{array}{l}72.80 \\
72.55 \\
72.30 \\
72.06 \\
71.81\end{array}$ & $\begin{array}{l}160 \\
161 \\
162 \\
163 \\
164\end{array}$ & $\begin{array}{l}7207.0 \\
7257.8 \\
7308.7 \\
7359.6 \\
7410.6\end{array}$ & $\begin{array}{l}50.774 \\
50.836 \\
50.897 \\
50.959 \\
51.020\end{array}$ & $\begin{array}{l}61.84 \\
61.71 \\
61.58 \\
61.46 \\
61.33\end{array}$ \\
\hline $\begin{array}{l}45 \\
46 \\
47 \\
48 \\
49\end{array}$ & $\begin{array}{l}1822.2 \\
1864.6 \\
1907.1 \\
1949.7 \\
1992.4\end{array}$ & $\begin{array}{l}42.381 \\
42.466 \\
42.552 \\
42.637 \\
42.723\end{array}$ & $\begin{array}{l}85.62 \\
85.53 \\
85.42 \\
85.31 \\
85.18\end{array}$ & $\begin{array}{l}105 \\
106 \\
107 \\
108 \\
109\end{array}$ & $\begin{array}{l}4512.1 \\
4559.3 \\
4606.5 \\
4653.8 \\
4701.2\end{array}$ & $\begin{array}{l}47.133 \\
47.205 \\
47.276 \\
47.347 \\
47.418\end{array}$ & $\begin{array}{l}71.57 \\
71.34 \\
71.10 \\
70.87 \\
70.64\end{array}$ & $\begin{array}{l}165 \\
166 \\
167 \\
168 \\
169\end{array}$ & $\begin{array}{l}7461.6 \\
7512.7 \\
7563.9 \\
7615.2 \\
7666.4\end{array}$ & $\begin{array}{l}51.082 \\
51.143 \\
51.204 \\
51.265 \\
51.325\end{array}$ & $\begin{array}{l}61.20 \\
61.07 \\
60.94 \\
60.82 \\
60.69\end{array}$ \\
\hline $\begin{array}{l}50 \\
51 \\
52 \\
53 \\
54\end{array}$ & $\begin{array}{l}2035.2 \\
2078.0 \\
2121.0 \\
2164.0 \\
2207.1\end{array}$ & $\begin{array}{l}42.808 \\
42.893 \\
42.977 \\
43.062 \\
43.147\end{array}$ & $\begin{array}{l}85.04 \\
84.89 \\
84.74 \\
84.57 \\
84.40\end{array}$ & $\begin{array}{l}110 \\
1111 \\
112 \\
113 \\
114\end{array}$ & $\begin{array}{l}4748.7 \\
4796.2 \\
4843.8 \\
4891.4 \\
4939.2\end{array}$ & $\begin{array}{l}47.488 \\
47.559 \\
47.629 \\
47.699 \\
47.768\end{array}$ & $\begin{array}{l}70.41 \\
70.18 \\
69.96 \\
69.74 \\
69.52\end{array}$ & $\begin{array}{l}170 \\
171 \\
172 \\
173 \\
174\end{array}$ & $\begin{array}{l}7717.8 \\
7769.2 \\
7820.7 \\
7872.2 \\
7923.8\end{array}$ & $\begin{array}{l}51.386 \\
51.446 \\
51.507 \\
51.567 \\
51.627\end{array}$ & $\begin{array}{l}60.57 \\
60.44 \\
60.32 \\
60.19 \\
60.07\end{array}$ \\
\hline $\begin{array}{l}55 \\
56 \\
57 \\
58 \\
59\end{array}$ & $\begin{array}{l}2250.3 \\
2293.6 \\
2336.9 \\
2380.4 \\
2423.9\end{array}$ & $\begin{array}{l}43.231 \\
43.315 \\
43.399 \\
43.483 \\
43.566\end{array}$ & $\begin{array}{l}84.21 \\
84.02 \\
83.83 \\
83.62 \\
83.41\end{array}$ & $\begin{array}{l}115 \\
116 \\
117 \\
118 \\
119\end{array}$ & $\begin{array}{l}4987 \cdot 0 \\
5034.9 \\
5082.8 \\
5130.8 \\
5178.9\end{array}$ & $\begin{array}{l}47.838 \\
47.907 \\
47.976 \\
48.045 \\
48.113\end{array}$ & $\begin{array}{l}69.30 \\
69.09 \\
68.88 \\
68.67 \\
68.46\end{array}$ & $\begin{array}{l}175 \\
176 \\
177 \\
178 \\
179\end{array}$ & $\begin{array}{l}7975.5 \\
8027.2 \\
8079.0 \\
8130.8 \\
8182.7\end{array}$ & $\begin{array}{l}51.687 \\
51.747 \\
51.807 \\
51.866 \\
51.926\end{array}$ & $\begin{array}{l}59.94 \\
59.82 \\
59.69 \\
59.57 \\
59.44\end{array}$ \\
\hline 60 & 2467.5 & 43.649 & 83.20 & 120 & 5227.0 & $48 \cdot 181$ & $68 \cdot 26$ & 180 & $8234 \cdot 7$ & $51.98 b$ & 59.32 \\
\hline
\end{tabular}


TABLE 8.3.2 Type $T$ thermocouples-thermoelectric voltages, $\mathrm{E}(\mathrm{T})$, Seebeck coefficients, $\mathrm{S}(\mathrm{T})$, and first derivative of the Seebeck coefficients, $\mathrm{dS} / \mathrm{dT}$, reference junctions at $0{ }^{\circ} \mathrm{C}$-Continued

\begin{tabular}{|c|c|c|c|c|c|c|c|c|c|c|c|}
\hline${ }^{\circ} \mathrm{C}$ & $\underset{\mu V}{E}$ & $\mu V /^{\circ} \mathrm{C}$ & $\begin{array}{l}d S / d T \\
n V /{ }^{\circ} C^{2}\end{array}$ & ${ }^{\circ} \mathrm{C}$ & $\underset{\mu V}{E}$ & $\underset{\mu V /{ }^{\circ} \mathrm{C}}{S}$ & $\begin{array}{l}\mathrm{dS} / \mathrm{dT} \\
\mathrm{nV} /{ }^{\circ} \mathrm{C}^{2}\end{array}$ & ${ }^{\circ} \mathrm{T}$ & $\underset{\mu V}{E}$ & $\underset{\mu V /{ }^{\circ} \mathrm{C}}{\mathrm{S}}$ & $\begin{array}{l}d S / d T \\
n V /{ }^{\circ} C^{2}\end{array}$ \\
\hline $\begin{array}{l}180 \\
181 \\
182 \\
183 \\
184\end{array}$ & $\begin{array}{l}8234.7 \\
8286.7 \\
8338.8 \\
8390.9 \\
8443.1\end{array}$ & $\begin{array}{l}51.985 \\
52.045 \\
52.104 \\
52.163 \\
52.222\end{array}$ & $\begin{array}{l}59.32 \\
59.19 \\
59.07 \\
58.94 \\
58.81\end{array}$ & $\begin{array}{l}240 \\
241 \\
242 \\
243 \\
244\end{array}$ & $\begin{array}{l}11455.8 \\
11511.1 \\
11566.5 \\
11621.9 \\
11677.4\end{array}$ & $\begin{array}{l}55.300 \\
55.351 \\
55.401 \\
55.452 \\
55.502\end{array}$ & $\begin{array}{l}50.80 \\
50.64 \\
50.48 \\
50.32 \\
50.17\end{array}$ & $\begin{array}{l}300 \\
301 \\
302 \\
303 \\
304\end{array}$ & $\begin{array}{l}14859 \cdot 8 \\
14917 \cdot 9 \\
14976 \cdot 1 \\
15034 \cdot 3 \\
15092 \cdot 5\end{array}$ & $\begin{array}{l}58.086 \\
58.129 \\
58.172 \\
58.215 \\
58.257\end{array}$ & $\begin{array}{l}42.86 \\
42.78 \\
42.69 \\
42.62 \\
42.54\end{array}$ \\
\hline $\begin{array}{l}185 \\
186 \\
187 \\
188 \\
189\end{array}$ & $\begin{array}{l}8495.3 \\
8547.6 \\
8600.0 \\
8652.4 \\
8704.9\end{array}$ & $\begin{array}{l}52.280 \\
52.339 \\
52.397 \\
52.456 \\
52.514\end{array}$ & $\begin{array}{l}58.69 \\
58.56 \\
58.43 \\
58.31 \\
58.18\end{array}$ & $\begin{array}{l}245 \\
246 \\
247 \\
248 \\
249\end{array}$ & $\begin{array}{l}11732.9 \\
11788.5 \\
11844.1 \\
11899.8 \\
11955.5\end{array}$ & $\begin{array}{l}55.552 \\
55.602 \\
55.652 \\
55.701 \\
55.751\end{array}$ & $\begin{array}{l}50.01 \\
49.85 \\
49.69 \\
49.54 \\
49.38\end{array}$ & $\begin{array}{l}305 \\
306 \\
307 \\
308 \\
309\end{array}$ & $\begin{array}{l}15150 \cdot 8 \\
15209 \cdot 1 \\
15267 \cdot 5 \\
15325 \cdot 9 \\
15384 \cdot 3\end{array}$ & $\begin{array}{l}58.300 \\
58.342 \\
58.385 \\
58.427 \\
58.469\end{array}$ & $\begin{array}{l}42.46 \\
42.39 \\
42.32 \\
42.25 \\
42.19\end{array}$ \\
\hline $\begin{array}{l}190 \\
191 \\
192 \\
193 \\
194\end{array}$ & $\begin{array}{l}8757.5 \\
8810.1 \\
8862.7 \\
8915.4 \\
8968.2\end{array}$ & $\begin{array}{l}52.572 \\
52.630 \\
52.688 \\
52.746 \\
52.803\end{array}$ & $\begin{array}{l}58.05 \\
57.92 \\
57.79 \\
57.66 \\
57.53\end{array}$ & $\begin{array}{l}250 \\
251 \\
252 \\
253 \\
254\end{array}$ & $\begin{array}{l}12011.3 \\
12067.1 \\
12123.0 \\
12178.9 \\
12234.9\end{array}$ & $\begin{array}{l}55.800 \\
55.849 \\
55.898 \\
55.947 \\
55.996\end{array}$ & $\begin{array}{l}49 \cdot 22 \\
49 \cdot 07 \\
48 \cdot 91 \\
48 \cdot 76 \\
48.60\end{array}$ & $\begin{array}{l}310 \\
311 \\
312 \\
313 \\
314\end{array}$ & $\begin{array}{l}15442 \cdot 8 \\
15501 \cdot 3 \\
15559 \cdot 9 \\
15618 \cdot 5 \\
15677.2\end{array}$ & $\begin{array}{l}58.511 \\
58.553 \\
58.595 \\
58.637 \\
58.679\end{array}$ & $\begin{array}{l}42.12 \\
42.06 \\
41.99 \\
41.93 \\
41.88\end{array}$ \\
\hline $\begin{array}{l}195 \\
196 \\
197 \\
198 \\
199\end{array}$ & $\begin{array}{l}9021.1 \\
9073.9 \\
9126.9 \\
9179.9 \\
9233.0\end{array}$ & $\begin{array}{l}52.861 \\
52.918 \\
52.975 \\
53.032 \\
53.089\end{array}$ & $\begin{array}{l}57.40 \\
57.27 \\
57.13 \\
57.00 \\
56.87\end{array}$ & $\begin{array}{l}255 \\
256 \\
257 \\
258 \\
259\end{array}$ & $\begin{array}{l}12290.9 \\
12347.0 \\
12403.1 \\
12459 \cdot 3 \\
12515.5\end{array}$ & $\begin{array}{l}56.044 \\
56.093 \\
56.141 \\
56.189 \\
56.237\end{array}$ & $\begin{array}{l}48 \cdot 45 \\
48 \cdot 30 \\
48 \cdot 14 \\
47.99 \\
47.84\end{array}$ & $\begin{array}{l}315 \\
316 \\
317 \\
318 \\
319\end{array}$ & $\begin{array}{l}15735.9 \\
15794 \cdot 6 \\
15853 \cdot 4 \\
15912.2 \\
15971.1\end{array}$ & $\begin{array}{l}58.721 \\
58.763 \\
58.805 \\
58.846 \\
58.888\end{array}$ & $\begin{array}{l}41.82 \\
41.76 \\
41.71 \\
41.65 \\
41.60\end{array}$ \\
\hline $\begin{array}{l}200 \\
201 \\
202 \\
203 \\
204\end{array}$ & $\begin{array}{l}9286.1 \\
9339.2 \\
9392.5 \\
9445.8 \\
9499.1\end{array}$ & $\begin{array}{l}53.146 \\
53.203 \\
53.259 \\
53.316 \\
53.372\end{array}$ & $\begin{array}{l}56.73 \\
56.60 \\
56.46 \\
56.32 \\
56.19\end{array}$ & $\begin{array}{l}260 \\
261 \\
262 \\
263 \\
264\end{array}$ & $\begin{array}{l}12571.7 \\
12628.0 \\
12684.4 \\
12740.8 \\
12797.3\end{array}$ & $\begin{array}{l}56.285 \\
56.332 \\
56.380 \\
56.427 \\
56.474\end{array}$ & $\begin{array}{l}47.69 \\
47.54 \\
47.39 \\
47.25 \\
47.10\end{array}$ & $\begin{array}{l}320 \\
321 \\
322 \\
323 \\
324\end{array}$ & $\begin{array}{l}16030.0 \\
16089.0 \\
16148.0 \\
16207.0 \\
16266.1\end{array}$ & $\begin{array}{l}58.929 \\
58.971 \\
59.012 \\
59.054 \\
59.095\end{array}$ & $\begin{array}{l}41.55 \\
41.50 \\
41.45 \\
41.40 \\
41.35\end{array}$ \\
\hline $\begin{array}{l}205 \\
206 \\
207 \\
208 \\
209\end{array}$ & $\begin{array}{l}9552.5 \\
9606.0 \\
9659.5 \\
9713.0 \\
9766.7\end{array}$ & $\begin{array}{l}53.428 \\
53.484 \\
53.540 \\
53.596 \\
53.651\end{array}$ & $\begin{array}{l}56.05 \\
55.91 \\
55.77 \\
55.63 \\
55.49\end{array}$ & $\begin{array}{l}265 \\
266 \\
267 \\
268 \\
269\end{array}$ & $\begin{array}{l}12853.8 \\
12910.3 \\
12966.9 \\
13023.5 \\
13080.2\end{array}$ & $\begin{array}{l}56.521 \\
56.568 \\
56.615 \\
56.661 \\
56.708\end{array}$ & $\begin{array}{l}46.95 \\
46.81 \\
46.67 \\
46.52 \\
46.38\end{array}$ & $\begin{array}{l}325 \\
326 \\
327 \\
328 \\
329\end{array}$ & $\begin{array}{l}16325 \cdot 2 \\
16384 \cdot 3 \\
16443 \cdot 5 \\
16502 \cdot 8 \\
16562.1\end{array}$ & $\begin{array}{l}59.137 \\
59.178 \\
59.219 \\
59.260 \\
59.301\end{array}$ & $\begin{array}{l}41.31 \\
41.26 \\
41.21 \\
41.17 \\
41.12\end{array}$ \\
\hline $\begin{array}{l}210 \\
211 \\
212 \\
213 \\
214\end{array}$ & $\begin{array}{r}9820.3 \\
9874.1 \\
9927.9 \\
9981.7 \\
10035.6\end{array}$ & $\begin{array}{l}53.707 \\
53.762 \\
53.817 \\
53.872 \\
53.927\end{array}$ & $\begin{array}{l}55.35 \\
55.20 \\
55.06 \\
54.92 \\
54.77\end{array}$ & $\begin{array}{l}270 \\
271 \\
272 \\
273 \\
274\end{array}$ & $\begin{array}{l}13136.9 \\
13193.7 \\
13250.5 \\
13307.4 \\
13364.3\end{array}$ & $\begin{array}{l}56.754 \\
56.800 \\
56.846 \\
56.892 \\
56.938\end{array}$ & $\begin{array}{l}46.24 \\
46.11 \\
45.97 \\
45.84 \\
45.70\end{array}$ & $\begin{array}{l}330 \\
331 \\
332 \\
333 \\
334\end{array}$ & $\begin{array}{l}16621.4 \\
16680.7 \\
16740.1 \\
16799.6 \\
16859.1\end{array}$ & $\begin{array}{l}59.343 \\
59.384 \\
59.425 \\
59.466 \\
59.506\end{array}$ & $\begin{array}{l}41.07 \\
41.02 \\
40.98 \\
40.93 \\
40.88\end{array}$ \\
\hline $\begin{array}{l}215 \\
216 \\
217 \\
218 \\
219\end{array}$ & $\begin{array}{l}10089.6 \\
10143.6 \\
10197.6 \\
10251.8 \\
10305.9\end{array}$ & $\begin{array}{l}53.982 \\
54.036 \\
54.091 \\
54.145 \\
54.199\end{array}$ & $\begin{array}{l}54.63 \\
54.48 \\
54.33 \\
54.18 \\
54.04\end{array}$ & $\begin{array}{l}275 \\
276 \\
277 \\
278 \\
279\end{array}$ & $\begin{array}{l}13421.3 \\
13478 \cdot 3 \\
13535 \cdot 3 \\
13592.4 \\
13649.6\end{array}$ & $\begin{array}{l}56.984 \\
57.029 \\
57.075 \\
57.120 \\
57.165\end{array}$ & $\begin{array}{l}45.57 \\
45.44 \\
45.31 \\
45.18 \\
45.06\end{array}$ & $\begin{array}{l}335 \\
336 \\
337 \\
338 \\
339\end{array}$ & $\begin{array}{l}16918.6 \\
16978.2 \\
17037.8 \\
17097.4 \\
17157.1\end{array}$ & $\begin{array}{l}59.547 \\
59.588 \\
59.629 \\
59.670 \\
59.710\end{array}$ & $\begin{array}{l}40.83 \\
40.77 \\
40.72 \\
40.67 \\
40.61\end{array}$ \\
\hline $\begin{array}{l}220 \\
221 \\
222 \\
223 \\
224\end{array}$ & $\begin{array}{l}10360.2 \\
10414.4 \\
10468.8 \\
10523.2 \\
10577.6\end{array}$ & $\begin{array}{l}54.253 \\
54.307 \\
54.360 \\
54.414 \\
54.467\end{array}$ & $\begin{array}{l}53.89 \\
53.74 \\
53.59 \\
53.44 \\
53.28\end{array}$ & $\begin{array}{l}280 \\
281 \\
282 \\
283 \\
284\end{array}$ & $\begin{array}{l}13706.8 \\
13764.0 \\
13821.3 \\
13878.6 \\
13936.0\end{array}$ & $\begin{array}{l}57.210 \\
57.255 \\
57.300 \\
57.344 \\
57.389\end{array}$ & $\begin{array}{l}44.93 \\
44.81 \\
44.69 \\
44.57 \\
44.46\end{array}$ & $\begin{array}{l}340 \\
341 \\
342 \\
343 \\
344\end{array}$ & $\begin{array}{l}17216 \cdot 8 \\
17276 \cdot 6 \\
17336 \cdot 4 \\
17396 \cdot 3 \\
17456 \cdot 2\end{array}$ & $\begin{array}{l}59.751 \\
59.791 \\
59.832 \\
59.872 \\
59.912\end{array}$ & $\begin{array}{l}40.55 \\
40.49 \\
40.42 \\
40.35 \\
40.28\end{array}$ \\
\hline $\begin{array}{l}225 \\
226 \\
227 \\
228 \\
229\end{array}$ & $\begin{array}{l}10632.1 \\
10686.6 \\
10741.2 \\
10795.9 \\
10850.6\end{array}$ & $\begin{array}{l}54.520 \\
54.573 \\
54.626 \\
54.679 \\
54.732\end{array}$ & $\begin{array}{l}53.13 \\
52.98 \\
52.82 \\
52.67 \\
52.52\end{array}$ & $\begin{array}{l}285 \\
286 \\
287 \\
288 \\
289\end{array}$ & $\begin{array}{l}13993.4 \\
14050.8 \\
14108.3 \\
14165.9 \\
14223.5\end{array}$ & $\begin{array}{l}57.433 \\
57.477 \\
57.522 \\
57.566 \\
57.610\end{array}$ & $\begin{array}{l}44.34 \\
44.23 \\
44.12 \\
44.01 \\
43.90\end{array}$ & $\begin{array}{l}345 \\
346 \\
347 \\
348 \\
349\end{array}$ & $\begin{array}{l}17516 \cdot 1 \\
17576.1 \\
17636 \cdot 1 \\
17696 \cdot 1 \\
17756.2\end{array}$ & $\begin{array}{l}59.953 \\
59.993 \\
60.033 \\
60.073 \\
60.113\end{array}$ & $\begin{array}{l}40.21 \\
40.13 \\
40.05 \\
39.97 \\
39.87\end{array}$ \\
\hline $\begin{array}{l}230 \\
231 \\
232 \\
233 \\
234\end{array}$ & $\begin{array}{l}10905.4 \\
10960.2 \\
11015.0 \\
11069.9 \\
11124.9\end{array}$ & $\begin{array}{l}54.784 \\
54.836 \\
54.889 \\
54.941 \\
54.992\end{array}$ & $\begin{array}{l}52.36 \\
52.21 \\
52.05 \\
51.89 \\
51.74\end{array}$ & $\begin{array}{l}290 \\
291 \\
292 \\
293 \\
294\end{array}$ & $\begin{array}{l}14281.1 \\
14338 \cdot 8 \\
14396 \cdot 5 \\
14454 \cdot 3 \\
14512.1\end{array}$ & $\begin{array}{l}57.653 \\
57.697 \\
57.741 \\
57.784 \\
57.828\end{array}$ & $\begin{array}{l}43.80 \\
43.69 \\
43.59 \\
43.49 \\
43.40\end{array}$ & $\begin{array}{l}350 \\
351 \\
352 \\
353 \\
354\end{array}$ & $\begin{array}{l}17816.4 \\
17876.5 \\
17936.8 \\
17997.0 \\
18057.3\end{array}$ & $\begin{array}{l}60.153 \\
60.192 \\
60.232 \\
60.272 \\
60.311\end{array}$ & $\begin{array}{l}39.78 \\
39.68 \\
39.57 \\
39.46 \\
39.34\end{array}$ \\
\hline $\begin{array}{l}235 \\
236 \\
237 \\
238 \\
239\end{array}$ & $\begin{array}{l}11179.9 \\
11235.0 \\
11290.1 \\
11345.3 \\
11400.5\end{array}$ & $\begin{array}{l}55.044 \\
55.096 \\
55.147 \\
55.198 \\
55.249\end{array}$ & $\begin{array}{l}51.58 \\
51.42 \\
51.27 \\
51.11 \\
50.95\end{array}$ & $\begin{array}{l}295 \\
296 \\
297 \\
298 \\
299\end{array}$ & $\begin{array}{l}14569.9 \\
14627.8 \\
14685.7 \\
14743.7 \\
14801.7\end{array}$ & $\begin{array}{l}57.871 \\
57.914 \\
57.958 \\
58.001 \\
58.044\end{array}$ & $\begin{array}{l}43.30 \\
43.21 \\
43.12 \\
43.03 \\
42.94\end{array}$ & $\begin{array}{l}355 \\
356 \\
357 \\
358 \\
359\end{array}$ & $\begin{array}{l}18117.6 \\
18178.0 \\
18238.4 \\
18298.9 \\
18359.3\end{array}$ & $\begin{array}{l}60.350 \\
60.389 \\
60.428 \\
60.467 \\
60.506\end{array}$ & $\begin{array}{l}39.22 \\
39.08 \\
38.94 \\
38.80 \\
38.64\end{array}$ \\
\hline 240 & 11455.8 & 55.300 & 50.80 & 300 & 14859.8 & 58.086 & 42.86 & 360 & 18419.9 & 60.545 & 38.47 \\
\hline
\end{tabular}


TABLE 8.3.2 Type $T$ thermocouples-thermoelectric voltages, $\mathrm{E}(\mathrm{T})$, Seebeck coefficients, S(T), and first derivative of the Seebeck coefficients, $\mathrm{dS} / \mathrm{dT}$, reference junctions at $0{ }^{\circ} \mathrm{C}$-Continued

\begin{tabular}{|c|c|c|c|c|c|c|c|c|c|c|c|}
\hline${ }^{\circ} \mathrm{C}$ & $\begin{array}{l}E \\
\mu V\end{array}$ & $\mu V^{\circ} \mathrm{C}$ & $\begin{array}{l}\mathrm{dS} / \mathrm{dT} \\
\mathrm{nV} /{ }^{\circ} \mathrm{C}^{2}\end{array}$ & ${ }^{\circ} \mathrm{C}$ & $\underset{\mu V}{E}$ & ${ }_{\mu V /^{\circ} \mathrm{C}}^{\mathrm{S}}$ & $\begin{array}{l}\mathrm{d} S / d T \\
\mathrm{nV} /{ }^{\circ} \mathrm{C}^{2}\end{array}$ & ${ }^{\circ} \mathrm{C}$ & $\underset{\mu V}{E}$ & $\mathrm{H}_{\mu}^{\mathrm{S}}{ }^{\circ} \mathrm{C}$ & $\begin{array}{l}d S / d T \\
n V /{ }^{\circ} C^{2}\end{array}$ \\
\hline $\begin{array}{l}360 \\
361 \\
362 \\
363 \\
364\end{array}$ & $\begin{array}{l}18419.9 \\
18480.4 \\
18541.0 \\
18601.7 \\
18662.3\end{array}$ & $\begin{array}{l}60.545 \\
60.583 \\
60.621 \\
60.659 \\
60.697\end{array}$ & $\begin{array}{l}38.47 \\
38.30 \\
38.12 \\
37.92 \\
37.72\end{array}$ & $\begin{array}{l}375 \\
376 \\
377 \\
378 \\
379\end{array}$ & $\begin{array}{l}19332.2 \\
19393.4 \\
19454.5 \\
19515.7 \\
19576.9\end{array}$ & $\begin{array}{l}61 \cdot 096 \\
61 \cdot 131 \\
61 \cdot 165 \\
61 \cdot 199 \\
61 \cdot 232\end{array}$ & $\begin{array}{l}34.64 \\
34.26 \\
33.88 \\
33.47 \\
33.04\end{array}$ & $\begin{array}{l}390 \\
391 \\
392 \\
393 \\
394\end{array}$ & $\begin{array}{l}20252 \cdot 3 \\
20313 \cdot 9 \\
20375.5 \\
20437 \cdot 2 \\
20498.8\end{array}$ & $\begin{array}{l}61.564 \\
61.591 \\
61.616 \\
61.641 \\
61.666\end{array}$ & $\begin{array}{l}26 \cdot 88 \\
26 \cdot 16 \\
25.42 \\
24 \cdot 65 \\
23.84\end{array}$ \\
\hline $\begin{array}{l}365 \\
366 \\
367 \\
368 \\
369\end{array}$ & $\begin{array}{l}18723.1 \\
18783.8 \\
18844.6 \\
18905.4 \\
18966.3\end{array}$ & $\begin{array}{l}60.735 \\
60.772 \\
60.809 \\
60.846 \\
60.883\end{array}$ & $\begin{array}{l}37.50 \\
37.28 \\
37.04 \\
36.79 \\
36.52\end{array}$ & $\begin{array}{l}380 \\
381 \\
382 \\
383 \\
384\end{array}$ & $\begin{array}{l}19638.2 \\
19699.4 \\
19760.7 \\
19822.1 \\
19883.5\end{array}$ & $\begin{array}{l}61.265 \\
61.297 \\
61.329 \\
61.360 \\
61.391\end{array}$ & $\begin{array}{l}32.59 \\
32.13 \\
31.64 \\
31.13 \\
30.60\end{array}$ & $\begin{array}{l}395 \\
396 \\
397 \\
398 \\
399\end{array}$ & $\begin{array}{l}20560 \cdot 5 \\
20622 \cdot 2 \\
20683 \cdot 9 \\
20745 \cdot 7 \\
20807 \cdot 4\end{array}$ & $\begin{array}{l}61 \cdot 689 \\
61 \cdot 712 \\
61 \cdot 733 \\
61.754 \\
61.774\end{array}$ & $\begin{array}{l}23.01 \\
22.14 \\
21.23 \\
20.29 \\
19.32\end{array}$ \\
\hline $\begin{array}{l}370 \\
371 \\
372 \\
373 \\
374\end{array}$ & $\begin{array}{l}19027.2 \\
19088.1 \\
19149.1 \\
19210.1 \\
19271.2\end{array}$ & $\begin{array}{l}60.919 \\
60.955 \\
60.991 \\
61.027 \\
61.062\end{array}$ & $\begin{array}{l}36.25 \\
35.96 \\
35.65 \\
35.33 \\
34.99\end{array}$ & $\begin{array}{l}385 \\
386 \\
387 \\
388 \\
389\end{array}$ & $\begin{array}{l}19944.9 \\
20006.3 \\
20067.8 \\
20129.3 \\
20190.8\end{array}$ & $\begin{array}{l}61.422 \\
61.451 \\
61.480 \\
61.509 \\
61.537\end{array}$ & $\begin{array}{l}30.04 \\
29.46 \\
28.85 \\
28.22 \\
27.56\end{array}$ & 400 & 20869.2 & 61.793 & 18.31 \\
\hline 375 & 19332.2 & 61.096 & 34.64 & 390 & 20252.3 & $61 \cdot 564$ & $26 \cdot 88$ & & & & \\
\hline
\end{tabular}


TABLE 8.3.3. Thermoelectric values at the fixed points for Type $T$ thermocouples

\begin{tabular}{|c|c|c|c|c|}
\hline Fixed point & $\begin{array}{l}\text { Temp. } \\
{ }^{\circ} \mathrm{C}\end{array}$ & $\begin{array}{c}E \\
\mu \mathrm{V}\end{array}$ & $\underset{\mu \mathrm{V} /{ }^{\circ} \mathrm{C}}{S}$ & $\begin{array}{l}d S / d T \\
\mathrm{nV} /{ }^{\circ} \mathrm{C}\end{array}$ \\
\hline $\begin{array}{l}\text { Helium NBP } \\
\text { Hydrogen TP } \\
\text { Hydrogen NBP } \\
\text { Neon TP } \\
\text { Neon NBP } \\
\text { Oxygen TP } \\
\text { Nitrogen TP } \\
\text { Nitrogen NBP } \\
\text { Oxygen NBP } \\
\text { Carbon Dioxide SP } \\
\text { Mercury FP } \\
\text { Ice point* } \\
\text { Ether TP } \\
\text { Water BP } \\
\text { Benzoic TP } \\
\text { Indium FP } \\
\text { Tin FP } \\
\text { Bismuth FP } \\
\text { Cadmium FP } \\
\text { Lead FP } \\
\text { Mercury BP }\end{array}$ & $\begin{array}{c}-268.935 \\
-259.340 \\
-252.870 \\
-248.595 \\
-246.048 \\
-218.789 \\
-210.002 \\
-195.802 \\
-182.962 \\
-78.476 \\
-38.862 \\
0.000 \\
26.870 \\
100.000 \\
122.370 \\
156.634 \\
231.9681 \\
271.442 \\
321.108 \\
327.502 \\
356.660\end{array}$ & $\begin{array}{r}-6256.29 \\
-6229.19 \\
-6197.73 \\
-6171.38 \\
-6153.58 \\
-5873.02 \\
-5753.28 \\
-5535.59 \\
-5314.72 \\
-2740.70 \\
-1434.94 \\
0.0 \\
1067.9 \\
4277.3 \\
5341.4 \\
7036.4 \\
11013.3 \\
13218.8 \\
16095.3 \\
16473.3 \\
18217.9\end{array}$ & $\begin{array}{l}1.408 \\
4.07 \\
5.645 \\
6.682 \\
7.298 \\
12.923 \\
14.305 \\
16.328 \\
18.067 \\
30.828 \\
35.022 \\
38.741 \\
40.829 \\
46.773 \\
48.343 \\
50.565 \\
54.887 \\
56.821 \\
58.975 \\
59.240 \\
60.415\end{array}$ & $\begin{array}{l}352.36 \\
244.17 \\
242.2 \\
242.42 \\
240.69 \\
166.41 \\
149.60 \\
137.63 \\
133.60 \\
110.82 \\
100.19 \\
66.38 \\
84.59 \\
72.80 \\
67.79 \\
62.29 \\
52.06 \\
46.05 \\
41.49 \\
41.19 \\
38.99\end{array}$ \\
\hline
\end{tabular}

*Junction point of different functions.

TABLE 8.3.4. Estimated maximum errors that occur when using reduced-bit arithmetic for the power series expansion for the thermoelectric voltage of Type T thermocouples

\begin{tabular}{|c|c|c|c|c|c|c|}
\hline \multirow[b]{2}{*}{ Temperature range } & \multirow[b]{2}{*}{ Degree } & \multicolumn{5}{|c|}{ Estimated maximum error in microvolts } \\
\hline & & 12 Bit & $16 \mathrm{Bit}$ & 24 Bit & $27 \mathrm{Bit}$ & $36 \mathrm{Bit}$ \\
\hline-270 to $-200^{\circ} \mathrm{C}$ & 14 & $\left({ }^{*}\right)$ & $\left({ }^{*}\right)$ & 30 & 1 & $<0.01$ \\
\hline-200 to & 14 & $\left({ }^{*}\right)$ & 700 & 3 & 0.3 & $<0.01$ \\
\hline 0 to $200^{\circ} \mathrm{C}$ & 8 & 5 & 0.2 & $<0.01$ & $<0.01$ & $<0.01$ \\
\hline 200 to $400^{\circ} \mathrm{C}$ & 8 & 80 & 6 & 0.03 & $<0.01$ & $<0.01$ \\
\hline
\end{tabular}

*A high-order polynomial with a low-bit machine causes extreme error.

8.4. Reference Functions and Tables for the Positive Thermoelement, Type TP, Copper Versus Platinum, $\mathbf{P t}-67$

The coefficients for the fourteenth degree expansion for the thermoelectric voltage of Type TP thermoelements versus $\mathrm{Pt}-67$ below $0{ }^{\circ} \mathrm{C}$ are given in table 8.4.1. The coefficients for the ninth degree expansion above $0{ }^{\circ} \mathrm{C}$ are also given in table 8.4.1. Errors caused by using reduced-bit arithmetic for calculating values of the functions are given in table 8.4.4.

The primary reference values for Type TP thermoelements iersus $\mathrm{Pt}-67$ are given in table 8.4.2. Values at selected fixed points are given in table 8.4.3. Graphs of the thermoelectric voltage, its first derivative (Seebeck coefficient), and second derivative are given in figures 8.4.1, 8.4.2, and 8.4.3, respectively.

It should be stressed that Type TP thermoele. ment material that conforms closely to the high temperature tabular value may not necessarily conform closely at low temperatures (below $0{ }^{\circ} \mathrm{C}$ ) and vice versa. If Type TP thermoelements are to be used for accurate measurements both above and below $0{ }^{\circ} \mathrm{C}$, then the material must be calibrated in the full temperature range, both above and below $0{ }^{\circ} \mathrm{C}$. Special selection of material will usually be required. 
TABLE 8.4.1. Power series expansion for the thermo. electric voltage of Type TP thermoelements versus platinum, $\mathrm{Pt}-67$

\begin{tabular}{|c|c|c|c|}
\hline $\begin{array}{c}\text { Tempera- } \\
\text { ture } \\
\text { range }\end{array}$ & Degree & Coefficients & Term \\
\hline $\begin{array}{c}-270 \text { to } \\
0^{\circ} \mathrm{C}\end{array}$ & 14 & $\begin{array}{l}5.8806261740 \times 10^{-2} \\
1.9658561192 \times 10^{-4} \\
1.7712284201 \times 10^{-4} \\
2.0479611841 \times 10^{-5} \\
9.4510605099 \times 10^{-7} \\
2.4639527148 \times 10^{-8} \\
4.0166759205 \times 10^{-10} \\
4.3256251496 \times 10^{-12} \\
3.1619504221 \times 10^{-14} \\
1.5784862573 \times 10^{-16} \\
5.3010783090 \times 10^{-19} \\
1.1454963751 \times 10^{-21} \\
1.4386009111 \times 10^{-24} \\
7.9795893156 \times 10^{-28}\end{array}$ & $\begin{array}{l}T \\
T^{2} \\
T^{3} \\
T^{4} \\
T^{5} \\
T^{6} \\
T^{7} \\
T^{8} \\
T^{8} \\
T^{10} \\
T^{11} \\
T^{12} \\
T^{13} \\
T^{14}\end{array}$ \\
\hline $\begin{array}{l}0 \text { to } \\
{ }_{400}{ }^{\circ} \mathrm{C}\end{array}$ & 9 & $\begin{array}{r}5.8806261740 \times \cdots \\
1.6201404918 \times 10^{-2} \\
1.1636815449 \times 10^{-4} \\
-1.6384754004 \times 10^{-6} \\
9.4887045900 \times 10^{-9} \\
-2.8443781735 \times 10^{-11} \\
4.3314365019 \times 10^{-14} \\
-2.6422248358 \times 10^{-17} \\
-2.5561127497 \times 10^{-22}\end{array}$ & $\begin{array}{l}T \\
T^{2} \\
T^{3} \\
T^{4} \\
T^{5} \\
T^{6} \\
T^{7} \\
T^{8} \\
T^{9}\end{array}$ \\
\hline
\end{tabular}

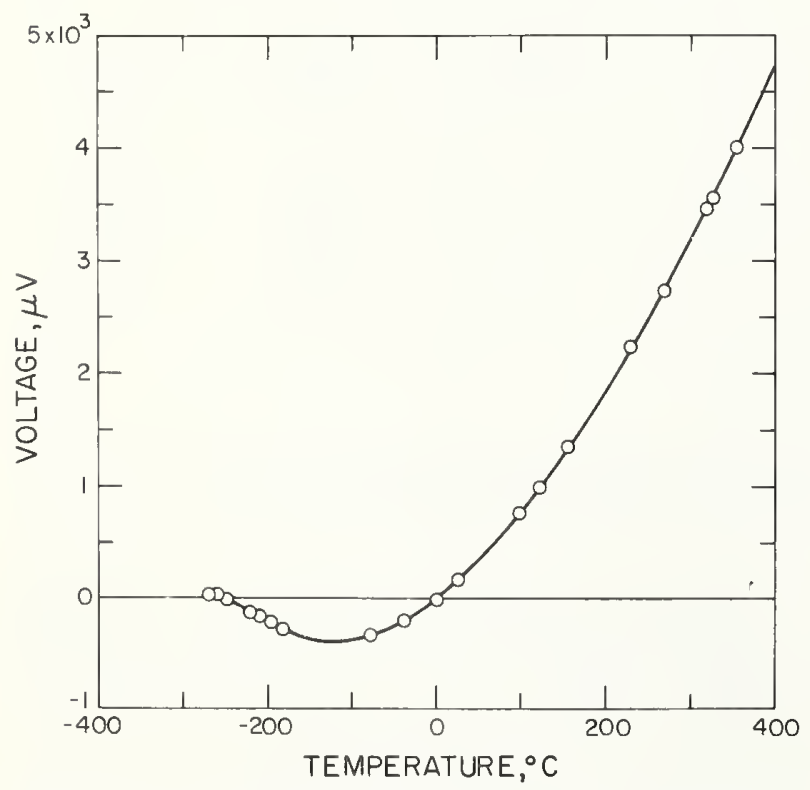

Figure 8.4.1. Thermoelectric voltage for Type TP thermo. elements versus platinum, $P t-67$.

The circles indicate values at various thermometric fixed points on the IPTS-68.

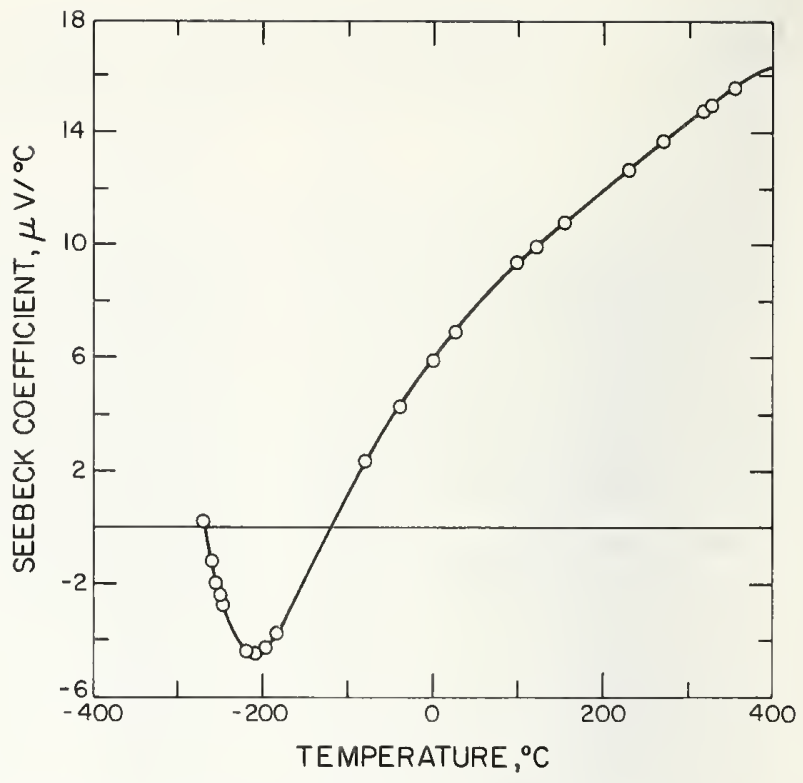

Figure 8.4.2. Seebeck coefficient for Type TP thermoelements versus platinum, $P t-67$.

The circles indicate values at various thermometric fixed points on the IPTS -68 .

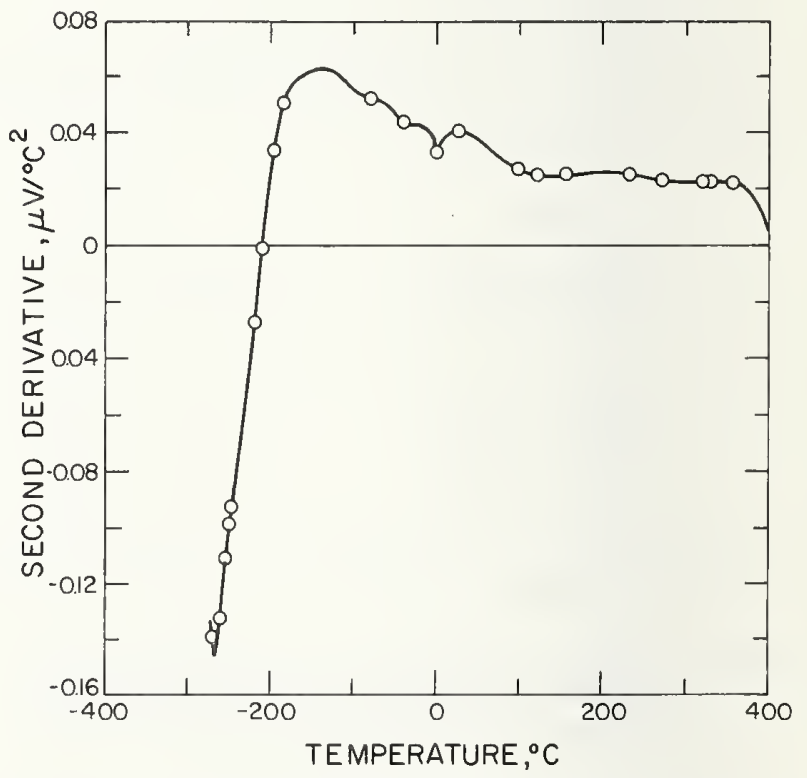

Figure 8.4.3. Second derivative of thermoelectric voltage for Type TP thermoelements versus platinum, $P_{t-67 .}$ The circles indicate values at various thermometric Gxed points on the IPTS -68 . 
TABLE 8.4.2. Type TP thermoelements versus platinum, $\mathrm{Pt}-67$-thermoelectric voltages, $\mathrm{E}(\mathrm{T})$, Seebeck coefficients, $\mathrm{S}(\mathrm{T})$, and first derivative of the Seebeck coefficients, dS/dT, reference junctions at $0^{\circ} \mathrm{C}$

\begin{tabular}{|c|c|c|c|c|c|c|c|c|c|c|c|}
\hline${ }^{\circ} \mathrm{C}$ & $\underset{\mu V}{E}$ & $\underset{\mu V /{ }^{\circ} \mathrm{C}}{S}$ & $\begin{array}{l}d S / d T \\
n V /{ }^{\circ} C^{2}\end{array}$ & $\begin{array}{r}\mathrm{T} \\
{ }^{\circ} \mathrm{C}\end{array}$ & $\underset{\mu V}{E}$ & $\underset{\mu V /{ }^{\circ} \mathrm{C}}{S}$ & $\begin{array}{l}\mathrm{dS} / \mathrm{dT} \\
\mathrm{nV} /{ }^{\circ} \mathrm{C}^{2}\end{array}$ & $\begin{array}{c}\mathrm{T} \\
{ }^{\circ} \mathrm{C}\end{array}$ & $\underset{\mu V}{E V}$ & $\underset{\mu V /{ }^{\circ} \mathrm{C}}{S}$ & $\begin{array}{l}\mathrm{dS} / \mathrm{dT} \\
\mathrm{nV} /{ }^{\circ} \mathrm{C}^{2}\end{array}$ \\
\hline $\begin{array}{l}-270 \\
-269 \\
-268 \\
-267 \\
-266\end{array}$ & $\begin{array}{l}19.66 \\
19.92 \\
20.02 \\
19.99 \\
19.81\end{array}$ & $\begin{array}{r}0.316 \\
0.180 \\
0.040 \\
-0.104 \\
-0.249\end{array}$ & $\begin{array}{l}-132.66 \\
-138.50 \\
-142.36 \\
-144.57 \\
-145.41\end{array}$ & $\begin{array}{l}-240 \\
-239 \\
-238 \\
-237 \\
-236\end{array}$ & $\begin{array}{l}-28.87 \\
-32.09 \\
-35.40 \\
-38.78 \\
-42.23\end{array}$ & $\begin{array}{l}-3.184 \\
-3.263 \\
-3.341 \\
-3.416 \\
-3.489\end{array}$ & $\begin{array}{l}-80.26 \\
-78.26 \\
-76.24 \\
-74.20 \\
-72.12\end{array}$ & $\begin{array}{l}-210 \\
-209 \\
-208 \\
-207 \\
-206\end{array}$ & $\begin{array}{l}-150.15 \\
-154.65 \\
-159.15 \\
-163.65 \\
-168.13\end{array}$ & $\begin{array}{l}-4.501 \\
-4.501 \\
-4.498 \\
-4.492 \\
-4.484\end{array}$ & $\begin{array}{r}-1.42 \\
1.47 \\
4.32 \\
7.11 \\
9.85\end{array}$ \\
\hline $\begin{array}{l}-265 \\
-264 \\
-263 \\
-262 \\
-261\end{array}$ & $\begin{array}{l}19.49 \\
19.02 \\
18.41 \\
17.66 \\
16.77\end{array}$ & $\begin{array}{l}-0.394 \\
-0.539 \\
-0.682 \\
-0.823 \\
-0.962\end{array}$ & $\begin{array}{l}-145.16 \\
-144.00 \\
-142.18 \\
-139.81 \\
-137.05\end{array}$ & $\begin{array}{l}-235 \\
-234 \\
-233 \\
-232 \\
-231\end{array}$ & $\begin{array}{l}-45.75 \\
-49.35 \\
-53.01 \\
-56.74 \\
-60.53\end{array}$ & $\begin{array}{l}-3.560 \\
-3.629 \\
-3.696 \\
-3.760 \\
-3.823\end{array}$ & $\begin{array}{l}-70.01 \\
-67.86 \\
-65.65 \\
-63.38 \\
-61.05\end{array}$ & $\begin{array}{l}-205 \\
-204 \\
-203 \\
-202 \\
-201\end{array}$ & $\begin{array}{l}-172.61 \\
-177.08 \\
-181.53 \\
-185.96 \\
-190.38\end{array}$ & $\begin{array}{l}-4.473 \\
-4.459 \\
-4.442 \\
-4.423 \\
-4.402\end{array}$ & $\begin{array}{l}12.53 \\
15.13 \\
17.67 \\
20.14 \\
22.52\end{array}$ \\
\hline $\begin{array}{l}-260 \\
-259 \\
-258 \\
-257 \\
-256\end{array}$ & $\begin{array}{l}15.74 \\
14.57 \\
13.28 \\
11.86 \\
10.31\end{array}$ & $\begin{array}{l}-1.097 \\
-1.229 \\
-1.359 \\
-1.484 \\
-1.607\end{array}$ & $\begin{array}{l}-134.01 \\
-130.80 \\
-127.48 \\
-124.13 \\
-120.80\end{array}$ & $\begin{array}{l}-230 \\
-229 \\
-228 \\
-227 \\
-226\end{array}$ & $\begin{array}{l}-64 \cdot 38 \\
-68 \cdot 29 \\
-72 \cdot 26 \\
-76 \cdot 28 \\
-80.36\end{array}$ & $\begin{array}{l}-3.882 \\
-3.940 \\
-3.995 \\
-4.047 \\
-4.097\end{array}$ & $\begin{array}{l}-58.66 \\
-56.20 \\
-53.67 \\
-51.08 \\
-48.43\end{array}$ & $\begin{array}{l}-200 \\
-199 \\
-198 \\
-197 \\
-196\end{array}$ & $\begin{array}{l}-194.77 \\
-199.13 \\
-203.47 \\
-207.78 \\
-212.06\end{array}$ & $\begin{array}{l}-4.378 \\
-4.353 \\
-4.324 \\
-4.294 \\
-4.262\end{array}$ & $\begin{array}{l}24.82 \\
27.04 \\
29.18 \\
31.22 \\
33.18\end{array}$ \\
\hline $\begin{array}{l}-255 \\
-254 \\
-253 \\
-252 \\
-251\end{array}$ & $\begin{array}{l}8.64 \\
6.86 \\
4.96 \\
2.95 \\
0.83\end{array}$ & $\begin{array}{l}-1.726 \\
-1.842 \\
-1.955 \\
-2.064 \\
-2.171\end{array}$ & $\begin{array}{l}-117.51 \\
-114.31 \\
-111.22 \\
-108.24 \\
-105.37\end{array}$ & $\begin{array}{l}-225 \\
-224 \\
-223 \\
-222 \\
-221\end{array}$ & $\begin{array}{r}-84.48 \\
-88.64 \\
-92.85 \\
-97.10 \\
-101.39\end{array}$ & $\begin{array}{l}-4.144 \\
-4.188 \\
-4.230 \\
-4.269 \\
-4.304\end{array}$ & $\begin{array}{l}-45.72 \\
-42.95 \\
-40.13 \\
-37.26 \\
-34.35\end{array}$ & $\begin{array}{l}-195 \\
-194 \\
-193 \\
-192 \\
-191\end{array}$ & $\begin{array}{l}-216.30 \\
-220.51 \\
-224.69 \\
-228.82 \\
-232.92\end{array}$ & $\begin{array}{l}-4.228 \\
-4.192 \\
-4.154 \\
-4.115 \\
-4.074\end{array}$ & $\begin{array}{l}35.05 \\
36.83 \\
38.52 \\
40.13 \\
41.64\end{array}$ \\
\hline $\begin{array}{l}-250 \\
-249 \\
-248 \\
-247 \\
-246\end{array}$ & $\begin{array}{r}-1.39 \\
-3.72 \\
-6.14 \\
-8.67 \\
-11.29\end{array}$ & $\begin{array}{l}-2.275 \\
-2.377 \\
-2.475 \\
-2.572 \\
-2.666\end{array}$ & $\begin{array}{r}-102.64 \\
-100.02 \\
-97.52 \\
-95.12 \\
-92.82\end{array}$ & $\begin{array}{l}-220 \\
-219 \\
-218 \\
-217 \\
-216\end{array}$ & $\begin{array}{l}-105.71 \\
-110.06 \\
-114.44 \\
-118.85 \\
-123.28\end{array}$ & $\begin{array}{l}-4.337 \\
-4.367 \\
-4.394 \\
-4.418 \\
-4.439\end{array}$ & $\begin{array}{l}-31.40 \\
-28.42 \\
-25.42 \\
-22.40 \\
-19.38\end{array}$ & $\begin{array}{l}-190 \\
-189 \\
-188 \\
-187 \\
-186\end{array}$ & $\begin{array}{l}-236.97 \\
-240.98 \\
-244.94 \\
-248.86 \\
-252.74\end{array}$ & $\begin{array}{l}-4.032 \\
-3.988 \\
-3.943 \\
-3.896 \\
-3.849\end{array}$ & $\begin{array}{l}43.08 \\
44.42 \\
45.69 \\
46.87 \\
47.97\end{array}$ \\
\hline $\begin{array}{l}-245 \\
-244 \\
-243 \\
-242 \\
-241\end{array}$ & $\begin{array}{l}-14.00 \\
-16.80 \\
-19.69 \\
-22.66 \\
-25.73\end{array}$ & $\begin{array}{l}-2.757 \\
-2.847 \\
-2.934 \\
-3.020 \\
-3.103\end{array}$ & $\begin{array}{l}-90.60 \\
-98.45 \\
-86.36 \\
-84.30 \\
-82.28\end{array}$ & $\begin{array}{l}-215 \\
-214 \\
-213 \\
-212 \\
-211\end{array}$ & $\begin{array}{l}-127.73 \\
-132.19 \\
-136.67 \\
-141.16 \\
-145.65\end{array}$ & $\begin{array}{l}-4.457 \\
-4.472 \\
-4.483 \\
-4.492 \\
-4.498\end{array}$ & $\begin{array}{r}-16.35 \\
-13.32 \\
-10.31 \\
-7.32 \\
-4.36\end{array}$ & $\begin{array}{l}-185 \\
-184 \\
-183 \\
-182 \\
-181\end{array}$ & $\begin{array}{l}-256.56 \\
-260.34 \\
-264.06 \\
-267.74 \\
-271.36\end{array}$ & $\begin{array}{l}-3.801 \\
-3.751 \\
-3.701 \\
-3.649 \\
-3.597\end{array}$ & $\begin{array}{l}49.00 \\
49.96 \\
50.85 \\
51.67 \\
52.43\end{array}$ \\
\hline-240 & -28.87 & -3.184 & $-80 \cdot 26$ & -210 & $-150 \cdot 15$ & -4.501 & -1.42 & -180 & -274.93 & -3.545 & 53.13 \\
\hline
\end{tabular}


TABLE 8.4.2. Type TP thermoelements versus platinum, $\mathrm{Pt}-67$-thermoelectric voltages, $\mathrm{E}(\mathrm{T})$, Seebeck coefficients, S(T), and first derivative of the Seebeck coefficients, dS/dT,

reference junctions at $0^{\circ} \mathrm{C}$-Continued

\begin{tabular}{|c|c|c|c|c|c|c|c|c|c|c|c|}
\hline${ }^{\mathrm{T}} \mathrm{C}$ & $\begin{array}{c}E \\
\mu V\end{array}$ & $\frac{\mathrm{S}}{\mu \mathrm{V}^{\circ}{ }^{\circ} \mathrm{C}}$ & $\begin{array}{l}\mathrm{dS} / \mathrm{dT} \\
\mathrm{nV} /{ }^{\circ} \mathrm{C}^{2}\end{array}$ & ${ }^{\circ} \mathrm{C}$ & $\begin{array}{c}E \\
\mu V\end{array}$ & $\frac{\mathrm{S}}{\mu \mathrm{V} /{ }^{\circ} \mathrm{C}}$ & $\begin{array}{l}\mathrm{dS} / \mathrm{dT} \\
\mathrm{nV} /{ }^{\circ} \mathrm{C}^{2}\end{array}$ & ${ }^{\mathrm{T}} \mathrm{C}$ & $\underset{\mu V}{E}$ & $\underset{\mu V /{ }^{\circ} \mathrm{C}}{S}$ & $\begin{array}{l}d S / d T \\
n V /{ }^{\circ} C^{2}\end{array}$ \\
\hline $\begin{array}{l}-180 \\
-179 \\
-178 \\
-177 \\
-176\end{array}$ & $\begin{array}{l}-274.93 \\
-278.45 \\
-281.91 \\
-285.32 \\
-288.68\end{array}$ & $\begin{array}{l}-3.545 \\
-3.491 \\
-3.437 \\
-3.382 \\
-3.327\end{array}$ & $\begin{array}{l}53.13 \\
53.78 \\
54.37 \\
54.91 \\
55.41\end{array}$ & $\begin{array}{l}-120 \\
-119 \\
-118 \\
-117 \\
-116\end{array}$ & $\begin{array}{l}-381.67 \\
-381.58 \\
-381.44 \\
-381.23 \\
-380.96\end{array}$ & $\begin{array}{l}0.057 \\
0.118 \\
0.178 \\
0.238 \\
0.297\end{array}$ & $\begin{array}{l}60.60 \\
60.36 \\
60.11 \\
59.84 \\
59.57\end{array}$ & $\begin{array}{l}-60 \\
-59 \\
-58 \\
-57 \\
-56\end{array}$ & $\begin{array}{l}-278 \cdot 24 \\
-274 \cdot 93 \\
-271.56 \\
-268.15 \\
-264.68\end{array}$ & $\begin{array}{l}3.291 \\
3.341 \\
3.390 \\
3.440 \\
3.489\end{array}$ & $\begin{array}{l}49 \cdot 88 \\
49.65 \\
49.40 \\
49.13 \\
48.85\end{array}$ \\
\hline $\begin{array}{l}-175 \\
-174 \\
-173 \\
-172 \\
-171\end{array}$ & $\begin{array}{l}-291.98 \\
-295.22 \\
-298.41 \\
-301.54 \\
-304.61\end{array}$ & $\begin{array}{l}-3.272 \\
-3.216 \\
-3.159 \\
-3.102 \\
-3.045\end{array}$ & $\begin{array}{l}55.86 \\
56.27 \\
56.65 \\
57.00 \\
57.32\end{array}$ & $\begin{array}{l}-115 \\
-114 \\
-113 \\
-112 \\
-111\end{array}$ & $\begin{array}{l}-380.63 \\
-380.25 \\
-379.80 \\
-379.30 \\
-378.73\end{array}$ & $\begin{array}{l}0.357 \\
0.416 \\
0.475 \\
0.533 \\
0.592\end{array}$ & $\begin{array}{l}59.28 \\
58.99 \\
58.69 \\
58.38 \\
58.07\end{array}$ & $\begin{array}{l}-55 \\
-54 \\
-53 \\
-52 \\
-51\end{array}$ & $\begin{array}{l}-261.17 \\
-257.61 \\
-254.00 \\
-250.34 \\
-246.63\end{array}$ & $\begin{array}{l}3.537 \\
3.586 \\
3.634 \\
3.682 \\
3.729\end{array}$ & $\begin{array}{l}48 \cdot 55 \\
48.24 \\
47.92 \\
47.59 \\
47.25\end{array}$ \\
\hline $\begin{array}{l}-170 \\
-169 \\
-168 \\
-167 \\
-166\end{array}$ & $\begin{array}{l}-307.63 \\
-310.59 \\
-313.49 \\
-316.33 \\
-319.12\end{array}$ & $\begin{array}{l}-2.988 \\
-2.930 \\
-2.872 \\
-2.814 \\
-2.755\end{array}$ & $\begin{array}{l}57.61 \\
57.88 \\
58.12 \\
58.35 \\
58.56\end{array}$ & $\begin{array}{l}-110 \\
-109 \\
-108 \\
-107 \\
-106\end{array}$ & $\begin{array}{l}-378.11 \\
-377.44 \\
-376.70 \\
-375.91 \\
-375.06\end{array}$ & $\begin{array}{l}0.649 \\
0.707 \\
0.764 \\
0.821 \\
0.878\end{array}$ & $\begin{array}{l}57.75 \\
57.43 \\
57.12 \\
56.80 \\
56.49\end{array}$ & $\begin{array}{l}-50 \\
-49 \\
-48 \\
-47 \\
-46\end{array}$ & $\begin{array}{l}-242.88 \\
-239.08 \\
-235.24 \\
-231.34 \\
-227.41\end{array}$ & $\begin{array}{l}3.776 \\
3.823 \\
3.869 \\
3.915 \\
3.961\end{array}$ & $\begin{array}{l}46.90 \\
46.55 \\
46.20 \\
45.85 \\
45.50\end{array}$ \\
\hline $\begin{array}{l}-165 \\
-164 \\
-163 \\
-162 \\
-161\end{array}$ & $\begin{array}{l}-321.84 \\
-324.51 \\
-327.12 \\
-329.67 \\
-332.16\end{array}$ & $\begin{array}{l}-2.696 \\
-2.638 \\
-2.579 \\
-2.519 \\
-2.460\end{array}$ & $\begin{array}{l}58.76 \\
58 \cdot 95 \\
59 \cdot 13 \\
59 \cdot 30 \\
59.46\end{array}$ & $\begin{array}{l}-105 \\
-104 \\
-103 \\
-102 \\
-101\end{array}$ & $\begin{array}{l}-374.15 \\
-373.19 \\
-372.17 \\
-371.10 \\
-369.97\end{array}$ & $\begin{array}{l}0.934 \\
0.990 \\
1.046 \\
1.101 \\
1.157\end{array}$ & $\begin{array}{l}56.17 \\
55.87 \\
55.57 \\
55.27 \\
54.99\end{array}$ & $\begin{array}{l}-45 \\
-44 \\
-43 \\
-42 \\
-41\end{array}$ & $\begin{array}{l}-223.42 \\
-219.39 \\
-215.32 \\
-211.20 \\
-207.04\end{array}$ & $\begin{array}{l}4.006 \\
4.051 \\
4.096 \\
4.140 \\
4.184\end{array}$ & $\begin{array}{l}45.16 \\
44.82 \\
44.50 \\
44.19 \\
43.89\end{array}$ \\
\hline $\begin{array}{l}-160 \\
-159 \\
-158 \\
-157 \\
-156\end{array}$ & $\begin{array}{l}-334.59 \\
-336.96 \\
-339.27 \\
-341.52 \\
-343.71\end{array}$ & $\begin{array}{l}-2.400 \\
-2.341 \\
-2.281 \\
-2.221 \\
-2.161\end{array}$ & $\begin{array}{l}59.62 \\
59.77 \\
59.92 \\
60.06 \\
60.21\end{array}$ & $\begin{array}{r}-100 \\
-99 \\
-98 \\
-97 \\
-96\end{array}$ & $\begin{array}{l}-368 \cdot 78 \\
-367.55 \\
-366.25 \\
-364.90 \\
-363.50\end{array}$ & $\begin{array}{l}1.211 \\
1.266 \\
1.320 \\
1.374 \\
1.428\end{array}$ & $\begin{array}{l}54 \cdot 71 \\
54 \cdot 45 \\
54 \cdot 19 \\
53 \cdot 95 \\
53.72\end{array}$ & $\begin{array}{l}-40 \\
-39 \\
-38 \\
-37 \\
-36\end{array}$ & $\begin{array}{l}-202.83 \\
-198.58 \\
-194.29 \\
-189.95 \\
-185.58\end{array}$ & $\begin{array}{l}4.228 \\
4.271 \\
4.315 \\
4.358 \\
4.401\end{array}$ & $\begin{array}{l}43.61 \\
43.35 \\
43.11 \\
42.90 \\
42.71\end{array}$ \\
\hline $\begin{array}{l}-155 \\
-154 \\
-153 \\
-152 \\
-151\end{array}$ & $\begin{array}{l}-345.84 \\
-347.91 \\
-349.92 \\
-351.87 \\
-353.76\end{array}$ & $\begin{array}{l}-2.100 \\
-2.040 \\
-1.980 \\
-1.919 \\
-1.858\end{array}$ & $\begin{array}{l}60.35 \\
60.49 \\
60.63 \\
60.77 \\
60.91\end{array}$ & $\begin{array}{l}-95 \\
-94 \\
-93 \\
-92 \\
-91\end{array}$ & $\begin{array}{l}-362.05 \\
-360.54 \\
-358.98 \\
-357.36 \\
-355.70\end{array}$ & $\begin{array}{l}1.482 \\
1.535 \\
1.588 \\
1.641 \\
1.694\end{array}$ & $\begin{array}{l}53.50 \\
53.30 \\
53.11 \\
52.93 \\
52.77\end{array}$ & $\begin{array}{l}-35 \\
-34 \\
-33 \\
-32 \\
-31\end{array}$ & $\begin{array}{l}-181.15 \\
-176.69 \\
-172.18 \\
-167.63 \\
-163.04\end{array}$ & $\begin{array}{l}4.443 \\
4.486 \\
4.528 \\
4.570 \\
4.612\end{array}$ & $\begin{array}{l}42.55 \\
42.41 \\
42.30 \\
42.21 \\
42.15\end{array}$ \\
\hline $\begin{array}{l}-150 \\
-149 \\
-148 \\
-147 \\
-146\end{array}$ & $\begin{array}{l}-355.59 \\
-357.35 \\
-359.06 \\
-360.70 \\
-362.28\end{array}$ & $\begin{array}{l}-1.797 \\
-1.736 \\
-1.675 \\
-1.613 \\
-1.552\end{array}$ & $\begin{array}{l}61.04 \\
61 \cdot 17 \\
61.30 \\
61.42 \\
61.54\end{array}$ & $\begin{array}{l}-90 \\
-89 \\
-88 \\
-87 \\
-86\end{array}$ & $\begin{array}{l}-353.97 \\
-352.20 \\
-350.38 \\
-348.50 \\
-346.57\end{array}$ & $\begin{array}{l}1.747 \\
1.800 \\
1.852 \\
1.904 \\
1.956\end{array}$ & $\begin{array}{l}52.62 \\
52.48 \\
52.36 \\
52.25 \\
52.16\end{array}$ & $\begin{array}{l}-30 \\
-29 \\
-28 \\
-27 \\
-26\end{array}$ & $\begin{array}{l}-158.41 \\
-153.73 \\
-149.01 \\
-144.26 \\
-139.45\end{array}$ & $\begin{array}{l}4.655 \\
4.697 \\
4.739 \\
4.781 \\
4.823\end{array}$ & $\begin{array}{l}42.11 \\
42.10 \\
42.10 \\
42.13 \\
42.16\end{array}$ \\
\hline $\begin{array}{l}-145 \\
-144 \\
-143 \\
-142 \\
-141\end{array}$ & $\begin{array}{l}-363 \cdot 80 \\
-365.26 \\
-366.66 \\
-368.00 \\
-369.27\end{array}$ & $\begin{array}{l}-1.490 \\
-1.429 \\
-1.367 \\
-1.305 \\
-1.243\end{array}$ & $\begin{array}{l}61.66 \\
61.76 \\
61.87 \\
61.96 \\
62.04\end{array}$ & $\begin{array}{l}-85 \\
-84 \\
-83 \\
-82 \\
-81\end{array}$ & $\begin{array}{l}-344.58 \\
-342.55 \\
-340.46 \\
-338.32 \\
-336.13\end{array}$ & $\begin{array}{l}2.009 \\
2.061 \\
2.113 \\
2.164 \\
2.216\end{array}$ & $\begin{array}{l}52.07 \\
51.99 \\
51.93 \\
51.87 \\
51.82\end{array}$ & $\begin{array}{l}-25 \\
-24 \\
-23 \\
-22 \\
-21\end{array}$ & $\begin{array}{l}-134.61 \\
-129.72 \\
-124.79 \\
-119.82 \\
-114.81\end{array}$ & $\begin{array}{l}4.865 \\
4.907 \\
4.950 \\
4.992 \\
5.034\end{array}$ & $\begin{array}{l}42.20 \\
42.25 \\
42.29 \\
42.33 \\
42.35\end{array}$ \\
\hline $\begin{array}{l}-140 \\
-139 \\
-138 \\
-137 \\
-136\end{array}$ & $\begin{array}{l}-370.48 \\
-371.63 \\
-372.72 \\
-373.75 \\
-374.71\end{array}$ & $\begin{array}{l}-1.181 \\
-1.119 \\
-1.056 \\
-0.994 \\
-0.932\end{array}$ & $\begin{array}{l}62.12 \\
62.18 \\
62.24 \\
62.28 \\
62.30\end{array}$ & $\begin{array}{l}-80 \\
-79 \\
-78 \\
-77 \\
-76\end{array}$ & $\begin{array}{l}-333.89 \\
-331.60 \\
-329.25 \\
-326.86 \\
-324.41\end{array}$ & $\begin{array}{l}2.268 \\
2.320 \\
2.372 \\
2.423 \\
2.475\end{array}$ & $\begin{array}{l}51.77 \\
51.73 \\
51.70 \\
51.66 \\
51.62\end{array}$ & $\begin{array}{l}-20 \\
-19 \\
-18 \\
-17 \\
-16\end{array}$ & $\begin{array}{r}-109.75 \\
-104.66 \\
-99.52 \\
-94.33 \\
-89.11\end{array}$ & $\begin{array}{l}5.077 \\
5.119 \\
5.161 \\
5.204 \\
5.246\end{array}$ & $\begin{array}{l}42.36 \\
42.34 \\
42.29 \\
42.20 \\
42.07\end{array}$ \\
\hline $\begin{array}{l}-135 \\
-134 \\
-133 \\
-132 \\
-131\end{array}$ & $\begin{array}{l}-375.61 \\
-376.45 \\
-377.22 \\
-377.94 \\
-378.59\end{array}$ & $\begin{array}{l}-0.869 \\
-0.807 \\
-0.745 \\
-0.683 \\
-0.620\end{array}$ & $\begin{array}{l}62.32 \\
62.32 \\
62.30 \\
62.27 \\
62.22\end{array}$ & $\begin{array}{l}-75 \\
-74 \\
-73 \\
-72 \\
-71\end{array}$ & $\begin{array}{l}-321.91 \\
-319.35 \\
-316.75 \\
-314.09 \\
-311.39\end{array}$ & $\begin{array}{l}2.526 \\
2.578 \\
2.630 \\
2.581 \\
2.732\end{array}$ & $\begin{array}{l}51.59 \\
51.55 \\
51.50 \\
51.45 \\
51.39\end{array}$ & $\begin{array}{l}-15 \\
-14 \\
-13 \\
-12 \\
-11\end{array}$ & $\begin{array}{l}-83.84 \\
-78.53 \\
-73.18 \\
-67.79 \\
-62.36\end{array}$ & $\begin{array}{l}5.288 \\
5.329 \\
5.371 \\
5.412 \\
5.453\end{array}$ & $\begin{array}{l}41.89 \\
41.67 \\
41.39 \\
41.07 \\
40.70\end{array}$ \\
\hline $\begin{array}{l}-130 \\
-129 \\
-128 \\
-127 \\
-126\end{array}$ & $\begin{array}{l}-379.18 \\
-379.70 \\
-380.17 \\
-380.57 \\
-380.91\end{array}$ & $\begin{array}{l}-0.558 \\
-0.496 \\
-0.434 \\
-0.372 \\
-0.310\end{array}$ & $\begin{array}{l}62.16 \\
62.08 \\
61.98 \\
61.86 \\
61.73\end{array}$ & $\begin{array}{l}-70 \\
-69 \\
-68 \\
-67 \\
-66\end{array}$ & $\begin{array}{l}-308.63 \\
-305.82 \\
-302.96 \\
-300.05 \\
-297.08\end{array}$ & $\begin{array}{l}2.784 \\
2.835 \\
2.886 \\
2.937 \\
2.988\end{array}$ & $\begin{array}{l}51 \cdot 32 \\
51 \cdot 24 \\
51 \cdot 15 \\
51 \cdot 04 \\
50.93\end{array}$ & $\begin{array}{l}-10 \\
-9 \\
-8 \\
-7 \\
-6\end{array}$ & $\begin{array}{l}-56.89 \\
-51.37 \\
-45.82 \\
-40.23 \\
-34.59\end{array}$ & $\begin{array}{l}5.494 \\
5.534 \\
5.573 \\
5.613 \\
5.651\end{array}$ & $\begin{array}{l}40.29 \\
39.85 \\
39.40 \\
38.95 \\
38.54\end{array}$ \\
\hline $\begin{array}{l}-125 \\
-124 \\
-123 \\
-122 \\
-121\end{array}$ & $\begin{array}{l}-381.19 \\
-381.41 \\
-381.57 \\
-381.66 \\
-381.70\end{array}$ & $\begin{array}{l}-0.249 \\
-0.187 \\
-0.126 \\
-0.065 \\
-0.004\end{array}$ & $\begin{array}{l}61.58 \\
61.42 \\
61.24 \\
61.04 \\
60.83\end{array}$ & $\begin{array}{l}-65 \\
-64 \\
-63 \\
-62 \\
-61\end{array}$ & $\begin{array}{l}-294.07 \\
-291.01 \\
-287.89 \\
-284.72 \\
-281.51\end{array}$ & $\begin{array}{l}3.039 \\
3.090 \\
3.141 \\
3.191 \\
3.241\end{array}$ & $\begin{array}{l}50.79 \\
50.64 \\
50.48 \\
50.30 \\
50.10\end{array}$ & $\begin{array}{l}-5 \\
-4 \\
-3 \\
-2 \\
-1\end{array}$ & $\begin{array}{r}-28.92 \\
-23.21 \\
-17.47 \\
-11.68 \\
-5.86\end{array}$ & $\begin{array}{l}5.690 \\
5.728 \\
5.766 \\
5.804 \\
5.842\end{array}$ & $\begin{array}{l}38.20 \\
37.96 \\
37.89 \\
38.03 \\
38.48\end{array}$ \\
\hline-120 & -381.67 & 0.057 & 60.60 & -60 & -278.24 & 3.291 & 49.88 & 0 & 0.00 & 5.881 & 32.40 \\
\hline
\end{tabular}


TABLE 8.4.2. Type TP thermoelements versus platinum, Pt-67-thermoelectric voltages, E(T), Seebeck coefficients, $\mathrm{S}(\mathrm{T})$, and first derivative of the Seebeck coefficients, $\mathrm{dS} / \mathrm{dT}$, reference junctions at $0^{\circ} \mathrm{C}$-Continued

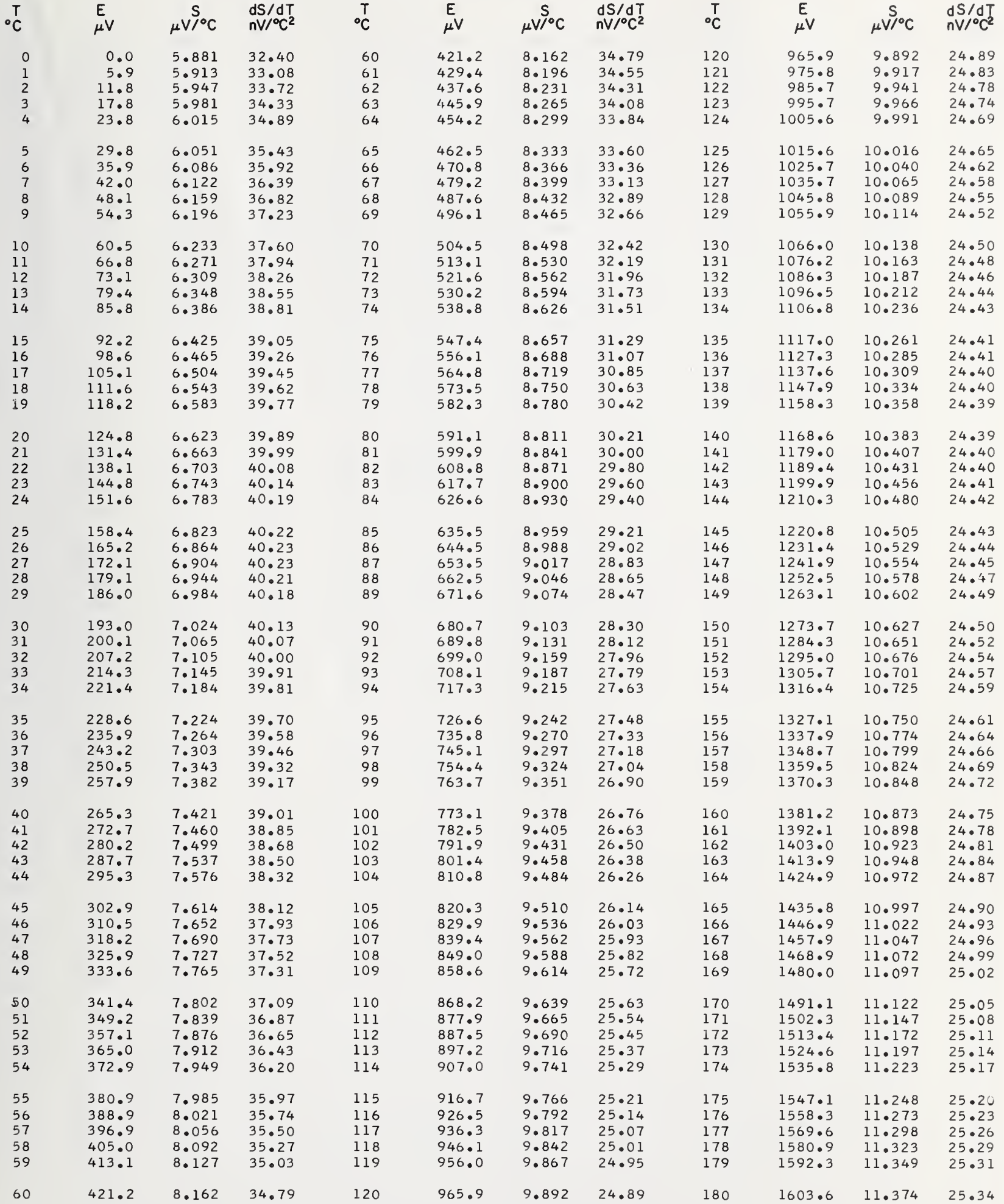


TABLE 8.4.2. Type TP thermoelements versus platinum, $\mathbf{P t}-67$-thermoelectric voltages, $\mathrm{E}(\mathrm{T})$, Seebeck coefficients, $\mathrm{S}(\mathrm{T})$, and first derivative of the Seebeck coefficients, $\mathrm{dS} / \mathrm{dT}$, reference junctions at $0^{\circ} \mathrm{C}$-Continued

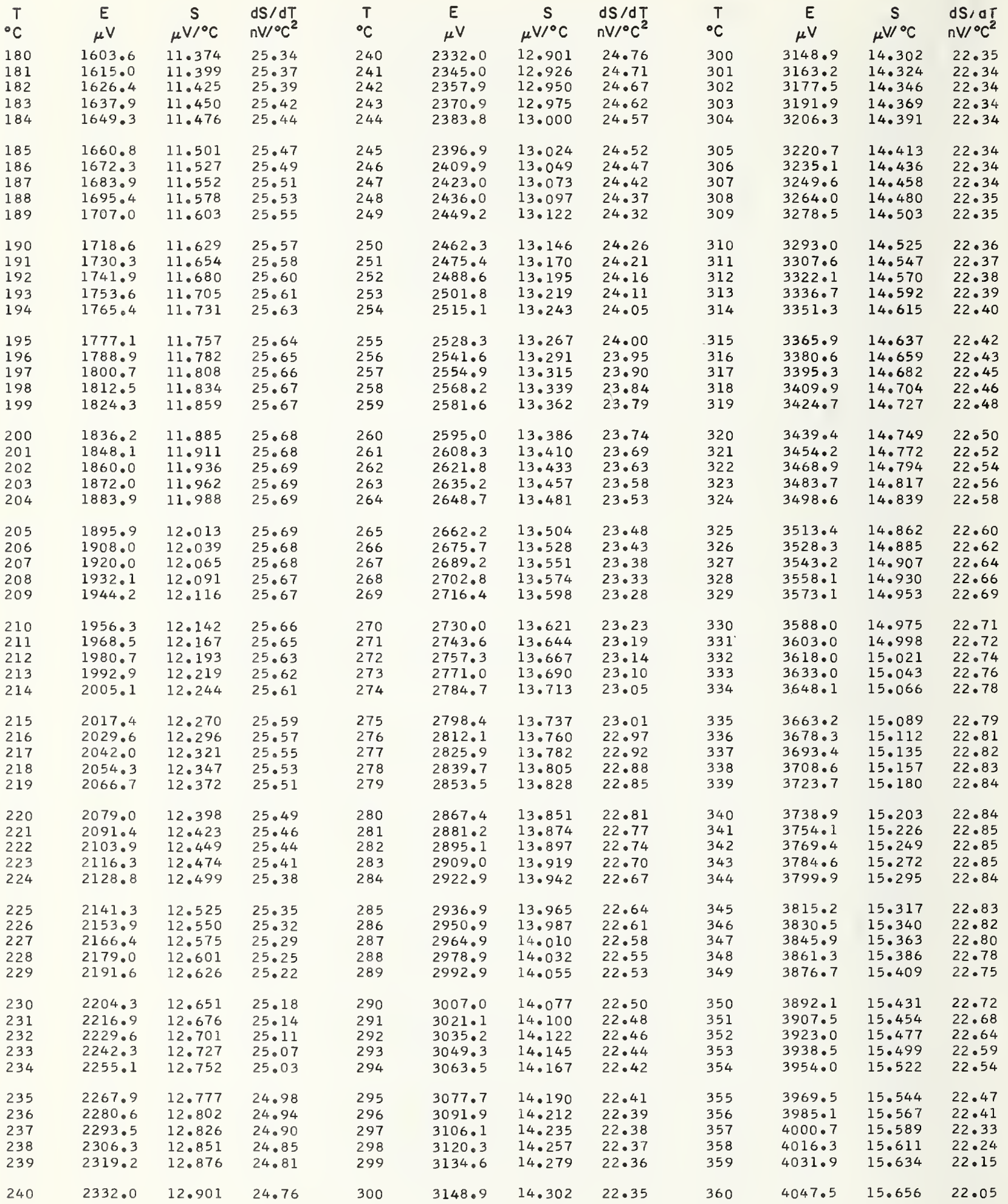


TABLE 8.4.2. Type TP thermoelements versus platinum, Pt-67-thermoelectric voltages, $\mathrm{E}(\mathrm{T})$, Seebeck coefficients, $\mathrm{S}(\mathrm{T})$, and first derivative of the Seebeck coefficients, $\mathrm{dS} / \mathrm{dT}$, reference junctions at $0^{\circ} \mathrm{C}$-Continued

\begin{tabular}{|c|c|c|c|c|c|c|c|c|c|c|c|}
\hline $\begin{array}{r}\mathrm{T} \\
{ }^{\circ} \mathrm{C}\end{array}$ & $\begin{array}{c}E \\
\mu V\end{array}$ & $\stackrel{S}{\mu V^{\circ}{ }^{\circ} \mathrm{C}}$ & $\begin{array}{l}\mathrm{dS} / \mathrm{dT} \\
\mathrm{nV} /{ }^{\circ} \mathrm{C}^{2}\end{array}$ & ${ }^{\circ} \mathrm{C}$ & $\begin{array}{c}E \\
\mu V\end{array}$ & $\stackrel{\mathrm{S}}{\mu \mathrm{V} /{ }^{\circ} \mathrm{C}}$ & $\begin{array}{l}\mathrm{dS} / \mathrm{dT} \\
\mathrm{nV} /{ }^{\circ} \mathrm{C}^{2}\end{array}$ & ${ }^{\circ} \mathrm{C}$ & $\begin{array}{c}E \\
\mu V\end{array}$ & $\stackrel{S}{\mu \mathrm{V} /{ }^{\circ} \mathrm{C}}$ & $\begin{array}{l}\mathrm{dS} / \mathrm{dT} \\
\mathrm{nV} /{ }^{\circ} \mathrm{C}^{2}\end{array}$ \\
\hline $\begin{array}{l}360 \\
361 \\
362 \\
363 \\
364\end{array}$ & $\begin{array}{l}4047 \cdot 5 \\
4063 \cdot 2 \\
4078 \cdot 9 \\
4094.6 \\
4110.3\end{array}$ & $\begin{array}{l}15.656 \\
15.678 \\
15.700 \\
15.721 \\
15.743\end{array}$ & $\begin{array}{l}22.05 \\
21.94 \\
21.82 \\
21.69 \\
21.55\end{array}$ & $\begin{array}{l}375 \\
376 \\
377 \\
378 \\
379\end{array}$ & $\begin{array}{l}4284.8 \\
4300.7 \\
4316.7 \\
4332.7 \\
4348.8\end{array}$ & $\begin{array}{l}15.968 \\
15.987 \\
16.006 \\
16.024 \\
16.042\end{array}$ & $\begin{array}{l}19.15 \\
18.84 \\
18.51 \\
18.17 \\
17.81\end{array}$ & $\begin{array}{l}390 \\
391 \\
392 \\
393 \\
394\end{array}$ & $\begin{array}{l}4526 \cdot 2 \\
4542 \cdot 4 \\
4558 \cdot 7 \\
4574 \cdot 9 \\
4591 \cdot 2\end{array}$ & $\begin{array}{l}16.211 \\
16.223 \\
16.234 \\
16.245 \\
16.255\end{array}$ & $\begin{array}{r}12.33 \\
11.68 \\
11.00 \\
10.29 \\
9.55\end{array}$ \\
\hline $\begin{array}{l}365 \\
366 \\
367 \\
368 \\
369\end{array}$ & $\begin{array}{l}4126.1 \\
4141.9 \\
4157.6 \\
4173.5 \\
4189.3\end{array}$ & $\begin{array}{l}15.764 \\
15.786 \\
15.807 \\
15.828 \\
15.849\end{array}$ & $\begin{array}{l}21.39 \\
21.23 \\
21.05 \\
20.87 \\
20.66\end{array}$ & $\begin{array}{l}380 \\
381 \\
382 \\
383 \\
384\end{array}$ & $\begin{array}{l}4364.8 \\
4380.9 \\
4397.0 \\
4413.1 \\
4429.2\end{array}$ & $\begin{array}{l}16.060 \\
16.077 \\
16.094 \\
16.110 \\
16.126\end{array}$ & $\begin{array}{l}17.42 \\
17.02 \\
16.59 \\
16.14 \\
15.67\end{array}$ & $\begin{array}{l}395 \\
396 \\
397 \\
398 \\
399\end{array}$ & $\begin{array}{l}4607 \cdot 4 \\
4623 \cdot 7 \\
4640 \cdot 0 \\
4656 \cdot 3 \\
4672 \cdot 5\end{array}$ & $\begin{array}{l}16.264 \\
16.272 \\
16.280 \\
16.286 \\
16.292\end{array}$ & $\begin{array}{l}8.77 \\
7.97 \\
7.13 \\
6.25 \\
5.34\end{array}$ \\
\hline $\begin{array}{l}370 \\
371 \\
372 \\
373 \\
374\end{array}$ & $\begin{array}{l}4205.2 \\
4221.0 \\
4236.9 \\
4252.9 \\
4268.8\end{array}$ & $\begin{array}{l}15.869 \\
15.890 \\
15.910 \\
15.929 \\
15.949\end{array}$ & $\begin{array}{l}20.45 \\
20.22 \\
19.98 \\
19.72 \\
19.44\end{array}$ & $\begin{array}{l}385 \\
386 \\
387 \\
388 \\
389\end{array}$ & $\begin{array}{l}4445 \cdot 3 \\
4461 \cdot 5 \\
4477 \cdot 7 \\
4493 \cdot 8 \\
4510 \cdot 0\end{array}$ & $\begin{array}{l}16.142 \\
16.157 \\
16.171 \\
16.185 \\
16.198\end{array}$ & $\begin{array}{l}15.18 \\
14.66 \\
14.12 \\
13.55 \\
12.95\end{array}$ & 400 & 4688.8 & 16.297 & 4.39 \\
\hline 375 & 4284.8 & 15.968 & 19.15 & 390 & $4526 \cdot 2$ & 16.211 & $12 \cdot 33$ & & & & \\
\hline
\end{tabular}


TABLE 8.4.3. Thermoelectric values at the fixed points for Type TP thermoelements versus platinum, $\mathrm{Pt}-67$

\begin{tabular}{|c|c|c|c|c|}
\hline Fixed point & $\begin{array}{c}\text { Temp. } \\
{ }^{\circ} \mathrm{C}\end{array}$ & $\begin{array}{c}E \\
\mu \mathrm{V}\end{array}$ & $\underset{\mu \mathrm{V} /{ }^{\circ} \mathrm{C}}{S}$ & $\begin{array}{c}d S / d T \\
\mathrm{nV} /{ }^{\circ} \mathrm{C}^{2}\end{array}$ \\
\hline $\begin{array}{l}\text { Helium NBP } \\
\text { Hydrogen TP } \\
\text { Hydrogen NBP } \\
\text { Neon TP } \\
\text { Neon NBP } \\
\text { Oxygen TP } \\
\text { Nitrogen TP } \\
\text { Nitrogen NBP } \\
\text { Oxygen NBP } \\
\text { Carbon Dioxide SP } \\
\text { Mercury FP } \\
\text { Ice point* } \\
\text { Ether TP } \\
\text { Water BP } \\
\text { Benzoic TP } \\
\text { Indium FP } \\
\text { Tin FP } \\
\text { Bismuth FP } \\
\text { Cadmium FP } \\
\text { Lead FP } \\
\text { Mercury BP }\end{array}$ & $\begin{array}{c}-268.935 \\
-259.340 \\
-252.870 \\
-248.595 \\
-246.048 \\
-218.789 \\
-210.002 \\
-195.802 \\
-182.962 \\
-78.476 \\
-38.862 \\
0.000 \\
26.870 \\
100.000 \\
122.370 \\
156.634 \\
231.9681 \\
271.442 \\
321.108 \\
327.502 \\
356.660\end{array}$ & $\begin{array}{r}19.92 \\
14.99 \\
4.71 \\
-4.69 \\
-11.16 \\
-110.98 \\
-150.14 \\
-212.90 \\
-264.20 \\
-330.38 \\
-197.99 \\
0.0 \\
171.2 \\
773.1 \\
989.4 \\
1344.7 \\
2229.2 \\
2749.7 \\
3455.8 \\
3550.7 \\
3995.4\end{array}$ & $\begin{array}{r}0.171 \\
-1.185 \\
-1.969 \\
-2.417 \\
-2.661 \\
-4.373 \\
-4.501 \\
-4.255 \\
-3.699 \\
2.347 \\
4.277 \\
5.881 \\
6.899 \\
9.378 \\
9.951 \\
10.790 \\
12.701 \\
13.654 \\
14.774 \\
14.919 \\
15.582\end{array}$ & $\begin{array}{r}-138.81 \\
-131.90 \\
-110.82 \\
-99.00 \\
-92.93 \\
-27.79 \\
-1.43 \\
33.56 \\
50.88 \\
51.71 \\
43.32 \\
32.40 \\
40.23 \\
26.76 \\
24.77 \\
24.66 \\
25.11 \\
23.17 \\
22.52 \\
22.65 \\
22.36\end{array}$ \\
\hline
\end{tabular}

*Junction point of different functions.

TABLE 8.4.4. Estimated maximum errors that occur when using reduced-bit arithmetic for the power series expansion for the thermoelectric voltage of Type TP thermoelements versus platinum, $\mathrm{Pt}-67$

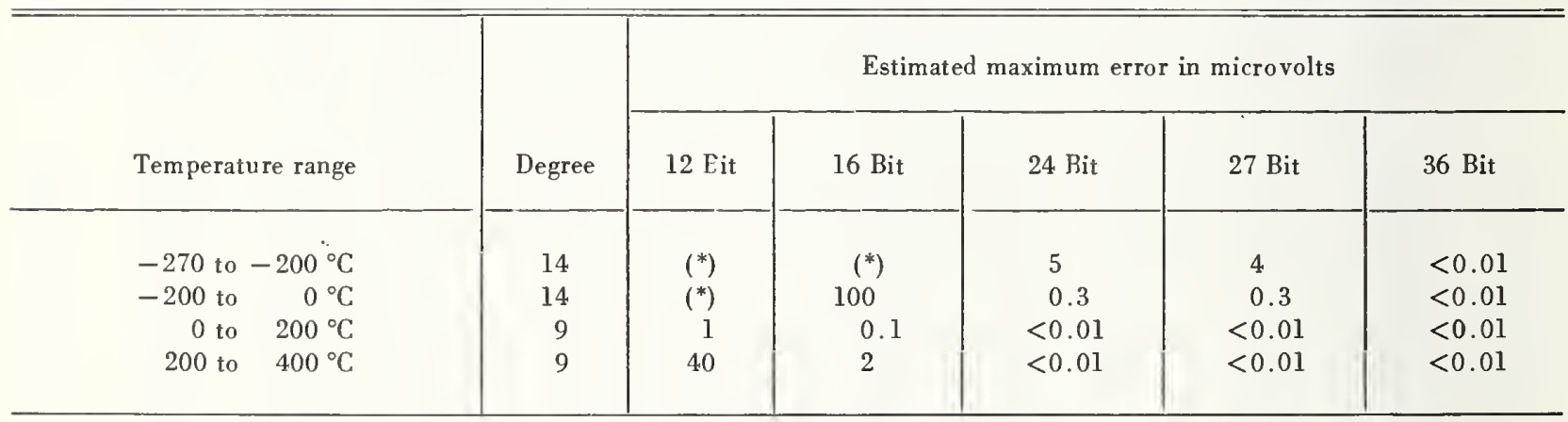

*A high-order polynomial with a low-bit machine calises extreme error.

8.5. Reference Functions and Tables for Platinum, $\mathrm{Pt}-67$, Versus the Negative Thermoelement, Type TN, a Copper-Nickel Alloy

The coefficients for the thirteenth degree expansion for the thermoelectric voltage of $\mathrm{Pt}-67$ versus Type TN (or EN) thermoelements below $0{ }^{\circ} \mathrm{C}$ are given in table 8.5.1. The coefficients for the ninth degree expansion above $0{ }^{\circ} \mathrm{C}$ are also given in table 8.5.1. Errors caused by using reduced-bit arithmetic for calculating values of the functions are given in table 8.5.4.

The primary reference values for $\mathrm{Pt}-67$ versus Type TN (or EN) thermoelements are given in table 8.5.2.
Values at selected fixed points are given in table 8.5.3. Graphs of the thermoelectric voltage, its first derivative (Seebeck coefficient), and second derivative are given in figures 8.5.1, 8.5.2, and 8.5.3, respectively.

It should be stressed that Type TN (or EN) thermocouple material that conforms closely to the high temperature tabular values may not necessarily conform closely at low temperatures (below $0^{\circ} \mathrm{C}$ ) and vice versa. If Type TN (or EN) thermoelements are to be used for accurate measurements both above and below $0{ }^{\circ} \mathrm{C}$, then the material must be calibrated in the full temperature range, both above and below $0{ }^{\circ} \mathrm{C}$. Special selection of material will usually be required. 
TABle 8.5.1. Power series expansion for the thermoelectric voltage of platinum, $\mathrm{Pt}-67$, versus Type TN (or EN) thermoelements

\begin{tabular}{|c|c|c|c|}
\hline $\begin{array}{c}\text { Tempera- } \\
\text { ture } \\
\text { range }\end{array}$ & Degree & Coefficients & Term \\
\hline $\begin{array}{c}-270 \text { to } \\
0^{\circ} \mathrm{C}\end{array}$ & 13 & $\begin{array}{r}3.2860147666 \times 10^{1} \\
2.4465371290 \times 10^{-2} \\
-6.3070457030 \times 10^{-5} \\
-5.0520527300 \times 10^{-7} \\
-4.0652039120 \times 10^{-8} \\
-1.8735086436 \times 10^{-9} \\
-3.9193498250 \times 10^{-11} \\
-4.6073273946 \times 10^{-13} \\
-3.3208257016 \times 10^{-15} \\
-1.5034792240 \times 10^{-17} \\
-4.1775287263 \times 10^{-20} \\
-6.5148906779 \times 10^{-23} \\
-4.3671808488 \times 10^{-26}\end{array}$ & $\begin{array}{l}T \\
T^{2} \\
T^{3} \\
T^{4} \\
T^{5} \\
T^{8} \\
T^{7} \\
T^{8} \\
T^{9} \\
T^{10} \\
T^{11} \\
T^{12} \\
T^{13}\end{array}$ \\
\hline $\begin{array}{l}0 \text { to } \\
\quad 1000{ }^{\circ} \mathrm{C}\end{array}$ & 9 & $\begin{array}{r}3.2860147666 \times 10^{1} \\
1.6988793174 \times 10^{-2} \\
9.0773681956 \times 10^{-5} \\
-5.5610808187 \times 10^{-7} \\
1.5431959604 \times 10^{-8} \\
-2.4838001634 \times 10^{-12} \\
2.3389721459 \times 10^{-15} \\
-1.1946296815 \times 10^{-18} \\
2.5561127497 \times 10^{-22}\end{array}$ & $\begin{array}{l}T \\
T^{2} \\
T^{3} \\
T^{4} \\
T^{6} \\
T^{8} \\
T^{7} \\
T^{8} \\
T^{8}\end{array}$ \\
\hline
\end{tabular}

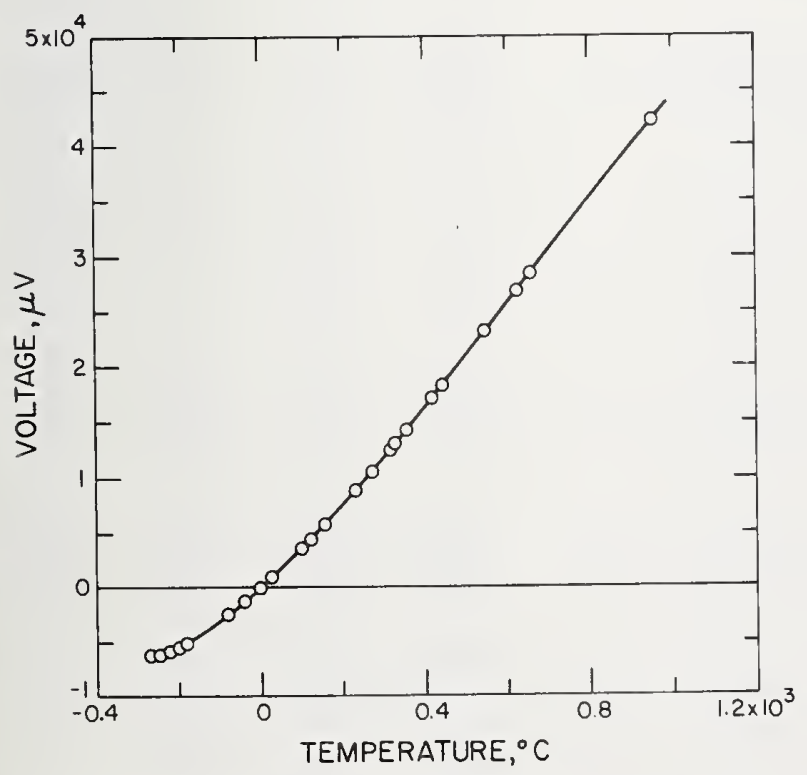

Figure 8.5.1. Thermoelectric voltage for platinum, $P t-67$, versus Type TN (or EN) thermoelements.

The circles indicate values at various thermometric fixed points on the IPTS -68 .

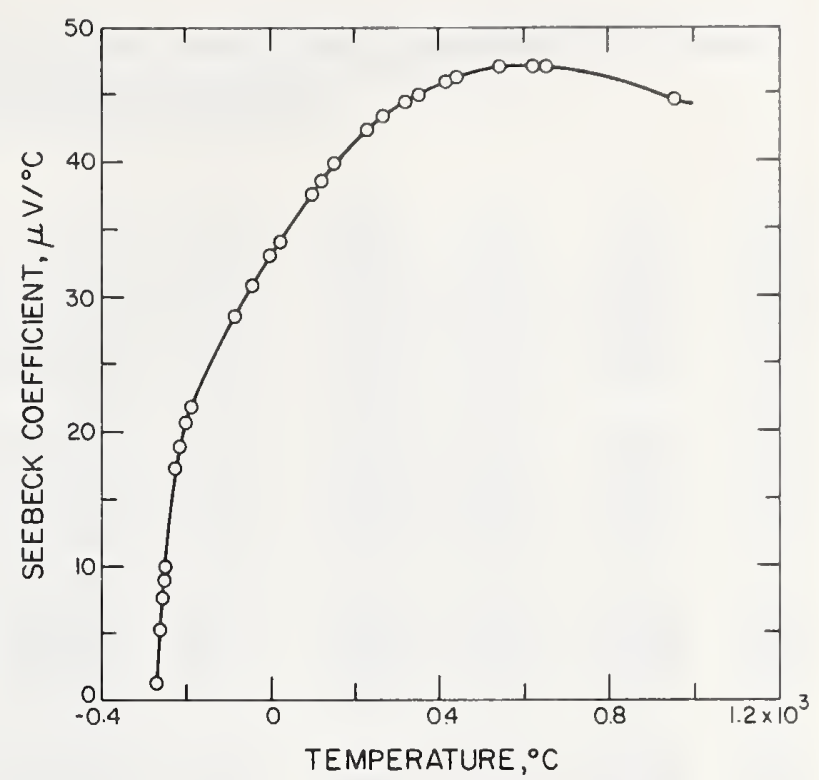

Figure 8.5.2. Seebeck coefficient for platinum, $P_{t-67}$, versus Type TN (or EN) thermoe'ements.

The circles indicate values at various thermometric fixed points on the IPTS 68 .

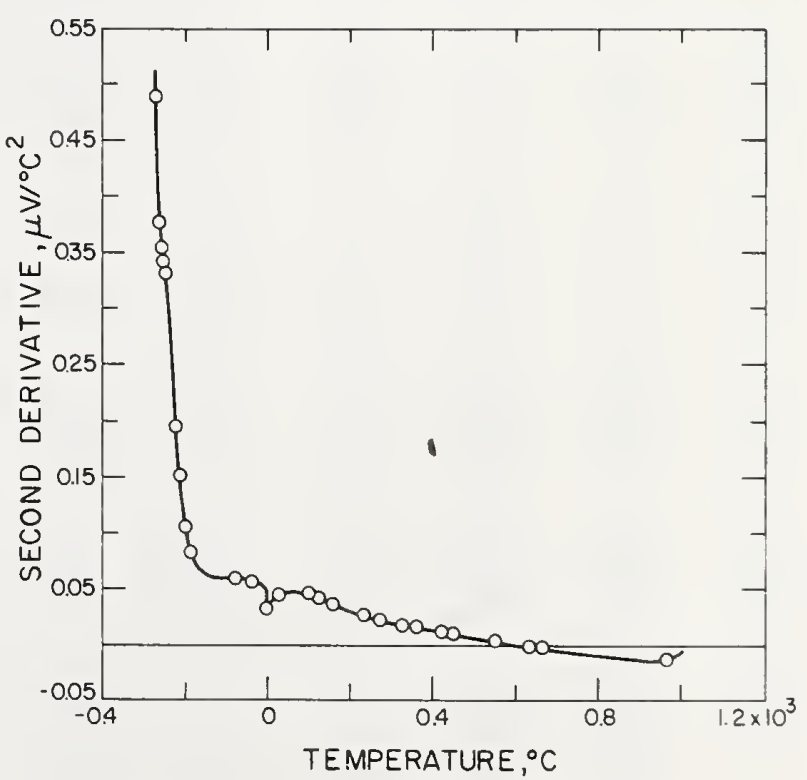

Figure 8.5.3. Second derivative of thermoelectric voltage for platinum, $P t-67$, versus Type TN (or EN) thermoelements. The circles indicate values at various thermometric fixed points on the IYTS -68 . 
TABle 8.5.2. Platinum, Pt-67, versus Type TN (or EN) thermoelements-thermoelectric voltages, $\mathrm{E}(\mathrm{T})$, Seebeck coefficients, $\mathrm{S}(\mathrm{T})$, and first derivative of the Seebeck coefficients,

$\mathrm{dS} / \mathrm{dT}$, reference junctions at $0^{\circ} \mathrm{C}$

\begin{tabular}{|c|c|c|c|c|c|c|c|c|c|c|c|}
\hline $\begin{array}{l}{ }^{\mathrm{T}} \\
{ }^{\circ} \mathrm{C}\end{array}$ & $\begin{array}{c}E \\
\mu V\end{array}$ & $\stackrel{\mathrm{S}}{\mu \mathrm{V} /{ }^{\circ} \mathrm{C}}$ & $\begin{array}{l}d S / d T \\
n V /{ }^{\circ} C^{2}\end{array}$ & $\begin{array}{l}{ }^{\top} \mathrm{C} \\
{ }^{\circ} \mathrm{C}\end{array}$ & $\begin{array}{c}E \\
\mu V\end{array}$ & $\stackrel{\mathrm{S}}{\mu \mathrm{V} /{ }^{\circ} \mathrm{C}}$ & $\begin{array}{l}d S / d T \\
n V /{ }^{\circ} C^{2}\end{array}$ & $\begin{array}{l}{ }^{\top} \\
{ }^{\circ} \mathrm{C}\end{array}$ & $\begin{array}{c}E \\
\mu V\end{array}$ & $\underset{\mu V /{ }^{\circ} \mathrm{C}}{S}$ & $\begin{array}{l}\mathrm{dS} / \mathrm{dT} \\
\mathrm{nV} /{ }^{\circ} \mathrm{C}^{2}\end{array}$ \\
\hline $\begin{array}{l}-270 \\
-269 \\
-268 \\
-267 \\
-266\end{array}$ & $\begin{array}{l}-6277 \cdot 24 \\
-6276.29 \\
-6274.84 \\
-6272.92 \\
-6270.55\end{array}$ & $\begin{array}{l}0.700 \\
1.205 \\
1.686 \\
2.148 \\
2.592\end{array}$ & $\begin{array}{l}517.60 \\
492.68 \\
471.14 \\
452.59 \\
436.65\end{array}$ & $\begin{array}{l}-240 \\
-239 \\
-238 \\
-237 \\
-236\end{array}$ & $\begin{array}{l}-6076 \cdot 22 \\
-6064 \cdot 15 \\
-6051 \cdot 78 \\
-6039 \cdot 11 \\
-6026 \cdot 14\end{array}$ & $\begin{array}{l}11.910 \\
12.218 \\
12.521 \\
12.820 \\
13.113\end{array}$ & $\begin{array}{l}310.31 \\
305.77 \\
301.05 \\
296.16 \\
291.11\end{array}$ & $\begin{array}{l}-210 \\
-209 \\
-208 \\
-207 \\
-206\end{array}$ & $\begin{array}{l}-5603.10 \\
-5584.22 \\
-5565.19 \\
-5546.02 \\
-5526.71\end{array}$ & $\begin{array}{l}18.806 \\
18.955 \\
19.100 \\
19.240 \\
19.377\end{array}$ & $\begin{array}{l}151.01 \\
146.75 \\
142.64 \\
138.67 \\
134.85\end{array}$ \\
\hline $\begin{array}{l}-265 \\
-264 \\
-263 \\
-262 \\
-261\end{array}$ & $\begin{array}{l}-6267.74 \\
-6264.51 \\
-6260.87 \\
-6256.82 \\
-6252.39\end{array}$ & $\begin{array}{l}3.022 \\
3.439 \\
3.845 \\
4.242 \\
4.632\end{array}$ & $\begin{array}{l}423.01 \\
411.36 \\
401.43 \\
392.97 \\
385.78\end{array}$ & $\begin{array}{l}-235 \\
-234 \\
-233 \\
-232 \\
-231\end{array}$ & $\begin{array}{l}-6012.89 \\
-5999.34 \\
-5985.52 \\
-5971.42 \\
-5957.05\end{array}$ & $\begin{array}{l}13.402 \\
13.685 \\
13.963 \\
14.235 \\
14.502\end{array}$ & $\begin{array}{l}285.91 \\
280.58 \\
275.14 \\
269.59 \\
263.96\end{array}$ & $\begin{array}{l}-205 \\
-204 \\
-203 \\
-202 \\
-201\end{array}$ & $\begin{array}{l}-5507.27 \\
-5487.69 \\
-5467.99 \\
-5448.16 \\
-5428.22\end{array}$ & $\begin{array}{l}19.510 \\
19.640 \\
19.765 \\
19.888 \\
20.008\end{array}$ & $\begin{array}{l}131.18 \\
127.66 \\
124.28 \\
121.04 \\
117.95\end{array}$ \\
\hline $\begin{array}{l}-260 \\
-259 \\
-258 \\
-257 \\
-256\end{array}$ & $\begin{array}{l}-6247.56 \\
-6242.36 \\
-6236.78 \\
-6230.83 \\
-6224.52\end{array}$ & $\begin{array}{l}5.014 \\
5.391 \\
5.763 \\
6.131 \\
6.495\end{array}$ & $\begin{array}{l}379.63 \\
374.37 \\
369.82 \\
365.85 \\
362.33\end{array}$ & $\begin{array}{l}-230 \\
-229 \\
-228 \\
-227 \\
-226\end{array}$ & $\begin{array}{l}-5942.42 \\
-5927.52 \\
-5912.38 \\
-5896.99 \\
-5881.36\end{array}$ & $\begin{array}{l}14.763 \\
15.019 \\
15.268 \\
15.512 \\
15.750\end{array}$ & $\begin{array}{l}258.26 \\
252.51 \\
246.72 \\
240.91 \\
235.09\end{array}$ & $\begin{array}{l}-200 \\
-199 \\
-198 \\
-197 \\
-196\end{array}$ & $\begin{array}{l}-5408.15 \\
-5387.97 \\
-5367.68 \\
-5347.27 \\
-5326.76\end{array}$ & $\begin{array}{l}20 \cdot 124 \\
20.238 \\
20.348 \\
20.457 \\
20.562\end{array}$ & $\begin{array}{l}115.00 \\
112.19 \\
109.51 \\
106.96 \\
104.54\end{array}$ \\
\hline $\begin{array}{l}-255 \\
-254 \\
-253 \\
-252 \\
-251\end{array}$ & $\begin{array}{l}-6217.85 \\
-6210.81 \\
-6203.42 \\
-6195.68 \\
-6187.58\end{array}$ & $\begin{array}{l}6.856 \\
7.214 \\
7.568 \\
7.920 \\
8.270\end{array}$ & $\begin{array}{l}359.15 \\
356.21 \\
353.42 \\
350.73 \\
348.05\end{array}$ & $\begin{array}{l}-225 \\
-224 \\
-223 \\
-222 \\
-221\end{array}$ & $\begin{array}{l}-5865.49 \\
-5849.39 \\
-5833.08 \\
-5816.54 \\
-5799.79\end{array}$ & $\begin{array}{l}15.982 \\
16.209 \\
16.429 \\
16.644 \\
16.853\end{array}$ & $\begin{array}{l}229.28 \\
223.50 \\
217.74 \\
212.04 \\
206.40\end{array}$ & $\begin{array}{l}-195 \\
-194 \\
-193 \\
-192 \\
-191\end{array}$ & $\begin{array}{l}-5306.15 \\
-5285.43 \\
-5264.61 \\
-5243.70 \\
-5222.69\end{array}$ & $\begin{array}{l}20.666 \\
20.767 \\
20.866 \\
20.963 \\
21.058\end{array}$ & $\begin{array}{r}102.24 \\
100.06 \\
98.00 \\
96.05 \\
94.21\end{array}$ \\
\hline $\begin{array}{l}-250 \\
-249 \\
-248 \\
-247 \\
-246\end{array}$ & $\begin{array}{l}-6179 \cdot 14 \\
-6170 \cdot 35 \\
-6161 \cdot 22 \\
-6151 \cdot 75 \\
-6141 \cdot 94\end{array}$ & $\begin{array}{l}8.616 \\
8.960 \\
9.302 \\
9.640 \\
9.975\end{array}$ & $\begin{array}{l}345.34 \\
342.56 \\
339.67 \\
336.65 \\
333.45\end{array}$ & $\begin{array}{l}-220 \\
-219 \\
-218 \\
-217 \\
-216\end{array}$ & $\begin{array}{l}-5782.83 \\
-5765.68 \\
-5748.32 \\
-5730.78 \\
-5713.06\end{array}$ & $\begin{array}{l}17.057 \\
17.255 \\
17.448 \\
17.635 \\
17.817\end{array}$ & $\begin{array}{l}200.83 \\
195.34 \\
189.95 \\
184.65 \\
179.47\end{array}$ & $\begin{array}{l}-190 \\
-189 \\
-188 \\
-187 \\
-186\end{array}$ & $\begin{array}{l}-5201.58 \\
-5180.39 \\
-5159.10 \\
-5137.72 \\
-5116.26\end{array}$ & $\begin{array}{l}21.151 \\
21.243 \\
21.333 \\
21.422 \\
21.509\end{array}$ & $\begin{array}{l}92.47 \\
90.83 \\
89.28 \\
87.81 \\
86.44\end{array}$ \\
\hline $\begin{array}{l}-245 \\
-244 \\
-243 \\
-242 \\
-241\end{array}$ & $\begin{array}{l}-6131 \cdot 80 \\
-6121 \cdot 33 \\
-6110.53 \\
-6099.41 \\
-6087.97\end{array}$ & $\begin{array}{l}10.307 \\
10.635 \\
10.960 \\
11.280 \\
11.597\end{array}$ & $\begin{array}{l}330.09 \\
326.53 \\
322.77 \\
318.82 \\
314.66\end{array}$ & $\begin{array}{l}-215 \\
-214 \\
-213 \\
-212 \\
-211\end{array}$ & $\begin{array}{l}-5695.15 \\
-5677.07 \\
-5658.82 \\
-5640.41 \\
-5621.83\end{array}$ & $\begin{array}{l}17.994 \\
18.166 \\
18.333 \\
18.495 \\
18.653\end{array}$ & $\begin{array}{l}174.40 \\
169.46 \\
164.64 \\
159.96 \\
155.42\end{array}$ & $\begin{array}{l}-185 \\
-184 \\
-183 \\
-182 \\
-181\end{array}$ & $\begin{array}{l}-5094.70 \\
-5073.07 \\
-5051.35 \\
-5029.54 \\
-5007.66\end{array}$ & $\begin{array}{l}21.595 \\
21.679 \\
21.762 \\
21.845 \\
21.926\end{array}$ & $\begin{array}{l}85.14 \\
83.92 \\
82.76 \\
81.68 \\
80.65\end{array}$ \\
\hline 240 & -6076.22 & 11.910 & 310.31 & -210 & $-5603 \cdot 10$ & 18.806 & 151.01 & -180 & -4985.69 & 22.006 & 79.69 \\
\hline
\end{tabular}


TABLE 8.5.2. Platinum, Pt-67, versus Type TN (or EN) thermoelements-thermoelectric voltages, $\mathrm{E}(\mathrm{T})$, Seebeck coefficients, S(T), and first derivative of the Seebeck coefficients,

$\mathrm{dS} / \mathrm{dT}$, reference junctions at $\mathrm{O}^{\circ} \mathrm{C}$-Continued

\begin{tabular}{|c|c|c|c|c|c|c|c|c|c|c|c|}
\hline${ }^{\top} \mathrm{C}$ & $\begin{array}{l}E \\
\mu V\end{array}$ & $\underset{\mu V /{ }^{\circ} \mathrm{C}}{S}$ & $\begin{array}{l}\mathrm{dS} / \mathrm{dT} \\
\mathrm{nV} /{ }^{\circ} \mathrm{C}^{2}\end{array}$ & $\begin{array}{c}\mathrm{T} \\
{ }^{\circ} \mathrm{C}\end{array}$ & $\underset{\mu}{E V}$ & $\begin{array}{c}S \\
\mu V /{ }^{\circ} \mathrm{C}\end{array}$ & $\begin{array}{l}d S / d T \\
n V /{ }^{\circ} C^{2}\end{array}$ & $\begin{array}{l}\mathrm{T} \\
{ }^{\circ} \mathrm{C}\end{array}$ & $\begin{array}{c}E \\
\mu V\end{array}$ & $\underset{\mu V /{ }^{\circ} \mathrm{C}}{\mathrm{S}}$ & $\begin{array}{l}\mathrm{dS} / \mathrm{dT} \\
\mathrm{nV} /{ }^{\circ} \mathrm{C}^{2}\end{array}$ \\
\hline $\begin{array}{l}-180 \\
-179 \\
-178 \\
-177 \\
-176\end{array}$ & $\begin{array}{l}-4985.69 \\
-4963.65 \\
-4941.52 \\
-4919.32 \\
-4897.04\end{array}$ & $\begin{array}{l}22.006 \\
22.085 \\
22.164 \\
22.241 \\
22.318\end{array}$ & $\begin{array}{l}79 \cdot 69 \\
78.78 \\
77.92 \\
77.10 \\
76.34\end{array}$ & $\begin{array}{l}-120 \\
-119 \\
-118 \\
-117 \\
-116\end{array}$ & $\begin{array}{l}-3540.95 \\
-3514.96 \\
-3488.90 \\
-3462.78 \\
-3436.60\end{array}$ & $\begin{array}{l}25.969 \\
26.029 \\
26.090 \\
26.150 \\
26.211\end{array}$ & $\begin{array}{l}60 \cdot 34 \\
60 \cdot 36 \\
60.38 \\
60.42 \\
60.45\end{array}$ & $\begin{array}{l}-60 \\
-59 \\
-58 \\
-57 \\
-56\end{array}$ & $\begin{array}{l}-1874.17 \\
-1844.59 \\
-1814.96 \\
-1785.27 \\
-1755.52\end{array}$ & $\begin{array}{l}29.549 \\
29.605 \\
29.662 \\
29.718 \\
29.775\end{array}$ & $\begin{array}{l}56.67 \\
56.60 \\
56.55 \\
56.50 \\
56.46\end{array}$ \\
\hline $\begin{array}{l}-175 \\
-174 \\
-173 \\
-172 \\
-171\end{array}$ & $\begin{array}{l}-4874.68 \\
-4852.25 \\
-4829.75 \\
-4807.17 \\
-4784.51\end{array}$ & $\begin{array}{l}22.394 \\
22.469 \\
22.544 \\
22.618 \\
22.691\end{array}$ & $\begin{array}{l}75.61 \\
74.91 \\
74.26 \\
73.63 \\
73.03\end{array}$ & $\begin{array}{l}-115 \\
-114 \\
-113 \\
-112 \\
-111\end{array}$ & $\begin{array}{l}-3410.35 \\
-3384.05 \\
-3357.69 \\
-3331.27 \\
-3304.79\end{array}$ & $\begin{array}{l}26.271 \\
26.332 \\
26.392 \\
26.453 \\
26.513\end{array}$ & $\begin{array}{l}60.49 \\
60.53 \\
60.58 \\
60.62 \\
60.67\end{array}$ & $\begin{array}{l}-55 \\
-54 \\
-53 \\
-52 \\
-51\end{array}$ & $\begin{array}{l}-1725.72 \\
-1695.86 \\
-1665.94 \\
-1635.97 \\
-1605.94\end{array}$ & $\begin{array}{l}29.831 \\
29.888 \\
29.944 \\
30.001 \\
30.057\end{array}$ & $\begin{array}{l}56.43 \\
56.41 \\
56.40 \\
56.40 \\
56.41\end{array}$ \\
\hline $\begin{array}{l}-170 \\
-169 \\
-168 \\
-167 \\
-166\end{array}$ & $\begin{array}{l}-4761.78 \\
-4738.98 \\
-4716.11 \\
-4693.17 \\
-4670.16\end{array}$ & $\begin{array}{l}22.764 \\
22.836 \\
22.907 \\
22.979 \\
23.049\end{array}$ & $\begin{array}{l}72.46 \\
71.91 \\
71.39 \\
70.89 \\
70.40\end{array}$ & $\begin{array}{l}-110 \\
-109 \\
-108 \\
-107 \\
-106\end{array}$ & $\begin{array}{l}-3278.24 \\
-3251.64 \\
-3224.97 \\
-3198.25 \\
-3171.46\end{array}$ & $\begin{array}{l}26.574 \\
26.635 \\
26.696 \\
26.756 \\
26.817\end{array}$ & $\begin{array}{l}60.71 \\
60.75 \\
60.80 \\
60.83 \\
60.87\end{array}$ & $\begin{array}{l}-50 \\
-49 \\
-48 \\
-47 \\
-46\end{array}$ & $\begin{array}{l}-1575.86 \\
-1545.72 \\
-1515.52 \\
-1485.26 \\
-1454.95\end{array}$ & $\begin{array}{l}30.113 \\
30.170 \\
30.226 \\
30.283 \\
30.339\end{array}$ & $\begin{array}{l}56.42 \\
56.45 \\
56.48 \\
56.51 \\
56.55\end{array}$ \\
\hline $\begin{array}{l}-165 \\
-164 \\
-163 \\
-162 \\
-161\end{array}$ & $\begin{array}{l}-4647.07 \\
-4623.92 \\
-4600.69 \\
-4577.40 \\
-4554.04\end{array}$ & $\begin{array}{l}23.119 \\
23.189 \\
23.258 \\
23.327 \\
23.396\end{array}$ & $\begin{array}{l}69.93 \\
69.48 \\
69.04 \\
68.62 \\
68.21\end{array}$ & $\begin{array}{l}-105 \\
-104 \\
-103 \\
-102 \\
-101\end{array}$ & $\begin{array}{l}-3144.61 \\
-3117.70 \\
-3090.73 \\
-3063.70 \\
-3036.61\end{array}$ & $\begin{array}{l}26.878 \\
26.939 \\
27.000 \\
27.061 \\
27.122\end{array}$ & $\begin{array}{l}60.90 \\
60.93 \\
60.95 \\
60.96 \\
60.97\end{array}$ & $\begin{array}{l}-45 \\
-44 \\
-43 \\
-42 \\
-41\end{array}$ & $\begin{array}{l}-1424.59 \\
-1394.16 \\
-1363.68 \\
-1333.14 \\
-1302.55\end{array}$ & $\begin{array}{l}30.396 \\
30.453 \\
30.509 \\
30.566 \\
30.623\end{array}$ & $\begin{array}{l}56.59 \\
56.64 \\
56.68 \\
56.73 \\
56.78\end{array}$ \\
\hline $\begin{array}{l}-160 \\
-159 \\
-158 \\
-157 \\
-156\end{array}$ & $\begin{array}{l}-4530.61 \\
-4507.11 \\
-4483.55 \\
-4459.91 \\
-4436.22\end{array}$ & $\begin{array}{l}23.464 \\
23.531 \\
23.598 \\
23.665 \\
23.732\end{array}$ & $\begin{array}{l}67.81 \\
67.42 \\
67.04 \\
66.67 \\
66.31\end{array}$ & $\begin{array}{r}-100 \\
-99 \\
-98 \\
-97 \\
-96\end{array}$ & $\begin{array}{l}-3009.46 \\
-2982.25 \\
-2954.97 \\
-2927.64 \\
-2900.24\end{array}$ & $\begin{array}{l}27.183 \\
27.244 \\
27.305 \\
27.366 \\
27.427\end{array}$ & $\begin{array}{l}60.98 \\
60.97 \\
60.96 \\
60.94 \\
60.91\end{array}$ & $\begin{array}{l}-40 \\
-39 \\
-38 \\
-37 \\
-36\end{array}$ & $\begin{array}{l}-1271.90 \\
-1241.19 \\
-1210.43 \\
-1179.60 \\
-1148.73\end{array}$ & $\begin{array}{l}30.679 \\
30.736 \\
30.793 \\
30.850 \\
30.907\end{array}$ & $\begin{array}{l}56.82 \\
56.86 \\
56.90 \\
56.93 \\
56.95\end{array}$ \\
\hline $\begin{array}{l}-155 \\
-154 \\
-153 \\
-152 \\
-151\end{array}$ & $\begin{array}{l}-4412.45 \\
-4388.62 \\
-4364.72 \\
-4340.76 \\
-4316.74\end{array}$ & $\begin{array}{l}23 \cdot 798 \\
23.864 \\
23.929 \\
23.994 \\
24.059\end{array}$ & $\begin{array}{l}65.96 \\
65.62 \\
65.29 \\
64.97 \\
64.66\end{array}$ & $\begin{array}{l}-95 \\
-94 \\
-93 \\
-92 \\
-91\end{array}$ & $\begin{array}{l}-2872.78 \\
-2845.26 \\
-2817.69 \\
-2790.05 \\
-2762.35\end{array}$ & $\begin{array}{l}27.488 \\
27.548 \\
27.609 \\
27.670 \\
27.731\end{array}$ & $\begin{array}{l}60.87 \\
60.82 \\
60.77 \\
60.70 \\
60.63\end{array}$ & $\begin{array}{l}-35 \\
-34 \\
-33 \\
-32 \\
-31\end{array}$ & $\begin{array}{l}-1117.79 \\
-1086.80 \\
-1055.75 \\
-1024.64 \\
-993.48\end{array}$ & $\begin{array}{l}30.964 \\
31.021 \\
31.078 \\
31.135 \\
31.192\end{array}$ & $\begin{array}{l}56.97 \\
56.97 \\
56.97 \\
56.95 \\
56.92\end{array}$ \\
\hline $\begin{array}{l}-150 \\
-149 \\
-148 \\
-147 \\
-146\end{array}$ & $\begin{array}{l}-4292.64 \\
-4268.49 \\
-4244.27 \\
-4219.99 \\
-4195.64\end{array}$ & $\begin{array}{l}24 \cdot 124 \\
24 \cdot 188 \\
24 \cdot 252 \\
24.315 \\
24.379\end{array}$ & $\begin{array}{l}64.36 \\
64.07 \\
63.78 \\
63.51 \\
63.25\end{array}$ & $\begin{array}{l}-90 \\
-89 \\
-88 \\
-87 \\
-86\end{array}$ & $\begin{array}{l}-2734.58 \\
-2706.76 \\
-2678.88 \\
-2650.94 \\
-2622.94\end{array}$ & $\begin{array}{l}27.791 \\
27.852 \\
27.912 \\
27.972 \\
28.033\end{array}$ & $\begin{array}{l}60.55 \\
60.46 \\
60.36 \\
60.26 \\
60.15\end{array}$ & $\begin{array}{l}-30 \\
-29 \\
-28 \\
-27 \\
-26\end{array}$ & $\begin{array}{l}-962.26 \\
-930.98 \\
-899.65 \\
-868.26 \\
-836.81\end{array}$ & $\begin{array}{l}31.249 \\
31.306 \\
31.362 \\
31.419 \\
31.476\end{array}$ & $\begin{array}{l}56.87 \\
56.81 \\
56.73 \\
56.64 \\
56.53\end{array}$ \\
\hline $\begin{array}{l}-145 \\
-144 \\
-143 \\
-142 \\
-141\end{array}$ & $\begin{array}{l}-4171.23 \\
-4146.75 \\
-4122.22 \\
-4097.62 \\
-4072.96\end{array}$ & $\begin{array}{l}24.442 \\
24 \cdot 505 \\
24.567 \\
24.630 \\
24.692\end{array}$ & $\begin{array}{l}62.99 \\
62.75 \\
62.52 \\
62.30 \\
62.09\end{array}$ & $\begin{array}{l}-85 \\
-84 \\
-83 \\
-82 \\
-81\end{array}$ & $\begin{array}{l}-2594.87 \\
-2566.75 \\
-2538.57 \\
-2510.33 \\
-2482.02\end{array}$ & $\begin{array}{l}28.093 \\
28.153 \\
28.213 \\
28.272 \\
28.332\end{array}$ & $\begin{array}{l}60.03 \\
59.90 \\
59.77 \\
59.63 \\
59.49\end{array}$ & $\begin{array}{l}-25 \\
-24 \\
-23 \\
-22 \\
-21\end{array}$ & $\begin{array}{l}-805.30 \\
-773.74 \\
-742.13 \\
-710.46 \\
-678.73\end{array}$ & $\begin{array}{l}31.532 \\
31.588 \\
31.645 \\
31.701 \\
31.756\end{array}$ & $\begin{array}{l}56.40 \\
56.25 \\
56.08 \\
55.90 \\
55.70\end{array}$ \\
\hline $\begin{array}{l}-140 \\
-139 \\
-138 \\
-137 \\
-136\end{array}$ & $\begin{array}{l}-4048.24 \\
-4023.45 \\
-3998.60 \\
-3973.70 \\
-3948.73\end{array}$ & $\begin{array}{l}24.754 \\
24.816 \\
24.877 \\
24.939 \\
25.000\end{array}$ & $\begin{array}{l}61.89 \\
61.71 \\
61.53 \\
61.37 \\
61.22\end{array}$ & $\begin{array}{l}-80 \\
-79 \\
-78 \\
-77 \\
-76\end{array}$ & $\begin{array}{l}-2453.66 \\
-2425.24 \\
-2396.76 \\
-2368.22 \\
-2339.62\end{array}$ & $\begin{array}{l}28.391 \\
28.451 \\
28.510 \\
28.569 \\
28.627\end{array}$ & $\begin{array}{l}59.34 \\
59.19 \\
59.04 \\
58.88 \\
58.73\end{array}$ & $\begin{array}{l}-20 \\
-19 \\
-18 \\
-17 \\
-16\end{array}$ & $\begin{array}{l}-646.94 \\
-615.10 \\
-583.21 \\
-551.26 \\
-519.25\end{array}$ & $\begin{array}{l}31.812 \\
31.867 \\
31.922 \\
31.977 \\
32.032\end{array}$ & $\begin{array}{l}55.48 \\
55.24 \\
54.98 \\
54.72 \\
54.43\end{array}$ \\
\hline $\begin{array}{l}-135 \\
-134 \\
-133 \\
-132 \\
-131\end{array}$ & $\begin{array}{l}-3923.70 \\
-3898.60 \\
-3873.45 \\
-3848.24 \\
-3822.96\end{array}$ & $\begin{array}{l}25.061 \\
25.122 \\
25.183 \\
25.244 \\
25.305\end{array}$ & $\begin{array}{l}61.08 \\
60.96 \\
60.84 \\
60.74 \\
60.65\end{array}$ & $\begin{array}{l}-75 \\
-74 \\
-73 \\
-72 \\
-71\end{array}$ & $\begin{array}{l}-2310.97 \\
-2282.25 \\
-2253.48 \\
-2224.65 \\
-2195.76\end{array}$ & $\begin{array}{l}28.686 \\
28.745 \\
28.803 \\
28.861 \\
28.919\end{array}$ & $\begin{array}{l}58.57 \\
58.41 \\
58.26 \\
58.10 \\
57.95\end{array}$ & $\begin{array}{l}-15 \\
-14 \\
-13 \\
-12 \\
-11\end{array}$ & $\begin{array}{l}-487.20 \\
-455.08 \\
-422.91 \\
-390.69 \\
-358.42\end{array}$ & $\begin{array}{l}32.086 \\
32.140 \\
32.194 \\
32.247 \\
32.300\end{array}$ & $\begin{array}{l}54.14 \\
53.83 \\
53.51 \\
53.18 \\
52.84\end{array}$ \\
\hline $\begin{array}{l}-130 \\
-129 \\
-128 \\
-127 \\
-126\end{array}$ & $\begin{array}{l}-3797.63 \\
-3772.23 \\
-3746.78 \\
-3721.26 \\
-3695.68\end{array}$ & $\begin{array}{l}25.365 \\
25.426 \\
25.486 \\
25.547 \\
25.607\end{array}$ & $\begin{array}{l}60.57 \\
60.50 \\
60.45 \\
60.40 \\
60.36\end{array}$ & $\begin{array}{l}-70 \\
-69 \\
-68 \\
-67 \\
-66\end{array}$ & $\begin{array}{l}-2166.81 \\
-2137.80 \\
-2108.74 \\
-2079.62 \\
-2050.44\end{array}$ & $\begin{array}{l}28.977 \\
29.035 \\
29.092 \\
29.150 \\
29.207\end{array}$ & $\begin{array}{l}57.80 \\
57.66 \\
57.52 \\
57.39 \\
57.26\end{array}$ & $\begin{array}{l}-10 \\
-9 \\
-8 \\
-7 \\
-6\end{array}$ & $\begin{array}{l}-326.09 \\
-293.72 \\
-261.28 \\
-228.80 \\
-196.27\end{array}$ & $\begin{array}{l}32.353 \\
32.405 \\
32.457 \\
32.509 \\
32.560\end{array}$ & $\begin{array}{l}52.50 \\
52.15 \\
51.80 \\
51.45 \\
51.10\end{array}$ \\
\hline $\begin{array}{l}-125 \\
-124 \\
-123 \\
-122 \\
-121\end{array}$ & $\begin{array}{l}-3670.05 \\
-3644.35 \\
-3618.59 \\
-3592.77 \\
-3566.89\end{array}$ & $\begin{array}{l}25.667 \\
25.728 \\
25.788 \\
25.848 \\
25.909\end{array}$ & $\begin{array}{l}60 \cdot 34 \\
60.32 \\
60.31 \\
60.31 \\
60.32\end{array}$ & $\begin{array}{l}-65 \\
-64 \\
-63 \\
-62 \\
-61\end{array}$ & $\begin{array}{l}-2021.20 \\
-1991.91 \\
-1962.56 \\
-1933.15 \\
-1903.69\end{array}$ & $\begin{array}{l}29.264 \\
29.321 \\
29.378 \\
29.435 \\
29.492\end{array}$ & $\begin{array}{l}57.14 \\
57.03 \\
56.93 \\
56.83 \\
56.75\end{array}$ & $\begin{array}{l}-5 \\
-4 \\
-3 \\
-2 \\
-1\end{array}$ & $\begin{array}{r}-163.68 \\
-131.05 \\
-98.36 \\
-65.62 \\
-32.84\end{array}$ & $\begin{array}{l}32.611 \\
32.661 \\
32.712 \\
32.762 \\
32.811\end{array}$ & $\begin{array}{l}50.74 \\
50.39 \\
50.03 \\
49.67 \\
49.30\end{array}$ \\
\hline-120 & 40.95 & 25.969 & $60 \cdot 34$ & -60 & $-1874 \cdot 17$ & 29.549 & 7 & 0 & 0 & 0 & 33.98 \\
\hline
\end{tabular}


TABLE 8.5.2. Platinum, Pt-67, versus Type TN (or EN) thermoelements-thermoelectric voltages, $\mathrm{E}(\mathrm{T})$, Seebeck coefficients, S(T), and first derivative of the Seebeck coefficients, $\mathrm{dS} / \mathrm{dT}$, reference junctions at $0^{\circ} \mathrm{C}$-Continued

${ }^{\circ} \mathrm{C}$

10
11
12
13
14

21

23
24

25

26

28

29

30

\section{$E$

\begin{abstract}
$\underset{\mu V /{ }^{\circ} \mathrm{C}}{\mathrm{S}}$
\end{abstract} $\mu \vee$

\section{9}

65.8

98.7

131.7

164.

197.8

230.9

264.0

297.2

330.

363.6

396.9

430.2

453.6

497.0

530.4

563.9

597.5

631.0

664.6

698.3

732.0

765.7

799.5

833.3

867.2

901.1

935.1

969.1

1003.1

1037.2

1071.4

1105.5

1139.8

1174.1

1208.4

1242.7

1277.2

1346.1

1380.7

1415.3

1449.9

1484.6

1519.4

1554.2
1589.0

1623.9

1658.8

1693.8

1728.8

1763.9

1834.2

1869.4

1904.7

1940.0

1975.4

2010.8

32.860

32.894

32.929

32.964

33.037

33.073

33.111

33.148

33.186

33.225

33.264

33.303

33.343

33.383

33.424

33.465

33.506

33.548

33.590

33.632

33.675

33.718

33.761

33.804

33.848

33.892

33.936

33.981

34.025

34.070

34.116

34.161

34.207

34.252

34.298

34.345

34.391

34.437

34.484

34.531

34.578

34.625

34.672

34.719

34.767

34.814

34.862

34.910

34.958

35.006

35.054

35.102

35.150

35.198

35.246

35.294

35.343

35.391

2046.3

35.439

\section{$d S / d T$} $n V /{ }^{\circ} \mathrm{C}^{2}$

33.98

34.52
35.04

35.55

36.05

36.54

7..01

37.47
37.92

38.36

38.79

39.20

39.60

40.00

40.38

40.75

41.11

41.45

41.79

42.44

42.74

43.04

43.33

43.61

43.88

44.14

44.39
44.63

44.86

45.09

45.30

45.51

45.71

45.90

46.08

46.26

46.42

46.58

46.74

46.88

47.02

47.15

47.27

47.39

47.50

47.60

47.70

47.79

47.87

47.95

48.02

48.09

48.14

48.20

48.25

48.29

48.33

$48 \cdot 36$

48.39

48.41

$$
\begin{gathered}
T \\
{ }^{\circ} \mathrm{C} \\
60 \\
60 \\
61 \\
62 \\
63 \\
64 \\
\\
65 \\
66 \\
67 \\
68 \\
69 \\
\\
70 \\
71 \\
72 \\
73 \\
74 \\
75 \\
75 \\
76 \\
78 \\
79
\end{gathered}
$$

$\stackrel{E}{\mu V}$

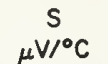

$d S / d T$
$n V /{ }^{\circ} C^{2}$

$\mathrm{T}$
${ }^{\circ} \mathrm{C}$

$2046.3 \quad 35.488$

$2081.8 \quad 35.536$

$2117.3 \quad 35.585$

$2188.6 \quad 35.682$

48.41

48.42

48.43

$48 \cdot 44$

48.44

48.44

$2224.3 \quad 35.730$

$2260.1 \quad 35.778$

$2295.9 \quad 35.827$

$2331.7 \quad 35.875$

48.43

48.42

48.40

$48 \cdot 38$

48.36

$2403.6 \quad 35.972$

$2439.6 \quad 36.020$

$2475.6 \quad 36.069$

$2511.7 \quad 36.117$

$48 \cdot 33$

48.30

48.26

48.22

$2584.0 \quad 36.213$

2620.3

2656.5

$2692.9 \quad 36.358$

48.17

48.12

48.07

48.02

47.96

$2765.7 \quad 36.454$

47.89

$2802.2 \quad 36.501$

$\begin{array}{ll}2838.7 & 36.549 \\ 2875.3 & 36.597\end{array}$

$2911.9 \quad 36.645$

47.83

47.76

47.69

$2948.6 \quad 36.692$

47.53

2985.3

36.740

$3058.8 \quad 36.834$

$3095.7 \quad 36.882$

47.45

47.37

$47 \cdot 28$

47.19

$3132.6 \quad 36.929$

$3169.6 \quad 36.976$

$47 \cdot 10$

47.00

$\begin{array}{ll}3206.6 & 37.023 \\ 3243.6 & 37.070\end{array}$

$3280.7 \quad 37.116$

46.91

46.80

$46 \cdot 70$ 
TABLE 8.5.2. Platinum, PI-67, versus Type TN (or EN) thermoelements-thermoelectric voltages, $\mathrm{E}(\mathrm{T})$, Seebeck coefficients, $\mathrm{S}(\mathrm{T})$, and first derivative of the Seebeck coefficients,

$\mathrm{dS} / \mathrm{dT}$, reference junctions at $0^{\circ} \mathrm{C}-$ Continued

\begin{tabular}{|c|c|c|c|c|c|c|c|c|c|c|c|}
\hline $\begin{array}{r}\mathrm{T} \\
{ }^{\circ} \mathrm{C}\end{array}$ & $\begin{array}{c}E \\
\mu^{V}\end{array}$ & $\underset{\mu V /{ }^{\circ} \mathrm{C}}{S}$ & $\begin{array}{l}\mathrm{dS} / \mathrm{dT} \\
\mathrm{nV} /{ }^{\circ} \mathrm{C}^{2}\end{array}$ & $\begin{array}{r}\mathrm{T} \\
{ }^{\circ} \mathrm{C}\end{array}$ & $\begin{array}{l}E \\
\mu V\end{array}$ & $\begin{array}{c}S \\
\mu V^{\circ}{ }^{\circ} \mathrm{C}\end{array}$ & $\begin{array}{l}\mathrm{dS} / \mathrm{dT} \\
\mathrm{nV} /{ }^{\circ} \mathrm{C}^{2}\end{array}$ & ${ }^{\mathrm{T}} \mathrm{C}$ & $\underset{\mu V}{E}$ & $\begin{array}{c}S \\
\mu V /{ }^{\circ} \mathrm{C}\end{array}$ & $\begin{array}{l}\mathrm{dS} / \mathrm{dT} \\
\mathrm{nV} /{ }^{\circ} \mathrm{C}^{2}\end{array}$ \\
\hline 180 & 6631.0 & 40.611 & 33.97 & 240 & 9123.7 & 42.399 & 26.03 & 300 & 11710.9 & 43.785 & 20.51 \\
\hline 181 & 6671.7 & 40.645 & 33.82 & $24 i$ & 9166.2 & 42.425 & 25.92 & 301 & 11754.7 & 43.805 & 20.43 \\
\hline 182 & 6712.3 & 40.679 & 33.67 & 242 & 9208.6 & 42.451 & 25.81 & 302 & 11798.5 & 43.826 & 20.35 \\
\hline 183 & 6753.0 & 40.713 & 33.52 & 243 & 9251.1 & 42.477 & 25.71 & 303 & 11842.4 & 43.846 & 20.28 \\
\hline 184 & 6793.8 & 40.746 & 33.37 & 244 & 9293.5 & 42.502 & 25.60 & 304 & 11886.2 & 43.866 & 20.20 \\
\hline 185 & 6834.5 & 40.779 & 33.22 & 245 & 9336.1 & 42.528 & 25.49 & 305 & $11930 \cdot 1$ & 43.886 & $20 \cdot 13$ \\
\hline 186 & 6875.3 & 40.812 & 33.07 & 246 & 9378.6 & 42.553 & 25.38 & 306 & 11974.0 & 43.907 & 20.05 \\
\hline 187 & 6916.1 & 40.845 & 32.92 & 247 & $9421 \cdot 2$ & 42.579 & 25.28 & 307 & 12017.9 & 43.927 & 19.98 \\
\hline 188 & 6957.0 & 40.878 & 32.78 & 248 & 9463.8 & 42.604 & 25.17 & 308 & 12061.8 & 43.947 & 19.91 \\
\hline 189 & 6997.9 & 40.911 & 32.63 & 249 & 9506.4 & 42.629 & 25.06 & 309 & 12105.8 & 43.966 & 19.83 \\
\hline 190 & 7038.8 & 40.944 & 32.48 & 250 & 9549.0 & 42.654 & 24.96 & 310 & 12149.8 & 43.986 & 19.76 \\
\hline 191 & 7079.8 & 40.976 & $32 \cdot 34$ & 251 & 9591.7 & 42.679 & 24.86 & 311 & 12193.8 & 44.006 & 19.69 \\
\hline 192 & 7120.8 & 41.008 & 32.19 & 252 & 9634.4 & 42.704 & 24.75 & 312 & 12237.8 & 44.026 & 19.62 \\
\hline 193 & 7161.8 & 41.040 & 32.05 & 253 & 9677.1 & 42.728 & 24.65 & 313 & 12281.8 & 44.045 & 19.54 \\
\hline 194 & 7202.9 & 41.072 & 31.90 & 254 & 9719.8 & 42.753 & 24.55 & 314 & 12325.9 & 44.065 & 19.47 \\
\hline 195 & 7244.0 & 41.104 & 31.76 & 255 & 9762.6 & 42.777 & 24.45 & 315 & 12369.9 & 44.084 & 19.40 \\
\hline 196 & 7285.1 & 41.136 & 31.62 & 256 & 9805.4 & 42.802 & 24.35 & 316 & $12414 \cdot 0$ & 44.103 & 19.33 \\
\hline 197 & 7326.2 & $41 \cdot 167$ & 31.48 & 257 & 9848.2 & 42.826 & $24 \cdot 25$ & 317 & 12458.2 & 44.123 & 19.26 \\
\hline 198 & 7367.4 & 41.199 & 31.33 & 258 & 9891.0 & 42.850 & $24 \cdot 15$ & 318 & $12502 \cdot 3$ & $44 \cdot 142$ & 19.19 \\
\hline 199 & 7408.6 & 41.230 & 31.19 & 259 & 9933.9 & 42.874 & 24.05 & 319 & 12546.4 & 44.161 & 19.12 \\
\hline 200 & 7449.9 & 41.261 & 31.05 & 260 & 9976.8 & 42.898 & 23.95 & 320 & 12590.6 & 44.180 & 19.05 \\
\hline 201 & 7491.1 & 41.292 & 30.91 & 261 & 10019.7 & 42.922 & 23.86 & 321 & $12634 \cdot 8$ & $44 \cdot 199$ & 18.98 \\
\hline 202 & 7532.5 & 41.323 & 30.77 & 262 & 10062.6 & 42.946 & 23.76 & 322 & 12679.0 & 44.218 & 18.91 \\
\hline 203 & 7573.8 & 41.354 & 30.64 & 263 & 10105.6 & 42.970 & 23.66 & 323 & 12723.2 & 44.237 & 18.84 \\
\hline 204 & 7615.2 & $41 \cdot 384$ & 30.50 & 264 & 10148.6 & 42.993 & 23.57 & 324 & 12767.5 & 44.256 & 18.77 \\
\hline 205 & 7656.6 & 41.415 & 30.36 & 265 & 10191.6 & 43.017 & 23.47 & 325 & 12811.7 & 44.275 & 18.70 \\
\hline 206 & 7698.0 & 41.445 & 30.23 & 266 & 10234.6 & 43.040 & 23.38 & 326 & 12856.0 & 44.293 & 18.64 \\
\hline 207 & 7739.4 & 41.475 & 30.09 & 267 & 10277.7 & 43.064 & 23.29 & 327 & $12900 \cdot 3$ & 44.312 & 18.57 \\
\hline 208 & 7780.9 & 41.505 & 29.96 & 268 & 10320.7 & 43.087 & 23.19 & 328 & 12944.7 & 44.330 & 18.50 \\
\hline 209 & 7822.5 & 41.535 & 29.82 & 269 & 10363.8 & 43.110 & 23.10 & 329 & 12989.0 & $44 \cdot 349$ & 18.43 \\
\hline 210 & 7864.0 & 41.565 & 29.69 & 270 & 10407.0 & 43.133 & 23.01 & 330 & 13033.4 & 44.367 & 18.37 \\
\hline 211 & 7905.6 & 41.594 & 29.56 & 271 & 10450.1 & $43 \cdot 156$ & 22.92 & 331 & 13077.7 & $44 \cdot 386$ & $18 \cdot 30$ \\
\hline 212 & 7947.2 & 41.624 & 29.43 & 272 & 10493.3 & 43.179 & 22.83 & 332 & 13122.1 & 44.404 & 18.23 \\
\hline 213 & 7988.8 & 41.653 & 29.29 & 273 & 10536.5 & 43.202 & $22 \cdot 74$ & 333 & 13166.5 & 44.422 & 18.17 \\
\hline 214 & 8030.5 & 41.682 & 29.16 & 274 & 10579.7 & 43.225 & 22.65 & 334 & 13211.0 & 44.440 & 18.10 \\
\hline 215 & 8072.2 & 41.712 & 29.04 & 275 & 10622.9 & 43.247 & 22.56 & 335 & 13255.4 & 44.458 & 18.03 \\
\hline 216 & 8113.9 & 41.741 & 28.91 & 276 & 10666.2 & 43.270 & 22.47 & 336 & 13299.9 & 44.476 & 17.97 \\
\hline 217 & 8155.7 & 41.769 & 28.78 & 277 & 10709.4 & 43.292 & $22 \cdot 38$ & 337 & $13344 \cdot 4$ & 44.494 & 17.90 \\
\hline 218 & 8197.5 & 41.798 & 28.65 & 278 & 10752.7 & 43.314 & $22 \cdot 30$ & 338 & $13388 \cdot 9$ & 44.512 & 17.83 \\
\hline 219 & 8239.3 & 41.827 & 28.52 & 279 & 10796.1 & 43.337 & $22 \cdot 21$ & 339 & $13433 \cdot 4$ & 44.530 & 17.77 \\
\hline 220 & 8281.1 & 41.855 & 28.40 & 280 & 10839.4 & 43.359 & 22.13 & 340 & 13477.9 & 44.548 & 17.70 \\
\hline 221 & 8323.0 & 41.884 & 28.27 & 281 & 10882.8 & 43.381 & 22.04 & 341 & 13522.5 & 44.565 & 17.64 \\
\hline 222 & 8364.9 & 41.912 & 28.15 & 282 & 10926.2 & 43.403 & 21.95 & 342 & 13567.1 & 44.583 & 17.57 \\
\hline 223 & 8406.8 & 41.940 & 28.03 & 283 & 10969.6 & 43.425 & 21.87 & 343 & 13611.7 & 44.600 & 17.51 \\
\hline 224 & 8448.8 & 41.968 & 27.90 & 284 & 11013.0 & 43.447 & 21.79 & 344 & 13656.3 & 44.618 & 17.44 \\
\hline 225 & 8490.7 & 41.996 & 27.78 & 285 & 11056.5 & 43.468 & 21.70 & 345 & 13700.9 & 44.635 & 17.38 \\
\hline 226 & 8532.8 & 42.023 & 27.66 & 286 & 11100.0 & 43.490 & 21.62 & 346 & 13745.5 & 44.653 & 17.32 \\
\hline 227 & 8574.8 & 42.051 & 27.54 & 287 & 11143.5 & 43.512 & 21.54 & 347 & 13790.2 & 44.670 & 17.25 \\
\hline 228 & 8616.9 & 42.078 & 27.42 & 288 & 11187.0 & 43.533 & 21.46 & 348 & 13834.9 & 44.687 & 17.19 \\
\hline 229 & 8659.0 & 42.106 & 27.30 & 289 & 11230.5 & 43.555 & 21.37 & 349 & 13879.6 & 44.704 & 17.12 \\
\hline 230 & 8701.1 & 42.133 & 27.18 & 290 & 11274.1 & 43.576 & 21.29 & 350 & 13924.3 & 44.721 & 17.06 \\
\hline 231 & 8743.2 & 42.160 & 27.06 & 291 & 11317.7 & 43.597 & 21.21 & 351 & 13969.0 & 44.738 & 17.00 \\
\hline 232 & 8785.4 & 42.187 & 26.95 & 292 & 11361.3 & 43.618 & $21 \cdot 13$ & 352 & 14013.8 & 44.755 & 16.93 \\
\hline 233 & 8827.6 & 42.214 & 26.83 & 293 & 11404.9 & 43.639 & 21.05 & 353 & 14058.5 & 44.772 & 16.87 \\
\hline 234 & 8869.8 & $42 \cdot 241$ & 26.71 & 294 & 11448.6 & 43.660 & 20.97 & 354 & 14103.3 & 44.789 & 16.80 \\
\hline 235 & 8912.1 & 42.267 & 26.60 & 295 & 11492.2 & 43.681 & 20.89 & 355 & 14148.1 & 44.806 & 16.74 \\
\hline 236 & 8954.4 & 42.294 & 26.48 & 296 & 11535.9 & 43.702 & 20.82 & 356 & 14192.9 & 44.823 & 16.68 \\
\hline 237 & 8996.7 & 42.320 & 26.37 & 297 & 11579.6 & 43.723 & 20.74 & 357 & 14237.7 & 44.839 & 16.61 \\
\hline 238 & 9039.0 & 42.347 & 26.26 & 298 & 11623.4 & $43 \cdot 744$ & 20.66 & 358 & 14282.6 & 44.856 & 16.55 \\
\hline 239 & 9081.4 & 42.373 & 26.15 & 299 & 11667.1 & 43.764 & 20.58 & 359 & 14327.5 & 44.872 & 16.49 \\
\hline 240 & 9123.7 & 42.399 & 26.03 & 300 & 11710.9 & 43.785 & 20.51 & 360 & 14372.3 & 44.889 & 16.42 \\
\hline
\end{tabular}


TABLE 8.5.2. Platinum, Pt-67, versus Type TN (or EN) thermoelements-thermoelectric voltages, $\mathrm{E}(\mathrm{T})$, Seebeck coefficients, $\mathrm{S}(\mathrm{T})$, and first derivative of the Seebeck coefficicnts,

$\mathrm{d} \mathrm{S} / \mathrm{dT}$, reference junctions at $0^{\circ} \mathrm{C}$-Continued

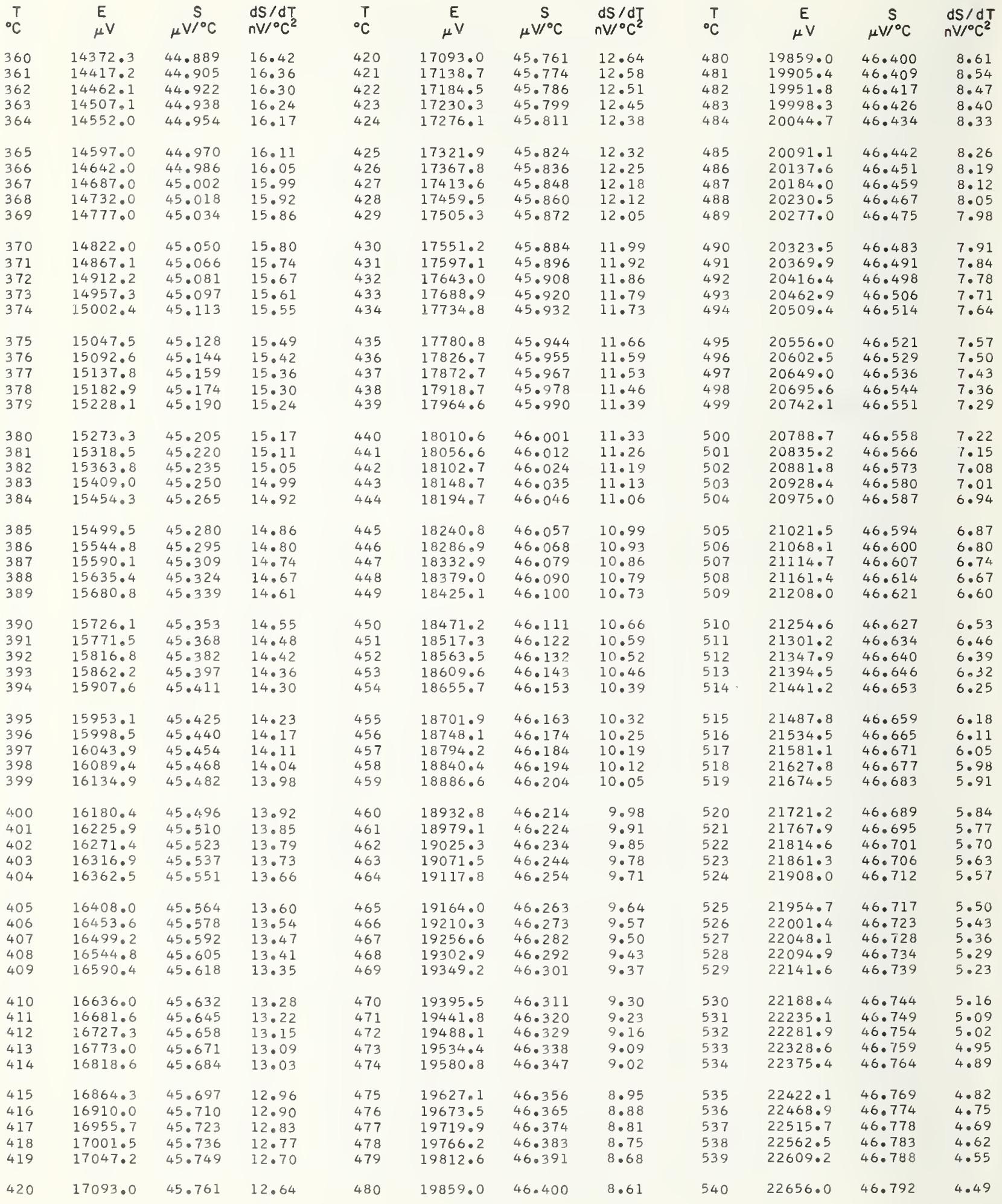


TABLe 8.5.2. Platinum, $\mathrm{Pt}-67$, versus Type TN (or EN) thermoelements-thermoelectric voltages, $\mathrm{E}(\mathrm{T})$, Seebeck coefficients, $\mathrm{S}(\mathrm{T})$, and first derivative of the Seebeck coefficients,

$\mathrm{dS} / \mathrm{dT}$, reference junctions at $0^{\circ} \mathrm{C}$-Continued

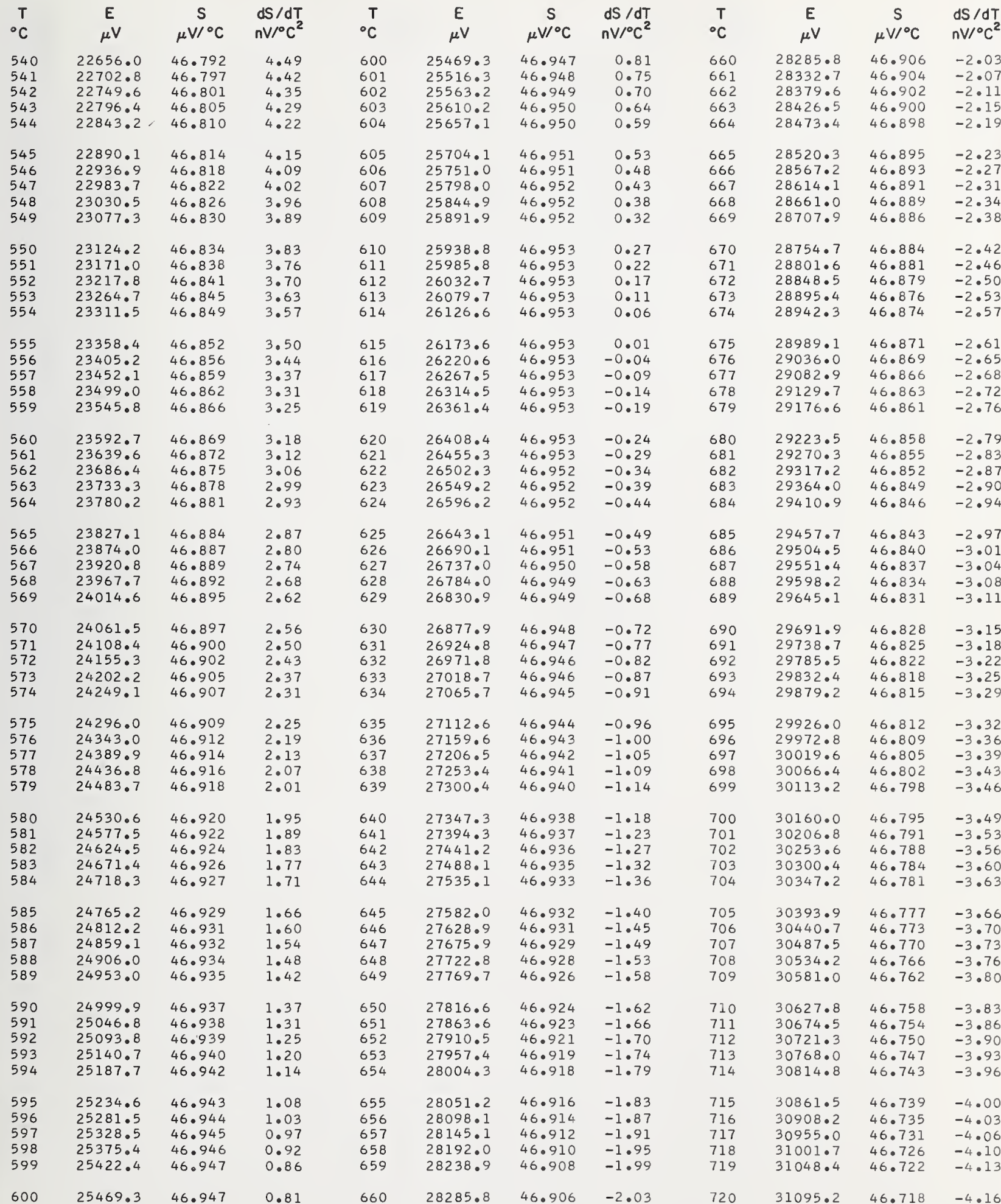


TABLE 8.5.2. Platinum, $\mathbf{P t}-67$, versus Type $T N$ (or EN) thermoelements-thermoelectric voltages, $\mathrm{E}(\mathrm{T})$, Seebeck coefficients, $\mathrm{S}(\mathrm{T})$, and first derivative of the Seebeck coefficients,

$\mathrm{dS} / \mathrm{dT}$, reference junctions at $0^{\circ} \mathrm{C}-$ Continued

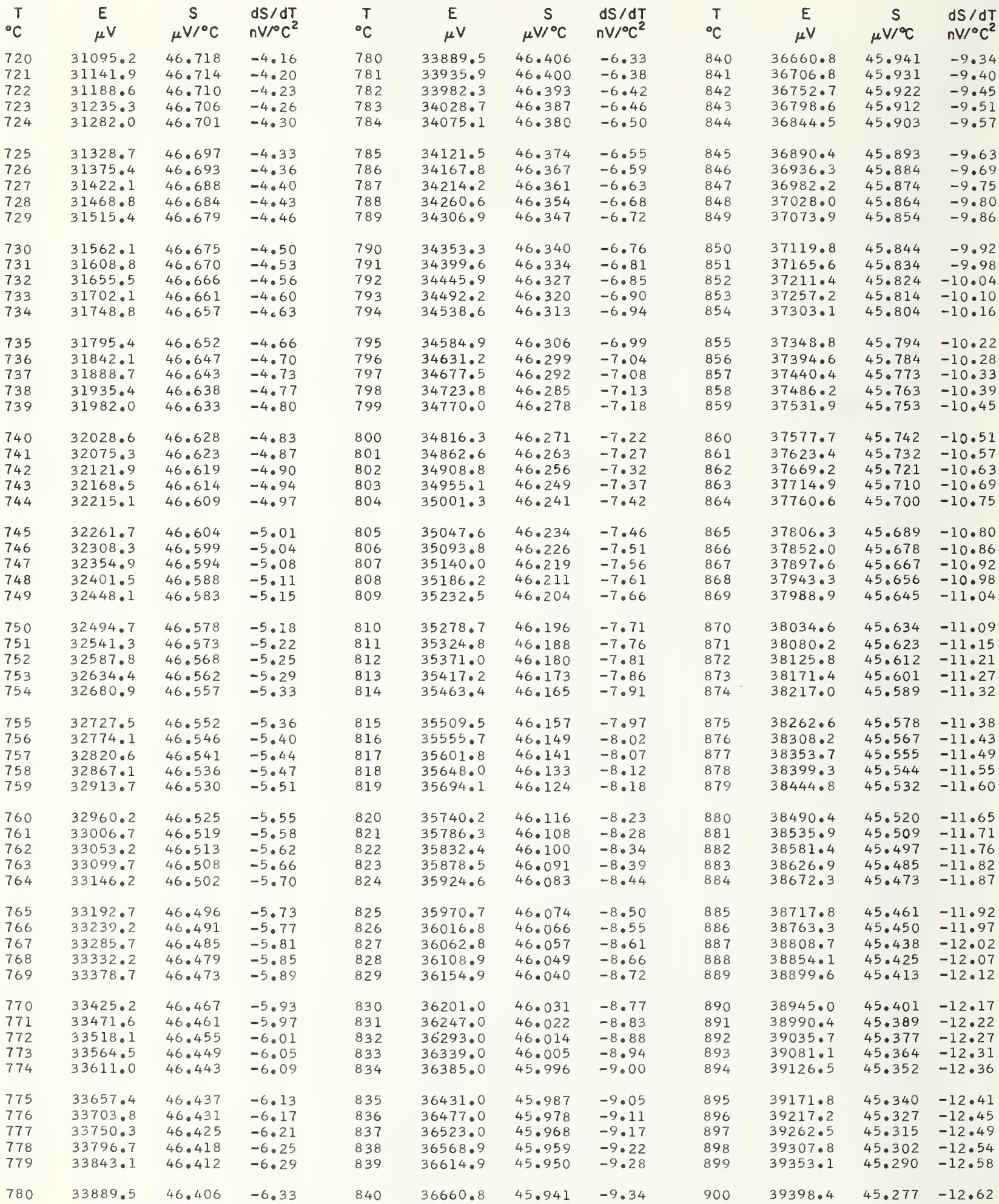


TABLE 8.5.2. Platinum, Pt-67, versus Type TN (or EN) thermoelements-thermoelectric voltages, $\mathrm{E}(\mathrm{T})$, Seebeck coefficients, $\mathrm{S}(\mathrm{T})$, and first derivative of the Seebeck coefficients, $\mathrm{dS} / \mathrm{dT}$, reference junctions at $0^{\circ} \mathrm{C}$-Continued

\begin{tabular}{|c|c|c|c|c|c|c|c|c|c|c|c|}
\hline${ }^{\circ} \mathrm{C}$ & $\begin{array}{c}E \\
\mu V\end{array}$ & $\stackrel{\mathrm{S}}{\mu V /{ }^{\circ} \mathrm{C}}$ & $\begin{array}{l}\mathrm{dS} / \mathrm{dT} \\
\mathrm{nV} /{ }^{\circ} \mathrm{C}^{2}\end{array}$ & ${ }^{\circ} \mathrm{C}$ & $\begin{array}{c}E \\
\mu V\end{array}$ & $\underset{\mu V /^{\circ} \mathrm{C}}{S}$ & $\begin{array}{l}\mathrm{dS} / \mathrm{dT} \\
\mathrm{nV} /{ }^{\circ} \mathrm{C}^{2}\end{array}$ & ${ }^{\circ} \mathrm{C}$ & $\begin{array}{c}E \\
\mu V\end{array}$ & $\frac{\mathrm{S}}{\mu \mathrm{V} /{ }^{\circ} \mathrm{C}}$ & $\begin{array}{l}\mathrm{dS} / \mathrm{dT} \\
\mathrm{nV} /{ }^{\circ} \mathrm{C}^{2}\end{array}$ \\
\hline $\begin{array}{l}900 \\
901 \\
902 \\
903 \\
904\end{array}$ & $\begin{array}{l}39398.4 \\
39443.6 \\
39488.9 \\
39534.1 \\
39579.4\end{array}$ & $\begin{array}{l}45.277 \\
45.265 \\
45.252 \\
45.239 \\
45.226\end{array}$ & $\begin{array}{l}-12.62 \\
-12.66 \\
-12.70 \\
-12.74 \\
-12.77\end{array}$ & $\begin{array}{l}935 \\
936 \\
937 \\
938 \\
939\end{array}$ & $\begin{array}{l}40975.1 \\
41019 \cdot 9 \\
41064.7 \\
41109 \cdot 5 \\
41154.3\end{array}$ & $\begin{array}{l}44.820 \\
44.807 \\
44.794 \\
44.781 \\
44.768\end{array}$ & $\begin{array}{l}-13.15 \\
-13.13 \\
-13.11 \\
-13.08 \\
-13.05\end{array}$ & $\begin{array}{l}970 \\
971 \\
972 \\
973 \\
974\end{array}$ & $\begin{array}{l}42536 \cdot 1 \\
42580.5 \\
42624 \cdot 9 \\
42669 \cdot 2 \\
42713.6\end{array}$ & $\begin{array}{l}44.394 \\
44.383 \\
44.373 \\
44.363 \\
44.353\end{array}$ & $\begin{array}{r}-10.45 \\
-10.30 \\
-10.14 \\
-9.98 \\
-9.81\end{array}$ \\
\hline $\begin{array}{l}905 \\
906 \\
907 \\
908 \\
909\end{array}$ & $\begin{array}{l}39624.6 \\
39669.8 \\
39715.0 \\
39760.2 \\
39805.3\end{array}$ & $\begin{array}{l}45.214 \\
45.201 \\
45.188 \\
45.175 \\
45.162\end{array}$ & $\begin{array}{l}-12 \cdot 81 \\
-12.84 \\
-12.88 \\
-12.91 \\
-12.94\end{array}$ & $\begin{array}{l}940 \\
941 \\
942 \\
943 \\
944\end{array}$ & $\begin{array}{l}41199 \cdot 1 \\
41243 \cdot 8 \\
41288 \cdot 5 \\
41333 \cdot 3 \\
41378.0\end{array}$ & $\begin{array}{l}44.755 \\
44.742 \\
44.729 \\
44.716 \\
44.703\end{array}$ & $\begin{array}{l}-13.02 \\
-12.99 \\
-12.95 \\
-12.91 \\
-12.87\end{array}$ & $\begin{array}{l}975 \\
976 \\
977 \\
978 \\
979\end{array}$ & $\begin{array}{l}42757 \cdot 9 \\
42802 \cdot 3 \\
42846 \cdot 6 \\
42890 \cdot 9 \\
42935 \cdot 2\end{array}$ & $\begin{array}{l}44 \cdot 344 \\
44 \cdot 334 \\
44 \cdot 325 \\
44 \cdot 315 \\
44 \cdot 306\end{array}$ & $\begin{array}{l}-9.63 \\
-9.45 \\
-9.27 \\
-9.08 \\
-8.88\end{array}$ \\
\hline $\begin{array}{l}910 \\
911 \\
912 \\
913 \\
914\end{array}$ & $\begin{array}{l}39850.5 \\
39895.6 \\
39940.8 \\
39985.9 \\
40031.0\end{array}$ & $\begin{array}{l}45.149 \\
45.136 \\
45.123 \\
45.110 \\
45.097\end{array}$ & $\begin{array}{l}-12.97 \\
-13.00 \\
-13.02 \\
-13.05 \\
-13.07\end{array}$ & $\begin{array}{l}945 \\
946 \\
947 \\
948 \\
949\end{array}$ & $\begin{array}{l}41422 \cdot 7 \\
41467 \cdot 4 \\
41512 \cdot 0 \\
41556 \cdot 7 \\
41601 \cdot 3\end{array}$ & $\begin{array}{l}44.690 \\
44.677 \\
44.664 \\
44.652 \\
44.639\end{array}$ & $\begin{array}{l}-12.82 \\
-12.77 \\
-12.72 \\
-12.67 \\
-12.61\end{array}$ & $\begin{array}{l}980 \\
981 \\
982 \\
983 \\
984\end{array}$ & $\begin{array}{l}42979.5 \\
43023.8 \\
43068 \cdot 1 \\
43112.4 \\
43156.7\end{array}$ & $\begin{array}{l}44 \cdot 298 \\
44 \cdot 289 \\
44 \cdot 281 \\
44.273 \\
44.265\end{array}$ & $\begin{array}{l}-8 \cdot 6 \\
-8 \cdot 4 \\
-8.2 \\
-8 \cdot 0 \\
-7.8\end{array}$ \\
\hline $\begin{array}{l}915 \\
916 \\
917 \\
918 \\
919\end{array}$ & $\begin{array}{l}40076 \cdot 1 \\
40121 \cdot 2 \\
40166 \cdot 2 \\
40211 \cdot 3 \\
40256 \cdot 3\end{array}$ & $\begin{array}{l}45.084 \\
45.071 \\
45.058 \\
45.045 \\
45.031\end{array}$ & $\begin{array}{l}-13 \cdot 10 \\
-13.12 \\
-13 \cdot 14 \\
-13.15 \\
-13.17\end{array}$ & $\begin{array}{l}950 \\
951 \\
952 \\
953 \\
954\end{array}$ & $\begin{array}{l}41646.0 \\
41690.6 \\
41735.2 \\
41779.8 \\
41824.4\end{array}$ & $\begin{array}{l}44.627 \\
44.614 \\
44.602 \\
44.589 \\
44.577\end{array}$ & $\begin{array}{l}-12 \cdot 54 \\
-12 \cdot 48 \\
-12 \cdot 41 \\
-12 \cdot 33 \\
-12.26\end{array}$ & $\begin{array}{l}985 \\
986 \\
987 \\
988 \\
989\end{array}$ & $\begin{array}{l}43200.9 \\
43245.2 \\
43289.4 \\
43333.7 \\
43377.9\end{array}$ & $\begin{array}{l}44.257 \\
44 \cdot 250 \\
44.242 \\
44.235 \\
44.229\end{array}$ & $\begin{array}{l}-7.56 \\
-7.32 \\
-7.07 \\
-6.82 \\
-6.56\end{array}$ \\
\hline $\begin{array}{l}920 \\
921 \\
922 \\
923 \\
924\end{array}$ & $\begin{array}{l}40301 \cdot 3 \\
40346 \cdot 3 \\
40391 \cdot 3 \\
40436 \cdot 3 \\
40481 \cdot 3\end{array}$ & $\begin{array}{l}45.018 \\
45.005 \\
44.992 \\
44.979 \\
44.965\end{array}$ & $\begin{array}{l}-13 \cdot 18 \\
-13.19 \\
-13.21 \\
-13.21 \\
-13.22\end{array}$ & $\begin{array}{l}955 \\
956 \\
957 \\
958 \\
959\end{array}$ & $\begin{array}{l}41868.9 \\
41913.5 \\
41958.0 \\
42002.6 \\
42047.1\end{array}$ & $\begin{array}{l}44.565 \\
44.553 \\
44.541 \\
44.529 \\
44.517\end{array}$ & $\begin{array}{l}-12 \cdot 18 \\
-12.09 \\
-12 \cdot 00 \\
-11.91 \\
-11.81\end{array}$ & $\begin{array}{l}990 \\
991 \\
992 \\
993 \\
994\end{array}$ & $\begin{array}{l}43422 \cdot 1 \\
43466.3 \\
43510.6 \\
43554.8 \\
43599.0\end{array}$ & $\begin{array}{l}44.222 \\
44.216 \\
44.210 \\
44.205 \\
44.199\end{array}$ & $\begin{array}{l}-6 \cdot 2 \\
-6 \cdot 0 \\
-5 \cdot 7 \\
-5 \cdot 4 \\
-5 \cdot 1\end{array}$ \\
\hline $\begin{array}{l}925 \\
926 \\
927 \\
928 \\
929\end{array}$ & $\begin{array}{l}40526.3 \\
40571 \cdot 2 \\
40616.1 \\
40661.1 \\
40706.0\end{array}$ & $\begin{array}{l}44.952 \\
44.939 \\
44.926 \\
44.913 \\
44.899\end{array}$ & $\begin{array}{l}-13 \cdot 23 \\
-13 \cdot 23 \\
-13 \cdot 23 \\
-13 \cdot 23 \\
-13 \cdot 22\end{array}$ & $\begin{array}{l}960 \\
961 \\
962 \\
963 \\
964\end{array}$ & $\begin{array}{l}42091.6 \\
42136.1 \\
42180.6 \\
42225.1 \\
42269.5\end{array}$ & $\begin{array}{l}44.505 \\
44.493 \\
44.482 \\
44.470 \\
44.459\end{array}$ & $\begin{array}{l}-11 \cdot 71 \\
-11 \cdot 61 \\
-11 \cdot 50 \\
-11.38 \\
-11.26\end{array}$ & $\begin{array}{l}995 \\
996 \\
997 \\
998 \\
999\end{array}$ & $\begin{array}{l}43643 \cdot 2 \\
43687 \cdot 4 \\
43731 \cdot 5 \\
43775.7 \\
43819.9\end{array}$ & $\begin{array}{l}44 \cdot 194 \\
44.190 \\
44.185 \\
44.181 \\
44.178\end{array}$ & $\begin{array}{l}-4 \cdot 83 \\
-4 \cdot 52 \\
-4 \cdot 20 \\
-3 \cdot 87 \\
-3 \cdot 53\end{array}$ \\
\hline $\begin{array}{l}930 \\
931 \\
932 \\
933 \\
934\end{array}$ & $\begin{array}{l}40750.9 \\
40795.7 \\
40840.6 \\
40885.5 \\
40930.3\end{array}$ & $\begin{array}{l}44.886 \\
44.873 \\
44.860 \\
44.846 \\
44.833\end{array}$ & $\begin{array}{l}-13 \cdot 22 \\
-13 \cdot 21 \\
-13 \cdot 20 \\
-13 \cdot 19 \\
-13.17\end{array}$ & $\begin{array}{l}965 \\
966 \\
967 \\
968 \\
969\end{array}$ & $\begin{array}{l}42314 \cdot 0 \\
42358 \cdot 4 \\
42402 \cdot 9 \\
42447 \cdot 3 \\
42491 \cdot 7\end{array}$ & $\begin{array}{l}44 \cdot 448 \\
44 \cdot 437 \\
44 \cdot 426 \\
44 \cdot 415 \\
44 \cdot 404\end{array}$ & $\begin{array}{l}-11 \cdot 14 \\
-11 \cdot 01 \\
-10 \cdot 88 \\
-10 \cdot 74 \\
-10 \cdot 60\end{array}$ & 1000 & $43864 \cdot 1$ & 44.174 & -3. \\
\hline 935 & 40975.1 & 44.820 & $-13 \cdot 15$ & 970 & $42536 \cdot 1$ & $44 \cdot 394$ & $-10 \cdot 45$ & & & & \\
\hline
\end{tabular}


TABLE 8.5.3. Thermoelectric values at the fixed points for platinum, $\mathrm{Pt}-67$, versus Type TN (or EN) thermoelements

\begin{tabular}{|c|c|c|c|c|}
\hline Fixed point & Temp. & $\begin{array}{c}E \\
\mu \mathrm{V}\end{array}$ & $\begin{array}{c}S \\
\mu \mathrm{V} /{ }^{\circ} \mathrm{C}\end{array}$ & $\begin{array}{c}d S / d T \\
\mathrm{nV} /{ }^{\circ} \mathrm{C}^{2}\end{array}$ \\
\hline $\begin{array}{l}\text { Helium NBP } \\
\text { Hydrogen TP } \\
\text { Hydrogen NBP } \\
\text { Neon TP } \\
\text { Neon NBP } \\
\text { Oxygen TP } \\
\text { Nitrogen TP } \\
\text { Nitrogen NBP } \\
\text { Oxygen NBP } \\
\text { Carbon Dioxide SP } \\
\text { Mercury FP } \\
\text { Ice point* } \\
\text { Ether TP } \\
\text { Water BP } \\
\text { Benzoic TP } \\
\text { Indium FP } \\
\text { Tin FP } \\
\text { Bismuth FP } \\
\text { Cadmium FP } \\
\text { Lead FP } \\
\text { Mercury BP } \\
\text { Zinc FP } \\
\text { Sulphur BP } \\
\text { Cu-Al FP } \\
\text { Antimony FP } \\
\text { Aluminum FP } \\
\text { Silver FP }\end{array}$ & $\begin{array}{c}-268.935 \\
-259.340 \\
-252.870 \\
-248.595 \\
-246.048 \\
-218.789 \\
-210.002 \\
-195.802 \\
-182.962 \\
-78.476 \\
-38.862 \\
0.000 \\
26.870 \\
100.000 \\
122.370 \\
156.634 \\
231.9681 \\
271.442 \\
321.108 \\
327.502 \\
356.660 \\
419.580 \\
444.674 \\
548.23 \\
630.74 \\
660.37 \\
961.93\end{array}$ & $\begin{array}{r}-6276.21 \\
-6244.17 \\
-6202.43 \\
-6166.69 \\
-6142.42 \\
-5762.03 \\
-5603.14 \\
-5322.69 \\
-5050.52 \\
-2410.33 \\
-1236.95 \\
0.0 \\
896.7 \\
3504.2 \\
4352.0 \\
5691.7 \\
8784.0 \\
10469.2 \\
12639.6 \\
12922.6 \\
14222.5 \\
17073.8 \\
18225.8 \\
23041.3 \\
26912.6 \\
28303.1 \\
42177.5\end{array}$ & $\begin{array}{r}1.237 \\
5.264 \\
7.614 \\
9.099 \\
9.959 \\
17.296 \\
18.806 \\
20.583 \\
21.766 \\
28.481 \\
30.744 \\
32.860 \\
33.930 \\
37.395 \\
38.392 \\
39.775 \\
42.186 \\
43.166 \\
44.201 \\
44.321 \\
44.834 \\
45.756 \\
46.053 \\
46.827 \\
46.947 \\
46.905 \\
44.483\end{array}$ & $\begin{array}{r}491.18 \\
376.07 \\
353.07 \\
341.41 \\
333.61 \\
194.20 \\
151.02 \\
104.07 \\
82.72 \\
59.11 \\
56.87 \\
33.98 \\
44.36 \\
46.04 \\
43.02 \\
37.63 \\
26.95 \\
22.88 \\
18.97 \\
18.53 \\
16.64 \\
12.67 \\
11.02 \\
3.94 \\
-0.76 \\
-2.05 \\
-11.50\end{array}$ \\
\hline
\end{tabular}

*Junction point of different functions.

TABLE 8.5.4. Estimated maximum errors that occur when using reduced-bit arithmetic for the power series expansion for the thermoelectric voltage of platinum, Pt-67, versus Type TN (or EN) thermoelements

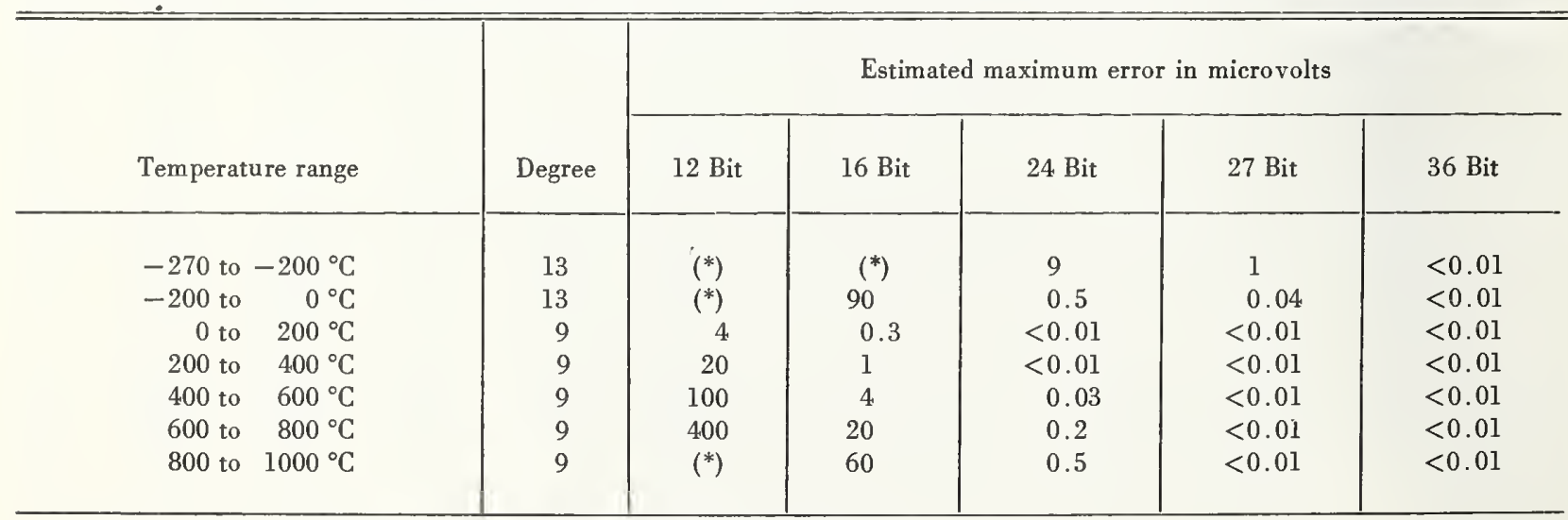

*A high-order polynomial with a low-bit machine causes extreme error. 


\section{Appendices}

\section{A1. General Introduction}

The primary tables and functions presented in the main text are more precise than is often necessary. Also the form of these data is not always the most usable for many applications. The purpose of the tables included in these appendices is to present the same data in different formats to satisfy special needs. Only the standard thermocouple types are re-represented, i.e., S, R, B, E, J, K, and T. Six tables will be given for each of the primary thermocouple combinations. The six tables are:

(1) Voltage as a function of temperature, $T$ in degrees Celsius, $0{ }^{\circ} \mathrm{C}$ reference temperature-the temperature interval is 1 degree Celsius and the voltage is expressed in millivolts rather than micro. volts. The voltage data are usually given to the nearest 0.001 millivolt (the primary tables given in the text have a resolution of 0.01 microvolt wherever the experimental data would allow).

(2) Voltage as a function of temperature, $T$ in degrees Fahrenheit, $32^{\circ} \mathrm{F}$ reference temperature -these tables are similar to those discussed in (1) except that the smaller Fahrenheit degree results in a finer temperature grid.

(3) Approximation coefficients for voltage as a function of temperature, $T$ in degrees Celsius, $E$ in microvolts, $0{ }^{\circ} \mathrm{C}$ reference temperature-these tables present reduced order approximations of the quartic form

$$
E=a_{0}+a_{1} T+a_{2} T^{2}+a_{3} T^{3}+a_{4} T^{4}
$$

for selected temperature ranges. Coefficients are also given for cubic and quadratic approximations. The maximum difference between $E$ as determined with the full precision coefficients given in the text and $E$ as determined by these approximation functions is also given for each order and temperature range.

(4) Temperature as a function of voltage, $T$ in degrees Celsius, $0{ }^{\circ} \mathrm{C}$ reference temperaturethese tables, obtained by iteration in the $E=f(T)$ data, are presented with 0.01 millivolt intervals in voltage and 0.01 degrees Celsius resolution in temperature. They are essentially the inverse tables from those described in (1) above.

(5) Temperature as a function of voltage, $T$ in degrees Fahrenheit, $32{ }^{\circ} \mathrm{F}$ reference temperature -these tables are similar to those discussed in (4) except that the temperatures are expressed in degrees Fahrenheit. They are essentially the inverse tables from those described in (2) above.

(6) Approximation functions for temperatures as a function of voltage, $T$ in degrees Celsius, $E$ in microvolts - these tables present reduced order approximations similar to those described in (3) for selected temperature ranges. The maximum difference between $T$ as determined by iteration in the full precision tables and $T$ as determined by these approximation functions is also given for each order and temperature range.

The table numbering scheme represents the particular thermocouple combination by the first digit, e.g., A2. represents Type S, A3. represents Type $R$, etc. The second digit indicates whether the data are presented as a function of temperature (.1.) or a function of voltage (.2.). The third digit is just the sequence of tables for a particular material and particular functional dependence; .1. indicates degrees Celsius, .2. indicates degrees Fahrenheit, and .3. indicates approximation equations.

All the tables and approximations presented in the appendices are based on reference junctions of $0{ }^{\circ} \mathrm{C}$ (for $\left.32^{\circ} \mathrm{F}\right)$. 


\section{A2. Supplementary Data for Type S-Platinum-10\% Rhodium Alloy Versus Platinum Thermocouples}

\section{A2.1. Data for Voltage as a Function of Temperature}

The full precision coefficients given in the main text are used to generate the voltage as a function of temperature data given in tables A2.1.1. and A2.1.2. Table A2.1.1. presents the data in degrees Celsius from $-50{ }^{\circ} \mathrm{C}$ to $1768{ }^{\circ} \mathrm{C}$ while table A2.1.2. presents the data in degrees Fahrenheit from $-58^{\circ} \mathrm{F}$ to $3214^{\circ} \mathrm{F}$. Table A2.1.3. contains quadratic, cubic, and quartic approximations to the data as a function of temperature in selected temperature ranges. The error range given in the table is the difference between the voltage as obtained from the full precision coefficients from the text and the respective reduced order approximations. The last entries in the cubic and quadratic groupings of table A2.1.3 represent variable reference junction corrections in the 0 to $50{ }^{\circ} \mathrm{C}$ temperature range. In the narrower temperature range near room temperatures, 20 to $25{ }^{\circ} \mathrm{C}$, the error range for the given quadratic equation is smaller than that listed in the last column: $\pm 0.02 \mu \mathrm{V}$.

TABLE A2.1.1. Type $S$ thermocouples-thermoelectric voltage as a function of temperature $\left({ }^{\circ} \mathrm{C}\right)$, reference junctions at $0^{\circ} \mathrm{C}$

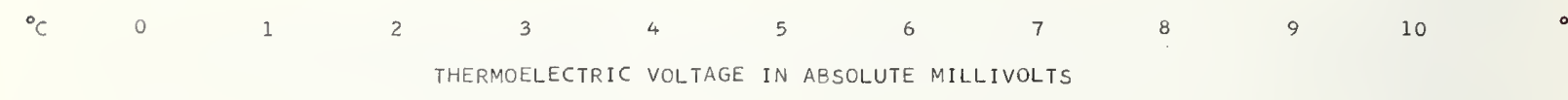

\begin{tabular}{|c|c|c|c|c|c|c|c|c|c|c|c|}
\hline 50 & 57 & & & & & & & & & & \\
\hline $\begin{array}{l}-40 \\
-30 \\
-20 \\
-10 \\
-\quad 0\end{array}$ & $\begin{array}{r}-0.1944 \\
-0.1501 \\
-0.1028 \\
-0.0527 \\
0.0000\end{array}$ & $\begin{array}{l}-0.1987 \\
-0.1547 \\
-0.1077 \\
-0.0579 \\
-0.0054\end{array}$ & $\begin{array}{l}-0.2029 \\
-0.1592 \\
-0.1125 \\
-0.0630 \\
-0.0107\end{array}$ & $\begin{array}{l}-0.2071 \\
-0.1637 \\
-0.1173 \\
-0.0680 \\
-0.0161\end{array}$ & $\begin{array}{l}-0.2113 \\
-0.1682 \\
-0.1221 \\
-0.0731 \\
-0.0214\end{array}$ & $\begin{array}{l}-0.2155 \\
-0.1726 \\
-0.1268 \\
-0.0781 \\
-0.0267\end{array}$ & $\begin{array}{l}-0.2196 \\
-0.1771 \\
-0.1315 \\
-0.0831 \\
-0.0319\end{array}$ & $\begin{array}{l}-0.2236 \\
-0.1815 \\
-0.1362 \\
-0.0881 \\
-0.0372\end{array}$ & $\begin{array}{l}-0.2277 \\
-0.1858 \\
-0.1409 \\
-0.0930 \\
-0.0424\end{array}$ & $\begin{array}{l}-0.2317 \\
-0.1901 \\
-0.1455 \\
-0.0979 \\
-0.0476\end{array}$ & $\begin{array}{l}-0.2357 \\
-0.1944 \\
-0.1501 \\
-0.1028 \\
-0.0527\end{array}$ \\
\hline
\end{tabular}


TABLE A2.1.1. Type S thermocouples-thermoelectric voltage as a function of temperature $\left({ }^{\circ} \mathrm{C}\right)$, reference junctions at $0{ }^{\circ} \mathrm{C}$-Continued

3

5

6

7

10

THERMOELECTRIC VOLTAGE IN ABSOLUTE MILLIVOLTS

\begin{tabular}{|c|c|c|c|c|c|c|c|c|c|c|c|}
\hline 0.0000 & .0054 & .0108 & 0163 & .0218 & 0.0273 & 0.0328 & 0.0384 & 0.0440 & 0.0496 & 0.0552 & \\
\hline 0.0552 & 0.0609 & 0.0666 & 0.0723 & 0.0780 & 0.0837 & 0.0895 & 0.0953 & 0.1011 & 0.1070 & 0.1128 & \\
\hline 0.1128 & 0.1187 & 0.1246 & 0.1305 & 0.1365 & 0.1425 & 0.1485 & 0.1545 & $0.16 u^{\prime}$ & 0.1666 & 0.1727 & \\
\hline 0.1727 & 0.1788 & 0.1849 & 0.1910 & 0.1972 & 0.2034 & 0.2096 & 0.2158 & 0.2221 & 0.2284 & 0.2346 & \\
\hline 0.2346 & 0.2410 & 0.2473 & 0.2536 & 0.2600 & 0.2664 & 0.2728 & 0.2792 & 0.2857 & 0.2922 & 0.2986 & \\
\hline 0.2986 & 0.3051 & 0.3117 & 0.3182 & 0.3248 & 0.3314 & 0.3380 & 0.3446 & 0.3512 & 0.3579 & 0.3645 & \\
\hline 0.3645 & 0.3712 & 0.3780 & 0.3847 & 0.3914 & 0.3982 & 0.4050 & 0.4118 & 0.4186 & 0.4254 & 0.4323 & \\
\hline 0.4323 & 0.4391 & 0.4460 & 0.4529 & 0.4598 & 0.4668 & 0.4737 & 0.4807 & 0.4877 & 0.4947 & 0.5017 & \\
\hline 0.5017 & 0.5087 & 0.5158 & 0.5228 & 0.5299 & 0.5370 & 0.5441 & 0.5513 & 0.5584 & 0.5656 & 0.5727 & \\
\hline 0.5727 & 0.5799 & 0.5871 & 0.5944 & 0.6016 & 0.6089 & 0.6161 & 0.6234 & 0.6307 & 0.6380 & 0.6453 & \\
\hline 0.6453 & 0.6527 & 0.6600 & 0.6674 & 0.6748 & 0.6822 & 0.6896 & 0.6970 & 0.7045 & 0.7119 & 0.7194 & \\
\hline 0.7194 & 0.7269 & 0.7344 & 0.7419 & 0.7494 & 0.7569 & 0.7645 & 0.7720 & 0.7796 & 0.7872 & 0.7948 & \\
\hline 0.7948 & 0.8024 & 0.8101 & 0.8177 & 0.8254 & 0.8330 & 0.8407 & 0.8484 & 0.8561 & 0.8638 & 0.8715 & \\
\hline 0.8715 & 0.8793 & 0.8870 & 0.8948 & 0.9026 & 0.9104 & 0.9182 & 0.9260 & 0.9338 & 0.9417 & 0.9495 & \\
\hline 0.9495 & 0.9574 & 0.9653 & 0.9731 & 0.9810 & 0.9889 & 0.9969 & 1.0048 & 1.0127 & 1.0207 & 1.0287 & \\
\hline 1.0287 & 1.0366 & 1.0446 & 1.0526 & 1.0606 & 1.0687 & 1.0767 & 1.0847 & 1.0928 & 1.1009 & 1.1089 & \\
\hline 1.1089 & 1.1170 & 1.1251 & 1.1332 & 1.1413 & 1.1495 & 1.1576 & 1.1657 & 1.1739 & 1.1821 & 1.1902 & \\
\hline 1.1902 & 1.1984 & 1.2066 & 1.2148 & 1.2231 & 1.2313 & 1.2395 & 1.2478 & 1.2560 & 1.2643 & 1.2726 & \\
\hline 1.2726 & 1.2808 & 1.2891 & 1.2974 & 1.3058 & 1.3141 & 1.3224 & 1.3308 & 1.3391 & 1.3475 & 1.3558 & \\
\hline 1.3558 & 1.3642 & 1.3726 & 1.3810 & 1.3894 & 1.3978 & 1.4062 & 1.4147 & 1.4231 & 1.4316 & 1.4400 & \\
\hline 1.4400 & 1.4485 & 1.4569 & 1.4654 & 1.4739 & 1.4824 & 1.4909 & 1.4994 & 1.5080 & 1.5165 & 1.5250 & \\
\hline 1.5250 & 1.5336 & 1.5421 & 1.5507 & 1.5593 & 1.5679 & 1.5765 & 1.5850 & 1.5937 & 1.6023 & 1.6109 & \\
\hline 1.6109 & 1.6195 & 1.6281 & 1.6368 & 1.6454 & 1.6541 & 1.6628 & 1.6714 & 1.6801 & 1.6888 & 1.6975 & \\
\hline 1.6975 & 1.7062 & 1.7149 & 1.7236 & 1.7324 & 1.7411 & 1.7498 & 1.7586 & 1.7673 & 1.7761 & 1.7849 & \\
\hline 1.7849 & 1.7936 & 1.8024 & 1.8112 & 1.8200 & 1.8288 & 1.8376 & 1.8464 & 1.8553 & 1.8641 & 1.8729 & \\
\hline 1.8729 & 1.8818 & 1.8906 & 1.8995 & 1.9083 & 1.9172 & 1.9261 & 1.9350 & 1.9439 & 1.9528 & 1.9617 & \\
\hline 1.9617 & 1.9706 & 1.9795 & 1.9884 & 1.9973 & 2.0063 & 2.0152 & 2.0242 & 2.0331 & 2.0421 & 2.0510 & \\
\hline 2.0510 & 2.0600 & 2.0690 & 2.0780 & 2.0870 & 2.0959 & 2.1049 & 2.1140 & 2.1230 & 2.1320 & 2.1410 & \\
\hline 2.1410 & 2.1500 & 2.1591 & 2.1681 & 2.1772 & 2.1862 & 2.1953 & 2.2043 & 2.2134 & 2.2225 & 2.2316 & \\
\hline 2.2316 & 2.2407 & 2.2497 & 2.2588 & 2.2679 & 2.2771 & 2.2862 & 2.2953 & 2.3044 & 2.3135 & 2.3227 & \\
\hline 2.3227 & 2.3318 & 2.3410 & 2.3501 & 2.3593 & 2.3684 & 2.3776 & 2.3868 & 2.3960 & 2.4051 & 2.4143 & \\
\hline 2.4143 & 2.4235 & 2.4327 & 2.4419 & 2.4511 & 2.4603 & 2.4696 & 2.4788 & 2.4880 & 2.4972 & 2.5065 & \\
\hline 2.5065 & 2.5157 & 2.5250 & 2.5342 & 2.5435 & 2.5527 & 2.5620 & 2.5713 & 2.5806 & 2.5898 & 2.5991 & \\
\hline 2.5991 & 2.6084 & 2.6177 & 2.6270 & 2.6363 & 2.6456 & 2.6549 & 2.6643 & 2.6736 & 2.6829 & 2.6922 & \\
\hline 2.6922 & 2.7016 & 2.7109 & 2.7203 & 2.7296 & 2.7390 & 2.7483 & 2.7577 & 2.7670 & 2.7764 & 2.7858 & \\
\hline 2.7858 & 2.7952 & 2.8046 & 2.8139 & 2.8233 & 2.8327 & 2.8421 & 2.8515 & 2.8609 & 2.8704 & 2.8798 & \\
\hline 2.8798 & 2.8892 & 2.8986 & 2.9081 & 2.9175 & 2.9269 & 2.9364 & 2.9458 & 2.9553 & 2.9647 & 2.9742 & \\
\hline 2.9742 & 2.9836 & 2.9931 & 3.0026 & 3.0121 & 3.0215 & 3.0310 & 3.0405 & 3.0500 & 3.0595 & 3.0690 & \\
\hline 3.0690 & 3.0785 & 3.0880 & 3.0975 & 3.1070 & 3.1165 & 3.1261 & 3.1356 & 3.1451 & 3.1546 & 3.1642 & \\
\hline 3.1642 & 3.1737 & 3.1833 & 3.1928 & 3.2024 & 3.2119 & 3.2215 & 3.2310 & 3.2406 & 3.2502 & 3.2597 & \\
\hline 3.2597 & 3.2693 & 3.2789 & & 3. & & 72 & 68 & & & & \\
\hline 3.3557 & 3.3653 & 3.3749 & 3.3845 & 3.3941 & 3.4037 & 3.4134 & 230 & 26 & 423 & 519 & \\
\hline 3.4519 & 3.4616 & 3.4712 & 3.4809 & 3.4905 & 3.5002 & 3.5098 & 3.5195 & 3.5292 & 3.5389 & 3.5485 & \\
\hline 3.5485 & 3.5582 & 3.5679 & 3.5776 & 3.5873 & 3.5970 & 3.6066 & 3.6163 & 3.6261 & 3.6358 & 3.6455 & \\
\hline 3.6455 & 3.6552 & 3.6649 & 3.6746 & 3.6843 & 3.6941 & 3.7038 & 3.7135 & 3.7232 & 3.7330 & 3.7427 & \\
\hline 3. & 3.7525 & 3. & 3. & 3. & 3.7 & 3. & 3.8110 & 3. & 305 & 403 & \\
\hline & 3.8501 & & & & 3.8892 & & 3.9088 & & 3.9284 & 3.9382 & \\
\hline 3.9382 & 3.9480 & 3.9578 & 3.9676 & 3.9774 & 3.9872 & 3.9970 & 4.0069 & 4.0167 & 4.0265 & 4.0363 & \\
\hline 4.0363 & 4.0462 & 4.0560 & 4.0659 & 4.0757 & 4.0856 & 4.0954 & 4.1053 & 4.1151 & 4.1250 & 4.1348 & \\
\hline 4.1348 & 4.1447 & 4.1546 & 4.1644 & 4.1743 & 4.1842 & 4.1941 & 4.2039 & 4.2138 & 4.2237 & 4.2336 & \\
\hline 4. & 4.2435 & 4. & 4.2633 & 4.2732 & 4.2831 & 4.2930 & 4.3029 & 128 & 227 & 4.3327 & \\
\hline 27 & 4.3426 & 4.3525 & 4.3624 & 4.3724 & 4.3823 & 4.3922 & 4.4022 & 4.4121 & 4.4221 & 4.4320 & \\
\hline 4.4320 & 4.4419 & 4.4519 & 4.4619 & 4.4718 & 4.4818 & 4.4917 & 4.5017 & 4.5117 & 4.5217 & 4.5316 & \\
\hline 4.5316 & 4.5416 & 4.5516 & 4.5616 & 4.5716 & 4.5816 & 4.5915 & 4.6015 & 4.6115 & 4.6215 & 4.6316 & \\
\hline 4.6316 & 4.6416 & 4.6516 & 4.6616 & 4.6716 & 4.6816 & 4.6916 & 4.7017 & 4.7117 & 4.7217 & 4.7318 & \\
\hline 4.7318 & 4.7418 & 4.7518 & 4.7619 & 4.7719 & 4. & 4. & 4.8021 & 4. & 4.8222 & 4.8323 & \\
\hline & 4.8423 & 4.8524 & 4.8625 & 4.8725 & $4 \cdot 8$ & 4.8927 & 4.9028 & 4.9129 & 4.9230 & 4.9331 & \\
\hline 4.9331 & 4.9432 & 4.9533 & 4.9634 & 4.9735 & 4.9836 & 4.9937 & 5.0038 & 5.0139 & 5.0240 & 5.0342 & \\
\hline 5.0342 & 5.0443 & 5.0544 & 5.0646 & 5.0747 & 5.0848 & 5.0950 & 5.1051 & 5.1153 & 5.1254 & 5.1356 & \\
\hline 5.1356 & 5.1457 & 5.1559 & 5.1661 & 5.1762 & 5.1864 & 5.1966 & 5.2067 & 5.2169 & 5.2271 & 5.2373 & \\
\hline 5.2373 & 5.2475 & 5.2577 & 5.2679 & 5.2781 & 5.2883 & 5.2985 & 5.3087 & 5.3189 & 5.3291 & 5.3394 & \\
\hline
\end{tabular}


TABLE A2.1.1. Type $S$ thermocouples-thermoelectric voltage as a function of temperature $\left({ }^{\circ} \mathrm{C}\right)$, reference junctions at $0^{\circ} \mathrm{C}$-Continued

${ }^{\circ} \mathrm{C}$

0

1

2

THERMOELECTRIC VOLTAGE IN ABSOLUTE MILLIVOLTS

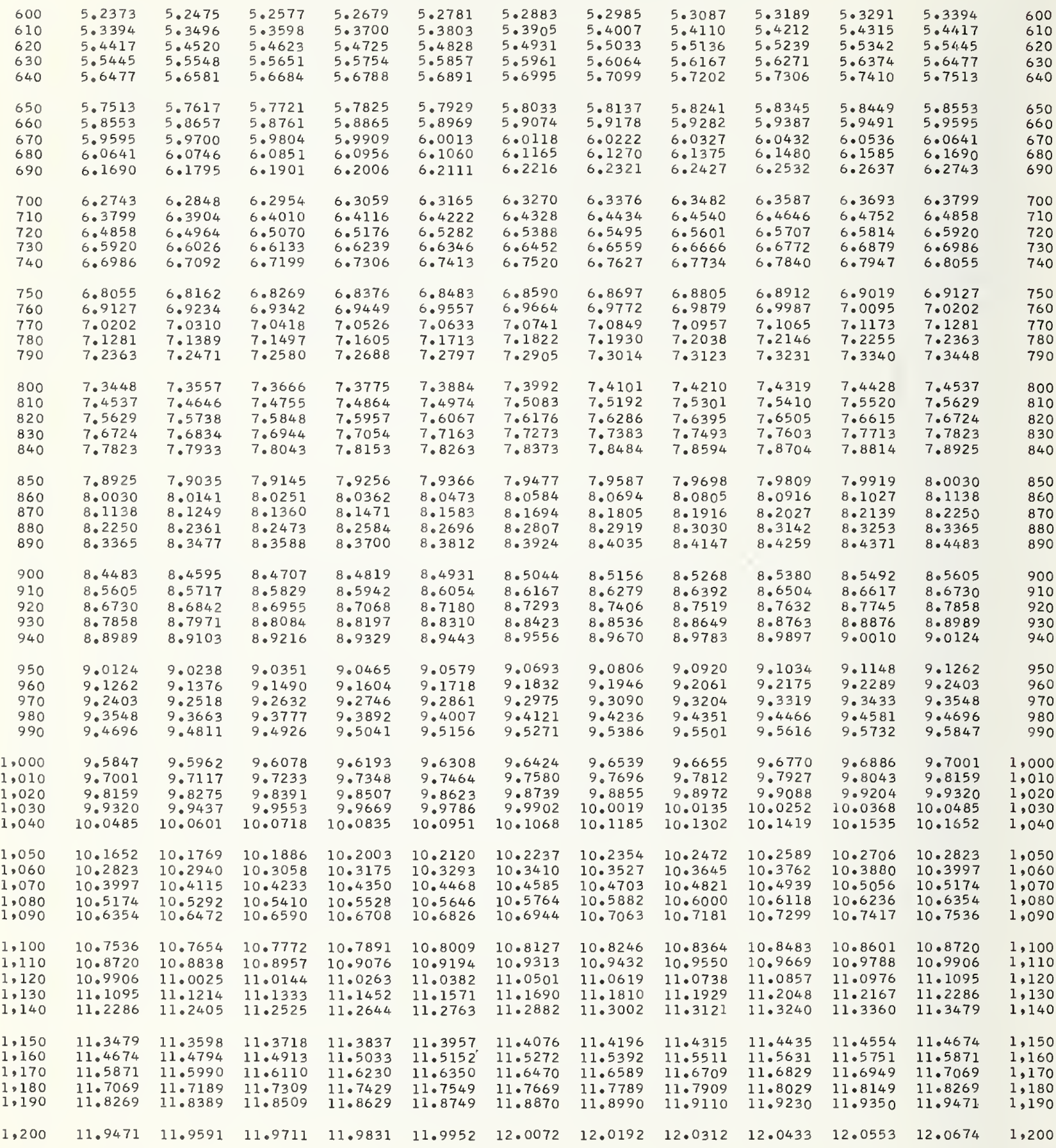

9 
TABLE A2.1.1. Type $S$ thermocouples-thermoelectric voltage as a function of temperature $\left({ }^{\circ} \mathrm{C}\right)$, reference junctions at $0^{\circ} \mathrm{C}$-Continued

3

4

5

6

7

THERMOELECTRIC VOLTAGE IN ABSOLUTE MILLIVOLTS

\begin{tabular}{|c|c|c|c|c|c|c|c|c|c|c|c|c|}
\hline 1,200 & 11.9471 & 11.9591 & 11.9711 & 11.9831 & 11.9952 & 12.0072 & 12.0192 & 12.0312 & 12.0433 & 12.0553 & 12.0674 & 1,200 \\
\hline & 12.0674 & 0794 & 914 & 12 & 155 & 1276 & 12 & 12.1516 & 10 & 12.1757 & 12.1878 & 1.210 \\
\hline 220 & & 12.1998 & 119 & 12 & 360 & 12.2481 & 12.2601 & 12.2722 & 12.2842 & 12.2963 & & 1,220 \\
\hline 1,230 & 12.3083 & 12.3204 & 12.3325 & 12.3445 & 12.3566 & 12.3687 & 12.3807 & 12.3928 & 12.4049 & 12.4170 & 12.4290 & 1,230 \\
\hline & 12.4290 & 12.4411 & 12.4532 & 12.4652 & 12.4773 & 12.4894 & 12.5015 & 12.5136 & 12.5256 & 12.5377 & 12.5498 & 1,240 \\
\hline 1,250 & 12.5498 & 2.5619 & 12.5740 & 12.5861 & 12.5981 & 12.6102 & 12.6223 & 12.6344 & 12.6465 & 12.6586 & 12.6707 & , \\
\hline 1,260 & 12.6707 & 2.6828 & 12.6949 & 12.7070 & 12.7191 & 12.7312 & 12.7433 & 12.7554 & 12.7675 & 12.7796 & 12.7917 & 1,260 \\
\hline 1,270 & 12.7917 & 2.8038 & 12.8159 & 12.8280 & 12.8401 & $12 \cdot 8522$ & 12.8643 & 12.8764 & 12.8885 & 12.9006 & 12.9127 & 1,270 \\
\hline 1,280 & 12.9127 & 12.9248 & 12.9369 & 12.9490 & 12.9611 & 12.9733 & 12.9854 & 12.9975 & 13.0096 & 13.0217 & 13.0338 &, 280 \\
\hline ,290 & 13.0338 & 13.0459 & 13.0581 & 13.0702 & 13.0823 & 13.0944 & 13.1065 & 13.1186 & 13.1308 & 13.1429 & 13.1550 & 1,290 \\
\hline 1,300 & 550 & 671 & 13.1792 & 13.1914 & 13.2035 & 156 & 13.2277 & 13.2398 & 13.2520 & 13.2641 & 13.2762 & 300 \\
\hline 1,310 & 3.2762 & 3.2883 & 13.3005 & 13.3126 & 13.3247 & 13.3369 & 13.3490 & 13.3611 & 13.3732 & 13.3854 & 13.3975 & .310 \\
\hline 1,320 & 13.3975 & 13.4096 & 13.4217 & 13.4339 & 13.4460 & 13.4581 & 13.4703 & 13.4824 & 13.4945 & 13.5067 & 13.5188 & 1,320 \\
\hline 330 & 13.5188 & 13.5309 & 13.5430 & 13.5552 & 13.5673 & 13.5794 & 13.5916 & 13.6037 & 13.6158 & 13.6280 & 13.6401 & 1,330 \\
\hline 340 & 3.6401 & 3.6522 & 13.6644 & 13.6765 & 13.6886 & 13.7008 & 13.7129 & 13.7250 & 13.7372 & 13.7493 & 13.7614 & 1,340 \\
\hline 1,350 & 3.7614 & 3.7736 & 13.7857 & 13.7978 & 13.8100 & 13.8221 & 13.8342 & 13.8464 & 13.8585 & 13.8706 & 13.8828 & 1,350 \\
\hline 1,360 & 13.8828 & 3.8949 & 13.9070 & 13.9192 & 313 & 434 & 556 & 677 & 9798 & & 041 & 360 \\
\hline 1,370 & 14.0041 & 14.0162 & 14.0284 & 14.0405 & 14.0526 & 14.0648 & 14.0769 & 14.0890 & 14.1012 & 14.1133 & 14.1254 & 1,370 \\
\hline 1,380 & 14.1254 & 14.1375 & 14.1497 & 14.1618 & 14.1739 & 14.1861 & 14.1982 & 14.2103 & 14.2224 & 14.2346 & 14.2467 & 1,380 \\
\hline 390 & 14.2467 & 14.2588 & 14.2710 & 14.2831 & 14.2952 & 14.3073 & 14.3195 & 316 & 14.3437 & $14 \cdot 3558$ & 14.3680 & 390 \\
\hline .00 & 80 & 14.3801 & 14.3922 & 14.4043 & 14.4164 & 14 & 107 & 28 & 14.4649 & 770 & 14.4892 & 400 \\
\hline 1,410 & 92 & 013 & 14. & 14.5255 & 376 & 97 & 619 & 740 & 861 & 382 & 103 & 1,410 \\
\hline 1,420 & 14.6103 & 14.6224 & 14.6345 & 14.6467 & 588 & 709 & 830 & 5951 & 7072 & 14.7193 & 14.7314 & 420 \\
\hline 1,430 & 14.7314 & 14.7435 & 14.7556 & 14.7677 & 14.7798 & 14.7919 & 14.8040 & 14.8161 & 14.8282 & 14.8403 & 14.8524 &, 430 \\
\hline 1,440 & 14.8524 & 14.8645 & 14.8766 & 14.8887 & 14.9008 & 14.9129 & 14.9250 & 14.9371 & 14.9492 & 14.9613 & 14.9734 & 1,440 \\
\hline 1,450 & 734 & 355 & 975 & 96 & 217 & 338 & 59 & 80 & 701 & 21 & 15 & 50 \\
\hline & 42 & 63 & 84 & 04 & 1 & 46 & 37 & 87 & 08 & & 0 & 460 \\
\hline 70 & 150 & 15. & 15. & 512 & 632 & 753 & 874 & 994 & 115 & 235 & 56 & 470 \\
\hline 80 & 356 & 15.3476 & 15.3597 & 15.3718 & 15.3838 & 959 & 079 & 200 & 320 & 441 & 561 & 1,480 \\
\hline 490 & 5.4561 & 15.4682 & 15.4802 & 15.4922 & 15.5043 & 15.5163 & 284 & 404 & 5524 & 645 & 765 & 1,490 \\
\hline 1,500 & $\begin{array}{l}15.5765 \\
15.6967\end{array}$ & $\begin{array}{l}5885 \\
7088\end{array}$ & 15. & $\begin{array}{l}26 \\
28\end{array}$ & 15 & $\begin{array}{l}15 \\
15\end{array}$ & $\begin{array}{l}37 \\
38\end{array}$ & & $\begin{array}{l}27 \\
28\end{array}$ & & & 500 \\
\hline 1,520 & $\begin{array}{l}12.0701 \\
15.8168\end{array}$ & $\begin{array}{l}12 . \\
15 .\end{array}$ & $\begin{array}{l}120^{\circ} \\
15 .\end{array}$ & $\begin{array}{l}15 \\
15\end{array}$ & $\begin{array}{l}15 \\
15\end{array}$ & 8 & 88 & 8 & 28 & 248 & $\begin{array}{l}168 \\
368\end{array}$ & $\begin{array}{l}1,510 \\
1,520\end{array}$ \\
\hline & & 15. & & 27 & & & & & & 446 & 566 & .530 \\
\hline 1,540 & 566 & 16.0685 & 16.0805 & 16.0925 & 16.1044 & 16.1 & 16. & 16.1403 & 523 & 1642 & 16.1762 & 1,540 \\
\hline $\begin{array}{l}1,550 \\
1,560\end{array}$ & $\begin{array}{l}16.1762 \\
16.2956\end{array}$ & $\begin{array}{l}381 \\
75\end{array}$ & $\begin{array}{l}16 . \\
16 .\end{array}$ & $\begin{array}{l}16 \\
16\end{array}$ & $\begin{array}{l}16 . \\
16 .\end{array}$ & $\begin{array}{l}16 \\
16\end{array}$ & & & $\begin{array}{l}717 \\
910\end{array}$ & & & $\begin{array}{l}550 \\
560\end{array}$ \\
\hline & & & 16 & 05 & & & & 81 & $\$ 100$ & 219 & 338 & 570 \\
\hline 1, & 38 & 16. & 16.5576 & 695 & 813 & & 51 & 70 & 89 & & & 580 \\
\hline 1,590 & 526 & 16.6645 & 16.6763 & 16.6882 & 16.7001 & 16.7119 & 238 & 356 & 475 & 93 & 712 & 590 \\
\hline & 12 & 0 & 16 & 067 & 35 & & & & & & & \\
\hline & & & & & & & & & & & 76 & 510 \\
\hline 1 & 76 & 94 & 17 & 17 & & & & & & & & \\
\hline & & & & & & & & & & & & 630 \\
\hline 1 , & 431 & 548 & 17.2665 & 783 & 17.2900 & 18 & 35 & 252 & 369 & +87 & 17.3604 & 1,640 \\
\hline 1,6 & 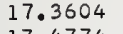 & 21 & 17 & 17 & 17 & & & & & & & \\
\hline & 774 & 391 & & & & & & & & & & \\
\hline & 42 & & 175 & 91 & & & & & & & & \\
\hline & 105 & 222 & 17.7338 & 54 & 570 & 17 & 301 & 17 & 33 & 49 & 64 & 1,680 \\
\hline & & 380 & 8495 & 17.8611 & 17.8726 & 17.8841 & 17.8957 & 17.9072 & 17.9187 & 17.9302 & 17.9417 & 1,690 \\
\hline 1,700 & 9417 & 532 & 17.9 & 17 & 17 & 17.95 & 5 & 1 & 33 & 8 & 1 & \\
\hline & & & & & & & & & & & & \\
\hline & 18 & 18.1811 & 18.1 & & 49 & & & & & & & 720 \\
\hline & & & & & & & & & & & & 30 \\
\hline & 18 & 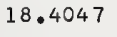 & 58 & 268 & 18.4379 & 18 & 18 & 18 & 18 & 28 & 18.5038 & 1,740 \\
\hline 1,7 & & 18.5147 & 18.5256 & 18.5365 & 18.5474 & 18 & 91 & 18. & 08 & 18.6016 & 18.6124 & 1,750 \\
\hline & & 32 & 39 & 447 & 54 & 61 & 68 & & 82 & & & 760 \\
\hline & 0 & 1 & 2 & 3 & 4 & 5 & 6 & 7 & 8 & 9 & 10 & \\
\hline
\end{tabular}


TABLE A2.1.2. Type $S$ thermocouples-thermoelectric voltage as a function of temperature $\left({ }^{\circ} \mathrm{F}\right)$, reference junctions at $32^{\circ} \mathrm{F}$

${ }^{\circ} \mathrm{F}$

1

2

3

4

5

6

7

8

9

10

${ }^{\circ} \mathrm{F}$

THERMOELECTRIC VOLTAGE IN ABSOLUTE MILLIVOLTS

$\begin{array}{lll}-50 & -0.2177 & -0.2200 \\ -40 & -0.1944 & -0.1968 \\ -30 & -0.1702 & -0.1726 \\ -20 & -0.1450 & -0.1475 \\ -10 & -0.1189 & -0.1215 \\ -0 & -0.0919 & -0.0946\end{array}$

\begin{tabular}{|c|c|c|}
\hline-0.2223 & -0.2246 & -0.2268 \\
\hline 1.195 & -0.2015 & -0.203 \\
\hline 175 & -0.1776 & -0.180 \\
\hline-0.1501 & -0.1526 & -0.1552 \\
\hline-0.1242 & -0.1268 & .1294 \\
\hline-0.0974 & -0.1001 & -0.1028 \\
\hline
\end{tabular}

-0.2290
-0.2062
-0.1824
-0.1577
-0.1320
-0.1055

$-0.2313$

$-0.233$

$-0.2357$

$-0.2085$

$-0.1602$

$-0.1873$

$-0.2132$

$-0.1652$

$-0.1398$

$\begin{array}{lll}-0.1921 & -0.1944\end{array}$

$-0.1677-0.1702$

$-0.1424-0.1450$

$-0.1136$

$-0.1162-0.1189$

$-50$

$-40$

$-30$

$-20$

$-10$

${ }^{\circ} \mathrm{F}$

2

3

4

6

7

8

9

10

${ }^{\circ} \mathrm{F}$ 
TABLE A2.1.2. Type $S$ thermocouples-thermoelectric voltage as a function of temperature $\left({ }^{\circ} \mathrm{F}\right)$, reference junctions at $32^{\circ} \mathrm{F}$-Continued

THERMOELECTRIC VOLTAGE IN ABSOLUTE MILLIVOLTS

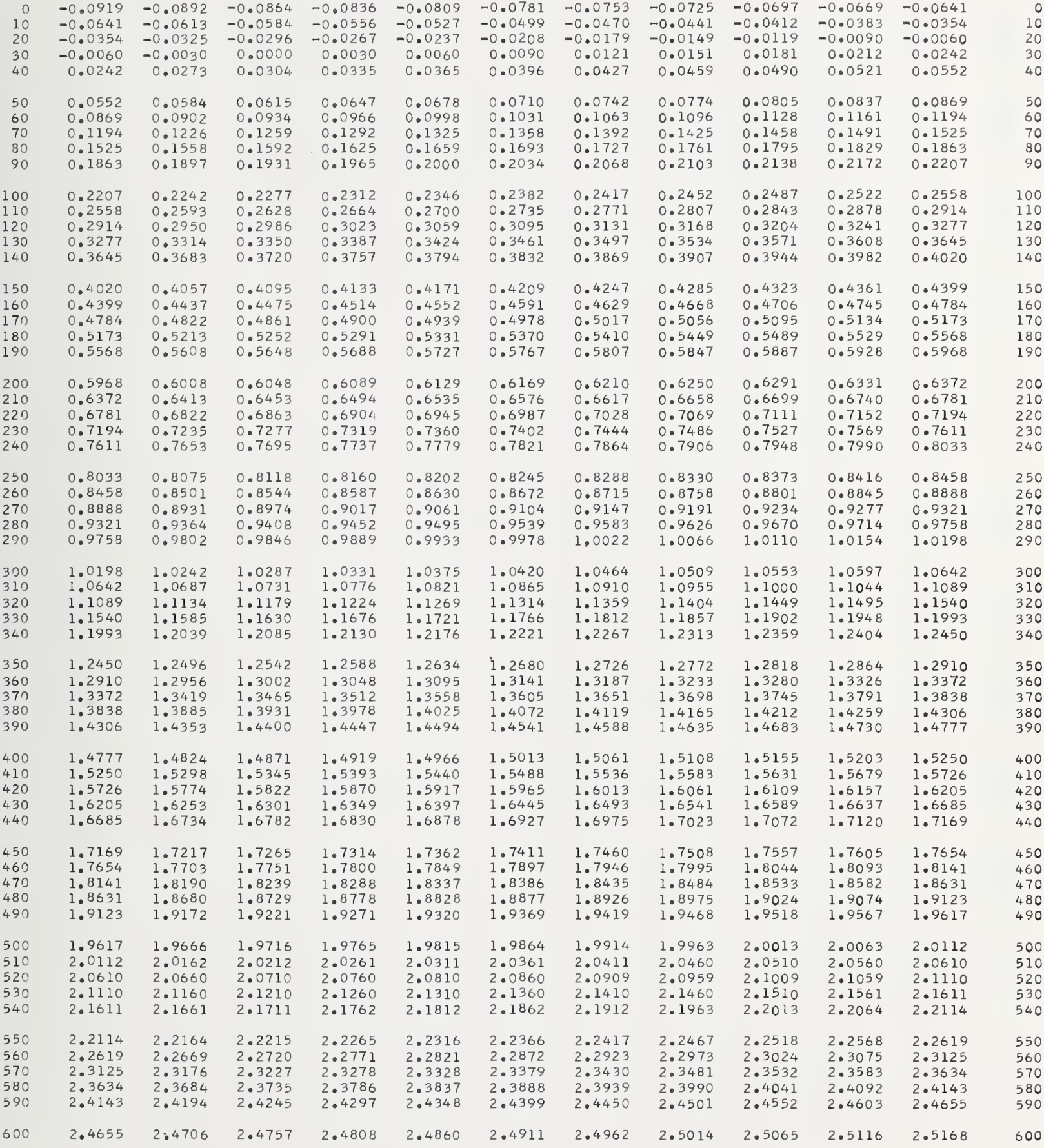


TABLE A2.1.2. Type $S$ thermocouples-thermoelectric voltage as a function of temperature $\left({ }^{\circ} \mathrm{F}\right)$, reference junctions at $32{ }^{\circ} \mathrm{F}$-Continued

5

6

7

8

9

10

${ }^{\circ} \mathrm{F}$

THERMOELECTRIC VOLTAGE IN ABSOLUTE MILLIVOLTS

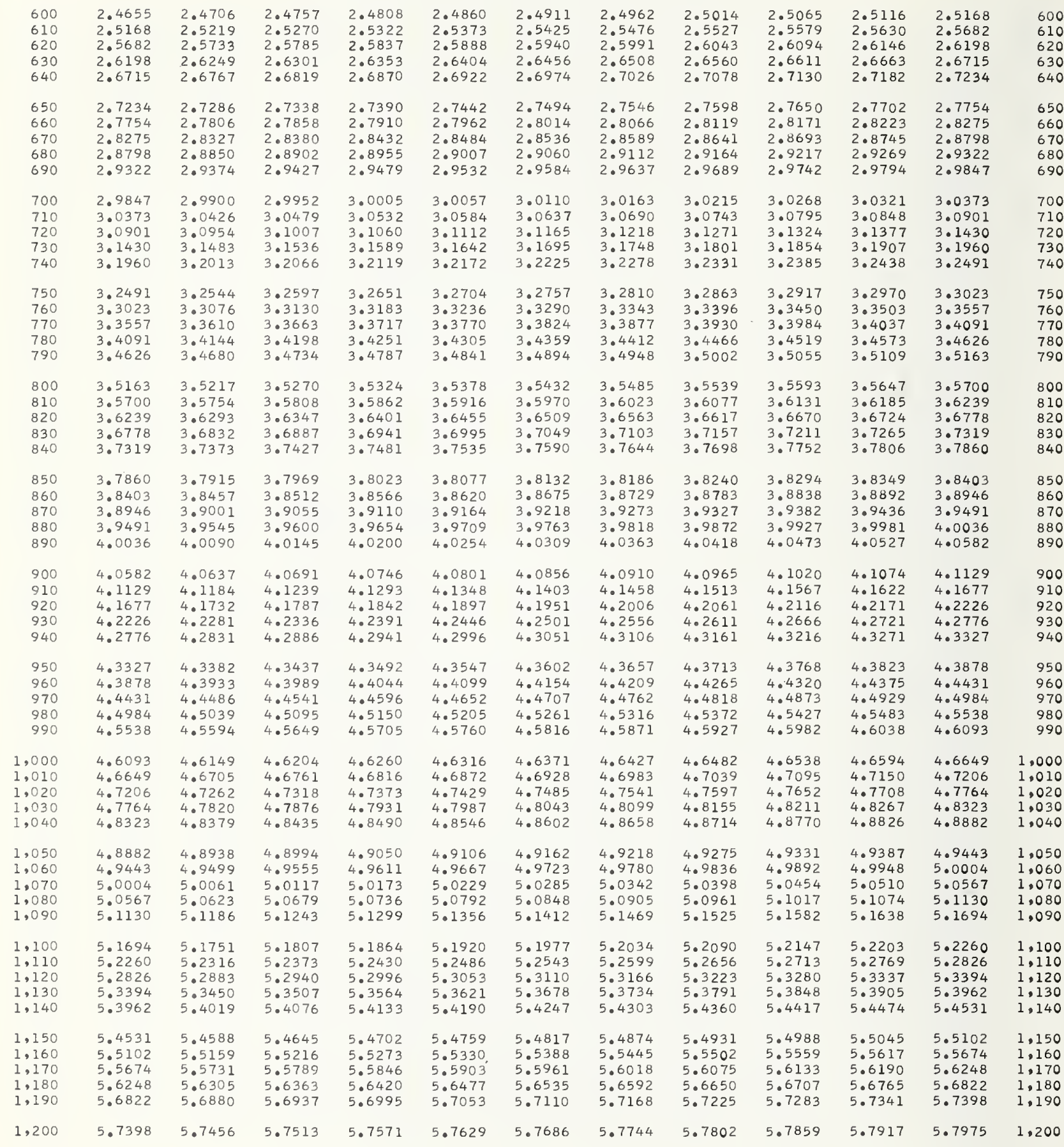


TABLE A2.1.2. Type $S$ thermocouples-thermoelectric voltage as a function of temperature $\left({ }^{\circ} \mathrm{F}\right)$, reference junctions at $32^{\circ} \mathrm{F}$-Continued

${ }^{\circ} \mathrm{F}$

0

5.7975

5.8553

5.9132

1,230

1,240

1,250

1,260

1,280

1,290

6.0292

6.0874

6.1457

6.2041

6.2626

1,300

6.3212

6.3799

6.4387

6.4976

6.5565

1,330
1,340

1,350

1,360

1.370

1,380
1,390

1,400

1,410

1,420

1,430

1,440

1,450

1,460

1.470

1,490

1,500

1,510

1.520

1,530

1,540

6.6156

6.6749

6.7342

6.7936

6.8531

6.9127

6.9724

7.0322

7.092

7.1521

7.2122

7.2725

7.3328

7.4537

7.5143

7.5751

7.6359

7.6968

7.7578

1,550

1,560

1.570

7.8190

7.8802

7.9415

8.0030

1.590

1,600

1,610

1,620

1,630

1,640

8.1879

8.2497

8.3117

8.3737

1,660

1,670

1,680

1,690

8.4359

8.4981

8.5605

8.6229

8.6855

1,700

1,710

8.7481

8.8109

8.8738

1,730
1.740

1,750

1,760

1,770

1,780

1,790

1,800

9.0629

THERMOELECTRIC VOLTAGE IN ABSOLUTE MILLIVOLTS

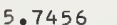

$5.7456 \quad 5.7513$

5.8033

5.8611

5.9189

5.8090

5.8668

5.9247

5.9827

6.0350

6.0932

. 1515

6.2099

6.2684

6.3270

6.3857

6.4445

6.5034

6.0408

6.0991

6.1574

6.2158

6.2743

6.3329

6.3916

6.4504

6.5093

6.5684

6.6216

6.6808

6.6275

6.6867

6.7460

6.8055

6.8650

6.9246

6.9843

7.0442

7.1041

7.0981

7.1641

7.2183

7.2785

7.3388

7.2243

7.2845

7.3448

7.4053

7.4598

7.5204

7.4658

7.5265

7.5872

7.7640

7.6481

7.7090

7.7701

7.8251

7.8863

7.9477

7.8312

7.8312
7.8925

7.9538

8.0153

8.0707

8.0768

$\begin{array}{ll}5.7571 & 5.7629\end{array}$

$5.8148 \quad 5.8206$

5.8726

5.9305

5.8784

5.9363

5.8264

5.9886

5.9944

$6.0467 \quad 6.0525$

$6.1049 \quad 6.1107$

6.16326 .1690

6.2216

6.2801

6.2275

6.2860

$6.3388 \quad 6.3446$

6.3975

6.4563

6.5152

6.4622

6.5211

6.5802

6.6334

6.6926

6.6393

6.7520

6.6986

6.7579

6.8173

6.8709

6.8769

6.9306

6.9365

6.9903

7.0502

7.1101

6.996

7.0561

7.1161

7.2303

7.2905

7.3509

7.2363

7.2363
7.2966

7.3569

7.4174

7.4719

7.4780

7.5325

7.5933

7.5386

7.6542

7.7151

7.5994

7.6602

7.776

7.7823

7.8373

7.8986

7.9600

7.8435

8.0214

7.9047

7. 9661

8.0276

8.0892

8. 1447

8.1508

.194

8.1385

8.2003

8.2064

8.2126

8.2683

.2745

8.3241

8.3862

8.3924

8.3986

8.4421

8.4483

8.5106

8.5730

8.6354

8. 5168

8.4608

8. 5231

8.5792

8.6417

8.6292

8.6980

8.7043

8.7607

8.7670

8.8297

8.8926

8.9556

8.8800

8.9430

8.9493

9.0124

9.0187

9.0693

9.0756

9.1389

9.0819

9.1452

9.2086

9.2721

8. 585

8.6479

8.7105 
TABLE A2.1.2. Type $S$ thermocouples-thermoelectric voltage as a function of temperature $\left({ }^{\circ} \mathrm{F}\right)$, reference junctions at $32{ }^{\circ} \mathrm{F}$-Continued

${ }^{\circ} \mathrm{F}$

0

1

2

3

4

5

6

7

8

9

10

${ }^{\circ} \mathrm{F}$

THERMOELECTRIC VOLTAGE IN ABSOLUTE MILLIVOLTS

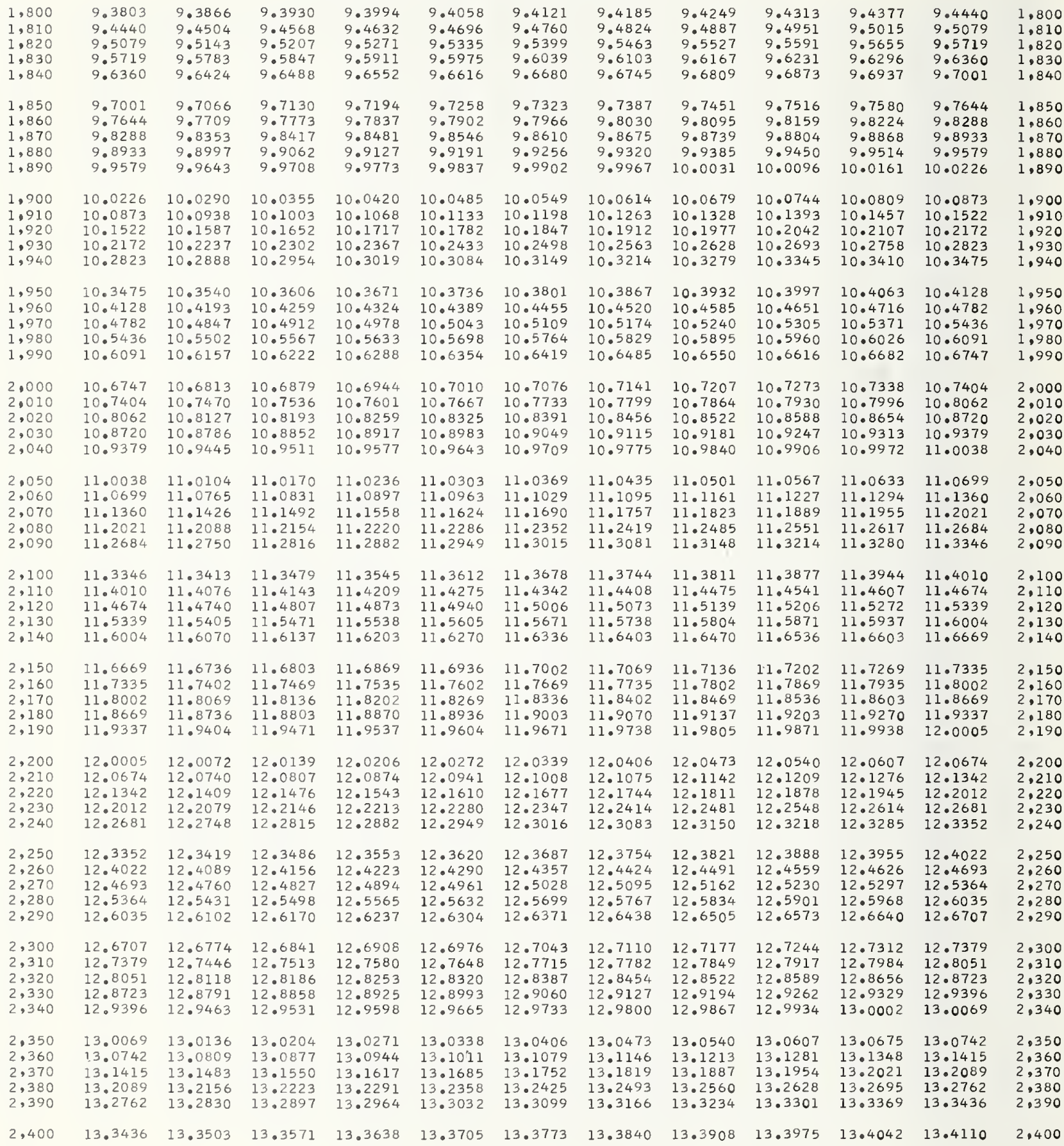

9.3803

9.5079

9.5719

9.6360

9.9579

10.2823

1.268

11.3346

11.4674

1.533

1.6669

12.000

12.0674

13.3436
9.7194

9.9127

.9191

10.0485

10.2433

10.3084

10.5698

10.7010

.7667

10.8983

.4275

11.0270

11.8269

12.027

12.2949

. 3620

12.4961

12.5632

12.6976

12.9665

13.168

13.3032

13.3705
4185

9.7387

9.9967

$10.0549 \quad 10.0614$

$0.3801 \quad 10.3867$

.3015

.3678

13.384

13.3908
9.431

9.559

9.716

10.0096

10.0744

$11.8536 \quad 11.8603$

$12.9934 \quad 13.0002$

3.0069

.350

360

.380

2.400

3

6

7

8

9

10 
TABLE A2.1.2. Type S thermocouples-thermoelectric voltage as a function of temperature $\left({ }^{\circ} \mathrm{F}\right)$, reference junctions at $32^{\circ} \mathrm{F}$-Continued

THERMOELECTRIC VOLTAGE IN ABSOLUTE MILLIVOLTS

\section{2,65
2,66
2,67}

2,670
2,680

2,680

2,700

2,710

2,730

2,730
2,740

2,750

2,760

2,770

2,780
2,790

2,800

2,800
2,81

2,810
2,82

2,830

2,840

2,850

2,86

2,870

2,880

2,890

2,900
2,910

2,910

2,93

2,940

2,950

2,960

2,970

2,980

2,990

3,000

\begin{abstract}
13.3436
13.4110

13.4784
13.5457

13.6131
\end{abstract}

13.6805

13.7480

13.8154

13.8828

13.9502

14.0176

14.0850

14.1524

14.2198

14.2871

14.3545

14.4218

14.4892

14.5565

14.6238

14.6911

14.7583

14.8255

14.8928

14.9599

15.0271

15.0942

15.1613

15.2284

15.2954

15.3624

15.4293

15.4963

15.5631

15.6967

15.7635

15.8302

15.8968

15.9634

16.0300

16.0964

16.1629

16.2293

16.2956

16.3618

16.4280

16.4942

16.5602

16.6262

16.6922

16.7580

16.8238

16.8895

16.9552

17.0207

17.0862

17.1516

17.2170

17.2822

17.3474

\begin{abstract}
$13.4177 \quad 13.4244$
$\begin{array}{ll}3.4851 & 13.4918\end{array}$

$13.5525 \quad 13.5592$

13.6199
\end{abstract}

$\begin{array}{lll}13.6873 & 13.6940\end{array}$

$13.7547 \quad 13.7614$

$13.8221 \quad 13.8288$

$13.8895 \quad 13.8963$

13.956913 .9637

$14.0243 \quad 14.0311$

$14.0917 \quad 14.0985$

$14.1591 \quad 14.1658$

$14.2265 \quad 14.2332$

14.2939

14.3612

14.4286

14.4959

14.5632

14.6305

14.6978

14.7650

14.8995

14.9666

15.0338

15.1009

15.1680

15.2351

15.3021

15.3691

15.4360

15.5029

15.5698

15.6366

15.7034

15.7702

15.8368

15.9035

15.9701

16.0366

16.103

16.1695

16.2359

14.3006

14.3680

14.4353

14.5026
14.5699

14.6372

14.7045

14.7718

14.8390

14.9062

14.9734

15.0405

15.1076

15.1747
15.2418

15.3088

13.4312
13.4986

13.5660
13.6334

13.4379

$\begin{array}{ll}13.5053 & 13.4447\end{array}$

$13.5727 \quad 13.5794$

13.7008

13.7682
13.8356

13.9030

13.9704

14.0378

14.1052

14.2400

14.3073

14.3747

14.5094

14.5767

14.6440

14.7112

14.7785
14.8457

14.9129

14.9801

15.0472

15.1143
15.1814

15.1814
15.2485

15.3155

15.3758

15.4427
15.5096

15.5765

15.3825

15.4494

15.5832

13.6401

13.6468

$13.7075 \quad 13.7143$

$13.7749 \quad 13.7817$

$\begin{array}{ll}13.8423 & 13.8491\end{array}$

$13.9097 \quad 13.916$

14.0445

14.1119

14.1793

14.2467

14.3141

14.381

14.5161

14.5834

14.6507

14.7180

14.7852

14.9196

14.9868

15.0539

15.1211

15.1881

15.2552

15.3892

15.4561

15.5230

15.5899

15.7101

15.7768

15.6500

16.3022

16.3685

16.4346

16.5668

16.6328

15.9101

15.7168

15.7835

15.8502

15.9168

15.9767

16.6987

16.7646

16.8304

16.8961

16.0433

16.1097

16.1762

16.0499

16.1164

16.1164
16.1828

16.2492

16.3088

16.3155

16.3751

16.4413

16.5074

16.5734

16.3817 
TABLE A2.1.2. Type $S$ thermocouples-thermoelectric voltage as a function of temperature $\left({ }^{\circ} \mathrm{F}\right)$, reference junctions at $32^{\circ} \mathrm{F}$-Continued

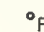

0

1

2

$\begin{array}{lllll}3,000 & 17.3474 & 17.3539 & 17.3604 & 17 \\ 3,010 & 17.4124 & 17.4189 & 17.4254 & 17 \\ 3,020 & 17.4774 & 17.4839 & 17.4904 & 17 \\ 3,030 & 17.5423 & 17.5488 & 17.5553 & 17 \\ 3,040 & 17.6071 & 17.6136 & 17.6201 & 17 \\ 3,050 & 17.6718 & 17.6783 & 17.6847 & 17 \\ 3,060 & 17.7363 & 17.7428 & 17.7492 & 17 \\ 3,070 & 17.8007 & 17.8072 & 17.8136 & 17 \\ 3,080 & 17.8649 & 17.8713 & 17.8777 & 170 \\ 3,090 & 17.9289 & 17.9353 & 17.9417 & 17 \\ 3,100 & 17.9927 & 17.9990 & 18.0054 & 18 \\ 3,110 & 18.0562 & 18.0625 & 18.0688 & 18 \\ 3,120 & 18.1194 & 18.1257 & 18.1320 & 18 \\ 3,130 & 18.1823 & 18.1886 & 18.1949 & 18 \\ 3,140 & 18.2449 & 18.2512 & 18.2574 & 18 \\ 3,150 & 18.3072 & 18.3134 & 18.3196 & 1 \\ 3,160 & 18.3690 & 18.3752 & 18.3814 & 18 \\ 3,170 & 18.4305 & 18.4366 & 18.4428 & 18 \\ 3,180 & 18.4916 & 18.4977 & 18.5038 & 1 \\ 3,190 & 18.5522 & 18.5583 & 18.5643 & 18 \\ 3,200 & 18.6124 & 18.6184 & 18.6244 & 18 \\ 3,210 & 18.6721 & 18.6780 & 18.6839 & 18 \\ & & & & \end{array}$

3

4

5

6

7

8

10

${ }^{\circ} \mathrm{F}$

HERMOELECTRIC VOLTAGE IN ABSOLUTE MILLIVOLTS

$\begin{array}{lllllllll}17.3669 & 17.3734 & 17.3799 & 17.3864 & 17.3929 & 17.3994 & 17.4059 & 17.4124 & 3,000 \\ 17.4319 & 17.4384 & 17.4449 & 17.4514 & 17.4579 & 17.4644 & 17.4709 & 17.4774 & 3,010 \\ 17.4969 & 17.5034 & 17.5099 & 17.5164 & 17.5229 & 17.5293 & 17.5358 & 17.5423 & 3,020 \\ 17.5618 & 17.5682 & 17.5747 & 17.5812 & 17.5877 & 17.5942 & 17.6006 & 17.6071 & 3,030 \\ 17.6265 & 17.6330 & 17.6395 & 17.6459 & 17.6524 & 17.6589 & 17.6653 & 17.6718 & 3,040 \\ 17.6912 & 17.6976 & 17.7041 & 17.7105 & 17.7170 & 17.7234 & 17.7299 & 17.7363 & 3,050 \\ 17.7557 & 17.7621 & 17.7686 & 17.7750 & 17.7814 & 17.7879 & 17.7943 & 17.8007 & 3,060 \\ 17.8200 & 17.8264 & 17.8329 & 17.8393 & 17.8457 & 17.8521 & 17.8585 & 17.8649 & 3,070 \\ 17.8841 & 17.8905 & 17.8969 & 17.9033 & 17.9097 & 17.9161 & 17.9225 & 17.9289 & 3,080 \\ 17.9481 & 17.9544 & 17.9608 & 17.9672 & 17.9736 & 17.9799 & 17.9863 & 17.9927 & 3,090 \\ 18.0117 & 18.0181 & 18.0245 & 18.0308 & 18.0371 & 18.0435 & 18.0498 & 18.0562 & 3,100 \\ 18.0752 & 18.0815 & 18.0878 & 18.0941 & 18.1005 & 18.1068 & 18.1131 & 18.1194 & 3,110 \\ 18.1383 & 18.1446 & 18.1509 & 18.1572 & 18.1635 & 18.1698 & 18.1760 & 18.1823 & 3,120 \\ 18.2011 & 18.2074 & 18.2137 & 18.2199 & 18.2262 & 18.2324 & 18.2387 & 18.2449 & 3,130 \\ 18.2636 & 18.2699 & 18.2761 & 18.2823 & 18.2885 & 18.2947 & 18.3010 & 18.3072 & 3,140 \\ 18.3258 & 18.3320 & 18.3381 & 18.3443 & 18.3505 & 18.3567 & 18.3629 & 18.3690 & 3,150 \\ 18.3875 & 18.3937 & 18.3998 & 18.4060 & 18.4121 & 18.4183 & 18.4244 & 18.4305 & 3,160 \\ 18.4489 & 18.4550 & 18.4611 & 18.4672 & 18.4733 & 18.4794 & 18.4855 & 18.4916 & 3,170 \\ 18.5098 & 18.5159 & 18.5220 & 18.5280 & 18.5341 & 18.5401 & 18.5462 & 18.5522 & 3,180 \\ 18.5703 & 18.5763 & 18.5824 & 18.5884 & 18.5944 & 18.6004 & 18.6064 & 18.6124 & 3,190 \\ 18.6303 & 18.6363 & 18.6423 & 18.6482 & 18.6542 & 18.6602 & 18.6661 & 18.6721 & 3,200 \\ 18.6899 & 18.6958 & & & & & & 3,210\end{array}$

3

4

5

6

7

8

9

10

${ }^{\circ} \mathrm{F}$ 
TABLE A2.1.3. Type $S$ thermocouples-quadratic, cubic, and quartic approximations to the data as a function of temperature $\left({ }^{\circ} \mathrm{C}\right)$ in selected temperature ranges. The expansion is of the form

$\mathrm{E}=\mathrm{a}_{0}+\mathrm{a}_{1} \mathrm{~T}+\mathrm{a}_{2} \mathrm{~T}^{2}+\mathrm{a}_{3} \mathrm{~T}^{3}+\mathrm{a}_{4} \mathrm{~T}^{4}$ where $\mathrm{E}$ is in microvolts and $\mathrm{T}$ is in degrees Celsius

Temperature

Range $\left({ }^{\circ} \mathrm{C}\right)$

\begin{tabular}{|c|c|c|}
\hline$a_{0}$ & & $a_{1}$ \\
\hline rgument & Exp. & Argument \\
\hline . . . & - & 5.5439639 \\
\hline . . & - . & 5. 8791282 \\
\hline$\cdots$ & . & 6.2516859 \\
\hline$\ldots$ & - . & 6. 5554932 \\
\hline$\ldots$. & .. & 6. 6834421 \\
\hline 8051591 & +2 & 8.7228147 \\
\hline 2412524 & +2 & 9.5827994 \\
\hline .0061921 & +2 & 9.4591354 \\
\hline 4352322 & +3 & 2.9873073 \\
\hline .3054176 & +3 & 3. 4129348 \\
\hline .8695058 & +2 & 6.4091373 \\
\hline .0863331 & +3 & 3. 9952876 \\
\hline .4180405 & +4 & 2. 0043202 \\
\hline .2703440 & +4 & -1.3532278 \\
\hline
\end{tabular}

$\frac{a_{2}}{\text { Igument }}$

Error

I. Quartic Equation

Exp.

- 50 to 900

0 to 1100

0 to 1400

0 to 1650

0 to 1768

400 to 1100

400 to 1400

400 to 1650

1050 to 1400

1050 to 1650

1400 to 1550

1400 to 1650

1400 to 1768

1666 to 1768

8. 2703440

$-1.3532278$

6. 1727088

6.5318477

6.7532549

6. 7665573

6. 7203042

8. 2834531

7. 5202132

6.6930160

3. 4602987

3. 4888591

3. 6416331

3.5056963

$-1.3424041$

$-1.7012950$

5.3994446

junction correction

1666 to 1768

riable reference junction correction

0 to 50

III. Quadratic Equation

\begin{tabular}{|c|c|c|c|}
\hline 50 & & & \\
\hline 0 & to & $\cdots \cdots \cdots$ & \\
\hline 0 & to 1400 & - & \\
\hline 0 & 50165 & & \\
\hline & 101030 & $\cdots \cdots$ & \\
\hline 0 & to 1768 & . . & \\
\hline 400 & to 1100 & -2.9751812 & +2 \\
\hline 400 & to 1400 & -3.8977488 & +2 \\
\hline 400 & to 1650 & -6.0634145 & +2 \\
\hline 1050 & to 1400 & 5719586 & +3 \\
\hline 1050 & to 1650 & -2.4585270 & +3 \\
\hline 1400 & to 1550 & -3.7608363 & +3 \\
\hline 1400 & to 1650 & -4.2764947 & +3 \\
\hline 1400 & to 1768 & -5.7168249 & +3 \\
\hline 1666 & to 1768 & -1.5978814 & +4 \\
\hline
\end{tabular}

Variable reference junction correction

0 to 50
7. 0208414

7. 2387148

7.4959163

7. 7773856

7. 9553026

8. 2381836

8.5122920

9.1029993

1.0540713
1.1994364

1. 3754357

1.4453542

1.6348865

2. 8439331

5.4231535
1.0103667

7. 9098118

5.8347856

4. 4519908

3. 9334084

6. 2984807

$-1.2077351$

$-9.7986687$

6. 9951678

6.4741403

3. 4664812

5. 8939317

$-1.8607781$

8. 0243878

5. 7640155

4. 4314159

3. 7355199

3. 7028557

3. 8113477

1. 5802448

2. 6472719

3. 6814923

6.4119568

6. 3883551

6. 2841184

6. 3768029

1. 7418790

1. 1066893

I. 2467754

-2
-3
-3
-3
-3
-4
-3
-4
-3
-3
-3
-3
-1
-2

-1.0944499
-6.7450002
-3.4351369
-1.6378513
-1.0384046
9.0526670
2.5723104
2.3967559
-1.8986036
-1.6163524
-2.7553724
-1.3595782
8.1899566
-1.0633404

-5
-6
-6
-6
-6
-7
-6
-6
-6
-6
-7
-6
-5
-5

4. 9628963

2. 5247577

9. $402220 \mathrm{C}$

2. 4140360

3. 4244511

$-2.9241601$

$-8.3681057$

$-7.8867971$

6. 5006637

7. 9103746

$-2.1606150$

$-3.4675031$

$-1.3556030$

$-1.7212343$

$-2.4622638$

$-1.3617466$

$-8.8324648$

$-8.6548628$

$-9.2098883$

2. 8242989

$-4.3957897$

$-8.3654340$

$-1.5800960$

$-1.5736364$

$-1.5499505$

$-1.5710024$

$-3.9666469$

$-2.2451634$

$-1.9934168$

-6
-6
-7
-7
-7
-8
-7
-7
-6
-6
-6
-6
-6
-5
-5

....

....

$\cdots$

.....

...

$\ldots .$.

....

.....

....

....

$\cdots$

....

....

....

,

2. 7110736

2. 3629498

2. 0280528

1. 7310445

1. 5630968

1. 6438011

1.4602609

1. 1089823

6.0483629

1.5127873

$-5.7526222$

$-8.1196867$

$-1.4335467$

$-4.9916234$

1.0940881

-3
-3
-3
-3
-3
-3
-3
-3
-4
-5
-4
-4
-3
-3

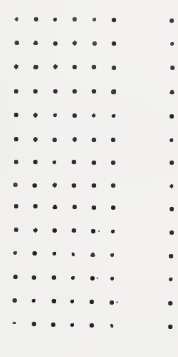

$\begin{array}{cc}a_{3} & a_{4} \\ \text { Argument Exp: Argument Exp. }\end{array}$

Range (LV)

Exact-Approx.

$-9 \quad-7$ to 14

-16 to 12

$-10 \quad-35$ to 25

$-10 \quad-55$ to 35

$-11 \quad-60$ to 35

$-10 \quad-1.6$ to 1.5

$-10 \quad-1.8$ to 1.9

$\begin{array}{ll}-11 & -.05 \text { to } .05\end{array}$

$-12 \quad-.05$ to .05

$-10 \quad-.05$ to .05

-.05 to .05

-1.0 to 1.3

-.05 to .05

-30 to 60

-51 to 31

-70 to 35

-70 to 35

-65 to 35

-6 to 10
-16 to 17

-16 to 17

-.05 to .05

-.05 to .05

-.05 to .05

-.05 to .05

-2 to 4

.05 to .05

-0.01 to +0.01

.... .. -90 to 110

.... .. -110 to 50

....... -140 to 70

...... -190 to 130

....... $\quad-260$ to 180

.... .. $\quad-1.1$ to 1.2

.... $\quad-22$ to 19

.... . . -80 to 60

.... . . -2.6 to 2.7

$\ldots . . . \quad-13$ to 13

.... $. . \quad-.2$ to .2

.... $\quad . .9$ to 1.0

....... . . 9 to 7

-.9 to 1.0

-0.1 to +0.2 


\section{A2.2. Data for Temperature as a Function of Voltage}

The temperature as a function of voltage data given in tables A2.2.1 and A2.2.2 were obtained by iteration in the primary equations for voltage as a function of temperature. Table A2.2.1 presents the data in millivolts from $-0.23 \mathrm{mV}$ to $18.69 \mathrm{mV}$ with temperatures given in degrees Celsius while table A2.2.2 presents similar data with temperatures in degrees Fahrenheit. Table A2.2.3 contains quadratic, cubic, and quartic approximations to the data as a function of voltage in selected temperature ranges. The error range given in the table represents the difference between the temperature found by iteration in the full precision tables from the text and from the respective reduced order approximations.

TABLE A2.2.1. Type $S$ thermocouples-temperature $\left({ }^{\circ} \mathrm{C}\right)$ as a function of thermoelectric voltage, reference junctions at $0^{\circ} \mathrm{C}$

\begin{tabular}{|c|c|c|c|c|c|c|c|c|c|c|c|c|}
\hline $\mathrm{mV}$ & .00 & .01 & .02 & .03 & .04 & .05 & .06 & .07 & .08 & .09 & .10 & $\mathrm{mV}$ \\
\hline & & & & TEMPE & ATURES IN & DEGREES & C IIPTS & 19681 & & & & \\
\hline $\begin{array}{l}-0.20 \\
-0.10 \\
-0.00\end{array}$ & $\begin{array}{r}-41.30 \\
-19.43 \\
0.00\end{array}$ & $\begin{array}{r}-43.68 \\
-21.48 \\
-1.86\end{array}$ & $\begin{array}{r}-46.10 \\
-23.57 \\
-3.74\end{array}$ & $\begin{array}{r}-48.57 \\
-25.68 \\
-5.63\end{array}$ & $\begin{array}{r}-27.81 \\
-7.54\end{array}$ & $\begin{array}{r}-29.98 \\
-9.47\end{array}$ & $\begin{array}{l}-32.18 \\
-11.42\end{array}$ & $\begin{array}{l}-34.41 \\
-13.39\end{array}$ & $\begin{array}{l}-36.67 \\
-15.38\end{array}$ & $\begin{array}{l}-38.97 \\
-17.39\end{array}$ & $\begin{array}{l}-41 \cdot 30 \\
-19.43\end{array}$ & $\begin{array}{l}-0.20 \\
-0.10 \\
-0.00\end{array}$ \\
\hline $\mathrm{mV}$ & .00 & .01 & .02 & .03 & .04 & .05 & .06 & .07 & .08 & .09 & .10 & $\mathrm{mV}$ \\
\hline
\end{tabular}


TABLE A2.2.1. Type $S$ thermocouples-temperature $\left({ }^{\circ} \mathrm{C}\right)$ as a function of thermoelectric voltage, reference junctions at $0^{\circ} \mathrm{C}$-Continued

$\mathrm{mV}$

.00

.01

.02

.03

.04

.05

.07

TEMPERATURES IN DEGREES C (IPTS 1968)

0.00

0.10

0.20

0.30

0.00

17.81

34.45

0.40

65.27

0.50

79.76

$0.60 \quad 93.78$

$0.70 \quad 107.40$

$\begin{array}{ll}0.80 & 120.68 \\ 0.90 & 133.67\end{array}$

$1.00 \quad 146.39$

$\begin{array}{ll}1.10 & 158.89 \\ 1.20 & 171.19\end{array}$

$1.30 \quad 183.31$

$1.40 \quad 195.26$

1.50

$\begin{array}{ll}1.50 & 218.74 \\ 1.70 & 230.29\end{array}$

1.90

253.06

2.00

2.10

2.20

2.40

2.50

2.60

2.80

2.90

264.30

275.45

286.52

297.52

$308 \cdot 44$

319.30

330.09

351.51

362.15

3.00

372.73

3.10

3.20

3.30

3.40

3.50

3.60

3.70

3.80

3.90

4.00

383.26

393.75

404.20

414.61

424.98

435.31

445.61

455.87

$466 \cdot 10$

486.47

496.60

$4.30 \quad 506.71$

4.40

4.50

4.60

4.70

4.80

4.90

5.00

5.10

5.20

5.30

5.40

5.50

5.60

5.70

5.80

5.90

6.00

16.78

526.83

536.85
546.83

556.79

566.72

576.62

586.50

596.34

606.15

615.93

625.67

635.38

645.05

654.69

673.87
1.84

19.52
36.06

51.74

66.74

81.18

95.16
108.74

121.99

134.95

147.65

160.13

172.41

196.45

208.24

219.90

231.44

242.86
254.19

265.42

276.56

287.62

298.61

320.38

331.17

341.90

363.21

373.78

384.31

394.80

405.25

415.65

426.02

436.35

446.64

467.13

477.32

487.48

497.6

507.72

517.79

527.83

537.85

547.83

557.79

567.71

577.61

587.48

597.32

607.13

616.90

626.65

636.35

646.01

655.65

665.25

3.67

37.67

53.27

68.21

82.60

110.08

123.30

136.23

148.91

161.37

173.63

$185 \cdot 71$

209.41

221.06

232.58

244.00

255.31

266.54

277.67

288.73

299.71

310.62

321.46

332.25

353.65

364.27

374.84

385.36

395.85

406.29

416.69

427.05

437.38

447.67

457.92

$468 \cdot 15$

478.34

488.50

498.63

508.72

518.79

528.83

538.85

548.83

558.78

578.60

588.47

598.30

608.11

617.88

627.62

637.32

646.98

656.61

674.83

675.79
5.49

22.91

39.26

54.79

69.67

84.01

111.42

137.51

150.17

162.60

174.84

198.82

210.58

222.21

233.73

245.13

256.44

267.65

278.78

289.83

300.80

$\begin{array}{rr}7.29 & 9.07 \\ 24.59 & 26.25 \\ 40.85 & 42.43 \\ 56.31 & 57.82 \\ 71.13 & 72.58\end{array}$

$\begin{array}{ll}10.84 & 12.60\end{array}$

44.00

59.32

74.02

85.42
99.27

86.82

100.64

$112.75 \quad 114.08$

$138.79 \quad 140.06$

151.42

163.84

176.06

$188 \cdot 11$

152.67

165.07

177.27

189.30

211.75

223.37

201.18

212.92

$234.87 \quad 236.02$

$246.27 \quad 247.40$

257.57

258.69

268.77

269.89

$279.89 \quad 281.00$

$290.93 \quad 292.03$

$301.89 \quad 302.99$

313.88

322.54

333.32

323.62

324.70

$\begin{array}{ll}334.40 & 335.47\end{array}$

$355.77 \quad 356.84$

354.71

365.33

375.89

366.38

367.44

$376.95 \quad 378.00$

886.41

396.89

407.33

387.46 
TABLE A2.2.1. Type $S$ thermocouples-temperature $\left({ }^{\circ} \mathrm{C}\right)$ as a function of thermoelectric voltage, reference junctions at $0^{\circ} \mathrm{C}$-Continued

$\mathrm{mV}$

.01

.02

6.10

6.20

$6.40 \quad 702.44$

6.50

6.60

6.70

6.80
6.90

7.00

7.10

7.20

7.30

7.50

7.60

7.70

8.00

8.10

8.20

8.30
8.40

8.50

8.60
8.70

8.80

8.90

9.00

9.10

9.20

9.30
9.40

9.50
9.60

9.70
9.80

9.90

10.00

10.10

10.20

10.30

10.40

10.50

10.60

10.70

10.80

10.90

11.00

11.20

11.30

11.40

11.50

11.60

11.7

11.80
11.90

12.00
673.87

683.42

692.95

711.90

721.34

740.13

749.49

758.82

768.12

777.40

786.65

795.87
805.07

814.24

841.6

674.83

684.38

693.90

703.39

712.85

722.28

731.69

741.07

750.42

769.05

778.32

787.57

796.79

805.99

815.16

824.30

833.42

842.52

850.68

859.73

868.75

877.75

886.73

895.68

904.61

913.52

922.40

931.26

948.91

957.70

966.47

975.22

983.94

992.65

1001.33

1009.99
1018.63

1027.24

1035.84

$\begin{array}{ll}1052.97 & 1053.83\end{array}$

$1061.51 \quad 1062.36$

$1070.02 \quad 1070.87$

$1078.52 \quad 1079.37$

$1087.00 \quad 1087.85$

$1095.47 \quad 1096.32$

$\begin{array}{ll}1103.92 & 1104.77 \\ 1112.36 & 1113.21\end{array}$

$1120.79 \quad 1121.63$

$1129.20 \quad 1130.04$

$1137.60 \quad 1138.44$

$1145.99 \quad 1146.82$

1154.36

1162.73

1171.08

1179.42

1187.76

1196.09

1204.40
675.79

685.33

694.85

704.33
713.79

723.23

732.63

742.01

$751 \cdot 36$
760.68

769.98

779.25

788.49

797.71

806.91

816.07

825.22

834.33

$843 \cdot 43$

852.49

861.54

870.56

879.55

888.52

897.47

906.39

915.30

924.17

933.03

941.86

950.67

959.46

968.22

976.96

985.68

994.38

1003.06

1011.72

1020.35

1028.97

1037.56
1046.13

1054.68

1063.21

1071.72

1080.22

1097.16

1105.61
1114.05

1122.47

1130.88

1139.28

1147.66

1156.04

1164.40
1172.75

1181.09

1189.43
1197.75

1197.75

.03

.04

.05

.06

.07

.08

.09

$\cdot 10$

$\mathrm{mV}$

TEMPERATURES IN DEGREES C (IPTS 1968)

$\begin{array}{lllll}676.74 & 677.70 & 678.65 & 679.61 & 680.56\end{array}$

$\begin{array}{lll}695.80 & 696.75 & 697.70 \\ 705.28 & 706.23 & 707.17\end{array}$

$\begin{array}{lll}714.74 & 715.68 & 716.63\end{array}$

689.14

698.64

680.56

690.09
699.59

709.07

717.57

718.51

$724 \cdot 17$

$725 \cdot 11$

742.94

743.88

735.45

726.99

736.39

727.93

752.29

761.61

770.91

744.82

745.75

737.32

764.40

765.33

771.84

80.18

789.42

798.63
807.82

790.34

799.55

808.74

773.69

774.62

782.95

791.06

800.47

809.66

792.19

801.39

783.8

793.11

816.99

826.13

817.90

818.82

835.24

827.04

836.15

827.95

837.06

$810 \cdot 58$

811.49

819.73

828.87

820.65
829.78

$837.97 \quad 838.88$

853.40

$845 \cdot 2$

846.15

47.06

347.96

862.44

863.34

864.25

880.45

889.42
898.36

872.36

881.35

890.31

873.26

882.25

891.21

900.15

874.16

883.14

$892 \cdot 10$
901.04

857.02

907.29

916.18

$908 \cdot 18$

909.07

909.96

925.06

917.07

925.95 
TABLE A2.2.1. Type S thermocouples-temperature $\left({ }^{\circ} \mathrm{C}\right)$ as a function of thermoelectric voltage, reference junctions at $0^{\circ} \mathrm{C}$-Continued

$\mathrm{mV}$ .00 .01 .02 .03
.05

.06

.07

TEMPERATURES IN DEGREES C (IPTS 1968)

\subsection{0 \\ 12.10 \\ 12.30}

12.40

12.50

12.60

12.80

12.90

13.00

13.10

13.20

13.40

13.50

13.60

13.70

13.80

13.90

14.00

14.20

14.30

14.40

14.50

14.60

14.70

14.80

14.90

15.00

15.10

15.20

15.30

15.40

15.50

15.60

15.70

15.80

15.90

16.00

16.10

16.20

16.30

16.40

16.50

16.6
16.7

16.70

16.90

17.0

17.10

17.2

17.30
17.40

17.50

17.50
17.60

17.70

17.80

1204.40

1212.71

1221.01

1229.31

1205.23

1213.54

1221.84

1237.60

1238.42

1245.88

1254.15

1262.42

1270.69

1278.95

1246.71

1254.98

1263.25

1271.52

1287.21

1295.46

1303.71

1311.96

1288.03

1296.29

1304.54

1312.79

1328.45

1336.69

1344.94

1353.18
1361.42

1329.28

1337.52

1345.76

1354.00
1362.24

1369.66

1377.90

1386.15

1394.40

1370.49

1378.73

1386.97

1395.22

1410.89

1419.15

1427.41

1435.67

1443.93

1411.72

1419.97

1428.23

1436.49

452.20

1468.76

1477.05

1485.34

1453.03

1461.31

1469.59

1477.88
1486.17

1493.64

1501.95

1510.27

1494.48

1502.79

1511.10

(5)

1526.93

1510

1535.28

1543.63

1552.00

1560.37

1568.76

1536.11

1544.47

1552.83

1561.21

1569.60

1577.16

1585.57

1593.99

1578.00

1586.41

1594.84

1603.28

1619.35

1627.84

1611.73

1636.34

1620.20

1628.69

1637.19

1645.70

1653.38

1654.24

1661.93

1662.79

1671.36

1679.09

1687.71

1688.58

1697.24

1206.07

1214.37

1222.67

\begin{tabular}{l}
971231.79 \\
\hline
\end{tabular}

1247.53

1255.81

1264.08

1272.34

1280.60

1288.86

1297.11

1305.36

1313.61

1330.10

1338.34

1346.58

1354.83

1363.07

1371.31

1379.55

1387.80

1396.04

1412.54

1420.80

1429.06

1437.32

1445.59

1453.86

1462.14

1470.42

1478.71
1487.00

1495.31

1503.62

1511.94

1520.26

1536.95

1545.30

1553.67

1562.05

1570.44

1578.84

1587.25

1595.68

1604.12

1621.05

1629.54

1638.04

1646.56

1655.09

1663.64

1672.22

1680.81

1689.44

1698.11

18.00

1705.08

1705.96

1706.83

1240.08

248.36

256.63

1264.90

1273.17

.

289.68

1306.19

1314.44

1330.92

1339.17

1347.41

1355.65
1363.89

1372.13

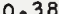

$\begin{array}{lll}1207.73 & 1208.56 & 1 \\ 1216.03 & 1216.86 & 1 \\ 1224.33 & 1225.16 & 1 \\ 1232.62 & 1233.45 & 1 \\ 1240.91 & 1241.74\end{array}$

1209.39

1217.69
1225.99

1218.52

$1234.28 \quad 1235.11$

1249.19

1265.73

$1282.25 \quad 1283.08$

1290.51

1291.34

1298.76
1307.01

1315.26

1299.59

1307.84

1316.08

1331.75

1339.99

1348.23

1332.57

1340.82

1349.06

1364.72

1357.30

$388.62 \quad 1389.45$

$1396.87 \quad 1397.69$

1373.78

1382.03

1390.27

1398.52

1250.84

1259.12

1267.38

1275.65

1283.91

1292.16

1300.41

1308.66

1316.91

1333.40

1341.64

1349.88

1358.12

1366.37

1374.61

1382.85

1391.10 
TABLE A2.2.1. Type $S$ thermocouples-temperature $\left({ }^{\circ} \mathrm{C}\right)$ as a function of thermoelectric voltage, reference junctions at $0^{\circ} \mathrm{C}$-Continued

\begin{tabular}{|c|c|c|c|c|c|c|c|c|c|c|c|c|}
\hline \multirow[t]{2}{*}{$m v$} & .00 & .01 & .02 & .03 & .04 & .05 & .06 & .07 & .08 & .09 & .10 & $m v$ \\
\hline & & & & TEMPE & RATURES & $N$ DEGREES & C IIPTS & $1968)$ & & & & \\
\hline $\begin{array}{l}18 \cdot 00 \\
18 \cdot 10 \\
18 \cdot 20 \\
18.30 \\
18.40\end{array}$ & $\begin{array}{l}1705.08 \\
1713.85 \\
1722.68 \\
1731.58 \\
1740.57\end{array}$ & $\begin{array}{l}1705.96 \\
1714.73 \\
1723.56 \\
1732.48 \\
1741.47\end{array}$ & $\begin{array}{l}1706.83 \\
1715.61 \\
1724.45 \\
1733.37 \\
1742.38\end{array}$ & $\begin{array}{l}1707.71 \\
1716.49 \\
1725.34 \\
1734.27 \\
1743.29\end{array}$ & $\begin{array}{l}1708 \cdot 58 \\
1717 \cdot 37 \\
1726.23 \\
1735.17 \\
1744.19\end{array}$ & $\begin{array}{l}1709.46 \\
1718.25 \\
1727.12 \\
1736.06 \\
1745.10\end{array}$ & $\begin{array}{l}1710.34 \\
1719.14 \\
1728.01 \\
1736.96 \\
1746.01\end{array}$ & $\begin{array}{l}1711.21 \\
1720.02 \\
1728.90 \\
1737.86 \\
1746.92\end{array}$ & $\begin{array}{l}1712.09 \\
1720.91 \\
1729.79 \\
1738.77 \\
1747.83\end{array}$ & $\begin{array}{l}1712.97 \\
1721.79 \\
1730.69 \\
1739.67 \\
1748.74\end{array}$ & $\begin{array}{l}1713.85 \\
1722.68 \\
1731.58 \\
1740.57 \\
1749.66\end{array}$ & $\begin{array}{l}18.00 \\
18.10 \\
18.20 \\
18.30 \\
18.40\end{array}$ \\
\hline $\begin{array}{l}18.50 \\
18.60\end{array}$ & $\begin{array}{l}1749.66 \\
1758.85\end{array}$ & $\begin{array}{l}1750.57 \\
1759.78\end{array}$ & $\begin{array}{l}1751.49 \\
1760.71\end{array}$ & $\begin{array}{l}1752.40 \\
1761.64\end{array}$ & $\begin{array}{l}1753.32 \\
1762.57\end{array}$ & $\begin{array}{l}1754.24 \\
1763.50\end{array}$ & $\begin{array}{l}1755.16 \\
1764.43\end{array}$ & $\begin{array}{l}1756.08 \\
1765.36\end{array}$ & $\begin{array}{l}1757.00 \\
1766.30\end{array}$ & $\begin{array}{l}1757.93 \\
1767.24\end{array}$ & 1758.85 & $\begin{array}{l}18.50 \\
18.60\end{array}$ \\
\hline
\end{tabular}

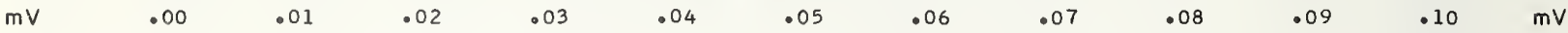

TABLE A2.2.2. Type $S$ thermocouples-temperature $\left({ }^{\circ} \mathrm{F}\right)$ as a function of thermoelectric voltage, reference junctions at $32{ }^{\circ} \mathrm{F}$

$\mathrm{mV}$

$.00-.01-.02$

03

$.04 \quad .05 \quad .06$

.07

.08

.09

.10

$\mathrm{mV}$

TEMPERATURES IN DEGREES F

$\begin{array}{lr}-0.20 & -42.35 \\ -0.10 & -2.97 \\ -0.00 & 32.00\end{array}$

$\begin{array}{rrr}-46.63 & -50.99 & -55.43 \\ -6.67 & -10.42 & -14.22 \\ 28.65 & 25.27 & 21.87\end{array}$

$-18 \cdot 07$
18.43

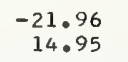

$-25.92$

$-29.93$
$-34.00$
4.32

$-38 \cdot 14$

0.70

$-42.35$

$-2.97$

0.20

$-0.10$

$-0.00$

m

.02

.04

.05

.06

.07

.08

.09

.10

$m v$ 
TABLE A2.2.2. Type $S$ thermocouples-temperature $\left({ }^{\circ} \mathrm{F}\right)$ as a function of thermoelectric voltage, reference junctions at $32^{\circ} \mathrm{F}$-Continued

$\mathrm{mV}$

.00

.0

.02

.03

.04

.05

.06

.07

.08

.09

$\cdot 10$

$m V$

TEMPERATURES IN DEGREES $F$

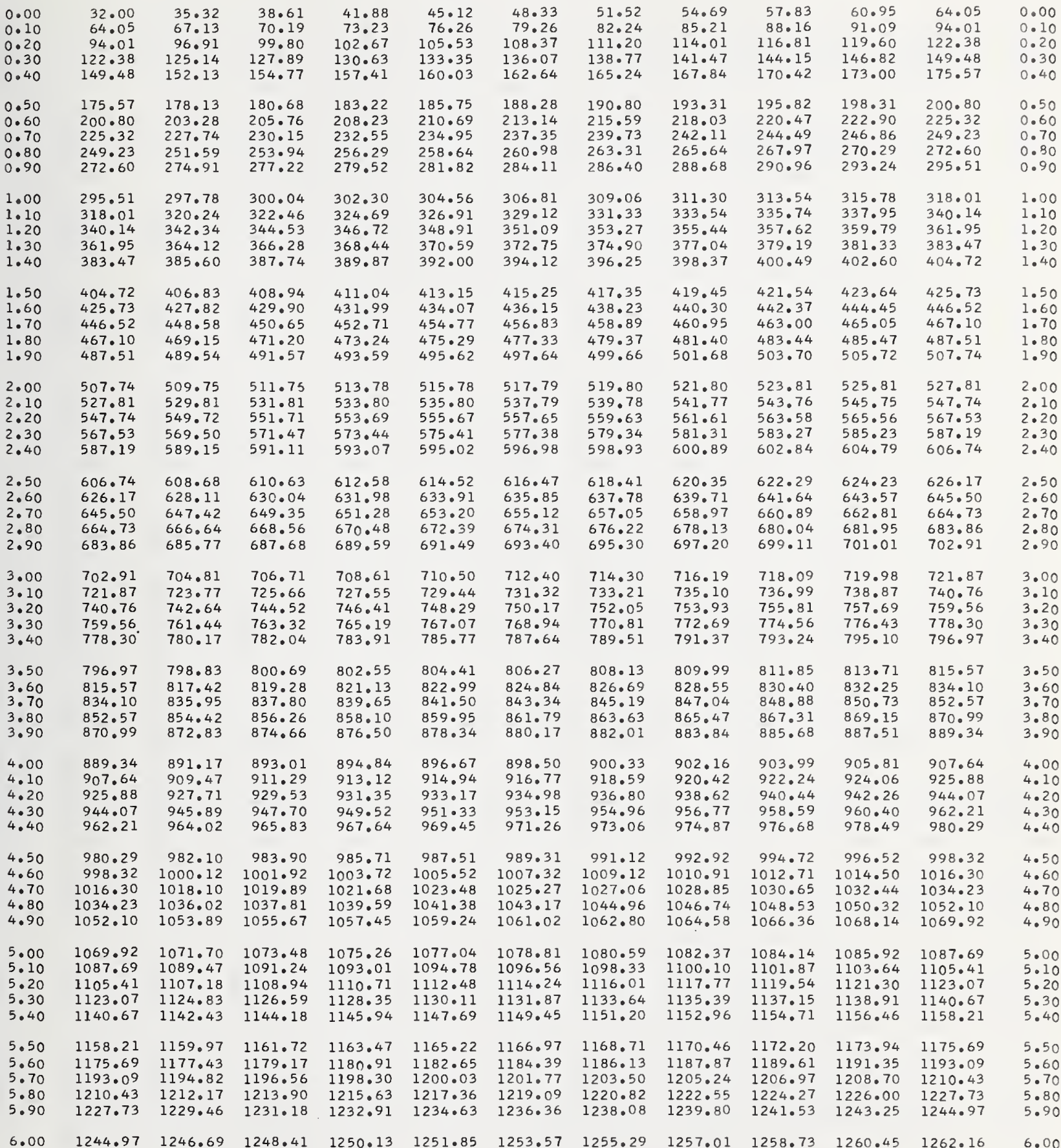

0.40

.50

.70

.00

1.20

.40

.50

1.70

.90

.20

.40

.70

90

10

3.40

3.60

3.80

.10

40

4.60

. 90

00

5.20

5.40

5.60

90

6.00
.00

.01
.03

.04

.05

.06
.08

.09

.10 
TABLE A2.2.2. Type $S$ thermocouples-temperature $\left({ }^{\circ} \mathrm{F}\right)$ as a function of thermoelectric voltage, reference junctions at $32^{\circ} \mathrm{F}$-Continued

$\mathrm{mV}$

.00

.01

.02

.03

\section{TEMPERATURES IN DEGREES $F$}

\begin{tabular}{|c|c|c|c|}
\hline 6.00 & 1244.97 & 1246.69 & 1248.41 \\
\hline 6.10 & 1262.16 & 1263.88 & 1265.59 \\
\hline 6.20 & 1279.30 & 1281.01 & 1282.72 \\
\hline 6.30 & 1296.39 & 1298.10 & 1299.80 \\
\hline 6.40 & 1313.43 & 1315.13 & $1316 \cdot 83$ \\
\hline 6.50 & 1330.42 & 1332.11 & 1333.81 \\
\hline 6.60 & 1347.35 & 1349.04 & 1350.74 \\
\hline 6.70 & 1364.24 & 1365.93 & 1367.61 \\
\hline 6.80 & 1381.08 & 1382.76 & 1384.45 \\
\hline 6.90 & 1397.88 & 1399.55 & 1401.23 \\
\hline 7.00 & 1414.62 & 1416.29 & 1417.96 \\
\hline 7.10 & 1431.32 & $1432 \cdot 98$ & 1434.65 \\
\hline 7.20 & 1447.97 & 1449.63 & 1451.29 \\
\hline 7.30 & 1464.57 & 1466.23 & 1467.88 \\
\hline 7.40 & $1481 \cdot 13$ & 1482.78 & 1484.43 \\
\hline $7 \cdot 50$ & $1497 \cdot 64$ & 1499.29 & 1500.93 \\
\hline 7.60 & 1514.10 & & 1517.39 \\
\hline 7.80 & 1546.90 & 1548.53 & 1550.17 \\
\hline 7.90 & 1563.23 & 1564.86 & 1566.49 \\
\hline 8.00 & 1579.52 & 1581.14 & 1582.77 \\
\hline $8 \cdot 10$ & 1595.76 & 1597.38 & 1599.00 \\
\hline $8 \cdot 20$ & 1611.96 & 1613.58 & 1615.19 \\
\hline 8.30 & 1628.11 & 1629.73 & 1631.34 \\
\hline 8.40 & 1644.23 & 1645.84 & 1647.45 \\
\hline $\begin{array}{l}8.50 \\
8.60\end{array}$ & $\begin{array}{l}1660.30 \\
1676.33\end{array}$ & $\begin{array}{l}1661.91 \\
1677.93\end{array}$ & $\begin{array}{l}1663.51 \\
1679.53\end{array}$ \\
\hline 8.70 & 1692.32 & 1693.92 & 1695.51 \\
\hline 8.80 & 1708.27 & 1709.86 & 1711.45 \\
\hline 8.90 & 1724.17 & 1725.76 & 1727.35 \\
\hline 9.00 & 1740.04 & 1741.62 & 1743.20 \\
\hline 9.10 & 1755.86 & 1757.44 & 1759.02 \\
\hline 9.20 & 1771.65 & 1773.22 & 1774.80 \\
\hline $9 \cdot 30$ & 1787.39 & 1788.96 & 1790.53 \\
\hline 9.40 & 1803.10 & 1804.66 & 1806.23 \\
\hline 9.50 & 1818.76 & $1820 \cdot 33$ & 1821.89 \\
\hline $\begin{array}{l}9.60 \\
9.70\end{array}$ & $\begin{array}{l}1834.39 \\
1849.98\end{array}$ & $\begin{array}{l}1835.95 \\
1851.53\end{array}$ & $\begin{array}{l}1837.51 \\
1853.09\end{array}$ \\
\hline 9.80 & 1865.53 & 1867.08 & 1868.63 \\
\hline 9.90 & 1881.04 & 1882 & .14 \\
\hline 10.00 & 1896.51 & 1898.06 & 1899.60 \\
\hline $10 \cdot 10$ & 1911.95 & 1913.49 & 1915.03 \\
\hline $10 \cdot 20$ & 1927.35 & 1928.89 & 1930.43 \\
\hline $10 \cdot 30$ & 1942.71 & 1944.25 & 1945.78 \\
\hline $10 \cdot 40$ & 1958.04 & 1959.57 & 1961.10 \\
\hline 10 & 1973.34 & 1974.87 & 1976.39 \\
\hline & 1988.61 & 1990.13 & 1991.66 \\
\hline $10 \cdot 70$ & 2003.85 & $2005 \cdot 37$ & 2006.89 \\
\hline $10 \cdot 80$ & 2019.06 & 2020.58 & $2022 \cdot 10$ \\
\hline 10.90 & 2034.25 & 2035.77 & 2037.29 \\
\hline & 2049.42 & 2050.93 & 2052.45 \\
\hline & $2064 \cdot 56$ & 2066.07 & 2067.58 \\
\hline & 2079.68 & 2081.19 & $2082 \cdot 70$ \\
\hline & 2094.77 & 2096.28 & 2097.79 \\
\hline & 2109.85 & 2111.36 & $2112 \cdot 86$ \\
\hline 11.50 & 2124.91 & 2126.41 & 2127.92 \\
\hline & 2139.95 & 2141.45 & 2142.95 \\
\hline & 2154.96 & 2156.47 & 2157.97 \\
\hline 11.80 & 2169.97 & 2171.47 & 2172.97 \\
\hline & 2184.95 & 2186.45 & 2187.95 \\
\hline 2.00 & 2199.92 & 2201.42 & 2202.92 \\
\hline
\end{tabular}

1250.13

$1267.31 \quad 126$

$1284.43 \quad 128$

138.4

1301.51

1286.14

1303.21

1253.57

1287.85

1304.91

$1335.50 \quad 1337.20$

1352.43

1402.90

1419.63

1436.32

$1469.54 \quad 1471.20$

1486.08

1502.58

$1519.03 \quad 1520.68$

1535.44

$1551.80 \quad 1553.43$

1568.12

1584.39

1600.62

1616.81

1632.95

1649.05

1665.11

1681.11366 .72

$1697.11 \quad 1698.70$

$1713.04 \quad 1714.63$

$1728.93 \quad 1730.52$

1321.93

1338.89

1355.80

1372.67

1406.25

1422.97

1439.65

1456.27

1472.85

1489.39

1505.87

1522.32

1538.72

1555.07

1556.70

1587.64

1603.86

1620.04

1652.27

$1744.79 \quad 1746.37$

$1760.60 \quad 1762.18$

$1776.37 \quad 1777.95$

$1792.11 \quad 1793.68$

1807.80

1809.37

$1823.45 \quad 1825.02$

$1839.07 \quad 1840.63$

$1854.65 \quad 1856.20$

$1870.18 \quad 1871.74$

1668.32

1684.33

1700.30

1716.22

1732.11

1747.95

1763.76

1779.52

1810.93

1826.58

1842.19

1857.76

1873.29

885.6

1887.23

$1901.15 \quad 1902.69$

$1916.57 \quad 1918.12$

$1931.96 \quad 1933.50$

$1947.31 \quad 1948.85$

1962.631964 .16

1904.24

1919.66

1935.04

1950.38

$1977.92 \quad 1979.45$

$1993.18 \quad 1994.7$

$2008.42 \quad 2009.94$

$2023.62 \quad 2025.14$

$2038.80 \quad 2040.32$

1980.98

2011.46

2026.66

$2053.96 \quad 2055.48$

$2069.10 \quad 2070.61$

$2084.21 \quad 2085.72$

$2099.30 \quad 2100.81$

2114.37

2115.88

2056.99

2072.12

2087.23

2102.32

2117.38

$2129.42 \quad 2130.92$

$\begin{array}{ll}2144.45 & 2145.96 \\ 2159.47 & 2160.97\end{array}$

$2159.47 \quad 2160.97$

$2174.47 \quad 2175.96$

2132.43

2147.46

2162.47

2189.45
1255.29

1272.45

1306.62

1323.63

1340.58

1357.49

1391.16

1407.93

1424.64

1457.93

1474.51

1507.52

1523.96

1540.35

1589.27

1605.48

1621.66

1637.79

1669.92

1685.93

1701.89

1717.81

1733.70

1749.54

1765.34

1781.10

$(796.82$

1812.50

1828.14

1843.75

1859.31

1874.84

1905.78

1921.19

1936.57

1951.91

1967.22

1257.01
1274.16

1291.27

1308.32

1325.32

1342.28

1359.18

1376.04

1392.84

1409.60

1426.31

1459.59

1476.16

1492.69

1509.17

1525.60

1541.99

1558.33

1574.63

1590.89

1607.10

1623.27

1639.40

1655.48

1671.53

1687.53

1703.49

1719.40

1735.28

1751.12

1766.91

1782.67

1814.07

1829.70

1845.30

1860.87

1876.39

1891.88

1982.50

1997.75

2012.98

2028.18

2043.35

1907.32

1922.73

1938.11

1953.45

1968.75

2058.50

2073.63

2088.74

2103.82

1984.03

1999.28

2014.50

2029.70

2044.87

2118.89

2060.02

2075.14

2090.25

2105.33

2133.93

2148.96

21 35.44

2178.96

2193.94

2165.47
2180.46

2195.44

2210.40

1258.73

$1292.98 \quad 1294.68$

$1310.02 \quad 1311.73$

1327.02

1343.97

1360.87

1377.72

1394.52

1411.27

1427.98

1444.64

1461.25

1477.82

1494.34

1510.81

1527.24

1543.63

1559.97

1592.51

1608.72

1657.09

1673.13

1689.12

1705.08

1720.99

1752.70

1752.70

1784.24

1799.96

1815.63

1831.27

1846.86

1862.42

1877.94

1893.42

1908.87

1924.27

1939.64

1954.98

1970.28

1985.56

2000.80

2016.02

2031.22

2046.39

2061.53

2076.66

2091.76

2106.84

2121.90

2136.94

2151.96

2166.97

2181.96

2196.93

2211.89 
TABLE A2.2.2. Type $S$ thermocouples-temperature $\left({ }^{\circ} \mathrm{F}\right)$ as a function of thermoelectric voltage, reference junctions at $32^{\circ} \mathrm{F}$-Continued

$\mathrm{mV}$

.00

.01

.02

.03

.04

.05

.06

.07

.08

.09

.10

$\mathrm{ml}$

TEMPERATURES IN DEGREES F

12.00

2199.92

$2201 \cdot 42$

12.10

12.30

12.40

12.50

12.60

$12 \cdot 70$

12.80

12.90

13.00

13.10

13.20

13.30

13.40

2214.88
2229.82

2244.75

2259.67

2216.38

2246.25

2274.58

2289.48

$2304 \cdot 36$

2319.24

2334.11

2261.16

2276.07

2290.96
2305.85

2320.73

$2348.97 \quad 2350.46$

$2363.83 \quad 2365.32$

$2378.68 \quad 2380.17$

$2393.53 \quad 2395.01$

2408.37

2409.86

13.50

2423.21

2424.70

13.60

13.70

13.80

2438.05

2452.89

2467.72

2439.53

2454.37
2469.20

2469.20
2484.04

2497.39

2498.88

14.00

14.10

14.20

14.30

14.40

2512.23

2527.07

2513.71

2528.55

2541.912543 .40

2556.76

2558.24

14.50

2571.61

2573.10

$2586.47 \quad 2587.95$

$2601.33 \quad 2602.82$

14.70

14.80

$2616.20 \quad 2617.69$

$2631.08 \quad 2632.57$

15.00

$15 \cdot 10$

15.20

15.30

15.40

$2645.97 \quad 2647.46$

$2660.86 \quad 2662.35$

$2675.77 \quad 2677.26$

$2690.69 \quad 2692.18$

$2705.62 \quad 2707.11$

15.50

15.60

15.70

$2720.56 \quad 2722.06$

$2735.52 \quad 2737.01$

$2750.49 \quad 2751.99$

$2765.47 \quad 2766.97$

15.90

16.00 $2780.48 \quad 2781.98$

202.92 2217.87 $2232 \cdot 81$

2247.74

2262.65

2277.56

2292.45

$2307 \cdot 34$

2322.22

2337.08

2204.41

$2219.37 \quad 2220.86$

$\begin{array}{lll}2235.80 & 2237.29\end{array}$

$2249.23 \quad 2250.72$

2264.15

2351.95

2366.80

396.50

2411.34

2426.18

2441.02

2455.85

2470.69

2485.52

$279.05 \quad 2280.54$

$2293.94 \quad 2295.43$

$2308.83 \quad 2310.31$

$2323.70 \quad 2325.19$

$2338.57 \quad 2340.06$

$2353.43 \quad 2354.92$

$2368.29 \quad 2369.77$

$2383.14 \quad 2384.62$

$397.98 \quad 2399.4$

$2427.66 \quad 2429.15$

$2442.50 \quad 2443.98$

$2457.34 \quad 2458.82$

$2472.17 \quad 2473.65$

2487.01

$2488 \cdot 49$

$2500 \cdot 36$

2515.20

2544.88

$2501.84 \quad 2503.33$

$2516.68 \quad 2518.16$

$2531.52 \quad 2533.01$

$2546.37 \quad 2547.85$

$2561.21 \quad 2562.70$

2574.58

2589.44

2604.30

2619.18

2634.06

$2576.07 \quad 2577.55$

$2590.93 \quad 2592.41$

$2605.79 \quad 2607.28$

$2620.66 \quad 2622.15$

$2635.54 \quad 2637.03$

$2648 \cdot 94$

2663.84
2678.75

2693.67

$2650.43 \quad 2651.92$

$2665.33 \quad 2666.82$

$2680.24 \quad 2681.74$

$2695.17 \quad 2696.66$

2708.61

$2710.10 \quad 2711.59$

$2725.05 \quad 2726.54$

$2740.01 \quad 2741.50$

$2754.98 \quad 2756.48$

2753.48

2768.47

2783.48

2784. 98

2771.47

2786.48

$2800.01 \quad 2801.51$

$2815.05 \quad 2816.56$

2830.112831 .62

$2845.20 \quad 2846.70$

$2860.30 \quad 2861.81$

2237.29

2267.13

2208.90

2223.85

2240.28

$2268.62 \quad 2270.11$

2282.03

2296.92

2283.52

2298.41

2326.68

2341.54

2313.29

2299.90

$2343.03 \quad 2344.52$

2356.40

2371.26

2386.11

2400.95

2430.63

2445.47

2460.30

2475.14

2489.97

2374.23

$2402.44 \quad 2403.92$

$2417.28 \quad 2418.76$

2446.95

2461.79

2476.62

2491.46

2504.81

2519.65
2534.49

2549.33

2506.29

$2535.97 \quad 2537.46$

$550.82 \quad 2552.30$

2579.04

2593.90

2608.76

2623.64

2638.52

2595.38

2610.25

2640.01

2653.41

2668.31

2683.23

2698.15

2654.90

2669.81

2684.72

2699.64

2728.04

2743.00

2757.98

2729.53

2759.48

2787.99

2789.

2803.01

2818.06

2833.13

2848.21

2819.57

2834.64

2849.72

2858.79

$2855.77 \quad 2857.28$

$2870.88 \quad 2872.40$

$2886.03 \quad 2887.54$

2873.91

2889.06

$2904 \cdot 23$

$2875.42 \quad 2876.94$

$2890.57 \quad 2892.09$

$2905.74 \quad 2907.26$

2878.4

2879.97

893.61

2908.78

2895.12

2910.30

2925.51

$2936.16 \quad 2937.69$

2939.2

2940.74

2949.89

$2951.41 \quad 2952.94$

$2954.47 \quad 2955.99$

17.00

$2946.84 \quad 2948.36$

$2962.11 \quad 2963.63$

$2977.40 \quad 2978.93$

$2992.73 \quad 2994.27$

2965.16 
TABLE A2.2.2. Type $S$ thermocouples-temperature $\left({ }^{\circ} \mathrm{F}\right)$ as a function of thermoelectric voltage, reference junctions at $32^{\circ} \mathrm{F}$-Continued

\begin{tabular}{|c|c|c|c|c|c|c|c|c|c|c|c|c|}
\hline \multirow[t]{2}{*}{$\mathrm{mV}$} & \multirow[t]{2}{*}{.00} & \multirow{2}{*}{.01} & \multirow{2}{*}{.02} & \multirow{2}{*}{.03} & .04 & .05 & .06 & \multirow[t]{2}{*}{.07} & \multirow[t]{2}{*}{.08} & \multirow[t]{2}{*}{.09} & \multirow[t]{2}{*}{$\cdot 10$} & \multirow[t]{2}{*}{$\mathrm{mV}$} \\
\hline & & & & & (Е) & ES IN & GREES F & & & & & \\
\hline $\begin{array}{l}18 \cdot 00 \\
18.10 \\
18 \cdot 20 \\
18.30 \\
18.40\end{array}$ & $\begin{array}{l}3101.15 \\
3116.93 \\
3132.82 \\
3148.85 \\
3165.03\end{array}$ & $\begin{array}{l}3102 \cdot 73 \\
3118 \cdot 51 \\
3134 \cdot 42 \\
3150.46 \\
3166.65\end{array}$ & $\begin{array}{l}3104.30 \\
3120.10 \\
3136.01 \\
3152.07 \\
3168.28\end{array}$ & $\begin{array}{l}3105.87 \\
3121.68 \\
3137.61 \\
3153.68 \\
3169.91\end{array}$ & $\begin{array}{l}3107.45 \\
3123.27 \\
3139.21 \\
3155.30 \\
3171.55\end{array}$ & $\begin{array}{l}3109.03 \\
3124.86 \\
3140.82 \\
3156.92 \\
3173.18\end{array}$ & $\begin{array}{l}3110.60 \\
3126.45 \\
3142.42 \\
3158.54 \\
3174.82\end{array}$ & $\begin{array}{l}3112.18 \\
3128.04 \\
3144.02 \\
3160.16 \\
3176.46\end{array}$ & $\begin{array}{l}3113 \cdot 76 \\
3129 \cdot 63 \\
3145.63 \\
3161.78 \\
3178 \cdot 10\end{array}$ & $\begin{array}{l}3115 \cdot 35 \\
3131 \cdot 23 \\
3147.24 \\
3163 \cdot 40 \\
3179 \cdot 74\end{array}$ & $\begin{array}{l}3116.93 \\
3132.82 \\
3148.85 \\
3165.03 \\
3181.38\end{array}$ & $\begin{array}{l}18.00 \\
18.10 \\
18.20 \\
18.30 \\
18.40\end{array}$ \\
\hline $\begin{array}{l}18.50 \\
18.60\end{array}$ & $\begin{array}{l}3181.38 \\
3197.94\end{array}$ & $\begin{array}{l}3183.03 \\
3199.60\end{array}$ & $\begin{array}{l}3184.68 \\
3201.27\end{array}$ & $\begin{array}{l}3186.33 \\
3202.94\end{array}$ & $\begin{array}{l}3187.98 \\
3204.62\end{array}$ & $\begin{array}{l}3189.63 \\
3206.29\end{array}$ & $\begin{array}{l}3191.29 \\
3207.97\end{array}$ & $\begin{array}{l}3192.95 \\
3209.65\end{array}$ & $\begin{array}{l}3194.61 \\
3211.34\end{array}$ & $\begin{array}{l}3196.27 \\
3213.02\end{array}$ & 3197.94 & $\begin{array}{l}18.50 \\
18.60\end{array}$ \\
\hline
\end{tabular}

$\begin{array}{lllllllllllllll}\mathrm{mV} & .00 & .01 & .02 & .03 & .04 & .05 & .06 & .07 & .08 & .09 & .10 & \mathrm{mV}\end{array}$

TABLE A2.2.3. Type $S$ thermocouples-quadratic, cubic, and quartic approximations to the data as a function of voltage in selected temperature ranges $\left({ }^{\circ} \mathrm{C}\right)$. The expansion is of the form $\mathrm{T}=\mathrm{a}_{0}+\mathrm{a}_{1} \mathrm{E}+\mathrm{a}_{2} \mathrm{E}^{2}+\mathrm{a}_{3} \mathrm{E}^{3}+\mathrm{a}_{4} \mathrm{E}^{4}$ where $\mathrm{E}$ is in microvolts and $\mathrm{T}$ is in degrees Celsius

Temperature Range $\left({ }^{\circ} \mathrm{C}\right)$

$\mathrm{a}_{0}$

I. Quartic Equation

Argument Exp.

Argument - 50 to 900

0 to 1100

0 to 1400

0 to 1650

0 to 1768

400 to 1100

400 to 1400

400 to 1650

1050 to 1400

1050 to 1650

1400 to 1550

1400 to 1650

1400 to 1768

1666 to 1768

.... . . 1.6414048

......

$\cdots \cdot$

$\cdots$

4. 1137317

4.4507790

4. 1670535

$-3.0938374$

1. 2226507

1. 3866867

1. 3923740

4. 5133695

2. 3131446

II. Cubic Equation

- 50 to 900

0 to 1100

0 to 1400

0 to 1650

o to 1768

400 to 1100

400 to 1400

400 to 1650

1050 to 1400

1050 to 1650

1400 to 1550

1400 to 1650

1400 to 1768

1666 to 1768

$\ldots \ldots$
$\ldots \ldots$
$\ldots \ldots$
3.9670850
3.4637308
3.0131902
1.1363334
1.6582222
1.4701444
-6.1978755
-5.7917146
-8.5574051

III. Quadratic Equation

- 50 to 900

0 to 1100

0 to 1400

0 to 1650

0 to 1768

400 to 1100

400 to 1400

400 to 1650

1050 to 1400

1050 to 1650

1400 to 1550

1400 to 1650

1400 to 1768

1666 to 1768
....

$\ldots$

....

4. 9665746

6. 1328808

7. 7694617

1. 5392695

2. 0492985

2. 8466845

3. 1839774

4. 1765334
1. 2155606

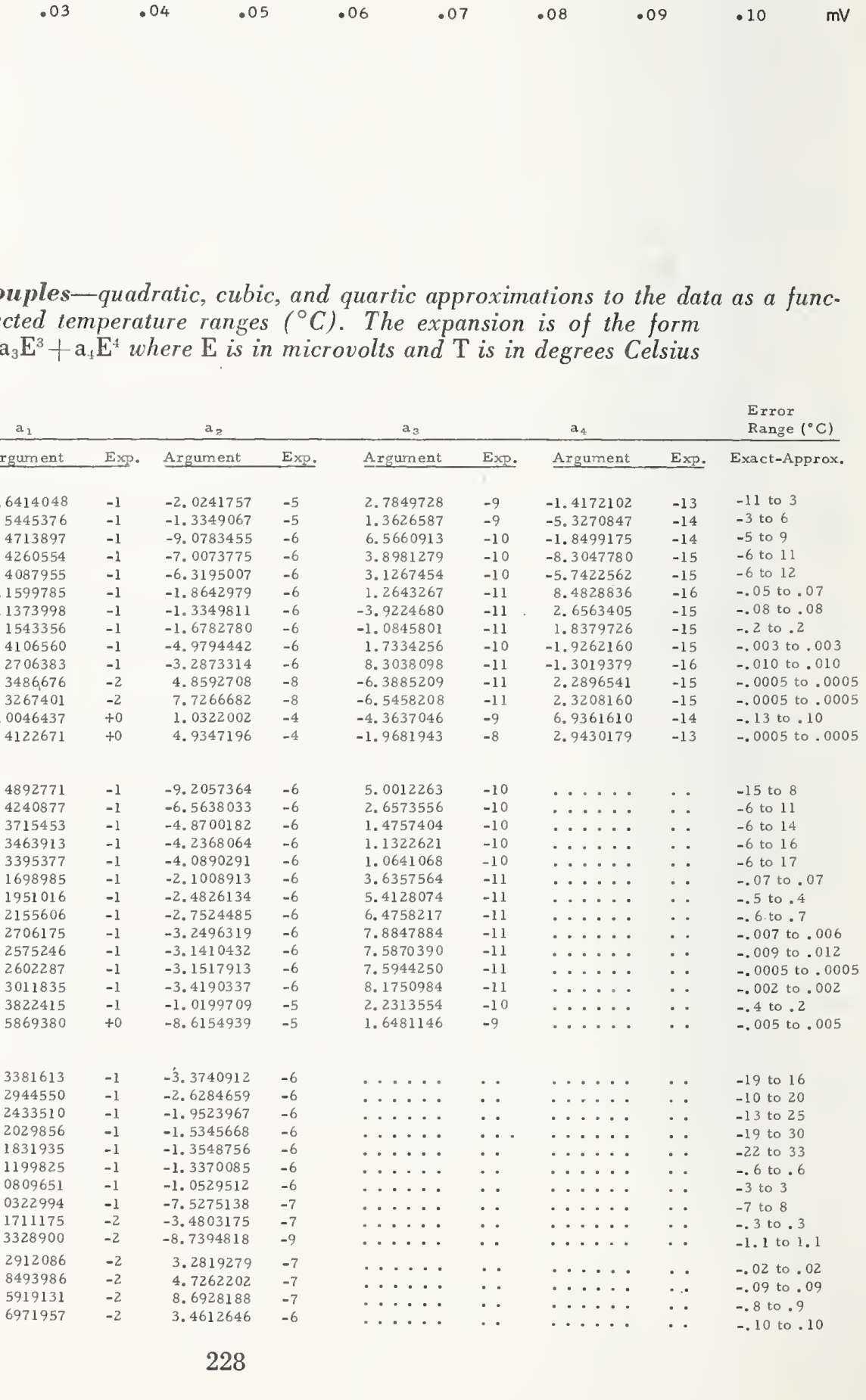

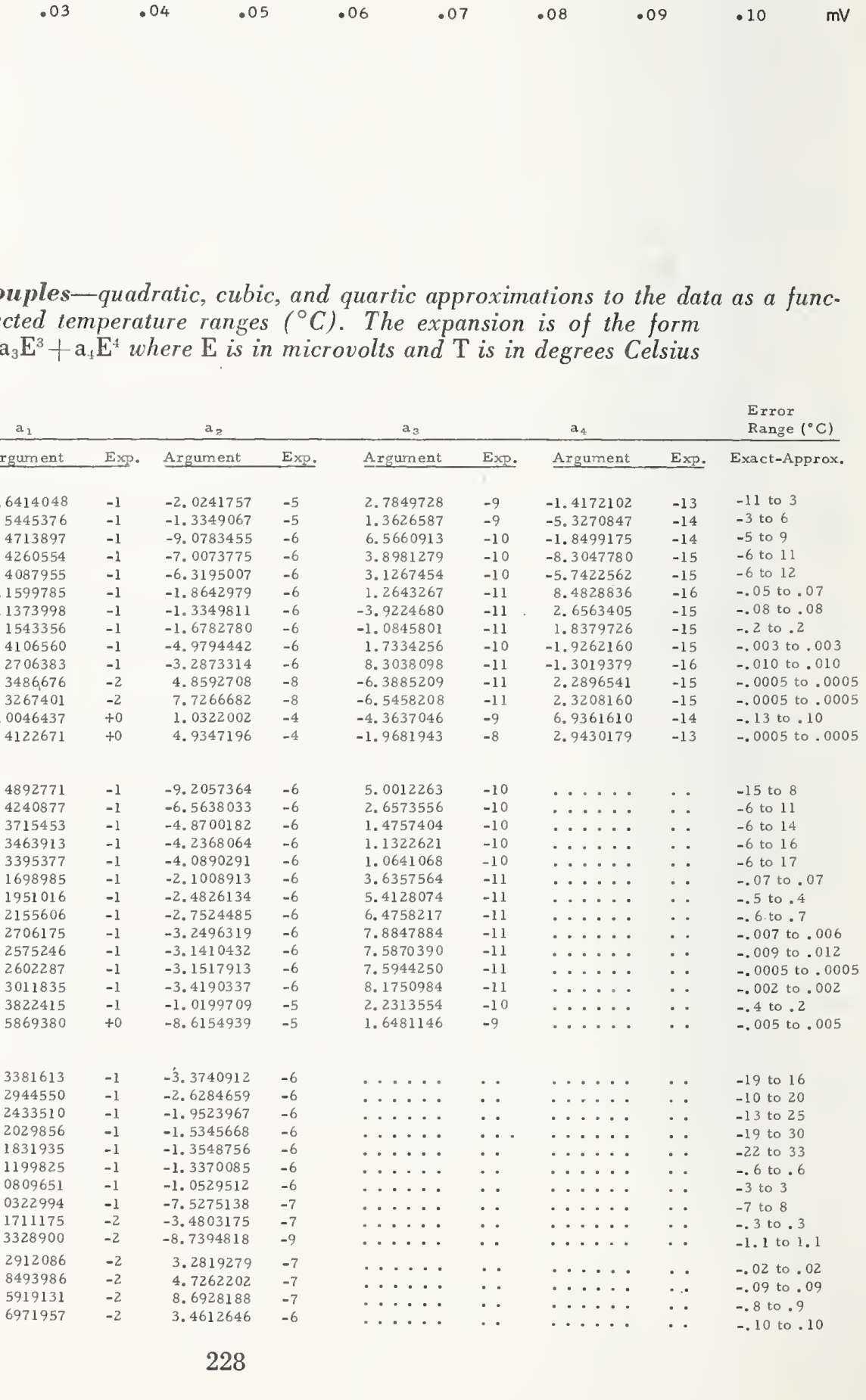

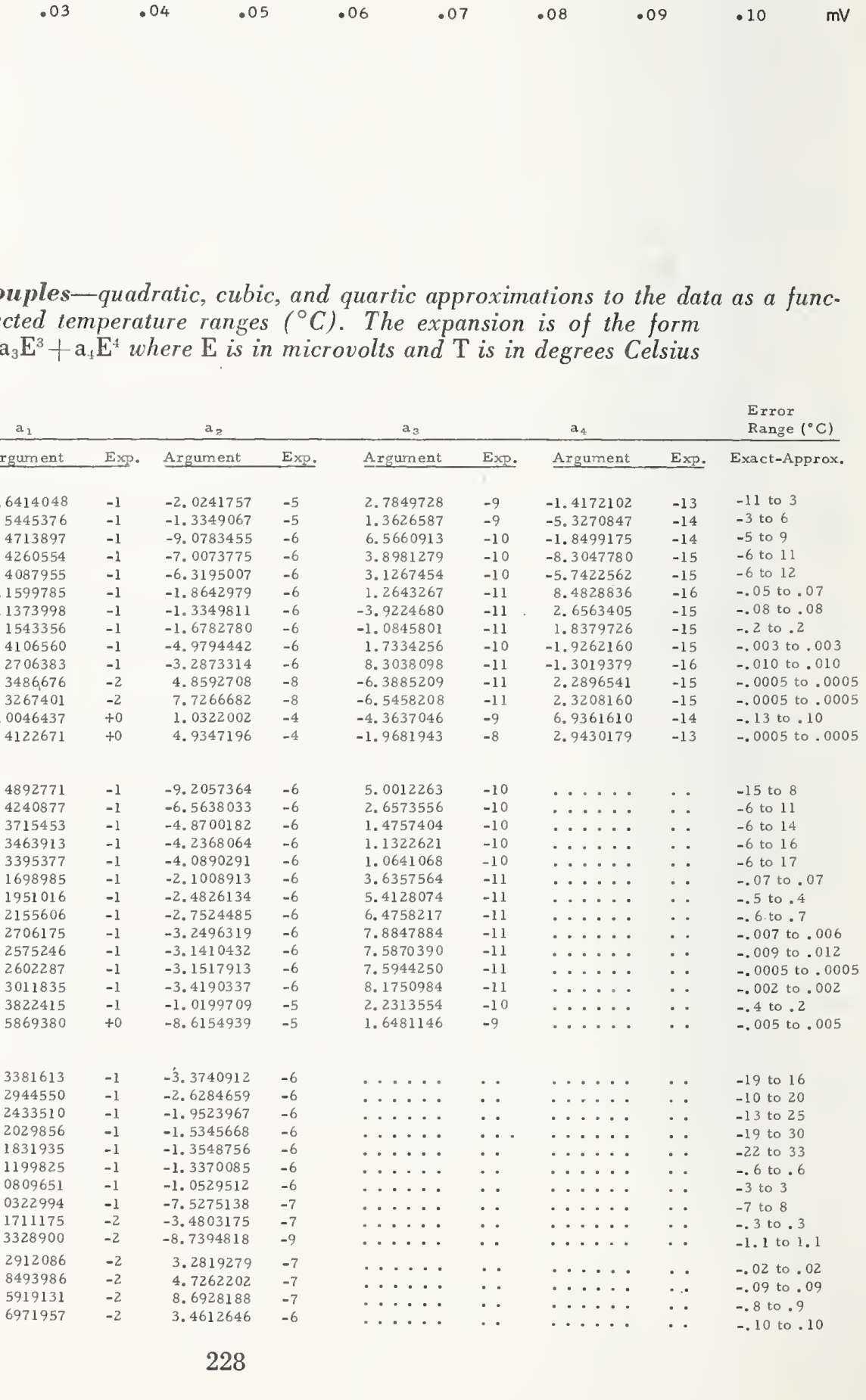

$$
\begin{array}{r}
1.6414048 \\
1.5445376 \\
1.4713897 \\
1.4260554 \\
1.4087955 \\
1.1599785 \\
1.1373998 \\
1.1543356 \\
1.4106560 \\
1.2706383 \\
9.3486676 \\
9.3267401 \\
-1.0046437 \\
-5.4122671
\end{array}
$$

1.4892771
1.4240877

1.4240877
1.3715453

1. 3715453
1. 3463913

1. 3395377

1. 1698985

1. 1951016

1. 2706175

1. 2575246

1. 2602287

1. 3011835

2. 3822415
1. 5869380

1. 3381613

1. 2944550

1. 2029856

1. 1831935

1.1199825

1.1199825
1.0809651

1. 0322994

9. 1711175

8. 3328900

7. 2912086

6. 8493986

5. 5919131

5.5919131
-3.6971957

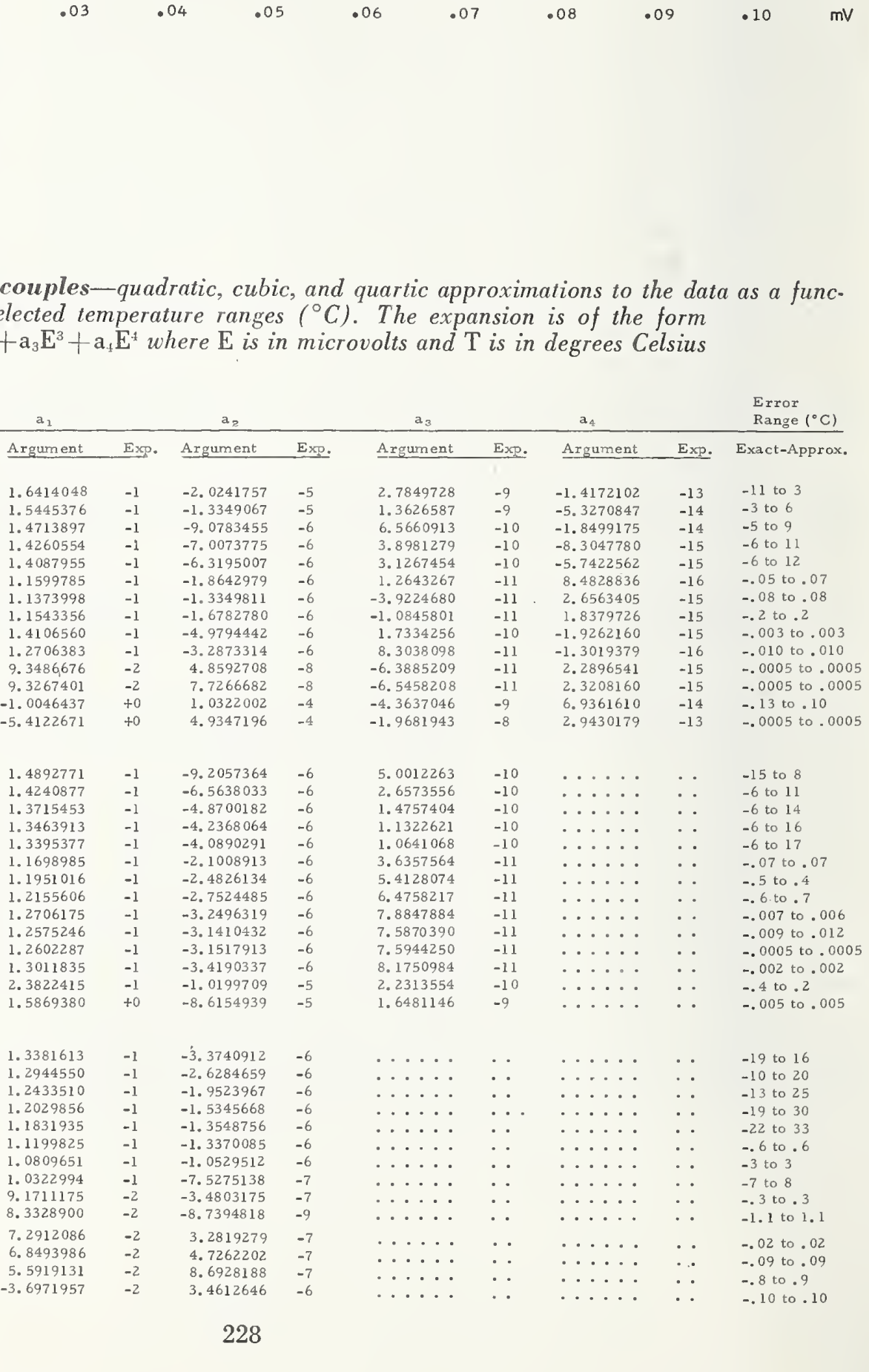

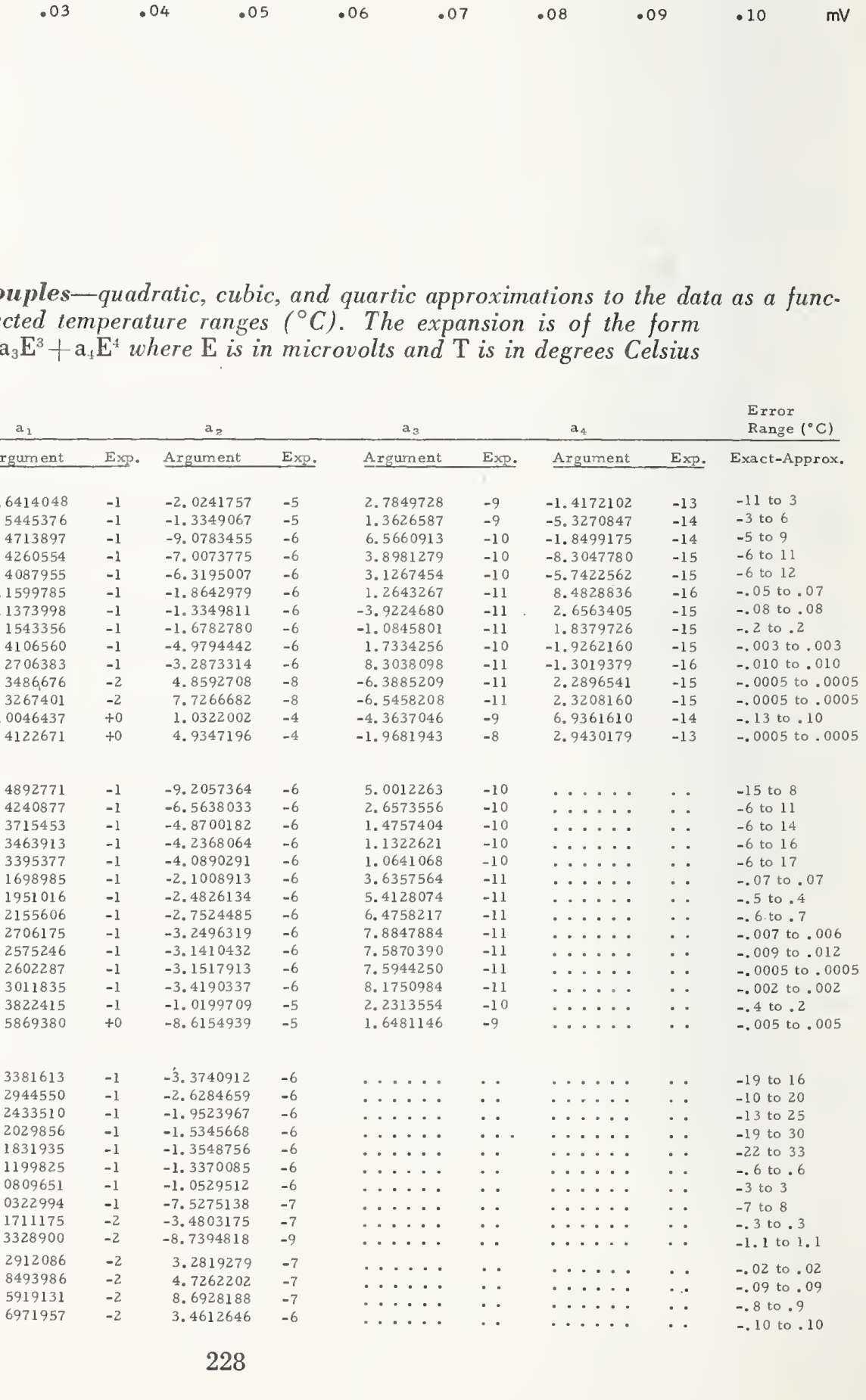

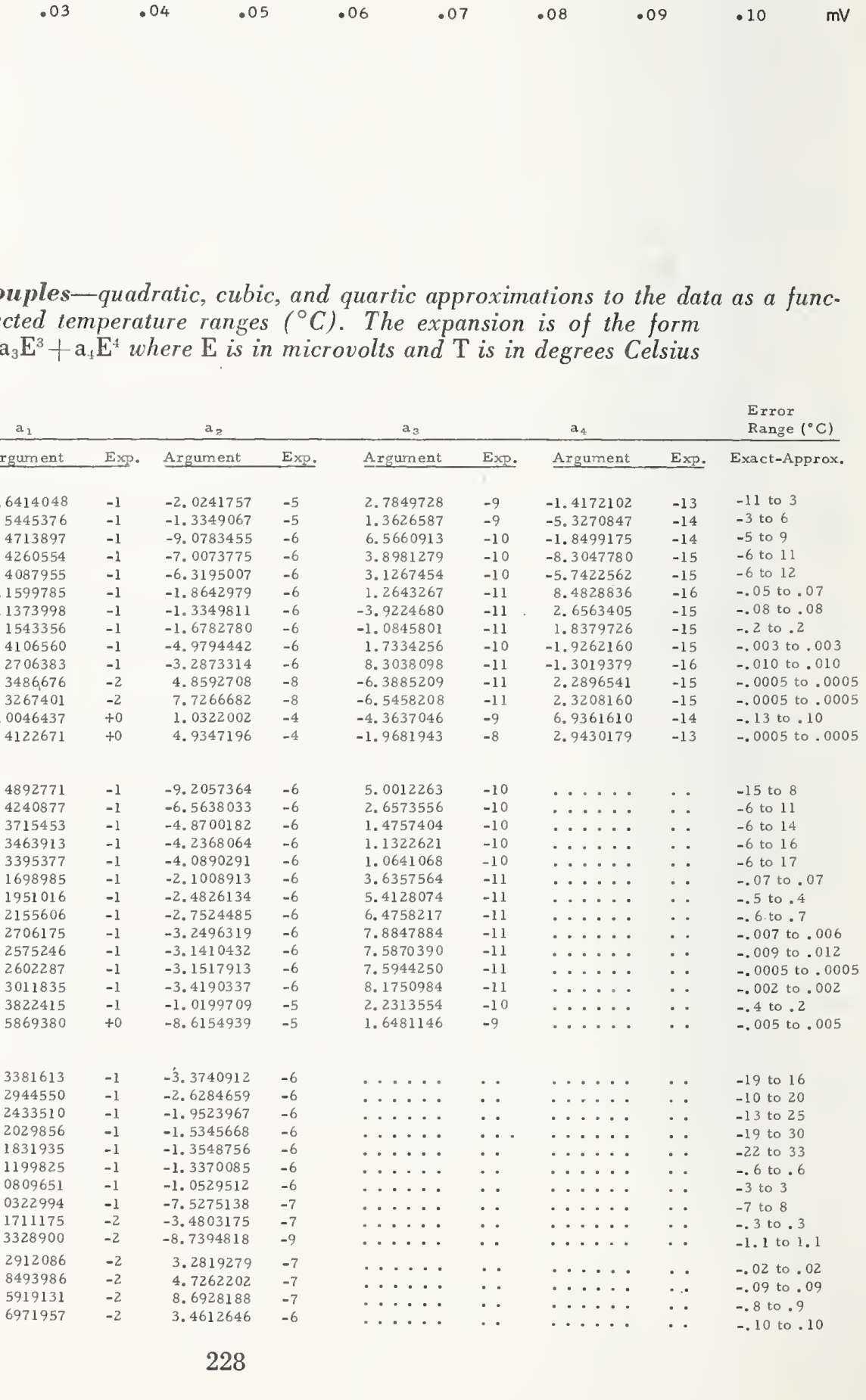

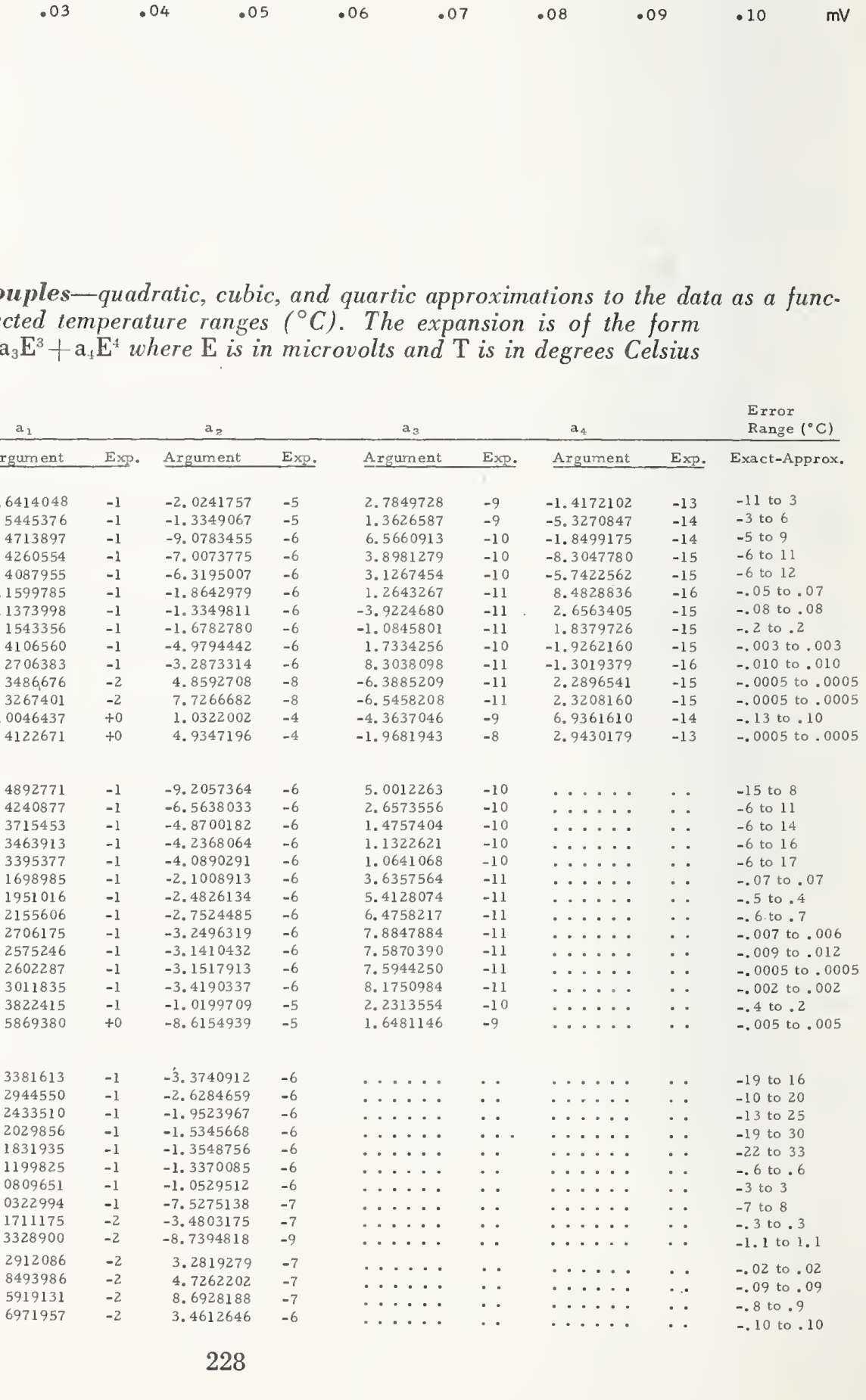

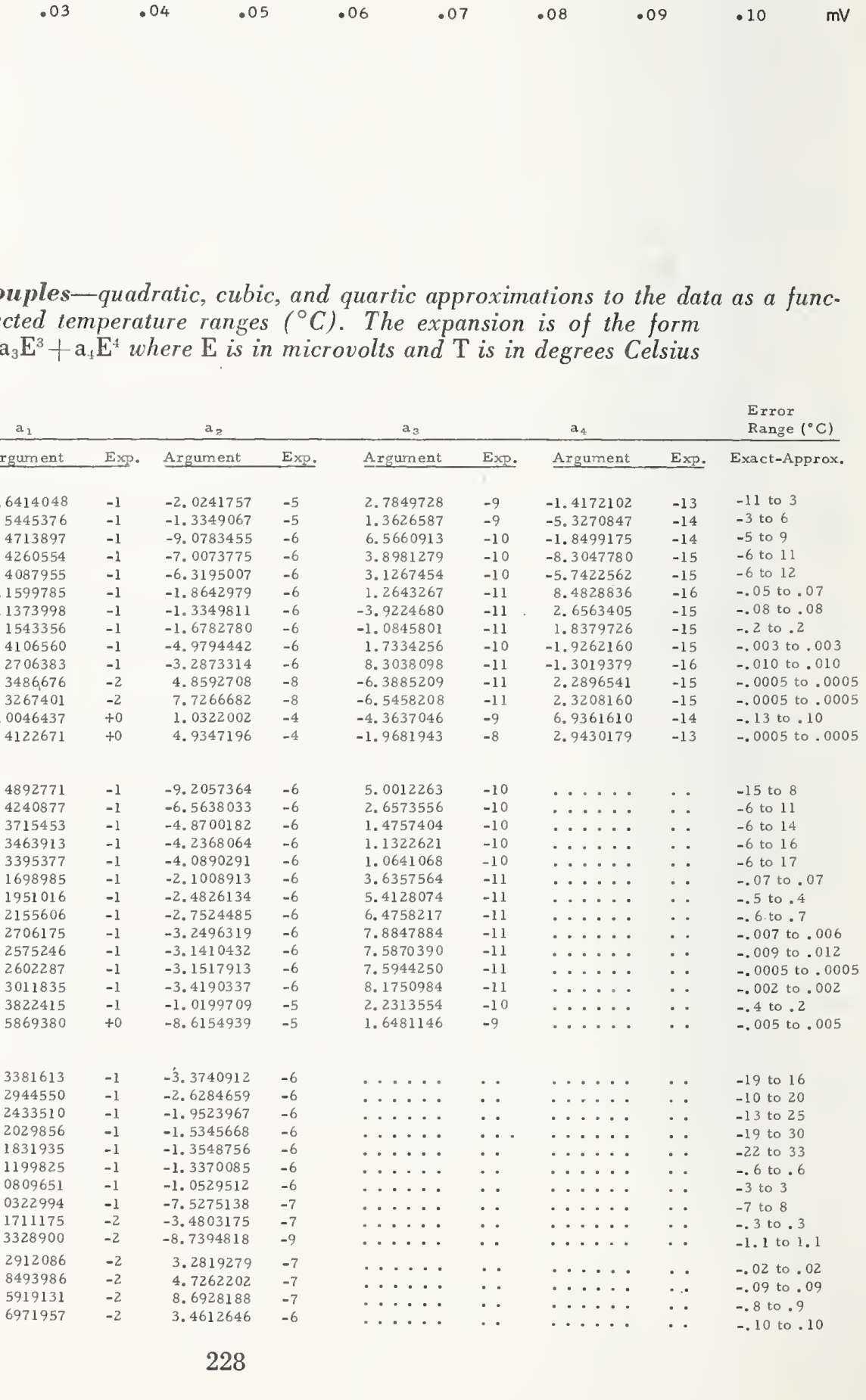

-3. 3740912 -2.6284659
-1.9523967

$-1.5345668$ $-1.3548756$

$-1.3370085$

$-1.0529512$

$-7.5275138$

$-3.4803175$

$-8.7394818$

3. 2819279

4. 7262202

8. 6928188

3. 4612646

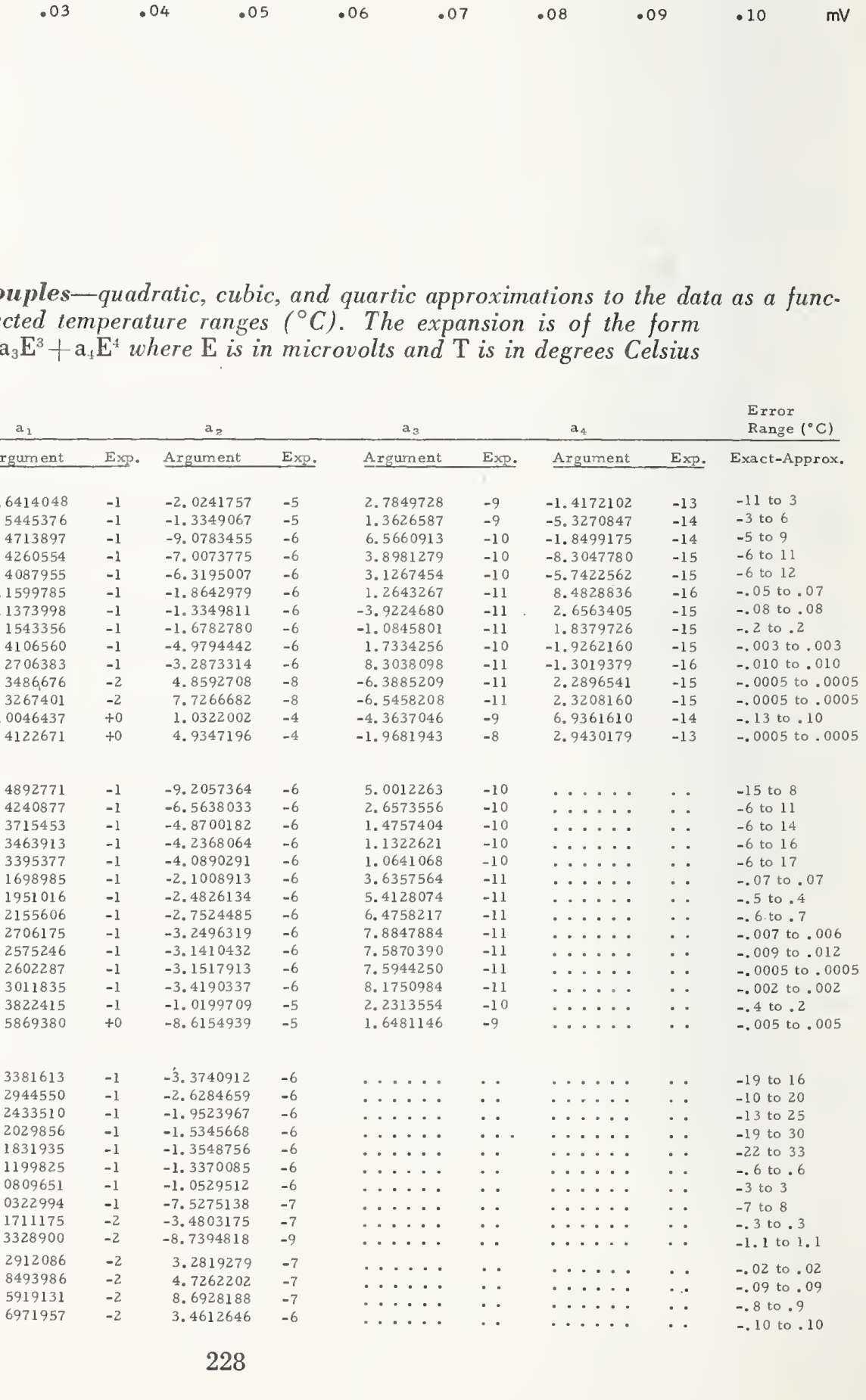

Error

Range ( ${ }^{\circ} \mathrm{C}$ )

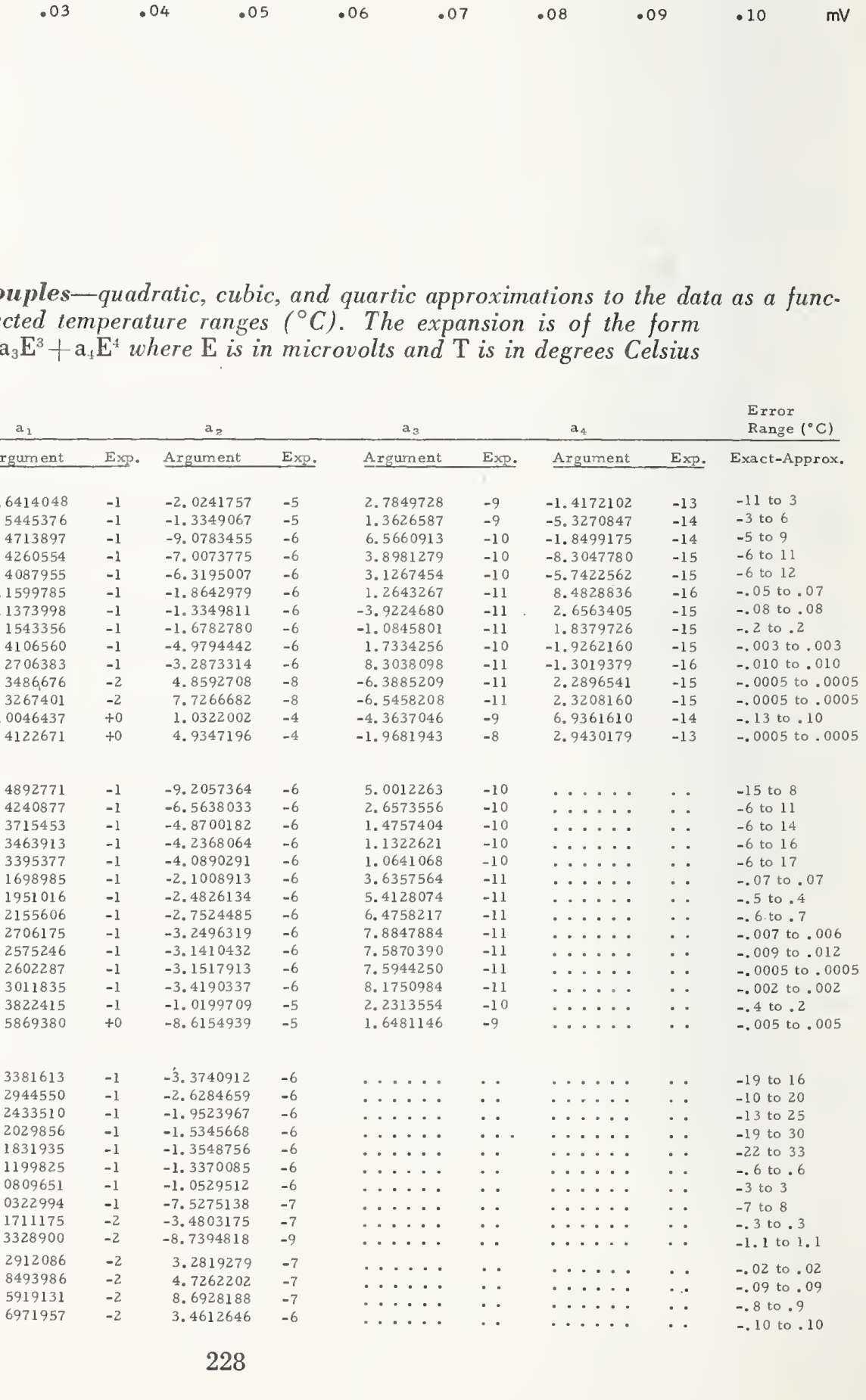

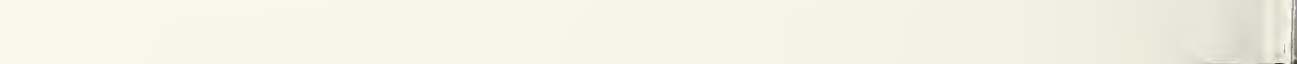

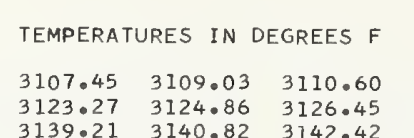




\section{A3. Supplementary Data for Type R-Platinum-13\% Rhodium Alloy versus Platinum Thermocouples}

\section{A3.1. Data for Voltage as a Function of Temperature}

The full precision coefficients given in the main text are used to generate the voltage as a function of temperature data given in tables A3.1.1 and A3.1.2. Table A3.1.1 presents the data in degrees Celsius from $-50{ }^{\circ} \mathrm{C}$ to $1768{ }^{\circ} \mathrm{C}$ while table A3.1.2 presents the data in degrees Fahrenheit from $-58^{\circ} \mathrm{F}$ to $3214^{\circ} \mathrm{F}$. Table A3.1.3 contains quadratic, cubic, and quartic approximations to the data as a function of temperature in selected temperature ranges. The error range given in the table is the difference between the voltage as obtained from the full precision coefficients from the text and the respective reduced order approximations. The last entries in the cubic and quadratic groupings of table A3.1.3 represent variable reference junction corrections in the 0 to $50{ }^{\circ} \mathrm{C}$ temperature range. In the narrower temperature range near room temperatures, 20 to $25{ }^{\circ} \mathrm{C}$, the error range for the given quadratic equation is smaller than that listed in the last column: $\pm 0.04 \mu \mathrm{V}$.

TABLE A3.1.1. Type $\boldsymbol{R}$ thermocouples-thermoelectric voltage as a function of temperature $\left({ }^{\circ} \mathrm{C}\right)$, reference junctions at $0^{\circ} \mathrm{C}$

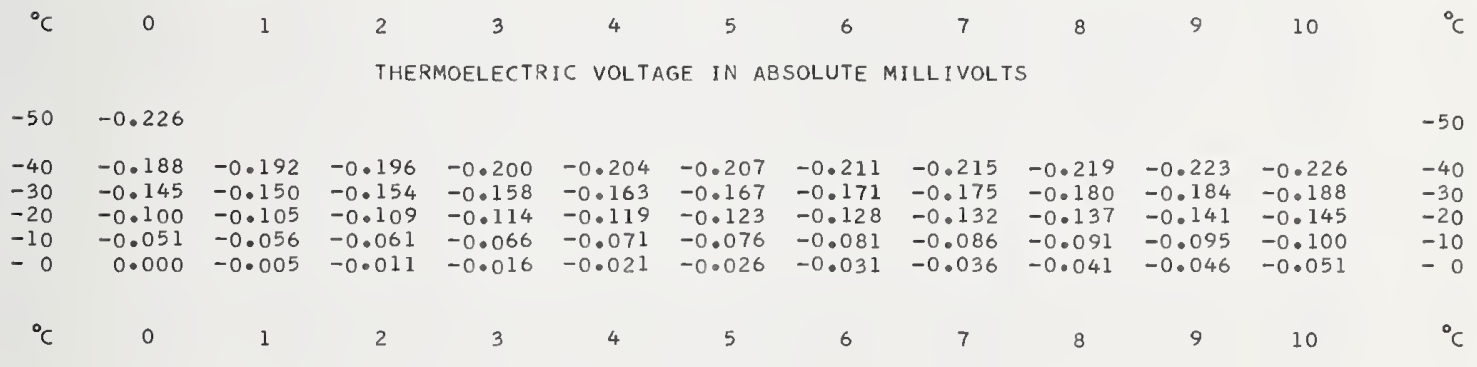


TABLE A3.1.1. Type $\boldsymbol{R}$ thermocouples-thermoelectric voltage as a function of temperature $\left({ }^{\circ} \mathrm{C}\right)$, reference junctions at $0^{\circ} \mathrm{C}$-Continued

40

5

70

80
90

10

110

120

130

150

160

170

190

200

21

230
240

250

260

270
280

290

300

310

33
34

350

360

370

380

400

410

420

440

450

460

470

490

500

510

520

540

550

560

580

590

600
1

0.054

0.111

0.171

0.232

0.296

0.363

.431

0.573

0.647

0.723

0.800

0.879

0.959

1.041

1.124
1.208

1.294

1.380

1. 468

1.647

1.738

1.830

1.923

2.017
2.111

2.207

2.303

2.400

2.498

2.596

2. 795

2.896

2.997

3.099

3.201

3. 304

3.407

3.511

3.721

3.826

3.933

4.039

4.146

4.254

4.362

4.471

4.580

4.689

4.799

4. 910

5.021

5.132

5.244

5.356

5.469

5.582
0.005

0.060

0.117

0.177

0.239

0.303

0.369

0.438

0.581

0.655

0.730

0.887

0.967

1.049

1.132
1.217

1.302

1.389

1. 477

1.566

1.747

1.839

1.932

2.026
2.121

2.216

2.313

2.410

2.508

2.606

2.705
2.805

2.906

3.007

3.109

3.211

3.418

3.522

3.626

3.731

3.943

4.050

4.157

4.265

4.373

4.481

4.591
4.700

4.810

4.921

5.032

5.143

5.255

5.368

5.480

5.594

(

34

5

6

7

8

9

10

${ }^{\circ} \mathrm{C}$

THERMOELECTRIC VOLTAGE IN ABSOLUTE MILLIVOLTS

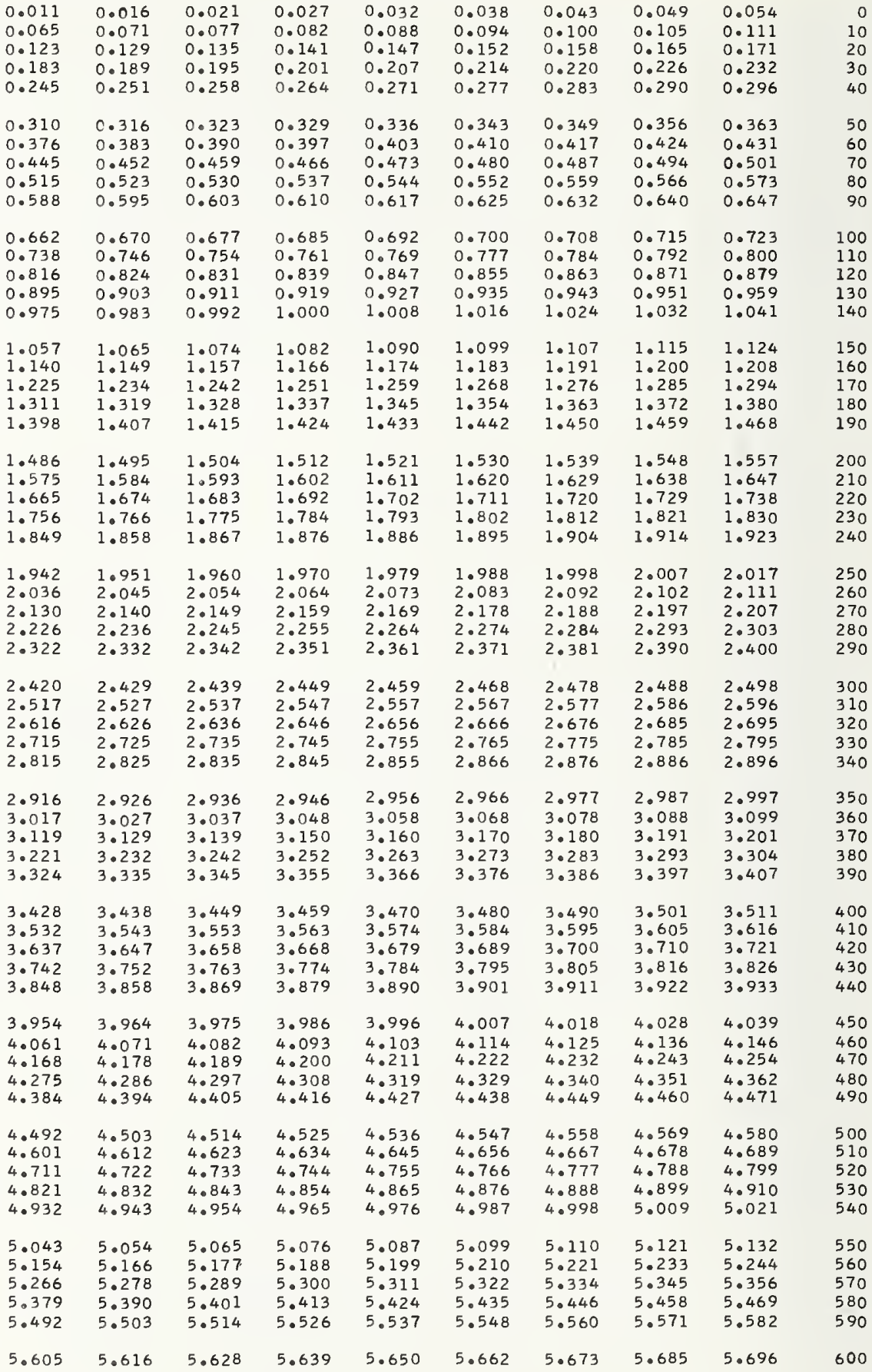

${ }^{\circ} \mathrm{C}$

0

1

2

3

4

5

6

7

8

9

10

${ }^{\circ} \mathrm{C}$ 
TABLE A3.1.1. Type $R$ thermocouples-thermoelectric voltage as a function of temperature $\left({ }^{\circ} \mathrm{C}\right)$, reference junctions at $0^{\circ} \mathrm{C}$-Continued

${ }^{\circ} \mathrm{C}$

0

1

2
3
5

6

\begin{abstract}
7
\end{abstract}
8

9

10

${ }^{\circ} \mathrm{C}$

\begin{tabular}{|c|c|c|c|c|c|c|c|c|c|c|c|c|}
\hline $\begin{array}{l}600 \\
610 \\
620 \\
630 \\
640\end{array}$ & $\begin{array}{l}5.582 \\
5.696 \\
5.810 \\
5.925 \\
6.040\end{array}$ & $\begin{array}{l}5.594 \\
5.707 \\
5.821 \\
5.936 \\
6.051\end{array}$ & $\begin{array}{l}5.605 \\
5.719 \\
5.833 \\
5.948 \\
6.063\end{array}$ & $\begin{array}{l}5.616 \\
5.730 \\
5.844 \\
5.959 \\
6.074\end{array}$ & $\begin{array}{l}5.628 \\
5.742 \\
5.856 \\
5.971 \\
6.086\end{array}$ & $\begin{array}{l}5.639 \\
5.753 \\
5.867 \\
5.982 \\
6.098\end{array}$ & $\begin{array}{l}5.650 \\
5.764 \\
5.879 \\
5.994 \\
6.109\end{array}$ & $\begin{array}{l}5.662 \\
5.776 \\
5.890 \\
6.005 \\
6.121\end{array}$ & $\begin{array}{l}5.673 \\
5.787 \\
5.902 \\
6.017 \\
6.132\end{array}$ & $\begin{array}{l}5.685 \\
5.799 \\
5.913 \\
6.028 \\
6.144\end{array}$ & $\begin{array}{l}5.696 \\
5.810 \\
5.925 \\
6.040 \\
6.155\end{array}$ & $\begin{array}{l}600 \\
610 \\
620 \\
630 \\
640\end{array}$ \\
\hline $\begin{array}{l}650 \\
660 \\
670 \\
680 \\
690\end{array}$ & $\begin{array}{l}6.155 \\
6.272 \\
6.388 \\
6.505 \\
6.623\end{array}$ & $\begin{array}{l}6.167 \\
6.283 \\
6.400 \\
6.517 \\
6.635\end{array}$ & $\begin{array}{l}6.179 \\
6.295 \\
6.412 \\
6.529 \\
6.647\end{array}$ & $\begin{array}{l}6.190 \\
6.307 \\
6.423 \\
6.541 \\
6.658\end{array}$ & $\begin{array}{l}6.202 \\
6.318 \\
6.435 \\
6.552 \\
6.670\end{array}$ & $\begin{array}{l}6.213 \\
6.330 \\
6.447 \\
6.564 \\
6.682\end{array}$ & $\begin{array}{l}6.225 \\
6.342 \\
6.458 \\
6.576 \\
6.694\end{array}$ & $\begin{array}{l}6.237 \\
6.353 \\
6.470 \\
6.588 \\
6.706\end{array}$ & $\begin{array}{l}6.248 \\
6.365 \\
6.482 \\
6.599 \\
6.718\end{array}$ & $\begin{array}{l}6.260 \\
6.377 \\
6.494 \\
6.611 \\
6.729\end{array}$ & $\begin{array}{l}6.272 \\
6.388 \\
6.505 \\
6.623 \\
6.741\end{array}$ & $\begin{array}{l}650 \\
660 \\
670 \\
680 \\
690\end{array}$ \\
\hline $\begin{array}{l}700 \\
710 \\
720 \\
730 \\
740\end{array}$ & $\begin{array}{l}6.741 \\
6.860 \\
6.979 \\
7.098 \\
7.218\end{array}$ & $\begin{array}{l}6.753 \\
6.872 \\
6.991 \\
7.110 \\
7.231\end{array}$ & $\begin{array}{l}6.765 \\
6.884 \\
7.003 \\
7.122 \\
7.243\end{array}$ & $\begin{array}{l}6.777 \\
6.895 \\
7.015 \\
7.134 \\
7.255\end{array}$ & $\begin{array}{l}6.789 \\
6.907 \\
7.027 \\
7.146 \\
7.267\end{array}$ & $\begin{array}{l}6.800 \\
6.919 \\
7.039 \\
7.158 \\
7.279\end{array}$ & $\begin{array}{l}6.812 \\
6.931 \\
7.051 \\
7.170 \\
7.291\end{array}$ & $\begin{array}{l}6.824 \\
6.943 \\
7.063 \\
7.182 \\
7.303\end{array}$ & $\begin{array}{l}6.836 \\
6.955 \\
7.074 \\
7.194 \\
7.315\end{array}$ & $\begin{array}{l}6.848 \\
6.967 \\
7.086 \\
7.206 \\
7.327\end{array}$ & $\begin{array}{l}6.860 \\
6.979 \\
7.098 \\
7.218 \\
7.339\end{array}$ & $\begin{array}{l}700 \\
710 \\
720 \\
730 \\
740\end{array}$ \\
\hline $\begin{array}{l}750 \\
760 \\
770 \\
780 \\
790\end{array}$ & $\begin{array}{l}7.339 \\
7.460 \\
7.582 \\
7.703 \\
7.826\end{array}$ & $\begin{array}{l}7.351 \\
7.472 \\
7.594 \\
7.716 \\
7.838\end{array}$ & $\begin{array}{l}7.363 \\
7.484 \\
7.606 \\
7.728 \\
7.850\end{array}$ & $\begin{array}{l}7.375 \\
7.496 \\
7.618 \\
7.740 \\
7.863\end{array}$ & $\begin{array}{l}7.387 \\
7.509 \\
7.630 \\
7.752 \\
7.875\end{array}$ & $\begin{array}{l}7.399 \\
7.521 \\
7.642 \\
7.765 \\
7.887\end{array}$ & $\begin{array}{l}7.412 \\
7.533 \\
7.655 \\
7.777 \\
7.900\end{array}$ & $\begin{array}{l}7.424 \\
7.545 \\
7.667 \\
7.789 \\
7.912\end{array}$ & $\begin{array}{l}7.436 \\
7.557 \\
7.679 \\
7.801 \\
7.924\end{array}$ & $\begin{array}{l}7.448 \\
7.569 \\
7.691 \\
7.814 \\
7.937\end{array}$ & $\begin{array}{l}7.460 \\
7.582 \\
7.703 \\
7.826 \\
7.949\end{array}$ & $\begin{array}{l}750 \\
760 \\
770 \\
780 \\
790\end{array}$ \\
\hline $\begin{array}{l}800 \\
810 \\
820 \\
830 \\
840\end{array}$ & $\begin{array}{l}7.949 \\
8.072 \\
8.196 \\
8.320 \\
8.445\end{array}$ & $\begin{array}{l}7.961 \\
8.085 \\
8.208 \\
8.333 \\
8.458\end{array}$ & $\begin{array}{l}7.973 \\
8.097 \\
8.221 \\
8.345 \\
8.470\end{array}$ & $\begin{array}{l}7.986 \\
8.109 \\
8.233 \\
8.358 \\
8.483\end{array}$ & $\begin{array}{l}7.998 \\
8.122 \\
8.246 \\
8.370 \\
8.495\end{array}$ & $\begin{array}{l}8.010 \\
8.134 \\
8.258 \\
8.383 \\
8.508\end{array}$ & $\begin{array}{l}8.023 \\
8.146 \\
8.271 \\
8.395 \\
8.520\end{array}$ & $\begin{array}{l}8.035 \\
8.159 \\
8.283 \\
8.408 \\
8.533\end{array}$ & $\begin{array}{l}8.047 \\
8.171 \\
8.295 \\
8.420 \\
8.545\end{array}$ & $\begin{array}{l}8.060 \\
8.184 \\
8.308 \\
8.433 \\
8.558\end{array}$ & $\begin{array}{l}8.072 \\
8.196 \\
8.320 \\
8.445 \\
8.570\end{array}$ & $\begin{array}{l}800 \\
810 \\
820 \\
830 \\
840\end{array}$ \\
\hline $\begin{array}{l}850 \\
860 \\
870 \\
880 \\
890\end{array}$ & $\begin{array}{l}8.570 \\
8.696 \\
8.822 \\
8.949 \\
9.076\end{array}$ & $\begin{array}{l}8.583 \\
8.709 \\
8.835 \\
8.961 \\
9.089\end{array}$ & $\begin{array}{l}8.595 \\
8.721 \\
8.847 \\
8.974 \\
9.101\end{array}$ & $\begin{array}{l}8.608 \\
8.734 \\
8.860 \\
8.987 \\
9.114\end{array}$ & $\begin{array}{l}8.621 \\
8.746 \\
8.873 \\
9.000 \\
9.127\end{array}$ & $\begin{array}{l}8.633 \\
8.759 \\
8.885 \\
9.012 \\
9.140\end{array}$ & $\begin{array}{l}8.646 \\
8.772 \\
8.898 \\
9.025 \\
9.152\end{array}$ & $\begin{array}{l}8.658 \\
8.784 \\
8.911 \\
9.038 \\
9.165\end{array}$ & $\begin{array}{l}8.671 \\
8.797 \\
8.923 \\
9.050 \\
9.178\end{array}$ & $\begin{array}{l}8.683 \\
8.810 \\
8.936 \\
9.063 \\
9.191\end{array}$ & $\begin{array}{l}8.696 \\
8.822 \\
8.949 \\
9.076 \\
9.203\end{array}$ & $\begin{array}{l}850 \\
860 \\
870 \\
880 \\
890\end{array}$ \\
\hline $\begin{array}{l}900 \\
910 \\
920 \\
930 \\
940\end{array}$ & $\begin{array}{l}9.203 \\
9.331 \\
9.460 \\
9.589 \\
9.718\end{array}$ & $\begin{array}{l}9.216 \\
9.344 \\
9.473 \\
9.602 \\
9.731\end{array}$ & $\begin{array}{l}9.229 \\
9.357 \\
9.485 \\
9.614 \\
9.744\end{array}$ & $\begin{array}{l}9.242 \\
9.370 \\
9.498 \\
9.627 \\
9.757\end{array}$ & $\begin{array}{l}9.254 \\
9.383 \\
9.511 \\
9.640 \\
9.770\end{array}$ & $\begin{array}{l}9.267 \\
9.395 \\
9.524 \\
9.653 \\
9.783\end{array}$ & $\begin{array}{l}9.280 \\
9.408 \\
9.537 \\
9.666 \\
9.796\end{array}$ & $\begin{array}{l}9.293 \\
9.421 \\
9.550 \\
9.679 \\
9.809\end{array}$ & $\begin{array}{l}9.306 \\
9.434 \\
9.563 \\
9.692 \\
9.822\end{array}$ & $\begin{array}{l}9.319 \\
9.447 \\
9.576 \\
9.705 \\
9.835\end{array}$ & $\begin{array}{l}9.331 \\
9.460 \\
9.589 \\
9.718 \\
9.848\end{array}$ & $\begin{array}{l}900 \\
910 \\
920 \\
930 \\
940\end{array}$ \\
\hline $\begin{array}{l}950 \\
960 \\
970 \\
980 \\
990\end{array}$ & $\begin{array}{r}9.848 \\
9.978 \\
10.109 \\
10.240 \\
10.371\end{array}$ & $\begin{array}{r}9.861 \\
9.991 \\
10.122 \\
10.253 \\
10.384\end{array}$ & $\begin{array}{r}9.874 \\
10.004 \\
10.135 \\
10.266 \\
10.398\end{array}$ & $\begin{array}{r}9.887 \\
10.017 \\
10.148 \\
10.279 \\
10.411\end{array}$ & $\begin{array}{r}9.900 \\
10.030 \\
10.161 \\
10.292 \\
10.424\end{array}$ & $\begin{array}{r}9.913 \\
10.043 \\
10.174 \\
10.305 \\
10.437\end{array}$ & $\begin{array}{r}9.926 \\
10.056 \\
10.187 \\
10.319 \\
10.450\end{array}$ & $\begin{array}{r}9.939 \\
10.069 \\
10.200 \\
10.332 \\
10.464\end{array}$ & $\begin{array}{r}9.952 \\
10.082 \\
10.213 \\
10.345 \\
10.477\end{array}$ & $\begin{array}{r}9.965 \\
10.095 \\
10.227 \\
10.358 \\
10.490\end{array}$ & $\begin{array}{r}9.978 \\
10.109 \\
10.240 \\
10.371 \\
10.503\end{array}$ & $\begin{array}{l}950 \\
960 \\
970 \\
980 \\
990\end{array}$ \\
\hline $\begin{array}{l}1,000 \\
1,010 \\
1,020 \\
1,030 \\
1,040\end{array}$ & $\begin{array}{l}10.503 \\
10.636 \\
10.768 \\
10.902 \\
11.035\end{array}$ & $\begin{array}{l}10.516 \\
10.649 \\
10.782 \\
10.915 \\
11.049\end{array}$ & $\begin{array}{l}10.530 \\
10.662 \\
10.795 \\
10.928 \\
11.062\end{array}$ & $\begin{array}{l}10.543 \\
10.675 \\
10.808 \\
10.942 \\
11.076\end{array}$ & $\begin{array}{l}10.556 \\
10.689 \\
10.822 \\
10.955 \\
11.089\end{array}$ & $\begin{array}{l}10.569 \\
10.702 \\
10.835 \\
10.968 \\
11.102\end{array}$ & $\begin{array}{l}10.583 \\
10.715 \\
10.848 \\
10.982 \\
11.116\end{array}$ & $\begin{array}{l}10.596 \\
10.729 \\
10.862 \\
10.995 \\
11.129\end{array}$ & $\begin{array}{l}10.609 \\
10.742 \\
10.875 \\
11.009 \\
11.143\end{array}$ & $\begin{array}{l}10.622 \\
10.755 \\
10.888 \\
11.022 \\
11.156\end{array}$ & $\begin{array}{l}10.636 \\
10.768 \\
10.902 \\
11.035 \\
11.170\end{array}$ & $\begin{array}{l}1,000 \\
1,010 \\
1,020 \\
1,030 \\
1,040\end{array}$ \\
\hline $\begin{array}{l}1,050 \\
1,060 \\
1,070 \\
1,080 \\
1,090\end{array}$ & $\begin{array}{l}11.170 \\
11.304 \\
11.439 \\
11.574 \\
11.710\end{array}$ & $\begin{array}{l}11.183 \\
11.318 \\
11.453 \\
11.588 \\
11.724\end{array}$ & $\begin{array}{l}11.196 \\
11.331 \\
11.466 \\
11.602 \\
11.737\end{array}$ & $\begin{array}{l}11.210 \\
11.345 \\
11.480 \\
11.615 \\
11.751\end{array}$ & $\begin{array}{l}11.223 \\
11.358 \\
11.493 \\
11.629 \\
11.765\end{array}$ & $\begin{array}{l}11.237 \\
11.372 \\
11.507 \\
11.642 \\
11.778\end{array}$ & $\begin{array}{l}11.250 \\
11.385 \\
11.520 \\
11.656 \\
11.792\end{array}$ & $\begin{array}{l}11.264 \\
11.399 \\
11.534 \\
11.669 \\
11.805\end{array}$ & $\begin{array}{l}11.277 \\
11.412 \\
11.547 \\
11.683 \\
11.819\end{array}$ & $\begin{array}{l}11.291 \\
11.426 \\
11.561 \\
11.697 \\
11.833\end{array}$ & $\begin{array}{l}11.304 \\
11.439 \\
11.574 \\
11.710 \\
11.846\end{array}$ & $\begin{array}{l}1,050 \\
1,060 \\
1,070 \\
1,080 \\
1,090\end{array}$ \\
\hline $\begin{array}{l}1,100 \\
1,110 \\
1,120 \\
1,130 \\
1,140\end{array}$ & $\begin{array}{l}11.846 \\
11.983 \\
12.119 \\
12.257 \\
12.394\end{array}$ & $\begin{array}{l}11.860 \\
11.996 \\
12.133 \\
12.270 \\
12.408\end{array}$ & $\begin{array}{l}11.874 \\
12.010 \\
12.147 \\
12.284 \\
12.421\end{array}$ & $\begin{array}{l}11.887 \\
12.024 \\
12.161 \\
12.298 \\
12.435\end{array}$ & $\begin{array}{l}11.901 \\
12.037 \\
12.174 \\
12.311 \\
12.449\end{array}$ & $\begin{array}{l}11.914 \\
12.051 \\
12.188 \\
12.325 \\
12.463\end{array}$ & $\begin{array}{l}11.928 \\
12.065 \\
12.202 \\
12.339 \\
12.476\end{array}$ & $\begin{array}{l}11.942 \\
12.078 \\
12.215 \\
12.353 \\
12.490\end{array}$ & $\begin{array}{l}11.955 \\
12.092 \\
12.229 \\
12.366 \\
12.504\end{array}$ & $\begin{array}{l}11.969 \\
12.106 \\
12.243 \\
12.380 \\
12.518\end{array}$ & $\begin{array}{l}11.983 \\
12.119 \\
12.257 \\
12.394 \\
12.532\end{array}$ & $\begin{array}{l}1,100 \\
1,110 \\
1,120 \\
1,130 \\
1,140\end{array}$ \\
\hline $\begin{array}{l}1,150 \\
1,160 \\
1,170 \\
1,180 \\
1,190\end{array}$ & $\begin{array}{l}12.532 \\
12.669 \\
12.808 \\
12.946 \\
13.085\end{array}$ & $\begin{array}{l}12.545 \\
12.683 \\
12.822 \\
12.960 \\
13.099\end{array}$ & $\begin{array}{l}12.559 \\
12.697 \\
12.835 \\
12.974 \\
13.113\end{array}$ & $\begin{array}{l}12.573 \\
12.711 \\
12.849 \\
12.988 \\
13.127\end{array}$ & $\begin{array}{l}12.587 \\
12.725 \\
12.863 \\
13.002 \\
13.140\end{array}$ & $\begin{array}{l}12.600 \\
12.739 \\
12.877 \\
13.016 \\
13.154\end{array}$ & $\begin{array}{l}12.614 \\
12.752 \\
12.891 \\
13.029 \\
13.168\end{array}$ & $\begin{array}{l}12.628 \\
12.766 \\
12.905 \\
13.043 \\
13.182\end{array}$ & $\begin{array}{l}12.642 \\
12.780 \\
12.918 \\
13.057 \\
13.196\end{array}$ & $\begin{array}{l}12.656 \\
12.794 \\
12.932 \\
13.071 \\
13.210\end{array}$ & $\begin{array}{l}12.669 \\
12.808 \\
12.946 \\
13.085 \\
13.224\end{array}$ & $\begin{array}{l}1,160 \\
1,170 \\
1,180 \\
1,190\end{array}$ \\
\hline 200 & 3.224 & 13.238 & 3.252 & 3.266 & 3.280 & .293 & 13.307 & 13.321 & 13.335 & 13.349 & 13.363 & 200 \\
\hline
\end{tabular}

4

5

6

7

8

9

10

${ }^{\circ} \mathrm{C}$ 
TABLE A3.1.1. Type $\boldsymbol{R}$ thermocouples-thermoelectric voltage as a function of temperature $\left({ }^{\circ} \mathrm{C}\right)$, reference junctions at $0^{\circ} \mathrm{C}$-Continued

${ }^{\circ} \mathrm{C}$
0

1

2

3

4

5

6

7

8

10

${ }^{\circ} \mathrm{C}$

\begin{tabular}{|c|c|c|c|c|c|c|c|c|c|c|c|c|}
\hline 1,200 & 13.224 & 13.238 & 13.252 & $13 \cdot 266$ & 13.280 & 13.293 & 13.307 & 13.321 & 13.335 & 13.349 & 13.363 & 1,200 \\
\hline 1,210 & 13.363 & $13 \cdot 377$ & 13.391 & 13.405 & 13.419 & 13.433 & 13.447 & 13.461 & 13.475 & 13.489 & 13.502 & 1,210 \\
\hline 1,220 & 13.502 & 13.516 & 13.530 & 13.544 & 13.558 & 13.572 & 13.586 & 13.600 & 13.614 & 13.628 & 13.642 & 1,220 \\
\hline $\begin{array}{l}1,230 \\
1,240\end{array}$ & 13.642 & 13.656 & 13.670 & 13.684 & 13.698 & 13.712 & 13.726 & 13.740 & $13 \cdot 754$ & 13.768 & 13.782 & 1,230 \\
\hline, 240 & 13.782 & 13.796 & 13.810 & 13.824 & 13.838 & 13.852 & 13.866 & 13.880 & 13.894 & 13.908 & 13.922 & 1,240 \\
\hline 1,250 & 13.922 & 13.936 & 13.950 & 13.964 & 13.978 & 13.992 & 14.006 & 14.020 & 14.034 & 14.048 & 14.062 & 1,250 \\
\hline 1,260 & 14.062 & 14.076 & 14.090 & $14 \cdot 104$ & 14.118 & 14.132 & 14.146 & 14.160 & 14.174 & 14.188 & 14.202 & 1,260 \\
\hline 1,270 & 14.202 & 14.216 & & 14.244 & & & 286 & 14.301 & $14 \cdot 315$ & 14.329 & 14.343 & 1,270 \\
\hline 1,280 & 14.343 & 14.357 & 14.371 & 14.385 & 14.399 & 14.413 & 14.427 & 14.441 & 14.455 & 14.469 & 14.483 & 1,280 \\
\hline 1,290 & 14.483 & 14.497 & 14.511 & 14.525 & 14.539 & 14.554 & 14.568 & 14.582 & 14.596 & 14.610 & 14.624 & 1,290 \\
\hline 1,300 & 14.624 & 14.638 & 14.652 & 14.666 & 14.680 & 14.694 & 14.708 & 14.722 & 14.737 & 14.751 & 14.765 & 1,300 \\
\hline 1,310 & 14.765 & 14.779 & 14.793 & 14.807 & 14.821 & 14.835 & 14.849 & 14.863 & 14.877 & 14.891 & 14.906 & 1,310 \\
\hline 1,320 & 14.906 & 14.920 & 14.934 & 14.948 & 14.962 & 14.976 & 14.990 & 15.004 & 15.018 & 15.032 & 15.047 & 1.320 \\
\hline 1,330 & 15.047 & 15.061 & 15.075 & 15.089 & 15.103 & 15.117 & 15.131 & 15.145 & 15.159 & 15.173 & 15.188 & 1,330 \\
\hline 1,340 & 15.188 & 15,202 & 15.216 & 15.230 & 15.244 & 15.258 & 15.272 & 15.286 & $15 \cdot 300$ & 15.315 & 15.329 & 1.340 \\
\hline 1,350 & 15.329 & 15.343 & 15.357 & 15.371 & 15.385 & 15.399 & 15.413 & 15.427 & 15.442 & 15.456 & 15.470 & 1,350 \\
\hline 1,360 & 15.470 & 15.484 & 15.498 & 15.512 & 15.526 & 15.540 & 555 & 569 & 583 & 597 & 15.611 & 1,360 \\
\hline 1,370 & 15.611 & 15.625 & 15.639 & 15.653 & 15.667 & 15.682 & 15.696 & 15.710 & 15.724 & 15.738 & 15.752 & 1.370 \\
\hline 1,380 & 15.752 & 15.766 & 15.780 & 15.795 & 15.809 & 15.823 & 837 & 51 & 15.865 & 15.879 & 15.893 & 1,380 \\
\hline 1,390 & 15.893 & $15 \cdot 908$ & 15.922 & 15.936 & 15.950 & 15.964 & 15.978 & 15.992 & 16.006 & 16.021 & 16.035 & 1,390 \\
\hline 1,400 & 16.035 & 6.049 & 16.063 & 16.077 & 16.091 & 6.105 & 16.119 & 16.134 & 16.148 & 16.162 & 16.176 & 1,400 \\
\hline 1,410 & & 16.190 & & 16.218 & & & & & & & & 1,410 \\
\hline 1,420 & 16.317 & 16.331 & 16.345 & 16.360 & 16.374 & 16.388 & 16.402 & 16 & 430 & 44 & 58 & 1,420 \\
\hline 1,430 & 16.458 & 16.472 & 16.487 & 16.501 & 16.515 & 16.529 & 16.543 & 16.557 & 16.571 & 16.585 & 16.599 & 1,430 \\
\hline 1,440 & 16. & 16.614 & 16.628 & 16.642 & 16.656 & 16.670 & 16.684 & 16.698 & 16.712 & 16.726 & 16.741 & 1,440 \\
\hline 1,450 & 1 & 6.755 & 769 & 16.783 & 7 & 811 & 25 & 9 & 53 & 16 & 82 &, 450 \\
\hline 1,460 & 16.882 & 16.896 & 310 & 16.924 & $93 \varepsilon$ & 952 & 966 & 80 & 94 & & & 1,460 \\
\hline 1,470 & 17.022 & 17.037 & 17 & 17.065 & 17.079 & 93 & 107 & 21 & 35 & 49 & 17 & 1,470 \\
\hline 1,480 & 17.163 & 17.177 & 17.192 & 17.206 & 17.220 & 17.234 & 17.248 & $17 \cdot 262$ & 17.276 & 17.290 & $17 \cdot 304$ & 1,480 \\
\hline 1,490 & 17.304 & 17.318 & 17.332 & 17.346 & 17.360 & 17.374 & 17.388 & 17.403 & 17.417 & 17.431 & 17.445 & 1,490 \\
\hline 1,500 & 17.445 & 17.459 & 17.473 & 17.487 & 17.501 & 17.515 & 529 & 543 & 57 & 71 & 85 & 500 \\
\hline & & 17. & & 17.627 & 1 & 55 & 59 & & 98 & 2 & & 10 \\
\hline 1,520 & 17. & 17.740 & 17.754 & 17.768 & $17 \cdot 782$ & 796 & 17.810 & 17.824 & 17.838 & 17.852 & 17.866 & 1.520 \\
\hline & & & & & 922 & 936 & 50 & 64 & & & & .530 \\
\hline 1.540 & 18.006 & 18.020 & 18.034 & 18.048 & 18.062 & 18.076 & 18.090 & 18.104 & 18 & 18. & 18 &, 540 \\
\hline $\begin{array}{l}1,550 \\
1,560\end{array}$ & $\begin{array}{l}18.146 \\
18.286\end{array}$ & $\begin{array}{l}18.160 \\
18.299\end{array}$ & $\begin{array}{l}18.174 \\
18.313\end{array}$ & $\begin{array}{l}88 \\
27\end{array}$ & $\begin{array}{l}18.202 \\
18.341\end{array}$ & $\begin{array}{l}18.216 \\
18.355\end{array}$ & $\begin{array}{l}18.230 \\
18.369\end{array}$ & $\begin{array}{l}18 \cdot 244 \\
18.383\end{array}$ & $\begin{array}{l}18.258 \\
18.397\end{array}$ & $\begin{array}{l}18.272 \\
18.411\end{array}$ & $\begin{array}{l}86 \\
25\end{array}$ & $\begin{array}{l}550 \\
560\end{array}$ \\
\hline 1,570 & 18.425 & 18.439 & 18.453 & 467 & 18.481 & 18.495 & 18.509 & 18.523 & 18.537 & 18.550 & & 570 \\
\hline 1,580 & 18 & 18.578 & 18.592 & 18.606 & 18.620 & 34 & & & & & & 80 \\
\hline 1,590 & 18.703 & 18.717 & 18.731 & 18.745 & 18.759 & 18.773 & 18.787 & 18.801 & 18.815 & 18.828 & 18.842 & 1,590 \\
\hline 1,6 & & 66 & & 84 & & & & & & & & \\
\hline 10 & & 18 & & 23 & & & & & & 06 & & 610 \\
\hline 1 , & & 19 & & & & & & & & 44 & 57 & 520 \\
\hline 1.630 & 19 & 19.271 & 19.285 & 19.299 & 19.313 & 19.326 & & & & & & .630 \\
\hline 1,640 & 19.395 & 19.409 & 19.423 & 19.437 & 19.450 & 19.464 & 19.478 & 19.492 & 19.505 & 19.519 & 19.533 & 1,640 \\
\hline 1,650 & 533 & 47 & & 574 & & & & & & & & \\
\hline & & & & & & & & & & & & 60 \\
\hline 70 & 19.807 & $19 \cdot 821$ & 19. & 19.848 & 862 & 19.875 & & & 16 & & & 670 \\
\hline 1,680 & 19.944 & 19.957 & 19.971 & 19.985 & 998 & & 20. & 039 & 20 . & 20.066 & 80 & 1,680 \\
\hline 1,69 & $20 \cdot 0$ & 20.093 & 20.107 & $20 \cdot 120$ & 20.134 & 20.148 & 20.161 & 20.175 & $20 \cdot 188$ & 20.202 & 20.215 & 1,690 \\
\hline & & 29 & & 56 & 69 & 2 & & & & & & \\
\hline & & & & & & & & & & & & 1,710 \\
\hline & & & & & & & & & & & & 1,720 \\
\hline & & 20.629 & 20.642 & 20.656 & 20.669 & 682 & 20.695 & 20.708 & 20.721 & & & 1,730 \\
\hline 1,740 & 20.748 & 20.761 & 20.774 & 20.787 & 20.800 & 20.813 & 20.826 & 20.839 & 20.852 & 20.865 & 20.878 & 1,740 \\
\hline 1,750 & 20.878 & 20.891 & 20.904 & 20.916 & 20.929 & 20.942 & 20.955 & 20.968 & 20.981 & 20.994 & 21.006 & \\
\hline & 21.006 & 21.019 & 21.032 & 21.045 & 21.05 .7 & 21.070 & 21.083 & 21.096 & 21.108 & & & 1,760 \\
\hline${ }^{\circ} \mathrm{C}$ & 0 & 1 & 2 & 3 & 4 & 5 & 6 & 7 & 8 & 9 & 10 & ${ }^{\circ} \mathrm{C}$ \\
\hline
\end{tabular}


TABLE A3.1.2. Type R thermocouples-thermoelectric voltage as a function of temperature $\left({ }^{\circ} \mathrm{F}\right)$, reference junctions at $32^{\circ} \mathrm{F}$

\begin{tabular}{|c|c|c|c|c|c|c|c|c|c|c|c|c|}
\hline \multirow[t]{2}{*}{${ }^{\circ} \mathrm{F}$} & 0 & 1 & 2 & 3 & 4 & 5 & 6 & 7 & 8 & 9 & 10 & ${ }^{u_{F}}$ \\
\hline & \multicolumn{11}{|c|}{ THERMOELECTRIC VOLTAGE IN ABSOLUTE MILLIVOLTS } & \\
\hline-50 & -0.210 & -0.212 & -0.214 & -0.216 & -0.218 & -0.220 & -0.222 & -0.224 & -0.226 & & & -50 \\
\hline $\begin{array}{l}-40 \\
-30 \\
-20 \\
-10 \\
-\quad 0\end{array}$ & $\begin{array}{l}-0.188 \\
-0.165 \\
-0.141 \\
-0.116 \\
-0.089\end{array}$ & $\begin{array}{l}-0.190 \\
-0.167 \\
-0.143 \\
-0.118 \\
-0.092\end{array}$ & $\begin{array}{l}-0.192 \\
-0.169 \\
-0.145 \\
-0.121 \\
-0.095\end{array}$ & $\begin{array}{l}-0.194 \\
-0.172 \\
-0.148 \\
-0.123 \\
-0.097\end{array}$ & $\begin{array}{l}-0.197 \\
-0.174 \\
-0.150 \\
-0.126 \\
-0.100\end{array}$ & $\begin{array}{l}-0.199 \\
-0.176 \\
-0.153 \\
-0.128 \\
-0.103\end{array}$ & $\begin{array}{l}-0.201 \\
-0.179 \\
-0.155 \\
-0.131 \\
-0.105\end{array}$ & $\begin{array}{l}-0.203 \\
-0.181 \\
-0.158 \\
-0.133 \\
-0.108\end{array}$ & $\begin{array}{l}-0.205 \\
-0.183 \\
-0.160 \\
-0.136 \\
-0.110\end{array}$ & $\begin{array}{l}-0.207 \\
-0.185 \\
-0.162 \\
-0.138 \\
-0.113\end{array}$ & $\begin{array}{l}-0.210 \\
-0.188 \\
-0.165 \\
-0.141 \\
-0.116\end{array}$ & $\begin{array}{l}-40 \\
-30 \\
-20 \\
-10 \\
-\quad 0\end{array}$ \\
\hline
\end{tabular}

$\begin{array}{llllllllllllllll}{ }^{\circ} \mathrm{F} & 0 & 1 & 2 & 3 & 4 & 5 & 6 & 7 & 8 & 9 & 10 & & 8 & \end{array}$


TABLE A3.1.2. Type $\boldsymbol{R}$ thermocouples-thermoelectric voltage as a function of temperature $\left({ }^{\circ} \mathrm{F}\right)$, reference junctions at $32^{\circ} \mathrm{F}$-Continued

o

1

2

3

$4 \quad 5$

$6 \quad 7$

$9 \quad 10 \quad{ }^{\circ} \mathrm{F}$

\begin{tabular}{|c|c|c|c|c|c|c|c|c|c|c|c|c|}
\hline $\begin{array}{r}0 \\
10 \\
20 \\
30 \\
40\end{array}$ & $\begin{array}{r}-0.089 \\
-0.063 \\
-0.035 \\
-0.006 \\
0.024\end{array}$ & $\begin{array}{r}-0.087 \\
-0.060 \\
-0.032 \\
-0.003 \\
0.027\end{array}$ & $\begin{array}{r}-0.084 \\
-0.057 \\
-0.029 \\
0.000 \\
0.030\end{array}$ & $\begin{array}{r}-0.082 \\
-0.054 \\
-0.026 \\
0.003 \\
0.033\end{array}$ & $\begin{array}{r}-0.079 \\
-0.051 \\
-0.023 \\
0.006 \\
0.036\end{array}$ & $\begin{array}{r}-0.076 \\
-0.049 \\
-0.020 \\
0.009 \\
0.039\end{array}$ & $\begin{array}{r}-0.073 \\
-0.046 \\
-0.017 \\
0.012 \\
0.042\end{array}$ & $\begin{array}{r}-0.071 \\
-0.043 \\
-0.015 \\
0.015 \\
0.045\end{array}$ & $\begin{array}{r}-0.068 \\
-0.040 \\
-0.012 \\
0.018 \\
0.048\end{array}$ & $\begin{array}{r}-0.065 \\
-0.037 \\
-0.009 \\
0.021 \\
0.051\end{array}$ & $\begin{array}{r}-0.063 \\
-0.035 \\
-0.006 \\
0.024 \\
0.054\end{array}$ & $\begin{array}{l}0 \\
10 \\
20 \\
30 \\
40\end{array}$ \\
\hline $\begin{array}{l}50 \\
60 \\
70 \\
80 \\
90\end{array}$ & $\begin{array}{l}0.054 \\
0.086 \\
0.118 \\
0.150 \\
0.184\end{array}$ & $\begin{array}{l}0.057 \\
0.089 \\
0.121 \\
0.154 \\
0.188\end{array}$ & $\begin{array}{l}0.060 \\
0.092 \\
0.124 \\
0.157 \\
0.191\end{array}$ & $\begin{array}{l}0.064 \\
0.095 \\
0.127 \\
0.161 \\
0.194\end{array}$ & $\begin{array}{l}0.067 \\
0.098 \\
0.131 \\
0.164 \\
0.198\end{array}$ & $\begin{array}{l}0.070 \\
0.101 \\
0.134 \\
0.167 \\
0.201\end{array}$ & $\begin{array}{l}0.073 \\
0.105 \\
0.137 \\
0.171 \\
0.205\end{array}$ & $\begin{array}{l}0.076 \\
0.108 \\
0.141 \\
0.174 \\
0.208\end{array}$ & $\begin{array}{l}0.079 \\
0.111 \\
0.144 \\
0.177 \\
0.212\end{array}$ & $\begin{array}{l}0.082 \\
0.114 \\
0.147 \\
0.181 \\
0.215\end{array}$ & $\begin{array}{l}0.086 \\
0.118 \\
0.150 \\
0.184 \\
0.218\end{array}$ & $\begin{array}{l}50 \\
60 \\
70 \\
80 \\
90\end{array}$ \\
\hline $\begin{array}{l}100 \\
110 \\
120 \\
130 \\
140\end{array}$ & $\begin{array}{l}0.218 \\
0.253 \\
0.289 \\
0.326 \\
0.363\end{array}$ & $\begin{array}{l}0.222 \\
0.257 \\
0.293 \\
0.329 \\
0.366\end{array}$ & $\begin{array}{l}0.225 \\
0.261 \\
0.296 \\
0.333 \\
0.370\end{array}$ & $\begin{array}{l}0.229 \\
0.264 \\
0.300 \\
0.337 \\
0.374\end{array}$ & $\begin{array}{l}0.232 \\
0.268 \\
0.304 \\
0.340 \\
0.378\end{array}$ & $\begin{array}{l}0.236 \\
0.271 \\
0.307 \\
0.344 \\
0.381\end{array}$ & $\begin{array}{l}0.239 \\
0.275 \\
0.311 \\
0.348 \\
0.385\end{array}$ & $\begin{array}{l}0.243 \\
0.278 \\
0.315 \\
0.351 \\
0.389\end{array}$ & $\begin{array}{l}0.246 \\
0.282 \\
0.318 \\
0.355 \\
0.393\end{array}$ & $\begin{array}{l}0.250 \\
0.286 \\
0.322 \\
0.359 \\
0.397\end{array}$ & $\begin{array}{l}0.253 \\
0.289 \\
0.326 \\
0.363 \\
0.400\end{array}$ & $\begin{array}{l}100 \\
110 \\
120 \\
130 \\
140\end{array}$ \\
\hline $\begin{array}{l}150 \\
160 \\
170 \\
180 \\
190\end{array}$ & $\begin{array}{l}0.400 \\
0.439 \\
0.478 \\
0.517 \\
0.557\end{array}$ & $\begin{array}{l}0.404 \\
0.443 \\
0.482 \\
0.521 \\
0.561\end{array}$ & $\begin{array}{l}0.408 \\
0.446 \\
0.485 \\
0.525 \\
0.565\end{array}$ & $\begin{array}{l}0.412 \\
0.450 \\
0.489 \\
0.529 \\
0.569\end{array}$ & $\begin{array}{l}0.416 \\
0.454 \\
0.493 \\
0.533 \\
0.573\end{array}$ & $\begin{array}{l}0.419 \\
0.458 \\
0.497 \\
0.537 \\
0.577\end{array}$ & $\begin{array}{l}0.423 \\
0.462 \\
0.501 \\
0.541 \\
0.581\end{array}$ & $\begin{array}{l}0.427 \\
0.466 \\
0.505 \\
0.545 \\
0.586\end{array}$ & $\begin{array}{l}0.431 \\
0.470 \\
0.509 \\
0.549 \\
0.590\end{array}$ & $\begin{array}{l}0.435 \\
0.474 \\
0.513 \\
0.553 \\
0.594\end{array}$ & $\begin{array}{l}0.439 \\
0.478 \\
0.517 \\
0.557 \\
0.598\end{array}$ & $\begin{array}{l}150 \\
160 \\
170 \\
180 \\
190\end{array}$ \\
\hline $\begin{array}{l}200 \\
210 \\
220 \\
230 \\
240\end{array}$ & $\begin{array}{l}0.598 \\
0.639 \\
0.681 \\
0.723 \\
0.766\end{array}$ & $\begin{array}{l}0.602 \\
0.643 \\
0.685 \\
0.727 \\
0.770\end{array}$ & $\begin{array}{l}0.606 \\
0.647 \\
0.689 \\
0.731 \\
0.774\end{array}$ & $\begin{array}{l}0.610 \\
0.651 \\
0.693 \\
0.736 \\
0.778\end{array}$ & $\begin{array}{l}0.614 \\
0.656 \\
0.697 \\
0.740 \\
0.783\end{array}$ & $\begin{array}{l}0.618 \\
0.660 \\
0.702 \\
0.744 \\
0.787\end{array}$ & $\begin{array}{l}0.622 \\
0.664 \\
0.706 \\
0.748 \\
0.791\end{array}$ & $\begin{array}{l}0.627 \\
0.668 \\
0.710 \\
0.753 \\
0.796\end{array}$ & $\begin{array}{l}0.631 \\
0.672 \\
0.714 \\
0.757 \\
0.800\end{array}$ & $\begin{array}{l}0.635 \\
0.676 \\
0.719 \\
0.761 \\
0.804\end{array}$ & $\begin{array}{l}0.639 \\
0.681 \\
0.723 \\
0.766 \\
0.809\end{array}$ & $\begin{array}{l}200 \\
210 \\
220 \\
230 \\
240\end{array}$ \\
\hline $\begin{array}{l}250 \\
260 \\
270 \\
280 \\
290\end{array}$ & $\begin{array}{l}0.809 \\
0.852 \\
0.897 \\
0.943 \\
0.986\end{array}$ & $\begin{array}{l}0.813 \\
0.857 \\
0.901 \\
0.946 \\
0.991\end{array}$ & $\begin{array}{l}0.817 \\
0.861 \\
0.905 \\
0.950 \\
0.995\end{array}$ & $\begin{array}{l}0.822 \\
0.866 \\
0.910 \\
0.955 \\
1.000\end{array}$ & $\begin{array}{l}0.826 \\
0.870 \\
0.914 \\
0.959 \\
1.004\end{array}$ & $\begin{array}{l}0.830 \\
0.874 \\
0.919 \\
0.964 \\
1.009\end{array}$ & $\begin{array}{l}0.835 \\
0.879 \\
0.923 \\
0.968 \\
1.013\end{array}$ & $\begin{array}{l}0.839 \\
0.883 \\
0.928 \\
0.973 \\
1.018\end{array}$ & $\begin{array}{l}0.844 \\
0.888 \\
0.932 \\
0.977 \\
1.022\end{array}$ & $\begin{array}{l}0.848 \\
0.892 \\
0.937 \\
0.982 \\
1.027\end{array}$ & $\begin{array}{l}0.852 \\
0.897 \\
0.941 \\
0.986 \\
1.032\end{array}$ & $\begin{array}{l}250 \\
260 \\
270 \\
280 \\
290\end{array}$ \\
\hline $\begin{array}{l}300 \\
310 \\
320 \\
330 \\
340\end{array}$ & $\begin{array}{l}1.032 \\
1.077 \\
1.124 \\
1.170 \\
1.217\end{array}$ & $\begin{array}{l}1.036 \\
1.082 \\
1.128 \\
1.175 \\
1.222\end{array}$ & $\begin{array}{l}1.041 \\
1.087 \\
1.133 \\
1.180 \\
1.227\end{array}$ & $\begin{array}{l}1.045 \\
1.091 \\
1.138 \\
1.184 \\
1.232\end{array}$ & $\begin{array}{l}1.050 \\
1.096 \\
1.142 \\
1.189 \\
1.236\end{array}$ & $\begin{array}{l}1.054 \\
1.101 \\
1.147 \\
1.194 \\
1.241\end{array}$ & $\begin{array}{l}1.059 \\
1.105 \\
1.152 \\
1.199 \\
1.246\end{array}$ & $\begin{array}{l}1.064 \\
1.110 \\
1.156 \\
1.203 \\
1.251\end{array}$ & $\begin{array}{l}1.068 \\
1.114 \\
1.161 \\
1.208 \\
1.255\end{array}$ & $\begin{array}{l}1.073 \\
1.119 \\
1.166 \\
1.213 \\
1.260\end{array}$ & $\begin{array}{l}1.077 \\
1.124 \\
1.170 \\
1.217 \\
1.265\end{array}$ & $\begin{array}{l}300 \\
310 \\
320 \\
330 \\
340\end{array}$ \\
\hline $\begin{array}{l}350 \\
360 \\
370 \\
380 \\
390\end{array}$ & $\begin{array}{l}1.265 \\
1.313 \\
1.361 \\
1.409 \\
1.458\end{array}$ & $\begin{array}{l}1.270 \\
1.318 \\
1.366 \\
1.414 \\
1.463\end{array}$ & $\begin{array}{l}1.274 \\
1.322 \\
1.371 \\
1.419 \\
1.468\end{array}$ & $\begin{array}{l}1.279 \\
1.327 \\
1.375 \\
1.424 \\
1.473\end{array}$ & $\begin{array}{l}1.284 \\
1.332 \\
1.380 \\
1.429 \\
1.478\end{array}$ & $\begin{array}{l}1.289 \\
1.337 \\
1.385 \\
1.434 \\
1.483\end{array}$ & $\begin{array}{l}1.294 \\
1.342 \\
1.390 \\
1.439 \\
1.488\end{array}$ & $\begin{array}{l}1.298 \\
1.346 \\
1.395 \\
1.444 \\
1.493\end{array}$ & $\begin{array}{l}1.303 \\
1.351 \\
1.400 \\
1.449 \\
1.498\end{array}$ & $\begin{array}{l}1.308 \\
1.356 \\
1.405 \\
1.453 \\
1.503\end{array}$ & $\begin{array}{l}1.313 \\
1.361 \\
1.409 \\
1.458 \\
1.508\end{array}$ & $\begin{array}{l}350 \\
360 \\
370 \\
380 \\
390\end{array}$ \\
\hline $\begin{array}{l}400 \\
410 \\
420 \\
430 \\
440\end{array}$ & $\begin{array}{l}1.508 \\
1.557 \\
1.607 \\
1.657 \\
1.708\end{array}$ & $\begin{array}{l}1.512 \\
1.562 \\
1.612 \\
1.662 \\
1.713\end{array}$ & $\begin{array}{l}1.517 \\
1.567 \\
1.617 \\
1.667 \\
1.718\end{array}$ & $\begin{array}{l}1.522 \\
1.572 \\
1.622 \\
1.672 \\
1.723\end{array}$ & $\begin{array}{l}1.527 \\
1.577 \\
1.627 \\
1.677 \\
1.728\end{array}$ & $\begin{array}{l}1.532 \\
1.582 \\
1.632 \\
1.682 \\
1.733\end{array}$ & $\begin{array}{l}1.537 \\
1.587 \\
1.637 \\
1.687 \\
1.738\end{array}$ & $\begin{array}{l}1.542 \\
1.592 \\
1.642 \\
1.692 \\
1.743\end{array}$ & $\begin{array}{l}1.547 \\
1.597 \\
1.647 \\
1.698 \\
1.748\end{array}$ & $\begin{array}{l}1.552 \\
1.602 \\
1.652 \\
1.703 \\
1.753\end{array}$ & $\begin{array}{l}1.557 \\
1.607 \\
1.657 \\
1.708 \\
1.758\end{array}$ & $\begin{array}{l}400 \\
410 \\
420 \\
430 \\
440\end{array}$ \\
\hline $\begin{array}{l}450 \\
460 \\
470 \\
480 \\
490\end{array}$ & $\begin{array}{l}1.758 \\
1.810 \\
1.861 \\
1.913 \\
1.964\end{array}$ & $\begin{array}{l}1.764 \\
1.815 \\
1.866 \\
1.918 \\
1.970\end{array}$ & $\begin{array}{l}1.769 \\
1.820 \\
1.871 \\
1.923 \\
1.975\end{array}$ & $\begin{array}{l}1.774 \\
1.825 \\
1.876 \\
1.928 \\
1.980\end{array}$ & $\begin{array}{l}1.779 \\
1.830 \\
1.882 \\
1.933 \\
1.985\end{array}$ & $\begin{array}{l}1.784 \\
1.835 \\
1.887 \\
1.938 \\
1.991\end{array}$ & $\begin{array}{l}1.789 \\
1.840 \\
1.892 \\
1.944 \\
1.996\end{array}$ & $\begin{array}{l}1.794 \\
1.845 \\
1.897 \\
1.949 \\
2.001\end{array}$ & $\begin{array}{l}1.799 \\
1.851 \\
1.902 \\
1.954 \\
2.006\end{array}$ & $\begin{array}{l}1.804 \\
1.856 \\
1.907 \\
1.959 \\
2.011\end{array}$ & $\begin{array}{l}1.810 \\
1.861 \\
1.913 \\
1.964 \\
2.017\end{array}$ & $\begin{array}{l}450 \\
460 \\
470 \\
480 \\
490\end{array}$ \\
\hline $\begin{array}{l}500 \\
510 \\
520 \\
530 \\
540\end{array}$ & $\begin{array}{l}2.017 \\
2.069 \\
2.122 \\
2.175 \\
2.228\end{array}$ & $\begin{array}{l}2.022 \\
2.074 \\
2.127 \\
2.180 \\
2.233\end{array}$ & $\begin{array}{l}2.027 \\
2.080 \\
2.132 \\
2.186 \\
2.239\end{array}$ & $\begin{array}{l}2.032 \\
2.085 \\
2.138 \\
2.191 \\
2.244\end{array}$ & $\begin{array}{l}2.038 \\
2.090 \\
2.143 \\
2.196 \\
2 \cdot 249\end{array}$ & $\begin{array}{l}2.043 \\
2.095 \\
2.148 \\
2.201 \\
2.255\end{array}$ & $\begin{array}{l}2.048 \\
2.101 \\
2.154 \\
2.207 \\
2.260\end{array}$ & $\begin{array}{l}2.053 \\
2.106 \\
2.159 \\
2.212 \\
2.266\end{array}$ & $\begin{array}{l}2.059 \\
2.111 \\
2.164 \\
2.217 \\
2.271\end{array}$ & $\begin{array}{l}2.064 \\
2.117 \\
2.170 \\
2.223 \\
2.276\end{array}$ & $\begin{array}{l}2.069 \\
2.122 \\
2.175 \\
2.228 \\
2.282\end{array}$ & $\begin{array}{l}500 \\
510 \\
520 \\
530 \\
540\end{array}$ \\
\hline $\begin{array}{l}550 \\
560\end{array}$ & $\begin{array}{l}2.282 \\
2.335\end{array}$ & $\begin{array}{l}2.287 \\
2.341\end{array}$ & $\begin{array}{l}2.292 \\
2.346\end{array}$ & $\begin{array}{l}2.298 \\
2.351\end{array}$ & $\begin{array}{l}2.303 \\
2.35 .7\end{array}$ & $\begin{array}{l}2.308 \\
2.362\end{array}$ & $\begin{array}{l}2.314 \\
2.368\end{array}$ & $\begin{array}{l}2.319 \\
2.373\end{array}$ & $\begin{array}{l}2 \cdot 325 \\
2 \cdot 378\end{array}$ & $\begin{array}{l}2.330 \\
2.384\end{array}$ & $\begin{array}{l}2.335 \\
2.389\end{array}$ & $\begin{array}{l}550 \\
560\end{array}$ \\
\hline $\begin{array}{l}570 \\
580 \\
590\end{array}$ & $\begin{array}{l}2.389 \\
2.443 \\
2.498\end{array}$ & $\begin{array}{l}2.395 \\
2.449 \\
2.503\end{array}$ & $\begin{array}{l}2.400 \\
2.454 \\
2.509\end{array}$ & $\begin{array}{l}2.405 \\
2.460 \\
2.514\end{array}$ & $\begin{array}{l}2 \cdot 411 \\
2.465 \\
2.520\end{array}$ & $\begin{array}{l}2.416 \\
2.471 \\
2.525\end{array}$ & $\begin{array}{l}2.422 \\
2.476 \\
2.531\end{array}$ & $\begin{array}{l}2.427 \\
2.481 \\
2.536\end{array}$ & $\begin{array}{l}2 \cdot 433 \\
2 \cdot 487 \\
2 \cdot 541\end{array}$ & $\begin{array}{l}2.438 \\
2.492 \\
2.547\end{array}$ & $\begin{array}{l}2.443 \\
2.498 \\
2.552\end{array}$ & $\begin{array}{l}570 \\
580 \\
590\end{array}$ \\
\hline 600 & 2.552 & 2.558 & 2.563 & 2.569 & 2.574 & 2.580 & 2.585 & 2.591 & 2.596 & 2.602 & 2.607 & 600 \\
\hline
\end{tabular}

1

2

3

\begin{abstract}
45
\end{abstract}

\begin{abstract}
67
\end{abstract}
8

9

10 
TABLE A3.1.2. Type R thermocouples-thermoelectric voltage as a function of temperature $\left({ }^{\circ} \mathrm{F}\right)$, reference junctions at $32{ }^{\circ} \mathrm{F}-$ Continued

${ }^{\circ} \mathrm{F}$

0

1

2

3

THERMOELECTRIC VOLTAGE IN ABSOLUTE MILLIVOLTS

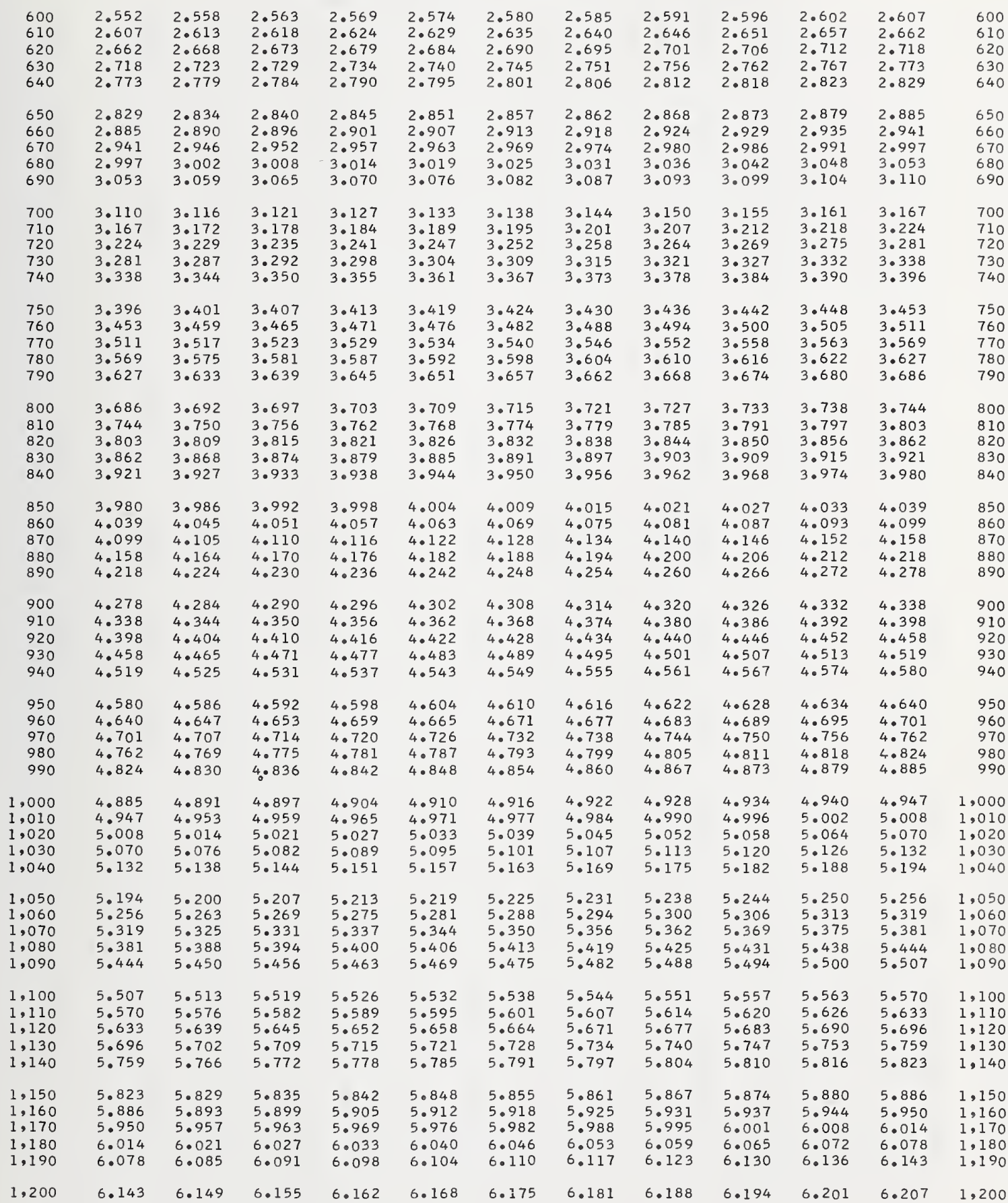

2

3

4

5

6

7

8

9

10

${ }^{\circ} \mathrm{F}$ 
TABLE A3.1.2. Type R thermocouples-thermoelectric voltage as a function of temperature $\left({ }^{\circ} \mathrm{F}\right)$, reference junctions at $32{ }^{\circ} \mathrm{F}$-Continued

THERMOELECTRIC VOLTAGE IN ABSOLUTE MILLIVOLTS

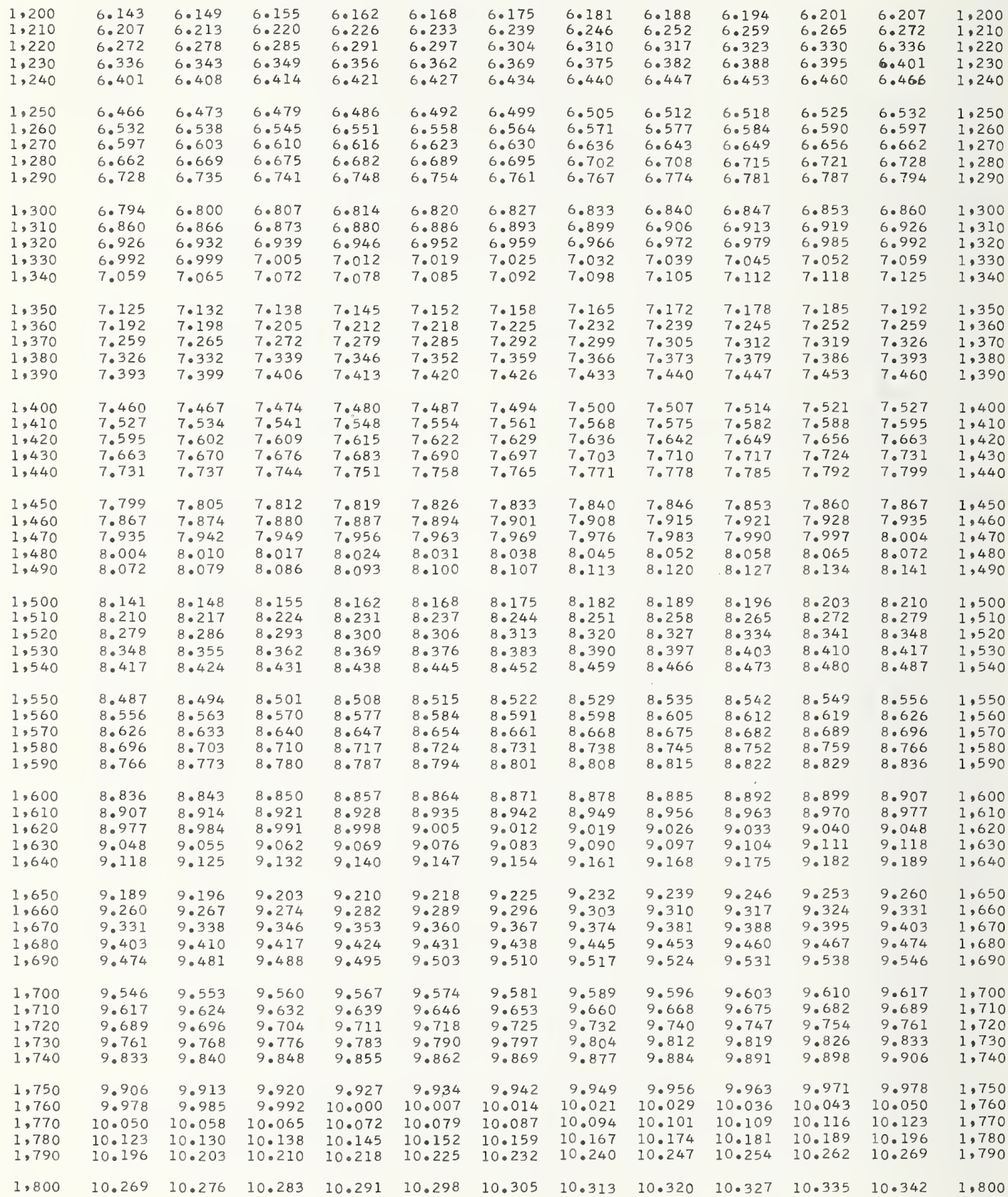

6

7

8

9 
TABLE A3.1.2. Type R thermocouples-thermoelectric voltage as a function of temperature $\left({ }^{\circ} \mathrm{F}\right)$, reference junctions at $32{ }^{\circ} \mathrm{F}$-Continued

${ }^{\circ} \mathrm{F}$

0

1
3
5

\begin{abstract}
6
\end{abstract}
7

8

9

10

THERMOELECTRIC VOLTAGE IN ABSOLUTE MILLIVOLTS

\begin{tabular}{|c|c|c|c|c|c|c|c|c|c|c|c|c|}
\hline 1,800 & 10.269 & 0.276 & 10.283 & 10.291 & 10.298 & 10.305 & 10.313 & 10.320 & 10.327 & 10.335 & 10.342 & 1,800 \\
\hline & 10.342 & .349 & 0.357 & .364 & 10.371 & 10.379 & 10.386 & 10.393 & 10.400 & 10.408 & 10.415 & 1,810 \\
\hline 1,820 & 10.415 & 10.422 & 10.430 & 0.437 & 10.444 & 10.452 & 10.459 & 10.466 & 10.474 & 10.481 & 10.488 & 1,820 \\
\hline 1,830 & 10.488 & 10.496 & 10.503 & 0.511 & 10.518 & 10.525 & 10.533 & 10.540 & 10.547 & 10.555 & 10.562 & 1,830 \\
\hline 1,840 & 10.562 & 10.569 & 10.577 & 10.584 & 10.591 & 10.599 & 10.606 & 10.613 & 10.621 & 10.628 & 10.636 & 1,840 \\
\hline 1,850 & 10.636 & 10.643 & 10.650 & 0.658 & 10.665 & .672 & .680 & 10.687 & 10.695 & 10.702 & 10.709 & 1,850 \\
\hline 1,860 & 19 & 10.717 & 10.724 & 731 & 10.739 & 0.746 & 54 & 61 & 768 & 10.776 & 10.783 & 1,860 \\
\hline & .783 & 10.791 & 10.798 & 10.805 & 10.813 & 10.820 & 828 & 10.835 & 10.842 & 10.850 & 10.857 & 1,870 \\
\hline 1,880 & 10.857 & 10.865 & 10.872 & 10.879 & 10.887 & 10.894 & 10.902 & 10.909 & 10.917 & 10.924 & 10.931 & 1,880 \\
\hline 1,890 & 10.931 & 10.939 & 10.946 & 10.954 & 10.961 & 10.968 & 10.976 & 10.983 & 10.991 & 10.998 & 11.006 & 1,890 \\
\hline 1,900 & 1.006 & 11.013 & 11.021 & 1.028 & 11.035 & 11.043 & 050 & 058 & 11.065 & 11.073 & 11.080 & 1,900 \\
\hline 1,910 & 30 & 11.088 & 11.095 & 11.102 & 11.110 & 117 & 25 & 32 & 40 & 47 & 5 & 910 \\
\hline 1,920 & 11.155 & 11.162 & 11.170 & 11.177 & 11.184 & 11.192 & 11.199 & 11.207 & 11.214 & 222 & & \\
\hline 1,930 & 1.229 & 11.237 & 11.244 & 11.252 & 11.259 & 11.267 & 11.274 & 11.282 & 11.289 & 11.297 & 11.304 & 1,930 \\
\hline 1,940 & 11.304 & 11.312 & 11.319 & 11.327 & 11.334 & 11.342 & 11.349 & 11.357 & 11.364 & 11.372 & 11.379 & 1,940 \\
\hline 1,950 & 1.379 & 1 & 11.394 & 11 & 09 & 11.417 & 424 & 11.432 & 11.439 & 11.447 & 11.454 & 1,950 \\
\hline 1,960 & 11.454 & 11.462 & 11.469 & 11.477 & 11.484 & & & & & 522 & &, 960 \\
\hline 1,970 & 11.529 & 11.537 & 11.544 & 11.552 & 11.559 & 11.567 & 11.574 & 82 & 11.590 & 11.597 & 11.605 & 1,970 \\
\hline 1,980 & 65 & 12 & 20 & & & & 650 & 57 & 11.665 & 11.672 & 80 & 1,980 \\
\hline 1,990 & 11.680 & 11.688 & 11.695 & 11.703 & 710 & 18 & 25 & 11.733 & 11.740 & 11.748 & 11.756 &, 990 \\
\hline 2,000 & 56 & 11 & 71 & 78 & 86 & 3 & 01 & 8 & 6 & 24 & 1 & 00 \\
\hline 2,010 & 11.831 & 11.839 & 11.846 & 11.854 & 11.861 & 11.869 & 77 & 384 & 892 & 11.899 & 11.907 & .010 \\
\hline 2,020 & 11.907 & 11.914 & 11.922 & 11.930 & & & & & 968 & 11.975 & 11.983 & \\
\hline 2,030 & 11.983 & 11.990 & 11.998 & 12.005 & 12.013 & 12.021 & 12.028 & 36 & 12.043 & 51 & 12.059 & 2,030 \\
\hline 2,040 & 12.059 & 12.066 & 12.074 & 12.081 & 12.089 & 12.097 & 12.104 & 12.112 & 12.119 & 12.127 & 12.135 & 2,040 \\
\hline 2 & 35 & .142 & & 57 & $65-2>3$ & 173 & 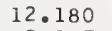 & 12.188 & 12.196 & 03 & 211 & .050 \\
\hline 2,060 & & & & & & & & & & & & \\
\hline 2,0 & 287 & 12.295 & 12.302 & 310 & 12.318 & 325 & 12.333 & 40 & $12 \cdot 348$ & 56 & $12 \cdot 363$ & 2,070 \\
\hline 2, & 63 & 371 & & & & 402 & 409 & 17 & 12.424 & 432 & 12.440 & 80 \\
\hline 2,090 & 12.440 & 12.447 & 12.455 & 12.463 & 12.470 & $12 \cdot 478$ & 12.486 & 12.493 & 12.501 & $12 \cdot 509$ & 12.516 & 90 \\
\hline 2, & & & & & & & & & & 5 & & \\
\hline & 33 & bo & 8 & 16 & 23 & 31 & 9 & 6 & 654 & 62 & 59 & 0 \\
\hline & 9 & 77 & & & & & & & 1 & & & \\
\hline 2,130 & 12.746 & 12. & 12.762 & 69 & 77 & 85 & 92 & & 8 & 15 & & 0 \\
\hline 2,140 & 12.823 & 12.831 & $12 \cdot 838$ & 12.846 & 12.854 & 12.862 & 12.869 & 12.877 & 12.885 & $1<\cdot 092$ & 12 & 0 \\
\hline 2,150 & Do & 08 & & 23 & 31 & & & & & & & \\
\hline & & & & & & & & & & & & \\
\hline & & & & & & & & & & & & \\
\hline 2, & 13 & 13.139 & 13.147 & 13 & 62 & 70 & 8 & 35 & 3 & 01 & 8 & 180 \\
\hline & 13.208 & 13.216 & 13.224 & 13.23 & 13.239 & 13.247 & 13.255 & 13.263 & 13.2 & 13.278 & 13.286 & 2,190 \\
\hline & & & & & & & & & & & & \\
\hline & & & & & & & & & & & & \\
\hline 2,220 & 13.440 & 13.448 & 13 & & & 479 & 13.487 & 95 & 2 & 10 & 13.518 & 220 \\
\hline & & & & & & & & & & 88 & & 230 \\
\hline 2 , & 13. & 13 & 3 & 13 & 13 & 13 & 13.042 & $=$ & 13.658 & 13.665 & 13.673 & 240 \\
\hline 2,2 & & & & & & & & & & & & \\
\hline & & & & & & & & & & & & \\
\hline & & & & & & & & & & & & \\
\hline 2,280 & 13. & 13.914 & 13.922 & 13.930 & 13 & 45 & & & & 76 & & 0 \\
\hline & & & 14.000 & 14.007 & 14.015 & 14.023 & 14.031 & 14.039 & 14.046 & 14.054 & 14.062 & \\
\hline 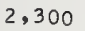 & .062 & 1 & 8 & & 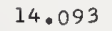 & & 14 & & & & & \\
\hline & & & & & & & & & & & & \\
\hline & & & & & & & & & & & & \\
\hline & & & & & & & & & & & & \\
\hline 2,340 & 14.374 & 14.382 & 14.389 & 14.397 & 14.405 & 14.413 & 14.421 & 14.429 & 14.436 & 14.444 & 14.452 & 2,340 \\
\hline & & & & & & & & & & & & \\
\hline & & & & & & & & 14 & & & & \\
\hline & & & & & & & & & & & & \\
\hline & & & & 14 & & 26 & & & & & & \\
\hline 2,390 & 14.765 & 14.772 & 14.780 & 14.788 & 14.796 & 14.804 & 14.812 & 14.819 & $14 \cdot 827$ & 14.835 & 14.843 &, 390 \\
\hline 2,400 & 14.843 & 14.851 & 14.859 & 14.866 & 14.874 & 14.882 & 14.890 & 14.898 & 14.906 & 14.913 & 14.921 &, 400 \\
\hline
\end{tabular}

\begin{abstract}
$10.269 \quad 10.276$ $10.342 \quad 10.349$

$10.636 \quad 10.643$
\end{abstract}

$10.709 \quad 10.717$

11.680

12.287

2.440

2.669

14.062

14.843
$4.851 \quad 14.859 \quad 14.866$

23

4

5

6

7

8

9

10

${ }^{\circ} \mathrm{F}$ 
TABLE A3.1.2. Type R thermocouples-thermoelectric voltage as a function of temperature $\left({ }^{\circ} \mathrm{F}\right)$, reference junctions at $32{ }^{\circ} \mathrm{F}$-Continued

$$
{ }^{\circ} \mathrm{F}
$$

0

1

2

3

4

5

6

7

8

9

10

${ }^{\circ} \mathrm{F}$

THERMOELECTRIC VOLTAGE IN ABSOLUTE MILLIVOLTS

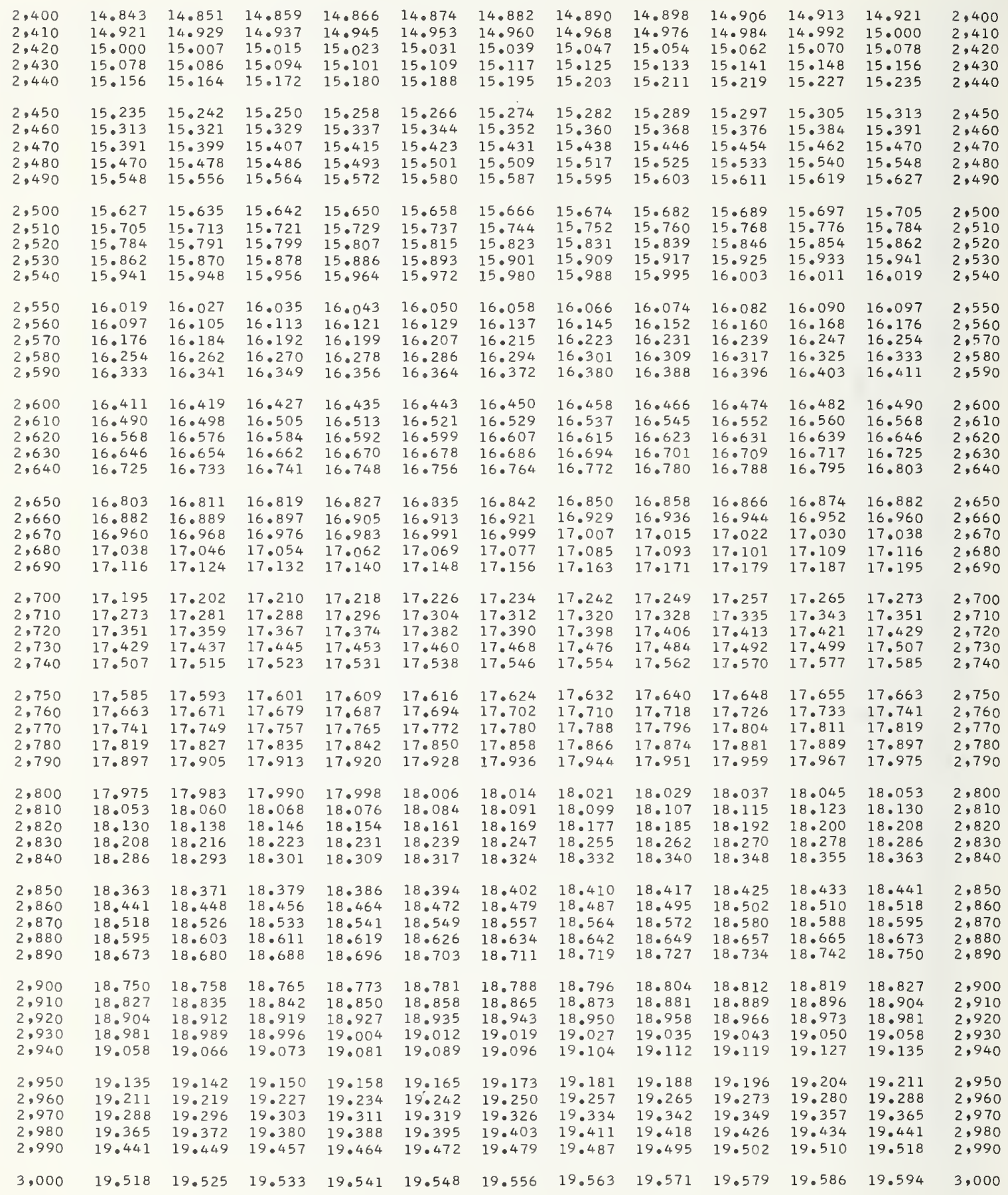

\begin{abstract}
2
\end{abstract}

\begin{abstract}
3
\end{abstract}

\begin{abstract}
4
\end{abstract}

\begin{abstract}
5
\end{abstract}

\begin{abstract}
6
\end{abstract}

\begin{abstract}
7
\end{abstract}

\begin{abstract}
8
\end{abstract}

\begin{abstract}
$9 \quad 10$
\end{abstract}


TABLE A3.1.2. Type R thermocouples-thermoelectric voltage as a function of temperature $\left({ }^{\circ} \mathrm{F}\right)$, reference junctions at $32^{\circ} \mathrm{F}$-Continued

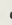

${ }^{\circ} \mathrm{F}$

0

1

2

3

4

5

6

7

8

9

10

${ }^{\circ} \mathrm{F}$

THERMOELECTRIC VOLTAGE IN ABSOLUTE MILLIVOLTS

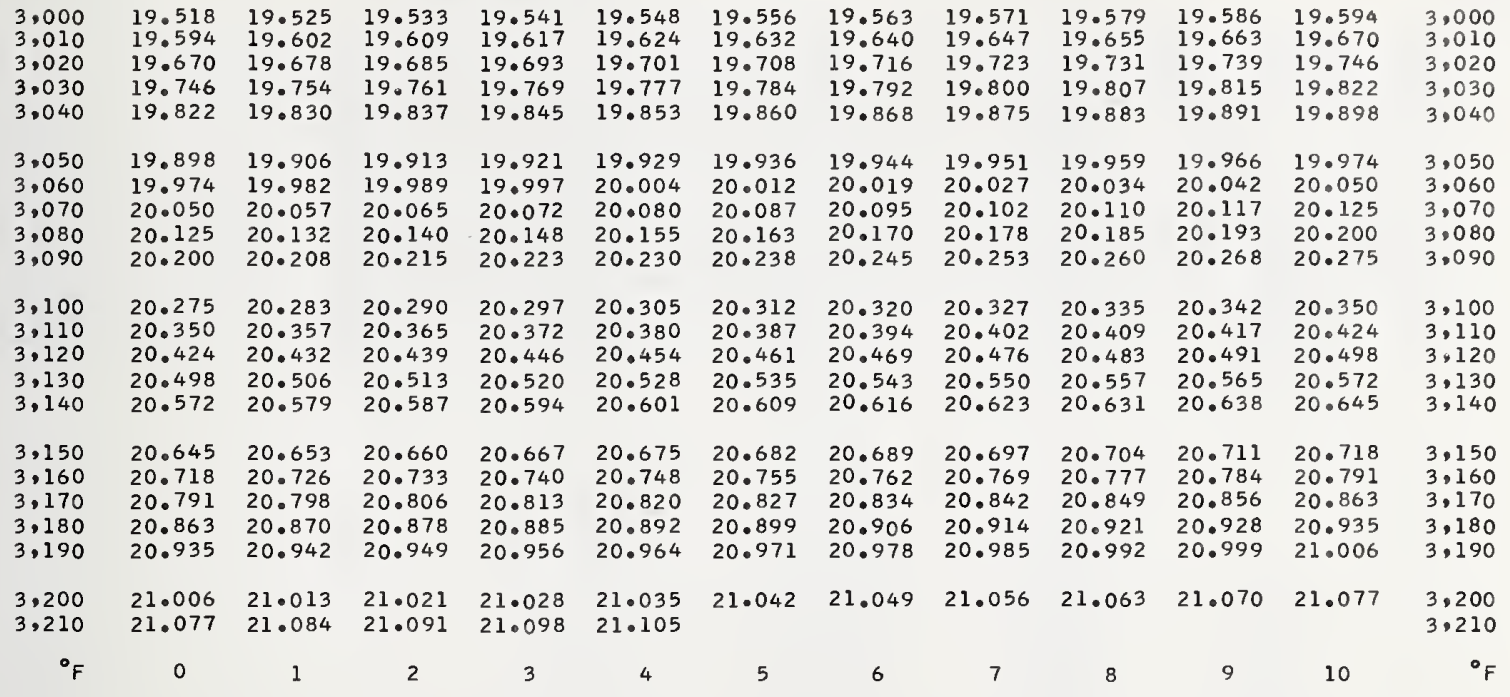


TABlE A3.1.3. Type $\boldsymbol{R}$ thermocouples-quadratic, cubic, and quartic approximations to the data as a function of temperature $\left({ }^{\circ} \mathrm{C}\right)$ in selected temperature ranges. The expansion is of the form

$\mathrm{E}=\mathrm{a}_{0}+\mathrm{a}_{1} \mathrm{~T}+\mathrm{a}_{2} \mathrm{~T}^{2}+\mathrm{a}_{3} \mathrm{~T}^{3}+\mathrm{a}_{4} \mathrm{~T}^{4}$ where $\mathrm{E}$ is in microvolts and $\mathrm{T}$ is in degrees Celsius

\begin{tabular}{|c|c|c|c|c|c|c|c|c|c|c|c|c|}
\hline \multirow{2}{*}{\multicolumn{2}{|c|}{$\begin{array}{l}\text { Temperature } \\
\text { Range }\left({ }^{\circ} \mathrm{C}\right)\end{array}$}} & \multicolumn{2}{|l|}{$a_{0}$} & \multicolumn{2}{|l|}{$a_{1}$} & \multicolumn{2}{|l|}{$a_{2}$} & \multicolumn{2}{|l|}{$a_{3}$} & \multicolumn{2}{|l|}{$a_{4}$} & \multirow{2}{*}{$\begin{array}{l}\text { Error } \\
\text { Range }\left({ }_{u} V\right) \\
\text { Exact-Approx. }\end{array}$} \\
\hline & & Argument & Exp. & Argument & Exp. & Argument & Exp. & Argument & Exp. & Argument & Exp. & \\
\hline \multicolumn{13}{|c|}{ I. Quartic Equation } \\
\hline-50 & to 900 & $\cdots \cdot$ & . . & 5. 4295008 & +0 & 1.1446885 & -2 & -1.1295306 & -5 & 5.0020496 & -9 & -7 to 15 \\
\hline 0 & to 1100 & . . . . & . . & 5. 7622558 & +0 & 9.2715271 & -3 & -7.1346883 & -6 & 2. 5877458 & -9 & -16 to 12 \\
\hline 0 & to 1400 & . . . & . . & 6. 1429722 & +0 & 7.1515857 & -3 & -3.7539447 & -6 & 9.6963832 & -10 & -35 to 25 \\
\hline 0 & to 1650 & $\cdot \cdot \cdot \cdot$ & $\cdot \cdot$ & 6.4615269 & to & 5. 7010917 & -3 & -1.8683292 & -6 & 2.3636365 & -10 & -55 to 35 \\
\hline 0 & to 1768 & $\cdot \cdot \cdot \cdot \cdot$ & $\therefore$ & 6.5962120 & +0 & 5. 1559203 & -3 & -1.2385309 & -6 & 1.8827643 & -11 & -65 to 35 \\
\hline 400 & to 1100 & -4.0674108 & +2 & 8. 7490294 & +0 & 1.7115155 & -3 & 7. 5039035 & -7 & -3.0096280 & -10 & -.4 to .5 \\
\hline 400 & to 1400 & -5.6047484 & +2 & 9.6731111 & +0 & -2.6994046 & -4 & 2.5536988 & -6 & -8.9155491 & -10 & -1.7 to 1.6 \\
\hline 400 & to 1650 & -5.4505828 & +2 & 9.5942872 & +o & -1.2813352 & -4 & 2. 4468512 & -6 & -8.6286756 & -10 & -2.1 to 1.8 \\
\hline 1050 & to 1400 & 1.6618159 & +3 & 2.3048526 & +o & 8. 7635426 & -3 & -2.3016819 & -6 & 7.4284923 & -11 & -.05 to .05 \\
\hline 1050 & to 1650 & 1.5132838 & +3 & 2.7958847 & to & 8.1571403 & -3 & -1.9701159 & -6 & 6.5568964 & -12 & -.05 to .05 \\
\hline 1400 & to 1550 & 2.4008703 & +3 & 4.1604579 & -1 & 1. 0549178 & -2 & -3.0383621 & -6 & 1.8540516 & -10 & -.05 to .05 \\
\hline 1400 & to 1650 & 1. 5787334 & +3 & 2.6321144 & +0 & 8.3100314 & -3 & -2.0332036 & -6 & 1.6260416 & -11 & -.05 to .05 \\
\hline 1400 & to 1768 & -7.1904948 & +4 & 1. 9442383 & +2 & -1.7913090 & -1 & 7.9264764 & -5 & -1.3187245 & -8 & -1.0 to 1.3 \\
\hline 1666 & to 1768 & 8.8532076 & +4 & -1.5014129 & +2 & 9.5376167 & -2 & -1.6644901 & -5 & -8.3062870 & -10 & -.05 to .05 \\
\hline \multicolumn{13}{|c|}{ II. Cubic Equation } \\
\hline-50 & to 900 & . . . . & . . & 6.0632060 & +0 & 7. 0729964 & -3 & -2.7461531 & -6 & . . . . & . & -30 to 60 \\
\hline 0 & to 1100 & .... & . & 6.4312595 & +0 & 5. 7063515 & -3 & -1.6171323 & -6 & . . . . & . . & -51 to 31 \\
\hline 0 & to 1400 & .... & . . & 6.6602336 & +0 & 4.9866412 & -3 & -1.1222144 & -6 & . . . . & . & -70 to 35 \\
\hline 0 & to 1650 & . . . . & . & 6.6681844 & +0 & 4. 9675968 & -3 & -1.1120895 & -6 & . . . . & . . & -70 to 40 \\
\hline 0 & to 1768 & . . . . & . . & 6.6164788 & +0 & 5. 0888113 & -3 & -1.1739757 & -6 & . . . . & . & -65 to 40 \\
\hline 400 & to 1100 & -3.3173012 & +2 & 8.2968261 & to & 2. 6896906 & -3 & -1.5226719 & -7 & .... & . & -.6 to .8 \\
\hline 400 & to 1400 & -1.4900615 & +2 & 7.4755900 & to & 3.8372620 & -3 & -6.5522906 & -7 & . . . & . . & -7 to 10 \\
\hline 400 & to 1650 & 7.0511332 & +1 & 6.5679703 & +o & 4.9717004 & -3 & -1.0905912 & -6 & . . . . & . & -17 to 19 \\
\hline 1050 & to 1400 & 1.4980000 & +3 & 2.8453533 & +0 & 8.0970910 & -3 & -1.9377143 & -6 & $\cdot \cdot \cdot \cdot \cdot$ & . & -.05 to .05 \\
\hline 1050 & to 1650 & 1.4925741 & +3 & 2.8588183 & +o & 8.0860331 & -3 & -1.9347086 & -6 & $\cdots \cdot$ & . & -.05 to .05 \\
\hline 1400 & to 1550 & 1.5265340 & +3 & 2.7908769 & to & 8.1313270 & -3 & -1.9447717 & -6 & $\cdot \cdot \cdot \cdot$ & $\cdot \cdot$ & -.05 to .05 \\
\hline 1400 & to 1650 & 1.4915384 & +3 & 2.8617020 & +0 & 8.0835951 & -3 & -1.9340590 & -6 & $\cdots \cdot \cdot$ & $\cdot \cdot$ & -.05 to .05 \\
\hline 1400 & to 1768 & 9.8946473 & +3 & -1.3614385 & +1 & 1.8829682 & -2 & -4.2655016 & -6 & $\cdot \cdot \cdot \cdot$ & $\cdot \cdot$ & -2 to 4 \\
\hline \multirow{2}{*}{\multicolumn{13}{|c|}{ Variable reference junction correction }} \\
\hline & & & & & & & & & & & & \\
\hline 0 & to 50 & $\cdots \cdots$ & $\cdots$ & 5.2891411 & +0 & 1.3844426 & -2 & -2.0889531 & -5 & $\cdots \cdot \cdots$ & $\cdots$ & -0.01 to +0.01 \\
\hline \multicolumn{13}{|c|}{ III. Quadratic Equation } \\
\hline-50 & to 900 & $\cdots \cdot \cdot$ & . & 7.0091249 & +0 & 3.6680622 & -3 & $\cdots \cdot \cdot$ & . & $\cdots \cdot \cdot$ & . & -100 to 120 \\
\hline 0 & to 1100 & $\cdots \cdots$ & . & 7.2706944 & +0 & 3. 2499597 & -3 & $\cdots \cdot \cdot$ & . & $\cdots \cdot \cdot$ & $\cdot$ & -130 to 60 \\
\hline 0 & to 1400 & $\ldots .$. & . & 7.6038268 & +o & 2.8172081 & -3 & $\cdots \cdot \cdot$ & . & . . . . & . & -160 to 90 \\
\hline 0 & to 1650 & $\cdots \cdot \cdots$ & $\cdot$ & 7.9670282 & +0 & 2.4339570 & -3 & $\cdot \cdots \cdot \cdot$ & $\cdot \cdot$ & $\cdots \cdot \cdot$ & $\cdot$ & -240 to 170 \\
\hline 0 & to 1768 & $\cdots \cdots$ & . & 8.1907195 & +o & 2.2229871 & -3 & $\cdot \cdot \cdot \cdot$ & $\cdot \cdot$ & $\therefore \cdot \cdot \cdot \cdot$ & $\cdot \cdot$ & -330 to 230 \\
\hline 400 & to 1100 & -3.8627420 & +2 & 8.5408889 & +o & 2.3470378 & -3 & $\cdot \cdot \cdot \cdot$ & $\cdot \cdot$ & $\cdot \cdot \cdot \cdot$ & $\cdot \cdot$ & -3 to 2 \\
\hline 400 & to 1400 & -5.2441977 & +2 & 8.9543660 & +0 & 2.0679233 & -3 & $\cdot \cdot \cdot \cdot$ & $\cdot \cdot$ & $\cdot \cdot \cdot \cdot \cdot$ & $\cdots$ & -31 to 25 \\
\hline 400 & to 1650 & -8.0082944 & +2 & 9.7098356 & +0 & 1.6179512 & -3 & $\cdots \cdots$ & - & $\cdots \cdots$ & . & -95 to 75 \\
\hline 1050 & to 1400 & -2.0139987 & +3 & 1.1528256 & +1 & 9.7566289 & -4 & $\cdot \cdot \cdot \cdot$ & $\cdot$ & $\cdot \cdot \cdot \cdot \cdot$ & $\cdot \cdot$ & -3.2 to 3.2 \\
\hline 1050 & to 1650 & -3.1042936 & +3 & 1.3315918 & +1 & 2. 5046320 & -4 & $\cdot \cdot \cdot \cdot \cdot$ & $\cdot \cdot$ & $\cdots \cdot \cdot \cdot$ & . & -16 to 16 \\
\hline 1400 & to 1550 & -4.7053323 & +3 & 1.5479630 & +1 & -4.7535391 & -4 & . . . & $\cdot \cdot$ & $\cdot \cdot \cdot \cdot$ & . & -.3 to .3 \\
\hline 1400 & to 1650 & -5.3395443 & +3 & 1.6339581 & +1 & -7.6649197 & -4 & $\cdots \cdot \cdot$ & . & .... & . & -1.1 to 1.2 \\
\hline 1400 & to 1768 & -6.9060256 & +3 & 1.8401669 & +1 & -1.4430259 & -3 & $\cdot \cdot \cdot \cdot \cdot$ & $\cdot \cdot$ & $\cdot \cdot \cdot \cdot \cdot$ & $\cdot \cdot$ & -10 to 9 \\
\hline 1666 & to 1768 & -1.7351473 & +4 & 3. 0715022 & +1 & -5.0686458 & -3 & $\cdots \cdot \cdot \cdot$ & $\cdot \cdot$ & $\cdots \cdot \cdot \cdot$ & $\cdot \cdot$ & -.9 to 1.0 \\
\hline \multicolumn{13}{|c|}{ Variable reference junction correction } \\
\hline 0 & to 50 & $\cdots \cdots$ & . & 5.3139863 & +0 & 1.2244376 & -2 & $\cdots \cdots$ & - & $\cdots \cdots$ & - & -0.1 to +0.2 \\
\hline
\end{tabular}




\section{A3.2. Data for Temperature as a Function of Voltage}

The temperature as a function of voltage data given in tables A3.2.1 and A3.2.2 were obtained by iteration in the primary equations for voltage as a function of temperature. Table A3.2.1 presents the data in millivolts from $-0.22 \mathrm{mV}$ to $21.10 \mathrm{mV}$ with temperatures given in degrees Celsius while table A3.2.2 presents similar data with temperatures in degrees Fahrenheit. Table A3.2.3 contains quadratic, cubic, and quartic approximations to the data as a function of voltage in selected temperature ranges. The error range given in the table represents the difference between the temperature found by iteration in the full precision tables from the text and from the respective reduced order approximations.

TABLE A3.2.1. Type $\boldsymbol{R}$ thermocouples-temperature $\left({ }^{\circ} \mathrm{C}\right)$ as a function of thermoelectric voltage, reference junctions at $0^{\circ} \mathrm{C}$

$\mathrm{mV}$

$$
.00 \quad .01 \quad .02
$$

$$
.03
$$$$
.04
$$$$
.05
$$

.06

.07

.08

.09

$-48 \cdot 27$

$0.00 \quad-1.90 \quad-3.82$

TEMPERATURES IN DEGREES C (IPTS 1968)

mV

$$
.00
$$

.01

.02

-26.52
-5.76

$-28 \cdot 76$
-7.72

-31.04
-9.71

$-33 \cdot 35$
-11.71

$-35 \cdot 71$
-13.74

-38.12
-15.80

-40.58
-17.88

-43.08
-20.00

$-0.20$

$-0.10$

.03

$.05 \quad .06$

.07

.08

.09

.10

$m V$ 
TABLE A3.2.1. Type $\boldsymbol{R}$ thermocouples-temperature $\left({ }^{\circ} \mathrm{C}\right)$ as a function of thermoelectric voltage, reference junctions at $0^{\circ} \mathrm{C}$ - Continued

.05

.06

.07

.08

.09

$\cdot 10$

$\mathrm{mV}$

\begin{tabular}{|c|c|c|c|c|c|c|c|c|c|c|c|c|}
\hline 0.00 & 0.00 & 1.88 & 3.74 & 5.59 & 7.42 & 9.23 & 11.03 & 12.81 & 14.58 & 16.33 & 18.07 & 0.00 \\
\hline $0 \cdot 10$ & 18.07 & 19.80 & 21.51 & 23.22 & 24.91 & 26.58 & 28.25 & 29.91 & 31.55 & 33.18 & 34.81 & 0.10 \\
\hline 0.20 & 34.81 & 36.42 & 38.03 & 39.62 & $41 \cdot 21$ & 42.79 & 44.35 & 45.91 & 47.47 & 49.01 & 50.54 & 0.20 \\
\hline 0.30 & 50.54 & 52.07 & 53.59 & 55.11 & 56.61 & 58.11 & 59.60 & 61.09 & 62.56 & 64.04 & 65.50 & 0.30 \\
\hline 0.40 & 65.50 & 66.96 & 68.41 & 69.86 & $71 \cdot 30$ & 72.74 & 74.17 & 75.59 & 77.01 & 78.42 & 79.83 & 0.40 \\
\hline 0.50 & 79.83 & 81.23 & 82.63 & 84.02 & 85.41 & 86.79 & 88.17 & 89.54 & 90.91 & 92.28 & 93.64 & 0.50 \\
\hline 0.60 & 93.64 & 94.99 & 96.34 & 97.69 & 99.03 & 100.37 & 101.70 & 103.04 & 104.36 & 105.68 & 107.00 & 0.60 \\
\hline 0.70 & 107.00 & $108 \cdot 32$ & 109.63 & $110 \cdot 94$ & $112 \cdot 24$ & 113.54 & 114.84 & 116.13 & 117.42 & 118.71 & 119.99 & 0.70 \\
\hline 0.80 & 119.99 & 121.28 & $122 \cdot 55$ & 123.83 & $125 \cdot 10$ & 126.37 & 127.63 & 128.89 & $130 \cdot 15$ & 131.41 & 132.66 & 0.80 \\
\hline 0.90 & 132.66 & 133.91 & $135 \cdot 16$ & 136.40 & 137.64 & 138.88 & 140.12 & 141.35 & 142.58 & 143.81 & 145.04 & 0.90 \\
\hline 1.00 & 145.04 & 146.26 & 147.48 & 148.70 & 149.91 & 151.13 & 152.34 & 153.55 & 154.75 & 155.96 & 157.16 & 1.00 \\
\hline 1.10 & $157 \cdot 16$ & 158.36 & 159.56 & 160.75 & 161.94 & 163.13 & 164.32 & 165.51 & 166.69 & 167.88 & 169.06 & 1.10 \\
\hline 1.20 & 169.06 & 170.23 & 171.41 & 172.58 & 173.76 & 174.93 & 176.09 & 177.26 & 178.43 & 179.59 & 180.75 & 1.20 \\
\hline 1.30 & 180.75 & 181.91 & 183.06 & $184 \cdot 22$ & 185.37 & 186.52 & 187.67 & 188.82 & 189.97 & 191.11 & 192.26 & 1.30 \\
\hline 1.40 & 192.26 & 193.40 & 194.54 & 195.68 & 196.81 & 197.95 & 199.08 & 200.21 & 201.34 & 202.47 & 203.60 & 1.40 \\
\hline 1.50 & 203.60 & $204 \cdot 72$ & 205.85 & 206.97 & 208.09 & 209.21 & 210.33 & 211.44 & 212.56 & 213.67 & $214 \cdot 78$ & 1.50 \\
\hline 1.60 & 214.78 & 215.89 & 217.00 & 218.11 & 219.22 & 220.32 & 221.43 & 222.53 & 223.63 & $224 \cdot 73$ & 225.83 & 1.60 \\
\hline 1.70 & 225.83 & 226.93 & 228.02 & 229.12 & 230.21 & 231.30 & 232.39 & 233.48 & 234.57 & 235.66 & 236.75 & 1.70 \\
\hline 1.80 & 236.75 & 237.83 & 238.91 & 240.00 & 241.08 & 242.16 & 243.24 & 244.31 & 245.39 & 246.47 & 247.54 & 1.80 \\
\hline 1.90 & 247.54 & 248.61 & 249.69 & 250.76 & 251.83 & 252.90 & 253.97 & 255.03 & 256.10 & 257.16 & 258.23 & 1.90 \\
\hline 2.00 & 258.23 & 259.29 & $260 \cdot 35$ & 261.41 & 262.47 & 263.53 & 264.59 & 265.64 & 266.70 & 267.75 & 268.81 & 2.00 \\
\hline 2.10 & 268.81 & 269.86 & 270.91 & 271.96 & 273.01 & 274.06 & 275.11 & 276.16 & 277.20 & 278.25 & 279.29 & 2.10 \\
\hline 2.20 & 279.29 & 280.34 & $281 \cdot 38$ & 282.42 & 283.46 & 284.50 & 285.54 & 286.58 & 287.61 & 288.65 & 289.69 & 2.20 \\
\hline 2.30 & 289.69 & 290.72 & 291.75 & 292.79 & 293.82 & 294.85 & 295.88 & 296.91 & 297.94 & 298.97 & 300.00 & 2.30 \\
\hline 2.40 & 300.00 & 301.02 & 302.05 & 303.07 & $304 \cdot 10$ & 305.12 & $306 \cdot 14$ & 307.16 & 308.18 & 309.20 & 310.22 & 2.40 \\
\hline 2.50 & 310.22 & 311.24 & 312.26 & 313.28 & 314.29 & 315.31 & 316.32 & $317 \cdot 34$ & 318.35 & 319.37 & $320 \cdot 38$ & 2.50 \\
\hline 2.60 & $320 \cdot 38$ & 321.39 & $322 \cdot 40$ & 323.41 & 324.42 & 325.43 & 326.44 & 327.44 & 328.45 & 329.45 & 330.46 & 2.60 \\
\hline 2.70 & 330.46 & 331.46 & 332.47 & 333.47 & 334.47 & 335.47 & 336.48 & 337.48 & 338.48 & 339.48 & 340.47 & 2.70 \\
\hline 2.80 & 340.47 & 341.47 & 342.47 & 343.47 & 344.46 & 345.46 & 346.45 & 347.45 & 348.44 & 349.43 & 350.42 & 2.80 \\
\hline 2.90 & 350.42 & 351.42 & 352.41 & 353.40 & 354.39 & 355.38 & 356.36 & 357.35 & 358.34 & 359.33 & 360.31 & 2.90 \\
\hline 3.00 & 360.31 & 361.30 & 362.28 & 363.27 & 364.25 & 365.23 & 366.22 & 367.20 & 368.18 & 369.16 & 370.14 & 3.00 \\
\hline 3.10 & 370.14 & 371.12 & 372.10 & 373.08 & 374.06 & 375.04 & 376.01 & 376.99 & 377.97 & 378.94 & 379.92 & 3.10 \\
\hline 3.20 & 379.92 & 380.89 & 381.87 & 382.84 & 383.81 & 384.78 & 385.76 & 386.73 & 387.70 & 388.67 & 389.64 & 3.20 \\
\hline 3.30 & 389.64 & 390.61 & 391.58 & 392.54 & 393.51 & 394.48 & 395.45 & 396.41 & 397.38 & 398.34 & 399.31 & 3.30 \\
\hline 3.40 & 399.31 & 400.27 & 401.23 & 402.20 & $403 \cdot 16$ & 404.12 & 405.08 & 406.05 & 407.01 & 407.97 & 408.93 & 3.40 \\
\hline 3.50 & 408.93 & 409.89 & 410.84 & 411.80 & 412.76 & 413.72 & 414.67 & 415.63 & 416.59 & 417.54 & 418.50 & 3.50 \\
\hline 3.60 & 418.50 & 419.45 & 420.41 & 421.36 & 422.31 & 423.27 & 424.22 & 425.17 & 426.12 & 427.07 & 428.02 & 3.60 \\
\hline 3.70 & 428.02 & 428.97 & 429.92 & 430.87 & 431.82 & 432.77 & 433.72 & 434.66 & 435.61 & 436.56 & 437.50 & 3.70 \\
\hline 3.80 & 437.50 & 438.45 & 439.39 & $440 \cdot 34$ & $441 \cdot 28$ & 442.23 & 443.17 & 444.11 & 445.06 & 446.00 & 446.94 & 3.80 \\
\hline 3.90 & 446.94 & 447.88 & 448.82 & 449.76 & 450.70 & 451.64 & 452.58 & 453.52 & 454.46 & 455.40 & 456.33 & 3.90 \\
\hline 4.00 & 456.33 & 457.27 & 458.21 & 459.14 & 460.08 & 461.02 & 461.95 & 462.89 & 463.82 & 464.75 & 465.69 & 4.00 \\
\hline 4.10 & 465.69 & 466.62 & 467.55 & 468.49 & 469.42 & 470.35 & 471.28 & 472.21 & 473.14 & 474.07 & 475.00 & 4.10 \\
\hline 4.20 & 475.00 & 475.93 & 476.86 & 477.79 & 478.71 & 479.64 & 480.57 & 481.50 & 482.42 & 483.35 & 484.27 & 4.20 \\
\hline 4.30 & 484.27 & 485.20 & 486.12 & 487.05 & 487.97 & 488.90 & 489.82 & 490.74 & 491.66 & 492.59 & 493.51 & $4 \cdot 30$ \\
\hline 4.40 & 493.51 & 494.43 & 495.35 & 496.27 & 497.19 & 498.11 & 499.03 & 499.95 & 500.87 & 501.79 & 502.70 & 4.40 \\
\hline 4.50 & 502.70 & 503.62 & 504.54 & 505.46 & $506 \cdot 37$ & 507.29 & 508.20 & 509.12 & 510.04 & 510.95 & 511.86 & 4.50 \\
\hline 4.60 & 511.86 & 512.78 & 513.69 & 514.61 & 515.52 & 516.43 & $517 \cdot 34$ & 518.25 & 519.17 & 520.08 & 520.99 & 4.60 \\
\hline 4.70 & 520.99 & 521.90 & 522.81 & 523.72 & 524.63 & 525.54 & 526.44 & 527.35 & 528.26 & $529 \cdot 17$ & 530.08 & 4.70 \\
\hline 4.80 & 530.08 & 530.98 & 531.89 & 532.79 & 533.70 & 534.61 & 535.51 & 536.42 & 537.32 & 538.22 & 539.13 & 4.80 \\
\hline 4.90 & 539.13 & 540.03 & 540.93 & 541.84 & 542.74 & 543.64 & 544.54 & 545.44 & 546.34 & $547 \cdot 25$ & $548 \cdot 15$ & 4.90 \\
\hline 5.00 & 548.15 & 549.05 & 549.95 & 550.84 & 551.74 & 552.64 & 553.54 & 554.44 & 555.34 & 556.23 & 557.13 & 5.00 \\
\hline 5.10 & 557.13 & 558.03 & 558.92 & 559.82 & 560.71 & 561.61 & 562.50 & 563.40 & 564.29 & 565.19 & 566.08 & 5.10 \\
\hline $5 \cdot 20$ & 566.08 & 566.97 & 567.87 & 568.76 & 569.65 & 570.54 & 571.44 & 572.33 & 573.22 & 574.11 & 575.00 & 5.20 \\
\hline 5.30 & 575.00 & 575.89 & 576.78 & 577.67 & 578.56 & 579.45 & 580.33 & 581.22 & 582.11 & 583.00 & 583.88 & 5.30 \\
\hline 5.40 & 583.88 & 584.77 & 585.66 & 586.54 & 587.43 & 588.32 & $589 \cdot 20$ & 590.09 & 590.97 & 591.85 & 592.74 & 5.40 \\
\hline 5.50 & 592.74 & 593.62 & 594.51 & 595.39 & 596.27 & 597.15 & 598.04 & 598.92 & 599.80 & 600.68 & 601.56 & 5.50 \\
\hline 5.60 & 601.56 & 602.44 & 603.32 & & $605: 08$ & 605.96 & 606.84 & 607.72 & 608.60 & 609.48 & 36 & 5.60 \\
\hline 5.70 & 610.36 & 611.23 & 612.11 & 612.99 & 613.87 & 614.74 & 615.62 & 616.49 & 617.37 & 618.25 & 619.12 & 5.70 \\
\hline 5.80 & 619.12 & 620.00 & 620.87 & 621.74 & 622.62 & 623.49 & 624.37 & 625.24 & 626.11 & 626.98 & 627.86 & 5.80 \\
\hline 5.90 & 627.86 & 628.73 & 629.60 & 630.47 & 631.34 & 632.21 & 633.08 & 633.95 & 634.82 & 635.69 & 636.55 & 5.90 \\
\hline 6.00 & 636.55 & 637.42 & 638.29 & 639.16 & 640.02 & 640.89 & 641.75 & 642.62 & 643.48 & 644.35 & 645.21 & 6.00 \\
\hline
\end{tabular}


TABLE A3.2.1. Type $\boldsymbol{R}$ thermocouples-temperature $\left({ }^{\circ} \mathrm{C}\right)$ as a function of thermoelectric voltage, reference junctions at $0^{\circ} \mathrm{C}$-Continued

$\mathrm{mV}$ .00 .01 .02 .03

TEMPERATURES IN DEGREES C (IPTS 1968 )

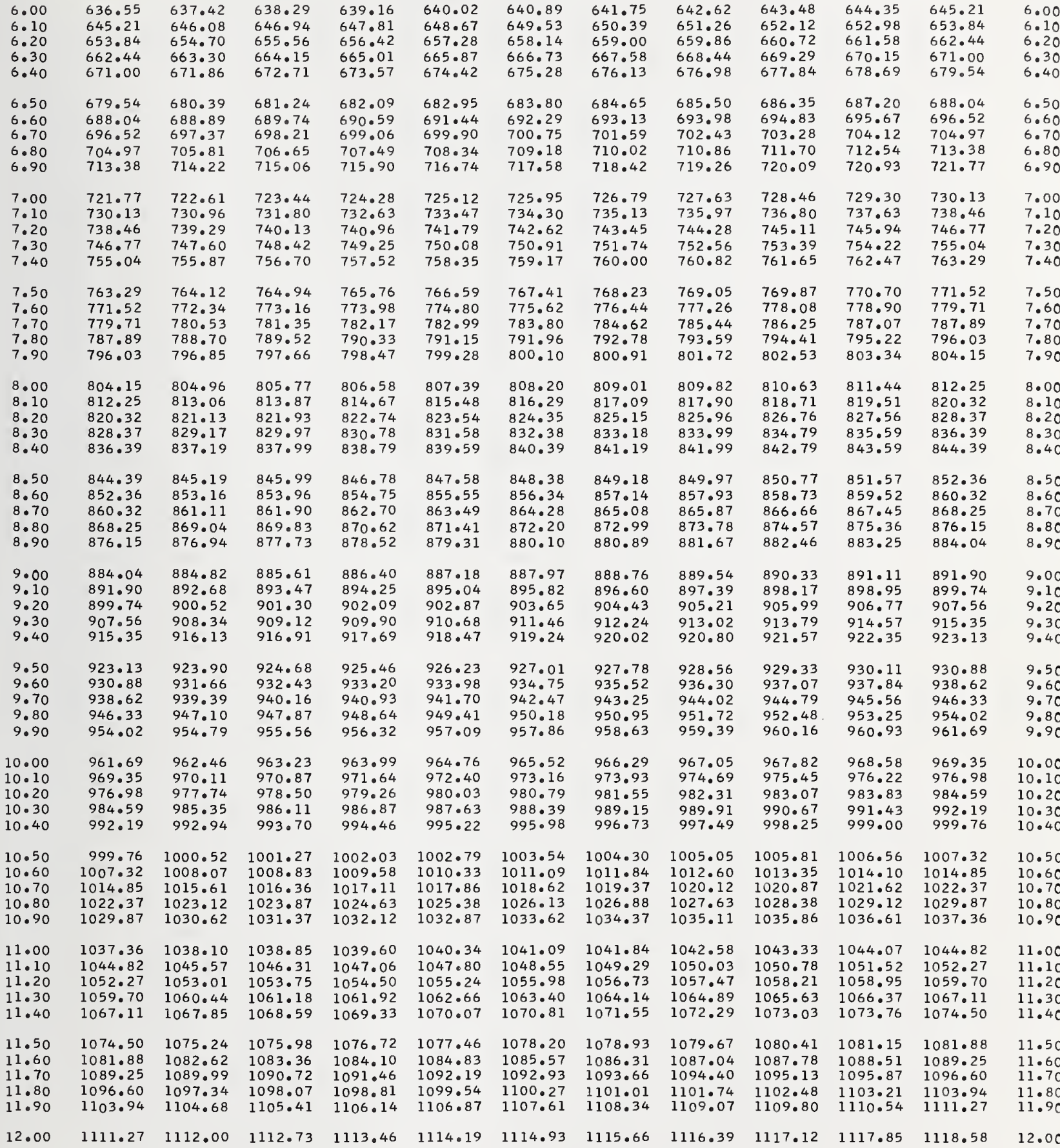

$\mathrm{mV}$
6.00

.30

6.50

6.60

6.90

7.40

.70

7.90

8.40

.50

8.60

9.00

.20

9.30

9.50

9.60
9.70

.80

10.10

0.40

.50

10.60
0.70

10.80

1.10

1.40

.50

.60

1.80

2.00
.00

.01

.02

.03

.04

.05

.06

.07

.08

.09

.10 
TABLE A3.2.1. Type $\mathbb{R}$ thermocouples-temperature $\left({ }^{\circ} \mathrm{C}\right)$ as a function of thermoelectric voltage, reference junctions at $0^{\circ} \mathrm{C}$ - Continued

$\mathrm{mV}$

.00

.02

.03

.04

.05

.06

.07

.08

.09

.10

$\mathrm{mV}$

TEMPERATURES IN DEGREES C (IPTS 1968)

\begin{tabular}{|c|c|c|c|c|c|c|c|c|c|c|c|c|}
\hline $\begin{array}{l}12.00 \\
12.10 \\
12.20 \\
12.30\end{array}$ & $\begin{array}{l}1111.27 \\
1118.58 \\
1125.88 \\
1133.17\end{array}$ & $\begin{array}{l}1112.00 \\
1119.31 \\
1126.61 \\
1133.90\end{array}$ & $\begin{array}{l}1112.73 \\
1120.04 \\
1127.34 \\
1134.63\end{array}$ & $\begin{array}{l}1113.46 \\
1120.77 \\
1128.07 \\
1135.35\end{array}$ & $\begin{array}{l}1114.19 \\
1121.50 \\
1128.80 \\
1136.08\end{array}$ & $\begin{array}{l}1114.93 \\
1122.23 \\
1129.53 \\
1136.81\end{array}$ & $\begin{array}{l}1115.66 \\
1122.96 \\
1130.25 \\
1137.54\end{array}$ & $\begin{array}{l}1116.39 \\
1123.69 \\
1130.98 \\
1138.26\end{array}$ & $\begin{array}{l}1117.12 \\
1124.42 \\
1131.71 \\
1138.99\end{array}$ & $\begin{array}{l}1117.85 \\
1125.15 \\
1132.44 \\
1139.72\end{array}$ & $\begin{array}{l}1118.58 \\
1125.88 \\
1133.17 \\
1140.45\end{array}$ & $\begin{array}{l}12 \cdot 00 \\
12 \cdot 10 \\
12 \cdot 20 \\
12 \cdot 30\end{array}$ \\
\hline $12 \cdot 40$ & 1140.45 & 1141.17 & $1141 \cdot 90$ & 1142.63 & $1143 \cdot 35$ & 1144.08 & $1144 \cdot 81$ & 1145.53 & 1146.26 & 1146.98 & 1147.71 & 12.40 \\
\hline $\begin{array}{l}12.50 \\
12.60 \\
12.70 \\
12.80 \\
12.90\end{array}$ & $\begin{array}{l}1147.71 \\
1154.97 \\
1162.21 \\
1169.44 \\
1176.67\end{array}$ & $\begin{array}{l}1148.44 \\
1155.69 \\
1162.93 \\
1170.17 \\
1177.39\end{array}$ & $\begin{array}{l}1149.16 \\
1156.41 \\
1163.66 \\
1170.89 \\
1178.11\end{array}$ & $\begin{array}{l}1149.89 \\
1157.14 \\
1164.38 \\
1171.61 \\
1178.83\end{array}$ & $\begin{array}{l}1150.61 \\
1157.86 \\
1165.10 \\
1172.33 \\
1179.55\end{array}$ & $\begin{array}{l}1151.34 \\
1158.59 \\
1165.83 \\
1173.06 \\
1180.28\end{array}$ & $\begin{array}{l}1152.06 \\
1159.31 \\
1166.55 \\
1173.78 \\
1181.00\end{array}$ & $\begin{array}{l}1152.79 \\
1160.04 \\
1167.27 \\
1174.50 \\
1181.72\end{array}$ & $\begin{array}{l}1153.52 \\
1160.76 \\
1168.00 \\
1175.22 \\
1182.44\end{array}$ & $\begin{array}{l}1154 \cdot 24 \\
1161.49 \\
1168.72 \\
1175.94 \\
1183.16\end{array}$ & $\begin{array}{l}1154.97 \\
1162.21 \\
1169.44 \\
1176.67 \\
1183.88\end{array}$ & $\begin{array}{l}12.50 \\
12.60 \\
12.70 \\
12.80 \\
12.90\end{array}$ \\
\hline $\begin{array}{l}13 \cdot 00 \\
13 \cdot 10 \\
13.20 \\
13.30 \\
13.40\end{array}$ & $\begin{array}{l}1183.88 \\
1191.09 \\
1198.28 \\
1205.47 \\
1212.65\end{array}$ & $\begin{array}{l}1184.60 \\
1191.81 \\
1199.00 \\
1206.19 \\
1213.37\end{array}$ & $\begin{array}{l}1185 \cdot 32 \\
1192 \cdot 53 \\
1199 \cdot 72 \\
1206.91 \\
1214.09\end{array}$ & $\begin{array}{l}1186.04 \\
1193.25 \\
1200.44 \\
1207.63 \\
1214.80\end{array}$ & $\begin{array}{l}1186 \cdot 76 \\
1193 \cdot 97 \\
1201.16 \\
1208 \cdot 34 \\
1215.52\end{array}$ & $\begin{array}{l}1187.49 \\
1194.69 \\
1201.88 \\
1209.06 \\
1216.24\end{array}$ & $\begin{array}{l}1188.21 \\
1195.41 \\
1202.60 \\
1209.78 \\
1216.96\end{array}$ & $\begin{array}{l}1188.93 \\
1196.13 \\
1203.32 \\
1210.50 \\
1217.67\end{array}$ & $\begin{array}{l}1189.65 \\
1196.84 \\
1204.03 \\
1211.22 \\
1218.39\end{array}$ & $\begin{array}{l}1190.37 \\
1197.56 \\
1204.75 \\
1211.93 \\
1219.11\end{array}$ & $\begin{array}{l}1191.09 \\
1198.28 \\
1205.47 \\
1212.65 \\
1219.82\end{array}$ & $\begin{array}{l}13.00 \\
13.10 \\
13.20 \\
13.30 \\
13.40\end{array}$ \\
\hline $\begin{array}{l}13.50 \\
13.60 \\
13.70 \\
13.80 \\
13.90\end{array}$ & $\begin{array}{l}1219.82 \\
1226 \cdot 99 \\
1234.15 \\
1241 \cdot 30 \\
1248.44\end{array}$ & $\begin{array}{l}1220.54 \\
1227.71 \\
1234.86 \\
1242.01 \\
1249.16\end{array}$ & $\begin{array}{l}1221.26 \\
1228.42 \\
1235.58 \\
1242.73 \\
1249.87\end{array}$ & $\begin{array}{l}1221.97 \\
1229 \cdot 14 \\
1236.29 \\
1243.44 \\
1250.59\end{array}$ & $\begin{array}{l}1222 \cdot 69 \\
1229 \cdot 85 \\
1237 \cdot 01 \\
1244 \cdot 16 \\
1251 \cdot 30\end{array}$ & $\begin{array}{l}1223.41 \\
1230.57 \\
1237.72 \\
1244.87 \\
1252.01\end{array}$ & $\begin{array}{l}1224 \cdot 12 \\
1231 \cdot 29 \\
1238 \cdot 44 \\
1245.59 \\
1252 \cdot 73\end{array}$ & $\begin{array}{l}1224.84 \\
1232.00 \\
1239.15 \\
1246.30 \\
1253.44\end{array}$ & $\begin{array}{l}1225.56 \\
1232.72 \\
1239.87 \\
1247.01 \\
1254.15\end{array}$ & $\begin{array}{l}1226.27 \\
1233 \cdot 43 \\
1240.58 \\
1247.73 \\
1254.87\end{array}$ & $\begin{array}{l}1226 \cdot 99 \\
1234 \cdot 15 \\
1241 \cdot 30 \\
1248 \cdot 44 \\
1255.58\end{array}$ & $\begin{array}{l}13.50 \\
13.60 \\
13.70 \\
13.80 \\
13.90\end{array}$ \\
\hline $\begin{array}{l}14 \cdot 00 \\
14.10 \\
14 \cdot 20 \\
14.30 \\
14.40\end{array}$ & $\begin{array}{l}1255.58 \\
1262.71 \\
1269.84 \\
1276.96 \\
1284.08\end{array}$ & $\begin{array}{l}1256.30 \\
1263.43 \\
1270.55 \\
1277.68 \\
1284.79\end{array}$ & $\begin{array}{l}1257.01 \\
1264.14 \\
1271.27 \\
1278.39 \\
1285.50\end{array}$ & $\begin{array}{l}1257.72 \\
1264.85 \\
1271.98 \\
1279.10 \\
1286.22\end{array}$ & $\begin{array}{l}1258 \cdot 44 \\
1265.57 \\
1272.69 \\
1279.81 \\
1286.93\end{array}$ & $\begin{array}{l}1259.15 \\
1266.28 \\
1273.40 \\
1280.52 \\
1287.64\end{array}$ & $\begin{array}{l}1259.86 \\
1266.99 \\
1274.12 \\
1281.24 \\
1288.35\end{array}$ & $\begin{array}{l}1260.58 \\
1267.70 \\
1274.83 \\
1281.95 \\
1289.06\end{array}$ & $\begin{array}{l}1261.29 \\
1268.42 \\
1275.54 \\
1282.66 \\
1289.77\end{array}$ & $\begin{array}{l}1262.00 \\
1269.13 \\
1276.25 \\
1283.37 \\
1290.48\end{array}$ & $\begin{array}{l}1262.71 \\
1269.84 \\
1276.96 \\
1284.08 \\
1291.19\end{array}$ & $\begin{array}{l}14.00 \\
14.10 \\
14.20 \\
14.30 \\
14.40\end{array}$ \\
\hline $\begin{array}{l}14.50 \\
14.60 \\
14.70 \\
14.80 \\
14.90\end{array}$ & $\begin{array}{l}1291.19 \\
1298.30 \\
1305.41 \\
1312.51 \\
1319.61\end{array}$ & $\begin{array}{l}1291.91 \\
1299.01 \\
1306.12 \\
1313.22 \\
1320.32\end{array}$ & $\begin{array}{l}1292.62 \\
1299.72 \\
1306.83 \\
1313.93 \\
1321.03\end{array}$ & $\begin{array}{l}1293.33 \\
1300.43 \\
1307.54 \\
1314.64 \\
1321.73\end{array}$ & $\begin{array}{l}1294 \cdot 04 \\
1301 \cdot 15 \\
1308 \cdot 25 \\
1315 \cdot 35 \\
1322.44\end{array}$ & $\begin{array}{l}1294.75 \\
1301.86 \\
1308.96 \\
1316.06 \\
1323.15\end{array}$ & $\begin{array}{l}1295.46 \\
1302.57 \\
1309.67 \\
1316.77 \\
1323.86\end{array}$ & $\begin{array}{l}1296.17 \\
1303.28 \\
1310.38 \\
1317.48 \\
1324.57\end{array}$ & $\begin{array}{l}1296.88 \\
1303.99 \\
1311.09 \\
1318.19 \\
1325.28\end{array}$ & $\begin{array}{l}1297.59 \\
1304.70 \\
1311.80 \\
1318.90 \\
1325.99\end{array}$ & $\begin{array}{l}1298 \cdot 30 \\
1305.41 \\
1312.51 \\
1319.61 \\
1326.70\end{array}$ & $\begin{array}{l}14.50 \\
14.60 \\
14.70 \\
14.80 \\
14.90\end{array}$ \\
\hline $\begin{array}{l}15.00 \\
15.10 \\
15.20 \\
15.30 \\
15.40\end{array}$ & $\begin{array}{l}1326.70 \\
1333.79 \\
1340.88 \\
1347.97 \\
1355.05\end{array}$ & $\begin{array}{l}1327.41 \\
1334.50 \\
1341.59 \\
1348.68 \\
1355.76\end{array}$ & $\begin{array}{l}1328.12 \\
1335.21 \\
1342.30 \\
1349.39 \\
1356.47\end{array}$ & $\begin{array}{l}1328.83 \\
1335.92 \\
1343.01 \\
1350.09 \\
1357.18\end{array}$ & $\begin{array}{l}1329 \cdot 54 \\
1336 \cdot 63 \\
1343.72 \\
1350.80 \\
1357.89\end{array}$ & $\begin{array}{l}1330.25 \\
1337.34 \\
1344.43 \\
1351.51 \\
1358.60\end{array}$ & $\begin{array}{l}1330 \cdot 96 \\
1338 \cdot 05 \\
1345 \cdot 13 \\
1352 \cdot 22 \\
1359 \cdot 30\end{array}$ & $\begin{array}{l}1331.66 \\
1338.75 \\
1345.84 \\
1352.93 \\
1360.01\end{array}$ & $\begin{array}{l}1332.37 \\
1339.46 \\
1346.55 \\
1353.64 \\
1360.72\end{array}$ & $\begin{array}{l}1333.08 \\
1340.17 \\
1347.26 \\
1354.35 \\
1361.43\end{array}$ & $\begin{array}{l}1333 \cdot 79 \\
1340 \cdot 88 \\
1347 \cdot 97 \\
1355 \cdot 05 \\
1362 \cdot 14\end{array}$ & $\begin{array}{l}15.00 \\
15.10 \\
15.20 \\
15.30 \\
15.40\end{array}$ \\
\hline $\begin{array}{l}15.50 \\
15.60 \\
15.70\end{array}$ & $\begin{array}{l}1362.14 \\
1369.22 \\
1376.30\end{array}$ & $\begin{array}{l}1362.85 \\
1369.93 \\
1377.01\end{array}$ & $\begin{array}{l}1363.55 \\
1370.64 \\
1377.72\end{array}$ & $\begin{array}{l}1364.26 \\
1371.34 \\
1378.43\end{array}$ & $\begin{array}{l}1364 \cdot 97 \\
1372 \cdot 05 \\
1379 \cdot 13\end{array}$ & $\begin{array}{l}1365.68 \\
1372.76 \\
1379.84\end{array}$ & $\begin{array}{l}1366.39 \\
1373.47 \\
1380.55\end{array}$ & $\begin{array}{l}1367.10 \\
1374.18 \\
1381.26\end{array}$ & $\begin{array}{l}1367.80 \\
1374.89 \\
1381.97\end{array}$ & $\begin{array}{l}1368.51 \\
1375.59 \\
1382.67\end{array}$ & $\begin{array}{l}1369 \cdot 22 \\
1376 \cdot 30 \\
1383 \cdot 38\end{array}$ & $\begin{array}{l}15.50 \\
15.60 \\
15.70\end{array}$ \\
\hline $\begin{array}{l}15.80 \\
15.90\end{array}$ & $\begin{array}{l}1383.38 \\
1390.46\end{array}$ & $\begin{array}{l}1384.09 \\
1391.17\end{array}$ & $\begin{array}{l}1384.80 \\
1391.88\end{array}$ & $\begin{array}{l}1385.51 \\
1392.59\end{array}$ & $\begin{array}{l}1386 \cdot 21 \\
1393 \cdot 29\end{array}$ & $\begin{array}{l}1386.92 \\
1394.00\end{array}$ & $\begin{array}{l}1387.63 \\
1394.71\end{array}$ & $\begin{array}{l}1388.34 \\
1395.42\end{array}$ & $\begin{array}{l}1389.05 \\
1396.13\end{array}$ & $\begin{array}{l}1389.75 \\
1396.83\end{array}$ & & $\begin{array}{l}15.80 \\
15.90\end{array}$ \\
\hline $\begin{array}{l}16.00 \\
16.10 \\
16.20 \\
16.30 \\
16.40\end{array}$ & $\begin{array}{l}1397.54 \\
1404.62 \\
1411.70 \\
1418.79 \\
1425.87\end{array}$ & $\begin{array}{l}1398.25 \\
1405.33 \\
1412.41 \\
1419.49 \\
1426.58\end{array}$ & $\begin{array}{l}1398.96 \\
1406.04 \\
1413.12 \\
1420.20 \\
1427.29\end{array}$ & $\begin{array}{l}1399.67 \\
1406.75 \\
1413.83 \\
1420.91 \\
1427.99\end{array}$ & $\begin{array}{l}1400 \cdot 37 \\
1407.46 \\
1414.54 \\
1421.62 \\
1428.70\end{array}$ & $\begin{array}{l}1401.08 \\
1408.16 \\
1415.24 \\
1422.33 \\
1429.41\end{array}$ & $\begin{array}{l}1401.79 \\
1408.87 \\
1415.95 \\
1423.04 \\
1430.12\end{array}$ & $\begin{array}{l}1402.50 \\
1409.58 \\
1416.66 \\
1423.74 \\
1430.83\end{array}$ & $\begin{array}{l}1403.21 \\
1410.29 \\
1417.37 \\
1424.45 \\
1431.54\end{array}$ & $\begin{array}{l}1403.92 \\
1411.00 \\
1418.08 \\
1425.16 \\
1432.24\end{array}$ & $\begin{array}{l}1404.62 \\
1411.70 \\
1418.79 \\
1425.87 \\
1432.95\end{array}$ & $\begin{array}{l}16.00 \\
16.10 \\
16.20 \\
16.30 \\
16.40\end{array}$ \\
\hline $\begin{array}{l}16.50 \\
16.60 \\
16.70 \\
16.80 \\
16.90\end{array}$ & $\begin{array}{l}1432.95 \\
1440.04 \\
1447.13 \\
1454 \cdot 22 \\
1461.31\end{array}$ & $\begin{array}{l}1433.66 \\
1440.75 \\
1447.83 \\
1454.92 \\
1462.02\end{array}$ & $\begin{array}{l}1434.37 \\
1441.46 \\
1448.54 \\
1455.63 \\
1462.73\end{array}$ & $\begin{array}{l}1435.08 \\
1442.16 \\
1449.25 \\
1456.34 \\
1463.44\end{array}$ & $\begin{array}{l}1435.79 \\
1442.87 \\
1449.96 \\
1457.05 \\
1464.15\end{array}$ & $\begin{array}{l}1436.50 \\
1443.58 \\
1450.67 \\
1457.76 \\
1464.86\end{array}$ & $\begin{array}{l}1437.20 \\
1444.29 \\
1451.38 \\
1458.47 \\
1465.56\end{array}$ & $\begin{array}{l}1437.91 \\
1445.00 \\
1452.09 \\
1459.18 \\
1466.27\end{array}$ & $\begin{array}{l}1438.62 \\
1445.71 \\
1452.80 \\
1459.89 \\
1466.98\end{array}$ & $\begin{array}{l}1439.33 \\
1446.42 \\
1453.51 \\
1460.60 \\
1467.69\end{array}$ & $\begin{array}{l}1440 \cdot 04 \\
1447 \cdot 13 \\
1454 \cdot 22 \\
1461 \cdot 31 \\
1468 \cdot 40\end{array}$ & $\begin{array}{l}16.50 \\
16.60 \\
16.70 \\
16.80 \\
16.90\end{array}$ \\
\hline $\begin{array}{l}17 \cdot 00 \\
17 \cdot 10 \\
17 \cdot 20 \\
17.30 \\
17.40\end{array}$ & $\begin{array}{l}1468.40 \\
1475.50 \\
1482.60 \\
1489.71 \\
1496.82\end{array}$ & $\begin{array}{l}1469.11 \\
1476.21 \\
1483.31 \\
1490.42 \\
1497.53\end{array}$ & $\begin{array}{l}1469 \cdot 82 \\
1476.92 \\
1484.02 \\
1491.13 \\
1498 \cdot 24\end{array}$ & $\begin{array}{l}1470.53 \\
1477.63 \\
1484.73 \\
1491.84 \\
1498.95\end{array}$ & $\begin{array}{l}1471 \cdot 24 \\
1478 \cdot 34 \\
1485.45 \\
1492.55 \\
1499.66\end{array}$ & $\begin{array}{l}1471.95 \\
1479.05 \\
1486.16 \\
1493.26 \\
1500.37\end{array}$ & $\begin{array}{l}1472.66 \\
1479.76 \\
1486.87 \\
1493.97 \\
1501.09\end{array}$ & $\begin{array}{l}1473.37 \\
1480.47 \\
1487.58 \\
1494.69 \\
1501.80\end{array}$ & $\begin{array}{l}1474.08 \\
1481.18 \\
1488.29 \\
1495.40 \\
1502.51\end{array}$ & $\begin{array}{l}1474.79 \\
1481.89 \\
1489.00 \\
1496.11 \\
1503.22\end{array}$ & $\begin{array}{l}1475.50 \\
1482.60 \\
1489.71 \\
1496.82 \\
1503.93\end{array}$ & $\begin{array}{l}17.00 \\
17.10 \\
17.20 \\
17.30 \\
17.40\end{array}$ \\
\hline $\begin{array}{l}17.50 \\
17.60 \\
17.70 \\
17.80 \\
17.90\end{array}$ & $\begin{array}{l}1503.93 \\
1511.05 \\
1518.17 \\
1525.30 \\
1532.44\end{array}$ & $\begin{array}{l}1504.64 \\
1511.76 \\
1518.89 \\
1526.02 \\
1533.15\end{array}$ & $\begin{array}{l}1505.36 \\
1512.48 \\
1519.60 \\
1526.73 \\
1533.86\end{array}$ & $\begin{array}{l}1506.07 \\
1513.19 \\
1520.31 \\
1527.44 \\
1534.58\end{array}$ & $\begin{array}{l}1506.78 \\
1513.90 \\
1521.02 \\
1528.16 \\
1535.29\end{array}$ & $\begin{array}{l}1507.49 \\
1514.61 \\
1521.74 \\
1528.87 \\
1536.01\end{array}$ & $\begin{array}{l}1508.20 \\
1515.32 \\
1522.45 \\
1529.58 \\
1536.72\end{array}$ & $\begin{array}{l}1508.91 \\
1516.04 \\
1523.16 \\
1530.30 \\
1537.43\end{array}$ & $\begin{array}{l}1509.63 \\
1516.75 \\
1523.88 \\
1531.01 \\
1538.15\end{array}$ & $\begin{array}{l}1510.34 \\
1517.46 \\
1524.59 \\
1531.72 \\
1538.86\end{array}$ & $\begin{array}{l}1511.05 \\
1518.17 \\
1525.30 \\
1532.44 \\
1539.58\end{array}$ & $\begin{array}{l}17.50 \\
17.60 \\
17.70 \\
17.80 \\
17.90\end{array}$ \\
\hline 10.00 & 1539.58 & 1540.29 & 1541.01 & 1541.72 & 1542.43 & 1543.15 & 1543.86 & 1544.58 & 1545.29 & 1546.01 & $1546 \cdot 72$ & 18.00 \\
\hline
\end{tabular}

$\mathrm{mV}$

.00

.01

.02

.03

.04

.05

.06

.07

.08

.09

.10

$\mathrm{mV}$ 
TABLE A3.2.1. Type $\boldsymbol{R}$ thermocouples-temperature $\left({ }^{\circ} \mathrm{C}\right)$ as a function of thermoelectric voltage, reference junctions at $0^{\circ} \mathrm{C}$-Continued

$\mathrm{mV}$ .00 .01 .02 .03 .04 .05 .06 .07 .08 .09 .10 $m \mathrm{r}$

TEMPERATURES IN DEGREES C (IPTS 1968 )

\begin{tabular}{|c|c|c|c|c|c|c|c|c|c|c|c|c|}
\hline $\begin{array}{l}18.00 \\
18.10 \\
18.20 \\
18.30 \\
18.40\end{array}$ & $\begin{array}{l}1539 \cdot 58 \\
1546 \cdot 72 \\
1553.88 \\
1561.04 \\
1568.20\end{array}$ & $\begin{array}{l}1540.29 \\
1547.44 \\
1554.59 \\
1561.75 \\
1568.92\end{array}$ & $\begin{array}{l}1541.01 \\
1548.15 \\
1555.31 \\
1562.47 \\
1569.64\end{array}$ & $\begin{array}{l}1541.72 \\
1548.87 \\
1556.02 \\
1563.19 \\
1570.35\end{array}$ & $\begin{array}{l}1542 \cdot 43 \\
1549 \cdot 58 \\
1556 \cdot 74 \\
1563 \cdot 90 \\
1571.07\end{array}$ & $\begin{array}{l}1543.15 \\
1550.30 \\
1557.46 \\
1564.62 \\
1571.79\end{array}$ & $\begin{array}{l}1543.86 \\
1551.01 \\
1558.17 \\
1565.34 \\
1572.51\end{array}$ & $\begin{array}{l}1544.58 \\
1551.73 \\
1558.89 \\
1566.05 \\
1573.22\end{array}$ & $\begin{array}{l}1545.29 \\
1552.45 \\
1559.60 \\
1566.77 \\
1573.94\end{array}$ & $\begin{array}{l}1546.01 \\
1553.16 \\
1560.32 \\
1567.49 \\
1574.66\end{array}$ & $\begin{array}{l}1546.72 \\
1553.88 \\
1561.04 \\
1568.20 \\
1575.38\end{array}$ & $\begin{array}{l}18.00 \\
18.10 \\
18.20 \\
18.30 \\
18.40\end{array}$ \\
\hline $\begin{array}{l}18.50 \\
18.60 \\
18.70 \\
18.80 \\
18.90\end{array}$ & $\begin{array}{l}1575 \cdot 38 \\
1582 \cdot 56 \\
1589 \cdot 75 \\
1596 \cdot 95 \\
1604 \cdot 16\end{array}$ & $\begin{array}{l}1576.09 \\
1583.28 \\
1590.47 \\
1597.67 \\
1604.88\end{array}$ & $\begin{array}{l}1576.81 \\
1584.00 \\
1591.19 \\
1598.39 \\
1605.60\end{array}$ & $\begin{array}{l}1577.53 \\
1584.72 \\
1591.91 \\
1599.11 \\
1606.32\end{array}$ & $\begin{array}{l}1578.25 \\
1585.43 \\
1592.63 \\
1599.83 \\
1607.04\end{array}$ & $\begin{array}{l}1578.97 \\
1586.15 \\
1593.35 \\
1600.55 \\
1607.76\end{array}$ & $\begin{array}{l}1579.69 \\
1586.87 \\
1594.07 \\
1601.27 \\
1608.48\end{array}$ & $\begin{array}{l}1580.40 \\
1587.59 \\
1594.79 \\
1601.99 \\
1609.21\end{array}$ & $\begin{array}{l}1581.12 \\
1588.31 \\
1595.51 \\
1602.71 \\
1609.93\end{array}$ & $\begin{array}{l}1581.84 \\
1589.03 \\
1596.23 \\
1603.43 \\
1610.65\end{array}$ & $\begin{array}{l}1582 \cdot 56 \\
1589 \cdot 75 \\
1596.95 \\
1604 \cdot 16 \\
1611.37\end{array}$ & $\begin{array}{l}18.50 \\
18.60 \\
18.70 \\
18.80 \\
18.90\end{array}$ \\
\hline $\begin{array}{l}19.00 \\
19.10 \\
19.20 \\
19.30 \\
19.40\end{array}$ & $\begin{array}{l}1611.37 \\
1618.60 \\
1625.84 \\
1633.08 \\
1640.34\end{array}$ & $\begin{array}{l}1612.09 \\
1619.32 \\
1626.56 \\
1633.81 \\
1641.06\end{array}$ & $\begin{array}{l}1612 \cdot 82 \\
1620 \cdot 05 \\
1627 \cdot 28 \\
1634 \cdot 53 \\
1641 \cdot 79\end{array}$ & $\begin{array}{l}1613.54 \\
1620.77 \\
1628.01 \\
1635.26 \\
1642.52\end{array}$ & $\begin{array}{l}1614 \cdot 26 \\
1621 \cdot 49 \\
1628 \cdot 73 \\
1635 \cdot 98 \\
1643 \cdot 24\end{array}$ & $\begin{array}{l}1614.98 \\
1622.22 \\
1629.46 \\
1636.71 \\
1643.97\end{array}$ & $\begin{array}{l}1615.71 \\
1622.94 \\
1630.18 \\
1637.43 \\
1644.70\end{array}$ & $\begin{array}{l}1616.43 \\
1623.66 \\
1630.91 \\
1638.16 \\
1645.43\end{array}$ & $\begin{array}{l}1617.15 \\
1624.39 \\
1631.63 \\
1638.89 \\
1646.15\end{array}$ & $\begin{array}{l}1617.88 \\
1625.11 \\
1632.36 \\
1639.61 \\
1646.88\end{array}$ & $\begin{array}{l}1618.60 \\
1625.84 \\
1633.08 \\
1640.34 \\
1647.61\end{array}$ & $\begin{array}{l}19.00 \\
19.10 \\
19.20 \\
19.30 \\
19.40\end{array}$ \\
\hline $\begin{array}{l}19.50 \\
19.60 \\
19.70 \\
19.80 \\
19.90\end{array}$ & $\begin{array}{l}1647.61 \\
1654.89 \\
1662.18 \\
1669.48 \\
1676.80\end{array}$ & $\begin{array}{l}1648.33 \\
1655.61 \\
1662.91 \\
1670.21 \\
1677.53\end{array}$ & $\begin{array}{l}1649.06 \\
1656.34 \\
1663.64 \\
1670.94 \\
1678.26\end{array}$ & $\begin{array}{l}1649.79 \\
1657.07 \\
1664.37 \\
1671.67 \\
1679.00\end{array}$ & $\begin{array}{l}1650.52 \\
1657.80 \\
1665.10 \\
1672.41 \\
1679.73\end{array}$ & $\begin{array}{l}1651.24 \\
1658.53 \\
1665.83 \\
1673.14 \\
1680.46\end{array}$ & $\begin{array}{l}1651.97 \\
1659.26 \\
1666.56 \\
1673.87 \\
1681.20\end{array}$ & $\begin{array}{l}1652.70 \\
1659.99 \\
1667.29 \\
1674.60 \\
1681.93\end{array}$ & $\begin{array}{l}1653.43 \\
1660.72 \\
1668 \cdot 02 \\
1675.33 \\
1682 \cdot 67\end{array}$ & $\begin{array}{l}1654.16 \\
1661.45 \\
1668.75 \\
1676.07 \\
1683.40\end{array}$ & $\begin{array}{l}1654 \cdot 89 \\
1662.18 \\
1669 \cdot 48 \\
1676.80 \\
1684 \cdot 14\end{array}$ & $\begin{array}{l}19.50 \\
19.60 \\
19.70 \\
19.80 \\
19.90\end{array}$ \\
\hline $\begin{array}{l}20 \cdot 00 \\
20 \cdot 10 \\
20 \cdot 20 \\
20 \cdot 30 \\
20 \cdot 40\end{array}$ & $\begin{array}{l}1684 \cdot 14 \\
1691 \cdot 50 \\
1698 \cdot 88 \\
1706 \cdot 30 \\
1713 \cdot 75\end{array}$ & $\begin{array}{l}1684.87 \\
1692.23 \\
1699.62 \\
1707.04 \\
1714.50\end{array}$ & $\begin{array}{l}1685.61 \\
1692.97 \\
1700 \cdot 36 \\
1707.79 \\
1715.25\end{array}$ & $\begin{array}{l}1686.34 \\
1693.71 \\
1701.10 \\
1708.53 \\
1716.00\end{array}$ & $\begin{array}{l}1687.08 \\
1694 \cdot 45 \\
1701.84 \\
1709.28 \\
1716.74\end{array}$ & $\begin{array}{l}1687.81 \\
1695.18 \\
1702.59 \\
1710.02 \\
1717.49\end{array}$ & $\begin{array}{l}1688 \cdot 55 \\
1695.92 \\
1703 \cdot 33 \\
1710 \cdot 77 \\
1718.24\end{array}$ & $\begin{array}{l}1689.28 \\
1696.66 \\
1704.07 \\
1711.51 \\
1718.99\end{array}$ & $\begin{array}{l}1690.02 \\
1697.40 \\
1704.81 \\
1712.26 \\
1719.74\end{array}$ & $\begin{array}{l}1690.76 \\
1698.14 \\
1705.56 \\
1713.00 \\
1720.49\end{array}$ & $\begin{array}{l}1691 \cdot 50 \\
1698 \cdot 88 \\
1706 \cdot 30 \\
1713.75 \\
1721.25\end{array}$ & $\begin{array}{l}20 \cdot 00 \\
20.10 \\
20.20 \\
20.30 \\
20.40\end{array}$ \\
\hline $\begin{array}{l}20.50 \\
20.60 \\
20.70 \\
20.80 \\
20.90\end{array}$ & $\begin{array}{l}1721 \cdot 25 \\
1728 \cdot 78 \\
1736.37 \\
1744.02 \\
1751.73\end{array}$ & $\begin{array}{l}1722.00 \\
1729.54 \\
1737.14 \\
1744.79 \\
1752.50\end{array}$ & $\begin{array}{l}1722.75 \\
1730.30 \\
1737.90 \\
1745.56 \\
1753.28\end{array}$ & $\begin{array}{l}1723.50 \\
1731.06 \\
1738.66 \\
1746.32 \\
1754.05\end{array}$ & $\begin{array}{l}1724.26 \\
1731.81 \\
1739.42 \\
1747.09 \\
1754.83\end{array}$ & $\begin{array}{l}1725.01 \\
1732.57 \\
1740.19 \\
1747.86 \\
1755.61\end{array}$ & $\begin{array}{l}1725 \cdot 76 \\
1733 \cdot 33 \\
1740.95 \\
1748.64 \\
1756.38\end{array}$ & $\begin{array}{l}1726.52 \\
1734.09 \\
1741.72 \\
1749.41 \\
1757.16\end{array}$ & $\begin{array}{l}1727.27 \\
1734.85 \\
1742.49 \\
1750.18 \\
1757.94\end{array}$ & $\begin{array}{l}1728.03 \\
1735.61 \\
1743.25 \\
1750.95 \\
1758.72\end{array}$ & $\begin{array}{l}1728.78 \\
1736.37 \\
1744.02 \\
1751.73 \\
1759.50\end{array}$ & $\begin{array}{l}20.50 \\
20.60 \\
20.70 \\
20.80 \\
20.90\end{array}$ \\
\hline $\begin{array}{l}21 \cdot 00 \\
21 \cdot 10\end{array}$ & $\begin{array}{l}1759.50 \\
1767.35\end{array}$ & 1760.28 & 1761.07 & 1761.85 & 1762.63 & 1763.42 & 1764.20 & 1764.99 & 1765.78 & 1766.57 & 1767.35 & $\begin{array}{l}21.00 \\
21.10\end{array}$ \\
\hline $\mathrm{mV}$ & .00 & .01 & .02 & .03 & .04 & .05 & .06 & .07 & .08 & .09 & .10 & $\mathrm{mV}$ \\
\hline
\end{tabular}

TABLE A3.2.2. Type $\boldsymbol{R}$ thermocouples-temperature $\left({ }^{\circ} \mathrm{F}\right)$ as a function of thermoelectric voltage, reference junctions at $32{ }^{\circ} \mathrm{F}$

$m V$ .00 $.02 \quad .03$ .04 .05 .06 .07 .08 .09 .10 $\mathrm{mV}$ TEMPERATURES IN DEGREES F

$-19 \cdot 76$
$18 \cdot 10$ $-23.86$ -28.04
10.92

.02

.04

.05

\begin{abstract}
.06
\end{abstract}
.00

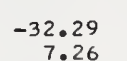

$$
7.26
$$

.07

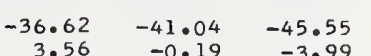

36.62
3.56 $-0.19$ $-3.99$ 
TABLE A3.2.2. Type $\boldsymbol{R}$ thermocouples-temperature $\left({ }^{\circ} \mathrm{F}\right)$ as a function of thermoelectric voltage, reference junctions at $32^{\circ} \mathrm{F}$-Continued

$m V$

.00

.01

.02

.03

TEMPERATURES IN DEGREES F

\begin{tabular}{|c|c|c|c|c|c|c|c|c|c|c|c|c|}
\hline $\begin{array}{l}0.00 \\
0.10\end{array}$ & $\begin{array}{l}32.00 \\
64.53\end{array}$ & $\begin{array}{l}35.39 \\
67.64\end{array}$ & $\begin{array}{l}38.74 \\
70.73\end{array}$ & $\begin{array}{l}42.06 \\
73.79\end{array}$ & $\begin{array}{l}45 \cdot 36 \\
76.83\end{array}$ & $\begin{array}{l}48.62 \\
79.85\end{array}$ & $\begin{array}{l}51.85 \\
82.85\end{array}$ & $\begin{array}{l}55.06 \\
85.83\end{array}$ & $\begin{array}{l}58.24 \\
88.79\end{array}$ & $\begin{array}{l}61.40 \\
91.73\end{array}$ & $\begin{array}{l}64.53 \\
94.66\end{array}$ & $\begin{array}{l}0.00 \\
0.10\end{array}$ \\
\hline $\begin{array}{l}0.10 \\
0.20\end{array}$ & $\begin{array}{l}64.53 \\
94.66\end{array}$ & $\begin{array}{l}67.64 \\
97.56\end{array}$ & $\begin{array}{r}70.73 \\
100.45\end{array}$ & 103.32 & 106.18 & 109.01 & 111.84 & 114.65 & 117.44 & 120.22 & 122.98 & $\begin{array}{l}0.10 \\
0.20\end{array}$ \\
\hline 0.30 & 122.98 & 125.73 & 128.47 & 131.19 & 133.90 & 136.60 & 139.28 & 141.96 & 144.62 & 147.27 & 149.90 & 0.30 \\
\hline 0.40 & 149.90 & $152 \cdot 53$ & $155 \cdot 14$ & 157.75 & $160 \cdot 34$ & 162.93 & 165.50 & 168.06 & 170.61 & 173.16 & 175.69 & 0.40 \\
\hline $\begin{array}{l}0.50 \\
0.60\end{array}$ & $\begin{array}{l}175.69 \\
200.54\end{array}$ & $\begin{array}{l}178.22 \\
202.98\end{array}$ & $\begin{array}{l}180.73 \\
205.42\end{array}$ & $\begin{array}{l}183.24 \\
207.84\end{array}$ & $\begin{array}{l}185 \cdot 74 \\
210.26\end{array}$ & $\begin{array}{l}188.23 \\
212.67\end{array}$ & $\begin{array}{l}190.71 \\
215.07\end{array}$ & $\begin{array}{l}193.18 \\
217.46\end{array}$ & $\begin{array}{l}195.64 \\
219.85\end{array}$ & $\begin{array}{l}198.10 \\
222.23\end{array}$ & $\begin{array}{l}200.54 \\
224.61\end{array}$ & $\begin{array}{l}0.50 \\
0.60\end{array}$ \\
\hline 0.70 & 224.61 & 226.97 & 229.33 & 231.69 & 234.04 & 236.38 & 238.71 & 241.04 & 243.36 & 245.68 & 247.99 & 0.70 \\
\hline 0.80 & 247.99 & 250.30 & 252.59 & 254.89 & 257.18 & 259.46 & 261.73 & 264.00 & 266.27 & 268.53 & 270.79 & 0.80 \\
\hline 0.90 & 270.79 & 273.04 & 275.28 & 277.52 & 279.76 & 281.99 & 284.21 & 286.43 & 288.65 & 290.86 & 293.07 & 0.90 \\
\hline $\begin{array}{l}1.00 \\
1.10\end{array}$ & $\begin{array}{l}293.07 \\
314.89\end{array}$ & 295.27 & $\begin{array}{l}297.47 \\
319.20\end{array}$ & 299.66 & 301.85 & $\begin{array}{l}304.03 \\
325.64\end{array}$ & $\begin{array}{l}306.21 \\
327.78\end{array}$ & $\begin{array}{l}308.39 \\
329.92\end{array}$ & $\begin{array}{l}310.56 \\
332.05\end{array}$ & $\begin{array}{l}312.72 \\
334.18\end{array}$ & $\begin{array}{l}314.89 \\
336.30\end{array}$ & $\begin{array}{l}1.00 \\
1.10\end{array}$ \\
\hline 1.20 & 336.30 & $\begin{array}{l}317.05 \\
338.42\end{array}$ & 340.54 & 342.65 & 344.76 & 346.87 & 348.97 & 351.07 & 353.17 & 355.26 & 357.35 & 1.20 \\
\hline 1.30 & 357.35 & 359.43 & 361.52 & 363.60 & 365.67 & 367.74 & 369.81 & 371.88 & 373.94 & 376.00 & 378.06 & 1.30 \\
\hline 1.40 & 378.06 & 380.12 & 382.17 & $384 \cdot 22$ & $386 \cdot 26$ & 388.30 & 390.34 & 392.38 & 394.41 & 396.45 & 398.47 & 1.40 \\
\hline 1.50 & 398.47 & 400.50 & $402 \cdot 52$ & 404.54 & 406.56 & 408.57 & 410.59 & 412.60 & 414.60 & 416.61 & 418.61 & .50 \\
\hline 1.60 & 418.61 & 420.61 & 422.61 & 424.60 & 426.59 & 428.58 & 430.57 & 432.55 & 434.53 & 436.51 & 438.49 & .60 \\
\hline 1.70 & 438.49 & 440.47 & 442.44 & 444.41 & $446 \cdot 38$ & 448.34 & 450.31 & 452.27 & 454.23 & 456.19 & 458.14 & 1.70 \\
\hline 1.80 & 458.14 & 460.09 & 462.04 & 463.99 & 465.94 & 467.88 & 469.83 & 471.77 & 473.70 & 475.64 & 477.57 & 1.80 \\
\hline 1.90 & 477.57 & 479.51 & $481 \cdot 44$ & $483 \cdot 36$ & $485 \cdot 29$ & 487.22 & 489.14 & 491.06 & 492.98 & 494.89 & 496.81 & 1.90 \\
\hline 2.00 & 496.81 & 498.72 & 500.63 & 502.54 & 504.45 & 506.35 & 508.26 & 510.16 & 512.06 & 513.96 & 515.85 & 2.00 \\
\hline 2.10 & 515.85 & 517.75 & 519.64 & 521.53 & 523.42 & 525.31 & 527.20 & 529.08 & 530.96 & 532.85 & 534.73 & 10 \\
\hline 2.20 & 534.73 & 536.60 & 538.48 & 540.36 & 542.23 & $544 \cdot 10$ & 545.97 & 547.84 & 549.71 & 551.57 & 553.44 & .20 \\
\hline $2 \cdot 30$ & 553.44 & 555.30 & 557.16 & 559.02 & $560 \cdot 88$ & 562.73 & 564.59 & 566.44 & 568.29 & 570.14 & 571.99 & 2.30 \\
\hline 2.40 & 571.99 & 573.84 & 575.68 & 577.53 & 579.37 & 581.21 & 583.06 & 584.89 & 586.73 & 588.57 & 590.40 & 2.40 \\
\hline 2.50 & 590.40 & 592.24 & 594.07 & 595.90 & 597.73 & 599.56 & 601.38 & 603.21 & 605.03 & 606.86 & 608.68 & 2.50 \\
\hline 2.60 & 608.68 & 610.50 & 612.32 & 614.14 & 615.95 & 617.77 & 619.58 & 621.40 & 623.21 & 625.02 & 626.83 & .60 \\
\hline 2.70 & 626.83 & 628.64 & 630.44 & 632.25 & 634.05 & 635.85 & 637.66 & 639.46 & 641.26 & 643.06 & 644.85 & .70 \\
\hline 2.80 & 644.85 & 646.65 & 648.44 & 650.24 & 652.03 & 653.82 & 655.61 & 657.40 & 659.19 & 660.98 & 662.76 & 2.80 \\
\hline & 662.76 & 664.55 & 666.33 & 668.11 & 669.90 & 671.68 & 673.46 & 675.23 & 677.01 & 678.79 & 680.56 & 2.90 \\
\hline 3.00 & 680.56 & 682.34 & 684.11 & 685.88 & 687.65 & 689.42 & 691.19 & 692.96 & 694.73 & 696.49 & 698.26 & .00 \\
\hline 3.10 & 698.26 & 700.02 & 701.78 & 703.55 & 705.31 & 707.07 & 708.83 & 710.58 & 712.34 & 714.10 & 715.85 & 10 \\
\hline 3.20 & 715.85 & 717.60 & 719.36 & 721.11 & 722.86 & 724.61 & 726.36 & 728.11 & 729.86 & 731.60 & 733.35 & 20 \\
\hline $3 \cdot 30$ & 733.35 & 735.09 & 736.84 & 738.58 & 740.32 & 742.06 & 743.80 & 745.54 & 747.28 & 749.02 & 750.75 & 3.30 \\
\hline 3.40 & 750.75 & 752.49 & 754.22 & 755.96 & 757.69 & 759.42 & 761.15 & 762.88 & 764.61 & 766.34 & 768.07 & 3.40 \\
\hline 3.50 & 768.07 & 769.79 & 771.52 & 773.24 & $774 \cdot 97$ & 776.69 & 778.41 & 780.14 & 781.86 & 783.58 & 785.30 & 3.50 \\
\hline 3.60 & 785.30 & 787.01 & 788.73 & 790.45 & 792.16 & & 795.59 & 797.31 & 799.02 & 800.73 & & 60 \\
\hline 3.70 & 802.44 & 804.15 & 805.86 & 807.57 & 809.28 & 810.98 & 812.69 & 814.39 & $816 \cdot 10$ & 817.80 & 819.51 & .70 \\
\hline 3.80 & 819.51 & 821.21 & $822 \cdot 91$ & 824.61 & 826.31 & 828.01 & 829.71 & $831 \cdot 40$ & 833.10 & 834.80 & 836.49 & 30 \\
\hline 3.90 & 836.49 & 838.19 & 839.88 & 841.57 & 843.26 & 844.96 & 846.65 & 848.34 & 850.03 & 851.71 & 853.40 & .90 \\
\hline 4.00 & 853.40 & 855.09 & 856.77 & 858.46 & 860.14 & 861.83 & 863.51 & 865.19 & 866.88 & 868.56 & 870.24 & .00 \\
\hline 4.10 & 870.24 & 871.92 & 873.60 & 875.27 & 876.95 & 878.63 & $880 \cdot 30$ & 881.98 & 883.65 & 885.33 & 887.00 & 10 \\
\hline 4.20 & 887.00 & 888.67 & 890.34 & 892.01 & 893.68 & 895.35 & 897.02 & 898.69 & $900 \cdot 36$ & 902.03 & 903.69 & 20 \\
\hline $4 \cdot 30$ & 903.69 & 905.36 & 907.02 & 908.69 & 910.35 & 912.01 & 913.67 & 915.33 & 916.99 & 918.65 & 920.31 & 4.30 \\
\hline $4 \cdot 40$ & 920.31 & 921.97 & 923.63 & 925.29 & 926.94 & 928.60 & 930.25 & 931.91 & 933.56 & 935.22 & 936.87 & 4.40 \\
\hline 4.50 & 936.87 & 938.52 & 940.17 & 941.82 & 943.47 & 945.12 & 946.77 & 948.42 & 950.06 & 951.71 & 953.36 & 4.50 \\
\hline 4.60 & 953.36 & 955.00 & 956.65 & 958.29 & 959.93 & 961.57 & 963.22 & & & & 78 & .60 \\
\hline 4.70 & 969.78 & 971.42 & 973.05 & 974.69 & 976.33 & 96 & 979.60 & 981.23 & 982.87 & 984.50 & 986.14 & 70 \\
\hline 4.80 & 986.14 & 987.77 & 989.40 & 991.03 & 992.66 & 994.29 & 995.92 & 997.55 & 999.18 & 1000.80 & 1002.43 & 4.80 \\
\hline 4.90 & 1002.43 & 1004.06 & 1005.68 & 1007.31 & 1008.93 & 1010.55 & 1012.18 & 1013.80 & 1015.42 & 1017.04 & 1018.66 & 4.90 \\
\hline 5.00 & 1018.66 & 1020.28 & 1021.90 & 1023.52 & 1025.14 & 1026.76 & 1028.37 & 1029.99 & 1031.60 & 103 & 1034.83 & 5.00 \\
\hline 5.10 & 1034.83 & 1036.45 & 1038.06 & 1039.67 & 1041.29 & 1042.90 & 1044.51 & 1046.12 & 1047.73 & 1049.34 & 1050.94 & .10 \\
\hline 5.20 & 1050.94 & 1052.55 & 1054.16 & 1055.77 & 1057.37 & 98 & 1060.58 & 1062.19 & 1063.79 & 1065.39 & 1067.00 & 0 \\
\hline & & 1068.60 & 1070.20 & 1071.80 & 1073.40 & 00 & 1076 & 107 & 80 & & & 5.30 \\
\hline 5.40 & 1082.99 & 1084.59 & $1086 \cdot 18$ & 1087.78 & 1089.37 & 1090.97 & 1092.56 & 1094.15 & 1095.75 & 1097.34 & 1098.93 & 5.40 \\
\hline 5.50 & 1098.93 & $1100 \cdot 52$ & 1102.11 & 1103.70 & 1105.29 & 1106.88 & 1108.47 & 1110.05 & 1111.64 & 1113.23 & 1114.81 & $\begin{array}{l}5.50 \\
5.60\end{array}$ \\
\hline $\begin{array}{l}5.60 \\
5.70\end{array}$ & $\begin{array}{l}1114.81 \\
1130.64\end{array}$ & $\begin{array}{l}1116.40 \\
1132.22\end{array}$ & $\begin{array}{l}1117.98 \\
1133.80\end{array}$ & $\begin{array}{l}1119.57 \\
1135.38\end{array}$ & $\begin{array}{l}1121 \cdot 15 \\
1136.96\end{array}$ & $\begin{array}{l}1122.73 \\
1138.54\end{array}$ & $\begin{array}{l}1124.32 \\
1140.11\end{array}$ & $\begin{array}{l}1125.90 \\
1141.69\end{array}$ & $\begin{array}{l}1127.48 \\
1143.27\end{array}$ & $\begin{array}{l}1129.06 \\
1144.84\end{array}$ & $\begin{array}{l}1130.64 \\
1146.42\end{array}$ & $\begin{array}{l}5.60 \\
5.70\end{array}$ \\
\hline 5.80 & 1146.42 & 1147.99 & 1149.57 & 1151.14 & 1152.71 & 1154.29 & 1155.86 & 1157.43 & 1159.00 & 1160.57 & 1162.14 & 5.80 \\
\hline 5.90 & $1162 \cdot 14$ & 1163.71 & $1165 \cdot 28$ & 1166.85 & $1168 \cdot 42$ & 1169.98 & 1171.55 & 1173.11 & 1174.67 & 1176.23 & 1177.80 & $=0$ \\
\hline 6.00 & 1177.80 & 1179.36 & 1180.92 & 1182.48 & 1184.04 & 1185.60 & 1187.16 & 1188.71 & 1190.27 & 1191.83 & 1193.38 & 6.00 \\
\hline $\mathrm{mV}$ & .00 & .01 & .02 & .03 & .04 & .05 & .06 & .07 & .08 & .09 & .10 & $\mathrm{mV}$ \\
\hline
\end{tabular}


TABLE A3.2.2. Type $\boldsymbol{R}$ thermocouples-temperature $\left({ }^{\circ} \mathrm{F}\right)$ as a function of thermoelectric voltage, reference junctions at $32^{\circ} \mathrm{F}$-Continued

$\mathrm{mV}$

.00

.01

.02

.03

.04

.05

.06

.07

.08

.09

$\cdot 10$

$\mathrm{mV}$

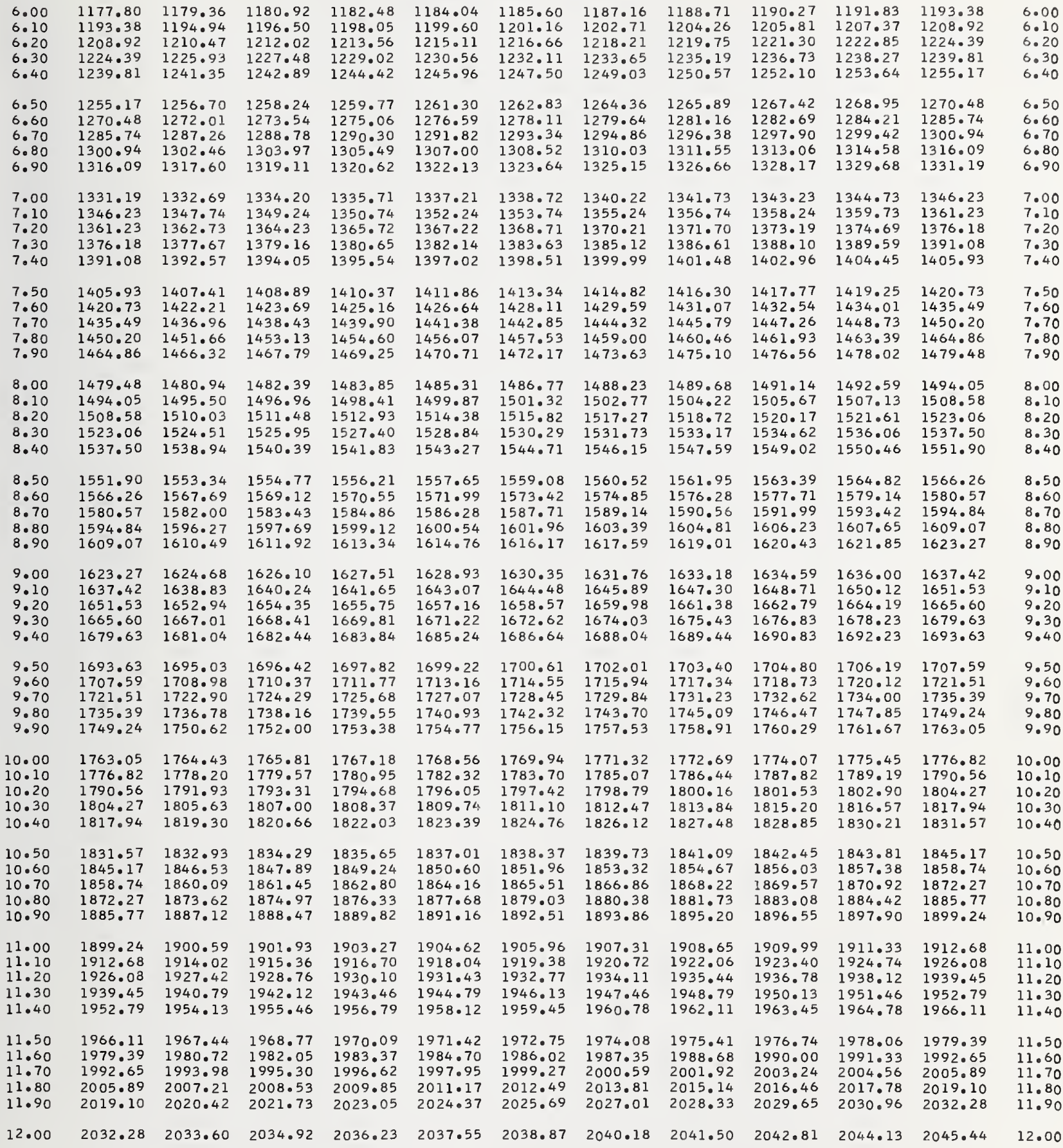

.03

.04

$.05 \quad .06$

.07

.08

.09

.10

$\mathrm{mV}$ 
TABLE A3.2.2. Type $\boldsymbol{R}$ thermocouples-temperature $\left({ }^{\circ} \mathrm{F}\right)$ as a function of thermoelectric voltage, reference junctions at $32^{\circ} \mathrm{F}$-Continued

\begin{tabular}{|c|c|c|c|c|c|c|c|c|c|c|c|c|}
\hline $\mathrm{mV}$ & .00 & .01 & .02 & .03 & .04 & .05 & .06 & .07 & .08 & .09 & .10 & $\mathrm{mV}$ \\
\hline & & & & & & & ES & & & & & \\
\hline .00 & 2032.28 & 2033.60 & 2034.92 & 2036.23 & 2037.55 & 2038.87 & 2040.18 & 2041.50 & 2042.81 & 2044.13 & 2045.44 & .00 \\
\hline 12.10 & 2045.44 & 2046.76 & 2048.07 & 2049.39 & 2050.70 & 2052.02 & 2053.33 & 2054.65 & 2055.96 & 2057.27 & 2058.58 & 12.10 \\
\hline $12 \cdot 20$ & 2058.58 & 2059.90 & 2061.21 & 2062.52 & 2063.84 & 2065.15 & 2066.46 & 2067.77 & 2069.08 & 2070.39 & 2071.70 & 12.20 \\
\hline 30 & 2071.70 & 2073.01 & 2074.33 & 2075.64 & 2076.95 & 2078.26 & 2079.57 & 2080.87 & $2082 \cdot 18$ & 2083.49 & 2084.80 & $12 \cdot 30$ \\
\hline 2.40 & 2084.80 & 2086.11 & 2087.42 & 2088.73 & 2090.04 & $2091 \cdot 34$ & 2092.65 & 2093.96 & 2095.27 & 2096.57 & 2097.88 & $12 \cdot 40$ \\
\hline $12 \cdot 50$ & 2097.88 & 2099.19 & 2100.49 & 2101.80 & 2103.10 & 2104.41 & 2105.72 & 2107.02 & 2108.33 & 2109.63 & 2110.94 & 12.50 \\
\hline $12 \cdot 60$ & 2110.94 & 2112.24 & 2113.55 & 2114.85 & $2116 \cdot 16$ & 2117.46 & 2118.76 & 2120.07 & 2121.37 & 2122.67 & 2123.98 & 12.60 \\
\hline $12 \cdot 70$ & 2123.98 & $2125 \cdot 28$ & 2126.58 & 2127.88 & $2129 \cdot 19$ & 2130.49 & 2131.79 & 2133.09 & 2134.39 & 2135.70 & 2137.00 & $12 \cdot 70$ \\
\hline 12.80 & 2137.00 & $2138 \cdot 30$ & 2139.60 & 2140.90 & $2142 \cdot 20$ & 2143.50 & $2144 \cdot 80$ & 2146.10 & 2147.40 & 2148.70 & 2150.00 & 12.80 \\
\hline 12.90 & $2150 \cdot 00$ & $2151 \cdot 30$ & $2152 \cdot 60$ & 2153.90 & $2155 \cdot 20$ & 2156.50 & 2157.79 & 2159.09 & 2160.39 & 2161.69 & 2162.99 & 12.90 \\
\hline 13.00 & 2162.99 & 2164.28 & 2165.58 & 2166.88 & $2168 \cdot 18$ & 2169.47 & 2170.77 & 2172.07 & 2173.36 & 2174.66 & 2175.96 & 13.00 \\
\hline 13.10 & 2175.96 & 2177.25 & 2178.55 & 2179.84 & 2181.14 & 2182.44 & 2183.73 & 2185 & 2186.32 & 2187.62 & 2188.91 & 13.10 \\
\hline 13.20 & 2188.91 & 2190.20 & 2191.50 & 2192.79 & 2194.09 & $2195 \cdot 38$ & 2196.68 & 2197.97 & 2199.26 & 2200.56 & 2201.85 & 13.20 \\
\hline $13 \cdot 30$ & 2201.85 & 2203.14 & $2204 \cdot 44$ & 2205.73 & 2207.02 & 2208.31 & 2209.61 & 2210.90 & 2212.19 & 2213.48 & 2214.77 & 13.30 \\
\hline 13.40 & 2214.77 & 2216.07 & $2217 \cdot 36$ & 2218.65 & 2219.94 & 2221.23 & 2222.52 & 2223.81 & 2225.10 & 2226.39 & 2227.68 & 13.40 \\
\hline 13.50 & 2227.68 & 2228.97 & 2230.26 & 2231.55 & 2232.84 & 2234.13 & 2235.42 & 2236.71 & 2238.00 & 2239.29 & 2240.58 & 13.50 \\
\hline 13.60 & $2240 \cdot 58$ & 2241.87 & 2243.16 & 2244.45 & 2245.74 & 2247.02 & 2248.31 & 2249.60 & 2250.89 & 2252.18 & 2253.47 & 13.60 \\
\hline 13.70 & 2253.47 & 2254.75 & 2256.04 & 2257.33 & 2258.62 & 2259.90 & 2261.19 & 2262.48 & 2263.76 & 2265.05 & $2266 \cdot 34$ & 13.70 \\
\hline 13.80 & 2266.34 & 2267.62 & 2268.91 & 2270.20 & 2271.48 & 2272.77 & 2274.06 & 2275.34 & 2276.63 & 2277.91 & 2279.20 & 13.80 \\
\hline & 2279.20 & 2280.48 & 2281.77 & 2283.05 & 2284.34 & $2285 \cdot 62$ & 2286.91 & 2288.19 & 2289.48 & 2290.76 & 2292.05 & 13.90 \\
\hline 14.00 & 2292.05 & 2293.33 & $2294 \cdot 62$ & 2295.90 & $2297 \cdot 18$ & 2298.47 & 2299.75 & 2301.04 & 2302.32 & 2303.60 & 2304.89 & 14.00 \\
\hline 14.10 & 2304.89 & 2306.17 & 2307.45 & 2308.74 & 2310.02 & 2311.30 & 2312.59 & 2313.87 & 2315.15 & 2316.43 & 2317.72 & 14.10 \\
\hline $14 \cdot 20$ & 2317.72 & 2319.00 & 2320.28 & 2321.56 & 2322.84 & 2324.13 & 2325.41 & .69 & 2327.97 & 2329.25 & 2330.54 & 14.20 \\
\hline $14 \cdot 30$ & 2330.54 & 2331.82 & 2333.10 & 2334.38 & 2335.66 & 2336.94 & 2338.22 & 2339.50 & 2340.79 & 2342.07 & 2343.35 & $14 \cdot 30$ \\
\hline 14.40 & 2343.35 & 2344.63 & 2345.91 & 2347.19 & 2348.47 & 2349.75 & 2351.03 & 2352.31 & 2353.59 & 2354.87 & 2356.15 & 14.40 \\
\hline $14 \cdot 50$ & 2356.15 & 2357.43 & 2358.71 & 2359.99 & 2361.27 & 2362.55 & .83 & 11 & 39 & 23 & 236 & 50 \\
\hline 14.60 & 2368.95 & 2370.22 & 2371.50 & 2372.78 & 2374.00 & 2375.34 & 2376.62 & 2377.90 & 2379.18 & 45 & 73 & .60 \\
\hline $14 \cdot 70$ & 2381.73 & 2383.01 & 2384.29 & 2385.57 & 2386.85 & $2388 \cdot 12$ & 2389.40 & 2390.68 & 2391.96 & 2393.24 & 2394.51 & 14.70 \\
\hline 14.80 & 2394.51 & 2395.79 & 2397.07 & 2398.35 & 2399.63 & 2400.90 & 2402.18 & 2403.46 & 2404.74 & 2406.01 & 2407.29 & 14.80 \\
\hline 14.90 & 2407.29 & 2408.57 & 2409.85 & 2411.12 & 2412.40 & 2413.68 & 2414.95 & 2416.23 & 2417.51 & 2418.78 & 2420.06 & 14.90 \\
\hline 15.00 & 2420.06 & 2421.34 & 2422.61 & 2423.89 & $2425 \cdot 17$ & 2426 . & 72 & 242 & 243 & $24=$ & 3 & .00 \\
\hline $15 \cdot 10$ & 2432.83 & 2434.10 & $2435 \cdot 38$ & 2436.65 & 2437.93 & 2439.21 & 2440.48 & 2441.76 & 2443.03 & 2444.31 & .59 & 15.10 \\
\hline 15.20 & 2445.59 & 2446.86 & 2448.14 & 2449.41 & 2450.69 & 2451.97 & 2453.24 & 2454.52 & 2455.79 & 2457.07 & 2458.34 & 15.20 \\
\hline 15.30 & 2458.34 & 2459.62 & 2460.89 & 2462.17 & 2463.45 & 2464.72 & 2466.00 & 2467.27 & 2468.55 & 2469.82 & 2471.10 & 15.30 \\
\hline 15.40 & 2471.10 & $2472 \cdot 37$ & 2473.65 & 2474.92 & $2476 \cdot 20$ & 2477.47 & 2478.75 & 2480.02 & $2481 \cdot 30$ & 2482.57 & 2483.85 & 15.40 \\
\hline 15.50 & 2483.85 & 2485.12 & 2486.40 & 2487.67 & 2488.95 & 2490.22 & 249 & 77 & 05 & 24 & 50 & 50 \\
\hline 15.60 & 2496.60 & 2497.87 & 2499.15 & 2500.42 & 2501.69 & 2502.97 & 25 & 52 & 79 & 07 & & 0 \\
\hline 15.70 & $2509 \cdot 34$ & 2510.62 & 2511.89 & 2513.17 & $2514 \cdot 44$ & 2515.72 & 2516.99 & 2518.26 & 2519.54 & 2520.81 & 2522.09 & 15.70 \\
\hline 15.80 & 2522.09 & $2523 \cdot 36$ & $2524 \cdot 64$ & 2525.91 & $2527 \cdot 19$ & 2528.46 & 2529.73 & 2531.01 & 2532.28 & 2533.56 & 2534.83 & 15.80 \\
\hline 15.90 & 2534.83 & $2536 \cdot 11$ & $2537 \cdot 38$ & 2538.66 & $2539 \cdot 93$ & 2541.20 & 2542.48 & 2543.75 & 2545.03 & 2546.30 & 2547.58 & 15.90 \\
\hline 16 & 58 & 35 & 25 & & & 25 & & & 7 & 5 & 2 & \\
\hline & 2560.32 & 2561 & 256 & 256 & 2565.42 & 256 & 25 & & 25 & & & 10 \\
\hline $16 \cdot 20$ & 2573 & 2574 & 2575 & 257 & $2578 \cdot 17$ & 2579 & .72 & 99 & 26 & 2584.54 & 2585.81 & 20 \\
\hline 16. & 2585.81 & 2587 & 258 & & 2590 & 2592 & 2593 & 74 & 01 & 2597.29 & & 30 \\
\hline 16.40 & 2598.56 & 2599.84 & 2601.11 & 2602.39 & 2603.66 & 2604.94 & 2606.21 & 2607.49 & 2608.76 & 2610.04 & 2611.31 & 16.40 \\
\hline 16 & 2611 & 261 & & & & & & & & & & \\
\hline 16 & 67 & 26 & 62 & & 26 & & & & 27 & 5 & 3 & .60 \\
\hline & 2636.83 & 2638 & 2639.38 & 264 & 2641. & 26 & & & 04 & & & \\
\hline 16.80 & 2649.59 & 2650.86 & 2652.14 & 2653.42 & 2654.69 & 2655.97 & 2657.25 & 8.52 & 9.80 & & & 16.80 \\
\hline 16. & 2662 & 2663 & 2664.91 & & 266 & 2668 & & & 26 & 26 & 26 & \\
\hline 17. & 13 & 40 & 68 & 26 & 26 & & & 07 & & & & \\
\hline & 2 & 268 & & & 26 & & & & & & & \\
\hline & & 2701 & 2703 & & & 2707 & 2708 & & & & & 20 \\
\hline 17.30 & 2713.48 & 2714.76 & 2716.03 & 2717.31 & 2718.59 & 2719.87 & 2721.15 & 2722.43 & 2723.71 & 2724.99 & 2726.27 & 17.30 \\
\hline & 2726.27 & 2727.55 & 2728.83 & 2730.11 & 2731.39 & 2732.67 & 2733.96 & 2735.24 & 2736.52 & 2737.80 & 2739.08 & 17.40 \\
\hline 17.50 & $2739.0^{8}$ & $274 C$ & 274 & 27 & 2744.2 & 27 & 27 & 27 & 27 & 11 & 9 & 17.5 \\
\hline & 2751 & 275 & & & & & & & & & & \\
\hline & 2764.71 & 2766.00 & 2767.28 & 2768.56 & 2769.84 & 2771.13 & 2772.41 & 2773.69 & 2774.98 & 2776.26 & 2777.55 & 70 \\
\hline 17.80 & 2777.55 & 2778.83 & 2780.11 & 2781.40 & 2782.68 & 2783.96 & 2785.25 & 278 & 82 & 278 & 2790.39 & \\
\hline 17.90 & 2790 & 2791.67 & 2792.96 & 2794.24 & 2795.53 & 2796.81 & $2798 \cdot 10$ & $2799 \cdot 38$ & 2800.67 & 2801.95 & 2803.24 & 17.5 \\
\hline 18.00 & 2803.24 & $2804 \cdot 52$ & 2805.81 & 2807.10 & $2808 \cdot 38$ & 2809.67 & 2810.96 & 2812.24 & 2813.53 & 2814.82 & 2816.10 & 18.00 \\
\hline
\end{tabular}

$\mathrm{mV}$

.03

.04

.05

.06

.07

.08

.09

.10

$\mathrm{mV}$ 
TABLE A3.2.2. Type $\boldsymbol{R}$ thermocouples-temperature $\left({ }^{\circ} \mathrm{F}\right)$ as a function of thermoelectric voltage, reference junctions at $32^{\circ} \mathrm{F}$-Continued

$\mathrm{mV}$

.0

.01

.02

.03

.04

.05

.06

.07

TEMPERATURES IN DEGREES $F$

18.00

18.10

18.20

18.30

18.40

18.50

18.60

18.70

18.80

18.90

19.00

19.10

19.20

19.30

19.40

19.50

19.60

19.70

19.80

19.90

20.00

$20 \cdot 10$

20.20

20.30

20.40

20.50

20.60

20.70

20.80

20.90

21.00

21.10

$2803 \cdot 24$
2816.10 2828.98

2841.86

2854.76

2867.68

2880.61

2893.55

2906.51

2919.48

2932.47

2945.48

2958.50

2971.55

2984.61

2997.69

3010.79

3023.92

3037.07

3050.24

3063.44

3076.69

3089.99

3103.34

3116.75

3130.24

3143.81

3157.47

3185.11

3199.11

3213.24
$2804.52 \quad 2805.81 \quad 2807.10$ 2817.39 2830.27 2843.15

2856.06

2868.97

2881.90

2894.84

2907.80

2920.78

2933.77

2946.78

2959.81

2972.85

2999.00

3012.11

3025.23

3038.38

3051.56

3064.77

3078.02

3091.32

3104.68

3118.10

3131.59

3145.17

3158.84

3172.62

$3200.51 \quad 3201.92$

2818.68

$2844.44 \quad 2845.73$

2858.64

$2870.26 \quad 2871.56$

$2883.19 \quad 2884.49$

2897.43

$2922.08 \quad 2923.38$

$2935.07 \quad 2936.37$

$2948.08 \quad 2949.38$

$2961.11 \quad 2962.41$

2974.16

2975.46

2988.53

3000.313001 .62

$3013.42 \quad 3014.73$

$3026.55 \quad 3027.86$

3039.70

3052.88

3041.01

3054.20

3066.09

3092.65

3106.02

3067.41

3080.67

3093.99

3107.36

3120.79

3132.95

3134.30
3147.90

3161.59

3175.38

3189.29

3203.33

$2808 \cdot 38$

2834.13

2847.02

2859.93

2872.85

2885.78

2898.73

2911.69

2924.67

2937.67

2950.69

2963.72

$\begin{array}{ll}2976.77 & 2978.08 \\ 2989.84 & 2991.15\end{array}$

3002.93

(6.24

9.17

3042.33

3055.52

3068.74

3082.00

3095.32

3108.70

3122.14

3135.66

3149.26

3162.96

3176.77

3204.74

3030.49

3043.65

3056.84

3070.06

3083.33

3096.65

3110.04

3150.63

3164.34

3178.16

3192.09

3206.15

3207.57

2810.96
2823.83
2836.71

2849.60

2862.51

2875.43

2888.37

2901.32

2914.29

2927.27

2940.27

2953.29
2966.33

2979.38

2992.46

3005.55

3018.67

3031.80

3044.97

3058.16

3071.39

3084.66

3097.99

3111.38

3124.84

3138.37

3152.00

3165.72

3179.54

3193.49

3153.36

3167.09

3180.93

3194.89

3208.98

2812.24

2838.00

2850.89

2876.73

2902.62

2915.59

2928.57

2941.57
2954.59

2967.63

2980.69
2993.77

3006.86

3033.12

3046.28

3059.48

3072.71

3099.33

3112.72

3126.19

3127.54

3141.09

3154.73

3168.47

3182.32

3196.30

3210.40

3211.82

.00

.01

.02

.03

.04

.05

.06

.07

.08

.09

$\cdot 10$

$\mathrm{mV}$

8.00

18.10

18.20

18.30

18.40

18.50
18.60

18.70

19.10

19.50

19.60

$m V$

18.80

18.90

19.00

19.20

19.30

19.40

19.70

19.80

19.90

20.00

20.10

20.20

20.30

20.40

20.50

20.60

20.70

20.80 
TABLE A3.2.3. Type $R$ thermocouples-quadratic, cubic, and quartic approximations to the data as a function of voltage in selected temperature ranges $\left({ }^{\circ} \mathrm{C}\right)$. The expansion is of the form $\mathrm{T}=\mathrm{a}_{0}+\mathrm{a}_{1} \mathrm{E}+\mathrm{a}_{2} \mathrm{E}^{2}+\mathrm{a}_{3} \mathrm{E}^{3}+\mathrm{a}_{4} \mathrm{E}^{4}$ where $\mathrm{E}$ is in microvolts and $\mathrm{T}$ is in degrees Celsius

\begin{tabular}{|c|c|c|c|c|c|c|c|c|c|c|c|}
\hline \multirow[t]{2}{*}{$\begin{array}{l}\text { Temperature } \\
\text { Range }\left({ }^{\circ} \mathrm{C}\right)\end{array}$} & $a_{0}$ & & $a_{1}$ & \multicolumn{3}{|c|}{$a_{2}$} & $a_{3}$ & \multicolumn{3}{|c|}{$a_{4}$} & \multirow{2}{*}{$\begin{array}{l}\begin{array}{l}\text { Error } \\
\text { Range }\left({ }^{\circ} \mathrm{C}\right)\end{array} \\
\text { Exact-Approx. }\end{array}$} \\
\hline & Argument & Exp. & Argument & Exp. & Argument & Exp. & Argument & Exp. & Argument & Exp. & \\
\hline \multicolumn{12}{|c|}{ I. Quartic Equation } \\
\hline - 50 to 900 & $\ldots \ldots$ & . . & 1.6251434 & -1 & -2.0454379 & -5 & 2.5404935 & .9 & -1.1767904 & .13 & -13 to 3 \\
\hline 0 to 1100 & $\ldots \ldots$ & . . & 1. 5239494 & -1 & -1.3755675 & -5 & 1.2610922 & -9 & -4.4281251 & -14 & -4 to 7 \\
\hline 0 to 1400 & $\cdots \cdots$ & . & 1.4441607 & -1 & -9.5014952 & -6 & 6.2073358 & -10 & -1.5622497 & -14 & -6 to 10 \\
\hline 0 to 1650 & $\ldots .$. & . & 1. 3944190 & -1 & -7.4485484 & -6 & 3. 8266182 & -10 & -7.4517277 & -15 & -7 to 13 \\
\hline 0 to 1768 & $\ldots \ldots$ & . & 1. 3752883 & -1 & -6.7651171 & -6 & 3.1420473 & -10 & -5.4254872 & -15 & -7 to 14 \\
\hline 400 to 1100 & 4.5509556 & +1 & 1.1284875 & -1 & -2.8603978 & -6 & 8.5173702 & -11 & -1.1440038 & -15 & -.04 to .04 \\
\hline 400 to 1400 & 4.9160016 & +1 & 1.1054589 & -1 & -2.3559046 & -6 & 3.9276248 & -11 & 3. 3369324 & -16 & -.08 to .09 \\
\hline 400 to 1650 & 4.8343651 & +1 & 1. 1098270 & -1 & -2.4353890 & -6 & 4.5164488 & -11 & 1.8172612 & -16 & -.10 to .12 \\
\hline 1050 to 1400 & -4.1134459 & +0 & 1.2738464 & -1 & -4.3132296 & -6 & 1. 3863582 & -10 & -1.5283798 & -15 & -.002 to .002 \\
\hline 1050 to 1650 & 3. 7487318 & +1 & 1. 1519304 & -1 & -2.9827002 & -6 & 7. 4538667 & -11 & -3.7809957 & -16 & -.011 to .011 \\
\hline 1400 to 1550 & 8.0559850 & +1 & 1.0442877 & -1 & -1.9827500 & -6 & 3. 3603790 & -11 & 2.4513433 & -16 & -.0005 to .0005 \\
\hline 1400 to 1650 & 1.4180146 & +2 & 9.0181346 & -2 & -7.4068329 & -7 & -1.4487255 & -11 & 9.4290495 & -16 & -.0005 to .0005 \\
\hline 1400 to 1768 & 3.1759093 & +3 & -5.8922431 & -1 & 5.6190639 & -5 & -2.1303241 & -9 & 3.0369250 & -14 & -.11 to .08 \\
\hline 1666 to 1768 & 1.2883437 & +4 & -2.6747958 & +0 & 2.2334214 & -4 & -8.0565860 & -9 & 1.0882779 & -13 & -.0007 to .0007 \\
\hline \multicolumn{12}{|l|}{ II. Cubic Equation } \\
\hline - 50 to 900 & $\ldots$ & . & 1. 4639267 & -1 & -9.6516598 & -6 & 4.7870066 & -10 & $\ldots \ldots$ & . & -17 to 10 \\
\hline 0 to 1100 & $\cdots \cdot \cdot$ & . & 1. 3925975 & -1 & -6.9755824 & -6 & 2.6013753 & -10 & $\cdots \cdots$ & $\cdot$ & -7 to 13 \\
\hline 0 to 1400 & .... & . . & 1. 3291312 & -1 & -5.1159870 & -6 & 1.4261258 & -10 & ..... & . & -8 to 17 \\
\hline 0 to 1650 & $\ldots \ldots$ & . & 1.2943791 & -1 & -4.3282878 & -6 & 1.0429596 & -10 & $\ldots \ldots$ & . & -8 to 20 \\
\hline 0 to 1768 & ....... & . & 1. 2827231 & -1 & -4.1012169 & -6 & 9.4846033 & -11 & $\cdots \cdots$ & . & -8 to 21 \\
\hline 400 to 1100 & 4.8206741 & +1 & 1.1114775 & -1 & -2.4842910 & -6 & 5.0387148 & -11 & $\cdots \cdots$ & . & -.07 to .07 \\
\hline 400 to 1400 & 4.7397025 & +1 & 1.1150030 & -1 & -2.5301296 & -6 & 5.2198550 & -11 & $\ldots \ldots$ & . & -.15 to .10 \\
\hline 400 to 1650 & 4.6674533 & +1 & 1.1179913 & -1 & -2.5659255 & -6 & 5. 3473173 & -11 & 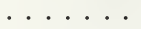 & • & -.12 to .20 \\
\hline 1050 to 1400 & 4.6486248 & +1 & 1.1225711 & -1 & -2.6264781 & -6 & 5. 5498996 & -11 & $\ldots \ldots$ & . & -.008 to .008 \\
\hline 1050 to 1650 & 5. 6939888 & +1 & 1.0992545 & -1 & -2.4547544 & -6 & 5.1322232 & -11 & ..... & . & -.022 to .020 \\
\hline 1400 to 1550 & 5.9754422 & +1 & 1.0930924 & -1 & -2.4117917 & -6 & 5.0356145 & -11 & $\ldots \ldots$ & . & -.0005 to .0005 \\
\hline 1400 to 1650 & 4. 8577986 & +1 & 1. 1126194 & -1 & -2.5253803 & -6 & 5.2555985 & -11 & . . . . & . . & -.002 to .002 \\
\hline 1400 to 1768 & -3.6801831 & +2 & 1.8138449 & -1 & 6.4482742 & -6 & 1.2549458 & -10 & ..... & . & -30 to .15 \\
\hline 1666 to 1768 & -6.0385387 & +3 & 1.0327854 & +0 & -4.9031858 & -5 & 8.3496401 & -10 & 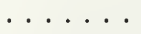 & . & -.004 to .004 \\
\hline \multicolumn{12}{|c|}{ III. Quadratic Equation } \\
\hline - 50 to 900 & $\ldots$ & . . & 1. 2930490 & -1 & -3.5743959 & -6 & 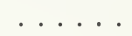 & . & $\ldots \ldots$ & . & -21 to 19 \\
\hline 0 to 1100 & $\ldots \ldots$ & . . 1 & 1. 2394223 & -1 & -2.7354208 & -6 & .... & . . & ..... & . & -13 to 25 \\
\hline 0 to 1400 & ..... & . & 1.1756389 & -1 & -1.9720760 & -6 & $\ldots .$. & . . & ..... & . & -18 to 32 \\
\hline 0 to 1650 & $\ldots \ldots$ & . & 1. 1279400 & -1 & -1.5298755 & -6 & $\ldots .$. & . & $\ldots \ldots$ & . & -24 to 39 \\
\hline 0 to 1768 & $\ldots \ldots$ & $\cdots$ & 1.1059188 & -1 & -1.3521642 & -6 & $\ldots$. & . & 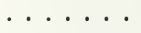 & 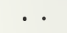 & -28 to 43 \\
\hline 400 to 1100 & 6.5734458 & +1 & 1.0299926 & -1 & -1.3322502 & -6 & $\ldots .$. & . & $\ldots \ldots$ & . & -1.3 to 1.1 \\
\hline 400 to 1400 & 8.1035455 & +1 & 9.8212995 & -2 & -1.0100842 & -6 & $\ldots .$. & $\cdot$ & $\cdots \cdot \cdot$ & $\cdot \cdot$ & -4 to 4 \\
\hline 400 to 1650 & 9.9131606 & +1 & 9.3227227 & -2 & -7.2969415 & -7 & $\ldots \ldots$ & . & ..... & . & -9 to 9 \\
\hline 1050 to 1400 & 1. 8304368 & +2 & 8.1681459 & -2 & -3.6178430 & -7 & $\ldots$ & $\cdot \cdot$ & 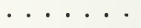 & $\cdot \cdot$ & -.26 to .24 \\
\hline 1050 to 1650 & 2.3296446 & +2 & 7. 4274394 & -2 & -9.1467292 & -8 & $\ldots \ldots$ & . & $\cdots \cdots$ & $\cdot \cdot$ & -1.2 to 1.2 \\
\hline 1400 to 1550 & 3.1055825 & +2 & 6.5211548 & -2 & 1. 7039953 & -7 & $\ldots$ & . & ..... & . & -.019 to .018 \\
\hline 1400 to 1650 & 3.4238682 & +2 & 6.1485536 & -2 & 2. 7924100 & -7 & ..... & & ..... & . & -.09 to .09 \\
\hline 1400 to 1768 & 4.2575948 & +2 & 5.2056334 & -2 & 5.4466917 & -7 & $\ldots \ldots$ & & $\ldots \ldots$ & . & -.7 to .8 \\
\hline 1666 to 1768 & 1.0787621 & +3 & -1.2735666 & -2 & 2.1501038 & -6 & $\ldots \ldots$ & . & . . . . & . & -.08 to .08 \\
\hline
\end{tabular}




\section{A4. Supplementary Data for Type B-Platinum-30\% Rhodium Alloy Versus Platinum-6\% Rhodium Alloy Thermocouples}

\section{A4.1. Data for Voltage as a Function of Temperature}

The full precision coefficients given in the main text are used to generate the voltage as a function of temperature data given in tables A4.1.1 and A4.1.2. Table A4.1.1 presents the data in degrees Celsius from $0{ }^{\circ} \mathrm{C}$ to $1820{ }^{\circ} \mathrm{C}$ while table A4.1.2 presents the data in degrees Fahrenheit from $32{ }^{\circ} \mathrm{F}$ to $3308^{\circ} \mathrm{F}$. Table A4.1.3 contains quadratic, cubic, and quartic approximations to the data as a function of temperature in selected temperature ranges. The error range given in the table is the difference between the voltage as obtained from the full precision coefficients from the text and the respective reduced order approximations. The last entries in the cubic and quadratic groupings of table A4.1.3 represent variable reference junction corrections in the 0 to $50{ }^{\circ} \mathrm{C}$ temperature range. In the narrower temperature range near room temperatures, 20 to $25{ }^{\circ} \mathrm{C}$, the error range for the given quadratic equation is smaller than that listed in the last column: $\pm 0.04 \mu \mathrm{V}$. 
TABLE A4.1.1. Type B thermocouples-thermoelectric voltage as a function of temperature $\left({ }^{\circ} \mathrm{C}\right)$, reference junctions at $0^{\circ} \mathrm{C}$

0

1

2

3

5

6

7

THERMOELECTRIC VOLTAGE IN ABSOLUTE MILLIVOLTS

\begin{tabular}{|c|c|c|c|c|c|c|c|c|c|c|c|c|}
\hline 0 & 0.000 & -0.000 & -0.000 & -0.001 & -0.001 & -0.001 & -0.001 & -0.001 & -0.002 & -0.002 & -0.002 & 0 \\
\hline 10 & -0.002 & -0.002 & -0.002 & -0.002 & -0.002 & -0.002 & -0.002 & -0.002 & -0.003 & -0.003 & -0.003 & 10 \\
\hline 20 & -0.003 & -0.003 & -0.003 & -0.003 & -0.003 & -0.002 & -0.002 & -0.002 & -0.002 & -0.002 & -0.002 & 20 \\
\hline 30 & -0.002 & $-0 \cdot 002$ & -0.002 & -0.002 & -0.002 & -0.001 & -0.001 & -0.001 & -0.001 & -0.001 & -0.000 & 30 \\
\hline 40 & -0.000 & -0.000 & -0.000 & $0 \cdot 000$ & 0.000 & 0.001 & 0.001 & 0.001 & 0.002 & 0.002 & 0.002 & 40 \\
\hline 50 & 0.002 & 0.003 & 0.003 & 0.003 & 0.004 & 0.004 & 0.004 & 0.005 & 0.005 & 0.006 & 0.006 & 50 \\
\hline 60 & 0.006 & 0.007 & 0.007 & 0.008 & 0.008 & 0.009 & 0.009 & 0.010 & 0.010 & 0.011 & 0.011 & 60 \\
\hline 0 & 0.011 & 0.012 & 0.012 & 0.013 & 0.014 & 0.014 & 0.015 & 0.015 & 0.016 & 0.017 & 0.017 & 70 \\
\hline 80 & 0.017 & 0.018 & 0.019 & 0.020 & 0.020 & 0.021 & 0.022 & 0.022 & 0.023 & 0.024 & 0.025 & 80 \\
\hline 90 & 0.025 & 0.026 & 0.026 & 0.027 & 0.028 & 0.029 & 0.030 & 0.031 & 0.031 & 0.032 & 0.033 & 90 \\
\hline 00 & 0.033 & 0.034 & 0.035 & 0.036 & 0.037 & 0.038 & 0.039 & 0.040 & 0.041 & 0.042 & 0.043 & 100 \\
\hline & 0.043 & 0.044 & 0.045 & 0.046 & 0.047 & 0.048 & 0.049 & 0.050 & 0.051 & 0.052 & 0.053 & 110 \\
\hline 120 & 0.053 & 0.055 & 0.056 & 0.057 & 0.058 & 0.059 & 0.060 & 0.062 & 0.063 & 0.064 & 0.065 & 120 \\
\hline 130 & 0.065 & 0.066 & 0.068 & 0.069 & 0.070 & 0.071 & 0.073 & 0.074 & 0.075 & 0.077 & 0.078 & 130 \\
\hline 140 & 0.078 & 0.079 & $0 \bullet 081$ & 0.082 & 0.083 & 0.085 & 0.086 & 0.088 & 0.089 & 0.091 & 0.092 & 140 \\
\hline 0 & 0.092 & 0.093 & 0.095 & 0.096 & 0.098 & 0.099 & 0.101 & 0.102 & 0.104 & 0.106 & 0.107 & 150 \\
\hline 0 & 0.107 & 0.109 & 0.110 & 0.112 & 0.113 & 0.115 & 0.117 & 0.118 & 0.120 & 0.122 & 0.123 & 160 \\
\hline & 0.123 & 0.125 & 0.127 & 0.128 & 0.130 & 0.132 & 0.133 & 0.135 & 0.137 & 0.139 & 0.140 & 170 \\
\hline 180 & 0.140 & 0.142 & 0.144 & 0.146 & 0.148 & 0.149 & 0.151 & 0.153 & 0.155 & 0.157 & 0.159 & 180 \\
\hline 190 & 0.159 & 0.161 & 0.163 & 0.164 & 0.166 & 0.168 & 0.170 & 0.172 & 0.174 & 0.176 & 0.178 & 190 \\
\hline 0 & 0.178 & 0.180 & 0.182 & 0.184 & 0.186 & 0.188 & 0.190 & 0.192 & 0.194 & 0.197 & 0.199 & 200 \\
\hline 10 & 0.199 & 0.201 & 0.203 & 0.205 & 0.207 & 0.209 & 0.211 & 0.214 & 0.216 & 0.218 & 0.220 & 210 \\
\hline & 0.220 & 0.222 & 0.225 & 0.227 & 0.229 & 0.231 & 0.234 & 0.236 & 0.238 & 0.240 & 0.243 & 220 \\
\hline 230 & 0.243 & 0.245 & 0.247 & 0.250 & 0.252 & 0.254 & 0.257 & 0.259 & 0.262 & 0.264 & 0.266 & 230 \\
\hline 0 & 0.266 & 0.269 & 0.271 & 0.274 & 0.276 & 0.279 & 0.281 & 0.284 & 0.286 & 0.289 & 0.291 & 240 \\
\hline 250 & 0.291 & 0.294 & 0.296 & 0.299 & 0.301 & 0.304 & 0.307 & 0.309 & 0.312 & 0.314 & 0.317 & 250 \\
\hline & 0.317 & 0.320 & 0.322 & 0.325 & 0.328 & 0.330 & 0.333 & 0.336 & 0.338 & 0.341 & 0.344 & 260 \\
\hline 70 & 0.344 & 0.347 & 0.349 & 0.352 & 0.355 & 0.358 & 0.360 & 0.363 & 0.366 & 0.369 & 0.372 & 270 \\
\hline 280 & 0.372 & 0.375 & 0.377 & 0.380 & 0.383 & 0.386 & 0.389 & 0.392 & 0.395 & 0.398 & 0.401 & 280 \\
\hline 290 & 0.401 & 0.404 & 0.406 & 0.409 & 0.412 & 0.415 & 0.418 & 0.421 & 0.424 & 0.427 & 0.431 & 290 \\
\hline & 0.431 & 0.434 & 0.437 & 0.440 & 0.443 & 0.446 & 0.449 & 0.452 & 0.455 & 0.458 & 0.462 & 300 \\
\hline 0 & 0.462 & 0.465 & 0.468 & 0.471 & 0.474 & 0.477 & 0.481 & 0.484 & 0.487 & 0.490 & 0.494 & 310 \\
\hline 20 & 0.494 & 0.497 & 0.500 & 0.503 & 0.507 & 0.510 & 0.513 & 0.517 & 0.520 & 0.523 & 0.527 & 320 \\
\hline 330 & 0.527 & 0.530 & 0.533 & 0.537 & 0.540 & 0.544 & 0.547 & 0.550 & 0.554 & 0.557 & 0.561 & 330 \\
\hline 340 & 0.561 & 0.564 & 0.568 & 0.571 & 0.575 & 0.578 & 0.582 & 0.585 & 0.589 & 0.592 & 0.596 & 340 \\
\hline 350 & 0.596 & 0.599 & 0.603 & 0.606 & 0.610 & 0.614 & 0.617 & 0.621 & 0.625 & 0.628 & 0.632 & 350 \\
\hline 0 & 0.632 & 0.636 & 0.639 & 0.643 & 0.647 & 0.650 & 0.654 & 0.658 & 0.661 & 0.665 & 0.669 & 360 \\
\hline 370 & 0.669 & 0.673 & 0.677 & 0.680 & 0.684 & 0.688 & 0.692 & 0.696 & 0.699 & 0.703 & 0.707 & 370 \\
\hline 380 & 0.707 & 0.711 & 0.715 & 0.719 & 0.723 & 0.727 & 0.730 & 0.734 & 0.738 & 0.742 & 0.746 & 380 \\
\hline 390 & 0.746 & 0.750 & 0.754 & 0.758 & 0.762 & 0.766 & 0.770 & 0.774 & 0.778 & 0.782 & 0.786 & 390 \\
\hline 400 & 0.786 & 790 & 0.794 & 0.799 & 0.803 & 0.807 & 0.811 & 0 & 0.819 & 23 & 7 & 400 \\
\hline 4. & 0.827 & 0.832 & 0.836 & 0.840 & 0.844 & 0.848 & 0.853 & 0.857 & 0.861 & 865 & 0.870 & 410 \\
\hline 420 & 0.870 & 0.874 & 0.878 & 0.882 & 0.887 & 0.891 & 0.895 & 0.900 & 0.904 & 0.908 & 0.913 & 420 \\
\hline 430 & 0.913 & 0.917 & 0.921 & 0.926 & 0.930 & 0.935 & 0.939 & 0.943 & 0.948 & 0.952 & 0.957 & 430 \\
\hline 440 & 0.957 & 0.961 & 0.966 & 0.970 & 0.975 & 0.979 & 0.984 & 0.988 & 0.993 & 0.997 & 1.002 & 440 \\
\hline 450 & 1.002 & 06 & 1.011 & 015 & 0 & & 9 & & 1. & & & 450 \\
\hline 460 & 1.048 & 1.052 & 1.057 & 1.062 & 1.066 & 1.071 & 1.076 & 1.081 & 1.085 & 1.090 & 1.095 & 460 \\
\hline 470 & 1.095 & 1.100 & 1.104 & 1.109 & 1.114 & 1.119 & 1.123 & 1.128 & 1.133 & 1.138 & 1.143 & 470 \\
\hline 480 & 1.143 & 1.148 & 1.152 & 1.157 & 1.162 & 1.167 & 1.172 & 1.177 & 1.182 & 1.187 & 1.192 & 480 \\
\hline 490 & 1.192 & 1.197 & 1.202 & 1.206 & 1.211 & 1.216 & 1.221 & 1.226 & 1.231 & 1.236 & 1.241 & 490 \\
\hline 500 & 1.241 & 1.24 & 1.252 & 1.257 & 1.262 & 1.2 & 1.272 & 1.277 & 1.282 & 37 & 92 & 500 \\
\hline 510 & 1.292 & & & 1.308 & 1.313 & 1.318 & 1.323 & 1.328 & 1.334 & 1.339 & & 510 \\
\hline 520 & 1.344 & 1.349 & 1.354 & 1.360 & 1.365 & 1.370 & 1.375 & 1.381 & 1.386 & 1.391 & 1.397 & 520 \\
\hline 530 & 1.397 & 1.402 & 1.407 & 1.413 & 1.418 & 1.423 & 1.429 & 1.434 & 1.439 & 1.445 & 1.450 & 530 \\
\hline 540 & 1.450 & 1.456 & 1.461 & 1.467 & 1.472 & 1.477 & 1.483 & 1.488 & 1.494 & 1.499 & 1.505 & 540 \\
\hline 550 & 1.505 & 1.510 & 1.516 & 1.521 & 1.527 & 1.532 & 1.538 & 1. & 1.549 & 1.555 & 50 & 550 \\
\hline 560 & 1.560 & & 1.571 & 1.577 & 1.583 & 1.588 & 1.594 & & 1.605 & 11 & 1.617 & 560 \\
\hline 570 & 1.617 & 1.622 & 1.628 & 1.634 & 1.639 & 1.645 & 1.651 & 1.6 & 1.662 & 1.668 & 1.674 & 570 \\
\hline 80 & 1.674 & 1. & 1.685 & 1.691 & 1.697 & 1.703 & 1.709 & 1.715 & 1.720 & 1.726 & 1.732 & 580 \\
\hline 590 & 1.732 & 1.738 & 1.744 & 1.750 & 1.756 & 1.762 & 1.767 & 1.773 & 1.779 & 1.785 & 1.791 & 590 \\
\hline C & 1.791 & 1.797 & 1.803 & 1.809 & 1.815 & 1.821 & 1.827 & 1.833 & 1.839 & 1.845 & 1.851 & 600 \\
\hline
\end{tabular}

${ }^{\circ} \mathrm{C}$

1

2

3

4

5

6

7

8

9

10

${ }^{\circ} \mathrm{C}$ 
TABLE A4.1.1. Type B thermocouples-thermoelectric voltage as a function of temperature $\left({ }^{\circ} \mathrm{C}\right)$, reference junctions at $0^{\circ} \mathrm{C}$-Continued

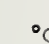

60
61
62
63
640
650
66
67
68
69
70
71
720
73
740
750
76
77
780
790
800
810
820
830
840
850
860
870
880
890
900
910
920
930
940
950
960
970
980
990

900

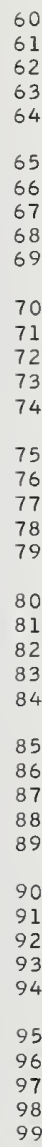

1,000

1,010

1,020

1,030

1,050

1,060

1,070

1,080

1,100

1,110

1,12

1,130

1,150

1,160

1,170

1,180

1,190

1,200

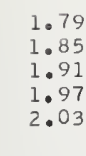

2. 100

2. 164

2.230

2. 363

2. 430

2.499

2.569

2. 639

710

2.782
2.855

2.928

3.003

3.078

3. 154

3.231

3.308

3.387
3.466

3.546

3.626
3.708

3.790

3.873

3. 957

4.041

4.126

4.212
4.298

4.386

4.386
4.474

4.562

4.652
4.742

4.833

4.924

5.016

5.109
5.202

5.297

5.391

5.487

5.583
5.680

5.777

5.875

5.973

6.073
6.172

6.273

6.374

6.475

6.577

6.783

1.797
1.857
1.918
1.980
2.043

2.105

2.171

2.302

2. 369

2. 437

2.506
2.576

2.646

2.717

2.789

2.862

3.010

3.086

3.162

3.239

3.316
3.395

3.474

3.554

3.634
3.716

3.798

3.881

3.965

4.049

4.135

4.220
4.307

4.394

4.483
4.571

4.661

4.751

4.842

4.933

5.025

5.212

5.306

5.401

5.496

5.593
5.689

5.787

5.885

5.983

6.083

6.182

$6.283 \quad 6.293$

6.384

6.588

6.690

6.794

1.803
1.863

1.924

2.049

2.113

2.177

2.444

2.513

2.583
2.653

2.724

2. 797

2. 869

2.943

3.018
3.093

3.169

3.246

3.324

3.402
3.482

3.562

3.643
3.724

3.806

3.890

3.973

4.058

4.143

4.229
4.316

4.403

4.491

4.580

4.760

4.851

5.035

5.221

2

THERMOELECTRIC VOLTAGE IN ABSOLUTE MILLIVOLTS

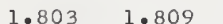

1.869

1.931

1.993

2.119

2.184

2.249

$2.376 \quad 2.383$

2.451

2.590

2.660

2.732

2. 804

2.877

2.951

3.025
3.101

3.177

3.254

3.332

3.410
3.490

3.570

3.651

3.732

3.815

3.982

4.066

4.152

4.238

4. 325

4.412

4.500

4.589

4.679

4.769

4.860

4. 952

5.044

5.137

5.231

$1.815 \quad 1.821$

1.875
1.937

1.999

1.882

2.005

1.827
1.888

2.062

2.126

2.068

$2.011 \quad 2.018$

1.833
1.894

2.132
2.197

2.139

2.081

2.256

2.263

2.203

2.145

2.269

2.210

2.343

2.322
2.390

2.329
2.396

2.458

2.465

2.403

2.410

2.527

2.597
2.667

2.739

2.534

2.604

2.674

2.472

2.478

2.54

2.611

2.548

2.618

2.753

2.689
2.760

2.8112 .818

2.884

2.958

2.892

2.826

2.899

2.833

3.033

2.966

3.040

2.97

3.048
3.124

2.906

2.980

3.055

3.131

3.185

3.192

3. 200

3.208

3.262

3.340
3.418

3.269

3.347

3.426

3.277

3.355

3.434

3.285

3.363

3.442

3.578

3.586

3.659

3.741

3.586
3.567

3.594

3.602

3.675

3.749

3.757

3.765

$3.840 \quad 3.848$

3.906

3.915

3.990

4.075

3.999

4.160

4.246
4.333

4.083

3.931

4.421

4.509

4.598

4.688 
TABLE A4.1.1. Type B thermocouples-thermoelectric voltage as a function of temperature $\left({ }^{\circ} \mathrm{C}\right)$, reference junctions at $0^{\circ} \mathrm{C}$-Continued

${ }^{\circ} \mathrm{C}$

0

1

THERMOELECTRIC VOLTAGE IN ABSOLUTE MILLIVOLTS

\begin{tabular}{|c|c|c|c|c|c|c|c|c|c|c|c|c|}
\hline $\begin{array}{l}1,200 \\
1,210 \\
1,220 \\
1,230 \\
1,240\end{array}$ & $\begin{array}{l}6.783 \\
6.887 \\
6.991 \\
7.096 \\
7.202\end{array}$ & $\begin{array}{l}6.794 \\
6.898 \\
7.002 \\
7.107 \\
7.212\end{array}$ & $\begin{array}{l}6.804 \\
6.908 \\
7.012 \\
7.117 \\
7.223\end{array}$ & $\begin{array}{l}6.814 \\
6.918 \\
7.023 \\
7.128 \\
7.233\end{array}$ & $\begin{array}{l}6.825 \\
6.929 \\
7.033 \\
7.138 \\
7.244\end{array}$ & $\begin{array}{l}6.835 \\
6.939 \\
7.044 \\
7.149 \\
7.255\end{array}$ & $\begin{array}{l}6.846 \\
6.950 \\
7.054 \\
7.159 \\
7.265\end{array}$ & $\begin{array}{l}6.856 \\
6.960 \\
7.065 \\
7.170 \\
7.276\end{array}$ & $\begin{array}{l}6.866 \\
6.971 \\
7.075 \\
7.181 \\
7.286\end{array}$ & $\begin{array}{l}6.877 \\
6.981 \\
7.086 \\
7.191 \\
7.297\end{array}$ & $\begin{array}{l}6.887 \\
6.991 \\
7.096 \\
7.202 \\
7.308\end{array}$ & $\begin{array}{l}1,200 \\
1,210 \\
1,220 \\
1,230 \\
1,240\end{array}$ \\
\hline $\begin{array}{l}.250 \\
, 260 \\
.270 \\
.280 \\
, 290\end{array}$ & $\begin{array}{l}7.308 \\
7.414 \\
7.521 \\
7.628 \\
7.736\end{array}$ & $\begin{array}{l}7.318 \\
7.425 \\
7.532 \\
7.639 \\
7.747\end{array}$ & $\begin{array}{l}7.329 \\
7.435 \\
7.542 \\
7.650 \\
7.758\end{array}$ & $\begin{array}{l}7.339 \\
7.446 \\
7.553 \\
7.661 \\
7.769\end{array}$ & $\begin{array}{l}7.350 \\
7.457 \\
7.564 \\
7.671 \\
7.780\end{array}$ & $\begin{array}{l}7.361 \\
7.467 \\
7.575 \\
7.682 \\
7.790\end{array}$ & $\begin{array}{l}7.371 \\
7.478 \\
7.585 \\
7.693 \\
7.801\end{array}$ & $\begin{array}{l}7.382 \\
7.489 \\
7.596 \\
7.704 \\
7.812\end{array}$ & $\begin{array}{l}7.393 \\
7.500 \\
7.607 \\
7.715 \\
7.823\end{array}$ & $\begin{array}{l}7.403 \\
7.510 \\
7.618 \\
7.725 \\
7.834\end{array}$ & $\begin{array}{l}7.414 \\
7.521 \\
7.628 \\
7.736 \\
7.845\end{array}$ & $\begin{array}{l}1,250 \\
1,260 \\
1,270 \\
1,280 \\
1,290\end{array}$ \\
\hline $\begin{array}{l}, 300 \\
.310 \\
, 320 \\
.330 \\
, 340\end{array}$ & $\begin{array}{l}7.845 \\
7.953 \\
8.063 \\
8.172 \\
8.283\end{array}$ & $\begin{array}{l}7.855 \\
7.964 \\
8.074 \\
8.183 \\
8.294\end{array}$ & $\begin{array}{l}7.866 \\
7.975 \\
8.085 \\
8.194 \\
8.305\end{array}$ & $\begin{array}{l}7.877 \\
7.986 \\
8.096 \\
8.205 \\
8.316\end{array}$ & $\begin{array}{l}7.888 \\
7.997 \\
8.107 \\
8.216 \\
8.327\end{array}$ & $\begin{array}{l}7.899 \\
8.008 \\
8.118 \\
8.227 \\
8.338\end{array}$ & $\begin{array}{l}7.910 \\
8.019 \\
8.128 \\
8.238 \\
8.349\end{array}$ & $\begin{array}{l}7.921 \\
8.030 \\
8.139 \\
8.249 \\
8.360\end{array}$ & $\begin{array}{l}7.932 \\
8.041 \\
8.150 \\
8.261 \\
8.371\end{array}$ & $\begin{array}{l}7.943 \\
8.052 \\
8.161 \\
8.272 \\
8.382\end{array}$ & $\begin{array}{l}7.953 \\
8.063 \\
8.172 \\
8.283 \\
8.393\end{array}$ & $\begin{array}{l}1,300 \\
1,310 \\
1,320 \\
1,330 \\
1,340\end{array}$ \\
\hline $\begin{array}{l}1,350 \\
.360 \\
1,370 \\
1,380 \\
.390\end{array}$ & $\begin{array}{l}8.393 \\
8.504 \\
8.616 \\
8.727 \\
8.839\end{array}$ & $\begin{array}{l}8.404 \\
8.515 \\
8.627 \\
8.738 \\
8.851\end{array}$ & $\begin{array}{l}8.415 \\
8.526 \\
8.638 \\
8.750 \\
8.862\end{array}$ & $\begin{array}{l}8.426 \\
8.538 \\
8.649 \\
8.761 \\
8.873\end{array}$ & $\begin{array}{l}8.437 \\
8.549 \\
8.660 \\
8.772 \\
8.884\end{array}$ & $\begin{array}{l}8.449 \\
8.560 \\
8.671 \\
8.783 \\
8.896\end{array}$ & $\begin{array}{l}8.460 \\
8.571 \\
8.683 \\
8.795 \\
8.907\end{array}$ & $\begin{array}{l}8.471 \\
8.582 \\
8.694 \\
8.806 \\
8.918\end{array}$ & $\begin{array}{l}8.482 \\
8.593 \\
8.705 \\
8.817 \\
8.929\end{array}$ & $\begin{array}{l}8.493 \\
8.604 \\
8.716 \\
8.828 \\
8.941\end{array}$ & $\begin{array}{l}8.504 \\
8.616 \\
8.727 \\
8.839 \\
8.952\end{array}$ & $\begin{array}{l}1,350 \\
1,360 \\
1,370 \\
1,380 \\
1,390\end{array}$ \\
\hline $\begin{array}{l}1,400 \\
1,410 \\
1,420 \\
1,430 \\
1,440\end{array}$ & $\begin{array}{l}8.952 \\
9.065 \\
9.178 \\
9.291 \\
9.405\end{array}$ & $\begin{array}{l}8.963 \\
9.076 \\
9.189 \\
9.303 \\
9.417\end{array}$ & $\begin{array}{l}8.974 \\
9.087 \\
9.201 \\
9.314 \\
9.428\end{array}$ & $\begin{array}{l}8.986 \\
9.099 \\
9.212 \\
9.326 \\
9.439\end{array}$ & $\begin{array}{l}8.997 \\
9.110 \\
9.223 \\
9.337 \\
9.451\end{array}$ & $\begin{array}{l}9.008 \\
9.121 \\
9.235 \\
9.348 \\
9.462\end{array}$ & $\begin{array}{l}9.020 \\
9.133 \\
9.246 \\
9.360 \\
9.474\end{array}$ & $\begin{array}{l}9.031 \\
9.144 \\
9.257 \\
9.371 \\
9.485\end{array}$ & $\begin{array}{l}9.042 \\
9.155 \\
9.269 \\
9.382 \\
9.497\end{array}$ & $\begin{array}{l}9.053 \\
9.167 \\
9.280 \\
9.394 \\
9.508\end{array}$ & $\begin{array}{l}9.065 \\
9.178 \\
9.291 \\
9.405 \\
9.519\end{array}$ & $\begin{array}{l}1,400 \\
1,410 \\
1,420 \\
1,430 \\
1,440\end{array}$ \\
\hline $\begin{array}{l}1,450 \\
1,460 \\
1,470 \\
1,480 \\
1,490\end{array}$ & $\begin{array}{l}9.519 \\
9.634 \\
9.748 \\
9.863 \\
9.979\end{array}$ & $\begin{array}{l}9.531 \\
9.645 \\
9.760 \\
9.875 \\
9.990\end{array}$ & $\begin{array}{r}9.542 \\
9.657 \\
9.771 \\
9.886 \\
10.002\end{array}$ & $\begin{array}{r}9.554 \\
9.668 \\
9.783 \\
9.898 \\
10.013\end{array}$ & $\begin{array}{r}9.565 \\
9.680 \\
9.794 \\
9.909 \\
10.025\end{array}$ & $\begin{array}{r}9.577 \\
9.691 \\
9.806 \\
9.921 \\
10.036\end{array}$ & $\begin{array}{r}9.588 \\
9.703 \\
9.817 \\
9.933 \\
10.048\end{array}$ & $\begin{array}{r}9.599 \\
9.714 \\
9.829 \\
9.944 \\
10.059\end{array}$ & $\begin{array}{r}9.611 \\
9.726 \\
9.840 \\
9.956 \\
10.071\end{array}$ & $\begin{array}{r}9.622 \\
9.737 \\
9.852 \\
9.967 \\
10.082\end{array}$ & $\begin{array}{r}9.634 \\
9.748 \\
9.863 \\
9.979 \\
10.094\end{array}$ & $\begin{array}{l}1,450 \\
1,460 \\
1,470 \\
1,480 \\
1,490\end{array}$ \\
\hline $\begin{array}{l}1,500 \\
1,510 \\
1,520 \\
1,530 \\
1,540\end{array}$ & $\begin{array}{l}10.094 \\
10.210 \\
10.325 \\
10.441 \\
10.558\end{array}$ & $\begin{array}{l}10.106 \\
10.221 \\
10.337 \\
10.453 \\
10.569\end{array}$ & $\begin{array}{l}10.117 \\
10.233 \\
10.349 \\
10.465 \\
10.581\end{array}$ & $\begin{array}{l}10.129 \\
10.244 \\
10.360 \\
10.476 \\
10.593\end{array}$ & $\begin{array}{l}10.140 \\
10.256 \\
10.372 \\
10.488 \\
10.604\end{array}$ & $\begin{array}{l}10.152 \\
10.268 \\
10.383 \\
10.500 \\
10.616\end{array}$ & $\begin{array}{l}10.163 \\
10.279 \\
10.395 \\
10.511 \\
10.627\end{array}$ & $\begin{array}{l}10.175 \\
10.291 \\
10.407 \\
10.523 \\
10.639\end{array}$ & $\begin{array}{l}10.187 \\
10.302 \\
10.418 \\
10.534 \\
10.651\end{array}$ & $\begin{array}{l}10.198 \\
10.314 \\
10.430 \\
10.546 \\
10.662\end{array}$ & $\begin{array}{l}10.210 \\
10.325 \\
10.441 \\
10.558 \\
10.674\end{array}$ & $\begin{array}{l}1,500 \\
1,510 \\
1,520 \\
1,530 \\
1,540\end{array}$ \\
\hline $\begin{array}{l}1,550 \\
1,560 \\
1,570 \\
1,580 \\
1,590\end{array}$ & $\begin{array}{l}10.674 \\
10.790 \\
10.907 \\
11.024 \\
11.141\end{array}$ & $\begin{array}{l}10.686 \\
10.802 \\
10.919 \\
11.035 \\
11.152\end{array}$ & $\begin{array}{l}10.697 \\
10.814 \\
10.930 \\
11.047 \\
11.164\end{array}$ & $\begin{array}{l}10.709 \\
10.825 \\
10.942 \\
11.059 \\
11.176\end{array}$ & $\begin{array}{l}10.721 \\
10.837 \\
10.954 \\
11.070 \\
11.187\end{array}$ & $\begin{array}{l}10.732 \\
10.849 \\
10.965 \\
11.082 \\
11.199\end{array}$ & $\begin{array}{l}10.744 \\
10.860 \\
10.977 \\
11.094 \\
11.211\end{array}$ & $\begin{array}{l}10.756 \\
10.872 \\
10.989 \\
11.105 \\
11.222\end{array}$ & $\begin{array}{l}10.767 \\
10.884 \\
11.000 \\
11.117 \\
11.234\end{array}$ & $\begin{array}{l}10.779 \\
10.895 \\
11.012 \\
11.129 \\
11.246\end{array}$ & $\begin{array}{l}10.790 \\
10.907 \\
11.024 \\
11.141 \\
11.257\end{array}$ & $\begin{array}{l}1,550 \\
1,560 \\
1,570 \\
1,580 \\
1,590\end{array}$ \\
\hline $\begin{array}{l}1,600 \\
1,610 \\
1,620 \\
1,630 \\
1,640\end{array}$ & $\begin{array}{l}11.257 \\
11.374 \\
11.491 \\
11.608 \\
11.725\end{array}$ & $\begin{array}{l}11.269 \\
11.386 \\
11.503 \\
11.620 \\
11.737\end{array}$ & $\begin{array}{l}11.281 \\
11.398 \\
11.515 \\
11.632 \\
11.749\end{array}$ & $\begin{array}{l}11.292 \\
11.409 \\
11.526 \\
11.643 \\
11.760\end{array}$ & $\begin{array}{l}11.304 \\
11.421 \\
11.538 \\
11.655 \\
11.772\end{array}$ & $\begin{array}{l}11.316 \\
11.433 \\
11.550 \\
11.667 \\
11.784\end{array}$ & $\begin{array}{l}11.328 \\
11.444 \\
11.561 \\
11.678 \\
11.795\end{array}$ & $\begin{array}{l}11.339 \\
11.456 \\
11.573 \\
11.690 \\
11.807\end{array}$ & $\begin{array}{l}11.351 \\
11.468 \\
11.585 \\
11.702 \\
11.819\end{array}$ & $\begin{array}{l}11.363 \\
11.480 \\
11.597 \\
11.714 \\
11.830\end{array}$ & $\begin{array}{l}11.374 \\
11.491 \\
11.608 \\
11.725 \\
11.842\end{array}$ & $\begin{array}{l}1,600 \\
1,610 \\
1,620 \\
1,630 \\
1,640\end{array}$ \\
\hline $\begin{array}{l}1,650 \\
1,660 \\
1,670 \\
1,680 \\
1,690\end{array}$ & $\begin{array}{l}11.842 \\
11.959 \\
12.076 \\
12.193 \\
12.310\end{array}$ & $\begin{array}{l}11.854 \\
11.971 \\
12.088 \\
12.205 \\
12.321 .\end{array}$ & $\begin{array}{l}11.866 \\
11.983 \\
12.099 \\
12.216 \\
12.333\end{array}$ & $\begin{array}{l}11.877 \\
11.994 \\
12.111 \\
12.228 \\
12.345\end{array}$ & $\begin{array}{l}11.889 \\
12.006 \\
12.123 \\
12.240 \\
12.356\end{array}$ & $\begin{array}{l}11.901 \\
12.018 \\
12.134 \\
12.251 \\
12.368\end{array}$ & $\begin{array}{l}11.912 \\
12.029 \\
12.146 \\
12.263 \\
12.380\end{array}$ & $\begin{array}{l}11.924 \\
12.041 \\
12.158 \\
12.275 \\
12.391\end{array}$ & $\begin{array}{l}11.936 \\
12.053 \\
12.170 \\
12.286 \\
12.403\end{array}$ & $\begin{array}{l}11.947 \\
12.064 \\
12.181 \\
12.298 \\
12.415\end{array}$ & $\begin{array}{l}11.959 \\
12.076 \\
12.193 \\
12.310 \\
12.426\end{array}$ & $\begin{array}{l}1,650 \\
1,660 \\
1,670 \\
1,680 \\
1,690\end{array}$ \\
\hline $\begin{array}{l}1,700 \\
1,710 \\
1,720 \\
1,730 \\
1,740\end{array}$ & $\begin{array}{l}12.426 \\
12.543 \\
12.659 \\
12.776 \\
12.892\end{array}$ & $\begin{array}{l}12.438 \\
12.555 \\
12.671 \\
12.787 \\
12.903\end{array}$ & $\begin{array}{l}12.450 \\
12.566 \\
12.683 \\
12.799 \\
12.915\end{array}$ & $\begin{array}{l}12.461 \\
12.578 \\
12.694 \\
12.811 \\
12.927\end{array}$ & $\begin{array}{l}12.473 \\
12.590 \\
12.706 \\
12.822 \\
12.938\end{array}$ & $\begin{array}{l}12.485 \\
12.601 \\
12.718 \\
12.834 \\
12.950\end{array}$ & $\begin{array}{l}12.496 \\
12.613 \\
12.729 \\
12.845 \\
12.961\end{array}$ & $\begin{array}{l}12.508 \\
12.624 \\
12.741 \\
12.857 \\
12.973\end{array}$ & $\begin{array}{l}12.520 \\
12.636 \\
12.752 \\
12.869 \\
12.985\end{array}$ & $\begin{array}{l}12.531 \\
12.648 \\
12.764 \\
12.380 \\
12.996\end{array}$ & $\begin{array}{l}12.543 \\
12.659 \\
12.776 \\
12.892 \\
13.008\end{array}$ & $\begin{array}{l}1,700 \\
1,710 \\
1,720 \\
1,730 \\
1,740\end{array}$ \\
\hline $\begin{array}{l}1,750 \\
1,760 \\
1,770 \\
1,780 \\
1,790\end{array}$ & $\begin{array}{l}13.008 \\
13.124 \\
13.239 \\
13.354 \\
13.470\end{array}$ & $\begin{array}{l}13.019 \\
13.135 \\
13.251 \\
13.366 \\
13.481\end{array}$ & $\begin{array}{l}13.031 \\
13.147 \\
13.262 \\
13.378 \\
13.493\end{array}$ & $\begin{array}{l}13.043 \\
13.158 \\
13.274 \\
13.389 \\
13.504\end{array}$ & $\begin{array}{l}13.054 \\
13.170 \\
13.285 \\
13.401 \\
13.516\end{array}$ & $\begin{array}{l}13.066 \\
13.181 \\
13.297 \\
13.412 \\
13.527\end{array}$ & $\begin{array}{l}13.077 \\
13.193 \\
13.308 \\
13.424 \\
13.539\end{array}$ & $\begin{array}{l}13.089 \\
13.204 \\
13.320 \\
13.435 \\
13.550\end{array}$ & $\begin{array}{l}13.100 \\
13.216 \\
13.331 \\
13.447 \\
13.562\end{array}$ & $\begin{array}{l}13.112 \\
13.228 \\
13.343 \\
13.458 \\
13.573\end{array}$ & $\begin{array}{l}13.124 \\
13.239 \\
13.354 \\
13.470 \\
13.585\end{array}$ & $\begin{array}{l}1,750 \\
1,760 \\
1,770 \\
1,780 \\
1,790\end{array}$ \\
\hline $\begin{array}{l}1,800 \\
1,810 \\
1,820\end{array}$ & $\begin{array}{l}13.585 \\
13.699 \\
13.814\end{array}$ & $\begin{array}{l}13.596 \\
13.711\end{array}$ & $\begin{array}{l}13.607 \\
13.722\end{array}$ & $\begin{array}{l}13.619 \\
13.733\end{array}$ & $\begin{array}{l}13.630 \\
13.745\end{array}$ & $\begin{array}{l}13.642 \\
13.756\end{array}$ & $\begin{array}{l}13.653 \\
13.768\end{array}$ & $\begin{array}{l}13.665 \\
13.779\end{array}$ & $\begin{array}{l}13.676 \\
13.791\end{array}$ & $\begin{array}{l}13.608 \\
13.802\end{array}$ & $\begin{array}{l}13.699 \\
13.814\end{array}$ & $\begin{array}{l}1,800 \\
1,810 \\
1,820\end{array}$ \\
\hline
\end{tabular}


TABLE A4.1.2. Type B thermocouples-thermoelectric voltage as a function of temperature $\left({ }^{\circ} \mathrm{F}\right)$, reference junctions at $32^{\circ} \mathrm{F}$

0
10

20

30
40

50
60
70
80
90

100

100
110
120
130

120
130

140

150

150
160
170

180
190

200

210

22

230
240

250

260

270
280

290

300

310

330

340

350

360

370
380

390

400

410

43

440

450

470

480

500

51

520

530

540

55

56
57

580

590

600
THERMOELECTRIC VOLTAGE IN ABSOLUTE MILLIVOLTS

0

1

THERTECTRIC VOLTAGE YN ABSOLUTE MILLIVOLTS
8

9

10

${ }^{\circ} \mathrm{F}$

\begin{tabular}{|c|c|c|c|c|c|c|c|c|c|c|c|}
\hline-0.001 & -0.001 & $\begin{array}{r}0.000 \\
-0.001\end{array}$ & $\begin{array}{l}-0.000 \\
-0.001\end{array}$ & $\begin{array}{l}-0.000 \\
-0.001\end{array}$ & $\begin{array}{l}-0.000 \\
-0.001\end{array}$ & $\begin{array}{l}-0.001 \\
-0.002\end{array}$ & $\begin{array}{l}-0.001 \\
-0.002\end{array}$ & $\begin{array}{l}-0.001 \\
-0.002\end{array}$ & $\begin{array}{l}-0.001 \\
-0.002\end{array}$ & $\begin{array}{l}-0.001 \\
-0.002\end{array}$ & $\begin{array}{l}30 \\
40\end{array}$ \\
\hline $\begin{array}{l}-0.002 \\
-0.002 \\
-0.003 \\
-0.002 \\
-0.002\end{array}$ & $\begin{array}{l}-0.002 \\
-0.002 \\
-0.003 \\
-0.002 \\
-0.002\end{array}$ & $\begin{array}{l}-0.002 \\
-0.002 \\
-0.003 \\
-0.002 \\
-0.002\end{array}$ & $\begin{array}{l}-0.002 \\
-0.003 \\
-0.003 \\
-0.002 \\
-0.002\end{array}$ & $\begin{array}{l}-0.002 \\
-0.003 \\
-0.003 \\
-0.002 \\
-0.002\end{array}$ & $\begin{array}{l}-0.002 \\
-0.003 \\
-0.003 \\
-0.002 \\
-0.001\end{array}$ & $\begin{array}{l}-0.002 \\
-0.003 \\
-0.003 \\
-0.002 \\
-0.001\end{array}$ & $\begin{array}{l}-0.002 \\
-0.003 \\
-0.002 \\
-0.002 \\
-0.001\end{array}$ & $\begin{array}{l}-0.002 \\
-0.003 \\
-0.002 \\
-0.002 \\
-0.001\end{array}$ & $\begin{array}{l}-0.002 \\
-0.003 \\
-0.002 \\
-0.002 \\
-0.001\end{array}$ & $\begin{array}{l}-0.002 \\
-0.003 \\
-0.002 \\
-0.002 \\
-0.001\end{array}$ & $\begin{array}{l}50 \\
60 \\
70 \\
80 \\
90\end{array}$ \\
\hline $\begin{array}{r}-0.001 \\
0.000 \\
0.002 \\
0.004 \\
0.006\end{array}$ & $\begin{array}{r}-0.001 \\
0.000 \\
0.002 \\
0.004 \\
0.006\end{array}$ & $\begin{array}{r}-0.001 \\
0.001 \\
0.002 \\
0.004 \\
0.007\end{array}$ & $\begin{array}{r}-0.001 \\
0.001 \\
0.002 \\
0.005 \\
0.007\end{array}$ & $\begin{array}{r}-0.000 \\
0.001 \\
0.003 \\
0.005 \\
0.007\end{array}$ & $\begin{array}{r}-0.000 \\
0.001 \\
0.003 \\
0.005 \\
0.007\end{array}$ & $\begin{array}{r}-0.000 \\
0.001 \\
0.003 \\
0.005 \\
0.008\end{array}$ & $\begin{array}{r}-0.000 \\
0.001 \\
0.003 \\
0.005 \\
0.008\end{array}$ & $\begin{array}{l}0.000 \\
0.002 \\
0.003 \\
0.006 \\
0.008\end{array}$ & $\begin{array}{l}0.000 \\
0.002 \\
0.004 \\
0.006 \\
0.009\end{array}$ & $\begin{array}{l}0.000 \\
0.002 \\
0.004 \\
0.006 \\
0.009\end{array}$ & $\begin{array}{l}100 \\
110 \\
120 \\
130 \\
140\end{array}$ \\
\hline $\begin{array}{l}0.009 \\
0.012 \\
0.015 \\
0.019 \\
0.023\end{array}$ & $\begin{array}{l}0.009 \\
0.012 \\
0.016 \\
0.019 \\
0.023\end{array}$ & $\begin{array}{l}0.009 \\
0.013 \\
0.016 \\
0.020 \\
0.024\end{array}$ & $\begin{array}{l}0.010 \\
0.013 \\
0.016 \\
0.020 \\
0.024\end{array}$ & $\begin{array}{l}0.010 \\
0.013 \\
0.017 \\
0.021 \\
0.025\end{array}$ & $\begin{array}{l}0.010 \\
0.014 \\
0.017 \\
0.021 \\
0.025\end{array}$ & $\begin{array}{l}0.011 \\
0.014 \\
0.017 \\
0.021 \\
0.026\end{array}$ & $\begin{array}{l}0.011 \\
0.014 \\
0.018 \\
0.022 \\
0.026\end{array}$ & $\begin{array}{l}0.011 \\
0.015 \\
0.018 \\
0.022 \\
0.027\end{array}$ & $\begin{array}{l}0.012 \\
0.015 \\
0.019 \\
0.023 \\
0.027\end{array}$ & $\begin{array}{l}0.012 \\
0.015 \\
0.019 \\
0.023 \\
0.027\end{array}$ & $\begin{array}{l}150 \\
160 \\
170 \\
180 \\
190\end{array}$ \\
\hline $\begin{array}{l}0.027 \\
0.032 \\
0.037 \\
0.043 \\
0.049\end{array}$ & $\begin{array}{l}0.028 \\
0.033 \\
0.038 \\
0.043 \\
0.049\end{array}$ & $\begin{array}{l}0.028 \\
0.033 \\
0.038 \\
0.044 \\
0.050\end{array}$ & $\begin{array}{l}0.029 \\
0.034 \\
0.039 \\
0.044 \\
0.050\end{array}$ & $\begin{array}{l}0.029 \\
0.034 \\
0.039 \\
0.045 \\
0.051\end{array}$ & $\begin{array}{l}0.030 \\
0.035 \\
0.040 \\
0.046 \\
0.052\end{array}$ & $\begin{array}{l}0.030 \\
0.035 \\
0.041 \\
0.046 \\
0.052\end{array}$ & $\begin{array}{l}0.031 \\
0.036 \\
0.041 \\
0.047 \\
0.053\end{array}$ & $\begin{array}{l}0.031 \\
0.036 \\
0.042 \\
0.047 \\
0.053\end{array}$ & $\begin{array}{l}0.032 \\
0.037 \\
0.042 \\
0.048 \\
0.054\end{array}$ & $\begin{array}{l}0.032 \\
0.037 \\
0.043 \\
0.049 \\
0.055\end{array}$ & $\begin{array}{l}200 \\
210 \\
220 \\
230 \\
240\end{array}$ \\
\hline $\begin{array}{l}0.055 \\
0.061 \\
0.068 \\
0.075 \\
0.083\end{array}$ & $\begin{array}{l}0.055 \\
0.062 \\
0.069 \\
0.076 \\
0.083\end{array}$ & $\begin{array}{l}0.056 \\
0.062 \\
0.069 \\
0.077 \\
0.084\end{array}$ & $\begin{array}{l}0.057 \\
0.063 \\
0.070 \\
0.077 \\
0.085\end{array}$ & $\begin{array}{l}0.057 \\
0.064 \\
0.071 \\
0.078 \\
0.086\end{array}$ & $\begin{array}{l}0.058 \\
0.064 \\
0.071 \\
0.079 \\
0.086\end{array}$ & $\begin{array}{l}0.058 \\
0.065 \\
0.072 \\
0.080 \\
0.087\end{array}$ & $\begin{array}{l}0.059 \\
0.066 \\
0.073 \\
0.080 \\
0.088\end{array}$ & $\begin{array}{l}0.060 \\
0.067 \\
0.074 \\
0.081 \\
0.089\end{array}$ & $\begin{array}{l}0.060 \\
0.067 \\
0.074 \\
0.082 \\
0.090\end{array}$ & $\begin{array}{l}0.061 \\
0.068 \\
0.075 \\
0.083 \\
0.090\end{array}$ & $\begin{array}{l}250 \\
260 \\
270 \\
280 \\
290\end{array}$ \\
\hline $\begin{array}{l}0.090 \\
0.099 \\
0.107 \\
0.116 \\
0.125\end{array}$ & $\begin{array}{l}0.091 \\
0.099 \\
0.108 \\
0.117 \\
0.126\end{array}$ & $\begin{array}{l}0.092 \\
0.100 \\
0.109 \\
0.118 \\
0.127\end{array}$ & $\begin{array}{l}0.093 \\
0.101 \\
0.110 \\
0.119 \\
0.128\end{array}$ & $\begin{array}{l}0.094 \\
0.102 \\
0.111 \\
0.120 \\
0.129\end{array}$ & $\begin{array}{l}0.094 \\
0.103 \\
0.111 \\
0.120 \\
0.130\end{array}$ & $\begin{array}{l}0.095 \\
0.104 \\
0.112 \\
0.121 \\
0.131\end{array}$ & $\begin{array}{l}0.096 \\
0.104 \\
0.113 \\
0.122 \\
0.132\end{array}$ & $\begin{array}{l}0.097 \\
0.105 \\
0.114 \\
0.123 \\
0.133\end{array}$ & $\begin{array}{l}0.098 \\
0.106 \\
0.115 \\
0.124 \\
0.134\end{array}$ & $\begin{array}{l}0.099 \\
0.107 \\
0.116 \\
0.125 \\
0.135\end{array}$ & $\begin{array}{l}300 \\
310 \\
320 \\
330 \\
340\end{array}$ \\
\hline $\begin{array}{l}0.135 \\
0.144 \\
0.155 \\
0.165 \\
0.176\end{array}$ & $\begin{array}{l}0.136 \\
0.145 \\
0.156 \\
0.166 \\
0.177\end{array}$ & $\begin{array}{l}0.137 \\
0.146 \\
0.157 \\
0.167 \\
0.178\end{array}$ & $\begin{array}{l}0.138 \\
0.147 \\
0.158 \\
0.168 \\
0.179\end{array}$ & $\begin{array}{l}0.138 \\
0.148 \\
0.159 \\
0.169 \\
0.180\end{array}$ & $\begin{array}{l}0.139 \\
0.149 \\
0.160 \\
0.171 \\
0.182\end{array}$ & $\begin{array}{l}0.140 \\
0.151 \\
0.161 \\
0.172 \\
0.183\end{array}$ & $\begin{array}{l}0.141 \\
0.152 \\
0.162 \\
0.173 \\
0.184\end{array}$ & $\begin{array}{l}0.142 \\
0.153 \\
0.163 \\
0.174 \\
0.185\end{array}$ & $\begin{array}{l}0.143 \\
0.154 \\
0.164 \\
0.175 \\
0.186\end{array}$ & $\begin{array}{l}0.144 \\
0.155 \\
0.165 \\
0.176 \\
0.187\end{array}$ & $\begin{array}{l}350 \\
360 \\
370 \\
380 \\
390\end{array}$ \\
\hline $\begin{array}{l}0.187 \\
0.199 \\
0.210 \\
0.223 \\
0.235\end{array}$ & $\begin{array}{l}0.188 \\
0.200 \\
0.212 \\
0.224 \\
0.236\end{array}$ & $\begin{array}{l}0.189 \\
0.201 \\
0.213 \\
0.225 \\
0.238\end{array}$ & $\begin{array}{l}0.191 \\
0.202 \\
0.214 \\
0.226 \\
0.239\end{array}$ & $\begin{array}{l}0.192 \\
0.203 \\
0.215 \\
0.228 \\
0.240\end{array}$ & $\begin{array}{l}0.193 \\
0.205 \\
0.217 \\
0.229 \\
0.242\end{array}$ & $\begin{array}{l}0.194 \\
0.206 \\
0.218 \\
0.230 \\
0.243\end{array}$ & $\begin{array}{l}0.195 \\
0.207 \\
0.219 \\
0.231 \\
0.244\end{array}$ & $\begin{array}{l}0.196 \\
0.208 \\
0.220 \\
0.233 \\
0.245\end{array}$ & $\begin{array}{l}0.197 \\
0.209 \\
0.221 \\
0.234 \\
0.247\end{array}$ & $\begin{array}{l}0.199 \\
0.210 \\
0.223 \\
0.235 \\
0.248\end{array}$ & $\begin{array}{l}400 \\
410 \\
420 \\
430 \\
440\end{array}$ \\
\hline $\begin{array}{l}0.248 \\
0.261 \\
0.275 \\
0.288 \\
0.303\end{array}$ & $\begin{array}{l}0.249 \\
0.262 \\
0.276 \\
0.290 \\
0.304\end{array}$ & $\begin{array}{l}0.251 \\
0.264 \\
0.277 \\
0.291 \\
0.305\end{array}$ & $\begin{array}{l}0.252 \\
0.265 \\
0.279 \\
0.293 \\
0.307\end{array}$ & $\begin{array}{l}0.253 \\
0.266 \\
0.280 \\
0.294 \\
0.308\end{array}$ & $\begin{array}{l}0.254 \\
0.268 \\
0.281 \\
0.295 \\
0.310\end{array}$ & $\begin{array}{l}0.256 \\
0.269 \\
0.283 \\
0.297 \\
0.311\end{array}$ & $\begin{array}{l}0.257 \\
0.271 \\
0.284 \\
0.298 \\
0.313\end{array}$ & $\begin{array}{l}0.258 \\
0.272 \\
0.286 \\
0.300 \\
0.314\end{array}$ & $\begin{array}{l}0.260 \\
0.273 \\
0.287 \\
0.301 \\
0.315\end{array}$ & $\begin{array}{l}0.261 \\
0.275 \\
0.288 \\
0.303 \\
0.317\end{array}$ & $\begin{array}{l}450 \\
460 \\
470 \\
480 \\
490\end{array}$ \\
\hline $\begin{array}{l}0.317 \\
0.332 \\
0.347 \\
0.362 \\
0.378\end{array}$ & $\begin{array}{l}0.318 \\
0.333 \\
0.348 \\
0.364 \\
0.380\end{array}$ & $\begin{array}{l}0.320 \\
0.335 \\
0.350 \\
0.365 \\
0.381\end{array}$ & $\begin{array}{l}0.321 \\
0.336 \\
0.351 \\
0.367 \\
0.383\end{array}$ & $\begin{array}{l}0.323 \\
0.338 \\
0.353 \\
0.369 \\
0.384\end{array}$ & $\begin{array}{l}0.324 \\
0.339 \\
0.355 \\
0.370 \\
0.386\end{array}$ & $\begin{array}{l}0.326 \\
0.341 \\
0.356 \\
0.372 \\
0.388\end{array}$ & $\begin{array}{l}0.327 \\
0.342 \\
0.358 \\
0.373 \\
0.389\end{array}$ & $\begin{array}{l}0.329 \\
0.344 \\
0.359 \\
0.375 \\
0.391\end{array}$ & $\begin{array}{l}0.330 \\
0.345 \\
0.361 \\
0.376 \\
0.392\end{array}$ & $\begin{array}{l}0.332 \\
0.347 \\
0.362 \\
0.378 \\
0.394\end{array}$ & $\begin{array}{l}500 \\
510 \\
520 \\
530 \\
540\end{array}$ \\
\hline $\begin{array}{l}0.394 \\
0.410 \\
0.427 \\
0.444 \\
0.462\end{array}$ & $\begin{array}{l}0.396 \\
0.412 \\
0.429 \\
0.446 \\
0.463\end{array}$ & $\begin{array}{l}0.397 \\
0.414 \\
0.431 \\
0.448 \\
0.465\end{array}$ & $\begin{array}{l}0.399 \\
0.415 \\
0.432 \\
0.449 \\
0.467\end{array}$ & $\begin{array}{l}0.401 \\
0.417 \\
0.434 \\
0.451 \\
0.469\end{array}$ & $\begin{array}{l}0.402 \\
0.419 \\
0.436 \\
0.453 \\
0.470\end{array}$ & $\begin{array}{l}0.404 \\
0.420 \\
0.437 \\
0.455 \\
0.472\end{array}$ & $\begin{array}{l}0.405 \\
0.422 \\
0.439 \\
0.456 \\
0.474\end{array}$ & $\begin{array}{l}0.407 \\
0.424 \\
0.441 \\
0.458 \\
0.476\end{array}$ & $\begin{array}{l}0.409 \\
0.425 \\
0.442 \\
0.460 \\
0.477\end{array}$ & $\begin{array}{l}0.410 \\
0.427 \\
0.444 \\
0.462 \\
0.479\end{array}$ & $\begin{array}{l}56 \\
57 \\
58 \\
59\end{array}$ \\
\hline 0.479 & 0.481 & 0.483 & 0.485 & 0.486 & 0.488 & 0.490 & 0.492 & 0.494 & 0.495 & 0.497 & 60 \\
\hline
\end{tabular}

${ }^{\circ} \mathrm{F}$

0

1

2

3

4

5

6

7

8

9

10

${ }^{\circ} \mathrm{F}$ 
TABLE A4.1.2. Type B thermocouples-thermoelectric voltage as a function of temperature $\left({ }^{\circ} \mathrm{F}\right)$, reference junctions at $32^{\circ} \mathrm{F}$-Continued

THERMOELECTRIC VOLTAGE IN ABSOLUTE MILLIVOLTS

\begin{tabular}{|c|c|c|c|c|c|c|c|c|c|c|c|c|}
\hline 600 & 0.479 & 0.481 & 0.483 & 0.485 & 0.486 & 0.488 & 0.490 & 0.492 & 0.494 & 0.495 & 0.497 & 600 \\
\hline 610 & 0.497 & 0.499 & 0.501 & 0.503 & 0.504 & 0.506 & 0.508 & 0.510 & 0.512 & 0.514 & 0.515 & 610 \\
\hline 620 & 0.515 & 0.517 & 0.519 & 0.521 & 0.523 & 0.525 & 0.527 & 0.528 & 0.530 & 0.532 & 0.534 & 620 \\
\hline 630 & 0.534 & 0.536 & 0.538 & 0.540 & 0.542 & 0.544 & 0.545 & 0.547 & 0.549 & 0.551 & 0.553 & 630 \\
\hline 640 & 0.553 & 0.555 & 0.557 & 0.559 & 0.561 & 0.563 & 0.565 & 0.566 & 0.568 & 0.570 & 0.572 & 640 \\
\hline 650 & 0.572 & 0.574 & 0.576 & 0.578 & 0.580 & 0.582 & 0.584 & 0.586 & 0.588 & 0.590 & 0.592 & 0 \\
\hline 660 & 0.592 & 0.594 & 0.596 & 0.598 & 0.600 & 0.602 & 0.604 & 0.606 & 0.608 & 0.610 & 0.612 & 6 \\
\hline 670 & 0.612 & 0.614 & 0.616 & 0.618 & 0.620 & 0.622 & 0.624 & 0.626 & 0.628 & 0.630 & 0.632 & 670 \\
\hline 680 & 0.632 & 0.634 & 0.636 & 0.638 & 0.640 & 0.642 & 0.644 & 0.646 & 0.648 & 0.650 & 0.652 & 68 \\
\hline 690 & 0.652 & 0.654 & 0.656 & 0.659 & 0.661 & 0.663 & 0.665 & 0.667 & 0.669 & 0.671 & 0.673 & 690 \\
\hline 700 & 0.673 & 0.675 & 0.677 & 0.679 & 0.682 & 0.684 & 0.686 & 0.688 & 0.690 & 0.692 & 0.694 & 70 \\
\hline 710 & 0.694 & 0.696 & 0.699 & 0.701 & 0.703 & 0.705 & 0.707 & 0.709 & 0.711 & 0.714 & 0.716 & \\
\hline 720 & 0.716 & 0.718 & 0.720 & 0.722 & 0.724 & 0.727 & 0.729 & 0.731 & 0.733 & 0.735 & 0.737 & 720 \\
\hline 730 & 0.737 & 0.740 & 0.742 & 0.744 & 0.746 & 0.748 & 0.751 & 0.753 & 0.755 & 0.757 & 0.759 & 730 \\
\hline 740 & 0.759 & 0.762 & 0.764 & 0.766 & 0.768 & 0.771 & 0.773 & 0.775 & 0.777 & 0.780 & 0.782 & 740 \\
\hline 750 & 0.782 & 0.784 & 0.786 & 0.789 & 0.791 & 0.793 & 0.795 & 0.798 & 0.800 & 0.802 & 0.804 & 750 \\
\hline 760 & 0.804 & 0.807 & 0.809 & 0.811 & 0.814 & 0.816 & 0.818 & 0.821 & 0.823 & 0.825 & 0.827 & 760 \\
\hline 770 & 0.827 & 0.830 & 0.832 & 0.834 & 0.837 & 0.839 & 0.841 & 0.844 & 0.846 & 0.848 & 0.851 & 770 \\
\hline 780 & 0.851 & 0.853 & 0.855 & 0.858 & 0.860 & 0.862 & 0.865 & 0.867 & 0.870 & 0.872 & 0.874 & 780 \\
\hline 790 & 0.874 & 0.877 & 0.879 & 0.881 & 0.884 & 0.886 & 0.889 & 0.891 & 0.893 & 0.896 & 0.898 & 790 \\
\hline 800 & 0.898 & 0.901 & 0.903 & 0.905 & 0.908 & 0.910 & 0.913 & 0.915 & 0.918 & 0.920 & 0.922 & $8 c$ \\
\hline 810 & 0.922 & 0.925 & 0.927 & 0.930 & 0.932 & 0.935 & 0.937 & 0.939 & 0.942 & 0.944 & 0.947 & 8 \\
\hline 820 & 0.947 & 0.949 & 0.952 & 0.954 & 0.957 & 0.959 & 0.962 & 0.964 & 0.967 & 0.969 & 0.972 & 820 \\
\hline 830 & 0.972 & 0.974 & 0.977 & 0.979 & 0.982 & 0.984 & 0.987 & 0.989 & 0.992 & 0.994 & 0.997 & 830 \\
\hline 840 & 0.997 & 0.999 & 1.002 & 1.004 & 1.007 & 1.009 & 1.012 & 1.014 & 1.017 & 1.020 & 1.022 & 840 \\
\hline 850 & 1.022 & 1.025 & 1.027 & 1.030 & 1.032 & 1.035 & 1.037 & 1.040 & 1.043 & 1.045 & 1.048 & 850 \\
\hline 860 & 1.048 & 1.050 & 1.053 & 1.056 & 1.058 & 1.061 & 1.063 & 1.066 & 1.069 & 1.071 & 1.074 & 860 \\
\hline 870 & 1.074 & 1.076 & 1.079 & 1.082 & 1.084 & 1.087 & 1.090 & 1.092 & 1.095 & 1.097 & 1.100 & 87 \\
\hline 880 & 1.100 & 1.103 & 1.105 & 1.108 & 1.111 & 1.113 & 1.116 & 1.119 & 1.121 & 1.124 & 1.127 & 880 \\
\hline 890 & 1.127 & 1.129 & 1.132 & 1.135 & 1.137 & 1.140 & 1.143 & 1.145 & 1.148 & 1.151 & 1.153 & 890 \\
\hline 900 & 1.153 & 1.156 & 1.159 & 1.162 & 1.164 & 1.167 & 1.170 & 1.172 & 1.175 & 1.178 & 1.181 & 900 \\
\hline 910 & 1.181 & 1.183 & 1.186 & 1.189 & 1.192 & 1.194 & 1.197 & 1.200 & 1.203 & 1.205 & 1.208 & 910 \\
\hline 920 & 1.208 & 1.211 & 1.214 & 1.216 & 1.219 & 1.222 & 1.225 & 1.228 & 1.230 & 1.233 & 1.236 & 920 \\
\hline 930 & 1.236 & 1.239 & 1.241 & 1.244 & 1.247 & 1.250 & 1.253 & 1.255 & 1.258 & 1.261 & 1.264 & 930 \\
\hline 940 & 1.264 & 1.267 & 1.270 & 1.272 & 1.275 & 1.278 & 1.281 & 1.284 & 1.287 & 1.289 & 1.292 & 940 \\
\hline 950 & 1.292 & 1.295 & 1.298 & 1.301 & 1.304 & 1.307 & 1.309 & 1.312 & 1.315 & 1.318 & 1.321 & 9 \\
\hline 960 & 1.321 & 1.324 & 1.327 & 1.330 & 1.332 & 1.335 & 1.338 & 1.341 & 1.344 & 1.347 & 1.350 & \\
\hline 970 & 1.350 & 1.353 & 1.356 & 1.359 & 1.361 & 1.364 & 1.367 & 1.370 & 1.373 & 1.376 & 1.379 & 970 \\
\hline 980 & 1.379 & 1.382 & 1.385 & 1.388 & 1.391 & 1.394 & 1.397 & 1.400 & 1.403 & 1.406 & 1.409 & 98 \\
\hline 990 & 1.409 & 1.411 & 1.414 & 1.417 & 1.420 & 1.423 & 1.426 & 1.429 & 1.432 & 1.435 & 1.438 & 990 \\
\hline 1,000 & 1.438 & 1.441 & 1.444 & 1.447 & 1.450 & 1.453 & 1.456 & 1.459 & 1.462 & 1.465 & 1.468 & 1,000 \\
\hline 1,010 & 1.468 & 1.471 & 1.474 & 1.477 & 1.480 & 1.483 & 1.487 & 1.490 & 1.493 & 1.496 & 1.499 & 1,010 \\
\hline 1,020 & 1.499 & 1.502 & 1.505 & 1.508 & 1.511 & 1.514 & 1.517 & 1.520 & 1.523 & 1.526 & 1.529 & 1,02 \\
\hline 1,030 & 1.529 & 1.532 & 1.536 & 1.539 & 1.542 & 1.545 & 1.548 & 1.551 & 1.554 & 1.557 & 1.560 & 1,030 \\
\hline 1,040 & 1.560 & 1.563 & 1.566 & 1.570 & 1.573 & 1.576 & 1.579 & 1.582 & 1.585 & 1.588 & 1.591 & 1,04 \\
\hline 1,050 & 1.591 & 1.595 & 1.598 & 1.601 & 1.604 & 1.607 & 1.610 & 1.613 & 1.617 & 1.620 & 1.623 & 1,05 \\
\hline 1,060 & 1.623 & 1.626 & 1.629 & 1.632 & 1.636 & 1.639 & 1.642 & 1.645 & 1.648 & 1.652 & 1.655 & 1,06 \\
\hline 1,070 & 1.655 & 1.658 & 1.661 & 1.664 & 1.668 & 1.671 & 1.674 & 1.677 & 1.680 & 1.684 & 1.687 & 1,07 \\
\hline 1,080 & 1.687 & 1.690 & 1.693 & 1.696 & 1.700 & 1.703 & 1.706 & 1.709 & 1.713 & 1.716 & 1.719 & 1,08 \\
\hline 1,090 & 1.719 & 1.722 & 1.726 & 1.729 & 1.732 & 1.735 & 1.739 & 1.742 & 1.745 & 1.748 & 1.752 & 1.09 \\
\hline 1,100 & 1.752 & 1.755 & 1 . & 1.762 & 1. & 1.768 & 1.771 & 1.775 & 1. & 1.781 & 1.785 & 1,1 \\
\hline 1,110 & 1.785 & 1.788 & 1.791 & & 1.798 & 1.801 & 1.804 & 1.808 & 1.811 & 1.814 & 1.818 & 1,110 \\
\hline 1,120 & 1.818 & 1.821 & 1.824 & 1.828 & 1.831 & 1.834 & 1.838 & 1.841 & 1.844 & 1.848 & 1.851 & 1,12 \\
\hline 1,130 & 1.851 & 1.855 & 1.858 & 1.861 & 1.865 & 1.868 & 1.871 & 1.875 & 1.878 & 1.882 & 1.885 & 1,13 \\
\hline 1,140 & 1.885 & 1.888 & 1.892 & 1.895 & 1.898 & 1.902 & 1.905 & 1.909 & 1.912 & 1.915 & 1.919 & 1.140 \\
\hline 1,150 & 1.919 & 1.922 & 1.926 & 1.929 & 1.933 & 1.936 & 1.939 & 1.943 & 1.946 & 1.950 & 1.953 & 1,15 \\
\hline 1,160 & 1.953 & 1.957 & 1.960 & 1.963 & 1.967 & 1.970 & 1.974 & 1.977 & 1.981 & 1.984 & 1.988 & 1,16 \\
\hline 1,170 & 1.988 & 1.991 & 1.995 & 1.998 & 2.002 & 2.005 & 2.009 & 2.012 & 2.015 & 2.019 & 2.022 & 1,170 \\
\hline 1,180 & 2.022 & 2.026 & 2.029 & 2.033 & 2.036 & 2.040 & 2.043 & 2.047 & 2.051 & 2.054 & 2.058 & 1,180 \\
\hline 1,190 & 2.058 & 2.061 & 2.065 & 2.068 & 2.072 & 2.075 & 2.079 & 2.082 & 2.086 & 2.089 & 2.093 & 1,190 \\
\hline 1,200 & 2.093 & 2.096 & 2.100 & 2.104 & 2.107 & 2.111 & 2.114 & 2.118 & 2.121 & 2.125 & $2 \cdot 128$ & 1,200 \\
\hline
\end{tabular}


TABLE A4.1.2. Type B thermocouples-thermoelectric voltage as a function of temperature $\left({ }^{\circ} \mathrm{F}\right)$, reference junctions at $32{ }^{\circ} \mathrm{F}$-Continued

THERMOELECTRIC VOLTAGE IN ABSOLUTE MILLIVOLTS

\begin{tabular}{|c|c|c|c|c|c|c|c|c|c|c|c|c|}
\hline $\begin{array}{l}1,200 \\
1,210 \\
1,220 \\
1,230 \\
1,240\end{array}$ & $\begin{array}{l}2.093 \\
2.128 \\
2.164 \\
2.201 \\
2.237\end{array}$ & $\begin{array}{l}2.096 \\
2.132 \\
2.168 \\
2.204 \\
2.241\end{array}$ & $\begin{array}{l}2.100 \\
2.136 \\
2.172 \\
2.208 \\
2.244\end{array}$ & $\begin{array}{l}2.104 \\
2.139 \\
2.175 \\
2.211 \\
2.248\end{array}$ & $\begin{array}{l}2.107 \\
2.143 \\
2.179 \\
2.215 \\
2.252\end{array}$ & $\begin{array}{l}2.111 \\
2.146 \\
2.182 \\
2.219 \\
2.255\end{array}$ & $\begin{array}{l}2.114 \\
2.150 \\
2.186 \\
2.222 \\
2.259\end{array}$ & $\begin{array}{l}2.118 \\
2.154 \\
2.190 \\
2.226 \\
2.263\end{array}$ & $\begin{array}{l}2.121 \\
2.157 \\
2.193 \\
2.230 \\
2.266\end{array}$ & $\begin{array}{l}2.125 \\
2.161 \\
2.197 \\
2.233 \\
2.270\end{array}$ & $\begin{array}{l}2 \cdot 128 \\
2 \cdot 164 \\
2 \cdot 201 \\
2 \cdot 237 \\
2 \cdot 274\end{array}$ & $\begin{array}{l}1,200 \\
1,210 \\
1,220 \\
1,230 \\
1,240\end{array}$ \\
\hline $\begin{array}{l}1,250 \\
1,260 \\
1,270 \\
1,280 \\
1,290\end{array}$ & $\begin{array}{l}2.274 \\
2.311 \\
2.348 \\
2.385 \\
2.423\end{array}$ & $\begin{array}{l}2.277 \\
2.314 \\
2.351 \\
2.389 \\
2.427\end{array}$ & $\begin{array}{l}2.281 \\
2.318 \\
2.355 \\
2.393 \\
2.430\end{array}$ & $\begin{array}{l}2.285 \\
2.322 \\
2.359 \\
2.396 \\
2.434\end{array}$ & $\begin{array}{l}2.288 \\
2.325 \\
2.363 \\
2.400 \\
2.438\end{array}$ & $\begin{array}{l}2.292 \\
2.329 \\
2.366 \\
2.404 \\
2.442\end{array}$ & $\begin{array}{l}2.296 \\
2.333 \\
2.370 \\
2.408 \\
2.446\end{array}$ & $\begin{array}{l}2.299 \\
2.337 \\
2.374 \\
2.412 \\
2.449\end{array}$ & $\begin{array}{l}2.303 \\
2.340 \\
2.378 \\
2.415 \\
2.453\end{array}$ & $\begin{array}{l}2.307 \\
2.344 \\
2.381 \\
2.419 \\
2.457\end{array}$ & $\begin{array}{l}2 \cdot 311 \\
2 \cdot 348 \\
2 \cdot 385 \\
2 \cdot 423 \\
2 \cdot 461\end{array}$ & $\begin{array}{l}1,25 \\
1,26 \\
1,27 \\
1,28 \\
1,29\end{array}$ \\
\hline $\begin{array}{l}1,300 \\
1,310 \\
1,320 \\
1,330 \\
1,340\end{array}$ & $\begin{array}{l}2.461 \\
2.499 \\
2.538 \\
2.576 \\
2.615\end{array}$ & $\begin{array}{l}2.465 \\
2.503 \\
2.542 \\
2.580 \\
2.619\end{array}$ & $\begin{array}{l}2.469 \\
2.507 \\
2.545 \\
2.584 \\
2.623\end{array}$ & $\begin{array}{l}2.472 \\
2.511 \\
2.549 \\
2.588 \\
2.627\end{array}$ & $\begin{array}{l}2.476 \\
2.515 \\
2.553 \\
2.592 \\
2.631\end{array}$ & $\begin{array}{l}2.480 \\
2.518 \\
2.557 \\
2.596 \\
2.635\end{array}$ & $\begin{array}{l}2.484 \\
2.522 \\
2.561 \\
2.600 \\
2.639\end{array}$ & $\begin{array}{l}2.488 \\
2.526 \\
2.565 \\
2.604 \\
2.643\end{array}$ & $\begin{array}{l}2.491 \\
2.530 \\
2.569 \\
2.608 \\
2.647\end{array}$ & $\begin{array}{l}2.495 \\
2.534 \\
2.573 \\
2.612 \\
2.651\end{array}$ & $\begin{array}{l}2.499 \\
2.538 \\
2.576 \\
2.615 \\
2.655\end{array}$ & $\begin{array}{l}1,30 \\
1,31 \\
1,32 \\
1,33 \\
1,34\end{array}$ \\
\hline $\begin{array}{l}1,350 \\
1,360 \\
1,370 \\
1,380 \\
1,390\end{array}$ & $\begin{array}{l}2.655 \\
2.694 \\
2.734 \\
2.774 \\
2.814\end{array}$ & $\begin{array}{l}2.659 \\
2.698 \\
2.738 \\
2.778 \\
2.818\end{array}$ & $\begin{array}{l}2.663 \\
2.702 \\
2.742 \\
2.782 \\
2.822\end{array}$ & $\begin{array}{l}2.667 \\
2.706 \\
2.746 \\
2.786 \\
2.826\end{array}$ & $\begin{array}{l}2.670 \\
2.710 \\
2.750 \\
2.790 \\
2.830\end{array}$ & $\begin{array}{l}2.674 \\
2.714 \\
2.754 \\
2.794 \\
2.835\end{array}$ & $\begin{array}{l}2.678 \\
2.718 \\
2.758 \\
2.798 \\
2.839\end{array}$ & $\begin{array}{l}2.682 \\
2.722 \\
2.762 \\
2.802 \\
2.843\end{array}$ & $\begin{array}{l}2.686 \\
2.726 \\
2.766 \\
2.806 \\
2.847\end{array}$ & $\begin{array}{l}2.690 \\
2.730 \\
2.770 \\
2.810 \\
2.851\end{array}$ & $\begin{array}{l}2.694 \\
2.734 \\
2.774 \\
2.814 \\
2.855\end{array}$ & $\begin{array}{l}1,35 \\
1,36 \\
1,37 \\
1,38 \\
1,39\end{array}$ \\
\hline $\begin{array}{l}1,400 \\
1,410 \\
1,420 \\
1,430 \\
1,440\end{array}$ & $\begin{array}{l}2.855 \\
2.896 \\
2.937 \\
2.978 \\
3.019\end{array}$ & $\begin{array}{l}2.859 \\
2.900 \\
2.941 \\
2.982 \\
3.024\end{array}$ & $\begin{array}{l}2.863 \\
2.904 \\
2.945 \\
2.986 \\
3.028\end{array}$ & $\begin{array}{l}2.867 \\
2.908 \\
2.949 \\
2.990 \\
3.032\end{array}$ & $\begin{array}{l}2.871 \\
2.912 \\
2.953 \\
2.995 \\
3.036\end{array}$ & $\begin{array}{l}2.875 \\
2.916 \\
2.957 \\
2.999 \\
3.040\end{array}$ & $\begin{array}{l}2.879 \\
2.920 \\
2.961 \\
3.003 \\
3.045\end{array}$ & $\begin{array}{l}2.883 \\
2.924 \\
2.966 \\
3.007 \\
3.049\end{array}$ & $\begin{array}{l}2.887 \\
2.928 \\
2.970 \\
3.011 \\
3.053\end{array}$ & $\begin{array}{l}2.892 \\
2.933 \\
2.974 \\
3.015 \\
3.057\end{array}$ & $\begin{array}{l}2.896 \\
2.937 \\
2.978 \\
3.019 \\
3.061\end{array}$ & $\begin{array}{l}1,4 \\
1,4 \\
1,4 \\
1,4 \\
1,4\end{array}$ \\
\hline $\begin{array}{l}1,450 \\
1,460 \\
1,470 \\
1,480 \\
1,490\end{array}$ & $\begin{array}{l}3.061 \\
3.103 \\
3.146 \\
3.188 \\
3.231\end{array}$ & $\begin{array}{l}3.065 \\
3.107 \\
3.150 \\
3.192 \\
3.235\end{array}$ & $\begin{array}{l}3.070 \\
3.112 \\
3.154 \\
3.197 \\
3.239\end{array}$ & $\begin{array}{l}3.074 \\
3.116 \\
3.158 \\
3.201 \\
3.244\end{array}$ & $\begin{array}{l}3.078 \\
3.120 \\
3.163 \\
3.205 \\
3.248\end{array}$ & $\begin{array}{l}3.082 \\
3.124 \\
3.167 \\
3.209 \\
3.252\end{array}$ & $\begin{array}{l}3.086 \\
3.129 \\
3.171 \\
3.214 \\
3.257\end{array}$ & $\begin{array}{l}3.091 \\
3.133 \\
3.175 \\
3.218 \\
3.261\end{array}$ & $\begin{array}{l}3.095 \\
3.137 \\
3.180 \\
3.222 \\
3.265\end{array}$ & $\begin{array}{l}3.099 \\
3.141 \\
3.184 \\
3.227 \\
3.269\end{array}$ & $\begin{array}{l}3.103 \\
3.146 \\
3.188 \\
3.231 \\
3.274\end{array}$ & $\begin{array}{l}1,45 \\
1,46 \\
1,47 \\
1,48 \\
1,49\end{array}$ \\
\hline $\begin{array}{l}1,500 \\
1,510 \\
1,520 \\
1,530 \\
1,540\end{array}$ & $\begin{array}{l}3.274 \\
3.317 \\
3.361 \\
3.404 \\
3.448\end{array}$ & $\begin{array}{l}3.278 \\
3.321 \\
3.365 \\
3.409 \\
3.453\end{array}$ & $\begin{array}{l}3.282 \\
3.326 \\
3.369 \\
3.413 \\
3.457\end{array}$ & $\begin{array}{l}3.287 \\
3.330 \\
3.374 \\
3.417 \\
3.461\end{array}$ & $\begin{array}{l}3.291 \\
3.334 \\
3.378 \\
3.422 \\
3.466\end{array}$ & $\begin{array}{l}3.295 \\
3.339 \\
3.382 \\
3.426 \\
3.470\end{array}$ & $\begin{array}{l}3.300 \\
3.343 \\
3.387 \\
3.431 \\
3.475\end{array}$ & $\begin{array}{l}3.304 \\
3.347 \\
3.391 \\
3.435 \\
3.479\end{array}$ & $\begin{array}{l}3.308 \\
3.352 \\
3.395 \\
3.439 \\
3.484\end{array}$ & $\begin{array}{l}3.313 \\
3.356 \\
3.400 \\
3.444 \\
3.488\end{array}$ & $\begin{array}{l}3.317 \\
3.361 \\
3.404 \\
3.448 \\
3.492\end{array}$ & $\begin{array}{l}1,50 \\
1,5 \\
1,52 \\
1,53 \\
1,54\end{array}$ \\
\hline $\begin{array}{l}1,550 \\
1,560 \\
1,570 \\
1,580 \\
1,590\end{array}$ & $\begin{array}{l}3.492 \\
3.537 \\
3.581 \\
3.626 \\
3.672\end{array}$ & $\begin{array}{l}3.497 \\
3.541 \\
3.586 \\
3.631 \\
3.676\end{array}$ & $\begin{array}{l}3.501 \\
3.546 \\
3.590 \\
3.635 \\
3.681\end{array}$ & $\begin{array}{l}3.506 \\
3.550 \\
3.595 \\
3.640 \\
3.685\end{array}$ & $\begin{array}{l}3.510 \\
3.555 \\
3.599 \\
3.644 \\
3.690\end{array}$ & $\begin{array}{l}3.515 \\
3.559 \\
3.604 \\
3.649 \\
3.694\end{array}$ & $\begin{array}{l}3.519 \\
3.564 \\
3.608 \\
3.653 \\
3.699\end{array}$ & $\begin{array}{l}3.523 \\
3.568 \\
3.613 \\
3.658 \\
3.703\end{array}$ & $\begin{array}{l}3.528 \\
3.573 \\
3.617 \\
3.662 \\
3.708\end{array}$ & $\begin{array}{l}3.532 \\
3.577 \\
3.622 \\
3.667 \\
3.712\end{array}$ & $\begin{array}{l}3.537 \\
3.581 \\
3.626 \\
3.672 \\
3.717\end{array}$ & $\begin{array}{l}1,5 \\
1,5 \\
1,5 \\
1,5 \\
1,5\end{array}$ \\
\hline $\begin{array}{l}1,600 \\
1,610 \\
1,620 \\
1,630 \\
1,640\end{array}$ & $\begin{array}{l}3.717 \\
3.762 \\
3.808 \\
3.854 \\
3.901\end{array}$ & $\begin{array}{l}3.721 \\
3.767 \\
3.813 \\
3.859 \\
3.905\end{array}$ & $\begin{array}{l}3.726 \\
3.772 \\
3.818 \\
3.864 \\
3.910\end{array}$ & $\begin{array}{l}3.731 \\
3.776 \\
3.822 \\
3.868 \\
3.915\end{array}$ & $\begin{array}{l}3.735 \\
3.781 \\
3.827 \\
3.873 \\
3.919\end{array}$ & $\begin{array}{l}3.740 \\
3.785 \\
3.831 \\
3.877 \\
3.924\end{array}$ & $\begin{array}{l}3.744 \\
3.790 \\
3.836 \\
3.882 \\
3.929\end{array}$ & $\begin{array}{l}3.749 \\
3.795 \\
3.841 \\
3.887 \\
3.933\end{array}$ & $\begin{array}{l}3.753 \\
3.799 \\
3.845 \\
3.891 \\
3.938\end{array}$ & $\begin{array}{l}3.758 \\
3.804 \\
3.850 \\
3.896 \\
3.943\end{array}$ & $\begin{array}{l}3.762 \\
3.808 \\
3.854 \\
3.901 \\
3.947\end{array}$ & $\begin{array}{l}1,60 \\
1,61 \\
1,62 \\
1,63 \\
1,64\end{array}$ \\
\hline $\begin{array}{l}1,650 \\
1,660 \\
1,670 \\
1,680 \\
1,690\end{array}$ & $\begin{array}{l}3.947 \\
3.994 \\
4.041 \\
4.088 \\
4.136\end{array}$ & $\begin{array}{l}3.952 \\
3.999 \\
4.046 \\
4.093 \\
4.140\end{array}$ & $\begin{array}{l}3.957 \\
4.003 \\
4.050 \\
4.098 \\
4.145\end{array}$ & $\begin{array}{l}3.961 \\
4.008 \\
4.055 \\
4.102 \\
4.150\end{array}$ & $\begin{array}{l}3.966 \\
4.013 \\
4.060 \\
4.107 \\
4.155\end{array}$ & $\begin{array}{l}3.971 \\
4.017 \\
4.064 \\
4.112 \\
4.159\end{array}$ & $\begin{array}{l}3.975 \\
4.022 \\
4.069 \\
4.117 \\
4.164\end{array}$ & $\begin{array}{l}3.980 \\
4.027 \\
4.074 \\
4.121 \\
4.169\end{array}$ & $\begin{array}{l}3.985 \\
4.031 \\
4.079 \\
4.126 \\
4.174\end{array}$ & $\begin{array}{l}3.989 \\
4.036 \\
4.083 \\
4.131 \\
4.178\end{array}$ & $\begin{array}{l}3.994 \\
4.041 \\
4.088 \\
4.136 \\
4.183\end{array}$ & $\begin{array}{l}1,6 \\
1,6 \\
1,6 \\
1,68 \\
1,6\end{array}$ \\
\hline $\begin{array}{l}1,700 \\
1,710 \\
1,720 \\
1,730 \\
1,740\end{array}$ & $\begin{array}{l}4.183 \\
4.231 \\
4.279 \\
4.327 \\
4.376\end{array}$ & $\begin{array}{l}4 \cdot 188 \\
4 \cdot 236 \\
4 \cdot 284 \\
4 \cdot 332 \\
4 \cdot 381\end{array}$ & $\begin{array}{l}4.193 \\
4 \cdot 241 \\
4.289 \\
4.337 \\
4.386\end{array}$ & $\begin{array}{l}4.198 \\
4.245 \\
4.294 \\
4.342 \\
4.391\end{array}$ & $\begin{array}{l}4.202 \\
4.250 \\
4.298 \\
4.347 \\
4.395\end{array}$ & $\begin{array}{l}4.207 \\
4.255 \\
4.303 \\
4.352 \\
4.400\end{array}$ & $\begin{array}{l}4.212 \\
4.260 \\
4.308 \\
4.357 \\
4.405\end{array}$ & $\begin{array}{l}4.217 \\
4.265 \\
4.313 \\
4.361 \\
4.410\end{array}$ & $\begin{array}{l}4.221 \\
4.269 \\
4.318 \\
4.366 \\
4.415\end{array}$ & $\begin{array}{l}4.226 \\
4.274 \\
4.323 \\
4.371 \\
4.420\end{array}$ & $\begin{array}{l}4 \cdot 231 \\
4 \cdot 279 \\
4.327 \\
4 \cdot 376 \\
4.425\end{array}$ & $\begin{array}{l}1,7 \\
1,7 \\
1,7 \\
1,7 \\
1,7\end{array}$ \\
\hline $\begin{array}{l}1,750 \\
1,760 \\
1,770 \\
1,780 \\
1,790\end{array}$ & $\begin{array}{l}4.425 \\
4.474 \\
4.523 \\
4.572 \\
4.622\end{array}$ & $\begin{array}{l}4.430 \\
4.479 \\
4.528 \\
4.577 \\
4.627\end{array}$ & $\begin{array}{l}4.435 \\
4.484 \\
4.533 \\
4.582 \\
4.632\end{array}$ & $\begin{array}{l}4.439 \\
4.488 \\
4.538 \\
4.587 \\
4.637\end{array}$ & $\begin{array}{l}4.444 \\
4.493 \\
4.543 \\
4.592 \\
4.642\end{array}$ & $\begin{array}{l}4.449 \\
4.498 \\
4.548 \\
4.597 \\
4.647\end{array}$ & $\begin{array}{l}4.454 \\
4.503 \\
4.552 \\
4.602 \\
4.652\end{array}$ & $\begin{array}{l}4.459 \\
4.508 \\
4.557 \\
4.607 \\
4.657\end{array}$ & $\begin{array}{l}4.464 \\
4.513 \\
4.562 \\
4.612 \\
4.662\end{array}$ & $\begin{array}{l}4.469 \\
4.518 \\
4.567 \\
4.617 \\
4.667\end{array}$ & $\begin{array}{l}4.474 \\
4.523 \\
4.572 \\
4.622 \\
4.672\end{array}$ & $\begin{array}{l}1,7 \\
1,7 \\
1,7 \\
1,7 \\
1,7\end{array}$ \\
\hline 800 & 4.672 & 4.677 & 4.682 & 4.687 & 4.692 & 4.697 & 4.702 & 4.707 & $4 \cdot 712$ & 4.717 & 4.722 & 1,9 \\
\hline
\end{tabular}


TaBle A4.1.2. Type B thermocouples-thermoelectric voltage as a function of temperature $\left({ }^{\circ} \mathrm{F}\right)$, reference junctions at $32^{\circ} \mathrm{F}$-Continued
3
4

5

6

7

8

9

10

${ }^{\circ} \mathrm{F}$

THERMOELECTRIC VOLTAGE IN ABSOLUTE MILLIVOLTS

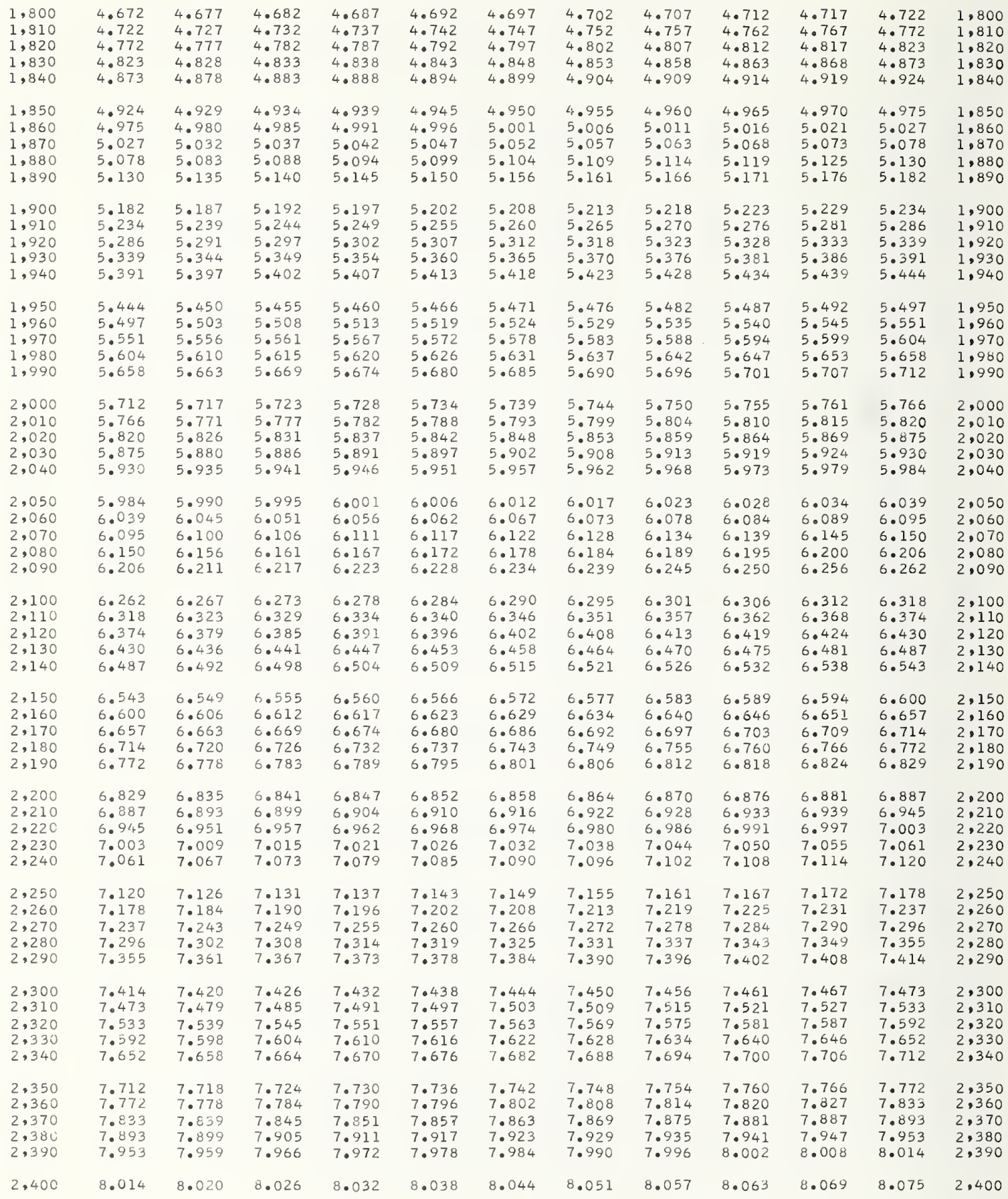


TABLE A4.1.2. Type B thermocouples-thermoelectric voltage as a function of temperature $\left({ }^{\circ} \mathrm{F}\right)$, reference junctions at $32{ }^{\circ} \mathrm{F}$-Continued

${ }^{\circ} \mathrm{F}$

2,400

2,420

2,430

2,440

2,450

2,460

2,470

2,480

2,490

2,500

2,510

2,520

2,530

2,540

2,550

2,560

2,570

2,580

2,590

2,600

2,610

2,620

2,630

2,640

2,650

2,660

2,670

2,680

2,690

2,700

2,710

2,720

2,730

2,740

2,750

2,760

2,770

2,790

2,800

2,810

2,820

2,830

2,840

2,850

2,96

2,870

2,880

2,890

2,900

2,910

2,220

2,730

2,940

2,950

2,960

2,970

2,980

2,990

3,000
1

$8.014 \quad 8.020$

8.075

8.136

8.197

8.081
8.142

8.203

$3.258 \quad 8.264$

8.319

8.381

8.326

8.442

8.504

8.566

8.628

8.690

8.752

8.814

8.939

9.002

9.065

9.128

9.191

9.254

9.317

9.380

9.443
9.507

9.570

9.634

9.697

9.761

9.825

9.889

9.953

10.017

10.081

8.387

8.449

8.510
8.572

8.634

8.696

8.758

8.821

8.883

8.946

9.008

9.071

9.134

9.260

9.323

9.386

9.450

9.577

9.640

9.704

9.768

9.831

9.895

9.959

10.023

10.145

10.152

$10.210 \quad 10.216$

$10.274 \quad 10.280$

10.338

10.403

10.467

10.532

10.596

10.661

10.726

10.790

10.855

10.920

10.985

11.050

11.115

10.345

10.409

10.474

10.538

10.603

10.668

10.732

10.797

10.862

10.926

10.991

10.933
10.998

1.06

11.17

11.244

11.309

11.374
11.439

11.186

$\begin{array}{ll}11.186 & 11.192 \\ 11.251 & 11.257\end{array}$

11.192

11.25

$\begin{array}{ll}11.381 & 11.387 \\ 11.446 & 11.452\end{array}$

11.504

11.56

11.511

11.517

$\begin{array}{lll}11.641 & 11.647\end{array}$

$11.764 \quad 11.706 \quad 11.71$

$11.829 \quad 11.836 \quad 11.842$

0

\author{
3
}

\author{
4
}

5

6

7

8

9

10

${ }^{\circ} \mathrm{F}$

THERMOELECTRIC VOLTAGE IN ABSOLUTE MILLIVOLTS

$8.026 \quad 8.032$

$8.038 \quad 8.044$

8.051

$8.057 \quad 8.063$

8.0698 .075

$8.130 \quad 8.136$

8.191

$8.160 \quad 8.166$

$8.221 \quad 8.227$

8.172

8.179

8.215

8.283

8.289

8. 295

8.240

8.246

8.252

8.197

8.258

2,400

2,410

2,420

8.338

8.344

8.350

8.356

8.362

8.467

8.412

8.418

8.479

8.424

8.369

8.375

8.381

2,440

8.461

8.529
8.591

8.473
8.535

8.535
8.597

8.541

8.486

8.603

8.609

8.554

8.436

8.560

8.442

2,450

8.58

8.653

8.659

8.665

8.671

8.616

8.622

8.504

8.566
8.628

2,460

2,470

2,480
2,490

8.709

8.771

8.715
8.777

8.721

$\begin{array}{ll}8.739 & 8.783 \\ 8.839 & 8.846\end{array}$

8.727

8.790

8.733

8.796

8.678

8.684

8.690

2,500

8.852

8.858

8.802

8.864

8.746
8.808

8.871

8.752

8.814

8.877

2,510

8.896

8.964

8. 971

8.977

8.983

9.021

9.027

9.033

9.040

9.046

8.989

9.084

9.090

9.096

9.102

9.165

9.109

9.172 
TABLE A4.1.2. Type B thermocouples-thermoelectric voltage as a function of temperature $\left({ }^{\circ} \mathrm{F}\right)$, reference junctions at $32{ }^{\circ} \mathrm{F}$-Continued

THERMOELECTRIC VOLTAGE IN ABSOLUTE MILLIVOLTS

\begin{tabular}{|c|c|c|c|c|c|c|c|c|c|c|c|c|}
\hline $\begin{array}{l}3,000 \\
3,010 \\
3,020 \\
3,030 \\
3,040\end{array}$ & $\begin{array}{l}11.829 \\
11.894 \\
11.959 \\
12.024 \\
12.089\end{array}$ & $\begin{array}{l}11.836 \\
11.901 \\
11.966 \\
12.031 \\
12.096\end{array}$ & $\begin{array}{l}11.842 \\
11.907 \\
11.972 \\
12.037 \\
12.102\end{array}$ & $\begin{array}{l}11.849 \\
11.914 \\
11.979 \\
12.044 \\
12.109\end{array}$ & $\begin{array}{l}11.855 \\
11.920 \\
11.985 \\
12.050 \\
12.115\end{array}$ & $\begin{array}{l}11.862 \\
11.927 \\
11.992 \\
12.057 \\
12.121\end{array}$ & $\begin{array}{l}11.868 \\
11.933 \\
11.998 \\
12.063 \\
12.128\end{array}$ & $\begin{array}{l}11.875 \\
11.940 \\
12.005 \\
12.070 \\
12.134\end{array}$ & $\begin{array}{l}11.881 \\
11.946 \\
12.011 \\
12.076 \\
12.141\end{array}$ & $\begin{array}{l}11.888 \\
11.953 \\
12.018 \\
12.083 \\
12.147\end{array}$ & $\begin{array}{l}11.894 \\
11.959 \\
12.024 \\
12.089 \\
12.154\end{array}$ & $\begin{array}{l}3,000 \\
3,010 \\
3,020 \\
3,030 \\
3,040\end{array}$ \\
\hline $\begin{array}{l}3,050 \\
3,060 \\
, 070 \\
3,080 \\
3,090\end{array}$ & $\begin{array}{l}12.154 \\
12.219 \\
12.284 \\
12.349 \\
12.413\end{array}$ & $\begin{array}{l}12.160 \\
12.225 \\
12.290 \\
12.355 \\
12.420\end{array}$ & $\begin{array}{l}12.167 \\
12.232 \\
12.297 \\
12.362 \\
12.426\end{array}$ & $\begin{array}{l}12.173 \\
12.238 \\
12.303 \\
12.368 \\
12.433\end{array}$ & $\begin{array}{l}12.180 \\
12.245 \\
12.310 \\
12.374 \\
12.439\end{array}$ & $\begin{array}{l}12.186 \\
12.251 \\
12.316 \\
12.381 \\
12.446\end{array}$ & $\begin{array}{l}12.193 \\
12.258 \\
12.323 \\
12.387 \\
12.452\end{array}$ & $\begin{array}{l}12.199 \\
12.264 \\
12.329 \\
12.394 \\
12.459\end{array}$ & $\begin{array}{l}12 \cdot 206 \\
12 \cdot 271 \\
12 \cdot 336 \\
12 \cdot 400 \\
12 \cdot 465\end{array}$ & $\begin{array}{l}12.212 \\
12.277 \\
12.342 \\
12.407 \\
12.472\end{array}$ & $\begin{array}{l}12.219 \\
12.284 \\
12.349 \\
12.413 \\
12.478\end{array}$ & $\begin{array}{l}3,050 \\
3,060 \\
3,070 \\
3,080 \\
3,090\end{array}$ \\
\hline $\begin{array}{l}3,100 \\
3,110 \\
3,120 \\
3,130 \\
3,140\end{array}$ & $\begin{array}{l}12.478 \\
12.543 \\
12.608 \\
12.672 \\
12.737\end{array}$ & $\begin{array}{l}12.485 \\
12.549 \\
12.614 \\
12.679 \\
12.743\end{array}$ & $\begin{array}{l}12.491 \\
12.556 \\
12.621 \\
12.685 \\
12.750\end{array}$ & $\begin{array}{l}12.498 \\
12.562 \\
12.627 \\
12.692 \\
12.756\end{array}$ & $\begin{array}{l}12.504 \\
12.569 \\
12.633 \\
12.698 \\
12.763\end{array}$ & $\begin{array}{l}12.511 \\
12.575 \\
12.640 \\
12.705 \\
12.769\end{array}$ & $\begin{array}{l}12.517 \\
12.582 \\
12.646 \\
12.711 \\
12.776\end{array}$ & $\begin{array}{l}12.523 \\
12.588 \\
12.653 \\
12.718 \\
12.782\end{array}$ & $\begin{array}{l}12.530 \\
12.595 \\
12.659 \\
12.724 \\
12.789\end{array}$ & $\begin{array}{l}12.536 \\
12.601 \\
12.666 \\
12.730 \\
12.795\end{array}$ & $\begin{array}{l}12.543 \\
12.608 \\
12.672 \\
12.737 \\
12.801\end{array}$ & $\begin{array}{l}3,100 \\
3,110 \\
3,120 \\
3,130 \\
3,140\end{array}$ \\
\hline $\begin{array}{l}3,150 \\
3,160 \\
3,170 \\
3,180 \\
3,190\end{array}$ & $\begin{array}{l}12.801 \\
12.866 \\
12.930 \\
12.995 \\
13.059\end{array}$ & $\begin{array}{l}12.808 \\
12.872 \\
12.937 \\
13.001 \\
13.066\end{array}$ & $\begin{array}{l}12.814 \\
12.879 \\
12.943 \\
13.008 \\
13.072\end{array}$ & $\begin{array}{l}12.821 \\
12.885 \\
12.950 \\
13.014 \\
13.070\end{array}$ & $\begin{array}{l}12.827 \\
12.892 \\
12.956 \\
13.021 \\
13.085\end{array}$ & $\begin{array}{l}12.834 \\
12.898 \\
12.963 \\
13.027 \\
13.091\end{array}$ & $\begin{array}{l}12.840 \\
12.905 \\
12.969 \\
13.034 \\
13.098\end{array}$ & $\begin{array}{l}12.847 \\
12.911 \\
12.976 \\
13.040 \\
13.104\end{array}$ & $\begin{array}{l}12.853 \\
12.918 \\
12.982 \\
13.046 \\
13.111\end{array}$ & $\begin{array}{l}12.860 \\
12.924 \\
12.988 \\
13.053 \\
13.117\end{array}$ & $\begin{array}{l}12.866 \\
12.930 \\
12.995 \\
13.059 \\
13.124\end{array}$ & $\begin{array}{l}3,150 \\
3,160 \\
3,170 \\
3,180 \\
3,190\end{array}$ \\
\hline $\begin{array}{l}3,200 \\
3,210 \\
3,220 \\
3,230 \\
3,240\end{array}$ & $\begin{array}{l}13.124 \\
13.188 \\
13.252 \\
13.316 \\
13.380\end{array}$ & $\begin{array}{l}13.130 \\
13.194 \\
13.258 \\
13.322 \\
13.337\end{array}$ & $\begin{array}{l}13.136 \\
13.201 \\
13.265 \\
13.329 \\
13.393\end{array}$ & $\begin{array}{l}13.143 \\
13.207 \\
13.271 \\
13.335 \\
13.399\end{array}$ & $\begin{array}{l}13.149 \\
13.213 \\
13.278 \\
13.342 \\
13.406\end{array}$ & $\begin{array}{l}13.156 \\
13.220 \\
13.284 \\
13.348 \\
13.412\end{array}$ & $\begin{array}{l}13.162 \\
13.226 \\
13.290 \\
13.354 \\
13.418\end{array}$ & $\begin{array}{l}13.169 \\
13.233 \\
13.297 \\
13.361 \\
13.425\end{array}$ & $\begin{array}{l}13.175 \\
13.239 \\
13.303 \\
13.367 \\
13.431\end{array}$ & $\begin{array}{l}13.181 \\
13.246 \\
13.310 \\
13.374 \\
13.438\end{array}$ & $\begin{array}{l}13.188 \\
13.252 \\
13.316 \\
13.380 \\
13.444\end{array}$ & $\begin{array}{l}3,200 \\
3,210 \\
3,220 \\
3,230 \\
3,240\end{array}$ \\
\hline $\begin{array}{l}3,250 \\
3,260 \\
3,270 \\
3,280 \\
3,290\end{array}$ & $\begin{array}{l}13.444 \\
13.508 \\
13.572 \\
13.635 \\
13.699\end{array}$ & $\begin{array}{l}13.450 \\
13.514 \\
13.578 \\
13.642 \\
13.706\end{array}$ & $\begin{array}{l}13.457 \\
13.521 \\
13.585 \\
13.648 \\
13.712\end{array}$ & $\begin{array}{l}13.463 \\
13.527 \\
13.591 \\
13.655 \\
13.718\end{array}$ & $\begin{array}{l}13.470 \\
13.533 \\
13.597 \\
13.661 \\
13.725\end{array}$ & $\begin{array}{l}13.476 \\
13.540 \\
13.604 \\
13.667 \\
13.731\end{array}$ & $\begin{array}{l}13.482 \\
13.546 \\
13.610 \\
13.674 \\
13.737\end{array}$ & $\begin{array}{l}13.489 \\
13.553 \\
13.616 \\
13.680 \\
13.744\end{array}$ & $\begin{array}{l}13.495 \\
13.559 \\
13.623 \\
13.686 \\
13.750\end{array}$ & $\begin{array}{l}13.502 \\
13.565 \\
13.629 \\
13.693 \\
13.756\end{array}$ & $\begin{array}{l}13.508 \\
13.572 \\
13.635 \\
13.699 \\
13.763\end{array}$ & $\begin{array}{l}3,250 \\
3,260 \\
3,270 \\
3,280 \\
3,290\end{array}$ \\
\hline 3,300 & 13.763 & 13.769 & 13.775 & 3.782 & 13.788 & 13.794 & 13.801 & 13.807 & 13.814 & & & 3,30 \\
\hline & & 1 & 2 & 3 & 4 & 5 & 6 & 1 & 8 & $y$ & 10 & \\
\hline
\end{tabular}


TABLE A4.1.3. Type $\boldsymbol{B}$ thermocouples-quadratic, cubic, and quartic approximations to the data as a function of temperature $\left({ }^{\circ} \mathrm{C}\right)$ in selected temperature ranges. The expansion is of the form $\mathrm{E}=\mathrm{a}_{0}+\mathrm{a}_{1} \mathrm{~T}+\mathrm{a}_{2} \mathrm{~T}^{2}+\mathrm{a}_{3} \mathrm{~T}^{3}+\mathrm{a}_{4} \mathrm{~T}^{4}$ where $\mathrm{E}$ is in microvolts and $\mathrm{T}$ is in degrees Celsius

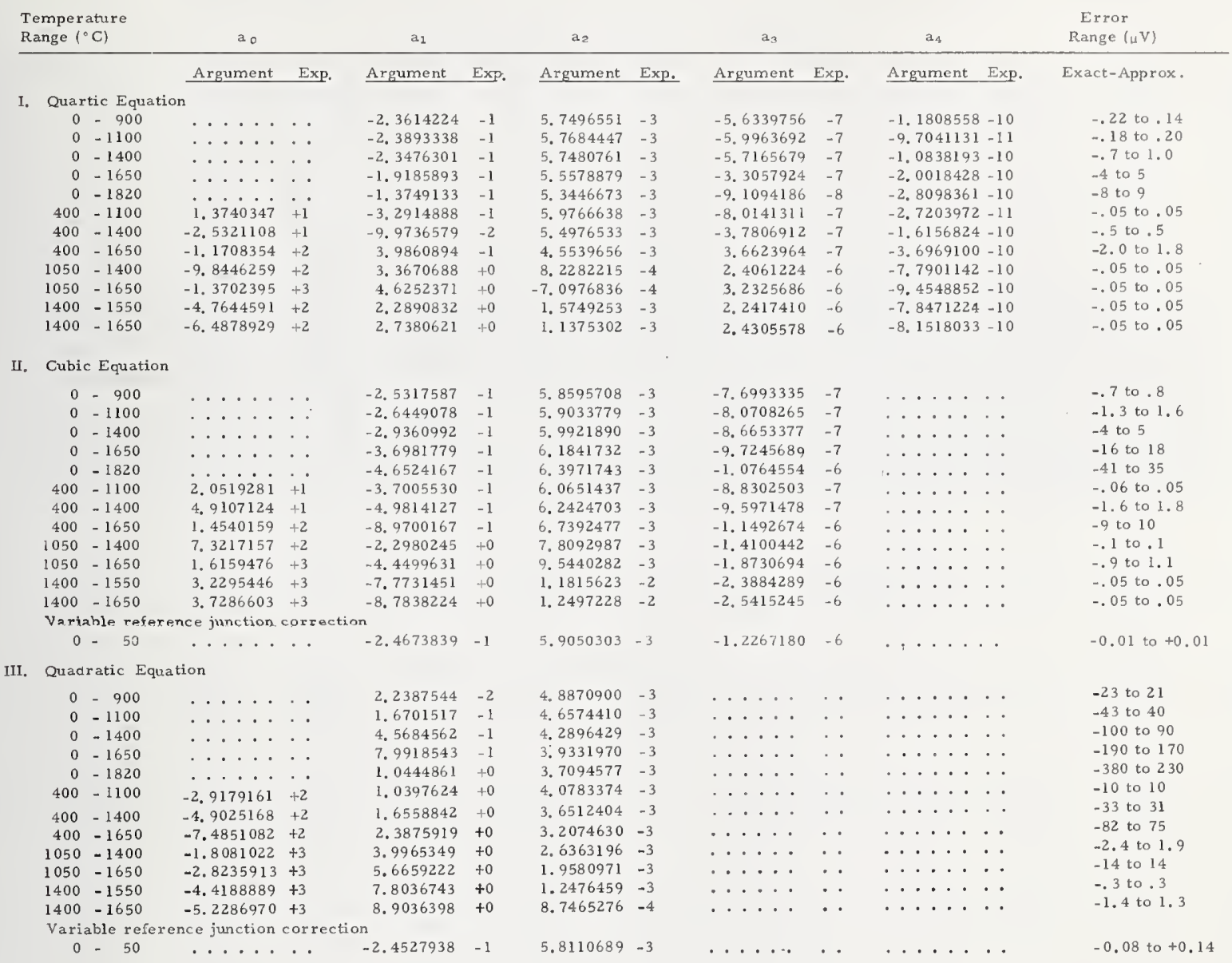




\section{A4.2. Data for Temperature as a Function of Voltage}

The temperature as a function of voltage data given in tables A4.2.1 and A4.2.2 were obtained by iteration in the primary equations for voltage as a function of temperature. Table A4.2.1 presents the data in millivolts from $0.0 \mathrm{mV}$ to $13.81 \mathrm{mV}$ with temperatures given in degrees Celsius while table A4.2.2 presents similar data with temperatures in degrees Fahrenheit. Table A4.2.3 contains quadratic, cubic, and quartic approximations to the data as a function of voltage in selected temperature ranges. The error range given in the table represents the difference between the temperature found by iteration in the full precision tables from the text and from the respective reduced order approximations. 
TABLE A4.2.1. Type $\boldsymbol{B}$ thermocouples-temperature $\left({ }^{\circ} \mathrm{C}\right)$ as a function of thermoelectric voltage, reference junctions at $0^{\circ} \mathrm{C}$

$m V$

.00

.01

.02

.03

.04

.05

.06

.07

TEMPERATURES IN DEGREES C (IPTS 1968)

$1124 \cdot 70$

125.71

1126.72

$1127.72 \quad 1128.73$

$\begin{array}{ll}1109.50 & 1110.52 \\ 1119.65 & 1120.66\end{array}$

$854 \cdot 26$

866.60

878.79

890.86
902.79

914.60

926.30
937.88

449.35

960.71

\subsection{8}

994.21

994.21
1005.19

1026.88

1037.60

1048.24 
TABLE A4.2.1. Type B thermocouples-temperature $\left({ }^{\circ} \mathrm{C}\right)$ as a function of thermoelectric voltage, reference junctions at $0^{\circ} \mathrm{C}$-Continued

TEMPERATURES IN DEGREES C (IPTS 1968)

\begin{tabular}{|c|c|c|c|c|c|c|c|c|c|c|c|c|}
\hline $\begin{array}{l}6.00 \\
6.10 \\
6.20 \\
6.30 \\
6.40\end{array}$ & $\begin{array}{l}1122.68 \\
1132.75 \\
1142.76 \\
1152.70 \\
1162.59\end{array}$ & $\begin{array}{l}1123.69 \\
1133.75 \\
1143.75 \\
1153.69 \\
1163.58\end{array}$ & $\begin{array}{l}1124.70 \\
1134.76 \\
1144.75 \\
1154.69 \\
1164.56\end{array}$ & $\begin{array}{l}1125.71 \\
1135.76 \\
1145.75 \\
1155.68 \\
1165.55\end{array}$ & $\begin{array}{l}1126.72 \\
1136.76 \\
1146.74 \\
1156.67 \\
1166.53\end{array}$ & $\begin{array}{l}1127.72 \\
1137.76 \\
1147.74 \\
1157.65 \\
1167.52\end{array}$ & $\begin{array}{l}1128.73 \\
1138.76 \\
1148.73 \\
1158.64 \\
1168.50\end{array}$ & $\begin{array}{l}1129.74 \\
1139.76 \\
1149.72 \\
1159.63 \\
1169.48\end{array}$ & $\begin{array}{l}1130.74 \\
1140.76 \\
1150.72 \\
1160.62 \\
1170.46\end{array}$ & $\begin{array}{l}1131.75 \\
1141.76 \\
1151.71 \\
1161.61 \\
1171.45\end{array}$ & $\begin{array}{l}1132.75 \\
1142.76 \\
1152.70 \\
1162.59 \\
1172.43\end{array}$ & $\begin{array}{l}6.00 \\
6.10 \\
6.20 \\
6.30 \\
6.40\end{array}$ \\
\hline $\begin{array}{l}6.50 \\
6.60 \\
6.70 \\
6.80 \\
6.90\end{array}$ & $\begin{array}{l}1172 \cdot 43 \\
1182 \cdot 21 \\
1191.93 \\
1201.61 \\
1211 \cdot 24\end{array}$ & $\begin{array}{l}1173.41 \\
1183.18 \\
1192.90 \\
1202.58 \\
1212.20\end{array}$ & $\begin{array}{l}1174 \cdot 39 \\
1184 \cdot 16 \\
1193 \cdot 87 \\
1203 \cdot 54 \\
1213 \cdot 16\end{array}$ & $\begin{array}{l}175.37 \\
185.13 \\
194.84 \\
204.51 \\
214.12\end{array}$ & $\begin{array}{l}1176.35 \\
1186.10 \\
1195.81 \\
1205.47 \\
1215.08\end{array}$ & $\begin{array}{l}1177.32 \\
1187.08 \\
1196.78 \\
1206.43 \\
1216.03\end{array}$ & $\begin{array}{l}1178.30 \\
1188.05 \\
1197.75 \\
1207.39 \\
1216.99\end{array}$ & $\begin{array}{l}1179.28 \\
1189.02 \\
1198.71 \\
1208.36 \\
1217.95\end{array}$ & $\begin{array}{l}1180.26 \\
1189.99 \\
1199.68 \\
1209.32 \\
1218.91\end{array}$ & $\begin{array}{l}1181.23 \\
1190.96 \\
1200.65 \\
1210.28 \\
1219.86\end{array}$ & $\begin{array}{l}1182 \cdot 21 \\
1191.93 \\
1201.61 \\
1211.24 \\
1220.82\end{array}$ & $\begin{array}{l}6.50 \\
6.60 \\
6.70 \\
6.80 \\
6.90\end{array}$ \\
\hline $\begin{array}{l}7.00 \\
7.10 \\
7.20 \\
7.30 \\
7.40\end{array}$ & $\begin{array}{l}1220.82 \\
1230.35 \\
1239.84 \\
1249.28 \\
1258.68\end{array}$ & $\begin{array}{l}1221.77 \\
1231.30 \\
1240.79 \\
1250.23 \\
1259.62\end{array}$ & $\begin{array}{l}1222.73 \\
1232.25 \\
1241.73 \\
1251.17 \\
1260.56\end{array}$ & $\begin{array}{l}1223.68 \\
1233.20 \\
1242.68 \\
1252.11 \\
1261.50\end{array}$ & $\begin{array}{l}1224.64 \\
1234.15 \\
1243.62 \\
1253.05 \\
1262.43\end{array}$ & $\begin{array}{l}1225.59 \\
1235.10 \\
1244.57 \\
1253.99 \\
1263.37\end{array}$ & $\begin{array}{l}1226 \cdot 54 \\
1236.05 \\
1245.51 \\
1254.93 \\
1264.31\end{array}$ & $\begin{array}{l}1227.50 \\
1237.00 \\
1246.45 \\
1255.87 \\
1265.24\end{array}$ & $\begin{array}{l}1228.45 \\
1237.95 \\
1247.40 \\
1256.81 \\
1266.18\end{array}$ & $\begin{array}{l}1229.40 \\
1238.89 \\
1248.34 \\
1257.75 \\
1267.11\end{array}$ & $\begin{array}{l}1230.35 \\
1239.84 \\
1249.28 \\
1258.68 \\
1268.04\end{array}$ & $\begin{array}{l}7.00 \\
7.10 \\
7.20 \\
7.30 \\
7.40\end{array}$ \\
\hline $\begin{array}{l}7.50 \\
7.60 \\
7.70 \\
7.80 \\
7.90\end{array}$ & $\begin{array}{l}1268.04 \\
1277.36 \\
1286.65 \\
1295.89 \\
1305.09\end{array}$ & $\begin{array}{l}1268.98 \\
1278.29 \\
1287.57 \\
1296.81 \\
1306.01\end{array}$ & $\begin{array}{l}1269.91 \\
1279.22 \\
1288.50 \\
1297.73 \\
1306.93\end{array}$ & $\begin{array}{l}1270.84 \\
1280.15 \\
1289.42 \\
1298.65 \\
1307.85\end{array}$ & $\begin{array}{l}1271.78 \\
1281.08 \\
1290.35 \\
1299.58 \\
1308.77\end{array}$ & $\begin{array}{l}1272.71 \\
1282.01 \\
1291.27 \\
1300.50 \\
1309.68\end{array}$ & $\begin{array}{l}1273.64 \\
1282.94 \\
1292.20 \\
1301.42 \\
1310.60\end{array}$ & $\begin{array}{l}1274.57 \\
1283.86 \\
1293.12 \\
1302.34 \\
1311.52\end{array}$ & $\begin{array}{l}1275.50 \\
1284.79 \\
1294.04 \\
1303.26 \\
1312.43\end{array}$ & $\begin{array}{l}1276.43 \\
1285 \cdot 72 \\
1294 \cdot 97 \\
1304 \cdot 18 \\
1313.35\end{array}$ & $\begin{array}{l}1277.36 \\
1286.65 \\
1295.89 \\
1305.09 \\
1314.27\end{array}$ & $\begin{array}{l}7.50 \\
7.60 \\
7.70 \\
7.80 \\
7.90\end{array}$ \\
\hline $\begin{array}{l}8.00 \\
8.10 \\
8.20 \\
8.30 \\
8.40\end{array}$ & $\begin{array}{l}1314.27 \\
1323.40 \\
1332.51 \\
1341.58 \\
1350.62\end{array}$ & $\begin{array}{l}1315.18 \\
1324.31 \\
1333.41 \\
1342.48 \\
1351.52\end{array}$ & $\begin{array}{l}1316 \cdot 10 \\
1325 \cdot 23 \\
1334 \cdot 32 \\
1343 \cdot 39 \\
1352 \cdot 42\end{array}$ & $\begin{array}{l}1317.01 \\
1326.14 \\
1335.23 \\
1344.29 \\
1353.32\end{array}$ & $\begin{array}{l}1317.92 \\
1327.05 \\
1336.14 \\
1345.20 \\
1354.23\end{array}$ & $\begin{array}{l}1318.84 \\
1327.96 \\
1337.05 \\
1346.10 \\
1355.13\end{array}$ & $\begin{array}{l}1319.75 \\
1328.87 \\
1337.95 \\
1347.01 \\
1356.03\end{array}$ & $\begin{array}{l}1320.67 \\
1329.78 \\
1338.86 \\
1347.91 \\
1356.93\end{array}$ & $\begin{array}{l}1321.58 \\
1330.64 \\
1339.77 \\
1348.81 \\
1357.83\end{array}$ & $\begin{array}{l}1322.49 \\
1331.60 \\
1340.67 \\
1349.72 \\
1358.73\end{array}$ & $\begin{array}{l}1323.40 \\
1332.51 \\
1341.58 \\
1350.62 \\
1359.63\end{array}$ & $\begin{array}{l}8.00 \\
8.10 \\
8.20 \\
8.30 \\
8.40\end{array}$ \\
\hline $\begin{array}{l}8.50 \\
8.60 \\
8.70 \\
8.80 \\
8.90\end{array}$ & $\begin{array}{l}1359.63 \\
1368.61 \\
1377.56 \\
1386.49 \\
1395.39\end{array}$ & $\begin{array}{l}1360.53 \\
1369.51 \\
1378.46 \\
1387.38 \\
1396.28\end{array}$ & $\begin{array}{l}1361.43 \\
1370.40 \\
1379.35 \\
1388.27 \\
1397.17\end{array}$ & $\begin{array}{l}1362.33 \\
1371.30 \\
1380.24 \\
1389.16 \\
1398.06\end{array}$ & $\begin{array}{l}1363 \cdot 22 \\
1372.19 \\
1381.14 \\
1390.05 \\
1398.94\end{array}$ & $\begin{array}{l}1364.12 \\
1373.09 \\
1382.03 \\
1390.94 \\
1399.83\end{array}$ & $\begin{array}{l}1365.02 \\
1373.99 \\
1382.92 \\
1391.83 \\
1400.72\end{array}$ & $\begin{array}{l}1365.92 \\
1374.88 \\
1383.81 \\
1392.72 \\
1401.61\end{array}$ & $\begin{array}{l}1366.82 \\
1375.77 \\
1384.71 \\
1393.61 \\
1402.49\end{array}$ & $\begin{array}{l}1367.71 \\
1376.67 \\
1385.60 \\
1394.50 \\
1403.38\end{array}$ & $\begin{array}{l}1368.61 \\
1377.56 \\
1386.49 \\
1395.39 \\
1404.27\end{array}$ & $\begin{array}{l}8.50 \\
8.60 \\
8.70 \\
8.80 \\
8.90\end{array}$ \\
\hline $\begin{array}{l}9.00 \\
9.10 \\
9.20 \\
9.30 \\
9.40\end{array}$ & $\begin{array}{l}1404.27 \\
1413.12 \\
1421.95 \\
1430.75 \\
1439.54\end{array}$ & $\begin{array}{l}1405.15 \\
1414.00 \\
1422.83 \\
1431.63 \\
1440.41\end{array}$ & $\begin{array}{l}1406.04 \\
1414.88 \\
1423.71 \\
1432.51 \\
1441.29\end{array}$ & $\begin{array}{l}1406.92 \\
1415.77 \\
1424.59 \\
1433.39 \\
1442.17\end{array}$ & $\begin{array}{l}1407.81 \\
1416.65 \\
1425.47 \\
1434.27 \\
1443.04\end{array}$ & $\begin{array}{l}1408.69 \\
1417.53 \\
1426.35 \\
1435.15 \\
1443.92\end{array}$ & $\begin{array}{l}1409.58 \\
1418.42 \\
1427.23 \\
1436.02 \\
1444.80\end{array}$ & $\begin{array}{l}1410.46 \\
1419.30 \\
1428.11 \\
1436.90 \\
1445.67\end{array}$ & $\begin{array}{l}1411.35 \\
1420.18 \\
1428.99 \\
1437.78 \\
1446.55\end{array}$ & $\begin{array}{l}1412.23 \\
1421.06 \\
1429.87 \\
1438.66 \\
1447.43\end{array}$ & $\begin{array}{l}1413 \cdot 12 \\
1421 \cdot 95 \\
1430 \cdot 75 \\
1439.54 \\
1448 \cdot 30\end{array}$ & $\begin{array}{l}9.00 \\
9.10 \\
9.20 \\
9.30 \\
9.40\end{array}$ \\
\hline $\begin{array}{l}9.50 \\
9.60 \\
9.70 \\
9.80 \\
9.90\end{array}$ & $\begin{array}{l}1448.30 \\
1457.05 \\
1465.77 \\
1474.48 \\
1483.18\end{array}$ & $\begin{array}{l}1449.18 \\
1457.92 \\
1466.65 \\
1475.35 \\
1484.05\end{array}$ & $\begin{array}{l}1450.05 \\
1458 \cdot 79 \\
1467.52 \\
1476.22 \\
1484.91\end{array}$ & $\begin{array}{l}1450.93 \\
1459.67 \\
1468.39 \\
1477.09 \\
1485.78\end{array}$ & $\begin{array}{l}1451.80 \\
1460.54 \\
1469.26 \\
1477.96 \\
1486.65\end{array}$ & $\begin{array}{l}1452.68 \\
1461.41 \\
1470.13 \\
1478.83 \\
1487.52\end{array}$ & $\begin{array}{l}1453.55 \\
1462.29 \\
1471.00 \\
1479.70 \\
1488.38\end{array}$ & $\begin{array}{l}1454.43 \\
1463.16 \\
1471.87 \\
1480.57 \\
1489.25\end{array}$ & $\begin{array}{l}1455 \cdot 30 \\
1464 \cdot 03 \\
1472 \cdot 74 \\
1481 \cdot 44 \\
1490 \cdot 12\end{array}$ & $\begin{array}{l}1456.17 \\
1464.90 \\
1473.61 \\
1482.31 \\
1490.99\end{array}$ & $\begin{array}{l}1457.05 \\
1465.77 \\
1474.48 \\
1483.18 \\
1491.85\end{array}$ & $\begin{array}{l}9.50 \\
9.60 \\
9.70 \\
9.80 \\
9.90\end{array}$ \\
\hline $\begin{array}{l}10.00 \\
10.10 \\
10.20 \\
10.30 \\
10.40\end{array}$ & $\begin{array}{l}1491.85 \\
1500.52 \\
1509.17 \\
1517.80 \\
1526.43\end{array}$ & $\begin{array}{l}1492.72 \\
1501.38 \\
1510.03 \\
1518.66 \\
1527.29\end{array}$ & $\begin{array}{l}1493.59 \\
1502.25 \\
1510.89 \\
1519.53 \\
1528.15\end{array}$ & $\begin{array}{l}1494.45 \\
1503.11 \\
1511.76 \\
1520.39 \\
1529.01\end{array}$ & $\begin{array}{l}1495.32 \\
1503.98 \\
1512.62 \\
1521.25 \\
1529.87\end{array}$ & $\begin{array}{l}1496.19 \\
1504.84 \\
1513.49 \\
1522.12 \\
1530.73\end{array}$ & $\begin{array}{l}1497.05 \\
1505.71 \\
1514.35 \\
1522.98 \\
1531.59\end{array}$ & $\begin{array}{l}1497 \cdot 92 \\
1506.57 \\
1515.21 \\
1523.84 \\
1532.46\end{array}$ & $\begin{array}{l}1498.79 \\
1507.44 \\
1516.08 \\
1524.70 \\
1533.32\end{array}$ & $\begin{array}{l}1499 \cdot 65 \\
1508 \cdot 30 \\
1516.94 \\
1525.56 \\
1534.18\end{array}$ & $\begin{array}{l}1500.52 \\
1509.17 \\
1517.80 \\
1526.43 \\
1535.04\end{array}$ & $\begin{array}{l}10.00 \\
10.10 \\
10.20 \\
10.30 \\
10.40\end{array}$ \\
\hline $\begin{array}{l}10.50 \\
10.60 \\
10.70 \\
10.80 \\
10.90\end{array}$ & $\begin{array}{l}1535.04 \\
1543.64 \\
1552.23 \\
1560.82 \\
1569.40\end{array}$ & $\begin{array}{l}1535.90 \\
1544.50 \\
1553.09 \\
1561.68 \\
1570.25\end{array}$ & $\begin{array}{l}1536 \cdot 76 \\
1545 \cdot 36 \\
1553 \cdot 95 \\
1562 \cdot 53 \\
1571 \cdot 11\end{array}$ & $\begin{array}{l}1537.62 \\
1546.22 \\
1554.81 \\
1563.39 \\
1571.97\end{array}$ & $\begin{array}{l}1538.48 \\
1547.08 \\
1555.67 \\
1564.25 \\
1572.82\end{array}$ & $\begin{array}{l}1539.34 \\
1547.94 \\
1556.53 \\
1565.11 \\
1573.68\end{array}$ & $\begin{array}{l}1540.20 \\
1548.80 \\
1557.39 \\
1565.97 \\
1574.54\end{array}$ & $\begin{array}{l}1541.06 \\
1549.66 \\
1558.24 \\
1566.82 \\
1575.40\end{array}$ & $\begin{array}{l}1541.92 \\
1550.52 \\
1559.10 \\
1567.68 \\
1576.25\end{array}$ & $\begin{array}{l}1542.78 \\
1551.38 \\
1559.96 \\
1568.54 \\
1577.11\end{array}$ & $\begin{array}{l}1543.64 \\
1552.23 \\
1560.82 \\
1569.40 \\
1577.97\end{array}$ & $\begin{array}{l}10.50 \\
10.60 \\
10.70 \\
10.80 \\
10.90\end{array}$ \\
\hline $\begin{array}{l}11.00 \\
11.10 \\
11.20 \\
11.30 \\
11.40\end{array}$ & $\begin{array}{l}1577.97 \\
1586.53 \\
1595.09 \\
1603.65 \\
1612.20\end{array}$ & $\begin{array}{l}1578.82 \\
1587.39 \\
1595.95 \\
1604.50 \\
1613.05\end{array}$ & $\begin{array}{l}1579.68 \\
1588.24 \\
1596.80 \\
1605.36 \\
1613.91\end{array}$ & $\begin{array}{l}1580.54 \\
1589.10 \\
1597.66 \\
1606.21 \\
1614.76\end{array}$ & $\begin{array}{l}1581.39 \\
1589.95 \\
1598.51 \\
1607.07 \\
1615.62\end{array}$ & $\begin{array}{l}1582.25 \\
1590.81 \\
1599.37 \\
1607.92 \\
1616.47\end{array}$ & $\begin{array}{l}1583.11 \\
1591.67 \\
1600.22 \\
1608.78 \\
1617.33\end{array}$ & $\begin{array}{l}1583.96 \\
1592.52 \\
1601.08 \\
1609.63 \\
1618.18\end{array}$ & $\begin{array}{l}1584.82 \\
1593.38 \\
1601.93 \\
1610.49 \\
1619.04\end{array}$ & $\begin{array}{l}1585.67 \\
1594.23 \\
1602.79 \\
1611.34 \\
1619.89\end{array}$ & $\begin{array}{l}1586.53 \\
1595.09 \\
1603.65 \\
1612.20 \\
1620.75\end{array}$ & $\begin{array}{l}11 \cdot 00 \\
11 \cdot 10 \\
11 \cdot 20 \\
11 \cdot 30 \\
11 \cdot 40\end{array}$ \\
\hline $\begin{array}{l}11.50 \\
11.60 \\
11.70 \\
11.80 \\
11.90\end{array}$ & $\begin{array}{l}1620.75 \\
1629.30 \\
1637.84 \\
1646.39 \\
1654.94\end{array}$ & $\begin{array}{l}1621.60 \\
1630.15 \\
1638.70 \\
1647.25 \\
1655.80\end{array}$ & $\begin{array}{l}1622.46 \\
1631.01 \\
1639.55 \\
1648.10 \\
1656.65\end{array}$ & $\begin{array}{l}1623.31 \\
1631.86 \\
1640.41 \\
1648.96 \\
1657.51\end{array}$ & $\begin{array}{l}1624 \cdot 17 \\
1632.72 \\
1641.26 \\
1649.81 \\
1658.36\end{array}$ & $\begin{array}{l}1625.02 \\
1633.57 \\
1642.12 \\
1650.67 \\
1659.22\end{array}$ & $\begin{array}{l}1625.88 \\
1634.43 \\
1642.97 \\
1651.52 \\
1660.07\end{array}$ & $\begin{array}{l}1626.73 \\
1635 \cdot 28 \\
1643.83 \\
1652.38 \\
1660.93\end{array}$ & $\begin{array}{l}1627.59 \\
1636.13 \\
1644.68 \\
1653.23 \\
1661.78\end{array}$ & $\begin{array}{l}1628.44 \\
1636.99 \\
1645.54 \\
1654.09 \\
1662.64\end{array}$ & $\begin{array}{l}1629.30 \\
1637.84 \\
1646.39 \\
1654.94 \\
1663.49\end{array}$ & $\begin{array}{l}11.50 \\
11.60 \\
11.70 \\
11.80 \\
11.90\end{array}$ \\
\hline$=.00$ & 1663.49 & 1664.35 & 1665.21 & 1666.06 & 1666.92 & 1667.77 & 1668.63 & 1669.48 & 1670.34 & 1671.19 & 1672.05 & $12 \cdot 0$ \\
\hline
\end{tabular}

$m V$

$.00 \quad .01$

.02

.03

.04

$.05 \quad .06$

.07

.08

$.09 \quad .10$

$m V$ 
TABLE A4.2.1. Type B thermocouples-temperature $\left({ }^{\circ} \mathrm{C}\right)$ as a function of thermoelectric voltage, reference junctions at $0^{\circ} \mathrm{C}$-Continued

$m v$

.00

.01

.02

.03

.04

.05

.06

.07

.08

.09

.10

$m \mathrm{~V}$

TEMPERATURES IN DEGREES C (IPTS 1968)

$\begin{array}{lll}12.00 & 1663.49 & 1664.35 \\ 12.10 & 1672.05 & 1672.91 \\ 12.20 & 1680.61 & 1681.46 \\ 12.30 & 1689.17 & 1690.03 \\ 12.40 & 1697.74 & 1698.60 \\ 12.50 & 1706.32 & 1707.18 \\ 12.60 & 1714.90 & 1715.76 \\ 12.70 & 1723.49 & 1724.35 \\ 12.80 & 1732.10 & 1732.96 \\ 12.90 & 1740.71 & 1741.57 \\ 13.00 & 1749.33 & 1750.19 \\ 13.10 & 1757.96 & 1758.83 \\ 13.20 & 1766.61 & 1767.48 \\ 13.30 & 1775.27 & 1776.14 \\ 13.40 & 1783.95 & 1784.82 \\ 13.50 & 1792.64 & 1793.51 \\ 13.60 & 1801.35 & 1802.22 \\ 13.70 & 1810.07 & 1810.95 \\ 13.80 & 1818.82 & 1819.69\end{array}$

1665.21
1673.76
1682.32
1690.89
1699.46
1708.03
1716.62
1725.21
1733.82
1742.43
1751.06
1759.69
1768.34
1777.01
1785.69
1794.38
1803.09
1811.82

$1666.06 \quad 1666.92$

1667.77

1674.62

1691.74

1675.47

$1700 \cdot 31$

1692.60

1684.89

1668.63

1669.48

1677.18

1685.75

1708.89

1.17

$1702.03 \quad 1702.89$

1678.04

686.60

$\begin{array}{lll}1717.48 & 1709.75 & 1710.61\end{array}$

1711.47

1703.74

1670.34

1678.90

1687.46

1696.03

1671.19

1672.05

1679.751680 .61

$1688.32 \quad 1689.17$

1697.74

1697.74
1706.32

1712.33

1713.18

1726.07

$1718.34 \quad 1719.20$

1720.06

$1713 \cdot 18$
1721.77

$1705 \cdot 40$

$1714 \cdot 90$

1734.68

$1735.54 \quad 1736.40 \quad 1737.26$

$1729.51 \quad 1730.37$

1714.04

1736.40

$174.26 \quad 1738.12$

1738.98

1731.23

$1743.29 \quad 1744.15$

1746.74

1747.60

1739.85

1723.49

.1732 .10

1740.71

1751.92

1752.78

1753.65

1754.51

1755.37

$1756 \cdot 24$

1757.10

1749.33

1769.21

$1761.42 \quad 1762.29$

1763.15

1764.021764 .88

1777.87

1770.08

1770.94

1771.81

1772.67

1773.54

1786.56

1787.42

1788.29

1780.48

1781.3

1782.21

1765.75

1757.96

1775.27

$1783.08 \quad 1783.95$

1783.95
1792.64

$1795 \cdot 25$

$\begin{array}{lll}1796.12 \quad 1796.99 & 1797.86\end{array}$

$\begin{array}{llll}1803.97 & 1804.84 & 1805.71 & 1606.58\end{array}$

1798.74

1790.90

1791.77

1799.61

1801.35

$\begin{array}{llll}1807.46 & 1808.33 & 1809.20 & 1810.07\end{array}$

$\begin{array}{llll}1813.57 & 1814.44 & 1815.32 & 1816.19\end{array}$

1817.07

1817.94

1818.82

$\mathrm{mV}$

.00

.01

.02

.03

.04

.05

.06

.07

.08

.09

.10

$\mathrm{mV}$ 
TABLE A4.2.2. Type B thermocouples-temperature $\left({ }^{\circ} F\right)$ as a function of thermoelectric voltage, reference junctions at $32^{\circ} \mathrm{F}$

$m V$

.0

.01

.02

.03

TEMPERATURES IN DEGREES F

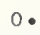

$0 \cdot 10$

$0 \cdot 10$

0.30

0.40

0.50

0.60

0.70

0.80

0.90

1.00

1.10

1.20

1.30
1.40

1.50

1.60

1.70

1.80

2.00

2.1

2.20

2.30

2.40

2.50

2.60

$2.70 \quad 1361.46$

$2.80 \quad 1386.46$

$2.90 \quad 1411.07$

$3.00 \quad 1435.32$

$3.10 \quad 1459.22$

3. $20 \quad 1482.80$

$3.30 \quad 1506.06$

$3.40 \quad 1529.03$

3.50

$3.60 \quad 1574.13$

$3.70 \quad 1596.20$

$3.80 \quad 1618.19$

$3.90 \quad 1639.86$

$4.00 \quad 1661.30-1663.43$

4.10 1682.51

$4.20 \quad 1703.52$

$4.30 \quad 1724.33$

$4.40 \quad 1744.93$

4.50 1765.35

$4.60 \quad 1785.59$

$4.70 \quad 1805.65$

$4.80 \quad 1825.54$

100

5.10

$5.30 \quad 1922.64$

$5.40 \quad 1941.63$

5.50

5.60

5.70

5.80
5.90

6.00
1551.72

1845.27

1864.84

1884.25

1903.52

153.93

323.35

419.60

495.21

617.03

669.16

717.35

762.41

804.90

$845 \cdot 25$

883.76

920.68

956.21

990.50

1023.70

1055.89

1087.19

1117.67

1176.42

1204.82

1232.61

1259.86

1286.58

1312.83
1338.62

1363.98

1388.93

1413.51

1437.72

1461.59

$1485 \cdot 14$

1531.31

1553.97

1576.36

1598.49

1620.37

1663.43

1684.62

1726.40

1746.98

1767.39

1787.60

1807.65

1827.52
1847.23

1866.79

1886.19

1905.44

$1960.48 \quad 1962.35$

$1979.19 \quad 1981.06$

$1997.78 \quad 1999.64$

$2016.25 \quad 2018.09$

2034.60

2052.83
$1924 \cdot 55$

$182 \cdot 64$

334.50

427.85

502.08

565.74

622.45

$674 \cdot 14$

721.99

766.77

809.03

$849 \cdot 18$

837.52

924.29

959.69

993.87

1026.96

1059.06

1090.27

1120.67

1150.33

1179.29

1207.62

1235.36

1262.55

1289.23

$1315 \cdot 43$

1341.17

1391.41

1415.95

1440.13

1463.96

1487.48

1510.68

1533.59

1556.22

1578.58

1600.68

1622.54

$1644 \cdot 16$

1665.56

1686.73

1707.70

1728.46

1769.42

1789.62

1809.64

1829.50

1849.20

1868.73

1888.12

1907.36

$1926 \cdot 45$

1964.23

1982.92

2001.49

2019.93

2038.25

mV

.00

.01

.02

\begin{abstract}
.05
\end{abstract}
355.53

443.82

515.50

577.56

627.83

679.09
726.59

771.10

813.13

853.09

891.26

963.16

997.23

1030.21

1062.22

1123.67

1182.15

1210.42

1238.10

1265.24

1291.87

1318.02

1369.00

393.88

1442.52

466.33

1512.99

1535.87

1558.47 1580.80
1602.88 1624.7

1646.31

1667.68

1688.84

1730.53

1751.08

1771.44
1791.63

$1851.16 \quad 1853.12$

$1870.68 \quad 1872.62$

$1890.05 \quad 1891.98$

$1909.27 \quad 1911.19$

$1928.35 \quad 1930.25$

1949.18

$1966.10 \quad 1967.98$

1986.64

$2021.77 \quad 2023.60$

$2040.08 \quad 2041.91$

$2058 \cdot 28$

$\begin{array}{ll}242.46 & 258.30 \\ 365.50 & 375.16 \\ 451.57 & 459.17 \\ 522.07 & 528.55 \\ 583.38 & 589.13 \\ & \\ 638.42 & 643.65 \\ 688.86 & 693.69 \\ 735.71 & 740.23 \\ 779.69 & 783.95 \\ 821.28 & 825.32\end{array}$

$860.86 \quad 864.71$

898.71

935.05

970.07

1003.91

902.40

938.61

973.50

1007.23

1036.691039 .91

1068.521071 .65

$1099.48 \quad 1102.53$

$1129.64 \quad 1132.62$

$1159.09 \quad 1161.99$

$1187.86 \quad 1190.70$

$1216.00 \quad 1218.79$

$1243.57 \quad 1246.30$

1270.611273 .28

1297.14

1323.20

1348.81

1374.01

1423.24

1447.31

1471.05

1494.47

1517.58

1540.41

$1562 \cdot 96$

1585.24

1607.27

1629.05

1650.60

1671.93

1693.04

1713.95

1734.65

1775.49

1795.64

1815.62

1835.43
1855.07

$1893.91 \quad 1895.83$

1913.10

1932.15

1969.85

1988.50

2007.03 
TABLE A4.2.2. Type $B$ thermocouples-temperature $\left({ }^{\circ} \mathrm{F}\right)$ as a function of thermoelectric voltage, reference junctions at $32^{\circ} \mathrm{F}$-Continued

.04

.05

.06

.07

.08

.09

.10

TEMPERATURES IN DEGREES F

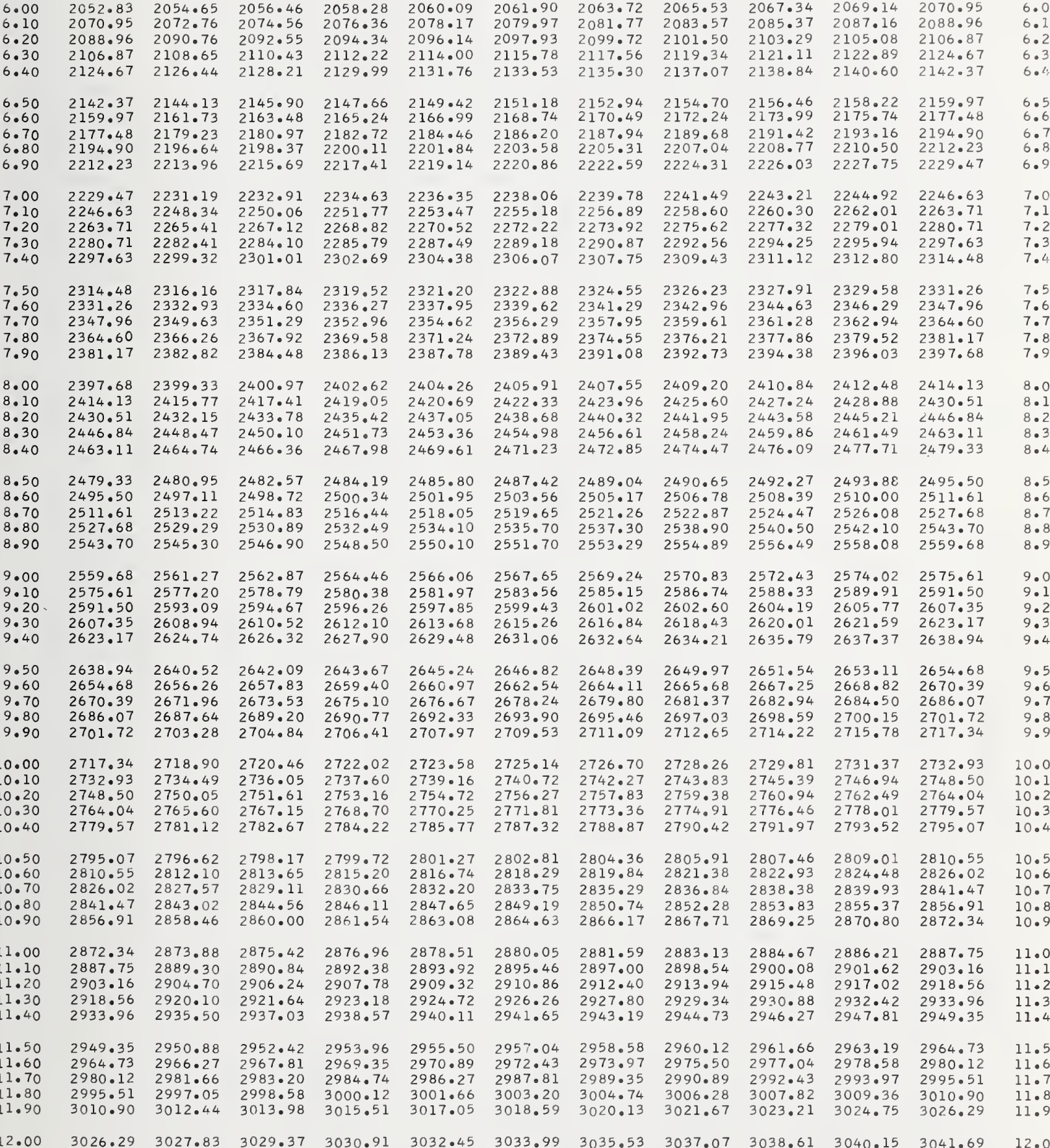

6.00

20

6.20

6.40

6.50

6.60

6.90

7.00

20

7.30

7.50

7.60

7.80

8.00

.40

8.50

8.70

8.83

8.90

9.00

20

9.30

9.40

9.50

9.60

9.70
9.80

.90

0.00

$10 \cdot 10$

0.30

10.40

10.50

0.60

10.80

10.90

1.00

1.10

1.30

11.40

11.50

1.60

1.80

11.90

12.00 
TABLE A4.2.2. Type B thermocouples-temperature $\left({ }^{\circ} \mathrm{F}\right)$ as a function of thermoelectric voltage, reference junctions at $32^{\circ} \mathrm{F}$-Continued

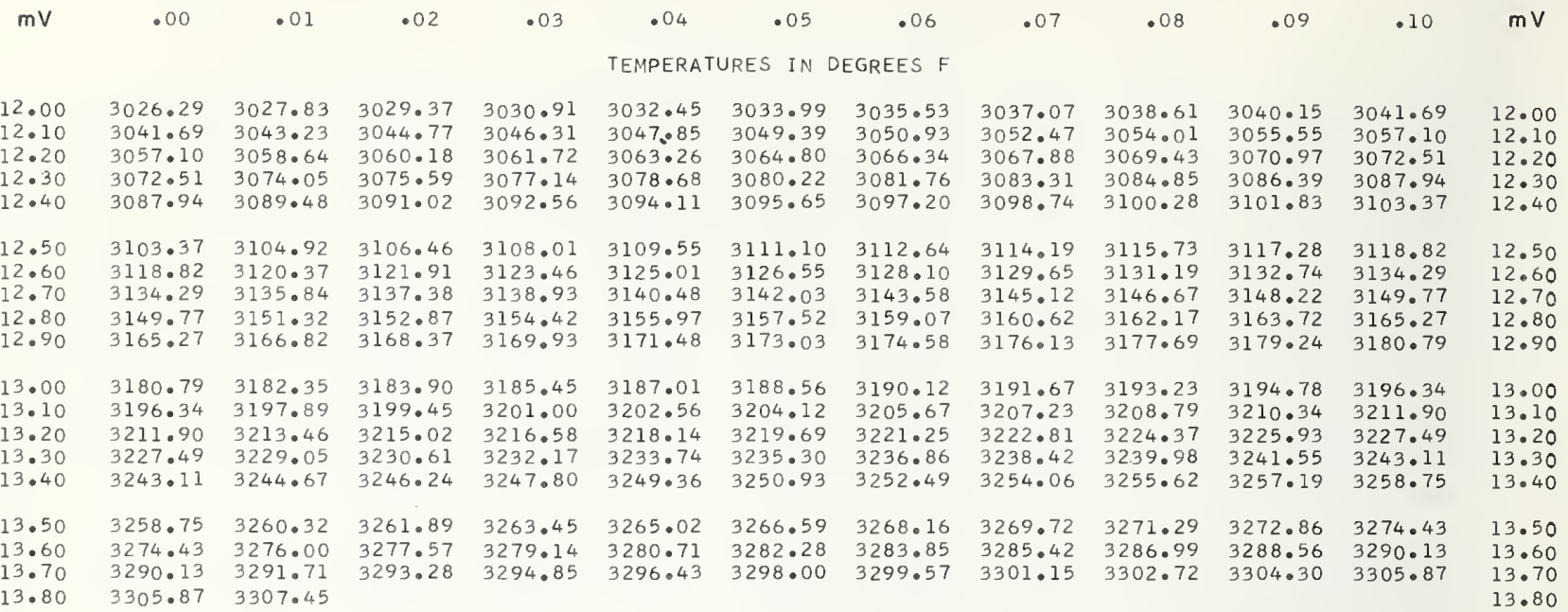

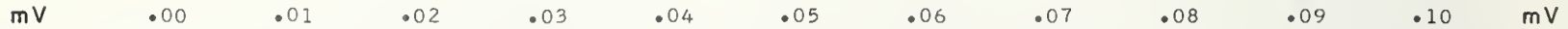

TABle A4.2.3. Type B thermocouples-quadratic, cubic, and quartic approximations to the data as a function of voltage in selected temperature ranges $\left({ }^{\circ} \mathrm{C}\right)$. The expansion is of the form $\mathrm{T}=\mathrm{a}_{0}+\mathrm{a}_{1} \mathrm{E}+\mathrm{a}_{2} \mathrm{E}^{2}+\mathrm{a}_{3} \mathrm{E}^{3}+\mathrm{a}_{4} \mathrm{E}^{1}$ where $\mathrm{E}$ is in microvolts and $\mathrm{T}$ is in degrees Celsius

Temperature

Argument Exp.

Argument Exp.

Argurnent Exp.

Argument Exp.

Argument Exp.

Error

1. Quartic Equation

$0-900$
$0-1100$
$0-1400$
$0-1650$
$0-1820$
$400-1100$
$400-1400$
$400-1650$
$1050-1400$
$1050-1650$
$1400-1550$
$400-1650$

$\begin{array}{ll}\ldots \ldots \\ \cdots \cdots \\ \cdots \cdots \\ 1.8946288 & +2 \\ 2.0949015 & +2 \\ 2.2354664 & +2 \\ 3.2188156 & +2 \\ 3.4418084 & +2 \\ 3.7140306 & +2 \\ 3.9253848 & +2\end{array}$

II. Cubic Equation

$\begin{aligned} 0 & -900 \\ 0 & -1100 \\ 0 & -1400 \\ 0 & -1650 \\ 0 & -1820 \\ 400 & -1100 \\ 400 & -1400 \\ 400 & -1650 \\ 1050 & -1400 \\ 1050 & -1650 \\ 1400 & =1550\end{aligned}$

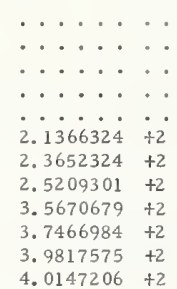

III. Quadratic Equation

$$
\begin{aligned}
0 & -900 \\
0 & -1100 \\
0 & -1400 \\
0 & -1650 \\
0 & -1820 \\
400 & -1100 \\
400 & -1400 \\
400 & -1650 \\
1050 & -1400 \\
1050 & -1650 \\
1400 & -1550 \\
1400 & -1650
\end{aligned}
$$

8.9244743
7.2874066
5.7822214
4.9929130
4.6255054
3.0966136
2.7222162
2.4988761
1.8282378
1.7031473
1.5828913
1.4979551

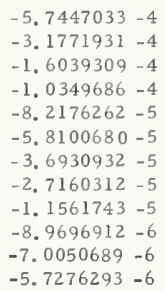

6.8242988 5. 5918644 4. 4541819 3. 8585853 3. 5829683 2.6366866 2.3102266 2. 1223567 1. 6256309 1. 5488865 1. 4733527

1. 4632380

-1
-1
-1
-1
-1
-1
-1
-1
-1
-1
-1
-1

$\begin{array}{lll}-2.4242314 & -4 \\ -1.3439422 & -4 \\ -6.7987267 & -5 \\ -4.4040462 & -5 \\ -3.5181242 & -5 \\ -3.0970222 & -5 \\ -1.9281120 & -5 \\ -1.4188409 & -5 \\ -7.1928422 & -6 \\ -6.1233244 & -6 \\ -5.3265821 & -6\end{array}$

$-5.2233585-6$

4. 7270957 3. 8926013 3. 1163728 2. 7022999 2. 5245307 2. 0807395 1. 8022330 1. 6307784 1. 2847162 1.1666506 1. 0323980 9. 8158446

$\begin{array}{ll}1.8053618 & -7 \\ 6.8254996 & -8 \\ 2.2187592 & -8 \\ 1.0792281 & -8 \\ 7.3717195 & -9 \\ 8.2483967 & -9 \\ 3.6830239 & -9 \\ 2.1299660 & -9 \\ 6.4320083 & -10 \\ 4.0789445 & -10 \\ 2.6714849 & -10 \\ 1.8192801 & -10\end{array}$

$-1.9719121-11$ $-5.1002233-12$ $-1.0678514-12$ $-3.9111456-13$ $-2.2913665-13$ $-4.7591774-13$ $-1.4483702-13$ $-6.4220755-14$ $-1.4544375-14$ $-6.6410259-15$ $-2.9082072-15$ $-7.8042686-16$

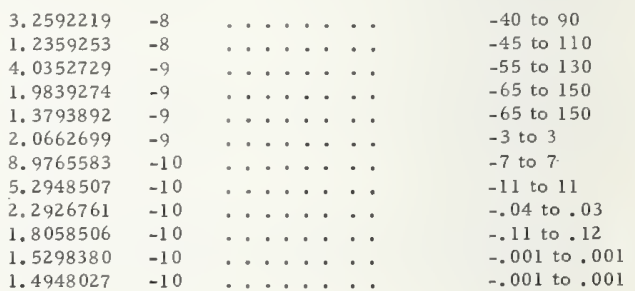

-30 to 75 -35 to 90 -45 to 110 -50 to 120 -.09 to 1.0

-3 to 3

-5 to 5

-.003 to .003

-.025 to .020

-.001 to .001

-.001 to .001 


\section{A5. Supplementary Data for Type E-Nickel-Chromium Alloy Versus Copper-Nickel Alloy Thermocouples}

\section{A5.1. Data for Voltage as a Function of Temperature}

The full precision coefficients given in the main text are used to generate the voltage as a functions of temperature data given in tables A5.1.1 and A5.1.2. Table A5.1.1 presents the data in degrees Celsius from $-270{ }^{\circ} \mathrm{C}$ to $1000{ }^{\circ} \mathrm{C}$ while table A5.1.2 presents the data in degrees Fahrenheit from $-454{ }^{\circ} \mathrm{F}$ to $1832{ }^{\circ} \mathrm{F}$. Table A5.1.3 contains quadratic, cubic, and quartic approximations to the data as a function of temperature in selected temperature ranges. The error range given in the table is the difference between the voltage as obtained from the full precision coefficients from the text and the respective reduced order approximations. The last entries in the cubic and quadratic groupings of table A5.1.3 represent variable reference junction corrections in the 0 to $50{ }^{\circ} \mathrm{C}$ temperature range.

TABLE A5.1.1. Type E thermocouples-thermoelectric voltage as a function of temperature $\left({ }^{\circ} \mathrm{C}\right)$, reference junctions at $0{ }^{\circ} \mathrm{C}$

$\begin{array}{lccccc}2 & 3 & 4 & 5 & 6 & 7 \\ \text { THERMOELECTRIC } & \text { VOLTAGE } & \text { IN } & \text { ABSOLUTE } & \text { MILLIVOLTS }\end{array}$

\begin{tabular}{|c|c|c|c|c|c|c|c|c|c|c|c|c|}
\hline $\begin{array}{l}-270 \\
-260 \\
-250\end{array}$ & $\begin{array}{l}-9.835 \\
-9.797 \\
-9.719\end{array}$ & $\begin{array}{l}-9.802 \\
-9.728\end{array}$ & $\begin{array}{l}-9.808 \\
-9.737\end{array}$ & $\begin{array}{l}-9.813 \\
-9.746\end{array}$ & $\begin{array}{l}9.817 \\
9.754\end{array}$ & $\begin{array}{l}-9.821 \\
-9.762\end{array}$ & $\begin{array}{l}9.825 \\
9.770\end{array}$ & $\begin{array}{l}-9.828 \\
-9.777\end{array}$ & $\begin{array}{l}-9.831 \\
-9.784\end{array}$ & $\begin{array}{l}-9.833 \\
-9.791\end{array}$ & $\begin{array}{l}-9.835 \\
-9.797\end{array}$ & $\begin{array}{l}-270 \\
-260 \\
-250\end{array}$ \\
\hline $\begin{array}{l}-240 \\
-230 \\
-220 \\
-210 \\
-200\end{array}$ & $\begin{array}{l}-9.604 \\
-9.455 \\
-9.274 \\
-9.063 \\
-8.824\end{array}$ & $\begin{array}{l}-9.617 \\
-9.472 \\
-9.293 \\
-9.085 \\
-8.850\end{array}$ & $\begin{array}{l}-9.630 \\
-9.488 \\
-9.313 \\
-9.107 \\
-8.874\end{array}$ & $\begin{array}{l}-9.642 \\
-9.503 \\
-9.332 \\
-9.129 \\
-8.899\end{array}$ & $\begin{array}{l}-9.654 \\
-9.519 \\
-9.350 \\
-9.151 \\
-8.923\end{array}$ & $\begin{array}{l}-9.666 \\
-9.534 \\
-9.368 \\
-9.172 \\
-8.947\end{array}$ & $\begin{array}{l}-9.677 \\
-9.549 \\
-9.386 \\
-9.193 \\
-8.971\end{array}$ & $\begin{array}{l}-9.688 \\
-9.563 \\
-9.404 \\
-9.214 \\
-8.994\end{array}$ & $\begin{array}{l}-9.699 \\
-9.577 \\
-9.421 \\
-9.234 \\
-9.017\end{array}$ & $\begin{array}{l}-9.709 \\
-9.591 \\
-9.438 \\
-9.254 \\
-9.040\end{array}$ & $\begin{array}{l}-9.719 \\
-9.604 \\
-9.455 \\
-9.274 \\
-9.063\end{array}$ & $\begin{array}{l}-240 \\
-230 \\
-220 \\
-210 \\
-200\end{array}$ \\
\hline $\begin{array}{l}-190 \\
-180 \\
-170 \\
-160 \\
-150\end{array}$ & $\begin{array}{l}-8.561 \\
-8.273 \\
-7.963 \\
-7.631 \\
-7.279\end{array}$ & $\begin{array}{l}-8.588 \\
-8.303 \\
-7.995 \\
-7.665 \\
-7.315\end{array}$ & $\begin{array}{l}-8.615 \\
-8.333 \\
-8.027 \\
-7.699 \\
-7.351\end{array}$ & $\begin{array}{l}-8.642 \\
-8.362 \\
-8.058 \\
-7.733 \\
-7.387\end{array}$ & $\begin{array}{l}-8.669 \\
-8.391 \\
-8.090 \\
-7.767 \\
-7.422\end{array}$ & $\begin{array}{l}-8.696 \\
-8.420 \\
-8.121 \\
-7.800 \\
-7.458\end{array}$ & $\begin{array}{l}-8.722 \\
-8.449 \\
-8.152 \\
-7.833 \\
-7.493\end{array}$ & $\begin{array}{l}-8.748 \\
-8.477 \\
-8.183 \\
-7.866 \\
-7.528\end{array}$ & & $\begin{array}{l}-8.799 \\
-8.533 \\
-8.243 \\
-7.931 \\
-7.597\end{array}$ & $\begin{array}{l}-8.824 \\
-8.561 \\
-8.273 \\
-7.963 \\
-7.631\end{array}$ & $\begin{array}{l}-190 \\
-180 \\
-170 \\
-160 \\
-150\end{array}$ \\
\hline $\begin{array}{l}-140 \\
-130 \\
-120 \\
-110 \\
-100\end{array}$ & $\begin{array}{l}-6.907 \\
-6.516 \\
-6.107 \\
-5.680 \\
-5.237\end{array}$ & $\begin{array}{l}-6.945 \\
-6.556 \\
-6.149 \\
-5.724 \\
-5.282\end{array}$ & $\begin{array}{l}-6.983 \\
-6.596 \\
-6.190 \\
-5.767 \\
-5.327\end{array}$ & $\begin{array}{l}-7.020 \\
-6.635 \\
-6.231 \\
-5.810 \\
-5.371\end{array}$ & & $\begin{array}{l}-7.095 \\
-6.714 \\
-6.314 \\
-5.896 \\
-5.460\end{array}$ & & $\begin{array}{l}-7.169 \\
-6.792 \\
-6.395 \\
-5.981 \\
-5.549\end{array}$ & & $\begin{array}{l}-7.243 \\
-6.869 \\
-6.476 \\
-6.065 \\
-5.637\end{array}$ & & $\begin{array}{l}-140 \\
-130 \\
-120 \\
-110 \\
-100\end{array}$ \\
\hline $\begin{array}{l}-90 \\
-80 \\
-70 \\
-60 \\
-50\end{array}$ & $\begin{array}{l}-4.777 \\
-4.301 \\
-3.811 \\
-3.306 \\
-2.787\end{array}$ & $\begin{array}{l}-4.824 \\
-4.350 \\
-3.860 \\
-3.357 \\
-2.839\end{array}$ & $\begin{array}{l}-4.870 \\
-4.398 \\
-3.910 \\
-3.408 \\
-2.892\end{array}$ & $\begin{array}{l}-4.916 \\
-4.446 \\
-3.959 \\
-3.459 \\
-2.944\end{array}$ & $\begin{array}{l}-4.963 \\
-4.493 \\
-4.009 \\
-3.509\end{array}$ & $\begin{array}{l}-5.009 \\
-4.541 \\
-4.058 \\
-3.560 \\
-3.048\end{array}$ & $\begin{array}{l}-5.055 \\
-4.588 \\
-4.107 \\
-3.610 \\
-3.100\end{array}$ & $\begin{array}{l}-5.100 \\
-4.636 \\
-4.156 \\
-3.661 \\
-3.152\end{array}$ & $\begin{array}{l}-5.146 \\
-4.683 \\
-4.204 \\
-3.711 \\
-3.203\end{array}$ & $\begin{array}{l}-5.191 \\
-4.730 \\
-4.253 \\
-3.761 \\
-3.254\end{array}$ & $\begin{array}{l}-5.237 \\
-4.777 \\
-4.301 \\
-3.811 \\
-3.306\end{array}$ & $\begin{array}{l}-90 \\
-80 \\
-70 \\
-60 \\
-50\end{array}$ \\
\hline $\begin{array}{l}-40 \\
-30 \\
-20 \\
-10 \\
-\quad 0\end{array}$ & $\begin{array}{r}-2.254 \\
-1.709 \\
-1.151 \\
-0.581 \\
0.000\end{array}$ & $\begin{array}{l}-2.308 \\
-1.764 \\
-1.208 \\
-0.639 \\
-0.059\end{array}$ & $\begin{array}{l}-2.362 \\
-1.819 \\
-1.264 \\
-0.696 \\
-0.117\end{array}$ & $\begin{array}{l}-2.416 \\
-1.874 \\
-1.320 \\
-0.754 \\
-0.176\end{array}$ & $\begin{array}{l}-2.469 \\
-1.929 \\
-1.376 \\
-0.811 \\
-0.234\end{array}$ & $\begin{array}{l}-2.522 \\
-1.983 \\
-1.432 \\
-0.868 \\
-0.292\end{array}$ & $\begin{array}{l}-2.575 \\
-2.038 \\
-1.487 \\
-0.925 \\
-0.350\end{array}$ & $\begin{array}{l}-2.628 \\
-2.092 \\
-1.543 \\
-0.982 \\
-0.408\end{array}$ & $\begin{array}{l}-2.681 \\
-2.146 \\
-1.599 \\
-1.038 \\
-0.466\end{array}$ & $\begin{array}{l}-2.734 \\
-2.200 \\
-1.654 \\
-1.095 \\
-0.524\end{array}$ & $\begin{array}{l}-2.787 \\
-2.254 \\
-1.709 \\
-1.151 \\
-0.581\end{array}$ & $\begin{array}{l}-4 \\
-3 \\
-2 \\
-1 \\
-\end{array}$ \\
\hline$c$ & 0 & 1 & 2 & 3 & 4 & 5 & 6 & 7 & 8 & 9 & 0 & \\
\hline
\end{tabular}


TABLE A5.1.1. Type E thermocouples-thermoelectric voltage as a function of temperature $\left({ }^{\circ} \mathrm{C}\right)$, reference junctions at $0^{\circ} \mathrm{C}$-Continued

2

4

5

6

7

8

9

10

${ }^{\circ} \mathrm{C}$

THERMOELECTRIC VOLTAGE IN ABSOLUTE MILLIVOLTS

\begin{tabular}{|c|c|c|c|c|c|c|c|c|c|c|c|}
\hline 0 & 0.000 & 0.059 & 0.118 & 0.176 & 0.235 & 0.295 & 0.354 & 0.413 & 0.472 & 0.532 & 0.591 \\
\hline $\begin{array}{l}10 \\
20\end{array}$ & $\begin{array}{l}0.591 \\
1.192\end{array}$ & $\begin{array}{l}0.651 \\
1.252\end{array}$ & $\begin{array}{l}0.711 \\
1.313\end{array}$ & $\begin{array}{l}0.770 \\
1.373\end{array}$ & $\begin{array}{l}0.830 \\
1.434\end{array}$ & $\begin{array}{l}0.890 \\
1.495\end{array}$ & $\begin{array}{l}0.950 \\
1.556\end{array}$ & $\begin{array}{l}1.011 \\
1.617\end{array}$ & $\begin{array}{l}1.071 \\
1.678\end{array}$ & $\begin{array}{l}1.131 \\
1.739\end{array}$ & 1.192 \\
\hline 30 & 1.801 & 1.862 & 1.924 & 1.985 & 2.047 & 2.109 & 2.171 & 2.233 & 2.295 & 2.357 & 2.419 \\
\hline 40 & 2.419 & 2.482 & 2.544 & 2.607 & 2.669 & 2.732 & 2.795 & 2.858 & 2.921 & 2.984 & 3.047 \\
\hline 50 & $3: 047$ & .110 & 3.173 & 3.237 & 3.300 & 3.364 & 3.428 & 3.491 & 3.555 & 3.619 & 3.683 \\
\hline 60 & & 748 & 812 & .876 & .941 & .005 & .070 & 4.134 & 4.199 & 4.264 & 4.329 \\
\hline 70 & 4.329 & $4 \cdot 394$ & 4.459 & 4.524 & 4.590 & 4.655 & 4.720 & 4.786 & 4.852 & 4.917 & 4.983 \\
\hline 80 & 4.983 & 5.049 & 5.115 & 5.181 & 5.247 & 5.314 & 5.380 & 5.446 & 5.513 & 5.579 & 5.646 \\
\hline 90 & 5.646 & 5.713 & 5.780 & 5.846 & 5,913 & 5.981 & 6.048 & 6.115 & 6.182 & 6.250 & 6.317 \\
\hline & 6.317 & 6.385 & 6.452 & 6.520 & 6.588 & 6.656 & 6.724 & 6.792 & 6.860 & 6.928 & 6.996 \\
\hline & 6.996 & 7.064 & 7.133 & 7.201 & 7.270 & 7.339 & 7.407 & 7.476 & 7.545 & 7.614 & 7.683 \\
\hline & 7.683 & 7.752 & 7.821 & 7.890 & 7.960 & 8.029 & 8.099 & 8.168 & 8.238 & 8.307 & 8.377 \\
\hline 30 & 8.377 & 8.447 & 8.517 & 8.587 & 8.657 & 8.727 & 8.797 & 8.867 & 8.938 & 9.008 & 9.078 \\
\hline 14 & 9.078 & 9.149 & 9.220 & 9.290 & 9.361 & 9.432 & 9.503 & 9.573 & 9.644 & 9.715 & 9.787 \\
\hline & 9.787 & 9.858 & 9.929 & .000 & 0.072 & 0.143 & 10.215 & 10.286 & 10.358 & 10.429 & 10.501 \\
\hline & 10.501 & 10.573 & 10.645 & 0.717 & 10.789 & 0.861 & 10.933 & 1.005 & 11.077 & 11.150 & 11.222 \\
\hline & 11.222 & 11.294 & 11.367 & 11.439 & 11.512 & 11.585 & 11.657 & 11.730 & 11.803 & 11.876 & 11.949 \\
\hline & 11.949 & $12 \cdot 022$ & 12.095 & 12.168 & 12.241 & 12.314 & 12.387 & 12.461 & 12.534 & 12.608 & 12.681 \\
\hline & 12.681 & 12.755 & 12.828 & 12.902 & 12.975 & 13.049 & 13.123 & 13.197 & 13.271 & 13.345 & 13.419 \\
\hline Do & 13.419 & 13.493 & 13.567 & 13.641 & 13.715 & 13.789 & 13.864 & 13.938 & 14.012 & 14.087 & 14.161 \\
\hline 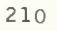 & 14.161 & 14.236 & 14.310 & 14.385 & 14.460 & 14.534 & 14.609 & 14.684 & 14.759 & 14.834 & 09 \\
\hline 220 & 14.909 & $14 \cdot 984$ & 15.059 & 15.134 & 15.209 & 15.284 & 15.359 & 15.435 & 15.510 & 15.585 & 15.661 \\
\hline & 15.661 & 15.736 & 312 & 387 & 963 & 038 & 16.114 & 0 & & & 17 \\
\hline 240 & 16.417 & 16.493 & 16.569 & 16.645 & 16.721 & 16.797 & 16.873 & 16.949 & 17.025 & 17.101 & 17.178 \\
\hline & 7.178 & 17.254 & 17.330 & .06 & 17.483 & 17.559 & 17.636 & 17. & 17.789 & 17.865 & 17.942 \\
\hline 260 & 17.942 & 18.018 & 18.095 & 18.172 & 18.248 & 18.325 & 18.402 & 18.479 & 18.556 & 18.633 & 18.710 \\
\hline 210 & 18.710 & 18.787 & 18.864 & 18.941 & 19.018 & 19.095 & 19.172 & 19.249 & 19.326 & & 19.481 \\
\hline 280 & 19.481 & 19.558 & 19.636 & 19.713 & 19.790 & $19 \cdot 868$ & $19 \cdot 945$ & 20.023 & 20.100 & 20.178 & 20.256 \\
\hline 290 & 20.256 & 20.333 & 20.411 & 20.488 & 20.566 & 20.644 & 20.722 & 20.800 & 20.877 & 20.955 & 21.033 \\
\hline 300 & 21.033 & 21.111 & 21.189 & 21.267 & 21.345 & 21.423 & 21.501 & 21.579 & 21.657 & 21.735 & 21.814 \\
\hline & 14 & 21.892 & 21.970 & 22.048 & 22 & 22 & 22.283 & & & & \\
\hline 320 & 22.597 & 22.675 & 22.754 & 22.832 & 22.911 & 22.989 & 23.068 & 23.147 & $23 \cdot 225$ & 23 & 383 \\
\hline 330 & 23.383 & 23.461 & 23.540 & 23.619 & 23.698 & 23.777 & 23.855 & 23.934 & 24.013 & 24.092 & 24.171 \\
\hline 340 & 24.171 & 24.250 & 24.329 & 24.408 & 24.487 & 24.566 & 24.645 & 24.724 & 24.803 & 24.882 & 24.961 \\
\hline 5 & 24.961 & & 25 & 99 & 78 & 857 & 37 & 25 & & & 25.754 \\
\hline 360 & 25 . & 33 & 25 & & 72 & & & & & & \\
\hline 370 & 26.549 & 26.628 & 26.708 & 26.787 & 26.867 & 26.947 & 27.026 & 2.7 .106 & 27.186 & 27.265 & 27.345 \\
\hline 380 & 27.345 & 27.425 & 27.504 & 27.584 & 27.664 & 27.744 & & & 27 & & 143 \\
\hline 390 & 28.143 & 28.223 & 28.303 & 28.383 & 28.463 & 28.543 & 28.623 & 28.703 & 28.783 & 28.863 & 28.943 \\
\hline 400 & 28.943 & 29.023 & 103 & 29.183 & 263 & 29.343 & & & & & \\
\hline 410 & 29. & 29.824 & 29. & 29 & 5 & & 25 & 05 & & & 46 \\
\hline & 30.546 & 30.627 & 30.707 & 30. & & 30 & & & & & \\
\hline 430 & 31.350 & 31.430 & 31.511 & 31.591 & 31.672 & 31.752 & 31.833 & 13 & 31.994 & 32 & 32.155 \\
\hline 440 & 32.155 & 32.235 & 32.316 & 32.396 & 32.477 & 32.557 & 32.638 & 32.719 & 32.799 & 32.880 & 32.960 \\
\hline 450 & 60 & .041 & 22 & & & & & & & & \\
\hline 460 & 33.767 & 33.848 & 33.928 & 34. & & 34. & & & & & \\
\hline 470 & 34. & 34.655 & 34.736 & 34.816 & 34.897 & 34.978 & 59 & 40 & 35.220 & & 35.382 \\
\hline 480 & 35.382 & 35.463 & 35.544 & 35.624 & 35.705 & 35.786 & 867 & & 36.029 & & $36 \cdot 190$ \\
\hline 49 & & & 36.352 & 36.433 & 36.514 & 36.595 & .675 & 36.756 & 36.837 & & 36.999 \\
\hline 500 & 99 & 0 & 37. & 37. & 3 & 3 & & & & & \\
\hline 510 & 08 & 37. & 37. & & & & & & & & \\
\hline 20 & & & & 38. & & 39.022 & & & & & \\
\hline 530 & 39. & 39.507 & 39.588 & 39. & 39.750 & 39.831 & & & 40 & 55 & 40.236 \\
\hline 540 & 40.236 & 40.316 & 40.397 & 40. & 40.559 & 40.640 & 40 & 40.802 & 40.883 & 40.964 & 41.045 \\
\hline 55 & & & & 41 & 4 & & & & & & \\
\hline 560 & & & 42 & 42. & 42.177 & 42.258 & & & & & \\
\hline 570 & 42.662 & 42.743 & 42.824 & 42.904 & 42.985 & 43.066 & 43 & 43 & 308 & & \\
\hline 580 & 43.470 & 43.551 & 43.632 & 43 & 43.793 & 43.874 & 43.955 & 44.035 & $44 \cdot 116$ & $44 \cdot 197$ & $44 \cdot 278$ \\
\hline 30 & 44.278 & $44 \cdot 358$ & 44.439 & 44.520 & 44.601 & 44.681 & 44.762 & 44.843 & 44.923 & 45.004 & 45.085 \\
\hline & 45.085 & 45.165 & 45.246 & 45.327 & 45.407 & 45.488 & 45.569 & 45.649 & 45.730 & 45.811 & 45.891 \\
\hline
\end{tabular}

${ }^{\circ} \mathrm{C}$

1

2

3

4

5

6

7

8

9

10

${ }^{\circ} \mathrm{C}$ 
TABLE A5.1.1. Type E thermocouples-thermoelectric voltage as a function of temperature $\left({ }^{\circ} \mathrm{C}\right)$, reference junctions at $0^{\circ} \mathrm{C}$-Continued

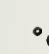

0

1

2
3

4

5

6

7

8

10

${ }^{\circ} \mathrm{C}$

\begin{tabular}{|c|c|c|c|c|c|c|c|c|c|c|c|c|}
\hline $\begin{array}{l}600 \\
610 \\
620 \\
630 \\
640\end{array}$ & $\begin{array}{l}45.085 \\
45.891 \\
46.697 \\
47.502 \\
48.306\end{array}$ & $\begin{array}{l}45.165 \\
45.972 \\
46.777 \\
47.582 \\
48.386\end{array}$ & $\begin{array}{l}45.246 \\
46.052 \\
46.858 \\
47.663 \\
48.467\end{array}$ & $\begin{array}{l}45.327 \\
46.133 \\
46.938 \\
47.743 \\
48.547\end{array}$ & $\begin{array}{l}45.407 \\
46.213 \\
47.019 \\
47.824 \\
48.627\end{array}$ & $\begin{array}{l}45.488 \\
46.294 \\
47.059 \\
47.904 \\
48.708\end{array}$ & $\begin{array}{l}45.569 \\
46.375 \\
47.180 \\
47.984 \\
48.788\end{array}$ & $\begin{array}{l}45.649 \\
46.455 \\
47.260 \\
48.065 \\
48.868\end{array}$ & $\begin{array}{l}45.730 \\
46.536 \\
47.341 \\
48.145 \\
48.949\end{array}$ & $\begin{array}{l}45.811 \\
46.616 \\
47.421 \\
48.226 \\
49.029\end{array}$ & $\begin{array}{l}45.891 \\
46.697 \\
47.502 \\
48.306 \\
49.109\end{array}$ & $\begin{array}{l}600 \\
610 \\
620 \\
630 \\
640\end{array}$ \\
\hline $\begin{array}{l}650 \\
660 \\
670 \\
680 \\
690\end{array}$ & $\begin{array}{l}49.109 \\
49.911 \\
50.713 \\
51.513 \\
52.312\end{array}$ & $\begin{array}{l}49.189 \\
49.992 \\
50.793 \\
51.593 \\
52.392\end{array}$ & $\begin{array}{l}49.270 \\
50.072 \\
50.873 \\
51.673 \\
52.472\end{array}$ & $\begin{array}{l}49.350 \\
50.152 \\
50.953 \\
51.753 \\
52.552\end{array}$ & $\begin{array}{l}49.430 \\
50.232 \\
51.033 \\
51.833 \\
52.632\end{array}$ & $\begin{array}{l}49.510 \\
50.312 \\
51.113 \\
51.913 \\
52.711\end{array}$ & $\begin{array}{l}49.591 \\
50.392 \\
51.193 \\
51.993 \\
52.791\end{array}$ & $\begin{array}{l}49.671 \\
50.472 \\
51.273 \\
52.073 \\
52.871\end{array}$ & $\begin{array}{l}49.751 \\
50.553 \\
51.353 \\
52.152 \\
52.951\end{array}$ & $\begin{array}{r}49.831 \\
50.633 \\
51.433 \\
52.232 \\
53.031\end{array}$ & $\begin{array}{l}49.911 \\
50.713 \\
51.513 \\
52.312 \\
53.110\end{array}$ & $\begin{array}{l}650 \\
660 \\
670 \\
680 \\
690\end{array}$ \\
\hline $\begin{array}{l}700 \\
710 \\
720 \\
730 \\
740\end{array}$ & $\begin{array}{l}53.110 \\
53.907 \\
54.703 \\
55.498 \\
56.291\end{array}$ & $\begin{array}{l}53.190 \\
53.987 \\
54.782 \\
55.577 \\
56.370\end{array}$ & $\begin{array}{l}53.270 \\
54.066 \\
54.862 \\
55.656 \\
56.449\end{array}$ & $\begin{array}{l}53.350 \\
54.146 \\
54.941 \\
55.736 \\
56.529\end{array}$ & $\begin{array}{l}53.429 \\
54.226 \\
55.021 \\
55.815 \\
56.608\end{array}$ & $\begin{array}{l}53.509 \\
54.305 \\
55.100 \\
55.894 \\
56.687\end{array}$ & $\begin{array}{l}53.589 \\
54.385 \\
55.180 \\
55.974 \\
56.766\end{array}$ & $\begin{array}{l}53.668 \\
54.464 \\
55.259 \\
56.053 \\
56.845\end{array}$ & $\begin{array}{l}53 \cdot 748 \\
54 \cdot 544 \\
55 \cdot 339 \\
56.132 \\
56.924\end{array}$ & $\begin{array}{l}53.828 \\
54.623 \\
55.418 \\
56.212 \\
57.004\end{array}$ & $\begin{array}{l}53.907 \\
54.703 \\
55.498 \\
56.291 \\
57.083\end{array}$ & $\begin{array}{l}700 \\
710 \\
720 \\
730 \\
740\end{array}$ \\
\hline $\begin{array}{l}750 \\
760 \\
770 \\
780 \\
790\end{array}$ & $\begin{array}{l}57.083 \\
57.873 \\
58.663 \\
59.451 \\
60.237\end{array}$ & $\begin{array}{l}57.162 \\
57.952 \\
58.742 \\
59.529 \\
60.316\end{array}$ & $\begin{array}{l}57.241 \\
58.031 \\
58.820 \\
59.608 \\
60.394\end{array}$ & $\begin{array}{l}57.320 \\
58.110 \\
58.899 \\
59.687 \\
60.473\end{array}$ & $\begin{array}{l}57.399 \\
58.189 \\
58.978 \\
59.765 \\
60.551\end{array}$ & $\begin{array}{l}57.478 \\
58.268 \\
59.057 \\
59.844 \\
60.630\end{array}$ & $\begin{array}{l}57.557 \\
58.347 \\
59.136 \\
59.923 \\
60.708\end{array}$ & $\begin{array}{l}57.636 \\
58.426 \\
59.214 \\
60.001 \\
60.787\end{array}$ & $\begin{array}{l}57.715 \\
58.505 \\
59.293 \\
60.080 \\
60.865\end{array}$ & $\begin{array}{l}57.794 \\
58.584 \\
59.372 \\
60.159 \\
60.944\end{array}$ & $\begin{array}{l}57.873 \\
58.663 \\
59.451 \\
60.237 \\
61.022\end{array}$ & $\begin{array}{l}750 \\
760 \\
770 \\
780 \\
790\end{array}$ \\
\hline $\begin{array}{l}800 \\
810 \\
820 \\
830 \\
840\end{array}$ & $\begin{array}{l}61.022 \\
61.806 \\
62.588 \\
63.368 \\
64.147\end{array}$ & $\begin{array}{l}61.101 \\
61.884 \\
62.666 \\
63.446 \\
64.225\end{array}$ & $\begin{array}{l}61.179 \\
61.962 \\
62.744 \\
63.524 \\
64.303\end{array}$ & $\begin{array}{l}61 \cdot 258 \\
62.041 \\
62.822 \\
63.602 \\
64.380\end{array}$ & $\begin{array}{l}61.336 \\
62.119 \\
62.900 \\
63.680 \\
64.458\end{array}$ & $\begin{array}{l}61 \cdot 414 \\
62.197 \\
62 \cdot 978 \\
63.758 \\
64.536\end{array}$ & $\begin{array}{l}61.493 \\
62.275 \\
63.056 \\
63.836 \\
64.614\end{array}$ & $\begin{array}{l}61.571 \\
62.353 \\
63.134 \\
63.914 \\
64.691\end{array}$ & $\begin{array}{l}61.649 \\
62.432 \\
63.212 \\
63.992 \\
64.769\end{array}$ & $\begin{array}{l}61.728 \\
62.510 \\
63.290 \\
64.069 \\
64.847\end{array}$ & $\begin{array}{l}61.806 \\
62.588 \\
63.368 \\
64.147 \\
64.924\end{array}$ & $\begin{array}{l}800 \\
810 \\
820 \\
830 \\
840\end{array}$ \\
\hline $\begin{array}{l}850 \\
860 \\
870 \\
880 \\
890\end{array}$ & $\begin{array}{l}64.924 \\
65.700 \\
66.473 \\
67.245 \\
68.015\end{array}$ & $\begin{array}{l}65.002 \\
65.777 \\
66.551 \\
67.322 \\
68.092\end{array}$ & $\begin{array}{l}65.080 \\
65.855 \\
66.628 \\
67.399 \\
68.169\end{array}$ & $\begin{array}{l}65.157 \\
65.932 \\
66.705 \\
67.476 \\
68.246\end{array}$ & $\begin{array}{l}65.235 \\
66.009 \\
66.782 \\
67.553 \\
68.323\end{array}$ & $\begin{array}{l}65.312 \\
66.087 \\
66.859 \\
67.630 \\
68.399\end{array}$ & $\begin{array}{l}65.390 \\
66.164 \\
66.937 \\
67.707 \\
68.476\end{array}$ & $\begin{array}{l}65.467 \\
66.241 \\
67.014 \\
67.784 \\
68.553\end{array}$ & $\begin{array}{l}65.545 \\
66.319 \\
67.091 \\
67.861 \\
68.630\end{array}$ & $\begin{array}{l}65.622 \\
66.396 \\
67.168 \\
67.938 \\
68.706\end{array}$ & $\begin{array}{l}65.700 \\
66.473 \\
67.245 \\
68.015 \\
68.783\end{array}$ & $\begin{array}{l}850 \\
860 \\
870 \\
880 \\
890\end{array}$ \\
\hline $\begin{array}{l}900 \\
910 \\
920 \\
930 \\
940\end{array}$ & $\begin{array}{l}68.783 \\
69.549 \\
70.313 \\
71.075 \\
71.835\end{array}$ & $\begin{array}{l}68.860 \\
69.626 \\
70.390 \\
71.151 \\
71.911\end{array}$ & $\begin{array}{l}68.936 \\
69.702 \\
70.466 \\
71.227 \\
71.987\end{array}$ & $\begin{array}{l}69.013 \\
69.779 \\
70.542 \\
71.304 \\
72.063\end{array}$ & $\begin{array}{l}69.090 \\
69.855 \\
70.618 \\
71.380 \\
72.139\end{array}$ & $\begin{array}{l}69.166 \\
69.931 \\
70.694 \\
71.456 \\
72.215\end{array}$ & $\begin{array}{l}69.243 \\
70.008 \\
70.771 \\
71.532 \\
72.290\end{array}$ & $\begin{array}{l}69.320 \\
70.084 \\
70.847 \\
71.608 \\
72.366\end{array}$ & $\begin{array}{l}69.396 \\
70.161 \\
70.923 \\
71.683 \\
72.442\end{array}$ & $\begin{array}{l}69.473 \\
70.237 \\
70.999 \\
71.759 \\
72.518\end{array}$ & $\begin{array}{l}69.549 \\
70.313 \\
71.075 \\
71.835 \\
72.593\end{array}$ & $\begin{array}{l}900 \\
910 \\
920 \\
930 \\
940\end{array}$ \\
\hline $\begin{array}{l}950 \\
960 \\
970 \\
980 \\
990\end{array}$ & $\begin{array}{l}72.593 \\
73.350 \\
74.104 \\
74.857 \\
75.608\end{array}$ & $\begin{array}{l}72.669 \\
73.425 \\
74.179 \\
74.932 \\
75.683\end{array}$ & $\begin{array}{l}72.745 \\
73.501 \\
74.255 \\
75.007 \\
75.758\end{array}$ & $\begin{array}{l}72.820 \\
73.576 \\
74.330 \\
75.082 \\
75.833\end{array}$ & $\begin{array}{l}72.896 \\
73.652 \\
74.405 \\
75.157 \\
75.908\end{array}$ & $\begin{array}{l}72.972 \\
73.727 \\
74.480 \\
75.232 \\
75.983\end{array}$ & $\begin{array}{l}73.047 \\
73.802 \\
74.556 \\
75.307 \\
76.058\end{array}$ & $\begin{array}{l}73.123 \\
73.878 \\
74.631 \\
75.382 \\
76.133\end{array}$ & $\begin{array}{l}73.199 \\
73.953 \\
74.706 \\
75.458 \\
76.208\end{array}$ & $\begin{array}{l}73.274 \\
74.029 \\
74.781 \\
75.533 \\
76.283\end{array}$ & $\begin{array}{l}73.350 \\
74.104 \\
74.857 \\
75.608 \\
76.358\end{array}$ & $\begin{array}{l}950 \\
960 \\
970 \\
980 \\
990\end{array}$ \\
\hline
\end{tabular}

$1,000 \quad 76.358$

THERMOELECTRIC VOLTAGE IN ABSOLUTE MILLIVOLTS 
TABLE A5.1.2. Type E thermocouples-thermoelectric voltage as a function of temperature $\left({ }^{\circ} \mathrm{F}\right)$, reference junctions at $32^{\circ} \mathrm{F}$

3

45

6

7

8

9

10

THERMOELECTRIC VOLTAGE IN ABSOLUTE MILLIVOLTS

\begin{tabular}{|c|c|c|c|c|c|c|c|c|c|c|c|c|}
\hline 450 & -9.830 & -9.832 & -9.833 & 9.834 & -9.835 & & & & & & & -450 \\
\hline $\begin{array}{l}-440 \\
-430 \\
-420 \\
-410 \\
-400\end{array}$ & $\begin{array}{l}-9.809 \\
-9.775 \\
-9.729 \\
-9.672 \\
-9.604\end{array}$ & $\begin{array}{l}-9.812 \\
-9.779 \\
-9.734 \\
-9.678 \\
-9.611\end{array}$ & $\begin{array}{l}-9.814 \\
-9.783 \\
-9.739 \\
-9.684 \\
-9.619\end{array}$ & $\begin{array}{l}-9.817 \\
-9.786 \\
-9.744 \\
-9.690 \\
-9.626\end{array}$ & $\begin{array}{l}-9.819 \\
-9.790 \\
-9.749 \\
-9.696 \\
-9.633\end{array}$ & $\begin{array}{l}-9.821 \\
-9.793 \\
-9.753 \\
-9.702 \\
-9.639\end{array}$ & $\begin{array}{l}-9.823 \\
-9.797 \\
-9.758 \\
-9.708 \\
-9.646\end{array}$ & $\begin{array}{l}-9.825 \\
-9.800 \\
-9.762 \\
-9.713 \\
-9.653\end{array}$ & $\begin{array}{l}-9.827 \\
-9.803 \\
-9.767 \\
-9.719 \\
-9.659\end{array}$ & $\begin{array}{l}-9.829 \\
-9.806 \\
-9.771 \\
-9.724 \\
-9.666\end{array}$ & $\begin{array}{l}-9.830 \\
-9.809 \\
-9.775 \\
-9.729 \\
-9.672\end{array}$ & $\begin{array}{l}-440 \\
-430 \\
-420 \\
-410 \\
-400\end{array}$ \\
\hline $\begin{array}{l}-390 \\
-380 \\
-370 \\
-360 \\
-350\end{array}$ & $\begin{array}{l}-9.526 \\
-9.437 \\
-9.338 \\
-9.229 \\
-9.112\end{array}$ & $\begin{array}{l}-9.534 \\
-9.446 \\
-9.348 \\
-9.241 \\
-9.124\end{array}$ & $\begin{array}{l}-9.542 \\
-9.455 \\
-9.358 \\
-9.252 \\
-9.136\end{array}$ & $\begin{array}{l}-9.550 \\
-9.464 \\
-9.368 \\
-9.263 \\
-9.148\end{array}$ & $\begin{array}{l}-9.558 \\
-9.473 \\
-9.378 \\
-9.274 \\
-9.160\end{array}$ & $\begin{array}{l}-9.566 \\
-9.482 \\
-9.388 \\
-9.285 \\
-9.172\end{array}$ & $\begin{array}{l}-9.574 \\
-9.491 \\
-9.398 \\
-9.296 \\
-9.184\end{array}$ & $\begin{array}{l}-9.582 \\
-9.500 \\
-9.408 \\
-9.306 \\
-9.195\end{array}$ & $\begin{array}{l}-9.589 \\
-9.509 \\
-9.418 \\
-9.317 \\
-9.207\end{array}$ & $\begin{array}{l}-9.597 \\
-9.517 \\
-9.427 \\
-9.327 \\
-9.218\end{array}$ & $\begin{array}{l}-9.604 \\
-9.526 \\
-9.437 \\
-9.338 \\
-9.229\end{array}$ & $\begin{array}{l}-390 \\
-380 \\
-370 \\
-360 \\
-350\end{array}$ \\
\hline $\begin{array}{l}-340 \\
-330 \\
-320 \\
-310 \\
-300\end{array}$ & $\begin{array}{l}-8.986 \\
-8.852 \\
-8.710 \\
-8.561 \\
-8.404\end{array}$ & $\begin{array}{l}-8.999 \\
-8.866 \\
-8.725 \\
-8.576 \\
-8.420\end{array}$ & $\begin{array}{l}-9.012 \\
-8.880 \\
-8.739 \\
-8.591 \\
-8.436\end{array}$ & $\begin{array}{l}-9.025 \\
-8.893 \\
-8.754 \\
-8.606 \\
-8.452\end{array}$ & $\begin{array}{l}-9.038 \\
-8.907 \\
-8.768 \\
-8.621 \\
-8.468\end{array}$ & $\begin{array}{l}-9.050 \\
-8.920 \\
-8.782 \\
-8.636 \\
-8.483\end{array}$ & $\begin{array}{l}-9.063 \\
-8.934 \\
-8.796 \\
-8.651 \\
-8.499\end{array}$ & $\begin{array}{l}-9.075 \\
-8.947 \\
-8.810 \\
-8.666 \\
-8.514\end{array}$ & $\begin{array}{l}-9.088 \\
-8.960 \\
-8.824 \\
-8.681 \\
-8.530\end{array}$ & $\begin{array}{l}-9.100 \\
-8.973 \\
-8.838 \\
-8.696 \\
-8.545\end{array}$ & $\begin{array}{l}-9.112 \\
-8.986 \\
-8.852 \\
-8.710 \\
-8.561\end{array}$ & $\begin{array}{l}-340 \\
-330 \\
-320 \\
-310 \\
-300\end{array}$ \\
\hline $\begin{array}{l}-290 \\
-280 \\
-270 \\
-260 \\
-250\end{array}$ & $\begin{array}{l}-8.240 \\
-8.069 \\
-7.891 \\
-7.707 \\
-7.516\end{array}$ & $\begin{array}{l}-8.257 \\
-8.086 \\
-7.909 \\
-7.726 \\
-7.535\end{array}$ & $\begin{array}{l}-8.273 \\
-8.104 \\
-7.927 \\
-7.744 \\
-7.555\end{array}$ & $\begin{array}{l}-8.290 \\
-8.121 \\
-7.945 \\
-7.763 \\
-7.574\end{array}$ & $\begin{array}{l}-8.306 \\
-8.138 \\
-7.963 \\
-7.781 \\
-7.593\end{array}$ & $\begin{array}{l}-8.323 \\
-8.155 \\
-7.981 \\
-7.800 \\
-7.612\end{array}$ & $\begin{array}{l}-8.339 \\
-8.172 \\
-7.999 \\
-7.818 \\
-7.631\end{array}$ & $\begin{array}{l}-8.355 \\
-8.189 \\
-8.016 \\
-7.837 \\
-7.650\end{array}$ & $\begin{array}{l}-8.372 \\
-8.206 \\
-8.034 \\
-7.855 \\
-7.669\end{array}$ & $\begin{array}{l}-8.388 \\
-8.223 \\
-8.051 \\
-7.873 \\
-7.688\end{array}$ & $\begin{array}{l}-8.404 \\
-8.240 \\
-8.069 \\
-7.891 \\
-7.707\end{array}$ & $\begin{array}{l}-290 \\
-280 \\
-270 \\
-260 \\
-250\end{array}$ \\
\hline $\begin{array}{l}-240 \\
-230 \\
-220 \\
-210 \\
-200\end{array}$ & $\begin{array}{l}-7.319 \\
-7.116 \\
-6.907 \\
-6.692 \\
-6.471\end{array}$ & $\begin{array}{l}-7.339 \\
-7.137 \\
-6.928 \\
-6.714 \\
-6.494\end{array}$ & $\begin{array}{l}-7.359 \\
-7.157 \\
-6.949 \\
-6.735 \\
-6.516\end{array}$ & $\begin{array}{l}-7.379 \\
-7.178 \\
-6.970 \\
-6.757 \\
-6.538\end{array}$ & $\begin{array}{l}-7.399 \\
-7.198 \\
-6.991 \\
-6.779 \\
-6.560\end{array}$ & $\begin{array}{l}-7.418 \\
-7.218 \\
-7.012 \\
-6.800 \\
-6.582\end{array}$ & $\begin{array}{l}-7.438 \\
-7.239 \\
-7.033 \\
-6.822 \\
-6.604\end{array}$ & $\begin{array}{l}-7.458 \\
-7.259 \\
-7.054 \\
-6.843 \\
-6.626\end{array}$ & $\begin{array}{l}-7.477 \\
-7.279 \\
-7.075 \\
-6.864 \\
-6.648\end{array}$ & $\begin{array}{l}-7.497 \\
-7.299 \\
-7.095 \\
-6.886 \\
-6.670\end{array}$ & $\begin{array}{l}-7.516 \\
-7.319 \\
-7.116 \\
-6.907 \\
-6.692\end{array}$ & $\begin{array}{l}-240 \\
-230 \\
-220 \\
-210 \\
-200\end{array}$ \\
\hline $\begin{array}{l}-190 \\
-180 \\
-170 \\
-160 \\
-150\end{array}$ & $\begin{array}{l}-6.245 \\
-6.013 \\
-5.776 \\
-5.534 \\
-5.287\end{array}$ & $\begin{array}{l}-6.268 \\
-6.037 \\
-5.800 \\
-5.559 \\
-5.312\end{array}$ & $\begin{array}{l}-6.291 \\
-6.060 \\
-5.824 \\
-5.583 \\
-5.337\end{array}$ & $\begin{array}{l}-6.314 \\
-6.084 \\
-5.848 \\
-5.607 \\
-5.362\end{array}$ & $\begin{array}{l}-6.336 \\
-6.107 \\
-5.872 \\
-5.632 \\
-5.386\end{array}$ & $\begin{array}{l}-6.359 \\
-6.130 \\
-5.896 \\
-5.656 \\
-5.411\end{array}$ & $\begin{array}{l}-6.382 \\
-6.153 \\
-5.919 \\
-5.680 \\
-5.436\end{array}$ & $\begin{array}{l}-6.404 \\
-6.176 \\
-5.943 \\
-5.704 \\
-5.460\end{array}$ & $\begin{array}{l}-6.427 \\
-6.199 \\
-5.967 \\
-5.728 \\
-5.485\end{array}$ & $\begin{array}{l}-6.449 \\
-6.222 \\
-5.990 \\
-5.752 \\
-5.510\end{array}$ & $\begin{array}{l}-6.471 \\
-6.245 \\
-6.013 \\
-5.776 \\
-5.534\end{array}$ & $\begin{array}{l}-190 \\
-180 \\
-170 \\
-160 \\
-150\end{array}$ \\
\hline $\begin{array}{l}-140 \\
-130 \\
-120 \\
-110 \\
-100\end{array}$ & $\begin{array}{l}-5.034 \\
-4.777 \\
-4.515 \\
-4.248 \\
-3.976\end{array}$ & $\begin{array}{l}-5.060 \\
-4.803 \\
-4.541 \\
-4.274 \\
-4.003\end{array}$ & $\begin{array}{l}-5.085 \\
-4.829 \\
-4.567 \\
-4.301 \\
-4.031\end{array}$ & $\begin{array}{l}-5.111 \\
-4.855 \\
-4.594 \\
-4.328 \\
-4.058\end{array}$ & $\begin{array}{l}-5.136 \\
-4.880 \\
-4.620 \\
-4.355 \\
-4.085\end{array}$ & $\begin{array}{l}-5.161 \\
-4.906 \\
-4.646 \\
-4.382 \\
-4.112\end{array}$ & $\begin{array}{l}-5.186 \\
-4.932 \\
-4.672 \\
-4.408 \\
-4.139\end{array}$ & $\begin{array}{l}-5.212 \\
-4.958 \\
-4.699 \\
-4.435 \\
-4.167\end{array}$ & $\begin{array}{l}-5.237 \\
-4.983 \\
-4.725 \\
-4.462 \\
-4.194\end{array}$ & $\begin{array}{l}-5.262 \\
-5.029 \\
-4.751 \\
-4.488 \\
-4.221\end{array}$ & $\begin{array}{l}-5.287 \\
-5.034 \\
-4.777 \\
-4.515 \\
-4.248\end{array}$ & $\begin{array}{l}-140 \\
-130 \\
-120 \\
-110 \\
-100\end{array}$ \\
\hline $\begin{array}{l}-90 \\
-80 \\
-70 \\
-60 \\
-50\end{array}$ & $\begin{array}{l}-3.700 \\
-3.419 \\
-3.134 \\
-2.845 \\
-2.552\end{array}$ & $\begin{array}{l}-3.728 \\
-3.447 \\
-3.163 \\
-2.874 \\
-2.581\end{array}$ & $\begin{array}{l}-3.755 \\
-3.476 \\
-3.192 \\
-2.903 \\
-2.611\end{array}$ & $\begin{array}{l}-3.783 \\
-3.504 \\
-3.220 \\
-2.932 \\
-2.640\end{array}$ & $\begin{array}{l}-3.811 \\
-3.532 \\
-3.249 \\
-2.961 \\
-2.670\end{array}$ & $\begin{array}{l}-3.838 \\
-3.560 \\
-3.277 \\
-2.990 \\
-2.699\end{array}$ & $\begin{array}{l}-3.866 \\
-3.588 \\
-3.306 \\
-3.019 \\
-2.728\end{array}$ & $\begin{array}{l}-3.894 \\
-3.616 \\
-3.334 \\
-3.048 \\
-2.758\end{array}$ & $\begin{array}{l}-3.921 \\
-3.644 \\
-3.363 \\
-3.077 \\
-2.787\end{array}$ & $\begin{array}{l}-3.949 \\
-3.672 \\
-3.391 \\
-3.106 \\
-2.816\end{array}$ & $\begin{array}{l}-3.976 \\
-3.700 \\
-3.419 \\
-3.134 \\
-2.845\end{array}$ & $\begin{array}{l}-90 \\
-80 \\
-70 \\
-60 \\
-50\end{array}$ \\
\hline $\begin{array}{l}-40 \\
-30 \\
-20 \\
-10 \\
-\quad 0\end{array}$ & $\begin{array}{l}-2.254 \\
-1.953 \\
-1.648 \\
-1.339 \\
-1.026\end{array}$ & $\begin{array}{l}-2.284 \\
-1.983 \\
-1.678 \\
-1.370 \\
-1.057\end{array}$ & $\begin{array}{l}-2.314 \\
-2.014 \\
-1.709 \\
-1.401 \\
-1.089\end{array}$ & $\begin{array}{l}-2.344 \\
-2.044 \\
-1.740 \\
-1.432 \\
-1.120\end{array}$ & $\begin{array}{l}-2.374 \\
-2.074 \\
-1.770 \\
-1.463 \\
-1.151\end{array}$ & $\begin{array}{l}-2.404 \\
-2.104 \\
-1.801 \\
-1.494 \\
-1.183\end{array}$ & $\begin{array}{l}-2.433 \\
-2.134 \\
-1.831 \\
-1.525 \\
-1.214\end{array}$ & $\begin{array}{l}-2.463 \\
-2.164 \\
-1.862 \\
-1.555 \\
-1.245\end{array}$ & $\begin{array}{l}-2.493 \\
-2.194 \\
-1.892 \\
-1.586 \\
-1.276\end{array}$ & $\begin{array}{l}-2.522 \\
-2.224 \\
-1.923 \\
-1.617 \\
-1.308\end{array}$ & $\begin{array}{l}-2.552 \\
-2.254 \\
-1.953 \\
-1.648 \\
-1.339\end{array}$ & $\begin{array}{l}-40 \\
-30 \\
-20 \\
-10 \\
-0\end{array}$ \\
\hline${ }^{\circ} \mathrm{p}$ & 0 & 1 & 2 & 3 & 4 & 5 & 6 & 7 & 8 & 9 & 10 & $r$ \\
\hline
\end{tabular}


TABLE A5.1.2. Type E thermocouples-thermoelectric voltage as a function of temperature $\left({ }^{\circ} \mathrm{F}\right)$, reference junctions at $32^{\circ} \mathrm{F}$-..Continued

0

1

\author{
23
}

$4 \quad 5$

6

7

1
2
30
40

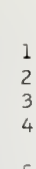

10
20
30
40
50
60
70

10

11

130

140

15

160

180

190

200
210

210
220

230

240

250

260

270

280
290

300

31
32

320
330
340

$\begin{array}{ll}-0.963 & -0.931 \\ -0.645 & -0.613 \\ -0.324 & -0.292\end{array}$

$-0.324-0.292$

$\begin{array}{ll}0.000 & 0.033 \\ 0.327 & 0.360\end{array}$

$0.591 \quad 0.624$

0.924

1. 259

1. 597

1. 937

2. 281

2.627

2. 977

3.32
3.68

4. 041

4. 401

4.764

5.130

5.498

5.869

6.242

6.618

6. 996

7.377

7. 760

8. 145

8. 532

8.922

9.314

9. 708

10.103

10.50

10.901
11.302

11.706

12.11

12.926

13.336

13.74

$14.161 \quad 13.789$

$14.576 \quad 14.618$

14.992

15.410

15.829

16.249

16.670

17.093
17.517

17.94

$17.942 \quad 17.994$

$18.795 \quad 18.838$

18.795

19.653

20.083

$20.514 \quad 20.558$

20.947

$21.380 \quad 21.42$

0.658

0.990

0.691

1.326

1.360

1.631
1.972

2.006

1.699

2.040

2.316
2.662

2. 350

3.012
3.364

2.697

3. 047

2.385

2.732

3.082

3. 755

3.790

4. 077

4. 113

4.801

5.166
5.535

5.906

6.280
6.656

7.034
7.415

7. 798

8. 184

8.961

4.474

4.837

4.149

4.510

4.874

5. 572

5.943

6.317

6.693

7.453

7.837

8. 222

8.610

9.000
9.392

5.609

5. 981

6.355

6.731

7.491

7.875

8.261

8.649

9.039
9.432

9.787

10.183

9. 826

10.223

..98 10.621

10.981
11.383

11.021
11.423

11.787

11.827

12.233

2.599

$13.008 \quad 12.640$

$13.419 \quad 13.460$

$-0.900$

$-0.581-0.868$

$\begin{array}{rr}-0.581 & -0.549 \\ -0.260 & -0.227\end{array}$

0.0650 .098

0.393

$\begin{array}{ll}0.724 & 0.757\end{array}$

$1.394 \quad 1.427$

2.075

1.767

2. 109

2.419

2. 767

3.117
3.470

2.454

2.802
3.152

3.152
3.506

3.826

4.185

3.862

4. 221

4.546

4.910
5.277

5.646

4.582

$4 \cdot 947$

5.314

6.018

6.392

6.769

7.530

7.914

8.300

9.078

9.471

9.866

10.262

10.661

11.061

11.868

12.273

12.681

12.72

6.055

6.430

6.807

7.568

7.952

8.338

9.118

9.510

9.905

10.302

10.701

11.101

1.908

2.314

2.722
3.131

$13.831 \quad 13.872$

13.501

13.91

13.542

13.955
14.368

$\begin{array}{llll}14.244 & 14.286 & 14.327 & 14.368 \\ 14.659 & 14.701 & 14.742 & 14.784\end{array}$

$\begin{array}{ll}15.076 & 15.11 \\ 15.493 & 15.535\end{array}$

$14 \cdot 742$
15.159

14.784
15.201
15.619

15.619

$\begin{array}{ll}5.912 & 15.954 \\ 6.333 & 16.375\end{array}$

6.755

16.375

15.996

16.417

16.038

16.459

7.305

17.602

$17.220-17.262$

17.644

17.687

$18.027 \quad 18.070 \quad 18.112$

$10.453 \quad 18.496$

18.539

17.729

18.155

18.581
19.009

$\begin{array}{ll}.801 & 18.924 \\ 19.309 & 19.352\end{array}$

19.73919 .782

18.966

19.395
19.825

$20.169 \quad 20.212 \quad 20.256$

$20.501 \quad 20.644 \quad 20.687$

$21.033 \quad 21.076$

$21.466 \quad 21.510$

21.120

19.438

19.868

20.299

20.730

21.163

$22 \cdot 24$

$8 \quad 22.292$

$22.336 \quad 22.379$

22.423

22.031

$\begin{array}{rr}-0.836 & -0.805 \\ -0.517 & -0.485 \\ -0.195 & -0.163 \\ 0.131 & 0.163\end{array}$

$0.459 \quad 0.492$

0.790
1.124

1.1241 .158

2.143 
TABLE A5.1.2. Type E thermocouples-thermoelectric voltage as a function of temperature $\left({ }^{\circ} \mathrm{F}\right)$, reference junctions at $32^{\circ} \mathrm{F}$-Continued

${ }^{\circ} \mathrm{F}$

0

1

2

3

THERMOELECTRIC VOLTAGE IN ABSOLUTE MILLIVOLTS

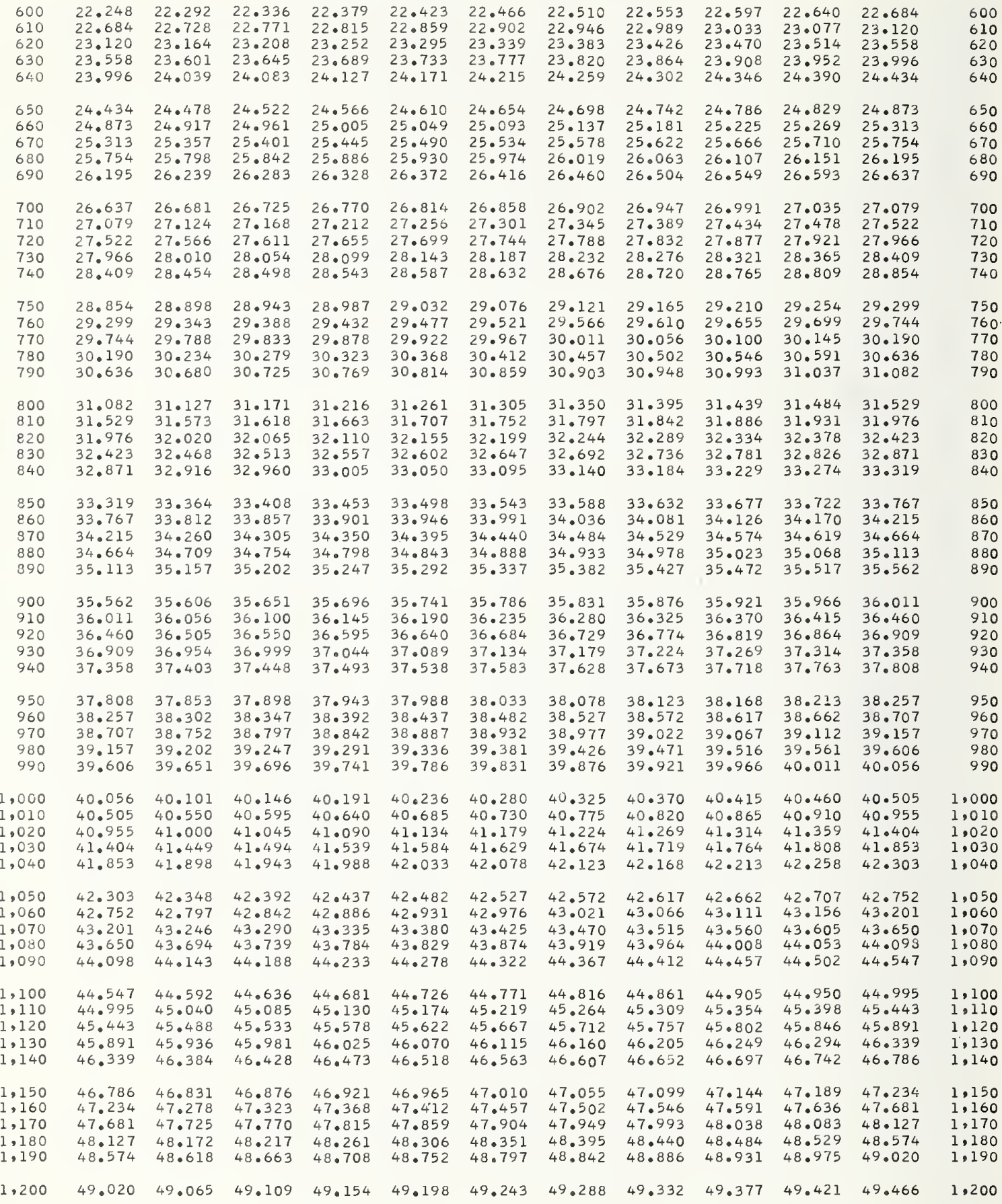
22.684 23.120 23.996

24.873

25.313

26.195

26.637

27.079

27.966

11.082

36.460

37.358

41.853

42.303

2.752

43.650

44.098

45.085

46.428

49.109
22.379

23.25

24.12 
TABLE A5.1.2. Type E thermocouples-thermoelectric voltage as a function of temperature $\left({ }^{\circ} \mathrm{F}\right)$, reference junctions at $32^{\circ} \mathrm{F}$-Continued

${ }^{\circ} \mathrm{F}$

1
1,210

1,220

1,230

1,240

1,250

1,260

1,270

1,280

1,290

1,300

1,310

1,320

1,330

1,340

1,350

1,360

1,370

1,380

1,390

1,400

1,410

1,420

1,430

1,440

1,450

1,460

1,470

1,480

1,490

1,500

1,510

1,520

1,530

1,540

1,550

1,560

1,570

1,580

1,590

1,600

1,610

1,620

1,630

1,640

1,550

1,660

1,670

1,680

1,690

1,700

1,710

1,730

1,740

1,750

1,760

1,770

1,780

1,790

1,800

$\begin{array}{ll}49.020 & 49.065 \\ 49.466 & 49.510 \\ 49.911 & 49.956 \\ 50.357 & 50.401 \\ 50.802 & 50.846\end{array}$

49.109

49.555

50.001

50.446
50.891

49.600

50.045

50.490

$51.246 \quad 51.291$

$51.691 \quad 51.735$

$52.135 \quad 52.179$

$.578 \quad 52.623$

53.02253 .066

53.465

53.907

53.951

55.233

55.674

56.115

56.555

57.434

57.873

58.312

58.750

59.188

59.626

60.063

60.499

60.935

61.371

61.806

62.240

63.108

63.974

64.406

64.838

65.269

65.700

66.130

66.559

66.988

67.416

67.844

68.271

68.698

69.124

69.549

69.974

70.398

70.821

71.244

71.667

72.088

72.509

72.930

73.350

73.769

73.769
74.188

74.606

75.02475 .065

51.335

51.780

52.223

52.667

53.110

51.380

51.824

2.268

(2.711

53.553

53.996

54.438

54.880

55.321

3.597

54.040

54.482
54.924

55.365

55.762

56.203

56.643

57.083

55.806

56.247
56.687

56.687

57.566

57.917

57.961

58.794

59.232

59.669

58.400

58.838

59.276

59.713

58.005

58.444

58.882

59.757

8.487

8.926

9.363

60.150

60.543

60.979

61.849

60.586

61.022

$60.194 \quad 60.237$

60.63

6.630

0.237

61.893

1.501

61.109

61.545

5

6

7

10

${ }^{\circ} \mathrm{F}$

2.718

62.327

62.371

61.980

62.761

63.62

64.017

64.061

62.805

62.414

2.848

63.671

63.282

64.104

64.147

64.493

64.536

64.881

65.312

66.173

65.355

65.786

64.967

65.398

6.302

66.602

66.645

66.688

66.73

67.15

67.502

67.117

67.972

67.588

68.399

68.442

68.357

68.826

68.868

69.251

69.677

70.101

69.294

69.719

70.144

70.059

70.525

70.567

70.906

70.948

70.991

$71.371 \quad 71.413$

$71.793 \quad 71.835$

$72.635 \quad 72.678$

72.593

73.014

73.056

73.098

73.517

73.853

74.689

74.313

73.936

74.773

75.107

74.397
.815

9.337

69.762

70.186

71.033

71.456

71.878

72.299

72.720

49.28

ILLIVOLTS

49.332

$49 \cdot 377$

49.421

49.466

49.911

50.357

50.802

$\begin{array}{lll}50.179 & 50.223 & 50.268\end{array}$ 
TABLE A5.1.2. Type $\boldsymbol{E}$ thermocouples-thermoelectric voltage as a function of temperature $\left({ }^{\circ} \mathrm{F}\right)$, reference junctions at $32{ }^{\circ} \mathrm{F}$-Continued

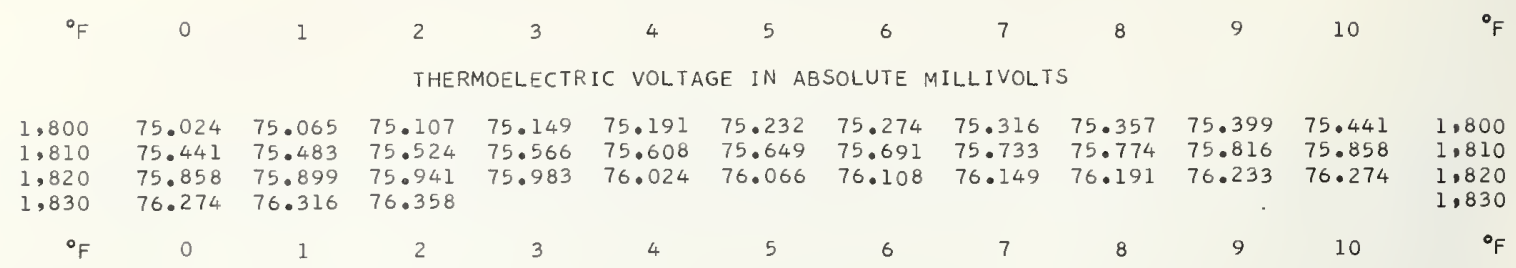

TABLE A5.1.3. Type $\boldsymbol{E}$ thermocouples-quadratic, cubic, and quartic approximations to the data as a func. tion of temperature $\left({ }^{\circ} \mathrm{C}\right)$ in selected temperature ranges. The expansion is of the form $\mathrm{E}=\mathrm{a}_{0}+\mathrm{a}_{1} \mathrm{~T}+\mathrm{a}_{2} \mathrm{~T}^{2}+\mathrm{a}_{3} \mathrm{~T}^{3}+\mathrm{a}_{4} \mathrm{~T}^{+}$where $\mathrm{E}$ is in microvolts and $\mathrm{T}$ is in degrees Celsius

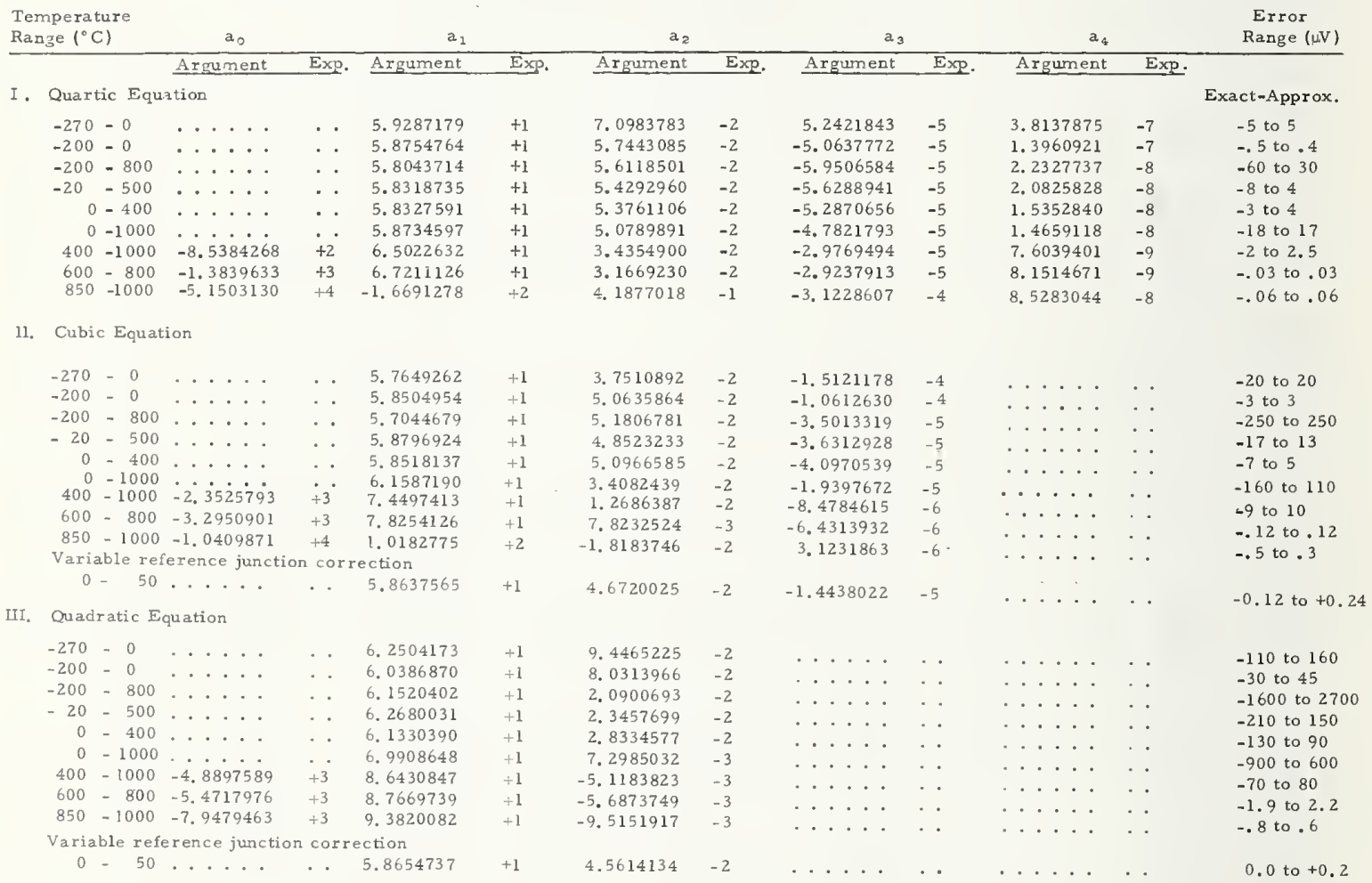




\section{A5.2. Data for Temperature as a Function of Voltage}

The temperature as a function of voltage data given in tables A5.2.1 and A5.2.2 were obtained by iteration in the primary equations for voltage as a function of temperatures. Table A5.2.1 presents the data in millivolts from $-9.83 \mathrm{mV}$ to $76.35 \mathrm{mV}$ with temperatures given in degrees Celsius while table A5.2.2 presents similar data with temperatures in degrees Fahrenheit. Table A5.2.3 contains quadratic, cubic, and quartic approximations to the data as a function of voltage in selected tem. perature ranges. The error range given in the table represents the difference between the temperature found by iteration in the full precision tables from the text and from the respective reduced order approximations.

TABLE A5.2.1. Type E thermocouples-temperature $\left({ }^{\circ} \mathrm{C}\right)$ as a function of thermoelectric voltage, reference junctions at $0^{\circ} \mathrm{C}$

$m$ V .00 .01 .02 .03

TEMPERATURES IN DEGREES C (IPTS IO6B)
$-9.80$

$-9.70$

$-9.60$

$-9.50$

$-9.40$

$-9.30$

$-9.20$

$-9.10$

$-9.00$

$-8.90$

$-8.80$

$-8 \cdot 70$

$-8.60$

$-8.50$

$-8.40$

$-8.30$

$-8 \cdot 20$

$-8.10$

$-8.00$

$-7.90$

$-7.80$

$-7.70$

$-7.60$

$-7.50$

$-7.40$

$-7.30$

$-7.20$

$-7.10$

$-7.00$

$-6.90$

$-6.80$

$-6.70$

$-6.60$

$-6 \cdot 50$

$-6.40$

$-6.30$

$-6 \cdot 20$

$-6.10$

$-6.00$

$\mathrm{mV}$

-262.45
-249.13
-240.45
-233.43
-227.34
-221.86
-216.83
-212.12
-207.68
-203.46
-199.42
-195.54
-191.80
-188.17
-184.66
-181.24
-177.90
-174.65
-171.47
-168.36
-165.31
-162.32
-159.38
-156.49
-153.65
-150.86
-148.11
-145.40
-142.72
-140.08
-137.48
-134.91
-132.36
-129.85
-127.37
-124.91
-122.48
-120.08
-117.70

$-264.68$ $-250.15$ $-241.22$

$-234.08$

$-227.92$

$-222.39$

$-217.31$

$-212 \cdot 58$

$-208 \cdot 12$

$-203.88$

$-199.82$

$-195.93$

$-192.17$

$-188.53$

$-185.00$

$-181 \cdot 57$

$-178.23$

$-174.97$

$-171.78$

$-168.67$

$-165.61$

$-162.61$

$-159.67$

$-156.78$

$-153.94$

$-151 \cdot 14$

$-148.38$

$-145.66$

$-142.99$

$-140 \cdot 34$

$-137.74$

$-135 \cdot 16$

$-132.62$

$-130.10$

$-127.62$

$-125.16$

$-120.32$

$-117.93$
267.64

-251.21
-242.01

$-234.74$

$-228.50$

$-222.92$

$-217.80$

$-213.04$

$-208.55$

$-204 \cdot 29$
$-200 \cdot 22$

$-196.31$

$-192.54$

$-188.89$

$-185.35$

$-181.91$

$-178.56$

$-175.29$

$-172.10$

$-168.97$

$-165.91$

$-162.91$

$-159.96$

$-157.07$

$-154.22$

$-151.41$

$-148.65$

$-145.93$

$-143 \cdot 25$

$-140.61$

$-138.00$

$-135 \cdot 42$

$-132.87$

$-130.35$

-127.86
-125.40

$-122.97$

-120.56
-118.17

\section{$\begin{array}{lllll}-252.32 & -253.49 & -254.71 & -256.01\end{array}$ \\ $-242.82-243.65$ \\ $-235.41-236.10$ \\ $-244.50$ \\ $-236.79$ \\ -245.37
-237.49}

$-229.09$

$-223.45$

$-218 \cdot 30$
$-213 \cdot 50$

$-208 \cdot 99$

$-204 \cdot 71$

$-200 \cdot 62$

$-196.69$

$-192.91$

$-189.25$

$-185.70$

$-182 \cdot 25$

$-178.89$

$-175.62$

$-172.42$

$-169 \cdot 28$

$-166.22$

$-163.21$

$-160.25$

$-157 \cdot 35$

$-154.50$

$-151.69$

$-148.93$

$-146.20$

$-143.52$

$-140.87$

$-138 \cdot 26$

$-135.6$

$-130.60$

$-128 \cdot 11$

$-123.21$

$-120.80$

$-118.41$
$-229.69$

$-223.99$

$-218.80$

209.43

$-201.02$

$-197.08$

$-193.28$

$-189.61$

$-186 \cdot 05$

$-182.59$

$-179.23$

$-175.94$

$-172.73$

$-169.59$

$-166.52$

$-163.51$

$-160.55$

$-157.64$

$-154.78$

$-151.97$

$-149.20$

$-146.48$

$-143.79$

$-141.13$

$-138.52$

$-135.93$

$-133.38$

$-130.85$

$-128 \cdot 36$

$-123.45$

$-121.04$

$-118.64$
$-213.97$
$-230.29$

$-224.54$

$-219.30$

$-214 \cdot 44$

$-209.87$

$-205.55$

$-201.42$

$-193.65$

$-189.97$

$-186.40$

$-182.93$

$-179.56$

$-176.27$

$-173.05$

$-169.91$

$-166.82$

$-163.80$

$-160.84$

$-157.93$

$-155.07$

$-152 \cdot 25$

$-149.48$

$-146 \cdot 75$

$-144.05$

$-141 \cdot 40$

$-138.78$

$-136 \cdot 19$

$-133.63$

$-131.10$

$-128.61$

$-126 \cdot 14$

$-123.69$

$-121 \cdot 28$
-118.88
$-230.90$

$-225.09$

$-219.80$

$-210.32$

$-205.97$

$-201.83$

$-197.85$

$-194.03$

$-190.33$

$-186.75$

$-183.28$

$-179.89$

$-176.59$

$-173.37$

$-170.22$

$-167.13$

$-164.10$

$-161.13$

$-155.35$

$-152.53$

$-149.75$

$-147.02$

$-144 \cdot 32$

$-141.66$

$-139.04$

$-136.45$

$-133.89$

$-131.36$

$-128.86$

$-126.38$

$-123.94$

$-121.52$

$-119.12$
$-158.22$

$-257.41$

$-246.27$

$-238.21$

$-231.52$

$-225.64$

$-220.31$

$-215.38$

$-206.40$

$-202.23$ 
TABLE A5.2.1. Type E thermocouples-temperature $\left({ }^{\circ} \mathrm{C}\right)$ as a function of thermoelectric voltage, reference junctions at $0^{\circ} \mathrm{C}$-Continued

$m \mathrm{v}$

.00

.01

.02

.03

.04

.05

.06

.07

.08

.09

.10

$\mathrm{mV}$

TEMPERATURES IN DEGREES C (IPTS 1968)

\begin{tabular}{|c|c|c|c|c|c|c|c|c|c|c|c|c|}
\hline 6.00 & -117.46 & $-117 \cdot 70$ & -117.93 & -118.17 & $-118 \cdot 41$ & -118.64 & $-118 \cdot 88$ & $-119 \cdot 12$ & $-119 \cdot 36$ & -119.60 & $-119 \cdot 84$ & $-6 \cdot 00$ \\
\hline $\begin{array}{l}-5.90 \\
-5.80 \\
-5.70 \\
-5.60 \\
-5.50\end{array}$ & $\begin{array}{l}-115.10 \\
-112.77 \\
-110.46 \\
-108.16 \\
-105.89\end{array}$ & $\begin{array}{l}-115.34 \\
-113.00 \\
-110.69 \\
-108.39 \\
-106.12\end{array}$ & $\begin{array}{l}-115.57 \\
-113.23 \\
-110.92 \\
-108.62 \\
-106.35\end{array}$ & $\begin{array}{l}-115.81 \\
-113.47 \\
-111.15 \\
-108.85 \\
-106.57\end{array}$ & $\begin{array}{l}-116.04 \\
-113.70 \\
-111.38 \\
-109.08 \\
-106.80\end{array}$ & $\begin{array}{l}-116.28 \\
-113.93 \\
-111.61 \\
-109.31 \\
-107.03\end{array}$ & $\begin{array}{l}-116.51 \\
-114.17 \\
-111.84 \\
-109.54 \\
-107.25\end{array}$ & $\begin{array}{l}-116.75 \\
-114.40 \\
-112.07 \\
-109.77 \\
-107.48\end{array}$ & $\begin{array}{l}-116.99 \\
-114.63 \\
-112.30 \\
-110.00 \\
-107.71\end{array}$ & $\begin{array}{l}-117.22 \\
-114.87 \\
-112.54 \\
-110.23 \\
-107.94\end{array}$ & $\begin{array}{l}-117.46 \\
-115.10 \\
-112.77 \\
-110.46 \\
-108.16\end{array}$ & $\begin{array}{l}-5.90 \\
-5.80 \\
-5.70 \\
-5.60 \\
-5.50\end{array}$ \\
\hline $\begin{array}{l}-5.40 \\
-5.30 \\
-5.20 \\
-5.10 \\
-5.00\end{array}$ & $\begin{array}{r}-103.64 \\
-101.41 \\
-99.19 \\
-96.99 \\
-94.81\end{array}$ & $\begin{array}{r}-103.86 \\
-101.63 \\
-99.41 \\
-97.21 \\
-95.03\end{array}$ & $\begin{array}{r}-104.09 \\
-101.85 \\
-99.63 \\
-97.43 \\
-95.25\end{array}$ & $\begin{array}{r}-104.31 \\
-102.07 \\
-99.85 \\
-97.65 \\
-95.46\end{array}$ & $\begin{array}{r}-104.54 \\
-102.30 \\
-100.07 \\
-97.87 \\
-95.68\end{array}$ & $\begin{array}{r}-104.76 \\
-102.52 \\
-100.30 \\
-98.09 \\
-95.90\end{array}$ & $\begin{array}{r}-104.99 \\
-102.74 \\
-100.52 \\
-98.31 \\
-96.12\end{array}$ & $\begin{array}{r}-105.21 \\
-102.97 \\
-100.74 \\
-98.53 \\
-96.34\end{array}$ & $\begin{array}{r}-105.44 \\
-103.19 \\
-100.96 \\
-98.75 \\
-96.55\end{array}$ & $\begin{array}{r}-105.67 \\
-103.42 \\
-101.18 \\
-98.97 \\
-96.77\end{array}$ & $\begin{array}{r}-105.89 \\
-103.64 \\
-101.41 \\
-99.19 \\
-96.99\end{array}$ & $\begin{array}{l}-5.40 \\
-5.30 \\
-5.20 \\
-5.10 \\
-5.00\end{array}$ \\
\hline $\begin{array}{l}-4.90 \\
-4.80 \\
-4.70 \\
-4.60 \\
-4.50\end{array}$ & $\begin{array}{l}-92.64 \\
-90.50 \\
-88.36 \\
-86.24 \\
-84.14\end{array}$ & $\begin{array}{l}-92.86 \\
-90.71 \\
-88.57 \\
-86.45 \\
-84.35\end{array}$ & $\begin{array}{l}-93.08 \\
-90.92 \\
-88.79 \\
-86.67 \\
-84.56\end{array}$ & $\begin{array}{l}-93.29 \\
-91.14 \\
-89.00 \\
-86.88 \\
-84.77\end{array}$ & $\begin{array}{l}-93 \cdot 51 \\
-91.35 \\
-89 \cdot 21 \\
-87.09 \\
-84.98\end{array}$ & $\begin{array}{l}-93.73 \\
-91.57 \\
-89.43 \\
-87.30 \\
-85.19\end{array}$ & $\begin{array}{l}-93.94 \\
-91.78 \\
-89.64 \\
-87.51 \\
-85.40\end{array}$ & $\begin{array}{l}-94.16 \\
-92.00 \\
-89.85 \\
-87.72 \\
-85.61\end{array}$ & $\begin{array}{l}-94.38 \\
-92.21 \\
-90.07 \\
-87.94 \\
-85.82\end{array}$ & $\begin{array}{l}-94.59 \\
-92.43 \\
-90.28 \\
-88.15 \\
-86.03\end{array}$ & $\begin{array}{l}-94.81 \\
-92.64 \\
-90.50 \\
-88.36 \\
-86.24\end{array}$ & $\begin{array}{l}-4.90 \\
-4.80 \\
-4.70 \\
-4.60 \\
-4.50\end{array}$ \\
\hline $\begin{array}{l}-4.40 \\
-4 \cdot 30 \\
-4.20 \\
-4.10 \\
-4.00\end{array}$ & $\begin{array}{l}-82.05 \\
-79.97 \\
-77.91 \\
-75.86 \\
-73.82\end{array}$ & $\begin{array}{l}-82.26 \\
-80.18 \\
-78.12 \\
-76.06 \\
-74.03\end{array}$ & $\begin{array}{l}-82.47 \\
-80.39 \\
-78.32 \\
-76.27 \\
-74.23\end{array}$ & $\begin{array}{l}-82.67 \\
-80.59 \\
-78.53 \\
-76.47 \\
-74.43\end{array}$ & $\begin{array}{l}-82.88 \\
-80.80 \\
-78.73 \\
-76.68 \\
-74.64\end{array}$ & $\begin{array}{l}-83.09 \\
-81.01 \\
-78.94 \\
-76.88 \\
-74.84\end{array}$ & $\begin{array}{l}-83.30 \\
-81.22 \\
-79.15 \\
-77.09 \\
-75.04\end{array}$ & $\begin{array}{l}-83.51 \\
-81.42 \\
-79.35 \\
-77.29 \\
-75.25\end{array}$ & $\begin{array}{l}-83.72 \\
-81.63 \\
-79.56 \\
-77.50 \\
-75.45\end{array}$ & $\begin{array}{l}-83.93 \\
-81.84 \\
-79.77 \\
-77.70 \\
-75.66\end{array}$ & $\begin{array}{l}-84.14 \\
-82.05 \\
-79.97 \\
-77.91 \\
-75.86\end{array}$ & $\begin{array}{l}-4.40 \\
-4.30 \\
-4.20 \\
-4.10 \\
-4.00\end{array}$ \\
\hline $\begin{array}{l}-3.90 \\
-3.80 \\
-3.70 \\
-3.60 \\
-3.50\end{array}$ & $\begin{array}{l}-71.80 \\
-69.78 \\
-67.78 \\
-65.79 \\
-63.81\end{array}$ & $\begin{array}{l}-72.00 \\
-69.98 \\
-67.98 \\
-65.99 \\
-64.01\end{array}$ & $\begin{array}{l}-72.20 \\
-70.19 \\
-68.18 \\
-66.19 \\
-64.21\end{array}$ & $\begin{array}{l}-72.40 \\
-70.39 \\
-68.38 \\
-66.39 \\
-64.41\end{array}$ & $\begin{array}{l}-72.61 \\
-70.59 \\
-68.58 \\
-66.59 \\
-64.60\end{array}$ & $\begin{array}{l}-72.81 \\
-70.79 \\
-68.78 \\
-66.79 \\
-64.80\end{array}$ & $\begin{array}{l}-73.01 \\
-70.99 \\
-68.98 \\
-66.98 \\
-65.00\end{array}$ & $\begin{array}{l}-73.21 \\
-71.19 \\
-69.18 \\
-67.18 \\
-65.20\end{array}$ & $\begin{array}{l}-73.42 \\
-71.39 \\
-69.38 \\
-67.38 \\
-65.40\end{array}$ & $\begin{array}{l}-73.62 \\
-71.59 \\
-69.58 \\
-67.58 \\
-65.59\end{array}$ & $\begin{array}{l}-73.82 \\
-71.80 \\
-69.78 \\
-67.78 \\
-65.79\end{array}$ & $\begin{array}{l}-3.90 \\
-3.80 \\
-3.70 \\
-3.60 \\
-3.50\end{array}$ \\
\hline $\begin{array}{l}-3.40 \\
-3.30 \\
-3.20 \\
-3.10 \\
-3.00\end{array}$ & $\begin{array}{l}-61.85 \\
-59.89 \\
-57.94 \\
-56.00 \\
-54.08\end{array}$ & $\begin{array}{l}-62.04 \\
-60.08 \\
-58.13 \\
-56.20 \\
-54.27\end{array}$ & $\begin{array}{l}-62.24 \\
-60.28 \\
-58.33 \\
-56 \cdot 39 \\
-54.46\end{array}$ & $\begin{array}{l}-62.43 \\
-60.47 \\
-58.52 \\
-56.58 \\
-54.65\end{array}$ & $\begin{array}{l}-62.63 \\
-60.67 \\
-58.72 \\
-56.78 \\
-54.85\end{array}$ & $\begin{array}{l}-62.83 \\
-60.87 \\
-58.91 \\
-56.97 \\
-55.04\end{array}$ & $\begin{array}{l}-63.02 \\
-61.06 \\
-59.11 \\
-57.16 \\
-55.23\end{array}$ & $\begin{array}{l}-63 \cdot 22 \\
-61 \cdot 26 \\
-59 \cdot 30 \\
-57 \cdot 36 \\
-55,42\end{array}$ & $\begin{array}{l}-63.42 \\
-61.45 \\
-59.50 \\
-57.55 \\
-55.62\end{array}$ & $\begin{array}{l}-63.62 \\
-61.65 \\
-59.69 \\
-57.75 \\
-55.81\end{array}$ & $\begin{array}{l}-63.81 \\
-61.85 \\
-59.89 \\
-57.94 \\
-56.00\end{array}$ & $\begin{array}{l}-3.40 \\
-3.30 \\
-3.20 \\
-3.10 \\
-3.00\end{array}$ \\
\hline $\begin{array}{l}-2.90 \\
-2.80 \\
-2.70 \\
-2.60 \\
-2.50\end{array}$ & $\begin{array}{l}-52.16 \\
-50.25 \\
-48.35 \\
-46.46 \\
-44.58\end{array}$ & $\begin{array}{l}-52.35 \\
-50.44 \\
-48.54 \\
-46.65 \\
-44.77\end{array}$ & $\begin{array}{l}-52.54 \\
-50.63 \\
-48.73 \\
-46.84 \\
-44.96\end{array}$ & $\begin{array}{l}-52.73 \\
-50.82 \\
-48.92 \\
-47.03 \\
-45.15\end{array}$ & $\begin{array}{l}-52.92 \\
-51.01 \\
-49.11 \\
-47.22 \\
-45.33\end{array}$ & $\begin{array}{l}-53.12 \\
-51.20 \\
-49.30 \\
-47.41 \\
-45.52\end{array}$ & $\begin{array}{l}-53.31 \\
-51.39 \\
-49.49 \\
-47.60 \\
-45.71\end{array}$ & $\begin{array}{l}-53.50 \\
-51.59 \\
-49.68 \\
-47.78 \\
-45.90\end{array}$ & $\begin{array}{l}-53.69 \\
-51.78 \\
-49.87 \\
-47.97 \\
-46.09\end{array}$ & $\begin{array}{l}-53.88 \\
-51.97 \\
-50.06 \\
-48.16 \\
-46.27\end{array}$ & $\begin{array}{l}-54.08 \\
-52.16 \\
-50.25 \\
-48.35 \\
-46.46\end{array}$ & $\begin{array}{l}-2.90 \\
-2.80 \\
-2.70 \\
-2.60 \\
-2.50\end{array}$ \\
\hline $\begin{array}{l}-2.40 \\
-2.30 \\
-2.20 \\
-2.10 \\
-2.00\end{array}$ & $\begin{array}{l}-42.71 \\
-40.85 \\
-38.99 \\
-37.14 \\
-35.31\end{array}$ & $\begin{array}{l}-42.90 \\
-41.03 \\
-39.18 \\
-37.33 \\
-35.49\end{array}$ & $\begin{array}{l}-43.08 \\
-41.22 \\
-39.36 \\
-37.51 \\
-35.67\end{array}$ & $\begin{array}{l}-43.27 \\
-41.40 \\
-39.55 \\
-37.70 \\
-35.86\end{array}$ & $\begin{array}{l}-43.46 \\
-41.59 \\
-39.73 \\
-37.88 \\
-36.04\end{array}$ & $\begin{array}{l}-43.64 \\
-41.78 \\
-39.92 \\
-38.07 \\
-36.22\end{array}$ & $\begin{array}{l}-43.83 \\
-41.96 \\
-40.10 \\
-38.25 \\
-36.41\end{array}$ & $\begin{array}{l}-44.02 \\
-42.15 \\
-40.29 \\
-38.44 \\
-36.59\end{array}$ & $\begin{array}{l}-44.21 \\
-42.34 \\
-40.47 \\
-38.62 \\
-36.78\end{array}$ & $\begin{array}{l}-44.39 \\
-42.52 \\
-40.66 \\
-38.81 \\
-36.96\end{array}$ & $\begin{array}{l}-44.58 \\
-42.71 \\
-40.85 \\
-38.99 \\
-37.14\end{array}$ & $\begin{array}{l}-2.40 \\
-2.30 \\
-2.20 \\
-2.10 \\
-2.00\end{array}$ \\
\hline $\begin{array}{l}-1.90 \\
-1.80 \\
-1.70 \\
-1.60 \\
-1.50\end{array}$ & $\begin{array}{l}-33.47 \\
-31.65 \\
-29.83 \\
-28.03 \\
-26.22\end{array}$ & $\begin{array}{l}-33.66 \\
-31.83 \\
-30.02 \\
-28.21 \\
-26.40\end{array}$ & $\begin{array}{l}-33.84 \\
-32.01 \\
-30.20 \\
-28.39 \\
-26.58\end{array}$ & $\begin{array}{l}-34.02 \\
-32.20 \\
-30.38 \\
-28.57 \\
-26.76\end{array}$ & $\begin{array}{l}-34.21 \\
-32.38 \\
-30.56 \\
-28.75 \\
-26.94\end{array}$ & $\begin{array}{l}-34.39 \\
-32.56 \\
-30.74 \\
-28.93 \\
-27.12\end{array}$ & $\begin{array}{l}-34.57 \\
-32.74 \\
-30.92 \\
-29.11 \\
-27.30\end{array}$ & $\begin{array}{l}-34.75 \\
-32.93 \\
-31.10 \\
-29.29 \\
-27.48\end{array}$ & $\begin{array}{l}-34.94 \\
-33.11 \\
-31.29 \\
-29.47 \\
-27.67\end{array}$ & $\begin{array}{l}-35.12 \\
-33.29 \\
-31.47 \\
-29.65 \\
-27.85\end{array}$ & $\begin{array}{l}-35.31 \\
-33.47 \\
-31.65 \\
-29.83 \\
-28.03\end{array}$ & $\begin{array}{l}-1.90 \\
-1.80 \\
-1.70 \\
-1.60 \\
-1.50\end{array}$ \\
\hline $\begin{array}{l}-1.40 \\
-1.30 \\
-1.20 \\
-1.10 \\
-1.00\end{array}$ & $\begin{array}{l}-24.43 \\
-22.64 \\
-20.86 \\
-19.09 \\
-17.32\end{array}$ & $\begin{array}{l}-24.61 \\
-22.82 \\
-21.04 \\
-19.27 \\
-17.50\end{array}$ & $\begin{array}{l}-24.79 \\
-23.00 \\
-21.22 \\
-19.44 \\
-17.68\end{array}$ & $\begin{array}{l}-24.97 \\
-23.18 \\
-21.40 \\
-19.62 \\
-17.85\end{array}$ & $\begin{array}{l}-25.15 \\
-23.36 \\
-21.57 \\
-19.80 \\
-18.03\end{array}$ & $\begin{array}{l}-25.33 \\
-23.54 \\
-21.75 \\
-19.98 \\
-18.21\end{array}$ & $\begin{array}{l}-25.51 \\
-23.72 \\
-21.93 \\
-20.15 \\
-18.38\end{array}$ & $\begin{array}{l}-25.69 \\
-23.89 \\
-22.11 \\
-20.33 \\
-18.56\end{array}$ & $\begin{array}{l}-25.87 \\
-24.07 \\
-22.29 \\
-20.51 \\
-18.74\end{array}$ & $\begin{array}{l}-26.05 \\
-24.25 \\
-22.47 \\
-20.69 \\
-18.91\end{array}$ & $\begin{array}{l}-26.22 \\
-24.43 \\
-22.64 \\
-20.86 \\
-19.09\end{array}$ & $\begin{array}{l}-1.40 \\
-1.30 \\
-1.20 \\
-1.10 \\
-1.00\end{array}$ \\
\hline $\begin{array}{l}-0.90 \\
-0.80 \\
-0.70 \\
-0.60 \\
-0.50\end{array}$ & $\begin{array}{r}-15.56 \\
-13.81 \\
-12.06 \\
-10.32 \\
-8.59\end{array}$ & $\begin{array}{r}-15.74 \\
-13.99 \\
-12.24 \\
-10.50 \\
-8.76\end{array}$ & $\begin{array}{r}-15.92 \\
-14.16 \\
-12.41 \\
-10.67 \\
-8.93\end{array}$ & $\begin{array}{r}-16.09 \\
-14.34 \\
-12.59 \\
-10.84 \\
-9.11\end{array}$ & $\begin{array}{r}-16.27 \\
-14.51 \\
-12.76 \\
-11.02 \\
-9.28\end{array}$ & $\begin{array}{r}-16.44 \\
-14.69 \\
-12.94 \\
-11.19 \\
-9.45\end{array}$ & $\begin{array}{r}-16.62 \\
-14.86 \\
-13.11 \\
-11.37 \\
-9.63\end{array}$ & $\begin{array}{r}-16.79 \\
-15.04 \\
-13.29 \\
-11.54 \\
-9.80\end{array}$ & $\begin{array}{r}-16.97 \\
-15.21 \\
-13.46 \\
-11.71 \\
-9.97\end{array}$ & $\begin{array}{l}-17.15 \\
-15.39 \\
-13.64 \\
-11.89 \\
-10.15\end{array}$ & $\begin{array}{l}-17.32 \\
-15.56 \\
-13.81 \\
-12.06 \\
-10.32\end{array}$ & $\begin{array}{l}-0.90 \\
-0.80 \\
-0.70 \\
-0.60 \\
-0.50\end{array}$ \\
\hline $\begin{array}{l}-0.40 \\
-0.30 \\
-0.20 \\
-0.10 \\
-0.00\end{array}$ & $\begin{array}{r}-6.86 \\
-5.14 \\
-3.42 \\
-1.71 \\
0.00\end{array}$ & $\begin{array}{l}-7.03 \\
-5.31 \\
-3.59 \\
-1.88 \\
-0.17\end{array}$ & $\begin{array}{l}-7.20 \\
-5.48 \\
-3.76 \\
-2.05 \\
-0.34\end{array}$ & $\begin{array}{l}-7.38 \\
-5.65 \\
-3.93 \\
-2.22 \\
-0.51\end{array}$ & $\begin{array}{l}-7.555 \\
-5.82 \\
-4.10 \\
-2.39 \\
-0.68\end{array}$ & $\begin{array}{l}-7.72 \\
-6.00 \\
-4.28 \\
-2.56 \\
-0.85\end{array}$ & $\begin{array}{l}-7.89 \\
-6.17 \\
-4.45 \\
-2.73 \\
-1.02\end{array}$ & $\begin{array}{l}-8.07 \\
-6.34 \\
-4.62 \\
-2.90 \\
-1.19\end{array}$ & $\begin{array}{l}-8.24 \\
-6.51 \\
-4.79 \\
-3.08 \\
-1.36\end{array}$ & $\begin{array}{l}-8.41 \\
-6.69 \\
-4.96 \\
-3.25 \\
-1.54\end{array}$ & $\begin{array}{l}-8.59 \\
-6.86 \\
-5.14 \\
-3.42 \\
-1.71\end{array}$ & $\begin{array}{l}-0.40 \\
-0.30 \\
-0.20 \\
-0.10 \\
-0.00\end{array}$ \\
\hline $\mathrm{mV}$ & .00 & .01 & .02 & .03 & .04 & .05 & .06 & .07 & .08 & .09 & .10 & $\mathrm{mV}$ \\
\hline
\end{tabular}


TABLE A5.2.1. Type E thermocouples-temperature $\left({ }^{\circ} \mathrm{C}\right)$ as a function of thermoelectric voltage, reference junctions at $0^{\circ} \mathrm{C}$-Continued

$m V$

.00

.01

.02

.03

.05

.06

.07

.08

.09

.10

$m V$

TEMPERATURES IN DEGREES C (IPTS 1968 )

\begin{tabular}{|c|c|c|c|c|c|c|c|c|c|c|c|c|}
\hline $\begin{array}{l}0.00 \\
0.10 \\
0.20 \\
0.30 \\
0.40\end{array}$ & $\begin{array}{l}0.00 \\
1.70 \\
3.40 \\
5.09 \\
6.78\end{array}$ & $\begin{array}{l}0.17 \\
1.87 \\
3.57 \\
5.26 \\
6.95\end{array}$ & $\begin{array}{l}0.34 \\
2.04 \\
3.74 \\
5.43 \\
7.12\end{array}$ & $\begin{array}{l}0.51 \\
2.21 \\
3.91 \\
5.60 \\
7.29\end{array}$ & $\begin{array}{l}0.68 \\
2.38 \\
4.08 \\
5.77 \\
7.46\end{array}$ & $\begin{array}{l}0.85 \\
2.55 \\
4.25 \\
5.94 \\
7.62\end{array}$ & $\begin{array}{l}1.02 \\
2.72 \\
4.42 \\
6.11 \\
7.79\end{array}$ & $\begin{array}{l}1.19 \\
2.89 \\
4.58 \\
6.27 \\
7.96\end{array}$ & $\begin{array}{l}1.36 \\
3.06 \\
4.75 \\
6.44 \\
8.13\end{array}$ & $\begin{array}{l}1.53 \\
3.23 \\
4.92 \\
6.61 \\
8.30\end{array}$ & $\begin{array}{l}1.70 \\
3.40 \\
5.09 \\
6.78 \\
8.47\end{array}$ & $\begin{array}{l}0.00 \\
0.10 \\
0.20 \\
0.30 \\
0.40\end{array}$ \\
\hline $\begin{array}{l}0.50 \\
0.60 \\
0.70 \\
0.80 \\
0.90\end{array}$ & $\begin{array}{r}8.47 \\
10.15 \\
11.82 \\
13.49 \\
15.16\end{array}$ & $\begin{array}{r}8.63 \\
10.31 \\
11.99 \\
13.66 \\
15.33\end{array}$ & $\begin{array}{r}8.80 \\
10.48 \\
12.16 \\
13.83 \\
15.49\end{array}$ & $\begin{array}{r}8.97 \\
10.65 \\
12.32 \\
13.99 \\
15.66\end{array}$ & $\begin{array}{r}9.14 \\
10.82 \\
12.49 \\
14.16 \\
15.83\end{array}$ & $\begin{array}{r}9.31 \\
10.98 \\
12.66 \\
14.33 \\
15.99\end{array}$ & $\begin{array}{r}9.47 \\
11.15 \\
12.83 \\
14.49 \\
16.16\end{array}$ & $\begin{array}{r}9.64 \\
11.32 \\
12.99 \\
14.66 \\
16.33\end{array}$ & $\begin{array}{r}9.81 \\
11.49 \\
13.16 \\
14.83 \\
16.49\end{array}$ & $\begin{array}{r}9.98 \\
11.65 \\
13.33 \\
14.99 \\
16.66\end{array}$ & $\begin{array}{l}10.15 \\
11.82 \\
13.49 \\
15.16 \\
16.83\end{array}$ & $\begin{array}{l}0.50 \\
0.60 \\
0.70 \\
0.80 \\
0.90\end{array}$ \\
\hline $\begin{array}{l}1.00 \\
1.10 \\
1.20 \\
1.30 \\
1.40\end{array}$ & $\begin{array}{l}16.83 \\
18.48 \\
20.14 \\
21.79 \\
23.44\end{array}$ & $\begin{array}{l}16.99 \\
18.65 \\
20.31 \\
21.96 \\
23.60\end{array}$ & $\begin{array}{l}17.16 \\
18.82 \\
20.47 \\
22.12 \\
23.77\end{array}$ & $\begin{array}{l}17.32 \\
18.98 \\
20.64 \\
22.29 \\
23.93\end{array}$ & $\begin{array}{l}17.49 \\
19.15 \\
20.80 \\
22.45 \\
24.10\end{array}$ & $\begin{array}{l}17.66 \\
19.31 \\
20.97 \\
22.62 \\
24.26\end{array}$ & $\begin{array}{l}17.82 \\
19.48 \\
21.13 \\
22.78 \\
24.42\end{array}$ & $\begin{array}{l}17.99 \\
19.64 \\
21.30 \\
22.94 \\
24.59\end{array}$ & $\begin{array}{l}18.15 \\
19.81 \\
21.46 \\
23.11 \\
24.75\end{array}$ & $\begin{array}{l}18.32 \\
19.97 \\
21.63 \\
23.27 \\
24.92\end{array}$ & $\begin{array}{l}18.48 \\
20.14 \\
21.79 \\
23.44 \\
25.08\end{array}$ & $\begin{array}{l}1.00 \\
1.10 \\
1.20 \\
1.30 \\
1.40\end{array}$ \\
\hline $\begin{array}{l}1.50 \\
1.60 \\
1.70 \\
1.80 \\
1.90\end{array}$ & $\begin{array}{l}25.08 \\
26.72 \\
28.36 \\
29.99 \\
31.61\end{array}$ & $\begin{array}{l}25.25 \\
26.88 \\
28.52 \\
30.15 \\
31.78\end{array}$ & $\begin{array}{l}25.41 \\
27.05 \\
28.68 \\
30.31 \\
31.94\end{array}$ & $\begin{array}{l}25.57 \\
27.21 \\
28.85 \\
30.48 \\
32.10\end{array}$ & $\begin{array}{l}25 \cdot 74 \\
27.38 \\
29.01 \\
30 \cdot 64 \\
32 \cdot 26\end{array}$ & $\begin{array}{l}25.90 \\
27.54 \\
29.17 \\
30.80 \\
32.43\end{array}$ & $\begin{array}{l}26.07 \\
27.70 \\
29.33 \\
30.96 \\
32.59\end{array}$ & $\begin{array}{l}26.23 \\
27.87 \\
29.50 \\
31.13 \\
32.75\end{array}$ & $\begin{array}{l}26.39 \\
28.03 \\
29.66 \\
31.29 \\
32.91\end{array}$ & $\begin{array}{l}26.56 \\
28.19 \\
29.82 \\
31.45 \\
33.07\end{array}$ & $\begin{array}{l}26.72 \\
28.36 \\
29.99 \\
31.61 \\
33.24\end{array}$ & $\begin{array}{l}1.50 \\
1.60 \\
1.70 \\
1.80 \\
1.90\end{array}$ \\
\hline $\begin{array}{l}2.00 \\
2.10 \\
2.20 \\
2.30 \\
2.40\end{array}$ & $\begin{array}{l}33.24 \\
34.86 \\
36.47 \\
38.08 \\
39.69\end{array}$ & $\begin{array}{l}33.40 \\
35.02 \\
36.63 \\
38.24 \\
39.85\end{array}$ & $\begin{array}{l}33.56 \\
35.18 \\
36.79 \\
38.41 \\
40.01\end{array}$ & $\begin{array}{l}33.72 \\
35.34 \\
36.96 \\
38.57 \\
40.17\end{array}$ & $\begin{array}{l}33 \cdot 89 \\
35.50 \\
37.12 \\
38.73 \\
40.33\end{array}$ & $\begin{array}{l}34.05 \\
35.66 \\
37.28 \\
38.89 \\
40.49\end{array}$ & $\begin{array}{l}34.21 \\
35.83 \\
37.44 \\
39.05 \\
40.65\end{array}$ & $\begin{array}{l}34.37 \\
35.99 \\
37.60 \\
39.21 \\
40.81\end{array}$ & $\begin{array}{l}34.53 \\
36.15 \\
37.76 \\
39.37 \\
40.97\end{array}$ & $\begin{array}{l}34.69 \\
36.31 \\
37.92 \\
39.53 \\
41.13\end{array}$ & $\begin{array}{l}34.86 \\
36.47 \\
38.08 \\
39.69 \\
41.30\end{array}$ & $\begin{array}{l}2.00 \\
2.10 \\
2.20 \\
2.30 \\
2.40\end{array}$ \\
\hline $\begin{array}{l}2.50 \\
2.60 \\
2.70 \\
2.80 \\
2.90\end{array}$ & $\begin{array}{l}41.30 \\
42.90 \\
44.49 \\
46.08 \\
47.67\end{array}$ & $\begin{array}{l}41.46 \\
43.06 \\
44.65 \\
46.24 \\
47.83\end{array}$ & $\begin{array}{l}41.62 \\
43.21 \\
44.81 \\
46.40 \\
47.99\end{array}$ & $\begin{array}{l}41.78 \\
43.37 \\
44.97 \\
46.56 \\
48.15\end{array}$ & $\begin{array}{l}41 \cdot 94 \\
43.53 \\
45.13 \\
46.72 \\
48.31\end{array}$ & $\begin{array}{l}42.10 \\
43.69 \\
45.29 \\
46.88 \\
48.47\end{array}$ & $\begin{array}{l}42.26 \\
43.85 \\
45.45 \\
47.04 \\
48.63\end{array}$ & $\begin{array}{l}42.42 \\
44.01 \\
45.61 \\
47.20 \\
48.78\end{array}$ & $\begin{array}{l}42.58 \\
44.17 \\
45.77 \\
47.36 \\
48.94\end{array}$ & $\begin{array}{l}42 \cdot 74 \\
44 \cdot 33 \\
45.93 \\
47.52 \\
49.10\end{array}$ & $\begin{array}{l}42.90 \\
44.49 \\
46.08 \\
47.67 \\
49.26\end{array}$ & $\begin{array}{l}2.50 \\
2.60 \\
2.70 \\
2.80 \\
2.90\end{array}$ \\
\hline $\begin{array}{l}3.00 \\
3.10 \\
3.20 \\
3.30 \\
3.40\end{array}$ & $\begin{array}{l}49.26 \\
50.84 \\
52.42 \\
53.99 \\
55.57\end{array}$ & $\begin{array}{l}49.42 \\
51.00 \\
52.58 \\
54.15 \\
55.72\end{array}$ & $\begin{array}{l}49.58 \\
51.16 \\
52.73 \\
54.31 \\
55.88\end{array}$ & $\begin{array}{l}49.73 \\
51.32 \\
52.89 \\
54.47 \\
56.04\end{array}$ & $\begin{array}{l}49.89 \\
51.47 \\
53.05 \\
54.62 \\
56.19\end{array}$ & $\begin{array}{l}50.05 \\
51.63 \\
53.21 \\
54.78 \\
56.35\end{array}$ & $\begin{array}{l}50.21 \\
51.79 \\
53.36 \\
54.94 \\
56.51\end{array}$ & $\begin{array}{l}50.37 \\
51.95 \\
53.52 \\
55.09 \\
56.66\end{array}$ & $\begin{array}{l}50.53 \\
52.10 \\
53.68 \\
55.25 \\
56.82\end{array}$ & $\begin{array}{l}50.68 \\
52.26 \\
53.84 \\
55.41 \\
56.98\end{array}$ & $\begin{array}{l}50.84 \\
52.42 \\
53.99 \\
55.57 \\
57.13\end{array}$ & $\begin{array}{l}3.00 \\
3.10 \\
3.20 \\
3.30 \\
3.40\end{array}$ \\
\hline $\begin{array}{l}3.50 \\
3.60 \\
3.70 \\
3.80 \\
3.90\end{array}$ & $\begin{array}{l}57.13 \\
58.70 \\
60.26 \\
61.82 \\
63.37\end{array}$ & $\begin{array}{l}57.29 \\
58.85 \\
60.41 \\
61.97 \\
63.53\end{array}$ & $\begin{array}{l}57.45 \\
59.01 \\
60.57 \\
62.13 \\
63.68\end{array}$ & $\begin{array}{l}57.60 \\
59.17 \\
60.73 \\
62.28 \\
63.84\end{array}$ & $\begin{array}{l}57.76 \\
59.32 \\
60.88 \\
62.44 \\
63.99\end{array}$ & $\begin{array}{l}57.92 \\
59.48 \\
61.04 \\
62.59 \\
64.15\end{array}$ & $\begin{array}{l}58.07 \\
59.63 \\
61.19 \\
62.75 \\
64.30\end{array}$ & $\begin{array}{l}58 \cdot 23 \\
59.79 \\
61.35 \\
62.90 \\
64.46\end{array}$ & $\begin{array}{l}58.39 \\
59.95 \\
61.51 \\
63.06 \\
64.61\end{array}$ & $\begin{array}{l}58 \cdot 54 \\
60.10 \\
61.66 \\
63 \cdot 22 \\
64.77\end{array}$ & $\begin{array}{l}58 \cdot 70 \\
60.26 \\
61.82 \\
63.37 \\
64.92\end{array}$ & $\begin{array}{l}3.50 \\
3.60 \\
3.70 \\
3.80 \\
3.90\end{array}$ \\
\hline $\begin{array}{l}4.00 \\
4.10 \\
4.20 \\
4.30 \\
4.40\end{array}$ & $\begin{array}{l}64.92 \\
66.47 \\
68.01 \\
69.55 \\
71.09\end{array}$ & $\begin{array}{l}65.08 \\
66.62 \\
68.17 \\
69.71 \\
71.25\end{array}$ & $\begin{array}{l}65.23 \\
66.78 \\
68.32 \\
69.86 \\
71.40\end{array}$ & $\begin{array}{l}65.39 \\
66.93 \\
68.48 \\
70.02 \\
71.55\end{array}$ & $\begin{array}{l}65.54 \\
67.09 \\
68.63 \\
70.17 \\
71.71\end{array}$ & $\begin{array}{l}65 \cdot 70 \\
67.24 \\
68.78 \\
70.32 \\
71.86\end{array}$ & $\begin{array}{l}65.85 \\
67.40 \\
68.94 \\
70.48 \\
72.01\end{array}$ & $\begin{array}{l}66.01 \\
67.55 \\
69.09 \\
70.63 \\
72.17\end{array}$ & $\begin{array}{l}66.16 \\
67.71 \\
69.25 \\
70.79 \\
72.32\end{array}$ & $\begin{array}{l}66.31 \\
67.86 \\
69.40 \\
70.94 \\
72.47\end{array}$ & $\begin{array}{l}66.47 \\
68.01 \\
69.55 \\
71.09 \\
72.63\end{array}$ & $\begin{array}{l}4.00 \\
4.10 \\
4.20 \\
4.30 \\
4.40\end{array}$ \\
\hline $\begin{array}{l}4.50 \\
4.60 \\
4.70 \\
4.80 \\
4.90\end{array}$ & $\begin{array}{l}72.63 \\
74.16 \\
75.69 \\
77.21 \\
78.74\end{array}$ & $\begin{array}{l}72.78 \\
74.31 \\
75.84 \\
77.37 \\
78.89\end{array}$ & $\begin{array}{l}72.93 \\
74.47 \\
75.99 \\
77.52 \\
79.04\end{array}$ & $\begin{array}{l}73.09 \\
74.62 \\
76.15 \\
77.67 \\
79.19\end{array}$ & $\begin{array}{l}73.24 \\
74.77 \\
76.30 \\
77.82 \\
79.34\end{array}$ & $\begin{array}{l}73.39 \\
74.92 \\
76.45 \\
77.97 \\
79.50\end{array}$ & $\begin{array}{l}73.55 \\
75.08 \\
76.60 \\
78.13 \\
79.65\end{array}$ & $\begin{array}{l}73.70 \\
75.23 \\
76.76 \\
78.28 \\
79.30\end{array}$ & $\begin{array}{l}73.85 \\
75.38 \\
76.91 \\
78.43 \\
79.95\end{array}$ & $\begin{array}{l}74.01 \\
75.53 \\
77.06 \\
78.58 \\
80.10\end{array}$ & $\begin{array}{l}74.16 \\
75.69 \\
77.21 \\
78.74 \\
80.26\end{array}$ & $\begin{array}{l}4.50 \\
4.60 \\
4.70 \\
4.80 \\
4.90\end{array}$ \\
\hline $\begin{array}{l}5.00 \\
5.10 \\
5.20 \\
5.30 \\
5.40\end{array}$ & $\begin{array}{l}80.26 \\
81.77 \\
83.29 \\
84.80 \\
86.30\end{array}$ & $\begin{array}{l}80.41 \\
81.92 \\
83.44 \\
84.95 \\
86.45\end{array}$ & $\begin{array}{l}80.56 \\
82.07 \\
83.59 \\
85.10 \\
86.60\end{array}$ & $\begin{array}{l}80.71 \\
82.23 \\
83.74 \\
85.25 \\
86.76\end{array}$ & $\begin{array}{l}80.86 \\
82.38 \\
83.89 \\
85.40 \\
86.91\end{array}$ & $\begin{array}{l}81.01 \\
82.53 \\
84.04 \\
85.55 \\
87.06\end{array}$ & $\begin{array}{l}81.17 \\
82.68 \\
84.19 \\
85.70 \\
87.21\end{array}$ & $\begin{array}{l}81.32 \\
82.83 \\
84.34 \\
85.85 \\
87.36\end{array}$ & $\begin{array}{l}81.47 \\
82.98 \\
84.49 \\
86.00 \\
87.51\end{array}$ & $\begin{array}{l}81.62 \\
83.13 \\
84.64 \\
86.15 \\
87.66\end{array}$ & $\begin{array}{l}81.77 \\
83.29 \\
84.80 \\
86.30 \\
87.81\end{array}$ & $\begin{array}{l}5.00 \\
5.10 \\
5.20 \\
5.30 \\
5.40\end{array}$ \\
\hline $\begin{array}{l}5.50 \\
5.60 \\
5.70 \\
5.80 \\
5.90\end{array}$ & $\begin{array}{l}87.81 \\
89.31 \\
90.81 \\
92.31 \\
93.80\end{array}$ & $\begin{array}{l}87.96 \\
89.46 \\
90.96 \\
92.46 \\
93.95\end{array}$ & $\begin{array}{l}88.11 \\
89.61 \\
91.11 \\
92.60 \\
94.10\end{array}$ & $\begin{array}{l}88.26 \\
89.76 \\
91.26 \\
92.75 \\
94.25\end{array}$ & $\begin{array}{l}88.41 \\
89.91 \\
91.41 \\
92.90 \\
94.40\end{array}$ & $\begin{array}{l}88.56 \\
90.06 \\
91.56 \\
93.05 \\
94.55\end{array}$ & $\begin{array}{l}88.71 \\
90.21 \\
91.71 \\
93.20 \\
94.69\end{array}$ & $\begin{array}{l}88.86 \\
90.36 \\
91.86 \\
93.35 \\
94.84\end{array}$ & $\begin{array}{l}89.01 \\
90.51 \\
92.01 \\
93.50 \\
94.99\end{array}$ & $\begin{array}{l}89.16 \\
90.66 \\
92.16 \\
93.65 \\
95.14\end{array}$ & $\begin{array}{l}89.31 \\
90.81 \\
92.31 \\
93.80 \\
95.29\end{array}$ & $\begin{array}{l}5.50 \\
5.60 \\
5.70 \\
5.80 \\
5.90\end{array}$ \\
\hline 6.00 & 95.29 & 95.44 & 5.59 & 5.74 & 95.89 & 96.03 & 96.18 & 96.33 & 96.48 & 96.63 & 96.78 & 6.00 \\
\hline
\end{tabular}

$m V$

$.00 \quad .01$

.02

.03

.04

$.05 \quad .06$
.07
.08
.09 $\cdot 10$
0.00

0.20

.40

0.50

0.70

.80
. .90

1.00

1.20

1.40

1.50

1.70

1.90

2.00

2.50

2.60
2.70

2.80
2.90

3.00

3.20

3.50

3.70

3.80
3.90

4.00

4.20

4.30
4.40

.50

4.70

4.80
4.90

5.00

5.20

5.30

5.50

70

5.80
5.90

6.00

$\mathrm{mV}$ 
TABLE A5.2.1. Type $\boldsymbol{E}$ thermocouples-temperature $\left({ }^{\circ} \mathrm{C}\right)$ as a function of thermoelectric voltage, reference junctions at $0^{\circ} \mathrm{C}$-Continued

$m V$ .00 .01 .02 .03 .04 .05 .06 .07 TEMPERATURES IN DEGREES C (IPTS 1968)

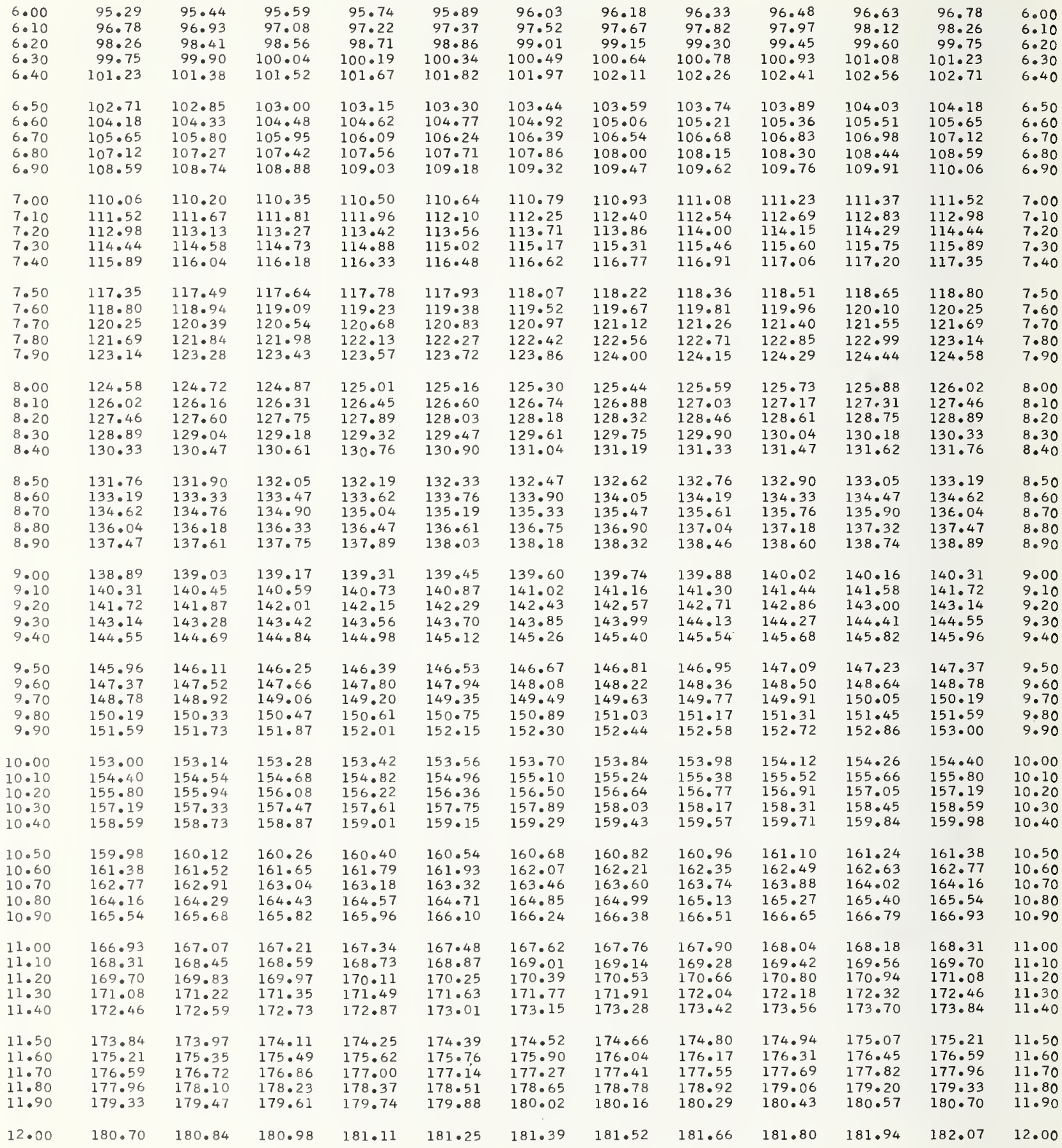


TABLE A5.2.1. Type E thermocouples-temperature $\left({ }^{\circ} \mathrm{C}\right)$ as a function of thermoelectric voltage, reference junctions at $0^{\circ} \mathrm{C}$-Continued

$m \vee$

.00

.01

.02

.03
.04

.05

.06

.07

.08

.09

.10

$m \vee$

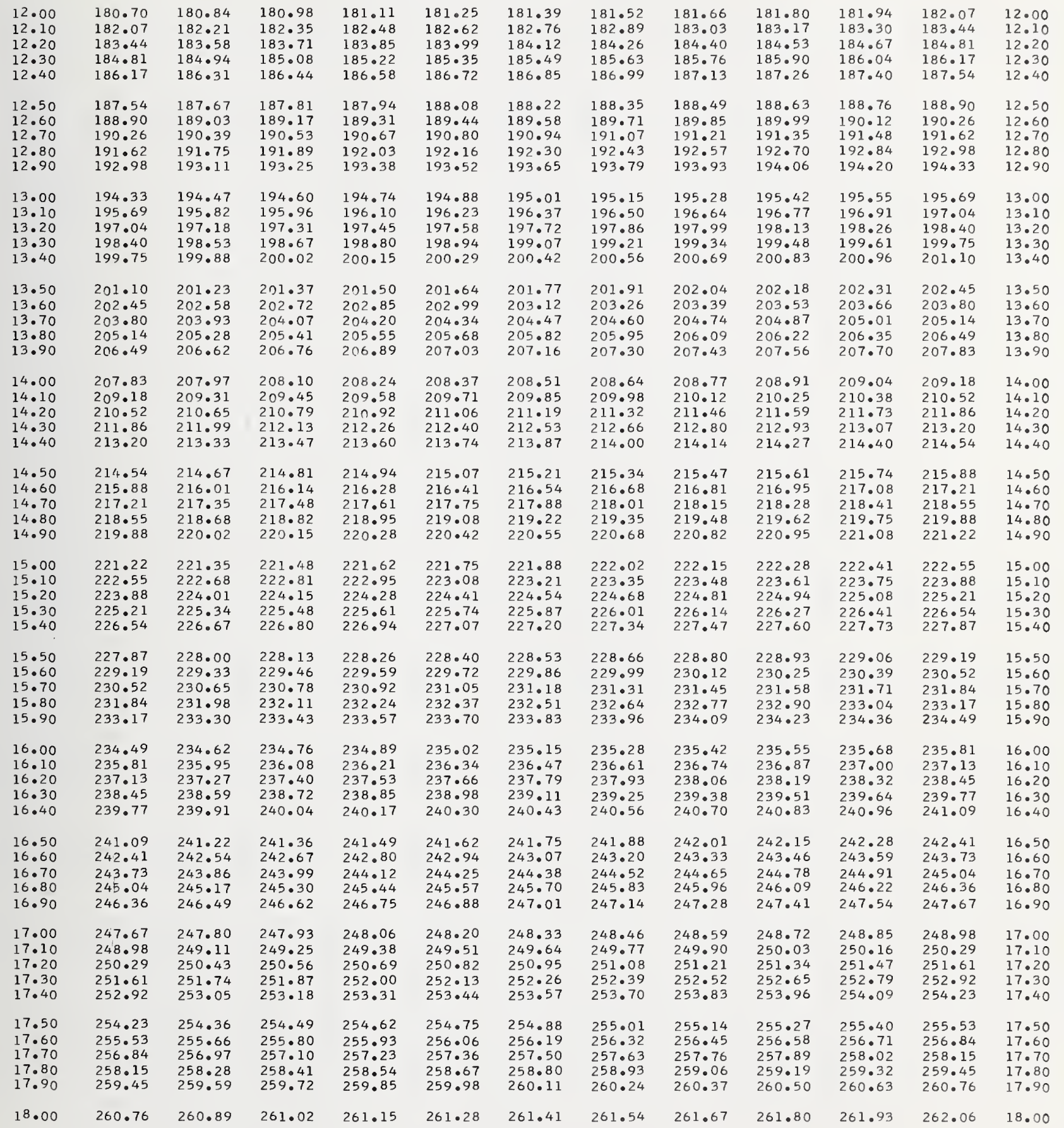

$m V$

.00

.01

.02

.03

.04

.05

.06

.07

.08

.09

.10

$m v$ 
TABLE A5.2.1. Type $\boldsymbol{E}$ thermocouples-temperature $\left({ }^{\circ} \mathrm{C}\right)$ as a function of thermoelectric voltage, reference junctions at $0^{\circ} \mathrm{C}$-Continued

.06

.07

.08

.09

.10

m V

\begin{tabular}{|c|c|c|c|c|c|c|c|c|c|c|c|c|}
\hline $\begin{array}{l}18.00 \\
18.10 \\
18.20 \\
18.30 \\
18.40\end{array}$ & $\begin{array}{l}260.76 \\
262.06 \\
263.37 \\
264.67 \\
265.97\end{array}$ & $\begin{array}{l}260.89 \\
262.19 \\
263.50 \\
264.80 \\
266.10\end{array}$ & $\begin{array}{l}261 \cdot 02 \\
262 \cdot 33 \\
263 \cdot 63 \\
264 \cdot 93 \\
266.23\end{array}$ & $\begin{array}{l}261.15 \\
262.46 \\
263.76 \\
265.06 \\
266.36\end{array}$ & $\begin{array}{l}261 \cdot 28 \\
262 \cdot 59 \\
263 \cdot 89 \\
265 \cdot 19 \\
266.49\end{array}$ & $\begin{array}{l}261.41 \\
262.72 \\
264.02 \\
265.32 \\
266.62\end{array}$ & $\begin{array}{l}261 \cdot 54 \\
262 \cdot 85 \\
264 \cdot 15 \\
265 \cdot 45 \\
266.75\end{array}$ & $\begin{array}{l}261.67 \\
262 \cdot 98 \\
264 \cdot 28 \\
265 \cdot 58 \\
266.88\end{array}$ & $\begin{array}{l}261.80 \\
263.11 \\
264.41 \\
265.71 \\
267.01\end{array}$ & $\begin{array}{l}261.93 \\
263 \cdot 24 \\
264 \cdot 54 \\
265 \cdot 84 \\
267.14\end{array}$ & $\begin{array}{l}262.06 \\
263.37 \\
264.67 \\
265.97 \\
267.27\end{array}$ & $\begin{array}{l}18.00 \\
18.10 \\
18.20 \\
18.30 \\
18.40\end{array}$ \\
\hline $\begin{array}{l}18.50 \\
18.60 \\
18.70 \\
18.80 \\
18.90\end{array}$ & $\begin{array}{l}267.27 \\
268.57 \\
269.87 \\
271.17 \\
272.47\end{array}$ & $\begin{array}{l}267.40 \\
268.70 \\
270.00 \\
271.30 \\
272.60\end{array}$ & $\begin{array}{l}267 \cdot 53 \\
268 \cdot 83 \\
270.13 \\
271.43 \\
272.73\end{array}$ & $\begin{array}{l}267.66 \\
268.96 \\
270.26 \\
271.56 \\
272.86\end{array}$ & $\begin{array}{l}267.79 \\
269.09 \\
270.39 \\
271.69 \\
272.99\end{array}$ & $\begin{array}{l}267.92 \\
269.22 \\
270.52 \\
271.82 \\
273.12\end{array}$ & $\begin{array}{l}268.05 \\
269 \cdot 35 \\
270.65 \\
271.95 \\
273.25\end{array}$ & $\begin{array}{l}268 \cdot 18 \\
269 \cdot 48 \\
270 \cdot 78 \\
272.08 \\
273.38\end{array}$ & $\begin{array}{l}268.31 \\
269.61 \\
270.91 \\
272.21 \\
273.51\end{array}$ & $\begin{array}{l}268.44 \\
269.74 \\
271.04 \\
272.34 \\
273.64\end{array}$ & $\begin{array}{l}268.57 \\
269.87 \\
271.17 \\
272.47 \\
273.77\end{array}$ & $\begin{array}{l}18.50 \\
18.60 \\
18.70 \\
18.80 \\
18.90\end{array}$ \\
\hline $\begin{array}{l}19.00 \\
19.10 \\
19.20 \\
19.30 \\
19.40\end{array}$ & $\begin{array}{l}273.77 \\
275.07 \\
276.36 \\
277.66 \\
278.95\end{array}$ & $\begin{array}{l}273.90 \\
275.20 \\
276.49 \\
277.79 \\
279.08\end{array}$ & $\begin{array}{l}274.03 \\
275.33 \\
276.62 \\
277.92 \\
279.21\end{array}$ & $\begin{array}{l}274.16 \\
275.46 \\
276.75 \\
278.05 \\
279.34\end{array}$ & $\begin{array}{l}274 \cdot 29 \\
275.58 \\
276.88 \\
278.18 \\
279.47\end{array}$ & $\begin{array}{l}274.42 \\
275.71 \\
277.01 \\
278.31 \\
279.60\end{array}$ & $\begin{array}{l}274 \cdot 55 \\
275.84 \\
277 \cdot 14 \\
278 \cdot 43 \\
279.73\end{array}$ & $\begin{array}{l}274.68 \\
275.97 \\
277.27 \\
278.56 \\
279.86\end{array}$ & $\begin{array}{l}274.81 \\
276.10 \\
277.40 \\
278.69 \\
279.99\end{array}$ & $\begin{array}{l}274.94 \\
276.23 \\
277.53 \\
278.82 \\
280.12\end{array}$ & $\begin{array}{l}275.07 \\
276.36 \\
277.66 \\
278.95 \\
280.25\end{array}$ & $\begin{array}{l}19.00 \\
19.10 \\
19.20 \\
19.30 \\
19.40\end{array}$ \\
\hline $\begin{array}{l}19.50 \\
19.60 \\
19.70 \\
19.80 \\
19.90\end{array}$ & $\begin{array}{l}280 \cdot 25 \\
281 \cdot 54 \\
282 \cdot 83 \\
284 \cdot 12 \\
285.42\end{array}$ & $\begin{array}{l}280 \cdot 38 \\
281 \cdot 67 \\
282 \cdot 96 \\
284 \cdot 25 \\
285 \cdot 54\end{array}$ & $\begin{array}{l}280.51 \\
281.80 \\
283.09 \\
284.38 \\
285.67\end{array}$ & $\begin{array}{l}280.63 \\
281.93 \\
283.22 \\
284.51 \\
285.80\end{array}$ & $\begin{array}{l}280.76 \\
282.06 \\
283.35 \\
284 \cdot 64 \\
285.93\end{array}$ & $\begin{array}{l}280.89 \\
282.19 \\
283.48 \\
284.77 \\
286.06\end{array}$ & $\begin{array}{l}281.02 \\
282.32 \\
283.61 \\
284.90 \\
286.19\end{array}$ & $\begin{array}{l}281 \cdot 15 \\
282 \cdot 44 \\
283.74 \\
285.03 \\
286.32\end{array}$ & $\begin{array}{l}281.28 \\
282.57 \\
283.87 \\
285.16 \\
286.45\end{array}$ & $\begin{array}{l}281.41 \\
282 \cdot 70 \\
283.99 \\
285.29 \\
286.58\end{array}$ & $\begin{array}{l}281.54 \\
282.83 \\
284.12 \\
285.42 \\
286.71\end{array}$ & $\begin{array}{l}19.50 \\
19.60 \\
19.70 \\
19.80 \\
19.90\end{array}$ \\
\hline $\begin{array}{l}20 \cdot 00 \\
20 \cdot 10 \\
20 \cdot 20 \\
20 \cdot 30 \\
20 \cdot 40\end{array}$ & $\begin{array}{l}286.71 \\
288.00 \\
289.28 \\
290.57 \\
291.86\end{array}$ & $\begin{array}{l}286.83 \\
288.12 \\
289.41 \\
290.70 \\
291.99\end{array}$ & $\begin{array}{l}286.96 \\
288 \cdot 25 \\
289 \cdot 54 \\
290.83 \\
292.12\end{array}$ & $\begin{array}{l}287.09 \\
288.38 \\
289.67 \\
290.96 \\
292.25\end{array}$ & $\begin{array}{l}287 \cdot 22 \\
288 \cdot 51 \\
289 \cdot 80 \\
291.09 \\
292.38\end{array}$ & $\begin{array}{l}287 \cdot 35 \\
288 \cdot 64 \\
289 \cdot 93 \\
291 \cdot 22 \\
292.50\end{array}$ & $\begin{array}{l}287.48 \\
288.77 \\
290.06 \\
291.35 \\
292.63\end{array}$ & $\begin{array}{l}287.61 \\
288.90 \\
290.19 \\
291.47 \\
292.76\end{array}$ & $\begin{array}{l}287.74 \\
289.03 \\
290.32 \\
291.60 \\
292.89\end{array}$ & $\begin{array}{l}287.87 \\
289.16 \\
290.44 \\
291.73 \\
293.02\end{array}$ & $\begin{array}{l}288.00 \\
289.28 \\
290.57 \\
291.86 \\
293.15\end{array}$ & $\begin{array}{l}20 \cdot 00 \\
20.10 \\
20.20 \\
20.30 \\
20.40\end{array}$ \\
\hline $\begin{array}{l}20.50 \\
20.60 \\
20.70 \\
20.80 \\
20.90\end{array}$ & $\begin{array}{l}293.15 \\
294.43 \\
295.72 \\
297.01 \\
298.29\end{array}$ & $\begin{array}{l}293 \cdot 28 \\
294 \cdot 56 \\
295.85 \\
297.13 \\
298.42\end{array}$ & $\begin{array}{l}293.41 \\
294.69 \\
295.98 \\
297.26 \\
298.55\end{array}$ & $\begin{array}{l}293.53 \\
294.82 \\
296.11 \\
297.39 \\
298.68\end{array}$ & $\begin{array}{l}293 \cdot 66 \\
294 \cdot 95 \\
296 \cdot 23 \\
297 \cdot 52 \\
298 \cdot 80\end{array}$ & $\begin{array}{l}293.79 \\
295.08 \\
296.36 \\
297.65 \\
298.93\end{array}$ & $\begin{array}{l}293.92 \\
295.21 \\
296.49 \\
297.78 \\
299.06\end{array}$ & $\begin{array}{l}294.05 \\
295.34 \\
296.62 \\
297.91 \\
299.19\end{array}$ & $\begin{array}{l}294.18 \\
295.46 \\
296.75 \\
298.03 \\
299.32\end{array}$ & $\begin{array}{l}294.31 \\
295.59 \\
296.88 \\
298.16 \\
299.45\end{array}$ & $\begin{array}{l}294.43 \\
295.72 \\
297.01 \\
298.29 \\
299.57\end{array}$ & $\begin{array}{l}20.50 \\
20.60 \\
20.70 \\
20.80 \\
20.90\end{array}$ \\
\hline $\begin{array}{l}21 \cdot 00 \\
21 \cdot 10 \\
21 \cdot 20 \\
21 \cdot 30 \\
21 \cdot 40\end{array}$ & $\begin{array}{l}299.57 \\
300.86 \\
302.14 \\
303.42 \\
304.70\end{array}$ & $\begin{array}{l}299 \cdot 70 \\
300.99 \\
302 \cdot 27 \\
303.55 \\
304.83\end{array}$ & $\begin{array}{l}299.83 \\
301.11 \\
302.40 \\
303.68 \\
304.96\end{array}$ & $\begin{array}{l}299.96 \\
301.24 \\
302.53 \\
303.81 \\
305.09\end{array}$ & $\begin{array}{l}300.09 \\
301.37 \\
302.65 \\
303.94 \\
305.22\end{array}$ & $\begin{array}{l}300.22 \\
301.50 \\
302.78 \\
304.06 \\
305.35\end{array}$ & $\begin{array}{l}300 \cdot 34 \\
301 \cdot 63 \\
302 \cdot 91 \\
304 \cdot 19 \\
305.47\end{array}$ & $\begin{array}{l}300.47 \\
301.76 \\
303.04 \\
304.32 \\
305.60\end{array}$ & $\begin{array}{l}300 \cdot 60 \\
301 \cdot 88 \\
303.17 \\
304.45 \\
305.73\end{array}$ & $\begin{array}{l}300.73 \\
302 \cdot 01 \\
303.30 \\
304.58 \\
305.86\end{array}$ & $\begin{array}{l}300.86 \\
302 \cdot 14 \\
303.42 \\
304 \cdot 70 \\
305.99\end{array}$ & $\begin{array}{l}21 \cdot 00 \\
21 \cdot 10 \\
21 \cdot 20 \\
21 \cdot 30 \\
21 \cdot 40\end{array}$ \\
\hline $\begin{array}{l}21 \cdot 50 \\
21 \cdot 60 \\
21 \cdot 70 \\
21.80 \\
21.90\end{array}$ & $\begin{array}{l}305.99 \\
307.27 \\
308.55 \\
309.83 \\
311.10\end{array}$ & $\begin{array}{l}306.11 \\
307.39 \\
308.67 \\
309.95 \\
311.23\end{array}$ & $\begin{array}{l}306 \cdot 24 \\
307.52 \\
308.80 \\
310.08 \\
311.36\end{array}$ & $\begin{array}{l}306.37 \\
307.65 \\
308.93 \\
310.21 \\
311.49\end{array}$ & $\begin{array}{l}306 \cdot 50 \\
307.78 \\
309.06 \\
310.34 \\
311.62\end{array}$ & $\begin{array}{l}306.63 \\
307.91 \\
309.19 \\
310.46 \\
311.74\end{array}$ & $\begin{array}{l}306.75 \\
308.03 \\
309.31 \\
310.59 \\
311.87\end{array}$ & $\begin{array}{l}306.88 \\
308.16 \\
309.44 \\
310.72 \\
312.00\end{array}$ & $\begin{array}{l}307.01 \\
308.29 \\
309.57 \\
310.85 \\
312.13\end{array}$ & $\begin{array}{l}307 \cdot 14 \\
308 \cdot 42 \\
309 \cdot 70 \\
310 \cdot 98 \\
312.25\end{array}$ & $\begin{array}{l}307.27 \\
308.55 \\
309.83 \\
311.10 \\
312.38\end{array}$ & $\begin{array}{l}21.50 \\
21 \cdot 60 \\
21.70 \\
21.80 \\
21.90\end{array}$ \\
\hline $\begin{array}{l}22 \cdot 00 \\
22 \cdot 10 \\
22.20 \\
22.30 \\
22.40\end{array}$ & $\begin{array}{l}312.38 \\
313.66 \\
314.94 \\
316.21 \\
317.49\end{array}$ & $\begin{array}{l}312.51 \\
313.79 \\
315.06 \\
316.34 \\
317.62\end{array}$ & $\begin{array}{l}312.64 \\
313.92 \\
315.19 \\
316.47 \\
317.74\end{array}$ & $\begin{array}{l}312.77 \\
314.04 \\
315.32 \\
316.60 \\
317.87\end{array}$ & $\begin{array}{l}312.89 \\
314 \cdot 17 \\
315.45 \\
316.72 \\
318.00\end{array}$ & $\begin{array}{l}313.02 \\
314.30 \\
315.58 \\
316.85 \\
318.13\end{array}$ & $\begin{array}{l}313.15 \\
314.43 \\
315.70 \\
316.98 \\
318.25\end{array}$ & $\begin{array}{l}313.28 \\
314.55 \\
315.83 \\
317.11 \\
318.38\end{array}$ & $\begin{array}{l}313.40 \\
314.68 \\
315.96 \\
317.23 \\
318.51\end{array}$ & $\begin{array}{l}313.53 \\
314.81 \\
316.09 \\
317.36 \\
318.64\end{array}$ & $\begin{array}{l}313.66 \\
314.94 \\
316.21 \\
317.49 \\
318.76\end{array}$ & $\begin{array}{l}22.00 \\
22.10 \\
22.20 \\
22.30 \\
22.40\end{array}$ \\
\hline $\begin{array}{l}22.50 \\
22.60 \\
22.70 \\
22.80 \\
22.90\end{array}$ & $\begin{array}{l}318.76 \\
320.04 \\
321.31 \\
322.59 \\
323.86\end{array}$ & $\begin{array}{l}318.89 \\
320.17 \\
321.44 \\
322.72 \\
323.99\end{array}$ & $\begin{array}{l}319.02 \\
320.29 \\
321.57 \\
322.84 \\
324.12\end{array}$ & $\begin{array}{l}319.15 \\
320.42 \\
321.70 \\
322.97 \\
324.24\end{array}$ & $\begin{array}{l}319.27 \\
320.55 \\
321.82 \\
323.10 \\
324.37\end{array}$ & $\begin{array}{l}319.40 \\
320.68 \\
321.95 \\
323.22 \\
324.50\end{array}$ & $\begin{array}{l}319.53 \\
320.80 \\
322.08 \\
323.35 \\
324.62\end{array}$ & $\begin{array}{l}319.66 \\
320.93 \\
322.21 \\
323.48 \\
324.75\end{array}$ & $\begin{array}{l}319.78 \\
321.06 \\
322.33 \\
323.61 \\
324.88\end{array}$ & $\begin{array}{l}319.91 \\
321.19 \\
322.46 \\
323.73 \\
325.01\end{array}$ & $\begin{array}{l}320.04 \\
321.31 \\
322.59 \\
323.86 \\
325.13\end{array}$ & $\begin{array}{l}22.50 \\
22.60 \\
22.70 \\
22.80 \\
22.90\end{array}$ \\
\hline $\begin{array}{l}23.00 \\
23.10 \\
23.20 \\
23.30 \\
23.40\end{array}$ & $\begin{array}{l}325.13 \\
326.41 \\
327.68 \\
328.95 \\
330.22\end{array}$ & $\begin{array}{l}325 \cdot 26 \\
326.53 \\
327.81 \\
329.08 \\
330.35\end{array}$ & $\begin{array}{l}325.39 \\
326.66 \\
327.93 \\
329.20 \\
330.47\end{array}$ & $\begin{array}{l}325.52 \\
326.79 \\
328.06 \\
329.33 \\
330.60\end{array}$ & $\begin{array}{l}325 \cdot 64 \\
326 \cdot 91 \\
328 \cdot 19 \\
329 \cdot 46 \\
330.73\end{array}$ & $\begin{array}{l}325.77 \\
327.04 \\
328.31 \\
329.58 \\
330.86\end{array}$ & $\begin{array}{l}325.90 \\
327.17 \\
328.44 \\
329.71 \\
330.98\end{array}$ & $\begin{array}{l}326.02 \\
327.30 \\
328.57 \\
329.84 \\
331.11\end{array}$ & $\begin{array}{l}326.15 \\
327.42 \\
328.69 \\
329.97 \\
331.24\end{array}$ & $\begin{array}{l}326.28 \\
327.55 \\
328.82 \\
330.09 \\
331.36\end{array}$ & $\begin{array}{l}326.41 \\
327.68 \\
328.95 \\
330.22 \\
331.49\end{array}$ & $\begin{array}{l}23.00 \\
23.10 \\
23.20 \\
23.30 \\
23.40\end{array}$ \\
\hline $\begin{array}{l}23.50 \\
23.60 \\
23.70 \\
23.80 \\
23.90\end{array}$ & $\begin{array}{l}331.49 \\
332.76 \\
334.03 \\
335.30 \\
336.57\end{array}$ & $\begin{array}{l}331.62 \\
332.89 \\
334.16 \\
335.42 \\
336.69\end{array}$ & $\begin{array}{l}331.74 \\
333.01 \\
334.28 \\
335.55 \\
336.82\end{array}$ & $\begin{array}{l}331.87 \\
333.14 \\
334.41 \\
335.68 \\
336.95\end{array}$ & $\begin{array}{l}332.00 \\
333.27 \\
334.54 \\
335.81 \\
337.07\end{array}$ & $\begin{array}{l}332.13 \\
333.39 \\
334.66 \\
335.93 \\
337.20\end{array}$ & $\begin{array}{l}332.25 \\
333.52 \\
334.79 \\
336.06 \\
337.33\end{array}$ & $\begin{array}{l}332.38 \\
333.65 \\
334.92 \\
336.19 \\
337.45\end{array}$ & $\begin{array}{l}332.51 \\
333.78 \\
335.04 \\
336.31 \\
337.58\end{array}$ & $\begin{array}{l}332.63 \\
333.90 \\
335.17 \\
336.44 \\
337.71\end{array}$ & $\begin{array}{l}332.76 \\
334.03 \\
335.30 \\
336.57 \\
337.83\end{array}$ & $\begin{array}{l}23.50 \\
23.50 \\
23.70 \\
23.80 \\
23.90\end{array}$ \\
\hline 24.00 & 337.83 & 337.96 & 338.09 & $338 \cdot 21$ & $338 \cdot 34$ & 338.47 & 338.59 & $338 \cdot 72$ & 338.85 & 338.97 & 339.10 & 24.00 \\
\hline
\end{tabular}


TABLE A5.2.1. Type E thermocouples-temperature $\left({ }^{\circ} \mathrm{C}\right)$ as a function of thermoelectric voltage, reference junctions at $0^{\circ} \mathrm{C}$-Continued

$m V$

.00

.01

.02

.03

.04

.05

.06

.07

.08

TEMPERATURES IN DEGREES C (IPTS 1968)

24.00

$24 \cdot 10$

24.20

24.30

337.83

339.10

340.37

24.40

342.90

337.96

339.23

340.50

341.76

340.62

341.89

338.21

339.48

340.75

342.01

$338 \cdot 34$

$338 \cdot 34$

339.61
340.88

342.14

338.47

339.74

$343 \cdot 15$

24.50

344.17

344.29

345.56

$\begin{array}{lll}24.80 & 347.96 & 348.09 \\ 24.90 & 349.22 & 349.35\end{array}$

25.00

350.49

$25 \cdot 00$

25.20

25.30

25.40

351.75

353.01

$354 \cdot 28$

350.61

351.88

$353 \cdot 14$

354.40

356.80

25.50

25.60

358.06

356.92

358.19

359.45

360.71

$\begin{array}{ll}25.80 & 360.58 \\ 25.90 & 361.84\end{array}$

26.00

26.10

26.20

26.30

26.40

363.10

361.97

363.23

364.48

365.62

366.87

368.13

$365 \cdot 74$

367.00

368.26

344.42

345.68

344.55

345.81

08

343.4

342.27

343.53

344.67

345.94

347.20

349.48

350.74

352.00

353.27

354.53

355.79

357.05

358.31
359.57

360.83

362 . 09

363.35

364.61

365.87

367.13

368.38

369.64

26.5

26.60
26.7

26.80

26.90

369.39

370.65
371.90

369.52

370.77

372.03

370.90

372.15

373.41

374.67

375.92

377.18

378.43

379.69

380.94

27.40

378.18

379.44

380.69

27.50

27.60

27.7

27.90

383.20

384.45

385.70

386.96

379.56

380.82

382.07

383.32

384.58

385.83

382.20

383.45

384.70

385.95

387.21

388.33

389.46

390.71

391.96

393.22

389.59

390.84

392.09

388.46

389.71

390.96

392.21

393.47

394.47

394.59

394.72

395.97

397.22

398.47

398.22

399.47

397.09

398.34

28.90

29. 0

29.1

400.72

400.84

402.09

$403 \cdot 34$

400.97

402.21

403.46

403.21

404.46

405.71

405.83

404.71

405.96

407.08

$407 \cdot 21$

408.46

408.21

409.45

410.70

409.58

410.82

409.70

410.95

412.20

413.19

413.32

413.44

348.47
349.73

350.87

352.13

353.39

354.65

350.99

352.26

353.52

354.78

357.18

358.44

360.96

357.30

358.56

361.08

362.22

363.48

364.74

367.25

368.51

369.77

371.02

372.28

373.54

376.05

377.30

378.56

379.81

381.07

382.32

383.57

384.83

386.08

387.33

388.58

389.84

391.09

392.34

393.59

394.84

396.09

397.34

398.59

399.84

401.09

402.34

404.84

406.08

407.33

408.58

409.83

411.07

413.57

344.80

346.06

347.33

348.59

349.86

351.12

352.38

353.64

354.91

356.17

357.43

358.69

359.95

361.21

363.60

363.73

$364.86 \quad 364.99$

$366.12 \quad 366.25$

368.64

367.50

368.76

369.89

371.15

373.66

370.02

371.28

372.53

373.79

$.03 \quad .04$ 
TABLE A5.2.1. Type E thermocouples-temperature $\left({ }^{\circ} \mathrm{C}\right)$ as a function of thermoelectric voltage, reference junctions at $0^{\circ} \mathrm{C}$-Continued

.04

.05

.06

.07

.08

.09

.10

$\mathrm{mV}$

TEMPERATURES IN DEGREES C (IPTS 1968)

\begin{tabular}{|c|c|c|c|c|c|c|c|c|c|c|c|c|}
\hline 30.00 & 413.19 & $413 \cdot 32$ & 413.44 & 413.57 & 413.69 & $413 \cdot 82$ & 413.94 & 414.07 & $414 \cdot 19$ & $414 \cdot 32$ & $414 \cdot 44$ & 30.00 \\
\hline $30 \cdot 10$ & $414 \cdot 44$ & 414.56 & 414.69 & 414.81 & $414 \cdot 94$ & 415.06 & 415.19 & 415.31 & $415 \cdot 44$ & 415.56 & $415 \cdot 69$ & 30.10 \\
\hline $30 \cdot 20$ & 415.69 & 415.81 & $415 \cdot 94$ & 416.06 & 416.18 & 416.31 & 416.43 & 416.56 & 416.68 & 416.81 & 416.93 & 30.20 \\
\hline $30 \cdot 30$ & 416.93 & 417.06 & $417 \cdot 18$ & $417 \cdot 31$ & $417 \cdot 43$ & 417.56 & $417 \cdot 68$ & 417.80 & 417.93 & 418.05 & 418.18 & $30 \cdot 30$ \\
\hline $30 \cdot 40$ & 418.18 & 418.30 & 418.43 & 418.55 & 418.68 & $418 \cdot 80$ & 418.93 & 419.05 & 419.17 & 419.30 & $419 \cdot 42$ & $30 \cdot 40$ \\
\hline $30 \cdot 50$ & 419.42 & 419.55 & 419.67 & 419.80 & 419.92 & 420.05 & $420 \cdot 17$ & 420.30 & $420 \cdot 42$ & 420.54 & 420.67 & $30 \cdot 50$ \\
\hline $30 \cdot 60$ & 420.67 & 420.79 & 420.92 & $421 \cdot 04$ & 421.17 & 421.29 & 421.42 & 421.54 & 421.66 & 421.79 & 421.91 & 30.60 \\
\hline $30 \cdot 70$ & 421.91 & 422.04 & $422 \cdot 16$ & $422 \cdot 29$ & $422 \cdot 41$ & $422 \cdot 54$ & $422 \cdot 66$ & 422.78 & 422.91 & 423.03 & $423 \cdot 16$ & 30.70 \\
\hline $30 \cdot 80$ & $423 \cdot 16$ & $423 \cdot 28$ & $423 \cdot 41$ & 423.53 & $423 \cdot 66$ & $423 \cdot 78$ & 423.91 & 424.03 & $424 \cdot 15$ & $424 \cdot 28$ & $424 \cdot 40$ & $30 \cdot 80$ \\
\hline $30 \cdot 90$ & 424.40 & $424 \cdot 53$ & 424.65 & $424 \cdot 78$ & 424.90 & 425.03 & $425 \cdot 15$ & 425.27 & $425 \cdot 40$ & 425.52 & 425.65 & 30.90 \\
\hline 31.00 & 425.65 & 425.77 & 425.90 & 426.02 & $426 \cdot 14$ & $426 \cdot 27$ & 426.39 & 426.52 & 426.64 & 426.77 & 426.89 & 31.00 \\
\hline $31 \cdot 10$ & 426.89 & 427.02 & $427 \cdot 14$ & 427.26 & $427 \cdot 39$ & 427.51 & 427.64 & $427 \cdot 76$ & 427.89 & 428.01 & 428.14 & 31.10 \\
\hline $31 \cdot 20$ & 428.14 & $428 \cdot 26$ & $428 \cdot 38$ & 428.51 & 428.63 & 428.76 & $428 \cdot 88$ & .01 & $429 \cdot 13$ & $429 \cdot 25$ & $429 \cdot 38$ & 31.20 \\
\hline 31.30 & $429 \cdot 38$ & $429 \cdot 50$ & 429.63 & $429 \cdot 75$ & $429 \cdot 88$ & 430.00 & 430.12 & 430.25 & $430 \cdot 37$ & $430 \cdot 50$ & 430.62 & $31 \cdot 30$ \\
\hline 31.40 & 430.62 & $430 \cdot 75$ & $430 \cdot 87$ & 431.00 & $431 \cdot 12$ & 431.24 & 431.37 & 431.49 & 431.62 & 431.74 & 431.87 & 31.40 \\
\hline 31.50 & 431.87 & 431.99 & 432.11 & 432.24 & 432.36 & 432.49 & 432.61 & 432.74 & 432.86 & 432.98 & 433.11 & 31.50 \\
\hline 31.60 & 433.11 & 433.23 & 433.36 & 433.48 & 433.61 & 433.73 & 433.85 & 433.98 & 434.10 & 434.23 & 434.35 & 31.60 \\
\hline 31.70 & 434.35 & 434.48 & 434.60 & 434.72 & 434.85 & 434.97 & 435.10 & 435.22 & 435.35 & 435.47 & 435.59 & 31.70 \\
\hline $31 \cdot 80$ & 435.59 & 435.72 & 435.84 & 435.97 & 436.09 & 436.22 & 436.34 & 436.46 & 436.59 & 436.71 & $436 \cdot 84$ & 31.80 \\
\hline 31.90 & 436.84 & 436.96 & 437.09 & 437.21 & 437.33 & 437.46 & 437.58 & 437.71 & 437.83 & 437.95 & 438.08 & 31.90 \\
\hline 32.00 & 438.08 & $438 \cdot 20$ & 438.33 & 438.45 & $438 \cdot 58$ & 438.70 & $438 \cdot 82$ & 438.95 & 439.07 & 439.20 & 439.32 & 32.00 \\
\hline 32.10 & 439.32 & 439.45 & 439.57 & 439.69 & $439 \cdot 82$ & $439 \cdot 94$ & 440.07 & $440 \cdot 19$ & $440 \cdot 31$ & 440.44 & 440.56 & 32.10 \\
\hline $32 \cdot 20$ & 440.56 & 440.69 & 440.81 & 440.94 & 441.06 & $441 \cdot 18$ & $441 \cdot 31$ & $441 \cdot 43$ & 441.56 & $441 \cdot 68$ & $441 \cdot 80$ & $32 \cdot 20$ \\
\hline 32.30 & $441 \cdot 80$ & 441.93 & 442.05 & $442 \cdot 18$ & $442 \cdot 30$ & 442.43 & 442.55 & 442.67 & 442.80 & 442.92 & 443.05 & 32.30 \\
\hline 32.40 & 443.05 & 443.17 & 443.29 & 443.42 & 443.54 & $443 \cdot 67$ & 443.79 & 443.92 & 444.04 & $444 \cdot 16$ & $444 \cdot 29$ & 32.40 \\
\hline 32.50 & 444.29 & 444.41 & 444.54 & 444.66 & $444 \cdot 78$ & 444.91 & 445.03 & 445.16 & 445.28 & 445.40 & 445.53 & 32.50 \\
\hline 32.60 & 445.53 & 445.65 & 445.78 & 445.90 & 446.03 & $446 \cdot 15$ & $446 \cdot 27$ & $446 \cdot 40$ & $446 \cdot 52$ & 446.65 & 446.77 & 32.60 \\
\hline 32.70 & 446.77 & 446.89 & 447.02 & $447 \cdot 14$ & $447 \cdot 27$ & 447.39 & 447.51 & 447.64 & 447.76 & 447.89 & 448.01 & 32.70 \\
\hline 32.80 & 448.01 & $448 \cdot 13$ & $448 \cdot 26$ & 448.38 & $448 \cdot 51$ & 448.63 & $448 \cdot 76$ & $448 \cdot 88$ & 449.00 & $449 \cdot 13$ & $449 \cdot 25$ & $32 \cdot 80$ \\
\hline 32.90 & 449.25 & $449 \cdot 38$ & $449 \cdot 50$ & $449 \cdot 62$ & $449 \cdot 75$ & 449.87 & 450.00 & 450.12 & 450.24 & 450.37 & 450.49 & 32.90 \\
\hline 33.00 & 450.49 & 450.62 & 450.74 & 450.86 & 450.99 & 451.11 & 451.24 & 451.30 & 451.48 & 451.61 & 451.73 & 33.00 \\
\hline 33.10 & 451.73 & $451 \cdot 86$ & $451 \cdot 98$ & 452.10 & 452.23 & $452 \cdot 35$ & $452 \cdot 48$ & 452.60 & $452 \cdot 72$ & $452 \cdot 85$ & 452.97 & 33.10 \\
\hline 33.20 & 452.97 & 453.10 & 453.22 & 453.34 & 453.47 & 453.59 & 453.72 & 453.84 & 453.96 & 454.09 & 454.21 & 33.20 \\
\hline $33 \cdot 30$ & 454.21 & $454 \cdot 34$ & 454.46 & 454.58 & 454.71 & 454.83 & 454.96 & 455.08 & 455.20 & 455.33 & 455.45 & 33.30 \\
\hline 33.40 & 455.45 & 455.58 & 455.70 & 455.82 & 455.95 & 456.07 & 456.20 & 456.32 & 456.44 & 456.57 & 456.69 & 33.40 \\
\hline 33.50 & 456.69 & 456.82 & 456.94 & 457.06 & 457.19 & 457.31 & 457.44 & 457.56 & 457.68 & 457.81 & 457.93 & 33.50 \\
\hline 33.60 & 457.93 & 458.06 & 458.18 & $458 \cdot 30$ & $458 \cdot 43$ & 458.55 & 458.68 & 458.80 & 458.92 & 459.05 & 459.17 & 33.60 \\
\hline 33.70 & 459.17 & 459.30 & 459.42 & 459.54 & 459.67 & 459.79 & 459.91 & 460.04 & 460.16 & 460.29 & 460.41 & 33.70 \\
\hline 33.80 & 460.41 & 460.53 & 460.66 & 460.78 & 460.91 & 461.03 & 461.15 & $461 \cdot 28$ & $461 \cdot 40$ & 461.53 & 461.65 & 33.80 \\
\hline 33.90 & $461 \cdot 65$ & 461.77 & 461.90 & 462.02 & $462 \cdot 15$ & 462.27 & 462.39 & 462.52 & 462.64 & 462.77 & 462.89 & 33.90 \\
\hline 34.00 & 462.89 & 463.01 & 463.14 & 463.26 & $463 \cdot 38$ & 463.51 & 463.63 & 463.76 & 463.88 & 464.00 & 464.13 & 34.00 \\
\hline 34.10 & 464.13 & 464.25 & $464 \cdot 38$ & 464.50 & $464 \cdot 62$ & 464.75 & 464.87 & 465.00 & 465.12 & 465.24 & 465.37 & 34.10 \\
\hline 34.20 & 465.37 & 465.49 & 465.61 & 465.74 & 465.86 & 465.99 & 466.11 & 466.23 & $466 \cdot 36$ & $466 \cdot 48$ & 466.61 & 34.20 \\
\hline $34 \cdot 30$ & 466.61 & 466.73 & 466.85 & 466.98 & $467 \cdot 10$ & 467.22 & 467.35 & 467.47 & 467.60 & 467.72 & 467.84 & 34.30 \\
\hline 34.40 & $467 \cdot 84$ & 467.97 & 468.09 & $468 \cdot 22$ & $468 \cdot 34$ & 468.46 & 468.59 & 468.71 & 468.83 & 468.96 & 469.08 & 34.40 \\
\hline 34.50 & 469.08 & $469 \cdot 21$ & $469 \cdot 33$ & 469.45 & 469.58 & 469.70 & 469.83 & 469.95 & 470.07 & $470 \cdot 20$ & $470 \cdot 32$ & 34.50 \\
\hline 34.60 & $470 \cdot 32$ & 470.44 & 470.57 & 470.69 & 470.82 & 470.94 & 471.06 & 471.19 & 471.31 & $471 \cdot 44$ & 471.56 & .60 \\
\hline 34.70 & $471 \cdot 56$ & $471 \cdot 68$ & $471 \cdot 81$ & 471.93 & 472.05 & $472 \cdot 18$ & $472 \cdot 30$ & 472.43 & 472.55 & 472.67 & 472.80 & 34.70 \\
\hline 34.80 & 472.80 & 472.92 & 473.04 & 473.17 & 473.29 & 473.42 & 473.54 & 473.66 & 473.79 & 473.91 & 474.04 & 34.80 \\
\hline 34.90 & 474.04 & 474.16 & $474 \cdot 28$ & 474.41 & 474.53 & 474.65 & $474 \cdot 78$ & 474.90 & 475.03 & 475.15 & 475.27 & 34.90 \\
\hline 35.00 & 475.27 & 475.40 & 475.52 & 475.64 & 475.77 & 475.89 & 476.02 & 476.14 & 476.26 & 476.39 & 476.51 & 35.00 \\
\hline 35.10 & 476.51 & 476.63 & $476 \cdot 76$ & 476.88 & 477.01 & 477.13 & 477.25 & 477.38 & 477.50 & 477.62 & 477.75 & 35.10 \\
\hline 35.20 & 477.75 & 477.87 & 478.00 & 478.12 & $478 \cdot 24$ & 478.37 & 478.49 & 478.61 & 478.74 & 478.86 & 478.99 & 35.20 \\
\hline 35.30 & 478.99 & 479.11 & 479.23 & 479.36 & $479 \cdot 48$ & 479.60 & 479.73 & 479.85 & 479.98 & 480.10 & 480.22 & 35.30 \\
\hline 35.40 & $480 \cdot 22$ & 480.35 & 480.47 & 480.59 & 480.72 & 480.84 & 480.97 & 481.09 & $481 \cdot 21$ & $481 \cdot 34$ & $481 \cdot 46$ & 35.40 \\
\hline 35.50 & 481.46 & 481.58 & $481 \cdot 71$ & 481.83 & $481 \cdot 96$ & 482.08 & $482 \cdot 20$ & 482.33 & $482 \cdot 45$ & 482.57 & 482.70 & 35.50 \\
\hline 35.60 & $482 \cdot 70$ & 482.82 & 482.95 & 483.07 & 483.19 & 483.32 & 483.44 & 483.56 & 483.69 & 483.81 & 483.94 & 35.60 \\
\hline 35.70 & 483.94 & 484.06 & $484 \cdot 18$ & $484 \cdot 31$ & $484 \cdot 43$ & 484.55 & 484.68 & 484.80 & 484.93 & 485.05 & 485.17 & 35.70 \\
\hline 35.80 & 485.17 & $485 \cdot 30$ & 485.42 & 485.54 & 485.67 & 485.79 & 485.91 & 486.04 & $486 \cdot 16$ & $486 \cdot 29$ & 486.41 & 35.80 \\
\hline 35.90 & 486.41 & 486.53 & 486.66 & 486.78 & 486.90 & 487.03 & 487.15 & 487.28 & 487.40 & 487.52 & 65 & 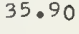 \\
\hline 36.00 & 487.65 & 487.77 & 487.89 & 488.02 & 488.14 & $488 \cdot 27$ & $488 \cdot 39$ & 488.51 & 488.64 & $488 \cdot 76$ & 488.88 & 36.00 \\
\hline
\end{tabular}

$m V$

$.00 \quad .01$

.02

.03

.04

.05

.06

.07

.08

.09

.10

$m V$ 
TABLE A5.2.1. Type E thermocouples-temperature $\left({ }^{\circ} \mathrm{C}\right)$ as a function of thermoelectric voltage, reference junctions at $0^{\circ} \mathrm{C}$-Continued

$m V$

.00

.01

.02

487.65

36.00

36.10

36.20

36.30

36.40

36.5

36.60

36.70

36.80

36.90

37.00

37.10

37.20

37.30

37.40

37.50

37.60

37.70

37.80

37.90

38.00

38.10

38.20

38.30

38.40

38.50

38.60

38.70

38.70

38.90

39.00

39.10

39.20

39.30

39.40

39.50

39.60

39.70

80

39.90

40.00

$40 \cdot 10$

$40 \cdot 20$

$40 \cdot 30$

40.40

40.50

40.60

40.70

40.80

40.90

41.00

41.10

41.20

41.30

41.40

41.50

41.60

41.70

41.80

41.90

42.00

$\mathrm{mV}$

512.37

513.61

514.85

516.08

518.55

519.79

521.02

522.26

523.50

524.73

525.97

527.20

528.44

529.67

530.91

532.15

533.38

534.62

535.85

537.09

538.33

539.56

540.80

542.03

543.27

544.50

545.74

546.98

548.21

549.45

550.69

551.92

553.16

554.39

555.63

556.87

558.10

559.34

560.58

561.81
487.77

489.01

490.24

491.48

492.72

493.95

495.19

496.43

497.66

498.90

500.14

501.37

502.61

503.84

505.08

506.32

507.55

508.79

510.03

511.26

512.50

513.73

514.97

516.20

517.44

518.68

519.91

521.15

522.38

523.62

524.86

526.09

527.33

528.56

529.80

531.03

532.27

533.51

534.74

537.21

538.45

539.68

540.92

542.16

543.39

544.63

545.86

547.10

548.34

549.57

550.81

552.05

553.28

554.52

555.75

556.99

558.23

559.46

560.70

561.94
487.89

489.13

490.37

491.60

492.84

494.08

495.31

496.55

497.79
499.02

500.26

501.50

502.73

503.97

506.44

507.68

508.91

510.15

511.38

512.62

513.86

515.09

516.33

517.56

518.80

520.04

21.27

522.51
523.74

524.98

526.21

527.45

528.69

529.92

$531 \cdot 16$

532.39

533.63

534.86

537.34

538.57

539.81

541.04

542.28

543.52

544.75

545.99

547.22

548.46

549.70

550.93

552.17

553.41
554.64

555.88

557.11

558.35

559.59

560.82

562.06

\begin{abstract}
.01
\end{abstract}

\begin{abstract}
.02
\end{abstract}

\begin{abstract}
.00
\end{abstract}
.01

\begin{tabular}{|c|c|c|c|c|}
\hline \multicolumn{2}{|c|}{ TEMPERATURES } & DEGREES & C IIPTS & 19681 \\
\hline 488.02 & $488 \cdot 14$ & 488.27 & 488.39 & 488 \\
\hline 489.25 & $489 \cdot 38$ & 489.50 & 489.63 & 489 \\
\hline 490.49 & 490.62 & 490.74 & 490.86 & 490 \\
\hline 491.73 & 491.85 & $491 \cdot 98$ & $492 \cdot 10$ & 492 \\
\hline 492.96 & 493.09 & 493.21 & 493.34 & \\
\hline 494.20 & 494.33 & 494.45 & 494.57 & 494 \\
\hline 495.44 & 495.56 & 495.69 & 495.81 & 495 \\
\hline 496.67 & 496.80 & 496.92 & 497.05 & 497 \\
\hline 497.91 & 498.03 & 498.16 & 498.28 & 498 \\
\hline 499.15 & $499 \cdot 27$ & 499.39 & 499.52 & 499 \\
\hline $500 \cdot 38$ & 500.51 & 500.63 & 500.75 & 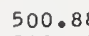 \\
\hline 501.62 & 501.74 & 501.87 & 501.99 & \\
\hline 502.86 & 502.98 & 503.10 & 503.23 & 503 \\
\hline 504.09 & $504 \cdot 22$ & $504 \cdot 34$ & $504 \cdot 46$ & 504 \\
\hline $505 \cdot 33$ & 505.45 & 505.58 & 505.70 & 505 \\
\hline 506.56 & 506.69 & 506.81 & 506.94 & 507 \\
\hline 507.80 & $507 \cdot 92$ & 508.05 & 508.17 & 508 \\
\hline 509.04 & $509 \cdot 16$ & 509.28 & 509.41 & \\
\hline 510.27 & 510.40 & 510.52 & 510.64 & 510 \\
\hline 511.51 & 511.63 & 511.76 & 511.88 & 512 \\
\hline 512.74 & 512.87 & 512.99 & 513.12 & 51 \\
\hline 513.98 & $514 \cdot 10$ & $514 \cdot 23$ & $514 \cdot 35$ & 51 \\
\hline 515.22 & $515 \cdot 34$ & 515.46 & 515.59 & 51 \\
\hline 516.45 & $516 \cdot 58$ & 516.70 & 516.82 & 516 \\
\hline 517.69 & $517 \cdot 81$ & 517.93 & 518.06 & 518 \\
\hline 518.92 & 519.05 & 519.17 & 519.29 & $=1$ \\
\hline $520 \cdot 16$ & $520 \cdot 28$ & 520.41 & 520.53 & 52 \\
\hline 521.40 & $521 \cdot 52$ & 521.64 & 521.77 & 521 \\
\hline 522.63 & $522 \cdot 75$ & 522.88 & 523.00 & 523 \\
\hline 523.87 & 523.99 & 524.11 & $524 \cdot 24$ & 524 \\
\hline $525 \cdot 10$ & $525 \cdot 23$ & $525 \cdot 35$ & 525.47 & \\
\hline 526. & $526 \cdot 46$ & 526.59 & 526.71 & $\begin{array}{l}52 \\
52\end{array}$ \\
\hline $\begin{array}{l}527.57 \\
528.81\end{array}$ & $527 \cdot 70$ & 527.82 & $527 \cdot 94$ & 5 \\
\hline $\begin{array}{l}528.81 \\
530.05\end{array}$ & $\begin{array}{l}528.93 \\
530.17\end{array}$ & $\begin{array}{l}529.06 \\
530.29\end{array}$ & $\begin{array}{l}529.18 \\
530.42\end{array}$ & 330 \\
\hline 531.28 & 531.40 & 531.53 & 531.65 & 531 \\
\hline 532.52 & 532.64 & 532.76 & 532.89 & 53 \\
\hline 533 & 533.88 & 534.00 & $534 \cdot 12$ & \\
\hline $\begin{array}{l}534.99 \\
536.22\end{array}$ & $\begin{array}{l}535 \cdot 11 \\
536 \cdot 35\end{array}$ & $\begin{array}{l}535.24 \\
536.47\end{array}$ & $\begin{array}{l}535.36 \\
536.60\end{array}$ & 5 \\
\hline & & 536.4 & & 536 \\
\hline 537 & 537 & 537.71 & 83 & \\
\hline & 538 & . 94 & 53 & 539 \\
\hline 539.93 & 540.06 & $540 \cdot 18$ & $540 \cdot 30$ & 54 \\
\hline 541.17 & $541 \cdot 29$ & 541.41 & $541 \cdot 54$ & 54 \\
\hline 542.40 & 542.53 & 542.65 & 542.77 & 542 \\
\hline 543.64 & 543.76 & 543.89 & & \\
\hline 544 & 545.00 & $545 \cdot 12$ & 545.25 & \\
\hline 546.11 & 546.24 & $546 \cdot 36$ & 546.48 & \\
\hline 547.35 & 547.47 & 547.59 & 547.72 & 547 \\
\hline 548.58 & 548.71 & 548.83 & 548.95 & 54 \\
\hline 549 & 94 & 7 & 550.19 & \\
\hline & 551 & & & \\
\hline 552.29 & 552.42 & $552 \cdot 54$ & 552.66 & 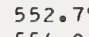 \\
\hline 553.53 & 553.65 & 553.78 & $553 \cdot 90$ & 55 \\
\hline 554.76 & 554.89 & 555.01 & $555 \cdot 14$ & . \\
\hline 556 & 556.12 & 556.25 & 556.37 & \\
\hline & 557.36 & 557.49 & 557.61 & \\
\hline & 558.60 & 558.72 & 558.85 & \\
\hline 559.71 & 559.83 & 559.96 & 560.08 & 56 \\
\hline 560.95 & 561.07 & 561.19 & $561 \cdot 32$ & \\
\hline $562 \cdot 18$ & 562.31 & 562.43 & 562.56 & 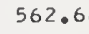 \\
\hline .03 & .04 & .05 & .06 & \\
\hline
\end{tabular}

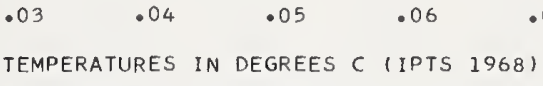

489.38

$490.49 \quad 490.62$

491.85

48.75

93.46

489.87

491.11

492.35

493.58

494.82

496.06

497.29

498.53

499.77

501.00

502.24

503.47

504.71

505.95

507.18

508.42

509.65

510.89

$512 \cdot 13$

513.36

514.60

515.83

517.07

518.31

519.54
520.78

522.01

523.25

524.48

525.72

526.96

528.19

529.43

530.66

531.90

533.13

534.37

535.61

536.84

538.08

539.31

540.55

541.79

543.02

544.26

545.49

546.73

547.97 
TABLE A5.2.1. Type E thermocouples-temperature $\left({ }^{\circ} \mathrm{C}\right)$ as a function of thermoelectric voltage, reference junctions at $0^{\circ} \mathrm{C}$-Continued

.05

.06

.07

.08

.09

.10

$m \mathrm{~V}$

TEMPERATURES IN DEGREES C (IPTS 1968)

\begin{tabular}{|c|c|c|c|c|c|c|c|c|c|c|c|c|}
\hline $\begin{array}{l}42 \cdot 00 \\
42 \cdot 10 \\
42 \cdot 20 \\
42 \cdot 30 \\
42.40\end{array}$ & $\begin{array}{l}561 \cdot 81 \\
563.05 \\
564 \cdot 29 \\
565.52 \\
566.76\end{array}$ & $\begin{array}{l}561.94 \\
563.17 \\
564.41 \\
565.65 \\
566.88\end{array}$ & $\begin{array}{l}562.06 \\
563.30 \\
564.53 \\
565.77 \\
567.01\end{array}$ & $\begin{array}{l}562.18 \\
563.42 \\
564.66 \\
565.89 \\
567.13\end{array}$ & $\begin{array}{l}562 \cdot 31 \\
563 \cdot 54 \\
564 \cdot 78 \\
566 \cdot 02 \\
567 \cdot 26\end{array}$ & $\begin{array}{l}562 \cdot 43 \\
563.67 \\
564.90 \\
566.14 \\
567.38\end{array}$ & $\begin{array}{l}562.56 \\
563.79 \\
565.03 \\
566.27 \\
567.50\end{array}$ & $\begin{array}{l}562.68 \\
563.92 \\
565.15 \\
566.39 \\
567.63\end{array}$ & $\begin{array}{l}562.80 \\
564.04 \\
565.28 \\
566.51 \\
567.75\end{array}$ & $\begin{array}{l}562.93 \\
564.16 \\
565.40 \\
566.64 \\
567.87\end{array}$ & $\begin{array}{l}563.05 \\
564.29 \\
565.52 \\
566.76 \\
568.00\end{array}$ & $\begin{array}{l}42.00 \\
42.10 \\
42.20 \\
42.30 \\
42.40\end{array}$ \\
\hline $\begin{array}{l}42.50 \\
42.60 \\
42.70 \\
42.80 \\
42.90\end{array}$ & $\begin{array}{l}568.00 \\
569.23 \\
570.47 \\
571.71 \\
572.95\end{array}$ & $\begin{array}{l}568.12 \\
569.36 \\
570.60 \\
571.83 \\
573.07\end{array}$ & $\begin{array}{l}568 \cdot 24 \\
569.48 \\
570.72 \\
571.96 \\
573.19\end{array}$ & $\begin{array}{l}568.37 \\
569.61 \\
570.84 \\
572.08 \\
573.32\end{array}$ & $\begin{array}{l}568.49 \\
569.73 \\
570.97 \\
572.20 \\
573.44\end{array}$ & $\begin{array}{l}568.62 \\
569.85 \\
571.09 \\
572.33 \\
573.56\end{array}$ & $\begin{array}{l}568.74 \\
569.98 \\
571.21 \\
572.45 \\
573.69\end{array}$ & $\begin{array}{l}568.86 \\
570.10 \\
571.34 \\
572.57 \\
573.81\end{array}$ & $\begin{array}{l}568.99 \\
570.22 \\
571.46 \\
572.70 \\
573.94\end{array}$ & $\begin{array}{l}569.11 \\
570.35 \\
571.58 \\
572.82 \\
574.06\end{array}$ & $\begin{array}{l}569 \cdot 23 \\
570.47 \\
571.71 \\
572.95 \\
574.18\end{array}$ & $\begin{array}{l}42.50 \\
42.60 \\
42.70 \\
42.80 \\
42.90\end{array}$ \\
\hline $\begin{array}{l}43.00 \\
43.10 \\
43.20 \\
43.30 \\
43.40\end{array}$ & $\begin{array}{l}574.18 \\
575.42 \\
576.66 \\
577.90 \\
579.13\end{array}$ & $\begin{array}{l}574.31 \\
575.54 \\
576.78 \\
578.02 \\
579.26\end{array}$ & $\begin{array}{l}574.43 \\
575.67 \\
576.91 \\
578.14 \\
579.38\end{array}$ & $\begin{array}{l}574.55 \\
575.79 \\
577.03 \\
578.27 \\
579.50\end{array}$ & $\begin{array}{l}574.68 \\
575.92 \\
577.15 \\
578.39 \\
579.63\end{array}$ & $\begin{array}{l}574.80 \\
576.04 \\
577.28 \\
578.51 \\
579.75\end{array}$ & $\begin{array}{l}574.93 \\
576.16 \\
577.40 \\
578.64 \\
579.88\end{array}$ & $\begin{array}{l}575.05 \\
576.29 \\
577.52 \\
578.76 \\
580.00\end{array}$ & $\begin{array}{l}575.17 \\
576.41 \\
577.65 \\
578.89 \\
580.12\end{array}$ & $\begin{array}{l}575.30 \\
576.53 \\
577.77 \\
579.01 \\
580.25\end{array}$ & $\begin{array}{l}575.42 \\
576.66 \\
577.90 \\
579.13 \\
580.37\end{array}$ & $\begin{array}{l}43.00 \\
43.10 \\
43.20 \\
43.30 \\
43.40\end{array}$ \\
\hline $\begin{array}{l}43.50 \\
43.60 \\
43.70 \\
43.80 \\
43.90\end{array}$ & $\begin{array}{l}580.37 \\
581.61 \\
582.85 \\
584.09 \\
585.32\end{array}$ & $\begin{array}{l}580 \cdot 50 \\
581 \cdot 73 \\
582 \cdot 97 \\
584 \cdot 21 \\
585.45\end{array}$ & $\begin{array}{l}580.62 \\
581.86 \\
583.09 \\
584.33 \\
585.57\end{array}$ & $\begin{array}{l}580.74 \\
581.98 \\
583.22 \\
584.46 \\
585.69\end{array}$ & $\begin{array}{l}580.87 \\
582 \cdot 10 \\
583.34 \\
584.58 \\
585.82\end{array}$ & $\begin{array}{l}580.99 \\
582.23 \\
583.47 \\
584.70 \\
585.94\end{array}$ & $\begin{array}{l}581.11 \\
582.35 \\
583.59 \\
584.83 \\
586.07\end{array}$ & $\begin{array}{l}581.24 \\
582.48 \\
583.71 \\
584.95 \\
586.19\end{array}$ & $\begin{array}{l}581.36 \\
582.60 \\
583.84 \\
585.08 \\
586.31\end{array}$ & $\begin{array}{l}581.49 \\
582 \cdot 72 \\
583.96 \\
585.20 \\
586.44\end{array}$ & $\begin{array}{l}581.61 \\
582.85 \\
584.09 \\
585.32 \\
586.56\end{array}$ & $\begin{array}{l}43.50 \\
43.60 \\
43.70 \\
43.80 \\
43.90\end{array}$ \\
\hline $\begin{array}{l}44.00 \\
44.10 \\
44.20 \\
44.30 \\
44.40\end{array}$ & $\begin{array}{l}586.56 \\
587.80 \\
589.04 \\
590.28 \\
591.52\end{array}$ & $\begin{array}{l}586.69 \\
587.92 \\
589.16 \\
590.40 \\
591.64\end{array}$ & $\begin{array}{l}586.81 \\
588.05 \\
589.29 \\
590.52 \\
591.76\end{array}$ & $\begin{array}{l}586.93 \\
588.17 \\
589.41 \\
590.65 \\
591.89\end{array}$ & $\begin{array}{l}587.06 \\
588.30 \\
589.53 \\
590.77 \\
592.01\end{array}$ & $\begin{array}{l}587.18 \\
588.42 \\
589.66 \\
590.90 \\
592.14\end{array}$ & $\begin{array}{l}587.30 \\
588.54 \\
589.78 \\
591.02 \\
592.26\end{array}$ & $\begin{array}{l}587.43 \\
588.67 \\
589.91 \\
591.14 \\
592.38\end{array}$ & $\begin{array}{l}587.55 \\
588.79 \\
590.03 \\
591.27 \\
592.51\end{array}$ & $\begin{array}{l}587.68 \\
588.91 \\
590.15 \\
591.39 \\
592.63\end{array}$ & $\begin{array}{l}587.80 \\
589.04 \\
590.28 \\
591.52 \\
592.75\end{array}$ & $\begin{array}{l}44.00 \\
44.10 \\
44.20 \\
44.30 \\
44.40\end{array}$ \\
\hline $\begin{array}{l}44.50 \\
44.60 \\
44.70 \\
44.80 \\
44.90\end{array}$ & $\begin{array}{l}592.75 \\
593.99 \\
595.23 \\
596.47 \\
597.71\end{array}$ & $\begin{array}{l}592.88 \\
594.12 \\
595.36 \\
596.60 \\
597.83\end{array}$ & $\begin{array}{l}593.00 \\
594.24 \\
595.48 \\
596.72 \\
597.96\end{array}$ & $\begin{array}{l}593.13 \\
594.37 \\
595.60 \\
596.84 \\
598.08\end{array}$ & $\begin{array}{l}593.25 \\
594.49 \\
595.73 \\
596.97 \\
598.21\end{array}$ & $\begin{array}{l}593.37 \\
594.61 \\
595.85 \\
597.09 \\
598.33\end{array}$ & $\begin{array}{l}593.50 \\
594.74 \\
595.98 \\
597.22 \\
598.45\end{array}$ & $\begin{array}{l}593.62 \\
594.86 \\
596.10 \\
597.34 \\
598.58\end{array}$ & $\begin{array}{l}593.75 \\
594.98 \\
596.22 \\
597.46 \\
598.70\end{array}$ & $\begin{array}{l}593.87 \\
595.11 \\
596.35 \\
597.59 \\
598.83\end{array}$ & $\begin{array}{l}593.99 \\
595.23 \\
596.47 \\
597.71 \\
598.95\end{array}$ & $\begin{array}{l}44.50 \\
44.60 \\
44.70 \\
44.80 \\
44.90\end{array}$ \\
\hline $\begin{array}{l}45.00 \\
45.10 \\
45.20 \\
45.30 \\
45.40\end{array}$ & $\begin{array}{l}598.95 \\
600.19 \\
601.43 \\
602.67 \\
603.91\end{array}$ & $\begin{array}{l}599.07 \\
600.31 \\
601.55 \\
602.79 \\
604.03\end{array}$ & $\begin{array}{l}599 \cdot 20 \\
600 \cdot 44 \\
601.68 \\
602.92 \\
604 \cdot 16\end{array}$ & $\begin{array}{l}599.32 \\
600.56 \\
601.80 \\
603.04 \\
604.28\end{array}$ & $\begin{array}{l}599 \cdot 45 \\
600.69 \\
601.93 \\
603 \cdot 17 \\
604 \cdot 40\end{array}$ & $\begin{array}{l}599.57 \\
600.81 \\
602.05 \\
603.29 \\
604.53\end{array}$ & $\begin{array}{l}599.69 \\
600.93 \\
602.17 \\
603.41 \\
604.65\end{array}$ & $\begin{array}{l}599.82 \\
601.06 \\
602.30 \\
603.54 \\
604.78\end{array}$ & $\begin{array}{l}599.94 \\
601.18 \\
602.42 \\
603.66 \\
604.90\end{array}$ & $\begin{array}{l}600.07 \\
601.31 \\
602.55 \\
603.78 \\
605.02\end{array}$ & $\begin{array}{l}600.19 \\
601.43 \\
602.67 \\
603.91 \\
605.15\end{array}$ & $\begin{array}{l}45.00 \\
45.10 \\
45.20 \\
45.30 \\
45.40\end{array}$ \\
\hline $\begin{array}{l}45.50 \\
45.60 \\
45.70 \\
45.80 \\
45.90\end{array}$ & $\begin{array}{l}605 \cdot 15 \\
606 \cdot 39 \\
607.63 \\
608.87 \\
610.11\end{array}$ & $\begin{array}{l}605 \cdot 27 \\
606 \cdot 51 \\
607.75 \\
608 \cdot 99 \\
610.23\end{array}$ & $\begin{array}{l}605 \cdot 40 \\
606 \cdot 64 \\
607 \cdot 88 \\
609 \cdot 12 \\
610 \cdot 36\end{array}$ & $\begin{array}{l}605.52 \\
606.76 \\
608.00 \\
609.24 \\
610.48\end{array}$ & $\begin{array}{l}605 \cdot 64 \\
606.89 \\
608 \cdot 13 \\
609.37 \\
610.61\end{array}$ & $\begin{array}{l}605.77 \\
607.01 \\
608.25 \\
609.49 \\
610.73\end{array}$ & $\begin{array}{l}605.89 \\
607.13 \\
608.37 \\
609.61 \\
610.85\end{array}$ & $\begin{array}{l}606.02 \\
607.26 \\
608.50 \\
609.74 \\
610.98\end{array}$ & $\begin{array}{l}606.14 \\
607.38 \\
608.62 \\
609.86 \\
611.10\end{array}$ & $\begin{array}{l}606.27 \\
607.51 \\
608.75 \\
609.99 \\
611.23\end{array}$ & $\begin{array}{l}606.39 \\
607.63 \\
608.87 \\
610.11 \\
611.35\end{array}$ & $\begin{array}{l}45.50 \\
45.60 \\
45.70 \\
45.80 \\
45.90\end{array}$ \\
\hline $\begin{array}{l}46 \cdot 00 \\
46 \cdot 10 \\
46 \cdot 20 \\
46 \cdot 30 \\
46 \cdot 40\end{array}$ & $\begin{array}{l}611.35 \\
612.59 \\
613.83 \\
615.07 \\
616.31\end{array}$ & $\begin{array}{l}611.47 \\
612.72 \\
613.96 \\
615.20 \\
616.44\end{array}$ & $\begin{array}{l}611.60 \\
612.84 \\
614.08 \\
615.32 \\
616.56\end{array}$ & $\begin{array}{l}611.72 \\
612.96 \\
614.20 \\
615.45 \\
616.69\end{array}$ & $\begin{array}{l}611.85 \\
613.09 \\
614.33 \\
615.57 \\
616.81\end{array}$ & $\begin{array}{l}611.97 \\
613.21 \\
614.45 \\
615.69 \\
616.94\end{array}$ & $\begin{array}{l}612.10 \\
613.34 \\
614.58 \\
615.82 \\
617.06\end{array}$ & $\begin{array}{l}612 \cdot 22 \\
613.46 \\
614.70 \\
615 \cdot 94 \\
617.18\end{array}$ & $\begin{array}{l}612 \cdot 34 \\
613 \cdot 58 \\
614 \cdot 83 \\
616 \cdot 07 \\
617.31\end{array}$ & $\begin{array}{l}612.47 \\
613.71 \\
614.95 \\
616.19 \\
617.43\end{array}$ & $\begin{array}{l}612.59 \\
613.83 \\
615.07 \\
616.31 \\
617.56\end{array}$ & $\begin{array}{l}46.00 \\
46.10 \\
46.20 \\
46.30 \\
46.40\end{array}$ \\
\hline $\begin{array}{l}46.50 \\
46.60 \\
46.70 \\
46.80 \\
46.90\end{array}$ & $\begin{array}{l}617.56 \\
618.80 \\
620.04 \\
621.28 \\
622.52\end{array}$ & $\begin{array}{l}617.68 \\
618.92 \\
620.16 \\
621.41 \\
622.65\end{array}$ & $\begin{array}{l}617.80 \\
619.05 \\
620.29 \\
621.53 \\
622.77\end{array}$ & $\begin{array}{l}617.93 \\
619.17 \\
620.41 \\
621.65 \\
622.90\end{array}$ & $\begin{array}{l}618.05 \\
619.29 \\
620.54 \\
621.78 \\
623.02\end{array}$ & $\begin{array}{l}618.18 \\
619.42 \\
620.66 \\
621.90 \\
623.14\end{array}$ & $\begin{array}{l}618.30 \\
619.54 \\
620.78 \\
622.03 \\
623.27\end{array}$ & $\begin{array}{l}618.43 \\
619.67 \\
620.91 \\
622.15 \\
623.39\end{array}$ & $\begin{array}{l}618.55 \\
619.79 \\
621.03 \\
622.27 \\
623.52\end{array}$ & $\begin{array}{l}618.67 \\
619.92 \\
621.16 \\
622.40 \\
623.64\end{array}$ & $\begin{array}{l}618.80 \\
620.04 \\
621.28 \\
622.52 \\
623.76\end{array}$ & $\begin{array}{l}46.50 \\
46.60 \\
46.70 \\
46.80 \\
46.90\end{array}$ \\
\hline $\begin{array}{l}47.00 \\
47.10 \\
47.20 \\
47.30 \\
47.40\end{array}$ & $\begin{array}{l}623.76 \\
625.01 \\
626.25 \\
627.49 \\
628.73\end{array}$ & $\begin{array}{l}623.89 \\
625.13 \\
626.37 \\
627.62 \\
628.86\end{array}$ & $\begin{array}{l}624.01 \\
625 \cdot 26 \\
626 \cdot 50 \\
627 \cdot 74 \\
628.98\end{array}$ & $\begin{array}{l}624.14 \\
625 \cdot 38 \\
626.62 \\
627.86 \\
629.11\end{array}$ & $\begin{array}{l}624 \cdot 26 \\
625.50 \\
626 \cdot 75 \\
627.99 \\
629.23\end{array}$ & $\begin{array}{l}624.39 \\
625.63 \\
626.87 \\
628.11 \\
629.36\end{array}$ & $\begin{array}{l}624.51 \\
625.75 \\
627.00 \\
628.24 \\
629.48\end{array}$ & $\begin{array}{l}624.63 \\
625.88 \\
627.12 \\
628.36 \\
629.60\end{array}$ & $\begin{array}{l}624 \cdot 76 \\
626.00 \\
627.24 \\
628.49 \\
629.73\end{array}$ & $\begin{array}{l}624.88 \\
626.13 \\
627.37 \\
628.61 \\
629.85\end{array}$ & $\begin{array}{l}625.01 \\
626.25 \\
627.49 \\
628.73 \\
629.98\end{array}$ & $\begin{array}{l}47.00 \\
47.10 \\
47.20 \\
47.30 \\
47.40\end{array}$ \\
\hline $\begin{array}{l}47.50 \\
47.60 \\
47.70 \\
47.80 \\
47.90\end{array}$ & $\begin{array}{l}629.98 \\
631.22 \\
632.46 \\
633.71 \\
634.95\end{array}$ & $\begin{array}{l}630.10 \\
631.34 \\
632.59 \\
633.83 \\
635.08\end{array}$ & $\begin{array}{l}630.23 \\
631.47 \\
632.71 \\
633.96 \\
635.20\end{array}$ & $\begin{array}{l}630.35 \\
631.59 \\
632.84 \\
634.08 \\
635.32\end{array}$ & $\begin{array}{l}630.47 \\
631.72 \\
632.96 \\
634.20 \\
635.45\end{array}$ & $\begin{array}{l}630.60 \\
631.84 \\
633.09 \\
634.33 \\
635.57\end{array}$ & $\begin{array}{l}630.72 \\
631.97 \\
633.21 \\
634.45 \\
635.70\end{array}$ & $\begin{array}{l}630.85 \\
632.09 \\
633.33 \\
634.58 \\
635.82\end{array}$ & $\begin{array}{l}630.97 \\
632.22 \\
633.46 \\
634.70 \\
635.95\end{array}$ & $\begin{array}{l}631.10 \\
632.34 \\
633.58 \\
634.83 \\
636.07\end{array}$ & $\begin{array}{l}631.22 \\
632.46 \\
633.71 \\
634.95 \\
636.19\end{array}$ & $\begin{array}{l}47.50 \\
47.60 \\
47.70 \\
47.80 \\
47.90\end{array}$ \\
\hline 48.00 & 636.19 & 636.32 & 636.44 & 636.57 & 636.69 & 636.82 & 636.94 & 637.07 & 637.19 & 637.31 & 637.44 & 48.00 \\
\hline & .00 & .01 & .02 & .03 & .04 & .05 & .06 & .07 & .08 & .09 & .10 & $m V$ \\
\hline
\end{tabular}


TABLE A5.2.1. Type E thermocouples-temperature $\left({ }^{\circ} \mathrm{C}\right)$ as a function of thermoelectric voltage, reference junctions at $0^{\circ} \mathrm{C}$-Continued

$m \mathrm{~V}$

.00

.01

.02

.03

.04

.05

.06

.07

.08

.09

.10

$m V$

TEMPERATURES IN DEGREES C (IPTS 1968)

\begin{tabular}{|c|c|c|c|c|c|c|c|c|c|c|c|c|}
\hline $\begin{array}{l}48.00 \\
48.10 \\
48.20 \\
48.30 \\
48.40\end{array}$ & $\begin{array}{l}636.19 \\
637.44 \\
638.68 \\
639.93 \\
641.17\end{array}$ & $\begin{array}{l}636.32 \\
637.56 \\
638.81 \\
640.05 \\
641.30\end{array}$ & $\begin{array}{l}636.44 \\
637.69 \\
638.93 \\
640.18 \\
641.42\end{array}$ & $\begin{array}{l}636.57 \\
637.81 \\
639.06 \\
640.30 \\
641.54\end{array}$ & $\begin{array}{l}636.69 \\
637.94 \\
639.18 \\
640.42 \\
641.67\end{array}$ & $\begin{array}{l}636.82 \\
638.06 \\
639.30 \\
640.55 \\
641.79\end{array}$ & $\begin{array}{l}636.94 \\
638.18 \\
639.43 \\
640.67 \\
641.92\end{array}$ & $\begin{array}{l}637.07 \\
638.31 \\
639.55 \\
640.80 \\
642.04\end{array}$ & $\begin{array}{l}637.19 \\
638.43 \\
639.68 \\
640.92 \\
642.17\end{array}$ & $\begin{array}{l}637.31 \\
638.56 \\
639.80 \\
641.05 \\
642.29\end{array}$ & $\begin{array}{l}637.44 \\
638.68 \\
639.93 \\
641.17 \\
642.42\end{array}$ & $\begin{array}{l}48.00 \\
48.10 \\
48.20 \\
48.30 \\
48.40\end{array}$ \\
\hline $\begin{array}{l}48.50 \\
48.60 \\
48.70 \\
48.80 \\
48.90\end{array}$ & $\begin{array}{l}642.42 \\
643.66 \\
644.90 \\
646.15 \\
647.39\end{array}$ & $\begin{array}{l}642.54 \\
643.78 \\
645.03 \\
646.27 \\
647.52\end{array}$ & $\begin{array}{l}642.66 \\
643.91 \\
645.15 \\
646.40 \\
647.64\end{array}$ & $\begin{array}{l}642.79 \\
644.03 \\
645.28 \\
646.52 \\
647.77\end{array}$ & $\begin{array}{l}642 \cdot 91 \\
644.16 \\
645.40 \\
646.65 \\
647.89\end{array}$ & $\begin{array}{l}643 \cdot 04 \\
644.28 \\
645.53 \\
646.77 \\
648.02\end{array}$ & $\begin{array}{l}643.16 \\
644.41 \\
645.65 \\
646.90 \\
648.14\end{array}$ & $\begin{array}{l}643.29 \\
644.53 \\
645.78 \\
647.02 \\
648.27\end{array}$ & $\begin{array}{l}643.41 \\
644.66 \\
645.90 \\
647.15 \\
648.39\end{array}$ & $\begin{array}{l}643.54 \\
644.78 \\
646.03 \\
647.27 \\
648.52\end{array}$ & $\begin{array}{l}643.66 \\
644 \cdot 90 \\
646.15 \\
647.39 \\
648.64\end{array}$ & $\begin{array}{l}48.50 \\
48.60 \\
48.70 \\
48.80 \\
48.90\end{array}$ \\
\hline $\begin{array}{l}49 \cdot 00 \\
49 \cdot 10 \\
49 \cdot 20 \\
49.30 \\
49.40\end{array}$ & $\begin{array}{l}648.64 \\
649.89 \\
651.13 \\
652.38 \\
653.62\end{array}$ & $\begin{array}{l}648.76 \\
650.01 \\
651.26 \\
652.50 \\
653.75\end{array}$ & $\begin{array}{l}648.89 \\
650.14 \\
651.38 \\
652.63 \\
653.87\end{array}$ & $\begin{array}{l}649.01 \\
650.26 \\
651.51 \\
652.75 \\
654.00\end{array}$ & $\begin{array}{l}649 \cdot 14 \\
650 \cdot 38 \\
651.63 \\
652.88 \\
654 \cdot 12\end{array}$ & $\begin{array}{l}649.26 \\
650.51 \\
651.75 \\
653.00 \\
654.25\end{array}$ & $\begin{array}{l}649.39 \\
650.63 \\
651.88 \\
653.13 \\
654.37\end{array}$ & $\begin{array}{l}649.51 \\
650.76 \\
652.00 \\
653.25 \\
654.50\end{array}$ & $\begin{array}{l}649.64 \\
650.88 \\
652.13 \\
653.37 \\
654.62\end{array}$ & $\begin{array}{l}649.76 \\
651.01 \\
652.25 \\
653.50 \\
654.75\end{array}$ & $\begin{array}{l}649.89 \\
651.13 \\
652.38 \\
653.62 \\
654.87\end{array}$ & $\begin{array}{l}49.00 \\
49.10 \\
49.20 \\
49.30 \\
49.40\end{array}$ \\
\hline $\begin{array}{l}49.50 \\
49.60 \\
49.70 \\
49.80 \\
49.90\end{array}$ & $\begin{array}{l}654.87 \\
656.12 \\
657.36 \\
658.61 \\
659.86\end{array}$ & $\begin{array}{l}654 \cdot 99 \\
656.24 \\
657.49 \\
658.73 \\
659.98\end{array}$ & $\begin{array}{l}655.12 \\
656.37 \\
657.61 \\
658.86 \\
660.11\end{array}$ & $\begin{array}{l}655.24 \\
656.49 \\
657.74 \\
658.98 \\
660.23\end{array}$ & $\begin{array}{l}655 \cdot 37 \\
656.62 \\
657.86 \\
659 \cdot 11 \\
660 \cdot 36\end{array}$ & $\begin{array}{l}655.49 \\
656.74 \\
657.99 \\
659.23 \\
660.48\end{array}$ & $\begin{array}{l}655.62 \\
656.86 \\
658.11 \\
659.36 \\
660.61\end{array}$ & $\begin{array}{l}655 \cdot 74 \\
656.99 \\
658.24 \\
659.48 \\
660.73\end{array}$ & $\begin{array}{l}655.87 \\
657.11 \\
658.36 \\
659.61 \\
660.85\end{array}$ & $\begin{array}{l}655.99 \\
657.24 \\
658.49 \\
659.73 \\
660.98\end{array}$ & $\begin{array}{l}656.12 \\
657.36 \\
658.61 \\
659.86 \\
661.10\end{array}$ & $\begin{array}{l}49.50 \\
49.60 \\
49.70 \\
49.80 \\
49.90\end{array}$ \\
\hline $\begin{array}{l}50 \cdot 00 \\
50 \cdot 10 \\
50 \cdot 20 \\
50 \cdot 30 \\
50 \cdot 40\end{array}$ & $\begin{array}{l}661 \cdot 10 \\
662 \cdot 35 \\
663 \cdot 60 \\
664 \cdot 85 \\
666.10\end{array}$ & $\begin{array}{l}661.23 \\
662.48 \\
663.72 \\
664 \cdot 97 \\
666.22\end{array}$ & $\begin{array}{l}661.35 \\
662.60 \\
663.85 \\
665 \cdot 10 \\
666.35\end{array}$ & $\begin{array}{l}661.48 \\
662.73 \\
663.97 \\
665.22 \\
666.47\end{array}$ & $\begin{array}{l}661.60 \\
662.85 \\
664 \cdot 10 \\
665 \cdot 35 \\
666 \cdot 59\end{array}$ & $\begin{array}{l}661.73 \\
662 \cdot 98 \\
664.22 \\
665.47 \\
666.72\end{array}$ & $\begin{array}{l}661.85 \\
663 \cdot 10 \\
664.35 \\
665.60 \\
666.84\end{array}$ & $\begin{array}{l}661.98 \\
663.23 \\
664.47 \\
665.72 \\
666.97\end{array}$ & $\begin{array}{l}662.10 \\
663.35 \\
664.60 \\
665.85 \\
667.09\end{array}$ & $\begin{array}{l}662 \cdot 23 \\
663 \cdot 47 \\
664 \cdot 72 \\
665 \cdot 97 \\
667 \cdot 22\end{array}$ & $\begin{array}{l}662.35 \\
663.60 \\
664.85 \\
666.10 \\
667 \cdot 34\end{array}$ & $\begin{array}{l}50.00 \\
50.10 \\
50.20 \\
50.30 \\
50.40\end{array}$ \\
\hline $\begin{array}{l}50 \cdot 50 \\
50 \cdot 60 \\
50 \cdot 70 \\
50.80 \\
50.90\end{array}$ & $\begin{array}{l}667.34 \\
668.59 \\
669.84 \\
671.09 \\
672.34\end{array}$ & $\begin{array}{l}667.47 \\
668.72 \\
669.97 \\
671.21 \\
672.46\end{array}$ & $\begin{array}{l}667.59 \\
668.84 \\
670.09 \\
671.34 \\
672.59\end{array}$ & $\begin{array}{l}667.72 \\
668 \cdot 97 \\
670.22 \\
671.46 \\
672.71\end{array}$ & $\begin{array}{l}667.84 \\
669.09 \\
670.34 \\
671 \cdot 59 \\
672.84\end{array}$ & $\begin{array}{l}667.97 \\
669 \cdot 22 \\
670.47 \\
671 \cdot 71 \\
672.96\end{array}$ & $\begin{array}{l}668.09 \\
669.34 \\
670.59 \\
671.84 \\
673.09\end{array}$ & $\begin{array}{l}668.22 \\
669.47 \\
670.71 \\
671.96 \\
673.21\end{array}$ & $\begin{array}{l}668.34 \\
669 \cdot 59 \\
670.84 \\
672.09 \\
673.34\end{array}$ & $\begin{array}{l}668.47 \\
669 \cdot 72 \\
670.96 \\
672.21 \\
673.46\end{array}$ & $\begin{array}{l}668.59 \\
669.84 \\
671.09 \\
672.34 \\
673.59\end{array}$ & $\begin{array}{l}50.50 \\
50.60 \\
50.70 \\
50.80 \\
50.90\end{array}$ \\
\hline $\begin{array}{l}51.00 \\
51.10 \\
51.20 \\
51.30 \\
51.40\end{array}$ & $\begin{array}{l}673.59 \\
674.84 \\
676.09 \\
677.34 \\
678.59\end{array}$ & $\begin{array}{l}673 \cdot 71 \\
674.96 \\
676.21 \\
677 \cdot 46 \\
678.71\end{array}$ & $\begin{array}{l}673.84 \\
675.09 \\
676.34 \\
677 \cdot 59 \\
678.84\end{array}$ & $\begin{array}{l}673.96 \\
675.21 \\
676.46 \\
677.71 \\
678.96\end{array}$ & $\begin{array}{l}674.09 \\
675 \cdot 34 \\
676.59 \\
677.84 \\
679.09\end{array}$ & $\begin{array}{l}674 \cdot 21 \\
675.46 \\
676.71 \\
677.96 \\
679.21\end{array}$ & $\begin{array}{l}674.34 \\
675.59 \\
676.84 \\
678.09 \\
679.34\end{array}$ & $\begin{array}{l}674.46 \\
675.71 \\
676.96 \\
678.21 \\
679.46\end{array}$ & $\begin{array}{l}674 \cdot 59 \\
675.84 \\
677.09 \\
678.34 \\
679.59\end{array}$ & $\begin{array}{l}674 \cdot 71 \\
675.96 \\
677.21 \\
678.46 \\
679.71\end{array}$ & $\begin{array}{l}674 \cdot 84 \\
676.09 \\
677.34 \\
678.59 \\
679.84\end{array}$ & $\begin{array}{l}51 \cdot 00 \\
51 \cdot 10 \\
51 \cdot 20 \\
51.30 \\
51.40\end{array}$ \\
\hline $\begin{array}{l}51.50 \\
51.60 \\
51.70 \\
51.80 \\
51.90\end{array}$ & $\begin{array}{l}679.84 \\
681.09 \\
682.34 \\
683.59 \\
684.84\end{array}$ & $\begin{array}{l}679.96 \\
681.21 \\
682.46 \\
683.71 \\
684.97\end{array}$ & $\begin{array}{l}680.09 \\
681.34 \\
682.59 \\
683.84 \\
685.09\end{array}$ & $\begin{array}{l}680.21 \\
681.46 \\
682 \cdot 71 \\
683.96 \\
685.22\end{array}$ & $\begin{array}{l}680 \cdot 34 \\
681 \cdot 59 \\
682 \cdot 84 \\
684 \cdot 09 \\
685 \cdot 34\end{array}$ & $\begin{array}{l}680.46 \\
681.71 \\
682.96 \\
684.21 \\
685.47\end{array}$ & $\begin{array}{l}680.59 \\
681.84 \\
683.09 \\
684.34 \\
685.59\end{array}$ & $\begin{array}{l}680 \cdot 71 \\
681 \cdot 96 \\
683 \cdot 21 \\
684.46 \\
685.72\end{array}$ & $\begin{array}{l}680.84 \\
682.09 \\
683.34 \\
684.59 \\
685.84\end{array}$ & $\begin{array}{l}680.96 \\
682.21 \\
683.46 \\
684.72 \\
685.97\end{array}$ & $\begin{array}{l}681.09 \\
682.34 \\
683.59 \\
684.84 \\
686.09\end{array}$ & $\begin{array}{l}51.50 \\
51.60 \\
51.70 \\
51.80 \\
51.90\end{array}$ \\
\hline $\begin{array}{l}52.00 \\
52.10 \\
52.20 \\
52.30 \\
52.40\end{array}$ & $\begin{array}{l}686.09 \\
687.34 \\
688.59 \\
689.85 \\
691.10\end{array}$ & $\begin{array}{l}686.22 \\
687 \cdot 47 \\
688 \cdot 72 \\
689 \cdot 97 \\
691 \cdot 22\end{array}$ & $\begin{array}{l}686 \cdot 34 \\
687 \cdot 59 \\
688 \cdot 85 \\
690 \cdot 10 \\
691 \cdot 35\end{array}$ & $\begin{array}{l}686.47 \\
687.72 \\
688.97 \\
690.22 \\
691.47\end{array}$ & $\begin{array}{l}686 \cdot 59 \\
687 \cdot 84 \\
689 \cdot 10 \\
690 \cdot 35 \\
691 \cdot 60\end{array}$ & $\begin{array}{l}686.72 \\
687 \cdot 97 \\
689 \cdot 22 \\
690 \cdot 47 \\
691 \cdot 73\end{array}$ & $\begin{array}{l}686.84 \\
688.09 \\
689.35 \\
690.60 \\
691.85\end{array}$ & $\begin{array}{l}686.97 \\
688.22 \\
689.47 \\
690.72 \\
691.98\end{array}$ & $\begin{array}{l}687.09 \\
688.34 \\
689.60 \\
690.85 \\
692.10\end{array}$ & $\begin{array}{l}687 \cdot 22 \\
688 \cdot 47 \\
689 \cdot 72 \\
690 \cdot 97 \\
692 \cdot 23\end{array}$ & $\begin{array}{l}687 \cdot 34 \\
688 \cdot 59 \\
689 \cdot 85 \\
691 \cdot 10 \\
692 \cdot 35\end{array}$ & $\begin{array}{l}52.00 \\
52.10 \\
52.20 \\
52.30 \\
52.40\end{array}$ \\
\hline $\begin{array}{l}52.50 \\
52.60 \\
52.70 \\
52.80 \\
52.90\end{array}$ & $\begin{array}{l}692.35 \\
693.60 \\
694.86 \\
696.11 \\
697.36\end{array}$ & $\begin{array}{l}692.48 \\
693.73 \\
694.98 \\
696.24 \\
697.49\end{array}$ & $\begin{array}{l}692.60 \\
693 \cdot 85 \\
695 \cdot 11 \\
696.36 \\
697 \cdot 61\end{array}$ & $\begin{array}{l}692.73 \\
693.98 \\
695.23 \\
696.49 \\
697.74\end{array}$ & $\begin{array}{l}692 \cdot 85 \\
694 \cdot 11 \\
695 \cdot 36 \\
696.61 \\
697.86\end{array}$ & $\begin{array}{l}692.98 \\
694.23 \\
695.48 \\
696.74 \\
697.99\end{array}$ & $\begin{array}{l}693 \cdot 10 \\
694 \cdot 36 \\
695.61 \\
696.86 \\
698.12\end{array}$ & $\begin{array}{l}693.23 \\
694.48 \\
695.73 \\
696.99 \\
698.24\end{array}$ & $\begin{array}{l}693.35 \\
694.61 \\
695.86 \\
697.11 \\
698.37\end{array}$ & $\begin{array}{l}693 \cdot 48 \\
694 \cdot 73 \\
695 \cdot 98 \\
697 \cdot 24 \\
698 \cdot 49\end{array}$ & $\begin{array}{l}693.60 \\
694.86 \\
696.11 \\
697.36 \\
698.62\end{array}$ & $\begin{array}{l}52.50 \\
52.60 \\
52.70 \\
52.80 \\
52.90\end{array}$ \\
\hline $\begin{array}{l}53.00 \\
53.10 \\
53.20 \\
53.30 \\
53.40\end{array}$ & $\begin{array}{l}698.62 \\
699.87 \\
701.12 \\
702.38 \\
703.63\end{array}$ & $\begin{array}{l}698.74 \\
700.00 \\
701.25 \\
702.50 \\
703.76\end{array}$ & $\begin{array}{l}698 \cdot 87 \\
700 \cdot 12 \\
701 \cdot 38 \\
702.63 \\
703.88\end{array}$ & $\begin{array}{l}698.99 \\
700.25 \\
701.50 \\
702.76 \\
704.01\end{array}$ & $\begin{array}{l}699 \cdot 12 \\
700 \cdot 37 \\
701 \cdot 63 \\
702 \cdot 88 \\
704 \cdot 14\end{array}$ & $\begin{array}{l}699.24 \\
700.50 \\
701.75 \\
703.01 \\
704.26\end{array}$ & $\begin{array}{l}699.37 \\
700 \cdot 62 \\
701.88 \\
703.13 \\
704.39\end{array}$ & $\begin{array}{l}699.49 \\
700.75 \\
702.00 \\
703.26 \\
704.51\end{array}$ & $\begin{array}{l}699.62 \\
700.87 \\
702.13 \\
703.38 \\
704.64\end{array}$ & $\begin{array}{l}699 \cdot 75 \\
701 \cdot 00 \\
702 \cdot 25 \\
703 \cdot 51 \\
704.76\end{array}$ & $\begin{array}{l}699.87 \\
701.12 \\
702.38 \\
703.63 \\
704.89\end{array}$ & $\begin{array}{l}53.00 \\
53.10 \\
53.20 \\
53.30 \\
53.40\end{array}$ \\
\hline $\begin{array}{l}53.50 \\
53.60 \\
53.70 \\
53.80 \\
53.90\end{array}$ & $\begin{array}{l}704.89 \\
706.14 \\
707.40 \\
708.65 \\
709.91\end{array}$ & $\begin{array}{l}705.01 \\
706.27 \\
707.52 \\
708.78 \\
710.03\end{array}$ & $\begin{array}{l}705.14 \\
706.39 \\
707.65 \\
708.90 \\
710.16\end{array}$ & $\begin{array}{l}705.26 \\
706.52 \\
707.77 \\
709.03 \\
710.29\end{array}$ & $\begin{array}{l}705 \cdot 39 \\
706 \cdot 65 \\
707 \cdot 90 \\
709 \cdot 16 \\
710.41\end{array}$ & $\begin{array}{l}705.52 \\
706.77 \\
708.03 \\
709.28 \\
710.54\end{array}$ & $\begin{array}{l}705 \cdot 64 \\
706 \cdot 90 \\
708 \cdot 15 \\
709 \cdot 41 \\
710.66\end{array}$ & $\begin{array}{l}705.77 \\
707.02 \\
708.28 \\
709.53 \\
710.79\end{array}$ & $\begin{array}{l}705.89 \\
707.15 \\
708.40 \\
709.66 \\
710.91\end{array}$ & $\begin{array}{l}706.02 \\
707.27 \\
708.53 \\
709.78 \\
711.04\end{array}$ & $\begin{array}{l}706 \cdot 14 \\
707.40 \\
708.65 \\
709.91 \\
711.16\end{array}$ & $\begin{array}{l}53.50 \\
53.60 \\
53.70 \\
53.80 \\
53.90\end{array}$ \\
\hline 54.00 & $711 \cdot 16$ & 711.29 & 711.42 & 711.54 & 711.67 & 711.79 & 711.92 & 712.04 & 712.17 & 712.30 & 712.42 & 54.00 \\
\hline
\end{tabular}

$m V$

.00

.01

.02

.03

.04

.05

.06

.07

.08

.09

.10 
TABLE A5.2.1. Type $\boldsymbol{E}$ thermocouples-temperature $\left({ }^{\circ} \mathrm{C}\right)$ as a function of thermoelectric voltage, reference junctions at $0^{\circ} \mathrm{C}$-Continued

$m V$

.0

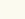

54.00

54.10

54.20

$54 \cdot 30$

54.40

54.50

54.60

54.70

54.80

54.90

55.00

55.10

55.20

55.30

55.40

55.50

55.60

55.70

55.80

55.90

56.00
56.10

56.20

56.30

56.40

56.50

56.60

56.70

56.80

56.90

57.00

57.10

57.20

57.30

57.40

57.50

57.60

57.70

57.80

57.90

58.00

58.10

58.20

58.30

58.40

58.50

58.60

58.70

58.80

58.90

59.00

59.10

59.20

59.30

59.40

59.50

59.60

59.70

59.80

59.90

60.00

711.16
712.42

713.68

714.93

717.45

718.70

719.96

721.22

722.48

723.74

725.00

726.25

727.51

728.77

730.03

731.29

732.55

735.07

736.33

737.59

738.85

740.12

741.38

742.64

743.90

745.17

746.43

747.69

748.95

750.22

751.48

752.75

754.01

755.27

756.54

757.81

759.07

$760 \cdot 34$

761.60

762.87

765.40

766.67

767.94

769.20

770.47

771.74

773.01

774.28

775.55

776.82

778.09

779.36

780.63

781.90

783.17

784.44

785.71

786.98

.01

.02

.03

.04

.05

.06

.07

.08

.09

.10

mV

TEMPERATURES IN DEGREES C (IPTS 1968)

711.29

$711 \cdot 42$

716.32

713.93

715.19

17.57

718.83

720.09

721.35

722.60

723.86

725.12

726.38

727.64

728.90

730.16

731.42

732.68

733.94

735.20

736.46

737.72

738.98

740.24

741.50

742.77

744.03

745.29

746.55

747.82

749.08

750.34

751.61

752.87

$754 \cdot 14$

755.40

756.67

757.93

759.20

760.46

761.73

763.00

764.26

765.53

766.80

768.06

769.33

770.60

771.87

773.14

716.44

717.70

718.96

721.47

722.73

723.99

725.25

726.51

$727 \cdot 76$
729.02

$730 \cdot 28$

731.54

732.80

735.32

736.58

737.85

739.11

740.37
741.63

742.89

744.15

745.42

$746 \cdot 68$

749.21

750.47

751.73

753.00

754.26

755.53

756.79

758.06

759.32

761.86

763.12

764.39

765.66
766.92

768.19

769.46

770.73

771.99

773.26

774.40

775.67

776.94

774.53
775.80

777.07

779.61

780.75

782.02

783.29

$780 \cdot 88$

782.15

783.42

784.69

785.96

$787.11 \quad 787.24$

$711 \cdot 54$

711.67

$711 \cdot 79$

$711.92 \quad 712.04$

712.92

$714.05 \quad 714.18$

$\begin{array}{ll}715.31 & 715.44 \\ 716.57 & 716.69\end{array}$

713.05

714.31

715.56

$\begin{array}{ll}715.69 & 715.81\end{array}$

717.82

717.95

$719.08 \quad 719.21$

$720 \cdot 34$

721.60

722.86

724.11

725.37

726.63

727.89

729.15

730.41

731.67

732.93

734.19

736.71

737.97

739.23

740.49

741.76

743.02

744.28

745.54

$746 \cdot 81$

749.33

750.60

751.86

753.13

754.39

755.65

756.92

758.18

759.45

761.98

763.25

764.52

765.78

767.05

768.32 
TABLE A5.2.1. Type E thermocouples-temperature $\left({ }^{\circ} \mathrm{C}\right)$ as a function of thermoelectric voltage, reference junctions at $0^{\circ} \mathrm{C}$-Continued

$m V$

.00

.01

.02

786.98

$60 \cdot 00$

$60 \cdot 10$

60.20

60.30

60.40

60.50

60.60

60.70

60.80

61.00

61.1

61.20

61.30

61.40

61.50

61.60

61.70

61.80

61.90

62.00

62.1

62.2

62.30

62.4

62.50

62.60

62.7

62.80

62.90

63.00

63.10

63.2

63.30

63.40

63.50

63.60

63.70

63.80

63.90

64.00

64.1

64.2

64.3

64.40

64.50

64.6

64.70

64.8

64.90

65.00

65.1

65.2

65.3

65.40

65.50

65.60

65.70

65.80

65.90

66.00

$m V$

812.48

813.76

815.04

816.32

817.60

818.88

820.16

821.44

822.72

824.00

825.28

826.56

827.84

829.12

830.41

831.69

832.97

834.26

835.54

836.82

838.11

839.39

840.68

841.97

843.25

844.54

845.82

847.11

848.40

849.69

850.98

852.26

853.55

854.84

856.13

857.42

858.71

860.00

861.30

862.59

863.88
787.11

788.38

789.65

790.93

792.20

793.47

794.75

796.02

797.29
798.57

799.84

801.12

802.39

803.67

804.95

806.22

807.50

808.78

810.05

811.33

812.61

813.89

815.17

816.44

817.72

819.00

820.28

821.56

824.12

825.41

826.69

827.97

829.25

830.53

831.82

833.10

834.38

835.67
836.95

838.24

839.52

840.81

842.09

843.38

844.67

845.95

847.24

848.53

849.82

851.10

852.39

853.68

854.97

856.26

857.55

858.84

860.13

861.42

862.72
787.24

788.51
789.78

791.05

792.33

793.60

794.87

796.15

798.70

799.97

801.25

802.52

803.80

805.07

806.35

807.63

808.90

810.18

811.46

812.74

814.01

815.29

816.57

817.85

819.13

820.41

821.69

822.97

825.53

826.82

828.10

829.38

830.66

831.95

833.23

834.51

835.80

837.08

838.37

839.65

840.94

842.22

843.51

$844 \cdot 80$

846.08

847.37

848.66

849.94

851.23

852.52

853.81

855.10

856.39

857.68

858.97

860.26

861.55

862.85

864.14

.03

.04

.05

.06

.07

.08

.09

.10

$\mathrm{mV}$

TEMPERATURES IN DEGREES C (IPTS 1968)

$\begin{array}{llllll}787.36 & 787.49 & 787.62 & 787.75 & 787.87 & 788.00 \\ 788.64 & 788.76 & 788.89 & 789.02 & 789.14 & 789.27 \\ 789.91 & 790.04 & 790.16 & 790.29 & 790.42 & 790.54 \\ 791.18 & 791.31 & 791.44 & 791.56 & 791.69 & 791.82 \\ 792.45 & 792.58 & 792.71 & 792.84 & 792.96 & 793.09 \\ & & & & & \\ 793.73 & 793.85 & 793.98 & 794.11 & 794.24 & 794.36 \\ 795.00 & 795.13 & 795.26 & 795.38 & 795.51 & 795.64 \\ 796.27 & 796.40 & 796.53 & 796.66 & 796.78 & 796.91 \\ 797.55 & 797.68 & 797.80 & 797.93 & 798.06 & 798.19 \\ 798.82 & 798.95 & 799.08 & 799.21 & 799.33 & 799.46\end{array}$

800.10

801.37

802.65

803.92

805.20

800.23

801.50

802.78

804.05

800.35

801.63

802.90

804.18

800.48

801.76

803.03

804.31

800.61

801.88

803.16

803.16
804.44

805.71

$800 \cdot 74$

802.01

803.29

804.56

805.84

806.48

807.75

809.03

810.31

806.61

807.88

809.16

806.73

808.01

806.86

806.99

808.26

809.54

$809.29 \quad 809.41$

811.71

812.86

814.14

815.42

816.70

817.98

812.99

814.27

815.55

816.83

811.84

(1)

811.97

813.12

814.40

813.25 
TABLE A5.2.1. Type $\boldsymbol{E}$ thermocouples-temperature $\left({ }^{\circ} \mathrm{C}\right)$ as a function of thermoelectric voltage, reference junctions at $0^{\circ} \mathrm{C}$-Continued

$\mathrm{mV}$

.02

.03

.04

.05

.06

.07

.08

.09

.10

$\mathrm{mV}$

TEMPERATURES IN DEGREES C (IPTS 1968)

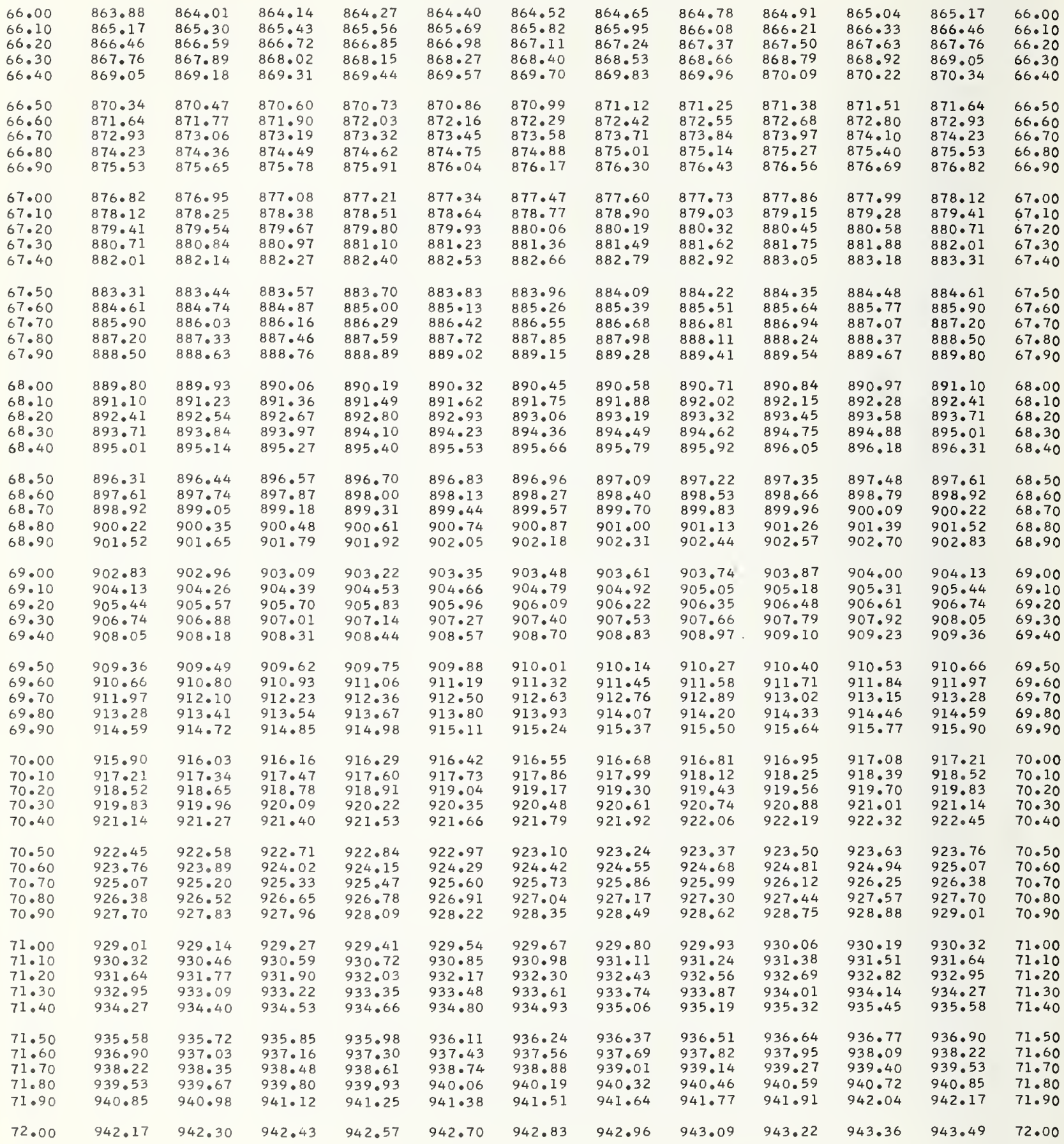

$\mathrm{mV}$

.02

.03

.04

.05

.06

.07

.08

.09

.10

$\mathrm{mV}$ 
TABLE A5.2.1. Type E thermocouples-temperature $\left({ }^{\circ} \mathrm{C}\right)$ as a function of thermoelectric voltage, reference junctions at $0^{\circ} \mathrm{C}$-Continued

$m \mathrm{v}$

42.17

943.49

944.81

946.13

947.45

948.77

950.09

951.41

952.73

954.05

955.37

956.70

958.02

959.34

960.67

961.99

963.32

964.64

965.97

967.29

968.62

969.95

971.28

972.60

973.93

975.26

976.59

977.92

979.25

980.58

981.91

983.24

984.57

985.90

987.23

988.57

989.90

991.23

992.56

993.90

995.23

996.56

997.90

999.23
.01

.02

942.30

943.62

944.94

946.26

947.58

948.90

950.22

951.54

952.86

954.18

955.51

956.83

958.15

959.48

960.80

$962 \cdot 12$

963.45

964.77

966.10

967.43

968.75

970.08

971.41

972.74

974.06

975.39

976.72

978.05

979.38

980.71

982.04

983.37

984.70

986.03

987.37

988.70

990.03

991.36

992.70

994.03

995.36

996.70

998.03

999.37
.03

.04

.05

.06

.07

.08

.09

.10

$\mathrm{mV}$

TEMPERATURES IN DEGREES C (IPTS 1968)

\begin{tabular}{|c|c|}
\hline $\begin{array}{l}942.43 \\
943.75 \\
945.07 \\
946.39 \\
947.71\end{array}$ & $\begin{array}{l}942.57 \\
943.88 \\
945.20 \\
946.52 \\
947.84\end{array}$ \\
\hline $\begin{array}{l}949.03 \\
950.35 \\
951.67 \\
952 \cdot 99 \\
954.32\end{array}$ & $\begin{array}{l}949.16 \\
950.48 \\
951.80 \\
953.13 \\
954.45\end{array}$ \\
\hline $\begin{array}{l}955.64 \\
956.96 \\
958.28 \\
959.61 \\
960.93\end{array}$ & $\begin{array}{l}955.77 \\
957.09 \\
958.42 \\
959.74 \\
961.06\end{array}$ \\
\hline $\begin{array}{l}962.26 \\
963.58 \\
964.91 \\
966.23 \\
967.56\end{array}$ & $\begin{array}{r}962.39 \\
963.71 \\
965.04 \\
966.37 \\
967.69\end{array}$ \\
\hline $\begin{array}{l}968 \cdot 89 \\
970 \cdot 21 \\
971 \cdot 54 \\
972 \cdot 87 \\
974 \cdot 20\end{array}$ & $\begin{array}{l}969.02 \\
970.35 \\
971.67 \\
973.00 \\
974.33\end{array}$ \\
\hline $\begin{array}{l}975.53 \\
976.85 \\
978.18 \\
979.51 \\
980.84\end{array}$ & $\begin{array}{l}975.66 \\
976.99 \\
978.32 \\
979.65 \\
980.98\end{array}$ \\
\hline $\begin{array}{l}982.17 \\
983.50 \\
984.84 \\
986.17 \\
987.50\end{array}$ & $\begin{array}{l}982.31 \\
983.64 \\
984.97 \\
986.30 \\
987.63\end{array}$ \\
\hline $\begin{array}{l}988.83 \\
990.16 \\
991 \cdot 50 \\
992 \cdot 83 \\
994 \cdot 16\end{array}$ & $\begin{array}{l}988.96 \\
990.30 \\
991.63 \\
992.96 \\
994.30\end{array}$ \\
\hline $\begin{array}{l}995.50 \\
996.83 \\
998.16 \\
999.50\end{array}$ & $\begin{array}{l}995.63 \\
996.96 \\
998.30 \\
999.63\end{array}$ \\
\hline
\end{tabular}

942.70
$944 \cdot 02$
$945 \cdot 33$

942.83

944.15

945.47

946.65

947.97

946.79

949.29

950.62

951.94

$953 \cdot 26$

954.58

955.90

957.23

958.55

950.87

961.20

948.11

942.96

943.09

$944.28 \quad 944.41$

945.60

945.73

949.43

950.75

952.07

953.39

954.71

$948 \cdot 24$

947.05

949.56

949.69

950.88

$952 \cdot 20$

953.52

951.01

952.33

953.65

956.03

957.36

958.68

960.01

954.98

962.52

961.33

956.17

957.49

956.30

957.62

58.8

958.95

960.14

962.65

963.85

965.17

966.50

967.82

963.98

965.31

$966 \cdot 63$

962.79

960.27

961.59

964.1

962.92

965.44

966.76

964.24

965.57

966.90

968.22

$969 \cdot 15$

970.48

971.81

969.28

969.28
970.61

971.94

968.0

969.42

970.74

972.07

969.55
970.88

972.20

97.13

$974 \cdot 46$

974.60

975.79

975.92

77.12

978.45

979.78

977.25

978.58

979.91

981.24

974.73

973.53

976.06

977.39

978.72

980.05

981.38

982.44

$983 \cdot 77$

985.10

982.57

982.57

985.24

986.57

982.71

984.04

985.37

986.70

987.77

987.90

989.10

989.23

990.56

991.76

993.10

994.43

991.90

993.23

994.56

995.76

997.10

998.43

995.90

997.23

998.57

999.90

$943 \cdot 22$
$944 \cdot 54$
$945 \cdot 86$
$947 \cdot 18$
$948 \cdot 50$

944.68
945.99

947.31

948.63

949.82

951.14

952.47

953.79

955.11

956.43

957.75

959.08

960.40

961.73

963.05

964.38

965.70

967.03

968.36

969.68

971.01

972.34

973.67

974.99

976.19

977.5

978.85

980.18

981.51

982.84

984.17

985.50

986.83

988.17

989.36

989.50

990.83

992.03

993.36

992.16

992.16

994.83

996.03

997.36

998.70

996.16

997.50

998.83 
TABle A5.2.2. Type E thermocouples-temperature $\left({ }^{\circ} \mathrm{F}\right)$ as a function of thermoelectric voltage, reference junctions at $32^{\circ} \mathrm{F}$

\begin{tabular}{|c|c|c|c|c|c|c|c|c|c|c|c|c|}
\hline $\mathrm{mV}$ & .00 & .01 & .02 & .03 & .04 & .05 & .06 & .07 & .08 & .09 & $\cdot 10$ & $\mathrm{mV}$ \\
\hline & & & & & & 5 I & s & & & & & \\
\hline $\begin{array}{l}-9.80 \\
-9.70 \\
-9.60 \\
-9.50\end{array}$ & $\begin{array}{l}-437.03 \\
-414.66 \\
-399.44 \\
-387.01\end{array}$ & $\begin{array}{l}-440.41 \\
-416 \cdot 43 \\
-400.80 \\
-388.17\end{array}$ & $\begin{array}{l}-444.42 \\
-418.27 \\
-402.20 \\
-389.34\end{array}$ & $\begin{array}{l}-449.76 \\
-420.19 \\
-403.62 \\
-390.53\end{array}$ & $\begin{array}{l}-422 \cdot 18 \\
-405.08 \\
-391 \cdot 74\end{array}$ & $\begin{array}{l}-424.28 \\
-406.57 \\
-392.97\end{array}$ & $\begin{array}{l}-426 \cdot 48 \\
-408 \cdot 10 \\
-394 \cdot 22\end{array}$ & $\begin{array}{l}-428.83 \\
-409.67 \\
-395.49\end{array}$ & $\begin{array}{l}-431.33 \\
-411.28 \\
-396.78\end{array}$ & $\begin{array}{l}-434 \cdot 05 \\
-412 \cdot 94 \\
-398 \cdot 10\end{array}$ & $\begin{array}{l}-437 \cdot 03 \\
-414 \cdot 66 \\
-399 \cdot 44\end{array}$ & $\begin{array}{l}-9.80 \\
-9.70 \\
-9.60 \\
-9.50\end{array}$ \\
\hline $\begin{array}{l}-9.40 \\
-9.30 \\
-9.20 \\
-9.10 \\
-9.00\end{array}$ & $\begin{array}{l}-376.18 \\
-366.41 \\
-357.41 \\
-349.00 \\
-341.05\end{array}$ & $\begin{array}{l}-377.21 \\
-367.35 \\
-358.29 \\
-349.82 \\
-341.83\end{array}$ & $\begin{array}{l}-378.25 \\
-368.30 \\
-359.16 \\
-350.64 \\
-342.61\end{array}$ & $\begin{array}{l}-379.30 \\
-369.25 \\
-360.05 \\
-351.47 \\
-343.39\end{array}$ & $\begin{array}{l}-380 \cdot 36 \\
-370 \cdot 22 \\
-360 \cdot 94 \\
-352 \cdot 30 \\
-344 \cdot 18\end{array}$ & $\begin{array}{l}-381.44 \\
-371.19 \\
-361.83 \\
-353.14 \\
-344.98\end{array}$ & $\begin{array}{l}-382.52 \\
-372.17 \\
-362.73 \\
-353.99 \\
-345.77\end{array}$ & $\begin{array}{l}33.62 \\
73.16 \\
53.64 \\
54.84 \\
46.57\end{array}$ & $\begin{array}{l}84 \cdot 74 \\
74 \cdot 15 \\
54.56 \\
55.69 \\
47 \cdot 38\end{array}$ & $\begin{array}{l}35.87 \\
75.16 \\
5.48 \\
6.55 \\
8.19\end{array}$ & $\begin{array}{l}-387.01 \\
-376.18 \\
-366.41 \\
-357.41 \\
-349.00\end{array}$ & $\begin{array}{l}-9.40 \\
-9.30 \\
-9.20 \\
-9.10 \\
-9.00\end{array}$ \\
\hline $\begin{array}{l}-8.90 \\
-8.80 \\
-8.70 \\
-8.60 \\
-8.50\end{array}$ & $\begin{array}{l}-333.49 \\
-326.25 \\
-319.29 \\
-312.58 \\
-306.07\end{array}$ & $\begin{array}{l}-334.23 \\
-326.96 \\
-319.98 \\
-313.24 \\
-306.71\end{array}$ & $\begin{array}{l}-334.98 \\
-327.68 \\
-320.67 \\
-313.90 \\
-307.36\end{array}$ & $\begin{array}{l}-335.72 \\
-328.39 \\
-321.35 \\
-314.57 \\
-308.00\end{array}$ & $\begin{array}{l}-336.48 \\
-329.11 \\
-322.05 \\
-315.24 \\
-308.65\end{array}$ & $\begin{array}{l}-337.23 \\
-329.84 \\
-322.74 \\
-315.91 \\
-309.30\end{array}$ & $\begin{array}{l}-337.99 \\
-330.56 \\
-323.44 \\
-316.58 \\
-309.95\end{array}$ & $\begin{array}{l}-338 \cdot 75 \\
-331.29 \\
-324.14 \\
-317.25 \\
-310.60\end{array}$ & $\begin{array}{l}-339.51 \\
-332.02 \\
-324.84 \\
-317.93 \\
-311.26\end{array}$ & $\begin{array}{l}40.28 \\
32.76 \\
25.55 \\
18.61 \\
11.92\end{array}$ & $\begin{array}{l}-341.05 \\
-333.49 \\
-326.25 \\
-319.29 \\
-312.58\end{array}$ & $\begin{array}{l}-8.90 \\
-8.80 \\
-8.70 \\
-8.60 \\
-8.50\end{array}$ \\
\hline $\begin{array}{l}-8 \cdot 40 \\
-8 \cdot 30 \\
-8 \cdot 20 \\
-8 \cdot 10 \\
-8.00\end{array}$ & $\begin{array}{l}-299.76 \\
-293.62 \\
-287.63 \\
-281.79 \\
-276.08\end{array}$ & $\begin{array}{l}-300.38 \\
-294.22 \\
-288.22 \\
-282.37 \\
-276.64\end{array}$ & $\begin{array}{l}-301.01 \\
-294.83 \\
-288.82 \\
-282.95 \\
-277.21\end{array}$ & $\begin{array}{l}-301.63 \\
-295.44 \\
-289.41 \\
-283.53 \\
-277.78\end{array}$ & $\begin{array}{l}-302.2 \\
-296.0 \\
-290.0 \\
-284.1 \\
-278.3\end{array}$ & $\begin{array}{l}-302.89 \\
-296.67 \\
-290.61 \\
-284.69 \\
-278.92\end{array}$ & $\begin{array}{l}-303.52 \\
-297.28 \\
-291.20 \\
-285.28 \\
-279.49\end{array}$ & $\begin{array}{l}-304.16 \\
-297.90 \\
-291.81 \\
-285.87 \\
-280.06\end{array}$ & $\begin{array}{l}-304.79 \\
-298.52 \\
-292.41 \\
-286.45 \\
-280.64\end{array}$ & $\begin{array}{l}-305.43 \\
-299.14 \\
-293.01 \\
-287.04 \\
-281.21\end{array}$ & $\begin{array}{l}-306.07 \\
-299.76 \\
-293.62 \\
-287.63 \\
-281.79\end{array}$ & $\begin{array}{l}-8.40 \\
-8.30 \\
-8.20 \\
-8.10 \\
-8.00\end{array}$ \\
\hline $\begin{array}{l}-7.90 \\
-7.80 \\
-7.70 \\
-7.60 \\
-7.50\end{array}$ & $\begin{array}{l}-270.49 \\
-265.01 \\
-259.64 \\
-254.36 \\
-249.17\end{array}$ & $\begin{array}{l}-271.04 \\
-265.55 \\
-260.17 \\
-254.88 \\
-249.69\end{array}$ & $\begin{array}{l}-271.60 \\
-266.10 \\
-260.70 \\
-255.41 \\
-250.20\end{array}$ & $\begin{array}{l}-272.15 \\
-266.64 \\
-261.24 \\
-255.93 \\
-250.72\end{array}$ & $\begin{array}{l}-272.71 \\
-267.19 \\
-261.77 \\
-256.46 \\
-251.24\end{array}$ & $\begin{array}{l}-273.27 \\
-267.74 \\
-262.31 \\
-256.99 \\
-251.75\end{array}$ & $\begin{array}{l}-273.83 \\
-268.28 \\
-262.85 \\
-257.51 \\
-252.27\end{array}$ & $\begin{array}{l}-274.39 \\
-268.83 \\
-263.39 \\
-258.04 \\
-252.79\end{array}$ & $\begin{array}{l}-274.95 \\
-269.38 \\
-263.93 \\
-258.57 \\
-253.31\end{array}$ & $\begin{array}{l}-275.51 \\
-269.94 \\
-264.47 \\
-259.10 \\
-253.84\end{array}$ & $\begin{array}{l}-276.08 \\
-270.49 \\
-265.01 \\
-259.64 \\
-254.36\end{array}$ & $\begin{array}{l}-7.90 \\
-7.80 \\
-7.70 \\
-7.60 \\
-7.50\end{array}$ \\
\hline $\begin{array}{l}-7.40 \\
-7.30 \\
-7.20 \\
-7.10 \\
-7.00\end{array}$ & $\begin{array}{l}-244.07 \\
-239.05 \\
-234.10 \\
-229.23 \\
-224.42\end{array}$ & $\begin{array}{l}-244.58 \\
-239.55 \\
-234.59 \\
-229.71 \\
-224.90\end{array}$ & $\begin{array}{l}-245.08 \\
-240.05 \\
-235.09 \\
-230.20 \\
-225.38\end{array}$ & $\begin{array}{l}-245.59 \\
-240.55 \\
-235.58 \\
-230.68 \\
-225.86\end{array}$ & $\begin{array}{l}-246.10 \\
-241.05 \\
-236.07 \\
-231.17 \\
-226.34\end{array}$ & $\begin{array}{l}-246.61 \\
-241.55 \\
-236.57 \\
-231.66 \\
-226.82\end{array}$ & $\begin{array}{l}-247.12 \\
-242.05 \\
-237.06 \\
-232.14 \\
-227.30\end{array}$ & $\begin{array}{l}-247.63 \\
-242.56 \\
-237.56 \\
-232.63 \\
-227.78\end{array}$ & $\begin{array}{l}-248.14 \\
-243.06 \\
-238.05 \\
-233.12 \\
-228.26\end{array}$ & $\begin{array}{l}-248.66 \\
-243.56 \\
-238.55 \\
-233.61 \\
-228.74\end{array}$ & $\begin{array}{l}-249.17 \\
-244.07 \\
-239.05 \\
-234.10 \\
-229.23\end{array}$ & $\begin{array}{l}-7.40 \\
-7.30 \\
-7.20 \\
-7.10 \\
-7.00\end{array}$ \\
\hline $\begin{array}{l}-6.90 \\
-6.80 \\
-6.70 \\
-6.60 \\
-6.50\end{array}$ & $\begin{array}{l}-219.68 \\
-214.99 \\
-210.37 \\
-205.80 \\
-201.29\end{array}$ & $\begin{array}{l}-220.15 \\
-215.46 \\
-210.83 \\
-206.26 \\
-201.73\end{array}$ & $\begin{array}{l}-220.62 \\
-215.93 \\
-211.29 \\
-206.71 \\
-202.18\end{array}$ & $\begin{array}{l}-221.09 \\
-216.39 \\
-211.75 \\
-207.17 \\
-202.63\end{array}$ & $\begin{array}{l}-221.57 \\
-216.86 \\
-212.21 \\
-207.62 \\
-203.09\end{array}$ & $\begin{array}{l}-222.04 \\
-217.33 \\
-212.68 \\
-208.08 \\
-203.54\end{array}$ & $\begin{array}{l}-222.52 \\
-217.80 \\
-213.14 \\
-208.54 \\
-203.99\end{array}$ & $\begin{array}{l}-222.99 \\
-218.27 \\
-213.60 \\
-208.99 \\
-204.44\end{array}$ & $\begin{array}{l}-223.47 \\
-218.74 \\
-214.06 \\
-209.45 \\
-204.89\end{array}$ & $\begin{array}{l}-223 \cdot 94 \\
-219 \cdot 21 \\
-214.53 \\
-209 \cdot 91 \\
-205.35\end{array}$ & $\begin{array}{l}-224.42 \\
-219.68 \\
-214.99 \\
-210.37 \\
-205.80\end{array}$ & $\begin{array}{l}-6.90 \\
-6.80 \\
-6.70 \\
-6.60 \\
-6.50\end{array}$ \\
\hline $\begin{array}{l}-6.40 \\
-6.30 \\
-6.20 \\
-6.10 \\
-6.00\end{array}$ & $\begin{array}{l}-196.82 \\
-192.40 \\
-188.03 \\
-183.71 \\
-179.43\end{array}$ & $\begin{array}{l}-197.26 \\
-192.84 \\
-188.47 \\
-184.14 \\
-179.85\end{array}$ & $\begin{array}{l}-197.71 \\
-193.28 \\
-188.90 \\
-184.57 \\
-180.28\end{array}$ & $\begin{array}{l}-198.15 \\
-193.72 \\
-189.34 \\
-185.00 \\
-180.71\end{array}$ & $\begin{array}{l}-198.60 \\
-194.16 \\
-189 \cdot 78 \\
-185.43 \\
-181.13\end{array}$ & $\begin{array}{l}-199.05 \\
-194.61 \\
-190.21 \\
-185.86 \\
-181.56\end{array}$ & $\begin{array}{l}-199.49 \\
-195.05 \\
-190.65 \\
-186.30 \\
-181.99\end{array}$ & $\begin{array}{l}-199.94 \\
-195.49 \\
-191.09 \\
-186.73 \\
-182.42\end{array}$ & $\begin{array}{l}-200.39 \\
-195.93 \\
-191.53 \\
-187.16 \\
-182.85\end{array}$ & $\begin{array}{l}-200 \cdot 84 \\
-196.38 \\
-191.96 \\
-187.60 \\
-183.28\end{array}$ & $\begin{array}{l}-201.29 \\
-196.82 \\
-192.40 \\
-188.03 \\
-183.71\end{array}$ & $\begin{array}{l}-6.40 \\
-6.30 \\
-6.20 \\
-6.10 \\
-6.00\end{array}$ \\
\hline
\end{tabular}

$\mathrm{mV}$

.02

.03

.04

.05

.06

.07

.08

.09

.10

$\mathrm{mV}$ 
TABLE A5.2.2. Type E thermocouples-temperature $\left({ }^{\circ} F\right)$ as a function of thermoelectric voltage, reference junctions at $32{ }^{\circ} \mathrm{F}$-Continued

$\mathrm{mV}$

.00

.01

.02

.03

.04

.05

.06

.07

.08

.09

.10

$\mathrm{mV}$

\begin{tabular}{|c|c|c|c|c|c|c|c|c|c|c|c|c|}
\hline 6.00 & -179.43 & -179.85 & -180.28 & -180.71 & $-181 \cdot 13$ & -181.56 & -181.99 & -182.42 & -182.85 & $-183 \cdot 28$ & -183.71 & 6.00 \\
\hline $\begin{array}{l}-5.90 \\
-5.80 \\
-5.70 \\
-5.60 \\
-5.50\end{array}$ & $\begin{array}{l}-175.18 \\
-170.98 \\
-166.82 \\
-162.70 \\
-158.61\end{array}$ & $\begin{array}{l}-175.61 \\
-171.40 \\
-167.24 \\
-163.11 \\
-159.01\end{array}$ & $\begin{array}{l}-176.03 \\
-171.82 \\
-167.65 \\
-163.52 \\
-159.42\end{array}$ & $\begin{array}{l}-176.45 \\
-172.24 \\
-168.07 \\
-163.93 \\
-159.83\end{array}$ & $\begin{array}{l}-176.88 \\
-172.66 \\
-168.48 \\
-164.34 \\
-160.24\end{array}$ & $\begin{array}{l}-177.30 \\
-173.08 \\
-168.90 \\
-164.75 \\
-160.65\end{array}$ & $\begin{array}{l}-177.72 \\
-173.50 \\
-169.31 \\
-165.17 \\
-161.06\end{array}$ & $\begin{array}{l}-178.15 \\
-173.92 \\
-169.73 \\
-165.58 \\
-161.47\end{array}$ & $\begin{array}{l}-178.57 \\
-174.34 \\
-170.15 \\
-165.99 \\
-161.87\end{array}$ & $\begin{array}{l}-179.00 \\
-174.76 \\
-170.57 \\
-166.41 \\
-162.29\end{array}$ & $\begin{array}{l}-179.43 \\
-175.18 \\
-170.98 \\
-166.82 \\
-162.70\end{array}$ & $\begin{array}{l}-5.90 \\
-5.80 \\
-5.70 \\
-5.60 \\
-5.50\end{array}$ \\
\hline $\begin{array}{l}-5.40 \\
-5.30 \\
-5.20 \\
-5.10 \\
-5.00\end{array}$ & $\begin{array}{l}-154.55 \\
-150.53 \\
-146.54 \\
-142.58 \\
-138.66\end{array}$ & $\begin{array}{l}-154.96 \\
-150.93 \\
-146.94 \\
-142.98 \\
-139.05\end{array}$ & $\begin{array}{l}-155.36 \\
-151.33 \\
-147.34 \\
-143.37 \\
-139.44\end{array}$ & $\begin{array}{l}-155.76 \\
-151.73 \\
-147.74 \\
-143.77 \\
-139.83\end{array}$ & $\begin{array}{l}-156.17 \\
-152.13 \\
-148.13 \\
-144.16 \\
-140.23\end{array}$ & $\begin{array}{l}-156.57 \\
-152.54 \\
-148.53 \\
-144.56 \\
-140.62\end{array}$ & $\begin{array}{l}-156.98 \\
-152.94 \\
-148.93 \\
-144.96 \\
-141.01\end{array}$ & $\begin{array}{l}-157.39 \\
-153.34 \\
-149.33 \\
-145.35 \\
-141.40\end{array}$ & $\begin{array}{l}-157.79 \\
-153.74 \\
-149.73 \\
-145.75 \\
-141.80\end{array}$ & $\begin{array}{l}-158 \cdot 20 \\
-154.15 \\
-150.13 \\
-146.14 \\
-142 \cdot 19\end{array}$ & $\begin{array}{l}-158.61 \\
-154.55 \\
-150.53 \\
-146.54 \\
-142.58\end{array}$ & $\begin{array}{l}-5.40 \\
-5.30 \\
-5.20 \\
-5.10 \\
-5.00\end{array}$ \\
\hline $\begin{array}{l}-4 \cdot 90 \\
-4 \cdot 80 \\
-4 \cdot 70 \\
-4 \cdot 60 \\
-4 \cdot 50\end{array}$ & $\begin{array}{l}-134.76 \\
-130.89 \\
-127.05 \\
-123.24 \\
-119.45\end{array}$ & $\begin{array}{l}-135.15 \\
-131.28 \\
-127.43 \\
-123.62 \\
-119.83\end{array}$ & $\begin{array}{l}-135.54 \\
-131.66 \\
-127.82 \\
-124.00 \\
-120.21\end{array}$ & $\begin{array}{l}-135.93 \\
-132.05 \\
-128.20 \\
-124.38 \\
-120.58\end{array}$ & $\begin{array}{l}-136 \cdot 32 \\
-132 \cdot 44 \\
-128 \cdot 58 \\
-124.76 \\
-120.96\end{array}$ & $\begin{array}{l}-136.71 \\
-132.82 \\
-128.97 \\
-125.14 \\
-121.34\end{array}$ & $\begin{array}{l}-137.10 \\
-133.21 \\
-129.35 \\
-125.52 \\
-121.72\end{array}$ & $\begin{array}{l}-137.49 \\
-133.60 \\
-129.74 \\
-125.90 \\
-122.10\end{array}$ & $\begin{array}{l}-137.88 \\
-133.98 \\
-130.12 \\
-126.29 \\
-122.48\end{array}$ & $\begin{array}{l}-138.27 \\
-134.37 \\
-130.51 \\
-126.67 \\
-122.86\end{array}$ & $\begin{array}{l}-138.66 \\
-134.76 \\
-130.89 \\
-127.05 \\
-123.24\end{array}$ & $\begin{array}{l}-4 \cdot 90 \\
-4.80 \\
-4 \cdot 70 \\
-4.60 \\
-4.50\end{array}$ \\
\hline $\begin{array}{l}-4 \cdot 40 \\
-4 \cdot 30 \\
-4 \cdot 20 \\
-4 \cdot 10 \\
-4 \cdot 00\end{array}$ & $\begin{array}{l}-115.69 \\
-111.95 \\
-108.24 \\
-104.55 \\
-100.88\end{array}$ & $\begin{array}{l}-116.06 \\
-112.32 \\
-108.61 \\
-104.91 \\
-101.25\end{array}$ & $\begin{array}{l}-116.44 \\
-112.70 \\
-108.98 \\
-105.28 \\
-101.61\end{array}$ & $\begin{array}{l}-116.81 \\
-113.07 \\
-109.35 \\
-105.65 \\
-101.98\end{array}$ & $\begin{array}{l}-117.19 \\
-113.44 \\
-109.72 \\
-106.02 \\
-102.34\end{array}$ & $\begin{array}{l}-117.57 \\
-113.82 \\
-110.09 \\
-106.39 \\
-102.71\end{array}$ & $\begin{array}{l}-117.94 \\
-114.19 \\
-110.46 \\
-106.76 \\
-103.08\end{array}$ & $\begin{array}{l}-118.32 \\
-114.56 \\
-110.83 \\
-107.13 \\
-103.44\end{array}$ & $\begin{array}{l}-118.70 \\
-114.94 \\
-111.21 \\
-107.50 \\
-103.81\end{array}$ & $\begin{array}{l}-119.07 \\
-115.31 \\
-111.58 \\
-107.87 \\
-104.18\end{array}$ & & $\begin{array}{l}-4.40 \\
-4.30 \\
-4.20 \\
-4.10 \\
-4.00\end{array}$ \\
\hline $\begin{array}{l}-3.90 \\
-3.80 \\
-3.70 \\
-3.60 \\
-3.50\end{array}$ & $\begin{array}{l}-97.23 \\
-93.61 \\
-90.01 \\
-86.43 \\
-82.86\end{array}$ & $\begin{array}{l}-97.60 \\
-93.97 \\
-90.37 \\
-86.78 \\
-83.22\end{array}$ & $\begin{array}{l}-97.96 \\
-94.33 \\
-90.73 \\
-87.14 \\
-83.57\end{array}$ & $\begin{array}{l}-98.33 \\
-94.70 \\
-91.09 \\
-87.50 \\
-83.93\end{array}$ & $\begin{array}{l}-98.69 \\
-95.06 \\
-91.45 \\
-87.86 \\
-84.29\end{array}$ & $\begin{array}{l}-99.05 \\
-95.42 \\
-91.81 \\
-88.21 \\
-84.64\end{array}$ & $\begin{array}{l}-99.42 \\
-95.78 \\
-92.17 \\
-88.57 \\
-85.00\end{array}$ & $\begin{array}{l}-99.78 \\
-96.14 \\
-92.53 \\
-88.93 \\
-85.36\end{array}$ & $\begin{array}{r}-100.15 \\
-96.51 \\
-92.89 \\
-89.29 \\
-85.71\end{array}$ & $\begin{array}{r}-100.51 \\
-96.87 \\
-93.25 \\
-89.65 \\
-86.07\end{array}$ & $\begin{array}{r}-100.88 \\
-97.23 \\
-93.61 \\
-90.01 \\
-86.43\end{array}$ & $\begin{array}{l}-3.90 \\
-3.80 \\
-3.70 \\
-3.60 \\
-3.50\end{array}$ \\
\hline $\begin{array}{l}-3.40 \\
-3.30 \\
-3.20 \\
-3.10 \\
-3.00\end{array}$ & $\begin{array}{l}-79.32 \\
-75.80 \\
-72.29 \\
-68.81 \\
-65.34\end{array}$ & $\begin{array}{l}-79.67 \\
-76.15 \\
-72.64 \\
-69.15 \\
-65.68\end{array}$ & $\begin{array}{l}-80.03 \\
-76.50 \\
-72.99 \\
-69.50 \\
-66.03\end{array}$ & $\begin{array}{l}-80.38 \\
-76.85 \\
-73.34 \\
-69.85 \\
-66.38\end{array}$ & $\begin{array}{l}-80.74 \\
-77.20 \\
-73.69 \\
-70.20 \\
-66.72\end{array}$ & $\begin{array}{l}-81.09 \\
-77.56 \\
-74.04 \\
-70.55 \\
-67.07\end{array}$ & $\begin{array}{l}-81.44 \\
-77.91 \\
-74.39 \\
-70.90 \\
-67.42\end{array}$ & $\begin{array}{l}-81.80 \\
-78.26 \\
-74.74 \\
-71.25 \\
-67.76\end{array}$ & $\begin{array}{l}-82.15 \\
-78.61 \\
-75.10 \\
-71.59 \\
-68.11\end{array}$ & $\begin{array}{l}-82.51 \\
-78.97 \\
-75.45 \\
-71.94 \\
-68.46\end{array}$ & $\begin{array}{l}-82.86 \\
-79.32 \\
-75.80 \\
-72.29 \\
-68.81\end{array}$ & $\begin{array}{l}-3.40 \\
-3.30 \\
-3.20 \\
-3.10 \\
-3.00\end{array}$ \\
\hline $\begin{array}{l}-2.90 \\
-2.80 \\
-2.70 \\
-2.60 \\
-2.50\end{array}$ & $\begin{array}{l}-61.89 \\
-58.45 \\
-55.03 \\
-51.63 \\
-48.25\end{array}$ & $\begin{array}{l}-62.23 \\
-58.79 \\
-55.38 \\
-51.97 \\
-48.59\end{array}$ & $\begin{array}{l}-62.58 \\
-59.14 \\
-55.72 \\
-52.31 \\
-48.92\end{array}$ & $\begin{array}{l}-62.92 \\
-59.48 \\
-56.06 \\
-52.65 \\
-49.26\end{array}$ & $\begin{array}{l}-63.26 \\
-59.82 \\
-56.40 \\
-52.99 \\
-49.60\end{array}$ & $\begin{array}{l}-63.61 \\
-60.17 \\
-56.74 \\
-53.33 \\
-49.94\end{array}$ & $\begin{array}{l}-63.95 \\
-60.51 \\
-57.08 \\
-53.67 \\
-50.28\end{array}$ & $\begin{array}{l}-64.30 \\
-60.85 \\
-57.42 \\
-54.01 \\
-50.62\end{array}$ & $\begin{array}{l}-64.65 \\
-61.20 \\
-57.77 \\
-54.35 \\
-50.95\end{array}$ & $\begin{array}{l}-64.99 \\
-61.54 \\
-58.11 \\
-54.69 \\
-51.29\end{array}$ & $\begin{array}{l}-65.34 \\
-61.89 \\
-58.45 \\
-55.03 \\
-51.63\end{array}$ & $\begin{array}{l}-2.90 \\
-2.80 \\
-2.70 \\
-2.60 \\
-2.50\end{array}$ \\
\hline $\begin{array}{l}-2.40 \\
-2.30 \\
-2.20 \\
-2.10 \\
-2.00\end{array}$ & $\begin{array}{l}-44.88 \\
-41.52 \\
-38.18 \\
-34.86 \\
-31.55\end{array}$ & $\begin{array}{l}-45.21 \\
-41.86 \\
-38.52 \\
-35.19 \\
-31.88\end{array}$ & $\begin{array}{l}-45.55 \\
-42.19 \\
-38.85 \\
-35.52 \\
-32.21\end{array}$ & $\begin{array}{l}-45.89 \\
-42.53 \\
-39.18 \\
-35.86 \\
-32.54\end{array}$ & $\begin{array}{l}-46.22 \\
-42.86 \\
-39.52 \\
-36.19 \\
-32.87\end{array}$ & $\begin{array}{l}-46.56 \\
-43.20 \\
-39.85 \\
-36.52 \\
-33.20\end{array}$ & $\begin{array}{l}-46.90 \\
-43.53 \\
-40.19 \\
-36.85 \\
-33.53\end{array}$ & $\begin{array}{l}-47.23 \\
-43.87 \\
-40.52 \\
-37.19 \\
-33.86\end{array}$ & $\begin{array}{l}-47.57 \\
-44.21 \\
-40.85 \\
-37.52 \\
-34.20\end{array}$ & $\begin{array}{l}-47.91 \\
-44.54 \\
-41.19 \\
-37.85 \\
-34.53\end{array}$ & $\begin{array}{l}-48.25 \\
-44.88 \\
-41.52 \\
-38.18 \\
-34.86\end{array}$ & $\begin{array}{l}-2.40 \\
-2.30 \\
-2.20 \\
-2.10 \\
-2.00\end{array}$ \\
\hline $\begin{array}{l}-1.90 \\
-1.80 \\
-1.70 \\
-1.60 \\
-1.50\end{array}$ & $\begin{array}{l}-28.25 \\
-24.97 \\
-21.70 \\
-18.45 \\
-15.20\end{array}$ & $\begin{array}{l}-28.58 \\
-25.30 \\
-22.03 \\
-18.77 \\
-15.53\end{array}$ & $\begin{array}{l}-28.91 \\
-25.63 \\
-22.35 \\
-19.10 \\
-15.85\end{array}$ & $\begin{array}{l}-29.24 \\
-25.95 \\
-22.68 \\
-19.42 \\
-16.18\end{array}$ & $\begin{array}{l}-29.57 \\
-26.28 \\
-23.01 \\
-19.75 \\
-16.50\end{array}$ & $\begin{array}{l}-29.90 \\
-26.61 \\
-23.33 \\
-20.07 \\
-16.82\end{array}$ & $\begin{array}{l}-30.23 \\
-26.94 \\
-23.66 \\
-20.40 \\
-17.15\end{array}$ & $\begin{array}{l}-30.5 \\
-27.2 \\
-23.9 \\
-20.7 \\
-17.4\end{array}$ & $\begin{array}{l}-30.89 \\
-27.60 \\
-24.32 \\
-21.05 \\
-17.80\end{array}$ & $\begin{array}{l}-31.22 \\
-27.92 \\
-24.64 \\
-21.38 \\
-18.12\end{array}$ & $\begin{array}{l}-31.5 \\
-28.2 \\
-24.9 \\
-21.7 \\
-18.4\end{array}$ & $\begin{array}{l}-1.90 \\
-1.80 \\
-1.70 \\
-1.60 \\
-1.50\end{array}$ \\
\hline $\begin{array}{l}-1.40 \\
-1.30 \\
-1.20 \\
-1.10 \\
-1.00\end{array}$ & $\begin{array}{r}-11.98 \\
-8.76 \\
-5.55 \\
-2.36 \\
0.82\end{array}$ & $\begin{array}{r}-12.30 \\
-9.08 \\
-5.87 \\
-2.68 \\
0.50\end{array}$ & $\begin{array}{r}-12.62 \\
-9.40 \\
-6.19 \\
-3.00 \\
0.18\end{array}$ & $\begin{array}{r}-12.94 \\
-9.72 \\
-6.51 \\
-3.32 \\
-0.14\end{array}$ & $\begin{array}{r}-13.27 \\
-10.04 \\
-6.83 \\
-3.64 \\
-0.45\end{array}$ & $\begin{array}{r}-13.59 \\
-10.37 \\
-7.16 \\
-3.96 \\
-0.77\end{array}$ & $\begin{array}{r}-13.91 \\
-10.69 \\
-7.48 \\
-4.28 \\
-1.09\end{array}$ & $\begin{array}{r}-14.23 \\
-11.01 \\
-7.80 \\
-4.60 \\
-1.41\end{array}$ & $\begin{array}{r}-14.56 \\
-11.33 \\
-8.12 \\
-4.92 \\
-1.73\end{array}$ & $\begin{array}{r}-14.88 \\
-11.65 \\
-8.44 \\
-5.23 \\
-2.04\end{array}$ & $\begin{array}{r}-15.20 \\
-11.98 \\
-8.76 \\
-5.55 \\
-2.36\end{array}$ & $\begin{array}{l}-1.40 \\
-1.30 \\
-1.20 \\
-1.10 \\
-1.00\end{array}$ \\
\hline $\begin{array}{l}-0.90 \\
-0.80 \\
-0.70 \\
-0.60 \\
-0.50\end{array}$ & $\begin{array}{r}3.99 \\
7.14 \\
10.29 \\
13.42 \\
16.54\end{array}$ & $\begin{array}{r}3.67 \\
6.83 \\
9.97 \\
13.11 \\
16.23\end{array}$ & $\begin{array}{r}3.35 \\
6.51 \\
9.66 \\
12.79 \\
15.92\end{array}$ & $\begin{array}{r}3.04 \\
6.20 \\
9.34 \\
12.48 \\
15.61\end{array}$ & $\begin{array}{r}2.72 \\
5.88 \\
9.03 \\
12.17 \\
15.30\end{array}$ & $\begin{array}{r}2.40 \\
5.57 \\
8.72 \\
11.86 \\
14.98\end{array}$ & $\begin{array}{r}2.09 \\
5.25 \\
8.40 \\
11.54 \\
14.67\end{array}$ & $\begin{array}{r}1.77 \\
4.93 \\
8.09 \\
11.23 \\
14.36\end{array}$ & $\begin{array}{r}1.45 \\
4.62 \\
7.77 \\
10.91 \\
14.05\end{array}$ & $\begin{array}{r}1.13 \\
4.30 \\
7.46 \\
10.60 \\
13.73\end{array}$ & $\begin{array}{r}0.82 \\
3.99 \\
7.14 \\
10.29 \\
13.42\end{array}$ & $\begin{array}{l}-0.90 \\
-0.80 \\
-0.70 \\
-0.60 \\
-0.50\end{array}$ \\
\hline $\begin{array}{l}-0.40 \\
-0.30 \\
-0.20 \\
-0.10 \\
-0.00\end{array}$ & $\begin{array}{l}19.66 \\
22.76 \\
25.85 \\
28.93 \\
32.00\end{array}$ & $\begin{array}{l}19.34 \\
22.45 \\
25.54 \\
28.62 \\
31.69\end{array}$ & $\begin{array}{l}25.23 \\
28.31 \\
31.39\end{array}$ & $\begin{array}{l}18.72 \\
21.83 \\
24.92 \\
28.01 \\
31.08\end{array}$ & $\begin{array}{l}18.41 \\
21.52 \\
24.61 \\
27.70 \\
30.77\end{array}$ & $\begin{array}{l}21.21 \\
24.30 \\
27.39 \\
30.47\end{array}$ & $\begin{array}{l}17.79 \\
20.90 \\
23.99 \\
27.08 \\
30.16\end{array}$ & $\begin{array}{l}17.48 \\
20.55 \\
23.69 \\
26.77 \\
29.85\end{array}$ & $\begin{array}{l}20.28 \\
23.38 \\
26.46 \\
29.54\end{array}$ & $\begin{array}{l}19.00 \\
19.97 \\
23.07 \\
26.16 \\
29.24\end{array}$ & $\begin{array}{l}16.54 \\
19.66 \\
22.76 \\
25.85 \\
28.93\end{array}$ & $\begin{array}{l}-0.40 \\
-0.30 \\
-0.20 \\
-0.10 \\
-0.00\end{array}$ \\
\hline
\end{tabular}

$\mathrm{mV}$

.00

.01

.02

.03

.04

.05

.06

.07

.08

.09

.10

$\mathrm{mV}$ 
TABLE A5.2.2. Type $\boldsymbol{E}$ thermocouples-temperature $\left({ }^{\circ} \mathrm{F}\right)$ as a function of thermoelectric voltage, reference junctions at $32^{\circ} \mathrm{F}$-Continued

$\mathrm{mV}$

.00

.01

.02

.03

.04

TEMPERATURES IN DEGREES F

\begin{tabular}{|c|c|c|c|}
\hline $\begin{array}{l}0.00 \\
0.10 \\
0.20 \\
0.30 \\
0.40\end{array}$ & $\begin{array}{l}32.00 \\
35.06 \\
38.12 \\
41.17 \\
44.21\end{array}$ & $\begin{array}{l}32 \cdot 31 \\
35 \cdot 37 \\
38.42 \\
41.47 \\
44.51\end{array}$ & $\begin{array}{l}32.61 \\
35.67 \\
38.73 \\
41.77 \\
44.81\end{array}$ \\
\hline $\begin{array}{l}0.50 \\
0.60 \\
0.70 \\
0.80 \\
0.90\end{array}$ & $\begin{array}{l}47.24 \\
50.26 \\
53.28 \\
56.29 \\
59.29\end{array}$ & $\begin{array}{l}47.54 \\
50.56 \\
53.58 \\
56.59 \\
59.59\end{array}$ & $\begin{array}{l}47.84 \\
50.87 \\
53.88 \\
56.89 \\
59.89\end{array}$ \\
\hline $\begin{array}{l}1.00 \\
1.10 \\
1.20 \\
1.30 \\
1.40\end{array}$ & $\begin{array}{l}62.29 \\
65.27 \\
68.25 \\
71.22 \\
74.19\end{array}$ & $\begin{array}{l}62.58 \\
65.57 \\
68.55 \\
71.52 \\
74.49\end{array}$ & $\begin{array}{l}62.88 \\
65.87 \\
68.85 \\
71.82 \\
74.78\end{array}$ \\
\hline $\begin{array}{l}1.50 \\
1.60 \\
1.70 \\
1.80 \\
1.90\end{array}$ & $\begin{array}{l}77.15 \\
80.10 \\
83.04 \\
85.98 \\
88.90\end{array}$ & $\begin{array}{l}77.44 \\
80.39 \\
83.33 \\
86.27 \\
89.20\end{array}$ & $\begin{array}{l}77.74 \\
80.69 \\
83.63 \\
86.56 \\
89.49\end{array}$ \\
\hline $\begin{array}{l}2.00 \\
2.10 \\
2.20 \\
2.30 \\
2.40\end{array}$ & $\begin{array}{r}91.83 \\
94.74 \\
97.65 \\
100.55 \\
103.44\end{array}$ & $\begin{array}{r}92.12 \\
95.03 \\
97.94 \\
100.84 \\
103.73\end{array}$ & $\begin{array}{r}92.41 \\
95.32 \\
98.23 \\
101.13 \\
104.02\end{array}$ \\
\hline $\begin{array}{l}2.50 \\
2.60 \\
2.70 \\
2.80 \\
2.90\end{array}$ & $\begin{array}{l}106.33 \\
109.21 \\
112.09 \\
114.95 \\
117.81\end{array}$ & $\begin{array}{l}106.62 \\
109.50 \\
112.37 \\
115.24 \\
118.10\end{array}$ & $\begin{array}{l}106.91 \\
109.79 \\
112.66 \\
115.53 \\
118.38\end{array}$ \\
\hline $\begin{array}{l}3.00 \\
3.10 \\
3.20 \\
3.30 \\
3.40\end{array}$ & $\begin{array}{l}120.67 \\
123.51 \\
126.36 \\
129.19 \\
132.02\end{array}$ & $\begin{array}{l}120.95 \\
123.80 \\
126.64 \\
129.47 \\
132.30\end{array}$ & $\begin{array}{l}121.24 \\
124.08 \\
126.92 \\
129.76 \\
132.58\end{array}$ \\
\hline $\begin{array}{l}3.50 \\
3.60 \\
3.70 \\
3.80 \\
3.90\end{array}$ & $\begin{array}{l}134.84 \\
137.66 \\
140.47 \\
143.27 \\
146.07\end{array}$ & $\begin{array}{l}135.12 \\
137.94 \\
140.75 \\
143.55 \\
146.35\end{array}$ & $\begin{array}{l}135.40 \\
138.22 \\
141.03 \\
143.83 \\
146.63\end{array}$ \\
\hline $\begin{array}{l}4.00 \\
4.10 \\
4.20 \\
4.30 \\
4.40\end{array}$ & $\begin{array}{l}148.86 \\
151.64 \\
154.42 \\
157.20 \\
159.97\end{array}$ & $\begin{array}{l}149.14 \\
151.92 \\
154.70 \\
157.48 \\
160.24\end{array}$ & $\begin{array}{l}149.42 \\
152.20 \\
154.98 \\
157.75 \\
160.52\end{array}$ \\
\hline $\begin{array}{l}4.50 \\
4.60 \\
4.70 \\
4.80 \\
4.90\end{array}$ & $\begin{array}{l}162.73 \\
165.49 \\
168.24 \\
170.98 \\
173.72\end{array}$ & $\begin{array}{l}163.01 \\
165.76 \\
168.51 \\
171.26 \\
174.00\end{array}$ & $\begin{array}{l}163.28 \\
166.04 \\
168.79 \\
171.53 \\
174.27\end{array}$ \\
\hline $\begin{array}{l}5.00 \\
5.10 \\
5.20 \\
5.30 \\
5.40\end{array}$ & $\begin{array}{l}176.46 \\
179.19 \\
181.91 \\
184.63 \\
187.35\end{array}$ & $\begin{array}{l}176.73 \\
179.46 \\
182.19 \\
184.90 \\
187.62\end{array}$ & $\begin{array}{l}177.01 \\
179.73 \\
182.46 \\
185.18 \\
187.89\end{array}$ \\
\hline $\begin{array}{l}5.50 \\
5.60 \\
5.70 \\
5.80 \\
5.90\end{array}$ & $\begin{array}{l}190.05 \\
192.76 \\
195.46 \\
198.15 \\
200.84\end{array}$ & $\begin{array}{l}190.33 \\
193.03 \\
195.73 \\
198.42 \\
201.11\end{array}$ & $\begin{array}{l}190.60 \\
193.30 \\
196.00 \\
198.69 \\
201.38\end{array}$ \\
\hline .00 & 203.52 & 203.79 & .06 \\
\hline
\end{tabular}

\section{$32.92 \quad 33.23$}

35.98

39.03

42.08

$45 \cdot 12$

48.15

$51 \cdot 17$

54.18

57.19

60.19

63.18

66.17

69.14

72.11
75.08

78.03

80.98

83.92

86.86

89.78

92.70

95.61

98.52

101.42

104.31

107.20

110.07

112.95

118.67

121.52

124.37

127.21

130.04

132.87

135.69

138.50

141.31

144.11

149.70

152.48

155.26

158.03

160.80

163.56

166.31

169.06

171.81

174.55

177.28

180.01

182.73

185.45

188.16

190.87

193.57

196.27

198.96

201.64

204.33

\subsection{9 \\ 36.29
39.34 \\ 42.38 \\ 45.42}

48.45

51.47
54.48

54.48

57.49

63.48

66.46

69.44

$72 \cdot 41$
75.37

78.33

$81 \cdot 28$

84.22

87.15

90.07

92.99

95.91

98.81

101.71

104.60

107.48

110.36
113.23

113.23

118.96

121.81

127.49

130.32

133.15

135.97

138.78

141.59

144.39
147.18

149.97

149.97
152.76

155.53

158.31
161.07

163.83

166.59

169.34

172.08

174.82

177.55

180.28

183.00

185.72

188.43

191.14

193.84

196.53

199.23

201.91

204.59
124.65

\section{$33.53 \quad 33.84$}

$36 \cdot 59$

39.64

42.69

45.72

48.75

51.77
54.78

57.79

60.79

63.78

66.76

66.76
69.74

72.71

78.62

81.57

84.51

87.44

90.37

93.28

96.20

99.10

102.00

104.89

107.77

110.65

113.52

119.24

122.09

124.94

127.77

130.60

133.43

136.25

139.06

141.87
144.67

147.46

150.25

153.04

161.35

164.11

166.86

169.61

172.35

175.09

177.82

180.55

183.27

185.99

191.41

194.11

199.50

202.18

204.86
33.84

39.95

42.99

46.03

49.05

52.07

55.09

58.09

61.09

64.08

67.06

70.04

73.00

78.92

81.86

84.80

87.73

90.66

93.58

96.49

99.39

$102 \cdot 29$
$105 \cdot 18$

108.06

110.94

113.81

116.67

122.38

125.22

128.06

130.89
133.71

136.53

139.34

142.15

144.95
147.74

150.53

150.53
153.31

156.09

158.86

161.63

164.38

167.14

169.89

172.63

175.37

$178 \cdot 10$

180.82

183.55

186.26

191.68

194.38

197.07

199.76
202.45

205.13
155.81
34.14

37.20

40.25

43.29
46.33

49.36

52.37

55.39

58.39

61.39

64.38

67.36

70.33

73.30
76.26

79.21

82.16

85.10

90.95

93.87

96.78

99.68

102.58

105.47

108.35

111.22

114.09

116.96

122.66

125.50

128.34

131.17
133.99

136.81

139.62

142.43

145.23
148.02

150.81

150.81
153.59

156.37

161.90

164.66

167.41

170.16

172.90

175.64

181.10

183.82

186.53

189.24

191.95

194.65

197.34

200.03
202.72

205.40 
TABLE A5.2.2. Type $\boldsymbol{E}$ thermocouples-temperature $\left({ }^{\circ} \mathrm{F}\right)$ as a function of thermoelectric voltage, reference junctions at $32^{\circ} \mathrm{F}$-Continued

$\mathrm{mV}$

.00

.01

.02

.03

.04

.05

.06

TEMPERATURES IN DEGREES F 
TABLE A5.2.2. Type E thermocouples-temperature $\left({ }^{\circ} \mathrm{F}\right)$ as a function of thermoelectric voltage, reference junctions at $32^{\circ} \mathrm{F}$-Continued

$\mathrm{mV}$

.01

.02

.03

.05

.06

.07

.08

.09

$\cdot 10$

$\mathrm{mV}$

TEMPERATURES IN DEGREES $F$

\begin{tabular}{|c|c|c|c|c|c|c|c|c|c|c|c|c|}
\hline $\begin{array}{l}12.00 \\
12.10 \\
12 \cdot 20 \\
12.30 \\
12.40\end{array}$ & $\begin{array}{l}357.27 \\
359.73 \\
362.19 \\
364.65 \\
367.11\end{array}$ & $\begin{array}{l}357.51 \\
359.98 \\
362.44 \\
364.90 \\
367.35\end{array}$ & $\begin{array}{l}357.76 \\
360.22 \\
362.68 \\
365.14 \\
367.60\end{array}$ & $\begin{array}{l}358.01 \\
360.47 \\
362.93 \\
365.39 \\
367.85\end{array}$ & $\begin{array}{l}358.25 \\
360.72 \\
363.18 \\
365.63 \\
368.09\end{array}$ & $\begin{array}{l}358 \cdot 50 \\
360 \cdot 96 \\
363 \cdot 42 \\
365 \cdot 88 \\
368 \cdot 34\end{array}$ & $\begin{array}{l}358.74 \\
361.21 \\
363.67 \\
366.13 \\
368.58\end{array}$ & $\begin{array}{l}358.99 \\
361.45 \\
363.91 \\
366.37 \\
368.83\end{array}$ & $\begin{array}{l}359.24 \\
361.70 \\
364.16 \\
366.62 \\
369.07\end{array}$ & $\begin{array}{l}359.48 \\
361.95 \\
364.41 \\
366.86 \\
369.32\end{array}$ & $\begin{array}{l}359.73 \\
362.19 \\
364.65 \\
367.11 \\
369.56\end{array}$ & $\begin{array}{l}12.00 \\
12.10 \\
12.20 \\
12.30 \\
12.40\end{array}$ \\
\hline $\begin{array}{l}12.50 \\
12.60 \\
12.70 \\
12.80 \\
12.90\end{array}$ & $\begin{array}{l}369.56 \\
372.02 \\
374.47 \\
376.91 \\
379.36\end{array}$ & $\begin{array}{l}369.81 \\
372.26 \\
374.71 \\
377.16 \\
379.60\end{array}$ & $\begin{array}{l}370.05 \\
372.51 \\
374.95 \\
377.40 \\
379.85\end{array}$ & $\begin{array}{l}370.30 \\
372.75 \\
375.20 \\
377.65 \\
380.09\end{array}$ & $\begin{array}{l}370.54 \\
373.00 \\
375.44 \\
377.89 \\
380.33\end{array}$ & $\begin{array}{l}370.79 \\
373.24 \\
375.69 \\
378.14 \\
380.58\end{array}$ & $\begin{array}{l}371.03 \\
373.49 \\
375.93 \\
378.38 \\
380.82\end{array}$ & $\begin{array}{l}371.28 \\
373.73 \\
376.18 \\
378.62 \\
381.07\end{array}$ & $\begin{array}{l}371.53 \\
373.98 \\
376.42 \\
378.87 \\
381.31\end{array}$ & $\begin{array}{l}371.77 \\
374.22 \\
376.67 \\
379.11 \\
381.56\end{array}$ & $\begin{array}{l}372.02 \\
374.47 \\
376.91 \\
379.36 \\
381.80\end{array}$ & $\begin{array}{l}12.50 \\
12.60 \\
12.70 \\
12.80 \\
12.90\end{array}$ \\
\hline $\begin{array}{l}13.00 \\
13.10 \\
13.20 \\
13.30 \\
13.40\end{array}$ & $\begin{array}{l}381.80 \\
384.24 \\
386.68 \\
389.11 \\
391.55\end{array}$ & $\begin{array}{l}382.04 \\
384 \cdot 48 \\
386.92 \\
389 \cdot 36 \\
391.79\end{array}$ & $\begin{array}{l}382.29 \\
384.73 \\
387.17 \\
389.60 \\
392.03\end{array}$ & $\begin{array}{l}382.53 \\
384.97 \\
387.41 \\
389.84 \\
392.28\end{array}$ & $\begin{array}{l}382.78 \\
385.22 \\
387.65 \\
390.09 \\
392.52\end{array}$ & $\begin{array}{l}383.02 \\
385.46 \\
387.90 \\
390.33 \\
392.76\end{array}$ & $\begin{array}{l}383.26 \\
385.70 \\
388.14 \\
390.57 \\
393.01\end{array}$ & $\begin{array}{l}383.51 \\
385.95 \\
388.38 \\
390.82 \\
393.25\end{array}$ & $\begin{array}{l}383.75 \\
386.19 \\
388.63 \\
391.06 \\
393.49\end{array}$ & $\begin{array}{l}384.00 \\
386.43 \\
388.87 \\
391.30 \\
393.73\end{array}$ & $\begin{array}{l}384.24 \\
386.68 \\
389.11 \\
391.55 \\
393.98\end{array}$ & $\begin{array}{l}13.00 \\
13.10 \\
13.20 \\
13.30 \\
13.40\end{array}$ \\
\hline $\begin{array}{l}13.50 \\
13.60 \\
13.70 \\
13.80 \\
13.90\end{array}$ & $\begin{array}{l}393.98 \\
396.41 \\
398.83 \\
401.26 \\
403.68\end{array}$ & $\begin{array}{l}394.22 \\
396.65 \\
399.08 \\
401.50 \\
403.92\end{array}$ & $\begin{array}{l}394.46 \\
396.89 \\
399.32 \\
401.74 \\
404.16\end{array}$ & $\begin{array}{l}394.71 \\
397.13 \\
399.56 \\
401.98 \\
404.41\end{array}$ & $\begin{array}{l}394.95 \\
397.38 \\
399.80 \\
402.23 \\
404.65\end{array}$ & $\begin{array}{l}395.19 \\
397.62 \\
400.05 \\
402.47 \\
404.89\end{array}$ & $\begin{array}{l}395.44 \\
397.86 \\
400 \cdot 29 \\
402 \cdot 71 \\
405.13\end{array}$ & $\begin{array}{l}395.68 \\
398.11 \\
400.53 \\
402.95 \\
405.37\end{array}$ & $\begin{array}{l}395.92 \\
398.35 \\
400.77 \\
403.20 \\
405.62\end{array}$ & $\begin{array}{l}396.16 \\
398.59 \\
401.02 \\
403.44 \\
405.86\end{array}$ & $\begin{array}{l}396.41 \\
398.83 \\
401.26 \\
403.68 \\
406.10\end{array}$ & $\begin{array}{l}13.50 \\
13.60 \\
13.70 \\
13.80 \\
13.90\end{array}$ \\
\hline $\begin{array}{l}14.00 \\
14.10 \\
14.20 \\
14.30 \\
14.40\end{array}$ & $\begin{array}{l}406.10 \\
408 \cdot 52 \\
410.93 \\
413.35 \\
415.76\end{array}$ & $\begin{array}{l}406.34 \\
408.76 \\
411.18 \\
413.59 \\
416.00\end{array}$ & $\begin{array}{l}406.58 \\
409.00 \\
411.42 \\
413.83 \\
416.24\end{array}$ & $\begin{array}{l}406.83 \\
409.24 \\
411.66 \\
414.07 \\
416.48\end{array}$ & $\begin{array}{l}407.07 \\
409.48 \\
411.90 \\
414.31 \\
416.72\end{array}$ & $\begin{array}{l}407.31 \\
409.73 \\
412.14 \\
414.55 \\
416.96\end{array}$ & $\begin{array}{l}407.55 \\
409.97 \\
412.38 \\
414.80 \\
417.21\end{array}$ & $\begin{array}{l}407.79 \\
410.21 \\
412.62 \\
415.04 \\
417.45\end{array}$ & $\begin{array}{l}408.03 \\
410.45 \\
412.87 \\
415.28 \\
417.69\end{array}$ & $\begin{array}{l}408.28 \\
410.69 \\
413.11 \\
415.52 \\
417.93\end{array}$ & $\begin{array}{l}408.52 \\
410.93 \\
413.35 \\
415.76 \\
418.17\end{array}$ & $\begin{array}{l}14.00 \\
14.10 \\
14.20 \\
14.30 \\
14.40\end{array}$ \\
\hline $\begin{array}{l}14.50 \\
14.60 \\
14.70 \\
14.80 \\
14.90\end{array}$ & $\begin{array}{l}418 \cdot 17 \\
420.58 \\
422.98 \\
425 \cdot 39 \\
427.79\end{array}$ & $\begin{array}{l}418.41 \\
420.82 \\
423.22 \\
425.63 \\
428.03\end{array}$ & $\begin{array}{l}418.65 \\
421.06 \\
423.46 \\
425.87 \\
428.27\end{array}$ & $\begin{array}{l}418.89 \\
421.30 \\
423.70 \\
426.11 \\
428.51\end{array}$ & $\begin{array}{l}419.13 \\
421.54 \\
423.94 \\
426.35 \\
428.75\end{array}$ & $\begin{array}{l}419.37 \\
421.78 \\
424.18 \\
426.59 \\
428.99\end{array}$ & $\begin{array}{l}419.61 \\
422.02 \\
424.43 \\
426.83 \\
429.23\end{array}$ & $\begin{array}{l}419.85 \\
422.26 \\
424.67 \\
427.07 \\
429.47\end{array}$ & $\begin{array}{l}420.10 \\
422.50 \\
424.91 \\
427.31 \\
429.71\end{array}$ & $\begin{array}{l}420 \cdot 34 \\
422.74 \\
425.15 \\
427.55 \\
429.95\end{array}$ & $\begin{array}{l}420.58 \\
422.98 \\
425.39 \\
427.79 \\
430.19\end{array}$ & $\begin{array}{l}14.50 \\
14.60 \\
14.70 \\
14.80 \\
14.90\end{array}$ \\
\hline $\begin{array}{l}15.00 \\
15.10 \\
15.20 \\
15.30 \\
15.40\end{array}$ & $\begin{array}{l}430.19 \\
432.59 \\
434.98 \\
437.38 \\
439.77\end{array}$ & $\begin{array}{l}430.43 \\
432.83 \\
435.22 \\
437.62 \\
440.01\end{array}$ & $\begin{array}{l}430.67 \\
433.07 \\
435.46 \\
437.86 \\
440.25\end{array}$ & $\begin{array}{l}430.91 \\
433.31 \\
435.70 \\
438.09 \\
440.49\end{array}$ & $\begin{array}{l}431.15 \\
433 \cdot 54 \\
435.94 \\
438 \cdot 33 \\
440.73\end{array}$ & $\begin{array}{l}431.39 \\
433.78 \\
436.18 \\
438.57 \\
440.96\end{array}$ & $\begin{array}{l}431.63 \\
434.02 \\
436.42 \\
438.81 \\
441.20\end{array}$ & $\begin{array}{l}431.87 \\
434.26 \\
436.66 \\
439.05 \\
441.44\end{array}$ & $\begin{array}{l}432.11 \\
434.50 \\
436.90 \\
439.29 \\
441.68\end{array}$ & $\begin{array}{l}432.35 \\
434.74 \\
437.14 \\
439.53 \\
441.92\end{array}$ & $\begin{array}{l}432.59 \\
434.98 \\
437.38 \\
439.77 \\
442.16\end{array}$ & $\begin{array}{l}15.00 \\
15.10 \\
15.20 \\
15.30 \\
15.40\end{array}$ \\
\hline $\begin{array}{l}15.50 \\
15.60 \\
15.70 \\
15.80 \\
15.90\end{array}$ & $\begin{array}{l}442.16 \\
444.55 \\
446.93 \\
449.32 \\
451.70\end{array}$ & $\begin{array}{l}442.40 \\
444.79 \\
447.17 \\
449.56 \\
451.94\end{array}$ & $\begin{array}{l}442.64 \\
445.03 \\
447.41 \\
449.80 \\
452.18\end{array}$ & $\begin{array}{l}442.88 \\
445.26 \\
447.65 \\
450.03 \\
452.42\end{array}$ & $\begin{array}{l}443.11 \\
445.50 \\
447.89 \\
450.27 \\
452.66\end{array}$ & $\begin{array}{l}443.35 \\
445.74 \\
448.13 \\
450.51 \\
452.89\end{array}$ & $\begin{array}{l}443.59 \\
445.98 \\
448.37 \\
450.75 \\
453.13\end{array}$ & $\begin{array}{l}443.83 \\
446.22 \\
448.60 \\
450.99 \\
453.37\end{array}$ & $\begin{array}{l}444.07 \\
446.46 \\
448.84 \\
451.23 \\
453.61\end{array}$ & $\begin{array}{l}444.31 \\
446.70 \\
449.08 \\
451.46 \\
453.85\end{array}$ & $\begin{array}{l}444.55 \\
446.93 \\
449.32 \\
451.70 \\
454.08\end{array}$ & $\begin{array}{l}15.50 \\
15.60 \\
15.70 \\
15.80 \\
15.90\end{array}$ \\
\hline $\begin{array}{l}16.00 \\
16.10 \\
16 \cdot 20 \\
16.30 \\
16.40\end{array}$ & $\begin{array}{l}454.08 \\
456.46 \\
458.84 \\
461.22 \\
463.59\end{array}$ & $\begin{array}{l}454.32 \\
456.70 \\
459.08 \\
461.46 \\
463.83\end{array}$ & $\begin{array}{l}454 \cdot 56 \\
456.94 \\
459.32 \\
461.69 \\
464.07\end{array}$ & $\begin{array}{l}454.80 \\
457.18 \\
459.56 \\
461.93 \\
464.30\end{array}$ & $\begin{array}{l}455.04 \\
457.42 \\
459.79 \\
462.17 \\
464.54\end{array}$ & $\begin{array}{l}455.27 \\
457.65 \\
460.03 \\
462.41 \\
464.78\end{array}$ & $\begin{array}{l}455.51 \\
457.89 \\
460.27 \\
462.64 \\
465.02\end{array}$ & $\begin{array}{l}455.75 \\
458.13 \\
460.51 \\
462.88 \\
465.25\end{array}$ & $\begin{array}{l}455.99 \\
458.37 \\
460.74 \\
463.12 \\
465.49\end{array}$ & $\begin{array}{l}456.23 \\
458.60 \\
460.98 \\
463.36 \\
465.73\end{array}$ & $\begin{array}{l}456.46 \\
458.84 \\
461.22 \\
463.59 \\
465.97\end{array}$ & $\begin{array}{l}16.00 \\
16.10 \\
16.20 \\
16.30 \\
16.40\end{array}$ \\
\hline $\begin{array}{l}16.50 \\
16.60 \\
16.70 \\
16.80 \\
16.90\end{array}$ & $\begin{array}{l}465.97 \\
468.34 \\
470.71 \\
473.07 \\
475.44\end{array}$ & $\begin{array}{l}466.20 \\
468.57 \\
470.94 \\
473.31 \\
475.68\end{array}$ & $\begin{array}{l}466.44 \\
468.81 \\
471.18 \\
473.55 \\
475.91\end{array}$ & $\begin{array}{l}466.68 \\
469.05 \\
471.42 \\
473.78 \\
476.15\end{array}$ & $\begin{array}{l}466.91 \\
469.29 \\
471.65 \\
474.02 \\
476.39\end{array}$ & $\begin{array}{l}467.15 \\
469.52 \\
471.89 \\
474.26 \\
476.62\end{array}$ & $\begin{array}{l}467.39 \\
469.76 \\
472.13 \\
474.49 \\
476.86\end{array}$ & $\begin{array}{l}467.63 \\
470.00 \\
472.36 \\
474.73 \\
477.10\end{array}$ & $\begin{array}{l}467.86 \\
470.23 \\
472.60 \\
474.97 \\
477.33\end{array}$ & $\begin{array}{l}468 \cdot 10 \\
470.47 \\
472.84 \\
475.20 \\
477.57\end{array}$ & $\begin{array}{l}468.34 \\
470.71 \\
473.07 \\
475.44 \\
477.81\end{array}$ & $\begin{array}{l}16.50 \\
16.60 \\
16.70 \\
16.80 \\
16.90\end{array}$ \\
\hline $\begin{array}{l}17.00 \\
17.10 \\
17.20 \\
17.30 \\
17.40\end{array}$ & $\begin{array}{l}477.81 \\
480.17 \\
482.53 \\
484.89 \\
487.25\end{array}$ & $\begin{array}{l}478.04 \\
480.41 \\
482.77 \\
485.13 \\
487.48\end{array}$ & $\begin{array}{l}478.28 \\
480.64 \\
483.00 \\
485.36 \\
487.72\end{array}$ & $\begin{array}{l}478.51 \\
480.88 \\
483.24 \\
485.60 \\
487.96\end{array}$ & $\begin{array}{l}478.75 \\
481.11 \\
483.47 \\
485.83 \\
488.19\end{array}$ & $\begin{array}{l}478.99 \\
481.35 \\
483.71 \\
486.07 \\
488.43\end{array}$ & $\begin{array}{l}479.22 \\
481.59 \\
483.95 \\
486.31 \\
488.66\end{array}$ & $\begin{array}{l}479 \cdot 46 \\
481 \cdot 82 \\
484 \cdot 18 \\
486 \cdot 54 \\
488.90\end{array}$ & $\begin{array}{l}479.70 \\
482.06 \\
484.42 \\
486.78 \\
489.13\end{array}$ & $\begin{array}{l}479.93 \\
482.29 \\
484.65 \\
487.01 \\
489.37\end{array}$ & $\begin{array}{l}480.17 \\
482.53 \\
484.89 \\
487.25 \\
489.61\end{array}$ & $\begin{array}{l}17.00 \\
17.10 \\
17.20 \\
17.30 \\
17.40\end{array}$ \\
\hline $\begin{array}{l}17.50 \\
17.60 \\
17.70 \\
17.80 \\
17.90\end{array}$ & $\begin{array}{l}489.61 \\
491.96 \\
494.32 \\
496.67 \\
499.02\end{array}$ & $\begin{array}{l}489.84 \\
492.20 \\
494.55 \\
496.90 \\
499.25\end{array}$ & $\begin{array}{l}490.08 \\
492.43 \\
494.79 \\
497.14 \\
499.49\end{array}$ & $\begin{array}{l}490.31 \\
492.67 \\
495.02 \\
497.37 \\
499.72\end{array}$ & $\begin{array}{l}490.55 \\
492.90 \\
495.26 \\
497.61 \\
499.96\end{array}$ & $\begin{array}{l}490.78 \\
493.14 \\
495.49 \\
497.84 \\
500.19\end{array}$ & $\begin{array}{l}491.02 \\
493.37 \\
495.73 \\
498.08 \\
500.43\end{array}$ & $\begin{array}{l}491.25 \\
493.61 \\
495.96 \\
498.31 \\
500.66\end{array}$ & $\begin{array}{l}491.49 \\
493.84 \\
496.20 \\
498.55 \\
500.90\end{array}$ & $\begin{array}{l}491.73 \\
494.08 \\
496.43 \\
498.78 \\
501.13\end{array}$ & $\begin{array}{l}491.96 \\
494 \cdot 32 \\
496.67 \\
499 \cdot 02 \\
501.37\end{array}$ & $\begin{array}{l}17.50 \\
17.60 \\
17.70 \\
17.80 \\
17.90\end{array}$ \\
\hline 18.00 & 501.37 & 501.60 & 501.84 & 502.07 & $502 \cdot 31$ & $502 \cdot 54$ & $502 \cdot 78$ & 503.01 & 503.25 & 503.48 & 503.72 & 18.00 \\
\hline
\end{tabular}

$m V$

.02

.03

.05

\begin{abstract}
.06
\end{abstract}
.07

.08

.09

.10

$m V$ 
TABLE A5.2.2. Type $\boldsymbol{E}$ thermocouples-temperature $\left({ }^{\circ} \mathrm{F}\right)$ as a function of thermoelectric voltage, reference junctions at $32^{\circ} \mathrm{F}$-Continued

$\mathrm{mV}$

.00

.01

.02

.03

.04

.05

.06

.07

.08

.09

.10

$\mathrm{mV}$

TEMPERATURES IN DEGREES $F$

\begin{tabular}{|c|c|c|c|c|c|c|c|c|c|c|c|c|}
\hline $\begin{array}{l}18.00 \\
18.10 \\
18.20 \\
18.30 \\
18.40\end{array}$ & $\begin{array}{l}501.37 \\
503.72 \\
506.06 \\
508.41 \\
510.75\end{array}$ & $\begin{array}{l}501.60 \\
503.95 \\
506.30 \\
508.64 \\
510.99\end{array}$ & $\begin{array}{l}501.84 \\
504 \cdot 19 \\
506.53 \\
508.88 \\
511.22\end{array}$ & $\begin{array}{l}502.07 \\
504.42 \\
506.77 \\
509.11 \\
511.45\end{array}$ & $\begin{array}{l}502.31 \\
504.65 \\
507.00 \\
509.35 \\
511.69\end{array}$ & $\begin{array}{l}502.54 \\
504.89 \\
507.24 \\
509.58 \\
511.92\end{array}$ & $\begin{array}{l}502.78 \\
505.12 \\
507.47 \\
509.81 \\
512.16\end{array}$ & $\begin{array}{l}503.01 \\
505.36 \\
507.70 \\
510.05 \\
512.39\end{array}$ & $\begin{array}{l}503.25 \\
505.59 \\
507.94 \\
510.28 \\
512.63\end{array}$ & $\begin{array}{l}503.48 \\
505.83 \\
508.17 \\
510.52 \\
512.86\end{array}$ & $\begin{array}{l}503.72 \\
506.06 \\
508.41 \\
510.75 \\
513.09\end{array}$ & $\begin{array}{l}18.00 \\
18.10 \\
18.20 \\
18.30 \\
18.40\end{array}$ \\
\hline $\begin{array}{l}18.50 \\
18.60 \\
18.70 \\
18.80 \\
18.90\end{array}$ & $\begin{array}{l}513.09 \\
515.43 \\
517.77 \\
520.11 \\
522.45\end{array}$ & $\begin{array}{l}513.33 \\
515.67 \\
518.01 \\
520.35 \\
522.68\end{array}$ & $\begin{array}{l}513.56 \\
515.90 \\
518.24 \\
520.58 \\
522.92\end{array}$ & $\begin{array}{l}513.80 \\
516.14 \\
518.48 \\
520.81 \\
523.15\end{array}$ & $\begin{array}{l}514.03 \\
516.37 \\
518.71 \\
521.05 \\
523.38\end{array}$ & $\begin{array}{l}514.26 \\
516.60 \\
518.94 \\
521.28 \\
523.62\end{array}$ & $\begin{array}{l}514.50 \\
516.84 \\
519.18 \\
521.52 \\
523.85\end{array}$ & $\begin{array}{l}514.73 \\
517.07 \\
519.41 \\
521.75 \\
524.08\end{array}$ & $\begin{array}{l}514.97 \\
517.31 \\
519.65 \\
521.98 \\
524.32\end{array}$ & $\begin{array}{l}515.20 \\
517.54 \\
519.88 \\
522.22 \\
524.55\end{array}$ & $\begin{array}{l}515.43 \\
517.77 \\
520.11 \\
522.45 \\
524.79\end{array}$ & $\begin{array}{l}18.50 \\
18.60 \\
18.70 \\
18.80 \\
18.90\end{array}$ \\
\hline $\begin{array}{l}19.00 \\
19.10 \\
19.20 \\
19.30 \\
19.40\end{array}$ & $\begin{array}{l}524.79 \\
527.12 \\
529.45 \\
531.78 \\
534.11\end{array}$ & $\begin{array}{l}525.02 \\
527.35 \\
529.69 \\
532.02 \\
534.35\end{array}$ & $\begin{array}{l}525.25 \\
527.59 \\
529.92 \\
532.25 \\
534.58\end{array}$ & $\begin{array}{l}525.49 \\
527.82 \\
530.15 \\
532.48 \\
534.81\end{array}$ & $\begin{array}{l}525.72 \\
528.05 \\
530.39 \\
532.72 \\
535.05\end{array}$ & $\begin{array}{l}525.95 \\
528.29 \\
530.62 \\
532.95 \\
535.28\end{array}$ & $\begin{array}{l}526.19 \\
528.52 \\
530.85 \\
533.18 \\
535.51\end{array}$ & $\begin{array}{l}526.42 \\
528.75 \\
531.08 \\
533.42 \\
535.75\end{array}$ & $\begin{array}{l}526.65 \\
528.99 \\
531.32 \\
533.65 \\
535.98\end{array}$ & $\begin{array}{l}526.89 \\
529.22 \\
531.55 \\
533.88 \\
536.21\end{array}$ & $\begin{array}{l}527.12 \\
529.45 \\
531.78 \\
534.11 \\
536.44\end{array}$ & $\begin{array}{l}19.00 \\
19.10 \\
19.20 \\
19.30 \\
19.40\end{array}$ \\
\hline $\begin{array}{l}19.50 \\
19.60 \\
19.70 \\
19.80 \\
19.90\end{array}$ & $\begin{array}{l}536.44 \\
538.77 \\
541.10 \\
543.42 \\
545.75\end{array}$ & $\begin{array}{l}536.68 \\
539.00 \\
541.33 \\
543.66 \\
545.98\end{array}$ & $\begin{array}{l}536.91 \\
539.24 \\
541.56 \\
543.89 \\
546.21\end{array}$ & $\begin{array}{l}537.14 \\
539.47 \\
541.80 \\
544.12 \\
546.44\end{array}$ & $\begin{array}{l}537.37 \\
539.70 \\
542.03 \\
544.35 \\
546.68\end{array}$ & $\begin{array}{l}537.61 \\
539.93 \\
542.26 \\
544.59 \\
546.91\end{array}$ & $\begin{array}{l}537.84 \\
540.17 \\
542.49 \\
544.82 \\
547.14\end{array}$ & $\begin{array}{l}538.07 \\
540.40 \\
542.73 \\
545.05 \\
547.37\end{array}$ & $\begin{array}{l}538.31 \\
540.63 \\
542.96 \\
545.28 \\
547.61\end{array}$ & $\begin{array}{l}538.54 \\
540.87 \\
543.19 \\
545.52 \\
547.84\end{array}$ & $\begin{array}{l}538.77 \\
541.10 \\
543.42 \\
545.75 \\
548.07\end{array}$ & $\begin{array}{l}19.50 \\
19.60 \\
19.70 \\
19.80 \\
19.90\end{array}$ \\
\hline $\begin{array}{l}20.00 \\
20.10 \\
20.20 \\
20.30 \\
20.40\end{array}$ & $\begin{array}{l}548.07 \\
550.39 \\
552.71 \\
555.03 \\
557.35\end{array}$ & $\begin{array}{l}548.30 \\
550.62 \\
552.94 \\
555.26 \\
557.58\end{array}$ & $\begin{array}{l}548.53 \\
550.86 \\
553.18 \\
555.50 \\
557.81\end{array}$ & $\begin{array}{l}548.77 \\
551.09 \\
553.41 \\
555.73 \\
558.05\end{array}$ & $\begin{array}{l}549.00 \\
551.32 \\
553.64 \\
555.96 \\
558.28\end{array}$ & $\begin{array}{l}549.23 \\
551.55 \\
553.87 \\
556.19 \\
558.51\end{array}$ & $\begin{array}{l}549.46 \\
551.78 \\
554.10 \\
556.42 \\
558.74\end{array}$ & $\begin{array}{l}549.70 \\
552.02 \\
554.34 \\
556.65 \\
558.97\end{array}$ & $\begin{array}{l}549.93 \\
552.25 \\
554.57 \\
556.89 \\
559.20\end{array}$ & $\begin{array}{l}550.16 \\
552.48 \\
554.80 \\
557.12 \\
559.44\end{array}$ & $\begin{array}{l}550.39 \\
552.71 \\
555.03 \\
557.35 \\
559.67\end{array}$ & $\begin{array}{l}20.00 \\
20.10 \\
20.20 \\
20.30 \\
20.40\end{array}$ \\
\hline $\begin{array}{l}20.50 \\
20.60 \\
20.70 \\
20.80 \\
20.90\end{array}$ & $\begin{array}{l}559.67 \\
561.98 \\
564.30 \\
566.61 \\
568.92\end{array}$ & $\begin{array}{l}559.90 \\
562.21 \\
564.53 \\
566.84 \\
569.15\end{array}$ & $\begin{array}{l}560.13 \\
562.45 \\
564.76 \\
567.07 \\
569.39\end{array}$ & $\begin{array}{l}560.36 \\
562.68 \\
564.99 \\
567.30 \\
569.62\end{array}$ & $\begin{array}{l}560.59 \\
562.91 \\
565.22 \\
567.54 \\
569.85\end{array}$ & $\begin{array}{l}560.82 \\
563.14 \\
565.45 \\
567.77 \\
570.08\end{array}$ & $\begin{array}{l}561.06 \\
563.37 \\
565.69 \\
568.00 \\
570.31\end{array}$ & $\begin{array}{l}561.29 \\
563.60 \\
565.92 \\
568.23 \\
570.54\end{array}$ & $\begin{array}{l}561.52 \\
563.83 \\
566.15 \\
568.46 \\
570.77\end{array}$ & $\begin{array}{l}561.75 \\
564.07 \\
566.38 \\
568.69 \\
571.00\end{array}$ & $\begin{array}{l}561.98 \\
564.30 \\
566.61 \\
568.92 \\
571.23\end{array}$ & $\begin{array}{l}20 \cdot 50 \\
20.60 \\
20.70 \\
20.80 \\
20.90\end{array}$ \\
\hline $\begin{array}{l}21.00 \\
21.10 \\
21.20 \\
21.30 \\
21.40\end{array}$ & $\begin{array}{l}571.23 \\
573.54 \\
575.85 \\
578.16 \\
580.47\end{array}$ & $\begin{array}{l}571.47 \\
573.78 \\
576.08 \\
578.39 \\
580.70\end{array}$ & $\begin{array}{l}571.70 \\
574.01 \\
576.32 \\
578.62 \\
580.93\end{array}$ & $\begin{array}{l}571.93 \\
574.24 \\
576.55 \\
578.85 \\
581.16\end{array}$ & $\begin{array}{l}572.16 \\
574.47 \\
576.78 \\
579.08 \\
581.39\end{array}$ & $\begin{array}{l}572.39 \\
574.70 \\
577.01 \\
579.32 \\
581.62\end{array}$ & $\begin{array}{l}572.62 \\
574.93 \\
577.24 \\
579.55 \\
581.85\end{array}$ & $\begin{array}{l}572.85 \\
575.16 \\
577.47 \\
579.78 \\
582.08\end{array}$ & $\begin{array}{l}573.08 \\
575.39 \\
577.70 \\
580.01 \\
582.31\end{array}$ & $\begin{array}{l}573.31 \\
575.62 \\
577.93 \\
580.24 \\
582.54\end{array}$ & $\begin{array}{l}573.54 \\
575.85 \\
578.16 \\
580.47 \\
582.77\end{array}$ & $\begin{array}{l}21.00 \\
21.10 \\
21.20 \\
21.30 \\
21.40\end{array}$ \\
\hline $\begin{array}{l}21.50 \\
21.60 \\
21.70 \\
21.80 \\
21.90\end{array}$ & $\begin{array}{l}582.77 \\
585.08 \\
587.38 \\
589.69 \\
591.99\end{array}$ & $\begin{array}{l}583.01 \\
585.31 \\
587.61 \\
589.92 \\
592.22\end{array}$ & $\begin{array}{l}583.24 \\
585.54 \\
587.84 \\
590.15 \\
592.45\end{array}$ & $\begin{array}{l}583.47 \\
585.77 \\
588.07 \\
590.38 \\
592.68\end{array}$ & $\begin{array}{l}583.70 \\
586.00 \\
588.30 \\
590.61 \\
592.91\end{array}$ & $\begin{array}{l}583.93 \\
586.23 \\
588.53 \\
590.84 \\
593.14\end{array}$ & $\begin{array}{l}584.16 \\
586.46 \\
588.76 \\
591.07 \\
593.37\end{array}$ & $\begin{array}{l}584.39 \\
586.69 \\
589.00 \\
591.30 \\
593.60\end{array}$ & $\begin{array}{l}584.62 \\
586.92 \\
589.23 \\
591.53 \\
593.83\end{array}$ & $\begin{array}{l}584.85 \\
587.15 \\
589.46 \\
591.76 \\
594.06\end{array}$ & $\begin{array}{l}585.08 \\
587.38 \\
589.69 \\
591.99 \\
594.29\end{array}$ & $\begin{array}{l}21.50 \\
21.60 \\
21.70 \\
21.80 \\
21.90\end{array}$ \\
\hline $\begin{array}{l}22.00 \\
22.10 \\
22.20 \\
22.30 \\
22.40\end{array}$ & $\begin{array}{l}594.29 \\
596.59 \\
598.89 \\
601.18 \\
603.48\end{array}$ & $\begin{array}{l}594.52 \\
596.82 \\
599.12 \\
601.41 \\
603.71\end{array}$ & $\begin{array}{l}594.75 \\
597.05 \\
599.35 \\
601.64 \\
603.94\end{array}$ & $\begin{array}{l}594.98 \\
597.28 \\
599.58 \\
601.87 \\
604.17\end{array}$ & $\begin{array}{l}595.21 \\
597.51 \\
599.81 \\
602.10 \\
604.40\end{array}$ & $\begin{array}{l}595.44 \\
597.74 \\
600.04 \\
602.33 \\
604.63\end{array}$ & $\begin{array}{l}595.67 \\
597.97 \\
600.27 \\
602.56 \\
604.86\end{array}$ & $\begin{array}{l}595.90 \\
598.20 \\
600.50 \\
602.79 \\
605.09\end{array}$ & $\begin{array}{l}596.13 \\
598.43 \\
600.72 \\
603.02 \\
605.32\end{array}$ & $\begin{array}{l}596.36 \\
598.66 \\
600.95 \\
603.25 \\
605.55\end{array}$ & $\begin{array}{l}596.59 \\
598.89 \\
601.18 \\
603.48 \\
605.78\end{array}$ & $\begin{array}{l}22.00 \\
22.10 \\
22.20 \\
22.30 \\
22.40\end{array}$ \\
\hline $\begin{array}{l}22.50 \\
22.60 \\
22.70 \\
22.80 \\
22.90\end{array}$ & $\begin{array}{l}605.78 \\
608.07 \\
610.37 \\
612.66 \\
614.95\end{array}$ & $\begin{array}{l}606.01 \\
608.30 \\
610.59 \\
612.89 \\
615.18\end{array}$ & $\begin{array}{l}606.24 \\
608.53 \\
610.82 \\
613.12 \\
615.41\end{array}$ & $\begin{array}{l}606.47 \\
608.76 \\
611.05 \\
613.35 \\
615.64\end{array}$ & $\begin{array}{l}606.69 \\
608.99 \\
611.28 \\
613.58 \\
615.87\end{array}$ & $\begin{array}{l}606.92 \\
609.22 \\
611.51 \\
613.80 \\
616.10\end{array}$ & $\begin{array}{l}607.15 \\
609.45 \\
611.74 \\
614.03 \\
616.32\end{array}$ & $\begin{array}{l}607.38 \\
609.68 \\
611.97 \\
614.26 \\
616.55\end{array}$ & $\begin{array}{l}607.61 \\
609.91 \\
612.20 \\
614.49 \\
616.78\end{array}$ & $\begin{array}{l}607.84 \\
610.14 \\
612.43 \\
614.72 \\
617.01\end{array}$ & $\begin{array}{l}608.07 \\
610.37 \\
612.66 \\
614.95 \\
617.24\end{array}$ & $\begin{array}{l}22.50 \\
22.60 \\
22.70 \\
22.80 \\
22.90\end{array}$ \\
\hline $\begin{array}{l}23.00 \\
23.10 \\
23.20 \\
23.30 \\
23.40\end{array}$ & $\begin{array}{l}617.24 \\
619.53 \\
621.82 \\
624.11 \\
626.40\end{array}$ & $\begin{array}{l}617.47 \\
619.76 \\
622.05 \\
624.34 \\
626.62\end{array}$ & $\begin{array}{l}617.70 \\
619.99 \\
622.28 \\
624.57 \\
626.85\end{array}$ & $\begin{array}{l}617.93 \\
620.22 \\
622.51 \\
624.79 \\
627.08\end{array}$ & $\begin{array}{l}618.16 \\
620.45 \\
622.74 \\
625.02 \\
627.31\end{array}$ & $\begin{array}{l}618.39 \\
620.68 \\
622.96 \\
625.25 \\
627.54\end{array}$ & $\begin{array}{l}618.62 \\
620.90 \\
623.19 \\
625.48 \\
627.77\end{array}$ & $\begin{array}{l}618.84 \\
621.13 \\
623.42 \\
625.71 \\
628.00\end{array}$ & $\begin{array}{l}619.07 \\
621.36 \\
623.65 \\
625.94 \\
628.23\end{array}$ & $\begin{array}{l}619.30 \\
621.59 \\
623.88 \\
626.17 \\
628.45\end{array}$ & $\begin{array}{l}619.53 \\
621.82 \\
624.11 \\
626.40 \\
628.68\end{array}$ & $\begin{array}{l}23.00 \\
23.10 \\
23.20 \\
23.30 \\
23.40\end{array}$ \\
\hline $\begin{array}{l}23.50 \\
23.60 \\
23.70 \\
23.80 \\
23.90\end{array}$ & $\begin{array}{l}628.68 \\
630.97 \\
633.25 \\
635.54 \\
637.82\end{array}$ & $\begin{array}{l}628.91 \\
631.20 \\
633.48 \\
635.76 \\
638.05\end{array}$ & $\begin{array}{l}629.14 \\
631.43 \\
633.71 \\
635.99 \\
638.28\end{array}$ & $\begin{array}{l}629.37 \\
631.65 \\
633.94 \\
636.22 \\
638.50\end{array}$ & $\begin{array}{l}629 \cdot 60 \\
631.88 \\
634.17 \\
636.45 \\
638.73\end{array}$ & $\begin{array}{l}629.83 \\
632.11 \\
634.39 \\
636.68 \\
638.96\end{array}$ & $\begin{array}{l}630.05 \\
632.34 \\
634.62 \\
636.91 \\
639.19\end{array}$ & $\begin{array}{l}630.28 \\
632.57 \\
634.85 \\
637.13 \\
639.48\end{array}$ & $\begin{array}{l}630.51 \\
632.80 \\
635.08 \\
637.36 \\
639.65\end{array}$ & $\begin{array}{l}630.74 \\
633.02 \\
635.31 \\
637.59 \\
639.87\end{array}$ & $\begin{array}{l}630 \cdot 97 \\
633 \cdot 25 \\
635 \cdot 54 \\
637 \cdot 82 \\
640 \cdot 10\end{array}$ & $\begin{array}{l}23.50 \\
23.60 \\
23.70 \\
23.80 \\
23.90\end{array}$ \\
\hline 24.00 & 640.10 & 640.33 & 640.56 & 640.79 & 641.01 & 641.24 & 641.47 & 641.70 & 641.93 & 642.15 & 642.38 & 24.00 \\
\hline
\end{tabular}

501.60
503.95
506.30
508.64
510.99
513.33
515.67
518.01
520.35

525.02

527.35
529.69

532.02

536.68

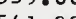

548.30

552.94

557.58

559.90

569.15

576.08

580.70

583.01

587.61

590.12

603.71

606.01

610.59

617.47

01

\begin{abstract}
.02
\end{abstract}
.03

\begin{abstract}
.04
\end{abstract}
502.78

507.47

514.50

19.18

21.52

526.19

533.1

535.51

547.14

549.46

554.10

556.42

570.31

577.24

579.55
581.85

588.76

595.67

600.27

04.86

611.74

618.62

625.48

627.77

632.34

636.91

641.47
503.01
505.36
507.70
510.05
512.39
514.73
517.07
519.41
521.75
524.08

526.42

533.42

538.07

45.05

549.70

56.65

53.60

570.54

79.78

384.39

593.60

600.50

602.79

607.38

609.68

616.55

625.71

634.85

639.48

641.70
.

531.3

535.98

547.6

554.57

566.15

568.46

580.0

593.83

600.72

605.32

612.20

632.80

637.36

641.93

642.15
$642 \cdot 38$
18.00

8.20

18.50

. 70

18.80

9.00

9.30

9.50

8.80

20.00

20.20

0.30

20.50

0.70

0.80

11.00

$21 \cdot 10$
$21 \cdot 20$

1.30

1.50

1.60

1.80

2.00

22.20

2.30
2.40

2.50

2.60
2.70

3.00

3.20

3.30
3.40

3.50

3.70

$m v$
.00
.08
.09
.10 
TABLE A5.2.2. Type E thermocouples-temperature $\left({ }^{\circ} \mathrm{F}\right)$ as a function of thermoelectric voltage, reference junctions at $32^{\circ} \mathrm{F}$-Continued

$\mathrm{mV}$

$.00 \quad .01 \quad .02$

.03

.04

.05

.06

.07

.08

.09

$\cdot 10$

$\mathrm{mV}$

TEMPERATURES IN DEGREES $F$

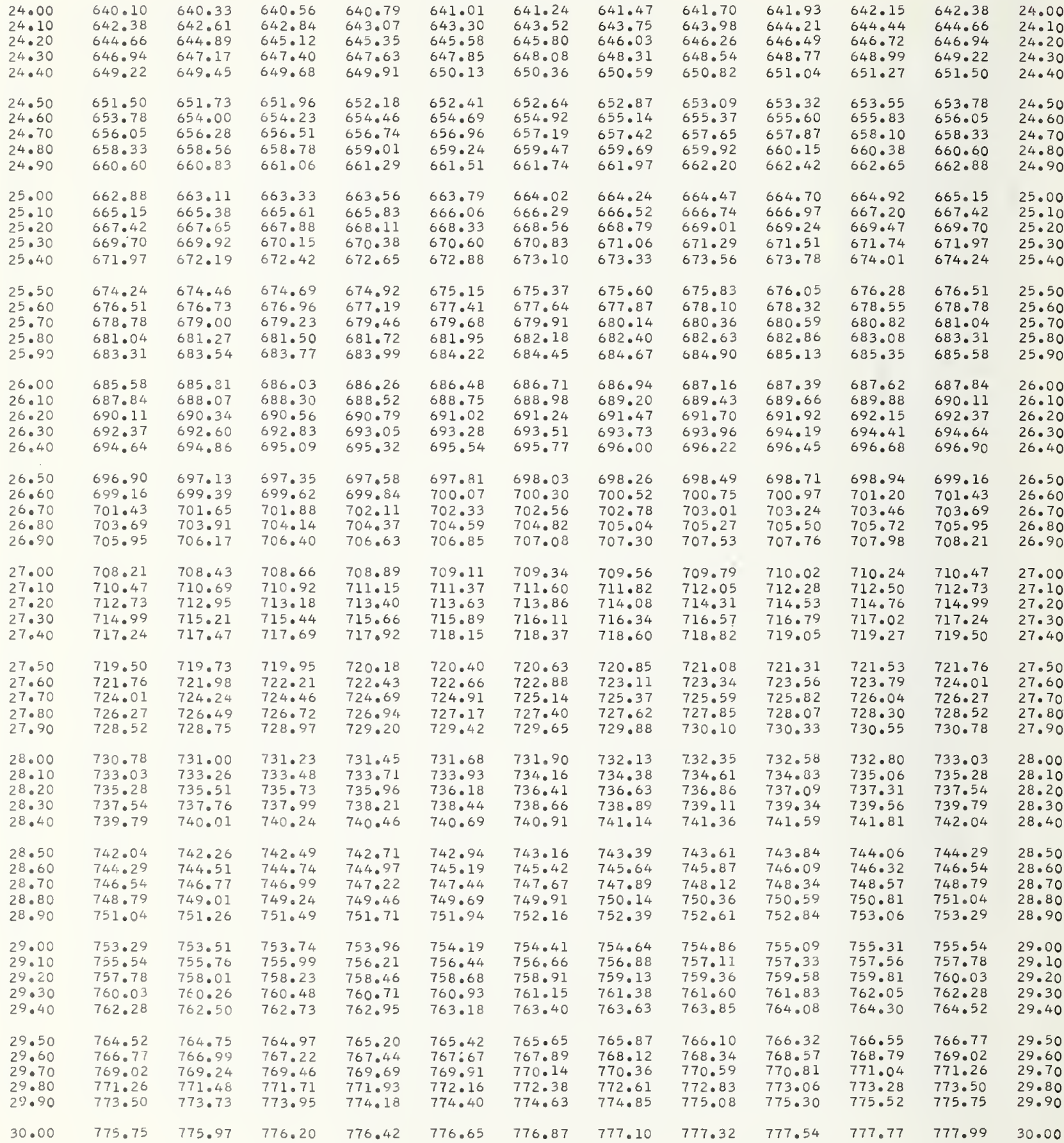

$m V$

.02

.03

.04

.05

.06

.07

.08

.09

.10

$m v$ 
TABLE A5.2.2. Type $\boldsymbol{E}$ thermocouples-temperature $\left({ }^{\circ} \mathrm{F}\right)$ as a function of thermoelectric voltage, reference junctions at $32^{\circ} \mathrm{F}$-Continued

$\mathrm{mV}$

.01

.02

.03

.04

.05

.06

.07

.08

.09

.10

$\mathrm{mV}$

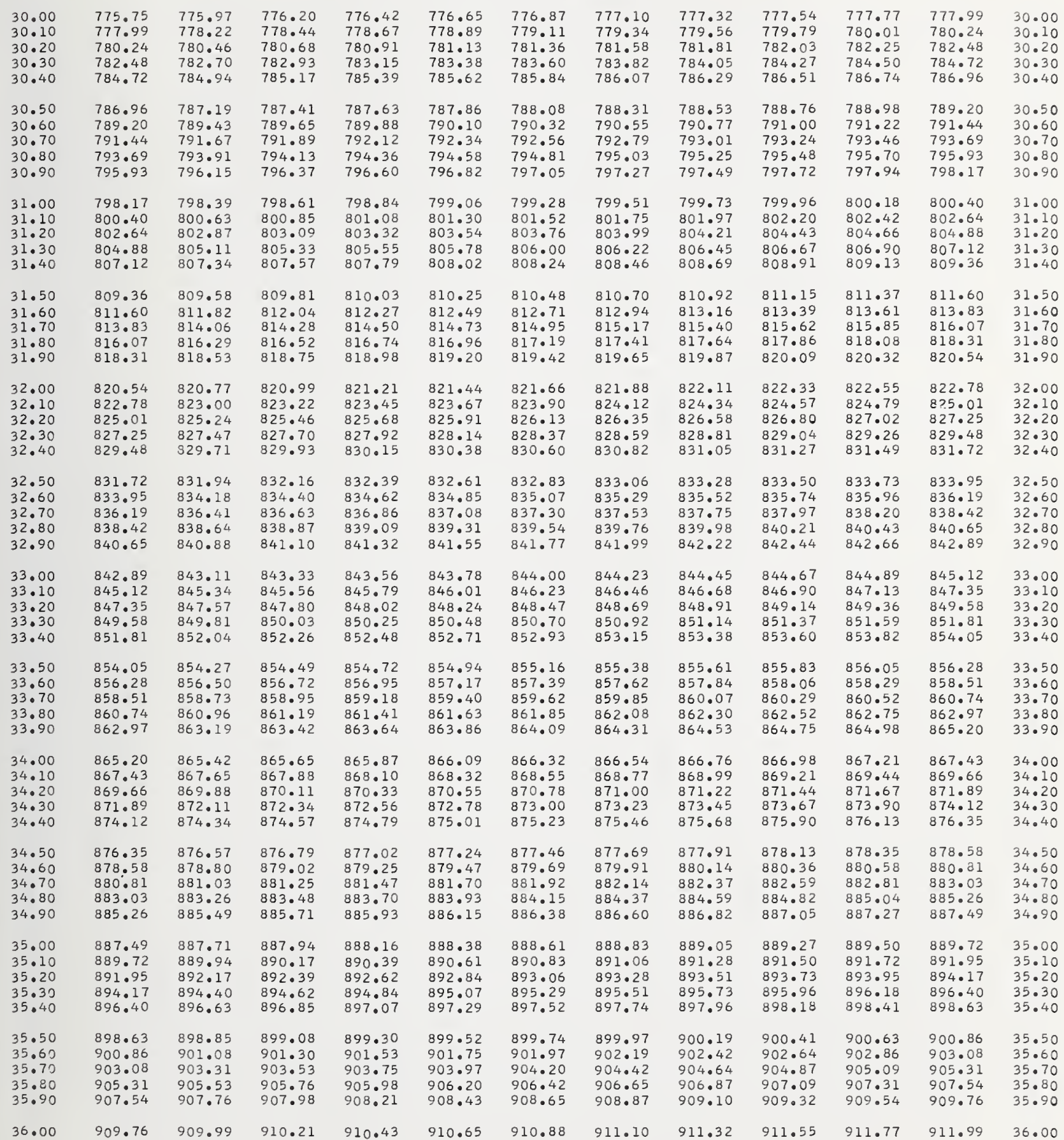

$m V$

.00

.01

.02

.03

.04

.05

.06

.07

.08

.09

.10

$\mathrm{mV}$ 
TABLE A5.2.2. Type $E$ thermocouples-iemperature $\left({ }^{\circ} \mathrm{F}\right)$ as a function of thermoelectric voltage, reference junctions at $32^{\circ} \mathrm{F}$-Continued

$\mathrm{mV}$
.01

.02

.03

.05

.06

.07

.08

.09

$\cdot 10$

$\mathrm{mV}$

TEMPERATURES IN DEGREES $F$

\begin{tabular}{|c|c|c|c|c|c|c|c|c|c|c|c|c|}
\hline $\begin{array}{l}36 \cdot 00 \\
36 \cdot 10 \\
36 \cdot 20 \\
36 \cdot 30 \\
36 \cdot 40\end{array}$ & $\begin{array}{l}909.76 \\
911.99 \\
914.22 \\
916.44 \\
918.67\end{array}$ & $\begin{array}{l}909.99 \\
912.21 \\
914.44 \\
916.67 \\
918.89\end{array}$ & $\begin{array}{l}910.21 \\
912.44 \\
914.66 \\
916.89 \\
919.11\end{array}$ & $\begin{array}{l}910.43 \\
912.66 \\
914.88 \\
917.11 \\
919.34\end{array}$ & $\begin{array}{l}910.65 \\
912.88 \\
915.11 \\
917.33 \\
919.56\end{array}$ & $\begin{array}{l}910.88 \\
913.10 \\
915.33 \\
917.56 \\
919.78\end{array}$ & $\begin{array}{l}911.10 \\
913.33 \\
915.55 \\
917.78 \\
920.00\end{array}$ & $\begin{array}{l}911.32 \\
913.55 \\
915.78 \\
918.00 \\
920.23\end{array}$ & $\begin{array}{l}911.55 \\
913.77 \\
916.00 \\
918.22 \\
920.45\end{array}$ & $\begin{array}{l}911.77 \\
913.99 \\
916.22 \\
918.45 \\
920.67\end{array}$ & $\begin{array}{l}911.99 \\
914.22 \\
916.44 \\
918.67 \\
920.89\end{array}$ & $\begin{array}{l}36.00 \\
36.10 \\
36.20 \\
36.30 \\
36.40\end{array}$ \\
\hline $\begin{array}{l}36.50 \\
36.60 \\
36.70 \\
36.80 \\
36.90\end{array}$ & $\begin{array}{l}920.89 \\
923.12 \\
925.35 \\
927.57 \\
929.80\end{array}$ & $\begin{array}{l}921.12 \\
923.34 \\
925.57 \\
927.79 \\
930.02\end{array}$ & $\begin{array}{l}921.34 \\
923 \cdot 57 \\
925.79 \\
928 \cdot 02 \\
930 \cdot 24\end{array}$ & $\begin{array}{l}921.56 \\
923.79 \\
926.01 \\
928.24 \\
930.47\end{array}$ & $\begin{array}{l}921.79 \\
924.01 \\
926.24 \\
928.46 \\
930.69\end{array}$ & $\begin{array}{l}922.01 \\
924.23 \\
926.46 \\
928.68 \\
930.91\end{array}$ & $\begin{array}{l}922.23 \\
924.46 \\
926.68 \\
928.91 \\
931.13\end{array}$ & $\begin{array}{l}922.45 \\
924.68 \\
926.90 \\
929.13 \\
931.36\end{array}$ & $\begin{array}{l}922.68 \\
924 \cdot 90 \\
927.13 \\
929.35 \\
931.58\end{array}$ & $\begin{array}{l}922.90 \\
925 \cdot 12 \\
927.35 \\
929.57 \\
931.80\end{array}$ & $\begin{array}{l}923.12 \\
925.35 \\
927.57 \\
929.80 \\
932.02\end{array}$ & $\begin{array}{l}36.50 \\
36.60 \\
36.70 \\
36.80 \\
36.90\end{array}$ \\
\hline $\begin{array}{l}37 \cdot 00 \\
37 \cdot 10 \\
37 \cdot 20 \\
37 \cdot 30 \\
37 \cdot 40\end{array}$ & $\begin{array}{l}932.02 \\
934.25 \\
936.47 \\
938.70 \\
940.92\end{array}$ & $\begin{array}{l}932.25 \\
934.47 \\
936.70 \\
938.92 \\
941.15\end{array}$ & $\begin{array}{l}932.47 \\
934.69 \\
936.92 \\
939.14 \\
941.37\end{array}$ & $\begin{array}{l}932.69 \\
934.92 \\
937.14 \\
939.37 \\
941.59\end{array}$ & $\begin{array}{l}932.91 \\
935.14 \\
937.36 \\
939.59 \\
941.81\end{array}$ & $\begin{array}{l}933.14 \\
935.36 \\
937.59 \\
939.81 \\
942.04\end{array}$ & $\begin{array}{l}933.36 \\
935.58 \\
937.81 \\
940.03 \\
942.26\end{array}$ & $\begin{array}{l}933.58 \\
935.81 \\
938.03 \\
940.26 \\
942.48\end{array}$ & $\begin{array}{l}933.80 \\
936.03 \\
938.25 \\
940.48 \\
942.70\end{array}$ & $\begin{array}{l}934.03 \\
936.25 \\
938.48 \\
940.70 \\
942.93\end{array}$ & $\begin{array}{l}934.25 \\
936.47 \\
938.70 \\
940.92 \\
943.15\end{array}$ & $\begin{array}{l}37.00 \\
37.10 \\
37.20 \\
37.30 \\
37.40\end{array}$ \\
\hline $\begin{array}{l}37.50 \\
37.60 \\
37.70 \\
37.80 \\
37.90\end{array}$ & $\begin{array}{l}943.15 \\
945.37 \\
947.60 \\
949.82 \\
952.05\end{array}$ & $\begin{array}{l}943.37 \\
945.60 \\
947.82 \\
950.05 \\
952.27\end{array}$ & $\begin{array}{l}943.59 \\
945.82 \\
948.04 \\
950.27 \\
952.49\end{array}$ & $\begin{array}{l}943.82 \\
946.04 \\
948.27 \\
950.49 \\
952.72\end{array}$ & $\begin{array}{l}944.04 \\
946.26 \\
948.49 \\
950.71 \\
952.94\end{array}$ & $\begin{array}{l}944.26 \\
946.49 \\
948.71 \\
950.94 \\
953.16\end{array}$ & $\begin{array}{l}944.48 \\
946.71 \\
948.93 \\
951.16 \\
953.38\end{array}$ & $\begin{array}{l}944.71 \\
946.93 \\
949.16 \\
951.38 \\
953.60\end{array}$ & $\begin{array}{l}944.93 \\
947.15 \\
949.38 \\
951.60 \\
953.83\end{array}$ & $\begin{array}{l}945.15 \\
947.38 \\
949.60 \\
951.83 \\
954.05\end{array}$ & $\begin{array}{l}945.37 \\
947.60 \\
949.82 \\
952.05 \\
954.27\end{array}$ & $\begin{array}{l}37.50 \\
37.60 \\
37.70 \\
37.80 \\
37.90\end{array}$ \\
\hline $\begin{array}{l}38.00 \\
38.10 \\
38.20 \\
38.30 \\
38.40\end{array}$ & $\begin{array}{l}954.27 \\
956 \cdot 50 \\
958.72 \\
960.95 \\
963 \cdot 17\end{array}$ & $\begin{array}{l}954.49 \\
956.72 \\
958.94 \\
961.17 \\
963.39\end{array}$ & $\begin{array}{l}954.72 \\
956.94 \\
959.17 \\
961.39 \\
963.62\end{array}$ & $\begin{array}{l}954.94 \\
957.16 \\
959.39 \\
961.61 \\
963.84\end{array}$ & $\begin{array}{l}955.16 \\
957.39 \\
959.61 \\
961.84 \\
964.06\end{array}$ & $\begin{array}{l}955.38 \\
957.61 \\
959.83 \\
962.06 \\
964.28\end{array}$ & $\begin{array}{l}955.61 \\
957.83 \\
960.06 \\
962.28 \\
964.51\end{array}$ & $\begin{array}{l}955.83 \\
958.05 \\
960.28 \\
962.50 \\
964.73\end{array}$ & $\begin{array}{l}956 \cdot 05 \\
958 \cdot 28 \\
960 \cdot 50 \\
962 \cdot 73 \\
964 \cdot 95\end{array}$ & $\begin{array}{l}956.27 \\
958.50 \\
960.72 \\
962.95 \\
965.17\end{array}$ & $\begin{array}{l}956 \cdot 50 \\
958 \cdot 72 \\
960.95 \\
963 \cdot 17 \\
965.39\end{array}$ & $\begin{array}{l}38.00 \\
38.10 \\
38.20 \\
38.30 \\
38.40\end{array}$ \\
\hline $\begin{array}{l}38.50 \\
38.60 \\
38.70 \\
38.80 \\
38.90\end{array}$ & $\begin{array}{l}965.39 \\
967.62 \\
969.84 \\
972.07 \\
974.29\end{array}$ & $\begin{array}{l}965.62 \\
967.84 \\
970.07 \\
972.29 \\
974.51\end{array}$ & $\begin{array}{l}965.84 \\
968.06 \\
970.29 \\
972.51 \\
974.74\end{array}$ & $\begin{array}{l}966.06 \\
968.29 \\
970.51 \\
972.74 \\
974.96\end{array}$ & $\begin{array}{l}966.28 \\
968.51 \\
970.73 \\
972.96 \\
975.18\end{array}$ & $\begin{array}{l}966.51 \\
968.73 \\
970.96 \\
973.18 \\
975.40\end{array}$ & $\begin{array}{l}966.73 \\
968.95 \\
971.18 \\
973.40 \\
975.63\end{array}$ & $\begin{array}{l}966.95 \\
969.18 \\
971.40 \\
973.63 \\
975.85\end{array}$ & $\begin{array}{l}967.17 \\
969.40 \\
971.62 \\
973.85 \\
976.07\end{array}$ & $\begin{array}{l}967.40 \\
969.62 \\
971.85 \\
974.07 \\
976.29\end{array}$ & $\begin{array}{l}967.62 \\
969.84 \\
972.07 \\
974.29 \\
976.52\end{array}$ & $\begin{array}{l}38.50 \\
38.60 \\
38.70 \\
38.80 \\
38.90\end{array}$ \\
\hline $\begin{array}{l}39.00 \\
39.10 \\
39.20 \\
39.30 \\
39.40\end{array}$ & $\begin{array}{l}976.52 \\
978.74 \\
980.97 \\
983.19 \\
985.41\end{array}$ & $\begin{array}{l}976.74 \\
978.96 \\
981.19 \\
983.41 \\
985.64\end{array}$ & $\begin{array}{l}976.96 \\
979 \cdot 19 \\
981 \cdot 41 \\
983 \cdot 63 \\
985.86\end{array}$ & $\begin{array}{l}977.18 \\
979.41 \\
981.63 \\
983.86 \\
986.08\end{array}$ & $\begin{array}{l}977.41 \\
979.63 \\
981.86 \\
984.08 \\
986.30\end{array}$ & $\begin{array}{l}977.63 \\
979.85 \\
982.08 \\
984.30 \\
986.53\end{array}$ & $\begin{array}{l}977.85 \\
980.08 \\
982.30 \\
984.52 \\
986.75\end{array}$ & $\begin{array}{l}978.07 \\
980.30 \\
982.52 \\
984.7 .5 \\
986.97\end{array}$ & $\begin{array}{l}978.30 \\
980.52 \\
982.75 \\
984.97 \\
987.19\end{array}$ & $\begin{array}{l}978 \cdot 52 \\
980 \cdot 74 \\
982 \cdot 97 \\
985 \cdot 19 \\
987 \cdot 42\end{array}$ & $\begin{array}{l}978.74 \\
980.97 \\
983.19 \\
985.41 \\
987.64\end{array}$ & $\begin{array}{l}39.00 \\
39.10 \\
39.20 \\
39.30 \\
39.40\end{array}$ \\
\hline $\begin{array}{l}39.50 \\
39.60 \\
39.70 \\
39.80 \\
39.90\end{array}$ & $\begin{array}{l}987.64 \\
989.86 \\
992.09 \\
994.31 \\
996.54\end{array}$ & $\begin{array}{l}987.86 \\
990.09 \\
992.31 \\
994.53 \\
996.76\end{array}$ & $\begin{array}{l}988.08 \\
990.31 \\
992.53 \\
994.76 \\
996.98\end{array}$ & $\begin{array}{l}988.31 \\
990.53 \\
992.75 \\
994.98 \\
997.20\end{array}$ & $\begin{array}{l}988.53 \\
990.75 \\
992.98 \\
995.20 \\
997.43\end{array}$ & $\begin{array}{l}988.75 \\
990.98 \\
993.20 \\
995.42 \\
997.65\end{array}$ & $\begin{array}{l}988.97 \\
991.20 \\
993.42 \\
995.65 \\
997.87\end{array}$ & $\begin{array}{l}989.20 \\
991.42 \\
993.64 \\
995.87 \\
998.09\end{array}$ & $\begin{array}{l}989.42 \\
991.64 \\
993.87 \\
996.09 \\
998.32\end{array}$ & $\begin{array}{l}989.64 \\
991.87 \\
994.09 \\
996.31 \\
998.54\end{array}$ & $\begin{array}{l}989.86 \\
992.09 \\
994.31 \\
996.54 \\
998.76\end{array}$ & $\begin{array}{l}39.50 \\
39.60 \\
39.70 \\
39.80 \\
39.90\end{array}$ \\
\hline $\begin{array}{l}40 \cdot 00 \\
40.10 \\
40 \cdot 20 \\
40 \cdot 30 \\
40.40\end{array}$ & $\begin{array}{r}998.76 \\
1000.99 \\
1003.21 \\
1005.43 \\
1007.66\end{array}$ & $\begin{array}{r}998.98 \\
1001.21 \\
1003.43 \\
1005.66 \\
1007.88\end{array}$ & $\begin{array}{r}999.21 \\
1001.43 \\
1003.65 \\
1005.88 \\
1008.10\end{array}$ & $\begin{array}{r}999.43 \\
1001.65 \\
1003.88 \\
1006.10 \\
1008.33\end{array}$ & $\begin{array}{r}999 \cdot 65 \\
1001.88 \\
1004 \cdot 10 \\
1006 \cdot 32 \\
1008 \cdot 55\end{array}$ & $\begin{array}{r}999 \cdot 87 \\
1002 \cdot 10 \\
1004 \cdot 32 \\
1006 \cdot 55 \\
1008 \cdot 77\end{array}$ & $\begin{array}{l}1000 \cdot 10 \\
1002 \cdot 32 \\
1004 \cdot 54 \\
1006 \cdot 77 \\
1008 \cdot 99\end{array}$ & $\begin{array}{l}1000.32 \\
1002.54 \\
1004.77 \\
1006.99 \\
1009.22\end{array}$ & $\begin{array}{l}1000 \cdot 54 \\
1002 \cdot 77 \\
1004 \cdot 99 \\
1007 \cdot 21 \\
1009 \cdot 44\end{array}$ & $\begin{array}{l}1000.76 \\
1002.99 \\
1005.21 \\
1007.44 \\
1009.66\end{array}$ & $\begin{array}{l}1000.99 \\
1003.21 \\
1005.43 \\
1007.66 \\
1009.88\end{array}$ & $\begin{array}{l}40 \cdot 00 \\
40.10 \\
40.20 \\
40.30 \\
40.40\end{array}$ \\
\hline $\begin{array}{l}40.50 \\
40.60 \\
40 \cdot 70 \\
40.80 \\
40.90\end{array}$ & $\begin{array}{l}1009 \cdot 88 \\
1012 \cdot 11 \\
1014 \cdot 33 \\
1016 \cdot 56 \\
1018 \cdot 78\end{array}$ & $\begin{array}{l}1010.11 \\
1012.33 \\
1014 \cdot 56 \\
1016.78 \\
1019.01\end{array}$ & $\begin{array}{l}1010.33 \\
1012.55 \\
1014.78 \\
1017.00 \\
1019.23\end{array}$ & $\begin{array}{l}1010.55 \\
1012.78 \\
1015.00 \\
1017.23 \\
1019.45\end{array}$ & $\begin{array}{l}1010.77 \\
1013.00 \\
1015.22 \\
1017.45 \\
1019.67\end{array}$ & $\begin{array}{l}1011.00 \\
1013.22 \\
1015.45 \\
1017.67 \\
1019.90\end{array}$ & $\begin{array}{l}1011.22 \\
1013.44 \\
1015.67 \\
1017.89 \\
1020.12\end{array}$ & $\begin{array}{l}1011.44 \\
1013.67 \\
1015.89 \\
1018.12 \\
1020.34\end{array}$ & $\begin{array}{l}1011.66 \\
1013.89 \\
1016.11 \\
1018.34 \\
1020.56\end{array}$ & $\begin{array}{l}1011.89 \\
1014.11 \\
1016.34 \\
1018.56 \\
1020.79\end{array}$ & $\begin{array}{l}1012 \cdot 11 \\
1014.33 \\
1016.56 \\
1018.78 \\
1021.01\end{array}$ & $\begin{array}{l}40.50 \\
40.60 \\
40.70 \\
40.80 \\
40.90\end{array}$ \\
\hline $\begin{array}{l}41 \cdot 00 \\
41 \cdot 10 \\
41 \cdot 20 \\
41 \cdot 30 \\
41 \cdot 40\end{array}$ & $\begin{array}{l}1021.01 \\
1023.23 \\
1025.46 \\
1027.68 \\
1029.91\end{array}$ & $\begin{array}{l}1021.23 \\
1023.46 \\
1025.68 \\
1027.91 \\
1030.13\end{array}$ & $\begin{array}{l}1021.45 \\
1023 \cdot 68 \\
1025.90 \\
1028 \cdot 13 \\
1030.35\end{array}$ & $\begin{array}{l}1021.68 \\
1023.90 \\
1026.13 \\
1028.35 \\
1030.58\end{array}$ & $\begin{array}{l}1021.90 \\
1024.12 \\
1026.35 \\
1028.57 \\
1030.80\end{array}$ & $\begin{array}{l}1022.12 \\
1024 \cdot 35 \\
1026.57 \\
1028.80 \\
1031.02\end{array}$ & $\begin{array}{l}1022.34 \\
1024.57 \\
1026.79 \\
1029.02 \\
1031.24\end{array}$ & $\begin{array}{l}1022.57 \\
1024.79 \\
1027.02 \\
1029.24 \\
1031.47\end{array}$ & $\begin{array}{l}1022.79 \\
1025.01 \\
1027.24 \\
1029.46 \\
1031.69\end{array}$ & $\begin{array}{l}1023.01 \\
1025.24 \\
1027.46 \\
1029.69 \\
1031.91\end{array}$ & $\begin{array}{l}1023.23 \\
1025.46 \\
1027.68 \\
1029.91 \\
1032.13\end{array}$ & $\begin{array}{l}41 \cdot 00 \\
41 \cdot 10 \\
41 \cdot 20 \\
41 \cdot 30 \\
41 \cdot 40\end{array}$ \\
\hline $\begin{array}{l}41 \cdot 50 \\
41 \cdot 60 \\
41 \cdot 70 \\
41 \cdot 80 \\
41 \cdot 90\end{array}$ & $\begin{array}{l}1032.13 \\
1034.36 \\
1036.59 \\
1038.81 \\
1041.04\end{array}$ & $\begin{array}{l}1032 \cdot 36 \\
1034 \cdot 58 \\
1036 \cdot 81 \\
1039 \cdot 03 \\
1041.26\end{array}$ & $\begin{array}{l}1032.58 \\
1034.81 \\
1037.03 \\
1039.26 \\
1041.48\end{array}$ & $\begin{array}{l}1032.80 \\
1035.03 \\
1037.25 \\
1039.48 \\
1041.71\end{array}$ & $\begin{array}{l}1033.02 \\
1035.25 \\
1037.48 \\
1039.70 \\
1041.93\end{array}$ & $\begin{array}{l}1033.25 \\
1035.47 \\
1037.70 \\
1039.92 \\
1042.15\end{array}$ & $\begin{array}{l}1033.47 \\
1035.70 \\
1037.92 \\
1040.15 \\
1042.37\end{array}$ & $\begin{array}{l}1033.69 \\
1035.92 \\
1038.14 \\
1040.37 \\
1042.60\end{array}$ & $\begin{array}{l}1033 \cdot 92 \\
1036 \cdot 14 \\
1038 \cdot 37 \\
1040.59 \\
1042.82\end{array}$ & $\begin{array}{l}1034.14 \\
1036.36 \\
1038.59 \\
1040.81 \\
1043.04\end{array}$ & $\begin{array}{l}1034.36 \\
1036.59 \\
1038.81 \\
1041.04 \\
1043.26\end{array}$ & $\begin{array}{l}41.50 \\
41.60 \\
41.70 \\
41.80 \\
41.90\end{array}$ \\
\hline 42.00 & 1043.26 & 1043.49 & 1043.71 & 1043.93 & $1044 \cdot 15$ & 1044.38 & 1044.60 & 1044.82 & $1045 \cdot 04$ & 1045.27 & 1045.49 & 42.00 \\
\hline
\end{tabular}

$\mathrm{mV}$

$.00 \quad .01$

.02

.03

.04

.05

.06

.07

.08

.09

$\cdot 10$

(1) 
TABLE A5.2.2. Type $\boldsymbol{E}$ thermocouples-temperature $\left({ }^{\circ} \mathrm{F}\right)$ as a function of thermoelectric voltage, reference junctions at $32^{\circ} \mathrm{F}$-Continued

$\mathrm{mV}$

.00

\author{
.01
}

.02

.03

.04

.05

.06

.07

.08

TEMPERATURES IN DEGREES F

\section{4}

42.0

42.20

$42 \cdot 30$

42.40

42.50

42.6

42.7

42.90

43.00

43.10

43.20

43.30

43.40

43.50

43.60

43.70

43.80

43.90

44.00

44.10

44.20

44.30

44.40

44.50

44.60
44.70

44.80

44.90

45.00

45.10

45.20

45.30

45.40

45.50

45.60

45.70

45.80

45.90

46.00

46.1

46.3

46.40

46.50

46.60

46.7

46.80

46.90

47.00

47.1

47.2

47.30

47.40

47.5

47.60

47.7

47.80

48.00

$\mathrm{mV}$

1045.49

1047.72

1052.17

1043.49

$1050.16 \quad 1050.39$

1043.93

1046.16

1048.38

1050.61

1044.15

$1046.38 \quad 1044.38$

$\begin{array}{lll}1050.83 & 1051.06 & 1051.28\end{array}$

1054.39

1056.62

1061.08

1063.30

1065.53

1067.76

1069.98

1072.21

1076.67

1078.90

1081.12

1083.35

1087.81

1090.04

1092.27

1094.50

1096.73

1098.96

1101.19

1103.42

1105.65

1110.11

$1112 \cdot 34$

1114.57

1116.80
1119.04

1121.27

1123.50

1125.73

1127.97

1054.62

1056.84

1057.07

$1063.53 \quad 1063.75$

1065.75

1067.98

1070.21

1072.44

1074.66

1076.89

1079.12

1081.35

1083.58

1085.80

1088.03

1090.26

1092.49

1094.72

1099.18

1101.41

1103.64

1105.37

1110.33

1112.56

1114.80

1117.03

1119.26

1121.49

1123.72

1125.96

1128.19

1130.20

1132.43

1134.66

1139.13

1141.37

1143.60

1145.84

1148.07

1150.31

1152.54

1154.78

1157.01

1159.25

1161.49

1163.72

1165.96

1168.20

1170.43

1172.67

1177.15

1132.65

1134.89

1137.12

$1139.36 \quad 1137.35$

$1141.59 \quad 1141.81$

1143.82

1146.06

1148.29

1150.53

1144.05

1146.28

1148.52

1150.75

1155.00

1157.24

1159.47

1161.71

1163.95

1166.18

1168.42

1170.66

1172.90

$1175.14 \quad 1175.36$

1177.37

1155.22

1157.46

1159.70

1161.93
1164.17

1166.41

1168.64

1170.88
1173.12

1055.06
1057.29

1059.52

1.061 .74

1063.97

1066.20

1068.43

1070.65

1072.88

1075.11

1077.34

1079.56

1081.79

1084.02

1086.25

1088.48

1090.71

1092.94

1095.17

1055.29

$1057.51 \quad 1055.51 \quad 1055.73$

$\begin{array}{lll}1059.74 & 1057.74 & 1057.96\end{array}$

$1061.97 \quad 1062.19 \quad 1062.41$

$1064.19 \quad 1064.42$

1066.42

1068.871069 .09

$\begin{array}{lll}1075.33 & 1075.55 & 1075.78\end{array}$

$1077.56 \quad 1077.78 \quad 1078.01$

$1079.79 \quad 1080.01 \quad 1080.23$

$1082.02 \quad 1082.24 \quad 1082.46$

$1084.24 \quad 1084.47 \quad 1084.69$

$1086.47 \quad 1086 \cdot 70$

1086.92

$1088.70 \quad 1088.93$

$1090.93 \quad 1091.15$

$1093.16 \quad 1093.38$

$1095.39 \quad 1095.61$

$1097.62 \quad 1097.84$

089.15

$1091 \cdot 38$

1093.61

1095.84

1098.07

$1099.85 \quad 1100.07$

$1102.08 \quad 1102.30$

$1104.31 \quad 1104.53$

$1100 \cdot 30$

1101.86

1104.09

1106.32

1106.54

1106.76

1104.76

1106.99

1111.23

$1110 \cdot 78$

1115.24

1117.47

1113.23

1115.47

$1117.70 \quad 1117.92$

$1119.93 \quad 1120.15$

1111.45

1113.68

1115.91

1118.14

1120.38

1121.94

1124.17

1126.40

1128.64

$1122.16 \quad 1122 \cdot 38$

$1124.39 \quad 1124.62$

$1126.63 \quad 1126.85$

$1128.86 \quad 1129.08$

$1122 \cdot 61$

1124.84

1127.07

1129.31

$1131.09 \quad 1131.31$

1133.10

1135.33

1137.57

1139.80

1133.32 
TABLE A5.2.2. Type E thermocouples-iemperature $\left({ }^{\circ} \mathrm{F}\right)$ as a function of thermoelectric voltage, reference junctions at $32^{\circ} \mathrm{F}$-Continued

$\mathrm{mV}$

.00

.01

.02

.03

.04

.05

.06

.07

.08

.09

.10

$\mathrm{mV}$

TEMPERATURES IN DEGREES F

\begin{tabular}{|c|c|c|c|c|c|c|c|c|c|c|c|c|}
\hline $\begin{array}{l}48.00 \\
48.10 \\
48.20 \\
48.30 \\
48.40\end{array}$ & $\begin{array}{l}1177.15 \\
1179.39 \\
1181.63 \\
1183.87 \\
1186.11\end{array}$ & $\begin{array}{l}1177.37 \\
1179.61 \\
1181.85 \\
1184.09 \\
1186.33\end{array}$ & $\begin{array}{l}1177.60 \\
1179.84 \\
1182.08 \\
1184.32 \\
1186.56\end{array}$ & $\begin{array}{l}1177.82 \\
1180.06 \\
1182.30 \\
1184.54 \\
1186.78\end{array}$ & $\begin{array}{l}1178.05 \\
1180.28 \\
1182.52 \\
1184.76 \\
1187.00\end{array}$ & $\begin{array}{l}1178.27 \\
1180 \cdot 51 \\
1182.75 \\
1184.99 \\
1187.23\end{array}$ & $\begin{array}{l}1178.49 \\
1180.73 \\
1182.97 \\
1185.21 \\
1187.45\end{array}$ & $\begin{array}{l}1178.72 \\
1180.96 \\
1183.20 \\
1185.44 \\
1187.68\end{array}$ & $\begin{array}{l}1178.94 \\
1181 \cdot 18 \\
1183.42 \\
1185.66 \\
1187.90\end{array}$ & $\begin{array}{l}1179.16 \\
1181.40 \\
1183.64 \\
1185.88 \\
1188.12\end{array}$ & $\begin{array}{l}1179 \cdot 39 \\
1181 \cdot 63 \\
1183 \cdot 87 \\
1186.11 \\
1188 \cdot 35\end{array}$ & $\begin{array}{l}48.00 \\
48.10 \\
48.20 \\
48.30 \\
48.40\end{array}$ \\
\hline $\begin{array}{l}48.50 \\
48.60 \\
48.70 \\
48.80 \\
48.90\end{array}$ & $\begin{array}{l}1188.35 \\
1190.59 \\
1192.83 \\
1195.07 \\
1197.31\end{array}$ & $\begin{array}{l}1188.57 \\
1190.81 \\
1193.05 \\
1195.29 \\
1197.54\end{array}$ & $\begin{array}{l}1188.80 \\
1191.04 \\
1193.28 \\
1195.52 \\
1197.76\end{array}$ & $\begin{array}{l}1189.02 \\
1191.26 \\
1193.50 \\
1195.74 \\
1197.98\end{array}$ & $\begin{array}{l}1189 \cdot 24 \\
1191.48 \\
1193 \cdot 72 \\
1195.97 \\
1198.21\end{array}$ & $\begin{array}{l}1189.47 \\
1191.71 \\
1193.95 \\
1196.19 \\
1198.43\end{array}$ & $\begin{array}{l}1189.69 \\
1191.93 \\
1194.17 \\
1196.41 \\
1198.66\end{array}$ & $\begin{array}{l}1189.92 \\
1192.16 \\
1194.40 \\
1196.64 \\
1198.88\end{array}$ & $\begin{array}{l}1190.14 \\
1192.38 \\
1194.62 \\
1196.86 \\
1199.10\end{array}$ & $\begin{array}{l}1190.36 \\
1192.60 \\
1194.85 \\
1197.09 \\
1199.33\end{array}$ & $\begin{array}{l}1190.59 \\
1192.83 \\
1195.07 \\
1197.31 \\
1199.55\end{array}$ & $\begin{array}{l}48.50 \\
48.60 \\
48.70 \\
48.80 \\
48.90\end{array}$ \\
\hline $\begin{array}{l}49.00 \\
49.10 \\
49.20 \\
49.30 \\
49.40\end{array}$ & $\begin{array}{l}1199.55 \\
1201.79 \\
1204.04 \\
1206.28 \\
1208.52\end{array}$ & $\begin{array}{l}1199.78 \\
1202.02 \\
1204.26 \\
1206.50 \\
1208.75\end{array}$ & $\begin{array}{l}1200 \cdot 00 \\
1202 \cdot 24 \\
1204.49 \\
1206.73 \\
1208.97\end{array}$ & $\begin{array}{l}1200 \cdot 23 \\
1202 \cdot 47 \\
1204 \cdot 71 \\
1206 \cdot 95 \\
1209 \cdot 20\end{array}$ & $\begin{array}{l}1200.45 \\
1202.69 \\
1204.93 \\
1207.18 \\
1209.42\end{array}$ & $\begin{array}{l}1200 \cdot 67 \\
1202 \cdot 92 \\
1205 \cdot 16 \\
1207 \cdot 40 \\
1209.64\end{array}$ & $\begin{array}{l}1200.90 \\
1203 \cdot 14 \\
1205 \cdot 38 \\
1207.63 \\
1209.87\end{array}$ & $\begin{array}{l}1201.12 \\
1203 \cdot 36 \\
1205.61 \\
1207.85 \\
1210.09\end{array}$ & $\begin{array}{l}1201.35 \\
1203.59 \\
1205.83 \\
1208.07 \\
1210.32\end{array}$ & $\begin{array}{l}1201.57 \\
1203.81 \\
1206.06 \\
1208 \cdot 30 \\
1210.54\end{array}$ & $\begin{array}{l}1201 \cdot 79 \\
1204 \cdot 04 \\
1206 \cdot 28 \\
1208 \cdot 52 \\
1210.77\end{array}$ & $\begin{array}{l}49.00 \\
49.10 \\
49.20 \\
49.30 \\
49.40\end{array}$ \\
\hline $\begin{array}{l}49.50 \\
49.60 \\
49.70 \\
49.80 \\
49.90\end{array}$ & $\begin{array}{l}1210.77 \\
1213.01 \\
1215.25 \\
1217.50 \\
1219.74\end{array}$ & $\begin{array}{l}1210.99 \\
1213.23 \\
1215.48 \\
1217.72 \\
1219.97\end{array}$ & $\begin{array}{l}1211 \cdot 21 \\
1213.46 \\
1215.70 \\
1217.95 \\
1220.19\end{array}$ & $\begin{array}{l}1211.44 \\
1213.68 \\
1215.93 \\
1218.17 \\
1220.42\end{array}$ & $\begin{array}{l}1211.66 \\
1213.91 \\
1216.15 \\
1218.40 \\
1220.64\end{array}$ & $\begin{array}{l}1211 \cdot 89 \\
1214 \cdot 13 \\
1216 \cdot 38 \\
1218.62 \\
1220.87\end{array}$ & $\begin{array}{l}1212 \cdot 11 \\
1214 \cdot 36 \\
1216 \cdot 60 \\
1218.85 \\
1221.09\end{array}$ & $\begin{array}{l}1212 \cdot 34 \\
1214 \cdot 58 \\
1216 \cdot 82 \\
1219 \cdot 07 \\
1221 \cdot 31\end{array}$ & $\begin{array}{l}1212.56 \\
1214.81 \\
1217.05 \\
1219.29 \\
1221.54\end{array}$ & $\begin{array}{l}1212.79 \\
1215.03 \\
1217.27 \\
1219.52 \\
1221.76\end{array}$ & $\begin{array}{l}1213.01 \\
1215.25 \\
1217.50 \\
1219.74 \\
1221.99\end{array}$ & $\begin{array}{l}49.50 \\
49.60 \\
49.70 \\
49.80 \\
49.90\end{array}$ \\
\hline $\begin{array}{l}50.00 \\
50.10 \\
50.20 \\
50.30 \\
50.40\end{array}$ & $\begin{array}{l}1221.99 \\
1224.23 \\
1226.48 \\
1228.73 \\
1230.97\end{array}$ & $\begin{array}{l}1222 \cdot 21 \\
1224 \cdot 46 \\
1226.70 \\
1228 \cdot 95 \\
1231 \cdot 20\end{array}$ & $\begin{array}{l}1222 \cdot 44 \\
1224 \cdot 68 \\
1226.93 \\
1229 \cdot 17 \\
1231.42\end{array}$ & $\begin{array}{l}1222.66 \\
1224.91 \\
1227.15 \\
1229.40 \\
1231.65\end{array}$ & $\begin{array}{l}1222.89 \\
1225.13 \\
1227.38 \\
1229.62 \\
1231.87\end{array}$ & $\begin{array}{l}1223.11 \\
1225 \cdot 36 \\
1227.60 \\
1229.85 \\
1232.10\end{array}$ & $\begin{array}{l}1223 \cdot 34 \\
1225 \cdot 58 \\
1227 \cdot 83 \\
1230 \cdot 07 \\
1232 \cdot 32\end{array}$ & $\begin{array}{l}1223.56 \\
1225.81 \\
1228.05 \\
1230.30 \\
1232.54\end{array}$ & $\begin{array}{l}1223.78 \\
1226.03 \\
1228.28 \\
1230.52 \\
1232 \cdot 77\end{array}$ & $\begin{array}{l}1224.01 \\
1226.25 \\
1228.50 \\
1230.75 \\
1232.99\end{array}$ & $\begin{array}{l}1224 \cdot 23 \\
1226 \cdot 48 \\
1228 \cdot 73 \\
1230 \cdot 97 \\
1233 \cdot 22\end{array}$ & $\begin{array}{l}50 \cdot 00 \\
50 \cdot 10 \\
50 \cdot 20 \\
50 \cdot 30 \\
50 \cdot 40\end{array}$ \\
\hline $\begin{array}{l}50.50 \\
50.60 \\
50.70 \\
50.80 \\
50.90\end{array}$ & $\begin{array}{l}1233.22 \\
1235.47 \\
1237.71 \\
1239.96 \\
1242.21\end{array}$ & $\begin{array}{l}1233.44 \\
1235.69 \\
1237.94 \\
1240.19 \\
1242.43\end{array}$ & $\begin{array}{l}1233.67 \\
1235.92 \\
1238.16 \\
1240.41 \\
1242.66\end{array}$ & $\begin{array}{l}1233.89 \\
1236.14 \\
1238.39 \\
1240.64 \\
1242.88\end{array}$ & $\begin{array}{l}1234.12 \\
1236.36 \\
1238.61 \\
1240.86 \\
1243.11\end{array}$ & $\begin{array}{l}1234.34 \\
1236.59 \\
1238.84 \\
1241.09 \\
1243.33\end{array}$ & $\begin{array}{l}1234.57 \\
1236.81 \\
1239.06 \\
1241.31 \\
1243.56\end{array}$ & $\begin{array}{l}1234.79 \\
1237.04 \\
1239.29 \\
1241.53 \\
1243.78\end{array}$ & $\begin{array}{l}1235.02 \\
1237.26 \\
1239.51 \\
1241.76 \\
1244.01\end{array}$ & $\begin{array}{l}1235.24 \\
1237.49 \\
1239.74 \\
1241.98 \\
1244.23\end{array}$ & $\begin{array}{l}1235.47 \\
1237.71 \\
1239.96 \\
1242.21 \\
1244.46\end{array}$ & $\begin{array}{l}50.50 \\
50.60 \\
50.70 \\
50.80 \\
50.90\end{array}$ \\
\hline $\begin{array}{l}51 \cdot 00 \\
51 \cdot 10 \\
51 \cdot 20 \\
51 \cdot 30 \\
51 \cdot 40\end{array}$ & $\begin{array}{l}1244 \cdot 46 \\
1246.71 \\
1248.96 \\
1251.21 \\
1253.46\end{array}$ & $\begin{array}{l}1244 \cdot 68 \\
1246 \cdot 93 \\
1249 \cdot 18 \\
1251 \cdot 43 \\
1253 \cdot 68\end{array}$ & $\begin{array}{l}1244.91 \\
1247.16 \\
1249.41 \\
1251.66 \\
1253.91\end{array}$ & $\begin{array}{l}1245.13 \\
1247.38 \\
1249.63 \\
1251.88 \\
1254.13\end{array}$ & $\begin{array}{l}1245.36 \\
1247.61 \\
1249.86 \\
1252.11 \\
1254.36\end{array}$ & $\begin{array}{l}1245.58 \\
1247.83 \\
1250.08 \\
1252.33 \\
1254.58\end{array}$ & $\begin{array}{l}1245.81 \\
1248.06 \\
1250.31 \\
1252.56 \\
1254.81\end{array}$ & $\begin{array}{l}1246.03 \\
1248.28 \\
1250.53 \\
1252.78 \\
1255.03\end{array}$ & $\begin{array}{l}1246.26 \\
1248.51 \\
1250.76 \\
1253.01 \\
1255.26\end{array}$ & $\begin{array}{l}1246.48 \\
1248 \cdot 73 \\
1250 \cdot 98 \\
1253.23 \\
1255.48\end{array}$ & $\begin{array}{l}1246.71 \\
1248.96 \\
1251.21 \\
1253.46 \\
1255.71\end{array}$ & $\begin{array}{l}51 \cdot 00 \\
51 \cdot 10 \\
51 \cdot 20 \\
51 \cdot 30 \\
51 \cdot 40\end{array}$ \\
\hline $\begin{array}{l}51.50 \\
51.60 \\
51.70 \\
51.80 \\
51.90\end{array}$ & $\begin{array}{l}1255.71 \\
1257.96 \\
1260.21 \\
1262.46 \\
1264.71\end{array}$ & $\begin{array}{l}1255.93 \\
1258.18 \\
1260.43 \\
1262.69 \\
1264.94\end{array}$ & $\begin{array}{l}1256 \cdot 16 \\
1258 \cdot 41 \\
1260.66 \\
1262 \cdot 91 \\
1265.16\end{array}$ & $\begin{array}{l}1256.38 \\
1258.63 \\
1260.88 \\
1263.14 \\
1265.39\end{array}$ & $\begin{array}{l}1256.61 \\
1258.86 \\
1261.11 \\
1263.36 \\
1265.61\end{array}$ & $\begin{array}{l}1256.83 \\
1259.08 \\
1261.33 \\
1263.59 \\
1265.84\end{array}$ & $\begin{array}{l}1257.06 \\
1259.31 \\
1261.56 \\
1263.81 \\
1266.06\end{array}$ & $\begin{array}{l}1257.28 \\
1259.53 \\
1261.78 \\
1264.04 \\
1266.29\end{array}$ & $\begin{array}{l}1257.51 \\
1259.76 \\
1262.01 \\
1264.25 \\
1266.51\end{array}$ & $\begin{array}{l}1257.73 \\
1259 \cdot 98 \\
1262.24 \\
1264 \cdot 49 \\
1266.74\end{array}$ & $\begin{array}{l}1257.96 \\
1260.21 \\
1262.46 \\
1264 \cdot 71 \\
1266.96\end{array}$ & $\begin{array}{l}51 \cdot 50 \\
51.60 \\
51.70 \\
51.80 \\
51.90\end{array}$ \\
\hline $\begin{array}{l}52.00 \\
52 \cdot 10 \\
52 \cdot 20 \\
52.30 \\
52.40\end{array}$ & $\begin{array}{l}1266.96 \\
1269 \cdot 22 \\
1271.47 \\
1273 \cdot 72 \\
1275.98\end{array}$ & $\begin{array}{l}1267.19 \\
1269.44 \\
1271.70 \\
1273.95 \\
1276.20\end{array}$ & $\begin{array}{l}1267.42 \\
1269.67 \\
1271.92 \\
1274.18 \\
1276.43\end{array}$ & $\begin{array}{l}1267.64 \\
1269.89 \\
1272.15 \\
1274.40 \\
1276.65\end{array}$ & $\begin{array}{l}1267.87 \\
1270.12 \\
1272.37 \\
1274.63 \\
1276.88\end{array}$ & $\begin{array}{l}1268.09 \\
1270.34 \\
1272.60 \\
1274.85 \\
1277.11\end{array}$ & $\begin{array}{l}1268 \cdot 32 \\
1270.57 \\
1272.82 \\
1275.08 \\
1277.33\end{array}$ & $\begin{array}{l}1268.54 \\
1270.79 \\
1273.05 \\
1275.30 \\
1277.56\end{array}$ & $\begin{array}{l}1268.77 \\
1271.02 \\
1273.27 \\
1275.53 \\
1277.78\end{array}$ & $\begin{array}{l}1268.99 \\
1271.25 \\
1273.50 \\
1275.75 \\
1278.01\end{array}$ & $\begin{array}{l}1269.22 \\
1271.47 \\
1273.72 \\
1275.98 \\
1278.23\end{array}$ & $\begin{array}{l}52 \cdot 00 \\
52 \cdot 10 \\
52 \cdot 20 \\
52.30 \\
52.40\end{array}$ \\
\hline $\begin{array}{l}52.50 \\
52.60 \\
52.70 \\
52.80 \\
52.90\end{array}$ & $\begin{array}{l}1278.23 \\
1280.49 \\
1282.74 \\
1285.00 \\
1287.25\end{array}$ & $\begin{array}{l}1278.46 \\
1280.71 \\
1282.97 \\
1285.22 \\
1287.48\end{array}$ & $\begin{array}{l}1278 \cdot 68 \\
1280 \cdot 94 \\
1283 \cdot 19 \\
1285 \cdot 45 \\
1287 \cdot 71\end{array}$ & $\begin{array}{l}1278.91 \\
1281.16 \\
1283.42 \\
1285.67 \\
1287.93\end{array}$ & $\begin{array}{l}1279 \cdot 13 \\
1281 \cdot 39 \\
1283.64 \\
1285.90 \\
1288 \cdot 16\end{array}$ & $\begin{array}{l}1279.36 \\
1281.62 \\
1283.87 \\
1286.13 \\
1288.38\end{array}$ & $\begin{array}{l}1279.59 \\
1281.84 \\
1284.10 \\
1286.35 \\
1288.61\end{array}$ & $\begin{array}{l}1279.81 \\
1282.07 \\
1284.32 \\
1286.58 \\
1288.83\end{array}$ & $\begin{array}{l}1280.04 \\
1282.29 \\
1284.55 \\
1286.80 \\
1289.06\end{array}$ & $\begin{array}{l}1280.26 \\
1282.52 \\
1284.77 \\
1287.03 \\
1289.28\end{array}$ & $\begin{array}{l}1280.49 \\
1282.74 \\
1285.00 \\
1287.25 \\
1289.51\end{array}$ & $\begin{array}{l}52.50 \\
52.60 \\
52.70 \\
52.80 \\
52.90\end{array}$ \\
\hline $\begin{array}{l}53.00 \\
53.10 \\
53.20 \\
53.30 \\
53.40\end{array}$ & $\begin{array}{l}1289.51 \\
1291.77 \\
1294.02 \\
1296.28 \\
1298.54\end{array}$ & $\begin{array}{l}1289.74 \\
1291.99 \\
1294.25 \\
1296.51 \\
1298.77\end{array}$ & $\begin{array}{l}1289.96 \\
1292.22 \\
1294.48 \\
1296.73 \\
1298.99\end{array}$ & $\begin{array}{l}1290.19 \\
1292.44 \\
1294.70 \\
1296.96 \\
1299.22\end{array}$ & $\begin{array}{l}1290.41 \\
1292.67 \\
1294.93 \\
1297.19 \\
1299.44\end{array}$ & $\begin{array}{l}1290.64 \\
1292.90 \\
1295.15 \\
1297.41 \\
1299.67\end{array}$ & $\begin{array}{l}1290 \cdot 86 \\
1293.12 \\
1295 \cdot 38 \\
1297.64 \\
1299.90\end{array}$ & $\begin{array}{l}1291.09 \\
1293.35 \\
1295.60 \\
1297.86 \\
1300.12\end{array}$ & $\begin{array}{l}1291.32 \\
1293.57 \\
1295.83 \\
1298.09 \\
1300.35\end{array}$ & $\begin{array}{l}1291.54 \\
1293.80 \\
1296.06 \\
1298.31 \\
1300.57\end{array}$ & $\begin{array}{l}1291.77 \\
1294.02 \\
1296.28 \\
1298.54 \\
1300.80\end{array}$ & $\begin{array}{l}53.00 \\
53.10 \\
53.20 \\
53.30 \\
53.40\end{array}$ \\
\hline $\begin{array}{l}53.50 \\
53.60 \\
53.70 \\
53.80 \\
53.90\end{array}$ & $\begin{array}{l}1300.80 \\
1303.06 \\
1305.32 \\
1307.58 \\
1309.84\end{array}$ & $\begin{array}{l}1301.02 \\
1303.28 \\
1305.54 \\
1307.80 \\
1310.06\end{array}$ & $\begin{array}{l}1301.25 \\
1303.51 \\
1305.77 \\
1308.03 \\
1310.29\end{array}$ & $\begin{array}{l}1301.48 \\
1303.74 \\
1305.99 \\
1308.25 \\
1310.51\end{array}$ & $\begin{array}{l}1301 \cdot 70 \\
1303 \cdot 96 \\
1306 \cdot 22 \\
1308 \cdot 48 \\
1310.74\end{array}$ & $\begin{array}{l}1301.93 \\
1304.19 \\
1306.45 \\
1308.71 \\
1310.97\end{array}$ & $\begin{array}{l}1302 \cdot 15 \\
1304.41 \\
1306.67 \\
1308.93 \\
1311.19\end{array}$ & $\begin{array}{l}1302 \cdot 38 \\
1304 \cdot 64 \\
1306 \cdot 90 \\
1309 \cdot 16 \\
1311.42\end{array}$ & $\begin{array}{l}1302.61 \\
1304.86 \\
1307.12 \\
1309.38 \\
1311.64\end{array}$ & $\begin{array}{l}1302.83 \\
1305.09 \\
1307.35 \\
1309.61 \\
1311.87\end{array}$ & $\begin{array}{l}1303.06 \\
1305.32 \\
1307.58 \\
1309.84 \\
1312.10\end{array}$ & $\begin{array}{l}53.50 \\
53.60 \\
53.70 \\
53.80 \\
53.90\end{array}$ \\
\hline 54.0 & 1312.10 & $1312 \cdot 32$ & 1312.55 & 1312.78 & 1313.00 & 1313.23 & 1313.45 & 1313.68 & 1313.91 & $1314 \cdot 13$ & $1314 \cdot 36$ & 54.00 \\
\hline
\end{tabular}

.01

.03

\begin{abstract}
.04
\end{abstract}

\begin{abstract}
.05
\end{abstract}

\begin{abstract}
.06
\end{abstract}
.07

\begin{abstract}
.08
\end{abstract}

\begin{abstract}
.09
\end{abstract}
.10

$\mathrm{mV}$ 
TABLE A5.2.2. Type E thermocouples-temperature $\left({ }^{\circ} \mathrm{F}\right)$ as a function of thermoelectric voltage, reference junctions at $32^{\circ} \mathrm{F}$-Continued

$m V$

.00

.01

.02

.03

.04

.05

.06

.07

.08

.09

.10

$m V$

TEMPERATURES IN DEGREES F

54.00
54.10
54.00
54.30
5
54.40
54.50
54.60
5
5
54.080
5
55.00
55.20
55.30
55.40$$
\begin{aligned}
& 54.10 \\
& 54.20 \\
& 54.30 \\
& 54.40 \\
& 54.50 \\
& 54.60 \\
& 54.70 \\
& 54.80 \\
& 54.90 \\
& 55.00 \\
& 55.10 \\
& 55.20 \\
& 55.30 \\
& 55.40
\end{aligned}
$$

\subsection{50 \\ 55.6
55.7}

$$
\begin{aligned}
& 55.80 \\
& 55.90
\end{aligned}
$$

56.00

56.00

56.2

56.3
56.4

56.40

56.5
56.6

56.60
56.70

56.8

56.9

57.0

57.1

57.2

57.3

57.4

57.5

57.60

57.70
57.8

57.9

58.0

58.1

58.2

58.3

58.4

58.5

58.6

58.70

58.8

58.9

59.0

59.1

59.2

59.30

59.4

59.5

59.6

59.7

59.80

59.90

60.00
1312.10

1314.58

$1316.62 \quad 1316.85$

$1318.88 \quad 1319.11$

$1321.14 \quad 1321.37$

1323.41

1325.67

1327.93

1330.20

1332.46

1334.73

1336.99

1339.26

1341.52

1343.79

1346.06

1348.32

1350.59

1352.86

1357.40

1359.67

1361.94

1364.21

1366.48

1368.75

1371.02

1373.30

1375.57

1377.84

1380.12

1382.39

1384.67

1386.94

1389.22

1391.49

1393.77

1396.05

1398.33

1400.61

1402.88

1405.16

1407.44

1409.72

1323.63

1325.90

1328.16
1330.42

1332.69

1337.22

1339.48

1344.02

1346.28

1348.55

1350.82

1353.09

1357.63

1359.90

1362.17

1366.71

1368.98

371.25

1373.52
1375.80

1378.07

1380.35

1382.62

1384.89

1387.17

1391.72

1394.00

1396.28

1398.55

1400.83

1403.11

1405.39

1407.67

1409.95

1412.00

1414.29

1416.57

1418.85

1421.13
1423.42

1425.70

1427.98

1430.27

1434.84

1437.13

1439.41

1443.99

1446.28

1448.57

1412.23

1414.51

1416.80

1419.08

1421.36

1423.64

1425.93

1428.21

1430.50

1432.78

1435.07

1437.36

1439.64

1441.93

1444.22
1446.51

1448.80
1334.95

$1312 \cdot 55$

1314.81

$1321.60 \quad 1321.82$

1323.86

1326.12
1328.39

1328.39
1330.65

1332.91

1335.18

1337.44

1339.71

1344.24

1346.51

1348.78

1351.05

1353.31

1357.85

1360.12

1362.39

1364.66

1366.94

1369.21

1371.48

1373.75

1376.02

1324.08

1326.35

1328.61
1330.88

1333.14

1335.41

1337.67

1339.94

1342.20
1344.47

1346.74

1349.00

1351.27

1353.54

1358.08

1360.35

1364.89

1367.16

1369.43

1371.71

1373.98

1376.25

1380.57

1382.85

1380.80

1385.12

1389.67

1391.95

1394.23

1396.50

1398.78

1401.06

1403.34

1405.62

1410.18

1383.07

1385.35

1387.63

1389.90

1392.18

1394.45

1396.73

1399.01

1403.57

1405.85

1408.13

1410.41

1313.00

1315.26

1315.491315 .71

$\begin{array}{lll}1322.05 & 1322.27 & 1322.50\end{array}$

1324.31

1326.57

1328.84

$1331 \cdot 10$

1335.63

1337.90

$1340 \cdot 16$

$1342 \cdot 43$

1346.96

1349.23

1351.50

1353.77

35.04

1360.58

1362.85

1365.12

1367.39

1369.66

1374.21

1376.48

1378.75

1381.0

1383.30

1385.58

387.8

1390.13

1392.41

1394.68

1395.96

1399.24

1401.52

1403.80 
TABLE A5.2.2. Type $\boldsymbol{E}$ thermocouples-temperature $\left({ }^{\circ} \mathrm{F}\right)$ as a function of thermoelectric voltage, reference junctions at $32^{\circ} \mathrm{F}$-Continued

$m V$

.00

.01

.02

.03

.04

.05

.06

.07

.08

.09

.10

$\mathrm{mV}$

TEMPERATURES IN DEGREES $F$

$60.00 \quad 1448.57 \quad 1448.80 \quad 1449.03$

60.10

60.20

$1450.86 \quad 1451.09$

$60.30-1455.14 \quad 1453.3$

60.40

60.50

60.60
60.70

60.70
60.80

60.90

1457.73

1460.02

1457.96

1453.61

$\begin{array}{ll}1449.25 & 1449.48 \\ 1451.54 & 1451.77 \\ 1453.83 & 1454.06\end{array}$

$\begin{array}{ll}1453.83 & 1454.06 \\ 1456.13 & 1456.35\end{array}$

1449.71
1452.00

1454.29

1458.19

1458.65

1456.58

1449.94

1454.52

$1464.61 \quad 1464.84$

1466.90

1464.84

1460.48

1462.77
1465.07

1465.07
1467.36

$1460.71 \quad 1460.94$

$1463.00 \quad 1463.23$

$1465.29 \quad 1465.52$

$1467.59 \quad 1467.82$

1461.17

1456.81

1469.19

1469.42

1469.65

61.00

61.20

$1471.49 \quad 1471.72$

$1473.78 \quad 1474.01$

1471.95

1469.88

1470.11

1463.46

1465.75

1468.05

1461.40

$1472.18 \quad 1472.41$

$1474.47 \quad 1474.70$

1476.54

1476.31

$\begin{array}{ll}1478.38 & 1478.61 \\ 1480.67 & 1480.90\end{array}$

1478.84

61.40

61.50

$1482.97 \quad 1483.20$

61.60

61.70

61.80

$1485.27 \quad 1485.50$

$1487.57 \quad 1487.80$

$1489.87 \quad 1490.10$

1483.43

1476.77

$1479.06 \quad 1479.00$

$1481.36 \quad 1481.59$

1472.64

1474.93

1477.23

1479.52

1481.82

$1483.66 \quad 1483.89$

$\begin{array}{lll}1485.96 & 1486.19\end{array}$

1488.03

1490.33

1488.26

1490.56

1488.49

1484.12

1486.42

1488.72

1491.02

1493.09

$1493 \cdot 32$

62.00

62.10

$1494.47 \quad 1494.70$

1494.93

$1495.16 \quad 1495.39$

$1497.46 \quad 1497.69$

$1499.76 \quad 1499.99$

$1499.07 \quad 1499.30$

1497.23

62.40

62.50

62.60

1501.371501 .60

1501.83

1503.90

1504.13

$502.06 \quad 1502.29$

$1504.36 \quad 1504.59$

1495.62

1497.92

1500.22

1502.52

$1506.67 \quad 1506.90$

$62.70-1510.581510 .81$

62.90

63.00

63.10

63.30
63.40

63.50

63.60

63.70

63.80

63.90

64.00

64.10
64.20

64.20
64.30

64.40

64.50

64.60

64.70

64.80
64.9

65.00

65.1

65.30
65.40

65.50

65.50
65.60

65.70

65.80
65.90

1515.19

1513.12

1513.35

1508.97

$1511.28 \quad 1511.51$

$1513.58 \quad 1513.8$

1507.13

1515.89

1516.12

1511.74

1514.04

$1517.50 \quad 1517.73$

$1519.81 \quad 1520.04$

1517.96

1522.11

1522.35

1520.27

$1518.19 \quad 1518.42$

$1520.50 \quad 1520.73$

$1522.81 \quad 1523.04$

$1525.12 \quad 1525.35$

$1527.42 \quad 1527.65$

$1526.73 \quad 1526.96$

1524.88

1.527 .19

1529.73

1529.96

$1532.04 \quad 1532.27$

$1534.35 \quad 1534.59$

1536.67

1536.67

1536.90

1534.12

$1533.66 \quad 1533.8$

1538.28

1538.52

1540.60

1540.83

1541.06

1541.29

$1539 \cdot 21$

1518.65

1520.96

1525.58

1527.89

1530.20

1532.51

1534.82

1537.13

1539.44

$1542.91 \quad 1543.14$

$\begin{array}{ll}1545.22 & 1545.45\end{array}$

1543.37

1545.69

1548.00

1543.60

1545.92

1548.46

1541.75

1544.07

1546.38

1548.69

1551.01

1552.17

1552.40

1552.63

1552.86

1555.18

1553.09

1553.33

1557.50

1555.4

1557.73

1555.64

1557.96

$1559.81 \quad 1560.05$

1562.131562 .36

1560.28

1562.60

1563.76

1561.90

1564.45

1564.68

1564.92

$1566.77 \quad 1567.00$

$1569.09 \quad 1569.32$

1573.73

1571.64

1567.24

1569.56
1571.88

1574.20

1576.06

1578.38

$1576 \cdot 29$

1576.52

1578.84

1581.17

1583.49

1585.35

1583.26

1585.82

1588.14

1587.68

1587.91

.03

.04

.05

1463.69

1465.98

$1472.87 \quad 1473.10$

$1475.16 \quad 1475.39$

$1477.46 \quad 1477.69$

$1479.75 \quad 1479.98$

1482.05

$1482 \cdot 28$

$1484 \cdot 35$

$65 \quad 1486.88$

$488.95 \quad 1489.18$

$\begin{array}{ll}1491.25 & 1491.48\end{array}$

$1495.85 \quad 1496.08$

$1498.15 \quad 1498.38$

$1500.45 \quad 1500.68$

$1502.75 \quad 1502.98$

1505.05

1505.28 
TABLE A5.2.2. Type E thermocouples-temperature $\left({ }^{\circ} \mathrm{F}\right)$ as a function of thermoelectric voltage, reference junctions at $32^{\circ} \mathrm{F}$-Continued

$\mathrm{mV}$

.00

.01

.02

.03

.04

.05

.06

TEMPERATURES IN DEGREES F

66.10

1586.98

1589.31

1591.64

66.30

66.40

66.50

66.60

66.70

66.80

66.90

67.00

67.10

67.10
67.20

67.30

67.40

67.50

67.60

67.7

67.80
67.90

68.0

68.10

68.20

68.30

68.40

68.50

68.60

68.70

68.80

68.90

69.00

69.10

69.20

69.30

69.40

69.50

69.60

69.7

69.80

69.90

70.00

70.10

70.20

70.30

70.40

70.50

$70 \cdot 60$

70.70

70.80

70.90

1596.29

1587.21

$1587.45 \quad 1587.68$

1598.62

1600.95

1603.28

1605.61

1607.95

1596.52

1594.43

1596.76

1594.66

1596.99

1598.85

1601.18

1603.51

1599.09

1601.65

$1603.75 \quad 1603.98$

$1608.181608 .41 \quad 1608.64$

1610.28

1612.61

1614.95

1617.28

1619.62

1610.51

1610.74

1612.84

1615.18

1617.5

1621.95

1624.29

1626.63

1628.97

1622.19

1624.52

1626.86

1631.31

1629.20

1633.65

1635.99

1638.33

1640.67

1643.02

1633.88

1636.22

1638.56

1640.91

1645.36

1647.70

1650.05

1652.40

1645.59

1647.94

1650.28

1654.74

1654.98

1657.09

1659.44

1661.79

1664.14

1666.49

1657.33

1659.68

1662.03

1664.38

1668.84

1669.08

1671.20

1673.55

1675.90

1671.43

1673.79

1676.14

1678.26

1678.50

1680.62

$1685.33 \quad 1685.57$

1687.69

1690.05

1692.41

1694.77

1697.13

1699.49

1701.86

1704.22

71.00

$71 \cdot 10$

$71 \cdot 30$

1706.58

1711.32

1713.68

1716.05

1718.42

1720.79

71.60

71.70

71.80

1723.16

1725.53

1690.28

1692.64 1695.00

1697.37

1699.73

1702.09

1704.46

1706.82

1709.19

1711.55

1713.92

1716.29

1718.66

1721.03

1723.40

613.08

8 1613.31

$1617.75 \quad 1617.98$

1620.32

$1622.42 \quad 1622.65$

$1624.76 \quad 1624.99$

$1627.10 \quad 1627.33$

$1629.43 \quad 1629.67$

1634.1

1636.46

$1641 \cdot 14$

1643.48

1645.83

1648.17

1650.52

1652.87

$1655.21 \quad 1655.45$

1657.56

1659.91

1660.15

1662.5

$1666.96 \quad 1667.20$

$1669.31 \quad 1669.55$

$1671.67 \quad 1671.90$

$1674.02 \quad 1674.26$

$1676.38 \quad 1676.61$

1678.7

1678.97

$1681.09 \quad 1681.32$

$1683.44 \quad 1683.68$

$1685.80 \quad 1686.04$

$1688.16 \quad 1688.40$

1690.52

$1690 \cdot 76$

$1692.88 \quad 1693.12$

$1695.24 \quad 1695.48$

$1697.60 \quad 1697.84$

$1699.97 \quad 1700.20$

1702.57

$1704.69 \quad 1704.93$

$1707.06 \quad 1707.29$

$1709.42 \quad 1709.66$

$1711.79 \quad 1712.03$

1714.39

$1716.53 \quad 1716.76$

178.901719 .13

$1723.64 \quad 1723.87$

$1726.01 \quad 1726.25$

$\begin{array}{lllll}1727.91 & 1728.14 & 1728.38 & 1728.62\end{array}$

$1597.22 \quad 1595.13 \quad 1595.36$

$1599.55 \quad 1599.79 \quad 1600.02$

$1601.88 \quad 1602.12 \quad 1602.35$

$1604.21 \quad 1604.45 \quad 1604.68$

$1606.55 \quad 1606.78 \quad 1607.01$

$1611.21 \quad 1611.44 \quad 1611.68$

1613.55

$\begin{array}{lll}1618.21 & 1618.45 & 1618.68\end{array}$

1620.551620 .78

1622.89

$1625 \cdot 23$

$1627.80 \quad 1628.03$

$\begin{array}{lll}69.90 & 1630.14 & 1630.37\end{array}$

1634.58

1639.27

1641.61

1643.95

1646.30

$1650.99 \quad 1651.22$

$1653.34 \quad 1653.57$

1655.68

1658.03

1660.38

1662.73

1665.08

67.43

1669.78

1672.14

1674.49

1676.85

1679.20

1681.56

1683.92

1686.27

1688.63

90.99

1693.35

1695.71

1698.08

1700.44

1705.17

1707.53

1709.90

$1712 \cdot 26$

$1714.63 \quad 1712.50$

$1717.00 \quad 1717.24$

1719.37

$1721.74 \quad 1719.61$

$\begin{array}{ll}1724.11 & 1724.35\end{array}$

$1726.48 \quad 1726.72$

$1728.85 \quad 1729.09$ 
TABLE A5.2.2. Type E thermocouples-temperature $\left({ }^{\circ} \mathrm{F}\right)$ as a function of thermoelectric voltage, reference junctions at $32^{\circ} \mathrm{F}$-Continued

$\mathrm{mV}$

.00

.02

.03

.04

.05

.06

.07

.08

.09

.10

$m v$

\begin{tabular}{|c|c|c|c|c|c|c|c|c|c|c|c|c|}
\hline $\begin{array}{l}72.00 \\
72.10 \\
72.20 \\
72.30 \\
72.40\end{array}$ & $\begin{array}{l}1727.91 \\
1730.28 \\
1732.65 \\
1735.03 \\
1737.40\end{array}$ & $\begin{array}{l}1728 \cdot 14 \\
1730.52 \\
1732.89 \\
1735.26 \\
1737.64\end{array}$ & $\begin{array}{l}1728.38 \\
1730.75 \\
1733.13 \\
1735.50 \\
1737.88\end{array}$ & $\begin{array}{l}1728.62 \\
1730.99 \\
1733.37 \\
1735.74 \\
1738.12\end{array}$ & $\begin{array}{l}1728.85 \\
1731.23 \\
1733.60 \\
1735.98 \\
1738.35\end{array}$ & $\begin{array}{l}1729.09 \\
1731.47 \\
1733.84 \\
1736.22 \\
1738.59\end{array}$ & $\begin{array}{l}1729.33 \\
1731.70 \\
1734.08 \\
1736.45 \\
1738.83\end{array}$ & $\begin{array}{l}1729.57 \\
1731.94 \\
1734.31 \\
1736.69 \\
1739.07\end{array}$ & $\begin{array}{l}1729.80 \\
1732.18 \\
1734.55 \\
1736.93 \\
1739.30\end{array}$ & $\begin{array}{l}1730.04 \\
1732.42 \\
1734.79 \\
1737.17 \\
1739.54\end{array}$ & $\begin{array}{l}1730.28 \\
1732.65 \\
1735.03 \\
1737.40 \\
1739.78\end{array}$ & $\begin{array}{l}72.00 \\
72.10 \\
72.20 \\
72.30 \\
72.40\end{array}$ \\
\hline $\begin{array}{l}72.50 \\
72.60 \\
72.70 \\
72.80 \\
72.90\end{array}$ & $\begin{array}{l}1739.78 \\
1742.16 \\
1744.53 \\
1746.91 \\
1749.29\end{array}$ & $\begin{array}{l}1740.02 \\
1742.39 \\
1744.77 \\
1747.15 \\
1749.53\end{array}$ & $\begin{array}{l}1740.25 \\
1742.63 \\
1745.01 \\
1747.39 \\
1749.77\end{array}$ & $\begin{array}{l}1740.49 \\
1742.87 \\
1745.25 \\
1747.63 \\
1750.01\end{array}$ & $\begin{array}{l}1740.73 \\
1743.11 \\
1745.49 \\
1747.86 \\
1750.24\end{array}$ & $\begin{array}{l}1740.97 \\
1743.35 \\
1745.72 \\
1748.10 \\
1750.48\end{array}$ & $\begin{array}{l}1741.21 \\
1743.58 \\
1745.96 \\
1748.34 \\
1750.72\end{array}$ & $\begin{array}{l}1741.44 \\
1743.82 \\
1746.20 \\
1748.58 \\
1750.96\end{array}$ & $\begin{array}{l}1741.68 \\
1744.06 \\
1746.44 \\
1748.82 \\
1751.20\end{array}$ & $\begin{array}{l}1741.92 \\
1744.30 \\
1746.67 \\
1749.05 \\
1751.43\end{array}$ & $\begin{array}{l}1742.16 \\
1744.53 \\
1746.91 \\
1749.29 \\
1751.67\end{array}$ & $\begin{array}{l}72.50 \\
72.60 \\
72.70 \\
72.80 \\
72.90\end{array}$ \\
\hline $\begin{array}{l}73.00 \\
73.10 \\
73.20 \\
73.30 \\
73.40\end{array}$ & $\begin{array}{l}1751.67 \\
1754.05 \\
1756.44 \\
1758.82 \\
1761.20\end{array}$ & $\begin{array}{l}1751.91 \\
1754.29 \\
1756.67 \\
1759.06 \\
1761.44\end{array}$ & $\begin{array}{l}1752.15 \\
1754.53 \\
1756.91 \\
1759.29 \\
1761.68\end{array}$ & $\begin{array}{l}1752.39 \\
1754.77 \\
1757.15 \\
1759.53 \\
1761.92\end{array}$ & $\begin{array}{l}1752.62 \\
1755.01 \\
1757.39 \\
1759.77 \\
1762.15\end{array}$ & $\begin{array}{l}1752.86 \\
1755.24 \\
1757.63 \\
1760.01 \\
1762.39\end{array}$ & $\begin{array}{l}1753.10 \\
1755.48 \\
1757.86 \\
1760.25 \\
1762.63\end{array}$ & $\begin{array}{l}1753.34 \\
1755.72 \\
1758.10 \\
1760.49 \\
1762.87\end{array}$ & $\begin{array}{l}1753.58 \\
1755.96 \\
1758.34 \\
1760.72 \\
1763.11\end{array}$ & $\begin{array}{l}1753.82 \\
1756.20 \\
1758.58 \\
1760.96 \\
1763.35\end{array}$ & $\begin{array}{l}1754.05 \\
1756.44 \\
1758.82 \\
1761.20 \\
1763.59\end{array}$ & $\begin{array}{l}73.00 \\
73.10 \\
73.20 \\
73.30 \\
73.40\end{array}$ \\
\hline $\begin{array}{l}73.50 \\
73.60 \\
73.70 \\
73.80 \\
73.90\end{array}$ & $\begin{array}{l}1763.59 \\
1765.97 \\
1768.36 \\
1770.74 \\
1773.13\end{array}$ & $\begin{array}{l}1763.82 \\
1766.21 \\
1768.59 \\
1770.98 \\
1773.37\end{array}$ & $\begin{array}{l}1764.06 \\
1766.45 \\
1768.83 \\
1771.22 \\
1773.61\end{array}$ & $\begin{array}{l}1764.30 \\
1766.69 \\
1769.07 \\
1771.46 \\
1773.85\end{array}$ & $\begin{array}{l}1764.54 \\
1766.92 \\
1769.31 \\
1771.70 \\
1774.08\end{array}$ & $\begin{array}{l}1764.78 \\
1767.16 \\
1769.55 \\
1771.94 \\
1774.32\end{array}$ & $\begin{array}{l}1765.02 \\
1767.40 \\
1769.79 \\
1772.17 \\
1774.56\end{array}$ & $\begin{array}{l}1765.25 \\
1767.64 \\
1770.03 \\
1772.41 \\
1774.80\end{array}$ & $\begin{array}{l}1765.49 \\
1767.88 \\
1770.27 \\
1772.65 \\
1775.04\end{array}$ & $\begin{array}{l}1765.73 \\
1768.12 \\
1770.50 \\
1772.89 \\
1775.28\end{array}$ & $\begin{array}{l}1765.97 \\
1768.36 \\
1770.74 \\
1773.13 \\
1775.52\end{array}$ & $\begin{array}{l}73.50 \\
73.60 \\
73.70 \\
73.80 \\
73.90\end{array}$ \\
\hline $\begin{array}{l}74 \cdot 00 \\
74 \cdot 10 \\
74 \cdot 20 \\
74.30 \\
74.40\end{array}$ & $\begin{array}{l}1775.52 \\
1777.91 \\
1780.30 \\
1782.69 \\
1785.08\end{array}$ & $\begin{array}{l}1775.76 \\
1778.14 \\
1780.53 \\
1782.92 \\
1785.32\end{array}$ & $\begin{array}{l}1776.00 \\
1778.38 \\
1780.77 \\
1783.16 \\
1785.55\end{array}$ & $\begin{array}{l}1776.23 \\
1778.62 \\
1781.01 \\
1783.40 \\
1785.79\end{array}$ & $\begin{array}{l}1776.47 \\
1778.86 \\
1781.25 \\
1783.64 \\
1786.03\end{array}$ & $\begin{array}{l}1776.71 \\
1779.10 \\
1781.49 \\
1783.88 \\
1786.27\end{array}$ & $\begin{array}{l}1776.95 \\
1779.34 \\
1781.73 \\
1784.12 \\
1786.51\end{array}$ & $\begin{array}{l}1777.19 \\
1779.58 \\
1781.97 \\
1784.36 \\
1786.75\end{array}$ & $\begin{array}{l}1777.43 \\
1779.82 \\
1782.21 \\
1784.60 \\
1786.99\end{array}$ & $\begin{array}{l}1777.67 \\
1780.06 \\
1782.45 \\
1784.84 \\
1787.23\end{array}$ & $\begin{array}{l}1777.91 \\
1780.30 \\
1782.69 \\
1785.08 \\
1787.47\end{array}$ & $\begin{array}{l}74.00 \\
74.10 \\
74.20 \\
74.30 \\
74.40\end{array}$ \\
\hline $\begin{array}{l}74.50 \\
74.60 \\
74.70 \\
74.80 \\
74.90\end{array}$ & $\begin{array}{l}1787.47 \\
1789.86 \\
1792.25 \\
1794.65 \\
1797.04\end{array}$ & $\begin{array}{l}1787.71 \\
1790.10 \\
1792.49 \\
1794.89 \\
1797.28\end{array}$ & $\begin{array}{l}1787.95 \\
1790 \cdot 34 \\
1792 \cdot 73 \\
1795 \cdot 12 \\
1797.52\end{array}$ & $\begin{array}{l}1788.18 \\
1790.58 \\
1792.97 \\
1795.36 \\
1797.76\end{array}$ & $\begin{array}{l}1788.42 \\
1790.82 \\
1793.21 \\
1795.60 \\
1798.00\end{array}$ & $\begin{array}{l}1788.66 \\
1791.06 \\
1793.45 \\
1795.84 \\
1798.24\end{array}$ & $\begin{array}{l}1788.90 \\
1791.30 \\
1793.69 \\
1796.08 \\
1798.48\end{array}$ & $\begin{array}{l}1789.14 \\
1791.53 \\
1793.93 \\
1796.32 \\
1798.72\end{array}$ & $\begin{array}{l}1789.38 \\
1791.77 \\
1794.17 \\
1796.56 \\
1798.96\end{array}$ & $\begin{array}{l}1789.62 \\
1792.01 \\
1794.41 \\
1796.80 \\
1799.19\end{array}$ & $\begin{array}{l}1789.86 \\
1792.25 \\
1794.65 \\
1797.04 \\
1799.43\end{array}$ & $\begin{array}{l}74.50 \\
74.60 \\
74.70 \\
74.80 \\
74.90\end{array}$ \\
\hline $\begin{array}{l}75.00 \\
75.10 \\
75.20 \\
75.30 \\
75.40\end{array}$ & $\begin{array}{l}1799.43 \\
1801.83 \\
1804.23 \\
1806.62 \\
1809.02\end{array}$ & $\begin{array}{l}1799.67 \\
1802.07 \\
1804.47 \\
1806.86 \\
1809.26\end{array}$ & $\begin{array}{l}1799.91 \\
1802.31 \\
1804.71 \\
1807.10 \\
1809.50\end{array}$ & $\begin{array}{l}1800.15 \\
1802.55 \\
1804.94 \\
1807.34 \\
1809.74\end{array}$ & $\begin{array}{l}1800.39 \\
1802.79 \\
1805.18 \\
1807.58 \\
1809.98\end{array}$ & $\begin{array}{l}1800.63 \\
1803.03 \\
1805.42 \\
1807.82 \\
1810.22\end{array}$ & $\begin{array}{l}1800.87 \\
1803.27 \\
1805.66 \\
1808.06 \\
1810.46\end{array}$ & $\begin{array}{l}1801.11 \\
1803.51 \\
1805.90 \\
1808.30 \\
1810.70\end{array}$ & $\begin{array}{l}1801.35 \\
1803.75 \\
1806.14 \\
1808.54 \\
1810.94\end{array}$ & $\begin{array}{l}1801.59 \\
1803.99 \\
1806.38 \\
1808.78 \\
1811.18\end{array}$ & $\begin{array}{l}1801.83 \\
1804.23 \\
1806.62 \\
1809.02 \\
1811.42\end{array}$ & $\begin{array}{l}75.00 \\
75.10 \\
75.20 \\
75.30 \\
75.40\end{array}$ \\
\hline $\begin{array}{l}75.50 \\
75.60 \\
75.70 \\
75.80 \\
75.90\end{array}$ & $\begin{array}{l}1811.42 \\
1813.82 \\
1816.21 \\
1818.61 \\
1821.01\end{array}$ & $\begin{array}{l}1811.66 \\
1814.06 \\
1816.45 \\
1818.85 \\
1821.25\end{array}$ & $\begin{array}{l}1811.90 \\
1814.30 \\
1816.69 \\
1819.09 \\
1821.49\end{array}$ & $\begin{array}{l}1812.14 \\
1814.54 \\
1816.93 \\
1819.33 \\
1821.73\end{array}$ & $\begin{array}{l}1812.38 \\
1814.78 \\
1817.17 \\
1819.57 \\
1821.97\end{array}$ & $\begin{array}{l}1812.62 \\
1815.01 \\
1817.41 \\
1819.81 \\
1822.21\end{array}$ & $\begin{array}{l}1812.86 \\
1815.25 \\
1817.65 \\
1820.05 \\
1822.45\end{array}$ & $\begin{array}{l}1813.10 \\
1815.49 \\
1817.89 \\
1820.29 \\
1822.69\end{array}$ & $\begin{array}{l}1813.34 \\
1815.73 \\
1818.13 \\
1820.53 \\
1822.93\end{array}$ & $\begin{array}{l}1813.58 \\
1815.97 \\
1818.37 \\
1820.77 \\
1823.17\end{array}$ & $\begin{array}{l}1813.82 \\
1816.21 \\
1818.61 \\
1821.01 \\
1823.41\end{array}$ & $\begin{array}{l}75.50 \\
75.60 \\
75.70 \\
75.80 \\
75.90\end{array}$ \\
\hline $\begin{array}{l}76.00 \\
76.10 \\
76.20 \\
76.30\end{array}$ & $\begin{array}{l}1823.41 \\
1825.82 \\
1828.22 \\
1830.62\end{array}$ & $\begin{array}{l}1823.65 \\
1826.06 \\
1828.46 \\
1830.86\end{array}$ & $\begin{array}{l}1823.89 \\
1826.30 \\
1828.70 \\
1831.10\end{array}$ & $\begin{array}{l}1824.13 \\
1826.54 \\
1828.94 \\
1831.34\end{array}$ & $\begin{array}{l}1824.37 \\
1826.78 \\
1829.18 \\
1831.58\end{array}$ & $\begin{array}{l}1824.61 \\
1827.02 \\
1829.42 \\
1831.82\end{array}$ & $\begin{array}{l}1824.85 \\
1827.26 \\
1829.66\end{array}$ & $\begin{array}{l}1825.09 \\
1827.50 \\
1829.90\end{array}$ & $\begin{array}{l}1825.33 \\
1827.74 \\
1830.14\end{array}$ & $\begin{array}{l}1825.58 \\
1827.98 \\
1830.38\end{array}$ & $\begin{array}{l}1825.82 \\
1828.22 \\
1830.62\end{array}$ & $\begin{array}{l}76 \cdot 00 \\
76 \cdot 10 \\
76 \cdot 20 \\
76 \cdot 30\end{array}$ \\
\hline
\end{tabular}

$m V$

.04

.05

.06

.07

.08

.09

$\cdot 10$

mV 
TABLE A5.2.3. Type E thermocouples-quadratic, cubic, and quartic approximations to the data as a function of voltage in selected temperature ranges $\left({ }^{\circ} \mathrm{C}\right)$. The expansion is of the form $\mathrm{T}=\mathrm{a}_{0}+\mathrm{a}_{1} \mathrm{E}+\mathrm{a}_{2} \mathrm{E}^{2}+\mathrm{a}_{3} \mathrm{E}^{3}+\mathrm{a}_{4} \mathrm{E}^{4}$ where $\mathrm{E}$ is in microvolts and $\mathrm{T}$ is in degrees Celsius

\begin{tabular}{|c|c|c|c|c|c|c|c|c|c|c|c|}
\hline $\begin{array}{l}\text { Temperature } \\
\left.\text { Range } 1{ }^{\circ} \mathrm{C}\right) \\
\end{array}$ & \multicolumn{2}{|l|}{ ¿o } & \multicolumn{2}{|l|}{$a_{1}$} & \multicolumn{2}{|l|}{$a_{2}$} & \multicolumn{2}{|l|}{$a_{3}$} & \multicolumn{2}{|l|}{$a_{4}$} & \multirow{2}{*}{$\begin{array}{c}\begin{array}{c}\text { Error } \\
\text { Range }\left({ }^{\circ} \mathrm{C}\right)\end{array} \\
\text { Exact-Approx. }\end{array}$} \\
\hline & Argument & Exp. & Argument & Exp. & Argument & Exp. & Argument & Exp. & Argument & Exp. & \\
\hline I. Quartic Equat & ion & & & & & & & & & & \\
\hline-270 to 0 & $\ldots .$. & . & 2. 8168878 & -3 & -8.5940057 & -6 & -1.4930918 & -9 & -8.7987588 & -14 & -9 to 6 \\
\hline-200 to 0 & $\ldots .$. & . & 1. 5726646 & -2 & -1.2102152 & -6 & -1.9577799 & -10 & -1.669629 .8 & -14 & -.3 to .3 \\
\hline-200 to 800 & .... & . & 1.8432856 & -2 & -3.2311582 & -7 & 6.9795810 & -12 & -5.1106852 & -17 & -8 to 7 \\
\hline-20 to 500 & .... & . & 1.6970287 & -2 & -2.0830603 & -7 & 4.6512717 & -12 & -4.1805785 & -17 & -.18 to .12 \\
\hline 0 to 400 & . . . . & . & 1.7022525 & -2 & -2.2097240 & -7 & 5. 4809314 & -12 & -5.7669892 & -17 & -.05 to .04 \\
\hline 0 to 1000 & . . . . & . & 1.6410783 & -2 & -1.3560189 & -7 & 1. 8600342 & -12 & -8.5537337 & -18 & -.9 to 1.4 \\
\hline 400 to 1000 & 1. 9669452 & +1 & 1.4207735 & -2 & -5.1844510 & -8 & 5.6361365 & -13 & 1.5646343 & -18 & -.03 to .03 \\
\hline 600 to 800 & 2. 5192188 & +1 & 1. 390952.9 & -2 & -4.7201133 & -8 & 5. 5638718 & -13 & -1.7775228 & -18 & -.0005 to .000 \\
\hline 850 to 1000 & -7.1102114 & +2 & 5.6554599 & -2 & -9.7013068 & -7 & 9.3938146 & -12 & -3.3333675 & -17 & -.001 to .001 \\
\hline 11. Cubic Equat & ion & & & & & & & & & & \\
\hline-270 to 0 & $\ldots$ & . & 2. 5551958 & -2 & 2.9621132 & -6 & 3.0768135 & -10 & .... & . & -13 to 8 \\
\hline-200 to 0 & ..... & .. & 1.8633205 & -2 & 4. 8347537 & -7 & 1.0509221 & -10 & . . . . & . & -1.1 to .8 \\
\hline-200 to 800 & $\ldots .$. & . & 1.8188334 & -2 & -2.0345919 & -7 & 1.9991341 & -12 & .... & . & -23 to 11 \\
\hline-20 to 500 & ..... & . & 1. 6588304 & -2 & -1.4544432 & -7 & 1.6926259 & -12 & .... & . & -.8 to .8 \\
\hline $\begin{array}{l}0 \text { to } 400 \\
0 \text { to } 1000\end{array}$ & $\therefore \dot{0}$ & $\therefore$ & $\begin{array}{l}1.6762456 \\
1.5684151\end{array}$ & -2 & -1.6713867 & -7 & 2.2710476 & -12 & $\ldots$. & $\cdots$ & $\begin{array}{l}-.4 \text { to } .4 \\
-3 \text { to } 4\end{array}$ \\
\hline 400 to 1000 & 2. 9347907 & +1 & $\begin{array}{l}\text { 1. } 5684151 \\
1.3385134\end{array}$ & $\begin{array}{l}-2 \\
-2\end{array}$ & & $\begin{array}{l}-8 \\
-8\end{array}$ & 5. 9738218 & -13 & $\cdots \cdot$ & $\cdots$ & $\begin{array}{l}-3 \text { to } 4 \\
-.09 \text { to } .08\end{array}$ \\
\hline 600 to 800 & 3.8917006 & +1 & 1. 2862075 & -2 & $\begin{array}{l}-2.6669218 \\
-1.7338216\end{array}$ & $\begin{array}{l}-8 \\
-8\end{array}$ & $\begin{array}{l}2.3388779 \\
1.7943524\end{array}$ & $\begin{array}{l}-13 \\
-13\end{array}$ & $\begin{array}{l}\cdots \\
\because \\
.\end{array}$ & $\therefore$ & -.001 to .001 \\
\hline 850 to 1000 & 1.1236815 & +2 & 9.7592314 & -3 & 2.6085395 & -8 & -2.1667359 & -14 & $\cdots$ & $\therefore$ & -.005 to .007 \\
\hline 111. Quadratic E & quation & & & & & & & & & & \\
\hline-270 to 0 & $\ldots .$. & . . & 1.0619851 & -2 & -1.4972165 & -6 & $\ldots$ & - • & $\ldots$ & . & -21 to 11 \\
\hline-200 to 0 & ..... & . & 1. 4752564 & -2 & -8.4746756 & -7 & . . . . & . & ..... & . & -3.9 to 2.3 \\
\hline-200 to 800 & . . . . & .. & 1. 5595433 & -2 & -4.5934669 & -8 & ..... & . . & ..... & . & -60 to 20 \\
\hline-20 to 500 & ..... & . & 1. 5607502 & -2 & -5.9146206 & -8 & .... & . & . . . & $\cdots$ & -3 to 4 \\
\hline 0 to 400 & . . . . & .. & 1. 5957698 & -2 & -7.6656343 & -8 & ..... & . & $\therefore$ & $\therefore$ & -2 to 3 \\
\hline D to 1000 & $\ldots \ldots$ & . . & 1. 4197624 & -2 & -1.6340830 & -8 & . . . & . & . . . . & $\cdot$ & -8 to 13 \\
\hline 400 to 1000 & 5. 8687427 & +1 & 1. 1530864 & -2 & 1.0276533 & -8 & . . . & . & ..... & $\cdot$ & -1.1 to 1.0 \\
\hline 600 to 800 & 6. 5319054 & +1 & 1. 1353750 & -2 & 1.1231637 & -8 & . . . . & . & . . . . & $\cdot$ & -.03 to .03 \\
\hline 850 to 1000 & 1.0476041 & +2 & 1.0083242 & -2 & 2.1492620 & -8 & . . . & . & . . . & . & -.005 to .007 \\
\hline
\end{tabular}




\section{A6. Supplementary Data for Type J-Iron Versus Copper-Nickel Alloy (SAMA) Thermocouples}

\section{A6.1. Data for Voltage as a Function of Temperature}

The full precision coefficients given in the main text are used to generate the voltage as a function of temperature data given in tables A6.1.1 and A6.1.2. Table A6.1.1 presents the data in degrees Celsius from $-210{ }^{\circ} \mathrm{C}$ to $1200{ }^{\circ} \mathrm{C}$ while table A6.1.2 presents the data in degrees Fahrenheit from $-350{ }^{\circ} \mathrm{F}$ to $2192{ }^{\circ} \mathrm{F}$. As discussed in section 6.2 of the text, the values given for Type $\mathrm{J}$ thermocouples above $760{ }^{\circ} \mathrm{C}\left(1400^{\circ} \mathrm{F}\right)$ are not suitable for precise temperature measurements. Table A6.1.3 contains quadratic, cubic, and quartic approximations to the data as a function of temperature in selected temperature ranges. The error range given in the table is the difference between the voltage as obtained from the full precision coefficients from the text and the respective reduced order approximations. The last entries in the cubic and quadratic groupings of table A6.1.3 represent variable reference junction corrections in the 0 to $50{ }^{\circ} \mathrm{C}$ temperature range. In the narrower temperature range near room tem. peratures, 20 to $25{ }^{\circ} \mathrm{C}$, the error range for the given quadratic equation is smaller than that listed in the last column: $\pm 0.2 \mu \mathrm{V}$.

TABLE A6.1.1. Type J thermocouples-thermoelectric voltage as a function of temperature $\left({ }^{\circ} \mathrm{C}\right)$, reference junctions at $0^{\circ} \mathrm{C}$

\begin{tabular}{|c|c|c|c|c|c|c|c|c|c|c|c|c|}
\hline${ }^{\circ} \mathrm{C}$ & 0 & 1 & 2 & 3 & 4 & 5 & 6 & 7 & 8 & 9 & 10 & \\
\hline & & & THE & ELECT & VOLTA & IN A & LUTE M & LL I VOL & & & & \\
\hline & $\begin{array}{l}-8.096 \\
-7.890\end{array}$ & 7.912 & 7.934 & -7.955 & -7.976 & -7.996 & -8.017 & -8.037 & -8.057 & -8.076 & -8.096 & $\begin{array}{l}-210 \\
-200\end{array}$ \\
\hline $\begin{array}{l}190 \\
180 \\
170 \\
160 \\
150\end{array}$ & $\begin{array}{l}-7.659 \\
-7.402 \\
-7.122 \\
-6.821 \\
-6.499\end{array}$ & $\begin{array}{l}-7.683 \\
-7.429 \\
-7.151 \\
-6.852 \\
-6.532\end{array}$ & $\begin{array}{l}-7.707 \\
-7.455 \\
-7.180 \\
-6.883 \\
-6.565\end{array}$ & $\begin{array}{l}-7.731 \\
-7.482 \\
-7.209 \\
-6.914 \\
-6.598\end{array}$ & $\begin{array}{l}-7.755 \\
-7.508 \\
-7.237 \\
-6.944 \\
-6.630\end{array}$ & $\begin{array}{l}-7.778 \\
-7.533 \\
-7.265 \\
-6.974 \\
-6.663\end{array}$ & $\begin{array}{l}-7.801 \\
-7.559 \\
-7.293 \\
-7.004 \\
-6.695\end{array}$ & $\begin{array}{l}-7.824 \\
-7.584 \\
-7.321 \\
-7.034 \\
-6.727\end{array}$ & $\begin{array}{l}-7.846 \\
-7.609 \\
-7.348 \\
-7.064 \\
-6.758\end{array}$ & $\begin{array}{l}-7.868 \\
-7.634 \\
-7.375 \\
-7.093 \\
-6.790\end{array}$ & $\begin{array}{l}-7.890 \\
-7.659 \\
-7.402 \\
-7.122 \\
-6.821\end{array}$ & $\begin{array}{l}-190 \\
-180 \\
-170 \\
-160 \\
-150\end{array}$ \\
\hline $\begin{array}{l}40 \\
.30 \\
20 \\
10 \\
.00\end{array}$ & $\begin{array}{l}-6.159 \\
-5.801 \\
-5.426 \\
-5.036 \\
-4.632\end{array}$ & $\begin{array}{l}-6.194 \\
-5.837 \\
-5.464 \\
-5.076 \\
-4.673\end{array}$ & $\begin{array}{l}6.228 \\
5.874 \\
5.502 \\
5.115\end{array}$ & $\begin{array}{l}-6.263 \\
-5.910 \\
-5.540 \\
-5.155 \\
-4.755\end{array}$ & $\begin{array}{l}-6.297 \\
-5.946 \\
-5.578 \\
-5.194 \\
-4.795\end{array}$ & $\begin{array}{l}-6.331 \\
-5.982 \\
-5.615 \\
-5.233 \\
-4.836\end{array}$ & $\begin{array}{l}-6.365 \\
-6.018 \\
-5.653 \\
-5.272 \\
-4.876\end{array}$ & $\begin{array}{l}-6.399 \\
-6.053 \\
-5.690 \\
-5.311 \\
-4.916\end{array}$ & $\begin{array}{l}-6.433 \\
-6.089 \\
-5.727 \\
-5.349 \\
-4.956\end{array}$ & $\begin{array}{l}-6.466 \\
-6.124 \\
-5.764 \\
-5.388 \\
-4.996\end{array}$ & $\begin{array}{l}-6.499 \\
-6.159 \\
-5.801 \\
-5.426 \\
-5.036\end{array}$ & $\begin{array}{l}-140 \\
-130 \\
-120 \\
-110\end{array}$ \\
\hline $\begin{array}{l}-90 \\
-80 \\
-70 \\
-60 \\
-50\end{array}$ & $\begin{array}{l}-4.215 \\
-3.785 \\
-3.344 \\
-2.892 \\
-2.431\end{array}$ & $\begin{array}{l}-4.257 \\
-3.829 \\
-3.389 \\
-2.938 \\
-2.478\end{array}$ & $\begin{array}{l}-4.299 \\
-3.872 \\
-3.433 \\
-2.984 \\
-2.524\end{array}$ & $\begin{array}{l}-4.341 \\
-3.915 \\
-3.478 \\
-3.029 \\
-2.570\end{array}$ & $\begin{array}{l}-4.383 \\
-3.958 \\
-3.522 \\
-3.074 \\
-2.617\end{array}$ & $\begin{array}{l}-4.425 \\
-4.001 \\
-3.566 \\
-3.120 \\
-2.663\end{array}$ & $\begin{array}{l}-4.467 \\
-4.044 \\
-3.610 \\
-3.165 \\
-2.709\end{array}$ & $\begin{array}{l}-4.508 \\
-4.087 \\
-3.654 \\
-3.210 \\
-2.755\end{array}$ & $\begin{array}{l}-4.550 \\
-4.130 \\
-3.698 \\
-3.255 \\
-2.801\end{array}$ & $\begin{array}{l}-4.591 \\
-4.172 \\
-3.742 \\
-3.299 \\
-2.847\end{array}$ & $\begin{array}{l}-4.632 \\
-4.215 \\
-3.785 \\
-3.344 \\
-2.892\end{array}$ & $\begin{array}{l}-90 \\
-80 \\
-70 \\
-60 \\
-50\end{array}$ \\
\hline $\begin{array}{l}-40 \\
-30 \\
-20 \\
-10 \\
-\quad 0\end{array}$ & $\begin{array}{r}-1.960 \\
-1.481 \\
-0.995 \\
-0.501 \\
0.000\end{array}$ & $\begin{array}{l}-2.008 \\
-1.530 \\
-1.044 \\
-0.550 \\
-0.050\end{array}$ & $\begin{array}{l}-2.055 \\
-1.578 \\
-1.093 \\
-0.600 \\
-0.101\end{array}$ & $\begin{array}{l}-2.102 \\
-1.626 \\
-1.141 \\
-0.650 \\
-0.151\end{array}$ & $\begin{array}{l}-2.150 \\
-1.674 \\
-1.190 \\
-0.699 \\
-0.201\end{array}$ & $\begin{array}{l}-2.197 \\
-1.722 \\
-1.239 \\
-0.748 \\
-0.251\end{array}$ & $\begin{array}{l}-2.244 \\
-1.770 \\
-1.288 \\
-0.798 \\
-0.301\end{array}$ & $\begin{array}{l}-2.291 \\
-1.818 \\
-1.336 \\
-0.847 \\
-0.351\end{array}$ & $\begin{array}{l}-2.338 \\
-1.865 \\
-1.385 \\
-0.896 \\
-0.401\end{array}$ & $\begin{array}{l}-2.384 \\
-1.913 \\
-1.433 \\
-0.945 \\
-0.451\end{array}$ & $\begin{array}{l}-2.431 \\
-1.960 \\
-1.481 \\
-0.995 \\
-0.501\end{array}$ & $\begin{array}{l}-3 \\
-2\end{array}$ \\
\hline${ }^{\circ} \mathrm{C}$ & 0 & 1 & 2 & 3 & 4 & 5 & 6 & 7 & 8 & 9 & 10 & \\
\hline
\end{tabular}


TABLE A6.1.1. Type J thermocouples-thermoelectric voltage as a function of temperature $\left({ }^{\circ} \mathrm{C}\right)$, reference junctions at $0^{\circ} \mathrm{C}$-Continued

5

6

8

9

10

THERMOELECTRIC VOLTAGE IN ABSOLUTE MILLIVOLTS

\begin{tabular}{|c|c|c|c|c|c|c|c|c|c|c|}
\hline 0.000 & 0.050 & 0.101 & 0.151 & 0.202 & 0.253 & 0.303 & 0.354 & 0.405 & 0.456 & 0.507 \\
\hline 507 & 0.558 & 0.609 & 0.660 & 0.711 & 0.762 & 0.813 & 0.865 & 0.916 & 0.967 & 1.019 \\
\hline 1.019 & 1.070 & 1.122 & 1.174 & 1.225 & 1.277 & 1.329 & 1.381 & 1.432 & 1.484 & 1.536 \\
\hline 1.536 & 1.588 & 1.640 & 1.693 & 1.745 & 1.797 & 1.849 & 1.901 & 1.954 & 2.006 & 2.058 \\
\hline 2.058 & 2.111 & 2.163 & 2.216 & 2.268 & 2.321 & 2.374 & 2.426 & 2.479 & 2.532 & 2.585 \\
\hline 2.585 & 2.638 & 2.691 & 2.743 & 2.796 & 2.849 & 2.902 & 2.956 & 3.009 & 3.062 & 3.115 \\
\hline 3.115 & 3.168 & 3.221 & 3.275 & 3.328 & 3.381 & 3.435 & 3.488 & 3.542 & 3.595 & 3.649 \\
\hline 3.649 & 3.702 & 3.756 & 3.809 & 3.863 & 3.917 & 3.971 & 4.024 & 4.078 & 4.132 & $4 \cdot 186$ \\
\hline 4.186 & 4.239 & 4.293 & $4 \cdot 347$ & 4.401 & 4.455 & 4.509 & 4.563 & 4.617 & 4.671 & 4.725 \\
\hline 4.725 & 4.780 & 4.834 & $4 \cdot 888$ & $4 \cdot 942$ & 4.996 & 5.050 & 5.105 & 5.159 & 5.213 & 5.268 \\
\hline 5.268 & 5.322 & 5.376 & 5.431 & 5.485 & 5.540 & 5.594 & 5.649 & 5.703 & 5.758 & 5.812 \\
\hline 5.812 & 5.867 & 5.921 & 5.976 & 6.031 & 6.085 & 6.140 & 6.195 & 6.249 & 6.304 & 6.359 \\
\hline 6.359 & 6.414 & 6.468 & 6.523 & 6.578 & 6.633 & 6.688 & 6.742 & 6.797 & 6.852 & 6.907 \\
\hline 6.907 & 6.962 & 7.017 & 7.072 & 7.127 & 7.182 & 7.237 & 7.292 & 7.347 & 7.402 & 7.457 \\
\hline 7.457 & 7.512 & 7.567 & 7.622 & 7.677 & 7.732 & 7.787 & 7.843 & 7.898 & 7.953 & 8.008 \\
\hline 8.008 & 8.063 & 8.118 & 8.174 & 8.229 & 8.284 & 8.339 & 8.394 & 8.450 & 8.505 & 8.560 \\
\hline 8.560 & 8.616 & 8.671 & 8.726 & 8.781 & 8.837 & 8.892 & 8.947 & 9.003 & 9.058 & 9.113 \\
\hline 9.113 & 9.169 & 9.224 & 9.279 & 9.335 & 9.390 & 9.446 & 9.501 & 9.556 & 9.612 & 9.667 \\
\hline 9.667 & 9.723 & 9.778 & 9.834 & 9.889 & 9.944 & 10.000 & 10.055 & 10.111 & $10 \cdot 166$ & 10.222 \\
\hline 10.222 & 10.277 & 10.333 & 10.388 & 10.444 & 10.499 & 10.555 & 10.610 & 10.666 & 10.721 & 10.777 \\
\hline 0.777 & 10.832 & $10 \cdot 888$ & 10.943 & 10.999 & 1.054 & 11.110 & 11.165 & 11.221 & 11.276 & 11.332 \\
\hline 11.332 & 11.387 & 11.443 & 11.498 & 11.554 & 1.609 & 665 & 11.720 & 176 & 11.831 & 11 \\
\hline 11.887 & 11.943 & 11.998 & 2.054 & 12.109 & .165 & 12.220 & $12 \cdot 276$ & 12.331 & 12.387 & $12 \cdot 442$ \\
\hline 12.442 & 12.498 & 12.553 & 12.609 & 12.664 & 12.720 & 12.776 & 12.831 & 12.887 & 12.942 & 12.998 \\
\hline 12.998 & 13.053 & 13.109 & $13 \cdot 164$ & 13.220 & 13.275 & 13.331 & 13.386 & 13.442 & 13.497 & 13.553 \\
\hline 13.553 & .608 & 13.664 & 13.719 & 13.775 & 3.830 & 13.886 & 13.941 & 13.997 & 14.052 & 14.108 \\
\hline 14.108 & 4.163 & 14.219 & 14.274 & 14.330 & 14.385 & 14.441 & 14.496 & 14.552 & 14.607 & 14.663 \\
\hline 14.663 & 14.718 & 14.774 & 14.829 & 14.885 & 14.940 & 14.995 & 15.051 & 15.106 & 15.162 & 15.217 \\
\hline 15.217 & 15.273 & 15.328 & 15.383 & 15.439 & 15.494 & 15.550 & 15.605 & 15.661 & 15.716 & 15.771 \\
\hline 15.771 & 15.827 & 15.882 & 15.938 & 15.993 & 16.048 & 16.104 & 16.159 & $16 \cdot 214$ & 16.270 & $16 \cdot 325$ \\
\hline 16.325 & 6.380 & 16.436 & 16.491 & 16.547 & 02 & 57 & & 68 & 16 & 79 \\
\hline & 34 & 16 & 17.044 & 17 & & & & & & \\
\hline 17.432 & 17.487 & 17.542 & 17.597 & 17.653 & 17.708 & 17.763 & 318 & 17.874 & 17.929 & 17.984 \\
\hline 17.984 & 18.039 & 18.095 & $18 \cdot 150$ & 18.205 & $18 \cdot 260$ & 16 & & 18. & 18.481 & \\
\hline 18.537 & 18.592 & 18.647 & 18.702 & 18.757 & 313 & 18.868 & 18.923 & 18.978 & 19.033 & 19.089 \\
\hline 19. & 4 & 9 & 54 & 1 & 4 & & & & & \\
\hline+0 & 5 & 19. & 306 & 19 & 16 & 71 & 6 & 81 & 20 & 192 \\
\hline 92 & 7 & $20 \cdot 3$ & 20.357 & 20. & 7 & & 20 & & 20 & \\
\hline 20.743 & 20.798 & 20.853 & 20.909 & 20.964 & 21.019 & 21.074 & 21.129 & 21 & 21.239 & 21.295 \\
\hline 1.295 & 21.350 & 21.405 & 21.460 & 21.515 & 21.570 & 21.625 & $\cdot 21.680$ & 21.736 & 21.791 & 21.846 \\
\hline 2 & 01 & 6 & 11 & 22 & 5 & & & & 22 & \\
\hline & 53 & 22 . & 22. & 22 & 22 & & & & & \\
\hline 22.949 & 23.004 & 23.060 & 23.115 & 23.170 & 23. & 23 & 23 & 23.391 & 23.446 & 23.501 \\
\hline 23.501 & 23.556 & 23.612 & 23.667 & 23.722 & 23.777 & 23.833 & 23. & 23.943 & 23.999 & 24.054 \\
\hline 24.054 & 24.109 & 24.164 & $24 \cdot 220$ & 24.275 & 4.330 & 24.386 & 24.441 & 24.496 & 24.552 & 24.607 \\
\hline 07 & 2 & & & & & & & & & \\
\hline & & 2 & & 2 & & & & & & \\
\hline & 2 & 25. & 25 & 25 & & & 26 & & 26 & 272 \\
\hline 72 & 2 & 26.383 & 26 & 26 & & 26 & & & 774 & 829 \\
\hline 26.829 & 26.885 & 26.941 & 26.997 & 27.053 & 27.109 & 27.165 & 27.220 & 27.276 & 27.332 & 27.388 \\
\hline 8 & & 2 & & & & & & & & \\
\hline & & & & & & & & & & \\
\hline 28. & & & & & & & & & 19 & \\
\hline 29.075 & 29.1 & 29.188 & 29. & 29.301 & 29. & 29 & & 29 & & \\
\hline 9.642 & & 29.755 & 29.812 & 29.869 & • 926 & & & 30.096 & 30.153 & \\
\hline 0 & & 30 & 30 & & & & & & & \\
\hline & & & & & & & & & & \\
\hline & & 31. & 31. & 31.586 & & 31. & 31 & 31.817 & 31.875 & 31.933 \\
\hline 33 & & 32.048 & 32.106 & & & $\begin{array}{l}80 \\
62\end{array}$ & & & 32.455 & 32.513 \\
\hline & & & & & 804 & & & & 33.038 & 33.096 \\
\hline 33.096 & 33.155 & 33.213 & 33.272 & 33.330 & 33.389 & 33.448 & 33.506 & 33.565 & 33.624 & 33.683 \\
\hline
\end{tabular}

${ }^{\circ} \mathrm{C}$

0

1

2

3

5

6

7

8

9

10

${ }^{\circ} \mathrm{C}$ 
TABLE A6.1.1. Type J thermocouples-thermoelectric voltage as a function of temperature $\left({ }^{\circ} \mathrm{C}\right)$, reference junctions at $0^{\circ} \mathrm{C}$-Continued

\begin{tabular}{|c|c|c|c|c|c|c|c|c|c|c|c|c|}
\hline \multirow[t]{2}{*}{${ }^{\circ} \mathrm{C}$} & 0 & 1 & 2 & 3 & 4 & 5 & 6 & 7 & 8 & 9 & 10 & ${ }^{\circ} \mathrm{C}$ \\
\hline & \multicolumn{12}{|c|}{ THERMOELECTRIC VOLTAGE IN ABSOLUTE MILLIVOLTS } \\
\hline $\begin{array}{l}600 \\
610\end{array}$ & $\begin{array}{l}33.096 \\
33.683\end{array}$ & $\begin{array}{l}33.155 \\
33.742\end{array}$ & $\begin{array}{l}33.213 \\
33.800\end{array}$ & $\begin{array}{l}33.272 \\
33.859\end{array}$ & $\begin{array}{l}33.330 \\
33.918\end{array}$ & $\begin{array}{l}33.389 \\
33.977\end{array}$ & $\begin{array}{l}33.448 \\
34.036\end{array}$ & $\begin{array}{l}33.506 \\
34.095\end{array}$ & $\begin{array}{l}33.565 \\
34.155\end{array}$ & $\begin{array}{l}33.624 \\
34.214\end{array}$ & $\begin{array}{l}33.683 \\
34.273\end{array}$ & $\begin{array}{l}600 \\
610\end{array}$ \\
\hline 620 & 34.273 & 34.332 & 34.391 & 34.451 & 34.510 & 34.569 & 34.629 & 34.688 & 34.748 & 34.807 & 34.867 & 620 \\
\hline $\begin{array}{l}630 \\
640\end{array}$ & $\begin{array}{l}34.867 \\
35.464\end{array}$ & $\begin{array}{l}34.926 \\
35.524\end{array}$ & $\begin{array}{l}34.986 \\
35.584\end{array}$ & $\begin{array}{l}35.046 \\
35.644\end{array}$ & $\begin{array}{l}35.105 \\
35.704\end{array}$ & $\begin{array}{l}35.165 \\
35.764\end{array}$ & $\begin{array}{l}35.225 \\
35.825\end{array}$ & $\begin{array}{l}35.285 \\
35.885\end{array}$ & $\begin{array}{l}35.344 \\
35.945\end{array}$ & $\begin{array}{l}35.404 \\
36.005\end{array}$ & $\begin{array}{l}35.464 \\
36.066\end{array}$ & $\begin{array}{l}630 \\
640\end{array}$ \\
\hline $\begin{array}{l}650 \\
660\end{array}$ & $\begin{array}{l}36.066 \\
36.671\end{array}$ & $\begin{array}{l}36 \cdot 126 \\
36 \cdot 732\end{array}$ & $\begin{array}{l}36.186 \\
36.792\end{array}$ & $\begin{array}{l}36.247 \\
36.853\end{array}$ & $\begin{array}{l}36.307 \\
36.914\end{array}$ & $\begin{array}{l}36.368 \\
36.975\end{array}$ & $\begin{array}{l}36.428 \\
37.036\end{array}$ & $\begin{array}{l}36.489 \\
37.097\end{array}$ & $\begin{array}{l}36.549 \\
37.158\end{array}$ & $\begin{array}{l}36.610 \\
37.219\end{array}$ & $\begin{array}{l}36.671 \\
37.280\end{array}$ & $\begin{array}{l}650 \\
660\end{array}$ \\
\hline 70 & 37.280 & 37.341 & 37.402 & 37.463 & 37.525 & 37.586 & 37.647 & 37.709 & 37.770 & 37.831 & 37.893 & 670 \\
\hline $\begin{array}{l}680 \\
690\end{array}$ & $\begin{array}{l}37.893 \\
38.510\end{array}$ & $\begin{array}{l}37.954 \\
38.572\end{array}$ & $\begin{array}{l}38.016 \\
38.633\end{array}$ & $\begin{array}{l}38.078 \\
38.695\end{array}$ & $\begin{array}{l}38.139 \\
38.757\end{array}$ & $\begin{array}{l}38.201 \\
38.819\end{array}$ & $\begin{array}{l}38.262 \\
38.882\end{array}$ & $\begin{array}{l}38.324 \\
38.944\end{array}$ & $\begin{array}{l}38.386 \\
39.006\end{array}$ & $\begin{array}{l}38.448 \\
39.068\end{array}$ & $\begin{array}{l}38.510 \\
39.130\end{array}$ & $\begin{array}{l}680 \\
690\end{array}$ \\
\hline $\begin{array}{l}700 \\
710\end{array}$ & $\begin{array}{l}39.130 \\
39.754\end{array}$ & $\begin{array}{l}39.192 \\
39.817\end{array}$ & $\begin{array}{l}39.255 \\
39.880\end{array}$ & $\begin{array}{l}39.317 \\
39.942\end{array}$ & $\begin{array}{l}39.379 \\
40.005\end{array}$ & $\begin{array}{l}39.442 \\
40.068\end{array}$ & $\begin{array}{l}39.504 \\
40.131\end{array}$ & $\begin{array}{l}39.567 \\
40.193\end{array}$ & $\begin{array}{l}39.629 \\
40.256\end{array}$ & $\begin{array}{l}39.692 \\
40.319\end{array}$ & $\begin{array}{l}39 \cdot 754 \\
40 \cdot 382\end{array}$ & $\begin{array}{l}700 \\
710\end{array}$ \\
\hline 720 & 40.382 & 40.445 & 40.508 & 40.571 & 40.634 & 40.697 & 40.760 & 40.823 & 40.886 & 40.950 & 41.013 & 720 \\
\hline 730 & 41.013 & 41.076 & $41 \cdot 139$ & 41.203 & $41 \cdot 266$ & 41.329 & 41.393 & 41.456 & $41 \cdot 520$ & 41.583 & 41.647 & 730 \\
\hline & 42.283 & 2,347 & 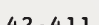 & 42 & a & & & & & & & \\
\hline 760 & 42.922 & (3) & 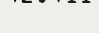 & 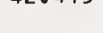 & - 2030 & -720002 & 42.000 & 420100 & $42018 \pi$ & 426000 & 720.022 & 76 \\
\hline
\end{tabular}


TABLE A6.1.1. Type J thermocouples extended range-thermoelectric voltage as a function of temperature $\left({ }^{\circ} \mathrm{C}\right)$, reference junctions at $0^{\circ} \mathrm{C}$

${ }^{\circ} \mathrm{C}$

0

1

2
3

4

5

6

7

8

9

10

${ }^{\circ} \mathrm{C}$

THERMOELECTRIC VOLTAGE IN ABSOLUTE MILLIVOLTS

\begin{tabular}{|c|c|c|c|c|c|c|c|c|c|c|c|c|}
\hline $\begin{array}{l}760 \\
770\end{array}$ & $\begin{array}{l}42.922 \\
43.563\end{array}$ & $\begin{array}{l}42.986 \\
43.627\end{array}$ & $\begin{array}{l}43.050 \\
43.692\end{array}$ & $\begin{array}{l}43.114 \\
43.756\end{array}$ & $\begin{array}{l}43.178 \\
43.820\end{array}$ & $\begin{array}{l}43.242 \\
43.885\end{array}$ & $\begin{array}{l}43.306 \\
43.949\end{array}$ & $\begin{array}{l}43.370 \\
44.014\end{array}$ & $\begin{array}{l}43.435 \\
44.078\end{array}$ & $\begin{array}{l}43.499 \\
44.142\end{array}$ & $\begin{array}{l}43.563 \\
44.207\end{array}$ & $\begin{array}{l}760 \\
770\end{array}$ \\
\hline 780 & 44.207 & 44.271 & $44 \cdot 336$ & 44.400 & 44.465 & 44.529 & 44.594 & 44.658 & 44.723 & 44.788 & 44.852 & 780 \\
\hline 790 & 44.852 & $44 \cdot 917$ & $44 \cdot 981$ & 45.046 & 45.111 & 45.175 & 45.240 & 45.304 & $45 \cdot 369$ & 45.434 & 45.498 & 790 \\
\hline 800 & 45.498 & 45.563 & 45.627 & 45.692 & 45.757 & 45.821 & 45.886 & 45.950 & 46.015 & 46.080 & 46.144 & 800 \\
\hline 810 & 46.144 & 46.209 & 46.273 & $46 \cdot 338$ & 46.403 & 46.467 & 46.532 & 46.596 & 46.661 & 46.725 & 46.790 & 810 \\
\hline 820 & 46.790 & 46.854 & 46.919 & 46.983 & 47.047 & 47.112 & 47.176 & 47.241 & 47.305 & 47.369 & 47.434 & 820 \\
\hline 830 & 47.434 & 47.498 & 47.562 & 47.627 & 47.691 & 47.755 & 47.819 & 47.884 & 47.948 & 48.012 & 48.076 & 830 \\
\hline 840 & 48.076 & 48.140 & 48.204 & 48.269 & 48.333 & 48.397 & 48.461 & 48.525 & 48.589 & 48.653 & 48.716 & 840 \\
\hline 850 & 48.716 & 48.780 & 48.844 & 48.908 & 48.972 & 49.036 & 49.099 & 49.163 & $49 \cdot 227$ & 49.291 & $49 \cdot 354$ & 850 \\
\hline 860 & 49.354 & 49.418 & 49.481 & 49.545 & 49.608 & 49.672 & 49.735 & 49.799 & 49.862 & 49.926 & 49.989 & 860 \\
\hline 870 & 49.989 & 50.052 & 50.116 & 50.179 & 50.242 & 50.305 & 50.369 & 50.432 & 50.495 & 50.558 & 50.621 & 870 \\
\hline 880 & 50.621 & 50.684 & 50.747 & 50.810 & 50.873 & 50.936 & 50.998 & 51.061 & $51 \cdot 124$ & 51.187 & 51.249 & 880 \\
\hline 890 & 51.249 & $51 \cdot 312$ & 51.375 & 51.437 & 51.500 & 51.562 & 51.625 & 51.687 & 51.750 & 51.812 & 51.875 & 890 \\
\hline 900 & 51.875 & 51.937 & 51.999 & 52.061 & 52.124 & 52.186 & 52.248 & 52.310 & 52.372 & 52.434 & 52.496 & 900 \\
\hline 910 & 52.496 & 52.558 & 52.620 & 52.682 & 52.744 & 52.806 & 52.868 & 52.929 & 52.991 & 53.053 & 53.115 & 910 \\
\hline 920 & 53.115 & 53.176 & 53.238 & 53.299 & 53.361 & 53.422 & 53.484 & 53.545 & 53.607 & 53.668 & 53.729 & 920 \\
\hline 930 & 53.729 & 53.791 & 53.852 & 53.913 & 53.974 & 54.035 & 54.096 & 54.157 & 54.219 & 54.280 & 54.341 & 930 \\
\hline 940 & 54.341 & 54.401 & 54.462 & 54.523 & 54.584 & $54 \cdot 645$ & 54.706 & 54.766 & 54.827 & 54.888 & $54 \cdot 948$ & 940 \\
\hline 950 & 54.948 & 55.009 & 55.070 & 55.130 & 55.191 & 55.251 & 55.312 & 55.372 & 55.432 & 55.493 & 55.553 & 950 \\
\hline 960 & 55.553 & 55.613 & 55.674 & 55.734 & 55.794 & 55.854 & 55.914 & 55.974 & 56.035 & 56.095 & 56.155 & 960 \\
\hline 970 & 56.155 & 56.215 & 56.275 & 56.334 & 56.394 & 56.454 & 56.514 & 56.574 & 56.634 & 56.693 & 56.753 & 970 \\
\hline 980 & 56.753 & 56.813 & 56.873 & 56.932 & 56.992 & 57.051 & 57.111 & 57.170 & 57.230 & 57.289 & 57.349 & 980 \\
\hline 990 & 57.349 & 57.408 & 57.468 & 57.527 & 57.586 & 57.646 & 57.705 & 57.764 & 57.824 & 57.883 & 57.942 & 990 \\
\hline $\begin{array}{l}1,000 \\
1,010\end{array}$ & 57.942 & 58.001 & $\begin{array}{l}58.060 \\
58.651\end{array}$ & $\begin{array}{l}58.120 \\
58.710\end{array}$ & 58.179 & $\begin{array}{l}58.238 \\
58.827\end{array}$ & 58.297 & $\begin{array}{l}58.356 \\
58.945\end{array}$ & 58.415 & 58.474 & 58.533 & 1,000 \\
\hline 1,020 & $\begin{array}{l}58.533 \\
59.121\end{array}$ & 59.180 & $\begin{array}{l}58.031 \\
59.239\end{array}$ & 59.298 & 59.356 & 59.415 & 59.474 & 59.532 & $\begin{array}{l}59 \cdot 004 \\
59 \cdot 591\end{array}$ & 59.650 & 59.708 & 1,020 \\
\hline 1.030 & 59.708 & 59.767 & 59.825 & 59.884 & 59.942 & 60.001 & 60.059 & 60.118 & 60.176 & 60.235 & 60.293 & 1,030 \\
\hline 1,040 & 60.293 & 60.351 & 60.410 & 60.468 & 60.527 & 60.585 & 60.643 & 60.702 & 60.760 & 60.818 & 60.876 & 1,040 \\
\hline 1.050 & 60.876 & 60.935 & 60.993 & 61.051 & 61.109 & 61.168 & 61.226 & 61.284 & $61 \cdot 342$ & 61.400 & 61.459 & 1,050 \\
\hline 1,060 & 61.459 & 61.517 & 61.575 & 61.633 & 61.691 & 61.749 & 61.807 & 61.865 & 61.923 & 61.981 & 62.039 & 1.060 \\
\hline 1,070 & 62.039 & 62.097 & 62.156 & 62.214 & 62.272 & 62.330 & 62.388 & 62.446 & 62.504 & 62.562 & 62.619 & 1,070 \\
\hline 1,080 & 62.619 & 62.677 & 62.735 & 62.793 & 62.851 & 62.909 & 62.967 & 63.025 & 63.083 & 63.141 & 63.199 & 1,080 \\
\hline 1,090 & 63.199 & 63.257 & 63.314 & 63.372 & 63.430 & 63.488 & 63.546 & 63.604 & 63.662 & 63.719 & 63.777 & 1,090 \\
\hline 1,100 & 63.777 & 63.835 & 63.893 & 63.951 & 64.009 & 64.066 & 64.124 & $64 \cdot 182$ & 64.240 & 64.298 & 64.355 & 1,100 \\
\hline 1,110 & 64.355 & 64.413 & 64.471 & 64.529 & 64.586 & 64.644 & 64.702 & 64.760 & 64.817 & 64.875 & 64.933 & 1,110 \\
\hline 1,120 & 64.933 & 64.991 & 65.048 & 65.106 & 65.164 & 65.222 & 65.279 & 65.337 & 65.395 & 65.453 & 65.510 & 1,120 \\
\hline 1,130 & 65.510 & 65.568 & 65.626 & 65.683 & 65.741 & 65.799 & 65.856 & 65.914 & 65.972 & 66.029 & 66.087 & 1,130 \\
\hline 1,140 & 66.087 & 66.145 & 66.202 & 66.260 & 66.318 & 66.375 & 66.433 & 66.491 & 66.548 & 66.606 & 66.664 & 1,140 \\
\hline 1,150 & 66.664 & 66.721 & 66.779 & 66.836 & 66.894 & 66.952 & 67.009 & 67.067 & 67.124 & 67.182 & 67.240 & 1.150 \\
\hline $\begin{array}{l}1,160 \\
1,170\end{array}$ & $\begin{array}{l}67.240 \\
67.815\end{array}$ & $\begin{array}{l}67.297 \\
67.873\end{array}$ & $\begin{array}{l}67.355 \\
67.930\end{array}$ & $\begin{array}{l}67.412 \\
67.988\end{array}$ & $\begin{array}{l}67.470 \\
68.045\end{array}$ & $\begin{array}{l}67.527 \\
68.103\end{array}$ & $\begin{array}{l}67.585 \\
68.160\end{array}$ & $\begin{array}{l}67.643 \\
68.217\end{array}$ & $\begin{array}{l}67.700 \\
68.275\end{array}$ & $\begin{array}{l}67.758 \\
68.332\end{array}$ & $\begin{array}{l}67.815 \\
68.390\end{array}$ & $\begin{array}{l}1,160 \\
1,170\end{array}$ \\
\hline 1,180 & 68.390 & 68.447 & 68.505 & 68.562 & 68.619 & 68.677 & 68.734 & 68.792 & 68.849 & 68.906 & 68.964 & 1,180 \\
\hline 1,190 & 68.964 & 69.021 & 69.078 & 69.135 & 69.193 & $69 \cdot 250$ & 69.307 & 69.364 & 69.422 & 69.479 & 69.536 & 1,190 \\
\hline 1,200 & 69.536 & & & & & & & & & & & 1.200 \\
\hline${ }^{\circ} \mathrm{C}$ & 0 & 1 & 2 & 3 & 4 & 5 & 6 & 7 & 8 & 9 & 10 & \\
\hline
\end{tabular}


TaBle A6.1.2. Type J thermocouples-thermoelectric voltage as a function of temperature $\left({ }^{\circ} \mathrm{F}\right)$, reference junctions at $32^{\circ} \mathrm{F}$

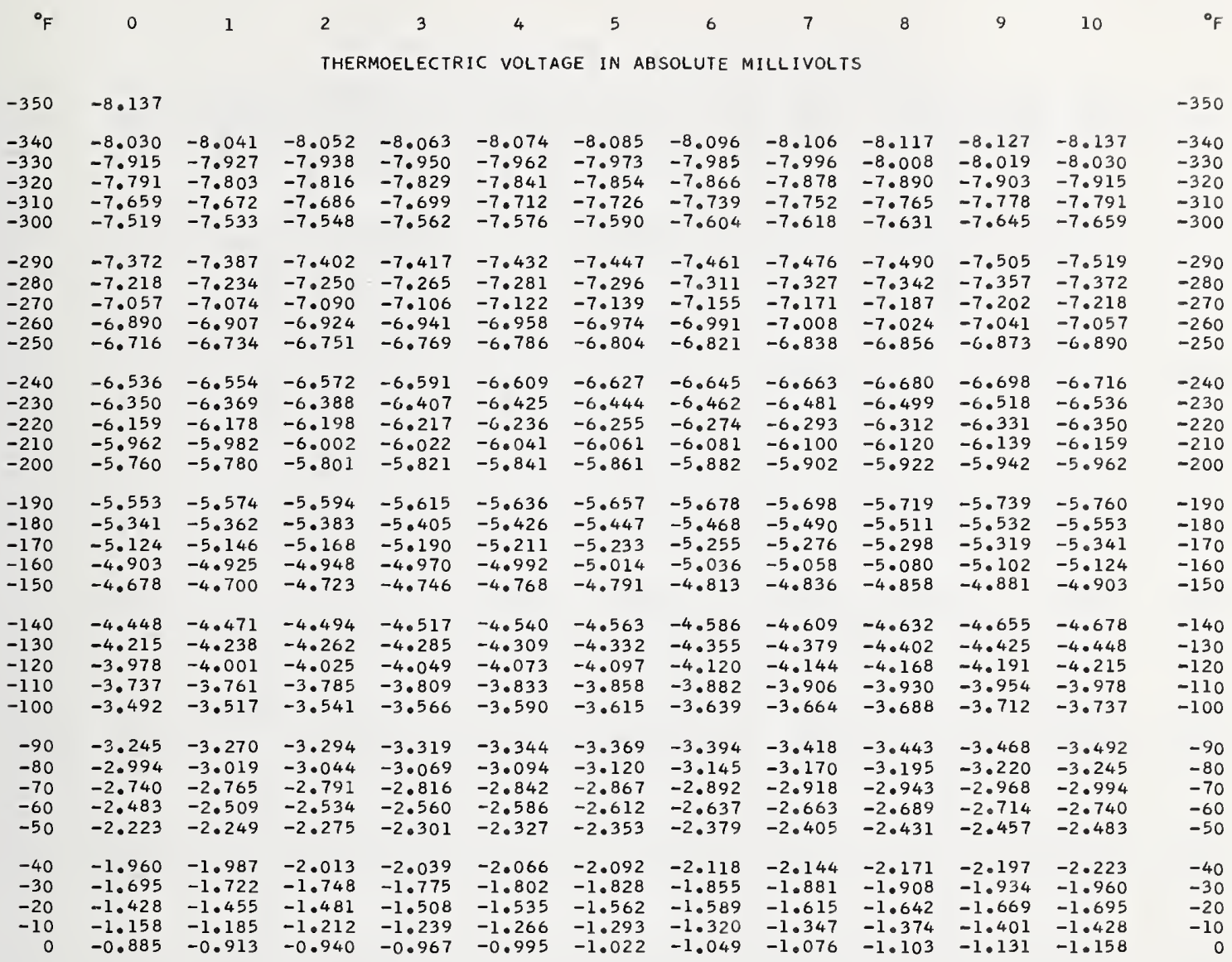


TABLE A6.1.2. Type J thermocouples-thermoelectric voltage as a function of temperature $\left({ }^{\circ} \mathrm{F}\right)$, reference junctions at $32{ }^{\circ} \mathrm{F}$-Continued

45

6

7

8

9

10

THERMOELECTRIC VOLTAGE IN ABSOLUTE MILLIVOLTS

\begin{tabular}{|c|c|c|c|c|c|c|c|c|c|c|c|c|}
\hline $\begin{array}{r}0 \\
10 \\
20 \\
30 \\
40\end{array}$ & $\begin{array}{r}-0.885 \\
-0.611 \\
-0.334 \\
-0.056 \\
0.224\end{array}$ & $\begin{array}{r}-0.858 \\
-0.583 \\
-0.307 \\
-0.028 \\
0.253\end{array}$ & $\begin{array}{r}-0.831 \\
-0.556 \\
-0.279 \\
0.000 \\
0.281\end{array}$ & $\begin{array}{r}-0.803 \\
-0.528 \\
-0.251 \\
0.028 \\
0.309\end{array}$ & $\begin{array}{r}-0.776 \\
-0.501 \\
-0.223 \\
0.056 \\
0.337\end{array}$ & $\begin{array}{r}-0.748 \\
-0.473 \\
-0.195 \\
0.084 \\
0.365\end{array}$ & $\begin{array}{r}-0.721 \\
-0.445 \\
-0.168 \\
0.112 \\
0.394\end{array}$ & $\begin{array}{r}-0.694 \\
-0.418 \\
-0.140 \\
0.140 \\
0.422\end{array}$ & $\begin{array}{r}-0.666 \\
-0.390 \\
-0.112 \\
0.168 \\
0.450\end{array}$ & $\begin{array}{r}-0.639 \\
-0.362 \\
-0.084 \\
0.196 \\
0.478\end{array}$ & $\begin{array}{r}-0.611 \\
-0.334 \\
-0.056 \\
0.224 \\
0.507\end{array}$ & $\begin{array}{l}10 \\
10 \\
20 \\
30\end{array}$ \\
\hline $\begin{array}{l}50 \\
60 \\
70 \\
80 \\
90\end{array}$ & $\begin{array}{l}0.507 \\
0.791 \\
1.076 \\
1.363 \\
1.652\end{array}$ & $\begin{array}{l}0.535 \\
0.819 \\
1.105 \\
1.392 \\
1.681\end{array}$ & $\begin{array}{l}0.563 \\
0.848 \\
1.134 \\
1.421 \\
1.710\end{array}$ & $\begin{array}{l}0.592 \\
0.876 \\
1.162 \\
1.450 \\
1.739\end{array}$ & $\begin{array}{l}0.620 \\
0.905 \\
1.191 \\
1.479 \\
1.768\end{array}$ & $\begin{array}{l}0.648 \\
0.933 \\
1.220 \\
1.507 \\
1.797\end{array}$ & $\begin{array}{l}0.677 \\
0.962 \\
1.248 \\
1.536 \\
1.826\end{array}$ & $\begin{array}{l}0.705 \\
0.990 \\
1.277 \\
1.565 \\
1.855\end{array}$ & $\begin{array}{l}0.734 \\
1.019 \\
1.306 \\
1.594 \\
1.884\end{array}$ & $\begin{array}{l}0.762 \\
1.048 \\
1.335 \\
1.623 \\
1.913\end{array}$ & $\begin{array}{l}0.791 \\
1.076 \\
1.363 \\
1.652 \\
1.942\end{array}$ & $\begin{array}{l}60 \\
70 \\
80 \\
90\end{array}$ \\
\hline $\begin{array}{l}100 \\
110 \\
120 \\
130 \\
140\end{array}$ & $\begin{array}{l}1.942 \\
2.233 \\
2.526 \\
2.820 \\
3.115\end{array}$ & $\begin{array}{l}1.971 \\
2.263 \\
2.555 \\
2.849 \\
3.145\end{array}$ & $\begin{array}{l}2.000 \\
2.292 \\
2.585 \\
2.879 \\
3.174\end{array}$ & $\begin{array}{l}2.029 \\
2.321 \\
2.614 \\
2.908 \\
3.204\end{array}$ & $\begin{array}{l}2.058 \\
2.350 \\
2.644 \\
2.938 \\
3.233\end{array}$ & $\begin{array}{l}2.088 \\
2.380 \\
2.673 \\
2.967 \\
3.263\end{array}$ & $\begin{array}{l}2.117 \\
2.409 \\
2.702 \\
2.997 \\
3.293\end{array}$ & $\begin{array}{l}2.146 \\
2.438 \\
2.732 \\
3.026 \\
3.322\end{array}$ & $\begin{array}{l}2.175 \\
2.467 \\
2.761 \\
3.056 \\
3.352\end{array}$ & $\begin{array}{l}2.204 \\
2.497 \\
2.791 \\
3.085 \\
3.381\end{array}$ & $\begin{array}{l}2.233 \\
2.526 \\
2.820 \\
3.115 \\
3.411\end{array}$ & $\begin{array}{l}100 \\
110 \\
120 \\
130 \\
140\end{array}$ \\
\hline $\begin{array}{l}150 \\
160 \\
170 \\
180 \\
190\end{array}$ & $\begin{array}{l}3.411 \\
3.708 \\
4.006 \\
4.305 \\
4.605\end{array}$ & $\begin{array}{l}3.441 \\
3.738 \\
4.036 \\
4.335 \\
4.635\end{array}$ & $\begin{array}{l}3.470 \\
3.768 \\
4.066 \\
4.365 \\
4.665\end{array}$ & $\begin{array}{l}3.500 \\
3.798 \\
4.096 \\
4.395 \\
4.695\end{array}$ & $\begin{array}{l}3.530 \\
3.827 \\
4.126 \\
4.425 \\
4.725\end{array}$ & $\begin{array}{l}3.560 \\
3.857 \\
4.156 \\
4.455 \\
4.755\end{array}$ & $\begin{array}{l}3.589 \\
3.887 \\
4.186 \\
4.485 \\
4.786\end{array}$ & $\begin{array}{l}3.619 \\
3.917 \\
4.216 \\
4.515 \\
4.816\end{array}$ & $\begin{array}{l}3.649 \\
3.947 \\
4.245 \\
4.545 \\
4.846\end{array}$ & $\begin{array}{l}3.678 \\
3.976 \\
4.275 \\
4.575 \\
4.876\end{array}$ & $\begin{array}{l}3.708 \\
4.006 \\
4.305 \\
4.605 \\
4.906\end{array}$ & $\begin{array}{l}150 \\
160 \\
170 \\
180 \\
190\end{array}$ \\
\hline $\begin{array}{l}200 \\
210 \\
220 \\
230 \\
240\end{array}$ & $\begin{array}{l}4.906 \\
5.207 \\
5.509 \\
5.812 \\
6.116\end{array}$ & $\begin{array}{l}4.936 \\
5.238 \\
5.540 \\
5.843 \\
6.146\end{array}$ & $\begin{array}{l}4.966 \\
5.268 \\
5.570 \\
5.873 \\
6.176\end{array}$ & $\begin{array}{l}4.996 \\
5.298 \\
5.600 \\
5.903 \\
6.207\end{array}$ & $\begin{array}{l}5.026 \\
5.328 \\
5.630 \\
5.934 \\
6.237\end{array}$ & $\begin{array}{l}5.057 \\
5.358 \\
5.661 \\
5.964 \\
6.268\end{array}$ & $\begin{array}{l}5.087 \\
5.389 \\
5.691 \\
5.994 \\
6.298\end{array}$ & $\begin{array}{l}5.117 \\
5.419 \\
5.721 \\
6.025 \\
6.328\end{array}$ & $\begin{array}{l}5.147 \\
5.449 \\
5.752 \\
6.055 \\
6.359\end{array}$ & $\begin{array}{l}5.177 \\
5.479 \\
5.782 \\
6.085 \\
6.389\end{array}$ & $\begin{array}{l}5.207 \\
5.509 \\
5.812 \\
6.116 \\
6.420\end{array}$ & $\begin{array}{l}200 \\
210 \\
220 \\
230 \\
240\end{array}$ \\
\hline $\begin{array}{l}250 \\
260 \\
270 \\
280 \\
290\end{array}$ & $\begin{array}{l}6.420 \\
6.724 \\
7.029 \\
7.335 \\
7.641\end{array}$ & $\begin{array}{l}6.450 \\
6.755 \\
7.060 \\
7.365 \\
7.671\end{array}$ & $\begin{array}{l}6.481 \\
6.785 \\
7.090 \\
7.396 \\
7.702\end{array}$ & $\begin{array}{l}6.511 \\
6.816 \\
7.121 \\
7.426 \\
7.732\end{array}$ & $\begin{array}{l}6.541 \\
6.846 \\
7.151 \\
7.457 \\
7.763\end{array}$ & $\begin{array}{l}6.572 \\
6.877 \\
7.182 \\
7.488 \\
7.794\end{array}$ & $\begin{array}{l}6.602 \\
6.907 \\
7.212 \\
7.518 \\
7.824\end{array}$ & $\begin{array}{l}6.633 \\
6.938 \\
7.243 \\
7.549 \\
7.855\end{array}$ & $\begin{array}{l}6.663 \\
6.968 \\
7.274 \\
7.579 \\
7.885\end{array}$ & $\begin{array}{l}6.694 \\
6.999 \\
7.304 \\
7.610 \\
7.916\end{array}$ & $\begin{array}{l}6.724 \\
7.029 \\
7.335 \\
7.641 \\
7.947\end{array}$ & $\begin{array}{l}250 \\
260 \\
270 \\
280 \\
290\end{array}$ \\
\hline $\begin{array}{l}300 \\
310 \\
320 \\
330 \\
340\end{array}$ & $\begin{array}{l}7.947 \\
8.253 \\
8.560 \\
8.867 \\
9.175\end{array}$ & $\begin{array}{l}7.977 \\
8.284 \\
8.591 \\
8.898 \\
9.206\end{array}$ & $\begin{array}{l}8.008 \\
8.315 \\
8.622 \\
8.929 \\
9.236\end{array}$ & $\begin{array}{l}8.039 \\
8.345 \\
8.652 \\
8.960 \\
9.267\end{array}$ & $\begin{array}{l}8.069 \\
8.376 \\
8.683 \\
8.990 \\
9.298\end{array}$ & $\begin{array}{l}8.100 \\
8.407 \\
8.714 \\
9.021 \\
9.329\end{array}$ & $\begin{array}{l}8.131 \\
8.437 \\
8.745 \\
9.052 \\
9.359\end{array}$ & $\begin{array}{l}8.161 \\
8.468 \\
8.775 \\
9.083 \\
9.390\end{array}$ & $\begin{array}{l}8.192 \\
8.499 \\
8.806 \\
9.113 \\
9.421\end{array}$ & $\begin{array}{l}8.223 \\
8.530 \\
8.837 \\
9.144 \\
9.452\end{array}$ & $\begin{array}{l}8.253 \\
8.560 \\
8.867 \\
9.175 \\
9.483\end{array}$ & $\begin{array}{l}300 \\
310 \\
320 \\
330 \\
340\end{array}$ \\
\hline $\begin{array}{l}350 \\
360 \\
370 \\
380 \\
390\end{array}$ & $\begin{array}{r}9.483 \\
9.790 \\
10.098 \\
10.407 \\
10.715\end{array}$ & $\begin{array}{r}9.513 \\
9.821 \\
10.129 \\
10.437 \\
10.746\end{array}$ & $\begin{array}{r}9.544 \\
9.852 \\
10.160 \\
10.468 \\
10.777\end{array}$ & $\begin{array}{r}9.575 \\
9.883 \\
10.191 \\
10.499 \\
10.807\end{array}$ & $\begin{array}{r}9.606 \\
9.914 \\
10.222 \\
10.530 \\
10.838\end{array}$ & $\begin{array}{r}9.636 \\
9.944 \\
10.252 \\
10.561 \\
10.869\end{array}$ & $\begin{array}{r}9.667 \\
9.975 \\
10.283 \\
10.592 \\
10.900\end{array}$ & $\begin{array}{r}9.698 \\
10.006 \\
10.314 \\
10.622 \\
10.931\end{array}$ & $\begin{array}{r}9.729 \\
10.037 \\
10.345 \\
10.653 \\
10.962\end{array}$ & $\begin{array}{r}9.760 \\
10.063 \\
10.376 \\
10.684 \\
10.992\end{array}$ & $\begin{array}{r}9.790 \\
10.098 \\
10.407 \\
10.715 \\
11.023\end{array}$ & $\begin{array}{l}350 \\
360 \\
370 \\
380 \\
390\end{array}$ \\
\hline $\begin{array}{l}400 \\
410 \\
420 \\
430 \\
440\end{array}$ & $\begin{array}{l}11.023 \\
11.332 \\
11.640 \\
11.949 \\
12.257\end{array}$ & $\begin{array}{l}11.054 \\
11.363 \\
11.671 \\
11.980 \\
12.288\end{array}$ & $\begin{array}{l}11.085 \\
11.393 \\
11.702 \\
12.010 \\
12.319\end{array}$ & $\begin{array}{l}11.116 \\
11.424 \\
11.733 \\
12.041 \\
12.350\end{array}$ & $\begin{array}{l}11.147 \\
11.455 \\
11.764 \\
12.072 \\
12.381\end{array}$ & $\begin{array}{l}11.177 \\
11.486 \\
11.794 \\
12.103 \\
12.411\end{array}$ & $\begin{array}{l}11.208 \\
11.517 \\
11.825 \\
12.134 \\
12.442\end{array}$ & $\begin{array}{l}11.239 \\
11.548 \\
11.856 \\
12.165 \\
12.473\end{array}$ & $\begin{array}{l}11.270 \\
11.578 \\
11.887 \\
12.196 \\
12.504\end{array}$ & $\begin{array}{l}11.301 \\
11.609 \\
11.918 \\
12.226 \\
12.535\end{array}$ & $\begin{array}{l}11.332 \\
11.640 \\
11.949 \\
12.257 \\
12.566\end{array}$ & $\begin{array}{l}400 \\
410 \\
420 \\
430 \\
440\end{array}$ \\
\hline $\begin{array}{l}450 \\
460 \\
470 \\
480 \\
490\end{array}$ & $\begin{array}{l}12.566 \\
12.874 \\
13.183 \\
13.491 \\
13.800\end{array}$ & $\begin{array}{l}12.597 \\
12.905 \\
13.214 \\
13.522 \\
13.830\end{array}$ & $\begin{array}{l}12.627 \\
12.936 \\
13.244 \\
13.553 \\
13.861\end{array}$ & $\begin{array}{l}12.658 \\
12.967 \\
13.275 \\
13.584 \\
13.892\end{array}$ & $\begin{array}{l}12.689 \\
12.998 \\
13.306 \\
13.615 \\
13.923\end{array}$ & $\begin{array}{l}12.720 \\
13.029 \\
13.337 \\
13.645 \\
13.954\end{array}$ & $\begin{array}{l}12.751 \\
13.059 \\
13.368 \\
13.676 \\
13.985\end{array}$ & $\begin{array}{l}12.782 \\
13.090 \\
13.399 \\
13.707 \\
14.015\end{array}$ & $\begin{array}{l}13.430 \\
13.738 \\
14.046\end{array}$ & $\begin{array}{l}12.843 \\
13.152 \\
13.460 \\
13.769 \\
14.077\end{array}$ & $\begin{array}{l}12.874 \\
13.183 \\
13.491 \\
13.800 \\
14.108\end{array}$ & $\begin{array}{l}450 \\
460 \\
470 \\
480 \\
490\end{array}$ \\
\hline $\begin{array}{l}500 \\
510 \\
520 \\
530 \\
540\end{array}$ & $\begin{array}{l}14.108 \\
14.416 \\
14.724 \\
15.032 \\
15.340\end{array}$ & $\begin{array}{l}14.139 \\
14.447 \\
14.755 \\
15.063 \\
15.371\end{array}$ & $\begin{array}{l}14.170 \\
14.478 \\
14.786 \\
15.094 \\
15.402\end{array}$ & $\begin{array}{l}14.200 \\
14.509 \\
14.817 \\
15.125 \\
15.433\end{array}$ & $\begin{array}{l}14.539 \\
14.848 \\
15.156 \\
15.464\end{array}$ & $\begin{array}{l}14.262 \\
14.570 \\
14.878 \\
15.186 \\
15.494\end{array}$ & $\begin{array}{l}14.293 \\
14.601 \\
14.909 \\
15.217 \\
15.525\end{array}$ & $\begin{array}{l}14.324 \\
14.632 \\
14.940 \\
15.248 \\
15.556\end{array}$ & $\begin{array}{l}14.663 \\
14.971 \\
15.279 \\
15.587\end{array}$ & $\begin{array}{l}14.385 \\
14.694 \\
15.002 \\
15.310 \\
15.617\end{array}$ & $\begin{array}{l}14.416 \\
14.724 \\
15.032 \\
15.340 \\
15.648\end{array}$ & $\begin{array}{l}500 \\
510 \\
520 \\
530 \\
540\end{array}$ \\
\hline $\begin{array}{l}550 \\
560 \\
570 \\
580 \\
590\end{array}$ & $\begin{array}{l}15.648 \\
15.956 \\
16.264 \\
16.571 \\
16.879\end{array}$ & $\begin{array}{l}15.679 \\
15.987 \\
16.294 \\
16.602 \\
16.909\end{array}$ & $\begin{array}{l}15.710 \\
16.018 \\
16.325 \\
16.633 \\
16.940\end{array}$ & $\begin{array}{l}15.741 \\
16.048 \\
16.356 \\
16.663 \\
16.971\end{array}$ & $\begin{array}{l}15.771 \\
16.079 \\
16.387 \\
16.694 \\
17.001\end{array}$ & $\begin{array}{l}15.802 \\
16.110 \\
16.417 \\
16.725 \\
17.032\end{array}$ & $\begin{array}{l}15.833 \\
16.141 \\
16.448 \\
16.756 \\
17.063\end{array}$ & $\begin{array}{l}15.864 \\
16.171 \\
16.479 \\
16.786 \\
17.094\end{array}$ & $\begin{array}{l}15.894 \\
16.202 \\
16.510 \\
16.817 \\
17.124\end{array}$ & $\begin{array}{l}15.925 \\
16.233 \\
16.540 \\
16.848 \\
17.155\end{array}$ & $\begin{array}{l}15.956 \\
16.264 \\
16.571 \\
16.879 \\
17.186\end{array}$ & $\begin{array}{l}560 \\
570 \\
580 \\
590\end{array}$ \\
\hline & 7.186 & 7.217 & 7.247 & 17.278 & 7.309 & 17.339 & 7.370 & 17.401 & 1.432 & 17.462 & 17.493 & 00 \\
\hline
\end{tabular}

1

2

3

4

5

6

7

8

9

10

${ }^{\circ} \mathrm{F}$ 
TABLE A6.1.2. Type $\boldsymbol{J}$ thermocouples-thermoelectric voltage as a function of temperature $\left({ }^{\circ} \mathrm{F}\right)$, reference junctions at $32^{\circ} \mathrm{F}$-Continued

${ }^{\circ} \mathrm{F}$

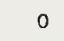

1

2

THERMOELECTRIC VOLTAGE IN ABSOLUTE MILLIVOLTS

\begin{tabular}{|c|c|c|c|c|c|c|c|c|c|c|c|c|}
\hline $\begin{array}{l}600 \\
610 \\
620 \\
630 \\
640\end{array}$ & $\begin{array}{l}17.186 \\
17.493 \\
17.800 \\
18.107 \\
18.414\end{array}$ & $\begin{array}{l}17.217 \\
17.524 \\
17.831 \\
18.138 \\
18.444\end{array}$ & $\begin{array}{l}17.247 \\
17.554 \\
17.861 \\
18.168 \\
18.475\end{array}$ & $\begin{array}{l}17.278 \\
17.585 \\
17.892 \\
18.199 \\
18.506\end{array}$ & $\begin{array}{l}17.309 \\
17.616 \\
17.923 \\
18.230 \\
18.537\end{array}$ & $\begin{array}{l}17.339 \\
17.646 \\
17.953 \\
18.260 \\
18.567\end{array}$ & $\begin{array}{l}17.370 \\
17.677 \\
17.984 \\
18.291 \\
18.598\end{array}$ & $\begin{array}{l}17.401 \\
17.708 \\
18.015 \\
18.322 \\
18.629\end{array}$ & $\begin{array}{l}17.432 \\
17.739 \\
18.046 \\
18.352 \\
18.659\end{array}$ & $\begin{array}{l}17.462 \\
17.769 \\
18.076 \\
18.383 \\
18.690\end{array}$ & $\begin{array}{l}17.493 \\
17.800 \\
18.107 \\
18.414 \\
18.721\end{array}$ & $\begin{array}{l}600 \\
610 \\
620 \\
630 \\
640\end{array}$ \\
\hline $\begin{array}{l}650 \\
660 \\
670 \\
680 \\
690\end{array}$ & $\begin{array}{l}18.721 \\
19.027 \\
19.334 \\
19.640 \\
19.947\end{array}$ & $\begin{array}{l}18.751 \\
19.058 \\
19.364 \\
19.671 \\
19.977\end{array}$ & $\begin{array}{l}18.782 \\
19.089 \\
19.395 \\
19.702 \\
20.008\end{array}$ & $\begin{array}{l}18.813 \\
19.119 \\
19.426 \\
19.732 \\
20.039\end{array}$ & $\begin{array}{l}18.843 \\
19.150 \\
19.456 \\
19.763 \\
20.069\end{array}$ & $\begin{array}{l}18.874 \\
19.180 \\
19.487 \\
19.793 \\
20.100\end{array}$ & $\begin{array}{l}18.905 \\
19.211 \\
19.518 \\
19.824 \\
20.131\end{array}$ & $\begin{array}{l}18.935 \\
19.242 \\
19.548 \\
19.855 \\
20.161\end{array}$ & $\begin{array}{l}18.966 \\
19.272 \\
19.579 \\
19.885 \\
20.192\end{array}$ & $\begin{array}{l}18.997 \\
19.303 \\
19.610 \\
19.916 \\
20.222\end{array}$ & $\begin{array}{l}19.027 \\
19.334 \\
19.640 \\
19.947 \\
20.253\end{array}$ & $\begin{array}{l}650 \\
660 \\
670 \\
680 \\
690\end{array}$ \\
\hline $\begin{array}{l}700 \\
710 \\
720 \\
730 \\
740\end{array}$ & $\begin{array}{l}20.253 \\
20.559 \\
20.866 \\
21.172 \\
21.478\end{array}$ & $\begin{array}{l}20.284 \\
20.590 \\
20.896 \\
21.203 \\
21.509\end{array}$ & $\begin{array}{l}20.314 \\
20.621 \\
20.927 \\
21.233 \\
21.540\end{array}$ & $\begin{array}{l}20.345 \\
20.651 \\
20.958 \\
21.264 \\
21.570\end{array}$ & $\begin{array}{l}20.376 \\
20.682 \\
20.988 \\
21.295 \\
21.601\end{array}$ & $\begin{array}{l}20.406 \\
20.713 \\
21.019 \\
21.325 \\
21.631\end{array}$ & $\begin{array}{l}20.437 \\
20.743 \\
21.049 \\
21.356 \\
21.662\end{array}$ & $\begin{array}{l}20.467 \\
20.774 \\
21.080 \\
21.386 \\
21.693\end{array}$ & $\begin{array}{l}20.498 \\
20.804 \\
21.111 \\
21.417 \\
21.723\end{array}$ & $\begin{array}{l}20.529 \\
20.835 \\
21.141 \\
21.448 \\
21.754\end{array}$ & $\begin{array}{l}20.559 \\
20.866 \\
21.172 \\
21.478 \\
21.785\end{array}$ & $\begin{array}{l}700 \\
710 \\
720 \\
730 \\
740\end{array}$ \\
\hline $\begin{array}{l}750 \\
760 \\
770 \\
780 \\
790\end{array}$ & $\begin{array}{l}21.785 \\
22.091 \\
22.397 \\
22.704 \\
23.010\end{array}$ & $\begin{array}{l}21.815 \\
22.122 \\
22.428 \\
22.735 \\
23.041\end{array}$ & $\begin{array}{l}21.846 \\
22.152 \\
22.459 \\
22.765 \\
23.072\end{array}$ & $\begin{array}{l}21.877 \\
22.183 \\
22.489 \\
22.796 \\
23.102\end{array}$ & $\begin{array}{l}21.907 \\
22.214 \\
22.520 \\
22.826 \\
23.133\end{array}$ & $\begin{array}{l}21.938 \\
22.244 \\
22.551 \\
22.857 \\
23.164\end{array}$ & $\begin{array}{l}21.968 \\
22.275 \\
22.581 \\
22.888 \\
23.194\end{array}$ & $\begin{array}{l}21.999 \\
22.305 \\
22.612 \\
22.918 \\
23.225\end{array}$ & $\begin{array}{l}22.030 \\
22.336 \\
22.643 \\
22.949 \\
23.256\end{array}$ & $\begin{array}{l}22.060 \\
22.367 \\
22.673 \\
22.980 \\
23.286\end{array}$ & $\begin{array}{l}22.091 \\
22.397 \\
22.704 \\
23.010 \\
23.317\end{array}$ & $\begin{array}{l}750 \\
760 \\
770 \\
780 \\
790\end{array}$ \\
\hline $\begin{array}{l}800 \\
810 \\
820 \\
830 \\
840\end{array}$ & $\begin{array}{l}23.317 \\
23.624 \\
23.931 \\
24.238 \\
24.546\end{array}$ & $\begin{array}{l}23.348 \\
23.655 \\
23.962 \\
24.269 \\
24.576\end{array}$ & $\begin{array}{l}23.378 \\
23.685 \\
23.992 \\
24.300 \\
24.607\end{array}$ & $\begin{array}{l}23.409 \\
23.716 \\
24.023 \\
24.330 \\
24.638\end{array}$ & $\begin{array}{l}23.440 \\
23.747 \\
24.054 \\
24.361 \\
24.669\end{array}$ & $\begin{array}{l}23.471 \\
23.777 \\
24.085 \\
24.392 \\
24.699\end{array}$ & $\begin{array}{l}23.501 \\
23.808 \\
24.115 \\
24.423 \\
24.730\end{array}$ & $\begin{array}{l}23.532 \\
23.839 \\
24.146 \\
24.453 \\
24.761\end{array}$ & $\begin{array}{l}23.563 \\
23.870 \\
24.177 \\
24.484 \\
24.792\end{array}$ & $\begin{array}{l}23.593 \\
23.900 \\
24.207 \\
24.515 \\
24.822\end{array}$ & $\begin{array}{l}23.624 \\
23.931 \\
24.238 \\
24.546 \\
24.853\end{array}$ & $\begin{array}{l}800 \\
810 \\
820 \\
830 \\
840\end{array}$ \\
\hline $\begin{array}{l}850 \\
860 \\
870 \\
880 \\
890\end{array}$ & $\begin{array}{l}24.853 \\
25.161 \\
25.469 \\
25.778 \\
26.087\end{array}$ & $\begin{array}{l}24.884 \\
25.192 \\
25.500 \\
25.809 \\
26.118\end{array}$ & $\begin{array}{l}24.915 \\
25.223 \\
25.531 \\
25.840 \\
26.148\end{array}$ & $\begin{array}{l}24.946 \\
25.254 \\
25.562 \\
25.870 \\
26.179\end{array}$ & $\begin{array}{l}24.976 \\
25.284 \\
25.593 \\
25.901 \\
26.210\end{array}$ & $\begin{array}{l}25.007 \\
25.315 \\
25.623 \\
25.932 \\
26.241\end{array}$ & $\begin{array}{l}25.038 \\
25.346 \\
25.654 \\
25.963 \\
26.272\end{array}$ & $\begin{array}{l}25.069 \\
25.377 \\
25.685 \\
25.994 \\
26.303\end{array}$ & $\begin{array}{l}25.099 \\
25.408 \\
25.716 \\
26.025 \\
26.334\end{array}$ & $\begin{array}{l}25.130 \\
25.438 \\
25.747 \\
26.056 \\
26.365\end{array}$ & $\begin{array}{l}25.161 \\
25.469 \\
25.778 \\
26.087 \\
26.396\end{array}$ & $\begin{array}{l}850 \\
860 \\
870 \\
880 \\
890\end{array}$ \\
\hline $\begin{array}{l}900 \\
910 \\
920 \\
930 \\
940\end{array}$ & $\begin{array}{l}26.396 \\
26.705 \\
27.016 \\
27.326 \\
27.637\end{array}$ & $\begin{array}{l}26.427 \\
26.736 \\
27.047 \\
27.357 \\
27.668\end{array}$ & $\begin{array}{l}26.458 \\
26.767 \\
27.078 \\
27.388 \\
27.699\end{array}$ & $\begin{array}{l}26.489 \\
26.798 \\
27.109 \\
27.419 \\
27.731\end{array}$ & $\begin{array}{l}26.520 \\
26.829 \\
27.140 \\
27.450 \\
27.762\end{array}$ & $\begin{array}{l}26.551 \\
26.860 \\
27.171 \\
27.482 \\
27.793\end{array}$ & $\begin{array}{l}26.582 \\
26.891 \\
27.202 \\
27.513 \\
27.824\end{array}$ & $\begin{array}{l}26.613 \\
26.922 \\
27.233 \\
27.544 \\
27.855\end{array}$ & $\begin{array}{l}26.644 \\
26.954 \\
27.264 \\
27.575 \\
27.886\end{array}$ & $\begin{array}{l}26.675 \\
26.985 \\
27.295 \\
27.606 \\
27.917\end{array}$ & $\begin{array}{l}26.705 \\
27.016 \\
27.326 \\
27.637 \\
27.949\end{array}$ & $\begin{array}{l}900 \\
910 \\
920 \\
930 \\
940\end{array}$ \\
\hline $\begin{array}{l}950 \\
960 \\
970 \\
980 \\
990\end{array}$ & $\begin{array}{l}27.949 \\
28.261 \\
28.573 \\
28.887 \\
29.201\end{array}$ & $\begin{array}{l}27.980 \\
28.292 \\
28.605 \\
28.918 \\
29.232\end{array}$ & $\begin{array}{l}28.011 \\
28.323 \\
28.636 \\
28.950 \\
29.264\end{array}$ & $\begin{array}{l}28.042 \\
28.355 \\
28.667 \\
28.981 \\
29.295\end{array}$ & & $\begin{array}{l}28.105 \\
28.417 \\
28.730 \\
29.044 \\
29.358\end{array}$ & & & $\begin{array}{l}28.198 \\
28.511 \\
28.824 \\
29.138 \\
29.452\end{array}$ & $\begin{array}{l}28.230 \\
28.542 \\
28.855 \\
29.169 \\
29.484\end{array}$ & $\begin{array}{l}28.261 \\
28.573 \\
28.887 \\
29.201 \\
29.515\end{array}$ & $\begin{array}{l}950 \\
960 \\
970 \\
980 \\
990\end{array}$ \\
\hline $\begin{array}{l}.030 \\
.040\end{array}$ & $\begin{array}{l}29.515 \\
29.831 \\
30.147 \\
30.464 \\
30.782\end{array}$ & $\begin{array}{l}29.547 \\
29.862 \\
30.179 \\
30.496 \\
30.813\end{array}$ & $\begin{array}{l}29.578 \\
29.894 \\
30.210 \\
30.527 \\
30.845\end{array}$ & $\begin{array}{l}29.610 \\
29.926 \\
30.242 \\
30.559 \\
30.877\end{array}$ & $\begin{array}{l}29.642 \\
29.957 \\
30.274 \\
30.591 \\
30.909\end{array}$ & $\begin{array}{l}29.673 \\
29.989 \\
30.305 \\
30.623 \\
30.941\end{array}$ & $\begin{array}{l}29.705 \\
30.020 \\
30.337 \\
30.654 \\
30.973\end{array}$ & & $\begin{array}{l}29.768 \\
30.084 \\
30.400 \\
30.718 \\
31.036\end{array}$ & $\begin{array}{l}29.799 \\
30.115 \\
30.432 \\
30.750 \\
31.068\end{array}$ & $\begin{array}{l}29.831 \\
30.147 \\
30.464 \\
30.782 \\
31.100\end{array}$ & $\begin{array}{l}.000 \\
.010 \\
.020 \\
.030 \\
.040\end{array}$ \\
\hline $\begin{array}{l}1,070 \\
1,080 \\
1,090\end{array}$ & $\begin{array}{l}31.420 \\
31.740 \\
32.061 \\
32.384\end{array}$ & $\begin{array}{l}31.452 \\
31.772 \\
32.094 \\
32.416\end{array}$ & $\begin{array}{l}31.164 \\
31.484 \\
31.804 \\
32.126 \\
32.448\end{array}$ & $\begin{array}{l}31.196 \\
31.516 \\
31.836 \\
32.158 \\
32.480\end{array}$ & $\begin{array}{l}31.228 \\
31.548 \\
31.868 \\
32.190 \\
32.513\end{array}$ & $\begin{array}{l}31.260 \\
31.580 \\
31.901 \\
32.222 \\
32.545\end{array}$ & $\begin{array}{l}31.292 \\
31.612 \\
31.933 \\
32.255 \\
32.577\end{array}$ & $\begin{array}{l}31.324 \\
31.644 \\
31.965 \\
32.287 \\
32.610\end{array}$ & $\begin{array}{l}31.356 \\
31.676 \\
31.997 \\
32.319 \\
32.642\end{array}$ & $\begin{array}{l}31.388 \\
31.708 \\
32.029 \\
32.351 \\
32.674\end{array}$ & $\begin{array}{l}31.420 \\
31.740 \\
32.061 \\
32.384 \\
32.707\end{array}$ & $\begin{array}{l}.050 \\
.060 \\
070 \\
080 \\
090\end{array}$ \\
\hline $\begin{array}{l}1,100 \\
1,110 \\
1,120 \\
1,130 \\
1,140\end{array}$ & $\begin{array}{l}32.707 \\
33.031 \\
33.356 \\
33.683 \\
34.010\end{array}$ & $\begin{array}{l}32.739 \\
33.064 \\
33.389 \\
33.715 \\
34.043\end{array}$ & $\begin{array}{l}32.772 \\
33.096 \\
33.422 \\
33.748 \\
34.076\end{array}$ & $\begin{array}{l}32.804 \\
33.129 \\
33.454 \\
33.781 \\
34.109\end{array}$ & $\begin{array}{l}32.836 \\
33.161 \\
33.487 \\
33.814 \\
34.141\end{array}$ & $\begin{array}{l}32.869 \\
33.194 \\
33.519 \\
33.846 \\
34.174\end{array}$ & $\begin{array}{l}32.901 \\
33.226 \\
33.552 \\
33.879 \\
34.207\end{array}$ & $\begin{array}{l}32.934 \\
33.259 \\
33.585 \\
33.912 \\
34.240\end{array}$ & $\begin{array}{l}33.291 \\
33.617 \\
33.945 \\
34.273\end{array}$ & $\begin{array}{l}32.999 \\
33.324 \\
33.650 \\
33.977 \\
34.306\end{array}$ & $\begin{array}{l}33.031 \\
33.356 \\
33.683 \\
34.010 \\
34.339\end{array}$ & $\begin{array}{l}1,110 \\
1,120 \\
1,130 \\
1,140\end{array}$ \\
\hline $\begin{array}{l}1,150 \\
1,160 \\
1,170 \\
1,180 \\
1,190\end{array}$ & $\begin{array}{l}34.339 \\
34.668 \\
34.999 \\
35.331 \\
35.664\end{array}$ & $\begin{array}{l}34.372 \\
34.701 \\
35.032 \\
35.364 \\
35.698\end{array}$ & $\begin{array}{l}34.405 \\
34.734 \\
35.065 \\
35.398 \\
35.731\end{array}$ & $\begin{array}{l}34.437 \\
34.767 \\
35.099 \\
35.431 \\
35.764\end{array}$ & $\begin{array}{l}34.470 \\
34.801 \\
35.132 \\
35.464 \\
35.798\end{array}$ & $\begin{array}{l}34.503 \\
34.834 \\
35.165 \\
35.498 \\
35.831\end{array}$ & $\begin{array}{l}34.536 \\
34.867 \\
35.198 \\
35.531 \\
35.865\end{array}$ & $\begin{array}{l}34.569 \\
34.900 \\
35.231 \\
35.564 \\
35.898\end{array}$ & $\begin{array}{l}34.602 \\
34.933 \\
35.265 \\
35.598 \\
35.932\end{array}$ & $\begin{array}{l}34.635 \\
34.966 \\
35.298 \\
35.631 \\
35.965\end{array}$ & $\begin{array}{l}34.668 \\
34.999 \\
35.331 \\
35.664 \\
35.999\end{array}$ & $\begin{array}{l}1,150 \\
1,160 \\
1,170 \\
1,180 \\
1,190\end{array}$ \\
\hline 1,200 & 35.999 & 36.032 & 36.066 & 36.099 & 36.133 & 36.166 & 36.200 & 36.233 & 36.267 & 36.301 & 36.334 & 200 \\
\hline
\end{tabular}

${ }^{\circ} \mathrm{F}$

30

660

80

690

10

40

50

760

80

800

30

850

860

80

900

20

940

50

960

80

, 000

, 010

, 030

.040

, 060

1,070
1,080

1,090

100

1,120

1,150

, 170

1.180

1,200
2

\begin{abstract}
3
\end{abstract}
4

5

6

7

8

9

10 
TABLE A6.1.2. Type J thermocouples-thermoelectric voltage as a function of temperature $\left({ }^{\circ} \mathrm{F}\right)$, reference junctions at $32^{\circ} \mathrm{F}$-Continued

\begin{tabular}{|c|c|c|c|c|c|c|c|c|c|c|c|c|}
\hline${ }^{\circ} \mathrm{F}$ & 0 & 1 & 2 & 3 & 4 & 5 & 6 & 7 & 8 & 9 & 10 & ${ }^{\circ} \mathrm{F}$ \\
\hline & & & THE & AOELEC & V VOL & E IN A & SOLUTE $M$ & ILLIVOLT & & & & \\
\hline $\begin{array}{l}1.200 \\
1.210 \\
1.220 \\
.2230 \\
., 240\end{array}$ & $\begin{array}{l}35.999 \\
36.334 \\
36.671 \\
37.009 \\
37.348\end{array}$ & $\begin{array}{l}36.032 \\
36.368 \\
36.705 \\
37.043 \\
37.382\end{array}$ & $\begin{array}{l}36.066 \\
36.401 \\
36.738 \\
37.076 \\
37.416\end{array}$ & $\begin{array}{l}36.099 \\
36.435 \\
36.772 \\
37.110 \\
37.450\end{array}$ & $\begin{array}{l}36.133 \\
36.469 \\
36.806 \\
37.144 \\
37.484\end{array}$ & $\begin{array}{l}36.166 \\
36.502 \\
36.840 \\
37.178 \\
37.518\end{array}$ & $\begin{array}{l}36.200 \\
36.536 \\
36.873 \\
37.212 \\
37.552\end{array}$ & $\begin{array}{l}36.233 \\
36.570 \\
36.907 \\
37.246 \\
37.586\end{array}$ & $\begin{array}{l}36.267 \\
36.603 \\
36.941 \\
37.280 \\
37.620\end{array}$ & $\begin{array}{l}36.301 \\
36.637 \\
36.975 \\
37.314 \\
37.654\end{array}$ & $\begin{array}{l}36.334 \\
36.671 \\
37.009 \\
37.348 \\
37.688\end{array}$ & $\begin{array}{l}1,200 \\
1,210 \\
1,220 \\
1,230 \\
1,240\end{array}$ \\
\hline $\begin{array}{l}250 \\
260 \\
270 \\
280 \\
290\end{array}$ & $\begin{array}{l}37.688 \\
38.030 \\
38.372 \\
38.716 \\
39.061\end{array}$ & $\begin{array}{l}37.722 \\
38.064 \\
38.407 \\
38.751 \\
39.096\end{array}$ & $\begin{array}{l}37.756 \\
38.098 \\
38.441 \\
38.785 \\
39.130\end{array}$ & $\begin{array}{l}37.790 \\
38.132 \\
38.475 \\
38.819 \\
39.165\end{array}$ & $\begin{array}{l}37.825 \\
38.167 \\
38.510 \\
38.854 \\
39.199\end{array}$ & $\begin{array}{l}37.859 \\
38.201 \\
38.544 \\
38.888 \\
39.234\end{array}$ & $\begin{array}{l}37.893 \\
38.235 \\
38.578 \\
38.923 \\
39.269\end{array}$ & $\begin{array}{l}37.927 \\
38.269 \\
38.613 \\
38.957 \\
39.303\end{array}$ & $\begin{array}{l}37.961 \\
38.304 \\
38.647 \\
38.992 \\
39.338\end{array}$ & $\begin{array}{l}37.995 \\
38.338 \\
38.682 \\
39.027 \\
39.373\end{array}$ & $\begin{array}{l}38.030 \\
38.372 \\
38.716 \\
39.061 \\
39.407\end{array}$ & $\begin{array}{l}1,250 \\
1,260 \\
1,270 \\
1,280 \\
1,290\end{array}$ \\
\hline $\begin{array}{l}300 \\
310 \\
320 \\
330 \\
340\end{array}$ & $\begin{array}{l}39.407 \\
39.754 \\
40.103 \\
40.452 \\
40.802\end{array}$ & $\begin{array}{l}39.442 \\
39.789 \\
40.138 \\
40.487 \\
40.837\end{array}$ & $\begin{array}{l}39.477 \\
39.824 \\
40.172 \\
40.522 \\
40.872\end{array}$ & $\begin{array}{l}39.511 \\
39.859 \\
40.207 \\
40.557 \\
40.908\end{array}$ & $\begin{array}{l}39.546 \\
39.894 \\
40.242 \\
40.592 \\
40.943\end{array}$ & $\begin{array}{l}39.581 \\
39.928 \\
40.277 \\
40.627 \\
40.978\end{array}$ & $\begin{array}{l}39.615 \\
39.963 \\
40.312 \\
40.662 \\
41.013\end{array}$ & $\begin{array}{l}39.650 \\
39.998 \\
40.347 \\
40.697 \\
41.048\end{array}$ & $\begin{array}{l}39.685 \\
40.033 \\
40.382 \\
40.732 \\
41.083\end{array}$ & $\begin{array}{l}39.720 \\
40.068 \\
40.417 \\
40.767 \\
41.118\end{array}$ & $\begin{array}{l}39.754 \\
40.103 \\
40.452 \\
40.802 \\
41.154\end{array}$ & $\begin{array}{l}1,300 \\
1,310 \\
1,320 \\
1,330 \\
1,340\end{array}$ \\
\hline $\begin{array}{l}350 \\
.360 \\
.370 \\
.380 \\
.390\end{array}$ & $\begin{array}{l}41.154 \\
41.506 \\
41.859 \\
42.212 \\
42.567\end{array}$ & $\begin{array}{l}41.189 \\
41.541 \\
41.894 \\
42.248 \\
42.602\end{array}$ & $\begin{array}{l}41.224 \\
41.576 \\
41.929 \\
42.283 \\
42.638\end{array}$ & $\begin{array}{l}41.259 \\
41.611 \\
41.965 \\
42.319 \\
42.673\end{array}$ & $\begin{array}{l}41.294 \\
41.647 \\
42.000 \\
42.354 \\
42.709\end{array}$ & $\begin{array}{l}41.329 \\
41.682 \\
42.035 \\
42.390 \\
42.744\end{array}$ & $\begin{array}{l}41.365 \\
41.717 \\
42.071 \\
42.425 \\
42.780\end{array}$ & $\begin{array}{l}41.400 \\
41.753 \\
42.106 \\
42.460 \\
42.815\end{array}$ & $\begin{array}{l}41.435 \\
41.788 \\
42.142 \\
42.496 \\
42.851\end{array}$ & $\begin{array}{l}41.470 \\
41.823 \\
42.177 \\
42.531 \\
42.886\end{array}$ & $\begin{array}{l}41.506 \\
41.859 \\
42.212 \\
42.567 \\
42.922\end{array}$ & $\begin{array}{l}1,350 \\
1,360 \\
1,370 \\
1.380 \\
1,390\end{array}$ \\
\hline 400 & 42.922 & & & & & & & & & & & 1,400 \\
\hline${ }^{\circ} \mathrm{F}$ & 0 & 1 & 2 & 3 & 4 & 5 & 6 & 7 & 8 & 9 & 10 & $F$ \\
\hline
\end{tabular}


TABLE A6.1.2. Type J thermocouples extended range-thermoelectric voltage as a function of temperature $\left({ }^{\circ} \mathrm{F}\right)$, reference junctions at $32^{\circ} \mathrm{F}$

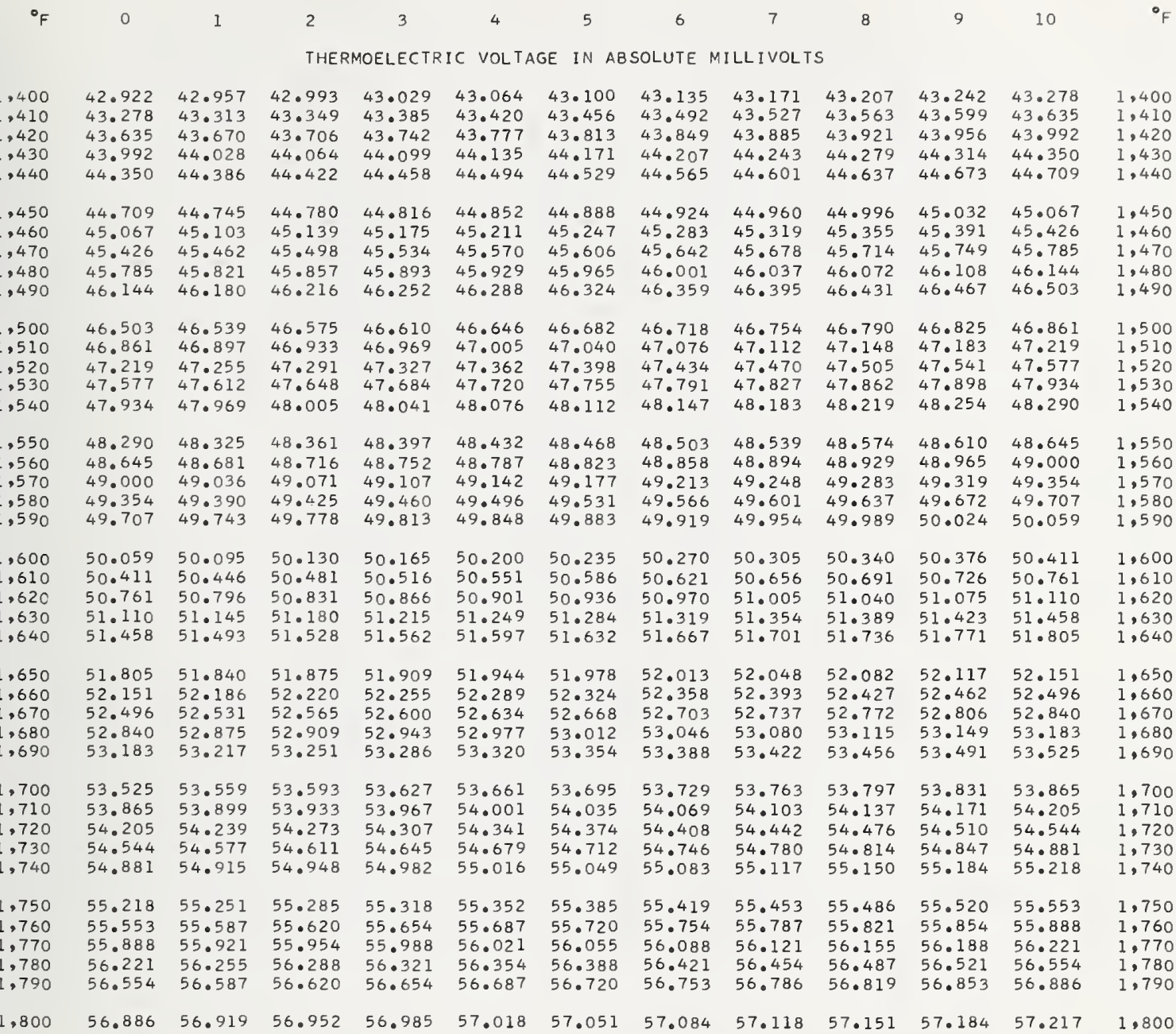


TABLE A6.1.2. Type J thermocouples extended range-thermoelectric voltage as a function of temperature $\left({ }^{\circ} \mathrm{F}\right)$, reference junctions at $32^{\circ} \mathrm{F}$-Continued

45

THERMOELECTRIC VOLTAGE IN ABSOLUTE MILLIVOLTS

1,80

1,81

1,820

1,830

1,840

1,850

1,860

1,870

1,880

1,890

1,900

1,910

1,920

1,930

1,940

1,950

1,960

1,970

1,980

1,990

2,000

2,010
2,020

2,030

2,040

2,050

2,060

2,070

2,080

2,090

2,100

2,110

2,120

2,130

2,140

2,150

2,160

2,170

2,180

2,190

\begin{abstract}
$\begin{array}{ll}57.547 & 57.250 \\ 57.586 & 57.909\end{array}$
$57.876 \quad 57.909$

$58.205 \quad 58.238$

$58.533 \quad 58.566$

$58.860 \quad 58.893$

$59.187 \quad 59.219$

$59.513 \quad 59.545$

$59.838 \quad 59.871$

$60.163 \quad 60.196$

$60.488 \quad 60.520$

$60.812 \quad 60.844$

61.13561 .168

61.459

61.781

61.491

$62.104 \quad 62.136$

$62.426 \quad 62.458$

$62.748 \quad 62.780$

$63.070 \quad 63.102$

63.392

$63.713 \quad 63.745$

$64.034 \quad 64.066$

64.355

64.676

64.387

64.997

64.708

$65.318 \quad 65.350$

$65.638 \quad 65.671$

$65.959 \quad 65.991$

66.27966 .311

$66.600 \quad 66.632$

$66.920 \quad 66.952$

$67.240 \quad 67.272$

$67.559 \quad 67.591$

67.879

67.911

$68.198 \quad 68.230$

$68.517 \quad 68.549$

$68.836 \quad 68.868$

$69.155 \quad 69.186$

69.472

69.504
\end{abstract}

$\begin{array}{lll}56.886 & 56.919 & 56.952 \\ 57.217 & 57.250 & 57.283\end{array}$

57.283
57.613

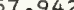

58.271

58.598

58.926

59.578

59.903

60.228

60.553

60.876

61.200

61.523

61.846

62.168

62.491

62.813

63.134

63.456

63.777

64.098

64.420

64.740

65.061

65.382
65.703

66.023

66.343

66.664

66.984

67.304

67.623

67.943

68.262

68.581

68.900

69.218

69.536

56.985
57.316
57.646
57.975

57.018

$57.349-57.051$

$57.349 \quad 57.382$

58.303

58.631

59.285

59.610

59.936

60.261

60.585

60.909

61.232

61.555

61.878

62.201

62.523
62.845

63.167

63.488

63.809

64.131

64.452

64.773

$\begin{array}{ll}58.008 & 58.041 \\ 58.336 & 58.369\end{array}$

57.712

58.664

$58.991 \quad 59.697$

59.31759 .350

$59.643 \quad 59.676$

59.968

60.001

60.293

60.941

61.265

61.588

60.974

57.084
57.415
57.745

57.74

58.402

61.910

62.233
62.555

62.555
62.877

63.199

1.94

62.265

62.587

62.909

63.520

63.842

63.552

64.163

63.874

64.195

64.516

64.805

64.837

65.093

65.414

65.735

66.055

65.125

65.446

65.767

66.087

66.375

66.407

65.158

65.478

65.799

66.119

66.696

67.016
67.336

67.655

66.728

67.975

67.368

67.687

68.294

$68.932 \quad 68.94$

$69.250 \quad 69.282$

66.760

67.080
67.400

67.719

68.039

58.729

59.382

59.708

60.033

60.358

60.682

61.652

57.118

57.778

58.10

58.435

57.810

$58.139 \quad 58.172$

58.762

59.089

59.415

59.741

58.500

60.390

60.715

61.038

61.362

61.685

59.121

59.448

59.773

60.098

61.975

62.297

62.007

62.330

$62.619 \quad 62.652$

62.94162 .974

63.263

63.295

63.584

63.906

$64.548 \quad 64.580$

$64.869 \quad 64.901$

60.423

60.747

61.071

61.394

61.717

58.827

59.154

59.480

59.806

60.455

60.779

61.103

61.426

62.039

62.362

62.684

63.006

63.327

62.072

62.394

62.716 
TABLE A6.1.3. Type J thermocouples-quadratic, cubic, and quartic approximations to the data as a func. tion of temperature $\left({ }^{\circ} \mathrm{C}\right)$ in selected temperature ranges. The expansion is of the form $\mathrm{E}=\mathrm{a}_{0}+\mathrm{a}_{1} \mathrm{~T}+\mathrm{a}_{2} \mathrm{~T}^{2}+\mathrm{a}_{3} \mathrm{~T}^{3}+\mathrm{a}_{4} \mathrm{~T}^{4}$ where $\mathrm{E}$ is in microvolts and $\mathrm{T}$ is in degrees Celsius

Temperature

Range $\left(\mathrm{C}^{\circ}\right)$

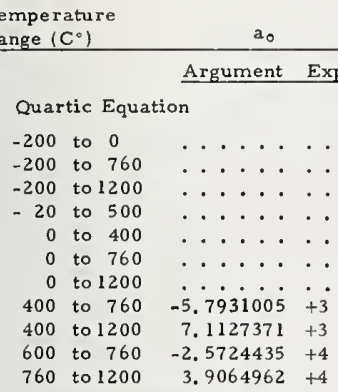

Quartic Equation

I. Cubic Equation

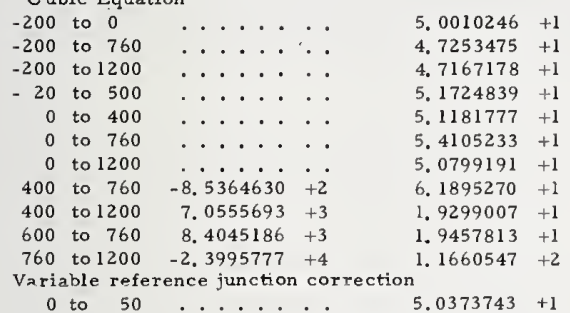

III. Quadratic Equation

Argument
3. 2009063
3.2898022
2. 3522650
2. 8062596
2. 8409137
2.0040854
-1.4207954
-1.1658430
5.3862730
-4.0418097
3. 6470921

2.0437543

2. 5046705

1. 9446043

1. 3054732

1.7947441

1. 7123662

1. 0477066

$-2.0833283$

5. 3184827

4. 3662315

$-4.6945343$

3.0167011
6.5722566

1. 0510184

5. 9801120

3. 2259487

4. 8483890

4. 8102627

4. 4372939

1. 3964245

1. 3743151

1. 8167261

$-1.0874407$

2.4476444
Error

Range ( $\mu$ V)

Argument
-6.3493968
-6.9936031
-2.2198295
-6.5666305
-6.7556436
-4.2235982
3.1325181
1.3184454
-2.2171472
4.2749984
-2.7029005

$-1.6133895$

$-1.7846422$

$-8.7617925$

$-1,4132471$

-2. 3602579

6. 1865084

$-3.6454477$

1. 9993203

$-2,1581517$

$-1.2504038$

1. 2266074

$-7.4293513-5$

$\begin{array}{lrl}-5 & 2.5174022 & -7 \\ -5 & 5.1112729 & -8 \\ -5 & 7.1373907 & -9 \\ -5 & 5.3587106 & -8 \\ -5 & 5.6382040 & -8 \\ -5 & 3.2819408 & -8 \\ -5 & -1.5023710 & -8 \\ -4 & -4.8218788 & -8 \\ -5 & 1.8445398 & - \\ -4 & 1.6174242 & -7 \\ -4 & 7.2113090 & -8\end{array}$

-2 to .3

-100 to 80

-500 to 600

-1.5 to 3.0

-. 8 to .5

-24 to 36

-210 to 160

-2.5 to 2.8

-110 to 100

-1 to 1

-11 to 11

-4 to 4

-500 to 500

-400 to 700

-35 to 35

-17 to 13

-130 to 100

-400 to 350

-8 to 8

-110 to 100

-.9 to .9

-26 to 28

-0.06 to +0.06

-50 to 55

-400 to 1500

-900 to 2200

-100 to 70

-70 to 50

-170 to 200

-550 to 550

-40 to 30

-400 to 400

-2.7 to 2.1

-45 to 50

-0.4 to +0.8 


\section{A6.2. Data for Temperature as a Function of Voltage}

The temperature as a function of voltage data given in tables A6.2.1 and A6.2.2 were obtained by iteration in the primary equations for voltage as a function of temperature. Table A6.2.1 presents the data in millivolts from $-8.09 \mathrm{mV}$ to $69.53 \mathrm{mV}$ with temperatures given in degrees Celsius while table A6.2.2 presents similar data with temperatures in degrees Fahrenheit. As discussed in section 6.2 of the text, the values given for Type J thermocouples above $760^{\circ} \mathrm{C}\left(1400{ }^{\circ} \mathrm{F}\right)$ are not suitable for precise temperature measurements. Table A6.2.3 contains quadratic, cubic, and quartic approximations to the data as a function of voltage in selected temperature ranges. The error range given in the table represents the difference between the temperature found by iteration in the full precision tables from the text and from the respective reduced order approximations.

TABLE A5.2.1. Type J thermocouples-temperature $\left({ }^{\circ} \mathrm{C}\right)$ as a function of thermoelectric voltage, reference junctions at $0^{\circ} \mathrm{C}$

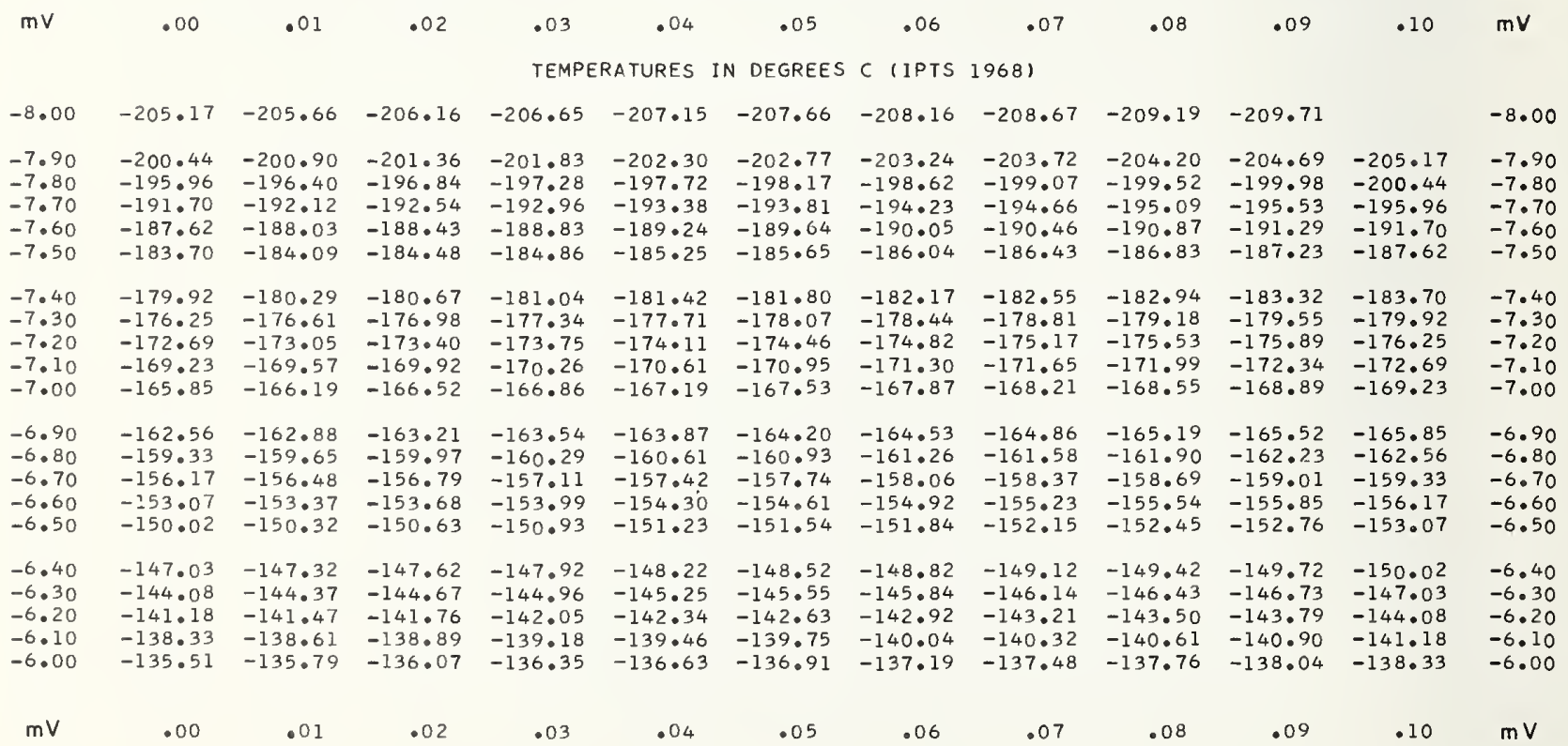


TABLE A6.2.1. Type J thermocouples-temperature $\left({ }^{\circ} \mathrm{C}\right)$ as a function of thermoelectric voltage, reference junctions at $0^{\circ} \mathrm{C}$-Continued

$\mathrm{mV}$

.00

.01

.02

.03

$.03 \quad .04$

.05

.06

.07

.08

.09

$\cdot 10$

$\mathrm{mV}$

TEMPERATURES IN DEGREES C (IPTS 1968)

\begin{tabular}{|c|c|c|c|c|c|c|c|c|c|c|c|c|}
\hline 6.00 & -135.51 & 135.79 & 136.07 & $-136 \cdot 35$ & $-136 \cdot 63$ & -136.91 & $-137 \cdot 19$ & $-137 \cdot 48$ & $-137 \cdot 76$ & $-138 \cdot 04$ & -138.33 & $-6 \cdot 00$ \\
\hline $\begin{array}{l}-5.90 \\
-5.80 \\
-5.70 \\
-5.60 \\
-5.50\end{array}$ & $\begin{array}{l}-132 \cdot 73 \\
-129.98 \\
-127.27 \\
-124.59 \\
-121.94\end{array}$ & $\begin{array}{l}-133 \cdot 00 \\
-130 \cdot 26 \\
-127.54 \\
-124 \cdot 86 \\
-122 \cdot 21\end{array}$ & $\begin{array}{l}-133 \cdot 28 \\
-130 \cdot 53 \\
-127 \cdot 81 \\
-125 \cdot 13 \\
-122 \cdot 47\end{array}$ & $\begin{array}{l}-133 \cdot 56 \\
-130 \cdot 80 \\
-128.08 \\
-125 \cdot 39 \\
-122.73\end{array}$ & $\begin{array}{l}-133 \cdot 84 \\
-131 \cdot 08 \\
-128 \cdot 35 \\
-125 \cdot 66 \\
-123 \cdot 00\end{array}$ & $\begin{array}{l}-134 \cdot 11 \\
-131 \cdot 35 \\
-128 \cdot 62 \\
-125.93 \\
-123.26\end{array}$ & $\begin{array}{l}-134 \cdot 39 \\
-131.63 \\
-128.89 \\
-126.20 \\
-123.53\end{array}$ & $\begin{array}{l}-134 \cdot 67 \\
-131 \cdot 90 \\
-129 \cdot 17 \\
-126 \cdot 46 \\
-123 \cdot 79\end{array}$ & $\begin{array}{l}-134.95 \\
-132.18 \\
-129.44 \\
-126.73 \\
-124.06\end{array}$ & $\begin{array}{l}-135 \cdot 23 \\
-132 \cdot 45 \\
-129 \cdot 71 \\
-127 \cdot 00 \\
-124 \cdot 33\end{array}$ & $\begin{array}{l}-135.51 \\
-132.73 \\
-129.98 \\
-127.27 \\
-124.59\end{array}$ & $\begin{array}{l}-5.90 \\
-5.80 \\
-5.70 \\
-5.60 \\
-5.50\end{array}$ \\
\hline $\begin{array}{l}-5.40 \\
-5.30 \\
-5.20 \\
-5.10 \\
-5.00\end{array}$ & $\begin{array}{l}-119.32 \\
-116.73 \\
-114.16 \\
-111.61 \\
-109.09\end{array}$ & $\begin{array}{l}-119.58 \\
-116.98 \\
-114.41 \\
-111.87 \\
-109.34\end{array}$ & $\begin{array}{l}-119 \cdot 84 \\
-117 \cdot 24 \\
-114 \cdot 67 \\
-112 \cdot 12 \\
-109 \cdot 59\end{array}$ & $\begin{array}{l}-120 \cdot 10 \\
-117 \cdot 50 \\
-114 \cdot 92 \\
-112 \cdot 37 \\
-109 \cdot 84\end{array}$ & $\begin{array}{l}-120 \cdot 37 \\
-117 \cdot 76 \\
-115 \cdot 18 \\
-112 \cdot 63 \\
-110 \cdot 10\end{array}$ & $\begin{array}{l}-120.63 \\
-118.02 \\
-115.44 \\
-112.88 \\
-110.35\end{array}$ & $\begin{array}{l}-120 \cdot 89 \\
-118 \cdot 28 \\
-115.69 \\
-113 \cdot 14 \\
-110.60\end{array}$ & $\begin{array}{l}-121.15 \\
-118.54 \\
-115.95 \\
-113.39 \\
-110.85\end{array}$ & $\begin{array}{l}-121 \cdot 42 \\
-118 \cdot 80 \\
-116 \cdot 21 \\
-113 \cdot 65 \\
-111 \cdot 11\end{array}$ & $\begin{array}{l}-121 \cdot 68 \\
-119 \cdot 06 \\
-116.47 \\
-113 \cdot 90 \\
-111 \cdot 36\end{array}$ & $\begin{array}{l}-121 \cdot 94 \\
-119 \cdot 32 \\
-116 \cdot 73 \\
-114 \cdot 16 \\
-111 \cdot 61\end{array}$ & $\begin{array}{l}-5 \cdot 40 \\
-5 \cdot 30 \\
-5.20 \\
-5 \cdot 10 \\
-5.00\end{array}$ \\
\hline $\begin{array}{l}-4 \cdot 90 \\
-4 \cdot 80 \\
-4 \cdot 70 \\
-4 \cdot 60 \\
-4 \cdot 50\end{array}$ & $\begin{array}{r}-106.59 \\
-104.11 \\
-101.66 \\
-99.22 \\
-96.80\end{array}$ & $\begin{array}{r}-106 \cdot 84 \\
-104 \cdot 36 \\
-101 \cdot 90 \\
-99 \cdot 46 \\
-97 \cdot 04\end{array}$ & $\begin{array}{r}-107.09 \\
-104.61 \\
-102.15 \\
-99.71 \\
-97.28\end{array}$ & $\begin{array}{r}-107.34 \\
-104.86 \\
-102.39 \\
-99.95 \\
-97.52\end{array}$ & $\begin{array}{r}-107.59 \\
-105.10 \\
-102.64 \\
-100.19 \\
-97.77\end{array}$ & $\begin{array}{r}-107.84 \\
-105 \cdot 35 \\
-102.88 \\
-100.44 \\
-98.01\end{array}$ & $\begin{array}{l}-108.09 \\
-105.60 \\
-103.13 \\
-100.68 \\
-98.25\end{array}$ & $\begin{array}{r}-108.34 \\
-105.85 \\
-103.37 \\
-100.92 \\
-98.49\end{array}$ & $\begin{array}{l}-108.59 \\
-106.09 \\
-103.62 \\
-101.17 \\
-98.73\end{array}$ & $\begin{array}{l}-108 \cdot 84 \\
-106 \cdot 34 \\
-103 \cdot 87 \\
-101 \cdot 41 \\
-98.98\end{array}$ & $\begin{array}{r}-109.09 \\
-106.59 \\
-104.11 \\
-101.66 \\
-99.22\end{array}$ & $\begin{array}{l}-4.90 \\
-4.80 \\
-4.70 \\
-4.60 \\
-4.50\end{array}$ \\
\hline $\begin{array}{l}-4 \cdot 40 \\
-4 \cdot 30 \\
-4 \cdot 20 \\
-4 \cdot 10 \\
-4 \cdot 00\end{array}$ & $\begin{array}{l}-94.40 \\
-92.02 \\
-89.65 \\
-87.30 \\
-84.97\end{array}$ & $\begin{array}{l}-94.64 \\
-92.26 \\
-89.89 \\
-87.54 \\
-85.20\end{array}$ & $\begin{array}{l}-94 \cdot 88 \\
-92 \cdot 49 \\
-90.12 \\
-87.77 \\
-85.43\end{array}$ & $\begin{array}{l}-95 \cdot 12 \\
-92 \cdot 73 \\
-90.36 \\
-88.00 \\
-85.67\end{array}$ & $\begin{array}{l}-95 \cdot 36 \\
-92 \cdot 97 \\
-90 \cdot 60 \\
-88 \cdot 24 \\
-85 \cdot 90\end{array}$ & $\begin{array}{l}-95.60 \\
-93.21 \\
-90.83 \\
-88.47 \\
-86.13\end{array}$ & $\begin{array}{l}-95.84 \\
-93.45 \\
-91.07 \\
-88.71 \\
-86.37\end{array}$ & $\begin{array}{l}-96.08 \\
-93.68 \\
-91.31 \\
-88.94 \\
-86.60\end{array}$ & $\begin{array}{l}-96.32 \\
-93.92 \\
-91.54 \\
-89.18 \\
-86.83\end{array}$ & $\begin{array}{l}-96.56 \\
-94.16 \\
-91.78 \\
-89.42 \\
-87.07\end{array}$ & $\begin{array}{l}-96.80 \\
-94.40 \\
-92.02 \\
-89.65 \\
-87.30\end{array}$ & $\begin{array}{l}-4 \cdot 40 \\
-4.30 \\
-4.20 \\
-4.10 \\
-4.00\end{array}$ \\
\hline $\begin{array}{l}-3.90 \\
-3.80 \\
-3.70 \\
-3.60 \\
-3.50\end{array}$ & $\begin{array}{l}-82.65 \\
-80.34 \\
-78.05 \\
-75.77 \\
-73.51\end{array}$ & $\begin{array}{l}-82.88 \\
-80.57 \\
-78 \cdot 28 \\
-76.00 \\
-73.73\end{array}$ & $\begin{array}{l}-83 \cdot 11 \\
-80.80 \\
-78.51 \\
-76.23 \\
-73.96\end{array}$ & $\begin{array}{l}-83 \cdot 34 \\
-81 \cdot 03 \\
-78 \cdot 74 \\
-76.45 \\
-74 \cdot 18\end{array}$ & $\begin{array}{l}-83 \cdot 57 \\
-81 \cdot 26 \\
-78 \cdot 96 \\
-76 \cdot 68 \\
-74 \cdot 41\end{array}$ & $\begin{array}{l}-83.80 \\
-81.49 \\
-79.19 \\
-76.91 \\
-74.64\end{array}$ & $\begin{array}{l}-84.04 \\
-81.72 \\
-79.42 \\
-77.14 \\
-74.86\end{array}$ & $\begin{array}{l}-84.27 \\
-81.95 \\
-79.65 \\
-77.36 \\
-75.09\end{array}$ & $\begin{array}{l}-84.50 \\
-82.18 \\
-79.88 \\
-77.59 \\
-75.32\end{array}$ & $\begin{array}{l}-84.73 \\
-82.42 \\
-80.11 \\
-77.82 \\
-75.54\end{array}$ & $\begin{array}{l}-84.97 \\
-82.65 \\
-80.34 \\
-78.05 \\
-75.77\end{array}$ & $\begin{array}{l}-3.90 \\
-3.80 \\
-3.70 \\
-3.60 \\
-3.50\end{array}$ \\
\hline $\begin{array}{l}-3.40 \\
-3.30 \\
-3.20 \\
-3.10 \\
-3.00\end{array}$ & $\begin{array}{l}-71 \cdot 25 \\
-69 \cdot 01 \\
-66 \cdot 78 \\
-64 \cdot 57 \\
-62 \cdot 36\end{array}$ & $\begin{array}{l}-71.48 \\
-69 \cdot 24 \\
-67 \cdot 01 \\
-64 \cdot 79 \\
-62.58\end{array}$ & $\begin{array}{l}-71.70 \\
-69.46 \\
-67.23 \\
-65.01 \\
-62.80\end{array}$ & $\begin{array}{l}-71.93 \\
-69.68 \\
-67.45 \\
-65.23 \\
-63.02\end{array}$ & $\begin{array}{l}-72.15 \\
-69.91 \\
-67.67 \\
-65.45 \\
-63.24\end{array}$ & $\begin{array}{l}-72.38 \\
-70.13 \\
-67.90 \\
-65.67 \\
-63.46\end{array}$ & $\begin{array}{l}-72 \cdot 60 \\
-70 \cdot 36 \\
-68 \cdot 12 \\
-65.90 \\
-63.68\end{array}$ & $\begin{array}{l}-72.83 \\
-70.58 \\
-68 \cdot 34 \\
-66.12 \\
-63.90\end{array}$ & $\begin{array}{l}-73.05 \\
-70.80 \\
-68.57 \\
-66.34 \\
-64.13\end{array}$ & $\begin{array}{l}-73.28 \\
-71.03 \\
-68.79 \\
-66.56 \\
-64.35\end{array}$ & $\begin{array}{l}-73.51 \\
-71.25 \\
-69.01 \\
-66.78 \\
-64.57\end{array}$ & $\begin{array}{l}-3.40 \\
-3.30 \\
-3.20 \\
-3.10 \\
-3.00\end{array}$ \\
\hline $\begin{array}{l}-2.90 \\
-2.80 \\
-2.70 \\
-2.60 \\
-2.50\end{array}$ & $\begin{array}{l}-60.17 \\
-57.98 \\
-55.80 \\
-53.64 \\
-51.48\end{array}$ & $\begin{array}{l}-60.38 \\
-58.20 \\
-56.02 \\
-53.86 \\
-51.70\end{array}$ & $\begin{array}{l}-60.60 \\
-58.42 \\
-56.24 \\
-54.07 \\
-51.91\end{array}$ & $\begin{array}{l}-60.82 \\
-58.63 \\
-56.46 \\
-54.29 \\
-52.13\end{array}$ & $\begin{array}{l}-61 \cdot 04 \\
-58 \cdot 85 \\
-56 \cdot 67 \\
-54 \cdot 50 \\
-52 \cdot 34\end{array}$ & $\begin{array}{l}-61.26 \\
-59.07 \\
-56.89 \\
-54.72 \\
-52.56\end{array}$ & $\begin{array}{l}-61.48 \\
-59.29 \\
-57.11 \\
-54.94 \\
-52.78\end{array}$ & $\begin{array}{l}-61.70 \\
-59.51 \\
-57.33 \\
-55.15 \\
-52.99\end{array}$ & $\begin{array}{l}-61.92 \\
-59.73 \\
-57.54 \\
-55.37 \\
-53.21\end{array}$ & $\begin{array}{l}-62.14 \\
-59.95 \\
-57.76 \\
-55.59 \\
-53.42\end{array}$ & $\begin{array}{l}-62.36 \\
-60.17 \\
-57.98 \\
-55.80 \\
-53.64\end{array}$ & $\begin{array}{l}-2.90 \\
-2.80 \\
-2.70 \\
-2.60 \\
-2.50\end{array}$ \\
\hline $\begin{array}{l}-2 \cdot 40 \\
-2 \cdot 30 \\
-2 \cdot 20\end{array}$ & $\begin{array}{l}-49 \cdot 34 \\
-47 \cdot 20 \\
-45 \cdot 07\end{array}$ & $\begin{array}{l}-49 \cdot 55 \\
-47.41 \\
-45.28\end{array}$ & $\begin{array}{l}-49 \cdot 76 \\
-47 \cdot 62 \\
-45 \cdot 49\end{array}$ & $\begin{array}{l}-49.98 \\
-47.84 \\
-45.71\end{array}$ & $\begin{array}{l}-50 \cdot 19 \\
-48 \cdot 05 \\
-45 \cdot 92\end{array}$ & $\begin{array}{l}-50.41 \\
-48.27 \\
-46.13\end{array}$ & $\begin{array}{l}-50.62 \\
-48.48 \\
-46.35\end{array}$ & $\begin{array}{l}-50.84 \\
-48.69 \\
-46.56\end{array}$ & $\begin{array}{l}-51.05 \\
-48.91 \\
-46.77\end{array}$ & $\begin{array}{l}-51.27 \\
-49.12 \\
-46.98\end{array}$ & $\begin{array}{l}-51 \cdot 48 \\
-49 \cdot 34 \\
-47.20\end{array}$ & $\begin{array}{l}-2.40 \\
-2.30 \\
-2.20\end{array}$ \\
\hline $\begin{array}{l}-2.10 \\
-2.00\end{array}$ & $\begin{array}{l}-42.95 \\
-40.83\end{array}$ & $\begin{array}{l}-43.16 \\
-41.05\end{array}$ & $\begin{array}{l}-43 \cdot 37 \\
-41.26\end{array}$ & $\begin{array}{l}-43.58 \\
-41.47\end{array}$ & $\begin{array}{l}-43 \cdot 79 \\
-41 \cdot 68\end{array}$ & $\begin{array}{l}-44.01 \\
-41.89\end{array}$ & $\begin{array}{l}-44 \cdot 22 \\
-42 \cdot 10\end{array}$ & $\begin{array}{l}-44 \cdot 43 \\
-42 \cdot 31\end{array}$ & $\begin{array}{l}-44 \cdot 64 \\
-42 \cdot 52\end{array}$ & $\begin{array}{l}-44 \cdot 86 \\
-42.74\end{array}$ & $\begin{array}{l}-45.07 \\
-42.95\end{array}$ & $\begin{array}{l}-2.10 \\
-2.00\end{array}$ \\
\hline $\begin{array}{l}-1.90 \\
-1.80 \\
-1.70 \\
-1.60 \\
-1.50\end{array}$ & $\begin{array}{l}-38.73 \\
-36.63 \\
-34.54 \\
-32.46 \\
-30.39\end{array}$ & $\begin{array}{l}-38.94 \\
-36.84 \\
-34.75 \\
-32.67 \\
-30.59\end{array}$ & $\begin{array}{l}-39.15 \\
-37.05 \\
-34.96 \\
-32.88 \\
-30.80\end{array}$ & $\begin{array}{l}-39.36 \\
-37.26 \\
-35.17 \\
-33.08 \\
-31.01\end{array}$ & $\begin{array}{l}-39.57 \\
-37.47 \\
-35 \cdot 38 \\
-33.29 \\
-31.21\end{array}$ & $\begin{array}{l}-39.78 \\
-37.68 \\
-35.59 \\
-33.50 \\
-31.42\end{array}$ & $\begin{array}{l}-39.99 \\
-37.89 \\
-35.80 \\
-33.71 \\
-31.63\end{array}$ & $\begin{array}{l}-40.20 \\
-38.10 \\
-36.01 \\
-33.92 \\
-31.84\end{array}$ & $\begin{array}{l}-40.41 \\
-38.31 \\
-36.21 \\
-34.13 \\
-32.05\end{array}$ & $\begin{array}{l}-40.62 \\
-38.52 \\
-36.42 \\
-34.33 \\
-32.25\end{array}$ & $\begin{array}{l}-40.83 \\
-38.73 \\
-36.63 \\
-34.54 \\
-32.46\end{array}$ & $\begin{array}{l}-1.90 \\
-1.80 \\
-1.70 \\
-1.60 \\
-1.50\end{array}$ \\
\hline $\begin{array}{l}-1.40 \\
-1.30 \\
-1.20 \\
-1.10 \\
-1.00\end{array}$ & $\begin{array}{l}-28 \cdot 32 \\
-26 \cdot 26 \\
-24 \cdot 20 \\
-22.15 \\
-20.11\end{array}$ & $\begin{array}{l}-28.52 \\
-26.46 \\
-24.41 \\
-22.36 \\
-20.31\end{array}$ & $\begin{array}{l}-28.73 \\
-26.67 \\
-24.61 \\
-22.56 \\
-20.52\end{array}$ & $\begin{array}{l}-28.94 \\
-26.87 \\
-24.82 \\
-22.77 \\
-20.72\end{array}$ & $\begin{array}{l}-29.14 \\
-27.08 \\
-25.02 \\
-22.97 \\
-20.93\end{array}$ & $\begin{array}{l}-29.35 \\
-27.29 \\
-25.23 \\
-23.18 \\
-21.13\end{array}$ & $\begin{array}{l}-29.56 \\
-27.49 \\
-25.43 \\
-23 \cdot 38 \\
-21.34\end{array}$ & $\begin{array}{l}-29.76 \\
-27.70 \\
-25.64 \\
-23.59 \\
-21.54\end{array}$ & $\begin{array}{l}-29.97 \\
-27.90 \\
-25.84 \\
-23.79 \\
-21.74\end{array}$ & $\begin{array}{l}-30.18 \\
-28.11 \\
-26.05 \\
-24.00 \\
-21.95\end{array}$ & $\begin{array}{l}-30.39 \\
-28 \cdot 32 \\
-26.26 \\
-24 \cdot 20 \\
-22 \cdot 15\end{array}$ & $\begin{array}{l}-1.40 \\
-1.30 \\
-1.20 \\
-1.10 \\
-1.00\end{array}$ \\
\hline $\begin{array}{l}-0.90 \\
-0.80 \\
-0.70 \\
-0.60 \\
-0.50\end{array}$ & $\begin{array}{r}-18.07 \\
-16.04 \\
-14.02 \\
-12.00 \\
-9.99\end{array}$ & $\begin{array}{l}-18 \cdot 28 \\
-16 \cdot 25 \\
-14 \cdot 22 \\
-12 \cdot 20 \\
-10 \cdot 19\end{array}$ & $\begin{array}{l}-18 \cdot 48 \\
-16 \cdot 45 \\
-14 \cdot 42 \\
-12 \cdot 40 \\
-10.39\end{array}$ & $\begin{array}{l}-18.68 \\
-16.65 \\
-14.63 \\
-12.61 \\
-10.59\end{array}$ & $\begin{array}{l}-18 \cdot 89 \\
-16.86 \\
-14 \cdot 83 \\
-12.81 \\
-10.79\end{array}$ & $\begin{array}{l}-19.09 \\
-17.06 \\
-15.03 \\
-13.01 \\
-10.99\end{array}$ & $\begin{array}{l}-19 \cdot 30 \\
-17 \cdot 26 \\
-15 \cdot 23 \\
-13 \cdot 21 \\
-11 \cdot 20\end{array}$ & $\begin{array}{l}-19.50 \\
-17.46 \\
-15.44 \\
-13.41 \\
-11.40\end{array}$ & $\begin{array}{l}-19.70 \\
-17.67 \\
-15.64 \\
-13.62 \\
-11.60\end{array}$ & $\begin{array}{l}-19.91 \\
-17.87 \\
-15.84 \\
-13.82 \\
-11.80\end{array}$ & $\begin{array}{l}-20.11 \\
-18.07 \\
-16.04 \\
-14.02 \\
-12.00\end{array}$ & $\begin{array}{l}-0.90 \\
-0.80 \\
-0.70 \\
-0.60 \\
-0.50\end{array}$ \\
\hline $\begin{array}{l}-0.40 \\
-0.30 \\
-0.20 \\
-0.10 \\
-0.00\end{array}$ & $\begin{array}{r}-7.98 \\
-5.98 \\
-3.98 \\
-1.99 \\
0.00\end{array}$ & $\begin{array}{l}-8 \cdot 18 \\
-6 \cdot 18 \\
-4 \cdot 18 \\
-2 \cdot 19 \\
-0.20\end{array}$ & $\begin{array}{l}-8 \cdot 38 \\
-6 \cdot 38 \\
-4 \cdot 38 \\
-2 \cdot 39 \\
-0.40\end{array}$ & $\begin{array}{l}-8.58 \\
-6.58 \\
-4.58 \\
-2.58 \\
-0.60\end{array}$ & $\begin{array}{l}-8 \cdot 78 \\
-6.78 \\
-4.78 \\
-2.78 \\
-0.79\end{array}$ & $\begin{array}{l}-8.98 \\
-6.98 \\
-4.98 \\
-2.98 \\
-0.99\end{array}$ & $\begin{array}{l}-9.18 \\
-7.18 \\
-5.18 \\
-3.18 \\
-1.19\end{array}$ & $\begin{array}{l}-9.39 \\
-7.38 \\
-5.38 \\
-3.38 \\
-1.39\end{array}$ & $\begin{array}{l}-9.59 \\
-7.58 \\
-5.58 \\
-3.58 \\
-1.59\end{array}$ & $\begin{array}{l}-9.79 \\
-7.78 \\
-5.78 \\
-3.78 \\
-1.79\end{array}$ & $\begin{array}{l}-9.99 \\
-7.98 \\
-5.98 \\
-3.98 \\
-1.99\end{array}$ & $\begin{array}{l}-0.40 \\
-0.30 \\
-0.20 \\
-0.10 \\
-0.10\end{array}$ \\
\hline
\end{tabular}

$-6 \cdot 00$

5.80

5.60

$-5 \cdot 40$

5.20

$-5.10$

4.80

$-4 \cdot 50$

4.20

4.00

3.90

3.80
3.70

3.60

$-3.40$

. 30

$-3.10$

$-2.90$

$-2.80$

$-2.70$

2.50

$-2.40$

2.30

$-2.10$

$-1.90$

1.80

$-1.60$

$-1.40$

1.30

1.10

$-1.00$

0.90

-0.80
-0.70

-0.60
-0.50

$-0.40$

$-0.20$

$-0.10$

$\mathrm{mV}$
.00

.01
.02

.03
.04
.06

.07
.08
.10 
TABLE A6.2.1. Type J thermocouples-temperature $\left({ }^{\circ} \mathrm{C}\right)$ as a function of thermoelectric voltage, reference junctions at $0^{\circ} \mathrm{C}-$ Continued

$\mathrm{mV}$

.00

.02

0.00

0.10

0.30

0.00

1.98

0.40

7.90

0.50

9.87

0.60

11.83

13.79

$\begin{array}{ll}0.80 & 15.74 \\ 0.90 & 17.69\end{array}$

$1.00 \quad 19.63$

$\begin{array}{ll}1.00 & 19.63 \\ 1.20 & 21.57 \\ 1.20 & 23.54\end{array}$

$\begin{array}{ll}1.30 & 25.44 \\ 1.40 & 27.37\end{array}$

$1.50 \quad 29.30$

$1.60 \quad 31.22$

$1.70 \quad 33.14$

$\begin{array}{ll}1.80 & 35.06 \\ 1.90 & 36.97\end{array}$

$2.00 \quad 38.88$

$2.10 \quad 40.79$

$2.20 \quad 42.70$

$2.30 \quad 44.60$

$2.50 \quad 48.39$

$\begin{array}{ll}2.50 & 50.29 \\ 2.70 & 52.18\end{array}$

$2.80 \quad 54.07$

$2.90 \quad 55.95$

$3.00 \quad 57.84$

$3.10 \quad 59.72$

$3.20 \quad 61.60$

$3.30 \quad 63.47$

$3.40 \quad 65.35$

$3.50 \quad 67.22$

$3.60 \quad 69.09$

$3.70 \quad 70.96$

$3.80 \quad 72.82$

$4.00 \quad 76.55$

$4.10 \quad 78.41$

$4.40 \quad 83.98$

$4.50 \quad 85.83$

$4.60 \quad 87.68$

$4.70 \quad 89.53$

4.80
$4.90 \quad 91.38$

$5.00 \quad 95.07$

5.10

5.20

5.30

5.40

5.50

5.60

5.70

5.80
5.90

96.91

98.75

100.59

104.27

106.11

107.94

109.78

13.44

$\begin{array}{ll}0.20 & 0.40 \\ 2.18 & 2.38 \\ 4.16 & 4.36 \\ 6.13 & 6.33 \\ 8.10 & 8.30\end{array}$

10.07

12.03

15.93

17.88

19.83

21.77

23.70

25.64
27.57

29.49

31.42

33.34

35.25
37.17

39.08

40.98

42.89

44.79

48.58

50.48
52.37

54.26

56.14

58.03

59.91

61.78

63.66

65.53

67.41

69.28

71.14

73.01
74.87

76.73

78.59

80.45

82.31

84.16

86.02

87.87

89.72

91.56

95.25

97.10

98.94

100.78

102.62

104.45

106.29

108.13

109.96

10.26
12.22

14.18

16.13

18.08

20.02

21.96

23.90

25.83
27.76

29.69

31.61

33.53

35.44

37.36

39.27

41.17

43.08
44.98

46.88

48.77

50.67

.56

56.33

58.21

60.09

61.97

63.85

65.72

67.59

69.46

71.33

73.20

75.06

76.92

78.78

80.64

82.49

84.35

86.20

88.05

89.90

91.75

95.44

97.28

99.12

100.96

102.80

104.64

106.47

108.31

$110 \cdot 14$
111.97

113.62

113.81

.04

.05

.06

.07

.08

.09

.10

$\mathrm{mV}$

TEMPERATURES IN DEGREES C (IPTS 1968)

$\begin{array}{ll}0.60 & 0.79 \\ 2.58 & 2.77 \\ 4.55 & 4.7 \\ 6.53 & 6.72 \\ 8.49 & 8.6\end{array}$

10.46

12.42

14.37

18.27

20.21

22.15

24.09

26.02

29.88

31.80

33.72

35.64

37.55

39.46

41.36

43.27

45.17
47.07

48.96

50.86

52.75

54.63

58.40

60.28

62.16

64.04

65.91

67.78

69.65

71.52

73.38

75.25

77.11

78.97

80.82

82.68

84.53

86.39

88.24

90.09

91.93

93.78

95.62

97.47

99.31

101.15

102.98

104.82

106.66

108.49

110.33

10.65

12.61

16.52

18.47

20.41

22.35

24.28

26.22

30.07

31.99

33.91

35.83

37.74

39.65

41.55

43.46

45.36
47.26

49.15

51.04

52.93

54.82

56.71

58.59

60.47

62.35

64.22

66.10

67.97

69.84

71.70

73.57

75.43

77.29

79.15

81.01

82.86

84.72

86.57

88.42

90.27

92.12

93.96

95.81

97.65

101.33

103.17

106.84

108.68

110.51

112.16

114.17

$\begin{array}{rr}0.99 & 1.19 \\ 2.97 & 3.17 \\ 4.95 & 5.15 \\ 6.92 & 7.12 \\ 8.89 & 9.08 \\ & \\ 10.85 & 11.05 \\ 12.81 & 13.00 \\ 14.76 & 14.96 \\ 16.71 & 16.91 \\ 18.66 & 18.85\end{array}$

1.39

3.37
5.34
7.31

7.31

1.59
3.57
5.54
7.51

7.51

11.24

15.15

17.10

$20.60 \quad 20.80$ 
TABLE A6.2.1. Type J thermocouples-temperature $\left({ }^{\circ} \mathrm{C}\right)$ as a function of thermoelectric voltage, reference junctions at $0^{\circ} \mathrm{C}$-Continued

$\mathrm{mV}$

.00

.01

.02

.03

.04

.05

.06

.07

.08

.09

.10

$m V$

\begin{tabular}{|c|c|c|c|c|c|c|c|c|c|c|c|c|}
\hline $\begin{array}{l}6.00 \\
6.10 \\
6.20 \\
6.30 \\
6.40\end{array}$ & $\begin{array}{l}113.44 \\
115.27 \\
117.10 \\
118.93 \\
120.75\end{array}$ & $\begin{array}{l}113.62 \\
115.45 \\
117.28 \\
119.11 \\
120.93\end{array}$ & $\begin{array}{l}113.81 \\
115.63 \\
117.46 \\
119.29 \\
121.12\end{array}$ & $\begin{array}{l}113.99 \\
115.82 \\
117.65 \\
119.47 \\
121.30\end{array}$ & $\begin{array}{l}114.17 \\
116.00 \\
117.83 \\
119.66 \\
121.48\end{array}$ & $\begin{array}{l}114.35 \\
116.18 \\
118.01 \\
119.84 \\
121.67\end{array}$ & $\begin{array}{l}114.54 \\
116.37 \\
118.19 \\
120.02 \\
121.85\end{array}$ & $\begin{array}{l}114.72 \\
116.55 \\
118.38 \\
120.20 \\
122.03\end{array}$ & $\begin{array}{l}114.90 \\
116.73 \\
118.56 \\
120.39 \\
122.21\end{array}$ & $\begin{array}{l}115.09 \\
116.92 \\
118.74 \\
120.57 \\
122.40\end{array}$ & $\begin{array}{l}115.27 \\
117.10 \\
118.93 \\
120.75 \\
122.58\end{array}$ & $\begin{array}{l}6.00 \\
6.10 \\
6.20 \\
6.30 \\
6.40\end{array}$ \\
\hline $\begin{array}{l}6.50 \\
6.60 \\
6.70 \\
6.80 \\
6.90\end{array}$ & $\begin{array}{l}122.58 \\
124.40 \\
126.23 \\
128.05 \\
129.87\end{array}$ & $\begin{array}{l}122.76 \\
124.58 \\
126.41 \\
128.23 \\
130.05\end{array}$ & $\begin{array}{l}122.94 \\
124.77 \\
126.59 \\
128.41 \\
130.23\end{array}$ & $\begin{array}{l}123.13 \\
124.95 \\
126.77 \\
128.60 \\
130.42\end{array}$ & $\begin{array}{l}123 \cdot 31 \\
125.13 \\
126.96 \\
128 \cdot 78 \\
130.60\end{array}$ & $\begin{array}{l}123.49 \\
125.31 \\
127.14 \\
128.96 \\
130.78\end{array}$ & $\begin{array}{l}123.67 \\
125.50 \\
127.32 \\
129.14 \\
130.96\end{array}$ & $\begin{array}{l}123.86 \\
125.68 \\
127.50 \\
129.32 \\
131.15\end{array}$ & $\begin{array}{l}124.04 \\
125.86 \\
127.68 \\
129.51 \\
131.33\end{array}$ & $\begin{array}{l}124 \cdot 22 \\
126.04 \\
127.87 \\
129.69 \\
131.51\end{array}$ & $\begin{array}{l}124.40 \\
126.23 \\
128.05 \\
129.87 \\
131.69\end{array}$ & $\begin{array}{l}6.50 \\
6.60 \\
6.70 \\
6.80 \\
6.90\end{array}$ \\
\hline $\begin{array}{l}7.00 \\
7.10 \\
7.20 \\
7.30 \\
7.40\end{array}$ & $\begin{array}{l}131.69 \\
133.51 \\
135.33 \\
137.15 \\
138.97\end{array}$ & $\begin{array}{l}131.87 \\
133.69 \\
135.51 \\
137.33 \\
139.15\end{array}$ & $\begin{array}{l}132.06 \\
133.87 \\
135.69 \\
137.51 \\
139.33\end{array}$ & $\begin{array}{l}132.24 \\
134.06 \\
135.88 \\
137.69 \\
139.51\end{array}$ & $\begin{array}{l}132.42 \\
134.24 \\
136.06 \\
137.88 \\
139.69\end{array}$ & $\begin{array}{l}132.60 \\
134.42 \\
136.24 \\
138.06 \\
139.87\end{array}$ & $\begin{array}{l}132 \cdot 78 \\
134.60 \\
136.42 \\
138.24 \\
140.06\end{array}$ & $\begin{array}{l}132.97 \\
134.78 \\
136.60 \\
138.42 \\
140.24\end{array}$ & $\begin{array}{l}133.15 \\
134.97 \\
136.78 \\
138.60 \\
140.42\end{array}$ & $\begin{array}{l}133.33 \\
135.15 \\
136.97 \\
138.78 \\
140.60\end{array}$ & $\begin{array}{l}133.51 \\
135.33 \\
137.15 \\
138.97 \\
140.78\end{array}$ & $\begin{array}{l}7.00 \\
7.10 \\
7.20 \\
7.30 \\
7.40\end{array}$ \\
\hline $\begin{array}{l}7.50 \\
7.60 \\
7.70 \\
7.80 \\
7.90\end{array}$ & $\begin{array}{l}140.78 \\
142.60 \\
144.41 \\
146.23 \\
148.04\end{array}$ & $\begin{array}{l}140.96 \\
142.78 \\
144.59 \\
146.41 \\
148.22\end{array}$ & $\begin{array}{l}141.15 \\
142.96 \\
144.78 \\
146.59 \\
148.40\end{array}$ & $\begin{array}{l}141.33 \\
143.14 \\
144.96 \\
146.77 \\
148.59\end{array}$ & $\begin{array}{l}141 \cdot 51 \\
143 \cdot 32 \\
145.14 \\
146.95 \\
148.77\end{array}$ & $\begin{array}{l}141.69 \\
143.51 \\
145.32 \\
147.13 \\
148.95\end{array}$ & $\begin{array}{l}141.87 \\
143.69 \\
145.50 \\
147.32 \\
149.13\end{array}$ & $\begin{array}{l}142.05 \\
143.87 \\
145.68 \\
147.50 \\
149.31\end{array}$ & $\begin{array}{l}142.23 \\
144.05 \\
145.86 \\
147.68 \\
149.49\end{array}$ & $\begin{array}{l}142.42 \\
144.23 \\
146.05 \\
147.86 \\
149.67\end{array}$ & $\begin{array}{l}142.60 \\
144.41 \\
146.23 \\
148.04 \\
149.85\end{array}$ & $\begin{array}{l}7.50 \\
7.60 \\
7.70 \\
7.80 \\
7.90\end{array}$ \\
\hline $\begin{array}{l}8.00 \\
8.10 \\
8.20 \\
8.30 \\
8.40\end{array}$ & $\begin{array}{l}149.85 \\
151.67 \\
153.48 \\
155.29 \\
157.10\end{array}$ & $\begin{array}{l}150.04 \\
151.85 \\
153.66 \\
155.47 \\
157.28\end{array}$ & $\begin{array}{l}150.22 \\
152.03 \\
153.84 \\
155.65 \\
157.46\end{array}$ & $\begin{array}{l}150.40 \\
152.21 \\
154.02 \\
155.83 \\
157.64\end{array}$ & $\begin{array}{l}150.58 \\
152.39 \\
154.20 \\
156.01 \\
157.82\end{array}$ & $\begin{array}{l}150.76 \\
152.57 \\
154.38 \\
156.19 \\
158.00\end{array}$ & $\begin{array}{l}150.94 \\
152.75 \\
154.56 \\
156.38 \\
158.19\end{array}$ & $\begin{array}{l}151.12 \\
152.93 \\
154.75 \\
156.56 \\
158.37\end{array}$ & $\begin{array}{l}151.30 \\
153.12 \\
154.93 \\
156.74 \\
158.55\end{array}$ & $\begin{array}{l}151.49 \\
153.30 \\
155.11 \\
156.92 \\
158.73\end{array}$ & $\begin{array}{l}151.67 \\
153.48 \\
155.29 \\
157.10 \\
158.91\end{array}$ & $\begin{array}{l}8.00 \\
8.10 \\
8.20 \\
8.30 \\
8.40\end{array}$ \\
\hline $\begin{array}{l}8.50 \\
8.60 \\
8.70 \\
8.80 \\
8.90\end{array}$ & $\begin{array}{l}158.91 \\
160.72 \\
162.53 \\
164.34 \\
166.14\end{array}$ & $\begin{array}{l}159.09 \\
160.90 \\
162.71 \\
164.52 \\
166.32\end{array}$ & $\begin{array}{l}159.27 \\
161.08 \\
162.89 \\
164.70 \\
166.51\end{array}$ & $\begin{array}{l}159.45 \\
161.26 \\
163.07 \\
164.88 \\
166.69\end{array}$ & $\begin{array}{l}159.63 \\
161.44 \\
163.25 \\
165.06 \\
166.87\end{array}$ & $\begin{array}{l}159.81 \\
161.62 \\
163.43 \\
165.24 \\
167.05\end{array}$ & $\begin{array}{l}160.00 \\
161.80 \\
163.61 \\
165.42 \\
167.23\end{array}$ & $\begin{array}{l}160.18 \\
161.99 \\
163.79 \\
165.60 \\
167.41\end{array}$ & $\begin{array}{l}160.36 \\
162.17 \\
163.97 \\
165.78 \\
167.59\end{array}$ & $\begin{array}{l}160 \cdot 54 \\
162.35 \\
164 \cdot 16 \\
165.96 \\
167.77\end{array}$ & $\begin{array}{l}160.72 \\
162.53 \\
164.34 \\
166.14 \\
167.95\end{array}$ & $\begin{array}{l}8.50 \\
8.60 \\
8.70 \\
8.80 \\
8.90\end{array}$ \\
\hline $\begin{array}{l}9.00 \\
9.10 \\
9.20 \\
9.30 \\
9.40\end{array}$ & $\begin{array}{l}167.95 \\
169.76 \\
171.56 \\
173.37 \\
175.18\end{array}$ & $\begin{array}{l}168.13 \\
169.94 \\
171.75 \\
173.55 \\
175.36\end{array}$ & $\begin{array}{l}168.31 \\
170.12 \\
171.93 \\
173.73 \\
175.54\end{array}$ & $\begin{array}{l}168.49 \\
170.30 \\
172.11 \\
173.91 \\
175.72\end{array}$ & $\begin{array}{l}168.67 \\
170.48 \\
172.29 \\
174.09 \\
175.90\end{array}$ & $\begin{array}{l}168.85 \\
170.66 \\
172.47 \\
174.27 \\
176.08\end{array}$ & $\begin{array}{l}169.04 \\
170.84 \\
172.65 \\
174.45 \\
176.26\end{array}$ & $\begin{array}{l}169.22 \\
171.02 \\
172.83 \\
174.63 \\
176.44\end{array}$ & $\begin{array}{l}169.40 \\
171.20 \\
173.01 \\
174.82 \\
176.62\end{array}$ & $\begin{array}{l}169.58 \\
171.38 \\
173.19 \\
175.00 \\
176.80\end{array}$ & $\begin{array}{l}169.76 \\
171.56 \\
173.37 \\
175.18 \\
176.98\end{array}$ & $\begin{array}{l}9.00 \\
9.10 \\
9.20 \\
9.30 \\
9.40\end{array}$ \\
\hline $\begin{array}{l}9.50 \\
9.60 \\
9.70 \\
9.80 \\
9.90\end{array}$ & $\begin{array}{l}176.98 \\
178.79 \\
180.59 \\
182.40 \\
184.20\end{array}$ & $\begin{array}{l}177.16 \\
178.97 \\
180.77 \\
182.58 \\
184.38\end{array}$ & $\begin{array}{l}177.34 \\
179.15 \\
180.95 \\
182.76 \\
184.56\end{array}$ & $\begin{array}{l}177.52 \\
179.33 \\
181.13 \\
182.94 \\
184.74\end{array}$ & $\begin{array}{l}177 \cdot 70 \\
179 \cdot 51 \\
181.31 \\
183.12 \\
184.92\end{array}$ & $\begin{array}{l}177.88 \\
179.69 \\
181.49 \\
183.30 \\
185.10\end{array}$ & $\begin{array}{l}178.06 \\
179.87 \\
181.67 \\
183.48 \\
185.28\end{array}$ & $\begin{array}{l}178.25 \\
180.05 \\
181.85 \\
183.66 \\
185.46\end{array}$ & $\begin{array}{l}178.43 \\
180.23 \\
182.03 \\
183.84 \\
185.64\end{array}$ & $\begin{array}{l}178.61 \\
180.41 \\
182.22 \\
184.02 \\
185.82\end{array}$ & $\begin{array}{l}178.79 \\
180.59 \\
182.40 \\
184.20 \\
186.00\end{array}$ & $\begin{array}{l}9.50 \\
9.60 \\
9.70 \\
9.80 \\
9.90\end{array}$ \\
\hline $\begin{array}{l}10.00 \\
10.10 \\
10.20 \\
10.30 \\
10.40\end{array}$ & $\begin{array}{l}186.00 \\
187.81 \\
189.61 \\
191.41 \\
193.21\end{array}$ & $\begin{array}{l}186.18 \\
187.99 \\
189.79 \\
191.59 \\
193.40\end{array}$ & $\begin{array}{l}186.36 \\
188.17 \\
189.97 \\
191.77 \\
193.58\end{array}$ & $\begin{array}{l}186.54 \\
188.35 \\
190.15 \\
191.95 \\
193.76\end{array}$ & $\begin{array}{l}186.72 \\
188.53 \\
190.33 \\
192.13 \\
193.94\end{array}$ & $\begin{array}{l}186.90 \\
188.71 \\
190.51 \\
192.31 \\
194.12\end{array}$ & $\begin{array}{l}187.09 \\
188.89 \\
190.69 \\
192.49 \\
194.30\end{array}$ & $\begin{array}{l}187.27 \\
189.07 \\
190.87 \\
192.67 \\
194.48\end{array}$ & $\begin{array}{l}187.45 \\
189.25 \\
191.05 \\
192.85 \\
194.66\end{array}$ & $\begin{array}{l}187.63 \\
189.43 \\
191.23 \\
193.03 \\
194.84\end{array}$ & $\begin{array}{l}187.81 \\
189.61 \\
191.41 \\
193.21 \\
195.02\end{array}$ & $\begin{array}{l}10.00 \\
10.10 \\
10.20 \\
10.30 \\
10.40\end{array}$ \\
\hline $\begin{array}{l}10.50 \\
10.60 \\
10.70 \\
10.80 \\
10.90\end{array}$ & $\begin{array}{l}195.02 \\
196.82 \\
198.62 \\
200.42 \\
202.22\end{array}$ & $\begin{array}{l}195.20 \\
197.00 \\
198.80 \\
200.60 \\
202.40\end{array}$ & $\begin{array}{l}195.38 \\
197.18 \\
198.98 \\
200.78 \\
202.59\end{array}$ & $\begin{array}{l}195.56 \\
197.36 \\
199.16 \\
200.96 \\
202.77\end{array}$ & $\begin{array}{l}195.74 \\
197.54 \\
199.34 \\
201.14 \\
202.95\end{array}$ & $\begin{array}{l}195.92 \\
197.72 \\
199.52 \\
201.32 \\
203.13\end{array}$ & $\begin{array}{l}196.10 \\
197.90 \\
199.70 \\
201.50 \\
203.31\end{array}$ & $\begin{array}{l}196.28 \\
198.08 \\
199.88 \\
201.68 \\
203.49\end{array}$ & $\begin{array}{l}196.46 \\
198.26 \\
200.06 \\
201.86 \\
203.67\end{array}$ & $\begin{array}{l}196.64 \\
198.44 \\
200.24 \\
202.04 \\
203.85\end{array}$ & $\begin{array}{l}196.82 \\
198.62 \\
200.42 \\
202.22 \\
204.03\end{array}$ & $\begin{array}{l}10.50 \\
10.60 \\
10.70 \\
10.80 \\
10.90\end{array}$ \\
\hline $\begin{array}{l}11.00 \\
11.10 \\
11.20 \\
11.30 \\
11.40\end{array}$ & $\begin{array}{l}204.03 \\
205.83 \\
207.63 \\
209.43 \\
211.23\end{array}$ & $\begin{array}{l}204.21 \\
206.01 \\
207.81 \\
209.61 \\
211.41\end{array}$ & $\begin{array}{l}204.39 \\
206.19 \\
207.99 \\
209.79 \\
211.59\end{array}$ & $\begin{array}{l}204.57 \\
206.37 \\
208.17 \\
209.97 \\
211.77\end{array}$ & $\begin{array}{l}204 \cdot 75 \\
206 \cdot 55 \\
208 \cdot 35 \\
210 \cdot 15 \\
211.95\end{array}$ & $\begin{array}{l}204.93 \\
206.73 \\
208.53 \\
210.33 \\
212.13\end{array}$ & $\begin{array}{l}205.11 \\
206.91 \\
208.71 \\
210.51 \\
212.31\end{array}$ & $\begin{array}{l}205.29 \\
207.09 \\
208.89 \\
210.69 \\
212.49\end{array}$ & $\begin{array}{l}205.47 \\
207.27 \\
209.07 \\
210.87 \\
212.67\end{array}$ & $\begin{array}{l}205.65 \\
207.45 \\
209.25 \\
211.05 \\
212.85\end{array}$ & $\begin{array}{l}205.83 \\
207.63 \\
209.43 \\
211.23 \\
213.03\end{array}$ & $\begin{array}{l}11.00 \\
11.10 \\
11.20 \\
11.30 \\
11.40\end{array}$ \\
\hline $\begin{array}{l}11.50 \\
11.60 \\
11.70 \\
11.80 \\
11.90\end{array}$ & $\begin{array}{l}213.03 \\
214.83 \\
216.63 \\
218.43 \\
220.23\end{array}$ & $\begin{array}{l}213.21 \\
215.01 \\
216.81 \\
218.61 \\
220.41\end{array}$ & $\begin{array}{l}213.39 \\
215.19 \\
216.99 \\
218.79 \\
220.59\end{array}$ & $\begin{array}{l}213.57 \\
215.37 \\
217.17 \\
218.97 \\
220.77\end{array}$ & $\begin{array}{l}213 \cdot 75 \\
215 \cdot 55 \\
217 \cdot 35 \\
219 \cdot 15 \\
220 \cdot 95\end{array}$ & $\begin{array}{l}213.93 \\
215.73 \\
217.53 \\
219.33 \\
221.13\end{array}$ & $\begin{array}{l}214.11 \\
215.91 \\
217.71 \\
219.51 \\
221.31\end{array}$ & $\begin{array}{l}214.29 \\
216.09 \\
217.89 \\
219.69 \\
221.49\end{array}$ & $\begin{array}{l}214.47 \\
216.27 \\
218.07 \\
219.87 \\
221.68\end{array}$ & $\begin{array}{l}214.65 \\
216.45 \\
218.25 \\
220.05 \\
221.86\end{array}$ & $\begin{array}{l}214.83 \\
216.63 \\
218.43 \\
220.23 \\
222.04\end{array}$ & $\begin{array}{l}11.50 \\
11.60 \\
11.70 \\
11.80 \\
11.90\end{array}$ \\
\hline 12.00 & 222.04 & $222 \cdot 22$ & 222.40 & 222.58 & $222 \cdot 76$ & 222.94 & 223.12 & 223.30 & 223.48 & 223.66 & 223.84 & 12.00 \\
\hline
\end{tabular}

$m v$

.00

.01

.02

.03

.04

.05

.06

.07

.08

.09

$\cdot 10$

$\mathrm{mV}$ 
TABLE A6.2.1. Type I thermocouples-temperature $\left({ }^{\circ} \mathrm{C}\right)$ as a function of thermoelectric voltage, reference junctions at $0^{\circ} \mathrm{C}$-Continued

$\mathrm{mV}$

.00

.01

.02

.03

.04

.05

.06

.07

TEMPERATURES IN DEGREES C (IPTS 1968)

\begin{tabular}{|c|c|c|c|c|c|c|c|c|c|c|c|c|}
\hline $\begin{array}{l}12 \cdot 00 \\
12.10 \\
12 \cdot 20 \\
12.30 \\
12 \cdot 40\end{array}$ & $\begin{array}{l}222 \cdot 04 \\
223 \cdot 84 \\
225 \cdot 64 \\
227 \cdot 44 \\
229 \cdot 24\end{array}$ & $\begin{array}{l}222 \cdot 22 \\
224 \cdot 02 \\
225 \cdot 82 \\
227 \cdot 62 \\
229 \cdot 42\end{array}$ & $\begin{array}{l}222 \cdot 40 \\
224.20 \\
226.00 \\
227.80 \\
229.60\end{array}$ & $\begin{array}{l}222 \cdot 58 \\
224 \cdot 38 \\
226 \cdot 18 \\
227.98 \\
229 \cdot 78\end{array}$ & $\begin{array}{l}222 \cdot 76 \\
224 \cdot 56 \\
226 \cdot 36 \\
228 \cdot 16 \\
229 \cdot 96\end{array}$ & $\begin{array}{l}222 \cdot 94 \\
224 \cdot 74 \\
226 \cdot 54 \\
228 \cdot 34 \\
230 \cdot 14\end{array}$ & $\begin{array}{l}223 \cdot 12 \\
224 \cdot 92 \\
226.72 \\
228 \cdot 52 \\
230 \cdot 32\end{array}$ & $\begin{array}{l}223 \cdot 30 \\
225 \cdot 10 \\
226.90 \\
228.70 \\
230.50\end{array}$ & $\begin{array}{l}223 \cdot 48 \\
225 \cdot 28 \\
227.08 \\
228.88 \\
230.68\end{array}$ & $\begin{array}{l}223.66 \\
225.46 \\
227.26 \\
229 \cdot 06 \\
230.86\end{array}$ & $\begin{array}{l}223.84 \\
225.64 \\
227.44 \\
229 \cdot 24 \\
231.04\end{array}$ & $\begin{array}{l}12.00 \\
12.10 \\
12.20 \\
12.30 \\
12.40\end{array}$ \\
\hline $\begin{array}{l}12.50 \\
12.60 \\
12.70 \\
12.80 \\
12.90\end{array}$ & $\begin{array}{l}231.04 \\
232.84 \\
234.64 \\
236.44 \\
238.24\end{array}$ & $\begin{array}{l}231.22 \\
233.02 \\
234.82 \\
236.62 \\
238.42\end{array}$ & $\begin{array}{l}231.40 \\
233 \cdot 20 \\
235.00 \\
236.80 \\
238.60\end{array}$ & $\begin{array}{l}231.58 \\
233 \cdot 38 \\
235.18 \\
236.98 \\
238 \cdot 78\end{array}$ & $\begin{array}{l}231 \cdot 76 \\
233 \cdot 56 \\
235 \cdot 36 \\
237 \cdot 16 \\
238 \cdot 96\end{array}$ & $\begin{array}{l}231.94 \\
233.74 \\
235.54 \\
237.34 \\
239.14\end{array}$ & $\begin{array}{l}232.12 \\
233.92 \\
235.72 \\
237 \cdot 52 \\
239 \cdot 32\end{array}$ & $\begin{array}{l}232.30 \\
234.10 \\
235.90 \\
237.70 \\
239.50\end{array}$ & $\begin{array}{l}232.48 \\
234.28 \\
236.08 \\
237.88 \\
239.68\end{array}$ & $\begin{array}{l}232.66 \\
234.46 \\
236.26 \\
238.06 \\
239.86\end{array}$ & $\begin{array}{l}232.84 \\
234.64 \\
236.44 \\
238.24 \\
240.04\end{array}$ & $\begin{array}{l}12.50 \\
12.60 \\
12.70 \\
12.80 \\
12.90\end{array}$ \\
\hline $\begin{array}{l}13.00 \\
13.10 \\
13.20 \\
13.30 \\
13.40\end{array}$ & $\begin{array}{l}240.04 \\
241.84 \\
243.64 \\
245 \cdot 44 \\
247.25\end{array}$ & $\begin{array}{l}240.22 \\
242.02 \\
243.82 \\
245.62 \\
247.43\end{array}$ & $\begin{array}{l}240.40 \\
242.20 \\
244.00 \\
245.80 \\
247.61\end{array}$ & $\begin{array}{l}240.58 \\
242.38 \\
244.18 \\
245.98 \\
247.79\end{array}$ & $\begin{array}{l}240 \cdot 76 \\
242 \cdot 56 \\
244 \cdot 36 \\
246 \cdot 16 \\
247.97\end{array}$ & $\begin{array}{l}240.94 \\
242.74 \\
244.54 \\
246.34 \\
248.15\end{array}$ & $\begin{array}{l}241.12 \\
242.92 \\
244.72 \\
246.53 \\
248.33\end{array}$ & $\begin{array}{l}241.30 \\
243.10 \\
244.90 \\
246.71 \\
248.51\end{array}$ & $\begin{array}{l}241.48 \\
243.28 \\
245.08 \\
246.89 \\
248.69\end{array}$ & $\begin{array}{l}241.66 \\
243.46 \\
245.26 \\
247.07 \\
248.87\end{array}$ & $\begin{array}{l}241.84 \\
243.64 \\
245.44 \\
247.25 \\
249.05\end{array}$ & $\begin{array}{l}13.00 \\
13.10 \\
13.20 \\
13.30 \\
13.40\end{array}$ \\
\hline $\begin{array}{l}13.50 \\
13.60 \\
13.70 \\
13.80 \\
13.90\end{array}$ & $\begin{array}{l}249.05 \\
250.85 \\
252.65 \\
254.45 \\
256.25\end{array}$ & $\begin{array}{l}249.23 \\
251.03 \\
252.83 \\
254.63 \\
256.43\end{array}$ & $\begin{array}{l}249.41 \\
251.21 \\
253.01 \\
254.81 \\
256.61\end{array}$ & $\begin{array}{l}249.59 \\
251.39 \\
253.19 \\
254.99 \\
256.79\end{array}$ & $\begin{array}{l}249.77 \\
251.57 \\
253.37 \\
255.17 \\
256.97\end{array}$ & $\begin{array}{l}249.95 \\
251.75 \\
253 \cdot 55 \\
255.35 \\
257.15\end{array}$ & $\begin{array}{l}250.13 \\
251.93 \\
253.73 \\
255.53 \\
257.33\end{array}$ & $\begin{array}{l}250.31 \\
252.11 \\
253.91 \\
255.71 \\
257.51\end{array}$ & $\begin{array}{l}250.49 \\
252.29 \\
254.09 \\
255.89 \\
257.69\end{array}$ & $\begin{array}{l}250.67 \\
252.47 \\
254.27 \\
256.07 \\
257.87\end{array}$ & $\begin{array}{l}250.85 \\
252.65 \\
254 \cdot 45 \\
\angle 56 \cdot 25 \\
258.05\end{array}$ & $\begin{array}{l}13.50 \\
13.60 \\
13.70 \\
13.80 \\
13.90\end{array}$ \\
\hline $\begin{array}{l}14.00 \\
14.10 \\
14.20 \\
14.30 \\
14.40\end{array}$ & $\begin{array}{l}258.05 \\
259.86 \\
261.66 \\
263.46 \\
265.26\end{array}$ & $\begin{array}{l}258 \cdot 24 \\
260.04 \\
261.84 \\
263 \cdot 64 \\
265 \cdot 44\end{array}$ & $\begin{array}{l}258.42 \\
260.22 \\
262.02 \\
263.82 \\
265.62\end{array}$ & $\begin{array}{l}258.60 \\
260.40 \\
262.20 \\
264.00 \\
265.80\end{array}$ & $\begin{array}{l}258 \cdot 78 \\
260 \cdot 58 \\
262 \cdot 38 \\
264 \cdot 18 \\
265 \cdot 98\end{array}$ & $\begin{array}{l}258.96 \\
260.76 \\
262.56 \\
264 \cdot 36 \\
266.17\end{array}$ & $\begin{array}{l}259 \cdot 14 \\
260 \cdot 94 \\
262 \cdot 74 \\
264 \cdot 54 \\
266 \cdot 35\end{array}$ & $\begin{array}{l}259 \cdot 32 \\
261 \cdot 12 \\
262 \cdot 92 \\
264 \cdot 72 \\
266.53\end{array}$ & $\begin{array}{l}259 \cdot 50 \\
261 \cdot 30 \\
263 \cdot 10 \\
264 \cdot 90 \\
266.71\end{array}$ & $\begin{array}{l}259.68 \\
261.48 \\
263.28 \\
265.08 \\
266.89\end{array}$ & $\begin{array}{l}259.86 \\
261.66 \\
263.46 \\
265.26 \\
267.07\end{array}$ & $\begin{array}{l}14.00 \\
14.10 \\
14.20 \\
14.30 \\
14.40\end{array}$ \\
\hline $\begin{array}{l}14.50 \\
14.60 \\
14.70 \\
14.80 \\
14.90\end{array}$ & $\begin{array}{l}267.07 \\
268.87 \\
270.67 \\
272.48 \\
274.28\end{array}$ & $\begin{array}{l}267.25 \\
269.05 \\
270.85 \\
272.66 \\
274.46\end{array}$ & $\begin{array}{l}267 \cdot 43 \\
269 \cdot 23 \\
271 \cdot 03 \\
272 \cdot 84 \\
274 \cdot 64\end{array}$ & $\begin{array}{l}267.61 \\
269.41 \\
271.21 \\
273.02 \\
274.82\end{array}$ & $\begin{array}{l}267.79 \\
269.59 \\
271.39 \\
273.20 \\
275.00\end{array}$ & $\begin{array}{l}267.97 \\
269.77 \\
271.57 \\
273.38 \\
275.18\end{array}$ & $\begin{array}{l}268.15 \\
269.95 \\
271.75 \\
273.56 \\
275.36\end{array}$ & $\begin{array}{l}268.33 \\
270.13 \\
271.93 \\
273.74 \\
275.54\end{array}$ & $\begin{array}{l}268.51 \\
270.31 \\
272.11 \\
273.92 \\
275.72\end{array}$ & $\begin{array}{l}268.69 \\
270.49 \\
272.29 \\
274.10 \\
275.90\end{array}$ & $\begin{array}{l}268.87 \\
270.67 \\
272.48 \\
274 \cdot 28 \\
276.08\end{array}$ & $\begin{array}{l}14.50 \\
14.60 \\
14.70 \\
14.80 \\
14.90\end{array}$ \\
\hline $\begin{array}{l}15 \cdot 00 \\
15 \cdot 10 \\
15 \cdot 20 \\
15 \cdot 30 \\
15 \cdot 40\end{array}$ & $\begin{array}{l}276.08 \\
277.89 \\
279.69 \\
281.49 \\
283.30\end{array}$ & $\begin{array}{l}276.26 \\
278.07 \\
279.87 \\
281.67 \\
283.48\end{array}$ & $\begin{array}{l}276.44 \\
278.25 \\
280.05 \\
281.85 \\
283.66\end{array}$ & $\begin{array}{l}276.62 \\
278.43 \\
280.23 \\
282.04 \\
283.84\end{array}$ & $\begin{array}{l}276 \cdot 80 \\
278 \cdot 61 \\
280 \cdot 41 \\
282 \cdot 22 \\
284 \cdot 02\end{array}$ & $\begin{array}{l}276.98 \\
278.79 \\
280.59 \\
282 \cdot 40 \\
284 \cdot 20\end{array}$ & $\begin{array}{l}277 \cdot 16 \\
278.97 \\
280.77 \\
282 \cdot 58 \\
284 \cdot 38\end{array}$ & $\begin{array}{l}277.34 \\
279.15 \\
280.95 \\
282.76 \\
284.56\end{array}$ & $\begin{array}{l}277.53 \\
279.33 \\
281.13 \\
282.94 \\
284.74\end{array}$ & $\begin{array}{l}277 \cdot 71 \\
279.51 \\
281 \cdot 31 \\
283 \cdot 12 \\
284 \cdot 92\end{array}$ & $\begin{array}{l}277.89 \\
279.69 \\
281.49 \\
283.30 \\
285.10\end{array}$ & $\begin{array}{l}15.00 \\
15.10 \\
15.20 \\
15.30 \\
15.40\end{array}$ \\
\hline $\begin{array}{l}15.50 \\
15.60 \\
15.70 \\
15.80 \\
15.90\end{array}$ & $\begin{array}{l}285 \cdot 10 \\
286.91 \\
288 \cdot 71 \\
290 \cdot 52 \\
292 \cdot 32\end{array}$ & $\begin{array}{l}285.28 \\
287.09 \\
288.89 \\
290.70 \\
292.50\end{array}$ & $\begin{array}{l}285 \cdot 46 \\
287 \cdot 27 \\
289 \cdot 07 \\
290 \cdot 88 \\
292.68\end{array}$ & $\begin{array}{l}285.64 \\
287.45 \\
289.25 \\
291.06 \\
292.86\end{array}$ & $\begin{array}{l}285.82 \\
287.63 \\
289.43 \\
291.24 \\
293.05\end{array}$ & $\begin{array}{l}286.01 \\
287.81 \\
289.61 \\
291.42 \\
293.23\end{array}$ & $\begin{array}{l}286.19 \\
287.99 \\
289.80 \\
291.60 \\
293.41\end{array}$ & $\begin{array}{l}286.37 \\
288.17 \\
289.98 \\
291.78 \\
293.59\end{array}$ & $\begin{array}{l}286.55 \\
288.35 \\
290.16 \\
291.96 \\
293.77\end{array}$ & $\begin{array}{l}286.73 \\
288.53 \\
290.34 \\
292.14 \\
293.95\end{array}$ & $\begin{array}{l}286.91 \\
288.71 \\
290.52 \\
292.32 \\
294.13\end{array}$ & $\begin{array}{l}15.50 \\
15.50 \\
15.70 \\
15.80 \\
15.90\end{array}$ \\
\hline $\begin{array}{l}16.00 \\
16.10 \\
16.20 \\
16.30 \\
16.40\end{array}$ & $\begin{array}{l}294 \cdot 13 \\
295 \cdot 93 \\
297 \cdot 74 \\
299 \cdot 55 \\
301.35\end{array}$ & $\begin{array}{l}294.31 \\
296.11 \\
297.92 \\
299.73 \\
301.53\end{array}$ & $\begin{array}{l}294 \cdot 49 \\
296.30 \\
298.10 \\
299 \cdot 91 \\
301.71\end{array}$ & $\begin{array}{l}294.67 \\
296.48 \\
298.28 \\
300.09 \\
301.89\end{array}$ & $\begin{array}{l}294 \cdot 85 \\
296.66 \\
298.46 \\
300 \cdot 27 \\
302.08\end{array}$ & $\begin{array}{l}295.03 \\
296.84 \\
298.64 \\
300.45 \\
302.26\end{array}$ & $\begin{array}{l}295.21 \\
297.02 \\
298.82 \\
300.63 \\
302.44\end{array}$ & $\begin{array}{l}295.39 \\
297.20 \\
299.00 \\
300.81 \\
302.62\end{array}$ & $\begin{array}{l}295.57 \\
297.38 \\
299.19 \\
300.99 \\
302.80\end{array}$ & $\begin{array}{l}295.75 \\
297.56 \\
299.37 \\
301.17 \\
302.98\end{array}$ & $\begin{array}{l}295.93 \\
297.74 \\
299.55 \\
301.35 \\
303.16\end{array}$ & $\begin{array}{l}16 \cdot 00 \\
16 \cdot 10 \\
16.20 \\
16.30 \\
16.40\end{array}$ \\
\hline $\begin{array}{l}16.50 \\
16.60 \\
16.70 \\
16.80 \\
16.90\end{array}$ & $\begin{array}{l}303.16 \\
304.97 \\
306.77 \\
308.58 \\
310.39\end{array}$ & $\begin{array}{l}303 \cdot 34 \\
305.15 \\
306.95 \\
308.76 \\
310.57\end{array}$ & $\begin{array}{l}303 \cdot 52 \\
305.33 \\
307.14 \\
308.94 \\
310.75\end{array}$ & $\begin{array}{l}303.70 \\
305.51 \\
307.32 \\
309.12 \\
310.93\end{array}$ & $\begin{array}{l}303 \cdot 88 \\
305.69 \\
307.50 \\
309 \cdot 30 \\
311.11\end{array}$ & $\begin{array}{l}304.06 \\
305.87 \\
307.68 \\
309.48 \\
311.29\end{array}$ & $\begin{array}{l}304 \cdot 24 \\
306 \cdot 05 \\
307 \cdot 86 \\
309 \cdot 67 \\
311.47\end{array}$ & $\begin{array}{l}304.42 \\
306.23 \\
308.04 \\
309.85 \\
311.65\end{array}$ & $\begin{array}{l}304.61 \\
306.41 \\
308.22 \\
310.03 \\
311.83\end{array}$ & $\begin{array}{l}304.79 \\
306.59 \\
308.40 \\
310.21 \\
312.02\end{array}$ & $\begin{array}{l}304.97 \\
306.77 \\
308 \cdot 58 \\
310.39 \\
312.20\end{array}$ & $\begin{array}{l}16.50 \\
16.60 \\
16.70 \\
16.80 \\
16.90\end{array}$ \\
\hline $\begin{array}{l}17.00 \\
17.10 \\
17.20 \\
17.30 \\
17.40\end{array}$ & $\begin{array}{l}312.20 \\
314.00 \\
315.81 \\
317.62 \\
319.43\end{array}$ & $\begin{array}{l}312.38 \\
314.19 \\
315.99 \\
317.80 \\
319.61\end{array}$ & $\begin{array}{l}312 \cdot 56 \\
314.37 \\
316.17 \\
317.98 \\
319.79\end{array}$ & $\begin{array}{l}312.74 \\
314.55 \\
316.36 \\
318.16 \\
319.97\end{array}$ & $\begin{array}{l}312.92 \\
314.73 \\
316.54 \\
318.34 \\
320.15\end{array}$ & $\begin{array}{l}313.10 \\
314.91 \\
316.72 \\
318.53 \\
320.33\end{array}$ & $\begin{array}{l}313.28 \\
315.09 \\
316.90 \\
318.71 \\
320.51\end{array}$ & $\begin{array}{l}313.46 \\
315.27 \\
317.08 \\
318.89 \\
320.70\end{array}$ & $\begin{array}{l}313.64 \\
315.45 \\
317.26 \\
319.07 \\
320.88\end{array}$ & $\begin{array}{l}313.82 \\
315.63 \\
317.44 \\
319.25 \\
321.06\end{array}$ & $\begin{array}{l}314.00 \\
315.81 \\
317.62 \\
319.43 \\
321.24\end{array}$ & $\begin{array}{l}17.00 \\
17.10 \\
17.20 \\
17.30 \\
17.40\end{array}$ \\
\hline $\begin{array}{l}17.50 \\
17.60 \\
17.70 \\
17.80 \\
17.90\end{array}$ & $\begin{array}{l}321.24 \\
323.05 \\
324.86 \\
326.67 \\
328.48\end{array}$ & $\begin{array}{l}321.42 \\
323.23 \\
325.04 \\
326.85 \\
328.66\end{array}$ & $\begin{array}{l}321.60 \\
323.41 \\
325.22 \\
327.03 \\
328.84\end{array}$ & $\begin{array}{l}321.78 \\
323.59 \\
325.40 \\
327.21 \\
329.02\end{array}$ & $\begin{array}{l}321.96 \\
323.77 \\
325 \cdot 58 \\
327.39 \\
329.20\end{array}$ & $\begin{array}{l}322.14 \\
323.95 \\
325.76 \\
327.57 \\
329.38\end{array}$ & $\begin{array}{l}322.32 \\
324.13 \\
325.94 \\
327.75 \\
329.56\end{array}$ & $\begin{array}{l}322.50 \\
324.31 \\
326.12 \\
327.93 \\
329.74\end{array}$ & $\begin{array}{l}322.69 \\
324.50 \\
326.30 \\
328.11 \\
329.92\end{array}$ & $\begin{array}{l}322.87 \\
324.68 \\
326.49 \\
328.30 \\
330.11\end{array}$ & $\begin{array}{l}323.05 \\
324.86 \\
326.67 \\
328.48 \\
330.29\end{array}$ & $\begin{array}{l}17.50 \\
17.60 \\
17.70 \\
17.80 \\
17.90\end{array}$ \\
\hline 18.00 & 330.29 & 330.47 & 330.65 & 330.83 & 331.01 & 331.19 & 331.37 & 331.55 & 331.73 & 331.92 & 332.10 & 18.00 \\
\hline $\mathrm{mV}$ & .00 & .01 & .02 & .03 & .04 & .05 & .06 & .07 & .08 & .05 & .10 & $\mathrm{mV}$ \\
\hline
\end{tabular}


TABLE A6.2.1. Type J thermocouples-temperature $\left({ }^{\circ} \mathrm{C}\right)$ as a function of thermoelectric voltage, reference junctions at $0^{\circ} \mathrm{C}$-Continued

$\mathrm{m} V$

.00

.01

.02

.03

.04

.05

.06

.07

.08

.09

.10

$\mathrm{mV}$

\begin{tabular}{|c|c|c|c|c|c|c|c|c|c|c|c|c|}
\hline 18.00 & 330.29 & $330 \cdot 47$ & 330.65 & 330.83 & 331.01 & 331.19 & 331.37 & 331.55 & 331.73 & 331.92 & $332 \cdot 10$ & 18.00 \\
\hline $18 \cdot 10$ & 332.10 & 332.28 & 332.46 & 332.64 & 332.82 & 333.00 & 333.18 & 333.36 & 333.54 & 333.73 & 333.91 & 18.10 \\
\hline 18.20 & 333.91 & 334.09 & 334.27 & 334.45 & 334.63 & 334.81 & 334.99 & 335.17 & 335.36 & 335.54 & 335.72 & 18.20 \\
\hline $18 \cdot 30$ & 335.72 & $335 \cdot 90$ & 336.08 & 336.26 & 336.44 & 336.62 & 336.80 & 336.98 & 337.17 & $337 \cdot 35$ & 337.53 & 18.30 \\
\hline 18.40 & 337.53 & 337.71 & 337.89 & 338.07 & $338 \cdot 25$ & $338 \cdot 43$ & 338.61 & 338.80 & 338.98 & 339.16 & 339.34 & 18.40 \\
\hline 18.50 & 339.34 & 339.52 & 339.70 & 339.88 & 340.06 & 340.24 & 340.43 & 340.61 & 340.79 & 340.97 & 341.15 & 18.50 \\
\hline 18.60 & 341.15 & 341.33 & 341.51 & 341.69 & 341.87 & 342.06 & 342.24 & 342.42 & 342.60 & 342.78 & 342.96 & 18.60 \\
\hline 18.70 & 342.96 & 343.14 & 343.32 & 343.50 & 343.69 & 343.87 & 344.05 & 344.23 & $344 \cdot 41$ & 344.59 & 344.77 & $18 \cdot 70$ \\
\hline 18.80 & 344.77 & 344.95 & 345.14 & 345.32 & 345.50 & 345.68 & 345.86 & 346.04 & 346.22 & 346.40 & 346.58 & 18.80 \\
\hline 18.90 & 346.58 & 346.77 & 346.95 & 347.13 & 347.31 & 347.49 & 347.67 & 347.85 & 348.03 & 348.22 & 348.40 & 18.90 \\
\hline $19 \cdot 00$ & 348.40 & 348.58 & 348.76 & 348.94 & 349.12 & 349.30 & 349.48 & 349.66 & 349.85 & 350.03 & 350.21 & 19.00 \\
\hline $19 \cdot 10$ & 350.21 & 350.39 & $350 \cdot 57$ & $350 \cdot 75$ & $350 \cdot 93$ & 351.11 & $351 \cdot 30$ & 351.48 & 351.66 & 351.84 & 352.02 & 19.10 \\
\hline $19 \cdot 20$ & 352.02 & 352.20 & $352 \cdot 38$ & 352.56 & 352.75 & 352.93 & 353.11 & 353.29 & 353.47 & 353.65 & 353.83 & 19.20 \\
\hline 19.30 & 353.83 & 354.01 & 354.20 & 354.38 & 354.56 & 354.74 & 354.92 & 355.10 & 355.28 & 355.46 & 355.65 & $19 \cdot 30$ \\
\hline 19.40 & 355.65 & 355.83 & 356.01 & 356.19 & 356.37 & 356.55 & 356.73 & 356.91 & 357.10 & 357.28 & 357.46 & 19.40 \\
\hline 19.50 & 357.46 & 357.64 & 357.82 & 358.00 & 358.18 & 358.36 & 358.55 & 358.73 & 358.91 & 359.09 & 359.27 & 19.50 \\
\hline 19.60 & 359.27 & 359.45 & 359.63 & 359.81 & 360.00 & 360.18 & 360.36 & 360.54 & 360.72 & 360.90 & 361.08 & 19.60 \\
\hline 19.70 & 361.08 & 361.26 & 361.45 & 361.63 & 361.81 & 361.99 & 362.17 & 362.35 & 362.53 & 362.71 & 362.90 & 19.70 \\
\hline 19.80 & 362.90 & 363.08 & 363.26 & 363.44 & 363.62 & 363.80 & 363.98 & 364.17 & 364.35 & 364.53 & 364.71 & 19.80 \\
\hline 19.90 & 364.71 & 364.89 & 365.07 & 365.25 & 365.43 & 365.62 & 365.80 & 365.98 & 366.16 & 366.34 & 366.52 & 19.90 \\
\hline $20 \cdot 00$ & $66 \cdot 52$ & 366.70 & 366.89 & 367.07 & $367 \cdot 25$ & 367.43 & 367.61 & 367.79 & 367.97 & 368.15 & 368.34 & 20.00 \\
\hline $20 \cdot 10$ & $368 \cdot 34$ & $368 \cdot 52$ & $368 \cdot 70$ & 368.88 & 369.06 & 369.24 & 369.42 & 369.61 & 369.79 & 369.97 & 370.15 & 20.10 \\
\hline $20 \cdot 20$ & $370 \cdot 15$ & 370.33 & 370.51 & 370.69 & 370.87 & 371.06 & 371.24 & 371.42 & 371.60 & 371.78 & 371.96 & 20.20 \\
\hline 20.30 & 371.96 & 372.14 & 372.33 & 372.51 & 372.69 & 372.87 & 373.05 & 373.23 & 373.41 & 373.59 & 373.78 & 20.30 \\
\hline 20.40 & 373.78 & 373.96 & 374.14 & $374 \cdot 32$ & $374 \cdot 50$ & 374.68 & $374 \cdot 86$ & 375.05 & 375.23 & 375.41 & 375.59 & 20.40 \\
\hline $20 \cdot 50$ & 375.59 & 375.77 & 375.95 & 376.13 & 376.32 & 376.50 & 376.68 & 376.86 & 377.04 & 377.22 & 377.40 & 20.50 \\
\hline $20 \cdot 60$ & 377.40 & 377.58 & 377.77 & 377.95 & $378 \cdot 13$ & 378.31 & 378.49 & 378.67 & 378.85 & 379.04 & 379.22 & 20.60 \\
\hline $20 \cdot 70$ & 379.22 & $379 \cdot 40$ & 379.58 & 379.76 & 379.94 & 380.12 & 380.31 & 380.49 & 380.67 & 380.85 & 381.03 & $20 \cdot 70$ \\
\hline $20 \cdot 80$ & 381.03 & 381.21 & 381.39 & 381.57 & $381 \cdot 76$ & 381.94 & 382.12 & 382.30 & 382.48 & $382 \cdot 66$ & 382.84 & 20.80 \\
\hline $20 \cdot 90$ & $382 \cdot 84$ & 383.03 & 383.21 & 383.39 & 383.57 & 383.75 & 383.93 & 384.11 & 384.30 & 384.48 & 384.66 & 20.90 \\
\hline 21.00 & 384.66 & $384 \cdot 84$ & 385.02 & 385.20 & $385 \cdot 38$ & 385.57 & 385.75 & 385.93 & 386.11 & 386.29 & 386.47 & 21.00 \\
\hline 21.10 & 386.47 & 386.65 & 386.83 & 387.02 & 387.20 & 387.38 & 387.56 & 387.74 & 387.92 & 388.10 & 388.29 & $21 \cdot 10$ \\
\hline 21.20 & 388.29 & 388.47 & 388.65 & 388.83 & 389.01 & 389.19 & 389.37 & 389.56 & 389.74 & 389.92 & 390.10 & 21.20 \\
\hline 21.30 & 390.10 & 390.28 & 390.46 & 390.64 & 390.83 & 391.01 & 391.19 & 391.37 & 391.55 & 391.73 & 391.91 & $21 \cdot 30$ \\
\hline 21.40 & 391.91 & 392.09 & $392 \cdot 28$ & 392.46 & $392 \cdot 64$ & 392.82 & 393.00 & 393.18 & 393.36 & 393.55 & 393.73 & 21.40 \\
\hline $\begin{array}{l}21.50 \\
21.60\end{array}$ & $\begin{array}{l}393.73 \\
395.54\end{array}$ & $\begin{array}{l}393.91 \\
395.72\end{array}$ & $\begin{array}{l}394.09 \\
395.90\end{array}$ & $\begin{array}{l}394.27 \\
396.08\end{array}$ & $\begin{array}{l}394.45 \\
396.27\end{array}$ & $\begin{array}{l}394.63 \\
396.45\end{array}$ & $\begin{array}{l}394.82 \\
396.63\end{array}$ & $\begin{array}{l}395.00 \\
396.81\end{array}$ & $\begin{array}{l}395.18 \\
396.99\end{array}$ & $\begin{array}{l}395.36 \\
397.17\end{array}$ & $\begin{array}{l}395.54 \\
397.35\end{array}$ & $\begin{array}{l}21.50 \\
21.60\end{array}$ \\
\hline 21.70 & 397.35 & 397.54 & 397.72 & 397.90 & 398.08 & 398.26 & 398.44 & 398.62 & 398.81 & 398.99 & 399.17 & 21.70 \\
\hline 21.80 & 399.17 & 399.35 & 399.53 & 399.71 & 399.89 & 400.07 & 400.26 & 400.44 & 400.62 & $400 \cdot 80$ & $400 \cdot 98$ & 21.80 \\
\hline 21.90 & $400 \cdot 98$ & 401.16 & 401.34 & 401.53 & 401.71 & 401.89 & 402.07 & 402.25 & 402.43 & 402.61 & 402.79 & 21.90 \\
\hline 22.00 & 402.79 & 402.98 & 403 & 403.34 & 403.52 & 70 & 403.88 & 06 & 25 & .43 & 61 & 2 \\
\hline $22 \cdot 10$ & $404 \cdot 61$ & 404.79 & $404 \cdot 97$ & 405.15 & 405.33 & 405.51 & • 70 & .88 & .06 & 406.24 & .42 & 22.10 \\
\hline 22.20 & 406.42 & 406.60 & 406.78 & 406.97 & 407.15 & 407.33 & 407.51 & 407.69 & 407.87 & 408.05 & 408.23 & 22.20 \\
\hline $22 \cdot 30$ & 408.23 & 408.42 & $408 \cdot 60$ & 408.78 & $408 \cdot 96$ & 409.14 & $409 \cdot 32$ & 409.50 & 409.69 & 409.87 & 410.05 & 22.30 \\
\hline 22.40 & 410.05 & 410.23 & $410 \cdot 41$ & 410.59 & $410 \cdot 77$ & 410.95 & $411 \cdot 14$ & 411.32 & $411 \cdot 50$ & $411 \cdot 68$ & 411.86 & $22 \cdot 40$ \\
\hline $22 \cdot 50$ & 411 & 412. & 412 & $412 \cdot 40$ & $412 \cdot 59$ & 412.77 & 412.95 & 413.13 & 31 & 413.49 & 41 & 2 \\
\hline 22.60 & & & & 414.22 & $414 \cdot 40$ & 414.58 & 414.76 & 414.94 & 415.12 & 415.30 & .49 & 22.60 \\
\hline 22.70 & 415.49 & 415.67 & 415.85 & 416.03 & 416.21 & 416.39 & 416.57 & 416.75 & 416.94 & 417.12 & 417.30 & 22.70 \\
\hline 22.80 & 417.30 & 417.48 & 417.66 & 417.84 & 418.02 & 418.20 & $418 \cdot 39$ & 418.57 & 418.75 & 418.93 & 419.11 & 22.80 \\
\hline 22.90 & 419.11 & 419.29 & 419.47 & 419.65 & 419.83 & 420.02 & 420.20 & 420.38 & 420.56 & 420.74 & 420.92 & 22.90 \\
\hline 23.00 & 42 & 42 & 42 & 421 & 421 & 42 & 422.01 & 19 & 37 & 422.55 & .73 & 23.00 \\
\hline 23.10 & 422 & 422 & 42 & 28 & 423 & 64 & 82 & 00 & . 18 & 424.36 & 55 & 23.10 \\
\hline 23.20 & 424.55 & 424.73 & 424.91 & 425.09 & $425 \cdot 27$ & 425.45 & 425.63 & 425.81 & 425.99 & $426 \cdot 18$ & $426 \cdot 36$ & $23 \cdot 20$ \\
\hline $23 \cdot 30$ & 426.36 & 426.54 & 426.72 & 426.90 & 427.08 & 427.26 & 427.44 & 427.62 & 427.81 & 427.99 & 428.17 & 23.30 \\
\hline 23.40 & 428.17 & 428.35 & 428.53 & 428.71 & $428 \cdot 89$ & 429.07 & 429.25 & 429.43 & 429.62 & $429 \cdot 80$ & 429.98 & 23.40 \\
\hline 23.50 & 429.98 & $430 \cdot 16$ & 43 & 430.52 & $430 \cdot 70$ & 430.88 & 431.06 & 25 & .43 & 431.61 & 431.79 & 23.50 \\
\hline 23.60 & 431.79 & 431.97 & 432.15 & 432.33 & 432.51 & 432.69 & 432.87 & 433.06 & 433.24 & 433.42 & 433.60 & 23.60 \\
\hline 23.70 & 433.60 & 433.78 & 433.96 & 434.14 & $434 \cdot 32$ & $434 \cdot 50$ & 434.68 & 434.87 & 435.05 & 435.23 & 435.41 & 23.70 \\
\hline 23.80 & 435.41 & 435.59 & 435.77 & 435.95 & 436.13 & 436.31 & 436.49 & 436.67 & 436.86 & 437.04 & 437.22 & 23.80 \\
\hline 23.90 & 437.22 & 437.40 & 437.58 & 437.76 & 437.94 & $438 \cdot 12$ & $438 \cdot 30$ & $438 \cdot 48$ & $438 \cdot 66$ & 438.85 & 439.03 & 23.90 \\
\hline 24.00 & 439.03 & 439.21 & 439.39 & 439.57 & $439 \cdot 75$ & 439.93 & 440.11 & 440.29 & 440.47 & 40.65 & 40.84 & .00 \\
\hline
\end{tabular}


TABLE A6.2.1. Type J thermocouples-temperature $\left({ }^{\circ} \mathrm{C}\right)$ as a function of thermoelectric voltage, reference junctions at $0^{\circ} \mathrm{C}$-Continued

$m V$

.00

.01

24.10

$24 \cdot 20$

24.30

24.40

$24 \cdot 50$

24.60
24.70

24.80

24.90

25.00

25.10

$25 \cdot 20$

25.30

25.40

25.5

25.60
25.70

25.80

25.90

26.00

26.10

26.20

26.30

26.40

26.5

26.6

26.70

26.80

26.90

27.00

27.10

27.30

27.40

27.50

27.60

27.70

27.80

27.90

28.00

28.10

28.20

28.30

28.40

28.50

28.60

28.70

28.80

28.90

29.00

29.10

29.20

29.30

29.40

29.50

29.60

29.70

29.80
29.90

30.00

$\mathrm{mV}$

440.84

$442 \cdot 64$

444.45

446.26

448.07

449.87

451.68

457.09

458.90

460.70

462.50

464.31

466.11

467.91

469.71

471.51

475.11

476.91

478.70

480.50

482.30

484.09

485.89

487.68

489.47

491.26

493.05

494.85

96.63

502.00

503.78

505.57

507.35

509.13

510.91

512.69

514.47

516.25

518.03

519.81

521.58

523.36

525.13

526.90

528.67

530.44

532.21

533.98

535.74

537.51

539.27

541.03

542.79

544.55

$546 \cdot 31$

$442 \cdot 82$

444.6

446.44

1.86

457.27

459.08

460.88

462.69
464.49

466.29

468.09

469.89

475.29

477.09

478.88

480.68

482.48

484.27

486.07

487.86

489.65

491.44

493.23

495.02

498.60

500.39

$502 \cdot 18$

503.96

505.75

507.53

511.09

512.87

516.43

518.21

525.31

528.85

530.62

532.38

534.15

537.68

539.44
541.21

.02

.03

.04

.05

.06

.07

.09

.10

$\mathrm{mV}$

TEMPERATURES IN DEGREES C (IPTS 1968 )

$439.21 \quad 439.39$

$448.25 \quad 448.43$

$\begin{array}{ll}450.05 & 450.23\end{array}$

$453.66 \quad 453.85$

455.65

457.45

461.06

462.87

464.67

466.47

$468 \cdot 27$

470.07

471.87

473.67

475.47

477.27

479.06

480.86

482.66

484.45

$486 \cdot 24$

488.04

489.83

491.62

493.41

495.20

498.78

500.57

$502 \cdot 35$

$504 \cdot 14$

505.92

507.71

509.49

511.27

513.05

514.83

$516 \cdot 61$

518.39

519.98

520.16

521.94

523.71

525.48

529.02

530.79

532.56

534.33

537.86

539.62

541.38

$542.97 \quad 543.14$

544.90

$546.48 \quad 546.66$

439.75

439.93

440.11

$441.56 \quad 441.74$

$443 \cdot 19$

444.99

$445 \cdot 17$

443.55

$\begin{array}{ll}446.98 & 447.16\end{array}$

448.61

450.41

454.03

455.83

$448 \cdot 79$

$450 \cdot 59$

$454.21 \quad 454.39$

457.64

459.44

461.24

463.05

464.85

466.65

468.45

470.25

472.05

475.65

477.45

479.24

481.04

482.84

484.63

486.42

488.22

490.01

491.80

493.59

495.38

497.17

498.96

500.75

502.53

504.32

506.10

507.89

509.67

511.45

513.23

515.01

516.79

518.56

$520 \cdot 34$

522.11

523.89

525.66

527.43

529.20

530.97

532.74

534.50

538.03

539.80

541.56 
TABLE A6.2.1. Type J thermocouples-temperature $\left({ }^{\circ} \mathrm{C}\right)$ as a function of thermoelectric voltage, reference junctions at $0^{\circ} \mathrm{C}$-Continued

.04

.05

.06

.07

.08

.09

$\cdot 10$

TEMPERATURES IN DEGREES C (IPTS 1968)

\begin{tabular}{|c|c|c|c|c|c|c|c|c|c|c|c|c|}
\hline $\begin{array}{l}30 \cdot 00 \\
30 \cdot 10 \\
30 \cdot 20 \\
30 \cdot 30 \\
30 \cdot 40\end{array}$ & $\begin{array}{l}546.31 \\
548.06 \\
549.82 \\
551.57 \\
553.33\end{array}$ & $\begin{array}{l}546.48 \\
548.24 \\
549.99 \\
551.75 \\
553.50\end{array}$ & $\begin{array}{l}546.66 \\
548.42 \\
550.17 \\
551.92 \\
553.68\end{array}$ & $\begin{array}{l}546.83 \\
548.59 \\
550.35 \\
552.10 \\
553.85\end{array}$ & $\begin{array}{l}547.01 \\
548 \cdot 77 \\
550.52 \\
552.27 \\
554.03\end{array}$ & $\begin{array}{l}547 \cdot 19 \\
548 \cdot 94 \\
550 \cdot 70 \\
552 \cdot 45 \\
554.20\end{array}$ & $\begin{array}{l}547 \cdot 36 \\
549 \cdot 12 \\
550 \cdot 87 \\
552 \cdot 62 \\
554 \cdot 38\end{array}$ & $\begin{array}{l}547.54 \\
549.29 \\
551.05 \\
552.80 \\
554.55\end{array}$ & $\begin{array}{l}547.71 \\
549.47 \\
551.22 \\
552.97 \\
554.73\end{array}$ & $\begin{array}{l}547.89 \\
549.64 \\
551.40 \\
553.15 \\
554.90\end{array}$ & $\begin{array}{l}548.06 \\
549.82 \\
551.57 \\
553.33 \\
555.08\end{array}$ & $\begin{array}{l}30 \cdot 00 \\
30 \cdot 10 \\
30 \cdot 20 \\
30 \cdot 30 \\
30.40\end{array}$ \\
\hline $\begin{array}{l}30 \cdot 50 \\
30 \cdot 60 \\
30 \cdot 70 \\
30 \cdot 80 \\
30 \cdot 90\end{array}$ & $\begin{array}{l}555.08 \\
556.83 \\
558.57 \\
560.32 \\
562.07\end{array}$ & $\begin{array}{l}555.25 \\
557.00 \\
558.75 \\
560.50 \\
562.24\end{array}$ & $\begin{array}{l}555.43 \\
557.18 \\
558.92 \\
560.67 \\
562.41\end{array}$ & $\begin{array}{l}555.60 \\
557.35 \\
559.10 \\
560.84 \\
562.59\end{array}$ & $\begin{array}{l}555 \cdot 78 \\
557 \cdot 53 \\
559 \cdot 27 \\
561.02 \\
562 \cdot 76\end{array}$ & $\begin{array}{l}555 \cdot 95 \\
557.70 \\
559.45 \\
561.19 \\
562.94\end{array}$ & $\begin{array}{l}556.13 \\
557.87 \\
559.62 \\
561.37 \\
563.11\end{array}$ & $\begin{array}{l}556.30 \\
558.05 \\
559.80 \\
561.54 \\
563.29\end{array}$ & $\begin{array}{l}556.48 \\
558.22 \\
559.97 \\
561.72 \\
563.46\end{array}$ & $\begin{array}{l}556.65 \\
558.40 \\
560.15 \\
561.89 \\
563.64\end{array}$ & $\begin{array}{l}556.83 \\
558.57 \\
560.32 \\
562.07 \\
563.81\end{array}$ & $\begin{array}{l}30.50 \\
30.60 \\
30.70 \\
30.80 \\
30.90\end{array}$ \\
\hline $\begin{array}{l}31.00 \\
31.10 \\
31.20 \\
31.30 \\
31.40\end{array}$ & $\begin{array}{l}563.81 \\
565.55 \\
567.29 \\
569.03 \\
570.77\end{array}$ & $\begin{array}{l}563.98 \\
565.73 \\
567.47 \\
569.21 \\
570.94\end{array}$ & $\begin{array}{l}564 \cdot 16 \\
565.90 \\
567.64 \\
569.38 \\
571.12\end{array}$ & $\begin{array}{l}564.33 \\
566.07 \\
567.81 \\
569.55 \\
571.29\end{array}$ & $\begin{array}{l}564 \cdot 51 \\
566.25 \\
567.99 \\
569.73 \\
571.46\end{array}$ & $\begin{array}{l}564.68 \\
566.42 \\
568.16 \\
569.90 \\
571.64\end{array}$ & $\begin{array}{l}564.85 \\
566.60 \\
568.34 \\
570.07 \\
571.81\end{array}$ & $\begin{array}{l}565.03 \\
566.77 \\
568.51 \\
570.25 \\
571.98\end{array}$ & $\begin{array}{l}565 \cdot 20 \\
566.94 \\
568 \cdot 68 \\
570.42 \\
572 \cdot 16\end{array}$ & $\begin{array}{l}565 \cdot 38 \\
567.12 \\
568.86 \\
570.60 \\
572.33\end{array}$ & $\begin{array}{l}565.55 \\
567.29 \\
569.03 \\
570.77 \\
572.51\end{array}$ & $\begin{array}{l}31 \cdot 00 \\
31.10 \\
31.20 \\
31.30 \\
31.40\end{array}$ \\
\hline $\begin{array}{l}31.50 \\
31.60 \\
31.70 \\
31.80 \\
31.90\end{array}$ & $\begin{array}{l}572.51 \\
574 \cdot 24 \\
575.97 \\
577.70 \\
579.43\end{array}$ & $\begin{array}{l}572.68 \\
574.41 \\
576.15 \\
577.88 \\
579.61\end{array}$ & $\begin{array}{l}572.85 \\
574.59 \\
576.32 \\
578.05 \\
579.78\end{array}$ & $\begin{array}{l}573.03 \\
574.76 \\
576.49 \\
578.22 \\
579.95\end{array}$ & $\begin{array}{l}573 \cdot 20 \\
574 \cdot 93 \\
576.67 \\
578 \cdot 40 \\
580.13\end{array}$ & $\begin{array}{l}573 \cdot 37 \\
575.11 \\
576.84 \\
578.57 \\
580.30\end{array}$ & $\begin{array}{l}573 \cdot 55 \\
575.28 \\
577 \cdot 01 \\
578 \cdot 74 \\
580.47\end{array}$ & $\begin{array}{l}573.72 \\
575.45 \\
577.19 \\
578.92 \\
580.64\end{array}$ & $\begin{array}{l}573.89 \\
575.63 \\
577.36 \\
579.09 \\
580.82\end{array}$ & $\begin{array}{l}574.07 \\
575.80 \\
577.53 \\
579.26 \\
580.99\end{array}$ & $\begin{array}{l}574 \cdot 24 \\
575 \cdot 97 \\
577 \cdot 70 \\
579 \cdot 43 \\
581.16\end{array}$ & $\begin{array}{l}31.50 \\
31.60 \\
31.70 \\
31.80 \\
31.90\end{array}$ \\
\hline $\begin{array}{l}32.00 \\
32.10 \\
32.20 \\
32.30 \\
32.40\end{array}$ & $\begin{array}{l}581 \cdot 16 \\
582.89 \\
584.62 \\
586.34 \\
588.06\end{array}$ & $\begin{array}{l}581.34 \\
583.06 \\
584.79 \\
586.51 \\
588.23\end{array}$ & $\begin{array}{l}581 \cdot 51 \\
583 \cdot 24 \\
584 \cdot 96 \\
586 \cdot 68 \\
588.40\end{array}$ & $\begin{array}{l}581.68 \\
583.41 \\
585.13 \\
586.86 \\
588.58\end{array}$ & $\begin{array}{l}581.85 \\
583.58 \\
585.30 \\
587.03 \\
588.75\end{array}$ & $\begin{array}{l}582.03 \\
583.75 \\
585.48 \\
587.20 \\
588.92\end{array}$ & $\begin{array}{l}582.20 \\
583.93 \\
585.65 \\
587.37 \\
589.09\end{array}$ & $\begin{array}{l}582.37 \\
584.10 \\
585.82 \\
587.54 \\
589.26\end{array}$ & $\begin{array}{l}582.54 \\
584 \cdot 27 \\
585.99 \\
587.72 \\
589.44\end{array}$ & $\begin{array}{l}582.72 \\
584.44 \\
586.17 \\
587.89 \\
589.61\end{array}$ & $\begin{array}{l}582.89 \\
584.62 \\
586.34 \\
588.06 \\
589.78\end{array}$ & $\begin{array}{l}32.00 \\
32.10 \\
32.20 \\
32.30 \\
32.40\end{array}$ \\
\hline 32.50 & 589.78 & 589.95 & 590.12 & 590.30 & 590.47 & 590.64 & 590.81 & 590.98 & $591 \cdot 16$ & $591 \cdot 33$ & 591.50 & 32.5 \\
\hline $\begin{array}{l}32.60 \\
32.70\end{array}$ & $\begin{array}{l}591 \cdot 50 \\
593 \cdot 22\end{array}$ & $\begin{array}{l}591.67 \\
593.39\end{array}$ & $\begin{array}{l}591.84 \\
593.56\end{array}$ & $\begin{array}{l}592.01 \\
593.73\end{array}$ & $\begin{array}{l}592.19 \\
593.90\end{array}$ & $\begin{array}{l}592.36 \\
594.07\end{array}$ & $\begin{array}{l}592.53 \\
594.25\end{array}$ & $\begin{array}{l}592.70 \\
594.42\end{array}$ & $\begin{array}{l}592.87 \\
594.59\end{array}$ & $\begin{array}{l}593.04 \\
594.76\end{array}$ & $\begin{array}{l}593.22 \\
594.93\end{array}$ & $\begin{array}{l}32.6 \\
32.7\end{array}$ \\
\hline $\begin{array}{l}32 \cdot 80 \\
32.90\end{array}$ & $\begin{array}{l}594.93 \\
596.65\end{array}$ & $\begin{array}{l}595.10 \\
596.82\end{array}$ & $\begin{array}{l}595.27 \\
596.99\end{array}$ & $\begin{array}{l}595.45 \\
597.16\end{array}$ & $\begin{array}{l}595 \cdot 62 \\
597.33\end{array}$ & $\begin{array}{l}595.79 \\
597.50\end{array}$ & $\begin{array}{l}595.96 \\
597.67\end{array}$ & $\begin{array}{l}596.13 \\
597.84\end{array}$ & $\begin{array}{l}596.30 \\
598.02\end{array}$ & $\begin{array}{l}596.47 \\
598 \cdot 19\end{array}$ & $\begin{array}{l}596 \cdot 65 \\
598 \cdot 36\end{array}$ & $\begin{array}{l}32.8 \\
32.9\end{array}$ \\
\hline $\begin{array}{l}33.00 \\
33.10 \\
33.20 \\
33.30 \\
33.40\end{array}$ & $\begin{array}{l}598 \cdot 36 \\
600 \cdot 07 \\
601 \cdot 78 \\
603 \cdot 48 \\
605 \cdot 19\end{array}$ & $\begin{array}{l}598.53 \\
600.24 \\
601.95 \\
603.65 \\
605.36\end{array}$ & $\begin{array}{l}598 \cdot 70 \\
600.41 \\
602.12 \\
603.82 \\
605.53\end{array}$ & $\begin{array}{l}598 \cdot 87 \\
600 \cdot 58 \\
602.29 \\
604.00 \\
605 \cdot 70\end{array}$ & $\begin{array}{l}599 \cdot 04 \\
600 \cdot 75 \\
602 \cdot 46 \\
604 \cdot 17 \\
605 \cdot 87\end{array}$ & $\begin{array}{l}599 \cdot 21 \\
600 \cdot 92 \\
602 \cdot 63 \\
604 \cdot 34 \\
606.04\end{array}$ & $\begin{array}{l}599 \cdot 38 \\
601.09 \\
602 \cdot 80 \\
604 \cdot 51 \\
606.21\end{array}$ & $\begin{array}{l}599 \cdot 55 \\
601 \cdot 26 \\
602 \cdot 97 \\
604 \cdot 68 \\
606.38\end{array}$ & $\begin{array}{l}599 \cdot 73 \\
601.43 \\
603 \cdot 14 \\
604 \cdot 85 \\
606.55\end{array}$ & $\begin{array}{l}599 \cdot 90 \\
601.61 \\
603 \cdot 31 \\
605.02 \\
606.72\end{array}$ & $\begin{array}{l}600.07 \\
601.78 \\
603.48 \\
605.19 \\
606.89\end{array}$ & $\begin{array}{l}33.00 \\
33.10 \\
33.20 \\
33.30 \\
33.40\end{array}$ \\
\hline $\begin{array}{l}33.50 \\
33.60 \\
33.70 \\
33.80 \\
33.90\end{array}$ & $\begin{array}{l}606.89 \\
608.59 \\
610.29 \\
611.99 \\
613.69\end{array}$ & $\begin{array}{l}607.06 \\
608.76 \\
610.46 \\
612.16 \\
613.86\end{array}$ & $\begin{array}{l}607.23 \\
608.93 \\
610.63 \\
612.33 \\
614.03\end{array}$ & $\begin{array}{l}607.40 \\
609.10 \\
610.80 \\
612.50 \\
614.20\end{array}$ & $\begin{array}{l}607 \cdot 57 \\
609 \cdot 27 \\
610 \cdot 97 \\
612 \cdot 67 \\
614 \cdot 37\end{array}$ & $\begin{array}{l}607 \cdot 74 \\
609 \cdot 44 \\
611 \cdot 14 \\
612 \cdot 84 \\
614 \cdot 54\end{array}$ & $\begin{array}{l}607 \cdot 91 \\
609 \cdot 61 \\
611 \cdot 31 \\
613.01 \\
614.71\end{array}$ & $\begin{array}{l}608 \cdot 08 \\
609 \cdot 78 \\
611 \cdot 48 \\
613 \cdot 18 \\
614 \cdot 88\end{array}$ & $\begin{array}{l}608.25 \\
609.95 \\
611.65 \\
613.35 \\
615.04\end{array}$ & $\begin{array}{l}608 \cdot 42 \\
610.12 \\
611.82 \\
613.52 \\
615.21\end{array}$ & $\begin{array}{l}608.59 \\
610.29 \\
611.99 \\
613.69 \\
615.38\end{array}$ & $\begin{array}{l}33.50 \\
33.60 \\
33.70 \\
33.80 \\
33.90\end{array}$ \\
\hline $\begin{array}{l}34 \cdot 00 \\
34 \cdot 10 \\
34 \cdot 20 \\
34 \cdot 30 \\
34.40\end{array}$ & $\begin{array}{l}615.38 \\
617.08 \\
618.77 \\
620.46 \\
622.15\end{array}$ & $\begin{array}{l}615 \cdot 55 \\
617.25 \\
618.94 \\
620.63 \\
622.31\end{array}$ & $\begin{array}{l}615 \cdot 72 \\
617.42 \\
619 \cdot 11 \\
620 \cdot 80 \\
622 \cdot 48\end{array}$ & $\begin{array}{l}615.89 \\
617.58 \\
619.28 \\
620.96 \\
622.65\end{array}$ & $\begin{array}{l}616 \cdot 06 \\
617 \cdot 75 \\
619 \cdot 44 \\
621 \cdot 13 \\
622 \cdot 82\end{array}$ & $\begin{array}{l}616.23 \\
617.92 \\
619.61 \\
621.30 \\
622.99\end{array}$ & $\begin{array}{l}616.40 \\
618.09 \\
619.78 \\
621.47 \\
623.16\end{array}$ & $\begin{array}{l}616.57 \\
618.26 \\
619.95 \\
621.64 \\
623.33\end{array}$ & $\begin{array}{l}616.74 \\
618.43 \\
620.12 \\
621.81 \\
623.49\end{array}$ & $\begin{array}{l}616.91 \\
618.60 \\
620.29 \\
621.98 \\
623.66\end{array}$ & $\begin{array}{l}617.08 \\
618.77 \\
620.46 \\
622.15 \\
623.83\end{array}$ & $\begin{array}{l}34.00 \\
34.10 \\
34.20 \\
34.30 \\
34.40\end{array}$ \\
\hline $\begin{array}{l}34.50 \\
34.60 \\
34.70 \\
34.80 \\
34.90\end{array}$ & $\begin{array}{l}623.83 \\
625.52 \\
627.20 \\
628.88 \\
630.56\end{array}$ & $\begin{array}{l}624 \cdot 00 \\
625.68 \\
627.37 \\
629.05 \\
630.73\end{array}$ & $\begin{array}{l}624 \cdot 17 \\
625.85 \\
627 \cdot 54 \\
629 \cdot 22 \\
630.89\end{array}$ & $\begin{array}{l}624.34 \\
626.02 \\
627.70 \\
629.38 \\
631.06\end{array}$ & $\begin{array}{l}624 \cdot 51 \\
626 \cdot 19 \\
627 \cdot 87 \\
629 \cdot 55 \\
631 \cdot 23\end{array}$ & $\begin{array}{l}624.67 \\
626.36 \\
628.04 \\
629.72 \\
631.40\end{array}$ & $\begin{array}{l}624.84 \\
626.53 \\
628.21 \\
629.89 \\
631.57\end{array}$ & $\begin{array}{l}625.01 \\
626.69 \\
628.38 \\
630.06 \\
631.73\end{array}$ & $\begin{array}{l}625 \cdot 18 \\
626.86 \\
628 \cdot 54 \\
630 \cdot 22 \\
631.90\end{array}$ & $\begin{array}{l}625.35 \\
627.03 \\
628.71 \\
630.39 \\
632.07\end{array}$ & $\begin{array}{l}625 \cdot 52 \\
627 \cdot 20 \\
628 \cdot 88 \\
630.56 \\
632.24\end{array}$ & $\begin{array}{l}34.5 \\
34.6 \\
34.7 \\
34.8 \\
34.9\end{array}$ \\
\hline $\begin{array}{l}35.00 \\
35.10 \\
35.20 \\
35.30 \\
35.40\end{array}$ & $\begin{array}{l}632.24 \\
633.91 \\
635.59 \\
637.26 \\
638.93\end{array}$ & $\begin{array}{l}632.40 \\
634.08 \\
635.75 \\
637.42 \\
639.09\end{array}$ & $\begin{array}{l}632.57 \\
634.25 \\
635.92 \\
637.59 \\
639.26\end{array}$ & $\begin{array}{l}632.74 \\
634.41 \\
636.09 \\
637.76 \\
639.43\end{array}$ & $\begin{array}{l}632 \cdot 91 \\
634.58 \\
636.25 \\
637.93 \\
639.60\end{array}$ & $\begin{array}{l}633.07 \\
634.75 \\
636.42 \\
638.09 \\
639.76\end{array}$ & $\begin{array}{l}633.24 \\
634.92 \\
636.59 \\
638.26 \\
639.93\end{array}$ & $\begin{array}{l}633.41 \\
635.08 \\
636.76 \\
638.43 \\
640.10\end{array}$ & $\begin{array}{l}633.58 \\
635.25 \\
636.92 \\
638.59 \\
640.26\end{array}$ & $\begin{array}{l}633.74 \\
635.42 \\
637.09 \\
638.76 \\
640.43\end{array}$ & $\begin{array}{l}633.91 \\
635.59 \\
637.26 \\
638.93 \\
640.60\end{array}$ & $\begin{array}{l}35.0 \\
35.1 \\
35.2 \\
35 \cdot 3 \\
35.4\end{array}$ \\
\hline $\begin{array}{l}35.50 \\
35.60 \\
35.70 \\
35.80 \\
35.90\end{array}$ & $\begin{array}{l}640.60 \\
642 \cdot 26 \\
643 \cdot 93 \\
645.59 \\
647.25\end{array}$ & $\begin{array}{l}640.76 \\
642.43 \\
644.09 \\
645.76 \\
647.42\end{array}$ & $\begin{array}{l}640.93 \\
642.60 \\
644.26 \\
645.92 \\
647.58\end{array}$ & $\begin{array}{l}641.10 \\
642.76 \\
644.43 \\
646.09 \\
647.75\end{array}$ & $\begin{array}{l}641 \cdot 26 \\
642 \cdot 93 \\
644 \cdot 59 \\
646 \cdot 26 \\
647 \cdot 92\end{array}$ & $\begin{array}{l}641.43 \\
643.10 \\
644.76 \\
646.42 \\
648.08\end{array}$ & $\begin{array}{l}641.60 \\
643.26 \\
644.93 \\
646.59 \\
648.25\end{array}$ & $\begin{array}{l}641.76 \\
643.43 \\
645.09 \\
646.75 \\
648.41\end{array}$ & $\begin{array}{l}641.93 \\
643.60 \\
645.26 \\
646.92 \\
648.58\end{array}$ & $\begin{array}{l}642.10 \\
643.76 \\
645.42 \\
647.09 \\
648.75\end{array}$ & $\begin{array}{l}642.26 \\
643.93 \\
645.59 \\
647.25 \\
648.91\end{array}$ & $\begin{array}{l}35.5 \\
35.6 \\
35.7 \\
35.8 \\
35.9\end{array}$ \\
\hline 36.00 & 648.91 & 649.08 & 649.24 & 649.41 & 649.58 & 649.74 & 649.91 & 650.07 & 650.24 & 650.40 & 650.57 & 36. \\
\hline
\end{tabular}

$\mathrm{mV}$

$.00 \quad .01$

.02

.03

.04

.05

.06

.07

.08
.09
.10
0.00 0.30

0.50 0.60 0.70
0.80 0.90

1.00 1.30
1.40

1.50 31.70 1.80 2.00 2.10 2.40 2.50 2.70 2.90

.00 3.20 3.40 3.70 3.80
3.90 4.00 34.10
4.20 4.30 4.50 4.80 5.00 5.10 5.30 5.40

60 5.90 
TABLE A6.2.1. Type J thermocouples-temperature $\left({ }^{\circ} \mathrm{C}\right)$ as a function of thermoelectric voltage, reference junctions at $0^{\circ} \mathrm{C}$-Continued

$\mathrm{mV}$
.00

.01

.02

.03

.04

.05

.06

.07

.08

.09

.10

$\mathrm{mV}$

TEMPERATURES IN DEGREES C (IPTS 1968)

\begin{tabular}{|c|c|c|c|c|c|c|c|c|c|c|c|c|}
\hline $\begin{array}{l}36.00 \\
36.10 \\
36.20 \\
36.30 \\
36.40\end{array}$ & $\begin{array}{l}648.91 \\
650.57 \\
652.23 \\
653.88 \\
655.53\end{array}$ & $\begin{array}{l}649.08 \\
650.74 \\
652.39 \\
654.05 \\
655.70\end{array}$ & $\begin{array}{l}649 \cdot 24 \\
650.90 \\
652.56 \\
654.21 \\
655.86\end{array}$ & $\begin{array}{l}649.41 \\
651.07 \\
652.72 \\
654.38 \\
656.03\end{array}$ & $\begin{array}{l}649.58 \\
651.23 \\
652.89 \\
654.54 \\
656.19\end{array}$ & $\begin{array}{l}649.74 \\
651.40 \\
653.05 \\
654.71 \\
656.36\end{array}$ & $\begin{array}{l}649 \cdot 91 \\
651.56 \\
653.22 \\
654.87 \\
656.52\end{array}$ & $\begin{array}{l}650.07 \\
651.73 \\
653.38 \\
655.04 \\
656.69\end{array}$ & $\begin{array}{l}650.24 \\
651.90 \\
653.55 \\
655.20 \\
656.85\end{array}$ & $\begin{array}{l}650.40 \\
652.06 \\
653.72 \\
655.37 \\
657.02\end{array}$ & $\begin{array}{l}650.57 \\
652.23 \\
653.88 \\
655.53 \\
657.18\end{array}$ & $\begin{array}{l}36 \cdot 0 \\
36 \cdot 1 \\
36 \cdot 2 \\
36 \cdot 3 \\
36.4\end{array}$ \\
\hline $\begin{array}{l}36.50 \\
36.60 \\
36.70 \\
36.80 \\
36.90\end{array}$ & $\begin{array}{l}657.18 \\
658.83 \\
660.48 \\
662.13 \\
663.77\end{array}$ & $\begin{array}{l}657.35 \\
659.00 \\
660.65 \\
662.29 \\
663.93\end{array}$ & $\begin{array}{l}657 \cdot 51 \\
659 \cdot 16 \\
660.81 \\
662 \cdot 46 \\
664 \cdot 10\end{array}$ & $\begin{array}{l}657.68 \\
659.33 \\
660.97 \\
662.62 \\
664.26\end{array}$ & $\begin{array}{l}657 \cdot 84 \\
659 \cdot 49 \\
661 \cdot 14 \\
662 \cdot 78 \\
664.43\end{array}$ & $\begin{array}{l}658.01 \\
659.66 \\
661.30 \\
662.95 \\
664.59\end{array}$ & $\begin{array}{l}658.17 \\
659.82 \\
661.47 \\
663.11 \\
664.76\end{array}$ & $\begin{array}{l}658.34 \\
659.99 \\
661.63 \\
663.28 \\
664.92\end{array}$ & $\begin{array}{l}658.50 \\
660.15 \\
661.80 \\
663.44 \\
665.08\end{array}$ & $\begin{array}{l}658.67 \\
660.32 \\
661.96 \\
663.61 \\
665.25\end{array}$ & $\begin{array}{l}658.83 \\
660.48 \\
662.13 \\
663.77 \\
665.41\end{array}$ & $\begin{array}{l}36.5 \\
36.6 \\
36.7 \\
36.8 \\
36.9\end{array}$ \\
\hline $\begin{array}{l}37.00 \\
37.10 \\
37.20\end{array}$ & $\begin{array}{l}665.41 \\
667.05 \\
668.69\end{array}$ & $\begin{array}{l}665.58 \\
667.22 \\
668.86\end{array}$ & $\begin{array}{l}665.74 \\
667.38 \\
669.02\end{array}$ & $\begin{array}{l}665.90 \\
667.54 \\
669.18\end{array}$ & $\begin{array}{l}666.07 \\
667.71 \\
669.35\end{array}$ & $\begin{array}{l}666.23 \\
667.87 \\
669.51\end{array}$ & $\begin{array}{l}666.40 \\
668.04 \\
669.67\end{array}$ & $\begin{array}{l}666.56 \\
668.20 \\
669.84\end{array}$ & $\begin{array}{l}666.72 \\
668.36 \\
670.00\end{array}$ & $\begin{array}{l}666.89 \\
668.53 \\
670.17\end{array}$ & $\begin{array}{l}667.05 \\
668.69 \\
670.33\end{array}$ & $\begin{array}{l}37.0 \\
37.1 \\
37.2\end{array}$ \\
\hline $\begin{array}{l}37.30 \\
37.40\end{array}$ & $\begin{array}{l}670.33 \\
671.96\end{array}$ & $\begin{array}{l}670.40 \\
672.13\end{array}$ & $\begin{array}{l}670.66 \\
672.29\end{array}$ & $\begin{array}{l}670.82 \\
672.45\end{array}$ & $\begin{array}{l}670.98 \\
672.62\end{array}$ & $\begin{array}{l}671.15 \\
672.78\end{array}$ & $\begin{array}{l}671.31 \\
672.94\end{array}$ & $\begin{array}{l}671.47 \\
673.11\end{array}$ & $\begin{array}{l}671.64 \\
673.27\end{array}$ & $\begin{array}{l}671.80 \\
673.43\end{array}$ & $\begin{array}{l}671.96 \\
673.60\end{array}$ & $\begin{array}{l}37 \cdot 3 \\
37 \cdot 4\end{array}$ \\
\hline $\begin{array}{l}37.50 \\
37.60 \\
37.70 \\
37.80 \\
37.90\end{array}$ & $\begin{array}{l}673.60 \\
675.23 \\
676.86 \\
678.49 \\
680.12\end{array}$ & $\begin{array}{l}673.76 \\
675.39 \\
677.02 \\
678.65 \\
680.28\end{array}$ & $\begin{array}{l}673.92 \\
675.56 \\
677.19 \\
678.81 \\
680.44\end{array}$ & $\begin{array}{l}674.09 \\
675.72 \\
677.35 \\
678.98 \\
680.60\end{array}$ & $\begin{array}{l}674.25 \\
675.88 \\
677.51 \\
679.14 \\
680.77\end{array}$ & $\begin{array}{l}674.41 \\
676.05 \\
677.67 \\
679.30 \\
680.93\end{array}$ & $\begin{array}{l}674.58 \\
676.21 \\
677.84 \\
679.47 \\
681.09\end{array}$ & $\begin{array}{l}674.74 \\
676.37 \\
678.00 \\
679.63 \\
681.25\end{array}$ & $\begin{array}{l}674.90 \\
676.53 \\
678.16 \\
679.79 \\
681.42\end{array}$ & $\begin{array}{l}675.07 \\
676.70 \\
678.33 \\
679.95 \\
681.58\end{array}$ & $\begin{array}{l}675.23 \\
676.86 \\
678.49 \\
680.12 \\
681.74\end{array}$ & $\begin{array}{l}37.5 \\
37.6 \\
37.7 \\
37.8 \\
37.9\end{array}$ \\
\hline $\begin{array}{l}38.00 \\
38.10 \\
38.20 \\
38.30 \\
38.40\end{array}$ & $\begin{array}{l}681.74 \\
683.36 \\
684.99 \\
686.61 \\
688.23\end{array}$ & $\begin{array}{l}681 \cdot 90 \\
683 \cdot 53 \\
685 \cdot 15 \\
686.77 \\
688.39\end{array}$ & $\begin{array}{l}682.07 \\
683.69 \\
685.31 \\
686.93 \\
688.55\end{array}$ & $\begin{array}{l}682.23 \\
683.85 \\
685.47 \\
687.09 \\
688.71\end{array}$ & $\begin{array}{l}682.39 \\
684.01 \\
685.64 \\
687.26 \\
688.87\end{array}$ & $\begin{array}{l}682.55 \\
684.18 \\
685.80 \\
687.42 \\
689.04\end{array}$ & $\begin{array}{l}682 \cdot 72 \\
684.34 \\
685.96 \\
687.58 \\
689.20\end{array}$ & $\begin{array}{l}682 \cdot 88 \\
684 \cdot 50 \\
686.12 \\
687.74 \\
689.36\end{array}$ & $\begin{array}{l}683.04 \\
684.66 \\
686.28 \\
687.90 \\
689.52\end{array}$ & $\begin{array}{l}683.20 \\
684.82 \\
686.45 \\
688.06 \\
689.68\end{array}$ & $\begin{array}{l}683.36 \\
684.99 \\
686.61 \\
688.23 \\
689.84\end{array}$ & $\begin{array}{l}38.0 \\
38.1 \\
38.2 \\
38.3 \\
38.4\end{array}$ \\
\hline $\begin{array}{l}38.50 \\
38.60 \\
38.70 \\
38.80 \\
38.90\end{array}$ & $\begin{array}{l}689.84 \\
691.46 \\
693.07 \\
694.69 \\
696.30\end{array}$ & $\begin{array}{l}690.01 \\
691.62 \\
693.23 \\
694.85 \\
696.46\end{array}$ & $\begin{array}{l}690.17 \\
691.78 \\
693.40 \\
695.01 \\
696.62\end{array}$ & $\begin{array}{l}690.33 \\
691.94 \\
693.56 \\
695.17 \\
696.78\end{array}$ & $\begin{array}{l}690.49 \\
692.11 \\
693.72 \\
695.33 \\
696.94\end{array}$ & $\begin{array}{l}690.65 \\
692.27 \\
693.88 \\
695.49 \\
697.10\end{array}$ & $\begin{array}{l}690.81 \\
692.43 \\
694.04 \\
695.65 \\
697.26\end{array}$ & $\begin{array}{l}690.97 \\
692.59 \\
694.20 \\
695.81 \\
697.42\end{array}$ & $\begin{array}{l}691.14 \\
692.75 \\
694.36 \\
695.97 \\
697.58\end{array}$ & $\begin{array}{l}691.30 \\
692.91 \\
694.52 \\
696.14 \\
697.75\end{array}$ & $\begin{array}{l}691.46 \\
693.07 \\
694.69 \\
696.30 \\
697.91\end{array}$ & $\begin{array}{l}38.5 \\
38.6 \\
38.7 \\
38.8 \\
38.9\end{array}$ \\
\hline $\begin{array}{l}39.00 \\
39.10 \\
39.20 \\
39.30 \\
39.40\end{array}$ & $\begin{array}{l}697 \cdot 91 \\
699 \cdot 51 \\
701 \cdot 12 \\
702.73 \\
704.33\end{array}$ & $\begin{array}{l}698.07 \\
699.68 \\
701.28 \\
702.89 \\
704.49\end{array}$ & $\begin{array}{l}698.23 \\
699.84 \\
701.44 \\
703.05 \\
704.65\end{array}$ & $\begin{array}{l}698.39 \\
700.00 \\
701.60 \\
703.21 \\
704.81\end{array}$ & $\begin{array}{l}698 \cdot 55 \\
700 \cdot 16 \\
701.76 \\
703.37 \\
704.97\end{array}$ & $\begin{array}{l}698.71 \\
700.32 \\
701.92 \\
703.53 \\
705.13\end{array}$ & $\begin{array}{l}698.87 \\
700.48 \\
702.08 \\
703.69 \\
705.29\end{array}$ & $\begin{array}{l}699.03 . \\
700.64 \\
702.24 \\
703.85 \\
705.45\end{array}$ & $\begin{array}{l}699.19 \\
700.80 \\
702.40 \\
704.01 \\
705.61\end{array}$ & $\begin{array}{l}699.35 \\
700.96 \\
702.57 \\
704.17 \\
705.77\end{array}$ & $\begin{array}{l}699.51 \\
701.12 \\
702.73 \\
704.33 \\
705.93\end{array}$ & $\begin{array}{l}39.0 \\
39.1 \\
39.2 \\
39.2 \\
39.2\end{array}$ \\
\hline $\begin{array}{l}39.50 \\
39.60 \\
39.70 \\
39.80 \\
39.90\end{array}$ & $\begin{array}{l}705.93 \\
707.53 \\
709.13 \\
710.73 \\
712.32\end{array}$ & $\begin{array}{l}706.09 \\
707.69 \\
709.29 \\
710.89 \\
712.48\end{array}$ & $\begin{array}{l}706.25 \\
707.85 \\
709.45 \\
711.05 \\
712.64\end{array}$ & $\begin{array}{l}706.41 \\
708.01 \\
709.61 \\
711.21 \\
712.80\end{array}$ & $\begin{array}{l}706.57 \\
708.17 \\
709.77 \\
711.37 \\
712.96\end{array}$ & $\begin{array}{l}706.73 \\
708.33 \\
709.93 \\
711.53 \\
713.12\end{array}$ & $\begin{array}{l}706.89 \\
708.49 \\
710.09 \\
711.69 \\
713.28\end{array}$ & $\begin{array}{l}707.05 \\
708.65 \\
710.25 \\
711.85 \\
713.44\end{array}$ & $\begin{array}{l}707.21 \\
708.81 \\
710.41 \\
712.01 \\
713.60\end{array}$ & $\begin{array}{l}707.37 \\
708.97 \\
710.57 \\
712.17 \\
713.76\end{array}$ & $\begin{array}{l}707.53 \\
709.13 \\
710.73 \\
712.32 \\
713.92\end{array}$ & $\begin{array}{l}39 . \\
39 . \\
39 . \\
39 . \\
39 .\end{array}$ \\
\hline $\begin{array}{l}40 \cdot 00 \\
40 \cdot 10 \\
40 \cdot 20 \\
40 \cdot 30 \\
40.40\end{array}$ & $\begin{array}{l}713.92 \\
715.51 \\
717.11 \\
718.70 \\
720.29\end{array}$ & $\begin{array}{l}714.08 \\
715.67 \\
717.26 \\
718.85 \\
720.44\end{array}$ & $\begin{array}{l}714.24 \\
715.83 \\
717.42 \\
719.01 \\
720.60\end{array}$ & $\begin{array}{l}714.40 \\
715.99 \\
717.58 \\
719.17 \\
720.76\end{array}$ & $\begin{array}{l}714 \cdot 56 \\
716 \cdot 15 \\
717 \cdot 74 \\
719 \cdot 33 \\
720 \cdot 92\end{array}$ & $\begin{array}{l}714.72 \\
716.31 \\
717.90 \\
719.49 \\
721.08\end{array}$ & $\begin{array}{l}714.88 \\
716.47 \\
718.06 \\
719.65 \\
721.24\end{array}$ & $\begin{array}{l}715.04 \\
716.63 \\
718.22 \\
719.81 \\
721.40\end{array}$ & $\begin{array}{l}715.19 \\
716.79 \\
718.38 \\
719.97 \\
721.56\end{array}$ & $\begin{array}{l}715.35 \\
716.95 \\
718.54 \\
720.13 \\
721.71\end{array}$ & $\begin{array}{l}715.51 \\
717.11 \\
718.70 \\
720.29 \\
721.87\end{array}$ & $\begin{array}{l}40 \cdot 0 \\
40 \cdot 1 \\
40 \cdot 2 \\
40 \cdot 3 \\
40.4\end{array}$ \\
\hline $\begin{array}{l}40.50 \\
40.60 \\
40.70 \\
40.80 \\
40.90\end{array}$ & $\begin{array}{l}721.87 \\
723.46 \\
725.05 \\
726.63 \\
728.21\end{array}$ & $\begin{array}{l}722.03 \\
723.62 \\
725.20 \\
726.79 \\
728.37\end{array}$ & $\begin{array}{l}722.19 \\
723.78 \\
725.36 \\
726.95 \\
728.53\end{array}$ & $\begin{array}{l}722.35 \\
723.94 \\
725.52 \\
727.11 \\
728.69\end{array}$ & $\begin{array}{l}722.51 \\
724.09 \\
725.68 \\
727.26 \\
728.85\end{array}$ & $\begin{array}{l}722.67 \\
724.25 \\
725.84 \\
727.42 \\
729.00\end{array}$ & $\begin{array}{l}722.83 \\
724.41 \\
726.00 \\
727.58 \\
729.16\end{array}$ & $\begin{array}{l}722.98 \\
724 \cdot 57 \\
726.16 \\
727.74 \\
729.32\end{array}$ & $\begin{array}{l}723.14 \\
724.73 \\
726.31 \\
727.90 \\
729.48\end{array}$ & $\begin{array}{l}723.30 \\
724.89 \\
726.47 \\
728.06 \\
729.64\end{array}$ & $\begin{array}{l}723.46 \\
725.05 \\
726.63 \\
728.21 \\
729.80\end{array}$ & $\begin{array}{l}40 . \\
40.5 \\
40 . \\
40.8 \\
40 .\end{array}$ \\
\hline $\begin{array}{l}41.00 \\
41 \cdot 10 \\
41.20 \\
41.30 \\
41.40\end{array}$ & $\begin{array}{l}729.80 \\
731.38 \\
732.96 \\
734.53 \\
736.11\end{array}$ & $\begin{array}{l}729.95 \\
731.53 \\
733.11 \\
734.69 \\
736.27\end{array}$ & $\begin{array}{l}730.11 \\
731.69 \\
733.27 \\
734.85 \\
736.43\end{array}$ & $\begin{array}{l}730.27 \\
731.85 \\
733.43 \\
735.01 \\
736.59\end{array}$ & $\begin{array}{l}730.43 \\
732.01 \\
733.59 \\
735.17 \\
736.74\end{array}$ & $\begin{array}{l}730.59 \\
732.17 \\
733.75 \\
735.32 \\
736.90\end{array}$ & $\begin{array}{l}730.74 \\
732.32 \\
733.90 \\
735.48 \\
737.06\end{array}$ & $\begin{array}{l}730.90 \\
732.48 \\
734.06 \\
735.64 \\
737.22\end{array}$ & $\begin{array}{l}731.06 \\
732.64 \\
734.22 \\
735.80 \\
737.37\end{array}$ & $\begin{array}{l}731.22 \\
732.80 \\
734.38 \\
735.95 \\
737.53\end{array}$ & $\begin{array}{l}731.38 \\
732.96 \\
734.53 \\
736.11 \\
737.69\end{array}$ & $\begin{array}{l}41.0 \\
41 . \\
41 . \\
41 .\end{array}$ \\
\hline $\begin{array}{l}41.50 \\
41.60 \\
41.70 \\
41.80 \\
41.90\end{array}$ & $\begin{array}{l}737.69 \\
739.26 \\
740.84 \\
742.41 \\
743.98\end{array}$ & $\begin{array}{l}737.85 \\
739.42 \\
741.00 \\
742.57 \\
744.14\end{array}$ & $\begin{array}{l}738.00 \\
739.58 \\
741.15 \\
742.73 \\
744.30\end{array}$ & $\begin{array}{l}738.16 \\
739.74 \\
741.31 \\
742.88 \\
744.45\end{array}$ & $\begin{array}{l}738.32 \\
739.89 \\
741.47 \\
743.04 \\
744.61\end{array}$ & $\begin{array}{l}738.48 \\
740.05 \\
741.62 \\
743.20 \\
744.77\end{array}$ & $\begin{array}{l}738.63 \\
740.21 \\
741.78 \\
743.35 \\
744.93\end{array}$ & $\begin{array}{l}738.79 \\
740.37 \\
741.94 \\
743.51 \\
745.08\end{array}$ & $\begin{array}{l}738.95 \\
740.52 \\
742.10 \\
743.67 \\
745.24\end{array}$ & $\begin{array}{l}739.11 \\
740.68 \\
742.25 \\
743.83 \\
745.40\end{array}$ & $\begin{array}{l}739.26 \\
740.84 \\
742.41 \\
743.98 \\
745.55\end{array}$ & $\begin{array}{l}41.5 \\
41.6 \\
41 . \\
41 . \\
41 .\end{array}$ \\
\hline $42 \cdot 00$ & 745.55 & 745.71 & 745.87 & 746.03 & $746 \cdot 18$ & $746 \cdot 34$ & 746.50 & 746.65 & 746.81 & 746.97 & 747.12 & 42. \\
\hline
\end{tabular}

$\mathrm{mV}$

.02

.03

.04

.05

.06

.07

.08

.09

.10

$m V$ 
TABLE A6.2.1. Type J thermocouples-temperature $\left({ }^{\circ} \mathrm{C}\right)$ as a function of thermoelectric voltage, reference junctions at $0^{\circ} \mathrm{C}$-Continued

$\mathrm{mV}$

.00

\subsection{0}

$42 \cdot 10$

42.20

42.30

42.40

42.50

42.60

42.70

42.80

42.90

$m V$

747.12

748.69

750.26

$\begin{array}{ll}745.55 & 745.71 \\ 747.12 & 747.28 \\ 748.69 & 748.85 \\ 750.26 & 750.42 \\ 751.83 & 751.99 \\ & \\ 753.40 & 753.55 \\ 754.96 & 755.12 \\ 756.53 & 756.68 \\ 758.09 & 758.25 \\ 759.66 & 759.81\end{array}$

.01

.02

.03

.04

.05

.06

.07

.08

.09

$\cdot 10$

$m V$

TEMPERATURES IN DEGREES C (IPTS 1968 )

745.87
747.44
749.01
750.58
752.14
753.71
755.28
756.84
758.41
759.97

746.03
747.60
749.16

746.18
747.75
749.32

$750.73 \quad 750.89$

752.30

752.46

746.34

747.91

749.48

751.05

746.50

748.07

749.64

746.65

748.22

749.79

752.61

751.20

751.36

752.93

753.87

755.43
757.00

754.02

$754 \cdot 18$

$\begin{array}{ll}755.59 & 755.75\end{array}$

$757.15 \quad 757.31$

754.34

755.90

757.47

758.56

758.72

758.87

759.03

754.49

756.06

757.62

759.19

746.81

748.38

749.95

751.52

753.08

754.65

756.22

757.78

759.34

746.97

748.54

750.11

751.67

753.24

754.81

756.37

757.94

759.50

747.12

748.69

750.26

751.83

753.40

754.96

756.53

758.09

759.66

42.60

42.70

42.80

42.90

$.00 \quad .01$

.02

.03

.04

.05

.06

.07

.08

.09

.10

$m V$ 
TABLE A6.2.1. Type J thermocouples extended range-temperature $\left({ }^{\circ} \mathrm{C}\right.$ ) as a function of thermoelectric voltage, reference junctions at $0^{\circ} \mathrm{C}$

$m \mathrm{~V}$ .00 .01 .02
.03

TEMPERATURES IN DEGREES C (IPTS 1968)
$42 \cdot 90$

43.00

43.10

43.30

43.50

43.60

43.70

43.80

43.90

44.00

$44 \cdot 10$

44.30
44.40

44.50

44.60

44.70

44.80

44.90

45.00

45.10

45.20

45.30

45.40

45.50

45.60

45.70

45.80

45.90

46.00

46.10

46.20

46.30

46.40

46.50

46.60

46.70

46.80

46.90

47.00

47.10

47.20

47.30

47.40

47.50

47.60

47.70

47.80

47.90

48.00
761.22

762.78

764.34

765.90

767.46

769.02

770.57

772.13

773.68

776.79

$778 \cdot 34$

779.89

781.44

782.99

784.54

786.09

787.64

789.19

$790 \cdot 74$

792.29

793.84

795.38

796.93

798.48

800.03

801.58

803.12

804.67

806.22

807.77

809.31

810.86

812.41

813.96

815.51

817.06

818.61

$820 \cdot 16$

821.71

823.26

824.82

826.37

827.92

829.47

831.03

832.58

834.14

835.70

837.25

838.81
761.38

761.53
$762.94-763.09$

$762.050 \quad 763.09$
764.05

$766.06 \quad 766.21$

767.62

769.17

770.73

772.28

$773 \cdot 84$

776.94

778.50

$780 \cdot 05$

781.60
783.15

784.70

786.25

787.80

789.35

790.90

792.44

793.99

795.54

797.09

798.63

$800 \cdot 18$

801.73

803.28

804.83

806.37

807.92

809.47

811.02

812.57

814.12

815.67

817.21

818.77

820.32

821.87

823.42

824.97

826.52

828.08

831.18

832.74

834.30

835.85

837.41

838.97
767.77

769.33

770.88

772.44
773.99

775.55

777.10

778.65

780.20

781.75

783.30

784.85

786.40

787.95

789.50

791.05

792.60

794.15

795.69

797.24

798.79

$800 \cdot 34$

801.88

803.43

804.98

806.53

808.08

809.62

811.17

814.27

815.82

817.37

818.92

820.47

822.02

823.57

825.13

826.68

828.23

831.34

832.90

834.45

836.01

839.12
760.13

761.69

763.25

764.81

766.37

767.93

769.48

771.04

772.60

774.15
775.70

777.26

778.81

$780 \cdot 36$

781.91

783.46

785.01

786.56

788.11

789.66

792.75

794.30

795.85

797.40

798.94

800.49

802.04

803.59

805.13

806.68

808.23

809.78

811.33

812.88

814.43

815.98

817.52

819.08

820.63

822.18

823.73

825.28

826.83

828.39

829.94

831.50

833.05

834.61

836.16

837.72

839.28

$760 \cdot 28$

760.43

$761.85 \quad 762.00$

$763.41 \quad 763.56$

$764.97 \quad 765.12$

$766.53 \quad 766.68$

768.08

768.24

769.64

771.20

769.80

$774.30 \quad 774.46$

777.41

$778.96 \quad 779.12$

$\begin{array}{ll}782.06 & 782.22\end{array}$

$783.61 \quad 783.77$

785.16

786.71

788.26

789.81

785.32

786.87

788.42

789.97

$91 \cdot 36$

791.51

792.91

$794.46 \quad 794.61$

797.55

$799 \cdot 10$

797.71 
TABLE A6.2.1. Type J thermocouples extended range-temperature $\left({ }^{\circ} \mathrm{C}\right)$ as a function of thermoelectric voltage, reference junctions at $0^{\circ} \mathrm{C}$-Continued

$\mathrm{mV}$

.00

.01

.02

.03

.04

.05

.06

.07

.08

.09

.10

$m v$

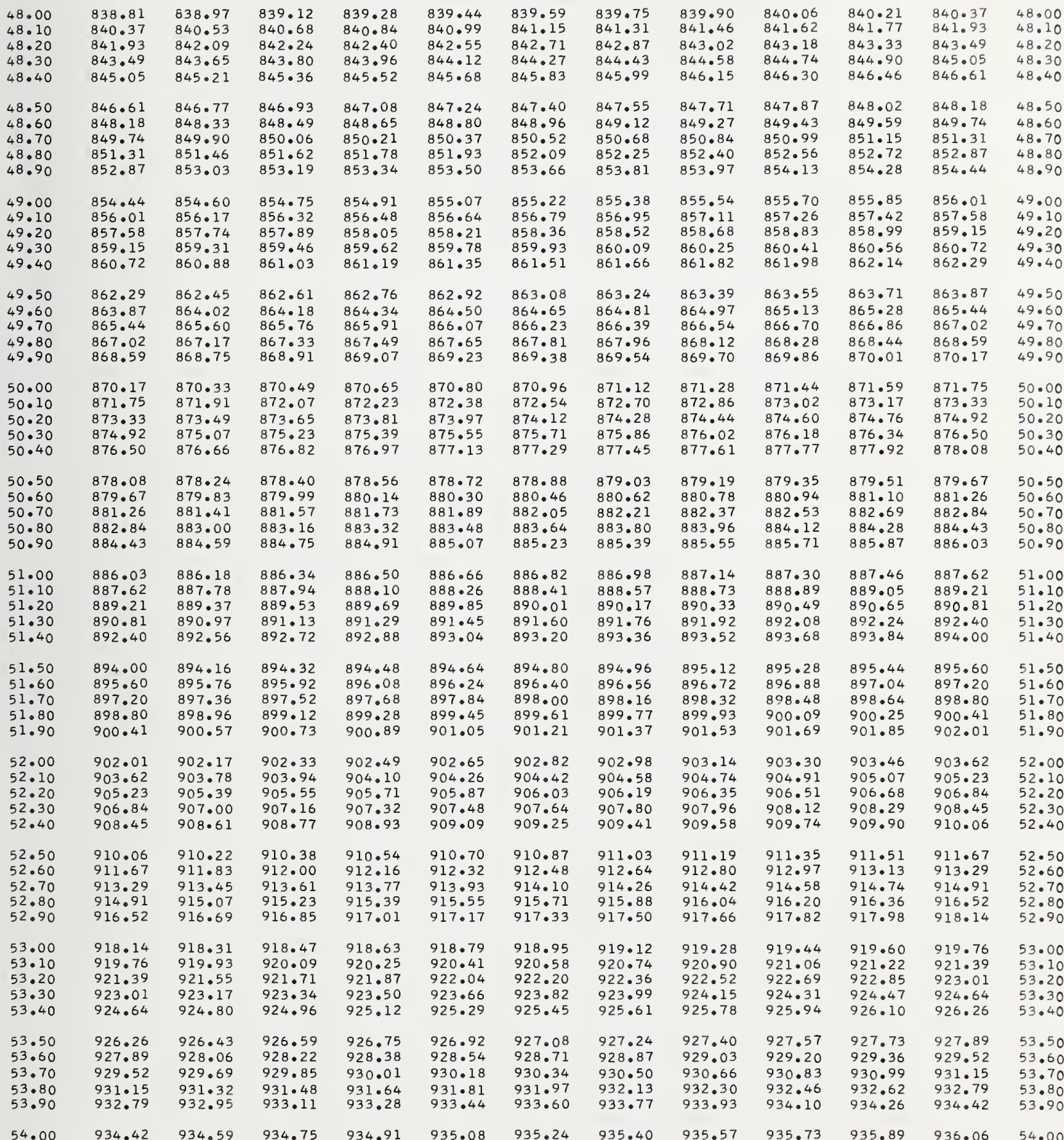


TABLE A6.2.1. Type J thermocouples extended range-temperature $\left({ }^{\circ} \mathrm{C}\right)$ as a function of thermoelectric voltage, reference junctions at $0^{\circ} \mathrm{C}-$ Continued

$\mathrm{mV}$

.00

.01

.02

.03

.04

.05

.06

.07

.08

.09

$\cdot 10$

$\mathrm{mV}$

TEMPERATURES IN DEGREES C (IPTS 1968)

\begin{tabular}{|c|c|c|c|c|c|c|c|c|c|c|c|c|}
\hline 54.00 & 934.42 & 934.59 & 934.75 & 934.91 & 935.08 & 935.24 & 935.40 & 935.57 & 935.73 & 935.89 & 936.06 & 54.00 \\
\hline 54.10 & 936.06 & 936.22 & 936.39 & 936.55 & 936.71 & 936.88 & 937.04 & 937.20 & $937 \cdot 37$ & 937.53 & 937.70 & 54.10 \\
\hline 54.20 & 937.70 & $937 \cdot 86$ & 938.02 & 938.19 & $938 \cdot 35$ & 938.52 & 938.68 & 938.84 & 939.01 & 939.17 & 939.34 & 54.20 \\
\hline 54.30 & 939.34 & 939.50 & 939.66 & 939.83 & 939.99 & 940.16 & 940.32 & 940.48 & 940.65 & 940.81 & 940.98 & 54.30 \\
\hline 54.40 & 940.98 & $941 \cdot 14$ & 941.30 & 941.47 & 941.63 & 941.80 & 941.96 & 942.13 & 942.29 & 942.45 & 942.62 & 54.40 \\
\hline 54.50 & 942.62 & 942.78 & 942.95 & 943.11 & 943.28 & 943.44 & 943.60 & 943.77 & 943.93 & 944.10 & 944.26 & 54.50 \\
\hline 54.60 & 944.26 & 944.43 & 944.59 & 944.76 & 944.92 & 945.08 & 945.25 & 945.41 & 945.58 & 945.74 & 945.91 & 54.60 \\
\hline 54.70 & 945.91 & 946.07 & 946.24 & 946.40 & 946.57 & 946.73 & 946.89 & 947.06 & 947.22 & 947.39 & 947.55 & 54.70 \\
\hline 54.80 & 947.55 & 947.72 & 947.88 & 948.05 & $948 \cdot 21$ & 948.38 & $948 \cdot 54$ & 948.71 & 948.87 & 949.04 & 949.20 & 54.80 \\
\hline 54.90 & 949.20 & 949.37 & 949.53 & 949.70 & 949.86 & 950.03 & 950.19 & 950.36 & 950.52 & 950.69 & 950.85 & 54.90 \\
\hline 55.00 & 950.85 & 951.02 & $951 \cdot 18$ & 951.35 & 951.51 & 951.68 & 951.84 & 952.01 & 952.17 & 952.34 & 952.50 & 55.00 \\
\hline 55.10 & 952.50 & 952.67 & 952.83 & 953.00 & 953.16 & 953.33 & 953.49 & 953.66 & 953.82 & 953.99 & 954.15 & 55.10 \\
\hline 55.20 & 954.15 & 954.32 & 954.48 & 954.65 & 954.82 & 954.98 & 955.15 & 955.31 & 955.48 & 955.64 & 955.81 & 55.20 \\
\hline 55.30 & 955.81 & 955.97 & 956.14 & 956.30 & 956.47 & 956.64 & 956.80 & 956.97 & 957.13 & 957.30 & 957.46 & 55.30 \\
\hline 55.40 & 957.46 & 957.63 & 957.79 & 957.96 & $958 \cdot 13$ & 958.29 & 958.46 & 958.62 & 958.79 & 958.95 & 959.12 & 55.40 \\
\hline 55.50 & 959.12 & 959.29 & 959.45 & 959.62 & 959.78 & 959.95 & 960.11 & 960.28 & 960.45 & 960.61 & $960 \cdot 78$ & 55.50 \\
\hline 55.60 & 960.78 & 960.94 & 961.11 & 961.28 & $961 \cdot 44$ & 961.61 & 961.77 & 961.94 & 962.11 & 962.27 & 962.44 & 55.60 \\
\hline 55.70 & 962.44 & 962.60 & 962.77 & $962 \cdot 94$ & 963.10 & 963.27 & 963.43 & 963.60 & 963.77 & 963.93 & 964.10 & 55.70 \\
\hline 55.80 & $964 \cdot 10$ & 964.27 & 964.43 & 964.60 & 964.76 & 964.93 & 965.10 & 965.26 & 965.43 & 965.60 & 965.76 & 55.80 \\
\hline 55.90 & 965.76 & 965.93 & 966.09 & 966.26 & $966 \cdot 43$ & 966.59 & 966.76 & 966.93 & 967.09 & 967.26 & 967.43 & 55.90 \\
\hline 56.00 & 967.43 & 967.59 & 967.76 & 967.92 & 968.09 & $968 \cdot 26$ & 968.42 & 968.59 & 968.76 & 968.92 & 969.09 & 56.00 \\
\hline 56.10 & 969.09 & 969.26 & $969 \cdot 42$ & 969.59 & 969.76 & 969.92 & 970.09 & 970.26 & 970.42 & 970.59 & 970.76 & 56.10 \\
\hline 56.20 & 970.76 & 970.92 & 971.09 & 971.26 & 971.42 & $971 \cdot 59$ & $971 \cdot 76$ & 971.92 & 972.09 & $972 \cdot 26$ & 972.42 & $56 \cdot 20$ \\
\hline 56.30 & 972.42 & 972.59 & 972.76 & 972.93 & 973.09 & 973.26 & 973.43 & 973.59 & 973.76 & 973.93 & 974.09 & 56.30 \\
\hline 56.40 & 974.09 & $974 \cdot 26$ & 974.43 & 974.60 & 974.76 & 974.93 & 975.10 & 975.26 & 975.43 & 975.60 & 975.76 & 56.40 \\
\hline $\begin{array}{l}56.50 \\
56.60\end{array}$ & 975.76 & 975.93 & $976 \cdot 10$ & 976.27 & 976.43 & 976.60 & 976.77 & 976.94 & $977 \cdot 10$ & 977.27 & $977 \cdot 44$ & 56.50 \\
\hline 56.60 & 977.44 & 977.60 & 977.77 & 977.94 & 978.11 & 978.27 & 978.44 & 978.61 & 978.78 & 978.94 & 979.11 & 56.60 \\
\hline 56.70 & 979.11 & 979.28 & 979.45 & 979.61 & 979.78 & 979.95 & 980.11 & 980.28 & 980.45 & 980.62 & 980.78 & 56.70 \\
\hline $56 \cdot 80$ & $980 \cdot 78$ & 980.95 & $981 \cdot 12$ & 981.29 & $981 \cdot 46$ & 981.62 & 981.79 & 981.96 & $982 \cdot 13$ & 982.29 & 982.46 & 56.80 \\
\hline 56.90 & 982.46 & 982.63 & $982 \cdot 80$ & 982.96 & $983 \cdot 13$ & 983.30 & 983.47 & 983.63 & 983.80 & 983.97 & 984.14 & 56.90 \\
\hline 57.00 & $984 \cdot 14$ & 984.31 & 984.47 & $984 \cdot 64$ & 984.81 & $984 \cdot 98$ & $985 \cdot 14$ & 985.31 & 985.48 & 985.65 & 985.82 & 57.00 \\
\hline $57 \cdot 10$ & 985.82 & 985.98 & 986.15 & 986.32 & 986.49 & 986.66 & 986.82 & 986.99 & 987.16 & 987.33 & 987.50 & 57.10 \\
\hline 57.20 & 987.50 & 987.66 & 987.83 & 988.00 & 988.17 & $988 \cdot 34$ & $988 \cdot 50$ & 988.67 & $988 \cdot 84$ & 989.01 & 989.18 & $57 \cdot 20$ \\
\hline $\begin{array}{l}57 \cdot 30 \\
57.40\end{array}$ & 989.18 & 989.35 & 989.51 & 989.68 & 989.85 & 990.02 & 990.19 & 990.35 & 990.52 & 990.69 & 990.86 & $57 \cdot 30$ \\
\hline & 990.80 & 991.03 & $991 \cdot 20$ & $991 \cdot 36$ & 991.53 & 991.10 & 991.87 & $992.04^{\circ}$ & $992 \cdot 21$ & 992.31 & 992.54 & 21.40 \\
\hline 57.50 & 992.54 & 992.71 & 992.88 & 993.05 & $993 \cdot 22$ & 993.39 & 993.55 & 993.72 & 993.89 & 994.06 & 994.23 & 57.50 \\
\hline 57.60 & 994.23 & 994.40 & 994.56 & 994.73 & $994 \cdot 90$ & 995.07 & 995.24 & 995.41 & 995.58 & 995.75 & 995.91 & 57.60 \\
\hline 57.70 & 995.91 & 996.08 & 996.25 & 996.42 & 996.59 & 996.76 & 996.93 & 997.09 & 997.26 & 997.43 & 997.60 & 57.70 \\
\hline 57.80 & 997.60 & 997.77 & 997.94 & 998.11 & 998.28 & 998.44 & 998.61 & 998.78 & 998.95 & 999.12 & 999.29 & 57.80 \\
\hline 57.90 & 999.29 & 999.46 & 999.63 & 999.80 & 999.96 & 1000.13 & 1000.30 & 1000.47 & 1000.64 & 1000.81 & 1000.98 & 57.90 \\
\hline 58.00 & $1000 \cdot 98$ & 1001.15 & 1001.32 & 1001.49 & 1001.65 & $1001 \cdot 82$ & 1001.99 & 1002.16 & 1002.33 & 1002.50 & 1002.67 & 58.00 \\
\hline & 1002.67 & 1002.84 & 1003.01 & 1003.18 & 1003.35 & 1003.51 & 1003.68 & 1003.85 & 1004.02 & 1004.19 & 1004.36 & $58 \cdot 10$ \\
\hline $58 \cdot 20$ & $1004 \cdot 36$ & 1004.53 & 1004.70 & $1004 \cdot 87$ & 1005.04 & 1005.21 & 1005.38 & 1005.55 & 1005.71 & 1005.88 & 1006.05 & $58 \cdot 20$ \\
\hline 58.30 & 1006.05 & $1006 \cdot 22$ & 1006.39 & 1006.56 & 1006.73 & 1006.90 & 1007.07 & 1007.24 & 1007.41 & 1007.58 & 1007.75 & $58 \cdot 30$ \\
\hline 58.40 & 1007.75 & 1007.92 & 1008.09 & 1008.26 & 1008.43 & 1008.59 & 1008.76 & 1008.93 & 1009.10 & 1009.27 & 1009.44 & 58.40 \\
\hline 58.50 & 1009.44 & 1009.61 & 1009.78 & 1009.95 & $1010 \cdot 12$ & 1010.29 & 1010.46 & 1010.63 & 1010.80 & 1010.97 & 1011.14 & 58.50 \\
\hline 58.60 & $1011 \cdot 14$ & 1011.31 & 1011.48 & 1011.65 & 1011.82 & 1011.99 & 1012.16 & 1012.33 & 1012.50 & 1012.67 & 1012.84 & 58.60 \\
\hline 58.70 & 1012.84 & 1013.01 & 1013.18 & 1013.34 & 1013.51 & 1013.68 & 1013.85 & 1014.02 & 1014.19 & 1014.36 & 1014.53 & 58.70 \\
\hline 58.80 & 1014.53 & 1014.70 & 1014.87 & 1015.04 & 1015.21 & 1015.38 & 1015.55 & 1015.72 & 1015.89 & 1016.06 & 1016.23 & 58.80 \\
\hline 58.90 & 1016.23 & $1016 \cdot 40$ & 1016.57 & 1016.74 & 1016.91 & 1017.08 & 1017.25 & 1017.42 & 1017.59 & 1017.76 & 1017.93 & 58.90 \\
\hline 59.00 & 1017.93 & 1018.10 & 1018.27 & 1018.44 & 1018.61 & 1018.78 & 1018.95 & 1019.12 & 1019.29 & 1019.46 & 1019.63 & 59.00 \\
\hline & 1019.63 & 1019.80 & 1019.97 & $1020 \cdot 14$ & $1020 \cdot 32$ & 1020.49 & 1020.66 & 1020.83 & 1021.00 & $1021 \cdot 17$ & 1021.34 & 59.10 \\
\hline $59 \cdot 20$ & $1021 \cdot 34$ & 1021.51 & 1021.68 & $1021 \cdot 85$ & 1022.02 & 1022.19 & $1022 \cdot 36$ & 1022.53 & 1022.70 & 1022.87 & 1023.04 & $59 \cdot 20$ \\
\hline 59.30 & 1023.04 & 1023.21 & 1023.36 & 1023.55 & 1023.72 & 1023.89 & 1024.06 & 1024.23 & 1024.40 & 1024.57 & 1024.74 & 59.30 \\
\hline 59.40 & $1024 \cdot 74$ & 1024.91 & 1025.08 & 1025.25 & $1025 \cdot 43$ & 1025.60 & 1025.77 & 1025.94 & 1026.11 & 1026.28 & 1026.45 & 59.40 \\
\hline 59.50 & 1026.45 & 1026.62 & 1026.79 & 1026.96 & 1027.13 & $1027 \cdot 30$ & 1027.47 & 1027.64 & 1027.81 & 1027.98 & 1028.15 & 59.50 \\
\hline & 1028.15 & 1028.32 & 1028.50 & 1028.67 & $1028 \cdot 8.4$ & 1029.01 & 1029.18 & 1029.35 & 1029.52 & 1029.69 & 1029.86 & 59.60 \\
\hline 59.70 & 1029.86 & 1030.03 & 1030.20 & 1030.37 & 1030.54 & 1030.71 & 1030.89 & 1031.06 & 1031.23 & 1031.40 & 1031.57 & 59.70 \\
\hline 59.80 & 1031.57 & 1031.74 & 1031.91 & 1032.08 & 1032.25 & 1032.42 & 1032.59 & 1032.76 & 1032.94 & 1033.11 & 1033.28 & 59.80 \\
\hline 59.90 & 1033.28 & 1033.45 & 1033.62 & 1033.79 & 1033.96 & 1034.13 & 1034.30 & 1034.47 & 1034.64 & 1034.82 & 1034.99 & 59.90 \\
\hline 60.00 & 1034.99 & 1035.16 & 1035.33 & 1035.50 & 1035.67 & 1035.84 & 1036.01 & 1036.18 & 1036.35 & 1036.53 & 1036.70 & 60.00 \\
\hline
\end{tabular}

$m \vee$

.00

.01

.02

.03

.04

.05

.06

.07

.08

.09

.10

$m v$ 
TABLE A6.2.1. Type J thermocouples extended range-temperature $\left({ }^{\circ} \mathrm{C}\right)$ as a function of thermoelectric voltage, reference junctions at $0^{\circ} \mathrm{C}-$ Continued

$m V$

.00

.01

.02

.03

.04

.05

.06

.07

.08

.09

.10

$m v$

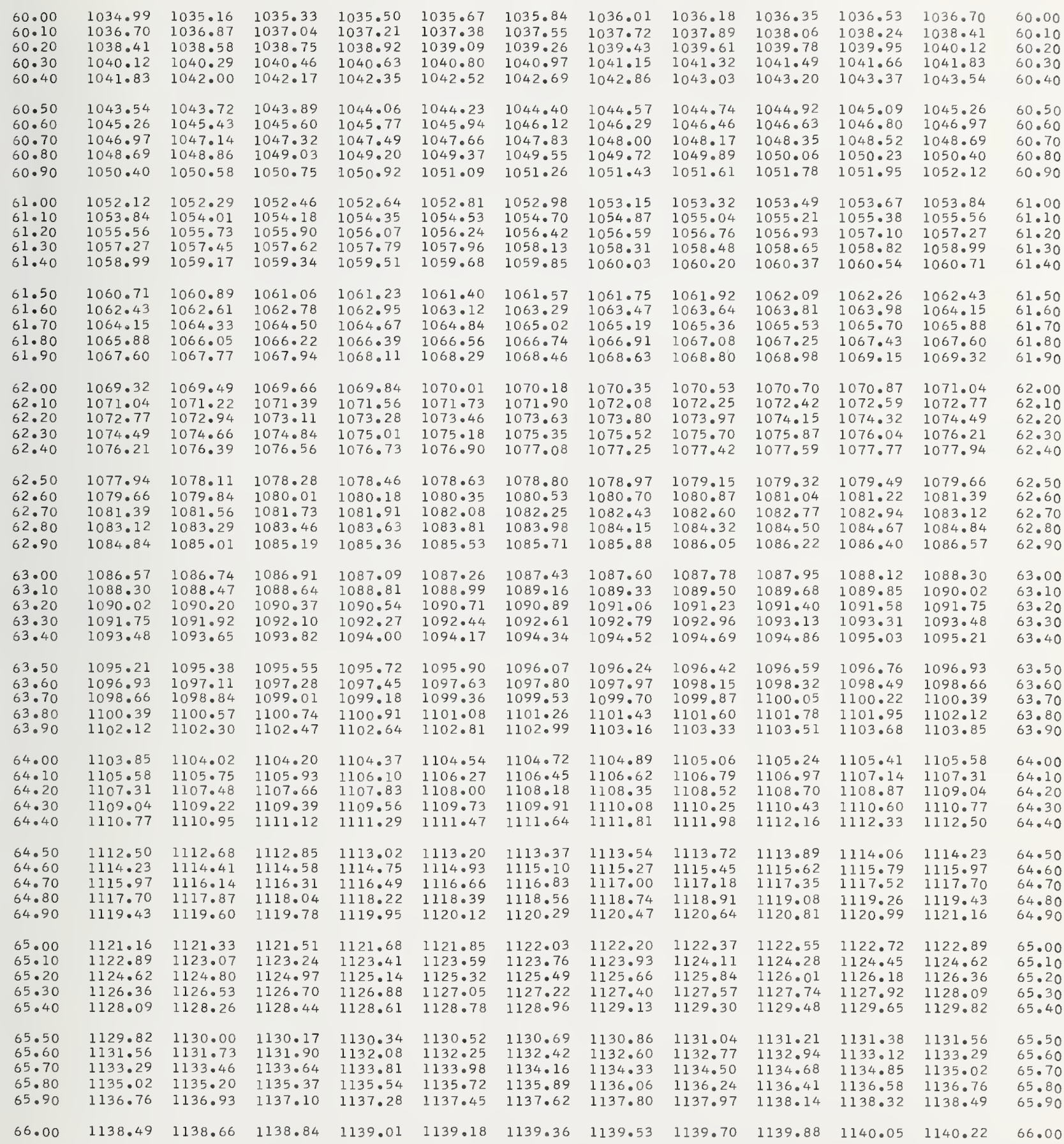

$\mathrm{mV}$
.01

.02

.03

\begin{abstract}
.04
\end{abstract}
.05

\begin{abstract}
.06
\end{abstract}

\begin{abstract}
.07
\end{abstract}

\begin{abstract}
.08
\end{abstract}
.09

.10

$m V$ 
TABLE A6.2.1. Type J thermocouples extended range-temperature $\left({ }^{\circ} \mathrm{C}\right)$ as a function of thermoelectric voltage, reference junctions at $0^{\circ} \mathrm{C}$-Continued

$\mathrm{mV}$

$.00 \quad .01 \quad .02$

.03

.04

.05

.06

.07

.08

.09

.10

$\mathrm{mV}$

TEMPERATURES IN DEGREES C (IPTS 1968)

\begin{tabular}{|c|c|c|c|c|c|c|c|c|c|c|c|c|}
\hline $\begin{array}{l}66 \cdot 00 \\
66 \cdot 10 \\
66 \cdot 20 \\
66 \cdot 30 \\
66 \cdot 40\end{array}$ & $\begin{array}{l}1138.49 \\
1140.22 \\
1141.96 \\
1143.69 \\
1145.43\end{array}$ & $\begin{array}{l}1138.66 \\
1140.40 \\
1142.13 \\
1143.87 \\
1145.60\end{array}$ & $\begin{array}{l}1138.84 \\
1140.57 \\
1142.30 \\
1144.04 \\
1145.77\end{array}$ & $\begin{array}{l}1139.01 \\
1140.74 \\
1142.48 \\
1144.21 \\
1145.95\end{array}$ & $\begin{array}{l}1139 \cdot 18 \\
1140 \cdot 92 \\
1142 \cdot 65 \\
1144 \cdot 39 \\
1146 \cdot 12\end{array}$ & $\begin{array}{l}1139.36 \\
1141.09 \\
1142.82 \\
1144.56 \\
1146.29\end{array}$ & $\begin{array}{l}1139.53 \\
1141.26 \\
1143.00 \\
1144.73 \\
1146.47\end{array}$ & $\begin{array}{l}1139.70 \\
1141.44 \\
1143.17 \\
1144.91 \\
1146.64\end{array}$ & $\begin{array}{l}1139.88 \\
1141.61 \\
1143.34 \\
1145.08 \\
1146.81\end{array}$ & $\begin{array}{l}1140.05 \\
1141.78 \\
1143.52 \\
1145.25 \\
1146.99\end{array}$ & $\begin{array}{l}1140.22 \\
1141.96 \\
1143.69 \\
1145.43 \\
1147.16\end{array}$ & $\begin{array}{l}66 \cdot 00 \\
66.10 \\
66 \cdot 20 \\
66 \cdot 30 \\
66.40\end{array}$ \\
\hline $\begin{array}{l}66.50 \\
66.60 \\
66.70 \\
66.80 \\
66.90\end{array}$ & $\begin{array}{l}1147 \cdot 16 \\
1148.90 \\
1150.63 \\
1152.37 \\
1154.10\end{array}$ & $\begin{array}{l}1147.33 \\
1149.07 \\
1150.80 \\
1152.54 \\
1154.28\end{array}$ & $\begin{array}{l}1147.51 \\
1149.24 \\
1150.98 \\
1152.71 \\
1154.45\end{array}$ & $\begin{array}{l}1147.68 \\
1149.42 \\
1151.15 \\
1152.89 \\
1154.62\end{array}$ & $\begin{array}{l}1147.86 \\
1149.59 \\
1151.33 \\
1153.06 \\
1154.80\end{array}$ & $\begin{array}{l}1148.03 \\
1149.76 \\
1151.50 \\
1153.23 \\
1154.97\end{array}$ & $\begin{array}{l}1148.20 \\
1149.94 \\
1151.67 \\
1153.41 \\
1155.14\end{array}$ & $\begin{array}{l}1148.38 \\
1150.11 \\
1151.85 \\
1153.58 \\
1155.32\end{array}$ & $\begin{array}{l}1148.55 \\
1150.28 \\
1152.02 \\
1153.76 \\
1155.49\end{array}$ & $\begin{array}{l}1148 \cdot 72 \\
1150 \cdot 46 \\
1152.19 \\
1153.93 \\
1155.66\end{array}$ & $\begin{array}{l}1148.90 \\
1150.63 \\
1152.37 \\
1154.10 \\
1155.84\end{array}$ & $\begin{array}{l}66.50 \\
66.60 \\
66.70 \\
66.80 \\
66.90\end{array}$ \\
\hline $\begin{array}{l}67 \cdot 00 \\
67 \cdot 10 \\
67 \cdot 20 \\
67 \cdot 30 \\
67.40\end{array}$ & $\begin{array}{l}1155.84 \\
1157.57 \\
1159.31 \\
1161.05 \\
1162.79\end{array}$ & $\begin{array}{l}1156.01 \\
1157.75 \\
1159.49 \\
1161.22 \\
1162.96\end{array}$ & $\begin{array}{l}1156 \cdot 19 \\
1157.92 \\
1159.66 \\
1161.40 \\
1163.13\end{array}$ & $\begin{array}{l}1156.36 \\
1158.10 \\
1159.83 \\
1161.57 \\
1163.31\end{array}$ & $\begin{array}{l}1156 \cdot 53 \\
1158 \cdot 27 \\
1160 \cdot 01 \\
1161.74 \\
1163 \cdot 48\end{array}$ & $\begin{array}{l}1156 \cdot 71 \\
1158 \cdot 44 \\
1160.18 \\
1161.92 \\
1163.65\end{array}$ & $\begin{array}{l}1156.88 \\
1158.62 \\
1160.35 \\
1162.09 \\
1163.83\end{array}$ & $\begin{array}{l}1157.05 \\
1158.79 \\
1160.53 \\
1162.26 \\
1164.00\end{array}$ & $\begin{array}{l}1157.23 \\
1158.96 \\
1160.70 \\
1162.44 \\
1164.18\end{array}$ & $\begin{array}{l}1157.40 \\
1159.14 \\
1160.87 \\
1162.61 \\
1164.35\end{array}$ & $\begin{array}{l}1157.57 \\
1159.31 \\
1161.05 \\
1162.79 \\
1164.52\end{array}$ & $\begin{array}{l}67.00 \\
67.10 \\
67.20 \\
67.30 \\
67.40\end{array}$ \\
\hline $\begin{array}{l}67.50 \\
67.60 \\
67.70 \\
67.80 \\
67.90\end{array}$ & $\begin{array}{l}1164.52 \\
1166.26 \\
1168.00 \\
1169 \cdot 74 \\
1171.48\end{array}$ & $\begin{array}{l}1164 \cdot 70 \\
1166.43 \\
1168.17 \\
1169 \cdot 91 \\
1171.65\end{array}$ & $\begin{array}{l}1164.87 \\
1166.61 \\
1168.35 \\
1170.09 \\
1171.82\end{array}$ & $\begin{array}{l}1165.04 \\
1166.78 \\
1168.52 \\
1170.26 \\
1172.00\end{array}$ & $\begin{array}{l}1165.22 \\
1166.96 \\
1168.69 \\
1170.43 \\
1172.17\end{array}$ & $\begin{array}{l}1165.39 \\
1167.13 \\
1168.87 \\
1170.61 \\
1172.35\end{array}$ & $\begin{array}{l}1165.57 \\
1167.30 \\
1169.04 \\
1170.78 \\
1172.52\end{array}$ & $\begin{array}{l}1165.74 \\
1167.48 \\
1169.22 \\
1170.95 \\
1172.69\end{array}$ & $\begin{array}{l}1165.91 \\
1167.65 \\
1169.39 \\
1171.13 \\
1172.87\end{array}$ & $\begin{array}{l}1166.09 \\
1167.82 \\
1169.56 \\
1171.30 \\
1173.04\end{array}$ & $\begin{array}{l}1166.26 \\
1168.00 \\
1169.74 \\
1171.48 \\
1173.22\end{array}$ & $\begin{array}{l}67.50 \\
67.60 \\
67.70 \\
67.80 \\
67.90\end{array}$ \\
\hline $\begin{array}{l}68 \cdot 00 \\
68 \cdot 10 \\
68 \cdot 20 \\
68 \cdot 30 \\
68 \cdot 40\end{array}$ & $\begin{array}{l}1173 \cdot 22 \\
1174 \cdot 96 \\
1176.70 \\
1178.44 \\
1180.18\end{array}$ & $\begin{array}{l}1173.39 \\
1175.13 \\
1176.87 \\
1178.61 \\
1180.35\end{array}$ & $\begin{array}{l}1173.56 \\
1175.30 \\
1177.04 \\
1178.78 \\
1180.53\end{array}$ & $\begin{array}{l}1173 \cdot 74 \\
1175 \cdot 48 \\
1177.22 \\
1178.96 \\
1180.70\end{array}$ & $\begin{array}{l}1173.91 \\
1175.65 \\
1177.39 \\
1179.13 \\
1180.87\end{array}$ & $\begin{array}{l}1174.09 \\
1175.83 \\
1177.57 \\
1179.31 \\
1181.05\end{array}$ & $\begin{array}{l}1174.26 \\
1176.00 \\
1177.74 \\
1179.48 \\
1181.22\end{array}$ & $\begin{array}{l}1174.43 \\
1176.17 \\
1177.91 \\
1179.66 \\
1181.40\end{array}$ & $\begin{array}{l}1174.61 \\
1176.35 \\
1178.09 \\
1179.83 \\
1181.57\end{array}$ & $\begin{array}{l}1174.78 \\
1176.52 \\
1178.26 \\
1180.00 \\
1181.74\end{array}$ & $\begin{array}{l}1174.96 \\
1176.70 \\
1178.44 \\
1180.18 \\
1181.92\end{array}$ & $\begin{array}{l}68.00 \\
68.10 \\
68.20 \\
68.30 \\
68.40\end{array}$ \\
\hline $\begin{array}{l}68.50 \\
68.60 \\
68.70 \\
68.80 \\
68.90\end{array}$ & $\begin{array}{l}1181.92 \\
1183.66 \\
1185.40 \\
1187.15 \\
1188.89\end{array}$ & $\begin{array}{l}1182.09 \\
1183.84 \\
1185.58 \\
1187.32 \\
1189.07\end{array}$ & $\begin{array}{l}1182.27 \\
1184.01 \\
1185.75 \\
1187.50 \\
1189.24\end{array}$ & $\begin{array}{l}1182.44 \\
1184.18 \\
1185.93 \\
1187.67 \\
1189.41\end{array}$ & $\begin{array}{l}1182 \cdot 62 \\
1184 \cdot 36 \\
1186.10 \\
1187 \cdot 85 \\
1189 \cdot 59\end{array}$ & $\begin{array}{l}1182.79 \\
1184.53 \\
1186.28 \\
1188.02 \\
1189.76\end{array}$ & $\begin{array}{l}1182.96 \\
1184.71 \\
1186.45 \\
1188.19 \\
1189.94\end{array}$ & $\begin{array}{l}1183.14 \\
1184.88 \\
1186.62 \\
1188.37 \\
1190.11\end{array}$ & $\begin{array}{l}1183.31 \\
1185.06 \\
1186.80 \\
1188.54 \\
1190.29\end{array}$ & $\begin{array}{l}1183.49 \\
1185.23 \\
1186.97 \\
1188.72 \\
1190.46\end{array}$ & $\begin{array}{l}1183.66 \\
1185.40 \\
1187.15 \\
1188.89 \\
1190.64\end{array}$ & $\begin{array}{l}68.50 \\
68.60 \\
68.70 \\
68.80 \\
68.90\end{array}$ \\
\hline $\begin{array}{l}69.00 \\
69.10 \\
69.20 \\
69 \cdot 30 \\
69.40\end{array}$ & $\begin{array}{l}1190.64 \\
1192.38 \\
1194.13 \\
1195.87 \\
1197.62\end{array}$ & $\begin{array}{l}1190.81 \\
1192.56 \\
1194.30 \\
1196.05 \\
1197.80\end{array}$ & $\begin{array}{l}1190.99 \\
1192.73 \\
1194.48 \\
1196.22 \\
1197.97\end{array}$ & $\begin{array}{l}1191.16 \\
1192.91 \\
1194.65 \\
1196.40 \\
1198.15\end{array}$ & $\begin{array}{l}1191.33 \\
1193.08 \\
1194.83 \\
1196.57 \\
1198.32\end{array}$ & $\begin{array}{l}1191.51 \\
1193.25 \\
1195.00 \\
1196.75 \\
1198.50\end{array}$ & $\begin{array}{l}1191.68 \\
1193.43 \\
1195.18 \\
1196.92 \\
1198.67\end{array}$ & $\begin{array}{l}1191.85 \\
1193.60 \\
1195.35 \\
1197.10 \\
1198.85\end{array}$ & $\begin{array}{l}1192.03 \\
1193.78 \\
1195.52 \\
1197.27 \\
1199.02\end{array}$ & $\begin{array}{l}1192.21 \\
1193.95 \\
1195.70 \\
1197.45 \\
1199.20\end{array}$ & $\begin{array}{l}1192.38 \\
1194.13 \\
1195.87 \\
1197.62 \\
1199.37\end{array}$ & $\begin{array}{l}69 \cdot 00 \\
69.10 \\
69.20 \\
69.30 \\
69.40\end{array}$ \\
\hline 69.50 & 1199.37 & $1199 \cdot 55$ & $1199 \cdot 72$ & 1199.89 & & & & & & & & 69.50 \\
\hline $\mathrm{mV}$ & .00 & .01 & .02 & .03 & .04 & .05 & .06 & .07 & .08 & .09 & .10 & $\mathrm{mV}$ \\
\hline
\end{tabular}


TABLE A6.2.2. Type J thermocouples-temperature $\left({ }^{\circ} \mathrm{F}\right)$ as a function of thermoelectric voltage, reference junctions at $32^{\circ} \mathrm{F}$

\begin{tabular}{|c|c|c|c|c|c|c|c|c|c|c|c|c|}
\hline $\mathrm{mV}$ & .00 & .01 & .02 & .03 & .04 & .05 & .06 & .07 & .08 & .09 & $\cdot 10$ & $\mathrm{mV}$ \\
\hline & & & & & TEMPER & RES IN & GREES $F$ & & & & & \\
\hline$-8 \cdot 00$ & -337.31 & -338.19 & -339.08 & -339.97 & -340.87 & -341.78 & -342.69 & -343.61 & -344.54 & -345.47 & & -8.00 \\
\hline $\begin{array}{l}-7.90 \\
-7.80 \\
-7.70 \\
-7.60 \\
-7.50\end{array}$ & $\begin{array}{l}-328.79 \\
-320.73 \\
-313.06 \\
-305.72 \\
-298.67\end{array}$ & $\begin{array}{l}-329.62 \\
-321.52 \\
-313.82 \\
-306.45 \\
-299.36\end{array}$ & $\begin{array}{l}-330.45 \\
-322.31 \\
-314.57 \\
-307.17 \\
-300.06\end{array}$ & $\begin{array}{l}-331.29 \\
-323.10 \\
-315.33 \\
-307.90 \\
-300.76\end{array}$ & $\begin{array}{l}-332.13 \\
-323.90 \\
-316.09 \\
-308.62 \\
-301.46\end{array}$ & $\begin{array}{l}-332.98 \\
-324.71 \\
-316.85 \\
-309.36 \\
-302.16\end{array}$ & $\begin{array}{l}-333.84 \\
-325.51 \\
-317.62 \\
-310.09 \\
-302.87\end{array}$ & $\begin{array}{l}-334.70 \\
-326.33 \\
-318.39 \\
-310.83 \\
-303.58\end{array}$ & $\begin{array}{l}-335.56 \\
-327.14 \\
-319.17 \\
-311.57 \\
-304.29\end{array}$ & $\begin{array}{l}-336.43 \\
-327.96 \\
-319.95 \\
-312.32 \\
-305.01\end{array}$ & $\begin{array}{l}-337.31 \\
-328.79 \\
-320.73 \\
-313.06 \\
-305.72\end{array}$ & $\begin{array}{l}-7.90 \\
-7.80 \\
-7.70 \\
-7.60 \\
-7.50\end{array}$ \\
\hline $\begin{array}{l}-7 \cdot 40 \\
-7 \cdot 30 \\
-7 \cdot 20 \\
-7 \cdot 10 \\
-7 \cdot 00\end{array}$ & $\begin{array}{l}-291.85 \\
-285.26 \\
-278.85 \\
-272.62 \\
-266.54\end{array}$ & $\begin{array}{l}-292.52 \\
-285.91 \\
-279.48 \\
-273.23 \\
-267.14\end{array}$ & $\begin{array}{l}-293.20 \\
-286.56 \\
-280.12 \\
-273.85 \\
-267.74\end{array}$ & $\begin{array}{l}-293.87 \\
-287.21 \\
-280.75 \\
-274.47 \\
-268.35\end{array}$ & $\begin{array}{l}-294.55 \\
-287.87 \\
-281.39 \\
-275.09 \\
-268.95\end{array}$ & $\begin{array}{l}-295.23 \\
-288.53 \\
-282.03 \\
-275.71 \\
-269.56\end{array}$ & $\begin{array}{l}-295.91 \\
-289.19 \\
-282.67 \\
-276.34 \\
-270.17\end{array}$ & $\begin{array}{l}-296.60 \\
-289.85 \\
-283.31 \\
-276.96 \\
-270.78\end{array}$ & $\begin{array}{l}-297.29 \\
-290.52 \\
-283.96 \\
-277.59 \\
-271.39\end{array}$ & $\begin{array}{l}-297.97 \\
-291.18 \\
-284.61 \\
-278.22 \\
-272.00\end{array}$ & $\begin{array}{l}-298.67 \\
-291.85 \\
-285.26 \\
-278.85 \\
-272.62\end{array}$ & $\begin{array}{l}-7.40 \\
-7.30 \\
-7.20 \\
-7.10 \\
-7.00\end{array}$ \\
\hline $\begin{array}{l}-6.90 \\
-6.80 \\
-6.70 \\
-6.60 \\
-6.50\end{array}$ & $\begin{array}{l}-260.60 \\
-254.79 \\
-249.10 \\
-243.52 \\
-238.04\end{array}$ & $\begin{array}{l}-261.19 \\
-255.37 \\
-249.66 \\
-244.07 \\
-238.58\end{array}$ & $\begin{array}{l}-261.78 \\
-255.94 \\
-250.23 \\
-244.63 \\
-239.13\end{array}$ & $\begin{array}{l}-262.37 \\
-256.52 \\
-250.80 \\
-245.18 \\
-239.67\end{array}$ & $\begin{array}{l}-262.96 \\
-257.10 \\
-251.36 \\
-245.74 \\
-240.22\end{array}$ & $\begin{array}{l}-263.55 \\
-257.68 \\
-251.93 \\
-246.30 \\
-240.77\end{array}$ & $\begin{array}{l}-264.15 \\
-258.26 \\
-252.50 \\
-246.85 \\
-241.31\end{array}$ & $\begin{array}{l}-264.74 \\
-258.84 \\
-253.07 \\
-247.41 \\
-241.86\end{array}$ & $\begin{array}{l}-265.34 \\
-259.43 \\
-253.64 \\
-247.97 \\
-242.41\end{array}$ & $\begin{array}{l}-265.94 \\
-260.01 \\
-254.22 \\
-248.54 \\
-242.97\end{array}$ & $\begin{array}{l}-266.54 \\
-260.60 \\
-254.79 \\
-249.10 \\
-243.52\end{array}$ & $\begin{array}{l}-6.90 \\
-6.80 \\
-6.70 \\
-6.60 \\
-6.50\end{array}$ \\
\hline $\begin{array}{l}-6 \cdot 40 \\
-6 \cdot 30 \\
-6 \cdot 20 \\
-6 \cdot 10 \\
-6 \cdot 00\end{array}$ & $\begin{array}{l}-232.65 \\
-227.35 \\
-222.13 \\
-216.99 \\
-211.92\end{array}$ & $\begin{array}{l}-233.18 \\
-227.87 \\
-222.65 \\
-217.50 \\
-212.42\end{array}$ & $\begin{array}{l}-233.72 \\
-228.40 \\
-223.17 \\
-218.01 \\
-212.92\end{array}$ & $\begin{array}{l}-234.26 \\
-228.93 \\
-223.69 \\
-218.52 \\
-213.43\end{array}$ & $\begin{array}{l}-234.79 \\
-229.46 \\
-224.21 \\
-219.03 \\
-213.94\end{array}$ & $\begin{array}{l}-235.33 \\
-229.99 \\
-224.73 \\
-219.55 \\
-214.44\end{array}$ & $\begin{array}{l}-235.87 \\
-230.52 \\
-225.25 \\
-220.06 \\
-214.95\end{array}$ & $\begin{array}{l}-236.41 \\
-231.05 \\
-225.77 \\
-220.58 \\
-215.46\end{array}$ & $\begin{array}{l}-236.95 \\
-231.58 \\
-226.30 \\
-221.09 \\
-215.97\end{array}$ & $\begin{array}{l}-237.49 \\
-232.12 \\
-226.82 \\
-221.61 \\
-216.48\end{array}$ & $\begin{array}{l}-238 \cdot 04 \\
-232 \cdot 65 \\
-227.35 \\
-222 \cdot 13 \\
-216.99\end{array}$ & $\begin{array}{l}-6 \cdot 40 \\
-6 \cdot 30 \\
-6 \cdot 20 \\
-6 \cdot 10 \\
-6.00\end{array}$ \\
\hline $\mathrm{mV}$ & .00 & .01 & .02 & .03 & .04 & .05 & .06 & .07 & .08 & .09 & $\cdot 10$ & $\mathrm{mV}$ \\
\hline
\end{tabular}


TABLE A6.2.2. Type J thermocouples-temperature $\left({ }^{\circ} \mathrm{F}\right)$ as a function of thermoelectric voltage, reference junctions at $32^{\circ} \mathrm{F}$-Continued

$\mathrm{mV}$

.00

.01

.02

.03

TEMPERATURES IN DEGREES F

\begin{tabular}{|c|c|c|c|c|c|c|c|c|c|c|c|c|}
\hline-6.00 & -211.92 & $-212 \cdot 42$ & $-212 \cdot 92$ & $-213 \cdot 43$ & $-213 \cdot 94$ & $-214 \cdot 44$ & -214.95 & -215.46 & -215.97 & $-216 \cdot 48$ & -216.99 & -6.00 \\
\hline $\begin{array}{l}-5.90 \\
-5.80 \\
-5.70 \\
-5.60 \\
-5.50\end{array}$ & $\begin{array}{l}-206.91 \\
-201.97 \\
-197.09 \\
-192.27 \\
-187.50\end{array}$ & $\begin{array}{l}-207.41 \\
-202.46 \\
-197.57 \\
-192.75 \\
-187.97\end{array}$ & $\begin{array}{l}-207.91 \\
-202.95 \\
-198.06 \\
-193.23 \\
-188.45\end{array}$ & $\begin{array}{l}-208.41 \\
-203.45 \\
-198.55 \\
-193.71 \\
-188.92\end{array}$ & $\begin{array}{l}-208.90 \\
-203.94 \\
-199.03 \\
-194.19 \\
-189.40\end{array}$ & $\begin{array}{l}-209.40 \\
-204.43 \\
-199.52 \\
-194.67 \\
-189.87\end{array}$ & $\begin{array}{l}-209.91 \\
-204.93 \\
-200.01 \\
-195.15 \\
-190.35\end{array}$ & $\begin{array}{l}-210.41 \\
-205.42 \\
-200.50 \\
-195.64 \\
-190.83\end{array}$ & $\begin{array}{l}-210.91 \\
-205.92 \\
-200.99 \\
-196.12 \\
-191.31\end{array}$ & $\begin{array}{l}-211.41 \\
-206.41 \\
-201.48 \\
-196.60 \\
-191.79\end{array}$ & $\begin{array}{l}-211.92 \\
-206.91 \\
-201.97 \\
-197.09 \\
-192.27\end{array}$ & $\begin{array}{l}-5.90 \\
-5.80 \\
-5.70 \\
-5.60 \\
-5.50\end{array}$ \\
\hline $\begin{array}{l}-5 \cdot 40 \\
-5 \cdot 30 \\
-5 \cdot 20 \\
-5 \cdot 10 \\
-5 \cdot 00\end{array}$ & $\begin{array}{l}-182 \cdot 78 \\
-178 \cdot 11 \\
-173 \cdot 48 \\
-168 \cdot 90 \\
-164 \cdot 36\end{array}$ & $\begin{array}{l}-183.25 \\
-178.57 \\
-173.94 \\
-169.36 \\
-164.81\end{array}$ & $\begin{array}{l}-183.72 \\
-179.04 \\
-174.40 \\
-169.81 \\
-165.27\end{array}$ & $\begin{array}{l}-184.19 \\
-179.50 \\
-174.86 \\
-170.27 \\
-165.72\end{array}$ & $\begin{array}{l}-184.66 \\
-179.97 \\
-175.33 \\
-170.73 \\
-166.17\end{array}$ & $\begin{array}{l}-185.13 \\
-180.43 \\
-175.79 \\
-171.19 \\
-166.63\end{array}$ & $\begin{array}{l}-185.60 \\
-180.90 \\
-176.25 \\
-171.64 \\
-167.08\end{array}$ & $\begin{array}{l}-186.07 \\
-181.37 \\
-176.71 \\
-172.10 \\
-167.54\end{array}$ & $\begin{array}{l}-186.55 \\
-181 \cdot 84 \\
-177 \cdot 18 \\
-172.56 \\
-167.99\end{array}$ & $\begin{array}{l}-187.02 \\
-182.31 \\
-177.64 \\
-173.02 \\
-168.45\end{array}$ & $\begin{array}{l}-187.50 \\
-182.78 \\
-178.11 \\
-173.48 \\
-168.90\end{array}$ & $\begin{array}{l}-5.40 \\
-5.30 \\
-5.20 \\
-5.10 \\
-5.00\end{array}$ \\
\hline $\begin{array}{l}-4 \cdot 90 \\
-4 \cdot 80 \\
-4 \cdot 70 \\
-4 \cdot 60 \\
-4 \cdot 50\end{array}$ & $\begin{array}{l}-159.86 \\
-155.41 \\
-150.98 \\
-146.60 \\
-142.24\end{array}$ & $\begin{array}{l}-160.31 \\
-155.85 \\
-151.42 \\
-147.03 \\
-142.68\end{array}$ & $\begin{array}{l}-160.76 \\
-156.29 \\
-151.86 \\
-147.47 \\
-143.11\end{array}$ & $\begin{array}{l}-161.21 \\
-156.74 \\
-152.31 \\
-147.91 \\
-143.54\end{array}$ & $\begin{array}{l}-161 \cdot 66 \\
-157.18 \\
-152.75 \\
-148.35 \\
-143.98\end{array}$ & $\begin{array}{l}-162.11 \\
-157.63 \\
-153.19 \\
-148.78 \\
-144.41\end{array}$ & $\begin{array}{l}-162.56 \\
-158.08 \\
-153.63 \\
-149.22 \\
-144.85\end{array}$ & $\begin{array}{l}-163.01 \\
-158.52 \\
-154.07 \\
-149.66 \\
-145.29\end{array}$ & $\begin{array}{l}-163.46 \\
-158.97 \\
-154.52 \\
-150.10 \\
-145.72\end{array}$ & $\begin{array}{l}-163.91 \\
-159.42 \\
-154.96 \\
-150.54 \\
-146.16\end{array}$ & $\begin{array}{l}-164.36 \\
-159.86 \\
-155.41 \\
-150.98 \\
-146.60\end{array}$ & $\begin{array}{l}-4 \cdot 90 \\
-4 \cdot 80 \\
-4 \cdot 70 \\
-4 \cdot 60 \\
-4 \cdot 50\end{array}$ \\
\hline $\begin{array}{l}-4 \cdot 40 \\
-4 \cdot 30 \\
-4 \cdot 20 \\
-4 \cdot 10 \\
-4 \cdot 00\end{array}$ & $\begin{array}{l}-137.92 \\
-133.63 \\
-129 \cdot 37 \\
-125.14 \\
-120.94\end{array}$ & $\begin{array}{l}-138.35 \\
-134.06 \\
-129.80 \\
-125.56 \\
-121.36\end{array}$ & $\begin{array}{l}-138 \cdot 78 \\
-134 \cdot 49 \\
-130.22 \\
-125 \cdot 99 \\
-121.78\end{array}$ & $\begin{array}{l}-139.21 \\
-134.92 \\
-130.65 \\
-126.41 \\
-122.20\end{array}$ & $\begin{array}{l}-139.65 \\
-135.34 \\
-131.07 \\
-126.83 \\
-122.62\end{array}$ & $\begin{array}{l}-140 \cdot 08 \\
-135.77 \\
-131.50 \\
-127.25 \\
-123.04\end{array}$ & $\begin{array}{l}-140.51 \\
-136.20 \\
-131.92 \\
-127.68 \\
-123.46\end{array}$ & $\begin{array}{l}-140.94 \\
-136.63 \\
-132.35 \\
-128.10 \\
-123.88\end{array}$ & $\begin{array}{l}-141 \cdot 38 \\
-137 \cdot 06 \\
-132 \cdot 78 \\
-128 \cdot 52 \\
-124 \cdot 30\end{array}$ & $\begin{array}{l}-141.81 \\
-137.49 \\
-133.20 \\
-128.95 \\
-124.72\end{array}$ & $\begin{array}{l}-142 \cdot 24 \\
-137 \cdot 92 \\
-133 \cdot 63 \\
-129 \cdot 37 \\
-125 \cdot 14\end{array}$ & $\begin{array}{l}-4 \cdot 40 \\
-4 \cdot 30 \\
-4 \cdot 20 \\
-4 \cdot 10 \\
-4.00\end{array}$ \\
\hline $\begin{array}{l}-3 \cdot 90 \\
-3.80 \\
-3 \cdot 70 \\
-3 \cdot 60 \\
-3.50\end{array}$ & $\begin{array}{l}-116 \cdot 76 \\
-112 \cdot 61 \\
-108 \cdot 49 \\
-104 \cdot 39 \\
-100 \cdot 31\end{array}$ & $\begin{array}{l}-117.18 \\
-113.03 \\
-108.90 \\
-104.80 \\
-100.72\end{array}$ & $\begin{array}{l}-117 \cdot 60 \\
-113 \cdot 44 \\
-109 \cdot 31 \\
-105 \cdot 21 \\
-101 \cdot 12\end{array}$ & $\begin{array}{l}-118.01 \\
-113.86 \\
-109.72 \\
-105.62 \\
-101.53\end{array}$ & $\begin{array}{l}-118 \cdot 43 \\
-114 \cdot 27 \\
-110.14 \\
-106.03 \\
-101.94\end{array}$ & $\begin{array}{l}-118.85 \\
-114.69 \\
-110.55 \\
-106.44 \\
-102.35\end{array}$ & $\begin{array}{l}-119 \cdot 27 \\
-115 \cdot 10 \\
-110 \cdot 96 \\
-106 \cdot 85 \\
-102 \cdot 75\end{array}$ & $\begin{array}{l}-119 \cdot 68 \\
-115 \cdot 52 \\
-111 \cdot 37 \\
-107 \cdot 26 \\
-103 \cdot 16\end{array}$ & $\begin{array}{l}-120.10 \\
-115.93 \\
-111.79 \\
-107.67 \\
-103.57\end{array}$ & $\begin{array}{l}-120.52 \\
-116.35 \\
-112.20 \\
-108.08 \\
-103.98\end{array}$ & $\begin{array}{l}-120 \cdot 94 \\
-116.76 \\
-112.61 \\
-108.49 \\
-104.39\end{array}$ & $\begin{array}{l}-3.90 \\
-3.80 \\
-3.70 \\
-3.60 \\
-3.50\end{array}$ \\
\hline $\begin{array}{l}-3 \cdot 40 \\
-3 \cdot 30 \\
-3 \cdot 20 \\
-3 \cdot 10 \\
-3 \cdot 00\end{array}$ & $\begin{array}{l}-96.26 \\
-92.22 \\
-88.21 \\
-84.22 \\
-80.25\end{array}$ & $\begin{array}{l}-96.66 \\
-92.63 \\
-88.61 \\
-84.62 \\
-80.65\end{array}$ & $\begin{array}{l}-97.07 \\
-93.03 \\
-89.01 \\
-85.02 \\
-81.04\end{array}$ & $\begin{array}{l}-97.47 \\
-93.43 \\
-89.41 \\
-85.42 \\
-81.44\end{array}$ & $\begin{array}{l}-97.88 \\
-93.83 \\
-89.81 \\
-85.82 \\
-81.84\end{array}$ & $\begin{array}{l}-98 \cdot 28 \\
-94 \cdot 24 \\
-90.22 \\
-86.21 \\
-82.23\end{array}$ & $\begin{array}{l}-98.69 \\
-94.64 \\
-90.62 \\
-86.61 \\
-82.63\end{array}$ & $\begin{array}{l}-99.09 \\
-95.04 \\
-91.02 \\
-87.01 \\
-83.03\end{array}$ & $\begin{array}{l}-99.50 \\
-95.45 \\
-91.42 \\
-87.41 \\
-83.43\end{array}$ & $\begin{array}{l}-99.90 \\
-95.85 \\
-91.82 \\
-87.81 \\
-83.82\end{array}$ & $\begin{array}{r}-100.31 \\
-96.26 \\
-92.22 \\
-88.21 \\
-84.22\end{array}$ & $\begin{array}{l}-3.40 \\
-3.30 \\
-3.20 \\
-3.10 \\
-3.00\end{array}$ \\
\hline $\begin{array}{l}-2 \cdot 90 \\
-2 \cdot 80 \\
-2 \cdot 70 \\
-2 \cdot 60 \\
-2 \cdot 50\end{array}$ & $\begin{array}{l}-76.30 \\
-72.36 \\
-68.45 \\
-64.55 \\
-60.67\end{array}$ & $\begin{array}{l}-76.69 \\
-72.76 \\
-68.84 \\
-64.94 \\
-61.06\end{array}$ & $\begin{array}{l}-77 \cdot 09 \\
-73 \cdot 15 \\
-69 \cdot 23 \\
-65 \cdot 33 \\
-61 \cdot 44\end{array}$ & $\begin{array}{l}-77.48 \\
-73.54 \\
-69.62 \\
-65.72 \\
-61.83\end{array}$ & $\begin{array}{l}-77 \cdot 88 \\
-73.94 \\
-70.01 \\
-66.11 \\
-62.22\end{array}$ & $\begin{array}{l}-78.27 \\
-74.33 \\
-70.40 \\
-66.50 \\
-62.61\end{array}$ & $\begin{array}{l}-78.67 \\
-74.72 \\
-70.80 \\
-66.89 \\
-63.00\end{array}$ & $\begin{array}{l}-79.06 \\
-75.12 \\
-71.19 \\
-67.28 \\
-63.38\end{array}$ & $\begin{array}{l}-79.46 \\
-75.51 \\
-71.58 \\
-67.67 \\
-63.77\end{array}$ & $\begin{array}{l}-79.85 \\
-75.90 \\
-71.97 \\
-68.06 \\
-64.16\end{array}$ & $\begin{array}{l}-80 \cdot 25 \\
-76 \cdot 30 \\
-72 \cdot 36 \\
-68 \cdot 45 \\
-64 \cdot 55\end{array}$ & $\begin{array}{l}-2.90 \\
-2.80 \\
-2.70 \\
-2.60 \\
-2.50\end{array}$ \\
\hline $\begin{array}{l}-2 \cdot 40 \\
-2 \cdot 30 \\
-2 \cdot 20 \\
-2 \cdot 10 \\
-2 \cdot 00\end{array}$ & $\begin{array}{l}-56.80 \\
-52.96 \\
-49.12 \\
-45.31 \\
-41.50\end{array}$ & $\begin{array}{l}-57.19 \\
-53.34 \\
-49.51 \\
-45.69 \\
-41.88\end{array}$ & $\begin{array}{l}-57.58 \\
-53.72 \\
-49.89 \\
-46.07 \\
-42.26\end{array}$ & $\begin{array}{l}-57.96 \\
-54.11 \\
-50.27 \\
-46.45 \\
-42.64\end{array}$ & $\begin{array}{l}-58.35 \\
-54.49 \\
-50.65 \\
-46.83 \\
-43.02\end{array}$ & $\begin{array}{l}-58.73 \\
-54.88 \\
-51.04 \\
-47.21 \\
-43.40\end{array}$ & $\begin{array}{l}-59 \cdot 12 \\
-55 \cdot 26 \\
-51.42 \\
-47.59 \\
-43.78\end{array}$ & $\begin{array}{l}-59.51 \\
-55.65 \\
-51.80 \\
-47.98 \\
-44.16\end{array}$ & $\begin{array}{l}-59.90 \\
-56.03 \\
-52.19 \\
-48.36 \\
-44.54\end{array}$ & $\begin{array}{l}-60.28 \\
-56.42 \\
-52.57 \\
-48.74 \\
-44.92\end{array}$ & $\begin{array}{l}-60.67 \\
-56.80 \\
-52.96 \\
-49.12 \\
-45.31\end{array}$ & $\begin{array}{l}-2.40 \\
-2.30 \\
-2.20 \\
-2.10 \\
-2.00\end{array}$ \\
\hline $\begin{array}{l}-1.90 \\
-1.80 \\
-1.70 \\
-1.60 \\
-1.50\end{array}$ & $\begin{array}{l}-37.71 \\
-33.94 \\
-30.18 \\
-26.43 \\
-22.69\end{array}$ & $\begin{array}{l}-38.09 \\
-34.32 \\
-30.55 \\
-26.80 \\
-23.07\end{array}$ & $\begin{array}{l}-38.47 \\
-34.69 \\
-30.93 \\
-27.18 \\
-23.44\end{array}$ & $\begin{array}{l}-38.85 \\
-35.07 \\
-31.30 \\
-27.55 \\
-23.81\end{array}$ & $\begin{array}{l}-39.23 \\
-35.45 \\
-31.68 \\
-27.93 \\
-24.19\end{array}$ & $\begin{array}{l}-39.61 \\
-35.82 \\
-32.06 \\
-28.30 \\
-24.56\end{array}$ & $\begin{array}{l}-39.99 \\
-36.20 \\
-32.43 \\
-28.68 \\
-24.93\end{array}$ & $\begin{array}{l}-40.36 \\
-36.58 \\
-32.81 \\
-29.05 \\
-25.31\end{array}$ & $\begin{array}{l}-40.74 \\
-36.96 \\
-33.19 \\
-29.43 \\
-25.68\end{array}$ & $\begin{array}{l}-41.12 \\
-37.34 \\
-33.56 \\
-29.80 \\
-26.06\end{array}$ & $\begin{array}{l}-41.50 \\
-37.71 \\
-33.94 \\
-30.18 \\
-26.43\end{array}$ & $\begin{array}{l}-1.90 \\
-1.80 \\
-1.70 \\
-1.60 \\
-1.50\end{array}$ \\
\hline $\begin{array}{l}-1 \cdot 40 \\
-1 \cdot 30 \\
-1 \cdot 20 \\
-1 \cdot 10 \\
-1 \cdot 00\end{array}$ & $\begin{array}{r}-18.97 \\
-15.26 \\
-11.56 \\
-7.87 \\
-4.20\end{array}$ & $\begin{array}{r}-19.34 \\
-15.63 \\
-11.93 \\
-8.24 \\
-4.57\end{array}$ & $\begin{array}{r}-19.72 \\
-16.00 \\
-12.30 \\
-8.61 \\
-4.93\end{array}$ & $\begin{array}{r}-20.09 \\
-16.37 \\
-12.67 \\
-8.98 \\
-5.30\end{array}$ & $\begin{array}{r}-20.46 \\
-16.74 \\
-13.04 \\
-9.35 \\
-5.67\end{array}$ & $\begin{array}{r}-20.83 \\
-17.11 \\
-13.41 \\
-9.72 \\
-6.04\end{array}$ & $\begin{array}{r}-21.20 \\
-17.49 \\
-13.78 \\
-10.09 \\
-6.40\end{array}$ & $\begin{array}{r}-21.58 \\
-17.86 \\
-14.15 \\
-10.45 \\
-6.77\end{array}$ & $\begin{array}{r}-21.95 \\
-18.23 \\
-14.52 \\
-10.82 \\
-7.14\end{array}$ & $\begin{array}{r}-22.32 \\
-18.60 \\
-14.89 \\
-11.19 \\
-7.51\end{array}$ & $\begin{array}{r}-22.69 \\
-18.97 \\
-15.26 \\
-11.56 \\
-7.87\end{array}$ & $\begin{array}{l}-1.40 \\
-1.30 \\
-1.20 \\
-1.10 \\
-1.00\end{array}$ \\
\hline $\begin{array}{l}-0.90 \\
-0.80 \\
-0.70 \\
-0.60 \\
-0.50\end{array}$ & $\begin{array}{r}-0.53 \\
3.12 \\
6.76 \\
10.40 \\
14.02\end{array}$ & $\begin{array}{r}-0.90 \\
2.76 \\
6.40 \\
10.03 \\
13.66\end{array}$ & $\begin{array}{r}-1.27 \\
2.39 \\
6.04 \\
9.67 \\
13.30\end{array}$ & $\begin{array}{r}-1.63 \\
2.03 \\
5.67 \\
9.31 \\
12.94\end{array}$ & $\begin{array}{r}-2.00 \\
1.66 \\
5.31 \\
8.95 \\
12.57\end{array}$ & $\begin{array}{r}-2.37 \\
1.29 \\
4.94 \\
8.58 \\
12.21\end{array}$ & $\begin{array}{r}-2.73 \\
0.93 \\
4.58 \\
8.22 \\
11.85\end{array}$ & $\begin{array}{r}-3.10 \\
0.56 \\
4.21 \\
7.86 \\
11.49\end{array}$ & $\begin{array}{r}-3.47 \\
0.20 \\
3.85 \\
7.49 \\
11.12\end{array}$ & $\begin{array}{r}-3.83 \\
-0.17 \\
3.49 \\
7.13 \\
10.76\end{array}$ & $\begin{array}{r}-4.20 \\
-0.53 \\
3.12 \\
6.76 \\
10.40\end{array}$ & $\begin{array}{l}-0.90 \\
-0.80 \\
-0.70 \\
-0.60 \\
-0.50\end{array}$ \\
\hline $\begin{array}{l}-0.40 \\
-0.30 \\
-0.20 \\
-0.10 \\
-0.00\end{array}$ & $\begin{array}{l}17 \cdot 64 \\
21 \cdot 24 \\
24 \cdot 84 \\
28 \cdot 42 \\
32 \cdot 00\end{array}$ & $\begin{array}{l}17.27 \\
20.88 \\
24.48 \\
28.06 \\
31.64\end{array}$ & $\begin{array}{l}16.91 \\
20.52 \\
24.12 \\
27.71 \\
31.29\end{array}$ & $\begin{array}{l}16.55 \\
20 \cdot 16 \\
23.76 \\
27.35 \\
30.93\end{array}$ & $\begin{array}{l}16.19 \\
19.80 \\
23.40 \\
26.99 \\
30.57\end{array}$ & $\begin{array}{l}15.83 \\
19.44 \\
23.04 \\
26.63 \\
30.21\end{array}$ & $\begin{array}{l}15.47 \\
19.08 \\
22.68 \\
26.27 \\
29.85\end{array}$ & $\begin{array}{l}15.11 \\
18.72 \\
22.32 \\
25.91 \\
29.50\end{array}$ & $\begin{array}{l}14.75 \\
18.36 \\
21.96 \\
25.55 \\
29.14\end{array}$ & $\begin{array}{l}14 \cdot 38 \\
18.00 \\
21.60 \\
25 \cdot 19 \\
28.78\end{array}$ & $\begin{array}{l}14 \cdot 02 \\
17.64 \\
21 \cdot 24 \\
24 \cdot 84 \\
28.42\end{array}$ & $\begin{array}{l}-0.40 \\
-0.30 \\
-0.20 \\
-0.10 \\
-0.00\end{array}$ \\
\hline$m v$ & .00 & .01 & .02 & .03 & .04 & .05 & .06 & .07 & .08 & .09 & $\cdot 10$ & $\mathrm{mV}$ \\
\hline
\end{tabular}


TABLE A6.2.2. Type J thermocouples-temperature $\left({ }^{\circ} \mathrm{F}\right)$ as a function of thermoelectric voltage, reference junctions at $32^{\circ} \mathrm{F}$-Continued

$\mathrm{mV}$

.00

.01

.03

.04

.05

.06

.07

.08

.09

$\cdot 10$

$\mathrm{mV}$

TEMPERATURES IN DEGREES $F$

\begin{tabular}{|c|c|c|c|c|c|c|c|c|c|c|c|}
\hline $\begin{array}{l}0.00 \\
0.10 \\
0.20 \\
0.30 \\
0.40\end{array}$ & $\begin{array}{l}32.00 \\
35.57 \\
39.13 \\
42.68 \\
46.23\end{array}$ & $\begin{array}{l}32.36 \\
35.93 \\
39.49 \\
43.04 \\
46.58\end{array}$ & $\begin{array}{l}32.71 \\
36.28 \\
39.84 \\
43.39 \\
46.93\end{array}$ & $\begin{array}{l}33.07 \\
36.64 \\
40.20 \\
43.75 \\
47.29\end{array}$ & $\begin{array}{l}33.43 \\
36.99 \\
40.55 \\
44.10 \\
47.64\end{array}$ & $\begin{array}{l}33.79 \\
37.35 \\
40.91 \\
44.46 \\
48.00\end{array}$ & $\begin{array}{l}34 \cdot 14 \\
37.71 \\
41 \cdot 26 \\
44.81 \\
48.35\end{array}$ & $\begin{array}{l}34.50 \\
38.06 \\
41.62 \\
45.16 \\
48.70\end{array}$ & $\begin{array}{l}34.86 \\
38.42 \\
41.97 \\
45.52 \\
49.06\end{array}$ & $\begin{array}{l}35.21 \\
38.77 \\
42.33 \\
45.87 \\
49.41\end{array}$ & $\begin{array}{l}35.57 \\
39.13 \\
42.68 \\
46.23 \\
49.76\end{array}$ \\
\hline $\begin{array}{l}0.50 \\
0.60 \\
0.70 \\
0.80 \\
0.90\end{array}$ & $\begin{array}{l}49.76 \\
53.29 \\
56.81 \\
60.33 \\
63.84\end{array}$ & $\begin{array}{l}50.12 \\
53.65 \\
57.17 \\
60.68 \\
64.19\end{array}$ & $\begin{array}{l}50.47 \\
54.00 \\
57.52 \\
61.03 \\
64.54\end{array}$ & $\begin{array}{l}50.82 \\
54.35 \\
57.87 \\
61.38 \\
64.89\end{array}$ & $\begin{array}{l}51 \cdot 18 \\
54 \cdot 70 \\
58.22 \\
61.73 \\
65.24\end{array}$ & $\begin{array}{l}51.53 \\
55.05 \\
58.57 \\
62.08 \\
65.59\end{array}$ & $\begin{array}{l}51.88 \\
55.41 \\
58.92 \\
62.43 \\
65.94\end{array}$ & $\begin{array}{l}52.24 \\
55.76 \\
59.28 \\
62.79 \\
66.29\end{array}$ & $\begin{array}{l}52.59 \\
56.11 \\
59.63 \\
63.14 \\
66.64\end{array}$ & $\begin{array}{l}52.94 \\
56.46 \\
59.98 \\
63.49 \\
66.99\end{array}$ & $\begin{array}{l}53.29 \\
56.81 \\
60.33 \\
63.84 \\
67.34\end{array}$ \\
\hline $\begin{array}{l}1.00 \\
1.10 \\
1.20 \\
1.30 \\
1.40\end{array}$ & $\begin{array}{l}67.34 \\
70.83 \\
74.32 \\
77.80 \\
81.27\end{array}$ & $\begin{array}{l}67.69 \\
71.18 \\
74.67 \\
78.15 \\
81.62\end{array}$ & $\begin{array}{l}68.04 \\
71.53 \\
75.01 \\
78.49 \\
81.97\end{array}$ & $\begin{array}{l}68.39 \\
71.88 \\
75.36 \\
78.84 \\
82.31\end{array}$ & $\begin{array}{l}68.74 \\
72.23 \\
75.71 \\
79.19 \\
82.66\end{array}$ & $\begin{array}{l}69.08 \\
72.58 \\
76.06 \\
79.54 \\
83.01\end{array}$ & $\begin{array}{l}69.43 \\
72.92 \\
76.41 \\
79.88 \\
83.35\end{array}$ & $\begin{array}{l}69.78 \\
73.27 \\
76.75 \\
80.23 \\
83.70\end{array}$ & $\begin{array}{l}70.13 \\
73.62 \\
77.10 \\
80.58 \\
84.05\end{array}$ & $\begin{array}{l}70.48 \\
73.97 \\
77.45 \\
80.93 \\
84.39\end{array}$ & $\begin{array}{l}70.83 \\
74.32 \\
77.80 \\
81.27 \\
84.74\end{array}$ \\
\hline $\begin{array}{l}1.50 \\
1.60 \\
1.70 \\
1.80 \\
1.90\end{array}$ & $\begin{array}{l}84.74 \\
88.20 \\
91.66 \\
95.11 \\
98.55\end{array}$ & $\begin{array}{l}85.09 \\
88.55 \\
92.00 \\
95.45 \\
98.90\end{array}$ & $\begin{array}{l}85.43 \\
88.89 \\
92.35 \\
95.80 \\
99.24\end{array}$ & $\begin{array}{l}85.78 \\
89.24 \\
92.69 \\
96.14 \\
99.59\end{array}$ & $\begin{array}{l}86.13 \\
89.59 \\
93.04 \\
96.49 \\
99.93\end{array}$ & $\begin{array}{r}86.47 \\
89.93 \\
93.38 \\
96.83 \\
100.27\end{array}$ & $\begin{array}{r}86.82 \\
90.28 \\
93.73 \\
97.18 \\
100.62\end{array}$ & $\begin{array}{r}87.16 \\
90.62 \\
94.07 \\
97.52 \\
100.96\end{array}$ & $\begin{array}{r}87.51 \\
90.97 \\
94.42 \\
97.87 \\
101.31\end{array}$ & $\begin{array}{r}87.86 \\
91.31 \\
94.76 \\
98.21 \\
101.65\end{array}$ & $\begin{array}{r}88.20 \\
91.66 \\
95.11 \\
98.55 \\
101.99\end{array}$ \\
\hline $\begin{array}{l}2.00 \\
2.10 \\
2.20 \\
2.30 \\
2.40\end{array}$ & $\begin{array}{l}101.99 \\
105.43 \\
108.86 \\
112.28 \\
115.70\end{array}$ & $\begin{array}{l}102.34 \\
105.77 \\
109.20 \\
112.62 \\
116.04\end{array}$ & $\begin{array}{l}102.68 \\
106.11 \\
109.54 \\
112.96 \\
116.38\end{array}$ & $\begin{array}{l}103.02 \\
106.46 \\
109.88 \\
113.30 \\
116.72\end{array}$ & $\begin{array}{l}103.37 \\
106.80 \\
110.23 \\
113.65 \\
117.06\end{array}$ & $\begin{array}{l}103.71 \\
107.14 \\
110.57 \\
113.99 \\
117.40\end{array}$ & $\begin{array}{l}104.05 \\
107.48 \\
110.91 \\
114.33 \\
117.75\end{array}$ & $\begin{array}{l}104.40 \\
107.83 \\
111.25 \\
114.67 \\
118.09\end{array}$ & $\begin{array}{l}104.74 \\
108.17 \\
111.59 \\
115.01 \\
118.43\end{array}$ & $\begin{array}{l}105.08 \\
108.51 \\
111.94 \\
115.36 \\
118.77\end{array}$ & $\begin{array}{l}105.43 \\
108.86 \\
112.28 \\
115.70 \\
119.11\end{array}$ \\
\hline $\begin{array}{l}2.50 \\
2.60 \\
2.70 \\
2.80 \\
2.90\end{array}$ & $\begin{array}{l}119.11 \\
122.52 \\
125.92 \\
129.32 \\
132.72\end{array}$ & $\begin{array}{l}119.45 \\
122.86 \\
126.26 \\
129.66 \\
133.06\end{array}$ & $\begin{array}{l}119.79 \\
123.20 \\
126.60 \\
130.00 \\
133.39\end{array}$ & $\begin{array}{l}120.13 \\
123.54 \\
126.94 \\
130.34 \\
133.73\end{array}$ & $\begin{array}{l}120.47 \\
123.88 \\
127.28 \\
130.68 \\
134.07\end{array}$ & $\begin{array}{l}120.81 \\
124.22 \\
127.62 \\
131.02 \\
134.41\end{array}$ & $\begin{array}{l}121.16 \\
124.56 \\
127.96 \\
131.36 \\
134.75\end{array}$ & $\begin{array}{l}121.50 \\
124.90 \\
128.30 \\
131.70 \\
135.09\end{array}$ & $\begin{array}{l}121.84 \\
125.24 \\
128.64 \\
132.04 \\
135.43\end{array}$ & $\begin{array}{l}122.18 \\
125.58 \\
128.98 \\
132.38 \\
135.77\end{array}$ & $\begin{array}{l}122.52 \\
125.92 \\
129.32 \\
132.72 \\
136.11\end{array}$ \\
\hline $\begin{array}{l}3.00 \\
3.10 \\
3.20 \\
3.30 \\
3.40\end{array}$ & $\begin{array}{l}136.11 \\
139.49 \\
142.87 \\
146.25 \\
149.63\end{array}$ & $\begin{array}{l}136.45 \\
139.83 \\
143.21 \\
146.59 \\
149.96\end{array}$ & $\begin{array}{l}136.78 \\
140.17 \\
143.55 \\
146.93 \\
150.30\end{array}$ & $\begin{array}{l}137.12 \\
140.51 \\
143.89 \\
147.26 \\
150.64\end{array}$ & $\begin{array}{l}137.46 \\
140.85 \\
144.23 \\
147.60 \\
150.97\end{array}$ & $\begin{array}{l}137.80 \\
141.18 \\
144.56 \\
147.94 \\
151.31\end{array}$ & $\begin{array}{l}138.14 \\
141.52 \\
144.90 \\
148.28 \\
151.65\end{array}$ & $\begin{array}{l}138.48 \\
141.86 \\
145.24 \\
148.61 \\
151.98\end{array}$ & $\begin{array}{l}138.82 \\
142.20 \\
145.58 \\
148.95 \\
152.32\end{array}$ & $\begin{array}{l}139.15 \\
142.54 \\
145.91 \\
149.29 \\
152.66\end{array}$ & $\begin{array}{l}139.49 \\
142.87 \\
146.25 \\
149.63 \\
153.00\end{array}$ \\
\hline $\begin{array}{l}3.50 \\
3.60 \\
3.70 \\
3.80 \\
3.90\end{array}$ & $\begin{array}{l}153.00 \\
156.36 \\
159.72 \\
163.08 \\
166.44\end{array}$ & $\begin{array}{l}153.33 \\
156.70 \\
160.06 \\
163.42 \\
166.77\end{array}$ & $\begin{array}{l}153.67 \\
157.03 \\
160.40 \\
163.75 \\
167.11\end{array}$ & $\begin{array}{l}154.01 \\
157.37 \\
160.73 \\
164.09 \\
167.44\end{array}$ & $\begin{array}{l}154.34 \\
157.71 \\
161.07 \\
164.42 \\
167.78\end{array}$ & $\begin{array}{l}154.68 \\
158.04 \\
161.40 \\
164.76 \\
168.11\end{array}$ & $\begin{array}{l}155.02 \\
158.38 \\
161.74 \\
165.09 \\
168.45\end{array}$ & $\begin{array}{l}155.35 \\
158.71 \\
162.07 \\
165.43 \\
168.78\end{array}$ & $\begin{array}{l}155.69 \\
159.05 \\
162.41 \\
165.77 \\
169.12\end{array}$ & $\begin{array}{l}156.02 \\
159.39 \\
162.75 \\
166.10 \\
169.45\end{array}$ & $\begin{array}{l}156.36 \\
159.72 \\
163.08 \\
166.44 \\
169.79\end{array}$ \\
\hline $\begin{array}{l}4.00 \\
4.10 \\
4.20 \\
4.30 \\
4.40\end{array}$ & $\begin{array}{l}169.79 \\
173.14 \\
176.48 \\
179.82 \\
183.16\end{array}$ & $\begin{array}{l}170.12 \\
173.47 \\
176.81 \\
180.16 \\
183.49\end{array}$ & $\begin{array}{l}170.46 \\
173.80 \\
177.15 \\
180.49 \\
183.83\end{array}$ & $\begin{array}{l}170.79 \\
174.14 \\
177.48 \\
180.82 \\
184.16\end{array}$ & $\begin{array}{l}171.13 \\
174.47 \\
177.82 \\
181.16 \\
184.49\end{array}$ & $\begin{array}{l}171.46 \\
174.81 \\
178.15 \\
181.49 \\
184.83\end{array}$ & $\begin{array}{l}171.80 \\
175.14 \\
178.49 \\
181.82 \\
185.16\end{array}$ & $\begin{array}{l}172.13 \\
175.48 \\
178.82 \\
182.16 \\
185.49\end{array}$ & $\begin{array}{l}172.47 \\
175.81 \\
179.15 \\
182.49 \\
185.83\end{array}$ & $\begin{array}{l}172.80 \\
176.15 \\
179.49 \\
182.83 \\
186.16\end{array}$ & $\begin{array}{l}173.14 \\
176.48 \\
179.82 \\
183.16 \\
186.49\end{array}$ \\
\hline $\begin{array}{l}4.50 \\
4.60 \\
4.70 \\
4.80 \\
4.90\end{array}$ & $\begin{array}{l}186.49 \\
189.83 \\
193.16 \\
196.48 \\
199.80\end{array}$ & $\begin{array}{l}186.83 \\
190.16 \\
193.49 \\
196.81 \\
200.14\end{array}$ & $\begin{array}{l}187.16 \\
190.49 \\
193.82 \\
197.15 \\
200.47\end{array}$ & $\begin{array}{l}187.49 \\
190.83 \\
194.15 \\
197.48 \\
200.80\end{array}$ & $\begin{array}{l}187.83 \\
191.16 \\
194.49 \\
197.81 \\
201.13\end{array}$ & $\begin{array}{l}188.16 \\
191.49 \\
194.82 \\
198.14 \\
201.46\end{array}$ & $\begin{array}{l}188.49 \\
191.82 \\
195.15 \\
198.48 \\
201.80\end{array}$ & $\begin{array}{l}188.83 \\
192.16 \\
195.48 \\
198.81 \\
202.13\end{array}$ & $\begin{array}{l}189.16 \\
192.49 \\
195.82 \\
199.14 \\
202.46\end{array}$ & $\begin{array}{l}189.49 \\
192.82 \\
196.15 \\
199.47 \\
202.79\end{array}$ & $\begin{array}{l}189.83 \\
193.16 \\
196.48 \\
199.80 \\
203.12\end{array}$ \\
\hline $\begin{array}{l}5.00 \\
5.10 \\
5.20 \\
5.30 \\
5.40\end{array}$ & $\begin{array}{l}203.12 \\
206.44 \\
209.76 \\
213.07 \\
216.38\end{array}$ & $\begin{array}{l}203.46 \\
206.77 \\
210.09 \\
213.40 \\
216.71\end{array}$ & $\begin{array}{l}203.79 \\
207.11 \\
210.42 \\
213.73 \\
217.04\end{array}$ & $\begin{array}{l}204.12 \\
207.44 \\
210.75 \\
214.06 \\
217.37\end{array}$ & $\begin{array}{l}204.45 \\
207.77 \\
211.08 \\
214.39 \\
217.70\end{array}$ & $\begin{array}{l}204.78 \\
208.10 \\
211.41 \\
214.73 \\
218.03\end{array}$ & $\begin{array}{l}205.12 \\
208.43 \\
211.75 \\
215.06 \\
218.36\end{array}$ & $\begin{array}{l}205.45 \\
208.76 \\
212.08 \\
215.39 \\
218.70\end{array}$ & $\begin{array}{l}205.78 \\
209.09 \\
212.41 \\
215.72 \\
219.03\end{array}$ & $\begin{array}{l}206.11 \\
209.43 \\
212.74 \\
216.05 \\
219.36\end{array}$ & $\begin{array}{l}206.44 \\
209.76 \\
213.07 \\
216.38 \\
219.69\end{array}$ \\
\hline $\begin{array}{l}5.50 \\
5.60\end{array}$ & $\begin{array}{l}219.69 \\
222.99\end{array}$ & $\begin{array}{l}220.02 \\
223.32\end{array}$ & $\begin{array}{l}220.35 \\
223.65\end{array}$ & $\begin{array}{l}220.68 \\
223.98\end{array}$ & $\begin{array}{l}221.01 \\
224.31\end{array}$ & $\begin{array}{l}221.34 \\
224.64\end{array}$ & $\begin{array}{l}221.67 \\
224.97\end{array}$ & $\begin{array}{l}222.00 \\
225.30\end{array}$ & $\begin{array}{l}222.33 \\
225.63\end{array}$ & $\begin{array}{l}222.66 \\
225.97\end{array}$ & $\begin{array}{l}222.99 \\
226.30\end{array}$ \\
\hline $\begin{array}{l}5.70 \\
5.80 \\
5.90\end{array}$ & $\begin{array}{l}226.30 \\
229.60 \\
232.89\end{array}$ & $\begin{array}{l}226.63 \\
229.93 \\
233.22\end{array}$ & $\begin{array}{l}226.96 \\
230.26 \\
233.55\end{array}$ & $\begin{array}{l}227.29 \\
230.59 \\
233.88\end{array}$ & $\begin{array}{l}227.62 \\
230.92 \\
234.21\end{array}$ & $\begin{array}{l}227.95 \\
231.25 \\
234.54\end{array}$ & $\begin{array}{l}228 \cdot 28 \\
231.57 \\
234.87\end{array}$ & $\begin{array}{l}228.61 \\
231.90 \\
235.20\end{array}$ & $\begin{array}{l}228.94 \\
232.23 \\
235.53\end{array}$ & $\begin{array}{l}229 \cdot 27 \\
232 \cdot 56 \\
235 \cdot 86\end{array}$ & $\begin{array}{l}229.60 \\
232.89 \\
236.19\end{array}$ \\
\hline 6.00 & 236.19 & 236.52 & 236.85 & 237.18 & 237.51 & 237.84 & 238.17 & 238.50 & 238.83 & 239.15 & 239.48 \\
\hline
\end{tabular}

$\mathrm{mV}$

.00

$.01 \quad .02$

.03

.04

.05

.06

.07

.08

.09

.10

$\mathrm{mV}$ 
TABLE A6.2.2. Type J thermocouples-temperature $\left({ }^{\circ} \mathrm{F}\right)$ as a function of thermoelectric voltage, reference junctions at $32^{\circ} \mathrm{F}$-Continued

$\mathrm{mV}$

.00

.01

.02

.03

.04

TEMPERATURES IN DEGREES F

$\begin{array}{llll}6.00 & 236.19 & 236.52 & 236.85 \\ 6.10 & 239.48 & 239.81 & 240.14 \\ 6.20 & 242.78 & 243.11 & 243.43 \\ 6.30 & 246.07 & 246.39 & 246.72 \\ 6.40 & 249.35 & 249.68 & 250.01 \\ 6.50 & 252.64 & 252.97 & 253.30 \\ 6.60 & 255.92 & 256.25 & 256.58 \\ 6.70 & 259.21 & 259.54 & 259.86 \\ 6.80 & 262.49 & 262.82 & 263.14 \\ 6.90 & 265.77 & 266.09 & 266.42 \\ 7.00 & 269.04 & 269.37 & 269.70 \\ 7.10 & 272.32 & 272.65 & 272.97 \\ 7.20 & 275.59 & 275.92 & 276.25 \\ 7.30 & 278.87 & 279.19 & 279.52 \\ 7.40 & 282.14 & 282.47 & 282.79 \\ 7.50 & & & \end{array}$

7.60

7.70 291.94

7.80

7.90

8.00

8.10

8.20

8.40

8.50
8.60

8.70

8.80

8.9

9.00

9.10

9.20

9.30

9.50

9.60

9.70

9.80

0.00

10.1

10.2

$10 \cdot 30$

10.40

10.50

10.60

10.70

10.80
10.90

11.00

11.1

11.20

11.30

11.40

11.50

11.60

11.70

11.80

11.90

12.00

$\mathrm{mV}$

295.21

298.47

301.74

305.00

311.52

314.78

318.04
321.29

324.55

327.81

331.06

334.31

337.56

340.82

347.32

350.57

353.82

357.06

360.31

363.56

366.81

370.05

373.30

376.54

379.79

383.03

386.27

389.52

392.76

396.00

399.25

402.49

405.73

408.97

412.22

415.46

418.70

421.94

425.18

428.42

431.66
285.73

289.00

292.27

295.5

302.06

305.33

308.59

286.06

289.33
292.60

295.86

299.13

302.39

305.65

308.91

312.17

315.11

318.36

321.62

324.88

334.64

337.89

341.14

344.39
347.64

350.89

354.14

357.39

360.64

363.88

367.13

370.38

376.87

380.11

383.36

386.60

389.84

393.09

396.33

399.57

402.81

406.06

409.30

412.54

415.78

419.02

425.51

428.75

318.69

321.95

325.20

328.46

334.96

338.22

341.47

344.72
347.97

351.22

354.47

357.71

360.96

367.45

370.70

373.95

377.19

380.44

383.68

386.92

390.17

393.41

396.65

399.90

403.14

406.38

409.62

42.86

419.35

422.59

425.83

429.07

$432 \cdot 31$
328.13

237.51

237.18

240.47

243.76

247.05

$250 \cdot 34$

253.63
256.91

260.19

263.47

266.75

270.03

273.30

276.58

279.85

283.12

286.39

289.66

292.92

296.19
299.45

302.72

305.98

309.24

312.50

315.76

319.01

322.27

325.53

328.78

335.29

338.54

341.79

345.04

351.54

354.79

358.04

361.29

240.80

244.09

247.38

250.67

253.95
257.24

260.52

263.80

270.35

273.63

276.90

$280 \cdot 18$

286.72

289.98

293.25

296.5
299.78

303.04

$306 \cdot 30$

309.56

312.82
316.08

319.34

322.60

325.85

329.11

335.61

338.87

342.12

348.62

351.87

355.12

$358 \cdot 36$

361.61

367.78

371.03

374.27

380.76

$368 \cdot 10$
371.35

374.60

377.84

381.08

384.00

387.25

390.49

393.73

396.98

400.22

403.46

406.70

409.95

413.19

416.43

419.67

422.91

426.15

429.39

384.33

387.57

390.82

394.06
397.30

400.54

403.79

407.03

410.27

416.75

420.00

$423.24^{\prime}$

426.48

429.72

432.96

432.64

.04

.05

237.84

$244.42 \quad 244.75$

247.71

254.28

257.57

8

267.41

270.68 
TABLE A6.2.2. Type J thermocouples-temperature $\left({ }^{\circ} \mathrm{F}\right)$ as a function of thermoelectric voltage, reference junctions at $32^{\circ} \mathrm{F}$-Continued

$\mathrm{mV}$

.00

.01

.02

.03

.04

.05

.06

.07

.08

.09

.10

$m V$

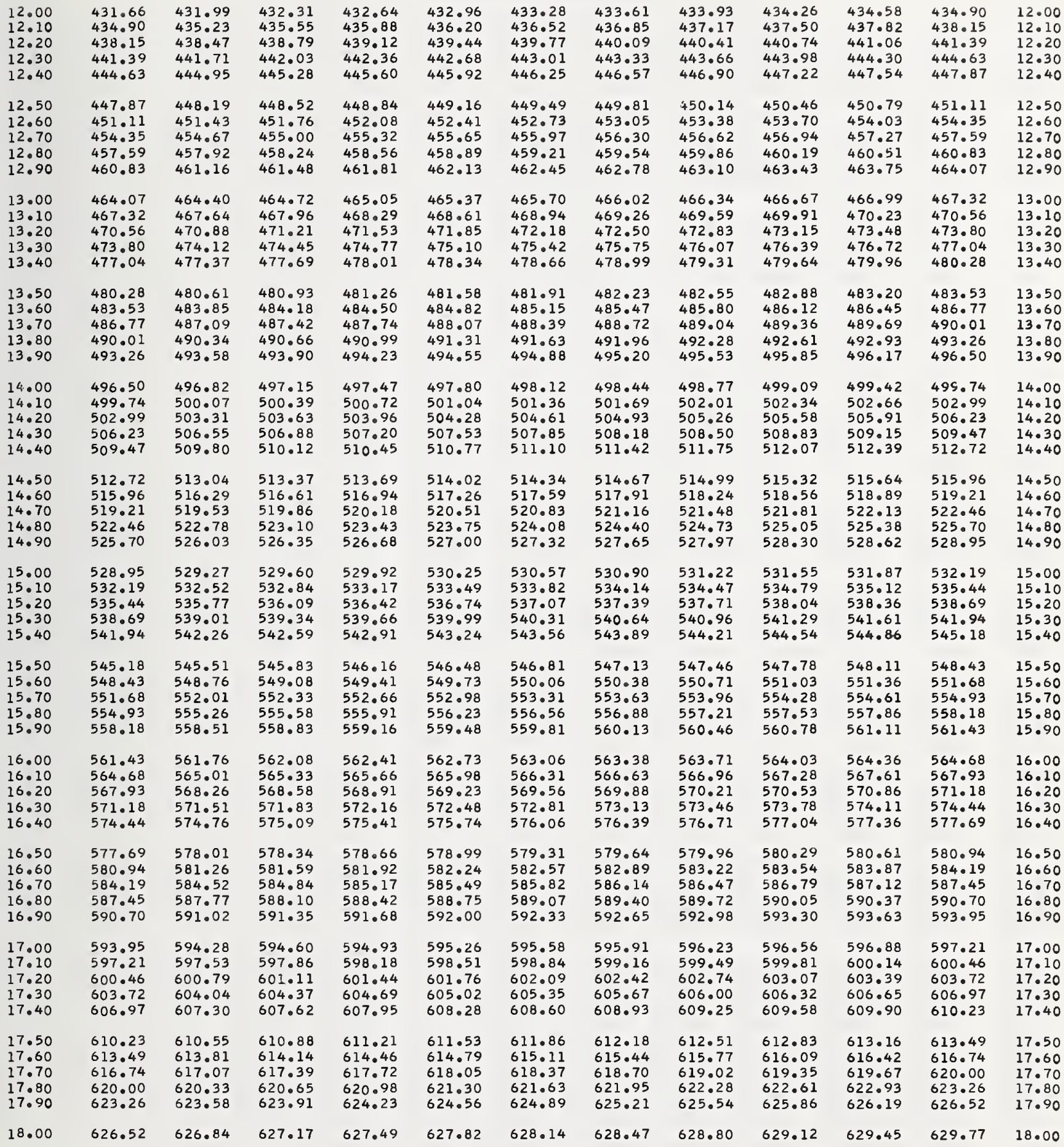

$\mathrm{mV}$

$.00 \quad .01 \quad .02$

.03

$\begin{array}{lll}.04 & .05 \quad .06\end{array}$

.07

.08

.09

.10

$\mathrm{mV}$

12.00 2.20

.50

12.70

.90

.10

13.50

.90

4.00

4.20

4.50

4.80

5.00 5.10
5.20

15.40

5.50

15.70

.80

16.00 16.20 16.30 .50 6.60 . 80 .00 7.20

.40

. 60 .00 
TABLE A6.2.2. Type J thermocouples-temperature $\left({ }^{\circ} \mathrm{F}\right)$ as a function of thermoelectric voltage, reference junctions at $32{ }^{\circ} \mathrm{F}$-Continued

mV

.00

.01

.02

.03

.05

.06

TEMPERATURES IN DEGREES F

18.00

18.00

626.52

626.84 630.10

18.20

18.30

18.40

18.50

18.6

18.70

18.80

18.90

19.00

19.10

19.20

19.30

19.40

19.50

19.60

19.70

19.80

19.90

20.00

$20 \cdot 1$

20.2

$20 \cdot 30$

$20 \cdot 50$

20.60

20.70

20.80

20.90

21.00

21.10

21.20

21.3

21.40

21.50

21.60

21.70

21.80

21.90

22.00

22.10

22.20

22.30

22.40

22.50

22.60

22.70

22.80

22.90

23.00

23.10

23.20

23.30

23.40

23.50

23.60

23.70

23.80

23.90

24.00

629.77

633.03

636.29

633.36

636.62

639.88

$642.81 \quad 643.14$

649.33

.66

646.40

652.92

656.18

659.11

659.44

662.70

$665.64 \quad 665.96$

$668.90 \quad 669.23$

672.16

672.49

675.42

678.69

675.75

679.01

682.28

$685.21 \quad 685.54$

688.48

688.80

691.74

692.07

695.33

698.27

701.53

704.80

698.59

701.86

708.06

711.33

714.59

717.86

708.39

711.65

714.92

718.18

721.45

724.38

727.65

724.71

727.98

$731 \cdot 24$

734.18

737.44

740.71

743.97

747.24

750.50

753.77

744.30

747.56

750.83

754.09

757.03

760.29

763.56

757.36

760.62

763.89

767.15

770.09

770.41

773.35

776.61

779.87

783.14

786.40

773.68

776.94

780.20

783.46

786.72

789.66

792.92

796.18

789.99

793.25

796.5

799.77

802.70

803.03

806.29

809.54

812.80

809.22

812.48

815.73

819.32

$822 \cdot 25$

822.57
627.17

627.49

636.94

640.20

643.46

646.72

649.98

.

656.50

659.77

663.03

666.29

669.55

672.81

676.08

679.34

682.60

685.87

689.13

692.39

695.66

698.92

702.19

705.45

708.71

711.98

715.24

718.51

721.77

725.04

728.30

731.57

734.83

738.10

741.36

744.63

747.89

751.16

754.42

757.68

760.95

764.21

767.48

770.74

774.00

777.26

780.53

783.79

787.05

790.31

793.57

796.83

800.09

803.35

806.61

809.87

813.13

816.39

819.64

822.90

640.53

647.05

650.31

553.57

656.83

660.09

663.35

666.62

669.88

679.67

682.93

686.19

689.46

692.72

695.98

699.25

702.51

712.31

715.57

718.83

722.10

725.36

728.63

731.89

738.42

744.95

751.48

754.75

758.01

761.27

764.54

771.06

774.33

777.59

780.85

784.11

787.38

790.64

793.90

797.16

800.42

806.94

810.20

627.49
630.75
634.01
637.27

627.82

631.08

634.34

637.59

640.85

644.11

673.14

676.40

705.78

709.04

741.69

748.22 
TABLE A6.2.2. Type J thermocouples-temperature $\left({ }^{\circ} \mathrm{F}\right)$ as a function of thermoelectric voltage, reference junctions at $32^{\circ} \mathrm{F}$-Continued

$\mathrm{mV}$

.00

.01

.02

.03

.04

.05

.06

TEMPERATURES IN DEGREES F

24

24.30

825.50

828.76

832.01

835.27

24.50

24.60

838.52

841.77

845.02

$24.80 \quad 848.27$

24.90

851.52

25.00

854.77

858.02

$\begin{array}{ll}25.20 & 861.26 \\ 25.30 & 864.51\end{array}$

25.40

867.75

25.50

871.00

25.60

25.70

25.80

874.24

877.48

880.7

25.90

883.96

26.00

887.20

890.43

26.20

26.30

893.67

896.90
900.13

26.50

903.37

26.60

26.70

26.80

26.90

906.59

909.82

913.05

916.28

27.00

27.10

919.50

922.72

925.94

27.40

929.16

27.50

935.59

27.60

27.70

27.80

938.81

942.02

945.23

948.44

28.00

28.10

951.65

954.85

958.05

961.26

28.40

28.50

964.45

967.65

970.85

$28.70 \quad 974.04$

28.80

977.23

980.42

29.00

29.10

983.61

986.79

989.97

993.16

996.33

822.57

825.83

829.08

832.34

835.59

838.84

842.10

45.35

851.85

855.09

858.34

861.59

864.83

868.08

871.32

874.56

877.80

881.04

887.52

890.76

893.99

897.22

903.69

906.92

910.15

913.37

916.60

919.82

923.04

926.26

929.48

932.70

935.92

939.13

942.34

945.55

948.76

951.97

955.17

958.37

961.58

964.77

967.97

971.17

974.36

977.55

980.74

983.93

987.11

990.29

993.47

996.65

999.5

$1005.85 \quad 1003.00$

$1009.02 \quad 1009.34$

1012.19

1015.35

1012.51

822.90

826.15

829.41

832.66

835.92

839.17

842.42

845.67

48.92

852.17

855.42

858.67

861.91

865.16

868.40

871.64

874.89

878.13

884.61

887.84

891.08

894.31

897.55

900.78

904.01

907.24

910.47

913.69

920.14

923.37

926.59

929.80

933.02

936.24

939.45

942.66

945.87

949.08

952.29

955.49

958.69

961.90

968.29

971.49

974.68

977.87

981.06

984.24

987.43

990.61

993.79
996.97

$1000 \cdot 14$

$1003 \cdot 32$

1006.49

1009.66
1012.82

823.22

823.55

823.88

$826.81 \quad 827.13$

$829.73 \quad 830.06$

832.99

833.31

830.39

836.24

836.57

836.89

824.20

827.46

830.71

837.22

839.49

842.75

846.00

839.82

843.07

846.32

849.57

852.50

855.74

858.99

862.24

865.48
868.73

859.32

862.56

865.81

869.05

871.97

872.29

$875.21 \quad 875.54$

$878.45 \quad 878.78$

$881.69 \quad 882.02$

888.17

891.40

885.25

888.49

891.73

894.96

$897.87 \quad 898.19$

901.10

901.43

904.33

907.56

910.79

914.02

907.89

911.11

$914 \cdot 34$

920.47

923.69

926.91

930.13

920.79

924.01

927.23

930.45

936.56

936.88

939.77

942.98

946.19

949.40

940.09

943.30

946.51

949.72

952.61

95.81
959.01

952.93 
TABLE A6.2.2. Type $J$ thermocouples-temperature $\left({ }^{\circ} F\right)$ as a function of thermoelectric voltage, reference junctions at $32^{\circ} \mathrm{F}$-Continued

$\mathrm{mV}$

.00

.01

.02

.03

TEMPERATURES IN DEGREES F

30.00

30.10

$30 \cdot 20$

30.30

30.40

30.50

30.60

30.70

$30 \cdot 80$
30.90

31.00

31.10

31.20

$31 \cdot 30$

31.50

31.60

31.70

31.90

32.00

32.10

32.20

32.30

32.40

32.50

32.60
32.70

32.80

32.90

33.00

33.20

33.30

33.40

33.50

33.60

33.70

33.80

34.00

34.1

34.20

34.30

34.40

34.50

34.60

34.70

34.8

34.90

35.00

35.10

35.20

35.40

35.50

35.60

35.70

35.80

35.90

36.00
$1015 \cdot 35$ 1018.83 $1021.67 \quad 1021.99$ $1024.83 \quad 1025.15$ 1027.99

1031.14 1037.75 $1040.58 \quad 1040.89$ $1043.72 \quad 1044.03$

$1046.86 \quad 1047.17$ $1049.99 \quad 1050.31$ $1053.13 \quad 1053.44$ $1056.26 \quad 1056.57$ $1059.38 \quad 1059.70$

$1062.51 \quad 1062.82$ $1065.63 \quad 1065.94$ $1068.75 \quad 1069.06$ $1071.87 \quad 1072.18$ $1074.98 \quad 1075.29$

$1078.09 \quad 1078.40$ $1081.20 \quad 1081.51$ $1084.31 \quad 1084.62$ $1087.41 \quad 1087.72$

$1090.51 \quad 1090.82$

$1093.61 \quad 1093.92$ $1096.70 \quad 1097.01$ $1099.79 \quad 1100.10$

$1102.88 \quad 1103.19$

$1105.96 \quad 1106.27$

$1109.04 \quad 1109.35$

$1112.12 \quad 1112.43$

$115.20 \quad 1115.50$

$1118.27 \quad 1118.58$

1121.34

1124.41 1127.47

1130.53

1133.59

1136.64

1139.69

148.821149 .13

$1151.86 \quad 1152.17$

$1154.90 \quad 1155.20$

$1157.93 \quad 1158.23$

$1160.96 \quad 1161.26$

$1163.98 \quad 1164.29$

1167.01

1170.03

1173.04

1176.05

1179.06

1182.07

1185.07

1188.07

1191.07

1194.06

1197.05

$1200 \cdot 04$
1167.31

1170.33

1173.34

1176.35

1179.36

1182.37

1185.37

1188.37

1191.37

1194.36

1197.35

1200.34
1015.99

1019.15

1022.31

1025.46

1028.62

1031.77
1034.92

1038.06

1041.21

1047.48

1050.62

1053.75

1056.88

1063.13

1066.26

1069.38

1072.49

1075.61

1078.72

1081.82

1084.93

1088.03

1094.22

1097.32

1100.41

1106.58

1109.66

1112.74

1115.81

1118.88

1121.95

1125.02

1128.08

1131.14

1134.20

1140.30

1143.35

1146.39

1149.43

1155.50

1158.54

1161.56

1164.59
1167.61

1170.63

1173.64

1176.66

1179.67

1185.67

1188.67

1191.67

1194.66

1197.65

1200.64
1016.30 $1022.62 \quad 1022.94$ $1025.78 \quad 1026.09$

$1028.93 \quad 1029.25$

$1032.08 \quad 1032.40$ $1035.23 \quad 1035.55$ $1038.38 \quad 1038.69$ $1041.52 \quad 1041.83$ $1044.66 \quad 1044.97$

$1047.80 \quad 1048.11$ $1050.93 \quad 1051.25$ $1054.07 \quad 1054.38$ $1057.20 \quad 1057.51$

$1060.32 \quad 1060.64$

$1063.45 \quad 1063.76$

$1066.57 \quad 1066.88$

$1069.69 \quad 1070.00$

$1072.80 \quad 1073.11$

$1075.92 \quad 1076.23$

$1079.03 \quad 1079.34$

$1082.13 \quad 1082.44$

$1085.24 \quad 1085.55$

1088.341088 .65

$1091.44 \quad 1091.75$

$1094.53 \quad 1094.84$

$1097.63 \quad 1097.94$

$1100.72 \quad 1101.03$

$1103.80 \quad 1104.11$

1106.89

1107.19

$1109.97 \quad 1110.28$

$1113.04 \quad 1113.35$

1116.121116 .43

$1119.19 \quad 1119.50$

1122.26

1125.32

1137.86

$1140.61 \quad 1140.91$

$1143.65 \quad 1143.96$

$1146.70 \quad 1147.00$

$1149.74 \quad 1150.04$

$1152.77 \quad 1153.08$

$1155.81 \quad 1156.11$

$1158.84 \quad 1159.14$

$1161.87 \quad 1162.17$

$1164.89 \quad 1165.19$

$1167.91 \quad 1168.21$

$1170.93 \quad 1171.23$

$1173.95 \quad 1174.25$

$1176.96 \quad 1177.26$

$1179.97 \quad 1180.27$

$1182.97 \quad 1183.27$

$1185.97 \quad 1186.27$

$1188.97 \quad 1189.27$

$1191.97 \quad 1192.27$

$1194.96 \quad 1195.26$

1197.95

1198.25

$1200.94 \quad 1201.24$

$1016.93 \quad 1017.25$

$1023.25 \quad 1023.57 \quad 1023.88$

$1026.41 \quad 1026.72 \quad 1027.04$

$1029.56 \quad 1029.88$

$1032.71 \quad 1033.03$

$\begin{array}{lll}035.86 & 1033.17 \quad 1033.34\end{array}$

$1039.01 \quad 1039.32 \quad 1039.63$

$1042.15 \quad 1042.46 \quad 1042.78$

$1045.29 \quad 1045.60 \quad 1045.92$

$1048.43 \quad 1048.74 \quad 1049.05$

$1051.56 \quad 1051.87 \quad 1052.19$

$1054.69 \quad 1055.00 \quad 1055.32$

$1057.82 \quad 1058.13 \quad 1058.45$

$1060.95 \quad 1061.26$

1064.07

$\begin{array}{lll}1070.31 & 1070.62 & 1070.93\end{array}$

$1073.43 \quad 1073.74 \quad 1074.05$

$\begin{array}{lll}1079.65 & 1079.96 & 1080.27\end{array}$

$1082.75 \quad 1083.07 \quad 1083.38$

$1085.86 \quad 1086.17 \quad 1086.48$

$1088.96 \quad 1089.27 \quad 1089.58$

1092.06

1095.15

1098.24

1101.33

1104.42

1098.55

1101.64 
TABLE A6.2.2. Type J thermocouples-temperature $\left({ }^{\circ} \mathrm{F}\right)$ as a function of thermoelectric voltage, reference junctions at $32^{\circ} \mathrm{F}$-Continued

$\mathrm{mV}$

.00

.02

.03

.04

.05

.06

.07

.08

.09

$\cdot 10$

$\mathrm{mV}$

TEMPERATURES IN DEGREES $F$

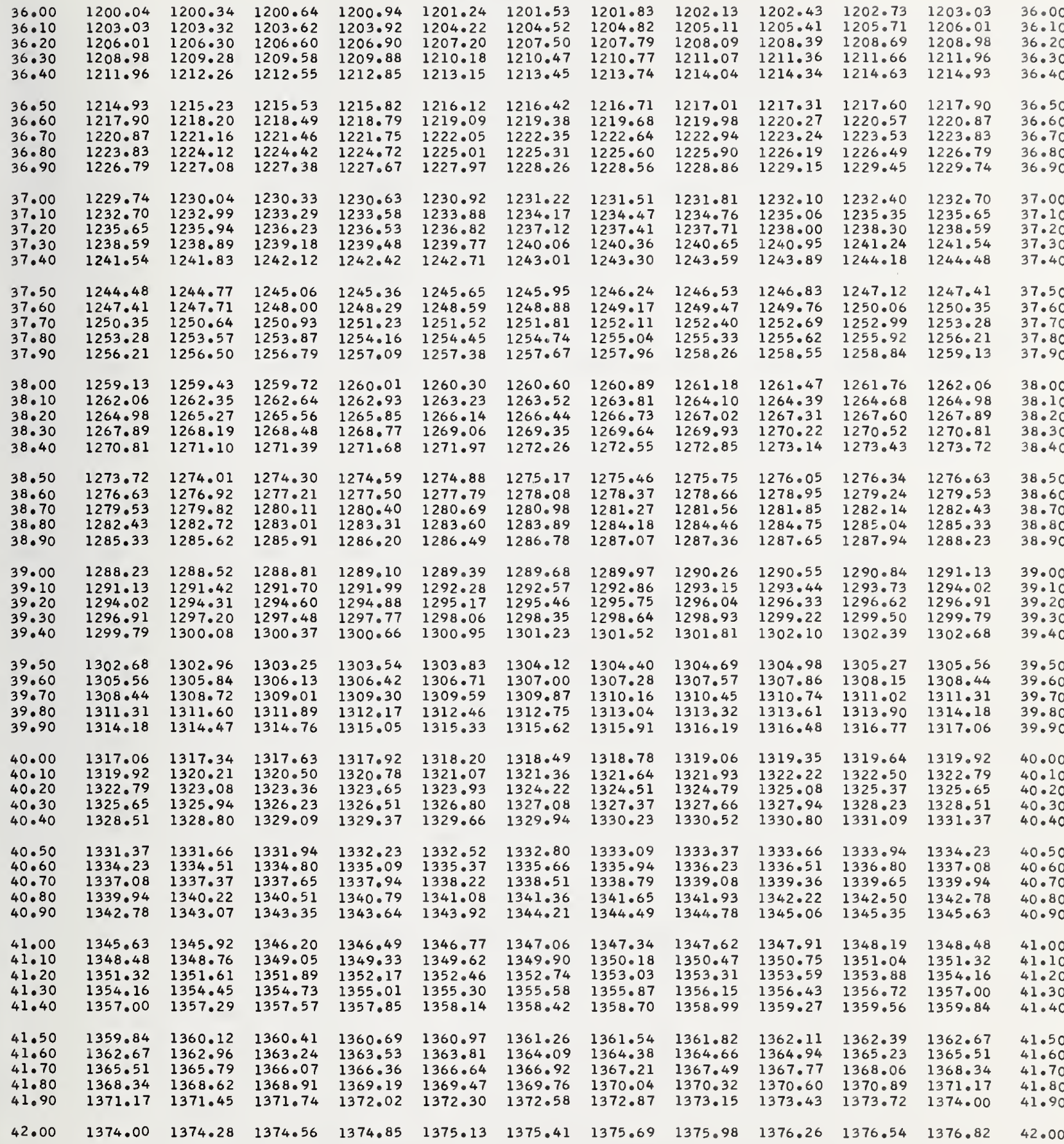

36.00

6.10

6.30

36.40

36.70

. 80

37.00

7.10

7.20

37.40

7.50

37.60

7.80

7.90

.00

.10

38.30

8.40

8.50

8.70

8.80

8.90

.

9.20

9.30

39.50

39.60

39.80

39.90

40.20

40.30
40.40

40.50

40.60

40.70

0.90

1.00

41.20

41.30

41.40

41.50

41.60
41.70

41.80

42.00
.00
.04

.05

.06
.08

.09
.10 
TABLE A6.2.2. Type J thermocouples-temperature $\left({ }^{\circ} \mathrm{F}\right)$ as a function of thermoelectric voltage, reference junctions at $32^{\circ} \mathrm{F}$-Continued

$m V$

$$
.00
$$

.01

.02

.03

.04

.05

.06

.07

TEMPERATURES IN DEGREES $F$

42.00

42.10

$42 \cdot 20$

$42 \cdot 30$

42.40

$42 \cdot 50$

42.60

$42 \cdot 70$

42.80

42.90

$1374.00 \quad 1374.28$

1376.82

$1379.65 \quad 1377.11$

$1382.47 \quad 1382.76$

1385.291385 .58

1388.12

$1390.93 \quad 1388.40$

$\begin{array}{ll}1390.93 & 1391.22 \\ 1393.75 & 1394.03\end{array}$

1396.571396 .85

1399.38

1396.85

$\begin{array}{ll}1374.56 & 1374.85 \\ 1377.39 & 1377.67 \\ 1380.21 & 1380.50 \\ 1383.04 & 1383.32 \\ 1385.86 & 1386.14 \\ 1388.68 & 1388.96 \\ 1391.50 & 1391.78 \\ 1394.31 & 1394.60 \\ 1397.13 & 1397.41\end{array}$

1375.13

1377.95

1380.78

1383.60
1386.42

$\begin{array}{ll}1375.41 & 1375.69\end{array}$

$\begin{array}{ll}1378.24 & 1378.52 \\ 1381.06 & 1381.34\end{array}$

$\begin{array}{ll}1381.06 & 1381.34 \\ 1383.88 & 1384.17\end{array}$

1386.71

1386.99

1389.24

1394.88

$\begin{array}{ll}1389.52 & 1389.81 \\ 1392.34 & 1392.62\end{array}$

1397.13

1399.94

1375.98

1378.80

1381.63

1384.45

1395.16

1395.44

1390.09

1392.91

1395.72

$1397.97 \quad 1398.26$

$1398 \cdot 54$

$m V$

$.00 \quad .01$

.02

.03

.04

.05

.06

\begin{abstract}
.08
\end{abstract}
.09

$\cdot 10$

$m V$

1376.26

1379.37

$1381.91 \quad 1382.19$

$1384 \cdot 73$
1387.55

1385.19

1387.83

$1390.37 \quad 1390.65$

1393.19

$1396.00 \quad 1393.47$

$1398.82 \quad 1396.29$

1396.57

42.70

42.90

.01

10

.07

.08

.09

.10

$m V$ 
TABLE A6.2.2. Type J thermocouples extended range-temperature $\left({ }^{\circ} \mathrm{F}\right)$ as a function of thermoelectric voltage, reference junctions at $32^{\circ} \mathrm{F}$

$\mathrm{mV}$

.00

.01

.02

.03

.04

.05

.06

.07

.08

.09

.10

$m V$

TEMPERATURES IN DEGREES $F$

42.90

43.00

43.10

43.20

43.30

43.40

43.50

43.60

43.7

43.80

43.90

44.0

44.10

44.20

44.30

44.40

44.50

44.6

44.70

44.80

44.90

45.00

45.10

45.20

45.30

45.4

45.50

45.60

45.7

45.80

45.90

46.00

46.20

46.30

46.40

46.50

46.60

46.7

46.80

46.90

47.00

47.1

47.20

47.30

47.40

47.5

47.6

47.70

47.8

47.90

48.00

$\mathrm{mV}$

1402.20

1405.01

1407.82

1410.62

1413.43

1416.23

1419.03

1421.83

1424.63

1427.43

1430.22

1433.02

1435.81

1438.60

1444.18

1446.97

1449.76

1452.55

1455.33

1458.12

1460.91

1463.69

1466.48

1469.26

1472.05

1474.84

1477.62

1480.41

1483.19

1485.98

1488.77

1491.55

1494.34

1497.13

1499.92

1502.71

1505.50

1508.29

1511.08

1513.87

1516.67

1519.46

1522.26

1525.05

1527.85

1530.65

1533.45

1536.25

1539.06

1541.86

00

.00

.01

.02

.03

$1400 \cdot 23$
1403.04

1400.51

$1400 \cdot 79$

1401.07
1403.88

$1405.85 \quad 1406.13 \quad 1406.41 \quad 1406.69$

1408.66

$1408.10 \quad 1408.38$

$1410.90 \quad 1411.18$

1411.47

1408.94

$1411.75 \quad 1412.03$

1409.50
1412.31

1404.16

1406.97

1409.78

1412.59

1414.83

1415.11

1415.39

1417.07

1417.35

$1416.51 \quad 1416.79$

$1419.31 \quad 1419.59$

$1424.91 \quad 1425.19$

$1427.71 \quad 1427.99$

1422.67

1420.15

1417.63

1417.91

1422.95

1428.26

1428.54

1420.43

1420.71

1418.19

1420.99

1423.79

$1426.03 \quad 1426.31$

$1428.82 \quad 1429.10$

1429.38

$430.50 \quad 1430.78$

$1436.09 \quad 1436.37$

$1438.88 \quad 1439.16$

1431.06

$1431 \cdot 34$

1431.90

$\begin{array}{llll}1434.051 & 1434.69\end{array}$

$\begin{array}{llll}1436.65 & 1436.92 & 1437.20 & 1437.48\end{array}$

1439.44

1439.72

1442.51

$1440.00 \quad 1440.27$

1432.18

1434.97

1437.76

1440.55

1445.02

1447.81

1450.59

1445.30

1448.08

1450.87

1450.32

1453.10

453.38

1456.17

1456.45

$1445.58 \quad 1445.85$

$1448.36 \quad 1448.64$

$1451.15 \quad 1451.43$

$1453.94 \quad 1454.22$

$1456.73 \quad 1457.01$

1458.96

1464.53

1467.31

1459.79

.181461

$1466.76 \quad 1467.04$

$1469.54 \quad 1469.82$

1470.10

1464.81

1467.59

1465.091465 .36

$\begin{array}{ll}1465.09 & 1465.36 \\ 1467.87 & 1468.15\end{array}$

$1470.66 \quad 1470.94$

1446.13

1448.92

1451.71

1454.50

1457.28

1460.07

1462.86

1465.64

1468.43

1471.21

$1472.33 \quad 1472.61$

$1477.90 \quad 1478.18$

1480.691480 .96

1472.89

$.89 \quad 1473.16$

1478.46

1481.24

1475.95

1473.44

473.44
476.23

1473.72

1474.00

$1478 \cdot 74$

$1479.01 \quad 1479.29$

$1481.80 \quad 1482.08$

1484.31

1484.59

1484.87

1486.82

$1489.05 \quad 1489.32$

$491.83 \quad 1492.11$

$1497.41 \quad 1497.69$

1492.39

1495.11

1497.97

1487.

1487.65

$1490.16 \quad 1490.44$

1492.951493 .23

1498.24

1495.74

1498.52

1496.01

1500.76

1501.03

1501.31

1498.80

$1502.99 \quad 1503.27$

$1505.78 \quad 1506.06$

$1508.57 \quad 1508.85$

1506.34

1509.13

1503.82

1506.61

1504.10

1506.89

1509.68

1501.59

1504.38

1507.17

1509.96

1512.20

1514.71

1517.51

1520.30

1514.99

1517.78

1520.58

1523.38

1526.17

1515.27 
TABLE A6.2.2. Type J thermocouples extended range-temperature $\left({ }^{\circ} \mathrm{F}\right)$ as a function of thermoelectric voltage, reference junctions at $32^{\circ} \mathrm{F}$-Continued

$m V$

.00

.01

.02

.03

.04

TEMPERATURES IN DEGREES F

48.00

$48 \cdot 10$

48.20

$48 \cdot 30$

48.40

$48 \cdot 50$
48.60

48.70

48.80

48.90

49.00

49.10

49.20
49.30

49.40

49.50

49.60

49.70

49.80

49.90

50.00

50.10

50.20

50.30

50.40

50.50

50.60

50.70

50.80

50.90

51. 00

$51 \cdot 10$

51.30

51.40

51.50

51.60

51.70

51.80

51.90

52.00

52.10

52.20

52.30

52.40

52.50

52.60

52.70

52.80

52.90

53.00

53.10

53.20

53.30

53.40

53.50

53.60

53.70

53,80

53.90

54.00

1541.86
1544.67

1542.14

1542.42

1547.47

1550.28

1544.95

1553.09

1550.56

1553.38

1555.91

1558.72

$1561 \cdot 54$

1556.19

1559.00

1561.82

1567.17

1569.99

1572.82

1575.64

1578.47

1581.30

1584.13

1586.96

1589.79

1592.63

1595.47

1567.45

1570.28

1573.10

1575.92

1578.75

1581.58

1584.41

1587.24

1590.08

1595.75

1598.31

1598.60

1601.15

1604.00

1606.85

1609.70

1601.44

1604.28

1607.13

1612.55

(6)

1615.40

1618.26

1621.12

1612.83

1615.69

1618.55

1621.41

1623.98

1624.27

1626.85

1627.13

1630.00

632.58

1638.33

1632.87

1635.7

1641.20

1644.08

1646.96

1649.85

1652.73

1644.37

1647.25

1650.1

1653.02

1655.62

1658.51

1655.91

1661.41

1658.80

1661.70

1664.31

1667.20

1664.60

1670.11

1667.49

1673.01

1675.92

1678.83

1681.74

1670.40

1676.21

1679.

1682.03

1684.66

1684.95

1687.58

1690.50

1693.42

1687.87

1690.79

1693.71

1696.35

1696.64

1699.28

1702.21

1699.57

1705.73

1708.08

1711.02

1711.3

1708.67

1714.55

1713.96

1542.70

1551.13

1553.94

1556.75

1559.57

1562.38

1565.20

1568.02

1570.84

1573.66

1576.49

1579.32

$1582 \cdot 15$

1584.98

1587.81

1590.64

1593.48

1599.16

1602.01

1604.85

1607.70

1610.55

$1542 \cdot 98$

1543.26

$1543 \cdot 54$

$\begin{array}{lll}1548.60 & 1548.88 & 1549.16\end{array}$

$1551.41 \quad 1551.69 \quad 1551.97$

1554.22

1554.50

1554.78

1557.03

$\begin{array}{lll}1557.31 & 1557.59\end{array}$

$\begin{array}{lll}1562.66 & 1560.13 & 1560.41\end{array}$

$\begin{array}{lll}1565.48 & 1565.76 & 1566.04\end{array}$

1568.30

1568.58

$1571.12 \quad 1571.40$

$\begin{array}{lll}1579.60 & 1579.88 & 1580.16 \\ 1582.43 & 1582.71 & 1582.99\end{array}$

$1585.26 \quad 1585.54 \quad 1585.83$

$1588.09 \quad 1588.38 \quad 1588.66$

$1590.93 \quad 1591.21 \quad 1591.50$

$1593.77 \quad 1594.05 \quad 1594.33$

1599.45

$1602 \cdot 29$

$1602.58 \quad 1602.86$

$\begin{array}{lll}1605.42 & 1605.71\end{array}$

$1607.99 \quad 1608.27 \quad 1608.56$

1610.84

1611.12

1611.41

1613.41

$1613.69 \quad 1613.98 \quad 1614.26$

$1616.26 \quad 1616.55 \quad 1616.83 \quad 1617.12$

$\begin{array}{llll}1619.12 & 1619.40 & 1619.69 & 1619.98\end{array}$

$1621.98 \quad 1622.26 \quad 1622.55 \quad 1622.84$

1625.13

1625.41

1627.71

1627.99

1628.28

$\begin{array}{llll}630.57 \quad 1630.86 & 1631.15 & 1628.57\end{array}$

1633.73

1631.43

$1634.02 \quad 1634.30$

1636.60

1639.48

1642.35

1645.23

1648.12

1651.00

1645.52

1648.40

1651.29

$1654 \cdot 18$

1656.78

1657.07

1659.38

1662.28

1662.57

1662.86

$1668.37 \quad 1668.66$

1668.08

1671.56

1670.98

1673.88

1676.79

1679.70

1674.17

1677

1679

1682.91

1674.47 
TABLE A6.2.2. Type J thermocouples extended range-temperature $\left({ }^{\circ} \mathrm{F}\right)$ as a function of thermoelectric voltage, reference junctions at $32^{\circ} \mathrm{F}$-Continued

$\mathrm{mV}$

.00

.01

.02

.03

.04

.05

.06

TEMPERATURES IN DEGREES F

54.00

54.10

54.20

54.30

54.50

54.60

54.70

54.90

55.00

55.10

55.20

55.30

55.40

55.50

55.60

55.70

55.80

55.90

56.00

56.10

56.20

56.30

56.40

56.50

56.60

56.70

56.80

56.90

57.00

57.10

57.20

57.30

57.40

57.50

57.60

57.70

57.80

57.90

58.00

58.10

58.20

58.30

58.40

58.50

58.60

58.70

58.80

58.90

59.00

59.10

59.20

59.30

59.40

59.50

59.60

59.70

59.80

59.90

60.00
1713.96

1716.91

1719.85

1722.80
1725.76

1728.71

1731.67

1734.63

1740.56

1743.53

1746.50

1749.48

1752.45

1755.43

1758.42

1761.40

1764.39

1770.37

1773.37

1776.36

1779.36

1782.36

1785.37

1788.38

1791.39

1794.40

1797.41

1800.43

1803.45

1806.47

1809.49

1812.52

1815.55

1818.58

1821.61

1824.64

1827.68

1830.72

1833.76

1836.80

1839.85

1842.90
1845.95

1849.00

1852.05

1855.10

1858.16

1864.28

1867.34

1870.41

1873.47

1876.54

1879.61

1882.68

1885.75

1888.82

1891.90

1894.98
1714.25

1720.15

1717.49

$1723.10 \quad 1723.39$

1726.05

1729.01

$1731.97 \quad 1732.26$

$\begin{array}{ll}1734.93 & 1735.22\end{array}$

$1740.86 \quad 1741.16$

1743.83

1746.80

1747.10

$1752.75 \quad 1753.05$

1758.71

1761.70

1764.69

1767.68

1770.67

1773.67

1776.66

1779.66

1782.67

1785.67

1791.69

1794.70

1800.73

1803.75

1806.77

1809.80

1812.82
1815.85

1818.88

1821.91

1824.95

1831.02

1834.07

1837.11

1840.15

1843.20
1846.25

1849.30

1852.35

1855.41

1858.47

1864.59

1867.65

1870.71

1873.78

1876.85

1879.91

1886.06

1889.13

1892.21

1895.28

1756.03

1762.00

1764.99

1767.98

1770.97

1776.96

1779.96

1782.97

1785.97

1788.98

1791.99

1795.00

1801.03

1804.05

1807.07

1810.10

1813.12

1816.15

1819.18

1822.22

1825.25

1828.29

1714.84

$1720.74 \quad 1721.03$

$1723.69 \quad 1723.98$

$1726.64 \quad 1726.94$

1729.60

1732.56

$1735.52 \quad 1735.82$

$1741.45 \quad 1741.75$

1744.42

1747.40

1747.69

$\begin{array}{ll}1753.35 & 1753.65 \\ 1756.33 & 1756.63\end{array}$

1715.43

1718.38

1715.73

$1724.28 \quad 1724.58$

$1727.23 \quad 1727.53$

1733.15

1736.11

1739.08

1730.49

1733.45

1736.41

1739.38

1745.02

1747.99

1750.97

1753.94

1756.93

1748.29

1751.26

1754.24

1757.22

$\begin{array}{lll}1759.31 & 1759.61\end{array}$

1762.30

$\begin{array}{ll}1765.29 & 1765.58 \\ 1768.28 & 1768.57\end{array}$

1759.61
1762.60

1759.91

$1771.27 \quad 1771.57$

1762.89
1765.88

1768.87

1760.21

1760.21

1766.18

1769.17

1774.26

1774.56

1774.86

$1777.26 \quad 1777.56$

$1783.27 \quad 1783.57$

1786.27

1786.57

1777.86

1780.86

1783.87

1789.28

$1792.29 \quad 1792.59$

$\begin{array}{ll}1795.30 & 1795.60 \\ 1793.32 & 1798.62\end{array}$

$1801.33 \quad 1801.64$

1789.88

1792.89

1795.91

1798.92

$1804.35 \quad 1804.66$

$1807.38 \quad 1807.68$

$1810.40 \quad 1810.70$

$1813.43 \quad 1813.73$

$1816.46 \quad 1816.76$

1804.96

1807.98

1811.01

1814.03

1817.06

$1819.49 \quad 1819.79$

$1822.52 \quad 1822.82$

$1825.56 \quad 1825.86$

$1828.59 \quad 1828.90$

1820.09

1823.13 
TABLE A6.2.2. Type J thermocouples extended range-temperature $\left({ }^{\circ} \mathrm{F}\right)$ as a function of thermoelectric voltage, reference junctions at $32^{\circ} \mathrm{F}$-Continued

$\mathrm{mV}$

\begin{abstract}
.01
\end{abstract}
.02

.03

.04

.05

.06

.07

.08

.09

.10

$\mathrm{mV}$

\begin{tabular}{|c|c|c|c|c|c|c|c|c|c|c|c|c|}
\hline $\begin{array}{l}60 \cdot 00 \\
60 \cdot 10 \\
60 \cdot 20 \\
60 \cdot 30 \\
60 \cdot 40\end{array}$ & $\begin{array}{l}1894 \cdot 98 \\
1898.05 \\
1901.13 \\
1904.21 \\
1907.30\end{array}$ & $\begin{array}{l}1895 \cdot 28 \\
1898.36 \\
1901.44 \\
1904.52 \\
1907.60\end{array}$ & $\begin{array}{l}1895.59 \\
1898.67 \\
1901.75 \\
1904.83 \\
1907.91\end{array}$ & $\begin{array}{l}1895.90 \\
1898.98 \\
1902.06 \\
1905.14 \\
1908.22\end{array}$ & $\begin{array}{l}1896.21 \\
1899.28 \\
1902.37 \\
1905.45 \\
1908.53\end{array}$ & $\begin{array}{l}1896.51 \\
1899.59 \\
1902.67 \\
1905.75 \\
1908.84\end{array}$ & $\begin{array}{l}1896.82 \\
1899.90 \\
1902.98 \\
1906.06 \\
1909.15\end{array}$ & $\begin{array}{l}1897.13 \\
1900.21 \\
1903.29 \\
1906.37 \\
1909.45\end{array}$ & $\begin{array}{l}1897.44 \\
1900.52 \\
1903.60 \\
1906.68 \\
1909.76\end{array}$ & $\begin{array}{l}1897.75 \\
1900.82 \\
1903.91 \\
1906.99 \\
1910.07\end{array}$ & $\begin{array}{l}1898.05 \\
1901.13 \\
1904.21 \\
1907.30 \\
1910.38\end{array}$ & $\begin{array}{l}60 \cdot 00 \\
60 \cdot 10 \\
60 \cdot 20 \\
60 \cdot 30 \\
60.40\end{array}$ \\
\hline $\begin{array}{l}60.50 \\
60.60 \\
60.70 \\
60.80 \\
60.90\end{array}$ & $\begin{array}{l}1910.38 \\
1913.46 \\
1916.55 \\
1919.64 \\
1922.73\end{array}$ & $\begin{array}{l}1910.69 \\
1913.77 \\
1916.86 \\
1919.95 \\
1923.04\end{array}$ & $\begin{array}{l}1911.00 \\
1914.08 \\
1917.17 \\
1920.26 \\
1923.35\end{array}$ & $\begin{array}{l}1911.31 \\
1914.39 \\
1917.48 \\
1920.57 \\
1923.65\end{array}$ & $\begin{array}{l}1911.61 \\
1914.70 \\
1917.79 \\
1920.87 \\
1923.96\end{array}$ & $\begin{array}{l}1911.92 \\
1915.01 \\
1918.09 \\
1921.18 \\
1924.27\end{array}$ & $\begin{array}{l}1912.23 \\
1915.32 \\
1918.40 \\
1921.49 \\
1924.58\end{array}$ & $\begin{array}{l}1912.54 \\
1915.63 \\
1918.71 \\
1921.80 \\
1924.89\end{array}$ & $\begin{array}{l}1912.85 \\
1915.93 \\
1919.02 \\
1922.11 \\
1925.20\end{array}$ & $\begin{array}{l}1913.16 \\
1916.24 \\
1919.33 \\
1922.42 \\
1925.51\end{array}$ & $\begin{array}{l}1913.46 \\
1916.55 \\
1919.64 \\
1922.73 \\
1925.82\end{array}$ & $\begin{array}{l}0.50 \\
0.60 \\
0.70 \\
0.80\end{array}$ \\
\hline $\begin{array}{l}61 \cdot 00 \\
61 \cdot 10 \\
61 \cdot 20 \\
61 \cdot 30 \\
61 \cdot 40\end{array}$ & $\begin{array}{l}1925.82 \\
1928.91 \\
1932.00 \\
1935.09 \\
1938.19\end{array}$ & $\begin{array}{l}1926.13 \\
1929.22 \\
1932.31 \\
1935.40 \\
1938.50\end{array}$ & $\begin{array}{l}1926.44 \\
1929.53 \\
1932.62 \\
1935.71 \\
1938.81\end{array}$ & $\begin{array}{l}1926.74 \\
1929.84 \\
1932.93 \\
1936.02 \\
1939.12\end{array}$ & $\begin{array}{l}1927.05 \\
1930.15 \\
1933.24 \\
1936.33 \\
1939.43\end{array}$ & $\begin{array}{l}1927.36 \\
1930.45 \\
1933.55 \\
1936.64 \\
1939.74\end{array}$ & $\begin{array}{l}1927.67 \\
1930.76 \\
1933.86 \\
1936.95 \\
1940.05\end{array}$ & $\begin{array}{l}.98 \\
.07 \\
.17 \\
.26 \\
.36\end{array}$ & $\begin{array}{l}.29 \\
.38 \\
.48 \\
.57 \\
.67\end{array}$ & $\begin{array}{l}1928.60 \\
1931.69 \\
1934.78 \\
1937.88 \\
1940.97\end{array}$ & $\begin{array}{l}.91 \\
.00 \\
.09 \\
.19 \\
.28\end{array}$ & $\begin{array}{l}.00 \\
.10 \\
.20 \\
.30 \\
.40\end{array}$ \\
\hline $\begin{array}{l}61.50 \\
61.60 \\
61.70 \\
61.80 \\
61.90\end{array}$ & $\begin{array}{l}1941.28 \\
1944.38 \\
1947.48 \\
1950.58 \\
1953.68\end{array}$ & $\begin{array}{l}1941.59 \\
1944.69 \\
1947.79 \\
1950.89 \\
1953.99\end{array}$ & $\begin{array}{l}1941.90 \\
1945.00 \\
1948.10 \\
1951.20 \\
1954.30\end{array}$ & $\begin{array}{l}1942.21 \\
1945.31 \\
1948.41 \\
1951.51 \\
1954.61\end{array}$ & $\begin{array}{l}1942.52 \\
1945.62 \\
1948.72 \\
1951.82 \\
1954.92\end{array}$ & $\begin{array}{l}1942.83 \\
1945.93 \\
1949.03 \\
1952.13 \\
1955.23\end{array}$ & $\begin{array}{l}1943 \cdot 14 \\
1946.24 \\
1949.34 \\
1952.44 \\
1955.54\end{array}$ & $\begin{array}{l}1943.45 \\
1946.55 \\
1949.65 \\
1952.75 \\
1955.85\end{array}$ & $\begin{array}{l}1943.76 \\
1946.86 \\
1949.96 \\
1953.06 \\
1956.16\end{array}$ & $\begin{array}{l}1944.07 \\
1947.17 \\
1950.27 \\
1953.37 \\
1956.47\end{array}$ & $\begin{array}{l}44.38 \\
47.48 \\
50.58 \\
53.68 \\
56.78\end{array}$ & $\begin{array}{r}.50 \\
.60 \\
.70 \\
.80\end{array}$ \\
\hline $\begin{array}{l}62 \cdot 00 \\
62 \cdot 10 \\
62 \cdot 20 \\
62 \cdot 30 \\
62 \cdot 40\end{array}$ & $\begin{array}{l}1956.78 \\
1959.88 \\
1962.98 \\
1966.08 \\
1969.19\end{array}$ & $\begin{array}{l}1957.09 \\
1960.19 \\
1963.29 \\
1966.39 \\
1969.50\end{array}$ & $\begin{array}{l}1957.40 \\
1960.50 \\
1963.60 \\
1966.70 \\
1969.81\end{array}$ & $\begin{array}{l}1957.71 \\
1960.81 \\
1963.91 \\
1967.01 \\
1970.12\end{array}$ & $\begin{array}{l}1958.02 \\
1961.12 \\
1964.22 \\
1967.32 \\
1970.43\end{array}$ & $\begin{array}{l}1958.33 \\
1961.43 \\
1964.53 \\
1967.63 \\
1970.74\end{array}$ & $\begin{array}{l}1958.64 \\
1961.74 \\
1964.84 \\
1967.94 \\
1971.05\end{array}$ & $\begin{array}{l}95 \\
05 \\
15 \\
25 \\
36\end{array}$ & $\begin{array}{l}.26 \\
.36 \\
.46 \\
.57 \\
.67\end{array}$ & $\begin{array}{l}.57 \\
.67 \\
.77 \\
.88 \\
.98\end{array}$ & $\begin{array}{l}88 \\
98 \\
08 \\
19 \\
29\end{array}$ & $\begin{array}{l}00 \\
10 \\
20 \\
30 \\
40\end{array}$ \\
\hline $\begin{array}{l}62.50 \\
62.60 \\
62.70 \\
62.80 \\
62.90\end{array}$ & $\begin{array}{l}1972.29 \\
1975.40 \\
1978.50 \\
1981.61 \\
1984.72\end{array}$ & $\begin{array}{l}1972.60 \\
1975.71 \\
1978.81 \\
1981.92 \\
1985.03\end{array}$ & $\begin{array}{l}1972.91 \\
1976.02 \\
1979.12 \\
1982.23 \\
1985.34\end{array}$ & $\begin{array}{l}1973.22 \\
1976.33 \\
1979.43 \\
1982.54 \\
1985.65\end{array}$ & $\begin{array}{l}1973.53 \\
1976.64 \\
1979.74 \\
1982.85 \\
1985.96\end{array}$ & $\begin{array}{l}1973.84 \\
1976.95 \\
1980.05 \\
1983.16 \\
1986.27\end{array}$ & $\begin{array}{l}1974.15 \\
1977.26 \\
1980.37 \\
1983.47 \\
1986.58\end{array}$ & $\begin{array}{l}1974.46 \\
1977.57 \\
1980.68 \\
1983.78 \\
1986.89\end{array}$ & $\begin{array}{l}1974.77 \\
1977.88 \\
1980.99 \\
1984.09 \\
1987.20\end{array}$ & $\begin{array}{l}1975.08 \\
1978.19 \\
1981.30 \\
1984.40 \\
1987.51\end{array}$ & $\begin{array}{l}1975.40 \\
1978.50 \\
1981.61 \\
1984.72 \\
1987.82\end{array}$ & $\begin{array}{l}2.60 \\
2.70 \\
2.80 \\
2.90\end{array}$ \\
\hline $\begin{array}{l}63.00 \\
63.10 \\
63.20 \\
63.30 \\
63.40\end{array}$ & $\begin{array}{l}1987.82 \\
1990.93 \\
1994.04 \\
1997.15 \\
2000.26\end{array}$ & $\begin{array}{l}1988.13 \\
1991.24 \\
1994.35 \\
1997.46 \\
2000.57\end{array}$ & $\begin{array}{l}1988.44 \\
1991.55 \\
1994.66 \\
1997.77 \\
2000.88\end{array}$ & $\begin{array}{l}1988.76 \\
1991.86 \\
1994.97 \\
1998.08 \\
2001.19\end{array}$ & $\begin{array}{l}1989.07 \\
1992.18 \\
1995.28 \\
1998.39 \\
2001.50\end{array}$ & $\begin{array}{l}1989.38 \\
1992.49 \\
1995.60 \\
1998.71 \\
2001.82\end{array}$ & $\begin{array}{l}1989.69 \\
1992.80 \\
1995.91 \\
1999.02 \\
2002.13\end{array}$ & $\begin{array}{l}1990.00 \\
1993.11 \\
1996.22 \\
1999.33 \\
2002.44\end{array}$ & $\begin{array}{l}1990.31 \\
1993.42 \\
1996.53 \\
1999.64 \\
2002.75\end{array}$ & $\begin{array}{l}1990.62 \\
1993.73 \\
1996.84 \\
1999.95 \\
2003.06\end{array}$ & $\begin{array}{r}.93 \\
+.04 \\
7.15 \\
.26 \\
.37\end{array}$ & $\begin{array}{l}30 \\
40\end{array}$ \\
\hline $\begin{array}{l}63.50 \\
63.60 \\
63.70 \\
63.80 \\
63.90\end{array}$ & $\begin{array}{l}2003 \cdot 37 \\
2006.48 \\
2009.59 \\
2012.71 \\
2015.82\end{array}$ & $\begin{array}{l}2003.68 \\
2006.79 \\
2009.91 \\
2013.02 \\
2016.13\end{array}$ & $\begin{array}{l}2003 \cdot 99 \\
2007.11 \\
2010.22 \\
2013.33 \\
2016.44\end{array}$ & $\begin{array}{l}2004.30 \\
2007.42 \\
2010.53 \\
2013.64 \\
2016.75\end{array}$ & $\begin{array}{l}2004.62 \\
2007.73 \\
2010.84 \\
2013.95 \\
2017.07\end{array}$ & $\begin{array}{l}2004.93 \\
2008.04 \\
2011.15 \\
2014.26 \\
2017.38\end{array}$ & $\begin{array}{l}2005.24 \\
2008.35 \\
2011.46 \\
2014.57 \\
2017.69\end{array}$ & $\begin{array}{l}2005.55 \\
2008.66 \\
2011.77 \\
2014.89 \\
2018.00\end{array}$ & $\begin{array}{l}2005.86 \\
2008.97 \\
2012.08 \\
2015.20 \\
2018.31\end{array}$ & $\begin{array}{l}2006.17 \\
2009.28 \\
2012.40 \\
2015.51 \\
2018.62\end{array}$ & $\begin{array}{l}06.48 \\
09.59 \\
12.71 \\
15.82 \\
18.93\end{array}$ & $\begin{array}{l}50 \\
60 \\
70 \\
80\end{array}$ \\
\hline $\begin{array}{l}64 \cdot 00 \\
64 \cdot 10 \\
64 \cdot 20 \\
64 \cdot 30 \\
64 \cdot 40\end{array}$ & $\begin{array}{l}2018.93 \\
2022.05 \\
2025.16 \\
2028.28 \\
2031.39\end{array}$ & $\begin{array}{l}2019.24 \\
2022.36 \\
2025.47 \\
2028.59 \\
2031.70\end{array}$ & $\begin{array}{l}2019.56 \\
2022.67 \\
2025.78 \\
2028.90 \\
2032.01\end{array}$ & $\begin{array}{l}2019 \cdot 87 \\
2022.98 \\
2026 \cdot 10 \\
2029 \cdot 21 \\
2032.33\end{array}$ & $\begin{array}{l}2020.18 \\
2023.29 \\
2026.41 \\
2029.52 \\
2032.64\end{array}$ & $\begin{array}{l}2020.49 \\
2023.60 \\
2026.72 \\
2029.83 \\
2032.95\end{array}$ & $\begin{array}{l}2020.80 \\
2023.92 \\
2027.03 \\
2030.14 \\
2033.26\end{array}$ & $\begin{array}{l}2021 \cdot 11 \\
2024.23 \\
2027.34 \\
2030.46 \\
2033.57\end{array}$ & $\begin{array}{l}2021.42 \\
2024.54 \\
2027.65 \\
2030.77 \\
2033.88\end{array}$ & $\begin{array}{l}2021.74 \\
2024.85 \\
2027.96 \\
2031.08 \\
2034.19\end{array}$ & $\begin{array}{l}2022 \cdot 05 \\
2025.16 \\
2028.28 \\
2031.39 \\
2034.51\end{array}$ & $\begin{array}{l}64.00 \\
64.10 \\
64.20 \\
64.30 \\
64.40\end{array}$ \\
\hline $\begin{array}{l}64.50 \\
64.60 \\
64.70 \\
64.80 \\
64.90\end{array}$ & $\begin{array}{l}2034.51 \\
2037.62 \\
2040.74 \\
2043.85 \\
2046.97\end{array}$ & $\begin{array}{l}2034.82 \\
2037.93 \\
2041.05 \\
2044.17 \\
2047.28\end{array}$ & $\begin{array}{l}2035.13 \\
2038.25 \\
2041.36 \\
2044.48 \\
2047.60\end{array}$ & $\begin{array}{l}2035.44 \\
2038.56 \\
2041.67 \\
2044.79 \\
2047.91\end{array}$ & $\begin{array}{l}2035.75 \\
2038.87 \\
2041.98 \\
2045.10 \\
2048.22\end{array}$ & $\begin{array}{l}2036.06 \\
2039.18 \\
2042.30 \\
2045.41 \\
2048.53\end{array}$ & $\begin{array}{l}2036.38 \\
2039.49 \\
2042.61 \\
2045.72 \\
2048.84\end{array}$ & $\begin{array}{l}2036.69 \\
2039.80 \\
2042.92 \\
2046.04 \\
2049.15\end{array}$ & $\begin{array}{l}2037.00 \\
2040.12 \\
2043.23 \\
2046.35 \\
2049.47\end{array}$ & $\begin{array}{l}2037.31 \\
2040.43 \\
2043.54 \\
2046.66 \\
2049.78\end{array}$ & $\begin{array}{l}2037.62 \\
2040.74 \\
2043.85 \\
2046.97 \\
2050.09\end{array}$ & $\begin{array}{l}64 \cdot 50 \\
64.60 \\
64.70 \\
64.80 \\
64.90\end{array}$ \\
\hline $\begin{array}{l}65.00 \\
65.10 \\
65.20 \\
65.30 \\
65.40\end{array}$ & $\begin{array}{l}2050.09 \\
2053.21 \\
2056.32 \\
2059.44 \\
2062.56\end{array}$ & $\begin{array}{l}2050.40 \\
2053.52 \\
2056.64 \\
2059.75 \\
2062.87\end{array}$ & $\begin{array}{l}2050.71 \\
2053.83 \\
2056.95 \\
2060.07 \\
2063.19\end{array}$ & $\begin{array}{l}2051.02 \\
2054.14 \\
2057.26 \\
2060.38 \\
2063.50\end{array}$ & $\begin{array}{l}2051.34 \\
2054.45 \\
2057.57 \\
2060.69 \\
2063.81\end{array}$ & $\begin{array}{l}2051.65 \\
2054.77 \\
2057.88 \\
2061.00 \\
2064.12\end{array}$ & $\begin{array}{l}2051.96 \\
2055.08 \\
2058.20 \\
2061.31 \\
2064.43\end{array}$ & $\begin{array}{l}27 \\
39 \\
51 \\
63 \\
74\end{array}$ & $\begin{array}{l}58 \\
70 \\
82 \\
94 \\
06\end{array}$ & $\begin{array}{l}2052.89 \\
2056.01 \\
2059.13 \\
2062.25 \\
2065.37\end{array}$ & $\begin{array}{l}.21 \\
.32 \\
.44 \\
.56 \\
.68\end{array}$ & $\begin{array}{l}00 \\
10 \\
20 \\
30\end{array}$ \\
\hline $\begin{array}{l}65.50 \\
65.60 \\
65.70 \\
65.80 \\
65.90\end{array}$ & $\begin{array}{l}2065.68 \\
2068.80 \\
2071.92 \\
2075.04 \\
2078.16\end{array}$ & $\begin{array}{l}2065.99 \\
2069.11 \\
2072.23 \\
2075.35 \\
2078.47\end{array}$ & $\begin{array}{l}2066.30 \\
2069.42 \\
2072.54 \\
2075.66 \\
2078.78\end{array}$ & $\begin{array}{l}2066.62 \\
2069.74 \\
2072.86 \\
2075.98 \\
2079.10\end{array}$ & $\begin{array}{l}2066.93 \\
2070.05 \\
2073.17 \\
2076.29 \\
2079.41\end{array}$ & $\begin{array}{l}2067.24 \\
2070.36 \\
2073.48 \\
2076.60 \\
2079.72\end{array}$ & $\begin{array}{r}.55 \\
.67 \\
.79 \\
.91 \\
.03\end{array}$ & $\begin{array}{l}86 \\
98 \\
10 \\
22 \\
34\end{array}$ & $\begin{array}{l}.18 \\
.30 \\
.42 \\
.54 \\
.66\end{array}$ & $\begin{array}{l}58.49 \\
71.61 \\
74.73 \\
77.85 \\
30.97\end{array}$ & $\begin{array}{l}.80 \\
.92 \\
.04 \\
.16 \\
.28\end{array}$ & $\begin{array}{l}65.60 \\
65.70 \\
65.80 \\
65.90\end{array}$ \\
\hline 0.00 & 081.28 & 2081.59 & 2081.90 & 2082.22 & 2082.53 & 2082.84 & 2083.15 & 2083.47 & 2083.78 & 2084.09 & 2084.40 & 0000 \\
\hline
\end{tabular}

$\mathrm{mV}$

.00

.01

.02

.03

.04

.05

.06

.07

.08

.09

.10

$m V$ 
TABLE 6.2.2. Type J thermocouples extended range-temperature $\left({ }^{\circ} \mathrm{F}\right)$ as a function of thermoelectric voltage, reference junctions at $32^{\circ} \mathrm{F}$-Continued

\begin{tabular}{|c|c|c|c|c|c|c|c|c|c|c|c|c|}
\hline \multirow[t]{2}{*}{$\mathrm{mV}$} & \multirow[t]{2}{*}{.00} & \multirow[t]{2}{*}{.01} & \multirow[t]{2}{*}{.02} & \multirow[t]{2}{*}{.03} & .04 & .05 & .06 & .07 & .08 & .09 & $\cdot 10$ & $\mathrm{mV}$ \\
\hline & & & & & \multicolumn{8}{|c|}{ TEMPERATURES IN DEGREES $F$} \\
\hline 6.00 & 2081.28 & 2081.59 & $2081 \cdot 90$ & 2082.22 & 2082.53 & $2082 \cdot 84$ & 2083.15 & 2083.47 & 2083.78 & 2084.09 & $2084 \cdot 40$ & 66.00 \\
\hline & 2084.40 & 2084.71 & 2085.03 & 2085.34 & 2085.65 & 2085.96 & 2086.27 & 2086.59 & 2086.90 & 2087.21 & 2087.52 & 66.10 \\
\hline 6.20 & 2087.52 & 2087.84 & $2088 \cdot 15$ & 2088.46 & 2088.77 & 2089.08 & 2089.40 & 2089.71 & 2090.02 & $2090 \cdot 33$ & 2090.65 & 66.20 \\
\hline 66. & 2090.65 & 2090.96 & 2091.27 & 2091.58 & 2091.89 & 2092.21 & 2092.52 & 2092.83 & 2093.14 & 2093.46 & 2093.77 & 66.30 \\
\hline 66.40 & 2093.77 & 2094.08 & 2094.39 & 2094.70 & 2095.02 & 2095.33 & 2095.64 & 2095.95 & 2096.27 & 2096.58 & 2096.89 & 66.40 \\
\hline 6.50 & 2096.89 & 2097.20 & 2097.51 & 2097.83 & 2098.14 & 2098.45 & 2098.76 & 2099.08 & 2099.39 & 2099.70 & 2100.01 & 66.50 \\
\hline & 210 & 2100.33 & 2100.64 & 2100.95 & 2101.26 & 2101.57 & .89 & 2102.20 & 2102.51 & 2102.82 & 2103 & 66.60 \\
\hline 66. & 2103.14 & 2103.45 & 2103.76 & 2104.07 & 210 & 2104.70 & 21 & 21 & 2105.64 & 2105.95 & 2106. & 66.70 \\
\hline 66.80 & 2106.26 & 2106.57 & 2106.89 & 2107.20 & 2107.51 & 2107.82 & .13 & 2108.45 & 2108.76 & 2109.07 & $2109 \cdot 38$ & 66.80 \\
\hline 66.90 & 2109.38 & $2109 \cdot 70$ & 2110.01 & 2110.32 & 2110.63 & 2110.95 & 2111.26 & 2111.57 & $2111 \cdot 88$ & 2112.20 & 2112.51 & 66.90 \\
\hline 57. & 2112.51 & 112.82 & 2113.13 & 45 & 113 & 211 & 2114.38 & 2114.70 & 2115.01 & 2115.32 & 2115 . & 67.00 \\
\hline & 3 & 211 & 211 & 57 & 211 & & & & & & & 10 \\
\hline 67 & 211 & 2119 & 211 & 211 & 212 & & & & & & & .20 \\
\hline 67 & 2121.89 & 2122. & 2122 & 2122.82 & 2123.14 & 2123 & & & & & & 30 \\
\hline 67 & 2125.01 & 2125.33 & 2125.64 & 2125.95 & 2126.26 & 2126 & .89 & 212 & 2127.52 & 2127.83 & 2128.14 & 7.40 \\
\hline 7. & 14 & 212 & 2128.77 & 129.08 & 2129. & 2125 & 213 & 2130.33 & 64 & 2130 & 2131 & 67.50 \\
\hline & & & & & & & & & & & & \\
\hline & 213 & 213 & 2135.02 & 213 & 213 & 213 & 21 & .59 & 90 & 2137.21 & 2137 & 70 \\
\hline & 21 & 213 & 213 & 47 & 21 & 21 & 21 & & 21 & 214 & 214 & .80 \\
\hline 67.90 & 2140.66 & 2140.97 & 2141.28 & 2141.60 & 2141 & 2142 & 21 & 21 & & 48 & & 67.90 \\
\hline & 2 & & & & .04 & 2. & 7 & 8 & 2. & 21 & 21 & .00 \\
\hline & 214 & 214 & 214 & & 2 & 214 & & & & 74 & 21 & 10 \\
\hline 68 & 21 & 215 & 21 & & & & & & & & & 20 \\
\hline 68.30 & 2153.19 & 2153.50 & 2153.81 & $2154 \cdot 13$ & 2154.44 & 2154.75 & 2155.07 & 2155.38 & 2155.69 & 2156.01 & 2156.32 & 68.30 \\
\hline 68.40 & 2156.32 & 2156.63 & 2156.95 & 2157.26 & 2157.57 & 215 & 215 & 21 & 2158 & 215 & 2159 & 68.40 \\
\hline 68. & 2155 & 2 & 160.08 & 2 & 2160. & 2 & 2 & 2 & 2. & 2 & 2] & \\
\hline & 216 & 0 & & 3 & & & & & & & & \\
\hline 68.70 & 2165.73 & 2166.04 & 2166.36 & 2166 & 216 & 2167.30 & 216 & 216 & 21 & 216 & 216 & 68.70 \\
\hline & 2168 & 2169 & 216 & & 2170.12 & 2170.44 & & & & & 21 & 68.80 \\
\hline 68.9 & 2172.00 & $2172 \cdot 32$ & 2172.63 & 2172.95 & 2173.26 & 2173.5 & 2173.89 & 217 & 2174 & 2174 . & 2175 . & 68.90 \\
\hline 69.00 & 2175 & 2175.46 & 2175.77 & 2176.09 & 2176.40 & 2176.72 & 2177.03 & 2177.34 & 2177.66 & 2177.97 & 2178.29 & 69.00 \\
\hline 69.10 & 2178 & 2178 & 217 & & 217 & 2179.86 & & & 2180.80 & 2181.12 & 2181.43 & 69.10 \\
\hline & 2181 & 2181.74 & 2182 & 2182 & 2182 & 2183.00 & 2183.32 & 218 & 218 & 2184.26 & 2184 & 69.20 \\
\hline & 2184.57 & 2184.89 & 2185.20 & 2185.52 & 2185.8 & 2186.15 & 2186.46 & 2186 & 2187 & 2187.40 & 2187. & 69.30 \\
\hline & 2187.72 & 2188.03 & 2188.35 & 2188.66 & 2188.98 & 2189.29 & 2189.61 & 2189.92 & 2190.24 & 2190.55 & 2190.87 & 69.40 \\
\hline 69.5 & 2190.87 & 2191.18 & 191.50 & 191.81 & & & & & & & & 9.50 \\
\hline
\end{tabular}

$\mathrm{mV}$

.02

.03

.04

.05

.06

.07

.08

.09

.10

mV 
TABLE A6.2.3. Type J thermocouples-quadratic, cubic, and quartic approximations to the data as a function of voltage in selected temperature ranges $\left({ }^{\circ} \mathrm{C}\right)$. The expansion is of the form

$\mathrm{T}=\mathrm{a}_{0}+\mathrm{a}_{1} \mathrm{E}+\mathrm{a}_{2} \mathrm{E}^{2}+\mathrm{a}_{3} \mathrm{E}^{3}+\mathrm{a}_{4} \mathrm{E}^{4}$ where $\mathrm{E}$ is in microvolts and $\mathrm{T}$ is in degrees Celsius

Temperature
Range $\left(\mathrm{C}^{\circ}\right)$

$a_{0}$

$a_{1} \quad a_{2}$

$a_{2} \quad a_{3}$

$a_{4}$

Error

I. Duartic Equation Argument Exp.

Argument Exp.

Argument Exp.

Argument Exp.

Argument

Exp.

$\begin{array}{rlllll}-200 & \text { to } 0 & \ldots & \ldots & \ldots \\ -200 & \text { to } 760 & \ldots & \ldots & \ldots \\ -200 & \text { to } 1200 & \ldots & \ldots & \ldots \\ -20 & \text { to } 500 & \ldots & \ldots & \ldots \\ 0 & \text { to } 400 & \ldots & \ldots & \ldots \\ 0 & \text { to } 760 & \ldots & \ldots & \cdots \\ 0 & \text { to } 1200 & \ldots & \ldots & \ldots \\ 400 & \text { to } 760 & 9.2808351 & +1 \\ 400 & \text { to } 1200 & -1.1075293 & +2 \\ 600 & \text { to } 760 & 1.8020713 & +2 \\ 760 & \text { to } 1200 & -6.3828680 & +2\end{array}$

$\begin{aligned} \text { 1. } 8843850 & -2 \\ 2.1155170 & -2 \\ 2.1676850 & -2 \\ 1.9745056 & -2 \\ 1.9750953 & -2 \\ 1.9323799 & -2 \\ 1.8134974 & -2 \\ 5.4463817 & -3 \\ \text { 2. } 8651303 & -2 \\ \text {-4. } 5284199 & -3 \\ \text { 7. } 4068749 & -2\end{aligned}$

$-1.2029733-6$

$-3.3513149-7$

-2. $1844464 \quad-7$

$-1.8094256 \quad-7$

$-1.8542600-7$

$-1.0306020-7$

$-5.6495930-8$

6. $5254537-7$

$\begin{array}{ll}-2.9758175 & -7\end{array}$

$1.0769294-6$

$-1.7177773-6$

$\begin{array}{rr}-2.5278593 & -10 \\ 1.2443997 & -11 \\ 3.9094347 & -12 \\ 7.8777919 & -12 \\ 8.3683958 & -12 \\ 3.7084018 & -12 \\ -2.4644023 & -12 \\ -1.3987013 & -11 \\ 2.5945419 & -12 \\ -2.1962321 & -11 \\ 2.1771293 & -11\end{array}$

$-2.5849263 \quad-14$

$-1.5227150-16$

$\begin{array}{ll}-2.4303017 & -17\end{array}$

$-1.1897222-16$

$-1,3280568-16$

$\begin{array}{ll}-5.1031937 & -17\end{array}$

2. $1141718-17$

$9.9364476-17$

$-4.9012035-18$

$\begin{array}{ll}\text { 1. } 5521511-16 \\ -9.9502571 & -17\end{array}$

$\begin{array}{ll}-9.9502571 & -17\end{array}$

Exact-Approx.

II. Cubic Equation

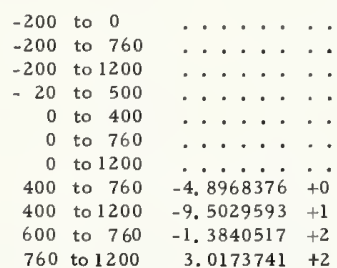

2. $1505558-2$

2. $1515056-2$

2. $0978541-2$

$1.9283042-2$

1. $9473887-2$

1. $8533724-2$

1. $9503772-2$

1. $8210534-2$

2. $7038308-2$

2. $9282700-2$

5. $2561347-3$

7. $0760633 \quad-7$

$\begin{array}{ll}-2.0083005 & -7\end{array}$

$-1.2232172 \quad-7$

$-8,0675605-8$

$-1.1226744-7$

4. $2760262-9$

$-5.9445161-8$

3. $9107118-8$

$-2.3904271-7$

$-2.6481733-7$

1. $5285291-7$

1. 4905372

2. 7148959

9. 9773144

1. 6027847

2. 7239574

-5. 3564407

3. 8077327

$-1.1248415$

1. 6991082

1. 6363524

$-6.1293733$

1. $7220554 \quad-2$

$-9.7062857 \quad-7$

$-5.8531132-8$

$-2.9457523-8$

$\begin{array}{ll}-2.9457523 & -8 \\ -1.9620173 & -8\end{array}$

$\begin{array}{ll}-1.9620173 & -8 \\ -2.9795010 & -8\end{array}$

$-2.7558559-8$

$-2.3056976 \quad-8$

$-7.0116467 \quad-8$

$\begin{array}{ll}-7.0116467 & -8 \\ -6.2082442 & -9\end{array}$

$-7.8370423-8$

4. $9405799 \quad-8$

....

$\ldots \ldots$

$\ldots .$.

....

$\cdots \cdots$

$\ldots \ldots$

$\cdots .$.

$\cdots \cdots$

$\therefore$.

$\ldots .$.

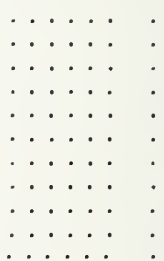

-4 to .5

-6 to 7

-14 to 10

-.07 to .06

-.03 to .05

-.9 to .7

-3 to 4

-.03 to .03

-1.3 to 1.6

-.001 to .001

-.15 to .11

$2.2229648-2$

1. $1000534-2$

760 to $760 \quad-4.9827896 \quad+1$

$\cdots \cdot \cdots$

....

.

.... $\cdot$

-1.2 to 1.2

-17 to 10

-27 to 7

-.8 to .7

-.3 to .4

-1.7 to 2.3

-5 to 6

-.17 to .17

-1.5 to 1.8

-.012 to .011

-.5 to .5

-4 to 3

-40 to 7

-50 to 15

-1.3 to 1.8

-.9 to 1.4

-3 to 3

-10 to 10

-.4 to .6

-7 to 7

-.06 to .07

-. 7 to .6 


\section{A7. Supplementary Data for Type K-Nickel-Chromium Alloy Versus Nickel-Aluminum Alloy Thermocouples}

\section{A7.1. Data for Voltage as a Function of Temperature}

The full precision coefficients given in the main text are used to generate the voltage as a function of temperature data given in tables A7.1.1 and A7.1.2. Table A7.1.1 presents the data in degrees Celsius from $-270{ }^{\circ} \mathrm{C}$ to $1372{ }^{\circ} \mathrm{C}$ while table A7.1.2 presents the data in degrees Fahrenheit from $-454^{\circ} \mathrm{F}$ to $2500^{\circ} \mathrm{F}$. Table A7.1.3 contains quadratic, cubic, and quartic approximations to the data as a function of temperature in selected temperature ranges. The error range given in the table is the difference between the voltage as obtained from the full precision coefficients from the text and the respective reduced order approximations. The last entries in the cubic and quadratic groupings of table A7.1.3 represent variable reference junction corrections in the 0 to $50{ }^{\circ} \mathrm{C}$ temperature range. In the narrower temperature range near room temperatures, 20 to $25^{\circ} \mathrm{C}$, the error range for the given quadratic equation is smaller than that listed in the last column: $\pm 0.2 \mu \mathrm{V}$.

TABLE A7.1.1. Type $\boldsymbol{K}$ thermocouples-thermoelectric voltage as a function of temperature $\left({ }^{\circ} \mathrm{C}\right)$, reference junctions at $0^{\circ} \mathrm{C}$

\begin{tabular}{|c|c|c|c|c|c|c|c|c|c|c|c|c|}
\hline${ }^{\circ} \mathrm{C}$ & 0 & 1 & 2 & 3 & 4 & 5 & 6 & 7 & 8 & 9 & 10 & ${ }^{\circ} \mathrm{C}$ \\
\hline & & & THER & MOELECTR & IC VOLTAG & GE IN $A B$ & SOLUTE M & ILLIVOLTS & & & & \\
\hline & -6.458 & & & & & & & & & & & -270 \\
\hline & -6.441 & $-6 \cdot 444$ & -6.446 & -6.448 & -6.450 & -6.452 & -6.453 & -6.455 & -6.456 & -6.457 & -6.458 & -260 \\
\hline 250 & -6.404 & -6.408 & -6.413 & -6.417 & -6.421 & -6.425 & -6.429 & -6.432 & -6.435 & -6.438 & -6.441 & -250 \\
\hline 240 & -6.344 & -6.351 & $-6 \cdot 358$ & $-6 \cdot 364$ & -6.371 & -6.377 & -6.382 & -6.388 & -6.394 & -6.399 & -6.404 & -240 \\
\hline 30 & -6.262 & -6.271 & -6.280 & -6.289 & -6.297 & -6.306 & -6.314 & -6.322 & -6.329 & -6.337 & -6.344 & -230 \\
\hline 220 & -6.158 & $-6 \cdot 170$ & $-6 \cdot 181$ & $-6 \cdot 192$ & -6.202 & -6.213 & -6.223 & -6.233 & -6.243 & -6.253 & -6.262 & -220 \\
\hline 16 & -6.035 & -6.048 & -6.061 & -6.074 & -6.087 & -6.099 & -6.111 & $-6 \cdot 123$ & -6.135 & $-6 \cdot 147$ & $-6 \cdot 158$ & -210 \\
\hline 200 & -5.891 & -5.907 & -5.922 & -5.936 & -5.951 & -5.965 & -5.980 & -5.994 & -6.007 & -6.021 & -6.035 & -200 \\
\hline 96 & -5.730 & -5.747 & -5.763 & -5.780 & -5.796 & -5.813 & -5.829 & -5.845 & -5.860 & -5.876 & -5.891 & -190 \\
\hline & -5.550 & -5.569 & -5.587 & -5.606 & -5.624 & -5.642 & -5.660 & -5.678 & $-5 \cdot 6$ & -5.712 & -5 & -180 \\
\hline-170 & -5.354 & -5.374 & $-5 \cdot 394$ & -5.414 & -5.434 & $-5 \cdot 454$ & -5.474 & -5.493 & -5.512 & -5.531 & -5.550 & -170 \\
\hline-160 & -5.141 & $-5 \cdot 163$ & -5.185 & -5.207 & -5.228 & -5.249 & -5.271 & -5.292 & -5.313 & -5.333 & $-5 \cdot 354$ & -160 \\
\hline 150 & $-4 \cdot 912$ & $-4 \cdot 936$ & -4.959 & $-4 \cdot 983$ & $-5 \cdot 00$ & -5.029 & -5.051 & -5 & $-5 \cdot 0$ & $-5 \cdot 1$ & $-5 \cdot 14$ & -150 \\
\hline 140 & -4.669 & -4.694 & -4.719 & -4.743 & -4.768 & -4.792 & -4.817 & -4.841 & -4.865 & -4.889 & -4.912 & -140 \\
\hline-130 & -4.410 & -4.437 & -4.463 & -4.489 & -4.515 & $-4 \cdot 541$ & -4.567 & -4.593 & $-4 \cdot 618$ & -4.644 & $-4 \cdot 669$ & -130 \\
\hline-120 & -4.138 & $-4 \cdot 166$ & -4.193 & -4.221 & -4.248 & $-4 \cdot 276$ & -4.303 & -4.330 & -4.357 & $-4 \cdot 384$ & -4.410 & -120 \\
\hline 110 & -3.852 & -3.881 & -3.910 & -3.939 & -3.968 & -3.997 & -4.025 & -4.053 & -4.082 & -4.110 & -4.138 & -110 \\
\hline-100 & -3.553 & -3.584 & -3.614 & -3.644 & -3.674 & -3.704 & -3.734 & -3.764 & -3.793 & -3.823 & -3 & -100 \\
\hline-90 & -3.242 & -3.274 & -3.305 & -3.337 & -3.368 & -3.399 & -3.430 & -3.461 & -3.492 & -3.523 & -3.553 & -90 \\
\hline & -2.920 & -2.953 & -2.985 & -3.018 & -3 & -3.082 & -3.115 & -3.147 & -3.179 & -3.211 & -3 . & -80 \\
\hline-70 & -2.586 & -2.620 & -2.654 & -2.687 & -2.721 & -2.754 & -2.788 & -2.821 & $-2 \cdot 854$ & -2.8 & -2 . & -70 \\
\hline-60 & -2.243 & -2.277 & -2.312 & $\begin{array}{l}-2.347 \\
-1.996\end{array}$ & $\begin{array}{l}-2.381 \\
-2.032\end{array}$ & -2.416 & $\begin{array}{l}-2.450 \\
-2.102\end{array}$ & -2.484 & -2.518 & -2.552 & -2.586 & -60 \\
\hline & -1.8 & -1.925 & $-1 \cdot 96$ & $-1 \cdot 9$ & -2 & -2.067 & -2.102 & -2.137 & $-2 \cdot 173$ & $-2 \cdot 208$ & $-2 \cdot 243$ & -50 \\
\hline-40 & -1.527 & -1.563 & -1.600 & -1.636 & -1.673 & -1.709 & -1.745 & -1.781 & -1.817 & -1.853 & -1.889 & -40 \\
\hline-30 & -1.156 & -1.193 & -1.231 & $-1 \cdot 268$ & -1.305 & -1.342 & -1.379 & -1.416 & -1.453 & -1.490 & -1.527 & -30 \\
\hline & -0.777 & & -0 & -0 . & -0.930 & -0.968 & -1.005 & -1.043 & -1.081 & -1.118 & -1.156 & -20 \\
\hline-1 & -0.392 & -0.431 & -0.469 & -0.508 & -0.547 & -0.585 & -0.624 & -0.662 & -0.701 & -0.7 & -0 & -10 \\
\hline 8 & & -0.039 & -0.079 & -0.118 & -0.157 & -0.197 & -0.236 & -0.275 & -0.314 & -0.353 & -0.392 & - \\
\hline${ }^{\circ} \mathrm{C}$ & 0 & 1 & 2 & 3 & 4 & 5 & 6 & 7 & 8 & 9 & 10 & ${ }^{\circ} \mathrm{C}$ \\
\hline
\end{tabular}


TABLE A7.1.1. Type $\boldsymbol{K}$ thermocouples-thermoelectric voltage as a function of temperature $\left({ }^{\circ} \mathrm{C}\right)$, reference junctions at $0^{\circ} \mathrm{C}$-Continued

45

THERMOELECTRIC VOLTAGE IN ABSOLUTE MILLIVOLTS

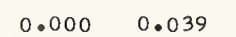

0.397

0.039

0.079

0.397

0.437

0.079
0.477

0.119

0.158

0.198

$0.879-0.919$

$1.285 \quad 1.325$

0.557

$0.198 \quad 0.238$

0.277

$0.960 \quad 1.000$

0.637

0.677

0.317

1.407

1.448

1.081

0.718
1.122

$1.611 \quad 1.652$

1.69

1.734

1.776

1.817

1.858

1.899

1.529

$2.146 \quad 2.188$

2.229

2.270

2.312

2.519
2.933

3. 349

2.560

2.975
3.390

2.501
3.016

2.643

2.270
2.684

2.312
2.726

1.940

$3.266 \quad 3.307$

3.681

3.722

3.805

3.432
3.847

3.058
3.473

3.100

3.141

2.353
2.767

3.888

3.930

3.971

4.178

4. 219

4. 261

4.549

5.001

4.632

4.673

4. 302

4.343

4. 384

4.960

5.368

5.409

5.042

5.083

4.714

4.755

4. 796

5.531

5.164

5.205

5.895

5.936

5. 976

5.612

6.218

6.258

6.298

6.338

6.378

6.016

6.619
7.019

6.659

6.699

6.739

6.779

6.419

7.139

7.179

6.819

7.498

7.937

7.578
7.977

7.618

3.183

4.012

7.817

7.857

7.897

8.336

8.216
8.617

8.256

8. 296

9.018

8.657

8.697

8.737

8.376

8.017

4.426

4.837

5.246

5.652
6.057

8.777

8.416

9.058

9.099

9.139

9.179

8.817

6.459

6.859

7.259

7.658

9.583

9.220

8.456

9.826

9.462
9.867

9.907

9.948

9.989

10.029

8.857

9.260

1.274

$10.315 \quad 10.355$

$\begin{array}{ll}10.233 & 1.274 \\ 10.641 & 10.682\end{array}$

$11.051 \quad 11.093$

$\begin{array}{ll}10.560 & 10.600 \\ 10.969 & 11.010\end{array}$

$\begin{array}{ll}11.381 & 11.422 \\ 11.793 & 11.835\end{array}$

11.876

11.504

$10.723 \quad 10.764$

$11.134 \quad 11.175$

11.546

11.175
11.587

10.39

10.070

0.357

$0.758 \quad 0.798$

1.203

$\begin{array}{ll}1.570 & 1.611 \\ 1.981 & 2.022\end{array}$

2.394

2.436

$2.809 \quad 2.850$

$3.224 \quad 3.266$

$3.639 \quad 3.681$

4.095

4.467

4.508

4.919

6.097

5.733

6.499

6.539

6.899

7.299

6.939

7.697

7.338

7.737

8.497

8.537

$8.898 \quad 8.938$

$9.300 \quad 9.341$

$9.705 \quad 9.745$

$10.111 \quad 10.151$

$\begin{array}{lllll}0.805 & 10.846 & 10.478 & 10.519 & 10.560\end{array}$

$\begin{array}{lllll}1.216 & 11.257 & 11.298 & 11.339 & 11.381\end{array}$

$\begin{array}{lllll}1.628 & 11.669 & 11.711 & 11.752 & 11.793\end{array}$

$12.207 \quad 12.249$

$12.623 \quad 12.564 \quad 12.290$

$\begin{array}{lll}12.623 & 12.664 & 12.706 \\ 13.039 & 13.080 & 13.122\end{array}$

12.332

12.373

12.000

12.083

2.125

2.166

12.207

$12.747 \quad 12.789$

$13.164 \quad 13.205$

12.83

12.456

$12.498 \quad 12.539$

13.539

$13.874 \quad 13.915$

13.957

13.581

13.623

13.247

13.28

$12.914 \quad 12.955$

12.581

12.623

$2.997 \quad 13.039$

$13.414 \quad 13.456$

$\begin{array}{lllll}3.705 & 13.748 & 13.790 & 13.832 & 13.874\end{array}$

$14.292 \quad 14.334$

14.376

4.418

14.041

$14.083 \quad 14.125$

$14.167 \quad 14.208$

4.250

14.292

14.838

14.460

$14.502 \quad 14.544$

14.586

14.796

15.636

14.838

16.100

15.721

14.922

14.96
15.384

14.58
15.006

14.628

14.670

14.712

$\begin{array}{lllll}14.964 & 15.006 & 15.048 & 15.090 & 15.132 \\ 15.384 & 15.426 & 15.468 & 15.510 & 15.552\end{array}$

$15.552 \quad 15.594$

15.974

16.016

16.058

16.142

16.184

$\begin{array}{lll}1505 & 15.847 & 15.468\end{array}$

$\begin{array}{lll}15.805 & 15.847 & 15.889 \\ 16.227 & 16.269 & 16.311\end{array}$

15.931

15.552

15.974

16.522

$16.564 \quad 16.607$

16.902

17.326

16.945

17.368

16.987

16.64

16.691

16.733

$\begin{array}{llllll}16.987 & 17.029 & 17.072 & 17.114 & 17.156 & 17.199 \\ 17.410 & 17.453 & 17.495 & 17.537 & 17.580 & 17.522\end{array}$

16.818

17.241

17.664

18.088

$\begin{array}{lll}18.216 & 18.258 & 18.301\end{array}$

$17.919 \quad 17.961$

$18.004 \quad 18.046$

$\begin{array}{lll}18.088 & 18.131 & 18.173\end{array}$

$18.513 \quad 18.555 \quad 18.598$

18.640

$18.683 \quad 18.725$

18.76

18.810

$18.853-18.895$

19.065

19.108

19.150 
TABLE A7.1.1. Type K thermocouples-thermoelectric voltage as a function of temperature $\left({ }^{\circ} \mathrm{C}\right)$, reference junctions at $0^{\circ} \mathrm{C}-$ Continued

${ }^{\circ} \mathrm{C}$

600
610
620
630
640
650
660
670
680
690
700
710
720
730
740
750
760
770
780
790
800
810
820
830
840
850
860
870
880
890
900
910
920
930
940
950
960
970
980
990

1.000

1,010

1,020

1,030

1,040

1,050

1,060

1,070

1,080

1,090

1,100

1,110

1,130
1,140

1,150

1,160

1,170

1,180

1,190

1,200
23

3

4

5

6

7

10

${ }^{\circ} \mathrm{C}$

THERMOELECTRIC VOLTAGE IN ABSOLUTE MILLIVOLTS

\begin{tabular}{|c|c|c|c|c|c|c|c|c|c|c|c|}
\hline $\begin{array}{l}24.902 \\
25.327 \\
25.751 \\
26.176 \\
26.599\end{array}$ & $\begin{array}{l}24.944 \\
25.369 \\
25.794 \\
26.218 \\
26.642\end{array}$ & $\begin{array}{l}24.987 \\
25.412 \\
25.836 \\
26.260 \\
26.684\end{array}$ & $\begin{array}{l}25.029 \\
25.454 \\
25.879 \\
26.303 \\
26.726\end{array}$ & $\begin{array}{l}25.072 \\
25.497 \\
25.921 \\
26.345 \\
26.769\end{array}$ & $\begin{array}{l}25.114 \\
25.539 \\
25.964 \\
26.387 \\
26.811\end{array}$ & $\begin{array}{l}25.157 \\
25.582 \\
26.006 \\
26.430 \\
26.853\end{array}$ & $\begin{array}{l}25.199 \\
25.624 \\
26.048 \\
26.472 \\
26.896\end{array}$ & $\begin{array}{l}25 \cdot 242 \\
25.666 \\
26.091 \\
26.515 \\
26.938\end{array}$ & $\begin{array}{l}25.284 \\
25.709 \\
26.133 \\
26.557 \\
26.980\end{array}$ & $\begin{array}{l}25.327 \\
25.751 \\
26.176 \\
26.599 \\
27.022\end{array}$ & $\begin{array}{l}600 \\
610 \\
620 \\
630 \\
640\end{array}$ \\
\hline $\begin{array}{l}7.022 \\
7.445 \\
27.867 \\
28.288 \\
28.709\end{array}$ & $\begin{array}{l}27.065 \\
27.487 \\
27.909 \\
28.330 \\
28.751\end{array}$ & $\begin{array}{l}27.107 \\
27.529 \\
27.951 \\
28.372 \\
28.793\end{array}$ & $\begin{array}{l}27.149 \\
27.572 \\
27.993 \\
28.414 \\
28.835\end{array}$ & $\begin{array}{l}27.192 \\
27.614 \\
28.035 \\
28.456 \\
28.877\end{array}$ & $\begin{array}{l}27.234 \\
27.656 \\
28.078 \\
28.498 \\
28.919\end{array}$ & $\begin{array}{l}27.276 \\
27.698 \\
28.120 \\
28.540 \\
28.961\end{array}$ & $\begin{array}{l}27.318 \\
27.740 \\
28.162 \\
28.583 \\
29.002\end{array}$ & $\begin{array}{l}27.361 \\
27.783 \\
28.204 \\
28.625 \\
29.044\end{array}$ & $\begin{array}{l}27.403 \\
27.825 \\
28.246 \\
28.667 \\
29.086\end{array}$ & $\begin{array}{l}27.445 \\
27.867 \\
28.288 \\
28.709 \\
29.128\end{array}$ & $\begin{array}{l}650 \\
660 \\
670 \\
680 \\
690\end{array}$ \\
\hline $\begin{array}{l}29.128 \\
29.547 \\
29.965 \\
30.383 \\
30.799\end{array}$ & $\begin{array}{l}29.170 \\
29.589 \\
30.007 \\
30.424 \\
30.840\end{array}$ & $\begin{array}{l}29.212 \\
29.631 \\
30.049 \\
30.466 \\
30.882\end{array}$ & $\begin{array}{l}29.254 \\
29.673 \\
30.091 \\
30.508 \\
30.924\end{array}$ & $\begin{array}{l}29.296 \\
29.715 \\
30.132 \\
30.549 \\
30.965\end{array}$ & $\begin{array}{l}29.338 \\
29.756 \\
30.174 \\
30.591 \\
31.007\end{array}$ & $\begin{array}{l}29.380 \\
29.798 \\
30.216 \\
30.632 \\
31.048\end{array}$ & $\begin{array}{l}29.422 \\
29.840 \\
30.257 \\
30.674 \\
31.090\end{array}$ & $\begin{array}{l}29.464 \\
29.882 \\
30.299 \\
30.716 \\
31.131\end{array}$ & $\begin{array}{l}29.505 \\
29.924 \\
30.341 \\
30.757 \\
31.173\end{array}$ & $\begin{array}{l}29.547 \\
29.965 \\
30.383 \\
30.799 \\
31.214\end{array}$ & $\begin{array}{l}700 \\
710 \\
720 \\
730 \\
740\end{array}$ \\
\hline $\begin{array}{l}31.214 \\
31.629 \\
32.042 \\
32.455 \\
32.866\end{array}$ & $\begin{array}{l}31.256 \\
31.670 \\
32.084 \\
32.496 \\
32.907\end{array}$ & $\begin{array}{l}31.297 \\
31.712 \\
32.125 \\
32.537 \\
32.948\end{array}$ & $\begin{array}{l}31.339 \\
31.753 \\
32.166 \\
32.578 \\
32.990\end{array}$ & $\begin{array}{l}31.380 \\
31.794 \\
32.207 \\
32.619 \\
33.031\end{array}$ & $\begin{array}{l}31.422 \\
31.836 \\
32.249 \\
32.661 \\
33.072\end{array}$ & $\begin{array}{l}31.463 \\
31.877 \\
32.290 \\
32.702 \\
33.113\end{array}$ & $\begin{array}{l}31.504 \\
31.918 \\
32.331 \\
32.743 \\
33.154\end{array}$ & $\begin{array}{l}31.546 \\
31.960 \\
32.372 \\
32.784 \\
33.195\end{array}$ & $\begin{array}{l}31.587 \\
32.001 \\
32.414 \\
32.825 \\
33.236\end{array}$ & $\begin{array}{l}31.629 \\
32.042 \\
32.455 \\
32.866 \\
33.277\end{array}$ & $\begin{array}{l}750 \\
760 \\
770 \\
780 \\
790\end{array}$ \\
\hline $\begin{array}{l}33.277 \\
33.686 \\
34.095 \\
34.502 \\
34.909\end{array}$ & $\begin{array}{l}33.318 \\
33.727 \\
34.136 \\
34.543 \\
34.949\end{array}$ & $\begin{array}{l}33.359 \\
33.768 \\
34.176 \\
34.583 \\
34.990\end{array}$ & $\begin{array}{l}33.400 \\
33.809 \\
34.217 \\
34.624 \\
35.030\end{array}$ & $\begin{array}{l}33.441 \\
33.850 \\
34.258 \\
34.665 \\
35.071\end{array}$ & $\begin{array}{l}33.482 \\
33.891 \\
34.299 \\
34.705 \\
35.111\end{array}$ & $\begin{array}{l}33.523 \\
33.931 \\
34.339 \\
34.746 \\
35.152\end{array}$ & $\begin{array}{l}33.564 \\
33.972 \\
34.380 \\
34.787 \\
35.192\end{array}$ & $\begin{array}{l}3.604 \\
4.013 \\
4.421 \\
4.827 \\
5.233\end{array}$ & $\begin{array}{l}33.645 \\
34.054 \\
34.461 \\
34.868 \\
35.273\end{array}$ & $\begin{array}{l}33.686 \\
34.095 \\
34.502 \\
34.909 \\
35.314\end{array}$ & $\begin{array}{l}800 \\
810 \\
820 \\
830 \\
840\end{array}$ \\
\hline $\begin{array}{l}35.314 \\
35.718 \\
36.121 \\
36.524 \\
36.925\end{array}$ & $\begin{array}{l}35.354 \\
35.758 \\
36.162 \\
36.564 \\
36.965\end{array}$ & $\begin{array}{l}35.395 \\
35.799 \\
36.202 \\
36.604 \\
37.005\end{array}$ & $\begin{array}{l}35.435 \\
35.839 \\
36.242 \\
36.644 \\
37.045\end{array}$ & $\begin{array}{l}35.476 \\
35.880 \\
36.282 \\
36.684 \\
37.085\end{array}$ & $\begin{array}{l}35.516 \\
35.920 \\
36.323 \\
36.724 \\
37.125\end{array}$ & $\begin{array}{l}35.557 \\
35.960 \\
36.363 \\
36.764 \\
37.165\end{array}$ & $\begin{array}{l}35.597 \\
36.000 \\
36.403 \\
36.804 \\
37.205\end{array}$ & $\begin{array}{l}35.637 \\
36.041 \\
36.443 \\
36.844 \\
37.245\end{array}$ & $\begin{array}{l}35.678 \\
36.081 \\
36.483 \\
36.885 \\
37.285\end{array}$ & $\begin{array}{l}35.718 \\
36.121 \\
36.524 \\
36.925 \\
37.325\end{array}$ & $\begin{array}{l}850 \\
860 \\
870 \\
880 \\
890\end{array}$ \\
\hline $\begin{array}{l}37.325 \\
37.724 \\
38.122 \\
38.519 \\
38.915\end{array}$ & $\begin{array}{l}37.365 \\
37.764 \\
38.162 \\
38.558 \\
38.954\end{array}$ & $\begin{array}{l}37.405 \\
37.803 \\
38.201 \\
38.598 \\
38.994\end{array}$ & $\begin{array}{l}37.445 \\
37.843 \\
38.241 \\
38.638 \\
39.033\end{array}$ & $\begin{array}{l}37.484 \\
37.883 \\
38.281 \\
38.677 \\
39.073\end{array}$ & $\begin{array}{l}37.524 \\
37.923 \\
38.320 \\
38.717 \\
39.112\end{array}$ & $\begin{array}{l}37.564 \\
37.963 \\
38.360 \\
38.756 \\
39.152\end{array}$ & $\begin{array}{l}37.604 \\
38.002 \\
38.400 \\
38.796 \\
39.191\end{array}$ & $\begin{array}{l}37.644 \\
38.042 \\
38.439 \\
38.836 \\
39.231\end{array}$ & $\begin{array}{l}37.684 \\
38.082 \\
38.479 \\
38.875 \\
39.270\end{array}$ & $\begin{array}{l}37.724 \\
38.122 \\
38.519 \\
38.915 \\
39.310\end{array}$ & $\begin{array}{l}900 \\
910 \\
920 \\
930 \\
940\end{array}$ \\
\hline $\begin{array}{l}39.310 \\
39.703 \\
40.096\end{array}$ & $\begin{array}{l}39.349 \\
39.743 \\
40.136\end{array}$ & $\begin{array}{l}39.388 \\
39.782 \\
40.175\end{array}$ & & $\begin{array}{l}39.467 \\
39.861 \\
40.253\end{array}$ & & & & & & & $\begin{array}{l}950 \\
960 \\
970\end{array}$ \\
\hline $\begin{array}{l}40.488 \\
40.879\end{array}$ & $\begin{array}{l}40.527 \\
40.918\end{array}$ & $\begin{array}{l}40.566 \\
40.957\end{array}$ & $\begin{array}{l}40.605 \\
40.996\end{array}$ & $\begin{array}{l}40.645 \\
41.035\end{array}$ & & $\begin{array}{l}40.723 \\
41.113\end{array}$ & $\begin{array}{l}40.762 \\
41.152\end{array}$ & & $\begin{array}{l}40.840 \\
41.230\end{array}$ & & $\begin{array}{l}980 \\
990\end{array}$ \\
\hline $\begin{array}{l}41.269 \\
41.657 \\
42.045 \\
42.432 \\
42.817\end{array}$ & $\begin{array}{l}41.308 \\
41.696 \\
42.084 \\
42.470 \\
42.856\end{array}$ & $\begin{array}{l}41.347 \\
41.735 \\
42.123 \\
42.509 \\
42.894\end{array}$ & $\begin{array}{l}41.385 \\
41.774 \\
42.161 \\
42.548 \\
42.933\end{array}$ & $\begin{array}{l}41.424 \\
41.813 \\
42.200 \\
42.586 \\
42.971\end{array}$ & $\begin{array}{l}41.463 \\
41.851 \\
42.239 \\
42.625 \\
43.010\end{array}$ & $\begin{array}{l}41.502 \\
41.890 \\
42.277 \\
42.663 \\
43.048\end{array}$ & $\begin{array}{l}41.541 \\
41.929 \\
42.316 \\
42.702 \\
43.087\end{array}$ & $\begin{array}{l}41.580 \\
41.968 \\
42.355 \\
42.740 \\
43.125\end{array}$ & $\begin{array}{l}41.619 \\
42.006 \\
42.393 \\
42.779 \\
43.164\end{array}$ & $\begin{array}{l}41.657 \\
42.045 \\
42.432 \\
42.817 \\
43.202\end{array}$ & $\begin{array}{l}.000 \\
.010 \\
.020 \\
.030 \\
.040\end{array}$ \\
\hline $\begin{array}{l}43.202 \\
43.585 \\
43.968 \\
44.349 \\
44.729\end{array}$ & $\begin{array}{l}43.240 \\
43.624 \\
44.006 \\
44.387 \\
44.767\end{array}$ & $\begin{array}{l}43.279 \\
43.662 \\
44.044 \\
44.425 \\
44.805\end{array}$ & $\begin{array}{l}43.317 \\
43.700 \\
44.082 \\
44.463 \\
44.843\end{array}$ & $\begin{array}{l}43.356 \\
43.739 \\
44.121 \\
44.501 \\
44.881\end{array}$ & $\begin{array}{l}43.394 \\
43.777 \\
44.159 \\
44.539 \\
44.919\end{array}$ & $\begin{array}{l}43.432 \\
43.815 \\
44.197 \\
44.577 \\
44.957\end{array}$ & $\begin{array}{l}43.471 \\
43.853 \\
44.235 \\
44.615 \\
44.995\end{array}$ & $\begin{array}{l}43.509 \\
43.891 \\
44.273 \\
44.653 \\
45.033\end{array}$ & $\begin{array}{l}43.547 \\
43.930 \\
44.311 \\
44.691 \\
45.070\end{array}$ & $\begin{array}{l}43.585 \\
43.968 \\
44.349 \\
44.729 \\
45.108\end{array}$ & $\begin{array}{l}1,050 \\
1,060 \\
1,070 \\
1,080 \\
1,090\end{array}$ \\
\hline $\begin{array}{l}45.108 \\
45.486 \\
45.863 \\
46.238 \\
46.612\end{array}$ & $\begin{array}{l}45.146 \\
45.524 \\
45.900 \\
46.275 \\
46.649\end{array}$ & $\begin{array}{l}45.184 \\
45.561 \\
45.938 \\
46.313 \\
46.687\end{array}$ & $\begin{array}{l}45 \cdot 222 \\
45.599 \\
45.975 \\
46.350 \\
46.724\end{array}$ & $\begin{array}{l}45.260 \\
45.637 \\
46.013 \\
46.388 \\
46.761\end{array}$ & $\begin{array}{l}45.297 \\
45.675 \\
46.051 \\
46.425 \\
46.799\end{array}$ & $\begin{array}{l}45.335 \\
45.712 \\
46.088 \\
46.463 \\
46.836\end{array}$ & $\begin{array}{l}5.373 \\
5.750 \\
6.126 \\
6.500 \\
6.873\end{array}$ & $\begin{array}{l}45.411 \\
45.787 \\
46.163 \\
46.537 \\
46.910\end{array}$ & $\begin{array}{l}45.448 \\
45.825 \\
46.201 \\
46.575 \\
46.948\end{array}$ & $\begin{array}{l}45.486 \\
45.863 \\
46.238 \\
46.612 \\
46.985\end{array}$ & $\begin{array}{l}1,100 \\
1,110 \\
1,120 \\
1,130 \\
1,140\end{array}$ \\
\hline $\begin{array}{l}46.985 \\
47.356 \\
47.726 \\
48.095 \\
48.462\end{array}$ & $\begin{array}{l}47.022 \\
47.393 \\
47.763 \\
48.132 \\
48.499\end{array}$ & $\begin{array}{l}47.059 \\
47.430 \\
47.800 \\
48.169 \\
48.536\end{array}$ & $\begin{array}{l}47.096 \\
47.468 \\
47.837 \\
48.205 \\
48.572\end{array}$ & $\begin{array}{l}47.134 \\
47.505 \\
47.874 \\
48.242 \\
48.609\end{array}$ & $\begin{array}{l}47.171 \\
47.542 \\
47.911 \\
48.279 \\
48.645\end{array}$ & $\begin{array}{l}47.208 \\
47.579 \\
47.948 \\
48.316 \\
48.682\end{array}$ & $\begin{array}{l}47.245 \\
47.616 \\
47.985 \\
48.352 \\
48.718\end{array}$ & $\begin{array}{l}47.282 \\
47.653 \\
48.021 \\
48.389 \\
48.755\end{array}$ & $\begin{array}{l}47.319 \\
47.689 \\
48.058 \\
48.426 \\
48.792\end{array}$ & $\begin{array}{l}47.356 \\
47.726 \\
48.095 \\
48.462 \\
48.828\end{array}$ & $\begin{array}{l}1,150 \\
1,160 \\
1,170 \\
1,180 \\
1,190\end{array}$ \\
\hline 828 & 3.865 & .901 & 48.937 & 8.974 & 49,010 & 49.047 & 49.083 & 49.120 & 49.156 & 49.192 & .200 \\
\hline
\end{tabular}

4

5

6

7

8

9

10
10

630

650

660
670

680

690

710

20

740

750

770

790

800

810

840

850

870

880
890

900

920

930
940

950

960
970

80

.000

.020

, 030
, 040

.050 , 060
, 070 , 080

090

110 , 130

150 , 160 180 , 200 
TABLE A7.1.1. Type K thermocouples-thermoelectric voltage as a function of temperature $\left({ }^{\circ} \mathrm{C}\right)$, reference junctions at $0^{\circ} \mathrm{C}$-Continued

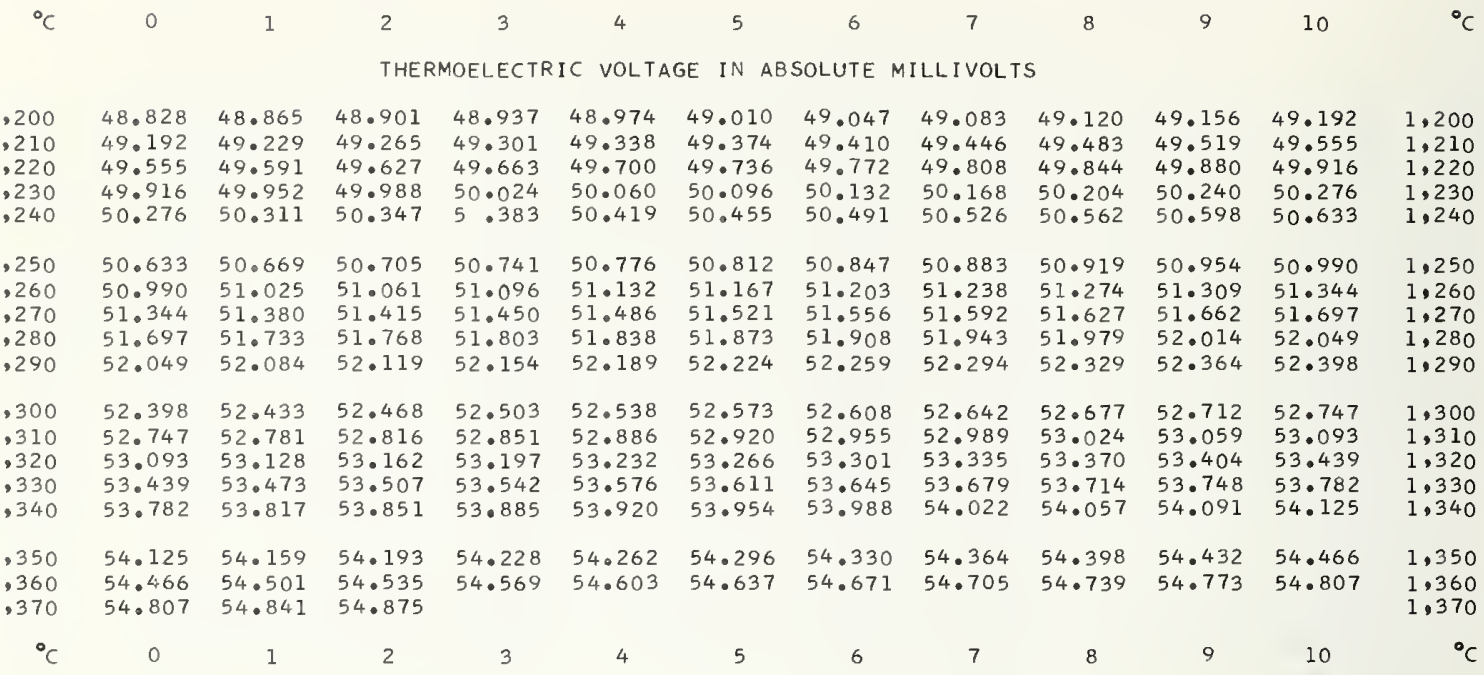


TABLE A7.1.2. Type $\boldsymbol{K}$ thermocouples-thermoelectric voltage as a function of temperature $\left({ }^{\circ} \mathrm{F}\right)$, reference junctions at $32^{\circ} \mathrm{F}$

\begin{tabular}{|c|c|c|}
\hline${ }^{\circ} \mathrm{F}$ & 0 & 1 \\
\hline-450 & -6.456 & -6.456 \\
\hline $\begin{array}{l}-440 \\
-430 \\
-420 \\
-410 \\
-400\end{array}$ & $\begin{array}{l}-6.447 \\
-6.431 \\
-6.409 \\
-6.380 \\
-6.344\end{array}$ & $\begin{array}{l}-6.448 \\
-6.433 \\
-6.411 \\
-6.383 \\
-6.348\end{array}$ \\
\hline $\begin{array}{l}-390 \\
-380 \\
-370 \\
-360 \\
-350\end{array}$ & $\begin{array}{l}-6.301 \\
-6.251 \\
-6.195 \\
-6.133 \\
-6.064\end{array}$ & $\begin{array}{l}-6.306 \\
-6.257 \\
-6.201 \\
-6.139 \\
-6.071\end{array}$ \\
\hline $\begin{array}{l}-340 \\
-330 \\
-320 \\
-310 \\
-300\end{array}$ & $\begin{array}{l}-5.989 \\
-5.908 \\
-5.822 \\
-5.730 \\
-5.632\end{array}$ & $\begin{array}{l}-5.997 \\
-5.917 \\
-5.831 \\
-5.739 \\
-5.642\end{array}$ \\
\hline $\begin{array}{l}-290 \\
-280 \\
-270 \\
-260 \\
-250\end{array}$ & $\begin{array}{l}-5.529 \\
-5.421 \\
-5.308 \\
-5.190 \\
-5.067\end{array}$ & $\begin{array}{l}-5.540 \\
-5.432 \\
-5.319 \\
-5.202 \\
-5.079\end{array}$ \\
\hline $\begin{array}{l}-240 \\
-230 \\
-220 \\
-210 \\
-200\end{array}$ & $\begin{array}{l}-4.939 \\
-4.806 \\
-4.669 \\
-4.527 \\
-4.381\end{array}$ & $\begin{array}{l}-4.952 \\
-4.819 \\
-4.683 \\
-4.541 \\
-4.396\end{array}$ \\
\hline $\begin{array}{l}-190 \\
-180 \\
-170 \\
-160 \\
-150\end{array}$ & $\begin{array}{l}-4.230 \\
-4.075 \\
-3.917 \\
-3.754 \\
-3.587\end{array}$ & $\begin{array}{l}-4.245 \\
-4.091 \\
-3.933 \\
-3.770 \\
-3.604\end{array}$ \\
\hline $\begin{array}{l}-140 \\
-130 \\
-120 \\
-110 \\
-100\end{array}$ & $\begin{array}{l}-3.417 \\
-3.242 \\
-3.065 \\
-2.883 \\
-2.699\end{array}$ & $\begin{array}{l}-3.434 \\
-3.260 \\
-3.082 \\
-2.902 \\
-2.717\end{array}$ \\
\hline $\begin{array}{l}-90 \\
-80 \\
-70 \\
-60 \\
-50\end{array}$ & $\begin{array}{l}-2.511 \\
-2.320 \\
-2.126 \\
-1.929 \\
-1.729\end{array}$ & $\begin{array}{l}-2.530 \\
-2.339 \\
-2.145 \\
-1.949 \\
-1.749\end{array}$ \\
\hline $\begin{array}{l}-40 \\
-30 \\
-20 \\
-10\end{array}$ & $\begin{array}{l}-1.527 \\
-1.322 \\
-1.114 \\
-0.904 \\
-0.692\end{array}$ & $\begin{array}{l}-1.547 \\
-1.342 \\
-1.135 \\
-0.925 \\
-0.714\end{array}$ \\
\hline
\end{tabular}

THERMOELECTRIC VOLTAGE IN ABSOLUTE MILLIVOLTS

\begin{tabular}{|c|c|c|c|c|c|c|c|c|c|}
\hline-6.457 & -6.457 & $-6 \cdot 458$ & & & & & & & -450 \\
\hline $\begin{array}{l}-6.449 \\
-6.435 \\
-6.414 \\
-6.386 \\
-6.352\end{array}$ & $\begin{array}{l}-6.450 \\
-6.436 \\
-6.416 \\
-6.389 \\
-6.355\end{array}$ & $\begin{array}{l}-6.451 \\
-6.438 \\
-6.419 \\
-6.392 \\
-6.359\end{array}$ & $\begin{array}{l}-6.452 \\
-6.440 \\
-6.421 \\
-6.395 \\
-6.363\end{array}$ & $\begin{array}{l}-6.453 \\
-6.441 \\
-6.423 \\
-6.398 \\
-6.366\end{array}$ & $\begin{array}{l}-6.454 \\
-6.443 \\
-6.425 \\
-6.401 \\
-6.370\end{array}$ & $\begin{array}{l}-6.454 \\
-6.444 \\
-6.427 \\
-6.404 \\
-6.373\end{array}$ & $\begin{array}{l}-6.455 \\
-6.445 \\
-6.429 \\
-6.406 \\
-6.377\end{array}$ & $\begin{array}{l}-6 \cdot 456 \\
-6 \cdot 447 \\
-6.431 \\
-6.409 \\
-6 \cdot 380\end{array}$ & $\begin{array}{l}-440 \\
-430 \\
-420 \\
-410 \\
-400\end{array}$ \\
\hline $\begin{array}{l}-6.310 \\
-6.262 \\
-6.207 \\
-6.146 \\
-6.078\end{array}$ & $\begin{array}{l}-6.315 \\
-6.267 \\
-6.213 \\
-6.152 \\
-6.085\end{array}$ & $\begin{array}{l}-6.319 \\
-6.272 \\
-6.219 \\
-6.158 \\
-6.092\end{array}$ & $\begin{array}{l}-6.323 \\
-6.277 \\
-6.224 \\
-6.165 \\
-6.099\end{array}$ & $\begin{array}{l}-6.328 \\
-6.282 \\
-6.230 \\
-6.171 \\
-6.106\end{array}$ & $\begin{array}{l}-6.332 \\
-6.287 \\
-6.235 \\
-6.177 \\
-6.113\end{array}$ & $\begin{array}{l}-6.336 \\
-6.292 \\
-6.241 \\
-6.183 \\
-6.119\end{array}$ & $\begin{array}{l}-6.340 \\
-6.296 \\
-6.246 \\
-6.189 \\
-6.126\end{array}$ & $\begin{array}{l}-6.344 \\
-6.301 \\
-6.251 \\
-6.195 \\
-6.133\end{array}$ & $\begin{array}{l}-390 \\
-380 \\
-370 \\
-360 \\
-350\end{array}$ \\
\hline $\begin{array}{l}-6.004 \\
-5.925 \\
-5.839 \\
-5.748 \\
-5.652\end{array}$ & $\begin{array}{l}-6.012 \\
-5.933 \\
-5.848 \\
-5.758 \\
-5.662\end{array}$ & $\begin{array}{l}-6.020 \\
-5.941 \\
-5.857 \\
-5.767 \\
-5.672\end{array}$ & $\begin{array}{l}-6.027 \\
-5.949 \\
-5.866 \\
-5.776 \\
-5.682\end{array}$ & $\begin{array}{l}-6.035 \\
-5.957 \\
-5.874 \\
-5.786 \\
-5.691\end{array}$ & $\begin{array}{l}-6.042 \\
-5.965 \\
-5.883 \\
-5.795 \\
-5.701\end{array}$ & $\begin{array}{l}-6.049 \\
-5.973 \\
-5.891 \\
-5.804 \\
-5.711\end{array}$ & $\begin{array}{l}-6.057 \\
-5.981 \\
-5.900 \\
-5.813 \\
-5.720\end{array}$ & $\begin{array}{l}-6.064 \\
-5.989 \\
-5.908 \\
-5.822 \\
-5.730\end{array}$ & $\begin{array}{l}-34 \\
-33 \\
-32 \\
-31 \\
-30\end{array}$ \\
\hline $\begin{array}{l}-5.550 \\
-5.443 \\
-5.331 \\
-5.214 \\
-5.092\end{array}$ & $\begin{array}{l}-5.561 \\
-5.454 \\
-5.342 \\
-5.226 \\
-5.104\end{array}$ & $\begin{array}{l}-5.571 \\
-5.465 \\
-5.354 \\
-5.238 \\
-5.116\end{array}$ & $\begin{array}{l}-5.581 \\
-5.476 \\
-5.365 \\
-5.249 \\
-5.129\end{array}$ & $\begin{array}{l}-5.592 \\
-5.487 \\
-5.376 \\
-5.261 \\
-5.141\end{array}$ & $\begin{array}{l}-5.602 \\
-5.497 \\
-5.388 \\
-5.273 \\
-5.153\end{array}$ & $\begin{array}{l}-5.612 \\
-5.508 \\
-5.399 \\
-5.285 \\
-5.165\end{array}$ & $\begin{array}{l}-5.622 \\
-5.519 \\
-5.410 \\
-5.296 \\
-5.178\end{array}$ & $\begin{array}{l}-5.632 \\
-5.529 \\
-5.421 \\
-5.308 \\
-5.190\end{array}$ & $\begin{array}{l}-29 \\
-28 \\
-27 \\
-26 \\
-25\end{array}$ \\
\hline $\begin{array}{l}-4.965 \\
-4.833 \\
-4.697 \\
-4.556 \\
-4.410\end{array}$ & $\begin{array}{l}-4.978 \\
-4.846 \\
-4.710 \\
-4.570 \\
-4.425\end{array}$ & $\begin{array}{l}-4.990 \\
-4.860 \\
-4.724 \\
-4.584 \\
-4.440\end{array}$ & $\begin{array}{l}-5.003 \\
-4.873 \\
-4.738 \\
-4.598 \\
-4.454\end{array}$ & $\begin{array}{l}-5.016 \\
-4.886 \\
-4.752 \\
-4.613 \\
-4.469\end{array}$ & $\begin{array}{l}-5.029 \\
-4.899 \\
-4.765 \\
-4.627 \\
-4.484\end{array}$ & $\begin{array}{l}-5.041 \\
-4.912 \\
-4.779 \\
-4.641 \\
-4.498\end{array}$ & $\begin{array}{l}-5.054 \\
-4.926 \\
-4.792 \\
-4.655 \\
-4.512\end{array}$ & $\begin{array}{l}-5.067 \\
-4.939 \\
-4.806 \\
-4.669 \\
-4.527\end{array}$ & $\begin{array}{l}-24 \\
-23 \\
-22 \\
-21 \\
-20\end{array}$ \\
\hline $\begin{array}{l}-4.261 \\
-4.107 \\
-3.949 \\
-3.787 \\
-3.621\end{array}$ & $\begin{array}{l}-4.276 \\
-4.122 \\
-3.965 \\
-3.803 \\
-3.637\end{array}$ & $\begin{array}{l}-4.291 \\
-4.138 \\
-3.981 \\
-3.819 \\
-3.654\end{array}$ & $\begin{array}{l}-4.306 \\
-4.153 \\
-3.997 \\
-3.836 \\
-3.671\end{array}$ & $\begin{array}{l}-4.321 \\
-4.169 \\
-4.012 \\
-3.852 \\
-3.688\end{array}$ & $\begin{array}{l}-4.336 \\
-4.184 \\
-4.028 \\
-3.868 \\
-3.704\end{array}$ & $\begin{array}{l}-4.351 \\
-4.200 \\
-4.044 \\
-3.884 \\
-3.721\end{array}$ & $\begin{array}{l}-4.366 \\
-4.215 \\
-4.060 \\
-3.901 \\
-3.737\end{array}$ & $\begin{array}{l}-4.381 \\
-4.230 \\
-4.075 \\
-3.917 \\
-3.754\end{array}$ & $\begin{array}{l}-19 \\
-18 \\
-17 \\
-16 \\
-15\end{array}$ \\
\hline $\begin{array}{l}-3.451 \\
-3.277 \\
-3.100 \\
-2.920 \\
-2.736\end{array}$ & $\begin{array}{l}-3.468 \\
-3.295 \\
-3.118 \\
-2.938 \\
-2.754\end{array}$ & $\begin{array}{l}-3.485 \\
-3.312 \\
-3.136 \\
-2.956 \\
-2.773\end{array}$ & $\begin{array}{l}-3.502 \\
-3.330 \\
-3.154 \\
-2.974 \\
-2.791\end{array}$ & $\begin{array}{l}-3.519 \\
-3.347 \\
-3.172 \\
-2.992 \\
-2.810\end{array}$ & $\begin{array}{l}-3.536 \\
-3.365 \\
-3.189 \\
-3.010 \\
-2.828\end{array}$ & $\begin{array}{l}-3.553 \\
-3.382 \\
-3.207 \\
-3.029 \\
-2.847\end{array}$ & $\begin{array}{l}-3.570 \\
-3.399 \\
-3.225 \\
-3.047 \\
-2.865\end{array}$ & $\begin{array}{l}-3.587 \\
-3.417 \\
-3.242 \\
-3.065 \\
-2.883\end{array}$ & $\begin{array}{l}-14 \\
-13 \\
-12 \\
-11 \\
-10\end{array}$ \\
\hline $\begin{array}{l}-2.549 \\
-2.358 \\
-2.165 \\
-1.968 \\
-1.769\end{array}$ & $\begin{array}{l}-2.567 \\
-2.377 \\
-2.184 \\
-1.988 \\
-1.789\end{array}$ & $\begin{array}{l}-2.586 \\
-2.397 \\
-2.204 \\
-2.008 \\
-1.809\end{array}$ & $\begin{array}{l}-2.605 \\
-2.416 \\
-2.223 \\
-2.028 \\
-1.829\end{array}$ & $\begin{array}{l}-2.624 \\
-2.435 \\
-2.243 \\
-2.047 \\
-1.849\end{array}$ & $\begin{array}{l}-2.643 \\
-2.454 \\
-2.262 \\
-2.067 \\
-1.869\end{array}$ & $\begin{array}{l}-2.661 \\
-2.473 \\
-2.281 \\
-2.087 \\
-1.889\end{array}$ & $\begin{array}{l}-2.680 \\
-2.492 \\
-2.300 \\
-2.106 \\
-1.909\end{array}$ & $\begin{array}{l}-2.699 \\
-2.511 \\
-2.320 \\
-2.126 \\
-1.929\end{array}$ & $\begin{array}{l}-90 \\
-80 \\
-70 \\
-60 \\
-50\end{array}$ \\
\hline $\begin{array}{l}-1.567 \\
-1.363 \\
-1.156 \\
-0.946 \\
-0.735\end{array}$ & $\begin{array}{l}-1.588 \\
-1.383 \\
-1.177 \\
-0.968 \\
-0.756\end{array}$ & $\begin{array}{l}-1.608 \\
-1.404 \\
-1.197 \\
-0.989 \\
-0.777\end{array}$ & $\begin{array}{l}-1.628 \\
-1.424 \\
-1.218 \\
-1.010 \\
-0.799\end{array}$ & $\begin{array}{l}-1.648 \\
-1.445 \\
-1.239 \\
-1.031 \\
-0.820\end{array}$ & $\begin{array}{l}-1.669 \\
-1.465 \\
-1.260 \\
-1.051 \\
-0.841\end{array}$ & $\begin{array}{l}-1.689 \\
-1.486 \\
-1.280 \\
-1.072 \\
-0.862\end{array}$ & $\begin{array}{l}-1.709 \\
-1.506 \\
-1.301 \\
-1.093 \\
-0.883\end{array}$ & $\begin{array}{l}-1.729 \\
-1.527 \\
-1.322 \\
-1.114 \\
-0.904\end{array}$ & $\begin{array}{l}-40 \\
-30 \\
-20 \\
-10 \\
-0\end{array}$ \\
\hline
\end{tabular}


TABLE A7.1.2. Type $\mathbf{K}$ thermocouples-thermoelectric voltage as a function of temperature $\left({ }^{\circ} \mathrm{F}\right)$, reference junctions at $32{ }^{\circ} \mathrm{F}$-Continued

THERMOELECTRIC VOLTAGE IN ABSOLUTE MILLIVOLTS

\begin{tabular}{|c|c|c|c|c|c|c|c|c|c|c|c|c|}
\hline 0 & -0.692 & -0.671 & -0.650 & -0.628 & -0.607 & -0.585 & -0.564 & -0.543 & -0.521 & -0.500 & -0.478 & 0 \\
\hline 10 & -0.478 & -0.457 & -0.435 & -0.413 & -0.392 & -0.370 & -0.349 & -0.327 & -0.305 & -0.284 & -0.262 & 10 \\
\hline 20 & -0.262 & $-0 \ldots 4 i$ & -0.218 & -0.197 & -0.175 & -0.153 & -0.131 & -0.109 & -0.088 & -0.066 & -0.044 & 20 \\
\hline 30 & -0.044 & $-0 \cdot c-\angle$ & 0.000 & 0.022 & 0.044 & 0.066 & 0.088 & 0.110 & 0.132 & 0.154 & 0.176 & 30 \\
\hline 40 & 0.176 & 0.198 & 0.220 & 0.242 & 0.264 & 0.286 & 0.308 & 0.331 & 0.353 & 0.375 & 0.397 & 40 \\
\hline 50 & 0.397 & 0.419 & 0.441 & 0.464 & 0.486 & 0.508 & 0.530 & 0.553 & 0.575 & 0.597 & 0.619 & 50 \\
\hline 60 & 0.619 & 0.642 & 0.664 & 0.686 & 0.709 & 0.731 & 0.753 & 0.776 & 0.798 & 0.821 & 0.843 & 60 \\
\hline 70 & 0.843 & 0.865 & 0.888 & 0.910 & 0.933 & 0.955 & 0.978 & 1.000 & 1.023 & 1.045 & 1.068 & 70 \\
\hline 80 & 1.068 & 1.090 & 1.113 & 1.135 & 1.158 & 1.181 & 1.203 & 1.226 & 1.248 & 1.271 & 1.294 & 80 \\
\hline 90 & 1.294 & 1.316 & 1.339 & 1.362 & 1.384 & 1.407 & 1.430 & 1.452 & 1.475 & 1.498 & 1.520 & 90 \\
\hline 100 & 1.520 & 1.543 & 1.566 & 1.589 & 1.611 & 1.634 & 1.657 & 1.680 & 1.703 & 1.725 & 1.748 & 100 \\
\hline 110 & 1.748 & 1.771 & 1.794 & 1.817 & 1.839 & 1.862 & 1.885 & 1.908 & 1.931 & 1.954 & 1.977 & 110 \\
\hline 120 & 1.977 & 2.000 & 2.022 & 2.045 & 2.068 & 2.091 & 2.114 & 2.137 & 2.160 & 2.183 & 2.206 & 120 \\
\hline 130 & 2.206 & 2.229 & 2.252 & 2.275 & 2.298 & 2.321 & 2.344 & 2.367 & 2.390 & 2.413 & 2.436 & 130 \\
\hline 140 & 2.436 & 2.459 & 2.482 & 2.505 & 2.528 & 2.551 & 2.574 & 2.597 & 2.620 & 2.643 & 2.666 & 140 \\
\hline 150 & 2.666 & 2.689 & 2.712 & 2.735 & 2.758 & 2.781 & 2.804 & 2.827 & 2.850 & 2.873 & 2.896 & 150 \\
\hline 160 & 2.896 & 2.920 & 2.943 & 2.966 & 2.989 & 3.012 & 3.035 & 3.058 & 3.081 & 3.104 & 3.127 & 160 \\
\hline $\begin{array}{l}170 \\
170\end{array}$ & 3.127 & 3.150 & 3.173 & 3.196 & 3.220 & 3.243 & 3.266 & 3.289 & 3.312 & 3.335 & 3.358 & 170 \\
\hline 180 & 3.358 & 3.381 & 3.404 & 3.427 & 3.450 & 3.473 & 3.496 & 3.519 & 3.543 & 3.566 & 3.589 & 180 \\
\hline 190 & 3.589 & 3.612 & 3.635 & 3.658 & 3.681 & 3.704 & 3.727 & 3.750 & 3.773 & 3.796 & 3.819 & 190 \\
\hline 200 & 3.819 & 3.842 & 3.865 & 3.888 & 3.911 & 3.934 & 3.957 & 3.980 & 4.003 & 4.026 & 4.049 & 200 \\
\hline 210 & 4.049 & 4.072 & 4.095 & 4.118 & 4.141 & 4.164 & 4.187 & 4.210 & 4.233 & 4.256 & 4.279 & 210 \\
\hline 220 & 4.279 & 4.302 & 4.325 & 4.348 & 4.371 & 4.394 & 4.417 & 4.439 & 4.462 & 4.485 & 4.508 & 220 \\
\hline 230 & 4.508 & 4.531 & 4.554 & 4.577 & 4.600 & 4.622 & 4.645 & 4.668 & 4.691 & 4.714 & 4.737 & 230 \\
\hline 240 & 4.737 & 4.759 & 4.782 & 4.805 & 4.828 & 4.851 & 4.873 & 4.896 & 4.919 & 4.942 & 4.964 & 240 \\
\hline 250 & 4.964 & 4.987 & 5.010 & 5.033 & 5.055 & 5.078 & 5.101 & 5.124 & 5.146 & 5.169 & 5.192 & 250 \\
\hline 260 & 5.192 & 5.214 & 5.237 & 5.260 & 5.282 & 5.305 & 5.327 & 5.350 & 5.373 & 5.395 & 5.418 & 260 \\
\hline 270 & 5.418 & 5.440 & 5.463 & 5.486 & 5.508 & 5.531 & 5.553 & 5.576 & 5.598 & 5.621 & 5.643 & 270 \\
\hline 280 & 5.643 & 5.666 & 5.688 & 5.711 & 5.733 & 5.756 & 5.778 & 5.801 & 5.823 & 5.846 & 5.868 & 280 \\
\hline 290 & 5.868 & 5.891 & 5.913 & 5.936 & 5.958 & 5.980 & 6.003 & 6.025 & 6.048 & 6.070 & 6.092 & 290 \\
\hline 300 & 6.092 & 6.115 & 6.137 & 6.160 & 6.182 & 6.204 & 6.227 & 6.249 & 6.271 & 6.294 & 6.316 & 300 \\
\hline 310 & 6.316 & 6.338 & 6.361 & 6.383 & 6.405 & 6.428 & 6.450 & 6.472 & 6.494 & 6.517 & 6.539 & 310 \\
\hline 320 & 6.539 & 6.561 & 6.583 & 6.606 & 6.628 & 6.650 & 6.672 & 6.695 & 6.717 & 6.739 & 6.761 & 320 \\
\hline 330 & 6.761 & 6.784 & 6.806 & 6.828 & 6.850 & 6.873 & 6.895 & 6.917 & 6.939 & 6.961 & 6.984 & 330 \\
\hline 340 & 6.984 & 7.006 & 7.028 & 7.050 & 7.072 & 7.094 & 7.117 & 7.139 & 7.161 & 7.183 & 7.205 & 340 \\
\hline 350 & 7.205 & 7.228 & 7.250 & 7.272 & 7.294 & 7.316 & 7.338 & 7.361 & 7.383 & 7.4 & 7.427 & 350 \\
\hline 360 & 7.427 & 7.449 & 7.471 & 7.494 & 7.516 & 7.538 & 7.560 & 7.582 & 7.604 & 7.627 & 7.649 & 360 \\
\hline 370 & 7.649 & 7.671 & 7.693 & 7.715 & 7.737 & 7.760 & 7.782 & 7.804 & 7.826 & 7.848 & 7.870 & 370 \\
\hline 380 & 7.870 & 7.893 & 7.915 & 7.937 & 7.959 & 7.981 & 8.003 & 8.026 & 8.048 & 8.070 & 8.092 & 380 \\
\hline 390 & 8.092 & 8.114 & 8.137 & 8.159 & 8.181 & 8.203 & 8.225 & 8.248 & 8.270 & 8.292 & 8.314 & 390 \\
\hline 400 & 8.314 & 336 & 8.359 & 8.381 & 3 & 8.425 & 8.448 & 8.470 & 8.492 & 8.5 & 8.537 & 400 \\
\hline 410 & 8.537 & 8.559 & 8 & 8.603 & 5 & 8.648 & & & & & & 410 \\
\hline 420 & 8.759 & 8.782 & 8.804 & 8.826 & 8.849 & 8.871 & 8.893 & 8.916 & 8.938 & 8.960 & 8.983 & 420 \\
\hline 430 & 8.983 & 9.005 & 9.027 & 9.0 & 9.072 & 9.094 & 9.117 & 9.139 & 9.161 & 9.184 & 9.206 & 430 \\
\hline 440 & 9.206 & 9.229 & 9.251 & 9.273 & 9.296 & 9.318 & 9.341 & 9.363 & 9.385 & 9.408 & 9.430 & 440 \\
\hline 450 & 9.430 & 9.453 & 9.475 & 9. & 9.5 & 9.5 & 9.565 & 9.588 & 9.6 & 3 & 9. & 450 \\
\hline 460 & 9.655 & 9.678 & & 9.7 & 9.745 & 9.768 & 9.790 & 9.813 & 9.835 & 9.858 & & 460 \\
\hline 470 & & & & & & & & & & 10. & & 470 \\
\hline 480 & 10.106 & 10.129 & 10.151 & 10.174 & 10.197 & 10.219 & 242 & 10.265 & 10.287 & 10.310 & & 480 \\
\hline 490 & 10.333 & 10.355 & 10.378 & 10.401 & 10.423 & 10.446 & 10.469 & 10.491 & 10.514 & 10.537 & 10.560 & 490 \\
\hline 500 & 10.560 & 82 & 5 & 28 & 0 & 3 & & & +1 & & & 500 \\
\hline 510 & 7 & & & & & & & & & & & 510 \\
\hline 520 & 11.015 & 11.038 & 11.061 & 11.083 & 11.106 & 11.129 & & & & & & 520 \\
\hline 530 & 11.243 & 11.266 & 11.289 & 11.312 & 11.335 & 11.358 & 11.381 & 11.404 & 11.426 & 11.449 & 11.472 & 530 \\
\hline 540 & 11.472 & 11.495 & 11.518 & 11.541 & 11.564 & 11.587 & 11.610 & 11.633 & 11.656 & 11.679 & 11.702 & 540 \\
\hline 550 & 11.702 & 11.725 & 11.748 & 11.770 & 11.793 & 11.8 & 11 & 52 & 11.885 & 58 & 11 & 550 \\
\hline 560 & & 11.954 & 11. & & $12 \cdot 0$ & & & & & & & 560 \\
\hline 570 & 12.161 & 12.184 & 12.207 & 12.230 & 12.254 & 12.277 & 12 & 12 & & 12 & & 570 \\
\hline 580 & 12.392 & 12.415 & 12.438 & 12.461 & 12.484 & 12.507 & 12.530 & 12.553 & 12.576 & 12.599 & 12.623 & 580 \\
\hline 590 & 12.623 & 12.646 & 12.669 & 12.692 & 12.715 & 12.738 & 12.761 & 12.784 & 12.807 & 12.831 & 12.854 & 590 \\
\hline 00 & 12.854 & 12.877 & 12.900 & 12.923 & 12.946 & 12.969 & 12.992 & 13.016 & 13.039 & 13.062 & 13.085 & 600 \\
\hline
\end{tabular}


TABLE A7.1.2. Type $\boldsymbol{K}$ thermocouples-thermoelectric voltage as a function of temperature $\left({ }^{\circ} \mathrm{F}\right)$, reference junctions at $32^{\circ} \mathrm{F}$-Continued

${ }^{\circ} \mathrm{F}$

0

23

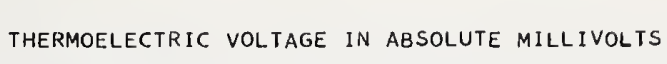

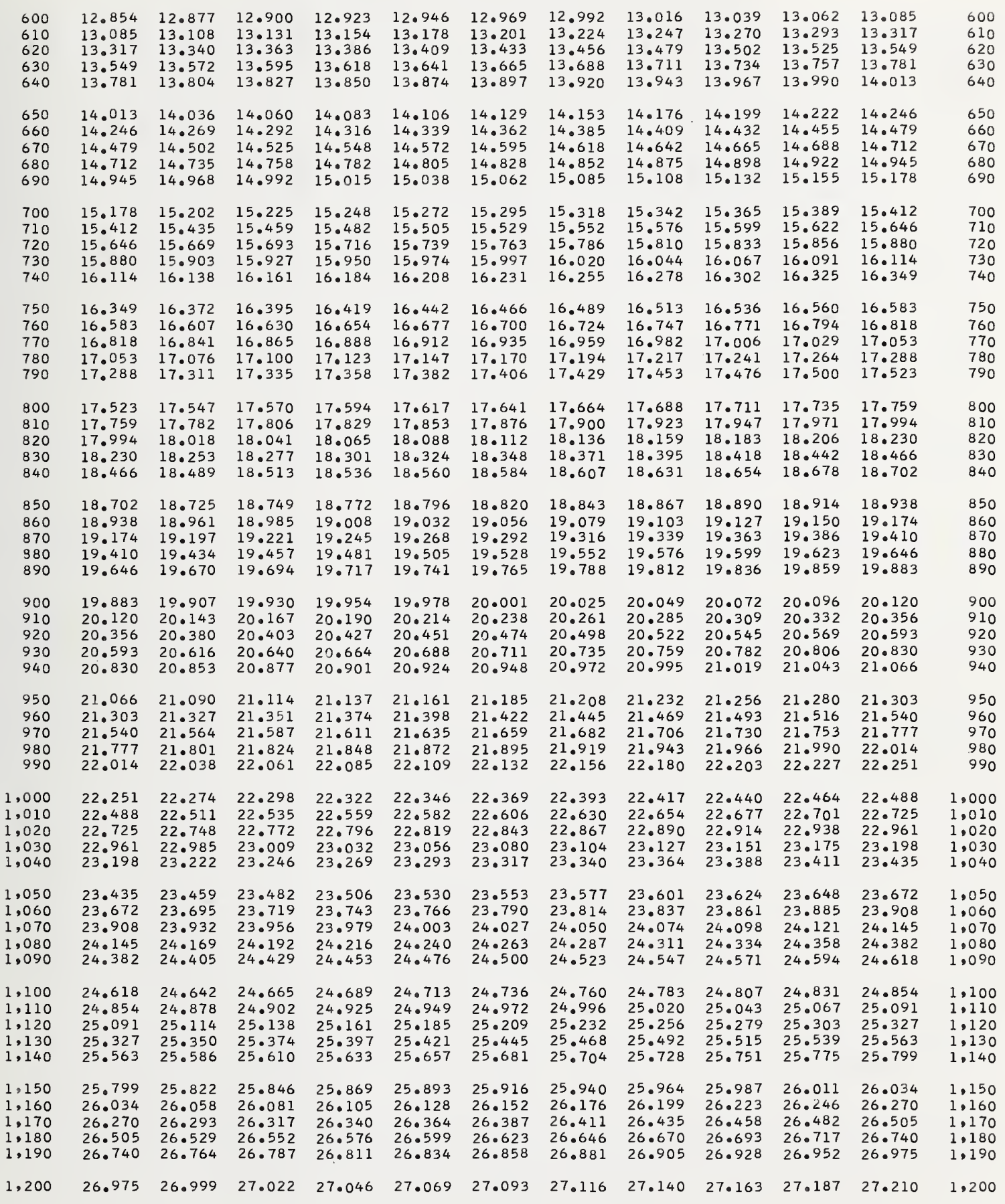

${ }^{\circ} \mathrm{F}$

00

10

20

40

650

60

80

690

700

720

730

50

60

780

800
810

820

840

850

860

880

00

920

50

60

80

990

, 000

.010

030

.040

(.060

070

, 090

, 100

, 110

, 130

140

160

170

.190

1.200 
TABLE A7.1.2. Type K thermocouples-thermoelectric voltage as a function of temperature $\left({ }^{\circ} \mathrm{F}\right)$, reference junctions at $32{ }^{\circ} \mathrm{F}$-Continued

${ }^{\circ}$

0

1

2

3

4

5

6

7

8

9

10

${ }^{\circ} \mathrm{F}$

THERMOELECTRIC VOLTAGE IN ABSOLUTE MILLIVOLTS

\begin{tabular}{|c|c|c|c|c|c|c|c|c|c|c|c|c|}
\hline $\begin{array}{l}1,200 \\
1,210 \\
1,220 \\
1,230 \\
1,240\end{array}$ & $\begin{array}{l}26.975 \\
27.210 \\
27.445 \\
27.679 \\
27.914\end{array}$ & $\begin{array}{l}26.999 \\
27.234 \\
27.468 \\
27.703 \\
27.937\end{array}$ & $\begin{array}{l}27.022 \\
27.257 \\
27.492 \\
27.726 \\
27.961\end{array}$ & $\begin{array}{l}27.046 \\
27.281 \\
27.515 \\
27.750 \\
27.984\end{array}$ & $\begin{array}{l}27.069 \\
27.304 \\
27.539 \\
27.773 \\
28.007\end{array}$ & $\begin{array}{l}27.093 \\
27.328 \\
27.562 \\
27.797 \\
28.031\end{array}$ & $\begin{array}{l}27.116 \\
27.351 \\
27.586 \\
27.820 \\
28.054\end{array}$ & $\begin{array}{l}27.140 \\
27.375 \\
27.609 \\
27.843 \\
28.078\end{array}$ & $\begin{array}{l}27.163 \\
27.398 \\
27.633 \\
27.867 \\
28.101\end{array}$ & $\begin{array}{l}27.187 \\
27.422 \\
27.656 \\
27.890 \\
28.124\end{array}$ & $\begin{array}{l}27.210 \\
27.445 \\
27.679 \\
27.914 \\
28.148\end{array}$ & $\begin{array}{l}1,200 \\
1,210 \\
1,220 \\
1,230 \\
1,240\end{array}$ \\
\hline $\begin{array}{l}1,250 \\
1,260 \\
1,270 \\
1,280 \\
1,290\end{array}$ & $\begin{array}{l}28.148 \\
28.382 \\
28.615 \\
28.849 \\
29.082\end{array}$ & $\begin{array}{l}28.171 \\
28.405 \\
28.639 \\
28.872 \\
29.105\end{array}$ & $\begin{array}{l}28.195 \\
28.428 \\
28.662 \\
28.895 \\
29.128\end{array}$ & $\begin{array}{r}28.218 \\
28.452 \\
28.685 \\
28.919 \\
29.152\end{array}$ & $\begin{array}{l}28 \cdot 241 \\
28.475 \\
28.709 \\
28.942 \\
29.175\end{array}$ & $\begin{array}{l}28.265 \\
28.498 \\
28.732 \\
28.965 \\
29.198\end{array}$ & $\begin{array}{l}28.288 \\
28.522 \\
28.755 \\
28.988 \\
29.221\end{array}$ & $\begin{array}{l}28.311 \\
28.545 \\
28.779 \\
29.012 \\
29.245\end{array}$ & $\begin{array}{l}28.335 \\
28.569 \\
28.802 \\
29.035 \\
29.268\end{array}$ & $\begin{array}{l}28.358 \\
28.592 \\
28.825 \\
29.058 \\
29.291\end{array}$ & $\begin{array}{l}28.382 \\
28.615 \\
28.849 \\
29.082 \\
29.315\end{array}$ & $\begin{array}{l}1,250 \\
1,260 \\
1,270 \\
1,280 \\
1,290\end{array}$ \\
\hline $\begin{array}{l}1,300 \\
1,310 \\
1,320 \\
1,330 \\
1,340\end{array}$ & $\begin{array}{l}29.315 \\
29.547 \\
29.780 \\
30.012 \\
30.244\end{array}$ & $\begin{array}{l}29.338 \\
29.570 \\
29.803 \\
30.035 \\
30.267\end{array}$ & $\begin{array}{l}29.361 \\
29.594 \\
29.826 \\
30.058 \\
30.290\end{array}$ & $\begin{array}{l}29.384 \\
29.617 \\
29.849 \\
30.081 \\
30.313\end{array}$ & $\begin{array}{l}29.408 \\
29.640 \\
29.872 \\
30.104 \\
30.336\end{array}$ & $\begin{array}{l}29.431 \\
29.663 \\
29.896 \\
30.128 \\
30.359\end{array}$ & $\begin{array}{l}29.454 \\
29.687 \\
29.919 \\
30.151 \\
30.383\end{array}$ & $\begin{array}{l}29.477 \\
29.710 \\
29.942 \\
30.174 \\
30.406\end{array}$ & $\begin{array}{l}29.501 \\
29.733 \\
29.965 \\
30.197 \\
30.429\end{array}$ & $\begin{array}{l}29.524 \\
29.756 \\
29.989 \\
30.220 \\
30.452\end{array}$ & $\begin{array}{l}29.547 \\
29.780 \\
30.012 \\
30.244 \\
30.475\end{array}$ & $\begin{array}{l}1,300 \\
1,310 \\
1,320 \\
1,330 \\
1,340\end{array}$ \\
\hline $\begin{array}{l}1,350 \\
1,360 \\
1,370 \\
1,380 \\
1,390\end{array}$ & $\begin{array}{l}30.475 \\
30.706 \\
30.937 \\
31.168 \\
31.399\end{array}$ & $\begin{array}{l}30.498 \\
30.730 \\
30.961 \\
31.191 \\
31.422\end{array}$ & $\begin{array}{l}30.521 \\
30.753 \\
30.984 \\
31.214 \\
31.445\end{array}$ & $\begin{array}{l}30.545 \\
30.776 \\
31.007 \\
31.237 \\
31.468\end{array}$ & $\begin{array}{l}30.568 \\
30.799 \\
31.030 \\
31.260 \\
31.491\end{array}$ & $\begin{array}{l}30.591 \\
30.822 \\
31.053 \\
31.283 \\
31.514\end{array}$ & $\begin{array}{l}30.614 \\
30.845 \\
31.076 \\
31.306 \\
31.537\end{array}$ & $\begin{array}{l}30.637 \\
30.868 \\
31.099 \\
31.329 \\
31.560\end{array}$ & $\begin{array}{l}30.660 \\
30.891 \\
31.122 \\
31.353 \\
31.583\end{array}$ & $\begin{array}{l}30.683 \\
30.914 \\
31.145 \\
31.376 \\
31.606\end{array}$ & $\begin{array}{l}30.706 \\
30.937 \\
31.168 \\
31.399 \\
31.629\end{array}$ & $\begin{array}{l}1,350 \\
1,360 \\
1,370 \\
1,380 \\
1,390\end{array}$ \\
\hline $\begin{array}{l}1,400 \\
1,410 \\
1,420 \\
1,430 \\
1,440\end{array}$ & $\begin{array}{l}31.629 \\
31.859 \\
32.088 \\
32.317 \\
32.546\end{array}$ & $\begin{array}{l}31.652 \\
31.882 \\
32.111 \\
32.340 \\
32.569\end{array}$ & $\begin{array}{l}31.675 \\
31.905 \\
32.134 \\
32.363 \\
32.592\end{array}$ & $\begin{array}{l}31.698 \\
31.927 \\
32.157 \\
32.386 \\
32.615\end{array}$ & $\begin{array}{l}31.721 \\
31.950 \\
32.180 \\
32.409 \\
32.638\end{array}$ & $\begin{array}{l}31.744 \\
31.973 \\
32.203 \\
32.432 \\
32.661\end{array}$ & $\begin{array}{l}31.767 \\
31.996 \\
32.226 \\
32.455 \\
32.683\end{array}$ & $\begin{array}{l}31.790 \\
32.019 \\
32.249 \\
32.478 \\
32.706\end{array}$ & $\begin{array}{l}31.813 \\
32.042 \\
32.272 \\
32.501 \\
32.729\end{array}$ & $\begin{array}{l}31.836 \\
32.065 \\
32.294 \\
32.523 \\
32.752\end{array}$ & $\begin{array}{l}31.859 \\
32.088 \\
32.317 \\
32.546 \\
32.775\end{array}$ & $\begin{array}{l}1,400 \\
1,410 \\
1,420 \\
1,430 \\
1,440\end{array}$ \\
\hline $\begin{array}{l}1,450 \\
1,460 \\
1,470 \\
1,480 \\
1,490\end{array}$ & $\begin{array}{l}32.775 \\
33.003 \\
33.231 \\
33.459 \\
33.686\end{array}$ & $\begin{array}{l}32.798 \\
33.026 \\
33.254 \\
33.482 \\
33.709\end{array}$ & $\begin{array}{l}32.821 \\
33.049 \\
33.277 \\
33.504 \\
33.732\end{array}$ & $\begin{array}{l}32.843 \\
33.072 \\
33.300 \\
33.527 \\
33.754\end{array}$ & $\begin{array}{l}32.866 \\
33.094 \\
33.322 \\
33.550 \\
33.777\end{array}$ & $\begin{array}{l}32.889 \\
33.117 \\
33.345 \\
33.573 \\
33.800\end{array}$ & $\begin{array}{l}32.912 \\
33.140 \\
33.368 \\
33.595 \\
33.823\end{array}$ & $\begin{array}{l}32.935 \\
33.163 \\
33.391 \\
33.618 \\
33.845\end{array}$ & $\begin{array}{l}32.958 \\
33.186 \\
33.413 \\
33.641 \\
33.868\end{array}$ & $\begin{array}{l}32.980 \\
33.208 \\
33.436 \\
33.664 \\
33.891\end{array}$ & $\begin{array}{l}33.003 \\
33.231 \\
33.459 \\
33.686 \\
33.913\end{array}$ & $\begin{array}{l}1,450 \\
1,460 \\
1,470 \\
1,480 \\
1,490\end{array}$ \\
\hline $\begin{array}{l}1,500 \\
1,510 \\
1,520 \\
1,530 \\
1,540\end{array}$ & $\begin{array}{l}33.913 \\
34.140 \\
34.366 \\
34.593 \\
34.818\end{array}$ & $\begin{array}{l}33.936 \\
34.163 \\
34.389 \\
34.615 \\
34.841\end{array}$ & $\begin{array}{l}33.959 \\
34.185 \\
34.412 \\
34.638 \\
34.863\end{array}$ & $\begin{array}{l}33.981 \\
34.208 \\
34.434 \\
34.660 \\
34.886\end{array}$ & $\begin{array}{l}34.004 \\
34.231 \\
34.457 \\
34.683 \\
34.909\end{array}$ & $\begin{array}{l}34.027 \\
34.253 \\
34.480 \\
34.705 \\
34.931\end{array}$ & $\begin{array}{l}34.049 \\
34.276 \\
34.502 \\
34.728 \\
34.954\end{array}$ & $\begin{array}{l}34.072 \\
34.299 \\
34.525 \\
34.751 \\
34.976\end{array}$ & $\begin{array}{l}34.095 \\
34.321 \\
34.547 \\
34.773 \\
34.999\end{array}$ & $\begin{array}{l}34.117 \\
34.344 \\
34.570 \\
34.796 \\
35.021\end{array}$ & $\begin{array}{l}34.140 \\
34.366 \\
34.593 \\
34.818 \\
35.044\end{array}$ & $\begin{array}{l}1,500 \\
1,510 \\
1,520 \\
1,530 \\
1,540\end{array}$ \\
\hline $\begin{array}{l}1,550 \\
1,560 \\
1,570 \\
1,580 \\
1,590\end{array}$ & $\begin{array}{l}35.044 \\
35.269 \\
35.494 \\
35.718 \\
35.942\end{array}$ & $\begin{array}{l}35.066 \\
35.291 \\
35.516 \\
35.741 \\
35.965\end{array}$ & $\begin{array}{l}35.089 \\
35.314 \\
35.539 \\
35.763 \\
35.987\end{array}$ & $\begin{array}{l}35.111 \\
35.336 \\
35.561 \\
35.785 \\
36.009\end{array}$ & $\begin{array}{l}35.134 \\
35.359 \\
35.583 \\
35.808 \\
36.032\end{array}$ & $\begin{array}{l}35.156 \\
35.381 \\
35.606 \\
35.830 \\
36.054\end{array}$ & $\begin{array}{l}35.179 \\
35.404 \\
35.628 \\
35.853 \\
36.077\end{array}$ & $\begin{array}{l}35.201 \\
35.426 \\
35.651 \\
35.875 \\
36.099\end{array}$ & $\begin{array}{l}35.224 \\
35.449 \\
35.673 \\
35.897 \\
36.121\end{array}$ & $\begin{array}{l}35.246 \\
35.471 \\
35.696 \\
35.920 \\
36.144\end{array}$ & $\begin{array}{l}35.269 \\
35.494 \\
35.718 \\
35.942 \\
36.166\end{array}$ & $\begin{array}{l}1,550 \\
1,560 \\
1.570 \\
1,580 \\
1.590\end{array}$ \\
\hline $\begin{array}{l}1,600 \\
1,610 \\
1,620 \\
1,630 \\
1,640\end{array}$ & $\begin{array}{l}36.166 \\
36.390 \\
36.613 \\
36.836 \\
37.058\end{array}$ & $\begin{array}{l}36.188 \\
36.412 \\
36.635 \\
36.858 \\
37.080\end{array}$ & $\begin{array}{l}36.211 \\
36.434 \\
36.657 \\
36.880 \\
37.103\end{array}$ & $\begin{array}{l}36.233 \\
36.457 \\
36.680 \\
36.902 \\
37.125\end{array}$ & $\begin{array}{l}36.256 \\
36.479 \\
36.702 \\
36.925 \\
37.147\end{array}$ & $\begin{array}{l}36.278 \\
36.501 \\
36.724 \\
36.947 \\
37.169\end{array}$ & $\begin{array}{l}36.300 \\
36.524 \\
36.746 \\
36.969 \\
37.191\end{array}$ & $\begin{array}{l}36.323 \\
36.546 \\
36.769 \\
36.991 \\
37.214\end{array}$ & $\begin{array}{l}36.345 \\
36.568 \\
36.791 \\
37.014 \\
37.236\end{array}$ & $\begin{array}{l}36.367 \\
36.590 \\
36.813 \\
37.036 \\
37.258\end{array}$ & $\begin{array}{l}36.390 \\
36.613 \\
36.836 \\
37.058 \\
37.280\end{array}$ & $\begin{array}{l}1,600 \\
1,610 \\
1.620 \\
1,630 \\
1,640\end{array}$ \\
\hline $\begin{array}{l}1,650 \\
1,660 \\
1,670 \\
1,680 \\
1,690\end{array}$ & $\begin{array}{l}37.280 \\
37.502 \\
37.724 \\
37.945 \\
38.166\end{array}$ & $\begin{array}{l}37.303 \\
37.524 \\
37.746 \\
37.967 \\
38.188\end{array}$ & $\begin{array}{l}37.325 \\
37.547 \\
37.768 \\
37.989 \\
38.210\end{array}$ & $\begin{array}{l}37.347 \\
37.569 \\
37.790 \\
38.011 \\
38.232\end{array}$ & $\begin{array}{l}37.369 \\
37.591 \\
37.812 \\
38.033 \\
38.254\end{array}$ & $\begin{array}{l}37.391 \\
37.613 \\
37.834 \\
38.055 \\
38.276\end{array}$ & $\begin{array}{l}37.413 \\
37.635 \\
37.857 \\
38.078 \\
38.298\end{array}$ & $\begin{array}{l}37.436 \\
37.657 \\
37.879 \\
38.100 \\
38.320\end{array}$ & $\begin{array}{l}37.458 \\
37.679 \\
37.901 \\
38.122 \\
38.342\end{array}$ & $\begin{array}{l}37.480 \\
37.702 \\
37.923 \\
38.144 \\
38.364\end{array}$ & $\begin{array}{l}37.502 \\
37.724 \\
37.945 \\
38.166 \\
38.387\end{array}$ & $\begin{array}{l}1,650 \\
1,660 \\
1,670 \\
1,680 \\
1,690\end{array}$ \\
\hline $\begin{array}{l}1,700 \\
1,710 \\
1,720 \\
1,730 \\
1,740\end{array}$ & $\begin{array}{l}38.387 \\
38.607 \\
38.827 \\
39.046 \\
39.266\end{array}$ & $\begin{array}{l}38.409 \\
38.629 \\
38.849 \\
39.068 \\
39.288\end{array}$ & $\begin{array}{l}38.431 \\
38.651 \\
38.871 \\
39.090 \\
39.310\end{array}$ & $\begin{array}{l}38.453 \\
38.673 \\
38.893 \\
39.112 \\
39.331\end{array}$ & $\begin{array}{l}38.475 \\
38.695 \\
38.915 \\
39.134 \\
39.353\end{array}$ & $\begin{array}{l}38.497 \\
38.717 \\
38.937 \\
39.156 \\
39.375\end{array}$ & $\begin{array}{l}38.519 \\
38.739 \\
38.959 \\
39.178 \\
39.397\end{array}$ & $\begin{array}{l}38.541 \\
38.761 \\
38.981 \\
39.200 \\
39.419\end{array}$ & $\begin{array}{l}38.563 \\
38.783 \\
39.003 \\
39.222 \\
39.441\end{array}$ & $\begin{array}{l}38.585 \\
38.805 \\
39.024 \\
39.244 \\
39.463\end{array}$ & $\begin{array}{l}38.607 \\
38.827 \\
39.046 \\
39.266 \\
39.485\end{array}$ & $\begin{array}{l}1,700 \\
1,710 \\
1,720 \\
1,730 \\
1,740\end{array}$ \\
\hline $\begin{array}{l}1,750 \\
1,760 \\
1,770 \\
1,780 \\
1,790\end{array}$ & $\begin{array}{l}39.485 \\
39.703 \\
39.922 \\
40.140 \\
40.358\end{array}$ & $\begin{array}{l}39.507 \\
39.725 \\
39.944 \\
40.162 \\
40.379\end{array}$ & $\begin{array}{l}39.529 \\
39.747 \\
39.965 \\
40.183 \\
40.401\end{array}$ & $\begin{array}{l}39.550 \\
39.769 \\
39.987 \\
40.205 \\
40.423\end{array}$ & $\begin{array}{l}39.572 \\
39.791 \\
40.009 \\
40.227 \\
40.445\end{array}$ & $\begin{array}{l}39.594 \\
39.813 \\
40.031 \\
40.249 \\
40.466\end{array}$ & $\begin{array}{l}39.616 \\
39.835 \\
40.053 \\
40.271 \\
40.488\end{array}$ & $\begin{array}{l}39.638 \\
39.856 \\
40.075 \\
40.292 \\
40.510\end{array}$ & $\begin{array}{l}39.660 \\
39.878 \\
40.096 \\
40.314 \\
40.532\end{array}$ & $\begin{array}{l}39.682 \\
39.900 \\
40.118 \\
40.336 \\
40.553\end{array}$ & $\begin{array}{l}39.703 \\
39.922 \\
40.140 \\
40.358 \\
40.575\end{array}$ & $\begin{array}{l}1,750 \\
1,760 \\
1,770 \\
1,780 \\
1,790\end{array}$ \\
\hline 1,800 & 40.575 & 40.597 & 40.619 & 40.640 & 40.662 & 40.684 & 40.705 & 40.727 & 40.749 & 40.770 & 40.792 & 1,800 \\
\hline
\end{tabular}

1

2

3

4

5

6

7

8

9

10

${ }^{\circ} \mathrm{F}$ 
TABLE A7.1.2. Type K thermocouples-thermoelectric voltage as a function of temperature $\left({ }^{\circ} \mathrm{F}\right)$, reference junctions at $32^{\circ} \mathrm{F}$-Continued

${ }^{\circ} \mathrm{F}$

0

1

1

2

THERMO

1,800

1,810

1,830

1,840

1,850

1,860

1,870

1,880

1,890

40.575

41.009

41.225

40.814
41.031

41.442

41.657

41.247

40.619
40.836

41.052

42.088

42.303

42.518

41.679

69
85

3

4

5

6

7

$\begin{array}{lll}40.640 & 40.662 & 40.684\end{array}$

$\begin{array}{lll}40.857 & 40.879 & 40.901 \\ 41.074 & 41.096 & 41.117\end{array}$

$41.290-41.312$

40.705

40.922

40

40.727

1,900

1,910

1,920

1,930

42.732

42.946

43.373

42.110

41.701

41.506

41.528

1.550

41.355

41.916

41.722

41.744

41.765

41.571

42.325

42.131

$41.938 \quad 41.959$

1.981

41.787

42.002

42.539

42.560

$42.367 \quad 42.389$

42.410

42.432

$42.753 \quad 42.775$

42.967

43.181

43.585

43.394

42.989

42.796

42.603

42.625

42.646

1,950

1,960

1,970

1,980

1,990

43.798

44.010

43.607

43.415

43.010

42.817

42.839

44.222

43.819

43.628

43.223

43.245

43.053

42.860

42.860
43.074
43.287

43.287
43.500

$43.436 \quad 43.458 \quad 43.479$

4.031

43.84

43.649

43.671

43.692

43.713

44.265

43.862

43.883

43.904

44.645

44.455

44.666

44.476

44.074

44.095

44.116

43.925

44.137

2,000

2,010

2,020

44.856

45.066

45.276

44.877

44.687

44.708

44.729

44.539
44.750

44.349

44.560

44.771

45.087

45.297

44.898

44.919

45.507

45.108

45.318

45.12

2,040

45.904

2,050

2,060

2,070

2,080

2,090

2,100

2,110

2,120

2,130

2,140

2,150

2,160

2,170

2,180

2,190

2,200

2,210

2.220

2,230

2,240

2,250

2,260

2.270

2,280

2,290

2,300

2,310

2,320

2,330

2,340

2,350

2,360

2,370

2,380

2,390

2,400

46.11

46.321

46.529

46.737

45.925

46.134

46.342 46.550

46.944

47.150

47.356

47.562

46.964

47.171

47.377

47.767

$47 \cdot 583$

47.972

48.177

47.993

8.381

48.197

48.401

48.605

48.990

48.808

45.737

45.339

$44.940 \quad 44.961$

44.982

$5.150 \quad 45.171$

$45.360 \quad 45.381$

45.192

45.402

4.612

45.946

45.758

$45.570 \quad 45.591$

45.821

46.155

46.571

$\begin{array}{lll}45.967 & 45.988 & 46.009\end{array}$

46.176

46.196

46.217

46.030

46.238

$\begin{array}{llll}46.384 & 46.404 & 46.425 & 46.446\end{array}$

$46.591 \quad 46.612 \quad 46.633$

46.799

46.819

46.840

46.654

46.861

46.985

47.006

47.026

47.047

47.068

47.398

47.603

47.212

47.233

$\begin{array}{rrr}47.439 & 47.459\end{array}$

$\begin{array}{lll}47.624 & 47.644 & 47.665\end{array}$

47.274

47.480

47.685

47.849

47.870

47.890

48.013

48.218

48.034

48.238

48.054

48.075

48.095

48.422

48.442

48.258

48.462

48.279

48.299

48.503

$48.686 \quad 48.706$

48.825
48.848

48.869

48.889

48.909

49.192

49.394

49.595

49.796

49.212

49.031

$49.051 \quad 49.071$

49.091

49.111
49.313

$\begin{array}{lllllll}49.414 & 49.434 & 49.454 & 49.474 & 49.495 & 49.515\end{array}$

49.615

49.615

49.836 
TABLE A7.1.2. Type $K$ thermocouples-thermoelectric voltage as a function of temperature $\left({ }^{\circ} \mathrm{F}\right)$, reference junctions at $32^{\circ} \mathrm{F}$-Continued

\begin{tabular}{|c|c|c|c|c|c|c|c|c|c|c|c|c|}
\hline \multirow[t]{2}{*}{${ }^{\circ} \mathrm{F}$} & 0 & 1 & 2 & 3 & 4 & 5 & 6 & 7 & 8 & 9 & 10 & ${ }^{\circ} \mathrm{F}$ \\
\hline & \multicolumn{12}{|c|}{ THERMOELECTRIC VOLTAGE IN ABSOLUTE MILLIVOLTS } \\
\hline $\begin{array}{l}2,400 \\
2,410 \\
2,420 \\
2,430 \\
2,440\end{array}$ & $\begin{array}{l}52.939 \\
53.132 \\
53.324 \\
53.515 \\
53.706\end{array}$ & $\begin{array}{l}52.959 \\
53.151 \\
53.343 \\
53.534 \\
53.725\end{array}$ & $\begin{array}{l}52.978 \\
53.170 \\
53.362 \\
53.553 \\
53.744\end{array}$ & $\begin{array}{l}52.997 \\
53.189 \\
53.381 \\
53.572 \\
53.763\end{array}$ & $\begin{array}{l}53.016 \\
53.209 \\
53.400 \\
53.592 \\
53.782\end{array}$ & $\begin{array}{l}53.036 \\
53.228 \\
53.419 \\
53.611 \\
53.801\end{array}$ & $\begin{array}{l}53.055 \\
53.247 \\
53.439 \\
53.630 \\
53.821\end{array}$ & $\begin{array}{l}53.074 \\
53.266 \\
53.458 \\
53.649 \\
53.840\end{array}$ & $\begin{array}{l}53.093 \\
53.285 \\
53.477 \\
53.668 \\
53.859\end{array}$ & $\begin{array}{l}53.113 \\
53.304 \\
53.496 \\
53.687 \\
53.878\end{array}$ & $\begin{array}{l}53.132 \\
53.324 \\
53.515 \\
53.706 \\
53.897\end{array}$ & $\begin{array}{l}2,400 \\
2,410 \\
2,420 \\
2,430 \\
2,440\end{array}$ \\
\hline $\begin{array}{l}2,450 \\
2,460 \\
2,470 \\
2,480 \\
2,490\end{array}$ & $\begin{array}{l}53.897 \\
54.087 \\
54.277 \\
54.466 \\
54.656\end{array}$ & $\begin{array}{l}53.916 \\
54.106 \\
54.296 \\
54.485 \\
54.675\end{array}$ & $\begin{array}{l}53.935 \\
54.125 \\
54.315 \\
54.504 \\
54.694\end{array}$ & $\begin{array}{l}53.954 \\
54.144 \\
54.334 \\
54.523 \\
54.712\end{array}$ & $\begin{array}{l}53.973 \\
54.163 \\
54.353 \\
54.542 \\
54.731\end{array}$ & $\begin{array}{l}53.992 \\
54.182 \\
54.372 \\
54.561 \\
54.750\end{array}$ & $\begin{array}{l}54.011 \\
54.201 \\
54.391 \\
54.580 \\
54.769\end{array}$ & $\begin{array}{l}54.030 \\
54.220 \\
54.410 \\
54.599 \\
54.788\end{array}$ & $\begin{array}{l}54.049 \\
54.239 \\
54.429 \\
54.618 \\
54.807\end{array}$ & $\begin{array}{l}54.068 \\
54.258 \\
54.447 \\
54.637 \\
54.826\end{array}$ & $\begin{array}{l}54.087 \\
54.277 \\
54.466 \\
54.656 \\
54.845\end{array}$ & $\begin{array}{l}2,450 \\
2,460 \\
2,470 \\
2,480 \\
2,490\end{array}$ \\
\hline 2,500 & 54.845 & & & & & & & & & & & 2.500 \\
\hline${ }^{\circ} \mathrm{F}$ & 0 & 1 & 2 & 3 & 4 & 5 & 6 & 7 & 8 & 9 & 10 & $F$ \\
\hline
\end{tabular}

TABle A7.1.3. Type $K$ thermocouples-quadratic, cubic, and quartic approximations to the data as a function of temperature $\left({ }^{\circ} \mathrm{C}\right)$ in selected temperature ranges. The expansion is of the form

$\mathrm{E}=\mathrm{a}_{0}+\mathrm{a}_{1} \mathrm{~T}+\mathrm{a}_{2} \mathrm{~T}^{2}+\mathrm{a}_{3} \mathrm{~T}^{3}+\mathrm{a}_{4} \mathrm{~T}^{4}$ where $\mathrm{E}$ is in microvolts and $\mathrm{T}$ is in degrees Celsius

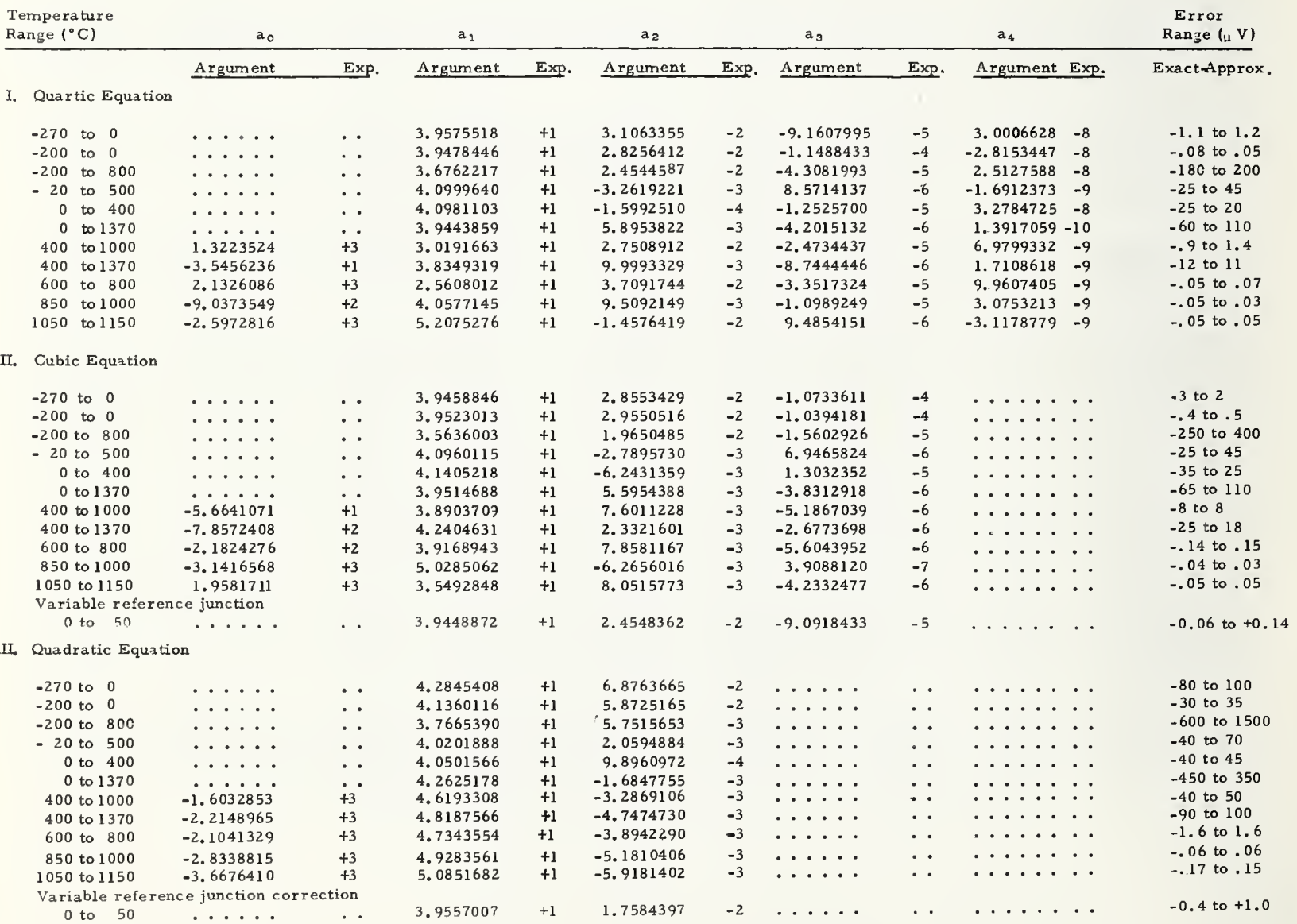




\section{A7.2. Data for Temperature as a Function of Voltage}

The temperature as a function of voltage data given in tables A7.2.1 and A7.2.2 were obtained by iteration in the primary equations for voltage as a function of temperature. Table A7.2.1 presents the data in millivolts from $-6.45 \mathrm{mV}$ to $54.87 \mathrm{mV}$ with temperatures given in degrees Celsius while table A7.2.2 presents similar data with temperatures in degrees Fahrenheit. Table A7.2.3 contains quadratic, cubic, and quartic approximations to the data as a function of voltage in selected temperature ranges. The error range given in the table represents the difference between the temperature found by iteration in the full precision tables from the text and from the respective reduced order approximations.

TABLE A7.2.1. Type $K$ thermocouples-temperature $\left({ }^{\circ} \mathrm{C}\right)$ as a function of thermoelectric voltage, reference junctions at $0^{\circ} \mathrm{C}$

$$
\mathrm{mV}
$$

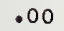

.01

$$
.02
$$

.03

.04

.05

.06

.07

.08

.09

$\mathrm{mV}$

TEMPERATURES IN DEGREES C (IPTS 1968 )

$\begin{array}{llll}-253.67 & -256.35 & -259.58 & -263.92\end{array}$

$\begin{array}{lll}-236.79 & -238.09 & -239.45 \\ -225.70 & -226.69 & -227.70\end{array}$

$\begin{array}{lll}-216.71 & -217.55 & -218.40\end{array}$

$-208 \cdot 91$

$-209.66$

$-210 \cdot 40$

$-240.87$

$-228.73-242.35$

$-219.26$

-220.13
-211.92

-243.92
-230.88
-221.02
-212.70
$-245.57$ -231.99
-221.92
$-213.48$

-247.34
-233.14

$-222.84$

$-223 \cdot 78$
$-215 \cdot 08$

$-6.20$

$-6.10$

$-6.00$

mV

.00

.01

.02

.03

.04

.05

.06

.07

.08

.09

$\cdot 10$

$m v$ 
TABLE A7.2.1. Type $K$ thermocouples-temperature $\left({ }^{\circ} \mathrm{C}\right)$ as a function of thermoelectric voltage, reference junctions at $0^{\circ} \mathrm{C}$-Continued

$\mathrm{mV}$

.00

$\cdot 0$

.02

.03

TEMPERATURES IN DEGREES C (IPTS 1968)

\begin{tabular}{|c|c|c|c|c|c|c|c|c|c|c|c|c|}
\hline 6.00 & $-207 \cdot 46$ & -208.18 & -208.91 & $-209 \cdot 66$ & $-210 \cdot 40$ & -211.16 & $-211 \cdot 92$ & $-212 \cdot 70$ & -213.48 & $-214 \cdot 27$ & $-215 \cdot 08$ & -6.00 \\
\hline $\begin{array}{l}-5.90 \\
-5.80 \\
-5.70 \\
-5.60 \\
-5.50\end{array}$ & $\begin{array}{l}-200 \cdot 57 \\
-194 \cdot 22 \\
-188 \cdot 28 \\
-182.68 \\
-177.36\end{array}$ & $\begin{array}{l}-201.23 \\
-194.83 \\
-188.86 \\
-183.23 \\
-177.88\end{array}$ & $\begin{array}{l}-201 \cdot 90 \\
-195.45 \\
-189.44 \\
-183.78 \\
-178.40\end{array}$ & $\begin{array}{l}-202.57 \\
-196.07 \\
-190.02 \\
-184.33 \\
-178.93\end{array}$ & $\begin{array}{l}-203 \cdot 25 \\
-196.70 \\
-190.61 \\
-184.88 \\
-179.46\end{array}$ & $\begin{array}{l}-203.94 \\
-197.33 \\
-191.20 \\
-185.44 \\
-179.99\end{array}$ & $\begin{array}{l}04.63 \\
97.97 \\
91.80 \\
86.00 \\
80.52\end{array}$ & $\begin{array}{l}-205.32 \\
-198.61 \\
-192.40 \\
-186.57 \\
-181.06\end{array}$ & $\begin{array}{l}-206.03 \\
-199.26 \\
-193.00 \\
-187.14 \\
-181.60\end{array}$ & $\begin{array}{l}6.74 \\
9.91 \\
3.60 \\
7.71 \\
2.14\end{array}$ & $\begin{array}{l}7.46 \\
0.57 \\
4.22 \\
8.28 \\
2.68\end{array}$ & $\begin{array}{l}-5.90 \\
-5.80 \\
-5.70 \\
-5.60 \\
-5.50\end{array}$ \\
\hline $\begin{array}{l}-5.40 \\
-5.30 \\
-5.20 \\
-5.10 \\
-5.00\end{array}$ & $\begin{array}{l}-172 \cdot 28 \\
-167 \cdot 40 \\
-162 \cdot 70 \\
-158 \cdot 15 \\
-153 \cdot 75\end{array}$ & $\begin{array}{l}-172 \cdot 78 \\
-167 \cdot 88 \\
-163 \cdot 16 \\
-158 \cdot 60 \\
-154 \cdot 18\end{array}$ & $\begin{array}{l}-173.28 \\
-168.36 \\
-163.62 \\
-159.05 \\
-154.62\end{array}$ & $\begin{array}{l}-173.78 \\
-168.84 \\
-164.09 \\
-159.50 \\
-155.06\end{array}$ & $\begin{array}{l}-174 \cdot 28 \\
-169 \cdot 33 \\
-164 \cdot 56 \\
-159 \cdot 95 \\
-155.50\end{array}$ & $\begin{array}{l}-174.79 \\
-169.81 \\
-165.03 \\
-160.41 \\
-155.94\end{array}$ & $\begin{array}{l}-175 \cdot 30 \\
-170.30 \\
-165.50 \\
-160.86 \\
-156.38\end{array}$ & $\begin{array}{l}-175.81 \\
-170.79 \\
-165.97 \\
-161.32 \\
-156.82\end{array}$ & $\begin{array}{l}-176.33 \\
-171.29 \\
-166.44 \\
-161.78 \\
-157.26\end{array}$ & $\begin{array}{l}-176.84 \\
-171.78 \\
-166.92 \\
-162 \cdot 24 \\
-157.71\end{array}$ & $\begin{array}{l}-177.36 \\
-172.28 \\
-167.40 \\
-162.70 \\
-158.15\end{array}$ & $\begin{array}{l}-5.40 \\
-5.30 \\
-5.20 \\
-5.10 \\
-5.00\end{array}$ \\
\hline $\begin{array}{l}-4 \cdot 90 \\
-4 \cdot 80 \\
-4 \cdot 70 \\
-4 \cdot 60 \\
-4 \cdot 50\end{array}$ & $\begin{array}{l}-149 \cdot 47 \\
-145.31 \\
-141.25 \\
-137.29 \\
-133.41\end{array}$ & $\begin{array}{l}-149.90 \\
-145.72 \\
-141.65 \\
-137.68 \\
-133.79\end{array}$ & $\begin{array}{l}-150.32 \\
-146.13 \\
-142.05 \\
-138.07 \\
-134.18\end{array}$ & $\begin{array}{l}-150 \cdot 74 \\
-146.55 \\
-142.46 \\
-138.47 \\
-134.56\end{array}$ & $\begin{array}{l}-151.17 \\
-146.96 \\
-142.86 \\
-138.86 \\
-134.95\end{array}$ & $\begin{array}{l}-151 \cdot 60 \\
-147 \cdot 38 \\
-143.27 \\
-139.26 \\
-135.34\end{array}$ & $\begin{array}{l}-152.02 \\
-147.79 \\
-143.67 \\
-139.65 \\
-135.73\end{array}$ & $\begin{array}{l}-152.45 \\
-148.21 \\
-144.08 \\
-140.05 \\
-136.11\end{array}$ & $\begin{array}{l}-152.88 \\
-148.63 \\
-144.49 \\
-140.45 \\
-136.50\end{array}$ & $\begin{array}{l}-153.32 \\
-149.05 \\
-144.90 \\
-140.85 \\
-136.89\end{array}$ & $\begin{array}{l}-153.75 \\
-149.47 \\
-145.31 \\
-141.25 \\
-137.29\end{array}$ & $\begin{array}{l}-4 \cdot 90 \\
-4.80 \\
-4.70 \\
-4.60 \\
-4.50\end{array}$ \\
\hline $\begin{array}{l}-4.40 \\
-4.30 \\
-4.20 \\
-4.10 \\
-4.00\end{array}$ & $\begin{array}{l}-129.61 \\
-125.89 \\
-122.24 \\
-118.65 \\
-115.12\end{array}$ & $\begin{array}{l}-129.99 \\
-126.26 \\
-122.60 \\
-119.01 \\
-115.47\end{array}$ & $\begin{array}{l}-130.37 \\
-126.63 \\
-122.96 \\
-119 \cdot 36 \\
-115.82\end{array}$ & $\begin{array}{l}-130 \cdot 74 \\
-127.00 \\
-123.33 \\
-119 \cdot 72 \\
-116.17\end{array}$ & $\begin{array}{l}-131.12 \\
-127.37 \\
-123.69 \\
-120.08 \\
-116.53\end{array}$ & $\begin{array}{l}-131.50 \\
-127.74 \\
-124.06 \\
-120.44 \\
-116.88\end{array}$ & $\begin{array}{l}-131.88 \\
-128.11 \\
-124.42 \\
-120.79 \\
-117.23\end{array}$ & $\begin{array}{l}-132.26 \\
-128.49 \\
-124.79 \\
-121.15 \\
-117.58\end{array}$ & $\begin{array}{l}-132.64 \\
-128.86 \\
-125.15 \\
-121.51 \\
-117.94\end{array}$ & $\begin{array}{l}.03 \\
.24 \\
.52 \\
.88 \\
.29\end{array}$ & $\begin{array}{l}-133.41 \\
-129.61 \\
-125.89 \\
-122.24 \\
-118.65\end{array}$ & $\begin{array}{l}-4.40 \\
-4.30 \\
-4.20 \\
-4.10 \\
-4.00\end{array}$ \\
\hline $\begin{array}{l}-3.90 \\
-3.80 \\
-3.70 \\
-3.60 \\
-3.50\end{array}$ & $\begin{array}{r}-111.65 \\
-108.23 \\
-104.86 \\
-101.54 \\
-98.26\end{array}$ & $\begin{array}{r}-111.99 \\
-108.57 \\
-105.20 \\
-101.87 \\
-98.59\end{array}$ & $\begin{array}{r}-112 \cdot 34 \\
-108 \cdot 91 \\
-105 \cdot 53 \\
-102 \cdot 20 \\
-98.91\end{array}$ & $\begin{array}{r}-112 \cdot 68 \\
-109 \cdot 25 \\
-105.87 \\
-102 \cdot 53 \\
-99.24\end{array}$ & $\begin{array}{r}-113.03 \\
-109.59 \\
-106.20 \\
-102.86 \\
-99.57\end{array}$ & $\begin{array}{r}-113.38 \\
-109.93 \\
-106.54 \\
-103.19 \\
-99.89\end{array}$ & $\begin{array}{l}-113.73 \\
-110.28 \\
-106.88 \\
-103.53 \\
-100.22\end{array}$ & $\begin{array}{l}-114.07 \\
-110.62 \\
-107.21 \\
-103.86 \\
-100.55\end{array}$ & $\begin{array}{l}-114.42 \\
-110.96 \\
-107.55 \\
-104.19 \\
-100.88\end{array}$ & $\begin{array}{l}-114.77 \\
-111.30 \\
-107.89 \\
-104.53 \\
-101.21\end{array}$ & $\begin{array}{l}-115.12 \\
-111.65 \\
-108.23 \\
-104.86 \\
-101.54\end{array}$ & $\begin{array}{l}-3.90 \\
-3.80 \\
-3.70 \\
-3.60 \\
-3.50\end{array}$ \\
\hline $\begin{array}{l}-3.40 \\
-3.30 \\
-3.20 \\
-3.10 \\
-3.00\end{array}$ & $\begin{array}{l}-95.02 \\
-91.83 \\
-88.67 \\
-85.54 \\
-82.46\end{array}$ & $\begin{array}{l}-95.35 \\
-92.15 \\
-88.98 \\
-85.86 \\
-82.76\end{array}$ & $\begin{array}{l}-95.67 \\
-92.46 \\
-89.30 \\
-86.17 \\
-83.07\end{array}$ & $\begin{array}{l}-95.99 \\
-92.78 \\
-89.61 \\
-86.48 \\
-83.38\end{array}$ & $\begin{array}{l}-96.31 \\
-93 \cdot 10 \\
-89.93 \\
-86.79 \\
-83.69\end{array}$ & $\begin{array}{l}-96.64 \\
-93.42 \\
-90.24 \\
-87.10 \\
-84.00\end{array}$ & $\begin{array}{l}-96.96 \\
-93 \cdot 74 \\
-90.56 \\
-87.41 \\
-84.31\end{array}$ & $\begin{array}{l}-97.29 \\
-94.06 \\
-90.88 \\
-87.73 \\
-84.61\end{array}$ & $\begin{array}{l}-97.61 \\
-94 \cdot 38 \\
-91.19 \\
-88.04 \\
-84.92\end{array}$ & $\begin{array}{l}-97.93 \\
-94.70 \\
-91.51 \\
-88.35 \\
-85.23\end{array}$ & $\begin{array}{l}-98.26 \\
-95.02 \\
-91.83 \\
-88.67 \\
-85.54\end{array}$ & $\begin{array}{l}-3.40 \\
-3.30 \\
-3.20 \\
-3.10 \\
-3.00\end{array}$ \\
\hline $\begin{array}{l}-2.90 \\
-2.80 \\
-2.70 \\
-2.60 \\
-2.50\end{array}$ & $\begin{array}{l}-79.40 \\
-76.37 \\
-73.37 \\
-70.40 \\
-67.46\end{array}$ & $\begin{array}{l}-79.70 \\
-76.67 \\
-73.67 \\
-70.70 \\
-67.76\end{array}$ & $\begin{array}{l}-80.01 \\
-76.97 \\
-73.97 \\
-71.00 \\
-68.05\end{array}$ & $\begin{array}{l}-80.31 \\
-77.28 \\
-74.27 \\
-71.29 \\
-68.34\end{array}$ & $\begin{array}{l}-80.62 \\
-77.58 \\
-74.57 \\
-71.59 \\
-68.64\end{array}$ & $\begin{array}{l}-80.92 \\
-77.88 \\
-74.87 \\
-71.89 \\
-68.93\end{array}$ & $\begin{array}{l}-81 \cdot 23 \\
-78 \cdot 18 \\
-75 \cdot 17 \\
-72 \cdot 18 \\
-69 \cdot 22\end{array}$ & $\begin{array}{l}-81.53 \\
-78.49 \\
-75.47 \\
-72.48 \\
-69.52\end{array}$ & $\begin{array}{l}-81.84 \\
-78.79 \\
-75.77 \\
-72.78 \\
-69.81\end{array}$ & $\begin{array}{l}-82.15 \\
-79.09 \\
-76.07 \\
-73.08 \\
-70.11\end{array}$ & $\begin{array}{l}-82.46 \\
-79.40 \\
-76.37 \\
-73.37 \\
-70.40\end{array}$ & $\begin{array}{l}-2.90 \\
-2.80 \\
-2.70 \\
-2.60 \\
-2.50\end{array}$ \\
\hline $\begin{array}{l}-2.40 \\
-2.30 \\
-2.20 \\
-2.10 \\
-2.00\end{array}$ & $\begin{array}{l}-64 \cdot 55 \\
-61.65 \\
-58.78 \\
-55.94 \\
-53.11\end{array}$ & $\begin{array}{l}-64.84 \\
-61.94 \\
-59.07 \\
-56.22 \\
-53.39\end{array}$ & $\begin{array}{l}-65.13 \\
-62.23 \\
-59.35 \\
-56.50 \\
-53.67\end{array}$ & $\begin{array}{l}-65 \cdot 42 \\
-62 \cdot 52 \\
-59 \cdot 64 \\
-56.79 \\
-53.96\end{array}$ & $\begin{array}{l}-65.71 \\
-62.81 \\
-59.93 \\
-57.07 \\
-54.24\end{array}$ & $\begin{array}{l}-66.00 \\
-63.10 \\
-60.21 \\
-57.36 \\
-54.52\end{array}$ & $\begin{array}{l}-66.29 \\
-63.39 \\
-60.50 \\
-57.64 \\
-54.80\end{array}$ & $\begin{array}{l}-66.58 \\
-63.67 \\
-60.79 \\
-57.93 \\
-55.09\end{array}$ & $\begin{array}{l}-66.88 \\
-63.96 \\
-61.08 \\
-58.21 \\
-55.37\end{array}$ & $\begin{array}{l}-67.17 \\
-64.25 \\
-61.36 \\
-58.50 \\
-55.65\end{array}$ & $\begin{array}{l}-67.46 \\
-64.55 \\
-61.65 \\
-58.78 \\
-55.94\end{array}$ & $\begin{array}{l}-2.40 \\
-2.30 \\
-2.20 \\
-2.10 \\
-2.00\end{array}$ \\
\hline $\begin{array}{l}-1.90 \\
-1.80 \\
-1.70 \\
-1.60 \\
-1.50\end{array}$ & $\begin{array}{l}-50.31 \\
-47.52 \\
-44.75 \\
-42.01 \\
-39.27\end{array}$ & $\begin{array}{l}-50.58 \\
-47.80 \\
-45.03 \\
-42.28 \\
-39.55\end{array}$ & $\begin{array}{l}-50.86 \\
-48.08 \\
-45.31 \\
-42.55 \\
-39.82\end{array}$ & $\begin{array}{l}-51.14 \\
-48.35 \\
-45.58 \\
-42.83 \\
-40.09\end{array}$ & $\begin{array}{l}-51 \cdot 42 \\
-48 \cdot 63 \\
-45 \cdot 86 \\
-43 \cdot 10 \\
-40.36\end{array}$ & $\begin{array}{l}-51 \cdot 71 \\
-48.91 \\
-46.13 \\
-43.38 \\
-40.64\end{array}$ & $\begin{array}{l}-51.99 \\
-49.19 \\
-46.41 \\
-43.65 \\
-40.91\end{array}$ & $\begin{array}{l}-52.27 \\
-49.47 \\
-46.69 \\
-43.93 \\
-41.18\end{array}$ & $\begin{array}{l}-52.55 \\
-49.75 \\
-46.97 \\
-44.20 \\
-41.46\end{array}$ & $\begin{array}{l}-52 \cdot 83 \\
-50.03 \\
-47.24 \\
-44.48 \\
-41.73\end{array}$ & $\begin{array}{l}-53.11 \\
-50.31 \\
-47.52 \\
-44.75 \\
-42.01\end{array}$ & $\begin{array}{l}-1.90 \\
-1.80 \\
-1.70 \\
-1.60 \\
-1.50\end{array}$ \\
\hline $\begin{array}{l}-1.40 \\
-1.30 \\
-1.20 \\
-1.10 \\
-1.00\end{array}$ & $\begin{array}{l}-36.56 \\
-33.86 \\
-31.18 \\
-28.51 \\
-25.86\end{array}$ & $\begin{array}{l}-36.83 \\
-34.13 \\
-31.45 \\
-28.78 \\
-26.12\end{array}$ & $\begin{array}{l}-37.10 \\
-34.40 \\
-31.71 \\
-29.04 \\
-26.39\end{array}$ & $\begin{array}{l}-37.37 \\
-34.67 \\
-31.98 \\
-29.31 \\
-26.65\end{array}$ & $\begin{array}{l}-37.64 \\
-34.94 \\
-32.25 \\
-29.58 \\
-26.92\end{array}$ & $\begin{array}{l}-37.92 \\
-35.21 \\
-32.52 \\
-29.84 \\
-27.18\end{array}$ & $\begin{array}{l}-38.19 \\
-35.48 \\
-32.79 \\
-30.11 \\
-27.45\end{array}$ & $\begin{array}{l}-38.46 \\
-35.75 \\
-33.06 \\
-30.38 \\
-27.71\end{array}$ & $\begin{array}{l}-38.73 \\
-36.02 \\
-33.32 \\
-30.64 \\
-27.98\end{array}$ & $\begin{array}{l}-39.00 \\
-36.29 \\
-33.59 \\
-30.91 \\
-28.25\end{array}$ & $\begin{array}{l}-39.27 \\
-36.56 \\
-33.86 \\
-31.18 \\
-28.51\end{array}$ & $\begin{array}{l}-1.40 \\
-1.30 \\
-1.20 \\
-1.10 \\
-1.00\end{array}$ \\
\hline $\begin{array}{l}-0.90 \\
-0.80 \\
-0.70 \\
-0.60 \\
-0.50\end{array}$ & $\begin{array}{l}-23.22 \\
-20.59 \\
-17.98 \\
-15.38 \\
-12.79\end{array}$ & $\begin{array}{l}-23.48 \\
-20.85 \\
-18.24 \\
-15.64 \\
-13.05\end{array}$ & $\begin{array}{l}-23 \cdot 75 \\
-21 \cdot 12 \\
-18 \cdot 50 \\
-15 \cdot 90 \\
-13 \cdot 30\end{array}$ & $\begin{array}{l}-24 \cdot 01 \\
-21 \cdot 38 \\
-18 \cdot 76 \\
-16.16 \\
-13.56\end{array}$ & $\begin{array}{l}-24 \cdot 27 \\
-21.64 \\
-19.02 \\
-16.42 \\
-13.82\end{array}$ & $\begin{array}{l}-24.54 \\
-21.90 \\
-19.28 \\
-16.68 \\
-14.08\end{array}$ & $\begin{array}{l}-24.80 \\
-22.17 \\
-19.55 \\
-16.94 \\
-14.34\end{array}$ & $\begin{array}{l}-25.07 \\
-22.43 \\
-19.81 \\
-17.20 \\
-14.60\end{array}$ & $\begin{array}{l}-25.33 \\
-22.69 \\
-20.07 \\
-17.46 \\
-14.86\end{array}$ & $\begin{array}{l}-25.59 \\
-22.96 \\
-20.33 \\
-17.72 \\
-15.12\end{array}$ & $\begin{array}{l}-25.86 \\
-23.22 \\
-20.59 \\
-17.98 \\
-15.38\end{array}$ & $\begin{array}{l}-0.90 \\
-0.80 \\
-0.70 \\
-0.60 \\
-0.50\end{array}$ \\
\hline $\begin{array}{l}-0.40 \\
-0.30 \\
-0.20 \\
-0.10 \\
-0.00\end{array}$ & $\begin{array}{r}-10.21 \\
-7.64 \\
-5.08 \\
-2.54 \\
0.00\end{array}$ & $\begin{array}{r}-10.47 \\
-7.90 \\
-5.34 \\
-2.79 \\
-0.25\end{array}$ & $\begin{array}{r}-10.72 \\
-8.15 \\
-5.60 \\
-3.05 \\
-0.51\end{array}$ & $\begin{array}{r}-10.98 \\
-8.41 \\
-5.85 \\
-3.30 \\
-0.76\end{array}$ & $\begin{array}{r}-11.24 \\
-8.67 \\
-6.11 \\
-3.56 \\
-1.01\end{array}$ & $\begin{array}{r}-11.50 \\
-8.92 \\
-6.36 \\
-3.81 \\
-1.27\end{array}$ & $\begin{array}{r}-11.76 \\
-9.18 \\
-6.62 \\
-4.06 \\
-1.52\end{array}$ & $\begin{array}{r}-12.01 \\
-9.44 \\
-6.87 \\
-4.32 \\
-1.78\end{array}$ & $\begin{array}{r}-12.27 \\
-9.70 \\
-7.13 \\
-4.57 \\
-2.03\end{array}$ & $\begin{array}{r}-12.53 \\
-9.95 \\
-7.39 \\
-4.83 \\
-2.28\end{array}$ & $\begin{array}{r}-12.79 \\
-10.21 \\
-7.64 \\
-5.08 \\
-2.54\end{array}$ & $\begin{array}{l}-0.40 \\
-0.30 \\
-0.20 \\
-0.10 \\
-0.00\end{array}$ \\
\hline$n v$ & .00 & 01 & .02 & 03 & .04 & .05 & .06 & 07 & .08 & .09 & .10 & \\
\hline
\end{tabular}


TABLE A7.2.1. Type $\mathbf{K}$ thermocouples-temperature $\left({ }^{\circ} \mathrm{C}\right)$ as a function of thermoelectric voltage, reference junctions at $0^{\circ} \mathrm{C}$-Continued

$\mathrm{m} \vee$

.00

.01

.02

.03

.04

.05

$.06 \quad .07$

.08

.09

.10

$\mathrm{mV}$

TEMPERATURES IN DEGREES C (IPTS 1968)

\begin{tabular}{|c|c|c|c|c|c|c|c|c|c|c|c|c|}
\hline $\begin{array}{l}0.00 \\
0.10 \\
0.20 \\
0.30 \\
0.40\end{array}$ & $\begin{array}{r}0.00 \\
2.53 \\
5.05 \\
7.57 \\
10.08\end{array}$ & $\begin{array}{r}0.25 \\
2.78 \\
5.30 \\
7.82 \\
10.33\end{array}$ & $\begin{array}{r}0.51 \\
3.03 \\
5.56 \\
8.07 \\
10.58\end{array}$ & $\begin{array}{r}0.76 \\
3.29 \\
5.81 \\
8.32 \\
10.83\end{array}$ & $\begin{array}{r}1.01 \\
3.54 \\
6.06 \\
8.57 \\
11.08\end{array}$ & $\begin{array}{r}1.27 \\
3.79 \\
6.31 \\
8.82 \\
11.33\end{array}$ & $\begin{array}{r}1.52 \\
4.04 \\
6.56 \\
9.07 \\
11.58\end{array}$ & $\begin{array}{r}1.77 \\
4.30 \\
6.81 \\
9.32 \\
11.83\end{array}$ & $\begin{array}{r}2.02 \\
4.55 \\
7.06 \\
9.57 \\
12.08\end{array}$ & $\begin{array}{r}2.28 \\
4.80 \\
7.32 \\
9.83 \\
12.33\end{array}$ & $\begin{array}{r}2.53 \\
5.05 \\
7.57 \\
10.08 \\
12.58\end{array}$ & $\begin{array}{l}0.00 \\
0.10 \\
0.20 \\
0.30 \\
0.40\end{array}$ \\
\hline $\begin{array}{l}0.50 \\
0.60 \\
0.70 \\
0.80 \\
0.90\end{array}$ & $\begin{array}{l}12.58 \\
15.07 \\
17.56 \\
20.05 \\
22.52\end{array}$ & $\begin{array}{l}12.83 \\
15.32 \\
17.81 \\
20.29 \\
22.77\end{array}$ & $\begin{array}{l}13.08 \\
15.57 \\
18.06 \\
20.54 \\
23.02\end{array}$ & $\begin{array}{l}13.33 \\
15.82 \\
18.31 \\
20.79 \\
23.27\end{array}$ & $\begin{array}{l}13.58 \\
16.07 \\
18.56 \\
21.04 \\
23.51\end{array}$ & $\begin{array}{l}13.83 \\
16.32 \\
18.81 \\
21.29 \\
23.76\end{array}$ & $\begin{array}{l}14.08 \\
16.57 \\
19.05 \\
21.53 \\
24.01\end{array}$ & $\begin{array}{l}14.33 \\
16.82 \\
19.30 \\
21.78 \\
24.25\end{array}$ & $\begin{array}{l}14.57 \\
17.07 \\
19.55 \\
22.03 \\
24.50\end{array}$ & $\begin{array}{l}14 \cdot 82 \\
17 \cdot 31 \\
19 \cdot 80 \\
22.28 \\
24.75\end{array}$ & $\begin{array}{l}15.07 \\
17.56 \\
20.05 \\
22.52 \\
25.00\end{array}$ & $\begin{array}{l}0.50 \\
0.50 \\
0.70 \\
0.80 \\
0.90\end{array}$ \\
\hline $\begin{array}{l}1.00 \\
1.10 \\
1.20 \\
1.30 \\
1.40\end{array}$ & $\begin{array}{l}25.00 \\
27.46 \\
29.92 \\
32.38 \\
34.83\end{array}$ & $\begin{array}{l}25.24 \\
27.71 \\
30.17 \\
32.63 \\
35.08\end{array}$ & $\begin{array}{l}25.49 \\
27.95 \\
30.42 \\
32.87 \\
35.32\end{array}$ & $\begin{array}{l}25.74 \\
28.20 \\
30.66 \\
33.12 \\
35.57\end{array}$ & $\begin{array}{l}25.98 \\
28.45 \\
30.91 \\
33.36 \\
35.81\end{array}$ & $\begin{array}{l}26.23 \\
28.69 \\
31.15 \\
33.61 \\
36.06\end{array}$ & $\begin{array}{l}26.48 \\
28.94 \\
31.40 \\
33.85 \\
36.30\end{array}$ & $\begin{array}{l}26.72 \\
29.19 \\
31.64 \\
34.10 \\
36.55\end{array}$ & $\begin{array}{l}26.97 \\
29.43 \\
31.89 \\
34 \cdot 34 \\
36.79\end{array}$ & $\begin{array}{l}27.22 \\
29.68 \\
32.13 \\
34.59 \\
37.03\end{array}$ & $\begin{array}{l}27.46 \\
29.92 \\
32.38 \\
34.83 \\
37.28\end{array}$ & $\begin{array}{l}1.00 \\
1.10 \\
1.20 \\
1.30 \\
1.40\end{array}$ \\
\hline $\begin{array}{l}1.50 \\
1.60 \\
1.70 \\
1.80 \\
1.90\end{array}$ & $\begin{array}{l}37.28 \\
39.72 \\
42.16 \\
44.60 \\
47.03\end{array}$ & $\begin{array}{l}37.52 \\
39.97 \\
42.40 \\
44.84 \\
47.27\end{array}$ & $\begin{array}{l}37.77 \\
40.21 \\
42.65 \\
45.08 \\
47.51\end{array}$ & $\begin{array}{l}38.01 \\
40.45 \\
42.89 \\
45.33 \\
47.76\end{array}$ & $\begin{array}{l}38 \cdot 26 \\
40.70 \\
43.14 \\
45.57 \\
48.00\end{array}$ & $\begin{array}{l}38.50 \\
40.94 \\
43.38 \\
45.81 \\
48.24\end{array}$ & $\begin{array}{l}38.75 \\
41.19 \\
43.62 \\
46.06 \\
48.48\end{array}$ & $\begin{array}{l}38.99 \\
41.43 \\
43.87 \\
46.30 \\
48.73\end{array}$ & $\begin{array}{l}39.23 \\
41.67 \\
44.11 \\
46.54 \\
48.97\end{array}$ & $\begin{array}{l}39.48 \\
41.92 \\
44.35 \\
46.78 \\
49.21\end{array}$ & $\begin{array}{l}39.72 \\
42.16 \\
44.60 \\
47.03 \\
49.46\end{array}$ & $\begin{array}{l}1.50 \\
1.60 \\
1.70 \\
1.80 \\
1.90\end{array}$ \\
\hline $\begin{array}{l}2.00 \\
2.10 \\
2.20 \\
2.30 \\
2.40\end{array}$ & $\begin{array}{l}49.46 \\
51.88 \\
54 \cdot 30 \\
56.72 \\
59.14\end{array}$ & $\begin{array}{l}49.70 \\
52.12 \\
54.54 \\
56.96 \\
59.38\end{array}$ & $\begin{array}{l}49.94 \\
52.36 \\
54.79 \\
57.21 \\
59.62\end{array}$ & $\begin{array}{l}50.18 \\
52.61 \\
55.03 \\
57.45 \\
59.86\end{array}$ & $\begin{array}{l}50.43 \\
52.85 \\
55.27 \\
57.69 \\
60.10\end{array}$ & $\begin{array}{l}50.67 \\
53.09 \\
55.51 \\
57.93 \\
60.35\end{array}$ & $\begin{array}{l}50.91 \\
53.33 \\
55.75 \\
58.17 \\
60.59\end{array}$ & $\begin{array}{l}51.15 \\
53.58 \\
56.00 \\
58.41 \\
60.83\end{array}$ & $\begin{array}{l}51.40 \\
53.82 \\
56.24 \\
58.66 \\
61.07\end{array}$ & $\begin{array}{l}51.64 \\
54.06 \\
56.48 \\
58.90 \\
61.31\end{array}$ & $\begin{array}{l}51 \cdot 88 \\
54 \cdot 30 \\
56 \cdot 72 \\
59 \cdot 14 \\
61.55\end{array}$ & $\begin{array}{l}2.00 \\
2.10 \\
2.20 \\
2.30 \\
2.40\end{array}$ \\
\hline $\begin{array}{l}2.50 \\
2.60 \\
2.70 \\
2.80 \\
2.90\end{array}$ & $\begin{array}{l}61.55 \\
63.97 \\
66.38 \\
68.79 \\
71.20\end{array}$ & $\begin{array}{l}61.79 \\
64 \cdot 21 \\
66.62 \\
69.03 \\
71.44\end{array}$ & $\begin{array}{l}62.04 \\
64.45 \\
66.86 \\
69.27 \\
71.68\end{array}$ & $\begin{array}{l}62.28 \\
64.69 \\
67.10 \\
69.51 \\
71.92\end{array}$ & $\begin{array}{l}62 \cdot 52 \\
64 \cdot 93 \\
67.34 \\
69 \cdot 75 \\
72.16\end{array}$ & $\begin{array}{l}62.76 \\
65.17 \\
67.58 \\
69.99 \\
72.40\end{array}$ & $\begin{array}{l}63.00 \\
65.41 \\
67.82 \\
70.23 \\
72.64\end{array}$ & $\begin{array}{l}63.24 \\
65.65 \\
68.06 \\
70.47 \\
72.88\end{array}$ & $\begin{array}{l}63.48 \\
65.90 \\
68.31 \\
70.71 \\
73.12\end{array}$ & $\begin{array}{l}63.72 \\
66.14 \\
68.55 \\
70.96 \\
73.36\end{array}$ & $\begin{array}{l}63.97 \\
66.38 \\
68.79 \\
71.20 \\
73.60\end{array}$ & $\begin{array}{l}2.50 \\
2.60 \\
2.70 \\
2.80 \\
2.90\end{array}$ \\
\hline $\begin{array}{l}3.00 \\
3.10 \\
3.20 \\
3.30 \\
3.40\end{array}$ & $\begin{array}{l}73.60 \\
76.01 \\
78.42 \\
80.83 \\
83.23\end{array}$ & $\begin{array}{l}73.85 \\
76.25 \\
78.66 \\
81.07 \\
83.47\end{array}$ & $\begin{array}{l}74.09 \\
76.49 \\
78.90 \\
81.31 \\
83.72\end{array}$ & $\begin{array}{l}74.33 \\
76.73 \\
79.14 \\
81.55 \\
83.96\end{array}$ & $\begin{array}{l}74 \cdot 57 \\
76 \cdot 97 \\
79 \cdot 38 \\
81 \cdot 79 \\
84 \cdot 20\end{array}$ & $\begin{array}{l}74.81 \\
77.22 \\
79.62 \\
82.03 \\
84.44\end{array}$ & $\begin{array}{l}75.05 \\
77.46 \\
79.86 \\
82.27 \\
84.68\end{array}$ & $\begin{array}{l}75.29 \\
77.70 \\
80.10 \\
82.51 \\
84.92\end{array}$ & $\begin{array}{l}75.53 \\
77.94 \\
80.34 \\
82.75 \\
85.16\end{array}$ & $\begin{array}{l}75.77 \\
78.18 \\
80.59 \\
82.99 \\
85.40\end{array}$ & $\begin{array}{l}76.01 \\
78.42 \\
80.83 \\
83.23 \\
85.64\end{array}$ & $\begin{array}{l}3.00 \\
3.10 \\
3.20 \\
3.30 \\
3.40\end{array}$ \\
\hline $\begin{array}{l}3.50 \\
3.60 \\
3.70\end{array}$ & $\begin{array}{l}85.64 \\
88.05 \\
90.46\end{array}$ & $\begin{array}{l}85.88 \\
88.29 \\
90.70\end{array}$ & $\begin{array}{l}86.12 \\
88.53 \\
90.94\end{array}$ & $\begin{array}{l}86.36 \\
88.77 \\
91.18\end{array}$ & $\begin{array}{l}86.61 \\
89.01 \\
91.42\end{array}$ & $\begin{array}{l}86.85 \\
89.26 \\
91.67\end{array}$ & $\begin{array}{l}87.09 \\
89.50 \\
91.91\end{array}$ & $\begin{array}{l}87.33 \\
89.74 \\
92.15\end{array}$ & $\begin{array}{l}87.57 \\
89.98 \\
92.39\end{array}$ & $\begin{array}{l}87.81 \\
90.22 \\
92.63\end{array}$ & $\begin{array}{l}88.05 \\
90.46 \\
92.87\end{array}$ & $\begin{array}{l}3.50 \\
3.60 \\
3.70\end{array}$ \\
\hline $\begin{array}{l}3.80 \\
3.90\end{array}$ & $\begin{array}{l}92.87 \\
95.28\end{array}$ & $\begin{array}{l}93.11 \\
95.53\end{array}$ & $\begin{array}{l}93.35 \\
95.77\end{array}$ & $\begin{array}{r}93.59 \\
96.01\end{array}$ & $\begin{array}{l}93.84 \\
96.25\end{array}$ & $\begin{array}{l}94.08 \\
96.49\end{array}$ & $\begin{array}{l}94 \cdot 32 \\
96.73\end{array}$ & $\begin{array}{l}94.56 \\
96.97\end{array}$ & $\begin{array}{l}94 \cdot 80 \\
97.22\end{array}$ & $\begin{array}{l}95.04 \\
97.46\end{array}$ & $\begin{array}{l}95.28 \\
97.70\end{array}$ & $\begin{array}{l}3.80 \\
3.90\end{array}$ \\
\hline $\begin{array}{l}4.00 \\
4.10 \\
4.20 \\
4.30 \\
4.40\end{array}$ & $\begin{array}{r}97.70 \\
100.11 \\
102.53 \\
104.95 \\
107.38\end{array}$ & $\begin{array}{r}97.94 \\
100.36 \\
102.77 \\
105.20 \\
107.62\end{array}$ & $\begin{array}{r}98.18 \\
100.60 \\
103.02 \\
105.44 \\
107.86\end{array}$ & $\begin{array}{r}98.42 \\
100.84 \\
103.26 \\
105.68 \\
108.10\end{array}$ & $\begin{array}{r}98.66 \\
101.08 \\
103.50 \\
105.92 \\
108.35\end{array}$ & $\begin{array}{r}98.91 \\
101.32 \\
103.74 \\
106.16 \\
108.59\end{array}$ & $\begin{array}{r}99.15 \\
101.57 \\
103.98 \\
106.41 \\
108.83\end{array}$ & $\begin{array}{r}99.39 \\
101.81 \\
104.23 \\
106.65 \\
109.07\end{array}$ & $\begin{array}{r}99.63 \\
102.05 \\
104.47 \\
106.89 \\
109.32\end{array}$ & $\begin{array}{r}99.87 \\
102.29 \\
104.71 \\
107.13 \\
109.56\end{array}$ & $\begin{array}{l}100.11 \\
102.53 \\
104.95 \\
107.38 \\
109.80\end{array}$ & $\begin{array}{l}4.00 \\
4.10 \\
4.20 \\
4.30 \\
4.40\end{array}$ \\
\hline $\begin{array}{l}4.50 \\
4.60 \\
4.70 \\
4.80 \\
4.90\end{array}$ & $\begin{array}{l}109.80 \\
112.23 \\
114.66 \\
117.10 \\
119.54\end{array}$ & $\begin{array}{l}110.05 \\
112.47 \\
114.91 \\
117.34 \\
119.78\end{array}$ & $\begin{array}{l}110.29 \\
112.72 \\
115.15 \\
117.59 \\
120.03\end{array}$ & $\begin{array}{l}110.53 \\
112.96 \\
115.39 \\
117.83 \\
120.27\end{array}$ & $\begin{array}{l}110.77 \\
113.20 \\
115.64 \\
118.07 \\
120.51\end{array}$ & $\begin{array}{l}111.02 \\
113.45 \\
115.88 \\
118.32 \\
120.76\end{array}$ & $\begin{array}{l}111.26 \\
113.69 \\
116.12 \\
118.56 \\
121.00\end{array}$ & $\begin{array}{l}111.50 \\
113.93 \\
116.37 \\
118.81 \\
121.25\end{array}$ & $\begin{array}{l}111.75 \\
114.18 \\
116.61 \\
119.05 \\
121.49\end{array}$ & $\begin{array}{l}111.99 \\
114.42 \\
116.86 \\
119.29 \\
121.73\end{array}$ & $\begin{array}{l}112.23 \\
114.66 \\
117.10 \\
119.54 \\
121.98\end{array}$ & $\begin{array}{l}4.50 \\
4.60 \\
4.70 \\
4.80 \\
4.90\end{array}$ \\
\hline $\begin{array}{l}5.00 \\
5.10 \\
5.20 \\
5.30 \\
5.40\end{array}$ & $\begin{array}{l}121.98 \\
124.42 \\
126.87 \\
129.33 \\
131.78\end{array}$ & $\begin{array}{l}122.22 \\
124.67 \\
127.12 \\
129.57 \\
132.03\end{array}$ & $\begin{array}{l}122.47 \\
124.91 \\
127.36 \\
129.82 \\
132.27\end{array}$ & $\begin{array}{l}122.71 \\
125.16 \\
127.61 \\
130.06 \\
132.52\end{array}$ & $\begin{array}{l}122.96 \\
125.40 \\
127.85 \\
130.31 \\
132.77\end{array}$ & $\begin{array}{l}123.20 \\
125.65 \\
128.10 \\
130.55 \\
133.01\end{array}$ & $\begin{array}{l}123.45 \\
125.89 \\
128.34 \\
130.80 \\
133.26\end{array}$ & $\begin{array}{l}123.69 \\
126.14 \\
128.59 \\
131.05 \\
133.50\end{array}$ & $\begin{array}{l}123.94 \\
126.38 \\
128.84 \\
131.29 \\
133.75\end{array}$ & $\begin{array}{l}124.18 \\
126.63 \\
129.08 \\
131.54 \\
134.00\end{array}$ & $\begin{array}{l}124.42 \\
126.87 \\
129.33 \\
131.78 \\
134.24\end{array}$ & $\begin{array}{l}5.00 \\
5.10 \\
5.20 \\
5.30 \\
5.40\end{array}$ \\
\hline $\begin{array}{l}5.50 \\
5.60 \\
5.70 \\
5.80 \\
5.90\end{array}$ & $\begin{array}{l}134.24 \\
136.71 \\
139.17 \\
141.64 \\
144.12\end{array}$ & $\begin{array}{l}134.49 \\
136.95 \\
139.42 \\
141.89 \\
144.37\end{array}$ & $\begin{array}{l}134.73 \\
137.20 \\
139.67 \\
142.14 \\
144.61\end{array}$ & $\begin{array}{l}134.98 \\
137.45 \\
139.91 \\
142.39 \\
144.86\end{array}$ & $\begin{array}{l}135.23 \\
137.69 \\
140.16 \\
142.63 \\
145.11\end{array}$ & $\begin{array}{l}135.47 \\
137.94 \\
140.41 \\
142.88 \\
145.36\end{array}$ & $\begin{array}{l}135.72 \\
138.19 \\
140.65 \\
143.13 \\
145.60\end{array}$ & $\begin{array}{l}135.97 \\
138.43 \\
140.90 \\
143.38 \\
145.85\end{array}$ & $\begin{array}{l}136.21 \\
138.68 \\
141.15 \\
143.62 \\
146.10\end{array}$ & $\begin{array}{l}136.46 \\
138.93 \\
141.40 \\
143.87 \\
146.35\end{array}$ & $\begin{array}{l}136.71 \\
139.17 \\
141.64 \\
144.12 \\
146.60\end{array}$ & $\begin{array}{l}5.50 \\
5.60 \\
5.70 \\
5.80 \\
5.90\end{array}$ \\
\hline 6.00 & 146.60 & 146.84 & 147.09 & 147.34 & 147.59 & 147.84 & 148.08 & $148 \cdot 33$ & 148.58 & 148.83 & 149.08 & .00 \\
\hline
\end{tabular}

$\mathrm{mV}$

$.00 \quad .01 \quad .02$

$.03 \quad .04$

$.05 \quad .06$

.07

.08

$.09 \quad .10$

$\mathrm{mV}$ 
TABLE A7.2.1. Type $\boldsymbol{K}$ thermocouples-temperature $\left({ }^{\circ} \mathrm{C}\right)$ as a function of thermoelectric voltage, reference junctions at $0^{\circ} \mathrm{C}$-Continued

$m V$

.00

.0

\begin{abstract}
.01
\end{abstract}

\begin{abstract}
.02
\end{abstract}
.03

.04

.05

.06

.07

TEMPERATURES IN DEGREES C (IPTS 1968)

\begin{tabular}{|c|c|c|c|c|c|c|c|c|c|c|c|c|}
\hline $\begin{array}{l}6.00 \\
6.10 \\
6.20 \\
6.30 \\
6.40\end{array}$ & $\begin{array}{l}146.60 \\
149.08 \\
151.56 \\
154.05 \\
156.54\end{array}$ & $\begin{array}{l}146.84 \\
149.32 \\
151.81 \\
154 \cdot 30 \\
156.79\end{array}$ & $\begin{array}{l}147.09 \\
149.57 \\
152.06 \\
154.54 \\
157.03\end{array}$ & $\begin{array}{l}147.34 \\
149.82 \\
152.31 \\
154.79 \\
157.28\end{array}$ & $\begin{array}{l}147.59 \\
150.07 \\
152.55 \\
155.04 \\
157.53\end{array}$ & $\begin{array}{l}147.84 \\
150.32 \\
152.80 \\
155.29 \\
157.78\end{array}$ & $\begin{array}{l}148.08 \\
150.57 \\
153.05 \\
155.54 \\
158.03\end{array}$ & $\begin{array}{l}148.33 \\
150.81 \\
153.30 \\
155.79 \\
158.28\end{array}$ & $\begin{array}{l}148.58 \\
151.06 \\
153.55 \\
156.04 \\
158.53\end{array}$ & $\begin{array}{l}148.83 \\
151.31 \\
153.80 \\
156.29 \\
158.78\end{array}$ & $\begin{array}{l}149.08 \\
151.56 \\
154.05 \\
156.54 \\
159.03\end{array}$ & $\begin{array}{l}6.00 \\
6.10 \\
6.20 \\
6.30 \\
6.40\end{array}$ \\
\hline $\begin{array}{l}6.50 \\
6.60 \\
6.70 \\
6.80 \\
6.90\end{array}$ & $\begin{array}{l}159.03 \\
161.52 \\
164.02 \\
166.52 \\
169.02\end{array}$ & $\begin{array}{l}159.28 \\
161.77 \\
164.27 \\
166.77 \\
169.27\end{array}$ & $\begin{array}{l}159.53 \\
162.02 \\
164.52 \\
167.02 \\
169.52\end{array}$ & $\begin{array}{l}159.78 \\
162.27 \\
164.77 \\
167.27 \\
169.77\end{array}$ & $\begin{array}{l}160.03 \\
162.52 \\
165.02 \\
167.52 \\
170.02\end{array}$ & $\begin{array}{l}160.28 \\
162.77 \\
165.27 \\
167.77 \\
170.27\end{array}$ & $\begin{array}{l}160.53 \\
163.02 \\
165.52 \\
168.02 \\
170.52\end{array}$ & $\begin{array}{l}160.77 \\
163.27 \\
165.77 \\
168.27 \\
170.77\end{array}$ & $\begin{array}{l}161.02 \\
163.52 \\
166.02 \\
168.52 \\
171.02\end{array}$ & $\begin{array}{l}161.27 \\
163.77 \\
166.27 \\
168.77 \\
171.27\end{array}$ & $\begin{array}{l}161.52 \\
164.02 \\
166.52 \\
169.02 \\
171.52\end{array}$ & $\begin{array}{l}6.50 \\
6.60 \\
6.70 \\
6.80 \\
6.90\end{array}$ \\
\hline $\begin{array}{l}7.00 \\
7.10 \\
7.20 \\
7.30 \\
7.40\end{array}$ & $\begin{array}{l}171.52 \\
174.03 \\
176.53 \\
179.04 \\
181.54\end{array}$ & $\begin{array}{l}171.77 \\
174.28 \\
176.78 \\
179.29 \\
181.79\end{array}$ & $\begin{array}{l}172.02 \\
174.53 \\
177.03 \\
179.54 \\
182.05\end{array}$ & $\begin{array}{l}172.27 \\
174.78 \\
177.28 \\
179.79 \\
182.30\end{array}$ & $\begin{array}{l}172 \cdot 52 \\
175 \cdot 03 \\
177 \cdot 53 \\
180 \cdot 04 \\
182 \cdot 55\end{array}$ & $\begin{array}{l}172.77 \\
175.28 \\
177.78 \\
180.29 \\
182.80\end{array}$ & $\begin{array}{l}173.03 \\
175.53 \\
178.04 \\
180.54 \\
183.05\end{array}$ & $\begin{array}{l}173.28 \\
175.78 \\
178.29 \\
180.79 \\
183.30\end{array}$ & $\begin{array}{l}173.53 \\
176.03 \\
178.54 \\
181.04 \\
183.55\end{array}$ & $\begin{array}{l}173.78 \\
176.28 \\
178.79 \\
181.29 \\
183.80\end{array}$ & $\begin{array}{l}174.03 \\
176.53 \\
179.04 \\
181.54 \\
184.05\end{array}$ & $\begin{array}{l}7.00 \\
7.10 \\
7.20 \\
7.30 \\
7.40\end{array}$ \\
\hline $\begin{array}{l}7.50 \\
7.60 \\
7.70 \\
7.80 \\
7.90\end{array}$ & $\begin{array}{l}184.05 \\
186.56 \\
189.06 \\
191.57 \\
194.08\end{array}$ & $\begin{array}{l}184.30 \\
186.81 \\
189.31 \\
191.82 \\
194.33\end{array}$ & $\begin{array}{l}184.55 \\
187.06 \\
189.57 \\
192.07 \\
194.58\end{array}$ & $\begin{array}{l}184.80 \\
187.31 \\
189.82 \\
192.32 \\
194.83\end{array}$ & $\begin{array}{l}185.05 \\
187.56 \\
190.07 \\
192.57 \\
195.08\end{array}$ & $\begin{array}{l}185.30 \\
187.81 \\
190.32 \\
192.82 \\
195.33\end{array}$ & $\begin{array}{l}185.55 \\
188.06 \\
190.57 \\
193.07 \\
195.58\end{array}$ & $\begin{array}{l}185.81 \\
188.31 \\
190.82 \\
193.32 \\
195.83\end{array}$ & $\begin{array}{l}186.06 \\
188.56 \\
191.07 \\
193.57 \\
196.08\end{array}$ & $\begin{array}{l}186.31 \\
188.81 \\
191.32 \\
193.83 \\
196.33\end{array}$ & $\begin{array}{l}186.56 \\
189.06 \\
191.57 \\
194.08 \\
196.58\end{array}$ & $\begin{array}{l}7.50 \\
7.60 \\
7.70 \\
7.80 \\
7.90\end{array}$ \\
\hline $\begin{array}{l}8.00 \\
8.10 \\
8.20\end{array}$ & $\begin{array}{l}196.58 \\
199.08 \\
201.59\end{array}$ & $\begin{array}{l}196.83 \\
199 \cdot 34 \\
201.84\end{array}$ & $\begin{array}{l}197.08 \\
199.59 \\
202.09\end{array}$ & $\begin{array}{l}197.33 \\
199.84 \\
202.34\end{array}$ & $\begin{array}{l}197.58 \\
200.09 \\
202.59\end{array}$ & $\begin{array}{l}197.83 \\
200.34 \\
202.84\end{array}$ & $\begin{array}{l}198.08 \\
200.59 \\
203.09\end{array}$ & $\begin{array}{l}198 \cdot 33 \\
200 \cdot 84 \\
203 \cdot 34\end{array}$ & $\begin{array}{l}198.58 \\
201.09 \\
203.59\end{array}$ & $\begin{array}{l}198.83 \\
201.34 \\
203.84\end{array}$ & $\begin{array}{l}199.08 \\
201.59 \\
204.09\end{array}$ & $\begin{array}{l}8.00 \\
8.10 \\
8.20\end{array}$ \\
\hline $\begin{array}{l}8.30 \\
8.40\end{array}$ & $\begin{array}{l}204.09 \\
206.59\end{array}$ & $\begin{array}{l}204 \cdot 34 \\
206 \cdot 84\end{array}$ & $\begin{array}{l}204.59 \\
207.09\end{array}$ & $\begin{array}{l}204 \cdot 84 \\
207 \cdot 34\end{array}$ & $\begin{array}{l}205.09 \\
207.59\end{array}$ & $\begin{array}{l}205.34 \\
207.84\end{array}$ & $\begin{array}{l}205.59 \\
208.09\end{array}$ & $\begin{array}{l}205.84 \\
208 \cdot 34\end{array}$ & $\begin{array}{l}206.09 \\
208.59\end{array}$ & $\begin{array}{l}206 \cdot 34 \\
208 \cdot 84\end{array}$ & $\begin{array}{l}206.59 \\
209.09\end{array}$ & $\begin{array}{l}8.30 \\
8.40\end{array}$ \\
\hline $\begin{array}{l}8.50 \\
8.60 \\
8.70 \\
8.80 \\
8.90\end{array}$ & $\begin{array}{l}209.09 \\
211.58 \\
214.08 \\
216.57 \\
219.06\end{array}$ & $\begin{array}{l}209 \cdot 34 \\
211.83 \\
214 \cdot 33 \\
216.82 \\
219 \cdot 31\end{array}$ & $\begin{array}{l}209.59 \\
212.08 \\
214.58 \\
217.07 \\
219.56\end{array}$ & $\begin{array}{l}209 \cdot 84 \\
212.33 \\
214 \cdot 82 \\
217 \cdot 32 \\
219 \cdot 81\end{array}$ & $\begin{array}{l}210.09 \\
212.58 \\
215.07 \\
217.57 \\
220.05\end{array}$ & $\begin{array}{l}210 \cdot 34 \\
212 \cdot 83 \\
215 \cdot 32 \\
217 \cdot 81 \\
220 \cdot 30\end{array}$ & $\begin{array}{l}210.58 \\
213.08 \\
215.57 \\
218.06 \\
220.55\end{array}$ & $\begin{array}{l}210.83 \\
213.33 \\
215.82 \\
218 \cdot 31 \\
220.80\end{array}$ & $\begin{array}{l}211.08 \\
213.58 \\
216.07 \\
218.56 \\
221.05\end{array}$ & $\begin{array}{l}211.33 \\
213.83 \\
216.32 \\
218.81 \\
221 \cdot 30\end{array}$ & $\begin{array}{l}211.58 \\
214.08 \\
216.57 \\
219.06 \\
221.55\end{array}$ & $\begin{array}{l}8.50 \\
8.60 \\
8.70 \\
8.80 \\
8.90\end{array}$ \\
\hline $\begin{array}{l}9.00 \\
9.10 \\
9.20 \\
9.30 \\
9.40\end{array}$ & $\begin{array}{l}221.55 \\
224.03 \\
226.51 \\
228.99 \\
231.47\end{array}$ & $\begin{array}{l}221.79 \\
224.28 \\
226.76 \\
229 \cdot 24 \\
231.72\end{array}$ & $\begin{array}{l}222.04 \\
224.53 \\
227.01 \\
229.49 \\
231.97\end{array}$ & $\begin{array}{l}222 \cdot 29 \\
224 \cdot 78 \\
227.26 \\
229.74 \\
232.21\end{array}$ & $\begin{array}{l}222 \cdot 54 \\
225.02 \\
227 \cdot 51 \\
229.98 \\
232.46\end{array}$ & $\begin{array}{l}222.79 \\
225.27 \\
227.75 \\
230.23 \\
232.71\end{array}$ & $\begin{array}{l}223.04 \\
225.52 \\
228.00 \\
230.48 \\
232.96\end{array}$ & $\begin{array}{l}223.29 \\
225.77 \\
228.25 \\
230.73 \\
233.20\end{array}$ & $\begin{array}{l}223.53 \\
226.02 \\
228.50 \\
230.98 \\
233.45\end{array}$ & $\begin{array}{l}223.78 \\
226.27 \\
228.75 \\
231.22 \\
233.70\end{array}$ & $\begin{array}{l}224.03 \\
226.51 \\
228.99 \\
231.47 \\
233.94\end{array}$ & $\begin{array}{l}9.00 \\
9.10 \\
9.20 \\
9.30 \\
9.40\end{array}$ \\
\hline $\begin{array}{l}9.50 \\
9.60 \\
9.70 \\
9.80 \\
9.90\end{array}$ & $\begin{array}{l}233.94 \\
236.42 \\
238.89 \\
241.35 \\
243.82\end{array}$ & $\begin{array}{l}234.19 \\
236.66 \\
239.13 \\
241.60 \\
244.06\end{array}$ & $\begin{array}{l}234.44 \\
236.91 \\
239.38 \\
241.85 \\
244.31\end{array}$ & $\begin{array}{l}234.69 \\
237.16 \\
239.63 \\
242.09 \\
244.55\end{array}$ & $\begin{array}{l}234 \cdot 93 \\
237 \cdot 40 \\
239 \cdot 87 \\
242 \cdot 34 \\
244 \cdot 80\end{array}$ & $\begin{array}{l}235.18 \\
237.65 \\
240.12 \\
242.58 \\
245.05\end{array}$ & $\begin{array}{l}235.43 \\
237.90 \\
240.37 \\
242.83 \\
245.29\end{array}$ & $\begin{array}{l}235.68 \\
238.15 \\
240.61 \\
243.08 \\
245.54\end{array}$ & $\begin{array}{l}235.92 \\
238.39 \\
240.86 \\
243.32 \\
245.79\end{array}$ & $\begin{array}{l}236.17 \\
238.64 \\
241.11 \\
243.57 \\
246.03\end{array}$ & $\begin{array}{l}236.42 \\
238.89 \\
241.35 \\
243.82 \\
246.28\end{array}$ & $\begin{array}{l}9.50 \\
9.60 \\
9.70 \\
9.80 \\
9.90\end{array}$ \\
\hline $\begin{array}{l}10.00 \\
10.10 \\
10.20 \\
10.30 \\
10.40\end{array}$ & $\begin{array}{l}246.28 \\
248.74 \\
251.19 \\
253.64 \\
256.09\end{array}$ & $\begin{array}{l}246.52 \\
248.98 \\
251.44 \\
253.89 \\
256.34\end{array}$ & $\begin{array}{l}246.77 \\
249.23 \\
251.68 \\
254.13 \\
256.58\end{array}$ & $\begin{array}{l}247.02 \\
249.47 \\
251.93 \\
254.38 \\
256.83\end{array}$ & $\begin{array}{l}247 \cdot 26 \\
249 \cdot 72 \\
252 \cdot 17 \\
254 \cdot 62 \\
257.07\end{array}$ & $\begin{array}{l}247.51 \\
249.96 \\
252.42 \\
254.87 \\
257.32\end{array}$ & $\begin{array}{l}247.75 \\
250.21 \\
252.66 \\
255.12 \\
257.56\end{array}$ & $\begin{array}{l}248.00 \\
250.45 \\
252.91 \\
255.36 \\
257.81\end{array}$ & $\begin{array}{l}248.24 \\
250.70 \\
253.15 \\
255.61 \\
258.05\end{array}$ & $\begin{array}{l}248.49 \\
250.95 \\
253.40 \\
255.85 \\
258.30\end{array}$ & $\begin{array}{l}248.74 \\
251 \cdot 19 \\
253.64 \\
256.09 \\
258.54\end{array}$ & $\begin{array}{l}10.00 \\
10.10 \\
10.20 \\
10.30 \\
10.40\end{array}$ \\
\hline $\begin{array}{l}10.50 \\
10.60 \\
10.70 \\
10.80 \\
10.90\end{array}$ & $\begin{array}{l}258.54 \\
260.99 \\
263.43 \\
265.87 \\
268.31\end{array}$ & $\begin{array}{l}258.79 \\
261.23 \\
263.68 \\
266.12 \\
268.55\end{array}$ & $\begin{array}{l}259.03 \\
261.48 \\
263.92 \\
266.36 \\
268.80\end{array}$ & $\begin{array}{l}259.28 \\
261.72 \\
264.16 \\
266.60 \\
269.04\end{array}$ & $\begin{array}{l}259 \cdot 52 \\
261.97 \\
264 \cdot 41 \\
266.85 \\
269.29\end{array}$ & $\begin{array}{l}259.77 \\
262.21 \\
264.65 \\
267.09 \\
269.53\end{array}$ & $\begin{array}{l}260.01 \\
262.45 \\
264.90 \\
267.34 \\
269.77\end{array}$ & $\begin{array}{l}260.26 \\
262.70 \\
265.14 \\
267.58 \\
270.02\end{array}$ & $\begin{array}{l}260 \cdot 50 \\
262 \cdot 94 \\
265 \cdot 38 \\
267 \cdot 82 \\
270.26\end{array}$ & $\begin{array}{l}260.74 \\
263.19 \\
265.63 \\
268.07 \\
270.50\end{array}$ & $\begin{array}{l}260.99 \\
263.43 \\
265.87 \\
268.31 \\
270.75\end{array}$ & $\begin{array}{l}10.50 \\
10.60 \\
10.70 \\
10.80 \\
10.90\end{array}$ \\
\hline $\begin{array}{l}11 \cdot 00 \\
11 \cdot 10 \\
11 \cdot 20 \\
11.30 \\
11.40\end{array}$ & $\begin{array}{l}270.75 \\
273.18 \\
275.61 \\
278.04 \\
280.47\end{array}$ & $\begin{array}{l}270.99 \\
273.42 \\
275.85 \\
278.28 \\
280.71\end{array}$ & $\begin{array}{l}271.23 \\
273.67 \\
276.10 \\
278.53 \\
280.95\end{array}$ & $\begin{array}{l}271.48 \\
273.91 \\
276.34 \\
278.77 \\
281 \cdot 20\end{array}$ & $\begin{array}{l}271 \cdot 72 \\
274 \cdot 15 \\
276.58 \\
279.01 \\
281.44\end{array}$ & $\begin{array}{l}271.96 \\
274.40 \\
276.83 \\
279.26 \\
281.68\end{array}$ & $\begin{array}{l}272.21 \\
274.64 \\
277.07 \\
279.50 \\
281.92\end{array}$ & $\begin{array}{l}272.45 \\
274.88 \\
277.31 \\
279.74 \\
282.17\end{array}$ & $\begin{array}{l}272.69 \\
275.13 \\
277.56 \\
279.98 \\
282.41\end{array}$ & $\begin{array}{l}272.94 \\
275.37 \\
277.80 \\
280.23 \\
282.65\end{array}$ & $\begin{array}{l}273.18 \\
275.61 \\
278.04 \\
280.47 \\
282.89\end{array}$ & $\begin{array}{l}11.00 \\
11.10 \\
11.20 \\
11.30 \\
11.40\end{array}$ \\
\hline $\begin{array}{l}11.50 \\
11.60 \\
11.70 \\
11.80 \\
11.90\end{array}$ & $\begin{array}{l}282.89 \\
285.32 \\
287.74 \\
290.16 \\
292.58\end{array}$ & $\begin{array}{l}283.14 \\
285.56 \\
287.98 \\
290.40 \\
292.82\end{array}$ & $\begin{array}{l}283.38 \\
285.80 \\
288.22 \\
290.64 \\
293.06\end{array}$ & $\begin{array}{l}283.62 \\
286.04 \\
288.47 \\
290.88 \\
293.30\end{array}$ & $\begin{array}{l}283 \cdot 86 \\
286 \cdot 29 \\
288 \cdot 71 \\
291 \cdot 13 \\
293 \cdot 54\end{array}$ & $\begin{array}{l}284 \cdot 11 \\
286 \cdot 53 \\
288 \cdot 95 \\
291 \cdot 37 \\
293 \cdot 79\end{array}$ & $\begin{array}{l}284.35 \\
286.77 \\
289.19 \\
291.61 \\
294.03\end{array}$ & $\begin{array}{l}284.59 \\
287.01 \\
289.43 \\
291.85 \\
294.27\end{array}$ & $\begin{array}{l}284.83 \\
287.25 \\
289.68 \\
292.09 \\
294.51\end{array}$ & $\begin{array}{l}285.08 \\
287.50 \\
289.92 \\
292.34 \\
294.75\end{array}$ & $\begin{array}{l}285 \cdot 32 \\
287 \cdot 74 \\
290 \cdot 16 \\
292 \cdot 58 \\
294.99\end{array}$ & $\begin{array}{l}11.50 \\
11.60 \\
11.70 \\
11.80 \\
11.90\end{array}$ \\
\hline 2.00 & 294.99 & 295.23 & 295.48 & 295.72 & 295.96 & 296.20 & 296.44 & 296.68 & 296.92 & 297.17 & 297.41 & 12.00 \\
\hline
\end{tabular}

$\mathrm{mV}$

$.00 \quad .01 \quad .02$

.03

.04

.05

.06

.07

.08

.09

.10

$\mathrm{mV}$ 
TABLE A7.2.1. Type $K$ thermocouples-temperature $\left({ }^{\circ} \mathrm{C}\right)$ as a function of thermoelectric voltage, reference junctions at $0^{\circ} \mathrm{C}$--Continued

$\mathrm{mV}$

.00

.01

.02

.03

TEMP

12
12
12
12
12
12
12
12
12

$\begin{array}{ll}297.41 \\ 12.20 & 299.82\end{array}$

$12.30 \quad 302.23$

12.40

12.50

12.60
12.70

12.80

12.90

13.00

13.10

13.2

13.30
13.40

13.50

13.60

13.7

13.80

13.90

14.00

14.10

14.20

14.30

14.40

14.50

14.70

14.80

14.90

15.00

15.10

15.20

15.3

15.40

15.50

15.6

15.70

15.80

15.90

16.00

16.10

16.20

16.30

16.40

16.50

16.6

16.70

16.80
16.90

17.00

17.10

17.20

17.30

17.40

17.50

17.60

17.70

17.80

17.90

18.00
295.23

297.65

300.06

302.47

$304 \cdot 88$

307.05

309.46

311.86

314.27
316.67

316.67

321.47

323.87

326.27

328.66

331.06

335.85

338.24

340.63

343.02

345.41

347.80

350.19

352.57

354.96

357.34

359.72

362.11

364.49

366.87

369.25

371.63

374.00

378.76

381.13

383.51

385.88

390.63

393.00

395.37

397.74

$400 \cdot 11$

402.48

404.84

411.94

414.31

416.67

419.03

421.40

423.76

426.12

428.48

430.84

433.20

435.56

437.92
388.25
307.29

309.70

312.10

314.51

319.31

321.71

324.11

328.90

331.30

333.69

336.09

338.48

340.87

343.26

345.65

348.04

350.42

352.81

355.20

357.58

359.96

362.34

364.73

367.11

369.49

371.86

374.24

376.62

379.00

381.37

383.75

386.12
388.49

390.86

393.24

395.61

397.98

$400 \cdot 34$

$402 \cdot 71$

405.08

412.18

414.54

416.91

419.27

421.63

423.99

426.36

428.72

431.08

433.44
435.79

438.15
295.48 297.89

300.54

302.71

305.12

307.53

309.94

$312 \cdot 34$

314.75

317.15

319.55
321.95

324.35

326.75

329.14

331.54

333.93

336.33

338.72

341.11

343.50

345.89

348.28

353.05

355.43

357.82

360.20

362.58

364.96

367.34

369.72

372.10

374.48

376.86

379.23

$381 \cdot 61$

383.98

386.36

388.73

391.10

393.47

395.84

398.21

400.58

402.95

405.32

407.68

410.05

412.41

414.78

417.14

419.51

421.87

424.23

426.59

428.95

431.31

433.67

438.39

295.72
298.13
300.54
302.95
305.36

307.77

310.18

312.58

314.99

317.39

319.79

322.19

324.59

26.99

329.38

331.78

334.17

336.57
338.96

341.35

343.74

346.13

348.51

350.90

353.29

355.67

358.06

360.44

362.82

365.20

367.58

369.96

372.34

374.72

377.09

379.47

381.85

384.22

386.59

388.97

391.34

393.71

396.08

398.45

400.82

403.19

405.55

410.29

412.65

415.02

417.38

419.74

422.10

424.47

426.83

429.19

431.55

433.91

438.62 
TABLE A7.2.1. Type $K$ thermocouples-temperature $\left({ }^{\circ} \mathrm{C}\right)$ as a function of thermoelectric voltage, reference junctions at $0^{\circ} \mathrm{C}$-Continued

$\mathrm{mV}$

.00

.01

.02

.03

TEMPERATURES IN DEGREES C (IPTS 1968)

$18 \cdot 00$

18.10

$18 \cdot 20$

18.30

18.40

18.50

18.60

18.70

18.80

18.90

19.00

19.10

$19 \cdot 20$

19.30

19.40

19.50

19.60

19.70

19.80

19.90

$20 \cdot 00$

$20 \cdot 10$

20.20

20.30

20.40

20.50

20.60

20.70

20.80

20.90

21.00

$21 \cdot 10$

21.20

21.30

21.40

21.50

21.60

21.70

21.80

21.90

22.00

22.10

22.20

22.30

22.40

22.50

22.60

22.70

22.80

22.90

23.00

23.10

23.20

23.30

23.40

23.50

23.60

23.70

23.80

23.90

24.00

437.92

440.27

442.63

444.99

447.34

449.70

452.05

456.76

459.11

461.47

463.82

466.17

468.52

470.87

473.22

475.57

477.92

480.27

482.62

484.97

487.32

489.67

492.02

494.36

496.71

499.06

501.40

503.75

506.10

508.44

510.79

515.48

517.83

520.17

522.52

524.86

527.21

531.90

534.24

538.93

541.28

543.62

545.97

548.31

550.66

553.00

555.35

557.69

560.04

564.73

567.08

569.43

571.77

574.12

576.47

578.82
438.15

440.51

442.87

445.22

447.58

449.93

452.29

454.64

457.00

461.70

464.05

466.41

468.76

471.11

473.46

475.81

$478 \cdot 16$

480.51

482.86

485.21

487.55

489.90

492.25

494.60

496.94

499.29

501.64

503.99

506.33

508.68

511.02

515.71

520.41

522.75

525.10

527.44

532.13
534.48

536.82

539.17

541.51

543.86

546.20

548.55

550.89

553.24

555.58

557.93

560.28

562.62

564.97

567.31

569.66

572.01

574.36

576.70

579.05
518.06

438.39

445.46
447.81

450.17

452.52

454.88

457.23
459.58

461.94

464.29

466.64

468.99

471.34

473.69

476.04

480.74

483.09

485.44

487.79

490.14

492.49

494.83

497.18

499.53

501.87

506.57

508.91

511.26

518.29

520.64

522.99

525.33

527.68

530.02

532.37

534.71

537.06

539.40

544.09

546.44

548.78

551.13
553.47

555.82

558.16

560.51

562.86

567.55

569.90

$572 \cdot 24$

574.59

576.94

579.29

439.10
441.45
443.81
446.17
448.52

$439 \cdot 33$

441.69

444.04
446.40

448.76

450.88

453.23

457.94

451.11

453.47

455.82

457.47

459.82

42.17

469.23

471.58

473.93

478.63

480.98

485.68

492.72

495.07

497.41

499.76

504.45

506.80

$509 \cdot 15$

511.49

516.18

520.87

523.22

525.5

530.26

532.60

537.29

549.02

551.36

556.05

558.40

563.09

570.13

.02

.03

.04

.05

.06 
TABLE A7.2.1. Type $\boldsymbol{K}$ thermocouples-temperature $\left({ }^{\circ} \mathrm{C}\right)$ as a function of thermoelectric voltage, reference junctions at $0^{\circ} \mathrm{C}$-Continued

$\mathrm{mV}$

.00

.01

.02

.03

.04

.05

.07

TEMPERATURES IN DEGREES C (IPTS 1968)

24.00

24.10

24.30

24.40

24.50

24.60

24.80
24.90

25.00

25.10

25.20

25.30

25.40

25.50

25.60

25.90

26.00

26.10

26.20

26.30

26.40

26.50

26.60

26.70

26.80

26.90

27.00

27.10

27.20

27.30

27.40

27.50

27.60

27.70

27.80

27.90

28.00

28.10

28.20

28.30

28.40

28.50

28.60

28.70

28.80

28.90

29.00

29.10

29.20

29.30

29.40

29.50

29.60

29.70

29.80

29.90

30.00

$m v$

$578.82 \quad 579.05$

581.16

583.51

585.86

590.56

592.91

595.26

597.61

602.31

604.67

607.02

609.37

611.73

614.08

616.43

621.15

623.50

625.86

628.22

630.58

632.94

635.30

637.66

640.02

642.38

644.74
647.11

649.47

651.83

654.20

656.57

658.93

661.30

663.67

666.04

668.4

670.79

673.16

675.53

677.9

680.28

682.66

685.04

687.42

689.80

692.18

694.56

696.94

699.32

701.71

704.10

706.48

708.87

711.26

713.65

716.04

718.44

720.83

581.40

586.10

588.45

590.79

593.14

595.50

597.85

600.20

602.55

604.90

607.25

609.61

611.96

614.32

616.67

619.03

621.38

623.74

626.10

628.45

630.81

633.17

637.89

640.25

642.62

644.98

647.34

649.71

652.07

654.44

656.80

659.17

661.54

663.91

666.28

668.6

673.40

675.77

678.14

680.52

682.90

685.27

687.65

690.03

692.41

694.80

697.18

699.56

701.95

704.33

706.72

709.11

711.50

713.89

718.68

721.07

579.29

581.63

586.33

588.68

591.03

593.38

595.73

598.08
600.43

602.78

605.14

607.49

609.84

612.20

614.55

616.91

619.26

621.62

623.97

626.33

628.69

631.05

633.41

635.77

638.13

640.49

42.85

645.21
647.58

649.94

652.31

654.67

657.04

659.41

661.78

664.15

668.89

671.26

673.63

676.01

678.38

680.76

683.13

685.51

687.89

690.27

692.65

695.03

697.42

699.80

702.19

704.57

706.96

709.35

711.74

714.13

718.91

721.31

$579.52 \quad 579.76$

$2 \quad 579.76 \quad 579.99$

581.87

584.22

584.45

588.92

591.26

593.61

598.32

600.67

603.02

605.37

607.72

610.08

612.43

614.79

617.14

619.50

621.85
624.21

626.57

628.93

631.28

633.64

636.00

638.36

640.73

643.09

645.45

647.81

650.18

652.54

654.91

657.28

659.65

662.01

664.38

671.50

673.87

676.24

678.62

681.00

683.37

685.75

688.13

690.51

692.89

697.66

700.04

702.43

704.81

707.20

709.59 
TABLE A7.2.1. Type $\boldsymbol{K}$ thermocouples-temperature $\left({ }^{\circ} \mathrm{C}\right)$ as a function of thermoelectric voltage, reference junctions at $0^{\circ} \mathrm{C}$-Continued

mV

.02

.03

.04

.05

.06

.07

.08

.09

$\cdot 10$

$\mathrm{mV}$

TEMPERATURES IN DEGREES C (IPTS 1968)

\begin{tabular}{|c|c|c|c|c|c|c|c|c|c|c|c|c|}
\hline $\begin{array}{l}30 \cdot 00 \\
30 \cdot 10 \\
30 \cdot 20 \\
30 \cdot 30 \\
30 \cdot 40\end{array}$ & $\begin{array}{l}720.83 \\
723.23 \\
725.62 \\
728.02 \\
730.42\end{array}$ & $\begin{array}{l}721.07 \\
723.47 \\
725.86 \\
728.26 \\
730.66\end{array}$ & $\begin{array}{l}721 \cdot 31 \\
723 \cdot 70 \\
726 \cdot 10 \\
728 \cdot 50 \\
730.90\end{array}$ & $\begin{array}{l}721 \cdot 55 \\
723.94 \\
726 \cdot 34 \\
728 \cdot 74 \\
731 \cdot 14\end{array}$ & $\begin{array}{l}721 \cdot 79 \\
724 \cdot 18 \\
726 \cdot 58 \\
728 \cdot 98 \\
731 \cdot 38\end{array}$ & $\begin{array}{l}722.03 \\
724.42 \\
726.82 \\
729.22 \\
731.62\end{array}$ & $\begin{array}{l}722.27 \\
724.66 \\
727.06 \\
729.46 \\
731.86\end{array}$ & $\begin{array}{l}722.51 \\
724.90 \\
727.30 \\
729.70 \\
732.10\end{array}$ & $\begin{array}{l}722.75 \\
725 \cdot 14 \\
727.54 \\
729.94 \\
732.34\end{array}$ & $\begin{array}{l}722.99 \\
725.38 \\
727.78 \\
730.18 \\
732.58\end{array}$ & $\begin{array}{l}723.23 \\
725.62 \\
728.02 \\
730.42 \\
732.82\end{array}$ & $\begin{array}{l}30.00 \\
30.10 \\
30.20 \\
30.30 \\
30.40\end{array}$ \\
\hline $\begin{array}{l}30.50 \\
30.60 \\
30.70 \\
30.80 \\
30.90\end{array}$ & $\begin{array}{l}732.82 \\
735.22 \\
737.62 \\
740.03 \\
742.43\end{array}$ & $\begin{array}{l}733.06 \\
735.46 \\
737.86 \\
740.27 \\
742.67\end{array}$ & $\begin{array}{l}733.30 \\
735.70 \\
738.10 \\
740.51 \\
742.91\end{array}$ & $\begin{array}{l}733.54 \\
735.94 \\
738.34 \\
740.75 \\
743.15\end{array}$ & $\begin{array}{l}733.78 \\
736.18 \\
738.58 \\
740.99 \\
743.40\end{array}$ & $\begin{array}{l}734.02 \\
736.42 \\
738.83 \\
741.23 \\
743.64\end{array}$ & $\begin{array}{l}734.26 \\
736.66 \\
739.07 \\
741.47 \\
743.88\end{array}$ & $\begin{array}{l}734.50 \\
736.90 \\
739.31 \\
741.71 \\
744.12\end{array}$ & $\begin{array}{l}734.74 \\
737.14 \\
739.55 \\
741.95 \\
744.36\end{array}$ & $\begin{array}{l}734 \cdot 98 \\
737.38 \\
739.79 \\
742.19 \\
744.60\end{array}$ & $\begin{array}{l}735.22 \\
737.62 \\
740.03 \\
742.43 \\
744.84\end{array}$ & $\begin{array}{l}30.50 \\
30.60 \\
30.70 \\
30.80 \\
30.90\end{array}$ \\
\hline $\begin{array}{l}31.00 \\
31.10 \\
31.20 \\
31.30 \\
31.40\end{array}$ & $\begin{array}{l}744.84 \\
747.25 \\
749.66 \\
752.07 \\
754.48\end{array}$ & $\begin{array}{l}745.08 \\
747.49 \\
749.90 \\
752.31 \\
754.72\end{array}$ & $\begin{array}{l}745.32 \\
747.73 \\
750.14 \\
752.55 \\
754.96\end{array}$ & $\begin{array}{l}745.56 \\
747.97 \\
750.38 \\
752.79 \\
755.20\end{array}$ & $\begin{array}{l}745.80 \\
748.21 \\
750.62 \\
753.03 \\
755.44\end{array}$ & $\begin{array}{l}746.04 \\
748.45 \\
750.86 \\
753.27 \\
755.68\end{array}$ & $\begin{array}{l}746.28 \\
748.69 \\
751.10 \\
753.51 \\
755.93\end{array}$ & $\begin{array}{l}746.52 \\
748.93 \\
751.34 \\
753.75 \\
756.17\end{array}$ & $\begin{array}{l}746.77 \\
749.17 \\
751.58 \\
754.00 \\
756.41\end{array}$ & $\begin{array}{l}747.01 \\
749.42 \\
751.83 \\
754.24 \\
756.65\end{array}$ & $\begin{array}{l}747.25 \\
749.66 \\
752.07 \\
754.48 \\
756.89\end{array}$ & $\begin{array}{l}31 \cdot 00 \\
31 \cdot 10 \\
31.20 \\
31.30 \\
31.40\end{array}$ \\
\hline $\begin{array}{l}31.50 \\
31.60 \\
31.70 \\
31.80 \\
31.90\end{array}$ & $\begin{array}{l}756.89 \\
759.31 \\
761.72 \\
764.14 \\
766.56\end{array}$ & $\begin{array}{l}757.13 \\
759.55 \\
761.96 \\
764.38 \\
766.80\end{array}$ & $\begin{array}{l}757.37 \\
759.79 \\
762.21 \\
764.62 \\
767.04\end{array}$ & $\begin{array}{l}757.62 \\
760.03 \\
762.45 \\
764.86 \\
767.28\end{array}$ & $\begin{array}{l}757.86 \\
760.27 \\
762 \cdot 69 \\
765.11 \\
767.53\end{array}$ & $\begin{array}{l}758.10 \\
760.51 \\
762.93 \\
765.35 \\
767.77\end{array}$ & $\begin{array}{l}758.34 \\
760.76 \\
763.17 \\
765.59 \\
768.01\end{array}$ & $\begin{array}{l}758.58 \\
761.00 \\
763.41 \\
765.83 \\
768.25\end{array}$ & $\begin{array}{l}758.82 \\
761.24 \\
763.66 \\
766.07 \\
768.49\end{array}$ & $\begin{array}{l}759.06 \\
761.48 \\
763.90 \\
766.32 \\
768.74\end{array}$ & $\begin{array}{l}759 \cdot 31 \\
761.72 \\
764 \cdot 14 \\
766.56 \\
768.98\end{array}$ & $\begin{array}{l}31.50 \\
31.60 \\
31.70 \\
31.80 \\
31.90\end{array}$ \\
\hline $\begin{array}{l}32.00 \\
32.10 \\
32.20 \\
32.30 \\
32.40\end{array}$ & $\begin{array}{l}768.98 \\
771.40 \\
773.82 \\
776.25 \\
778.67\end{array}$ & $\begin{array}{l}769.22 \\
771.64 \\
774.06 \\
776.49 \\
778.91\end{array}$ & $\begin{array}{l}769.46 \\
771.88 \\
774.31 \\
776.73 \\
779.16\end{array}$ & $\begin{array}{l}769.70 \\
772.13 \\
774.55 \\
776.97 \\
779.40\end{array}$ & $\begin{array}{l}769.95 \\
772.37 \\
774.79 \\
777.22 \\
779.64\end{array}$ & $\begin{array}{l}770.19 \\
772.61 \\
775.03 \\
777.46 \\
779.88\end{array}$ & $\begin{array}{l}770.43 \\
772.85 \\
775.28 \\
777.70 \\
780.13\end{array}$ & $\begin{array}{l}770.67 \\
773.09 \\
775.52 \\
777.94 \\
780.37\end{array}$ & $\begin{array}{l}770.91 \\
773.34 \\
775.76 \\
778.19 \\
780.61\end{array}$ & $\begin{array}{l}771.16 \\
773.58 \\
776.00 \\
778.43 \\
780.86\end{array}$ & $\begin{array}{l}771.40 \\
773.82 \\
776.25 \\
778.67 \\
781.10\end{array}$ & $\begin{array}{l}32.00 \\
32.10 \\
32.20 \\
32.30 \\
32.40\end{array}$ \\
\hline $\begin{array}{l}32.50 \\
32.60 \\
32.70 \\
32.80 \\
32.90\end{array}$ & $\begin{array}{l}781.10 \\
783.53 \\
785.96 \\
788.39 \\
790.82\end{array}$ & $\begin{array}{l}781.34 \\
783.77 \\
786.20 \\
788.63 \\
791.06\end{array}$ & $\begin{array}{l}781.58 \\
784.01 \\
786.44 \\
788.87 \\
791.31\end{array}$ & $\begin{array}{l}781.83 \\
784 \cdot 26 \\
786.69 \\
789 \cdot 12 \\
791.55\end{array}$ & $\begin{array}{l}782 \cdot 07 \\
784 \cdot 50 \\
786.93 \\
789 \cdot 36 \\
791.79\end{array}$ & $\begin{array}{l}782.31 \\
784.74 \\
787.17 \\
789.60 \\
792.04\end{array}$ & $\begin{array}{l}782.56 \\
784.98 \\
787.42 \\
789.85 \\
792.28\end{array}$ & $\begin{array}{l}782.80 \\
785.23 \\
787.66 \\
790.09 \\
792.52\end{array}$ & $\begin{array}{l}783.04 \\
785.47 \\
787.90 \\
790.33 \\
792.77\end{array}$ & $\begin{array}{l}783.28 \\
785.71 \\
788.14 \\
790.58 \\
793.01\end{array}$ & $\begin{array}{l}783.53 \\
785.96 \\
788.39 \\
790.82 \\
793.26\end{array}$ & $\begin{array}{l}32.50 \\
32.60 \\
32.70 \\
32.80 \\
32.90\end{array}$ \\
\hline $\begin{array}{l}33.00 \\
33.10 \\
33.20 \\
33.30 \\
33.40\end{array}$ & $\begin{array}{l}793.26 \\
795.69 \\
798.13 \\
800.57 \\
803.01\end{array}$ & $\begin{array}{l}793.50 \\
795.93 \\
798.37 \\
800.81 \\
803.25\end{array}$ & $\begin{array}{l}793.74 \\
796.18 \\
798.62 \\
801.05 \\
803.49\end{array}$ & $\begin{array}{l}793.99 \\
796.42 \\
798.86 \\
801.30 \\
803.74\end{array}$ & $\begin{array}{l}794.23 \\
796.67 \\
799.10 \\
801.54 \\
803.98\end{array}$ & $\begin{array}{l}794.47 \\
796.91 \\
799.35 \\
801.79 \\
804.23\end{array}$ & $\begin{array}{l}794.72 \\
797.15 \\
799.59 \\
802.03 \\
804.47\end{array}$ & $\begin{array}{l}794.96 \\
797.40 \\
799.83 \\
802.27 \\
804.72\end{array}$ & $\begin{array}{l}795.20 \\
797.64 \\
800.08 \\
802.52 \\
804.96\end{array}$ & $\begin{array}{l}795 \cdot 45 \\
797.88 \\
800.32 \\
802.76 \\
805 \cdot 20\end{array}$ & $\begin{array}{l}795.69 \\
798.13 \\
800.57 \\
803.01 \\
805.45\end{array}$ & $\begin{array}{l}33.00 \\
33.10 \\
33.20 \\
33.30 \\
33.40\end{array}$ \\
\hline $\begin{array}{l}33.50 \\
33.60 \\
33.70 \\
33.80 \\
33.90\end{array}$ & $\begin{array}{l}805.45 \\
807.89 \\
810.34 \\
812.78 \\
815.23\end{array}$ & $\begin{array}{l}805.69 \\
808.14 \\
810.58 \\
813.03 \\
815.47\end{array}$ & $\begin{array}{l}805.94 \\
808.38 \\
810.83 \\
813.27 \\
815.72\end{array}$ & $\begin{array}{l}806.18 \\
808.62 \\
811.07 \\
813.52 \\
815.96\end{array}$ & $\begin{array}{l}806.43 \\
808.87 \\
811.31 \\
813.76 \\
816.21\end{array}$ & $\begin{array}{l}806.67 \\
809.11 \\
811.56 \\
814.01 \\
816.45\end{array}$ & $\begin{array}{l}806.91 \\
809.36 \\
811.80 \\
814.25 \\
816.70\end{array}$ & $\begin{array}{l}807.16 \\
809.60 \\
812.05 \\
814.50 \\
816.94\end{array}$ & $\begin{array}{l}807.40 \\
809.85 \\
812.29 \\
814.74 \\
817.19\end{array}$ & $\begin{array}{l}807.65 \\
810.09 \\
812.54 \\
814.98 \\
817.43\end{array}$ & $\begin{array}{l}807.89 \\
810.34 \\
812.78 \\
815.23 \\
817.68\end{array}$ & $\begin{array}{l}33.50 \\
33.60 \\
33.70 \\
33.80 \\
33.90\end{array}$ \\
\hline $\begin{array}{l}34.00 \\
34 \cdot 10 \\
34.20 \\
34 \cdot 30 \\
34.40\end{array}$ & $\begin{array}{l}817.68 \\
820.13 \\
822.58 \\
825.04 \\
827.49\end{array}$ & $\begin{array}{l}817.92 \\
820.37 \\
822.83 \\
825.28 \\
827.74\end{array}$ & $\begin{array}{l}818.17 \\
820.62 \\
823.07 \\
825.53 \\
827.98\end{array}$ & $\begin{array}{l}818.41 \\
820.87 \\
823.32 \\
825.77 \\
828.23\end{array}$ & $\begin{array}{l}818.66 \\
821.11 \\
823.56 \\
826.02 \\
828.47\end{array}$ & $\begin{array}{l}818.90 \\
821.36 \\
823.81 \\
826.26 \\
828.72\end{array}$ & $\begin{array}{l}819.15 \\
821.60 \\
824.05 \\
826.51 \\
828.96\end{array}$ & $\begin{array}{l}819.39 \\
821.85 \\
824.30 \\
826.75 \\
829.21\end{array}$ & $\begin{array}{l}819.64 \\
822.09 \\
824.54 \\
827.00 \\
829.46\end{array}$ & $\begin{array}{l}819.88 \\
822.34 \\
824.79 \\
827.25 \\
829.70\end{array}$ & $\begin{array}{l}820.13 \\
822.58 \\
825.04 \\
827.49 \\
829.95\end{array}$ & $\begin{array}{l}34.00 \\
34.10 \\
34.20 \\
34.30 \\
34.40\end{array}$ \\
\hline $\begin{array}{l}34.50 \\
34.60 \\
34.70 \\
34.80 \\
34.90\end{array}$ & $\begin{array}{l}829.95 \\
832.41 \\
834.87 \\
837.33 \\
839.79\end{array}$ & $\begin{array}{l}830.19 \\
832.65 \\
835.11 \\
837.57 \\
840.04\end{array}$ & $\begin{array}{l}830.44 \\
832.90 \\
835.36 \\
837.82 \\
840.28\end{array}$ & $\begin{array}{l}830.69 \\
833.14 \\
835.60 \\
838.07 \\
840.53\end{array}$ & $\begin{array}{l}830.93 \\
833.39 \\
835.85 \\
838.31 \\
840.78\end{array}$ & $\begin{array}{l}831.18 \\
833.64 \\
836.10 \\
838.56 \\
841.02\end{array}$ & $\begin{array}{l}831.42 \\
833.88 \\
836.34 \\
838.81 \\
841.27\end{array}$ & $\begin{array}{l}831.67 \\
834.13 \\
836.59 \\
839.05 \\
841.52\end{array}$ & $\begin{array}{l}831.91 \\
834.37 \\
836.84 \\
839.30 \\
841.76\end{array}$ & $\begin{array}{l}832.16 \\
834.62 \\
837.08 \\
839.54 \\
842.01\end{array}$ & $\begin{array}{l}832.41 \\
834.87 \\
837.33 \\
839.79 \\
842.26\end{array}$ & $\begin{array}{l}34.50 \\
34.60 \\
34.70 \\
34.80 \\
34.90\end{array}$ \\
\hline $\begin{array}{l}35.00 \\
35 \cdot 10 \\
35.20 \\
35.30 \\
35.40\end{array}$ & $\begin{array}{l}842.26 \\
844.72 \\
847.19 \\
849.66 \\
852.13\end{array}$ & $\begin{array}{l}842.50 \\
844.97 \\
847.44 \\
849.91 \\
852.38\end{array}$ & $\begin{array}{l}842.75 \\
845.21 \\
847.68 \\
850.15 \\
852.62\end{array}$ & $\begin{array}{l}842.99 \\
845.46 \\
847.93 \\
850.40 \\
852.87\end{array}$ & $\begin{array}{l}843 \cdot 24 \\
845.71 \\
848.18 \\
850.65 \\
853.12\end{array}$ & $\begin{array}{l}843.49 \\
845.96 \\
848.42 \\
850.89 \\
853.37\end{array}$ & $\begin{array}{l}843.73 \\
846.20 \\
848.67 \\
851.14 \\
853.61\end{array}$ & $\begin{array}{l}843.98 \\
846.45 \\
848.92 \\
851.39 \\
853.86\end{array}$ & $\begin{array}{l}844.23 \\
846.70 \\
849.16 \\
851.64 \\
854.11\end{array}$ & $\begin{array}{l}844.47 \\
846.94 \\
849.41 \\
851.88 \\
854.35\end{array}$ & $\begin{array}{l}844.72 \\
847.19 \\
849 \cdot 66 \\
852.13 \\
854.60\end{array}$ & $\begin{array}{l}35.00 \\
35.10 \\
35.20 \\
35.30 \\
35.40\end{array}$ \\
\hline $\begin{array}{l}35.50 \\
35.60 \\
35.70 \\
35.80 \\
35.90\end{array}$ & $\begin{array}{l}854.60 \\
857.08 \\
859.55 \\
862.03 \\
864.51\end{array}$ & $\begin{array}{l}854.85 \\
857.32 \\
859.80 \\
862.28 \\
864.76\end{array}$ & $\begin{array}{l}855.10 \\
857.57 \\
860.05 \\
862.52 \\
865.00\end{array}$ & $\begin{array}{l}855.34 \\
857.82 \\
860.29 \\
862.77 \\
865.25\end{array}$ & $\begin{array}{l}855.59 \\
858.07 \\
860.54 \\
863.02 \\
865.50\end{array}$ & $\begin{array}{l}855.84 \\
858.31 \\
860.79 \\
863.27 \\
865.75\end{array}$ & $\begin{array}{l}856.09 \\
858.56 \\
861.04 \\
863.52 \\
866.00\end{array}$ & $\begin{array}{l}856.33 \\
858.81 \\
861.29 \\
863.76 \\
866.24\end{array}$ & $\begin{array}{l}856.58 \\
859.06 \\
861.53 \\
864.01 \\
866.49\end{array}$ & $\begin{array}{l}856.83 \\
859.30 \\
861.78 \\
864.26 \\
866.74\end{array}$ & $\begin{array}{l}857.08 \\
859.55 \\
862.03 \\
864.51 \\
866.99\end{array}$ & $\begin{array}{l}35.50 \\
35.60 \\
35.70 \\
35.80 \\
35.90\end{array}$ \\
\hline 6.00 & 866.99 & 867.24 & 867.48 & 867.73 & 867.98 & 868.23 & 868.48 & 868.73 & 868.97 & 869.22 & 869.47 & 36.00 \\
\hline
\end{tabular}

$\mathrm{mV}$

.00

.01

.02

.03

.04

.05

.06

.07

.08
.09

.10 
TABle A7.2.1. Type $\boldsymbol{K}$ thermocouples-temperature $\left({ }^{\circ} \mathrm{C}\right)$ as a function of thermoelectric voltage, reference junctions at $0^{\circ} \mathrm{C}$-Continued

.02

\author{
.03
}

$\begin{array}{llll}.04 & .05 \quad .06 \quad .07\end{array}$

.08

.09

.10

$m \vee$

TEMPERATURES IN DEGREES C (IPTS 1968)

\begin{tabular}{|c|c|c|c|c|c|c|c|c|c|c|c|c|}
\hline $\begin{array}{l}6.00 \\
6.10 \\
6.20 \\
6.30 \\
6.40\end{array}$ & $\begin{array}{l}866.99 \\
869.47 \\
871.95 \\
874.44 \\
876.93\end{array}$ & $\begin{array}{l}867.24 \\
869.72 \\
872.20 \\
874.69 \\
877.18\end{array}$ & $\begin{array}{l}867.48 \\
869.97 \\
872.45 \\
874.94 \\
877.42\end{array}$ & $\begin{array}{l}867.73 \\
870.22 \\
872.70 \\
875.19 \\
877.67\end{array}$ & $\begin{array}{l}867.98 \\
870.46 \\
872.95 \\
875.43 \\
877.92\end{array}$ & $\begin{array}{l}868.23 \\
870.71 \\
873.20 \\
875.68 \\
878.17\end{array}$ & $\begin{array}{l}868.48 \\
870.96 \\
873.45 \\
875.93 \\
878.42\end{array}$ & $\begin{array}{l}868.73 \\
871.21 \\
873.69 \\
876.18 \\
878.67\end{array}$ & $\begin{array}{l}868.97 \\
871.46 \\
873.94 \\
876.43 \\
878.92\end{array}$ & $\begin{array}{l}869.22 \\
871.71 \\
874.19 \\
876.68 \\
879.17\end{array}$ & $\begin{array}{l}869.47 \\
871.95 \\
874.44 \\
876.93 \\
879.41\end{array}$ & $\begin{array}{l}36.00 \\
36.10 \\
36.20 \\
36.30 \\
36.40\end{array}$ \\
\hline $\begin{array}{l}36.50 \\
6.60 \\
36.70\end{array}$ & $\begin{array}{l}879.41 \\
881.90 \\
884.40\end{array}$ & $\begin{array}{l}879.66 \\
882.15 \\
884.65\end{array}$ & $\begin{array}{l}879.91 \\
882.40 \\
884.90\end{array}$ & $\begin{array}{l}880.16 \\
882.65 \\
885.14\end{array}$ & $\begin{array}{l}880 \cdot 41 \\
882 \cdot 90 \\
885 \cdot 39\end{array}$ & $\begin{array}{l}880.66 \\
883.15 \\
885.64\end{array}$ & & & $\begin{array}{l}881.41 \\
883.90 \\
886.39\end{array}$ & $\begin{array}{l}881.66 \\
884.15 \\
886.64\end{array}$ & $\begin{array}{l}881.90 \\
884.40 \\
886.89\end{array}$ & $\begin{array}{l}36.50 \\
36.60 \\
36.70\end{array}$ \\
\hline $\begin{array}{l}36.80 \\
36.90\end{array}$ & $\begin{array}{l}886.89 \\
889.39\end{array}$ & $\begin{array}{l}887.14 \\
889.63\end{array}$ & $\begin{array}{l}887.39 \\
889.88\end{array}$ & $\begin{array}{l}887.64 \\
890.13\end{array}$ & $\begin{array}{l}887.89 \\
890.38\end{array}$ & $\begin{array}{l}888.14 \\
890.63\end{array}$ & $\begin{array}{l}888.39 \\
890.88\end{array}$ & $\begin{array}{l}888 \cdot 64 \\
891.13\end{array}$ & $\begin{array}{l}888.89 \\
891.38\end{array}$ & $\begin{array}{l}889.14 \\
891.63\end{array}$ & $\begin{array}{l}889.39 \\
891.88\end{array}$ & $\begin{array}{l}36.80 \\
36.90\end{array}$ \\
\hline $\begin{array}{l}37.00 \\
37.10 \\
37.20 \\
37.30 \\
37.40\end{array}$ & $\begin{array}{l}891.88 \\
894.38 \\
896.88 \\
899.38 \\
901.88\end{array}$ & $\begin{array}{l}892.13 \\
894.63 \\
897.13 \\
899.63 \\
902.13\end{array}$ & $\begin{array}{l}892.38 \\
894.88 \\
897.38 \\
899.88 \\
902.39\end{array}$ & $\begin{array}{l}892.63 \\
895.13 \\
897.63 \\
900.13 \\
902.64\end{array}$ & $\begin{array}{l}892.88 \\
895.38 \\
897.88 \\
900.38 \\
902.89\end{array}$ & $\begin{array}{l}893.13 \\
895.63 \\
898.13 \\
900.63 \\
903.14\end{array}$ & $\begin{array}{l}893.38 \\
895.88 \\
898.38 \\
900.88 \\
903.39\end{array}$ & $\begin{array}{l}893.63 \\
896.13 \\
898.63 \\
901.13 \\
903.64\end{array}$ & $\begin{array}{l}893.88 \\
896.38 \\
898.88 \\
901.38 \\
903.89\end{array}$ & $\begin{array}{l}894.13 \\
896.63 \\
899.13 \\
901.63 \\
904.14\end{array}$ & $\begin{array}{l}894.38 \\
896.88 \\
899.38 \\
901.88 \\
904.39\end{array}$ & $\begin{array}{l}37.00 \\
37.10 \\
37.20 \\
37.30 \\
37.40\end{array}$ \\
\hline $\begin{array}{l}37.50 \\
37.60 \\
37.70 \\
37.80 \\
37.90\end{array}$ & $\begin{array}{l}904.39 \\
906.90 \\
909.40 \\
911.91 \\
914.42\end{array}$ & $\begin{array}{l}904.64 \\
907.15 \\
909.65 \\
912.16 \\
914.68\end{array}$ & $\begin{array}{l}904.89 \\
907.40 \\
909.91 \\
912.42 \\
914.93\end{array}$ & $\begin{array}{l}905.14 \\
907.65 \\
910.16 \\
912.67 \\
915.18\end{array}$ & $\begin{array}{l}905.39 \\
907.90 \\
910.41 \\
912.92 \\
915.43\end{array}$ & $\begin{array}{l}905.64 \\
908.15 \\
910.66 \\
913.17 \\
915.68\end{array}$ & $\begin{array}{l}905.89 \\
908.40 \\
910.91 \\
913.42 \\
915.93\end{array}$ & $\begin{array}{l}906.14 \\
908.65 \\
911.16 \\
913.67 \\
916.18\end{array}$ & $\begin{array}{l}906.39 \\
908.90 \\
911.41 \\
913.92 \\
916.44\end{array}$ & $\begin{array}{l}906.65 \\
909.15 \\
911.66 \\
914.17 \\
916.69\end{array}$ & $\begin{array}{l}906.90 \\
909.40 \\
911.91 \\
914.42 \\
916.94\end{array}$ & $\begin{array}{l}37.50 \\
37.60 \\
37.70 \\
37.80 \\
37.90\end{array}$ \\
\hline $\begin{array}{l}38.00 \\
38.10 \\
38.20 \\
38.30 \\
38.40\end{array}$ & $\begin{array}{l}916.94 \\
919.45 \\
921.97 \\
924.49 \\
927.01\end{array}$ & $\begin{array}{l}917.19 \\
919.70 \\
922.22 \\
924.74 \\
927.26\end{array}$ & $\begin{array}{l}917.44 \\
919.96 \\
922.47 \\
924.99 \\
927.51\end{array}$ & $\begin{array}{l}917.69 \\
920.21 \\
922.72 \\
925.24 \\
927.76\end{array}$ & $\begin{array}{l}917.94 \\
920.46 \\
922.98 \\
925.49 \\
928.01\end{array}$ & $\begin{array}{l}918.20 \\
920.71 \\
923.23 \\
925.75 \\
928.27\end{array}$ & $\begin{array}{l}918.45 \\
920.96 \\
923.48 \\
926.00 \\
928.52\end{array}$ & $\begin{array}{l}918.70 \\
921.21 \\
923.73 \\
926.25 \\
928.77\end{array}$ & $\begin{array}{l}918.95 \\
921.47 \\
923.98 \\
926.50 \\
929.02\end{array}$ & $\begin{array}{l}919.20 \\
921.72 \\
924.23 \\
926.75 \\
929.28\end{array}$ & $\begin{array}{l}919.45 \\
921.97 \\
924.49 \\
927.01 \\
929.53\end{array}$ & $\begin{array}{l}38.00 \\
38.10 \\
38.20 \\
38.30 \\
38.40\end{array}$ \\
\hline $\begin{array}{l}38.50 \\
38.60 \\
38.70 \\
38.80 \\
38.90\end{array}$ & $\begin{array}{l}929.53 \\
932.05 \\
934.58 \\
937.10 \\
939.63\end{array}$ & $\begin{array}{l}929.78 \\
932.30 \\
934.83 \\
937.35 \\
939.88\end{array}$ & $\begin{array}{l}930.03 \\
932.56 \\
935.08 \\
937.61 \\
940.13\end{array}$ & $\begin{array}{l}930.28 \\
932.81 \\
935.33 \\
937.86 \\
940.39\end{array}$ & $\begin{array}{l}930.54 \\
933.06 \\
935.59 \\
938.11 \\
940.64\end{array}$ & $\begin{array}{l}930.79 \\
933.31 \\
935.84 \\
938.37 \\
940.89\end{array}$ & $\begin{array}{l}931.04 \\
933.57 \\
936.09 \\
938.62 \\
941.15\end{array}$ & $\begin{array}{l}931.29 \\
933.82 \\
936.34 \\
938.87 \\
941.40\end{array}$ & $\begin{array}{l}931.55 \\
934.07 \\
936.60 \\
939.12 \\
941.65\end{array}$ & $\begin{array}{l}931.80 \\
934.32 \\
936.85 \\
939.38 \\
941.91\end{array}$ & $\begin{array}{l}932.05 \\
934.58 \\
937.10 \\
939.63 \\
942.16\end{array}$ & $\begin{array}{l}38.50 \\
38.60 \\
38.70 \\
38.80 \\
38.90\end{array}$ \\
\hline $\begin{array}{l}39.00 \\
39.10 \\
39.20 \\
39.30 \\
39.40\end{array}$ & $\begin{array}{l}942.16 \\
944.69 \\
947.22 \\
949.76 \\
952.29\end{array}$ & $\begin{array}{l}942.41 \\
944.94 \\
947.48 \\
950.01 \\
952.55\end{array}$ & $\begin{array}{l}942 \cdot 66 \\
945.20 \\
947.73 \\
950.26 \\
952.80\end{array}$ & $\begin{array}{l}942.92 \\
945.45 \\
947.98 \\
950.52 \\
953.05\end{array}$ & $\begin{array}{l}943.17 \\
945.70 \\
948.24 \\
950.77 \\
953.31\end{array}$ & $\begin{array}{l}943.42 \\
945.96 \\
948.49 \\
951.03 \\
953.56\end{array}$ & $\begin{array}{l}943.68 \\
946.21 \\
948.74 \\
951.28 \\
953.82\end{array}$ & $\begin{array}{l}943.93 \\
946.46 \\
949.00 \\
951.53 \\
954.07\end{array}$ & $\begin{array}{l}944 \cdot 18 \\
946 \cdot 72 \\
949.25 \\
951.79 \\
954 \cdot 32\end{array}$ & $\begin{array}{l}944.44 \\
946.97 \\
949.50 \\
952.04 \\
954.58\end{array}$ & $\begin{array}{l}944.69 \\
947.22 \\
949.76 \\
952.29 \\
954.83\end{array}$ & $\begin{array}{l}39.00 \\
39.10 \\
39.20 \\
39.30 \\
39.40\end{array}$ \\
\hline $\begin{array}{l}39.50 \\
39.60 \\
39.70 \\
39.80 \\
39.90\end{array}$ & $\begin{array}{l}954.83 \\
957.37 \\
959.91 \\
962.46 \\
965.00\end{array}$ & $\begin{array}{l}955.09 \\
957.63 \\
960.17 \\
962.71 \\
965.25\end{array}$ & $\begin{array}{l}955.34 \\
957.88 \\
960.42 \\
962.96 \\
965.51\end{array}$ & $\begin{array}{l}955.59 \\
958.13 \\
960.68 \\
963.22 \\
965.76\end{array}$ & $\begin{array}{l}955.85 \\
958.39 \\
960.93 \\
963.47 \\
966.02\end{array}$ & $\begin{array}{l}956.10 \\
958.64 \\
961.18 \\
963.73 \\
966.27\end{array}$ & $\begin{array}{l}956.36 \\
958.90 \\
961.44 \\
963.98 \\
966.53\end{array}$ & $\begin{array}{l}956.61 \\
959.15 \\
961.69 \\
964.24 \\
966.78\end{array}$ & $\begin{array}{l}956.86 \\
959.40 \\
961.95 \\
964.49 \\
967.04\end{array}$ & $\begin{array}{l}957.12 \\
959.66 \\
962.20 \\
964.75 \\
967.29\end{array}$ & $\begin{array}{l}957.37 \\
959.91 \\
962.46 \\
965.00 \\
967.55\end{array}$ & $\begin{array}{l}39.50 \\
39.60 \\
39.70 \\
39.80 \\
39.90\end{array}$ \\
\hline $\begin{array}{l}40.00 \\
40.10 \\
40.20 \\
40.30 \\
40.40\end{array}$ & $\begin{array}{l}967.55 \\
970.09 \\
972.64 \\
975.20 \\
977.75\end{array}$ & $\begin{array}{l}967.80 \\
970.35 \\
972.90 \\
975.45 \\
978.00\end{array}$ & $\begin{array}{l}968.06 \\
970.60 \\
973.15 \\
975.71 \\
978.26\end{array}$ & $\begin{array}{l}968.31 \\
970.86 \\
973.41 \\
975.96 \\
978.51\end{array}$ & $\begin{array}{l}968.57 \\
971.11 \\
973.66 \\
976.22 \\
978.77\end{array}$ & $\begin{array}{l}968.82 \\
971.37 \\
973.92 \\
976.47 \\
979.03\end{array}$ & $\begin{array}{l}969.07 \\
971.62 \\
974.17 \\
976.73 \\
979.28\end{array}$ & $\begin{array}{l}969.33 \\
971.88 \\
974.43 \\
976.98 \\
979.54\end{array}$ & $\begin{array}{l}969.58 \\
972.13 \\
974.68 \\
977.24 \\
979.79\end{array}$ & $\begin{array}{l}969.84 \\
972.39 \\
974.94 \\
977.49 \\
980.05\end{array}$ & $\begin{array}{l}970.09 \\
972.64 \\
975.20 \\
977.75 \\
980.30\end{array}$ & $\begin{array}{l}40.00 \\
40.10 \\
40.20 \\
40.30 \\
40.40\end{array}$ \\
\hline $\begin{array}{l}40.50 \\
40.60 \\
40.70 \\
40.80 \\
40.90\end{array}$ & $\begin{array}{l}980.30 \\
982.86 \\
985.42 \\
987.98 \\
990.54\end{array}$ & $\begin{array}{l}980.56 \\
983.12 \\
985.67 \\
988.23 \\
990.80\end{array}$ & $\begin{array}{l}980.81 \\
983.37 \\
985.93 \\
988.49 \\
991.05\end{array}$ & $\begin{array}{l}981.07 \\
983.63 \\
986.19 \\
988.75 \\
991.31\end{array}$ & $\begin{array}{l}981.33 \\
983.88 \\
986.44 \\
989.00 \\
991.56\end{array}$ & $\begin{array}{l}981.58 \\
984.14 \\
986.70 \\
989.26 \\
991.82\end{array}$ & $\begin{array}{l}981.84 \\
984.39 \\
986.95 \\
989.51 \\
992.08\end{array}$ & $\begin{array}{l}982.09 \\
984.65 \\
987.21 \\
989.77 \\
992.33\end{array}$ & $\begin{array}{l}982.35 \\
984.91 \\
987.47 \\
990.03 \\
992.59\end{array}$ & $\begin{array}{l}.60 \\
.16 \\
.72 \\
.28 \\
.85\end{array}$ & $\begin{array}{l}982.86 \\
985.42 \\
987.98 \\
990.54 \\
993.10\end{array}$ & $\begin{array}{l}40.50 \\
40.60 \\
40.70 \\
40.80 \\
40.90\end{array}$ \\
\hline $\begin{array}{l}41.00 \\
41.10 \\
41.20\end{array}$ & $\begin{array}{l}993.10 \\
995.67 \\
998.24\end{array}$ & $\begin{array}{l}993.36 \\
995.92 \\
998.49\end{array}$ & & $\begin{array}{l}993.87 \\
996.44 \\
999.01\end{array}$ & $\begin{array}{l}994.13 \\
996.69 \\
999.26\end{array}$ & & & $\begin{array}{r}994.90 \\
997.46 \\
1000.03\end{array}$ & $\begin{array}{r}995.16 \\
997.72 \\
1000.29\end{array}$ & $\begin{array}{r}995.41 \\
997.98 \\
1000.55\end{array}$ & $\begin{array}{l}.67 \\
.24 \\
.80\end{array}$ & $\begin{array}{l}41.00 \\
41.10 \\
41.20\end{array}$ \\
\hline $\begin{array}{l}41.30 \\
41.40\end{array}$ & $\begin{array}{l}1000 \cdot 80 \\
1003.37\end{array}$ & $\begin{array}{l}1001.06 \\
1003.63\end{array}$ & $\begin{array}{l}1001.32 \\
1003.89\end{array}$ & $\begin{array}{l}001 \cdot 57 \\
004 \cdot 15\end{array}$ & $\begin{array}{l}1001.83 \\
1004.40\end{array}$ & $\begin{array}{l}1002.09 \\
1004.66\end{array}$ & $\begin{array}{l}1002 \cdot 35 \\
1004 \cdot 92\end{array}$ & $\begin{array}{l}.60 \\
.17\end{array}$ & & & $\begin{array}{l}1003.37 \\
1005.95\end{array}$ & $\begin{array}{l}41.30 \\
41.40\end{array}$ \\
\hline $\begin{array}{l}41.50 \\
41.60 \\
41.70 \\
41.80 \\
41.90\end{array}$ & $\begin{array}{l}1005.95 \\
1008.52 \\
1011.10 \\
1013.67 \\
1016.25\end{array}$ & $\begin{array}{l}1006.20 \\
1008.78 \\
1011.35 \\
1013.93 \\
1016.51\end{array}$ & $\begin{array}{l}1006 \cdot 46 \\
1009 \cdot 04 \\
1011.61 \\
1014.19 \\
1016.77\end{array}$ & $\begin{array}{l}1006.72 \\
1009.29 \\
1011.87 \\
1014.45 \\
1017.03\end{array}$ & $\begin{array}{l}1006.98 \\
1009.55 \\
1012.13 \\
1014.70 \\
1017.28\end{array}$ & $\begin{array}{l}1007.23 \\
1009.81 \\
1012.38 \\
1014.96 \\
1017.54\end{array}$ & $\begin{array}{l}1007.49 \\
1010.07 \\
1012.64 \\
1015.22 \\
1017.80\end{array}$ & $\begin{array}{l}1007.75 \\
1010.32 \\
1012.90 \\
1015.48 \\
1018.06\end{array}$ & $\begin{array}{l}1008.01 \\
1010.58 \\
1013.16 \\
1015.74 \\
1018.32\end{array}$ & $\begin{array}{l}1008.26 \\
1010.84 \\
1013.42 \\
1015.99 \\
1018.58\end{array}$ & $\begin{array}{l}1008.52 \\
1011.10 \\
1013.67 \\
1016.25 \\
1018.83\end{array}$ & $\begin{array}{l}41.50 \\
41.60 \\
41.70 \\
41.80 \\
41.90\end{array}$ \\
\hline .00 & 018.83 & 019.09 & 019.35 & 19.61 & 19. & 020.12 & $20 \cdot ?$ & 120.6 & 020.90 & 21. & 21.6 & \\
\hline
\end{tabular}

$m V$

.00

.01

.02

.03

$.04 \quad .05$

.06

.07

.08

.09

.10

$\mathrm{mV}$ 
TABLE A7.2.1. Type $\boldsymbol{K}$ thermocouples-temperature $\left({ }^{\circ} \mathrm{C}\right)$ as a function of thermoelectric voltage, reference junctions at $0^{\circ} \mathrm{C}$-Continued

$m \mathrm{r}$

.02

.04

.05

.06

.07

.08

.09

$\cdot 10$

$m \vee$

\section{TEMPERATURES IN DEGREES C (IPTS 1968)}

42.00

$1018.83 \quad 1019.09$

42.20

1021.42

1019.35

$1019.61 \quad 1019.87$

1020.12

1021.93

$1022.19 \quad 1022.45$

$1020.12 \quad 1020.38$

1020.64

$1020 \cdot 90$

$\begin{array}{llll}42.30 & 1026.59 & 1026.85 & 1027.10\end{array}$

1024.78

1025.04

1022.71

1022.97

1023.23

1023.48

$1029.95 \quad 1030.21$

1030.47

$1028 \cdot 14$

$42 \cdot 50$

1032.02

$1032 \cdot 28$

132.54

$1032 \cdot 80$

$1034 \cdot 88$

$42 \cdot 60$

42.80

$1034.36 \quad 1034.62$

1036.95

1037.21

1039.81

1040.07

1035.14

$1037.73 \quad 1037.99$

1040.331040 .59

1033.06

1030.73

1028.40

1030.99

1028.66

1031.25

1023.74

1028.92

1033.32

1035.65
1038.25

1040.85

1038.51

1041.10

1033.58

1033.84

1036.171036 .43

$1041.36 \quad 1041.62$

1034.10

1043.18

1045.52

43.00

1044.74

1045.00

1045.26

43.20

43.30

43.4

1049.95

1047.60

$1052.81 \quad 1050.47$

1055.16

43.50

43.70

43.80

43.90

1055.68

1048.13

1050.73

1045.78

1048.391048 .65

$1050.99 \quad 1051.25$

$1055.33 \quad 1053.60 \quad 1053.86$

$1046 \cdot 30$

1055.42

1058.29

1060.90

1060.38

1065.61

1068.22

1060.64

1063.25

1065.87

1063.51

1066.13

44.0

1070.84

1071.10

1068.75

1058.55

1058.81

1059.07

1061.16

1063.78

1066.39

1069.01

.

1066.05

1069.27

1066.91

1071.63

44.20

44.30

$44 \cdot 40$

44.50

44.6

44.7

44.8
44.90

45. 00

45.10

45.20

45.3

45.4

45.50

45.70

45.8

45.90

46.00

46.1

46.3

46.40

46.5

46.6

46.70

46.8
46.9

47.00

47.10

47.20

47.3

47.40

47.5

47.60

47.70

47.80

47.90

48.00

1076.08

1073.72

$1071 \cdot 37$

1074.25

1071.89

1072.15

$1074.51 \quad 1074.77$

$1077.13 \quad 1077.40$

$1079.76 \quad 1080.02$

$1078.97 \quad 107.9 .23$

$1081 \cdot 34$

1083.96

$1084 \cdot 23$

1084.49

1084.75

1087.39

1090.02

1086.861087 .12

$1092.13 \quad 1092.39$

$1094 \cdot 50$

$1094 \cdot 76$

1095.03

1095.29

1082.65

$\begin{array}{lll}1087.65 & 1087.91 & 1088.18\end{array}$

$1090.28 \quad 1090.55 \quad 1090.81$

$1092.92 \quad 1093.18 \quad 1093.45$

$1095.56 \quad 1095.82 \quad 1096.08$

1097.93

$1098.20 \quad 1098.46 \quad 1098.72$

$1097 \cdot 14$

1097.40

1097.67

1100.57

1103.22

1105.87

1105.07

$1102.69 \quad 1102.95$

$1105.34 \quad 1105.60$

$1107.98 \quad 1108.25$

1108.51

$1100.84 \quad 1101.10$

$1103.48 \quad 1103.75$

$1106.131106 .39 \quad 1106.66$

1106.66
1109.31

1110.37

1110.63

1110.90

1111.16

1113.32

1116.47

1111.43

115.68

$1118 \cdot 33$

1120.99

$1115.94 \quad 1116.21$

$1118.60 \quad 1118.87$

$1121.26 \quad 1121.53$

1119.13

1121.79

$1114.08 \quad 1114.35 \quad 1114.61$

$\begin{array}{lll}1116.74 & 1117.00 & 1117.27\end{array}$

$1119.40 \quad 1119.66 \quad 1119.93$

$1122.06 \quad 1122.32 \quad 1122.59$

1124.45

$\begin{array}{lll}1124.72 & 1124.99 & 1125.25\end{array}$

1123.65

1128.99

1131.65

$1123.92 \quad 1124.19$

$1129.25 \quad 1129.52$

$1131.92 \quad 1132.19$

1127.12

1129.79

1132.46

$1127.39 \quad 1127.65$

$1130.05 \quad 1130.32$

$1132.72 \quad 1132.99$

1127.92

1130.59
1133.26

134.33

134.59

134.86

$\begin{array}{lll}1139.68 & 1139.94 & 1140.21\end{array}$

1142.35

1745.04

1147.72

$1142.62 \quad 1142.89$

$1145.30 \quad 1145.57$

1137.80

1140.48

1143.16

$1145 \cdot 84$

$1138.07 \quad 1138.34$

$1140.75 \quad 1141.01$

$1143.43 \quad 1143.69$

$1146.11 \quad 1146.38$

$1148.79 \quad 1149.06$

151021

1151.48

1151.75

1153.10

$1153.36 \quad 1153.63$

$1156.06 \quad 1156.33$

1153.90

1156.59

1159.29

1161.18

1158.

1159.02

1163.88

1164.15

1161.99

$1154.17 \quad 1154.44$

$1156.86 \quad 1157.13$

$1159.56 \quad 1159.83$

$1162.26 \quad 1162.53$

1138.61

1141.28 
TABLE A7.2.1. Type K thermocouples-temperature $\left({ }^{\circ} \mathrm{C}\right)$ as a function of thermoelectric voltage, reference junctions at $0^{\circ} \mathrm{C}$-Continued

$m V$

.00

.01

.02

.03

.04

.05

.06

.07

.08

.09

.10

$m v$

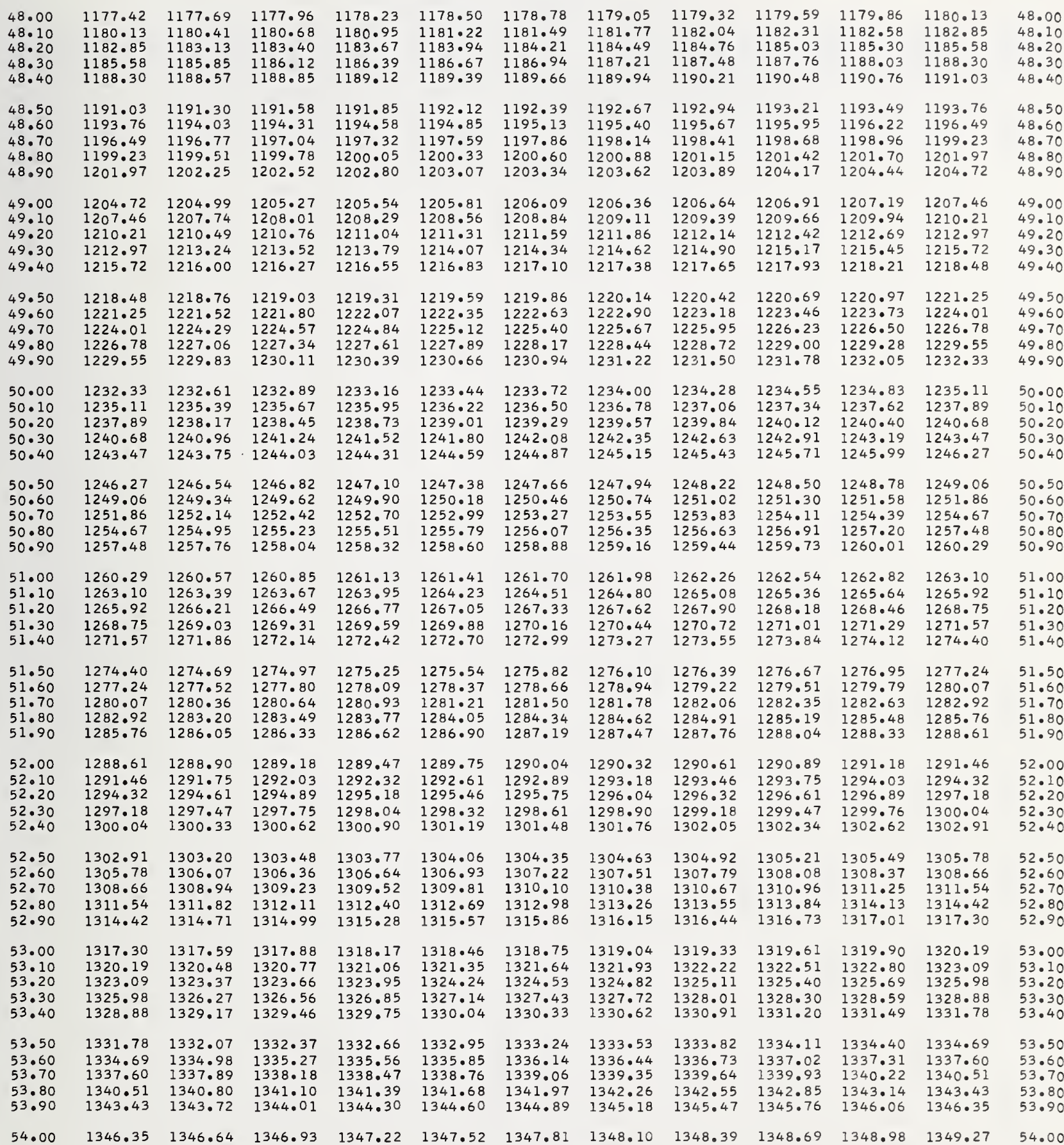


TABLE A7.2.1. Type $\boldsymbol{K}$ thermocouples-temperature $\left({ }^{\circ} \mathrm{C}\right)$ as a function of thermoelectric voltage, reference junctions at $0^{\circ} \mathrm{C}$-Continued

\begin{tabular}{|c|c|c|c|c|c|c|c|c|c|c|c|c|}
\hline \multirow[t]{2}{*}{$m V$} & .00 & .01 & .02 & .03 & .04 & .05 & .06 & .07 & .08 & .09 & .10 & $\mathrm{mV}$ \\
\hline & & & & TEM & R & EGF & C IIPTS & $1968)$ & & & & \\
\hline $\begin{array}{l}54.00 \\
54.10 \\
54.20 \\
54.30 \\
54.40\end{array}$ & $\begin{array}{l}1346.35 \\
1349.27 \\
1352.19 \\
1355.12 \\
1358.05\end{array}$ & $\begin{array}{l}1346.64 \\
1349.56 \\
1352.49 \\
1355.41 \\
1358.35\end{array}$ & $\begin{array}{l}1346.93 \\
1349.85 \\
1352.78 \\
1355.71 \\
1358.64\end{array}$ & $\begin{array}{l}1347.22 \\
1350.15 \\
1353.07 \\
1356.00 \\
1358.93\end{array}$ & $\begin{array}{l}1347.52 \\
1350.44 \\
1353.37 \\
1356.29 \\
1359.22\end{array}$ & $\begin{array}{l}1347.81 \\
1350.73 \\
1353.66 \\
1356.59 \\
1359.52\end{array}$ & $\begin{array}{l}1348.10 \\
1351.02 \\
1353.95 \\
1356.88 \\
1359.81\end{array}$ & $\begin{array}{l}1348.39 \\
1351.32 \\
1354.24 \\
1357.17 \\
1360.10\end{array}$ & $\begin{array}{l}1348.69 \\
1351.61 \\
1354.54 \\
1357.47 \\
1360.40\end{array}$ & $\begin{array}{l}1348.98 \\
1351.90 \\
1354.83 \\
1357.76 \\
1360.69\end{array}$ & $\begin{array}{l}1349.27 \\
1352 \cdot 19 \\
1355.12 \\
1358.05 \\
1360.98\end{array}$ & $\begin{array}{l}54.00 \\
54.10 \\
54.20 \\
54.30 \\
54.40\end{array}$ \\
\hline $\begin{array}{l}54.50 \\
54.60 \\
54.70 \\
54.80\end{array}$ & $\begin{array}{l}1360 \cdot 98 \\
1363 \cdot 92 \\
1366 \cdot 86 \\
1369.80\end{array}$ & $\begin{array}{l}1361.28 \\
1364.21 \\
1367.15 \\
1370.09\end{array}$ & $\begin{array}{l}1361 \cdot 57 \\
1364 \cdot 51 \\
1367.45 \\
1370.39\end{array}$ & $\begin{array}{l}1361.87 \\
1364.80 \\
1367.74 \\
1370.58\end{array}$ & $\begin{array}{l}1362.16 \\
1365.09 \\
1368.03 \\
1370.97\end{array}$ & $\begin{array}{l}1362.45 \\
1365.39 \\
1368.33 \\
1371.27\end{array}$ & $\begin{array}{l}1362.75 \\
1365.68 \\
1368.62 \\
1371.56\end{array}$ & $\begin{array}{l}1363.04 \\
1365.98 \\
1368.91 \\
1371.86\end{array}$ & $\begin{array}{l}1363 \cdot 33 \\
1366 \cdot 27 \\
1369 \cdot 21\end{array}$ & $\begin{array}{l}1363.63 \\
1356.56 \\
1369.50\end{array}$ & $\begin{array}{l}1363.92 \\
1366.86 \\
1369.80\end{array}$ & $\begin{array}{l}54.50 \\
54.60 \\
54.70 \\
54.80\end{array}$ \\
\hline
\end{tabular}

.03

.04

.05

.06

.07

.08

.09

.10

$\mathrm{mV}$ 
TABLE A7.2.2. Type $\boldsymbol{K}$ thermocouples-temperature $\left({ }^{\circ} \mathrm{F}\right)$ as a function of thermoelectric voltage, reference junctions at $32^{\circ} \mathrm{F}$$$
\mathrm{mV}
$$

$$
.00
$$$$
.01
$$$$
.02
$$$$
.03
$$$$
.04
$$$$
.05
$$$$
.06
$$$$
.07
$$$$
.08
$$$$
.09
$$$$
.10
$$

TEMPERATURES IN DEGREES F

$\begin{array}{lll}-6.40 & -416.66 & -420.42 \\ -6.30 & -389.77 & -391.96 \\ -6.20 & -370.80 & -372.51 \\ -6.10 & -355.14 & -356.60 \\ -6.00 & -341.42 & -342.73\end{array}$

$$
\begin{array}{lll}
-424.61 & -429.43 & -435.24 \\
-394.22 & -396.57 & -399.01 \\
-374.26 & -376.04 & -377.86 \\
-358.09 & -359.59 & -361.12 \\
-344.05 & -345.38 & -346.73
\end{array}
$$$$
-376.04
$$$$
-399.01
$$

-376.04
-359.59

$-361.12$

$-443.05$

$-401.56-404.23$

$-379.72-381.63$

$-407.05$

$-383.58$

$-345.38$

$-346.73$

$\begin{array}{ll}-362.67 & -364.24 \\ -348.09 & -349.46\end{array}$

-365.84
-350.86

$-410.03$

$-367.46$

$-352.27$

$-413.22$

$-387.64$

$-416.66$

$-389.77$

$-370.80$

$-353.69-355.14$

$-6.40$

$-6.30$

$-6.10$

$\mathrm{mV}$

.00

.01

.02

.03

.04

.05

.06

.07

.08

.09

.10

$m v$ 
TABLE A7.2.2. Type $\boldsymbol{K}$ thermocouples-temperature $\left({ }^{\circ} \mathrm{F}\right)$ as a function of thermoelectric voltage, reference junctions at $32^{\circ} \mathrm{F}$-Continued

$m \vee$

.00

.01

.02
.04

.05

.06

.07

.08

.09

.10

$\mathrm{mV}$

\begin{tabular}{|c|c|c|c|c|c|c|c|c|c|c|c|c|}
\hline-6.00 & $-341 \cdot 42$ & -342.73 & -344.05 & $-345 \cdot 38$ & $-346 \cdot 73$ & -348.09 & $-349 \cdot 46$ & -350.86 & -352.27 & -353.69 & -355.14 & -6.00 \\
\hline $\begin{array}{l}-5.90 \\
-5.80 \\
-5.70 \\
-5.60 \\
-5.50\end{array}$ & $\begin{array}{l}-329.02 \\
-317.59 \\
-306.90 \\
-296.83 \\
-287.25\end{array}$ & $\begin{array}{l}-330.21 \\
-318.69 \\
-307.94 \\
-297.81 \\
-288.19\end{array}$ & $\begin{array}{l}-331.42 \\
-319.81 \\
-308.99 \\
-298.80 \\
-289.13\end{array}$ & $\begin{array}{l}-332.63 \\
-320.93 \\
-310.04 \\
-299.79 \\
-290.07\end{array}$ & $\begin{array}{l}-333.85 \\
-322.06 \\
-311.10 \\
-300.79 \\
-291.03\end{array}$ & $\begin{array}{l}-335.08 \\
-323.20 \\
-312.16 \\
-301.80 \\
-291.98\end{array}$ & $\begin{array}{l}-336.33 \\
-324.35 \\
-313.23 \\
-302.81 \\
-292.94\end{array}$ & $\begin{array}{l}-337.58 \\
-325.50 \\
-314.31 \\
-303.82 \\
-293.90\end{array}$ & $\begin{array}{l}-338.85 \\
-326.67 \\
-315.40 \\
-304.84 \\
-294.87\end{array}$ & $\begin{array}{l}-340.13 \\
-327.84 \\
-316.49 \\
-305.87 \\
-295.85\end{array}$ & $\begin{array}{l}-341.42 \\
-329.02 \\
-317.59 \\
-306.90 \\
-296.83\end{array}$ & $\begin{array}{l}-5.90 \\
-5.80 \\
-5.70 \\
-5.60 \\
-5.50\end{array}$ \\
\hline $\begin{array}{l}-5.40 \\
-5.30 \\
-5.20 \\
-5.10 \\
-5.00\end{array}$ & $\begin{array}{l}-278.10 \\
-269.32 \\
-260.85 \\
-252.68 \\
-244.75\end{array}$ & $\begin{array}{l}-279.00 \\
-270.18 \\
-261.69 \\
-253.48 \\
-245.53\end{array}$ & $\begin{array}{l}-279.90 \\
-271.05 \\
-262.52 \\
-254.29 \\
-246.32\end{array}$ & $\begin{array}{l}-280.80 \\
-271.92 \\
-263.36 \\
-255.10 \\
-247.10\end{array}$ & $\begin{array}{l}-281.71 \\
-272.79 \\
-264.20 \\
-255.92 \\
-247.89\end{array}$ & $\begin{array}{l}-282.63 \\
-273.67 \\
-265.05 \\
-256.73 \\
-248.68\end{array}$ & $\begin{array}{l}-283.54 \\
-274.55 \\
-265.90 \\
-257.55 \\
-249.48\end{array}$ & $\begin{array}{l}-284.46 \\
-275.43 \\
-266.75 \\
-258.37 \\
-250.27\end{array}$ & $\begin{array}{l}-285 \cdot 39 \\
-276 \cdot 32 \\
-267 \cdot 60 \\
-259 \cdot 20 \\
-251.07\end{array}$ & $\begin{array}{l}-286.32 \\
-277.21 \\
-268.46 \\
-260.02 \\
-251.87\end{array}$ & $\begin{array}{l}-287.25 \\
-278.10 \\
-269.32 \\
-260.85 \\
-252.68\end{array}$ & $\begin{array}{l}-5.40 \\
-5.30 \\
-5.20 \\
-5.10 \\
-5.00\end{array}$ \\
\hline $\begin{array}{l}-4.90 \\
-4.80 \\
-4.70 \\
-4.60 \\
-4.50\end{array}$ & $\begin{array}{l}-237.05 \\
-229.56 \\
-222.25 \\
-215.11 \\
-208 \cdot 14\end{array}$ & $\begin{array}{l}-237.81 \\
-230.30 \\
-222.97 \\
-215.82 \\
-208.83\end{array}$ & $\begin{array}{l}-238.57 \\
-231.04 \\
-223.70 \\
-216.53 \\
-209.52\end{array}$ & $\begin{array}{l}-239.34 \\
-231.79 \\
-224.42 \\
-217.24 \\
-210.21\end{array}$ & $\begin{array}{l}-240.10 \\
-232.53 \\
-225.15 \\
-217.95 \\
-210.91\end{array}$ & $\begin{array}{l}-240.87 \\
-233.28 \\
-225.88 \\
-218.66 \\
-211.61\end{array}$ & $\begin{array}{l}-241.64 \\
-234.03 \\
-226.61 \\
-219.38 \\
-212.31\end{array}$ & $\begin{array}{l}-242.42 \\
-234.78 \\
-227.35 \\
-220.09 \\
-213.01\end{array}$ & $\begin{array}{l}3.19 \\
5.54 \\
8.08 \\
0.81 \\
3.71\end{array}$ & $\begin{array}{l}3.97 \\
6.29 \\
8.82 \\
1.53 \\
4.41\end{array}$ & $\begin{array}{l}-244.75 \\
-237.05 \\
-229.56 \\
-222.25 \\
-215.11\end{array}$ & $\begin{array}{l}-4.90 \\
-4.80 \\
-4.70 \\
-4.60 \\
-4.50\end{array}$ \\
\hline $\begin{array}{l}-4 \cdot 40 \\
-4 \cdot 30 \\
-4 \cdot 20 \\
-4 \cdot 10 \\
-4 \cdot 00\end{array}$ & $\begin{array}{l}-201.30 \\
-194.60 \\
-188.03 \\
-181.57 \\
-175.22\end{array}$ & $\begin{array}{l}-201.98 \\
-195.27 \\
-188.68 \\
-182.21 \\
-175.85\end{array}$ & $\begin{array}{l}-202.66 \\
-195.93 \\
-189.33 \\
-182.85 \\
-176.48\end{array}$ & $\begin{array}{l}-203.34 \\
-196.60 \\
-189.99 \\
-183.49 \\
-177.11\end{array}$ & $\begin{array}{l}-204.02 \\
-197 \cdot 27 \\
-190.64 \\
-184.14 \\
-177.75\end{array}$ & $\begin{array}{l}-204 \cdot 70 \\
-197 \cdot 94 \\
-191 \cdot 30 \\
-184 \cdot 78 \\
-178 \cdot 38\end{array}$ & $\begin{array}{l}-205.39 \\
-198.61 \\
-191.96 \\
-185.43 \\
-179.02\end{array}$ & $\begin{array}{l}-206.07 \\
-199.28 \\
-192.62 \\
-186.08 \\
-179.65\end{array}$ & $\begin{array}{l}-206.76 \\
-199.95 \\
-193.28 \\
-186.73 \\
-180.29\end{array}$ & $\begin{array}{l}-207.45 \\
-200.63 \\
-193.94 \\
-187.38 \\
-180.93\end{array}$ & $\begin{array}{l}-208 \cdot 14 \\
-201 \cdot 30 \\
-194.60 \\
-188 \cdot 03 \\
-181.57\end{array}$ & $\begin{array}{l}-4.40 \\
-4.30 \\
-4.20 \\
-4.10 \\
-4.00\end{array}$ \\
\hline $\begin{array}{l}-3.90 \\
-3.80 \\
-3.70 \\
-3.60 \\
-3.50\end{array}$ & $\begin{array}{l}-168.97 \\
-162.81 \\
-156.75 \\
-150.77 \\
-144.87\end{array}$ & $\begin{array}{l}-169.59 \\
-163.43 \\
-157.35 \\
-151.36 \\
-145.46\end{array}$ & $\begin{array}{l}-170.21 \\
-164.04 \\
-157.96 \\
-151.96 \\
-146.04\end{array}$ & $\begin{array}{l}-170.83 \\
-164.65 \\
-158.56 \\
-152.55 \\
-146.63\end{array}$ & $\begin{array}{l}-171 \cdot 46 \\
-165 \cdot 26 \\
-159 \cdot 16 \\
-153 \cdot 15 \\
-147 \cdot 22\end{array}$ & $\begin{array}{l}-172.08 \\
-165.88 \\
-159.77 \\
-153.75 \\
-147.81\end{array}$ & $\begin{array}{l}-172.71 \\
-166.50 \\
-160.38 \\
-154.35 \\
-148.40\end{array}$ & $\begin{array}{l}-173.33 \\
-167.11 \\
-160.99 \\
-154.95 \\
-148.99\end{array}$ & $\begin{array}{l}-173.96 \\
-167.73 \\
-161.59 \\
-155.55 \\
-149.58\end{array}$ & $\begin{array}{l}-174.59 \\
-168.35 \\
-162.20 \\
-156.15 \\
-150.18\end{array}$ & $\begin{array}{l}-175.22 \\
-168 \cdot 97 \\
-162 \cdot 81 \\
-156 \cdot 75 \\
-150 \cdot 77\end{array}$ & $\begin{array}{l}-3.90 \\
-3.80 \\
-3.70 \\
-3.60 \\
-3.50\end{array}$ \\
\hline $\begin{array}{l}-3.40 \\
-3.30 \\
-3.20 \\
-3.10 \\
-3.00\end{array}$ & $\begin{array}{l}-139 \cdot 04 \\
-133.29 \\
-127.60 \\
-121.98 \\
-116.42\end{array}$ & $\begin{array}{l}-139.62 \\
-133.86 \\
-128.17 \\
-122.54 \\
-116.97\end{array}$ & $\begin{array}{l}-140 \cdot 20 \\
-134 \cdot 43 \\
-128 \cdot 73 \\
-123 \cdot 10 \\
-117 \cdot 53\end{array}$ & $\begin{array}{l}-140.78 \\
-135.01 \\
-129.30 \\
-123.66 \\
-118.08\end{array}$ & $\begin{array}{l}-141 \cdot 36 \\
-135 \cdot 58 \\
-129 \cdot 87 \\
-124 \cdot 22 \\
-118 \cdot 64\end{array}$ & $\begin{array}{l}-141.95 \\
-136.16 \\
-130.44 \\
-124.78 \\
-119.19\end{array}$ & $\begin{array}{l}-142.53 \\
-136.73 \\
-131.01 \\
-125.35 \\
-119.75\end{array}$ & $\begin{array}{l}-143.11 \\
-137.31 \\
-131.58 \\
-125.91 \\
-120.31\end{array}$ & $\begin{array}{l}-143.70 \\
-137.89 \\
-132.15 \\
-126.47 \\
-120.86\end{array}$ & $\begin{array}{l}-144 \cdot 28 \\
-138 \cdot 46 \\
-132 \cdot 72 \\
-127 \cdot 04 \\
-121.42\end{array}$ & $\begin{array}{l}-144.87 \\
-139.04 \\
-133.29 \\
-127.60 \\
-121.98\end{array}$ & $\begin{array}{l}-3.40 \\
-3.30 \\
-3.20 \\
-3.10 \\
-3.00\end{array}$ \\
\hline $\begin{array}{l}-2.90 \\
-2.80 \\
-2.70 \\
-2.60 \\
-2.50\end{array}$ & $\begin{array}{r}-110.92 \\
-105.47 \\
-100.07 \\
-94.73 \\
-89.43\end{array}$ & $\begin{array}{l}-111.46 \\
-106.01 \\
-100.61 \\
-95.26 \\
-89.96\end{array}$ & $\begin{array}{r}-112.01 \\
-106.55 \\
-101.15 \\
-95.79 \\
-90.49\end{array}$ & $\begin{array}{r}-112.56 \\
-107.10 \\
-101.69 \\
-96.33 \\
-91.02\end{array}$ & $\begin{array}{r}-113.11 \\
-107.64 \\
-102.23 \\
-96.86 \\
-91.54\end{array}$ & $\begin{array}{r}-113.66 \\
-108.19 \\
-102.76 \\
-97.39 \\
-92.07\end{array}$ & $\begin{array}{r}-114.21 \\
-108.73 \\
-103.30 \\
-97.93 \\
-92.60\end{array}$ & $\begin{array}{r}-114.76 \\
-109.28 \\
-103.84 \\
-98.46 \\
-93.13\end{array}$ & $\begin{array}{r}-115.31 \\
-109.82 \\
-104.39 \\
-99.00 \\
-93.67\end{array}$ & $\begin{array}{r}-115.87 \\
-110.37 \\
-104.93 \\
-99.54 \\
-94.20\end{array}$ & $\begin{array}{r}-116.42 \\
-110.92 \\
-105.47 \\
-100.07 \\
-94.73\end{array}$ & $\begin{array}{l}-2.90 \\
-2.80 \\
-2.70 \\
-2.60 \\
-2.50\end{array}$ \\
\hline $\begin{array}{l}-2.40 \\
-2.30 \\
-2.20 \\
-2.10 \\
-2.00\end{array}$ & $\begin{array}{l}-84.18 \\
-78.97 \\
-73.81 \\
-68.68 \\
-63.60\end{array}$ & $\begin{array}{l}-84.70 \\
-79.49 \\
-74.32 \\
-69.20 \\
-64.11\end{array}$ & $\begin{array}{l}-85.23 \\
-80.01 \\
-74.84 \\
-69.71 \\
-64.61\end{array}$ & $\begin{array}{l}-85.75 \\
-80.53 \\
-75.35 \\
-70.22 \\
-65.12\end{array}$ & $\begin{array}{l}-86.28 \\
-81.05 \\
-75.87 \\
-70.73 \\
-65.63\end{array}$ & $\begin{array}{l}-86.80 \\
-81.57 \\
-76.39 \\
-71.24 \\
-66.14\end{array}$ & $\begin{array}{l}-87.33 \\
-82.09 \\
-76.90 \\
-71.75 \\
-66.65\end{array}$ & $\begin{array}{l}-87.85 \\
-82.61 \\
-77.42 \\
-72.27 \\
-67.15\end{array}$ & $\begin{array}{l}-88.38 \\
-83.14 \\
-77.94 \\
-72.78 \\
-67.66\end{array}$ & $\begin{array}{l}-88.90 \\
-83.66 \\
-78.46 \\
-73.30 \\
-68.17\end{array}$ & $\begin{array}{l}-89.43 \\
-84.18 \\
-78.97 \\
-73.81 \\
-68.68\end{array}$ & $\begin{array}{l}-2.40 \\
-2.30 \\
-2.20 \\
-2.10 \\
-2.00\end{array}$ \\
\hline $\begin{array}{l}-1.90 \\
-1.80 \\
-1.70 \\
-1.60 \\
-1.50\end{array}$ & $\begin{array}{l}-58.55 \\
-53.54 \\
-48.56 \\
-43.61 \\
-38.69\end{array}$ & $\begin{array}{l}-59.05 \\
-54.04 \\
-49.05 \\
-44.10 \\
-39.18\end{array}$ & $\begin{array}{l}-59.56 \\
-54.54 \\
-49.55 \\
-44.60 \\
-39.67\end{array}$ & $\begin{array}{l}-60.06 \\
-55.04 \\
-50.05 \\
-45.09 \\
-40.17\end{array}$ & $\begin{array}{l}-60.56 \\
-55.54 \\
-50.54 \\
-45.58 \\
-40.66\end{array}$ & $\begin{array}{l}-61.07 \\
-56.04 \\
-51.04 \\
-46.08 \\
-41.15\end{array}$ & $\begin{array}{l}-61.57 \\
-56.54 \\
-51.54 \\
-46.57 \\
-41.64\end{array}$ & $\begin{array}{l}-62.08 \\
-57.04 \\
-52.04 \\
-47.07 \\
-42.13\end{array}$ & $\begin{array}{l}-62.59 \\
-57.54 \\
-52.54 \\
-47.56 \\
-42.62\end{array}$ & $\begin{array}{l}-63.09 \\
-58.05 \\
-53.04 \\
-48.06 \\
-43.12\end{array}$ & $\begin{array}{l}-63.60 \\
-58.55 \\
-53.54 \\
-48.56 \\
-43.61\end{array}$ & $\begin{array}{l}-1.90 \\
-1.80 \\
-1.70 \\
-1.60 \\
-1.50\end{array}$ \\
\hline $\begin{array}{l}-1 \cdot 40 \\
-1.30 \\
-1.20 \\
-1.10 \\
-1.00\end{array}$ & $\begin{array}{l}-33.81 \\
-28.95 \\
-24.12 \\
-19.32 \\
-14.55\end{array}$ & $\begin{array}{l}-34.30 \\
-29.44 \\
-24.60 \\
-19.80 \\
-15.02\end{array}$ & $\begin{array}{l}-34.78 \\
-29.92 \\
-25.09 \\
-20.28 \\
-15.50\end{array}$ & $\begin{array}{l}-35.27 \\
-30.41 \\
-25.57 \\
-20.76 \\
-15.98\end{array}$ & $\begin{array}{l}-35.76 \\
-30.89 \\
-26.05 \\
-21.24 \\
-16.45\end{array}$ & $\begin{array}{l}-36.25 \\
-31.38 \\
-26.53 \\
-21.72 \\
-16.93\end{array}$ & $\begin{array}{l}-36.74 \\
-31.86 \\
-27.02 \\
-22.20 \\
-17.41\end{array}$ & $\begin{array}{l}-37.22 \\
-32.35 \\
-27.50 \\
-22.68 \\
-17.89\end{array}$ & $\begin{array}{l}-37.71 \\
-32.83 \\
-27.98 \\
-23.16 \\
-18.36\end{array}$ & $\begin{array}{l}-38.20 \\
-33.32 \\
-28.47 \\
-23.64 \\
-18.84\end{array}$ & $\begin{array}{l}-38.69 \\
-33.81 \\
-28.95 \\
-24.12 \\
-19.32\end{array}$ & $\begin{array}{l}-1.40 \\
-1.30 \\
-1.20 \\
-1.10 \\
-1.00\end{array}$ \\
\hline $\begin{array}{l}-0.90 \\
-0.80 \\
-0.70 \\
-0.60 \\
-0.50\end{array}$ & $\begin{array}{r}-9.79 \\
-5.07 \\
-0.36 \\
4.32 \\
8.98\end{array}$ & $\begin{array}{r}-10.27 \\
-5.54 \\
-0.83 \\
3.85 \\
8.52\end{array}$ & $\begin{array}{r}-10.74 \\
-6.01 \\
-1.30 \\
3.39 \\
8.05\end{array}$ & $\begin{array}{r}-11.22 \\
-6.48 \\
-1.77 \\
2.92 \\
7.59\end{array}$ & $\begin{array}{r}-11.69 \\
-6.95 \\
-2.24 \\
2.45 \\
7.12\end{array}$ & $\begin{array}{r}-12.17 \\
-7.43 \\
-2.71 \\
1.98 \\
6.65\end{array}$ & $\begin{array}{r}-12.64 \\
-7.90 \\
-3.18 \\
1.51 \\
6.19\end{array}$ & $\begin{array}{r}-13.12 \\
-8.37 \\
-3.65 \\
1.05 \\
5.72\end{array}$ & $\begin{array}{r}-13.59 \\
-8.85 \\
-4.12 \\
0.58 \\
5.25\end{array}$ & $\begin{array}{r}-14.07 \\
-9.32 \\
-4.59 \\
0.11 \\
4.79\end{array}$ & $\begin{array}{r}-14.55 \\
-9.79 \\
-5.07 \\
-0.36 \\
4.32\end{array}$ & $\begin{array}{l}-0.90 \\
-0.80 \\
-0.70 \\
-0.60 \\
-0.50\end{array}$ \\
\hline $\begin{array}{l}-0.40 \\
-0.30 \\
-0.20 \\
-0.10 \\
-0.00\end{array}$ & $\begin{array}{l}13.62 \\
18.24 \\
22.85 \\
27.43 \\
32.00\end{array}$ & $\begin{array}{l}13.16 \\
17.78 \\
22.39 \\
26.97 \\
31.54\end{array}$ & $\begin{array}{l}12.70 \\
17.32 \\
21.93 \\
26.52 \\
31.09\end{array}$ & $\begin{array}{l}12.23 \\
16.86 \\
21.47 \\
26.06 \\
30.63\end{array}$ & $\begin{array}{l}11 \cdot 7.7 \\
16.40 \\
21.01 \\
25.60 \\
30.17\end{array}$ & $\begin{array}{l}11 \cdot 30 \\
15 \cdot 94 \\
20 \cdot 55 \\
25 \cdot 14 \\
29 \cdot 72\end{array}$ & $\begin{array}{l}10.84 \\
15.47 \\
20.09 \\
24.68 \\
29.26\end{array}$ & $\begin{array}{l}10.38 \\
15.01 \\
19.63 \\
24.22 \\
28.80\end{array}$ & $\begin{array}{r}9.91 \\
14.55 \\
19.17 \\
23.77 \\
28.35\end{array}$ & $\begin{array}{r}9.45 \\
14.09 \\
18.71 \\
23.31 \\
27.89\end{array}$ & $\begin{array}{r}8.98 \\
13.62 \\
18.24 \\
22.85 \\
27.43\end{array}$ & $\begin{array}{l}-0.40 \\
-0.30 \\
-0.20 \\
-0.10 \\
-0.00\end{array}$ \\
\hline $\mathrm{mV}$ & .00 & .01 & .02 & .03 & .04 & .05 & .06 & .07 & .08 & .09 & .10 & $m v$ \\
\hline
\end{tabular}


TABLE A7.2.2. Type K thermocouples-temperature $\left({ }^{\circ} \mathrm{F}\right)$ as a function of thermoelectric voltage, reference junctions at $32^{\circ} \mathrm{F}$-Continued

$\mathrm{mV}$

.00

.01

.02

.03

.04

.05

.06

.07

.08

.09

.10

$\mathrm{mV}$

\begin{tabular}{|c|c|c|c|c|c|c|c|c|c|c|c|c|}
\hline $\begin{array}{l}0.00 \\
0.10 \\
0.20 \\
0.30 \\
0.40\end{array}$ & $\begin{array}{l}32.00 \\
36.55 \\
41.09 \\
45.62 \\
50.14\end{array}$ & $\begin{array}{l}32.46 \\
37.01 \\
41.55 \\
46.07 \\
50.59\end{array}$ & $\begin{array}{l}32.91 \\
37.46 \\
42.00 \\
46.53 \\
51.04\end{array}$ & $\begin{array}{l}33.37 \\
37.92 \\
42.45 \\
46.98 \\
51.49\end{array}$ & $\begin{array}{l}33.82 \\
38.37 \\
42.91 \\
47.43 \\
51.94\end{array}$ & $\begin{array}{l}34.28 \\
38.82 \\
43.36 \\
47.88 \\
52.39\end{array}$ & $\begin{array}{l}34.73 \\
39.28 \\
43.81 \\
48.33 \\
52.84\end{array}$ & $\begin{array}{l}35.19 \\
39.73 \\
44.26 \\
48.78 \\
53.29\end{array}$ & $\begin{array}{l}35.64 \\
40.19 \\
44.72 \\
49.23 \\
53.74\end{array}$ & $\begin{array}{l}36.10 \\
40.64 \\
45.17 \\
49.69 \\
54.19\end{array}$ & $\begin{array}{l}36.55 \\
41.09 \\
45.62 \\
50.14 \\
54.64\end{array}$ & $\begin{array}{l}0.00 \\
0.10 \\
0.20 \\
0.30 \\
0.40\end{array}$ \\
\hline $\begin{array}{l}0.50 \\
0.60 \\
0.70 \\
0.80 \\
0.90\end{array}$ & $\begin{array}{l}54.64 \\
59.13 \\
63.61 \\
68.08 \\
72.54\end{array}$ & $\begin{array}{l}55.09 \\
59.58 \\
64.06 \\
68.53 \\
72.99\end{array}$ & $\begin{array}{l}55.54 \\
60.03 \\
64.51 \\
68.98 \\
73.43\end{array}$ & $\begin{array}{l}55.99 \\
60.48 \\
64.95 \\
69.42 \\
73.88\end{array}$ & $\begin{array}{l}56.44 \\
60.93 \\
65.40 \\
69.87 \\
74.32\end{array}$ & $\begin{array}{l}56.89 \\
61.37 \\
65.85 \\
70.31 \\
74.77\end{array}$ & $\begin{array}{l}57 \cdot 34 \\
61 \cdot 82 \\
66 \cdot 30 \\
70 \cdot 76 \\
75 \cdot 21\end{array}$ & $\begin{array}{l}57.79 \\
62.27 \\
66.74 \\
71.21 \\
75.66\end{array}$ & $\begin{array}{l}58.23 \\
62.72 \\
67.19 \\
71.65 \\
76.10\end{array}$ & $\begin{array}{l}58.68 \\
63.17 \\
67.64 \\
72.10 \\
76.55\end{array}$ & $\begin{array}{l}59.13 \\
63.61 \\
68.08 \\
72.54 \\
76.99\end{array}$ & $\begin{array}{l}0.50 \\
0.60 \\
0.70 \\
0.80 \\
0.90\end{array}$ \\
\hline $\begin{array}{l}1.00 \\
1.10 \\
1.20 \\
1.30 \\
1.40\end{array}$ & $\begin{array}{l}76.99 \\
81.43 \\
85.86 \\
90.28 \\
94.70\end{array}$ & $\begin{array}{l}77.44 \\
81.88 \\
86.31 \\
90.73 \\
95.14\end{array}$ & $\begin{array}{l}77.88 \\
82.32 \\
86.75 \\
91.17 \\
95.58\end{array}$ & $\begin{array}{l}78.33 \\
82.76 \\
87.19 \\
91.61 \\
96.02\end{array}$ & $\begin{array}{l}78.77 \\
83.21 \\
87.63 \\
92.05 \\
96.46\end{array}$ & $\begin{array}{l}79.21 \\
83.65 \\
88.07 \\
92.49 \\
96.90\end{array}$ & $\begin{array}{l}79.66 \\
84.09 \\
88.52 \\
92.93 \\
97.34\end{array}$ & $\begin{array}{l}80.10 \\
84.53 \\
88.96 \\
93.37 \\
97.78\end{array}$ & $\begin{array}{l}80.54 \\
84.98 \\
89.40 \\
93.82 \\
98.22\end{array}$ & $\begin{array}{l}80.99 \\
85.42 \\
89.84 \\
94.26 \\
98.66\end{array}$ & $\begin{array}{l}81.43 \\
85.86 \\
90.28 \\
94.70 \\
99.10\end{array}$ & $\begin{array}{l}1.00 \\
1.10 \\
1.20 \\
1.30 \\
1.40\end{array}$ \\
\hline $\begin{array}{l}1.50 \\
1.60 \\
1.70 \\
1.80 \\
1.90\end{array}$ & $\begin{array}{r}99.10 \\
103.50 \\
107.89 \\
112.27 \\
116.65\end{array}$ & $\begin{array}{r}99.54 \\
103.94 \\
108.33 \\
112.71 \\
117.09\end{array}$ & $\begin{array}{r}99.98 \\
104.38 \\
108.77 \\
113.15 \\
117.52\end{array}$ & $\begin{array}{l}100.42 \\
104.82 \\
109.21 \\
113.59 \\
117.96\end{array}$ & $\begin{array}{l}100.86 \\
105.26 \\
109.64 \\
114.02 \\
118.40\end{array}$ & $\begin{array}{l}101.30 \\
105.70 \\
110.08 \\
114.46 \\
118.84\end{array}$ & $\begin{array}{l}101.74 \\
106.13 \\
110.52 \\
114 \cdot 90 \\
119.27\end{array}$ & $\begin{array}{l}102.18 \\
106.57 \\
110.96 \\
115.34 \\
119.71\end{array}$ & $\begin{array}{l}102.62 \\
107.01 \\
111.40 \\
115.77 \\
120.15\end{array}$ & $\begin{array}{l}103.06 \\
107.45 \\
111.83 \\
116.21 \\
120.58\end{array}$ & $\begin{array}{l}103.50 \\
107.89 \\
112.27 \\
116.65 \\
121.02\end{array}$ & $\begin{array}{l}1.50 \\
1.60 \\
1.70 \\
1.80 \\
1.90\end{array}$ \\
\hline $\begin{array}{l}2.00 \\
2.10 \\
2.20 \\
2.30 \\
2.40\end{array}$ & $\begin{array}{l}121.02 \\
125.38 \\
129.74 \\
134.10 \\
138.45\end{array}$ & $\begin{array}{l}121.46 \\
125.82 \\
130.18 \\
134.53 \\
138.88\end{array}$ & $\begin{array}{l}121.89 \\
126.26 \\
130.62 \\
134.97 \\
139.32\end{array}$ & $\begin{array}{l}122.33 \\
126.69 \\
131.05 \\
135.40 \\
139.75\end{array}$ & $\begin{array}{l}122.77 \\
127.13 \\
131.49 \\
135.84 \\
140.19\end{array}$ & $\begin{array}{l}123.20 \\
127.56 \\
131.92 \\
136.27 \\
140.62\end{array}$ & $\begin{array}{l}123.64 \\
128.00 \\
132.36 \\
136.71 \\
141.06\end{array}$ & $\begin{array}{l}124.08 \\
128.44 \\
132.79 \\
137.14 \\
141.49\end{array}$ & $\begin{array}{l}124.51 \\
128.87 \\
133.23 \\
137.58 \\
141.93\end{array}$ & $\begin{array}{l}124.95 \\
129.31 \\
133.66 \\
138.01 \\
142.36\end{array}$ & $\begin{array}{l}125 \cdot 38 \\
129 \cdot 74 \\
134 \cdot 10 \\
138.45 \\
142.80\end{array}$ & $\begin{array}{l}2.00 \\
2.10 \\
2.20 \\
2.30 \\
2.40\end{array}$ \\
\hline $\begin{array}{l}2.50 \\
2.60 \\
2.70 \\
2.80 \\
2.90\end{array}$ & $\begin{array}{l}142.80 \\
147.14 \\
151.48 \\
155.82 \\
160.15\end{array}$ & $\begin{array}{l}143.23 \\
147.57 \\
151.91 \\
156.25 \\
160.59\end{array}$ & $\begin{array}{l}143.66 \\
148.01 \\
152.35 \\
156.68 \\
161.02\end{array}$ & $\begin{array}{l}144.10 \\
148.44 \\
152.78 \\
157.12 \\
161.45\end{array}$ & $\begin{array}{l}144.53 \\
148.88 \\
153.21 \\
157.55 \\
161.89\end{array}$ & $\begin{array}{l}144.97 \\
149.31 \\
153.65 \\
157.99 \\
162.32\end{array}$ & $\begin{array}{l}145.40 \\
149.74 \\
154.08 \\
158.42 \\
162.75\end{array}$ & $\begin{array}{l}145.84 \\
150.18 \\
154.52 \\
158.85 \\
163.19\end{array}$ & $\begin{array}{l}146.27 \\
150.61 \\
154.95 \\
159.29 \\
163.62\end{array}$ & $\begin{array}{l}146.70 \\
151.05 \\
155.38 \\
159.72 \\
164.05\end{array}$ & $\begin{array}{l}147.14 \\
151.48 \\
155.82 \\
160.15 \\
164.49\end{array}$ & $\begin{array}{l}2.50 \\
2.60 \\
2.70 \\
2.80 \\
2.90\end{array}$ \\
\hline $\begin{array}{l}3.00 \\
3.10 \\
3.20 \\
3.30 \\
3.40\end{array}$ & $\begin{array}{l}164.49 \\
168.82 \\
173.15 \\
177.49 \\
181.82\end{array}$ & $\begin{array}{l}164.92 \\
169.25 \\
173.59 \\
177.92 \\
182.25\end{array}$ & $\begin{array}{l}165.35 \\
169.69 \\
174.02 \\
178.35 \\
182.69\end{array}$ & $\begin{array}{l}165.79 \\
170.12 \\
174.45 \\
178.79 \\
183.12\end{array}$ & $\begin{array}{l}166.22 \\
170.55 \\
174.89 \\
179.22 \\
183.55\end{array}$ & $\begin{array}{l}166.65 \\
170.99 \\
175.32 \\
179.65 \\
183.99\end{array}$ & $\begin{array}{l}167.09 \\
171.42 \\
175.75 \\
180.09 \\
184.42\end{array}$ & $\begin{array}{l}167.52 \\
171.85 \\
176.19 \\
180.52 \\
184.85\end{array}$ & $\begin{array}{l}167.95 \\
172.29 \\
176.62 \\
180.95 \\
185.29\end{array}$ & $\begin{array}{l}168.39 \\
172.72 \\
177.05 \\
181.39 \\
185.72\end{array}$ & $\begin{array}{l}168.82 \\
173.15 \\
177.49 \\
181.82 \\
186.16\end{array}$ & $\begin{array}{l}3.00 \\
3.10 \\
3.20 \\
3.30 \\
3.40\end{array}$ \\
\hline $\begin{array}{l}3.50 \\
3.60 \\
3.70 \\
3.80 \\
3.90\end{array}$ & $\begin{array}{l}186.16 \\
190.49 \\
194.83 \\
199.17 \\
203.51\end{array}$ & $\begin{array}{l}186.59 \\
190.92 \\
195.26 \\
199.60 \\
203.95\end{array}$ & $\begin{array}{l}187.02 \\
191.36 \\
195.70 \\
200.04 \\
204.38\end{array}$ & $\begin{array}{l}187.46 \\
191.79 \\
196.13 \\
200.47 \\
204.81\end{array}$ & $\begin{array}{l}187.89 \\
192.23 \\
196.56 \\
200.91 \\
205.25\end{array}$ & $\begin{array}{l}188.32 \\
192.66 \\
197.00 \\
201.34 \\
205.68\end{array}$ & $\begin{array}{l}188 \cdot 76 \\
193.09 \\
197.43 \\
201.77 \\
206.12\end{array}$ & $\begin{array}{l}189.19 \\
193.53 \\
197.87 \\
202.21 \\
206.55\end{array}$ & $\begin{array}{l}189.62 \\
193.96 \\
198.30 \\
202.64 \\
206.99\end{array}$ & $\begin{array}{l}190.06 \\
194.39 \\
198.73 \\
203.08 \\
207.42\end{array}$ & $\begin{array}{l}190.49 \\
194.83 \\
199.17 \\
203.51 \\
207.86\end{array}$ & $\begin{array}{l}3.50 \\
3.60 \\
3.70 \\
3.80 \\
3.90\end{array}$ \\
\hline $\begin{array}{l}4.00 \\
4.10 \\
4.20 \\
4.30 \\
4.40\end{array}$ & $\begin{array}{l}207.86 \\
212.21 \\
216.56 \\
220.92 \\
225.28\end{array}$ & $\begin{array}{l}208.29 \\
212.64 \\
216.99 \\
221.35 \\
225.71\end{array}$ & $\begin{array}{l}208 \cdot 73 \\
213 \cdot 08 \\
217 \cdot 43 \\
221.79 \\
226.15\end{array}$ & $\begin{array}{l}209.16 \\
213.51 \\
217.87 \\
222.22 \\
226.59\end{array}$ & $\begin{array}{l}209.60 \\
213.95 \\
218.30 \\
222.66 \\
227.02\end{array}$ & $\begin{array}{l}210.03 \\
214.38 \\
218.74 \\
223.10 \\
227.46\end{array}$ & $\begin{array}{l}210.47 \\
214.82 \\
219.17 \\
223.53 \\
227.90\end{array}$ & $\begin{array}{l}210.90 \\
215.25 \\
219.61 \\
223.97 \\
228.33\end{array}$ & $\begin{array}{l}211.34 \\
215.69 \\
220.04 \\
224.41 \\
228.77\end{array}$ & $\begin{array}{l}211.77 \\
216.12 \\
220.48 \\
224.84 \\
229.21\end{array}$ & $\begin{array}{l}212 \cdot 21 \\
216 \cdot 56 \\
220 \cdot 92 \\
225 \cdot 28 \\
229 \cdot 64\end{array}$ & $\begin{array}{l}4.00 \\
4.10 \\
4.20 \\
4.30 \\
4.40\end{array}$ \\
\hline $\begin{array}{l}4.50 \\
4.60 \\
4.70 \\
4.80 \\
4.90\end{array}$ & $\begin{array}{l}229.64 \\
234.02 \\
238.39 \\
242.78 \\
247.17\end{array}$ & $\begin{array}{l}230.08 \\
234.45 \\
238.83 \\
243.22 \\
247.61\end{array}$ & $\begin{array}{l}230.52 \\
234.89 \\
239.27 \\
243.66 \\
248.05\end{array}$ & $\begin{array}{l}230.96 \\
235.33 \\
239.71 \\
244.09 \\
248.49\end{array}$ & $\begin{array}{l}231.39 \\
235.77 \\
240.15 \\
244.53 \\
248.92\end{array}$ & $\begin{array}{l}231.83 \\
236.21 \\
240.59 \\
244.97 \\
249.36\end{array}$ & $\begin{array}{l}232.27 \\
236.64 \\
241.02 \\
245.41 \\
249.80\end{array}$ & $\begin{array}{l}232.70 \\
237.08 \\
241.46 \\
245.85 \\
250.24\end{array}$ & $\begin{array}{l}233.14 \\
237.52 \\
241.90 \\
246.29 \\
250.68\end{array}$ & $\begin{array}{l}233 \cdot 58 \\
237.96 \\
242.34 \\
246.73 \\
251.12\end{array}$ & $\begin{array}{l}234 \cdot 02 \\
238.39 \\
242.78 \\
247.17 \\
251.56\end{array}$ & $\begin{array}{l}4.50 \\
4.60 \\
4.70 \\
4.80 \\
4.90\end{array}$ \\
\hline $\begin{array}{l}5.00 \\
5.10 \\
5.20 \\
5.30 \\
5.40\end{array}$ & $\begin{array}{l}251.56 \\
255.96 \\
260.37 \\
264.79 \\
269.21\end{array}$ & $\begin{array}{l}252.00 \\
256.40 \\
260.81 \\
265.23 \\
269.65\end{array}$ & $\begin{array}{l}252.44 \\
256.85 \\
261.26 \\
265.67 \\
270.09\end{array}$ & $\begin{array}{l}252.88 \\
257.29 \\
261.70 \\
266.11 \\
270.54\end{array}$ & $\begin{array}{l}253.32 \\
257.73 \\
262.14 \\
266.55 \\
270.98\end{array}$ & $\begin{array}{l}253.76 \\
258.17 \\
262.58 \\
267.00 \\
271.42\end{array}$ & $\begin{array}{l}254.20 \\
258.61 \\
263.02 \\
267.44 \\
271.86\end{array}$ & $\begin{array}{l}254.64 \\
259.05 \\
263.46 \\
267.88 \\
272.31\end{array}$ & $\begin{array}{l}255.08 \\
259.49 \\
263.90 \\
268.32 \\
272.75\end{array}$ & $\begin{array}{l}255.52 \\
259.93 \\
264.35 \\
268.77 \\
273.19\end{array}$ & $\begin{array}{l}255.96 \\
260.37 \\
264.79 \\
269.21 \\
273.64\end{array}$ & $\begin{array}{l}5.00 \\
5.10 \\
5.20 \\
5.30 \\
5.40\end{array}$ \\
\hline $\begin{array}{l}5.50 \\
5.60 \\
5.70 \\
5.80 \\
5.90\end{array}$ & $\begin{array}{l}273.64 \\
278.07 \\
282.51 \\
286.96 \\
291.41\end{array}$ & $\begin{array}{l}274.08 \\
278.51 \\
282.96 \\
287.40 \\
291.86\end{array}$ & $\begin{array}{l}274.52 \\
278.96 \\
283.40 \\
287.85 \\
292.30\end{array}$ & $\begin{array}{l}274.97 \\
279.40 \\
283.84 \\
288.29 \\
292.75\end{array}$ & $\begin{array}{l}275.41 \\
279.85 \\
284.29 \\
288.74 \\
293.19\end{array}$ & $\begin{array}{l}275.85 \\
280.29 \\
284.73 \\
289.18 \\
293.64\end{array}$ & $\begin{array}{l}276.30 \\
280.73 \\
285.18 \\
289.63 \\
294.09\end{array}$ & $\begin{array}{l}276.74 \\
281.18 \\
285.62 \\
290.08 \\
294.53\end{array}$ & $\begin{array}{l}277.18 \\
281.62 \\
286.07 \\
290.52 \\
294.98\end{array}$ & $\begin{array}{l}277.63 \\
282.07 \\
286.51 \\
290.97 \\
295.42\end{array}$ & $\begin{array}{l}278.07 \\
282.51 \\
286.96 \\
291.41 \\
295.87\end{array}$ & $\begin{array}{l}5.50 \\
5.60 \\
5.70 \\
5.80 \\
5.90\end{array}$ \\
\hline 6.00 & 295.87 & 296.32 & 296.76 & 297.21 & 297.66 & 298.10 & 298.55 & 299.00 & 299.44 & 299.89 & $300 \cdot 34$ & \\
\hline
\end{tabular}

$\mathrm{mV}$

.00

.01

.02

.03

.04

.05

.06

.07

.08

.09

.10

$m V$

0.00

.20

- 30

.50

.70

.90

.00

.20

.40

50

. 70

.90

.00

. 20

.40

70

.90

- 00

.20

.40

70

.90

.00

.20

.40

.50

.70

.80
.90

.00

.10
.20

.50

.70

.80
.90

.00 
TABLE 87.2.2. Type $K$ thermocouples-temperature $\left({ }^{\circ} \mathrm{F}\right)$ as a function of thermoelectric voltage, reference junctions at $32^{\circ} \mathrm{F}$-Continued

mV

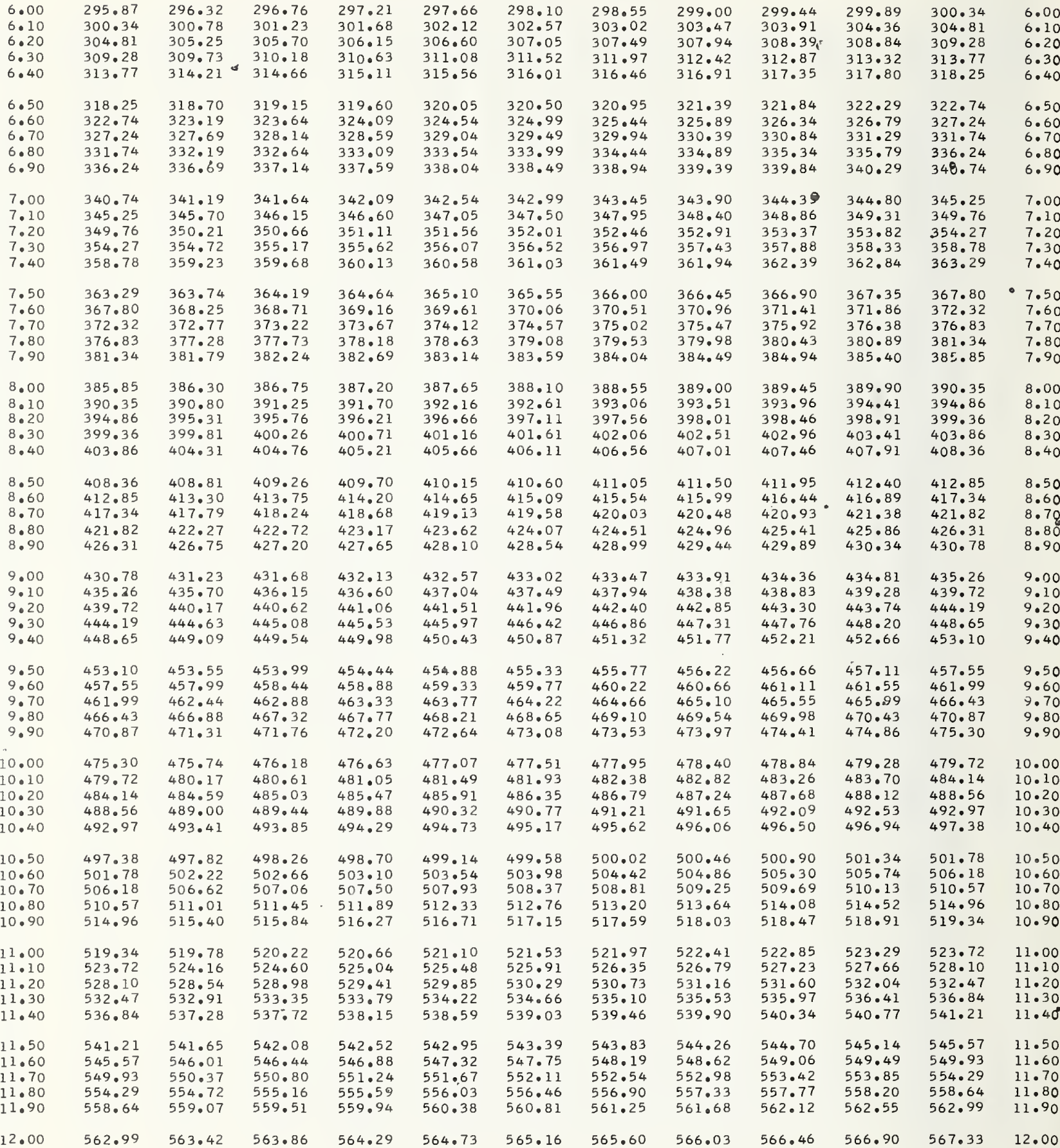

$\begin{array}{lll}.03 & .04 & .05 \\ \text { TEMPERATURES IN DEGREES F }\end{array}$

.06

.07

.10

"TEMPERATURES IN DEgREes F

.08

.09

$\mathrm{mV}$ 
TABLE A7.2.2. Type $K$ thermocouples-temperature $\left({ }^{\circ} \mathrm{F}\right)$ as a function of thermoelectric voltage, reference junctions at $32^{\circ} \mathrm{F}$-Continued

$\mathrm{mV}$

.00

(1)

\begin{tabular}{|c|c|c|c|c|c|c|c|c|c|c|c|}
\hline $\begin{array}{l}12.00 \\
12.10 \\
12.20 \\
12.30 \\
12.40\end{array}$ & $\begin{array}{l}562.99 \\
567.33 \\
571.68 \\
576.02 \\
580.36\end{array}$ & $\begin{array}{l}563.42 \\
567.77 \\
572.11 \\
576.45 \\
580.79\end{array}$ & $\begin{array}{l}563.86 \\
568.20 \\
572.55 \\
576.89 \\
581.22\end{array}$ & $\begin{array}{l}564.29 \\
568.64 \\
572.98 \\
577.32 \\
581.66\end{array}$ & $\begin{array}{l}564.73 \\
569.07 \\
573.41 \\
577.75 \\
582.09\end{array}$ & $\begin{array}{l}565.16 \\
569.51 \\
573.85 \\
578.19 \\
582.52\end{array}$ & $\begin{array}{l}565.60 \\
569.94 \\
574.28 \\
578.62 \\
582.96\end{array}$ & $\begin{array}{l}566.03 \\
570.37 \\
574.72 \\
579.05 \\
583.39\end{array}$ & $\begin{array}{l}566.46 \\
570.81 \\
575.15 \\
579.49 \\
583.82\end{array}$ & $\begin{array}{l}566.90 \\
571.24 \\
575.58 \\
579.93 \\
584.26\end{array}$ & $\begin{array}{l}567.33 \\
571.68 \\
576.02 \\
580.36 \\
584.69\end{array}$ \\
\hline $\begin{array}{l}13.50 \\
13.60 \\
13.70 \\
13.80 \\
13.90\end{array}$ & $\begin{array}{l}627.91 \\
632.22 \\
636.53 \\
640.83 \\
645.14\end{array}$ & $\begin{array}{l}628.34 \\
632.65 \\
636.96 \\
641.26 \\
645.57\end{array}$ & $\begin{array}{l}628.77 \\
633.08 \\
637.39 \\
641.69 \\
646.00\end{array}$ & $\begin{array}{l}629.20 \\
633.51 \\
637.82 \\
642.12 \\
646.43\end{array}$ & $\begin{array}{l}629.63 \\
633.94 \\
638.25 \\
642.55 \\
646.86\end{array}$ & $\begin{array}{l}630.06 \\
634.37 \\
638.68 \\
642.98 \\
647.29\end{array}$ & $\begin{array}{l}630.49 \\
634.80 \\
639.11 \\
643.41 \\
647.72\end{array}$ & $\begin{array}{l}630.93 \\
635.23 \\
639.54 \\
643.84 \\
648.15\end{array}$ & $\begin{array}{l}631.36 \\
635.66 \\
639.97 \\
644.28 \\
648.58\end{array}$ & $\begin{array}{l}631.79 \\
636.10 \\
640.40 \\
644.71 \\
649.01\end{array}$ & $\begin{array}{l}632.22 \\
636.53 \\
640.83 \\
645.14 \\
649.44\end{array}$ \\
\hline $\begin{array}{l}14.50 \\
14.60 \\
14.70 \\
14.80 \\
14.90\end{array}$ & $\begin{array}{l}670.92 \\
675.21 \\
679.50 \\
683.79 \\
688.08\end{array}$ & $\begin{array}{l}671.35 \\
675.64 \\
679.93 \\
684.22 \\
688.51\end{array}$ & $\begin{array}{l}671.78 \\
676.07 \\
680.36 \\
684.65 \\
688.94\end{array}$ & $\begin{array}{l}672.21 \\
676.50 \\
680.79 \\
685.08 \\
689.36\end{array}$ & $\begin{array}{l}672.64 \\
676.93 \\
681.22 \\
685.51 \\
689.79\end{array}$ & $\begin{array}{l}673.07 \\
677.36 \\
681.65 \\
685.94 \\
690.22\end{array}$ & $\begin{array}{l}673.50 \\
677.79 \\
682.08 \\
686.36 \\
690.65\end{array}$ & $\begin{array}{l}673.93 \\
678.22 \\
682.51 \\
686.79 \\
691.08\end{array}$ & $\begin{array}{l}674.36 \\
678.65 \\
682.93 \\
687.22 \\
691.51\end{array}$ & $\begin{array}{l}674.78 \\
679.07 \\
683.36 \\
687.65 \\
691.93\end{array}$ & $\begin{array}{l}675.21 \\
679.50 \\
683.79 \\
688.08 \\
692.36\end{array}$ \\
\hline $\begin{array}{l}15.00 \\
15.10 \\
15.20 \\
15.30 \\
15.40\end{array}$ & $\begin{array}{l}692.36 \\
696.65 \\
700.93 \\
705.21 \\
709.49\end{array}$ & $\begin{array}{l}692.79 \\
697.07 \\
701.36 \\
705.64 \\
709.92\end{array}$ & $\begin{array}{l}693.22 \\
697.50 \\
701.78 \\
706.06 \\
710.34\end{array}$ & $\begin{array}{l}693.65 \\
697.93 \\
702.21 \\
706.49 \\
710.77\end{array}$ & $\begin{array}{l}694.08 \\
698.36 \\
702.64 \\
706.92 \\
711.20\end{array}$ & $\begin{array}{l}694.51 \\
698.79 \\
703.07 \\
707.35 \\
711.63\end{array}$ & $\begin{array}{l}694.93 \\
699.22 \\
703.50 \\
707.78 \\
712.05\end{array}$ & $\begin{array}{l}695.36 \\
699.64 \\
703.92 \\
708.20 \\
712.48\end{array}$ & $\begin{array}{l}695.79 \\
700.07 \\
704.35 \\
708.63 \\
712.91\end{array}$ & $\begin{array}{l}696.22 \\
700.50 \\
704.78 \\
709.06 \\
713.34\end{array}$ & $\begin{array}{l}696.65 \\
700.93 \\
705.21 \\
709.49 \\
713.76\end{array}$ \\
\hline $\begin{array}{l}15.50 \\
15.60 \\
15.70 \\
15.80 \\
15.90\end{array}$ & $\begin{array}{l}713.76 \\
718.04 \\
722.31 \\
726.59 \\
730.86\end{array}$ & $\begin{array}{l}714.19 \\
718.47 \\
722.74 \\
727.01 \\
731.29\end{array}$ & $\begin{array}{l}714.62 \\
718.90 \\
723.17 \\
727.44 \\
731.71\end{array}$ & $\begin{array}{l}715.05 \\
719.32 \\
723.60 \\
727.87 \\
732.14\end{array}$ & $\begin{array}{l}715.48 \\
719.75 \\
724.02 \\
728.30 \\
732.57\end{array}$ & $\begin{array}{l}715.90 \\
720.18 \\
724.45 \\
728.72 \\
732.99\end{array}$ & $\begin{array}{l}716.33 \\
720.61 \\
724.88 \\
729.15 \\
733.42\end{array}$ & $\begin{array}{l}716.76 \\
721.03 \\
725.31 \\
729.58 \\
733.85\end{array}$ & $\begin{array}{l}717.19 \\
721.46 \\
725.73 \\
730.00 \\
734.27\end{array}$ & $\begin{array}{l}717.61 \\
721.89 \\
726.16 \\
730.43 \\
734.70\end{array}$ & $\begin{array}{l}718.04 \\
722.31 \\
726.59 \\
730.86 \\
735.13\end{array}$ \\
\hline $\begin{array}{l}16.50 \\
16.60 \\
16.70 \\
16.80 \\
16.90\end{array}$ & $\begin{array}{l}756.46 \\
760.72 \\
764.98 \\
769.24 \\
773.50\end{array}$ & $\begin{array}{l}756.88 \\
761.14 \\
765.40 \\
769.66 \\
773.92\end{array}$ & $\begin{array}{l}757.31 \\
761.57 \\
765.83 \\
770.09 \\
774.35\end{array}$ & $\begin{array}{l}757.74 \\
762.00 \\
766.26 \\
770.52 \\
774.77\end{array}$ & $\begin{array}{l}758.16 \\
762.42 \\
766.68 \\
770.94 \\
775.20\end{array}$ & $\begin{array}{l}758.59 \\
762.85 \\
767.11 \\
771.37 \\
775.62\end{array}$ & $\begin{array}{l}759.01 \\
763.27 \\
767.53 \\
771.79 \\
776.05\end{array}$ & $\begin{array}{l}759.44 \\
763.70 \\
767.96 \\
772.22 \\
776.47\end{array}$ & $\begin{array}{l}759.87 \\
764.13 \\
768.39 \\
772.64 \\
776.90\end{array}$ & $\begin{array}{l}760.29 \\
764.55 \\
768.81 \\
773.07 \\
777.33\end{array}$ & $\begin{array}{l}760.72 \\
764.98 \\
769.24 \\
773.50 \\
777.75\end{array}$ \\
\hline $\begin{array}{l}17.00 \\
17.10 \\
17.20 \\
17.30 \\
17.40\end{array}$ & $\begin{array}{l}777.75 \\
782.01 \\
786.26 \\
790.51 \\
794.76\end{array}$ & $\begin{array}{l}778.18 \\
782.43 \\
786.69 \\
790.94 \\
795.19\end{array}$ & $\begin{array}{l}778.60 \\
782.86 \\
787.11 \\
791.36 \\
795.61\end{array}$ & $\begin{array}{l}779.03 \\
783.28 \\
787.54 \\
791.79 \\
796.04\end{array}$ & $\begin{array}{l}779.45 \\
783.71 \\
787.96 \\
792.21 \\
796.46\end{array}$ & $\begin{array}{l}779.88 \\
784.13 \\
788.39 \\
792.64 \\
796.89\end{array}$ & $\begin{array}{l}780.30 \\
784.56 \\
788.81 \\
793.06 \\
797.32\end{array}$ & $\begin{array}{l}780.73 \\
784.98 \\
789.24 \\
793.49 \\
797.74\end{array}$ & $\begin{array}{l}781.16 \\
785.41 \\
789.66 \\
793.91 \\
798.17\end{array}$ & $\begin{array}{l}781.58 \\
785.84 \\
790.09 \\
794.34 \\
798.59\end{array}$ & $\begin{array}{l}782.01 \\
786.26 \\
790.51 \\
794.76 \\
799.02\end{array}$ \\
\hline $\begin{array}{l}17.50 \\
17.60 \\
17.70 \\
17.80 \\
17.90\end{array}$ & $\begin{array}{l}799.02 \\
803.26 \\
807.51 \\
811.76 \\
816.00\end{array}$ & $\begin{array}{l}799.44 \\
803.69 \\
807.94 \\
812.18 \\
816.43\end{array}$ & $\begin{array}{l}799.86 \\
804.11 \\
808.36 \\
812.61 \\
816.85\end{array}$ & $\begin{array}{l}800.29 \\
804.54 \\
808.79 \\
813.03 \\
817.28\end{array}$ & $\begin{array}{l}800.71 \\
804.96 \\
809.21 \\
813.46 \\
817.70\end{array}$ & $\begin{array}{l}801.14 \\
805.39 \\
809.64 \\
813.88 \\
818.13\end{array}$ & $\begin{array}{l}801.56 \\
805.81 \\
810.06 \\
814.31 \\
818.55\end{array}$ & $\begin{array}{l}801.99 \\
806.24 \\
810.48 \\
814.73 \\
818.98\end{array}$ & $\begin{array}{l}802.41 \\
806.66 \\
810.91 \\
815.16 \\
819.40\end{array}$ & $\begin{array}{l}802.84 \\
807.09 \\
811.33 \\
815.58 \\
819.82\end{array}$ & $\begin{array}{l}803.26 \\
807.51 \\
811.76 \\
816.00 \\
820.25\end{array}$ \\
\hline 18.00 & 820.25 & 820.67 & 821.10 & 821.52 & 821.95 & 822.37 & 822.80 & 823.22 & 823.64 & 824.07 & 824.49 \\
\hline
\end{tabular}

TEMPERATURES IN DEGREES $F$ 
TABLE A7.2.2. Type $K$ thermocouples-temperature $\left({ }^{\circ} \mathrm{F}\right)$ as a function of thermoelectric voltage, reference junctions at $32^{\circ} \mathrm{F}$-Continued

$\mathrm{mV}$

.01

.02

820.25

18.00

18.10

$18.20^{\circ}$

18.30

18.40

$18 \cdot 50$

18.60

18.70

18.80

18.90

19.00

19.10

19.20

19.30

19.40

19.50

19.60

19.70

19.80

19.90

20.00

$20 \cdot 10$

$20 \cdot 20$

20.30

20.40

20.50

20.60

20.70

20.80

20.90

21.00

21.10

21.20

21.30

21.40

21.50

21.60

21.70

21.80

21.90

22.00

22.10

22.20

22.30

22.40

22.50

22.60

22.70

22.80

22.90

23.00

23.10

23.20

23.30

23.40

23.50

23.60

23.70

23.80

23.90

\subsection{9 \\ 828,74}

832.98

837.22

841.46

845.70

849.93

54.17

862.64

866.87

871.11

875.34

879.57

883.80

888.03

892.26

896.49

900.72

904.95

909.18

913.40

917.63

921.85

926.08

930.30

934.53

938.75

942.97

947.20

951.42

955.64

959.86

968.31

972.53

976.75

980.97

985.19

989.41

993.64

997.86

1002.08

1006.30

1010.52

1023.1819 .38

$1027.41 \quad 1027.83$

$1031.63 \quad 1032.05$

$1035.85 \quad 1036.27$

$1040.07 \quad 1040.50$

$1044.30 \quad 1044.72$

1048.52

$1052.74 \quad 1053.17$

$1056.97 \quad 1057.39$

$1061.19 \quad 1061.61$

1065.42

1069.64

1065.84

$1073.87 \quad 1074.29 \quad 1074.71$

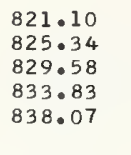

$842 \cdot 30$

846.54

850.78

859.25

863.49

867.72

871.95

876.19

880.42

$884 \cdot 65$

888.88

893.11

897.34

901.57

905.79

910.02

914.25

918.47

922.70

926.92

931.15

935.37

939.60

943.82

948.04

952.26

956.49

960.71

964.93

969.15

973.37

977.60

981.82

986.04

990.26

994.48

998.70

1002.92

1007.14

1011.36

1015.59

1019.81

1024.03

$1028 \cdot 25$

$1032 \cdot 47$

1036.7

1040.92

1045.14

1053.59

1057.81

1062.04

$1066.26 \quad 1062.46$

1070.491070 .91

851.20

855.44

863.91

$868 \cdot 14$

872.38

876.61
880.84

885.07

889.30

893.53

997.76

906.22

$910 \cdot 44$

923.12

927.35

931.57

935.79

944.24

948.46

956.91

969.57

973.80

982.24

986.46

990.68

994.90

99.12

TEMPERATURES IN DEGREES F

$\begin{array}{llll}821.52 & 821.95 & 822.37 & 822.80 \\ 825.77 & 826.19 & 826.61 & 827.04 \\ 830.01 & 830.43 & 830.86 & 831.28 \\ 834.25 & 834.67 & 835.10 & 835.52 \\ 838.49 & 838.91 & 839.34 & 839.76\end{array}$

$843 \cdot 15$

847.39

851.63

$843.58 \quad 844.00$

$847.81 \quad 848.24$

$852.05 \quad 852.48$

$860.10 \quad 860.52 \quad 860.95$

864.33

868.57

872.80

877.03

864.76

$865 \cdot 18$

$868.99 \quad 869.41$

$873.22 \quad 873.65$

85.50

$881.69 \quad 882.11$

885.50

885.92

893.96

898. 18

$902 \cdot 41$

890.15

$886 \cdot 34$

$898.61 \quad 899.03$

906.64

910.87

915.09

907.06

907.48

$911.29 \quad 911.71$

$915.52 \quad 915.94$

$919.74 \quad 920.16$

923.54

923.97

924.39

927.77

$928.19 \quad 928.61$

931.99

936.22

940.44

93

936.64

940.86

932.84

937.06

937.06

945.09

945.51

948.89

957.33

949.31

953.53

957.75

949.73

953.95

958.18

962.40

966.20

966.62

970.00

970.42

970.84

974.22

978.44

982.66

986.88

974.64

978.86

983.0

975.06

991.10

995.32

999.54 
TABLE A7.2.2. Type $K$ thermocouples-temperature $\left({ }^{\circ} \mathrm{F}\right)$ as a function of thermoelectric voltage, reference junctions at $32^{\circ} \mathrm{F}$-Continued

$m V$

.00

00

.01

.02

.03

.04

.06

.07

.08

.09

$\cdot 10$

$m \vee$

\section{TEMPERATURES IN DEGREES F}

\begin{tabular}{|c|c|c|c|c|c|c|c|c|c|c|c|c|}
\hline $\begin{array}{l}24.00 \\
24.10 \\
24.20 \\
24.30 \\
24.40\end{array}$ & $\begin{array}{l}1073.87 \\
1078.10 \\
1082.32 \\
1086.55 \\
1090.78\end{array}$ & $\begin{array}{l}1074.29 \\
1078.52 \\
1082.75 \\
1086.97 \\
1091.20\end{array}$ & $\begin{array}{l}1074.71 \\
1078.94 \\
1083.17 \\
1087.40 \\
1091.62\end{array}$ & $\begin{array}{l}1075.14 \\
1079.36 \\
1083.59 \\
1087.82 \\
1092.05\end{array}$ & $\begin{array}{l}1075.56 \\
1079.79 \\
1084.01 \\
1088.24 \\
1092.47\end{array}$ & $\begin{array}{l}1075.98 \\
1080.21 \\
1084.44 \\
1088.66 \\
1092.89\end{array}$ & $\begin{array}{l}1076.40 \\
1080.63 \\
1084.86 \\
1089.09 \\
1093.32\end{array}$ & $\begin{array}{l}1076.83 \\
1081.05 \\
1085.28 \\
1089.51 \\
1093.74\end{array}$ & $\begin{array}{l}1077.25 \\
1081.48 \\
1085.70 \\
1089.93 \\
1094.16\end{array}$ & $\begin{array}{l}1077.67 \\
1081.90 \\
1086.13 \\
1090.36 \\
1094.59\end{array}$ & $\begin{array}{l}1078.10 \\
1082.32 \\
1086.55 \\
1090.78 \\
1095.01\end{array}$ & $\begin{array}{l}24.00 \\
24.10 \\
24.20 \\
24.30 \\
24 \cdot 40\end{array}$ \\
\hline $\begin{array}{l}24.50 \\
24.60 \\
24.70 \\
24.80 \\
24.90\end{array}$ & $\begin{array}{l}1095.01 \\
1099.24 \\
1103.47 \\
1107.70 \\
1111.93\end{array}$ & $\begin{array}{l}1095.43 \\
1099.66 \\
1103.89 \\
1108.12 \\
1112.36\end{array}$ & $\begin{array}{l}1095.85 \\
1100.08 \\
1104.31 \\
1108.55 \\
1112.78\end{array}$ & $\begin{array}{l}1096.28 \\
1100.51 \\
1104.74 \\
1108.97 \\
1113.20\end{array}$ & $\begin{array}{l}1096.70 \\
1100.93 \\
1105.16 \\
1109.39 \\
1113.63\end{array}$ & $\begin{array}{l}1097.12 \\
1101.35 \\
1105.58 \\
1109.82 \\
1114.05\end{array}$ & $\begin{array}{l}1097.55 \\
1101.78 \\
1106.01 \\
1110.24 \\
1114.47\end{array}$ & $\begin{array}{l}1097.97 \\
1102.20 \\
1106.43 \\
1110.66 \\
1114.90\end{array}$ & $\begin{array}{l}1098.39 \\
1102.62 \\
1106.85 \\
1111.09 \\
1115.32\end{array}$ & $\begin{array}{l}1098.81 \\
1103.05 \\
1107.28 \\
1111.51 \\
1115.74\end{array}$ & $\begin{array}{l}1099.24 \\
1103.47 \\
1107.70 \\
1111.93 \\
1116.17\end{array}$ & $\begin{array}{l}24.50 \\
24.50 \\
24.70 \\
24.80 \\
24.90\end{array}$ \\
\hline $\begin{array}{l}25.00 \\
25.10 \\
25.20 \\
25.30 \\
25.40\end{array}$ & $\begin{array}{l}1116.17 \\
1120.40 \\
1124.63 \\
1128.87 \\
1133.11\end{array}$ & $\begin{array}{l}1116.59 \\
1120.82 \\
1125.06 \\
1129.29 \\
1133.53\end{array}$ & $\begin{array}{l}1117.01 \\
1121.25 \\
1125.48 \\
1129.72 \\
1133.95\end{array}$ & $\begin{array}{l}1117.44 \\
1121.67 \\
1125.90 \\
1130.14 \\
1134.38\end{array}$ & $\begin{array}{l}1117.86 \\
1122.09 \\
1126.33 \\
1130.56 \\
1134.80\end{array}$ & $\begin{array}{l}1118.28 \\
1122.52 \\
1126.75 \\
1130.99 \\
1135.22\end{array}$ & $\begin{array}{l}1118.71 \\
1122.94 \\
1127.18 \\
1131.41 \\
1135.65\end{array}$ & $\begin{array}{l}1119.13 \\
1123.36 \\
1127.60 \\
1131.84 \\
1136.07\end{array}$ & $\begin{array}{l}1119.55 \\
1123.79 \\
1128.02 \\
1132.26 \\
1136.50\end{array}$ & $\begin{array}{l}1119.98 \\
1124.21 \\
1128.45 \\
1132.68 \\
1136.92\end{array}$ & $\begin{array}{l}1120.40 \\
1124.63 \\
1128.87 \\
1133.11 \\
1137.34\end{array}$ & $\begin{array}{l}25.00 \\
25.10 \\
25.20 \\
25.30 \\
25.40\end{array}$ \\
\hline $\begin{array}{l}25.50 \\
25.60 \\
25.70 \\
25.80 \\
25.90\end{array}$ & $\begin{array}{l}1137.34 \\
1141.58 \\
1145.82 \\
1150.06 \\
1154.30\end{array}$ & $\begin{array}{l}1137.77 \\
1142.01 \\
1146.25 \\
1150.49 \\
1154.73\end{array}$ & $\begin{array}{l}1138.19 \\
1142.43 \\
1146.67 \\
1150.91 \\
1155.15\end{array}$ & $\begin{array}{l}1138.62 \\
1142.85 \\
1147.09 \\
1151.34 \\
1155.58\end{array}$ & $\begin{array}{l}1139.04 \\
1143.28 \\
1147.52 \\
1151.76 \\
1156.00\end{array}$ & $\begin{array}{l}1139.46 \\
1143.70 \\
1147.94 \\
1152.18 \\
1156.43\end{array}$ & $\begin{array}{l}1139.89 \\
1144.13 \\
1148.37 \\
1152.61 \\
1156.85\end{array}$ & $\begin{array}{l}1140.31 \\
1144.55 \\
1148.79 \\
1153.03 \\
1157.27\end{array}$ & $\begin{array}{l}1140.73 \\
1144.97 \\
1149.21 \\
1153.46 \\
1157.70\end{array}$ & $\begin{array}{l}1141.16 \\
1145.40 \\
1149.64 \\
1153.88 \\
1158.12\end{array}$ & $\begin{array}{l}1141.58 \\
1145.82 \\
1150.06 \\
1154.30 \\
1158.55\end{array}$ & $\begin{array}{l}25.50 \\
25.60 \\
25.70 \\
25.80 \\
25.90\end{array}$ \\
\hline $\begin{array}{l}26.00 \\
26.10 \\
26.20 \\
26.30 \\
26.40\end{array}$ & $\begin{array}{l}1158.55 \\
1162.79 \\
1167.04 \\
1171.28 \\
1175.53\end{array}$ & $\begin{array}{l}1158.97 \\
1163.22 \\
1167.46 \\
1171.71 \\
1175.96\end{array}$ & $\begin{array}{l}1159.40 \\
1163.64 \\
1167.89 \\
1172.13 \\
1176.38\end{array}$ & $\begin{array}{l}1159.82 \\
1164.07 \\
1168.31 \\
1172.56 \\
1176.81\end{array}$ & $\begin{array}{l}1160.25 \\
1164.49 \\
1168.74 \\
1172.98 \\
1177.23\end{array}$ & $\begin{array}{l}1160.67 \\
1164.91 \\
1169.16 \\
1173.41 \\
1177.66\end{array}$ & $\begin{array}{l}1161.09 \\
1165.34 \\
1169.58 \\
1173.83 \\
1178.08\end{array}$ & $\begin{array}{l}1161.52 \\
1165.76 \\
1170.01 \\
1174.26 \\
1178.51\end{array}$ & $\begin{array}{l}1161.94 \\
1166.19 \\
1170.43 \\
1174.68 \\
1178.93\end{array}$ & $\begin{array}{l}1162.37 \\
1166.61 \\
1170.86 \\
1175.11 \\
1179.36\end{array}$ & $\begin{array}{l}1162.79 \\
1167.04 \\
1171.28 \\
1175.53 \\
1179.78\end{array}$ & $\begin{array}{l}26.00 \\
26.10 \\
26.20 \\
26.30 \\
26.40\end{array}$ \\
\hline $\begin{array}{l}26 \cdot 50 \\
26.60 \\
26.70 \\
26.80 \\
26.90\end{array}$ & $\begin{array}{l}1179.78 \\
1184.03 \\
1188.28 \\
1192.54 \\
1196.79\end{array}$ & $\begin{array}{l}1180.21 \\
1184.46 \\
1188.71 \\
1192.96 \\
1197.21\end{array}$ & $\begin{array}{l}1180.63 \\
1184.88 \\
1189.13 \\
1193.39 \\
1197.64\end{array}$ & $\begin{array}{l}1181.06 \\
1185.31 \\
1189.56 \\
1193.81 \\
1198.07\end{array}$ & $\begin{array}{l}1181.48 \\
1185.73 \\
1189.98 \\
1194.24 \\
1198.49\end{array}$ & $\begin{array}{l}1181.91 \\
1186.16 \\
1190.41 \\
1194.66 \\
1198.92\end{array}$ & $\begin{array}{l}1182.33 \\
1186.58 \\
1190.83 \\
1195.09 \\
1199.34\end{array}$ & $\begin{array}{l}1182.76 \\
1187.01 \\
1191.26 \\
1195.51 \\
1199.77\end{array}$ & $\begin{array}{l}1183.18 \\
1187.43 \\
1191.68 \\
1195.94 \\
1200.19\end{array}$ & $\begin{array}{l}1183.61 \\
1187.86 \\
1192.11 \\
1196.36 \\
1200.62\end{array}$ & $\begin{array}{l}1184.03 \\
1188.28 \\
1192.54 \\
1196.79 \\
1201.05\end{array}$ & $\begin{array}{l}26.50 \\
26.60 \\
26.70 \\
26.80 \\
26.90\end{array}$ \\
\hline $\begin{array}{l}27.00 \\
27.10 \\
27.20 \\
27.30 \\
27.40\end{array}$ & $\begin{array}{l}1201.05 \\
1205.30 \\
1209.56 \\
1213.82 \\
1218.08\end{array}$ & $\begin{array}{l}1201.47 \\
1205.73 \\
1209.99 \\
1214.25 \\
1218.51\end{array}$ & $\begin{array}{l}1201.90 \\
1206.15 \\
1210.41 \\
1214.67 \\
1218.93\end{array}$ & $\begin{array}{l}1202.32 \\
1206.58 \\
1210.84 \\
1215.10 \\
1219.36\end{array}$ & $\begin{array}{l}1202.75 \\
1207.01 \\
1211.26 \\
1215.53 \\
1219.79\end{array}$ & $\begin{array}{l}1203.17 \\
1207.43 \\
1211.69 \\
1215.95 \\
1220.21\end{array}$ & $\begin{array}{l}1203.60 \\
1207.86 \\
1212.12 \\
1216.38 \\
1220.64\end{array}$ & $\begin{array}{l}1204.02 \\
1208.28 \\
1212.54 \\
1216.80 \\
1221.07\end{array}$ & $\begin{array}{l}1204.45 \\
1208.71 \\
1212.97 \\
1217.23 \\
1221.49\end{array}$ & $\begin{array}{l}1204.88 \\
1209.13 \\
1213.39 \\
1217.66 \\
1221.92\end{array}$ & $\begin{array}{l}1205.30 \\
1209.56 \\
1213.82 \\
1218.08 \\
1222.35\end{array}$ & $\begin{array}{l}27.00 \\
27.10 \\
27.20 \\
27.30 \\
27.40\end{array}$ \\
\hline $\begin{array}{l}27.50 \\
27.60 \\
27.70 \\
27.80 \\
27.90\end{array}$ & $\begin{array}{l}1222.35 \\
1226.61 \\
1230.88 \\
1235.14 \\
1239.41\end{array}$ & $\begin{array}{l}1222.77 \\
1227.04 \\
1231.30 \\
1235.57 \\
1239.84\end{array}$ & $\begin{array}{l}1223.20 \\
1227.46 \\
1231.73 \\
1236.00 \\
1240.27\end{array}$ & $\begin{array}{l}1223.62 \\
1227.89 \\
1232.16 \\
1236.42 \\
1240.69\end{array}$ & $\begin{array}{l}1224.05 \\
1228.32 \\
1232.58 \\
1236.85 \\
1241.12\end{array}$ & $\begin{array}{l}1224.48 \\
1228.74 \\
1233.01 \\
1237.28 \\
1241.55\end{array}$ & $\begin{array}{l}1224.90 \\
1229.17 \\
1233.44 \\
1237.71 \\
1241.98\end{array}$ & $\begin{array}{l}1225.33 \\
1229 \cdot 60 \\
1233.86 \\
1238.13 \\
1242.40\end{array}$ & $\begin{array}{l}1225.76 \\
1230.02 \\
1234.29 \\
1238.56 \\
1242.83\end{array}$ & $\begin{array}{l}1226.18 \\
1230.45 \\
1234.72 \\
1238.99 \\
1243.26\end{array}$ & $\begin{array}{l}1226.61 \\
1230.88 \\
1235.14 \\
1239.41 \\
1243.68\end{array}$ & $\begin{array}{l}27.50 \\
27.60 \\
27.70 \\
27.80 \\
27.90\end{array}$ \\
\hline $\begin{array}{l}28.00 \\
28.10 \\
28.20 \\
28.30 \\
28.40\end{array}$ & $\begin{array}{l}1243.68 \\
1247.96 \\
1252.23 \\
1256.51 \\
1260.79\end{array}$ & $\begin{array}{l}1244.11 \\
1248.39 \\
1252.66 \\
1256.94 \\
1261.21\end{array}$ & $\begin{array}{l}1244.54 \\
1248.81 \\
1253.09 \\
1257.36 \\
1261.64\end{array}$ & $\begin{array}{l}1244.97 \\
1249.24 \\
1253.52 \\
1257.79 \\
1262.07\end{array}$ & $\begin{array}{l}1245.39 \\
1249.67 \\
1253.94 \\
1258.22 \\
1262.50\end{array}$ & $\begin{array}{l}1245.82 \\
1250.09 \\
1254.37 \\
1258.65 \\
1262.93\end{array}$ & $\begin{array}{l}1246.25 \\
1250.52 \\
1254.80 \\
1259.08 \\
1263.35\end{array}$ & $\begin{array}{l}1246.68 \\
1250.95 \\
1255.23 \\
1259.50 \\
1263.78\end{array}$ & $\begin{array}{l}1247.10 \\
1251.38 \\
1255.65 \\
1259.93 \\
1264.21\end{array}$ & $\begin{array}{l}1247.53 \\
1251.80 \\
1256.08 \\
1260.36 \\
1264.64\end{array}$ & $\begin{array}{l}1247.96 \\
1252.23 \\
1256.51 \\
1260.79 \\
1265.07\end{array}$ & $\begin{array}{l}28.00 \\
28.10 \\
28.20 \\
28.30 \\
28.40\end{array}$ \\
\hline $\begin{array}{l}28.50 \\
28.60 \\
28.70 \\
28.80 \\
28.90\end{array}$ & $\begin{array}{l}1265.07 \\
1269.35 \\
1273.63 \\
1277.92 \\
1282.20\end{array}$ & $\begin{array}{l}1265.49 \\
1269.78 \\
1274.06 \\
1278.35 \\
1282.63\end{array}$ & $\begin{array}{l}1265.92 \\
1270.20 \\
1274.49 \\
1278.77 \\
1283.06\end{array}$ & $\begin{array}{l}1266.35 \\
1270.63 \\
1274.92 \\
1279.20 \\
1283.49\end{array}$ & $\begin{array}{l}1266.78 \\
1271.06 \\
1275.35 \\
1279.63 \\
1283.92\end{array}$ & $\begin{array}{l}1267.21 \\
1271.49 \\
1275.77 \\
1280.06 \\
1284.35\end{array}$ & $\begin{array}{l}1267.64 \\
1271.92 \\
1276.20 \\
1280.49 \\
1284.78\end{array}$ & $\begin{array}{l}1268.06 \\
1272.35 \\
1276.63 \\
1280.92 \\
1285.21\end{array}$ & $\begin{array}{l}1268.49 \\
1272.77 \\
1277.06 \\
1281.35 \\
1285.64\end{array}$ & $\begin{array}{l}1268.92 \\
1273.20 \\
1277.49 \\
1281.78 \\
1286.06\end{array}$ & $\begin{array}{l}1269.35 \\
1273.63 \\
1277.92 \\
1282.20 \\
1286.49\end{array}$ & $\begin{array}{l}28.50 \\
28.60 \\
28.70 \\
28.80 \\
28.90\end{array}$ \\
\hline $\begin{array}{l}29.00 \\
29.10 \\
29.20 \\
29.30 \\
29.40\end{array}$ & $\begin{array}{l}1286.49 \\
1290.78 \\
1295.08 \\
1299.37 \\
1303.67\end{array}$ & $\begin{array}{l}1286.92 \\
1291.21 \\
1295.51 \\
1299.80 \\
1304.10\end{array}$ & $\begin{array}{l}1291.64 \\
1295.94 \\
1300.23 \\
1304.53\end{array}$ & $\begin{array}{l}1287.78 \\
1292.07 \\
1296.37 \\
1300.66 \\
1304.96\end{array}$ & $\begin{array}{l}1288.21 \\
1292.50 \\
1296.80 \\
1301.09 \\
1305.39\end{array}$ & $\begin{array}{l}1288.64 \\
1292.93 \\
1297.22 \\
1301.52 \\
1305.82\end{array}$ & $\begin{array}{l}1289.07 \\
1293.36 \\
1297.65 \\
1301.95 \\
1306.25\end{array}$ & $\begin{array}{l}1293.79 \\
1298.08 \\
1302.38 \\
1306.68\end{array}$ & $\begin{array}{l}1289.93 \\
1294.22 \\
1298.51 \\
1302.81 \\
1307.11\end{array}$ & $\begin{array}{l}1290.36 \\
1294.65 \\
1298.94 \\
1303.24 \\
1307.54\end{array}$ & $\begin{array}{l}1290.78 \\
1295.08 \\
1299.37 \\
1303.67 \\
1307.97\end{array}$ & $\begin{array}{l}29.00 \\
29.10 \\
29.20 \\
29.30 \\
29.40\end{array}$ \\
\hline $\begin{array}{l}29.50 \\
29.60 \\
29.70 \\
29.80 \\
29.90\end{array}$ & $\begin{array}{l}1312.27 \\
1316.57 \\
1320.88 \\
1325.19\end{array}$ & $\begin{array}{l}1312.70 \\
1317.00 \\
1321.31 \\
1325.62\end{array}$ & $\begin{array}{l}1313.13 \\
1317.43 \\
1321.74 \\
1326.05\end{array}$ & $\begin{array}{l}1313.56 \\
1317.86 \\
1322.17 \\
1326.48\end{array}$ & $\begin{array}{l}1313.99 \\
1318.29 \\
1322.60 \\
1326.91\end{array}$ & $\begin{array}{l}1314.42 \\
1318.73 \\
1323.03 \\
1327.34\end{array}$ & $\begin{array}{l}1314.85 \\
1319.16 \\
1323.46 \\
1327.77\end{array}$ & $\begin{array}{l}1315.28 \\
1319.59 \\
1323.89 \\
1328.20\end{array}$ & $\begin{array}{l}1311.41 \\
1315.71 \\
1320.02 \\
1324.32 \\
1328.63\end{array}$ & $\begin{array}{l}1311.84 \\
1316.14 \\
1320.45 \\
1324.75 \\
1329.06\end{array}$ & $\begin{array}{l}1312.27 \\
1316.57 \\
1320.88 \\
1325.19 \\
1329.49\end{array}$ & $\begin{array}{l}29.50 \\
29.60 \\
29.70 \\
29.80 \\
29.90\end{array}$ \\
\hline 00 & 29.49 & 29.93 & 330.36 & 30.79 & 31.22 & 31.65 & 32.08 & 32.51 & 332.94 & 333.38 & 1333.81 & 30.00 \\
\hline
\end{tabular}
1085.28

114.90

1123.36 1127.60 1136.07

1140.3 1148.79 1153.03 1170.01 1178.51
.00

.01

.02

.03
.04
.05 
TABLE A7.2.2. Type $\boldsymbol{K}$ thermocouples-temperature $\left({ }^{\circ} \mathrm{F}\right)$ as a function of thermoelectric voltage, reference junctions at $32^{\circ} \mathrm{F}$-Continued

.05

.06

.07

.08

.09

TEMPERATURES IN DEGREES F

\begin{tabular}{|c|c|c|c|c|c|c|c|c|c|c|c|c|}
\hline $\begin{array}{l}30.00 \\
30.10 \\
30.20 \\
30.30 \\
30.40\end{array}$ & $\begin{array}{l}1329.49 \\
1333.81 \\
1338.12 \\
1342.44 \\
1346.75\end{array}$ & $\begin{array}{l}1329.93 \\
1334.24 \\
1338.55 \\
1342.87 \\
1347.19\end{array}$ & $\begin{array}{l}1330.36 \\
1334.67 \\
1338.98 \\
1343.30 \\
1347.62\end{array}$ & $\begin{array}{l}1330.79 \\
1335.10 \\
1339.41 \\
1343.73 \\
1348.05\end{array}$ & $\begin{array}{l}1331.22 \\
1335.53 \\
1339.85 \\
1344.16 \\
1348.48\end{array}$ & $\begin{array}{l}1331.65 \\
1335.96 \\
1340.28 \\
1344.59 \\
1348.91\end{array}$ & $\begin{array}{l}1332.08 \\
1336.39 \\
1340.71 \\
1345.03 \\
1349.35\end{array}$ & $\begin{array}{l}1332.51 \\
1336.83 \\
1341.14 \\
1345.46 \\
1349.78\end{array}$ & $\begin{array}{l}1332.94 \\
1337.26 \\
1341.57 \\
1345.89 \\
1350.21\end{array}$ & $\begin{array}{l}1333.38 \\
1337.69 \\
1342.00 \\
1346.32 \\
1350.64\end{array}$ & $\begin{array}{l}1333.81 \\
1338.12 \\
1342.44 \\
1346.75 \\
1351.07\end{array}$ & $\begin{array}{l}30.00 \\
30.10 \\
30.20 \\
30.30 \\
30.40\end{array}$ \\
\hline $\begin{array}{l}0.50 \\
0.60 \\
0.70 \\
0.80 \\
0.90\end{array}$ & $\begin{array}{l}1351.07 \\
1355.40 \\
1359.72 \\
1364.05 \\
1368.38\end{array}$ & $\begin{array}{l}1351.51 \\
1355.83 \\
1360.15 \\
1364.48 \\
1368.81\end{array}$ & $\begin{array}{l}1351.94 \\
1356.26 \\
1360.59 \\
1364.91 \\
1369.24\end{array}$ & $\begin{array}{l}1352.37 \\
1356.69 \\
1361.02 \\
1365.35 \\
1369.68\end{array}$ & $\begin{array}{l}1352.80 \\
1357.13 \\
1361.45 \\
1365.78 \\
1370.11\end{array}$ & $\begin{array}{l}1353.24 \\
1357.56 \\
1361.89 \\
1366.21 \\
1370.54\end{array}$ & $\begin{array}{l}1353.67 \\
1357.99 \\
1362.32 \\
1366.65 \\
1370.98\end{array}$ & $\begin{array}{l}1354.10 \\
1358.42 \\
1362.75 \\
1367.08 \\
1371.41\end{array}$ & $\begin{array}{l}1354.53 \\
1358.86 \\
1363.18 \\
1367.51 \\
1371.84\end{array}$ & $\begin{array}{l}1354.96 \\
1359.29 \\
1363.62 \\
1367.95 \\
1372.28\end{array}$ & $\begin{array}{l}1355.40 \\
1359.72 \\
1364.05 \\
1368.38 \\
1372.71\end{array}$ & $\begin{array}{l}30.50 \\
30.60 \\
30.70 \\
30.80\end{array}$ \\
\hline $\begin{array}{l}1.00 \\
1.10 \\
1.20 \\
1.30 \\
1.40\end{array}$ & $\begin{array}{l}1372.71 \\
1377.04 \\
1381.38 \\
1385.72 \\
1390.06\end{array}$ & $\begin{array}{l}1373.14 \\
1377.48 \\
1381.81 \\
1386.15 \\
1390.50\end{array}$ & $\begin{array}{l}1373.58 \\
1377.91 \\
1382.25 \\
1386.59 \\
1390.93\end{array}$ & $\begin{array}{l}1374.01 \\
1378.35 \\
1382.68 \\
1387.02 \\
1391.36\end{array}$ & $\begin{array}{l}1374.44 \\
1378.78 \\
1383.12 \\
1387.46 \\
1391.80\end{array}$ & $\begin{array}{l}1374.88 \\
1379.21 \\
1383.55 \\
1387.89 \\
1392.23\end{array}$ & $\begin{array}{l}1375.31 \\
1379.65 \\
1383.98 \\
1388.32 \\
1392.67\end{array}$ & $\begin{array}{l}1375.74 \\
1380.08 \\
1384.42 \\
1388.76 \\
1393.10\end{array}$ & $\begin{array}{l}1376.18 \\
1380.51 \\
1384.85 \\
1389.19 \\
1393.54\end{array}$ & $\begin{array}{l}1376.61 \\
1380.95 \\
1385.29 \\
1389.63 \\
1393.97\end{array}$ & $\begin{array}{l}1377.04 \\
1381.38 \\
1385.72 \\
1390.06 \\
1394.40\end{array}$ & $\begin{array}{l}31.00 \\
31.10 \\
31.20 \\
31.30 \\
31.40\end{array}$ \\
\hline $\begin{array}{l}1.50 \\
1.60 \\
1.70 \\
1.80 \\
1.90\end{array}$ & $\begin{array}{l}1394.40 \\
1398.75 \\
1403.10 \\
1407.45 \\
1411.80\end{array}$ & $\begin{array}{l}1394.84 \\
1399.19 \\
1403.53 \\
1407.89 \\
1412.24\end{array}$ & $\begin{array}{l}1395.27 \\
1399.62 \\
1403.97 \\
1408.32 \\
1412.67\end{array}$ & $\begin{array}{l}1395.71 \\
1400.06 \\
1404.40 \\
1408.76 \\
1413.11\end{array}$ & $\begin{array}{l}1396.14 \\
1400.49 \\
1404.84 \\
1409.19 \\
1413.55\end{array}$ & $\begin{array}{l}1396.58 \\
1400.92 \\
1405.27 \\
1409.63 \\
1413.98\end{array}$ & $\begin{array}{l}1397.01 \\
1401.36 \\
1405.71 \\
1410.06 \\
1414.42\end{array}$ & $\begin{array}{l}1397.45 \\
1401.79 \\
1406.14 \\
1410.50 \\
1414.85\end{array}$ & $\begin{array}{l}1397.88 \\
1402.23 \\
1406.58 \\
1410.93 \\
1415.29\end{array}$ & $\begin{array}{l}1398.32 \\
1402.66 \\
1407.02 \\
1411.37 \\
1415.72\end{array}$ & $\begin{array}{l}1398.75 \\
1403.10 \\
1407.45 \\
1411.80 \\
1416.16\end{array}$ & $\begin{array}{l}31.50 \\
31.60 \\
31.70 \\
31.80 \\
31.90\end{array}$ \\
\hline $\begin{array}{l}32 \cdot 00 \\
32 \cdot 10 \\
32 \cdot 20 \\
32 \cdot 30 \\
32 \cdot 40\end{array}$ & $\begin{array}{l}1416.16 \\
1420.52 \\
1424.88 \\
1429.24 \\
1433.61\end{array}$ & $\begin{array}{l}1416.60 \\
1420.95 \\
1425.32 \\
1429.68 \\
1434.05\end{array}$ & $\begin{array}{l}1417.03 \\
1421.39 \\
1425.75 \\
1430.12 \\
1434.48\end{array}$ & $\begin{array}{l}1417.47 \\
1421.83 \\
1426.19 \\
1430.55 \\
1434.92\end{array}$ & $\begin{array}{l}1417.90 \\
1422.26 \\
1426.62 \\
1430.99 \\
1435.36\end{array}$ & $\begin{array}{l}1418.34 \\
1422.70 \\
1427.06 \\
1431.43 \\
1435.79\end{array}$ & $\begin{array}{l}1418.77 \\
1423.13 \\
1427.50 \\
1431.86 \\
1436.23\end{array}$ & $\begin{array}{l}1419.21 \\
1423.57 \\
1427.93 \\
1432.30 \\
1436.67\end{array}$ & $\begin{array}{l}1419.65 \\
1424.01 \\
1428.37 \\
1432.74 \\
1437.10\end{array}$ & $\begin{array}{l}1420.08 \\
1424.44 \\
1428.81 \\
1433.17 \\
1437.54\end{array}$ & $\begin{array}{l}1420.52 \\
1424.88 \\
1429.24 \\
1433.61 \\
1437.98\end{array}$ & $\begin{array}{l}32.00 \\
32.10 \\
32.20 \\
32.30 \\
32.40\end{array}$ \\
\hline $\begin{array}{l}32.50 \\
32.60 \\
32.70 \\
32.80 \\
32.90\end{array}$ & $\begin{array}{l}1437.98 \\
1442.35 \\
1446.72 \\
1451.10 \\
1455.48\end{array}$ & $\begin{array}{l}1438.41 \\
1442.79 \\
1447.16 \\
1451.54 \\
1455.92\end{array}$ & $\begin{array}{l}1438.85 \\
1443.22 \\
1447.60 \\
1451.97 \\
1456.35\end{array}$ & $\begin{array}{l}1439.29 \\
1443.66 \\
1448.03 \\
1452.41 \\
1456.79\end{array}$ & $\begin{array}{l}1439.73 \\
1444.10 \\
1448.47 \\
1452.85 \\
1457.23\end{array}$ & $\begin{array}{l}1440.16 \\
1444.53 \\
1448.91 \\
1453.29 \\
1457.67\end{array}$ & $\begin{array}{l}1440.60 \\
1444.97 \\
1449.35 \\
1453.73 \\
1458.11\end{array}$ & $\begin{array}{l}1441.04 \\
1445.41 \\
1449.79 \\
1454.16 \\
1458.54\end{array}$ & $\begin{array}{l}1441.47 \\
1445.85 \\
1450.22 \\
1454.60 \\
1458.98\end{array}$ & $\begin{array}{l}1441.91 \\
1446.28 \\
1450.66 \\
1455.04 \\
1459.42\end{array}$ & $\begin{array}{l}1442.35 \\
1446.72 \\
1451.10 \\
1455.48 \\
1459.86\end{array}$ & $\begin{array}{l}32.50 \\
32.60 \\
32.70 \\
32.80 \\
32.90\end{array}$ \\
\hline $\begin{array}{l}3.00 \\
3.10 \\
3.20 \\
3.30 \\
3.40\end{array}$ & $\begin{array}{l}459.86 \\
464.24 \\
468.63 \\
473.02 \\
477.41\end{array}$ & $\begin{array}{l}1460.30 \\
1464.68 \\
1469.07 \\
1473.46 \\
1477.85\end{array}$ & $\begin{array}{l}460.74 \\
465.12 \\
469 \cdot 51 \\
473.90 \\
478.29\end{array}$ & $\begin{array}{l}1461.17 \\
1465.56 \\
1469.95 \\
1474.34 \\
1478.73\end{array}$ & $\begin{array}{l}1461.61 \\
1466.00 \\
1470.39 \\
1474.78 \\
1479.17\end{array}$ & $\begin{array}{l}1462.05 \\
1466.44 \\
1470.82 \\
1475.22 \\
1479.61\end{array}$ & $\begin{array}{l}1462.49 \\
1466.88 \\
1471.26 \\
1475.65 \\
1480.05\end{array}$ & $\begin{array}{l}1462.93 \\
1467.31 \\
1471.70 \\
1476.09 \\
1480.49\end{array}$ & $\begin{array}{l}1463.37 \\
1467.75 \\
1472.14 \\
1476.53 \\
1480.93\end{array}$ & $\begin{array}{l}1463.80 \\
1468.19 \\
1472.58 \\
1476.97 \\
1481.37\end{array}$ & $\begin{array}{l}1464.24 \\
1468.63 \\
1473.02 \\
1477.41 \\
1481.81\end{array}$ & $\begin{array}{l}33.00 \\
33.10 \\
33.20 \\
33.30 \\
33.40\end{array}$ \\
\hline $\begin{array}{l}3.50 \\
3.60 \\
3.70 \\
3.80 \\
3.90\end{array}$ & $\begin{array}{l}481.81 \\
486.20 \\
490.60 \\
495.01 \\
499.41\end{array}$ & $\begin{array}{l}1482.25 \\
1486.64 \\
1491.04 \\
1495.45 \\
1499.85\end{array}$ & $\begin{array}{l}482.69 \\
487.08 \\
491.49 \\
495.89 \\
500.30\end{array}$ & $\begin{array}{l}1483.13 \\
1487.52 \\
1491.93 \\
1496.33 \\
1500.74\end{array}$ & $\begin{array}{l}1483.57 \\
1487.96 \\
1492.37 \\
496.77 \\
501.18\end{array}$ & $\begin{array}{l}1484.01 \\
1488.40 \\
1492.81 \\
1497.21 \\
1501.62\end{array}$ & $\begin{array}{l}1484.45 \\
1488.84 \\
1493.25 \\
1497.65 \\
1502.06\end{array}$ & $\begin{array}{l}1484.88 \\
1489.28 \\
1493.69 \\
1498.09 \\
1502.50\end{array}$ & $\begin{array}{l}1485 \cdot 32 \\
1489.72 \\
1494.13 \\
1498.53 \\
1502.94\end{array}$ & $\begin{array}{l}1485.76 \\
1490.16 \\
1494.57 \\
1498.97 \\
1503.38\end{array}$ & $\begin{array}{l}1486.20 \\
1490.60 \\
1495.01 \\
1499.41 \\
1503.82\end{array}$ & $\begin{array}{l}33.50 \\
33.60 \\
33.70 \\
33.80 \\
33.90\end{array}$ \\
\hline $\begin{array}{l}34.10 \\
34.20 \\
34.30 \\
34.40\end{array}$ & $\begin{array}{l}503.82 \\
508.23 \\
512.65 \\
517.06 \\
521.48\end{array}$ & $\begin{array}{l}1504.26 \\
1508.67 \\
1513.09 \\
1517.51 \\
1521.93\end{array}$ & $\begin{array}{l}1504.70 \\
1509.12 \\
1513.53 \\
1517.95 \\
1522.37\end{array}$ & $\begin{array}{l}1509.56 \\
1513.97 \\
1518.39 \\
1522.81\end{array}$ & $\begin{array}{l}1510.00 \\
1514.41 \\
1518.83 \\
1523.25\end{array}$ & $\begin{array}{l}1510.44 \\
1514.86 \\
1519.27 \\
1523.69\end{array}$ & $\begin{array}{l}1506.47 \\
1510.88 \\
1515.30 \\
1519.72 \\
1524.14\end{array}$ & $\begin{array}{l}1511.32 \\
1515.74 \\
1520.16 \\
1524.58\end{array}$ & $\begin{array}{l}1507.35 \\
1511.76 \\
1516.18 \\
1520.60 \\
1525.02\end{array}$ & $\begin{array}{l}1507.79 \\
1512.21 \\
1516.62 \\
1521.04 \\
1525.46\end{array}$ & $\begin{array}{l}1508.23 \\
1512.65 \\
1517.06 \\
1521.48 \\
1525.91\end{array}$ & $\begin{array}{l}34.00 \\
34.10 \\
34.20 \\
34.30 \\
34.40\end{array}$ \\
\hline $\begin{array}{l}4.50 \\
4.60 \\
4.70 \\
4.80 \\
4.90\end{array}$ & $\begin{array}{l}525.91 \\
530.33 \\
534.76 \\
539.19 \\
543.62\end{array}$ & $\begin{array}{l}1526.35 \\
1530.77 \\
1535.20 \\
1539.63 \\
1544.07\end{array}$ & $\begin{array}{l}1526.79 \\
1531.22 \\
1535.64 \\
1540.08 \\
1544.51\end{array}$ & $\begin{array}{l}1521.03 \\
1531.66 \\
1536.09 \\
1540.52 \\
1544.95\end{array}$ & $\begin{array}{l}1527.68 \\
1532.10 \\
1536.53 \\
1540.96 \\
1545.40\end{array}$ & $\begin{array}{l}1532.54 \\
1536.97 \\
1541.41 \\
1545.84\end{array}$ & $\begin{array}{l}1528.56 \\
1532.99 \\
1537.42 \\
1541.85 \\
1546.28\end{array}$ & $\begin{array}{l}1533.43 \\
1537.86 \\
1542.29 \\
1546.73\end{array}$ & $\begin{array}{l}1529.45 \\
1533.87 \\
1538.30 \\
1542.74 \\
1547.17\end{array}$ & $\begin{array}{l}1529.89 \\
1534.32 \\
1538.75 \\
1543.18 \\
1547.62\end{array}$ & $\begin{array}{l}1530.33 \\
1534.76 \\
1539.19 \\
1543.62 \\
1548.06\end{array}$ & $\begin{array}{l}34.50 \\
34.60 \\
34.70 \\
34.80 \\
34.90\end{array}$ \\
\hline $\begin{array}{l}35.00 \\
35.10 \\
35.20 \\
35.30 \\
35.40\end{array}$ & $\begin{array}{l}1548.06 \\
1552.50 \\
1556.94 \\
1561.39 \\
1565.83\end{array}$ & $\begin{array}{l}1548.50 \\
1552.94 \\
1557.38 \\
1561.83 \\
1566.28\end{array}$ & $\begin{array}{l}1548.95 \\
1553.39 \\
1557.83 \\
1562.27 \\
1566.72\end{array}$ & $\begin{array}{l}1549.39 \\
1553.83 \\
1558.27 \\
1562.72 \\
1567.17\end{array}$ & $\begin{array}{l}1549.83 \\
1558.72 \\
1563.16 \\
1567.61\end{array}$ & $\begin{array}{l}1554.72 \\
1559.16 \\
1563.61 \\
1568.06\end{array}$ & $\begin{array}{l}1550.72 \\
1555.16 \\
1559.61 \\
1564.05 \\
1568.50\end{array}$ & $\begin{array}{l}1551.17 \\
1555.61 \\
1560.05 \\
1564.50 \\
1568.95\end{array}$ & $\begin{array}{l}1551.61 \\
1556.05 \\
1560.50 \\
1564.94 \\
1569.39\end{array}$ & $\begin{array}{l}1552.05 \\
1556.50 \\
1560.94 \\
1565.39 \\
1569.84\end{array}$ & $\begin{array}{l}1552.50 \\
1556.94 \\
1561.39 \\
1565.83 \\
1570.28\end{array}$ & $\begin{array}{l}35.00 \\
35.10 \\
35.20 \\
35.30 \\
35.40\end{array}$ \\
\hline $\begin{array}{l}35.50 \\
35.60 \\
35.70 \\
35.80 \\
35.90\end{array}$ & $\begin{array}{l}1570.28 \\
1574.74 \\
1579.19 \\
1583.65 \\
1588.11\end{array}$ & $\begin{array}{l}1570.73 \\
1575.18 \\
1579.64 \\
1584.10 \\
1588.56\end{array}$ & $\begin{array}{l}1571.17 \\
1575.63 \\
1580.08 \\
1584.54 \\
1589.01\end{array}$ & $\begin{array}{l}1571.62 \\
1576.07 \\
1580.53 \\
1584.99 \\
1589.45\end{array}$ & $\begin{array}{l}1572.06 \\
1576.52 \\
1580.98 \\
1585.44 \\
1589.90\end{array}$ & $\begin{array}{l}1572.51 \\
1576.96 \\
1581.42 \\
1585.88 \\
1590.35\end{array}$ & $\begin{array}{l}1572.96 \\
1577.41 \\
1581.87 \\
1586.33 \\
1590.79\end{array}$ & $\begin{array}{l}1573.40 \\
1577.86 \\
1582.31 \\
1586.78 \\
1591.24\end{array}$ & $\begin{array}{l}1573.85 \\
1578.30 \\
1582.76 \\
1587.22 \\
1591.69\end{array}$ & $\begin{array}{l}1574.29 \\
1578.75 \\
1583.21 \\
1587.67 \\
1592.13\end{array}$ & $\begin{array}{l}1574.74 \\
1579.19 \\
1583.65 \\
1588.11 \\
1592.58\end{array}$ & $\begin{array}{l}35.50 \\
35.60 \\
35.70 \\
35.80 \\
35.90\end{array}$ \\
\hline 政 & क्ष & 593.03 & 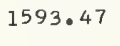 & 393072 & 594.37 & > & 595.26 & 595.71 & 596.15 & 596.60 & 597.05 & \\
\hline
\end{tabular}


TABLE A7.2.2. Type K thermocouples-temperature $\left({ }^{\circ} \mathrm{F}\right)$ as a function of thermoelectric voltage, reference junctions at $32^{\circ} \mathrm{F}$-Continued

$m V$

.00

.01

.02

.03

.04

.05

.06

.07

.08

.09

.10

$m V$

TEMPERATURES IN DEGREES F$$
\begin{aligned}
& 36.00 \\
& 36.10 \\
& 36.20 \\
& 36.30 \\
& 36.40 \\
& 36.50 \\
& 36.70 \\
& 36.80 \\
& 37.00 \\
& 37.10 \\
& 37.50 \\
& 37.80 \\
& 37.90
\end{aligned}
$$
$\begin{array}{ll}1597.49 & 1597.94 \\ 1601.96 & 1602.41\end{array}$

1643.23

$1607.78 \quad 1608.23$

$1612.26 \quad 1612.71$

1616.74

1621.22

1625.71

1634.69

1639.19

1643.68

1652.69

1657.20

1661.71

1666.22

1670.73
1675.25

1679.77

$1684 \cdot 30$

1688.83

1693.36

1702.43

1617.19

\subsection{0 \\ 38.60}

38.70

38.90

39.00

39.1

39.2

39.3

39.40

39.5

39.6

39.70

39.90

\section{0}

\section{1}

40.20

40.40

40.50

$$
\begin{aligned}
& 40.50 \\
& 40.60
\end{aligned}
$$$$
40.7
$$$$
\begin{aligned}
& 40.80 \\
& 40.90
\end{aligned}
$$

\subsection{0}

41.10

41.20
41.30

41.40

41.50

41.60

41.70

41.80
41.90

42.00
$1593.03 \quad 1593.47$

159

$\begin{array}{lll}1601.52 & 1601.96 & 1602.41 \\ 1605.99 & 1606.44 & 1606.89\end{array}$

1610.47

1614.95

1619.43

1623.91

$1615.39 \quad 1615.84$ $1619.88 \quad 1620.33$ $1624.36 \quad 1624.81$ $1628.85 \quad 1629.30$

1632.89

1637.39

1641.88

1646.38

1650.8

1655.39

1659.90

1664.41

1668.93

1673.44

1637.84

1642.33

1646.83

1651.34

1660.35

1664.86

1669.38

1673.90

1633.79

1598.39

1607.33

1611.81

1616.29

1620.77

1625.26

1629.75

1638.29

1642.78

1647.28

1656.29

1638.74

1647.73

1652.24

1660.80

1665.32

1669.83

1674.35

1661.25

1665.77

1670.28

1674.80
1679.32

1682.49

1687.01

1682.94

1691.54

1700.61

1692.00

1692.45

1701.07

1705.15

1709.69

1714.24

1718.78

1705.60

1714.69

1719.24

1727.89

1732.44

1737.00

1741.56

1746.13

1750.70

1755.27

1759.84

1764.42

1769.00

1773.58

1778.17
1782.76

1787.35

1723.79

1728.34

1732.90

1737.46

1742.02

1751.15

1755.73

1760.30

1764.88

1769.46

1774.04

1778.63

1783.22

1787.81
1792.41

1796.55

1801.15

1797.01

1801.6

1805.75

1810.36

1814.97

1806.21

1810.82

1815.43

1819.59

1824.20

1828.82

1820.05

1824.66

1829.29

1838.07

1838.54

1842.70

1847.34

1843.17

1847.80

1851.97

1852.44

1856.61
1861.25

1857.08

861.72

1866.37
1683.39

1696.98
1701.52

1706.06

1710.60

1715.14

1728.80

1733.35

1737.91

1742.48

1683.85

1688.37

1692.90

1697.44

1701.97

1706.51

1711.05

1715.60

1724.70

1729.25

1733.81

1742.93

1747.50

1751.61

1756.18

1760.76

1765.34

1752.07

1756.64

1761.22

1765.79
1770.37

1774.50

1779.09
1783.68

1788.27

1774.96

1779.55
1784.14

1784.14

1793.33

1797.47

1797.93

1802.53

1806.67

1811.28

1815.89

1811.74

1816.36

1820.51

1825.13

1829.75

1820.97

1825.59

1830.21

1834.83

1839.00

1839.46

1843.63

1848.26

1852.90

1844.09

1848.73

1853.36
1858.00

1862.18

1862.65

1867.29
1719.69

1706.97

1711.51

1716.05

1720.60

1725.15 
TABLF A7.2.2. Type $K$ thermocouples-temperature $\left(^{\circ} \mathrm{F}\right)$ as a function of thermoelectric voltage, reference junctions at $32^{\circ} \mathrm{F}$-Continued

$\mathrm{mV}$

.00

.01

.02

$1865.90 \quad 1866.37$

42.00

$42 \cdot 20$

42.30

42.50

42.6

42.70

42.80

42.90

43.00

43.10

43.20

43.3

$4 \cdot 40$

43.50

43.60
43.70

43.90

44.00

44.1

44.20

44.3
44.4

44.50

44.6

44.7
44.8

44.90

45.0

45.1

$45 \cdot 20$

45.30

45.40

45.50

45.60

45.7

45.80

45.90

46.0

46.1

46.20

46.30

46.40

46.50

46.60

46.70

46.8

46.90

47.00

47.10

47.20

47.30

47.40

47.50

47.60

47.70

47.80

47.90

48.00

$\mathrm{mV}$

$1875.20 \quad 1875.67$

$\begin{array}{ll}1879.86 & 1880.32 \\ 1884.52 & 1884.98\end{array}$

1866.83

$1876 \cdot 13$

1880.79

$1885 \cdot 45$

$1889.18 \quad 1889.64$

$898.51 \quad 1898.98$

1890.11

1894.78
1899.45

1904.12

1907.86

1903.65

1912.54

1913.01

1903.79

1917.22

1921.91

1926.59

1931.29

1935.98

1940.68

1950.09

1954.80

1959.51

1964.23

1968.95

1973.68

1978.40

$1983 \cdot 14$

1987.87

1992.61

$2006.85 \quad 2007.33$

2011.61

2016.37

2016.84

2021.60

2030.66

2035.44

2040.22

2045.00

2031.14

2035.92

2040.70

2045.48

1913.47

1918.16

1922.84

1927.53

1932.23

1936.92

1941.62

1946.33

1951.03

1955.74

1960.46

1965.18

1969.90

1974.62

1979.35

1984.08

1988.82

1993.56

$1998 \cdot 30$

2003.05

2007.80

$2012 \cdot 56$

2017.32

2022.08

2026.85

2031.62

2036.39

2041.17

2045.96

2050.75

2054.58

64.65

$2073.79 \quad 2074.27$

2055.54

2060.33

$2065 \cdot 13$

2069.94

2074.75

2078.60

2079.08

2079.56

2084.38

2089.20

2094.03

2098.86

2103.70

2108.54

2113.39

2118.24

2117.27

2122.12

2122.61

2123.09

2127.95

2132.82

2137.69

2136.71

2141.59

2146.47

32.33

137.20

2142.08

2142.56

2147.44

.03

.04

.05

.06

.07

.09

.10

$\mathrm{mV}$

TEMPERATURES IN DEGREES F

$\begin{array}{llll}1867.29 & 1867.76 & 1868.22 & 1868.69\end{array}$

1872.411872 .081873 .69

$\begin{array}{llll}1876.60 & 1877.06 & 1877.53 & 1877.99\end{array}$

$\begin{array}{llll}1881.25 & 1881.72 & 1882.19 & 1882.65\end{array}$

1890.58

$\begin{array}{lllll}1895.24 & 1895.71 & 1896.18 & 1896.64\end{array}$

$\begin{array}{lll}899.91 & 1900.38 & 1900.85\end{array}$

904.59

1909.26

1913.94

1918.63

1923.31

1928.00

1932.70

1937.39

1942.09

1946.80

1951.50

1956.21

1960.93

1965.65

1970.37

1975.09

1979.82

1984.56

1989.29

1994.03

1998.78

2003.53

$2008 \cdot 28$

2013.03

2017.79

2022.56

2027.32

$2032 \cdot 10$

2036.87

2041.65

2046.44

2056.02

2060.81

2065.61

2070.42

2075.23

$2080 \cdot 04$

2084.86

2089.69

2094.51

2099.35

2104.18

2109.02

2113.87

2118.72

2123.58

2128.44

2133.30

2138.18

2143.05

2147.93

$2151.35 \quad 2151.84 \quad 2152.33 \quad 2152.82$

02

\begin{abstract}
.03
\end{abstract}

\begin{abstract}
.04
\end{abstract}
.06

$\begin{array}{ll}1869.15 & 1869.62 \\ 1873.81 & 1874.27\end{array}$

$1878.46 \quad 1878.93$

$1883.12 \quad 1883.58$

1874.74

1879.39

1884.05

1887.78

1888.25

$1892.44 \quad 1892.91$

1897.11

1901.78

1906.46

1911.13

$\begin{array}{lll}914.41 & 1914.88 & 1915.35\end{array}$

$\begin{array}{lll}1919.09 & 1919.56 & 1920.03\end{array}$

$1923.78 \quad 1924.25$

$\begin{array}{lll}1928.47 & 1928.94 & 1929.41 \\ 1933.16 & 1933.63 & 1934.10\end{array}$

$\begin{array}{lll}1937.86 & 1938.33 \quad 1938.80\end{array}$

$\begin{array}{lll}1942.56 & 1943.03 & 1943.50\end{array}$

$1951.97 \quad 1952.45 \quad 1952.92$

$961.40 \quad 1961.87$

$1966.12 \quad 1966.59$

1971.31

$1980.30 \quad 1980.77$

$1985.03 \quad 1985.50$ 
TABLE A7.2.2. Type $K$ thermocouples-temperature $\left({ }^{\circ} \mathrm{F}\right)$ as a function of thermoelectric voltage, reference junctions at $32^{\circ} \mathrm{F}$-Continued

mV

.00

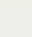

\section{8}

48.10

48.30

48.40

48.50

48.60
48.70

48.8

48.90

49.00

49.10

49.20

49.30

49.40

49.50

49.60

49.70

49.80

49.90

50.00

50.10

20

50.30
50.40

$50 \cdot 50$

50.60

50.70

50.80

50.90

51.00

51.10

$51 \cdot 20$

51.30

51.50

51.60

51.70

51.80

51.90

52.00

52.10

52.2

52.30

52.40

52.50

52.6

52.70

52.80

52.90

53.00

53.10

53. 20

53.30

53.40

53.50

53.60

53.70

53.80

53.90

54.00

2151.35

2151.84

2156.24

2166.04

2170.94

2156.73

161.63

2166.53
2171.43

2157.22

2162.12

2167.02

2171.92

2175.85

$2176 \cdot 34$

2176.84

2181.75

2185.69

2195.55

2186.18

2191.11

2191.60

2196.54

$2205.43 \quad 2205.93$

$2210.38 \quad 2210.88$

$2215.34 \quad 2215.83$

2220.30

2220.80

$2206.42 \quad 2206.92$

2211.37

$2216.33 \quad 2216.83$

2221.29

2221.79

$2225.27 \quad 2225.76$

$2230.24 \quad 2230.74$

$2235.22 \quad 2235.72$

$2240.21 \quad 2240.70$

2226.26

$2236.22 \quad 2236.72$

$2241.20 \quad 2241.70$

2245.20

2245.70

$2246 \cdot 20$

2246.70

$2251.20 \quad 2251.70$

$2256.20 \quad 2256.70$

2261.21 2261.71

260.212260 .71

$2265.23 \quad 2265.73$

$2270.25 \quad 2270.75$

$2271.25 \quad 2271.76$

$2276.28 \quad 2276.79$

$2281.32 \quad 2281.82$

$2286.36 \quad 2286.87$

$2291.41 \quad 2291.92$

$2295.46 \quad 2295.96$

$2296.47 \quad 2296.98$

$2301.53 \quad 2302.04$

$2306.60 \quad 2307.11$

$2311.68 \quad 2312.19$

$2316.76 \quad 2317.27$

$2325.93 \quad 2326.44$

$2331.03 \quad 2331.54$

$2336.13 \quad 2336.65$

$2341.25 \quad 2341.76$

$2346.37 \quad 2346.88$

2326.95

$2337.16 \quad 2337.67$

$2342.27 \quad 2342.79$

2347.40

2347.91

$2351.50 \quad 2352.01$

$2356.63 \quad 2357.15$

$2361.78 \quad 2362.29$

$2352.53 \quad 2353.04$

$2357.66 \quad 2358.18$

$2362.80 \quad 2363.32$

$2367.95 \quad 2368.47$

$2372.08 \quad 2372.59$

2373.11

2373.63

$2378.27 \quad 2378.79$

$2383.44 \quad 2383.96$

$2388.62 \quad 2389.14$

387.582380 .10

$2392.76 \quad 2393$.

$2397.95 \quad 2398.47$

2394.32

2398.99

2399.51

$2403.15 \quad 2403.67$

$2408.35 \quad 2408.87$

$2413.55 \quad 2414.07$

$2404.19 \quad 2404.71$

$2409.39 \quad 2409.91$

$2414.60 \quad 2415.12$

$2423.99 \quad 2424.51$

2419.81

$2425 \cdot 55$

$2430.26 \quad 2430.78$

$2435.49 \quad 2436.01$

$2440.73 \quad 2441.25$

2439.582440 .20

$2444.92 \quad 2445.45$

$2450.17 \quad 2450.70$

$2445.97 \quad 2446.50$

2451.22

2451.75

$2456.48 \quad 2457.00$

.04

.05

.06

.07

.08

.09

.10

$m V$

TURES IN DEGREES $F$

$\begin{array}{lll}2153.31 & 2153.80 & 2154.28 \\ 2158.20 & 2158.69 & 2159.18 \\ 2163.10 & 2163.59 & 2164.08 \\ 2168.00 & 2168.49 & 2168.98 \\ 2172.91 & 2173.40 & 2173.89\end{array}$

$2154.77 \quad 2155.26$ $2159.67 \quad 2160.16$ $2164.57 \quad 2165.06$ $2169.47 \quad 2169.96$ $2174.38 \quad 2174.87$

2155.75 2160.65 2165.55 2170.45

$2179.29 \quad 2179.78$ $2182.74 \quad 2183.23 \quad 2183.72$ $\begin{array}{lll}2187.66 & 2188.15 & 2188.65\end{array}$ $2192.59 \quad 2193.08 \quad 2193.58$ $2197.53 \quad 2198.02$

2198.51

$2202.47 \quad 2202.96 \quad 2203.45$ $2207.41 \quad 2207.91 \quad 2208.40$ $2212.36 \quad 2212.86 \quad 2213.36$ $2217.32 \quad 2217.82 \quad 2218.31$ $\begin{array}{lll}2222.29 & 2222.78 & 2223.28\end{array}$

$2184.21 \quad 2184.71$ $2189.14 \quad 2189.63$ $2194.07 \quad 2194.56$

$2199.01 \quad 2199.50$

$2227.26 \quad 2227.75 \quad 2228.25$ $\begin{array}{lll}232.23 & 2232.73 & 2233.23\end{array}$ $2237.21 \quad 2237.71 \quad 2238.21$ $2242.20 \quad 2242.70 \quad 2243.20$ $2247.20 \quad 2247.70 \quad 2248.20$

2203.95 2208.90 2213.85 2218.81 2223.78

2204.44 $2209 \cdot 39$ 2214.35 $2219 \cdot 31$

2228.75 $2243.70 \quad 2244.20$ $2175 \cdot 36$

$2156 \cdot 24$ 2161.14 2166.04 2170.94

$2180.28 \quad 2180.77$ $2185.20 \quad 2185.69$ $2190.12 \quad 2190.62$ $2195.06 \quad 2195.55$ $2199.99 \quad 2200.49$

$2204.94 \quad 2205.43$ $2209.89 \quad 2210.38$ $2214.84 \quad 2215.34$ $2219.80 \quad 2220.30$ $2224.77 \quad 2225.27$

$2229.74 \quad 2230.24$ $2234.72 \quad 2235.22$ $2239.71 \quad 2240.21$ $2244.70 \quad 2245.20$

$2252.20 \quad 2252.70 \quad 2253.20$ $2257.20 \quad 2257.70 \quad 2258.20$ $2262.21 \quad 2262.72 \quad 2263.22$ $2267.23 \quad 2267.74 \quad 2268.24$ $2272.26 \quad 2272.76 \quad 2273.26$

$2277.29 \quad 2277.79 \quad 2278.30$ $2282.33 \quad 2282.83 \quad 2283.34$ $2287.37 \quad 2287.88 \quad 2288.38$ $2292.42 \quad 2292.93 \quad 2293.44$ 2297.48

$2302.55 \quad 2303.05 \quad 2303.56$ $2307.62 \quad 2308.12 \quad 2308.63$ $2312.69 \quad 2313.20 \quad 2313.71$ $2317.78 \quad 2318.29 \quad 2318.80$ $2322.87 \quad 2323.38 \quad 2323.89$

$2327.97 \quad 2328.48 \quad 2328.99$ $2333.07 \quad 2333.58 \quad 2334.09$ $2338.18 \quad 2338.69 \quad 2339.20$ $2343.30 \quad 2343.81 \quad 2344.32$ $2348.42 \quad 2348.93 \quad 2349.45$

$\begin{array}{llll}2353.55 & 2354.07 & 2354.58\end{array}$ $2358.69 \quad 2359.20 \quad 2359.72$ $2363.83 \quad 2364.35 \quad 2364.86$ $2368.98 \quad 2369.50 \quad 2370.02$ $2374.14 \quad 2374.66 \quad 2375.17$

$2379.31 \quad 2379.82 \quad 2380.34$ $2384.48 \quad 2384.99 \quad 2385.51$ $2389.65 \quad 2390.17 \quad 2390.69$ $\begin{array}{lll}2394.84 & 2395.36 & 2395.88\end{array}$ $\begin{array}{lll}2400.03 & 2400.55 & 2401.07\end{array}$

2253.70 2259.21 2268.742269 $2273.77 \quad 2274.27$

$2278.80 \quad 2279.31$ $283.84 \quad 2284.35$ $2288.89 \quad 2289.39$ $2293.94 \quad 2294.45$ $2299.00 \quad 2299.51$ 
TABLE A7.2.2. Type $\boldsymbol{K}$ thermocouples-temperature $\left({ }^{\circ} \mathrm{F}\right)$ as a function of thermoelectric voltage, reference junctions at $32^{\circ} \mathrm{F}$-Continued

$\mathrm{mV}$ $.00 \quad .01 \quad .02$
$.03 \quad .04$

TEMPERATURES IN DEGREES F

$\begin{array}{llllllll}54.00 & 2455.43 & 2455.95 & 2456.48 & 2457.00 & 2457.53 & 2458.06 & 2458.58 \\ 54.10 & 2460.69 & 2461.21 & 2461.74 & 2462.26 & 2462.79 & 2463.32 & 2463.84 \\ 54.20 & 2465.95 & 2466.48 & 2467.00 & 2467.53 & 2468.06 & 2468.58 & 2469.11 \\ 54.30 & 2471.22 & 2471.75 & 2472.27 & 2472.80 & 2473.33 & 2473.86 & 2474.38 \\ 54.40 & 2476.49 & 2477.02 & 2477.55 & 2478.08 & 2478.60 & 2479.13 & 2479.66 \\ & & & & & & & \\ 54.50 & 2481.77 & 2482.30 & 2482.83 & 2483.36 & 2483.89 & 2484.41 & 2484.94 \\ 54.60 & 2487.06 & 2487.58 & 2488.11 & 2488.64 & 2489.17 & 2489.70 & 2490.23 \\ 54.70 & 2492.34 & 2492.87 & 2493.40 & 2493.93 & 2494.46 & 2494.99 & 2495.52 \\ 54.80 & 2497.63 & 2498.16 & 2498.69 & 2499.22 & 2499.75 & 2500.28 & 2500.81\end{array}$

$\mathrm{mV}$
$.00 \quad .01$
.02
.03
.04
.05
.06

\section{$\begin{array}{ll}2459.11 & 2459.63 \\ 2464.37 & 2464.90 \\ 2469.64 & 2470.17\end{array}$}

$\begin{array}{ll}2474.91 & 2475.44 \\ 2480.19 & 2480.72\end{array}$

2485.47

$2490.76 \quad 2491.29$

2501.34

TABLE A7.2.3. Type $\mathbf{K}$ thermocouples-quadratic, cubic, and quartic approximations to the data as a function of voltage in selected temperature ranges $\left({ }^{\circ} \mathrm{C}\right)$. The expansion is of the form

$\mathrm{T}=\mathrm{a}_{0}+\mathrm{a}_{1} \mathrm{E}+\mathrm{a}_{2} \mathrm{E}^{2}+\mathrm{a}_{3} \mathrm{E}^{3}+\mathrm{a}_{4} \mathrm{E}^{4}$ where $\mathrm{E}$ is in microvolts and $\mathrm{T}$ is in degrees Celsius

\begin{tabular}{|c|c|c|c|c|c|c|c|c|c|c|c|c|}
\hline \multirow{2}{*}{\multicolumn{2}{|c|}{$\begin{array}{l}\text { Temperature } \\
\text { Range }\left({ }^{\circ} \mathrm{C}\right)\end{array}$}} & $a_{0}$ & & $a_{1}$ & \multicolumn{3}{|c|}{$a_{2}$} & $a_{3}$ & \multicolumn{3}{|c|}{$a_{4}$} & $\begin{array}{c}\text { Error } \\
\text { Range }\left({ }^{\circ} \mathrm{C}\right) \\
\end{array}$ \\
\hline & & Argument & Exp. & Argument & Exp. & Argument & Exp. & Argument & Exp. & Argument & Exp. & Exact-Approx. \\
\hline \multicolumn{13}{|c|}{ I. Quartic Equation } \\
\hline-270 & to 0 & ..... & - & 1.2329875 & -2 & -1.4434305 & -5 & -4.2824995 & -9 & -4.2028679 & -13 & -11 to $R$ \\
\hline-200 & to 0 & $\cdots \cdot \cdot$ & - & 2. 3783697 & -2 & -2.4382217 & -6 & -6.8203073 & -10 & -9.4854031 & -14 & -.5 to .5 \\
\hline-200 & to 800 & .... & . . & 2.8346886 & -2 & -5.8008526 & -7 & 2.5720615 & -11 & -3.6813679 & -16 & -8 to 10 \\
\hline-20 & to 500 & .... & . . & 2.4363851 & -2 & 5.6206931 & -8 & -3.8825620 & -12 & 3.9120208 & -17 & -1.2 to .6 \\
\hline 0 & to 400 & .... & • & 2.4383248 & -2 & 9.7830251 & -9 & 3. 6276965 & -12 & -2.5756438 & -16 & -.5 to .6 \\
\hline 0 & to 1370 & $\ldots \ldots$ & . & 2.5132785 & -2 & -6.0883423 & -8 & 5.5358209 & -13 & 9.3720918 & -18 & $-2.4 \operatorname{tn} 1.2$ \\
\hline 400 & to 1000 & -2.4707112 & +1 & 2.9465633 & -2 & -3.1332620 & -7 & 6.5075717 & -12 & -3.9663834 & -17 & -.02 to .02 \\
\hline 400 & to 1370 & 6.2300671 & +0 & 2.4955374 & -2 & -7.8788333 & -8 & 1.3269743 & -12 & 1.5580541 & -18 & -.3 to .3 \\
\hline 600 & to 800 & -3.9480992 & +1 & 3.1425797 & -2 & -4.0905633 & -7 & 8.5482602 & -12 & -5.5696636 & -17 & -.001 to .001 \\
\hline 850 & to 1000 & -3.1617495 & +0 & 2.7115517 & -2 & -2.1941995 & -7 & 4.8782826 & -12 & -2.9316611 & -17 & -.0012 to .0012 \\
\hline 1050 & to 1150 & 2.3615582 & +2 & 1.1066277 & -3 & 8.2516607 & -7 & -1.3558849 & -11 & 9.1638500 & -17 & -.001 to .001 \\
\hline \multicolumn{13}{|c|}{ Cubic Equation } \\
\hline-270 & to 0 & ..... & . . & 3.7031567 & -2 & 6.8919680 & -6 & 1. 1244287 & -9 & - & . & -16 to 10 \\
\hline-200 & to 0 & .... & • & 2.7891399 & -2 & 1.4926570 & -6 & 4.2157153 & -10 & .... & . & -1.3 to 1.2 \\
\hline-200 & to 800 & $\cdots$ & . & 2.8553599 & -2 & -3.6679062 & -7 & 7.1156035 & -12 & .... & . & -18 to 7 \\
\hline-20 & to 500 & . . . & - & 2.4428628 & -2 & 3.7535481 & -8 & -2.3295275 & -12 & $\cdots \cdot$ & . & -1.1 to .6 \\
\hline 0 & to 400 & . . . & . & 2.4153681 & -2 & 9.0047640 & -8 & -4.6004855 & -12 & .... & . & -.6 to .8 \\
\hline 0 & to 1370 & . . . . & . & 2.5439047 & -2 & -9.3297004 & -8 & 1.5521594 & -12 & $\cdots \cdot$ & . . & -3.2 to 1.2 \\
\hline 400 & to 1000 & -2.1833545 & +0 & 2.6006699 & -2 & -1.2132890 & -7 & 1.9304990 & -12 & . . . . & . & -.5 to .5 \\
\hline 400 & to 1370 & 4.4041973 & +0 & 2. 5198680 & -2 & -9.0154824 & -8 & 1.5496930 & -12 & ........ & $\therefore$ & -.3 to .3 \\
\hline 600 & to 800 & -2.8636527 & -1 & 2. 5984415 & -2 & -1.2676511 & -7 & 2. 0620304 & -12 & .... & . & -.003 to .003 \\
\hline 850 & to 1000 & 5.9524244 & +1 & 2. 0548488 & -2 & 3. 8308685 & -8 & 3.8732336 & -13 & .... & . & -.001 to .001 \\
\hline 1050 & to 1150 & -1.4211929 & +2 & 3.4690180 & -2 & -2.9259543 & -7 & 2.9707233 & -12 & $\ldots$ & . & -.001 to .001 \\
\hline \multicolumn{13}{|c|}{ Quadratic Equation } \\
\hline-270 & to 0 & . . . & . & 1.4537885 & -2 & -3.6430496 & -6 & $\ldots$ & . & . & . & -25 to 13 \\
\hline-200 & to 0 & $\cdot \cdots \cdot$ & - & 2.1080616 & -2 & -2.0618373 & -6 & $\cdots \cdot \cdot$ & . & $\cdots \cdot \cdot$ & . & -4.5 to 3.5 \\
\hline-200 & to 800 & . . . & . & 2.6112875 & -2 & -7.2451071 & -8 & •. • • & - & $\cdots \cdot \cdot$ & . & -45 to 12 \\
\hline-20 & to 500 & .... & . . & 2. 4860578 & -2 & -2.9525505 & -8 & $\ldots \ldots$ & - & $\cdots \cdot$ & . & -1.6 to .8 \\
\hline 0 & to 400 & .... & • & 2.4689438 & -2 & -1.4594344 & -8 & .... & - & .... & . & -1.1 to 1.0 \\
\hline 0 & to 1370 & ..... & . . & 2.3405437 & -2 & 2.5074673 & -8 & .... & . & .... & . & -9 to 12 \\
\hline 400 & to 1000 & 3. 8025098 & +1 & 2.1401089 & -2 & 4.5686566 & -8 & .... & - & ..... & . & -1.2 to 1.0 \\
\hline 400 & to 1370 & 5.8997501 & +1 & 1.9745441 & -2 & 7. 5044894 & -8 & $\ldots$ & . & .... & . & -3 to 3.5 \\
\hline 600 & to 800 & 4.9507604 & +1 & 2.0790061 & -2 & 5.2938546 & -8 & $\cdots \cdots$ & . & .. & . & -.05 to .05 \\
\hline 850 & to 1000 & 8.1170593 & +1 & 1.8847481 & -2 & 8.2799269 & -8 & .... & . & . . & . & -.003 to .003 \\
\hline 1050 & to 1150 & 1.2994246 & +2 & 1.6574989 & -2 & 1.0929505 & -7 & $\cdots \cdot \cdot$ & . & $\ldots$ & . & -.006 to .006 \\
\hline
\end{tabular}




\section{A8. Supplementary Data for Type T-Copper Versus Copper-Nickel Alloy Thermocouples}

\section{A8.1. Data for Voltage as a Function of Temperature}

The full precision coefficients given in the main text are used to generate the voltage as a function of temperature data given in tables A8.1.1 and A8.1.2. Table A8.1.1 presents the data in degrees Celsigus from $-270{ }^{\circ} \mathrm{C}$ to $400{ }^{\circ} \mathrm{C}$ while table A8.1.2 presents the data in degrees Fahrenheit from $-454{ }^{\circ} \mathrm{F}$ to $752{ }^{\circ} \mathrm{F}$. Table 8.1.3 contains quadratic, cubic, and quartic approximations to the data as a function of temperature in selected temperature ranges. The error range given in the table is the difference between the voltage as obtained from the full precision coefficients from the text and the respective reduced order approximations. The last entries in the cubic and quadratic groupings of table A8.1.3 represent variable reference junction corrections in the 0 to $50{ }^{\circ} \mathrm{C}$ temperature range. In the narrower temperature range near room temperatures, 20 to $25^{\circ} \mathrm{C}$, the error range for the given quad. ratic equation is smaller than that listed in the last column: $\pm 0.1 \mu \mathrm{V}$.

TABLE A8.1.1. Type $\boldsymbol{T}$ thermocouples-thermoelectric voltage as a function of temperature $\left({ }^{\circ} \mathrm{C}\right)$, reference junctions at $0^{\circ} \mathrm{C}$

$\begin{array}{lccccc}2 & 3 & 4 & 5 & 6 & 7 \\ \text { THERMOELECTRIC } & \text { VOLTAGE } & \text { IN } & \text { ABSOLUTE } & \text { MILLIVOLTS }\end{array}$

$\begin{array}{lll}-270 & -6.258 & \\ -260 & -6.232 & -6.236 \\ -250 & -6.181 & -6.187 \\ -240 & -6.105 & -6.114 \\ -230 & -6.007 & -6.018 \\ -220 & -5.889 & -5.901 \\ -210 & -5.753 & -5.767 \\ -200 & -5.603 & -5.619 \\ -190 & -5.439 & -5.456 \\ -180 & -5.261 & -5.279 \\ -170 & -5.069 & -5.089 \\ -160 & -4.865 & -4.886 \\ -150 & -4.648 & -4.670 \\ & & \\ -140 & -4.419 & -4.442 \\ -130 & -4.177 & -4.202 \\ -120 & -3.923 & -3.949 \\ -110 & -3.656 & -3.684 \\ -100 & -3.378 & -3.407 \\ & & \\ -90 & -3.089 & -3.118 \\ -80 & -2.788 & -2.818 \\ -70 & -2.475 & -2.507 \\ -60 & -2.152 & -2.185 \\ -50 & -1.819 & -1.853 \\ -40 & -1.475 & -1.510 \\ -30 & -1.121 & -1.157 \\ -20 & -0.757 & -0.794 \\ -10 & -0.383 & -0.421 \\ --0 & 0.000 & -0.039\end{array}$

$$
\begin{array}{llll}
-6.239 & -6.242 & -6.245 & -6.248 \\
-6.193 & -6.198 & -6.204 & -6.209 \\
-6.122 & -6.130 & -6.138 & -6.146 \\
-6.028 & -6.039 & -6.049 & -6.059 \\
-5.914 & -5.926 & -5.938 & -5.950 \\
-5.782 & -5.795 & -5.809 & -5.823 \\
-5.634 & -5.650 & -5.665 & -5.680 \\
-5.473 & -5.489 & -5.506 & -5.522 \\
-5.297 & -5.315 & -5.333 & -5.351 \\
-5.109 & -5.128 & -5.147 & -5.167 \\
-4.907 & -4.928 & -4.948 & -4.969 \\
-4.693 & -4.715 & -4.737 & -4.758 \\
-4.466 & -4.489 & -4.512 & -4.535 \\
-4.226 & -4.251 & -4.275 & -4.299 \\
-3.974 & -4.000 & -4.026 & -4.051 \\
-3.711 & -3.737 & -3.764 & -3.791 \\
-3.435 & -3.463 & -3.491 & -3.519 \\
& & & \\
-3.147 & -3.177 & -3.206 & -3.235 \\
-2.849 & -2.879 & -2.909 & -2.939 \\
-2.539 & -2.570 & -2.602 & -2.633 \\
-2.218 & -2.250 & -2.283 & -2.315 \\
-1.886 & -1.920 & -1.953 & -1.987 \\
& & & \\
-1.544 & -1.579 & -1.614 & -1.648 \\
-1.192 & -1.228 & -1.263 & -1.299 \\
-0.830 & -0.867 & -0.903 & -0.940 \\
-0.458 & -0.496 & -0.534 & -0.571 \\
-0.077 & -0.116 & -0.154 & -0.193
\end{array}
$$$$
-6.245
$$$$
-6.248
$$

$$
-6.130
$$$$
-5.926
$$$$
-6.204
$$$$
-6.209
$$

$$
-6.251
$$$$
-6
$$$$
\begin{array}{ll}
-6.138 & -6.146 \\
-6.049 & -6.059
\end{array}
$$$$
-5.938
$$$$
\begin{aligned}
& -6.059 \\
& -5.950
\end{aligned}
$$$$
-6.153
$$$$
\begin{aligned}
& -6.068 \\
& -5.962
\end{aligned}
$$$$
\begin{aligned}
& -5.962 \\
& -5.836
\end{aligned}
$$$$
-5.695
$$$$
-5.506
$$$$
\begin{array}{lll}
-5.333 & -5.351 & -5.369 \\
-5.147 & -5.167 & -5.186
\end{array}
$$

$$
\begin{array}{ll}
-5.522 & -5.539 \\
-5.351 & -5.369
\end{array}
$$$$
-5.167
$$

$-4.948$

$-5.167-5.186$

$-4.489-4.512$

$-4.758$

$-3.711-3.000$

$-4.000-4.026$

$-4.535$

-4.989
-4.780

$$
\begin{aligned}
& -6.253 \\
& -6.219 \\
& -6.160 \\
& -6.078 \\
& -5.973 \\
& -5.850 \\
& -5.710 \\
& -5.555 \\
& -5.387
\end{aligned}
$$

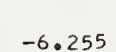

\section{$-4.581$}

$-4.347$

$-4.026-4.051$

$\begin{array}{ll}-4.077 & -4.102 \\ -3.818 & -3.84\end{array}$

$\begin{array}{lll}-3.737 & -3.764 & -3.791 \\ -3.463 & -3.491 & -3.519\end{array}$

-3.818
-3.547

$-3.844$

$-2.879$

$-2.570-2.602$

$-2.250-2.283$

$-1.920$

$-1.579-1.614$

$-1.228$

$-0.867-0.903$

$\begin{array}{lll}-0.496 & -0.534 & -0.571\end{array}$

-3.235
-2.939

$-2.633$

-2.315
-1.987

$-2.970$

$-3.293$

$-2.999$

$-2.695$

$-2.380$

-2.348
-2.020

$-2.053$

-6.255
-6.224

$-6.167$

-6.087
-5.985

-5.985
-5.863

$-5.724$

$-5.571$

$-5.404$

$-5.223$

$-5.030$

$-4.823$

$-4.603$

-4.371
-4.127

-3.870
-3.602

$-3.321$

$-3.029$

$-2.726$

$-2.412$

$-2.087$

$-6.256-6.258$

$-6.228-6.232$

$-6.174-6.181$

$-6.096-6.105$

$-5.996-6.007$

$\begin{array}{ll}-5.876 & -5.889\end{array}$

$\begin{array}{ll}-5.739 & -5.753\end{array}$

$-5.587-5.603$

$-5.421-5.439$

$\begin{array}{ll}-5.242 & -5.261\end{array}$

$-5.050-5.069$

$-4.844-4.865$

$-1.717$

$\begin{array}{ll}-1.682 & -1.7117 \\ -1.334 & -1.370 \\ -0.976 & -1.013\end{array}$

$-1.751$

$-4.626$

$-4.395$

$-4.152-4.419$

$-3.629-3.923$

$-3.350-3.378$

$-3.059-3.089$

$\begin{array}{lll}-2.757 & -2.788\end{array}$

$\begin{array}{ll}-2.444 & -2.475\end{array}$

$\begin{array}{ll}-2.444 & -2.475 \\ -2.120 & -2.152\end{array}$

$-1.405$

$-1.049$

$\begin{array}{ll}-1.785 & -1.819\end{array}$

$-1.440-1.475$

$\begin{array}{llll}-0.646 & -0.683 & -0.720 & -0.757\end{array}$

$\begin{array}{llll}-0.269 & -0.307 & -0.345 & -0.383\end{array}$ 
TABLE A8.1.1. Type $T$ thermocouples-thermoelectric voltage as a function of temperature $\left({ }^{\circ} \mathrm{C}\right)$, reference junctions at $0^{\circ} \mathrm{C}$-Continued
3

4

5

6

8

9

10

${ }^{\circ} \mathrm{C}$

THERMOELECTRIC VOLTAGE IN ABSOLUTE MILLIVOLTS

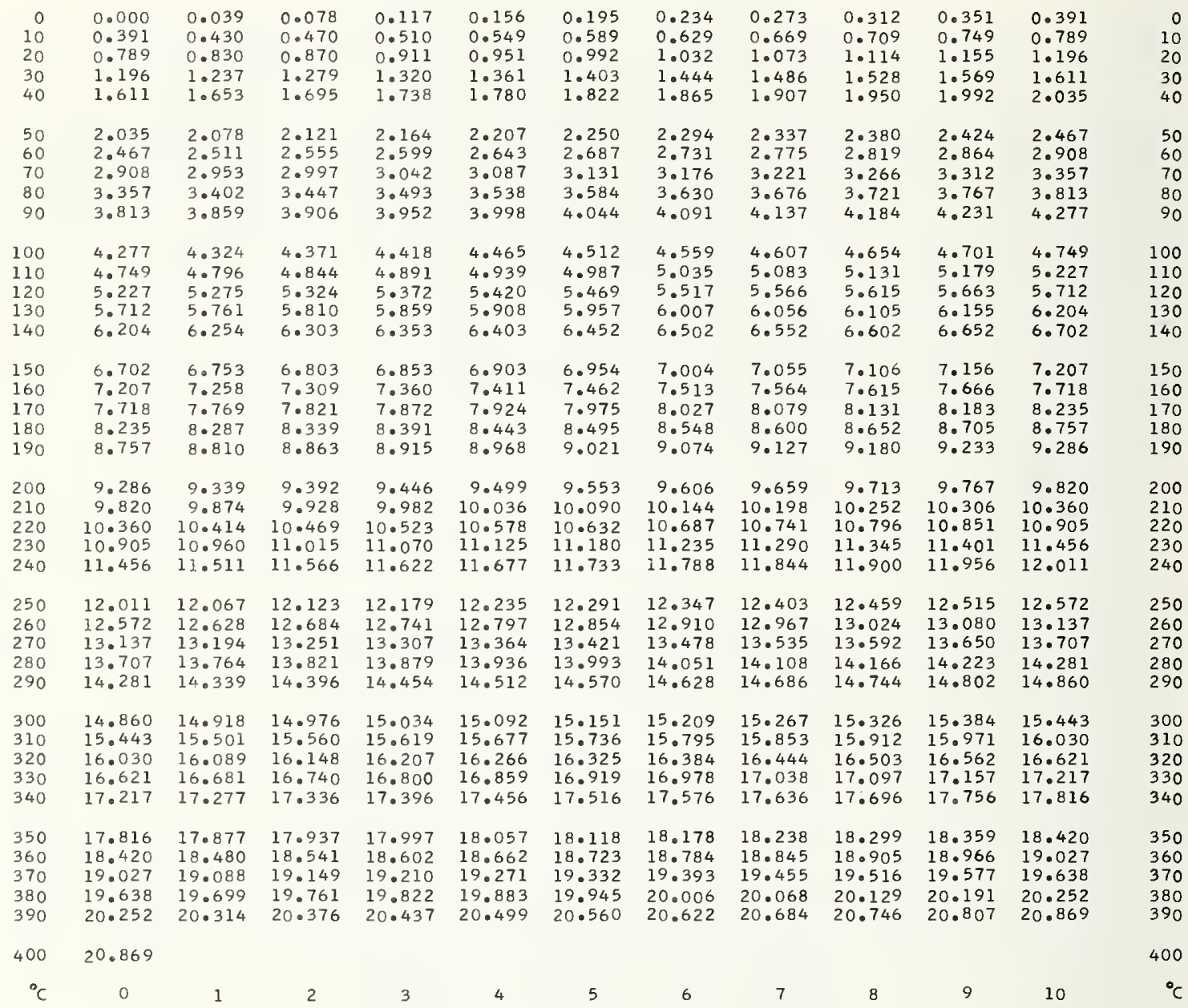


TABLE A8.1.2. Type T thermocouples-thermoelectric voltage as a function of temperature $\left({ }^{\circ} \mathrm{F}\right)$, reference junctions at $32^{\circ} \mathrm{F}$

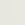

${ }^{\circ} \mathrm{F}$

0

1

2

3

4

5

6

7

8

9

10

${ }^{\circ} \mathrm{F}$

THERMOELECTRIC VOLTAGE IN ABSOLUTE MILLIVOLTS

\begin{tabular}{|c|c|c|c|c|c|c|c|c|c|c|c|c|}
\hline-450 & -6.254 & -6.255 & -6.256 & -6.257 & -6.258 & & & & & & & -450 \\
\hline $\begin{array}{l}-440 \\
-430 \\
-420 \\
-410 \\
-400\end{array}$ & $\begin{array}{l}-6.240 \\
-6.217 \\
-6.187 \\
-6.150 \\
-6.105\end{array}$ & $\begin{array}{l}-6.242 \\
-6.220 \\
-6.191 \\
-6.154 \\
-6.110\end{array}$ & $\begin{array}{l}-6.243 \\
-6.223 \\
-6.194 \\
-6.158 \\
-6.115\end{array}$ & $\begin{array}{l}-6.245 \\
-6.225 \\
-6.197 \\
-6.162 \\
-6.119\end{array}$ & $\begin{array}{l}-6.247 \\
-6.227 \\
-6.200 \\
-6.166 \\
-6.124\end{array}$ & $\begin{array}{l}-6.248 \\
-6.230 \\
-6.203 \\
-6.170 \\
-6.128\end{array}$ & $\begin{array}{l}-6.250 \\
-6.232 \\
-6.206 \\
-6.173 \\
-6.133\end{array}$ & $\begin{array}{l}-6.251 \\
-6.234 \\
-6.209 \\
-6.177 \\
-6.137\end{array}$ & $\begin{array}{l}-6.252 \\
-6.236 \\
-6.212 \\
-6.181 \\
-6.142\end{array}$ & $\begin{array}{l}-6.253 \\
-6.238 \\
-6.215 \\
-6.184 \\
-6.146\end{array}$ & $\begin{array}{l}-6.254 \\
-6.240 \\
-6.217 \\
-6.187 \\
-6.150\end{array}$ & $\begin{array}{l}-440 \\
-430 \\
-420 \\
-410 \\
-400\end{array}$ \\
\hline $\begin{array}{l}-390 \\
-380 \\
-370 \\
-360 \\
-350\end{array}$ & $\begin{array}{l}-6.053 \\
-5.995 \\
-5.930 \\
-5.860 \\
-5.785\end{array}$ & $\begin{array}{l}-6.059 \\
-6.001 \\
-5.937 \\
-5.867 \\
-5.792\end{array}$ & $\begin{array}{l}-6.064 \\
-6.007 \\
-5.943 \\
-5.874 \\
-5.800\end{array}$ & $\begin{array}{l}-6.069 \\
-6.013 \\
-5.950 \\
-5.881 \\
-5.808\end{array}$ & $\begin{array}{l}-6.075 \\
-6.019 \\
-5.957 \\
-5.889 \\
-5.815\end{array}$ & $\begin{array}{l}-6.080 \\
-6.025 \\
-5.963 \\
-5.896 \\
-5.823\end{array}$ & $\begin{array}{l}-6.085 \\
-6.030 \\
-5.969 \\
-5.903 \\
-5.830\end{array}$ & $\begin{array}{l}-6.090 \\
-6.036 \\
-5.976 \\
-5.910 \\
-5.838\end{array}$ & $\begin{array}{l}-6.095 \\
-6.042 \\
-5.982 \\
-5.916 \\
-5.845\end{array}$ & $\begin{array}{l}-6.100 \\
-6.048 \\
-5.988 \\
-5.923 \\
-5.853\end{array}$ & $\begin{array}{l}-6.105 \\
-6.053 \\
-5.995 \\
-5.930 \\
-5.860\end{array}$ & $\begin{array}{l}-390 \\
-380 \\
-370 \\
-360 \\
-350\end{array}$ \\
\hline $\begin{array}{l}-340 \\
-330 \\
-320 \\
-310 \\
-300\end{array}$ & $\begin{array}{l}-5.705 \\
-5.620 \\
-5.532 \\
-5.439 \\
-5.341\end{array}$ & $\begin{array}{l}-5.713 \\
-5.629 \\
-5.541 \\
-5.448 \\
-5.351\end{array}$ & $\begin{array}{l}-5.721 \\
-5.638 \\
-5.550 \\
-5.457 \\
-5.361\end{array}$ & $\begin{array}{l}-5.729 \\
-5.646 \\
-5.559 \\
-5.467 \\
-5.371\end{array}$ & $\begin{array}{l}-5.737 \\
-5.655 \\
-5.568 \\
-5.476 \\
-5.381\end{array}$ & $\begin{array}{l}-5.745 \\
-5.663 \\
-5.576 \\
-5.486 \\
-5.390\end{array}$ & $\begin{array}{l}-5.753 \\
-5.672 \\
-5.585 \\
-5.495 \\
-5.400\end{array}$ & $\begin{array}{l}-5.761 \\
-5.680 \\
-5.594 \\
-5.504 \\
-5.410\end{array}$ & $\begin{array}{l}-5.769 \\
-5.688 \\
-5.603 \\
-5.513 \\
-5.419\end{array}$ & $\begin{array}{l}-5.777 \\
-5.697 \\
-5.612 \\
-5.522 \\
-5.429\end{array}$ & $\begin{array}{l}-5.785 \\
-5.705 \\
-5.620 \\
-5.532 \\
-5.439\end{array}$ & $\begin{array}{l}-340 \\
-330 \\
-320 \\
-310 \\
-300\end{array}$ \\
\hline $\begin{array}{l}-290 \\
-280 \\
-270 \\
-260 \\
-250\end{array}$ & $\begin{array}{l}-5.240 \\
-5.135 \\
-5.025 \\
-4.912 \\
-4.794\end{array}$ & $\begin{array}{l}-5.250 \\
-5.145 \\
-5.036 \\
-4.923 \\
-4.806\end{array}$ & $\begin{array}{l}-5.261 \\
-5.156 \\
-5.047 \\
-4.935 \\
-4.818\end{array}$ & $\begin{array}{l}-5.271 \\
-5.167 \\
-5.058 \\
-4.946 \\
-4.830\end{array}$ & $\begin{array}{l}-5.281 \\
-5.177 \\
-5.069 \\
-4.958 \\
-4.842\end{array}$ & $\begin{array}{l}-5.291 \\
-5.188 \\
-5.080 \\
-4.969 \\
-4.853\end{array}$ & $\begin{array}{l}-5.301 \\
-5.198 \\
-5.091 \\
-4.980 \\
-4.865\end{array}$ & $\begin{array}{l}-5.311 \\
-5.209 \\
-5.102 \\
-4.992 \\
-4.877\end{array}$ & $\begin{array}{l}-5.321 \\
-5.219 \\
-5.113 \\
-5.003 \\
-4.889\end{array}$ & $\begin{array}{l}-5.331 \\
-5.230 \\
-5.124 \\
-5.014 \\
-4.900\end{array}$ & $\begin{array}{l}-5.341 \\
-5.240 \\
-5.135 \\
-5.025 \\
-4.912\end{array}$ & $\begin{array}{l}-290 \\
-280 \\
-270 \\
-260 \\
-250\end{array}$ \\
\hline $\begin{array}{l}-240 \\
-230 \\
-220 \\
-210 \\
-200\end{array}$ & $\begin{array}{l}-4.673 \\
-4.548 \\
-4.419 \\
-4.286 \\
-4.149\end{array}$ & $\begin{array}{l}-4.685 \\
-4.560 \\
-4.432 \\
-4.299 \\
-4.163\end{array}$ & $\begin{array}{l}-4.698 \\
-4.573 \\
-4.445 \\
-4.313 \\
-4.177\end{array}$ & $\begin{array}{l}-4.710 \\
-4.586 \\
-4.458 \\
-4.326 \\
-4.191\end{array}$ & $\begin{array}{l}-4.722 \\
-4.598 \\
-4.471 \\
-4.339 \\
-4.204\end{array}$ & $\begin{array}{l}-4.734 \\
-4.611 \\
-4.484 \\
-4.353 \\
-4.218\end{array}$ & $\begin{array}{l}-4.746 \\
-4.623 \\
-4.497 \\
-4.366 \\
-4.232\end{array}$ & $\begin{array}{l}-4.758 \\
-4.636 \\
-4.509 \\
-4.379 \\
-4.245\end{array}$ & $\begin{array}{l}-4.770 \\
-4.648 \\
-4.522 \\
-4.392 \\
-4.259\end{array}$ & $\begin{array}{l}-4.782 \\
-4.661 \\
-4.535 \\
-4.406 \\
-4.272\end{array}$ & $\begin{array}{l}-4.794 \\
-4.673 \\
-4.548 \\
-4.419 \\
-4.286\end{array}$ & $\begin{array}{l}-240 \\
-230 \\
-220 \\
-210 \\
-200\end{array}$ \\
\hline $\begin{array}{l}-190 \\
-180 \\
-170 \\
-160 \\
-150\end{array}$ & $\begin{array}{l}-4.009 \\
-3.864 \\
-3.717 \\
-3.565 \\
-3.410\end{array}$ & $\begin{array}{l}-4.023 \\
-3.879 \\
-3.732 \\
-3.580 \\
-3.425\end{array}$ & $\begin{array}{l}-4.037 \\
-3.894 \\
-3.746 \\
-3.596 \\
-3.441\end{array}$ & $\begin{array}{l}-4.051 \\
-3.908 \\
-3.761 \\
-3.611 \\
-3.457\end{array}$ & $\begin{array}{l}-4.065 \\
-3.923 \\
-3.776 \\
-3.626 \\
-3.472\end{array}$ & $\begin{array}{l}-4.079 \\
-3.937 \\
-3.791 \\
-3.641 \\
-3.488\end{array}$ & $\begin{array}{l}-4.093 \\
-3.951 \\
-3.806 \\
-3.656 \\
-3.503\end{array}$ & $\begin{array}{l}-4.107 \\
-3.966 \\
-3.820 \\
-3.671 \\
-3.519\end{array}$ & $\begin{array}{l}-4.121 \\
-3.980 \\
-3.835 \\
-3.687 \\
-3.534\end{array}$ & $\begin{array}{l}-4.135 \\
-3.994 \\
-3.850 \\
-3.702 \\
-3.550\end{array}$ & $\begin{array}{l}-4.149 \\
-4.009 \\
-3.864 \\
-3.717 \\
-3.565\end{array}$ & $\begin{array}{l}-190 \\
-180 \\
-170 \\
-160 \\
-150\end{array}$ \\
\hline $\begin{array}{l}-140 \\
-130 \\
-120 \\
-110 \\
-100\end{array}$ & $\begin{array}{l}-3.251 \\
-3.089 \\
-2.923 \\
-2.753 \\
-2.581\end{array}$ & $\begin{array}{l}-3.267 \\
-3.105 \\
-2.939 \\
-2.771 \\
-2.598\end{array}$ & $\begin{array}{l}-3.283 \\
-3.121 \\
-2.956 \\
-2.788 \\
-2.616\end{array}$ & $\begin{array}{l}-3.299 \\
-3.138 \\
-2.973 \\
-2.805 \\
-2.633\end{array}$ & $\begin{array}{l}-3.315 \\
-3.154 \\
-2.989 \\
-2.822 \\
-2.650\end{array}$ & $\begin{array}{l}-3.331 \\
-3.170 \\
-3.006 \\
-2.838 \\
-2.667\end{array}$ & $\begin{array}{l}-3.347 \\
-3.186 \\
-3.023 \\
-2.855 \\
-2.685\end{array}$ & $\begin{array}{l}-3.362 \\
-3.203 \\
-3.039 \\
-2.872 \\
-2.702\end{array}$ & $\begin{array}{l}-3.378 \\
-3.219 \\
-3.056 \\
-2.889 \\
-2.719\end{array}$ & $\begin{array}{l}-3.394 \\
-3.235 \\
-3.072 \\
-2.906 \\
-2.736\end{array}$ & $\begin{array}{l}-3.410 \\
-3.251 \\
-3.089 \\
-2.923 \\
-2.753\end{array}$ & $\begin{array}{l}-140 \\
-130 \\
-120 \\
-110 \\
-100\end{array}$ \\
\hline $\begin{array}{l}-90 \\
-80 \\
-70 \\
-60 \\
-.50\end{array}$ & $\begin{array}{l}-2.405 \\
-2.225 \\
-2.042 \\
-1.856 \\
-1.667\end{array}$ & $\begin{array}{l}-2.422 \\
-2.243 \\
-2.061 \\
-1.875 \\
-1.686\end{array}$ & $\begin{array}{l}-2.440 \\
-2.261 \\
-2.079 \\
-1.894 \\
-1.705\end{array}$ & $\begin{array}{l}-2.458 \\
-2.279 \\
-2.098 \\
-1.912 \\
-1.724\end{array}$ & $\begin{array}{l}-2.475 \\
-2.297 \\
-2.116 \\
-1.931 \\
-1.743\end{array}$ & $\begin{array}{l}-2.493 \\
-2.315 \\
-2.134 \\
-1.950 \\
-1.762\end{array}$ & $\begin{array}{l}-2.511 \\
-2.333 \\
-2.152 \\
-1.968 \\
-1.781\end{array}$ & $\begin{array}{l}-2.528 \\
-2.351 \\
-2.171 \\
-1.987 \\
-1.800\end{array}$ & $\begin{array}{l}-2.546 \\
-2.369 \\
-2.189 \\
-2.005 \\
-1.819\end{array}$ & $\begin{array}{l}-2.563 \\
-2.387 \\
-2.207 \\
-2.024 \\
-1.838\end{array}$ & $\begin{array}{l}-2.581 \\
-2.405 \\
-2.225 \\
-2.042 \\
-1.856\end{array}$ & $\begin{array}{l}-90 \\
-80 \\
-70 \\
-60 \\
-50\end{array}$ \\
\hline $\begin{array}{l}-40 \\
-30 \\
-20 \\
-10 \\
-0\end{array}$ & $\begin{array}{l}-1.475 \\
-1.279 \\
-1.081 \\
-0.879 \\
-0.674\end{array}$ & $\begin{array}{l}-1.494 \\
-1.299 \\
-1.101 \\
-0.899 \\
-0.695\end{array}$ & $\begin{array}{l}-1.513 \\
-1.319 \\
-1.121 \\
-0.920 \\
-0.716\end{array}$ & $\begin{array}{l}-1.533 \\
-1.338 \\
-1.141 \\
-0.940 \\
-0.736\end{array}$ & $\begin{array}{l}-1.552 \\
-1.358 \\
-1.160 \\
-0.960 \\
-0.757\end{array}$ & $\begin{array}{l}-1.571 \\
-1.377 \\
-1.180 \\
-0.980 \\
-0.777\end{array}$ & $\begin{array}{l}-1.591 \\
-1.397 \\
-1.200 \\
-1.000 \\
-0.798\end{array}$ & $\begin{array}{l}-1.610 \\
-1.416 \\
-1.220 \\
-1.021 \\
-0.818\end{array}$ & $\begin{array}{l}-1.629 \\
-1.436 \\
-1.240 \\
-1.041 \\
-0.838\end{array}$ & $\begin{array}{l}-1.648 \\
-1.455 \\
-1.260 \\
-1.061 \\
-0.859\end{array}$ & $\begin{array}{l}-1.667 \\
-1.475 \\
-1.279 \\
-1.081 \\
-0.879\end{array}$ & $\begin{array}{l}-40 \\
-30 \\
-20 \\
-10 \\
-0\end{array}$ \\
\hline$F$ & 0 & 1 & 2 & 3 & 4 & 5 & 6 & 7 & 8 & 9 & 10 & $F$ \\
\hline
\end{tabular}


TABLE A8.1.2. Type T thermocouples-thermoelectric voltage as a function of temperature $\left({ }^{\circ} \mathrm{F}\right)$, reference junctions at $32{ }^{\circ} \mathrm{F}$-Continued

6

8

9

10

THERMOELECTRIC VOLTAGE IN ABSOLUTE MILLIVOLTS

\begin{tabular}{|c|c|c|c|c|c|c|c|c|c|c|c|c|}
\hline 0 & -0.674 & -0.654 & -0.633 & -0.613 & -0.592 & -0.571 & -0.550 & -0.529 & -0.509 & -0.488 & -0.467 & 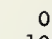 \\
\hline 10 & -0.467 & -0.446 & -0.425 & -0.404 & -0.383 & -0.362 & -0.341 & -0.320 & -0.299 & -0.277 & -0.256 & 10 \\
\hline 20 & -0.256 & -0.235 & -0.214 & -0.193 & -0.171 & -0.150 & -0.129 & -0.107 & -0.086 & -0.064 & -0.043 & 20 \\
\hline 30 & -0.043 & -0.022 & 0.000 & 0.022 & 0.043 & 0.065 & 0.086 & 0.108 & 0.130 & 0.151 & 0.173 & 30 \\
\hline 40 & 0.173 & 0.195 & 0.216 & 0.238 & 0.260 & 0.282 & 0.303 & 0.325 & 0.347 & 0.369 & 0.391 & 40 \\
\hline 50 & 0.391 & 0.413 & 0.435 & 0.457 & 0.479 & 0.501 & 0.523 & 0.545 & 0.567 & 0.589 & 0.611 & 50 \\
\hline 60 & 0.611 & 0.634 & 0.656 & 0.678 & 0.700 & 0.722 & 0.745 & 0.767 & 0.789 & 0.812 & 0.834 & 60 \\
\hline 70 & 0.834 & 0.857 & 0.879 & 0.902 & 0.924 & 0.947 & 0.969 & 0.992 & 1.014 & 1.037 & 1.060 & 70 \\
\hline 80 & 1.060 & 1.082 & 1.105 & 1.128 & $1 \cdot 151$ & 1.173 & 1.196 & 1.219 & 1.242 & 1.265 & 1.288 & 80 \\
\hline 90 & 1.288 & 1.311 & 1.334 & 1.357 & 1.380 & 1.403 & 1.426 & 1.449 & 1.472 & 1.495 & 1.518 & 90 \\
\hline 100 & 1.518 & 1.542 & 1.565 & 1.588 & 1.611 & 1.635 & 1.658 & 1.681 & 1.705 & 1.728 & 1.752 & 100 \\
\hline 110 & 1.752 & 1.775 & 1.799 & 1.822 & 1.846 & 1.869 & 1.893 & 1.917 & 1.940 & 1.964 & 1.988 & 110 \\
\hline 120 & 1.988 & 2.011 & 2.035 & 2.059 & 2.083 & 2.107 & 2.131 & 2.154 & 2.178 & 2.202 & 2.226 & 120 \\
\hline 130 & 2.226 & 2.250 & 2.274 & 2.298 & 2.322 & 2.347 & 2.371 & 2.395 & 2.419 & 2.443 & 2.467 & 130 \\
\hline 140 & 2.467 & 2.492 & 2.516 & 2.540 & 2.565 & 2.589 & 2.613 & 2.638 & 2.662 & 2.687 & 2.711 & 140 \\
\hline 150 & 2.711 & 2.736 & 2.760 & 2.785 & 2.809 & 2.834 & 2.859 & 2.883 & 2.908 & 2.933 & 2.958 & 150 \\
\hline 160 & 2.958 & 2.982 & 3.007 & 3.032 & 3.057 & & 107 & 131 & 3.156 & 3.181 & 3.206 & 160 \\
\hline 170 & 3.206 & 3.231 & 3.256 & 3.281 & 3.307 & 3.332 & 3.357 & 3.382 & 3.407 & 3.432 & 3.458 & 170 \\
\hline 180 & 3.458 & 3.483 & 3.508 & 3.533 & 3.559 & 3.584 & 3.609 & 3.635 & 3.660 & 3.686 & 3.711 & 180 \\
\hline 190 & 3.711 & 3.737 & 3.762 & 3.788 & 3.813 & 3.839 & 3.864 & 3.890 & 3.916 & 3.941 & 3.967 & 190 \\
\hline 200 & 3.967 & 3.993 & 4.019 & 4.044 & 4.070 & 4.096 & 4.122 & 4.148 & 4.174 & 4.199 & 4.225 & 200 \\
\hline 210 & 4.225 & 4.251 & 4.277 & 4.303 & 4.329 & 4.355 & 4.381 & 4.408 & 4.434 & 4.460 & 4.486 & 210 \\
\hline 220 & 4.486 & 4.512 & 4.538 & 4.565 & 4.591 & 4.617 & 4.643 & 4.670 & 4.696 & 4.722 & 4.749 & 220 \\
\hline 230 & 4.749 & 4.775 & 4.801 & 4.828 & 4.854 & 4.881 & 4.907 & 4.934 & 4.960 & 4.987 & 5.014 & 230 \\
\hline 240 & 5.014 & 5.040 & 5.067 & 5.093 & 5.120 & 5.147 & 5.174 & 5.200 & 5.227 & 5.254 & 5.281 & 240 \\
\hline 250 & 5.281 & 5.307 & 5.334 & 5.361 & 5.388 & .415 & $5: 442$ & 5.469 & 5.496 & 5.523 & 5.550 & 250 \\
\hline 260 & 5.550 & 5.577 & 5.604 & 5.631 & 5.658 & 5.685 & 5.712 & 5.739 & 5.767 & 5.794 & 5.821 & 260 \\
\hline 270 & 5.821 & 5.848 & 5.875 & 5.903 & 5.930 & 5.957 & 5.985 & 6.012 & 6.039 & 6.067 & 6.094 & 270 \\
\hline 280 & 6.094 & 6.122 & 6.149 & 6.177 & 6.204 & 6.232 & 6.259 & 6.287 & 6.314 & 6.342 & 6.369 & 280 \\
\hline 290 & 6.369 & 6.397 & 6.425 & 6.452 & 6.480 & 6.508 & 6.536 & 6.563 & 6.591 & 6.619 & 6.647 & 290 \\
\hline 300 & 6.647 & 6.675 & 6.702 & 6.730 & 6.758 & 6.786 & 6.814 & 6.842 & 6.8 & 6.898 & 6.926 & 300 \\
\hline 310 & 6.926 & 6.954 & 6.982 & 7.010 & 7.038 & & & & & & 07 & 310 \\
\hline 320 & 7.207 & 7.235 & 7.263 & 7.292 & 7.320 & 7.348 & 7.377 & 7.405 & 7.433 & 7.462 & 7.490 & 320 \\
\hline 330 & 7.490 & 7.518 & 7.547 & 7.575 & 7.604 & 7.632 & 7.661 & 7.689 & 7.718 & 7.746 & 7.775 & 330 \\
\hline 340 & 7.775 & 7.804 & 7.832 & 7.861 & 7.889 & 7.918 & 7.947 & 7.975 & 8.004 & 8.033 & 8.062 & 340 \\
\hline 350 & 8.062 & 8.090 & 8.1 & 8.148 & 8 & 6 & 8.2 & 8. & 8. & 8.321 & 8.350 & 350 \\
\hline 360 & 8.350 & 8.379 & 8.408 & 8.437 & 8.466 & 8.495 & 8.524 & 8.553 & 8.583 & 8.612 & 8.641 & 360 \\
\hline 370 & 8.641 & 8.670 & 8.699 & 8.728 & 8.757 & 8.787 & 8.816 & 8.845 & 8.874 & 8.904 & 8.933 & 370 \\
\hline 380 & 8.933 & 8.962 & 8.992 & 9.021 & 9.050 & 9.080 & 9.109 & 9.139 & 9.168 & 9.198 & 9.227 & 380 \\
\hline 390 & 9.227 & 9.257 & 9.286 & 9.316 & 9.345 & 9.375 & 9.404 & 9.434 & 9.464 & 9.493 & 9.523 & 390 \\
\hline 400 & 9.523 & 9.553 & 9.582 & 9.612 & 9 & 9.6 & .701 & & 1 & & 0 & 400 \\
\hline 410 & 9.820 & 9.850 & 880 & 0 & & 70 & 10.0 & & 0 & 90 & 120 & 410 \\
\hline 420 & 10.120 & 10.150 & $10 \cdot 180$ & 10.210 & 10.240 & 10.270 & 10.300 & 10.330 & $10 \cdot 360$ & 10 & 10.420 & 420 \\
\hline 430 & 10.420 & 10.451 & 10.481 & 10.511 & 10.541 & 10.572 & 10.602 & 10.632 & 10.662 & 10.693 & 10.723 & 430 \\
\hline 440 & 10.723 & 10.753 & 10.784 & 10.814 & 10.845 & 10.875 & 10.905 & 10.936 & 10.966 & 10.997 & 11.027 & 440 \\
\hline 450 & 11.027 & .058 & 8 & 9 & 9 & 1 & 1 & & 2 & & 3 & 450 \\
\hline 460 & 31.333 & 364 & & 5 & & & & & & & & 460 \\
\hline 470 & 11.640 & 11.671 & 11.702 & 11.733 & 11.764 & 11.795 & 11.826 & 11.856 & 11.887 & 11.918 & 11.949 & 470 \\
\hline 480 & 11.949 & 11.980 & 12.011 & 12.042 & 12.073 & $12 \cdot 104$ & 12.135 & $12 \cdot 1$ & 12.198 & 12.229 & 12.260 & 480 \\
\hline 490 & 12.260 & 12.291 & 12.322 & 12.353 & 12.384 & 12.416 & 12.447 & 12.478 & 12.509 & 12.540 & 12.572 & 490 \\
\hline 500 & 12. & 12.603 & 4 & 12. & & & & 91 & 22 & 12 & 12 & 500 \\
\hline 510 & 12.8 & & & & & & & & 37 & & 13.200 & 510 \\
\hline 520 & 200 & 1 & & & & & & & 53 & 85 & 516 & 520 \\
\hline 530 & 13.516 & 13.548 & 13.580 & 13.611 & 13.643 & 13.675 & 13.707 & 39 & 13.770 & 02 & 13.834 & 530 \\
\hline 540 & 13.834 & 13.866 & 13.898 & 13.930 & 13.961 & 13.993 & 14.025 & 14.057 & 14.089 & 14.121 & 14.153 & 540 \\
\hline 550 & 3 & 14.185 & 14.217 & 14.2 & 14. & 14 & 14 & 77 & 09 & 41 & & 550 \\
\hline 560 & & & & & & & & & & & & 560 \\
\hline 570 & 14.795 & 14.828 & 14.860 & 14.892 & 14.924 & 14.957 & 989 & 15.021 & 15.054 & 15.086 & 15.118 & 570 \\
\hline 580 & 15.118 & 15.151 & 15.183 & 15.216 & 15.248 & 15.280 & 15.313 & 15.345 & 15.378 & 15.410 & 15.443 & 580 \\
\hline 590 & 15.443 & 15.475 & 15.508 & 15.540 & 15.573 & 15.605 & 15.638 & 15.671 & 15.703 & 15.736 & 15.769 & 590 \\
\hline or & 15.769 & 15.801 & 15.834 & 15.866 & 5.899 & 15.932 & 15.965 & 15.997 & 16.030 & 16.063 & 16.096 & 600 \\
\hline
\end{tabular}

\begin{abstract}
4
\end{abstract}

\begin{abstract}
5
\end{abstract}
6

\begin{abstract}
7
\end{abstract}
8

10 
TABLE A8.1.2. Type T thermocouples-thermoelectric voltage as a function temperature $\left({ }^{\circ} \mathrm{F}\right)$, reference junctions at $32^{\circ} \mathrm{F}$-Continued

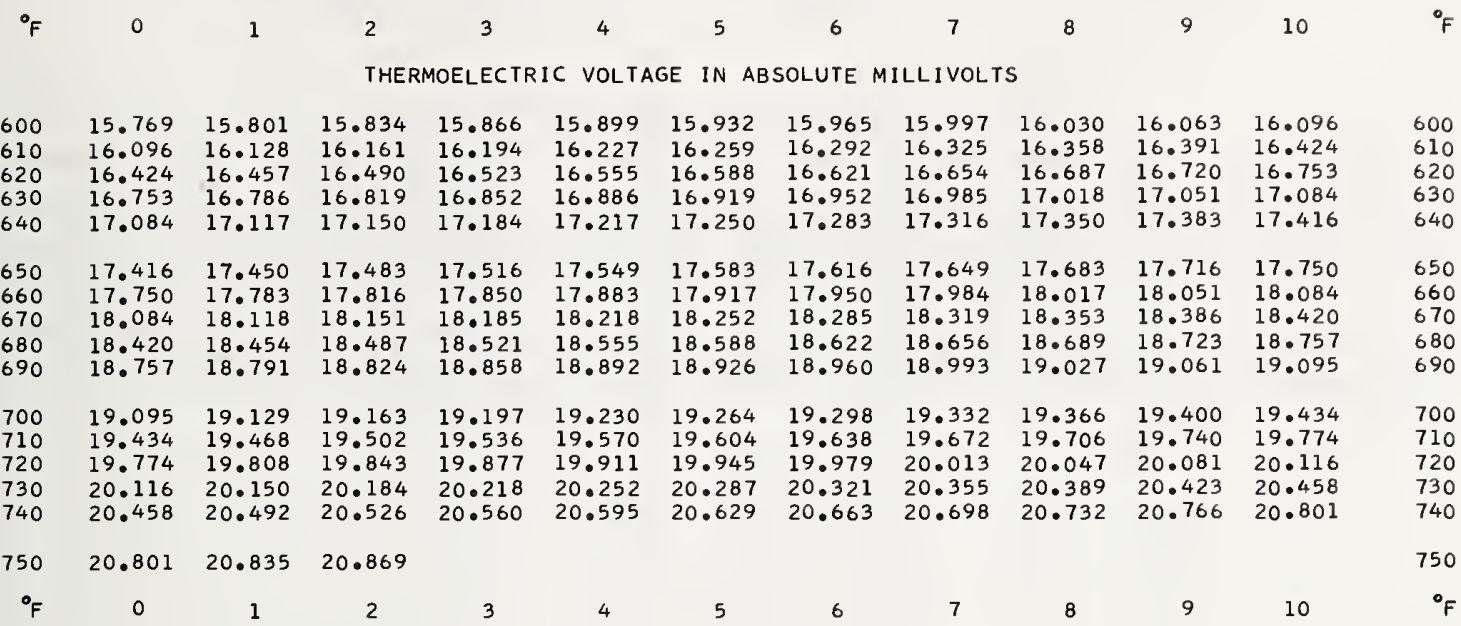

TABLE A8.1.3. Type Thermocouples-quadratic, cubic, and quartic approximations to the data as a function of temperature $\left({ }^{\circ} \mathrm{C}\right)$ in selected temperature ranges. The expansion is of the form $\mathrm{E}=\mathrm{a}_{0}+\mathrm{a}_{1} \mathrm{~T}+\mathrm{a}_{2} \mathrm{~T}^{2}+\mathrm{a}_{3} \mathrm{~T}^{3}+\mathrm{a}_{4} \mathrm{~T}^{4}$ where $\mathrm{E}$ is in microvolts and $\mathrm{T}$ is in degrees Celsius

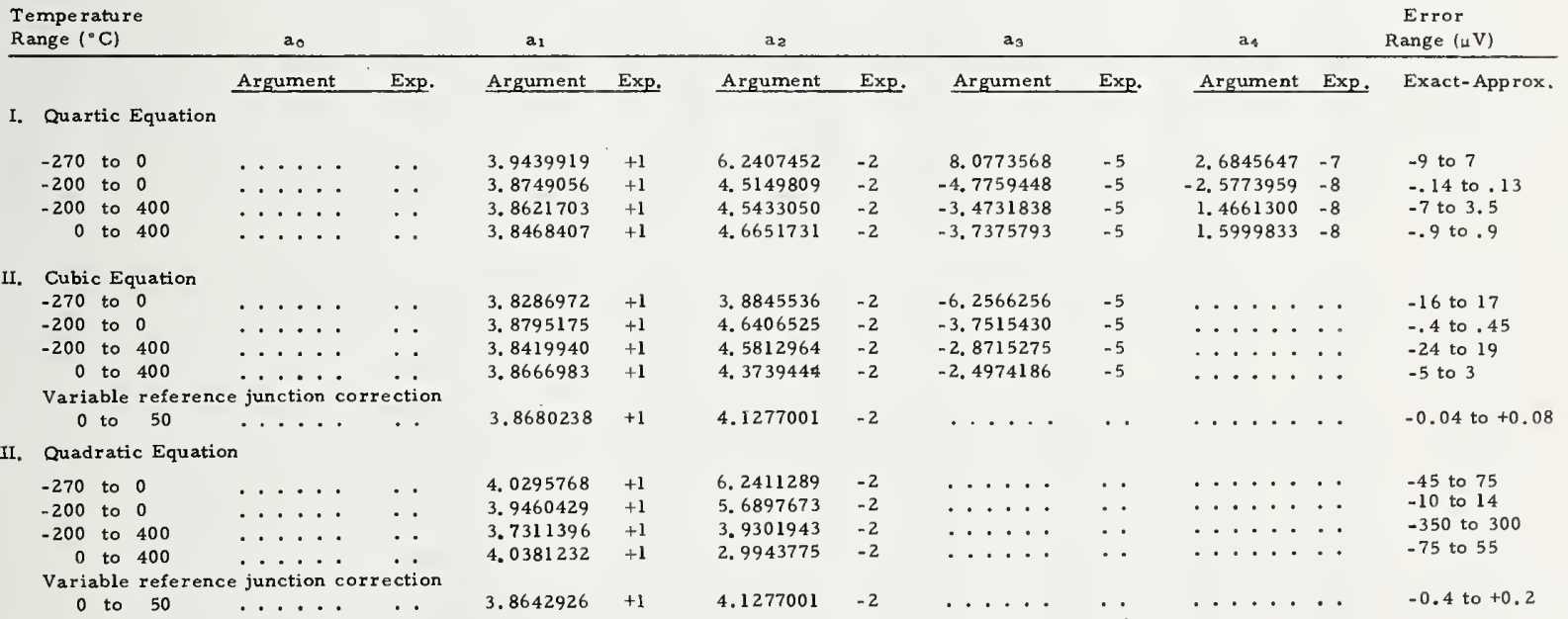




\section{A8.2. Data for Temperature as a Function of Voltage}

The temperature as a function of voltage data given in tables A8.2.1 and A8.2.2 were obtained by iteration in the primary equations for voltage as a function of temperature. Table A8.2.1 presents the data in millivolts from $-6.25 \mathrm{mV}$ to $20.86 \mathrm{mV}$ with temperatures given in degrees Celsius while table A8.2.2 presents similar data with temperatures in degrees Fahrenheit. Table A8.2.3 contains quadratic, cubic, and quartic approximations to the data as a function of voltage in selected temperature ranges. The error range given in the table represents the difference between the temperature found by iteration in the full precision tables from the text and from the respective reduced order approximations.

TABLE A8.2.1. Type $T$ thermocouples-temperature $\left({ }^{\circ} \mathrm{C}\right)$ as a function of thermoelectric voltage, reference junctions at $0^{\circ} \mathrm{C}$

$\mathrm{mV}$

$\begin{array}{cc}.00 & .01 \\ & \\ -253.28 & -255.16 \\ 239.42 & -240.57 \\ 229.38 & -230.30\end{array}$

.02

$$
\begin{array}{cc}
.03 & .04 \\
\text { TEMPERATURES IN } \\
-259.54 & -262.25 \\
-242.97 & -244.24
\end{array}
$$$$
.05
$$$$
.06
$$$$
.07
$$$$
.08
$$$$
.09
$$$$
.10
$$

$\mathrm{mV}$

TEMPERATURES IN DEGREES C (IPTS 1968)

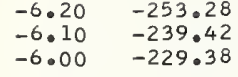


TABLE A8.2.1. Type T thermocouples-temperature $\left({ }^{\circ} \mathrm{C}\right)$ as a function of thermoelectric voltage, reference junctions at $0^{\circ} \mathrm{C}$-Continued

$m V$

.00

.01

.02

.03

.05

.06

.07

.08

.09

.10

$m$

TEMPERATURES IN DEGREES C (IPTS 1968)

\begin{tabular}{|c|c|c|c|c|c|c|c|c|c|c|c|c|}
\hline-6.00 & $-229 \cdot 38$ & $-230 \cdot 30$ & $-231 \cdot 23$ & $-232 \cdot 18$ & $-233 \cdot 14$ & $-234 \cdot 13$ & $-235 \cdot 14$ & -236.17 & -237.23 & -238.31 & $-239 \cdot 42$ & -6.00 \\
\hline $\begin{array}{l}-5.90 \\
-5.80 \\
-5.70 \\
-5.60 \\
-5.50\end{array}$ & $\begin{array}{l}-220.91 \\
-213.33 \\
-206.35 \\
-199.81 \\
-193.64\end{array}$ & $\begin{array}{l}-221.71 \\
-214.05 \\
-207.02 \\
-200.45 \\
-194.24\end{array}$ & $\begin{array}{l}-222 \cdot 52 \\
-214.79 \\
-207 \cdot 70 \\
-201.09 \\
-194.85\end{array}$ & $\begin{array}{l}-223.33 \\
-215.53 \\
-208.39 \\
-201.73 \\
-195.46\end{array}$ & $\begin{array}{l}-224 \cdot 16 \\
-216.27 \\
-209 \cdot 08 \\
-202.38 \\
-196.07\end{array}$ & $\begin{array}{l}-225.00 \\
-217.03 \\
-209.77 \\
-203.03 \\
-196.69\end{array}$ & $\begin{array}{l}-225.85 \\
-217.79 \\
-210.47 \\
-203.69 \\
-197.31\end{array}$ & $\begin{array}{l}-226.72 \\
-218.56 \\
-211.18 \\
-204.34 \\
-197.93\end{array}$ & $\begin{array}{l}-227.59 \\
-219.33 \\
-211.89 \\
-205.01 \\
-198.55\end{array}$ & $\begin{array}{l}-228.48 \\
-220.11 \\
-212.60 \\
-205.68 \\
-199.18\end{array}$ & $\begin{array}{l}-229 \cdot 38 \\
-220.91 \\
-213.33 \\
-206 \cdot 35 \\
-199.81\end{array}$ & $\begin{array}{l}-5.90 \\
-5.80 \\
-5.70 \\
-5.60 \\
-5.50\end{array}$ \\
\hline $\begin{array}{l}-5.40 \\
-5.30 \\
-5.20 \\
-5.10 \\
-5.00\end{array}$ & $\begin{array}{l}-187.77 \\
-182.15 \\
-176.75 \\
-171.55 \\
-166.53\end{array}$ & $\begin{array}{l}-188.34 \\
-182.70 \\
-177.28 \\
-172.07 \\
-167.02\end{array}$ & $\begin{array}{l}-188 \cdot 92 \\
-183 \cdot 25 \\
-177 \cdot 82 \\
-172 \cdot 58 \\
-167 \cdot 52\end{array}$ & $\begin{array}{l}-189.50 \\
-183.81 \\
-178.35 \\
-173.10 \\
-168.02\end{array}$ & $\begin{array}{l}-190.08 \\
-184.37 \\
-178.89 \\
-173.61 \\
-168.52\end{array}$ & $\begin{array}{l}-190.67 \\
-184.93 \\
-179.43 \\
-174.13 \\
-169.02\end{array}$ & $\begin{array}{l}-191.26 \\
-185.49 \\
-179.97 \\
-174.65 \\
-169.52\end{array}$ & $\begin{array}{l}-191.85 \\
-186.06 \\
-180.51 \\
-175.17 \\
-170.03\end{array}$ & $\begin{array}{l}-192 \cdot 44 \\
-186.62 \\
-181 \cdot 05 \\
-175 \cdot 70 \\
-170 \cdot 54\end{array}$ & $\begin{array}{l}-193 \cdot 04 \\
-187.20 \\
-181.60 \\
-176.23 \\
-171.04\end{array}$ & $\begin{array}{l}-193 \cdot 64 \\
-187.77 \\
-182 \cdot 15 \\
-176.75 \\
-171.55\end{array}$ & $\begin{array}{l}-5 \cdot 40 \\
-5 \cdot 30 \\
-5 \cdot 20 \\
-5 \cdot 10 \\
-5 \cdot 00\end{array}$ \\
\hline $\begin{array}{l}-4 \cdot 90 \\
-4 \cdot 80 \\
-4.70 \\
-4 \cdot 60 \\
-4.50\end{array}$ & $\begin{array}{l}-161.66 \\
-156.93 \\
-152.33 \\
-147.85 \\
-143.48\end{array}$ & $\begin{array}{l}-162.14 \\
-157.40 \\
-152.79 \\
-148.30 \\
-143.91\end{array}$ & $\begin{array}{l}-162 \cdot 62 \\
-157 \cdot 87 \\
-153 \cdot 24 \\
-148 \cdot 74 \\
-144 \cdot 35\end{array}$ & $\begin{array}{l}-163.11 \\
-158 \cdot 34 \\
-153 \cdot 70 \\
-149 \cdot 19 \\
-144.78\end{array}$ & $\begin{array}{l}-163 \cdot 59 \\
-158 \cdot 81 \\
-154 \cdot 16 \\
-149.63 \\
-145 \cdot 22\end{array}$ & $\begin{array}{l}-164.08 \\
-159 \cdot 28 \\
-154.62 \\
-150.08 \\
-145.65\end{array}$ & $\begin{array}{l}-164.56 \\
-159.75 \\
-155.08 \\
-150.53 \\
-146.09\end{array}$ & $\begin{array}{l}-165.05 \\
-160.23 \\
-155.54 \\
-150.98 \\
-146.53\end{array}$ & $\begin{array}{l}-165.54 \\
-160.70 \\
-156.00 \\
-151.43 \\
-146.97\end{array}$ & $\begin{array}{l}-166.04 \\
-161.18 \\
-156.47 \\
-151.88 \\
-147.41\end{array}$ & $\begin{array}{l}-166.53 \\
-161.66 \\
-156.93 \\
-152.33 \\
-147.85\end{array}$ & $\begin{array}{l}-4.90 \\
-4.80 \\
-4.70 \\
-4.60 \\
-4.50\end{array}$ \\
\hline $\begin{array}{l}-4 \cdot 40 \\
-4 \cdot 30 \\
-4 \cdot 20 \\
-4 \cdot 10 \\
-4 \cdot 00\end{array}$ & $\begin{array}{l}-139 \cdot 21 \\
-135.03 \\
-130.94 \\
-126.93 \\
-122.99\end{array}$ & $\begin{array}{l}-139 \cdot 63 \\
-135 \cdot 44 \\
-131 \cdot 34 \\
-127 \cdot 32 \\
-123 \cdot 38\end{array}$ & $\begin{array}{l}.05 \\
.86 \\
.75 \\
.72 \\
.77\end{array}$ & $\begin{array}{l}-140 \cdot 48 \\
-136 \cdot 27 \\
-132 \cdot 16 \\
-128 \cdot 12 \\
-124 \cdot 17\end{array}$ & $\begin{array}{l}-140 \cdot 90 \\
-136 \cdot 69 \\
-132 \cdot 56 \\
-128 \cdot 52 \\
-124 \cdot 56\end{array}$ & $\begin{array}{l}-141.33 \\
-137.11 \\
-132.97 \\
-128.92 \\
-124.95\end{array}$ & $\begin{array}{l}-141.76 \\
-137.53 \\
-133.38 \\
-129 \cdot 32 \\
-125.34\end{array}$ & $\begin{array}{l}-142 \cdot 19 \\
-137 \cdot 94 \\
-133 \cdot 79 \\
-129 \cdot 73 \\
-125 \cdot 74\end{array}$ & $\begin{array}{l}-142 \cdot 62 \\
-138 \cdot 36 \\
-134.20 \\
-130.13 \\
-126.13\end{array}$ & $\begin{array}{l}-143.05 \\
-138.79 \\
-134.62 \\
-130.53 \\
-126.53\end{array}$ & $\begin{array}{l}-143 \cdot 48 \\
-139 \cdot 21 \\
-135.03 \\
-130.94 \\
-126.93\end{array}$ & $\begin{array}{l}-4 \cdot 40 \\
-4 \cdot 30 \\
-4 \cdot 20 \\
-4 \cdot 10 \\
-4 \cdot 00\end{array}$ \\
\hline $\begin{array}{l}-3.90 \\
-3.80 \\
-3.70 \\
-3.60 \\
-3.50\end{array}$ & $\begin{array}{l}-119.13 \\
-115.34 \\
-111.61 \\
-107 \cdot 94 \\
-104.33\end{array}$ & $\begin{array}{l}-119.52 \\
-115.72 \\
-111.98 \\
-108 \cdot 30 \\
-104.69\end{array}$ & $\begin{array}{l}-119 \cdot 90 \\
-116 \cdot 09 \\
-112 \cdot 35 \\
-108 \cdot 67 \\
-105 \cdot 04\end{array}$ & $\begin{array}{l}-120 \cdot 28 \\
-116.47 \\
-112.72 \\
-109.03 \\
-105.40\end{array}$ & $\begin{array}{l}-120.67 \\
-116.85 \\
-113.09 \\
-109 \cdot 40 \\
-105.76\end{array}$ & $\begin{array}{l}-121 \cdot 05 \\
-117 \cdot 23 \\
-113 \cdot 47 \\
-109 \cdot 77 \\
-106.13\end{array}$ & $\begin{array}{l}-121.44 \\
-117.61 \\
-113.84 \\
-110.13 \\
-106.49\end{array}$ & $\begin{array}{l}-121.83 \\
-117.99 \\
-114.21 \\
-110.50 \\
-106.85\end{array}$ & $\begin{array}{l}-122 \cdot 22 \\
-118 \cdot 37 \\
-114 \cdot 59 \\
-110 \cdot 87 \\
-107.21\end{array}$ & $\begin{array}{l}-122 \cdot 60 \\
-118 \cdot 75 \\
-114 \cdot 96 \\
-111 \cdot 24 \\
-107.58\end{array}$ & $\begin{array}{l}-122 \cdot 99 \\
-119 \cdot 13 \\
-115 \cdot 34 \\
-111 \cdot 61 \\
-107.94\end{array}$ & $\begin{array}{l}-3.90 \\
-3.80 \\
-3.70 \\
-3.60 \\
-3.50\end{array}$ \\
\hline $\begin{array}{l}-3 \cdot 40 \\
-3 \cdot 30 \\
-3.20\end{array}$ & $\begin{array}{r}-100.77 \\
-97.26 \\
-93.80\end{array}$ & $\begin{array}{r}-101.12 \\
-97.61 \\
-94.14\end{array}$ & $\begin{array}{r}-101 \cdot 48 \\
-97 \cdot 96 \\
-94.49\end{array}$ & $\begin{array}{r}-101.83 \\
-98.31 \\
-94.83\end{array}$ & $\begin{array}{r}-102 \cdot 18 \\
-98.66 \\
-95.18\end{array}$ & $\begin{array}{r}-102.54 \\
-99.01 \\
-95.52\end{array}$ & $\begin{array}{r}-102.90 \\
-99.36 \\
-95.87\end{array}$ & $\begin{array}{r}-103.25 \\
-99.71 \\
-96.22\end{array}$ & $\begin{array}{r}-103.61 \\
-100.06 \\
-96.56\end{array}$ & $\begin{array}{r}-103.97 \\
-100.41 \\
-96.91\end{array}$ & $\begin{array}{r}-104.33 \\
-100.77 \\
-97.26\end{array}$ & $\begin{array}{l}-3.40 \\
-3.30 \\
-3.20\end{array}$ \\
\hline $\begin{array}{l}-3.10 \\
-3.00\end{array}$ & $\begin{array}{l}-90.39 \\
-87.02\end{array}$ & $\begin{array}{l}-90.73 \\
-87.35\end{array}$ & $\begin{array}{l}-91.07 \\
-87.69\end{array}$ & $\begin{array}{l}-91.41 \\
-38.02\end{array}$ & $\begin{array}{l}-91 \cdot 75 \\
-88 \cdot 36\end{array}$ & $\begin{array}{l}-92.09 \\
-88.70\end{array}$ & $\begin{array}{l}-92.43 \\
-89.03\end{array}$ & $\begin{array}{l}-92.77 \\
-89.37\end{array}$ & $\begin{array}{l}-93.11 \\
-89.71\end{array}$ & $\begin{array}{l}-93.46 \\
-90.05\end{array}$ & $\begin{array}{l}-93.80 \\
-90.39\end{array}$ & $\begin{array}{l}-3.10 \\
-3.00\end{array}$ \\
\hline $\begin{array}{l}-2.90 \\
-2.80 \\
-2.70 \\
-2.60 \\
-2.50\end{array}$ & $\begin{array}{l}-83.69 \\
-80.41 \\
-77.16 \\
-73.95 \\
-70.77\end{array}$ & $\begin{array}{l}-84.02 \\
-80.73 \\
-77.48 \\
-74.27 \\
-71.09\end{array}$ & $\begin{array}{l}-84.35 \\
-81.06 \\
-77.81 \\
-74.59 \\
-71.41\end{array}$ & $\begin{array}{l}-84.69 \\
-81.39 \\
-78.13 \\
-74.91 \\
-71.72\end{array}$ & $\begin{array}{l}-85 \cdot 02 \\
-81 \cdot 72 \\
-78 \cdot 45 \\
-75 \cdot 23 \\
-72.04\end{array}$ & $\begin{array}{l}-85.35 \\
-82 \cdot 04 \\
-78.78 \\
-75.55 \\
-72.36\end{array}$ & $\begin{array}{l}-85.68 \\
-82.37 \\
-79.10 \\
-75.87 \\
-72.67\end{array}$ & $\begin{array}{l}-86.02 \\
-82.70 \\
-79.43 \\
-76.19 \\
-72.99\end{array}$ & $\begin{array}{l}-86.35 \\
-83.03 \\
-79.75 \\
-76.51 \\
-73.31\end{array}$ & $\begin{array}{l}-86.68 \\
-83.36 \\
-80.08 \\
-76.84 \\
-73.63\end{array}$ & $\begin{array}{l}-87.02 \\
-83.69 \\
-80.41 \\
-77.16 \\
-73.95\end{array}$ & $\begin{array}{l}-2.90 \\
-2.80 \\
-2.70 \\
-2.60 \\
-2.50\end{array}$ \\
\hline $\begin{array}{l}-2.40 \\
-2.30 \\
-2.20 \\
-2.10 \\
-2.00\end{array}$ & $\begin{array}{l}-67.63 \\
-64.53 \\
-61.45 \\
-58.41 \\
-55.39\end{array}$ & $\begin{array}{l}-67.95 \\
-64.84 \\
-61.76 \\
-58.71 \\
-55.69\end{array}$ & $\begin{array}{l}-68 \cdot 26 \\
-65.15 \\
-62.06 \\
-59.01 \\
-55.99\end{array}$ & $\begin{array}{l}-68 \cdot 57 \\
-65.46 \\
-62.37 \\
-59.32 \\
-56.29\end{array}$ & $\begin{array}{l}-68 \cdot 89 \\
-65.77 \\
-62.68 \\
-59.62 \\
-56.60\end{array}$ & $\begin{array}{l}-69.20 \\
-66.08 \\
-62.99 \\
-59.93 \\
-56.90\end{array}$ & $\begin{array}{l}-69.51 \\
-66.39 \\
-63.29 \\
-60.23 \\
-57.20\end{array}$ & $\begin{array}{l}-69.83 \\
-66.70 \\
-63.60 \\
-60.54 \\
-57.50\end{array}$ & $\begin{array}{l}-70.14 \\
-67.01 \\
-63.91 \\
-60.84 \\
-57.80\end{array}$ & $\begin{array}{l}-70 \cdot 46 \\
-67.32 \\
-64.22 \\
-61.15 \\
-58.11\end{array}$ & $\begin{array}{l}-70.77 \\
-67.63 \\
-64.53 \\
-61.45 \\
-58.41\end{array}$ & $\begin{array}{l}-2.40 \\
-2.30 \\
-2.20 \\
-2.10 \\
-2.00\end{array}$ \\
\hline $\begin{array}{l}-1.90 \\
-1.80 \\
-1.70 \\
-1.60 \\
-1.50\end{array}$ & $\begin{array}{l}-52.41 \\
-49.45 \\
-46.51 \\
-43.61 \\
-40.72\end{array}$ & $\begin{array}{l}-52.70 \\
-49.74 \\
-46.81 \\
-43.90 \\
-41.01\end{array}$ & $\begin{array}{l}-53.00 \\
-50.04 \\
-47.10 \\
-44.19 \\
-41.30\end{array}$ & $\begin{array}{l}-53.30 \\
-50.33 \\
-47.39 \\
-44.48 \\
-41.59\end{array}$ & $\begin{array}{l}-53.60 \\
-50.63 \\
-47.68 \\
-44.77 \\
-41.87\end{array}$ & $\begin{array}{l}-53.90 \\
-50.92 \\
-47.98 \\
-45.06 \\
-42.16\end{array}$ & $\begin{array}{l}-54 \cdot 20 \\
-51 \cdot 22 \\
-48 \cdot 27 \\
-45 \cdot 35 \\
-42 \cdot 45\end{array}$ & $\begin{array}{l}-54.49 \\
-51.52 \\
-48.56 \\
-45.64 \\
-42.74\end{array}$ & $\begin{array}{l}-54.79 \\
-51.81 \\
-48.86 \\
-45.93 \\
-43.03\end{array}$ & $\begin{array}{l}-55.09 \\
-52.11 \\
-49.15 \\
-46.22 \\
-43.32\end{array}$ & $\begin{array}{l}-55.39 \\
-52.41 \\
-49.45 \\
-46.51 \\
-43.61\end{array}$ & $\begin{array}{l}-1.90 \\
-1.80 \\
-1.70 \\
-1.60 \\
-1.50\end{array}$ \\
\hline $\begin{array}{l}-1.40 \\
-1.30 \\
-1.20 \\
-1.10 \\
-1.00\end{array}$ & $\begin{array}{l}-37.87 \\
-35.03 \\
-32.22 \\
-29.42 \\
-26.65\end{array}$ & $\begin{array}{l}-38.15 \\
-35.31 \\
-32.50 \\
-29.70 \\
-26.93\end{array}$ & $\begin{array}{l}-38.44 \\
-35.60 \\
-32.78 \\
-29.98 \\
-27.21\end{array}$ & $\begin{array}{l}-38.72 \\
-35.88 \\
-33.06 \\
-30.26 \\
-27.48\end{array}$ & $\begin{array}{l}-39 \cdot 01 \\
-36 \cdot 16 \\
-33 \cdot 34 \\
-30.54 \\
-27 \cdot 76\end{array}$ & $\begin{array}{l}-39.29 \\
-36.44 \\
-33.62 \\
-30.82 \\
-28.04\end{array}$ & $\begin{array}{l}-39.58 \\
-36.73 \\
-33.90 \\
-31.10 \\
-28.31\end{array}$ & $\begin{array}{l}-39.86 \\
-37.01 \\
-34.18 \\
-31.38 \\
-28.59\end{array}$ & $\begin{array}{l}-40.15 \\
-37.30 \\
-34.47 \\
-31.66 \\
-28.87\end{array}$ & $\begin{array}{l}-40.44 \\
-37.58 \\
-34.75 \\
-31.94 \\
-29.15\end{array}$ & $\begin{array}{l}-40.72 \\
-37.87 \\
-35.03 \\
-32.22 \\
-29.42\end{array}$ & $\begin{array}{l}-1.40 \\
-1.30 \\
-1.20 \\
-1.10 \\
-1.00\end{array}$ \\
\hline $\begin{array}{l}-0.90 \\
-0.80 \\
-0.70 \\
-0.60 \\
-0.50\end{array}$ & $\begin{array}{l}-23.91 \\
-21.18 \\
-18.47 \\
-15.78 \\
-13.10\end{array}$ & $\begin{array}{l}-24.18 \\
-21.45 \\
-18.74 \\
-16.04 \\
-13.37\end{array}$ & $\begin{array}{l}-24.45 \\
-21.72 \\
-19.01 \\
-16.31 \\
-13.64\end{array}$ & $\begin{array}{l}-24.73 \\
-21.99 \\
-19.28 \\
-16.58 \\
-13.90\end{array}$ & $\begin{array}{l}-25.00 \\
-22.27 \\
-19.55 \\
-16.85 \\
-14.17\end{array}$ & $\begin{array}{l}-25.28 \\
-22.54 \\
-19.82 \\
-17.12 \\
-14.44\end{array}$ & $\begin{array}{l}-25.55 \\
-22.81 \\
-20.09 \\
-17.39 \\
-14.70\end{array}$ & $\begin{array}{l}-25.83 \\
-23.08 \\
-20.36 \\
-17.66 \\
-14.97\end{array}$ & $\begin{array}{l}-26.10 \\
-23.36 \\
-20.63 \\
-17.93 \\
-15.24\end{array}$ & $\begin{array}{l}-26.38 \\
-23.63 \\
-20.90 \\
-18.20 \\
-15.51\end{array}$ & $\begin{array}{l}-26.65 \\
-23.91 \\
-21.18 \\
-18.47 \\
-15.78\end{array}$ & $\begin{array}{l}-0.90 \\
-0.80 \\
-0.70 \\
-0.60 \\
-0.50\end{array}$ \\
\hline $\begin{array}{l}-0.40 \\
-0.30 \\
-0.20 \\
-0.10 \\
-0.00\end{array}$ & $\begin{array}{r}-10.45 \\
-7.81 \\
-5.19 \\
-2.59 \\
0.00\end{array}$ & $\begin{array}{r}-10.71 \\
-8.08 \\
-5.45 \\
-2.85 \\
-0.26\end{array}$ & $\begin{array}{r}-10.98 \\
-8.34 \\
-5.72 \\
-3.11 \\
-0.52\end{array}$ & $\begin{array}{r}-11.24 \\
-8.60 \\
-5.98 \\
-3.37 \\
-0.78\end{array}$ & $\begin{array}{r}-11.51 \\
-8.87 \\
-6.24 \\
-3.63 \\
-1.03\end{array}$ & $\begin{array}{r}-11.77 \\
-9.13 \\
-6.50 \\
-3.89 \\
-1.29\end{array}$ & $\begin{array}{r}-12.04 \\
-9.39 \\
-6.76 \\
-4.15 \\
-1.55\end{array}$ & $\begin{array}{r}-12.31 \\
-9.66 \\
-7.03 \\
-4.41 \\
-1.81\end{array}$ & $\begin{array}{r}-12.57 \\
-9.92 \\
-7.29 \\
-4.67 \\
-2.07\end{array}$ & $\begin{array}{r}-12.84 \\
-10.19 \\
-7.55 \\
-4.93 \\
-2.33\end{array}$ & $\begin{array}{r}-13.10 \\
-10.45 \\
-7.81 \\
-5.19 \\
-2.59\end{array}$ & $\begin{array}{l}-0.40 \\
-0.30 \\
-0.20 \\
-0.10 \\
-0.00\end{array}$ \\
\hline
\end{tabular}

mV

.00

.01

.02

.03

.04

.05

.06

.07

.08

.09

$\cdot 10$

$\mathrm{mV}$ 
TABLE A8.2.1. Type T thermocouples-temperature $\left({ }^{\circ} \mathrm{C}\right)$ as a function of thermoelectric voltage, reference junctions at $0^{\circ} \mathrm{C}$-Continued

.04

.05

TEMP

0.00

0.10

0.20

0.30

0.40

0.50

0.60

0.70

0.80
0.90

1.00

1.10
1.20

1.30

1.40

1.50

1.60

1.70

1.80

1.90

2.00

2.10

2.20

2.30

.40

2. 50

2. 60

2.80

2.90

3.00

3.10

3.20

3.30

.4

3. 50

3.60

3.90

4. $00 \quad 94.04$

$4.10 \quad 96.20$

$4.20 \quad 98.34$

4. $30 \quad 100.48$

$4.40 \quad 102.62$

4.50 .104 .74

$4.60 \quad 106.86$

$4.80 \quad 111.08$

$4.90 \quad 113.18$

$5.00 \quad 115.27$

$5.10 \quad 117.36$

$5.20 \quad 119.44$

$\begin{array}{ll}5.30 & 121.51 \\ 5.40 & 123.58\end{array}$

$5.50 \quad 125.64$

$5.60 \quad 127.70$

5.70

5.80

5.90

6.00

125.75

131.79

135.87

0.26
2.83
5.39
7.95

0.52

3.09

5.65

8.20

10.48

13.01

15.52

18.02

20.51
22.99

25.45

27.90
30.34

32.76

35.18

37.58

39.97

42.35

44.71

47.07

49.41

51.74
54.07

56.38

58.68

60.97

63.25

65.53

67.79

70.04

72.29

74.52
76.75

78.97

81.17

83.37

85.57

87.75

89.93

92.10

94.26

96.41

98.56

100.70
102.83

102.83

104.96
107.07

111.29

113.39

115.48

117.57

119.65

121.72
123.79

125.85

127.90

129.95

134.04

136.07

13.26

15.77

18.27

20.76
23.23

25.69

28.14
30.58

33.00

35.42

37.82

40.21

42.58

44.95
47.30

49.65

51.98

54.30

58.91

61.20

63.48

70.27

72.51

74.74
76.97

79.19

81.39

83.59

85.79

92.31

94.47

96.63

98.77

100.91

103.04

105.17

107.29

109.40

113.60

115.69

117.77

121.83

123.99

130.16

132.20

136.27

$$
\begin{aligned}
& 0.77 \\
& 3.35
\end{aligned}
$$$$
5.91
$$

8.45

$13.51^{\circ}$

13.51
16.02
18.52

18.52
21.01
23.48

25.94

28.39
30.82

33.25

35.66

38.06

40.44

42.82

$45 \cdot 18$
47.54

49.88

49.88
52.21

52.21
54.53

56.84

61.43

$68.02 \quad 68.24$

$68 \cdot 24$
70.49

72.73

74.97

77.19

79.41

83.81

86.00

90.15

90.36
92.53

94.69

96.84

101.12

103.26

105.38

107.50

109.61

111.71

115.90

117.98

120.06

122.13

$126.05 \quad 126.26$

$128.11 \quad 128.31$

130.36

132.41
134.44

136.48

1.03
3.60
6.16
8.71
11.24
13.76
16.27
18.77
21.25

1.29

3.86

6.42

11.50

14.02

$16 \cdot 52$

19.02

23.73

26.19

28.63
31.07

33.49

35.90

38.30

40.68

43.06

45.42
47.77

50.11

52.44
54.76

57.07

59.37

61.66

63.94

66.21

68.47

70.72

$72 \cdot 96$

$75 \cdot 19$
77.41

79.63

81.84

84.03

86.22

$88 \cdot 41$

90.58

92.75

94.9

97.06

99.20

101.34

103.4

105.5

107.7
109.8

111.92

114.02

21.50
23.97

26.43

28.88

31.31

33.73

36.14

38.53

40.92

43.29

45.66
48.01

50.35

52.67

54.99

59.60

61.89

64.16

66.43

68.69

70.94

73.18

75.41

77.64

79.85
82.06

84.25

86.44

88.62

90.80

92.96

95.12

97.27

99.42

101.55

103.68

105.80

107.92 
TABLE A8.2.1. Type T thermocouples-temperature $\left({ }^{\circ} \mathrm{C}\right)$ as a function of thermoelectric voltage, reference junctions at $0^{\circ} \mathrm{C}$-Continued

$\mathrm{mV}$
.00

.01

.02

\author{
02
}

.03

.04

.05

.06

.07

.08

.09

.10

$\mathrm{mV}$

\begin{tabular}{|c|c|c|c|c|c|c|c|c|c|c|c|c|}
\hline $\begin{array}{l}6.00 \\
6.10 \\
6.20 \\
6.30 \\
6.40\end{array}$ & $\begin{array}{l}135.87 \\
137.90 \\
139.92 \\
141.94 \\
143.95\end{array}$ & $\begin{array}{l}136.07 \\
138.10 \\
140.12 \\
142.14 \\
144.15\end{array}$ & $\begin{array}{l}136 \cdot 27 \\
138 \cdot 30 \\
140 \cdot 32 \\
142 \cdot 34 \\
144 \cdot 35\end{array}$ & $\begin{array}{l}136.48 \\
138.50 \\
140.52 \\
142.54 \\
144.55\end{array}$ & $\begin{array}{l}136 \cdot 68 \\
138 \cdot 70 \\
140.73 \\
142.74 \\
144.75\end{array}$ & $\begin{array}{l}136.88 \\
138.91 \\
140.93 \\
142.94 \\
144.95\end{array}$ & $\begin{array}{l}137.08 \\
139.11 \\
141.13 \\
143.14 \\
145.15\end{array}$ & $\begin{array}{l}137.29 \\
139.31 \\
141.33 \\
143.34 \\
145.35\end{array}$ & $\begin{array}{l}137.49 \\
139.51 \\
141.53 \\
143.55 \\
145.55\end{array}$ & $\begin{array}{l}137.69 \\
139.72 \\
141.73 \\
143.75 \\
145.75\end{array}$ & $\begin{array}{l}137.90 \\
139.92 \\
141.94 \\
143.95 \\
145.95\end{array}$ & $\begin{array}{l}6.00 \\
6.10 \\
6.20 \\
6.30 \\
6.40\end{array}$ \\
\hline $\begin{array}{l}6.50 \\
6.60 \\
6.70 \\
6.80 \\
6.90\end{array}$ & $\begin{array}{l}145.95 \\
147.96 \\
149.95 \\
151.94 \\
153.93\end{array}$ & $\begin{array}{l}146.15 \\
148.16 \\
150.15 \\
152.14 \\
154.13\end{array}$ & $\begin{array}{l}146 \cdot 36 \\
148 \cdot 36 \\
150 \cdot 35 \\
152 \cdot 34 \\
154 \cdot 33\end{array}$ & $\begin{array}{l}146.56 \\
148.56 \\
150.55 \\
152.54 \\
154.53\end{array}$ & $\begin{array}{l}146.76 \\
148.76 \\
150.75 \\
152.74 \\
154.72\end{array}$ & $\begin{array}{l}146.96 \\
148.96 \\
150.95 \\
152.94 \\
154.92\end{array}$ & $\begin{array}{l}147 \cdot 16 \\
149 \cdot 15 \\
151.15 \\
153 \cdot 14 \\
155 \cdot 12\end{array}$ & $\begin{array}{l}147 \cdot 36 \\
149 \cdot 35 \\
151 \cdot 35 \\
153 \cdot 34 \\
155 \cdot 32\end{array}$ & $\begin{array}{l}147.56 \\
149.55 \\
151.55 \\
153.53 \\
155.52\end{array}$ & $\begin{array}{l}147.76 \\
149.75 \\
151.75 \\
153.73 \\
155.72\end{array}$ & $\begin{array}{l}147.96 \\
149.95 \\
151.94 \\
153.93 \\
155.91\end{array}$ & $\begin{array}{l}6.50 \\
6.60 \\
6.70 \\
6.80 \\
6.90\end{array}$ \\
\hline $\begin{array}{l}7.00 \\
7.10 \\
7.20 \\
7.30 \\
7.40\end{array}$ & $\begin{array}{l}155.91 \\
157.89 \\
159.86 \\
161.83 \\
163.79\end{array}$ & $\begin{array}{l}156.11 \\
158.09 \\
160.06 \\
162.03 \\
163.99\end{array}$ & $\begin{array}{l}156 \cdot 31 \\
158 \cdot 28 \\
160.26 \\
162 \cdot 22 \\
164.18\end{array}$ & $\begin{array}{l}156.51 \\
158.48 \\
160.45 \\
162.42 \\
164.38\end{array}$ & $\begin{array}{l}156 \cdot 70 \\
158.68 \\
160.65 \\
162.62 \\
164.58\end{array}$ & $\begin{array}{l}156.90 \\
158.88 \\
160.85 \\
162.81 \\
164.77\end{array}$ & $\begin{array}{l}157.10 \\
159.07 \\
161.04 \\
163.01 \\
164.97\end{array}$ & $\begin{array}{l}157.30 \\
159.27 \\
161.24 \\
163.20 \\
165.16\end{array}$ & $\begin{array}{l}157.50 \\
159.47 \\
161.44 \\
163.40 \\
165.36\end{array}$ & $\begin{array}{l}157.69 \\
159.67 \\
161.63 \\
163.60 \\
165.56\end{array}$ & $\begin{array}{l}157.89 \\
159.86 \\
161.83 \\
163.79 \\
165.75\end{array}$ & $\begin{array}{l}7.00 \\
7.10 \\
7.20 \\
7.30 \\
7.40\end{array}$ \\
\hline $\begin{array}{l}7.50 \\
7.60 \\
7.70 \\
7.80 \\
7.90\end{array}$ & $\begin{array}{l}165.75 \\
167.70 \\
169.65 \\
171.60 \\
173.54\end{array}$ & $\begin{array}{l}165.95 \\
167.90 \\
169.85 \\
171.79 \\
173.73\end{array}$ & $\begin{array}{l}166.14 \\
168.09 \\
170.04 \\
171.99 \\
173.93\end{array}$ & $\begin{array}{l}166.34 \\
168.29 \\
170.24 \\
172.18 \\
174.12\end{array}$ & $\begin{array}{l}166.53 \\
168.48 \\
170.43 \\
172.37 \\
174.31\end{array}$ & $\begin{array}{l}166.73 \\
168.68 \\
170.63 \\
172.57 \\
174.51\end{array}$ & $\begin{array}{l}166.92 \\
168.87 \\
170.82 \\
172.76 \\
174.70\end{array}$ & $\begin{array}{l}167.12 \\
169.07 \\
171.02 \\
172.96 \\
174.89\end{array}$ & $\begin{array}{l}167.31 \\
169.26 \\
171.21 \\
173.15 \\
175.09\end{array}$ & $\begin{array}{l}167.51 \\
169.46 \\
171.40 \\
173.34 \\
175.28\end{array}$ & $\begin{array}{l}167.70 \\
169.65 \\
171.60 \\
173.54 \\
175.47\end{array}$ & $\begin{array}{l}7.50 \\
7.60 \\
7.70 \\
7.80 \\
7.90\end{array}$ \\
\hline $\begin{array}{l}8.00 \\
8.10 \\
8.20 \\
8.30 \\
8.40\end{array}$ & $\begin{array}{l}175.47 \\
177.41 \\
179.33 \\
181.26 \\
183.17\end{array}$ & $\begin{array}{l}175.67 \\
177.60 \\
179.53 \\
181.45 \\
183.37\end{array}$ & $\begin{array}{l}175.86 \\
177.79 \\
179.72 \\
181.64 \\
183.56\end{array}$ & $\begin{array}{l}176.05 \\
177.98 \\
179.91 \\
181.83 \\
183.75\end{array}$ & $\begin{array}{l}176 \cdot 25 \\
178 \cdot 18 \\
180 \cdot 10 \\
182 \cdot 02 \\
183.94\end{array}$ & $\begin{array}{l}176.44 \\
178.37 \\
180.29 \\
182.22 \\
184.13\end{array}$ & $\begin{array}{l}176.63 \\
178.56 \\
180.49 \\
182.41 \\
184.32\end{array}$ & $\begin{array}{l}176.83 \\
178.76 \\
180.68 \\
182.60 \\
184.52\end{array}$ & $\begin{array}{l}177.02 \\
178.95 \\
180.87 \\
182.79 \\
184.71\end{array}$ & $\begin{array}{l}177.21 \\
179.14 \\
181.06 \\
182.98 \\
184.90\end{array}$ & $\begin{array}{l}177.41 \\
179.33 \\
181.26 \\
183.17 \\
185.09\end{array}$ & $\begin{array}{l}8.00 \\
8.10 \\
8.20 \\
8.30 \\
8.40\end{array}$ \\
\hline $\begin{array}{l}8.50 \\
8.60 \\
8.70 \\
8.80 \\
8.90\end{array}$ & $\begin{array}{l}185.09 \\
187.00 \\
188.91 \\
190.81 \\
192.71\end{array}$ & $\begin{array}{l}185.28 \\
187.19 \\
189.10 \\
191.00 \\
192.90\end{array}$ & $\begin{array}{l}185.47 \\
187.38 \\
189.29 \\
191.19 \\
193.09\end{array}$ & $\begin{array}{l}185.66 \\
187.57 \\
189.48 \\
191.38 \\
193.28\end{array}$ & $\begin{array}{l}185.85 \\
187.76 \\
189.67 \\
191.57 \\
193.47\end{array}$ & $\begin{array}{l}186.05 \\
187.95 \\
189.86 \\
191.76 \\
193.65\end{array}$ & $\begin{array}{l}186.24 \\
188.14 \\
190.05 \\
191.95 \\
193.84\end{array}$ & $\begin{array}{l}186.43 \\
188.33 \\
190.24 \\
192.14 \\
194.03\end{array}$ & $\begin{array}{l}186.62 \\
188.53 \\
190.43 \\
192.33 \\
194.22\end{array}$ & $\begin{array}{l}186.81 \\
188.72 \\
190.62 \\
192.52 \\
194.41\end{array}$ & $\begin{array}{l}187.00 \\
188.91 \\
190.81 \\
192.71 \\
194.60\end{array}$ & $\begin{array}{l}8.50 \\
8.60 \\
8.70 \\
8.80 \\
8.90\end{array}$ \\
\hline $\begin{array}{l}9.00 \\
9.10 \\
9.20 \\
9.30 \\
9.40\end{array}$ & $\begin{array}{l}194.60 \\
196.49 \\
198.38 \\
200 \cdot 26 \\
202 \cdot 14\end{array}$ & $\begin{array}{l}194.79 \\
196.68 \\
198.57 \\
200.45 \\
202.33\end{array}$ & $\begin{array}{l}194.98 \\
196.87 \\
198.76 \\
200.64 \\
202.52\end{array}$ & $\begin{array}{l}195.17 \\
197.06 \\
198.94 \\
200.83 \\
202.70\end{array}$ & $\begin{array}{l}195.36 \\
197.25 \\
199.13 \\
201.01 \\
202.89\end{array}$ & $\begin{array}{l}195.55 \\
197.44 \\
199.32 \\
201.20 \\
203.08\end{array}$ & $\begin{array}{l}195.74 \\
197.62 \\
199.51 \\
201.39 \\
203.27\end{array}$ & $\begin{array}{l}195.93 \\
197.81 \\
199.70 \\
201.58 \\
203.45\end{array}$ & $\begin{array}{l}196.11 \\
198.00 \\
199.89 \\
201.77 \\
203.64\end{array}$ & $\begin{array}{l}196.30 \\
198.19 \\
200.07 \\
201.95 \\
203.83\end{array}$ & $\begin{array}{l}196.49 \\
198.38 \\
200.26 \\
202.14 \\
204.02\end{array}$ & $\begin{array}{l}9.00 \\
9.10 \\
9.20 \\
9.30 \\
9.40\end{array}$ \\
\hline $\begin{array}{l}9.50 \\
9.60 \\
9.70 \\
9.80 \\
9.90\end{array}$ & $\begin{array}{l}204.02 \\
205.89 \\
207.76 \\
209.62 \\
211.48\end{array}$ & $\begin{array}{l}204.20 \\
206.08 \\
207.94 \\
209.81 \\
211.67\end{array}$ & $\begin{array}{l}204 \cdot 39 \\
206 \cdot 26 \\
208 \cdot 13 \\
209 \cdot 99 \\
211 \cdot 85\end{array}$ & $\begin{array}{l}204.58 \\
206.45 \\
208.32 \\
210.18 \\
212.04\end{array}$ & $\begin{array}{l}204 \cdot 77 \\
206 \cdot 64 \\
208 \cdot 50 \\
210 \cdot 37 \\
212 \cdot 23\end{array}$ & $\begin{array}{l}204.95 \\
206.82 \\
208.69 \\
210.55 \\
212.41\end{array}$ & $\begin{array}{l}205.14 \\
207.01 \\
208.88 \\
210.74 \\
212.60\end{array}$ & $\begin{array}{l}205.33 \\
207.20 \\
209.06 \\
210.92 \\
212.78\end{array}$ & $\begin{array}{l}205.51 \\
207.38 \\
209.25 \\
211.11 \\
212.97\end{array}$ & $\begin{array}{l}205.70 \\
207.57 \\
209.43 \\
211.30 \\
213.15\end{array}$ & $\begin{array}{l}205.89 \\
207.76 \\
209.62 \\
211.48 \\
213.34\end{array}$ & $\begin{array}{r}9.50 \\
9.60 \\
9.70 \\
9.80 \\
9.90\end{array}$ \\
\hline $\begin{array}{l}10.00 \\
10.10 \\
10.20 \\
10.30 \\
10.40\end{array}$ & $\begin{array}{l}213.34 \\
215.19 \\
217.04 \\
218.89 \\
220.73\end{array}$ & $\begin{array}{l}213.52 \\
215.38 \\
217.23 \\
219.08 \\
220.92\end{array}$ & $\begin{array}{l}213.71 \\
215.56 \\
217.41 \\
219.26 \\
221.10\end{array}$ & $\begin{array}{l}213.90 \\
215.75 \\
217.60 \\
219.44 \\
221.29\end{array}$ & $\begin{array}{l}214.08 \\
215.93 \\
217.78 \\
219.63 \\
221.47\end{array}$ & $\begin{array}{l}214.27 \\
216.12 \\
217.97 \\
219.81 \\
221.65\end{array}$ & $\begin{array}{l}214 \cdot 45 \\
216 \cdot 30 \\
218 \cdot 15 \\
220 \cdot 00 \\
221.84\end{array}$ & $\begin{array}{l}214.64 \\
216.49 \\
218.34 \\
220.18 \\
222.02\end{array}$ & $\begin{array}{l}214 \cdot 82 \\
216.67 \\
218 \cdot 52 \\
220.37 \\
222 \cdot 21\end{array}$ & $\begin{array}{l}215.01 \\
216.86 \\
218.71 \\
220.55 \\
222.39\end{array}$ & $\begin{array}{l}215.19 \\
217.04 \\
218.89 \\
220.73 \\
222.57\end{array}$ & $\begin{array}{l}10.00 \\
10.10 \\
10.20 \\
10.30 \\
10.40\end{array}$ \\
\hline $\begin{array}{l}10.50 \\
10.60 \\
10.70 \\
10.80 \\
10.90\end{array}$ & $\begin{array}{l}222.57 \\
224.41 \\
226.24 \\
228.08 \\
229.90\end{array}$ & $\begin{array}{l}222.76 \\
224.59 \\
226.43 \\
228.26 \\
230.08\end{array}$ & $\begin{array}{l}222.94 \\
224.78 \\
226.61 \\
228.44 \\
230.27\end{array}$ & $\begin{array}{l}223.13 \\
224.96 \\
226.79 \\
228.62 \\
230.45\end{array}$ & $\begin{array}{l}223.31 \\
225.15 \\
226.98 \\
228.81 \\
230.63\end{array}$ & $\begin{array}{l}223.49 \\
225.33 \\
227.16 \\
228.99 \\
230.81\end{array}$ & $\begin{array}{l}223.68 \\
225.51 \\
227.34 \\
229.17 \\
231.00\end{array}$ & $\begin{array}{l}223.86 \\
225.70 \\
227.53 \\
229.35 \\
231.18\end{array}$ & $\begin{array}{l}224.04 \\
225.88 \\
227.71 \\
229.54 \\
231.36\end{array}$ & $\begin{array}{l}224.23 \\
226.06 \\
227.89 \\
229.72 \\
231.54\end{array}$ & $\begin{array}{l}224.41 \\
226.24 \\
228.08 \\
229.90 \\
231.73\end{array}$ & $\begin{array}{l}10.50 \\
10.60 \\
10.70 \\
10.80 \\
10.90\end{array}$ \\
\hline $\begin{array}{l}11.00 \\
11.10 \\
11.20 \\
11.30 \\
11.40\end{array}$ & $\begin{array}{l}231.73 \\
233.55 \\
235.36 \\
237.18 \\
238.99\end{array}$ & $\begin{array}{l}231.91 \\
233.73 \\
235.55 \\
237.36 \\
239.17\end{array}$ & $\begin{array}{l}232.09 \\
233.91 \\
235.73 \\
237.54 \\
239.35\end{array}$ & $\begin{array}{l}232.27 \\
234.09 \\
235.91 \\
237.72 \\
239.53\end{array}$ & $\begin{array}{l}232.45 \\
234.27 \\
236.09 \\
237.90 \\
239.71\end{array}$ & $\begin{array}{l}232.64 \\
234.46 \\
236.27 \\
238.09 \\
239.90\end{array}$ & $\begin{array}{l}232.82 \\
234.64 \\
236.45 \\
238.27 \\
240.08\end{array}$ & $\begin{array}{l}233.00 \\
234.82 \\
236.64 \\
238.45 \\
240.26\end{array}$ & $\begin{array}{l}233.18 \\
235.00 \\
236.82 \\
238.63 \\
240.44\end{array}$ & $\begin{array}{l}233.37 \\
235.18 \\
237.00 \\
238.81 \\
240.62\end{array}$ & $\begin{array}{l}233.55 \\
235.36 \\
237.18 \\
238.99 \\
240.80\end{array}$ & $\begin{array}{l}11.00 \\
11.10 \\
11.20 \\
11.30 \\
11.40\end{array}$ \\
\hline $\begin{array}{l}11.50 \\
11.60 \\
11.70 \\
11.80 \\
11.90\end{array}$ & $\begin{array}{l}240.80 \\
242.60 \\
244.41 \\
246.21 \\
248.00\end{array}$ & $\begin{array}{l}240.98 \\
242.79 \\
244.59 \\
246.39 \\
248.18\end{array}$ & $\begin{array}{l}241.16 \\
242.97 \\
244.77 \\
246.57 \\
248.36\end{array}$ & $\begin{array}{l}241.34 \\
243.15 \\
244.95 \\
246.75 \\
248.54\end{array}$ & $\begin{array}{l}241.52 \\
243.33 \\
245.13 \\
246.93 \\
248.72\end{array}$ & $\begin{array}{l}241.70 \\
243.51 \\
245.31 \\
247.11 \\
248.90\end{array}$ & $\begin{array}{l}241.88 \\
243.69 \\
245.49 \\
247.29 \\
249.08\end{array}$ & $\begin{array}{l}242.06 \\
243.87 \\
245.67 \\
247.46 \\
249.26\end{array}$ & $\begin{array}{l}242.24 \\
244.05 \\
245.85 \\
247.64 \\
249.44\end{array}$ & $\begin{array}{l}242.42 \\
244.23 \\
246.03 \\
247.82 \\
249.62\end{array}$ & $\begin{array}{l}242.60 \\
244.41 \\
246.21 \\
248.00 \\
249.80\end{array}$ & $\begin{array}{l}11.50 \\
11.60 \\
11.70 \\
11.80 \\
11.90\end{array}$ \\
\hline 12.00 & 249.80 & $249 \cdot 98$ & 250.16 & 250.34 & 250.51 & 250.69 & 250.87 & 251.05 & 251.23 & 251.41 & 251.59 & 12.00 \\
\hline
\end{tabular}


TABLE A8.2.1. Type T thermocouples-temperature $\left({ }^{\circ} \mathrm{C}\right)$ as a function of thermoelectric voltage, reference junctions at $0^{\circ} \mathrm{C}$-Continued

$m v$

.0

.02

.03

TEMPERATURES IN DEGREES C (IPTS 1968)

\begin{tabular}{|c|c|c|c|c|c|c|c|c|c|c|c|c|}
\hline $\begin{array}{l}12.00 \\
12.10 \\
12.20 \\
12.30 \\
12.40\end{array}$ & $\begin{array}{l}249.80 \\
251.59 \\
253.38 \\
255.16 \\
256.94\end{array}$ & $\begin{array}{l}249.98 \\
251.77 \\
253.56 \\
255.34 \\
257.12\end{array}$ & $\begin{array}{l}250 \cdot 16 \\
251 \cdot 95 \\
253 \cdot 73 \\
255 \cdot 52 \\
257 \cdot 30\end{array}$ & $\begin{array}{l}250.34 \\
252.13 \\
253.91 \\
255.70 \\
257.48\end{array}$ & $\begin{array}{l}250 \cdot 51 \\
252 \cdot 30 \\
254 \cdot 09 \\
255 \cdot 88 \\
257 \cdot 66\end{array}$ & $\begin{array}{l}250.69 \\
252.48 \\
254.27 \\
256.05 \\
257.84\end{array}$ & $\begin{array}{l}250.87 \\
252.66 \\
254.45 \\
256.23 \\
258.01\end{array}$ & $\begin{array}{l}251.05 \\
252.84 \\
254.63 \\
256.41 \\
258.19\end{array}$ & $\begin{array}{l}251.23 \\
253.02 \\
254.81 \\
256.59 \\
258.37\end{array}$ & $\begin{array}{l}251.41 \\
253.20 \\
254.98 \\
256.77 \\
258.55\end{array}$ & $\begin{array}{l}251.59 \\
253.38 \\
255.16 \\
256.94 \\
258.72\end{array}$ & $\begin{array}{l}12.00 \\
12.10 \\
12.20 \\
12.30 \\
12.40\end{array}$ \\
\hline $\begin{array}{l}12.50 \\
12.60 \\
12.70 \\
12.80 \\
12.90\end{array}$ & $\begin{array}{l}258.72 \\
260.50 \\
262.28 \\
264.05 \\
265.82\end{array}$ & $\begin{array}{l}258.90 \\
260.68 \\
262.45 \\
264.23 \\
265.99\end{array}$ & $\begin{array}{l}259.08 \\
260.86 \\
262.63 \\
264.40 \\
266.17\end{array}$ & $\begin{array}{l}259.26 \\
261.03 \\
262.81 \\
264.58 \\
266.35\end{array}$ & $\begin{array}{l}259 \cdot 44 \\
261 \cdot 21 \\
262 \cdot 99 \\
264 \cdot 76 \\
266 \cdot 52\end{array}$ & $\begin{array}{l}259.61 \\
261.39 \\
263.16 \\
264.93 \\
266.70\end{array}$ & $\begin{array}{l}259.79 \\
261.57 \\
263.34 \\
265.11 \\
266.88\end{array}$ & $\begin{array}{l}259.97 \\
261.74 \\
263.52 \\
265.29 \\
267.05\end{array}$ & $\begin{array}{l}260.15 \\
261.92 \\
263.69 \\
265.46 \\
267.23\end{array}$ & $\begin{array}{l}260.32 \\
262.10 \\
263.87 \\
265.64 \\
267.41\end{array}$ & $\begin{array}{l}260.50 \\
262.28 \\
264.05 \\
265.82 \\
267.58\end{array}$ & $\begin{array}{l}12.50 \\
12.60 \\
12.70 \\
12.80 \\
12.90\end{array}$ \\
\hline $\begin{array}{l}13.00 \\
13.10 \\
13.20 \\
13.30 \\
13.40\end{array}$ & $\begin{array}{l}267.58 \\
269.35 \\
271.11 \\
272.87 \\
274.63\end{array}$ & $\begin{array}{l}267.76 \\
269.53 \\
271.29 \\
273.05 \\
274.80\end{array}$ & $\begin{array}{l}267.94 \\
269.70 \\
271.46 \\
273.22 \\
274.98\end{array}$ & $\begin{array}{l}268.11 \\
269.88 \\
271.64 \\
273.40 \\
275.15\end{array}$ & $\begin{array}{l}268.29 \\
270.05 \\
271.81 \\
273.57 \\
275.33\end{array}$ & $\begin{array}{l}268.47 \\
270.23 \\
271.99 \\
273.75 \\
275.50\end{array}$ & $\begin{array}{l}268.64 \\
270.41 \\
272.17 \\
273.92 \\
275.68\end{array}$ & $\begin{array}{l}268.82 \\
270.58 \\
272.34 \\
274.10 \\
275.85\end{array}$ & $\begin{array}{l}269.00 \\
270.76 \\
272.52 \\
274.28 \\
276.03\end{array}$ & $\begin{array}{l}269.17 \\
270.93 \\
272.69 \\
274.45 \\
276.21\end{array}$ & $\begin{array}{l}269.35 \\
271.11 \\
272.87 \\
274.63 \\
276.38\end{array}$ & $\begin{array}{l}13.00 \\
13.10 \\
13.20 \\
13.30 \\
13.40\end{array}$ \\
\hline $\begin{array}{l}13.50 \\
13.60 \\
13.70 \\
13.80 \\
13.90\end{array}$ & $\begin{array}{l}276.38 \\
278.13 \\
279.88 \\
281.63 \\
283.37\end{array}$ & $\begin{array}{l}276.56 \\
278.31 \\
280.06 \\
281.80 \\
283.55\end{array}$ & $\begin{array}{l}276.73 \\
278.48 \\
280.23 \\
281.98 \\
283.72\end{array}$ & $\begin{array}{l}276.91 \\
278.66 \\
280.41 \\
282.15 \\
283.90\end{array}$ & $\begin{array}{l}277.08 \\
278.83 \\
280.58 \\
282.33 \\
284.07\end{array}$ & $\begin{array}{l}277.26 \\
279.01 \\
280.76 \\
282.50 \\
284.24\end{array}$ & $\begin{array}{l}277.43 \\
279.18 \\
280.93 \\
282.68 \\
284.42\end{array}$ & $\begin{array}{l}277.61 \\
279.36 \\
281.10 \\
282.85 \\
284.59\end{array}$ & $\begin{array}{l}277.78 \\
279.53 \\
281.28 \\
283.02 \\
284.77\end{array}$ & $\begin{array}{l}277.96 \\
279.71 \\
281.45 \\
283.20 \\
284.94\end{array}$ & $\begin{array}{l}278.13 \\
279.88 \\
281.63 \\
283.37 \\
285.12\end{array}$ & $\begin{array}{l}13.50 \\
13.60 \\
13.70 \\
13.80 \\
13.90\end{array}$ \\
\hline $\begin{array}{l}14.00 \\
14.10 \\
14.20 \\
14.30 \\
14.40\end{array}$ & $\begin{array}{l}285.12 \\
286.86 \\
288.59 \\
290 \cdot 33 \\
292.06\end{array}$ & $\begin{array}{l}285.29 \\
287.03 \\
288.77 \\
290.50 \\
292.23\end{array}$ & $\begin{array}{l}285.46 \\
287.20 \\
288.94 \\
290.67 \\
292.41\end{array}$ & $\begin{array}{l}285.64 \\
287.38 \\
289.11 \\
290.85 \\
292.58\end{array}$ & $\begin{array}{l}285.81 \\
287.55 \\
289.29 \\
291.02 \\
292.75 .\end{array}$ & $\begin{array}{l}285.99 \\
287.72 \\
289.46 \\
291.19 \\
292.93\end{array}$ & $\begin{array}{l}286.16 \\
287.90 \\
289.63 \\
291.37 \\
293.10\end{array}$ & $\begin{array}{l}286.33 \\
288.07 \\
289.81 \\
291.54 \\
293.27\end{array}$ & $\begin{array}{l}286.51 \\
288.25 \\
289.98 \\
291.71 \\
293.45\end{array}$ & $\begin{array}{l}286.68 \\
288.42 \\
290.15 \\
291.89 \\
293.62\end{array}$ & $\begin{array}{l}286.86 \\
288.59 \\
290.33 \\
292.06 \\
293.79\end{array}$ & $\begin{array}{l}14.00 \\
14.10 \\
14.20 \\
14.30 \\
14.40\end{array}$ \\
\hline $\begin{array}{l}14.50 \\
14.60 \\
14.70 \\
14.80 \\
14.90\end{array}$ & $\begin{array}{l}293.79 \\
295.52 \\
297.25 \\
298.97 \\
300.69\end{array}$ & $\begin{array}{l}293.96 \\
295.69 \\
297.42 \\
299.14 \\
300.86\end{array}$ & $\begin{array}{l}294.14 \\
295.87 \\
297.59 \\
299.31 \\
301.04\end{array}$ & $\begin{array}{l}294.31 \\
296.04 \\
297.76 \\
299.49 \\
301.21\end{array}$ & $\begin{array}{l}294.49 \\
296.21 \\
297.94 \\
299.66 \\
301.38\end{array}$ & $\begin{array}{l}294.66 \\
296.38 \\
298.11 \\
299.83 \\
301.55\end{array}$ & $\begin{array}{l}294.83 \\
296.56 \\
298.28 \\
300.00 \\
301.72\end{array}$ & $\begin{array}{l}295.00 \\
296.73 \\
298.45 \\
300.18 \\
301.90\end{array}$ & $\begin{array}{l}295.17 \\
296.90 \\
298.63 \\
300.35 \\
302.07\end{array}$ & $\begin{array}{l}295.35 \\
297.07 \\
298.80 \\
300.52 \\
302.24\end{array}$ & $\begin{array}{l}295.52 \\
297.25 \\
298.97 \\
300.69 \\
302.41\end{array}$ & $\begin{array}{l}14.50 \\
14.60 \\
14.70 \\
14.80 \\
14.90\end{array}$ \\
\hline $\begin{array}{l}15.00 \\
15.10 \\
15.20 \\
15.30 \\
15.40\end{array}$ & $\begin{array}{l}302 \cdot 41 \\
304.13 \\
305.84 \\
307.56 \\
309.27\end{array}$ & $\begin{array}{l}302 \cdot 58 \\
304 \cdot 30 \\
306.02 \\
307.73 \\
309.44\end{array}$ & $\begin{array}{l}302.76 \\
304.47 \\
306.19 \\
307.90 \\
309.61\end{array}$ & $\begin{array}{l}302.93 \\
304.64 \\
306.36 \\
308.07 \\
309.78\end{array}$ & $\begin{array}{l}303.10 \\
304.82 \\
306.53 \\
308.24 \\
309.95\end{array}$ & $\begin{array}{l}303.27 \\
304.99 \\
306.70 \\
308.41 \\
310.12\end{array}$ & $\begin{array}{l}303.44 \\
305.16 \\
306.87 \\
308.58 \\
310.29\end{array}$ & $\begin{array}{l}303.61 \\
305.33 \\
307.04 \\
308.76 \\
310.46\end{array}$ & $\begin{array}{l}303.79 \\
305.50 \\
307.21 \\
308.93 \\
310.64\end{array}$ & $\begin{array}{l}303.96 \\
305.67 \\
307.39 \\
309.10 \\
310.81\end{array}$ & $\begin{array}{l}304.13 \\
305.84 \\
307.56 \\
309.27 \\
310.98\end{array}$ & $\begin{array}{l}15.00 \\
15.10 \\
15.20 \\
15.30 \\
15.40\end{array}$ \\
\hline $\begin{array}{l}15.50 \\
15.60 \\
15.70 \\
15.80 \\
15.90\end{array}$ & $\begin{array}{l}310.98 \\
312.68 \\
314.39 \\
316.09 \\
317.79\end{array}$ & $\begin{array}{l}311.15 \\
312.85 \\
314.56 \\
316.26 \\
317.96\end{array}$ & $\begin{array}{l}311.32 \\
313.03 \\
314.73 \\
316.43 \\
318.13\end{array}$ & $\begin{array}{l}311.49 \\
313.20 \\
314.90 \\
316.60 \\
318.30\end{array}$ & $\begin{array}{l}311.66 \\
313.37 \\
315.07 \\
316.77 \\
318.47\end{array}$ & $\begin{array}{l}311.83 \\
313.54 \\
315.24 \\
316.94 \\
318.64\end{array}$ & $\begin{array}{l}312.00 \\
313.71 \\
315.41 \\
317.11 \\
318.81\end{array}$ & $\begin{array}{l}312.17 \\
313.88 \\
315.58 \\
317.28 \\
318.98\end{array}$ & $\begin{array}{l}312.34 \\
314.05 \\
315.75 \\
317.45 \\
319.15\end{array}$ & $\begin{array}{l}312.51 \\
314.22 \\
315.92 \\
317.62 \\
319.32\end{array}$ & $\begin{array}{l}312.68 \\
314.39 \\
316.09 \\
317.79 \\
319.49\end{array}$ & $\begin{array}{l}15.50 \\
15.60 \\
15.70 \\
15.80 \\
15.90\end{array}$ \\
\hline $\begin{array}{l}16.00 \\
16.10 \\
16.20 \\
16.30 \\
16.40\end{array}$ & $\begin{array}{l}319.49 \\
321.19 \\
322.88 \\
324.57 \\
326.26\end{array}$ & $\begin{array}{l}319.66 \\
321.36 \\
323.05 \\
324.74 \\
326.43\end{array}$ & $\begin{array}{l}319.83 \\
321.53 \\
323.22 \\
324.91 \\
326.60\end{array}$ & $\begin{array}{l}320.00 \\
321.70 \\
323.39 \\
325.08 \\
326.77\end{array}$ & $\begin{array}{l}320.17 \\
321.87 \\
323.56 \\
325.25 \\
326.94\end{array}$ & $\begin{array}{l}320.34 \\
322.03 \\
323.73 \\
325.42 \\
327.11\end{array}$ & $\begin{array}{l}320 \cdot 51 \\
322 \cdot 20 \\
323.90 \\
325.59 \\
327.28\end{array}$ & $\begin{array}{l}320.68 \\
322.37 \\
324.07 \\
325.76 \\
327.45\end{array}$ & $\begin{array}{l}320.85 \\
322.54 \\
324.24 \\
325.93 \\
327.62\end{array}$ & $\begin{array}{l}321.02 \\
322.71 \\
324.41 \\
326.10 \\
327.78\end{array}$ & $\begin{array}{l}321.19 \\
322.88 \\
324.57 \\
326.26 \\
327.95\end{array}$ & $\begin{array}{l}16.00 \\
16.10 \\
16.20 \\
16.30 \\
16.40\end{array}$ \\
\hline $\begin{array}{l}16.50 \\
16.60 \\
16.70 \\
16.80 \\
16.90\end{array}$ & $\begin{array}{l}327.95 \\
329.64 \\
331.32 \\
333.01 \\
334.69\end{array}$ & $\begin{array}{l}328.12 \\
329.81 \\
331.49 \\
333.18 \\
334.86\end{array}$ & $\begin{array}{l}328.29 \\
329.98 \\
331.66 \\
333.34 \\
335.02\end{array}$ & $\begin{array}{l}328.46 \\
330.15 \\
331.83 \\
333.51 \\
335.19\end{array}$ & $\begin{array}{l}328.63 \\
330.31 \\
332.00 \\
333.68 \\
335.36\end{array}$ & $\begin{array}{l}328.80 \\
330.48 \\
332.17 \\
333.85 \\
335.53\end{array}$ & $\begin{array}{l}328.97 \\
330.65 \\
332.33 \\
334.02 \\
335.70\end{array}$ & $\begin{array}{l}329.13 \\
330.82 \\
332.50 \\
334.18 \\
335.86\end{array}$ & $\begin{array}{l}329.30 \\
330.99 \\
332.67 \\
334.35 \\
336.03\end{array}$ & $\begin{array}{l}329.47 \\
331.16 \\
332.84 \\
334.52 \\
336.20\end{array}$ & $\begin{array}{l}329.64 \\
331.32 \\
333.01 \\
334.69 \\
336.37\end{array}$ & $\begin{array}{l}16.50 \\
16.60 \\
16.70 \\
16.80 \\
16.90\end{array}$ \\
\hline $\begin{array}{l}17.00 \\
17.10 \\
17.20 \\
17.30 \\
17.40\end{array}$ & $\begin{array}{l}336.37 \\
338.04 \\
339.72 \\
341.39 \\
343.06\end{array}$ & $\begin{array}{l}336.53 \\
338.21 \\
339.89 \\
341.56 \\
343.23\end{array}$ & $\begin{array}{l}336.70 \\
338.38 \\
340.05 \\
341.73 \\
343.40\end{array}$ & $\begin{array}{l}336.87 \\
338.55 \\
340.22 \\
341.89 \\
343.56\end{array}$ & $\begin{array}{l}337.04 \\
338.71 \\
340.39 \\
342.06 \\
343.73\end{array}$ & $\begin{array}{l}337.21 \\
338.88 \\
340.55 \\
342.23 \\
343.90\end{array}$ & $\begin{array}{l}337.37 \\
339.05 \\
340.72 \\
342.39 \\
344.06\end{array}$ & $\begin{array}{l}337.54 \\
339.22 \\
340.89 \\
342.56 \\
344.23\end{array}$ & $\begin{array}{l}337.71 \\
339.38 \\
341.06 \\
342.73 \\
344.40\end{array}$ & $\begin{array}{l}337.88 \\
339.55 \\
341.22 \\
342.90 \\
344.56\end{array}$ & $\begin{array}{l}338.04 \\
339.72 \\
341.39 \\
343.06 \\
344.73\end{array}$ & $\begin{array}{l}17.00 \\
17.10 \\
17.20 \\
17.30 \\
17.40\end{array}$ \\
\hline $\begin{array}{l}17.50 \\
17.60 \\
17.70 \\
17.80 \\
17.90\end{array}$ & $\begin{array}{l}344.73 \\
346.40 \\
348.06 \\
349.73 \\
351.39\end{array}$ & $\begin{array}{l}344.90 \\
346.57 \\
348.23 \\
349.89 \\
351.56\end{array}$ & $\begin{array}{l}345.07 \\
346.73 \\
348.40 \\
350.06 \\
351.72\end{array}$ & $\begin{array}{l}345.23 \\
346.90 \\
348.56 \\
350.23 \\
351.89\end{array}$ & $\begin{array}{l}345.40 \\
347.07 \\
348.73 \\
350.39 \\
352.05\end{array}$ & $\begin{array}{l}345.57 \\
347.23 \\
348.90 \\
350.56 \\
352.22\end{array}$ & $\begin{array}{l}345.73 \\
347.40 \\
349.06 \\
350.73 \\
352.39\end{array}$ & $\begin{array}{l}345.90 \\
347.56 \\
349.23 \\
350.89 \\
352.55\end{array}$ & $\begin{array}{l}346.07 \\
347.73 \\
349.40 \\
351.06 \\
352.72\end{array}$ & $\begin{array}{l}346.23 \\
347.90 \\
349.56 \\
351.22 \\
352.88\end{array}$ & $\begin{array}{l}346.40 \\
348.06 \\
349.73 \\
351.39 \\
353.05\end{array}$ & $\begin{array}{l}17.50 \\
17.60 \\
17.70 \\
17.80 \\
17.90\end{array}$ \\
\hline 18.00 & 353.05 & 353.22 & 353.38 & 353.55 & 353.71 & 353.88 & 354.04 & 354.21 & $354 \cdot 38$ & 354.54 & 354.71 & 18.00 \\
\hline
\end{tabular}

$.00 \quad .01$

.02

.03

.04

.05

.06

.07

.08

.09

- 10

$m V$ 
TABLE A8.2.1. Type $\boldsymbol{T}$ thermocouples-temperature $\left({ }^{\circ} \mathrm{C}\right)$ as a function of thermoelectric voltage, reference junctions at $0^{\circ} \mathrm{C}$-Continued

\begin{tabular}{|c|c|c|c|c|c|c|c|c|c|c|c|c|}
\hline $\mathrm{mV}$ & .00 & .01 & .02 & $\begin{array}{l}.03 \\
\text { TEMPE }\end{array}$ & $\begin{array}{l}.04 \\
\text { ATURES IN }\end{array}$ & $\begin{array}{c}.05 \\
\text { DEGREES }\end{array}$ & $\begin{array}{c}.06 \\
\text { C IIPTS }\end{array}$ & $\begin{array}{l}.07 \\
19681\end{array}$ & .08 & .09 & .10 & $\mathrm{mV}$ \\
\hline $\begin{array}{l}18.00 \\
18.10 \\
18.20 \\
18.30 \\
18.40\end{array}$ & $\begin{array}{l}353.05 \\
354.71 \\
356.36 \\
358.02 \\
359.67\end{array}$ & $\begin{array}{l}353.22 \\
354.87 \\
356.53 \\
358.18 \\
359.84\end{array}$ & $\begin{array}{l}353 \cdot 38 \\
355.04 \\
356.70 \\
358.35 \\
360.00\end{array}$ & $\begin{array}{l}353.55 \\
355.21 \\
356.86 \\
358.52 \\
360.17\end{array}$ & $\begin{array}{l}353.71 \\
355.37 \\
357.03 \\
358.68 \\
360.33\end{array}$ & $\begin{array}{l}353.88 \\
355.54 \\
357.19 \\
358.85 \\
360.50\end{array}$ & $\begin{array}{l}354.04 \\
355.70 \\
357.36 \\
359.01 \\
360.66\end{array}$ & $\begin{array}{l}354.21 \\
355.87 \\
357.52 \\
359.18 \\
360.83\end{array}$ & $\begin{array}{l}354 \cdot 38 \\
356.03 \\
357.69 \\
359.34 \\
360.99\end{array}$ & $\begin{array}{l}354.54 \\
356.20 \\
357.85 \\
359.51 \\
361.16\end{array}$ & $\begin{array}{l}354.71 \\
356.36 \\
358.02 \\
359.67 \\
361.32\end{array}$ & $\begin{array}{l}18.00 \\
18.10 \\
18.20 \\
18.30 \\
18.40\end{array}$ \\
\hline $\begin{array}{l}18.50 \\
18.60 \\
18.70 \\
18.80 \\
18.90\end{array}$ & $\begin{array}{l}361.32 \\
362.97 \\
364.62 \\
366.27 \\
367.91\end{array}$ & $\begin{array}{l}361.49 \\
363 \cdot 14 \\
364.78 \\
366.43 \\
368 \cdot 08\end{array}$ & $\begin{array}{l}361.65 \\
363.30 \\
364.95 \\
366.60 \\
368.24\end{array}$ & $\begin{array}{l}361.82 \\
363.47 \\
365.11 \\
366.76 \\
368.40\end{array}$ & $\begin{array}{l}361.98 \\
363.63 \\
365.28 \\
366.92 \\
368.57\end{array}$ & $\begin{array}{l}362.15 \\
363.80 \\
365.44 \\
367.09 \\
368.73\end{array}$ & $\begin{array}{l}362.31 \\
363.96 \\
365.61 \\
367.25 \\
368.90\end{array}$ & $\begin{array}{l}362.48 \\
364.13 \\
365.77 \\
367.42 \\
369.06\end{array}$ & $\begin{array}{l}362.64 \\
364.29 \\
365.94 \\
367.58 \\
369.23\end{array}$ & $\begin{array}{l}362.81 \\
364.46 \\
366.10 \\
367.75 \\
369.39\end{array}$ & $\begin{array}{l}362.97 \\
364.62 \\
366.27 \\
367.91 \\
369.55\end{array}$ & $\begin{array}{l}18.50 \\
18.60 \\
18.70 \\
18.80 \\
18.90\end{array}$ \\
\hline $\begin{array}{l}19.00 \\
19.10 \\
19.20 \\
19.30 \\
19.40\end{array}$ & $\begin{array}{l}369.55 \\
371.19 \\
372.83 \\
374.47 \\
376.11\end{array}$ & $\begin{array}{l}369.72 \\
371.36 \\
373.00 \\
374.64 \\
376.27\end{array}$ & $\begin{array}{l}369.88 \\
371.52 \\
373.16 \\
374.80 \\
376.44\end{array}$ & $\begin{array}{l}370.05 \\
371.69 \\
373.33 \\
374.96 \\
376.60\end{array}$ & $\begin{array}{l}370.21 \\
371.85 \\
373.49 \\
375.13 \\
376.76\end{array}$ & $\begin{array}{l}370.37 \\
372.01 \\
373.65 \\
375.29 \\
376.93\end{array}$ & $\begin{array}{l}370 \cdot 54 \\
372 \cdot 18 \\
373 \cdot 82 \\
375.45 \\
377.09\end{array}$ & $\begin{array}{l}370.70 \\
372.34 \\
373.98 \\
375.62 \\
377.25\end{array}$ & $\begin{array}{l}370.87 \\
372.51 \\
374.14 \\
375.78 \\
377.42\end{array}$ & $\begin{array}{l}371.03 \\
372.67 \\
374.31 \\
375.95 \\
377.58\end{array}$ & $\begin{array}{l}371.19 \\
372.83 \\
374.47 \\
376.11 \\
377.74\end{array}$ & $\begin{array}{l}19.00 \\
19.10 \\
19.20 \\
19.30 \\
19.40\end{array}$ \\
\hline $\begin{array}{l}19.50 \\
19.60 \\
19.70 \\
19.80 \\
19.90\end{array}$ & $\begin{array}{l}377.74 \\
379.38 \\
381.01 \\
382.64 \\
384.27\end{array}$ & $\begin{array}{l}377.91 \\
379.54 \\
381.17 \\
382.80 \\
384.43\end{array}$ & $\begin{array}{l}378.07 \\
379.70 \\
381.34 \\
382.97 \\
384.60\end{array}$ & $\begin{array}{l}378.23 \\
379.87 \\
381.50 \\
383.13 \\
384.76\end{array}$ & $\begin{array}{l}378.40 \\
380.03 \\
381.66 \\
383.29 \\
384.92\end{array}$ & $\begin{array}{l}378.56 \\
380.19 \\
381.82 \\
383.45 \\
385.08\end{array}$ & $\begin{array}{l}378.72 \\
380.36 \\
381.99 \\
383.62 \\
385.25\end{array}$ & $\begin{array}{l}378.89 \\
380.52 \\
382.15 \\
383.78 \\
385.41\end{array}$ & $\begin{array}{l}379.05 \\
380.68 \\
382.31 \\
383.94 \\
385.57\end{array}$ & $\begin{array}{l}379.21 \\
380.85 \\
382.48 \\
384.11 \\
385.73\end{array}$ & $\begin{array}{l}379 \cdot 38 \\
381.01 \\
382.64 \\
384 \cdot 27 \\
385.90\end{array}$ & $\begin{array}{l}19.50 \\
19.60 \\
19.70 \\
19.80 \\
19.90\end{array}$ \\
\hline $\begin{array}{l}20 \cdot 00 \\
20 \cdot 10 \\
20 \cdot 20 \\
20 \cdot 30 \\
20 \cdot 40\end{array}$ & $\begin{array}{l}385.90 \\
387.52 \\
389.15 \\
390.77 \\
392.40\end{array}$ & $\begin{array}{l}386.06 \\
387.69 \\
389.31 \\
390.94 \\
392.56\end{array}$ & $\begin{array}{l}386.22 \\
387.85 \\
389.47 \\
391.10 \\
392.72\end{array}$ & $\begin{array}{l}386.39 \\
388.01 \\
389.64 \\
391.26 \\
392.88\end{array}$ & $\begin{array}{l}386.55 \\
388.17 \\
389.80 \\
391.42 \\
393.05\end{array}$ & $\begin{array}{l}386.71 \\
388.34 \\
389.96 \\
391.59 \\
393.21\end{array}$ & $\begin{array}{l}386.87 \\
388.50 \\
390.12 \\
391.75 \\
393.37\end{array}$ & $\begin{array}{l}387.04 \\
388.66 \\
390.29 \\
391.91 \\
393.53\end{array}$ & $\begin{array}{l}387.20 \\
388.82 \\
390.45 \\
392.07 \\
393.70\end{array}$ & $\begin{array}{l}387.36 \\
388.99 \\
390.61 \\
392.23 \\
393.86\end{array}$ & $\begin{array}{l}387.52 \\
389.15 \\
390.77 \\
392.40 \\
394.02\end{array}$ & $\begin{array}{l}20 \cdot 00 \\
20.10 \\
20 \cdot 20 \\
20 \cdot 30 \\
20.40\end{array}$ \\
\hline $\begin{array}{l}20.50 \\
20.60 \\
20.70 \\
20.80\end{array}$ & $\begin{array}{l}394.02 \\
395.64 \\
397.26 \\
398.88\end{array}$ & $\begin{array}{l}394.18 \\
395.80 \\
397.42 \\
399.04\end{array}$ & $\begin{array}{l}394.34 \\
395.96 \\
397.58 \\
399.20\end{array}$ & $\begin{array}{l}394.51 \\
396.13 \\
397.75 \\
399.37\end{array}$ & $\begin{array}{l}394.67 \\
396.29 \\
397.91 \\
399.53\end{array}$ & $\begin{array}{l}394.83 \\
396.45 \\
398.07 \\
399.69\end{array}$ & $\begin{array}{l}394.99 \\
396.61 \\
398.23 \\
399.85\end{array}$ & $\begin{array}{l}395.15 \\
396.77 \\
398.39\end{array}$ & $\begin{array}{l}395.32 \\
396.94 \\
398.56\end{array}$ & $\begin{array}{l}395 \cdot 48 \\
397 \cdot 10 \\
398 \cdot 72\end{array}$ & $\begin{array}{l}395.64 \\
397.26 \\
398.88\end{array}$ & $\begin{array}{l}20.50 \\
20.60 \\
20.70 \\
20.80\end{array}$ \\
\hline $\mathrm{mV}$ & .00 & .01 & .02 & .03 & .04 & .05 & .06 & .07 & .08 & .09 & .10 & $\mathrm{mV}$ \\
\hline
\end{tabular}


TABLE A8.2.2. Type Thermocouples-temperature $\left({ }^{\circ} \mathrm{F}\right)$ as a function of thermoelectric voltage, reference junctions at $32^{\circ} \mathrm{F}$

$\begin{array}{lll}.00 \quad .01 \quad .02 & .03\end{array}$

.04

.05

.06

.07

.08

.09

.10

$\mathrm{mV}$

TEMPERATURES IN DEGREES $F$

$-6 \cdot 20$

$-6 \cdot 10$

$-423.90$

$-398.96-427.28$

$-380.88$

$-401.02-403.15$

$-435.17$

$-440.05-446.25$

$-6.00$

$\begin{array}{lll}-382.53 & -384.21 & -385.92\end{array}$

$\begin{array}{ll}-407.64 & -410.0 \\ -387.66 & -389.4\end{array}$

-412.50
-391.25

$-415.10$

$-417.85$

$-420.77$

-423.90
-398.96

$-6.20$

$-6.10$

$-6.00$

$m v$

.00

.01

.02

.03

.04

.05

.06

.07

.08

.09

$\cdot 10$

$\mathrm{mV}$ 
TABLE A8.2.2. Type $T$ thermocouples-temperature $\left({ }^{\circ} \mathrm{F}\right)$ as a function of thermoelectric voltage, reference junctions at $32^{\circ} \mathrm{F}$-Continued

$\mathrm{mV}$ .00 .01 .02 .03 $.04 \quad .05 \quad .06$ TEMPERATURES IN DEGREES $F$

\begin{tabular}{|c|c|c|c|c|c|c|c|c|c|c|c|c|}
\hline 6.00 & -380.88 & -382.53 & -384.21 & -385.92 & -387.66 & -389.43 & $-391 \cdot 25$ & -393.11 & -395.01 & -396.96 & -398.96 & -6.00 \\
\hline $\begin{array}{l}-5.90 \\
-5.80 \\
-5.70 \\
-5.60 \\
-5.50\end{array}$ & $\begin{array}{l}-365.63 \\
-351.99 \\
-339.42 \\
-327.67 \\
-316.56\end{array}$ & $\begin{array}{l}-367.07 \\
-353.30 \\
-340.64 \\
-328.81 \\
-317.64\end{array}$ & $\begin{array}{l}-358.53 \\
-354.62 \\
-341.87 \\
-329.96 \\
-318.73\end{array}$ & $\begin{array}{l}-370.00 \\
-355.95 \\
-343.10 \\
-331.12 \\
-319.83\end{array}$ & $\begin{array}{l}-371.49 \\
-357.29 \\
-344.34 \\
-332.28 \\
-320.93\end{array}$ & $\begin{array}{l}-373.01 \\
-358.65 \\
-345.59 \\
-333.46 \\
-322.04\end{array}$ & $\begin{array}{l}-374.54 \\
-360.02 \\
-346.85 \\
-334.63 \\
-323.15\end{array}$ & $\begin{array}{l}-376.09 \\
-361.40 \\
-348.12 \\
-335.82 \\
-324.27\end{array}$ & $\begin{array}{l}-377.66 \\
-362.80 \\
-349.40 \\
-337.01 \\
-325.40\end{array}$ & $\begin{array}{l}-379.26 \\
-364.21 \\
-350.69 \\
-338.21 \\
-326.53\end{array}$ & $\begin{array}{l}-380.88 \\
-365.63 \\
-351.99 \\
-339.42 \\
-327.67\end{array}$ & $\begin{array}{l}-5.90 \\
-5.80 \\
-5.70 \\
-5.60 \\
-5.50\end{array}$ \\
\hline $\begin{array}{l}-5.40 \\
-5.30 \\
-5.20 \\
-5.10 \\
-5.00\end{array}$ & $\begin{array}{l}-305.98 \\
-295.87 \\
-286.16 \\
-276.80 \\
-267.75\end{array}$ & $\begin{array}{l}-307.02 \\
-296.86 \\
-287.11 \\
-277.72 \\
-268.64\end{array}$ & $\begin{array}{l}-308.06 \\
-297.86 \\
-288.07 \\
-278.64 \\
-269.54\end{array}$ & $\begin{array}{l}-309.10 \\
-298.86 \\
-289.03 \\
-279.57 \\
-270.44\end{array}$ & $\begin{array}{l}-310.15 \\
-299.86 \\
-290.00 \\
-280.50 \\
-271.34\end{array}$ & $\begin{array}{l}-311.21 \\
-300.87 \\
-290.97 \\
-281.44 \\
-272.24\end{array}$ & $\begin{array}{l}-312.27 \\
-301.89 \\
-291.94 \\
-282.37 \\
-273.14\end{array}$ & $\begin{array}{l}-313.33 \\
-302.90 \\
-292.92 \\
-283.31 \\
-274.05\end{array}$ & $\begin{array}{l}-314.40 \\
-303.92 \\
-293.90 \\
-284.26 \\
-274.97\end{array}$ & $\begin{array}{l}-315.48 \\
-304.95 \\
-294.88 \\
-285.21 \\
-275.88\end{array}$ & $\begin{array}{l}-316.56 \\
-305.98 \\
-295.87 \\
-286.16 \\
-276.80\end{array}$ & $\begin{array}{l}-5.40 \\
-5.30 \\
-5.20 \\
-5.10 \\
-5.00\end{array}$ \\
\hline $\begin{array}{l}-4 \cdot 90 \\
-4 \cdot 80 \\
-4.70 \\
-4.60 \\
-4.50\end{array}$ & $\begin{array}{l}-258.99 \\
-250.48 \\
-242.20 \\
-234.13 \\
-226.26\end{array}$ & $\begin{array}{l}-259.85 \\
-251.32 \\
-243.02 \\
-234.93 \\
-227.04\end{array}$ & $\begin{array}{l}-260.72 \\
-252.16 \\
-243.84 \\
-235.73 \\
-227.82\end{array}$ & $\begin{array}{l}-261.59 \\
-253.01 \\
-244.66 \\
-236.53 \\
-228.61\end{array}$ & $\begin{array}{l}-262.46 \\
-253.85 \\
-245.49 \\
-237.34 \\
-229.39\end{array}$ & $\begin{array}{l}-263.34 \\
-254.70 \\
-246.31 \\
-238.14 \\
-230.18\end{array}$ & $\begin{array}{l}-264.22 \\
-255.56 \\
-247.14 \\
-238.95 \\
-230.96\end{array}$ & $\begin{array}{l}-265.10 \\
-256.41 \\
-247.97 \\
-239.76 \\
-231.75\end{array}$ & $\begin{array}{l}-265.98 \\
-257.27 \\
-248.81 \\
-240.57 \\
-232.55\end{array}$ & $\begin{array}{l}-266.86 \\
-258.13 \\
-249.64 \\
-241.39 \\
-233.34\end{array}$ & $\begin{array}{l}-267.75 \\
-258.99 \\
-250.48 \\
-242.20 \\
-234.13\end{array}$ & $\begin{array}{l}-4.90 \\
-4.80 \\
-4.70 \\
-4.60 \\
-4.50\end{array}$ \\
\hline $\begin{array}{l}-4 \cdot 40 \\
-4 \cdot 30 \\
-4 \cdot 20 \\
-4 \cdot 10 \\
-4 \cdot 00\end{array}$ & $\begin{array}{l}-218.57 \\
-211.05 \\
-203.69 \\
-196.47 \\
-189.39\end{array}$ & $\begin{array}{l}-219.33 \\
-211.80 \\
-204.42 \\
-197.18 \\
-190.09\end{array}$ & $\begin{array}{l}-220.10 \\
-212.54 \\
-205.15 \\
-197.90 \\
-190.79\end{array}$ & $\begin{array}{l}-220.86 \\
-213.29 \\
-205.88 \\
-198.62 \\
-191.50\end{array}$ & $\begin{array}{l}-221.63 \\
-214.04 \\
-206.61 \\
-199.34 \\
-192.20\end{array}$ & $\begin{array}{l}-222.40 \\
-214.79 \\
-207.35 \\
-200.06 \\
-192.91\end{array}$ & $\begin{array}{l}-223.17 \\
-215.55 \\
-208.09 \\
-200.78 \\
-193.62\end{array}$ & $\begin{array}{l}-223.94 \\
-216.30 \\
-208.83 \\
-201.51 \\
-194.33\end{array}$ & $\begin{array}{l}-224.71 \\
-217.06 \\
-209.57 \\
-202.23 \\
-195.04\end{array}$ & $\begin{array}{l}-225.49 \\
-217.81 \\
-210.31 \\
-202.96 \\
-195.75\end{array}$ & $\begin{array}{l}-226.26 \\
-218.57 \\
-211.05 \\
-203.69 \\
-196.47\end{array}$ & $\begin{array}{l}-4.40 \\
-4.30 \\
-4.20 \\
-4.10 \\
-4.00\end{array}$ \\
\hline $\begin{array}{l}-3.90 \\
-3.80 \\
-3.70 \\
-3.60 \\
-3.50\end{array}$ & $\begin{array}{l}-182.44 \\
-175.61 \\
-168.90 \\
-162.29 \\
-155.79\end{array}$ & $\begin{array}{l}-183.13 \\
-176.29 \\
-169.56 \\
-162.95 \\
-156.43\end{array}$ & $\begin{array}{l}-183.82 \\
-176.97 \\
-170.23 \\
-163.60 \\
-157.08\end{array}$ & $\begin{array}{l}-184.51 \\
-177.65 \\
-170.90 \\
-164.26 \\
-157.73\end{array}$ & $\begin{array}{l}-185.20 \\
-178.33 \\
-171.57 \\
-164.92 \\
-158.38\end{array}$ & $\begin{array}{l}-185.90 \\
-179.01 \\
-172.24 \\
-165.58 \\
-159.03\end{array}$ & $\begin{array}{l}-186.59 \\
-179.69 \\
-172.91 \\
-166.24 \\
-159.68\end{array}$ & $\begin{array}{l}-187.29 \\
-180.38 \\
-173.58 \\
-166.90 \\
-160.33\end{array}$ & $\begin{array}{l}-187.99 \\
-181.06 \\
-174.26 \\
-167.57 \\
-160.98\end{array}$ & $\begin{array}{l}-188.69 \\
-181.75 \\
-174.93 \\
-168.23 \\
-161.64\end{array}$ & $\begin{array}{l}-189.39 \\
-182.44 \\
-175.61 \\
-168.90 \\
-162.29\end{array}$ & $\begin{array}{l}-3.90 \\
-3.80 \\
-3.70 \\
-3.60 \\
-3.50\end{array}$ \\
\hline $\begin{array}{l}-3.40 \\
-3.30 \\
-3.20 \\
-3.10 \\
-3.00\end{array}$ & $\begin{array}{l}-149.38 \\
-143.07 \\
-136.84 \\
-130.70 \\
-124.63\end{array}$ & $\begin{array}{l}-150.02 \\
-143.69 \\
-137.46 \\
-131.31 \\
-125.24\end{array}$ & $\begin{array}{l}-150.66 \\
-144.32 \\
-138.08 \\
-131.92 \\
-125.84\end{array}$ & $\begin{array}{l}-151.29 \\
-144.95 \\
-138.70 \\
-132.53 \\
-126.44\end{array}$ & $\begin{array}{l}-151.93 \\
-145.53 \\
-139.32 \\
-133.15 \\
-127.05\end{array}$ & $\begin{array}{l}-152.57 \\
-146.21 \\
-139.94 \\
-133.76 \\
-127.66\end{array}$ & $\begin{array}{l}-153.21 \\
-146.85 \\
-140.57 \\
-134.37 \\
-128.26\end{array}$ & $\begin{array}{l}-153.86 \\
-147.48 \\
-141.19 \\
-134.99 \\
-128.87\end{array}$ & $\begin{array}{l}-154.50 \\
-148.11 \\
-141.82 \\
-135.61 \\
-129.48\end{array}$ & $\begin{array}{l}-155.14 \\
-148.75 \\
-142.44 \\
-136.22 \\
-130.09\end{array}$ & $\begin{array}{l}-155.79 \\
-149.38 \\
-143.07 \\
-136.84 \\
-130.70\end{array}$ & $\begin{array}{l}-3.40 \\
-3.30 \\
-3.20 \\
-3.10 \\
-3.00\end{array}$ \\
\hline $\begin{array}{l}-2.90 \\
-2.80 \\
-2.70 \\
-2.60 \\
-2.50\end{array}$ & $\begin{array}{l}-118.65 \\
-112.73 \\
-106.89 \\
-101.11 \\
-95.39\end{array}$ & $\begin{array}{l}-119.24 \\
-113.32 \\
-107.47 \\
-101.68 \\
-95.96\end{array}$ & $\begin{array}{l}-119.84 \\
-113.91 \\
-108.05 \\
-102.26 \\
-96.53\end{array}$ & $\begin{array}{r}-120.43 \\
-114.50 \\
-108.63 \\
-102.83 \\
-97.10\end{array}$ & $\begin{array}{r}-121.03 \\
-115.09 \\
-109.22 \\
-103.41 \\
-97.67\end{array}$ & $\begin{array}{l}-121.63 \\
-115.68 \\
-109.80 \\
-103.99 \\
-98.24\end{array}$ & $\begin{array}{r}-122.23 \\
-116.27 \\
-110.38 \\
-104.57 \\
-98.81\end{array}$ & $\begin{array}{l}-122.83 \\
-116.86 \\
-110.97 \\
-105.15 \\
-29.39\end{array}$ & $\begin{array}{l}-123.43 \\
-117.46 \\
-111.56 \\
-105.73 \\
-99.96\end{array}$ & $\begin{array}{l}-124.03 \\
-118.05 \\
-112.14 \\
-106.31 \\
-100.53\end{array}$ & $\begin{array}{l}-124.63 \\
-118.65 \\
-112.73 \\
-106.89 \\
-101.11\end{array}$ & $\begin{array}{l}-2.90 \\
-2.80 \\
-2.70 \\
-2.60 \\
-2.50\end{array}$ \\
\hline $\begin{array}{l}-2.40 \\
-2.30 \\
-2.20 \\
-2.10 \\
-2.00\end{array}$ & $\begin{array}{l}-89.74 \\
-84.15 \\
-78.61 \\
-73.13 \\
-67.71\end{array}$ & $\begin{array}{l}-90.30 \\
-84.71 \\
-79.17 \\
-73.68 \\
-68.25\end{array}$ & $\begin{array}{l}-90.87 \\
-85.26 \\
-79.72 \\
-74.23 \\
-68.79\end{array}$ & $\begin{array}{l}-91.43 \\
-85.82 \\
-80.27 \\
-74.77 \\
-69.33\end{array}$ & $\begin{array}{l}-92.00 \\
-86.38 \\
-80.82 \\
-75.32 \\
-69.87\end{array}$ & $\begin{array}{l}-92.56 \\
-86.94 \\
-81.37 \\
-75.87 \\
-70.41\end{array}$ & $\begin{array}{l}-93.13 \\
-87.50 \\
-81.93 \\
-76.42 \\
-70.96\end{array}$ & $\begin{array}{l}-93.69 \\
-88.06 \\
-82.48 \\
-76.96 \\
-71.50\end{array}$ & $\begin{array}{l}-94.26 \\
-88.62 \\
-33.04 \\
-77.51 \\
-72.04\end{array}$ & $\begin{array}{l}-94.83 \\
-89.18 \\
-83.59 \\
-78.06 \\
-72.59\end{array}$ & $\begin{array}{l}-95.39 \\
-89.74 \\
-84.15 \\
-78.61 \\
-73.13\end{array}$ & $\begin{array}{l}-2.40 \\
-2.30 \\
-2.20 \\
-2.10 \\
-2.00\end{array}$ \\
\hline $\begin{array}{l}-1.90 \\
-1.80 \\
-1.70 \\
-1.60 \\
-1.50\end{array}$ & $\begin{array}{l}-62.33 \\
-57.01 \\
-51.73 \\
-46.49 \\
-41.30\end{array}$ & $\begin{array}{l}-62.87 \\
-57.54 \\
-52.25 \\
-47.01 \\
-41.82\end{array}$ & $\begin{array}{l}-63.40 \\
-58.07 \\
-52.78 \\
-47.54 \\
-42.34\end{array}$ & $\begin{array}{l}-63.94 \\
-58.60 \\
-53.31 \\
-48.06 \\
-42.86\end{array}$ & $\begin{array}{l}-64.48 \\
-59.13 \\
-53.83 \\
-48.58 \\
-43.37\end{array}$ & $\begin{array}{l}-65.01 \\
-59.66 \\
-54.36 \\
-49.10 \\
-43.89\end{array}$ & $\begin{array}{l}-65.55 \\
-60.20 \\
-54.89 \\
-49.63 \\
-44.41\end{array}$ & $\begin{array}{l}-66.09 \\
-60.73 \\
-55.42 \\
-50.15 \\
-44.93\end{array}$ & $\begin{array}{l}-66.63 \\
-61.26 \\
-55.95 \\
-50.68 \\
-45.45\end{array}$ & $\begin{array}{l}-67.17 \\
-61.80 \\
-56.48 \\
-51.20 \\
-45.97\end{array}$ & $\begin{array}{l}-67.71 \\
-62.33 \\
-57.01 \\
-51.73 \\
-46.49\end{array}$ & $\begin{array}{l}-1.90 \\
-1.80 \\
-1.70 \\
-1.60 \\
-1.50\end{array}$ \\
\hline $\begin{array}{l}-1.40 \\
-1.30 \\
-1.20 \\
-1.10 \\
-1.00\end{array}$ & $\begin{array}{l}-36.16 \\
-31.05 \\
-25.99 \\
-20.96 \\
-15.98\end{array}$ & $\begin{array}{l}-26.67 \\
-31.56 \\
-26.49 \\
-21.47 \\
-16.48\end{array}$ & $\begin{array}{l}-37.18 \\
-32.07 \\
-27.00 \\
-21.97 \\
-16.97\end{array}$ & $\begin{array}{l}-37.70 \\
-32.58 \\
-27.50 \\
-22.47 \\
-17.47\end{array}$ & $\begin{array}{l}-38.21 \\
-33.09 \\
-28.01 \\
-22.97 \\
-17.97\end{array}$ & $\begin{array}{l}-38.73 \\
-33.60 \\
-28.52 \\
-23.47 \\
-18.47\end{array}$ & $\begin{array}{l}-39.2 \\
-34.1 \\
-29.0 \\
-23.9 \\
-18.9\end{array}$ & $\begin{array}{l}-39.76 \\
-34.62 \\
-29.53 \\
-24.48 \\
-19.46\end{array}$ & $\begin{array}{l}-40.27 \\
-35.13 \\
-30.04 \\
-24.98 \\
-19.96\end{array}$ & $\begin{array}{l}-40.79 \\
-35.65 \\
-30.55 \\
-25.49 \\
-20.46\end{array}$ & $\begin{array}{l}-41.30 \\
-36.16 \\
-31.05 \\
-25.99 \\
-20.96\end{array}$ & $\begin{array}{l}-1.40 \\
-1.30 \\
-1.20 \\
-1.10 \\
-1.00\end{array}$ \\
\hline $\begin{array}{l}-0.90 \\
-0.80 \\
-0.70 \\
-0.60 \\
-0.50\end{array}$ & $\begin{array}{r}-11.03 \\
-6.12 \\
-1.24 \\
3.60 \\
8.41\end{array}$ & $\begin{array}{r}-11.52 \\
-6.61 \\
-1.73 \\
3.12 \\
7.93\end{array}$ & $\begin{array}{r}-12.02 \\
-7.10 \\
-2.21 \\
2.64 \\
7.45\end{array}$ & $\begin{array}{r}-12.51 \\
-7.59 \\
-2.70 \\
2.15 \\
6.97\end{array}$ & $\begin{array}{r}-13.00 \\
-6.08 \\
-3.19 \\
1.67 \\
6.49\end{array}$ & $\begin{array}{r}-13.50 \\
-8.57 \\
-3.67 \\
1.19 \\
6.01\end{array}$ & $\begin{array}{r}-13.99 \\
-9.06 \\
-4.16 \\
0.70 \\
5.53\end{array}$ & $\begin{array}{r}-14.49 \\
-9.55 \\
-4.65 \\
0.22 \\
5.05\end{array}$ & $\begin{array}{r}-14.99 \\
-10.04 \\
-5.14 \\
-0.27 \\
4.57\end{array}$ & $\begin{array}{r}-15.48 \\
-10.54 \\
-5.63 \\
-0.75 \\
4.09\end{array}$ & $\begin{array}{r}-15.98 \\
-11.03 \\
-6.12 \\
-1.24 \\
3.60\end{array}$ & $\begin{array}{l}-0.90 \\
-0.80 \\
-0.70 \\
-0.60 \\
-0.50\end{array}$ \\
\hline $\begin{array}{l}-0.40 \\
-0.30 \\
-0.20 \\
-0.10 \\
-0.00\end{array}$ & $\begin{array}{l}13.19 \\
17.94 \\
22.65 \\
27.34 \\
32.00\end{array}$ & $\begin{array}{l}12.71 \\
17.46 \\
22.18 \\
26.87 \\
31.54\end{array}$ & $\begin{array}{l}16.99 \\
21.71 \\
26.40 \\
31.07\end{array}$ & $\begin{array}{l}16.52 \\
21.24 \\
25.94 \\
30.60\end{array}$ & $\begin{array}{l}16.04 \\
20.77 \\
25.47 \\
30.14\end{array}$ & $\begin{array}{l}15.57 \\
20.30 \\
25.00 \\
29.67\end{array}$ & $\begin{array}{l}15.09 \\
19.83 \\
24.53 \\
29.21\end{array}$ & $\begin{array}{l}14.62 \\
19.35 \\
24.06 \\
28.74\end{array}$ & $\begin{array}{r}9.37 \\
14.14 \\
18.88 \\
23.59 \\
28.27\end{array}$ & $\begin{array}{r}8.89 \\
13.67 \\
18.41 \\
23.12 \\
27.81\end{array}$ & $\begin{array}{r}8.41 \\
13.19 \\
17.94 \\
22.65 \\
27.34\end{array}$ & $\begin{array}{l}-0.30 \\
-0.20 \\
-0.10 \\
-0.00\end{array}$ \\
\hline
\end{tabular}

.07

.08

.09

$\cdot 10$

$\mathrm{mV}$
$.00 \quad .01$

.02
.03
.04
.06 
TABLE A8.2.2. Type $T$ thermocouples-temperature $\left({ }^{\circ} \mathrm{F}\right)$ as a function of thermoelectric voltage, reference junctions at $32^{\circ} \mathrm{F}$-Continued

$.04 \quad .05 \quad .06$

.07

TEMPERATURES IN DEGREES $F$

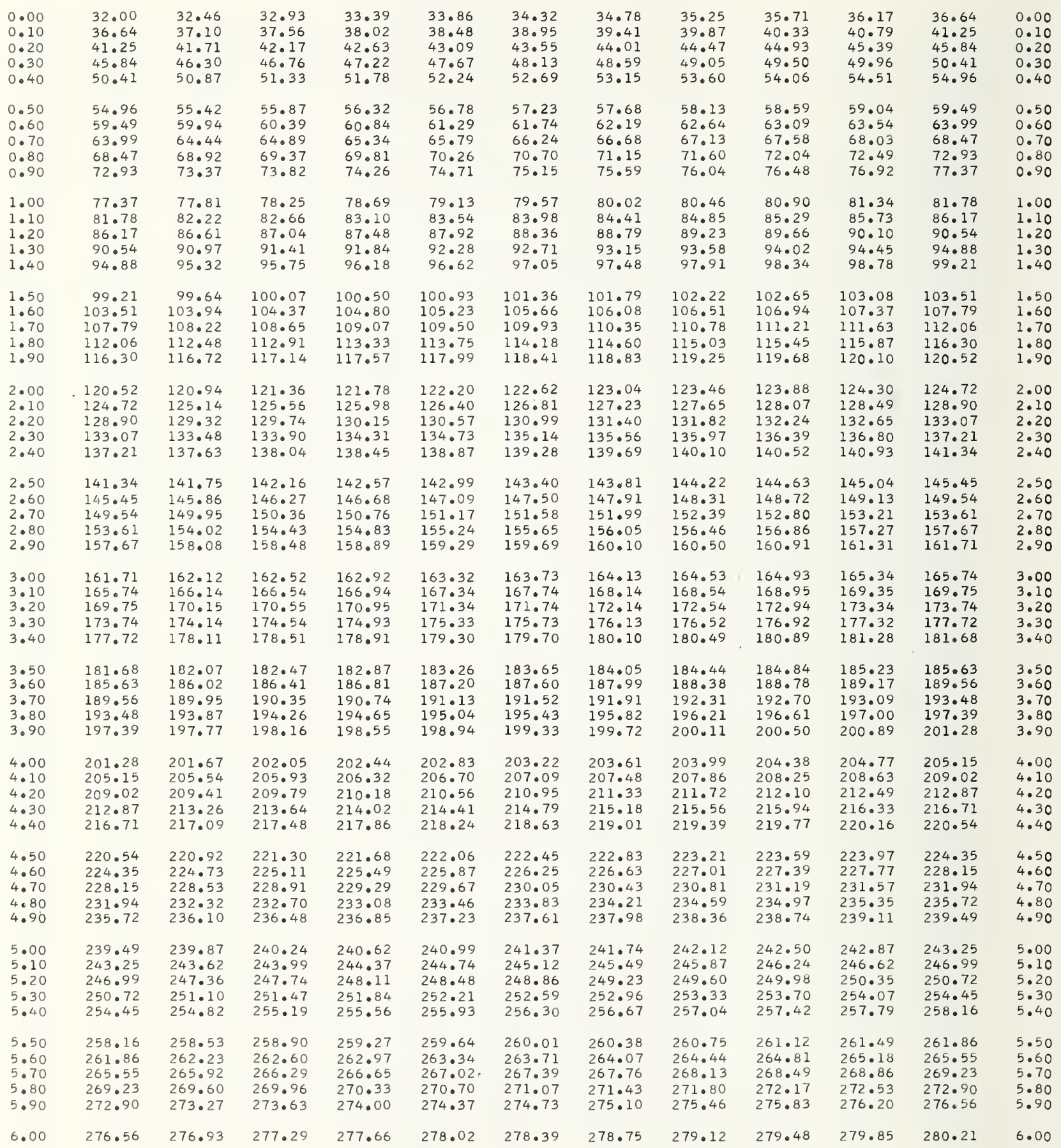

$\mathrm{mV}$

$.00 \quad .01 \quad .02$

.03

$.04 \quad .05$

.06

.07

.08

.09

$\cdot 10$

$m v$ 
TABLE A8.2.2. Type $T$ thermocouples-temperature $\left({ }^{\circ} F\right)$ as a function of thermoelectric voltage, reference junctions at $32^{\circ} \mathrm{F}$-Continued

$\mathrm{mV}$

.00

.01

.02

.03

.04

.05

.06

.07

.08

.09

.10

$\mathrm{mV}$

TEMPERATURES IN DEGREES $F$

\begin{tabular}{|c|c|c|c|c|c|c|c|c|c|c|c|c|}
\hline $\begin{array}{l}6.00 \\
6.10 \\
6.20 \\
6.30 \\
6.40\end{array}$ & $\begin{array}{l}276.56 \\
280.21 \\
283.85 \\
287.48 \\
291.11\end{array}$ & $\begin{array}{l}276 \cdot 93 \\
280.58 \\
284 \cdot 22 \\
287 \cdot 85 \\
291.47\end{array}$ & $\begin{array}{l}277.29 \\
280.94 \\
284 \cdot 58 \\
288.21 \\
291.83\end{array}$ & $\begin{array}{l}277.66 \\
281.30 \\
284.94 \\
288.57 \\
292.19\end{array}$ & $\begin{array}{l}278.02 \\
281.67 \\
285.31 \\
288.93 \\
292.55\end{array}$ & $\begin{array}{l}278.39 \\
282.03 \\
285.67 \\
289.30 \\
292.91\end{array}$ & $\begin{array}{l}278.75 \\
282.40 \\
286.03 \\
289.66 \\
293.27\end{array}$ & $\begin{array}{l}279.12 \\
282.76 \\
286.40 \\
290.02 \\
293.64\end{array}$ & $\begin{array}{l}279.48 \\
283.12 \\
286.76 \\
290.38 \\
294.00\end{array}$ & $\begin{array}{l}279 \cdot 85 \\
283.49 \\
287.12 \\
290 \cdot 74 \\
294 \cdot 36\end{array}$ & $\begin{array}{l}280.21 \\
283.85 \\
287.48 \\
291.11 \\
294.72\end{array}$ & $\begin{array}{l}6.00 \\
6.10 \\
6.20 \\
6.30 \\
6.40\end{array}$ \\
\hline $\begin{array}{l}6.50 \\
6.60 \\
6.70 \\
6.80 \\
6.90\end{array}$ & $\begin{array}{l}294 \cdot 72 \\
298 \cdot 32 \\
301.92 \\
305.50 \\
309.08\end{array}$ & $\begin{array}{l}295.08 \\
298.68 \\
302.27 \\
305.86 \\
309.43\end{array}$ & $\begin{array}{l}295.44 \\
299.04 \\
302.63 \\
306.22 \\
309.79\end{array}$ & $\begin{array}{l}295.80 \\
299.40 \\
302.99 \\
306.57 \\
310.15\end{array}$ & $\begin{array}{l}296.16 \\
299.76 \\
303.35 \\
306.93 \\
310.50\end{array}$ & $\begin{array}{l}296.52 \\
300.12 \\
303.71 \\
307.29 \\
310.86\end{array}$ & $\begin{array}{l}296.88 \\
300.48 \\
304.07 \\
307.65 \\
311.22\end{array}$ & $\begin{array}{l}297.24 \\
300.84 \\
304.43 \\
308.00 \\
311.57\end{array}$ & $\begin{array}{l}297.60 \\
301.20 \\
304.78 \\
308.36 \\
311.93\end{array}$ & $\begin{array}{l}297.96 \\
301.56 \\
305.14 \\
308.72 \\
312.29\end{array}$ & $\begin{array}{l}298.32 \\
301.92 \\
305.50 \\
309.08 \\
312.64\end{array}$ & $\begin{array}{l}6.50 \\
6.60 \\
6.70 \\
6.80 \\
6.90\end{array}$ \\
\hline $\begin{array}{l}7.00 \\
7.10 \\
7.20 \\
7.30 \\
7.40\end{array}$ & $\begin{array}{l}312.64 \\
316.20 \\
319.75 \\
323.29 \\
326.83\end{array}$ & $\begin{array}{l}313.00 \\
316.56 \\
320.11 \\
323.65 \\
327.18\end{array}$ & $\begin{array}{l}313 \cdot 36 \\
316.91 \\
320 \cdot 46 \\
324 \cdot 00 \\
327.53\end{array}$ & $\begin{array}{l}313.71 \\
317.27 \\
320.82 \\
324.35 \\
327.88\end{array}$ & $\begin{array}{l}314.07 \\
317.62 \\
321.17 \\
324.71 \\
328.24\end{array}$ & $\begin{array}{l}314.42 \\
317.98 \\
321.52 \\
325.06 \\
328.59\end{array}$ & $\begin{array}{l}314.78 \\
318.33 \\
321.88 \\
325.41 \\
328.94\end{array}$ & $\begin{array}{l}315.14 \\
318.69 \\
322 \cdot 23 \\
325.77 \\
329.29\end{array}$ & $\begin{array}{l}315.49 \\
319.04 \\
322.59 \\
326.12 \\
329.65\end{array}$ & $\begin{array}{l}315.85 \\
319.40 \\
322.94 \\
326.47 \\
330.00\end{array}$ & $\begin{array}{l}316.20 \\
319.75 \\
323.29 \\
326.83 \\
330.35\end{array}$ & $\begin{array}{l}7.00 \\
7.10 \\
7.20 \\
7.30 \\
7.40\end{array}$ \\
\hline $\begin{array}{l}7.50 \\
7.60 \\
7.70 \\
7.80 \\
7.90\end{array}$ & $\begin{array}{l}330.35 \\
333.87 \\
337.38 \\
340.88 \\
344.37\end{array}$ & $\begin{array}{l}330 \cdot 70 \\
334.22 \\
337.73 \\
341.23 \\
344.72\end{array}$ & $\begin{array}{l}331.06 \\
334.57 \\
338.08 \\
341.58 \\
345.07\end{array}$ & $\begin{array}{l}331.41 \\
334.92 \\
338.43 \\
341.93 \\
345.42\end{array}$ & $\begin{array}{l}331.76 \\
335.27 \\
338.78 \\
342.27 \\
345.76\end{array}$ & $\begin{array}{l}332.11 \\
335.62 \\
339.13 \\
342.62 \\
346.11\end{array}$ & $\begin{array}{l}332.46 \\
335.97 \\
339.48 \\
342.97 \\
346.46\end{array}$ & $\begin{array}{l}332.81 \\
336.32 \\
339.83 \\
343.32 \\
346.81\end{array}$ & $\begin{array}{l}333.17 \\
336.68 \\
340.18 \\
343.67 \\
347.16\end{array}$ & $\begin{array}{l}333.52 \\
337.03 \\
340.53 \\
344.02 \\
347.51\end{array}$ & $\begin{array}{l}333.87 \\
337.38 \\
340.88 \\
344.37 \\
347.85\end{array}$ & $\begin{array}{l}7.50 \\
7.60 \\
7.70 \\
7.80 \\
7.90\end{array}$ \\
\hline $\begin{array}{l}8.00 \\
8.10 \\
8.20 \\
8.30 \\
8.40\end{array}$ & $\begin{array}{l}347.85 \\
351.33 \\
354.80 \\
358.26 \\
361.71\end{array}$ & $\begin{array}{l}348.20 \\
351.68 \\
355.15 \\
358.61 \\
362.06\end{array}$ & $\begin{array}{l}348.55 \\
352.02 \\
355.49 \\
358.95 \\
362.40\end{array}$ & $\begin{array}{l}348.90 \\
352.37 \\
355.84 \\
359.30 \\
362.75\end{array}$ & $\begin{array}{l}349.25 \\
352.72 \\
356.18 \\
359.64 \\
363.09\end{array}$ & $\begin{array}{l}349.59 \\
353.07 \\
356.53 \\
359.99 \\
363.44\end{array}$ & $\begin{array}{l}349.94 \\
353.41 \\
356.88 \\
360.33 \\
363.78\end{array}$ & $\begin{array}{l}350.29 \\
353.76 \\
357.22 \\
360.68 \\
364.13\end{array}$ & $\begin{array}{l}350.64 \\
354.11 \\
357.57 \\
361.02 \\
364.47\end{array}$ & $\begin{array}{l}350.98 \\
354.45 \\
357.91 \\
361.37 \\
364.82\end{array}$ & $\begin{array}{l}351.33 \\
354.80 \\
358.26 \\
361.71 \\
365.16\end{array}$ & $\begin{array}{l}8.00 \\
8.10 \\
8.20 \\
8.30 \\
8.40\end{array}$ \\
\hline $\begin{array}{l}8.50 \\
8.60 \\
8.70 \\
8.80 \\
8.90\end{array}$ & $\begin{array}{l}365.16 \\
368.60 \\
372.03 \\
375.46 \\
378.87\end{array}$ & $\begin{array}{l}365 \cdot 50 \\
368 \cdot 94 \\
372 \cdot 37 \\
375 \cdot 80 \\
379 \cdot 21\end{array}$ & $\begin{array}{l}365.85 \\
369.29 \\
372.72 \\
376.14 \\
379.56\end{array}$ & $\begin{array}{l}366.19 \\
369.63 \\
373.06 \\
376.48 \\
379.90\end{array}$ & $\begin{array}{l}366.54 \\
369.97 \\
373.40 \\
376.82 \\
380.24\end{array}$ & $\begin{array}{l}366 \cdot 88 \\
370 \cdot 32 \\
373 \cdot 74 \\
377.17 \\
380.58\end{array}$ & $\begin{array}{l}367.22 \\
370.66 \\
374.09 \\
377.51 \\
380.92\end{array}$ & $\begin{array}{l}367.57 \\
371.00 \\
374.43 \\
377.85 \\
381.26\end{array}$ & $\begin{array}{l}367.91 \\
371.35 \\
374.77 \\
378.19 \\
381.60\end{array}$ & $\begin{array}{l}368.26 \\
371.69 \\
375.11 \\
378.53 \\
381.94\end{array}$ & $\begin{array}{l}368.60 \\
372.03 \\
375.46 \\
378.87 \\
382.28\end{array}$ & $\begin{array}{l}8.50 \\
8.60 \\
8.70 \\
8.80 \\
8.90\end{array}$ \\
\hline $\begin{array}{l}9.00 \\
9.10 \\
9.20 \\
9.30 \\
9.40\end{array}$ & $\begin{array}{l}382.28 \\
385.69 \\
389.08 \\
392.47 \\
395.85\end{array}$ & $\begin{array}{l}382.62 \\
386.03 \\
389.42 \\
392.81 \\
396.19\end{array}$ & $\begin{array}{l}382 \cdot 96 \\
386 \cdot 37 \\
389 \cdot 76 \\
393 \cdot 15 \\
396.53\end{array}$ & $\begin{array}{l}383.30 \\
386.71 \\
390.10 \\
393.49 \\
396.87\end{array}$ & $\begin{array}{l}383.65 \\
387.05 \\
390.44 \\
393.83 \\
397.21\end{array}$ & $\begin{array}{l}383.99 \\
387.39 \\
390.78 \\
394.16 \\
397.54\end{array}$ & $\begin{array}{l}384 \cdot 33 \\
387.72 \\
391.12 \\
394.50 \\
397.88\end{array}$ & $\begin{array}{l}384.67 \\
388.06 \\
391.46 \\
394.84 \\
398.22\end{array}$ & $\begin{array}{l}385.01 \\
388.40 \\
391.79 \\
395.18 \\
398.56\end{array}$ & $\begin{array}{l}385.35 \\
388.74 \\
392.13 \\
395.52 \\
398.89\end{array}$ & $\begin{array}{l}385.69 \\
389.08 \\
392.47 \\
395.85 \\
399.23\end{array}$ & $\begin{array}{l}9.00 \\
9.10 \\
9.20 \\
9.30 \\
9.40\end{array}$ \\
\hline $\begin{array}{l}9.50 \\
9.60 \\
9.70 \\
9.80 \\
9.90\end{array}$ & $\begin{array}{l}399 \cdot 23 \\
402.60 \\
405.96 \\
409.32 \\
412.67\end{array}$ & $\begin{array}{l}399.57 \\
402.94 \\
406.30 \\
409.65 \\
413.00\end{array}$ & $\begin{array}{l}399 \cdot 90 \\
403 \cdot 27 \\
406.63 \\
409.99 \\
413.34\end{array}$ & $\begin{array}{l}400.24 \\
403.61 \\
406.97 \\
410.32 \\
413.67\end{array}$ & $\begin{array}{l}400.58 \\
403.95 \\
407.31 \\
410.66 \\
414.01\end{array}$ & $\begin{array}{l}400.92 \\
404.28 \\
407.64 \\
410.99 \\
414.34\end{array}$ & $\begin{array}{l}401 \cdot 25 \\
404.62 \\
407.98 \\
411.33 \\
414.67\end{array}$ & $\begin{array}{l}401.59 \\
404.95 \\
408.31 \\
411.66 \\
415.01\end{array}$ & $\begin{array}{l}401.93 \\
405.29 \\
408.65 \\
412.00 \\
415.34\end{array}$ & $\begin{array}{l}402.26 \\
405.63 \\
408.98 \\
412.33 \\
415.68\end{array}$ & $\begin{array}{l}402 \cdot 60 \\
405.96 \\
409 \cdot 32 \\
412.67 \\
416.01\end{array}$ & $\begin{array}{l}9.50 \\
9.60 \\
9.70 \\
9.80 \\
9.90\end{array}$ \\
\hline $\begin{array}{l}10.00 \\
10.10 \\
10.20 \\
10.30 \\
10.40\end{array}$ & $\begin{array}{l}416.01 \\
419.35 \\
422.68 \\
426.00 \\
429.32\end{array}$ & $\begin{array}{l}416.34 \\
419.68 \\
423.01 \\
426.34 \\
429.65\end{array}$ & $\begin{array}{l}416.68 \\
420.01 \\
423.34 \\
426.67 \\
429.98\end{array}$ & $\begin{array}{l}417.01 \\
420.35 \\
423.68 \\
427.00 \\
430.32\end{array}$ & $\begin{array}{l}417.35 \\
420.68 \\
424.01 \\
427.33 \\
430.65\end{array}$ & $\begin{array}{l}417.68 \\
421.01 \\
424.34 \\
427.66 \\
430.98\end{array}$ & $\begin{array}{l}418.01 \\
421.35 \\
424.67 \\
427.99 \\
431.31\end{array}$ & $\begin{array}{l}418.35 \\
421.68 \\
425.01 \\
428.33 \\
431.64\end{array}$ & $\begin{array}{l}418.68 \\
422.01 \\
425.34 \\
428.66 \\
431.97\end{array}$ & $\begin{array}{l}419.01 \\
422.35 \\
425.67 \\
428.99 \\
432.30\end{array}$ & $\begin{array}{l}419.35 \\
422.68 \\
426.00 \\
429.32 \\
432.63\end{array}$ & $\begin{array}{l}10 \cdot 00 \\
10 \cdot 10 \\
10 \cdot 20 \\
10 \cdot 30 \\
10 \cdot 40\end{array}$ \\
\hline $\begin{array}{l}10.50 \\
10.60 \\
10.70 \\
10.80 \\
10.90\end{array}$ & $\begin{array}{l}432.63 \\
435.94 \\
439 \cdot 24 \\
442.54 \\
445.82\end{array}$ & $\begin{array}{l}432.96 \\
436.27 \\
439.57 \\
442.86 \\
446.15\end{array}$ & $\begin{array}{l}433.30 \\
436.60 \\
439.90 \\
443.19 \\
446.48\end{array}$ & $\begin{array}{l}433.63 \\
436.93 \\
440.23 \\
443.52 \\
446.81\end{array}$ & $\begin{array}{l}433.96 \\
437.26 \\
440.56 \\
443.85 \\
447.14\end{array}$ & $\begin{array}{l}434.29 \\
437.59 \\
440.89 \\
444.18 \\
447.47\end{array}$ & $\begin{array}{l}434.62 \\
437.92 \\
441.22 \\
444.51 \\
447.79\end{array}$ & $\begin{array}{l}434.95 \\
438.25 \\
441.55 \\
444.84 \\
448.12\end{array}$ & $\begin{array}{l}435.28 \\
438.58 \\
441.88 \\
445.17 \\
448.45\end{array}$ & $\begin{array}{l}435.61 \\
438.91 \\
442.21 \\
445.50 \\
448.78\end{array}$ & $\begin{array}{l}435.94 \\
439.24 \\
442.54 \\
445.82 \\
449.11\end{array}$ & $\begin{array}{l}10.50 \\
10.60 \\
10.70 \\
10.80 \\
10.90\end{array}$ \\
\hline $\begin{array}{l}11.00 \\
11.10 \\
11.20 \\
11.30 \\
11.40\end{array}$ & $\begin{array}{l}449.11 \\
452.38 \\
455.66 \\
458.92 \\
462.18\end{array}$ & $\begin{array}{l}449.44 \\
452.71 \\
455.98 \\
459.25 \\
462.51\end{array}$ & $\begin{array}{l}449.76 \\
453.04 \\
456.31 \\
459.58 \\
462.83\end{array}$ & $\begin{array}{l}450.09 \\
453.37 \\
456.64 \\
459.90 \\
463.16\end{array}$ & $\begin{array}{l}450.42 \\
453.69 \\
456.96 \\
460.23 \\
463.49\end{array}$ & $\begin{array}{l}450.75 \\
454.02 \\
457.29 \\
460.55 \\
463.81\end{array}$ & $\begin{array}{l}451.07 \\
454.35 \\
457.62 \\
460.88 \\
464.14\end{array}$ & $\begin{array}{l}451.40 \\
454.68 \\
457.94 \\
461.21 \\
464.46\end{array}$ & $\begin{array}{l}451.73 \\
455.00 \\
458.27 \\
461.53 \\
464.79\end{array}$ & $\begin{array}{l}452.06 \\
455.33 \\
458.60 \\
461.86 \\
465.11\end{array}$ & $\begin{array}{l}452.38 \\
455.66 \\
458.92 \\
462.18 \\
465.44\end{array}$ & $\begin{array}{l}11.00 \\
11.10 \\
11.20 \\
11.30 \\
11.40\end{array}$ \\
\hline $\begin{array}{l}11.50 \\
11.60 \\
11.70 \\
11.80 \\
11.90\end{array}$ & $\begin{array}{l}465.44 \\
468.69 \\
471.93 \\
475.17 \\
478.41\end{array}$ & $\begin{array}{l}465.76 \\
469.01 \\
472.26 \\
475.50 \\
478.73\end{array}$ & $\begin{array}{l}466.09 \\
469.34 \\
472.58 \\
475.82 \\
479.05\end{array}$ & $\begin{array}{l}466.41 \\
469.66 \\
472.91 \\
476.14 \\
479.38\end{array}$ & $\begin{array}{l}466.74 \\
469.99 \\
473.23 \\
476.47 \\
479.70\end{array}$ & $\begin{array}{l}467.06 \\
470.31 \\
473.55 \\
476.79 \\
480.02\end{array}$ & $\begin{array}{l}467.39 \\
470.64 \\
473.88 \\
477.11 \\
480.34\end{array}$ & $\begin{array}{l}467.71 \\
470.96 \\
474.20 \\
477.44 \\
480.67\end{array}$ & $\begin{array}{l}468 \cdot 04 \\
471 \cdot 28 \\
474 \cdot 52 \\
477 \cdot 76 \\
480.99\end{array}$ & $\begin{array}{l}468 \cdot 36 \\
471.61 \\
474.85 \\
478.08 \\
481.31\end{array}$ & $\begin{array}{l}468.69 \\
471.93 \\
475.17 \\
478.41 \\
481.64\end{array}$ & $\begin{array}{l}11.50 \\
11.60 \\
11.70 \\
11.80 \\
11.90\end{array}$ \\
\hline 12.00 & 481.64 & 481.96 & 482.28 & 482.60 & 482.93 & 483.25 & 483.57 & 483.89 & 484.21 & 484.54 & 484.86 & 12.00 \\
\hline
\end{tabular}

$\mathrm{mV}$

.00

.01

.02

.03

.04

.05

.06

.07
.08
.09 
TABLE A8.2.2. Type T thermocouples-temperature $\left({ }^{\circ} \mathrm{F}\right)$ as a function of thermoelectric voltage, reference junctions at $32^{\circ} \mathrm{F}$-Continued

$\mathrm{mV}$
.01
.02

.03

.05

.06

.07

.08

.09

$\cdot 10$

$\mathrm{mV}$

TEMPERATURES IN DEGREES $F$

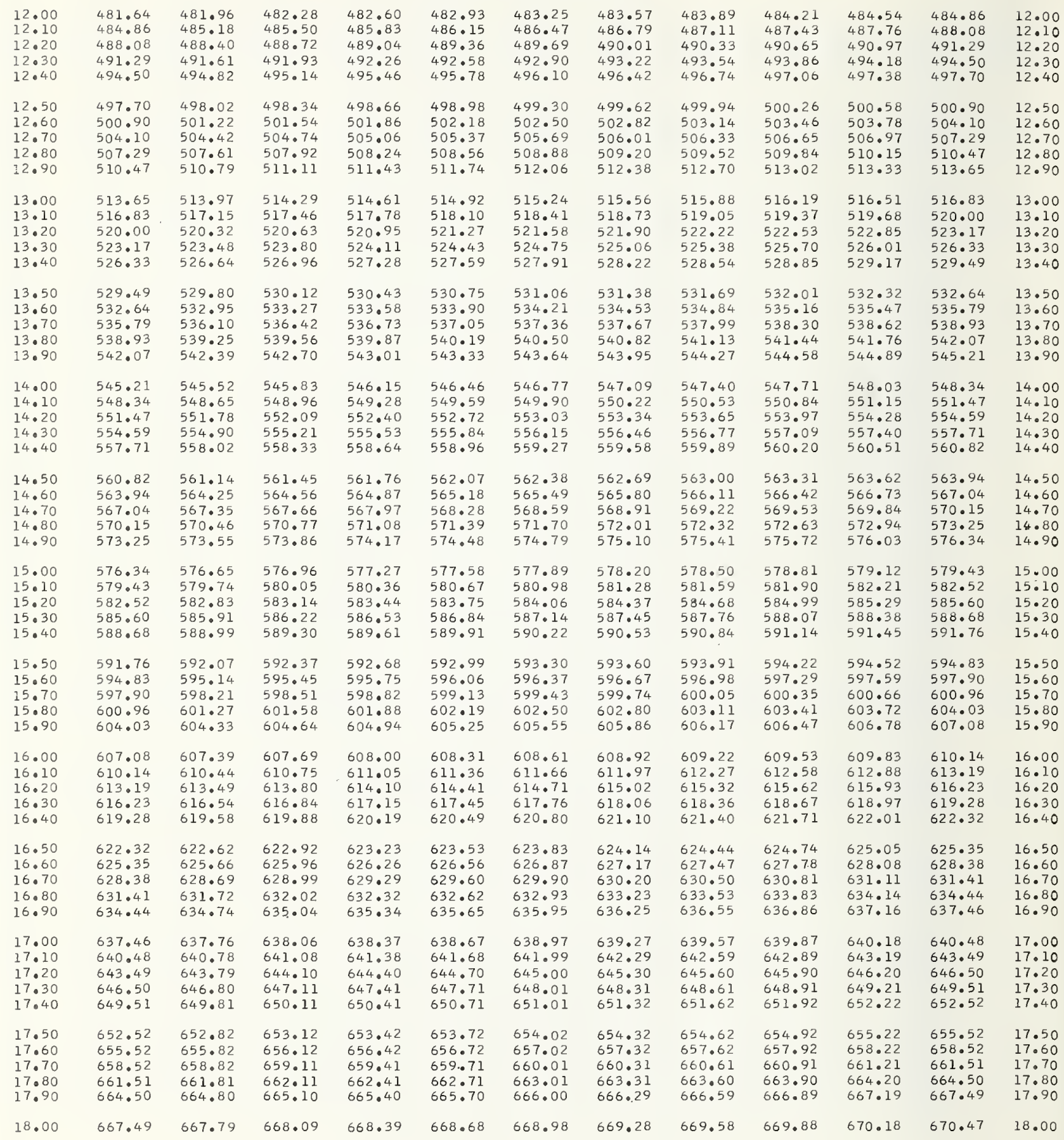

$m V$

$.00 \quad .01 \quad .02$

TEMPERATURES IN DEGR

489.69

496.10

499.30

505.06

511.43

514.61

520.95

530.43

539.87

546.15

552.40

555.53

574.17

77.27

583.44

586.53

592.68

598.82

601.88

608.00

617.15

20.19

23.23

629.29

638.37

647.41

653.42

656.42

665.40

668.39
$512 \cdot 38$

515.56

521.90

$528 \cdot 22$

540.82

547.09

550.22

559.58

575.10

81.28

587.45

90.53

93.60

99.74

802.80

608.92

. 02

621.10

$624 \cdot 14$

630.20

633.23

639.27

648.31

654.32

657.32

663.31

669.28
483.89
487.11
490.33
493.54
496.74
499.94
503.14
506.33
509.52

515.88

522.22

525.38

531.6

541.13

547.40

550.5

556.77

559.89

587.76

596.9

606.17

609.22

618.36

630.50

639.5

648.61

669.58

.03

$.04 \quad .05$

\begin{abstract}
.06
\end{abstract}

$.07 \quad .08$

528.85

553.97

560.20

575.72

584.99

591.14

621.71

624074

630.8

666.89

670.18

\begin{abstract}
670.47
.10
\end{abstract}

$\mathrm{mV}$ 
TABLE A8.2.2. Type $T$ thermocouples-temperature $\left({ }^{\circ} F\right)$ as a function of thermoelectric voltage, reference junctions at $32^{\circ} \mathrm{F}$-Continued

m

.00

667.49

670.47

673.46

676.43

679.41

$682 \cdot 38$

685.35

$688 \cdot 32$

691.28

694.24

697.20

$697 \cdot 20$
700.15

703.10

706.05

19.40

709.00

19.50

19.60

19.70

711.94

714.88

717.82

720.75

723.68

667.79

670.77

673.75

676.73

679.71

682.68

685.65

688.61

691.58

694.54

697.49

700.45

703.40

706.34

$712 \cdot 23$

$715 \cdot 17$

718.11

721.05

721.05
723.98

726.62

726.91

729.54

732.47

735.39

729.84
732.76

732.76

738.61

741.23

741.53

$744.15 \quad 744.44$

$\begin{array}{ll}749.98 & 750.28\end{array}$

671.07

674.05

677.03

680.00

682.98

685.94
688.91

688.91
691.87

694.83

697.79

700.74
703.69

703.69

709.58

712.53

715.47

718.40

$721 \cdot 34$

724.27

727.20

730.13
733.05

733.05
735.98

$735.98,736.27$

741.82

744.74

750.57

747.94

750.86

668.39

671.37
674.35

677.33

680.30

683.27

686.24
689.21

692.17

698.08

701.04
703.99

706.93

709.88

712.82

718.70

721.63
724.56

727.49

730.42

20.70

.00

.01

.02

.03

$\mathrm{mV}$

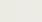

$.04 \quad .05 \quad .06$

.07

.08

.09

.10

$m V$

TEMPERATURES IN DEGREES $F$

$\begin{array}{lll}668.68 & 668.98 & 669.28\end{array}$

$\begin{array}{ll}671.67 & 671.97 \\ 674.65 & 674.95\end{array}$

674.65

674.95

672.26

675.24

669.58

672.56

675.54

680.90

683.87

$686.54 \quad 686.83$

680.50

689.80

692.46

695.42

692.76

695.72

681.19

$678 \cdot 52$

$684.16 \quad 684.46$

$687.13 \quad 687.43$

$690.09 \quad 690.39$

693.06

690.39
693.35

696.31

$698 \cdot 38$

698.67

$701 \cdot 33$
$704 \cdot 28$

707.23

701.63

$704.58 \quad 704.87$

699.26

702.22

705.17

708.11

$710.47 \quad 710.76$

$713 \cdot 12$

713.41

711.06

716.05

716.35

713.70

718.99

719.28

716.64

714.00

716.94

719.87

722.51

724.86

725.15

725.44

722.8

725.74

727.79

728.08

728.37

730.71

733.64

731.01

733.93

731.30

728.67

731.59

734.52

737.44

737.15

740.36

742.40

739.78

740.07

742.69

$745.32 \quad 745.61$

742.99

743.28

746.19

748.82

751.73

749.11

751.44

751.15

.04

.05

.06

.07

.08

669.88

672.86

675.84

678.81

681.79

684.76

687.72

690.69

693.65

696.61

699.56

702.51

705.46

$711 \cdot 35$

714.29

717.23

$720 \cdot 17$

723.10

726.03

728.96

731.88

734.81

737.73

740.65

743.57

746.49

670.18

673.16

676.14

682.08

670.47

673.46

676.43

679.41

682.38

685.05

688.02

690.98

693.94

696.90

$685 \cdot 35$

688.32

691.28

694.24

699.85

702.81

705.76

$700 \cdot 15$

703.10

706.05

709.00

$711.64 \quad 711.94$

714.59

714.88

$717.52 \quad 717.82$

$720.46 \quad 720.75$

723.39

726.32

723.68

726.62

$729 \cdot 25$

$732 \cdot 18$

$735 \cdot 10$

$729 \cdot 54$

$732 \cdot 47$

735.39

738.31

$740.94 \quad 741.23$

743.86

744.15

747.07

749.69

749.98

.09

.10

$m v$

TABLE A8.2.3. Type T thermocouples-quadratic, cubic, and quartic approximations to the data as a function of voltage in selected temperature ranges $\left({ }^{\circ} \mathrm{C}\right)$. The expansion is of the form 

FORM NBS.114A 11.71:

\begin{tabular}{|c|c|}
\hline $\begin{array}{l}\text { U.S. DEPT. OF COMM. } \\
\text { BIBLIOGRAPHIC DATA } \\
\text { SHEET }\end{array}$ & $\begin{array}{l}\text { 7. PUBLICATION OR REPORT NO. } \\
\text { NBS MN-125 }\end{array}$ \\
\hline
\end{tabular}

2. Gov't Accession 3. Recipient's Accession No. 4. TITLE AND SUBTITLE

Thermocouple Reference Tables Based on the IPTS-68 No.

5. Publication Date

March 1974

6. Performing Organization Code

8. Performing Organization

7. AUTHOR(S) R. L. Powell, W. J. Hall, C. Hyink, Jr., L. L. Sparks, G. W. Burns, M. G. Scroger, H. H. Plumb

9. PERF ORMING ORGANIZATION NAME AND ADDRESS

NATIONAL BUREAU OF STANDARDS

DEPARTMENT OF COMMERCE

WASHINGTON, D.C. 20234

12. Sponsoring Organization Name and Address

13. Type of Report \& Period Covered

Final

Same as No. 9

14. Sponsoring Agency Code

15. SUP PLEMENTARY NOTES

Supersedes NBS Circular 561, April 27, 1955.

16. ABSTRACT (A 200-word or less factual summary of most significant information. If document includes a significant bibliography or literature surve $y$, mention it here.)

Revision of the International Practical Temperature Scale requires that there be changes for all accurately tabulated thermophysical values. Revised reference data for thermocouples have been generated in a cooperative program between groups of the National Bureau of Standards in Boulder and Gaithersburg. This Monograph contains tables, analytic expressions, various approximations, and explanatory text. Only the standard letter-designated thermocouples are described: noble metal Types $\mathrm{S}, \mathrm{R}$, and $\mathrm{B}$ and base metal Types $\mathrm{E}, \mathrm{J}, \mathrm{K}$, and $\mathrm{T}$. Their appropriate "single-leg" or thermoelement versus Pt-67 values are also included. The new reference data reflect not only revisions in the temperature scale, but also slight changes in the materials themselves and improvements in data fitting methods. The temperature ranges vary for different types, from a low of $-270{ }^{\circ} \mathrm{C}$ for Type $\mathrm{E}$ to a high of $1820{ }^{\circ} \mathrm{C}$ for Type $\mathrm{B}$. The main functions and tables are given in terms of Celsius degrees and microvolts. Tables in the appendices represent the data with less precision, in millivolts, and in degrees Fahrenheit as well as Celsius. Approximate quadratic, cubic, and quartic analytic expressions are also given for each thermocouple type in various temperature ranges.

17. KEY WORDS (Alphabetical order, separated by semicolons)

Base metal alloys; noble metal alloys; temperature scale; temperature standards; thermocouples; thermometry.

\begin{tabular}{|c|c|c|}
\hline $\begin{array}{l}\text { 18. AVAILABILITY STATEMENT } \\
X] \text { UNLIMITED. }\end{array}$ & $\begin{array}{l}\text { 19. SECURITY CLASS } \\
\text { (THIS REPORT) } \\
\text { UNCL ASSIF IED }\end{array}$ & $\begin{array}{l}\text { 21. NO. OF PAGES } \\
410\end{array}$ \\
\hline $\begin{array}{l}\square \text { FOR OFFICIAL DISTRIBUTION. DO NOT RELEASE } \\
\text { TO NTIS. }\end{array}$ & $\begin{array}{l}\text { 20. SECURITY CLASS } \\
\text { (THIS PAGE) } \\
\text { UNCL ASSIFIED }\end{array}$ & $\begin{array}{r}\text { 22. Price } \\
\$ 4.55\end{array}$ \\
\hline
\end{tabular}



PERIODiCALS

JOURNAL OF RESEARCH reports National Burcau of Standards research and development in physics, mathcmatics, and chemistry. Comprchensive scientific papers give complete details of the work, including laboratory data, experimental procedures, and theoretical and mathematical analyses. Illustrated with photographs, drawings, and charts. Includes listings of other NBS papers as issued.

Published in two sections, available separately:

\section{- Physics and Chemistry (Section A)}

Papers of interest primarily to scientists working in these fields. This section covers a broad range of physical and chemical research, with major emphasis on standards of physical measurement, fundamental constants, and properties of matter. Issued six times a year. Annual subscription: Domestic, $\$ 17.00$; Foreign, \$21.25.

\section{- Mathematical Sciences (Section B)}

Studies and compilations designed mainly for the mathematician and theoretical physicist. Topics in mathematical statistics, theory of experiment design, numerical analysis, theoretical physics and chemistry, logical design and programming of computers and computer systems. Short numerical tables. Issucd quarterly. Annual subscription: Donestic, $\$ 9.00$; Foreign, $\$ 11.25$.

\section{DIMENSIONS, NBS}

The best single source of information concerning the Bureau's measurement, research, developmental, cooperative, and publication activities, this monthly publication is designed for the layman and also for the industry-oriented individual whose daily work involves intimate contact with science and technology - for engineers, chemists, physicists, research managers, product-development managers, and company executives. Annual subscription: Domestic, $\$ 6.50$; Foreign, $\$ 8.25$.

\section{NONPERIODICALS}

Applied Mathematics Series. Mathrmatical tables manuals, and studics.

Building Science Series. Research results, test methods, and performance criteria of building matcrials, components, systcuns, and structures.

Handbooks. Recommended codes of engineering and industrial practice (including safety codes) $d e-$ veloped in cooperation with interested industries, professional organizations, and regulatory bodies.

Special Publications. Proccedings of NBS conferences, bibliographies, annual rcports, wall charts, pamphlets, etc.

Monographs. Major contributions to the technical literature on various subjects related to the Burcau's scientific and technical activities.

National Standard Reference Data Series. NSRDS provides quantitative data on the physical and chemical properties of materials, compiled from the world's literature and critically evaluated.

Product Standards. Provide requirements for sizes, types, quality, and methods for testing various industrial products. These standards are developed cooperativcly with interested Government and industry groups and provide the basis for common understanding of product characteristics for both buyers and sellers. Their use is voluntary.

Technical Notes. This series consists of communications and reports (covering both other-agency and NBS-sponsored work) of limited or transitory intercst.

Federal Information Processing Standards Publications. This serics is the official publication within the Federal Government for information on standards adopted and promulgated under the Public Law 89-306, and Bureau of the Budget Circular A-86 entitled, Standardization of Data Elements and Codes in Data Systems.

Consumer Information Series. Practical information, based on NBS research and experience, covering arcas of interest to the consumer. Easily understandable language and illustrations provide useful background knowledge for shopping in today's technological marketplacc.

\section{BIBLIOGRAPHIC SUBSCRIPTION SERVICES}

The following current-a wareness and literature-survey bibliographies are issued periodically by the Bureau:

Cryogenic Data Center Current Awareness Service (Publications and Reports of Interest in Crvogenics). A literature survey issued weekly. Annual subscription: Domestic, $\$ 20.00$; foreign, $\$ 25.00$.

Liquefied Natural Gas. A literature survey issued quarterly. Annual subscription: $\$ 20.00$.

Superconducting Devices and Materials. A literature survey issued quarterly. Annual subscription: $\$ 20.00$. Send subscription orders and remittances for the preceding bibliographic services to the U.S. Department of Commerce, National Technical Information Service, Springfield, Va. 22151.

Electromagnetic Metrology Current Awareness Service (Abstracts of Sclected Articles on Measurement Techniques and Standards of Electromagnetic Quantities from D-C to Millimeter-Wave Frequencies). Issued monthly. Annual subscription: $\$ 100.00$ (Special rates for multi-subscriptions). Send subscription order and remittance to the Electromagnetic Metrology Information Center. Electromagnetics Division, National Bureau of Standards, Boulder, Colo. 80302.

Order NBS publications (except Bibliographic Subscription Services) from: Superintendent of Documents. Gorernment Printing Office, Washington, D.C. 20402. 



AME्श्2 
